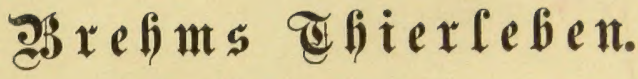

Reunter Band.

Solorirte $\mathfrak{A}$ Bg gabe. 



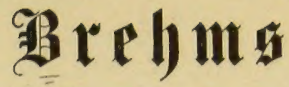

T $\mathfrak{f} \mathfrak{i} \mathfrak{e} \mathfrak{i} \mathfrak{d} \mathfrak{e} \mathfrak{j} \mathfrak{e}$ $\mathfrak{A}$ rrgemeine §uแd

3reite umgearbeitete und vermegrte 2 uflage. Solorite $\mathfrak{A} u$ ggabe.

yierte Abtheilumg - Wirbellofe đ̂hiere.

Exitex Band.

Seipzig.

Berlag bes Bibliographifden Inftitut. 1884. 


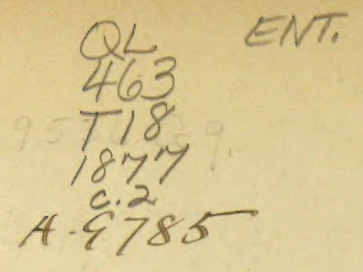

CORNELL UNIVERSITY LIBRARY' 


\title{
Die Juiften,
}

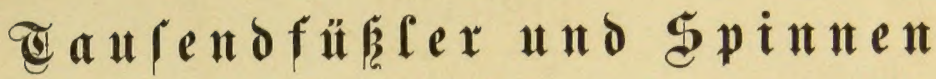

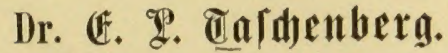
Mit 277 abbildugen im Tert und 21 Iafeln bon Emil sdjutiot.

$$
\text { Reipzig. }
$$

Berlag bes Bibliographifden Snitituts.

$$
1884 .
$$




$$
\text { A. } 9785
$$

$Q L 463$

T18

1884 


\section{Borwort zแt zweiten $\mathfrak{A} แ f$ lage.}

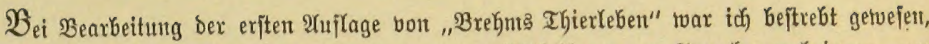
müglidjft viełe Thiere aus ber mir übertragenen Irbtgeilung zur Spradje zu bringen, um

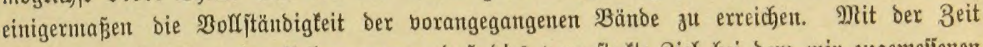

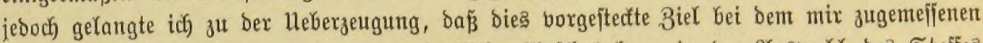

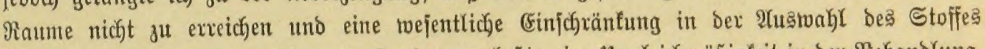

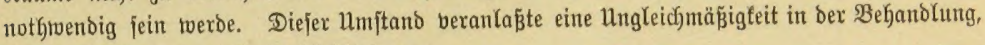
seldche ferbjtredend nidgt Geabjichtigt war.

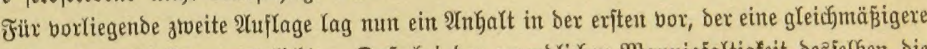

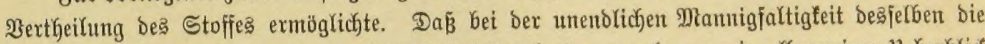

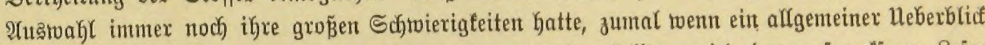

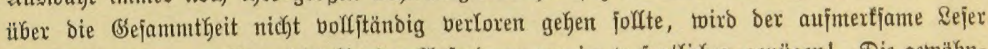
Geurtheilen tönnen. Mägge biejelbe ben 2Ynforberungen im wejentliçen genügen! Die getwöhn=

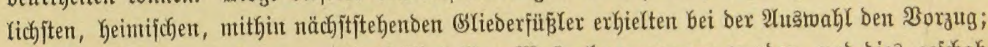

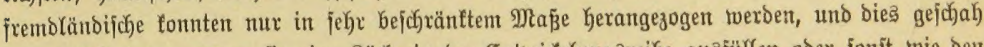

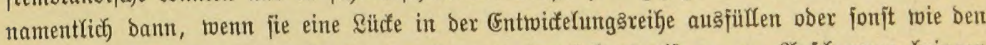

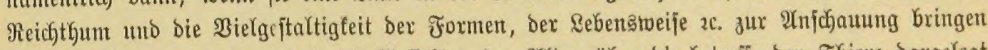

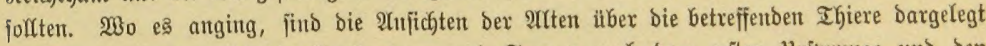
roorben, bagegen nicht bie (Exwägungen uno Fragen nađ̆ bem exften Hriprunge uno ben

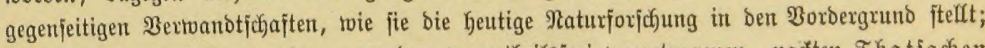
e马 ijt bies unterfaffen worben, um ben voruntheilsfrei vorgetragenen, nacten Thatjadyen

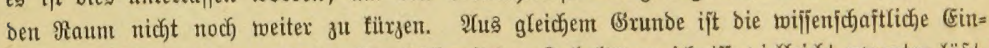

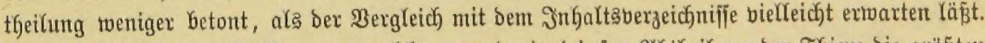

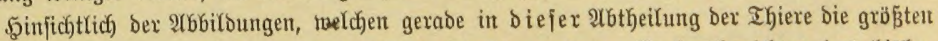

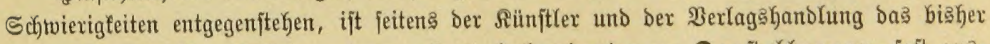

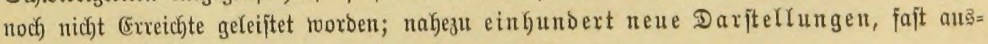

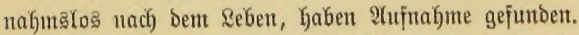

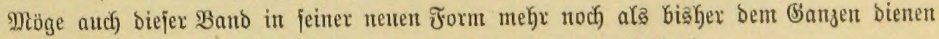
uno bem, "Ifjierteben" zu einer a llgemeinen Inerfennung verfelfen!

balle.

\section{๕. ธ. Eafdenterg.}





\section{3ubalt be uenten Bande.}

\section{Infekten.}

Ein Blid auf bas Seben ber Befanmttreit

\section{(Exfte Dronung: Säfer (Coleoptera oder Eleutherata).}

\section{Tiำfzeber (Coleoptera pentamera).}

Erfte Gamilie: Gandfäfer (Cieindelidae).

1. Sippe: Eicinbelinen . . . . . . 30 Felo = Sandfäfer (Cicindela eampestris) . 30

2. Sippe: Eollyriten . . . . . . . 32 \&anghalitger Sanbeafer (Collyris longicollis)

3weite Familie: Rauffäjer (Carabicidae).

1. Eipte: Elaphrimen . . . . . . 33 ller= Rajdffajer (Elaphrus riparius) . . 33

2. Sippe: Enabinter. . . . . . . 33 Sartenlauffäfer (Carabus hortensis) . . 35 (Solbhenne (Carabus auratus) . . . . 35 (Sebirgs = (5oldobene (Carabus auronitens) 36 ßuppenrïuber (Calosoma sycophanta) . 36 尺leiser Rletterlaufäfer (Calosoma inquisitor) . . . . . . . . . 37

3. Siptse: Bradfinitten . . . . . . 37 2ombarbirfäfer (Brachinus crepitans) . 38

4. Sipqe: \$ericalinent . . . . . . . 38 Sefpenit = \&auffäfer (Mormolyce phyllodes) 38

5. Sippe: Scaritinen. . . . . . . . . 39 Riefen = Fingerfäper (Scarites pyraemon). 39

6. Silwe: Bterofitifinen . . . . . . 40 Betreibe= \&auffifer (Zabrus gitbus) . . 40

Dritte J̃nnilie: Sdjwimmtäjer (Dytieidae).

1. Sippe: Dyticinen . . . . . . . . 43 (5efäuntex gabenifdubimmtifer (Dytieus marginalis)
Gejurditer Fabenịd) sulcatus) . . . . . . . . 48

2. Sippe: 5ुyoroporinen. . . . . . 48

Hydroporus elegans . . . . . . . 48

3. Sippe: 5alipfinen, 2Baffectreter . . . 48

Cnemidotus caesus - Haliplus . , , 48

Bierte Familie: Zaumteltäfer (Gyrinidae).

Gyrinus strigipennis : . . . . . . 49

Taudtenber Drebthifer (Gyrinus mergus) 50

Gyrinus natator . . . . . . . 50

รีünfte Fanilie: Bafïerfäfer (Hydrophilidae).

Sippe: 5noroptitiner. . . . . . . 51

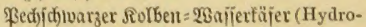
philus piceus) . . . . . . . 51

Sđ)watzer Rolbert= 2Bajierfiljer (Hydrous aterrimus). . . . . . . . 53

¿auffäferartiger Rolben = Wajlerfifier (Hydrous caraboides) . . . . . . 53

Sedffte Jamitie: furzfïgler (Staphylinidae).

1. Sipte: Staplablininer . . . . . . 54 (S) oloftreifiger Mioberfifer (Staphylinus caesareus). . . . . . . . . . 55

Rurzbaarige Staply)line (Staphylinus pubescens) . . . . . . . . 56

Stittender Mobertifer (Oeypus olens) . 56 Erzjarbener Mijtlicb (Philonthus aenens) 56

2. Sipse: Orbtelinen . . . . . . . 56 Motber Pilzfurgftügler (Oxyporus rufus) 56

3. Sippe: ßäberiner . . . . . . . . . llfer= Moberfäfec (Paederus riparius) . 56 
Siebente Familie: Bielapbioen (Pselaphidae).

Siptre: Bravigetinen . . . . . . . 57

(Selber Reutentäjer (Claviger foveolatus) 57

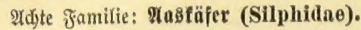

Sippe: Silphinen.

(Senteiner Tobtenyritber (Necrophorus vespillo)

Deut\{d)er 'Tootengräber (Necrophorus germanus)

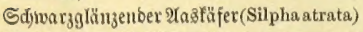
Rotbbaljiger Fasfüfer (Silpha thoraciea) Bierpunttiger $\mathfrak{A}$ (a)täer (Silpha quadripunctata)

Neunte Frmilie: Stubfäfer (Histeridae).

Sippe: Sifterinen . . . . . . . 65 Mift= Stußfäfex (Hister fimetarius) . . 65

Hetaerius sesquicornis - Saprinus , . 65

Belnte đamilie: Gramzläjer (Nitidulariae). Sipse: Nitioulutert . . . . . . . . 66

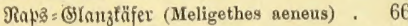

\section{(EIfte ‡ramilie: Speđfäfer (Dermestidae).}

Spedfuffer (Dermestes lardarius) . . . 68

Belzfäjer (Attagenus pellio) . . . . 70

RabinetE̋̈fer (Anthrenus museorum) . . 71

Simbeerminoe.(Byturus tomentosus) . . 72

3wölfte Familie: İugenfäfer (Byrrhidae).

Sippe: Byrrfitur . . . . . . . . . 72

Piffentïfer (Byrrhus) . . . . . . 72

\section{Dreizerynte Familie: Sammborntäfer (Pectini- cornia ober Lucanidae).}

1. Sinpe: Sir[afster, Eucanen . . . . 73

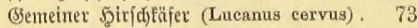

2. Sippe: Butferfäfer, Bafjariben (Passalus) , 76

Bierzelynte Familie: BInttjorntäfer (Lamellicornia ober Scarabaeidae).

Mift füpr (Lamellicornia laparostictica).

1. Sipte: Mifftafer int engeren Sinu (Coprophaga)

Seifiger झilfenorefier (Ateuchus sacer) .

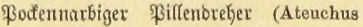
variolosus).

Sisyphus Schaefferi - Copris - Phanaeus - Onthophagus . . . . .

2. Sippe: Dungfäfer, 2Apgobtinen . . . (5trabentoer Dungfäfer (Aphodius fossor)

3. Sippe: Roz̧fäfer, Seotrupinen ....

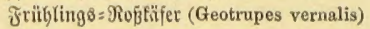

Bemeiner Noß̈lafer (Geotrupes stercorarius) . . . . . . 82

Dreifjorn (Geotrupes Typhoeus) . . . 83

クebeli[dneiber (Lethrus cephalotes) . . 83

\&aubfäfer (Lamellicornia pleurostictica).

4. Sippe: Melolontfinen . . . . . . . 84

(Semeiner S) Rnifüfer (Melolontha vulgaris) 84

Rop̈faptanien = Raubfäfer (Melolontha hippocastani) . . . . . . . . . 84

Serber (Melolontha fullo) . . . . . 87

Brndfăfer (Rhizotrogus solstitialis) . . 88

5. Sippe: Nuteliben . . . . . . . . 89

(Setreibe = Raubfafer (Anisoplia fruticola). $\quad 89$

(Sarten = \&aubfäjer (Phyllopertha horticola) . 90

6. Sippe: Riefentifer, Drunftinen . . . . 90

Serfuleätïfer (Dynastes Hercules) . . 91

(S) lefant (Megalosoma elephas) . . . . 91

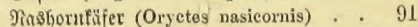

7. Sipve: Melitophilen . . . . . . 92

Riefen= (5oliatl) (Goliathus giganteus) . 93

(Sabelnaje (Dicranorrhina Smithi) . . 93

(Ssemeiner Bolofafer (Cetonia aurata) . 93

Marmoritte (Setonie (Cetonia marmorata) 94

Seberfäfer (Osmoderma eremita) . . . 95

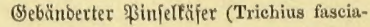
tus). . . . . . . 95

\&angarmiger \$infelfạper (Euchirus Iongimanus).

Funfzebnte Familie: \$rătttäfer (Buprestidne).

1. Sippe: Julobinten . . . . . . . . . 97

Julodis fascicularis . . . . . . . 97

2. Sippe: Eforcophoriben . . . . . . . 97

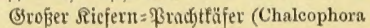

Mariana) . . . . . . . 97

3. Sippe: Bupreftiben ... . . . . . 97

Sinden= Pradjtfäfer (Poecilonota rutilans) 97

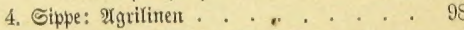

3weiflectiger Sdymalbaud) (Agrilus bigut-

tatus). . . . . . . . 98

5. Sipwe: Tradypinen . . . . . . . . . 98

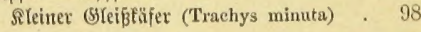

Sedjzebnte Frmilie: Sduclfäier, Sdjmicøe (Elateridae).

1. Sippe: Agrmsmintı . . . . . . 100 Mลืu|grauter Sd) nus) . . . . . . . . 101

2. Sippe: Elaterinert. . . . . . 101 Rauber Sthmied (Athous hirtus) . . . 101

(Eucujo (Pyrophorus noctilueus) . . . 103

Gintidyellefifer (Agriotes segetis) . . 104

Siebsebyte Frmulie: Dastilliden (Dascillidae).

Sippe: Dascillinen . . . . . . . . 106

(Streisfilfer (Dascillus cervinus). . . . 106 


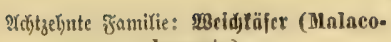
dermata).

1. Sipwe: Reudjtfäfer, Rampbrinen . . . 107

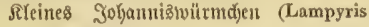
splendidula) . . . . . . 108

(5roßsc3 Sobannisioutumdjen (Lampyris noctiluca). . . . . . . 108

Photinus pyralis . . . . . . 109

2. Sipwe: Telephorinent . . . . . . 110 (Senteiner 2 geidjtôfer (Telephorus fuseus) 111

3. Sipbe: Meluriben. . . . . . . . . 112 (Sropjer Blajenfäfer (Malachius neneus) 112

Neunzeryte đantilie: Buntfäfcr (Cleridae).

Sippe: Bletinten . . . . . . 113

2meifenartiger Buntfäfer (Clerus formicarius) .

Bemeiner Smmentăfer (Trichodes apiarius)

113

\section{1wangigfte Familie: Golybohrer (Xylophagi,} Bostrychidae).

1. Sippe: Ftiment . . . . . . 114

S̊räuterbi๕ほ (Ptinus fur). . . . . 114

Meffungelber Boljrtifer (Niptus holo-

leucus) . . . . . . . 114

2. Sippe: 2rnobiinen . . . . . 115

Bunter Rlopftafer (Anobium tessellatum) 115

Trob̧topf (Anobium pertinax) . . . . 115

(B) freifter WSerfyolzfäfer (Anobium striatum). . . . . . . . . 116

Brobfäfer (Anobium paniceum). . . . 116

\section{Beridjiebenzelier (Heteromera).}

Einunbzเuanzigfte familie: Edowargtäfer (Tenebrionidae).

1. Sippe: Blaptimert .

(Semeiner Trauerfiffer (Blaps mortisaga) 118

2. Gippe: \$imeliiner, Feiffafer . . . . 118

Pimelia distincta . . . . . . . . 119

3. Sipte: Iencfrioniuen . . . . . . 119

Miebleäfer (T'enebrio molitor) . . . . 119

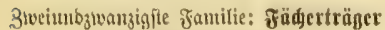

(Rhipiphoridae).

Seltfamer Fräderträget (Metoecus paradoxus) .

Dreimbzlunkigigfe framitie: \$flafterfäfer (Vesicantia ober Cantharidae).

1. Sippe: MRetoinen ...... 122

Bunter Deffafer (Meloö variegatus) . . 125

(3emeiner Yhaiঊutrm (Meloë prosearabreus)
2. Sippe: Mnlabrinet ....... 126

Jeberbujd)fäfer (Cerocoma Schacfferi) . 126

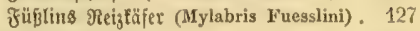

3. Sippe: (Santfyarinen . . . . . 127

Spanifaje frtiege (Lytta vesieatoria) . 127

4. Sippe: Sitaritten . . . . . . 128

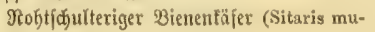

ralis) . . . . . . . .

Bierzeber (Pseudopentamera).

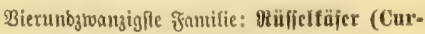
culionidae).

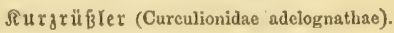

1. Sippe: Bradyberinen. . . . . . . . 131

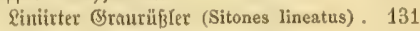

Cyphus - Platyomus - Compsus . . 132

2. Sippe: Dtiorlyndjinen . . . . . . 132

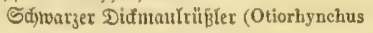
niger) . . . . . . . . . . .

(S) furdyter (Otiorhynchussulcatus), braun= beiniger Diđ̆maultüß̄ไer (Otiorhynchus picipes), Spib̧?opf (Otiorhynchus ni-

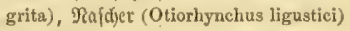

(S)ünxüß̧ler (Phyllobius - Metallites Polydrosus) . . . . . . . . 134

3. Sippe: Bradjucerinet, Rurbböruter . . . 134

Brachycerus . . . . . . . . 134

¿augrüßß̨er (Curculionidae phanerognathae).

4. Sippe: Oleoninen . . . . . . . . 135

\&äbmentor Stengelbobrer (Lixus paraplecticus) . . . . . . . . 135

5. Sippe: 5gylobiiner . . . . . . . 135

(3rober Fidjtemiilifeltäfer (Irylobius abietis) . . . . . . . . 136

Sleiner Fidotenthilfelfifer (Hylobius pinastrï) . . . . . . . 13\%

Steiner Ricfernriffeffïjer (Pissodes notatus) 132

4

34

... . . 137

6. Sippe: 9tpioniner. . . . . . . . 137

Commeliebentes Spikmäus̆tn (Apion apricans) . . . . . . . 139

Apion assimile, trifolii, craccae, ulicis, Sayi, Havipes, ulicicola, radiolus . . 139

7. Gipte: Attelabinen . . . . . 140 Saciet= Ditfforffïfer (Apoderus coryli) , 140

Eantghalfiger Didfopfrübler (Apoderus longicollis). . . . . . . . 141

afterriififerfffer (Attelabus cureulionoides) 141

8. Sippe: Mithomaceriner . . . . . . . 142

Stabifolauer Mekenftedyer (Rhynchites betuleti) . . . . . . 142

Patwerfitedjer (Rhynchites populi) . . . 146 
Sdywarer Bitfenftedber (Rhynchites betulae)

3̧wcinabftedser (Rhynchites conicts) .

Bfatripwenftedfer (Rhynchites alliariae).

ZFfaumenbolbrct (Rhynchitos cupreas)

9. Gippe: Banlaniminest

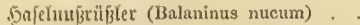

(Srofier Eidjelbolyrer (Balaninus glandium) . . . . . . . .

fiteiner Gidyelbohrer (Balaninus turbatus).

10. Sippe: 2(nthonominten

2rpelstittenfted)er (Anthonomus pomorum)

Birnfnospenftecter (Anthonomus pyri) .

Steinfucitbofrer (Anthonomus druparum)

Budjenfpringrïlfler (Orchestes fagi) .

11. Sippe: Sioninen . . . . . .

Brammury= Blattfdiaber (Cionus ecrofulariac)

12. Sippe: (Ert)storfyndinen. . . . . .

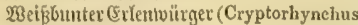
lapathi)

13. Sippe: (5eutforbynduiter . . . .

Rolylgallemilipler (Ceuthorhynchus sulcicollis)

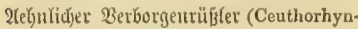
chus assimilis)

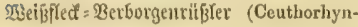
ehus macula-alba)

14. Sippe: Baribinert.

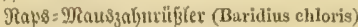

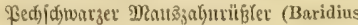
picinus).

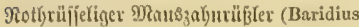
cuprirostris)

15. Sique: Ealmorinen

Zavanijojer ßalnbulguer (Rhynchophorus Scliach).

Gdywarzer fornuutu (Calandra granaria)

Neißzfäjer (Calandra oryzae)

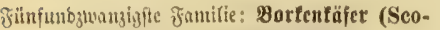
Iythdae, friiber llostrychidae).

1. Sipke: Sylepinimen

(S) wỏet sàieferımarffüfer (Binstophagus piniperda)

Rlenter Ricferumatffifer (Blastophagus minor)

2. Sippe: Boftudfinen . . . . . .

Semeiner BurTentifer, Budboruder (Bostrychus typographus).

Bostrychus dispar.

3. Sipte: Scolntincn

Broper Rilfteriptintfäfer (Eccoptogaster scolytus, Scolytus destruetor $O \ell_{\text {. }}$. . 158

Ecite 58
Birten - Sylintlafer (Ecoptogaster destructor, Scolytus Ratzeburgi). . . 161

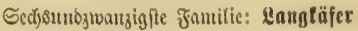
(Brenthilne).

Sippe: Brentyuten . . . . . . . . 161

Brenthus Anchorago . . . . . . 162

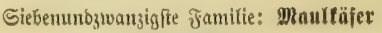
(Anthribilae).

Sippe: Bafitropinen . . . . . . 162

25eißßfectiger Maulfifer (Antbribus albinus) . . . . . . . . . 163

ภินrรfนโ] (Brachytarsus seabrosus - varius) $16{ }^{\prime 3}$

2ritunogivantzigfte Familic: Bodföfer, Baugbörnev (Capricornin, Longicornia).

Breitbỏ de (Prionida).

1. Sippe: Prioninen . . . . . . . 165

Serber, Foritboft (Prionus coriarius) - 165

3intntermatu (Ergates faber) . . . . 166

\section{Sciräg topfbücte (Cerambycidae).}

2. Sipve: Spundyline . . . . . . . 166 EBnrbftifer (Spondylis buprestoides) . . 166

3. Silpe: (5erambucinter. . . . . . . 167

Seldobol (Cerambyx heros) . . . . 167

Sanibluerfer (Cerambyx cerdo) . . . 167

Mo[d)

4. Sifte: Eeftutinten, Mfterböde . . . . 168

(3sefpornter Gdjmalbout (Strangalia armata) . . . . . . . . . . 168

Bierbinbiger Sđamalbod (Strangalia quadrifusciata) . . . . . . . . 169

Beränberfidjer Gdjmalbod (Toxotus meridianns) . . . . . . . 169

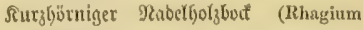
indagator). . . . . . . . . 170

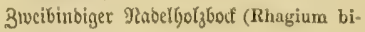
fasciatum) . . . . . . . . 170

5. Sippe: Recrbaliner . . . . . . . 170

(5ruber Salboct $=$ Bodtaffer (Necydalis major) . . . . . . . . 170

6. Sippe: Eallibiturt, Stycibenbüde. . . . 170

5a11ơbot (IIylotrupes bajulus) . . . 170

Berïnberlidjer Sdjeibenbodtäer (Callidium variubile) . . . . . . . 171

B(auer Scheibuttäfex (Callidium violaceum) . . . . . . . . . 172

7. Giple: (Srytinen . . . . . . . 172

(Senteiner :Biboerfilfer (Clytus arietis) . 172

Clytus xhamni, arvicola . . . . . 172

\section{Spitsböde (Lamiidae).}

8. Sippe: Dorcabioninen, (Erbböfe . . . . 173 Rreuztragender (Erbbod (Doreadion crux) 173 


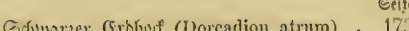
(Sreilet (Erbboce (Doreadion fuliginator)

9. Sippe: Ramihter . . . . . . . . 173

(Egagrinirter @̧eber (Lamia textor) . . 173

10. Eipte: Ircantf)ocinincn . . . . . . 171 Binmerbod, Sdjteiner (Acanthocinus aedilis)

11. Sipte: Enterbinen, Misalzentüde... . 175 (5irofier \$3appertgod (Saperda carcharias). 175 ropentbod (Saperda populnea) . . , 175

12. Sipte: Photïnten . . . . . . 170 5alelbüff́tyen (Oberea linearis) . . 176

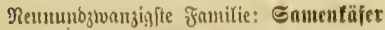
(Bruehidae).

Erbjenfäfer (Bruchus pisi) . . . . 177

Bohnentäfer (Bruchus rufimanus). . , 178 Semeinet Samentäfer (Bruchus granarius) . . . . . . . 178 ¿injenfäịt (Bruchus lentis) . . . . 178

Dreiß̧igfte Jamilic: Brnttfäjer (Chrysomelidae).

1. Sipwe: Donaciuten, Githiflïier . . . 179 Fieberflee : Estriffälex (Donacia clavipes) 180

2. Siwte: Eriocerinen. . . . . . 181 ¿ifienhähndien (Crioceris merdigera). . 181 Spargelfalyudyen (Crioceris asparagi) , 181 Bmölfpunttinges Birpfäferchen (Crioceris duodecimpunctata) . . . . . 181

3. Silwe: (SInthriuten, Sadfăfer . . . . 182 Biersunftiger Sactfäfer (Clythra qualripunctata) . . . . . 182

4. Sipye: (Eripptoceptyalinen, Falfäfer . . 182 Cryptocephalus sericeus . . . . 182

5. Sippe: (Sfrnfomelinen . . . . . 183 Stofer Pappel=23lattfufer (Lina populi) 183
Silcter Fappel=Glatifüer (Lina tremulae) .

Eeitc

Timarcha - Chrysomela violacea, cerealis, fastuosa, graminis, diluta.

Eolorabo = Jartoficlfijel (Leptinotarsa decemlineata) . . . . . . . 184

Leptinotarsa juncta - Spię̧träger (Doryphora) - Calligraplia - Paropsis . . 186

6. Sippe: Balexucincu, Juthtenfer . . . 187

Adimonia tanaceti . . . . . . . 187

Eđ̆nteeballen : Jurtitfüfer (Galeruca viburni) . . . . . . . . 187

UInten: futdiffäier (Galeruca xanthomeIaena). . . . . . . . 187

Erlen= $\mathfrak{B}$ Inttfäfer (Agelastica alni) . . 187

7. Sippe: 5nlticinen, Eroflube . . . . 188

Raps: Eroflot) (Psylliodes chrysocephala) 188

Scohl : (Exoffoly (Haltica oleracea) . . 189

(sidjen= (Eroffol) (Iraltica crueae) . . . 189

(5)lbftreifiger (Eroftor) (Phyllotreta, nemorum) . . . . . . . 190

Boniger (Eriflor) (Phyllotreta flexuosa) . 190

8. Giłpe: Eafíbinen, Gditbfäjer . . . . 190

ఇebefiner Grtilbfäfer (Cassida nebulosa) 190

Mesomphalia conspersa - Desmonota variolosa. . . . . . . . 192

\section{Dreizeber (Trimera)}

Fimunbbreißigfte Familie: Mlaricufäjerd̆en (Coccinellidae).

Sippe: (Soccinellinen . . . . . . 192

Siebenpunft (Coccinella septempunctata) . . . . . . . . 193

Coccinella impustulata, dispar, Micraspis duodecimpunctata, Chilocorus bipustulatus

\section{3weite Dronung: Soutffinfer, בัumen (IIymenoptera, Piezata).}

\section{Stadjefträger (IIymenoptera aculeata). \\ 5nonigluespen. \\ Crffe Fantilie: BLumenwespen, Bicnen (H. antho- phila). \\ Seite}

(5)efrige Biencr (Apes sociales).

1. Sippe: 2rpinet. . . . . . . . . . 20

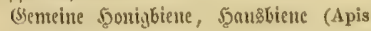
mel ifica) . . . . . . . .

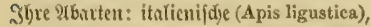
cgbvtifide (Apis fasciata), afrifanijuje, 3iene un MRabagnstar . . . . 215
2. Sipke: Mithonen . . . . . . 215

Melipona - Trigona - Tetragona . . 215

Melipona scutellaris - Trigona flaveola 216

Trigona cilipos. . . . . . . . . 217

3. Sifke: Bombinen, Sumuteln . ... 218

(5tblyummel (Bombus terrestris) - (Sar: tenlimumel (Bombus hortorum) . . 221

Steintbummel (Bombus lapidarius) Plooshtummel (Bombus muscoram) , 221

(5infame Bienen (Apes solitaria).

4. Sippe: Sdbienenfammler (Fobilegiben) . Raublgarige \$jelzbiene (Anthophora hirsuta) 
2rbgeftulste $\mathfrak{B e}_{\mathrm{g}}$ biene (Anthophora retusa) Band = Betzbiente (Anthophora parietina) (Semeine 5portıbicne (Eucera longicornis) Safirifdye 5olybiene (Xylocopa caffra)

Biolettfiigelige 5oljbiette (Xylocopa violacer)

5. Sizpe: Sdjenfelfammler (Wherilegiben) .

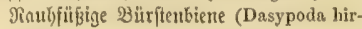
tipes)

Sdirantis Erobicne (Andrena Schrankella)

Sreife Erobiene (Andrena cineraria).

Brmungejdenfelte (5rbbiene (Androna fulvicrus)

Orobe Balfenbiene. (IIylaeus grandis)

アauke Seibenbicue (Collotes hirta) .

6. Cippe: Baudfoummler (Shftrilegiben) .

Mörtelbiene (Chalicodoma muraria) .

Sugelbiene (Anthidium) . . . . .

(Geb̧örnte Manterbiene (Osmia bicornis).

Bemeiner Blattidyneiber (Megachile centuncularis) . . . . . . . . 233

7. Sippe: Sdymarokerbienen . . . . . 235

Feljen $=$, Felo $=$, Sommer $=, \mathfrak{B}$ alo $=$ Sdyma $=$ rolizerlyummel (Apathus rupestris, campestris, aestivalis, saltuum).

Weipiflectige $2 \mathrm{sespenbiene} \mathrm{Nomada} \mathrm{Ro-}$ berjeotiana)

(Semeiue 2 arfienbiene (Melecta punctata)

Puntirte Baffenbiene (Melecta luctuosa) .

fiegelbienten (Coelioxys).

\section{Bueite Familie: Faltentwesిpen, 20 çిpen (Diploptera, Vesparia).}

1. Siqke: Sdjmarokermespen, Maffarinen. Celonites apiformis - Ceramius Fonscolombi

2. Sippe: Rebmmespen, Eumenimen . . . 238

Diauer $=$ Lebmtoespe (Odynerus parietum) 239 Antilopent = \&elntucsipe (Odynerus Antilope) . . . . . . . . . Bahnbeinige Selymwespe (Odynerus spinipes) ßidlenwespe (Eumenes pomiformis) . . 241

3. Siptre: Papierwespen, gefillige Bestpen, Beß̈= yiner:

Polybia sedula, rejecta - Chatergus chartarius - Tatua morio . . .

Polybia liliacoa, eayennensis, ampullaria - Chatergus apicalis - Nectarinia .

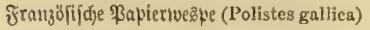
Sorutife (Vespa crabro) . . . . . . Rotbe, geneine, beutidye Reske (Tespa rufa, vulgaris, germanica)
Mittlere 2 coste (Vespa media) - Mailb= nesye (Vespa silvestris) . . . . . 2.18

Samolwespenartige Papierivespe (Belonogaster).

\section{Dritte fnutifie: Ameifen (Formicidne).}

1. Sitwe: Drĭfenameifen, Jormtinen . . 262

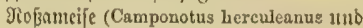
ligniperdus) . . . . . . . . . 262

Nothe Malbameife (Formica rufa) . . 262

Blutrotge Raubameife (Formica sanguinea) . . . . . . . . 263

Silwarge \$olzamelje (Lasius fuliginosus) 264

Braute 2rmeife (Lasius niger), gelbe (Lasius flavus) . . . . . . . . 264

2. Siswe: Bangenameifen, Drontomadintent . 264

Odontomachus . . . . . . . , 264

3. Sippe: Stadjelameifen, Fonerinen . . . 264

4. Sippe: Blinbameifen, Dorilinen . . . 264

Treiberameife (Anomma arcens) . . . 264

5. Gipte: Nutotenameifen, Marmicinen. . 265

Ninjenameile (Tetramorium caespitum) . 265

Fothe $2(m e i f e$ (Myrmica laevinodis) . . 266

\{derbautreibenoe atmeife Ayrmica molificans).......... . . 266

(Ecitons (Eciton rapax, legioais) . . . 267

Eeitoa hamatum, drepanophorum. . . 268

ßabicour = 2 meife (Eciton canadense). . 269

3utgs ober Bifitenameife (Oecodoma cophalotes) ....... . 270

\section{Bierte familie: geterogynen (Heterogyna).}

1. Sippe: Spinnenameifen, Mutillinen . . 273

(Eurokäifde Sfinnenameife (Mutilla europrea) . . . . . . . . . 273

2. Sipwe: Doldymespen, Scoltunen . . . 274 Sotbtöfige Doldhuespe (Scolia erythrocephala) . . . . . . . . . 274

Barten =Dolduruespe (Scolia hortorum) . 275 গollwe?ten (Tiphis) . . . . . , 275

Fünfte Familie: $\mathfrak{B c g l u e s} p e n$ (Pompllidao).

Ratatenfijcje Regiveâse (Pompilus nata-

lensis) . . . . . . . . 276

Pompilus trivialis . . . . . . . . 278

Gemeine 28egtrespe (Pompilus viaticus) 278

Priocnemis variegatus, Agenia punctum, domestica)

\section{Sedffte Fantifte: Grabs, Mlordvegpen (Sphegidae, Crabronidne).}

1. Sizpe: Ranpentöoter, Spheginen. . . . 279 Belbjliigeliger Raupentïster (Sphex flaviponnis) 


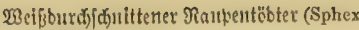
albisecta) .

Daurex=Sfinnentöbter (Pelopoeus destillatorius), Pelopoeus spirifex, blauer uno píeifenber Spimentibter (Pelopocus chalybeus uno fistularius) .

Rauthe Sanblvestre (1'sammophila hirsuta) Brmeine Gutburespe (Ammophila sabulosa) . . . . . . 281

2. Siwhe: Slathoesper, Mellininen . . . . 204 2Afer: (Slattloebpe (Mellinus arvensis) , 2it Santb=(S)(attwe save (Mellinus sabulosus) . 281

3. Sitwe: Wirbetweasen, Bentbectuen . . . 281 (Semeine 23 ir belmeste (Bembix rostratus) 285 Monedula signata. . . . . . . . 205

4. Eivte: Philautbinen. . . . . . . 205

Bientuivolf (Pbilanthus triangulum) . . 285

Cerceris vespoides. . . . . . 286

Bradjtfäfertöbter (Cerceris bupresticida) 2,7

Conno: Rnnotentesse (Cereeris arenaria) 287

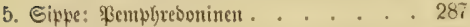
Benteine Töpferivespe (Trypoxylonfigulus) $20 \%$

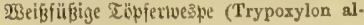
bitarse)....... 287

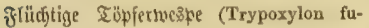
gax) . . . . . . . . 287

(5) aurifions) . . . . . . . . 287

6. Sipte: Siefurespen, (5rabroninen . . . 20 f

Crossocerus scutatus, elongatulus. . . 288

(Sefieltc Siefwe ape (Crabro striatus). . 288

Thyreopus patellatus. . . . . . 288

(Stenteine Striefive 3 pe (Oxybelus uniglumis) 288

II. Legr §̧renträger (Hymenoptera terebrantia).

\section{Giebente Familie: (5olbwespen (Chrysidno).}

1. Sippe: ßarnopinen . . . . . . . . 290 Fleifdrotbe (3) blowespe (Parnopes carnea) 290

2. Silte: Shrmfuten. . . . . . . 291 Bstinzenoe Dorngolbivespe (Stilbum splendidum).

Blane (Solbivespe (Chrysis cyanea) . . 291

(Senteine Bolbrueste (Chrysis ignita) . 291

3. Siptse: Sebudjrinen . . . . . . . 292

SB̉niglidie Soldowes̄e (Hedyehrum lucidulum). . . . . . . . . 292

Rofige (Solowespe (Hedychrum roseum) 292

4. Sippe: Brompinen. . . . . . . . . 292

Omalus auratus, Elampus aeneus, bidentulus

2chte Familie: (5nllucspen (Cynipillae).

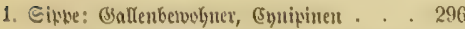
Benteine Ballawfefluespe (Cynips scutellaris)
Cynips foli, longiventris, agama o "

Cidjenzałfen = (3)llwespe (Cynips gemmae) . . . . 298

Cy:ips lignicola, tinctoria . . . . . 298

Cynips Psenes - Andricus . . . . 298

Ed)uanm = (Saltwespe (Teras terminalis) 299

fliighelloje Wurzel=Sallwespe (Biorhiza aptera). . . . . . . . 299

3rumbeer = (Balliveşue (Diastrophus rubi) 300

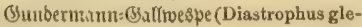
chomao) . . . . . . . 300

(5emeine Rto/engaUtwešpe (Rhodites rosao) 300

lhodites eglanteriae . . . . . . 301

Synergus facialis - Aulax. . . . . 301

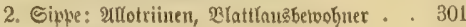

Allotria . . . . . . . . . 301

3. Sippe: Figitinen, ßarajiten . . . . 301

4. Sippe: Jbaliuten, nit ber einzigen 2 rt: Dicfferförmige Sdymarotser: (3athoçిpe (Ibalia cultellator). . . . . . . 302

302

\section{Rente Familie: Prottotrupier (Procto. trupidae).}

Silpe: Scellointen . . . . . . 303

Eierivesłe (Teleas laeviusculus unb terebrans).

\section{Bełnte Familie: Behrmeåpen (Chalcididne, Pteromalidae).}

1. Sikpe: Toryminen . . . . . . . 304

Torymus regius . . . . . . . . 301

2. Sippe: ßteromaliner. . . . . . . 304

Raubflügelivespe (Pteromalus puparum) 304

3. Sippe: Egarcibien. . . . . . 305

(5) lbilectige Sdyenteltuestye (Chalcis clavipes) . . . . . . . . . 305

(5ieftiefte Sdjenfeltueape (Sinicra elaripes) 305

\section{(5ijte fantilie: Qungermeâนen (Evaniadne).}

1. Sipte: 尺urz [drmänze . . . . . . . 306 Rlciute Şungerivespe (Brachygaster minuta) . . . . . . . 306

2. Sippe: Ranjf(d)uinge . . . . . . . . 306 (3iditureste (Foenus assectator) . . . 306 Pjeiltriäger (Foenus jaculator). . . . 306

\section{Buorfte familie: GaInpfwespentuerivandte, Bracouiden (Bracouidae).}

1. Sipte: (5ejd) foifentututer, Elicofomen . . 307 Iphibicx (Aphidius) . . . . . . . 307

Rleitbüudje (Microgaster glomeratus, nemorum)

Hacrocentrus marginator . . . . 30s 
2. Sippe: Rutuontüurer, Eycloftomen . . . 309 Bracon palpebrator . . . . . . . 309 Spathius clavatus . . . . . . . . 310

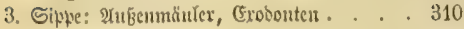
Alysia manducator . . . . . . . 310

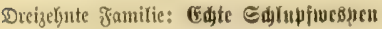 (Ichneumonidao).}

1. Sitte: Trbihoninct . . . . . 314

Exenterus marginatorius. . . . . . 314

Bassus albosignatus . . . . . . . 314

2. Sipte: Sictermeenpen, Spioninte . . . 315

Banchus falcator . . . . . . 315

Siefernlwimuer $=$ Sidjefhesse (Anomalon circumflexum) . . . . . . . 316

Ophion - Paniscus . . . . . . . 317

3. Sipts: Sctncunoninen . . . . . . 319

Ichneumon pisorius, fusorius - Amblyteles . . . . 320

4. Sippe: (5ruptimen . . . . . . 320

Phygadeuon pteronorum. . . . . . 321

Cryptus tarsoleucus . . . . . . . 321

Mesostenus gladiator . . . . . . 322

Hemiteles areator . . . . . . . . 322

5. Silve: Bimplatien . . . . . . . . 322

1Rhyssa persuasoria . . . . . . . 322

Ephialtes imperator . . . . . . . 323

Pimpla instigator . . . . . . . . 324

Glypta resinanre . . . . . . 325

\section{Bierzelyte Famifie: \$flanzentueßpen}

(II. phytophaga).

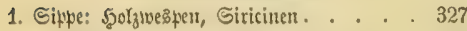

(Semeinte 5olghueape (Sirex juveneus). . 327

Niefentyolgwešpe (Sirex gigas) . . . 328
2. Sipte: 5atmineshen, (5ethitent... 330

(Semeine Santntueăte (Cephus pygmacus) 330

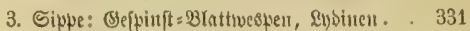

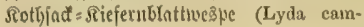
pestris) . . . . . . . . 331

Brobe Rieferubinattuegepe (Lyda stellata) 332

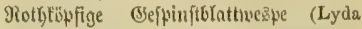
erythrocophala), (3efellige fifitenblatt: weầe (Lyda hypotrophica), Bitu = (3e=

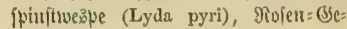
fpinftuespe (Lyda inanita) . . . . 332

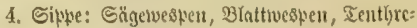
binert. . . . . . . . .

Sieferu = Stammbormwespe (Lophyrus pini)

Stadjelbcerblattivesite (Nematus ventricosus) . . . . . . . . . 334

Dolorus . . . . . . . . 335

Sdjwarge Sirfodjolattmestre (Eriocampa adumbrata) . . . . . . . 335

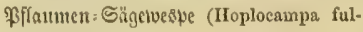
vicornis) . . . . . . 335

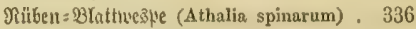

(Brütue Bínthucope (Tenthredo sealaris) - Tentluredo viridis . . . . . . 337

(Sclbgebörnte Blattrucsife (Tenthredo flavicornis) . . . . . . . . . .

Braunivur = 2 Inthę) (Allantus scrofulariae) . . . . . . . . . 337

5. Sipke: 2 Büritjörner, 52ytotomitien . . . 338

Rojen = Bürfthorrtuegse (Ilylotoma rosae) 338

Sauerborn= Bürfthoruveșe (Hylotoma berberidis). . . . . . . . . . 338

Strittioru (Schizocera) . . . . . . 339

6. Sippe: Rnopfbörner, Eimbectuen . . . 339

Birfen= Rnoqf Gornue

\section{Dritte Dronung: Sometterfinge, gaffer (Lepidoptera, Glossata).}

\section{(3) rofifalter (Macrolepidoptera).}

Erfte Fanilie: Tagialter (Diurna, Rhopalocern).

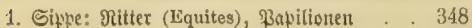
21mphriftı (Oxnithoptera Amphrisus) . 348

\$riamis (Ornithoptera Priamus). . . 349

Cdjmalbeujdjuanz (Papilio Machaon) . 349

Esgelfalter (Papilio podalirius). . . . 349

(5urius (Leptocircus Curius) . . . . 350

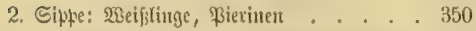
(Sroper Roblweipling (Pieris brassicae) . 350 Sleiner Roblweißling (1'ieris rapae) . . 352 Jectentucipling (Pieris napi). . . . . 352 23aumbeißling (Pieris crataegi) . . . 353 2(urorajalter (Anthocharis cardaminis) . 354 he

31

2


(Srober Gisuogel (Limenitis populi) . . 359 Sdfillerjalter (Apatura Iris, Apatura Ilia) 359

4. Sipte: Mtorphiuen . . . . . . . 360

Neoptolemus (Morpho Neoptolemus) . . 360

5. Cinpe: Reugler, Gattrinen . . . . 361

Roftbinbe, Semele (Satyrus Semele) . . 361

Brileis (Satyrus Briseis). . . . . . 362

Ђoniggrasffalter (Satyrus Alcyone). . . 362

Sirfertgraจิfalter (Epinephele Hyperanthus) 362

Sanbauge (Epinephele Janira). . . . 362

MRauerfucts (Pararge Megaera) , . . 363

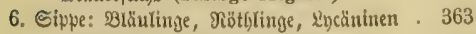

Biereidjenfalterden (Theela quercus). . 363

Fetrerbogel (Polyommatus virgaureae) - 364

Beflecter freterialter (Polyommatus

Phlaeas) . . . . . . . . . 364

5anubedjelfalter (Lyeaena Icarus) , . . 366

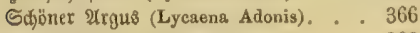

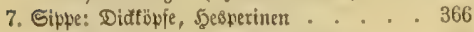

Stridgfalterduen (Lesperia comma) . . 366

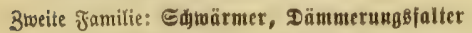
(Sphingidae, Crepuscularia).

1. Sippe: Spindetreibige Sdjwärmer, Spţin= ginen ......... . 368

Tobtentopf (Acherontia Atropos) . . 368

Rainveibenjđjwärmer (Sphinx ligustri) . 369

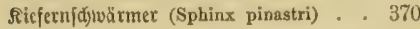

23olfవెmild)f(t)würmer (Sphinx euphorbiae) 371

Sleanber[d)wărmer (Sphinx nerii) . . . 371

2. Sippe: Badenjdjwämer, Smeriutginen . 372

ßappeljđ)wärmex (Smerinthus populi) - 372

धbentopfauenauge (Smerinthus ocellatus). 373

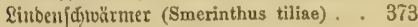

3. Sippe: Breitteibig̨e Sţruämuer . . . . 373

Radjtfergenfdjulinter (Macroglossa oenotherao)......... . . 373

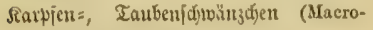
glossa stellatarum) . . . . . . . 374

Ђummelfifyuämmer (Macroglossa fuci-

formis unt bombyliformis . . . . 37

Dritte Gamilie: golffofier (Xylothropha).

1. Sipte: Orasflïgler, Gejïnen . . . . 375

Soเnif|

2(pfelbaumglåflügler (Sesia myopiformis) 376

2. Sipue: Botrer, (Solfinel . . . . . 376

Wecibenbobrer (Cossus ligniperda) . . . 376

\section{Wierte §anilie: (5beloniaricr, Bären (Chelo- niariae).}

1. Gipte: \$Bibberdyen, Brutströpfdjen, 3ygä= niuelt . . . . . .

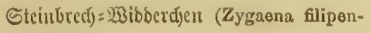
dulao) . . . . . . : .

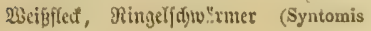
Phegea) . . . . . . . .

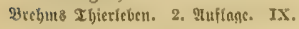

2. Sippe: Bären, Eupretinetr. . . . . 378

Brauner Vür (Aretia caja). . . . . 379

ßurłurbår (Arctia purpurea) - Sungier (Callimorpha domiuula) - Spanifde Jabne (Callimorpha Hera)

\section{Fünfte đamilte: Spinner (Bombyeidae).}

1. Sippe: Radjpfauenaugar, Gaturninen .

\{ilantf)us: Spinner (Saturnia Cynthia). 381

(sbinefifder (Eidjen = Seibenfpinner (Satuxnia Pernyi)

Japanefijder Eidjen=Seibenfpituer (Saturnia Yama mayu).

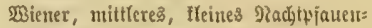
auge (Saturnia pyri, spini, carpini) . 385

2. Sipte: Ebelipinuser, Sericinen . . . 385

Maulbeerfpinner, Scibenipinuer (Bombyx mori) . . . . . . . . . 385

3. Silpe: BIluden, Bafropadjinen . . . 387

fiefernfpimer (Gastropacha pini) . . 387

Ringelfpintex (Gastropacha neustria) . 359

4. Sipte: Sadträger, $\mathfrak{F}$ hudinen . . . . . 390

Psyche helix . . . . . . . . 390

Molyreutopf (Psyche unicolor). . . . 391

5. Sippe: Stretfïßе, Itparinen . . . . 392

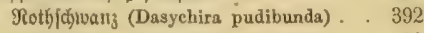

23eidettpisuner (Dasychira salicis) . . 393

(Solbafter (Porthesia chrysorrhoea) . . 393

Sdjwair (Porthesia auriflua) . . . . 395

Sdywammpinner, Didtopf (Ocneria dispar). . . . . . . . 395

शoutue (Ocneria monacha) . . . . 397

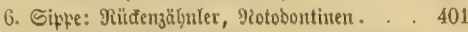

Eidjen = \$roceffionsfpinuer (Cnethocampa processionea) . . . . . . . . 401

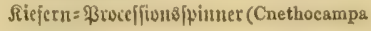
pinivora) . . . . . . . . 402

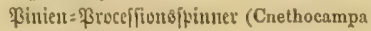
pityocampa) . . . . . . . . . 403

Otojacr Baberfótuanz (Harpyia vinula) . 403

3udjenffinner (Stauropus fagi) . . . 404

\section{Sedffie framilie: Eulcn (Noctuidae).}

1. Sipte: Spimerartige (Eulen, Bombncsinen 405

Biautopf, Brillenvogel (Diloba coeruleocephala) . . . . . . 405

Iljorn= \$feilmotte (Acronycta aceris) . 406

Orion (Moma Orion) . . . . . . . 406

2. Gipts: Sabeniner . . . . . . . 406

@uctencure (Hadena basilinea) . . . 406

D)attgezeidutete Eule (Hadena infesta) . 407

Flobtrauteute (Mamestra persicariae) . 408

Juttergrą̧eule (Neuronia popularis) . . 408

(Siนふืยนle (Charaeas graminis) . . . . 408

2) (angolbeule (Brotolomia meticulosa) . 409 
3. Sinve: Drtfofinct ........ 410

(benciuc Jichrfoltencule (Nonagria typhae) $\$ 10$ Imerifanijdyct 5eer)um (Leucania extranea). . . . . . . . 410

Sicjerneule (Trachea piniperda) , , . $\$ 11$

Feloulmeneule (Cosmia diffinis) . . . 412

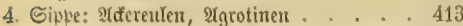

(Etojaly), 5ausmutter (Agrotis pronuba) 41:3

Winterjanteule (Agrotis segetum) . . 413

2fustujejcidjen (Agrotis exchunationis) . 414

Minbenforbige भadereute (Agrotis corticea) 115

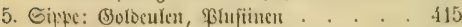

(Banum, 2)tifloneule (K'lusia gamma) . 415

6. Sispe: Oplizfinten . . . . . . 416

Shauç Srbenobnono (Catoeala fraxini) . 416

Motbes 2 eiden= Drbentobanto (Catocala nupta)

416

\section{Siebente Fantic: Gnamner (feometridae).}

Birfenjpanter (Amphidasis betularia) . 418

Birujpamer (Phigalia pilosaria) . . . 418

(Urofser frofffpanter (Hibernia defoliaria) 418

slcinex Froftffaumer (Chcimatobia bru- 419 mata) . . . . . . . . 419

תieferuffanner (Bupalus piniarius) . . 120

Gpiç6utb (Larentia hastata) . . . . 122

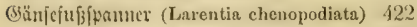

Sarlefit (Abraxas grossulariata) . . . 12\%

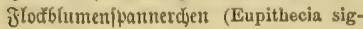
nata)

2iegtrittpauner (Lythria purpuraria) . 421

\section{Sleiufarter (Microlepidoptera).}

2(d)te Frmilie: MBidler ('Tortricidae).

(3tünvidfer (Tortrix viridana) , . . 426

RiteferngnIfer = Widfler (Retina resinella) .426

Siejetutricb = 2Sictfer (Retina Buolima) . 126

Rebfarbener (Exbfenvidter (Grapholitha nebritana) . . . . . . . . . . 427

Monofletiger (Erbientuiffer (Grapholitha dorsana) ........ 427 2ufefiviďrer (Grapholith pomonella). . 428 Pflnumentefler (Grapholitha funcbrana) 428

\section{Reunte Fnuilic: BünsIer, \&idjtmotten} (Pyralidae).

1. Sippe: \$yzalinert. . . . . , 429

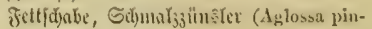
guinalis) . . . . . . . 429

Mety) 3 üı

2. Sinte: Sutunen . . . . . . . 430

Betrcibçü̈ı\&ler (Botys frumentalis) . . 430

Rüb antłfeifer (Botys margatritalis) . . 431

Sirfezünßler (Botys silacealis) . . . 431

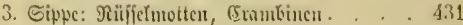

4. Sipte: W3adismtotten, Bafferinen. . . 431

Bicucnmotte (Galleria mellonella) . . 431

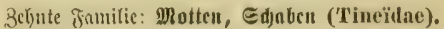

1. Sipke: (Ed)te Motten, Timcïuen . . . 433

Siorumotte, weiß̧ex Rormwutm (Tinea granella)

Sileiber =, Felzmutte (Tinea pellionella, tapetzella) . . . . . . 434

2. Gippe: Eangfülyler, grofinen . . . . 435 (3rüıеr \&aıtģiüb)ler (Adela virilella). . 4:35

3. Sipte: Gibnumzenutten, Sobpronomeutiucn 435 Itpe Yban = (Sefpinftmotte (IIyponomeuta malinella) . . . . . . 435

4. Sippe: 33rcitteibize Motten, Belcstinen. . 436 Dunfetrippige Sïlnmelfobabe (Depressaria nervosa) . . . . . . 436

5. Sippe: Miniter, Orncilarinen. . . . . 437 Flicbermotte (Gracilaria syringella) 。 437

6. Sippe: Sïđd)enträger, (Eolcothorinen . 438 \&Hird)en = Mntinimutte (Coloophora laricinella) . . . . . . .

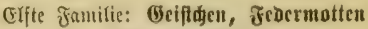 (Pterophoridao).}

Pterophorus pterodactylus, pentadactylus - Alucita polydaetyla . . . . 439

\section{Bierte Dronung: Zweiffingler (Diptora, Antliata).}

\section{Eanglürucr (Nematocera).}

Erfte Familie: Gtcdmatiden (Culieidae).

Sippe: Euliciner . . . . . . . . . 446

(Seringelte Eterímulife (Culex annulatus) $\$ 46$

(Sentcine Etedjutide (Culex pipiens). . 447

Mostitus (Culex molestus, trifureatus, pulicaris)

Erite

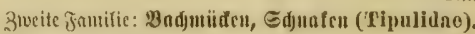

Sipqe: Tipulinen . . . . . . $\mathbf{4 4 8}$ Soblf (f)

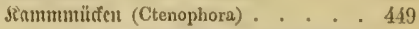

Dritte Familie: Pilzmiiden (Myectophilidae).

Sipte: Sciariner. . . . . . . . 449 5ecrovurm = Z ranterutilite (Sciara militaris) 450 9imn= I raucrmïđen . . . . . . 45? 
Siente Familie: (5aftmiiden (Cecidomyidae).

Sipke: (Gecisomuiner. . . . . . . . . 453 Betreibeverwüfter (Cecidomyin destruetor) 453

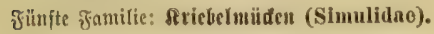

Columbatfđer Mä̆đe (Simulia Colum. baczensis) .

\section{Sccjpte Familie: פantmüden, Gcibenflicgen} (Bibionidae).

Mär $x_{z}=5$ aarntüde (Bibio marei) . . . 456 Barten=55armilde (Bibio hortulanus) . 457

\section{Sur子hörner (Brachyeera).}

Siebente Famifie: $9 x+m i c n$ (Tabanidae).

1. Gipne: Tabanimen. . . . . . . 457 Rinberborenfe (Tabanus bovinus) . . 457

2. Gippe: \$angunincis . . . . . . 458 Blintobremfe (Chrysops coecutiens) . . 408 (STaüungige Brcmife (Tabanus glaucopis) 458

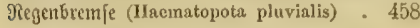

2rotte Familie: Raubliegen (Asilidae).

1. Sippre: Szafidotafliegen, Dafypogoninen . . 459 Selanbifíne Sanbidjtofliege (Dioctria oelandica) . . . . . . . . 459

Deutidier Steifbart (Dasypogon teutonus) 460

2. Sippe: Shorbftiegen, Rnplyrinen . . . 460 (3elbleibige Morofliege (Laphria gilva) . 460

3. Sipte: Naubficgen, 2fjilinen . . . . 460 5orniffenartige গaubfliege (A silus crabroniformis) . . . . . . . . 461

Asilus cyanurus . . . . . . . 461

Reunte Fanilie: Inแaflicgen (Empidae).

Sinpe: Empitest . . . . . . . . . 461

(Semürfelte Sdynefienficge (Empis tessellata)

\section{Bchnte Fantilie: Gdjtucber (Bombyliidae).}

1. Sipqe: Antbracinen . . . . . . 462 (bemeiner Srauerfintoker (Anthrax somiatra). . . . . . . . . 462

2. Sippe: Bombultinelt . . . . . . 463

(Senteinfđjweber (Bombylius venosus). . 463

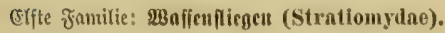

Sippe: Strationninert . . . . . . 463

Senteine Baffenflicge (Strationays chnmaleon) . . . . . . . . . 464

3mölfte Familie: Sdjuirrfticgen (Syrphidue).

1. Sippe: Gyrthinen. . . . . . 465 Monofledige Solywirtitiege (Syrphus scleniticus).
2. Sippe: Bolucelfincer

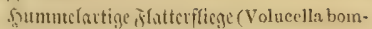
bylans). . . . . . . . 467

Dutch) jucineube flatterftiege (Volucella pellucens). . . . . . . . 467

3. Sipte: Eriftalinent ....... 467

Sd)lammfflicge (Eristalis tenax) . . . 467

Ielophilus pendulus, trivittatus . . . 468

4. Sipte: Eeriinen . . . . . . . 468

(Eomowaratige Etielbormpliege (C'eria conopsoides).

Drcizeryte Familie: BInfentöłic, Didfopfiliegen (Conopidne).

1. Sipwe: Sonopinen. , . . . . 469 Beftreifte Dicfforiflieze (Conops vittatus) 4109

2. Gipke: Mryopitert. . . . . . . 470 Reftrother RYafcutolf (Myopa ferruginea) 470

Bierzelgnte Familie: Dafierfienen, Bremen (0estridae).

Magnenbrente bes Pjertes (Gastrophilus equi) . . . . . . . . 471

Rajentreme deș Sdjafes (Cephalomyia ovis) . . . . . . . . . 472

5autbrente bes Rinbes(Iypoderma bovis) $\quad 472$

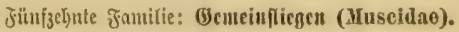

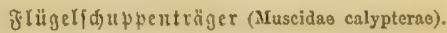

1. Sippe: Sthnelfilicgen, Tidfutinent. . . 474 Brïbte Raukenflicge (Echinomyia grossa) 474 \$itbe 9trupeufliege (Echinomyia ferox). 474

2. Sikpe: Fleifajpliegen, Sarcoptraginen. . . 474 (Jraue frleiffajliege (Sareophaga carnaria) 474

3. Sikve: fliegent, M)htsinent . . . . 475 Stubenfliege (Musea domestica) . . 475 Blaue Sd)meíffliege (Calliphora vomitoria) 476 Stedffliege (Stomoxys calcitrans) . . 478

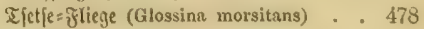

4. Sipte: Blumenfliegen, 2tuthombinen . . 479 31vicberfliege (Anthomyia ceparum) 。 479 Rufritiege (Anthomyia brassicae), Jiobies: denfliene (Anthomyia radicum), Mint: felfliege (Anthomyia conformis), Lattidf): fliege (Anthomyia lactucae) . . . 479

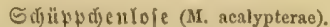

5. Sippe: 230trntieger, Truprbinen . . . . 480 Shargelfliene (Platyparon poceiloptera) . 480 Sirfidfltegre (Spilographa cernsi) . . . 480

6. Sipte: Brïntutget, EGlotopittet. . . 481

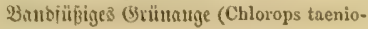
pus). . . . . . . . 481 Fritflienge (Oscinis frit) . . . . 482 


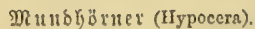

Sedjeljnte framilie: Buđelfiegen (P'horidae).

Diđe Buđterfitcge (Phora incrassata) . . 482

Buppengebärer (Pupipara).

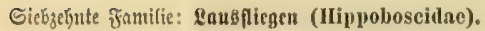

Sdyajzede (Melophagus ovinus) . . . 484

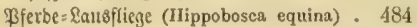

Sd)tunlben: \&aușfliegc (Stenopteryx hirun-

dinis) . . . . . . . , 484

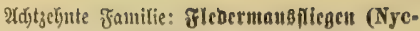
teribidae) . . . . . 484

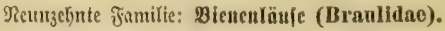

3rinbe Bienentaus (Braula cooca) . . 485

Fritgerlofe (Aphaniptera).

Swansigfte Frmilie: Flölge (Pulicidae).

1. Sippe: Ediste grtbhe, Fulicinen. . . . 486

(Genteinter $\widetilde{F}$ lol (P'olex irritans) . . 486

2. Sippe: Sanbflibe . . . . . . 487

(Eidjao, Sanbffol) (Rhynchoprion penetrans) ..... 487

\section{Flinfte Dronung: Z̈ek-, (Bitterffügler (Neuroptera).}

\section{Erf̧e శgamilie: Großnitgler (Megaloptera).}

1. Sippe: Ameifenlöiven, Murnteoninen. . 490

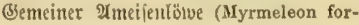
micarius) . . . . . . . . . 490

llnģeflecte भmeijenjunģer (Myrmeleon formicalynx) . . . . . . . . 492

Eangfübleriger Imtijentürve (Mryrmeleon tetragrammicus) . . . . . . . . 492

Buteß S4ymetterlingsibaft (Ascalaphus macaronius) . . . . . . . . 493

2. Siltse: Florfienen, \$remerobtinen . . 493

(Scmeine florflicge (Chrysopa valgaris). 493

Minube Eatojutgfer (Iemerobius hirtus) 494

Sweite Frntifie: Sdjwanjiungịctn (Sialidao).

1. Sipte: Ramelhals= Fliegen, Mhapribitnen . 495 Didfüblerige Ramelhalo: Fliege (Rhaphidia voer Inocellia crassicornis) . . . 495

2. Sity'e: Majfer= Jlorfliegen, Sialiuen . . 496 (3emeine 25njfet = Florfliege (Sialis lutaria) 496
Rutifarbige $23 a$ lier= Jlorfliege (Sialis fuliginosa).

Scite 497

Dritte đantilie: Sdynabljungfern (Panorpidae).

Benteite Sforpionfliege (Panorpa communis) . . . . . . . . . 497

Diudenurtige S(t)nabelfungier (Bittacus tipularius) . . . . . . . . . . 498

(Sictf(t)ergaft (Boreus hiemalis). . . . 498

Bierte Familie: ftödjcrungieru (Plnyganeidao).

1. Sippe: Simnoplifintr . . . . . 499

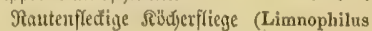
rhombicus) . . . . . . . . 499

2. Sikps: Bhrbganeitren . . . . . . . . 500 Seftriemte Siblgerfliege (Phryganea striata) 500

Fünfte §amilie: Drejflïgler (Stylopidae).

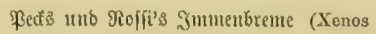
Pecki, X̌enos 1lossii) . . . . 503

\section{Sedflte Dronung: Sinulkerfe, Geradfiugfer (Gymognatha, Opthoptera).}

$$
\text { Pseudoneuroptera. }
$$

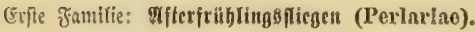

¿nvifcymängigellferftiege (Perla bicaudata) 506

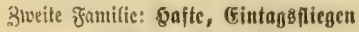

(Ephemeridae).

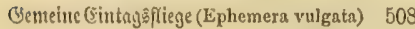

Genteilus 1lieraas (Palingenia horaria) Selte

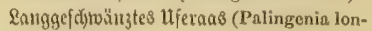
gicauda) . . . . . . . . 509

Dritte Fanilie: Mafierĭungicru (Odonata).

1. Sippe: Seciungferu, 2 grioniner . . . . 516 Benteine Srejungier (Calopteryx virgo). 516 Berlobte Seejumger (Lestes sponsa) . . 516 
Breitbcinige Sd)lanfiungfer (Platyenemis penipes) . . . . . . . 518

2. Sitwe: Sdymafiumgfern, 2ejdynimen . . . 518 Srofse Sdymaljungfer (Aeschna grandis) 518

3. Sippe: \$lattbäud)e, Ribellufinen . . . 518 (Semeiner ßIntt6nud) (Libellula depressa) 518 Bierflectiger \$lattbaud) (Libellula quadrianaculata). . . . . . . 519

Bictte Familie: Фołgläıfe (Psocilae). Sierpuntige 5olzlaus (Psocus quadripunctatus). . . . . . . . 521 Sinuirte 5oljlans (Psocus lineatus) . . 521 Staublaus (Troctes pulsatorius) , . 521

Orthoptera gregaria (gefellige stauterfe).

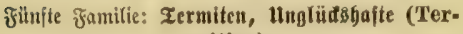
mitina).

Seșpes Termite (Termes Lespesi). . . 526 Belbbalfige Termite (Calotermes flavicol-

lis) . . . . . . . . . 530

Sriegerifdye Zerunite (Termes bellicosts) 530 Magere Termite (Termes obesus). . . 530 Sdjredflidje Termite (Termes dirus) . . 530 Sidjtjdjeue Termite (Termes lucifugus) , 531

Orthoptera cursoria (laufenbe Sauferfe). Sedjte Familic: Sdabeit (Blattila). Deutidje Sdjabe (Blatta germanica) . 535 Saphlänbijue Gdjabe (Blatta Iapponica). 537 (Sefledte Sdjnbe (Blattr maculata) . . 537

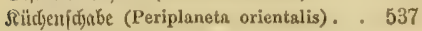
Ynerifuifde Gdjube (Periplaneta amexicana). . . . . . . . . 539 Riejenfdjabe (Blabera gigantea) . . 539

Orthoptera gressoria ([dreitende $\Omega$ auterfe).

Siebente Famille: Fangiðrcüen (Mantodea).

(Sottcônbeterin (Mantis religiosa). . . 540

2trgentinifd) Fangfdrecte (Mantis argentina). . . . . . . . . 542

Rarolinifdie Ғarıjd)recfe (Mantis carolina) 543

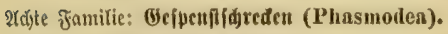

1. Sippe: Stabjatectert, Bacilimen ... . 544 Dornfübige Befpenifidyrecte (Cyphocrania acanthopus) . . . . . . . 546 (Sedhrte Stabfdrecte (Bactria aurita). . 5.16

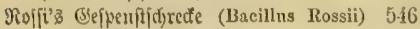

2. Sippe: Blattfinteder, \$bvdiuter . . . . 546 Wanbelnbes Blatt (1'hyllium siccifolium) $5 \pm 6$

Orthoptera saltatoria (Gitpfenbe Sauferfe).

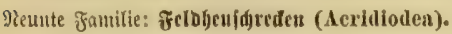

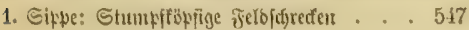
Sibnfrifmifbe 23 moerbeufibrefe (Gryl. lus devastator) ....... 54
Wanber: 3ughenfdirecte (Pachytylus migratorius) .

Gilte

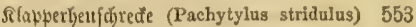

Banbirte Jaenfĭrecte (Oedipoda fasciata) 553

Sinitrter (Srąhüpfer (Gomphocerus lineatus) .

Dider (Srå์

Stalienijaje Scujajrecte (Caloptenus italicus). . . . . . . . . . 554

Taturijd) Şeujúdecte (Acridium tataricum) . .. . . . . . . 555

2. Sippe: Spibtopfige Sdjredel . . . . . 555

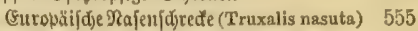

3. Sippe: Siragenffireften (Platyparyphea). . 555

(3) meine Dornidjecte (Tetrix subulata) . 556

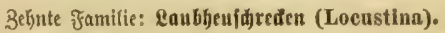

1. Sippe: Bratyporinten. . . . . . 556

Bebornte Einformidjređe (Hetrodes spinulosus) . . . . . . . 557

2. Sippe: DReconteminet. . . . . . 557

(Eidjenidjtede (Meconema varium). . . 557

3. Sippe: \$5anteropterinen . . . . 557

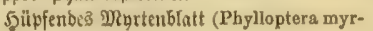
tifolia) . . . . . . . 558

(Befenferte Blattiditede (Phylloptera fonestrata) . . . . . . . . 558

4. Siple: Socuptinten . . . . . . . 558

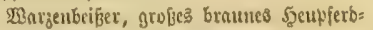
(j)en (Decticus verrucivorus). . . 558

Bropes grimes \$eนpfero (Locusta viridissim 2$). . . . . .558$

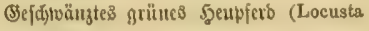
caudata) . . . . . . . . 559

3witfdjert)eu[d]rede (Locusta cantans). . 559

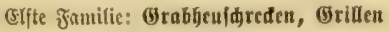
(Gryllodea).

1. Siphe: Edytc Srillen, Brbllinent . . . 559

Jelogrille (Gryllus campestris). . . . 559

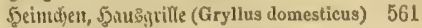

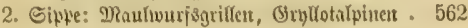

(Someine Daulivurpagrifle (Gryllotalpa vulgaris) . . . . . . 562

Dermatoptera (J̈̋̈djetflïgler).

3wölite Janifie: Ochrlinge (Forfleulima).

(Srofert Dhrivuru (Labidura gigantea) . 564

(5)meiner Sly laria) . . . . . . . 565

Physopoda (fraieuflïgler).

Dreizelynte framilie: Brajenjüß̈er (Tripidae).

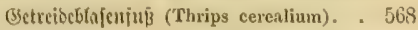

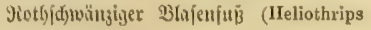
haemorrhoidalis). . . . . . 568 
Thysanura (30ttenโd)wïnae).

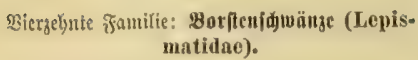

Budfergaft, fif dfdjen (Lepisma saccharina)

Fütrfalfnte Familie: Eprimgidnünge (Podurilne).

(Stetjaderfló, (Desoria glacialis). . . . 569

3ottiget Sprittgfdytuan (Podura villosa) 570

Bleigrauer Springífjuanz (1'odura plumbea). 570

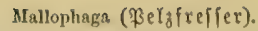

Ecile

Sedjsebnte familie: gederlinge (Philopteridro). 5undeIn!s (Trichodectes latus) . . . 5i1 Biegenlaus (Trichodectes elimax). . . 571

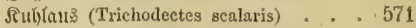
(S)inlfefneifer (Docophorus adustus) , . 571 Pfalt=Feberting (Goniodes falcicornis) . 571

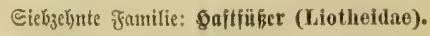

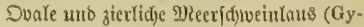
ropus ovalis unb gracilis). . . . . 572 Şüf)rtfaus (Menopon palliđum) . . . 572

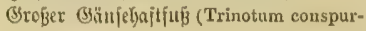
catum) . . . . . . . 572

\section{Giebente Dronung: Sdjubeflerfe, Sofbodier (Rhynchota, Ilemiptera).}

\section{Thierไäufe (Zoophthires).}

Erfte familie: (Edte Räuf́ (Pediculidae).

Sopffaus (Pediculus capitis) . . . . 574

R̂eiberłaus (Pediculus vestimenti) . . 574

Fil $\}_{3}$ lau (Phthirius inguinalis). . . . 575

Iracmatopinus . . . . . . . 575

\section{Pfranzen Läu「e (Phytophthires).}

3weite Familie: Sdjilıräujc (Coceidae).

1. Sipwe: (Edjte Sdjildläufe, Coccinen . . 575

(ङidjenjujitbla!s (Lecanium quereus) . 576

23einfdiflotans (Lecanium vitis) . . 576

Rermeŝfdilblauß̊ (Lecanium ilicis). . . 576

Siod)entille (Coccus excti). . . . . 576

Ytamma[j]ilblaus (Coceus manniparus) . 578

Indfidjilblaus (Coccus lacea) . . . 578

2. Sippe: Unedjte Sdjildïuje. . . . . 579

Yeffiel=9iófrenโau (Dorthesia urticae) . 579

ßofnifje Rodjentlle (Porphyrophora po-

lonica) . . . . . . . 579

Sdjülftraut=\{nus (Aleurodes chelidonii). 580

Dritte Familic: Rindenläuje (Chermesidae).

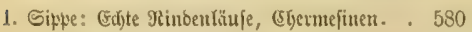
(Semeine Tammentaus (Chermes abietis) 580 Elirdfenlaus (Chermes laricis) . . . 581

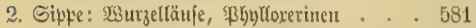
Eicjen= Yimbenlats (Phylloxera quercus) 581 Rebłaı (Phylloxera vastatrix)。 . . . 582

Biecte Familie: Blattläuje (Aphidae).

1. Sippe: (Edte 23 rattlätfe . . , . 586

Sd)neeballblattlaus(Aphis viburni), 2thjef= Grattfous, grïne uno rötflidje (Aphis mali uno sorbi), Sirfdjblattlato (Aphis
Ecite

cerasi), Johamiß̧6erblattlaus (Aphis ribis), (Erbfenblattlaus (Aphis ulmariae), Tiojenblattlaus (Aphis rosae) . . . 587

2. Sipџe: Słrumläuje. . . . . . . 590 WBeiben= Baumlaus (Lachnus punctatus) 590 Eidyent= Baumtaus (Lachnus quercus) . 590

3. Sipve: Touln̈ule . . . . . . 590

B(uttau3 (Schizoneura lanigera) ․ . 590

Milfter: Б̧aargallentaus (Schizoneura 1anuginosa) . . . . . . 591

4. Sippe: Bałtenläule . . . . . . 591

Blattlaus ber fleinen Rüfterngalle (Tetraneura ulmi) . . . . . . 591

Bappel= S5.tlentans (Pemphigus bursarius) 591

\section{Finnfte Fantilie: Blattflöge (Psyllidao).}

Binfen= BLattfloh (Livia juncorum) . . 592

(Binfter = B Tattflof) (Psylla genistae) . . 593

Birn = anto 2lpfelfauger (Psylla pyri, Psylla mali) . . . . . . . 593

\section{Birpen (Cicadaria, ILomoptera).}

Sechfte Famitie: fitrimgirpen (Cicadellidao).

1. Sippe: Зaffinen . . . . . . 593

Nofencifabe (Typhlocyba rosae) . . . 593

BSierpunttige 20 argencifabe (Tottigonia quadripunctata) . . . . . . 594

Dlrenjirpo (Ledra auritr) . . . . 594

2. Sippe: (Eетсорінет. . . . . . . 594

Edraumcifabe (Aphrophora spumaria) , 594

Weibertifabe (Aphrophora salicis). . . 594

Doppeltbanbirte Etiruzirpe (Cercopis bivittata). . . . . . . 595

BZutflectige Stimulitpe (Cereopis sanguinolenta) . . . . . . 595 
Siebente శamilie: gudclgirpen (Mombracidae).

Bsefïnte Dornjirfe (Centrotus cornutus) 595

Nekaberige Sinotenzirpe (IIeteronotus reticulatus) . . . . . . . . . , 596

Sd)langenzirje (Hypsauchenia balista) . 596 Sobje Sotmizitue (Membracis elevata). . 596

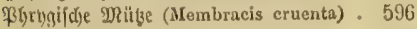

Stierzirtue (Itemiptycha punctata). . . 596

2(d)te Familie: Leudjţirpen (Fulgorillao).

Berippte MRintrcilabe (Cixius nervosus). 597

(Europäifdjer Saternentrïger (Pseudophana europaea) . . . . . . . .

(Eginefif đ̆er Raternenträger (Fulgorn candelaria) . . . . . . . . 598

Suximanifduet Saternentrüger (Fulgora laternaria) .

Nentte ฐonnilie: ๔ingzirpen (Cicadidae, Stridulantia).

\$rtädtige Sintgzirpe (Cieada speciosa) , 600

Y)amma $=$ Sifabe (Cicada orni) . . . . 600

$23 \cap \pi$ ก

Cryptocerata, Ber6orgenfüf)erige.

3ernte Trmifie: Müdenidjwimuter (Notouectidae).

1. Sippe: Coritiuen . . . . . . . 601

(Seoffroy's Studerluanze (Corixa Geoffroyi) 601

2. Sipke: Notontectitent . . . . . 602

(S)enteiner Ritidenjdyuimuter (Notonecta glauca). . . . . . . . . . 602

Ricjen|j)wimmivarıze (Belostoma grande) 603

Dftitoifde Sdyvimmmanze (Diplonychus

rusticus)

(EIfte Familie: Mafiet: Sforpiontunnen (Nepilda).

1. Sippe: Prucoriner . . . . . . . . 602

(5emeine Siflwimutwanze (Naucoris cimi-

coides). . . . . . . 603

2. Sippe: 刃etinell . . . . . . . 603

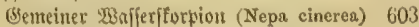

Gd)tueifwulıze (Ranatra linearis) . . . 603

$$
\text { Gymnocerata, Somgfïlfyerige. }
$$

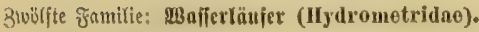

1. Siłpe: Teidyläufer. . . . . . . . 604

Tetchlỉufer (Limnobates stagnorum) . . 604

2. Siq廿e: פzafferlïufer . . . . . 605

Sumpf : Raijerthufer (IIydrometra palu-

(lum) . . . . . . . 605

(Bemeiner Bad)liufer (Velia currens). . 605
Dreizer)nte Familie: Miferläufer (Saldidae, Oculata).

Bierfidjer Mferfăufer (Salda elegantula).

Bierzelyute Fantilie: Gdjteitmanzen (Reduvidae).

Nenolvanze (Arilus serratus) . . . . 606

Siothwanlige (Reduvius personatus). . . 606

Bhutrothe Sdyreitivanze (IIarpactor cruen-

tus) . . . . . . . 607

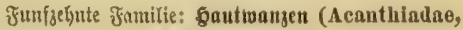
Iombranacei).

1. Sippe: Iingiuert . . . . . 607

Bertuanbte 93 ute tivanze (Tingis affinis). 607

2. Sippe: $\mathscr{H}$ rabinen . . . . . 607

Semeine Minbentvanze (Aradus corticalis) 608

3. Sippe: 2(cantlistert. . . . . . . 608

Bettivanze (Cimex lectularius) . . . 608

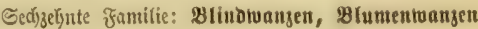
(Capsidae).

Beffreifte Edjönomize (Calocoris striatellus) . . . . . . . . 610

Borftenuanzen (Miris), Blinbibuızen (Capsus) . . . . . . 610

Sicbzefnte Fantific: Langivanzen (Lygaeidae).

1. Siktre: હücigentet . . . . . . 610

Ilngeflïgeite Feuerioanze (Pyrrhocoris apterus) . . . . . . . 610

2. Sippe: Eygäinten . . . . . . . 611

Ritteriwanze (Lygaeus equestris) . . 611

Didfidjertel (1'achymerus) . . . . 612

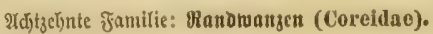

1. Sippe: (Soreinen . . . . . . 612

Saumtwanje (Syromastes maarginatus) . 613

Tlautenfürmige Mantowanze (Verlusia

rhombica) . . . . . . . . 613

2. Sipke: Sdynafenmanzen, Berytinen . . 613

ธd)!nfenvanze (Berytus tipularius) . . 613

Nenmehnte Fanilie: Edjilduangen (Pentatomidae).

SoGtivanise (Eurydema oleraceum). . . 614

Spilłkitig (Aelia acuminata). . . . 615

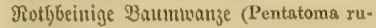
fipes) . . . . . . . 615

Bejälynte Ctadjeliwanze (Acanthosoma dentatum) . . . . . . 615

5ottentottenwange (Eurygaster maurus). 615 


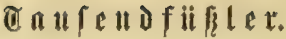

\section{Erfte Drbung: Ëiuparfürfer (Chilopoda, Syngnatla).}

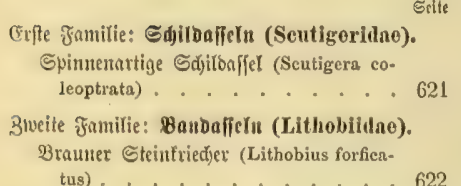

Dritte Familie: Bangenaffeln (Scolopendridae).

\&ucrs = Banbaffel (Scolopendra Lucasi) . 622

Branbts Sintgentaffer (Scolopendra Brand-

tians) . . . . . 623
Bantonfiel von 23ahia (Scolopendropsis Bahiensis) . . . . . . . . . 623

গivtlye Bantorfiet (Scolopocryptops rufa). 623

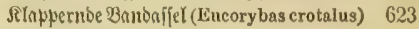

Biette Fantifie: (Erofifin (Geophilidao).

(Sabriets Crtbaffer (Geophilus Gabrielis). 623

Eangfithlerige Erbaffel (Geophilus longicornis) . . . . . . .

Fruckttiebente (5rbajfet (Geophilus earpophilus). . . . . . . .

\section{3weite Dronung: Zweiparafüß̨er (Diplopoda, Chilognatha).}

\begin{abstract}
Erfte Frmilie: Єajmurafielı (Julitae).
(Bemeiner Bielfuß (Julus terrestris) . 626

Sarbaffiel (Julus sabulosus) . . . 626

Setupfter Bielfuß (Julus guttulatus) - 626
\end{abstract}

B'weite Fantilie: Randalfeln (Polydesmidae).

Platte Stanbajift (Polydesmus complana-

tus) . . . . . . . 627

Eeite
626
626
626

Dritte Fantilie: Gaugafieln (Polyzonidae).

Deutijle Saugalfel (Polyzonium germanicum).

\section{Biette Familie: Routthicre (Glomeridao).}

(3) făumte Sdjalentifel (Glomeris limbata) 629

Bctusfte Sdidalenaffel (Glomeris guttulata) 629

\section{Spintutuiexe (Arachnoida).}

\section{Erfte Dromung: Gliederfpintuen (Arthrogastra).}

Erfte Franifie: $\mathfrak{B a}$ algenlpiunen (Solipugno). (Semeine Ralgenipime (Solpuga araneoides) . . . . . . . . 632 Snoifdye Kalzenjpinne (Solpuga vorax). 632 Galeodes striolata unt Galeodes graecus 632

3tucite Jantilie: Eforpione (Scorpionidso).

1. Sippe: Telegoninen . . . . . 637 Berffiebenfarbiger Sforpion (Telegonus versicolor). . . . . . . 638

2. Sippe: Eforpiontuten. . . . . . 638

Molyren[forpion (Brotheas maurus) . . 638

\$̧ณůffurpion (Scorpio europacus). . . 638

Jelfenfforpion (Scorpio afer) . . . . 638

(Eapenfer Sforpion (Opistophthalmus eapensis)
Getite

3. Sipte: Eentrutinen . . . . . 638

Itmerifanifdjer Sforpion (Centrurus americanus) . . . . . . . 639

Sottentottenfforpion (Centrurus hottentottus). . . . . . . . . 639

4. Sippe: Anbroctoninen . . . . . 639

Jelojforpios (Buthus oceitanus) . . . 639

Dritte Fnmilie: grterfforpione (Psendoseorpionidta).

Bitderfforwion (Chelifer cancroides) , . 639

Banzemartige Sforpionutitbe (Chelifer cimicoides) . . . . . . . 640

Rinbenfforpion (Obisitm muscorum). . 640 
Bierte Familic: Gforpionfpinucu (Pedipalpi).

1. Sippe: Theтtyphoninen . . . . . . 640

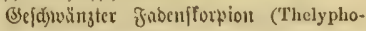
nus candatus). . . . . . . . 640

2. Giple: \$rtruninen. . . . . . 641 Eangarmiger Tarantelferpion (Phrynus lunatus) . . . . . . 641
Fünfte Familie: Afterfpinuen (Phalangillae).

1. Sippe: Dpitioninet . . . . . . . 612

32eberfucd)t, franfer (Opilio parietinus uno cornutus) . . . . . . 643

2. Sippe: (sonyleptiner. . . . . . 643 STummbeir (Gonyleptes curvipes) . . 643

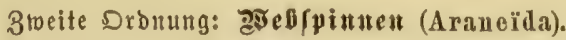

\section{Bierlungler (Tetrapneumones). \\ Erffe Fantifie: Bogeripinuen, Bufdipinuen (Mygalidao).}

1. Sippe: Mingalinen. . . . . . . 649

Blonbi"s Sufdjpirtue (Mrgale Blondii) . 650

(Semeine Bogerfpime (Mygale avicularia) 650

2. Sippe: Minirfpimten. . . . . . 652

Sauvages' Minir|pitne (Cteniza fodiens) 652

\$ed)braune Miorofpime (Atypus piceus) 653

Sweilungler (Dipleumones).

Anfăfige (Sedentariae).

3meite Familie: Otadfinnten (Orbitelae, Epeiridao).

(3)

Beftrefte Striferfpime (Tetragnatha extensa) . . . . . . . .

Snrrgenartige Dorujpimue (Gasteracantha arcuata)

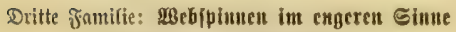

(Inequitelae, Therididae).

Berguebffiume (Linyphia montana) • . 659

Befrängte $23 e b$ fpinte (Theridium redimi-

tum). . . . . . . 660

Małuignatte (Latrodectus tredecingut-

tatus) . . . . . . 660
Etite

Bierte Fanilie: Gadipitmen (Tubitelae, Drassidae).

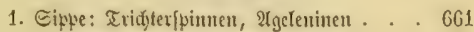

5รณเฉ็pinne (Tegenaria domestica) . . 661

Demeine Rabyriutbfpintue (Agelena labyrinthica) . . . . 663

2. Sipte: Sadfinuten, Draflimen .. . . 664

Bemeime 230 fferfpinne (Argyroneta «qua. tica). . . . . . . . . . 664

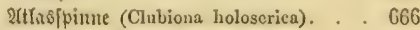

3. Sippe: Rübrenfpinten, Dusterinen . . . 666

Sellerjpinue (Segestria senoculata) . . 667

Jünfte Familie: Straben|pinnen (Thomisidae).

Srïntidje ภrabkenfpinne (Thomisus virescens). . . . . . . . 668

Umtherfdyoeifenbe Rrabbenjpinne (Thomisus viaticus) . . . . . . . 668

Utherfd) toeifenbe (Vagabundae).

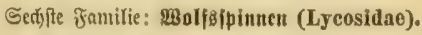

Seranbete Jagbjpinue (Dolomedes fimbriata) . . . . . . 671

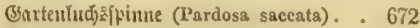
2fulifde Tarantel (Tarantula Apulise) 673

Slebente Familie: Springs, Tigeripintuen (Attidae). Sartefins 5ูüpffpinne (Salticus seenicus) 675 Sarminrotlye Springfpime (Eresus cinaberinus) ....... 676

\section{Dritte Dronung: Zzicbent (Acarina).}

(Exfte familie: Ranfmilben (Trombididae).

Bemeine Sammetmitbe (Trombidium holosericeum). . . . . . . . 678

Mitbenfpiutue (Tetranychus telarius) . 678

5erbft = (Srasimil6e (Leptus autumnalis) .
Stite

31weite Familie: 23affermilben (Hydrarachnidae).

Singelige §lu[milbe (Atax spinipes) . . 680

giothe $23 a f f e r m i l b e$ (Arrenurus abster-

gens) ......... 680 
Eeise Ferifidje Gaumizcte (Argas persicus) . 687 Miufdelfürmige Summzete (Argas reflexus) . . . . . . . 687

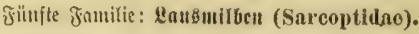

నä[entilbe (Acarus domesticus) . . . 689

Methluilfe (Acarus farinae). . . . . 690

Tyroglyphus feculae, Acarus destructor 690

Jerăkunilbe bes Mienlofen (Sarcoptes hominis) . . . . 690

5̧arbalgntilbe Des Mienf(d)en (Demodex hominis) . . . . . . 693

\section{Bierte Drbung: Bungenwirnter (Linguatulidae, Pentastomidae).}

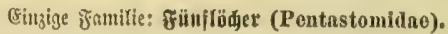

Banbtuurntartiget 3utrgentutrm (Pentrstomum taenioides, denticulatum). . . . . . . 694t

\section{Fünfte Dronung: Jirebs-, Bffefpiunen (Pantopoda, Pyenogonidac).}

(Eimzige Famitie: Mfielipintru (Pycuogonidae).

Hfer = Shinbelajfet (Pycnogonum littorale) . . . . . Ecite

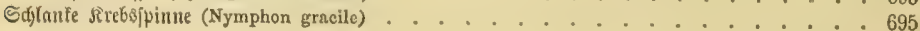




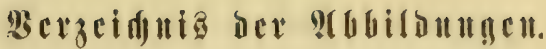

\section{duf befouderen Tafelu.}

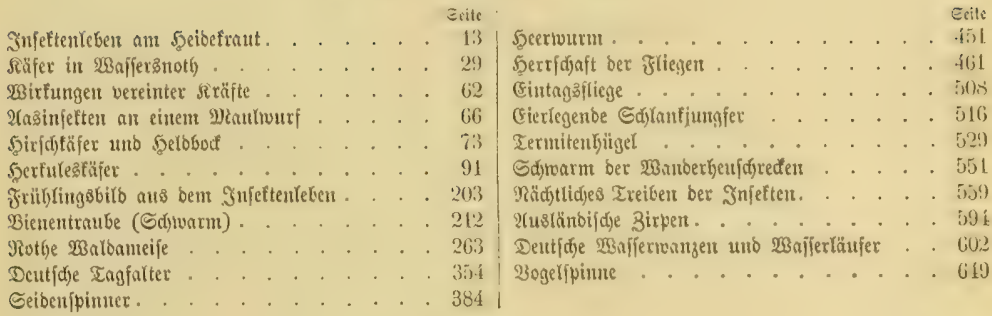

\section{BuI TExt.}

กopf = uno Munbthette von §njeften . . .

\section{siäfr.}

Terb = Sandfüfer Langhalfiger Eanofinfer.

$u_{\text {fer }}=$ Mafich fäfer .

Rarve ber Bolblyemie

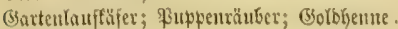

23 ombarbirfäfer

(S) chen it = \&auffäer

Riefer $=$ Fingerfinfer

Betreibelauifäfer.

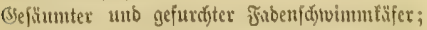

Iydroporus; Cnemidotus; lauftïferartiger Siol= bentuafferfifier.

Drebtäfer

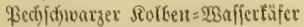

Eigelyău besీictben .

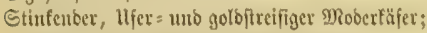

Stapbuline; 9Rifticb; \$irzturgfiaglex .

(Selber Seulentialer

Toetengräber .

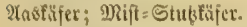

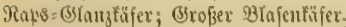

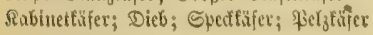

5reiliger \$illenoreker \$otennarbiger \$3illenbrelser . . . . . . . 79

Dutugtiffer . . . . . . . . . . 81

Sreifjorn . . . . . . . . . . . 8'?

Broiebelgornfäfer. . . . . . . . . . . 8. 8.

Maiftäfer; Serber; Brad)fäfer . . . . . . 85

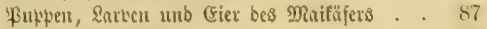

Setreibe= \&aubtäfer . . . . . . . . 8!

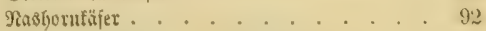

Ghbeluafe: Nofentäfer; ßinfeltäfer . . . . . 94

Riefern= Pradttäjer . . . . . . . . . 97

ङutuio. . . . . . . . . . . 103

Santidunellfäjer . . . . . . . 10 t

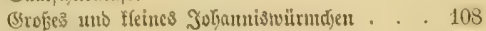

qiłargenfinjer . . . . . . . . . . 112

Buntfäfer; §munentiffer . . . . . . . . 113

Bunter sifopftïfer . . . . . . . . 115

Traucrfajex; Rave von Blaps producta. . . 118

Pimelia distincta; Mlebltäfer . . . . . . . 119

Findjertrigger . . . . . . . . . . . 121

Bututer Delfüfer; gemeiner Mainurm . . . 125

Spaniide flicge. . . . . . . . . . . 127

Bienentäfer . . . . . . . . . . . . 129

Brautübler . . . . . . . . . . . . 1323

Brofer fduvarger Müfieffifer $20 . \quad$. . . . . 133

\&ülntenber Stengelbobrer . . . . . . . 1350

Grofzet Jidjtentüfjeltäfer . . . . . . . . 136 
STeiner Sieferntilfelthfer . . . . . . . . . 138

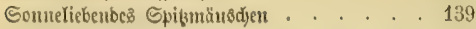

Eanghalfiger Diffotrübler . . . . . . 141

5afelbidtopjtäfer; Sfternilffelfäfer; Nebenftedjer; Wayperfiediet

Бajelnuโzrỉßler

2(pferbrütenftedyer; Bimfnoštenftedyer

Dudjentübler.

ErYentwürger; 23raunwurg = 23 Gattiçaber

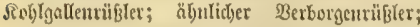

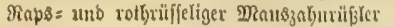

Palmbolyrex

Brober uno flciter Sicjermunffäfex .

2udboructer

RAlffer|plitttäfer; Eccoptogaster destructor

Brenthus Anchorago

23 ciß̄flectiget MRaurfäfet

Berber; Bimunermann .

Satue bes seloboces

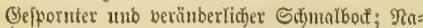
bellyolzbod

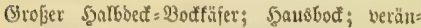
berlidjer unb blauer Sdjeibenbod; genteiner 23iboerfäfer; freugtragenber Exbbot

Weber; Simmerbod; groger\$appelboct; शropentbod Rarve bes arofien Rayuelbodes.

Rarve Desి भispenbodę .

Erbjentaffer; Bohnentäfer; gemeiner Smuentäfer

Jicberflee = Silvillfäfer

23ierpunttiger Sadfäfer

Sleiner ßappelblntțäfer

Golorabo= Sartoffelfäfer; Leptinotarsa juncta

Erlenbinttfäfer

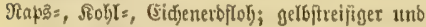
Eogiger (Erbflol

Rebeliger Gduibtäpex

Mesomphalia consper'sa

Gicbenpuntt uno anbere cocciullenarten

\section{Sautfiugler.}

Regbolyrer ber großsen 5olgwespe.

Jtïgel, \{dyentatifd

198

Sanobiente

23abenifü ber beutidjen Biene; itatienijdje unb calustidje Biene. .

Groljummel.

Berfichiebene Feljbienen; gemeine Syornbiene.

Biolettflïgelige 5oorzbiene .

Bürftenbiente; verjajicbene Grobienen; grofze $23 a$ = Ienbieste.

grörtelbiene

Benteiner Brattjdyucioer:

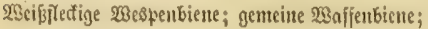
תicgelbiene .

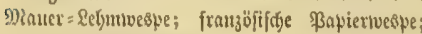
gemeine dolomespe
20.

Gimblue Rencuartige ßapiertuesిte . . . . . 252

Jiothe 23aldomeife; No Rantile . . . . , 262

Bifitenameife . . . . . . . . . . 270

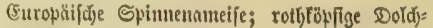
tvešle. . . . . . . . . . . 274

Serfificbene 2 egiveșpen . . . . . . . 277

Scmeine Wegnespe; Daurer = Spinnentobster; Bientenwolf . . . . . . . . 280

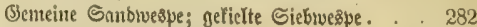

Berffjicbene Brabrwespen . . . . . . . . 288

(S)länzente Dorngoloweşpe; blaue, gemeite uno tönigliçe Blolblvespe. . . . . . . . 291

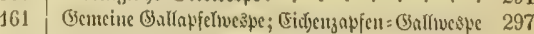

162 3erfdiebene Baltweßspen . . . . . . . 299

163 Nofengaltweske . . . . . . . . 300

165 Gierivespe 2c. . . . . . . . . . 303

167 Sdifentelneștest . . . . . . . . 305

Ffeirtrïger. . . . . . . . . . . 306

169 Microgaster nemorum . . . . . . . 308

Bracon palpebrator. . . . . . . . . 309

Macrocentrus; Spathius; Alysia. . . . . . 310

Exenterus; Bassus; Banchus . . . . . . 315

Riefernjpinmes: Sidjelweope . . . . . . . 316

Ichneumon; Cryptus; Mesostenus; Ephialtos . 321

Pimpla instigator . . . . . . . . . . 324

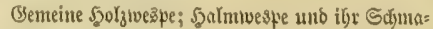
rolzer. . . . . . . . . . . 328

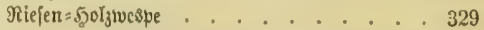

Rotbjad = Ritefernblattwespe; R̂tefern = Rammborı= weske............ 332

Rübert= Blattwespe . . . . . . . . 336

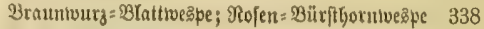

Bitfen= Snopflormuespe ... . . . . 339

\section{S̆metterlinge.}

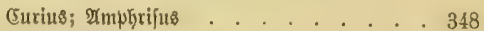

Baumneifyting . . . . . . . . . . 353

Tagpfaucnauge; Sanbauge . . . . . . . 357

ఇcoptolemus . . . . . . . . . . . 360

Mauerfucts . . . . . . . . . . . 363

(5išngel; Fenervogel; Feuerfalter; 2lbonis;;

Strichfalterdjen; ßerlbinbe. . . . . . . 365

Siefernjdilvärmer . . . . . . . . 370

Dleanber[d)tvärmer . . . . . . . . . . 371

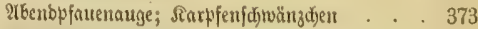

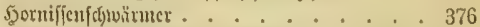

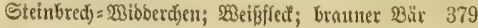

\{ilantbušfpinner. . . . . . . . . . . 381

Sieferufpiuner . . . . . . . . . . . 388

Ningelfpinter. . . . . . . . . . . . 390

Benteiner Sadtrïget . . . . . . . . . 391

Mothfdyvan . . . . . . . . . . 392

Solbafter; Sdjwan . . . . . . . . . 394

Shtwanmpininuer . . . . . . . . . . $39 €$ 


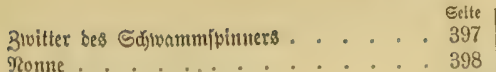

Eidyet = Proceffiontsfpinner . . . . . . . 402

Sabelfawarz; Budjenfpiuner. . . . . . 403

Flügel einer (Eule, โđjematijđ) . . . . . . 404

Drion; Duedeneule. . . . . . . . . 407

Futtergtaseule; Mangoloeule; Brเสôeule . . 409

Forleule; Jelbulmeneule . . . . . . . . 412

Nothes Beiben = Drbenbibant . . . . , 416

Birfenjpanter. . . . . . . . . . . 418

Brober, fleiner Jroftfanuer unb Bertwande . 419

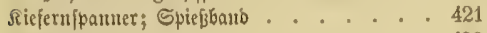

(ङӓперивбрапиег. . . . . . . . . . . 422

Sortetil . . . . . . . . . 423

Flofolumen[panner; פEgtrittppanter . . . . 424

Srïmvider . . . . . . . . . : 426

Ricferngallentwiderler, Riefernttiebiviďler, Glypta resinanao . . . . . . . . . 427

Monbflediaer (5rbjentuider . . . . . . 428

Dbitmabe; Meblzümoler ....... . 429

ritiblantafeifer . . . . . . . . 430

28udjş djabe; Romntotte . . . . . . . 432

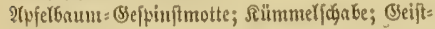
d)ent

Sürdbentmintmotte . . . . . . 438

\section{3weiflügโex.}

Müt(enffïger; Muscibenflïget . . . . . . 442

Beringelte Stectulüe. . . . . . . 447

5ecrustrm $=$ Trauernulife . . . . . . . . 450

Sctreibevertwilfter. . . . . . . . . . 454

(5olumbatidjer Mäude . . . . . . . . . 455

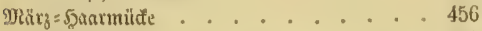

Niuberbremle . . . . . . . . . . 457

Delanbifdje Szabidgtsfliege; getwïrfelte Sdunepfen= fliege.

Trauerífuluber . . . . . . . . . 462

(Semeine Waffenfliege . . . . . . 464

Mronbflectige Sdjuirrfliege. . . . . . . . 466

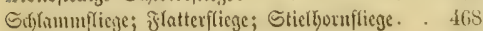

Yiagenbreme beş Bferoes . . . . . . . . 471

Rajenbreme deç Stifafeß . . . . . . 472

Sautbreme bes Rinbes. . . . . . . . 473

23ilbe Raupenfliege . . . . . . . . . 474

Schnciffliege . . . . . . . . . . . 476

Ifetle= folicge . . . . . . . . . . . 479

Spargelfticge . . . . . . . . . 480

Banbjllbiges Srïnauge . . . . . . . 481

Pferbehusffiege , . . . . . . . . . 484

(Senteince §lol) . . . . . . . . 487

\section{Metsfiitglet.}

Benteiner शrmeifentöue.

Bemeine grorficge ........ 491

Didfïlflerige Samelfutsfliege.
Grameine פrofferforftiege

Bemcine Sforbionftiege . . . . . . . . . 497

Rautenfledige Rüberiungfer . . . . . . . 499

Bhrugarioengebäu|e. . . . . . . . . . 501

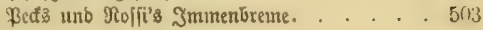

\section{(5erablingler.}

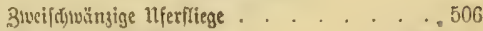

Bemeine EintagBfliege . . . . . . 508, 509

(Semeines llfercas . . . . . . . 510, 511

Semeiner ß(attbaud) . . . . . . . . . 519

¿iniirte 5olgl九ü . . . . . . . . . 521

Ғุaนฺิ vor Termes Lespesi . . . . . . . 527

Sdjratlide uns frienerifdje Termite . . . . 531

Deutjde uno Sapwlïnoilde Sdjabe. . . . . 535

กtidjen [jabe . . . . . . . . . . 538

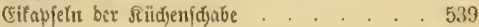

Bottesmbeterin . . . . . . . . . . 541

Rofit's Befpenfifirede. . . . . . . . . 544

KBatibelnoes BYatt . . . . . . . . 515

Mुanberlyeufdrecte . . . . . . . . 552

Semeine Dornfdjucede . . . . . . . . 555

Bebornte (Siuthorntidyrede; (Fidjen[d)rcde . . . 557

Fellogrille . . . . : . . . . . 560

Maulwurfögrifle . . . . . . . . . . 56 (33

(Sroß̌er uno gentcinter Dhthuurm . . . . . 565

Betreibe= 8 Tajenfuß . . . . . . . . 567

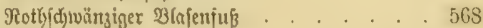

3udergaif . . . . . . . . . . . . 569

(5letfdjerflol) . . . . . . . . . . . . 569

3ottiger Spring/dinans . . . . . . . 570

Bfalt= Feberling . . . . . . . . . 571

\section{S.jubbelferíe.}

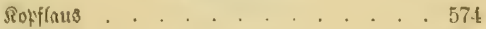

Gilglnus. . . . . . . . . . . . 575

fodsenifle . . . . . . . . . . 577

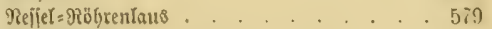

Tannenluus . . . . . . . . . . 581

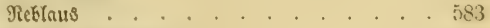

28cibert $=23$ anukikus . . . . . . . . . . 590

(Sinfter Blattflol). . . . . . . . . . . 593

Strenzirte: Sdyumeifabe . . . . . . 594

(5chörnte Dornzitue. . . . . . . . . 5095

Mintrcifnbe; Rnternenttïger . . . . . . . 597

Manuncifnbe; Singcilabe . . . . . . . . 600

Bterlidger llferläufer. . . . . . . . . . 605

Rotlymatse. . . . . . . . . . . 606

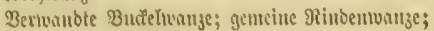

Bettivinge . . . . . . . . 608

Septreifte Sob̈ntuange . . . . . . . . 610

llitgeflingelte Jemertusuze . . . . . . . . 611

Saumuanze; Sdjutemuanze . . . . . . 613

Spibling; rotgbenige Banmuanze; geziffute

Sturieliwatic......... . . 615

5ottentottenwanze . . . . . . . . . . 616 


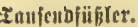

23rauter Stchufriedier; Scolopendra insignis . 622

\&ucas = Banbaffel. . . . . . . . . . 623

Sautgfilylcrige (Erbafiel . . . . . . . . 621

Oenteinet Biełfuß . . . . . . . . 626

Flatte Nanbaj[el. . . . . . . . . 627

(Befäunte Sđjalenafiel. . . . . . . 629

\section{Epimentjicre.}

Bentcine 2 Bat

Jelbfforpion . . . . . . . . . . . . 636

2Bücherfforpion. . . . . . . . . . . 639

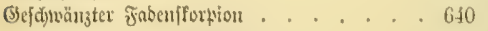

Eangarmiger Tarautelffortiout . . . . . 641

Sirnmmbeiniger (3om)leptes . . . . . . 643

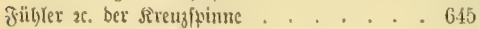

Saubagç' Minirfpiute . . . . . . . . 652

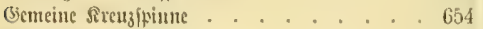

Beftrefte Stridetipime . . . . . 657
Eute

Butgctattige Dornfpinute . . . . . . 658

Befränzte 2066jpime . . . . . . . . . . 660

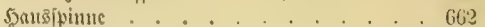

2zafferfpiune . . . . . . . . . 666

Setferpintue . . . . . . . . . 6667

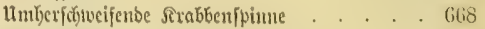

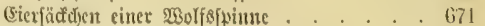

Bartentudjspinue . . . . . . . . . 072

Rpultide Earantel . . . . . . . 6ri

Sarteting = Sütifininue . . . . . . . . 675

Sorbenillmilbe. . . . . . . . Gis

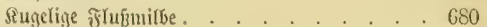

(Bismeine Stëferntilbe . . . . . . . . 681

Munbtheile bes gemeinen S5orgbodes . . . 6\$3

(5emeiner 5007 grod . . . . . . G84

Siolettruther 5jolzbod . . . . . . 686

Mrufdyelfürntige Saumzede . . . . . . GSS

Silifentilbe . . . . . . . . 690

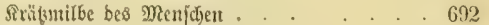

5aarbalgmil6e bes MReuldyen . . . . . . 693

Mfer= Spintelaffer . . . . . . . . . . 695

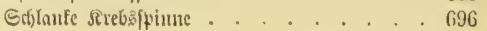




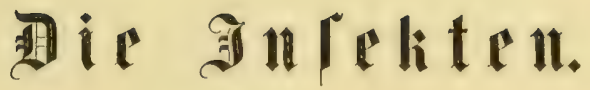





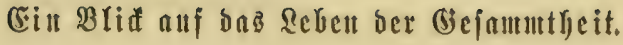

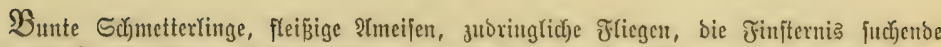

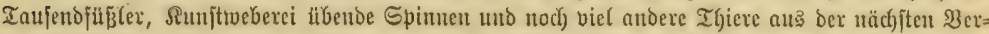

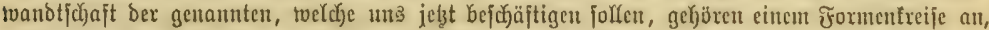

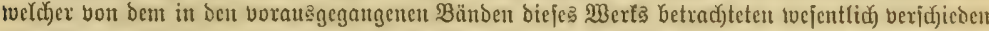

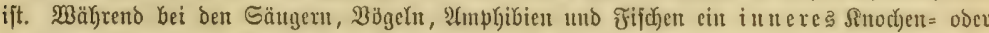

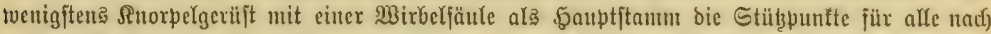

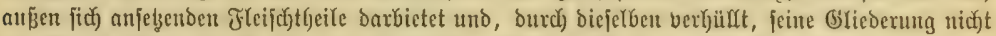

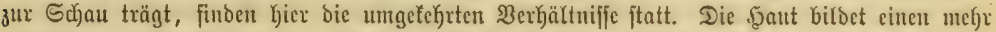

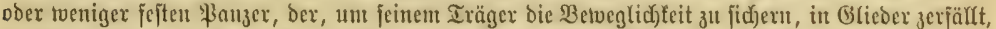

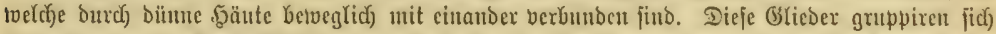
bei ben einen in Sopf, פMittel = und SinterYeib, bei Den anberen verf(h)uelyen bie beiben erften

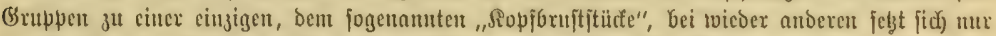

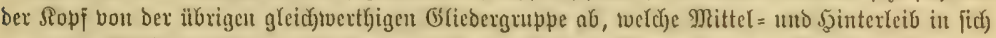

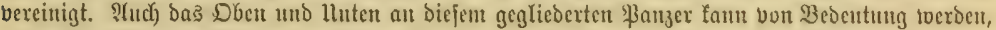

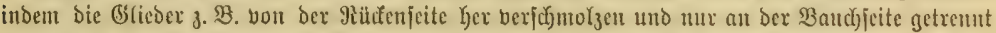

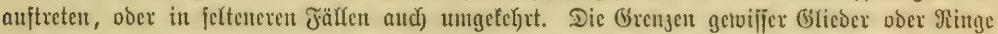

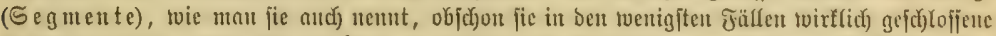

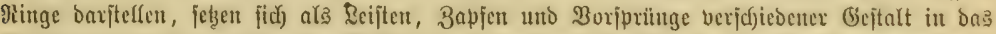

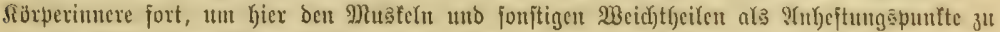

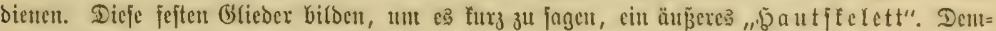

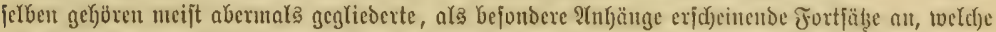

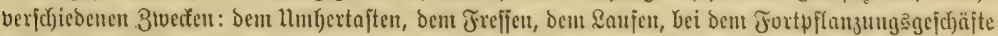

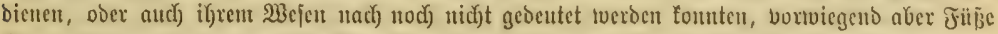

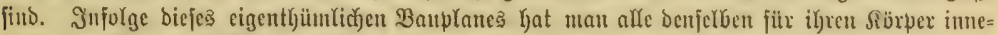

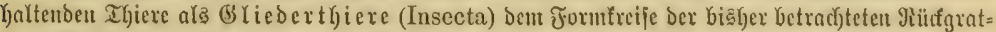

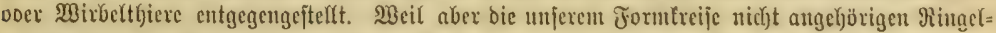

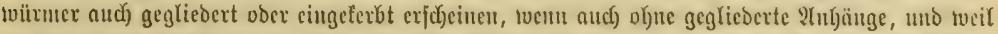

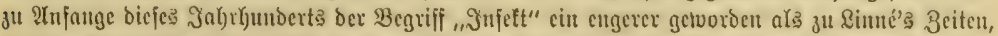

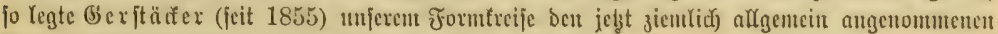

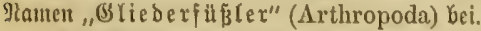

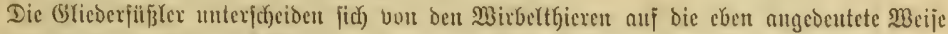

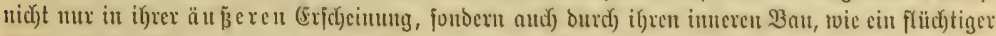

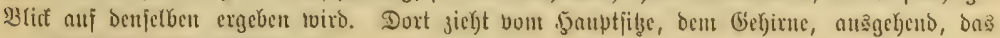




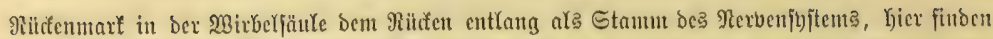

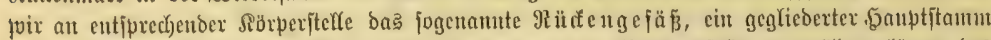

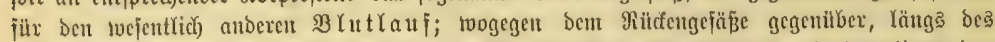

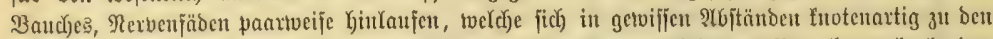

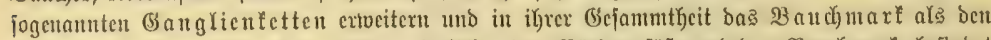

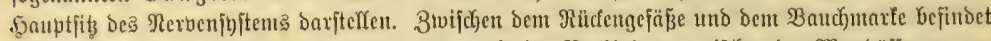

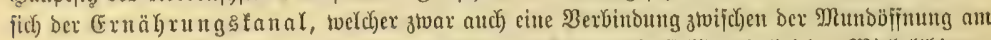

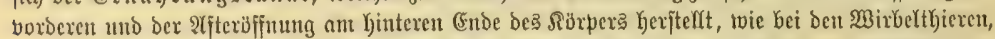

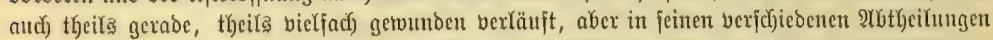

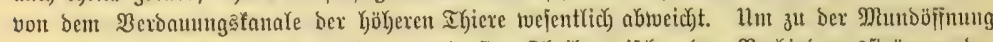

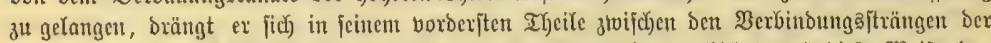

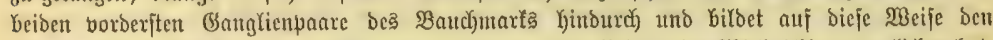

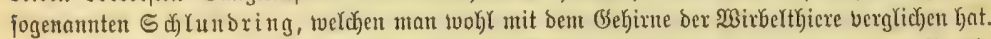

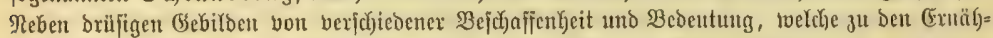

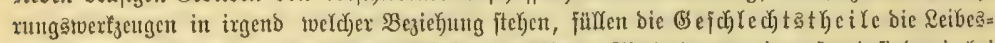

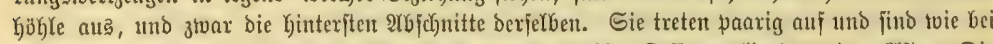

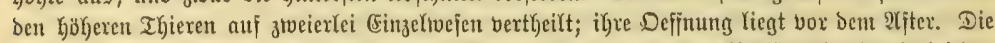

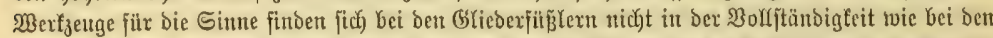

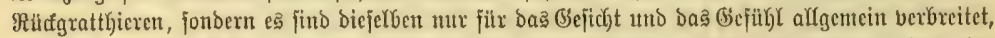

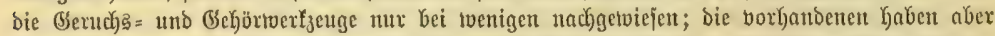

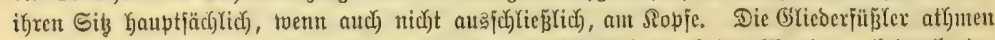

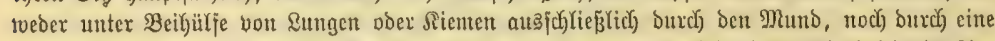
aut Ropfe gelegene Deffinumg, fonteru ber ganze Rärper twirb bei biejer Thätigteit in $\mathfrak{A}=$

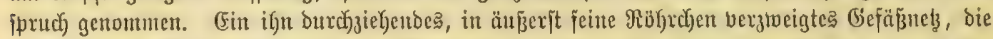

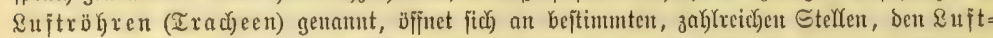

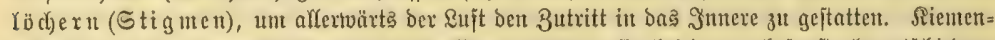

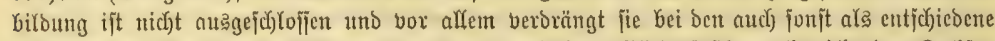

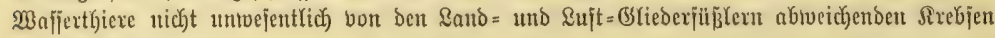
bie suftlöcher.

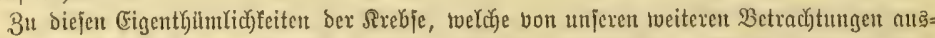

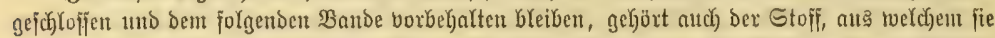

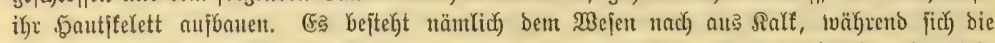

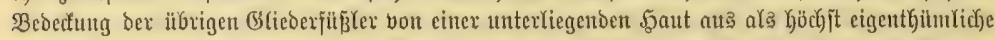

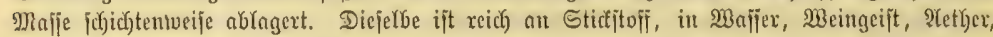

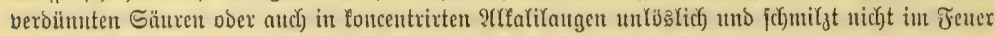

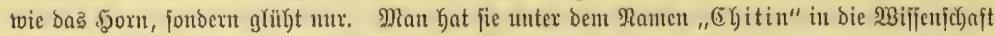

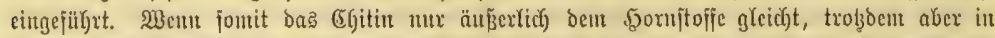

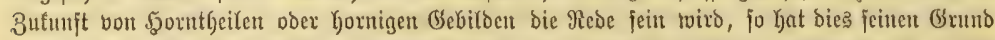
it ber mun eimual eingebiurgerten \{4t

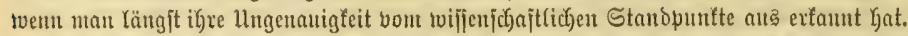

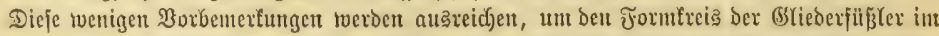

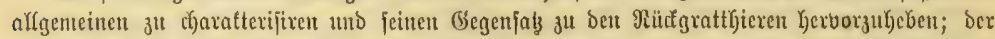

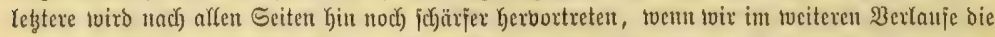

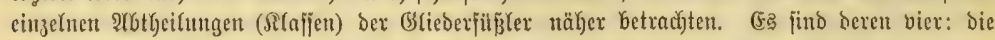

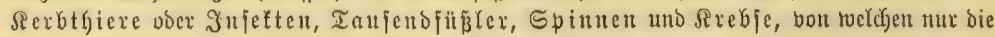
brei erften biejem Bande angebören jollen. 


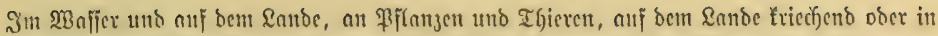

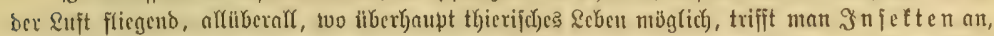

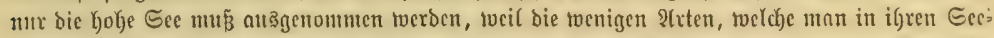
tangen gefumben hat, an bereinzelt find. Je tweiter nad ben \$olen Gin, befto bereinzelter, dejto

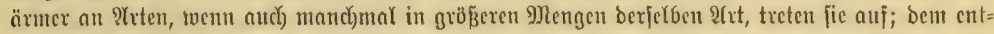

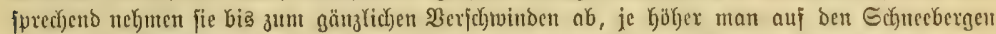

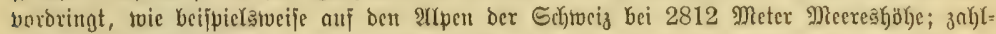

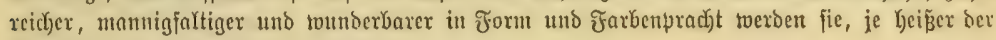

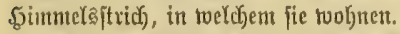

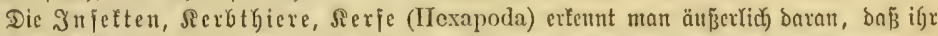

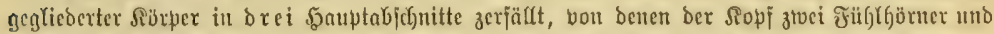

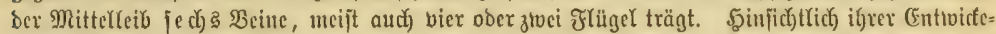

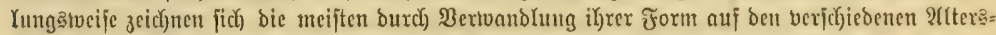

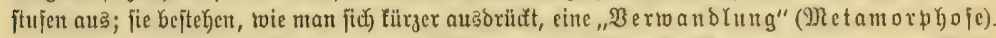

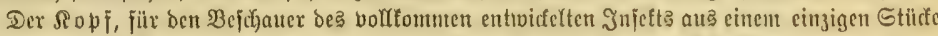

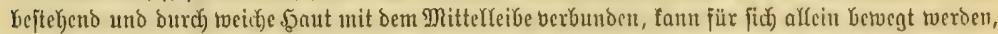

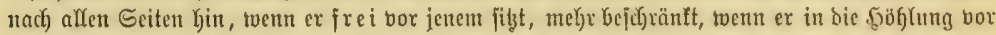

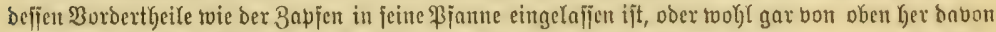

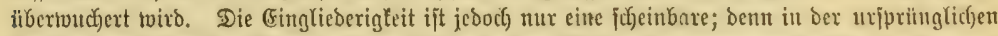

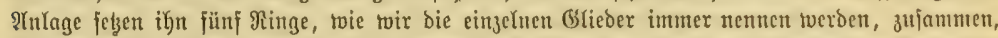

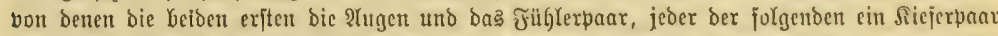

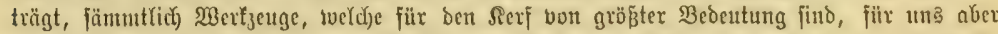

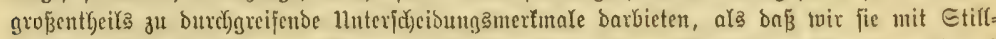

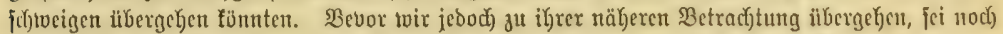

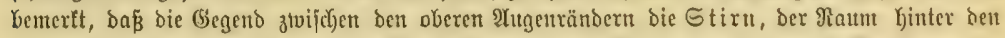

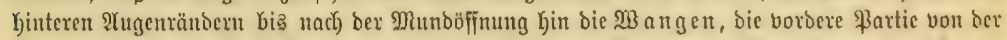

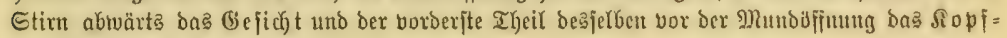
fchild (clypeus) genant twirb.

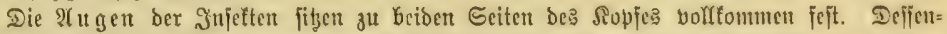

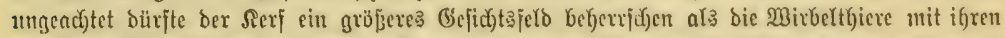

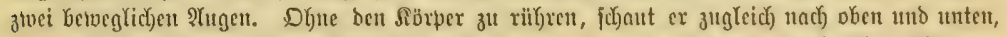

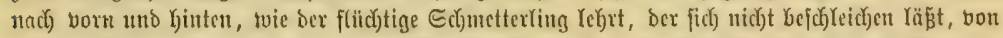

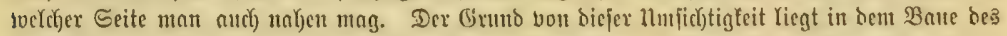

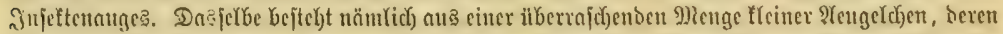

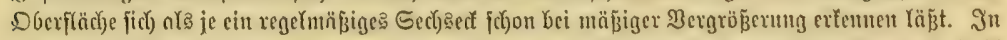

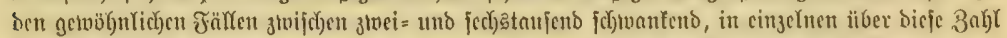

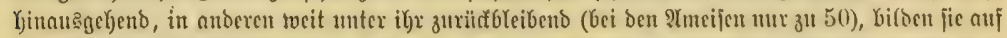

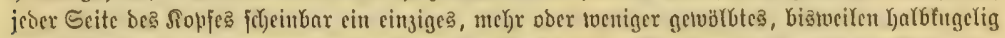

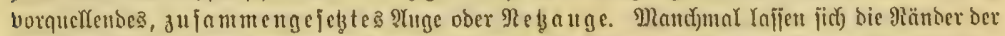

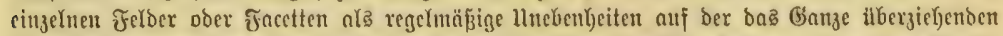

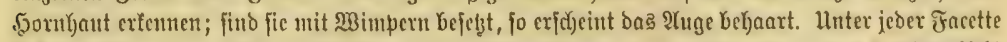

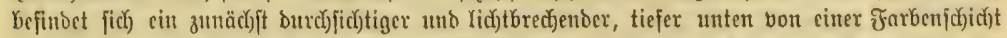

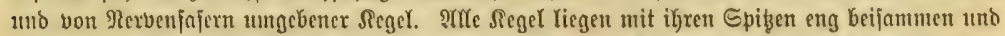

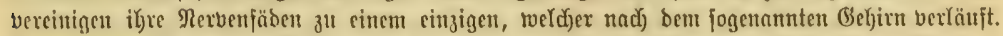

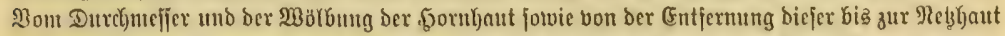

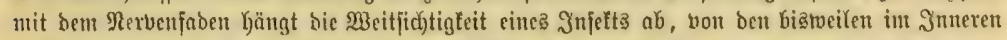

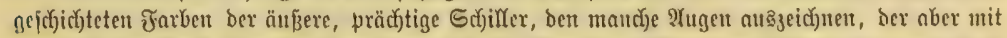

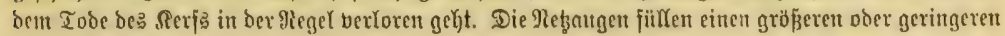




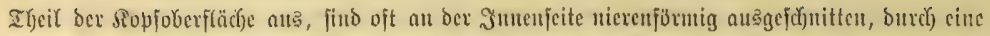

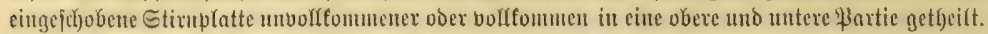

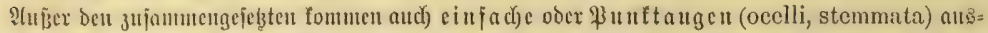

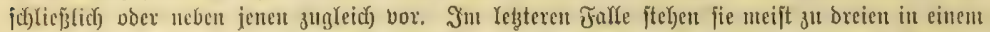

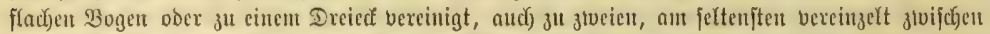

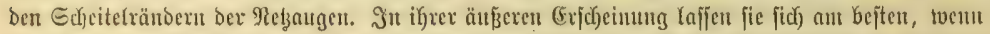

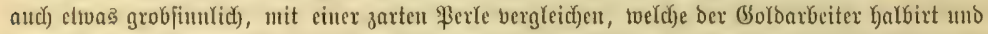

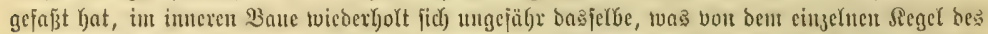

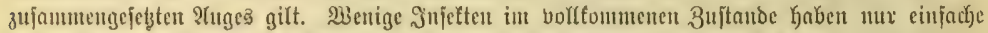

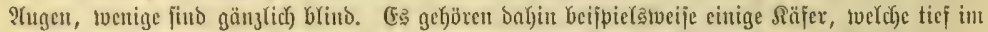

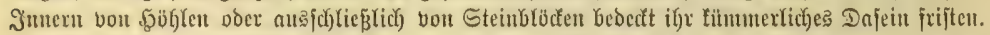

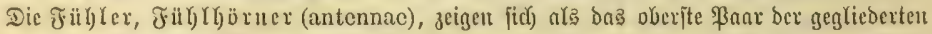

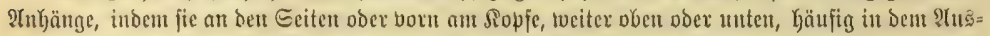

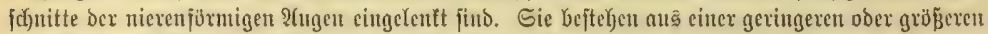

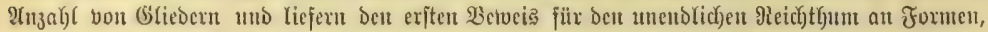

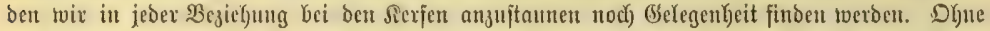

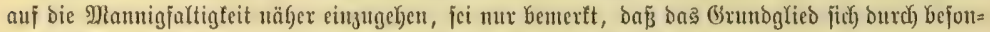

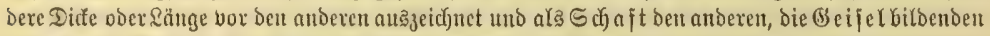

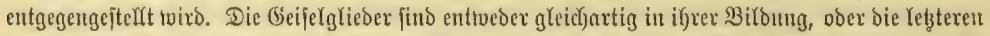

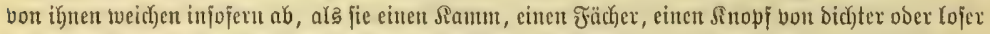

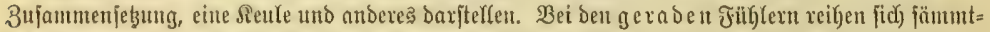

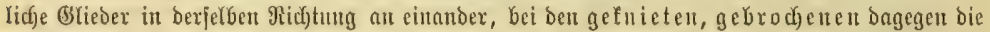
Geifelglieber unter einent $\mathfrak{B i n f e l}_{\text {an }}$ Den meijt verlängerten Schajt, und diejer FaIf gab wegen ber

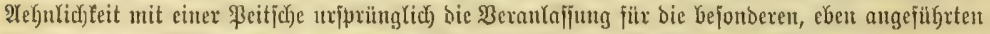

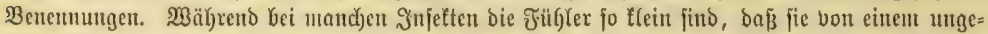

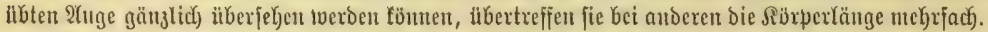

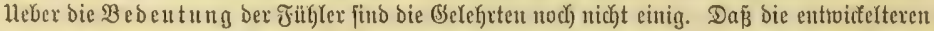

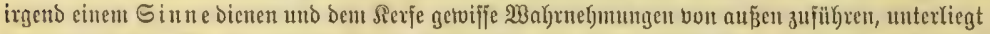

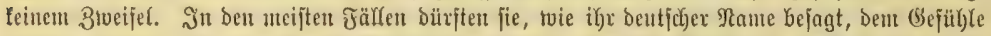

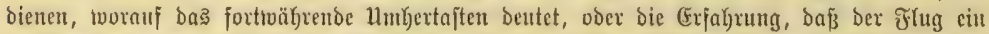

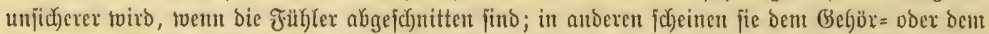
(Gerud)

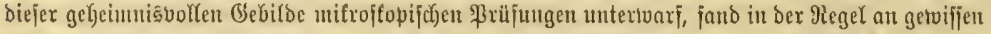

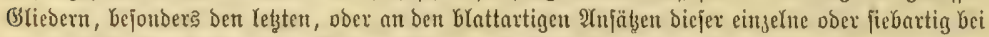

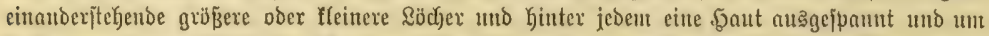

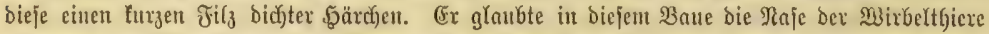

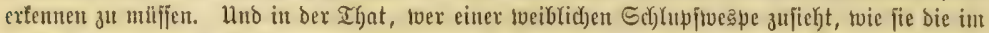

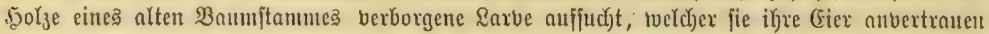

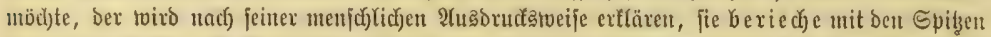

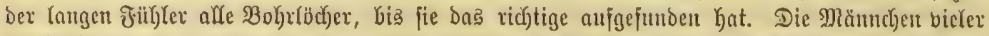

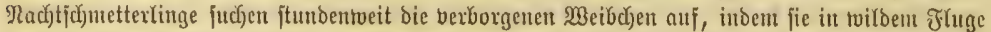

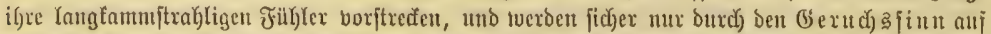

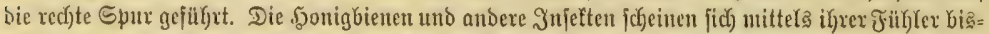

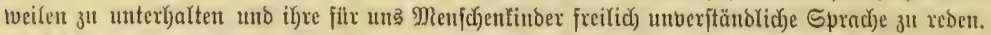

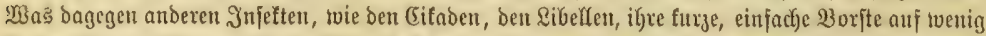

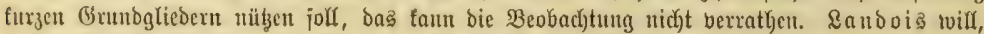

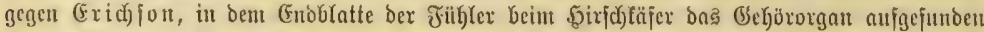

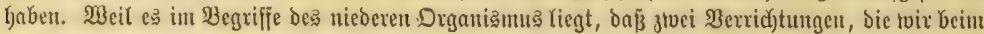




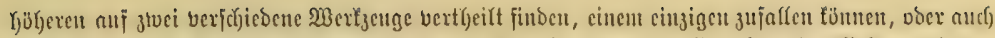

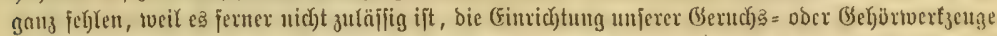

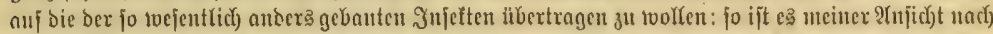

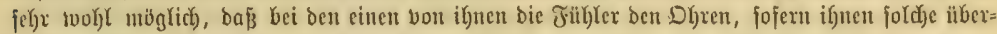

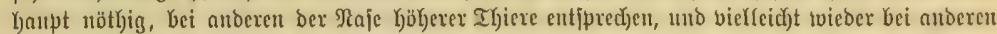

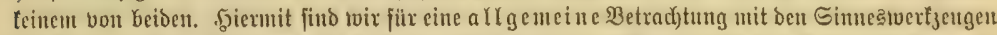

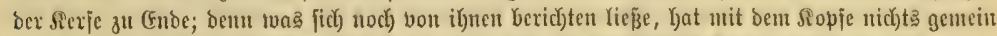

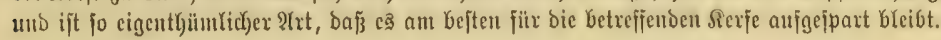

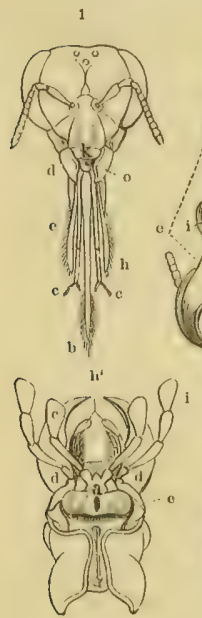

5
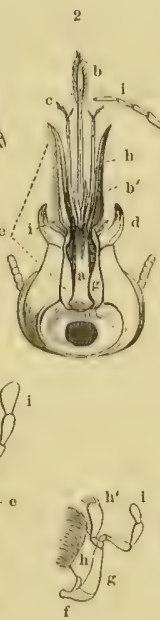

7
9

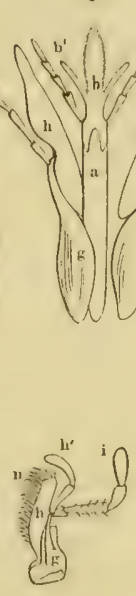

6

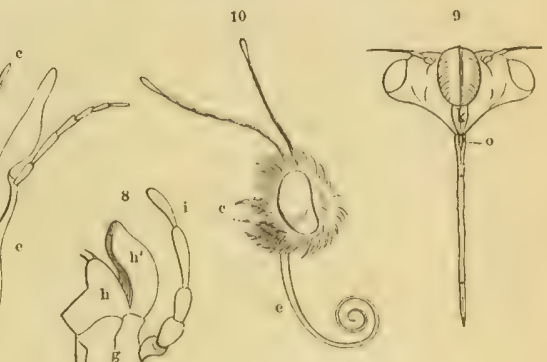

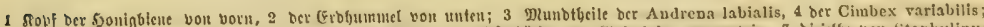
5 frovf 5 s $^{2}$ rorustes

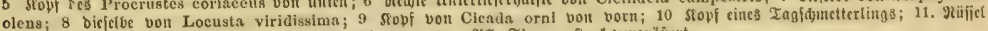

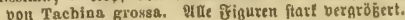

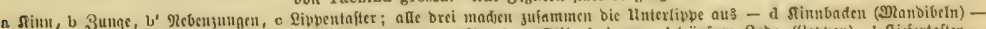

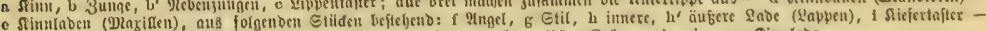

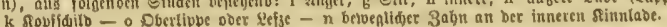

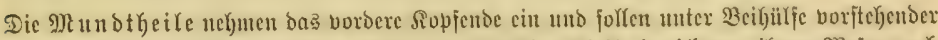

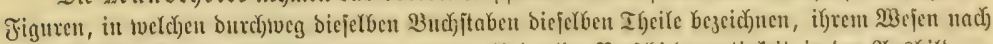

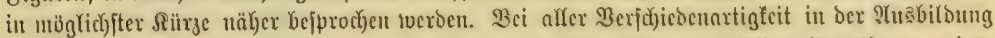

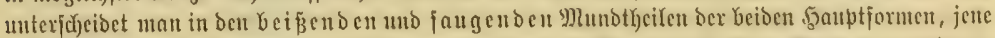

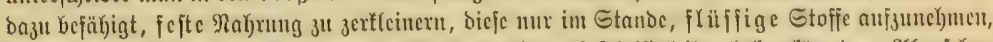

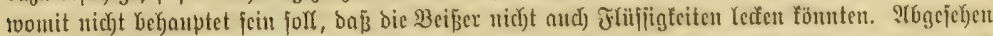

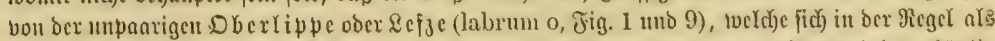

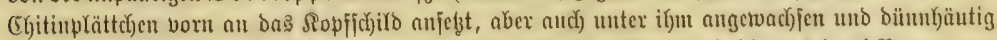

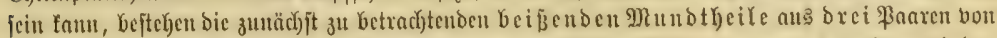

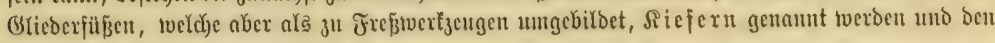
brei Yebten Sopfringen angebeftet fino.

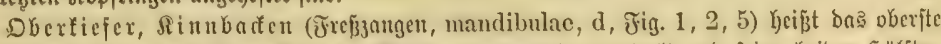

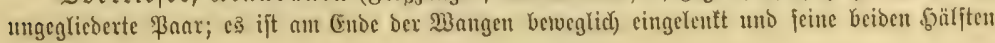




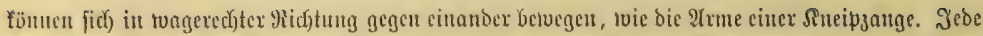

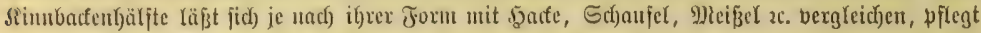

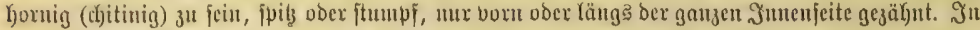

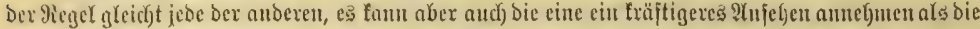

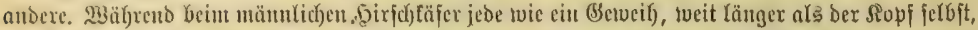

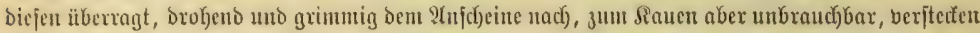

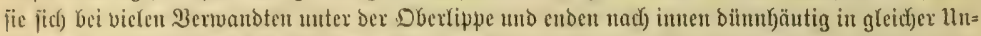

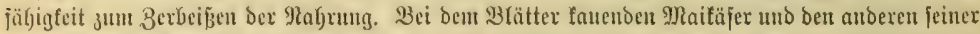

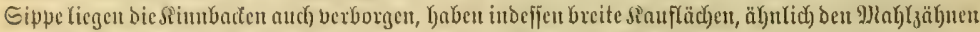

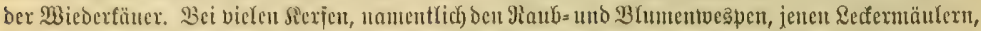

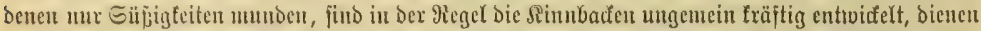

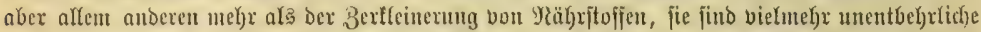

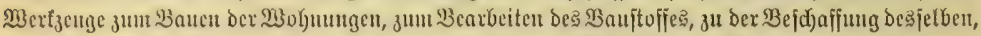

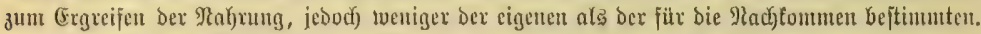

Uluterfiefer, siunlabe (maxillae, e, Fig. 1-5 und Fig. 6-8) nemt man bas jtveite,

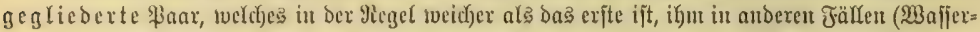

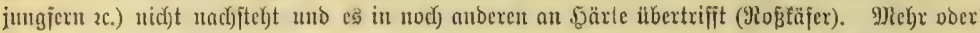

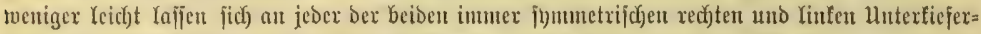

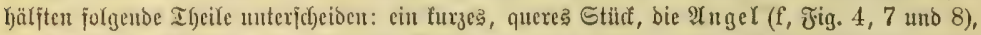

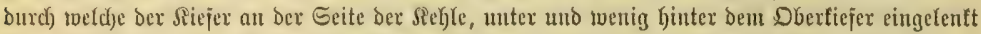
ift. Dic ?tugel geht aus ber breiefigen in bie langgebelynte bis jtabjörmige Geftalt über uno ijt

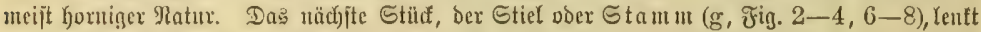

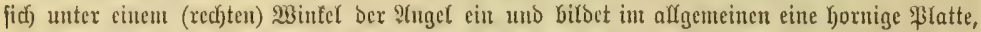

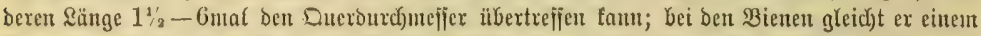

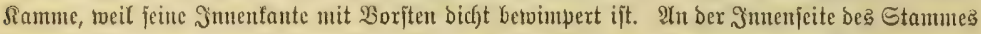

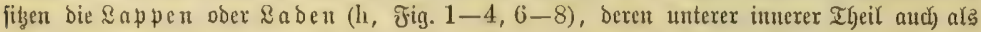

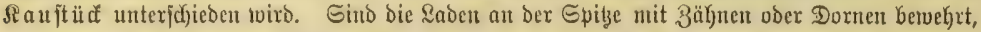

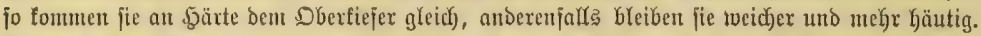

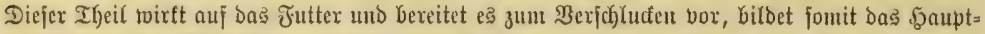
glied Dę̧ ganzen Ricjers, ex bejtegt mux aus einem Lappen (h, Fig. 1-3), wie bei mand)en

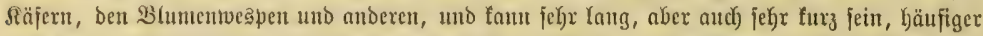

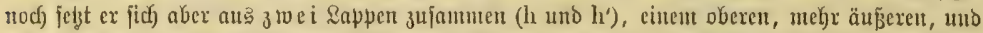
cincm unteren, mebr) nach imen gelegenen. Dabei fuben bie berf(c)iedenartigiten Derbärtniffe

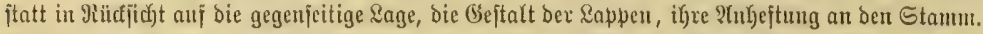

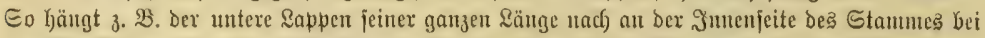

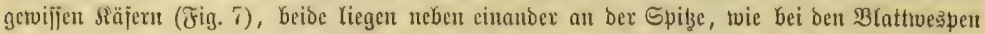

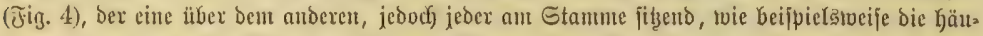

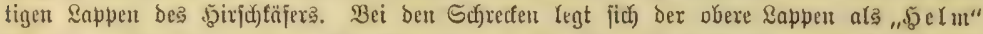

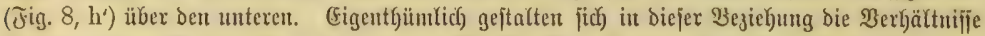

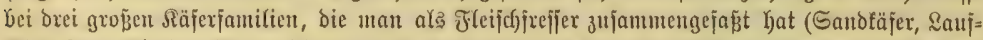

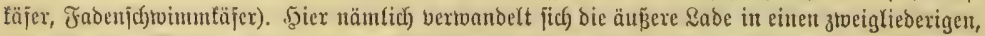

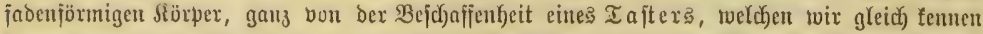

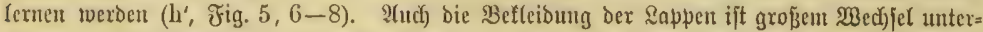

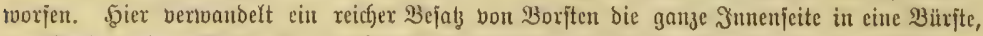

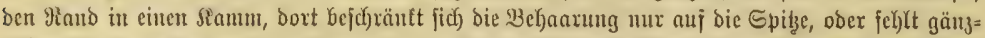

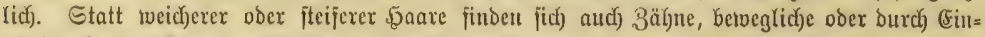

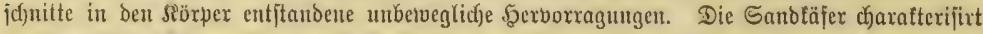

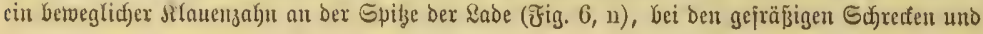




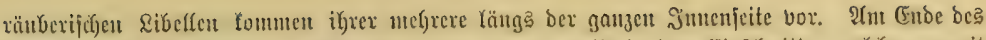

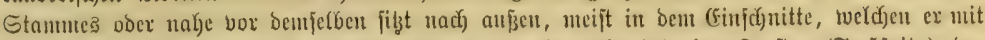

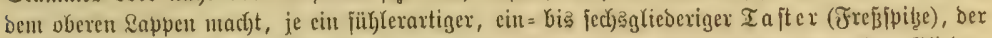
Silcfertafter (jalpus maxillaris, i, Jig. $2-5,6-8$ ). Gegenjeitige Ränge ber Obfieber, namentlick aber bie Gejtalt bexjelben, beoingen allerlei Mnterjuhiebe.

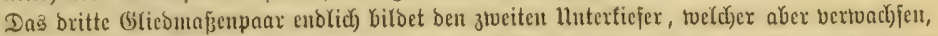

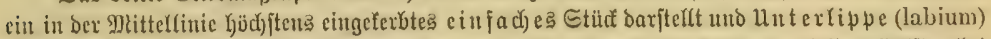

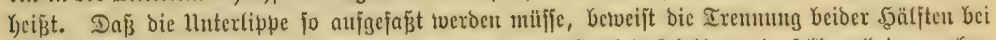

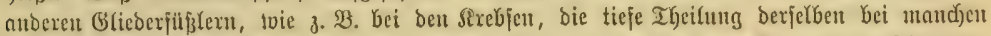
Sï̈fern und ben Sthredfen, forvie ferner bie Begentuart von ztwei weiteren Taftern, ben \&ippen=

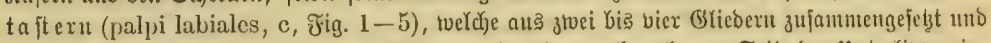

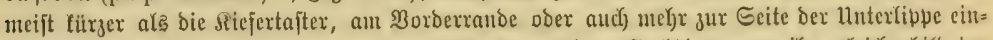

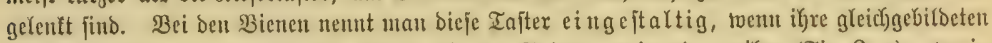

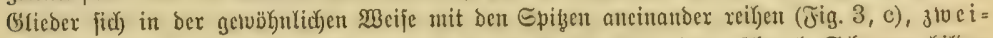

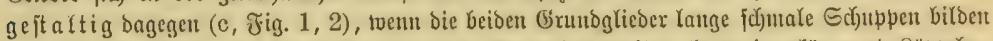

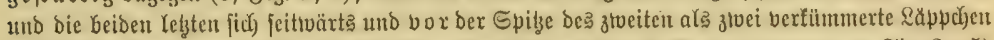

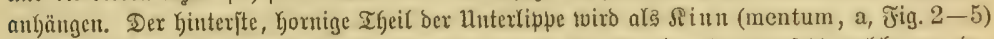

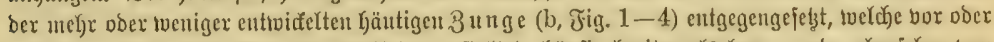

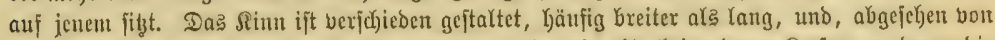

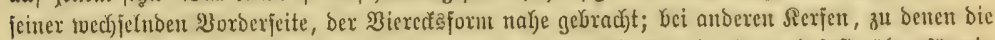

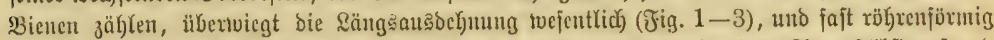

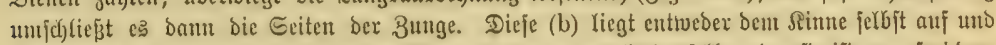

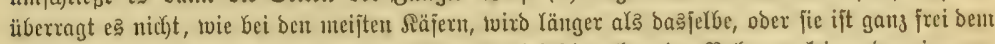

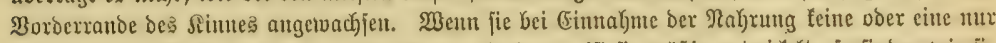
untergeoronete Rolle fpielt, fo Genterth man fie faum; ijt fie mäpig entwitelt, fo finden tvir jie

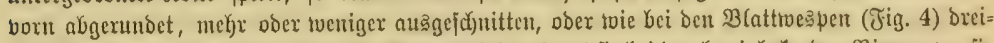

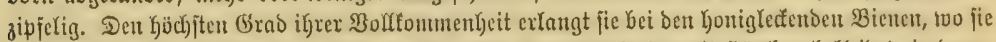

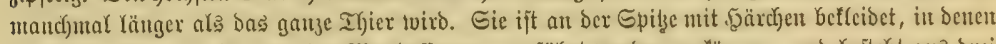

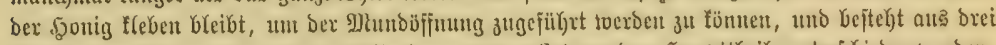

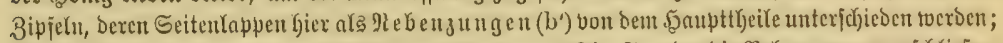

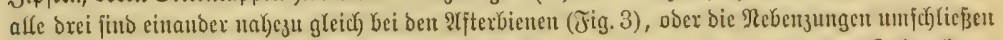

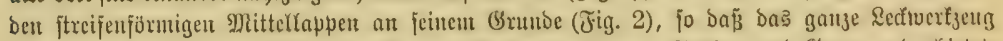

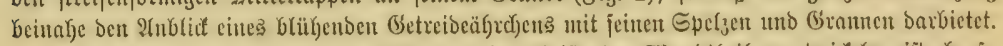

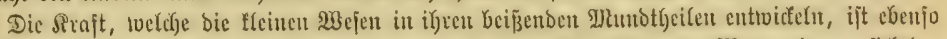

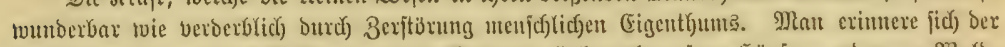

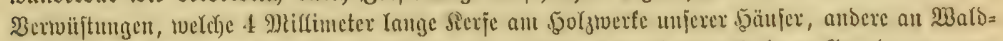

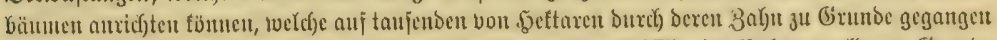

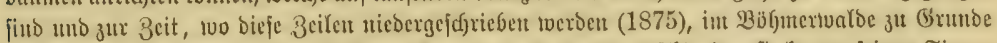

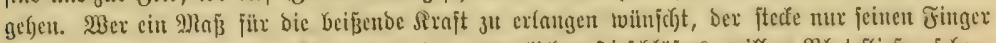

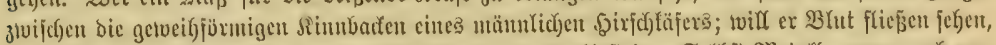

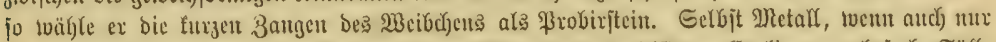

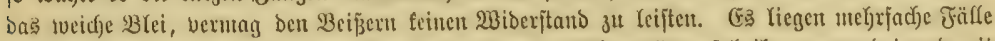

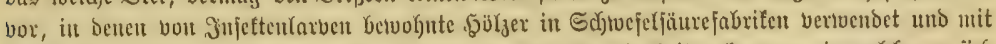

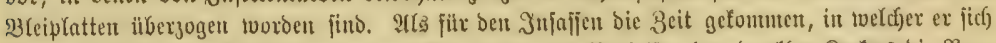

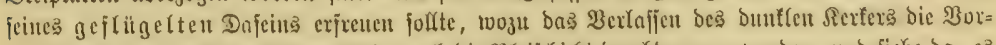

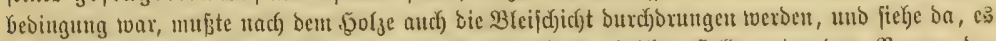

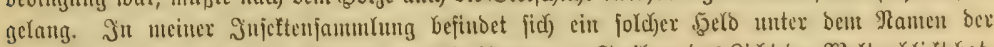

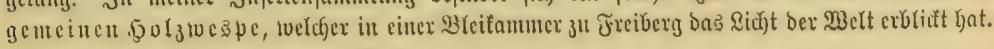




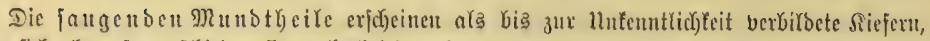
Infien fick aber, fo veridjicoen fie aud bei ben einzelneu Dromungen auftreten, auf bic einzelute

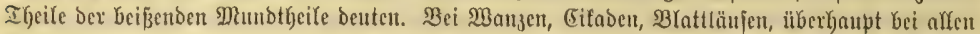

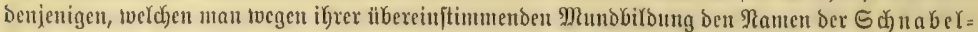

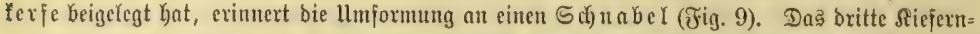

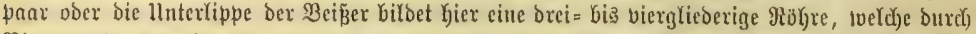

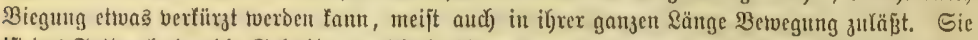

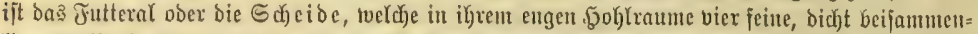

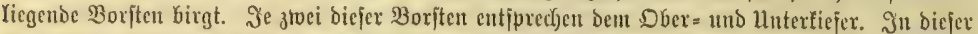

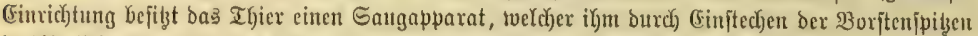

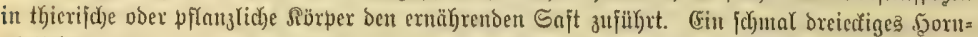
plättd)en, auf Der Dberfeite ber Sdjeibentunrzel augebeftet (c), entfpridgt ber Dberlippe, von Infteru

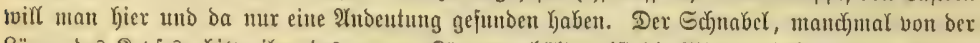

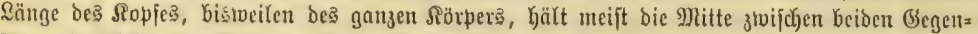

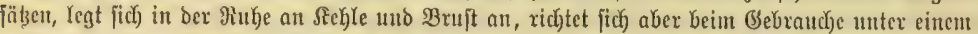

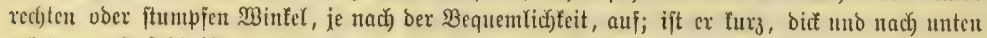

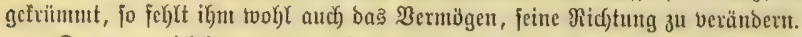

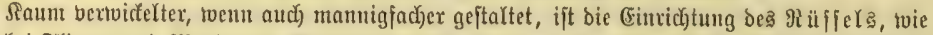

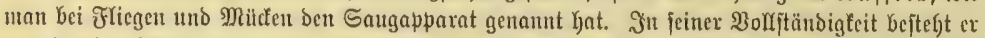

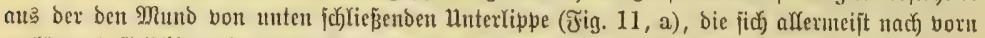

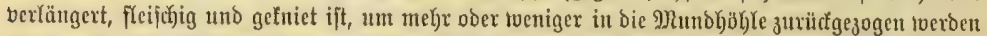

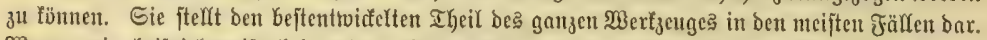
Wenn, toie beippieläncife bei unjerer Stubenfliege, bie llnterlippe it einer Saugftäd)e endint,

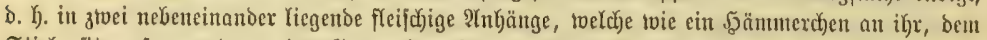
Etiele, fikzen, fo ment man baz Ganze cinen Saugr il fifel (Fig. 11); bei ifnt pflegen bie übrigen Theile biß auf bie Rippentajter mełre ober toeniger zu verfümmern. Der Unterlippe Yiegt die meijt

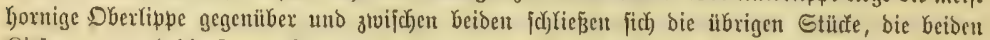

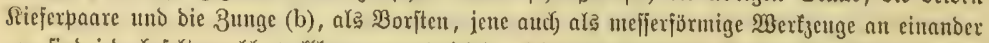

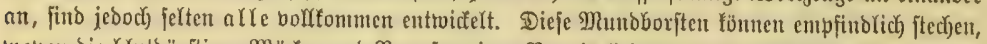

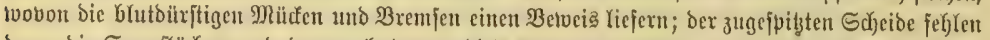

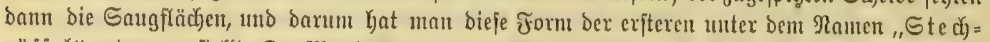

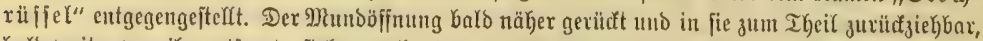

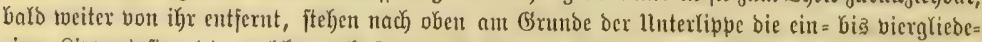
rigen Sippentajter (c), rueldye nack) Jorm, Jarbe uno joujtiger Bejdyafientyeit oft gute llnter= jcheioungamertmale abgeben.

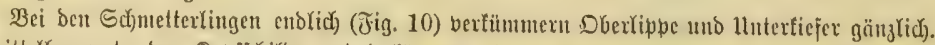
llumittelbar unter ben Sopfichillde ragt ein längerer ober lürzerer, Gärterer ober weicherer Streifen

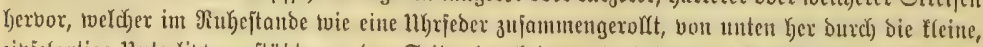
zipjelartige llnterlippe gejtïbst, an ben Seiten ourch beren breiglieberige Tajter (c) eingejd)loffen

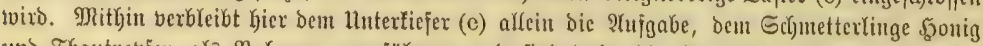

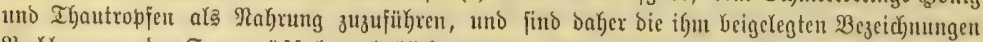

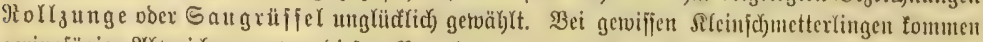

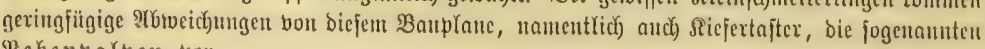
ßebenpalpen, yor.

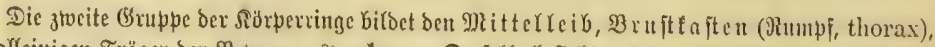

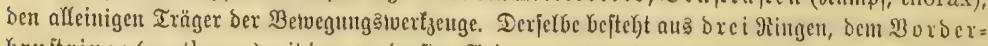

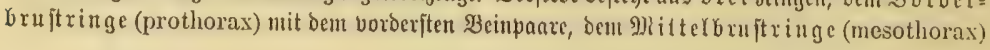




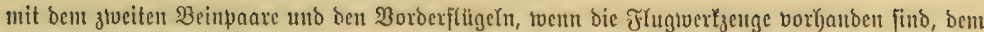
Sinterbruftriuge (metathorax) mit ben Ginterften Beinen und Fïgełn. Se nad) Den $\mathfrak{B} e=$ biurfniffe find bicje brei Ringe verfffiebenartig entroidelt und ber eine meijt übertwiegend. Bei

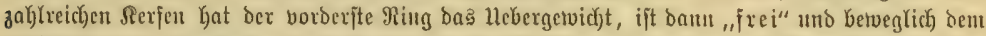

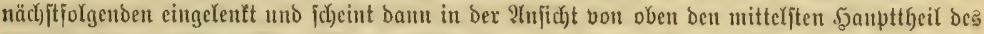

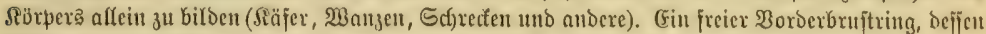

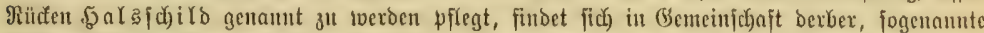

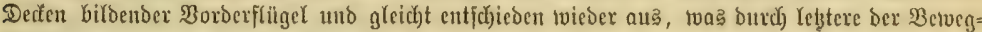

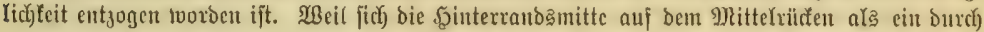

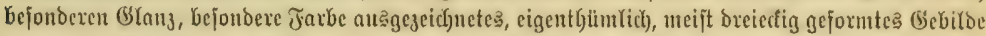
gegen feine llungebung abhebt, jo hat nan bieje Etefle gleicf)falf mit cinem bejonderen Planen

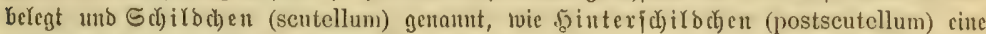

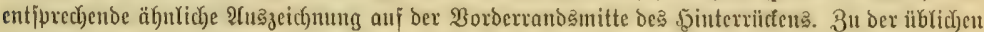

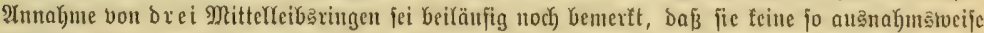

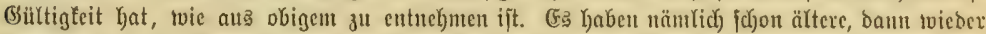
vergeffene, in ber Reuzeit abermals aufgenommene uno von neuem geprïfte anatomijdye uno

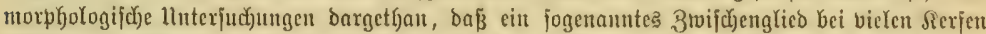

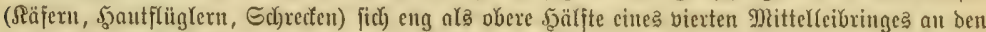

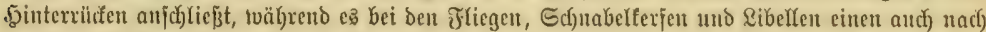

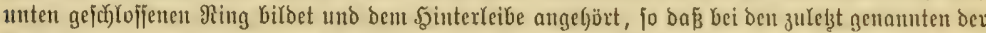

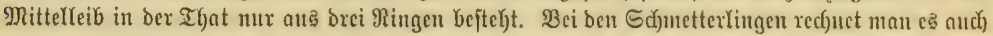

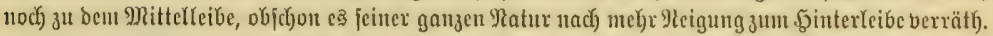

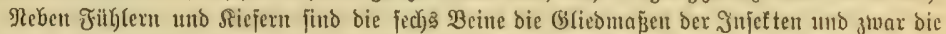

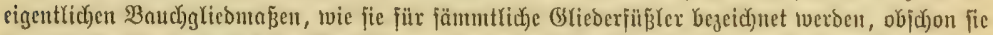
bei ben Snfeften nientals an Baudece, fondern an bex Bruft jteben. Jebes Snjettenbein beftebt,

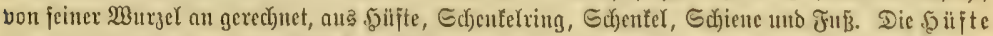

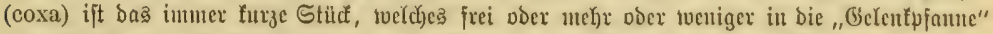

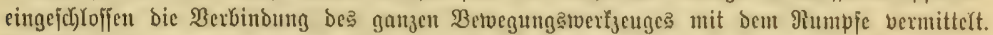

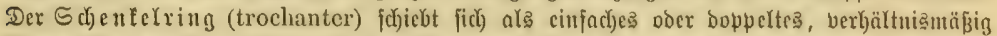

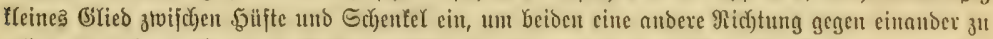

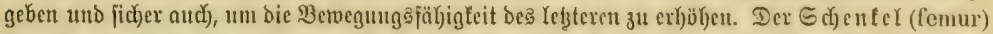

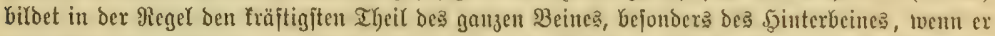

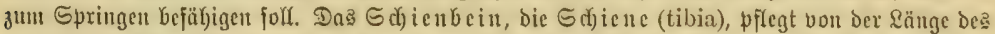

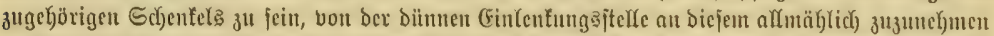

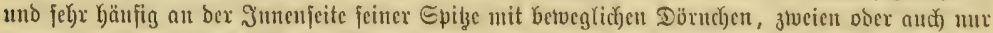

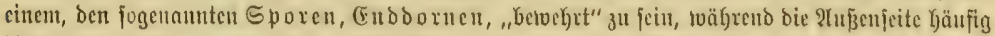

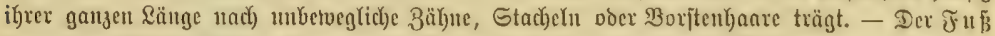

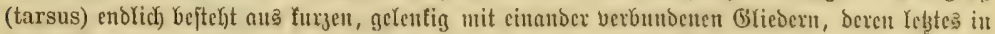

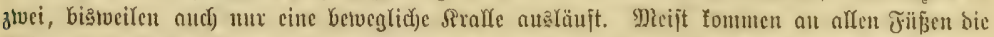

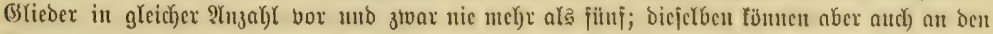

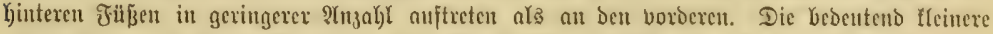

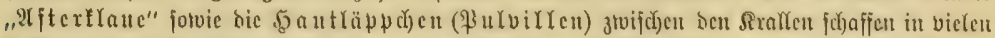

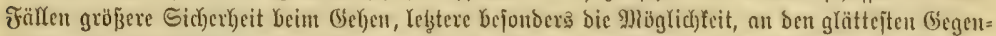

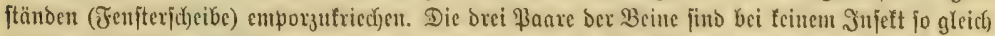

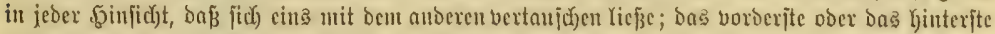

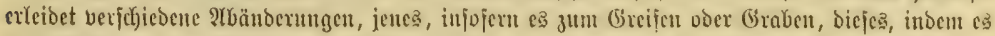

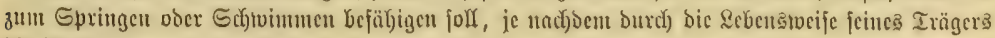
bie Berrichtung geboten ift. 


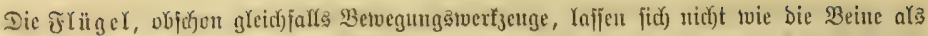

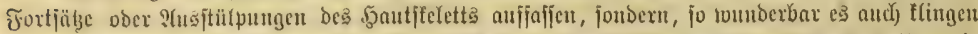

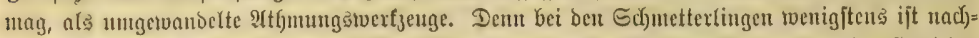

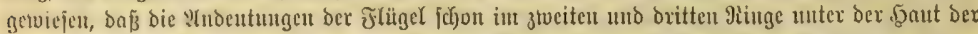

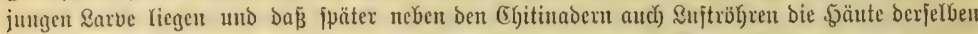

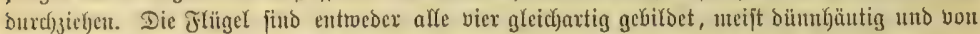

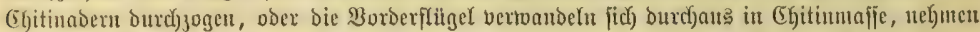

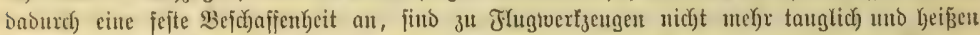

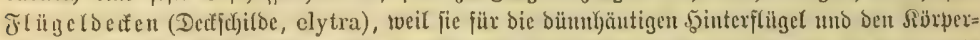

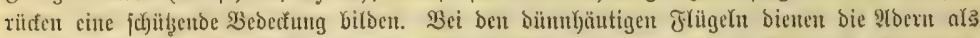

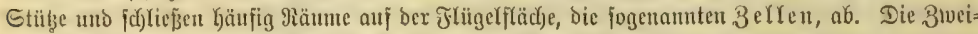

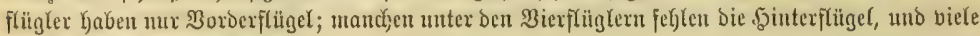

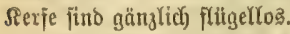

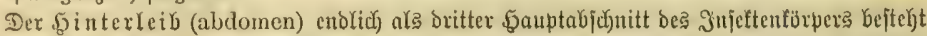

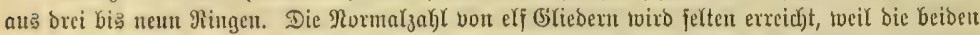

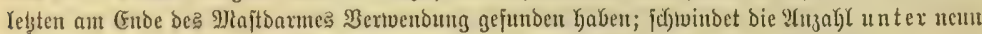

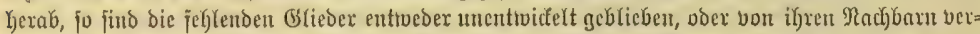

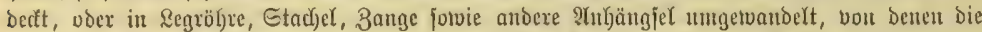

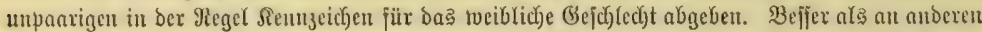

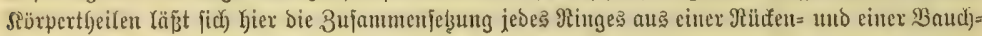

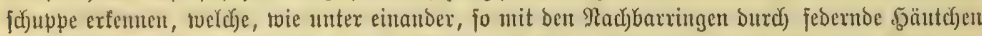

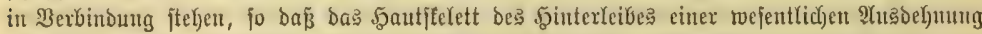

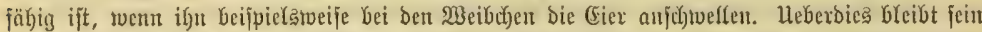

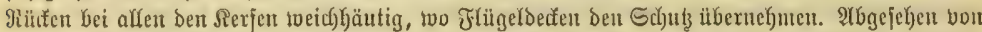

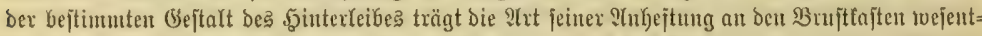

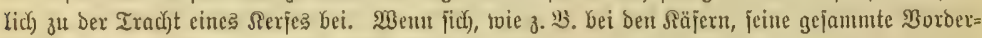

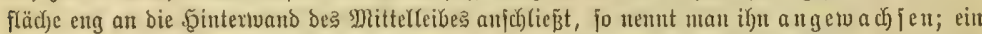

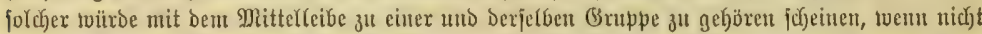

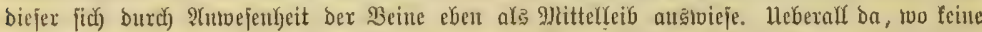

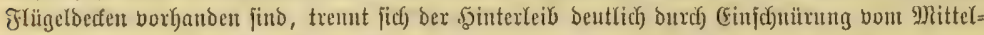

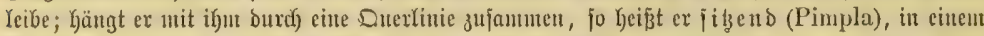

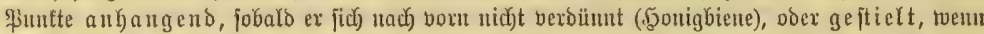

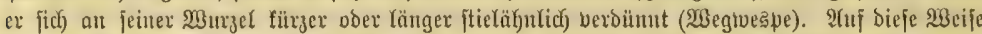

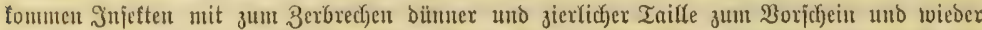

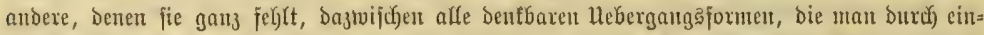

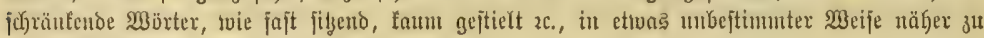
bezeidunen pflegt.

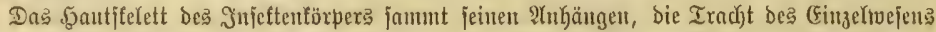

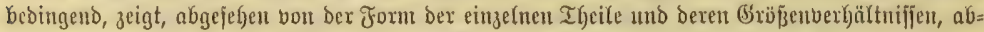

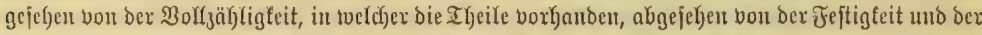

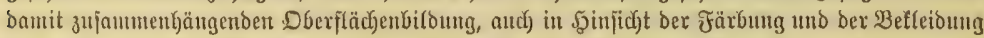

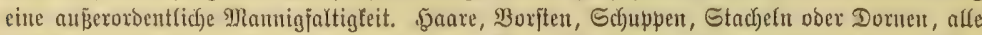

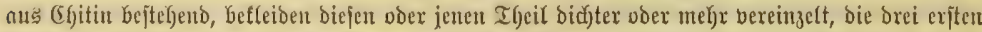

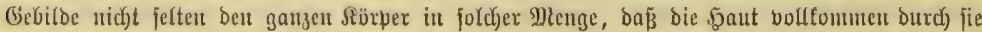

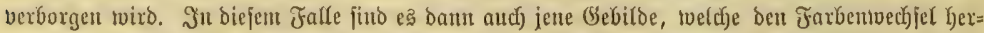

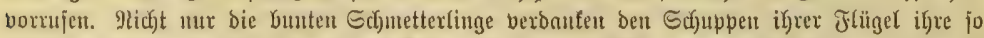

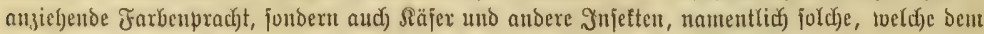

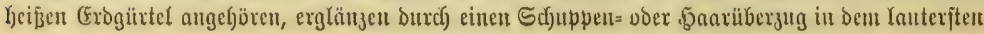


Golde, in reinten Gitbex, wie Emaragbe und andere ed Ete Eteine; bie Exhuppen jüben lojer als

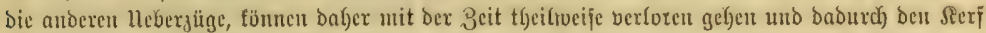

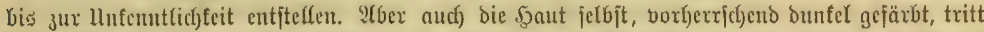

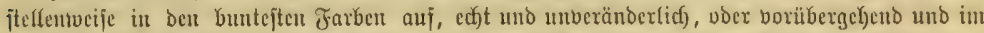

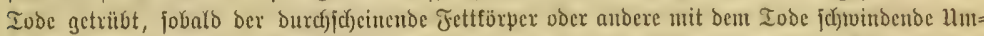

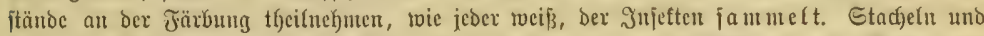

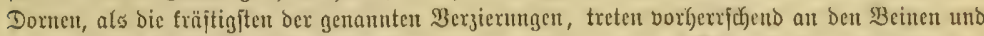
vereinjelt als $\mathscr{T}$ ț

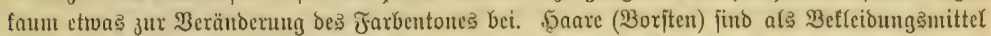

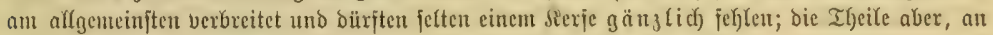
weldyen fie bem unberwaffneten Aruge entgeben, bezeidjnet man als nadit.

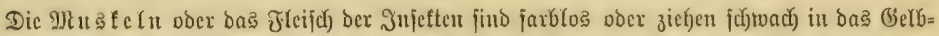

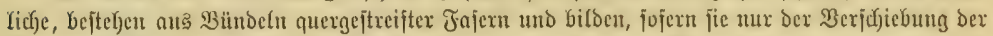

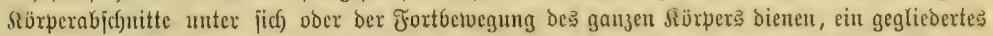

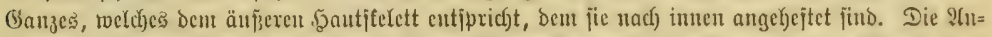

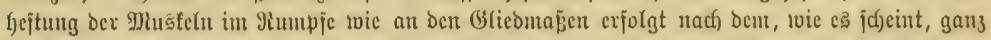

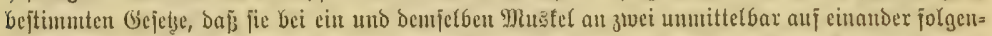

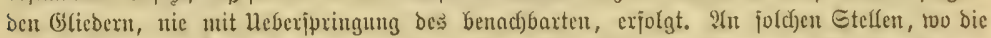

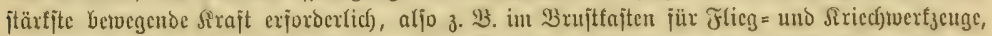

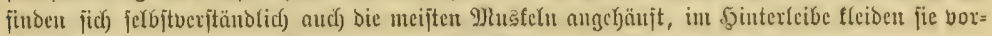

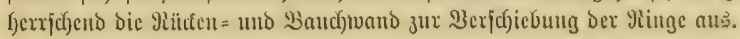

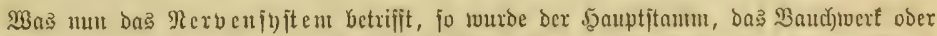

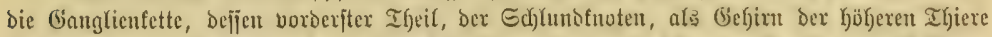

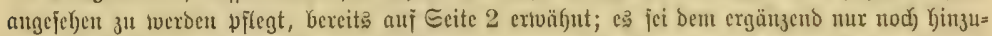

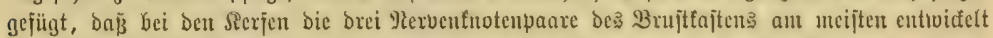

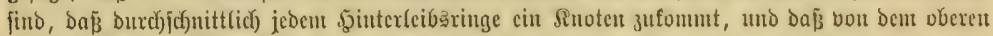

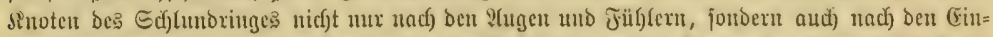

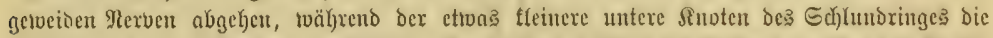
feinigen nach ben ग)

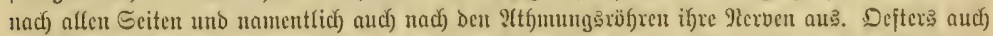

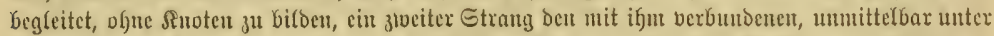

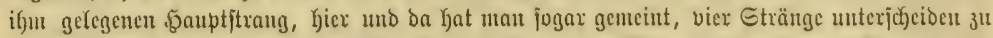

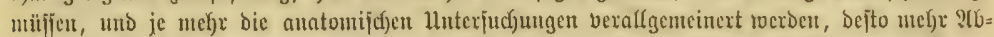

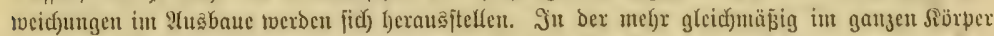

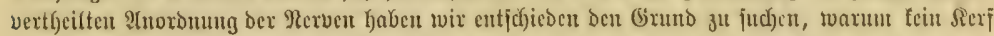

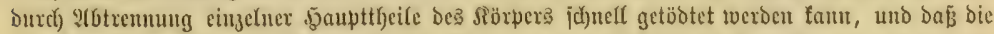

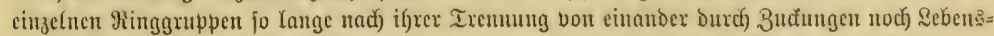

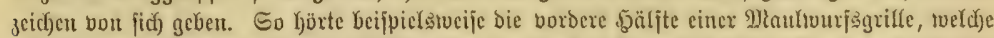

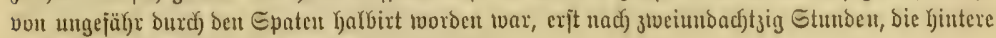
exjt nach fundertundacht Stunben auf zu zứen.

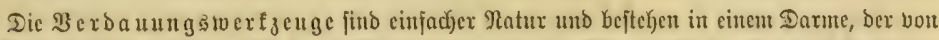

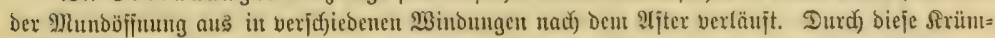

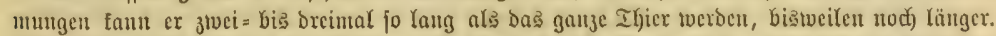

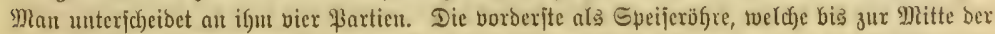

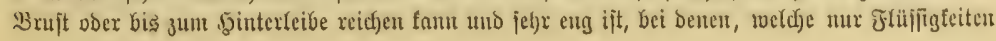




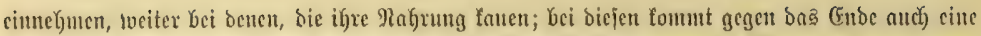

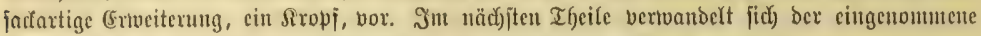

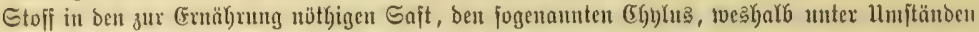

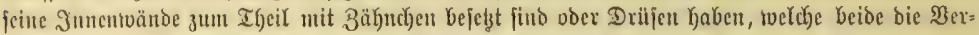

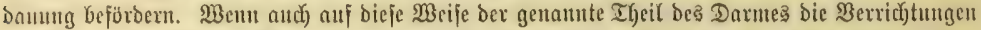
bez g)

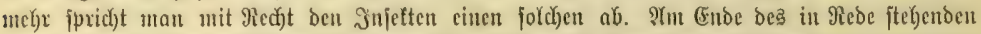

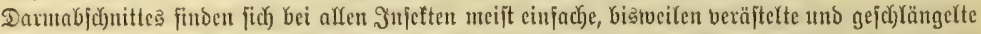

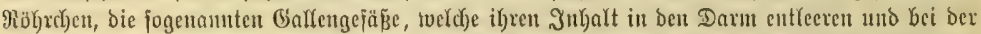

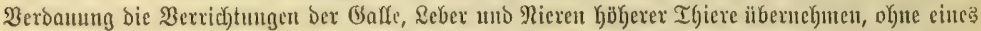
biejer Drgane jelbjt zu fein. Dex ziemlich furze oritte, mit einem Blinbonrm verjebene Igril

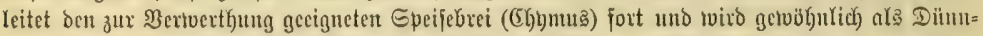
barn bezeichnet, währens Der Dictoarm mit bem Maftoarme als bas Enoe ber ganzen 3Dr= tefrung bas Unverdauliche aus bem Sö̈per entiernt.

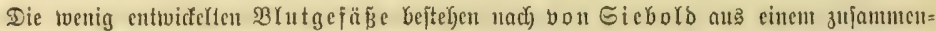

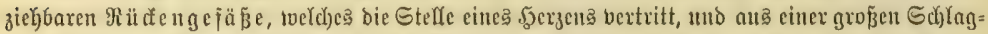

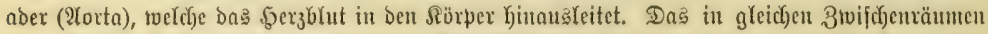

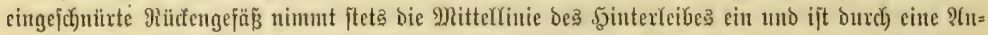

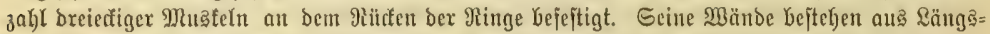

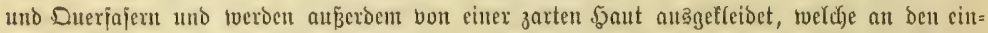

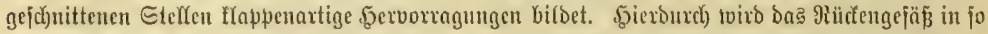

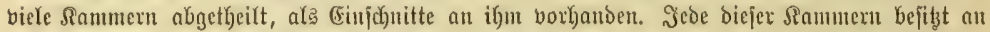

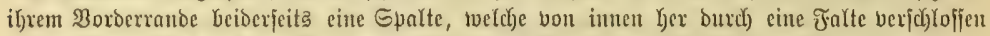

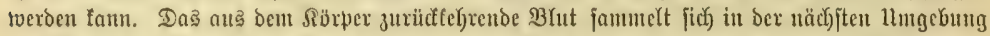

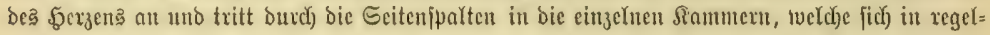

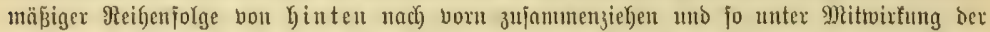

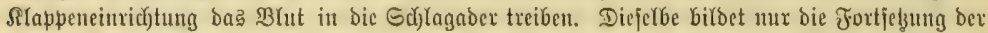

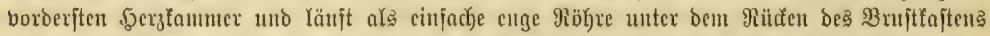

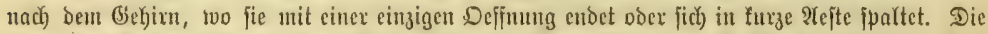

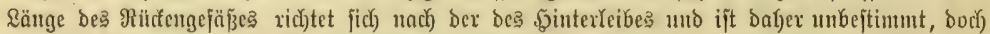

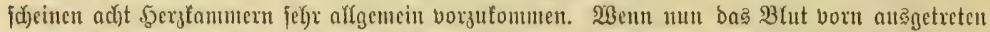

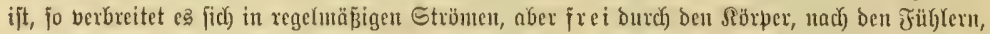

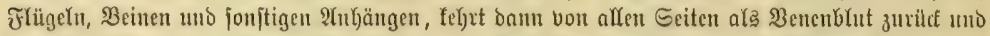

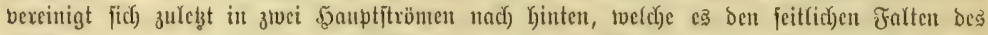

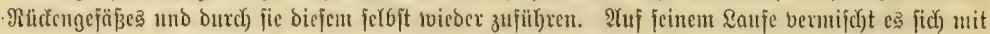

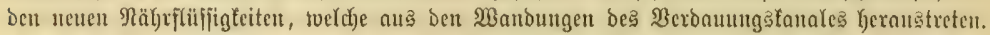

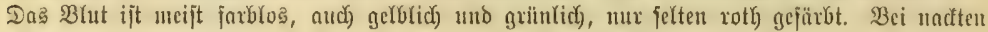

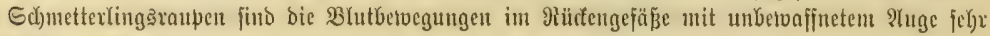
wohl zit ertennen.

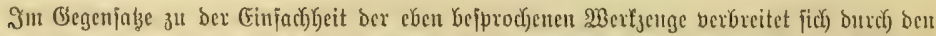

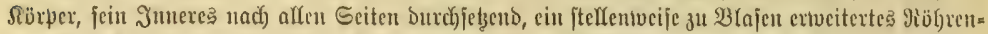

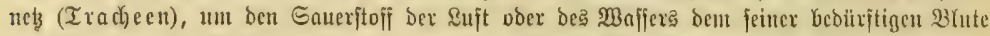

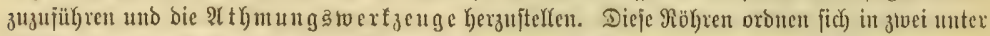

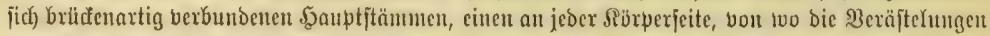

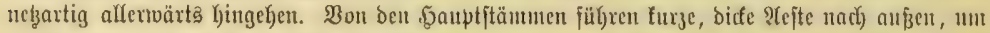
in Den \&uft 



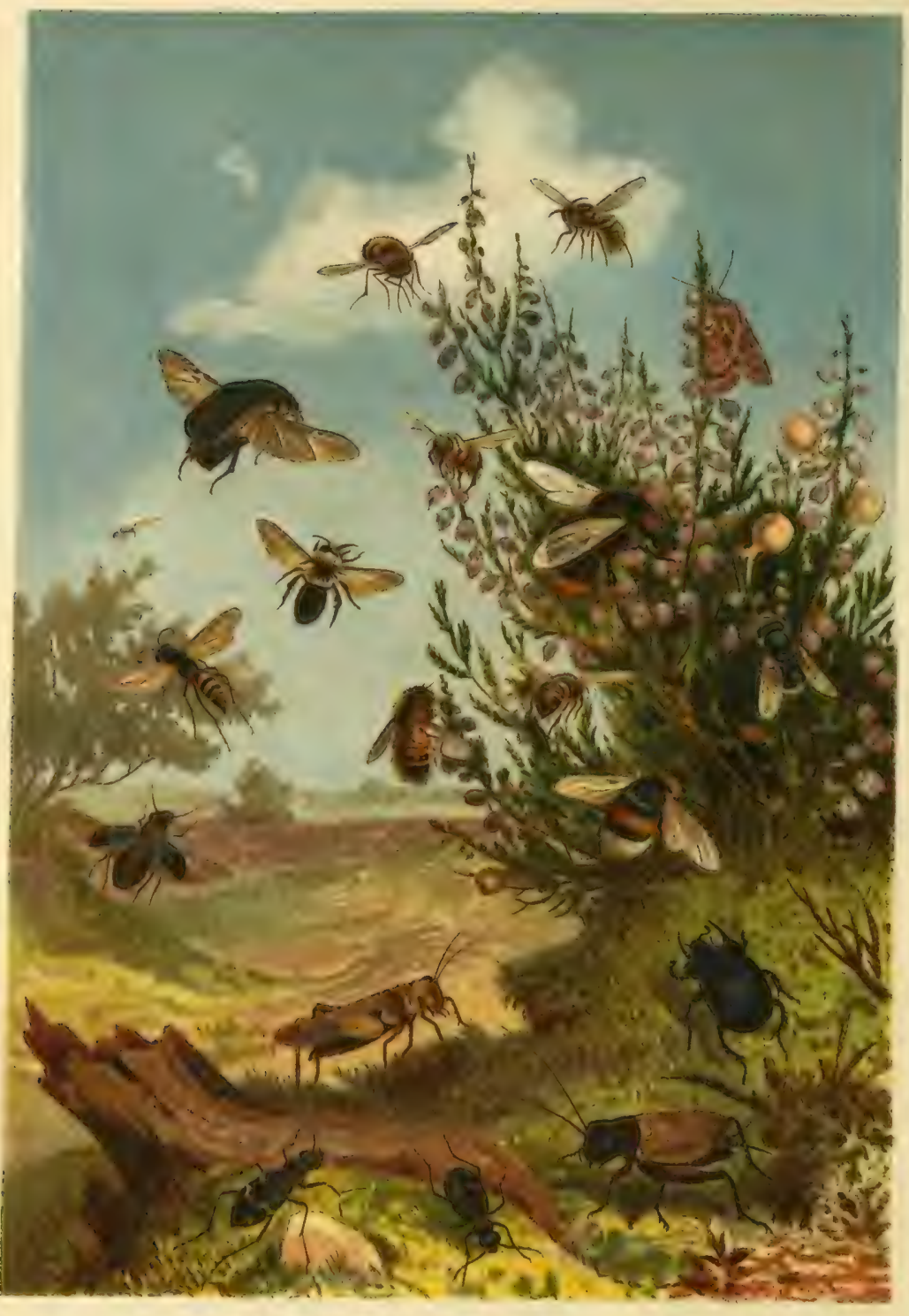

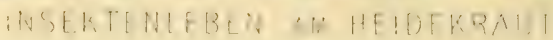




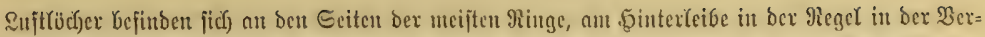

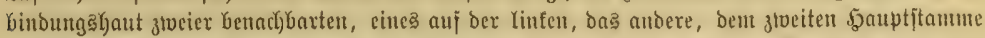

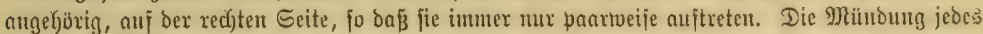

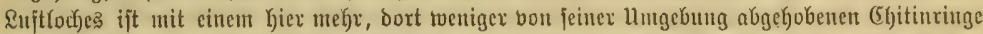

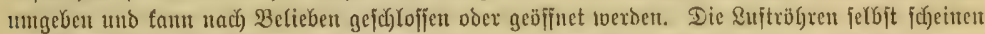

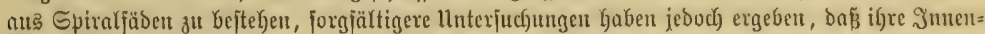

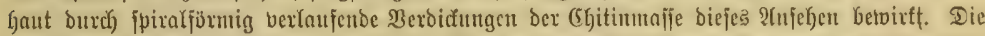
Glajigen (Evtweiterungen, welthe ben bejten Fliegeru an zaflreichjten zufonmen und an bie luft=

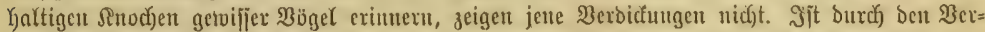

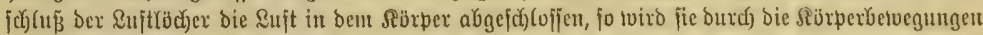

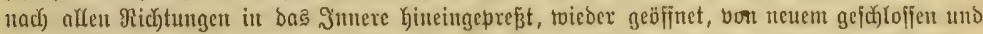

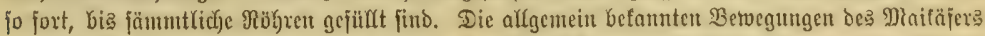

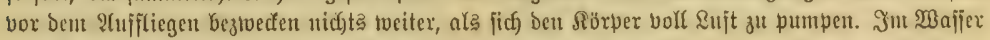

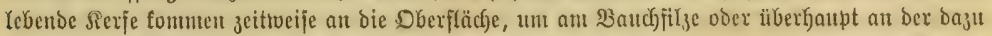

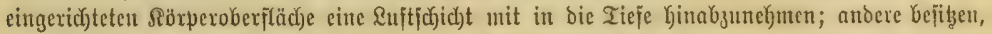

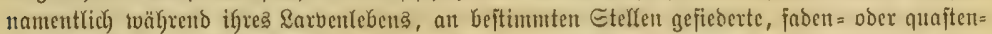

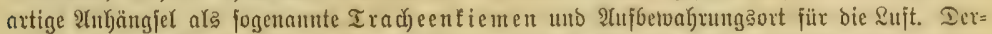

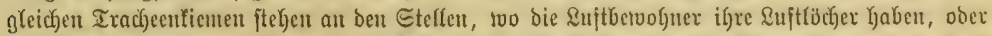

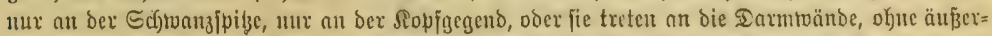

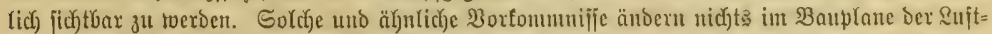
rüh)ren, fonberu geben nux bie Mannigfaltigfeit in ber 2 trt unb Meije zu erfennen, tvie bicje gejpeijt

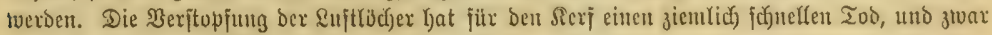
Durch) (Exjticitung, zur Folge.

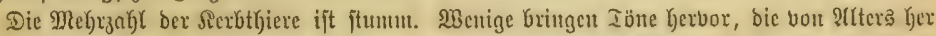

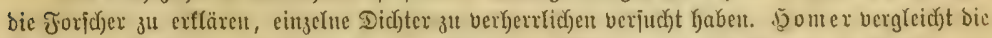

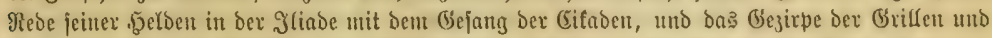

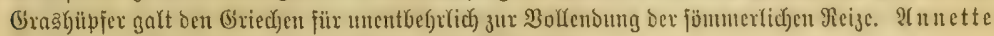
bon Drofte = \$ill

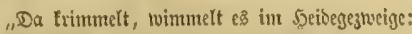

Die (3)ille brebt gejdyuinto bas : Beindjen am,

Streidyt an bes Thanes Soloplyonium

ltno fwelt fo [djäferlid) bie Liebeageige.

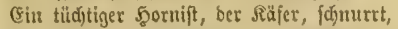

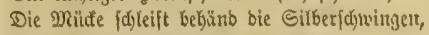

Dnaj heffer ber Triaugel möge tlingent;

Distant uno audi Tentor bie flicge furt;

llno intmer meljeno ibren wertben (S)urt,

Die reidje Ratze um bes feibes Dritten,

Ift als Baffit bie Bicte eingejd)rittent.

Sdjwerfantig boctent in ber 23 titte, runmeไn

Die Rontraviolen bie träjen summiclit.

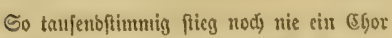

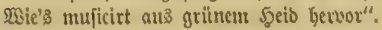

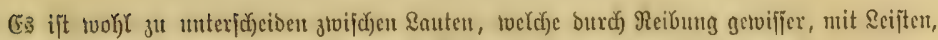

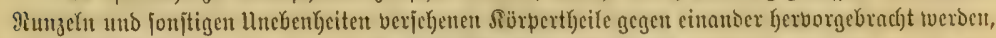

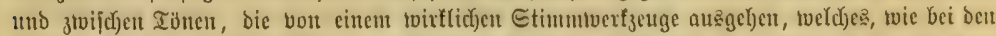

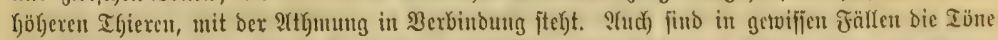

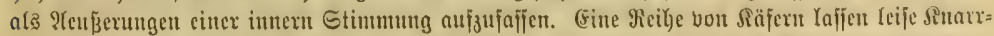

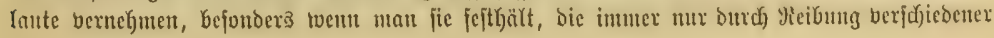




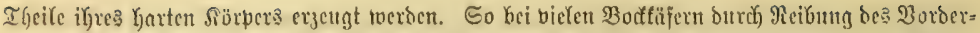

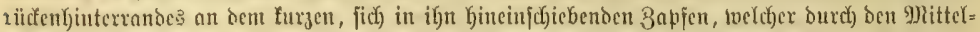

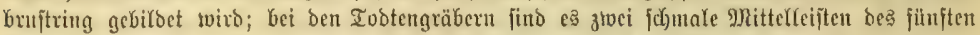

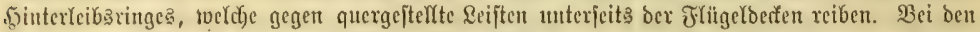

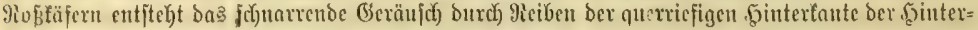

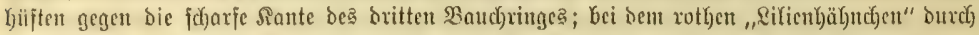
bie geleiflete Seitentante ber Frïgeldecten gegen bie getöntelte, entiprect)ende Stelfe am sginter=

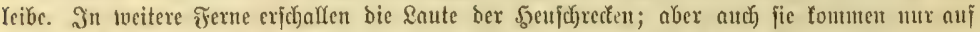

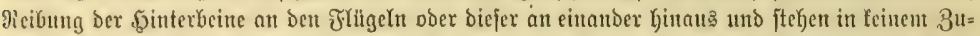

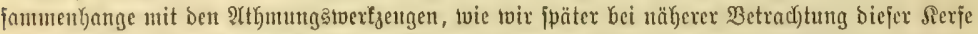

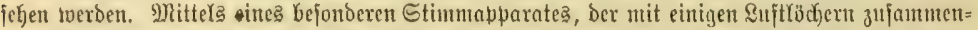

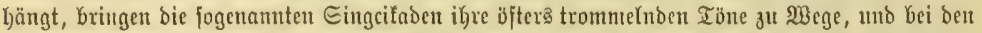

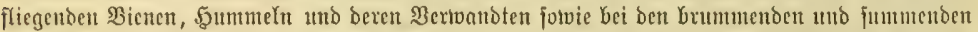

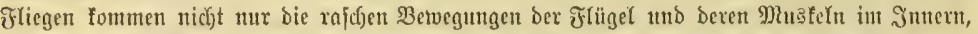

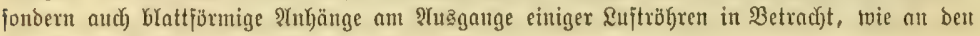
betreffenden Steffen näGer erłäutert merben jolf.

Die Fortpflanzung gatoerf Einzeltwejen, und toem man von "Sinjeftenstoittern" [pricht, jo beriteht man barunter bamn

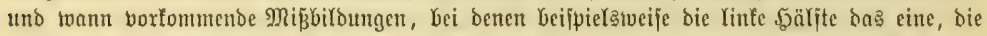
redjte bas andere Gejulecut in cinem Reibe vereinigt, ober too in GeYiebiger nnderer Meije eine

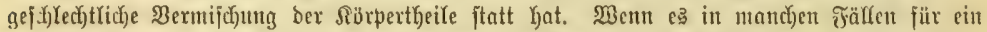

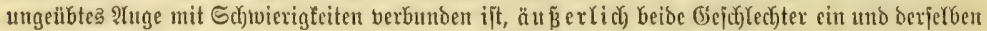

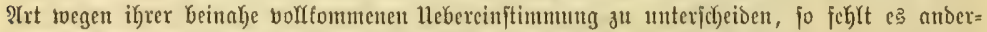

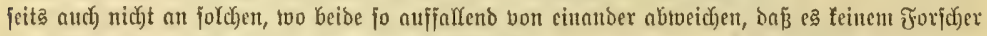

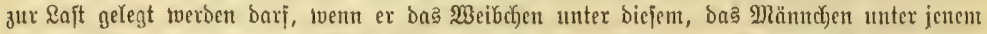

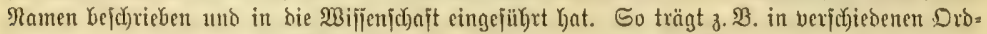

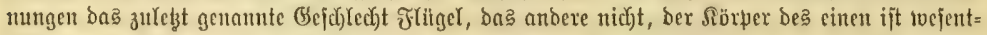

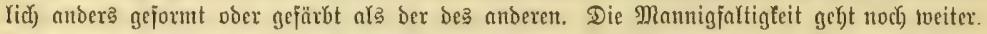

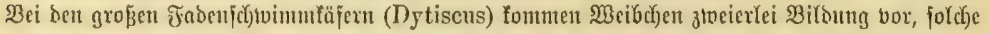

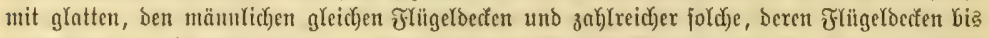

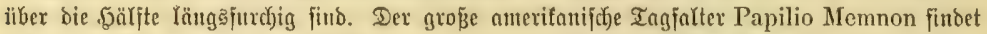

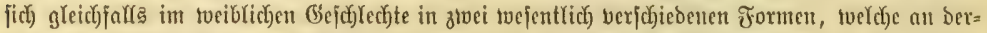
ferben Dertlichteit fliegen amb ohne llebergänge fund; bie einen Weibdgen tweid)en von ben Mäแn=

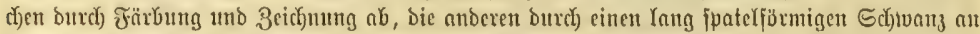
jebem Sinterftügel. Gin anderer in Rorbamerifa gemeiner Sdytualbenfiftuant, Papilio Turnns,

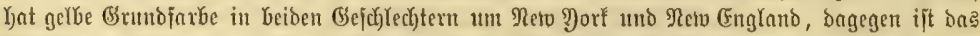

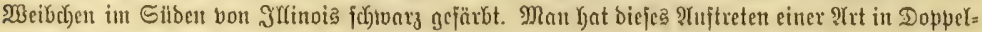

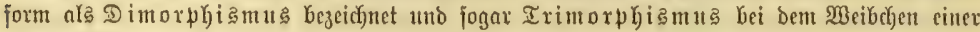
britten Falteract (Papilio Ormenus) beobadjtet. In neuerer 3eit ijt bic eben angedentete

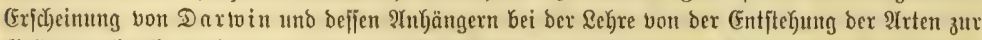
Gicltung gebracht worden, locil aber, wie von Riejentuettex an einer Stelfe jehr ridjtig bemertt,

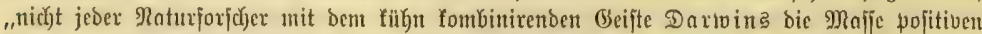

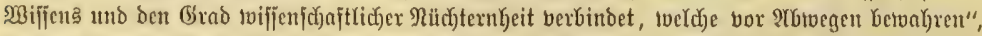

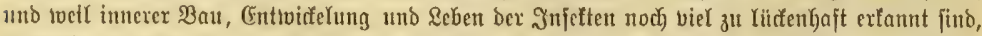

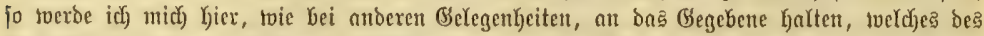

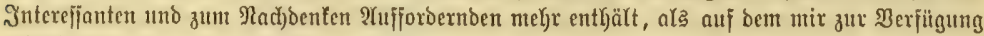
gejtelften Raunte untergebradyt toeroen fann. 


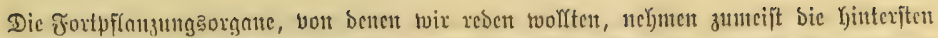

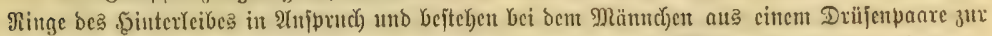

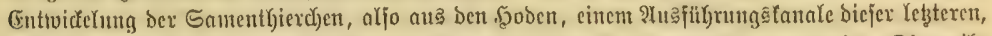

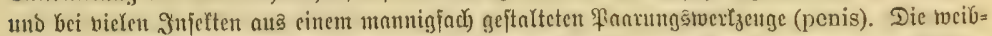

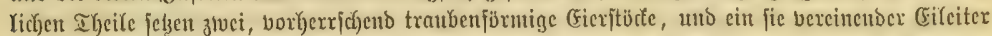

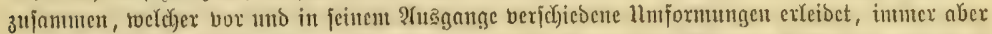

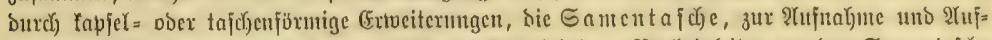
betwahrung bes mänuYichen Samens biloct. (Exjt bei Dem Borbeigleiten an Der Eamentajche

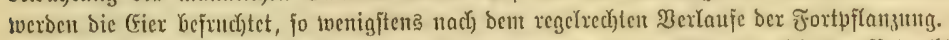

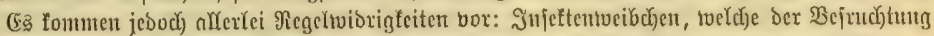

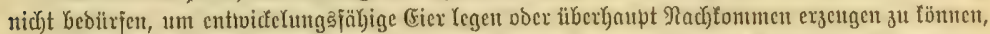
tvie getviffe Galltweșpen ber Battungen Cynips und Neuroterus, cinige Edfiloläuje (Lecanium

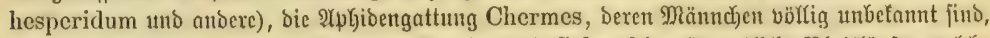

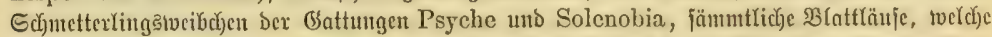

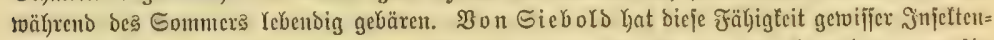

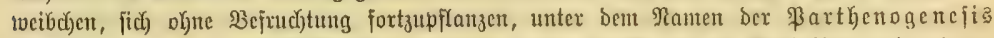

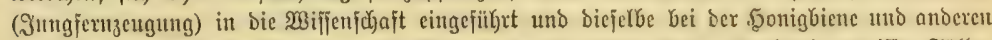

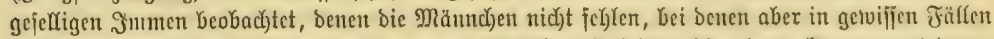

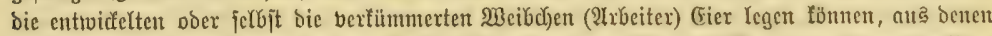

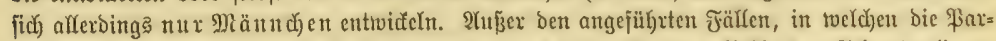

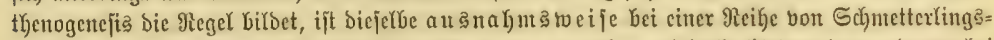
sweibchyen und bei ber Stachelbeerblattweäpe (Nematus ventricosas) Geobad)tet roorden, unto jwar bei

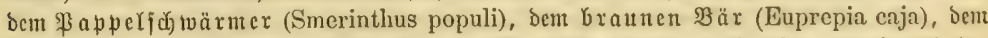
Riejerufpiuner (Gastropacha pini), Dem Maulberipiuner (Bombyx mori) uno ber Saturnia Polyphemus zu wicberkolten Malen. Wegen bes Kohen Sntereffec, welche sicje Ex=

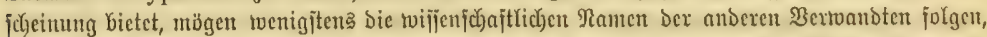

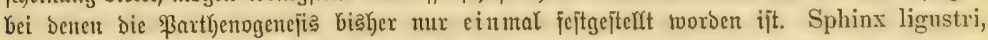
Smcrinthus ocellatus, Euprepia villica, Gastropacha quercifolia, potatoria, quercus, Liparis dispar, ochropoda, Orgyia pudibunda, Psyche apiformis, Finen uno ben antocren

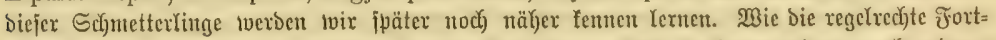

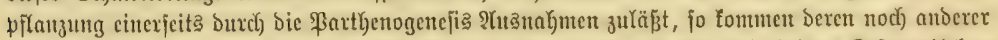

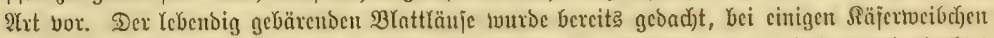

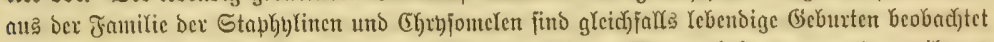

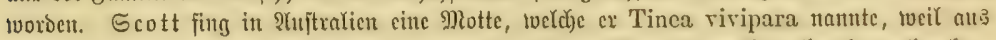

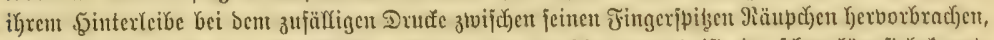

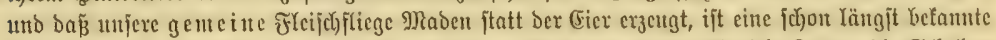

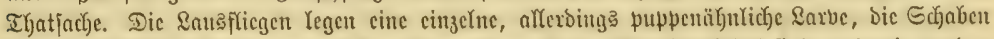

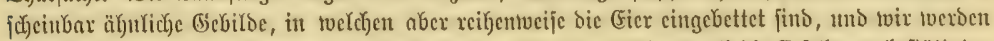

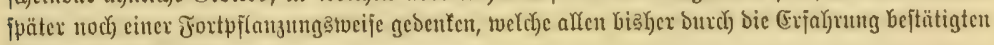
Bejejzen .fohol jpricht.

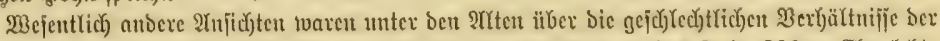

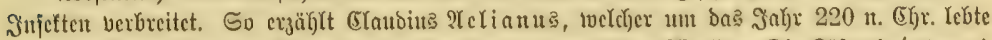

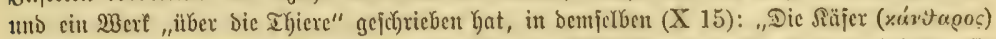

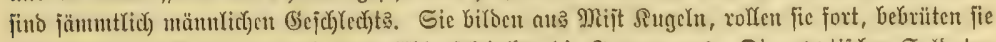

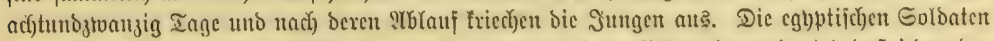

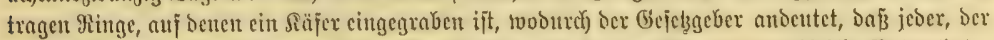

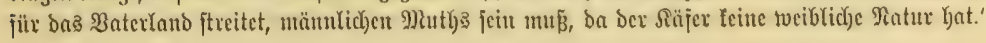




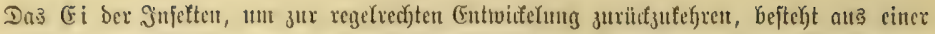
feiten, Yeberartigen Schale, an beren Snmenjeite fidf bie zarte Dotterhant anlegt. Diejerbe un=

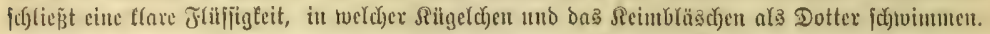

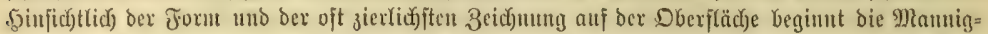

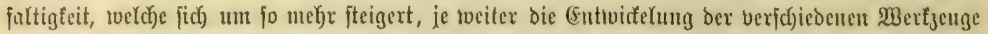

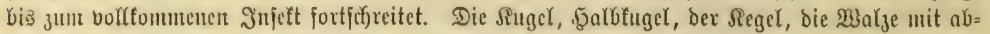

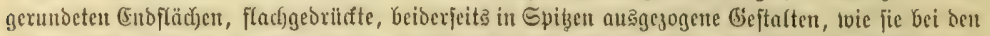

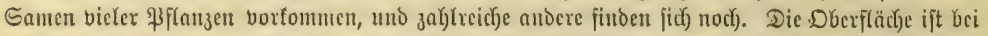

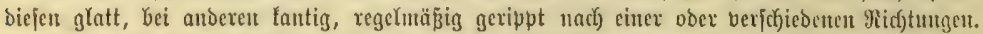

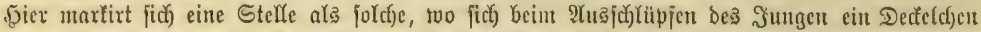

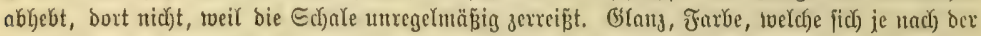

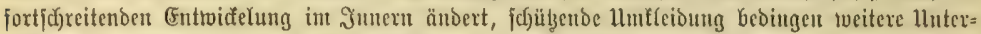

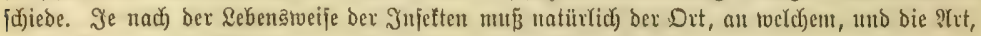
toie bie Cier von ben Weibchen abgejetzt rerben, ander: auşallen.

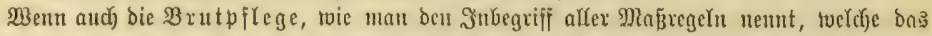

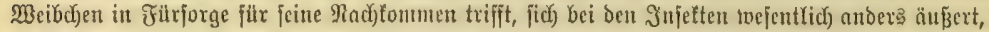

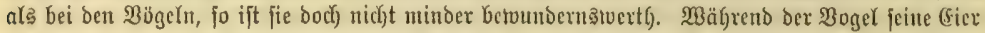

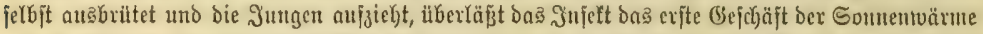

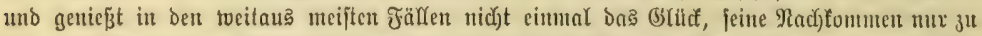

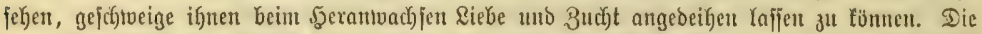

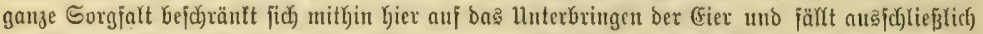

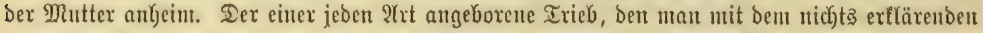

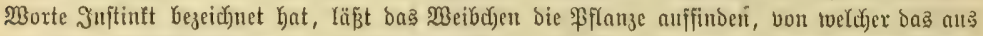

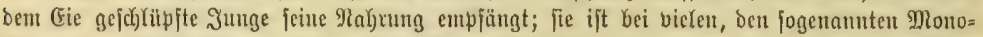
pljagen, eine febr beftimmte, Gei ben \$olyphagen (Piełerleifrejfenden) eine beliebige ober zrvifichen

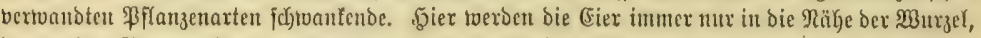

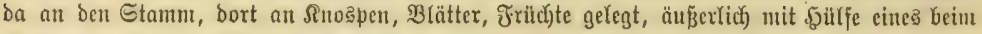

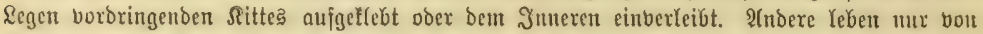

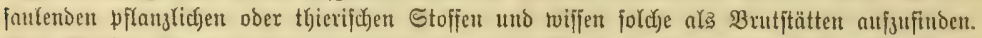

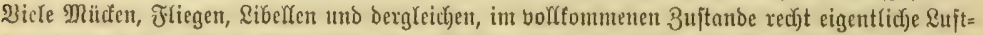

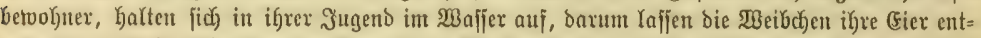
weber in basjelbe fallen oder bejeftigen fie an Wajferpflamzen. Soldbe, bie in ben Reibern anderer

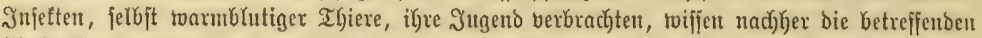

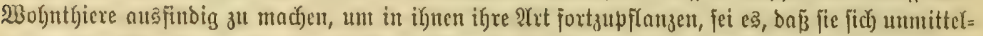

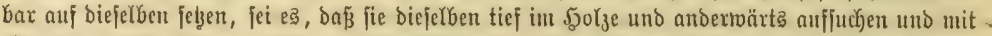

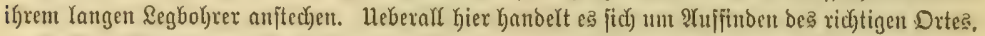

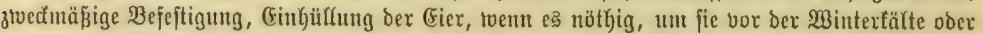

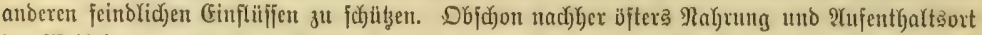

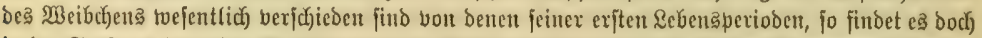

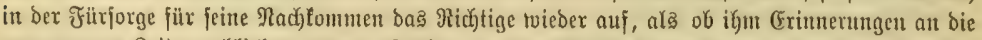

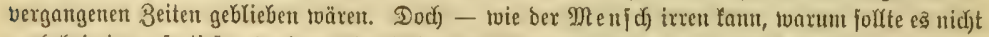

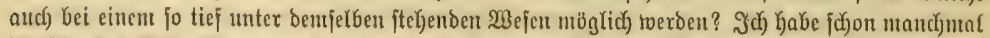

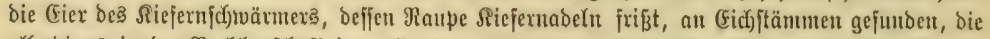

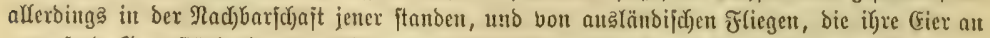

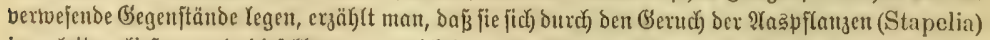

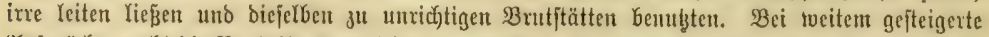

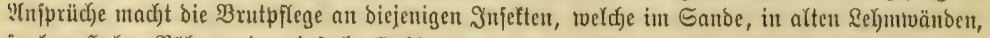

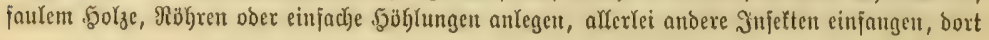




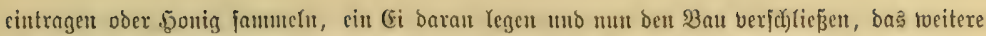

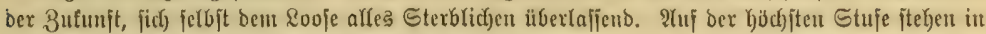

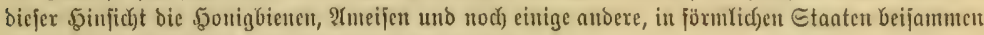

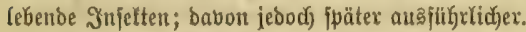

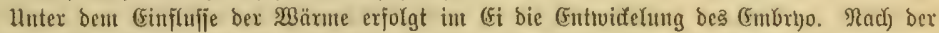

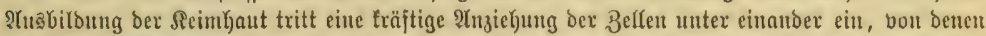

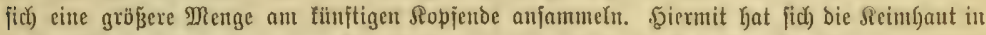
bent einfach)en, zungenförmigen "Sicimftreifen" untgetwanbelt, burd) tveitere P(uziehung thei(t ficd) ber Reim|treifen nach Geiben Seiten in zuve ftrangförmige, neben eitander verfaujende, anf ber

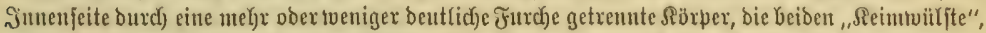

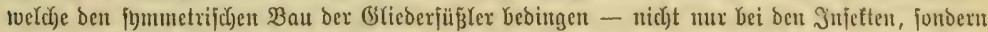

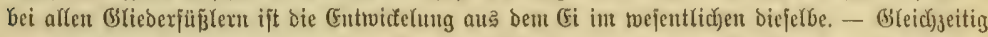

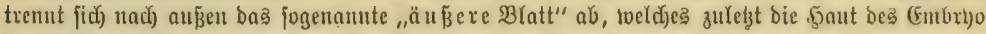

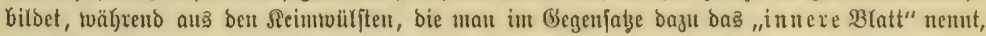

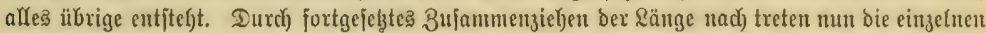

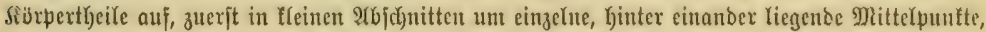

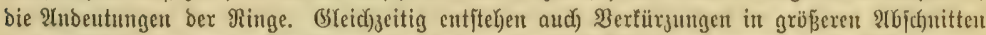

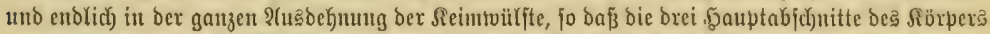
unterfajeibbar tverden. Die (Entrvidelung, bie toir in bas (Eingelue nidj)t toeiter verjolgen fönten,

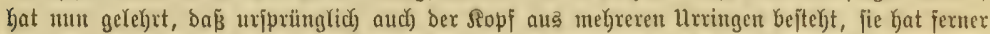
Fingergeige an bie Şand gegeben jür bie Deutung bejonders ber Siefern und vorderften Beine, Deren $\mathfrak{B e r r i d j}$ tungen, toie fpäter bei ben Epinnen und Sirebjen gezcigt twerbent wirb, nidjt in ber

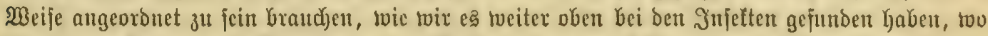

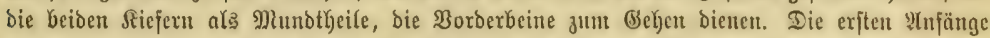

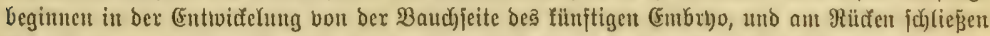

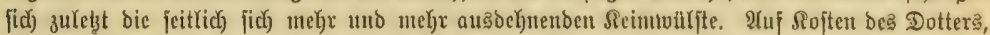

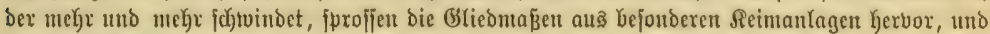

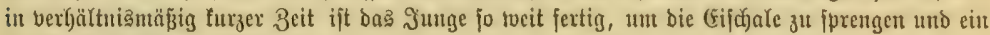
felbjtändiges Reber zu beginnen.

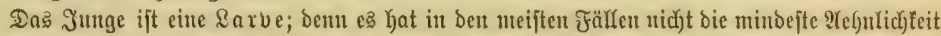

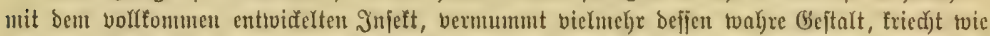

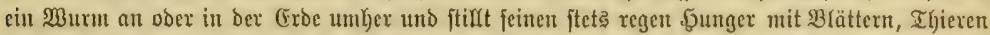

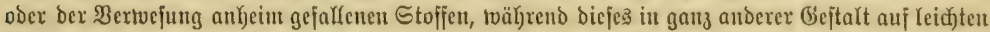

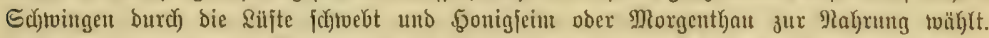

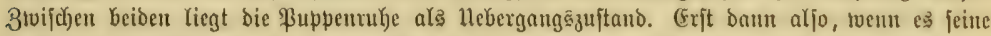

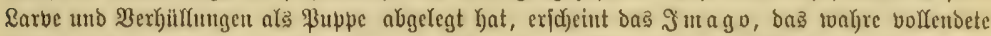

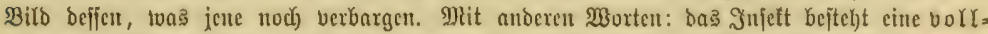

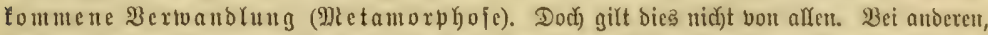

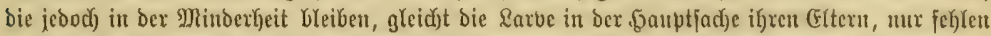

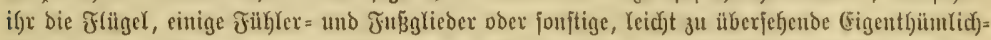

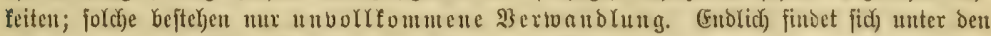

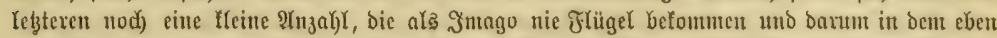

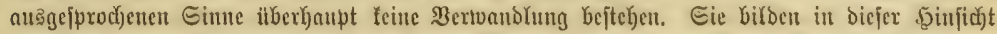

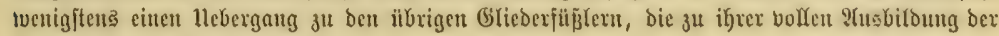
Bertwandlung gar nicht beblirfen.

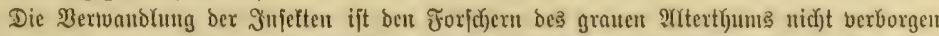

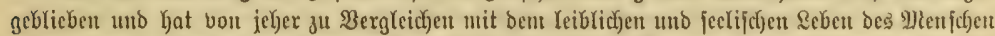

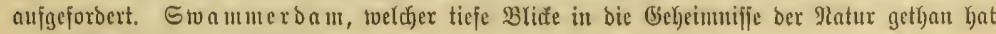

Urebmo zhiericben. 2. शuflage. Ix. 


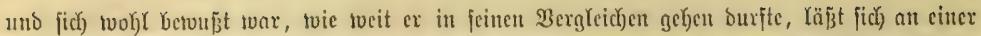

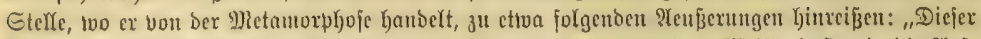

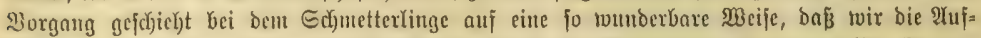

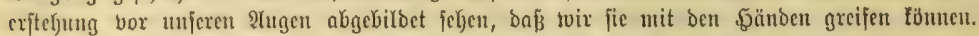

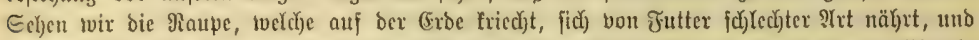

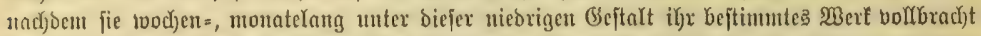

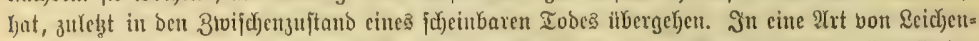

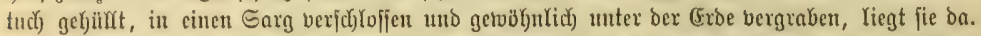

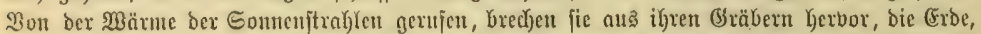

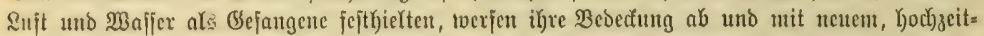

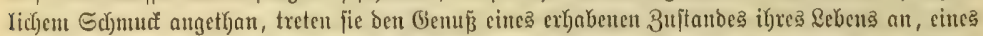

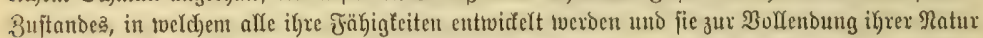

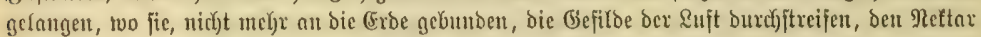

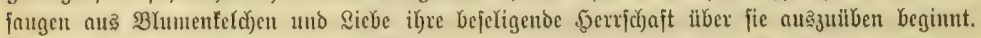

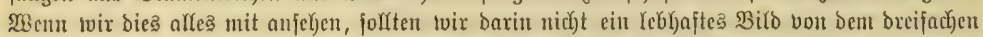

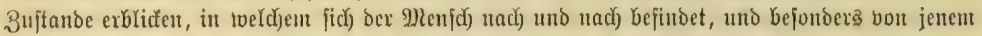

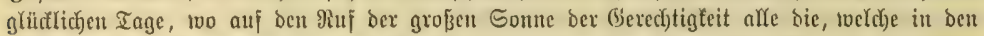

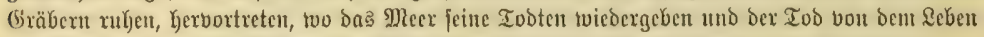

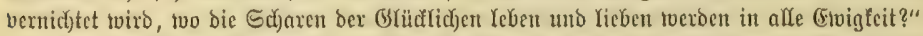

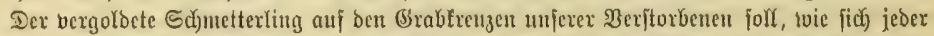

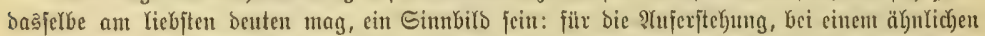

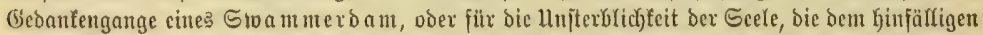

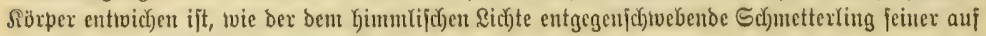

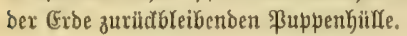

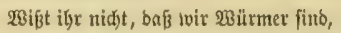

(3eboren, um ben engelăbuliç)en Sđ̆metterling gu bitben?

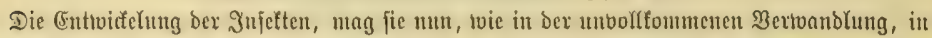

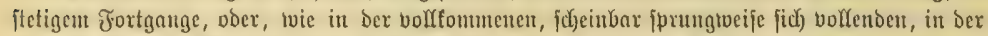

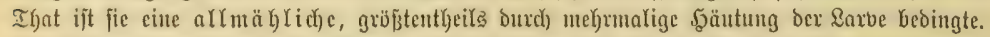

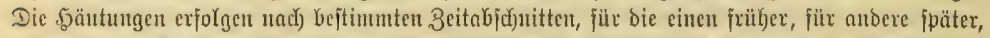

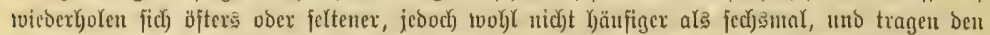

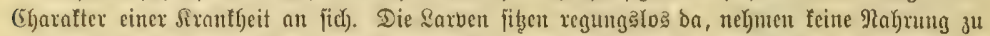

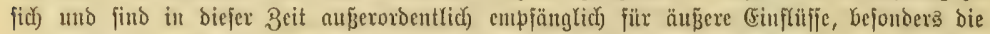

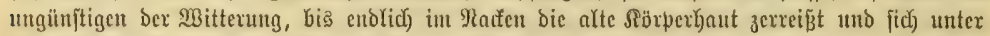

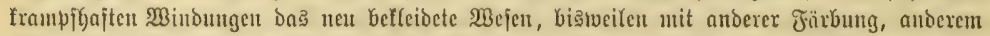

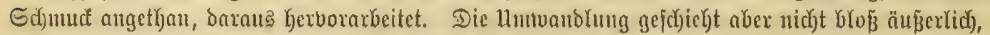

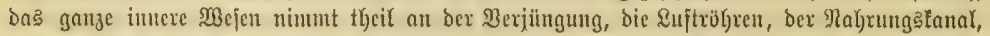

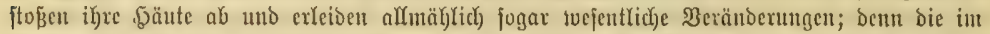

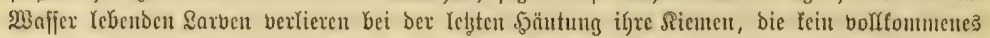

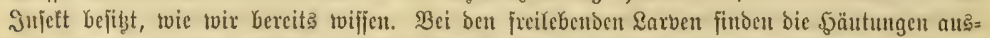

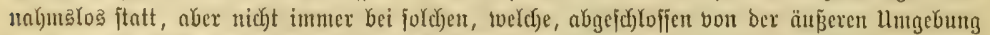

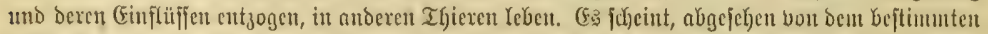

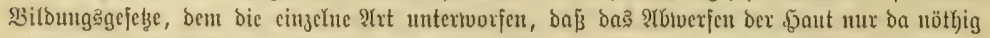

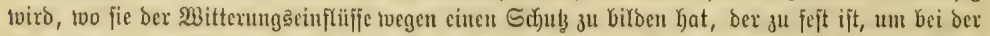

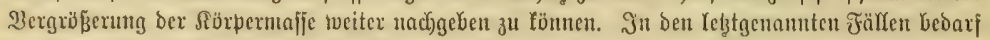

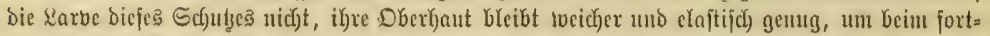

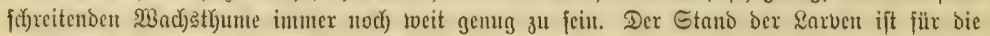

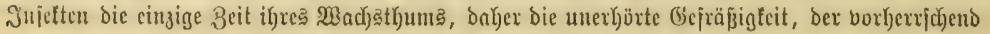




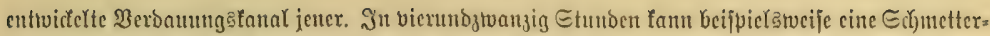

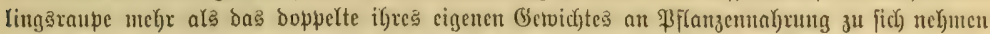

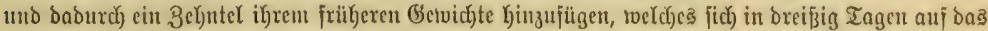

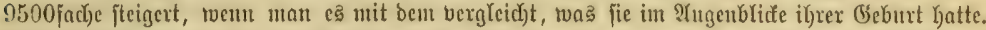

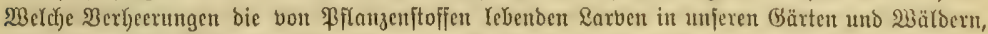

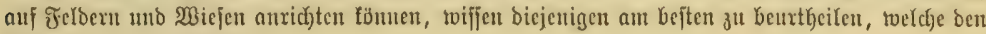
Edjaben zut tragen Gatten.

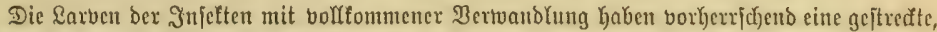

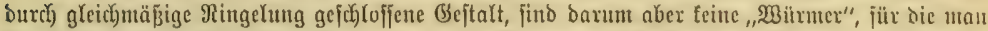

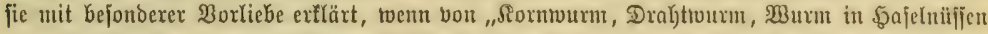

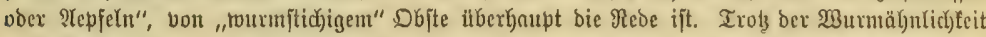

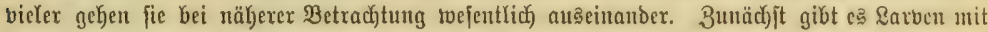
Beincn und Latben ohne Beine. Die exjten zeigen bann regelmtäpig an ben brei crjten, auf ben

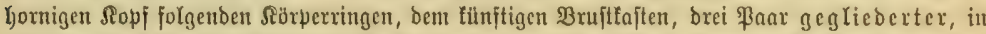

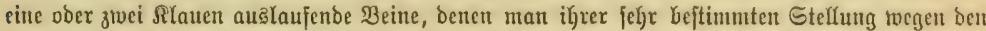

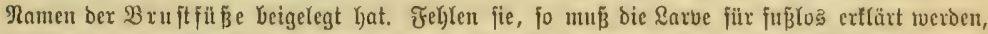
jelbjt Damu, toen wargige f̧erborragungen bie Stelfe jener vertreten follten. शtu[̧er den Brujt=

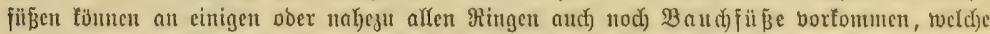

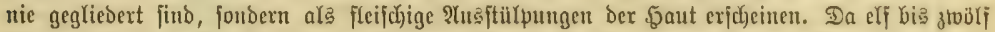

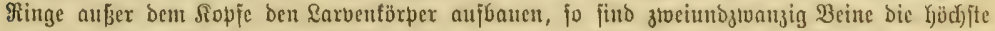

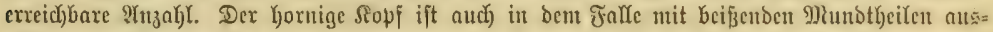

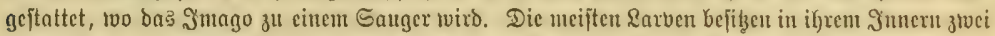

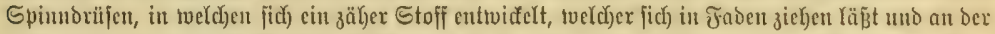

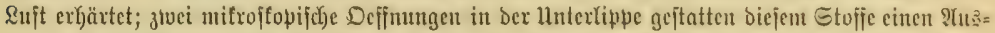

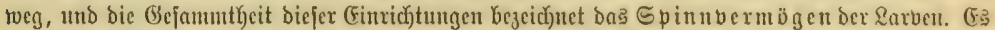

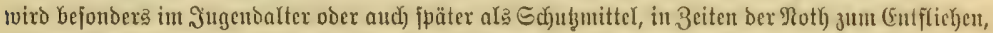

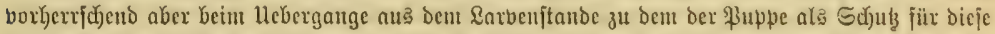

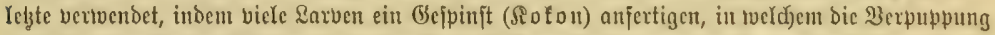

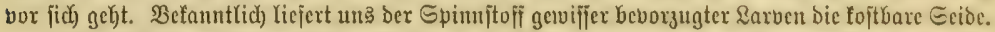

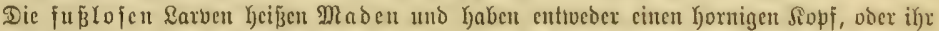

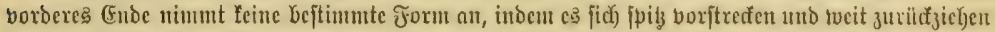

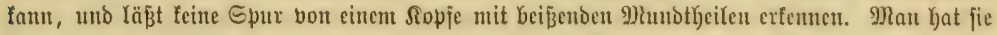

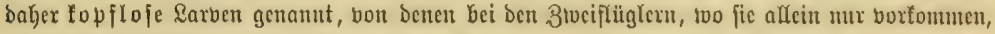
eingehender bericktet twerden joll.

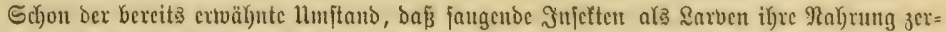

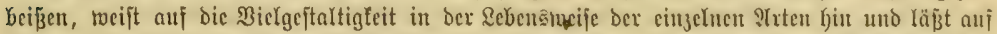

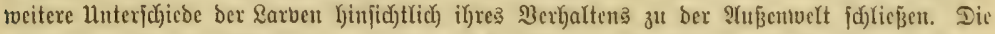
cinen leben jrei auf Pflanzen und zeiduen fid nicht jeften burd) bunte Farben ober alferlyano

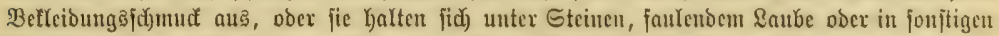

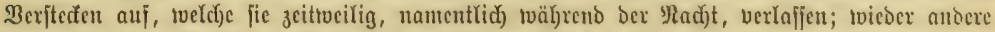

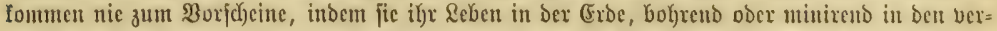

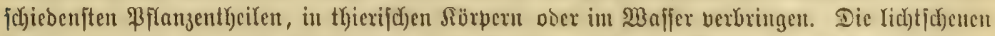

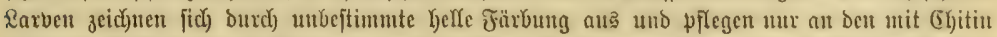

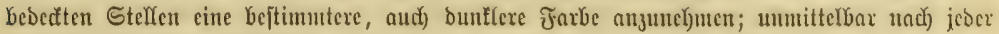
foüutung find fie an bleich)ftrm.

Benn bemmach) bie Larve als bas in ber (Entwidelumg begriffene nod) unreife Jujett

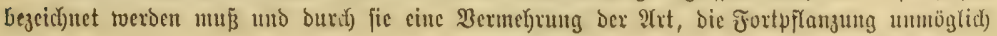




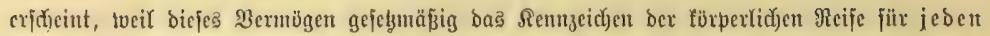

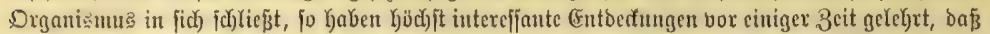

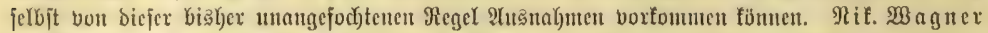

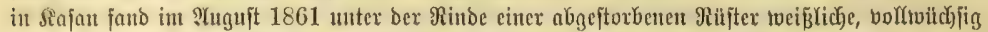

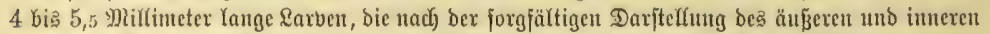

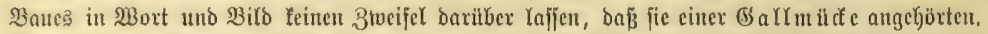

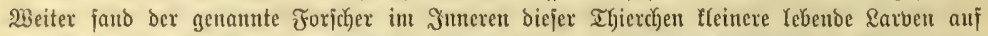

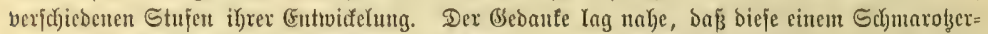

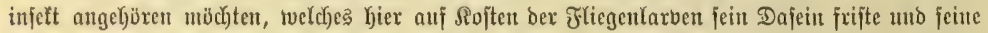

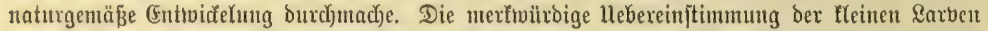

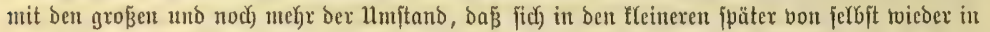

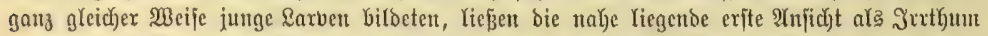

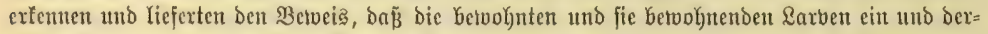

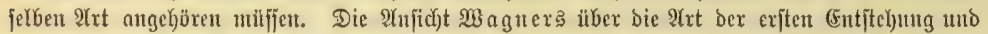

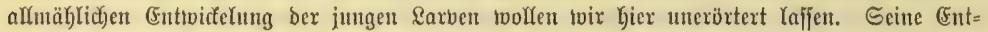

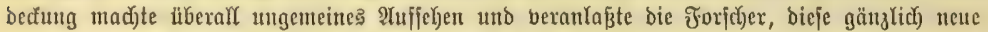

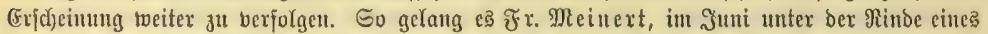

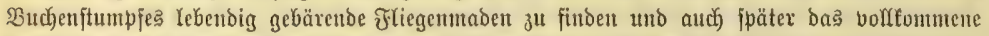

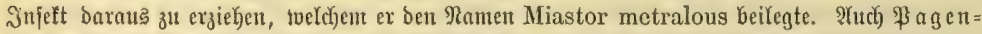

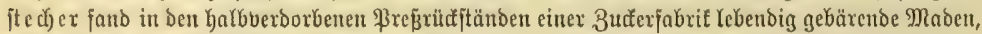

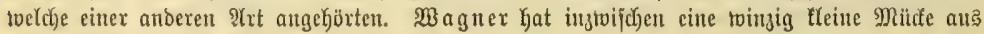
jeinen Rarben exzogent.

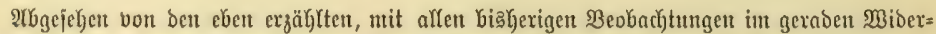

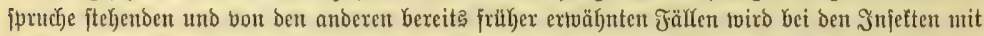

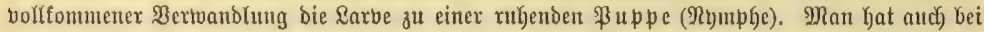

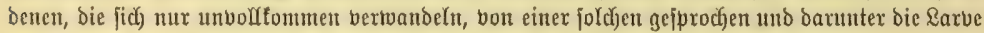

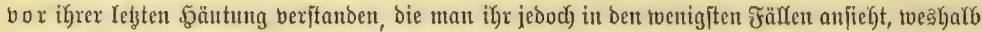

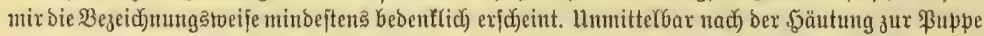

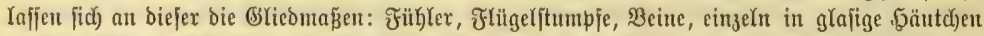

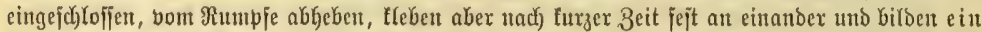

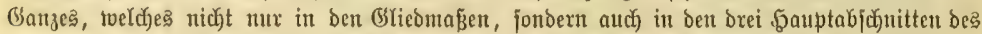

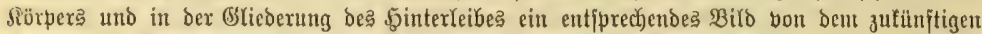

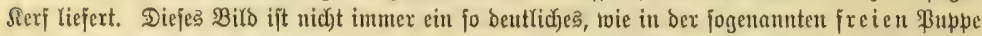

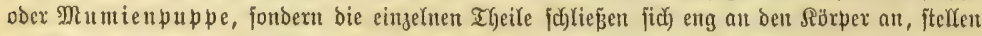

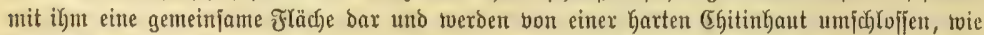

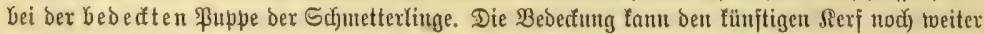

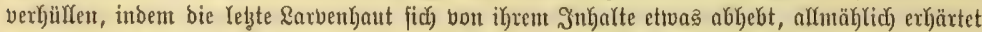

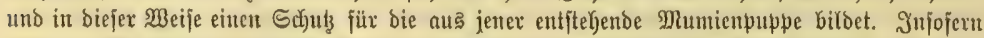

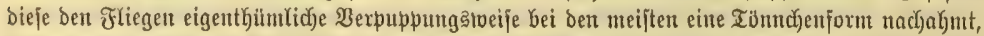

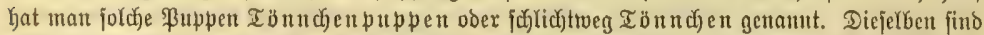

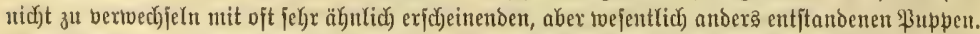

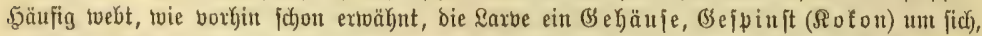

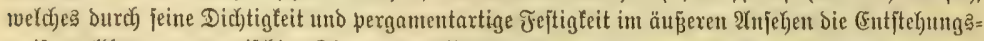

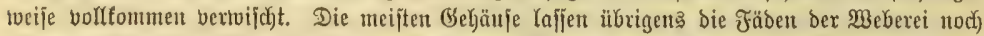

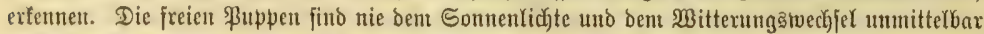
preis gegeben, fondern in ber Erbe, unter Rnub, Rinde, in Inneren anderer Sïrper verborgen.

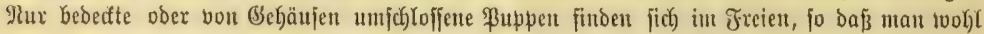




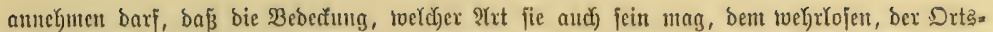

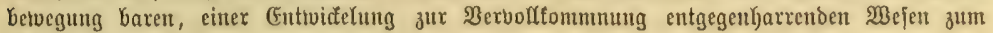
Schube biene.

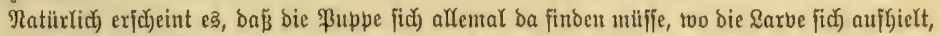

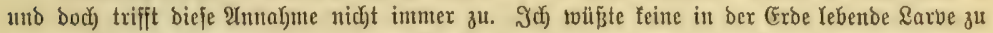
nennen, bie zur Bexpuppung ausె Dexjelben Kerausginge, genug bagegen, bie auj Brättern, in

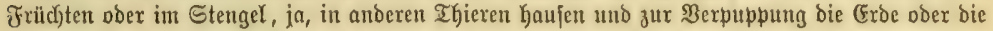

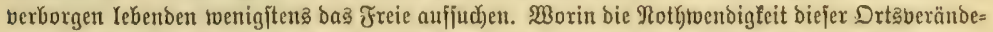

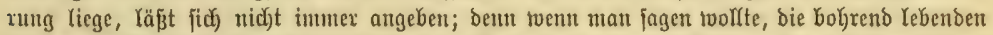

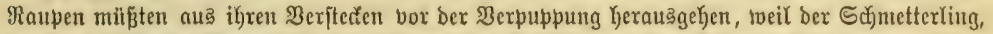

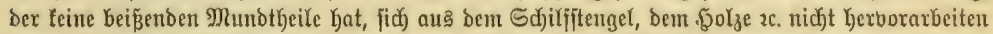

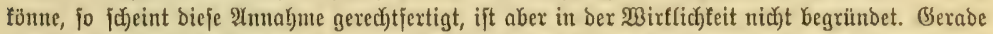

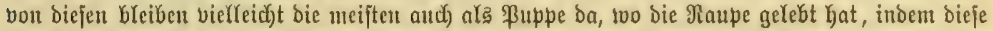

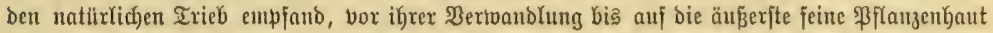

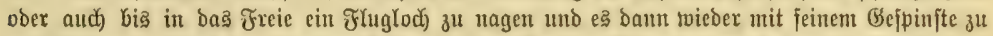

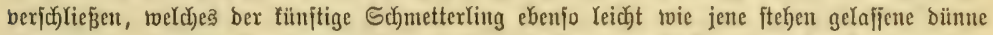

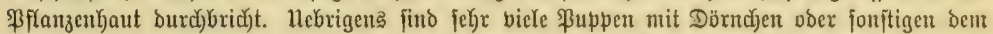
Thuge toenig bemerfbaren (Finrichtungen berfeken, mit benten fie an ihrer llmgebung Kaften, um

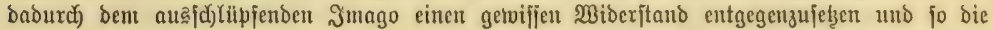

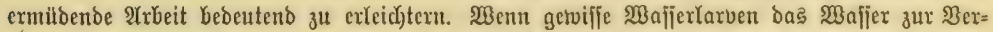

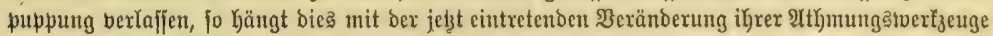

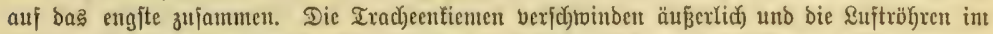

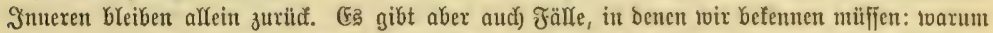

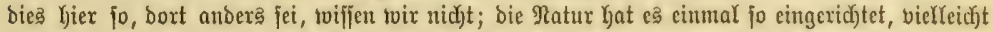

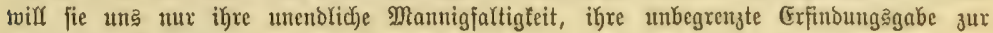
Injodjaung bringen.

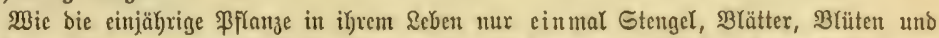

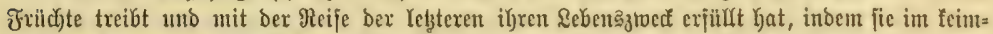

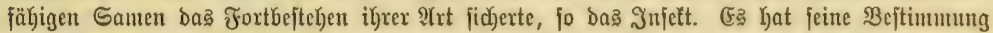

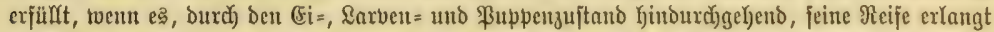

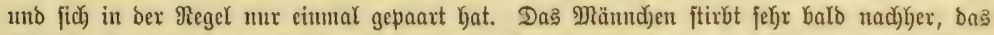

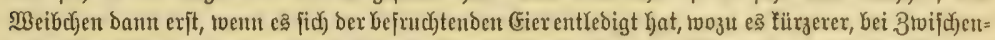

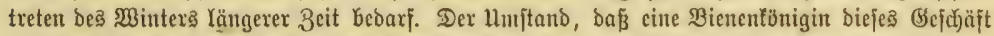

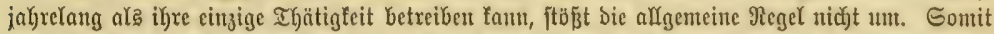

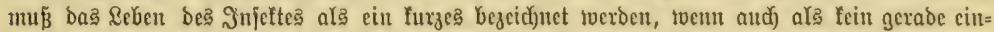

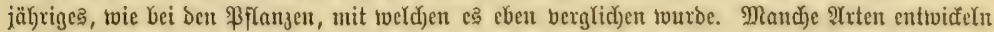

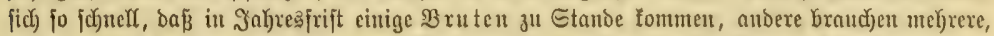

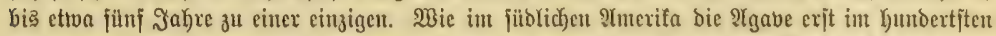

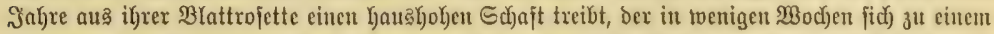

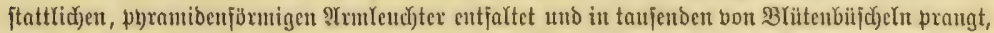

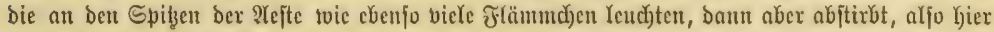

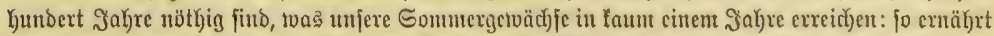

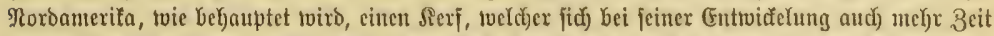

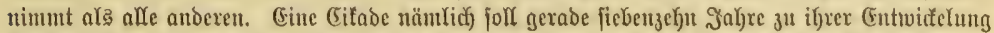

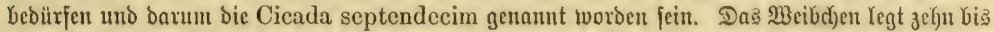

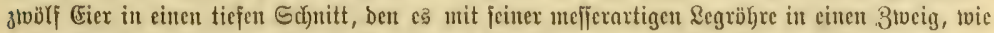

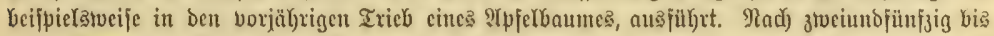

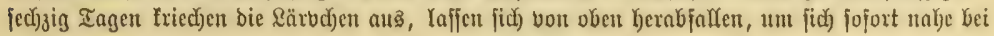




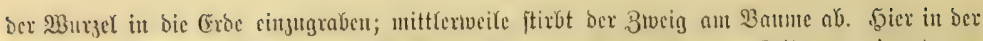

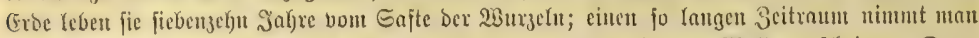

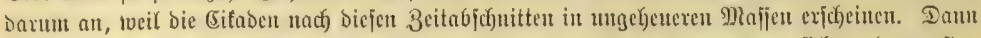

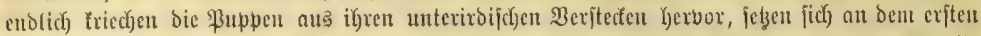

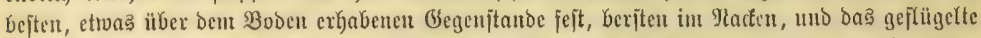

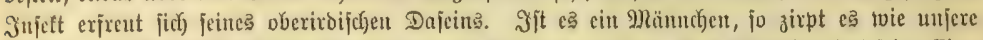

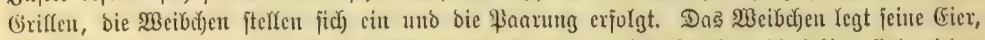

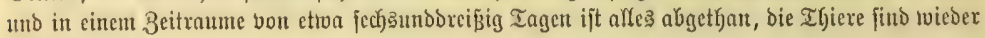
verichtountoen.

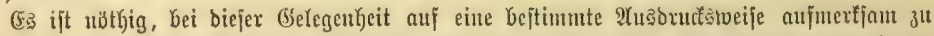

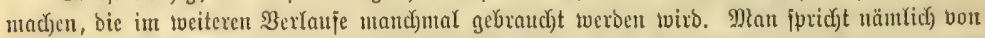

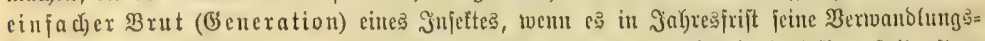

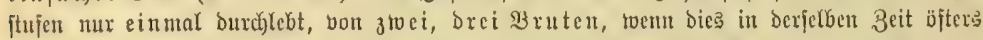

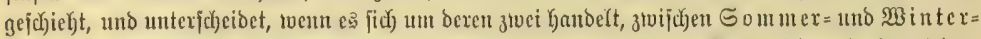

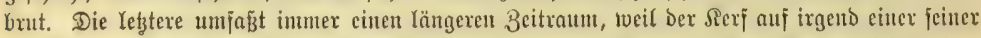

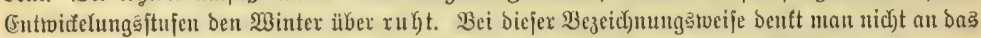

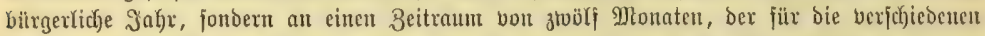

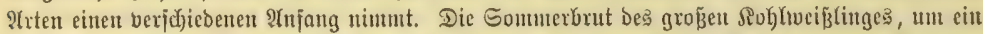

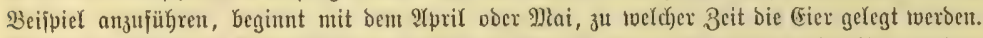

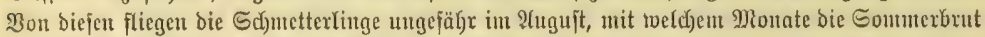

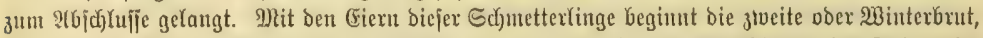

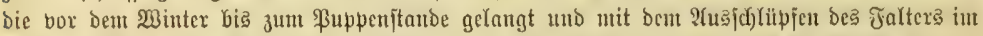

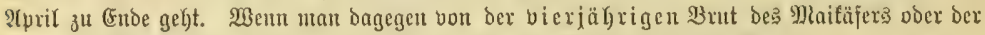
jiebenzeryjährigen jener (Sitabe jprid)t, jo legt man bie Salenderjafye zu Grunto.

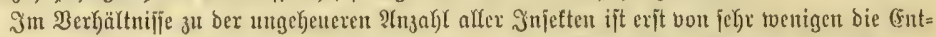

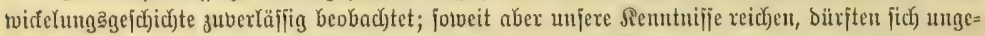

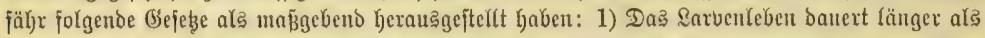

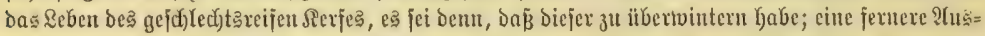

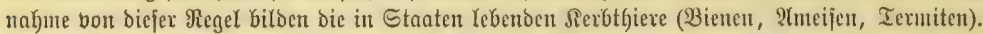
2) Die bohrenben ober unterirbijd)en Rarven braudyen längere Beit zu ifrer (Entividefung ala bie

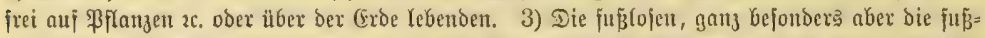

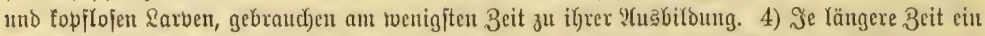

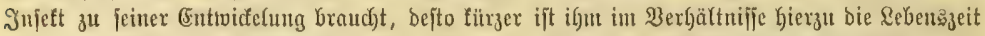

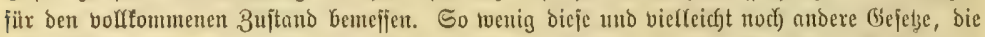

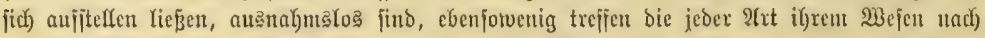

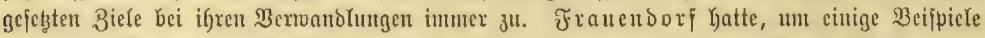

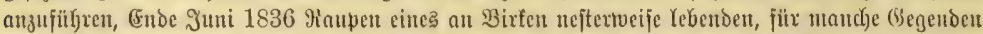

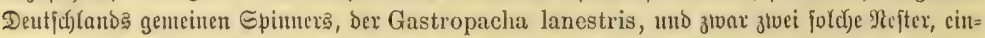

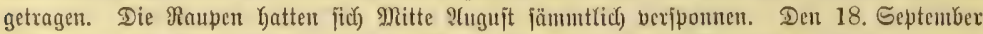

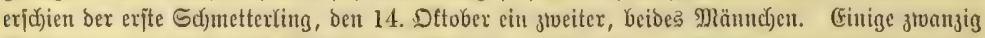

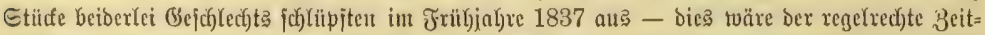

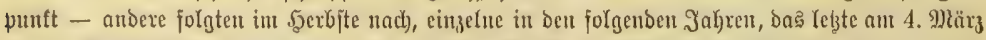

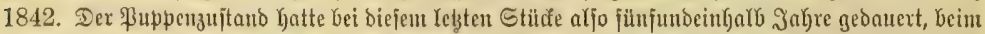

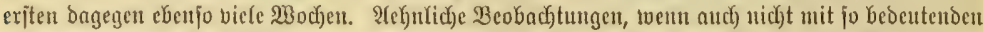

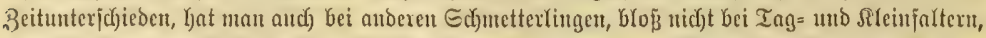
gemacht. In einem Faffe, wef(c) Qarven einer genteinen ग)

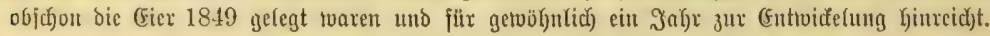




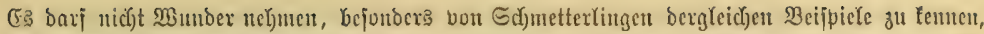

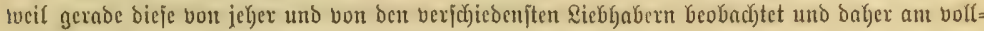

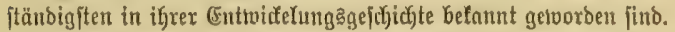

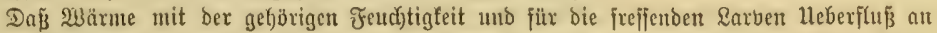

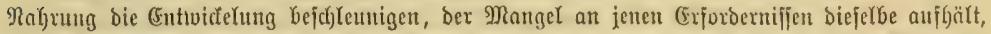

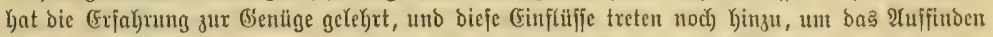

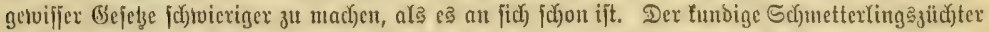

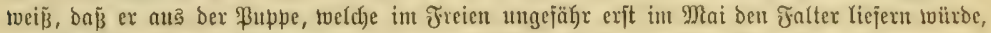

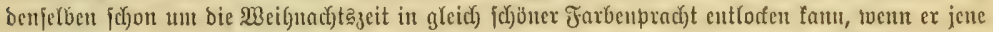

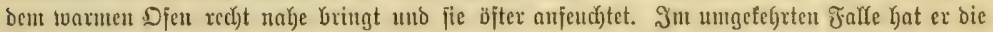

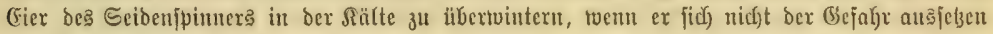

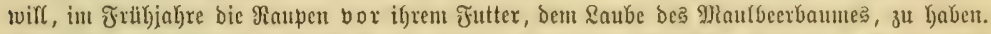

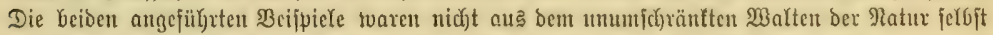

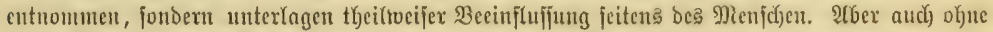

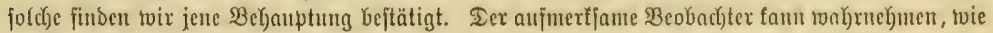

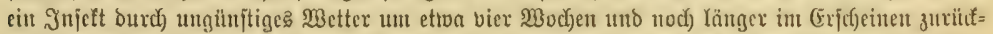

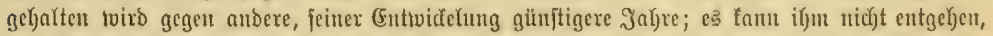

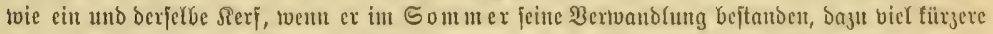

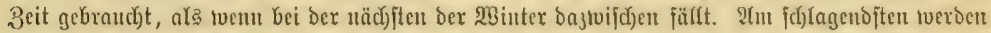

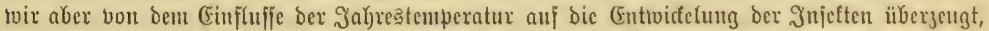

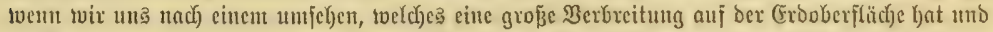

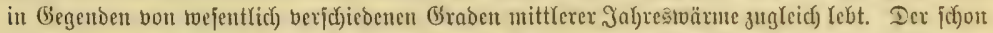

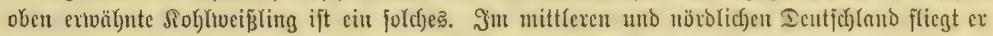

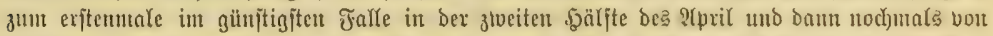

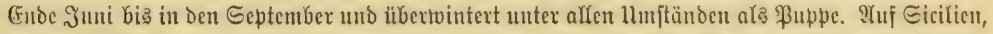

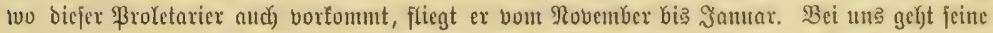

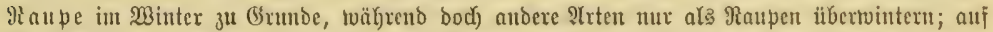
Sicilien tam fie bie SRälte bes gelinberen Winters ertragen. Mlan fönnte nun glauben, Daß̧ it

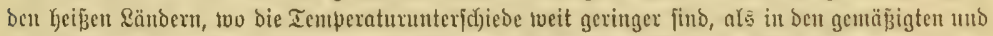

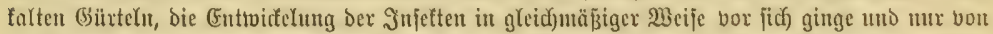

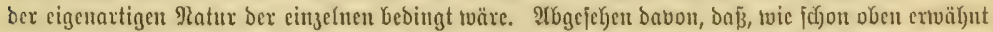

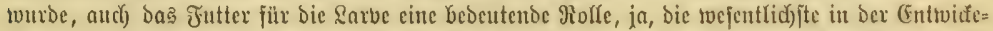

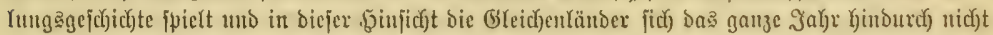

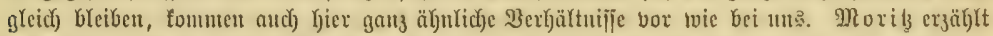

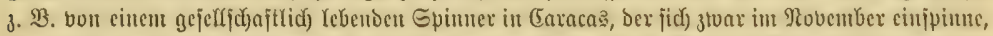

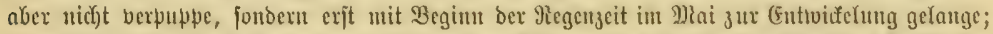

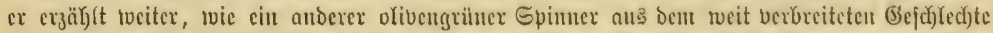

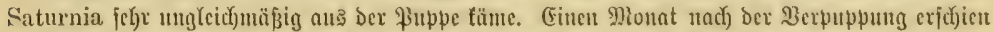

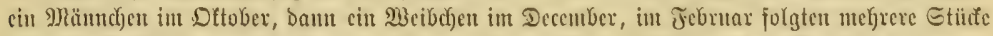

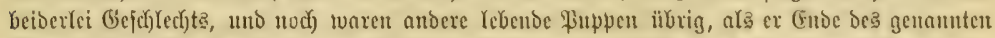

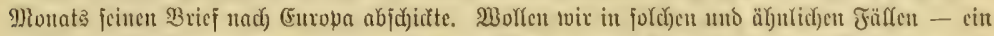

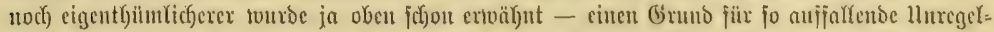

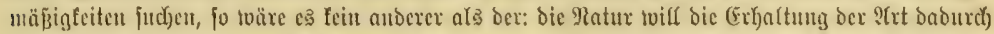

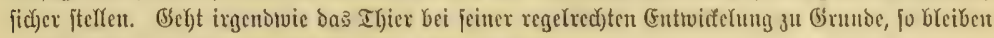
anbere übrig, bie fick bem (bejelse nicht gejügt hatten.

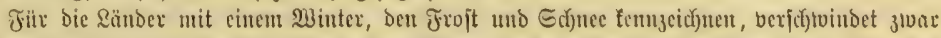

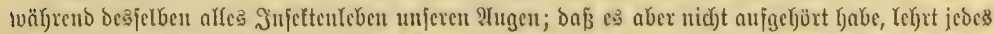

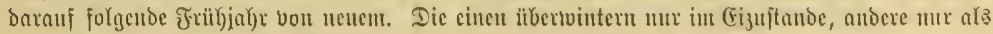




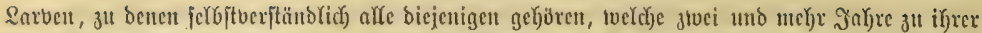

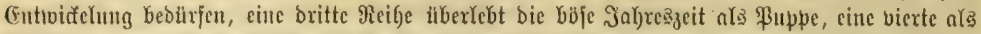

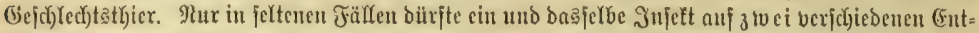

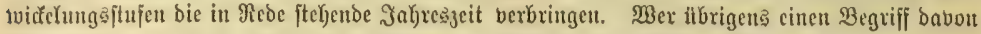

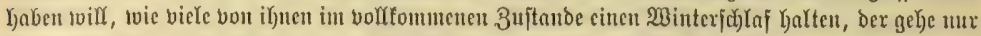

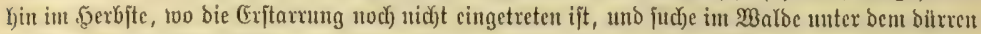

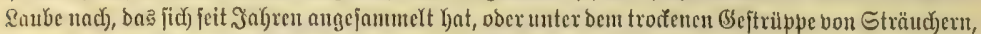

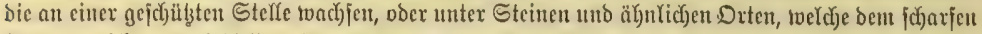

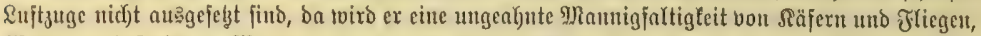

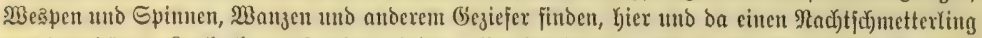

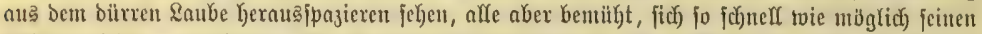

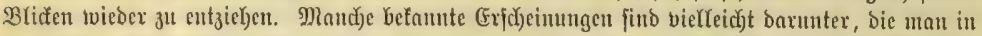

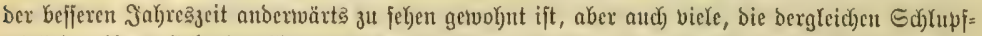

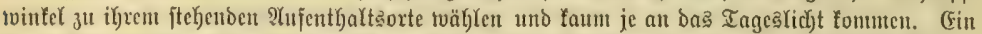

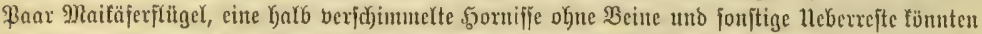

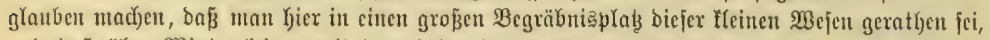
und Daß̧

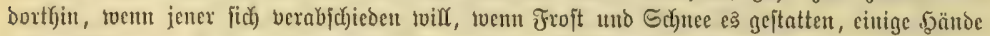

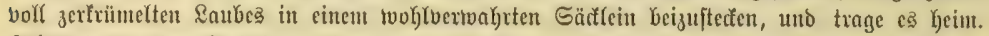
Echüttet man ben Şnfalt, nadjoem ex eitige Stunden in Der warmen Etube gelegen, in cin

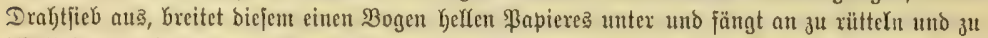

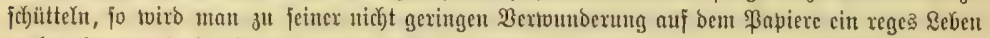

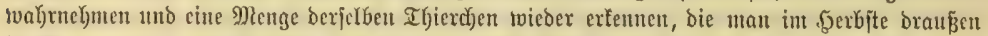

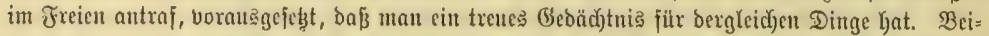

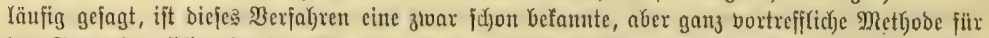
ben Eammler, fich mit einer Renge, bejonbers fleinerer Iffere, zu bereict)ern, bic ex auj bett

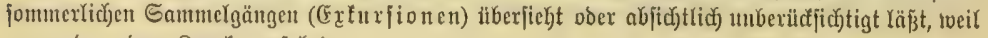
er gerabe andere Bruede berfolgt.

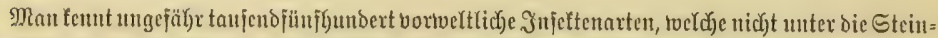

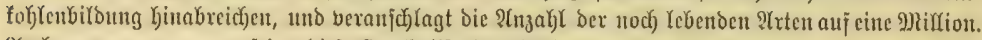

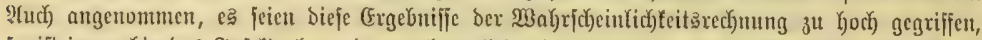

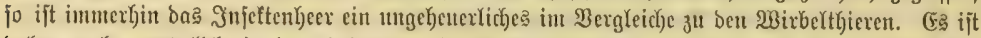

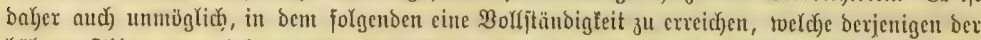

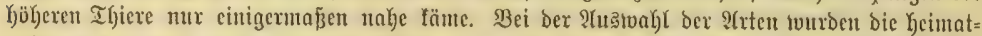

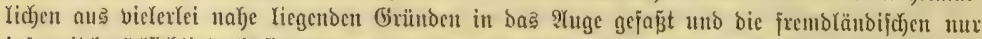

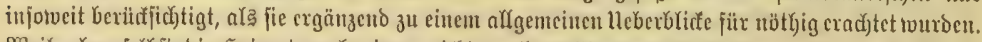
Weil aber jelbjt bie ફeimat noch einen nicht ju belwältigenden Stoff bieten würoe, jo fiel bie

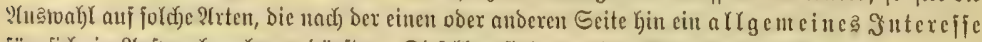

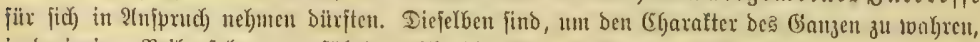
in berjenigen Reikenjolge vorgefüfrt, weldye bic Enjtentatifer in ber Bearbeitung ber cinzelnen Dronungen einzulfalten pillegen. 


\section{Erfte Grounng.}

\section{Die Säfer (Coleoptera, Eleutherata).}

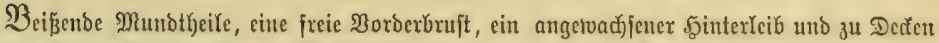

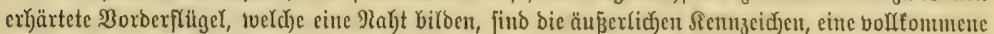

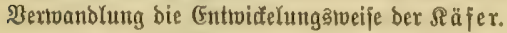

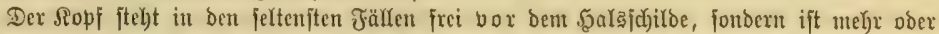

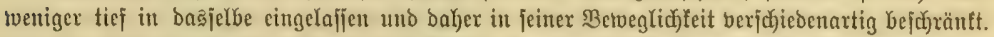
Tư feine Anlyeftungąweife unb auf feine Beftalt, von Der bie Bertängerung der vorberen Gégend

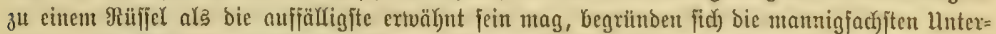

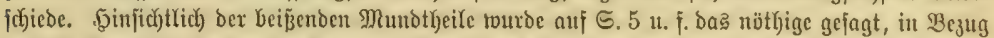

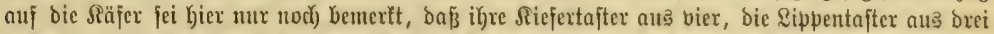

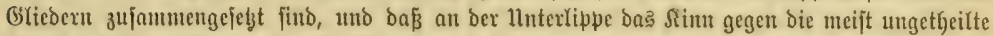

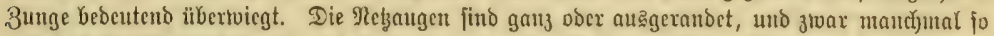

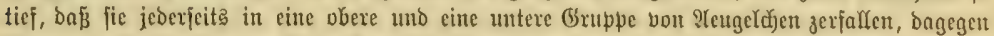

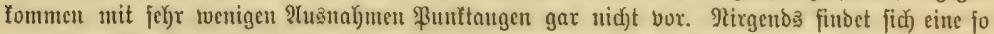

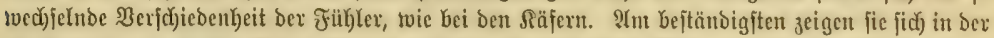

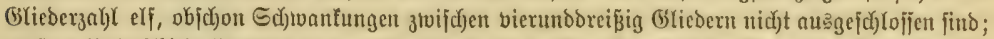

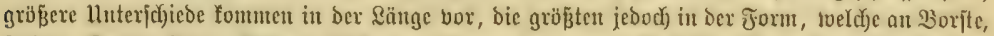

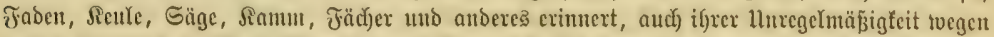

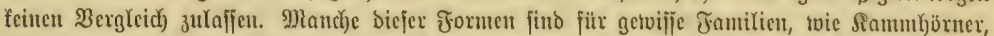

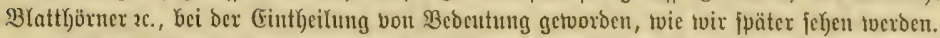

Der freic Borberbruftring gelangt hier, wie bei alfen anderen iffn bejizenden Sierfen, gegen

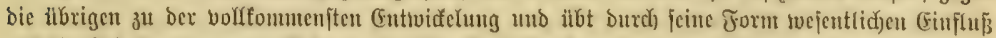

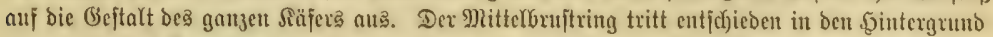

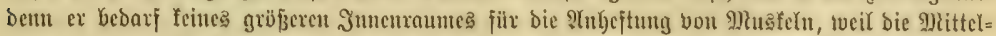

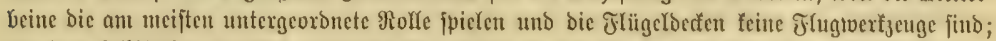

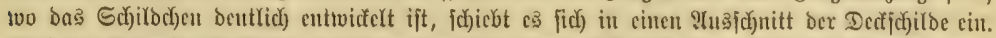

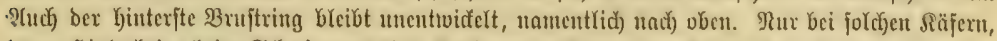

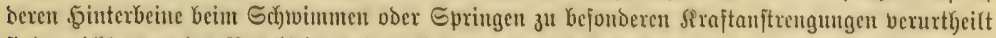

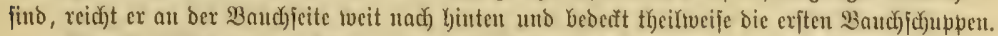

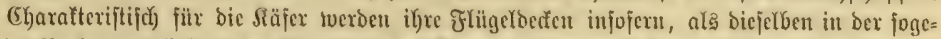

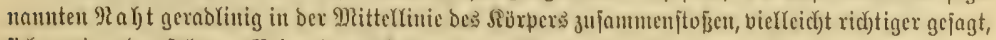

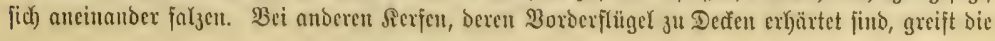




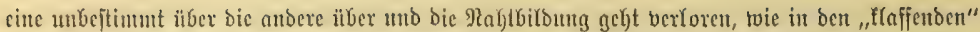

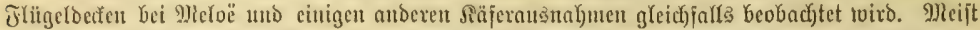

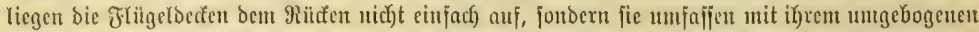

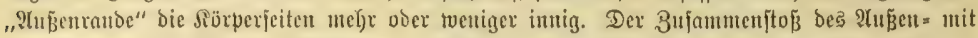

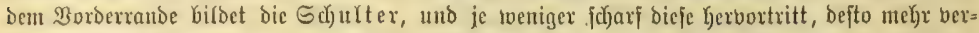

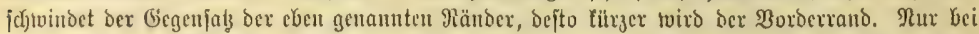

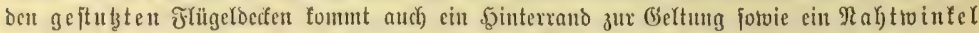

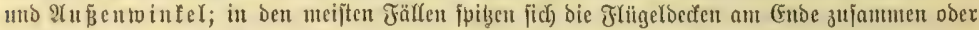

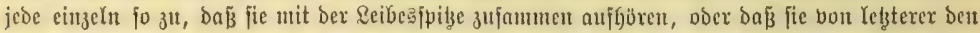

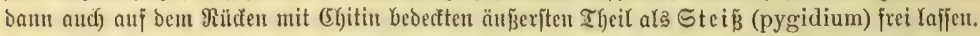

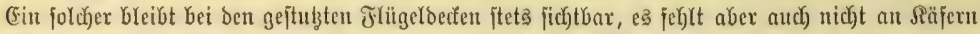

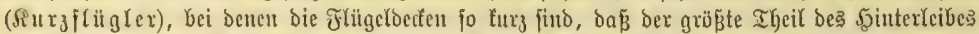

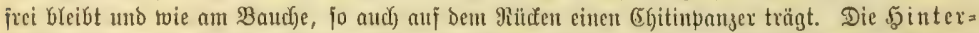

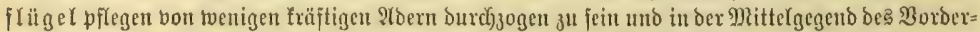

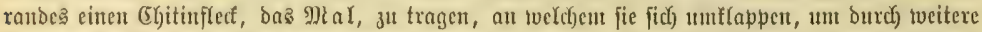

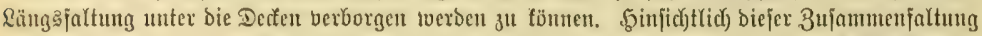

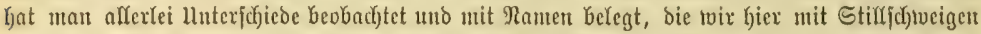

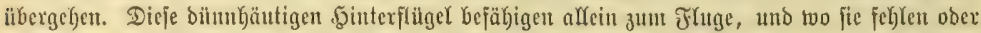

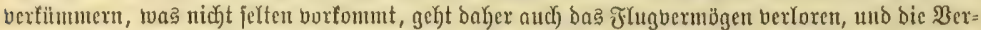

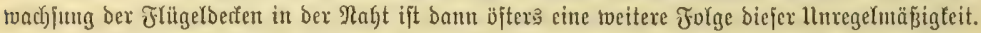

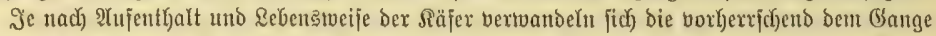

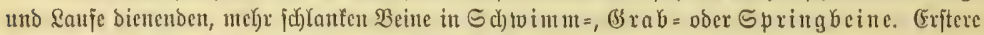

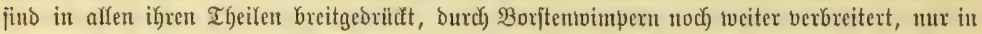

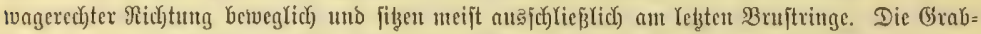

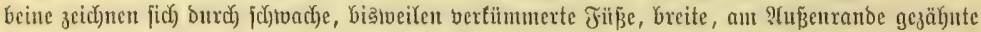

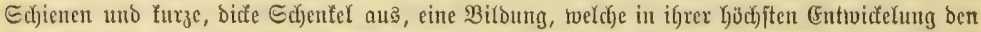

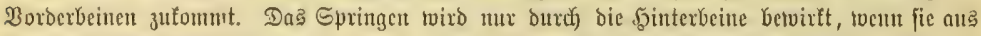

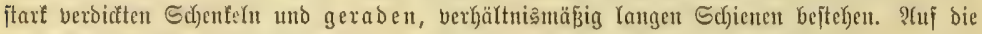

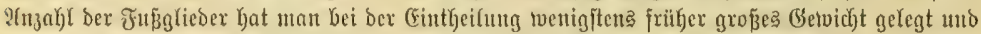

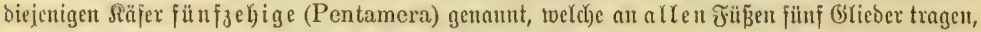

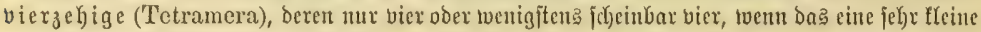

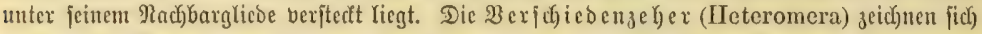

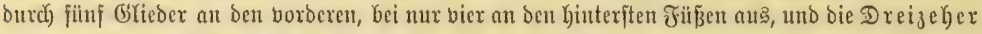

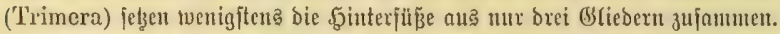

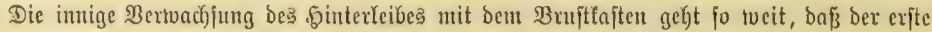

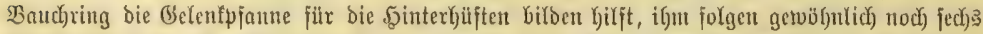

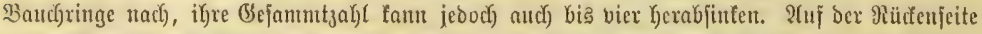

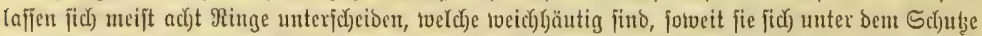

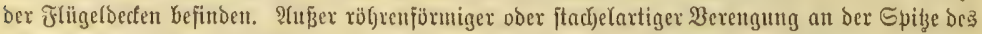

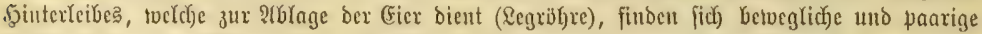

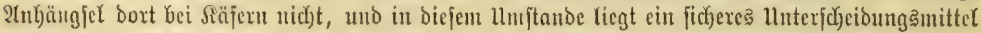

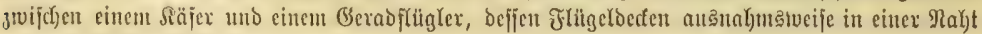

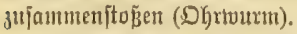

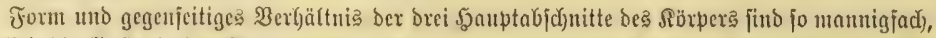

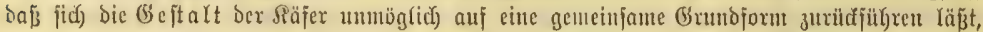

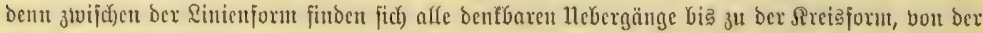

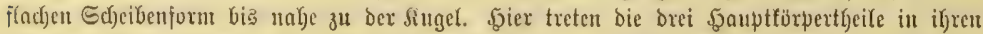

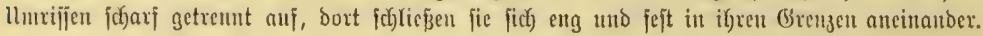




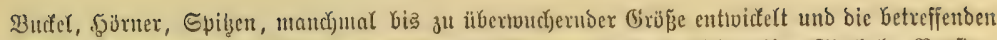

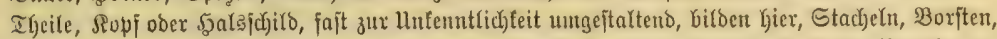

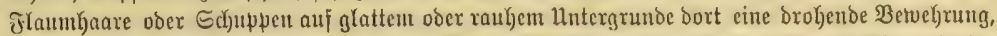

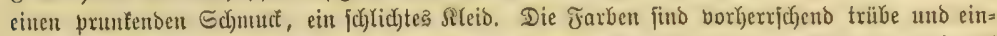

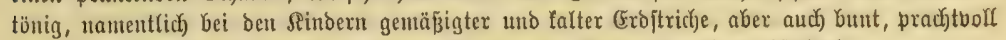

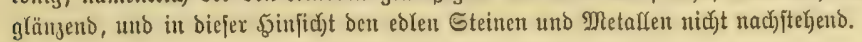

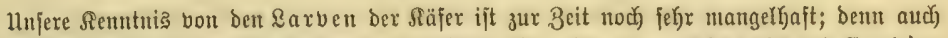
angenomunen, baj̃ zu ben ject)

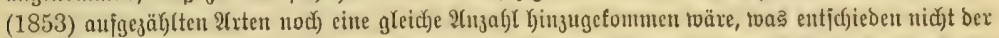

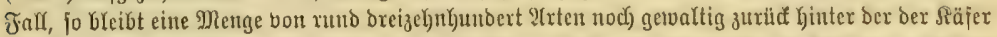

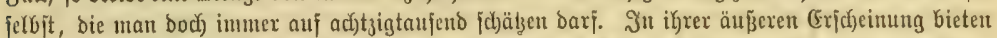

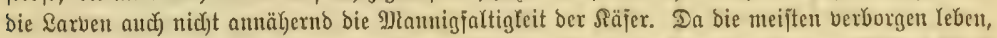

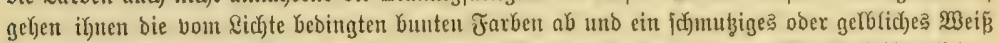

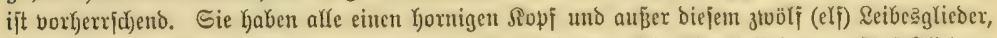

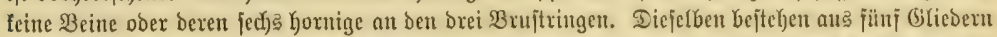
unb endigen in eine, bei cinigen Familien in zlvei uno in einzelnen Fäffen in brei Sirallett. Der

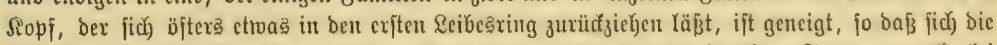

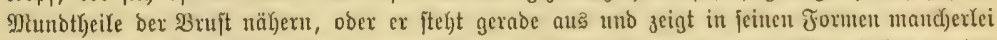

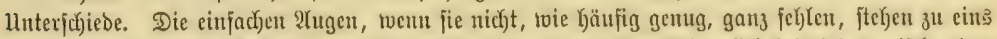

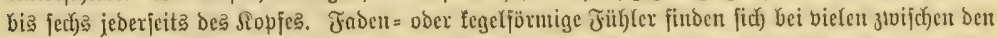

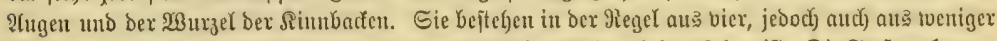

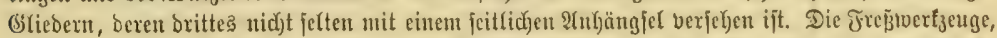

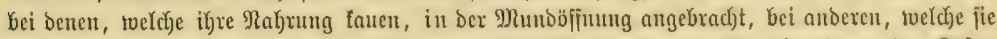

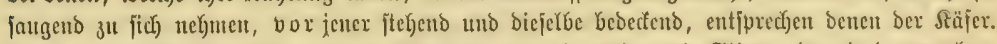

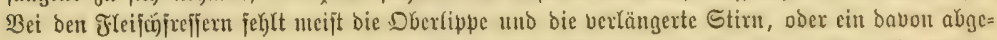

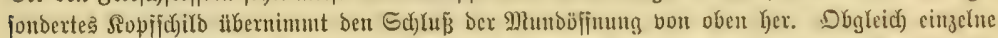

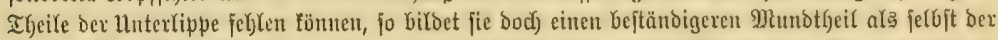

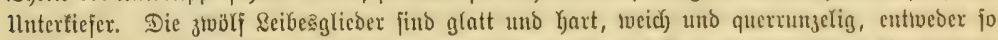

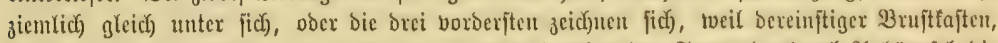

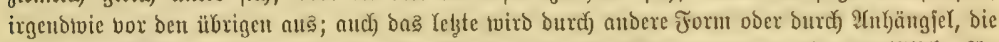

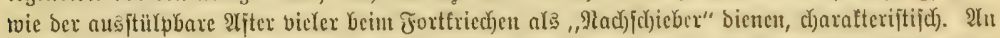

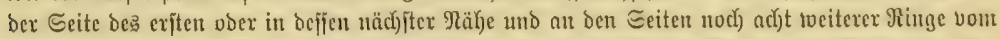
vierten ab liegen bei ben ztwäljpingeligen Sïferlarben bie Ruftlöd)er; bei ben un elf̈gliebrigen ber

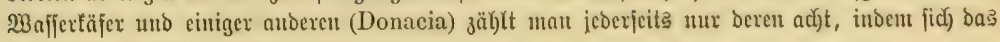
neunte mit ber Reibesppitze vereinight.

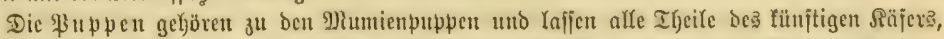

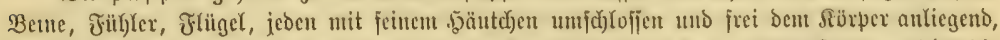

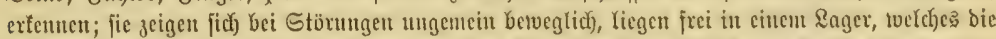

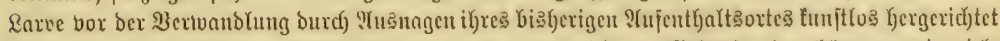

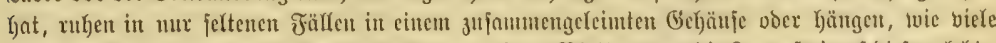

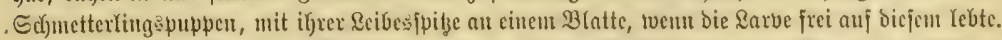

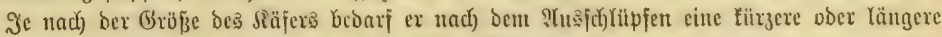

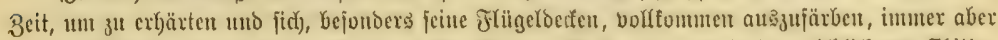

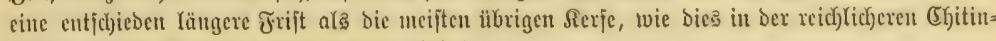

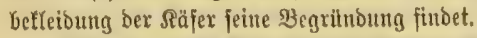

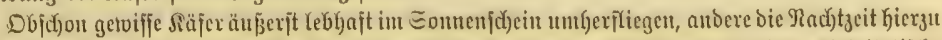

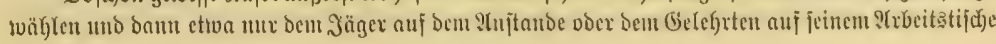




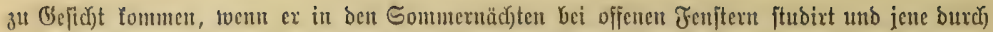

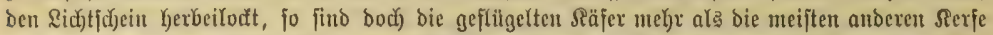
an Den Boben oder bie ign Gebectenden Pflauzen gebunben, leben Gier geräujchlos und verftectt,

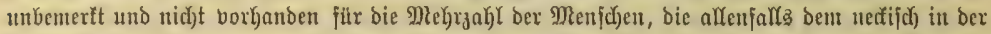

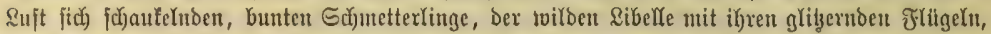

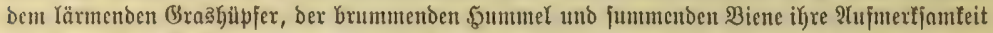

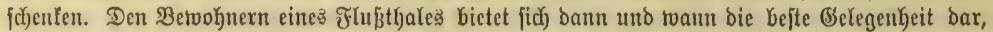

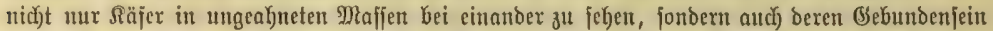

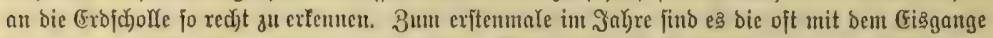

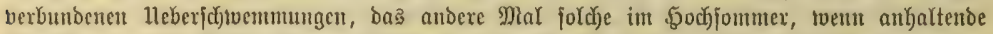

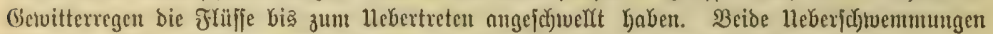

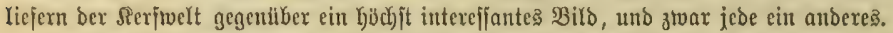

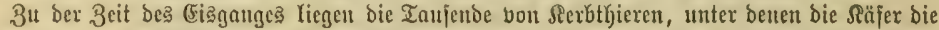

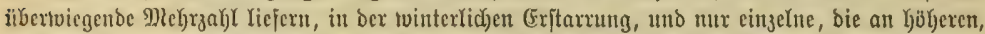

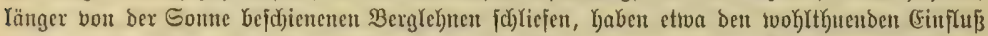
bon beren Strablen empfunben uno fangen an, ihre (Śliedmaß̌en zu recten. Da fommen bie falten

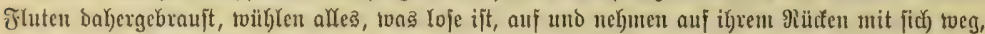

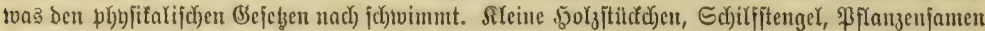

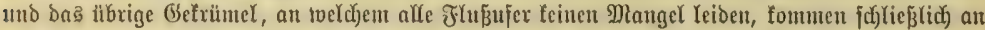

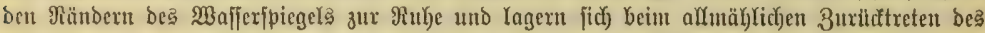

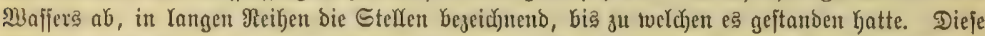
Iblngerungen find bie rebenben 3eugeu von bem, twaß auf bem überfluteten 30 ben gelegen hat,

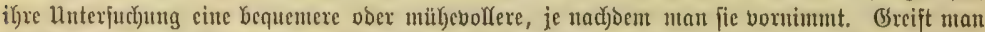

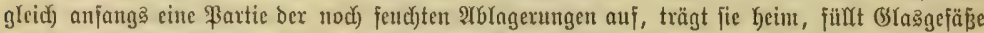

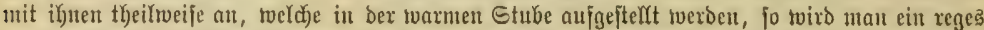

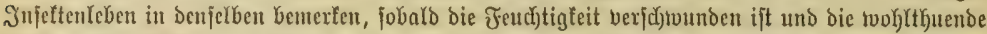

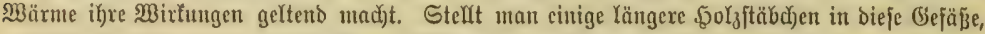

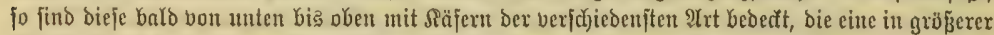

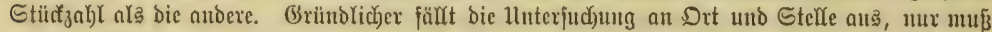

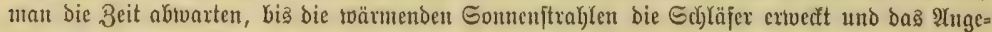

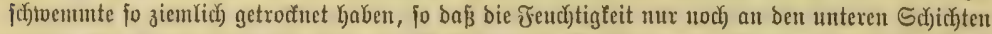

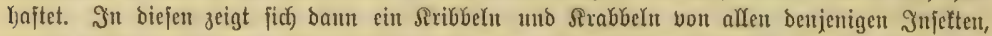

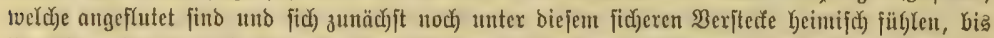

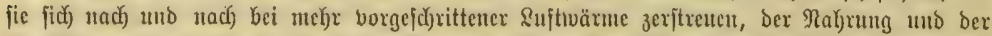

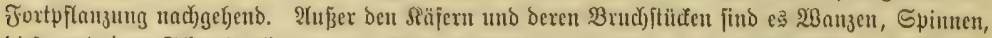

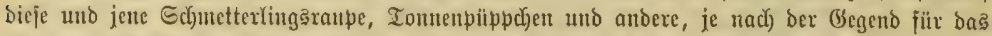

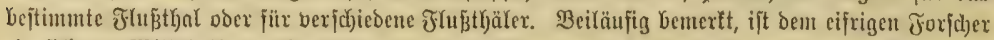
cin fid)eres झRittel Yjerdurch) geboten, bie in boffomuenem Bujtande übervinternden fiajerarten feiner Begeno fennen 子u Yernen.

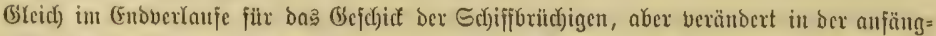

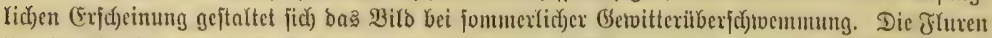

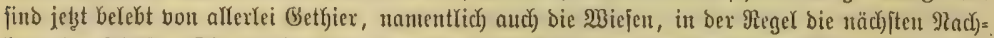

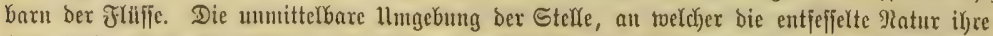

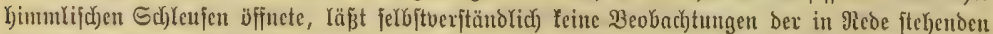

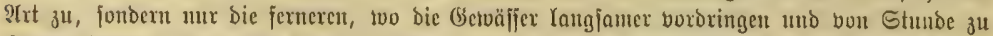

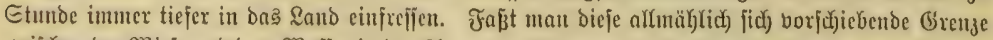

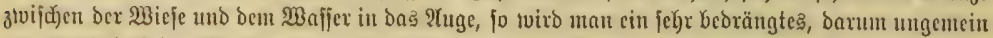

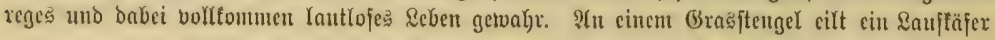





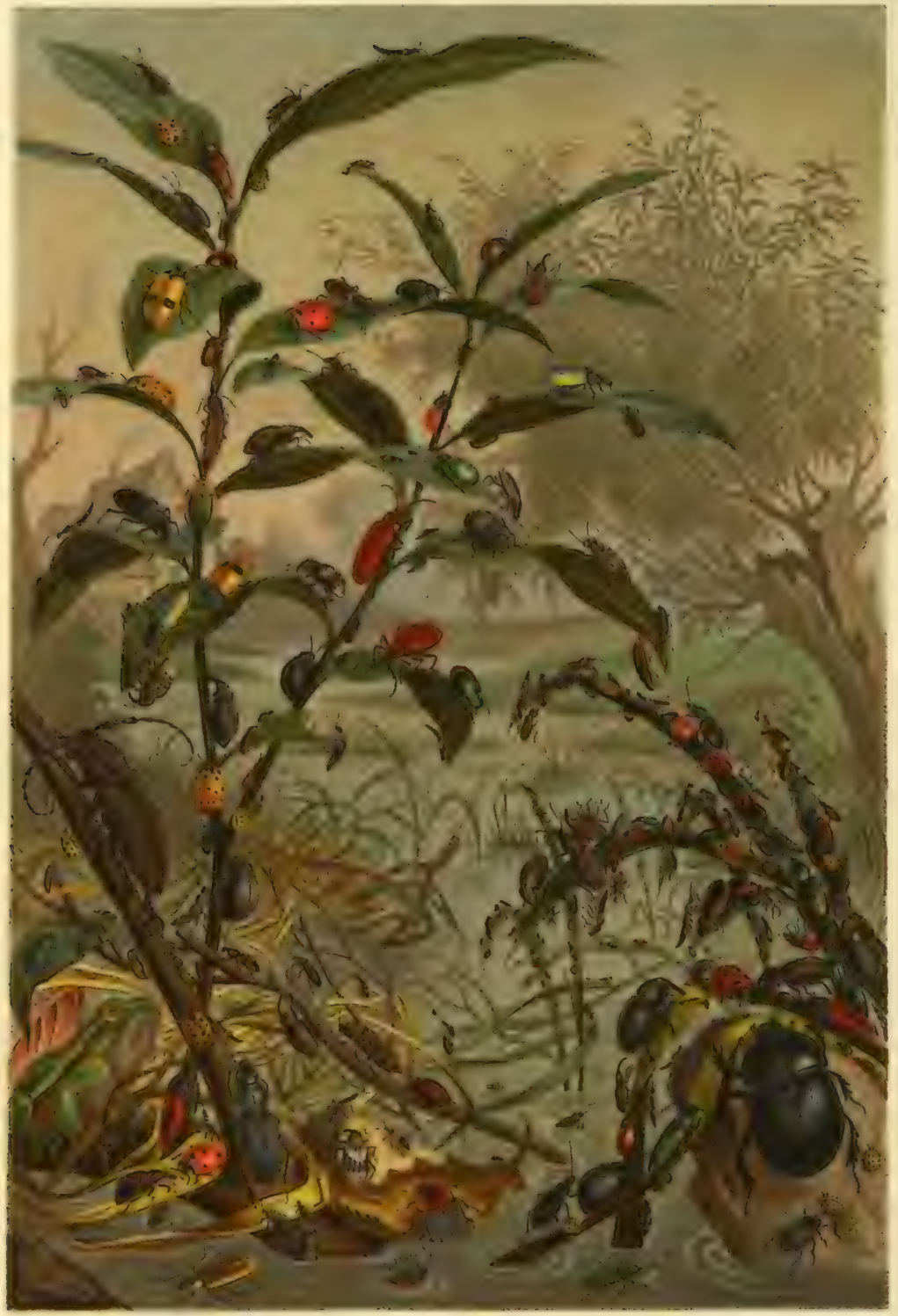




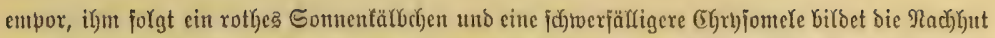

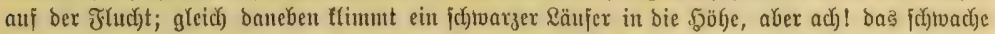

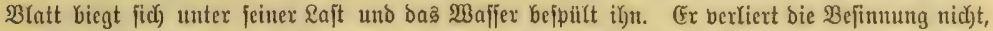

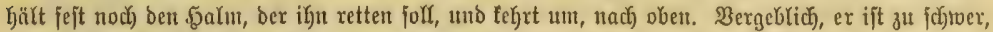

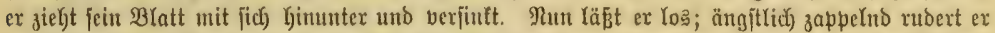

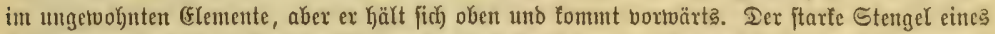

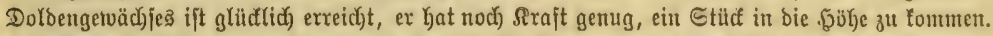

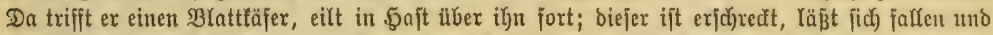

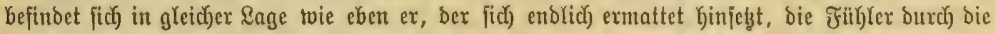

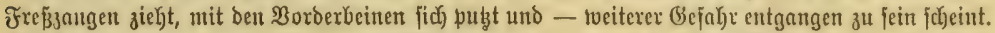

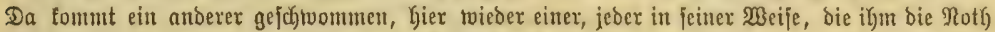

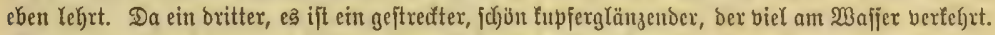
Wie erjtarrt ftrečt biejer Sdjilffäfer feine fech) Beine von fid), bie Jüt)(er gerade vor und läß̄t

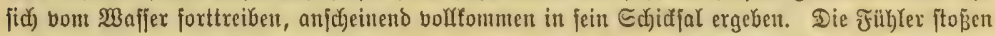

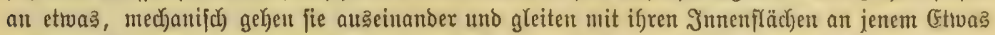

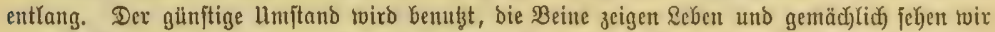

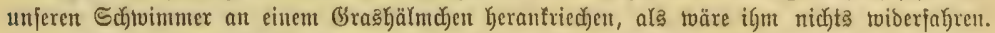

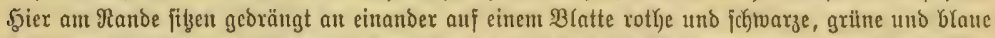

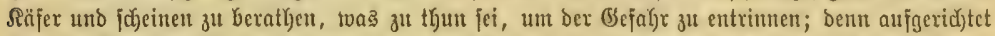

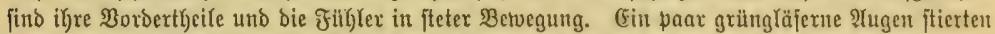

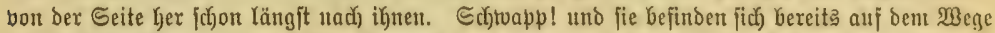

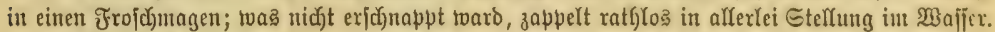

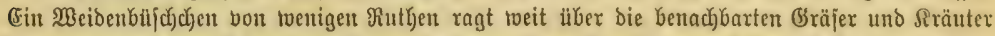

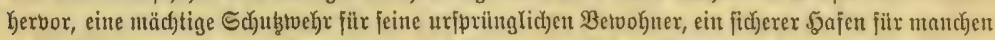
Edjiffbrïchigen. Darum ift es aber aud belebt von jeglidjent Bolfe. Rubig fneift ber fdylanfe

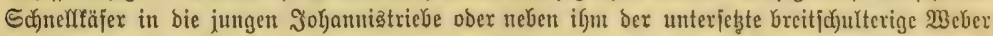

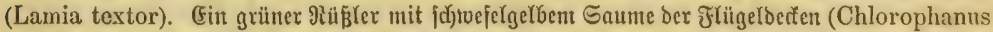
viridis), fein Diäund)

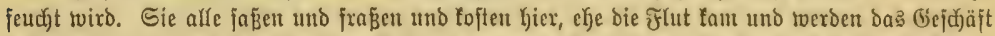

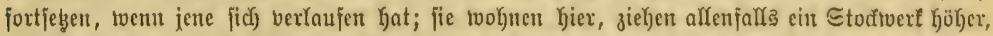

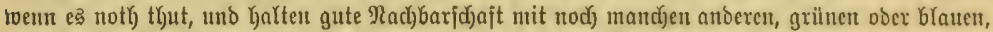

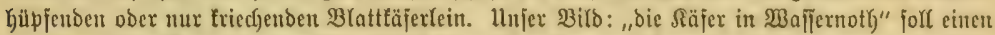

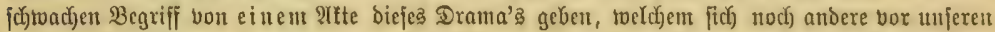

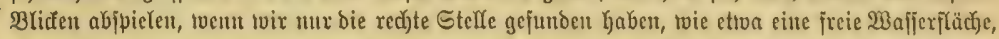

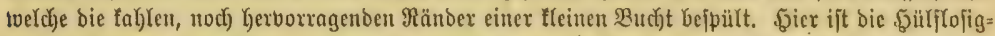

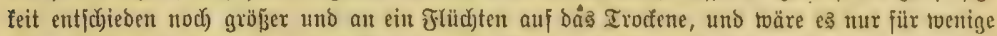

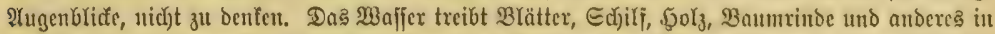

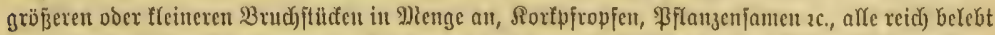

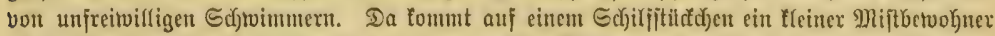

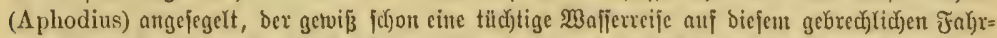

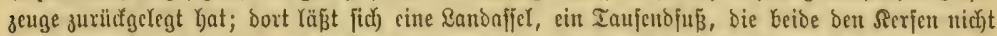

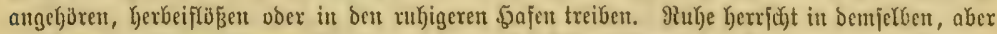

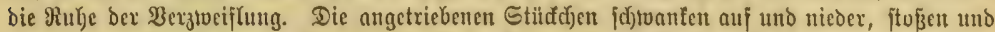

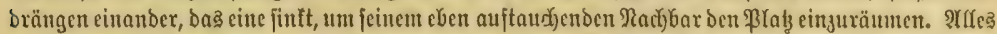

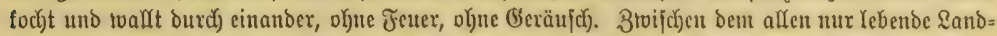

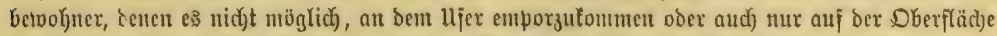

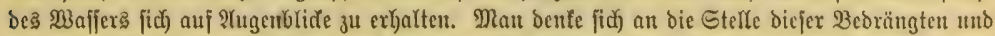

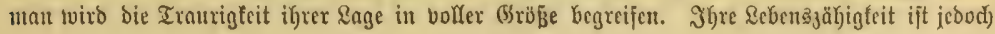




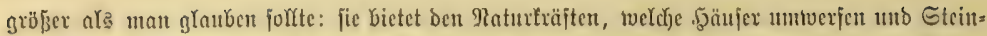

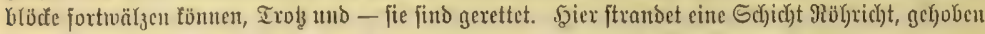

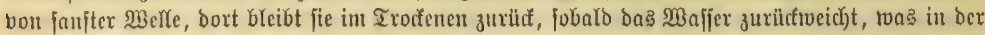

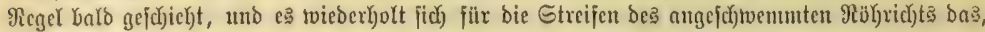

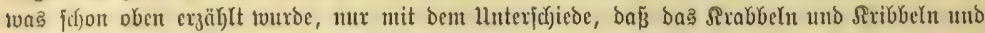

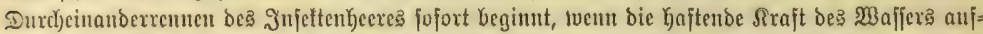
gełjört hat. Menn man aber zu biejem Beitpuntte bie Schar ber (Seretteten mujtert, mu[ man fick

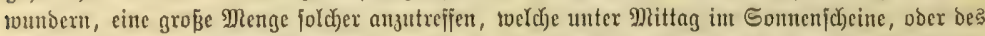

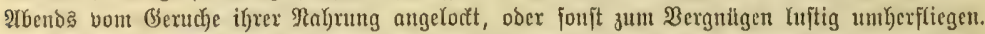

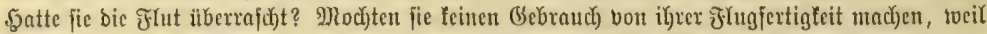

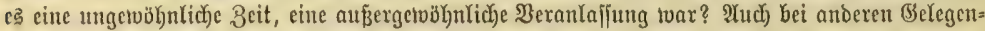

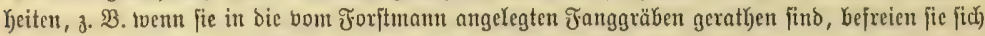

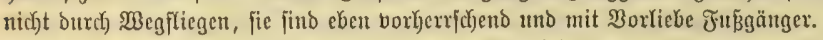

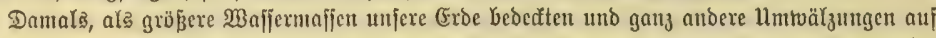

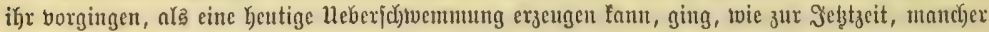
Säjer zu (5runde, ber nad) und nad), aber in foffilex Form, Den Forjd)ern wieber 3 (Befidjt getommen ift. Mant fent jebst gegen taufend 2 rten; fie beginten im Steinfoh) (engebirge, mefren

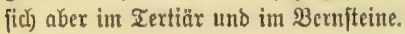

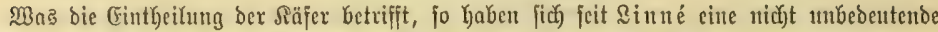

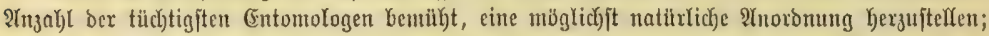

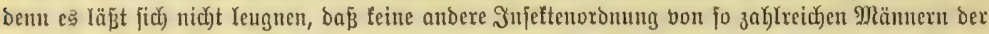
Wiffenfcfaft bearbeitet torden ijt, tvie gerade bie Siäpr. Ein Fabricius, \&atreille, We ft =

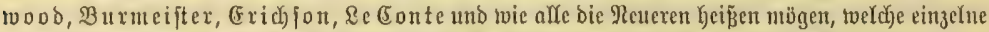

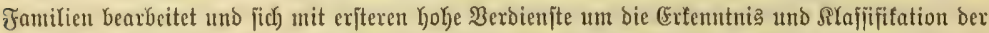

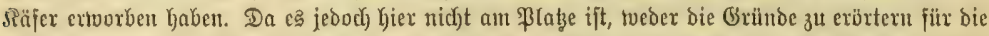

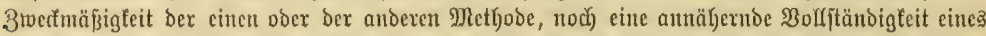
Enjtents zu geben, fo füGren roir bie paar näher zu befpred)enden $\mathfrak{A r t e n}$ unter ben Familien und in ber Reiłenfolge auf, weldye Sacorbaire annimmt. Derfelbe lyat uns in feinen "Genera des Coleoptères" ein unfterbliches Werf hinterlafjen, bas feit dem Jahyre 1854 bie volfe Ifyätig=

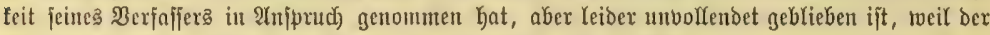

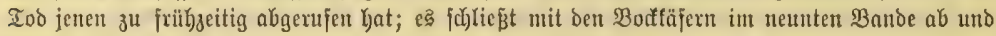
d)aralterifirt feine $\mathfrak{P} r \mathrm{r}$, fonbern nur bie Giattungen uno Fantilien.

Det Feld = Sanbfäjer (Cicindelä campestris) ijt eit mittelgroferer grïner fiäjer von

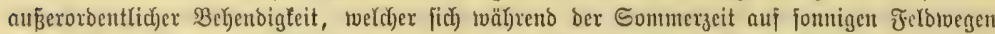

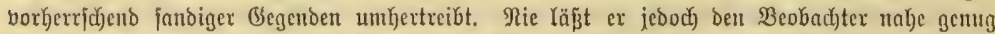

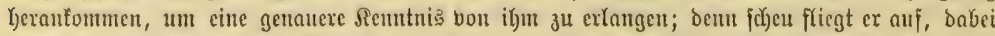

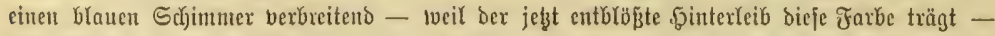

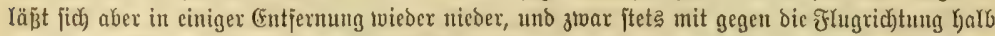

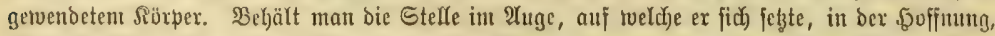
if) bod) nod) zu Hbertaj(d)en, fo fliegen, wenn bie (Segend einigermajen reid) an ifnen ijt, inzluijd)en rechts uno Yinf: ztvei, brei andere auf, und efje mau beljutfancu Schrittes jenen \$untte naht, wo

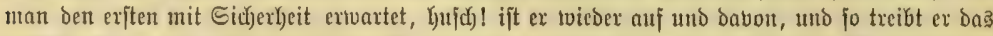

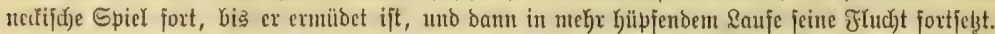

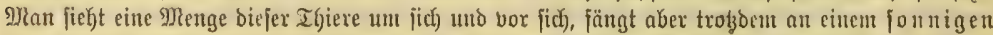

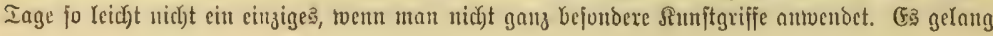




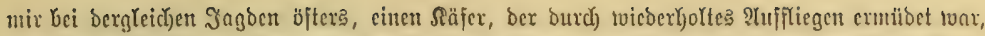

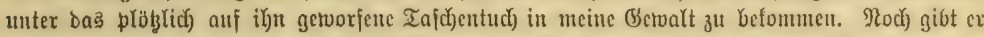

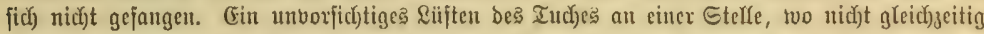
bie Finger zufajien - uno ex ift twieber auj und bavon. Wie aber geberbet ex fict), wemn jene

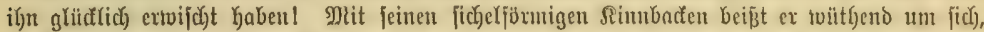

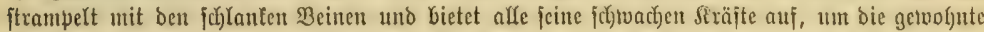

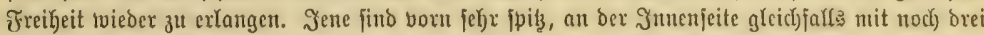

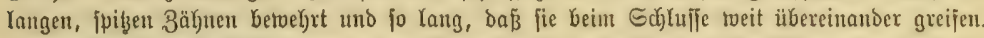

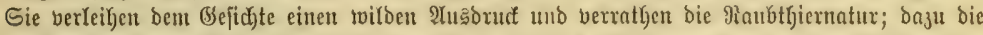

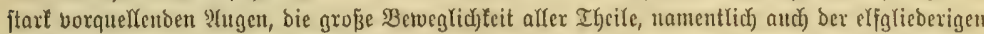

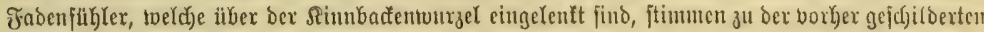

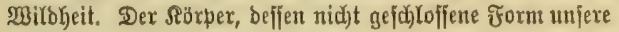

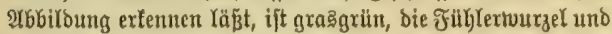
bie mertlid behaarten Beine jodjinmern fupjerröthlich, fünf

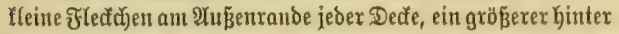
ber Mitte auf ber Sdjeibe, potvie baß groß̉e, nidjt getielte

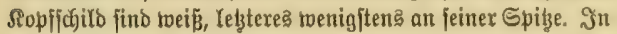
Dex (Brunofarbe, tweldje mitunter in Glau tibergeht, uno ill ber

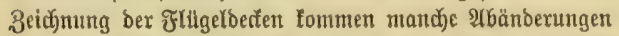

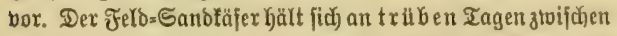
(8)a

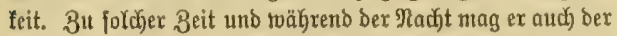

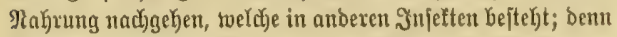

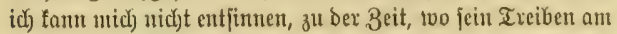

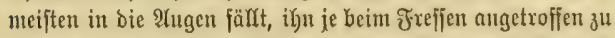
baben. In ber abenteuerlidjen $\mathbb{L} a \times$ be fallen bas blafig auF=

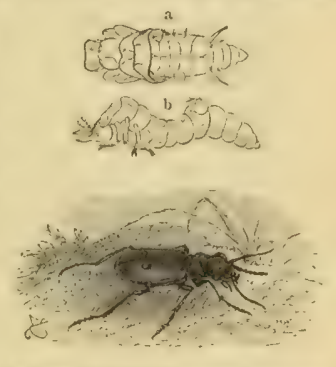

felo: 5 a $\pi$ bläfex (Ciclndela campqestris).

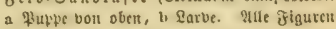
fdyuad, vergröbert.

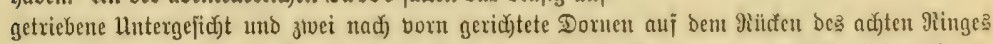

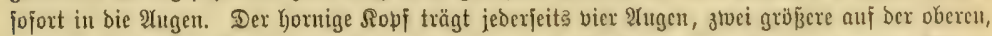

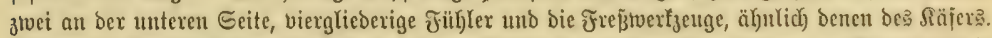

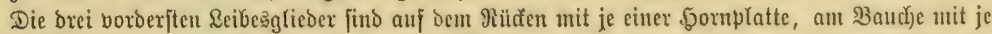

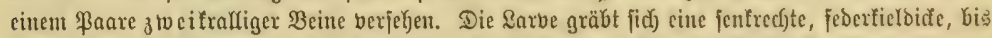

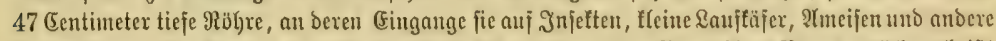

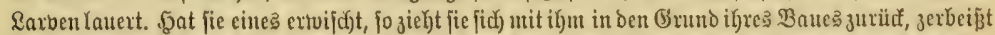

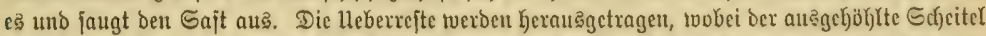

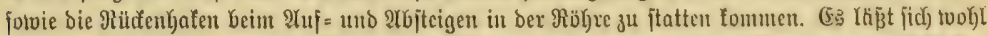

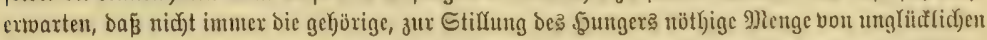

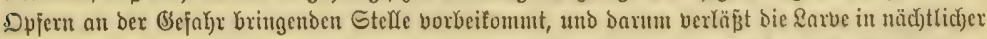

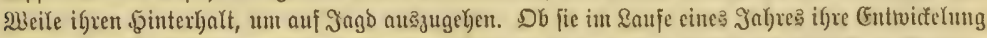

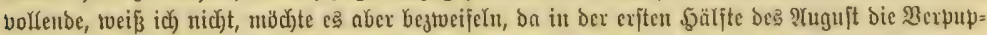

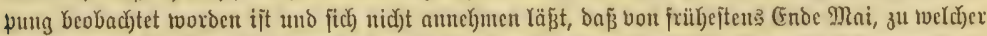

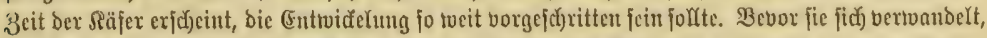

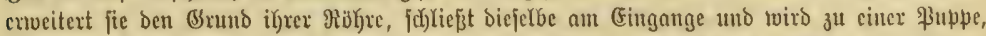

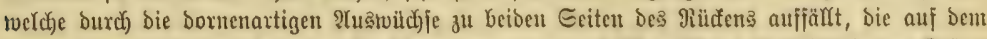

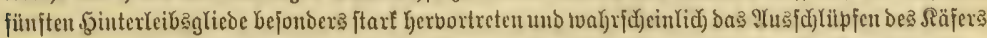

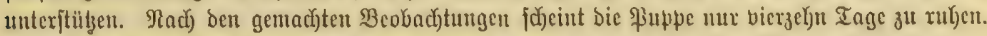

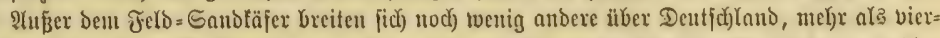

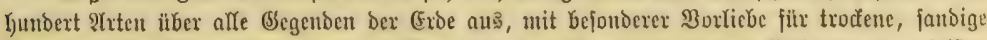

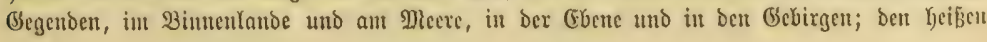




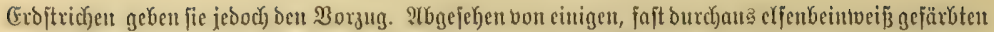

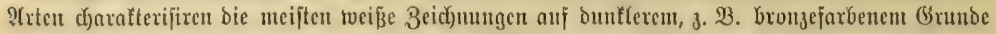

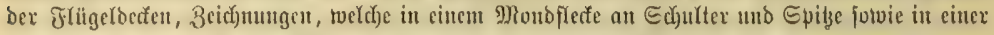

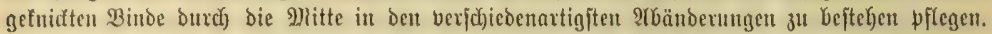

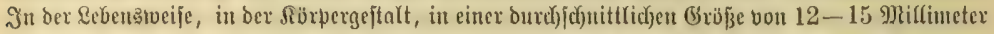
jtimmen jie libercin und folgende Merfmale verbinden alle ju einer Gattung. Der Dinterleib

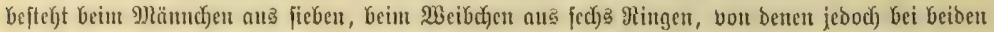

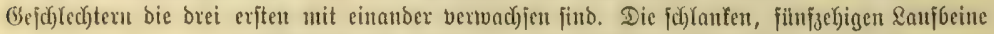

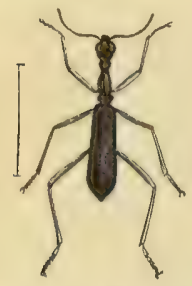

Salighalliger Ganbeäler (Cullyitis longienllis), ber. gröfert.

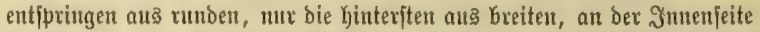

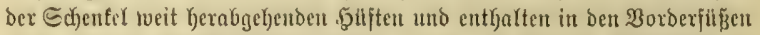

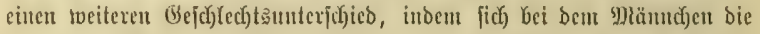

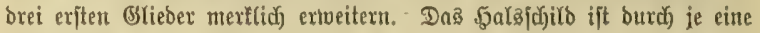

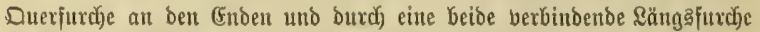

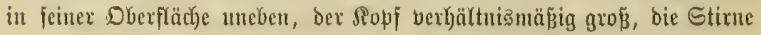
flach), bas Sinn tief ausgerantoet, bie 3unge bertümmert, Für)lex unঠ

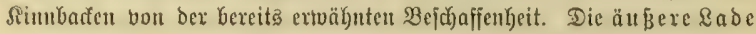
bes unterfiefers bilbet einen areiglieberigen $T$ after und bie Spibe ber intueren trägt einen beroglidjen 3ahn (Jig. 6, 5. 5).

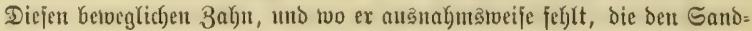
täjern eigene Sürpertradjt haben noch etwa bicrhumbert nndere, auf ver= irshiedene Gattungen bertheilte Prten mit cinandex gemein uno er berbinbet fie zu ber Familie ber Eanbfäfer (Cicindelidae), toeldye neteroinga von ben burd) bie jonftige

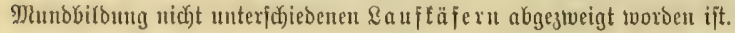

Der Kanghalfige Sandtä fer (Collyris longicollis) aus Dftindien möge einc ber geftrect=

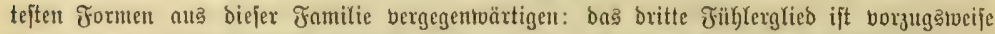

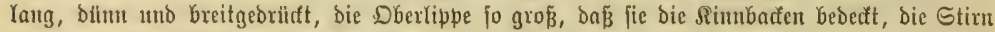

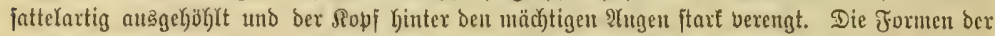

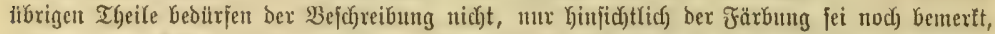

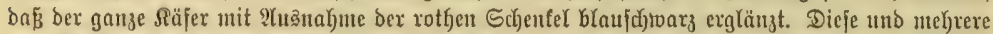

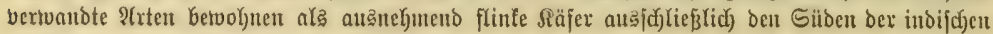
Б̧albinjeln und bie benachbarten Sunoainjeln.

Die \&auftäfer (Carabicidac) ftehen in jeber Bejiebung uno vor alfeut burch bie Tafterform

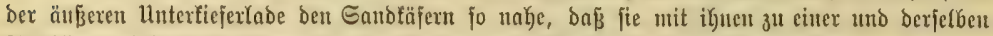
Fanilie vereinigt tuären, toenn ifnen nidjt ber betveglidje Zahn an bex Spize ber Junnenlabe fefylte.

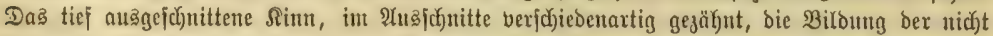

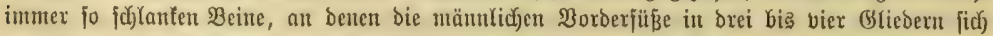

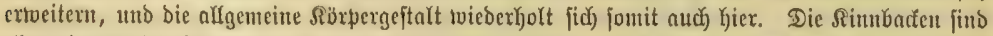
aber nie vou ber \&änge, wie bort, nie mit fpitzen 3ähnen läng马 ber gangen Innenfeite betwebrt;

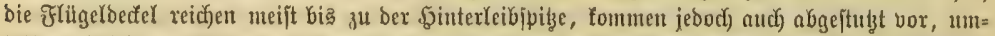

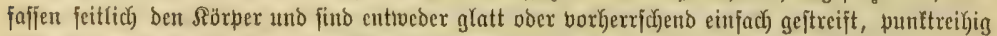
geftreift, gerippt in ben mannigfad)jten 2bänderungen, nidùt felten fehłen bie Flügel unter ihnen

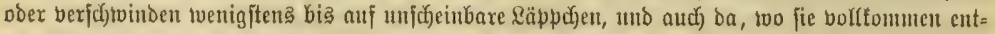

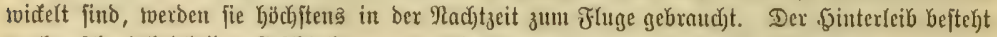

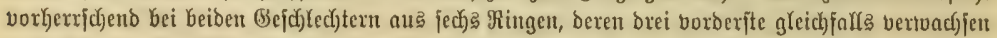
fino. Die ben Sandfäfern eigenen bu nten Frarben fommen juar a 


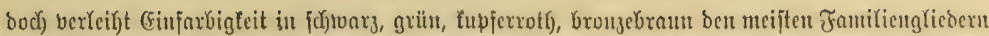

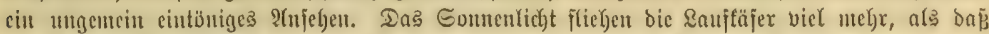

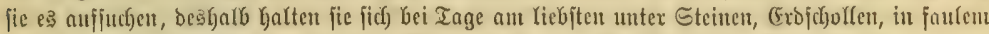

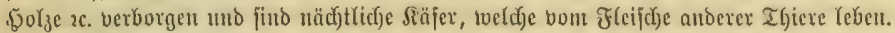

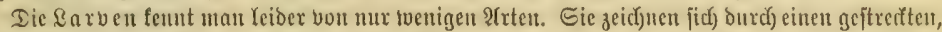

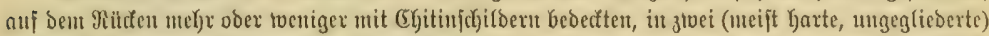

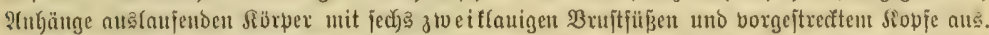

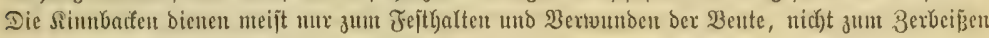

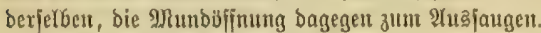

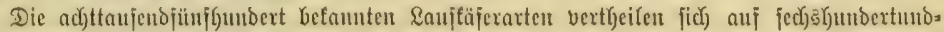
breizehn Gattungen uno betwohnen bie ganze (Erbe, fudseinen it ben gentäßigten uno faĺten Tfyeilen

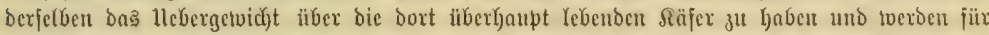

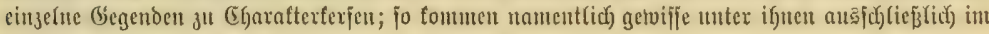
Gebirge, nientala in ber (Ebene bor, unb umgeferrt.

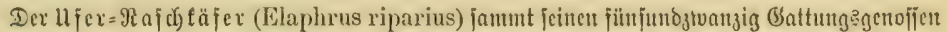

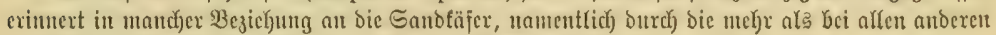

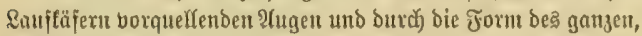
alferoing ftets ffeineren Rörpers, wie ein 23ergleid) Der be

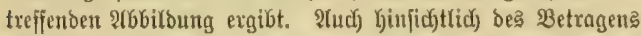

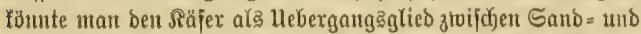
Sauffäjern betradyten. (5x Yiebt näm(id) ben Gonnenjadyein, inbem er twährento beşjelben mit auß̧erorbentfidjer Scfnelligteit

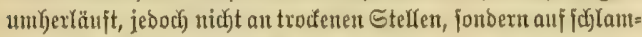

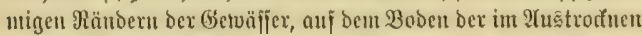

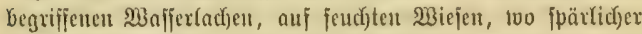
Gra

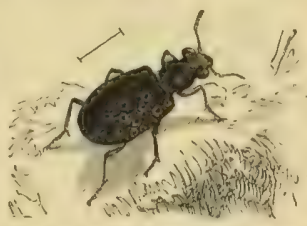

Ufer.?af offëfer Flaphrus riparius), vergeofect.

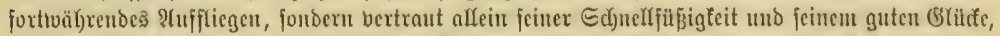

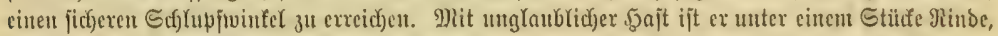

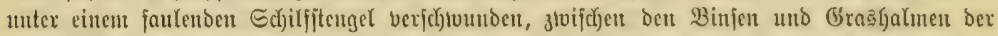

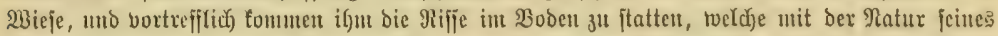

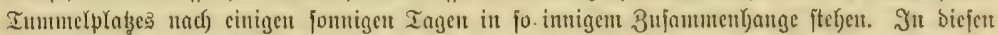

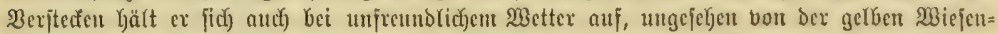

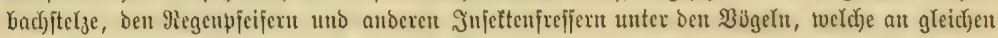

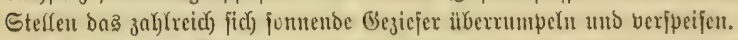

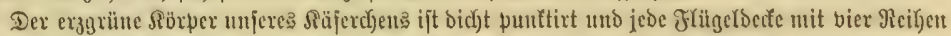

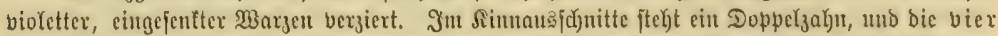

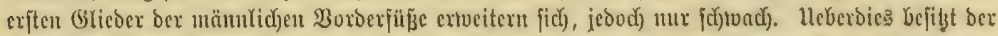

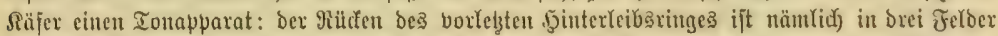

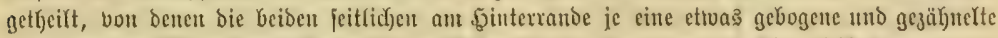

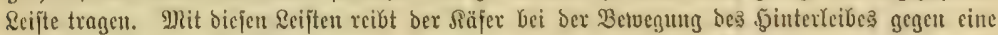

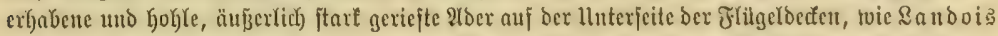

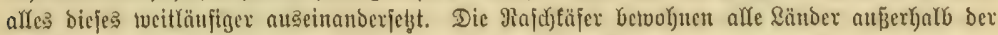
Wendefreife, nur imerfalb berfelben werben fie burd) bie Eanofiffer vertreten. Bei unB fonmen

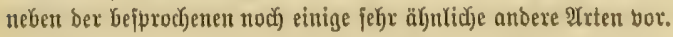

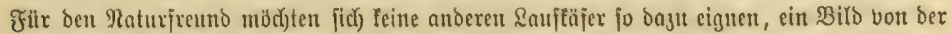

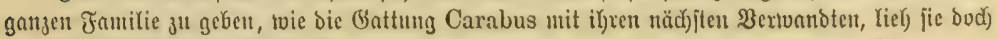
Brrụm Ibierlober. 2, 2tuflage. IX. 


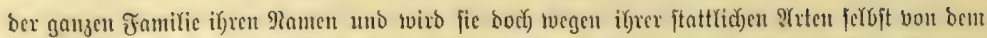

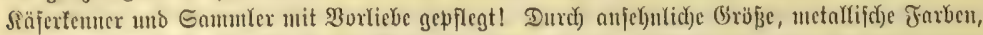

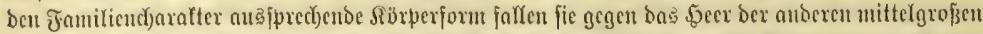

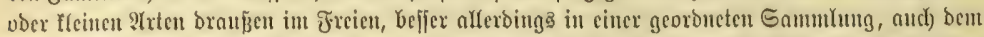

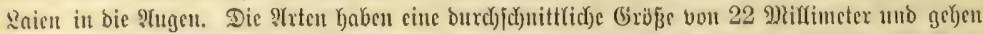

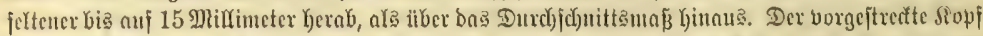

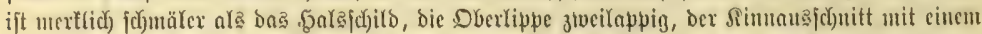

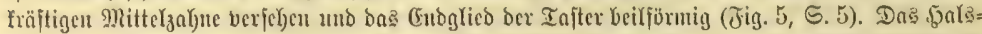

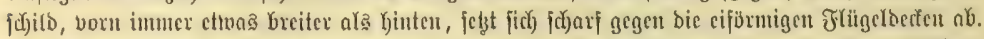

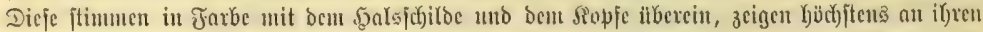

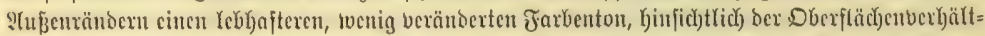

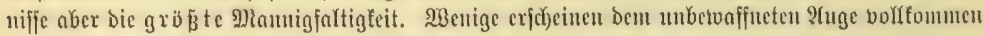

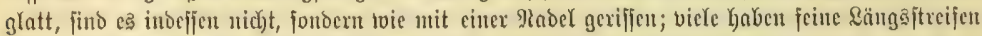

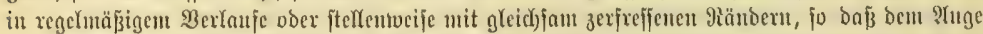

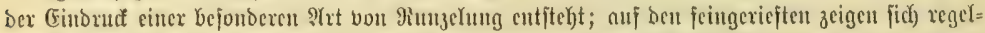

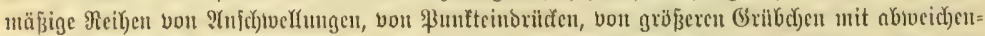
Dem uno erhöhtem Farbenglanze, twie bei beut hier vorgefügrten Gartenlanffäfer. Wiro bie Sberfläct)e unebenex, fo treten wenige Rängstippen (brei auf jeocr Derfe) als ftumpfe Reiften

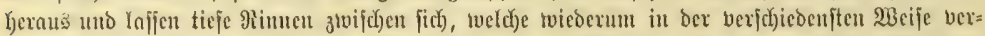

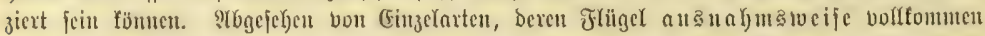

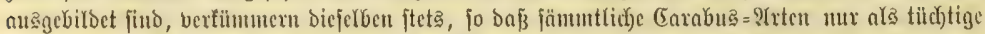

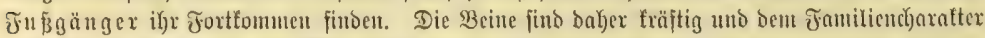

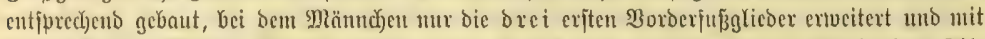

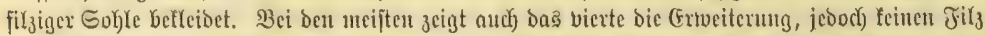

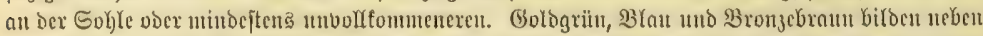

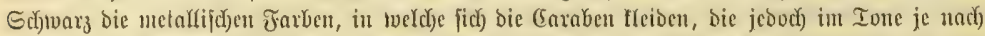

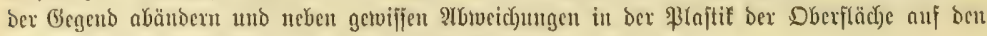

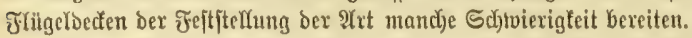

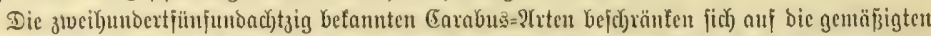

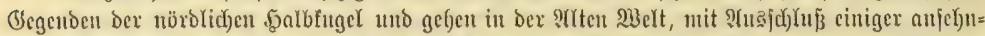

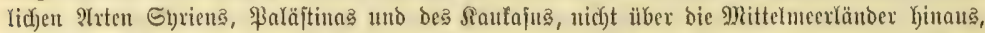

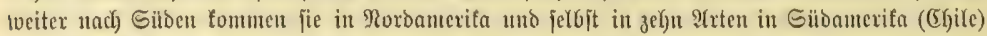

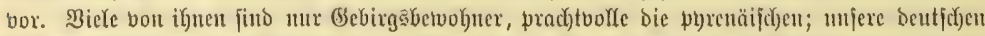

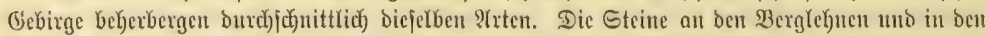

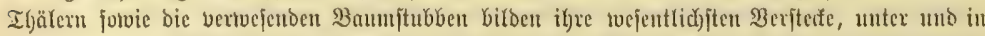

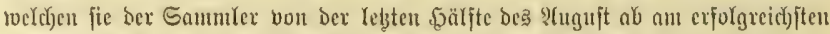

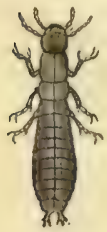

Sarbe bolt Carabus aniatus

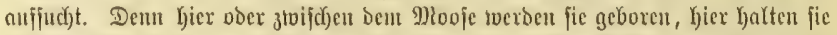
fid) über Iag verborgen, Yjier Yiegen fie in Der twinterlichen Erjtarrung. Die in bex Ebene Yebenden Arten finben in den Mäldern diejelben Beritecfe, in ben Gärten uno

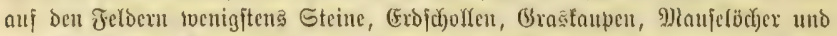

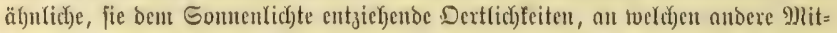

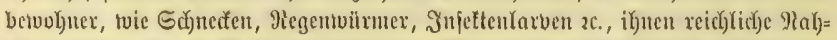

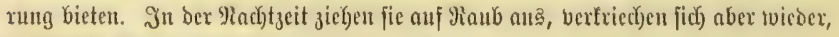
fubald bie Solme emporjteigt.

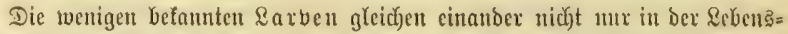

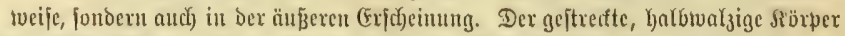

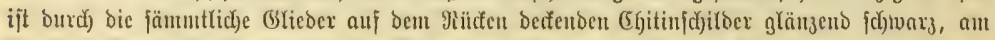

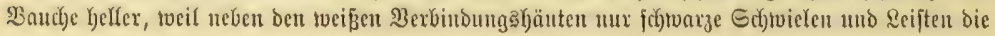


eryärteten Etelfen anbenten. Dex vierectige, vorgeftrectte Siopf ift mit vierglicoerigen Füh)leru,

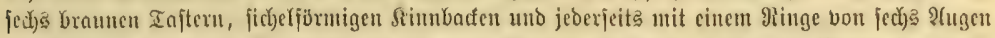

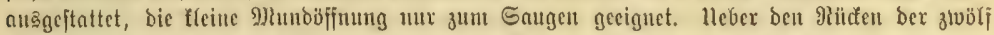

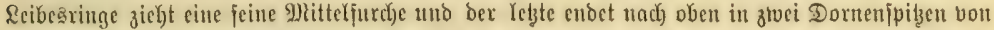

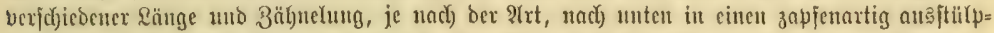

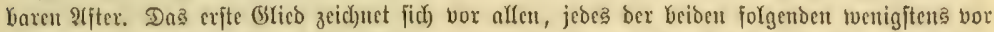

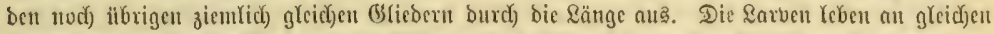

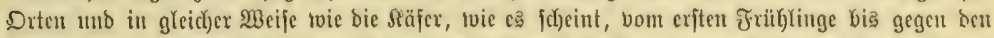

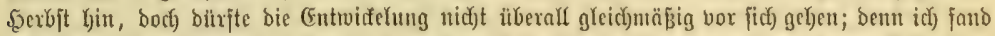

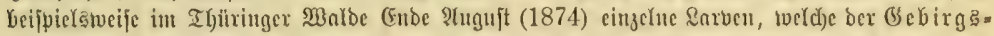

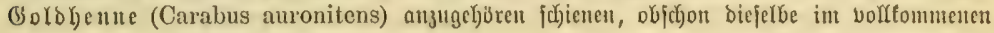

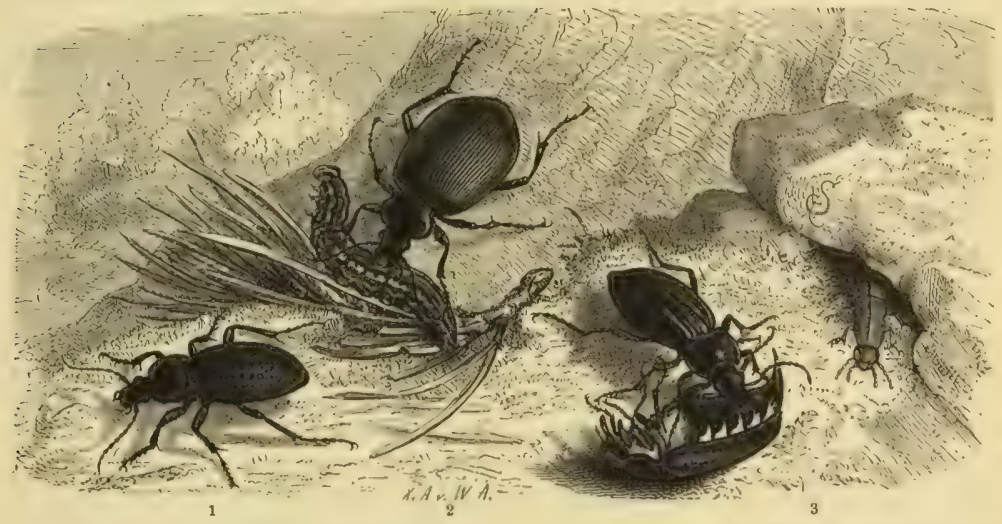

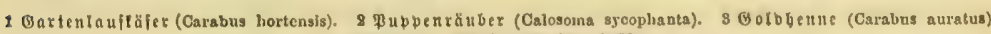
nebf sarbe. Qlue in natirtiøes Gröbe.

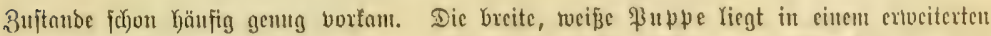

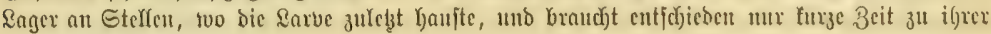
feruerent Gntwidelung.

Der Gartenlauffäfer: (Carabus hortensis), wie \&inné bie Art genaunt hat, Yebt Käufinger

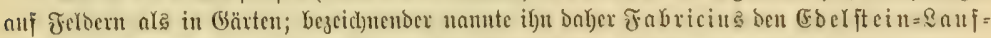

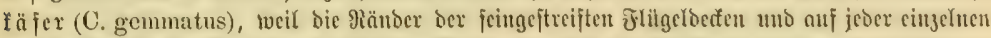

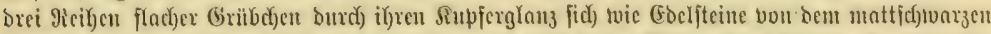

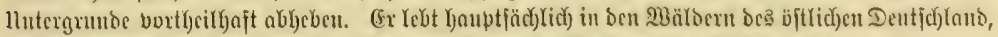

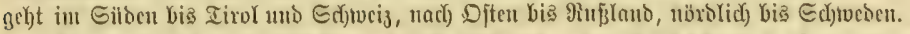

Dex goldgritue \&auffäfer, bie Golblenue, der Goldjefmied (Carabus amatus)

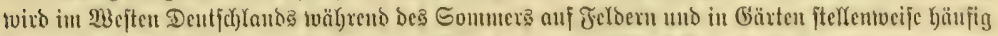

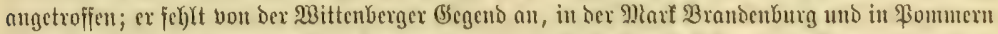

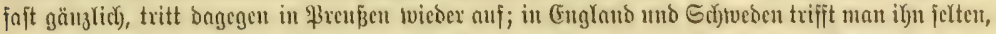

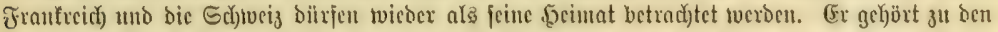

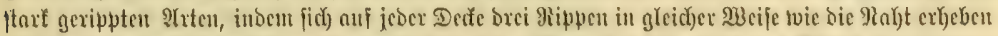

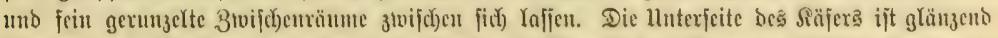

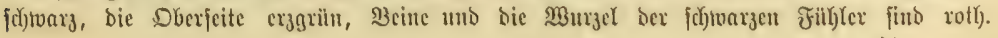




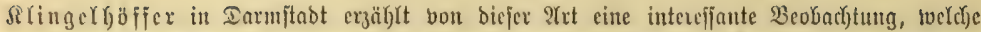

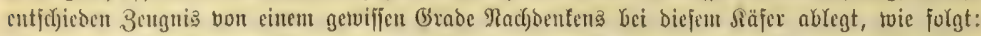

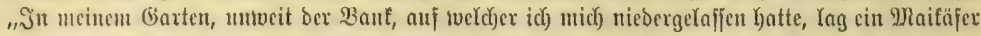

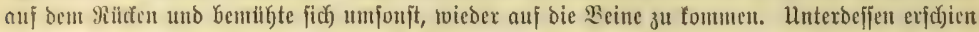

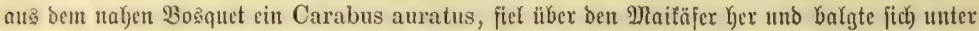

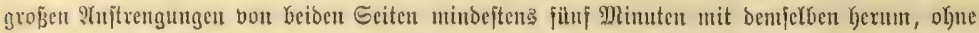

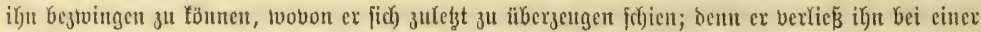

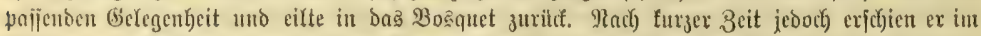

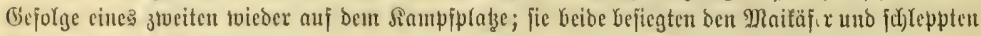
ibts nach ifrem $\mathfrak{B e r f t e c t e " . ~}$

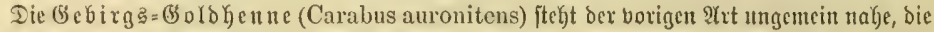

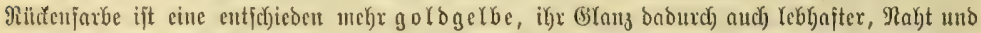

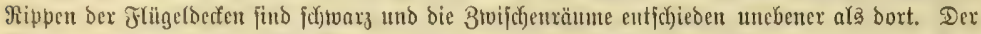

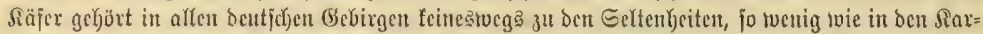

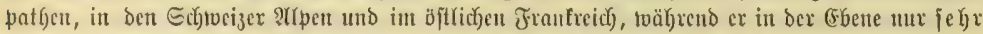

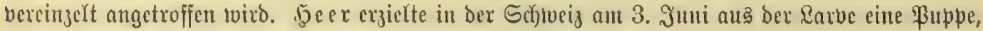

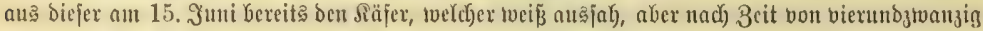

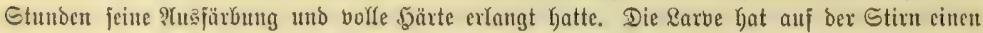

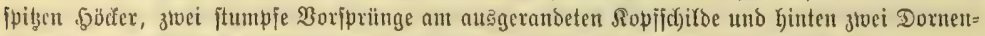

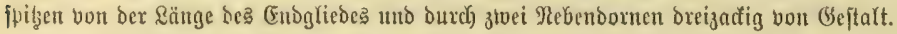

Der ßuppenräuber, Bandit, Mor ofä fer (Calosoma sycophanta, Fig. 2, 5. 35) fter)t

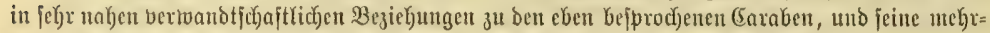

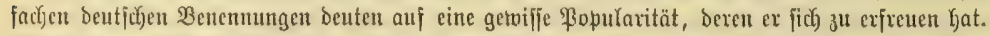

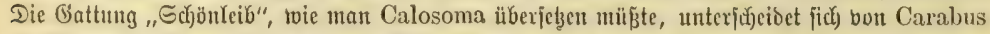

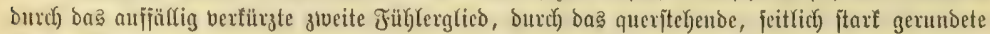

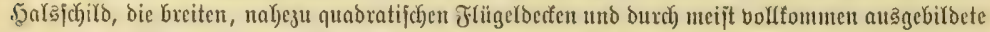

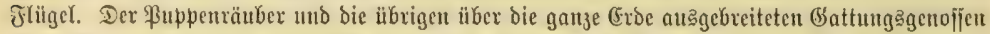

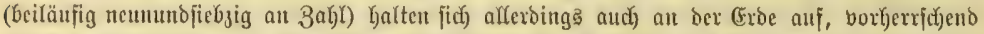

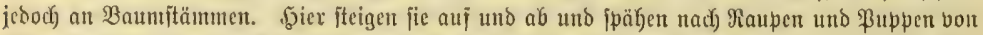
Eefjurtterlingen und nach den Rarven anderer freilebender Sierfe, swetche fie nit groferer (Sier

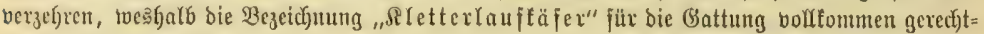
jertight erjocheinen bürte.

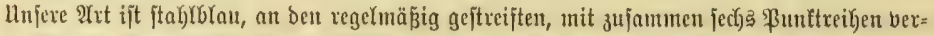

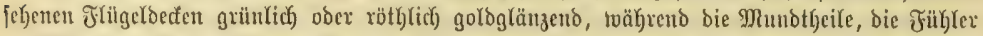

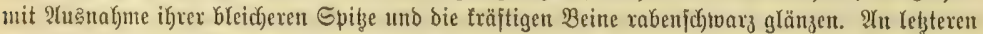

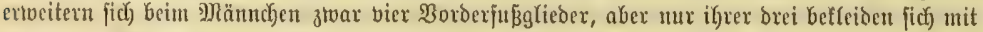

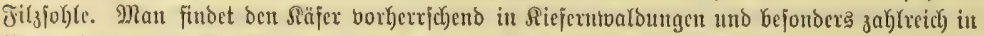

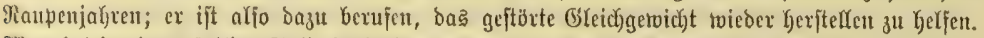

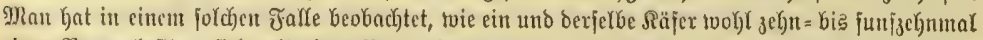

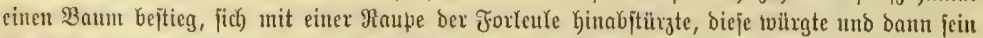

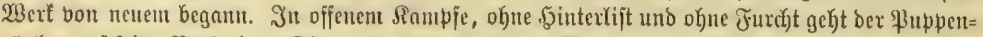

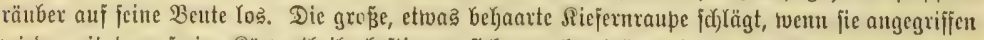

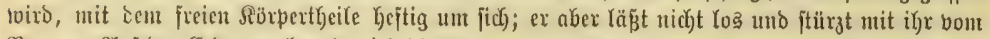

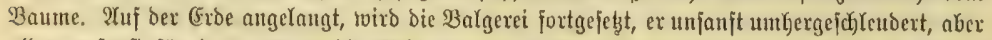

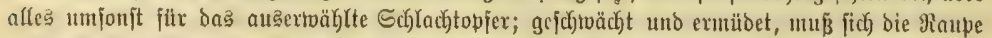

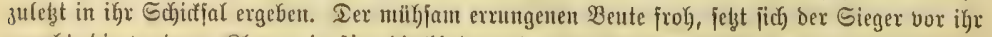
i) urecht, bie borderen Sitauen in fie, bie Ginteren in ben (eroboden einfichlagend, und berarbeitet 


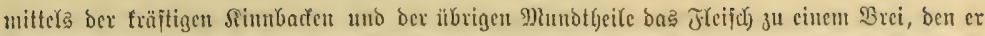

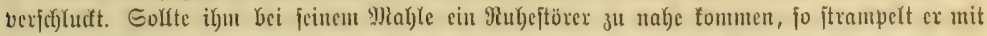

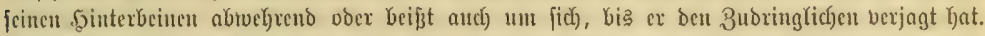

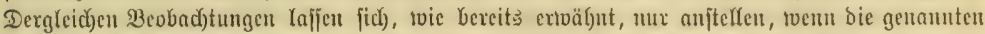

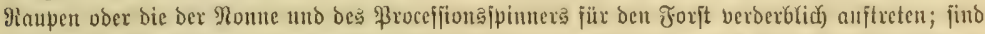

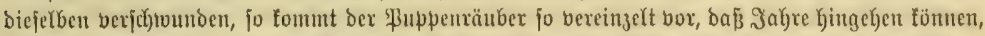

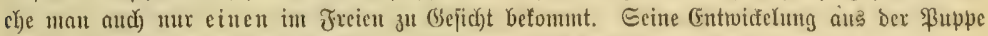

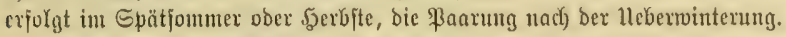

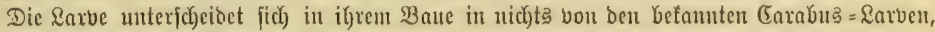

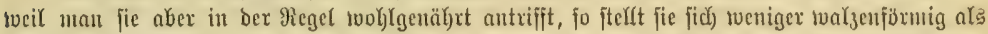

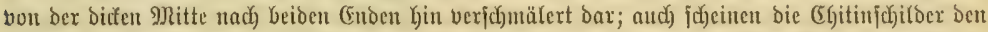

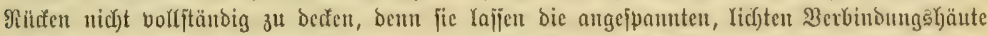

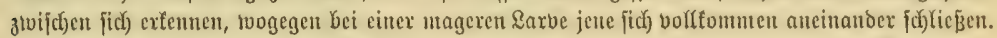

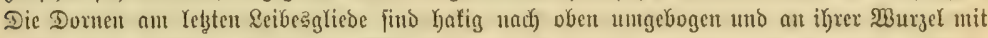

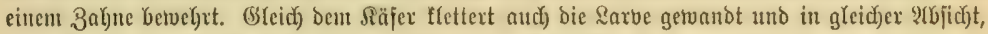

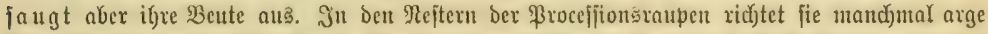

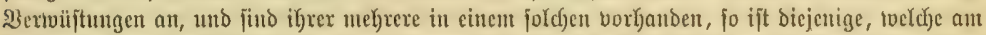

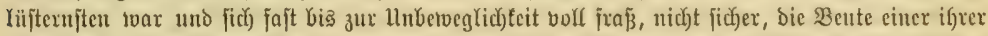
noch betweglicheren Edbtuejtern zu socroen. Wenn fie zur Berpuppung reif ijt, gräbt jie fich flach)

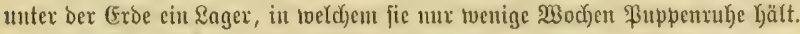

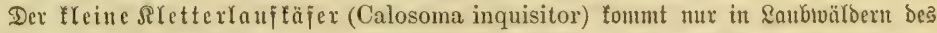

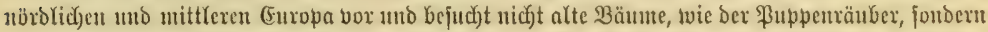

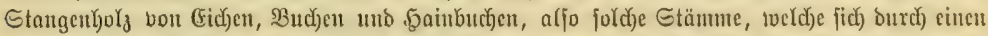

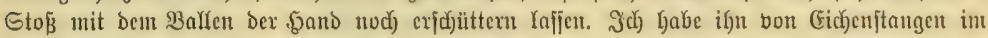

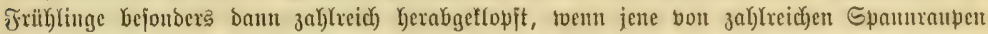

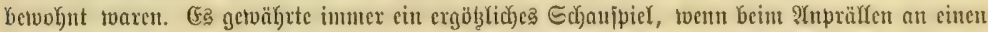

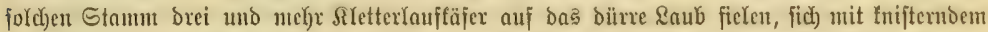

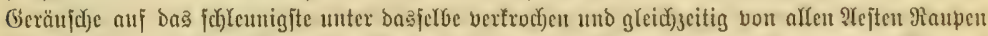
tvie (Erbängte an ihren Fäben Kerabljingen. Sịt bie Gejah)r vorïber, jo bäumen bie filetterer

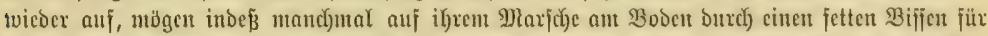

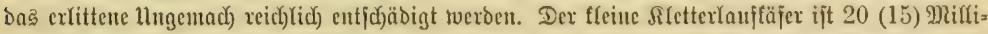

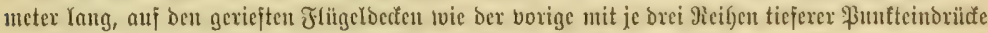

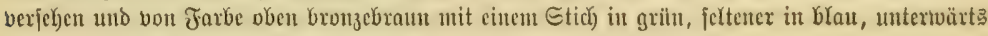

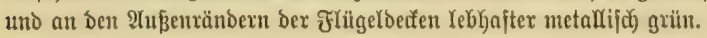

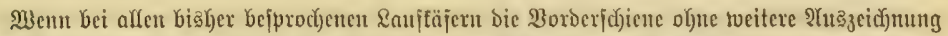

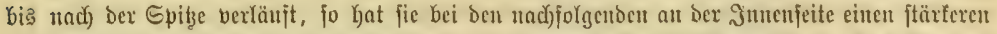

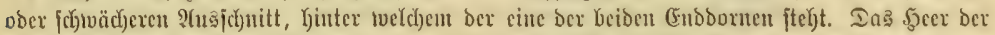

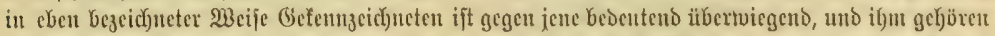

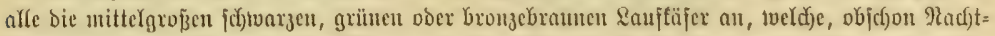

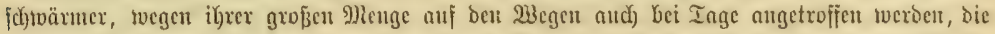

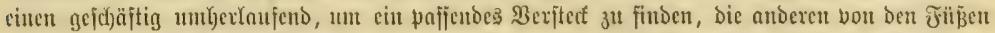

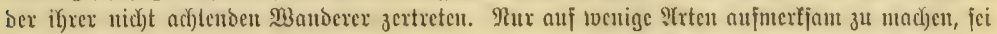
noch bergünnt.

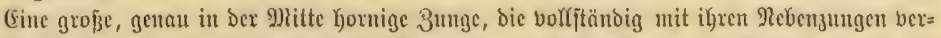

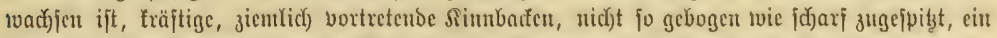

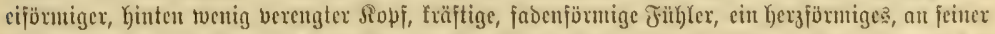

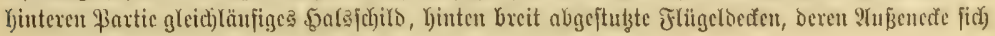




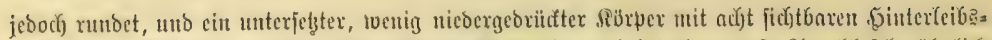

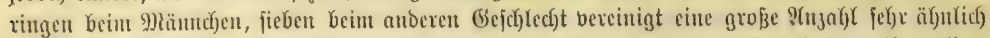

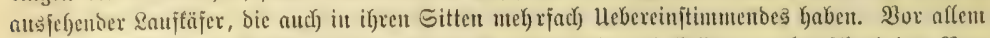

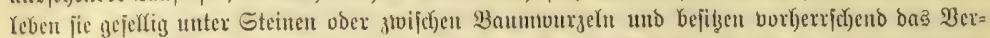

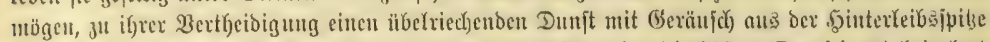

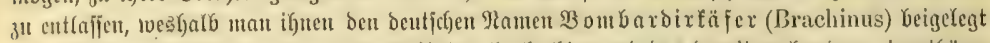

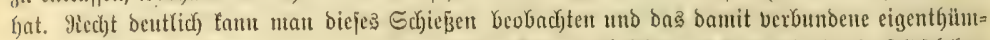

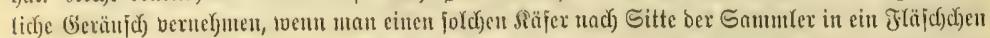

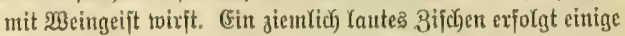

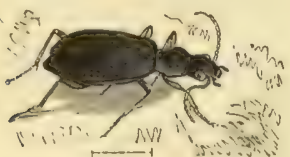

Wombarbirläfer (Brachians crepitans) vergröbert. Male Ginterehander, bis ber jum Tobe Berurtheilte jeit ßulver verjulyolien hat uno ermattet bie Waffen ftredt. Dieje intereffanten Säjer fonmen in affen Ränbern, mit 2tuänabnte

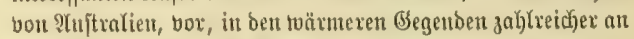

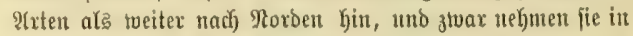

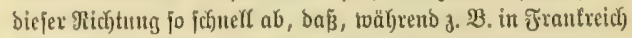

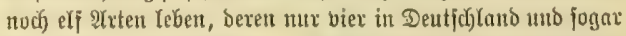
nur eine - jefri jelten - in Sdytueben angetroffen triro.

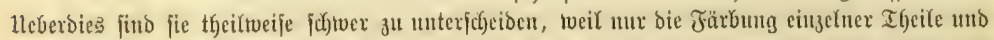

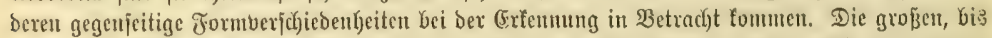

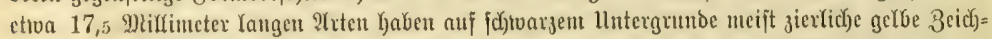

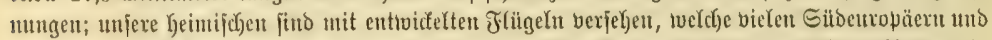

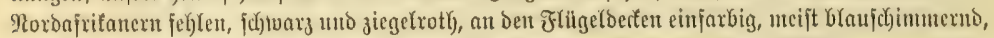

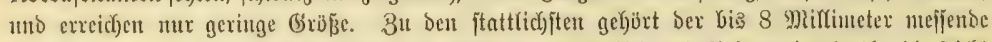

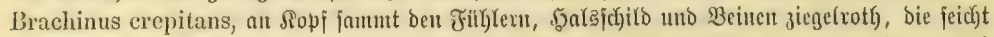

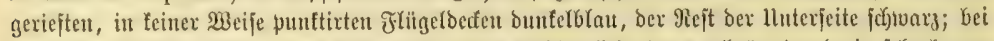

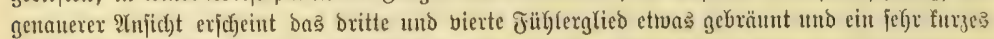

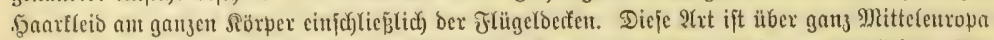

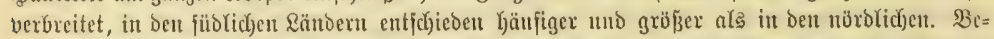

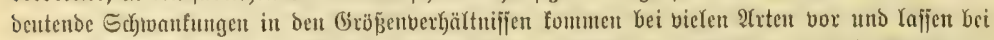

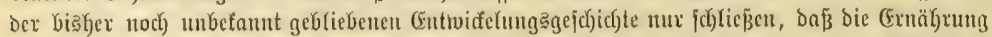

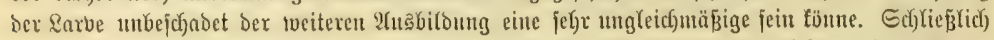

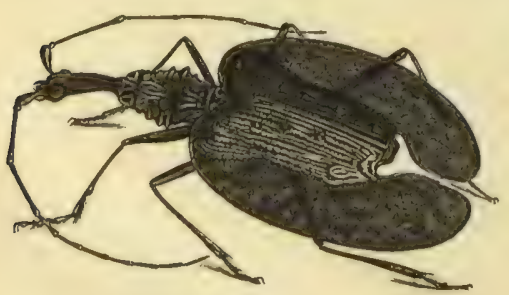

Ge fperft-\$auftäfer (Arormolyce phyllodes), isbr tleines Eremplar.

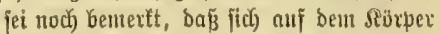
ober an ben OStiebntaßen ber Bombardir= täjer häufig łilze entwid̛eln, weldye bie= jelben jeit 1850 , wo Rouget zuerjt bie

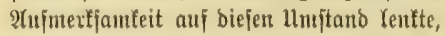
zu einer gejudyten Waare für bic piljbeflijie= nen SBotanifer werben Kiefent.

(Entichieben bie abenteuer(id) jte Forn aller \&auftäjex begegnet un in bent (5) e= fpeujt = \&auffäfer (Mormolyco pluyllodes) aนa క̧aba, too er jehr hod) in bie (oc= birge hinaujgeht. Die beiftehende Figur, nac) einem f(einen Räfex entwoxfen, ba

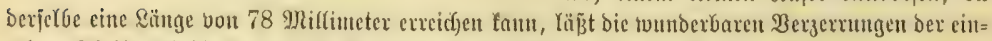

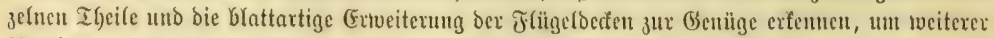

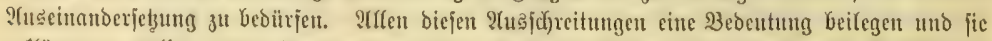

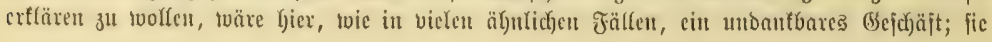




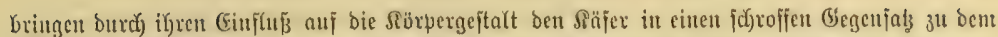

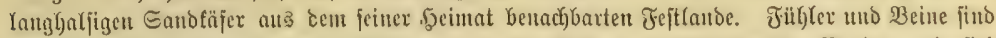

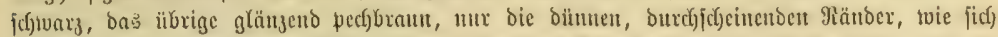

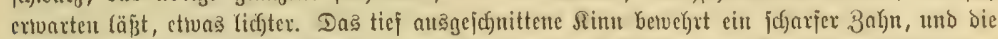
fräftigen Iafter laufen in fajt tonlzige, am Gnbe gerundete Estieber aus. Die Rarbe gleicht in ber

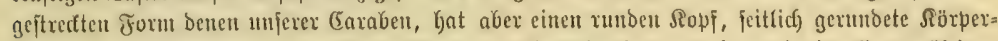
glieber, bon benen nur bas exjte volffommen, bie folgenben von je zlvei vieredigen, fleinen

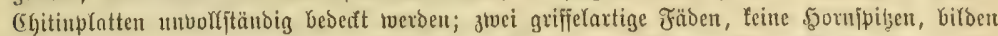

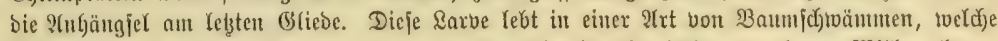

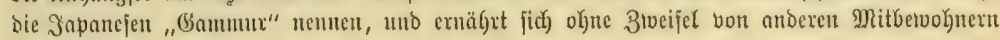
biejer Sdjtuämme.

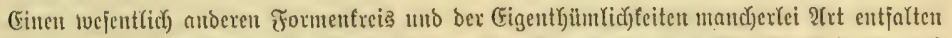

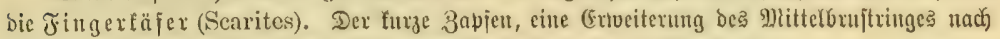

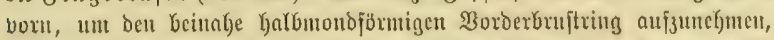

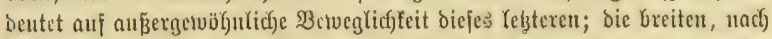

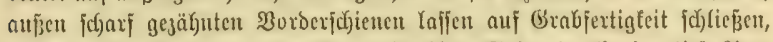

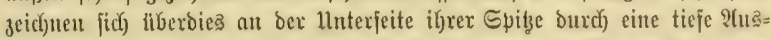

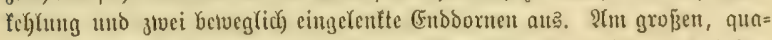
Dratifichen Siopfe extangen bie brokenden Simubaten bei toeitem bas llever= getvicht; die breilappige Dberlippe uro bie Fiiblex find tur\}, Yelztere pert=

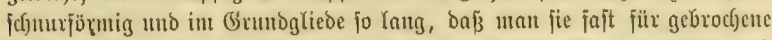

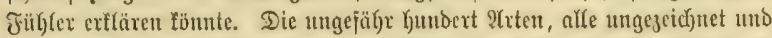

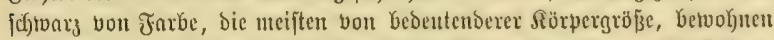

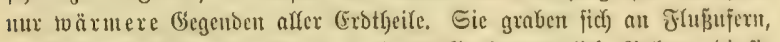

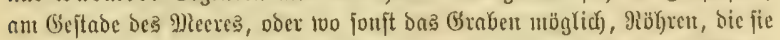

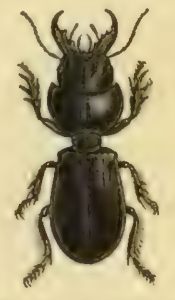

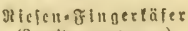
(Searites pyracmon), natiit. Gröbe. bei Iage nid)t gern verlafien, fonbern auf Beute (auerno burd) ifyent Sï̈rper

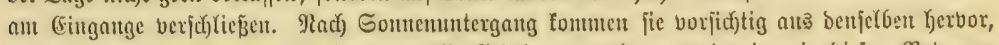

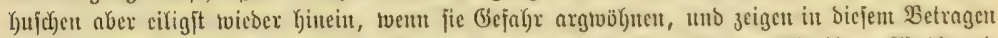

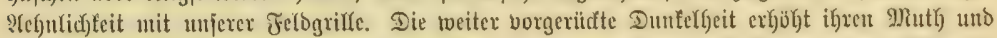

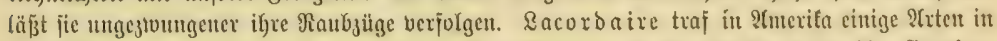

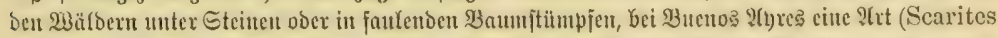

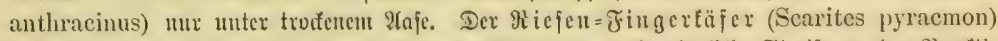

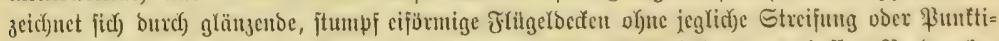

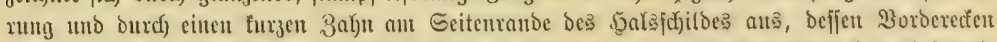

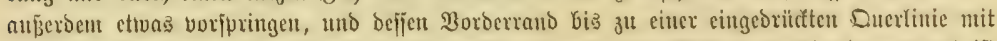
jeinen Serbftrichen berjeben ift. Diejer Jingerfäfer betwoljut bic Siujten Des 9littefmeeres unt ijt

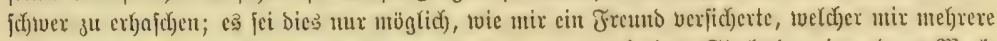
Stüte aus Epanien utitbrachte, wem e

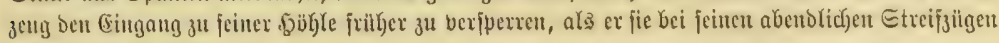
เvieder erreicht ljätte.

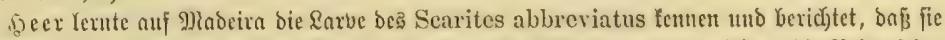

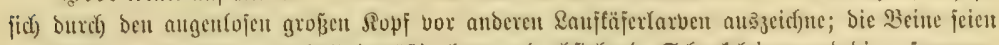

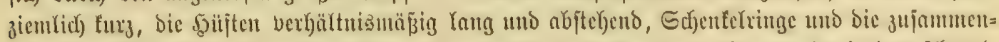

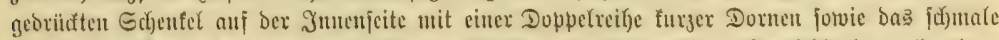

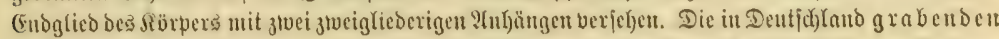

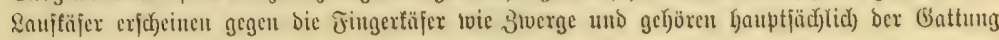
Dyschirius an. 


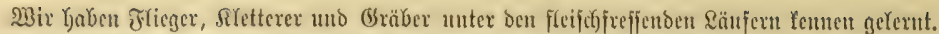

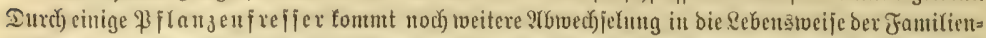

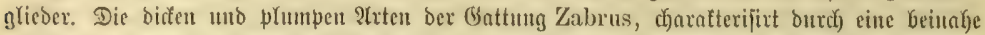

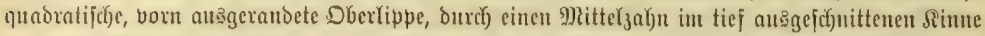

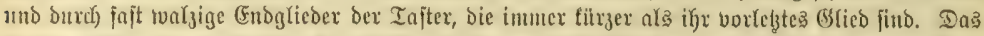

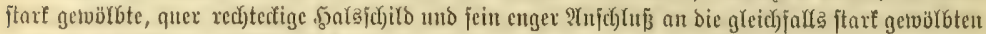

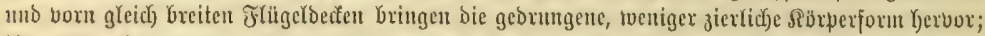

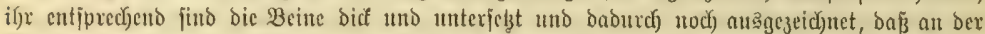

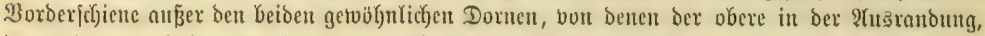

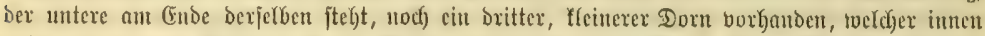

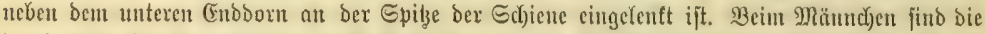

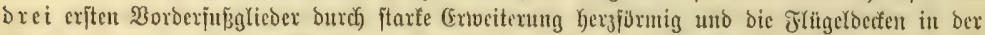

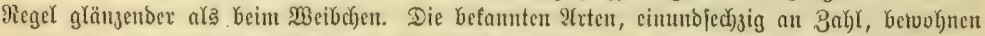

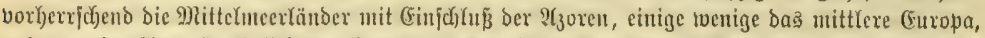

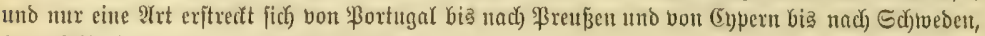

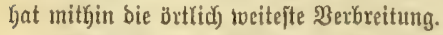

Dicfe eine Irt ift ber Betreibelauffäfer (Zabrus gibbus), ber burch fein maffenthaftez

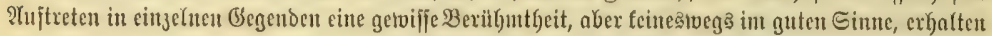

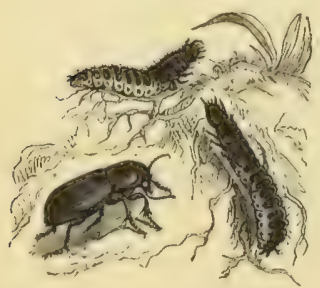

Betreibelaufläfer (7abrus glbbns), matiirl. Grölie.

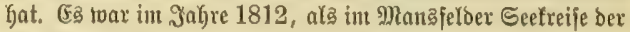

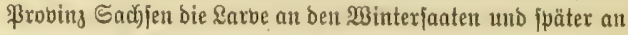
ber jungen Berfte bebeutenden Sdjaden anridjtete, uno jwar:

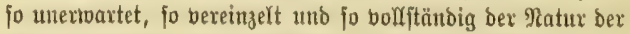

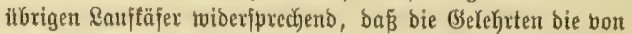
Germar befannt gegebene Ifyatjache, als auf irgend welchen Jirthume berufent, in 3toeifel ju ziełen begantnen. Seit ben

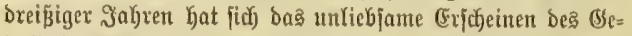
treidelauffäfers öfter toiederbolt in ben verfdjiedenjten Iheilen ber Probing Sadjien, am ßhein, in ber heutigen Provins §annover, in Şöbmen uno andertwärț. \$e öfter uno je aff= feitiger bie शufmerfjanteit anj biejen Getreioefeino gelentt loorben ift, bejto beftimmter hat man fid bon ber Scjäblichteit

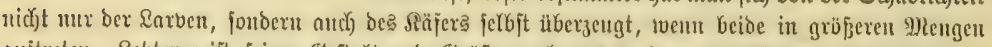

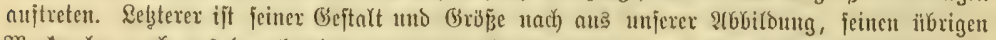

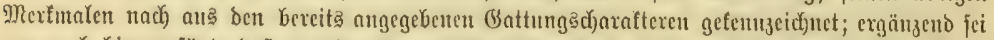

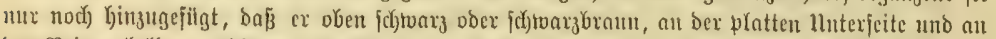

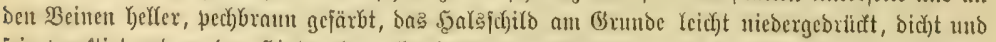

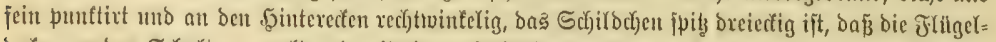

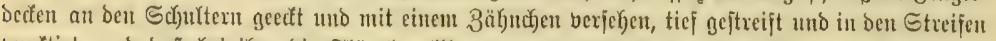

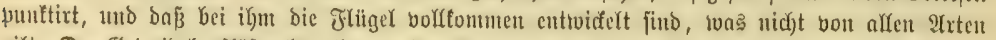

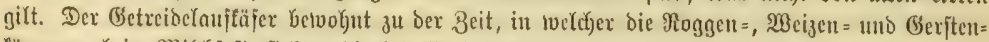

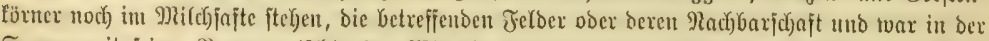

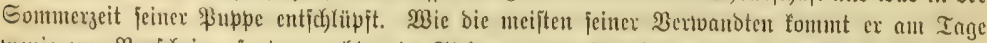

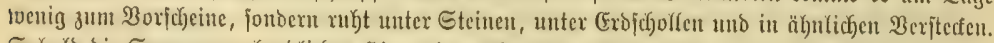

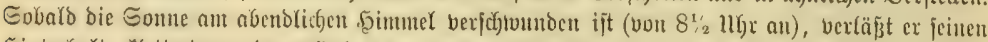

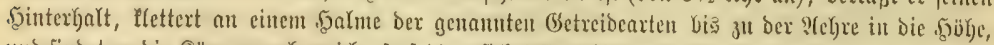

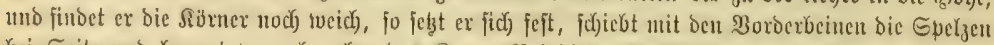

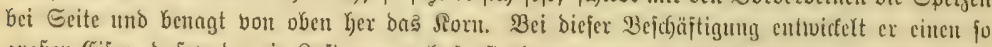

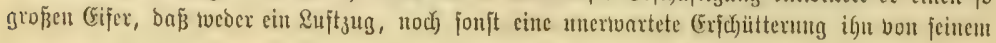




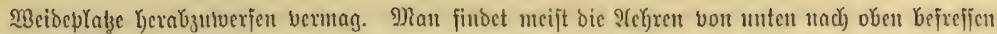

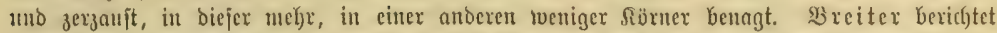

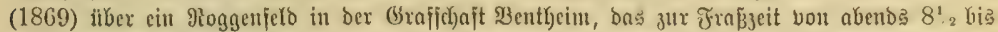

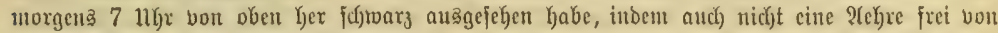

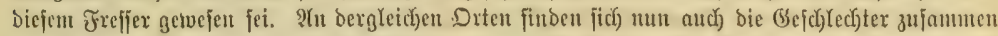

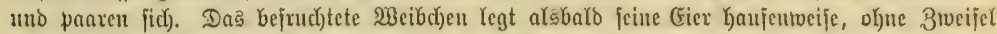

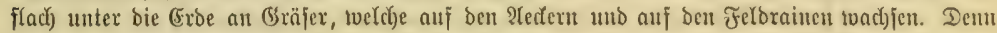

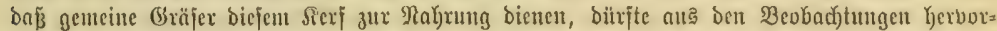

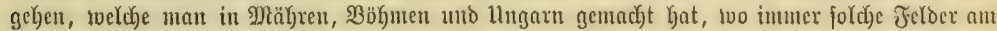

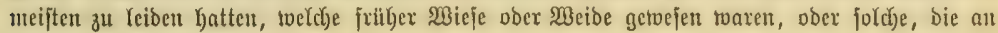
Wiejen angrenjten.

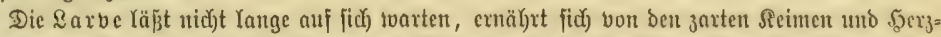

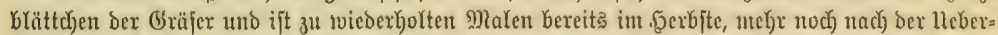

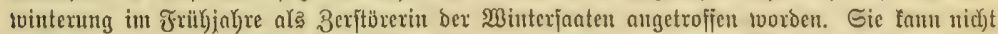

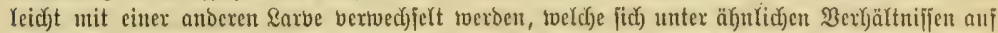

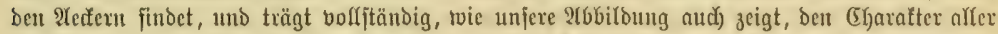

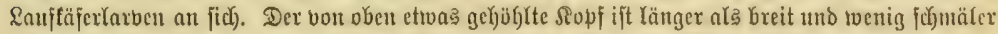

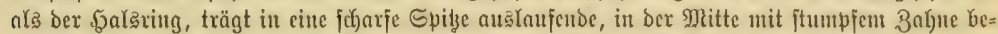

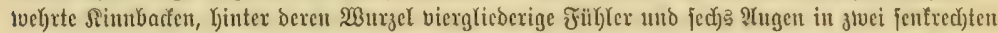

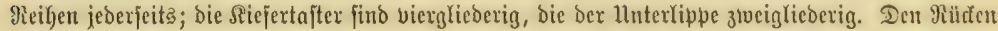

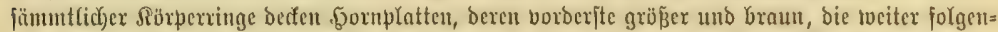

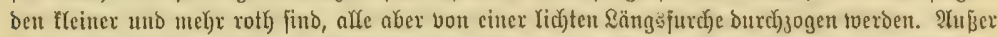

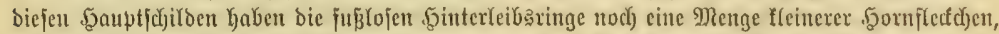

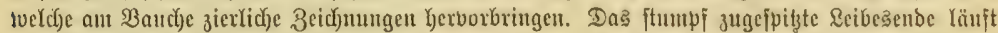

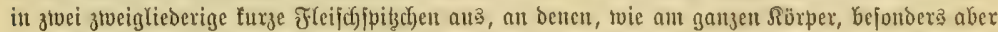

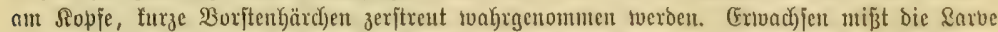

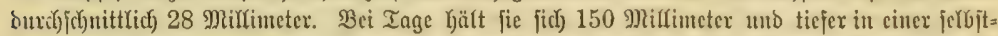

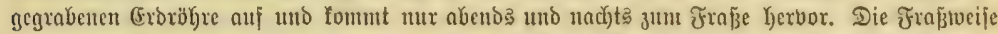

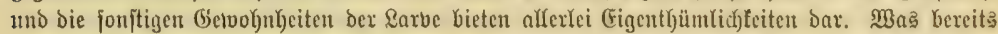

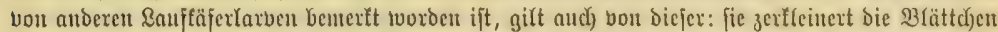

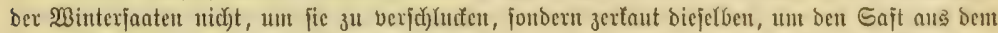

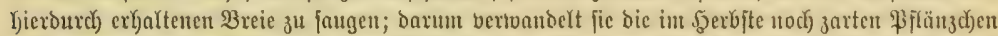

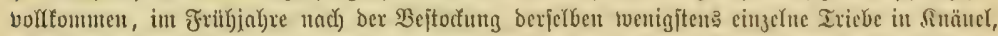

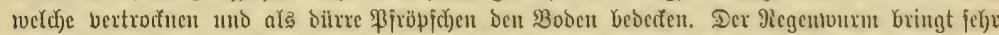

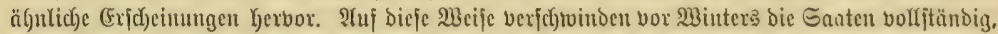

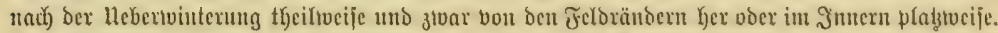

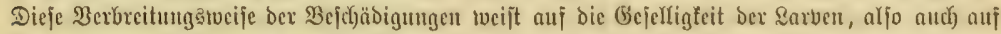

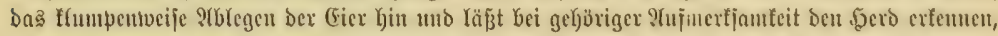

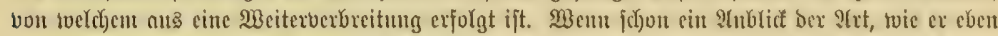

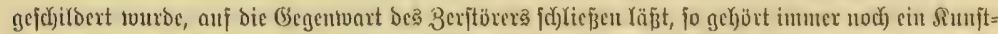

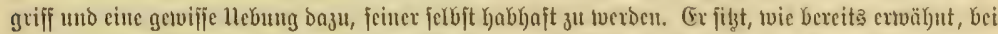

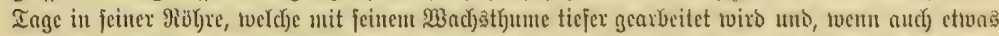

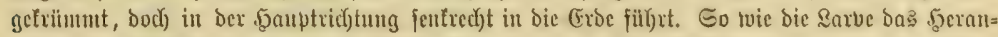

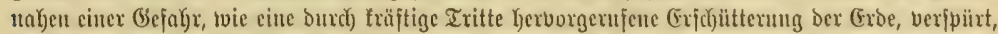

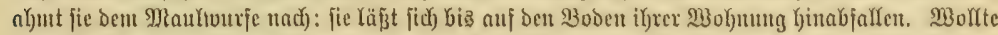

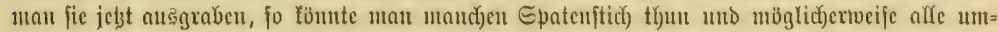

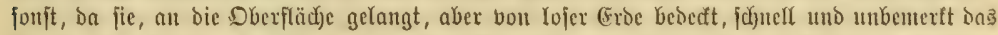

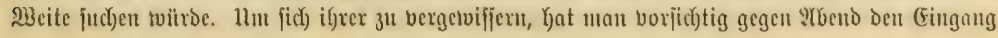




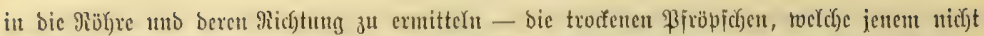

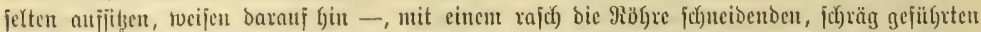

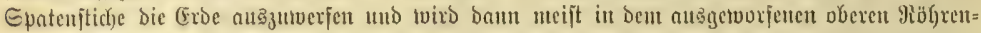

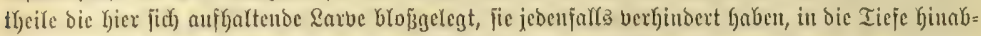

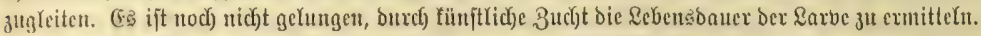
Die gefangenen Rarven frejien jich gegenfeitig an mo anf, jobalo bas gebotente Betreide nicht bie

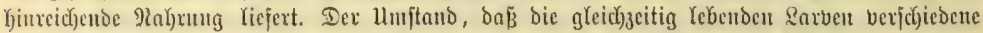

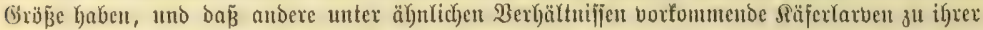

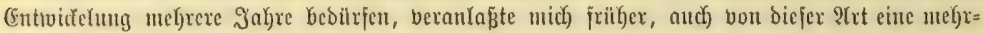

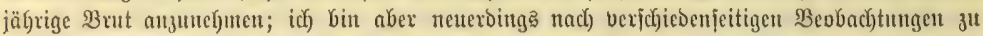

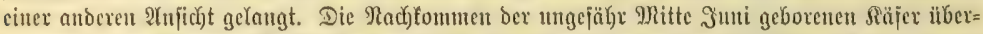

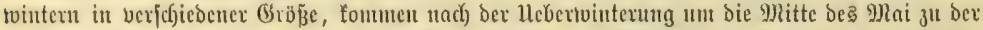

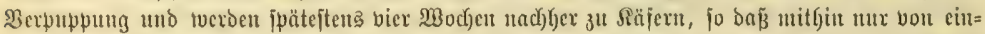

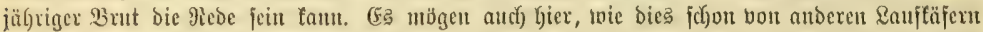

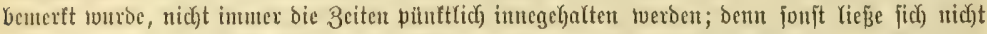

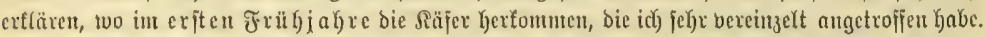

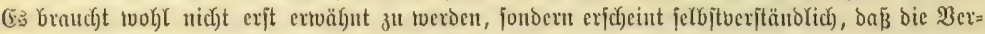
puppung iu Grunbe ber ettwas extweiterten ßöhre exfolgt.

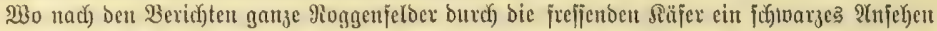

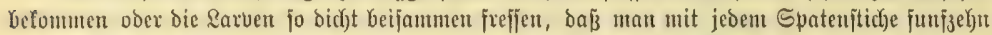

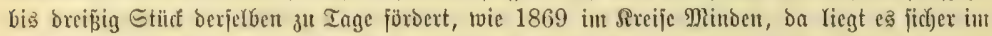

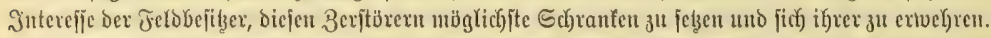

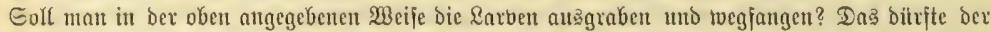

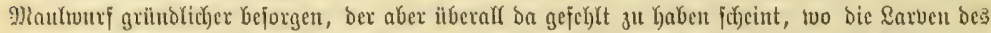

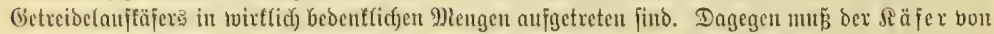

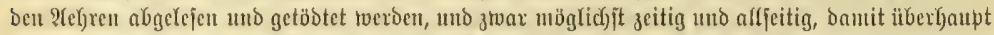

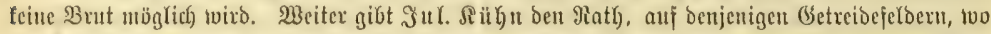
Dex Räfer beobachtet tourde, unto two bie (Eicrablage verumuthet werbent Darf, jogleich) nach) Dex (Ernte

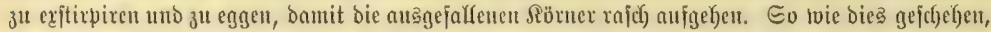

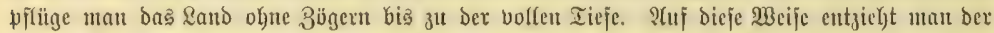

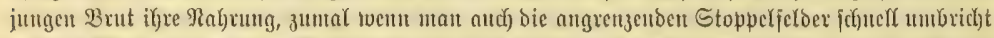

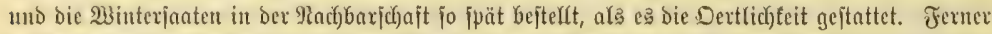

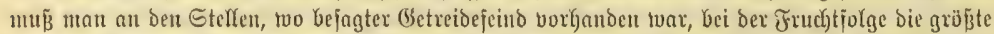

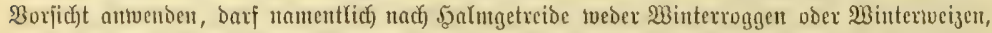

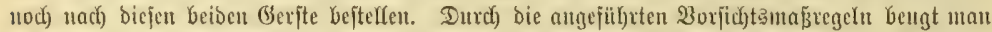

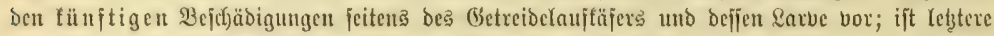

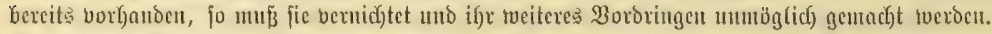

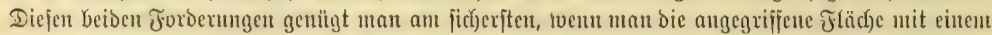

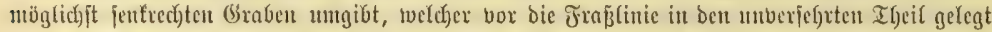

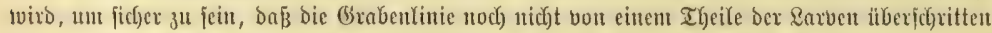
wurbe. Dieje Gräben erfalten ant zweffmäßigiten eine Tieje von 48 bis 62 (5entinter bei einer

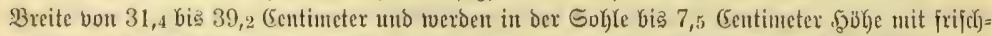

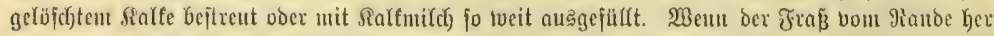

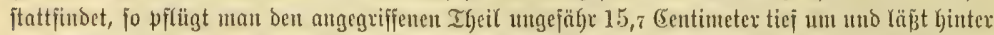

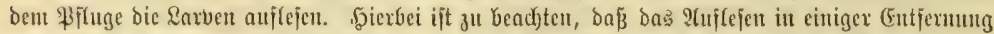

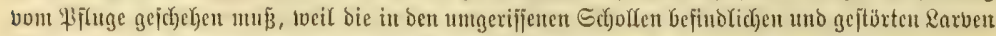

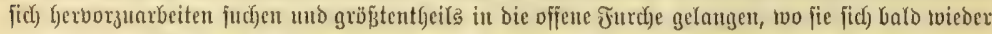

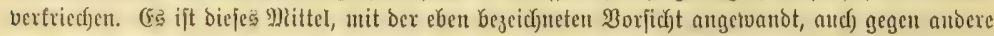




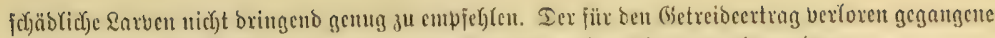

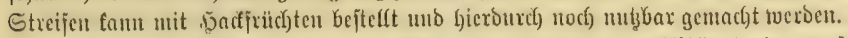

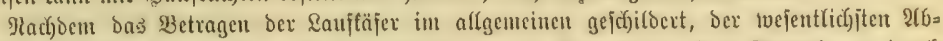

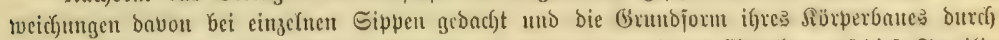

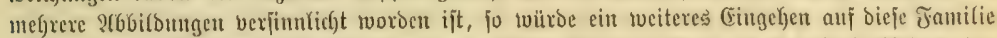

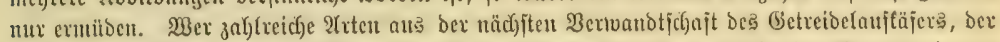

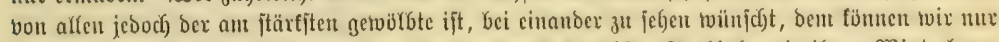

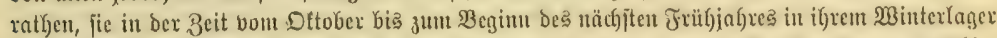

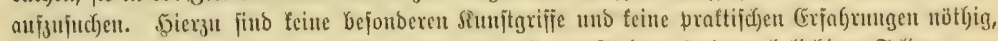

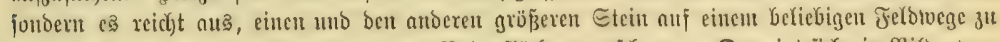

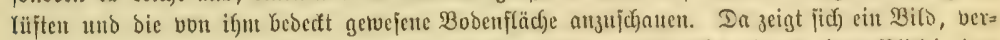

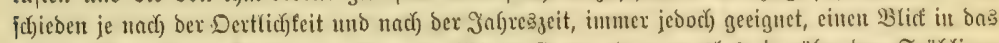

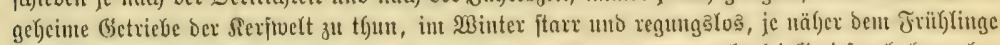

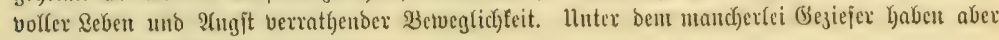
bie Säujer fict)ertid bas Hevergetvidut.

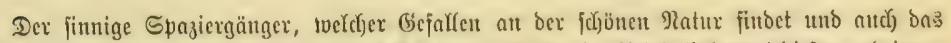

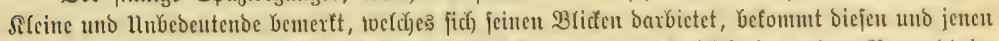

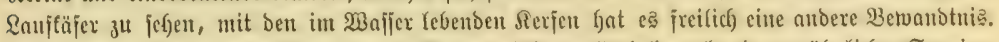

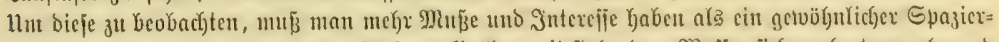

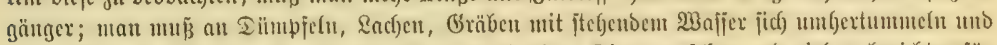

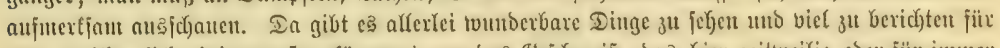

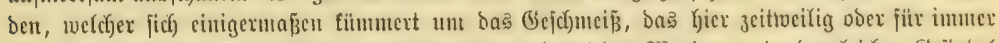

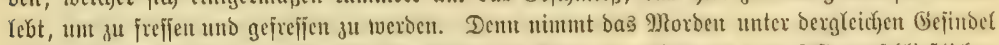

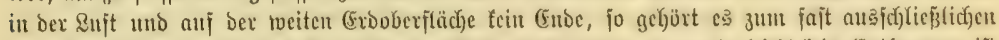

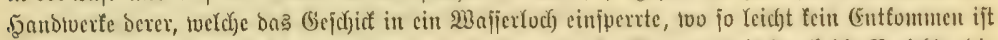

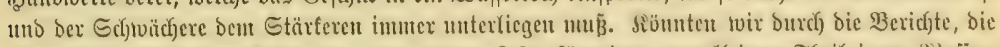

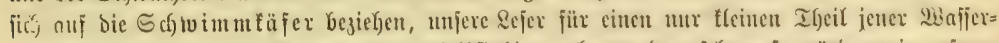

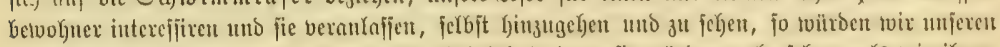

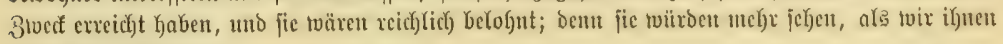
G)

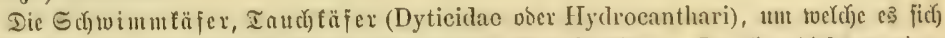

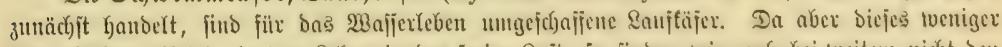

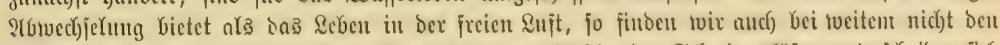

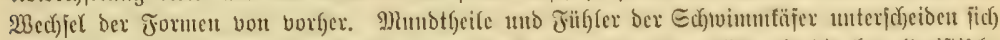

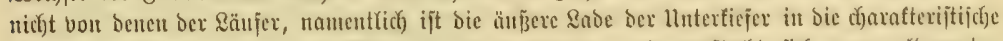

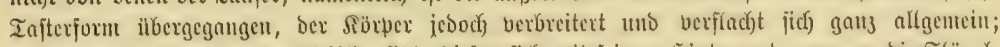

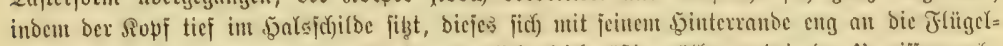

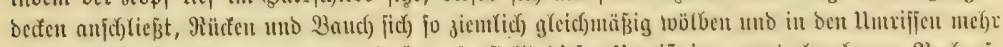

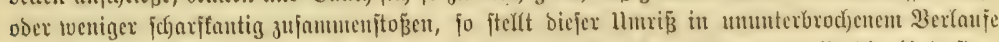

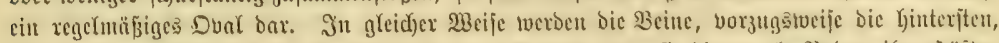

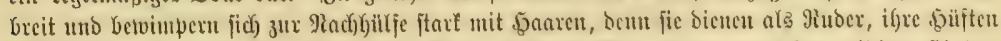

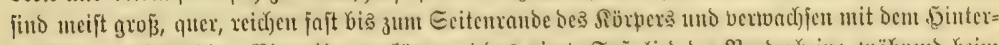

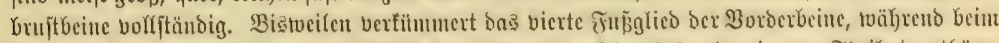

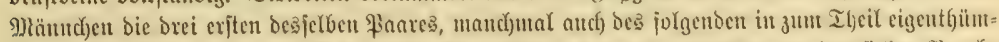

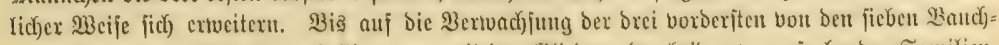

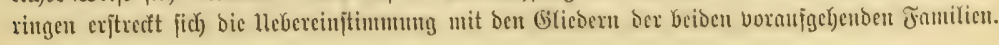




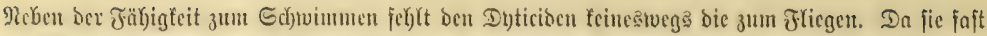

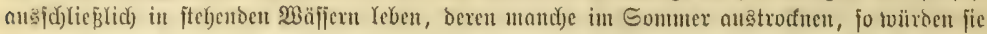

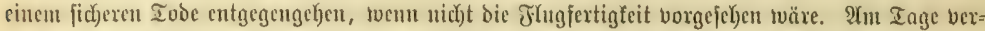

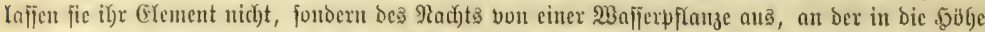

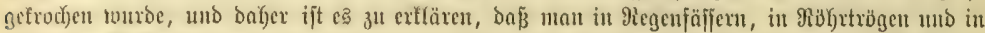

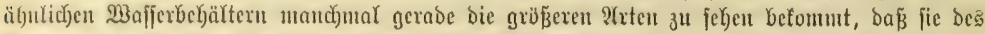

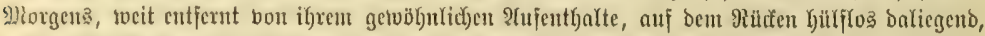

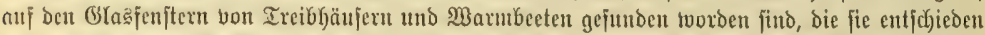

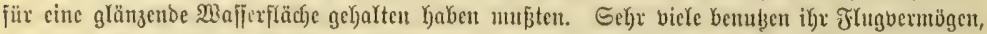

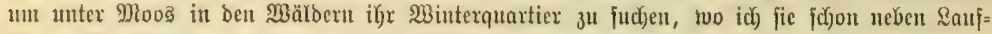

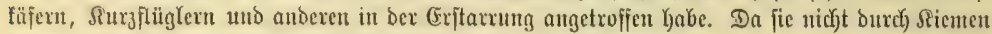

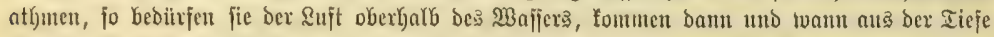

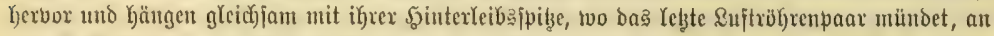

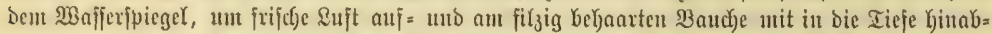

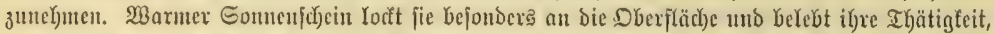

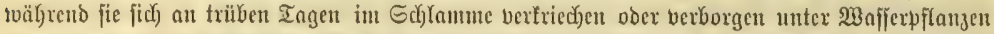

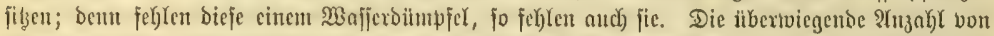

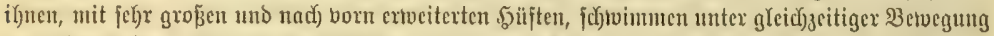

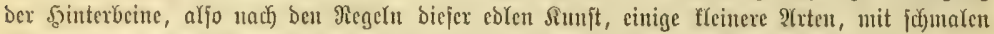

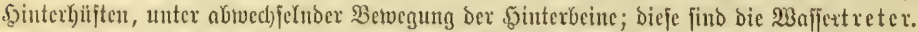

Sin Begug anf bie \&arben müjfen toir twieder unfere grope Umviffengeit betennen; von ben

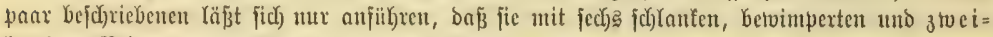

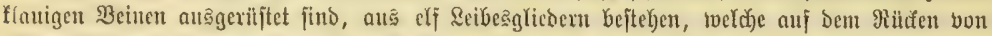

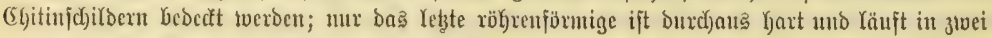

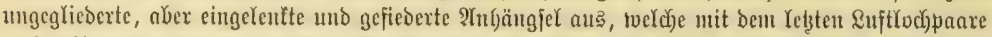

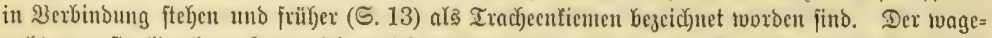

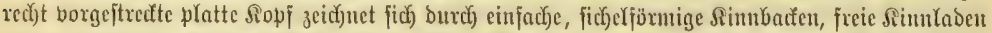
mit einglicberigen Iajtern, cin furzes, fleifichiges Sinn mit zweiglieberigen Injtern und feine Epur

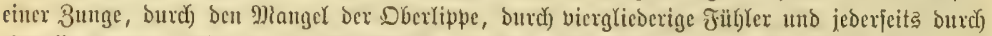
ciute (6ruppe yon fect)

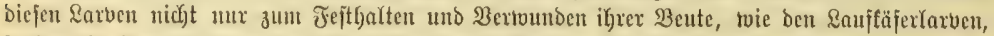

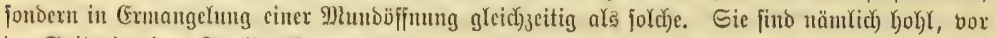

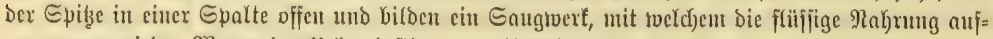

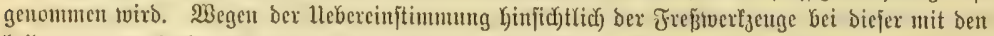

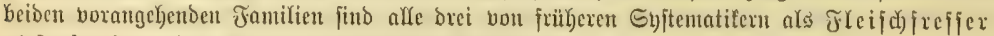
(Adephagi) зu einer (Gruppe zujammengeitellt voorbent.

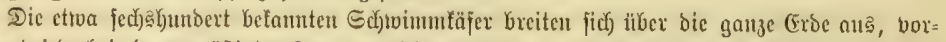

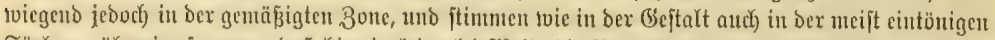

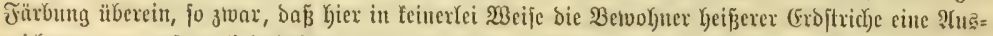

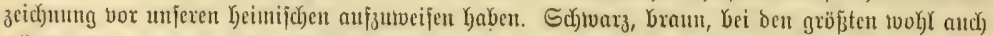

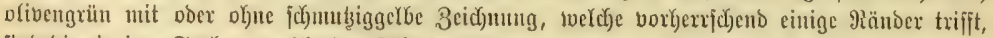

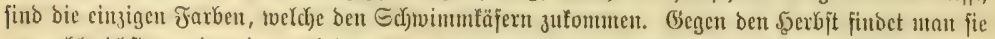

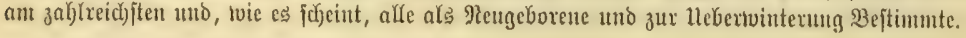

Der gefüumte Fabenfdutu immfäfer (Dyticus marginalis) it unferer umftebenden

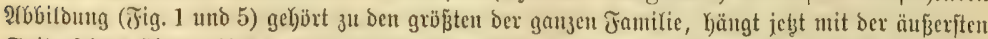

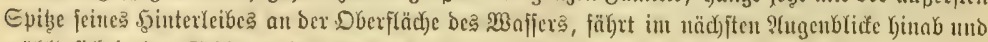

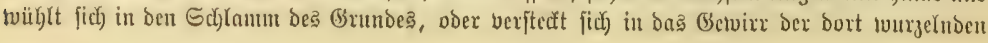




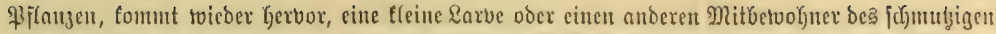

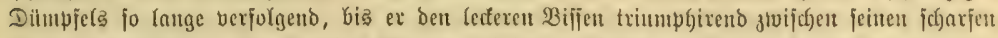

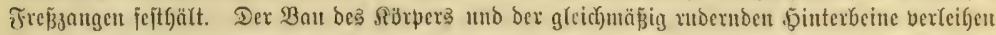

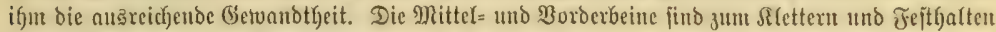

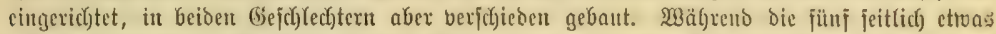

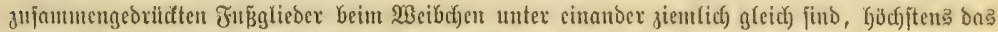

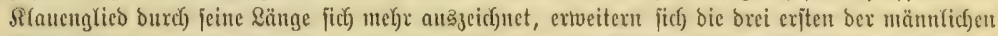

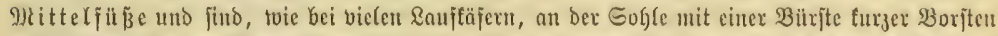

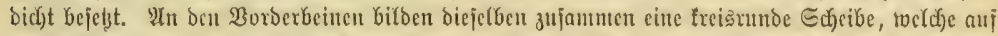

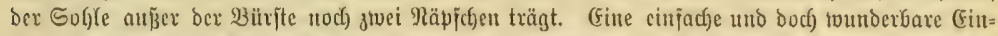

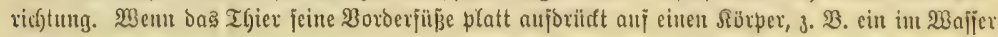

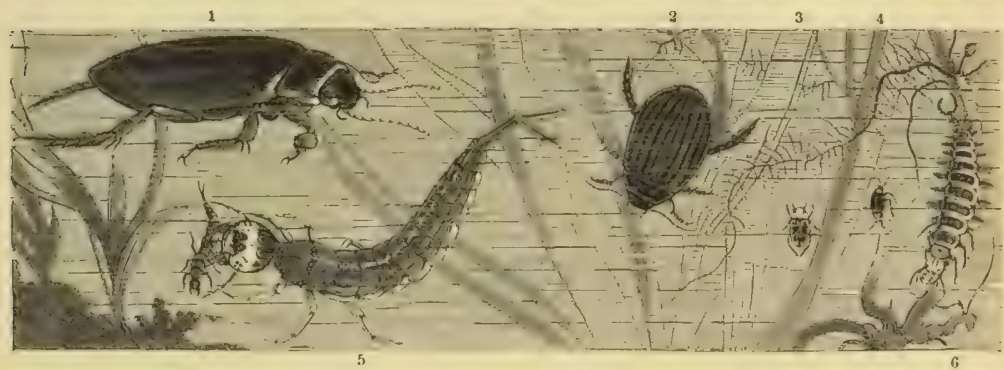

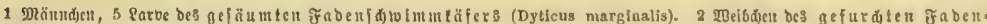

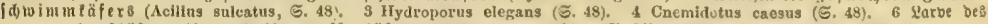

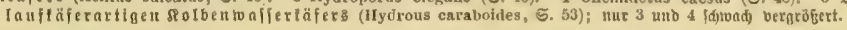

Liegendes श)

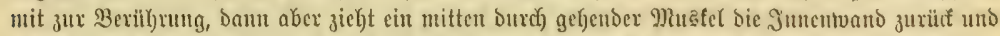

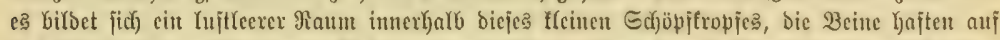

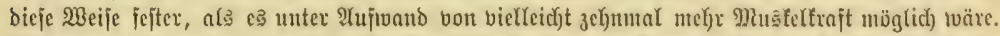
Die inmer glänjende, niemals najfe Sberfläche des ganzen Sï̈rpers ijt oben bunfel olivengrïu

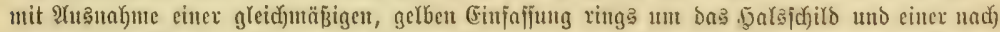

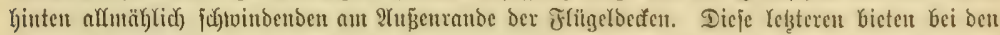

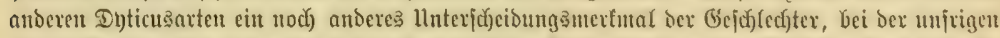

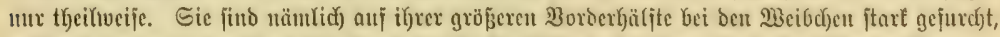

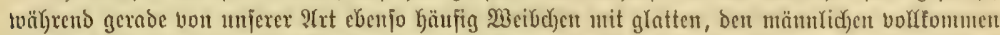

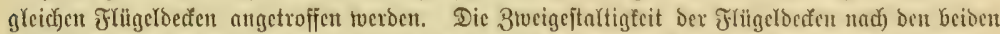

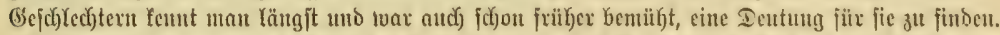

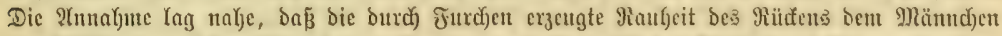

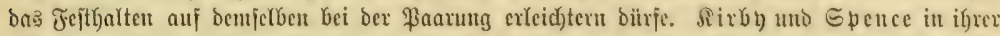

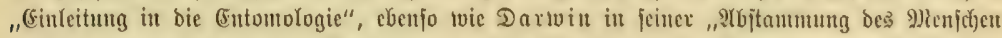

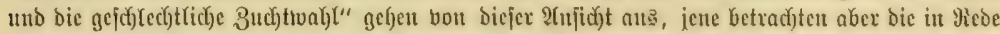

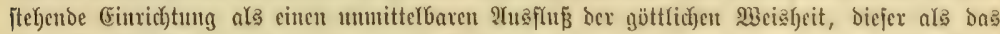

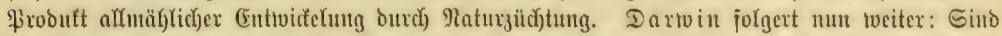

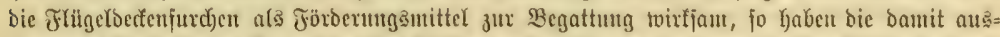

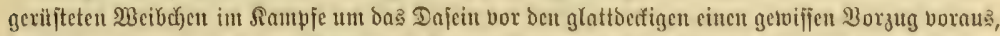

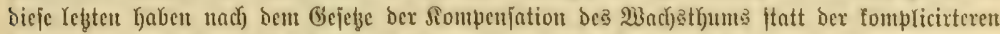

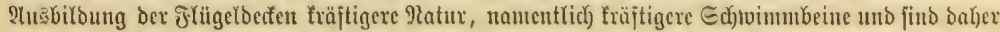




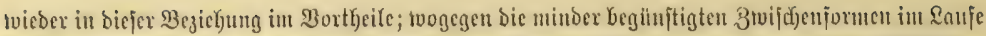

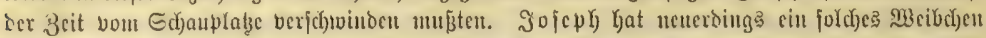

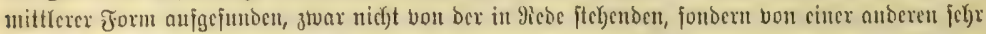

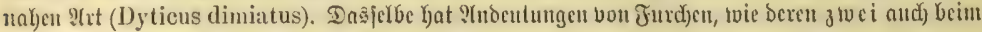

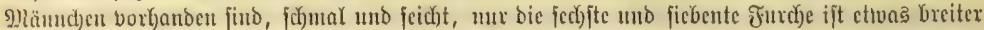

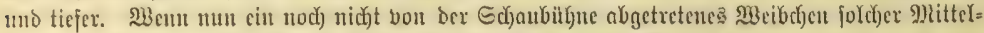

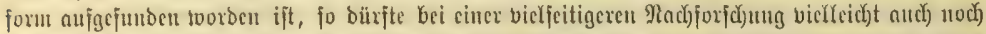

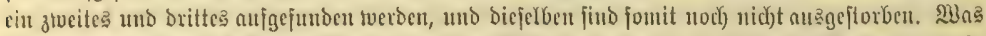

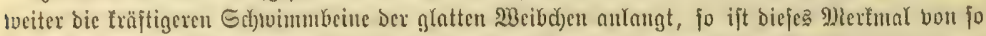

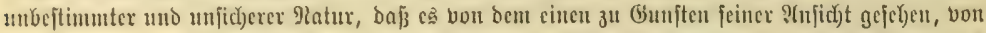

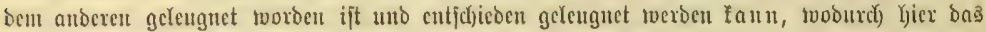

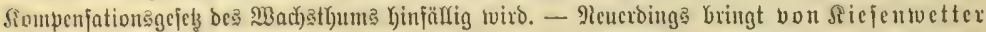

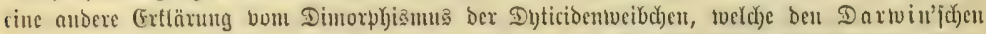

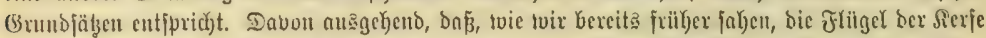

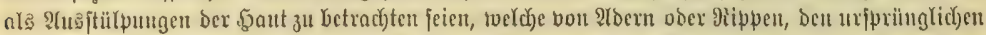

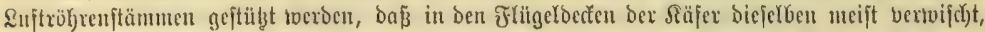

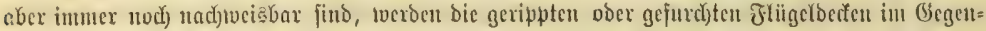

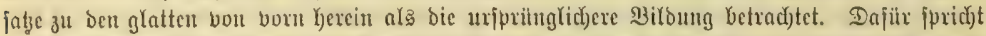

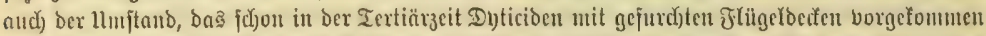

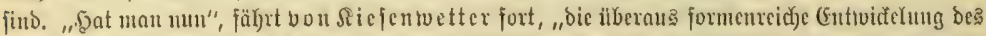

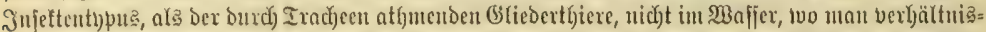

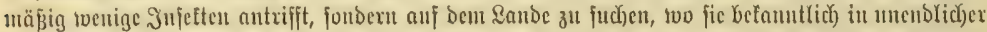

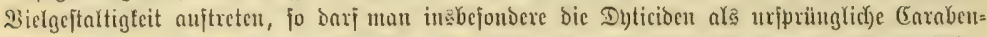

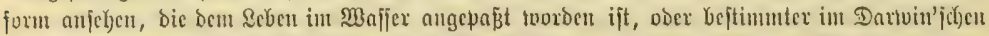

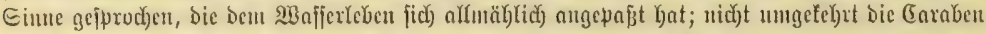

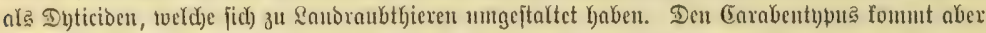

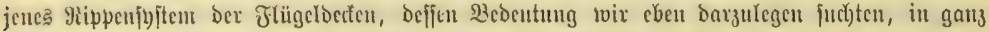

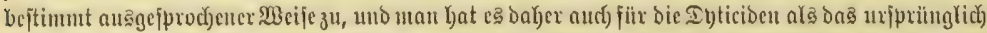

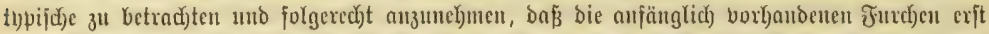

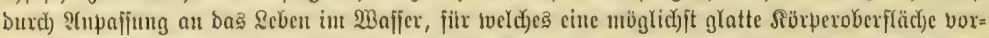

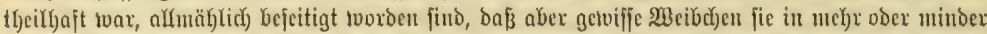

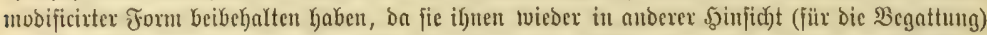

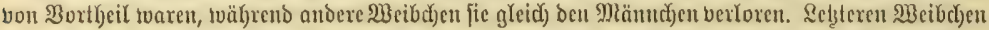

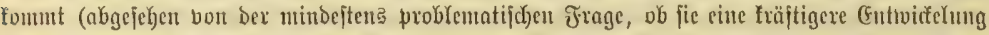

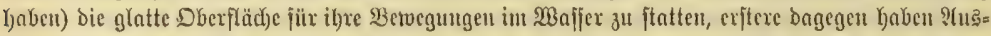

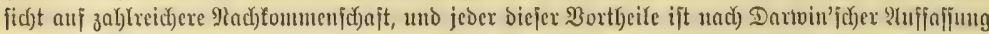

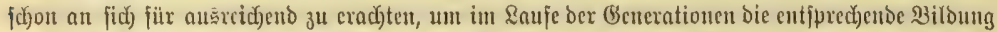

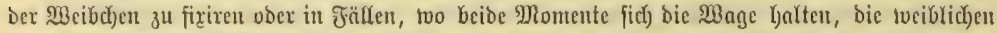

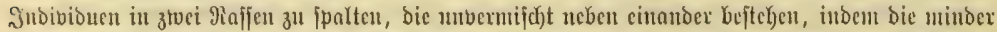

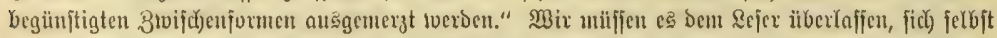

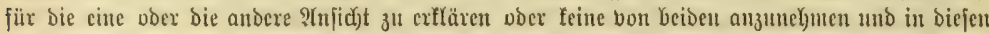

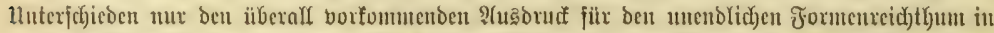

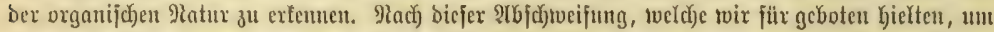

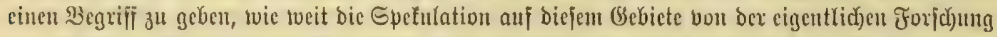

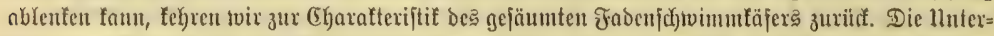

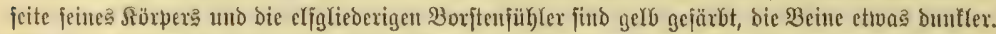

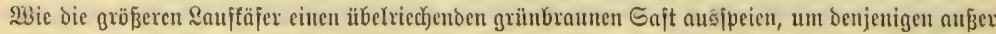

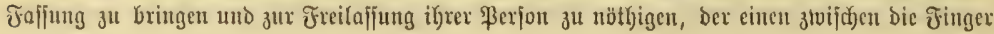




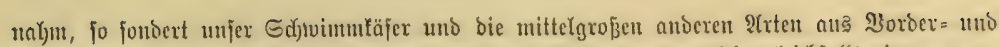

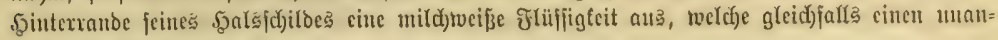
genelymen (Berud) berbreitet.

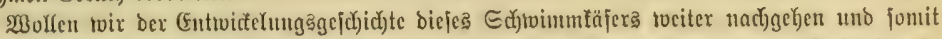

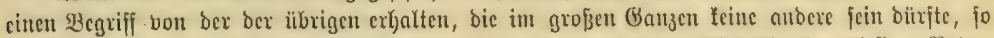

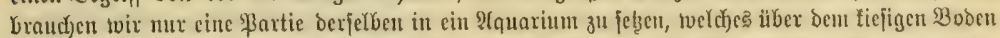

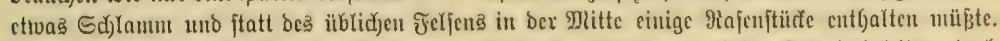

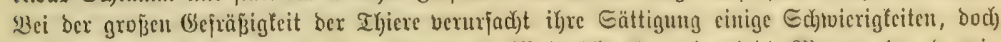

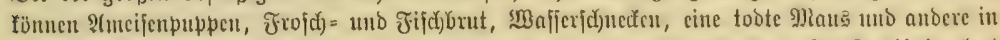

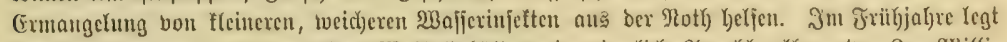

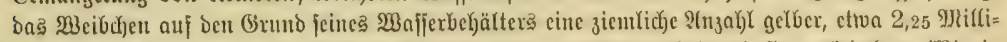

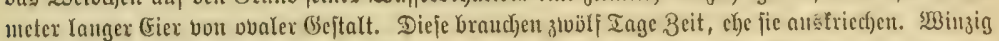

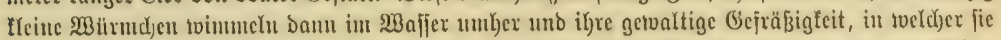

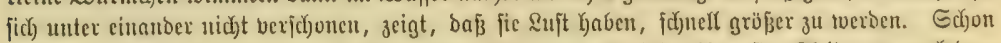

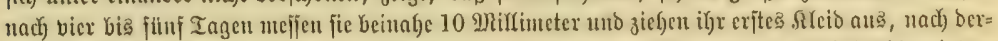

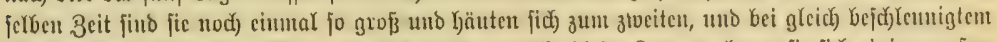

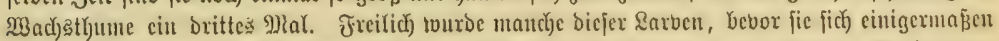
fräftigte, bie Beute eine ftärferen Stäubera, twic cinte Sibelfenlarbe und anderex. Sim fpäteren

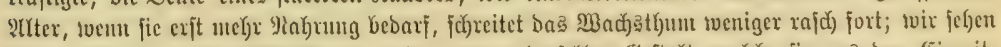

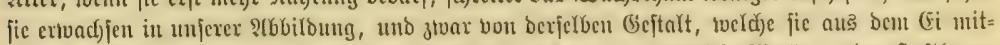

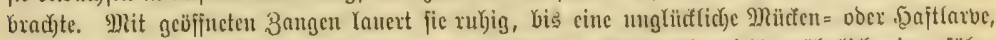

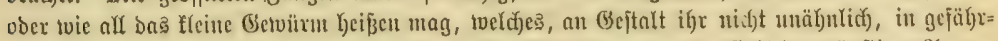

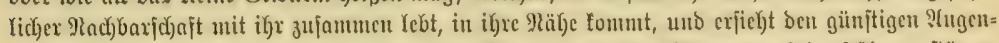

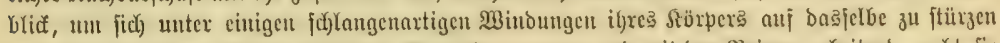

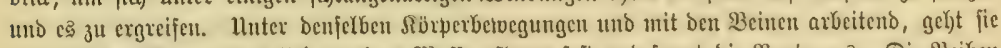

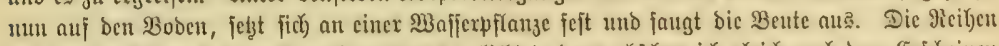

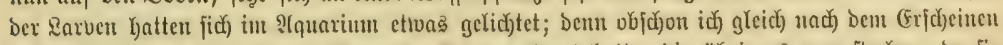
ber jungen Rärved)en zu beren હef)utze Die Siäfer entfernt hatte, bie vibrigen mun fterben, Da fie

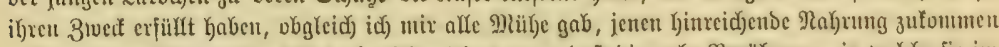

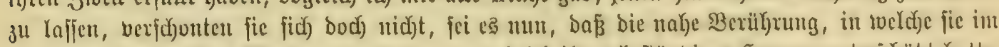

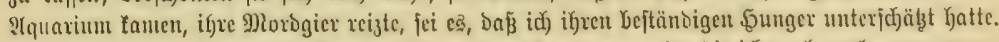

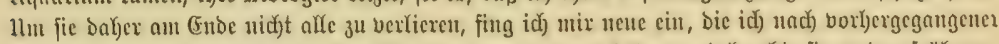

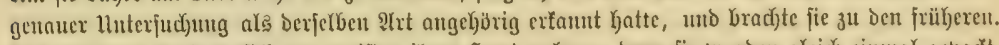

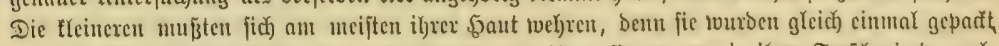

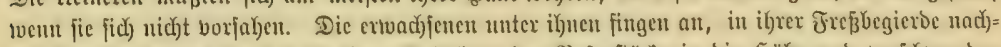

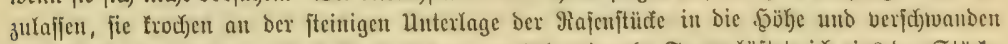

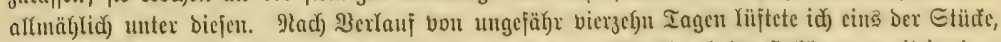

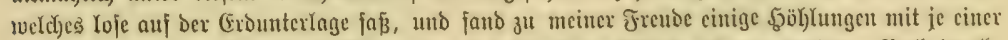

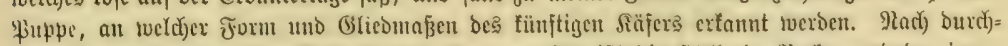

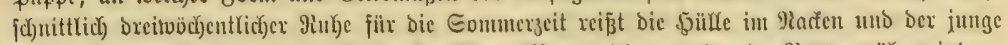

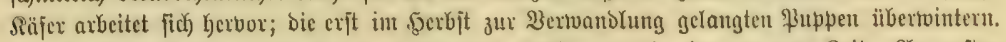

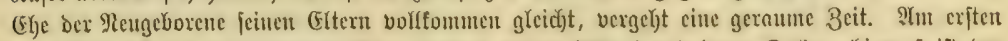

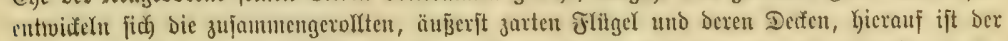

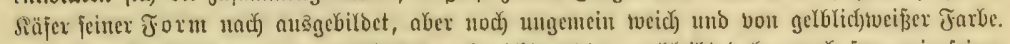

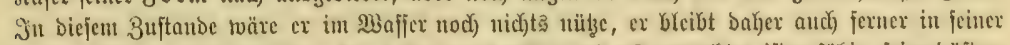

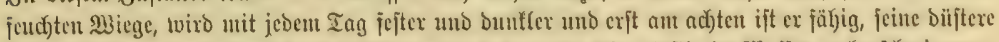

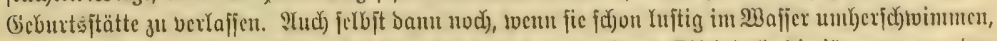

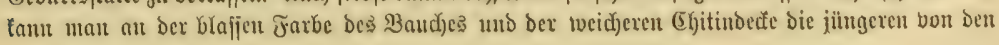




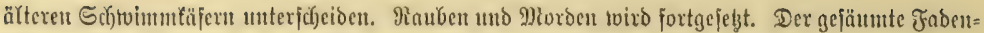

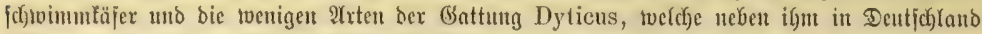

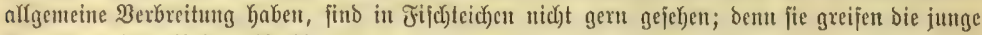
Brut an und verhindern ifr 2 (t) fomunen.

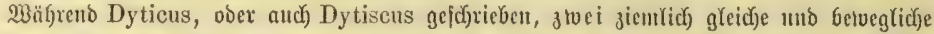

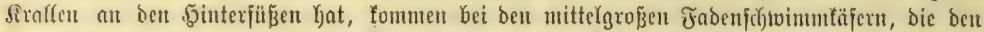
Gattungen $\Delta$ cilius uno IHydaticus angebüren, ztwei ungleidje vor, Deten obere fejt ift, bei Cybister

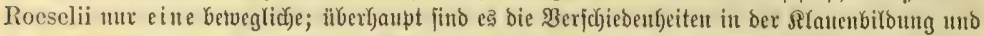

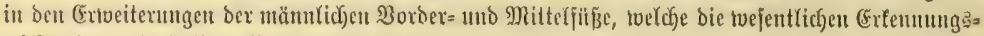
zeidjen ber aufgejtellten Battungen abgeben.

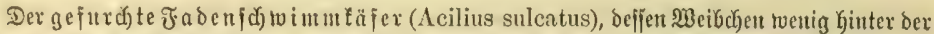

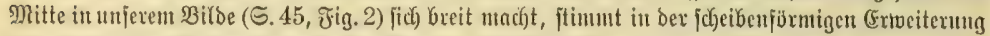

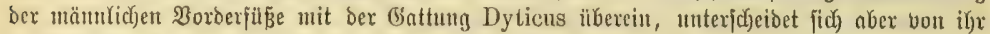

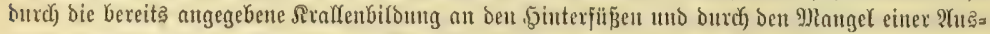

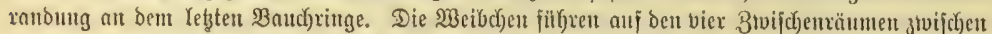

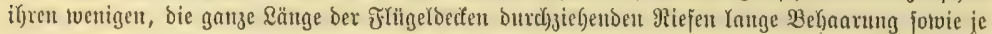

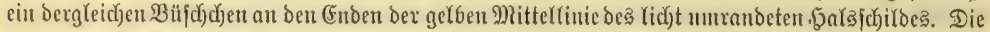

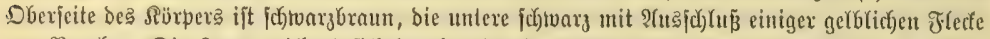

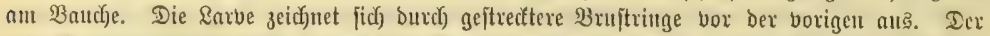

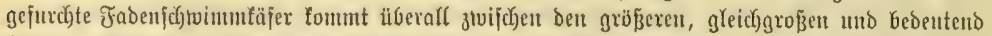

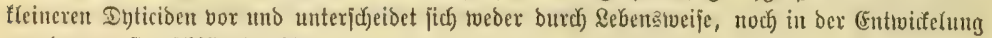
von der zuexit gejujilderten 2 rt.

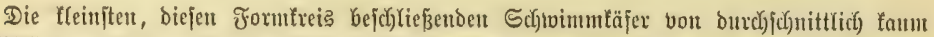

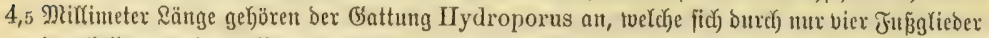

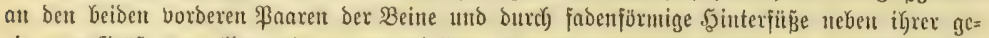

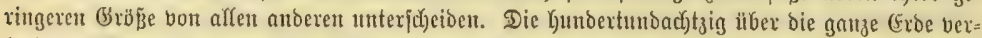

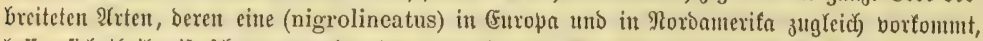

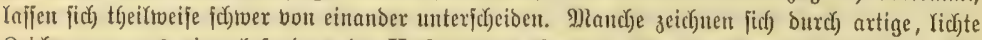

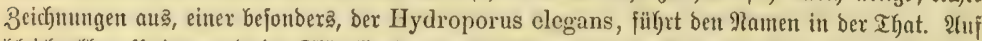

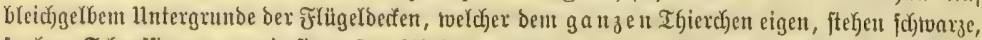

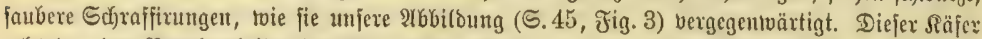

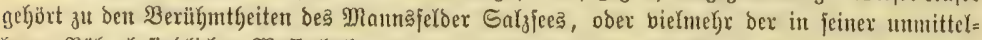

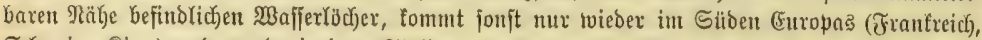

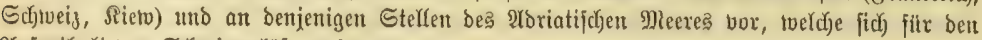
Aujentfalt bon Schroimmtäfern eignent.

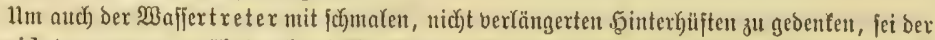

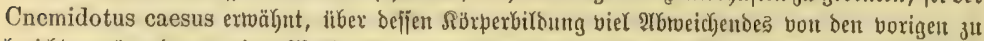

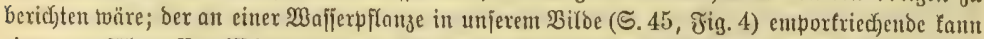
cinen ungefäbren Begriff babon geben. Die größjte $\mathfrak{B r e i t e ~ e r f a n g t ~ b e r ~ f i a ̈ j e r ~ v o n ~ e i n e r ~ S c h u l t e r e d e ~}$

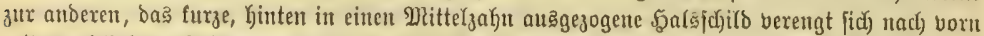

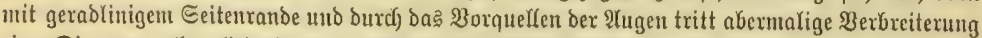
cin. Die nur zehnglieberigen, der Stirn eingelentten Filhler und bie bedeutendere Ränge be?

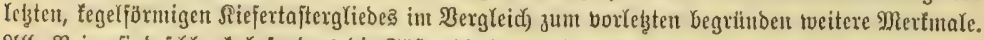

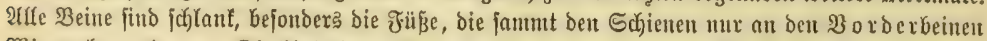
Wimperbaare tragen. Die Yjinterften Schenfel fieht man bló̧ an ber Spiłze, weil eine mächtige,

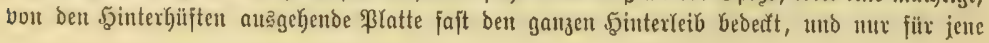




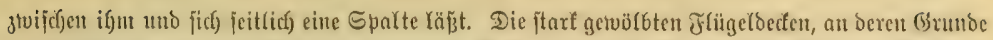

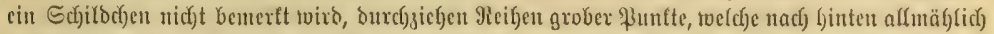

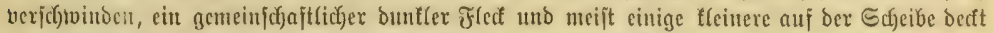

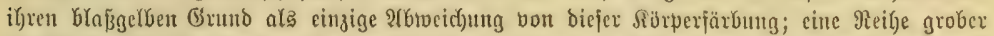

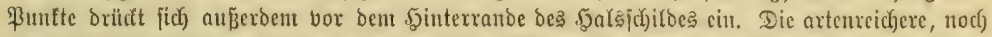

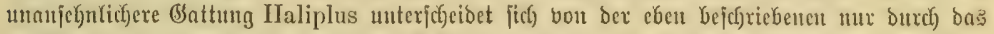

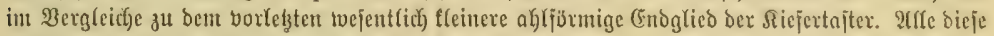

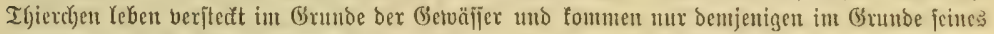

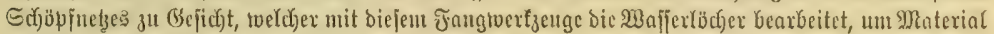
jür feine seäfexjammlung zu erhalten.

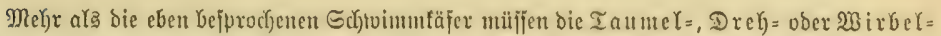

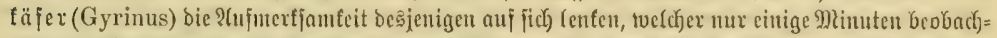

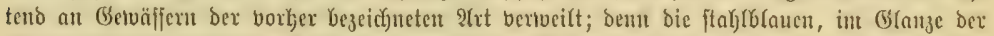

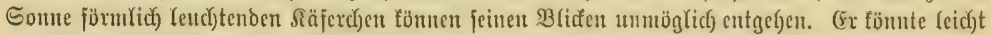

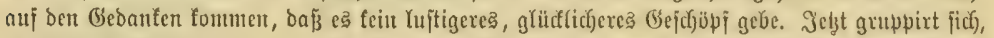

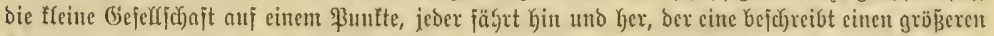

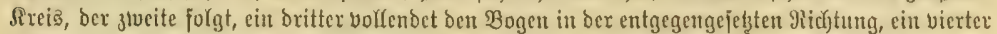

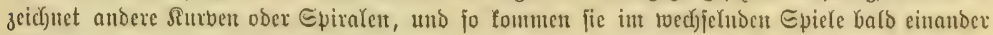

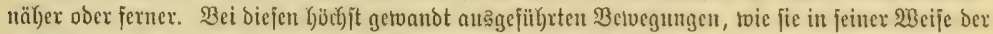

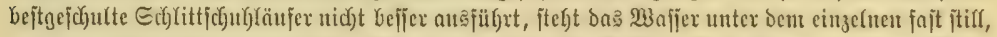

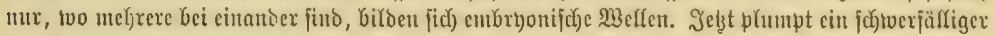

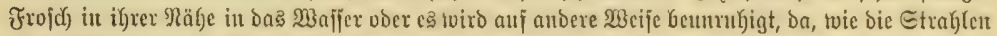

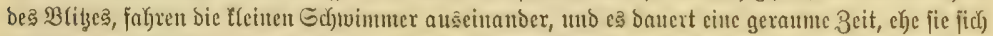

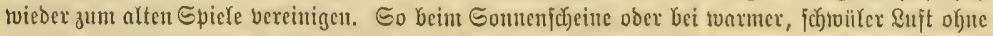

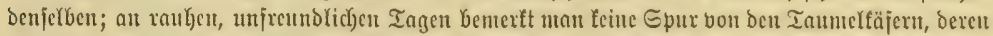

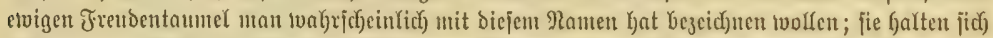

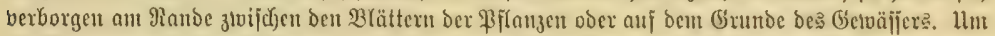

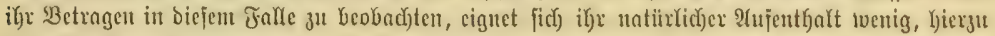

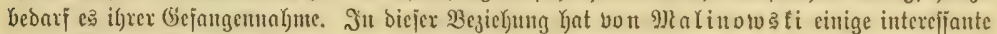

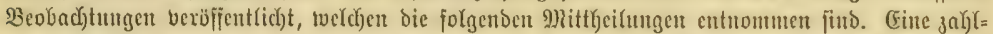

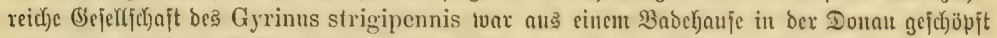

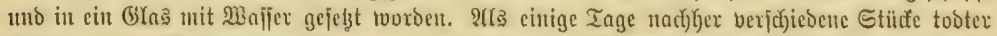

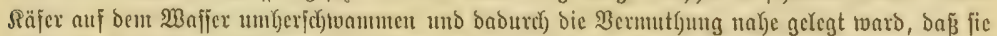

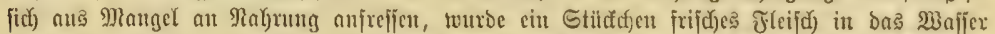

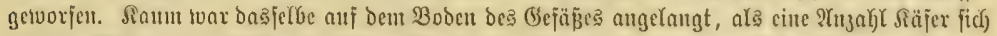

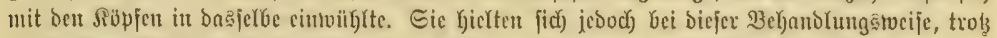

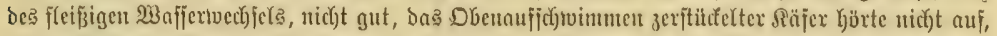

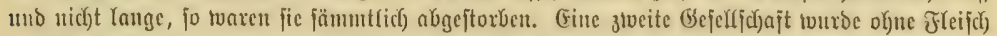

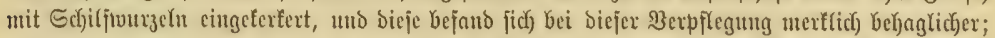

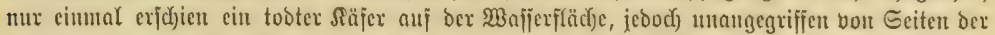

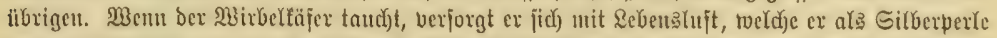

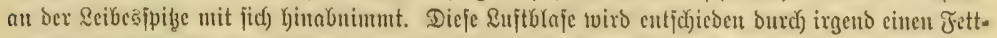

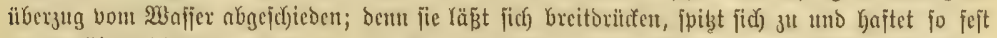

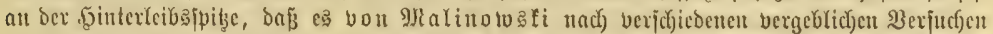

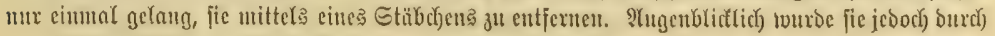




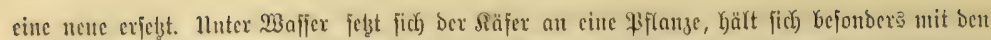

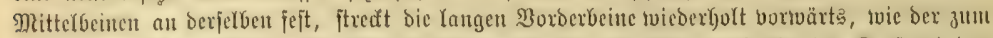

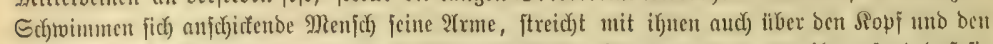

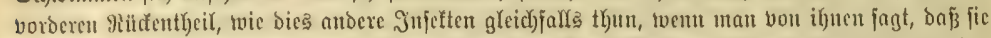

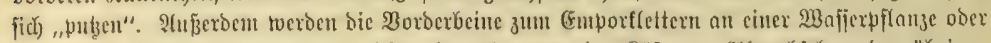
zแnแ blo

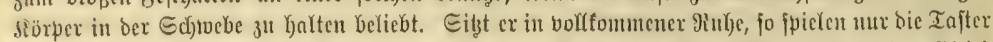

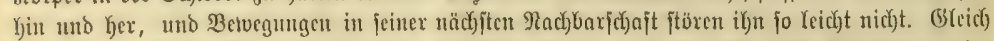

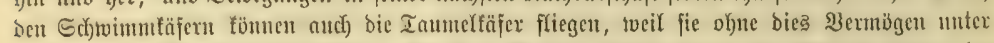

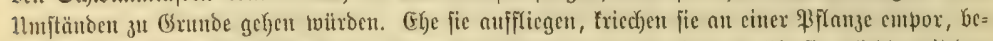

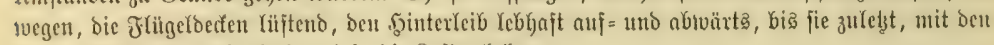
Beinen Yosłaffend, fid fichroirtento in bie \&ujt erbeben.

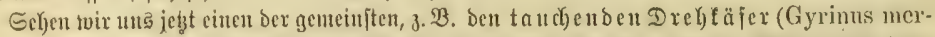

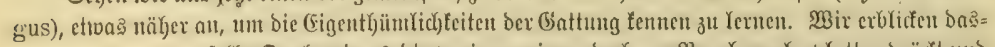

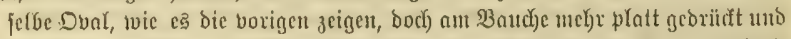

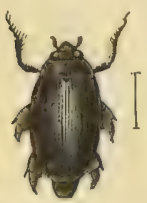

Iathenber Dreb. lïfer i(igidnus mergus), bergríbert.

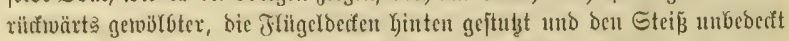

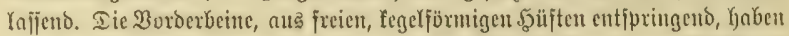
fičc) armartig verfängert, bie Kinteren, Deren Soujten feft mit bem Bruftbeine

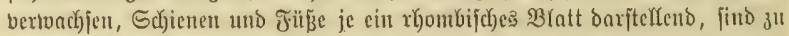

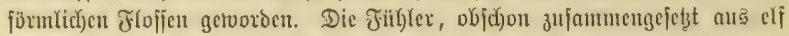

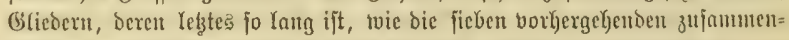

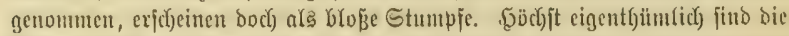
Plugen grbiloct, indem jebes bon cinem breiten Duexjteifen in eitre obere uno

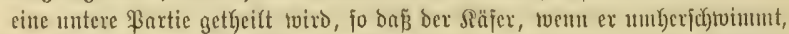

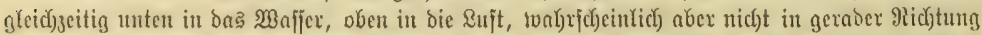

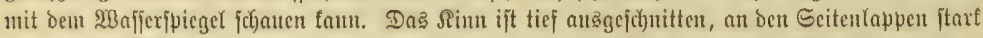

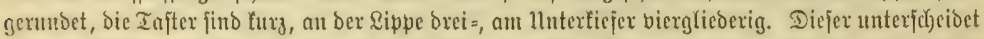

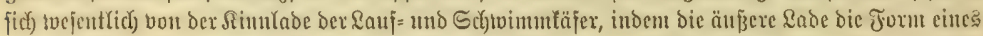

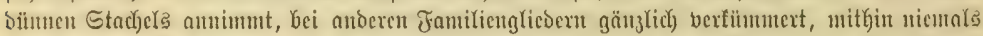

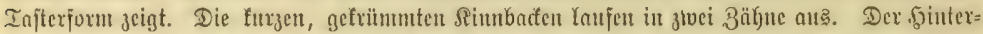

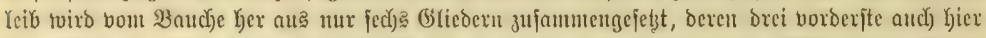

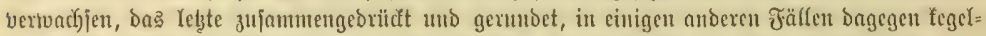

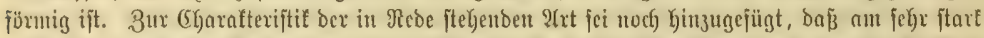

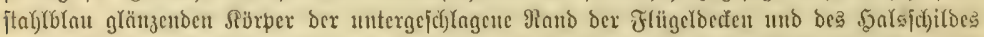

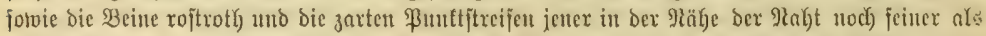

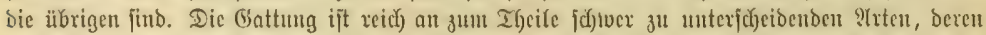

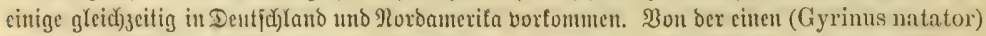

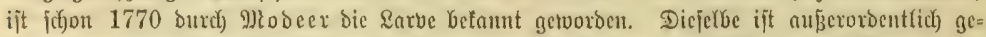

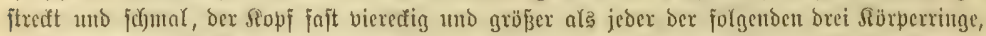

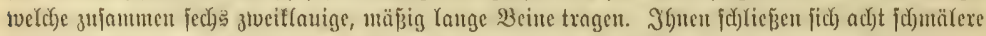

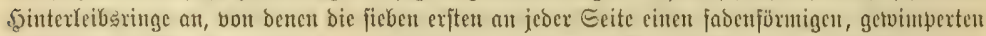

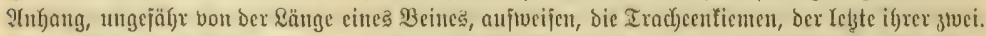

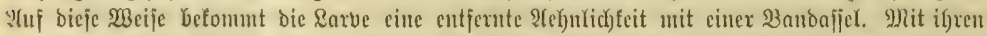

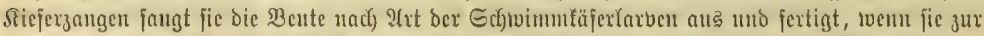

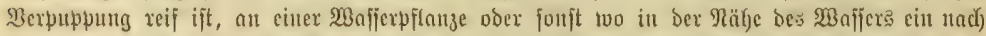

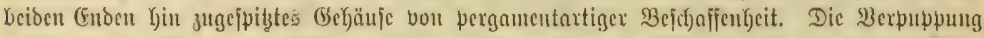

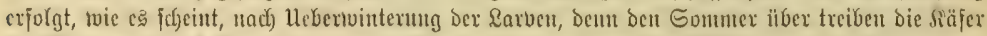

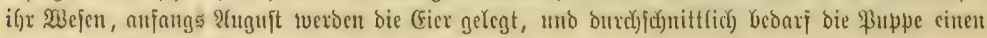




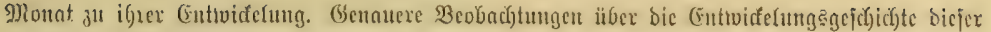

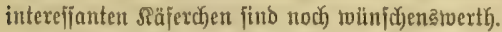

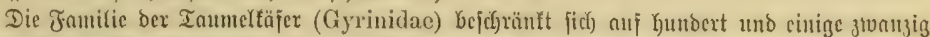

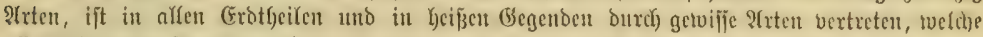

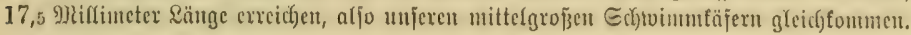

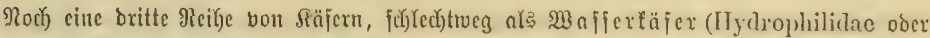

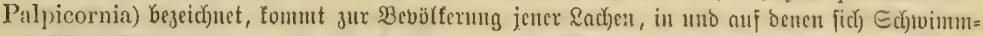

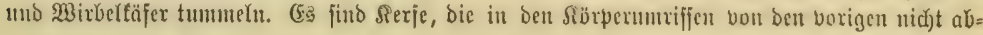

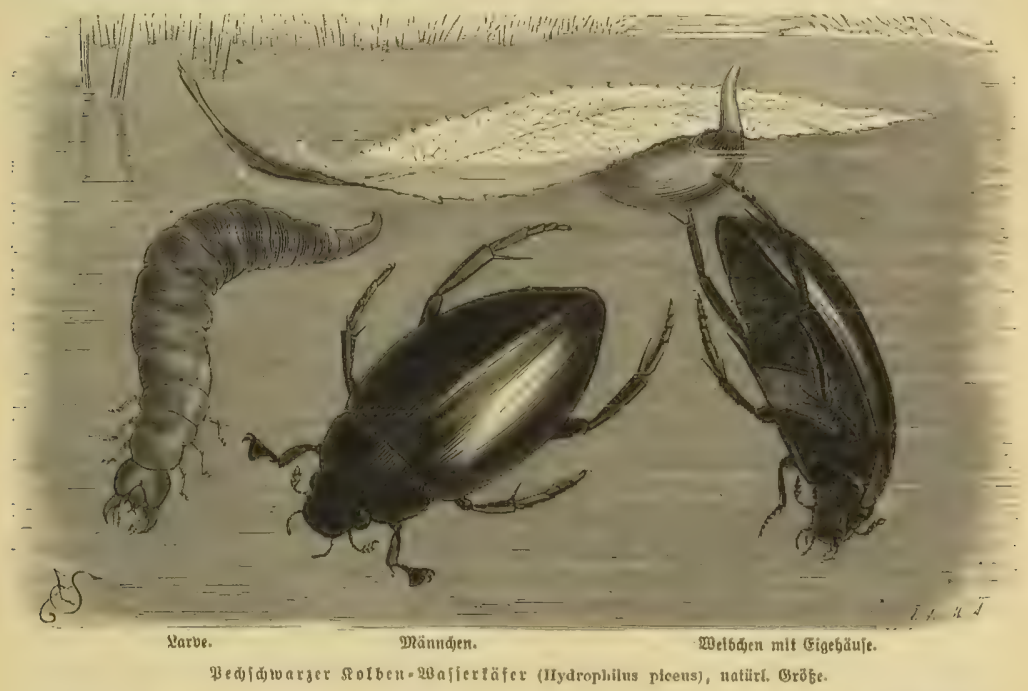

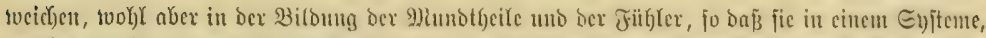

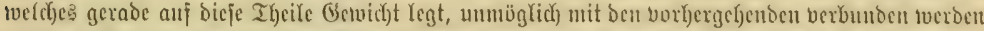

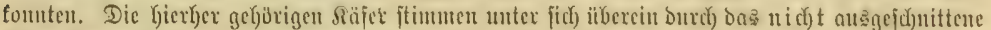

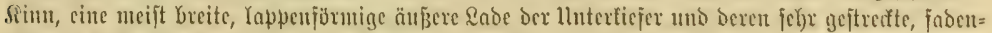

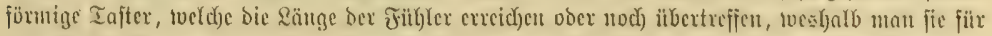

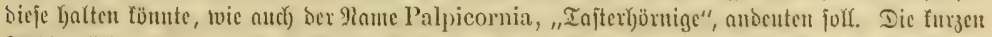

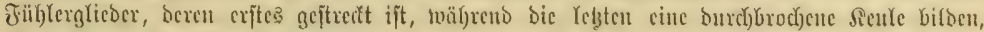

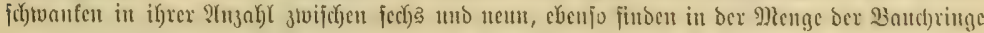

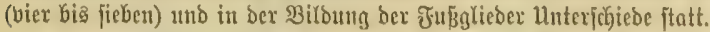

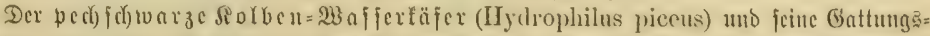

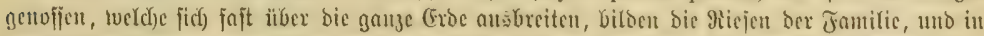

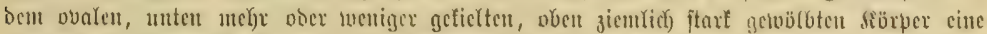

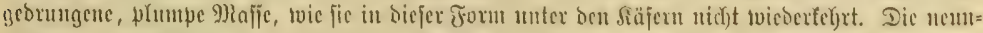

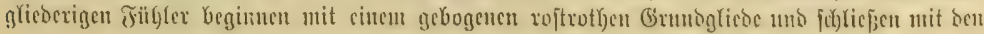




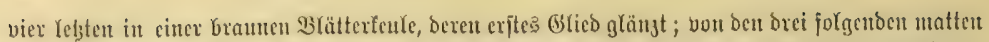

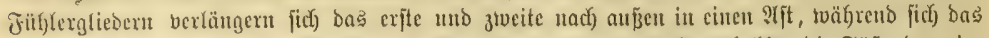

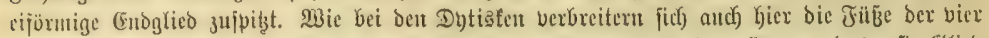

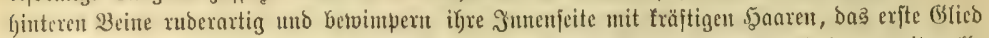

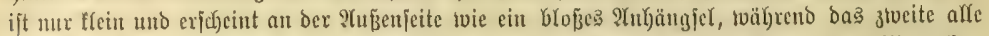
anderen an Sänge ilbertrifit; Gierin beruht ber eine (Egarafter ber gansen Sippe. Das Männd)en

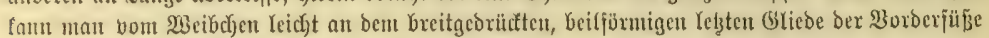

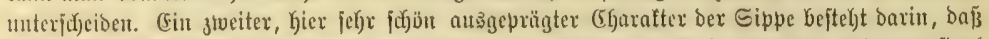

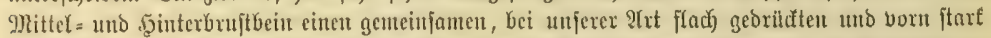

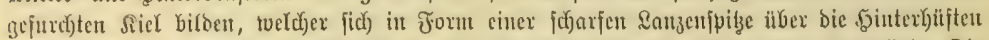

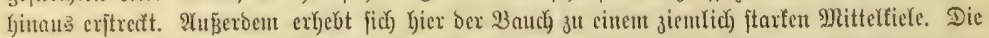

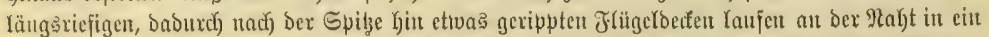

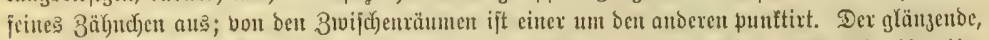

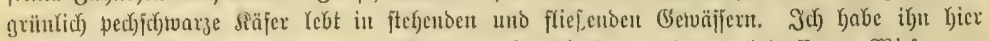

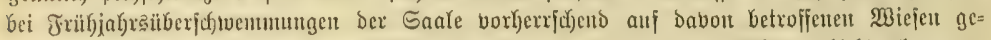

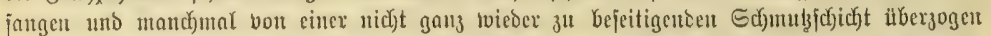

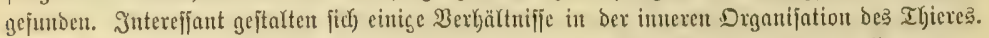

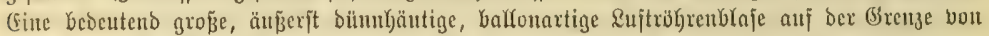

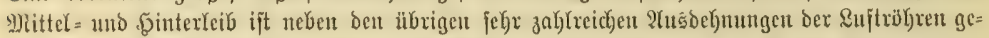

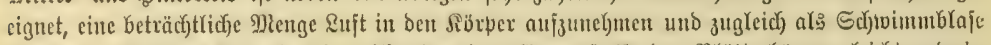

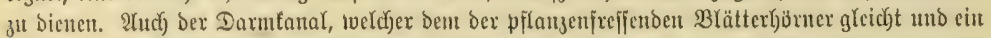

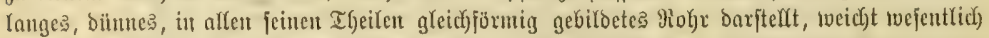

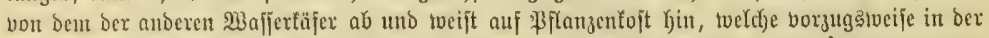

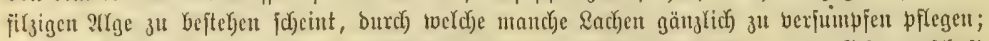

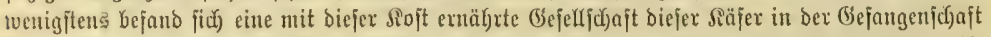

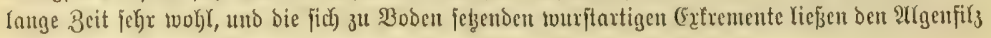
sicht verfenten.

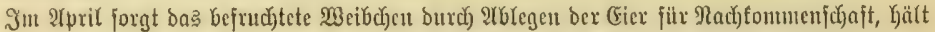

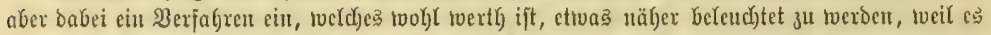

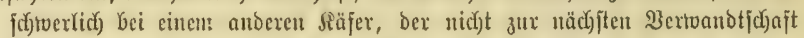

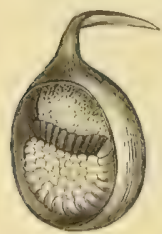

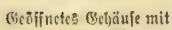
(Eictu, vergrö́fert.

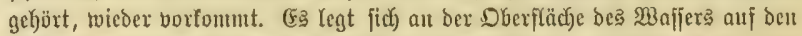

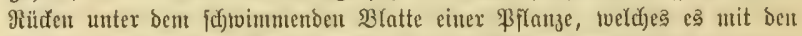

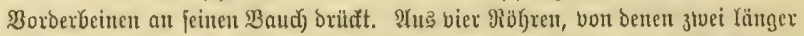

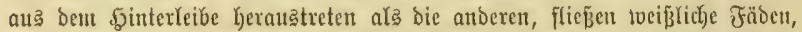

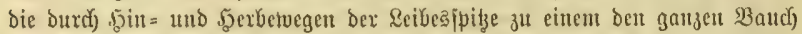

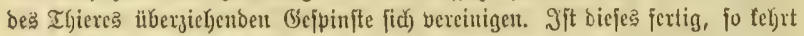

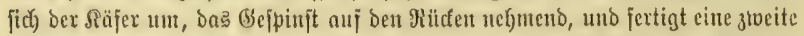

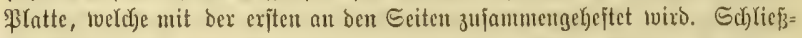
(ich) jitect ex mit beut Sointerłeibe in einem vorn offenen Gacfe. Denjelben

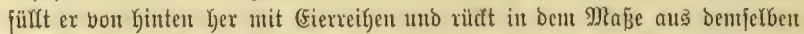

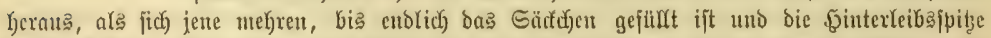

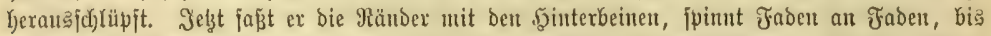

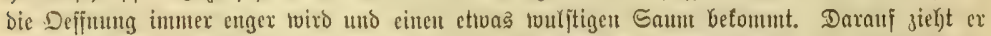

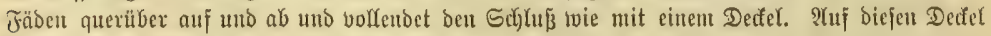

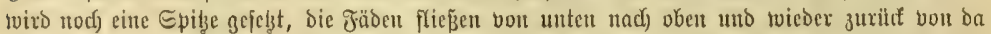

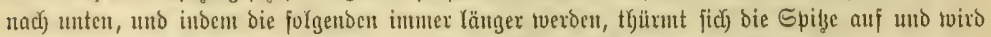

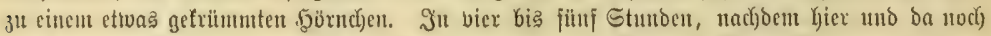

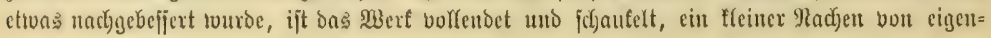




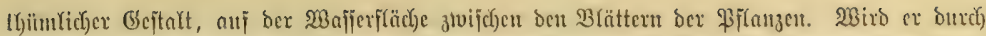

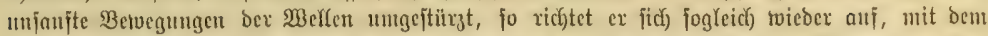

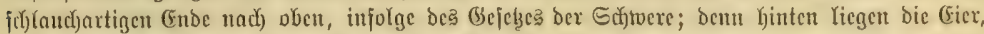

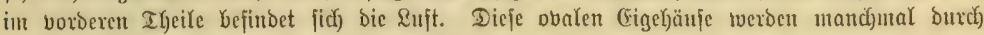
authajtende Pfflanzentheilchen zur Unfenntrichteit entifellt.

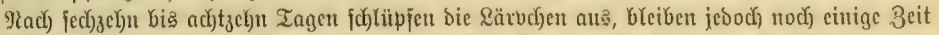

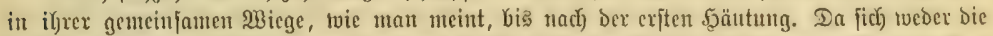

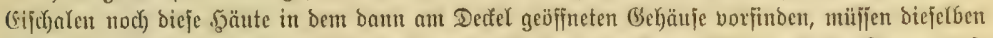

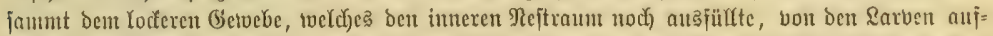

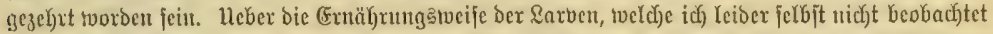

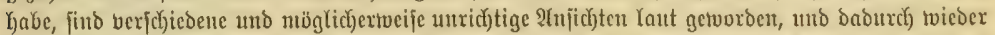

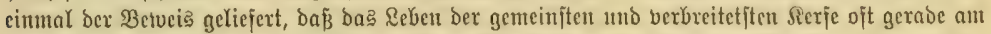

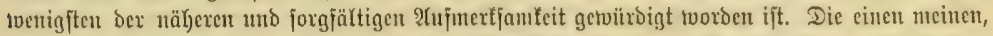

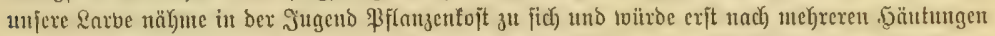

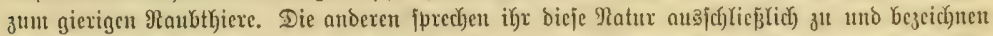

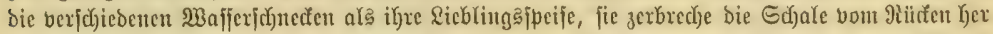

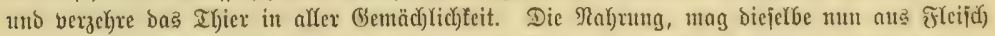

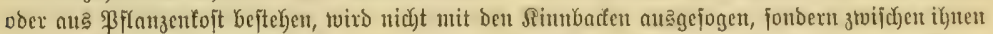

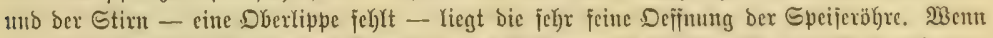
11tan bie \&arbe ergreijt, obex ber Edynabel cincs :

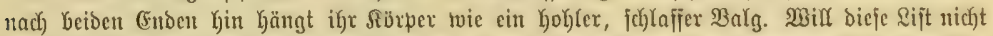

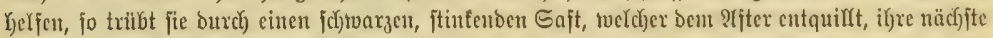

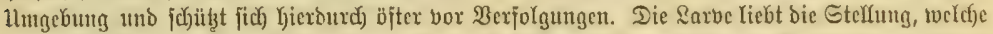

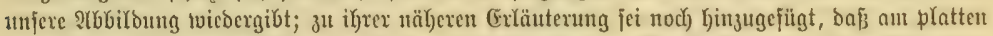

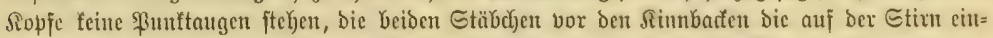

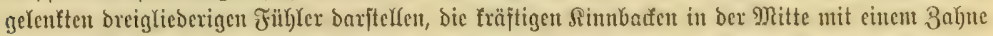

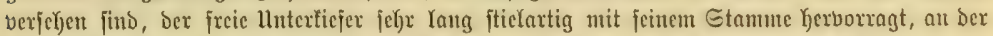

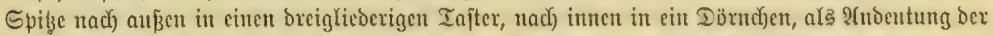

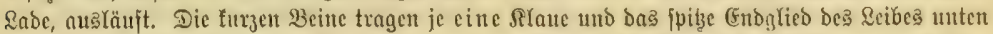

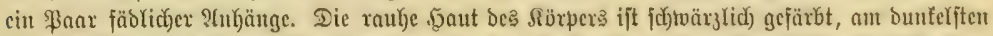

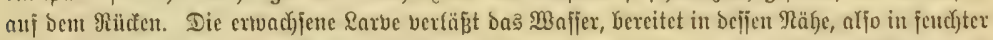

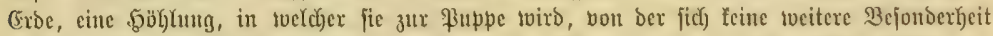

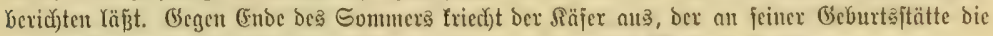

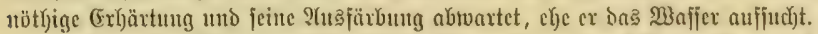

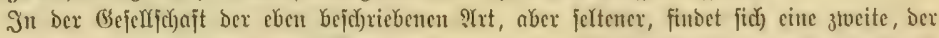

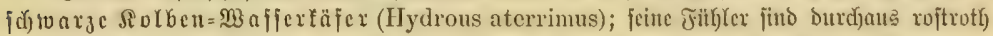

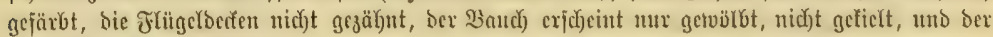
Bruftiel vorn oljne Furdide.

Dex bid gemeinere rauff̈̈frartige Rolben=

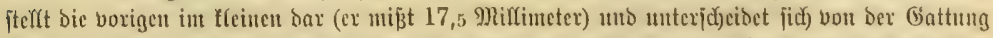

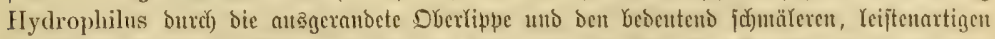

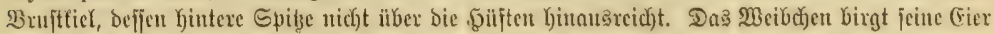

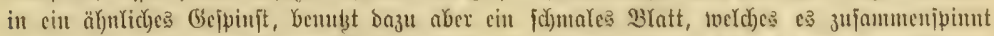

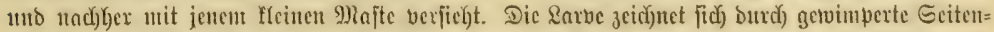

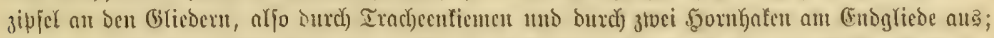

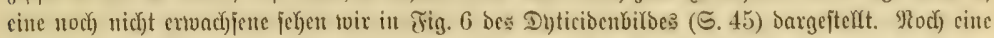

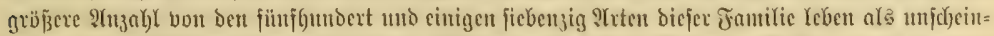

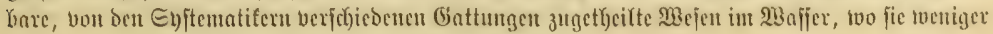




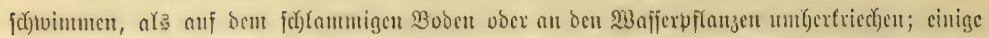

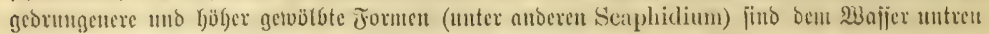
getworben uno Kaben bie Matur ber झRijteajer angenommen.

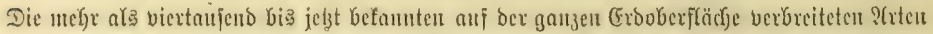

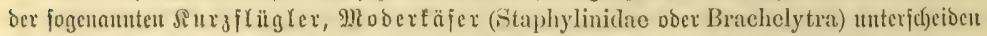

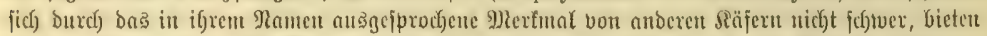

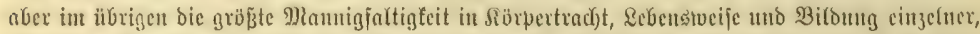

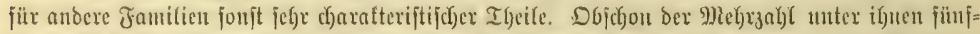

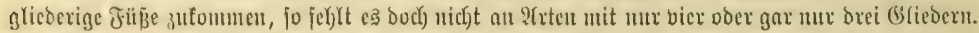

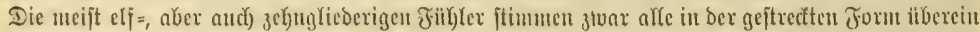
und find in ber Regel fabenjörmig, es fommen indeffen ant an ber Spibe berdiate, injofge bes

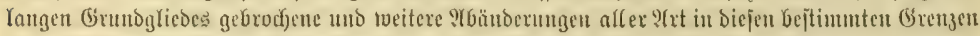

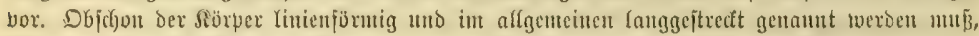

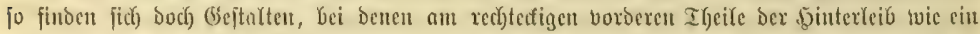

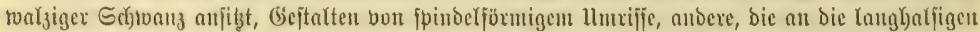

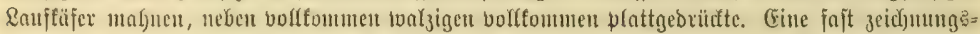

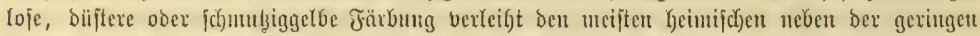

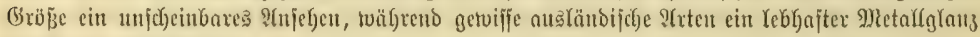

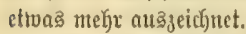

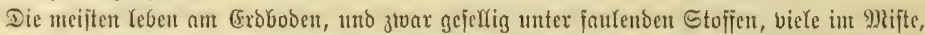

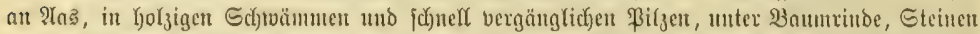

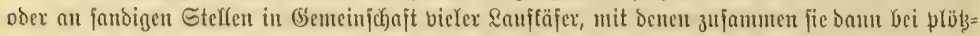

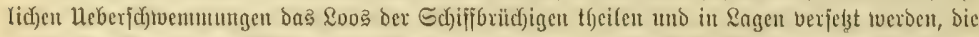

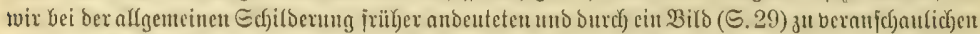

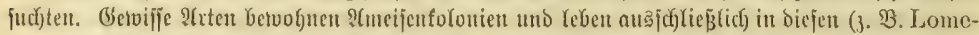

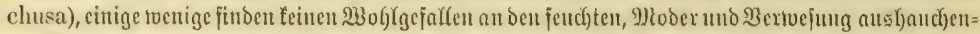

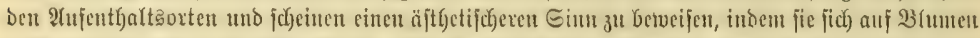

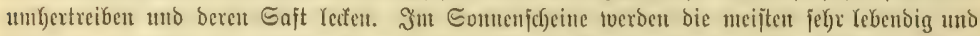

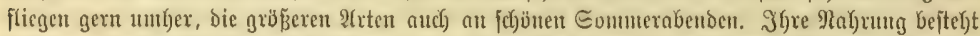

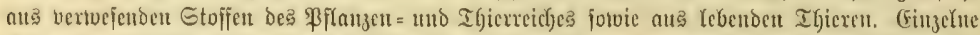

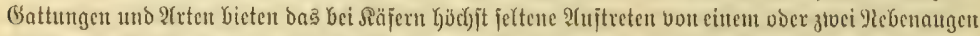

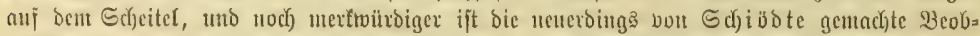
achtung vour \&ebendiggebiren einiger Eiionuerifoner Der Battungen Spirachtha unb Corotoca.

Die Rarben ber Staphblinen gleidyen barum ben volffoumenten Jinfeften mefje als anbere,

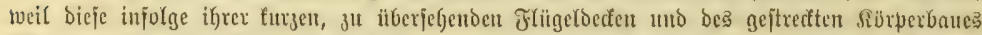

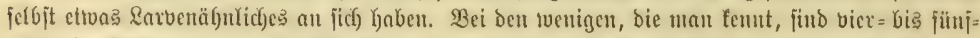
gliederige Jiibler, ciu biอ fechs

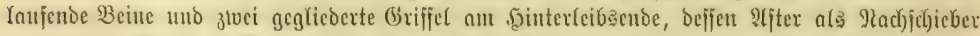

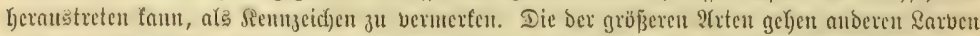

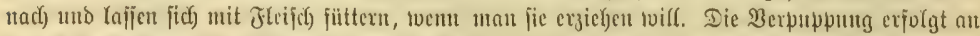

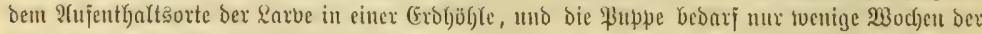

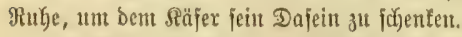

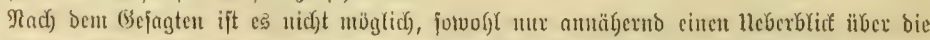

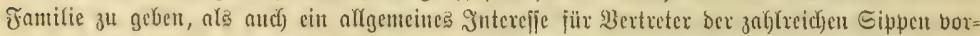

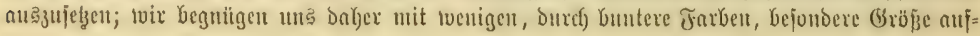




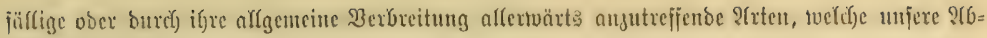
bildung borjüfret.

Sex goldfteifige IJoderfäjer (Staphylinus cuesareus, Fig. 6) mit bem rotgflitge=

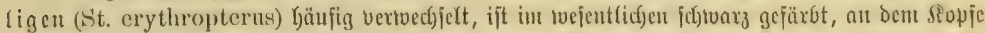

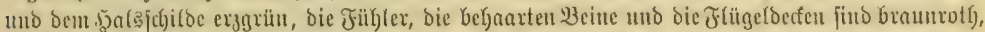

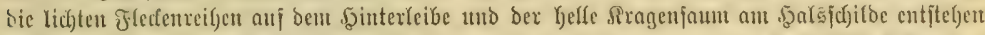

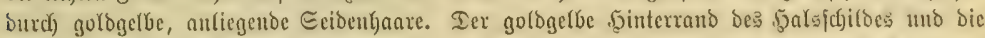

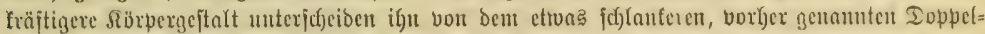

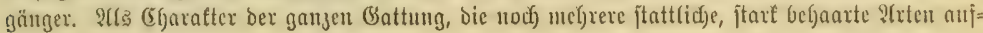

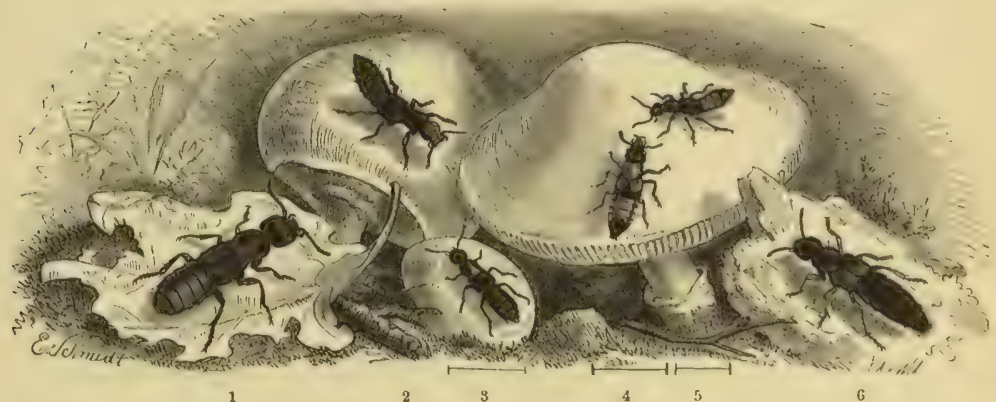

1 Stinfender Nobertäfer (Ocypus olens). 2 Surzbatiger Etaphyline (Staphylinus pubescens). 3 (Exgfarbener Diftlieb (Phlonthus aeneus). 4 g otger $\$$ if

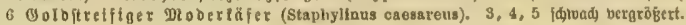

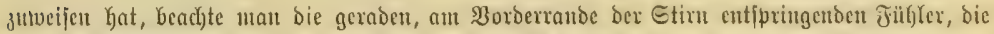

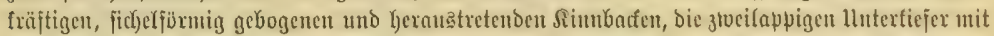

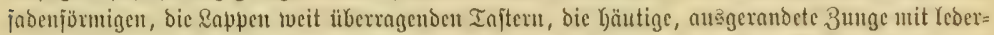

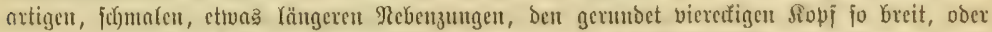

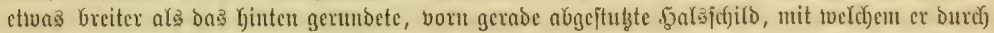

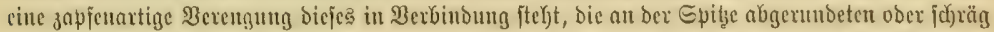

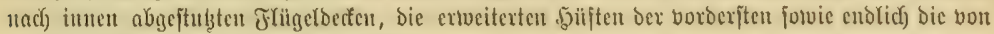
einander abjtebenoct Der mittelften Beine.

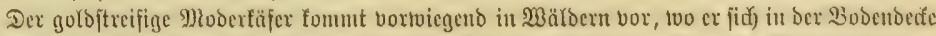

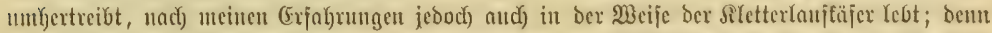

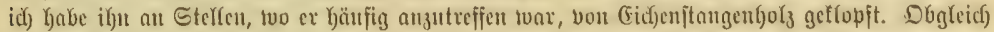

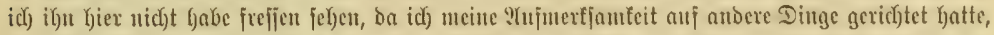

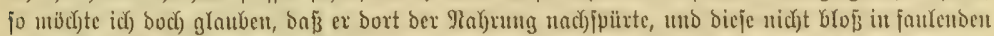

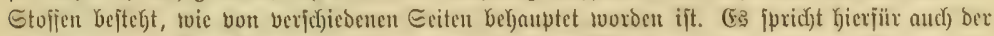

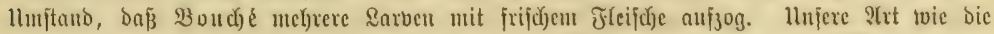

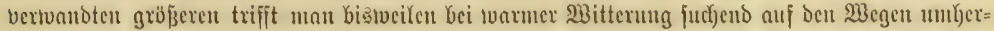

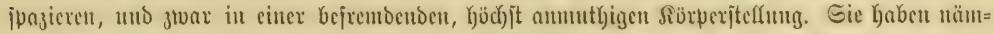

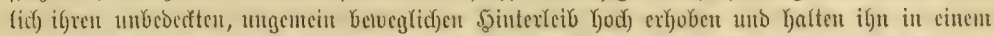

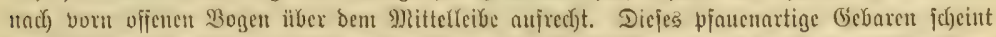

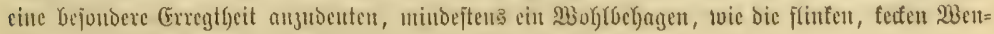

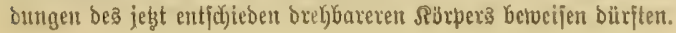




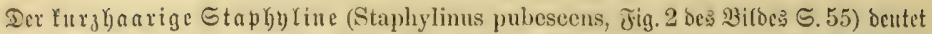

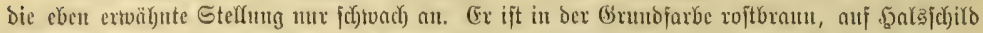

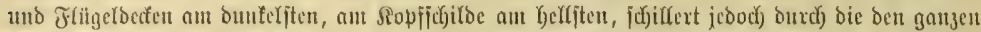

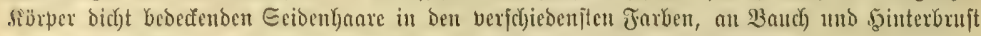

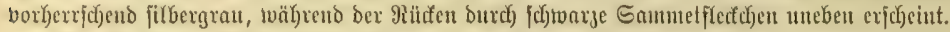

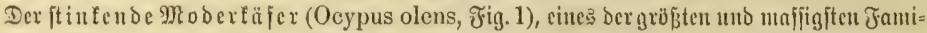

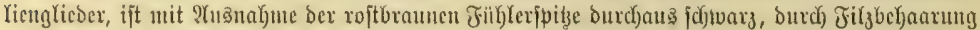

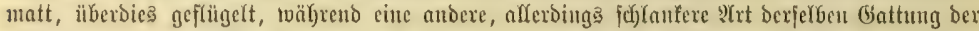

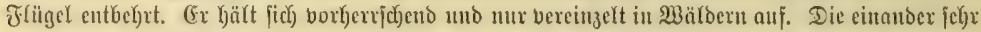

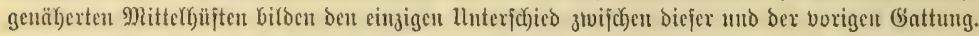

Der erzfarbene Miftrieb (Plilonthus aeneus, Jig. 3) gefört einer aub Gutbert curo=

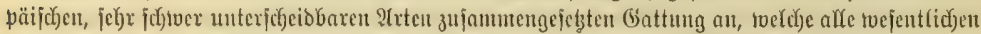
Derfmale mit ben beiben vorangebenden gemein Gat uno (iid) mur burch cine ungetfecilte, vorn ab=

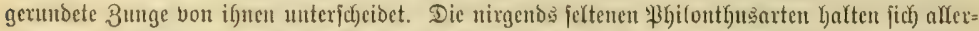

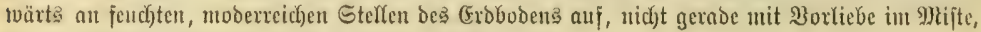

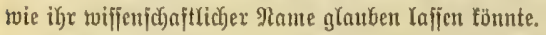

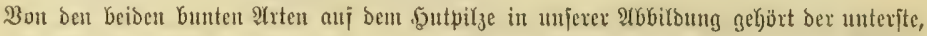

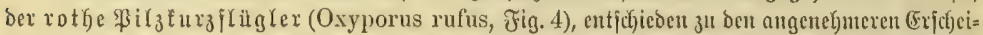

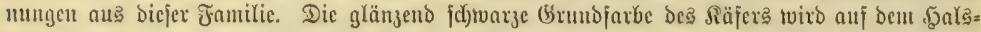

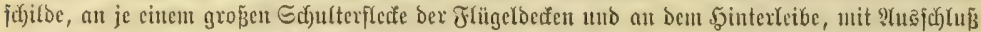

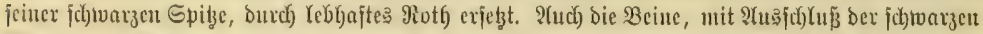

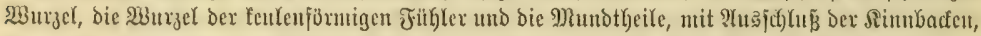

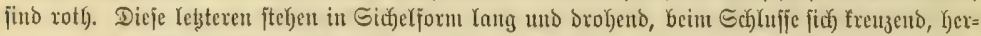

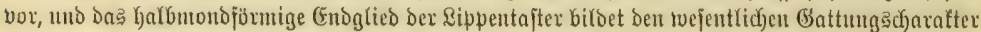

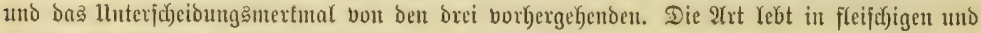

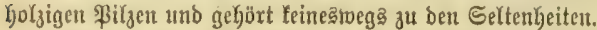

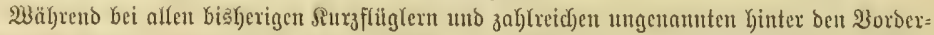

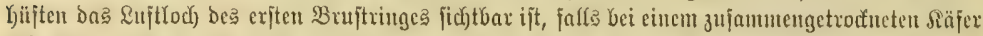

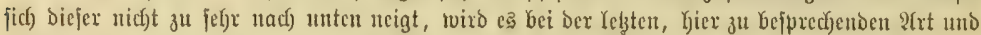

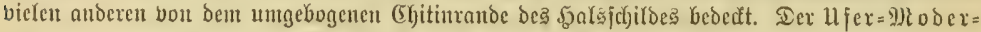
fäfer (Paederus riparius, Jig. 5) ift roth, mur an Siopfe fammt ben Fithlerjpižn, an ben

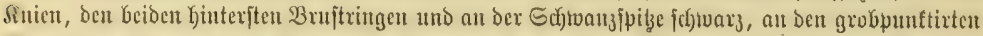

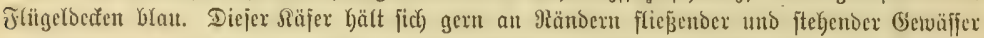

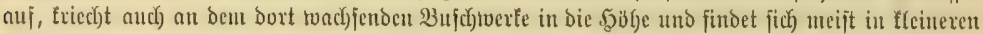

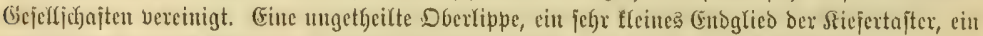

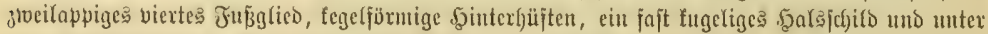

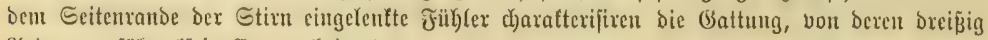
2trten ungejäbr elf in Guropa Geimaten.

Die Plelaphioen (Pselaphidac), tvingige, ntauche intereffante Geite barbietende Räferthen,

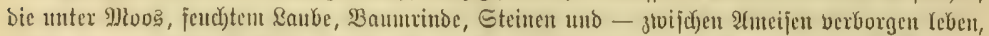

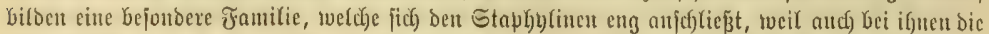

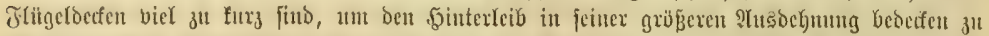

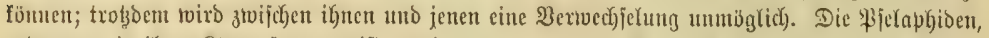

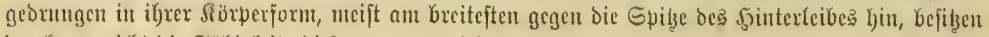

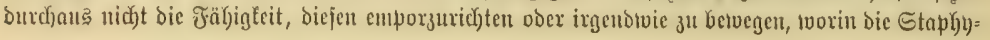




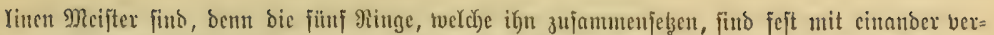

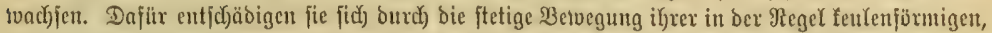

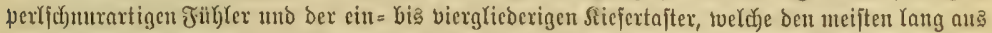

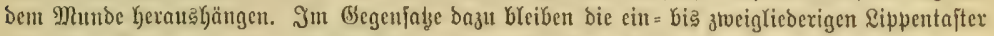

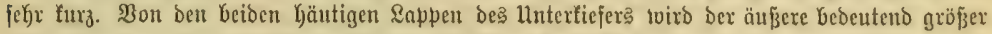

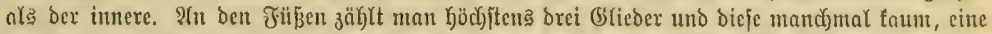

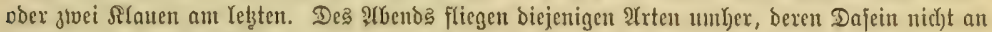

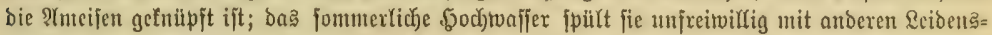

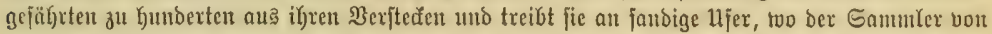

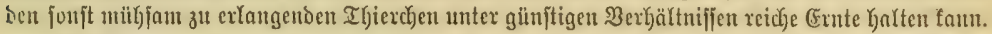

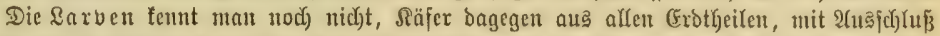

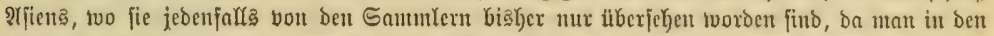

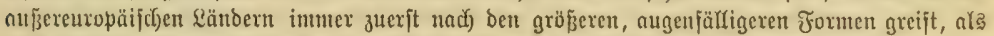
ıtach) fo unf (j)

Der gुelbe Seulenfä fer (Claviger testaceus, jełzt foveolatus genaunt), ber ljier in ftarfer

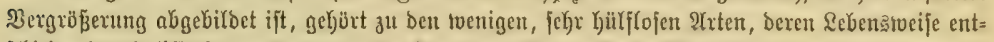

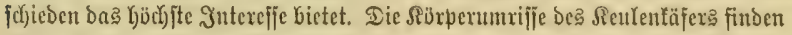

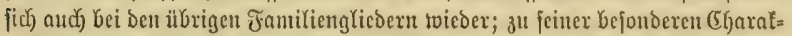

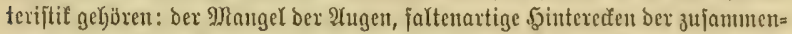

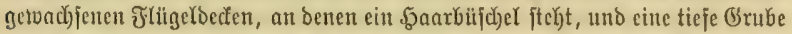

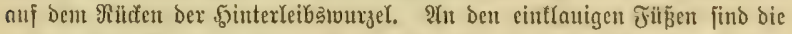

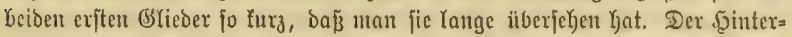
Yeib glänzt am meiften, tweil ihm nur an Der Epiłze bie Behaarung be马 iibrigen Siörpers zufonmt, crij)eint faft fugelig, hat an ben Eeiten einen

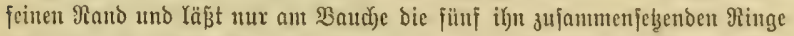

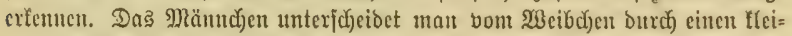

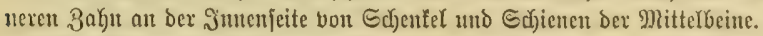

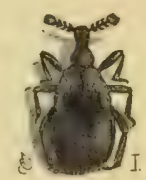

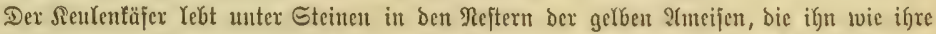

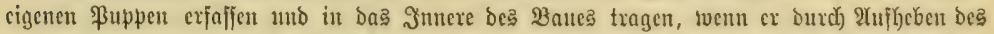

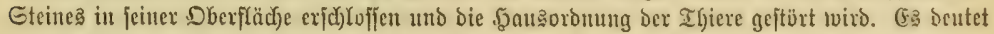

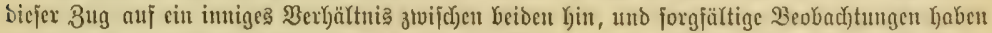

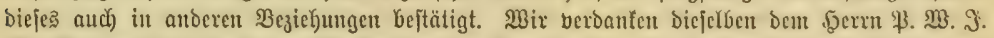

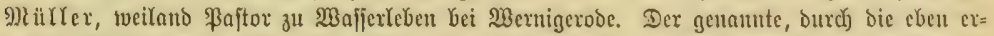

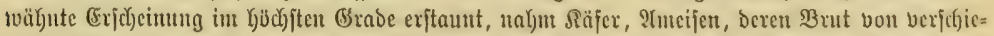

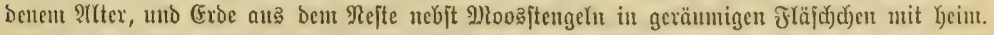

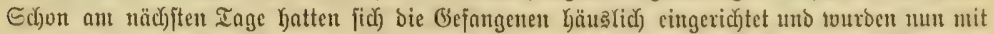

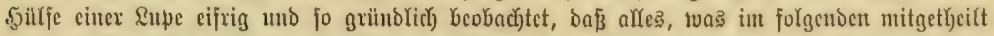

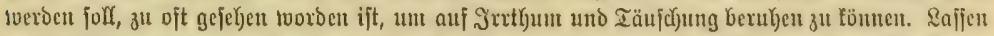

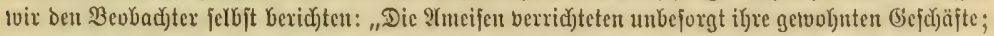

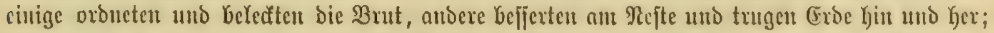

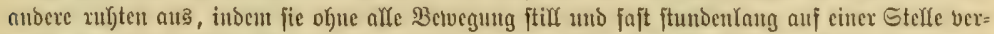

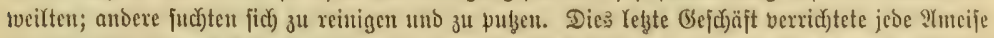

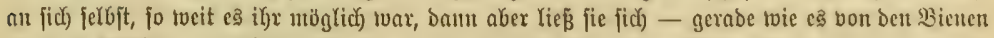

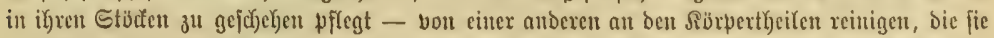

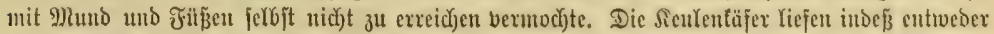

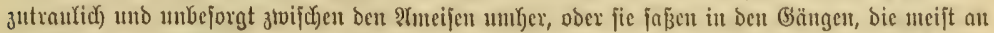

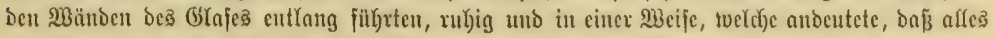

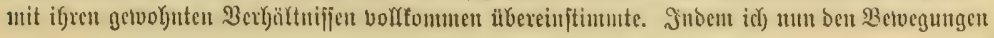




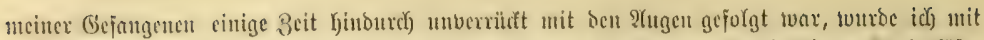

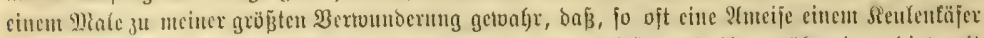

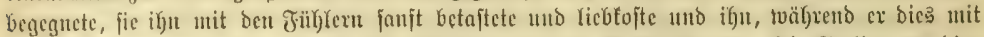

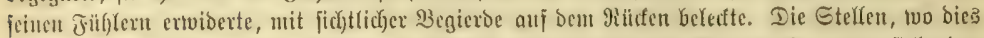

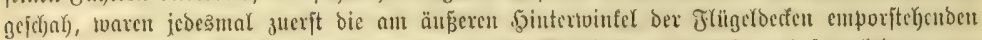

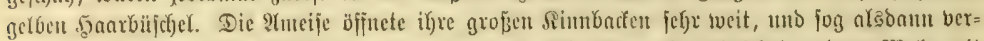

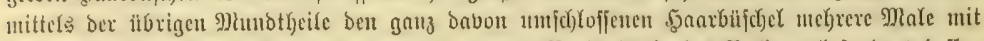

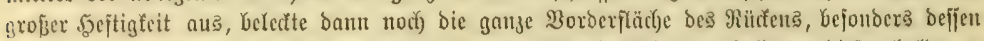

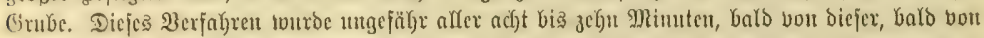

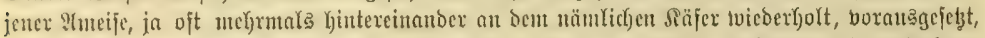

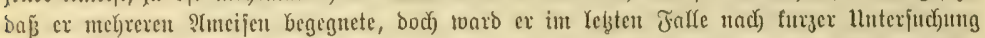

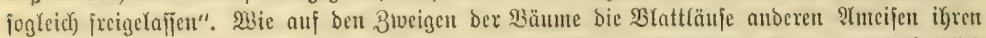

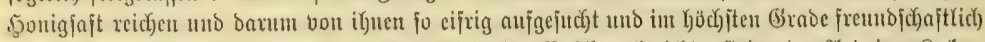

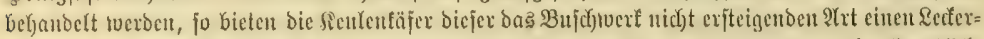

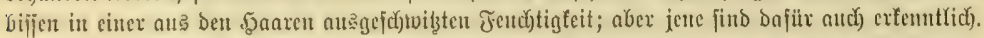

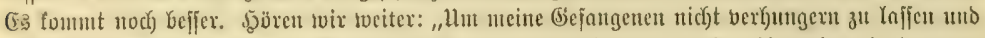

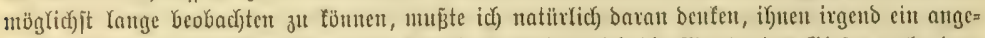

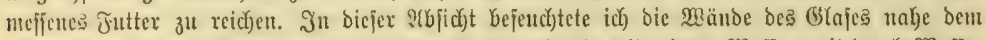

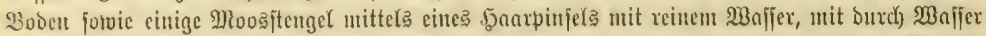

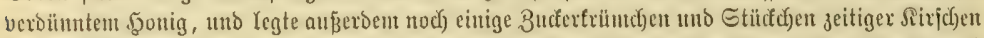

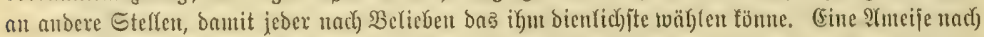

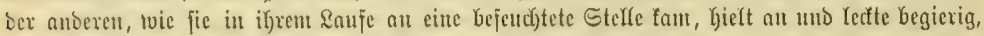

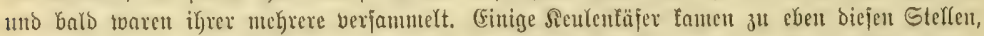

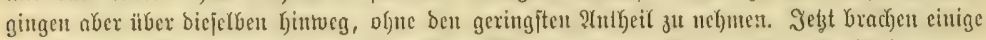

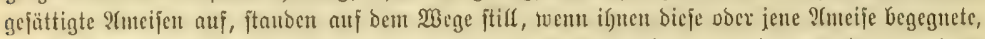
welche bie Epeije nod) nid)t gejunden hatte, fütterten bie hungerigen unb gingen weiter, un bas=

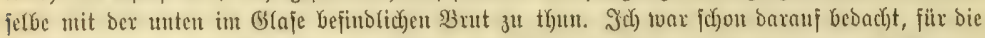

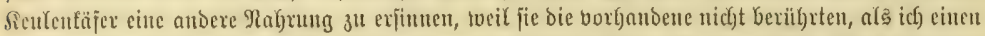

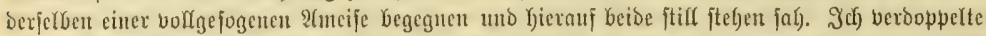

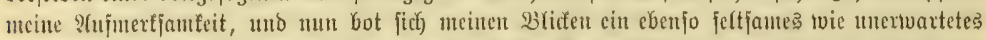

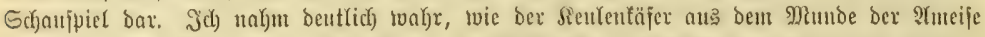

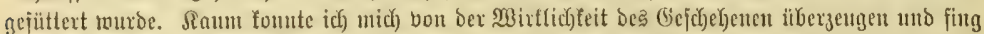

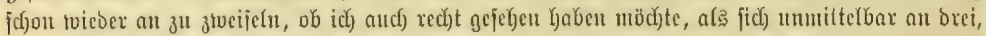

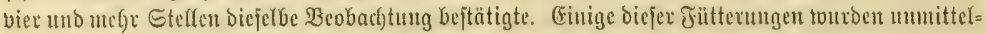
bar an ber Want be马 Fläj(d)

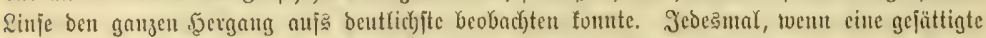

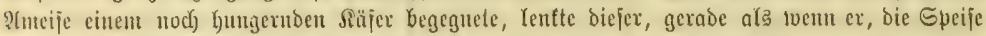

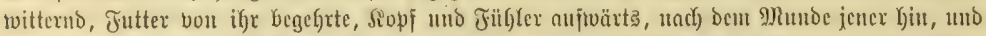
mun bricben fie beibe jtifl fteben. Mach vorhergegantgenem gegenjeitigen Berïlyren unb Streichełn

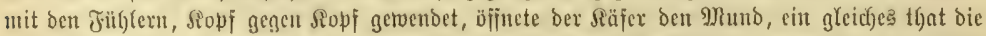

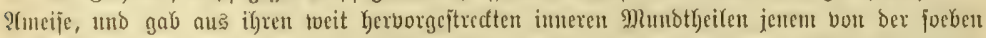

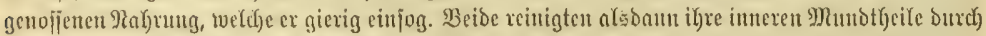

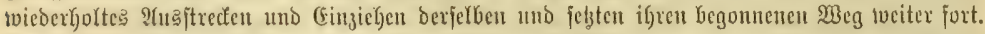

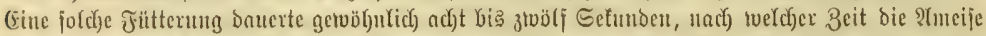

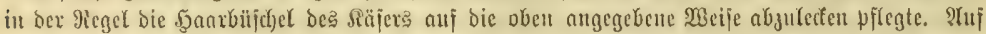

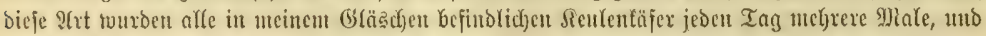

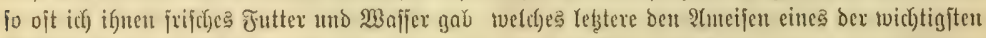

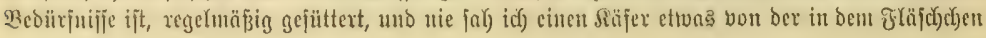




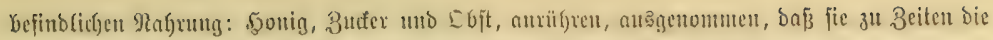

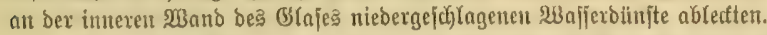

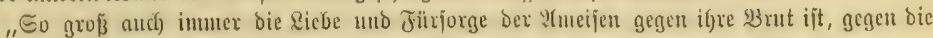

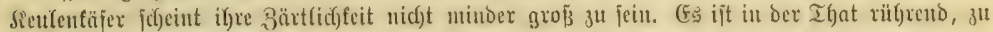

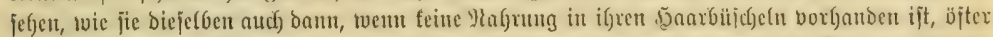

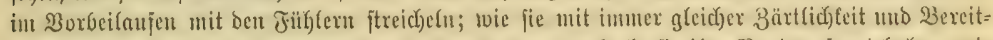

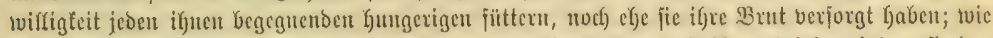

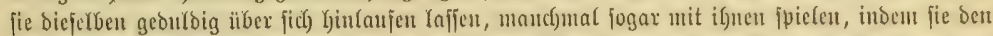

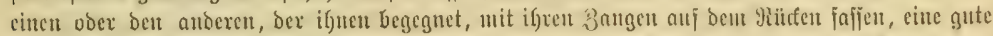

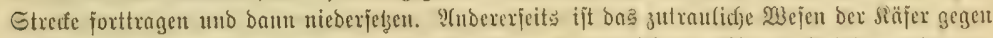

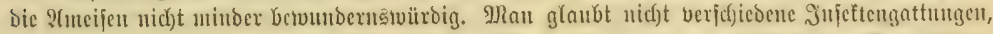

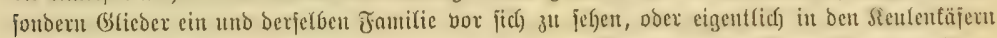

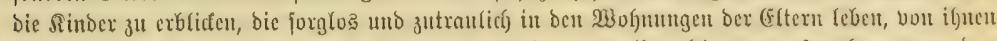

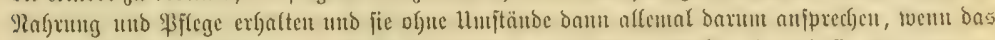

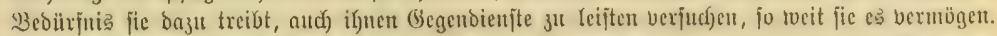

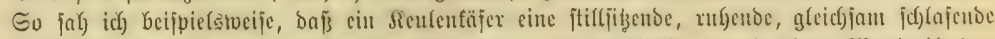

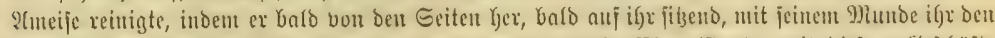

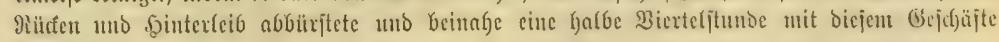
3ubradste".

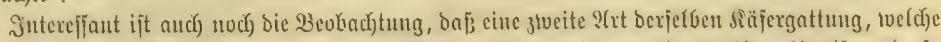

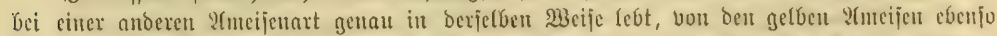

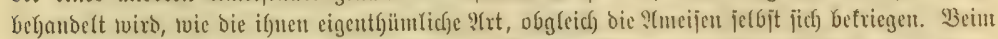

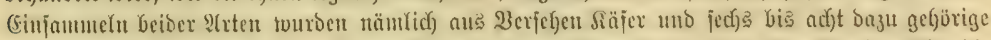

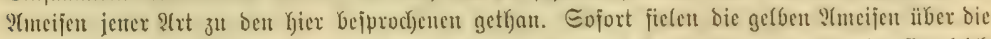

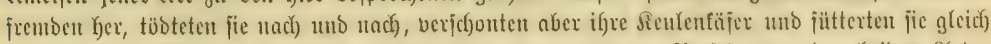

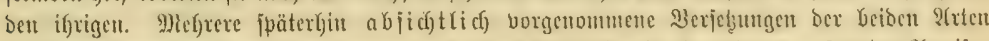

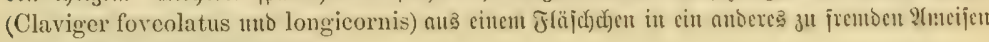
beitätigten biefelbe Beobadjtıng.

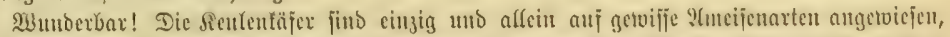

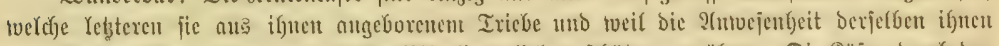

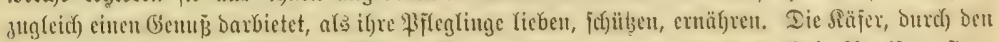

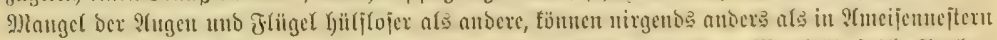

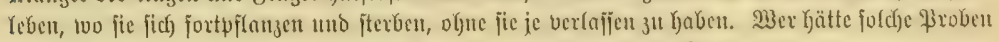
aujopfernder Freundfojajt uno Riebe berborgen miter Steinen gejucht?

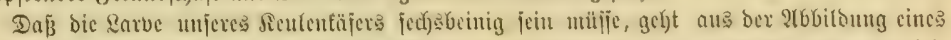

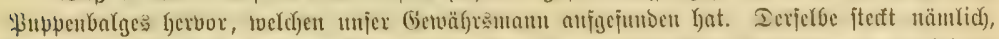

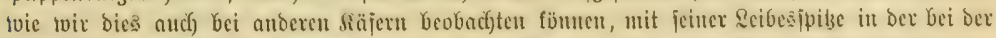

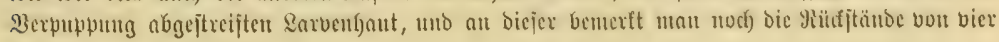
1) 3 eintudsett.

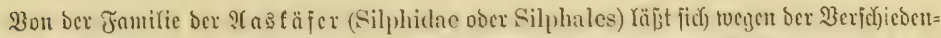

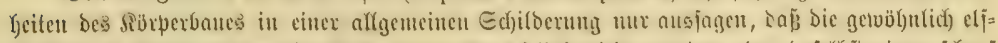

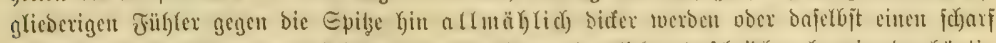

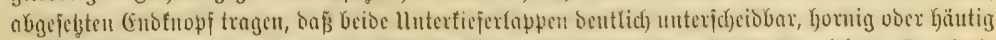

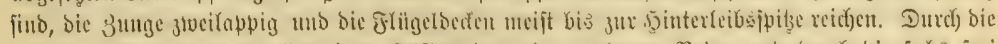

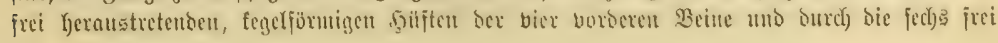




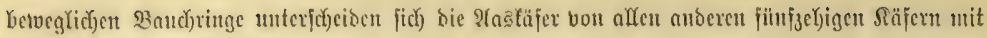

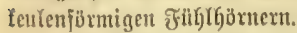

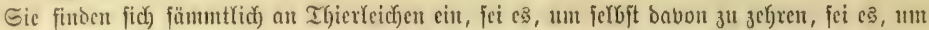

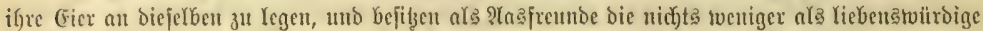

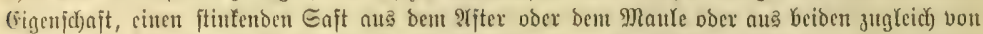

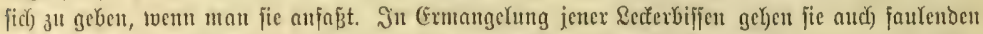

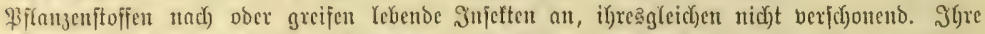

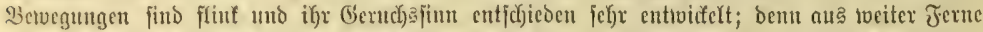

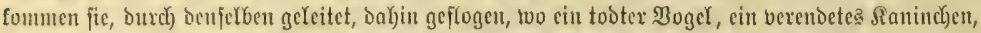

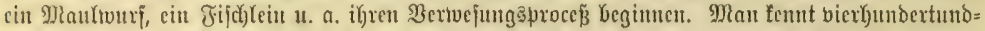

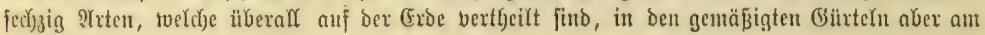

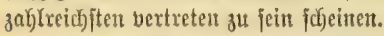

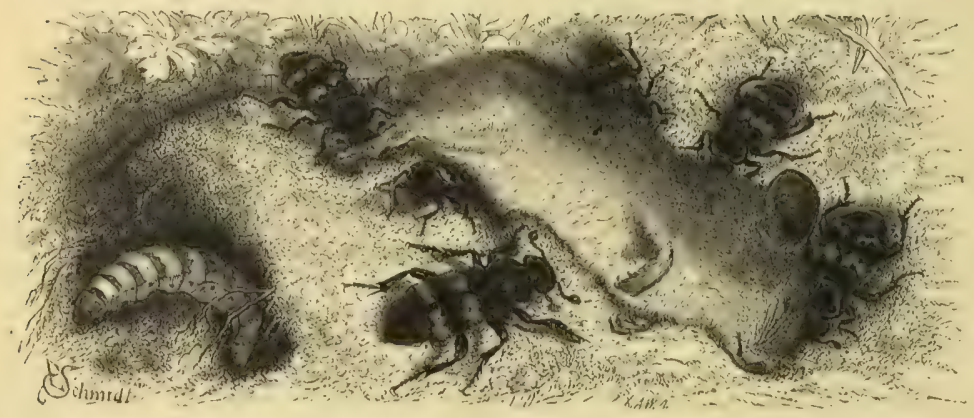

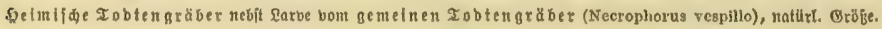

Die \&arben fimmen in bex Rebensmeije unter fich uno mit ben Säjern überein, aber nicht,

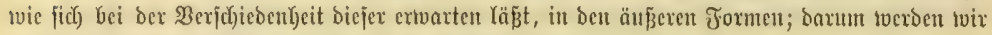
auf fie bei ben vorzufilyrenden Gaattungen zuriałfommen.

Dex gemeine Tobtengräber (Necrophorus vespillo) Yjat nit jeinen bierzig und einigen

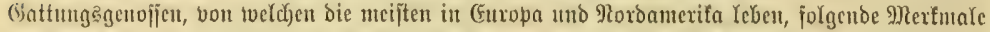

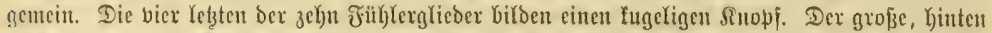

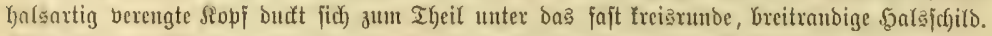

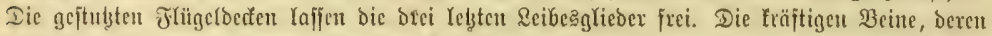

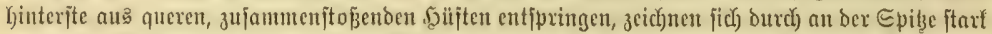

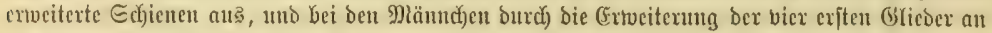

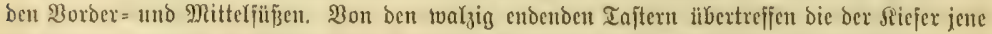

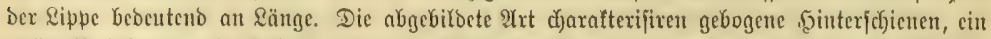

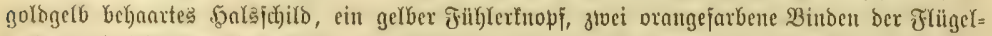

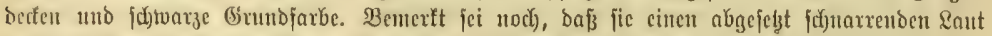

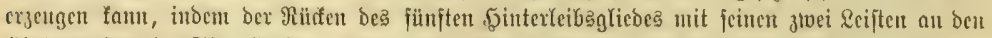

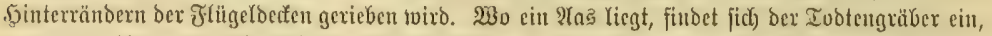

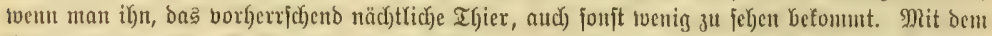

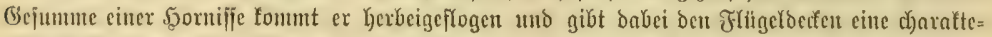

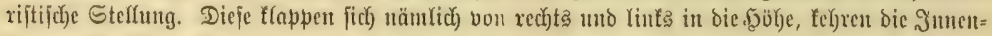

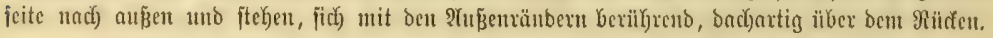




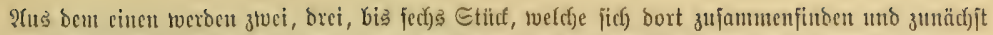

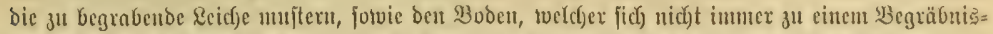

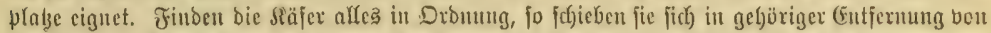

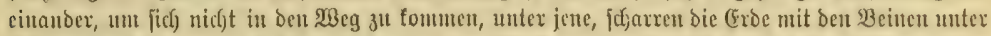

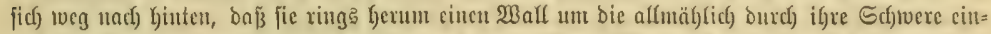

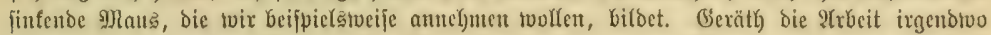

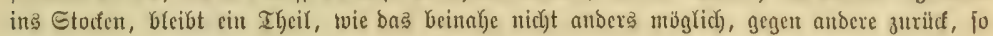

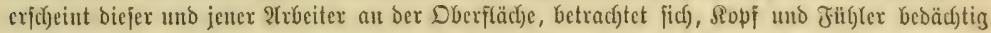

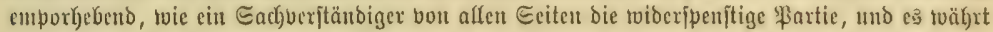

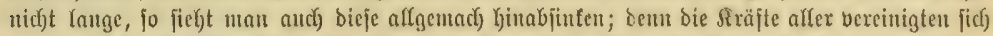

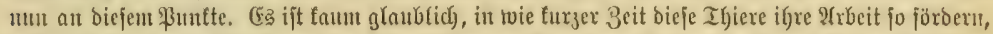

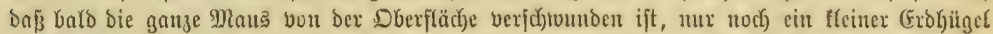

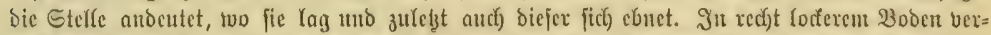

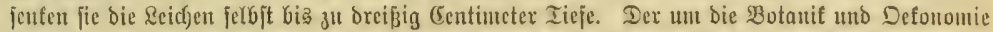

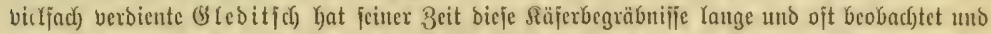

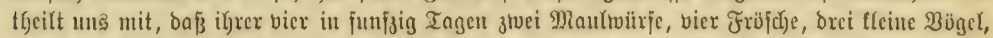

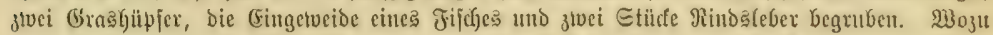

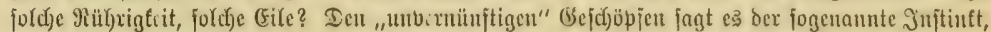

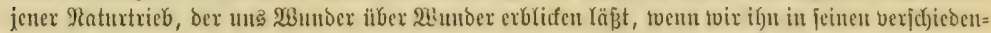

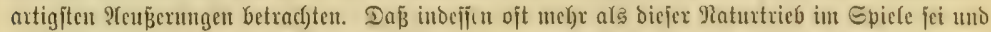

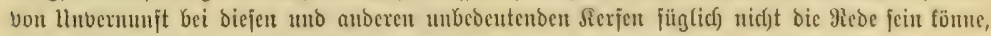
betweijt folgenbe Thatjadje: Iodtungräber, benen man cin 2tas jefroebento über ber (5rbe an einen

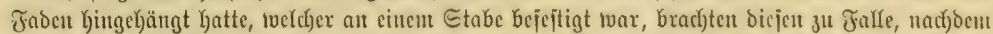

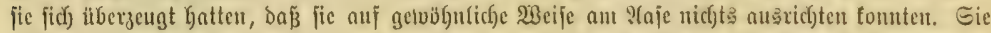

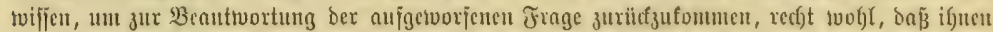

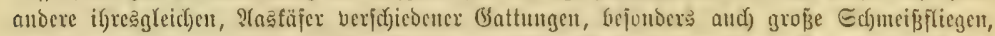

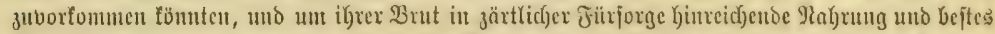

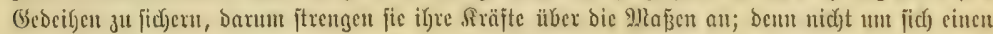

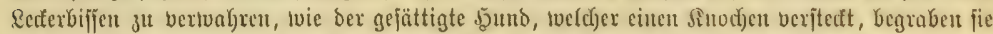

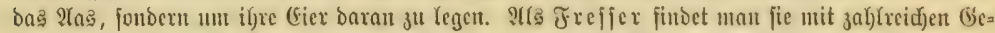

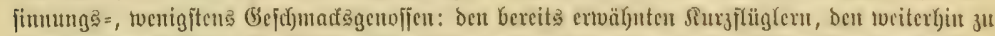

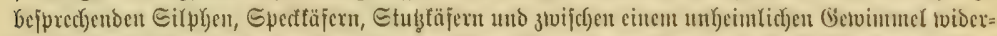

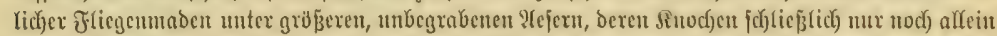

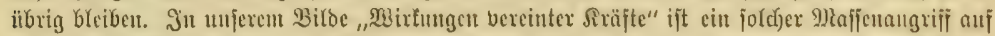

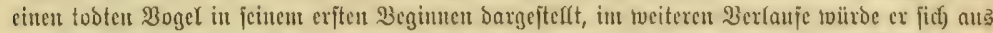

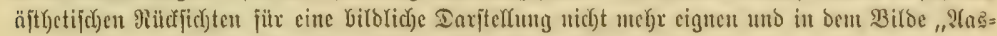
injeften" fintet fick eine :(nzah) Der befanntejten Fornen vereinigt.

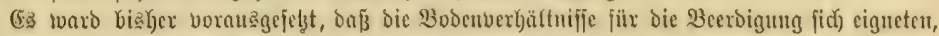

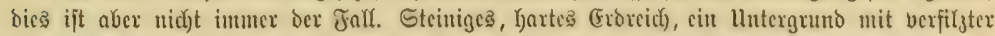

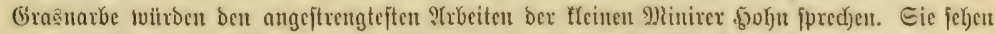

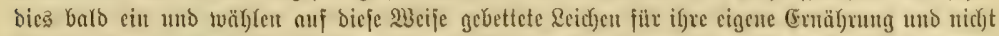

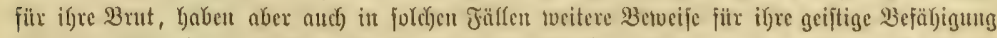

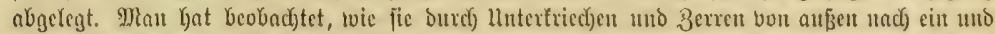

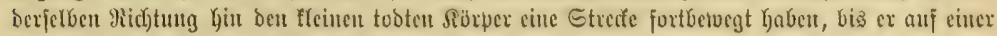
benad) barten, ifren 3tweden entipred)enden Unterlage ange(anght sonx.

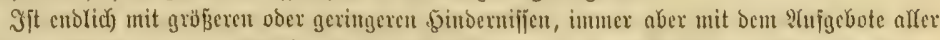

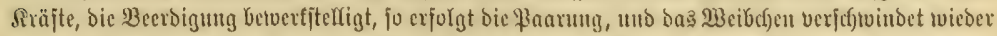

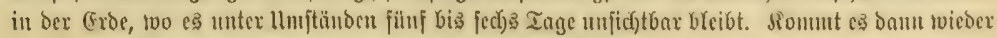




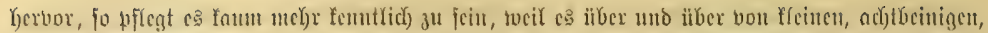

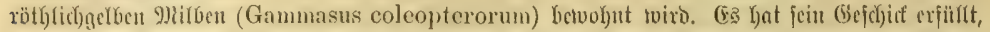

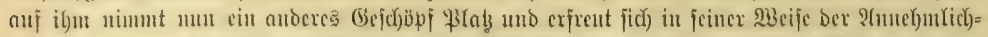

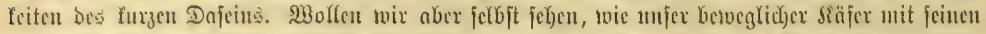

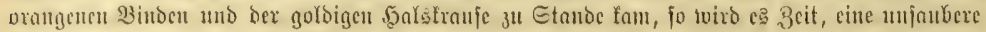

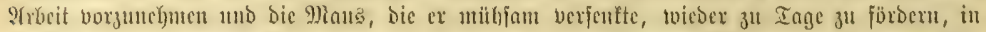

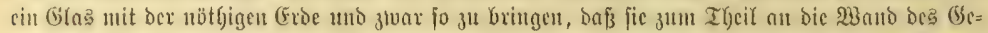

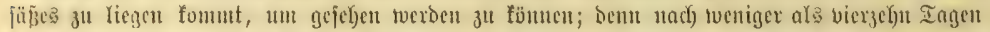

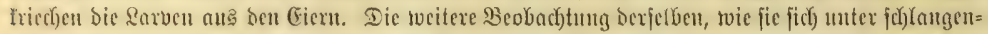

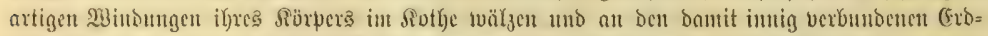

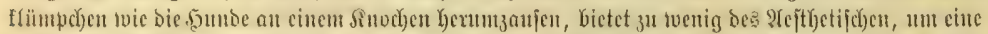

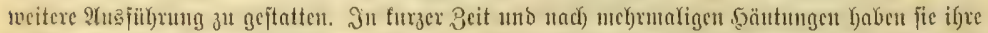

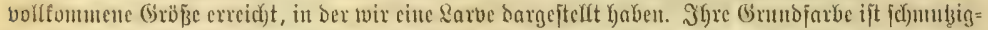

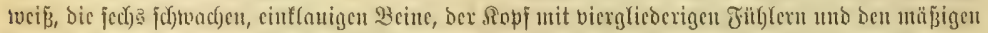

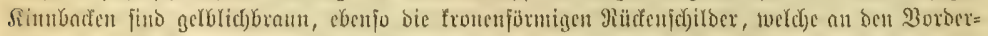

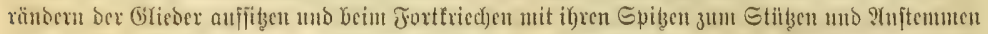

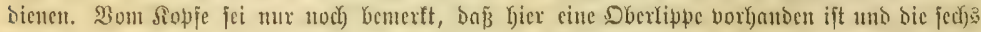

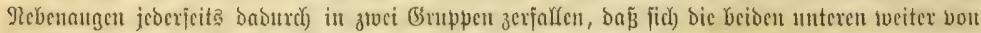

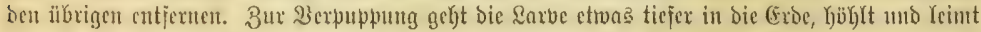

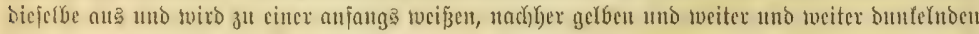

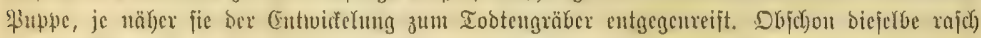

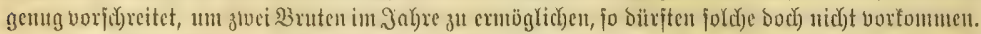

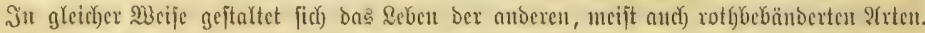

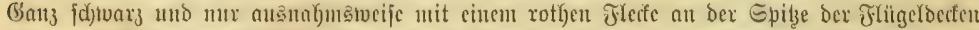

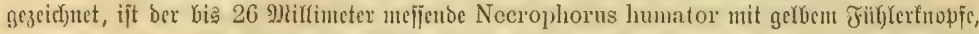

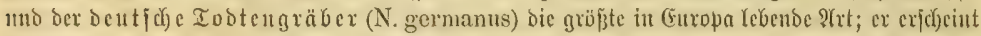

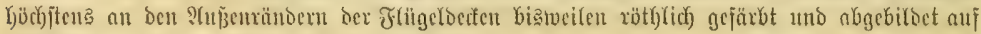

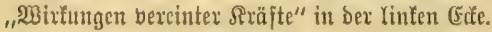

Die Gattung ser In

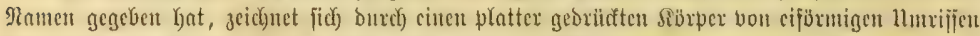

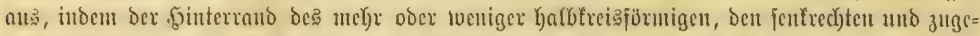

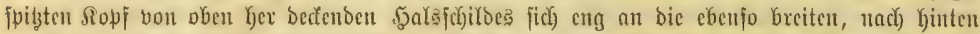

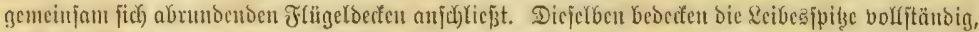

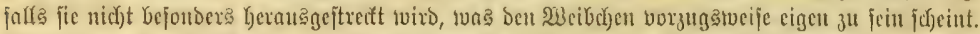

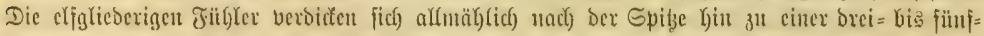

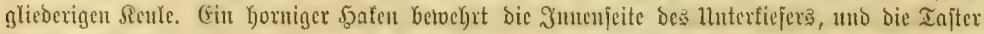
Deşjelben finto roic Gei Den Tostengräberu Yänger ala bie Rippentajter.

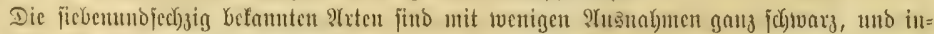

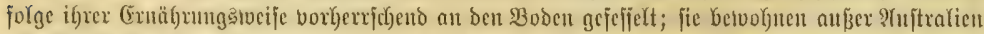

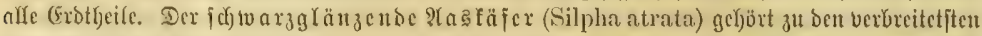

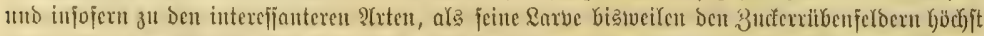

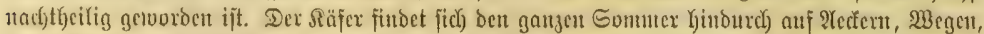

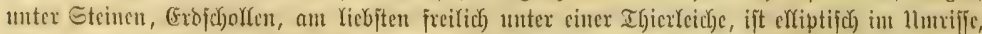

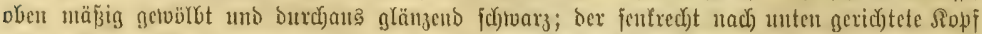

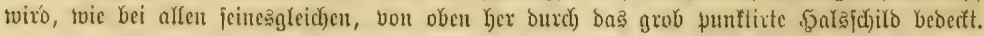

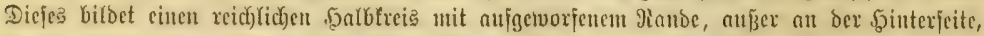

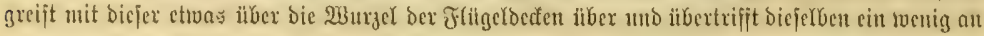




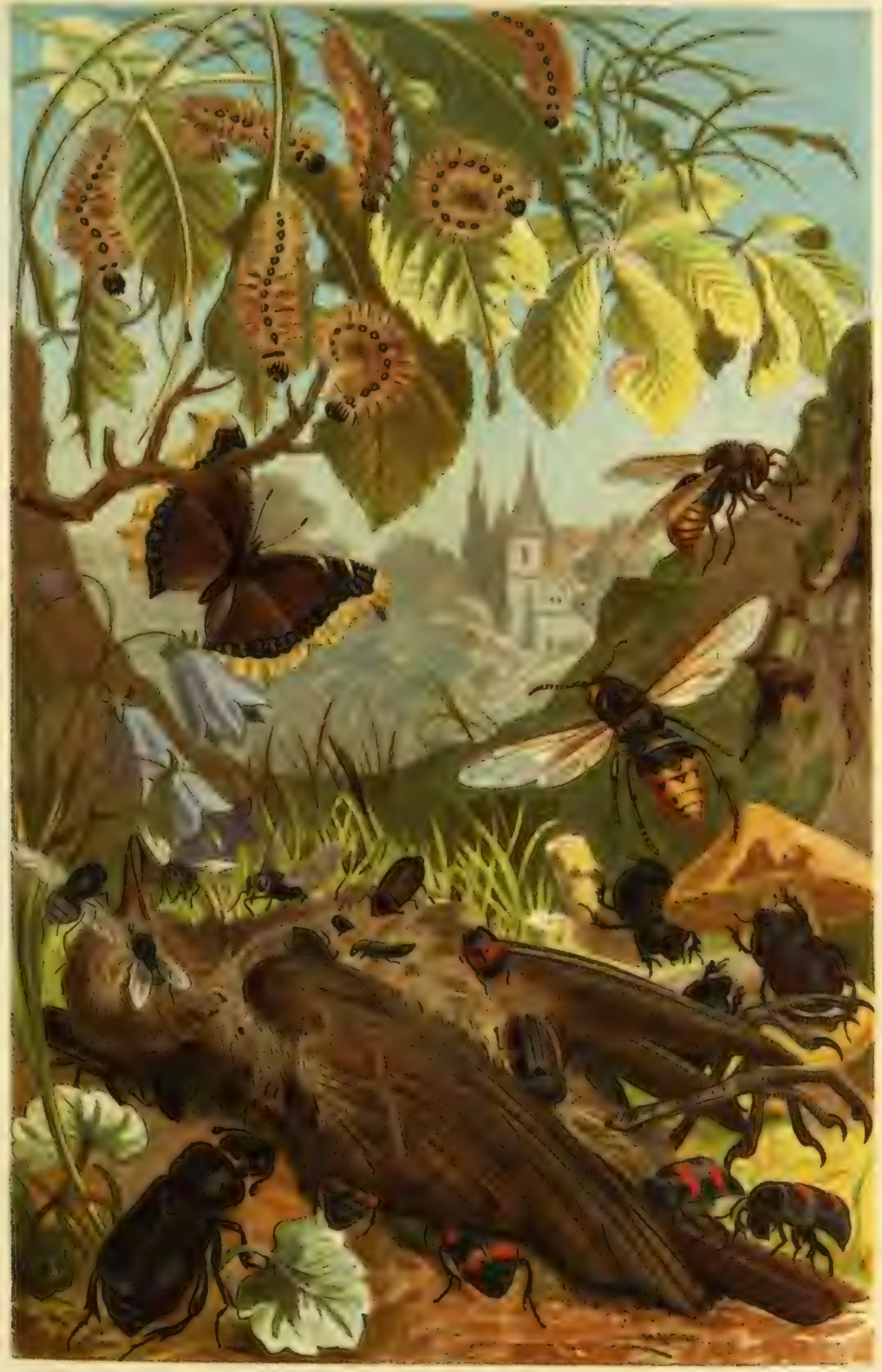

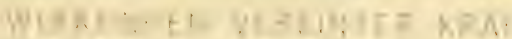





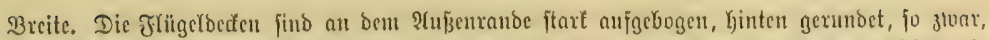

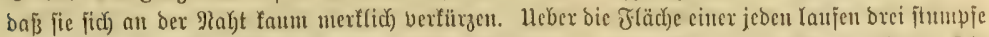

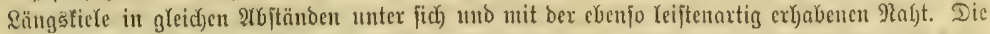

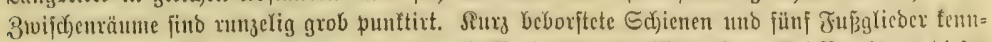

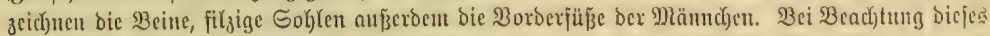

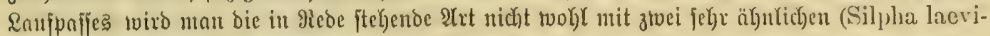
gata und reticulata) vertwechjełn fönnen.

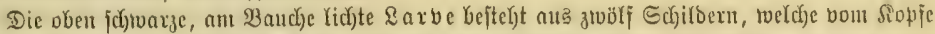

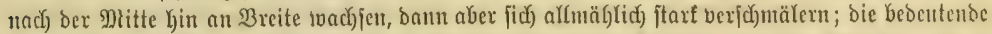

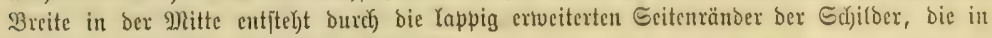
berjelben Meije fidj bei anberen Silphen= Yarben niçst zu wieberfolen brandid)t. Das (Enoglieb trägt an ber Spitze zwei fleijc)ige Turyänge. Die ulber fite hinaügehende Fort=

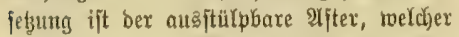

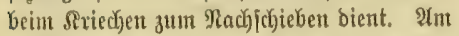
veritecten Sopfe bemertt man oreigliebexige, ziemlich Innge Fillyler uno finter ifjrer \$urget vier, weiter unten noch stoei Reben= nugen. Fün getoöbnlich bält fict) bie Sarbe, tvie bicjenigen bex Hibrigen $\mathfrak{A r t e n ,}$ verborgen

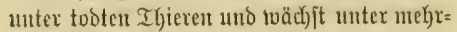
maligen 5ättungen jodnelf heran, fommt

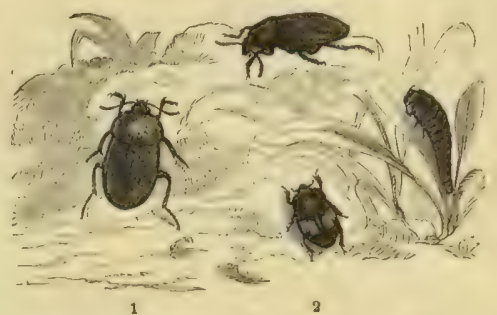

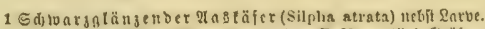
2 Dhift. Gtu bfäfex (Hister fmetarius, 5. 65), natiurf. Gródc.

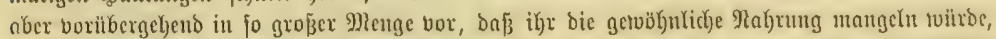

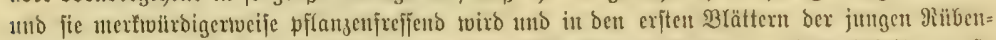

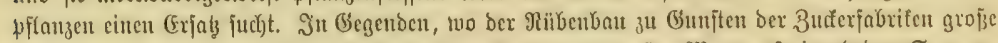

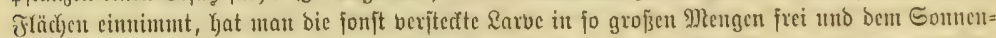

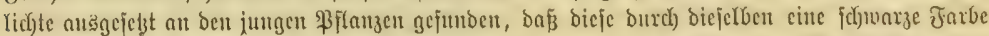

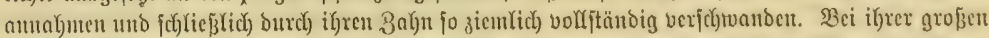

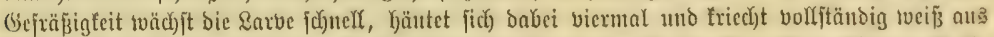

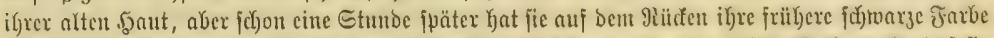

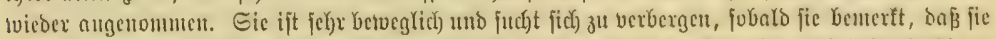

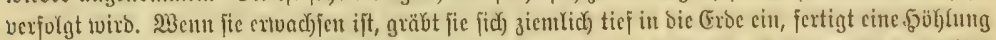

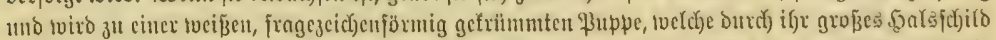

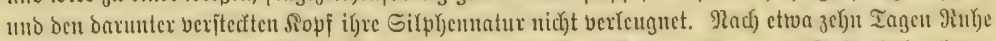

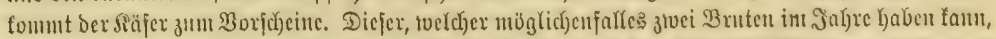

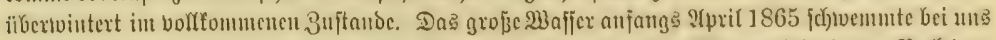

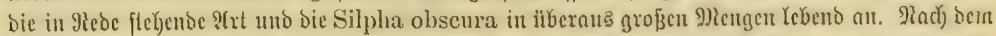

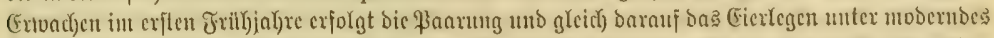

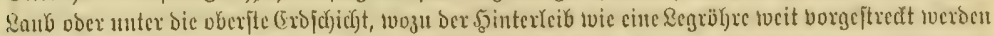

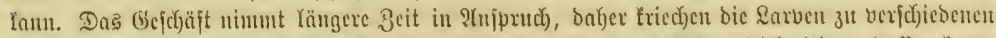

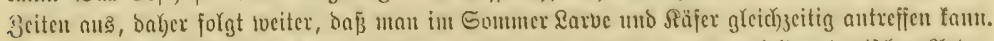

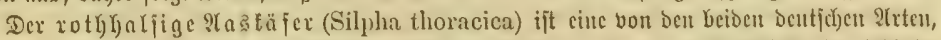

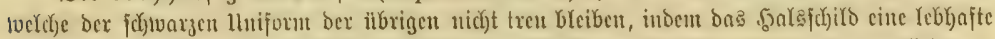

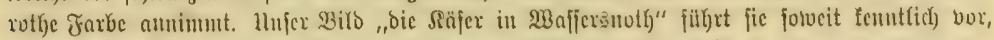

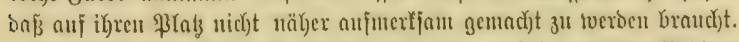

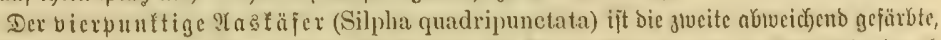

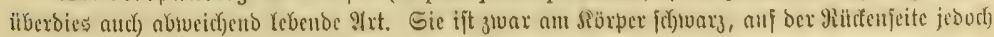




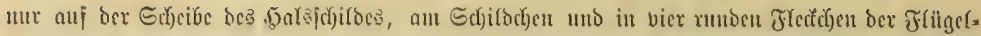

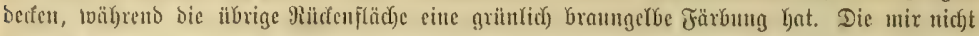

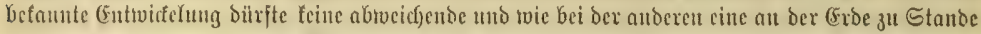

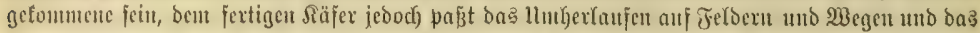

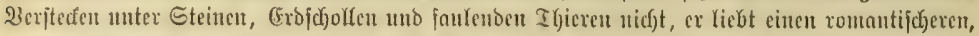

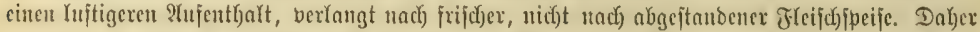

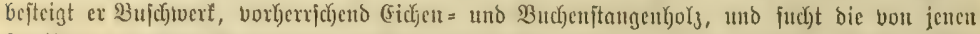

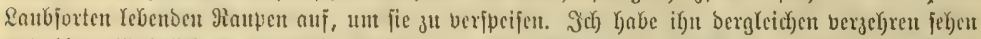

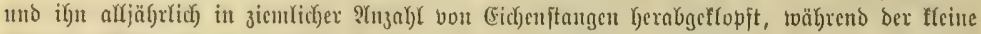

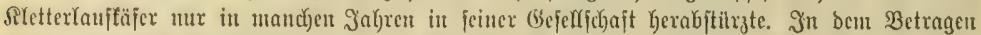
beiber, jobald fie unten angelangt finto, befteht ein vefentlicher lluterfichied. Der \&äufer, wie tvix

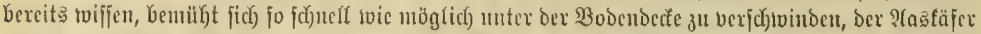

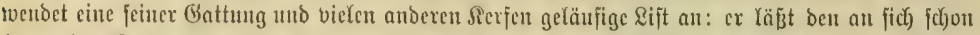

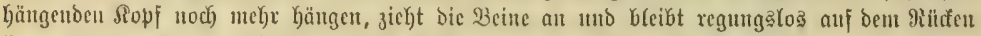

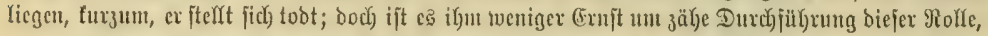

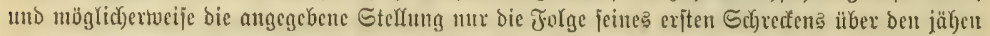

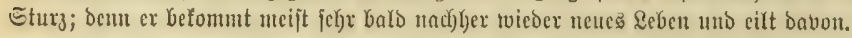

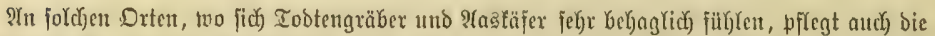

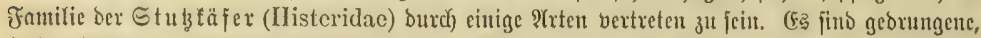

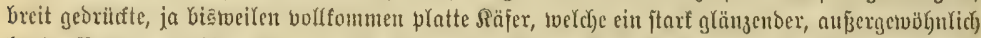

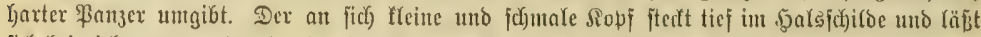

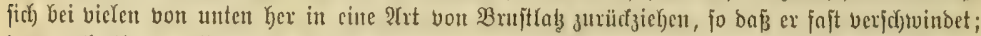

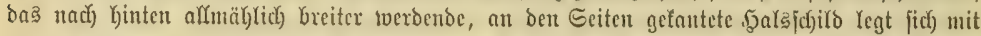

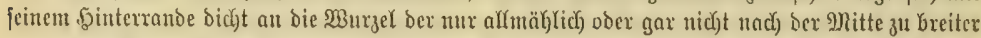

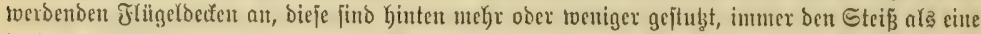

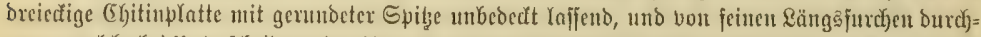

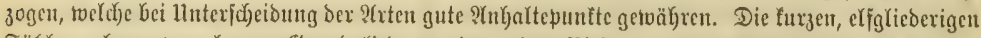

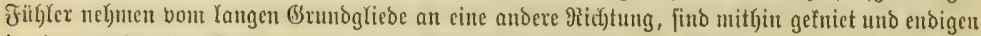

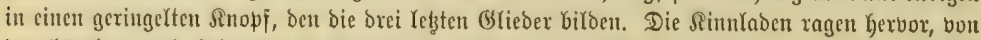

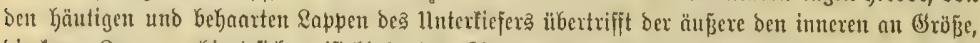

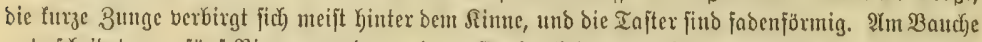

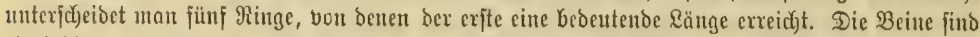

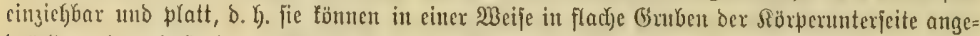

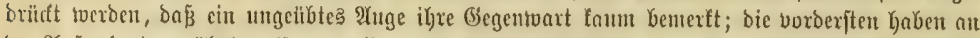

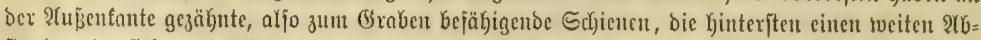
ftand unter fich), uno alfe tragen fabenförnige, fünfglieberige (felten vierglieberige) Finje, welde

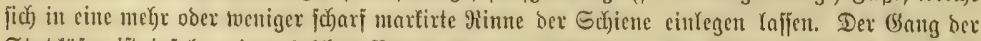

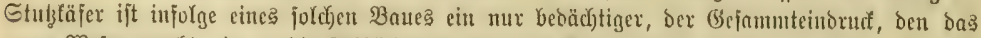

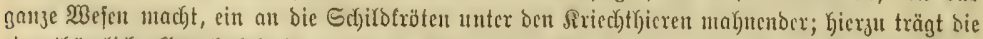

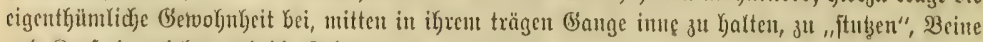

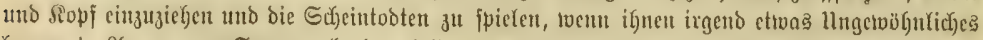
begegnet. 2(n warmen Eommerabenoen, feltener unter ber ftrab)(enden 2)tittagahige, feben fie and

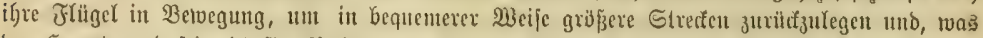

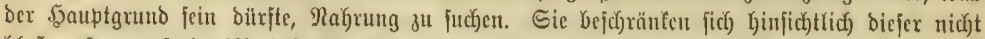

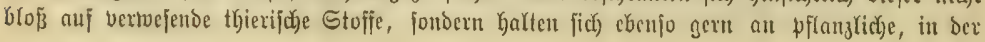


PUf

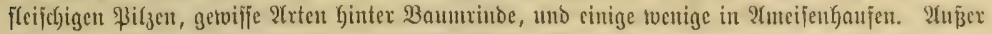

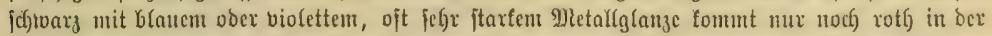

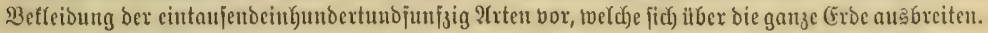

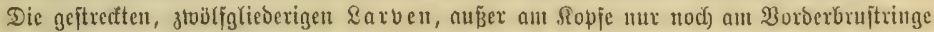

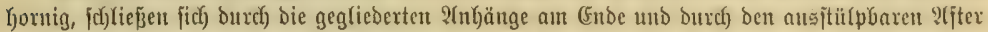

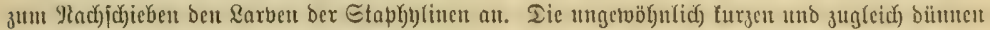

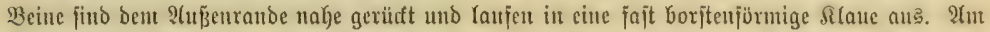

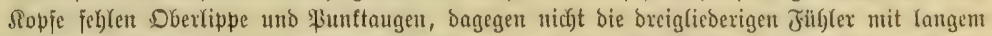

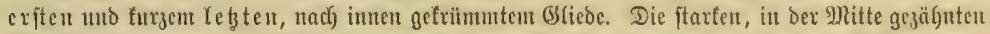

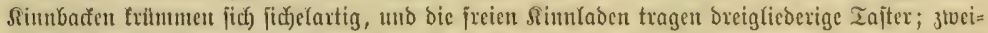

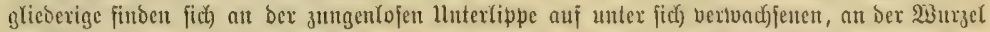

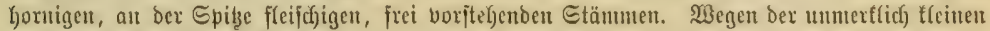

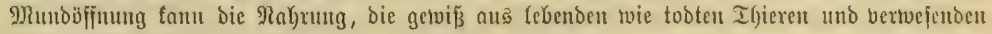
Pfianzenitofien bejteht, nux jaugeno aujgenommen werben.

Der Mift= 5 tubafäfer (IIister fimetarius oder sinuatus) gefört ju Denjenigen Janilien=

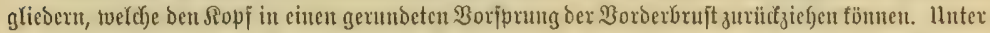
einem Stimrande Yenfen bie gebrod)enen, in eine ovale, breigliebcrige Sicule mbenben Jügler cin,

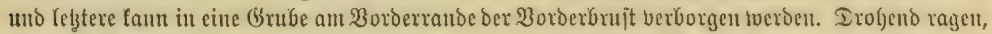

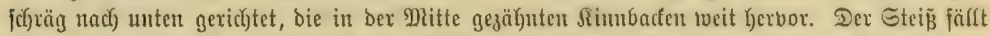

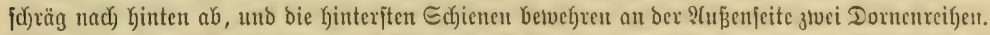

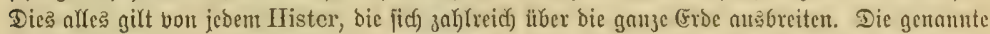

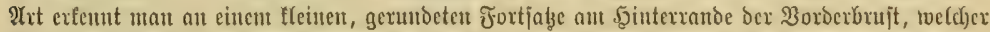

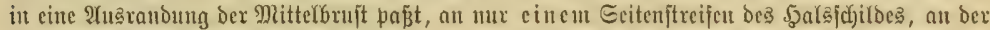

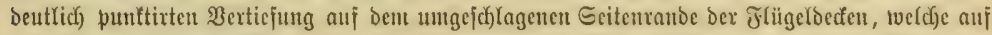

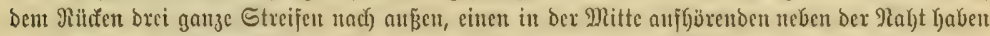
und mit einem rotfen Flecfe gezeid)uct find, Defien Formt unjere 2tbbiloung (ङ. 63, Jig. 2) ver:=

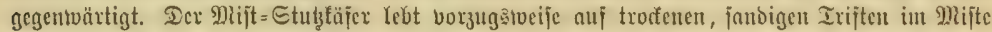

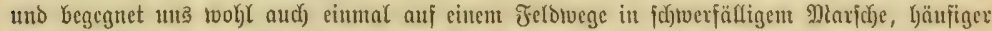

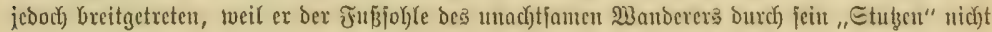
parizen fonnte.

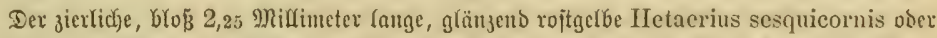

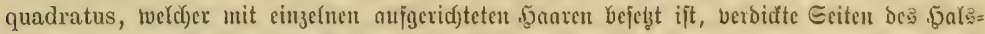

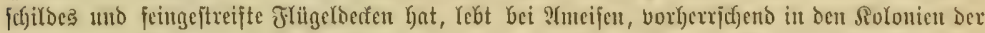

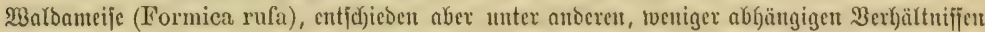

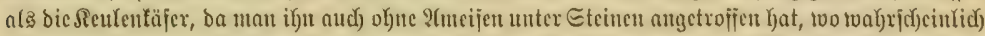

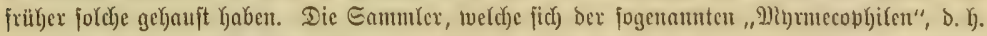

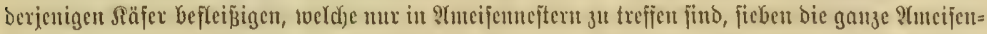

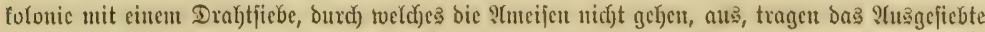

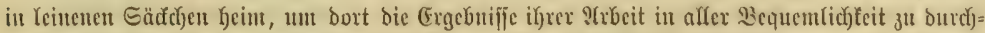

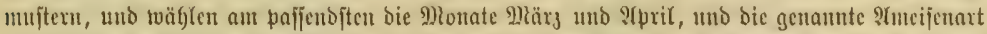

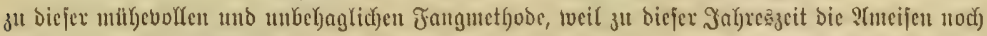

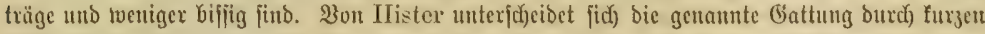

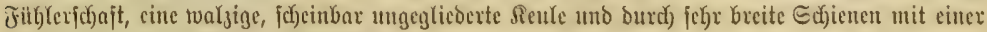

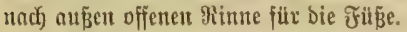

Dic Sapriuen (Saprinus) biloen ucben ben jifteren bic artenreidffte Gattung ber gauzen

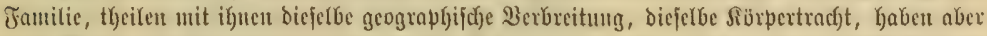

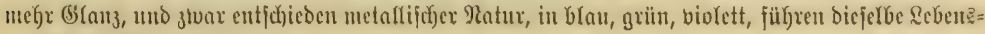
2rebms zgictebca. 2. 2tuifage. IX. 


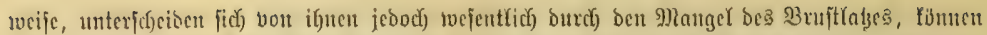

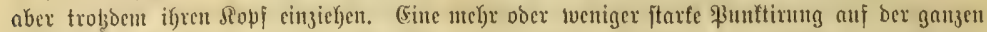

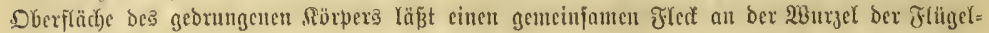
becten unberilyrt.

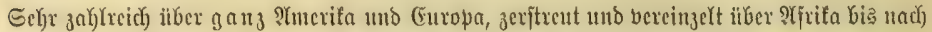

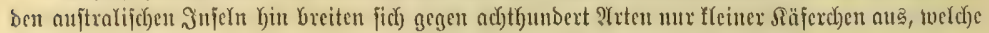

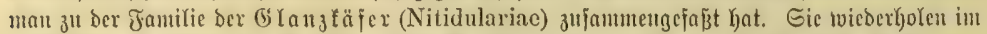

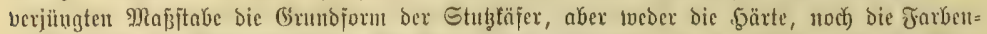

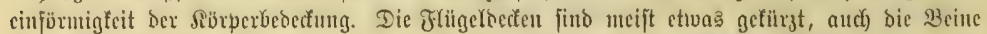

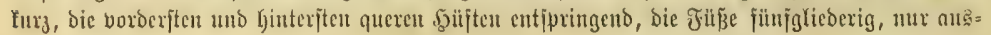

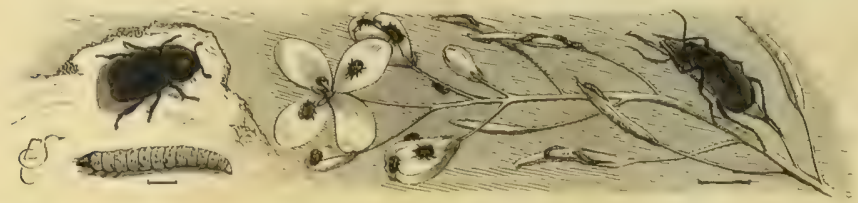

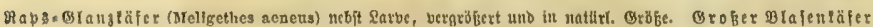
(Malachius aeneus), bergrb̈̈̈ert.

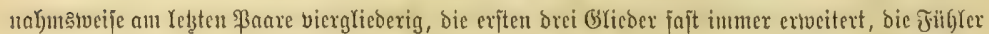
uid)t getnict und in einen brei= bis bierglieberigen Rnopf auslaufeno. Der Hnterfiejer tuird gröp̈tentgeils nutr bon einem Rappen gebildet.

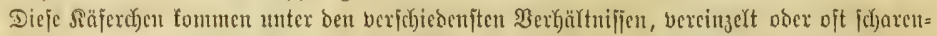

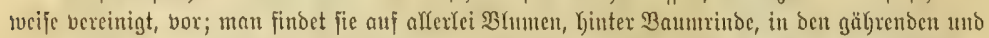

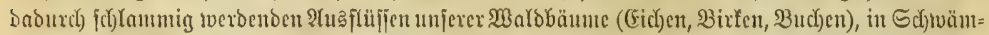

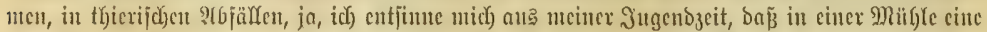

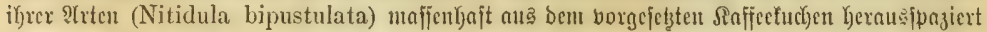

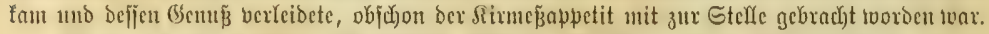

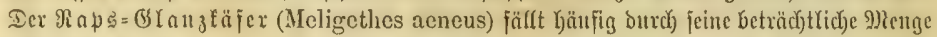

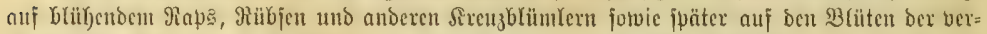

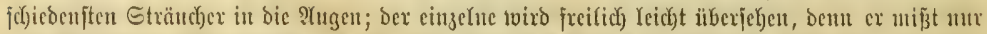

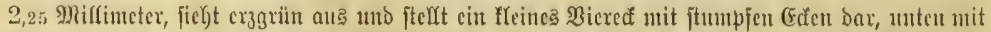

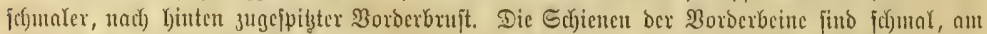

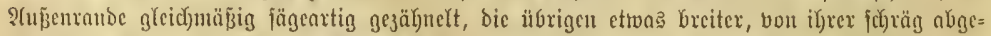

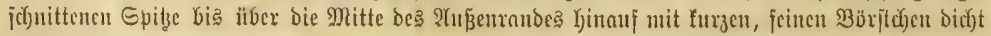
berwimpert.

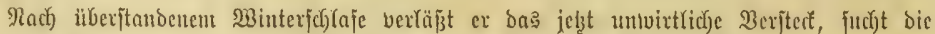

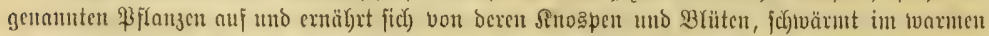

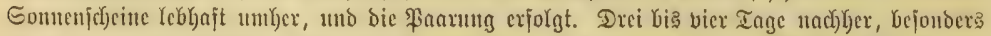

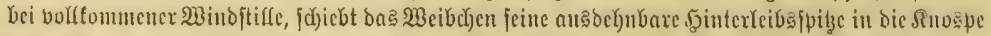

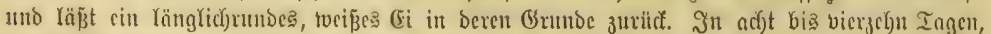

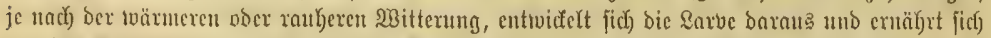

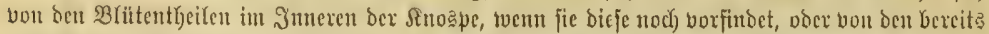

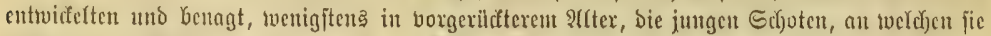

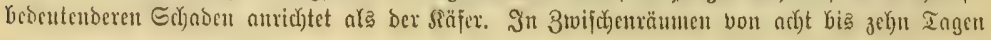




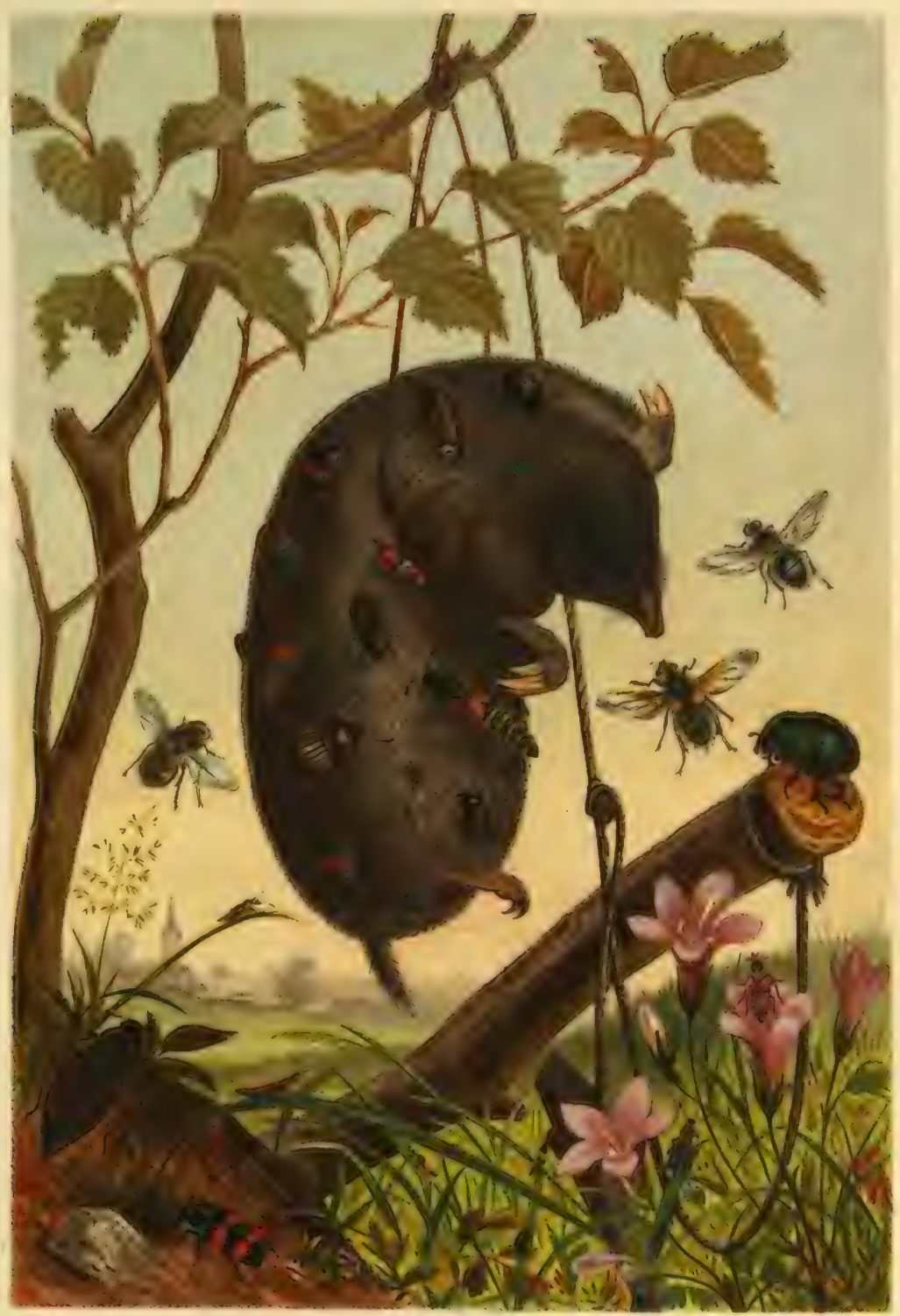





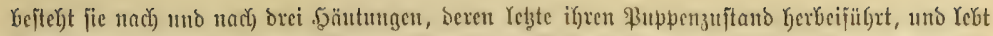

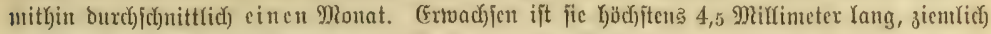

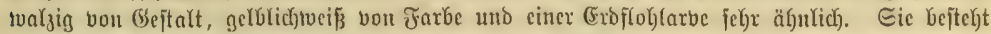

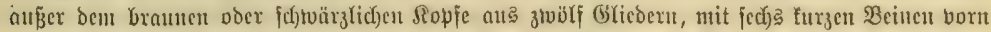

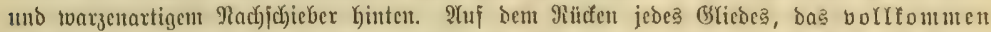

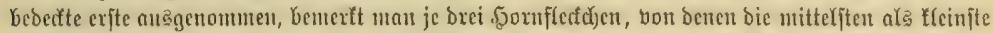

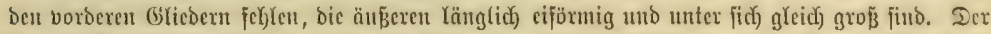

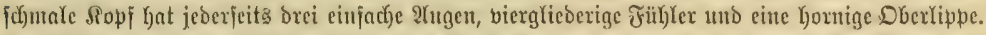

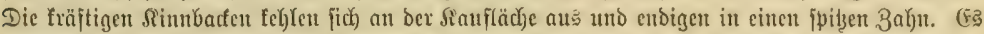

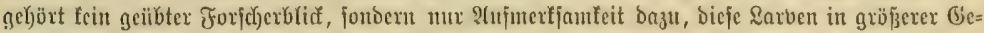

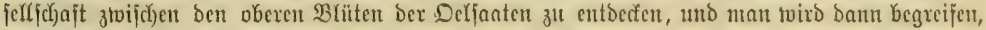

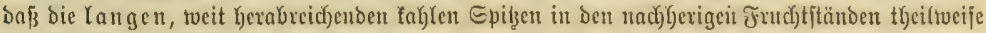
auf ihre Rechnung fommen.

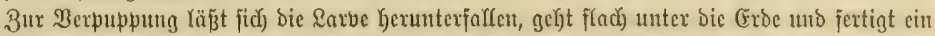

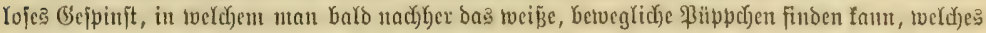

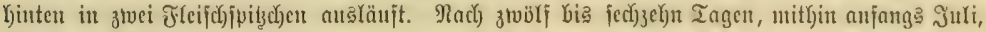

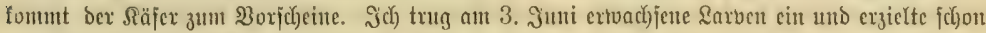

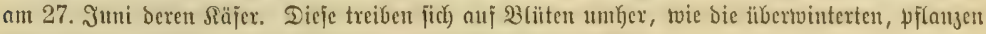

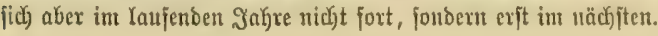

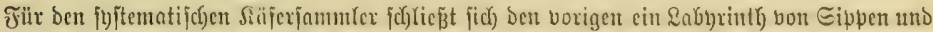

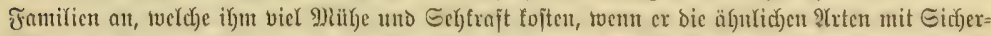

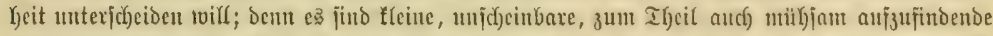

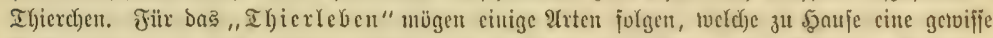

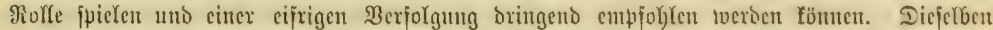

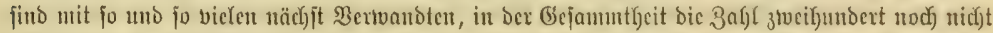

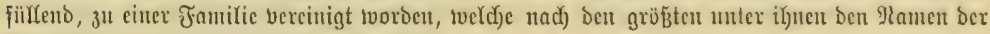
Epect tä fer (Dermestidae) exhalten hat.

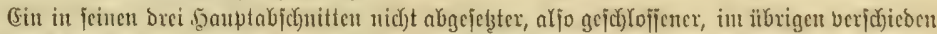

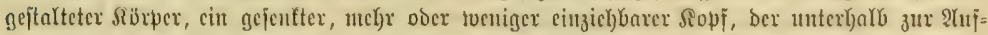

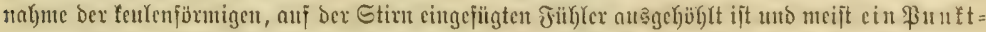

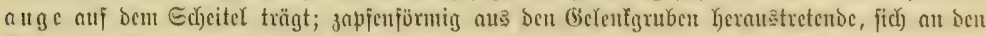

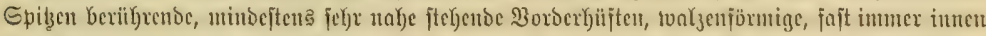

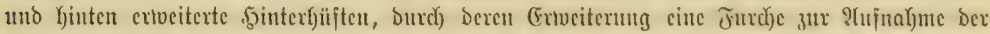

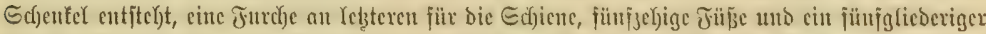

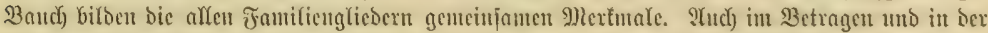

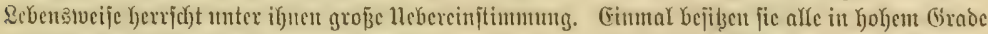

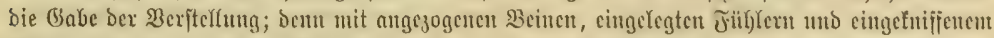

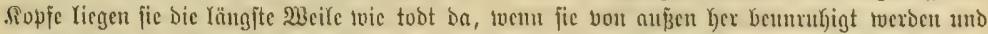

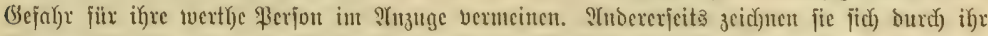

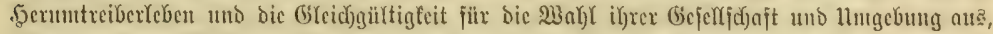

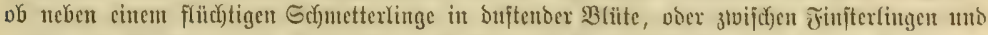

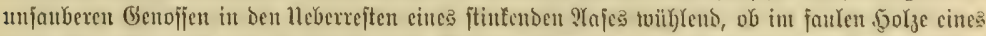

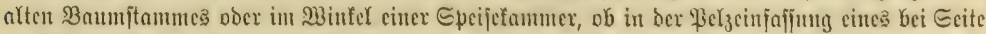

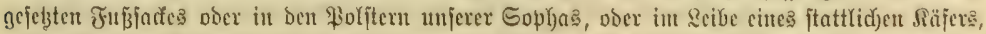

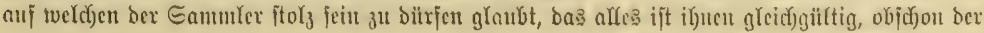




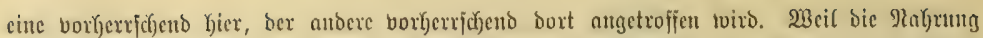

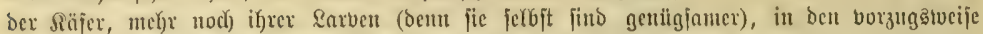

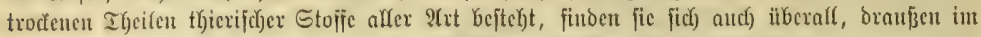

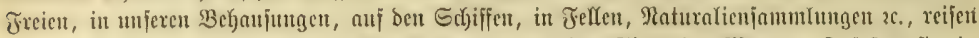

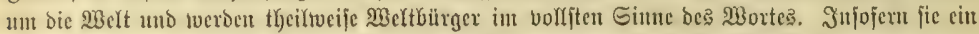

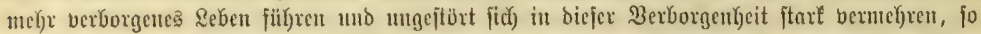

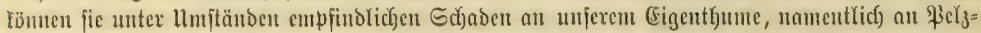

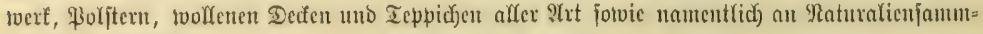
lungett, antidhtett.

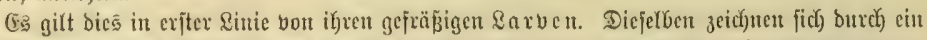

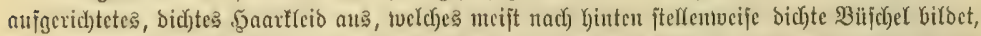

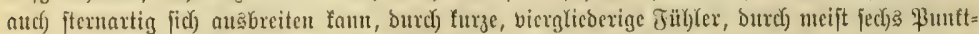

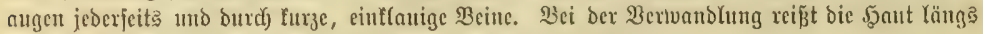

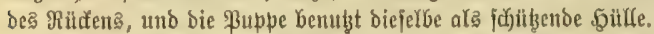

Der Epectfäfer (Dermestes lardarius, Jig. 6, 7) wiro unter feinen fiebenunboierzig

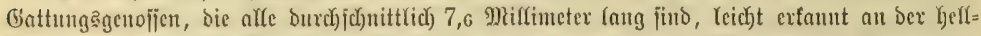

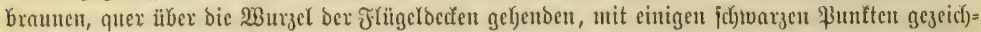

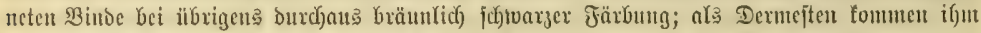

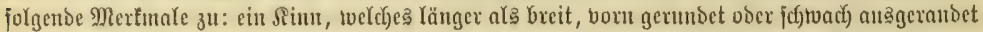

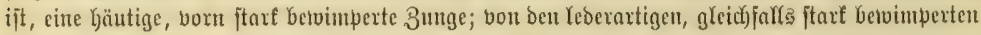

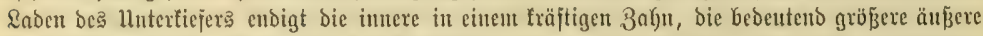

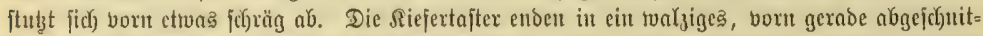

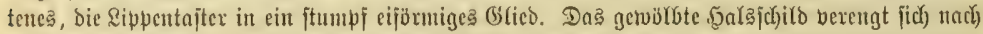

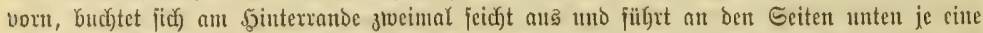

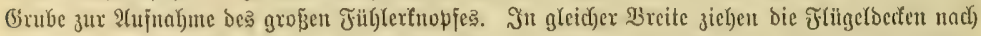

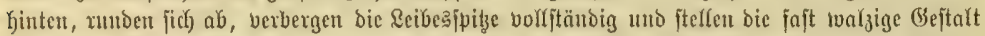

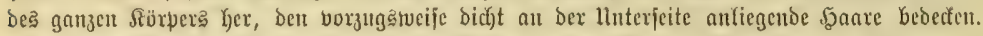

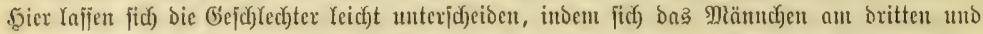

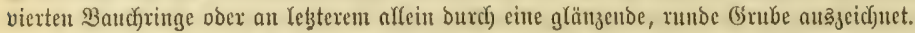

Tie gejtrecte, nad hinten berjüngte \&ar ve wirb beinabe noch einutal jo Yantg toie ber Säfer,

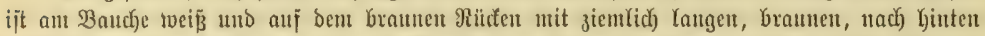

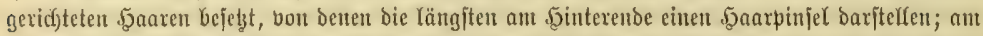

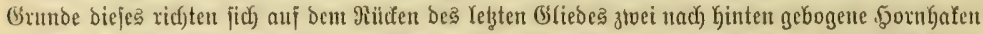

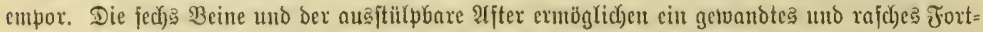

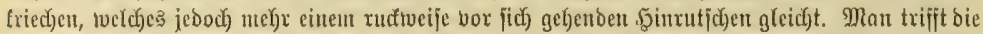

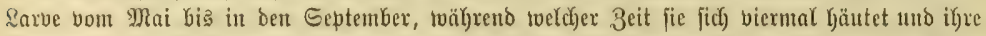

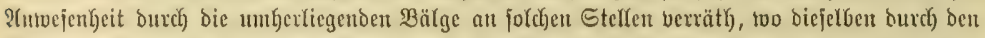

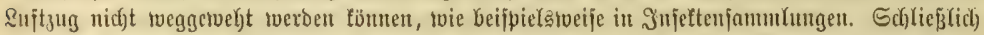

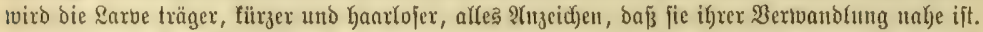

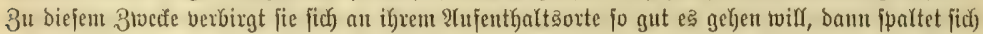

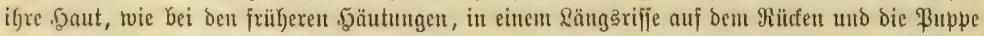

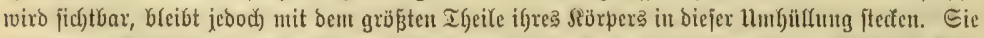

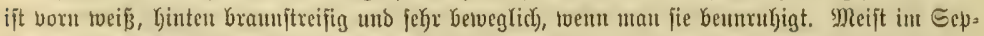

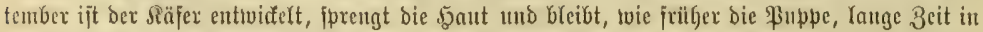

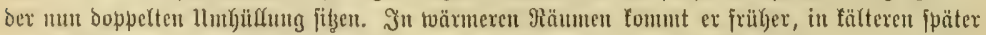

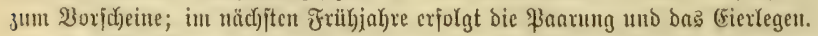

Dex Epedfäjer und feine Rarbe findet jid) nicht bloß in Speifetammern, jondern ttberall, two

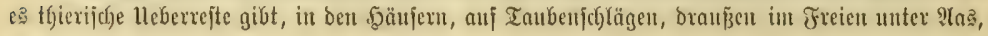




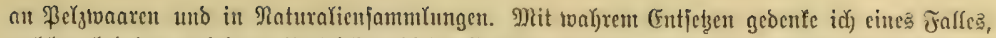
lweldyer bei best gełeimen llmtrieben biejer Gejeffen baran mahnt, toic man auj feiner sut fein

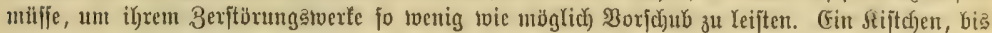
obenan mit aufeitanoer gejchichteten Säfern aus פBrafilien angefülut uto zugenagelt, Katte

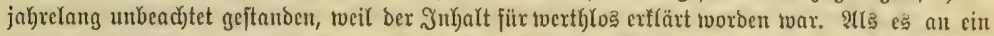

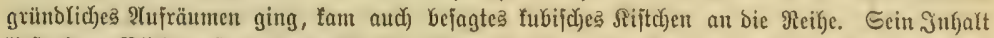

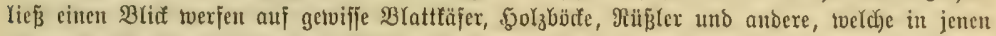

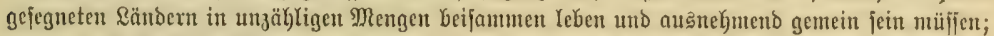

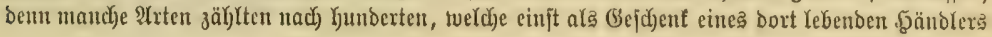

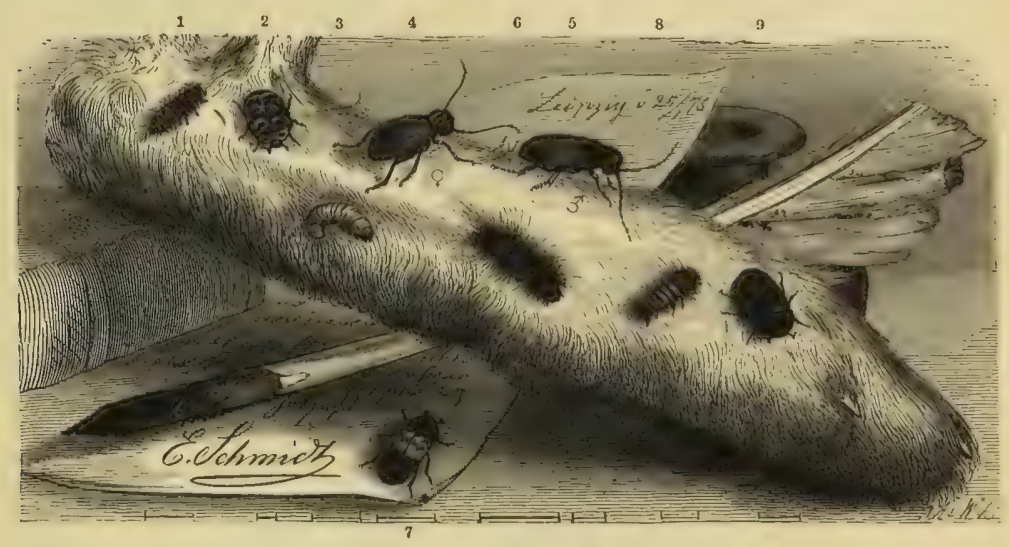

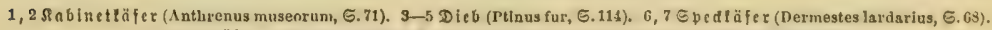

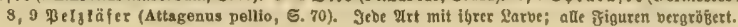

cingegangen twaten. Madjoem mit einer getwifien Borftedst, un bie wenigen unzerbrodfenen

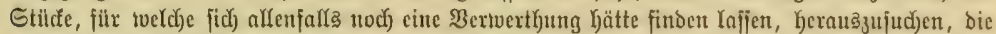

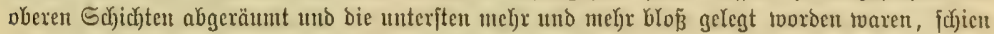
mit einen MaYe Reben in Die Salyre alten Reichen getounten zu fein; Denn Betwegung uno ztoar

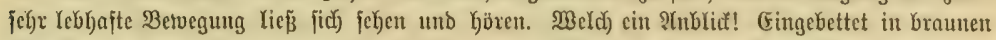

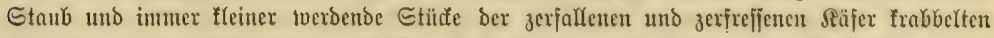

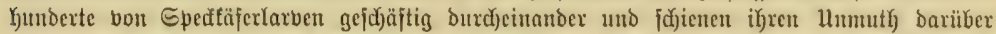

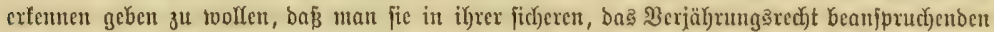

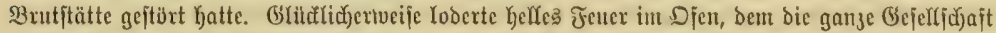

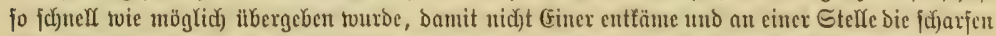
3ähne hätte prïfen fünnen, wo die Mirfungen entfoj)ieden viel entpfinblidjer hätten twerden fünnen.

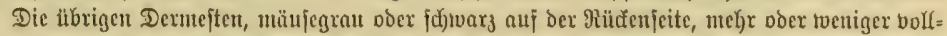

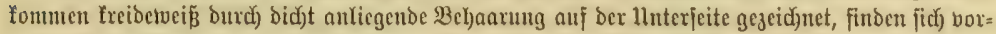

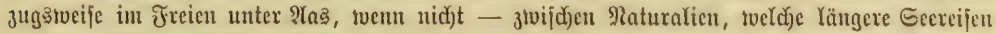
zurüafgelegt haben und unjureidjend vexpadt toorben twaren.

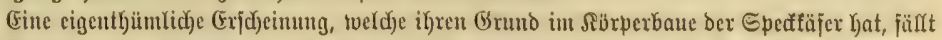
bem Eammler auf, ber getwohnt ift, bie von iłm getöbteten Säfex, bevor fie volftommen troden

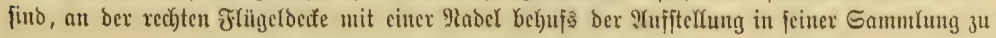




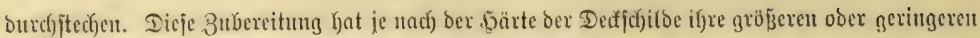

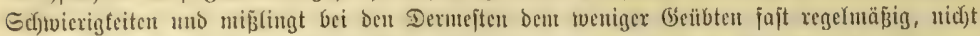

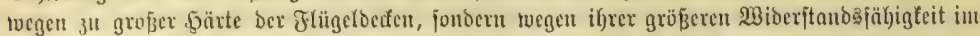

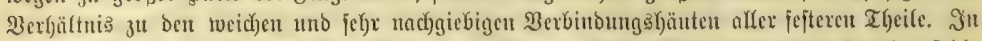

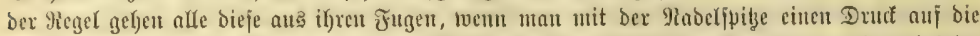

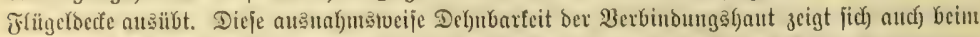

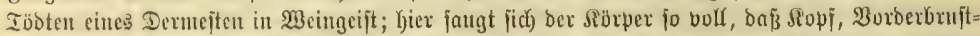

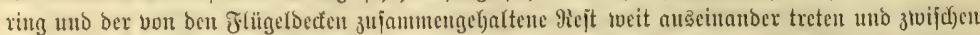

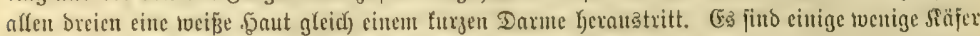

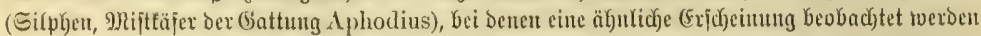

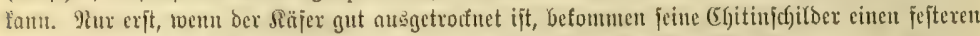

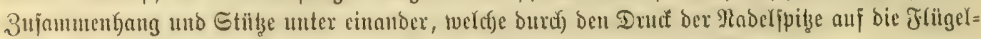

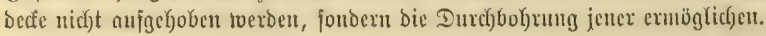

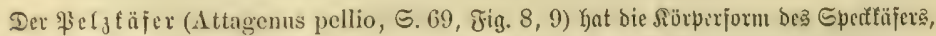

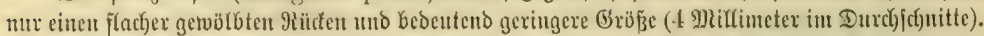

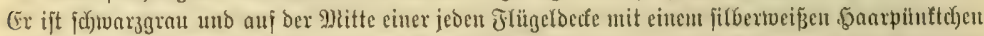

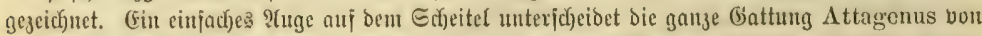

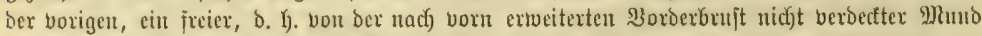
unb nahe beijammenftehende 9littelbeine zeicfnen fie vor ben anderen, mit einem Rebenauge ber= jehenen Battungen aus.

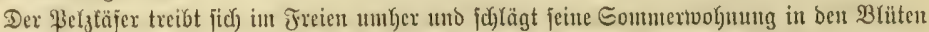

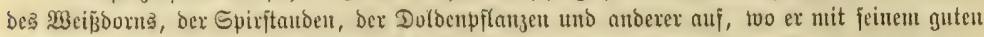
Freunde, Dem undher zu bejpred)enden Sabinetfäjer, und mandjem anberen Serfe in bejtem Gin=

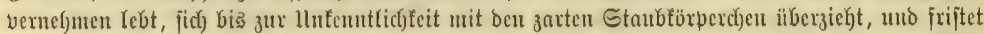

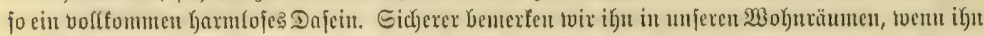

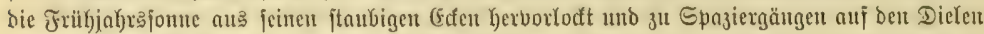

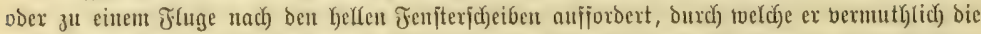

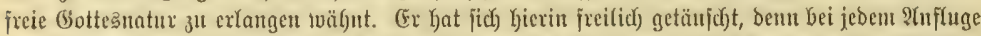

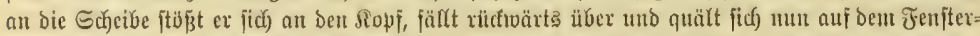

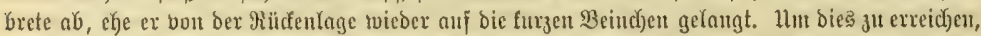

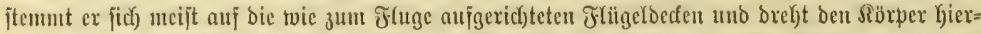

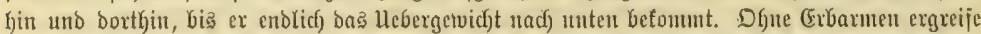

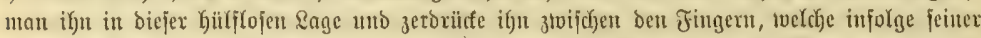

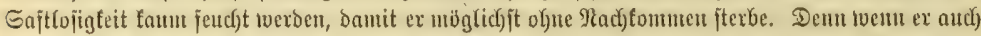

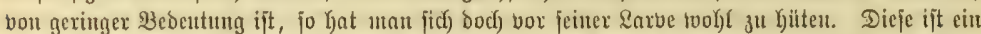

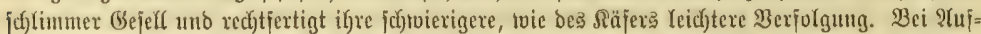

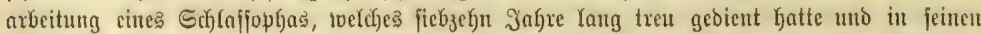

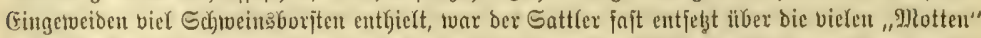

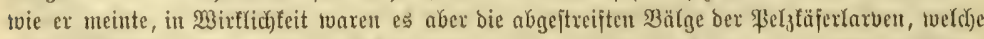

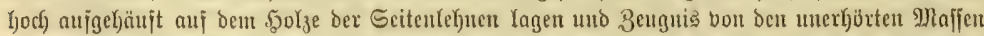

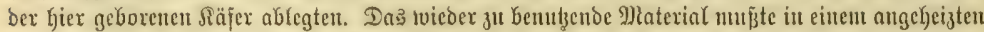

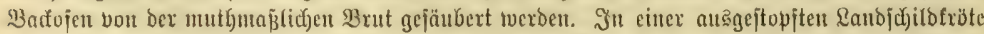

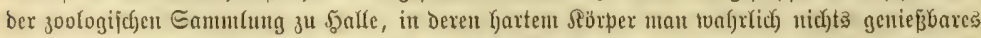

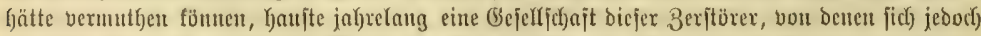

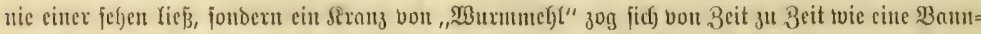

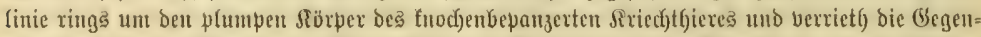

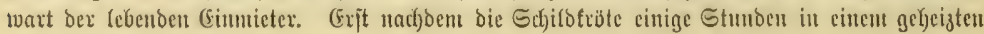




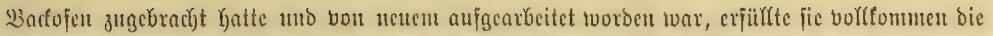

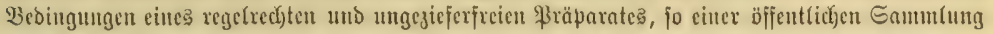

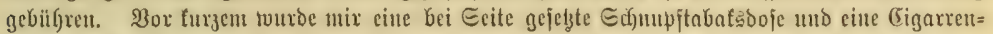

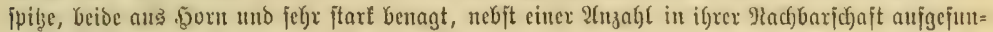

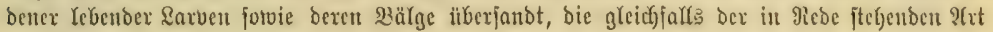
angebörten.

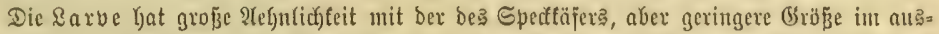

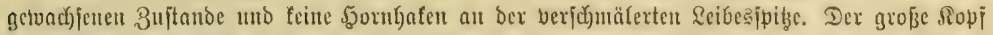

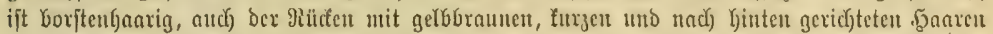

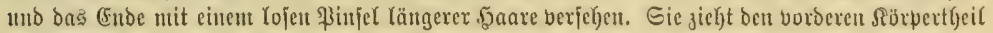

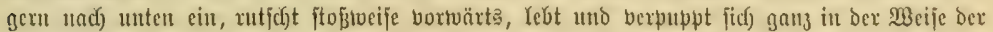

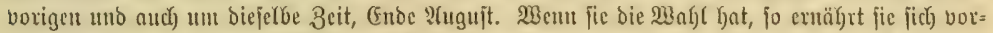

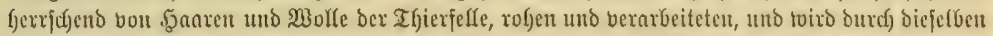

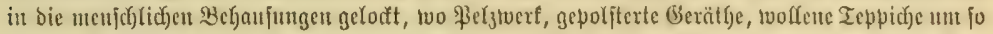

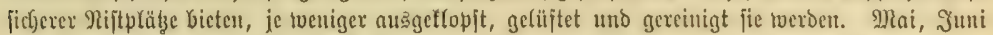

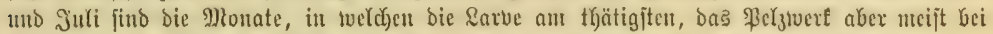

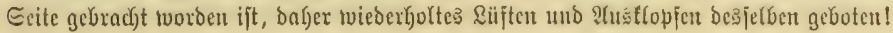

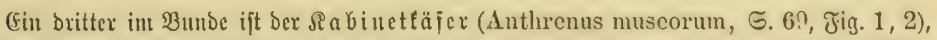

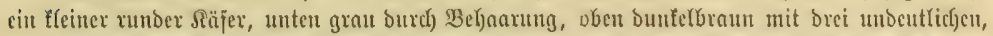

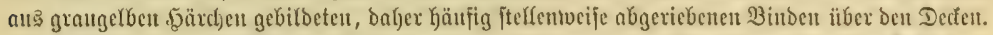

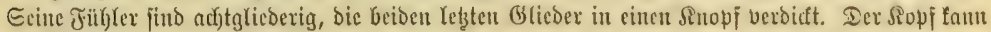

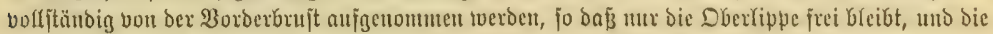

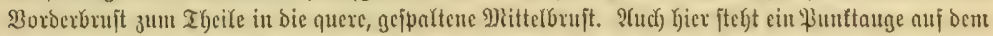

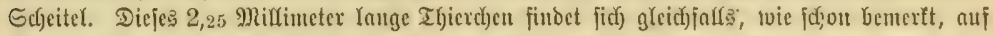

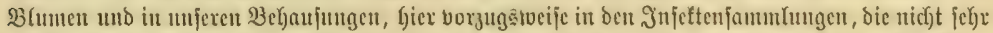

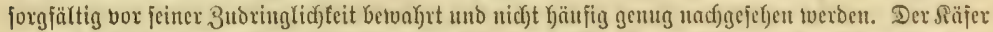

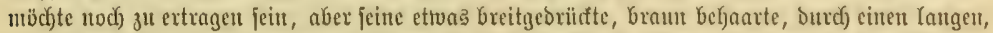

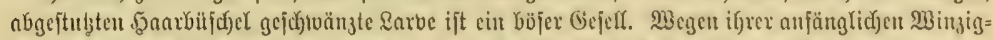

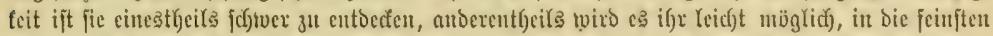

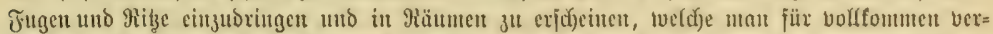

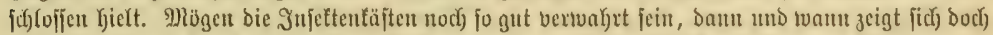

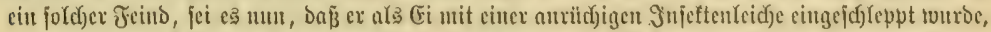
fei $\mathrm{e}$, on

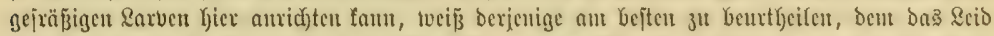

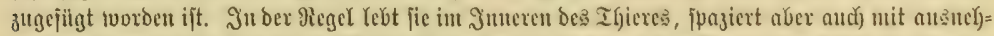

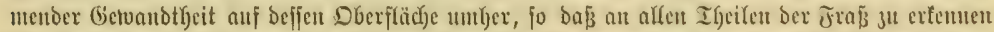

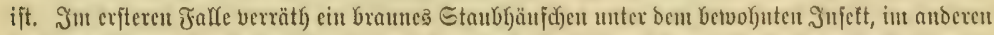

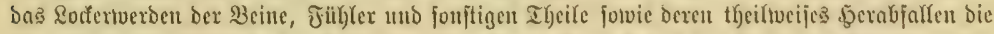

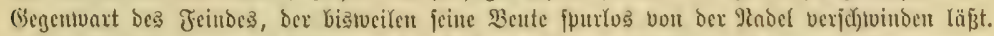

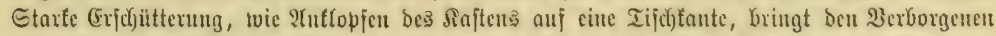

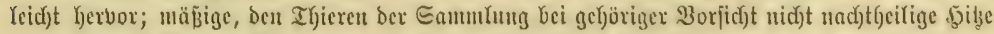

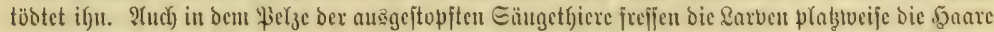

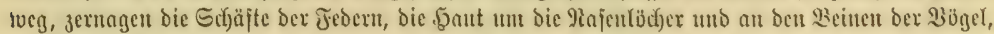

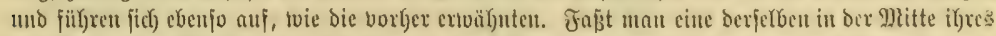

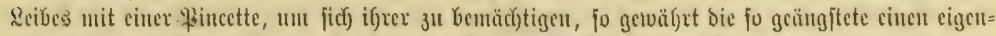

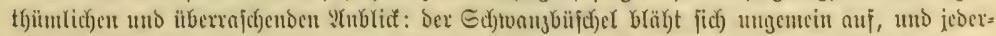

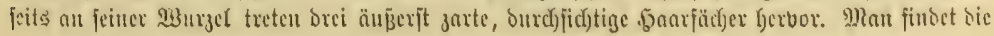




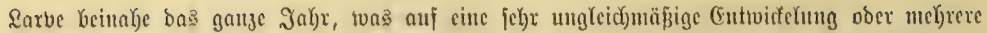

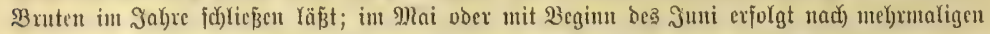

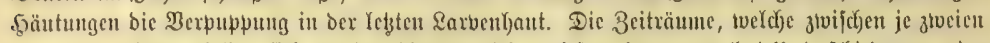

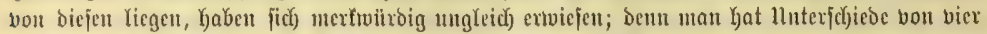

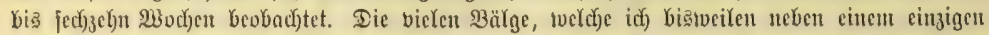

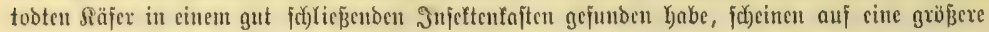

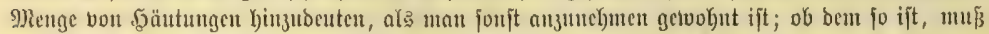

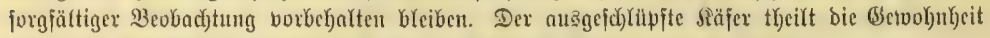

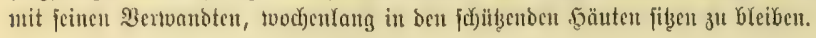

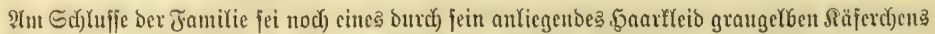

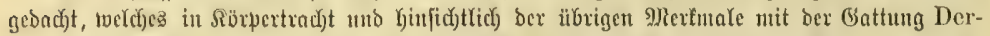

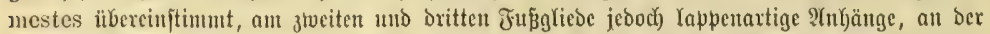

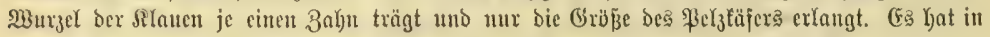

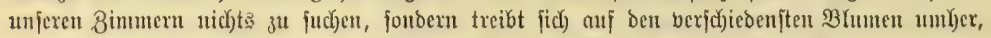

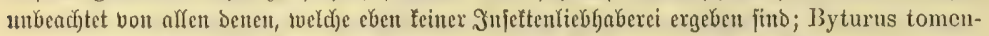

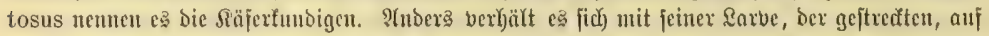

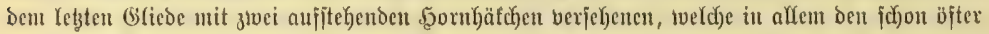

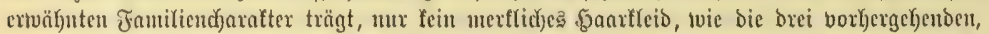

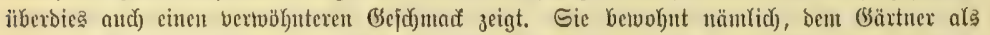

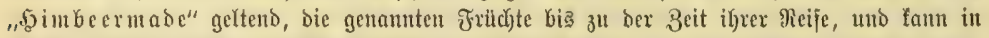

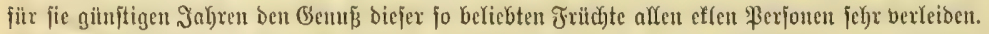

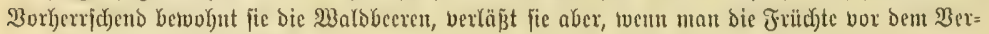
braudje einige Beit cintwäfjert.

Bon Der Yängeren Recthe ber Frantifien, weldye bic Syftemtatiter folgen Yaffen, ebe tvicorr

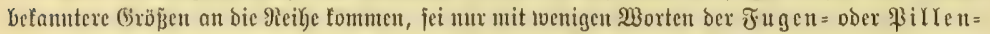

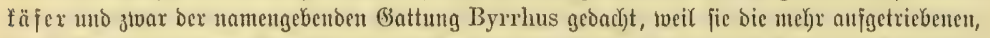

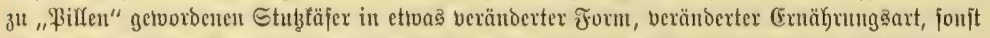

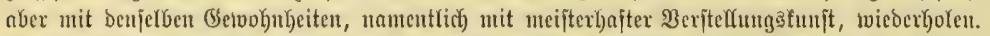

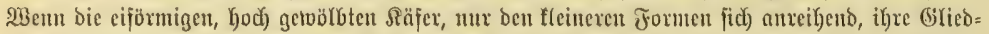

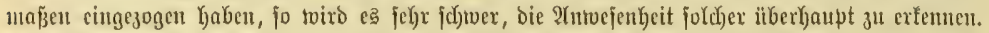

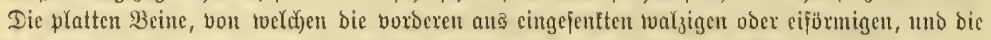

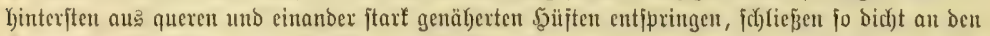

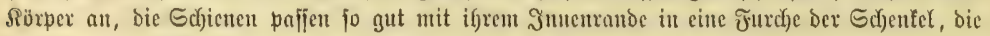

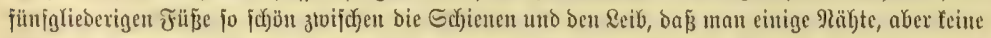

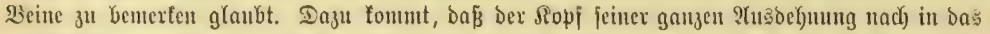

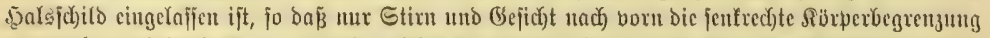

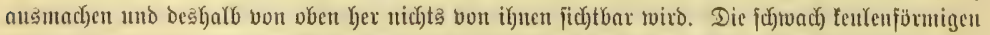

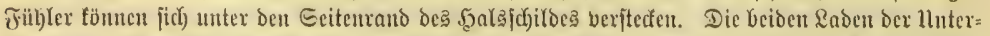

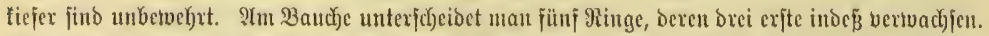

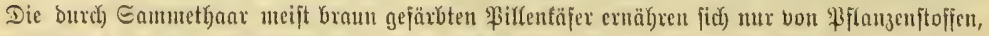
bon פloos uno Dimen Gefrämel; Denn man findet fie oft in größeren Gefelfichaften an fonnen= veroramten Berghängen, unter Eteinen, aber aud in Den (bebirgen hod) oben, two bie Iemperatur sine ftets nicbere zu fein pflegt; in unfidjerem (Bange friedfan fie in Sommer Yangjan anf Iriften

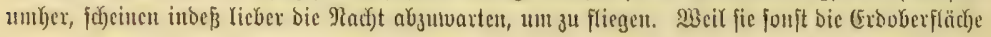





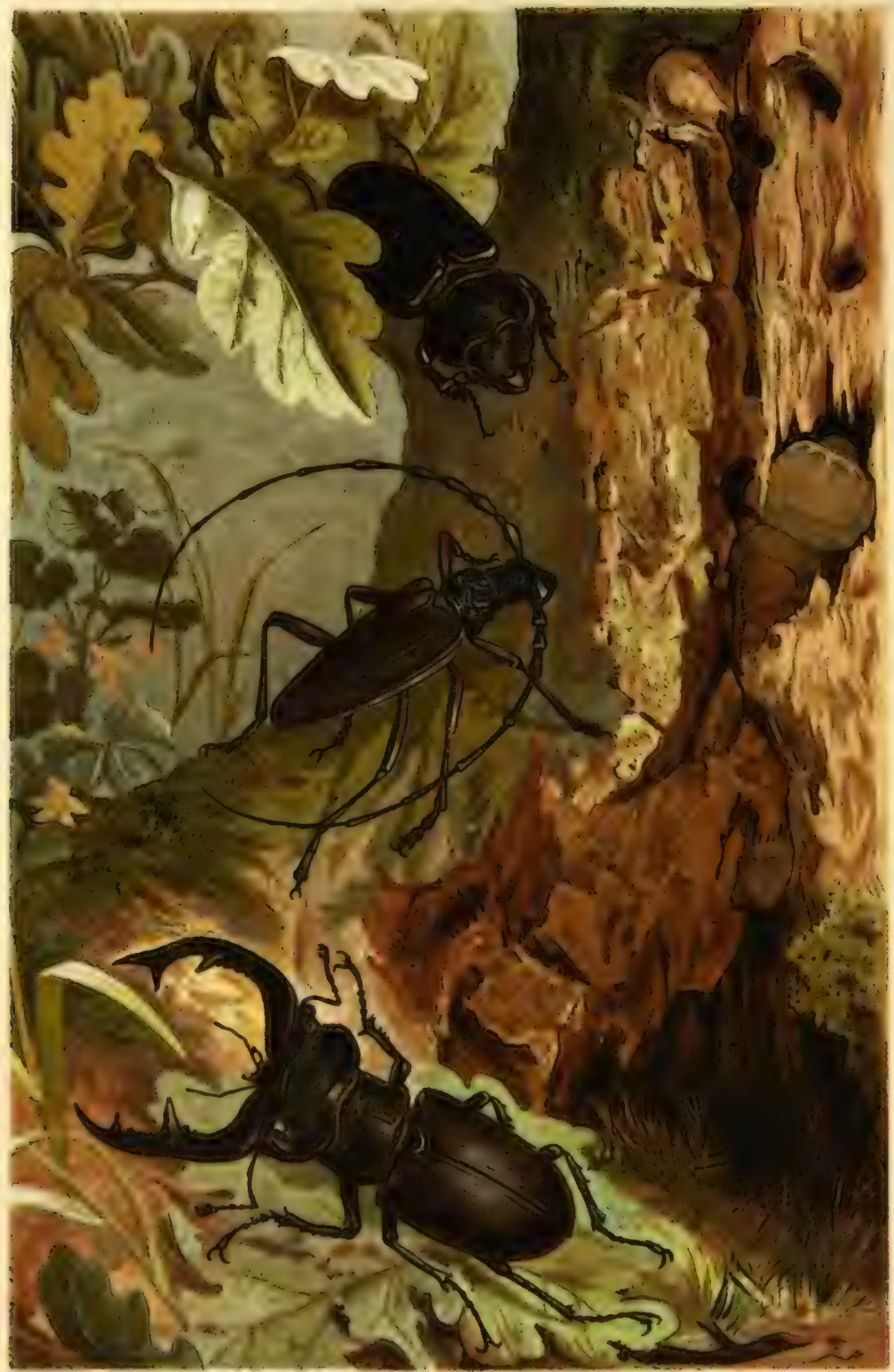




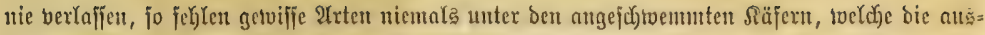
getretenen Berwäjjex im Fruifjałre mit fich filígren.

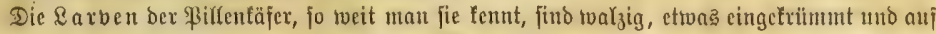

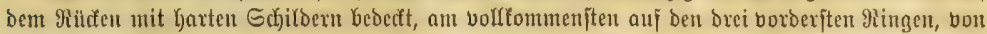
benen ber erjte jo lang tvie bie beiben folgenden zujammen ijt, auf ben vibrigen fino bie Edjitoer

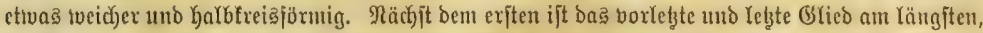

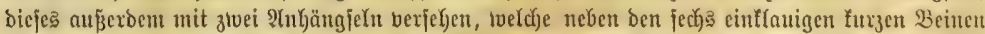

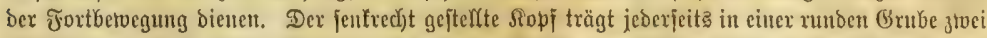

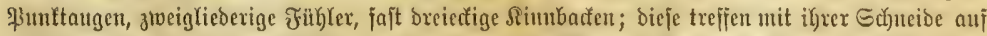

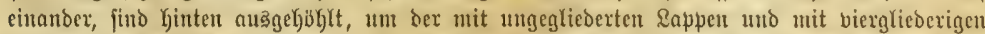

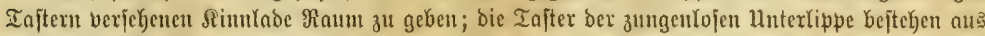

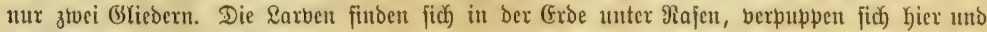
tveroen vor Minters zum Räjer.

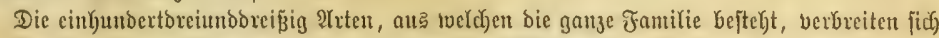
nux

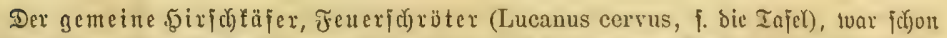

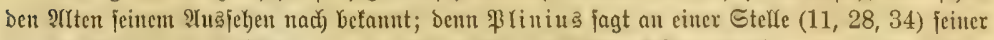

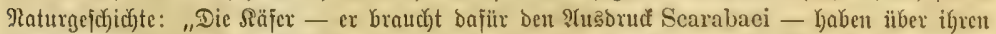
fuchtwachen Flügeln eine Karte Decfe, aber feinex hat einen Stacfel. Dagegen gibt e马 eine groje

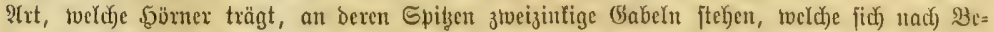

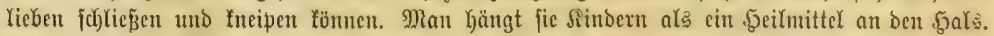

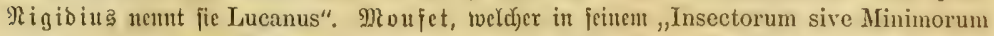

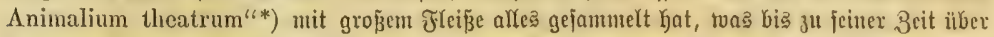

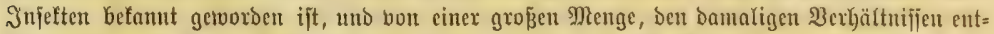

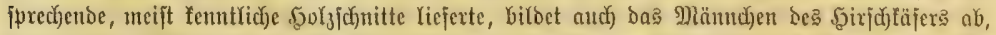

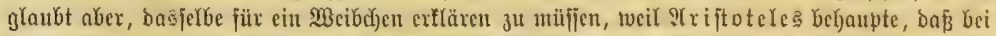

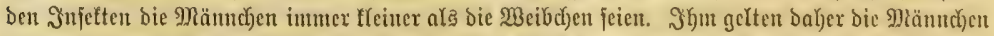

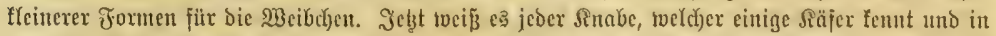

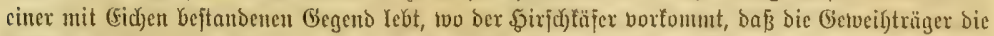

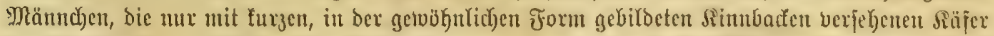

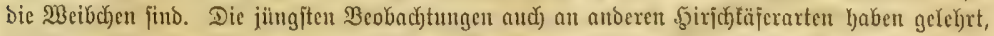

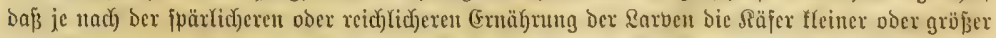

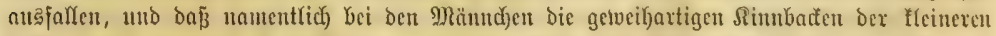

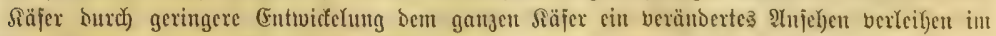

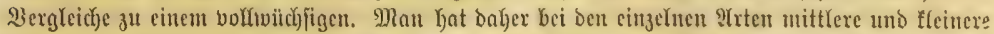

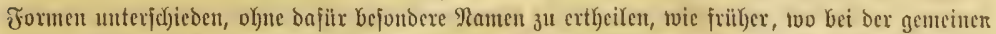

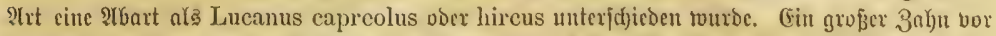

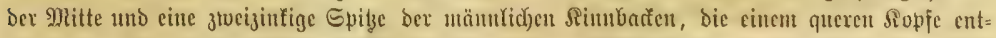

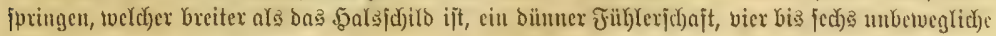

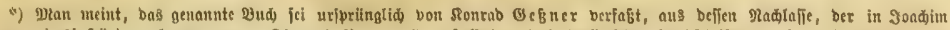

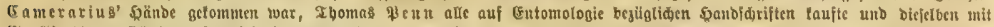

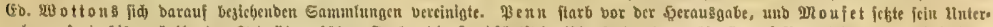

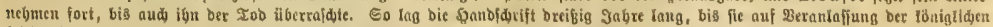

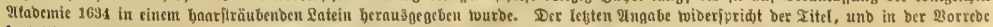

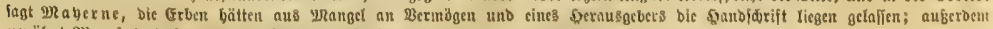

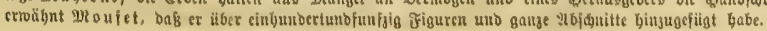




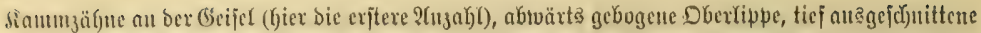

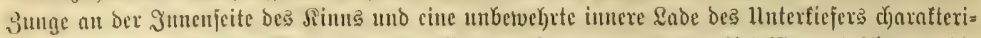
firen neben ber gejtreften Sibrperform bie Gattung Lucanus. Ilnjere 2frt ift matt fohtuarj, bie

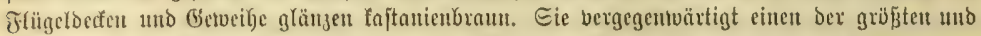

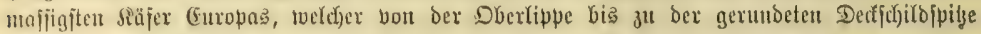

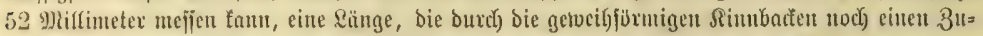

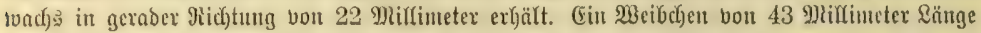

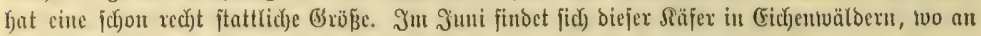

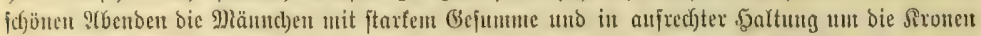

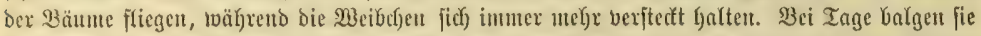

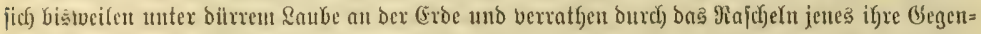

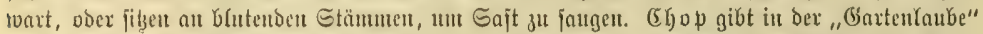

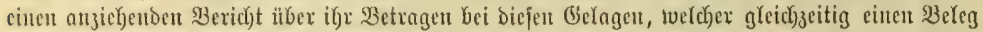

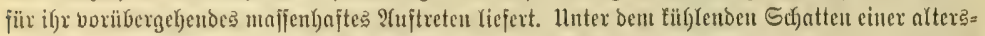

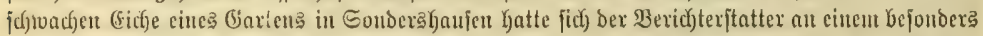

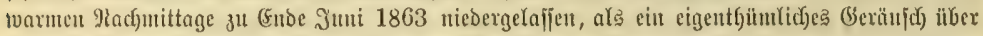
ifu jeine 24

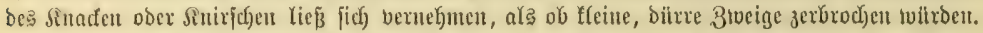

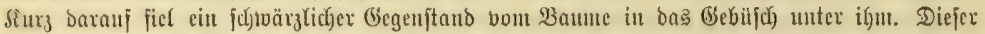

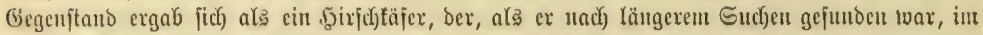

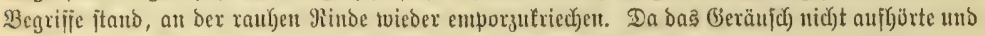

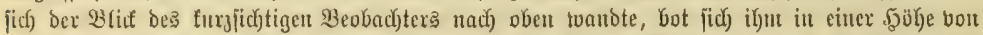

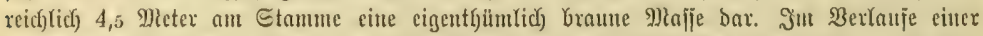

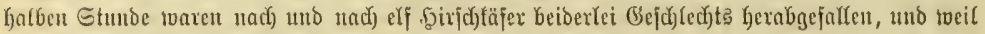

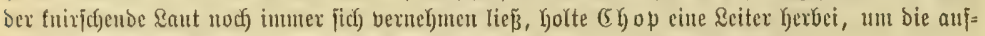

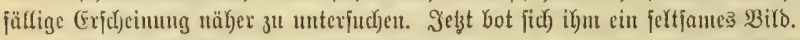

Tuf einex Fläche von etwa $\{2$ Euabratentimeter war an ber alten Borte Eajt Gerabgeflofifen.

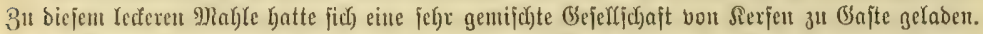

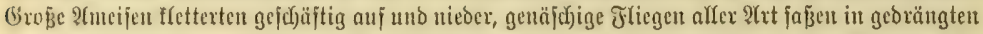

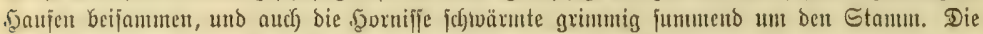

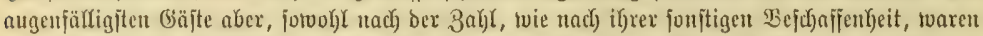

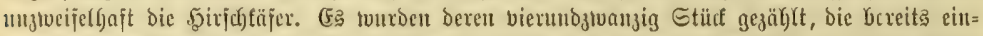

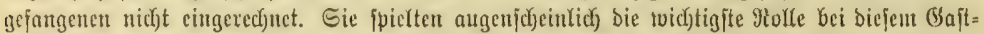

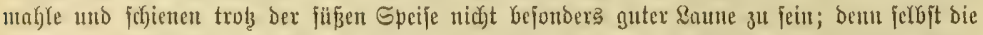

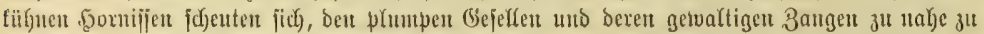

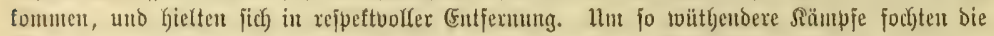

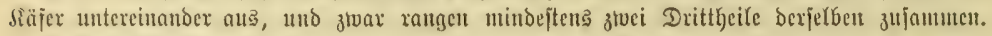

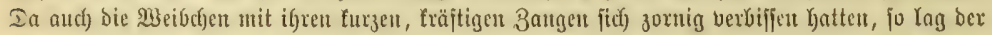

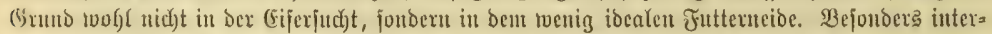

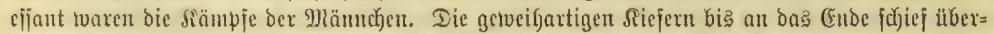

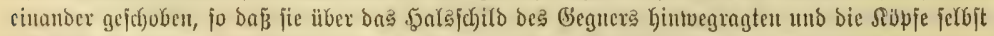

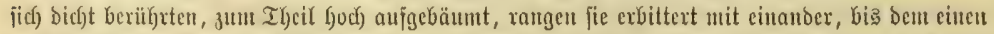

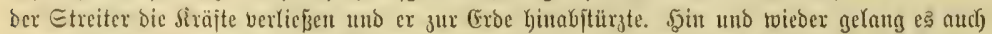

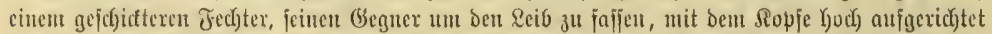

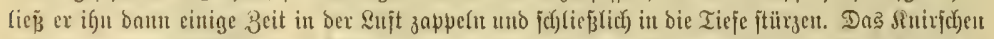

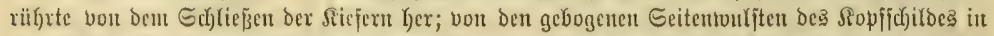

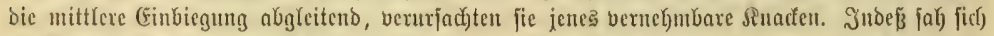

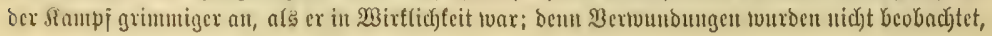




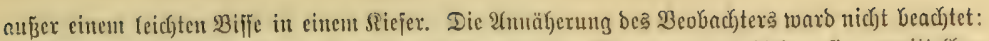

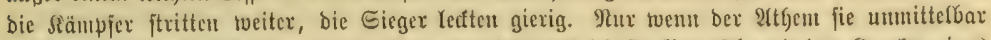

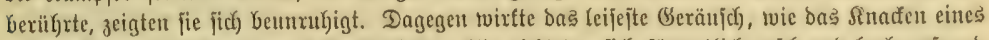

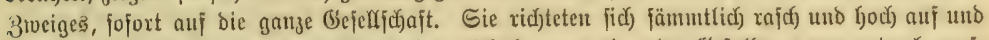

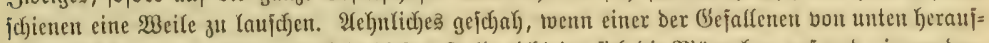

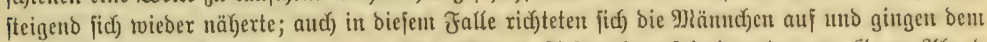
Gegner etwo eine Epante lang mit toeit geöfïuten Sicjern fampfgierig entgegen. Begen 2 bend

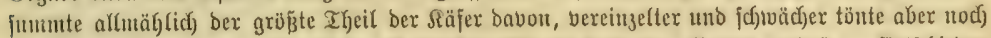

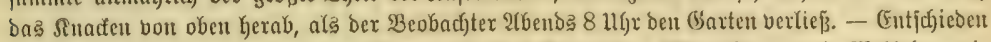

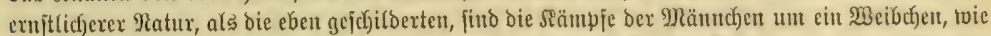

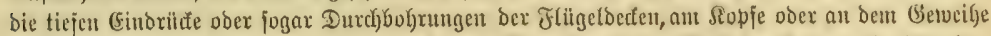

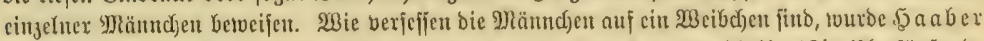

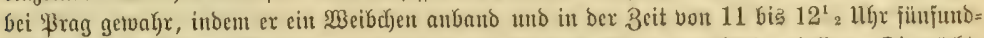

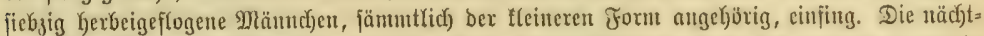

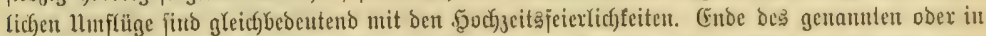

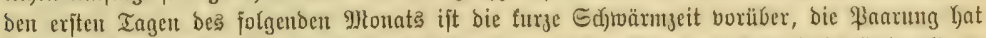

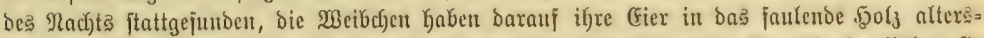

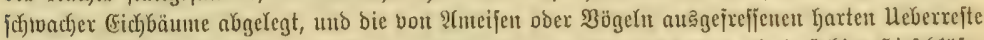

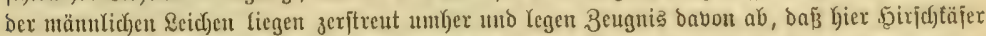

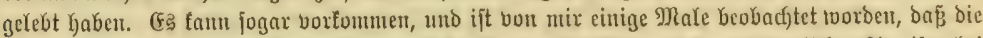

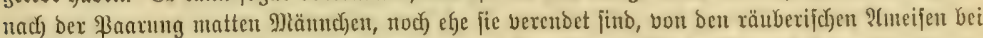

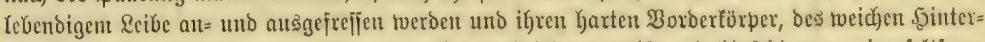

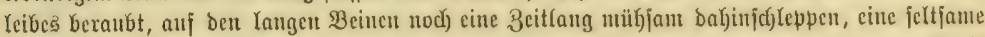

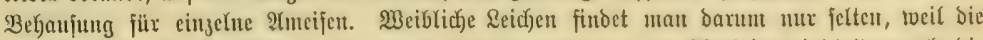

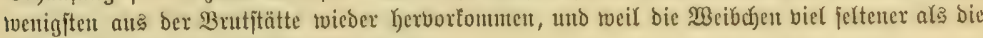

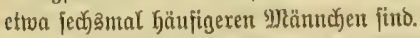

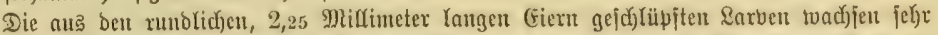

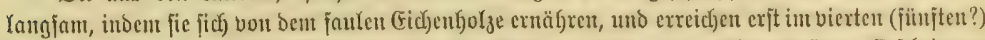

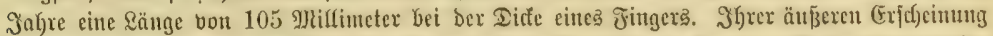
nad) gleid)t bie Rarve benen ifrex Jamifiengenofjen. Sie trägt ant hornigen Sopje vierglicoerige

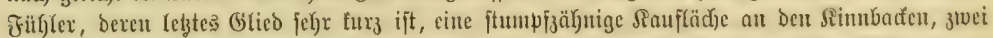

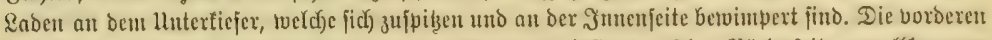

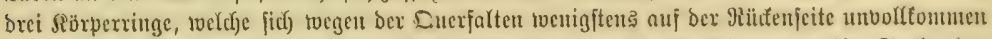
von cinanoer abgrenzen, tragen fect) fräjtig cntwoiffelte, einffauige Beine von gelber frarbe, ber

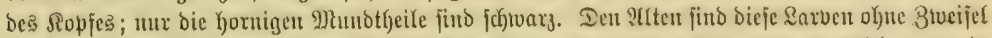

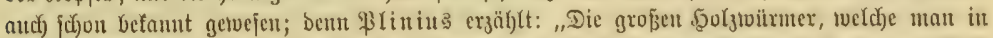

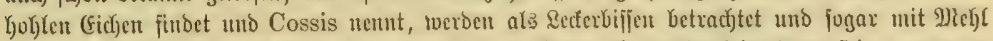

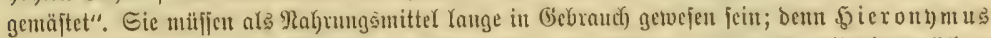

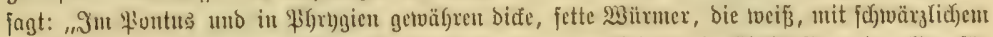

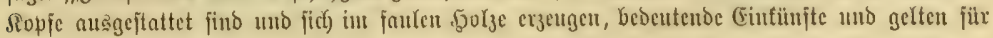
eine jebri fectere Speife".

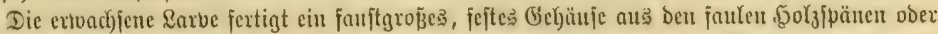

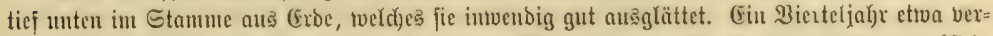

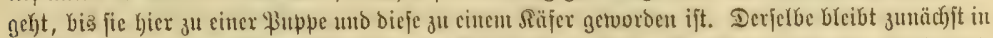

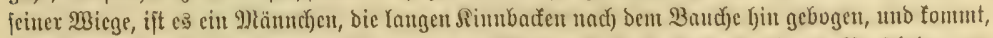

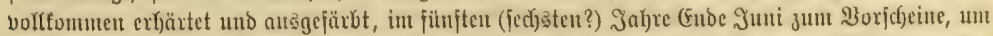

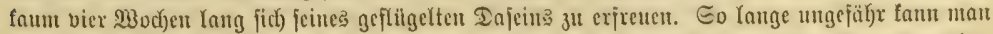

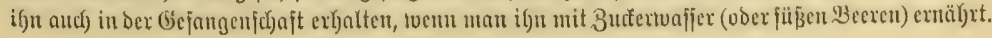




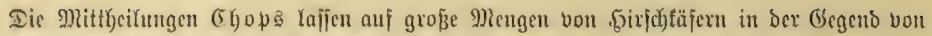

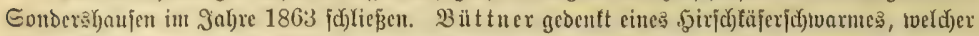
it ber Sitfece crttant und bei Ribau angejurwemunt worben ift. Cormeliug berid)tet von ber

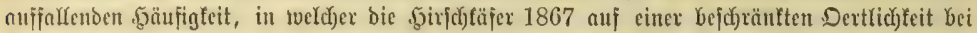

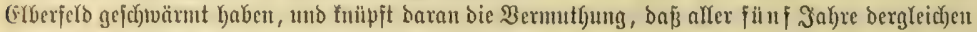

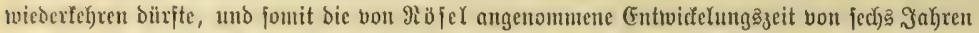

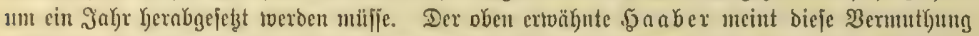

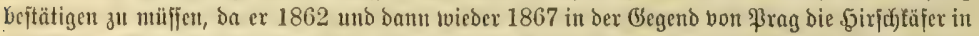

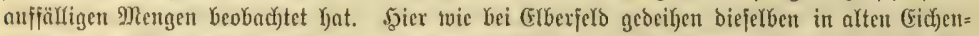

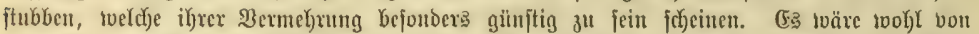

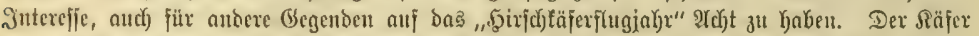

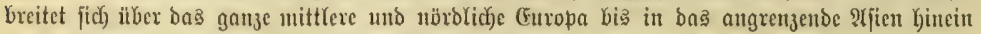
aus und jefylt naturtich nux in ben eichentojen Gegendent.

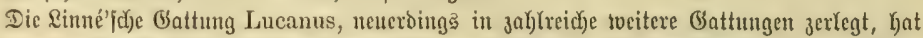
23ertreter in allen (Erbtheilen, bie meipten in ?rïien, näd)ftoen in Sildamerifa (34), bie toenigften

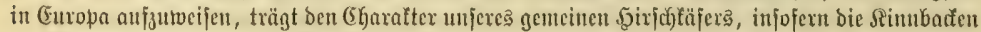

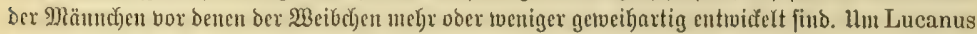

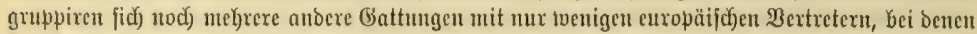

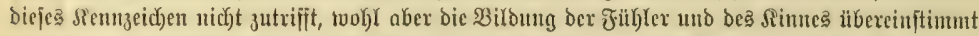

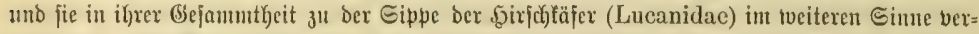

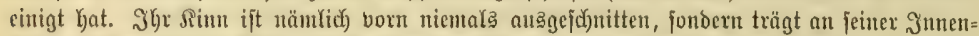

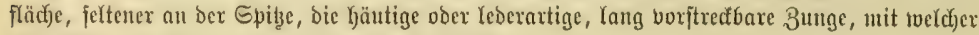
Dieje Siäer mux Gajt als গlahrung

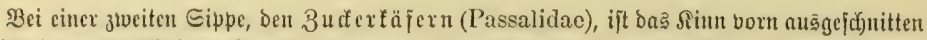

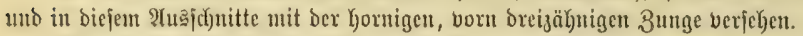

Dic 3ufferfäjer, twejentlick in Der Gattung Passalus vertreten, vicbertyolen ungefälyr

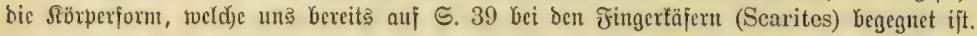

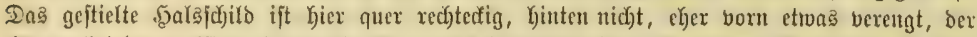

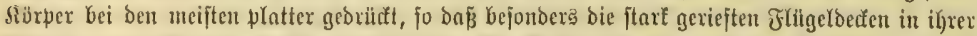

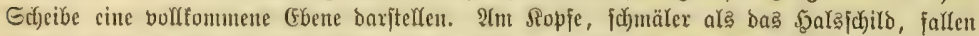

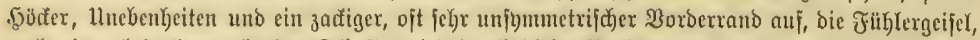

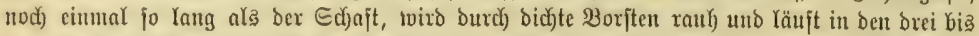

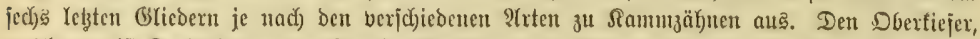

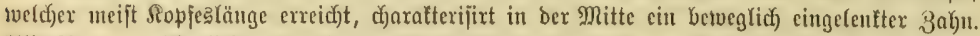

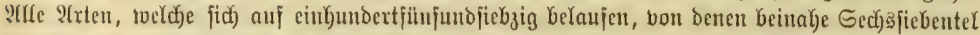

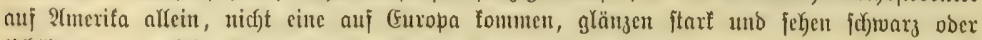

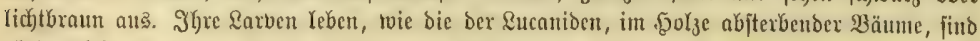
glatt, nicht querfaltig, Gaben ztweiglicderige Füblex unb cin mur mangelfaft entwideltes britteß Jußpaar.

Die beiden Gippen bex \&ucanioen und झafjaliben bitben zufanmen cine neuterbings von bet

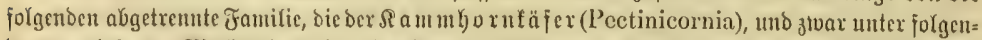

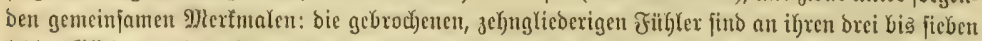

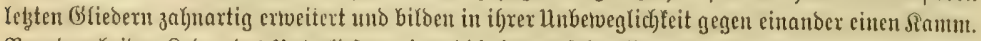

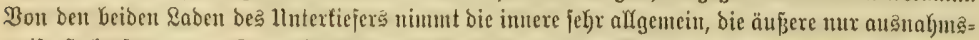

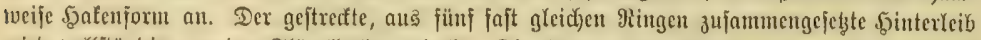

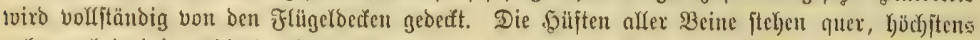

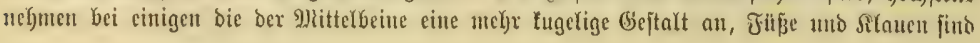




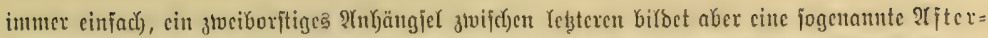

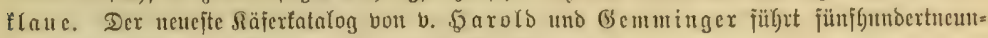

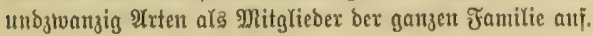

Die Brattgöruer, Blatthorutäjer (Lamellicornia, Scarabacidac) bilocs bic ficf)

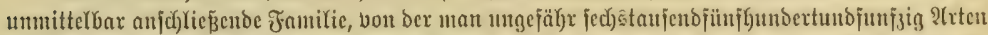

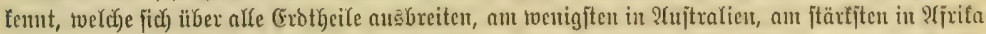

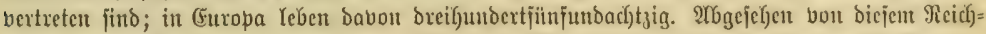

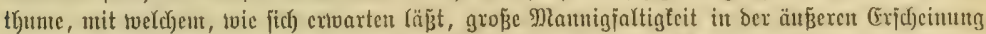

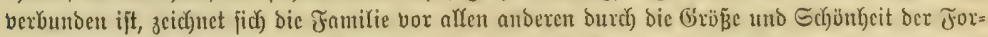

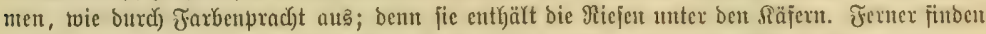

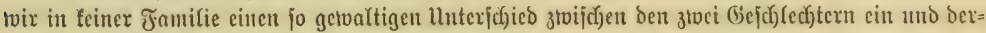

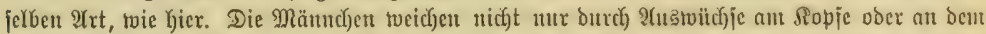

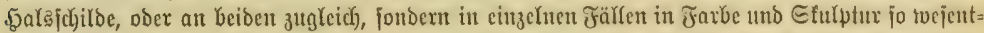

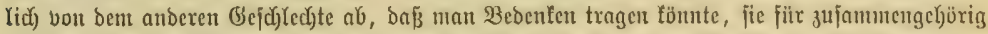

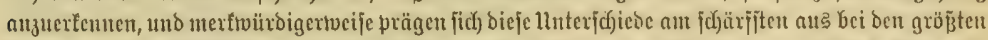

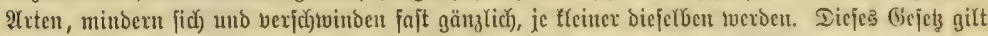

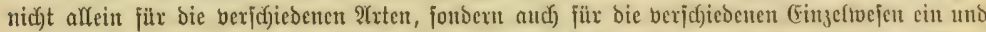

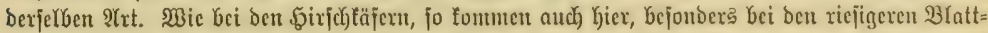

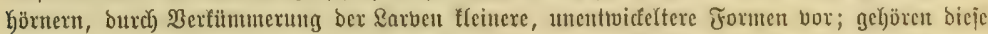

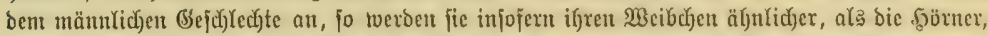

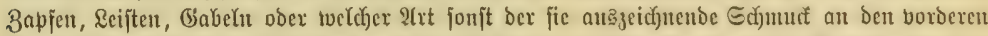

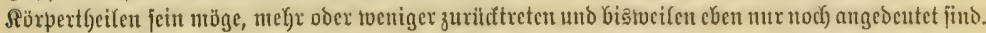

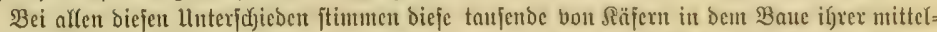

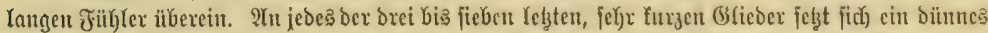

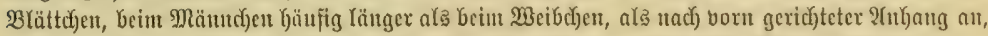

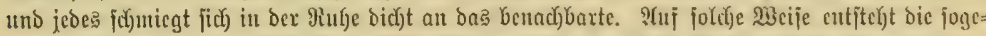

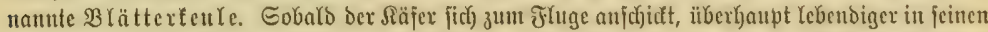

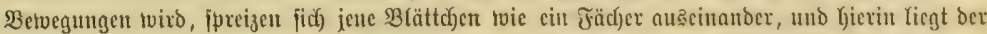

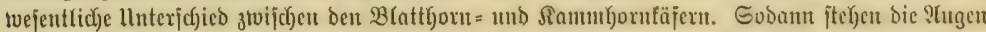

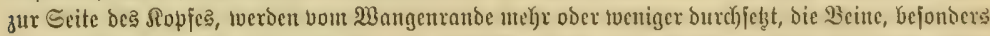

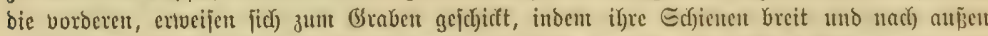

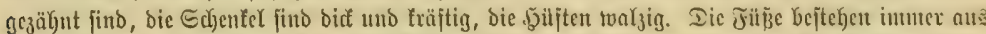

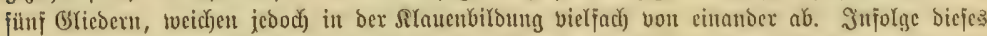

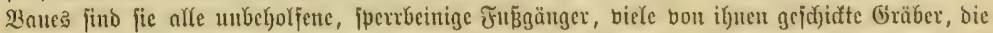

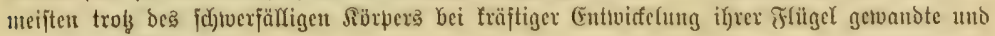

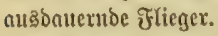

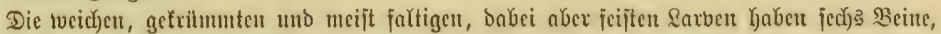

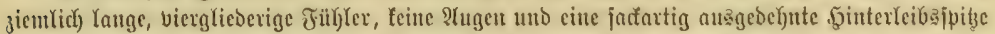

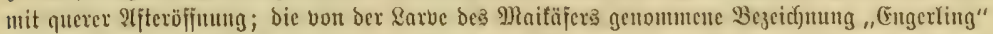

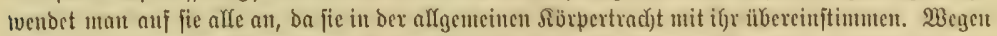

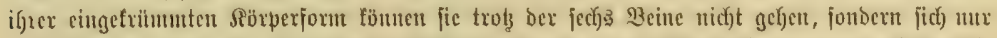

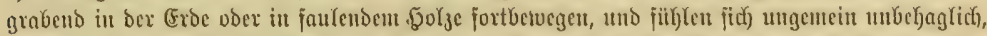

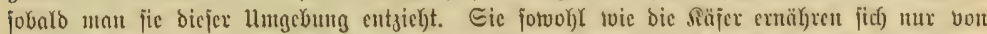

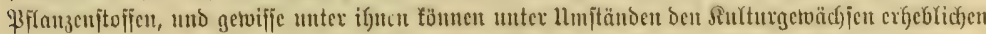

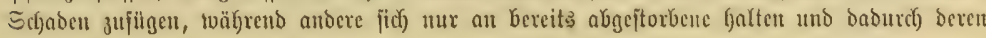


1lmietzung in Danmerbe bejad)

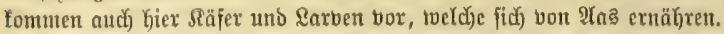

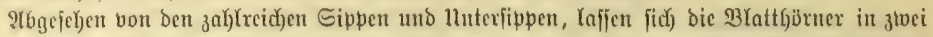
Jorden bringen, bic Tamellicomia laparostictica und pleurostietica, ober in bic S) ift fä fer

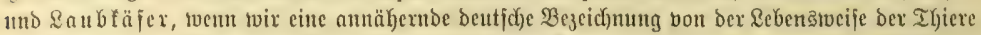

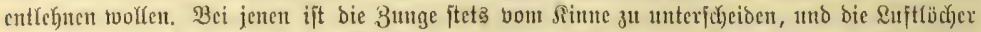

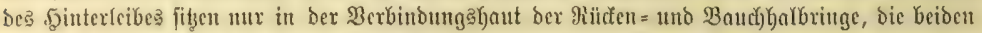
Raben bes Unterfieferes ber Rarben fund frei; bei biejen ift bie 3unge häufig hornig uno nit ón

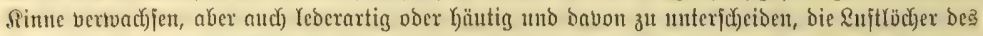

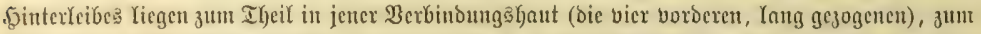

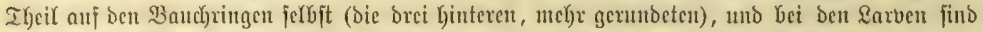

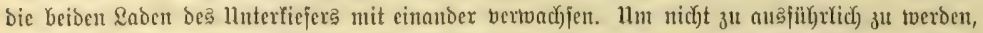

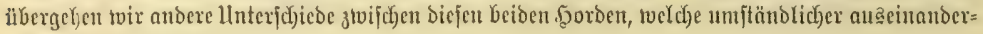
geję̧t toerden mǖten.

Die Mift f̈̈px in engeren Sinne (Coprophaga) Kaben Dbertippe, Dberficfer und 3unge

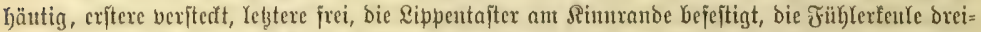

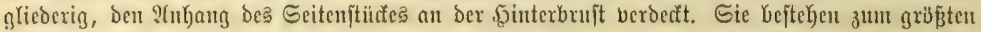

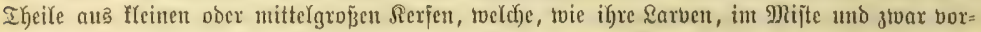

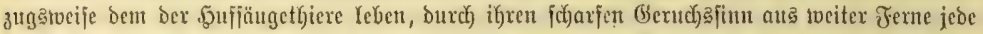

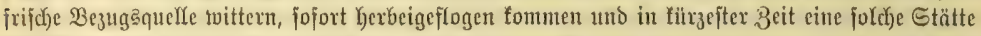

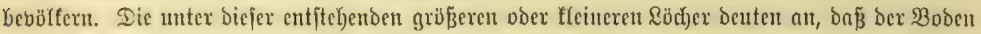

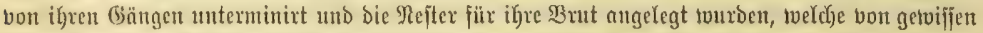

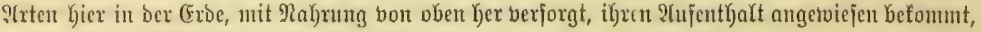
bon anberen in bem Düngerfaujen jelbit.

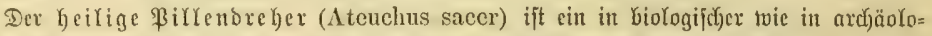

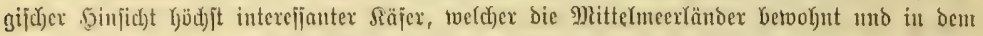

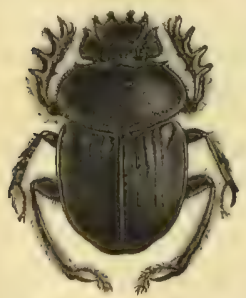

Syeiliger Millenbreber (. Iteuclus sacer), matirl. (Bröbe. Ibierfultus ber alten Eghpter eine Rolle gefpielt bat. Sie fanben

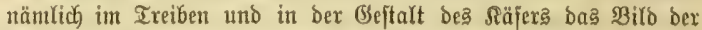

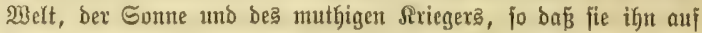
Dentmälen baxiftelten und, in fololjałem Map̃ tabe ms Stein gehauen (bie jogenannten "Ecarabäen"), in iGren Iempeln aufiftelften. 2 elian $(10,15)$ jagt: "Die Räfer (cantharos nent ex fie) fino

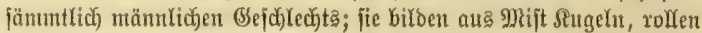

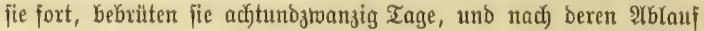

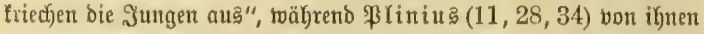
crzählt: "Sie machen ungeheure \$iffen aus \$Mift, rolfen fie ridctwärts mit den Fü

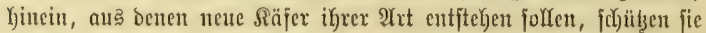

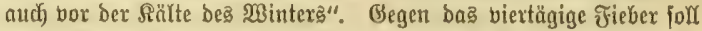

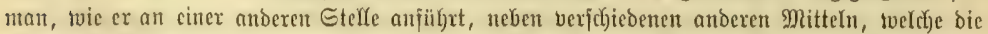

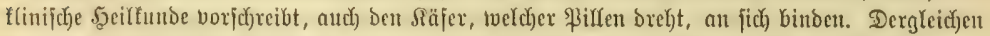

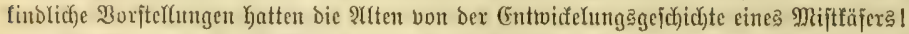

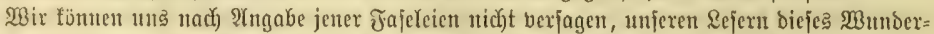

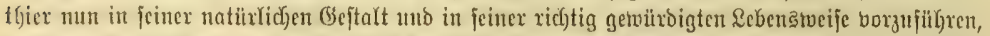

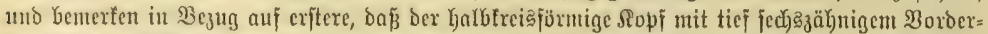

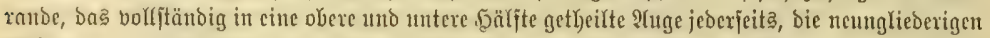

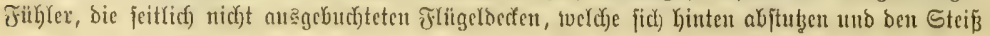




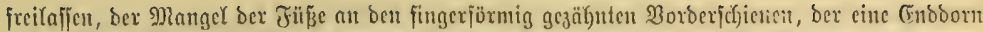

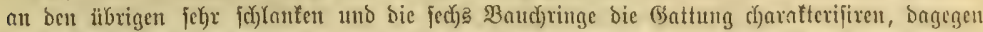

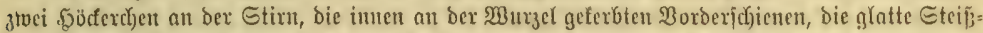

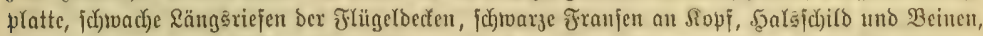

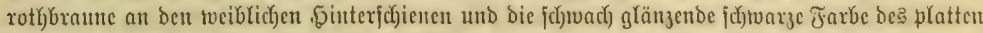

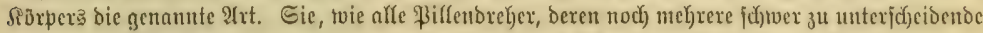

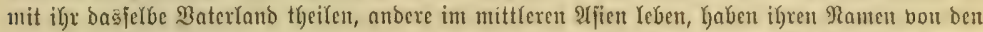

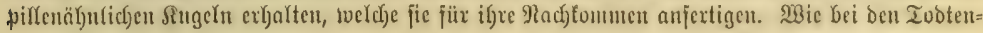

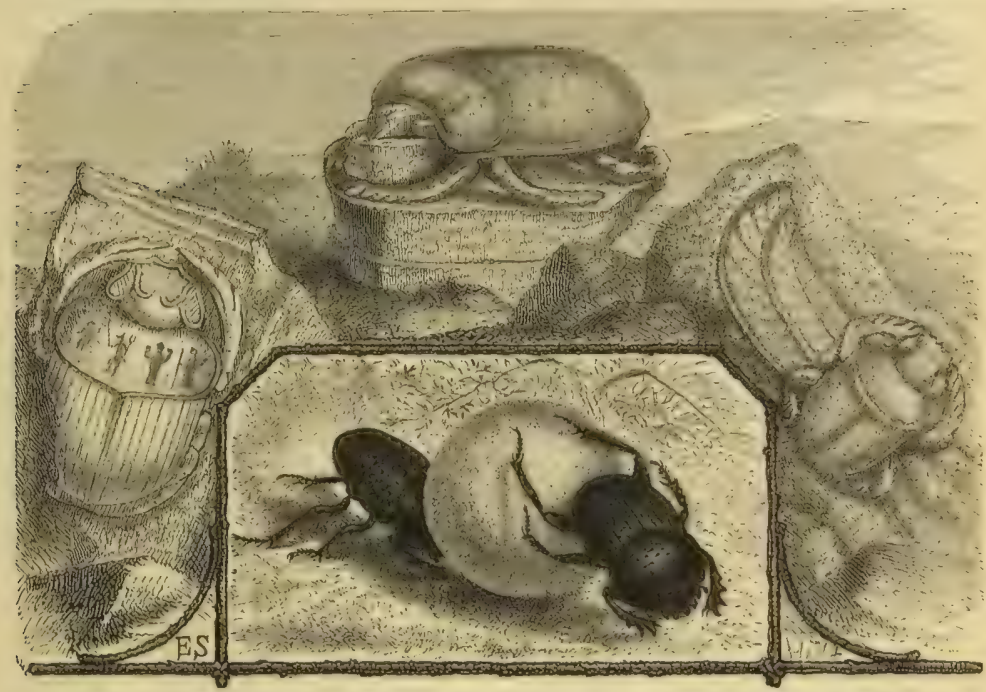

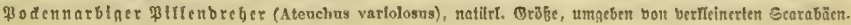

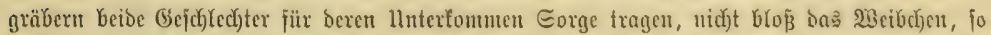

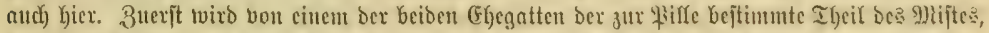

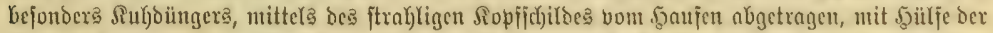

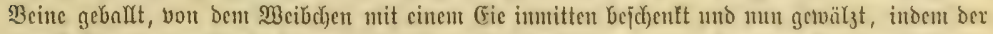

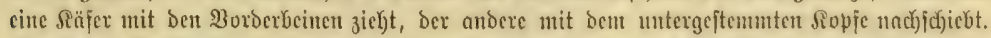

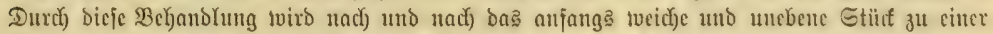

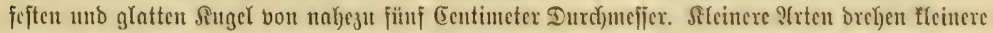

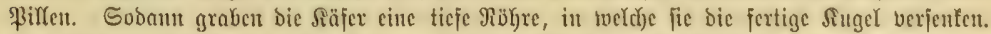

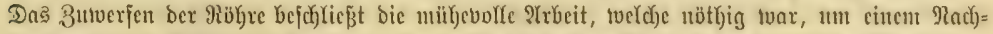

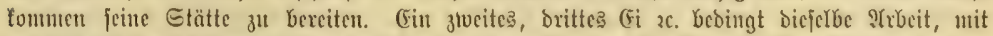

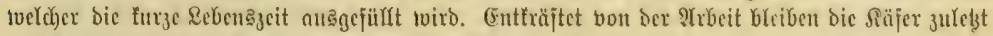
ant Schauplatge ihree Thaten liegen unb verentoen.

In ber vergrabenen Singel erbrübt neus Reben, bas oi tviro zur Rnrve, uno bieje findet ben

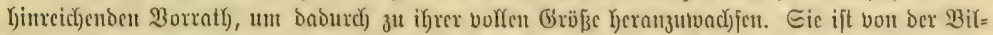

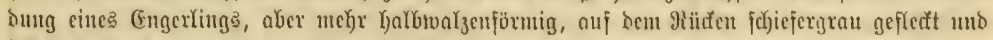

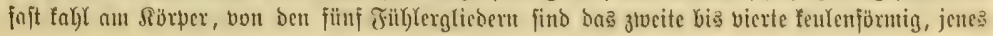




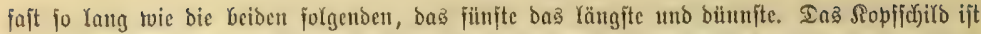

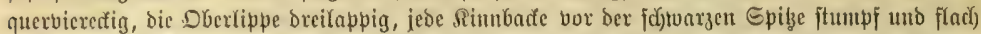

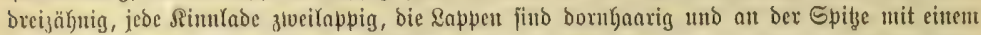
Jorulgaten betwehrt, ifre Iafter vierglieberig, bie ber \&ippe furg uno jweigliederig. Dieje Rarbe

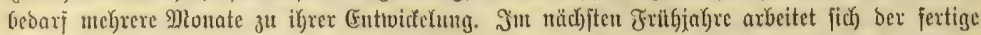

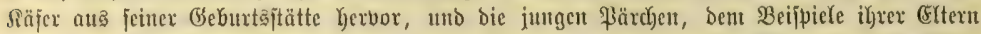

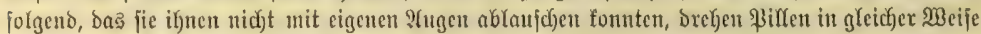

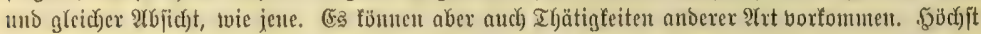

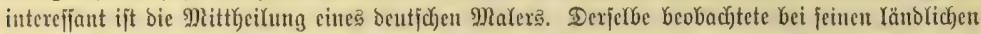

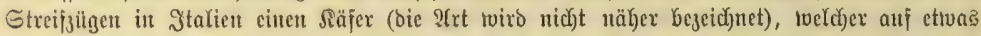

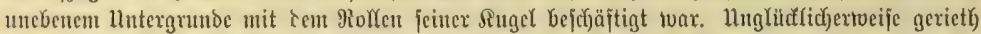

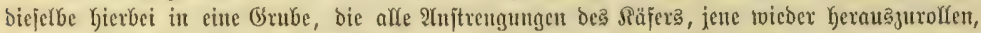

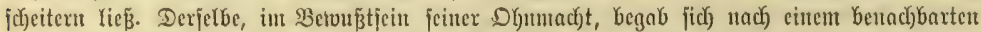
Dunghaujen, verjafwant in bemielben, fam aber bald svieber Gervor - in Begleitung bon bret

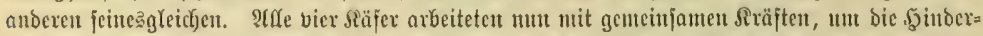

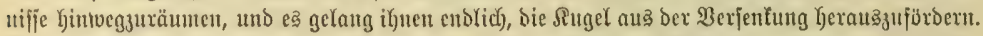

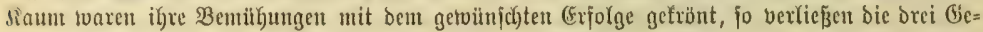

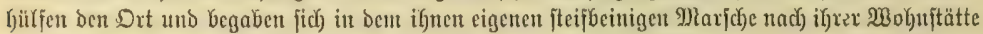

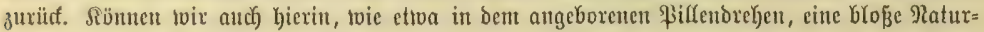

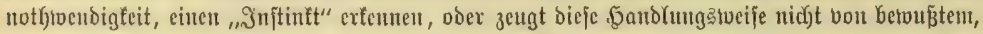

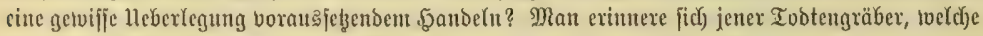

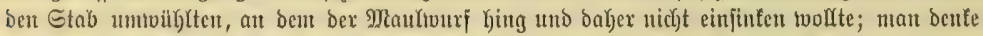

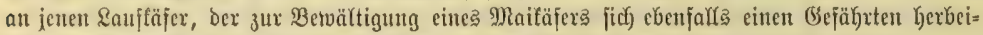

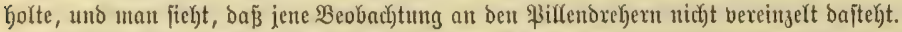

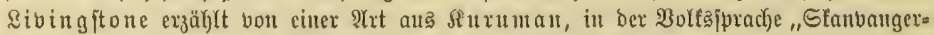

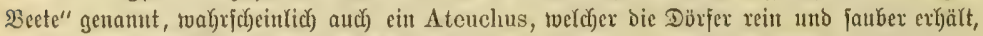

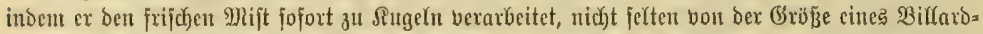

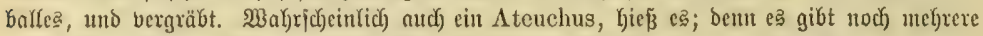

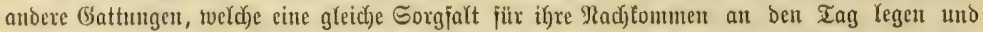

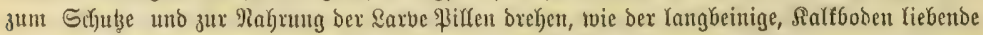

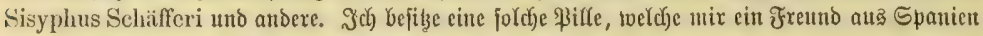

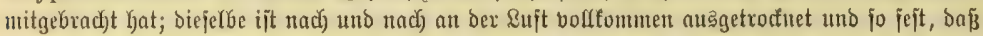

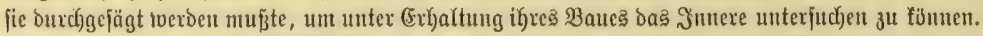

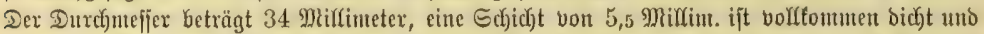

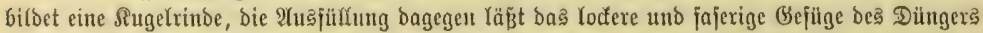

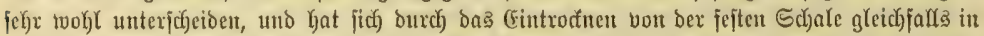

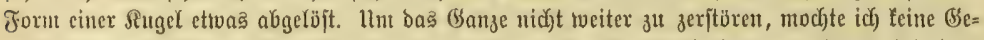
walt amvenden, olne weldhe nidjt toeiter vorzubringen ijt. Sn Der jebr hart geworbenen, fajerigen

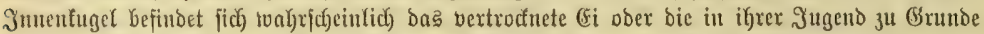

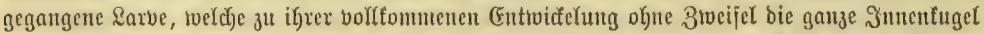

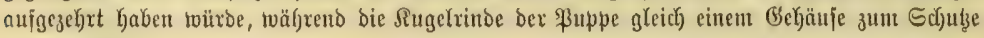
gebient hätte.

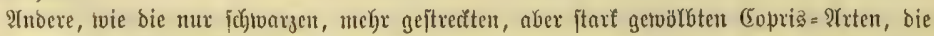
theilmeife prachtooff metallijich blau, grün, golbig, roth erglänzenden Slibamerifaner ber Gattung

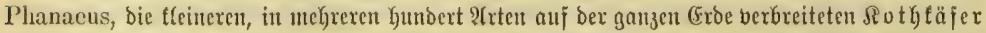
(Onthophagus), Yeben in gröperen (Gejelfichaften in Mifte, graben untex bemjelben \&jcher, in

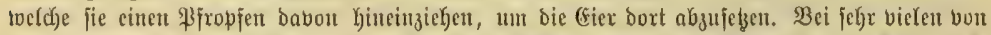

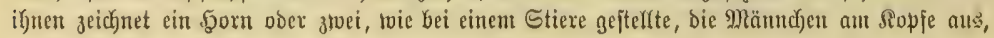




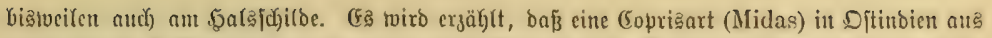

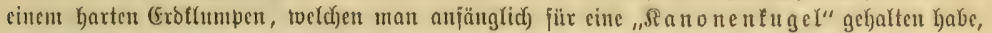

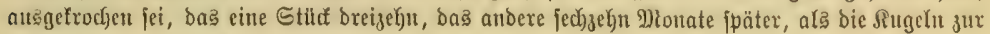
Beobactutung aujgeboben tworben waren.

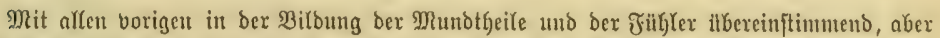

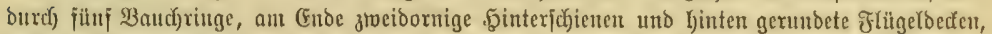

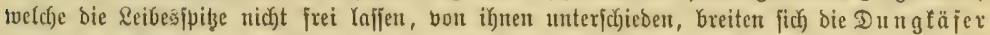
(Aphodius) in mefreren fundert 2 rten itber bie ganze Eroe aus, am zahtreidy)ten (115)

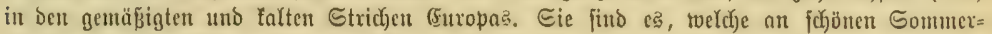
nbenden poer bei Sonnenjchein am Tage zu taujenden in ber Sujt unherfliegen unb wie bie

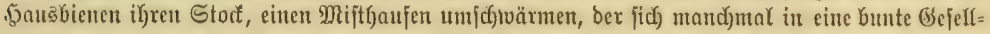
f(f)aft biefer treinen (befelfer aujgelöjt zu haben fcheint. Sie erleichtern fich igr Reben, graben

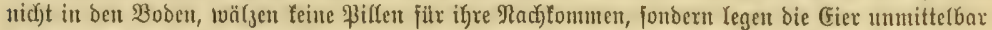

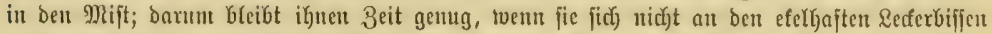

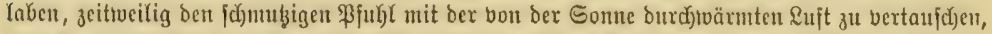

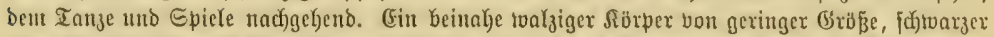
ober fofmubig brautner farbe tonmt faft allen zu. Der Kalbfreisförmig gerundete fopf bud)tet

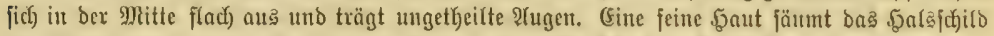

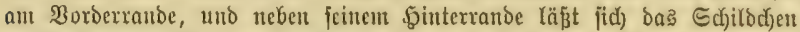
beutlid) unterf(c)eiden. Die Mitterfliften füb genähert, uno bic Winterhüiften

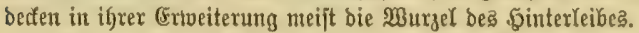

Der grabenbe Duugtäjer (Aphodius fossor), glänzenbjờtwarz von

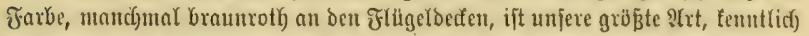
an ben vor bent Frugen in cine fleine gerundete (Ecfe erweiterten fropfichilbe, an

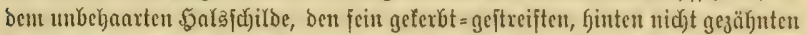

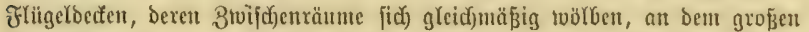

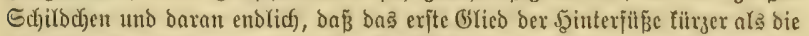

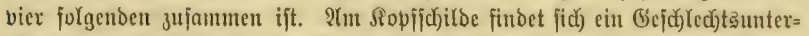

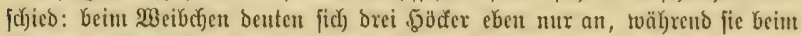

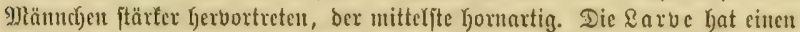

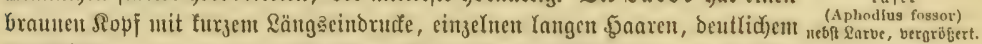
Sepffichilde und gerunbeter Dberlippe, fünfgliederige Filif)(ex, berent mittelites
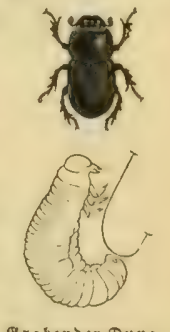
täfer

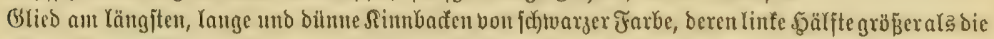

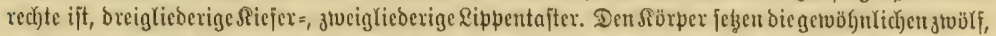

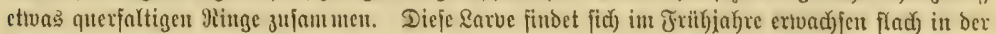

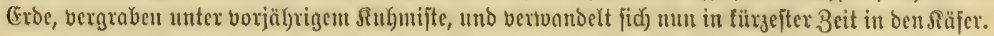

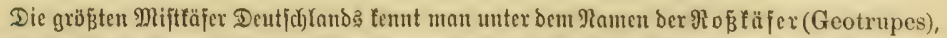

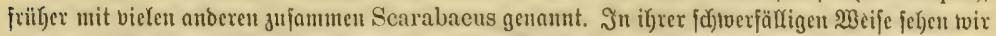

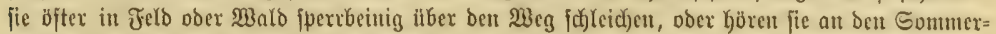
abenden mit Yautem Gebrumme an unferen Dryen vorbeifanfen. Bei ifnen find DberYippe und

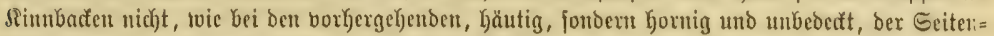

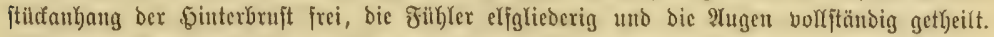

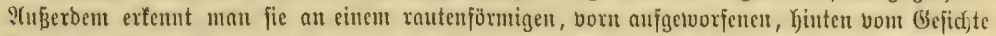

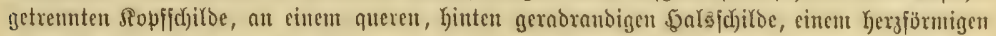

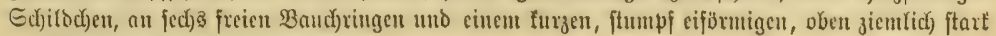




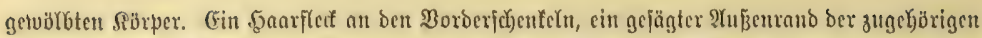
Ectyienen und vier Sianten an ben übrigen zeichnen bic Beine aus. Jnocm bie Inuge, unterịeits

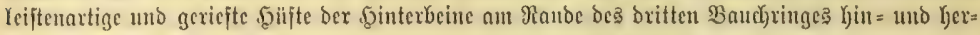
reibt, cntîteht ein jdywady fidnarrenter Rnut olyne jeglidye Bebentung.

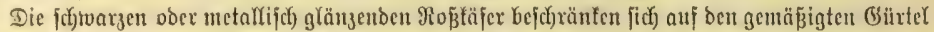

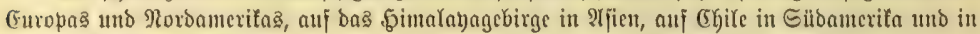
शrita auf bie Rorbtilite.

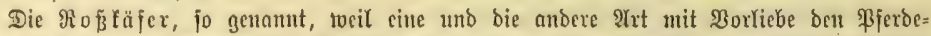

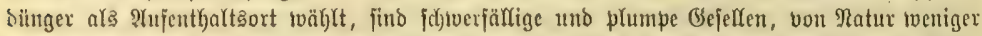

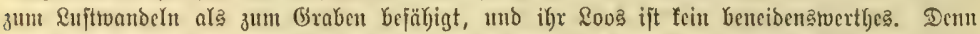

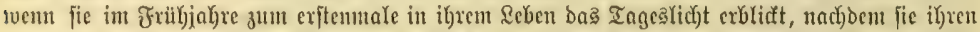

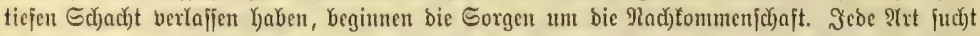

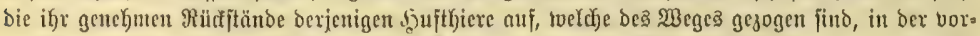

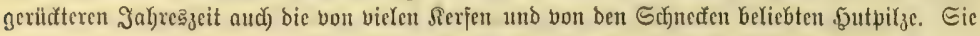

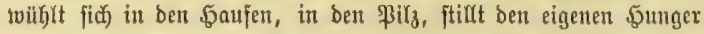

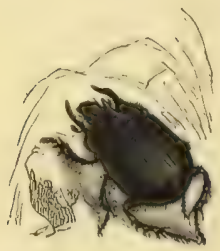

Männduct bç Dreiborns (Gootropes Typhoeus), Matiirl. Grö̉ce.

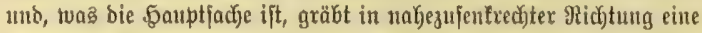

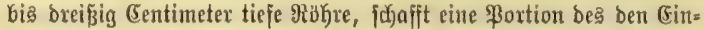

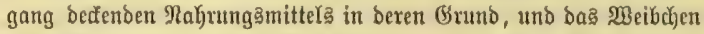
bejdyentt bie vorgerid)tete Brutjtätte mit einem (Eie. So viele (Fier abgejeyst toeroen folfen, fo biefe Schachte fino fut graben uno meift auch fo biele Dungitätten bon neuem aufzujuchen; Denn biejer eine

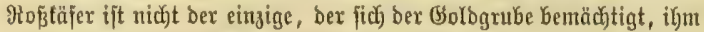
gefellen fich andere feinesigleidjen, jeinex (5attung, feiner Fanilie zu, und fo mandber andere Säfer, befjen toir bereits gedadjten unb ben

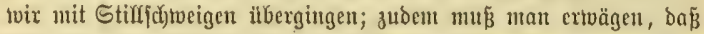

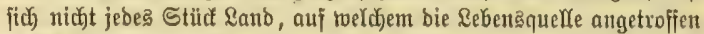

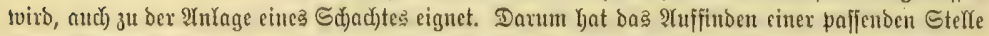

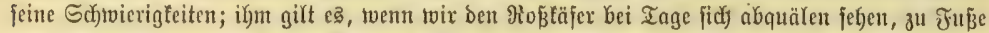

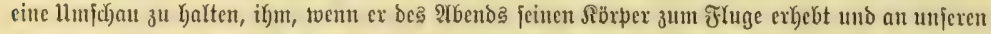

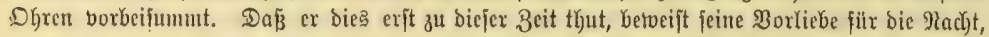

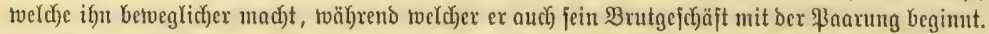

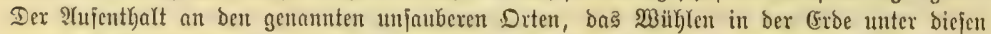

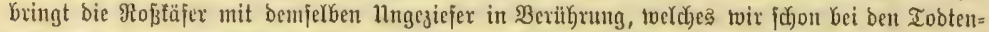

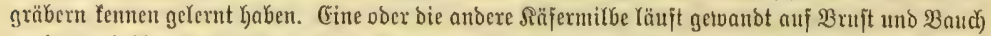

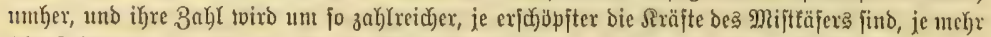

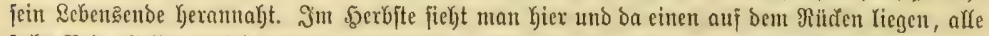

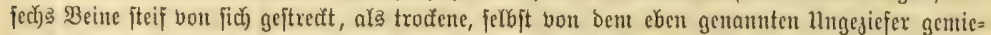

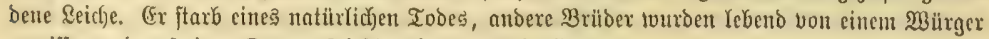
ergriffen und auf eiten Dorn geppießt, wie jo mandje Jummer.

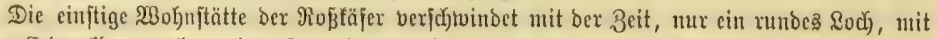

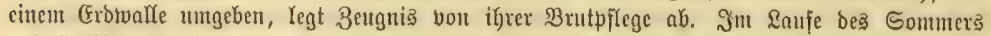

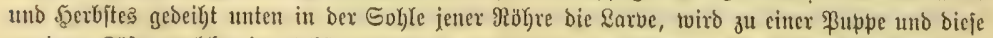

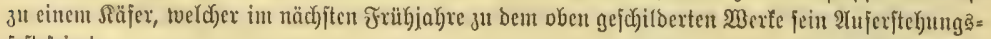
fejt feiert.

Der Fr ühling

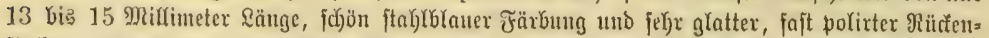

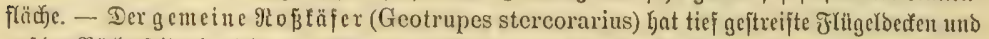

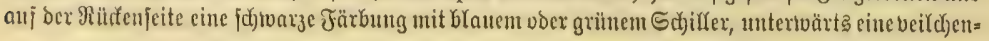




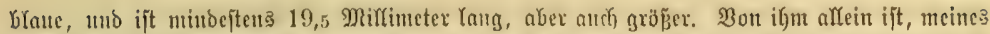

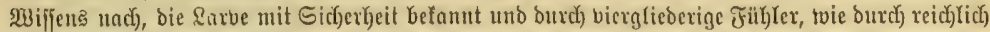

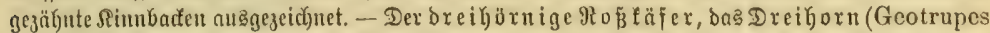

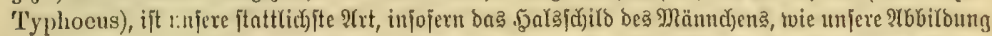

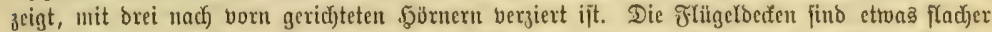

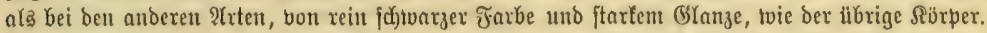

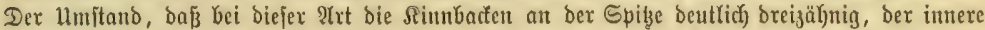

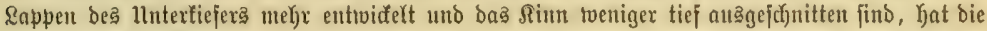

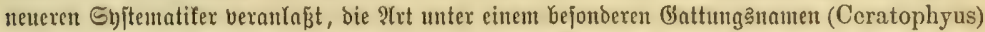
von ben anberen abjujdeiben. Sie findet jich vorkerrjchend auf dürren Irijten, wo Sdjaje tweiben,

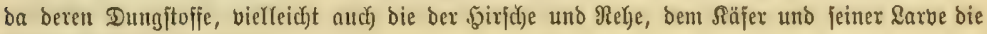
beliebtejte शakrung bieten.

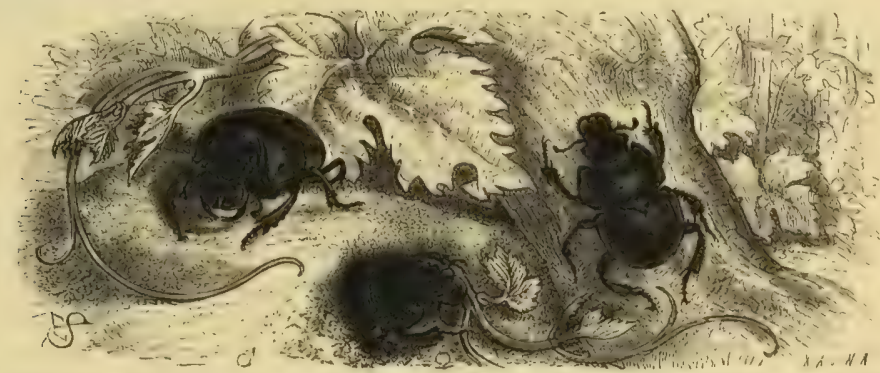

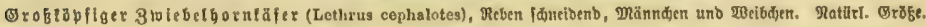

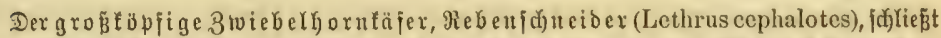

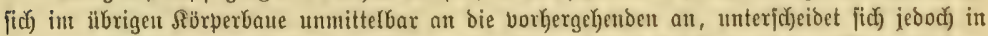

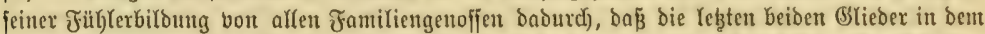
brittleb̧ten abgeftutzen Élicbe eingelaffen find, tvie bas Snuere ciner 3roiebel in ifyre Schalen,

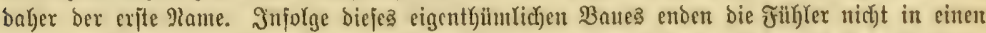
Fäd)ex uto fobeinen mux ans neun (Slicbern zujanmenge[elzt zu jein. lleberbies find bie Sinn=

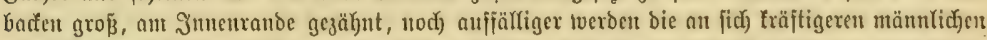

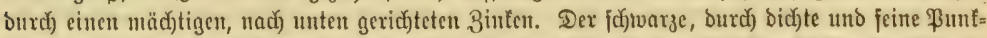

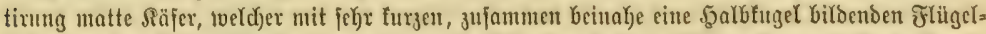

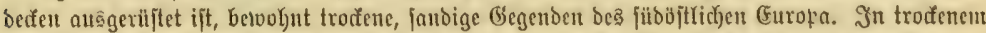

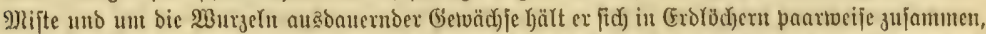

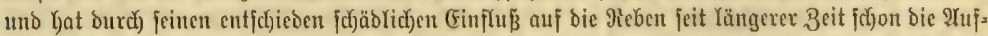

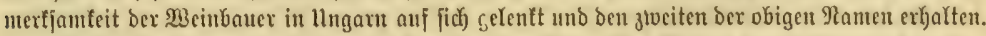

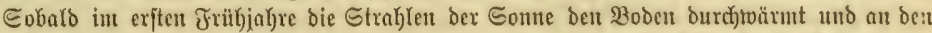

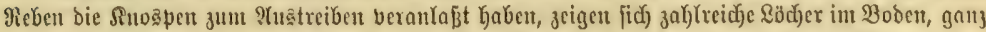

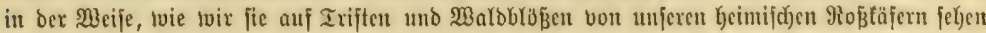

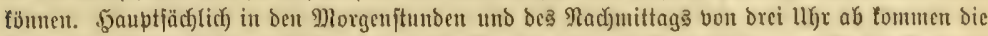

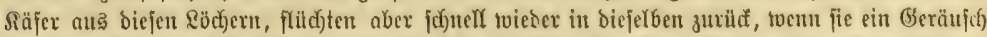

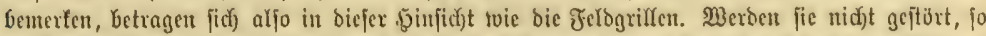

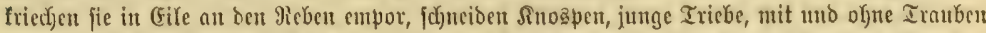

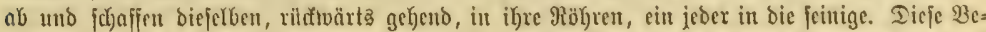

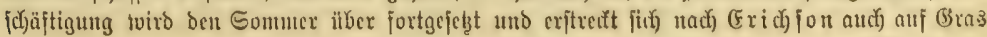




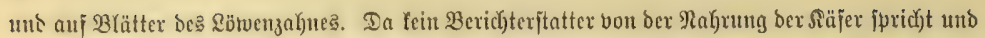

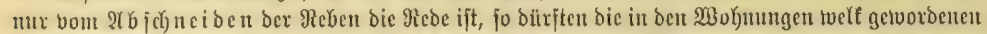

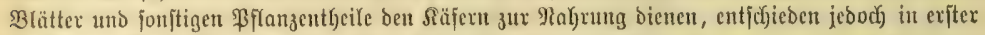

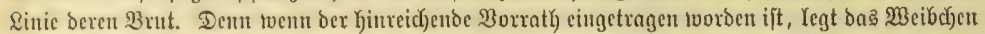

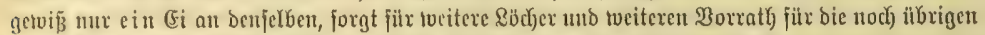

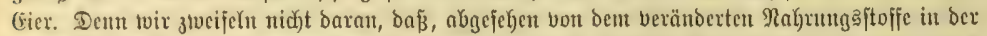

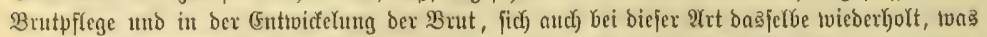

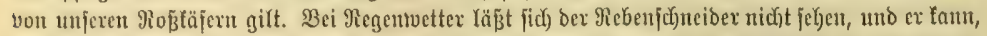

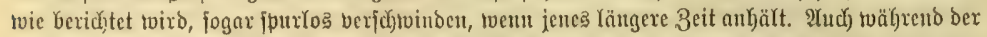

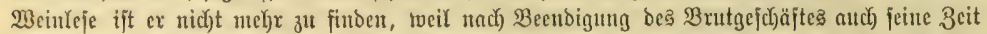

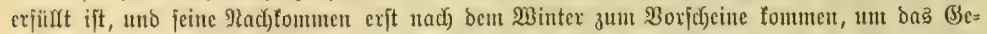

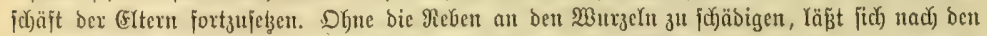

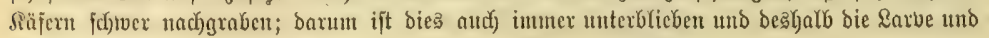

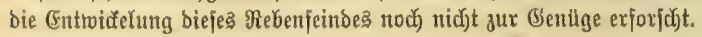

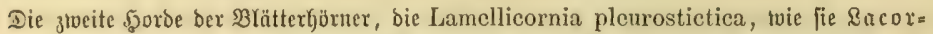

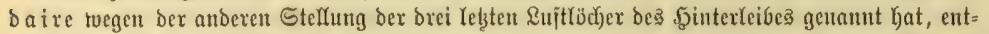

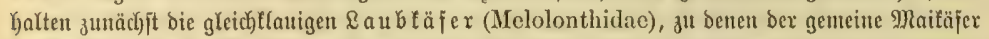

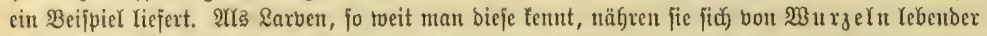

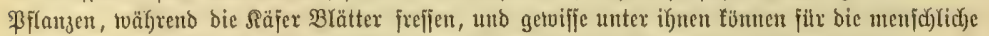
Defonomie im hodbften Grabe nad)theilig twerben, went fie fteflenveife in groperen Mengen auf=

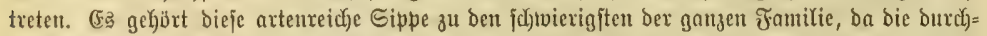

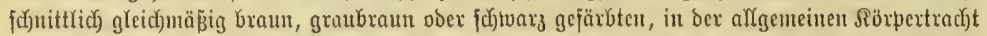

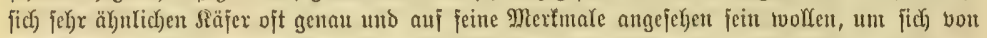

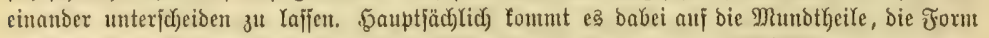

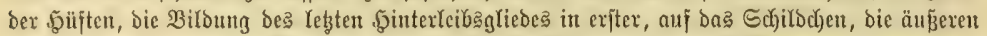

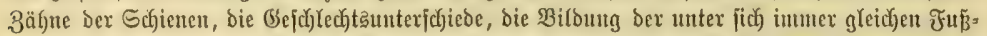

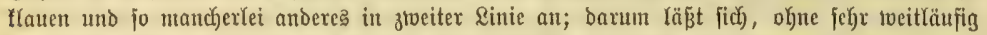

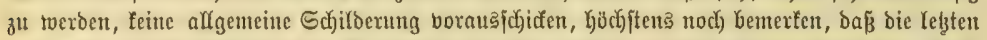

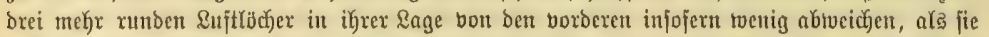

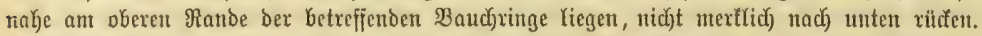

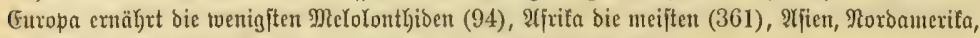

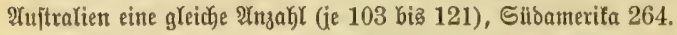

Der ge me ine $\mathfrak{M}$ a i fä fer (Melolontha vulgaris) möge die ganze Sippe bergegentuätigen.

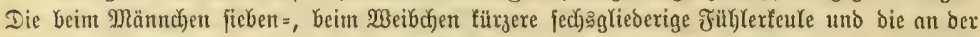

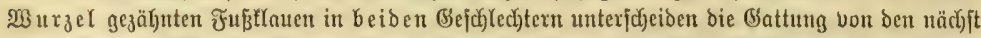

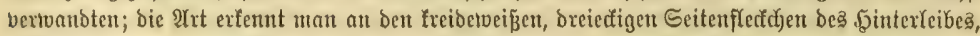

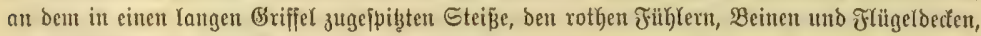

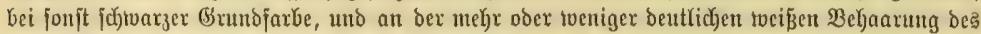

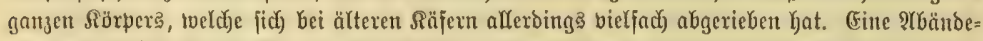

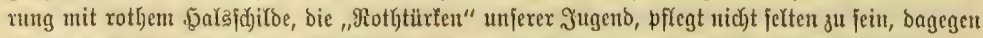

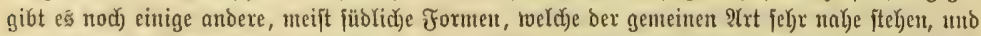

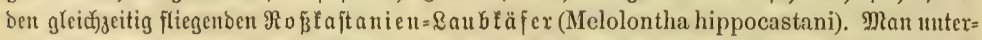

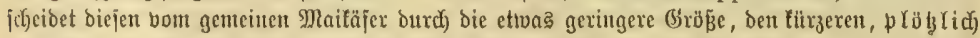

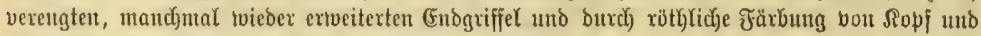

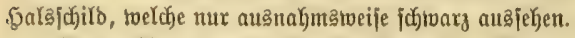

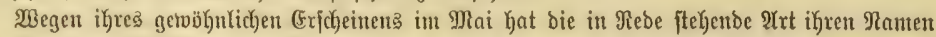

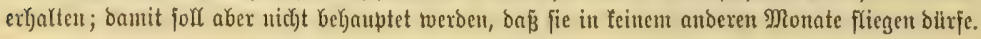




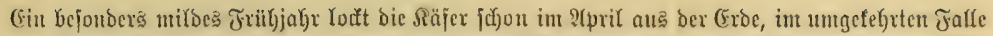

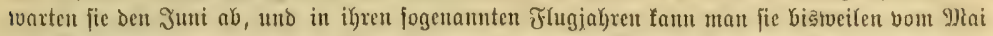

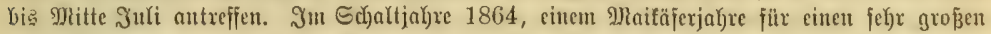

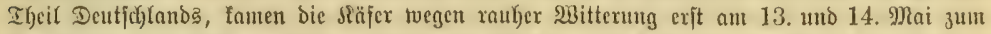

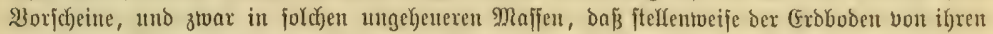

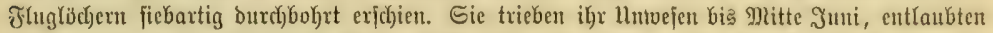

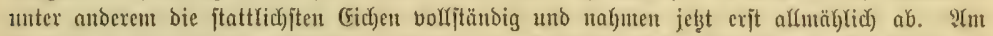

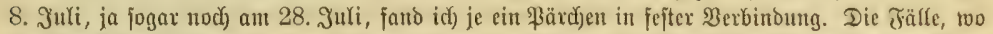

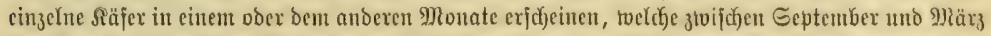

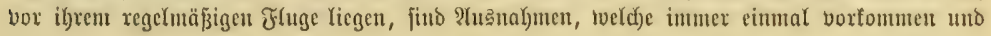

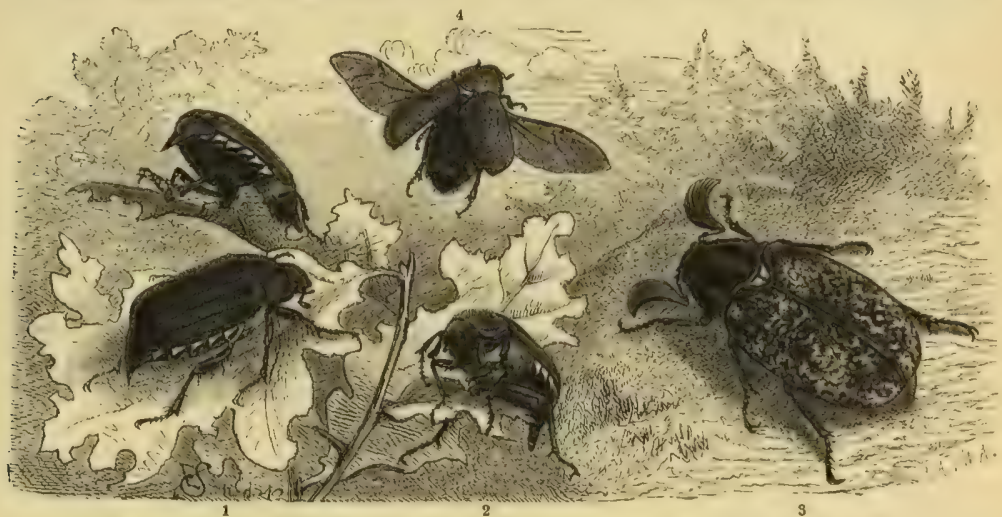

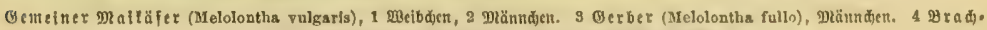

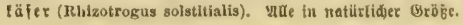

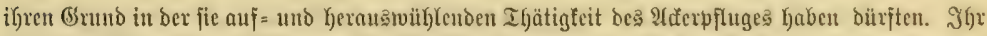

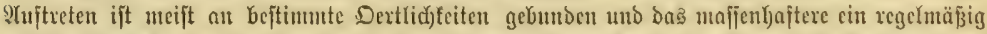
tviederfehrendes. In ben meiften Gegenden Deutjchlando hat man alfe vier Jahre bicje bem

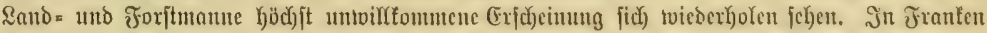

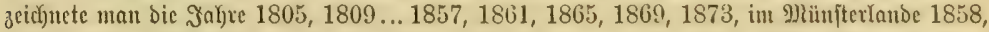
$1862,1866,1870,1874$, in Bexlin 1828, 1832, $1830 \ldots 1860,1864,1868,1872$ auf. De $=$

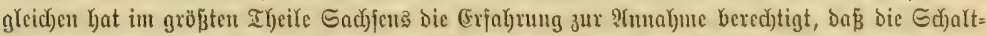

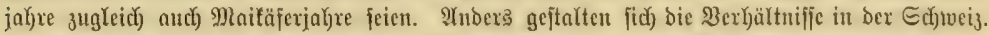

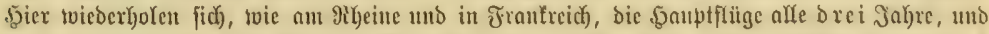

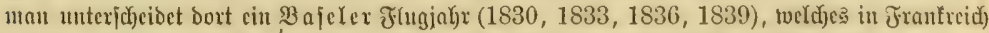

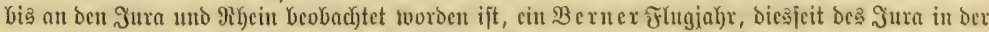

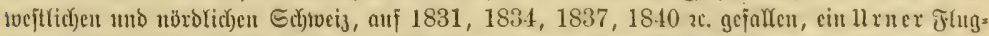

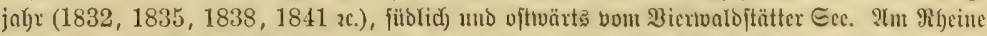

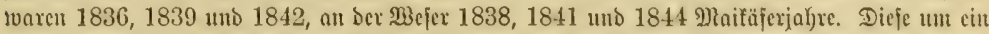

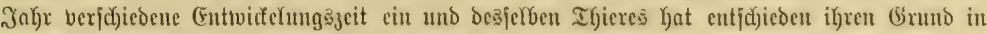

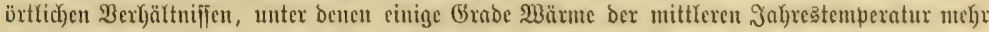
poer weniger ben \$auptgruno abgeben biriten:

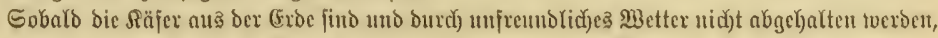

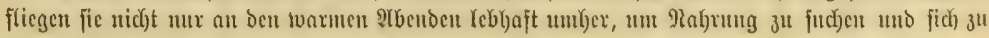




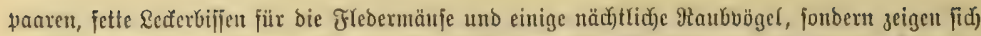

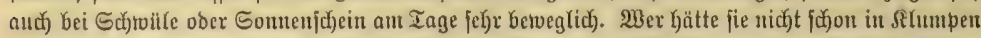

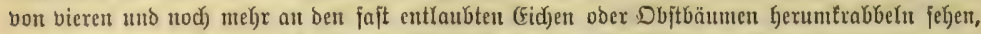

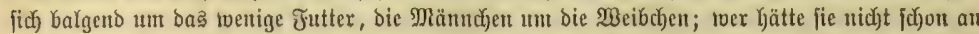

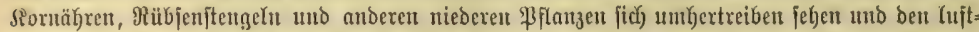

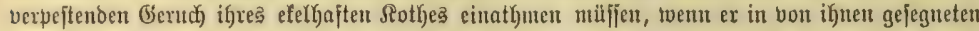

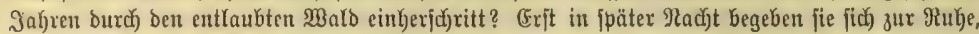
uno am jrühen Morgen jotvie an einzelnen rauben Tagen bängen fie mit angezogenen Beinen

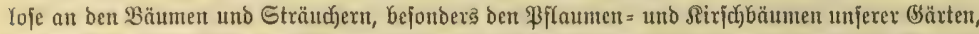

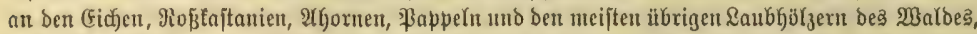

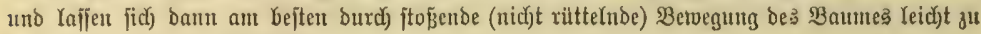
Falle bringen und einjammeln.

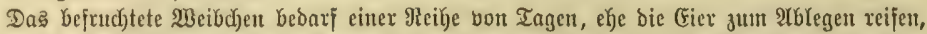

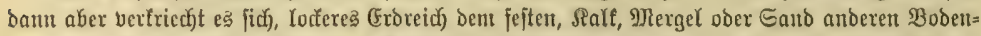

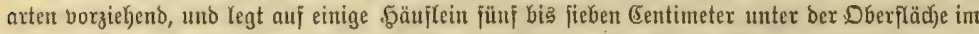

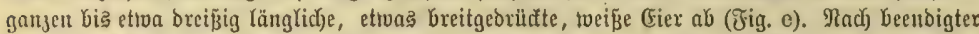

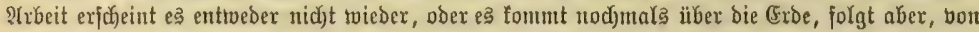

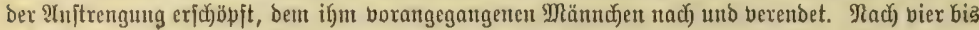

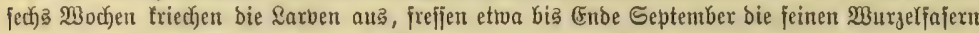
in ibrer Hngebung oder aud) bie reid) mit bergleid)en abgejtorbenen untermij(fifte (5roe, uno graben

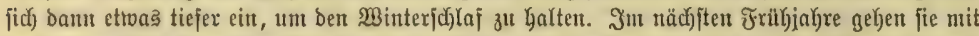

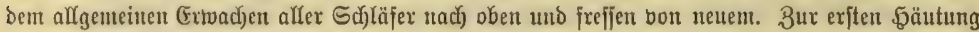
begeben fie fid) bald barauf wieber tiefer. Raud ber Rüdfefr unter bie Pflamzenderfe beginnen fie

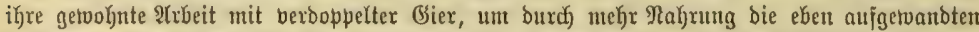

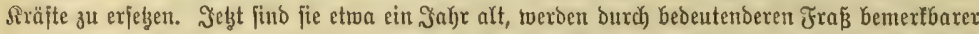

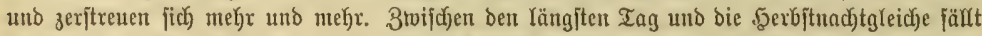

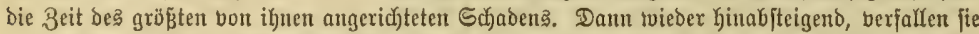

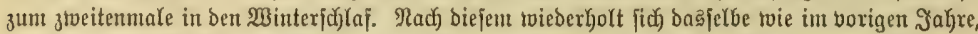

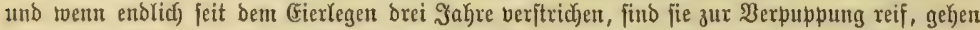
tvieber tiejer Ginab, und man fant annebmen, baß gegen ben 2Tuguft bis anjangs September

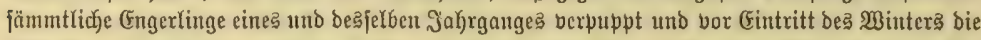

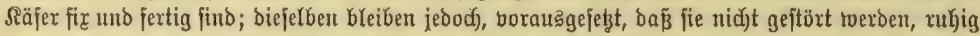

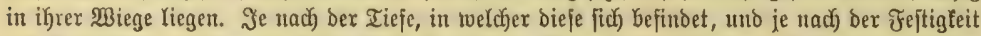
Des (Eroreidyes, tweld)es den Räfer bectt, braucht ex läıgere ober fürzere Beit, Gevor ex auf ber

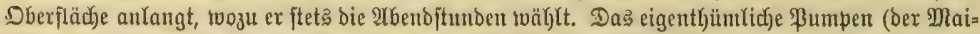

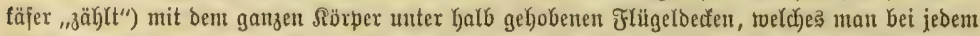

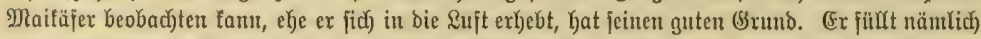

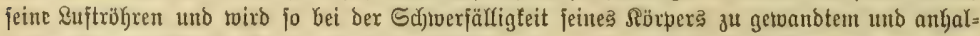

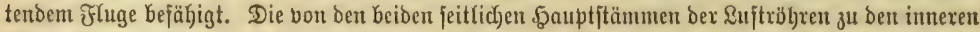

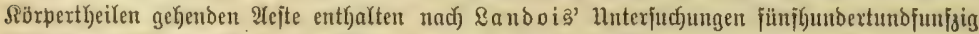

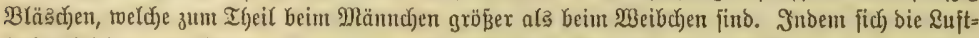

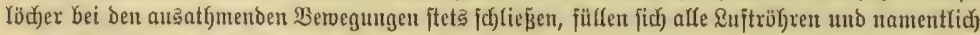

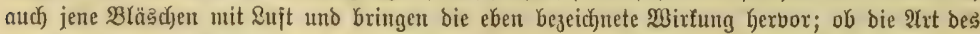

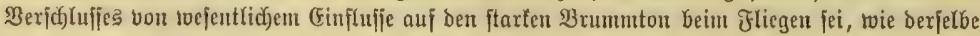

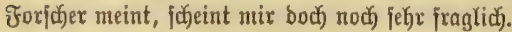

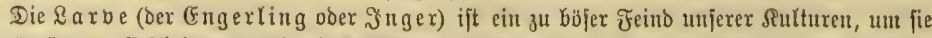

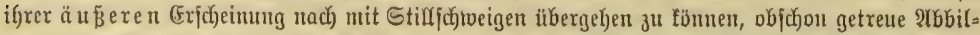

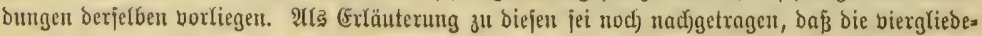




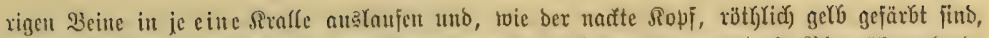

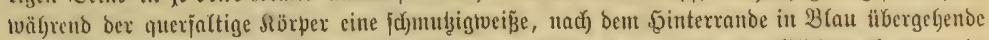

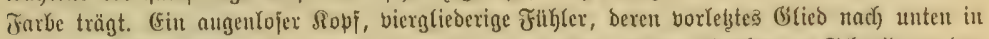

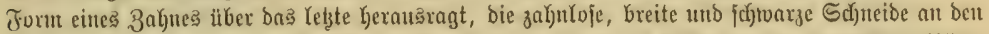

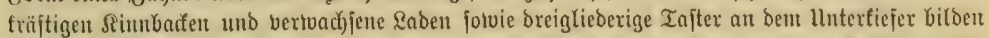

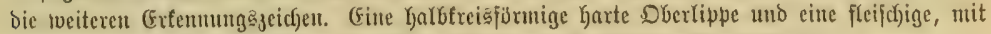

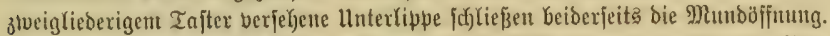

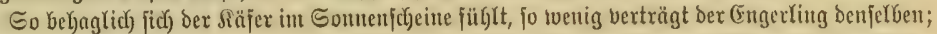

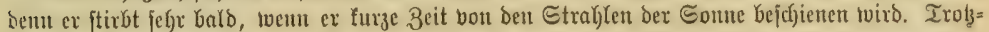

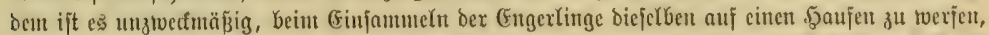

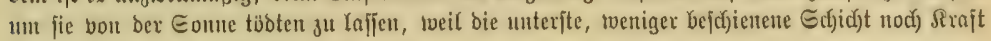
gentug befibt, unt burch) (Fingraben fict) zu retten und roieder zu entroeichen. Das (Einjanumeln ber Engerlinge in geringer Entfernung Ginter bem \$fluge ijt bas cine Mrittel, um fid vor ben $\mathfrak{B e j}$ jäbi= gungen bexferben zu fithex, ein ztweite? und feiner Wirfung nacly nod burd, greifenderes befteht int Sammełn uno Iobten der $\Omega$ äfer in jebem Jahre und

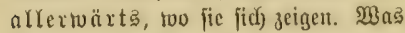
in biejer Đinficht geleiftet toetoen tünne, hat unter anberem im Ifugjałyre 1868

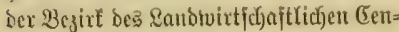

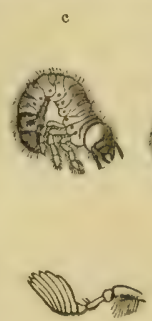

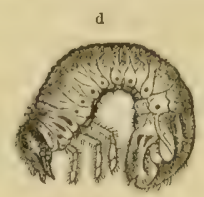

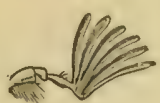

b
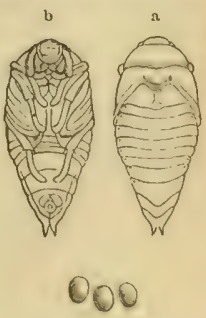

e

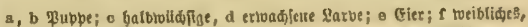

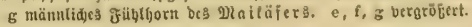
tralvereinaber \$robing Sadjjen betwiejen.

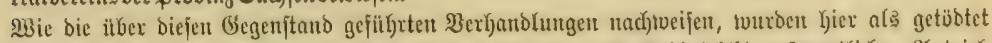

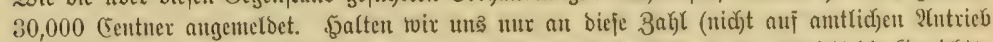

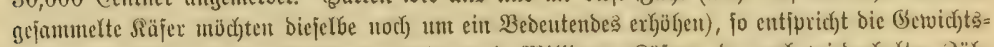

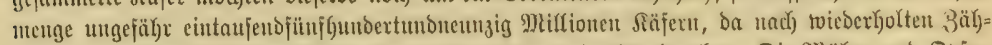

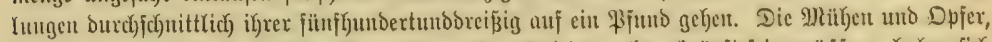

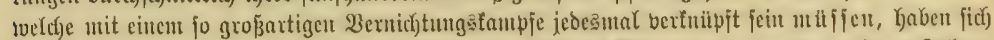

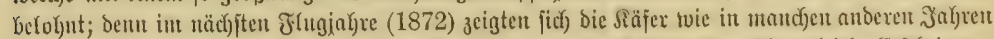

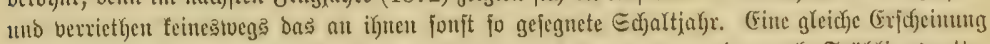

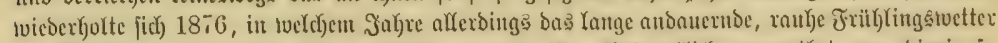

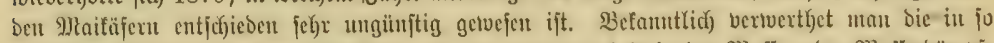

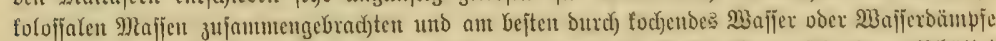

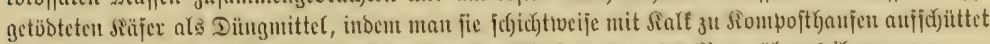

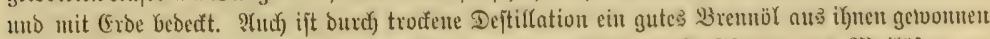

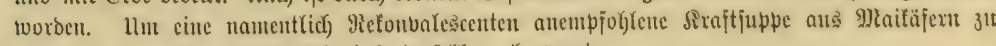

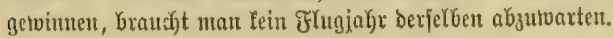

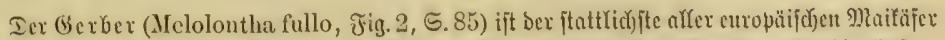

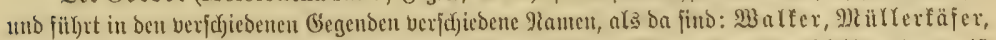

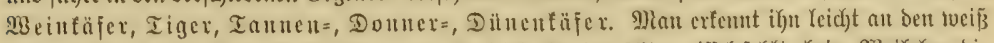

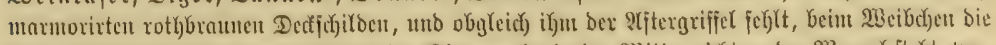

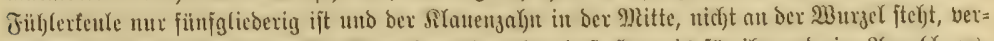

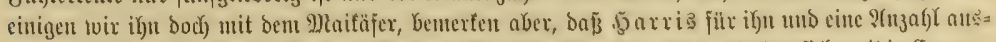

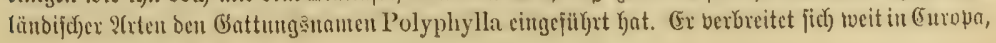




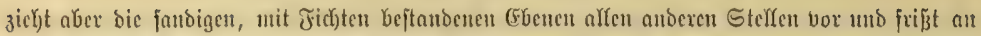

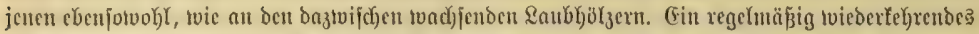

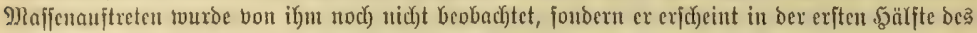

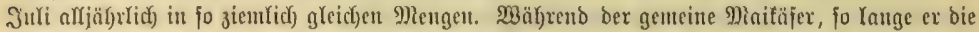

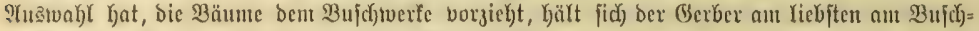
swerfe uno an ben fogenantent bitrftigen siefernfuffeln auf. Went er bou biefen herabgeflopft

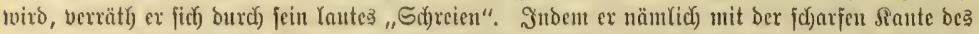

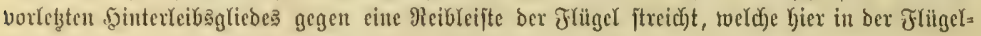
beugung liegt, exzeugt ex eimen ungemein Yauten 3irpton.

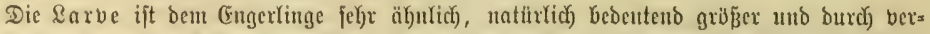

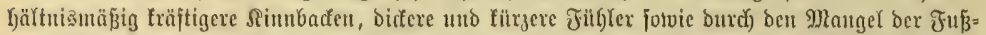

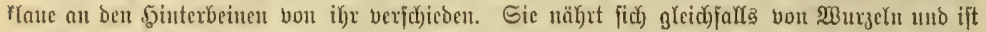

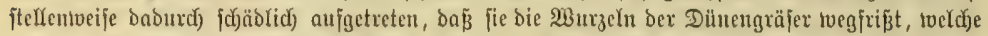

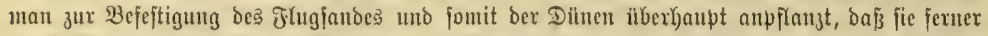

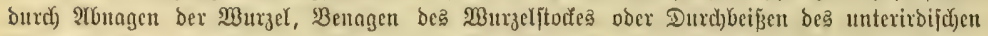

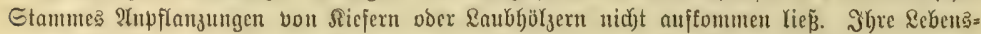

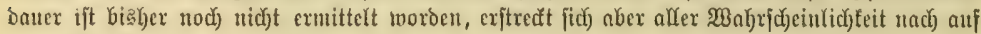
mehrere Jabre.

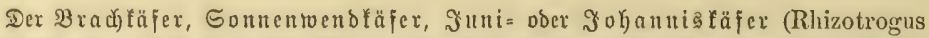

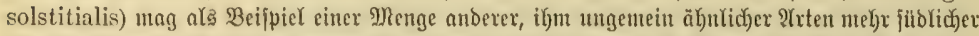
Gegenden bem Befod)luffe ber ganzen Sippe der Raubtäfer bienen. (Er ift, wie fein Bilb (S. 8.) bar:

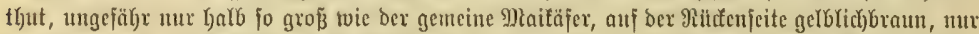

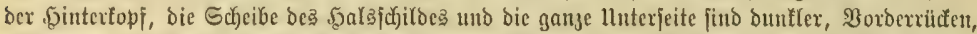

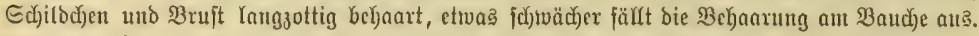

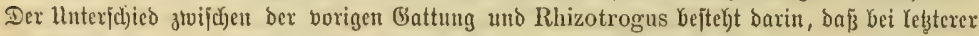

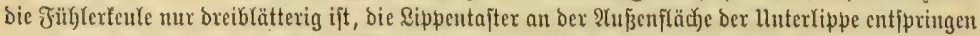
und eifömig endigen. Der 2(jtergriffel fehlt hier wie bei bem Gerber.

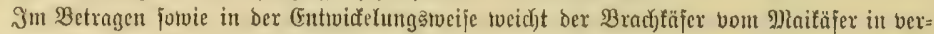

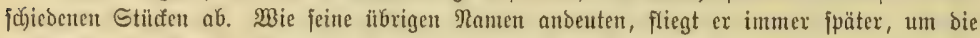

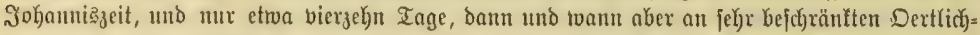

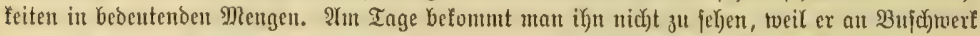
unto nach) meinen (Exjahrungen namentlid) an Den jungen DVftbäument ruht, weldje bie breiteren

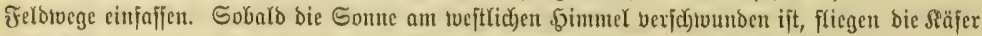

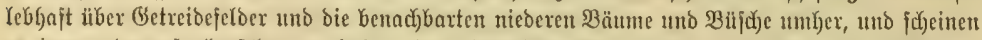
Eอ immer barauf abgejeljen zu Gaben, bem Karmlojen Spaziergänger fo Yäjtig als möglicd zu

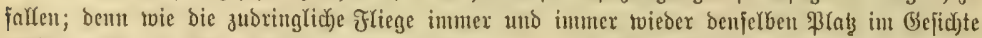

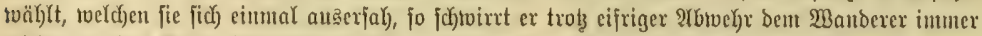

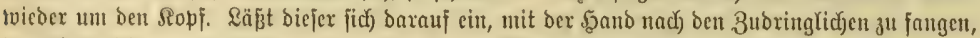

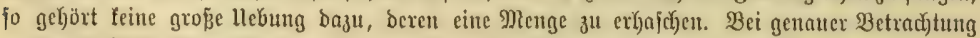

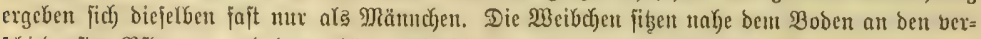

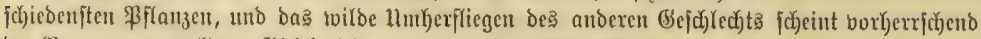

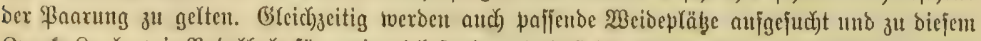

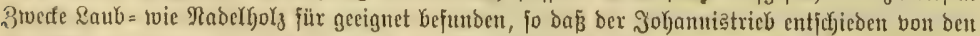

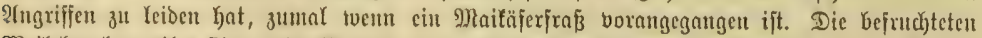

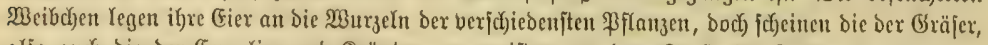

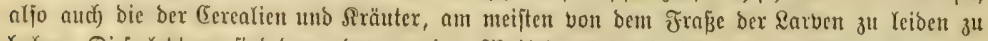

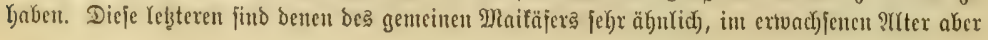




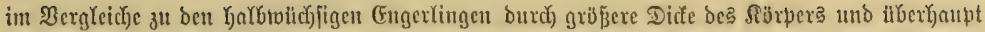

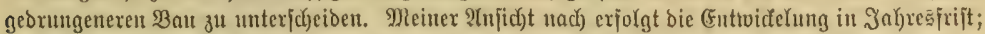

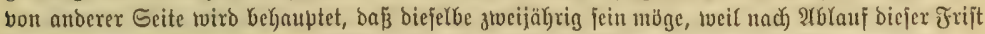

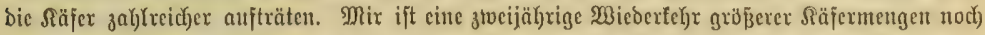

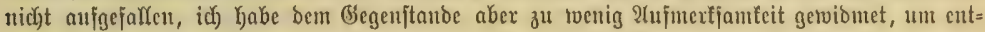

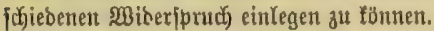

Die Sebenabauer biefer 2 trt und anderer noch fleinerer, theilweife anderen Gattungen

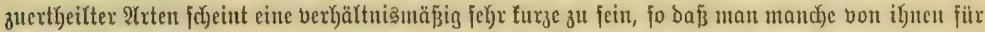

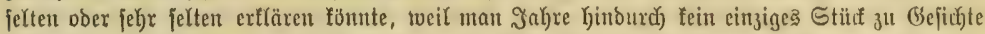
befommen Kat, toährend man fie Gutoertweije hätte cinjanmełn fümen, wenn man bei oder

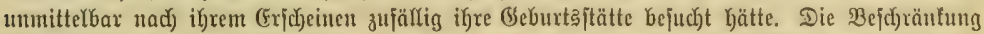

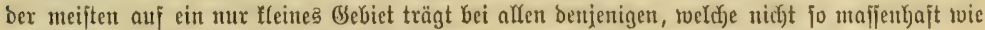

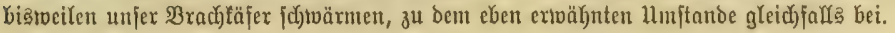

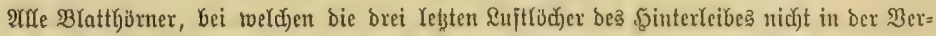

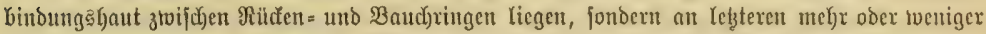

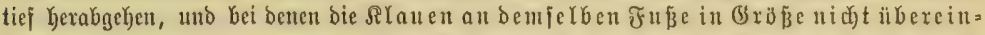
ftimmen, bilben bie andere Eippe Dex Blattfäfer, bie ber Ruteliben. Jłhre hornige 3unge

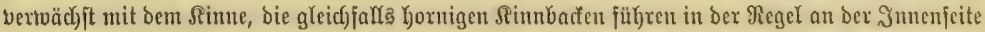

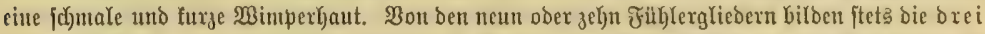

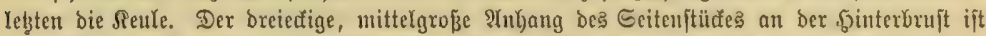

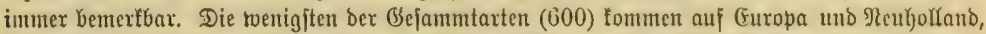

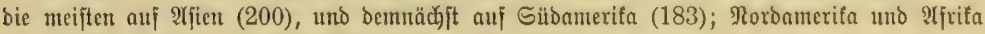
fteken fid in $\mathfrak{B}$ ezielyung auf Die Artenmengen ziemlid nahe.

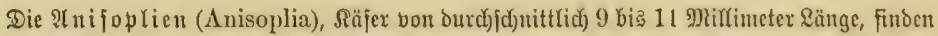

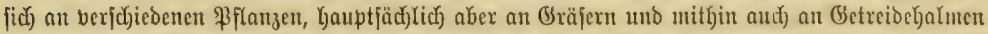

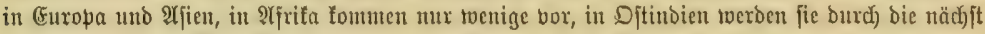
bertwanote Battung Dinorhina bertreten, in $\mathfrak{A}$ merifa jeblen fie gänjličc). Der ziertiç) Getreibe=\&aubfäfer (Anisoplia

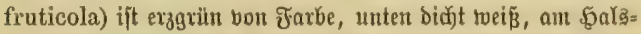

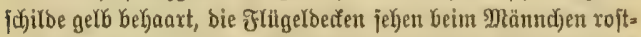
roth auล, mer) gelb beim Weibdjen, unb find bei biejem um bas Echjlbdfen mit einem gemeinjamen bieredigen Flecfe bon ber

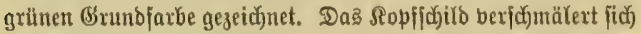
bei affen 2rten biejer (Sattung nad) born unb biegt fick) am Ranbe auf, bebecft aber babei bie Dberlippe solltändig. Die äuß̧ere

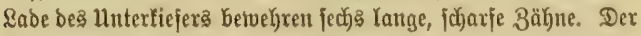

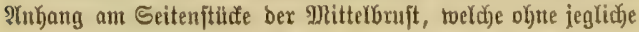
Jecrborragung bleibt, ift bebectt, an ben vorberjten Jilisen bie

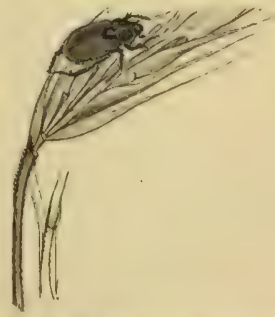

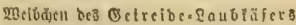
(Anisoplia fruticola), nutiurl. Bröje. äuß̄ere, Hberall gröpere Slaue born gefpalten. Die genante

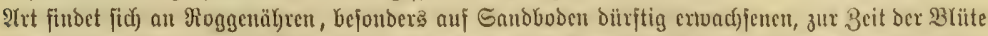

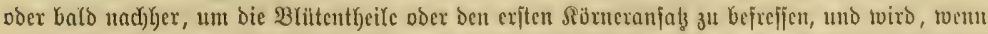

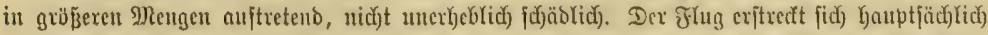

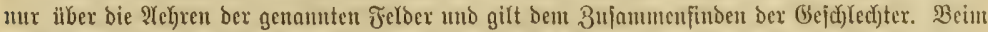

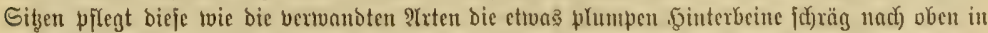

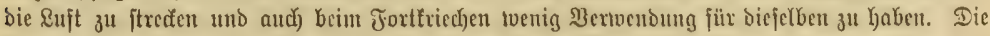

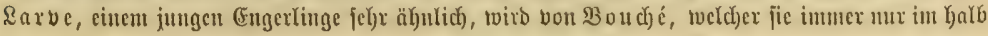




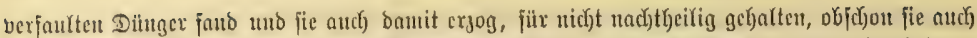

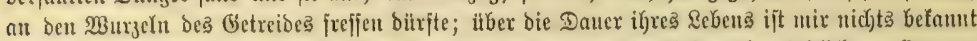

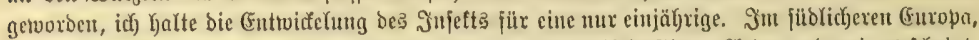

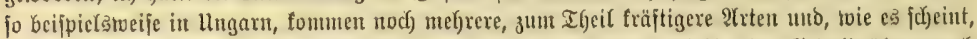

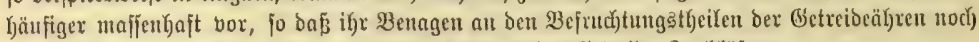

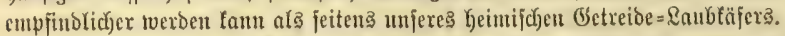

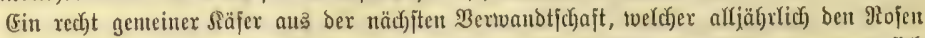

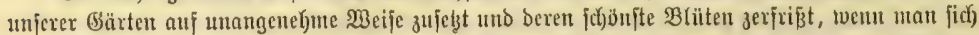

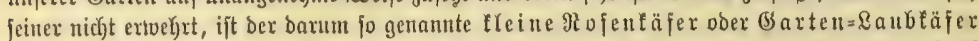
(Phyllopertha horticola), jenes 9 Gis 11 Milfimeter meffende, glänzeno blaugrüue, ftar

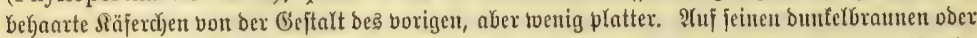

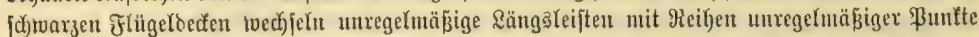

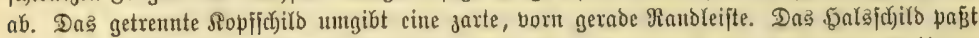

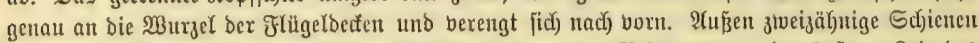

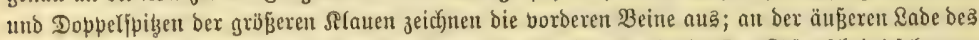

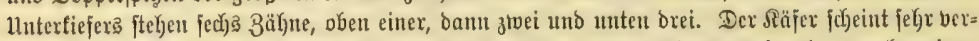

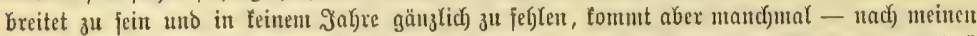
Beobad)tungen nidjt in rege

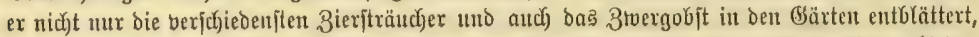

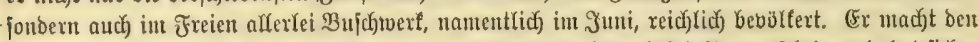

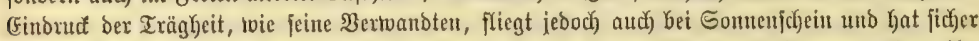

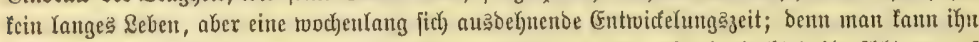

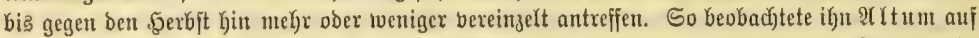

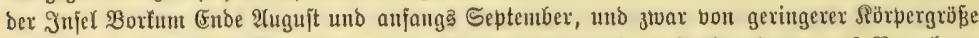

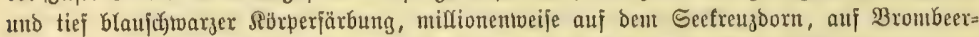

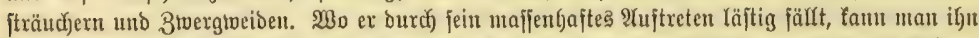

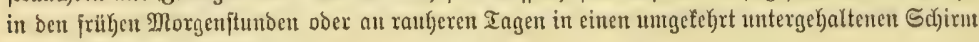
leicht abtlopfen uno tobten.

Die Barbe lebt an ben Wurzeln berjodjiedener Etauben uno berjájont aud Topigeton̈dje

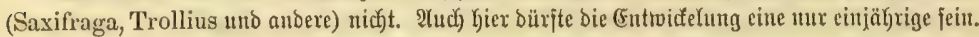

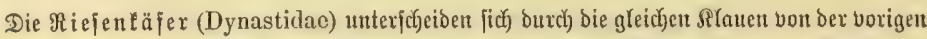

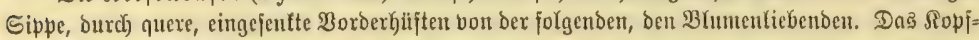

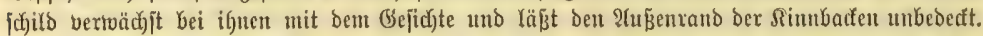
Dieje jüto hornig, iunen gezähnt uno meift auf furze Strecfen mit Saaruminern bejełzt. Der äupere Sappen ber Hnterficjer vertwäd)it mit dem inneren und bie fornige 3unge utt bem Rimne.

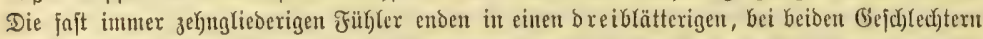

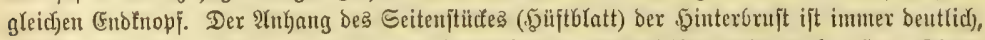

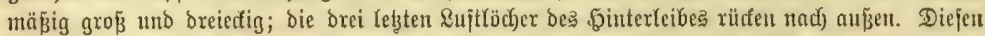

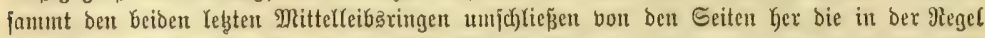

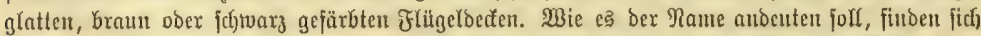

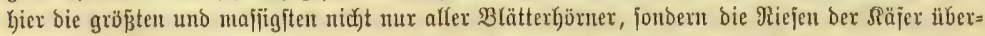

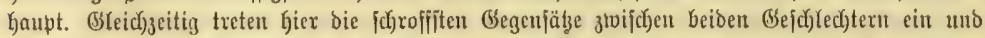
berfelben $\mathfrak{A}$ rt in ber oben angebeuteten Beije Kervor. Die Männchen find meift an $\mathfrak{B}$ orderrüđen

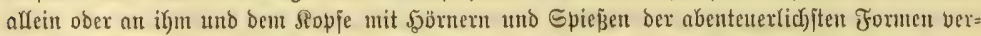

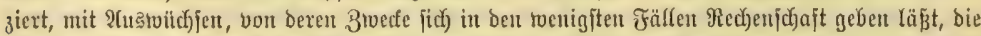

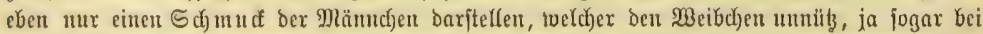

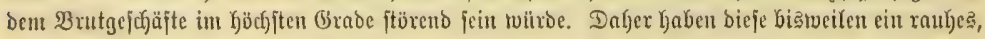





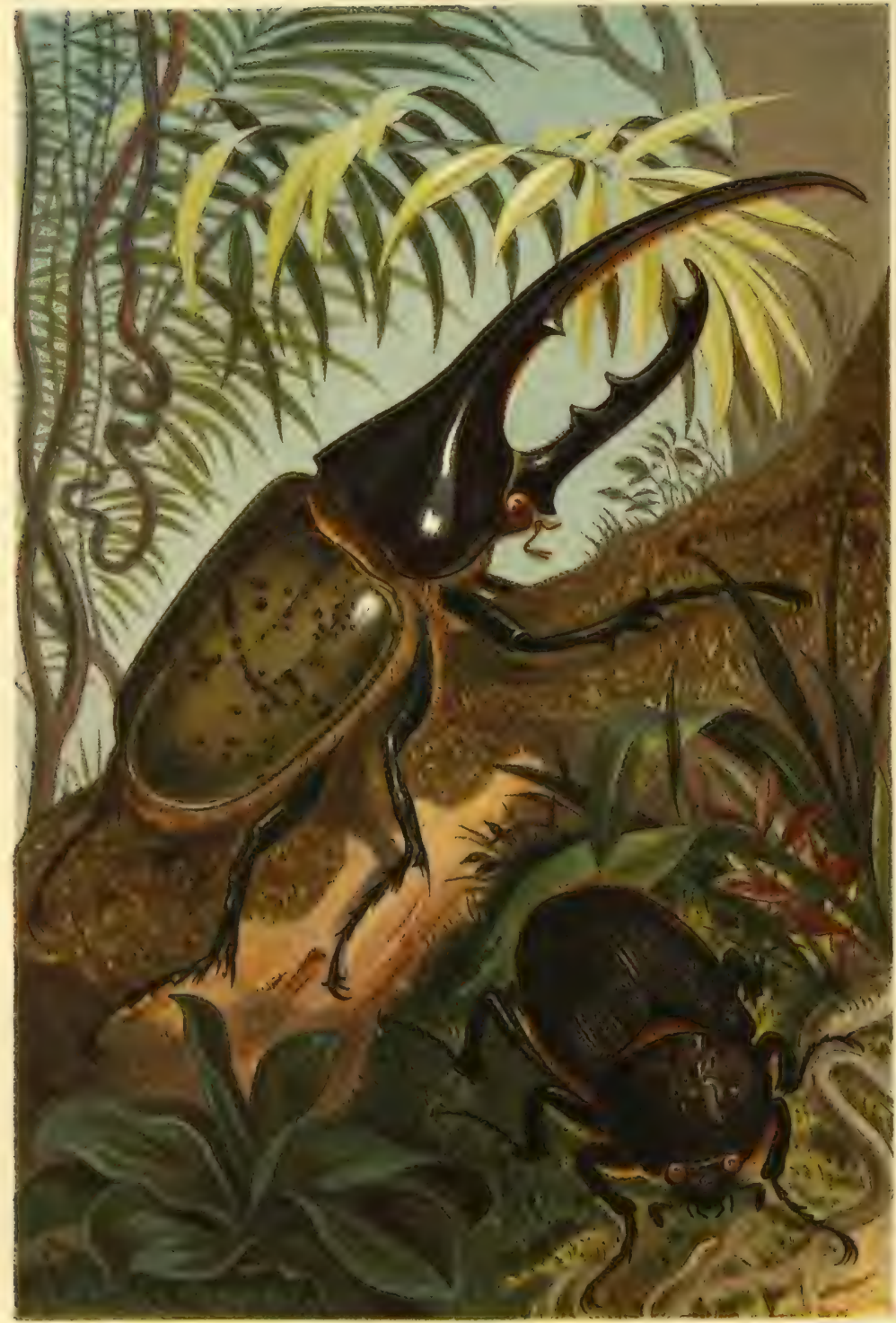

it r.h II I H I F : R 


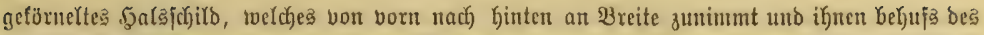

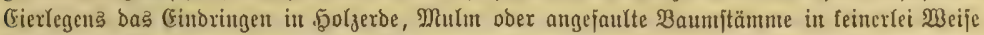

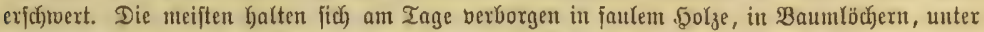

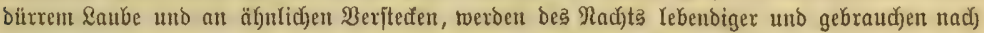

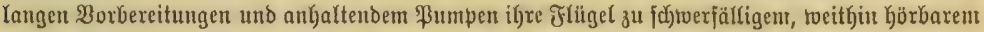

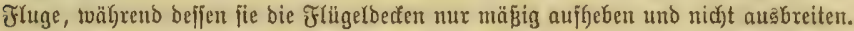

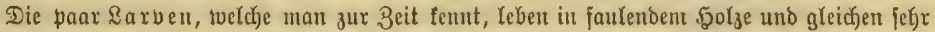
benen ber Raubtäfer burch) bie Duerjalten unb burd) bie fadartige (Frtveiterung bes Reibesende马; im Berfältnis zum gebrungenen, feiften Reibe erfajeint ber Sopf fämal. Bähne an ber Spibe

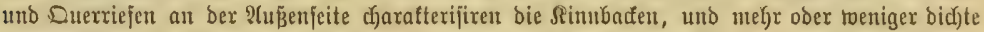

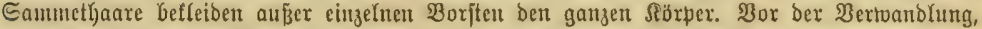
tveld)er ein mefrijäfriges Reben vorausgegangen ift, fertigen bie Rarven ein jejtes Gełäufe aus ciner biden Schicht iffrex llmgebung, in tweldfent ber Seäfer fo lantge vertveilt, Gis er, volftonmen

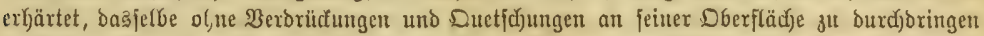

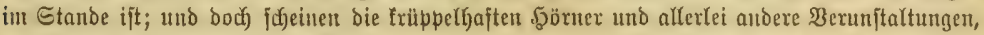

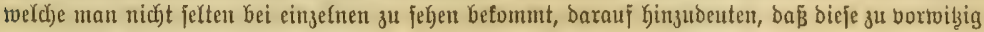

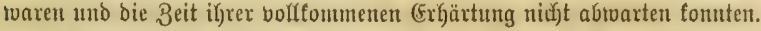

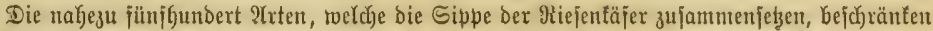

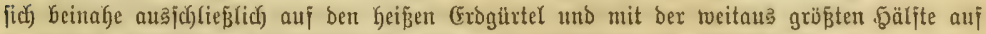
Amerifa, bereinzelte, weniger riefige $\mathfrak{A}$ rten fonmen zeritreut in alfen (Erotfeilen vor.

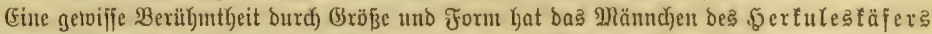
(Dynastes Hereules) erlangt. Das̄jelfe wirb bis 157 Ixilfinteter lang, bon benten ein bom

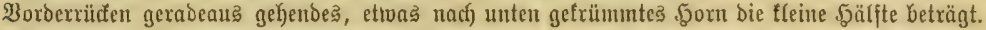

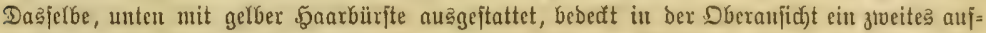

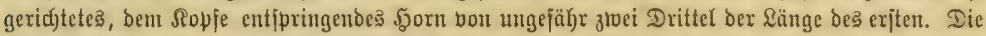

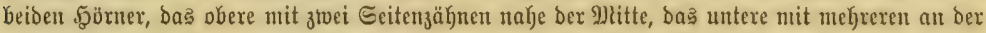

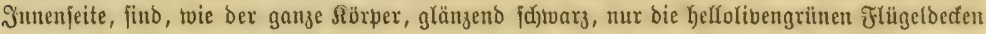

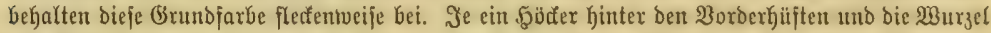

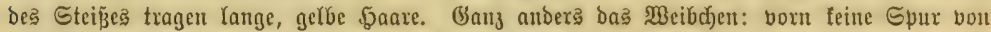

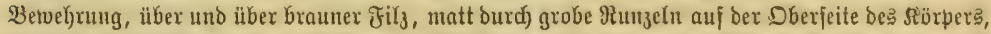

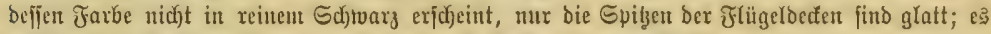

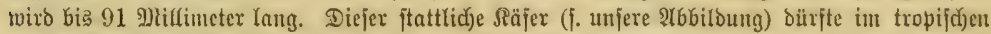
2(merifa nidd)t eben zu ben Eeltengeiten gehören, tvie bie europäifjen Eanmtungen betveijen.

Mtoufet bildet eine andere verivanote ITrt, Den (Elejanten (Megalosoma elephas), ab

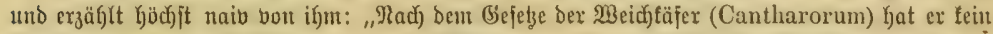
Weibchen, fonbern ift jelbjt fein eigener Sdjüpjer; er bringt felbjt feine 9lachfonmen fervor,

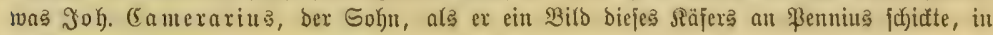
folgendem Dijtychon artig auąorücute:

\footnotetext{
„Me neque mas gignit, neque femina concipit, autor

Ipse miki solus, seminiumque milii".
}

\section{So trieb man bamals $\Re$ aturgejodidyte!}

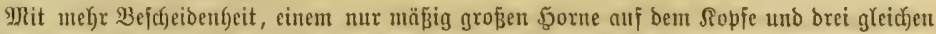

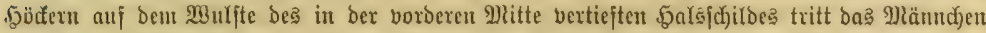

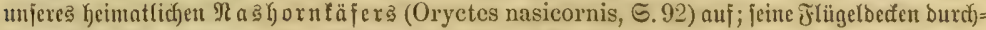

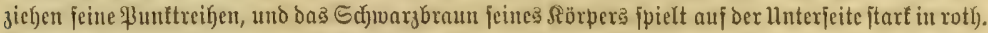

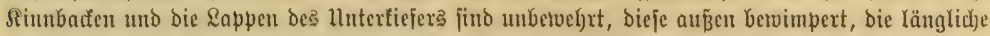

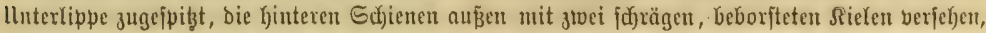

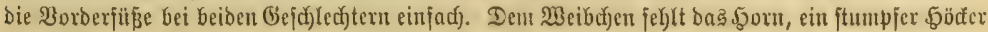




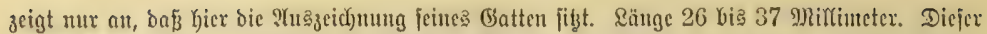

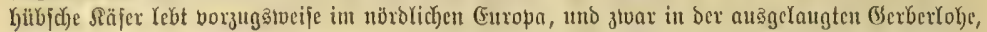

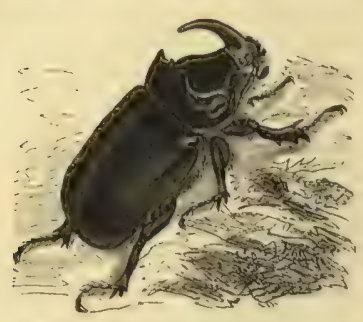

Männd)en bes Raßborntäfers (Oryctes nasicornis), "Hatürl. Orö̈e. mit weldyer bie Warmbeete in ben Runftgärten eingefä́t

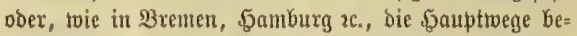
ftreut toerben. Wo ex fids einmal eingeniftet hat, pflegt

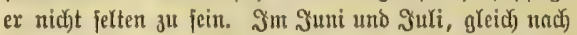
feinem (Erjicheinen, exjolgt bie \$aarung, nad) weldyer bas Männdyen ftirft, oas Weibdyent in bie Rohe friecht, um vereingelt jeine (fier abjulegen. Dieje fonmen ungejägr (Ende Fuguit aus, bie \&arben braudjen abex mehrere Sabre, ehe fie aus bex mageren Sojt himreidjente Stah)=

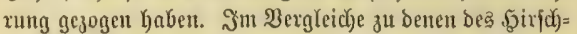

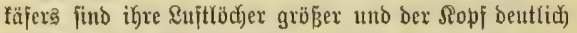
punttirt. Bur Berpuppung géfen fic tiejer in bie (Eroc, fertigen ein eirunbes (bekäuje, in sweldyem nach burch)=

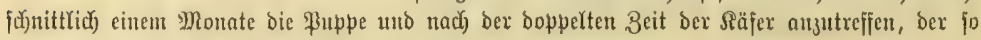
lange barin verbleibt, bis ex bolltommen erbärtet ift.

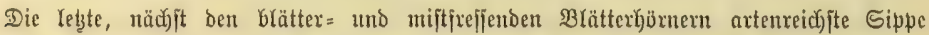
bilden bie brunenYiebenden (Melitophila), biejenigen unter allen, weldye bie bolfendetjtent

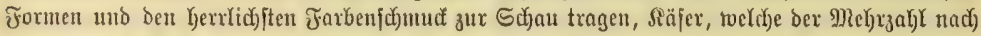

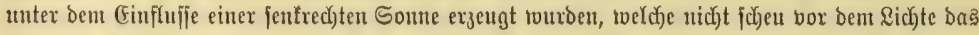
näd)tlidje Dunfel abwarten, ehe fie aus ifren Berftecfen herworfoumen, fonbern als Freunde

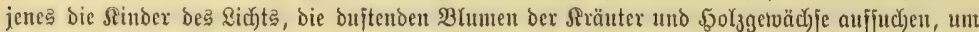

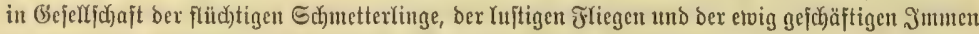

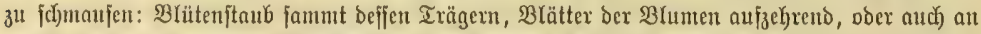

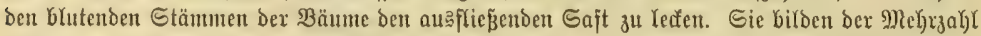
nach - twir twifjen, da

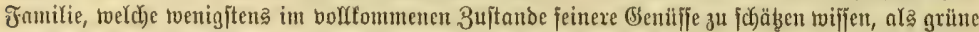

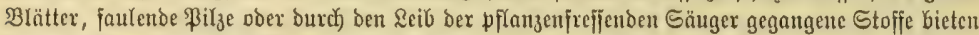
fönnen. Der gebrungene Rörper bon borkerrjcheno mittlerer Größje ijt mäß̈ig abgeplattet, in ben

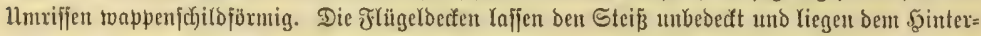

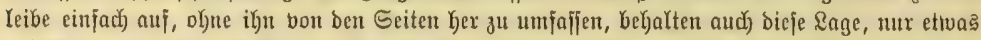

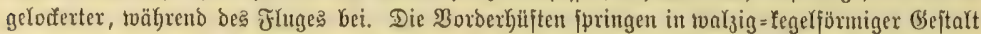

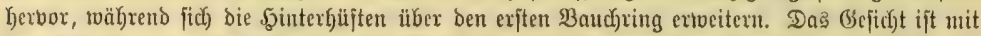

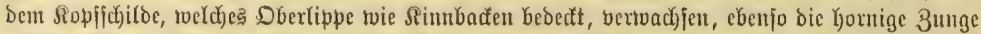

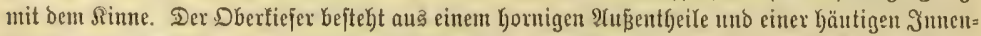

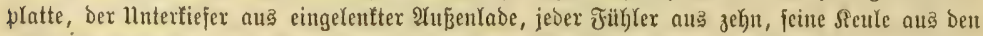

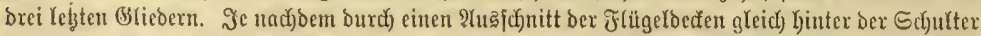

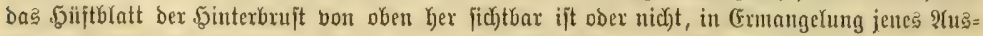

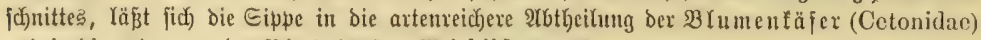
uno in bie artenarme ber ßinfeltäjer (Trichiidae) zerlegen.

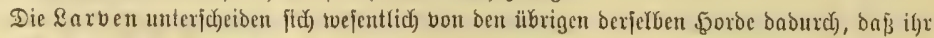

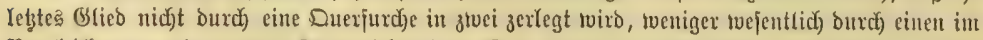

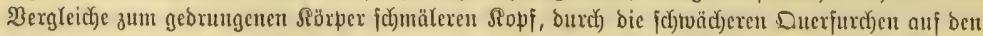

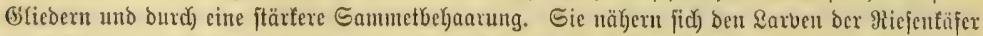

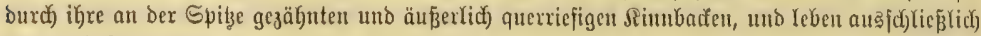
bon mulmigem 5olze. 


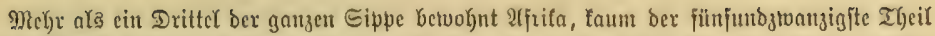

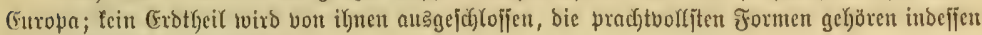
nux bem heif̧en Erogiitrtel an.

Bollendet im Baue fteht ber mänuliche Riefen=(Soliath (Goliathus giganteus ober

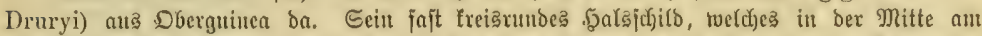

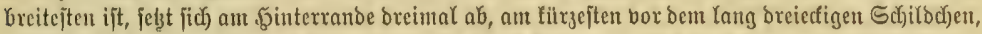
weldyes bedeutend mehr nack binten liegt als bic Echultern, wiff jo vicl jagen als: bie Magt ber

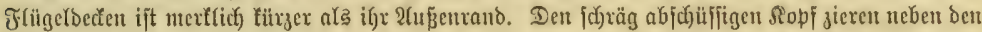
Flugen zlvei ftumpfe, aufgerichtete \&appen und vorn cine breite, furge, an ben Spitzen gejtubte

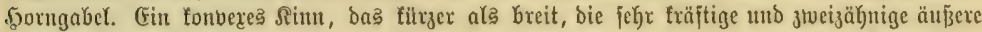

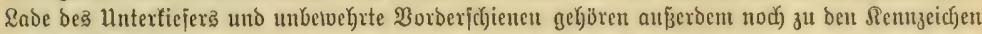

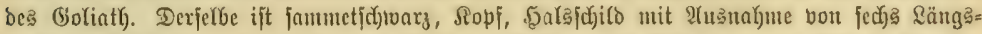

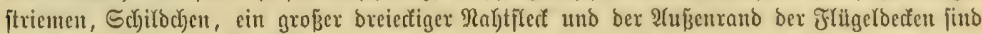

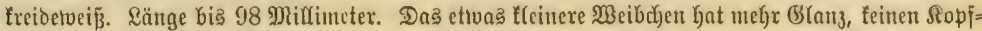

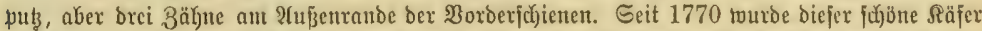

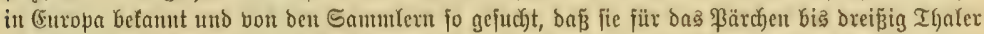

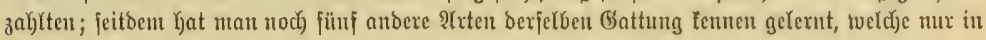
Pjrifa borfommt.

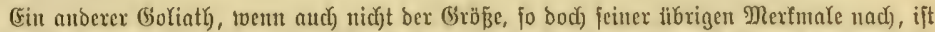

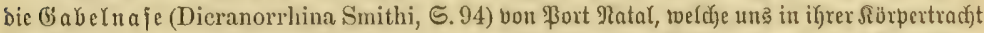

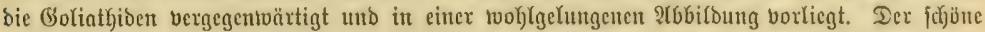

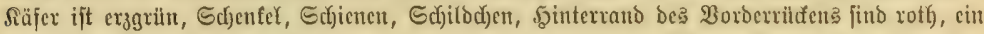
vertwifd)ter Flect auf befien Scheibe, bie fänmtfid)en Ränder und je ztwei Fllecfe ber braungelben

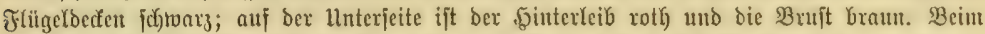

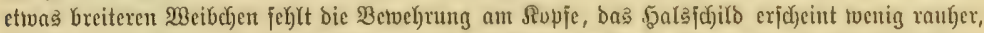

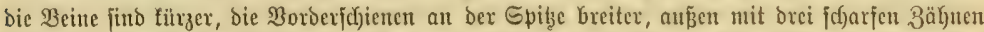

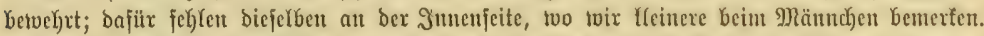

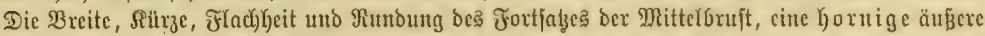

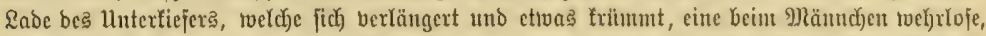

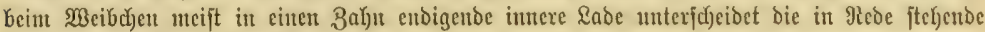
(battung bon ifren naken $\mathfrak{B e r t w a n b t e n . ~}$

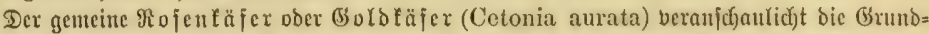
form ber ganzen Sippe. Wex follte ifn nidjt femen, ben gologrünen Säfer mit cinigen toeiß̄=

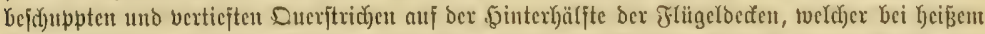

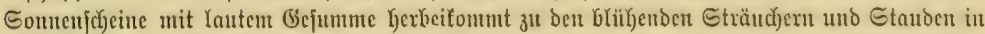

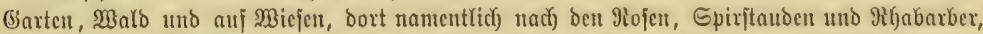

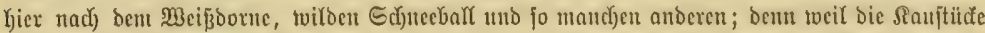
jeinex Unterfiefer weid) find, fo fau er nur die zarten $\mathfrak{B}$ lätter ber Błumen zerbeif̧en oder Eajt

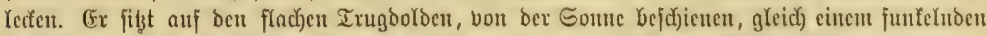

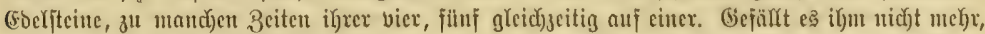

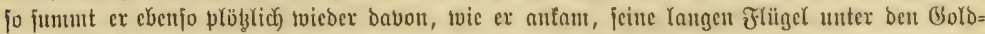

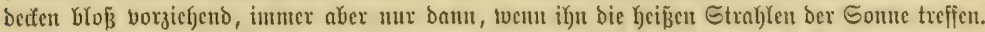
Edfeint bieje(be nidjt, jo fibst er ftumbenlang feft auf berjelben Etelle wie fod)(afent, und fried)t

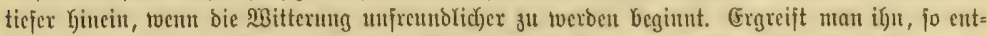

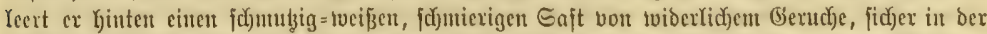

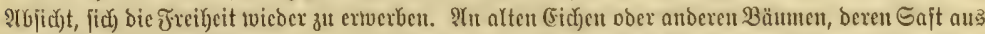

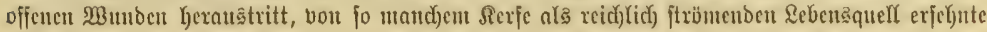

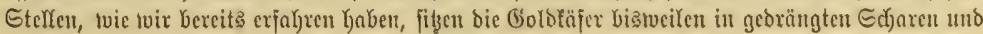




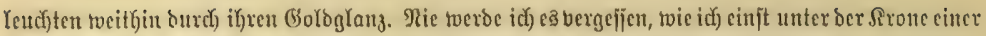

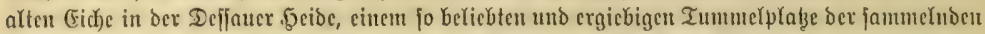

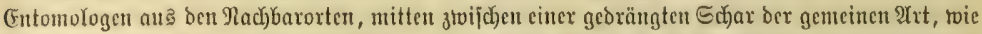

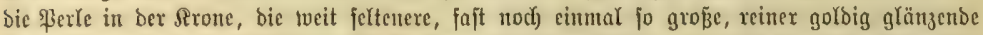

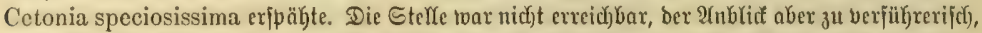
um nicht alleß zu berjuchen, jene ßerle in meinen Bejitz zu bringen. Der Epazierftoct wato zum

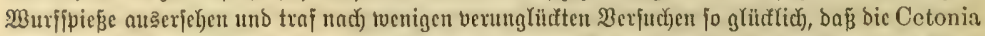
speciosissima nebft einigen genteinen Rojentäjern vor Sd)rect herabfielen, währeno eit Iheil ber übrigen ruhig weiter zechte, ein anderer im Fluge bavon rauf(b)te. Schäblich werben bic

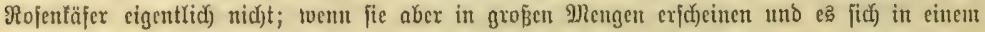

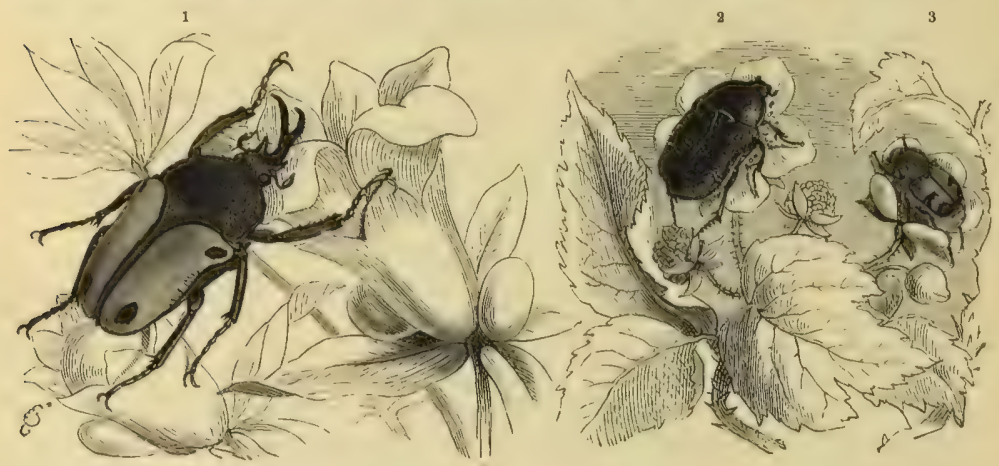

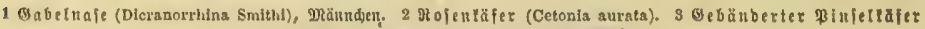

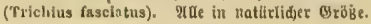

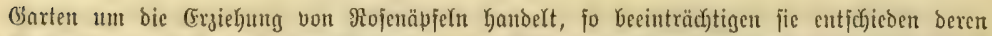

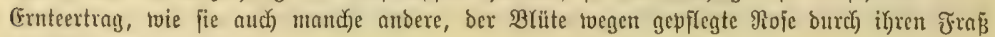
berunitalten.

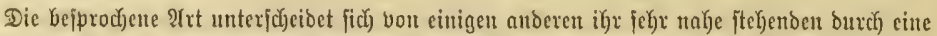

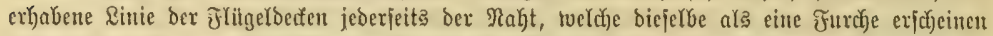

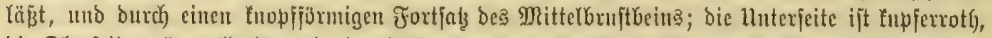

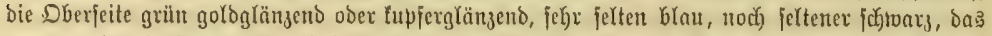

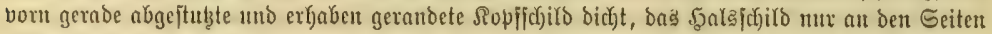
bicht punftirt. Ridjt fie, fonbern eine ihr fehr nałe ftel)ende, in Gilden Guropas vorfommende Trt birfite es geivejen fein, weldje $\mathfrak{A}$ riftoteles Melolon tha aurata genannt hat, und weldye

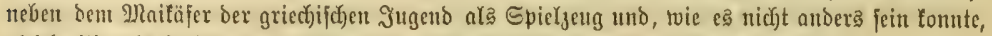

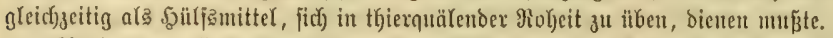

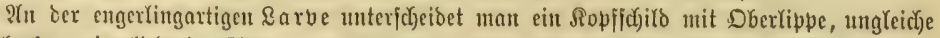
Simubarfen, vierglieberige Siejex=, jueiglieberige Sippentajter und biergliederige Fiugler, weldye cinem Ђö̈fer aufitizen. Die furzen Beine Yaujen in einen ffauenlojen Rnopf aus und ber Seiten=

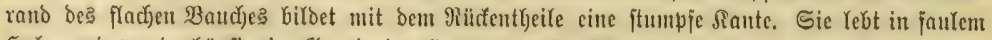

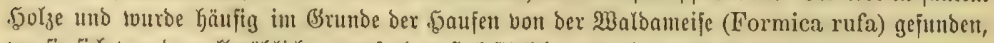

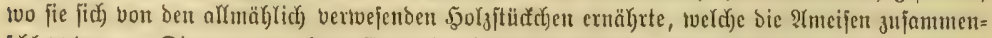
f(c) (eppten. - Die marmorirte Cetonie (Cetonia marmorata), dunterbram mit mebreren

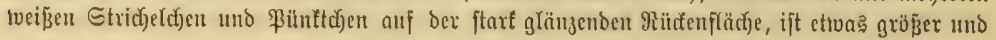




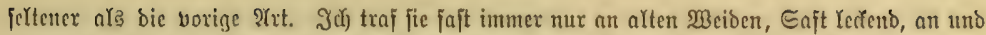

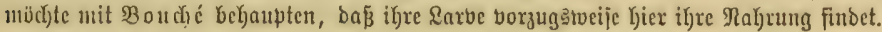

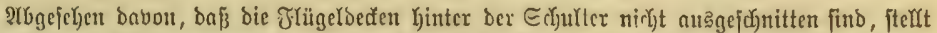

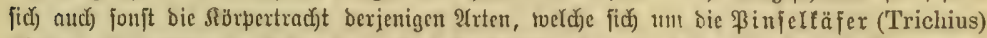

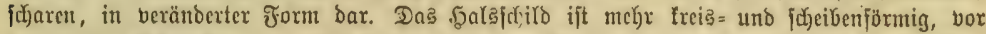

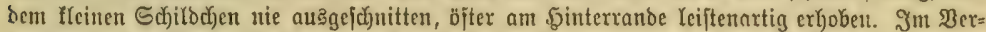

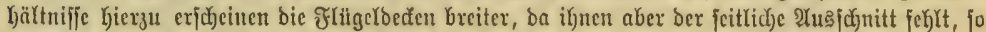
milifen fie beim fluge erkoben twerden.

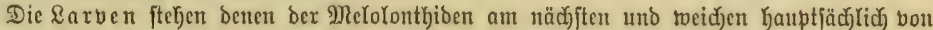

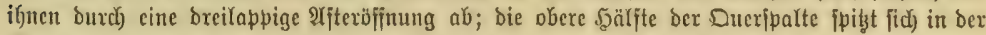
J)itte zu, bie untere befommt an ber entfpred)enden Stelle cine furze Spalte.

Der Eremit, Seberfäfer (Osmoderma eremita) berdient zutäd)ft ber Ertoälynung als

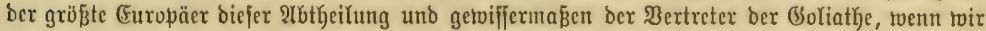

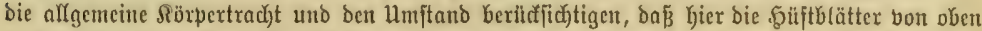

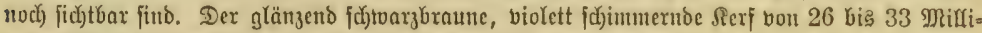

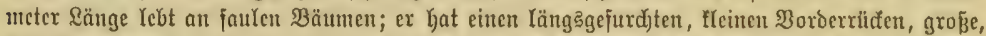

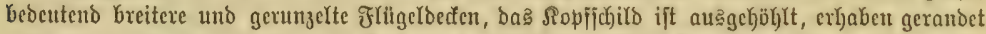

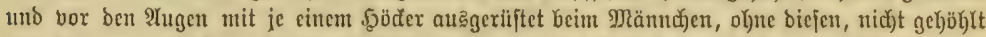

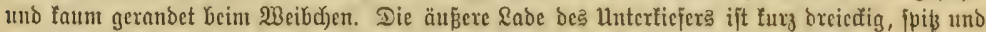
fornig, und ein ftarf gebogenex, fpiber 3ałn entet bie innere Rabe. Der Rcoerfäjer, wie er

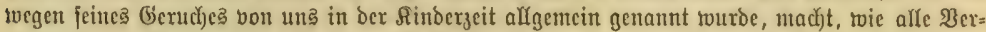

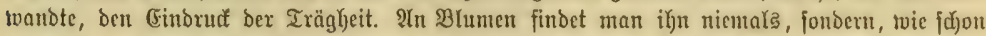
crtwälynt, an jaulen Bäumen. Weil in mand)en Gegenden als joldhe bie Weidon in biejer

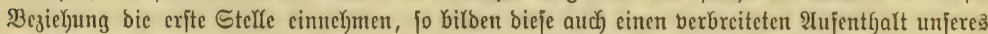

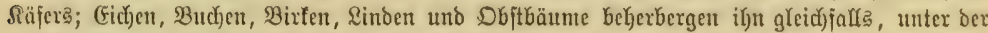

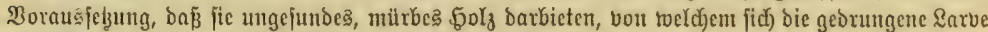

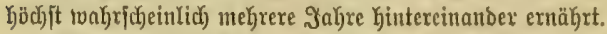

(Einen fremblidjeren (Findruaf ala der (Eremit mad)t ber E. 94 abgebildete gebänderte Pinfeltäjer (Trichius fasciatus). Die நüftblätter fitto von oben nidust fichtliç), bic

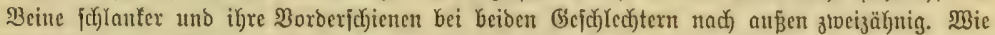

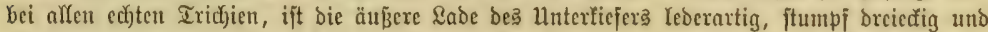
bie innere unbervel)rt, bas Ropfichild länger als brcit, vorn auegebuchtet, fammt Sopf uno

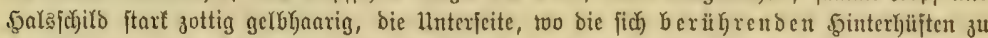

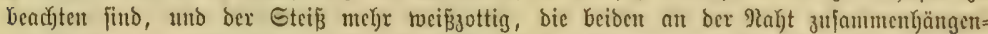

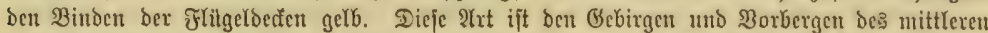

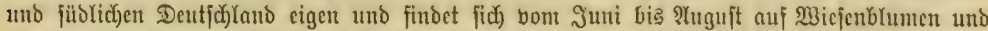

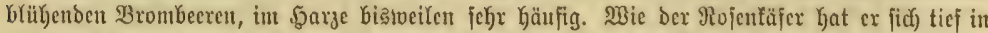

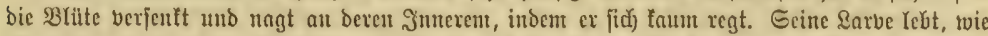

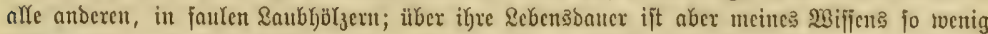

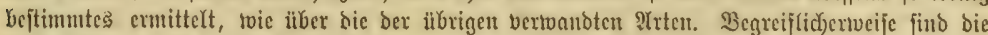
Beobad)tungen alfer in bicjer Weife Yebenden \&arben mit Gdjwierigfeiten aller Sat verbundent.

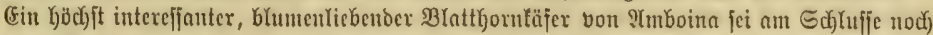

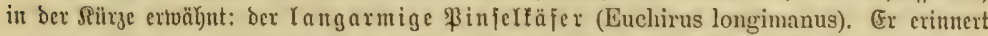

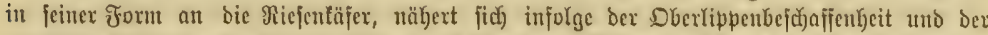

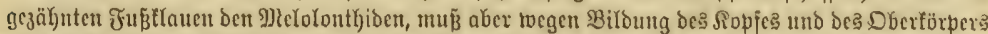

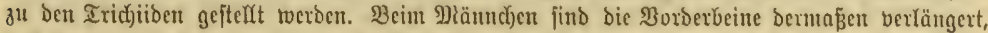

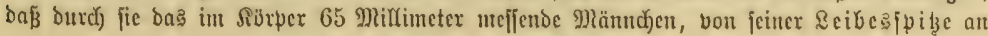




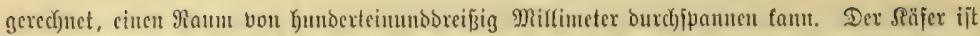

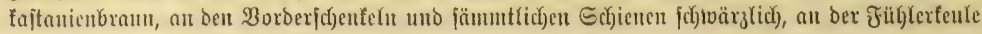
roth gefärbt, untertuärţ gelbbraun behaart.

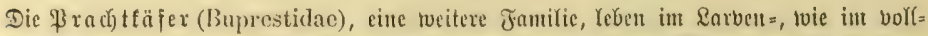

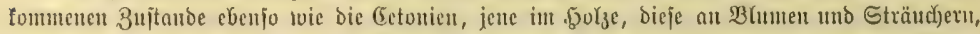

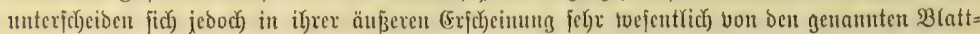

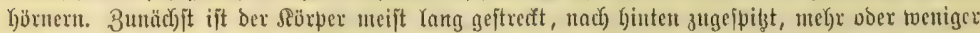

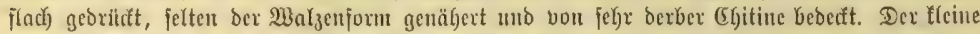

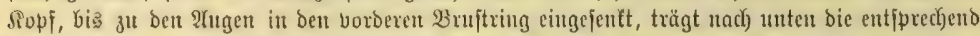

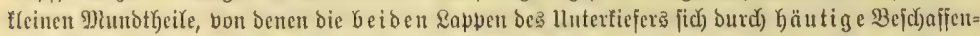

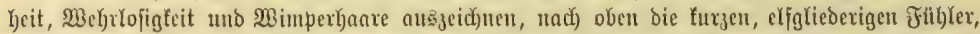

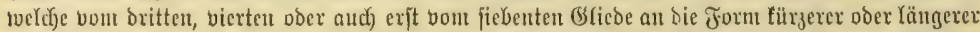

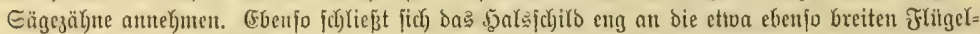

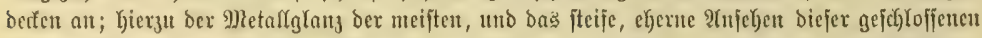
Formen ift voflendet. Die furzen $\mathfrak{B e i n e}$ cignen fid) twenig zum Gange, bie borberjten unb mitteljten

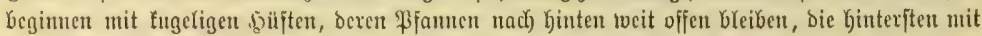

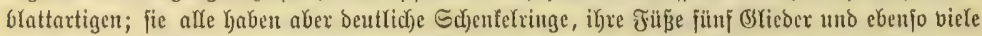
Der Sinterleib, an twelchem bie beiben exften aber vertwachjen. Die \$orderbruft läuft in einen

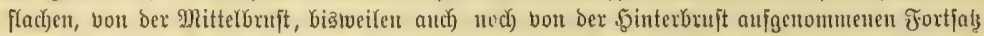

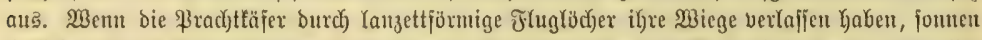

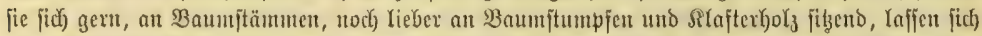

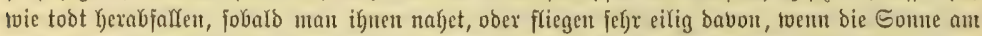

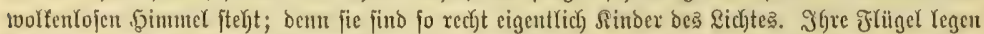

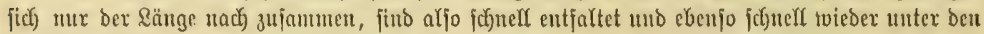
fait gleidiflangen Deden untergebracht.

Die Rarben, utr von tvenigen Frten gefanut, Yeben Kinter ber Rinte gefunder oder fränfeln=

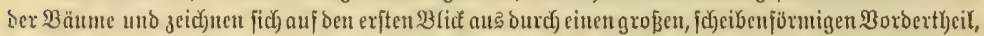

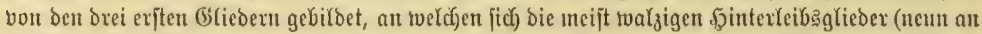

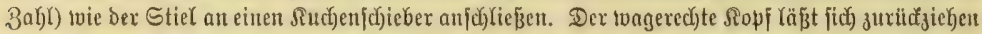

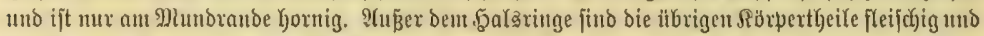

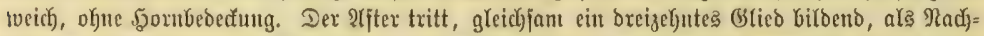

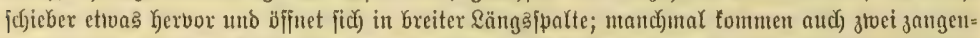

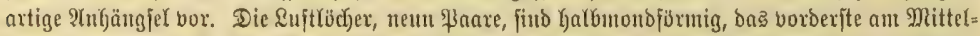

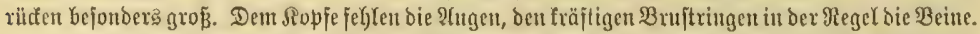

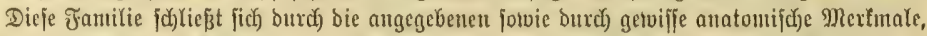

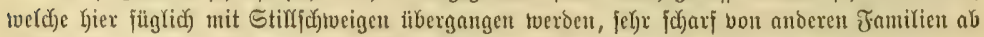

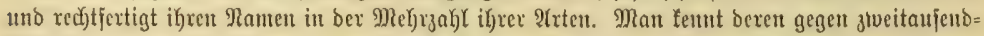

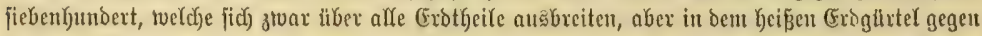

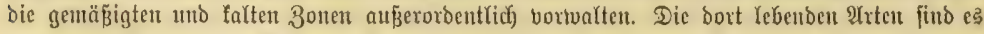

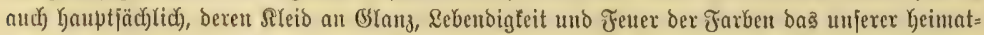

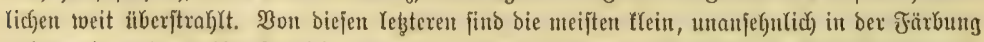

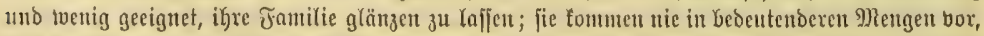

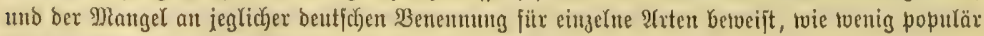
fie fich biahter gemadid haben.

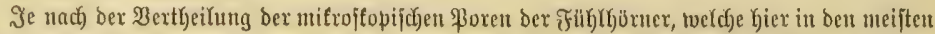

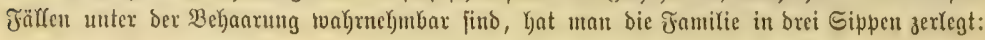




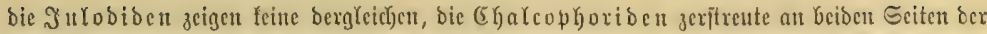

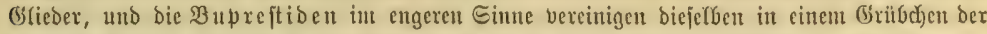

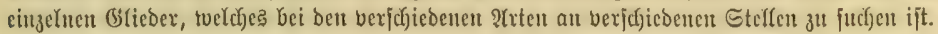

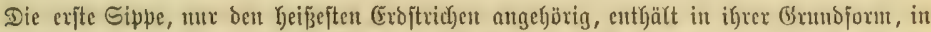

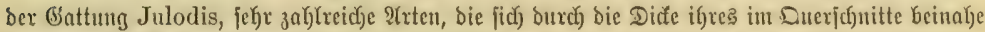

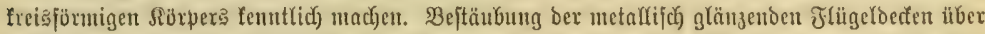

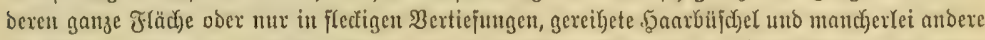

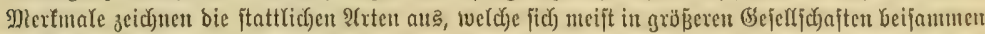
finden. So fübrt bie 26 Mriflimeter Yange, in ber Mitte 11 Miffimeter breite uno eben da

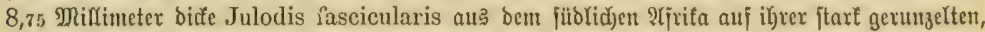

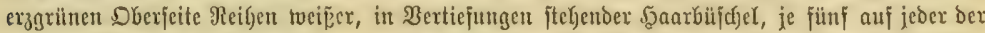

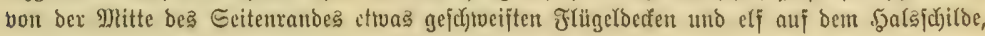

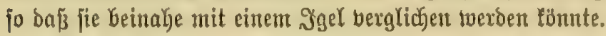

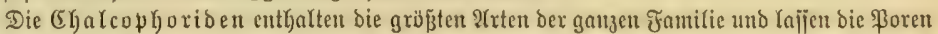
Der Fïh)

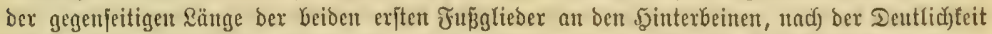

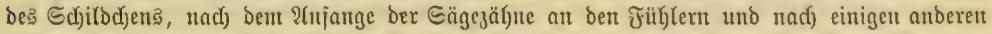
Mertmalen unterjcheiben fid) bie verichiedenen Gattungen, beren mebrere in (Europa פertreter aujzutweijen haben.

Der groß̧e Riefern=ßrad)tfäfer (Chalcophora Mariana), bram crzarben, tweiß̄

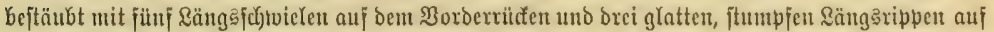

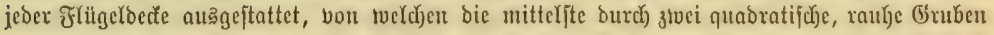

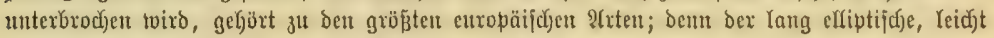

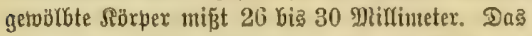
Edjildachen ift zwar borbanden, aber fefr flein uno

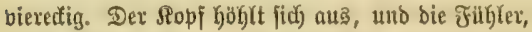
beren Ģlieder länger ałs breit find, verfefjen fid vom vierten an mit ftumpfen Sägezähnet. Dic Irt Yebt in ben Rieferntwäldern bex norbbeutjojen janbigen (Ebenen, wirb benjelben aber nicht jdjäblich, Denn bie Rarbe fript nux in ben fiefernftöden unb in ben Stämnten abgejtorbener Bäume. Mix geben

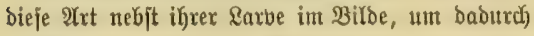
bie Familie in einter ifrer Đauptformen zu bergegen= tvärtigen.

Bei Den echten Bupreftidea, Deren Jüh)(er=

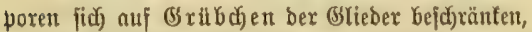

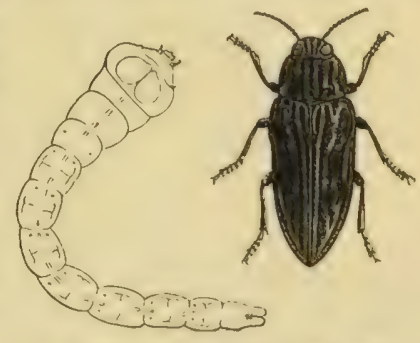

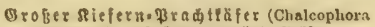
Mariana) nebit Qurbe, natïr. Sröbe.

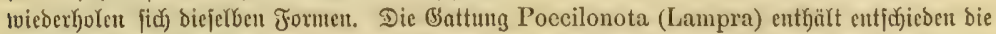

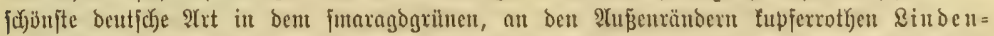

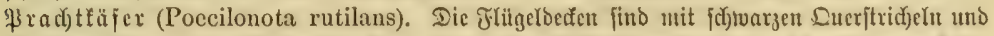

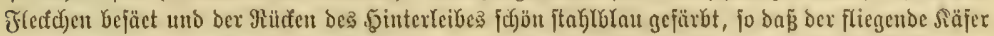

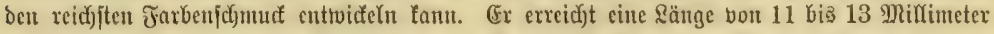

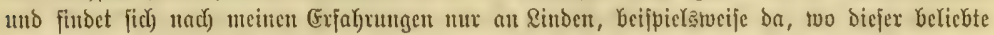

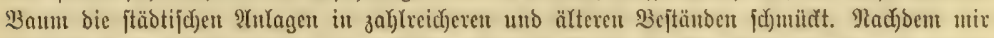

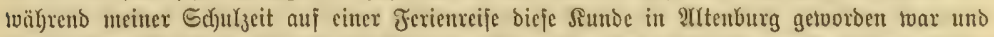

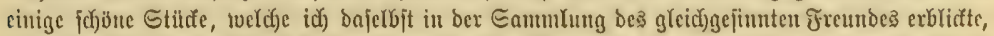

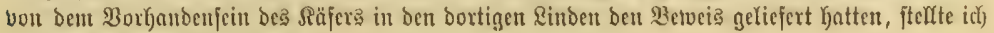

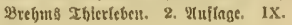




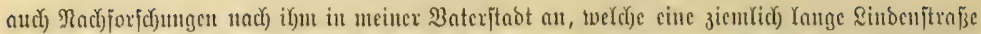

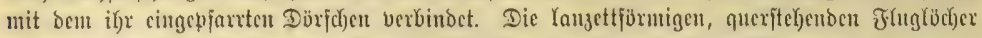

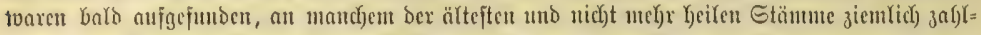

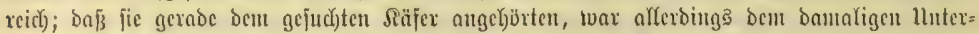

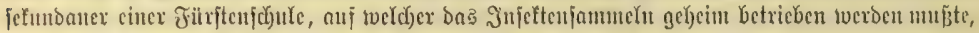

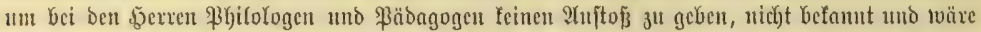
i. twahrij)

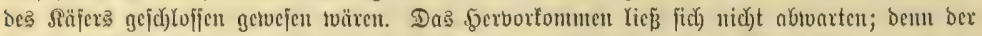

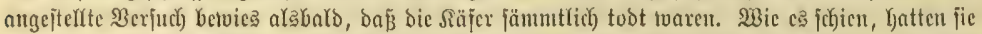

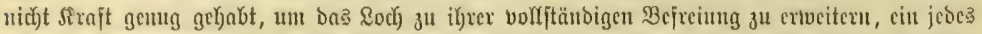

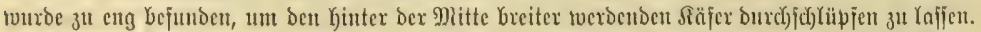

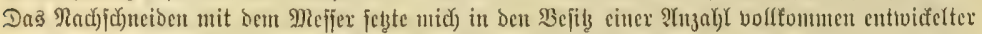

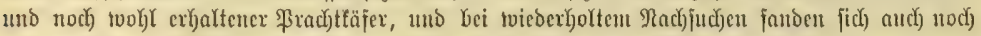

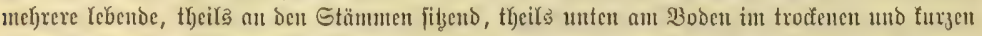

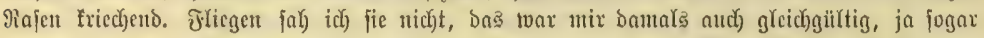

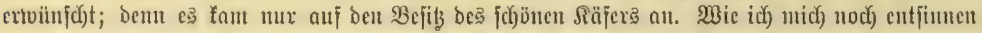

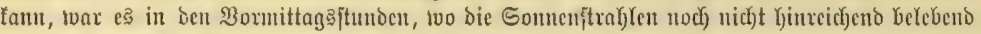

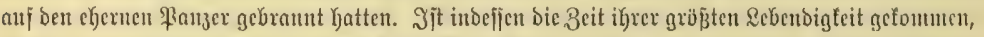

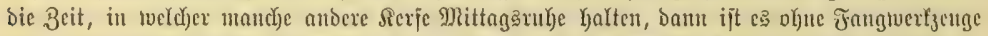

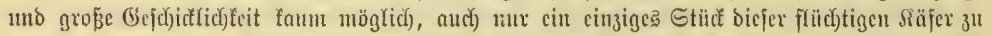

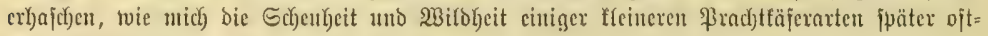
male gelehrt hat.

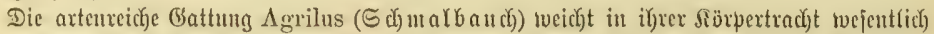

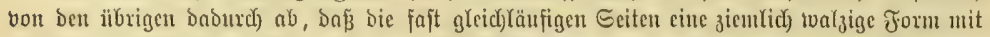

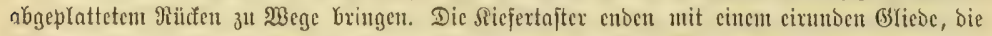

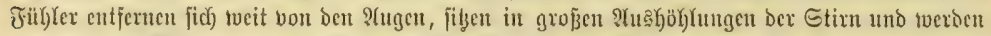
vom vierten Giliede an gefägt. Daß Salşfyjifd ift breiter als lang, ant fointerrande ztweimal

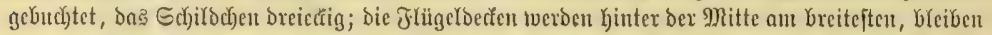

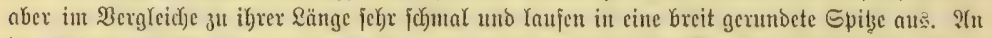

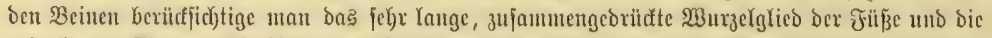

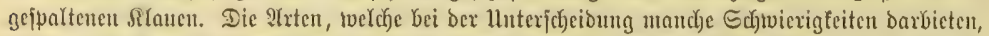

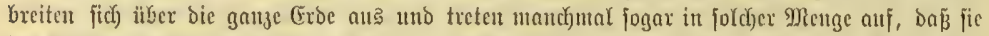

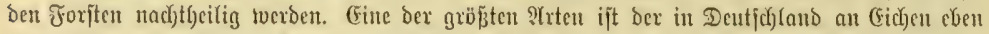

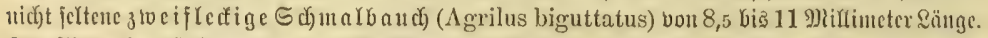

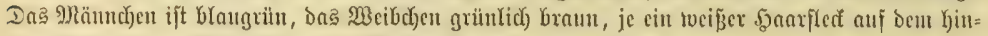

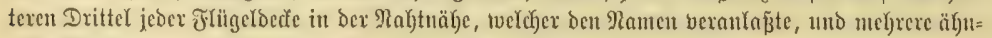
Yidje Frecidjen ant ben Seiten ber $\mathfrak{B a u d}$ )ringe Yajpen ilyn Yeidjt ertentment.

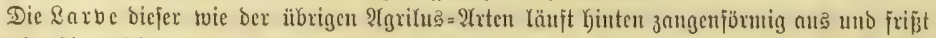

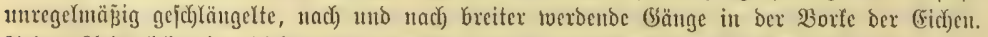

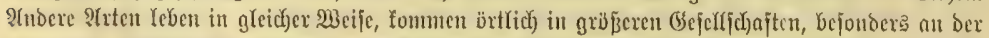

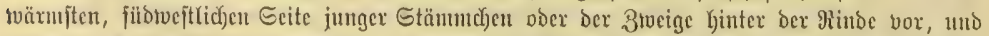

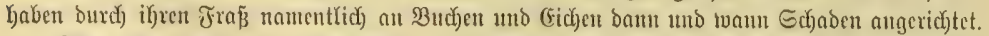

Man findet bei uns auf ben Blältern ber Wolftweiben nicht felten cin fleincs platte, faft

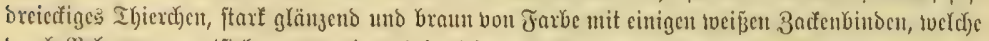

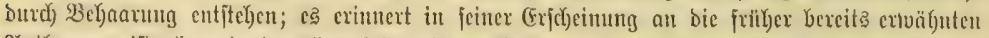

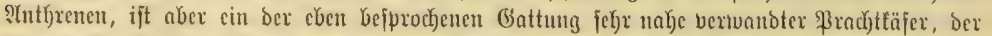

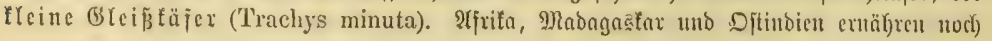


einige Prten, bie meiften Yeben jedod) in (Emropa. Das mertwitroigite an ihnen und an nod) ztvei 3ugebörigen (Battungen (Brachys uno $\Lambda$ phanisticus) ijt bic \&ebentart ber Sarben, tweld)e fid)

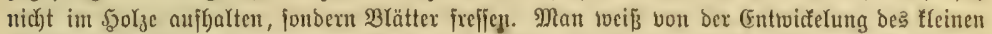

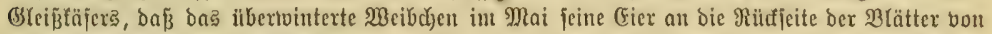

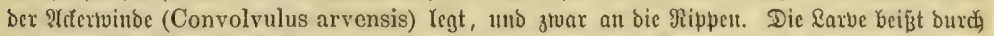

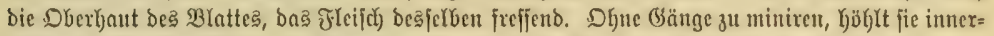

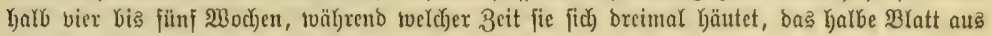

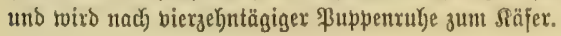

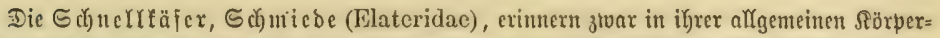

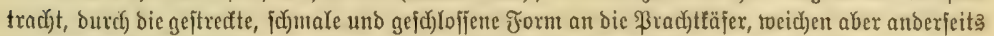

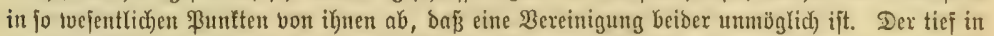

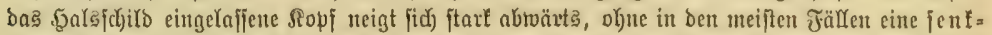

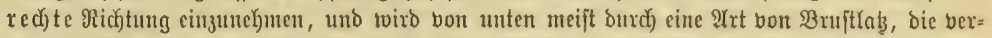

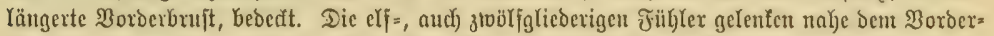

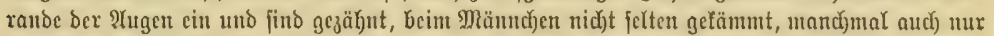
fabenfïrmig. Die Doertippe ift beuttich, jeder Rappen beș Untertiefers Glattartig uno betwimpert,

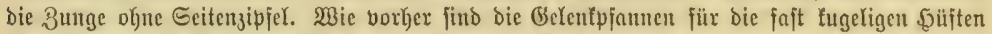

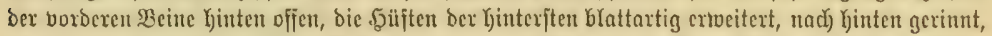

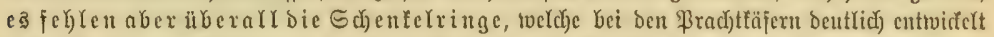

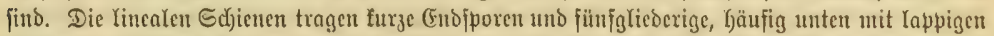

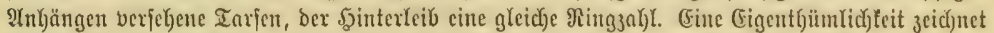

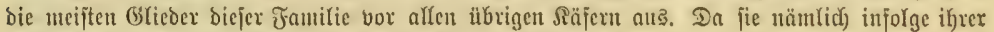

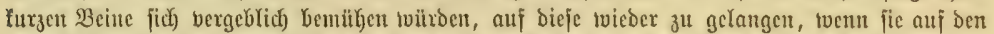

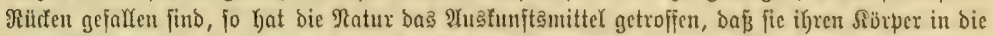

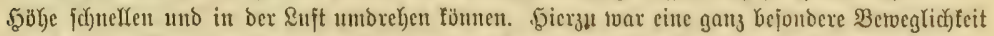

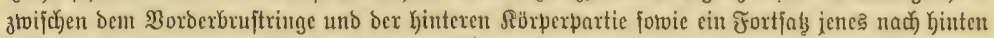

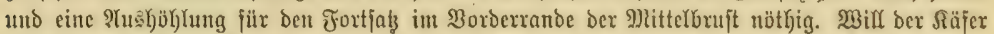

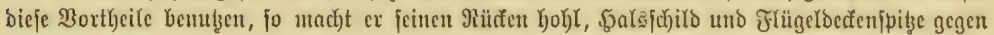

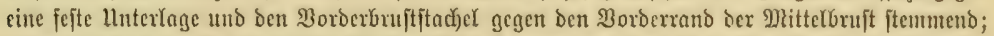

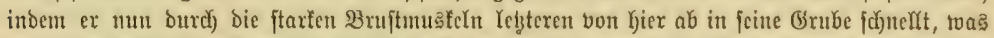

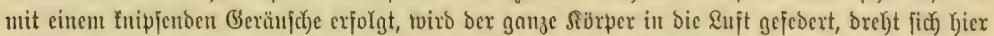

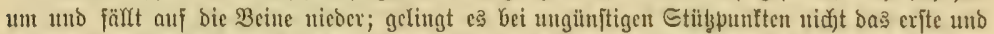

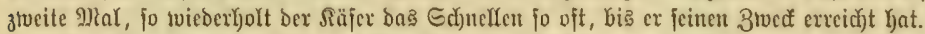

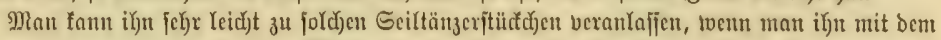

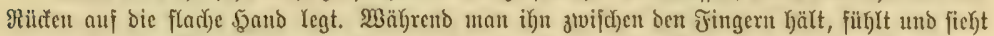

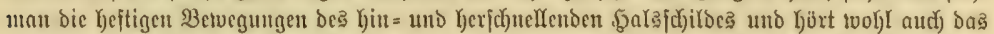

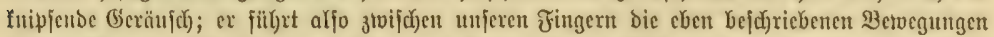

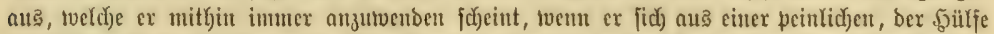

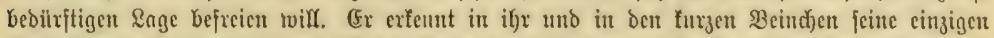

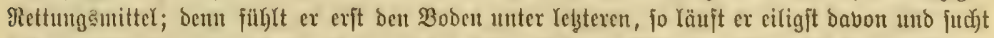

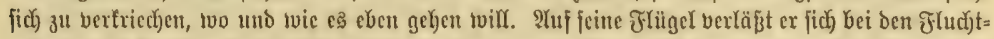

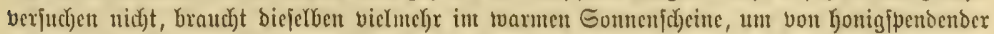

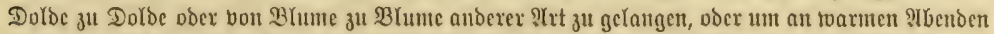

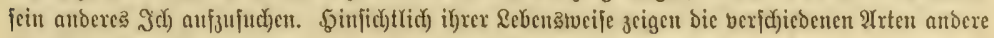

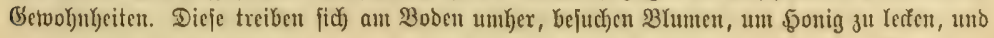




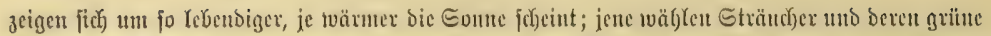

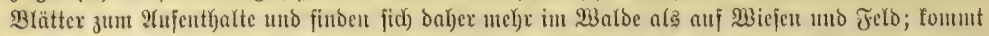
man ihnen zu nabe, fo faffen fie fich) mit angezogenen Seinen zux (crbe faffen unb finb baun meift,

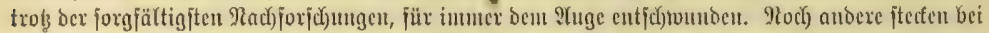

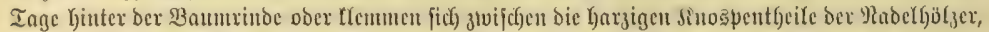

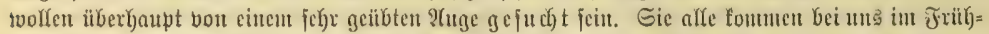

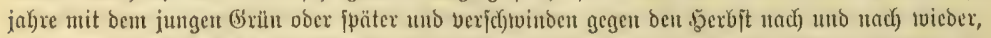

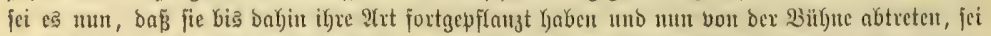

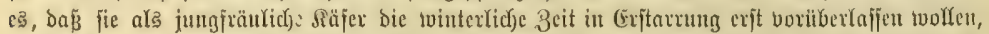

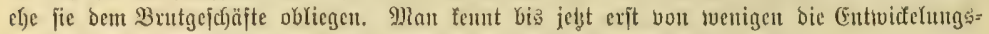

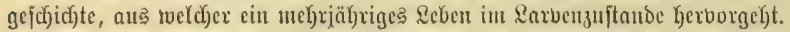

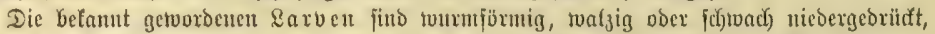

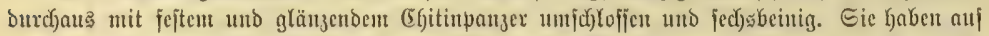

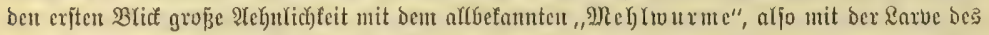

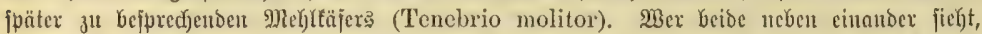

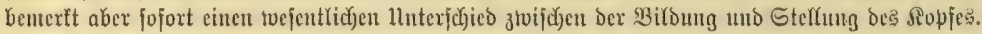

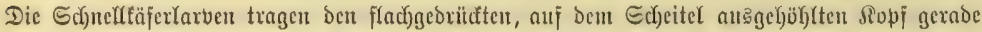

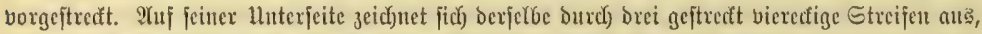

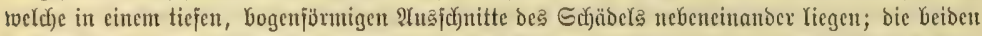

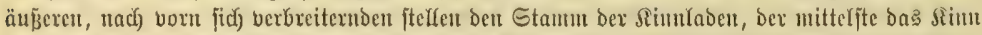

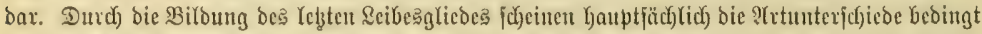

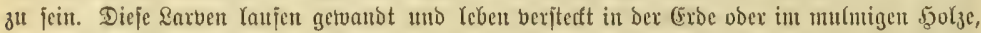

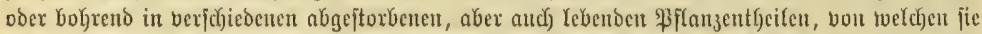

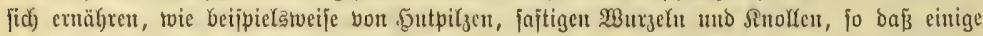

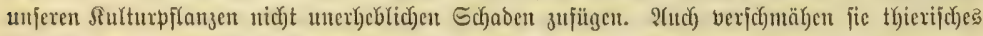

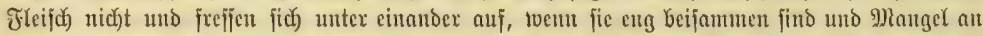

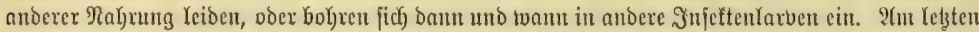

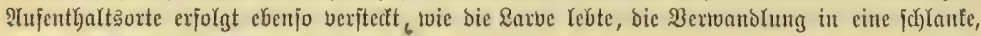

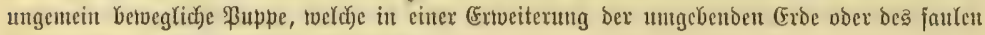
5olzes oftre 3tweifel nux fuzge 3eit ruht.

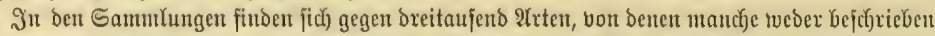
noch benannt fint. Sie breiten fid) itber affe Grotheile aus, find in ben warnten und heipen

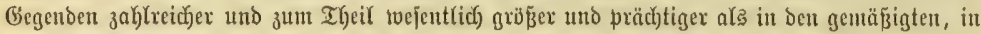

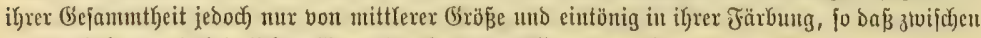

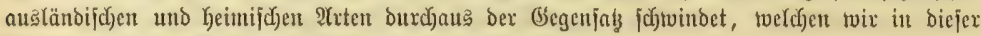
Beziehung bei ben Prachttäfern fennen gelernt Kaben.

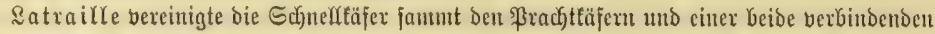
fleineren Familie, ben hier mit Stifljhbeigen ibergangenen (Eucueniben, zu ber Gruppe der

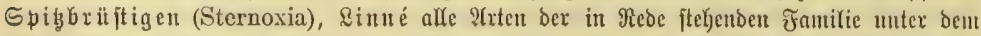

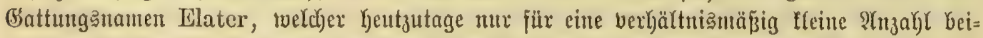

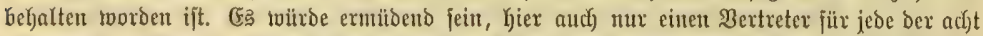

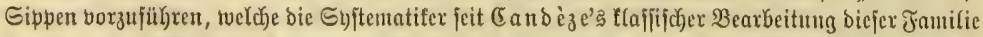

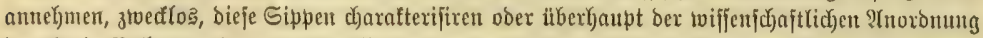

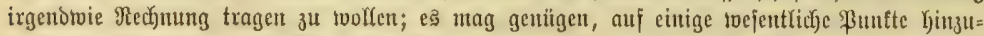

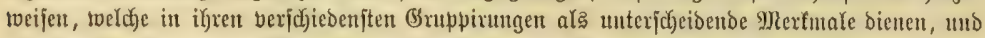

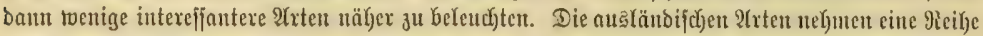

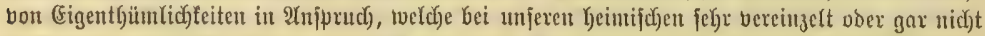

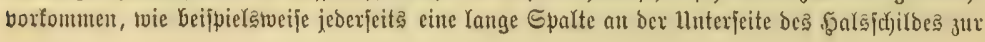




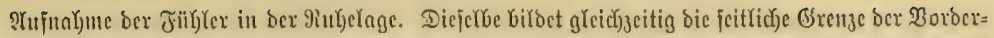

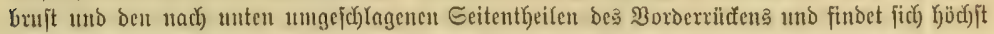

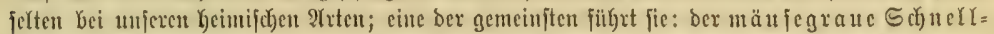

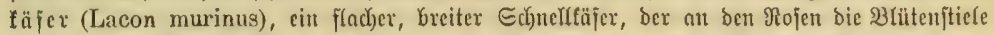

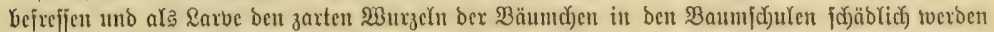

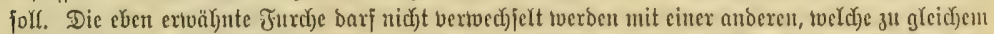

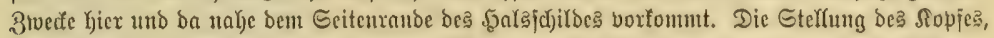

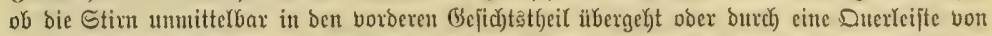

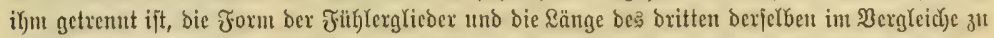

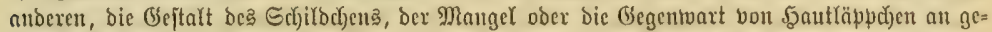
toiffen JüBgliebert, bie Gejtalt Der Greiten Şinterbiliften uno anderes fommen für alle bie EYate=

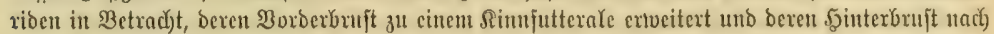

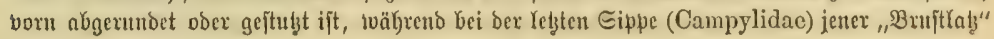

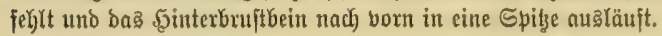

Dex rau

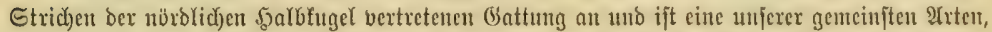

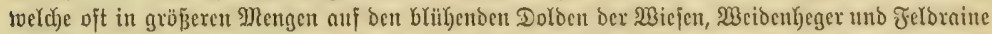

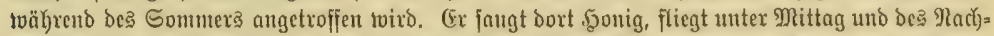

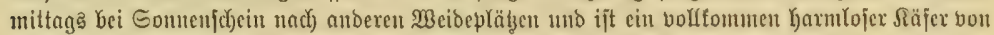

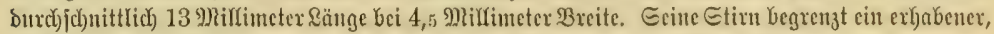

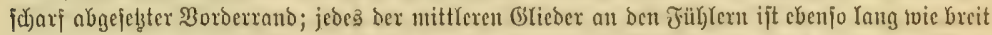

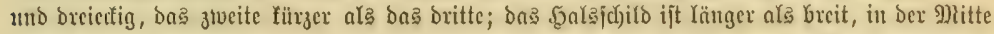

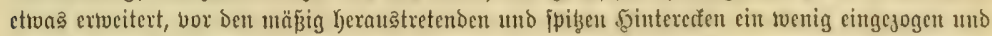

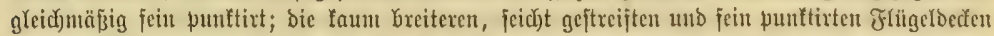

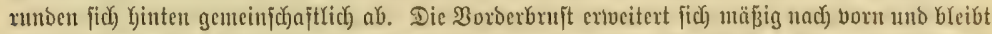

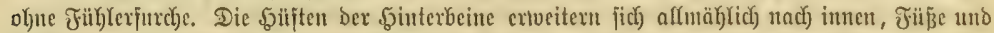

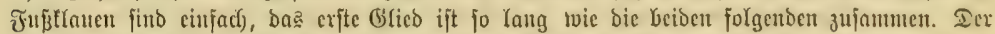

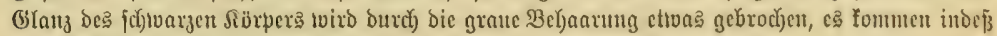

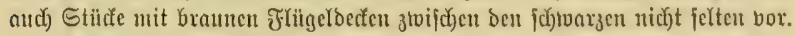

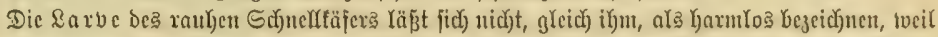
fie, went it gröperen Mengen an ciner Eteffe vortommens, unjeren Sinturpflanzen nerf(id)en

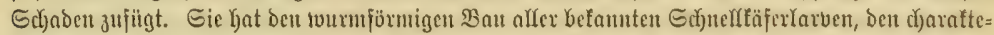

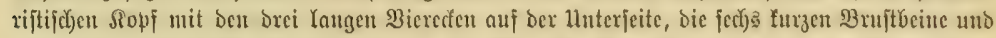

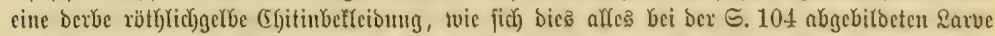

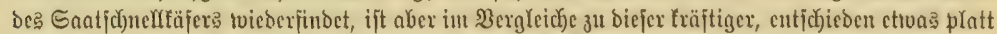

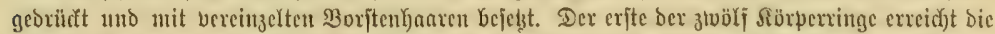

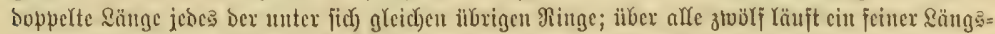

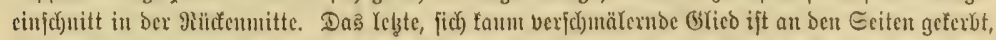

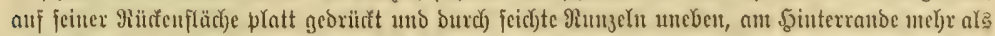

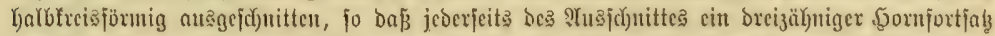

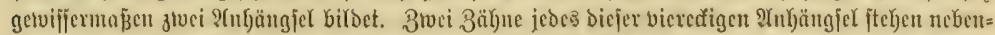

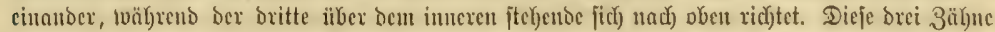
Hffrgen fantunt Den ftumtpen .jerborragungen an Den geferbten mo Yeiftenartigen Seiten Des

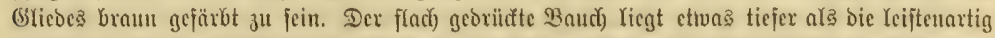

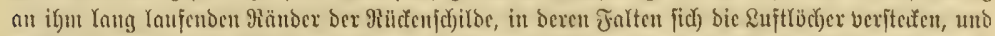

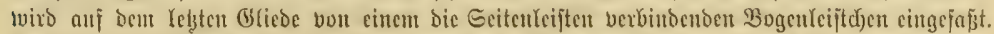

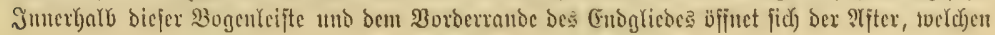




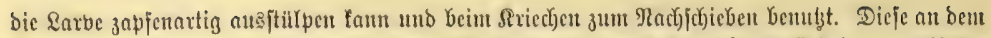

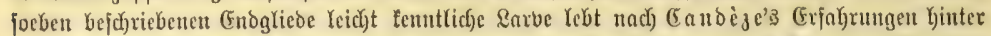

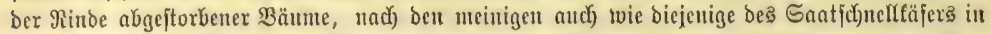

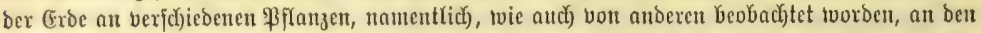
3uferriben. Wenn fie, wie ber Engerting, ben Bart und bie Spitze der jungen Ribe benagt,

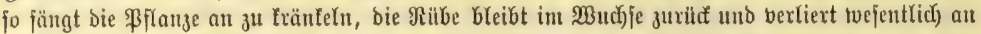

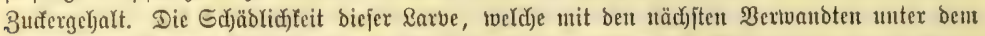

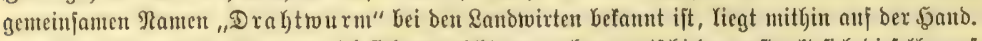

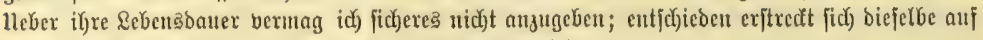
mefyrere Jahre, wie von allen anderen angenommen twirb.

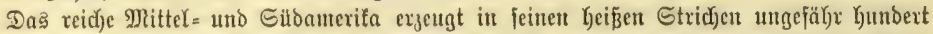

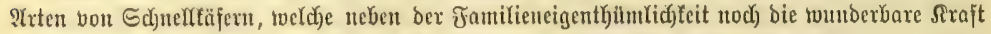

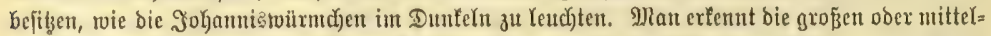

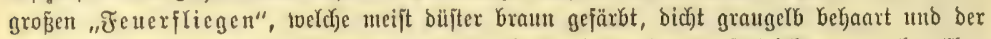
Gattung Pyrophorus jugetfeilt toorben find, Yeidjt an einem etwas aujgetriebenen, twachsgerben

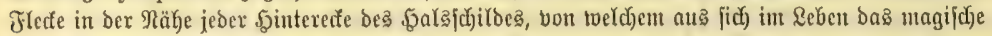

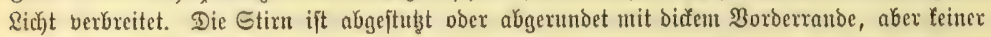

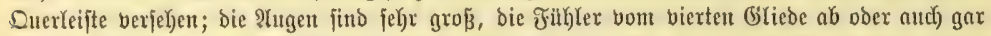

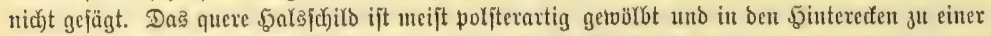

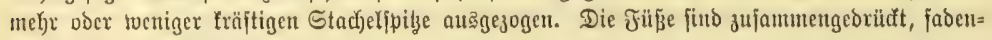
jörmig uno unterfyalb behaart.

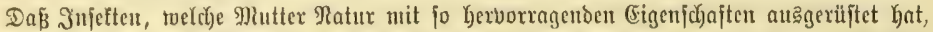

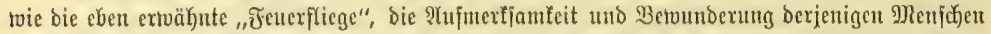

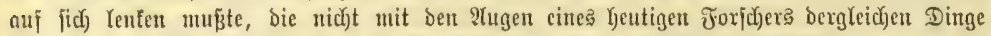

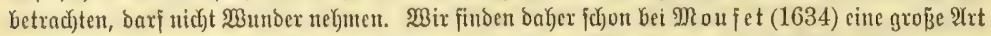
Yeiblic) abgebildet unb bej(d)ricben. (Ex nenut ben Räjer Cicindela, griect)ijch Kephalolampis,

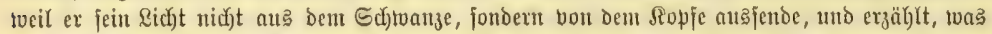

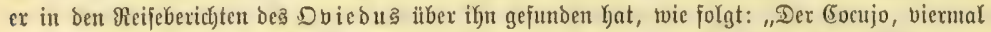

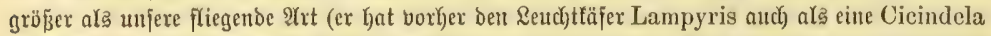

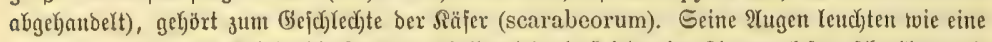

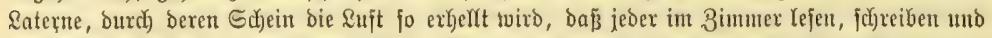
andere Berridytungen bornchmen famn. Mebrere vereinigt geben ein weit hefferes Ridct, fo

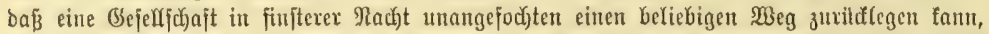

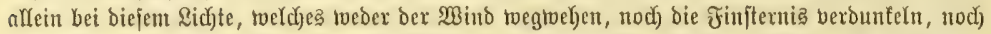

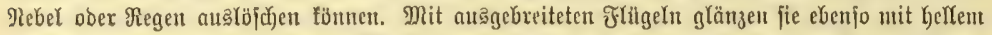

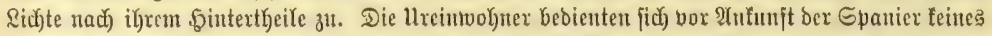

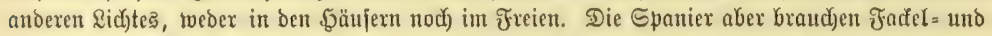

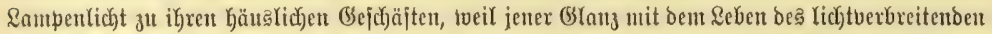

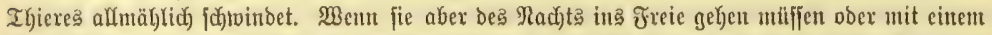

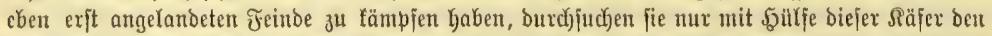

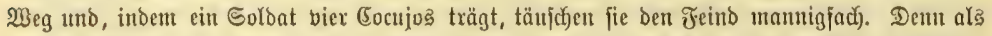

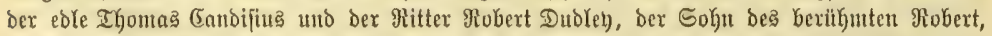

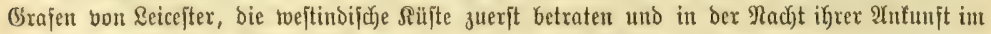
benad)barten Walde unzählige \&ichter, wie bon brennenden Fadeln, unertwartet Geranmahen fahen:

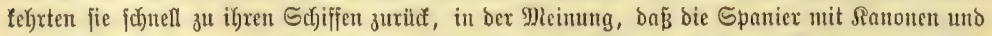

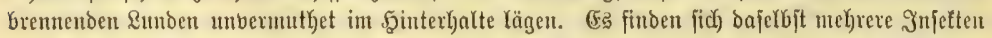
bicjer Gattung, aber tweil der (5ocujo unter alten ben Borrang hat, übergeht Dviebus bie ibbrigen

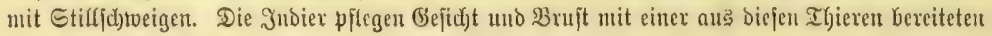




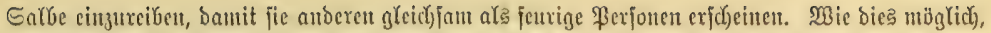

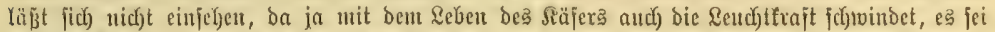

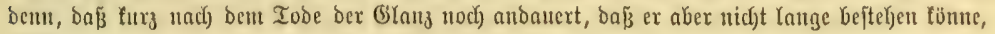
ijt fitudjer.

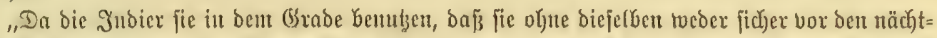

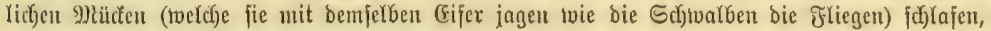

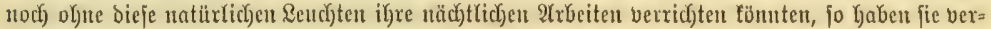

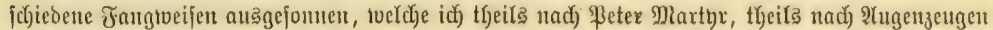

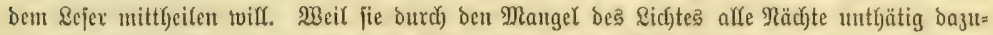
Yiegen genüthigt fino, gehen bie S̈toier mit einem brcmenoen Scheite aus, uno mit Yauter Stimme

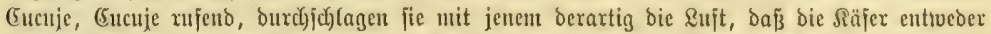

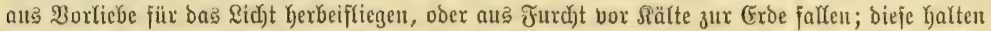

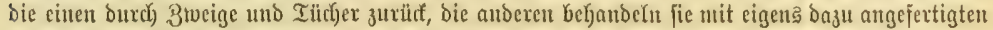

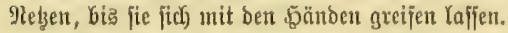

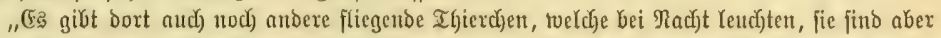

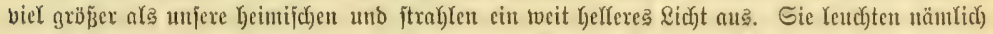

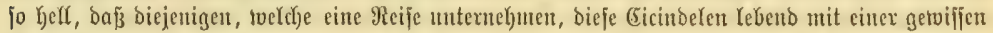

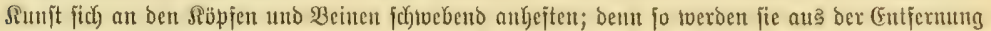

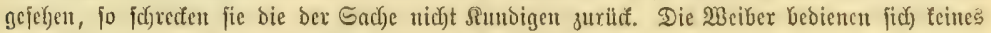

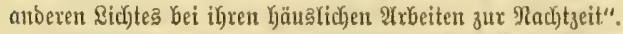

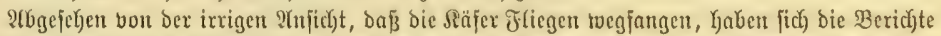

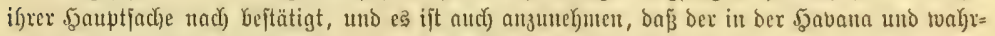

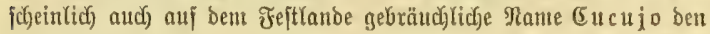
fefr verbreiteten Pyrophorus noctilucus ber neueren beseidynet. গad)

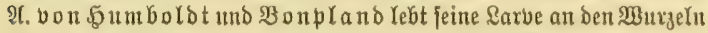
Des Bufferrohres, wo fie bistweilen bedentenben Edjaben antidftet,

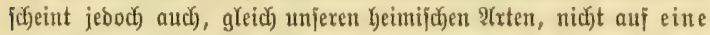

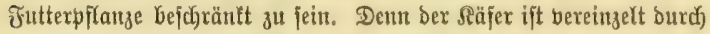

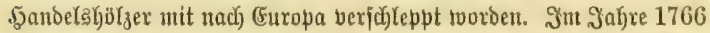

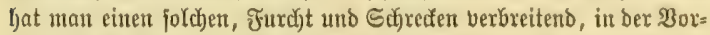
itabt von St. Pntoine in \$aris untherfliegen fehen, lus in ben fedjziger Jahren biejes Jahrbunberts fah Snellen van einen in Reiben, tweldyer auj (5ampedyeholy gefangen toordent toar, und

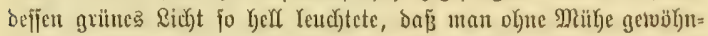

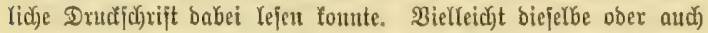

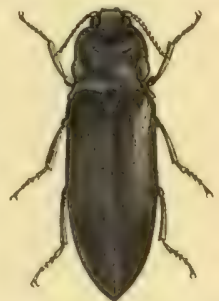

(5 ucu 10 (Pyrophnrus nnctilucus), nalürs. Bröje.

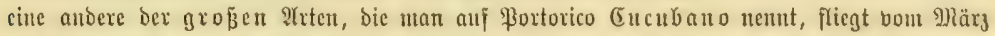

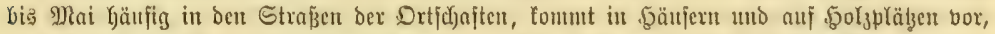

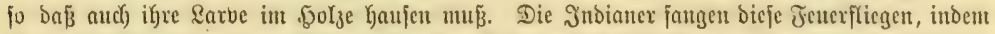

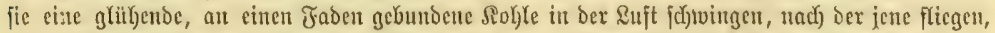

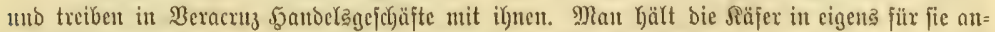
gefertigten Siätidyen aus feinem Drabte, fütert fie mit Scheibdjen von 3uderrogr unb - babet

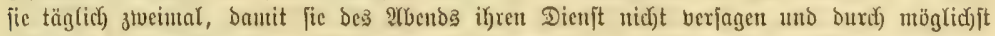

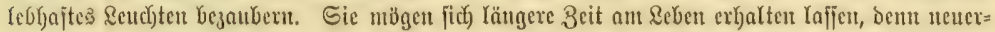

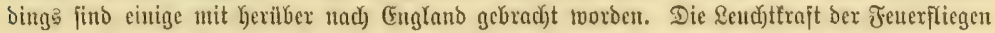
wiro in Den verif(t)iedenen Gegenden zu verfochiedenen Bwecten bemulzt. Eo fitectt man einige in

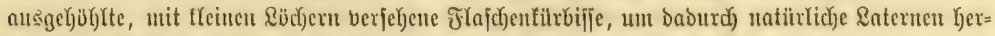

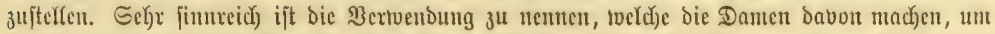

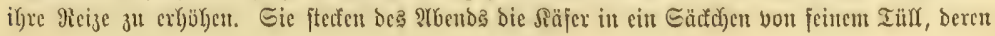




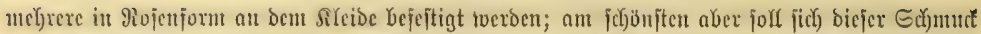

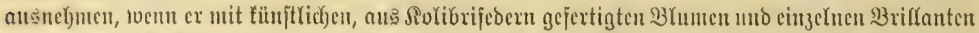

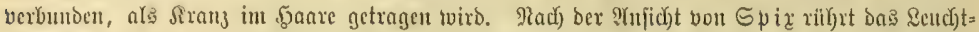

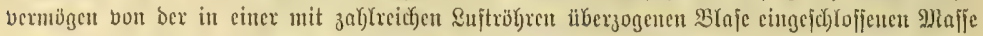

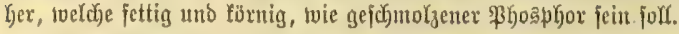

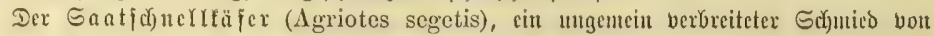

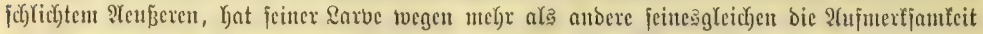

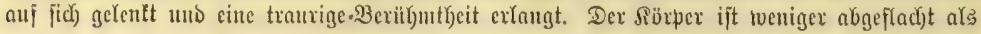

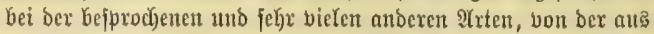

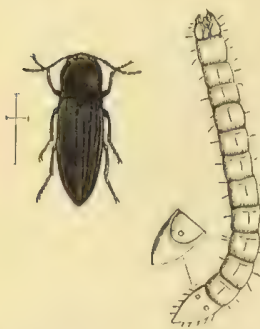

Eantfinluelthifer (Agrintes segetls)

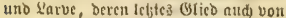

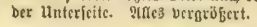
ber Abbildung zu erjebenden Form. Die Stim wirb burd) feine Duexiurche bom (Sejichte getrennt, fondern biegt fict) in ber 9litte abwärts, beiberjeits über ben gluno hit einen Ranb bildeno.

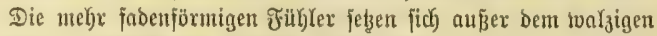

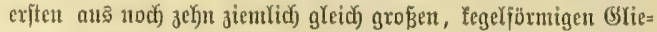
Dern zufammen, von Denen mur baş Yeb̧te Ranzettjorm annimmt. Das boxn jtarf poljterartig getwölbte und an Den Eifen gerundete

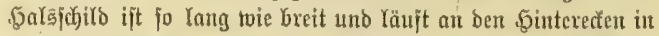

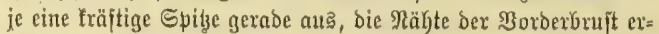

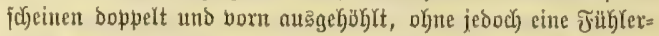

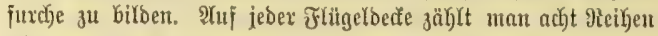

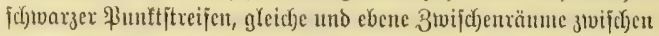
ficid) Iaffend, von bencu ber zlueite und vierte (yon ber Slaht

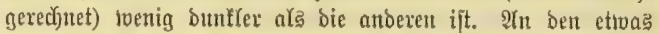

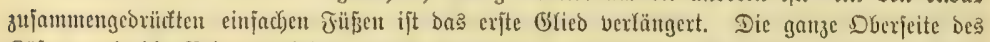

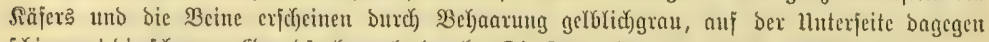

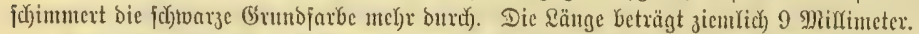

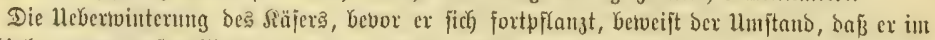

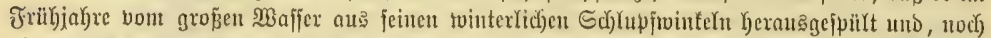

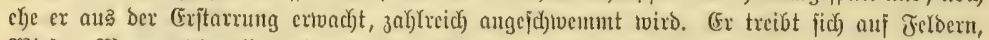

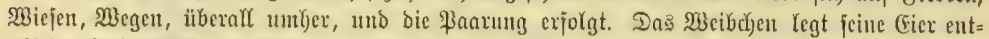

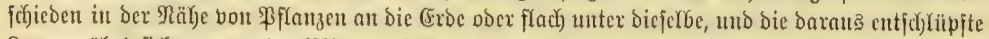

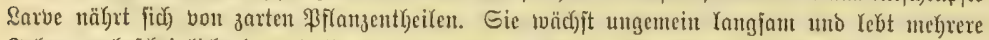

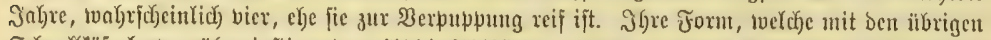

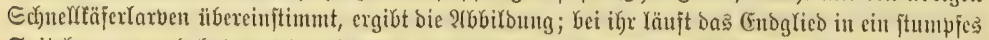

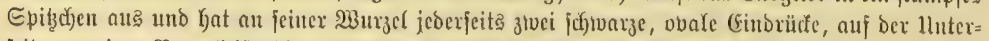

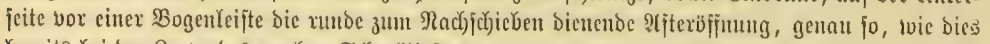

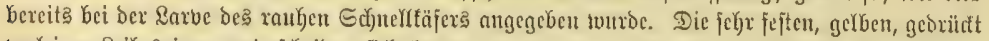

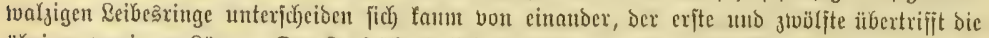

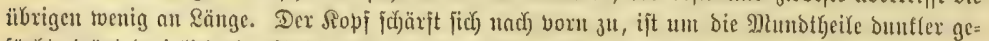

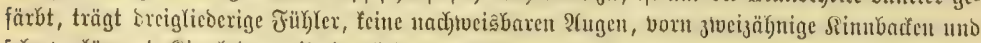

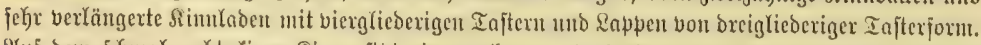

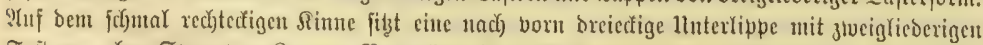

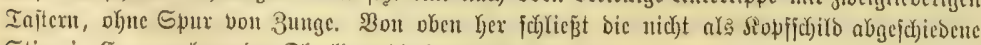
Etim in Erntantgelung der Dberlippe Die Munbiffmung.

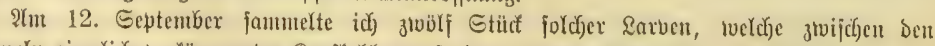

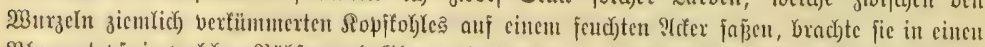

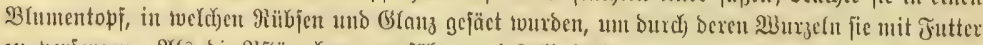

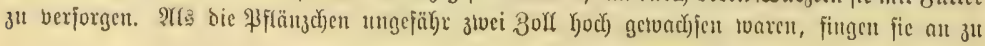




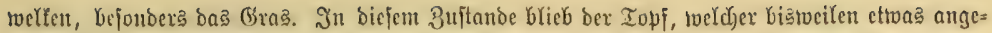

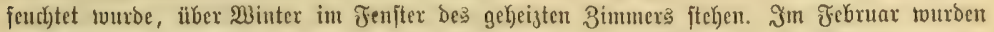

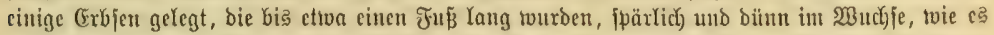
bie Jalyresgeit mit fich brachte; plöbzlid) aber fingen fie an zu toclfen. Tm 6. Suli unter=

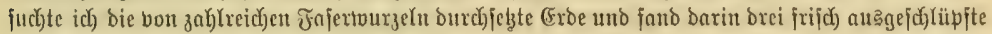

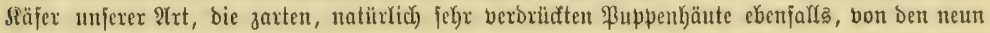
iibrigen \&atben aber teine Spur.

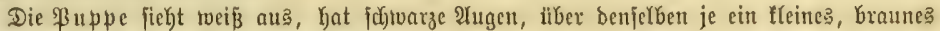

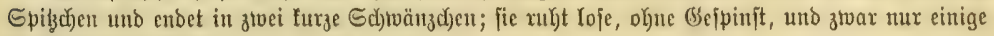
Wodjen in ber (Exde.

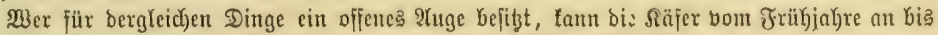

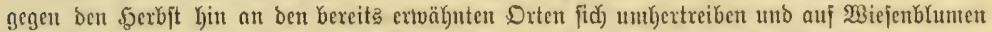

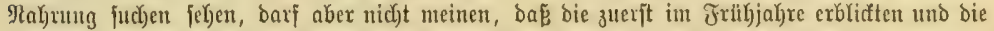

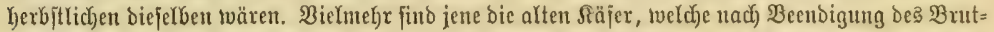

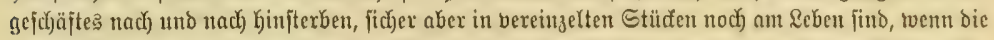

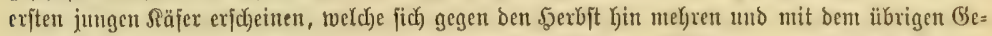

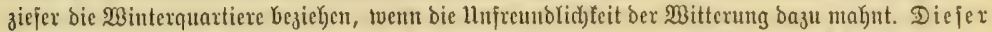

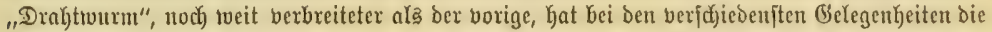
Tupmerfanteit auf fich gelentt und faum eine Borticbe fïr Geftimunte Surturpflanzen an ben

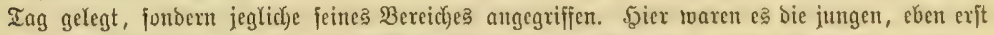

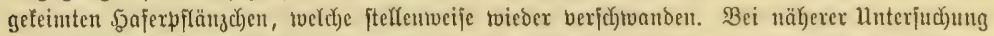

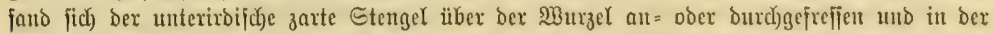

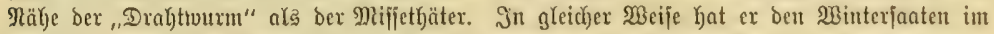

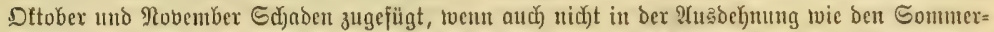
jaater. Dort hat er bie jungen (Erbjentffanzen aur unterirbifchen Etengel benagt und baburd)

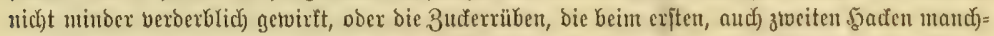

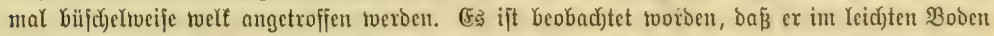

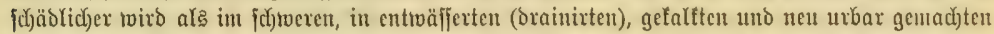

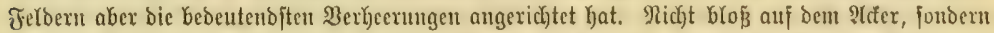

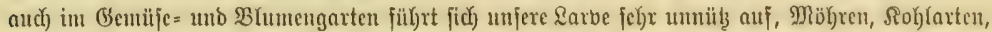
Galat, Revfojen, Relfen, Riliengetväd) je uno andere zerftüreno, uno fordert fomit bie Betroffenen zu eineut $\mathfrak{B e r n i}$ )tungątampje gegen fite heraus.

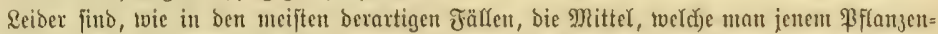

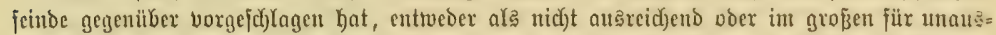

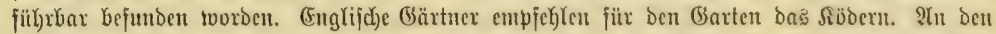

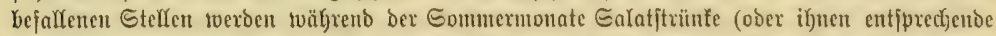

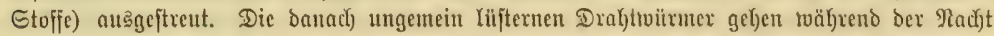
zal)freid) au ben Räber und miljien jeben Morgen bou bemijelben abgelejen unb eingefammelt

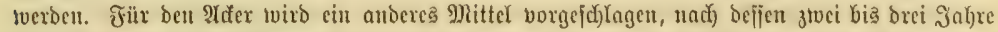

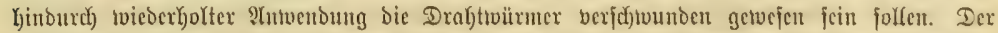

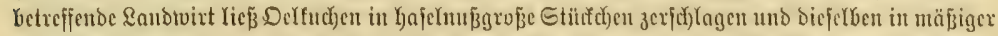

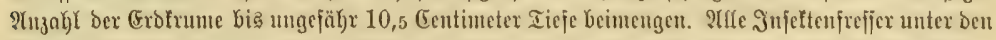

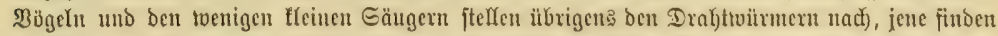

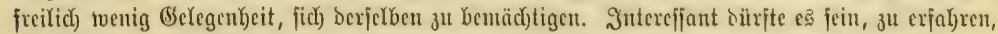

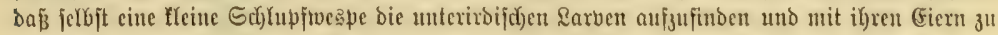
bejchenten seif̧. Sollar hat fie erzogen uno mit Dem Ramen Bracon dispar belegt. 


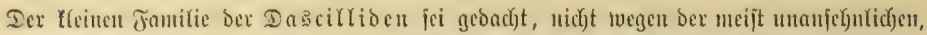

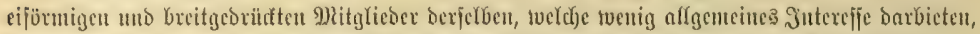

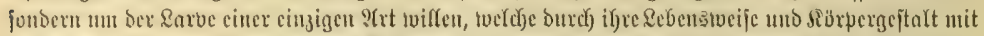

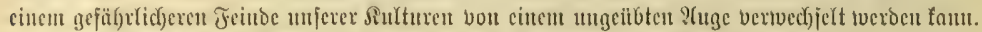

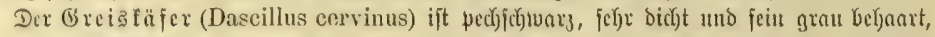

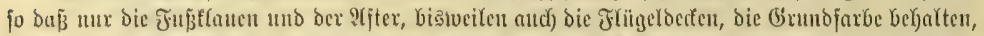

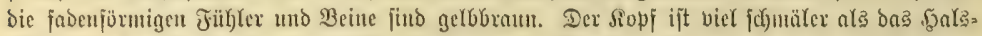

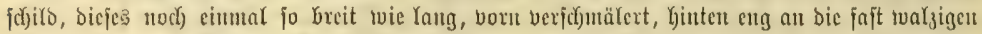

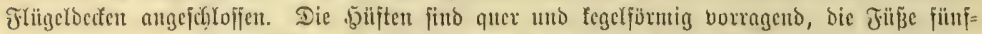

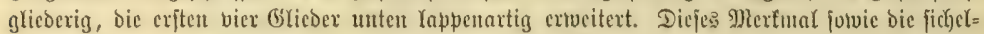

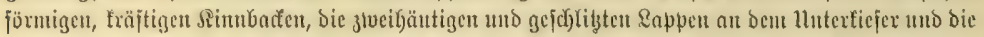

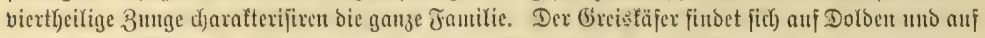

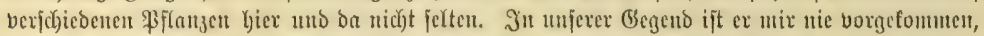

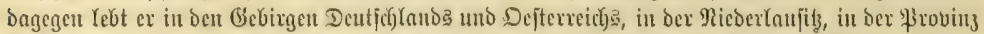

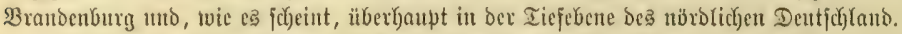

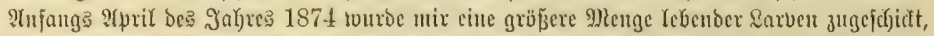

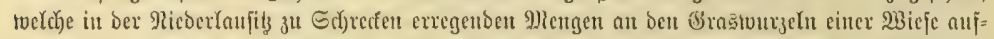

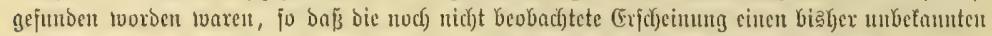

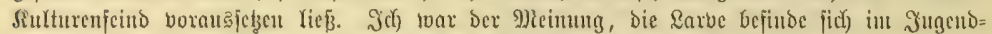

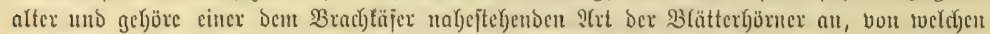

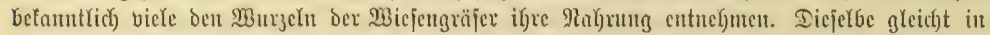

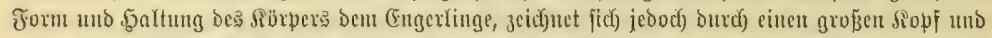

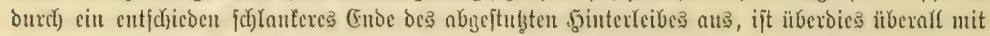

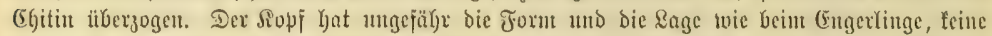

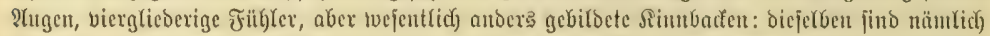

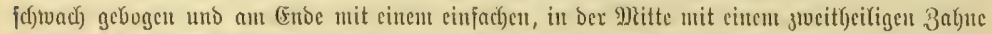

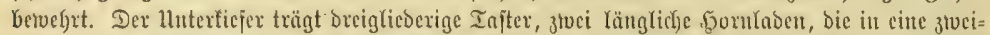

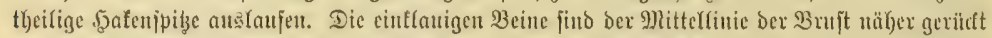

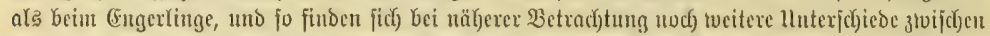

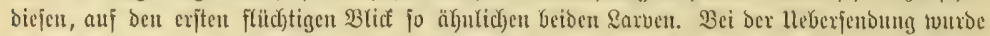

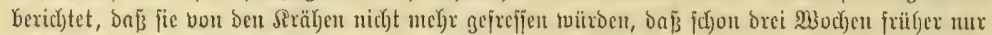

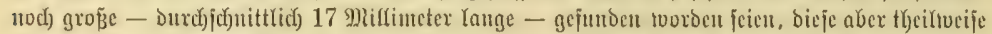

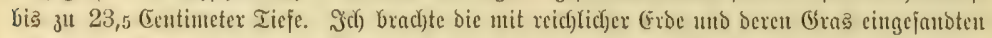

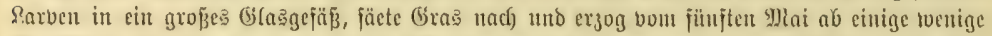

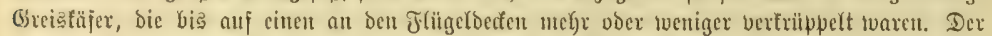

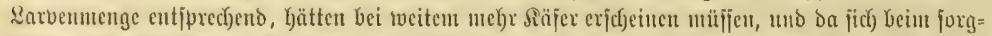

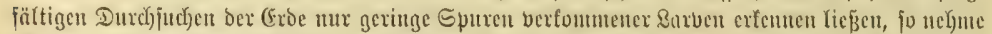

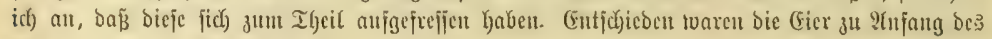
borangegangenen Friibjahres abnejeßst roorden.

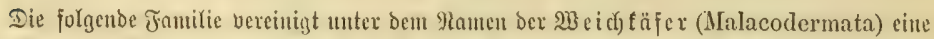

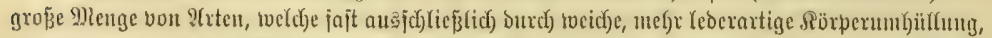

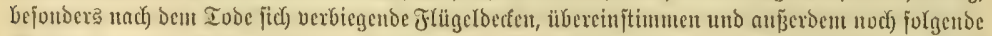

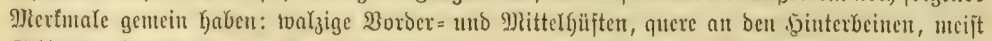

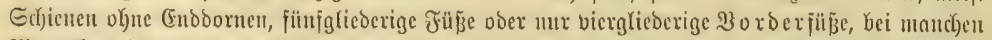

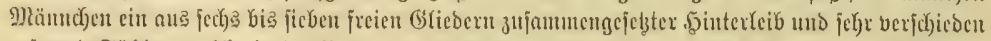

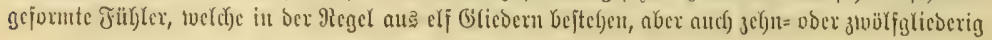




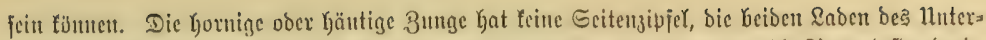

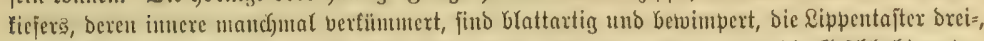

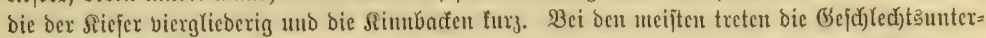

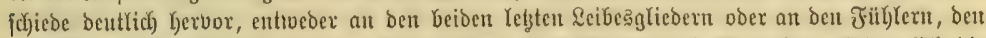

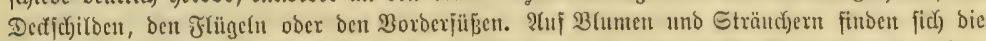
meijten ber hierber gefjürenden Jerje zum Iheil aber nicht, um baje(bjt Silß̈igfeiten zu fuchen,

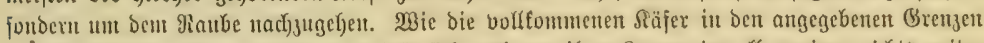

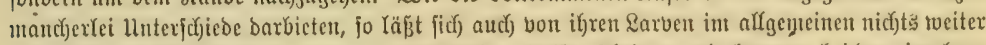

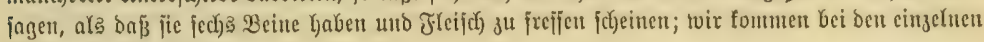
Sippen auj fie zurild.

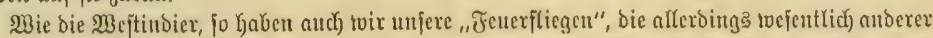

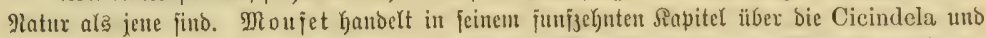

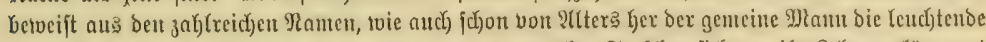

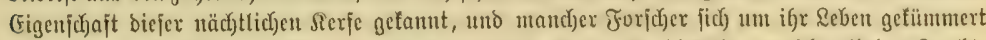

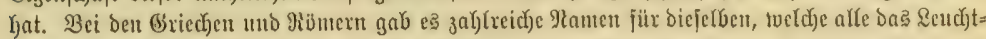

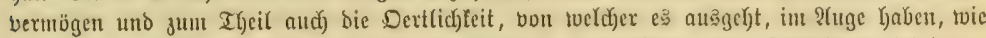
lampuris, pygolampis, kysolampis, pyrolampis, bostrykos, pyrgolampis zc. bei jencu, cicindela, nocticula, nitedula, lucio, lucula, luciola, lucernuta, venus z. bei biefer.

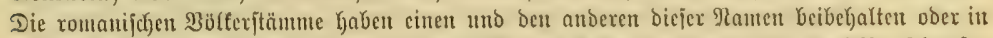

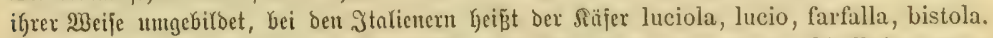
fuogola, lacervola, luiserola, bei ben Spaniern lyziergana, luciernega. Die Polen nennen iłı zknotnike, chrzazezik, swiccacy; bic llıgarı eycltwudoeklo, bogaratska vilantso; bie Franzofen Ver luissant, mouche claire; bie Eugländer gloworme, shine-worme, glass-

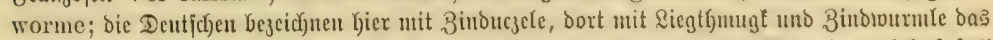

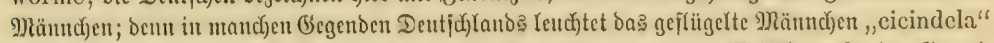

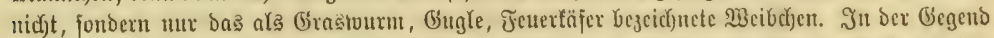

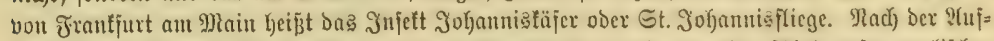

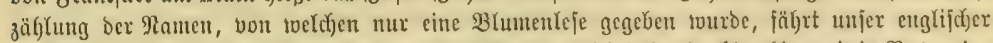

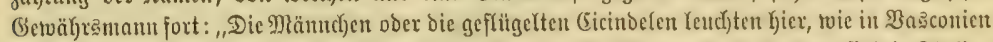

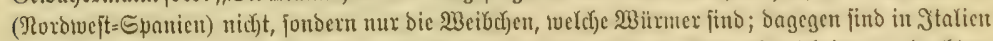

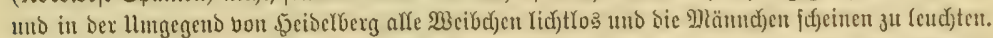

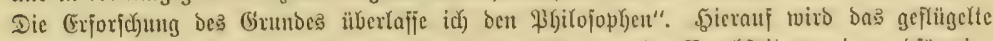

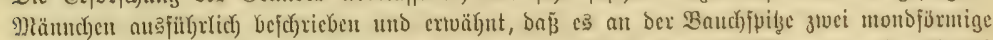

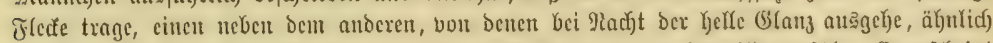

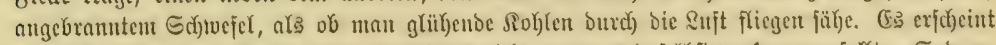

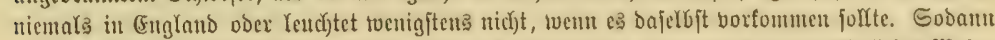

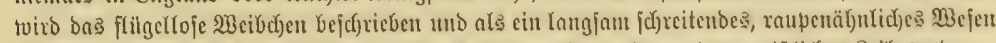

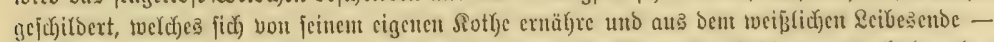

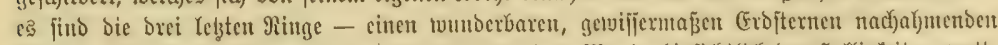

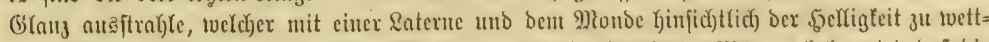

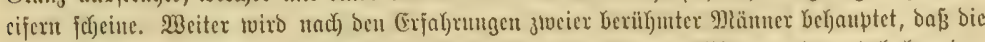

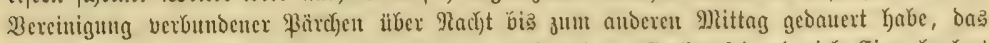

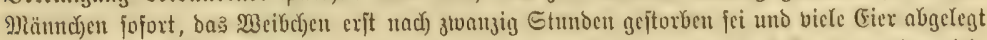

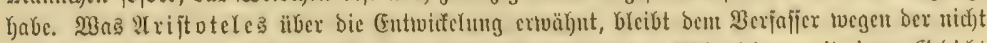

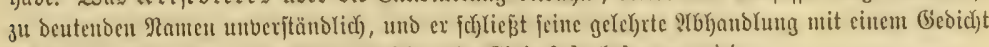

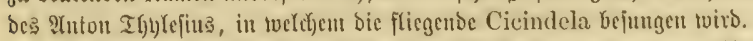

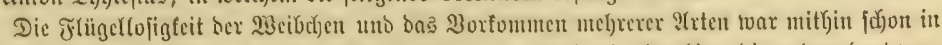

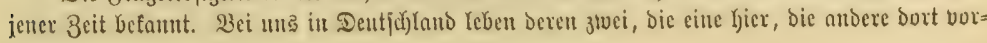




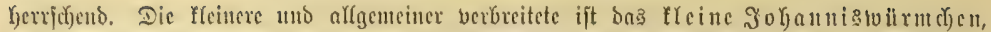

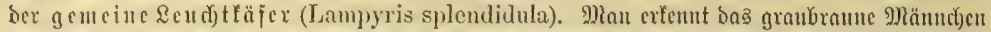

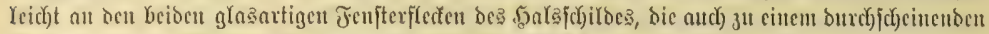

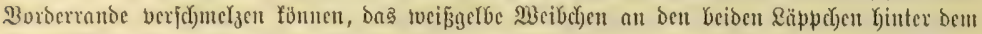

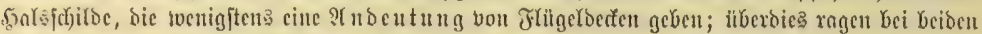

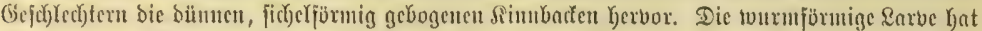

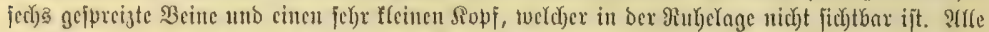

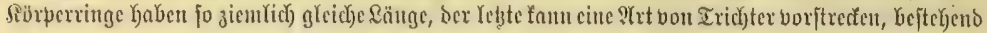

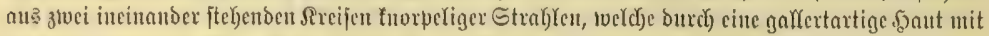
cinander verbunden find. Dicje beiben Etrab)lentreife fund ein= und anszierbar und bilden cin fïr

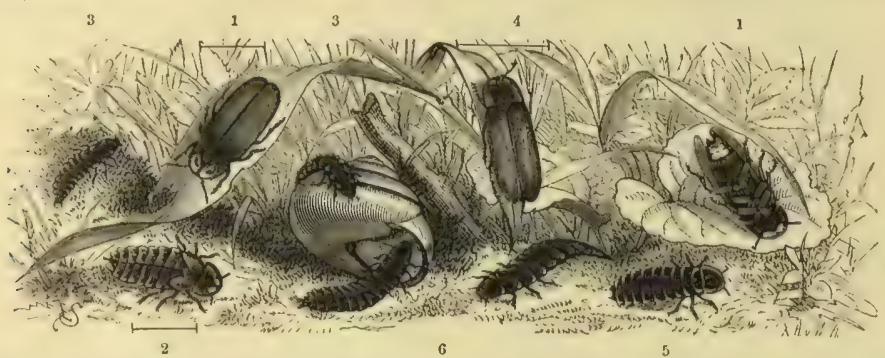

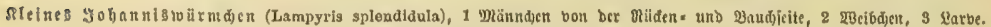

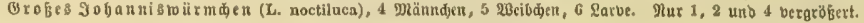

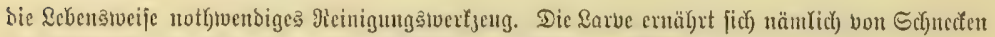

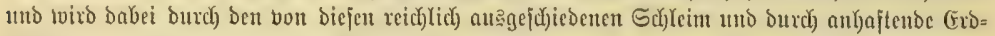

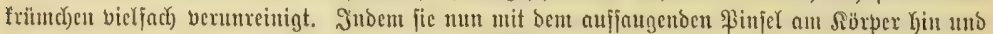

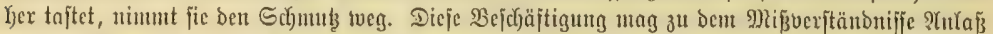

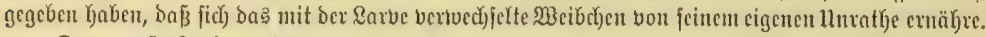

Dnక grofie Jol)an

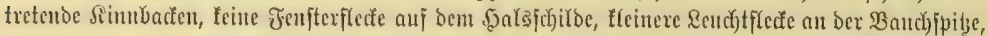

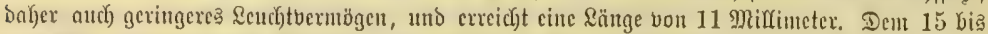

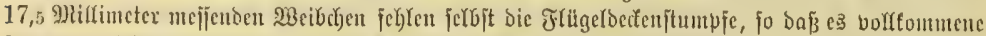

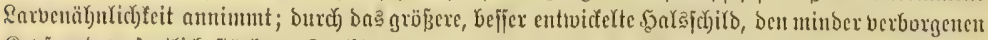

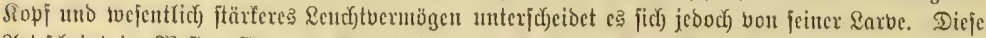

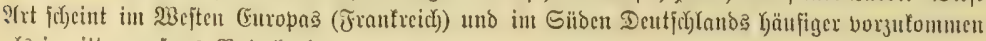

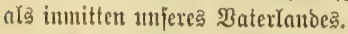

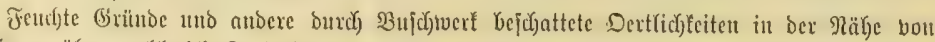

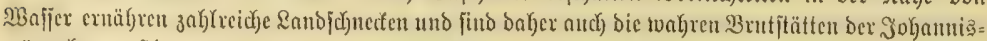

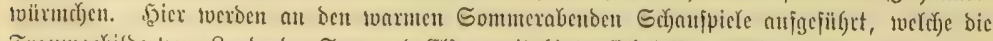

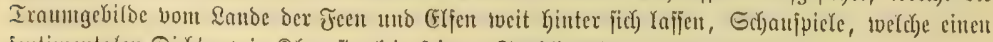

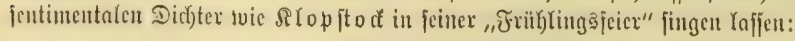

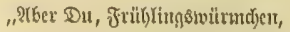

Das̉ grïnlidjgolben neben mir fpicht,

Du Yebft uno bift biefteidjt,

2(d), nid)t unpletbfic)!

- - - -

- - - Ydi Yerne bann,

Dr cine Seele bas gotoene 28 ünndjen hatte". 


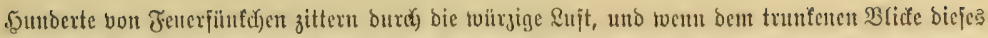

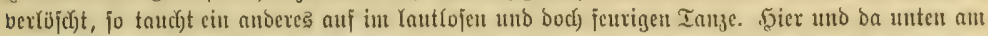

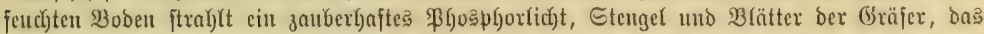

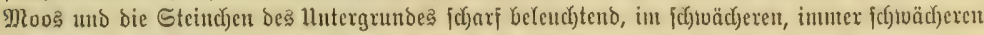

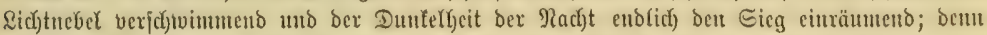

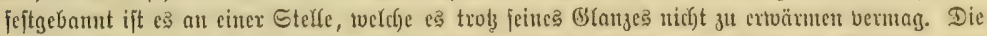

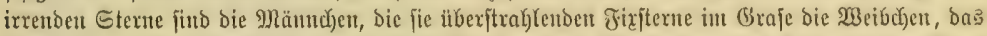

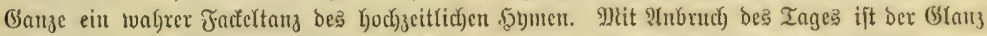

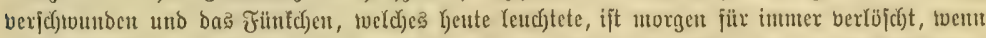

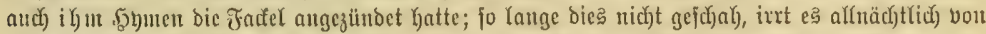

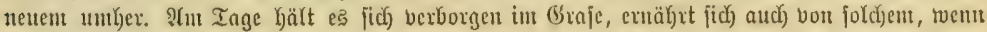

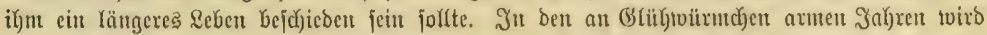

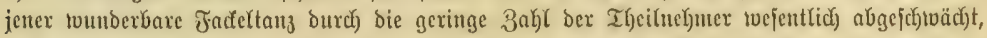

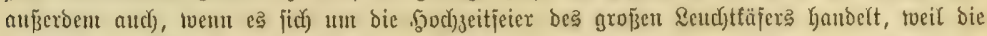

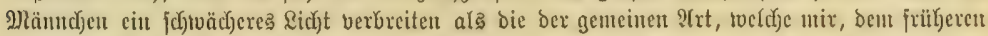

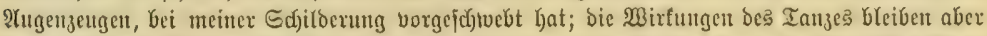

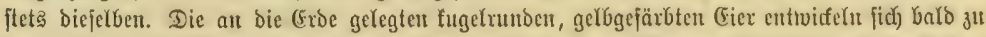
ben uns bereit befannt getvorbenen Rarven, weld)e iu ertwad)jeneren 3uịtanbe nad) ber lleber=

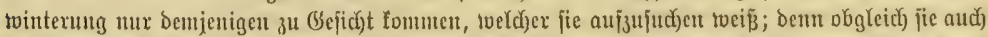

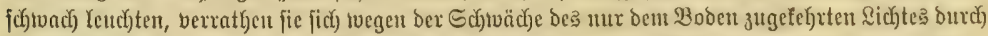

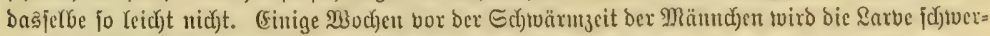

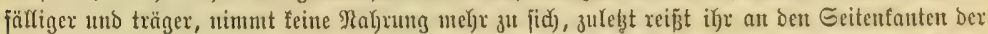

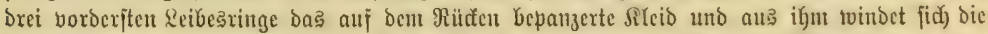

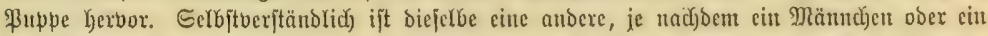

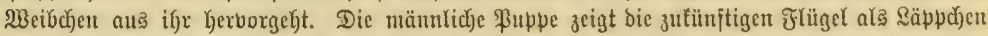

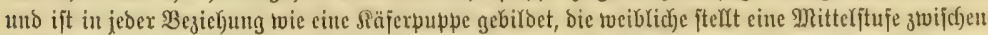

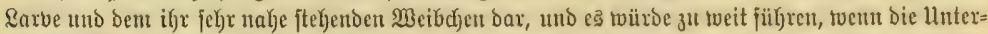

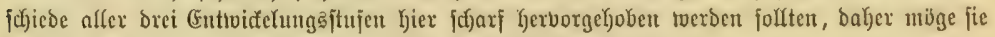
fux als eine twenig eingefrumute, rubento হarbe begeidjuet toeroen.

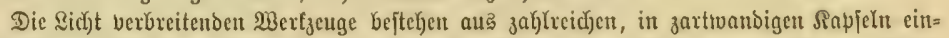

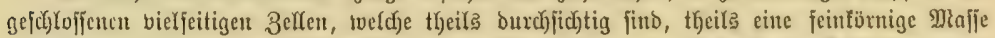

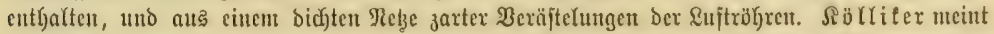

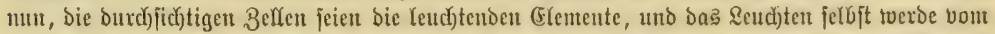

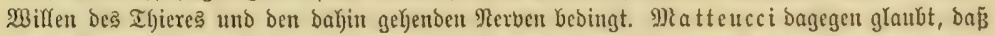

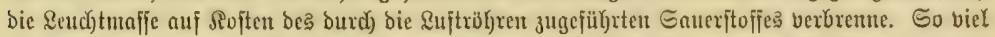

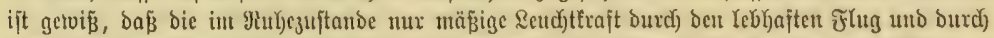

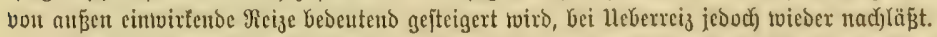

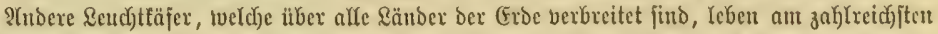

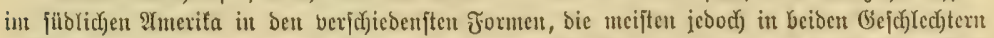

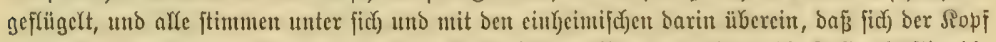

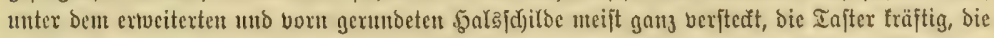

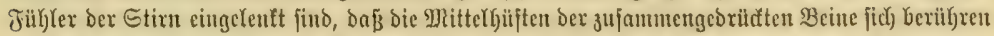

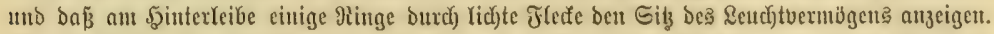

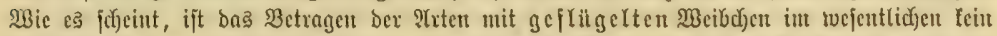

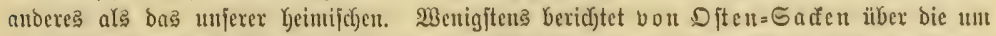
Waffington gemeinjte STt, bie Lightning bug (Photinus pyralis) ungefähr in folgen๖er Weife:

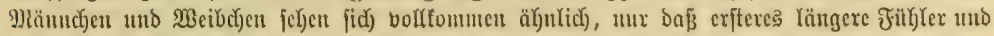

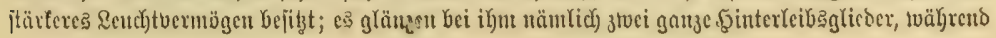




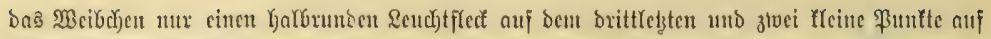

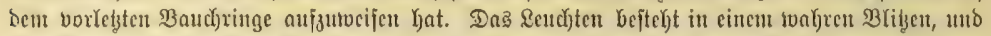

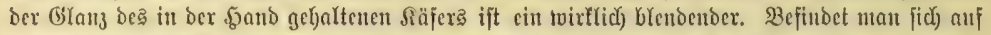

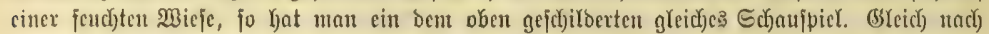

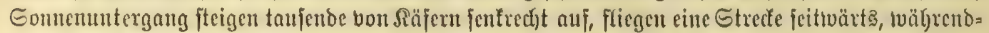

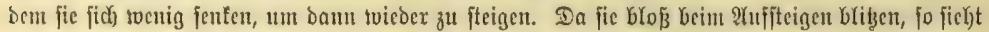

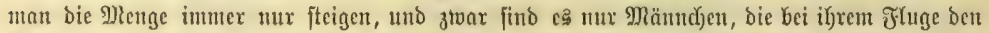

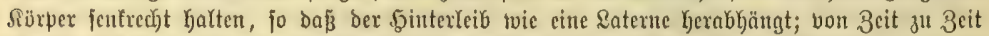

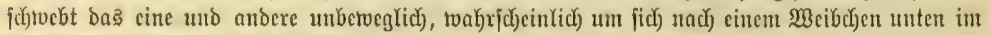

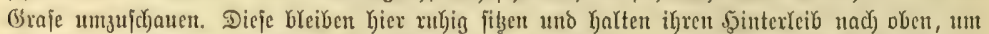

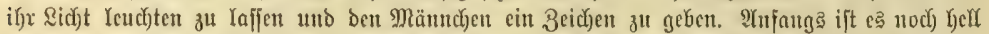

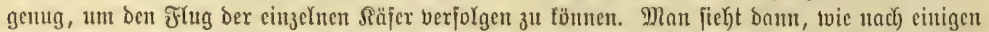

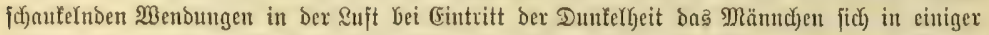

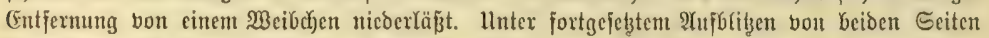

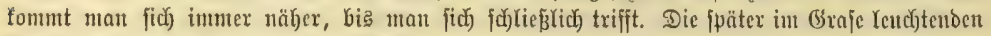

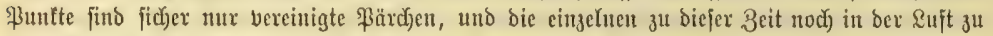

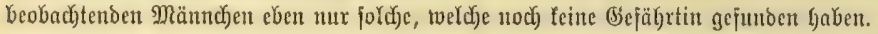

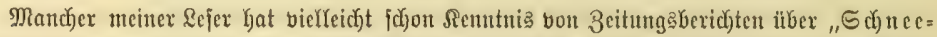

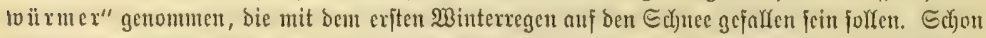

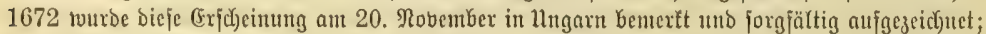

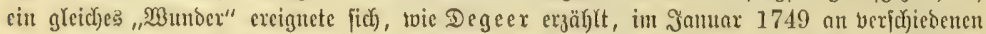

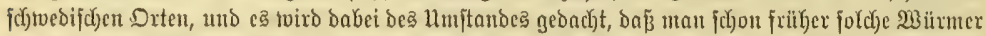

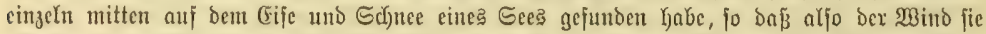

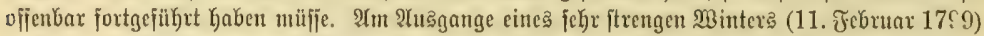

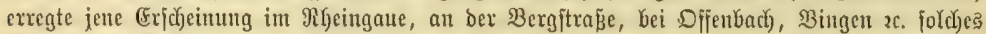

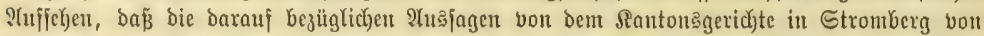

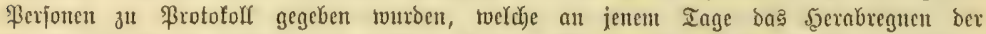

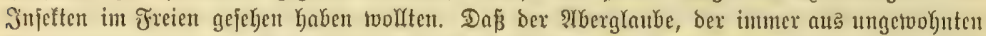

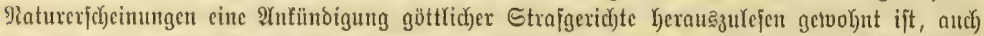

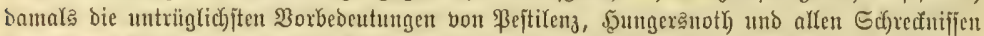

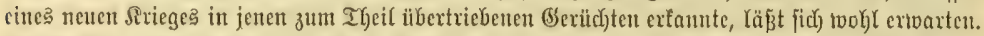

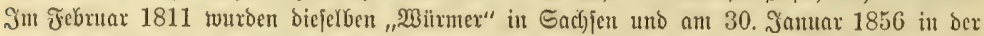

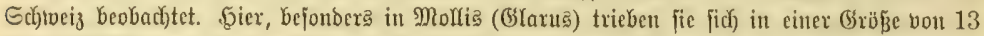

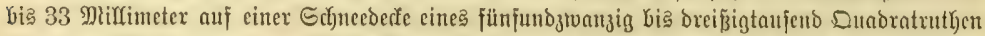

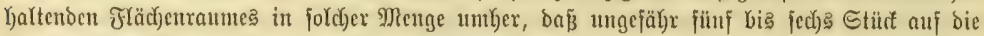

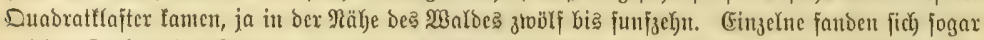

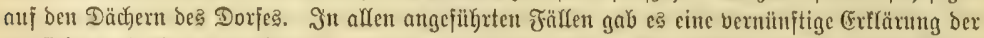

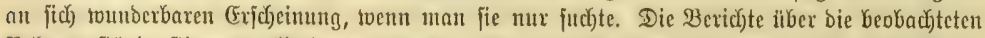

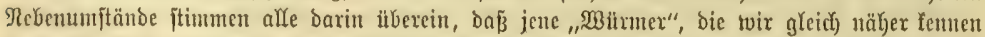
lemen toeroen, uno bon benen zunäd)ft bentertt jein mag, baß̃ fie unter Stcinen, Laub ober an

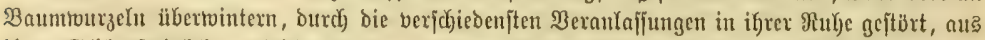

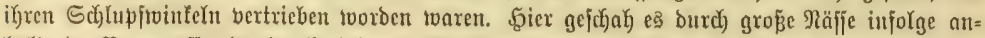

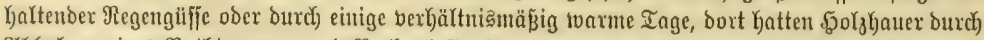

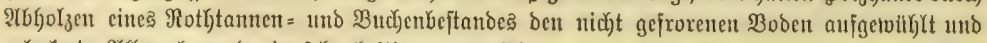
gelocfert. Anfemal ward ein fefyr heitiger, zum Iheil orfanartiger Gturm beobachtet, ber biefe Ifierchen mit noch) manchen anderen ebenjo Yebenden und in jenen Berid)ten thei(tweije nuth nam=

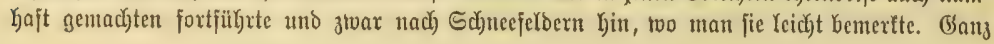




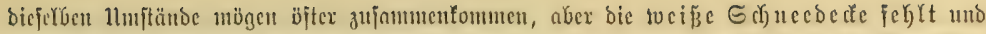

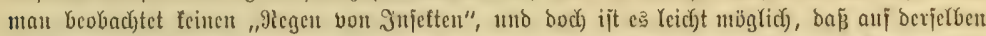

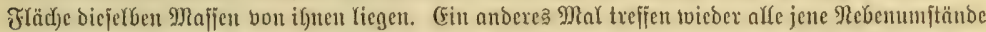

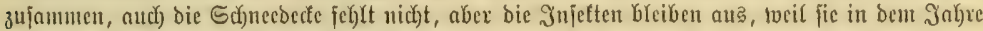

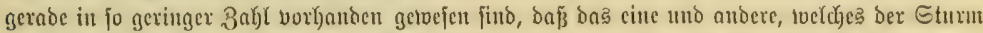
vor fick Gerjagte, unbeuterft bleibt. Das $\mathfrak{W u n d e r}$ ift aljo getöft und ber natürlicke 3 ufammen= bang aufgetlärt.

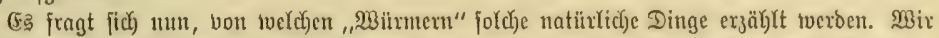

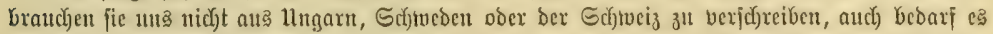

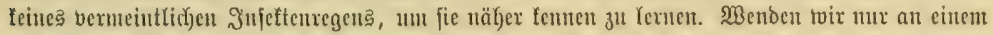

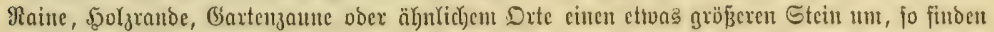
ivir im Winter unter anderen in ciner runden Grube, mit etruas (Eroe bedectt, in Kalomonoförmiger

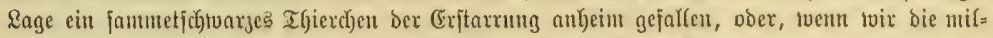

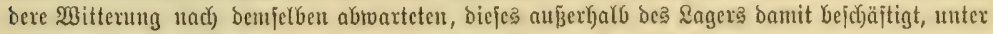

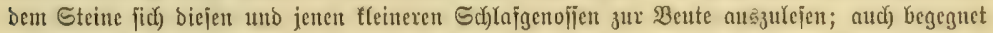

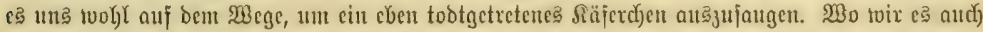
antreffen miögen, intuer extemen roir es gleich) vor ben anberen burch) bent bunfeln, fammetartigen

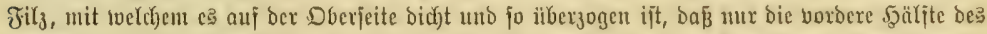
Sopfes frei breibt. Derfelbe ift platt, hornig, hat zroei \$lugen, cin \$aar furze, drciglieberige

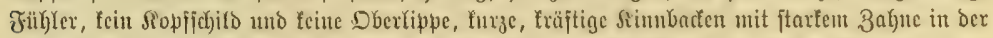

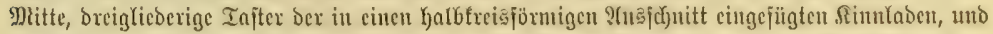

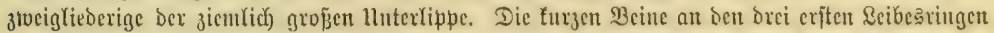

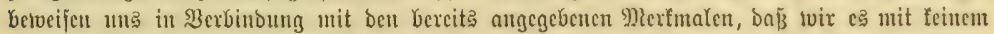

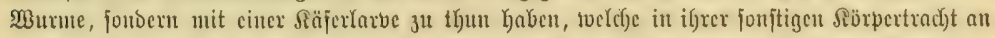

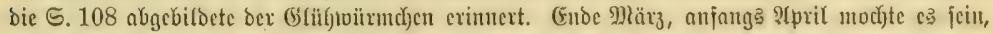

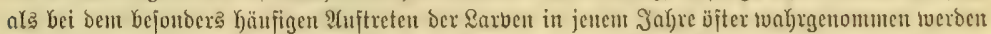

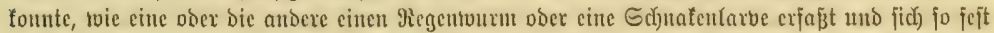

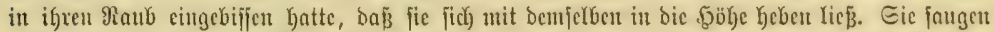

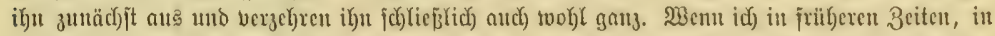

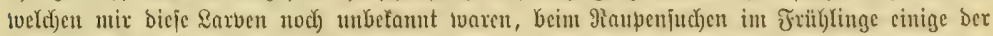

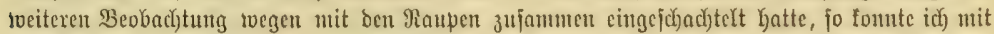

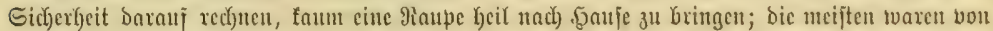

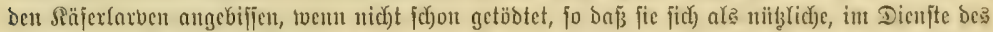

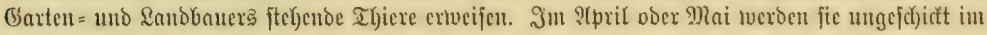

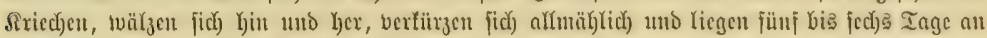

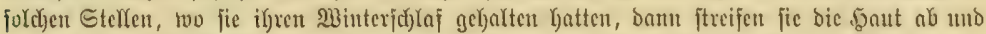

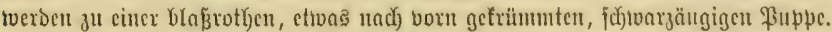

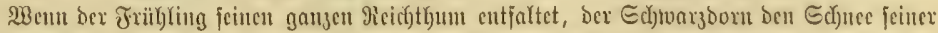

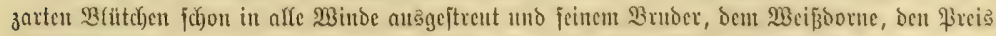

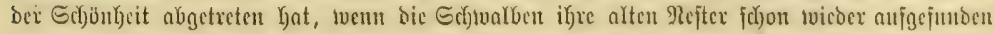

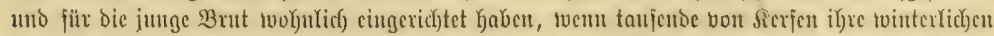

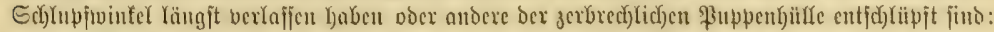

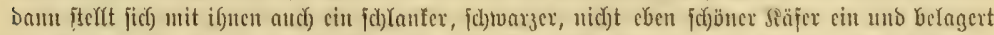

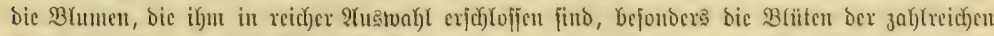

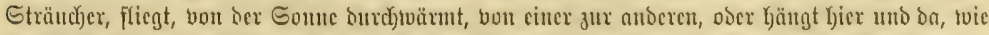

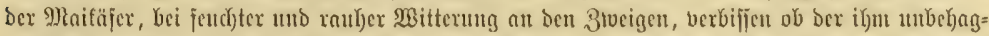

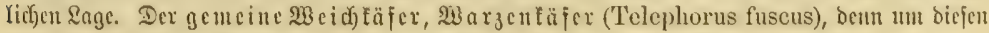

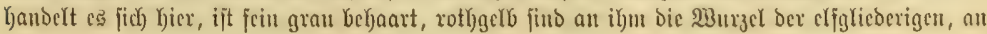




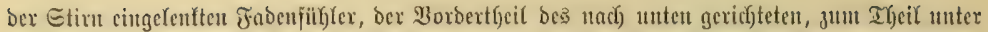

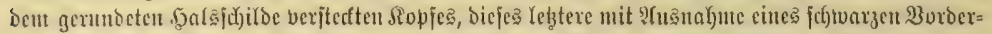

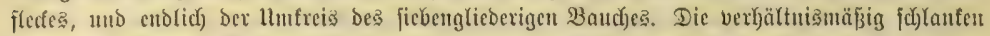

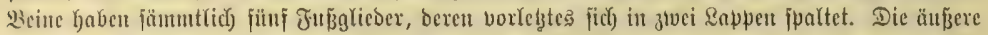

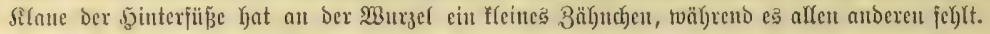

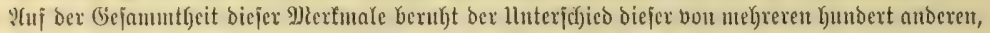

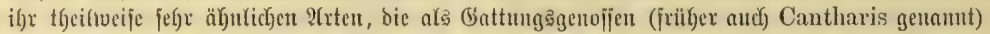

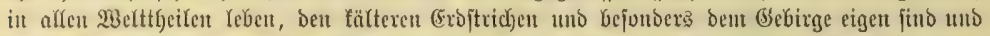

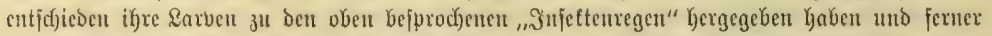

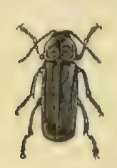

200 a rentiafer (Telephorus fus (11s), (d)Ivad) bet Bröicrt.

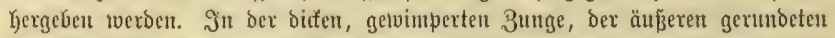

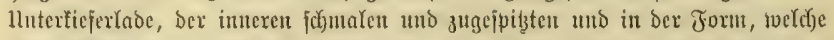

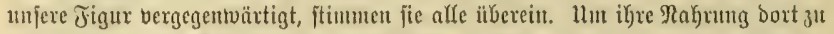

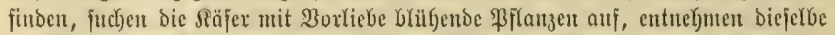

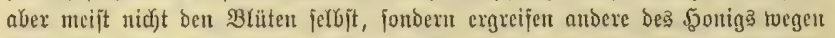

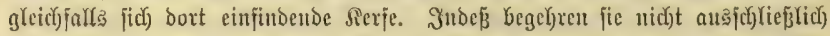

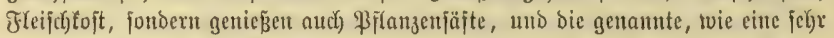

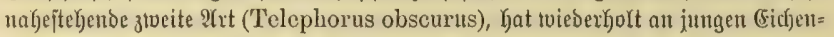

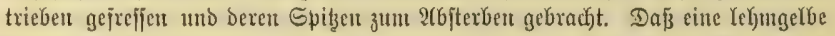

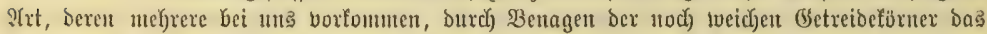

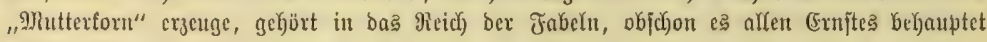
tworden ift.

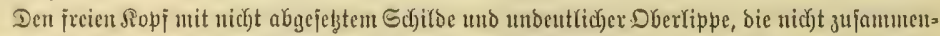

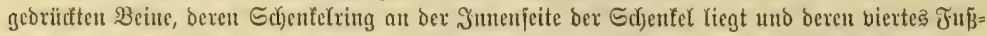

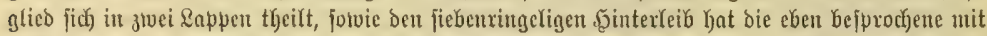
noch) anberen, borzugstweife in 2(merifa heimatenden (Santtungen gemein, weshalb nan biefe affe 3u Der Sippe ber Ielephoribent bereinigt hat.

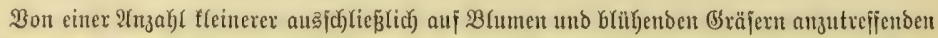

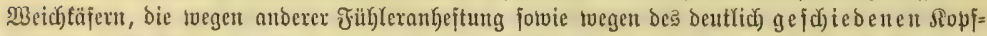

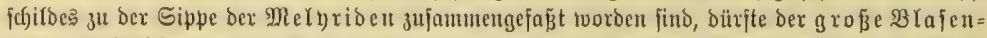

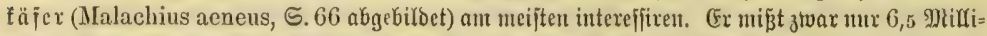

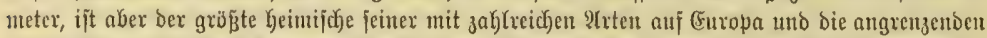

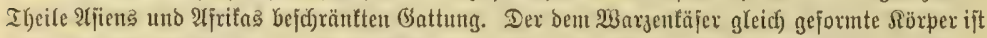

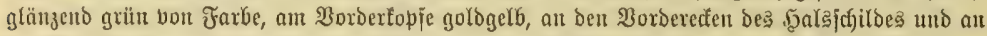

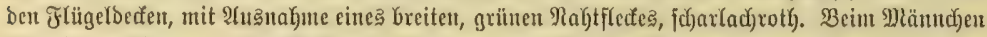

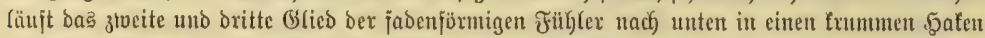
aus; bieje fitzen z wif

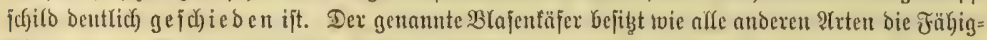

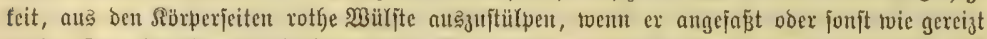

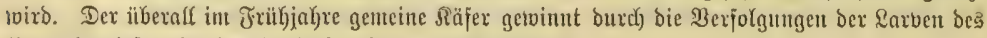

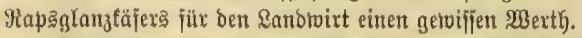

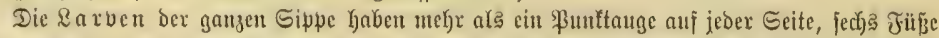

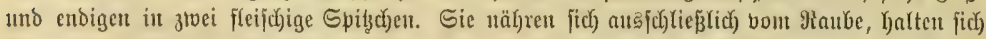

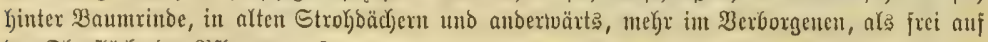
Der Dberflädye ber \$flanzen auf. 


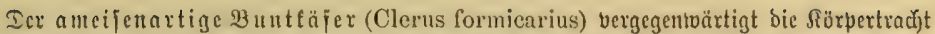

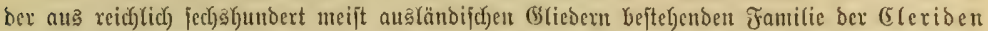
(Cleridae); fie finden fidf fajt afle an altem .jolgtoerfe uno leben gleid) ifren Rarven vom Raube. Der genannte Buntfäfer zeigt fich Yäufig it Mabeltuäldern, Gejonders an abgejchlagenen ober

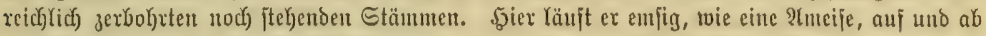

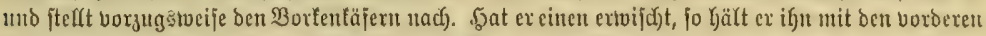

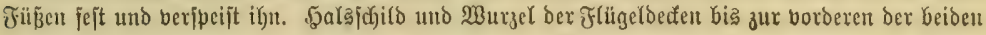

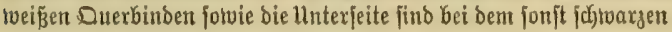
Säjer roth gefärbt. Die nałe an Gundert, jämmtlich buntell uno auf Der ganzen (Eroe berbreiteten 2rten Kaben ała gemeinjame IJerfmałe cine jweilappige 3unge, ein groß̧es, quer beilförmiges (Enoglieo ber \&ippentajtex, eit vierectiges Sinn, ausgeranbete Dbexlippe uno 2tugen, bas jechjte bis adjte Brleb ber Fübler fürzer als bie bor"

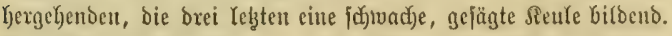

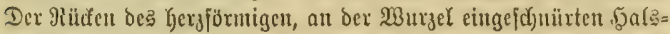

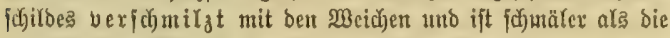

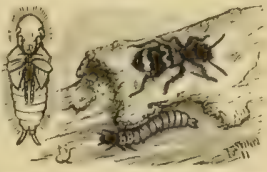

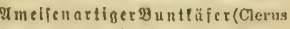
formicarius) webit Saroe uno \$uppe. alle: vergröbert.

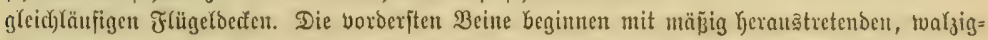

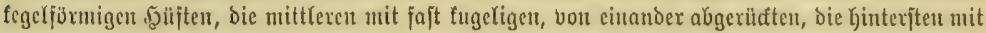

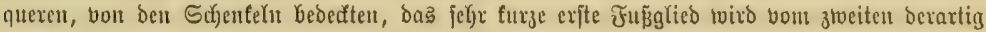

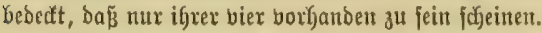

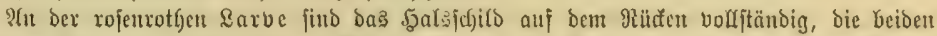

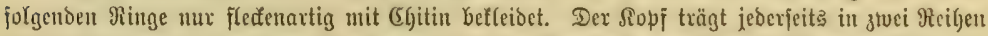

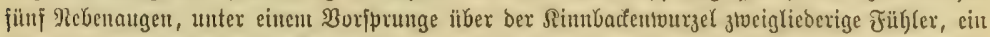
f(6)maleả, pergamentartiges Sopfidjilo, eine vorgeftrefte, born gebudjtete Dberlippe, furze, orei= glieberige Riefertafter uno ziveiglicberige Rippentafter auf hornigen, an ber Wurzel vertwachjenen

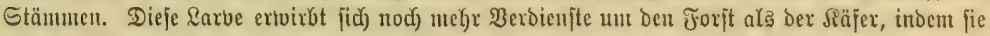

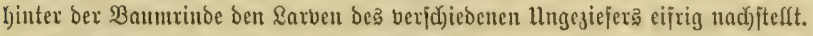

Sräftiger, fonjt aber bou benfelben alfgemeinen Baute, gejtalten fid) bie Jmutenfäfer

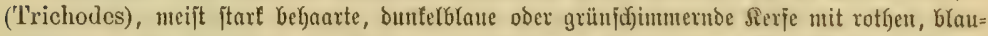
gebälberten oder umgefelynt mit Glnuen, rothgebänberten Frügeldeden. Jgre Dberlippe ijt jajt vierestig, ber Dberfiefer an ber Epitze breizägnig, Der lluterfiefer aus zrvei gejranjten \&appen uno

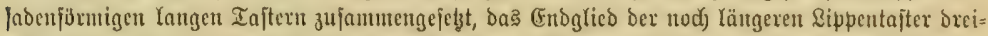

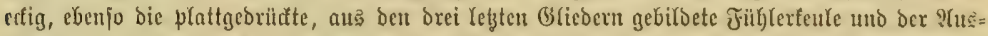

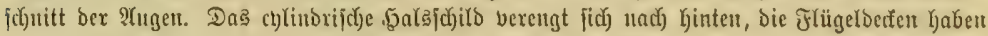

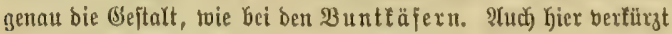

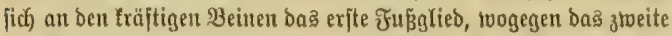
bex Jinterbeine eine Yange Warze barftelft. Daș Siertelfundert

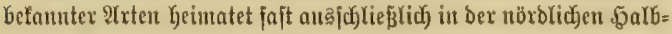
fuger; jie fteffen fich ouf $\mathfrak{B}$ (umen ein, bejonders ben Dolben und Spixjtanben, un Jago auf andere S̈njeften zu madjen.

Der gemeine J゙mmenfäfex (Trichodes apiarius), von

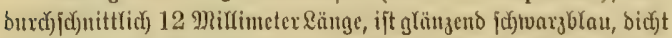
punftirt und raubyaarig; bie grob punftirten Flïgeldedent ertveitern

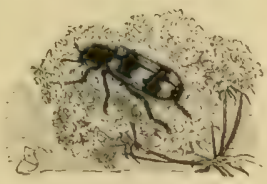

马umentäfer (Trlehodes aplarius), vergrȫct.

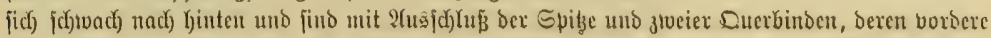

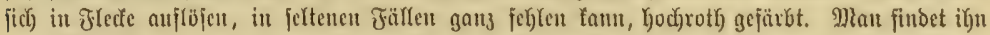

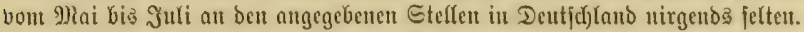

Dic \&aruc gleicht ocr beß Buntfäjers ungemein, ift utr etwas gebrungencr, nad) hinten

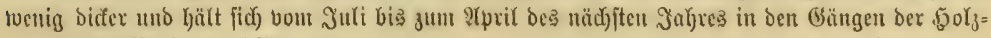




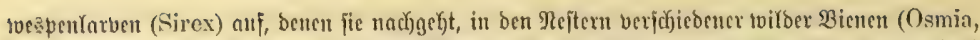
Megachile), aber auch in betten ber \$onigbiene, too fie \&nrven, \$uppen uno Kerabgetoorjene, balb

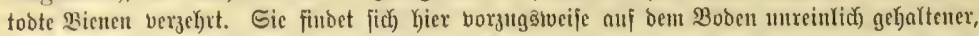

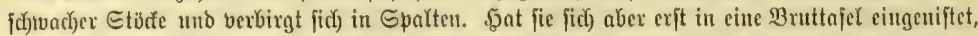

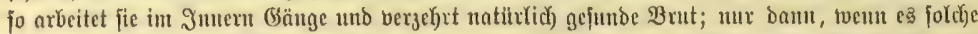

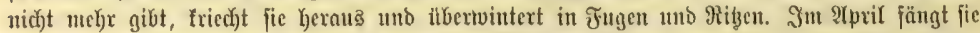

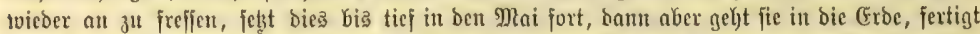
cine 5öblung, toetche fie austapejiert, und wird in brei bis vicr Iagen zu ciner mit ber oben

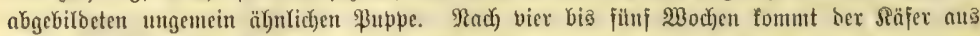

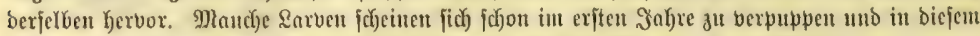

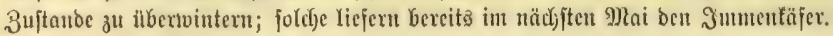

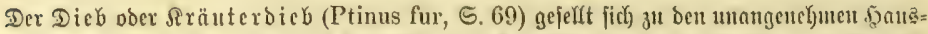

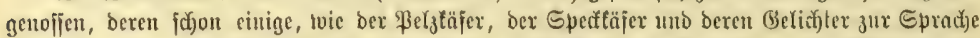

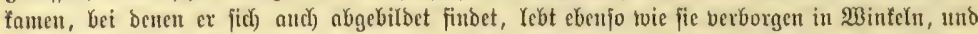

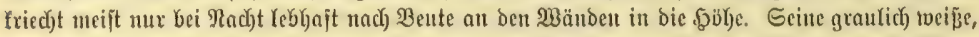

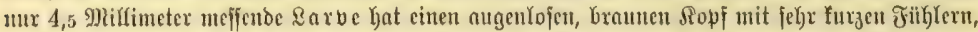

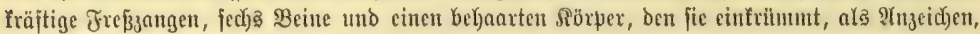

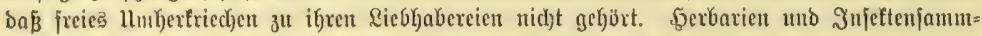

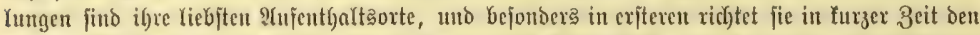

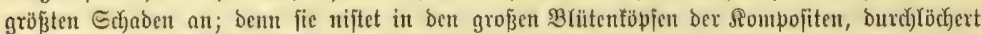

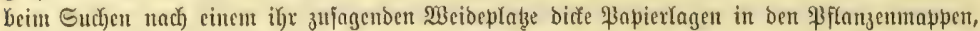

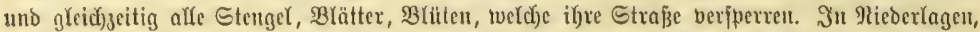

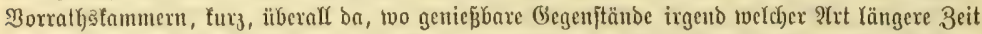

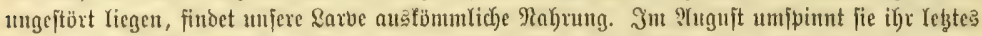

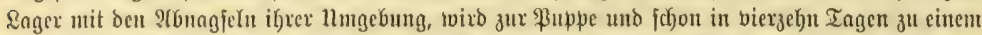

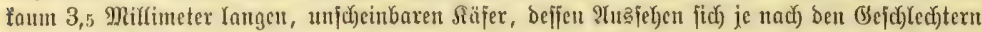

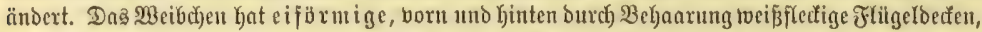

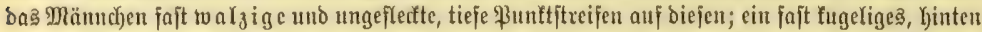

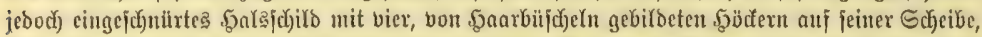

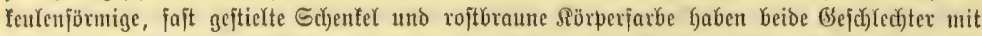
cinander gemein und unterjcheiben fie bon anderen Rrten. Die Gattung Ptinus (Bobrtäfer) viro crfannt an ben eingezogenen Ropje, den genäberten, fasenförmigen, bont vierten (Blicbe an

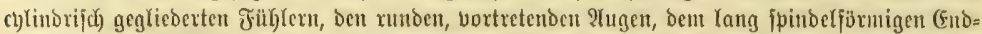

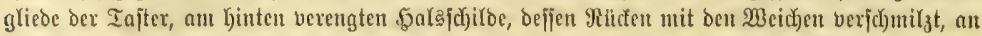

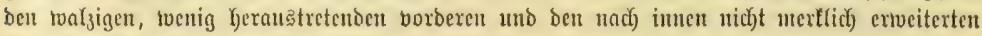
Ginterften Ðुüjten.

\$in uno twieber zeigen fid in ben menf(d)

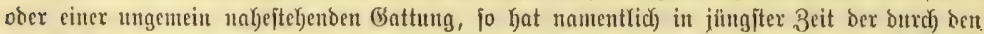

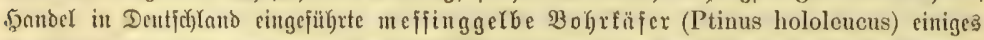

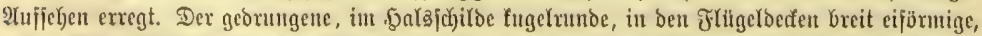

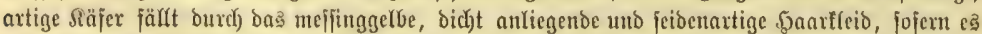

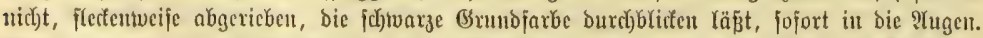
Wegen bes georungenen Bane ftumpi ift, toäfreno jene ganzrandig, diejer jpiłz bei Ptinus ift, hat ntan unjeren Säfer einer bejon=

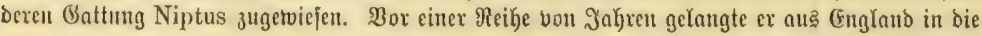




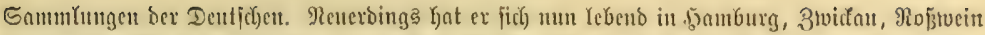

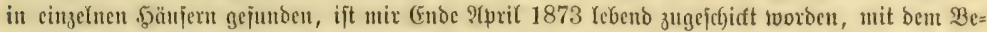

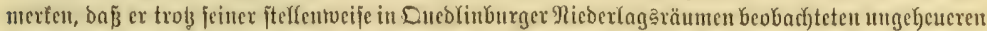

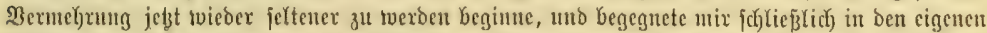

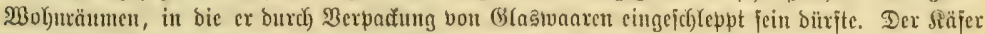

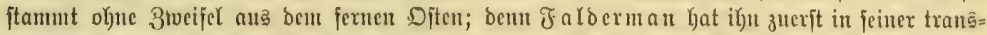

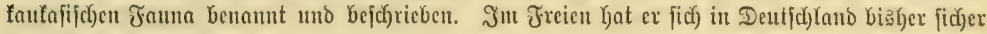
nud) nicht portgepflanzt.

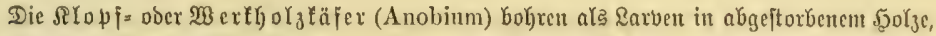

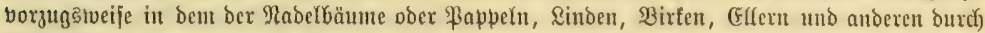

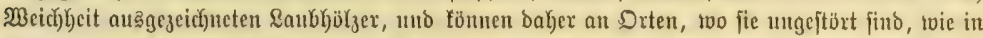

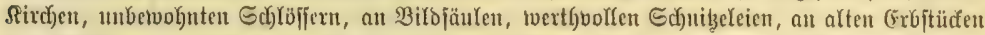

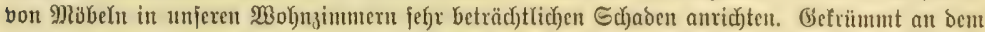

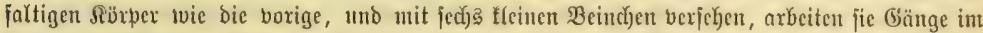

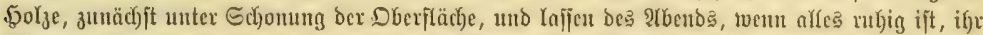

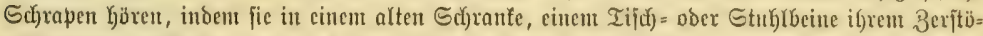

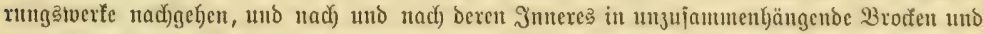

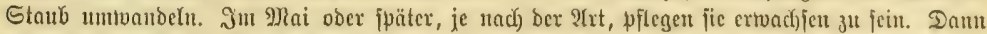

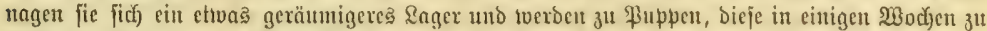

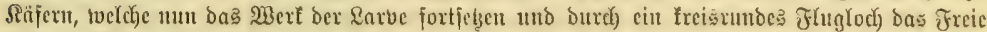

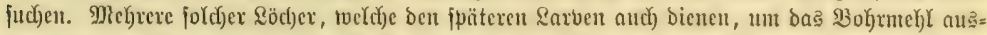

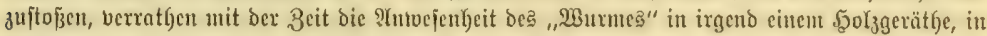

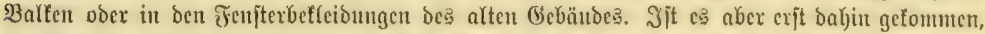

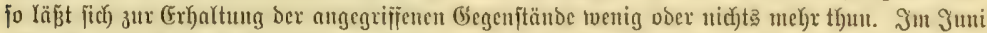

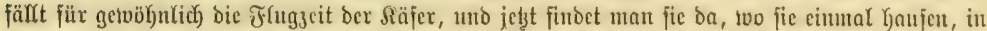

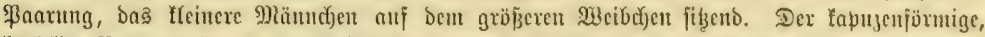

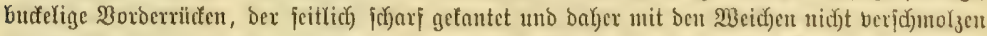

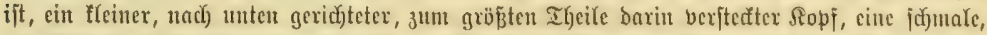

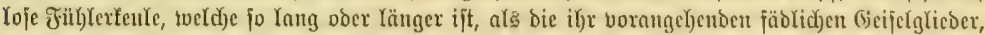

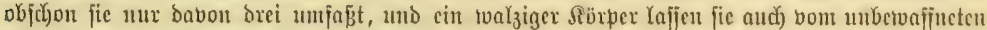
शluge erfenmen. Das (Enoglied ber Rippentafter ertucitert fich) uno ijt geftudzt, bie Epitze ber Simu=

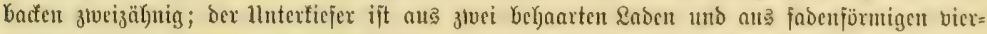

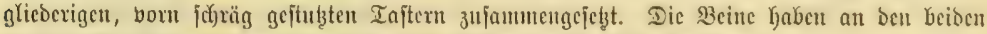

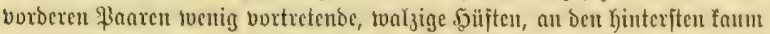

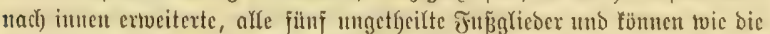

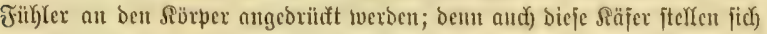

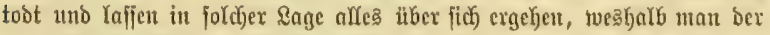

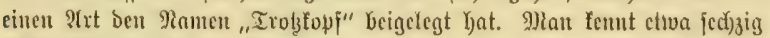
2Trten, Deren Ђälfte in (5uropa Geimatet.

Der Gunte Rlopffäfer (Anobium tessellatum) ijt ber größte von

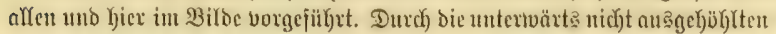

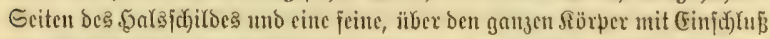

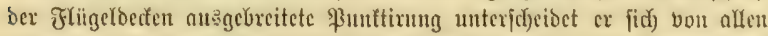

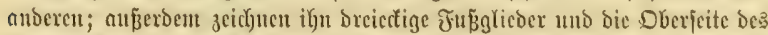

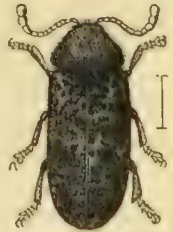

$B^{3}$ unter $S$ I opfläfer Anobium te'ssellatumi), verntö̈́žt.

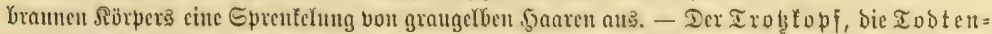

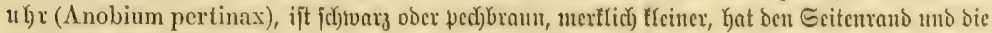

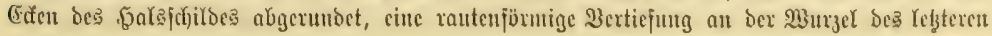




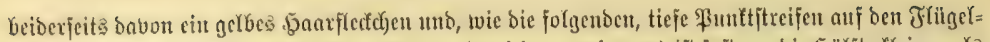

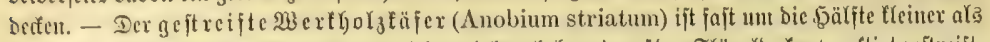

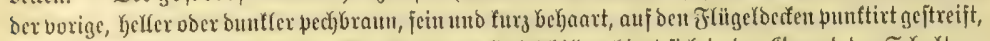

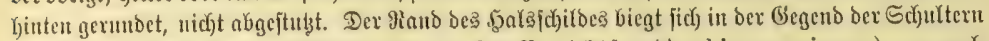

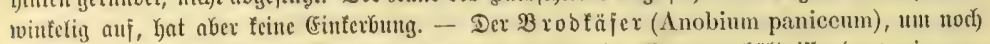

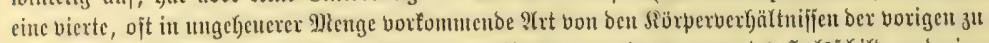

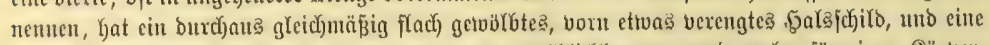

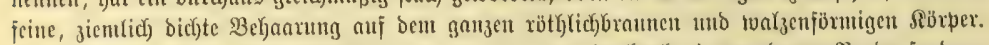

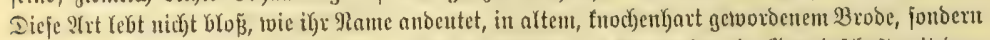

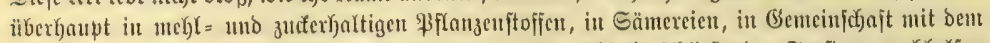

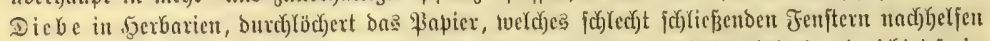

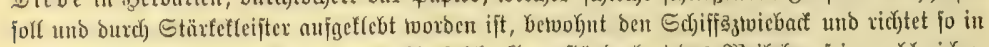

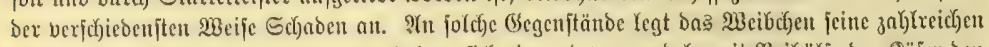

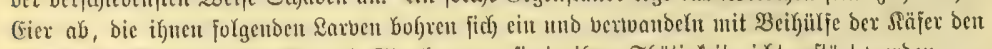
betreffenden Jiörper in Broden un Stanb, twenn fie in ifyer Tgätigfeit nidgt gejtört twerden.

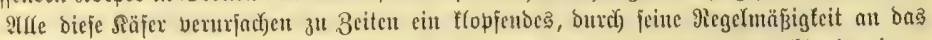

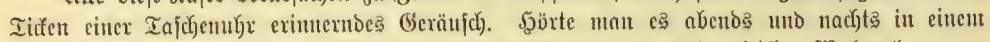

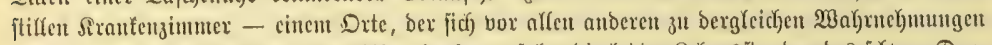

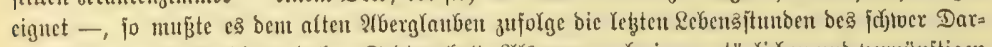

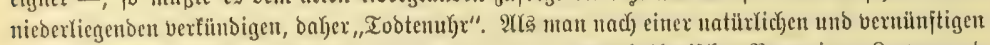

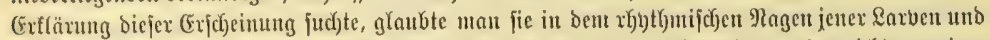

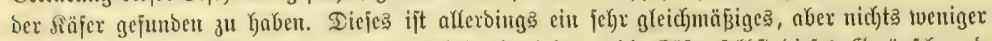

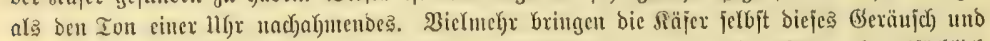

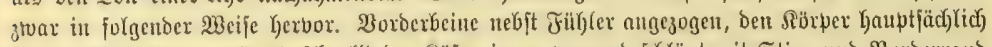

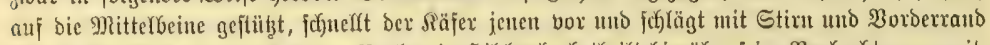

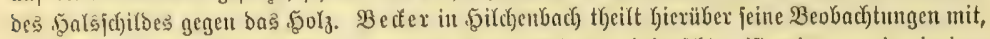

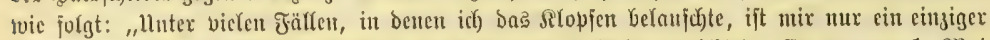

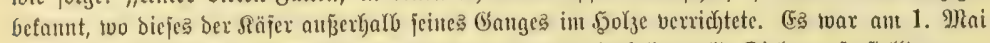

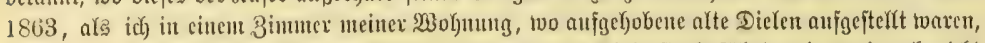

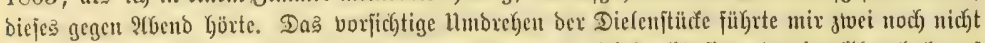

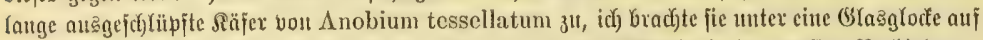

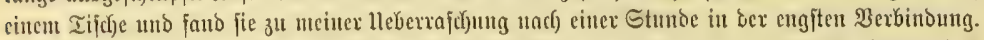
श(

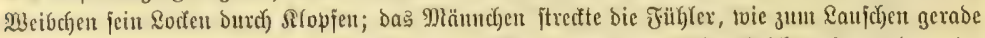

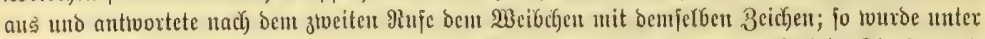

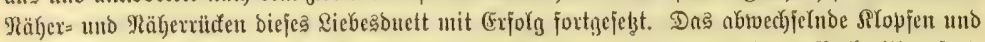

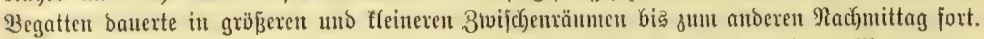

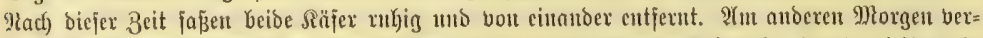

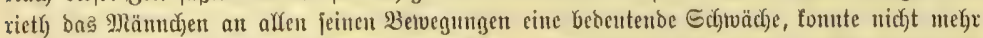

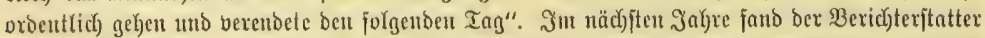

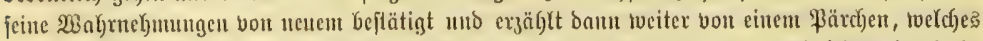

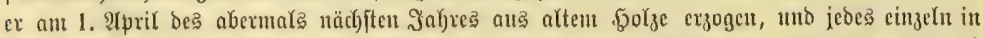

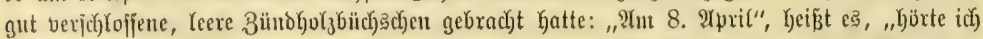

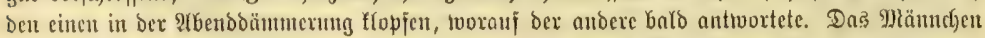

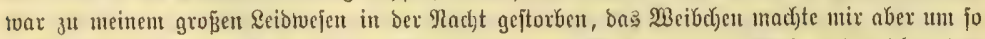

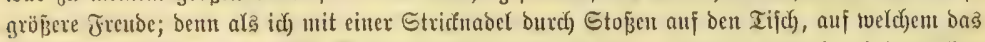
Э̧ücf)

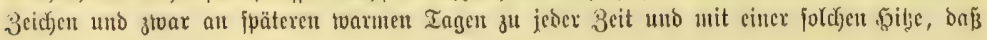




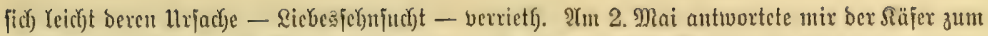

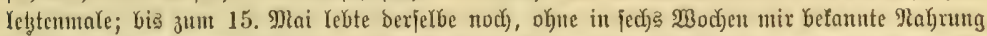

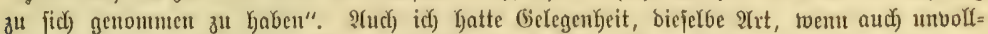

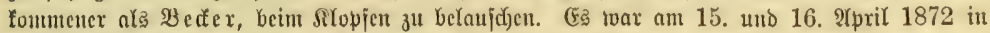

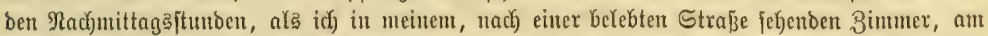

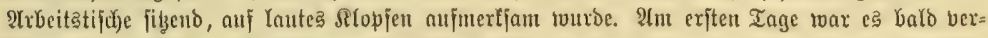

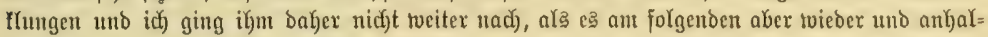

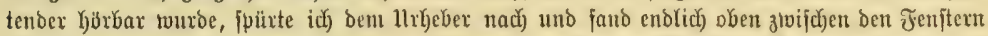

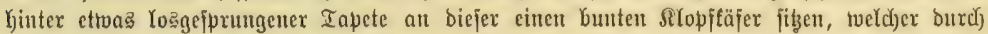
Etopen an bas fteife und jedernde ßapier ein befonders Yautes Geräufch hervorgebracht hatte.

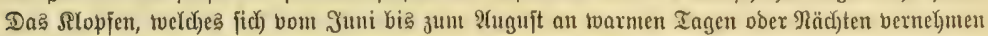

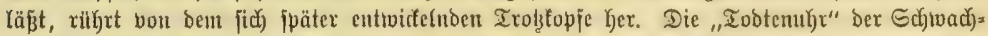

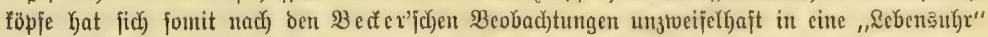

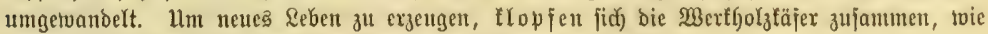

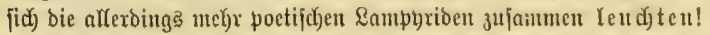

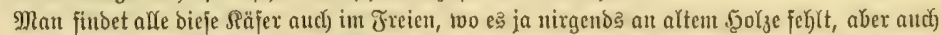

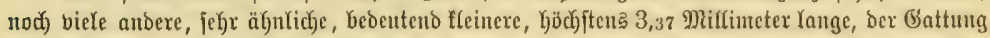

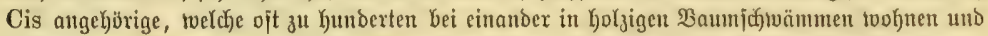
barin ebento bohyren, wie bie bejprod)enen im solze. Sacorbaire soeijt fie mit nod) mebreren anderen Gsattungen einer befonderen Familie ju, Iväl)rend tvix es vorzogen, fie mit ben vorigen

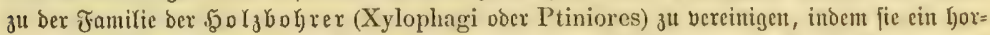

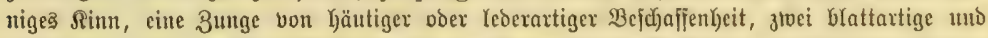
getvimperte Raben, meift elfglieberige, box ben Hugen eingelentte Jüh)er, tvarzige ober fugelige

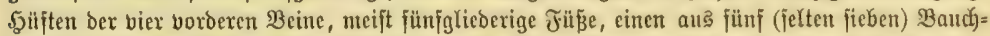

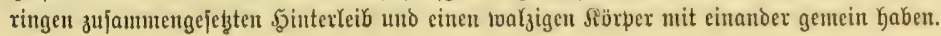

Mit ber Familie ber Gchtwarzfäfex ober Tenebrioniben (Melasomata, Tenebrio-

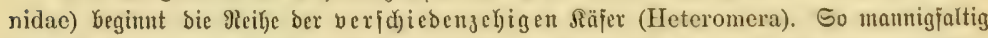

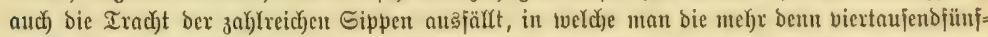

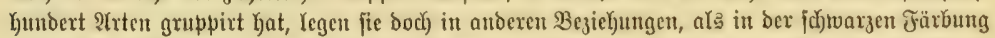

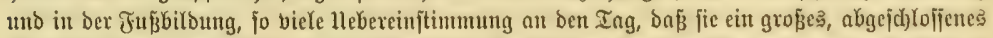

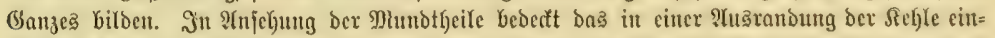

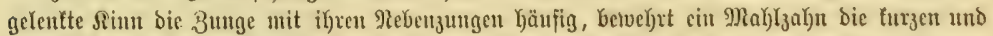
fräjtigen Rimbarfen an Grunde, ijt von ben beioen Rappen bes 11 nterfiefers ber innere fleinere

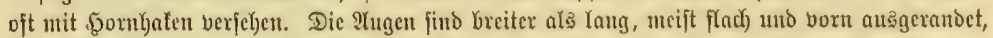
bie Fïb)

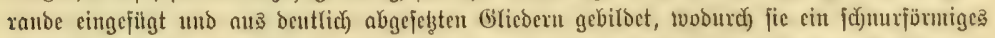

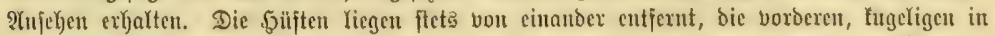

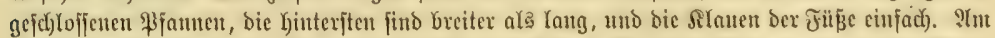

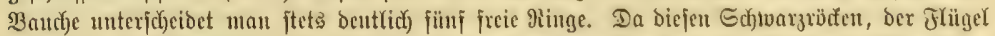

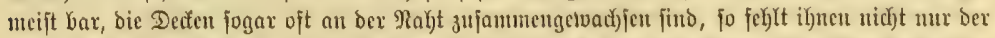

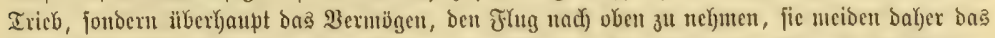

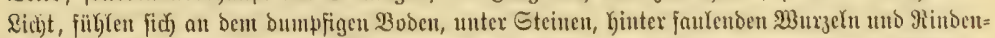

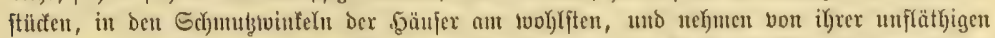

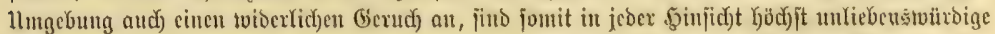

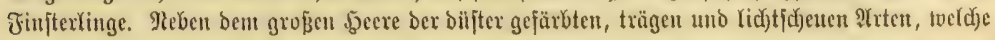




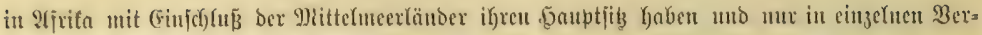

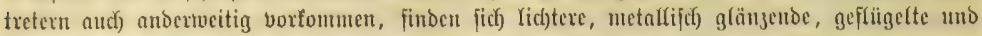

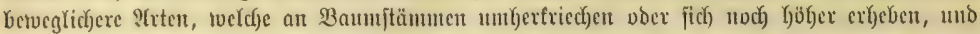

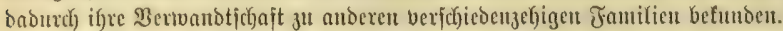

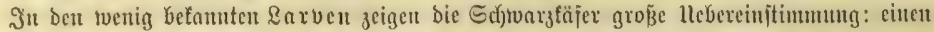

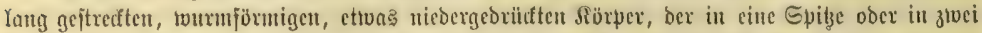

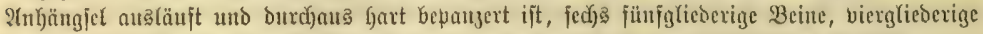

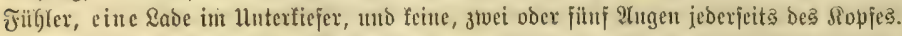

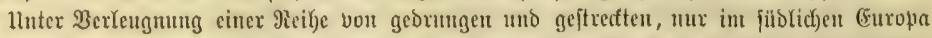

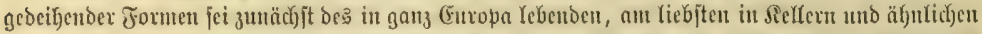

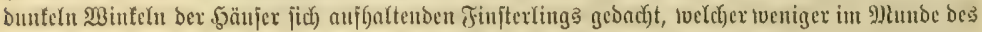

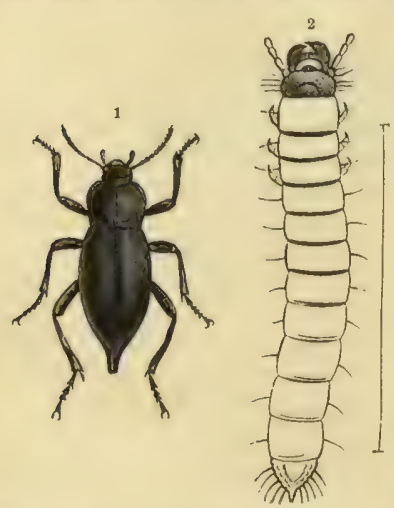

1 Ucmeincr $\approx$ xaucrläfer (Blaps mortisaga), 2 garbc vol Blajs jroducta; beibe bergrö̈

Boltes, als it der Edfriftjprad)e unter bem Stanen beș genteineu Irauerfäjers ober Tootentäfers (Blaps mortisaga) jein erbäruliçę Dajein jrijtet. Fuch Moufet ertäbnt ifn neben ben Sojaben uto nteint, er würoe getviß̄ unbefannt geblteben jein, เoenn

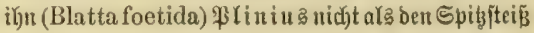
näher bezeichnet Gätte, ba ex ołne bieje (cigenjidyajt mit anderen, namentlidj piffentorehenden siäjern leiḑt ver=

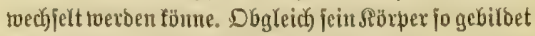

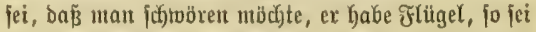

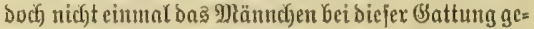

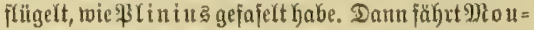
fet port: „(Fr Yebt in Sellerm und ijt Gajtfreuno ber

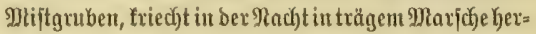
bor, fehrt aber beim Leifejten Inzeichen von Sicht ober Der menfidjlichen Stimme in bie Finfternis zurülit; it Mahrbeit ein jufambajtes und int höbjiften Grabe

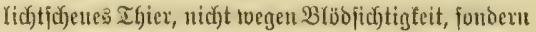

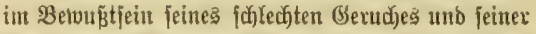

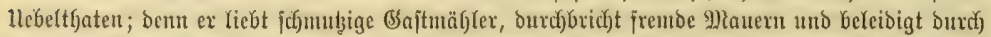

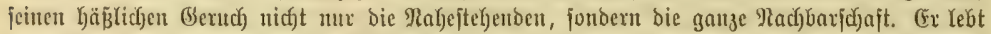

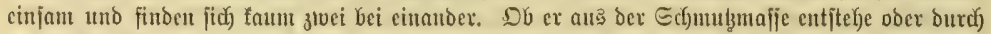

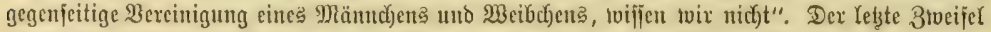

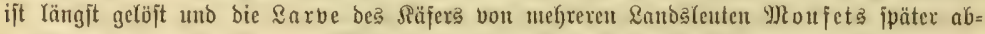

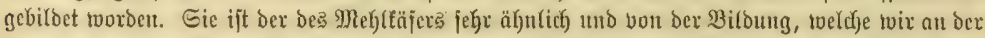
fier gegebenen des Blaps producta erfenten. İm übrigen übertreibt Rou

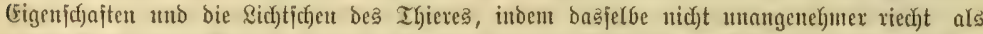

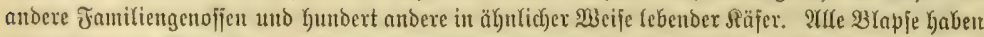

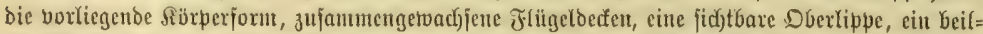
förmiges Endglieo ber Riejertajter, cine unter Der rautenförmigen Sinnplatte berftecfte 3urge, an

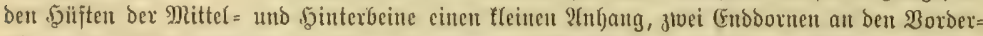

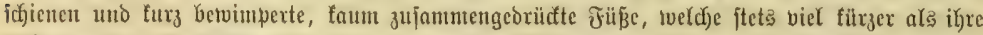

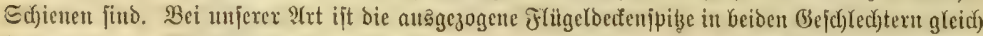

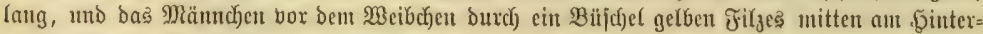
ranbe bes erjten $\mathfrak{B a u t}$ juringes auzagezeichnet.

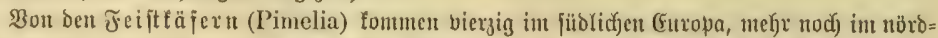

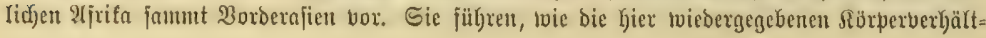




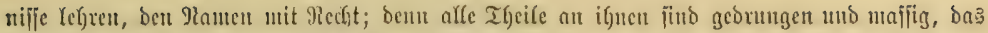

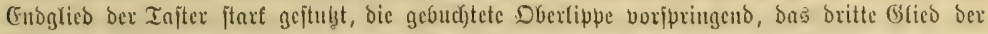

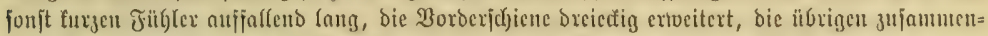

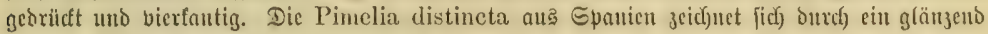

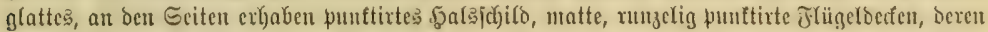

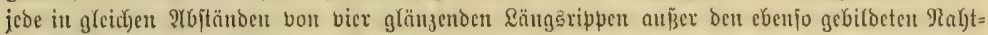

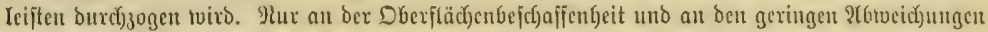

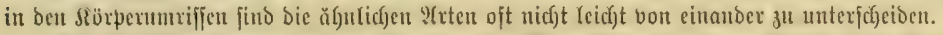

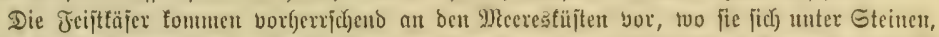

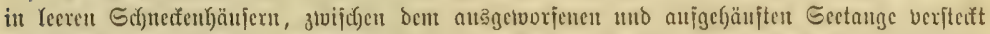

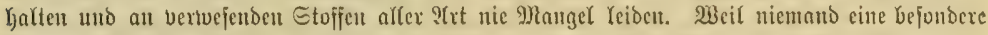

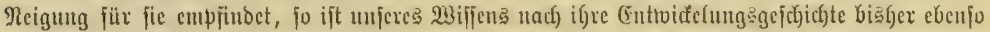

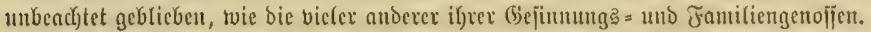

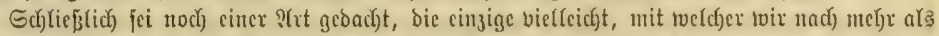

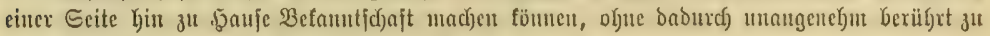

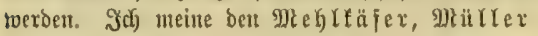
(Tenebrio molitor). Der vififenjidajtlid)e Grat= turgsnante ift auf bic gange Familie übertragen toorden, nidyt als ob ber siäfer biejelbe am bejten vergegentoärtigte, fonbern fichyer nur barum, tweil man feime verbreitetfte Befanntjchajt borausgejetyt yat. Die beutjichen Benennungen benten nuj feinen Ilufenthalt uno jeinc Beburtâjtätte, beneu zujorge toir uns nid̆t roundern bürfen, vorübergehent eine fciner brauner Flügelocfent oder lleberrejte feine magexen Sörpers, bielleid)t aud jeine Sarbe in
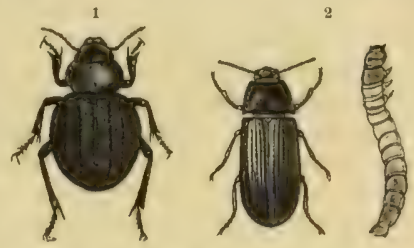

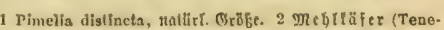
brio nolitor) uno feine ミacue; beibe bergröbert.

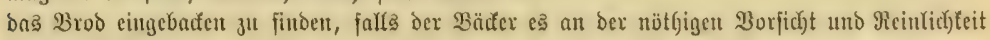
Gat feblen rafjen.

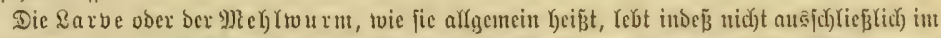

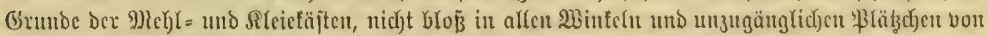

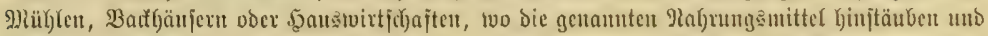

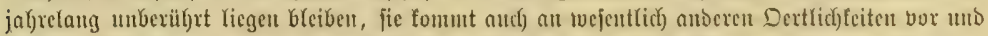

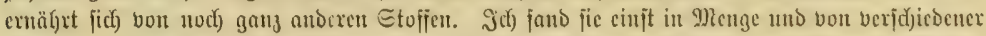

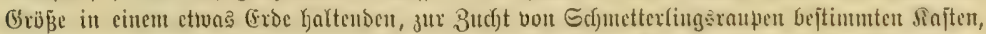

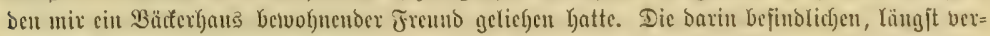

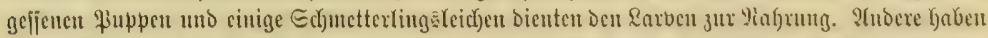

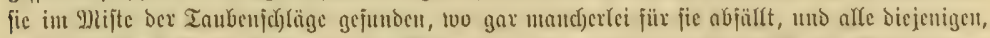

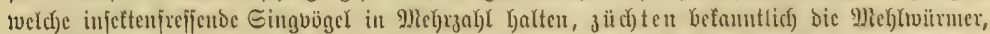

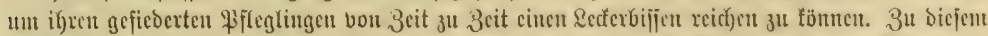
3)

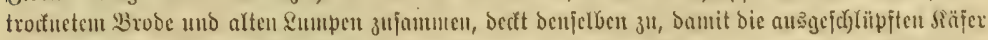

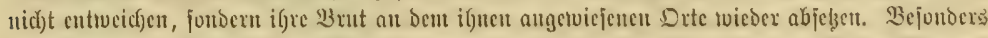

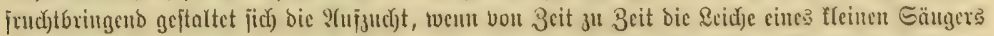

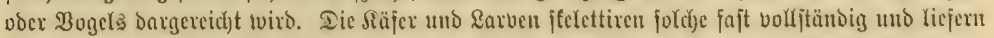

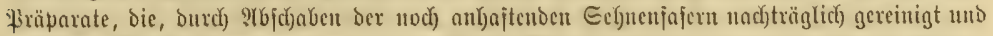

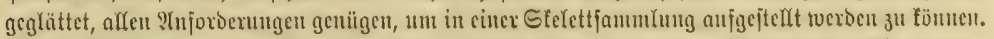

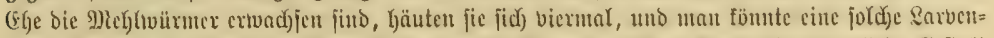

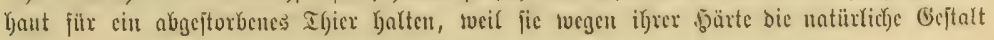




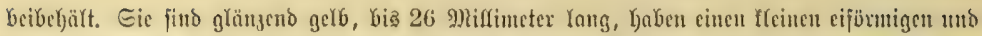

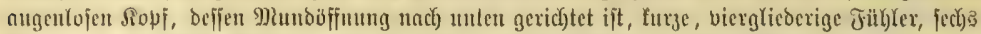

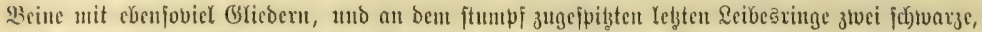

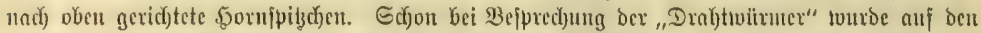

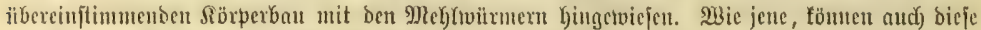

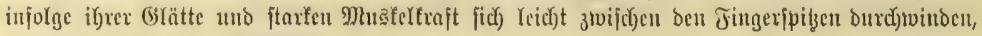
twenn man fite nidjt recht fejtbält.

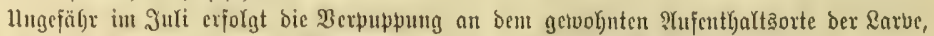

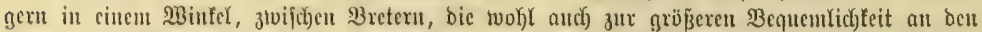

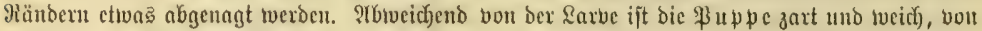

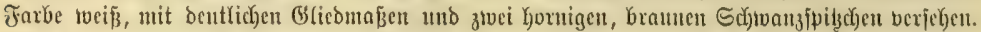

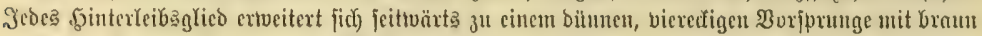

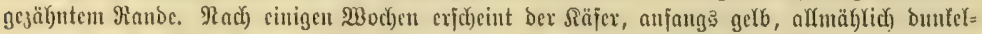

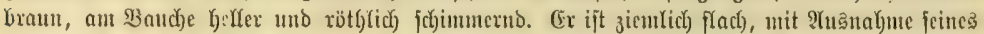

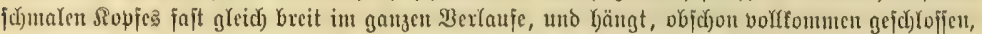

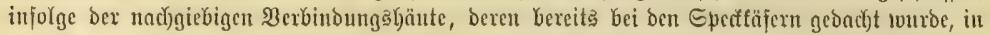
Den brei Şaupttheilen Yoje зufanmten. Der platte, born gerunocte Sopj fteht gerabe vor uno trägt an feinen Scitentänoern bie eljglieberigen, fămmrjörmigen, nach) ber Spizze f(h)ivad) verbictten

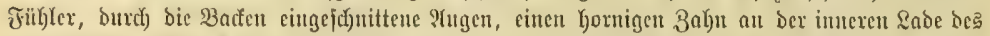

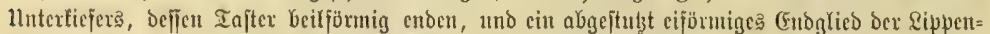

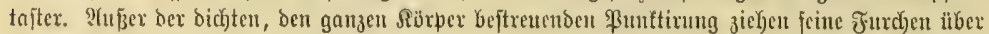

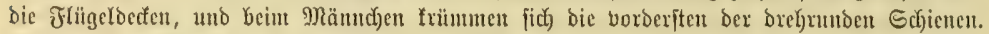

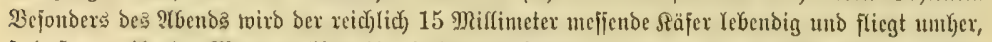

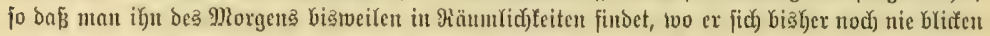

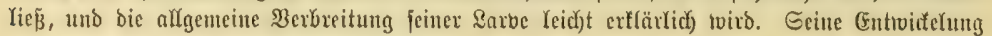

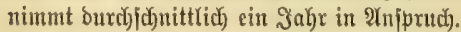

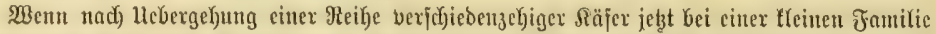

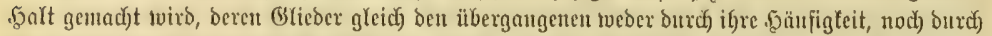

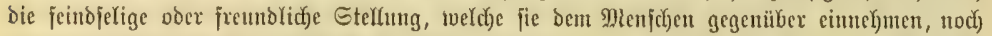

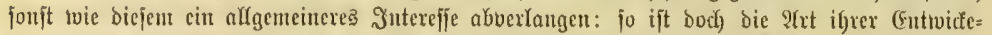

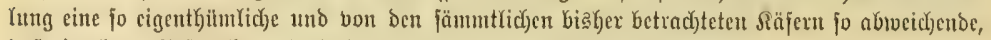

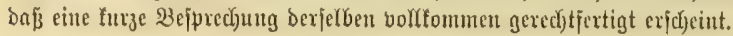

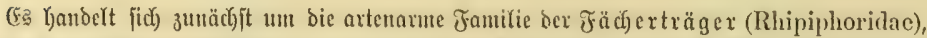

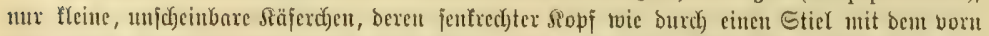

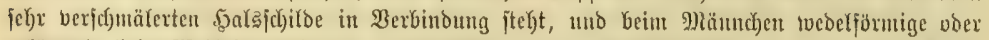

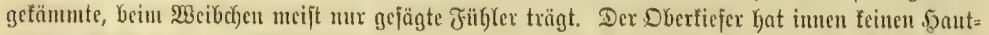

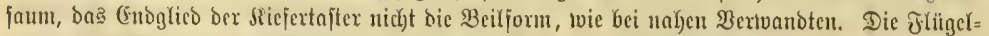

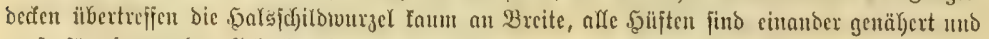
zapjenjörmig aus ben Gełentgruben vorgejtreät.

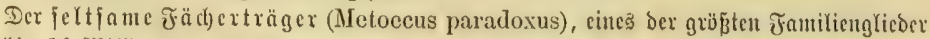

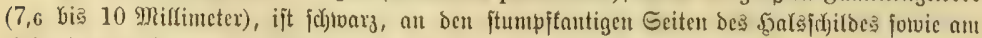

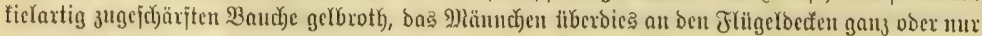

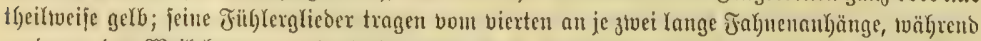

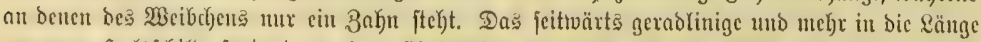

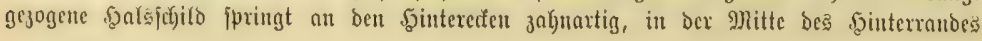




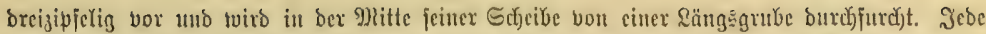

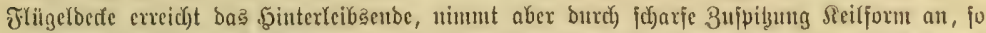

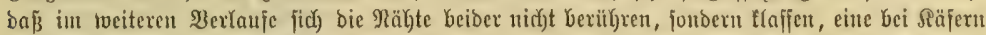

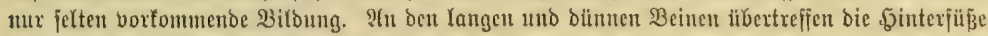
ifre Sdyienten uno ifyre Sdjenfel an \&änge.

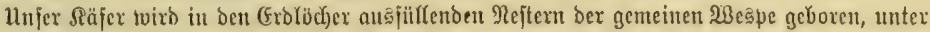

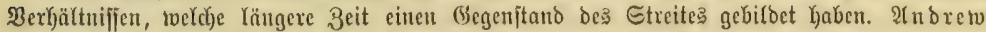

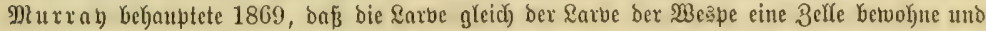

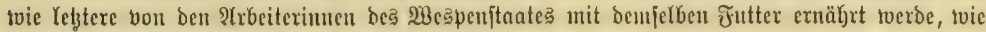

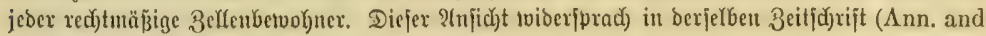
Mag. Nat. Hist. Ser. IV.) uno in bemjelben Jahre Smith, indem ex fid auj Stone's

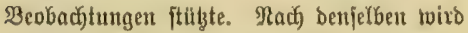

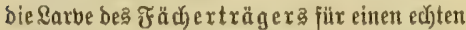
Schmaroterer crttärt. Das Weibchen regt feit Gi in eine Meśpenzelfe, uno jobald bie in biejer

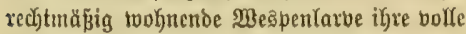
Grö̉e erlangt uno bie 3elle bereit jugefponnen Kat, um ifrer tweiteren $\mathfrak{B e r t w a n b e l u n g ~ e n t = ~}$ gegenzugeher, bohrt fid bie mittlertweile bem Metoecus-(Fie entich)liipfte Rarbe in biejelbe

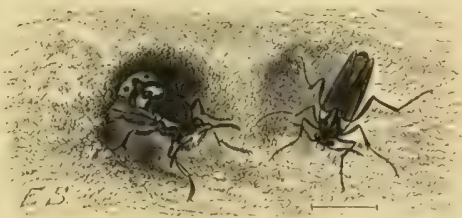

Eeltinmer F્äd)erträner (Jetoecns paradoxus) neben cincu 2 Bspennefte, natürl. Grö ie.

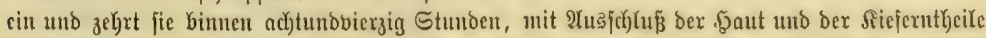

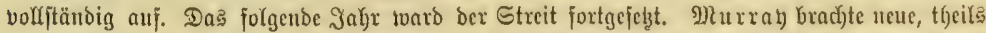

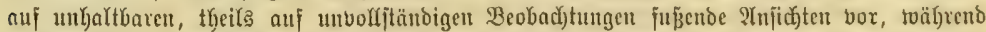

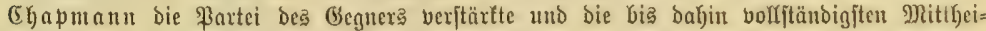

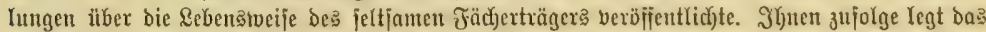

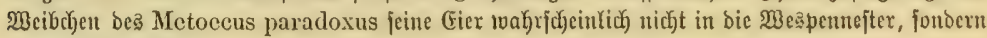
außerbark bexjelben.

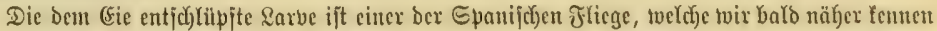

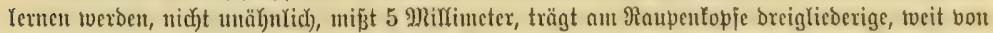

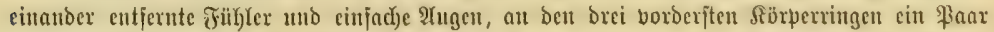

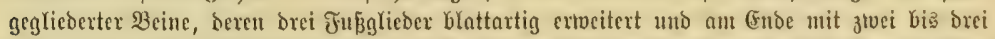

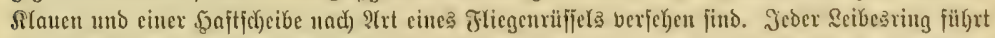

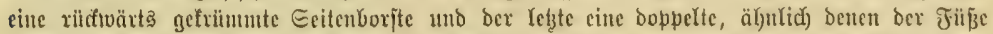

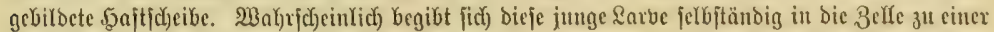

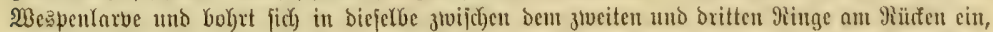

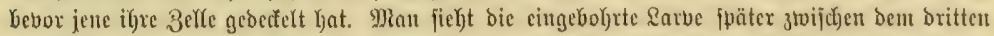

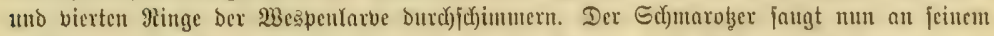

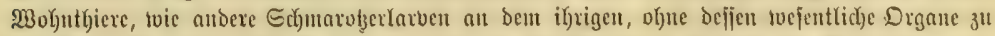

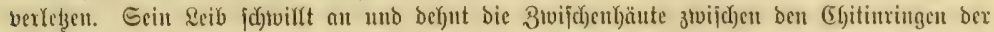

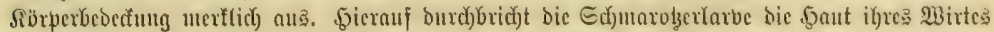

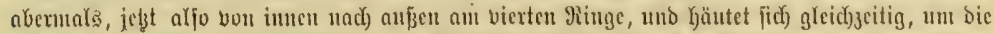

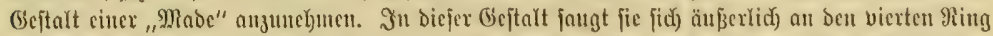

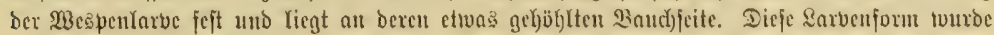

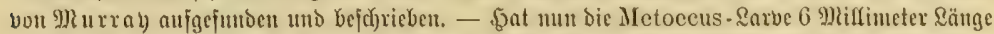

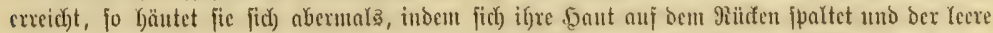

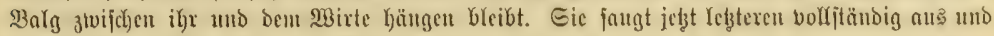

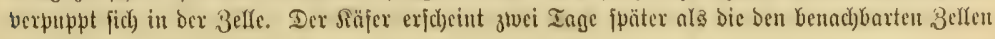




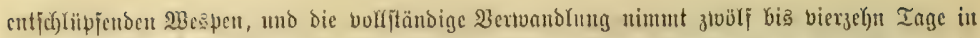

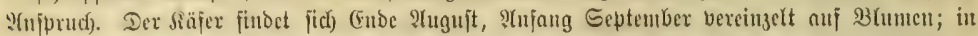

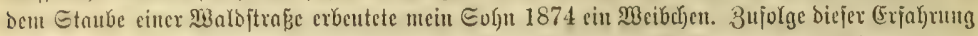

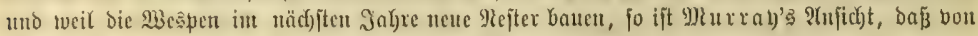

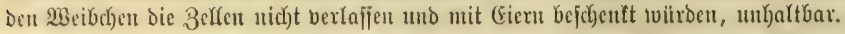

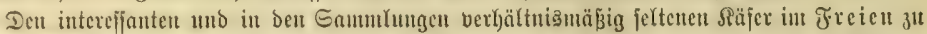

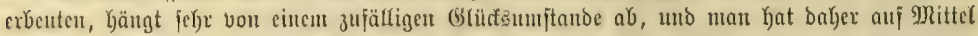

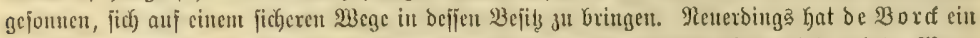

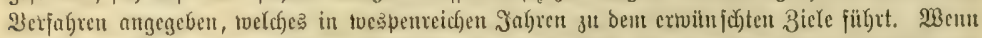

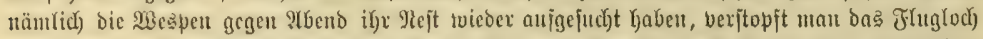
burch) cinen mit mögliçj) ftutenden (exböle (Solaröl, Benzin, aucb) Ierpentinöl) getränften

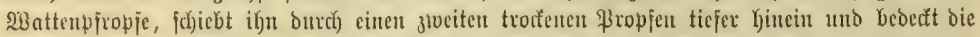

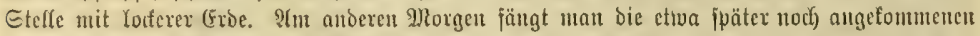

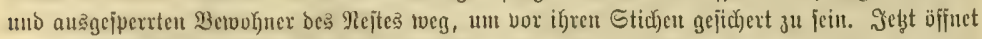

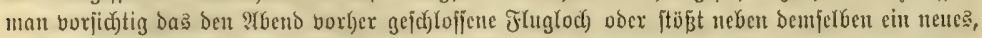

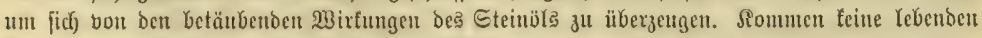

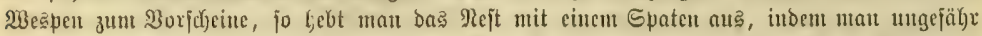

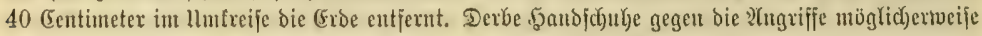

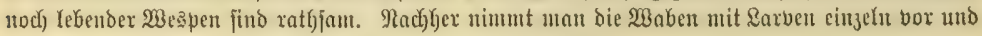
finbet jo bie Metoecus, wenn joldje - - vortganden toaren.

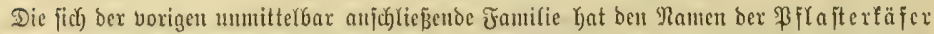

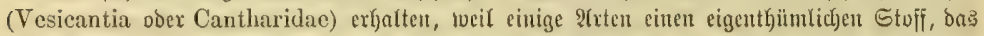

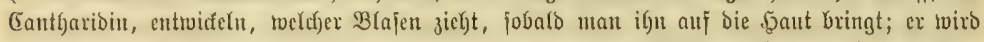

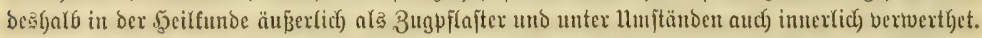

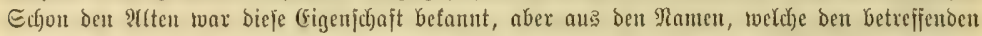

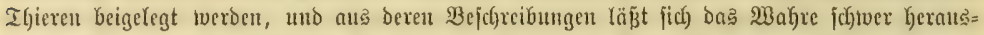

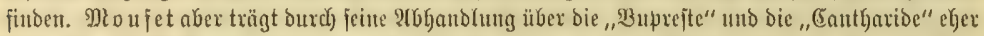

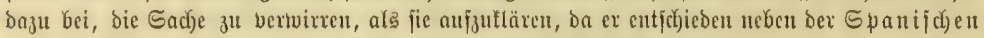
Fliege aud eirtige Raraben und andere nicht zu beutende Säjer abbilbet.

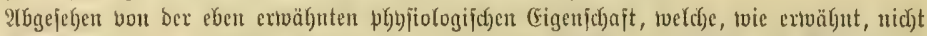

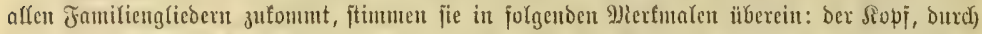

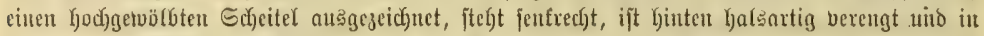

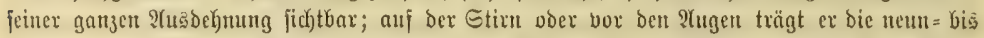

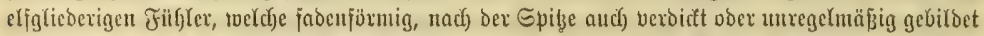

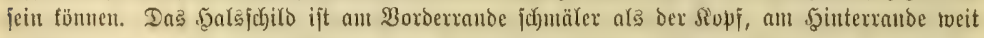

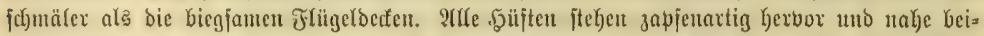

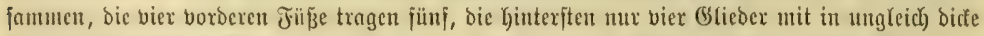

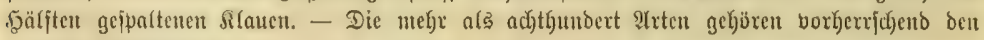

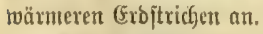

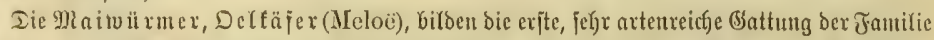

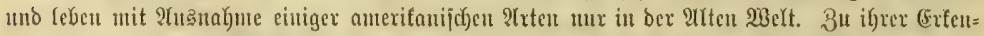

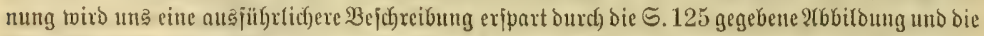

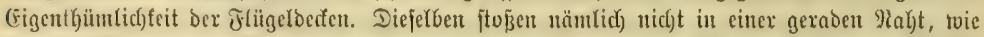
bei jajt allen anteren Siajern, aneinander, fondern bie eine legt fick an ber 23uzel über bie

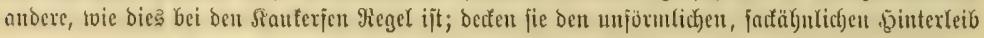




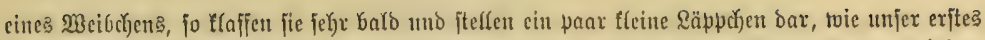

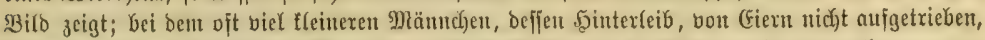

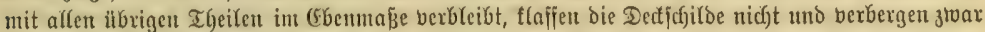

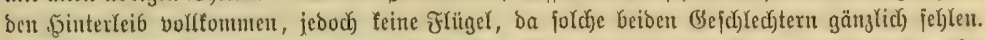

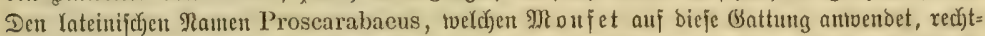

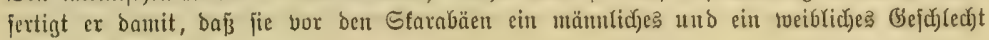
vorant hätte.

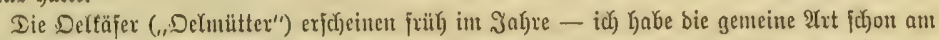
11. Mtär3 angetroffen - friechen in Braje, an befīen Etengelu und auf $\mathfrak{B e g e n ~ u m b e r , ~ i m ~}$

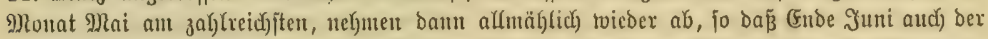

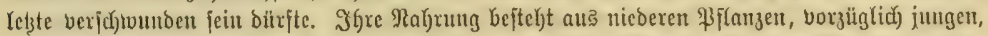

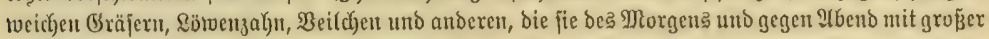
Gejräpigteit verzefren. Dabei unffanmern jie bie Futterpflanze mit ben Iangen Beinen, bringen bie zu verzefrenden Ifeile mit einem ber Borberbeine Geran, halten bann und wann bei ifjent

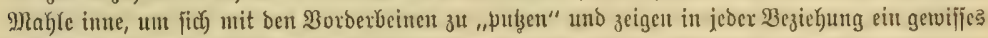

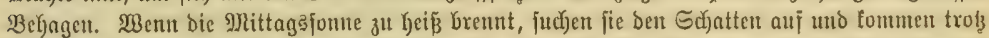

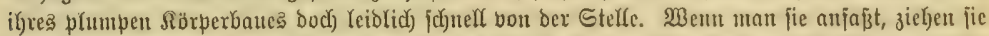

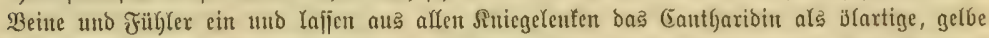

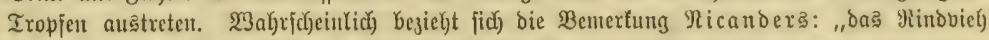

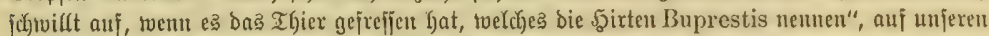

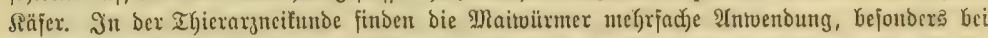

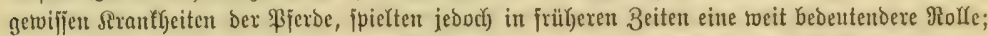
benu e? tvir berichtet, Daß̧ fie bon ben Dithmarjchen getrod̆net, zerrieben und mit Bier getrunten

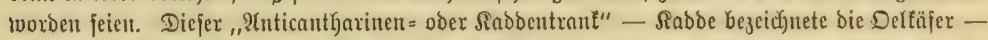

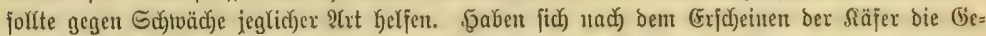

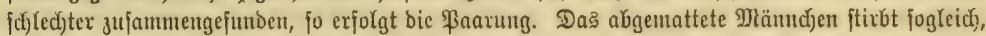

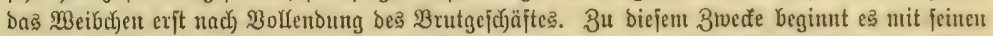
פुorderbeinen in uidyt zu Yodferex (Erbe cin \&od) zu graben, twälgrend bie übrigen Beine zur Jort=

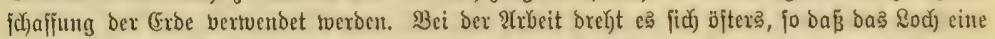

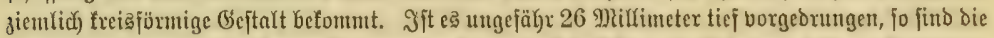

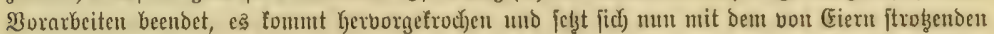

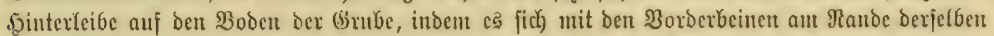

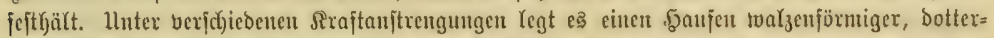

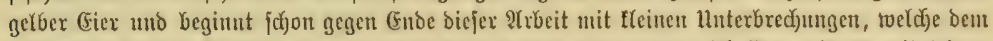
Gammeln frijd)er Siräfte gelten, fo biele (Exbe toieber herunter an jd)affen, als es mit feinen

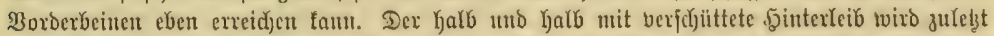

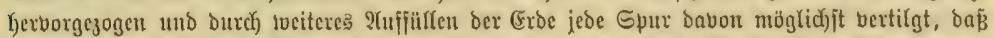

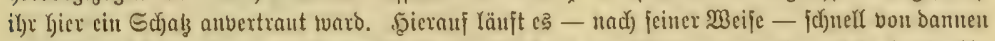

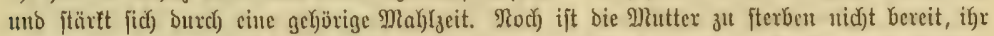

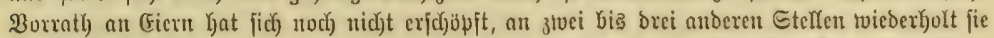

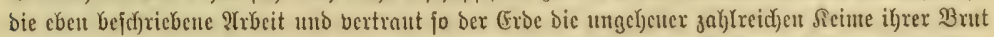

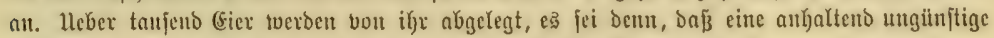

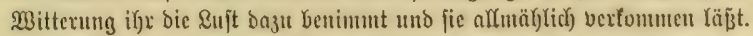

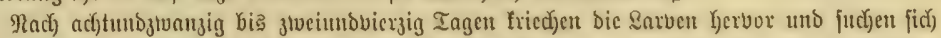

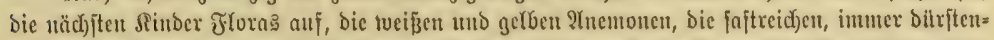

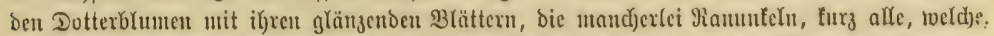

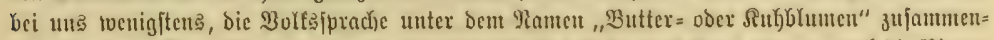

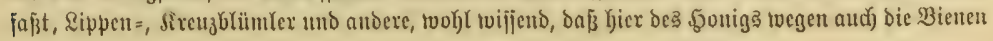




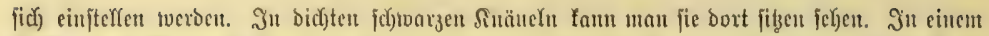

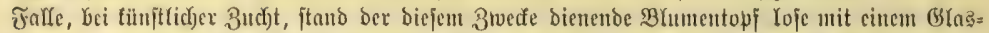

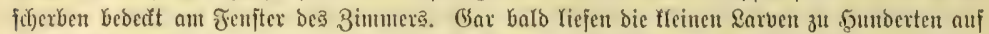

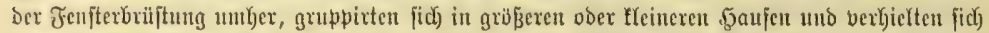

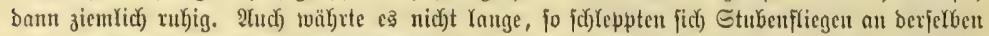

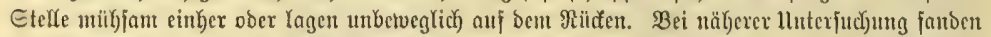

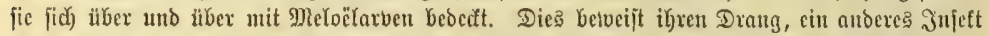

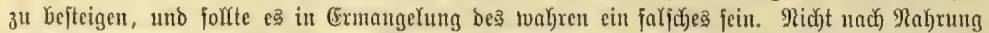

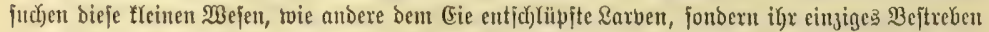

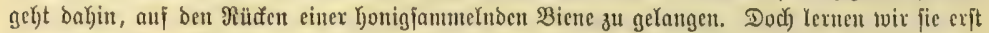
fenten, um fie an Błumen ober auf bem fözper einer Biene tvieberzufinden. Die Melö̌larbe ift

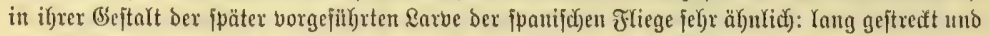

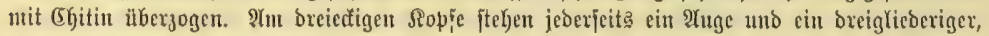

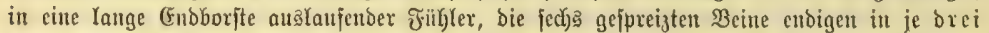

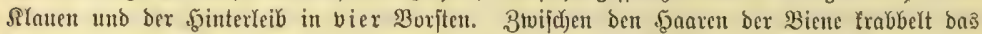

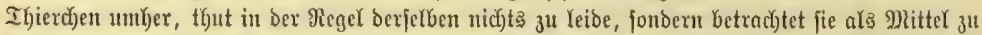

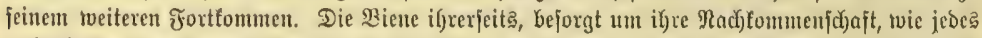

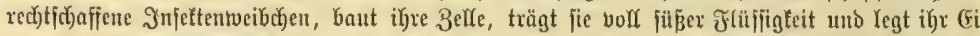

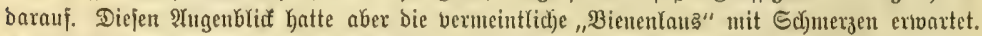

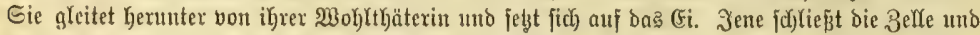

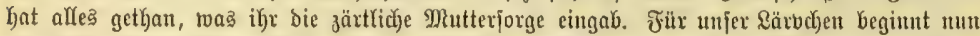

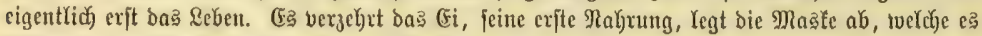

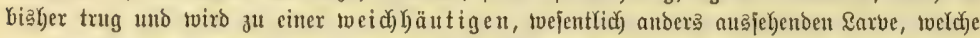

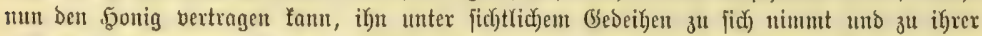

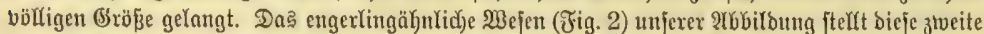

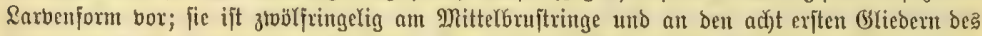

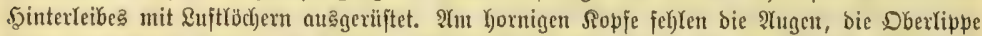

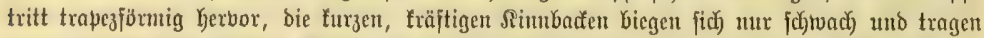

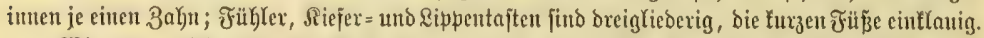

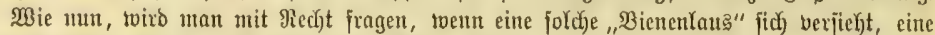

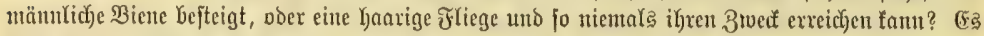

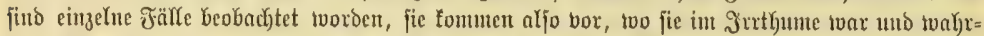

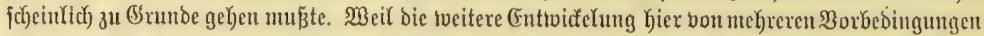

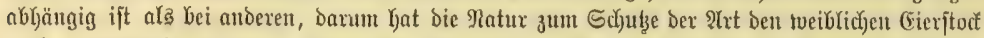

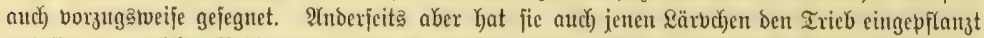

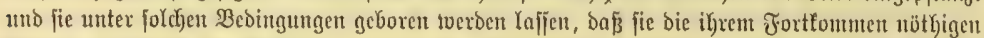
Bienen (bejonders ber Gattung Antophora, Macrocera angeljörig, autch $A_{\text {pis }}$ unto andere) Gerausfinden.

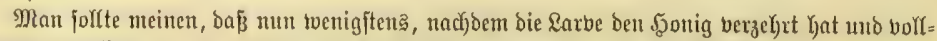

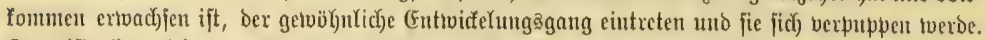

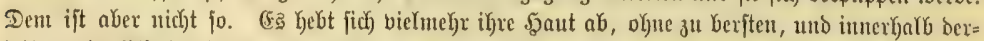

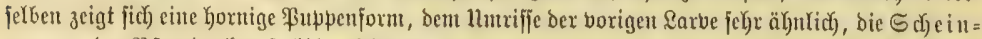

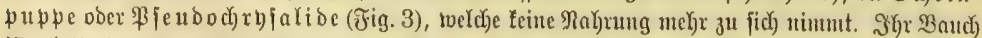

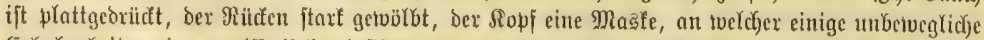

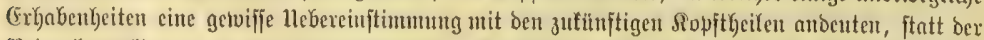

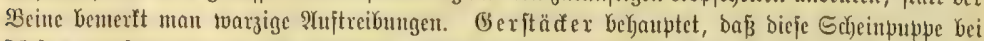

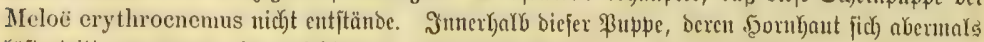

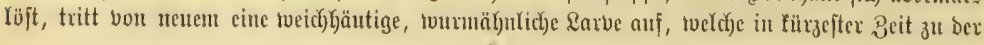




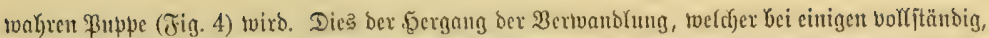

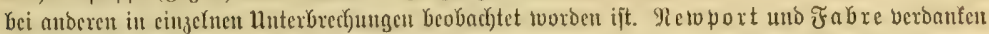

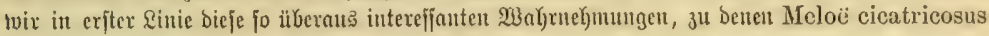
bell Betweiß lieferte.

Ser bunte Delfäfer (Meloë variegatus ober majalis) verbreitet fict) über ganz (Europa, da?

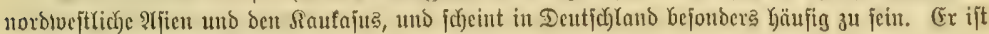

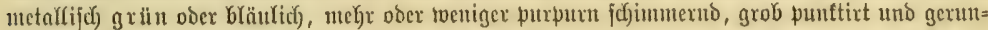

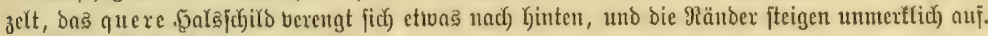

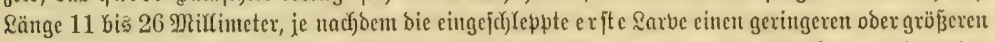

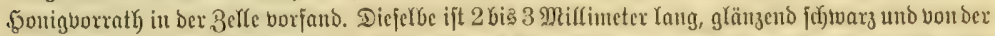

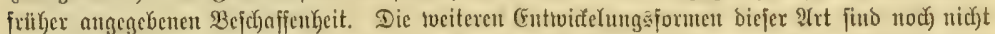

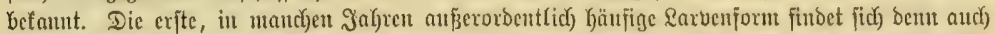

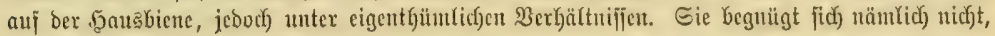
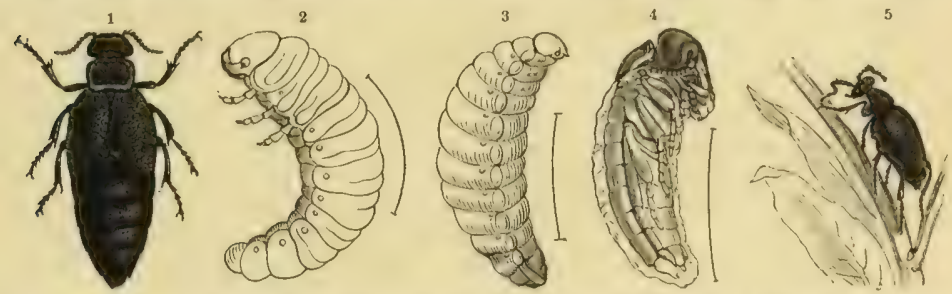

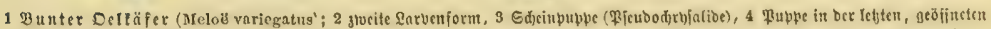

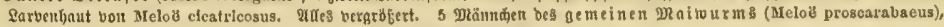
natürliđje Brö̌ce.

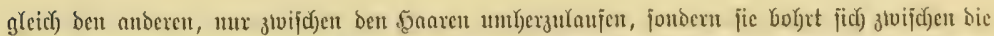

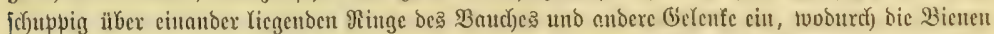

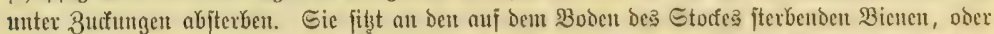

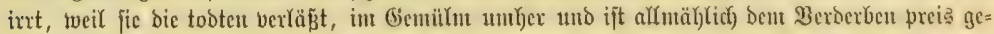

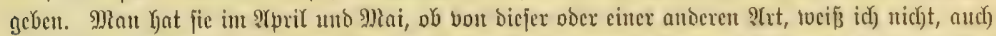

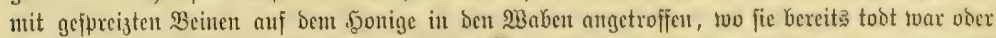

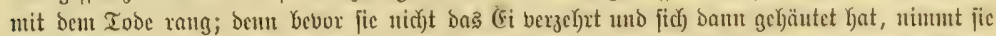

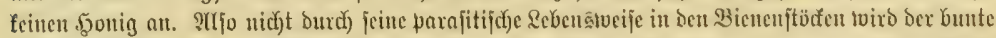

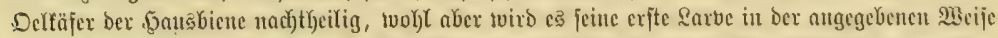
fiir bie Irachtbienen, burd) tucldye fie fich in ben Etodf cinbringen Yaffen, für bie jungen, eben

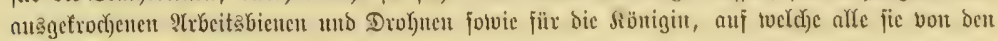

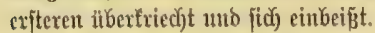

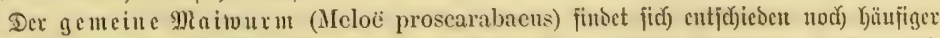

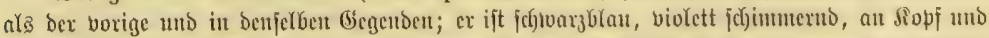

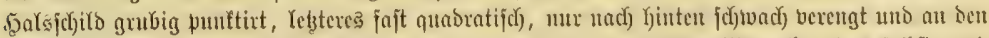

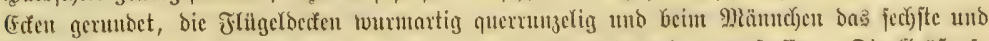

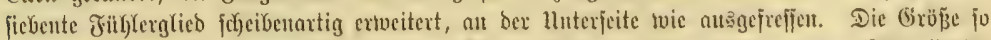

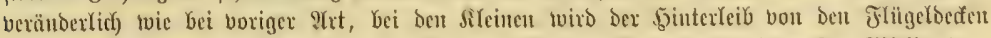

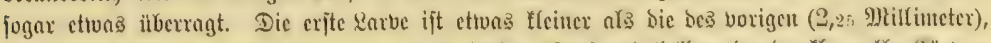

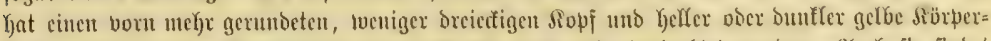

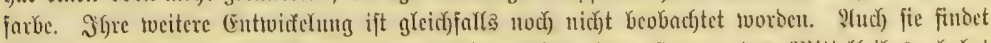

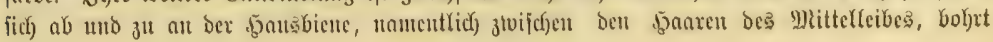




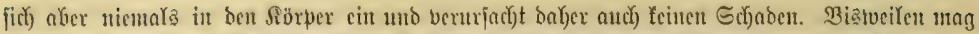

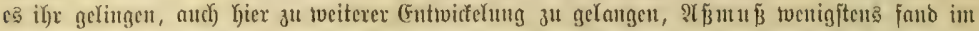

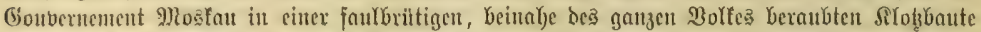

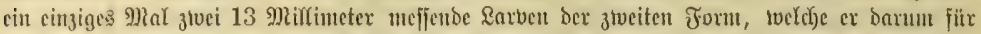

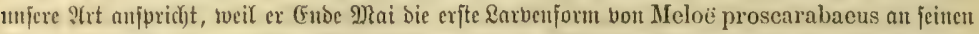

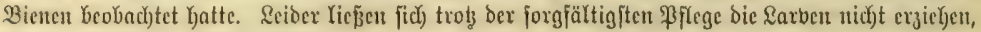
fondern ftarben nack twenigen Tagen.

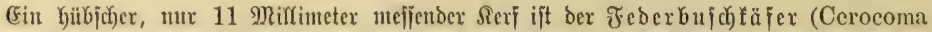

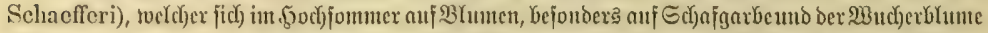

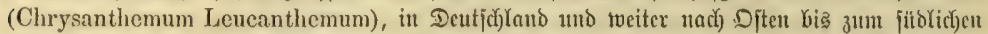

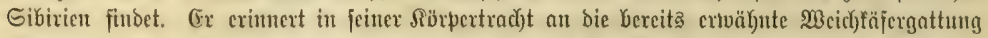

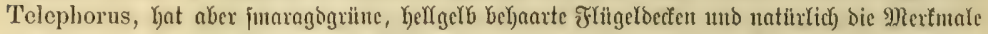

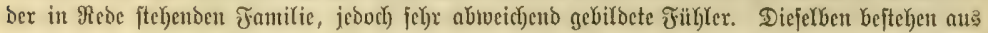

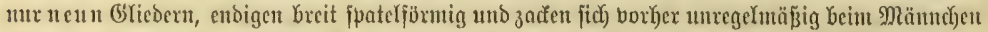

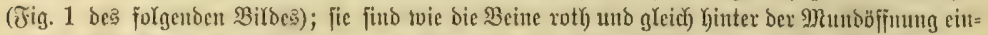

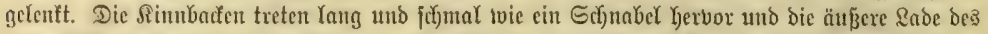

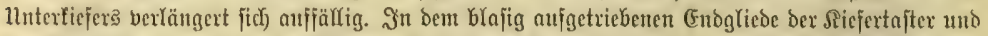

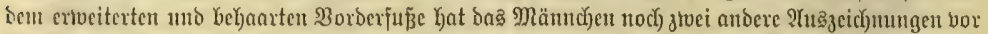

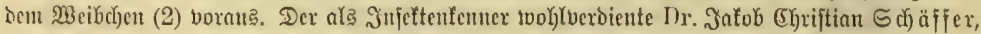

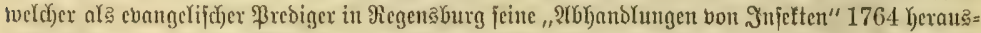

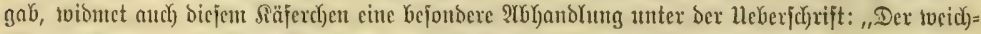

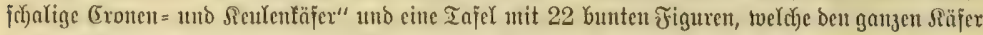

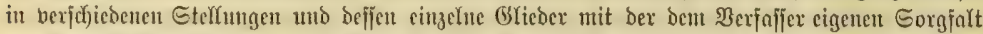

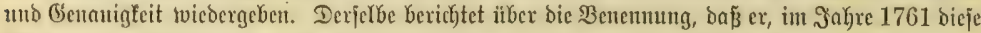

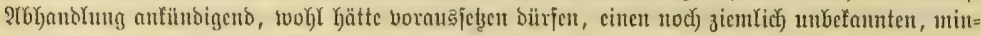

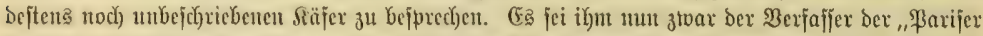

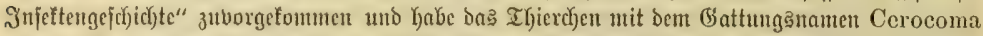

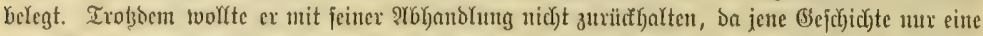

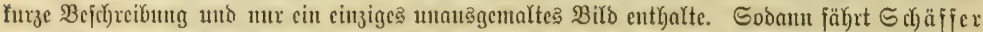

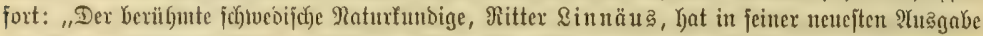

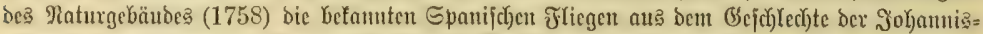

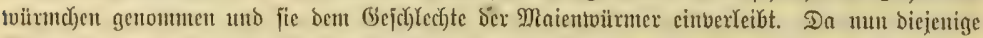

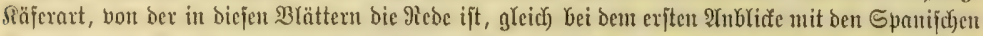

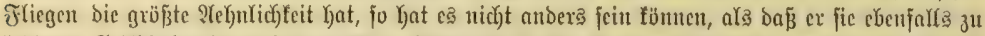

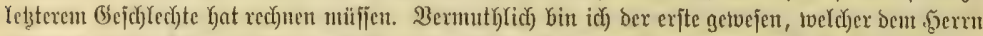

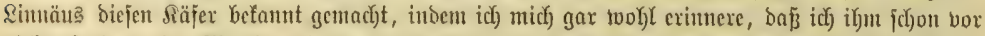

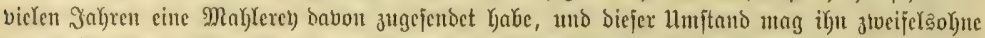

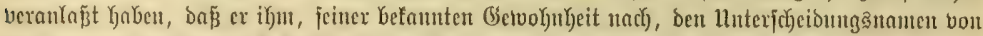

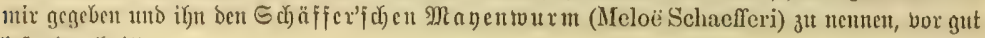
befunoen Kat".

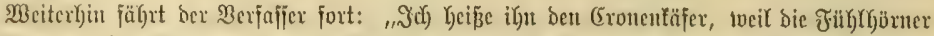

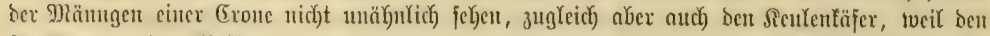

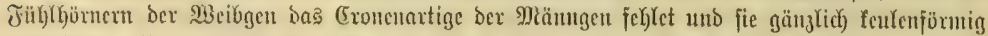

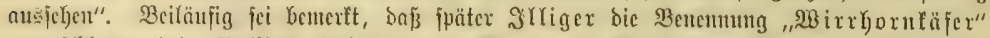

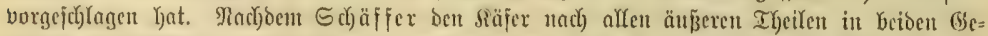

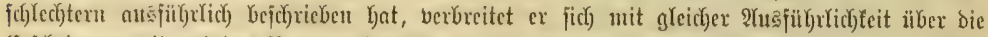

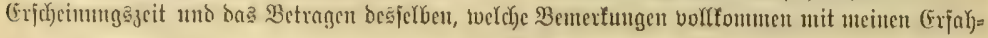




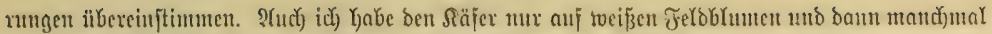

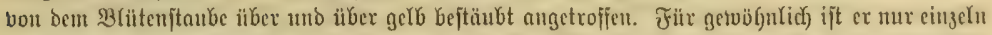

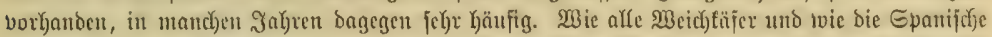

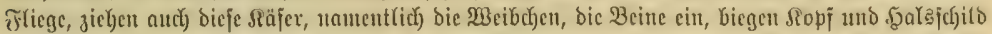

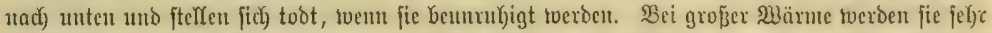

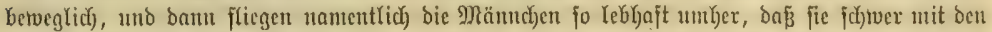

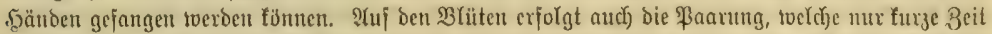

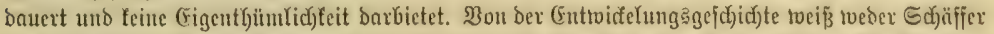

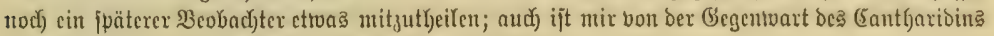

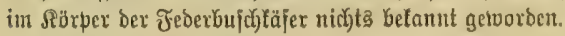

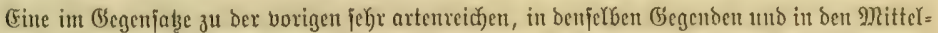

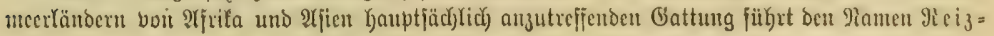

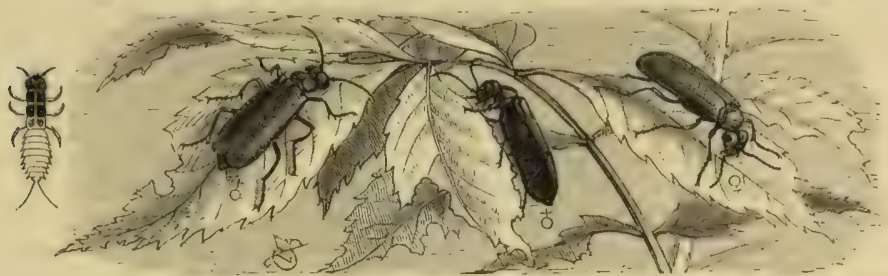

ङралll

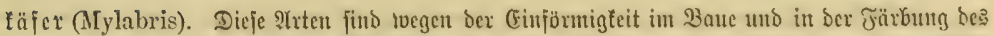

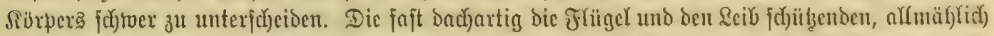

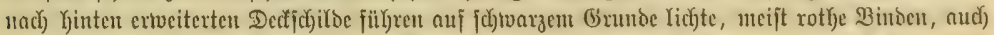

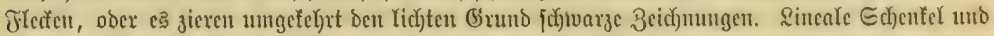

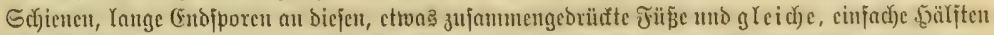

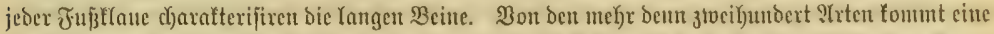

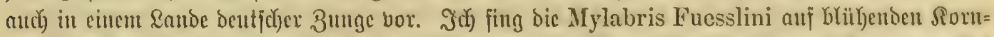

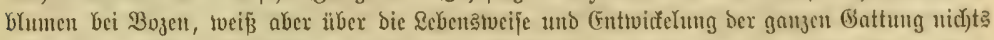

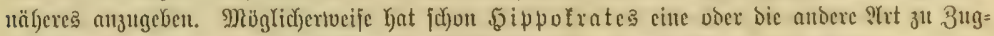

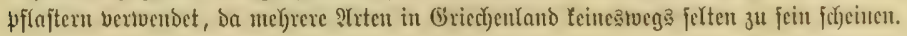

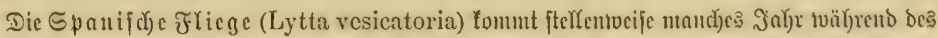

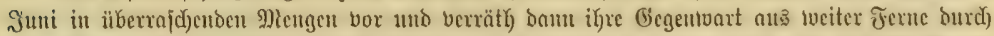

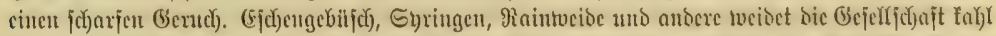

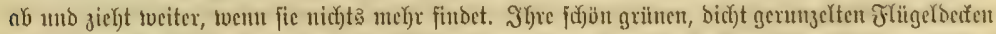

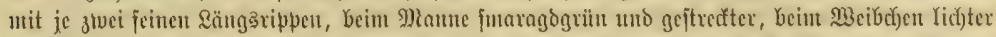

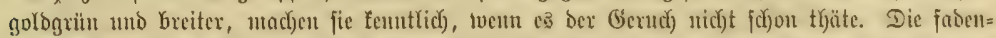

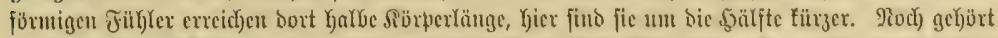

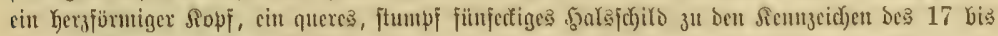

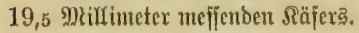

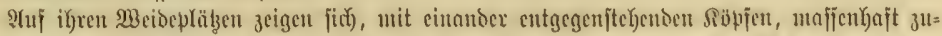

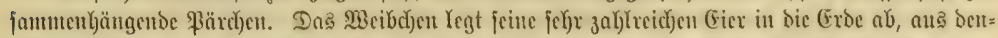

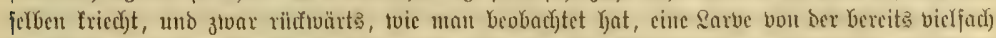

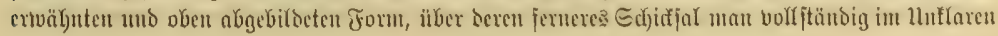




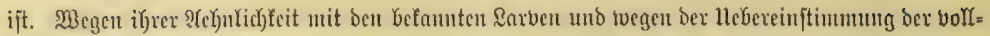

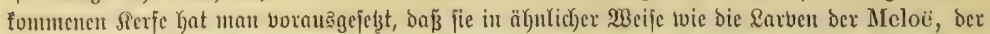

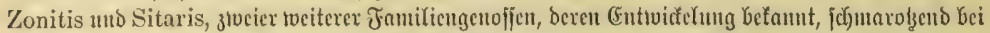

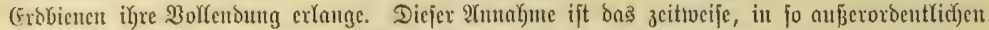

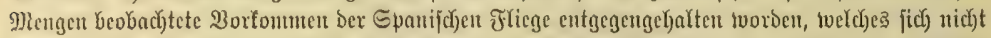

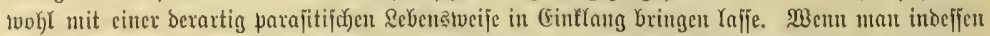

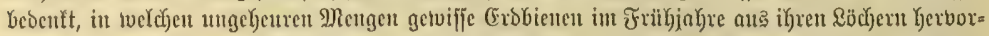

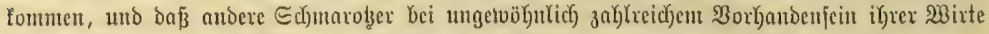

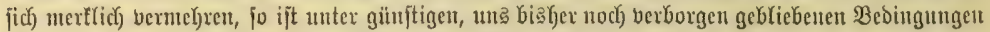

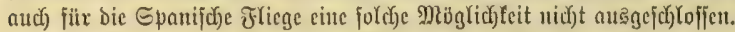

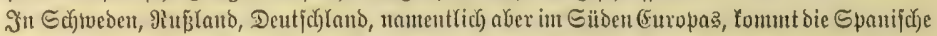

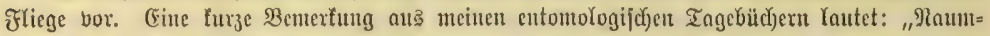
Gurg a. S., 16. Suni 1850. Soloffale \$Rengen bon Lytta vesicatoria an Ligustrum vulgare uno

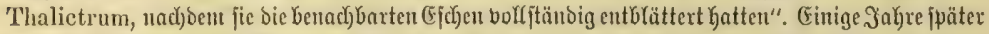

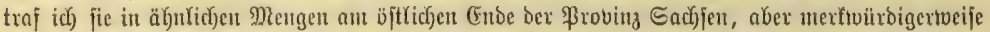

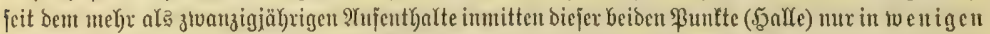

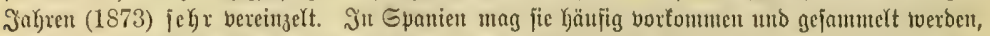

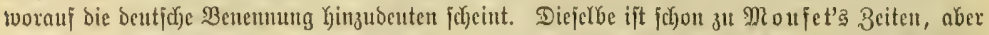

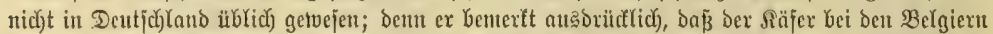

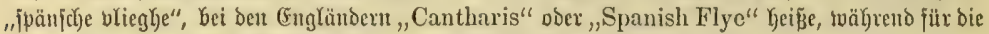

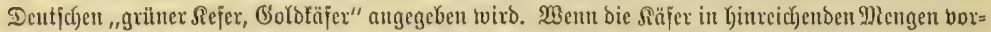

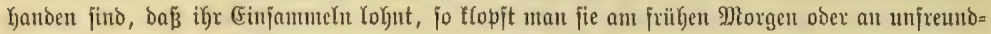

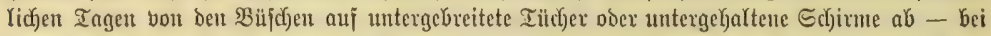

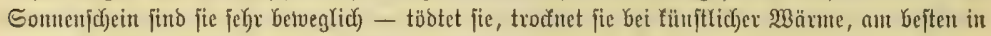

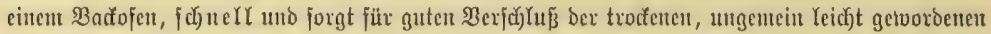
Wante. Fein zerrieben mb mit einem Binbejtoffe vermijht, liejern jie bas befaunte Bugpflajter,

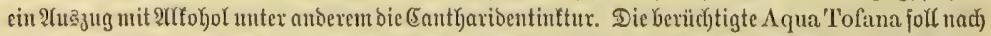

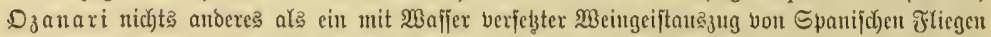

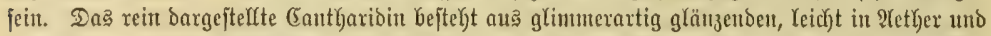

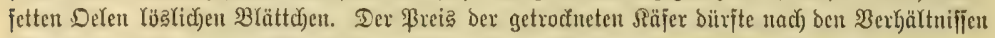

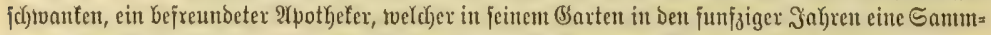
lung veranjtaltet Katte, erzielte beim Berfoufe nad) Berliu einen Thaler für bos Pfund.

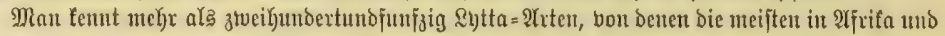

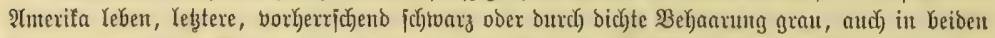
Färbungen geftreift, fino neueroinģ alङ bejonbere Battung ,Epicauta" bon Lytta getrennt, woil

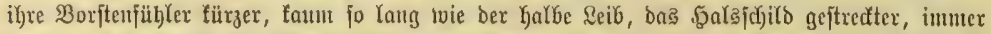

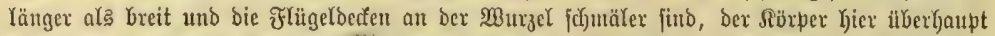

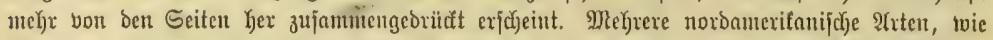
Epieauta cinerea uno vittata, foumen bisweilen in ungel)eneren פ̇engen auf Rartoffelftant

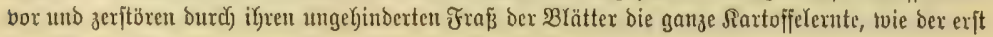
neuerbing fo berüdjtigt getworbene (Solotabo = Rartoffeltäjer.

Der rothidulterige Bienenfäfer (Sitaris muralis, friber Necydalis humeralis) ift

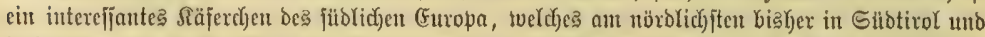

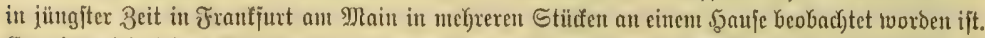

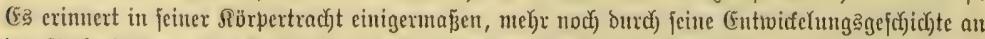

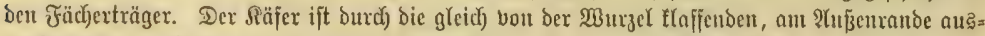

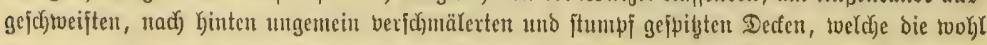




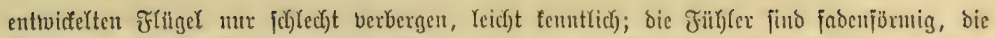

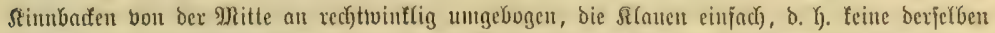

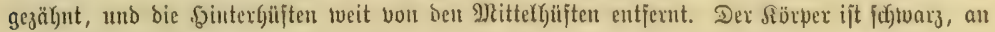
ben Sifultert roth.

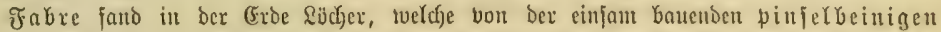

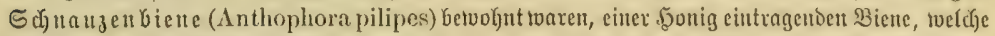

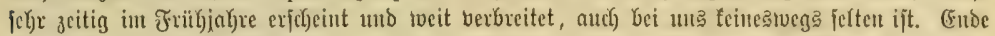

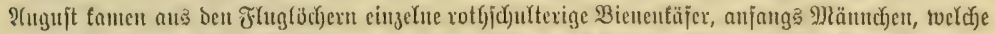

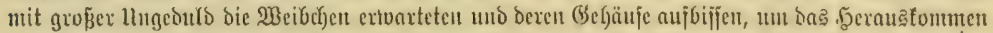

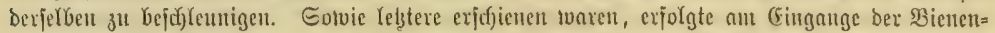

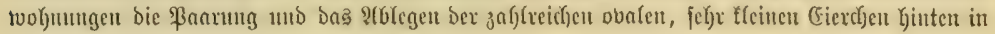
ben zu Den Bienentejtern fülyrenden (5roböbren,

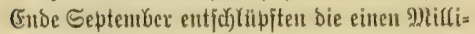
nteter Yangen Rarben von beiftehender Forn (a), ausgereichnet butch) Inuge Füh)(ex, Yange, Yang= behante Beine, zwei gefrümunte Schivantz= borjten am jtumpf angeppibzteu Reibesende uno

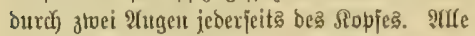
bieje Mterfmale potvie bie harte Rörperbetlei butg eximnern an bie expte Rntbenform ber vorher befprod)enen familiengrieder. Die \&üry= (j)en find aujerordentliç) betweglid), verlajien jeboch ihre Beburtajitätte nidyst, uno fiłzen

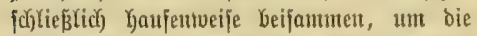
Wintermonnte zu verjod)(ajen. Mait bem (Ex=

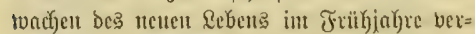
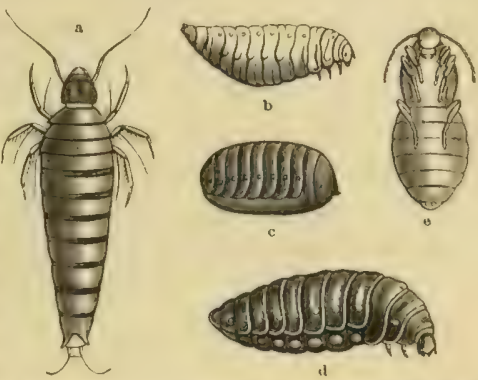

a Erfte, b sucite, d britte Sarvinform, c Sdjcinpuppe, o Puppe

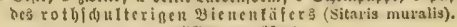

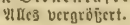
Iajęt bie rechtmäßigen Bellenbetvofnter, bie

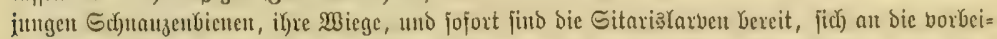

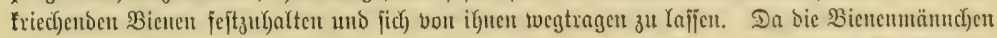

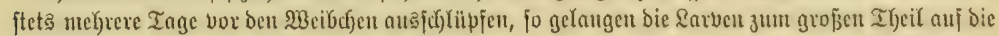

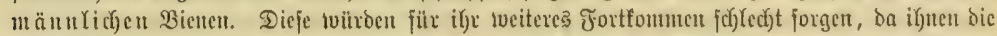

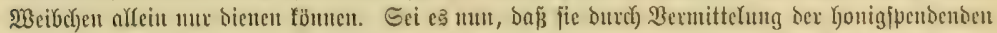

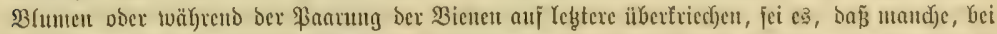

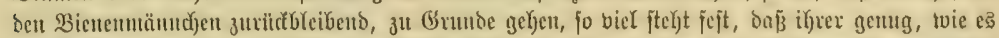

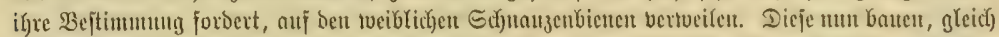

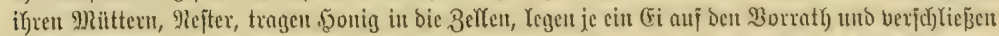

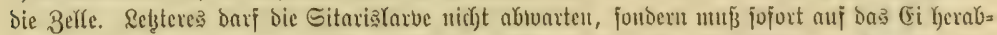

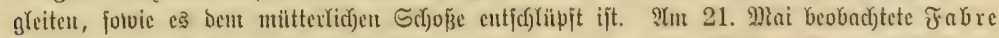

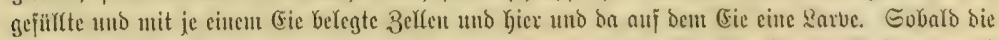

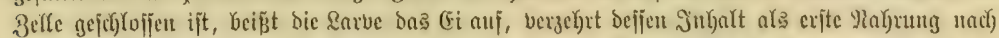

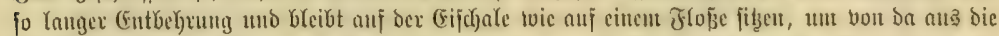

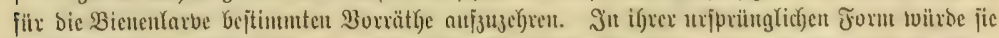

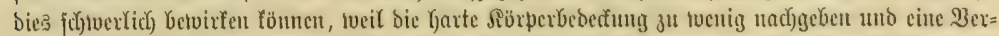

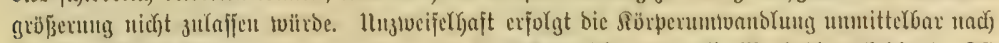

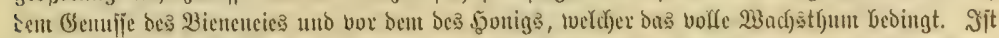

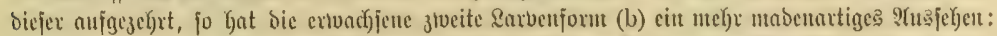

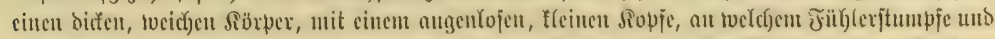

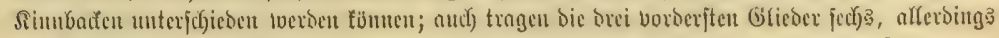
brcbuts Thicrteben. 2. Ruflage. Ix. 


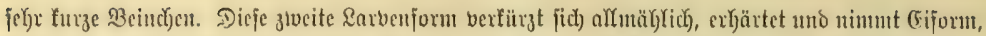

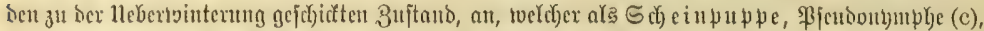

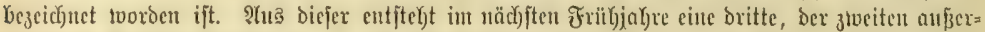

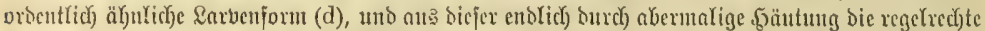

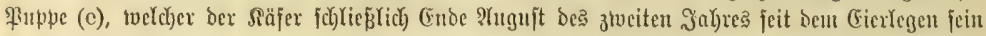
Dajein verbantt.

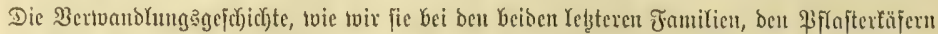

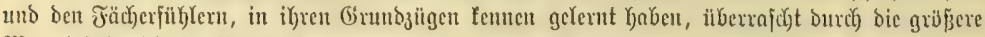
M) Zannigfaltigfeit im Nergleiche zu ben zwei llebergangaformen ber Rarve uno ber ßuppe bei ben

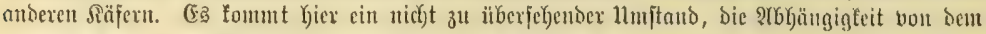

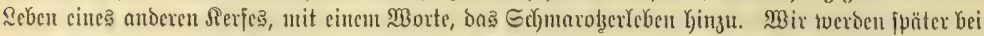

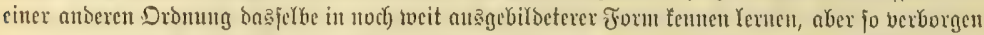

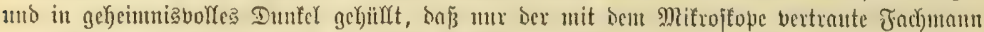

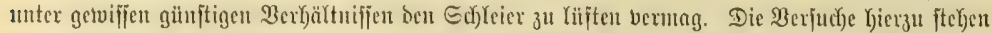

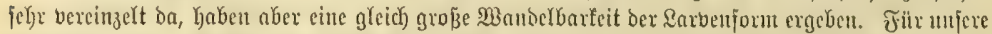

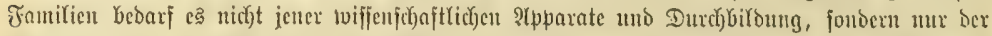

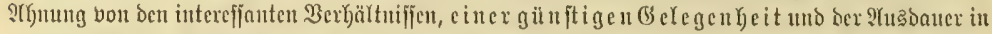

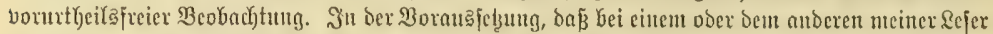

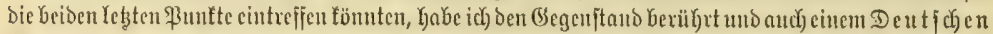
Gelegentyeit geboten, benjelben tweiter zu verfolgen, un zи berichtigen ober zu berbolfftändigen.

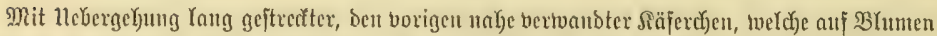

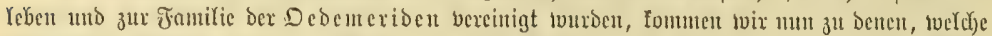

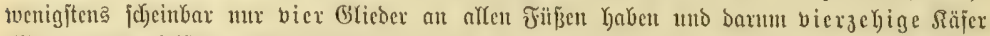

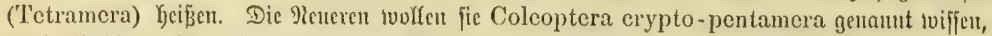

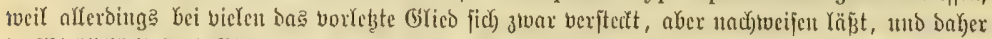
in Mirftichteit fünf Ǵlieser vorlyanden fund. Dic Rüffelfäjer (Cureulionina) werden unfere

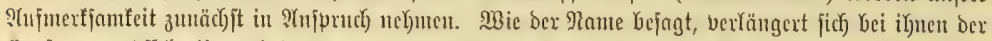

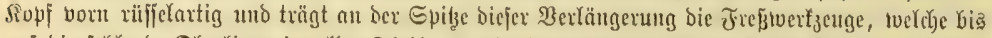

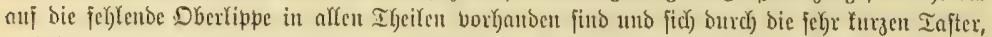

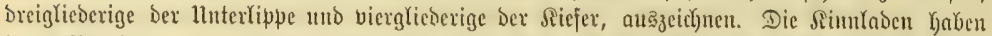

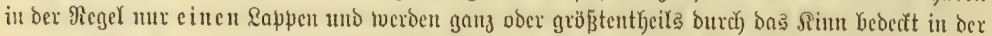

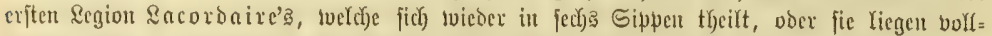

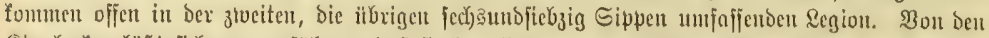

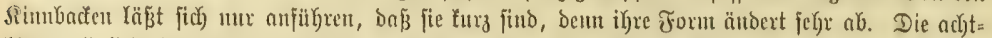

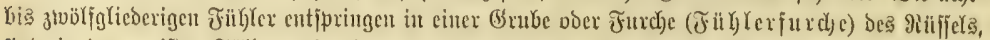

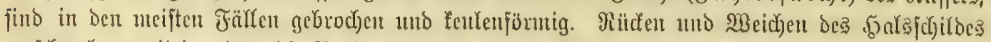

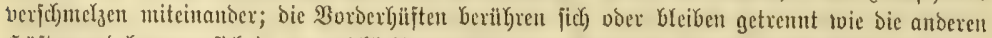

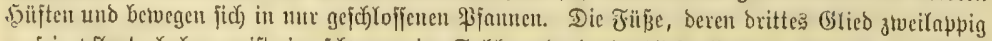

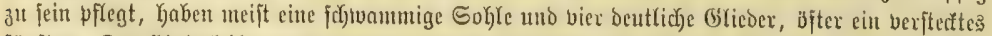

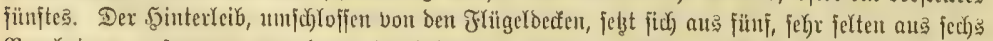

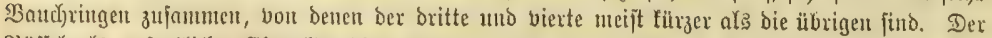

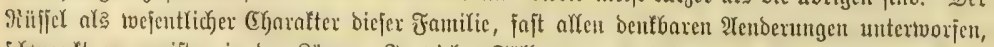

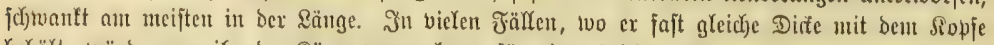

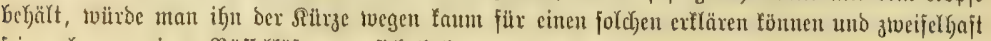

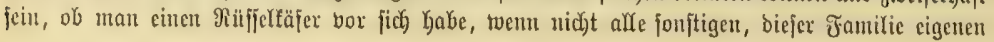




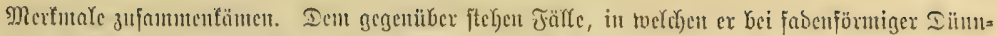

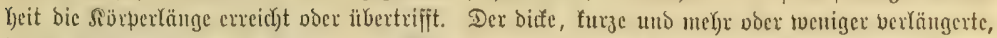

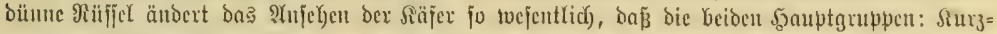

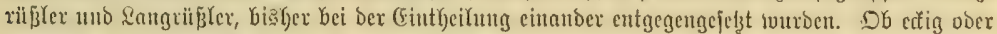

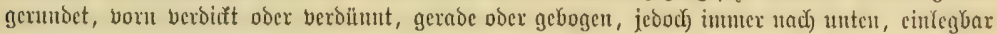

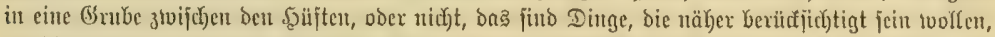

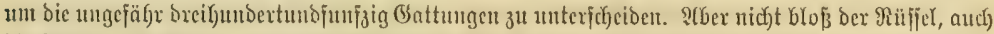

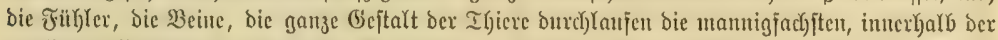

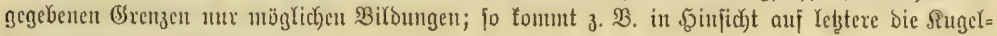
form neben ber Rinie bor.

Die fänm

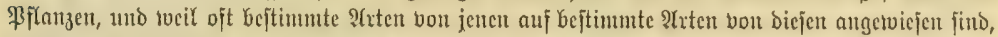

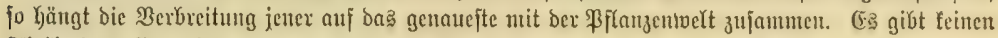

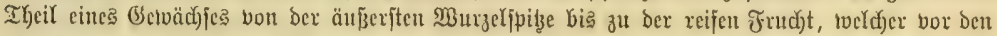
Itngriffen ifyrer \&arben gejidyert twäre.

Dicje gleichen an meijten benen Der Dicbfäfer unter Den Solzbohrem, Kaben einen runden,

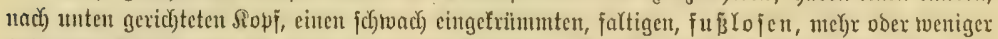

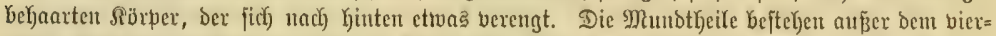

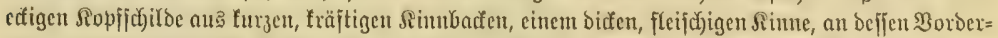

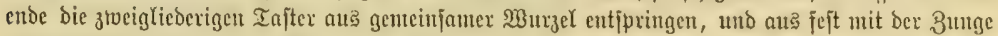
verwad)jener, Getvintperter Simenlade des Ilntertiefers. Dic Fühler find mur toarzenfürmig, bie Ifugen nidyt ober in geringer 2 (nzab) borhanoen.

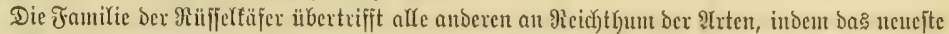

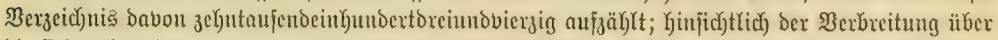

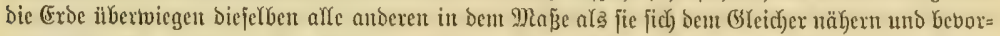

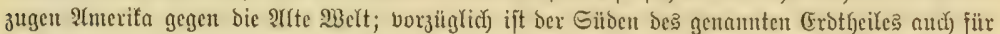

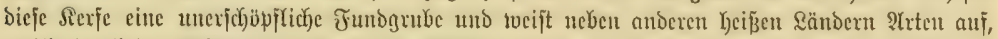

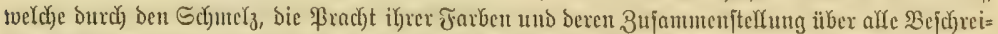

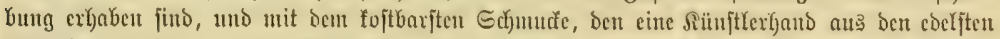

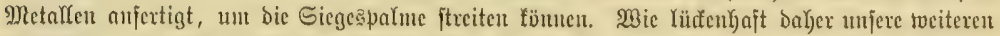

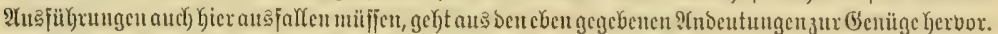

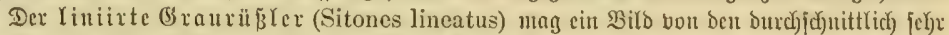

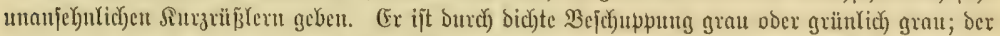

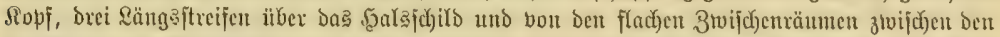

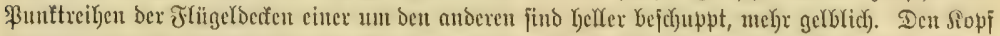

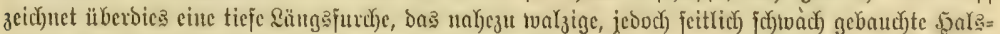

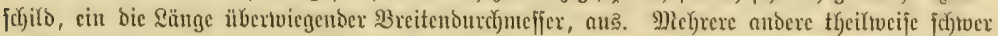

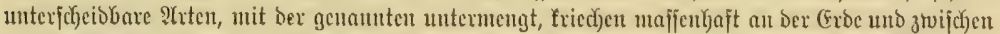

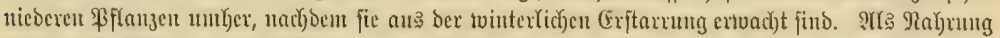

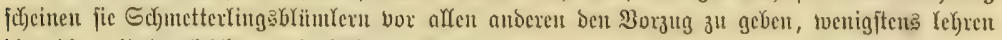

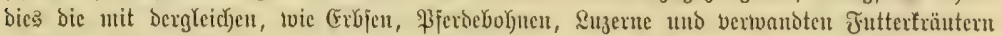

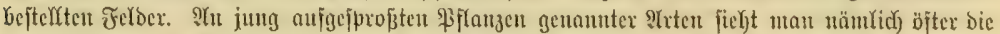

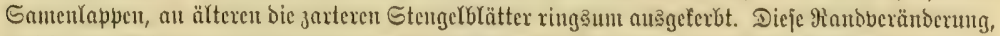

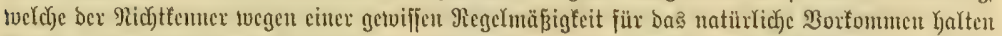

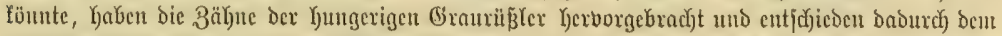

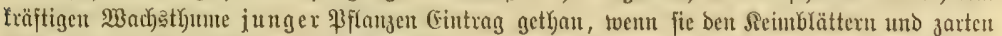

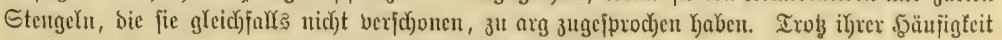

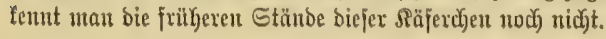




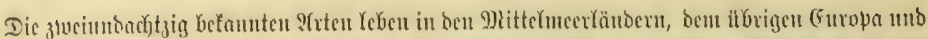

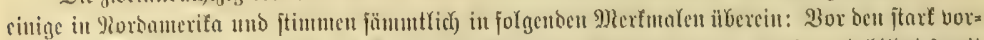

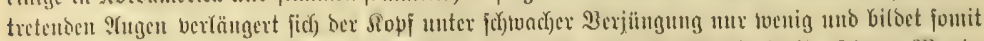

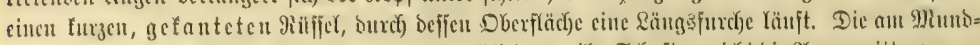

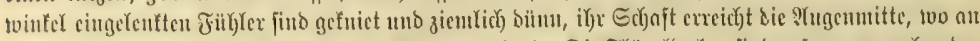

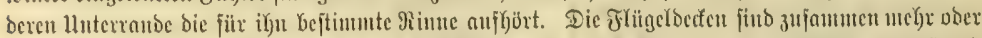

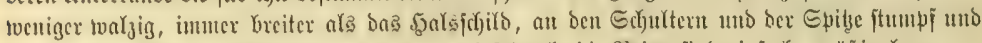

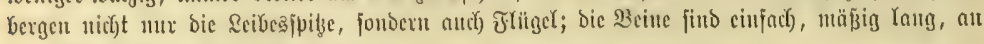
ben Edyienenenten ohne fornhaten.

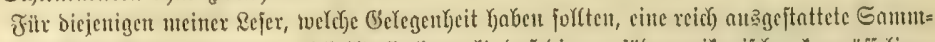

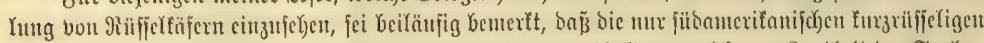
Gattungen Cyphus, Platyomus unb Compsus Prten entyalten, weldye an 3artfeit ber Farben
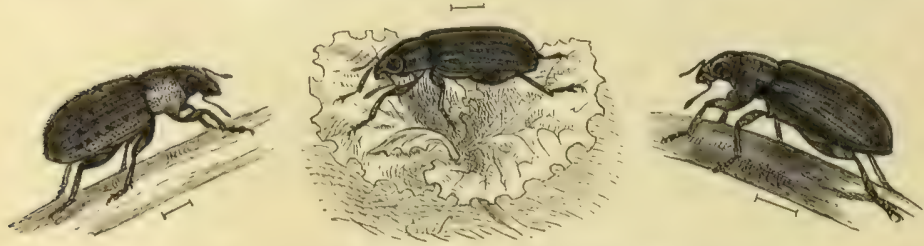

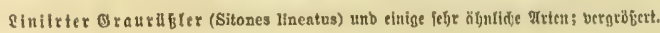

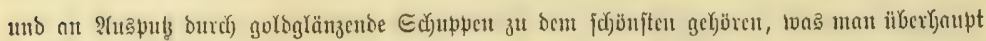
in biejer .̧inficht jeken tam.

Dex jod)tonz

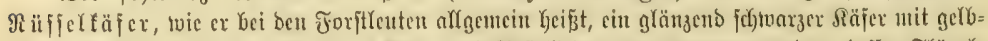

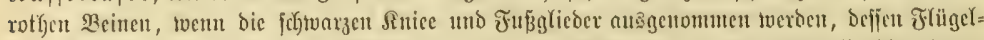

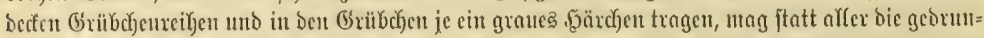

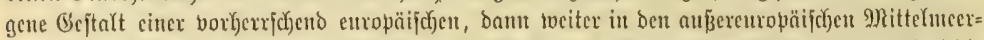

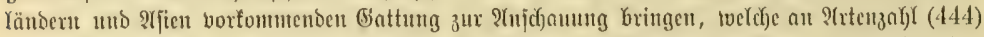

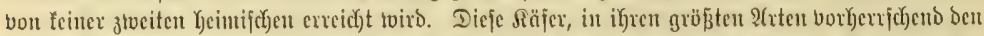

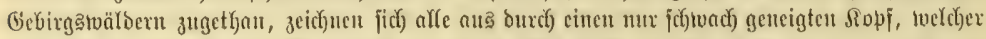

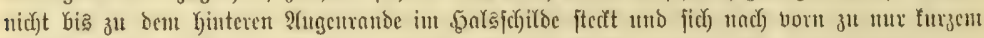

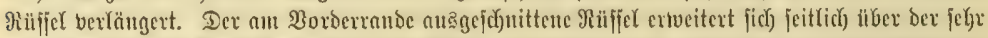

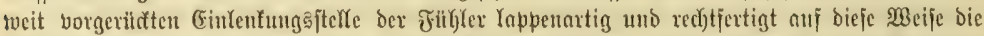

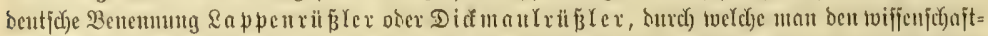

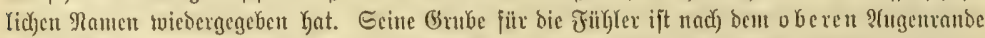

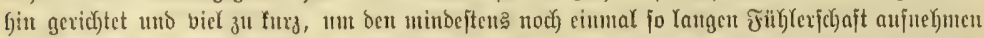

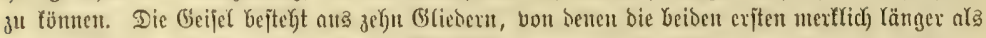

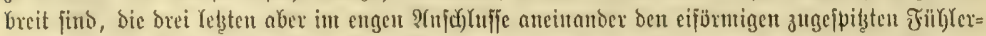

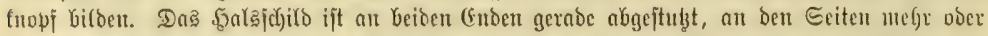

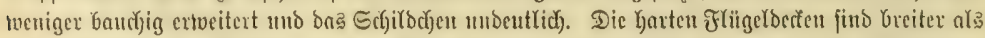

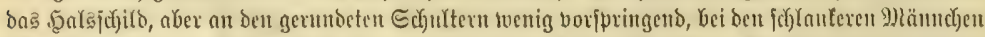

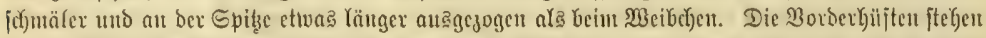

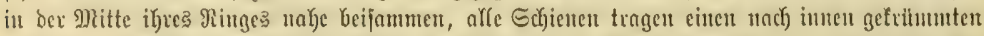

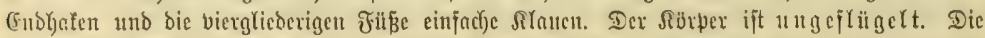

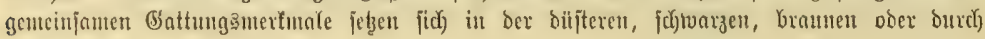




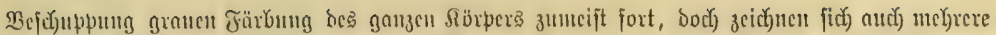

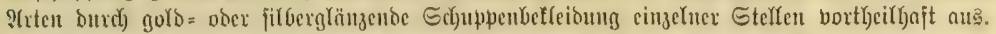

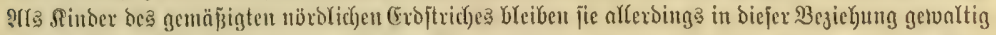

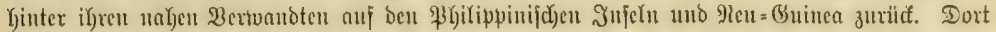

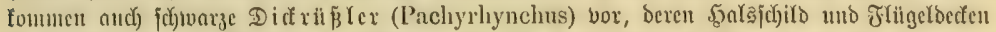

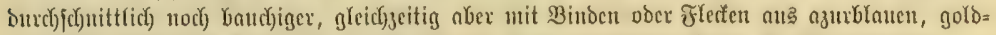

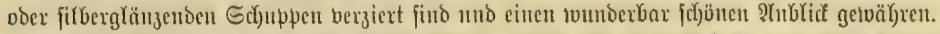

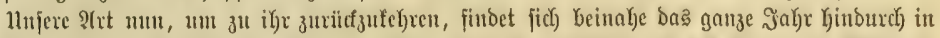

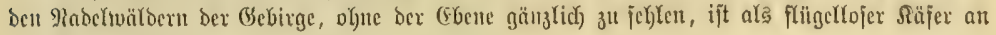
igre Gełurtgitätte gebunden uno baher immer ba 3u finden, wo fie fith einmal eingebingert yat. $20 m$ भugujt ab uno jpäter triffit man den Siäper in jeiner

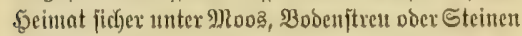
an, wic Yjalb exjtarrt uno ungemein träge. Da man mun in feiner Uungebung bie leberrejte jeiner Britber głeidjfalla reichlidy untherliegen fiebt, jo fantn es zroifelfait bleiben, ob ex ben Stein alb feinen Seichenjtein, ober nur ala ben Dot betradjet

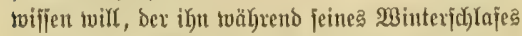
jd) übett jolf. Beibe Fnnalgmen Yaffen fich mit eiss ander vereinigen: ift ex Yebensmuloe und roiff ex einen rubigen \$laţ baben, an twelchem ex fein mildes 5aupt niederlege, po ijt ex cin alter Räjer, ber jeinen Rebenģ twed exfiulft hat; will ex bout nur ben 23 intex berich)lajen, fo suurde er in \&auje be? Sonumerā in Schoß̉e dex Eroe geboren, befam aber noch sujt, fich braußen in ber झelt umzu=

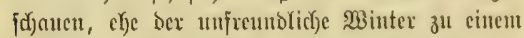

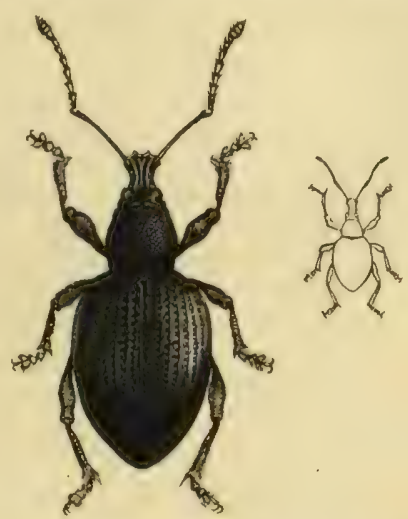

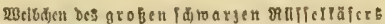
(Otiosliynchus niger), verßrófert uno it natifrlider Oröge. abcumaligen Berfriect)en zrwingt. Dem jei nun,

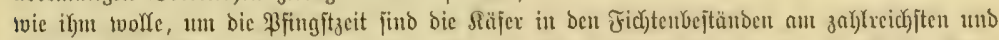

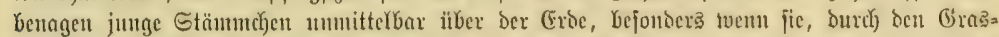

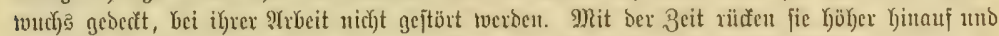

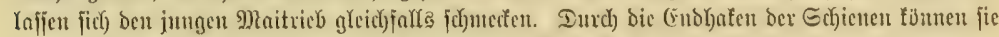

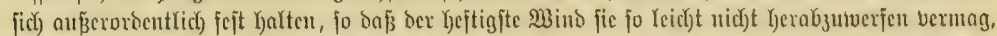

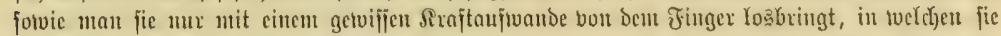

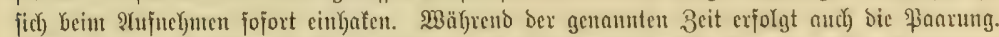

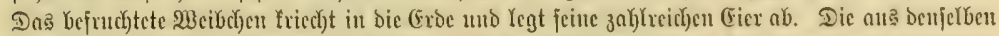

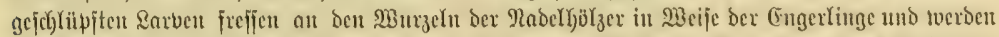

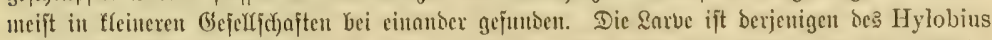

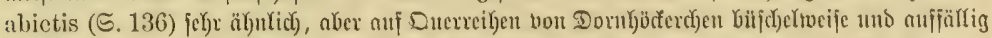

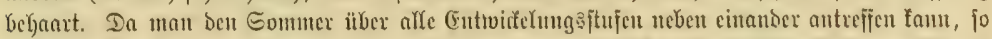

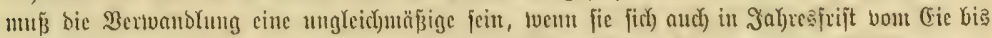

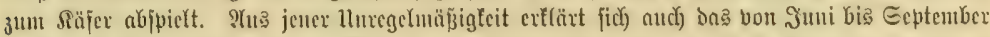

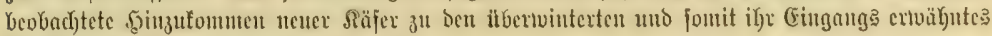

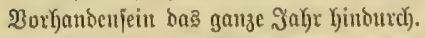

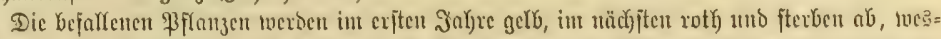

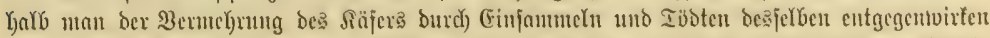

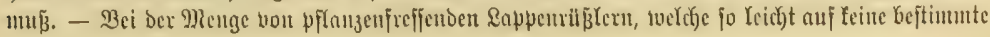




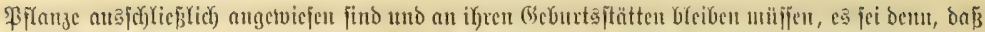

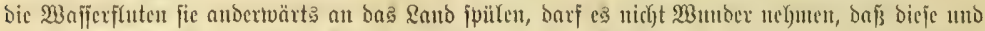

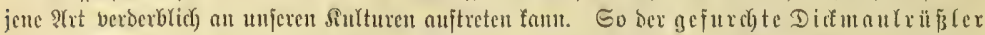

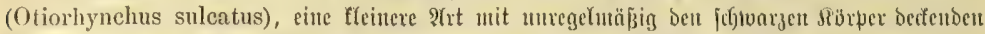

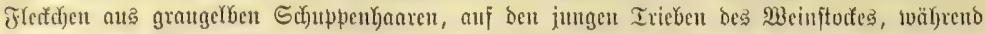

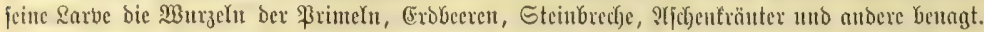

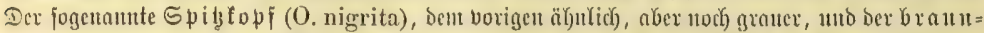

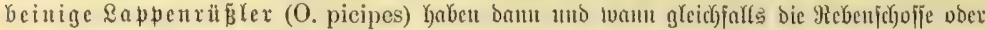

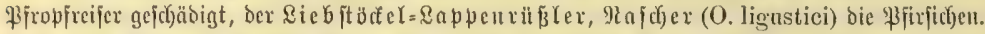

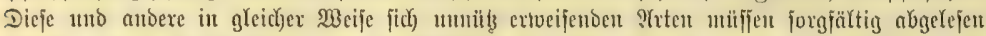

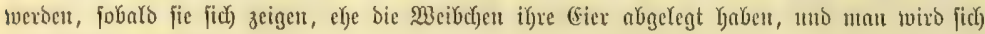
ifrer balo entlebigent.

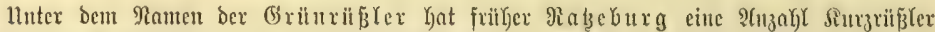

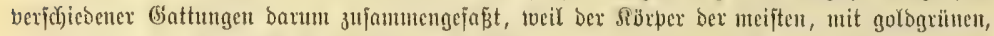

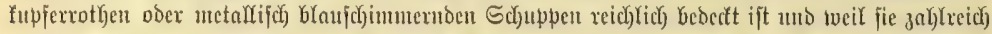

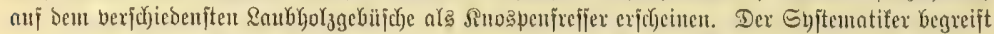

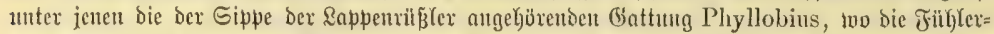

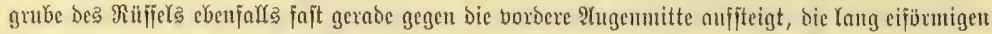

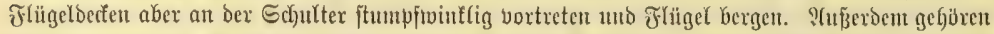
hierber einige in Shjteme vorangefente geflügette Gattungen, namentlich Metallites mit

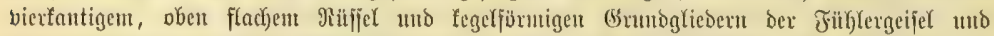

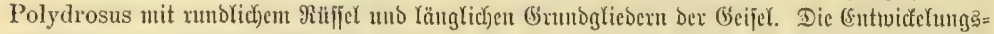

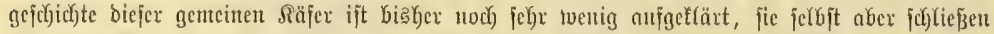

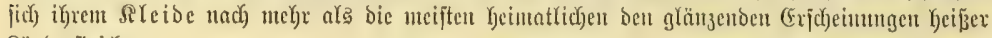
Sänderjutidje ant.

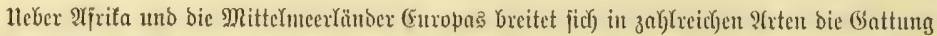

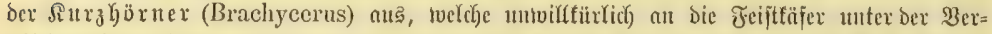

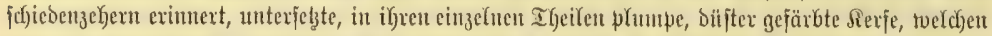

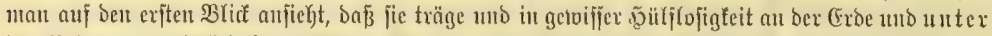

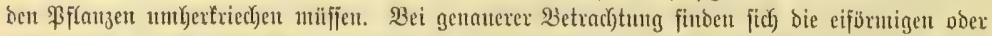

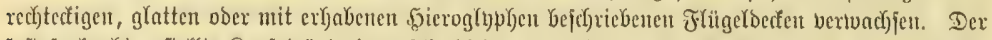

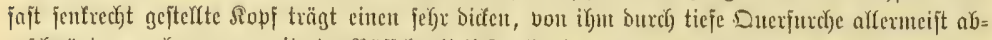

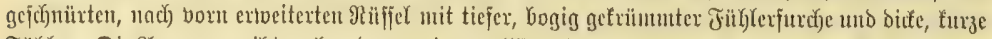

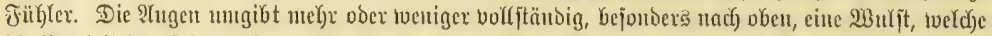

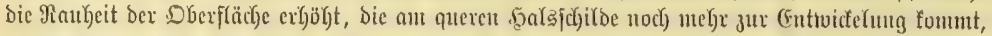

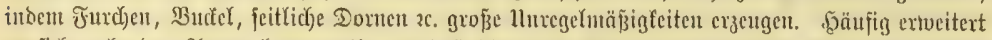

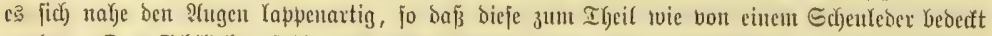

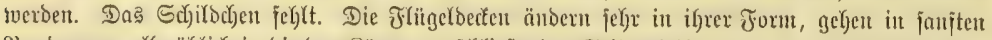

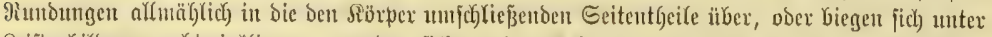

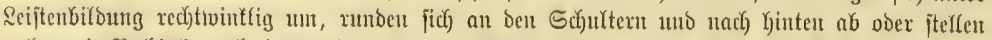

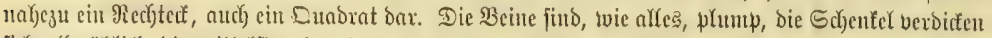

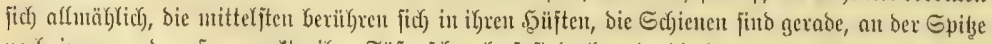

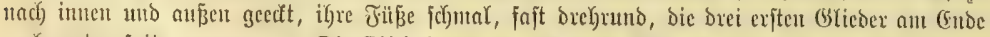

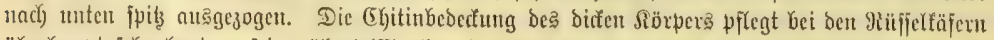

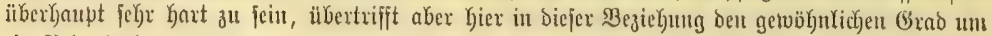
ein Bebeutende?. 


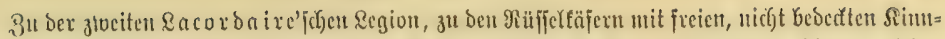

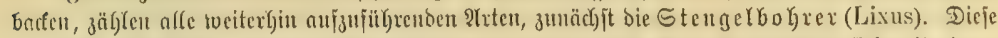

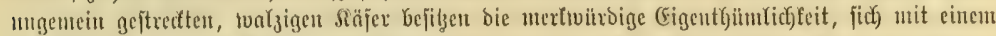

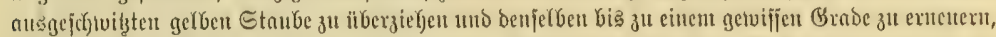

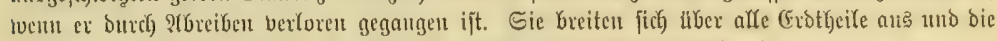

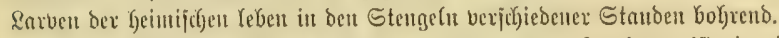

Dex Yähmende Stengelbohrex (Lixus paraplecticus) ijt ein eigenthümlich gebouter

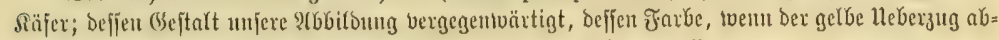

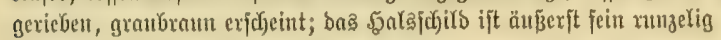

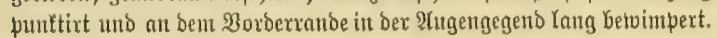
Э̧)

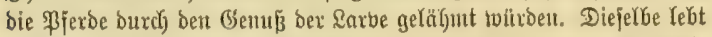

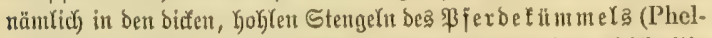
landrium aquaticum, netteroinga Oenanthe aquatica) gleid)yeitig

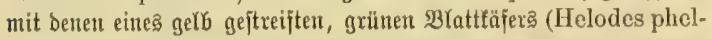
landrii), in Sium latifolium und anderen ant Waffer ftehenben

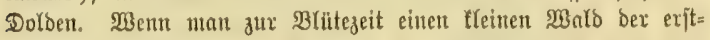
genannten an Rande eites Suntp

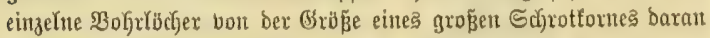

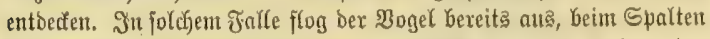
ber unverletzten Stengel findet man zu biejer Beit Yoje in einem ber

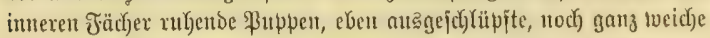
und tweiß̧e Säfer, aber andid) bolffommen ausgebilocte, twełd)en mur

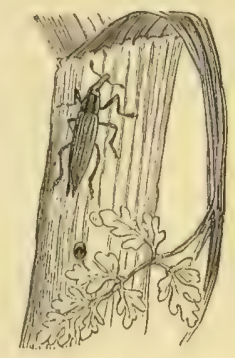

Q⿱艹⿵\zh22口 (Lixus paraplecticus), natitel. Grofer.

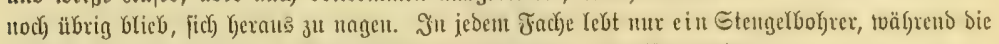

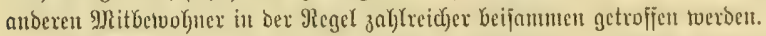

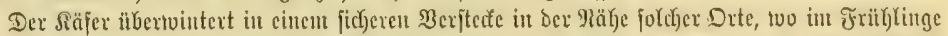

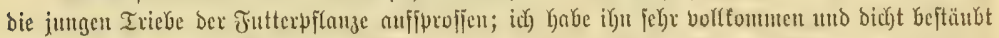
unter anderen an 30. Geptember 1872 in einer mit feiner Jutterpflanze umjäumten, зи der Зcit

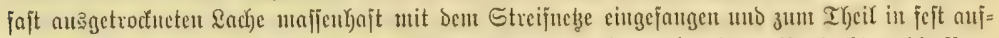

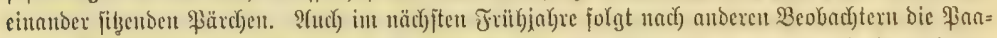

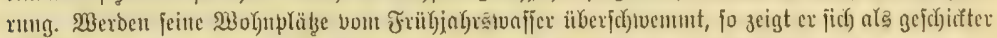

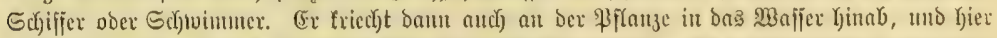

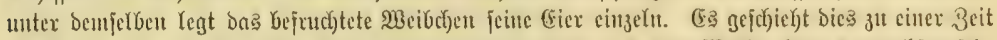

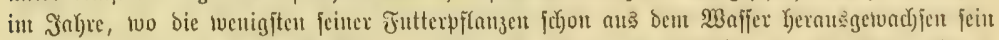

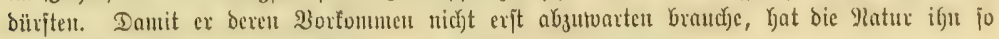

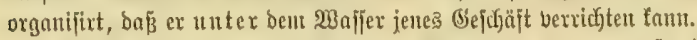

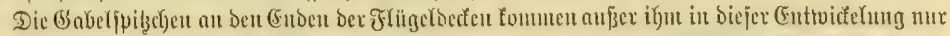

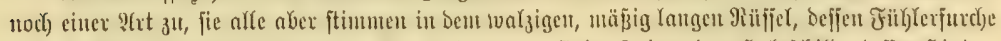

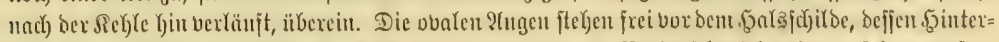

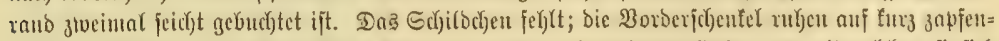

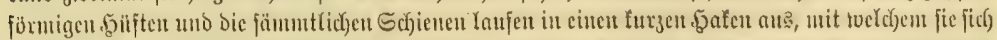

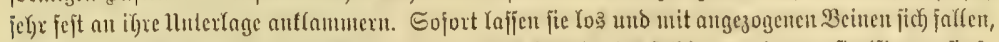

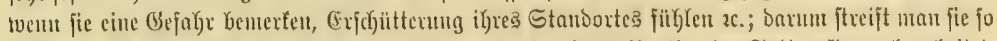

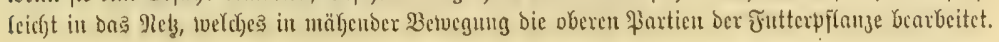

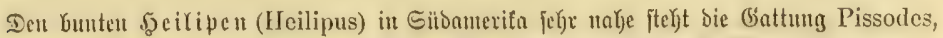

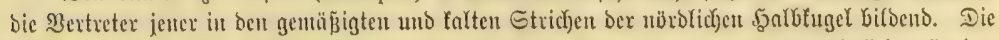

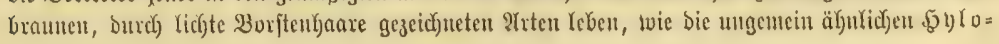




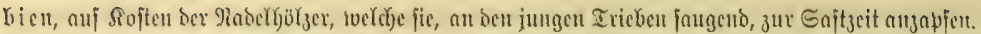

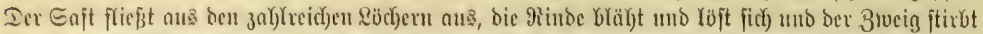

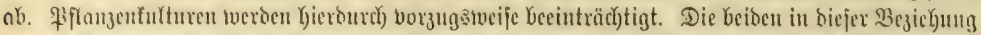

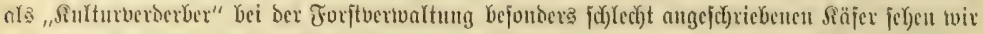

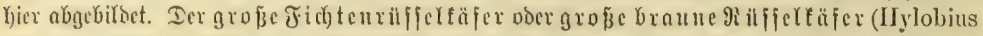

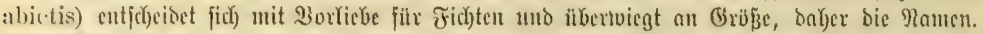

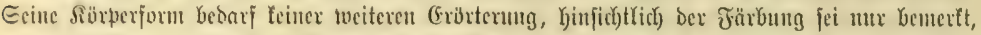

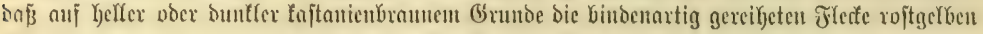

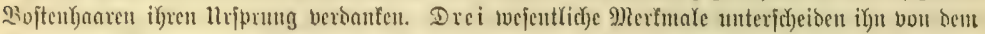

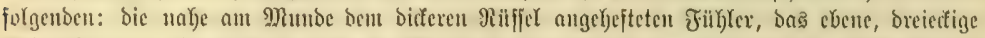

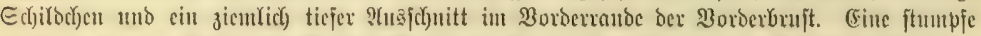

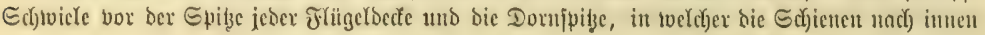

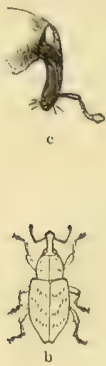

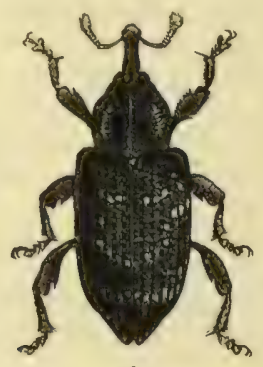

a

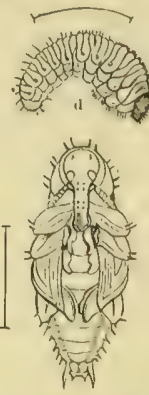

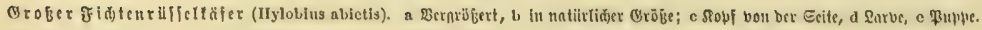

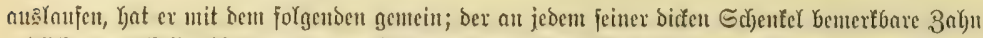

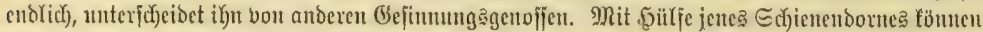

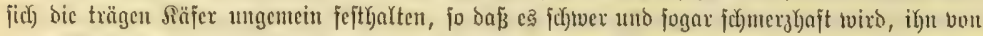

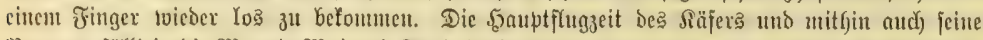

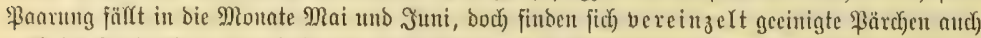

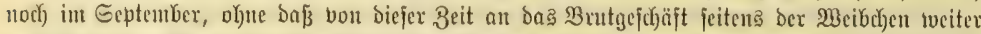

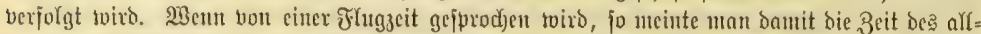

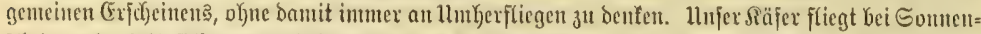

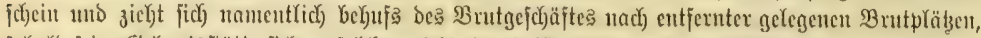

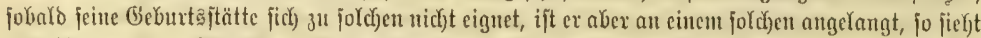

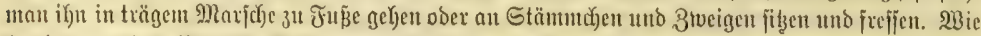
bere't ertoäl)nt, iłt ex ein Silturverberber, indem ex älteren Stämumen mit differ, härterer Riuto

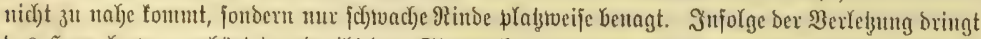

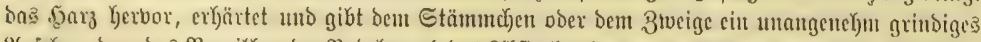

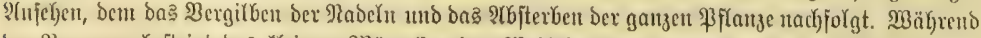

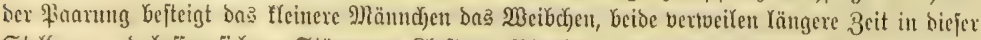

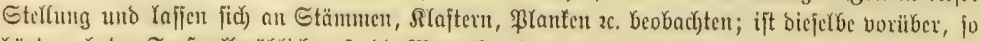

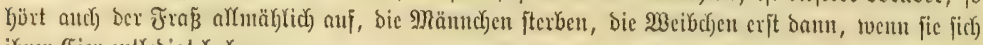
ifrer Cier entrebigt Kabcr.

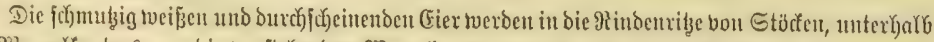

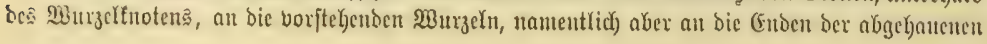




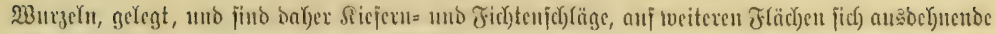

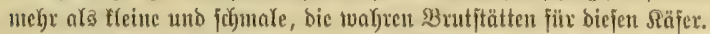

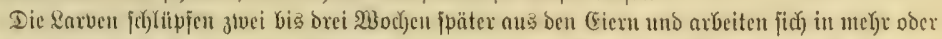

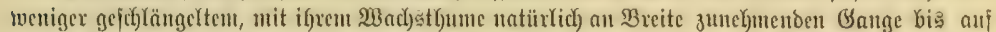

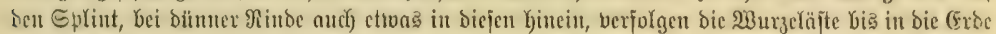

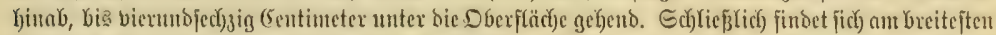

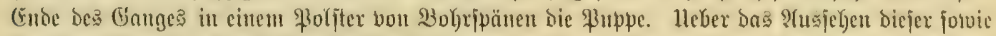

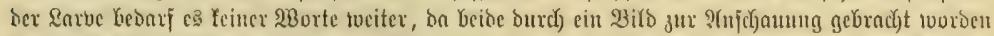

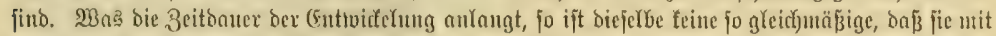

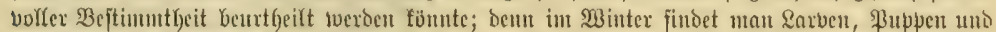

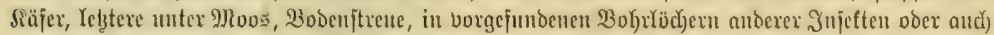

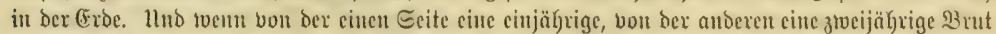

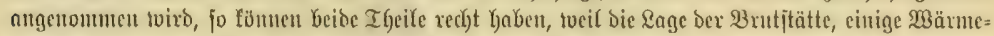

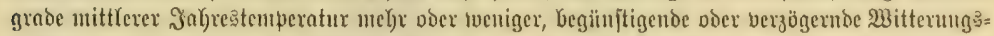

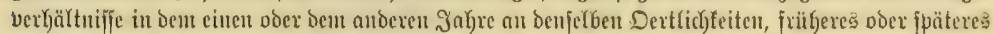

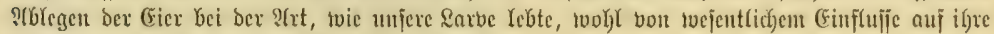
joduefle ober verzögerte Enttviffełung jein tömen.

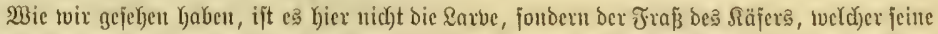

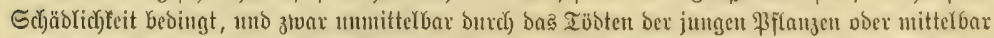

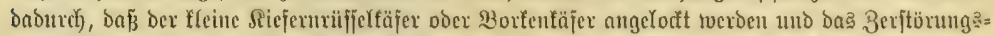

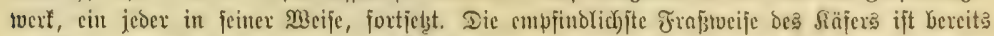

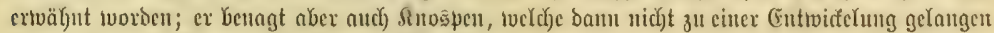

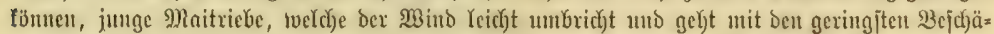

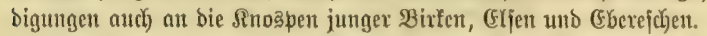

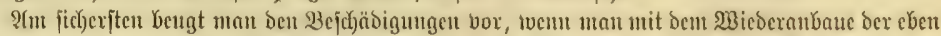

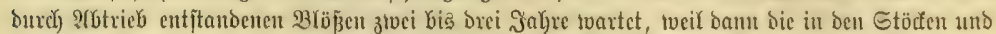

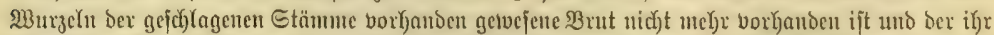

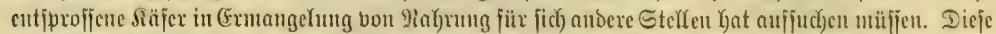

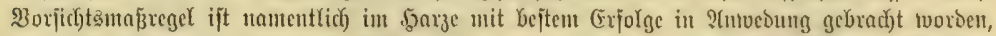

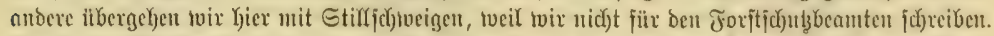

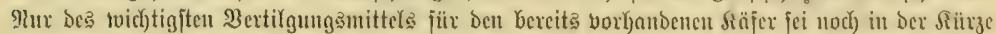

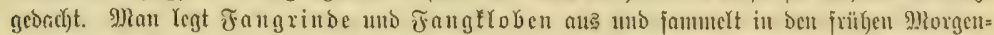

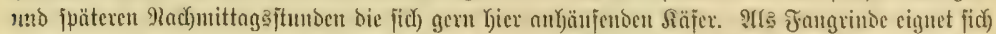

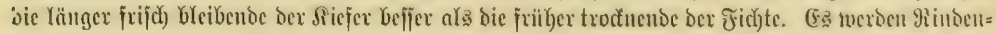

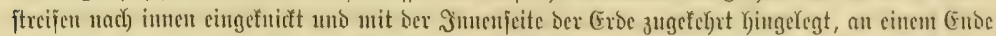

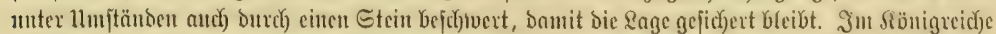

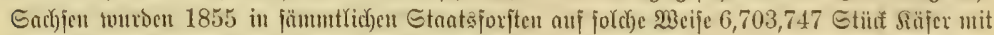

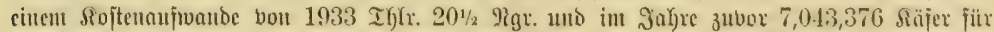

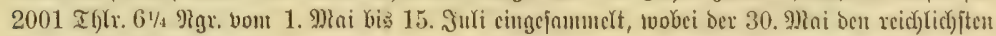
Ertrag geliefert Kat.

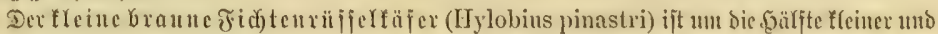

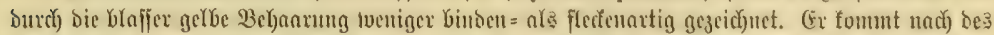

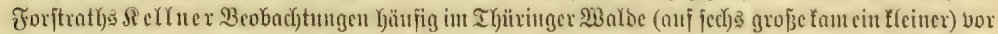

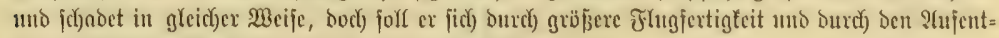

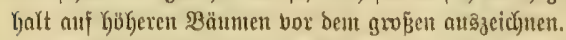

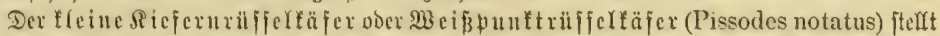

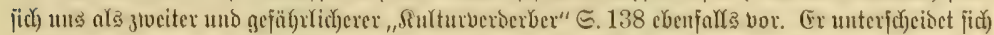

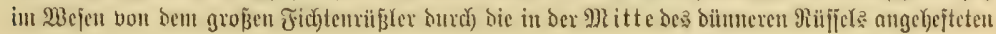




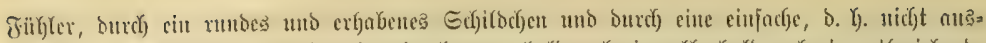

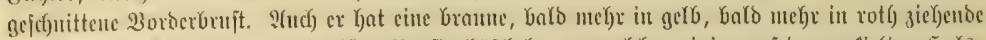

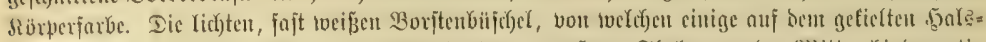

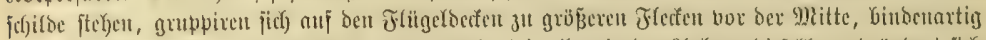

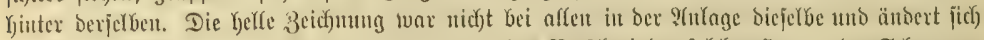

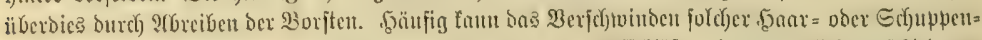

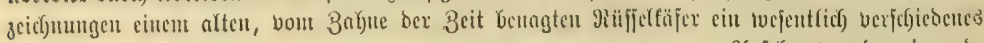

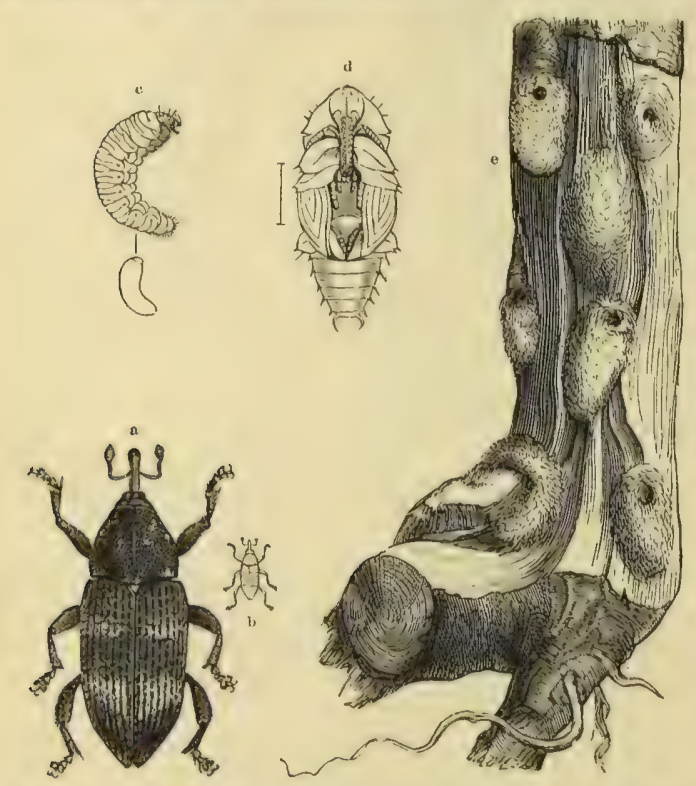

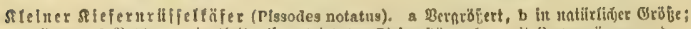

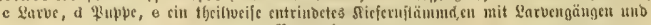
Buђpentngeris.

P(njekent bon bent jugend= lick frijocu verteiben. llujer Pissodes notatus (n̈ß̧t fich) unter mehreren anberen (Sattunģgengenofjen an bex ungleichen \$suntti= rung feiner Flügeldedfen erfenuen. Die ßuntte näm= (ich), weldye in Streifent uber biejelben Ginzichen, toerbent aut ber slltite ber Decten vič gröp̄ex uno nefymen eine beinabe vies= ectige Geftalt an gegen bie ffeineren mb ruttoent

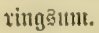

Wie ber großje brame Ruiljelfäfer exjodyeint autly bicjer ffeine im I্নtai, je= bod) it größ̄erer Mlenge uno in weiterex 23erbrei= tung ała jener. 2Hipang? geht ex tur bem Fraße nad), indem er bie Pinte Der Riejern und $\mathfrak{B e t}_{\text {) }}=$ mouthastiejern, jeltener ber Rürdyen und Fidften anjticl)t, den Müfjel ber=

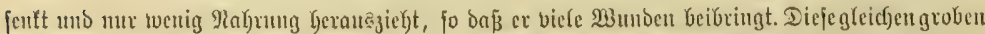

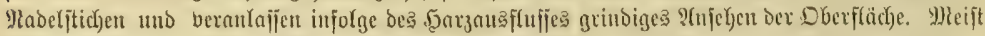

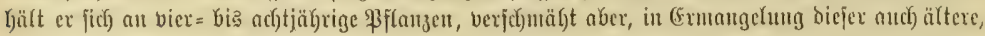

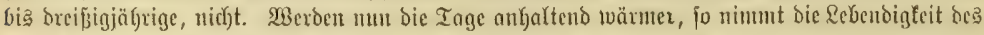

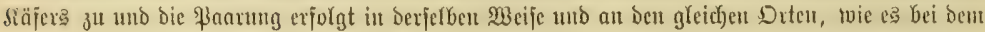

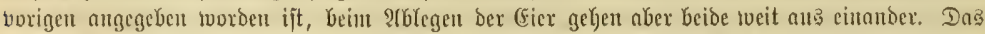

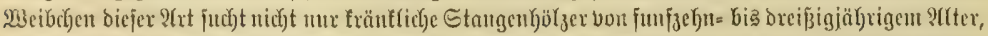

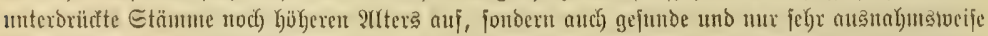

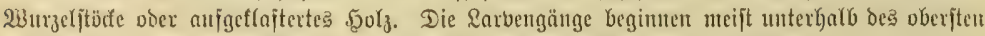

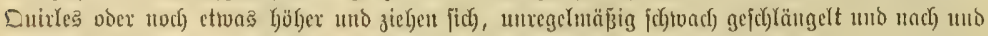

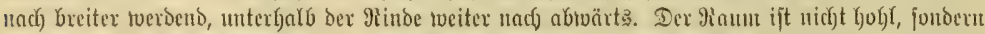

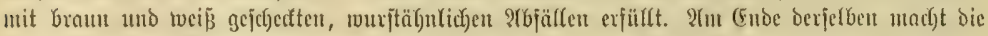

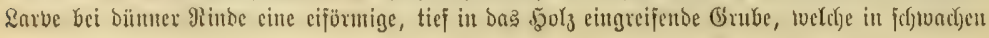




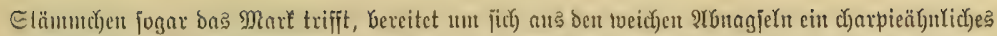

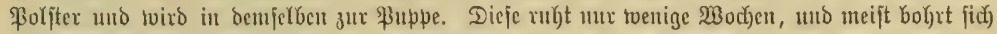

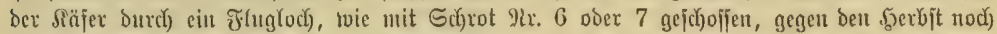

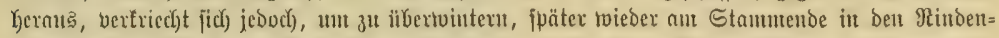

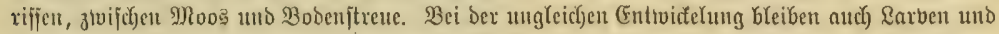

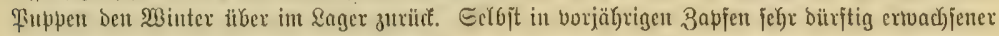
Siefern hat man bie Ravben bereinzelt ober biş zu breien allgetroffent.

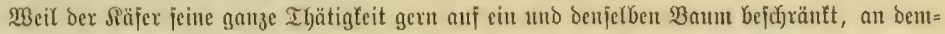

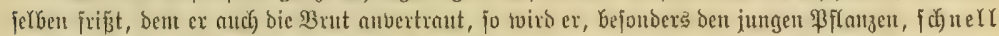

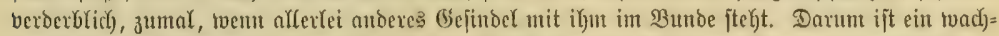

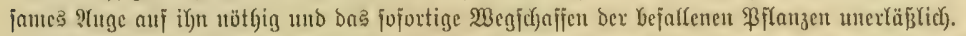

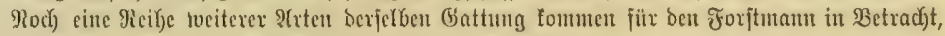

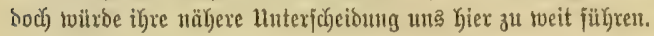

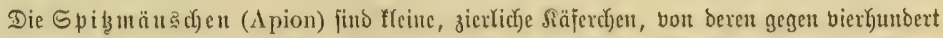

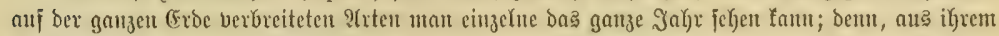

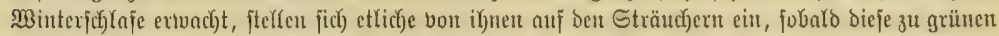

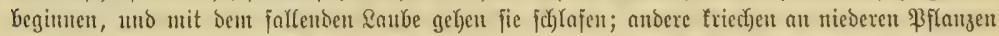

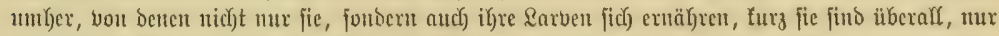

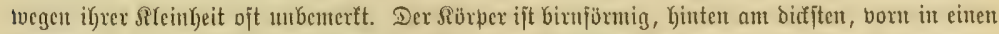

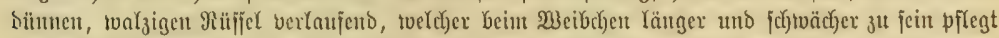

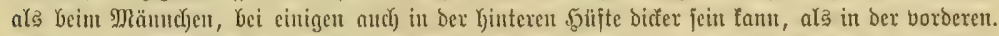

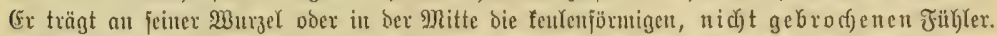

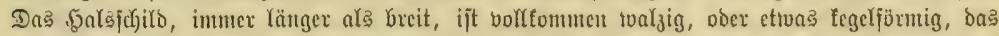

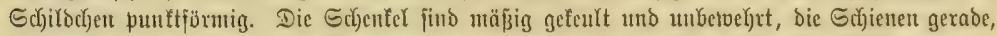

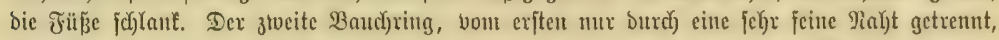

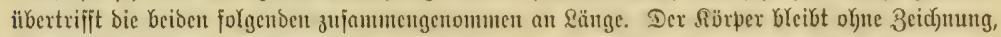

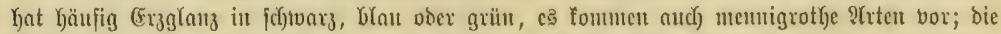

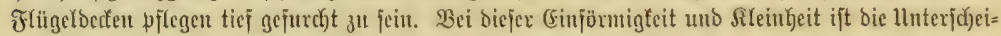
Dung vielex 2(rten mit bedeutenden Schtvierigfeiten berbunben.

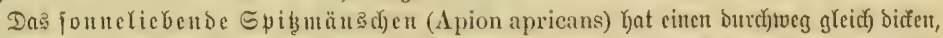

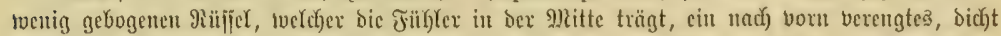

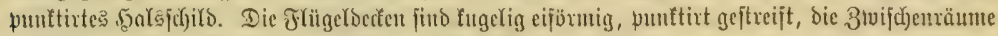

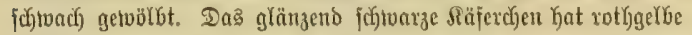

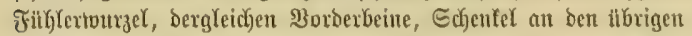

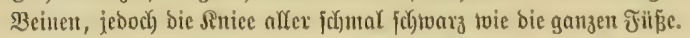

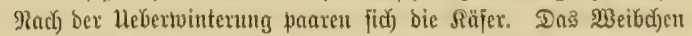

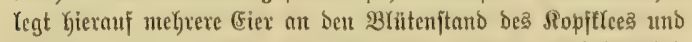

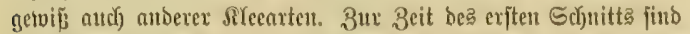

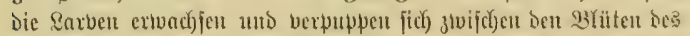
Sïpfichens. Db in Demjelben Jahre eine zweite Brut ju Stande

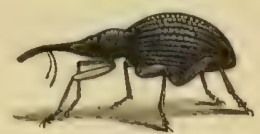

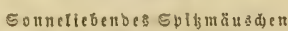
(Apion apricans), vergribett.

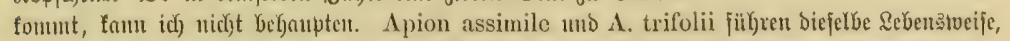

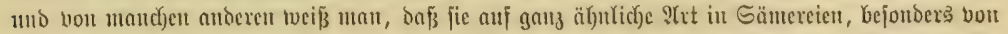

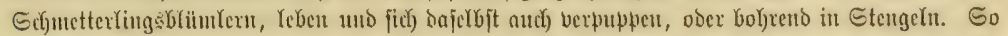

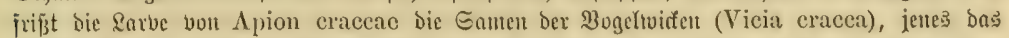

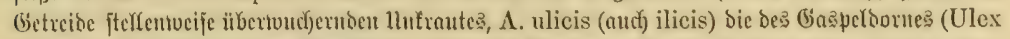
europaens), ba norbancrifanijode $\Lambda$. Sayi bie Siönter ber Baptisia tinetoria. Apion flavi-

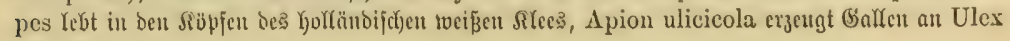




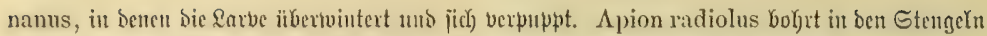

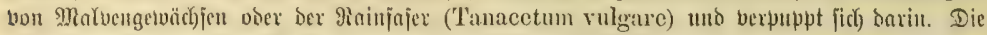

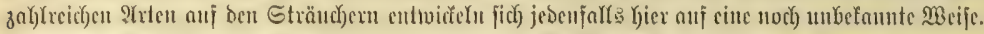

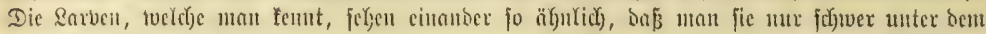
9lifroftope unterjodyeiden foum.

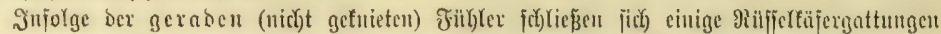

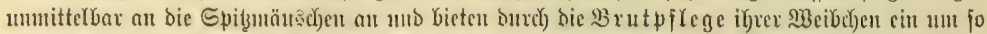

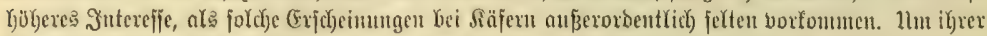

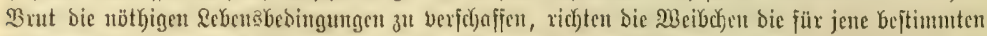

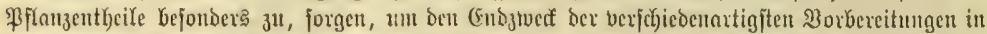

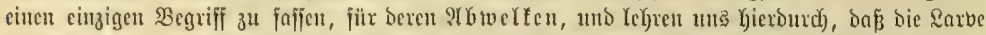

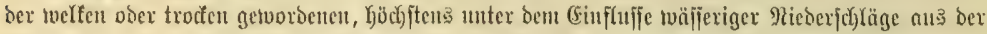

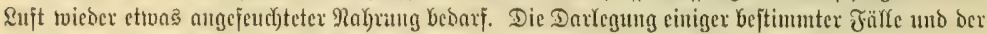

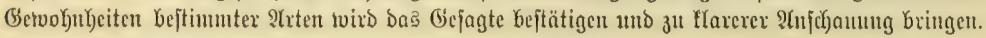

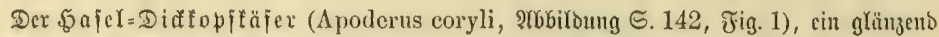

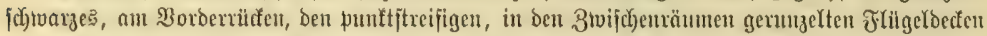

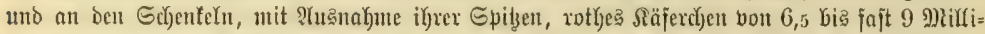

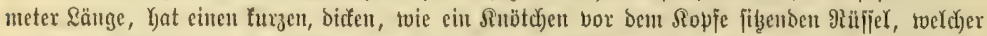

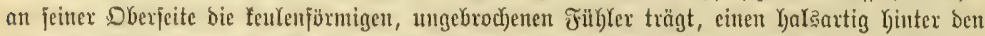

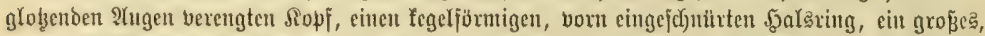

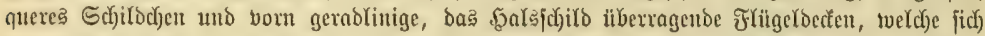

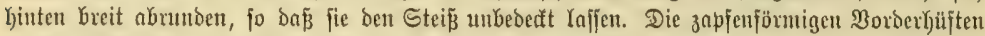

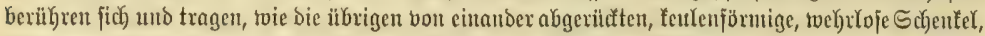

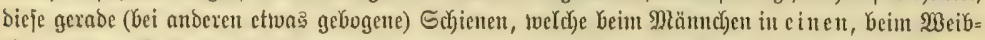

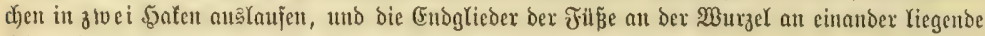

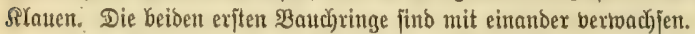

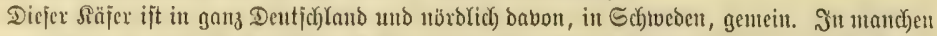

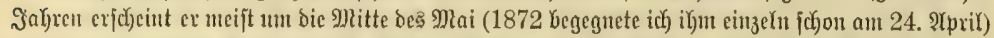

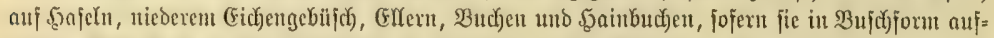
treten. Gein Fraß̃ an ben betreffenden \&nubhölzern ift ofne Bebeutung, bagegen fallen bie von den

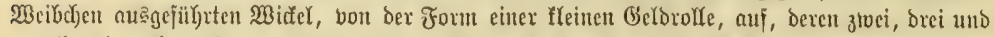

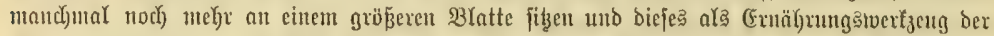

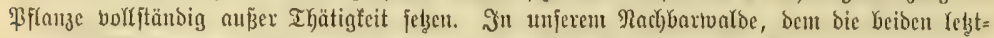

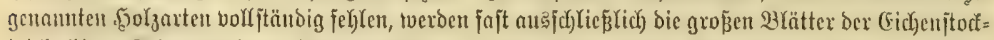

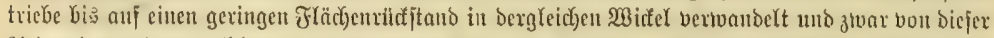

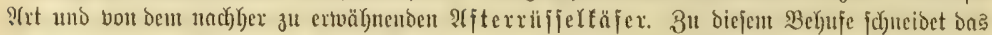

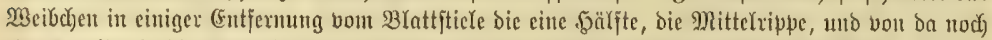

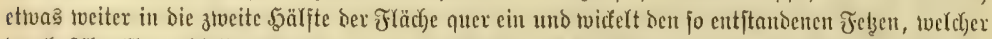

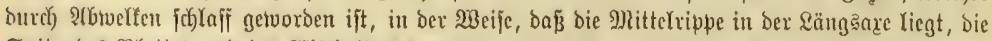

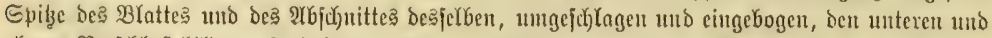

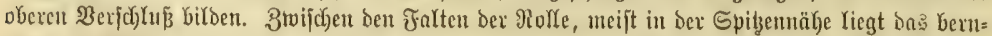

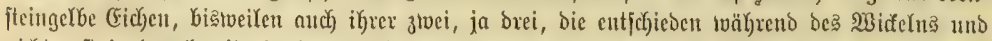

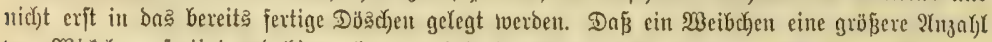

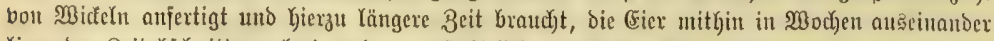

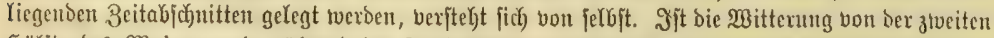

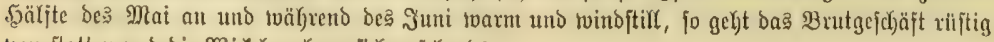

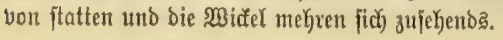




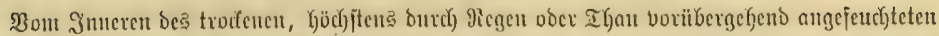

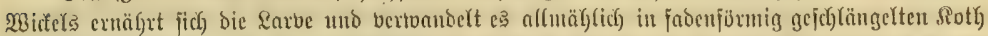

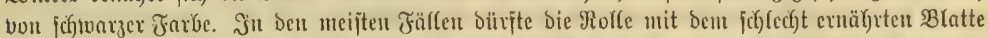

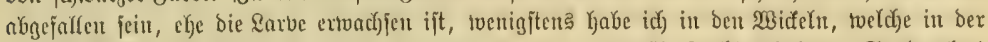

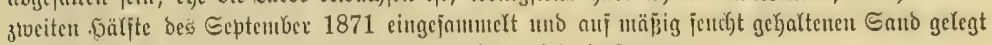
worden waren, noch am 25. 2pril 1872 ertwadjiene, lebende \&arven ant=

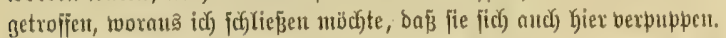

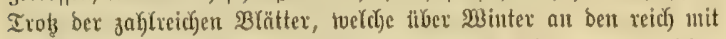

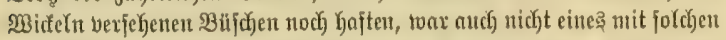
melyx zu finden, toeder an (Fichenbujche, nod) an der (Eroe. Die 2tugabe

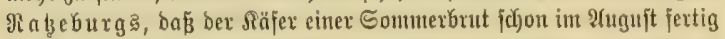

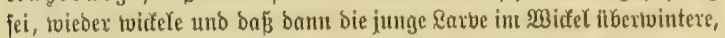

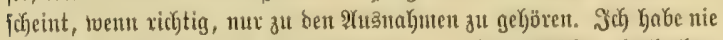

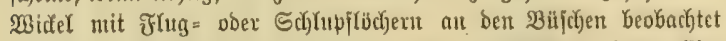

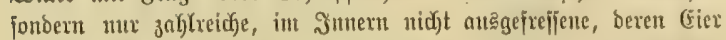
mithin nicht gux (Entrvidelung gelangt fein fomntest. Solfte nidgt

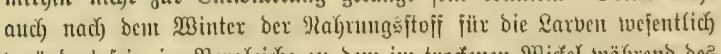

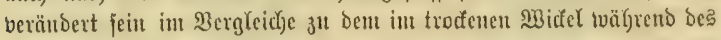

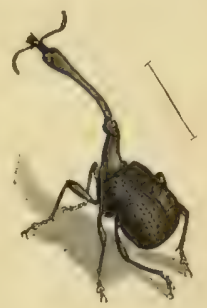
Gommers gebotenen?

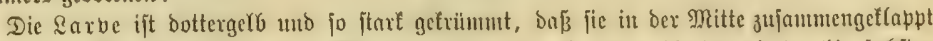

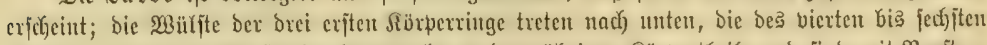

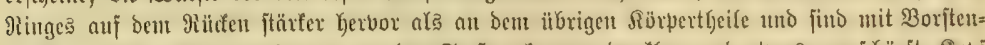

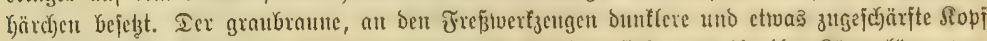

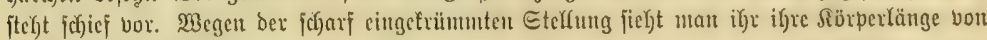
11 Millimeter nicht all.

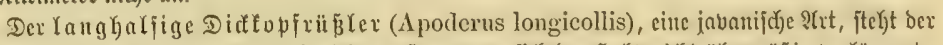

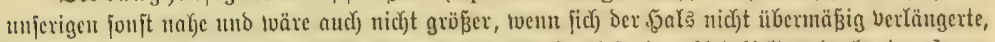
bejonocrs beint 92)

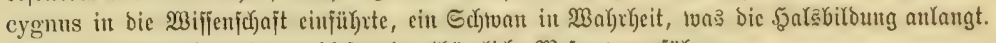

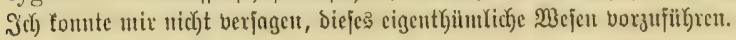

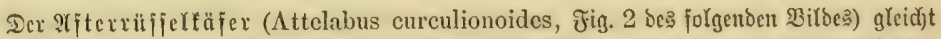

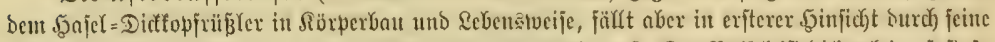

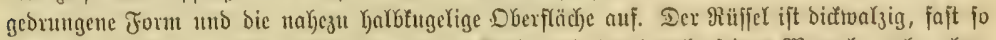

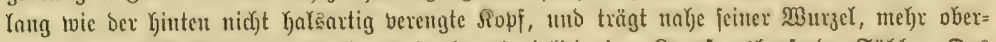

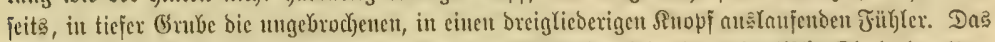

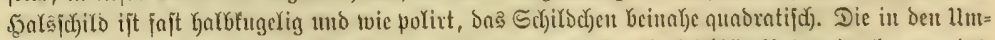

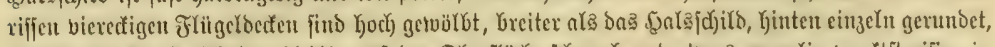

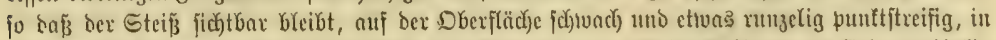

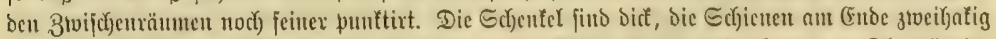

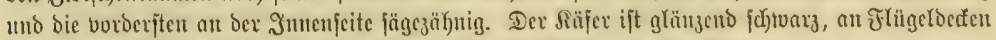

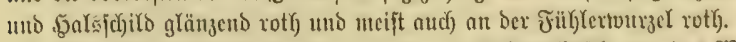

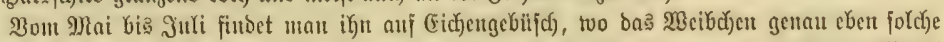

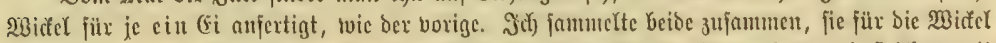

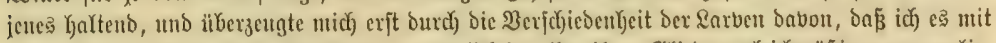

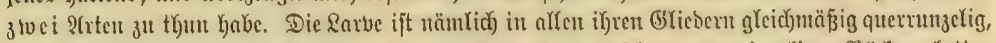

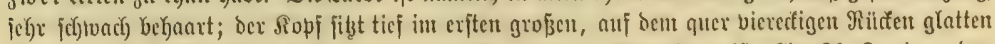

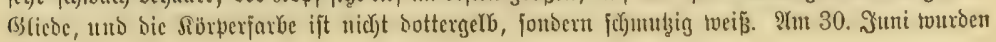




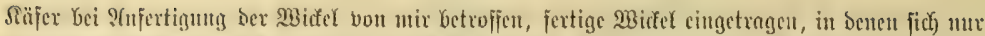

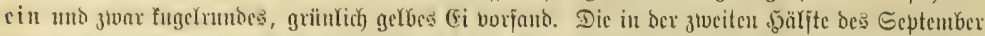

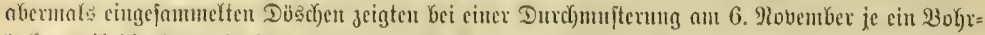

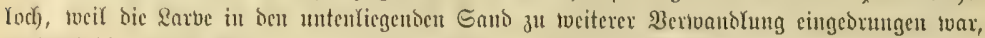

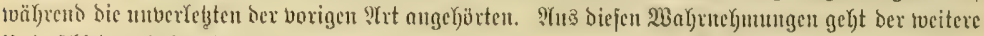

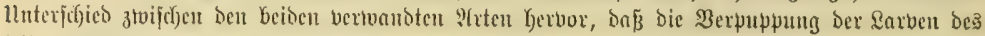
Ifterritiferfififerß in ber Ex de erfolgt.

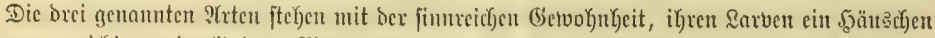

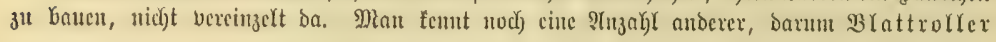

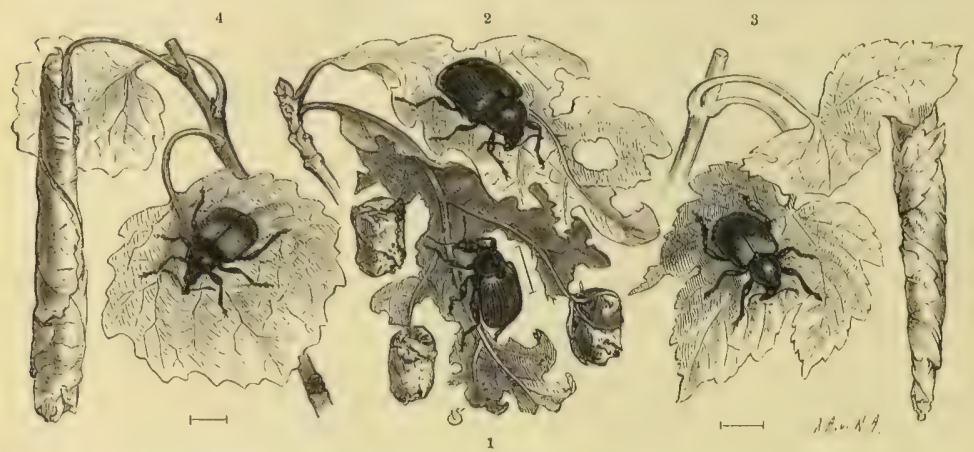

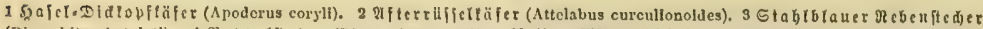

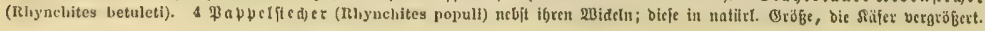

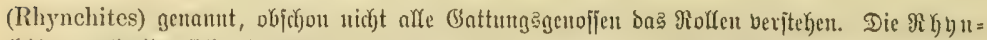

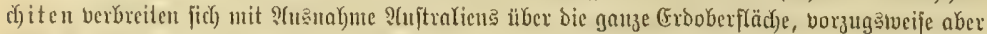

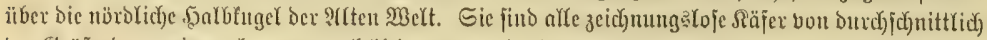

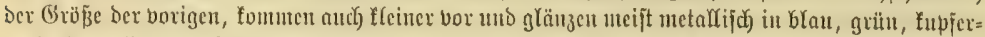

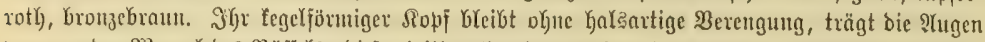

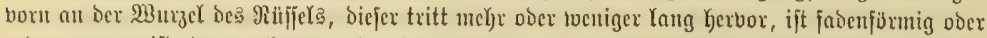

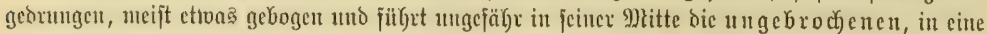

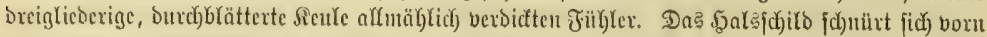

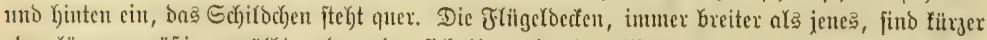

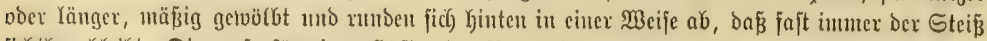

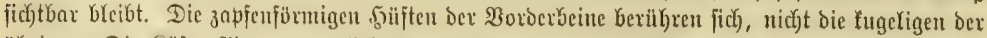

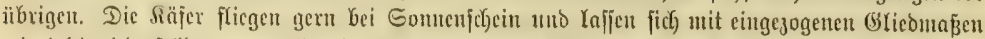

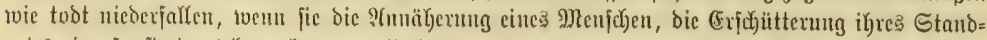

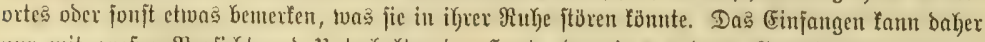

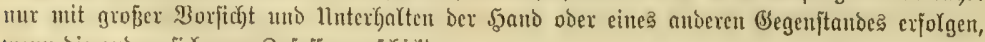
roen bie ansere fidf jum 3 ufaffen anjobictt.

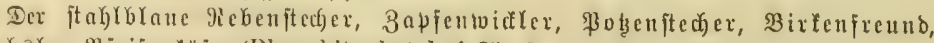
Dred)

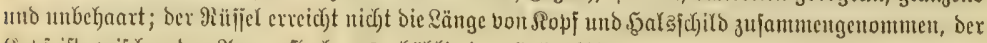

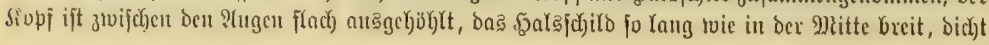




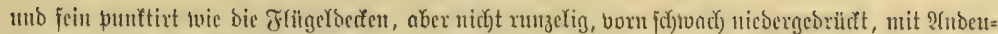

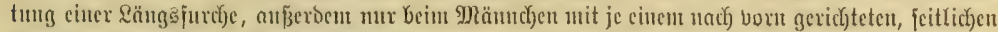

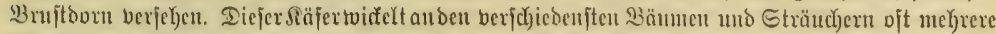

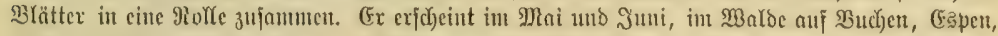

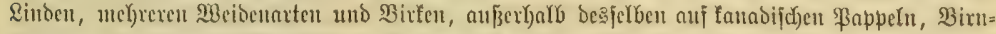

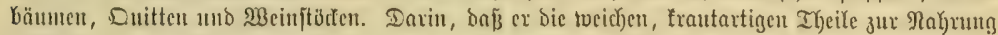

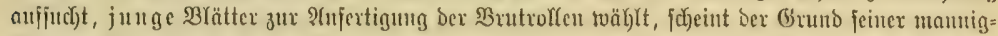

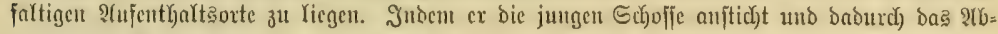

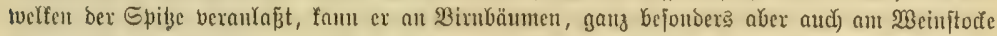

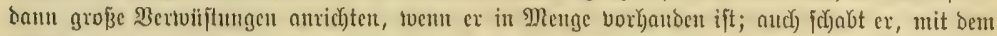

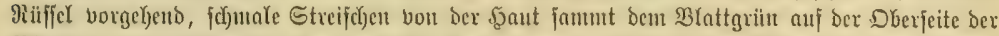

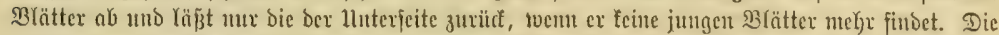

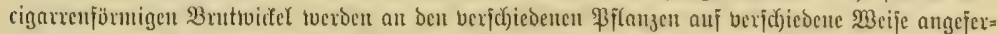

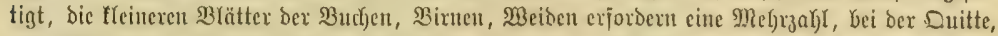

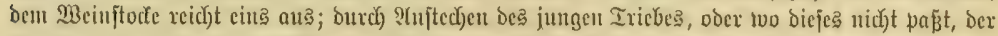

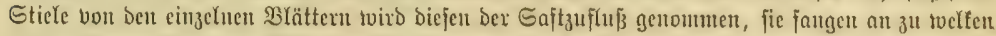

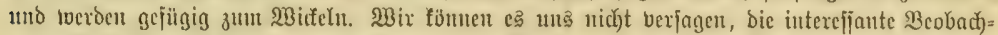

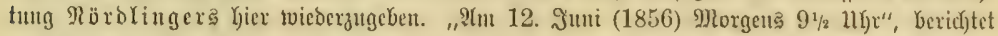

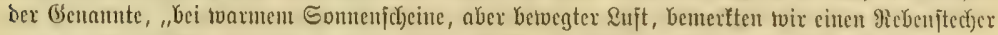

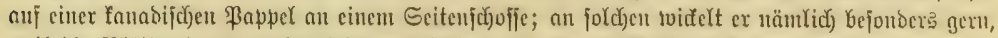

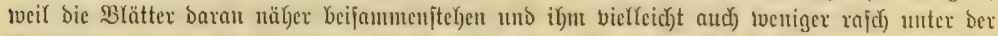

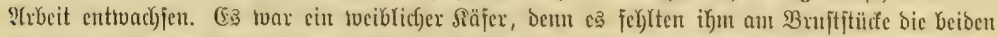

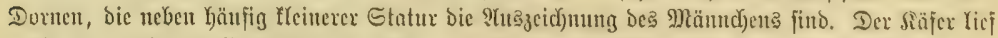

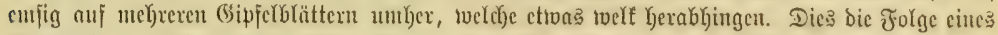

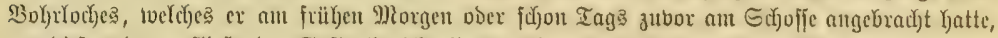

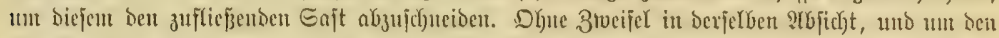

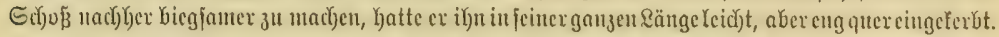

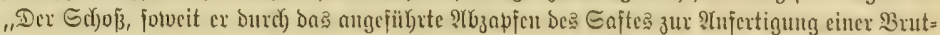

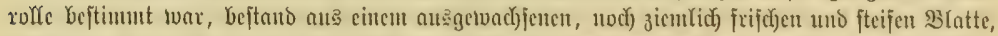

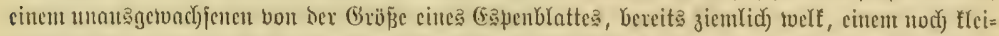

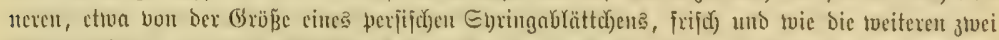

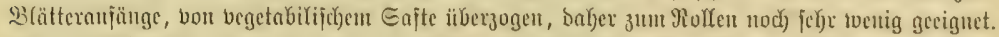

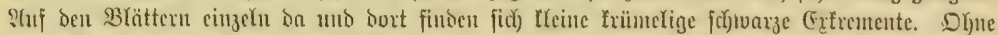

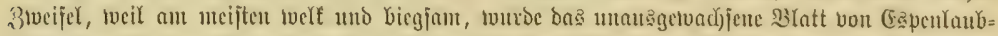

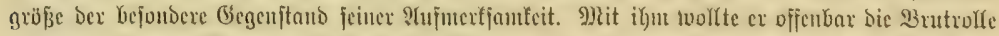

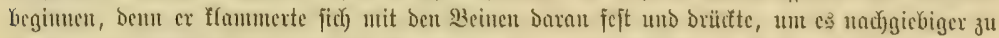

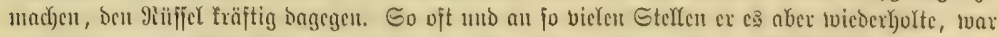

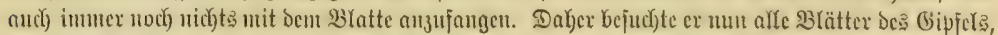

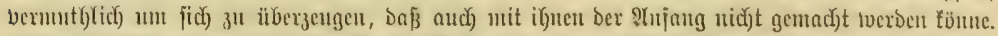

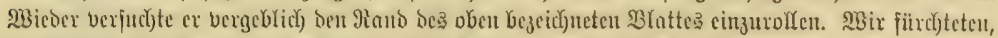

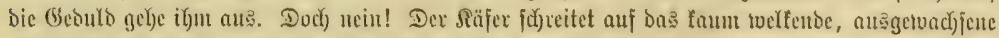

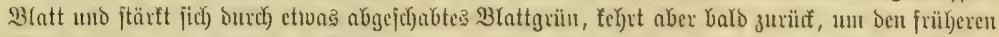

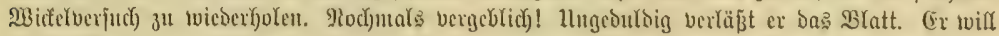

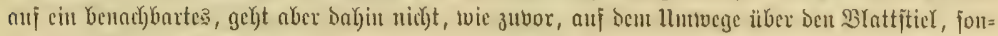

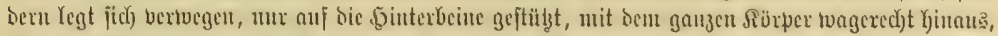

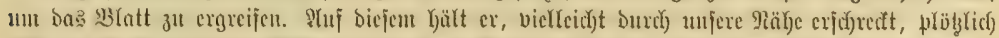

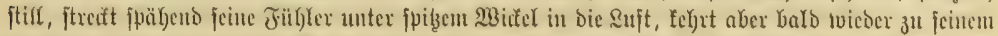

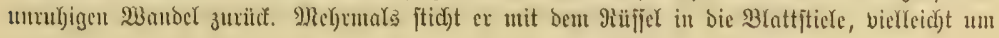




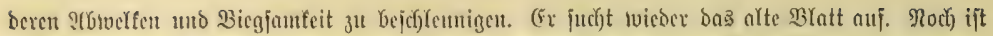

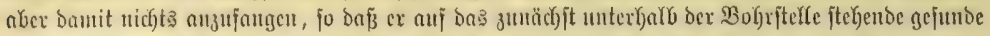

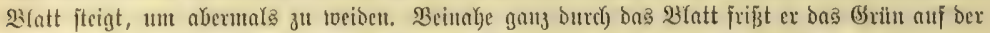

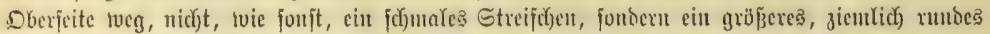

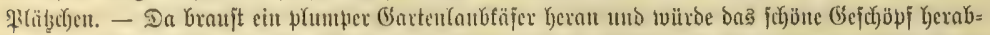

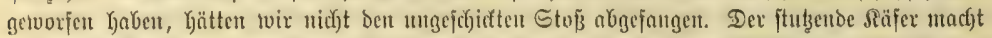

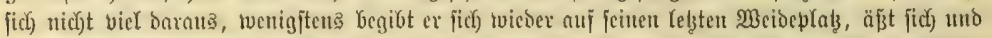

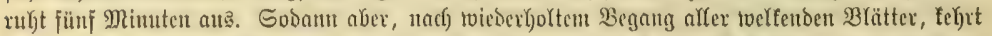

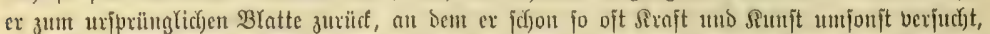

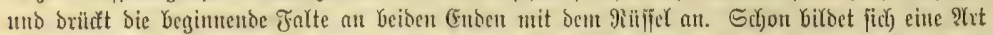

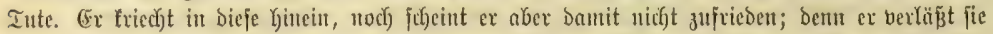

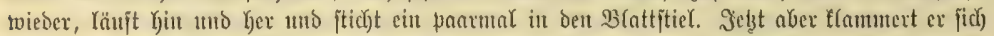

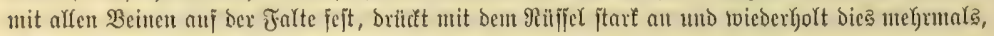

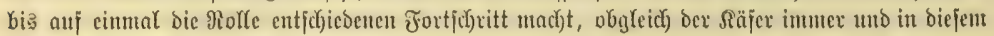

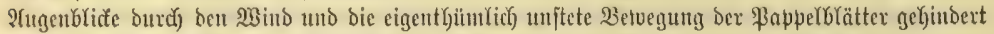

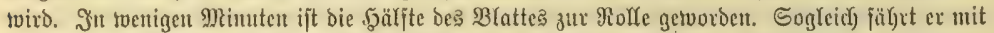

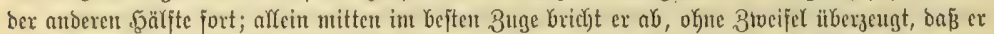
auff bie angejangene Meije nicht zu Ende fonmen werde, und jührt auf andere Weije fort. Dentlid)

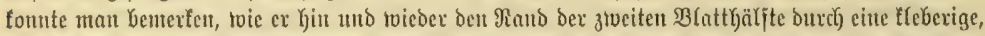

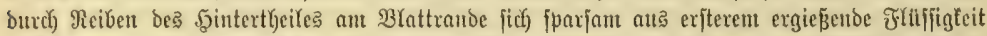

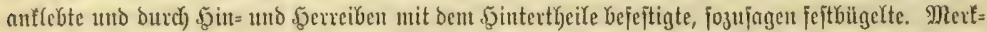

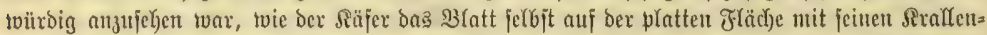

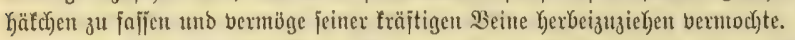

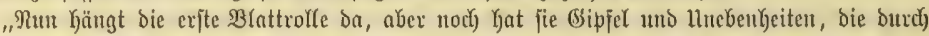

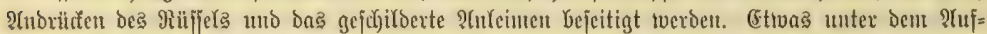

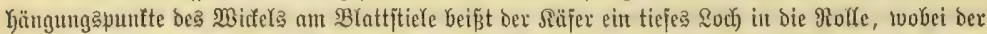

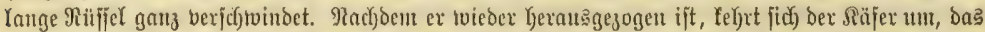

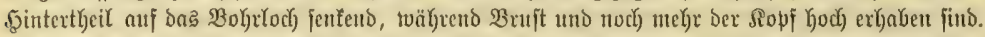

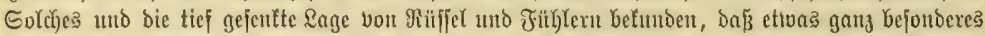

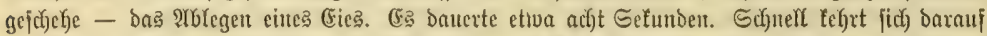

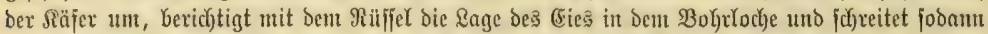

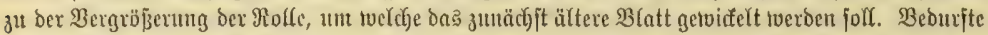

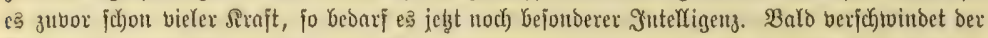

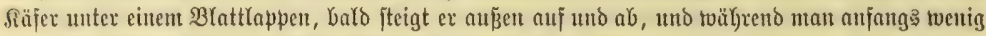

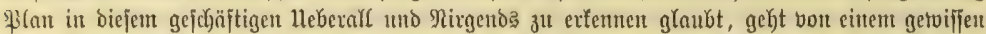

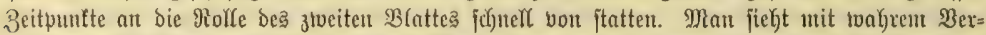

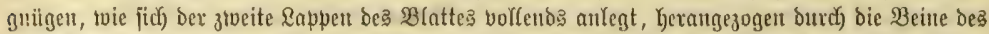

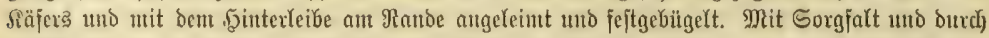

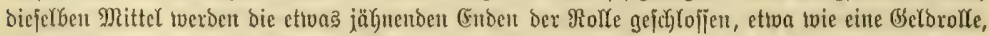

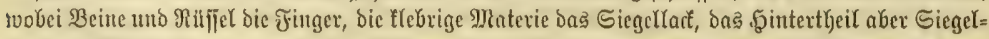

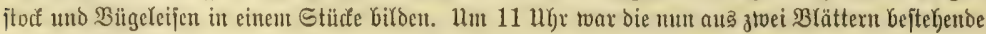
Polle fertig.

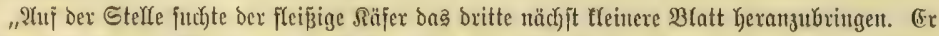

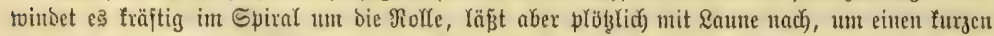

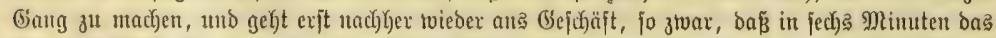

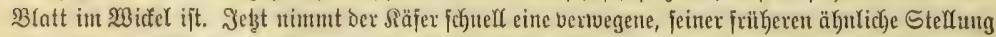

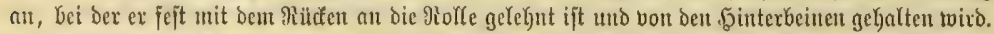

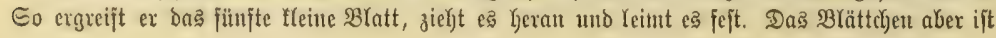




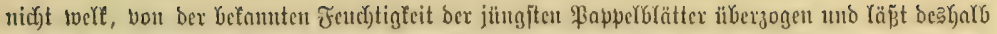

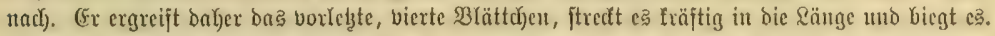

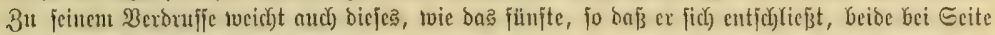

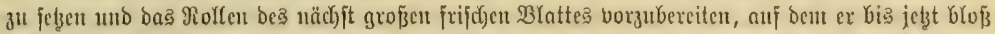

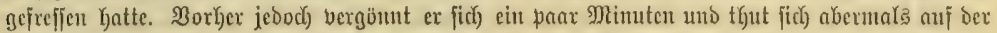

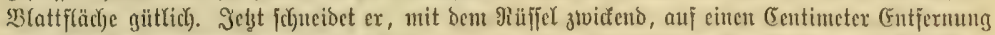

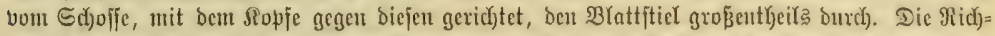

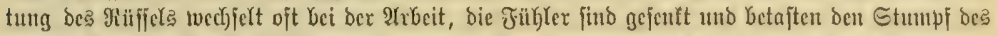

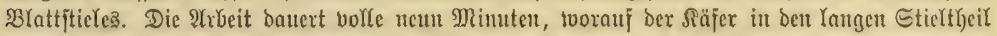

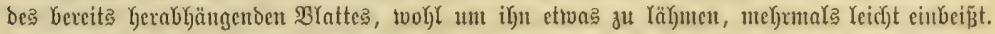

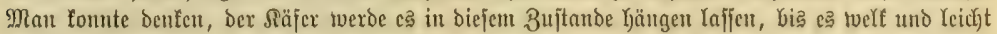

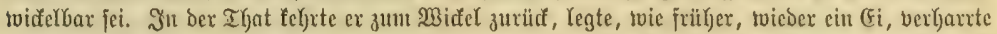

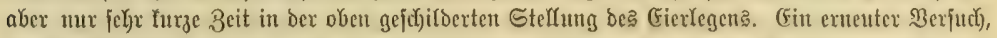
bie (Endblättchen zu rollen, Kat feinen volfitänoigen (

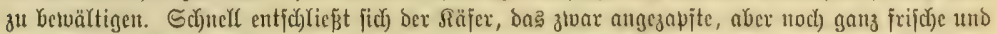

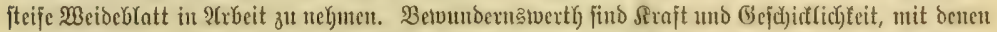

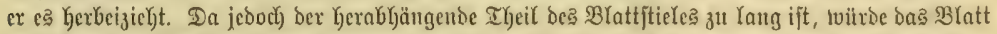

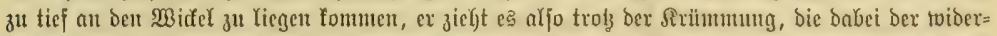

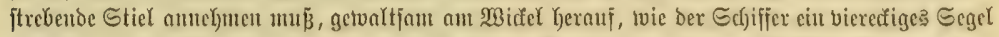

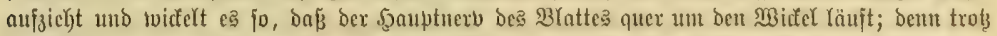

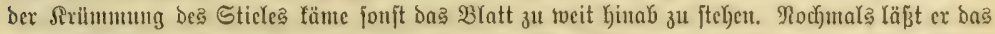

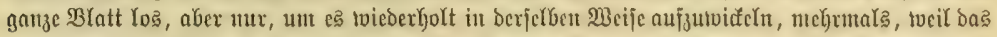

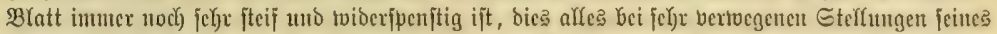

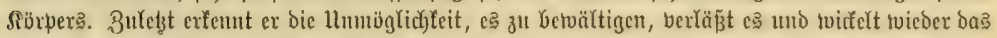

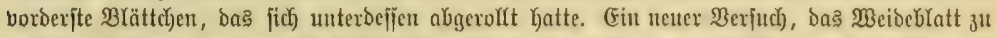

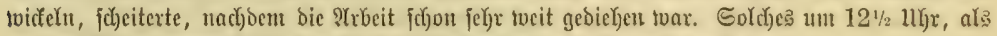

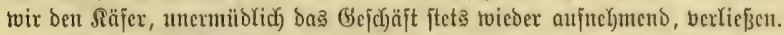

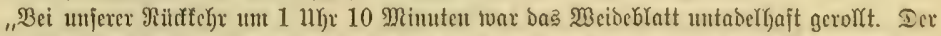

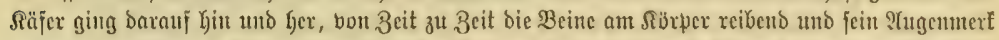

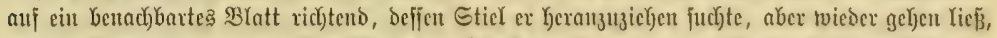

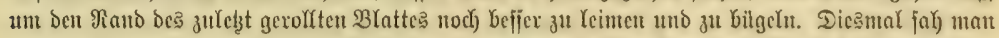

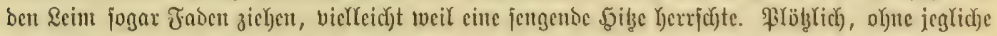

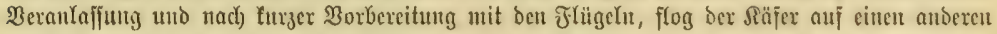

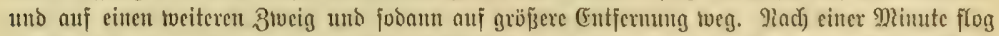

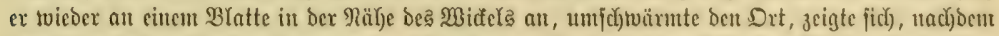

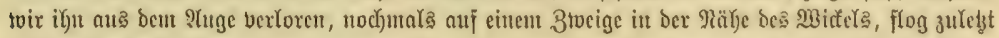
aber fuir immer toeg."

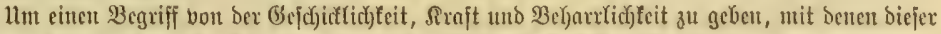

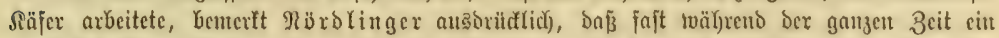

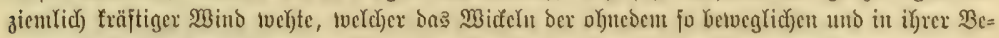

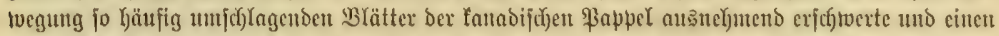

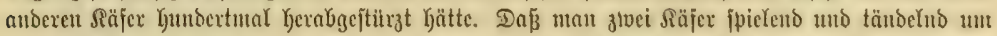

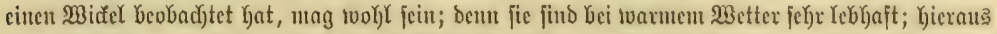

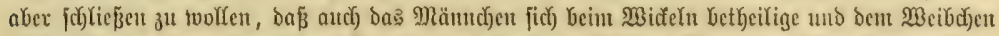

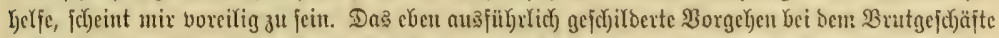

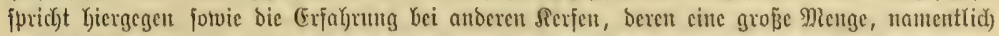

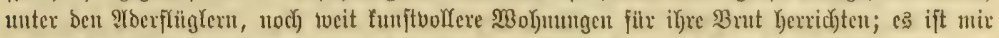

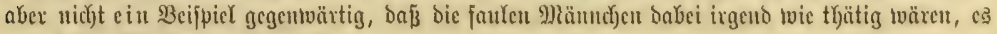
Brebma I biettebcr. 2. 2tuflage. IX. 


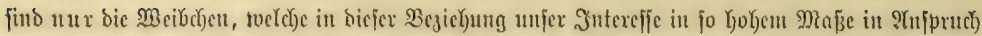

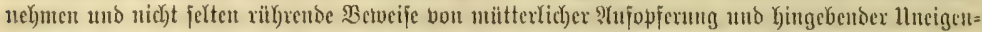

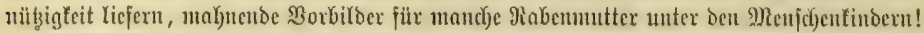

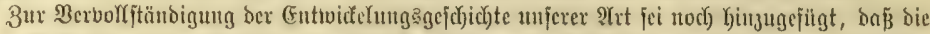

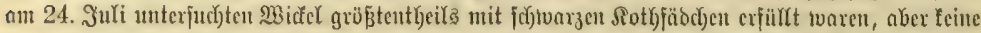

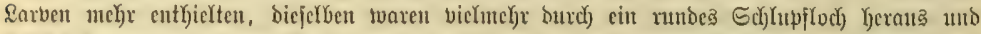
3 bis 4 centimeter tief in bie (Froe gegangen, wo fie in einer ungefähr erbjengrofen, invenbig geglät=

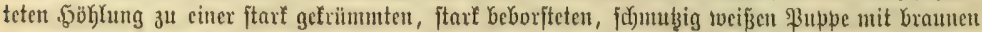

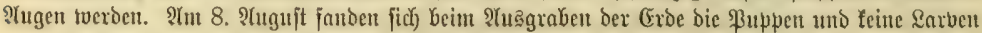

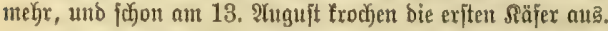

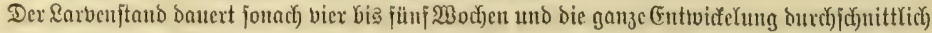

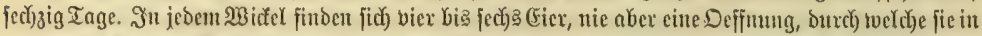

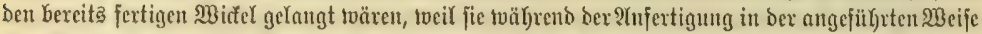

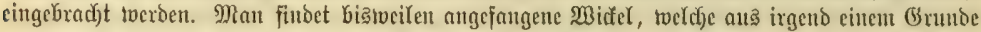

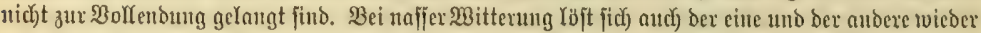

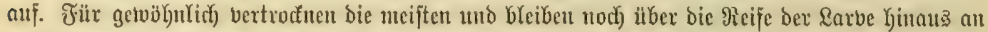

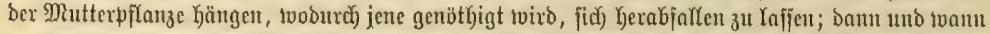

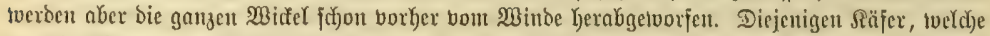

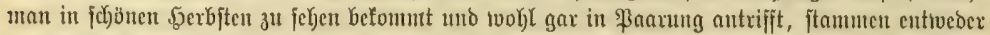

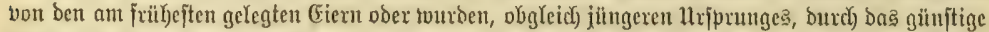

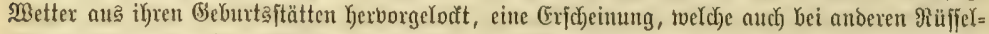

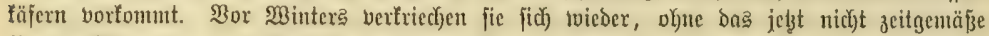
Brutgejchäft weiter zu betreiben; benn ztwei Generationen in Jahre, welche man früber wohl angenommen hat, toilroen gegen bie Regel fein.

Der \$apłelftecher (Rhynchites populi, Jig. 4, S. 142) ift bem vorigen fehr ähnlich), aber

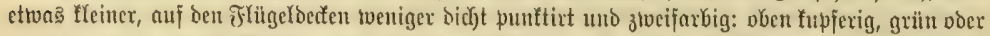

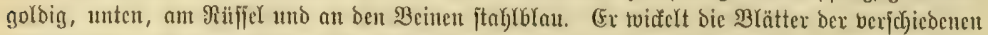
Fappelarten, ferhr gern bie ber Bittexpappel uno bertvendet zu bem cigarrenartigen Wiofel nur cit

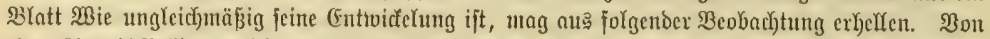

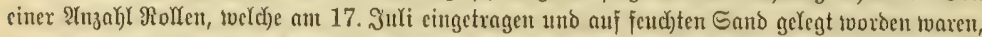

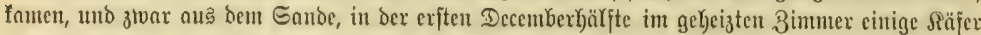

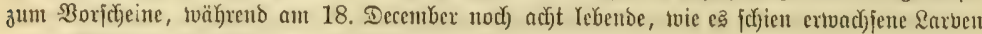
in ben Midfeln aujgejunden witrden, in jedem nux eine Sarbe.

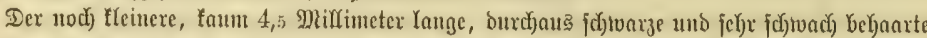

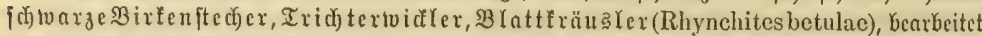
Die Blätter ber $\mathfrak{B i z f e n , ~ ( E ) ~}$

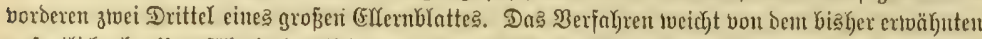

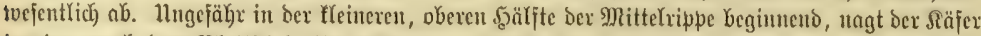

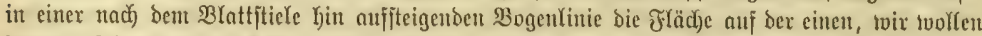
fagen auf ber rechten, Seite ourd), läß̈t bie ifym begeguenoen Geitenrippen unverlebst, in ent=

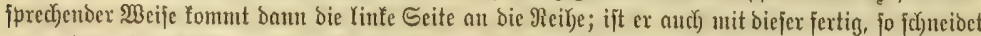

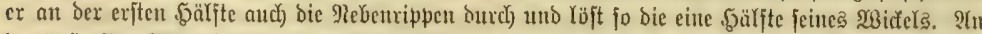

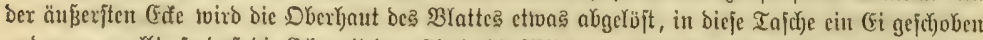

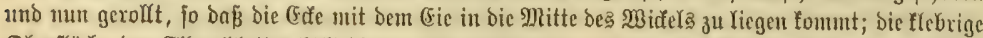

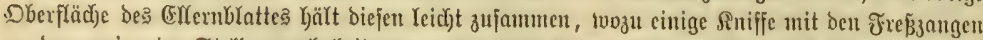

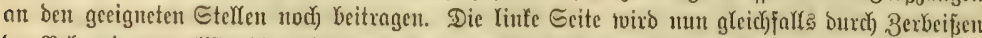

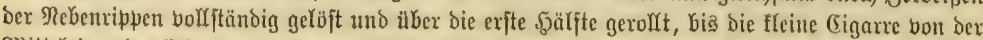
פlitteYrippe de 


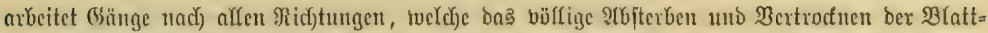

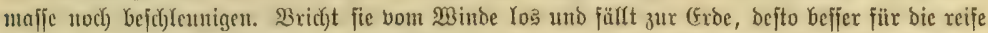

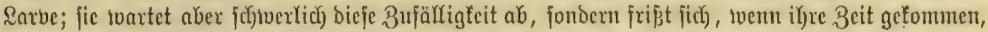

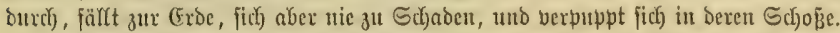

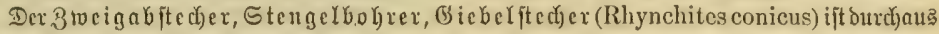

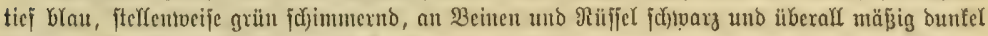

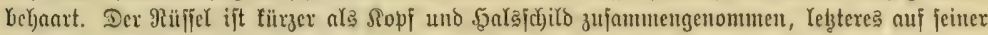

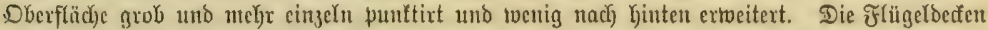

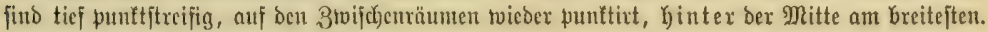

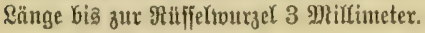

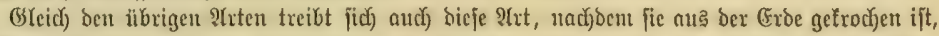

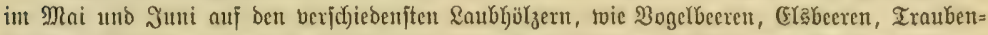

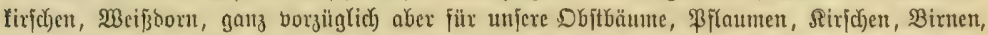

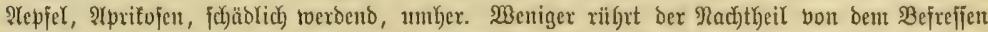

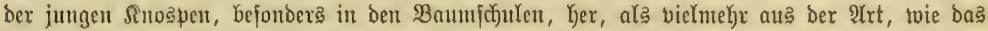

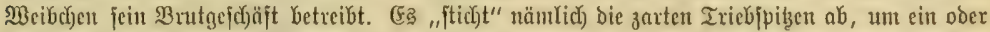

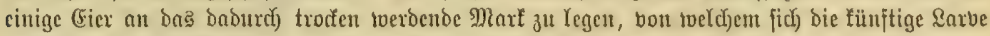

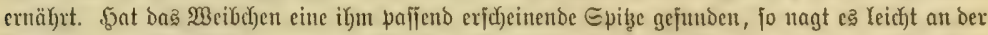

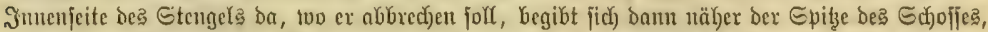

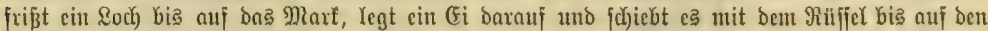

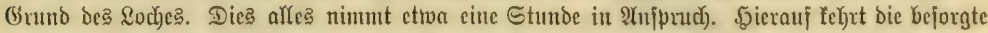

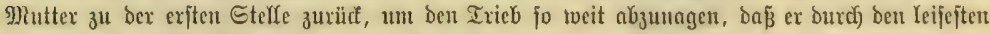

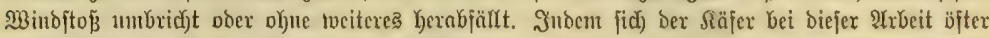
unterbridyt, fidc) wieber nach ber Epitze begibt unb nad)fieht, ob allez in Dronung fei, berbraudjt

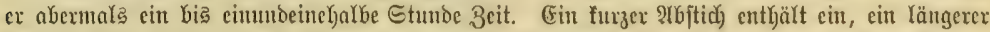

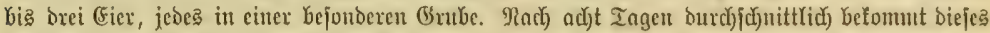

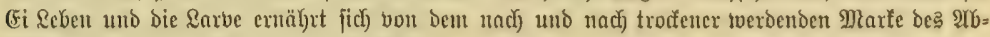

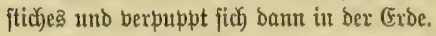

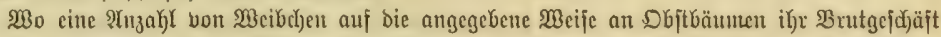
betreiben, richten fie nicht utbedeutenden Edjaben an und man fan ber Wieberholung Desfelben

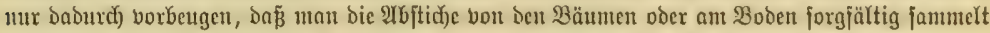

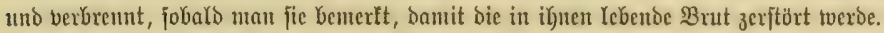

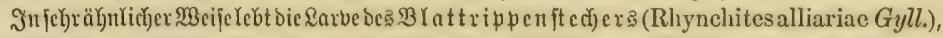

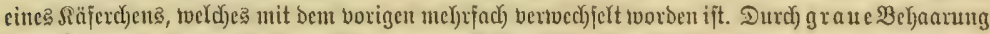

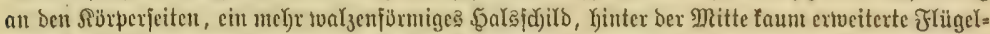

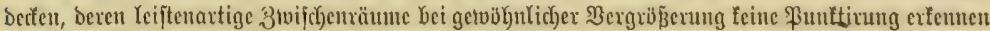

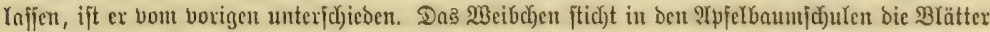

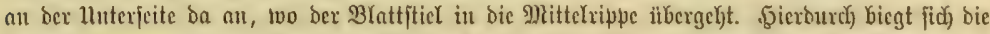

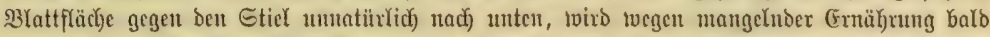

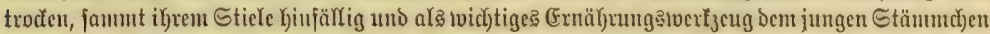

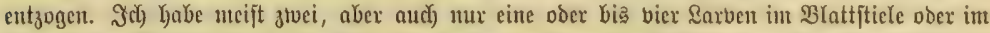

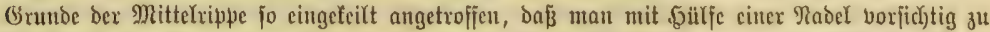

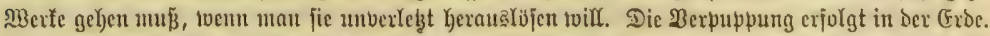

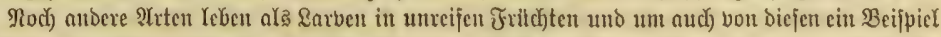

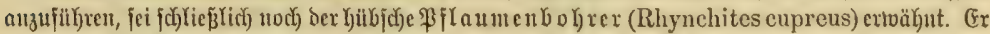

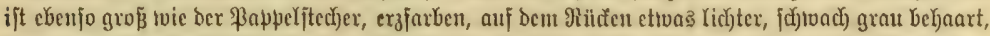

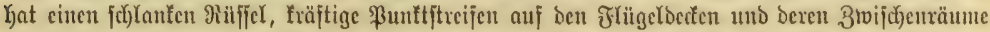

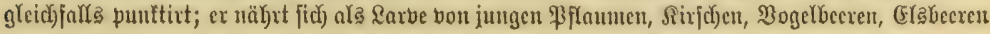




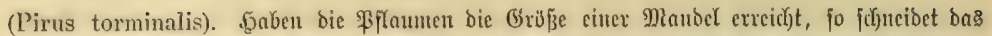

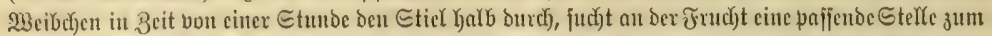

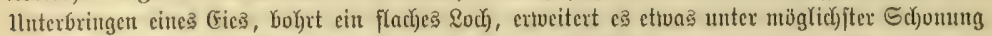

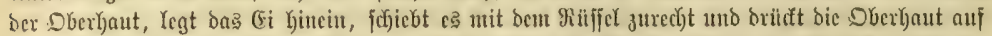

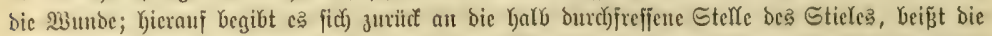

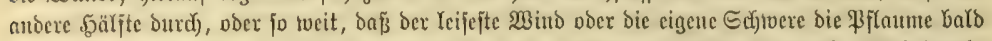

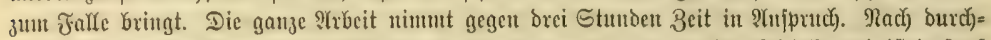

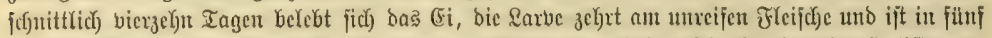
bis fect) 230 d)

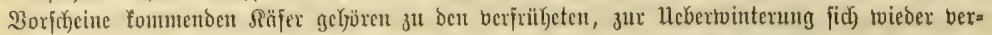

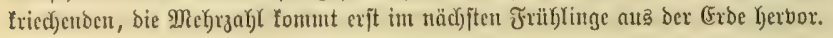

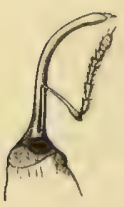

c
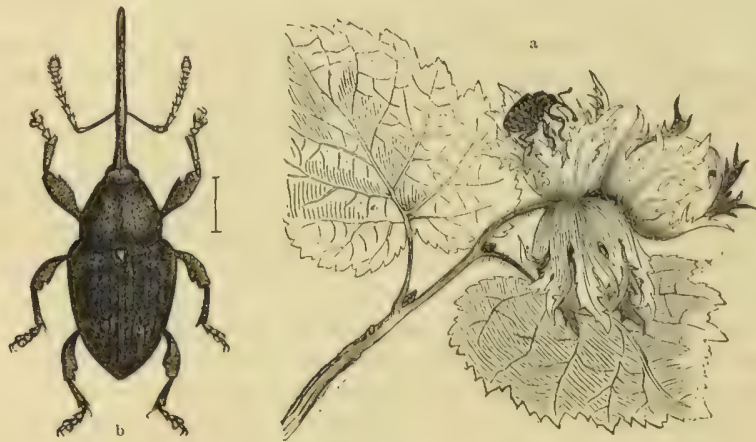

\$afeln o Sopf bon bee Esite, flart bergrö bett.

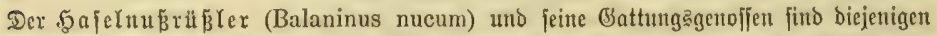

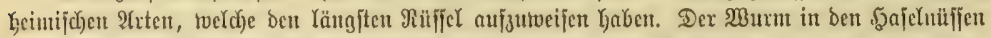

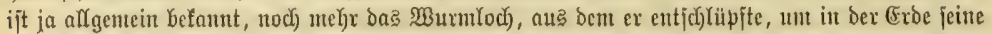

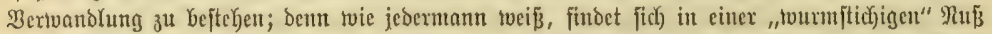

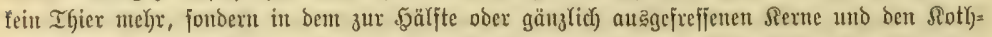

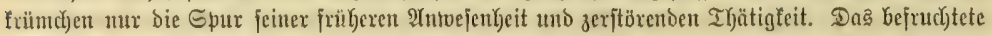

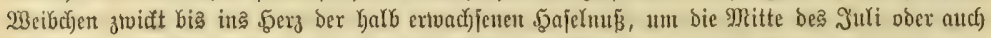

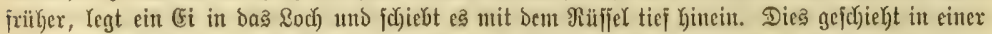

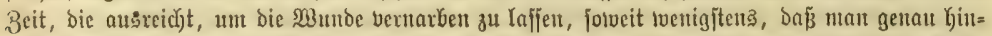

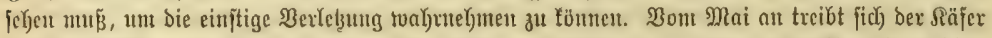

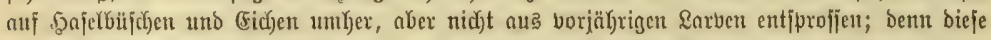

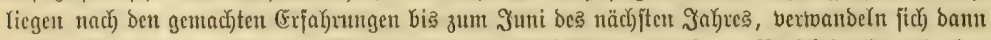

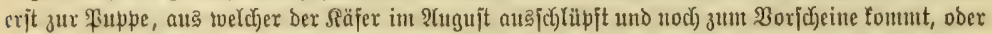

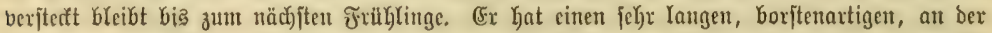

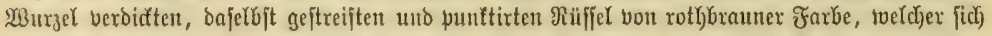

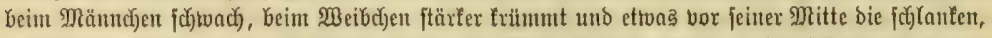

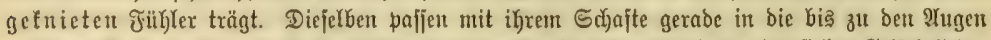

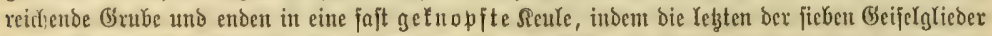

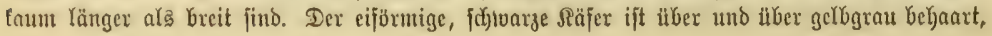




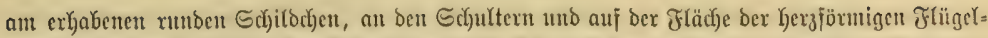

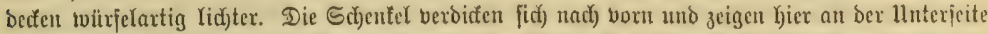

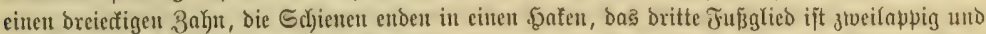

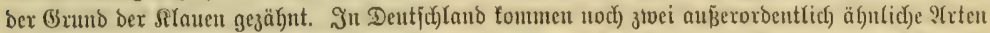

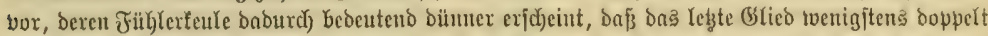

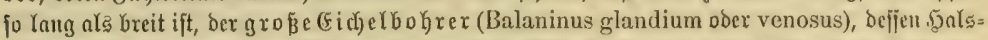

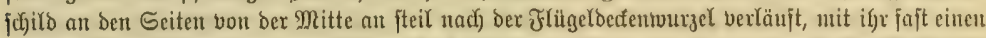

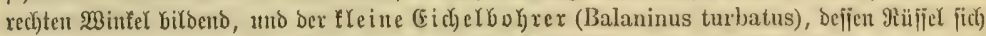

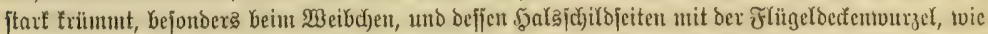

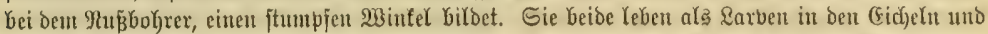

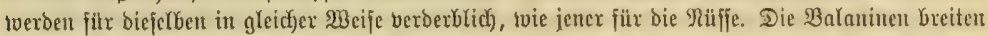

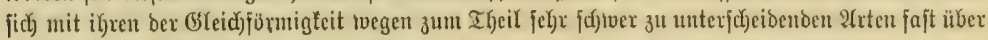
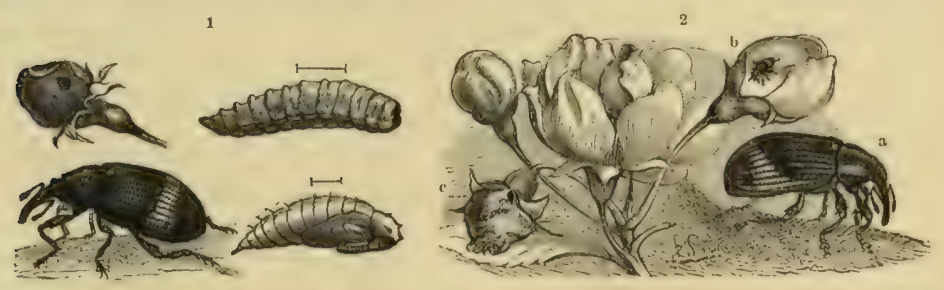

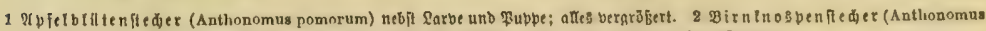

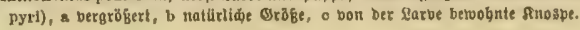

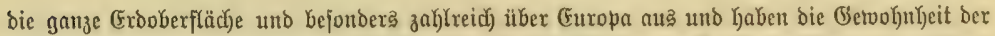

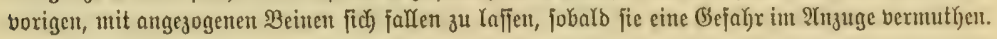

Die Blïtenfted)er (Anthonomus) fömte man ber fiörpertradyt nady fïr grişere, plumpe

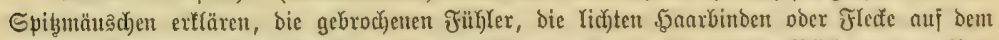

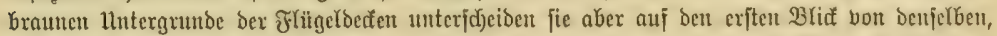

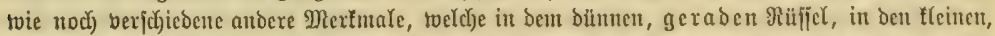

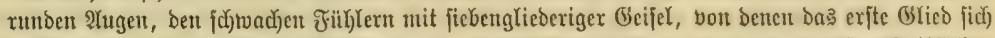

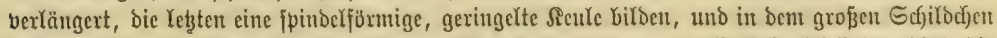

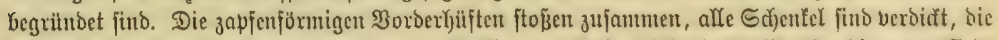

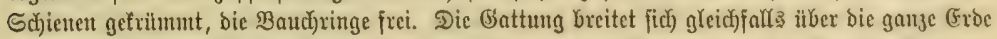

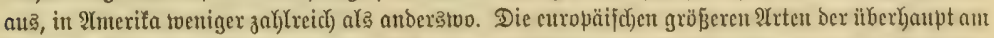

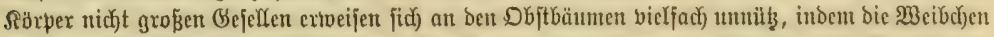

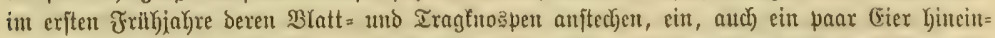

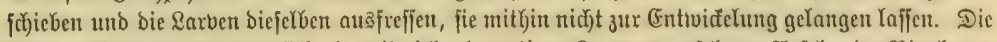

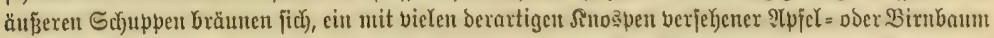

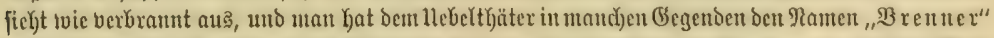

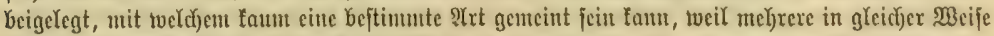

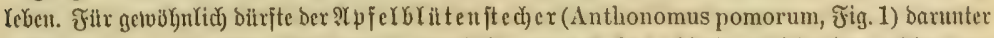

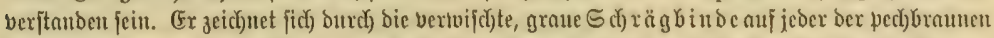

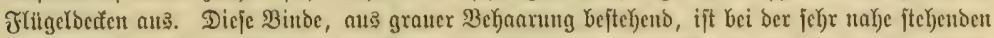
glveiten 2rt, bei bem $\mathfrak{B}$ irnfuospenjted)er (Anthonomus pyri, Fig. 2) gerabe und erreid)t bie

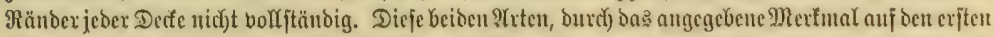

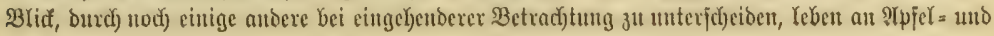




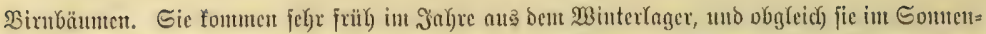

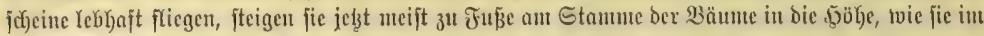

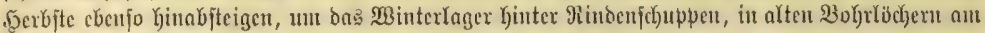

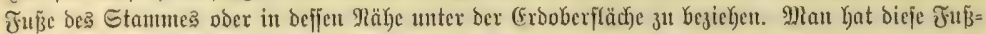

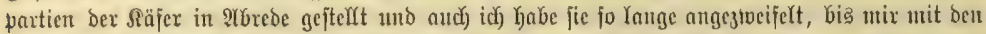

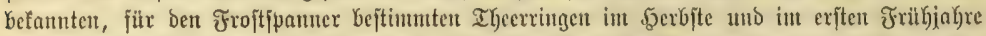

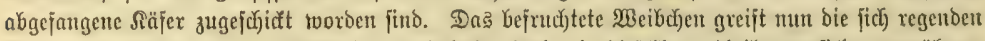

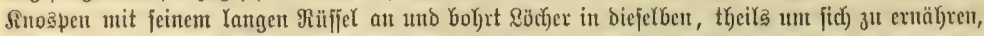

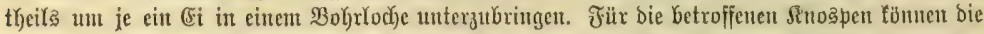

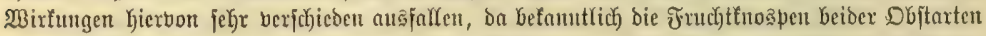

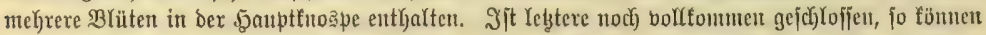
melgrere Blätenfnospen getroffen tweroen; exfolgt bant bie Entfaltung, jo bleiben bie mit cinent

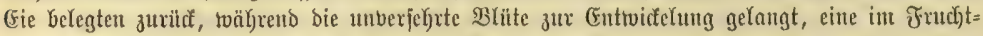

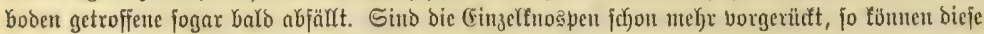
jämmtlid) mit (eiern belegt twerden; afle vertrortnen und jeben tvie verbrannt aus, twähreno fid

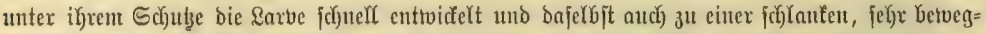

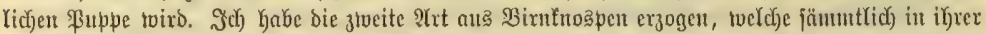

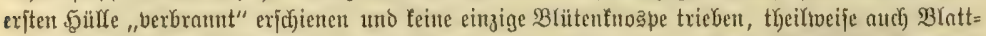

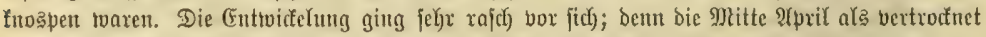
eingetragenen Sauptfno

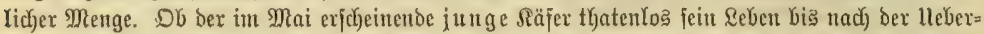

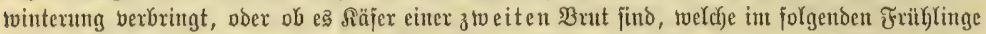

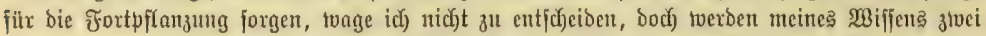

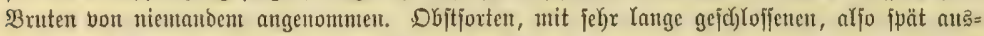

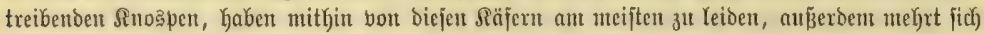

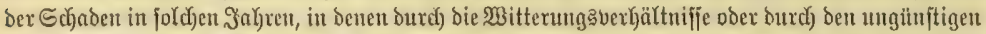

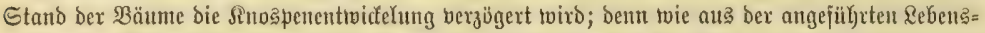

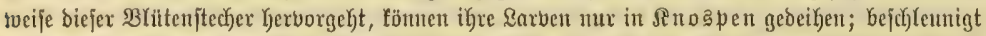

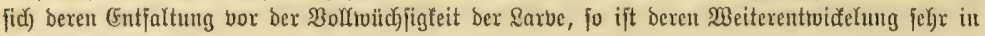
Frage gejtellt.

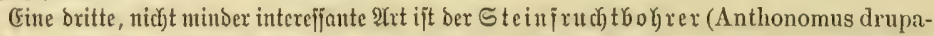

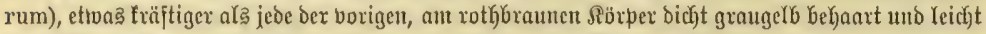

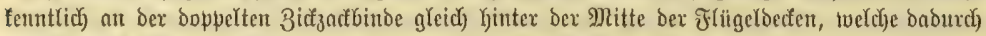

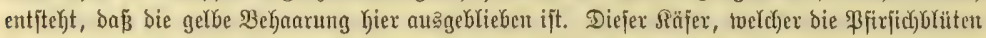

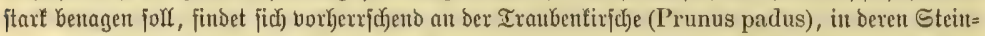

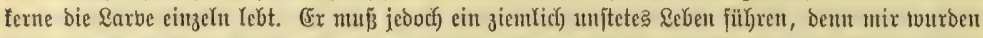

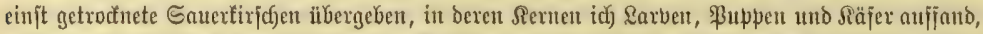

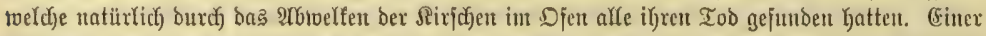

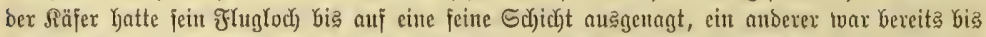

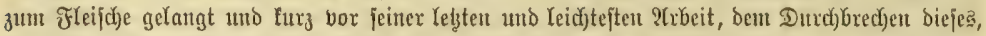

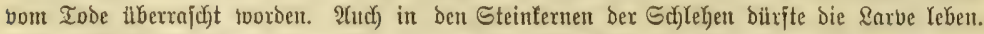

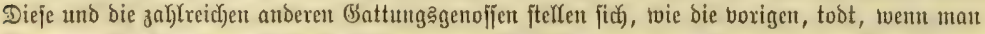

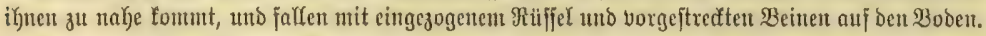

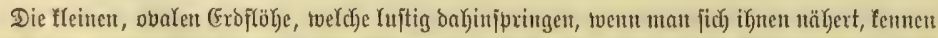

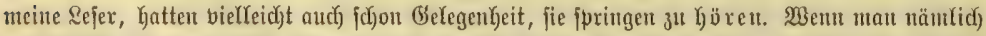

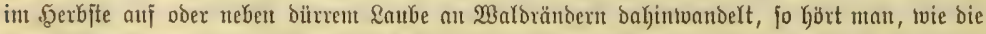
zum Heberwintern Gier verjammelte Schar biejer Heinen Springer anf bą büre \&aub wieder 


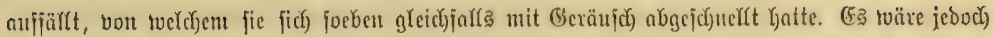

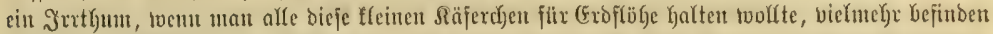
fich) getwiffe Minffelfüfer in gleidjer \&nge. Bon jenen fpäter nod) einige Morte; bon biejen fei benterft,

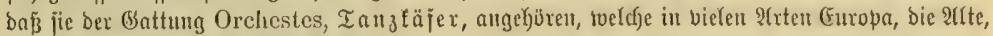
aber auch) bie গeue Wert betwohnt.

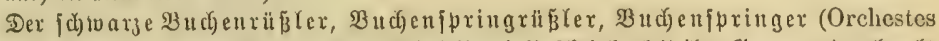

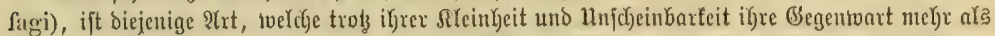

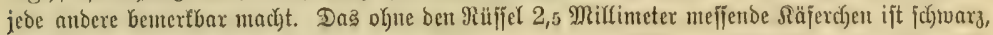

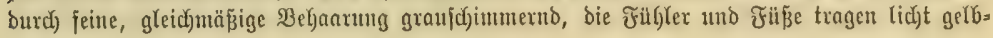

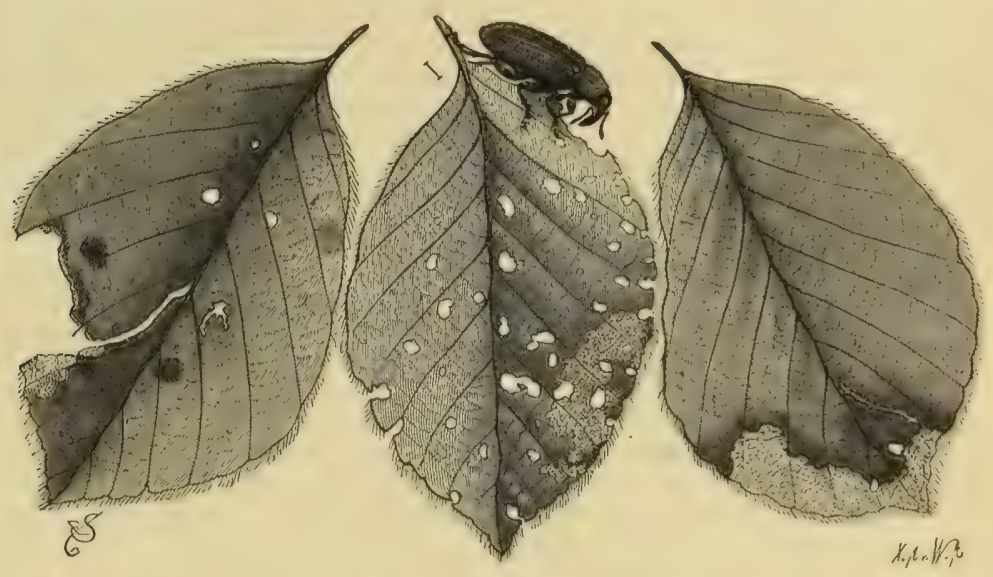

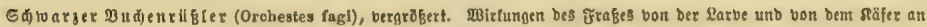
Budjenblättern.

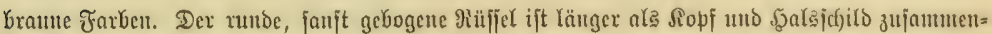

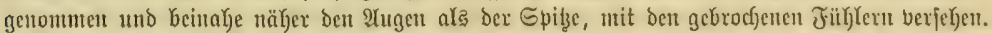

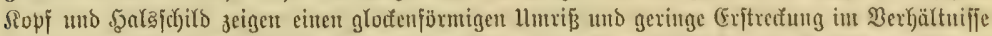

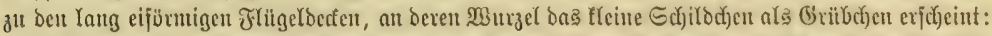

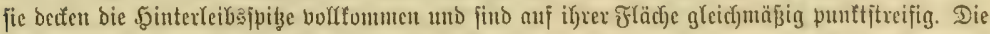

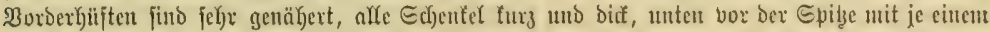

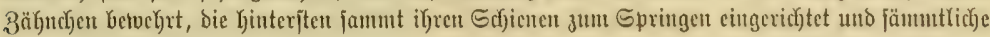
STlauen am Orunde zohnartig eriveitert.

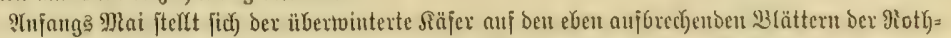

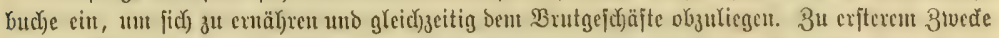

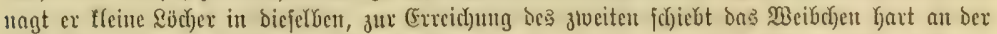

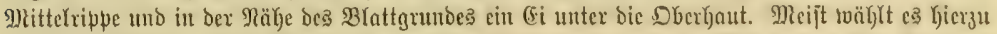

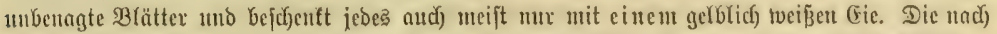

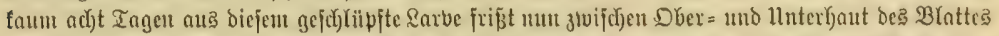

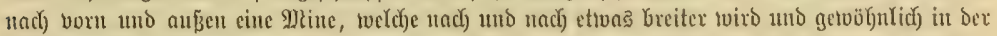

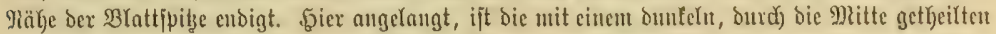

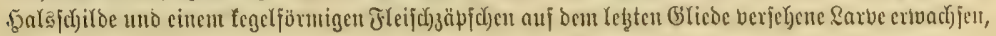




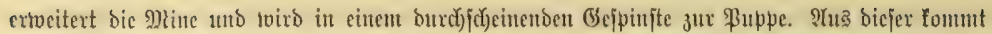

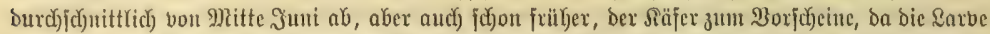

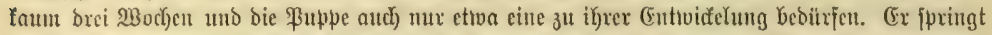

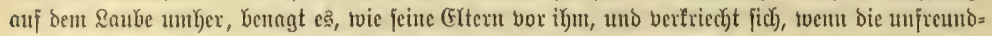

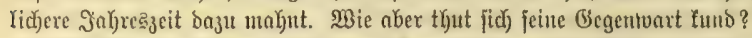

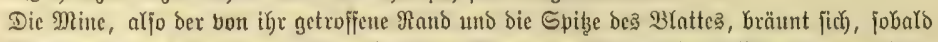

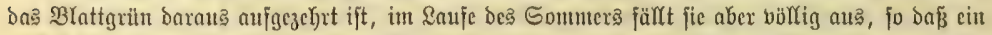

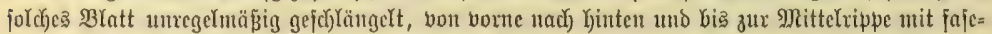

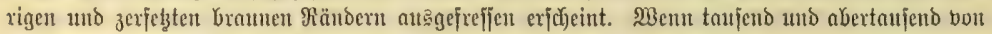

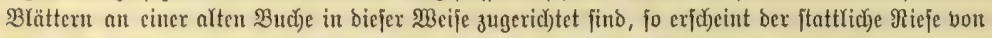

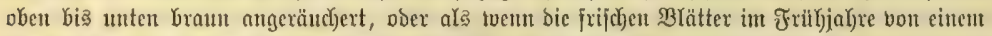

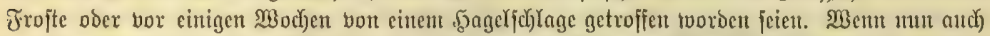

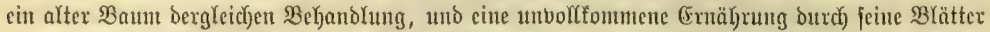

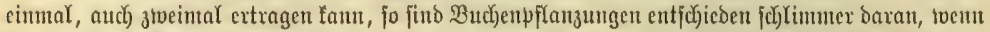

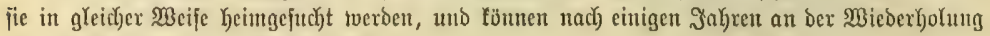

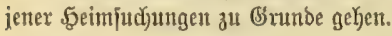

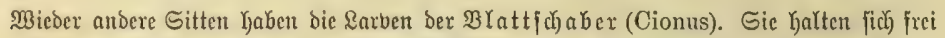
an ben Błüten und jungen Santenfapfeln getoiffex \$flanzen auf, wobei ifuen feine Seine zu ftatten

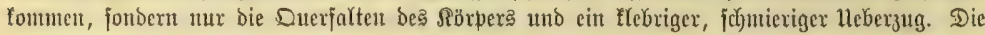

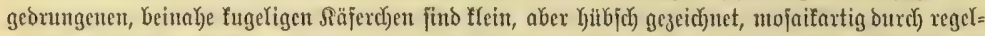

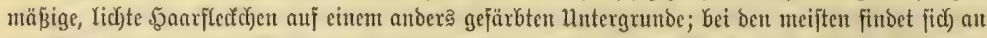

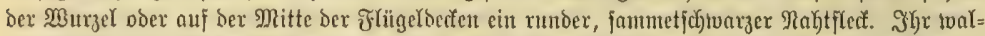

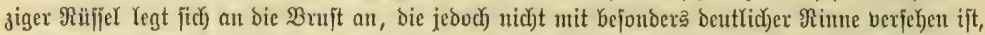

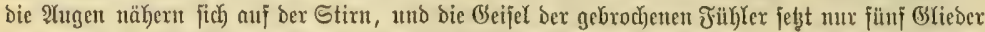

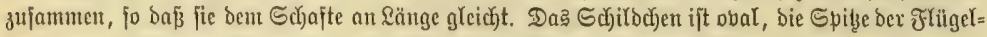

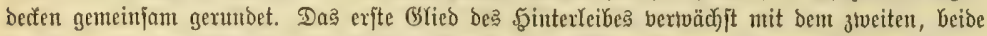

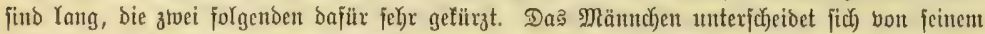

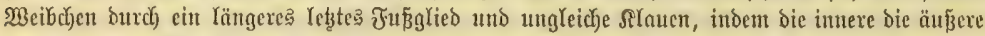

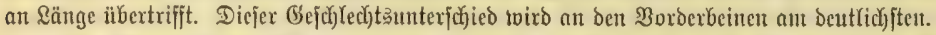

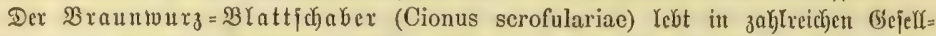

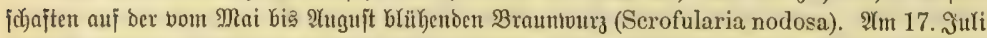

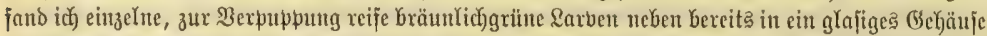

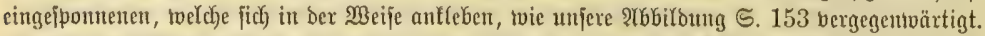

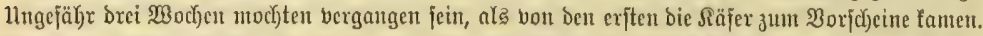

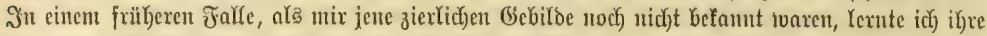

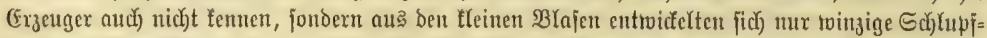
tveåpen (Chrysocharis conspicua), der Fantilie Dex Pterontalinent antgelörig. Der Räfer ijt

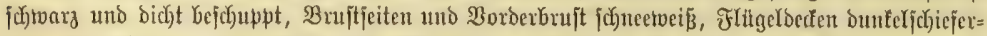

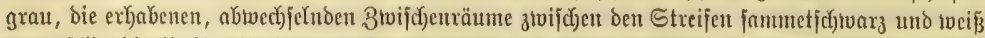

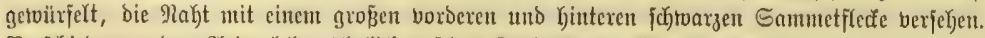

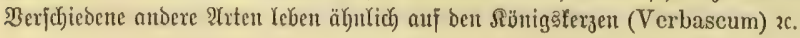

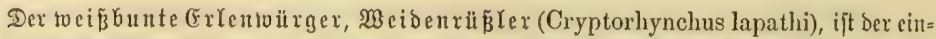

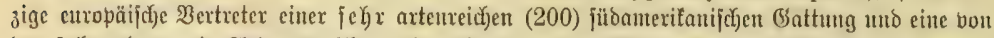

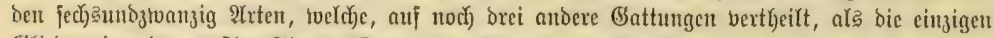

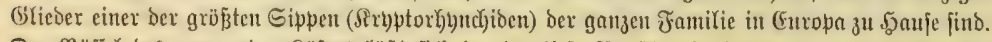

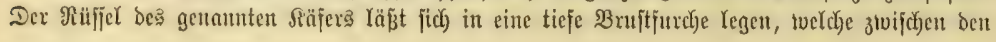




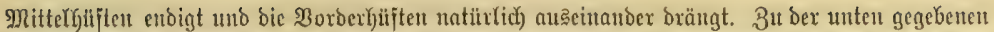

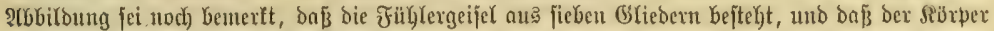

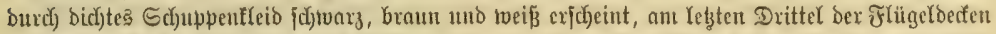

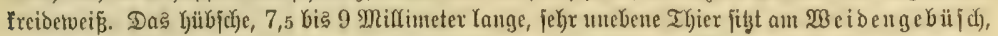

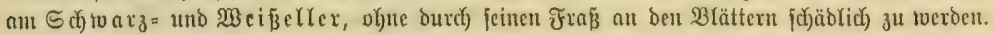

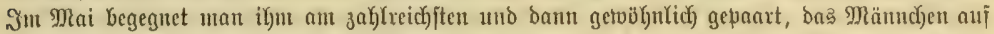

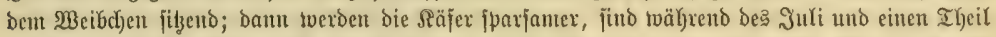

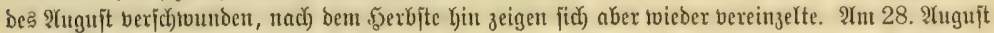

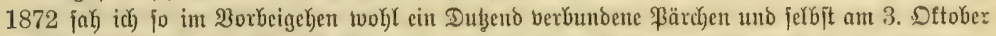

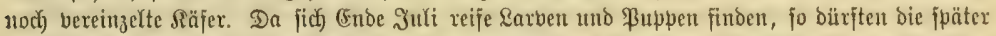

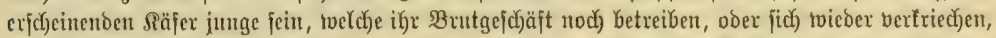

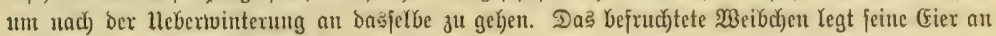

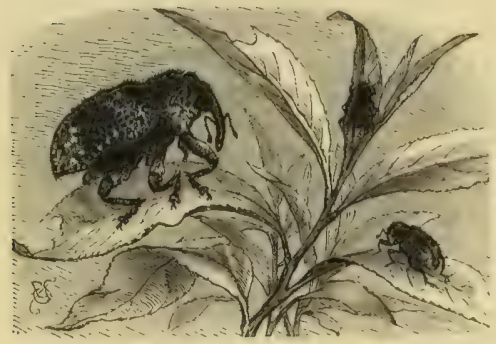

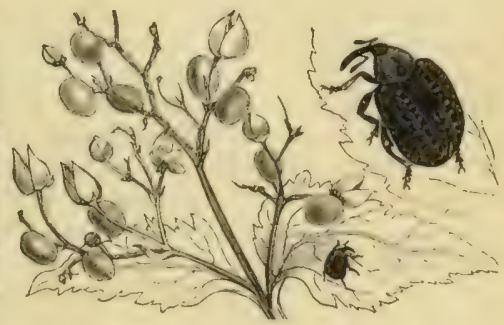

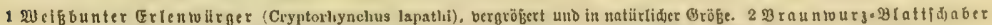

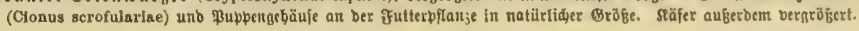

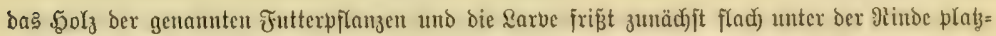

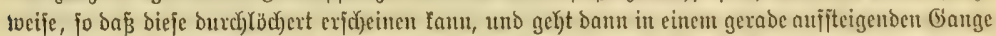

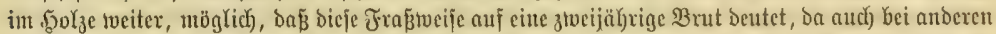

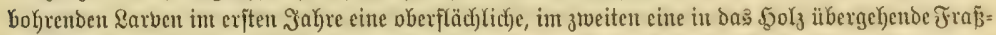

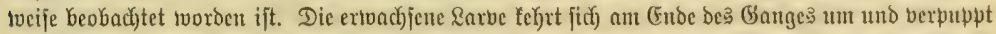

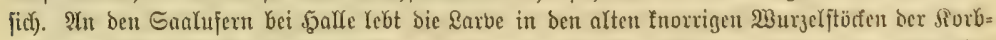

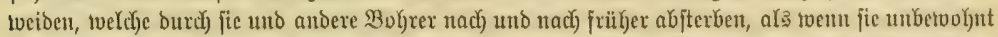

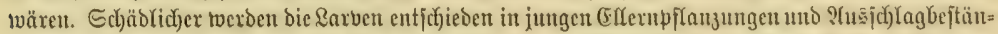

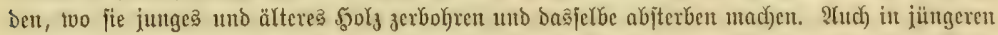

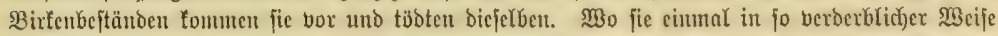

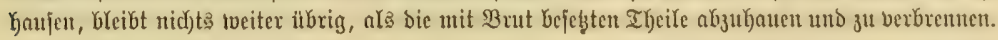

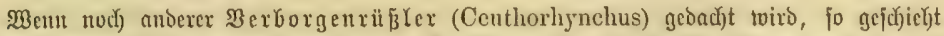

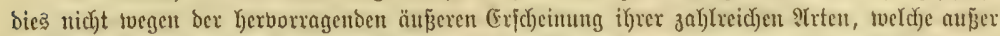

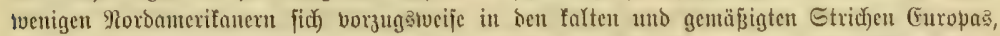

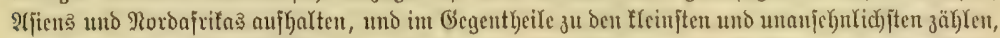

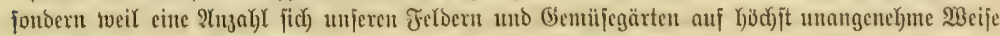

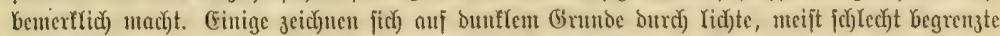

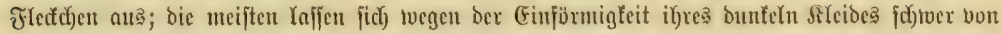

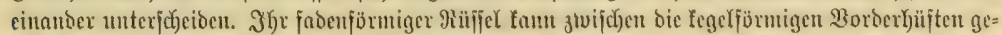

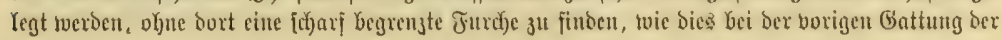




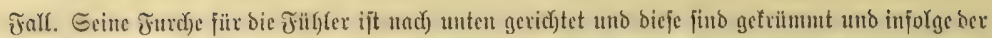

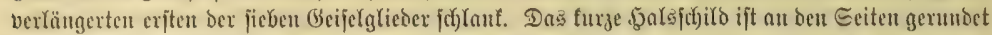

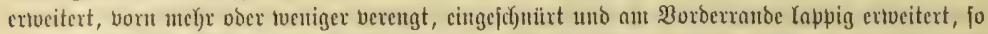

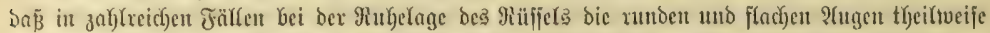

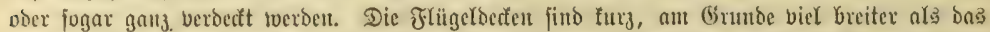

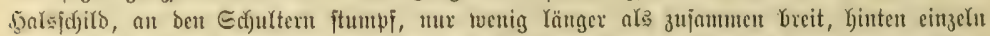

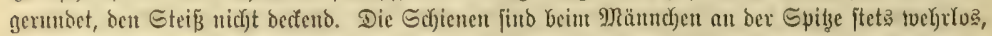

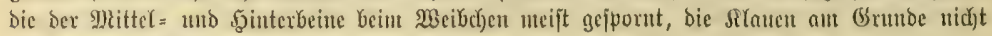
зujanmengetvadyjen.

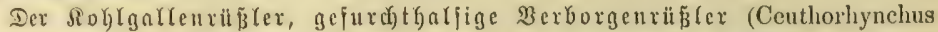

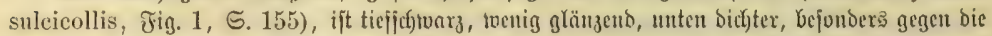

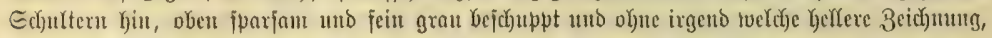

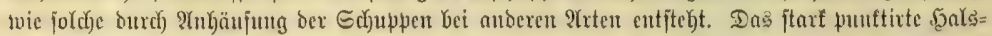

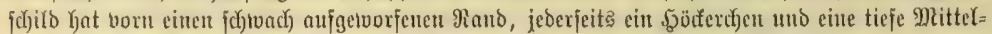

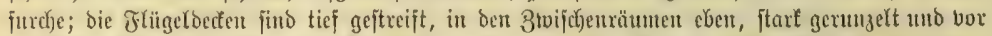

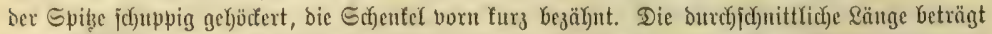

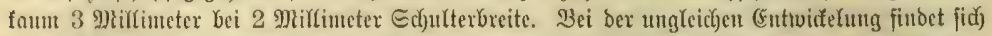

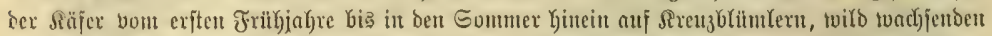

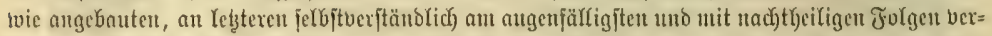

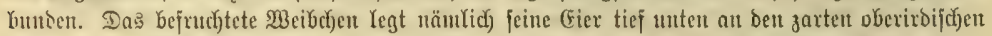

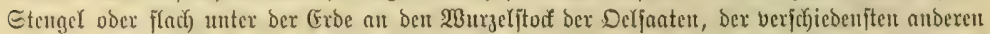

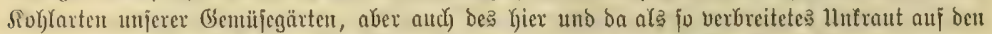

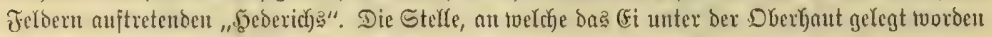

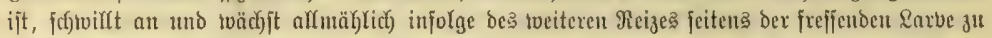

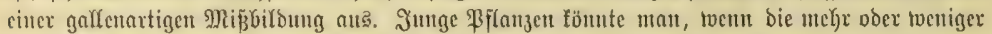

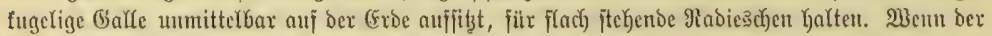

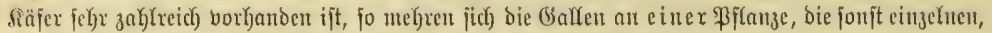

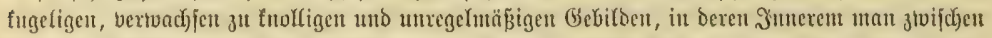

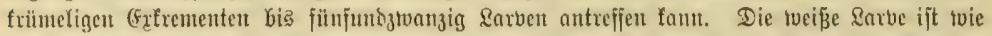

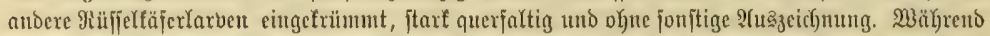

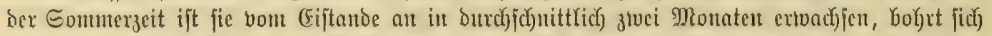

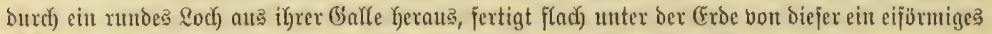

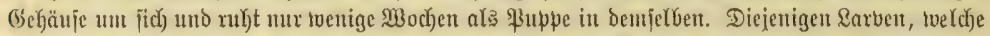
jpäter gelegten Eicru entjprojpen finb, übertvintern in ifren OSallen, tvie man an ben Minterjaaten

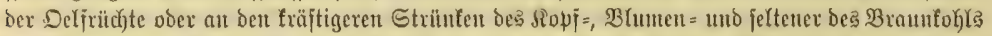
beobachten fant. Dic burch) fpätere (Eietablage an ben bereitz fräftigen Strünten ber gennunten

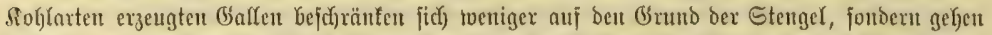

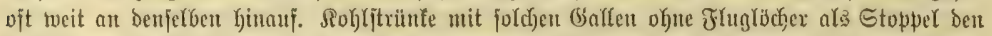

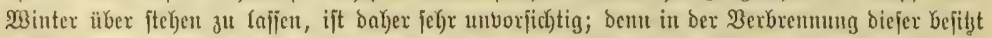

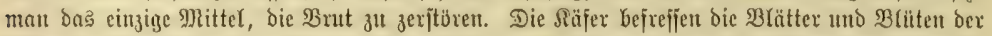

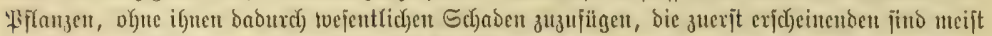

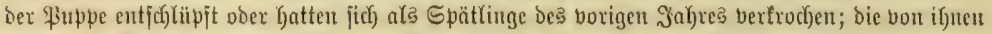

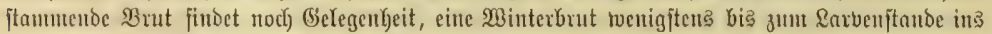

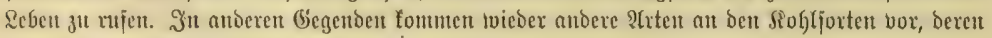
sarven gleichjalts im Smteren bohyren, ónne Gallen zu ergeugen.

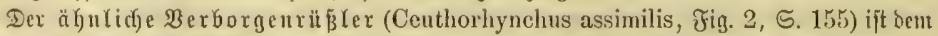

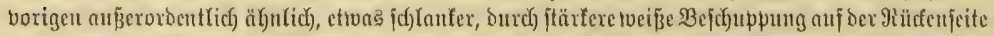

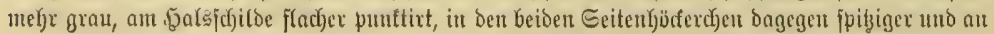




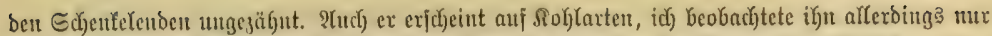

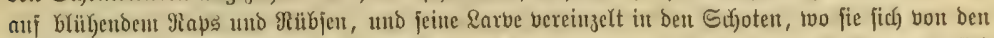

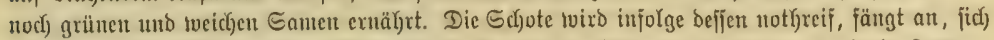

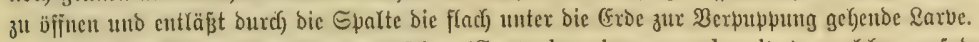

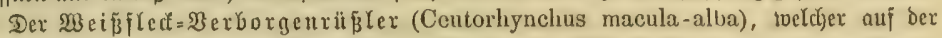

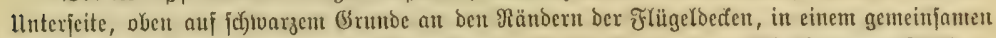

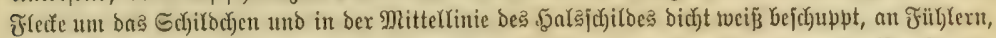

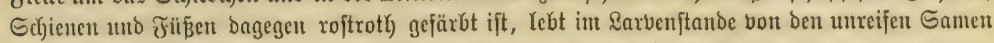

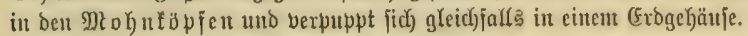

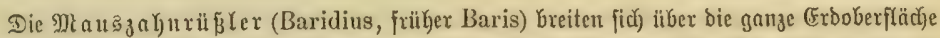

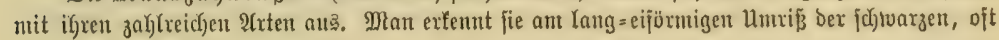

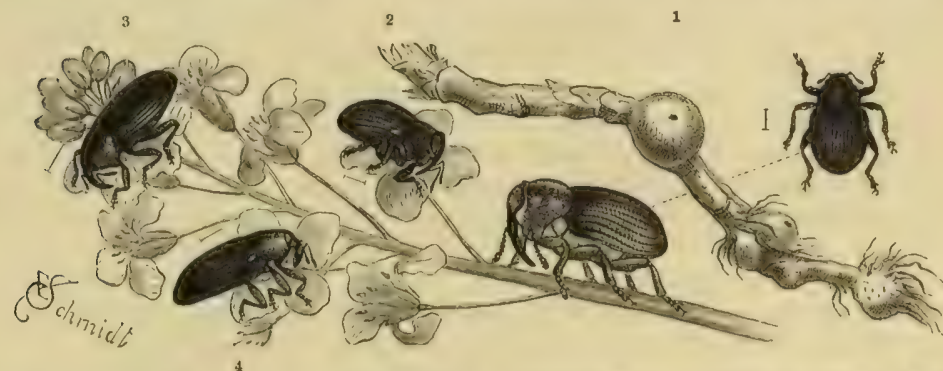

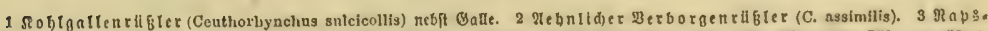
Di a 4 s $a$ b)

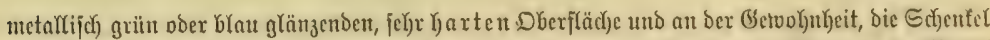

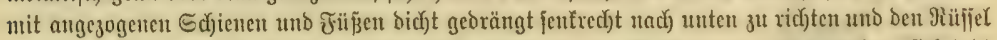
nit jeiner Spize au bie borberen auzubrïrfen, went fie, um $\mathfrak{B e r f o l g u n g e n ~ z u ~ e n t g e l ) e n , ~ f i c k ) ~ t o o t ~}$

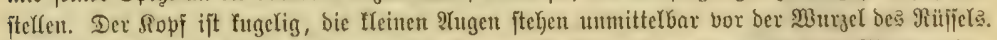

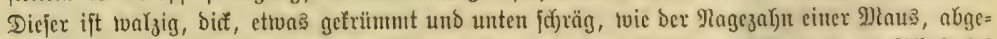

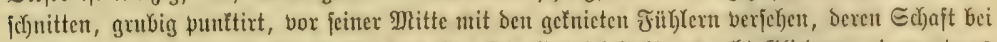

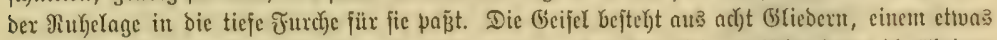

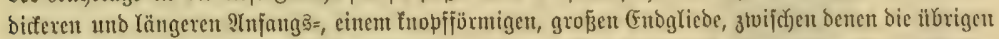
\{ec)

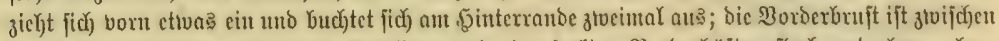

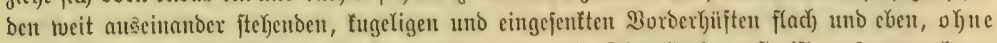

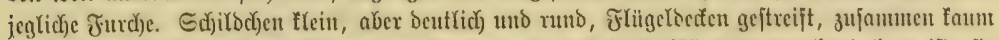

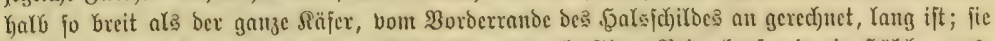

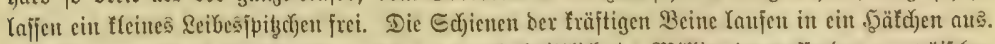

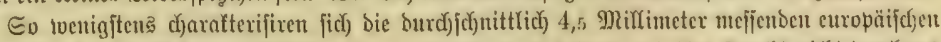

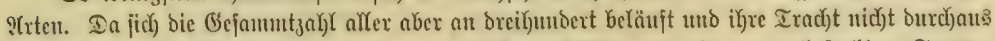
ïbereinftimmt, fo geben Die unferigen von Den fod)önen, trăftigeren, mitunter mełrfarbigen Formen

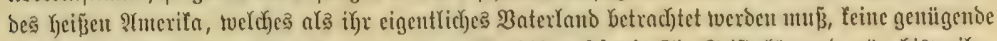

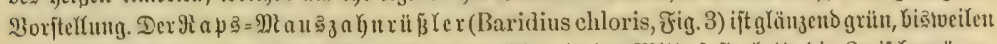

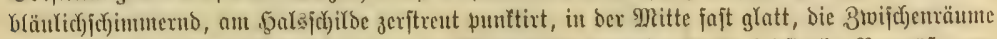

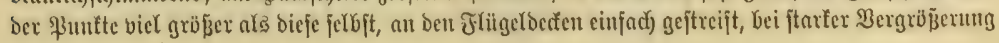




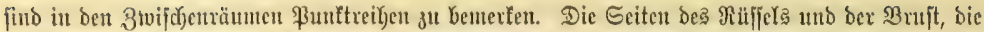

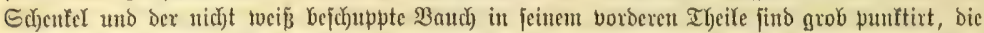

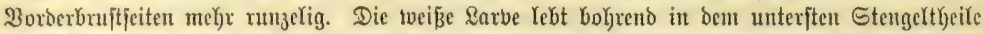

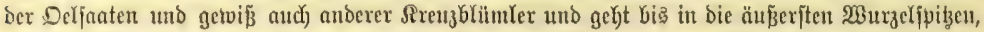

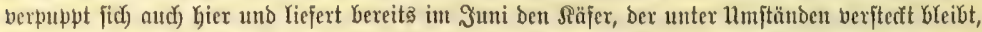

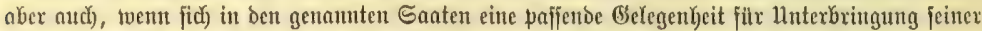

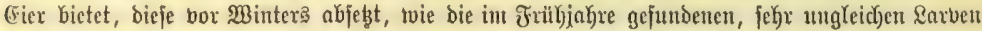

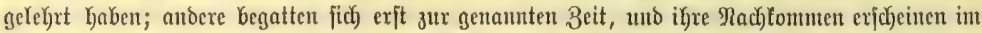

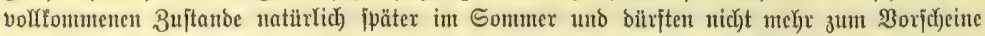
fommen. - Der ped) fdutwarze Maugzahnrü anderen Rofyljorten, bie ex aber in Ermangelung bon Şerbftinaten mu im Frithylinge mit (Eiern

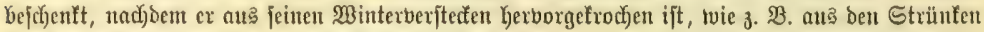

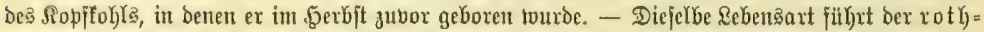

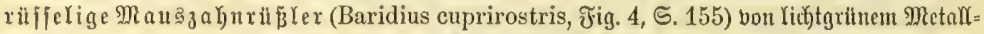

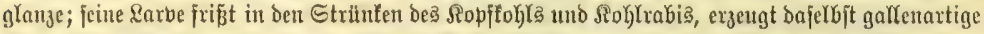

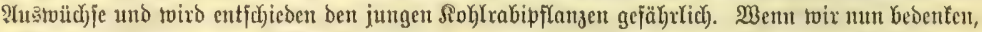

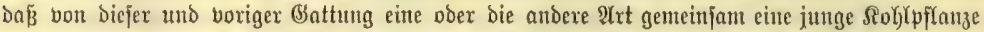

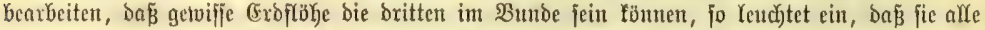

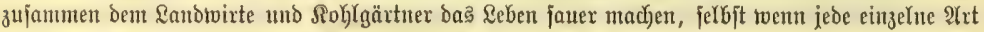
für ifren IGeil mit mäßsigen $\mathfrak{A n j p r u ̈ d ) e n ~ a u j t r i t t . ~}$

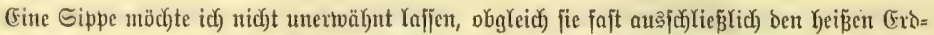

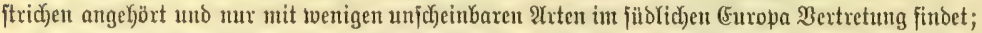

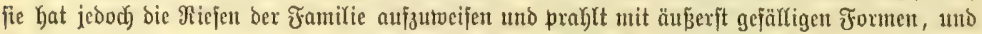

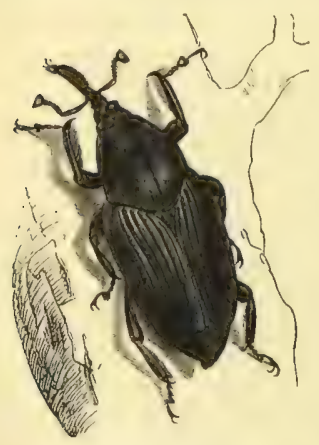

Javanifider $\mathfrak{\text { almbohter (Rhyncho. }}$ phorus Schach), natilir. Eröße. uberbies jpielt eines ifrer roingigiten Orfieder eine getwiffe Rolle auf unjeren Somböben. OYne biele Morte um bie CGarafteriftif ber Sippe oder einer und ber anderen Gattung zu berlieren, vergegentwärtige idj in bem jabanijufen Palmbohxer (Rhynchophorus Schach) die Brunoform

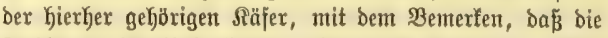
Fühler bon ben biakger tennen gelemten buxdy bie abroeidyende Bildung desె (Enogliebes twejentlic) berjofieden fint und bei anderen berwanbten ein zum Theil roieder anderes, aber

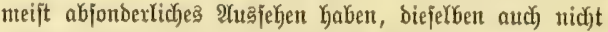
weiter als bis zum exjten Drittel ber Rüffellänge vorrücfen, baß̧ ber Stei

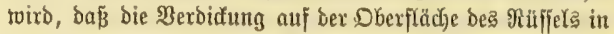
einer bichten ఏaarbitute und bie Farbe bes ganzen IYieres in einem öfters twie mit Dujt itbergogenen Sdywarzbraun be= fteht, tweldyes hier und ba, bejonbers auf ber Scheibe be?

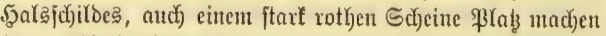

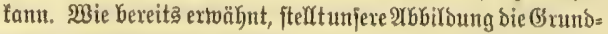

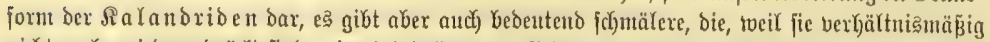

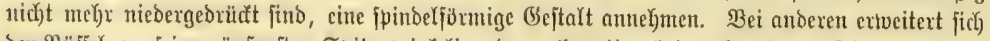

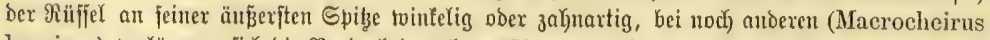

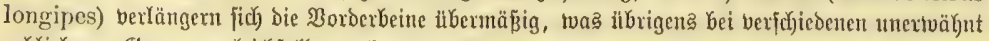

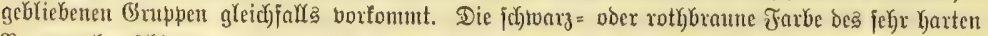

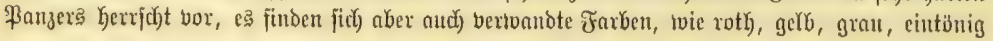




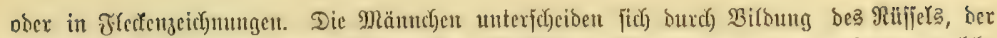

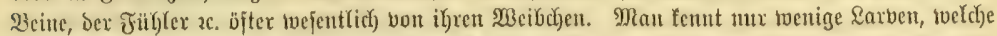

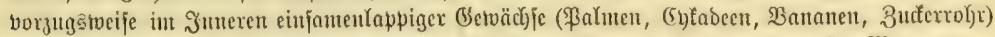

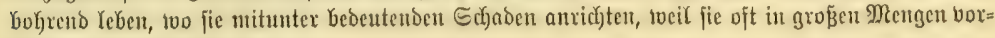
fommen, baher $\mathfrak{F a l m b o h r e x . ~}$

Tuf bie fleinften Arten dex ganzen Sippe will Racordaixe ben fonjt alfen gegebenen

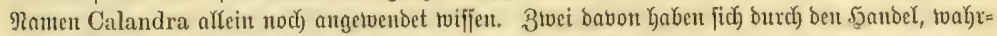

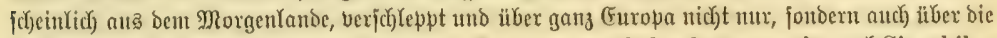

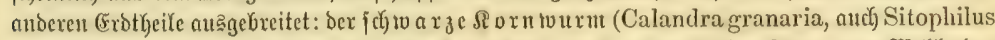

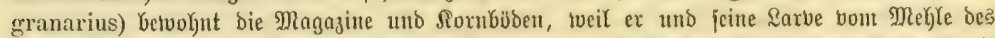

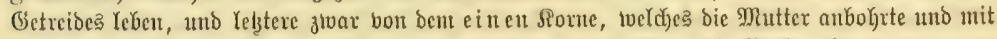

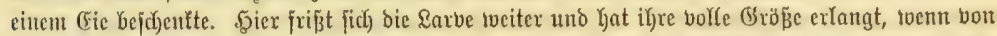

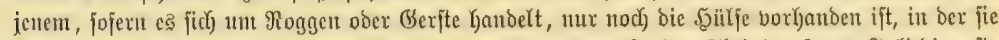

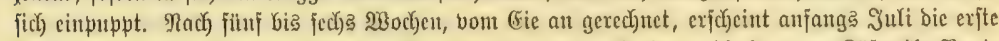
Brut von ben übertvinterten Räfern. Bierzehn Iage fpäter beginnen bie jungen Säfer ihr Brut=

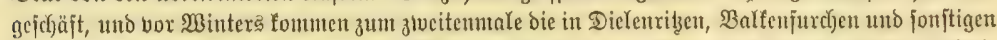

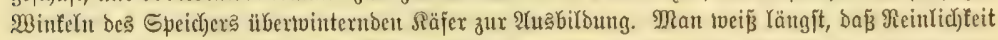

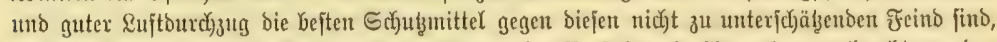

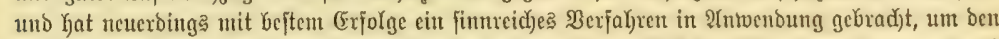

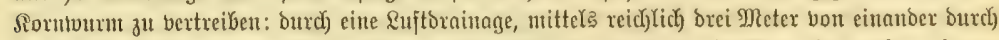

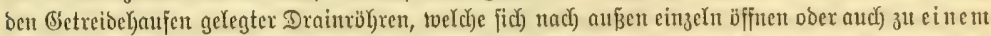

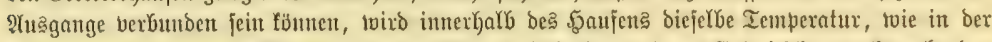

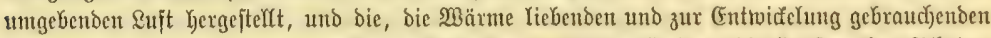

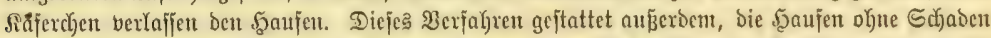

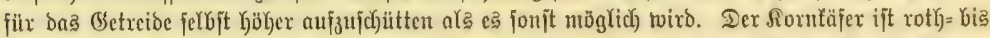

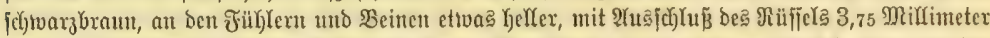

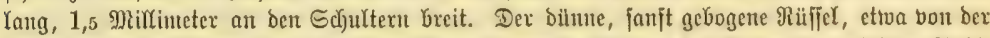

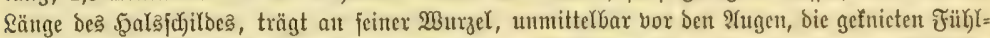

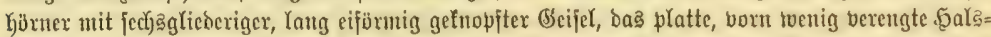

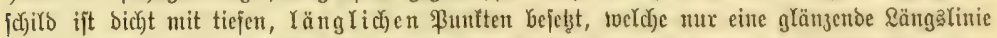

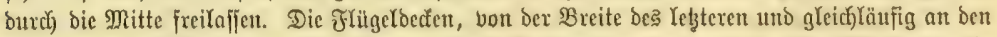

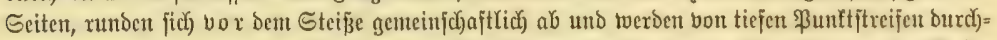

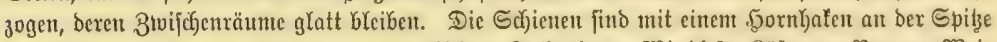

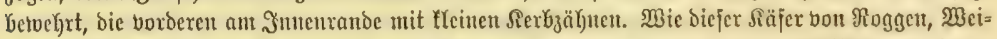

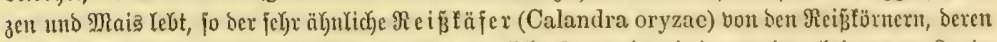

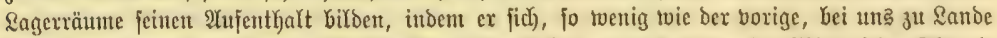

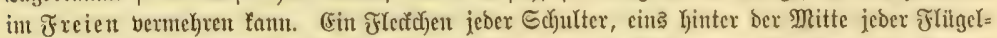

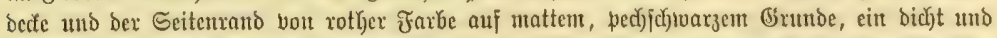

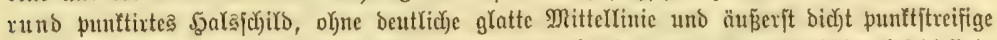

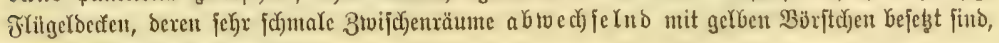
unterjodjeiden ifn bom boxigen.

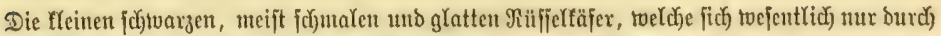

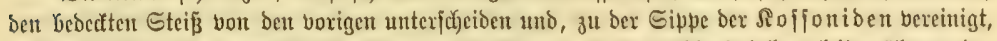

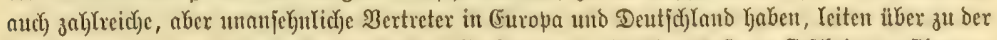

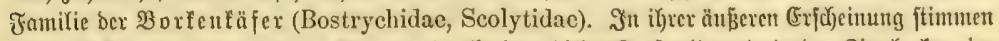

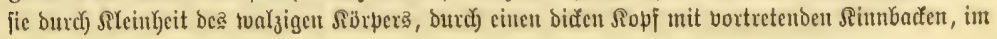




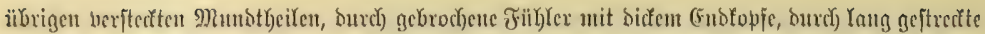

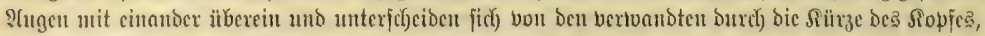

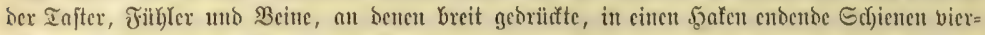

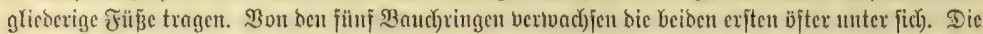

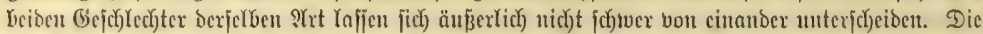

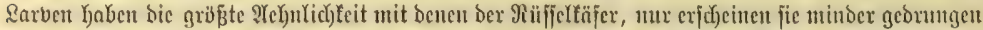

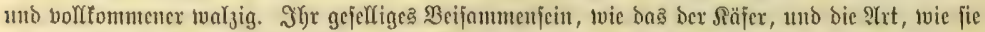

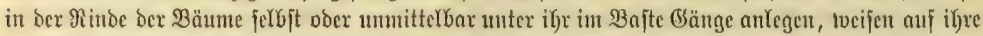

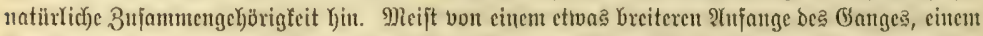

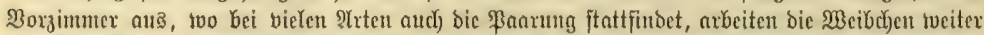

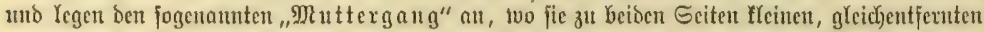
श्(n

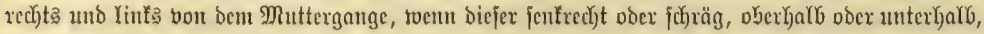

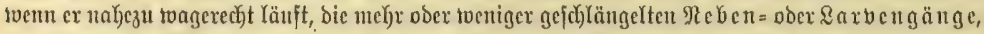

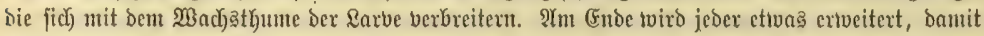

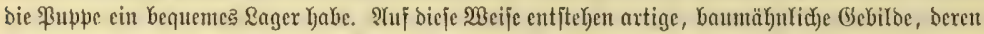

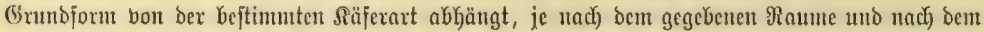

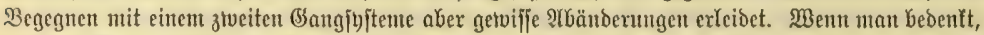

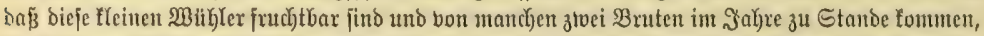

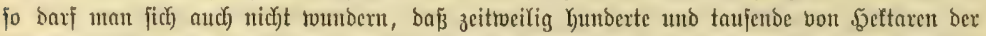

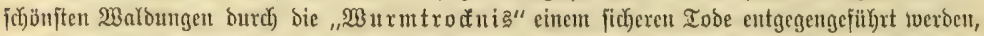

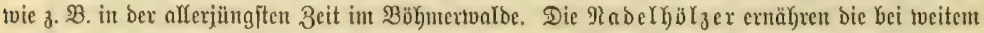

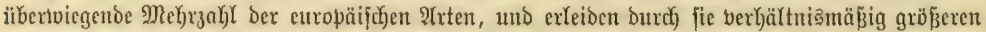

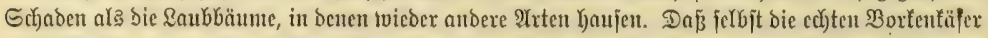

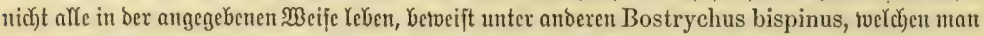
bohrent in den rantenben 3 weigen ber gemeinen Mahorebe (Clematis vitalba) findet, Der Bostrychus

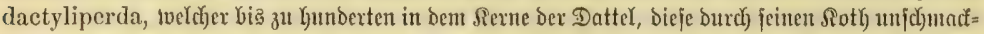
Kajt mad)eno, uno in der Betelnuß (Areca Katechu) zur (Entwidfelung gełangt. Wn crfterer Frt Gat

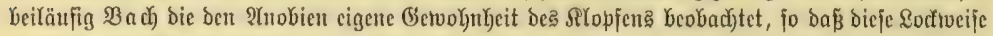
bei mekreren Prten ber Familie zu vermuthen nake liegt.

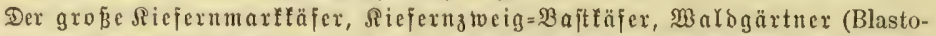
phagus, ober Hylesinus piniperda,, .159 ), mag famunt bem fleinen bie Gattung vergegentoürtigen. (Fin fenfrechter, von oben fichtbarer Sopf, fein getörnclte शTugen, ein eiförniger geringelter Fiibler=

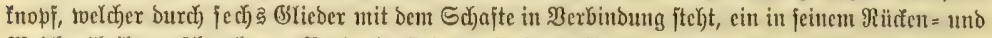

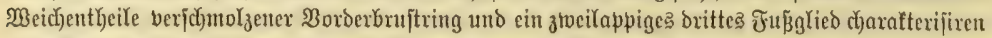

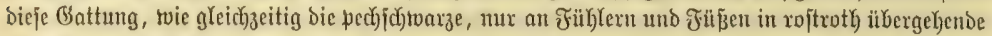

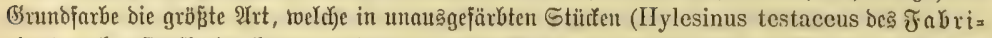

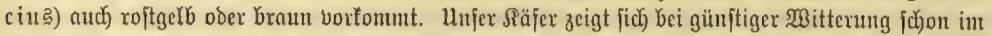

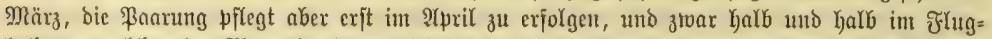

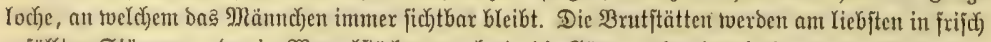

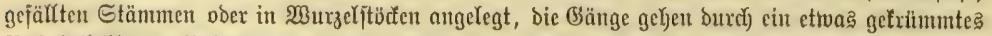

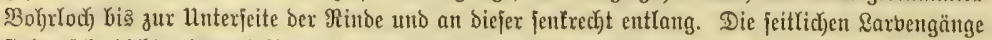

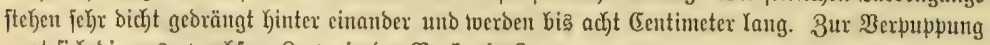
nagt fich bie ausgetwadfjene Sarbe in ber $\mathfrak{B}$ orfe ein \&ager.

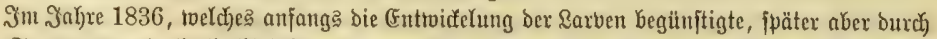

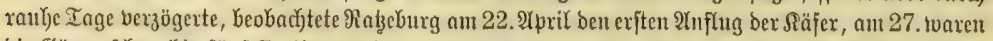

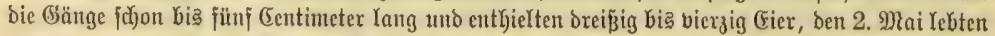

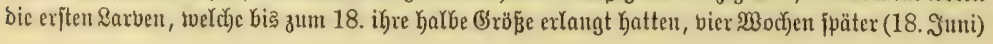




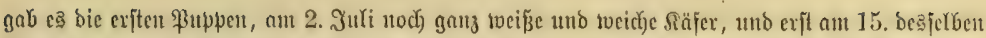

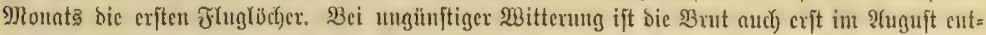

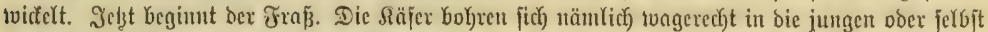

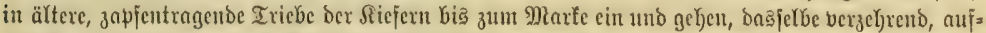

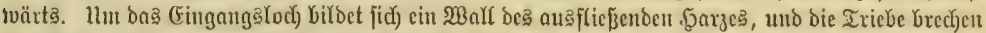

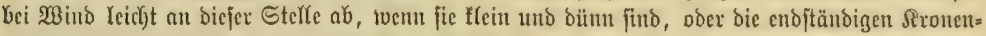

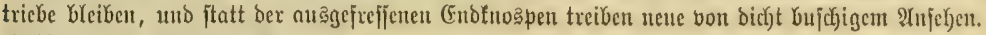
Weil auf bieje Meije ber $\mathfrak{B a u m}$

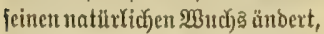
twie ein unter bem Scfnitte lïnjt $=$ lid) gezüchteter, jo hat man ben

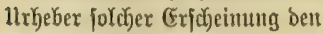
"Waldgärtner" gentant. (5x geht zur Hebertwinterung ber

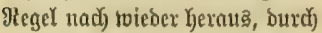

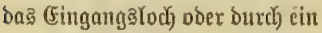
neu angelegtes tocitex oben, jucht bas hoke \$orz auf uno berfriedjt (iid) ant ben Stämmten bidyt über

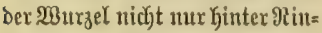
Detifduppen, fonbern in eigens bazu gebohrten, oft bia zum \$ajte reichenden Södjern. Der Walogärtner geht jutbrich in Deutjod)land fo tweit, tvie bie Riefern borfommen, nüroliç, bis

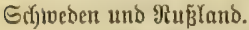

Dex fehr äbnlidye fleine Siefernmarffäfex (Blastoplagas minor) unter jocheidet fict) uidyt immer burd geringere Größ̧е bom borigen, fondern nur
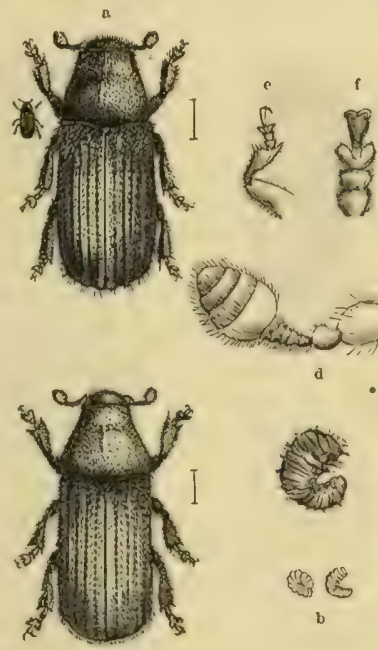

h
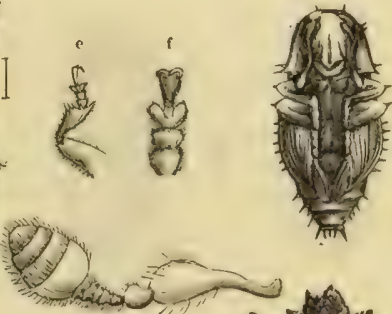

d
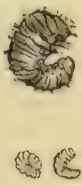

b

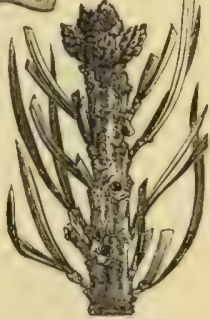

g

Orober Sicfertuarlläfer (nlastoplagus plalperda). a Sïfer, b Rarbe,

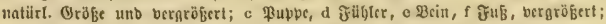

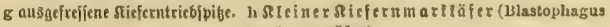
minor), vergröbert. baburd), baß̄ bie Saarzeike in

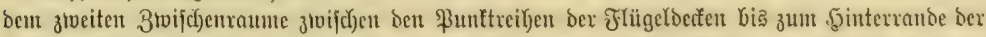

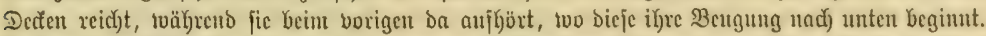

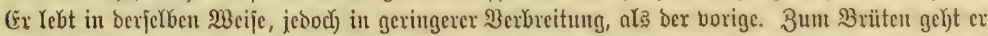

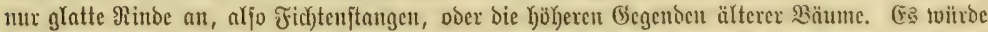

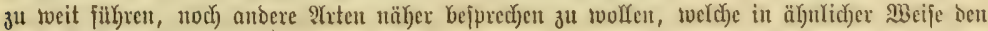
Siefern gejälgrYiç) tverden.

Die ed)ten Borfenfäfex (Bostrychus ober Tomicus) Kaben cincu fugcligen Siopf und fünf=

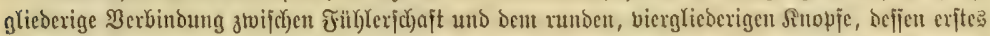

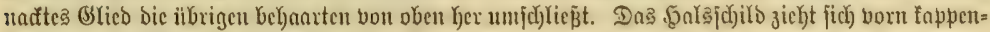

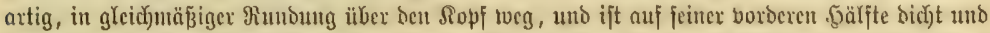

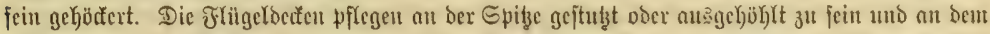

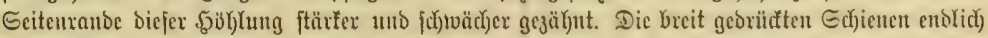

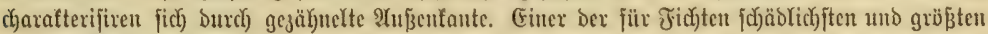

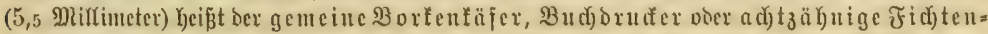

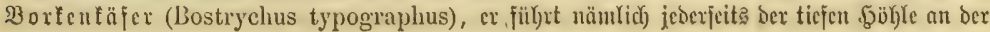




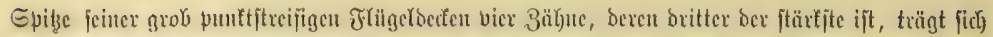

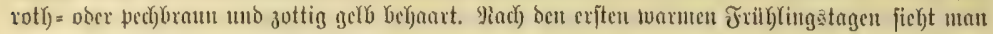

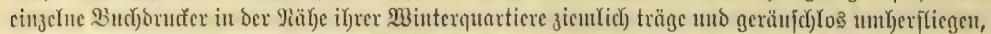

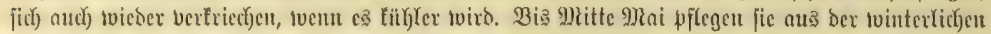

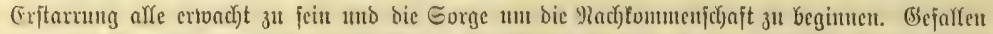

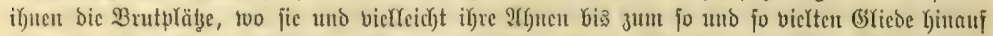

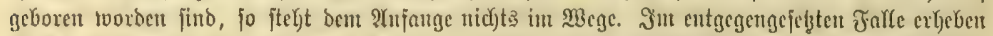

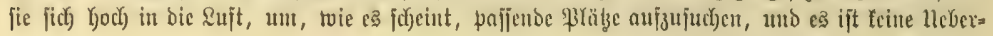
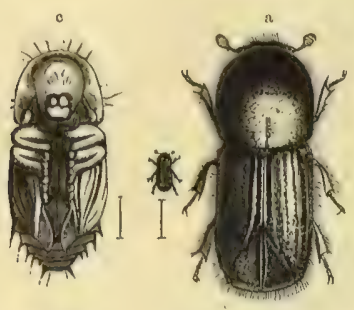

$g$

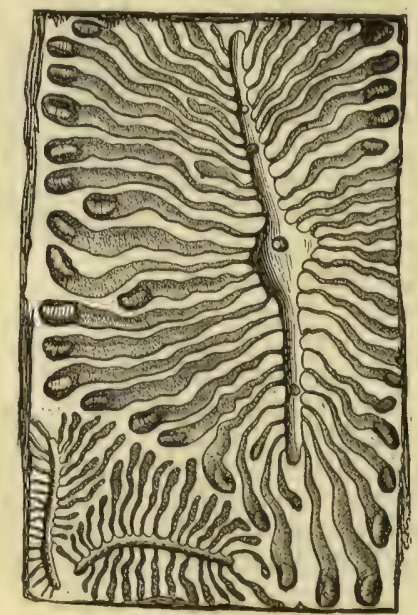

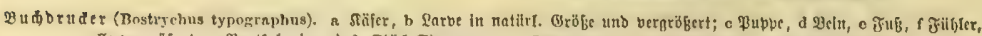

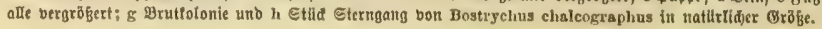

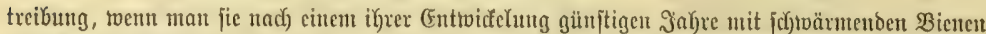

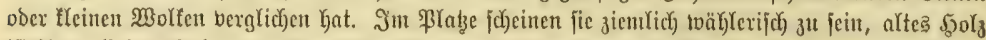

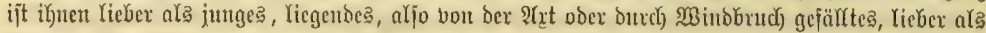

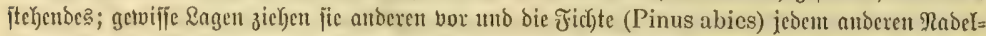

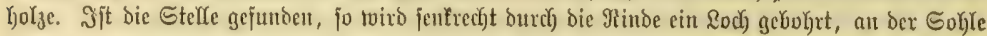

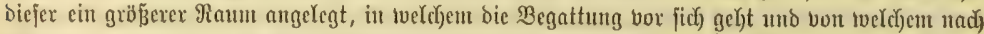

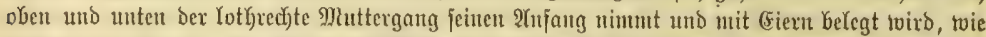

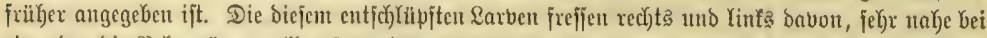

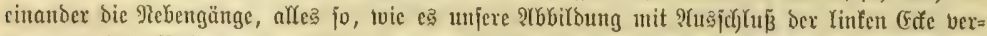

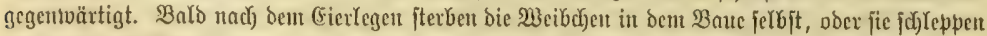

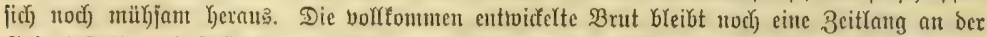

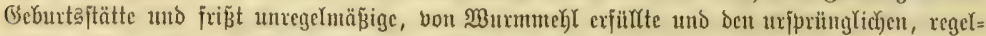

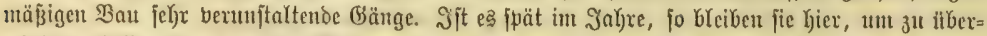

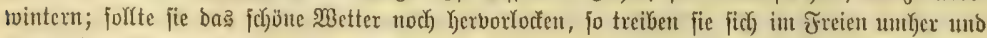

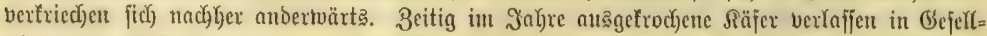

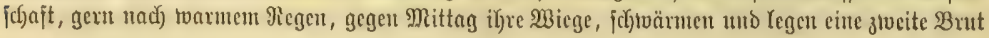


an, bie unter ben günjtigiten $11 m$ f̈änden nor) zur volfen (Entroidelung gelangt, in ben utciften

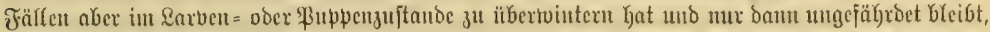

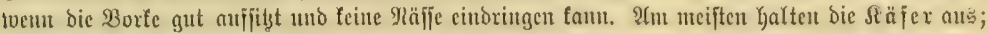

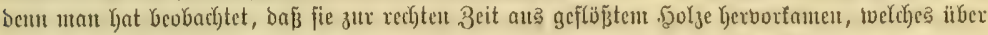

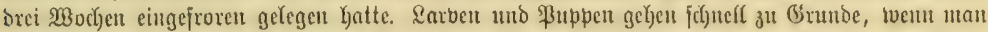

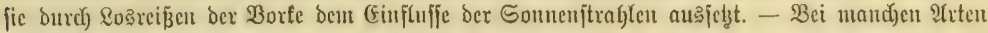

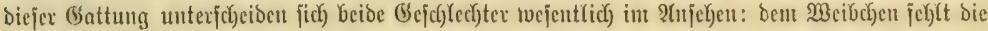

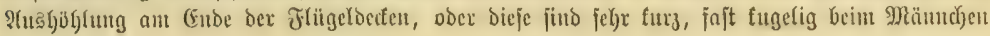
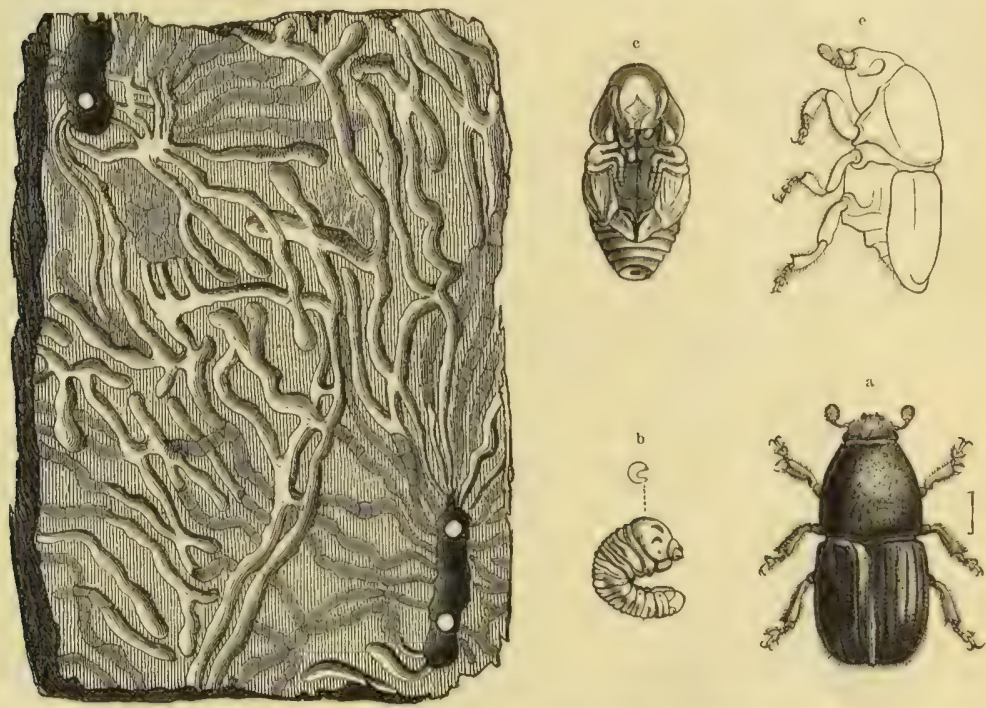

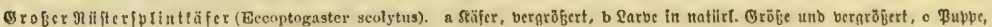

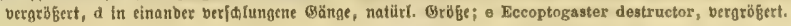

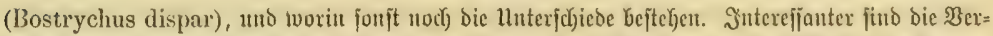

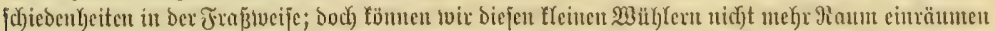

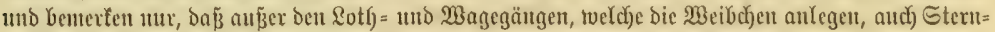

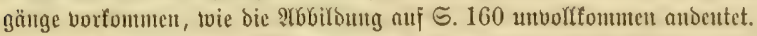

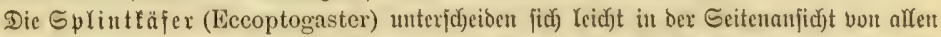

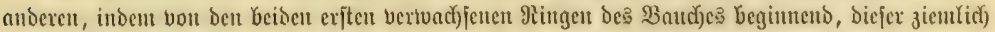
itcil nack) oben anfifteint, wie ber Kier ffizzirte Eccoptogaster destruetor (Jig. e) Yehrt. Die

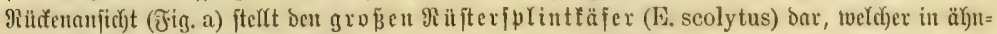

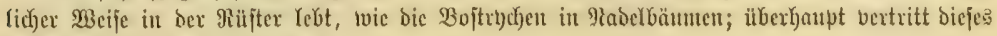
(Bejd)(ed)t jenea fitr bie Raubbör

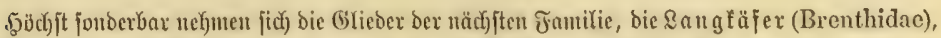

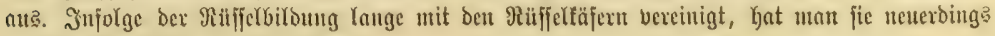

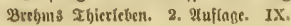




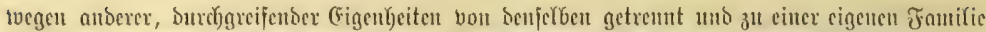

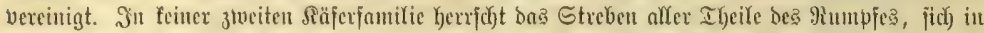
Die Ränge an: 3 zot)

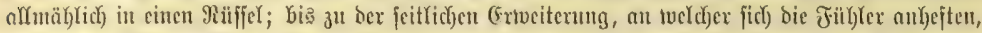

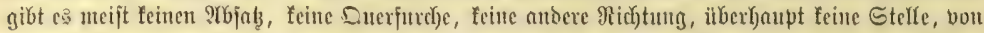

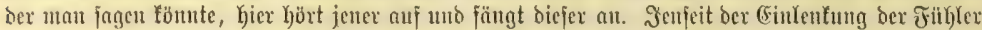

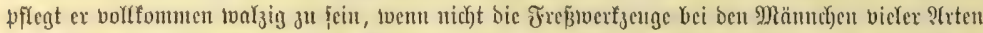

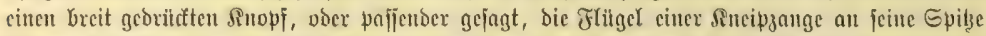

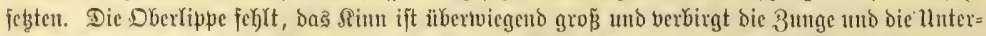

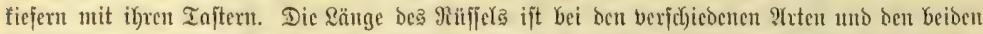

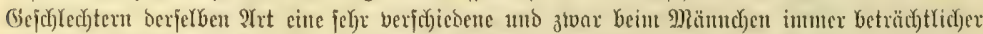

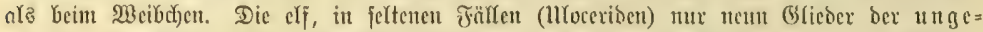

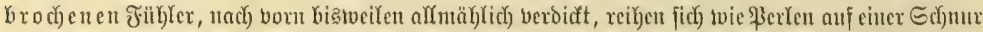

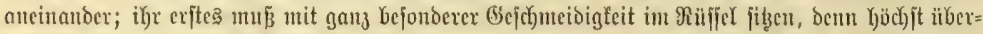

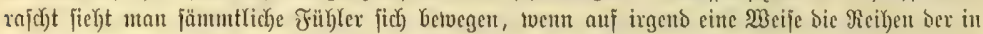

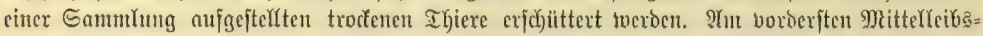

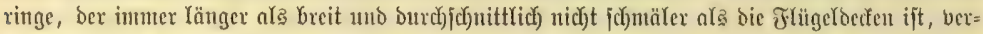
fđud)

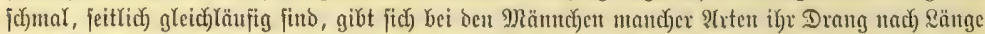

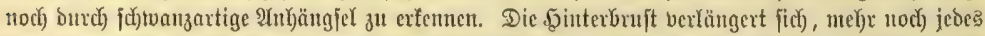

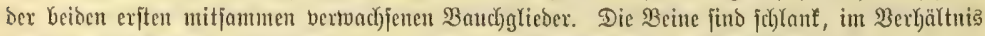
zum \inealen Siörper nicht eben Inng zu nennen, bie Sgitfen ber vorberften flack fugelig, fajt cin=

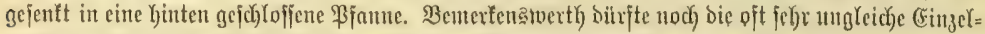

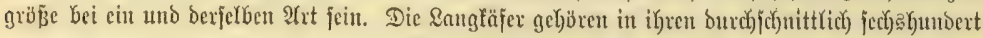

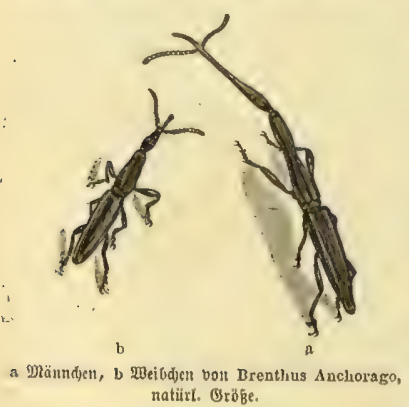
2rrten bis auf eine (Amorphocephalus coronatus) beß füblič)en (Europa ben übrigen (Erotheilen an, PHerita nicht vorkerrichend, tvie man friber meinte, als bie vielen afiatifichen Arten nod) unbefannt waren. Sie Yeben gejellig hinter Baumrinde, entfernen fict) aljo sejentlict) in biejer

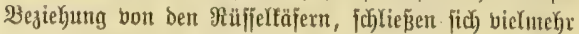
ben 5orgfrefiern in tweiteften Sinne bes Wortes an. Dic

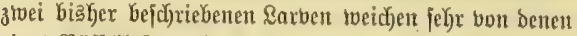

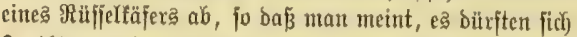
Jrrthünter eingejojlicten Kaben, uno biejelben feinem Rangtäjer angehörent. Der in Brajilien genteine Brenthus Anchorago möge eiue $\mathfrak{B}$ oritelfung vou ben eben befpro=

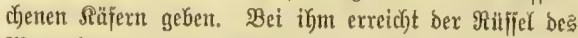
Männchenę eine bebeutendere \&änge ala bei jebem anderen

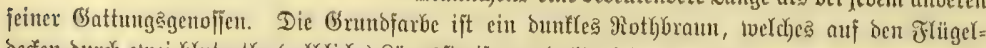

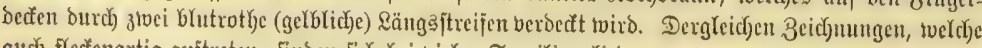
aud) flectenartig aujtreten, finden fich bei biełen Familiengliebern.

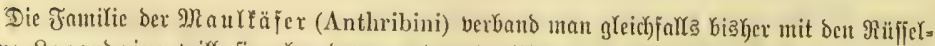

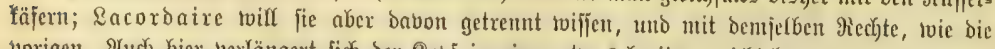
vorigen. Thd Gier verlängert fich ber Ropf in eitnen etwas breiten, nich)t Yangen, nie ivalzigen,

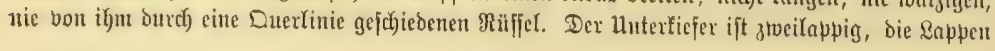




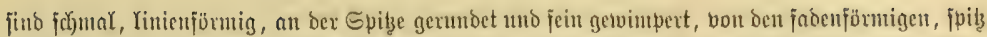

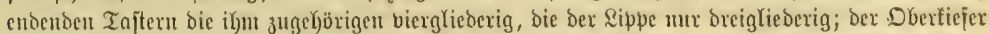

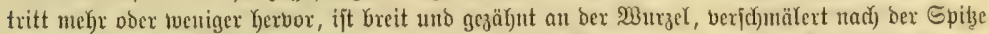
hin. Dic Dberlippe ijt beutlidb, born gerundet und bervimpert. Die nicht gebrod)enen

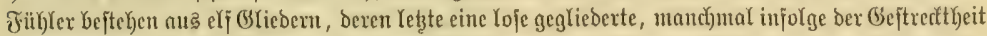

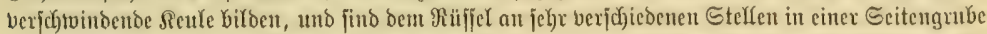

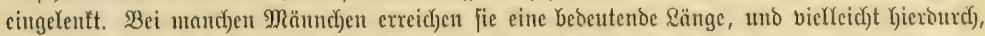

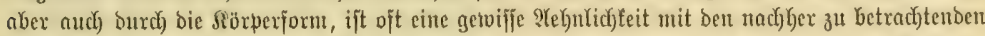

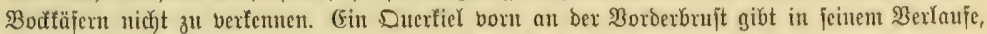

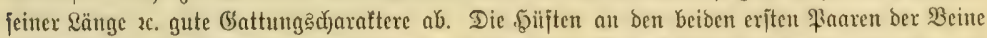

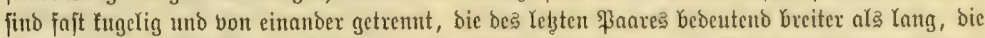

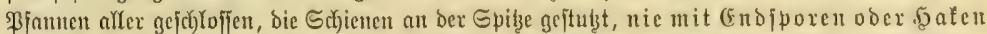

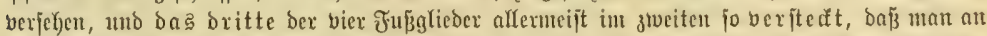

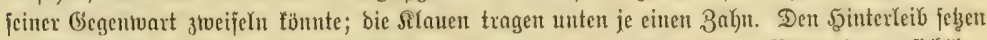

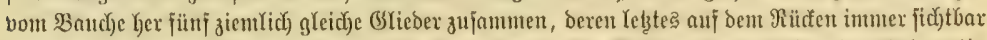

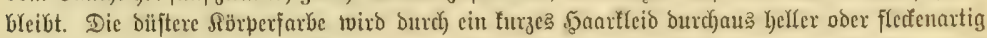

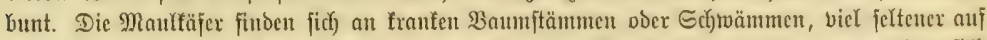

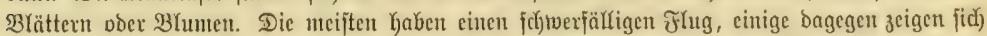

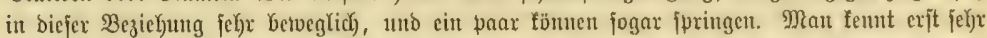

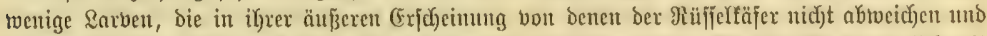

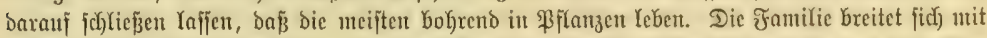

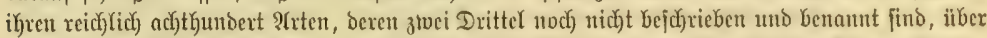

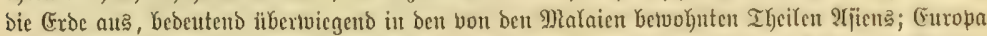

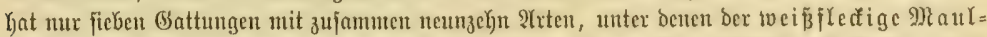

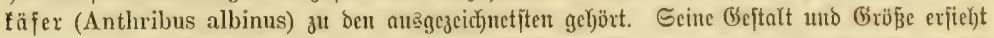

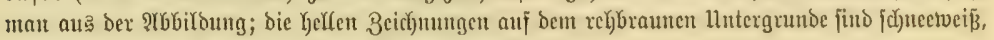

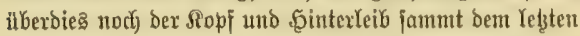

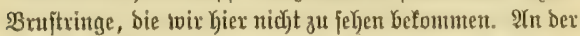

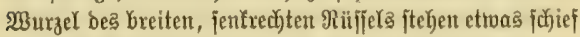
bie nierenförmigen $\mathfrak{F}$ ugen, vor innen bie fajt fabenförmi=

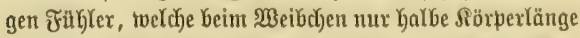

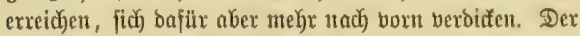

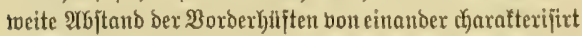
bie 2Art nod im befonderen. Şd fand fie bistweiken an

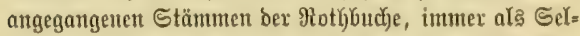

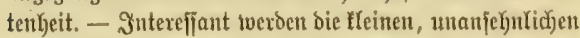

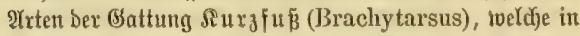

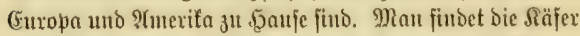
auf $\mathfrak{B l u m e n , ~ b i e ~ E a r b e n ~ u n t e r ~ D e n ~ G r a u m e n , ~ Y y a l b t u g e = ~}$

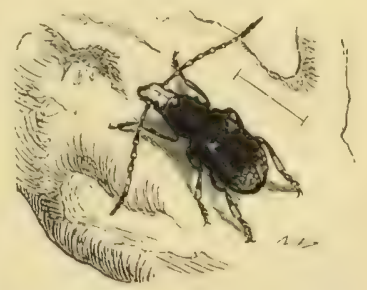

20elBffediger MR aulfäfer (Anthribus albinus),

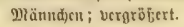

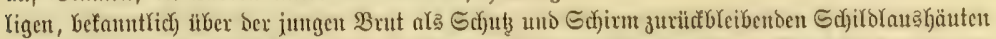

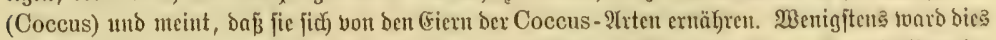
von Brachytarsus seabrosus und B. varius bcobachtet. Beibes find fleine, ftumtpi eiförmige

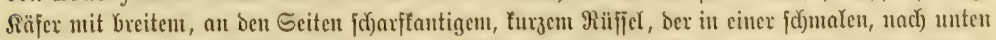

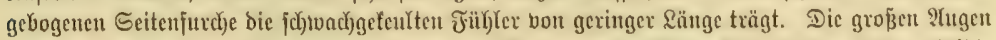

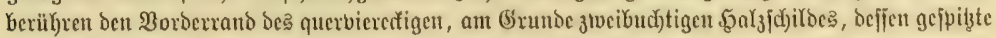

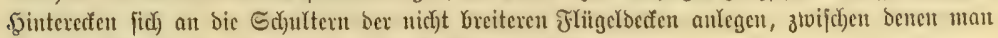

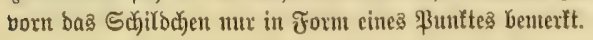




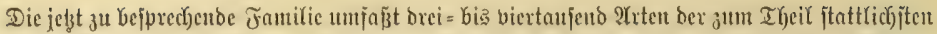

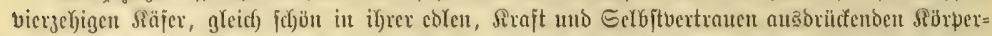

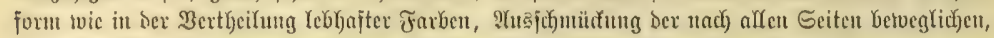

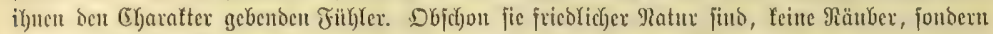

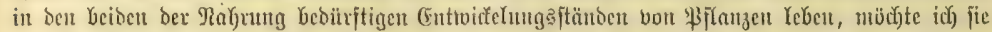

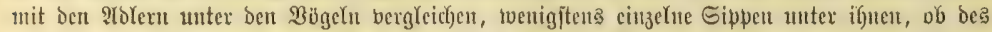

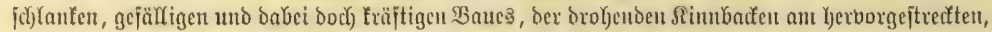

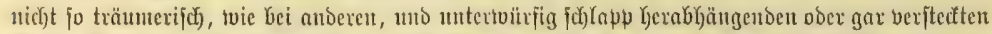

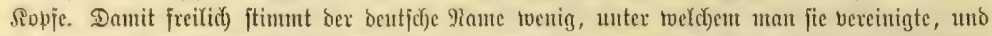

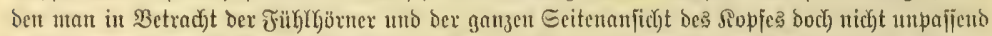

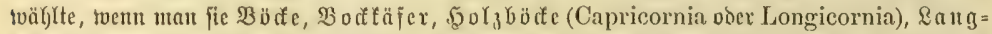

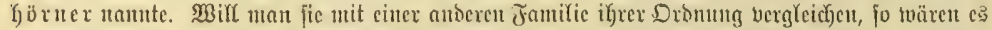

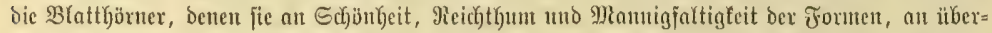

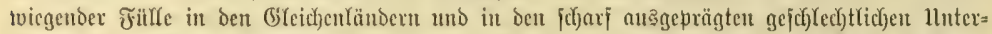

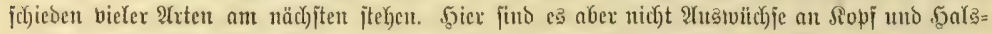

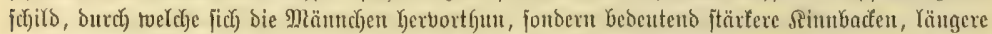

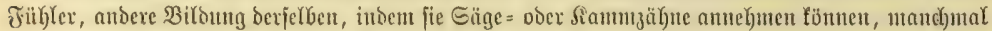

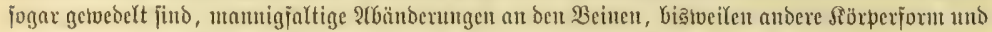

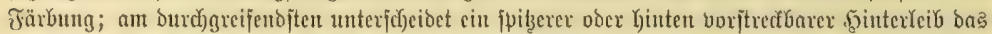

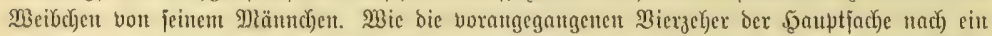
riifjelartig berlängerter Ropf d)arafterifirte, fo bie Bzörfe Yange, häufig den Rörper übertreffente,

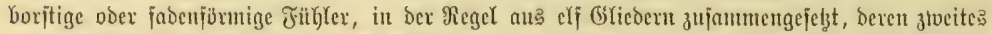

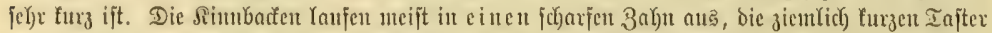

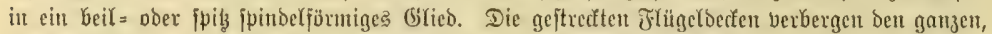

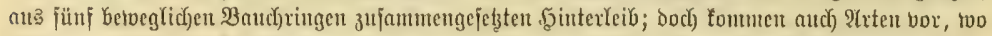

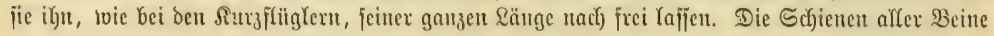
tragen (Enbjporen und bie Đüften Dex boroerften berübren fid nicht.

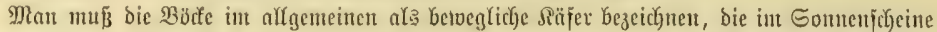

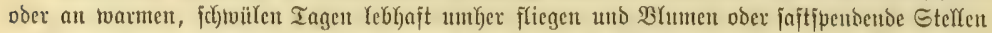

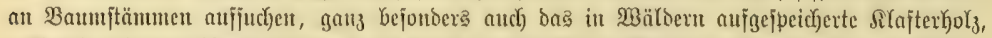

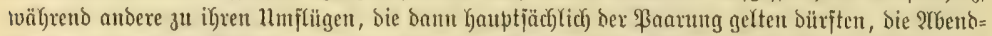

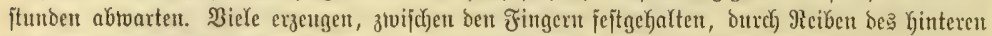
Borberrildentandes an bem turzen, in iGn cingejchobenen (5nbe des Mittelrütents ein eintöniges,

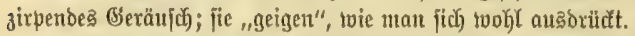

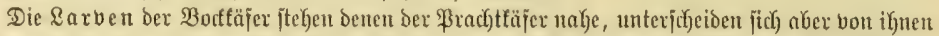

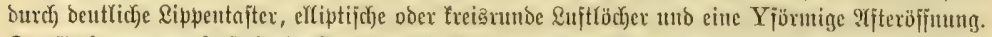

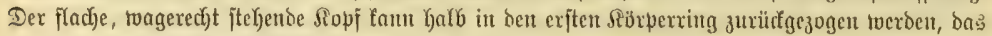

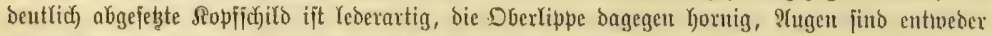

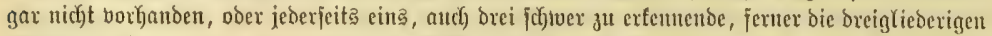

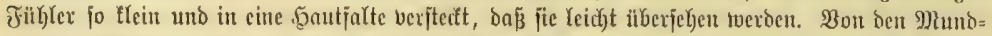

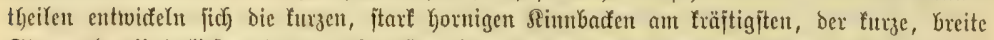

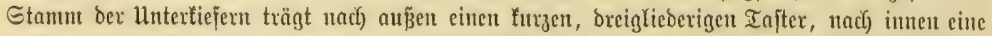

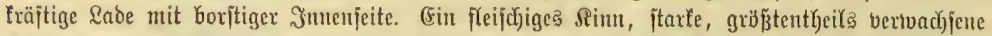

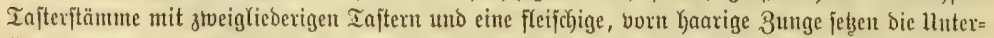

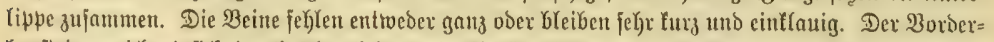

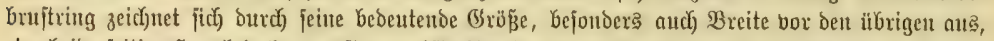

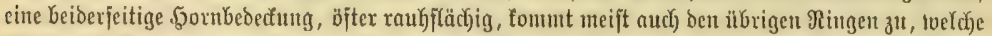

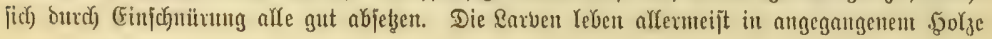




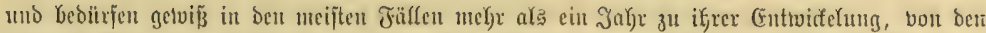

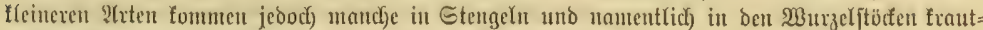

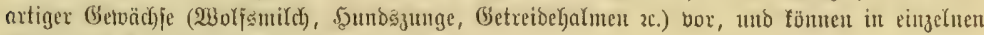
Fällen den Sulturgetwächjen nadjtheilig toerden.

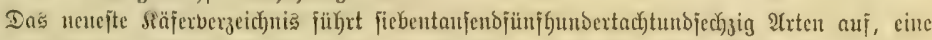

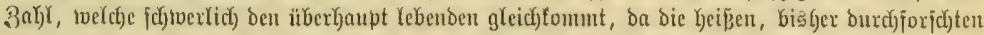

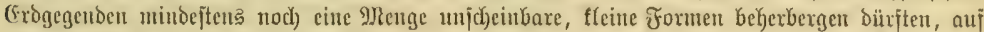

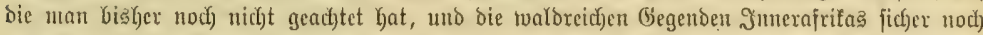

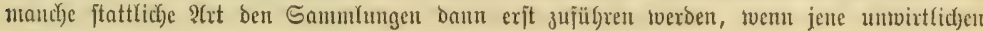

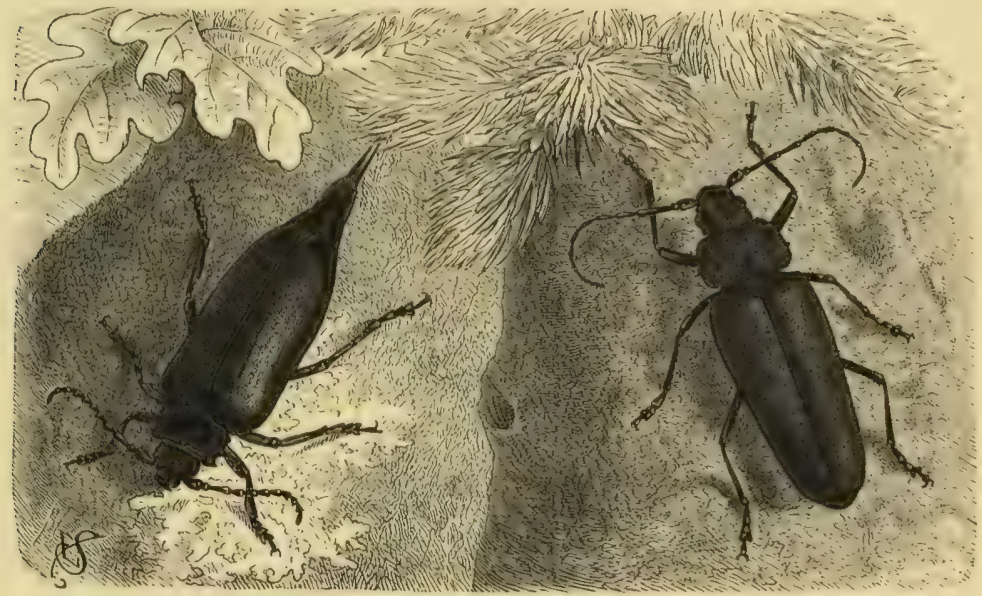

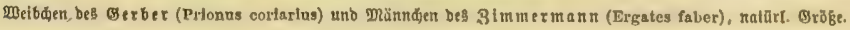

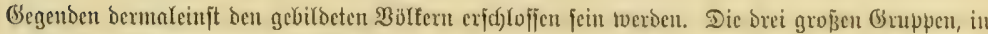

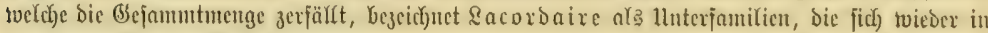
Der mannigfad)ften Meife gliebern.

Die $B$ reitböde (Prionidae) umfafien als exite unterjanilie bic breiteren, plumpen, gleicl)=

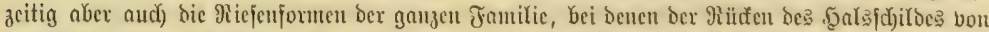

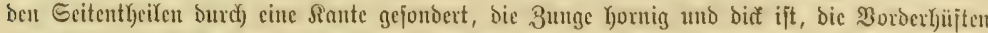

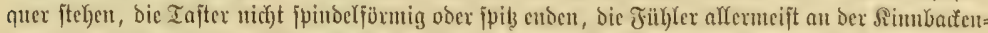

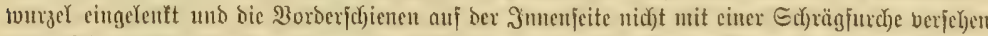

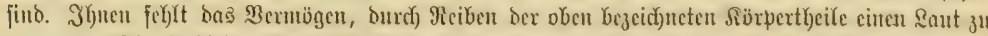

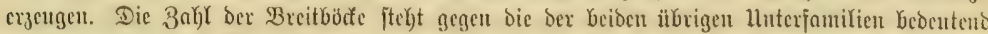

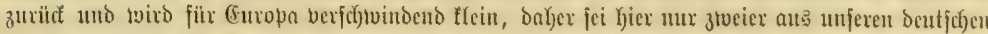
Wäldern gedact)t.

Dex Gerber, Forftbout (Prionus coriarius), autch ber Gägeborf, fofern man unter bicfem

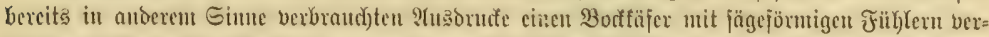

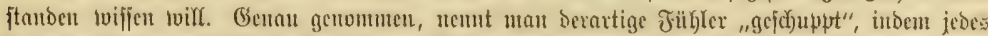

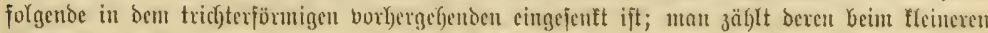

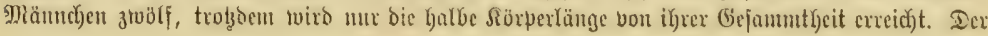




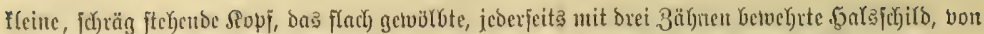

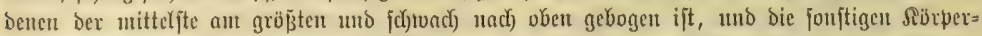

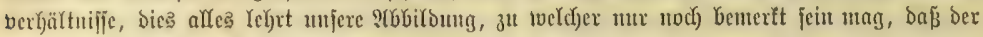

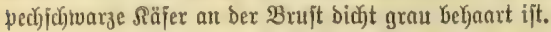

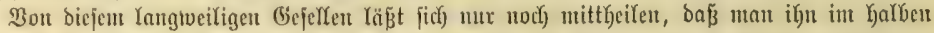

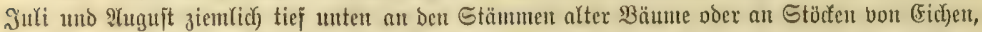

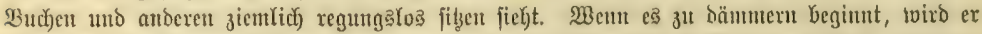

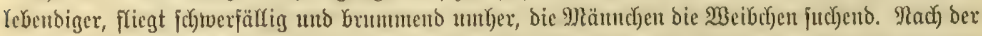

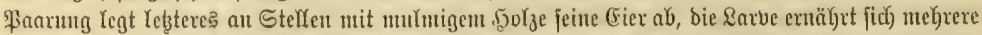

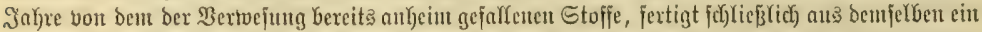

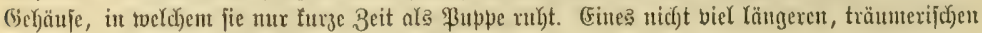

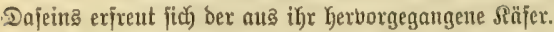

Der Bintmermann (Ergates faber) ift gejtrecfter uno meift Yänger als ber vorige, hat

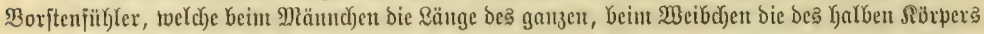

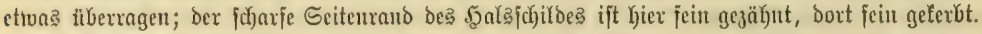

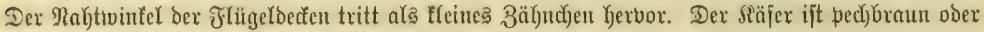

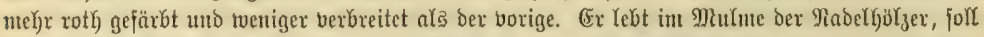

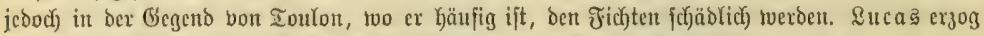
bie \&arben, indeut er fie in Siäften mit feutht geljaltenen Sägejpänen brad)te.

Die ztweite lluterfamilie, Cerambycidae, weldye Bentenung von anderen auf bie ganze

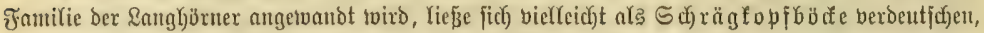

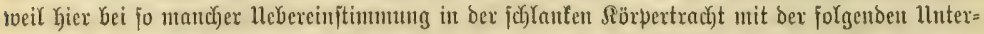

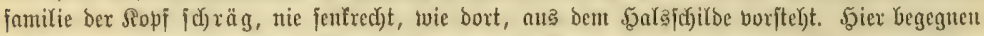

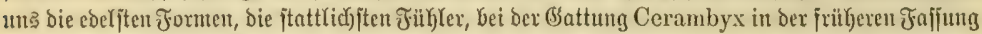

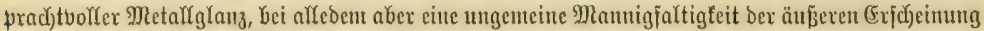

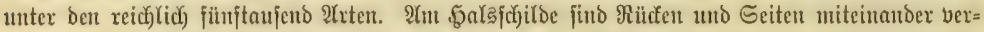

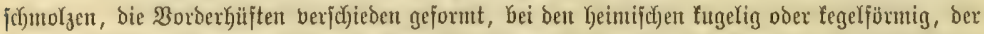
oben erwähnte "Zirpapparat" borkanden. Die Bunge ift Yjäutig, Das (5nogfied Der Tajter nich)t

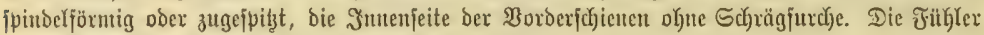

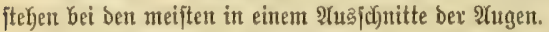

Der $\mathfrak{B a r b f a ̈ f e r ~ ( S p o n d y l i s ~ b u p r e s t o i d e s ) ~ i j t ~ n o d ) ~ f e i t ~ e c t ) t e r ~ ( E e r a n t b b c i o e , ~ a b e r ~ a u d ) ~}$

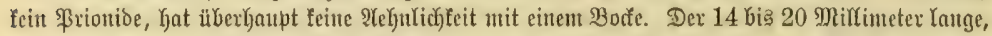

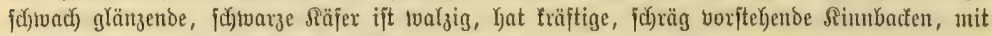

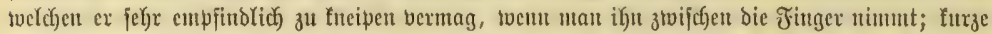

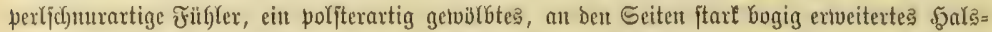

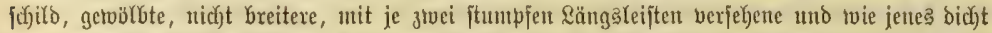

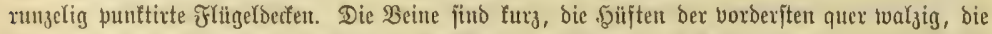

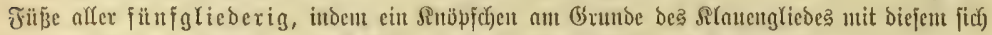

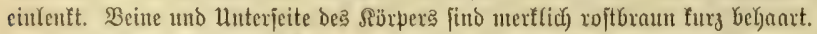

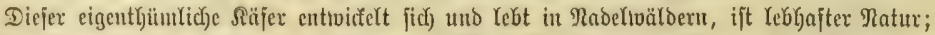

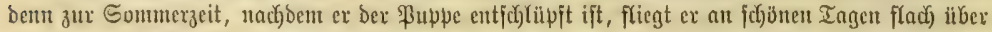

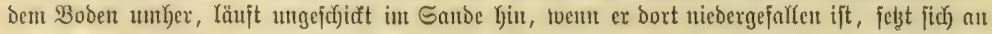

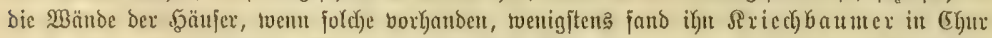

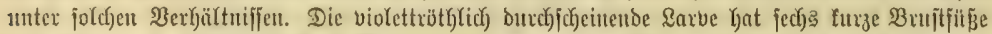

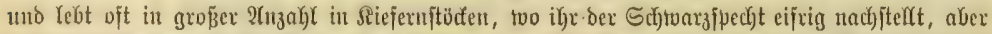

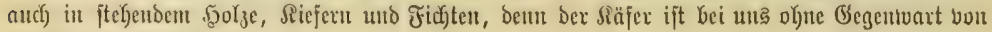
Stubben ziemlich häufig. 


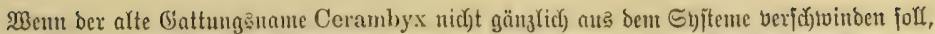

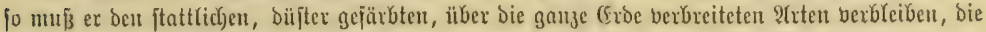

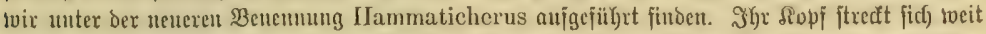

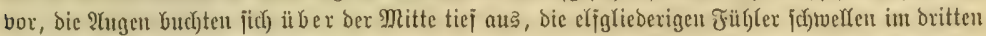

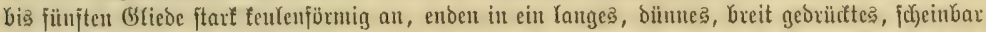

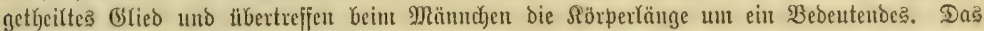

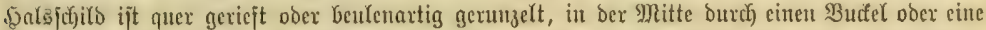

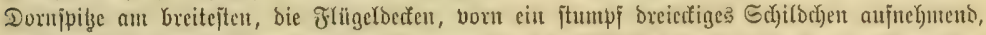

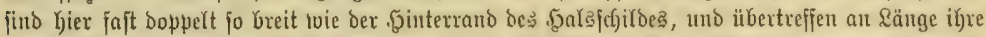

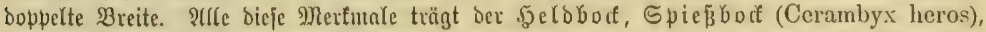

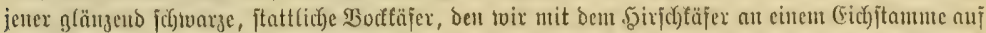

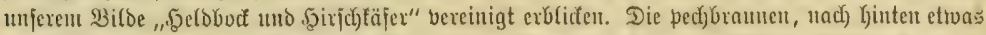

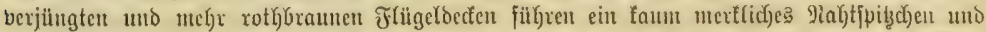
werben toeiter nach born inuter rungeliger; unterhalb uno an ben Beinen jefjimuert ber Siäjes burd, Seiónbefaarung firtbertueip.

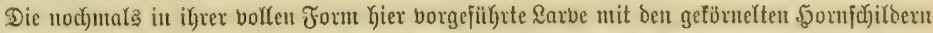

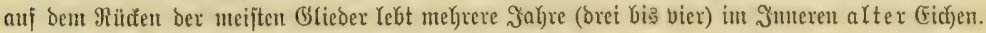

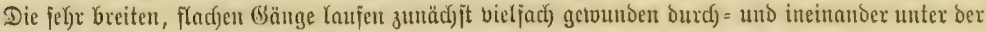

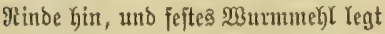
fict) zivifichen fie und bie Minde, bam: aber fübren fie tief in bas $50 \gamma_{3}$ und nehmen bistweilen eine ungeheure Breite an. Daß̄ biełe Rarben bett alten

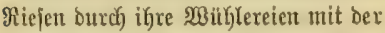
3eit zu Orunde richten tönnen, Yiegt

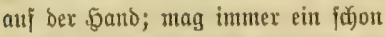
etruas angegangener Stanm füt bie

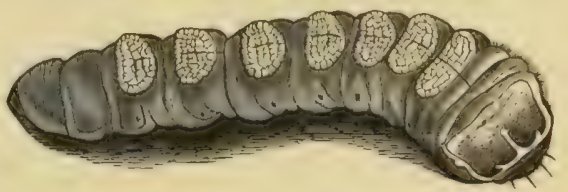

Sarbe bes \$elb bodes (Cerambyx heros), natlit. Sröfe.

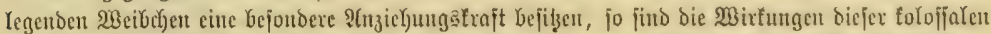

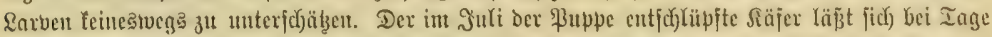

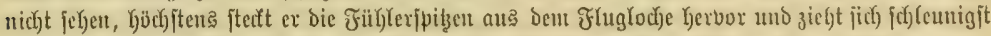

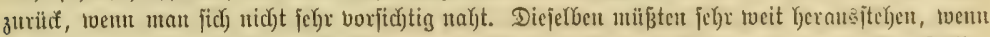

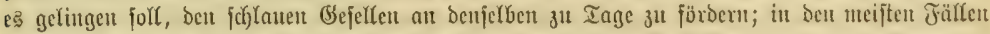

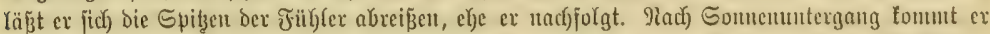

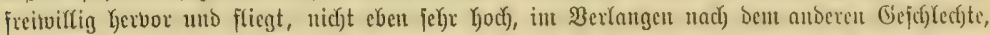

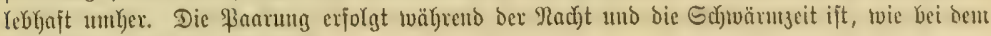

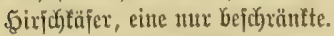

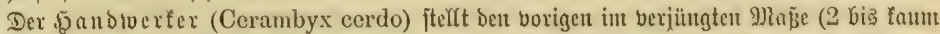

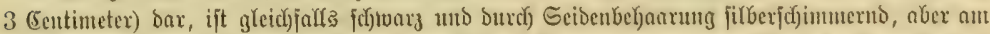

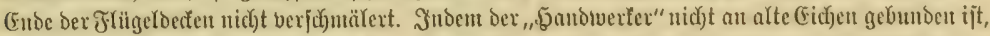

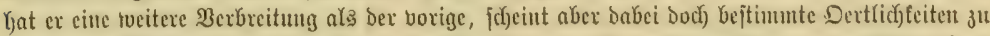

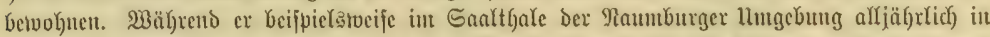

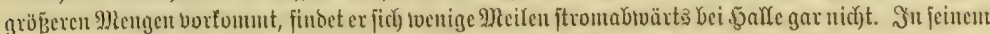

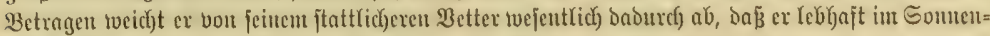

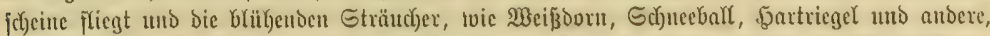

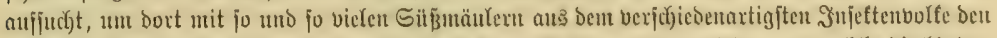

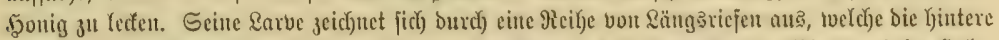

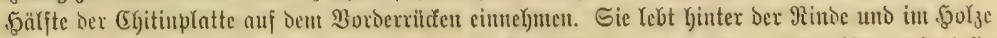

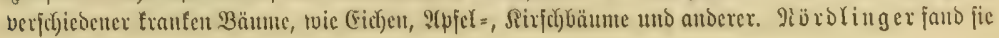




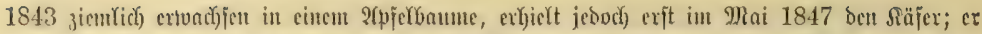

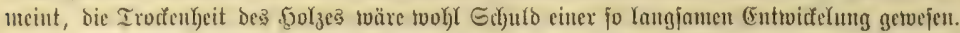

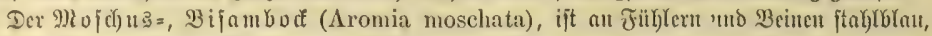

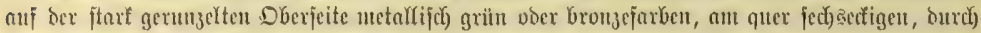

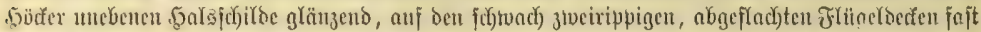

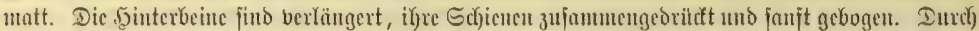

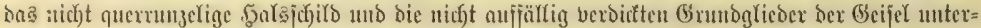

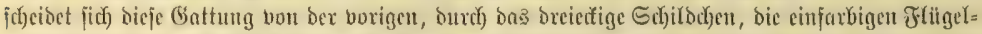

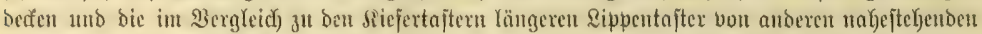
Gathugen. Dic injulge ifres ftarfen Gerud)e mit vbigen Ramen belegte Prt Yebt im Rarben=

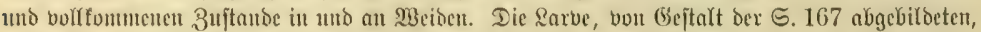

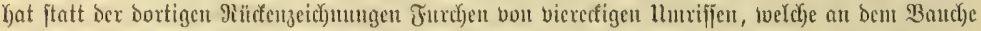

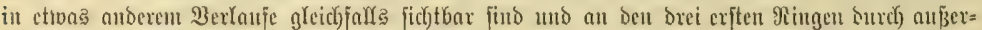

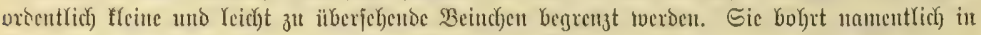

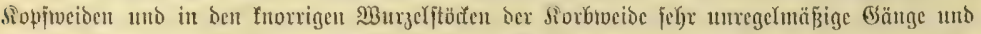

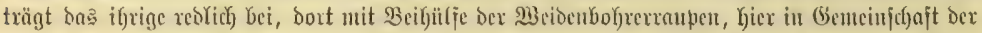

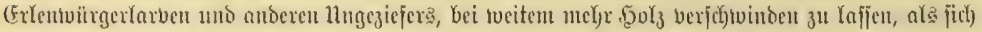

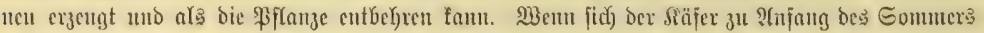

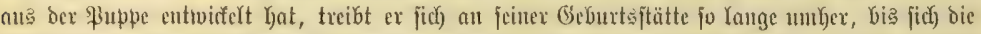

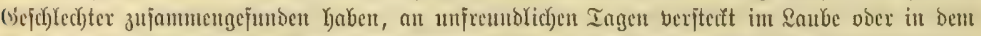

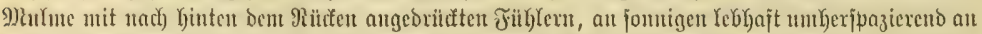

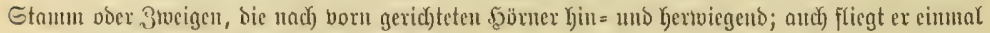
babon mo fudbt jeineşgleichen andertoärts auf.

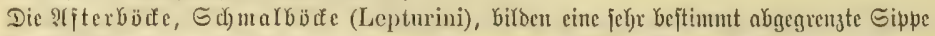

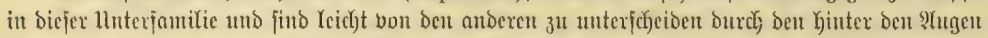

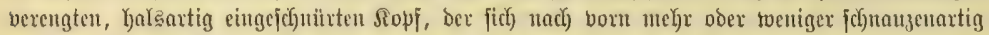

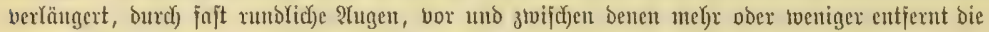

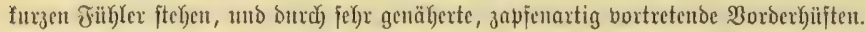

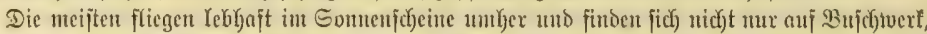

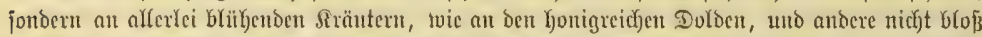

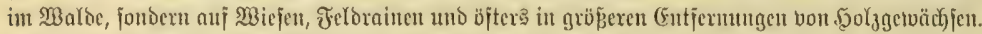

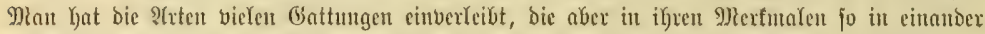

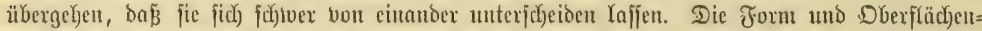

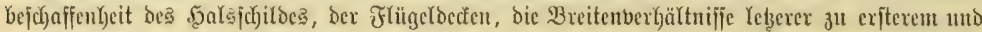

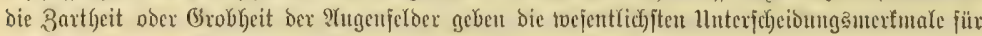
bie Battungen ab. Die Rarben ermähren fictc bou faulem Şolje.

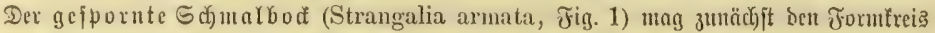

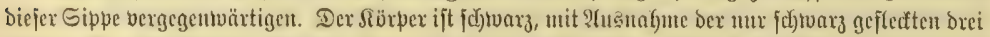

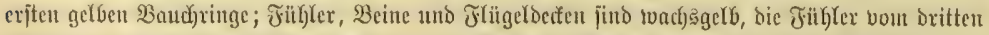

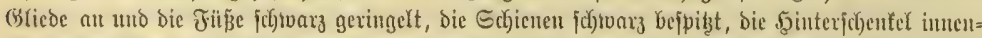

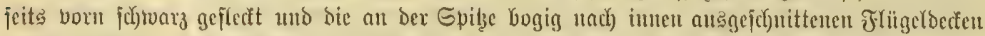

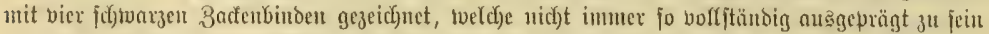

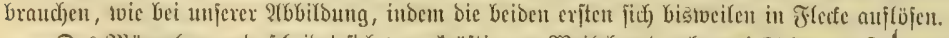

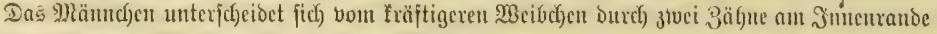

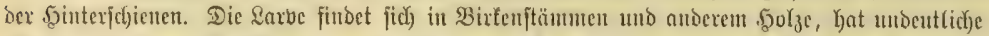

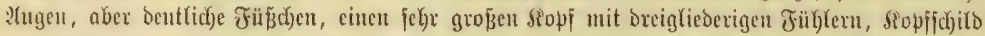

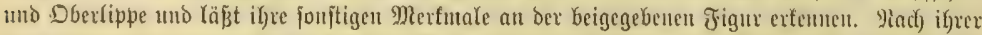

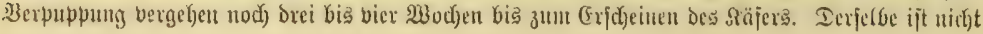




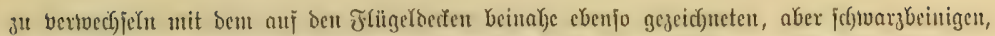

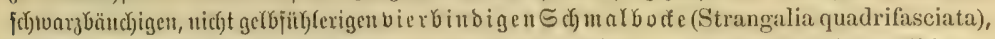

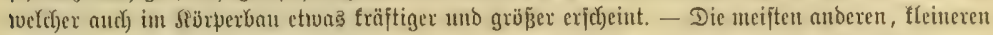

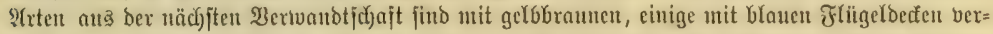

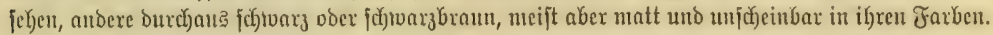

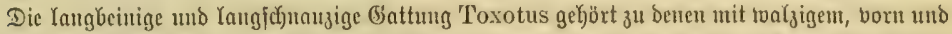

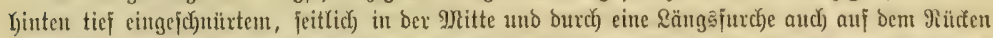

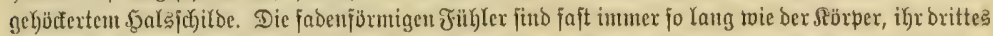

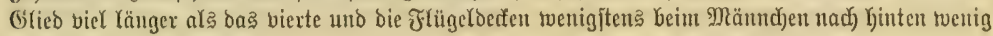

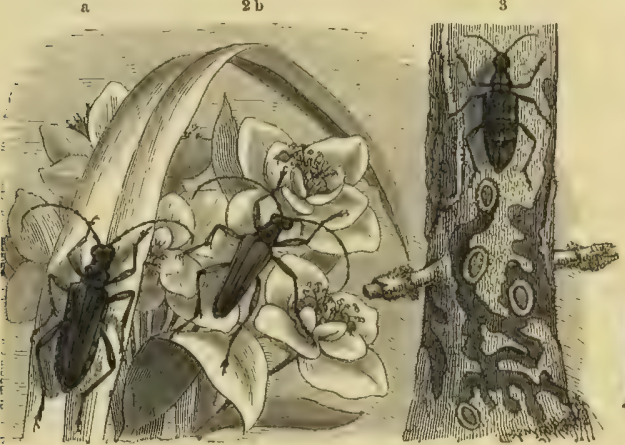

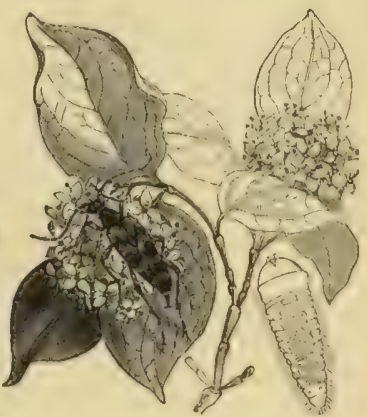

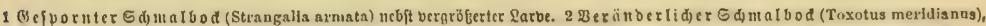

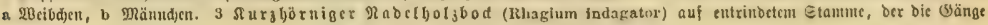
feince Sarve geigt. UII

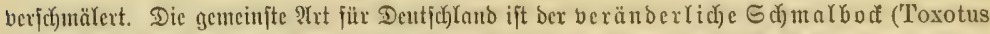

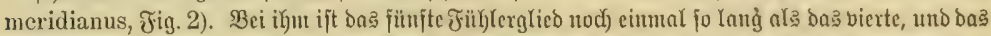

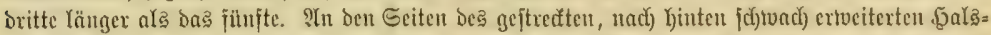

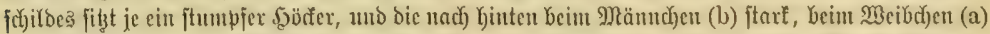

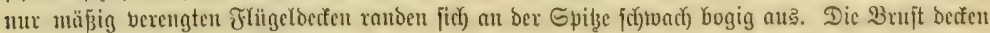

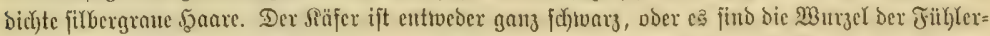

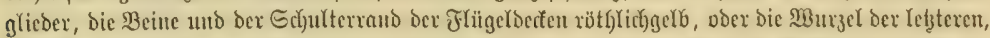

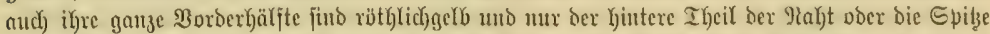
jơ)

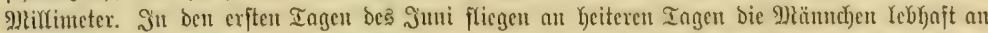

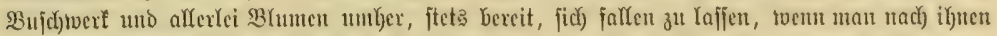

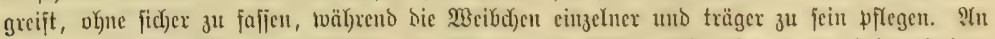

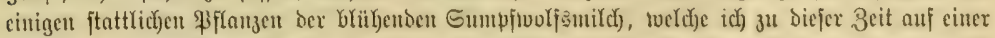

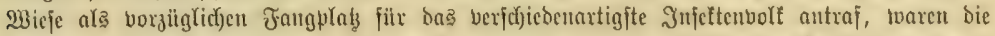

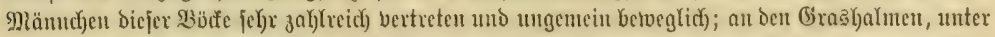

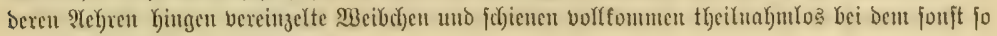
itbernus regen Rebent rings um fie.

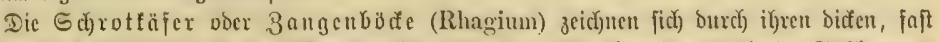

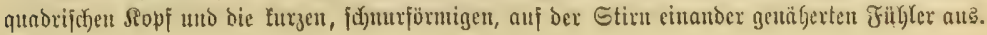




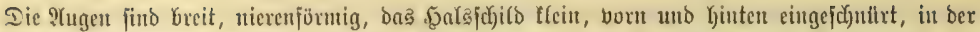

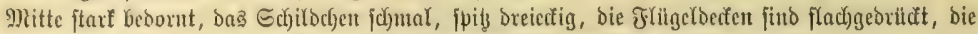

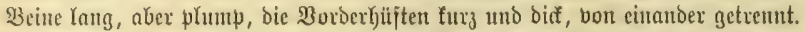

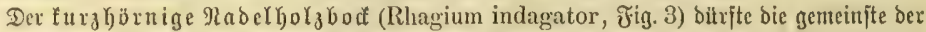

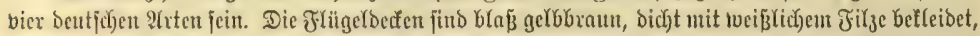

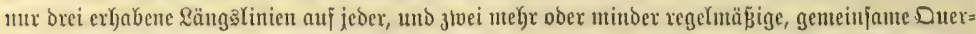

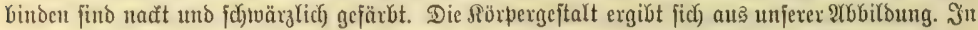

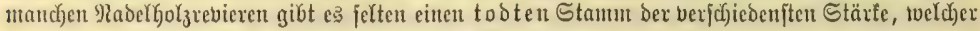

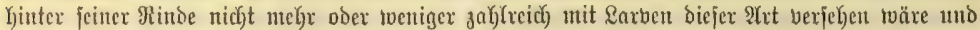

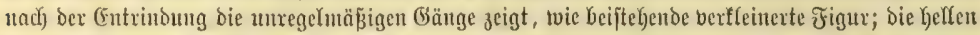

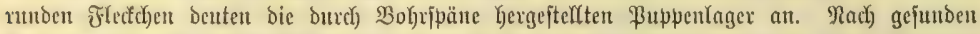

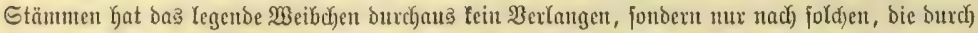

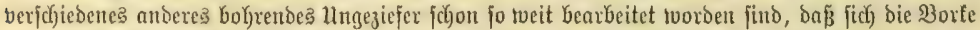

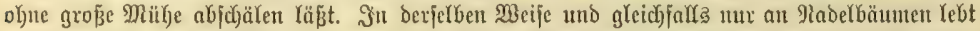

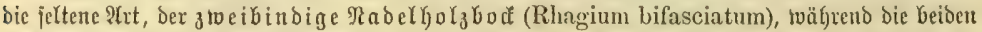

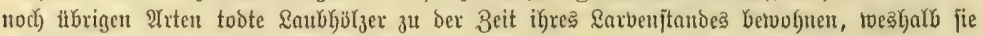
fänuntlid) jür Den Foriłt ofne jeglidje ßedeutung find.

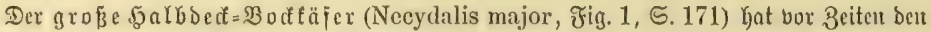

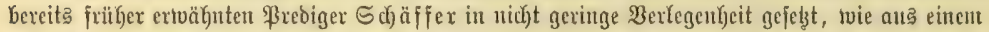

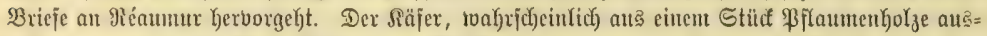

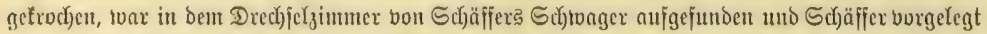

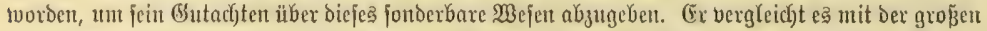

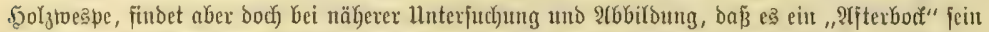

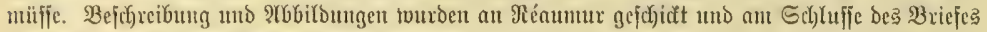

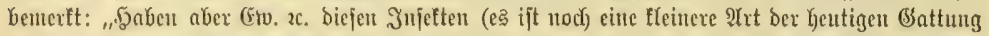
Molorchus babei) cinen zweifelabne cigentfict)eren unb befjeren Namen fichon bejtimmt, fo twerbe

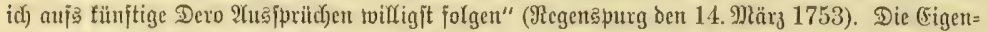

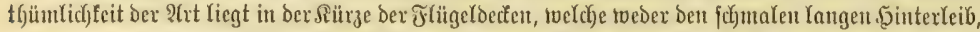

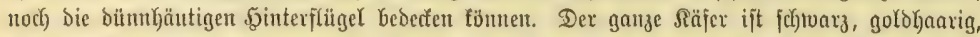

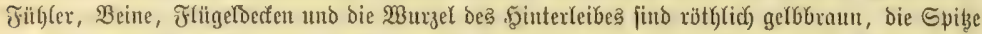

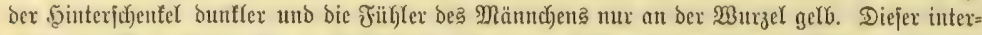

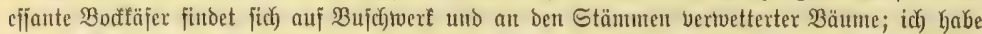

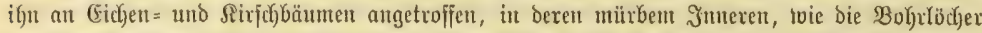

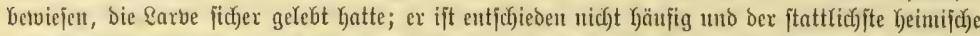
Bertreter biejer bejonders in Sübamerifa Yebenden, aus tounderlichen Gejtalten bejtebendent Sippe.

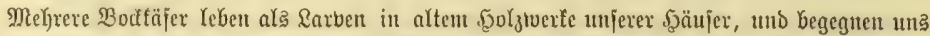

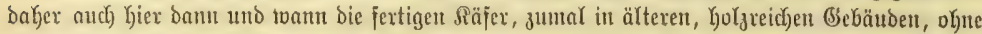

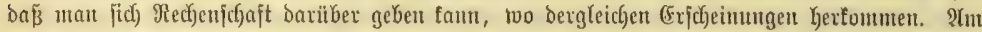

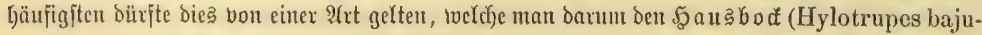

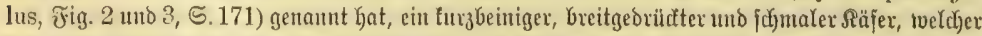

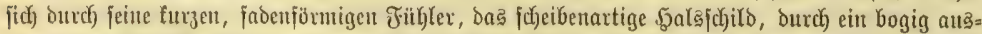

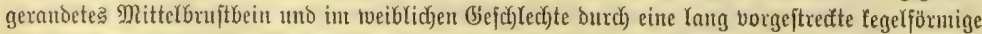

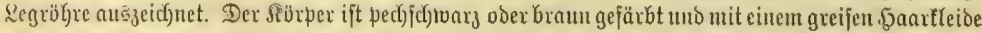

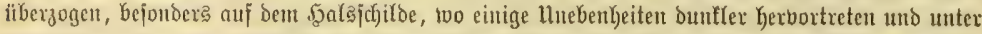

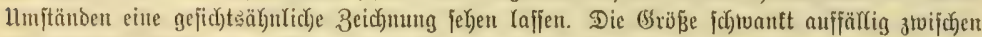

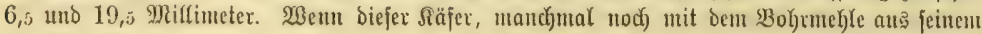




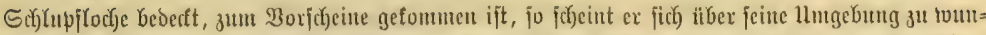

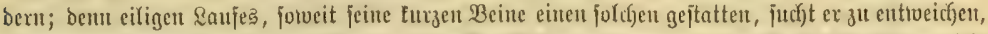

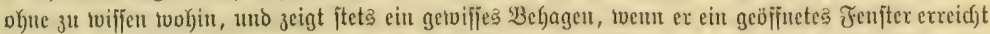

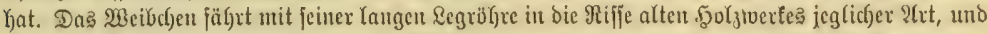

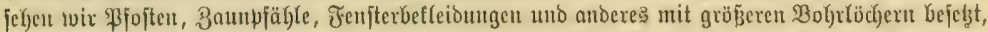

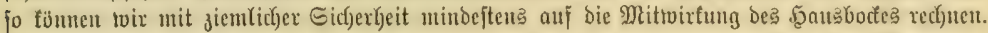
Sciue Rarve betwohnte bor Beiten bie Eeitenuänoe und ben bünen Boben eines Jujeftentajten?,

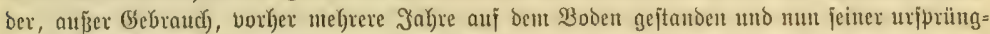

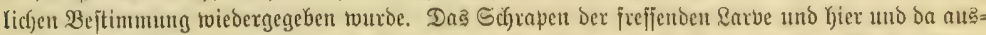

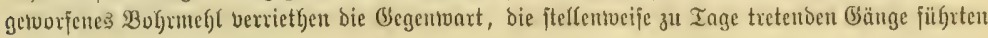

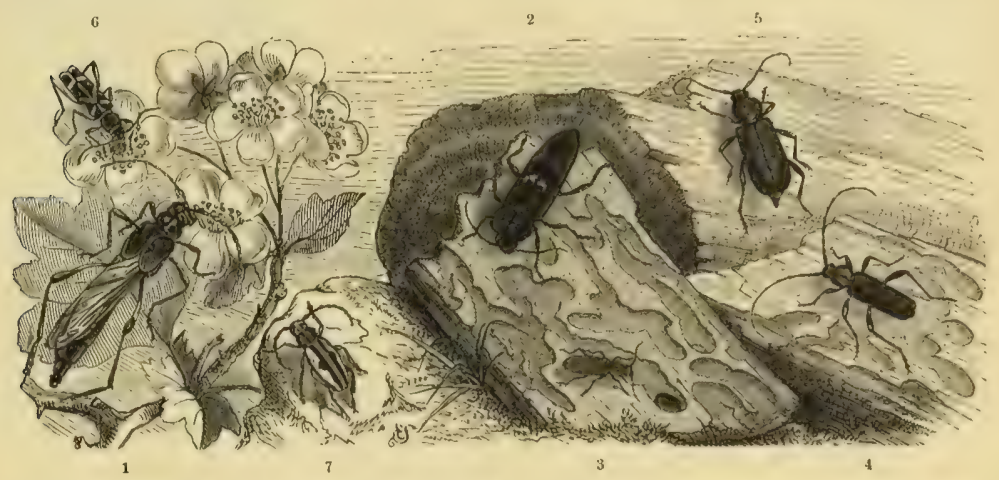

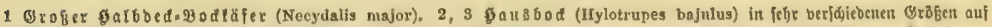

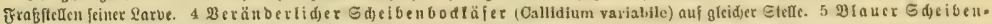

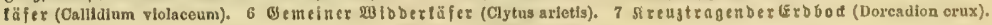
get in ratüllidjer Bróse.

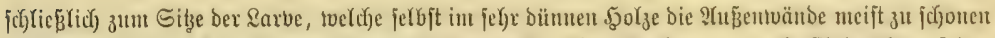

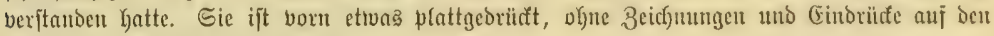

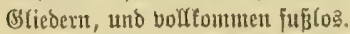

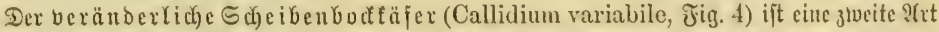

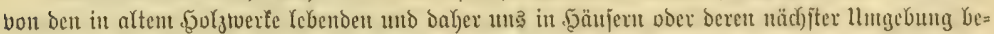

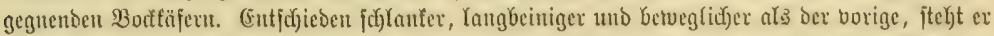

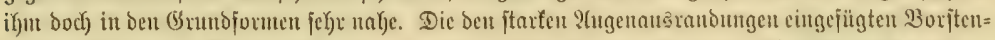

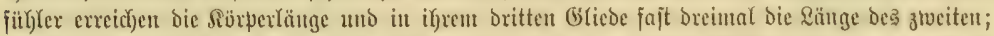
bas .

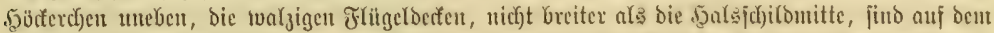

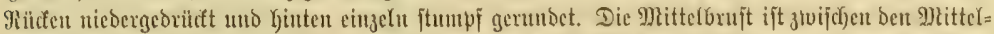

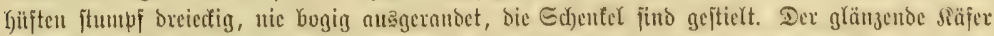

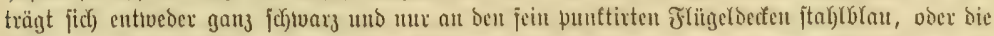

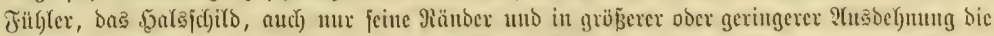

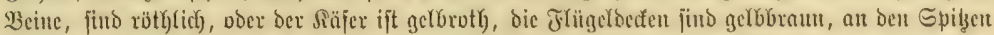

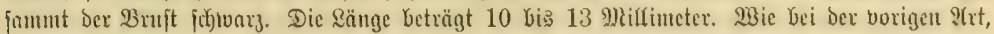

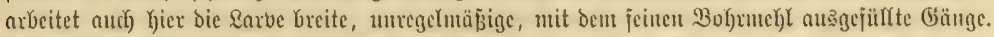

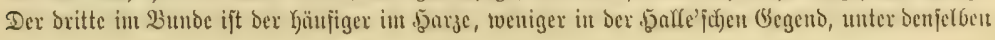




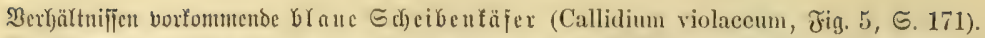

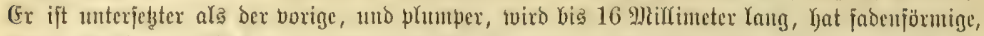

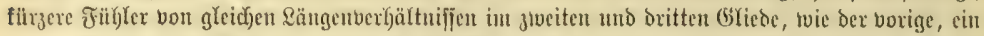

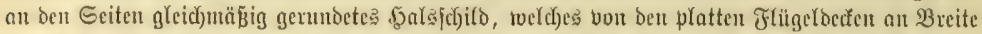

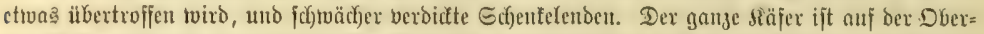

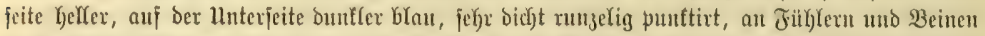

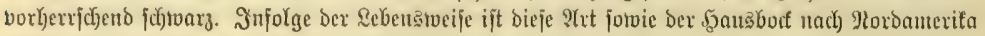

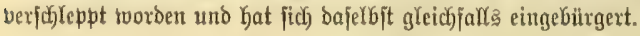

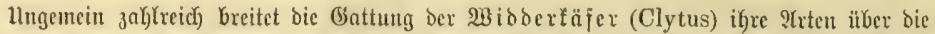

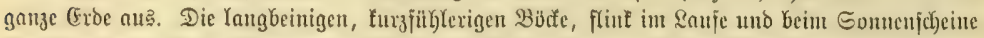

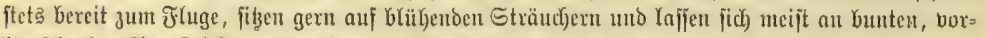

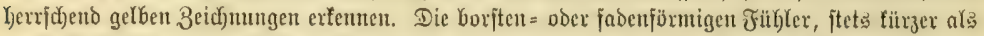

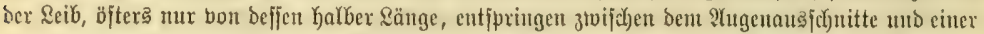

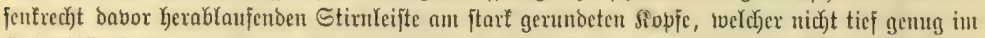

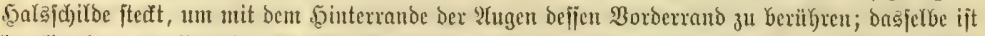

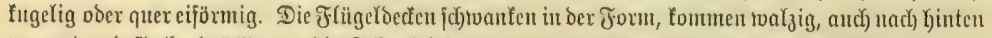

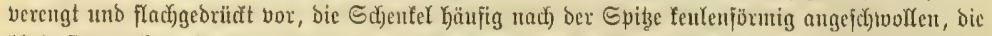

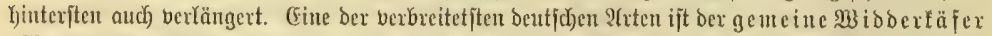

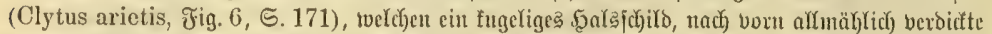
Edyentel und einzeln an der Epibe abgerundete, twaly

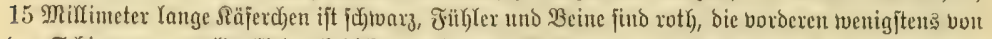

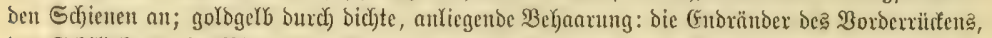

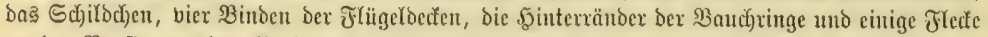

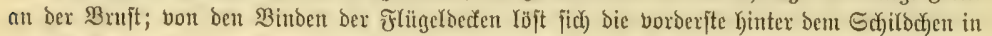

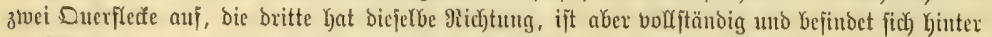

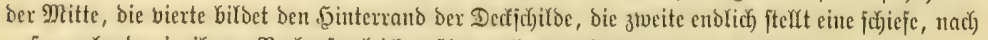

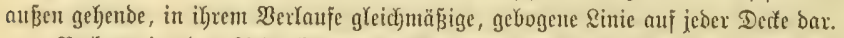

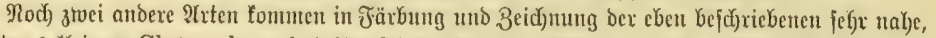
ber etrons fleinere Clytus rhamni, beffen Flecte Ginter Den Schultern nich)t als lleberbleibjel einter

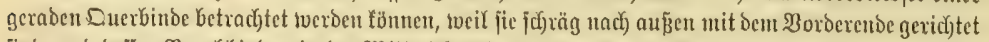

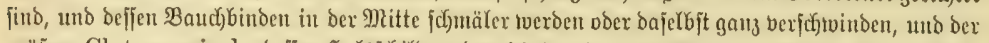

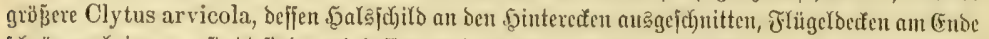

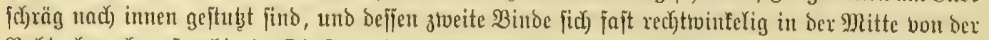

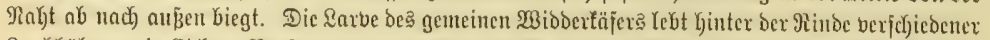
Eaubhölzer, wie (Eic)

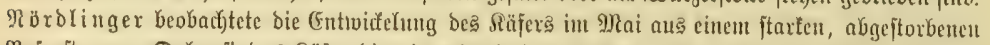

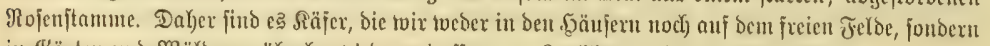

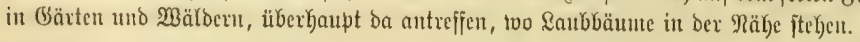

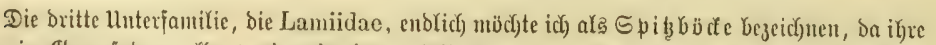

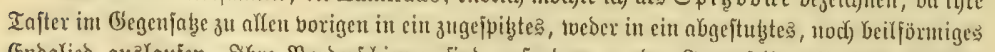

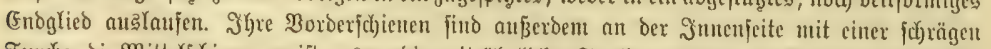

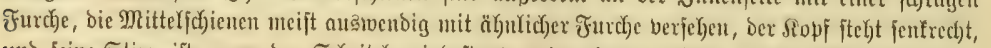

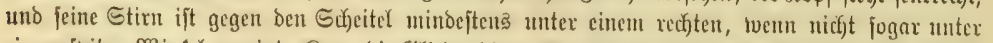

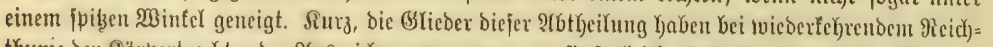

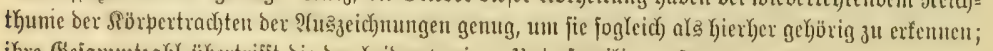

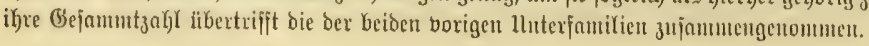


T(Ggejelyen bon ciner Uebergangsfippe, two bex Sopj nod) nicht bie gcjorderte Etellung hat,

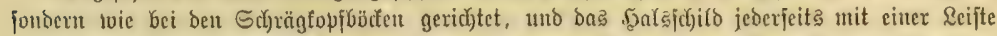

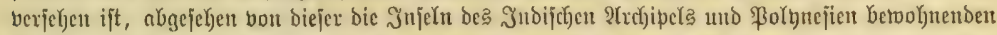
Eippe, tritt uns eine andere, bie ber (Exbbö dé zuerit entgegen. Sie mag an ber artenreid)en,

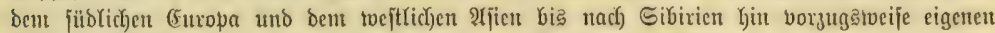

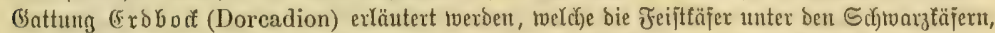

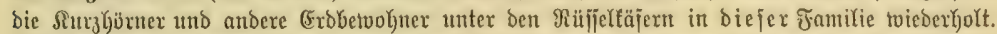

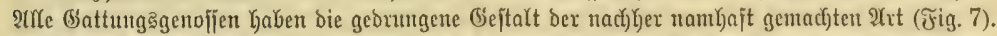

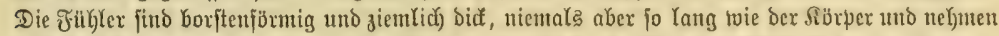

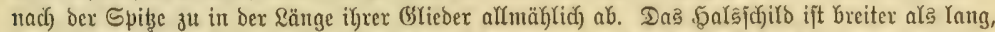

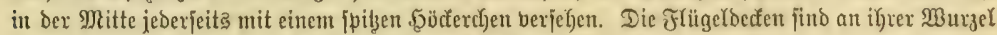

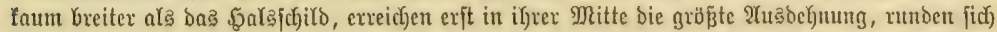

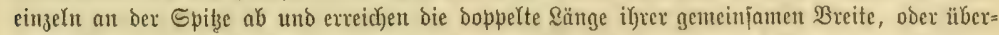

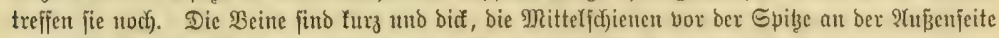

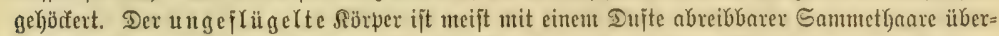

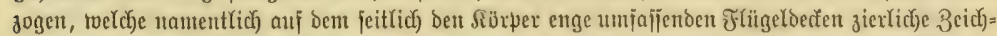

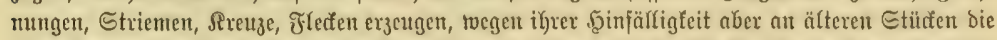

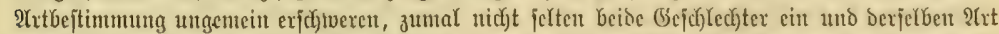

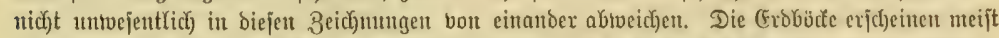

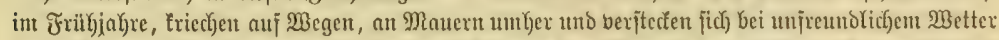

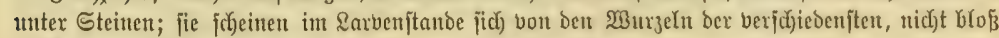
der holzigen $\mathfrak{P}$ flanzen зu ernälyren.

(Fine ber fleinjten uno zierlichjpten 2aten ijt ber bei Embrna und in jenen Gegenden faum jeltene

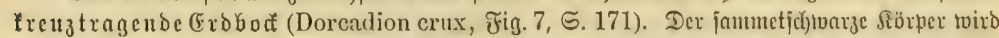

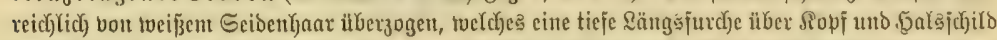

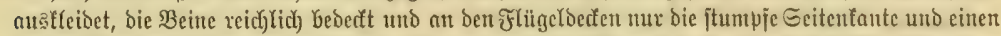

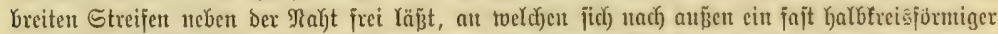

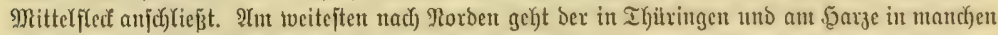

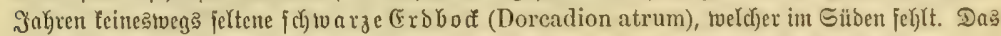
bis itber 16 Mirfimeter mefiende Thier ift burchaus jodjtwarz, hat auj bent jehr grob uno vertworren

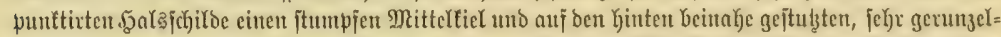

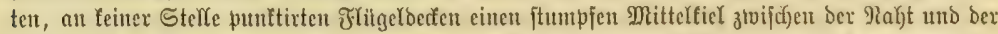

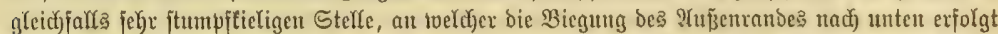
(Seitenfante). Mit ifm zugleid) pflegt, aber jeltener uno weiter jüblid) geheno, Der greije (ErD =

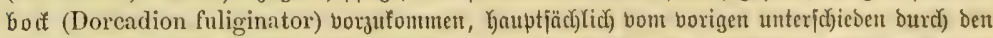

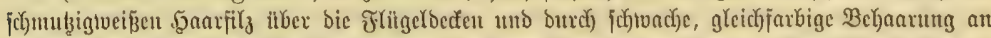

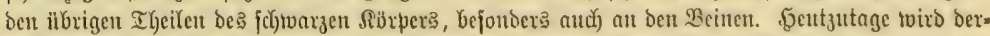

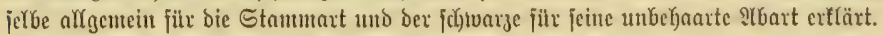

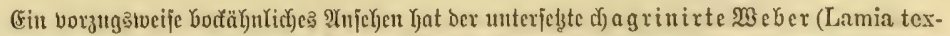

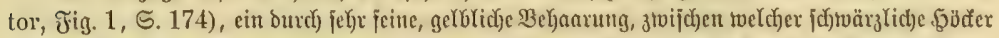

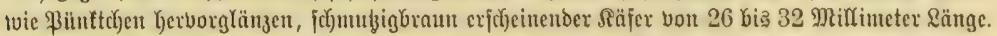

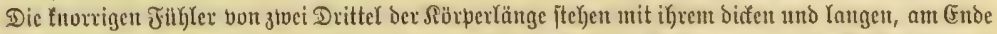

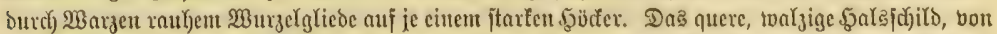

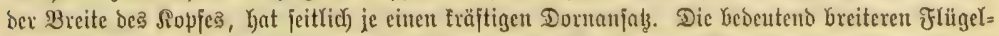

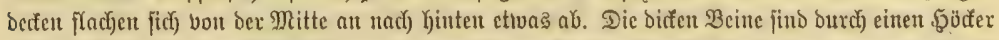

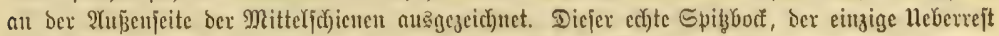

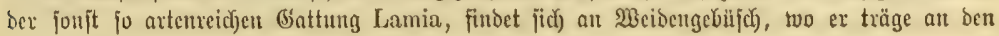




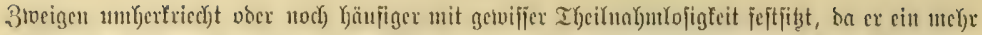

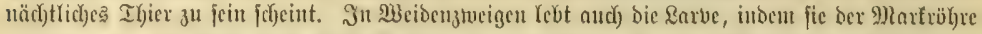

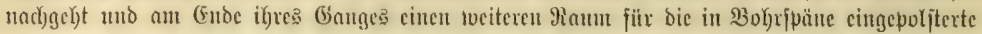

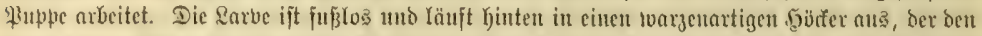

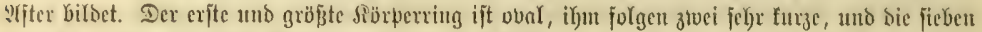

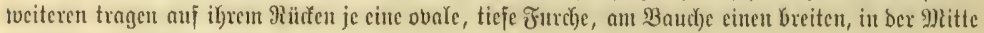
cingezogenen Dutereitomit.

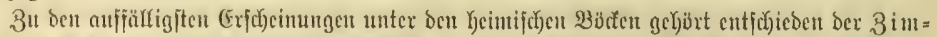

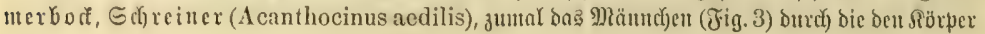

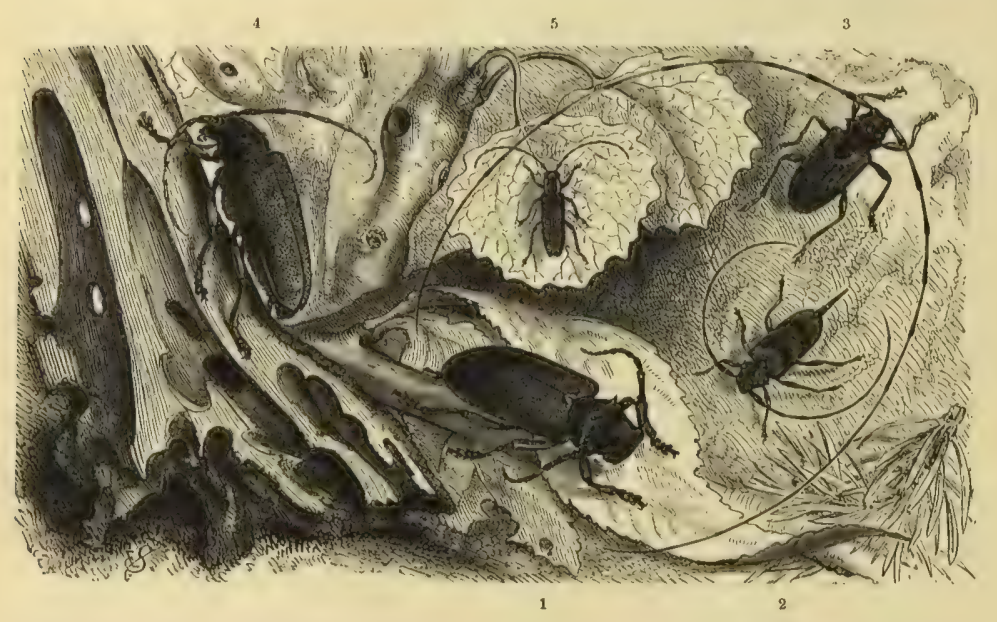

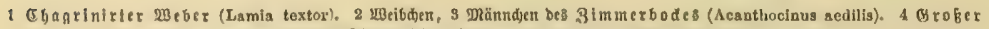

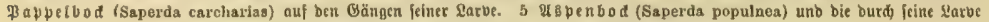

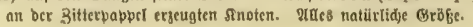

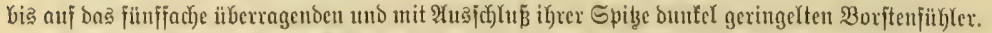

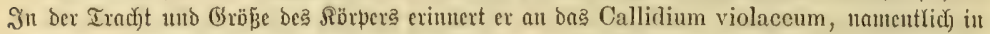

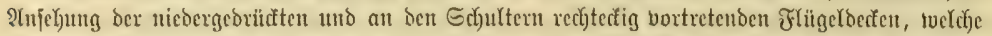

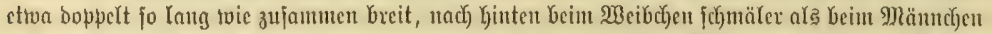

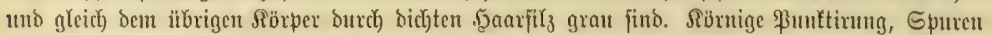

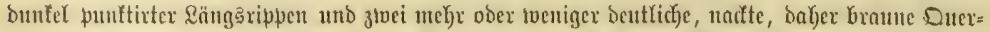

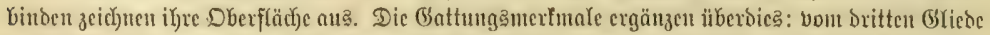

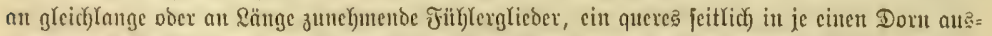

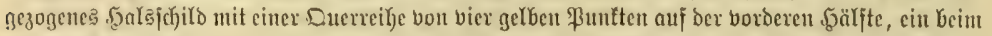

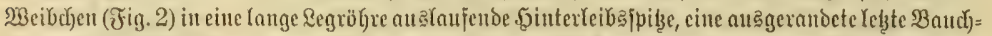

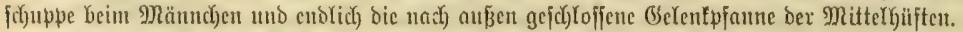

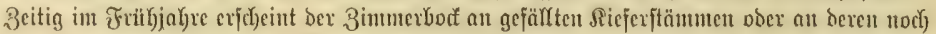

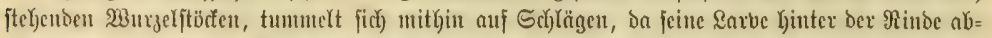

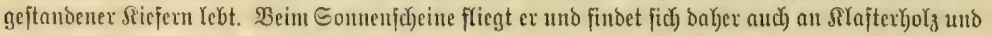

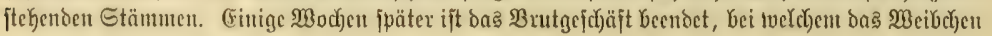




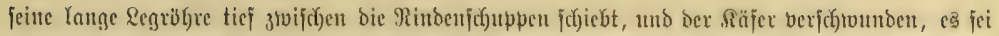

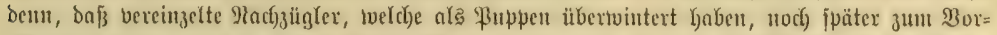

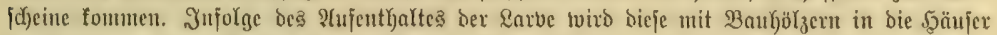

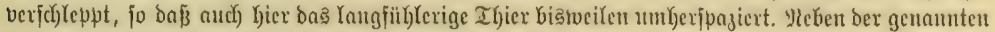

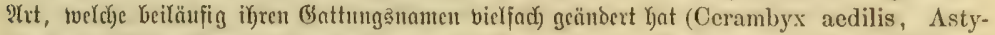
nomus), (eben nock) einige tocniger gemeine in (Guropa und in शorbanerifa, indem bic Gattung cine weitere Berbreitung nicht fundet.

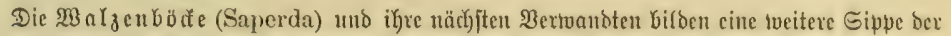

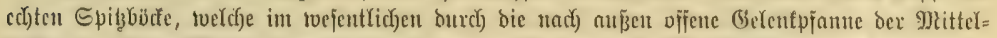

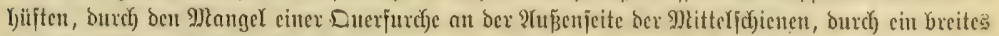

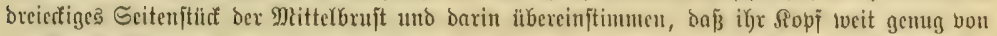

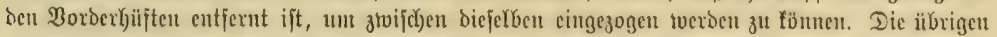

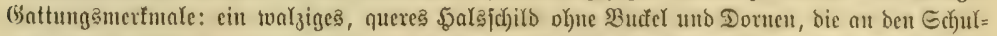

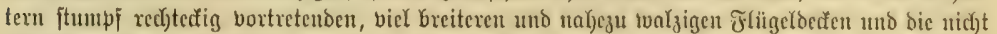

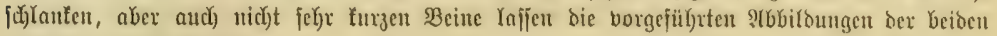
gemeiniten 2 inten erfennen.

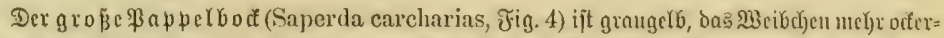

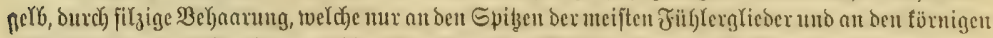

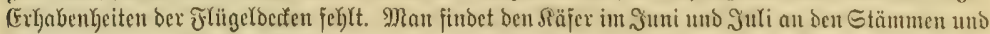

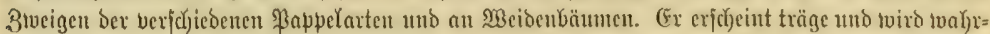

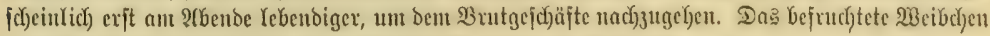

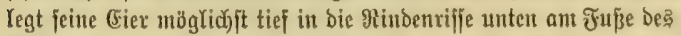
Stammes, und bie jenen entich)(üpiten \&arben jreifen im exiten

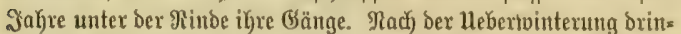
gen fie in bas. 5oly cin und fteigen in bempelben in geraber $\Re$ ich)=

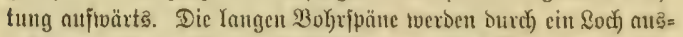

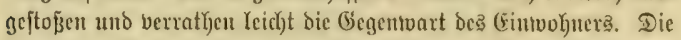

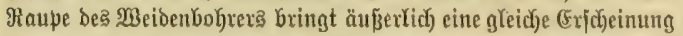

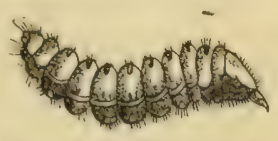

Sarve bes nro ben Pnupelo odes, natiit. Gröge.

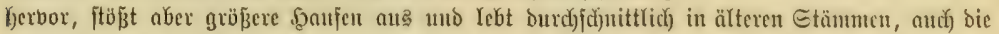

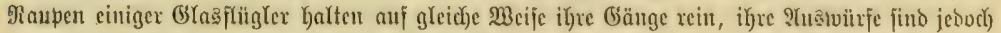

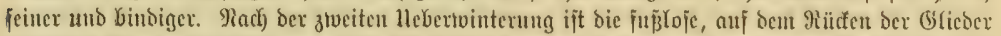

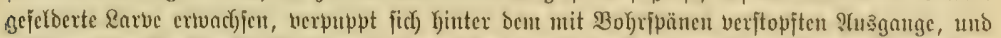

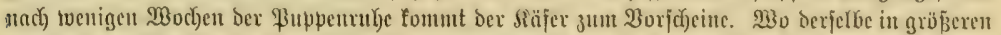

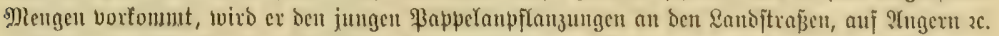

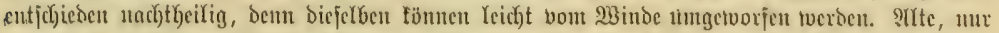

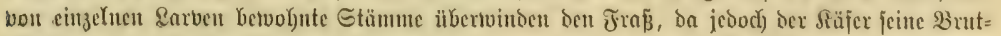

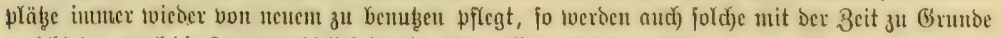

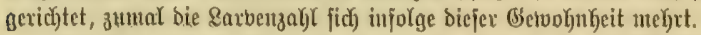

Dex İ burd) firgige \$eknamug grün

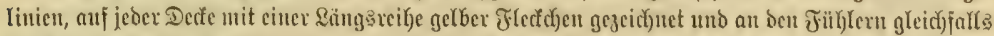

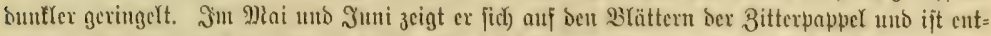

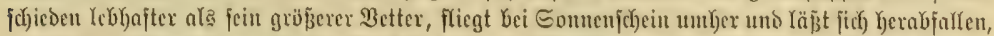

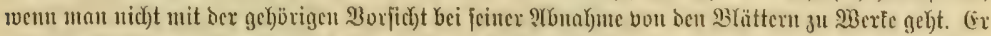

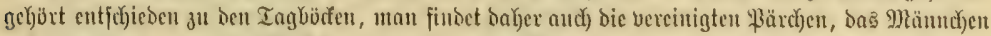

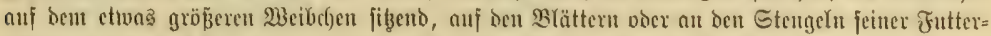

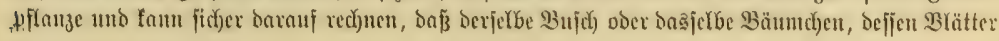




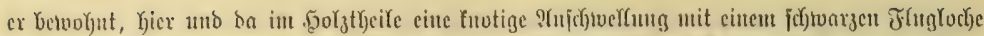

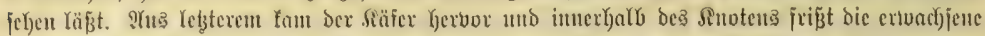

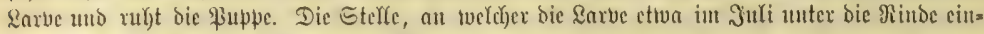

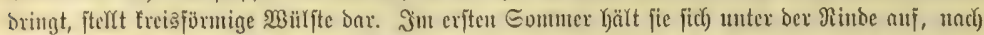

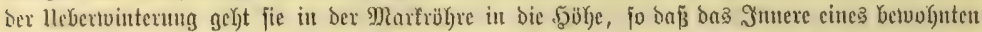

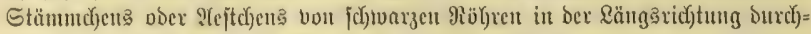
jebt ijt, in beren Folge ber âjt meijt abjtirbt, weil in ber Regel ente gröjpere Menge bon Rarben Wolynung in ifyn genoumuten Kat. 23egen ber untergeordueten Bebeutung ber 2tspen für ben Forft, twerben bie Wirfungen biejer \&arbe wentiger

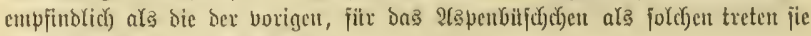
aber entidjiedent berberbricler auf.

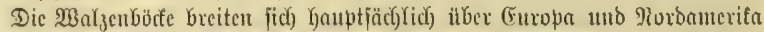

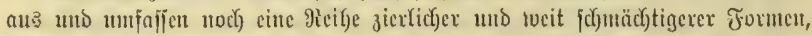

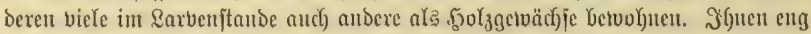

Rerarögerte Sarbe bes

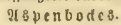

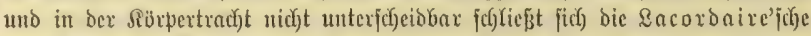
lebste Sippe ber Phytoecidae an, bou boriger nux burch bie fitanenbildomg

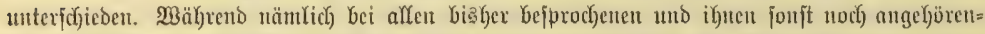

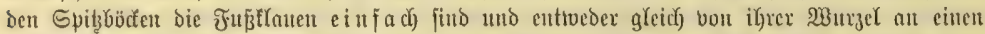

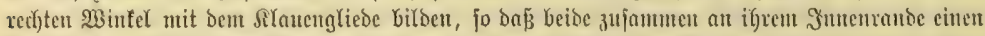

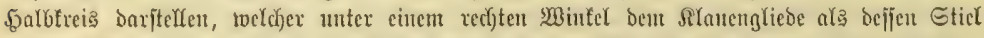

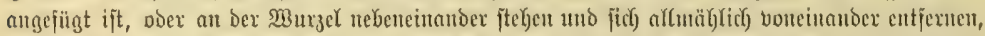

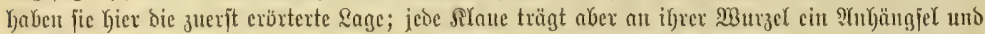

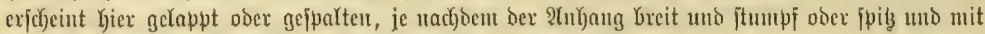

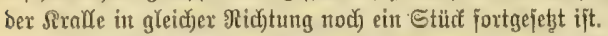

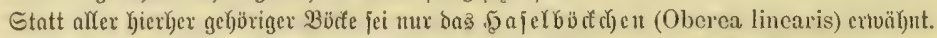

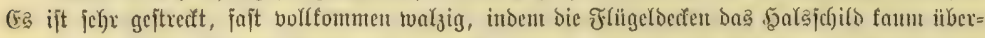

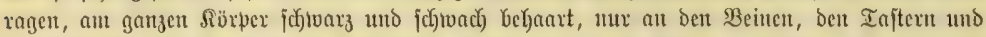

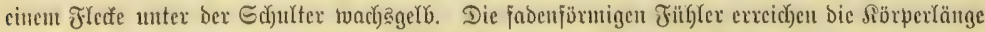

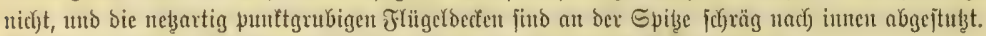

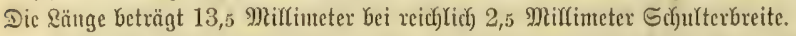

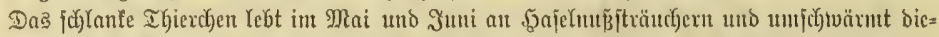

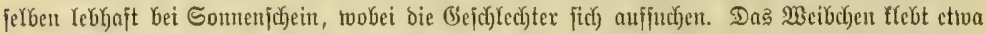

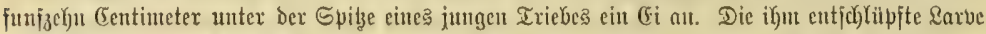

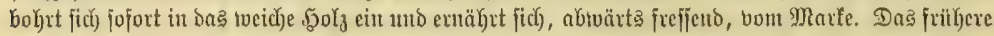

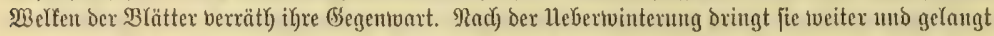

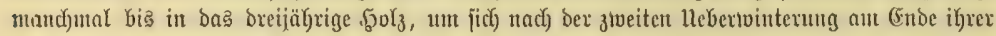

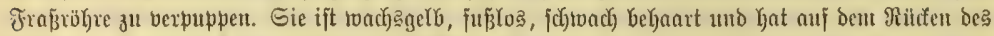

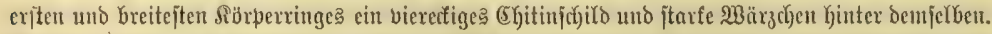

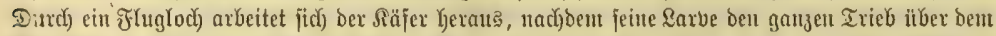

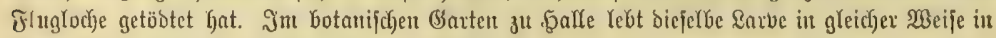
bec genteinen ฐopjentjaintbuctie (Ostrya vulgaris).

Die Samentäfer, Muffelfäfer (Bruchidae), fino fleine ovale, oben tweniger als unten

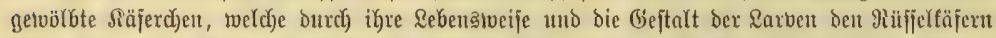

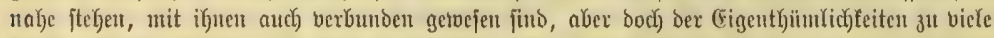

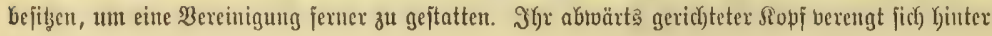




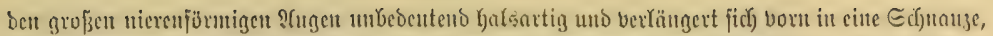
wic bei mand

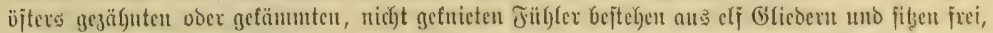

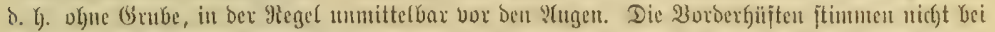

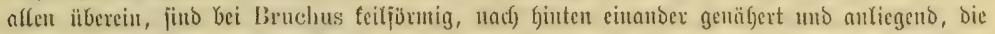

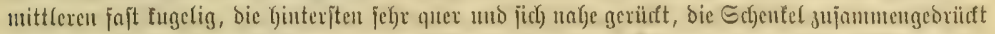

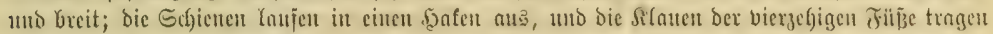

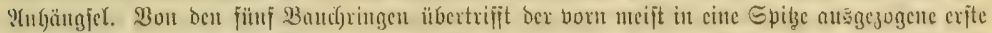

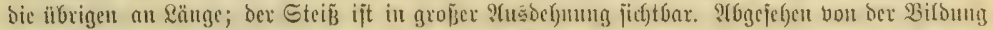

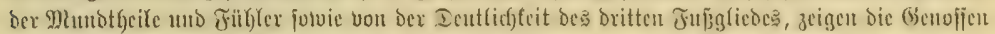

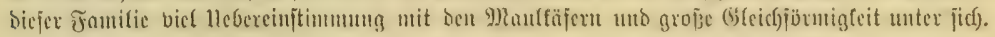

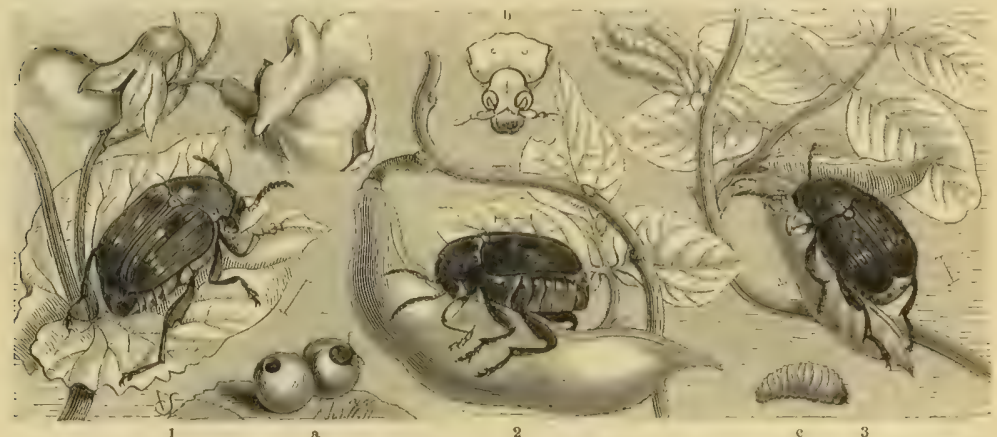

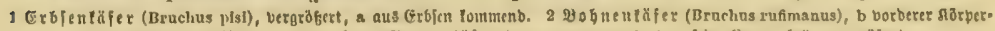

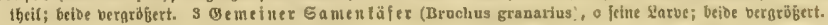

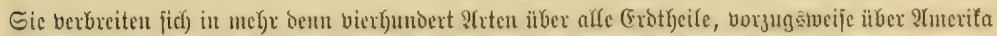

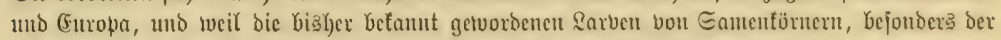

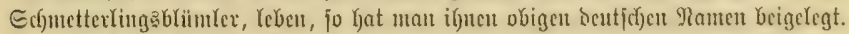

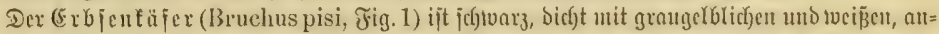

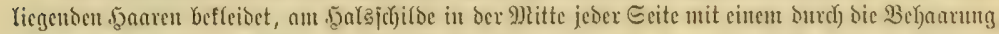

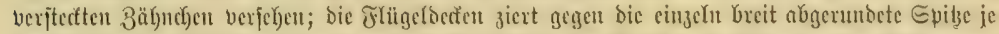

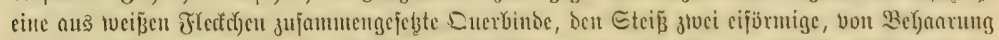

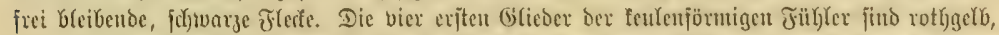

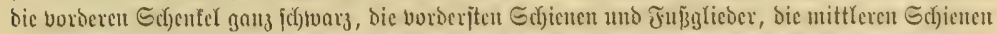

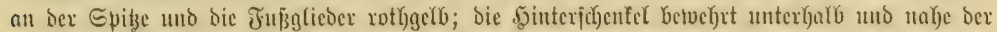

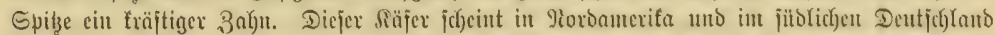

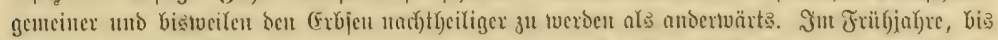

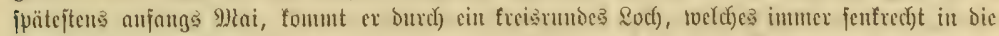

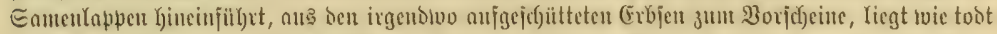

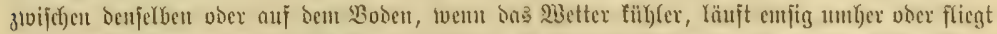

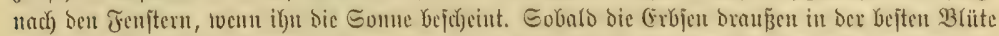

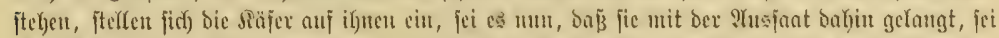

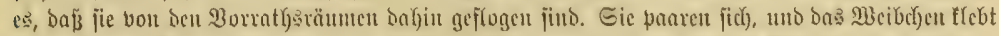

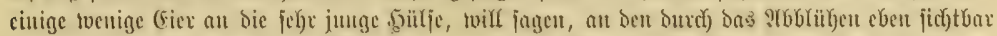

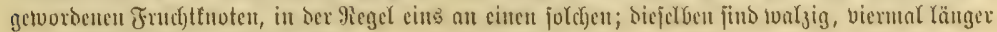

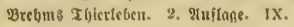




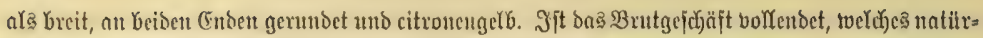

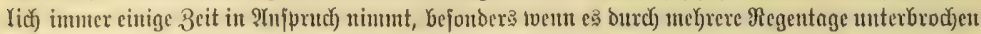

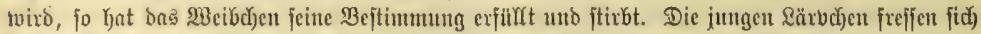

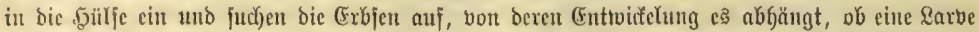

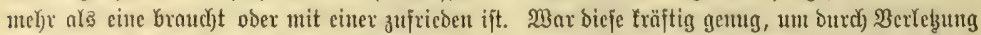

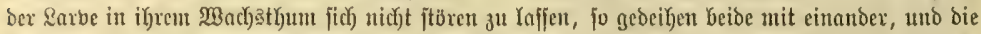

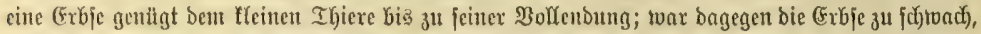

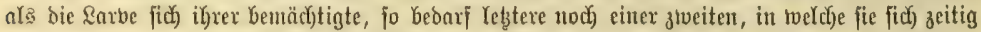

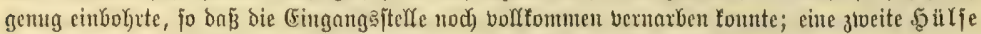

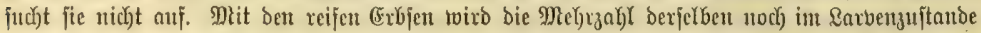

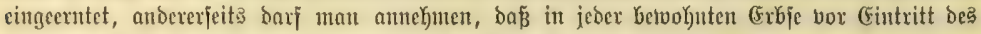

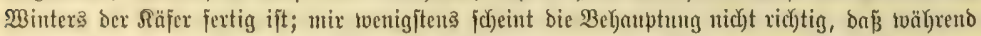

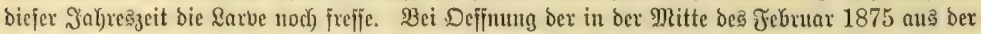

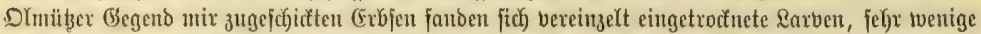

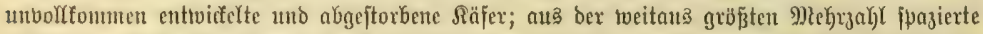

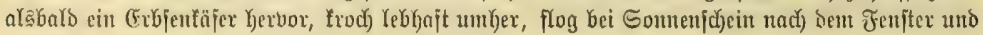
zeighte überhaupt groß̋e Frende ilber feine Befreiung.

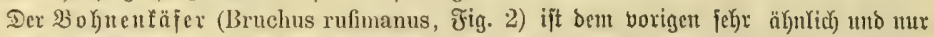

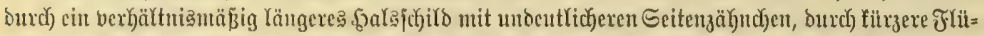

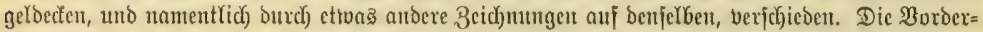

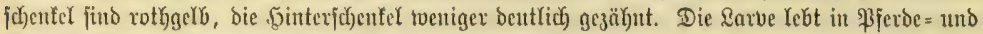

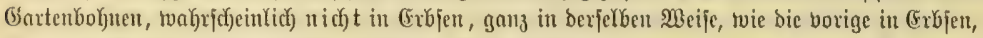

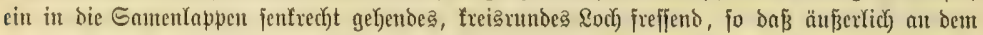
Samen feine Berletzung zu exfenten ift, e

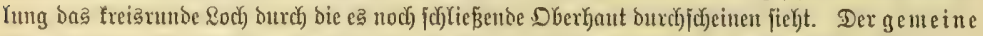

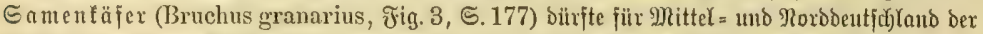

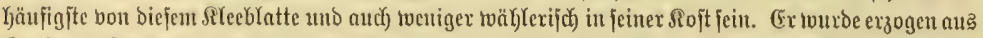

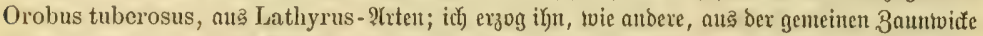
(Vicia sepium), und als Schäbiger ber \$ferbebohne (V. faba) tviro ex gleichfalls angeflagt. Bei

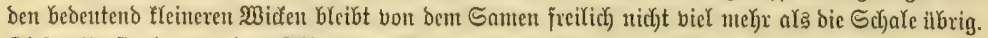
Diejer llmitand mag bem Thiere ben Winteraujentyalt in jeiner Wiege berleiben; rechyet man

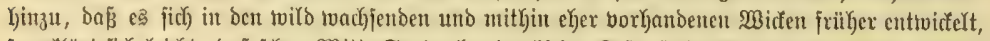

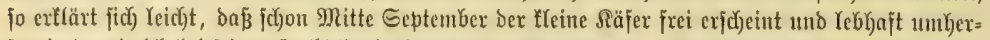

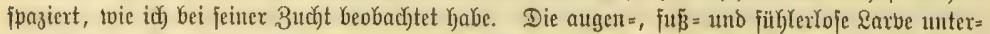

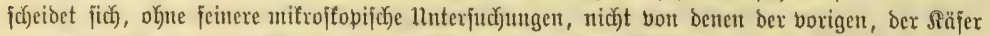

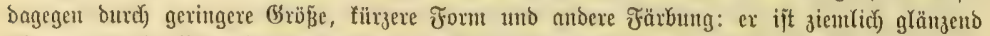

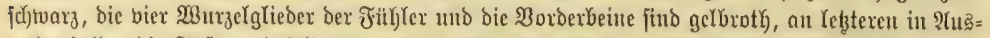

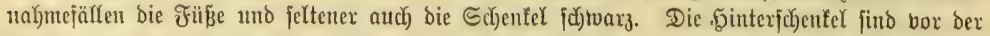

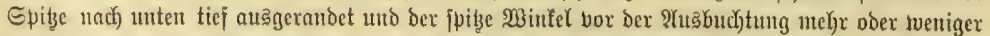

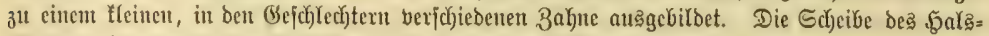

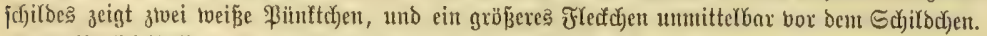

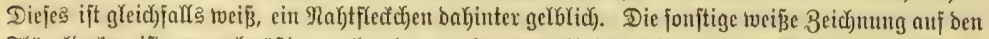

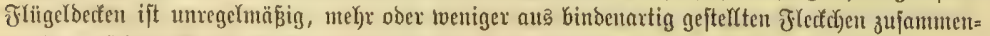

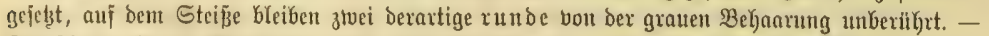
Der Sinfentäjer (Bruchus lentis) geht bie Rinfen au, und andere Frten ben Samen allberer

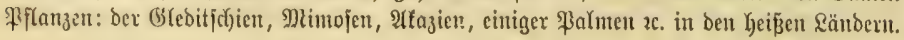




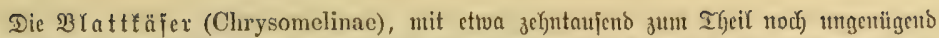

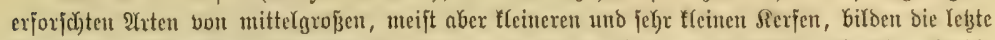

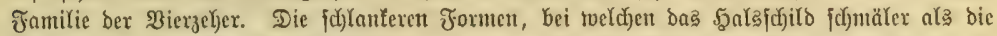

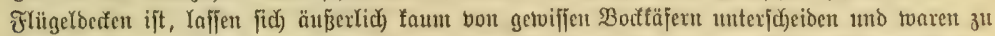

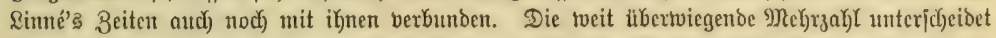

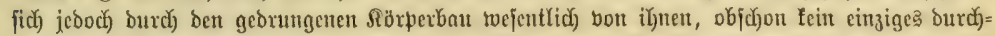

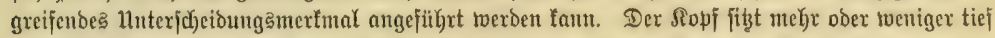

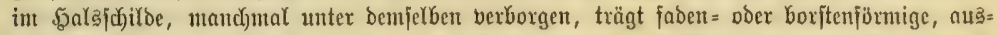

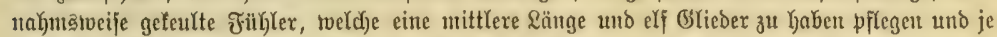

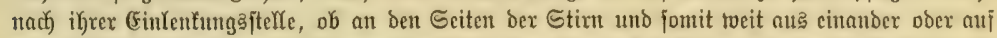

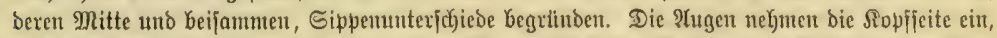

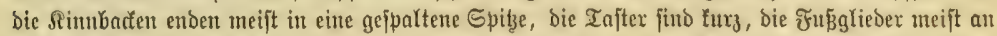

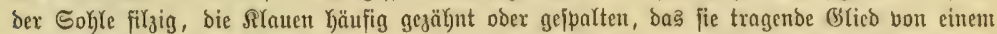

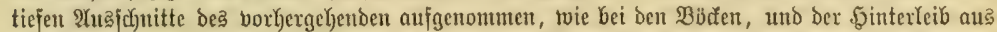

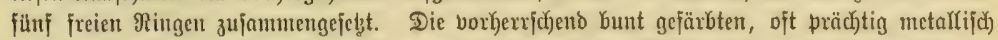

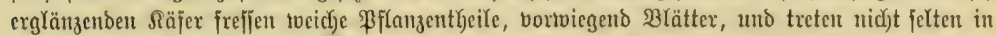

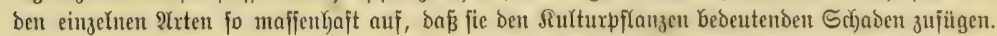

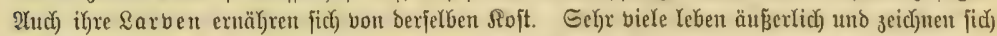
bann burdy buntlere, oft buntere Farben aus, andere bohreno in ben toeidyeren Igheilen, nie aber

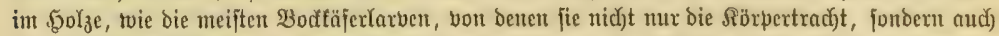

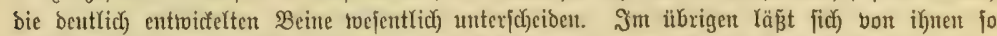

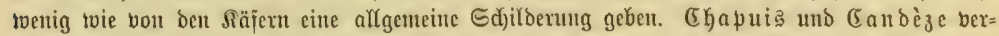
theilen fie in folgende fün Gruppen: 1) Bejtrefte Lazben bon tweißer Farbe und faft ronlziger

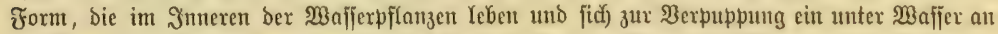

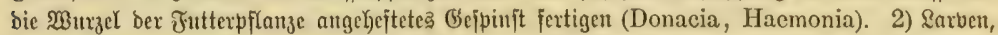

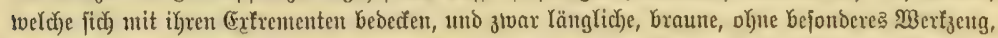
sm jene zu tragen; zur Bertonolung gehen fie in bic Erbe (Crioceris und Lema), ober breit

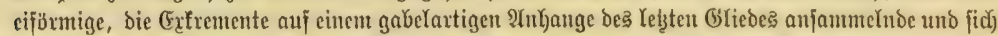

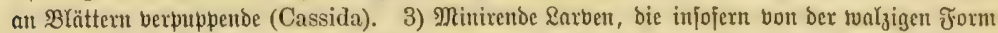

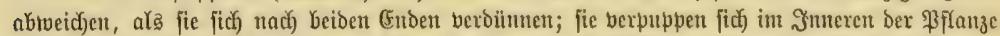
Doer in ber (Erbe (Altica), andere Keben im J゙neren ber Blätter, Yaben aber feitliche Marzen

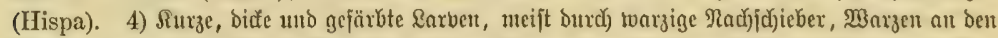

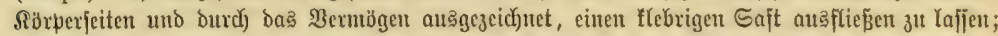

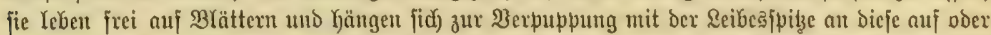

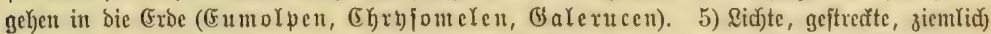

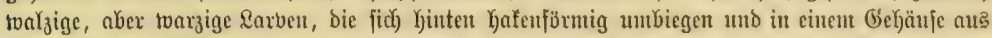

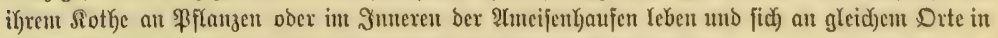

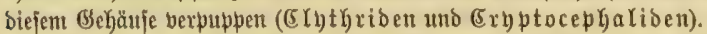

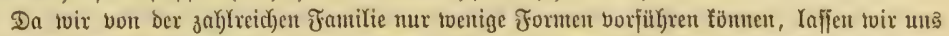

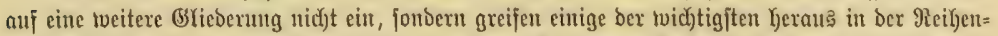
forge, in ber fie bie Syjtemntifer zu bringen pflegen. Die judjünen S d) ilffä fer (Donacia) fommen

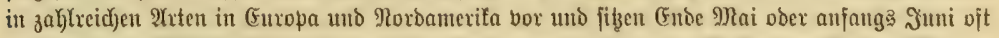

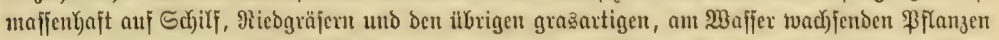
Doer auf ben jodvintmtenben Brättern anberer, in beren Theilen ifre Rarbe gelebt hat. Dem

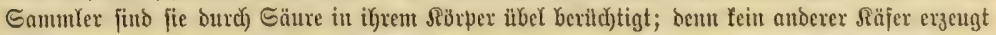

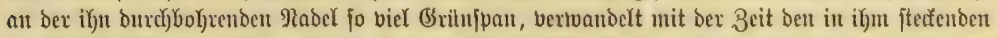

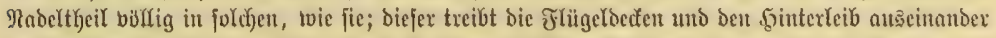

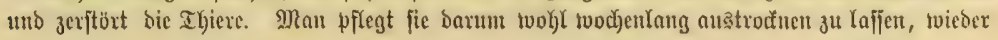




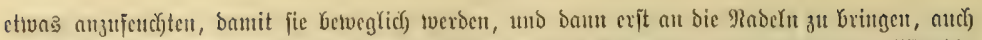

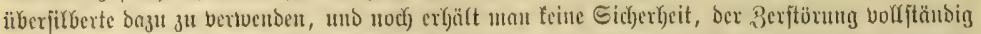

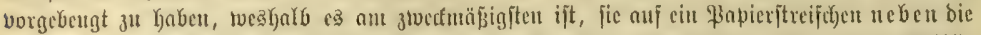

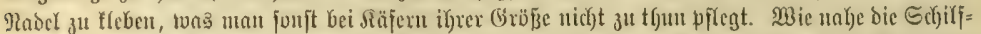

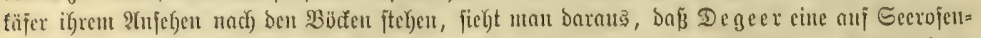
blättern auzutreffende \$(rt, Donacia crassipes, ale Leptura aquatiea befodr) riebeu bat. Der feuleu =

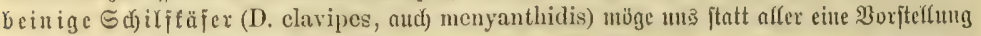

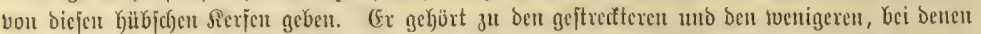

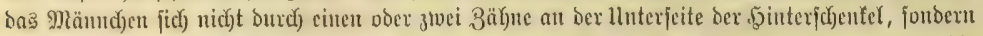

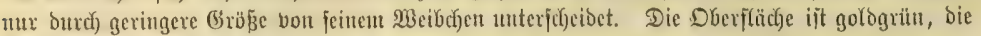

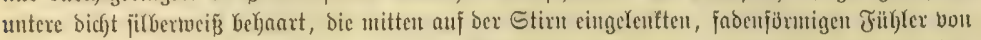

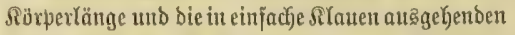

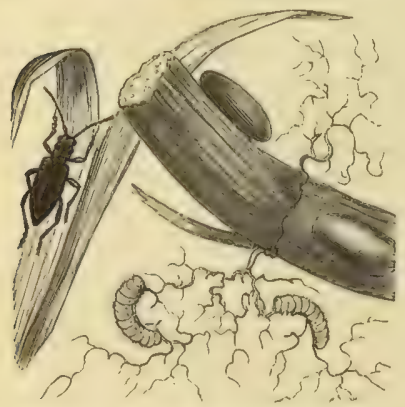

flebertles.ङd)tlftäfer (Donacla menyanthidis) nebit Larve und Puppengebäufe, natirt. Gróbe.

Beine rütblid. Das vierectige, vorn beiderjeit? geböcferte uno in ber Mritte leicht ausigebuchtete

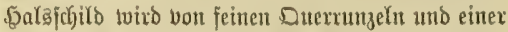

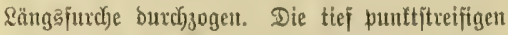

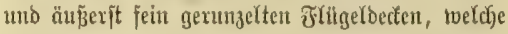
fich) hinten einzeln abrunden uno etwas verfidsmälern, find über boppelt fo lang toie zufammen breit; bie Jinterjhenfel erreichen die Epilze berfelben, bie

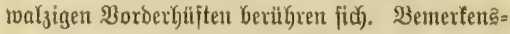
werth ijt nod) bei allen Schiljfäfen beverjte Baudd=

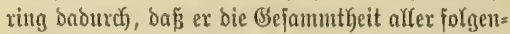
Den an \&änge noch übertrifit. Diejen im tweiblicken (Gejd)ledyt bis reid)lid) 11 Milfimeter mefjenten Edrilffäfex fonto iď), wie alfe anderen Irten, nux

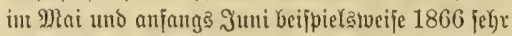
bäufig und gepaant am gemeinen Schilfe umperer

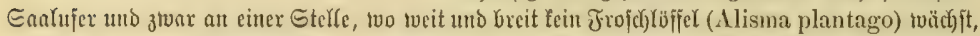

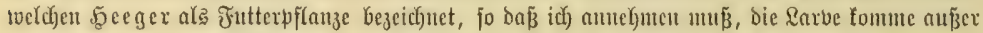

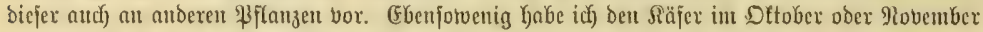

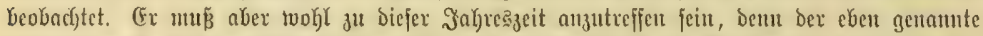

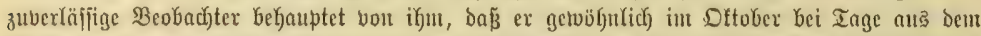

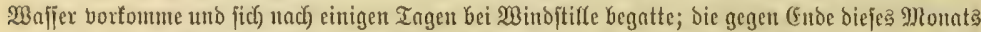

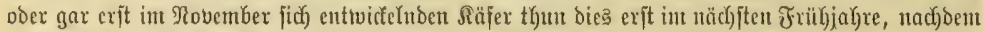

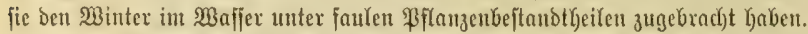

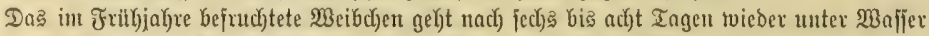
unt legt bei Tage feine (Fier eiugeln an bie biden Wurgelu ber Fntterpflanzen; vierzig bis funjaig

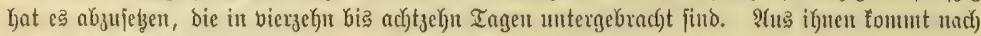

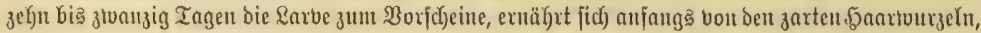

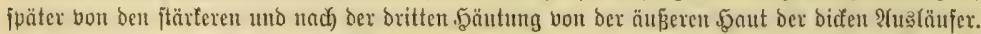

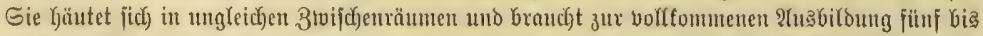

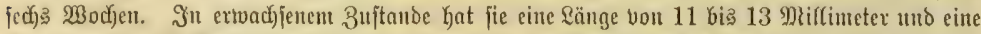

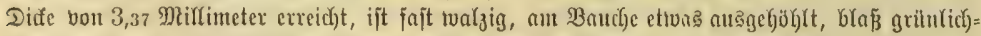

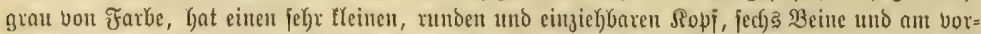

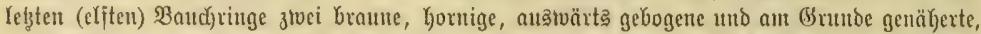

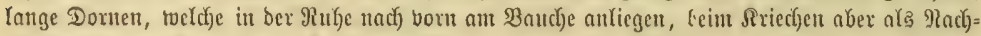
jófieber bienen. Der hornige Sopf erreidft faum ben vierten Theil bon ber Breite dę̧ nittreren 


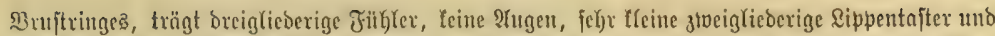
cincu Unterficjer, bejfen imere Rnde Yeberartig uno berfehrt eiförmig, bie äußere ebenfo gebirbet,

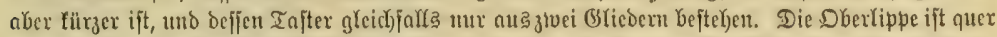

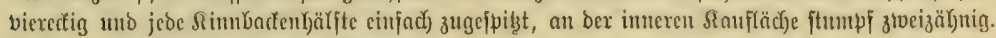

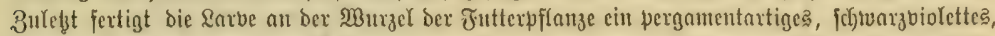

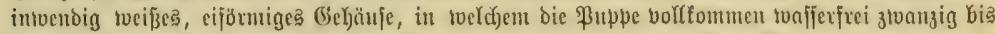

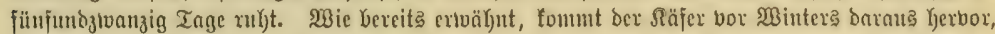

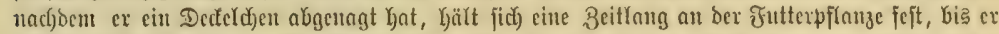

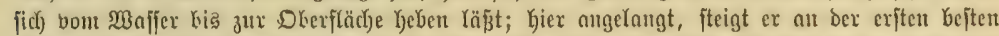

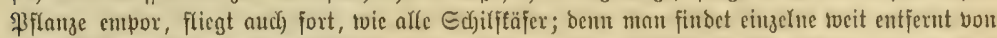

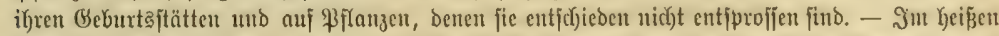

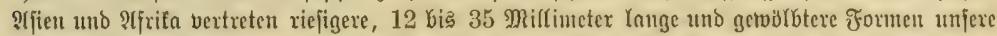

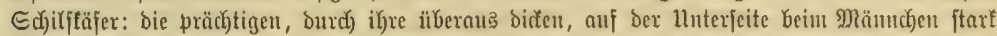

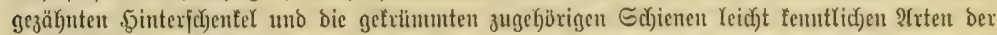
Gattung Sagra, weldye man an bie Spizze ber Familie zu ftellen pflegt.

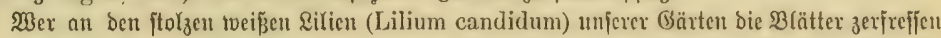

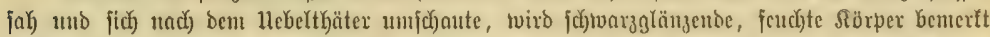

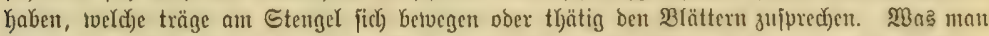

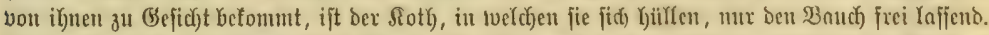

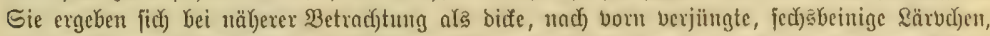

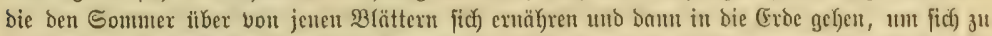

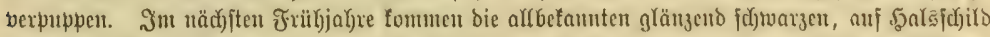

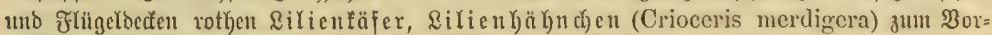

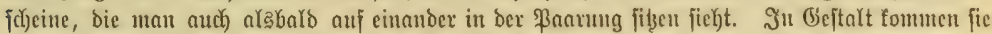
ben Echilffäfern nahe, fino jedod) gedrungener, ihye jodyunfömnigen, mur halbe Sibrpertäuge

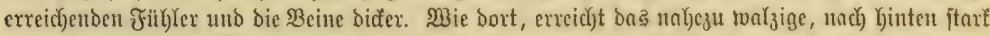

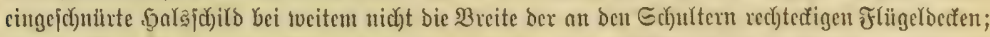

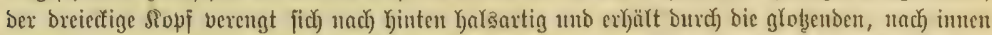

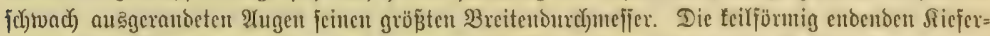

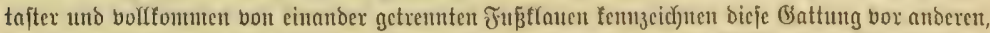

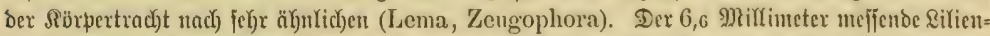

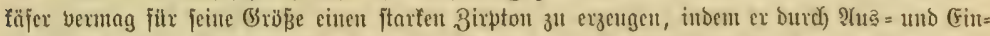

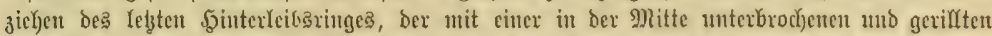

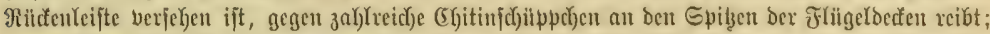

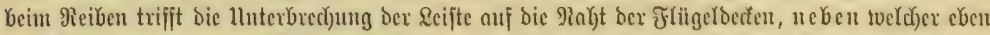

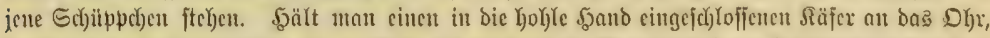

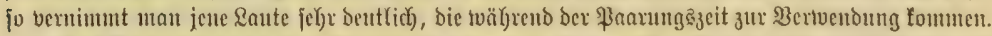

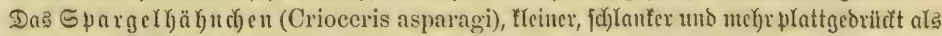

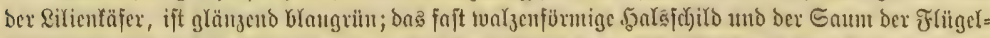

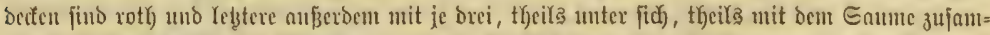

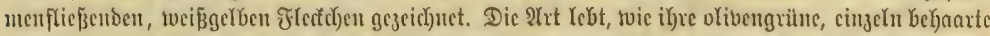

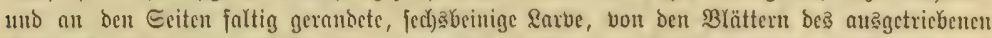

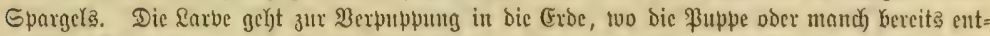

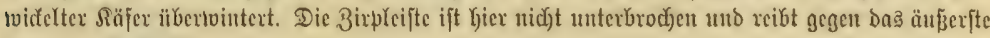
(5noe ber Dectichildee.

Dna z w

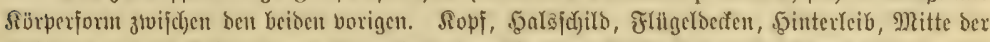

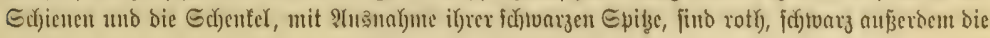




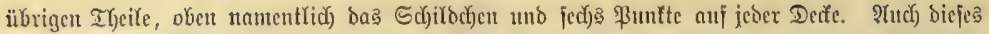

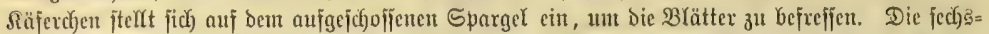

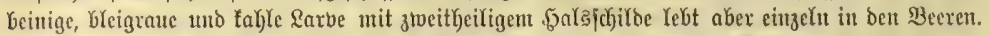

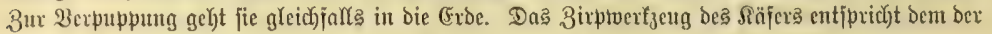

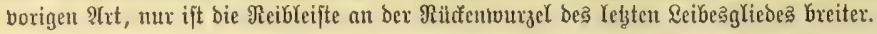

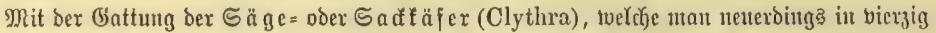

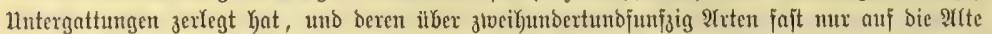

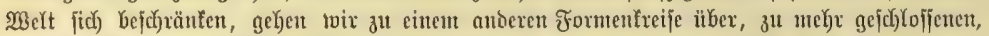

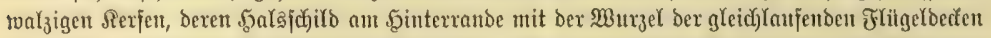
ganz oder fajt gauz in ber Breite übereinjtinumt. Bei ber genamten Battung fteht ber fopf fent=

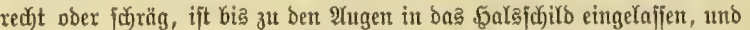

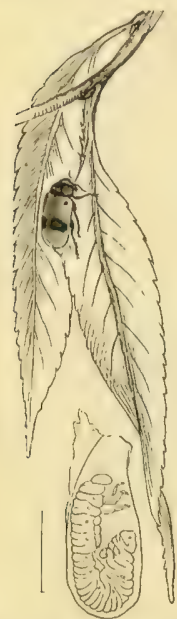

Dierpunttiger Eadläfer (Clythra quadripunctata), natlicl. Gröbe unb feine bce"

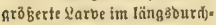

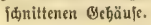
bie neift gejägten futrzen Fühler Yenten jïch) unter jêten ein und ftehen injolge ber breiten Stirn weit aus einanber. Die Rinnbacen enden in brei 马ähne, und bie Yjornige 3 unge ift vorn gerundet ober geitulgt. Bei viełen berlängern

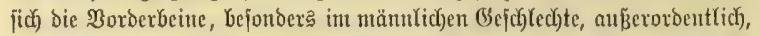
haben aber, wie bie anderen, ungejpartene RTauen. Das exjte Sinterteibes=

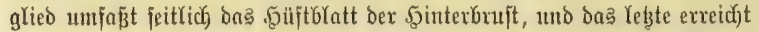
die Ränge jenes ober libertrifjt fie noch. - Der bierpunttige Sa a täfer (Clythra quadripunctata) ift glänzend forbtwary, unten fein gran befarart, auf jeber ber gelbrothen, glänzenden fritgeldecten mit ztwei jod)twarzen flecten gezeidynet, einem fleineren an ber Schulterbeule, einem gröperen Ginter ber Mitte, bindenartig über beide Flügeldečen gelegt; bie ßorberbeine zeich)nen

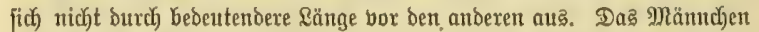

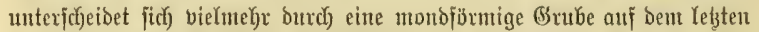
Baudhringe bom Meibdyen, welches hiex mux eine Rängs̆jurthe zeight. Der

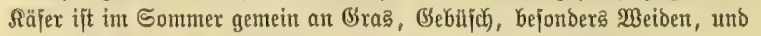

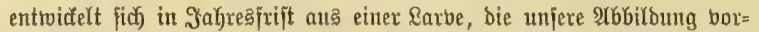

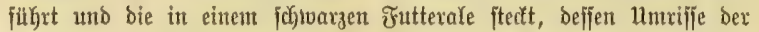

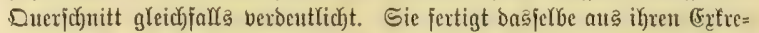
menten, fpinnt es oben zu uno irgentroo an zum Meberwintern, fobann nockmals, wenn fie fich verpuppen tvill. IIm bifieren lluterende fonmt nach twenigen Wod)en ber Säfer aut bentjelben Kerbor, inden ex beu Boden

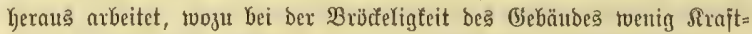

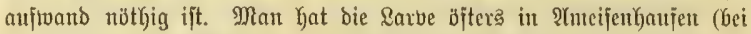

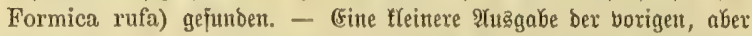

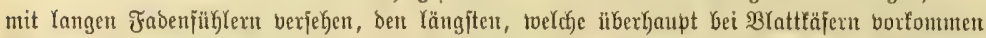
fömnen, Gilden bie ₹arffäfex (Cryptocephalus). Man fönnte fie ala , Berborgenföpfe" be=

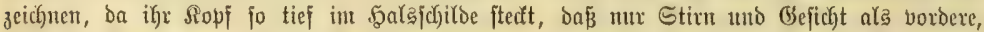

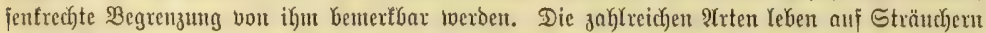

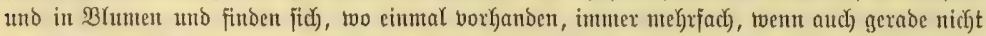

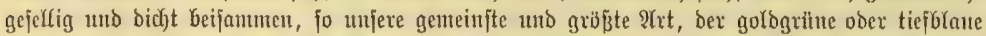

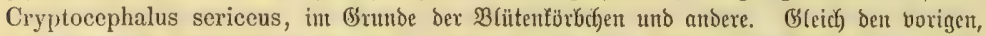

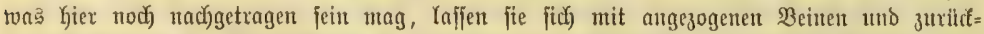

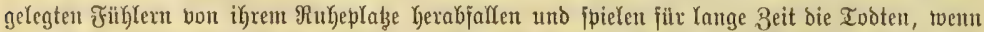
man ifuen nicht Ginteicheno vorjidytig naht. (E⿱

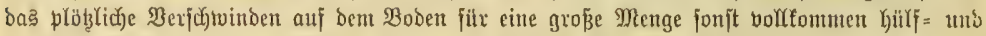

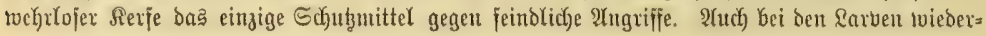




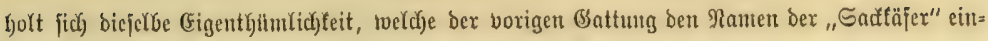
gebradyt lyat.

Die (E) r b fomerinen im engiten Sinte bes Mortes ftrefent ben Slopf vor, tragen bie faben=

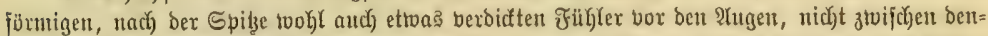

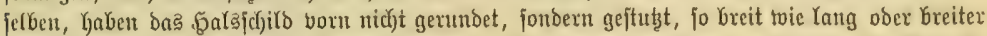

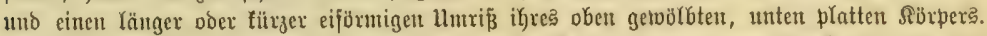

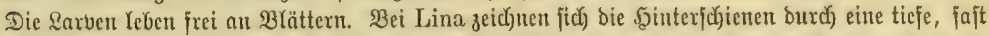

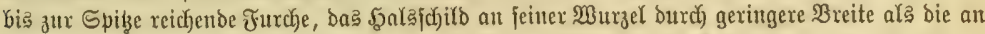

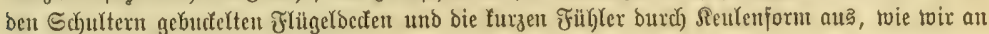
ber Yjier abgebildeten $\mathfrak{A r t}$ fehent töntuet.

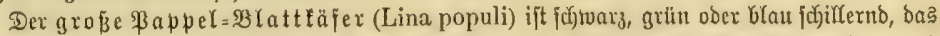

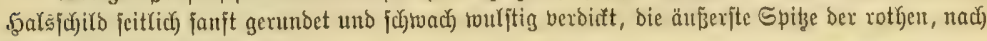
bem Iobe ftart berbleidjenden Jlïgeldecten julytwary. Bei Dent etwas tfeineren, ebenjo gefärbten fleinen $\mathfrak{\beta}$ appel= Bratteäfer (Lina tremulae, a) ift bas . Қalsjudild jeit= fich gerabe, nach bortt un= merffich berengt, neben bem Rande mit grob punttirter Furche verjeben, roodurch bie= jer ftart suljịtig exjodyeint, uno Den Fritgelderten fehit bas jabtwarge Spibachen. Beibe Yrten fommen auf Meiben= uno ßappelgebuifich, bejon= Dere ben jungen Bittexpap= peln, häuffg neben einanber bor uto exficheinen dajelbjt nack) ifremt $\mathfrak{B}$ interjch)(aje, jo= balo bie Blättex zu grünen beginnen. Die \$aarung ex= jolgt, uno Das Weibchen legt bie rötb)(ich)en (Fier neben ein= anber, meipt an bie llnterjeite
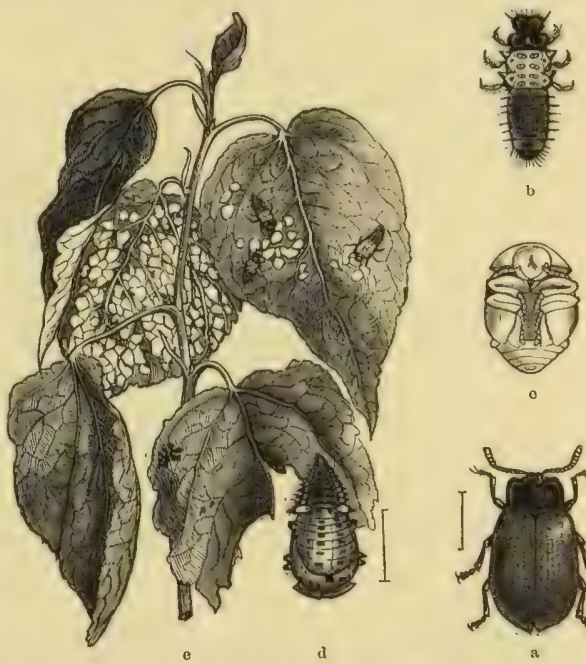

○

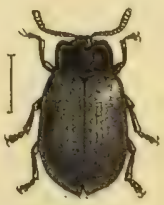

a

a Rleiner Pappetolattläfer (Lina trensulae), b frine Sarbe, c feine \$upbe in ber

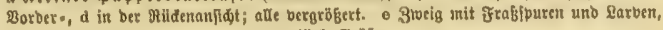
natilit. Sröse. ber Brätter, ungefähr zełn

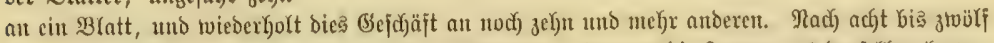

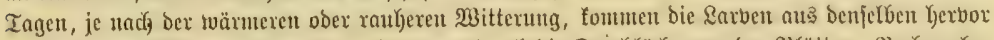

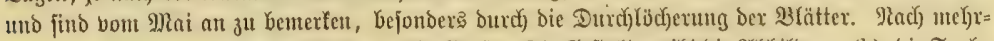

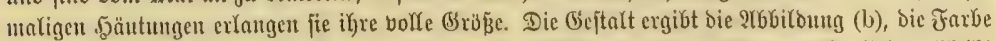

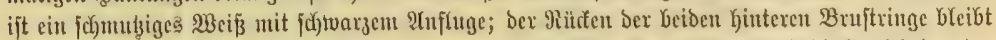

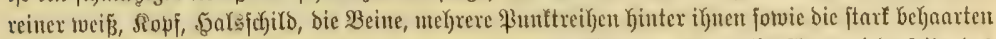

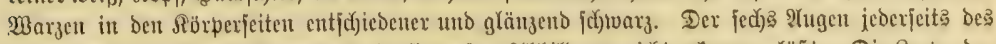

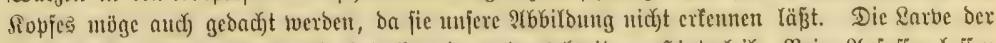

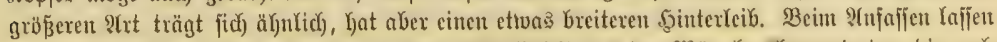

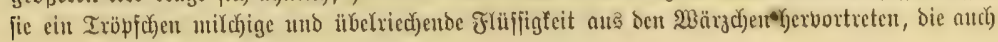




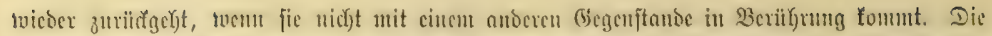

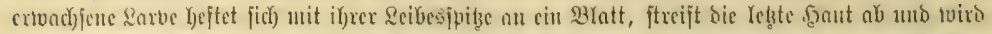

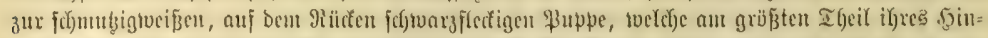

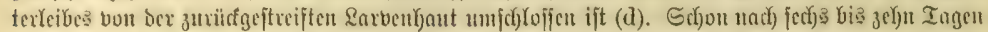

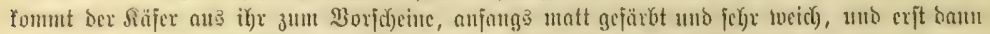

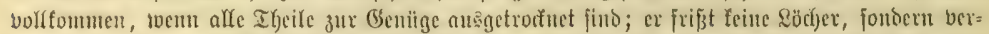

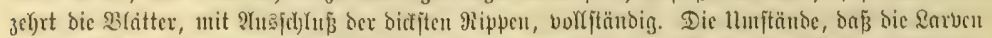

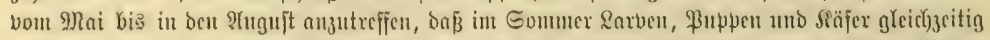

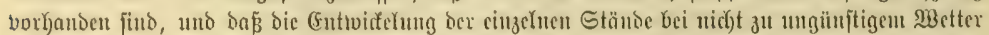

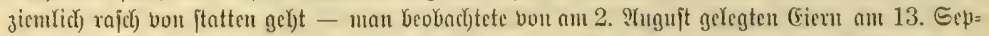

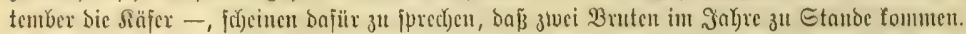

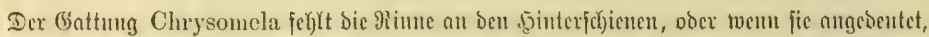

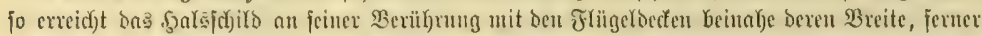

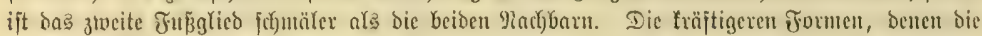

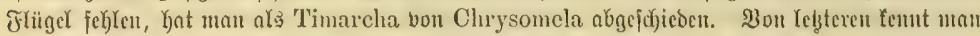

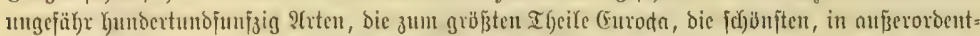

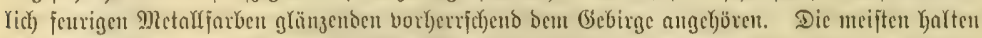

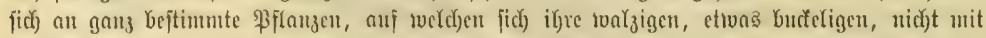

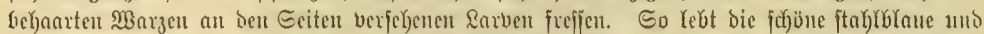
yolinte Chrysomela violacea an berfichicosenen ग)tuzentarten (Mentha), bie roth ober golding

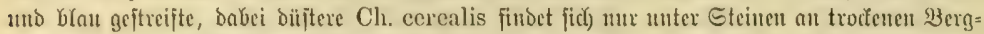

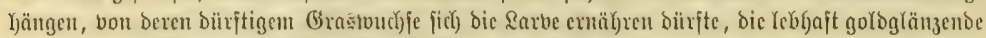
unto auf ben Frïgeldecten blnu gejtreifte Ch. fastuosa an Galeopsis versicolor, bie grübere,

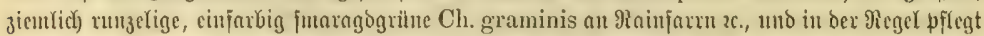

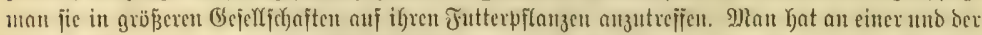

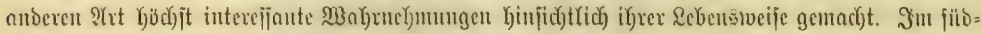

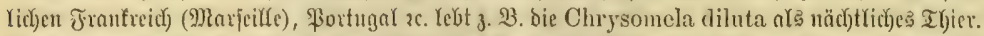

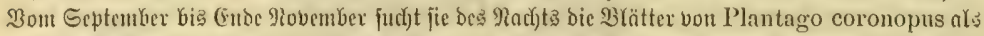

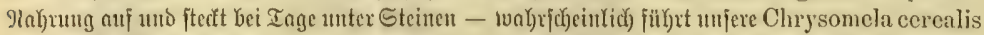

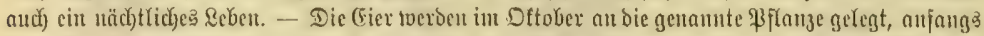

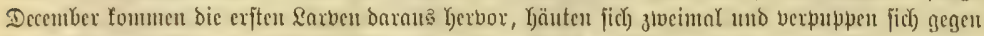

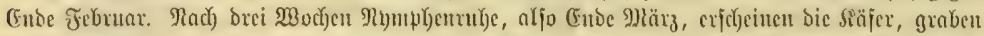

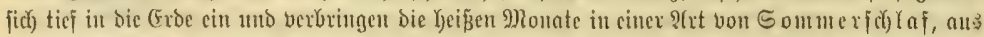

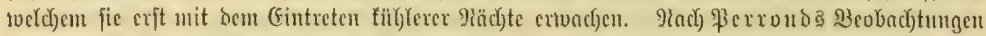
bringen bic beiben präd)tigen ?frten Chrysomela (Oreina) superba und speciosa \&arven zur

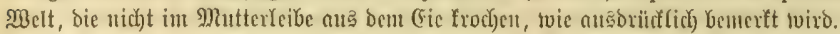

Der Colorado= Rartofferfäfer (Leptinotarsa decemlineata) hat ficl) feit ctuma fumf=

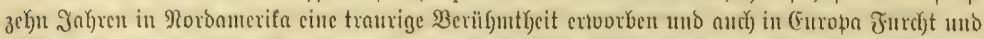

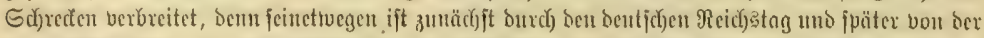

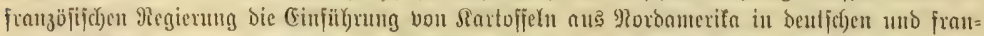

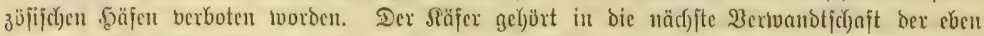

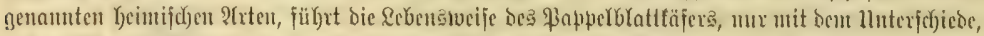

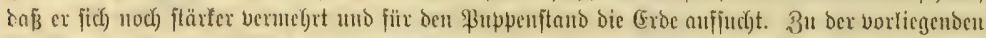

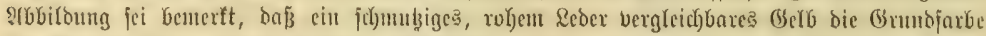

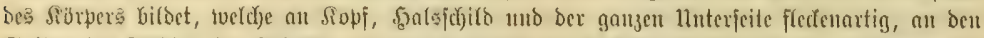

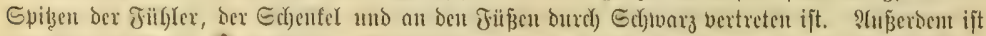

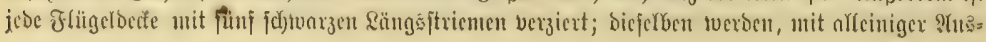




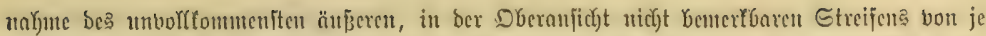

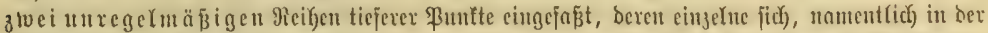

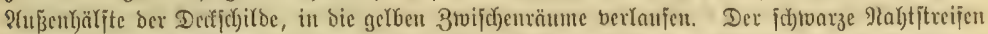

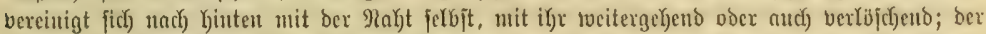

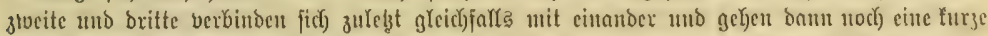

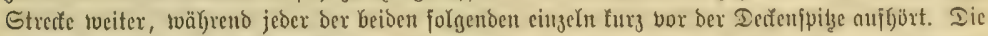

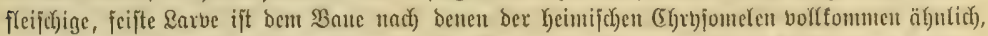

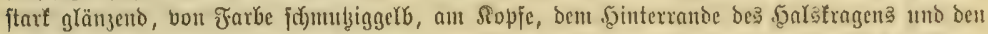

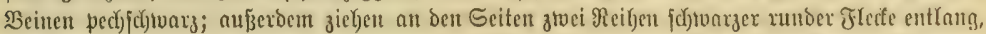
tweldye ant ztweiten uno britten Ringe merffid) fleiner find, wem fie nicht ganz ober theiltweije

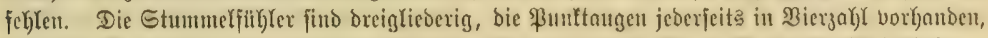

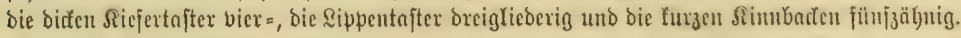

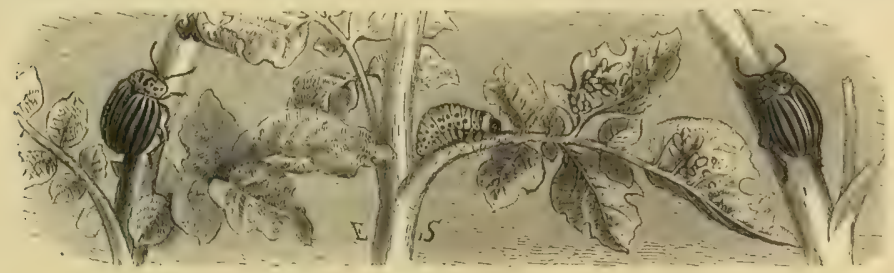

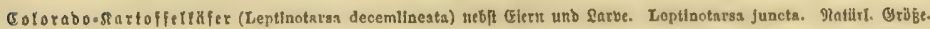

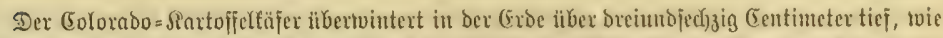

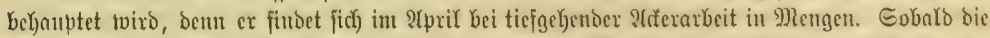

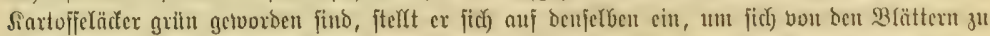

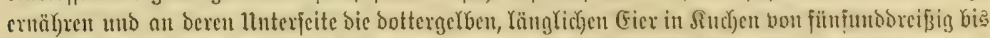

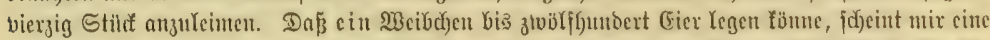

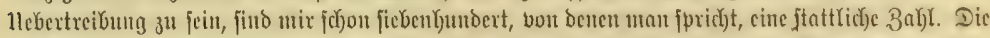

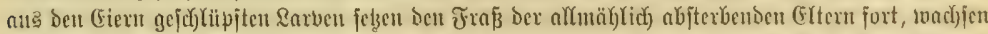

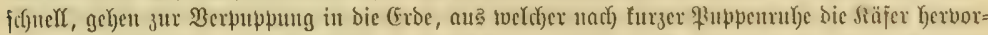
funmen, beren Brut nod) cine britte zux Entwiffełung briugen folf. Eclbit bann, wenu wir beren

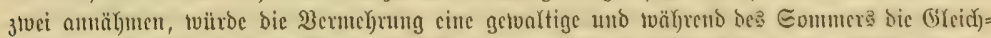

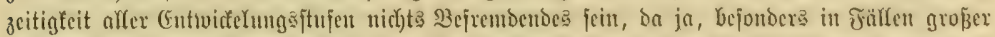

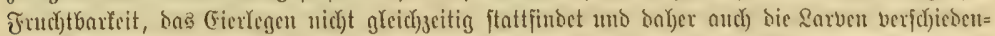

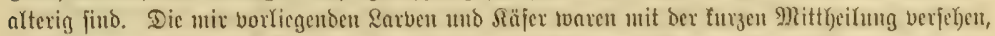

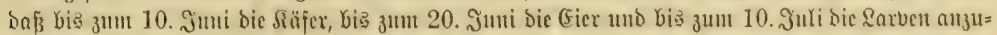

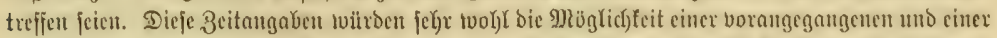

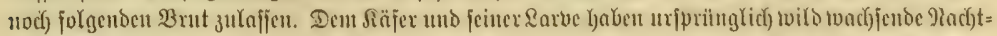

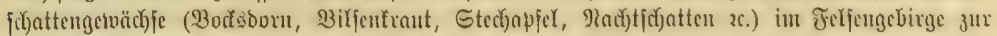

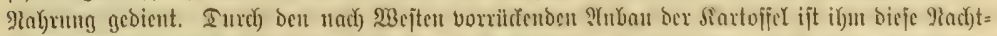

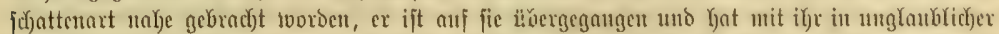

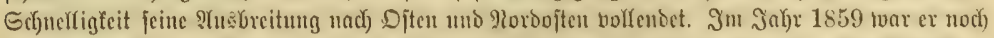

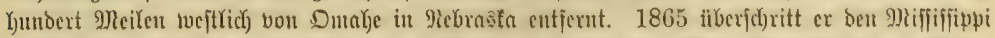

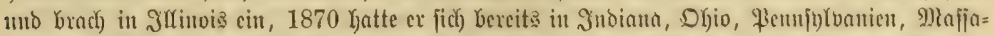

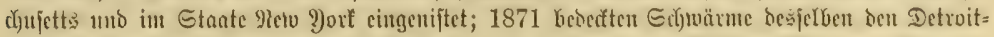

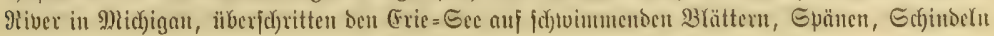




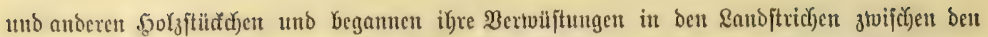

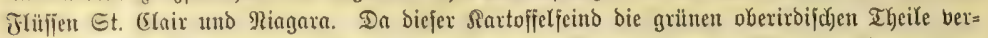

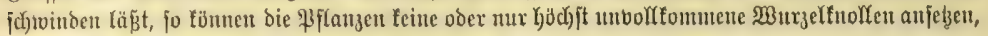

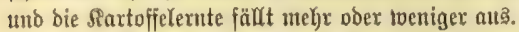

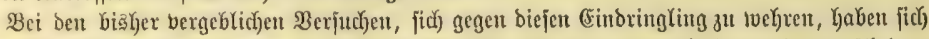

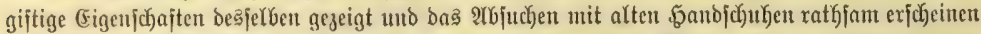

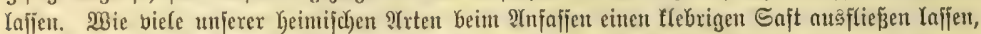

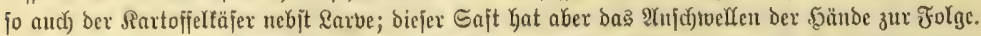

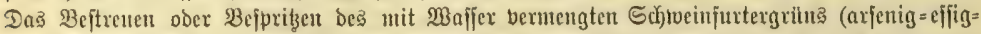

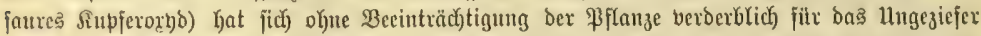

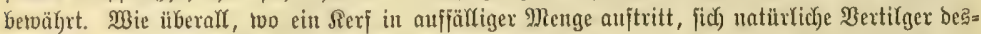
felben einfinden, fo antd) bier. (Eine Ranpenftiege (Tachina) Yegt ihre (Fier an bie \&arben, bie Rarven getvifjer Marientäferdyen zefren bie Rartoffelfäferlarben auf, Rauftäfer, Schreitwanzen,

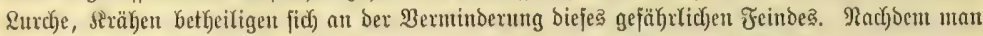

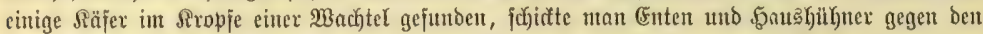

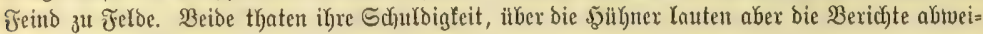
djeno, uno hier und ba jollen fie baraul geitorben fein.

Da nach Der angejiilyrten Rebensweije Der Rartoffelfäfer mit ben Sartoffelu felbjt nidata zu

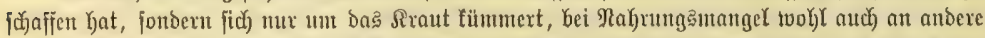

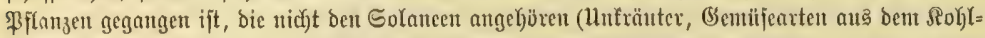

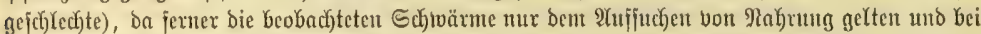

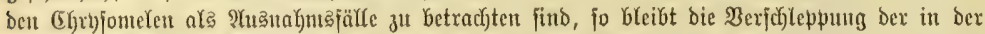

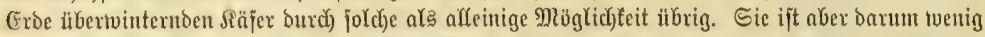

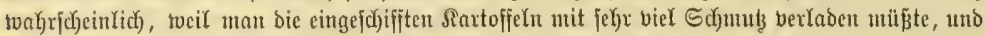

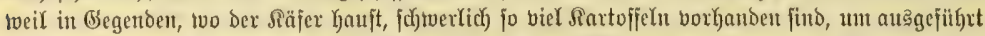

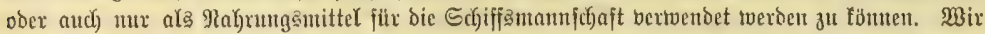

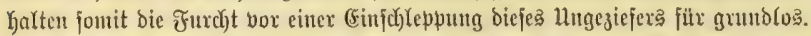

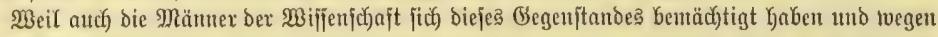

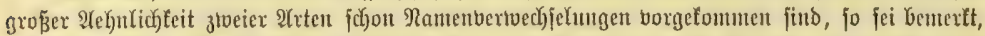

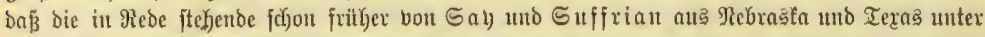

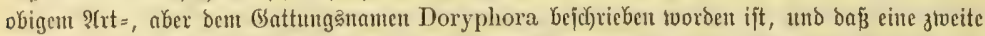

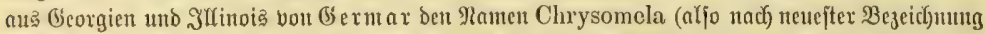
Leptinotarsa) juneta exhalten hat. Diejelbe ift 5.185 gleichfalle abgebildet und bon ber vorigen

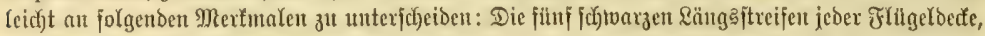

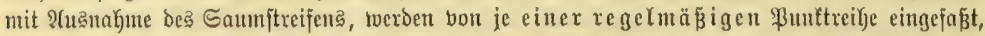

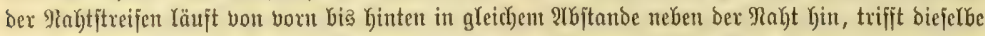
nie, Der ztweite ijt nach Ginten ber fïrzefte, ber britte und vierte find an ifrem (Enbe vereinigt, bis=

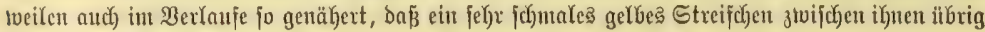

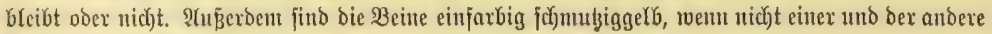
¡d htwarge Echenfelflect vortonmt.

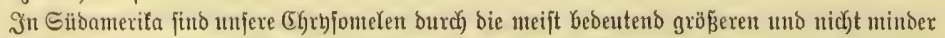

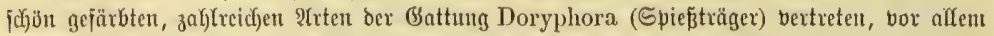

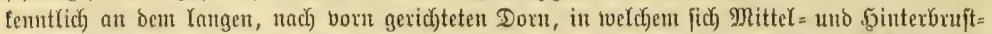

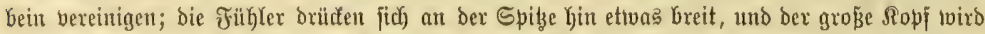

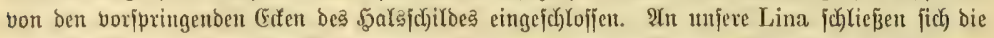

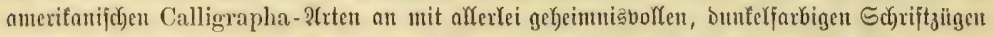

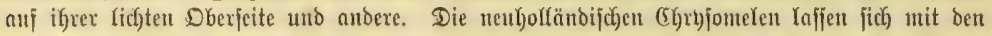
unjerigen gleichjalls nickt vereinigen, fie haben allermeif́t burch raulye Oberfläche cin matteß 


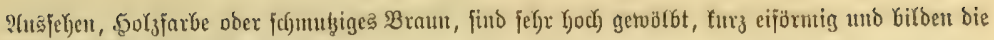
OSattung Paropsis (Notoclea).

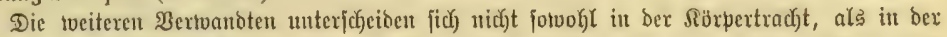

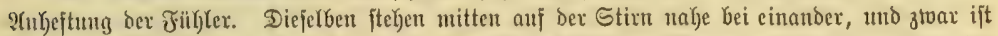

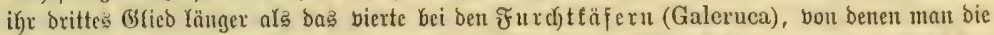
fräjtigeren formen, beren längere ala vorn breite Flügeldecten fid nad) hinten ertweitern, als Ade-

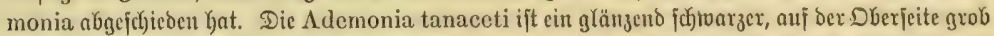

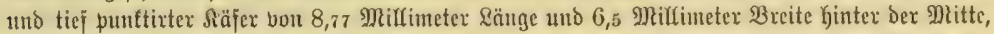

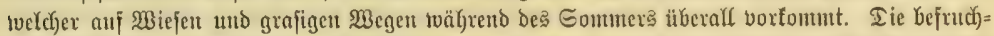

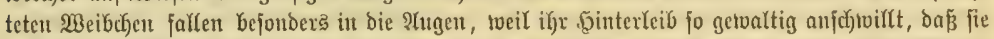

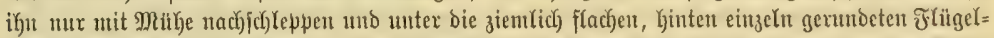

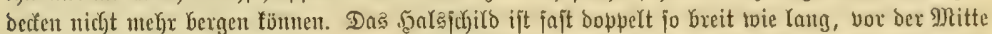

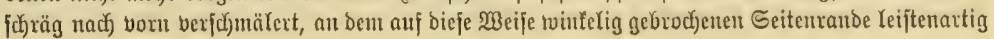
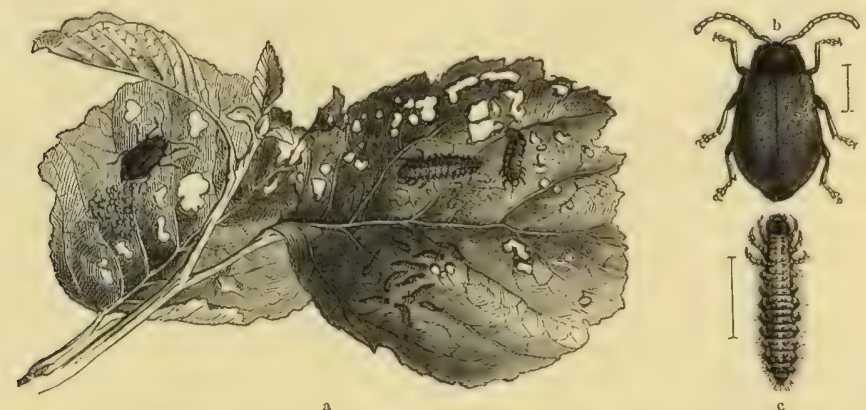

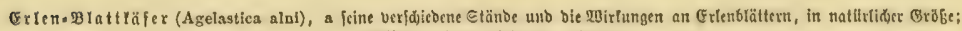
b Säfer, o Larbe, beibe vergtöbert.

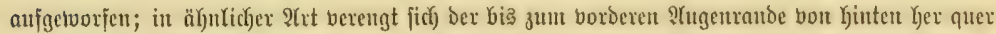

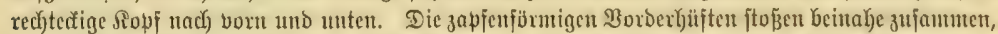

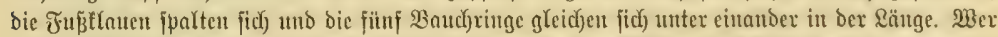

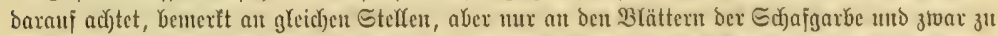

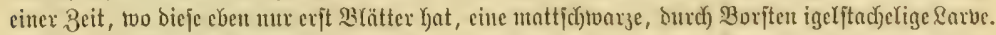

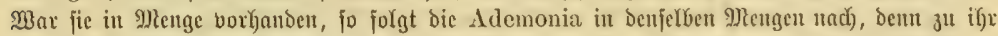

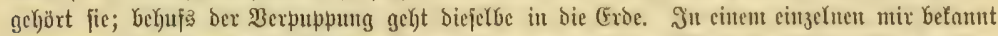

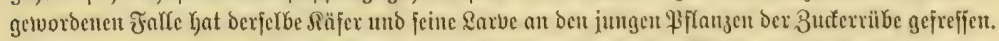

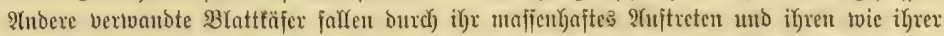

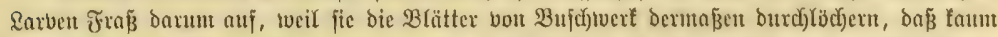

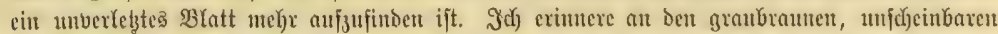

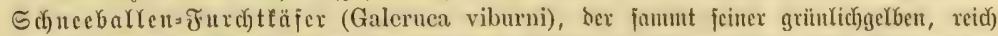

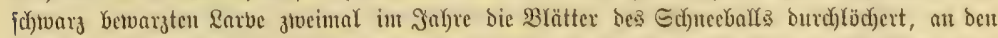

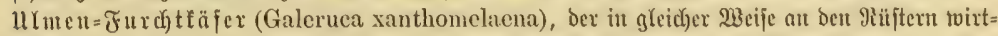

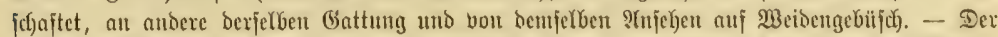

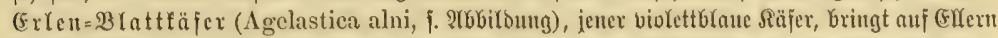

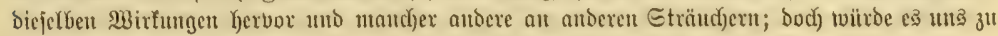

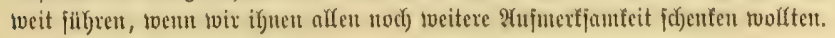




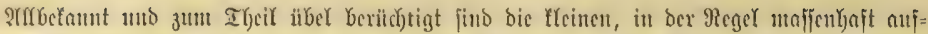

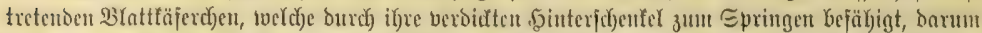

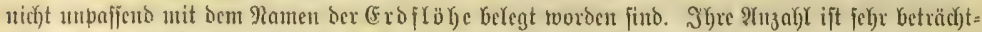

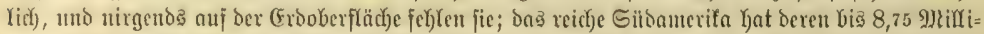

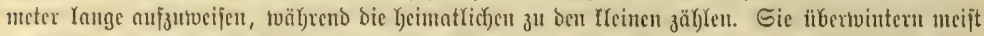

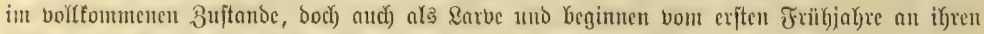

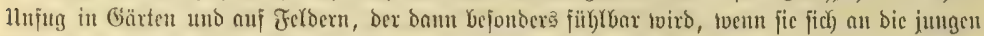

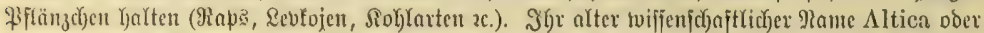

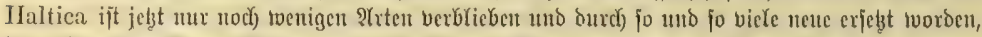

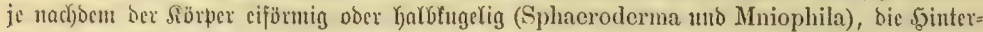

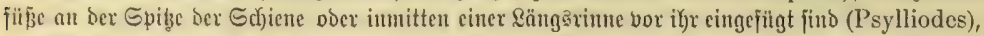

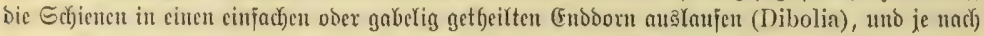

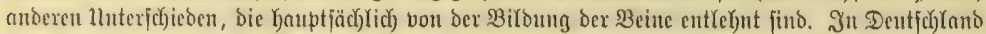
Yeben in runocr 3nh) Gunoert Irten, bon benen bicle fich unt an eine Pflanze Galten, bie uteiften

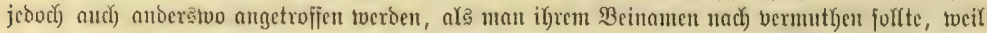

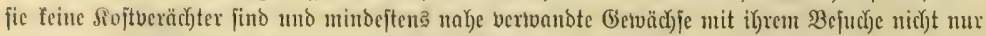
Geehren, foutbern fich nud jux Tafel bei ifnen laben.

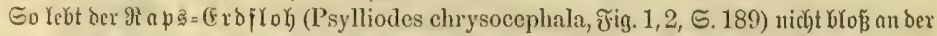

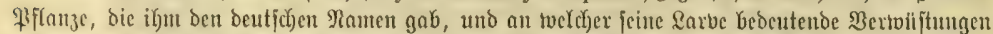

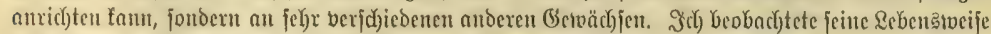

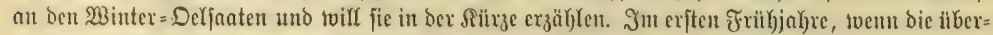

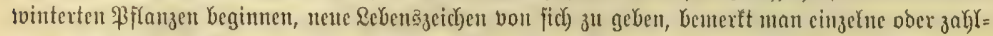

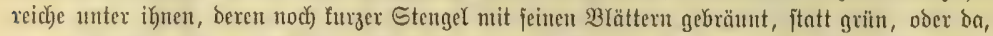

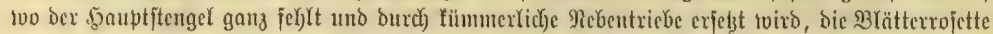

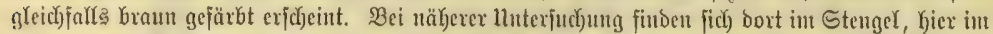

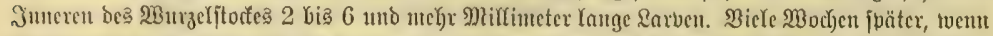

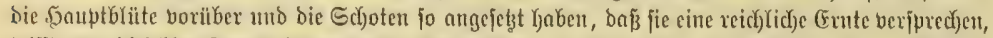

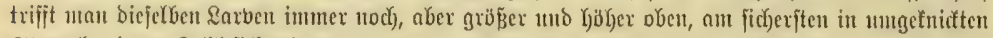

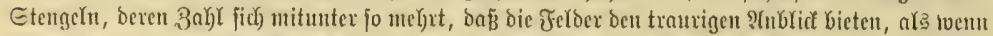

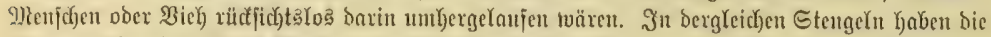

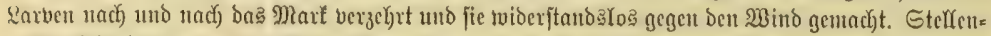

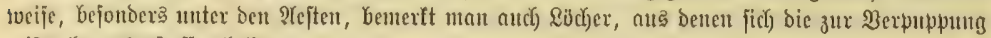
reifen heraughefrejen habent.

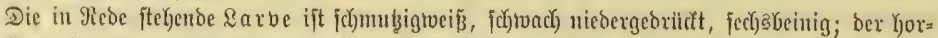

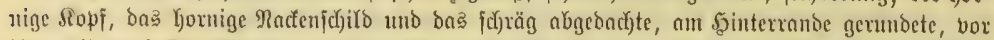

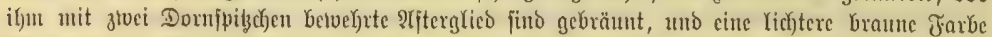

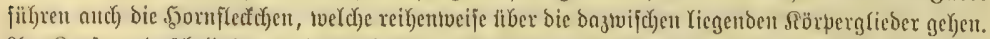

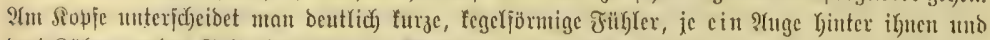

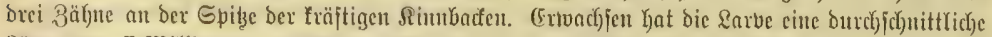

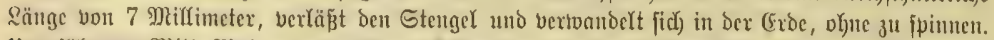

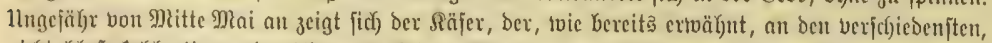

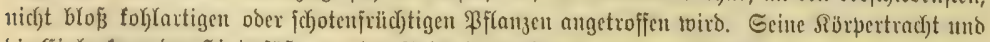

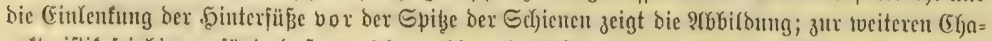

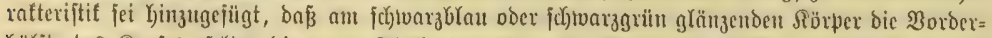

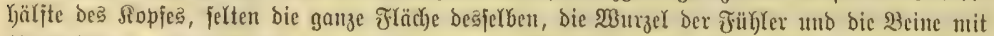

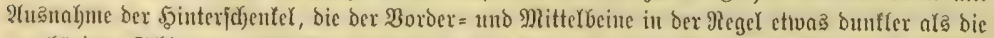

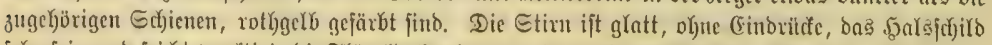

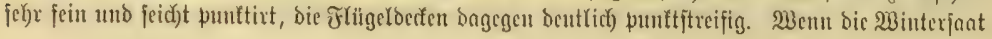




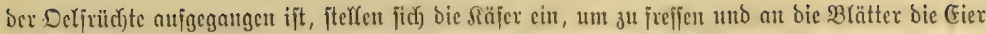
cinzeln abzulegen, was toochenlang fortgcjegt woird; benut bie nad) ber Ucbertvinterung in fo ver=

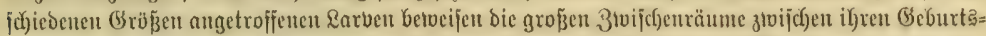

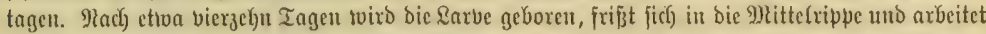

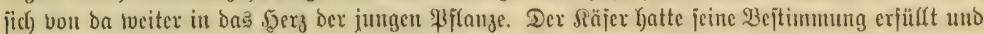

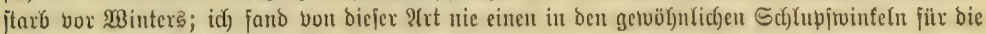

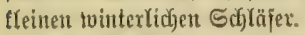

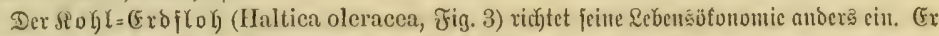

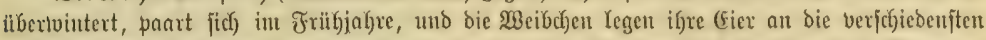
\$flanzen, an tveไt)en bie Sarbe nach)

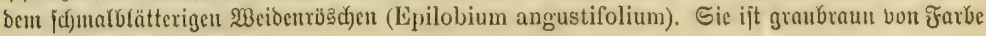

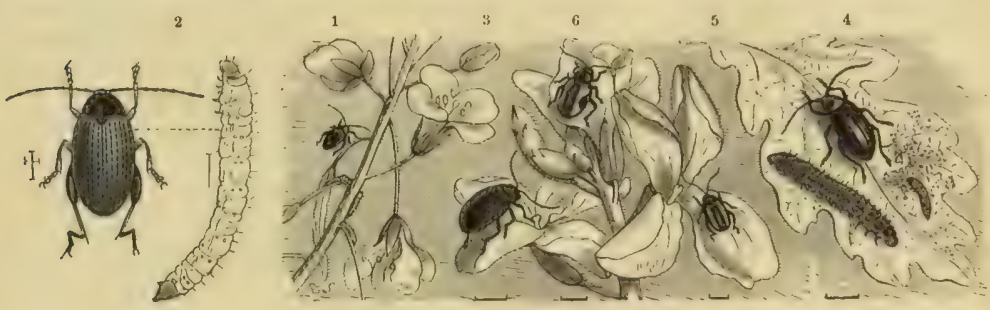

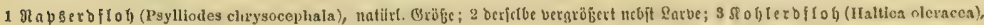

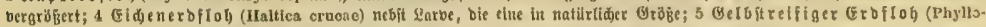
treta nemorum); 6 gogiger Erbflob (Phyllotreta texuoss), bergrobert.

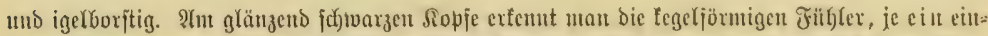

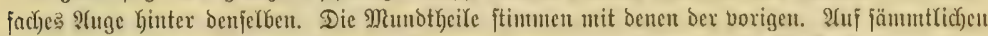

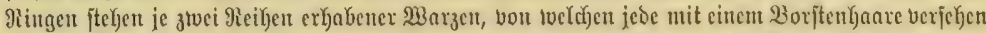

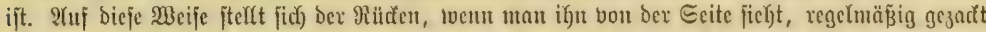

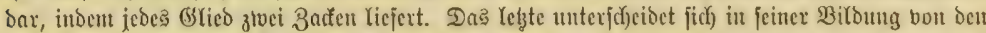

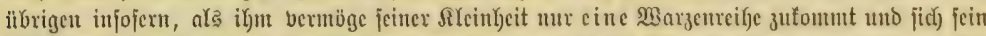

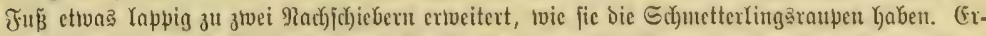
Iuachfen ift fie etina 6 9)

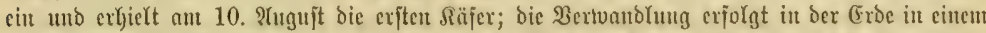

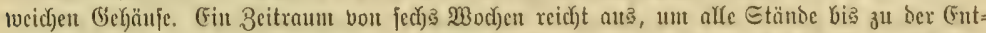

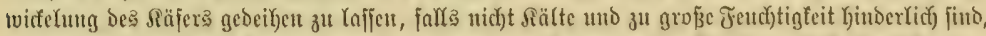

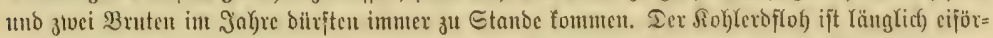

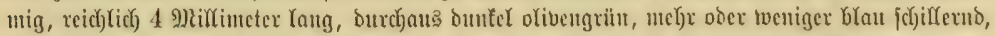

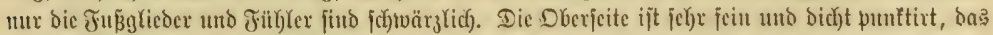

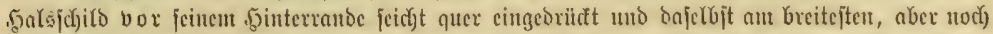

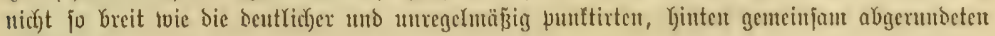
Flïgelderfen.

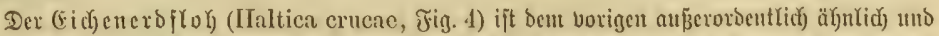

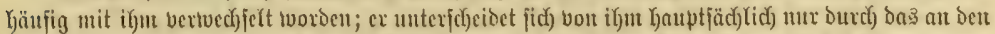

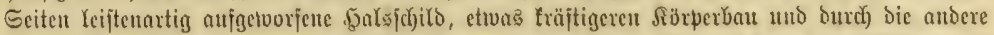

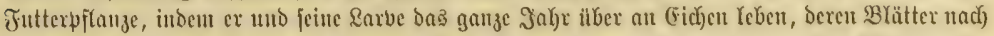

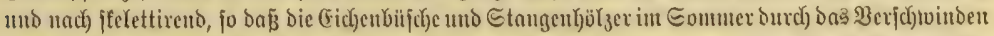

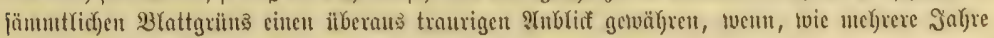




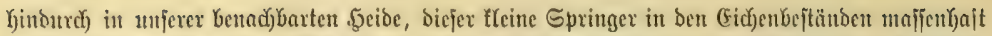

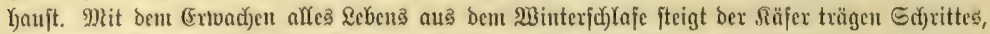
nod) toeniz Spannfrajt in Den Springumsteln verratbend, aแs feinem feuchten Winterlager bom

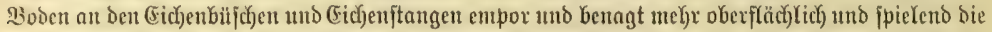

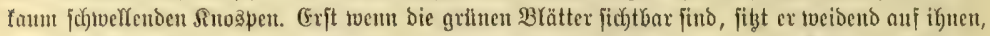

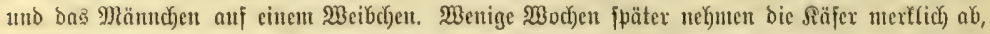

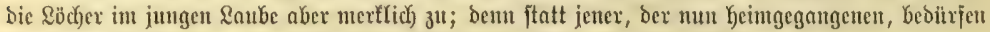

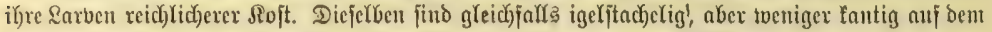

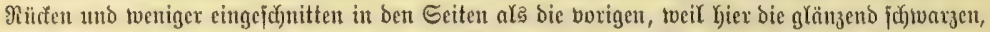

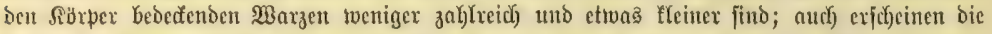

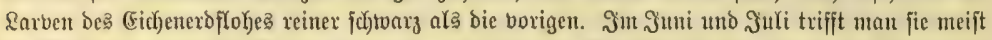

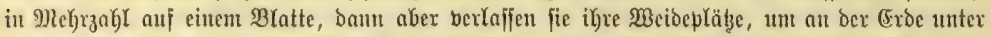

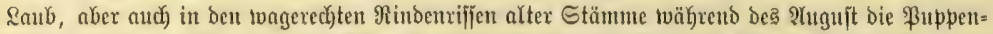

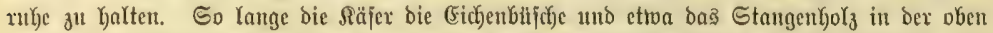

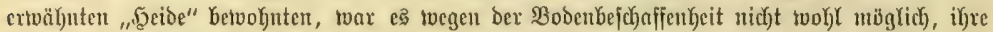

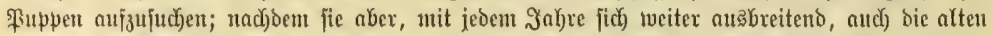

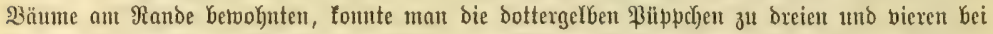

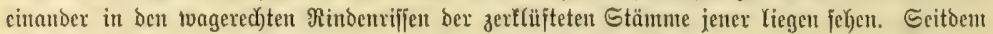

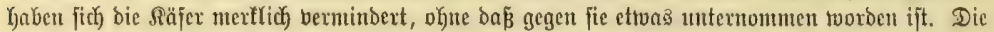

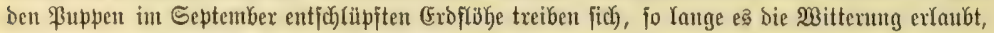

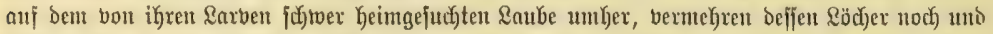

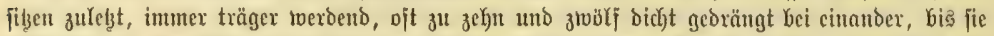

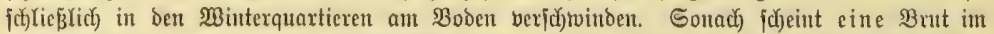

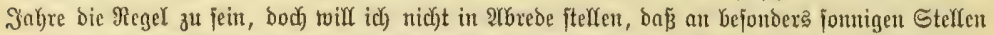
1uto bei günjtigen Witterunģ⿹勹巳

Der gerbit reifige (5 r filog (Phyllotreta nemorum, Fig. 5, S. 189), beffen \&atbe in den

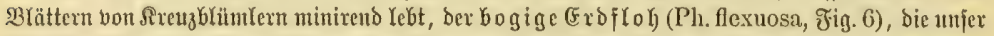

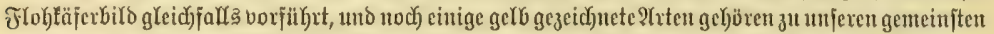

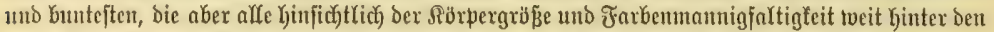

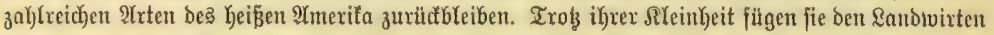

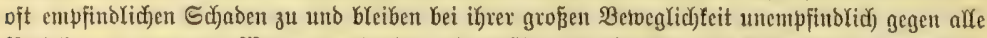

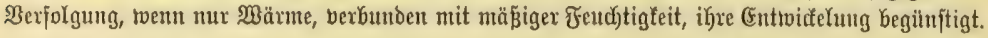

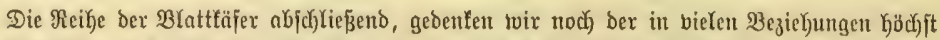
eigentbümlicyen Sofild fäfer (Cassida). Die obalen Rerfe laffen fich leidgt an bem born gerun=

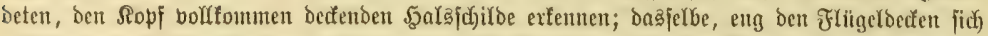

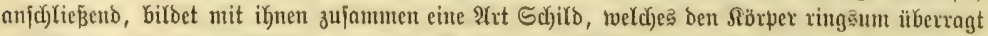

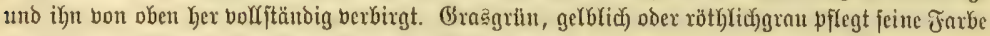

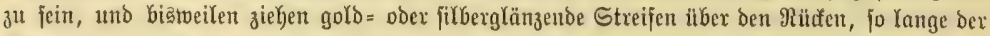

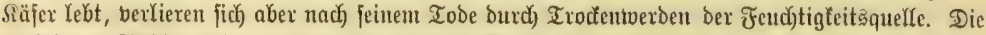

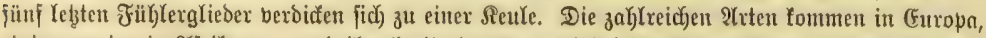

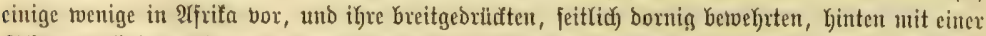

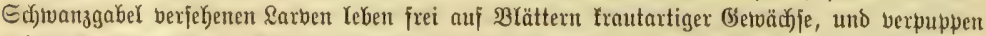
(id) auch an benjelben. Sie alfe ulbertwintern in volffommenen 3uftande und porgen mit Beginn

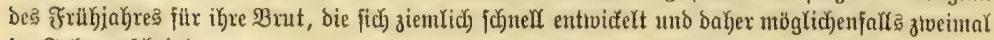
im Jabre erjodyeint.

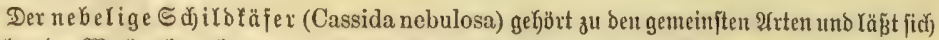

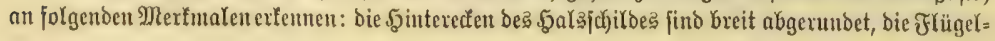




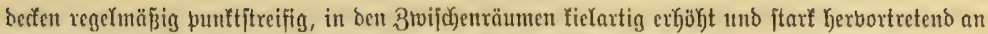

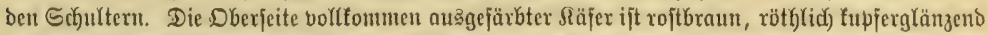

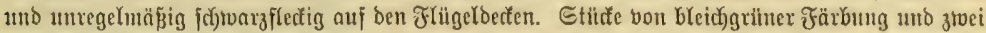

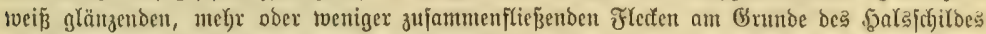

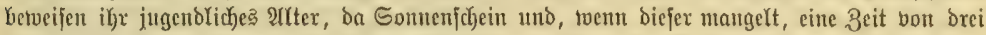

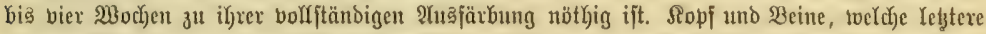

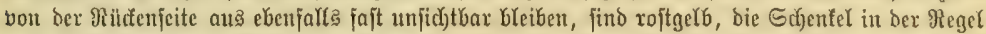

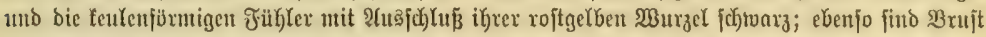

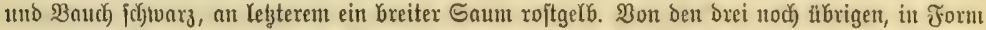

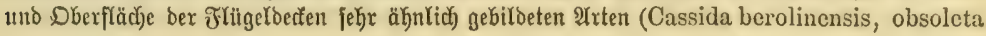
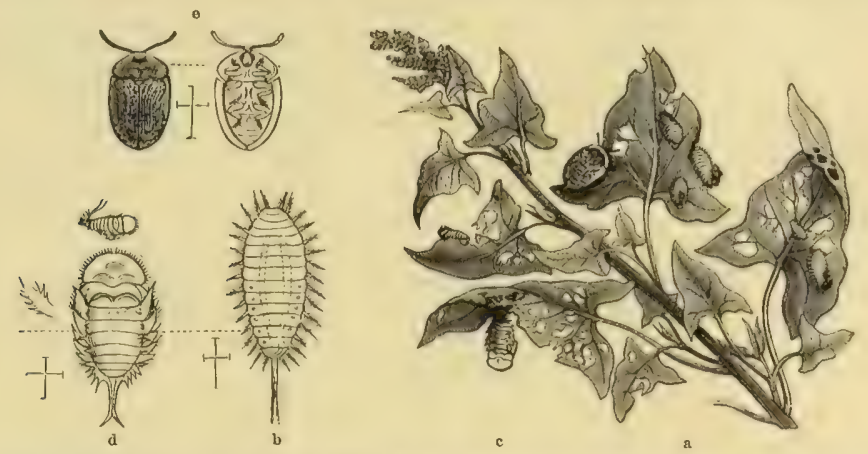

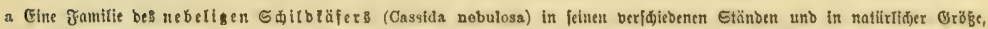

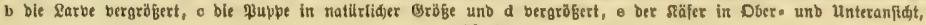
bergrößert.

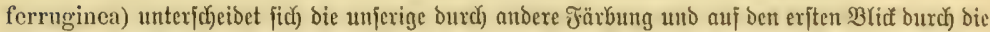

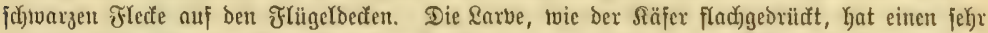

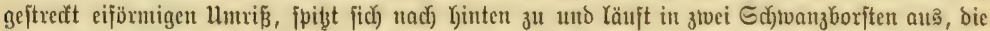

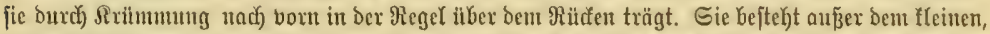

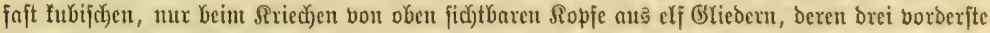

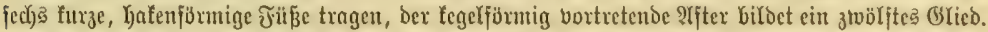

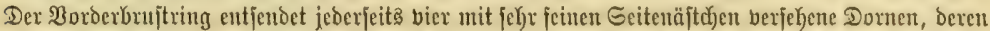

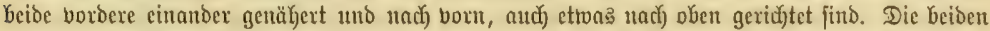

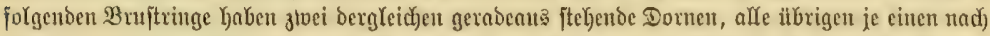

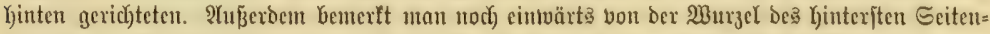

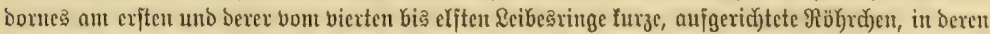

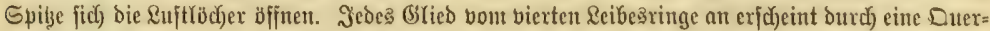

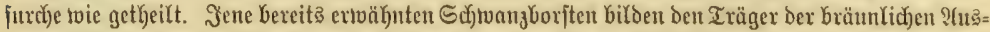

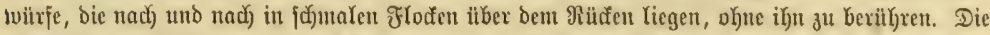

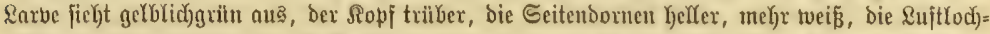

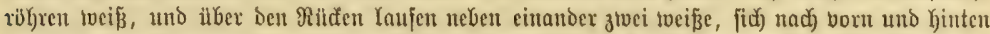

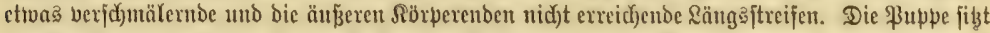

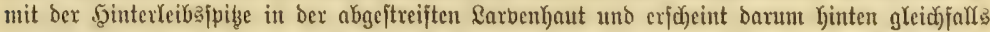

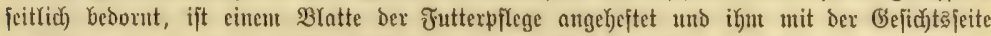

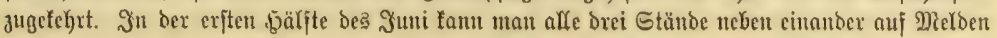




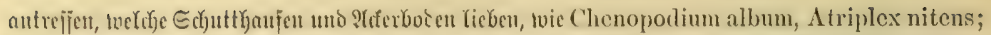

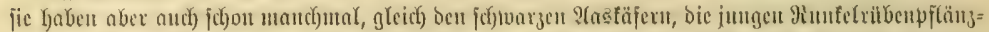

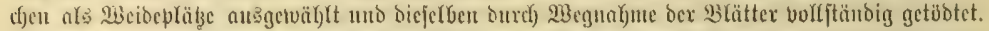

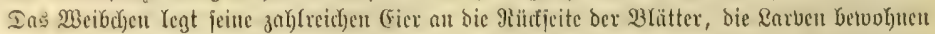

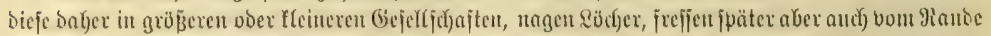

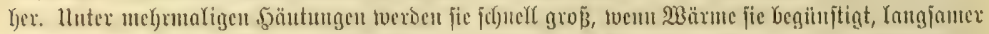

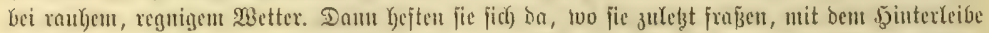

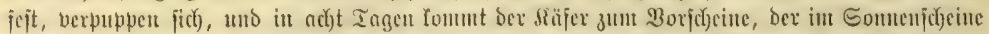

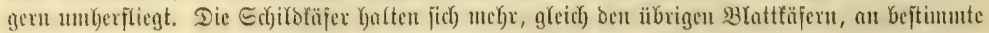

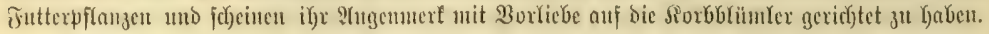

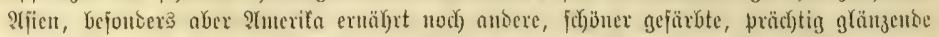

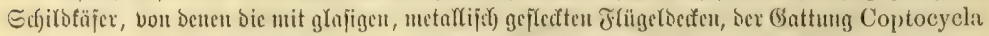

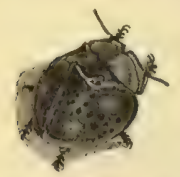

DIesomphalia conspersa

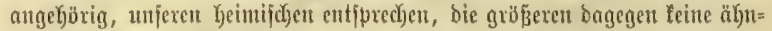

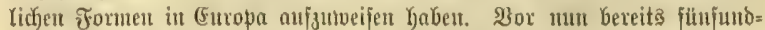

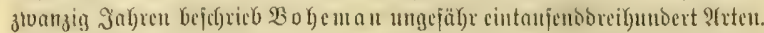

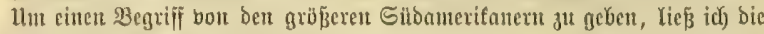
Mesomphalia conspersa Germar (stigmatica Dej.) abjilden uno

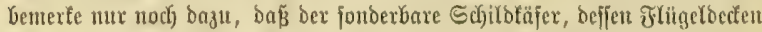

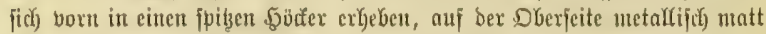

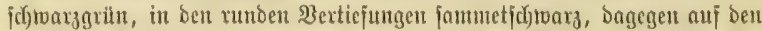

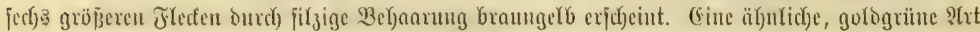

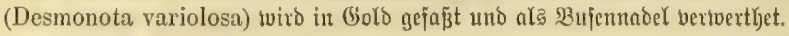

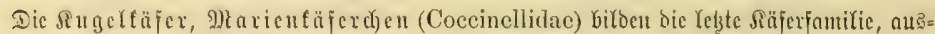

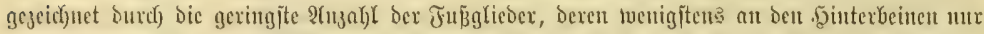

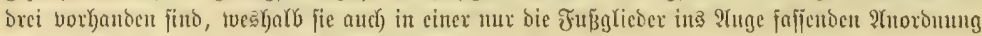
Dreizelger ('l'rimera) genant tworben finto.

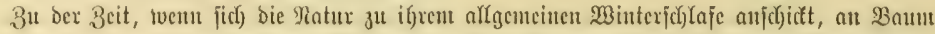

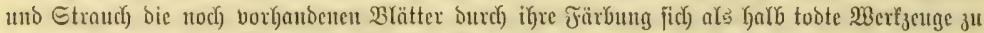

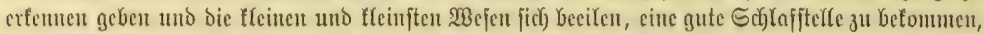

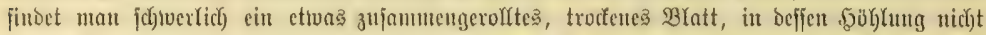

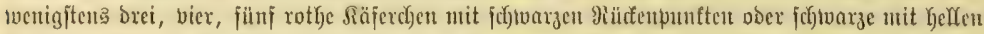

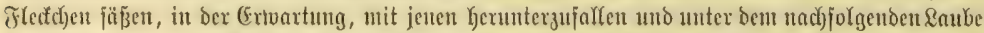

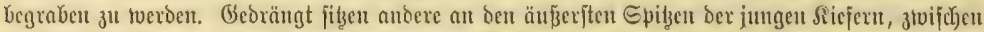

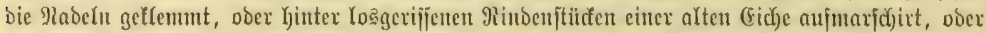

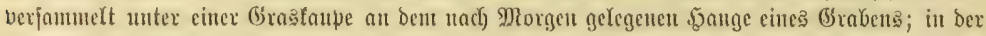

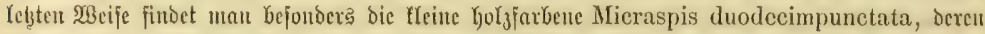

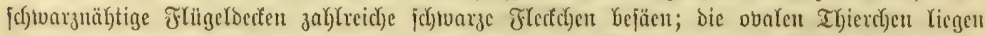

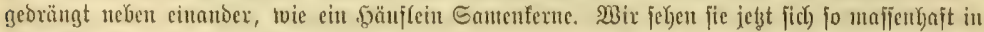

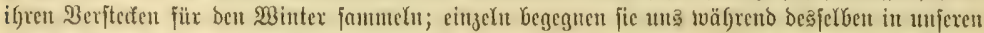
3inutern, und ben ganzen Sommer hindurd) ü bexalf im Freien, aber ftets am zaljfreichjten ba,

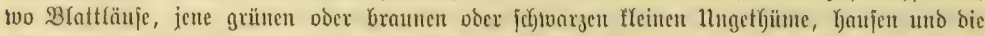

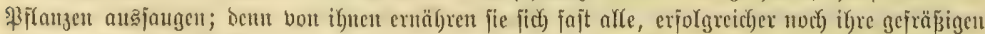

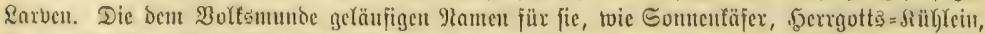

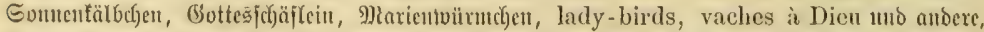

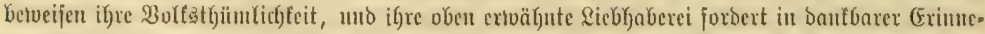

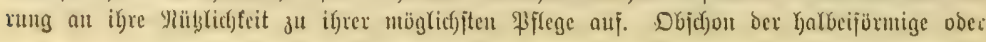




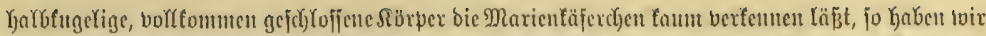

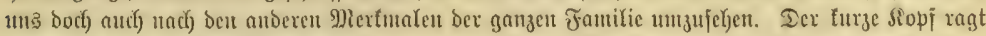

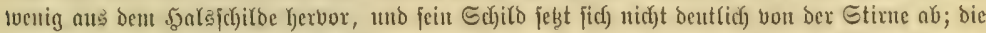

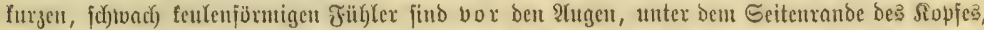

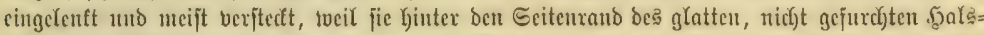

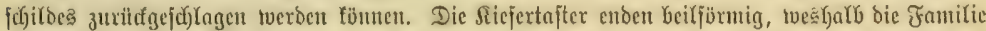

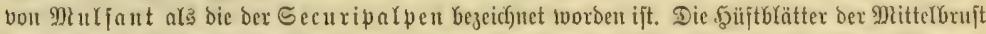

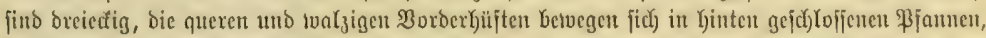

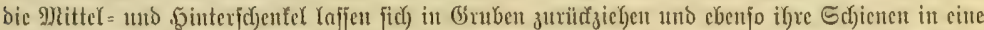

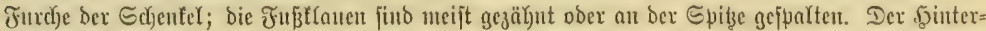

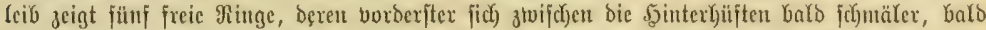

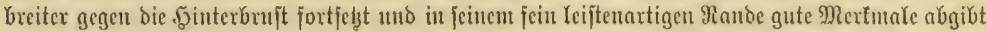

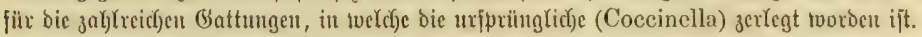

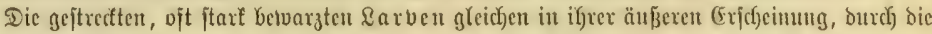

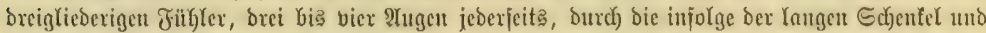

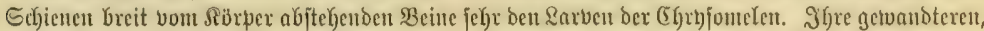

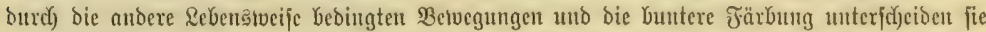

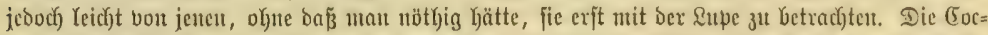

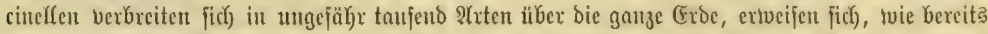

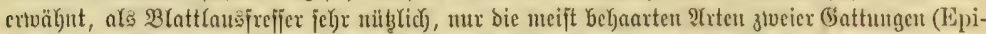
lachna, Lasia) hat man neueroing faumt ifren Rarven als \$flanzenjepijer feuten gelernt.

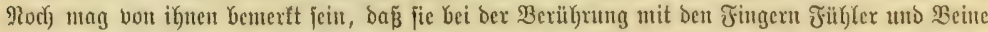

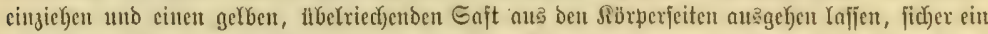

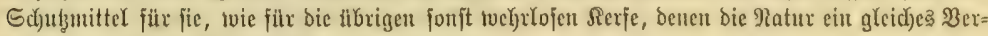
mögen auf bet furzen Rebenżueg mitgegeben Kat.

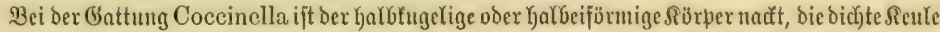

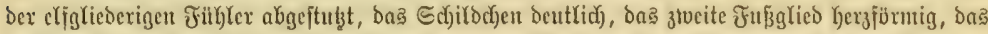

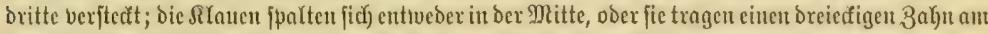
Grunde. Der Siebenpunt, fiebenpunftite Marienfäfer (Coccinella septempunctata,

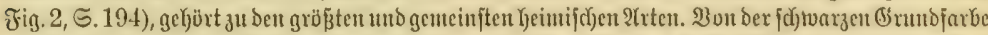

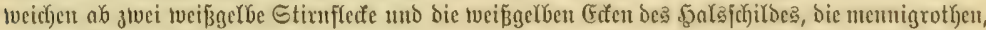

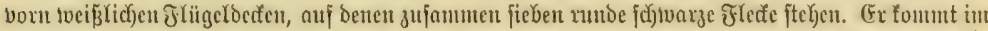

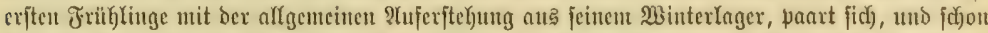

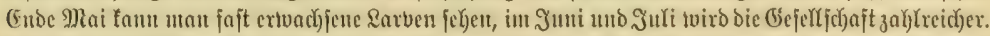

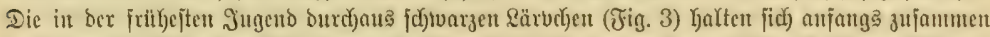

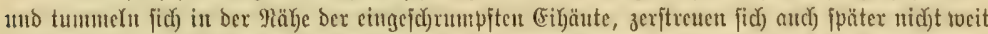
won einander. Die forgjane \$lutter Katte fie ba untergebradjt, two fie in ben $\mathfrak{3}$ Yattlaustolonien

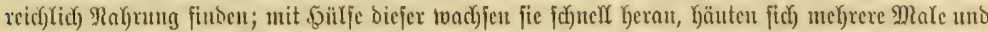

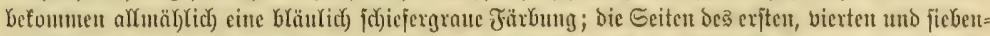

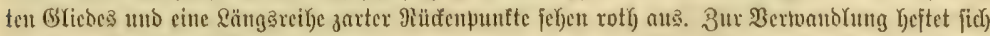

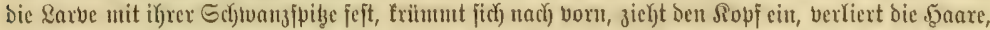

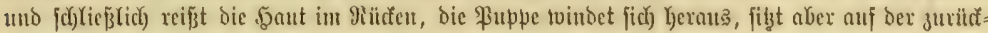

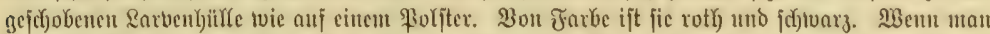

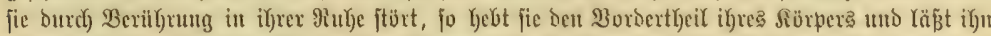

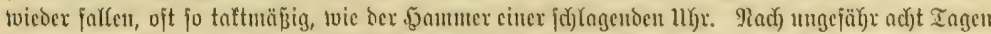

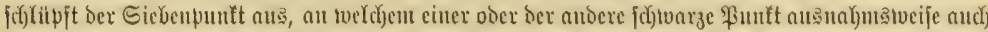

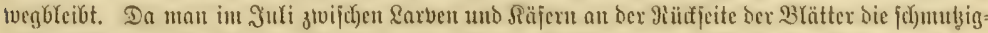

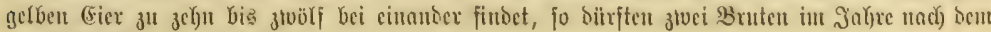




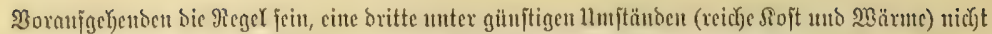

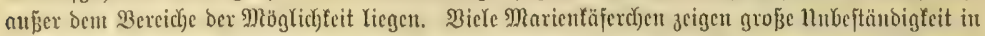

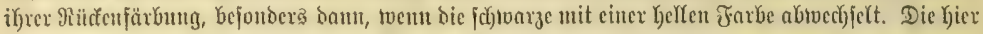

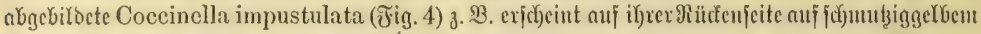

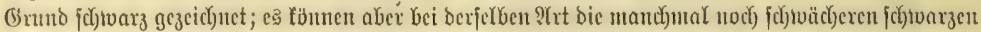

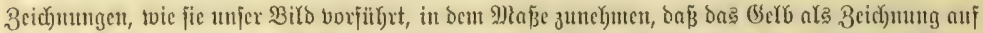

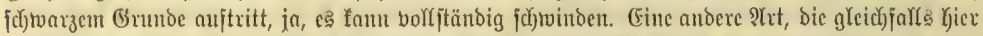

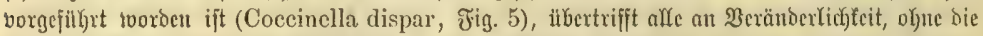

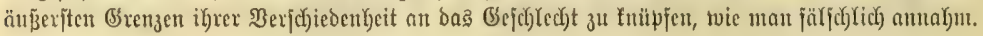

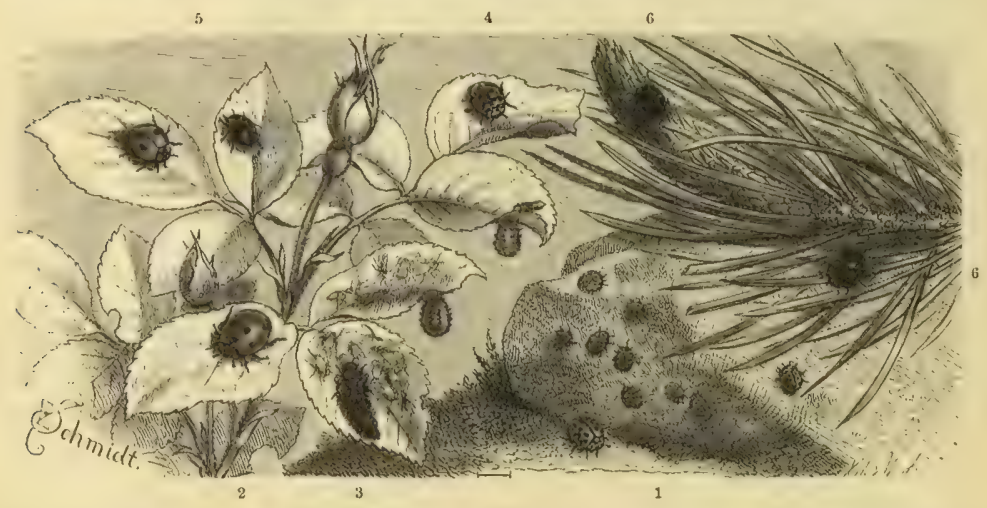

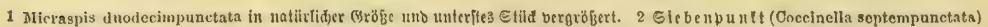

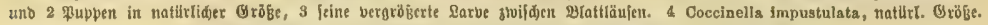

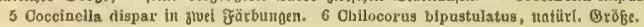

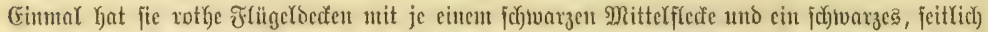

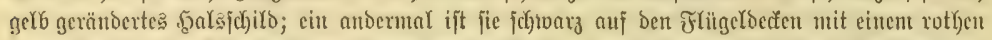

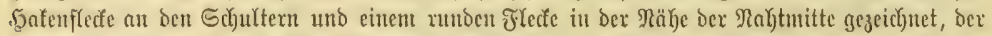

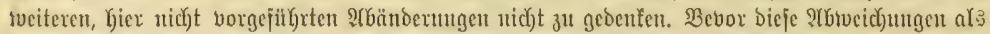

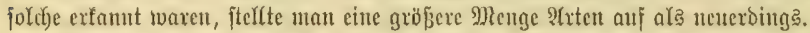

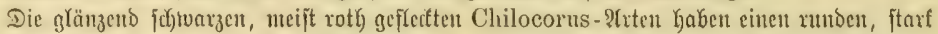
getuölbten Siörper, furze, mux neunglicberigie, in cine fpindelförutge Sente autstanfende Jiib)

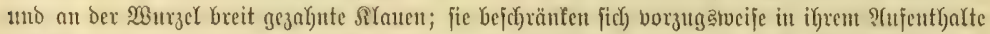

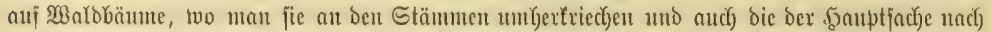

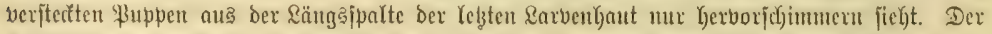

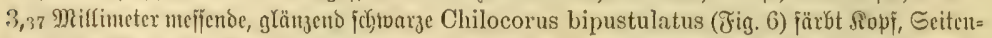

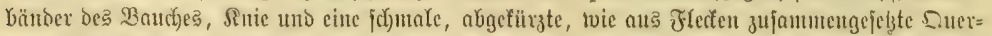

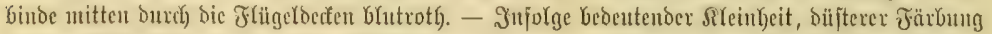

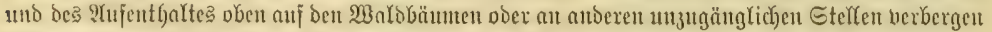

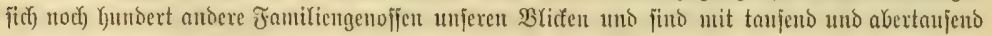
anteren Siäjern fü alfe stidgtjammler itberfaupt nicht auj ber Welt. 


\section{Bweite (Orònก!.}

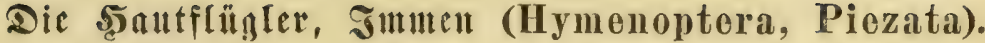

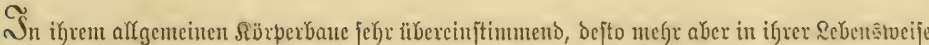

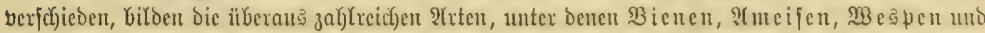

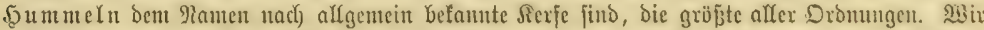

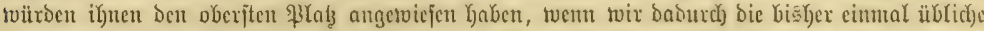

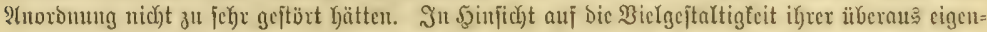

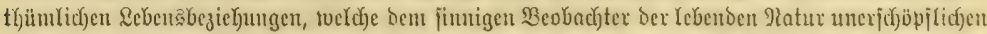

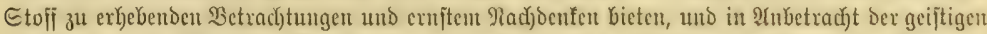

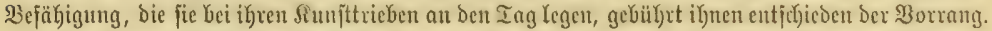

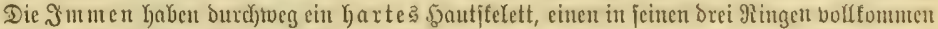

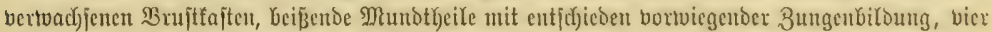

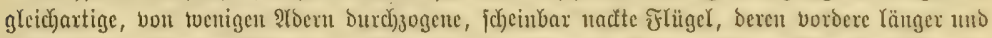

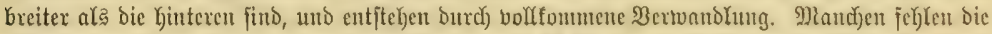

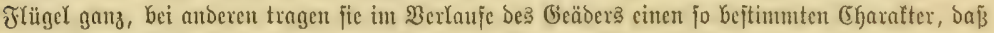

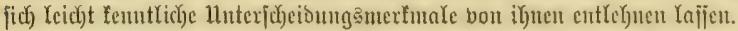

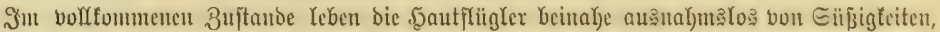

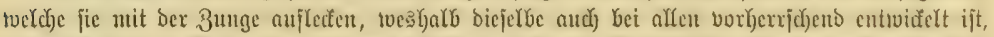

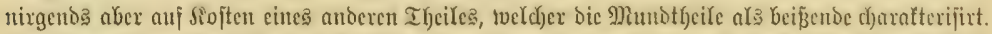

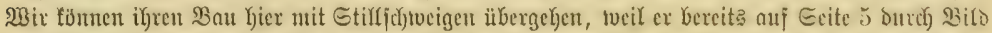

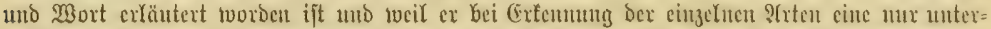

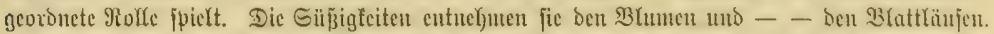

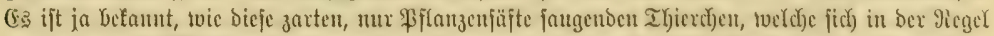

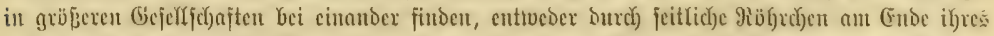

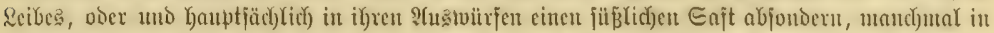

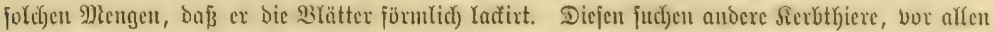

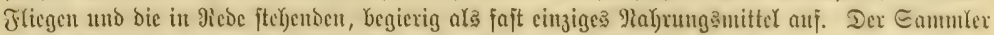

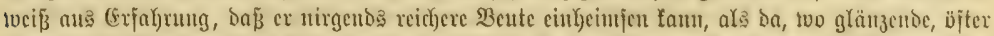

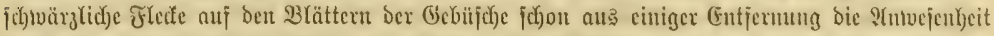

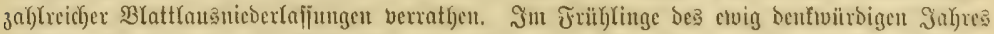

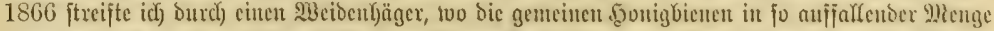

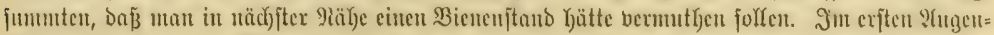

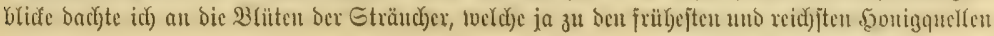




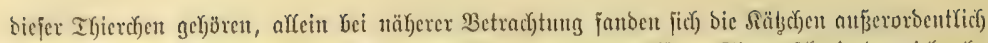

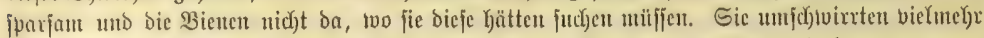

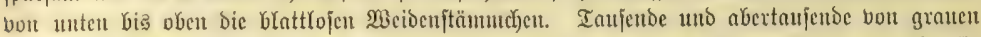

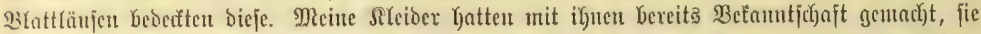
wareu über und ïber mit ihnen bebeăt uno von ihnen bejudelt, weil man iujolge bes bichten

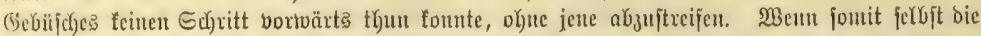

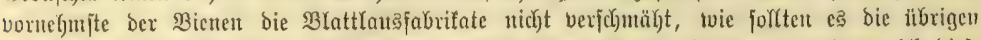

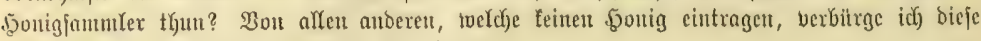
Riebraberci nack) meinen Yangjährigen (Exjabrungen.

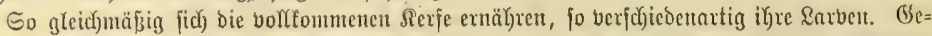

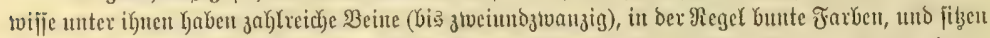

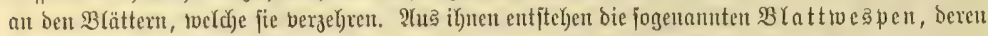

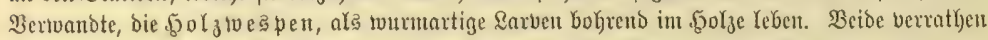

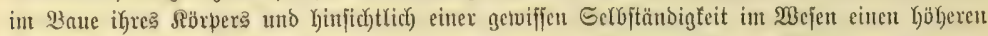

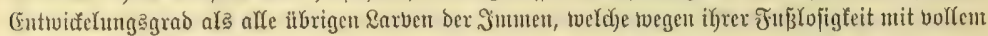

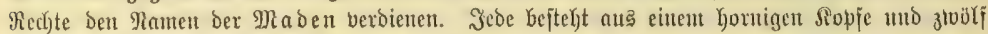

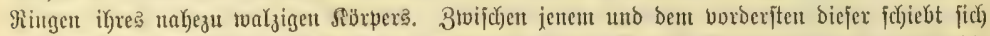

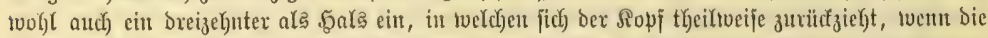

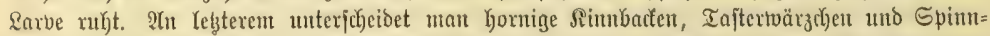

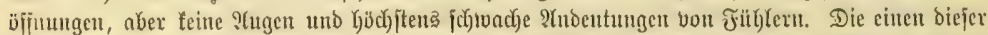

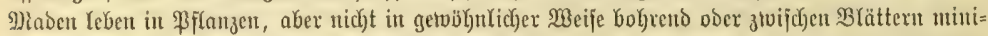

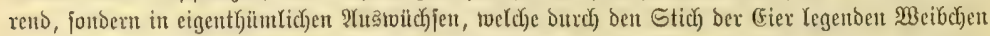
veranlasit werben uno als Ballen allgemein befount futs. Maut gab barum ben aus ifhen

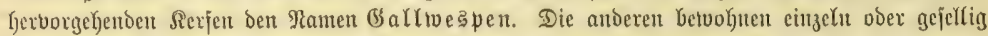

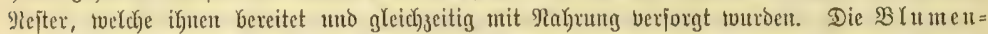

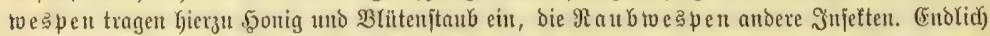

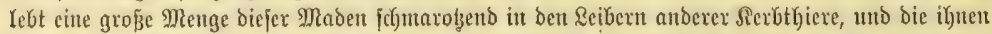

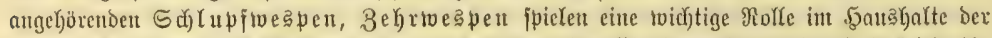

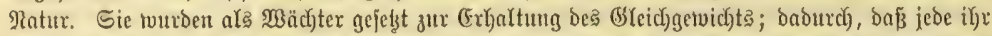

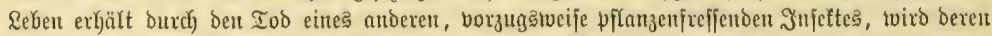

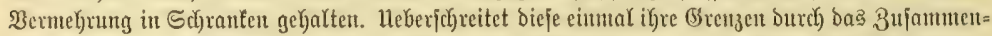

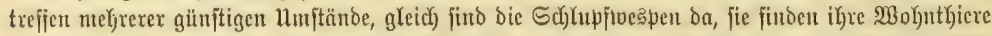

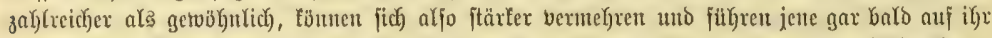

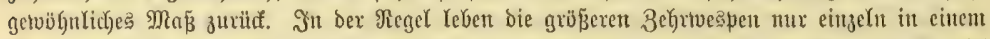
Mirte, bic fteineren nicht felten in Fanilien zu humberten, und man wiro fick cinen Begriff machen fönten von bex Minzigfeit viełer, ıcun man erfä)

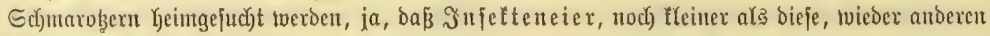
Sdjutarobern bas Reben gebent.

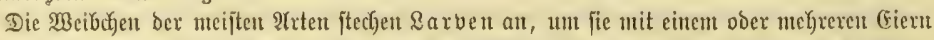

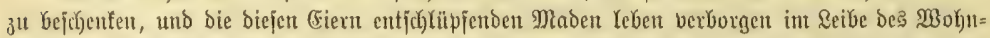

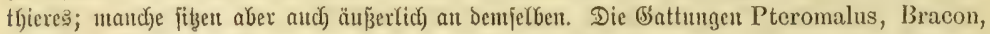
Spathius, Tryphon, Phygadeuon, Cryptus, Pimpla und andere, weldye tvir jpäter fentuen Yeruen

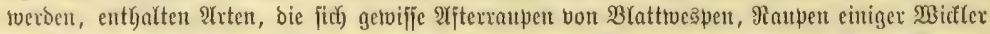

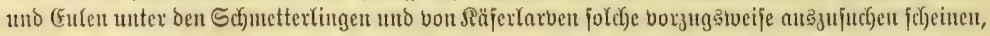

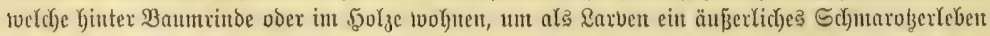

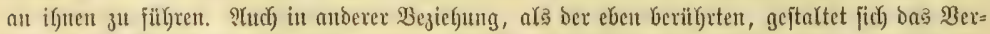

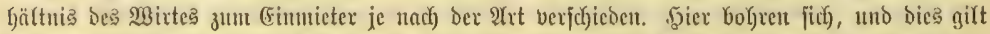

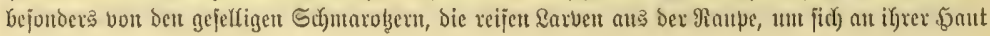




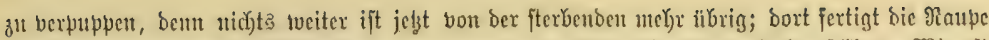

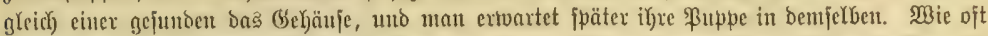

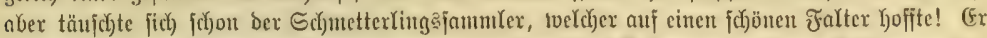

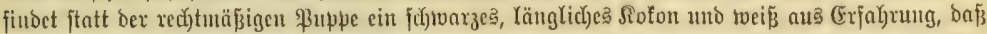

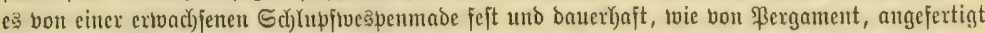

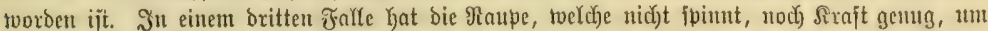

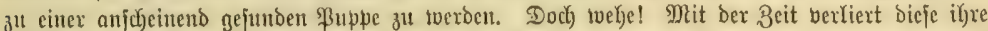

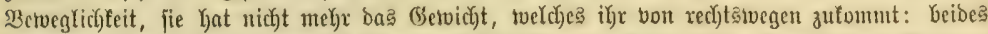

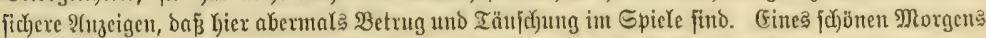

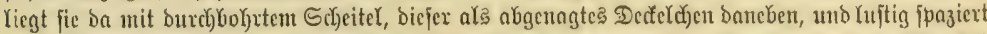

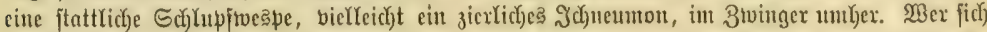

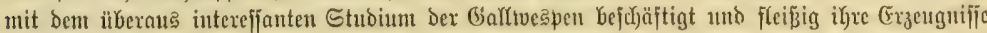

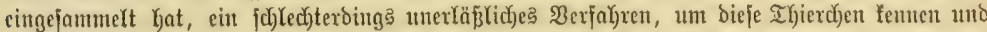

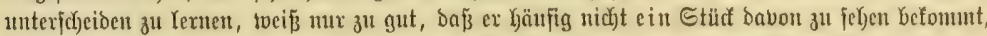

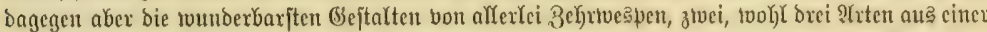

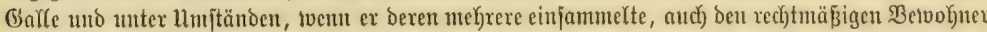

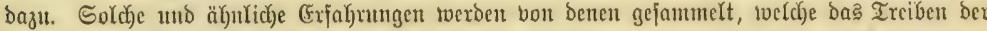

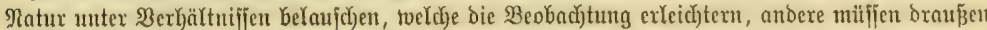

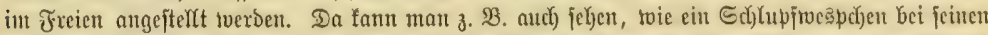

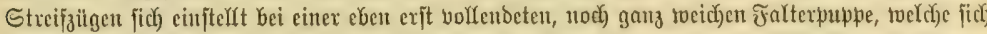

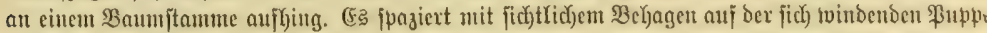

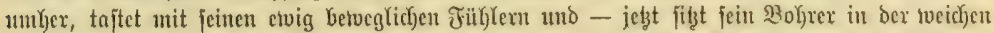

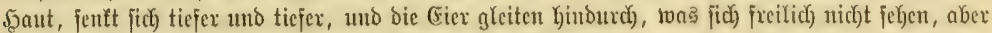

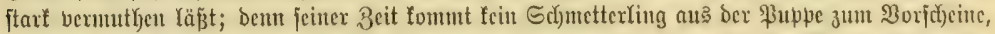

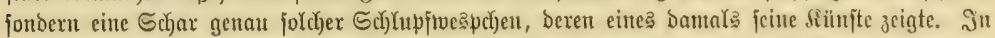

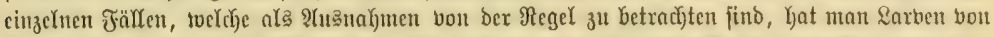

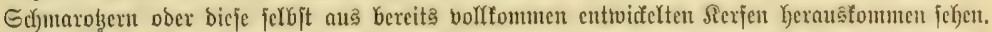

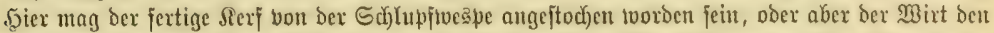

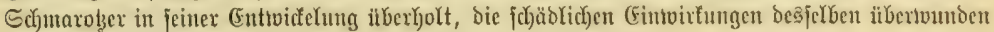

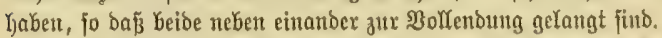

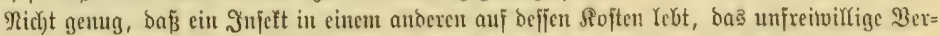

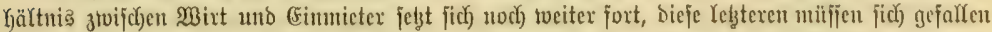

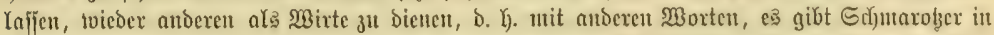

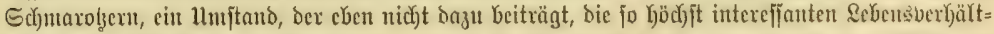

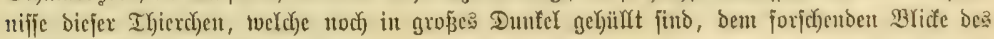
3eobadyterä flar zu Yegen.

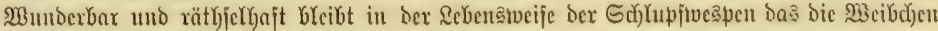

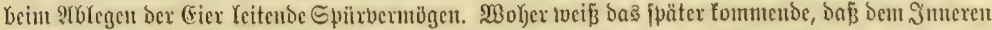

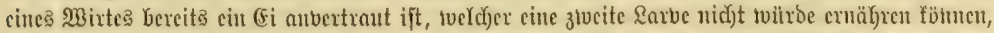

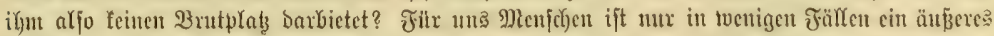

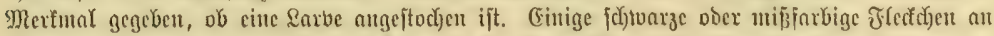

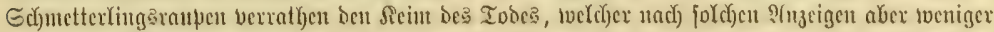

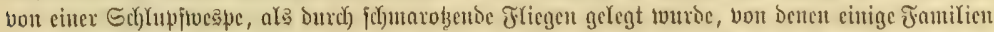

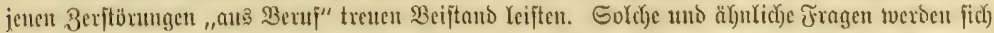

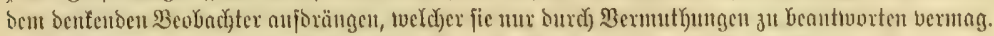

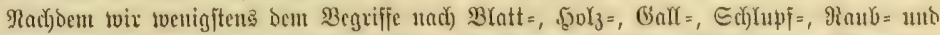

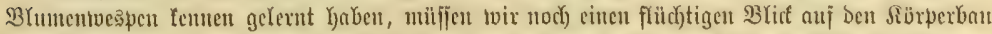

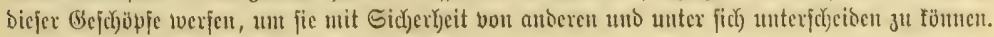




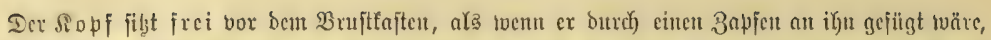
exfifeint, bou oben gejel)en, fajt inmer breiter als lang, er ift cin "Duerfopj" int wah)ren Simne

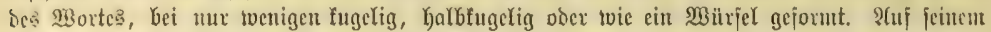
E(f)itel bemerft man ziemlid) authahmesłos brei Plebenaugen, weldhe wie \$erldyen erglänzen, bie

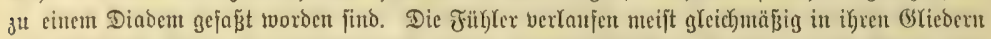

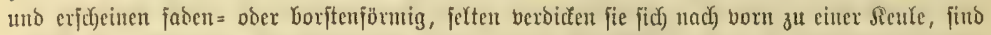
gerade ober gebrochen. Der Ränge nach) werben jie nie übermäpig groß̈, nock berichtwindeno fleit

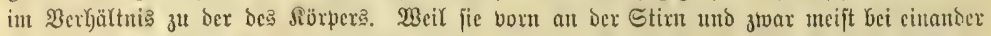

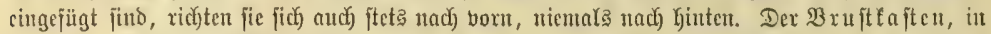

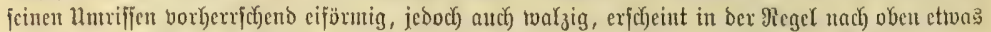

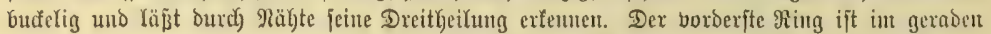
Segenjabze zu bem bex Räjex am twenigiten entwictêt, fommt

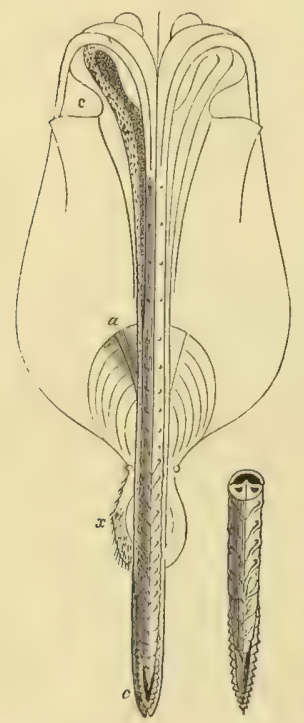

Regbobrer ber groben 5 ol 3 to espe (Sirex gigas) mit feiuter Edjeibe, reditz danebeu oic Evita Defielben obme iolde. $x$ Edjuary. iw be bez syinterleibes. Dei o-a ber Muz. fclupparat jum Mufridsten bes Bohrers. Bebeutende Bergróferuing.

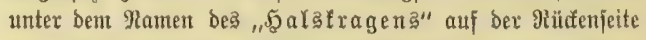
nur toenig zur Geltung und an ber Brujt mux jo weit, ald ox

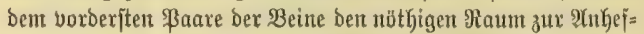

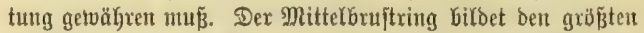

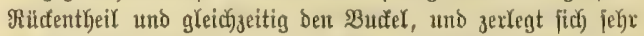

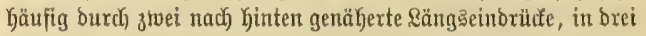
\$artien, die fogenantent \&appen, Defien mitteljter in S dyild = d) en endet. Der fleinere britte Burtring entolidy bietet in feiner glatten ober burch) Seiften mannigjach in Felder getheilten Oberfläche uno in jeinem borderen, Dberen uno abjidjujitgen Ginteren Theile für zahlreiche Smmen wichtige (5xtenmung

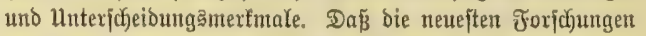

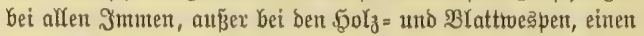

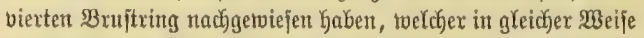

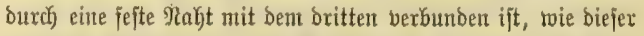
mit Dem Mritterủuten, twilf ich hiex nur ertoäfnen und babei

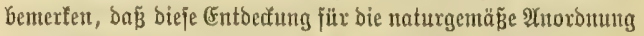

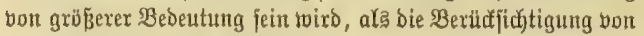
cinem ober ztoei Schenfelringen.

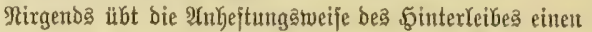
fo twefentridjen (Finfluß auf bie Röpertrad)t eines Serbthieres aus, twie fier, indem alfe fromen, angeroad)jene, jiţ̧enoe, anţän= gende und gejtielte; wie fie auf Seite 10 bejprochen iouroen, anzutreffen find. Ged)

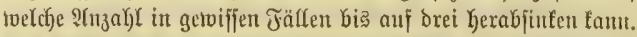
Das Göchjite Interejie nimmt aber bie tounderbare (Fintid)tung bes

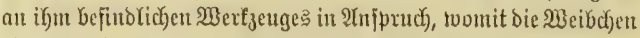

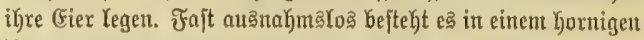

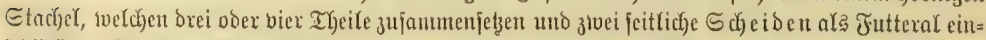

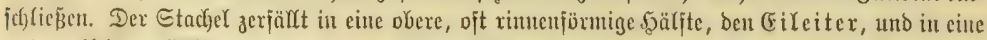

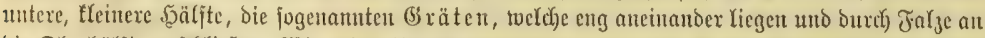

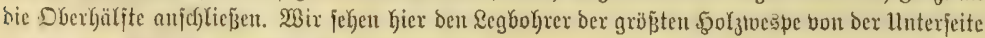

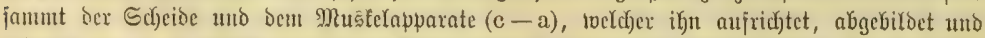

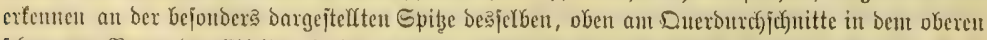

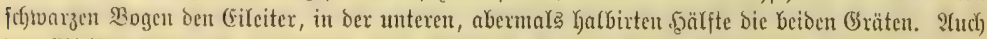

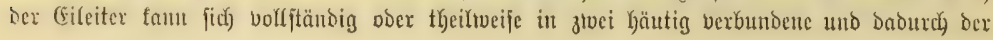




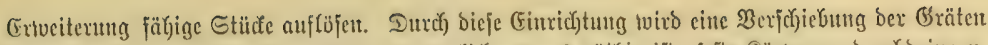

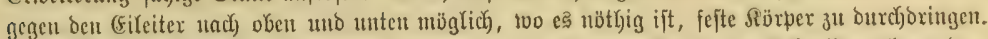

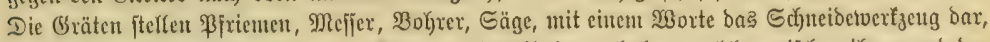

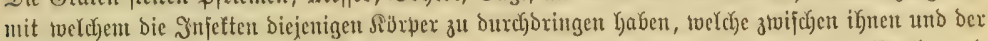

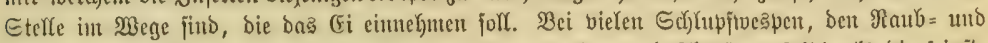

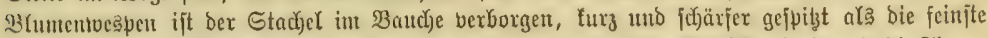

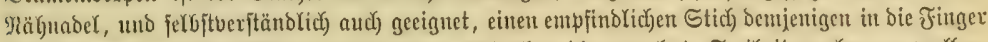

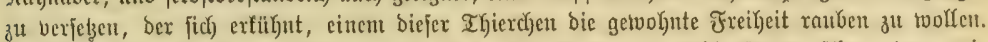

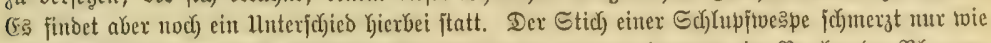

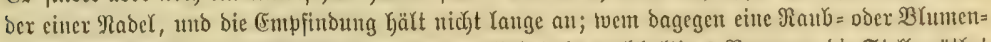

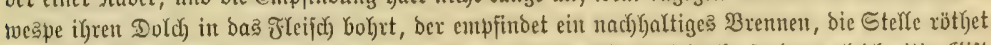

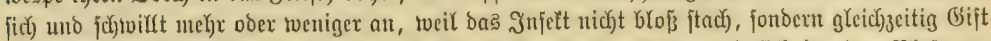

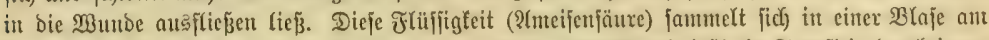

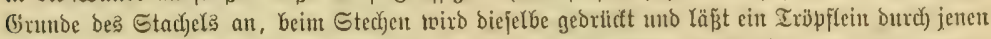

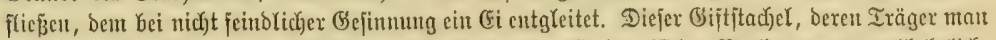

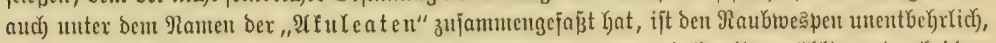

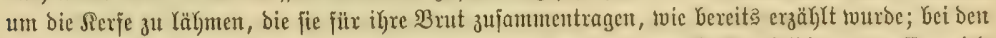

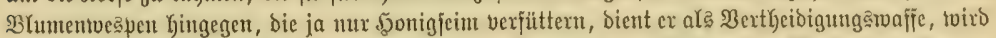

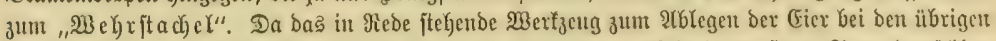

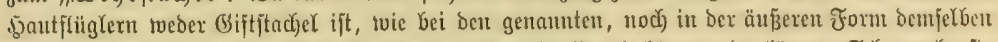

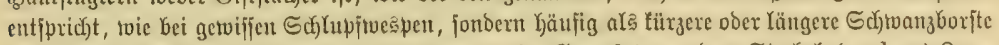

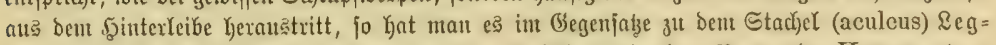

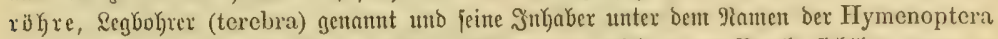

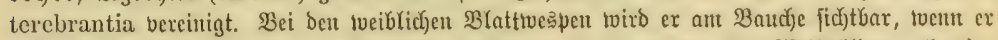

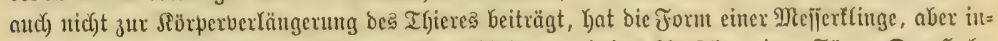

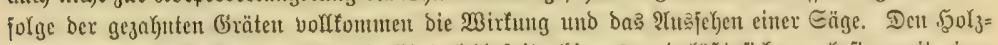

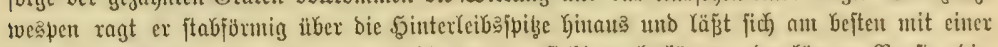

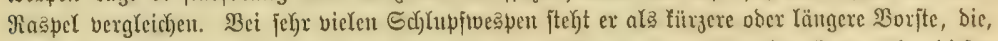

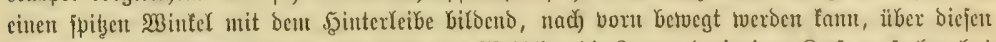

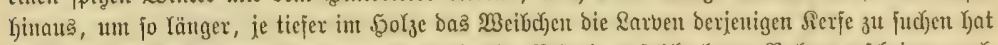

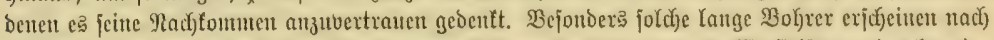
bem Tobe des Thieres als brei fabenförmige Schtwanjborften, bie mittefïte fteifer - ber Gomige

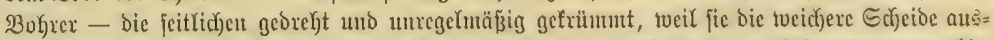

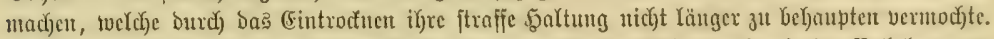

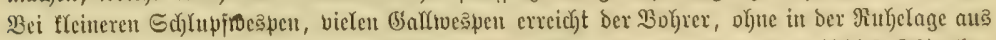

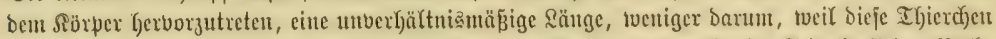

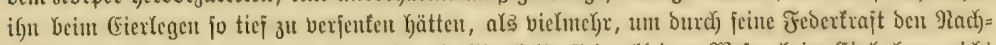

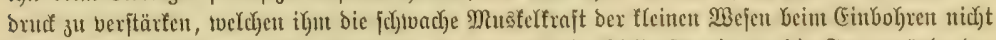

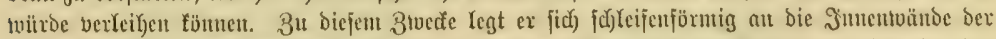

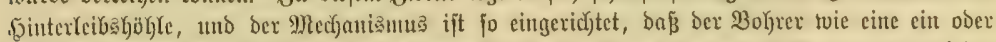

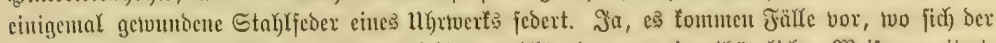

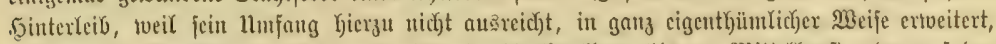

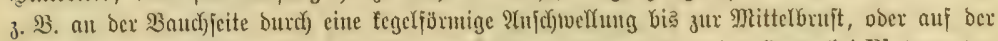

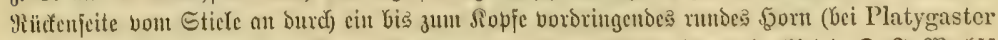

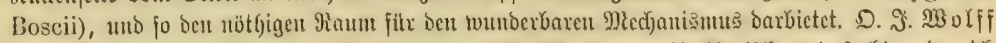

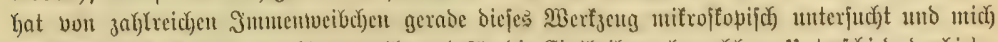

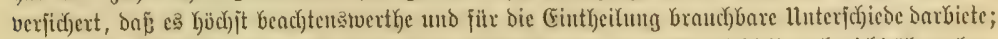

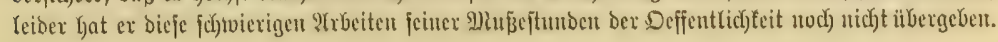




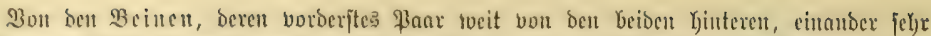

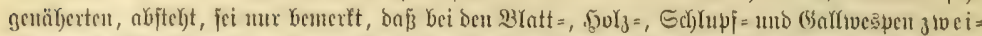

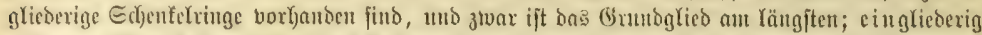

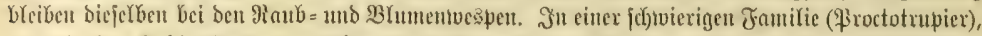

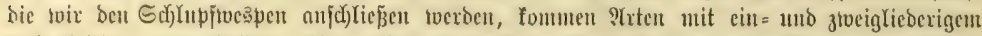

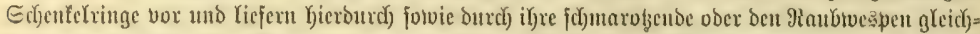

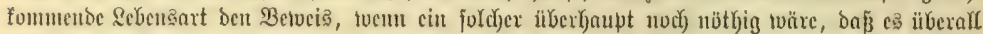

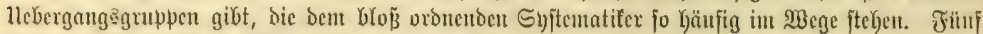
Glieber bilben in Den meiften đäßen ben Fuß̄.

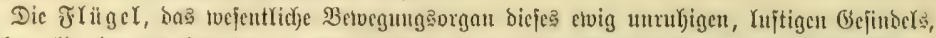

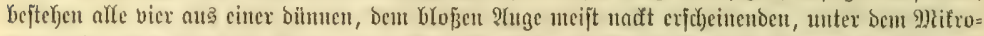

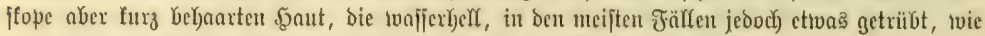

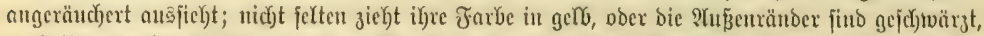

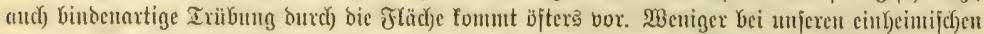

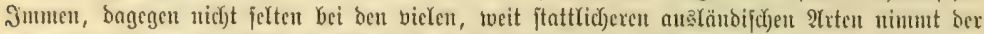

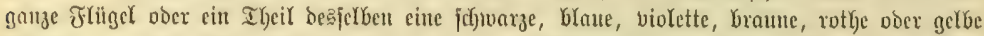

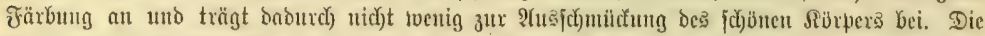

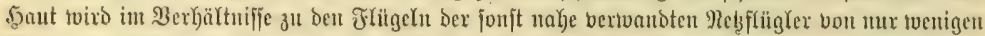

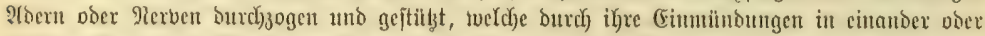

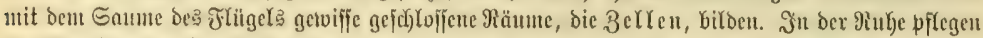

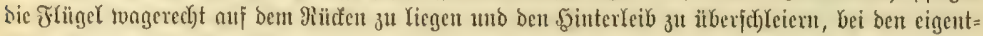

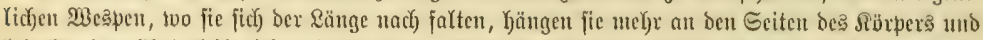

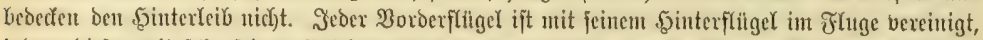

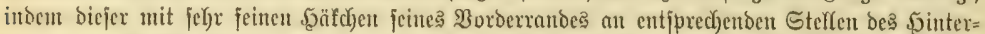

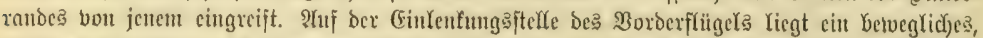

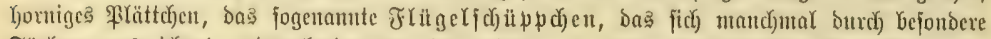

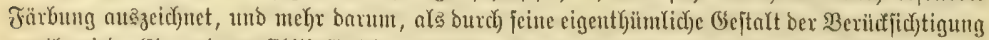

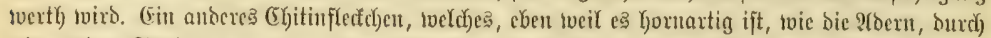

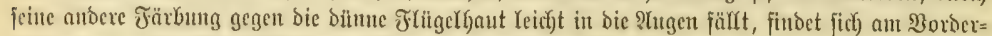

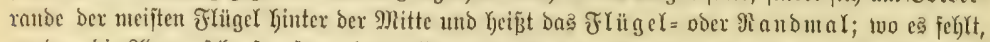

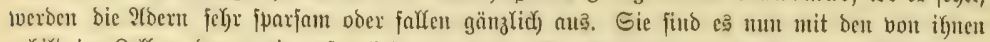

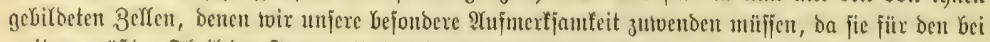

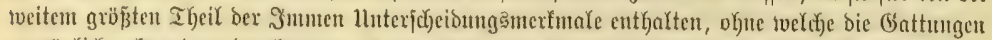

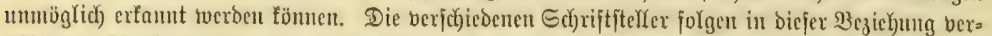

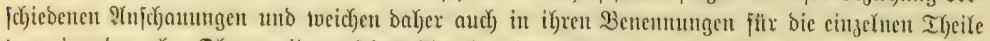

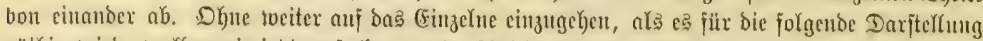

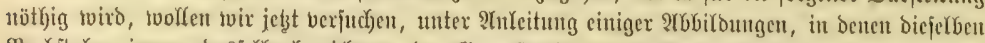

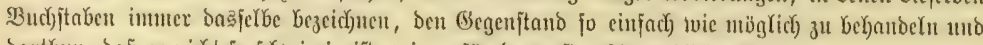

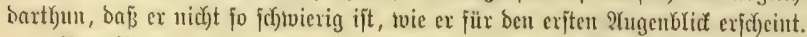

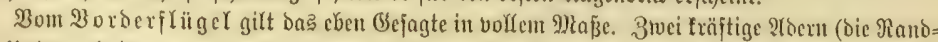

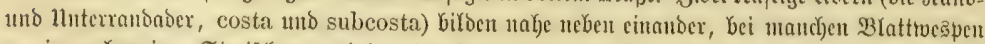

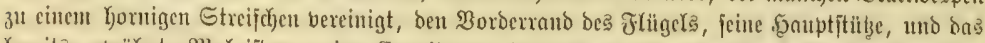

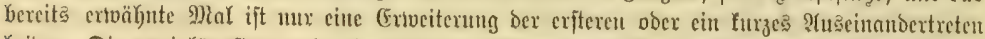

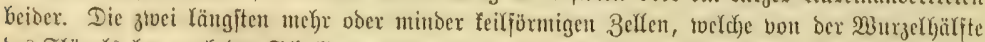

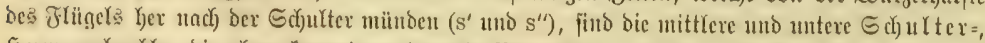

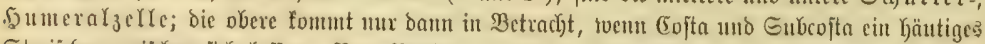

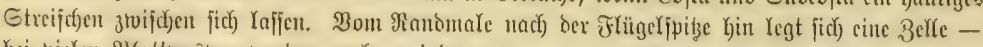

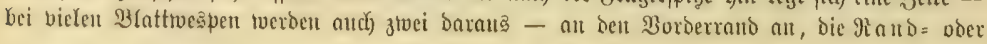




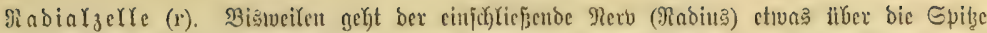

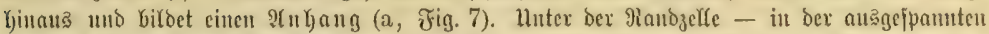

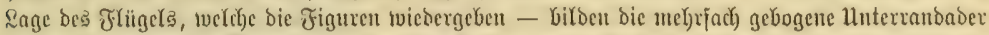

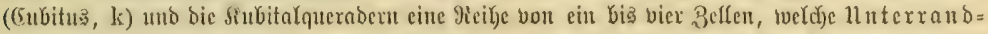

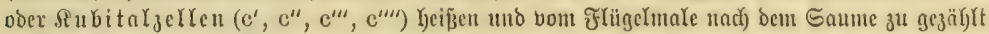

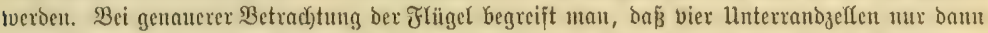

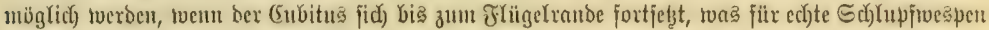

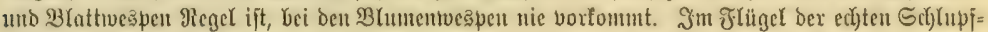

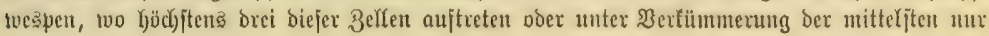

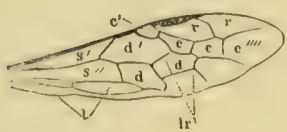

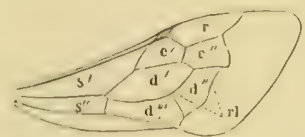
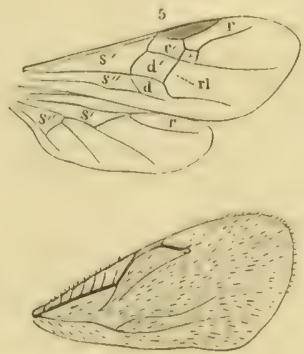

8
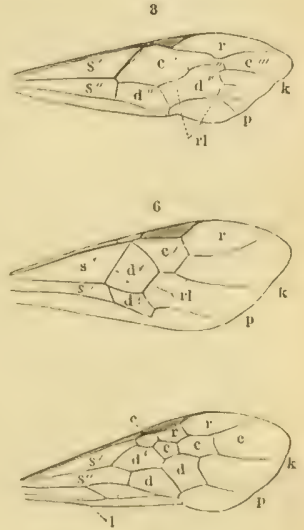

9

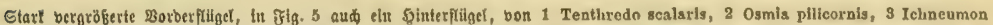
pisorlus, 4 Cerceris, 5 Enzinus, 6 Eubadizon, 7 Crabro stilatus, 8 Chrysolampus solitarius, 9 Athalia apinartun. 2ibern:

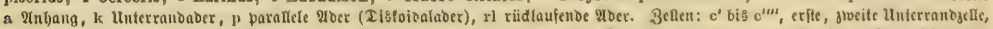

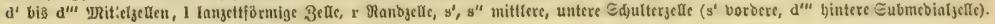

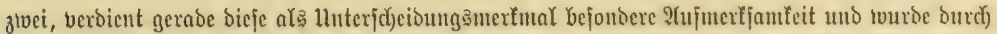

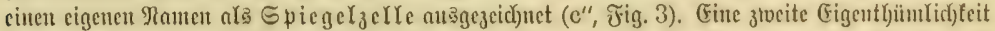

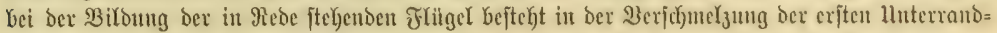

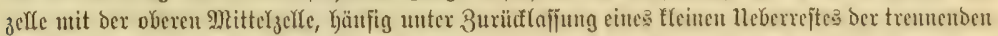

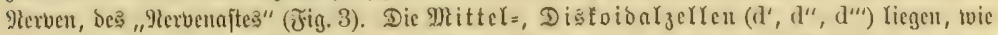

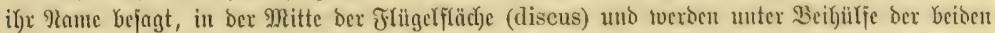

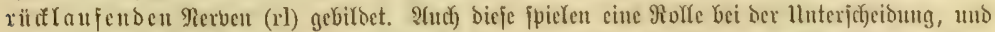

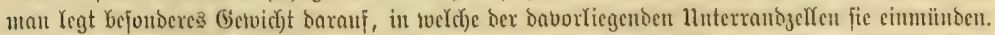

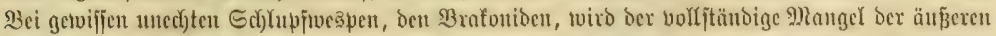

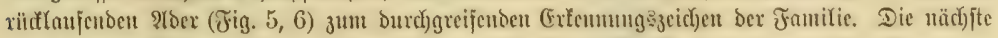

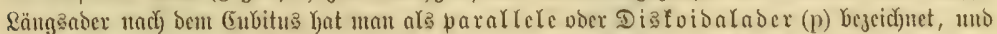

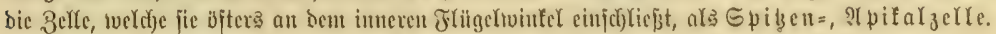

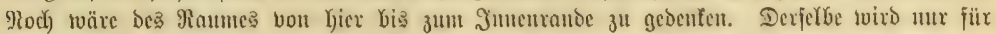

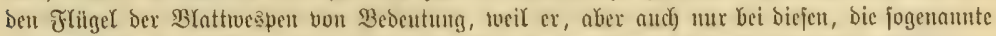

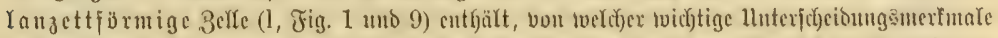

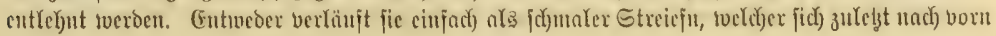


und Ginten ctwas henfelartig ertweitert, it bie Ed)ulter, oder fie twiro burd) eine felyr turge gera de

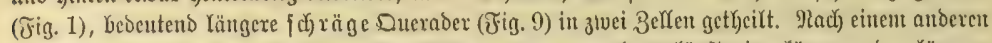

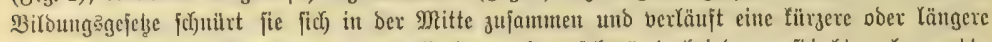

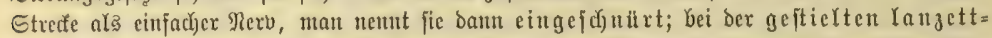

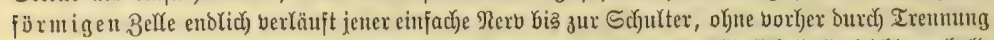

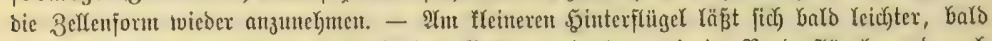

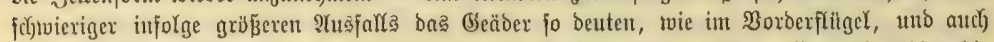

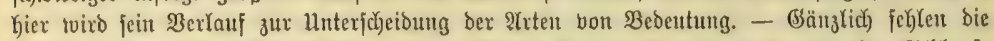

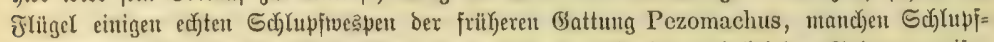
twespenverwanden, einigen Salfinjeften, Den arbeitenden Ifneifen und bei ben Spintmenameijen ben Meibd)ent.

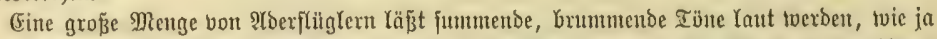

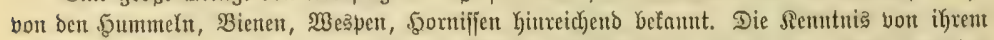

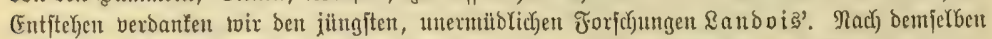

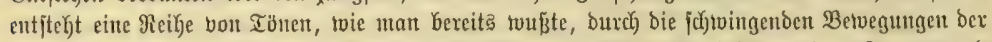

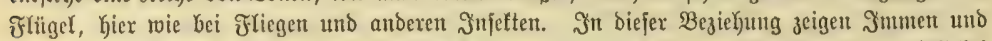

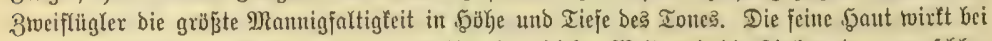

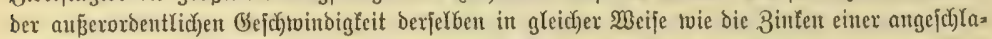

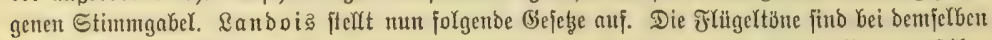

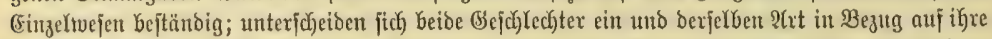

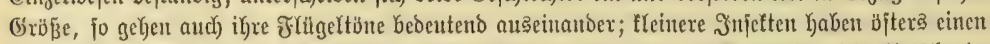

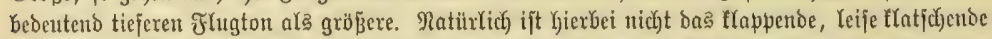

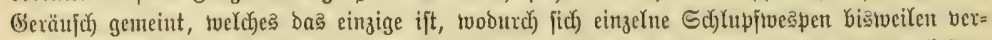

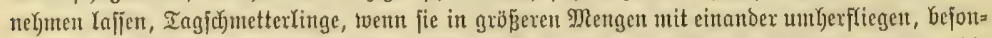

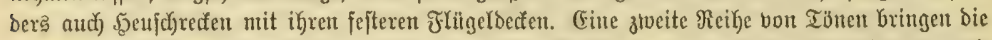

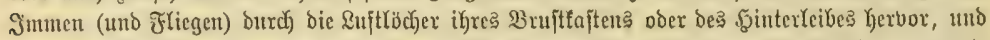

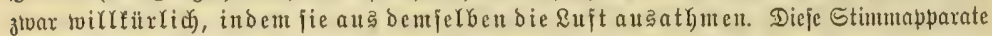
laffen fich ant bejten vergleichen mit ben Mirfungen ber Zungenpfeifen, bent es twerden babci

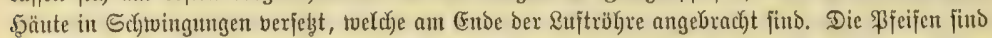
bie Eujtrobren, auf beren umgetheiltem (ende ber Stimuapparat aufibst, twie ber fieblfopf auf Der

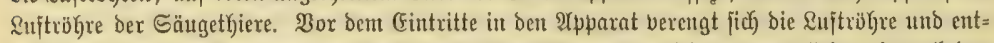

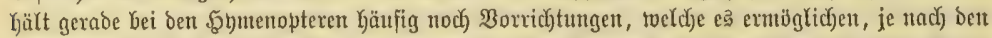

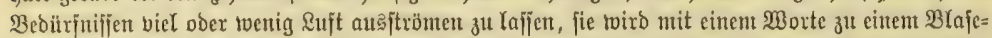

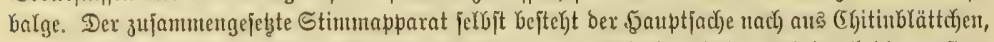

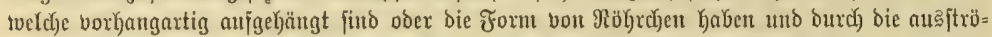

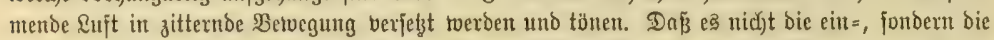

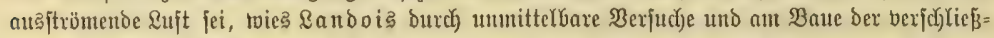
baren \&uftlüb,yer, bex Gefannten (Eingänge zu ben \&ujtröhren, nach; ja, ex gintg baun nock) toeitex

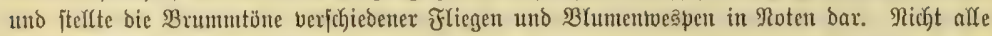

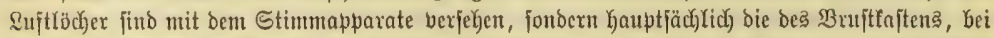

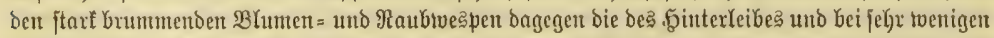
beibe jugleich. So interefijant bicjer Begenjtand immer fein mag, jo fömten toir ihn hier aus

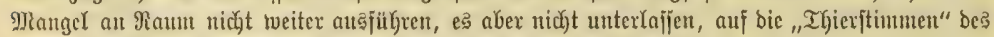
oben genannten ßerjafjerş Kinzutweifen (Jreiburg in Breizgau 1874).

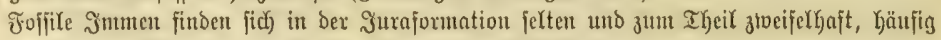
bagegen, bejonders :

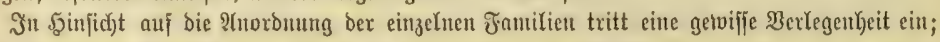

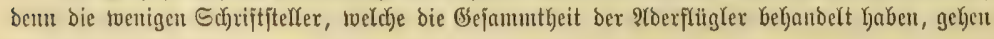





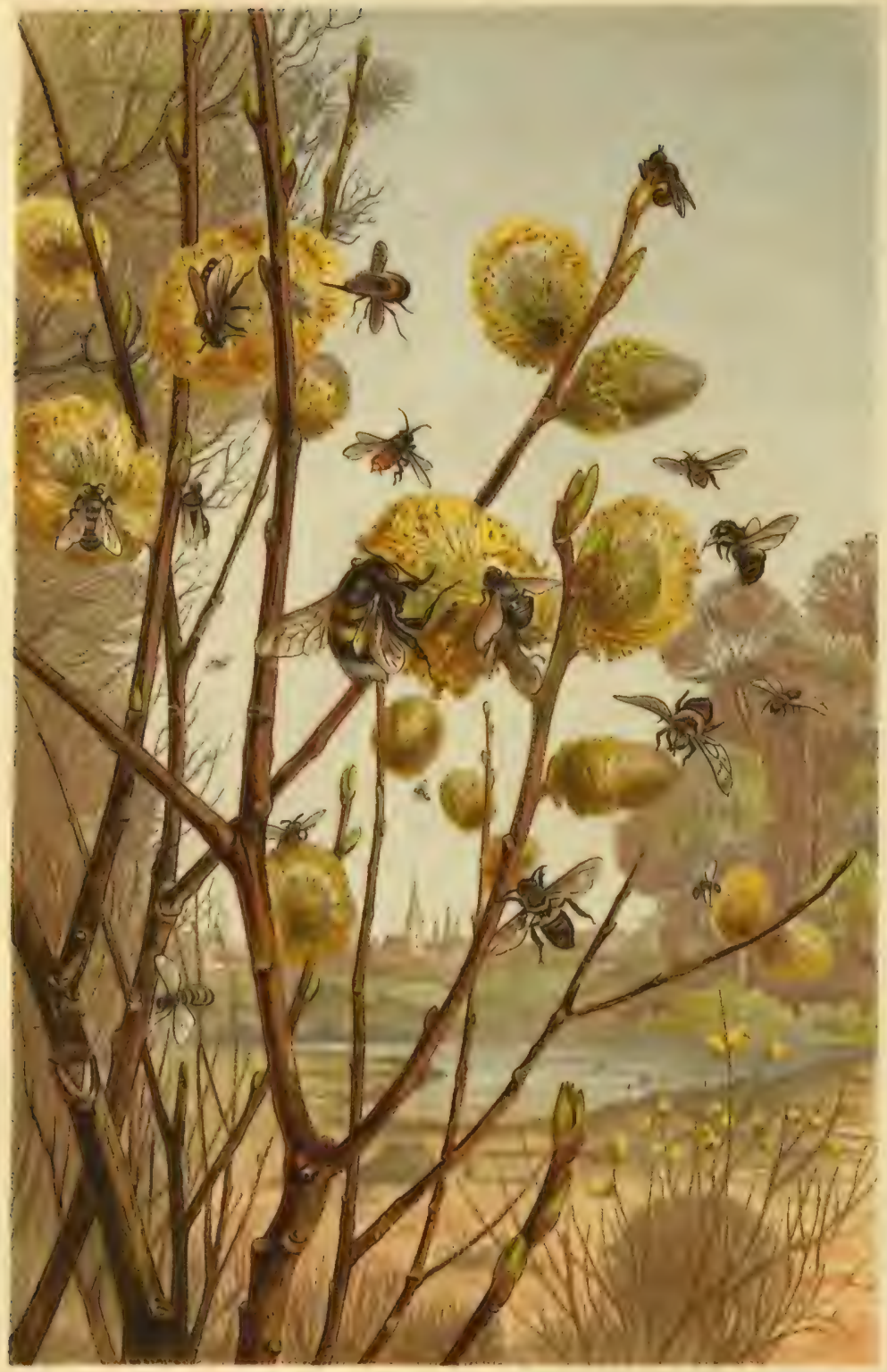




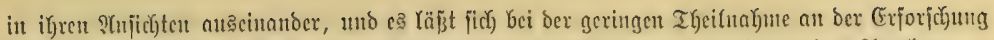

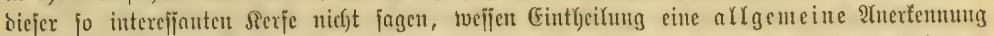

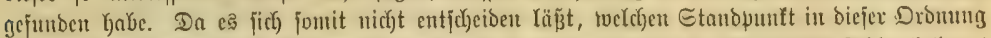

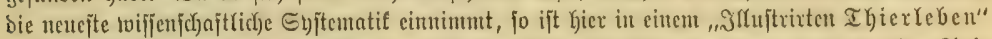
unb bei ber lüdenthajten $\mathfrak{B e r}$ and

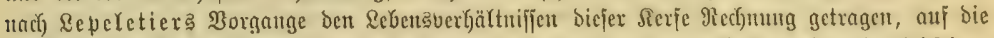

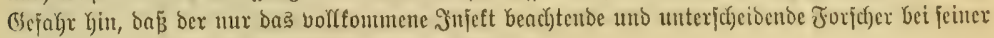
Stnorbuung ou anberen Ergebnififen gelangen fönute.

Die Brumentwespcu, Bienen (Anthophila), tweldye wir als erjte Framilie an bic Epilze

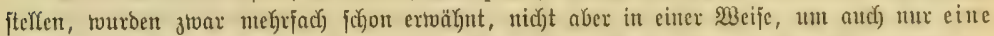

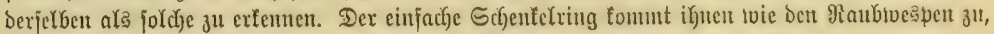

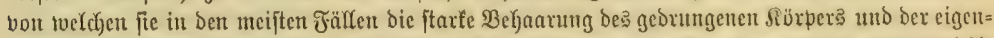

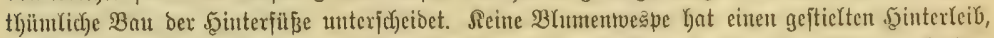

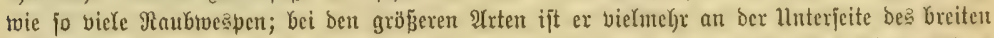

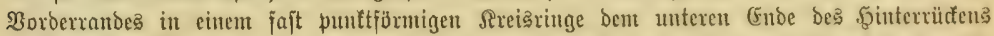

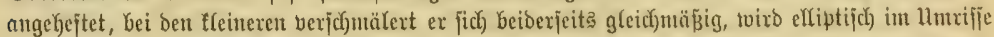

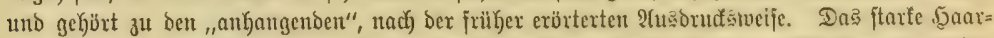

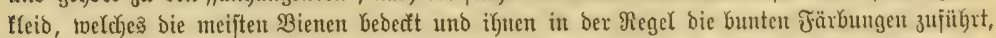

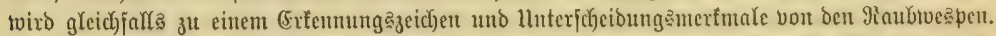

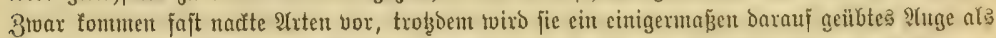

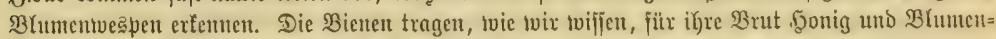

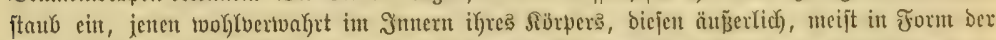

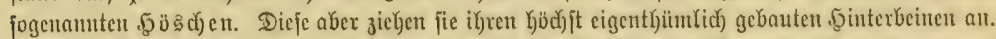

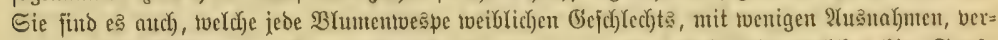

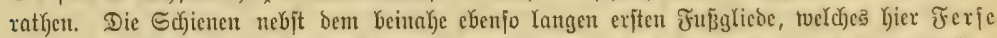

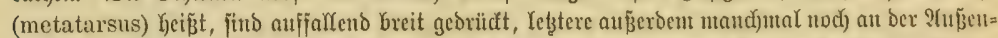

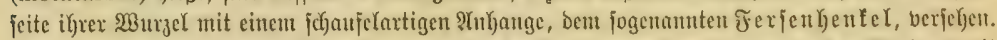

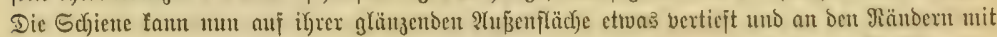

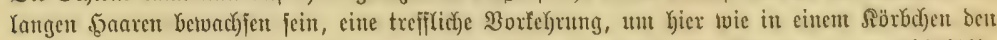

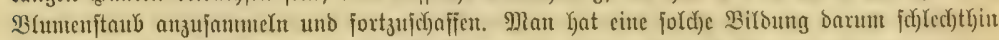

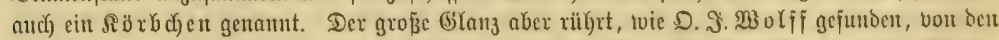

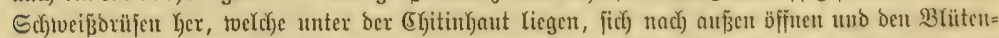

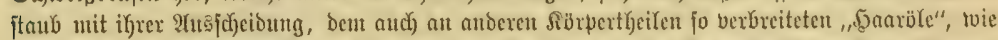

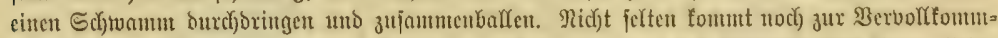

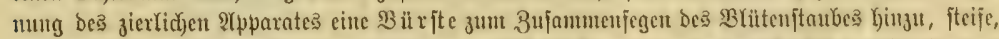

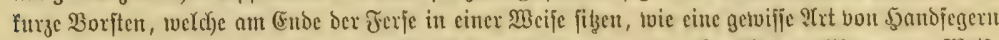

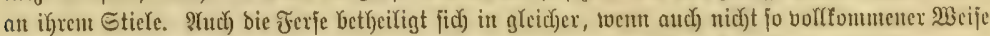

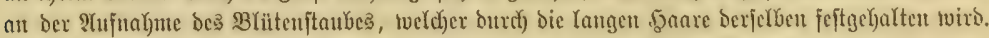

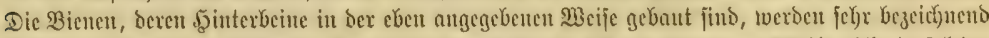

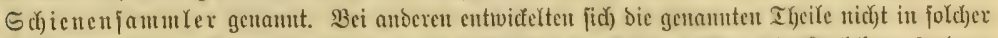

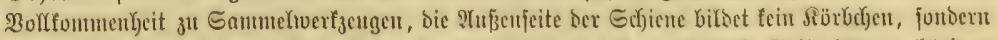

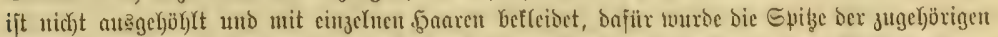

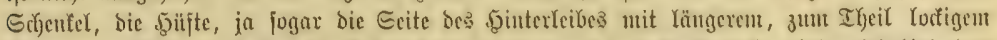

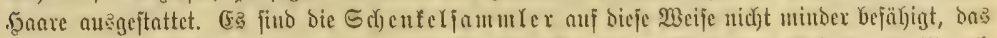

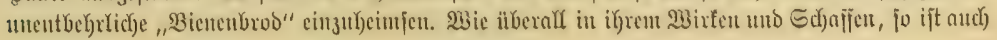




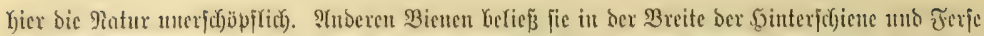

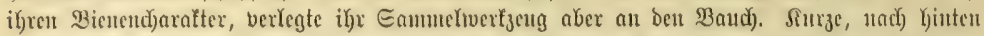

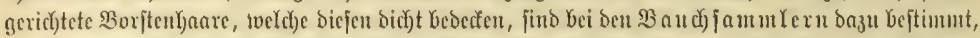

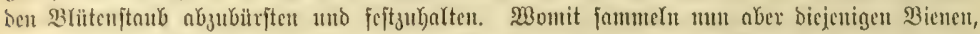

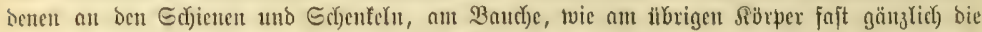

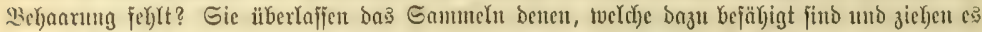

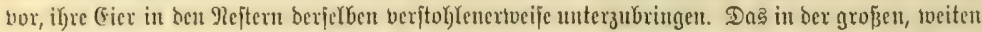

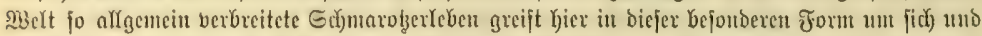

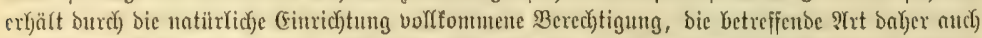

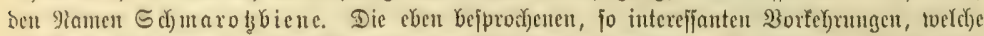

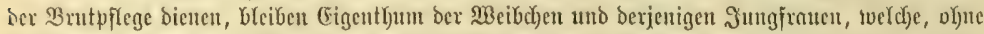

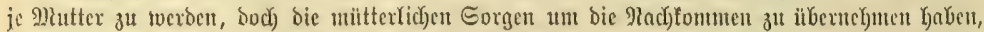

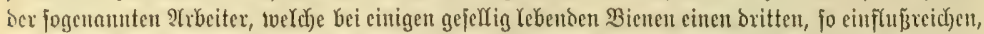

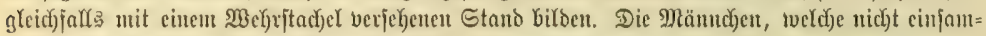

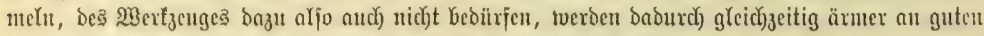

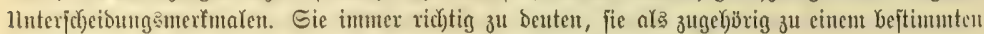

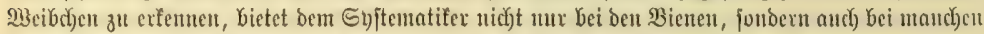

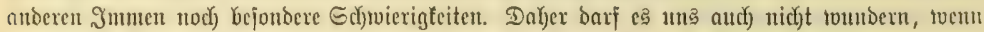

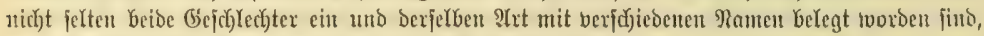

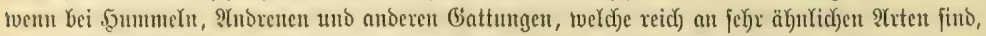

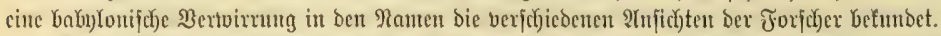

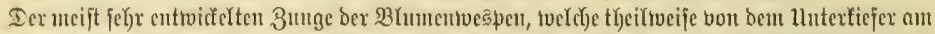

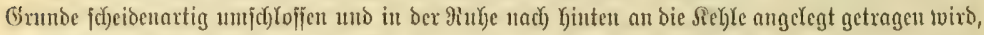

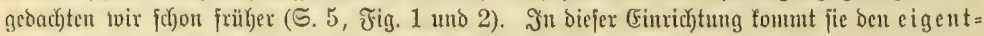

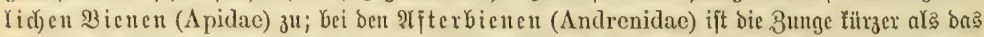

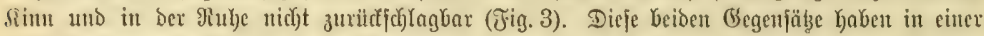

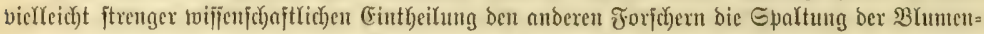

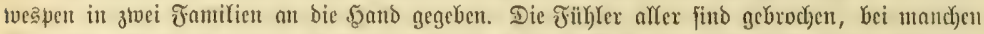

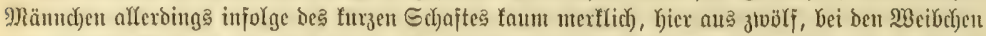

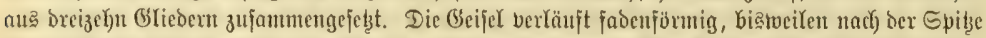

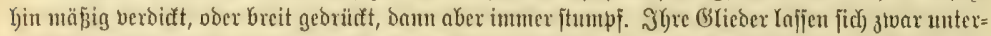

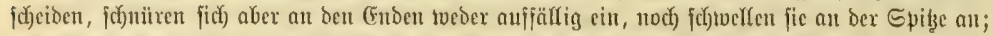

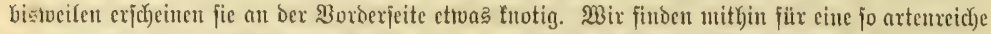

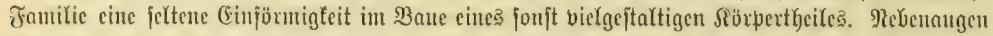

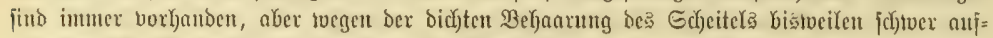

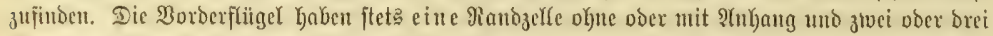

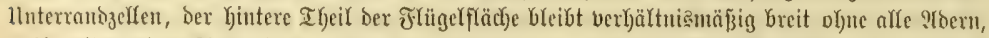

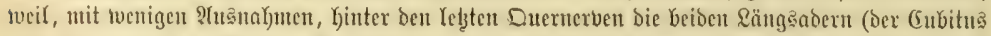

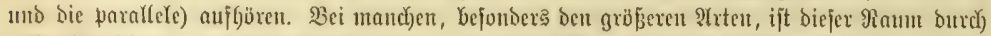

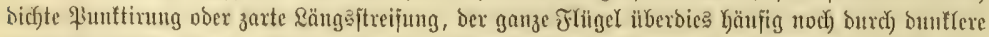
Färbung ausgeseicfunct. Wo nur ztvei Unterrandzeflen vorfommen, mlinden bic beiden rürf=

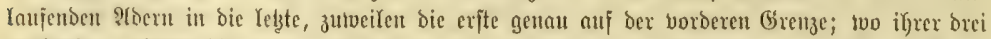

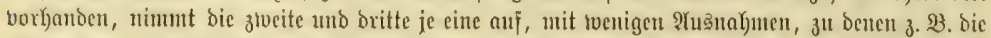

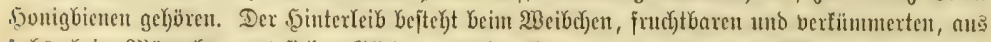
fect)

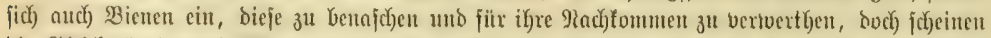

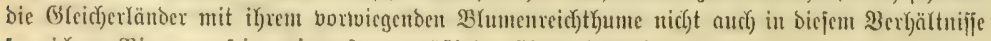
fo reich) an Bienen zu fein, toie unjere gemäpigten Đimmeläftriche. 
Die gemeine 5outigbicue, 5a ausbicue ( $\Lambda$ pis mellifica), zeichuet fich) ourch ben Manget

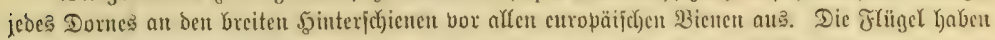

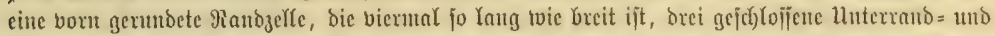

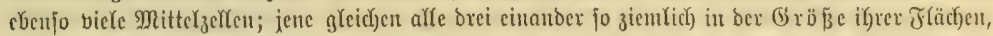

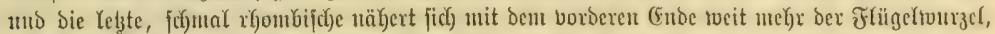

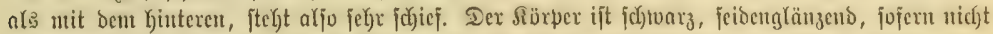

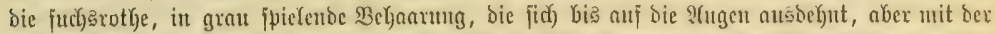

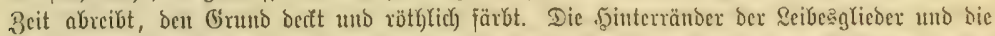

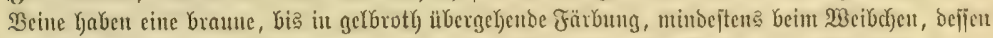

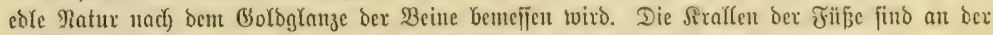

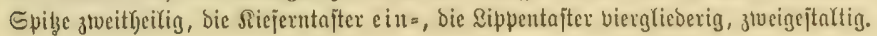

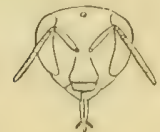

a

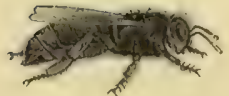

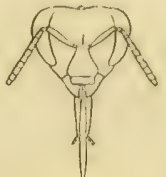

b

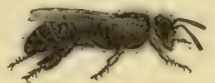

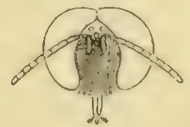

(5)

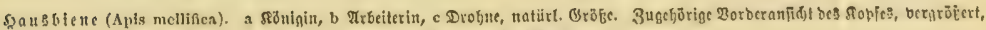
iber feoce ber brei formen.

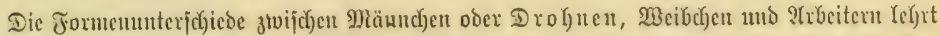

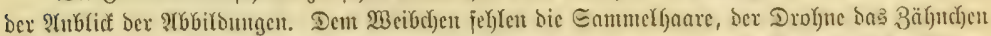

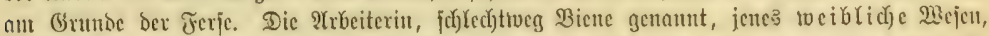

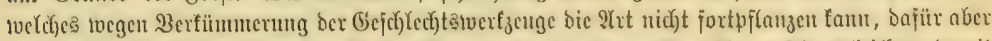

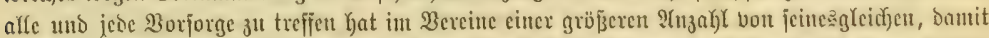

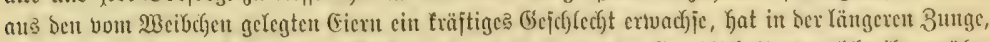

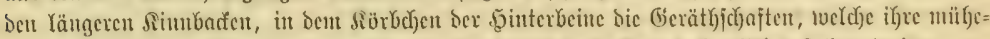
volfen ?treiten ate

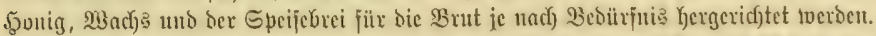

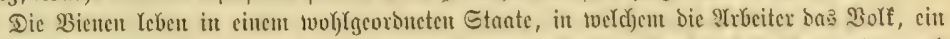

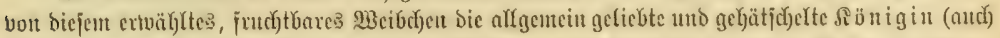

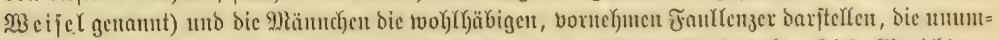

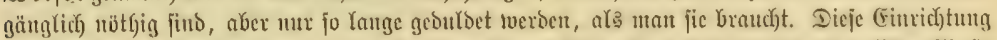

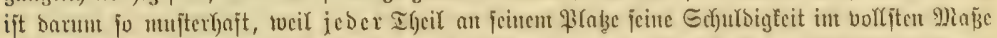

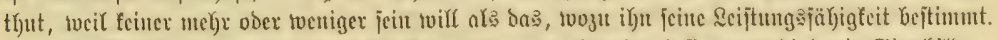

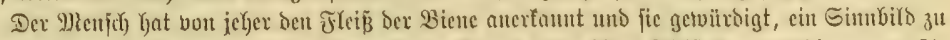

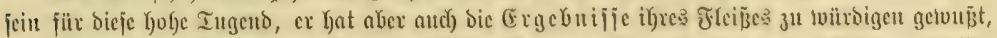

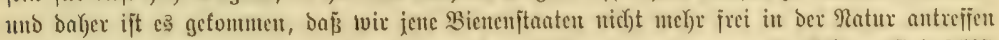

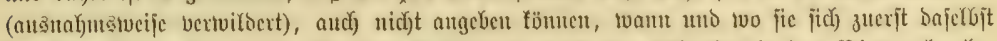

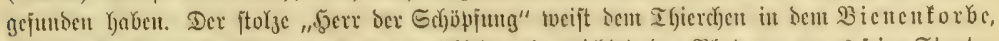

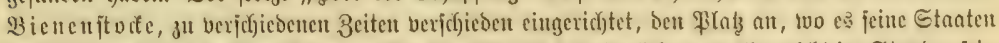

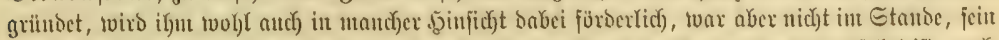

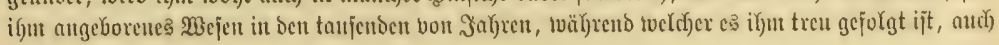




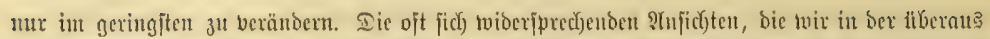

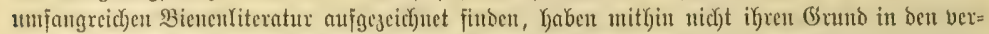

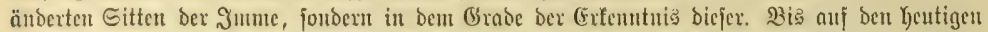

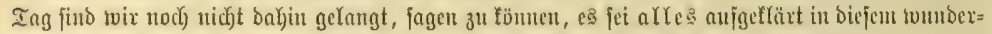

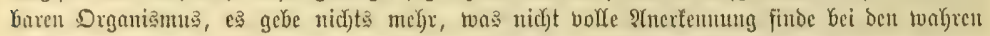

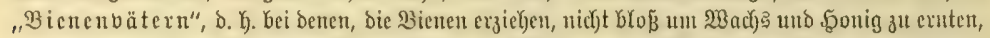

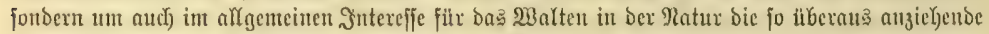

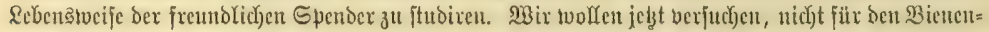

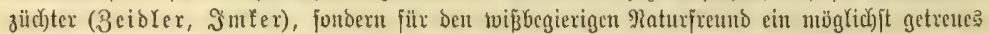

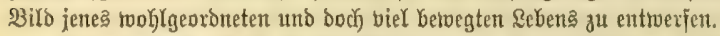

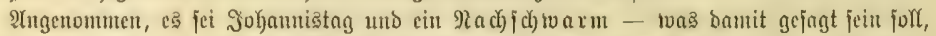
wixb bie Folge Yehren - poeben bolfitänoig cingejangen in einen Yeeven fiajten mit ben befanuten,

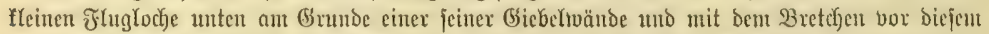

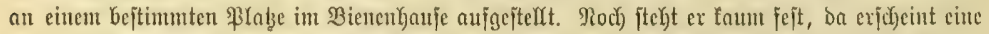

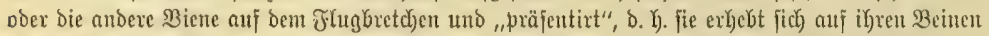

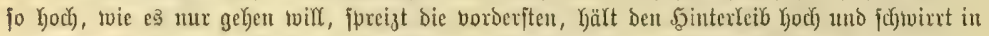

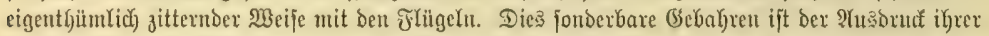

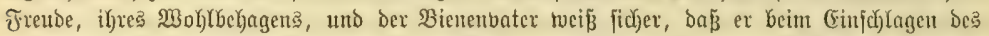

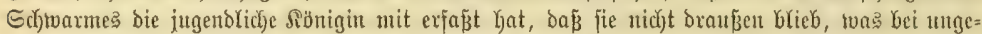

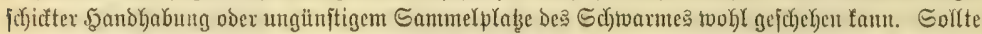

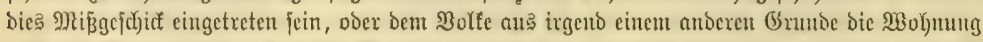

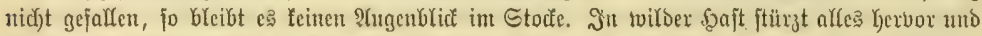

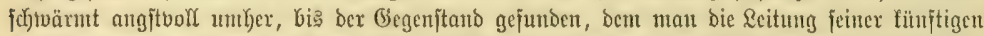

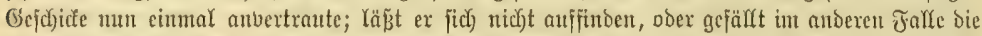

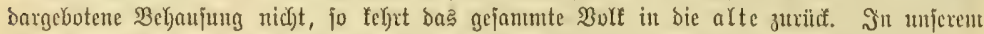

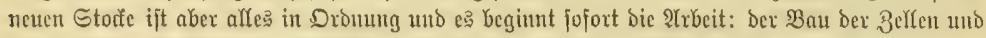

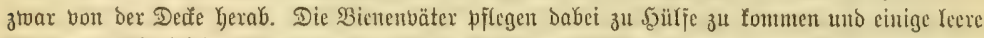

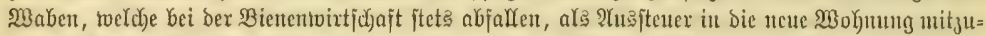

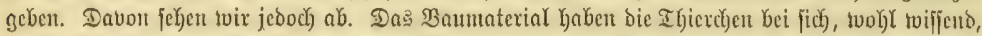
Daß̧ bie Käus̆

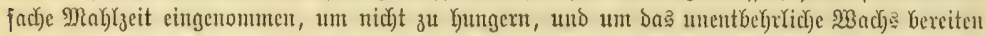

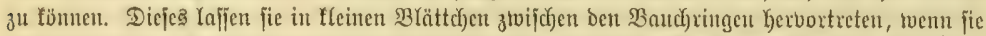

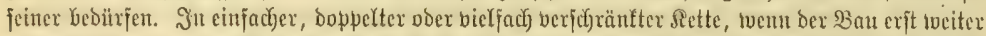

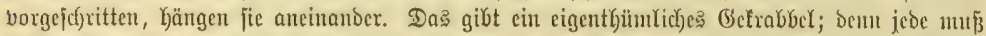

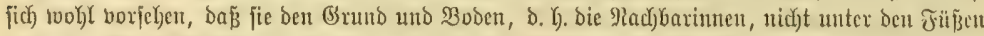

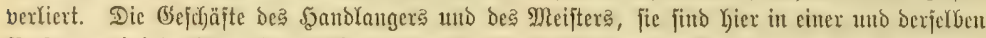

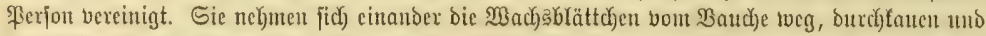

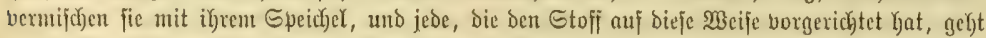

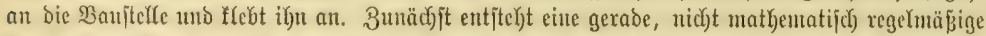
Siante ober Reijte, an bieje twerden rechts und Yintes mit ben Sciten ancinander ftopende ano mit

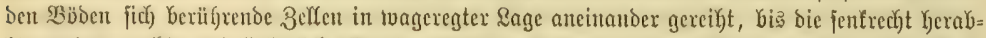

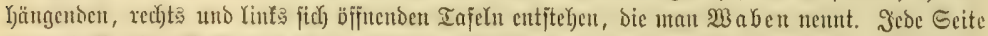

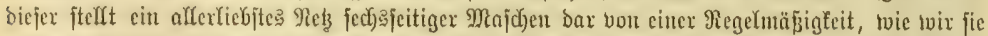

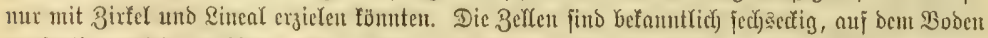

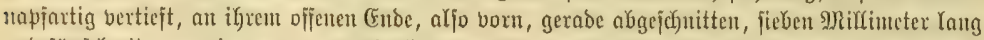

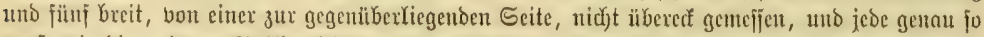

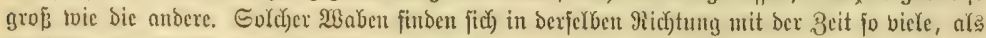

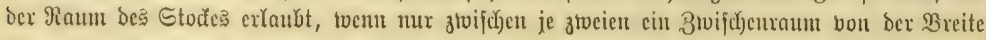




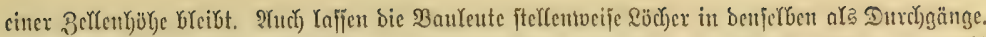

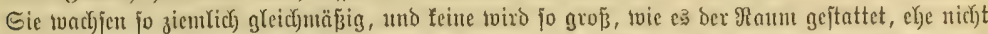
bie antorent angelegt und gleidfyeitig mit ertweitert tworben. Dod) greifen wir ber (Eiturichtung nicht

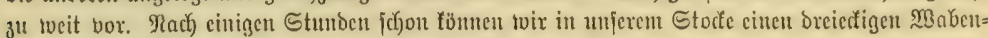
jipfel bon etro 10,5 (Eentimeter ins Beviert Kerabyängen jehen.

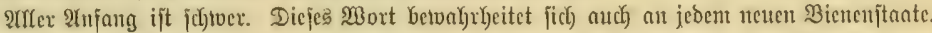

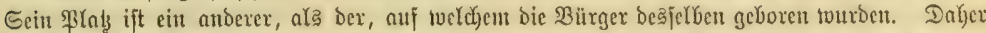

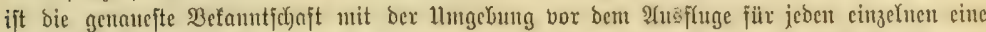

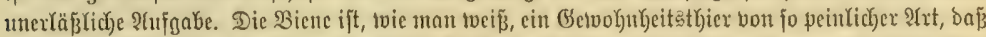
fie mebrere Male erit genau an berjefben Stelle anfliegt, bie fie als ben (Fingang in ihren Ban

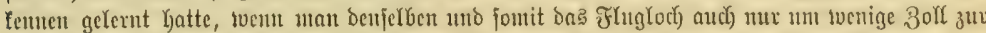

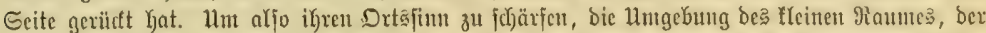

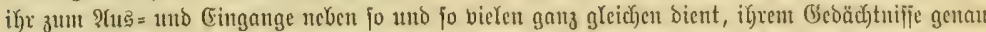

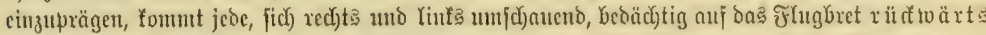

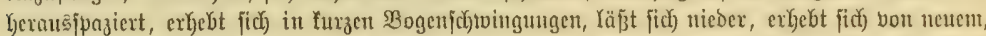

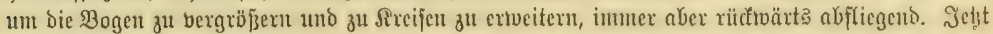

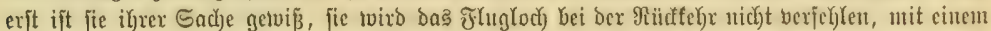

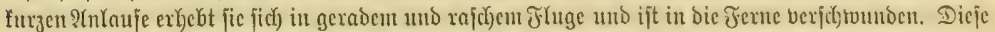

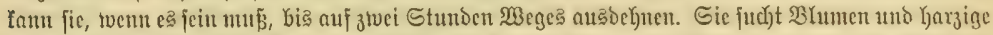

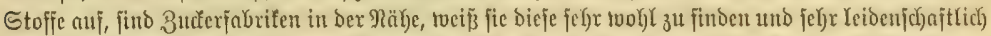

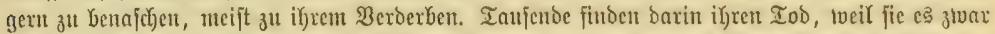
veriftehen, hituein, aber nidjt wieder Kerauşzufonmen. S(h)uer belaben fliegen fie gegen bie fenfter, arbeiten jich Daran ab, jaffen ermattet 34 Boben uno fonmen um. Biererlei viro eingetragen,

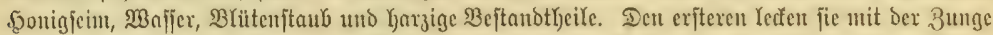

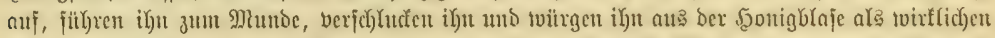

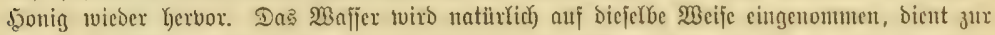

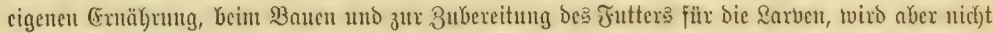

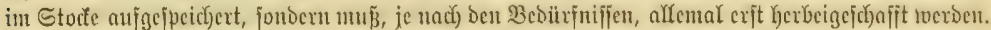

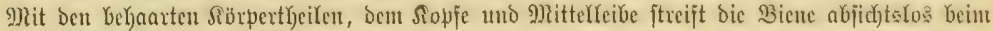

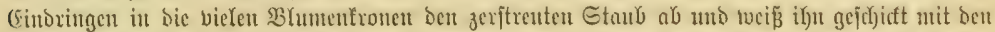

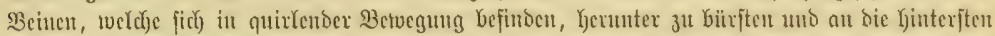

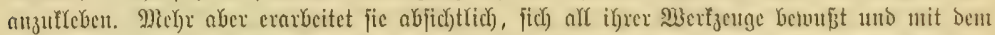

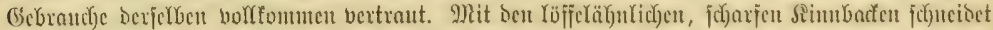

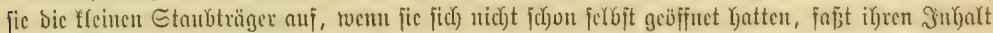

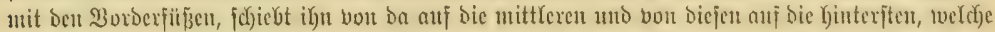

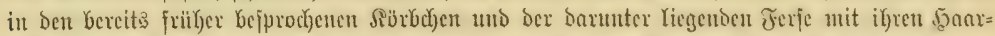

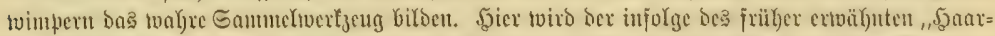

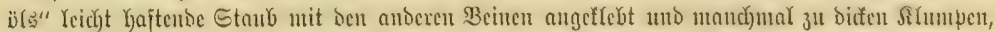

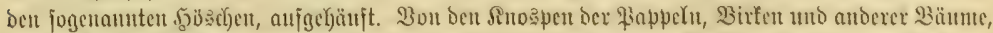

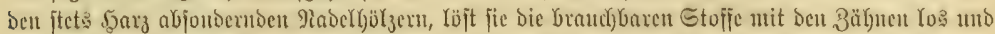

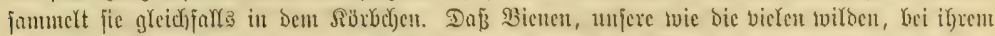

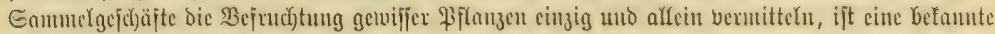
Thatjache, an welokje beiläuftg eximert jein mag.

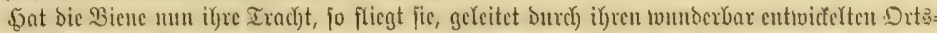

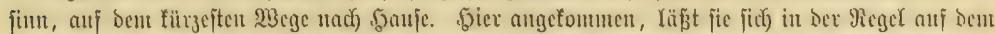

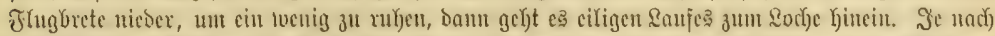

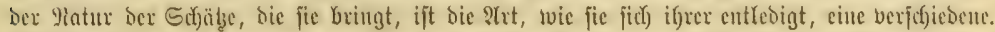

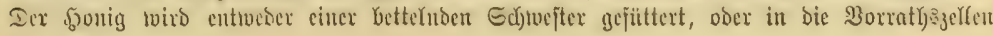




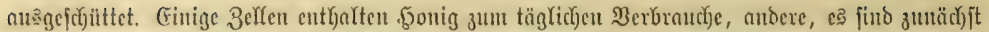

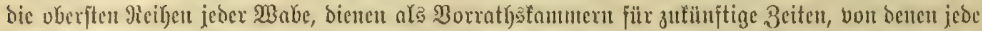
volfe fogleich mit cintent Mad)

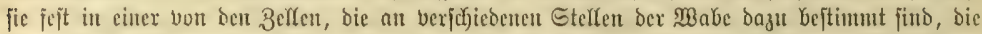

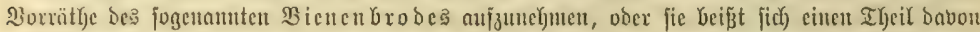

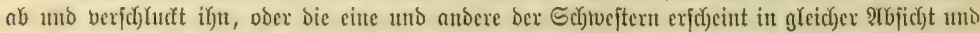

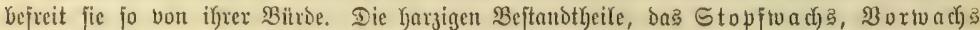

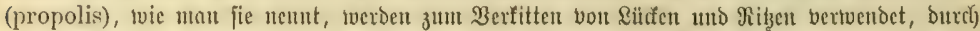

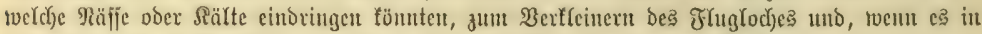

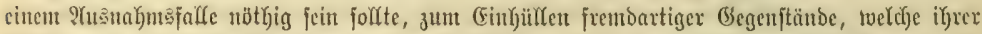

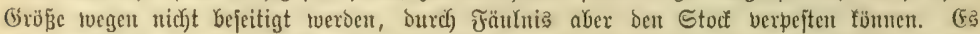

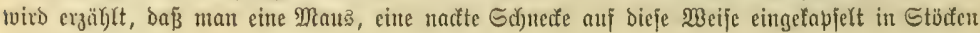
gejunden habe.

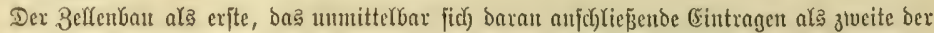

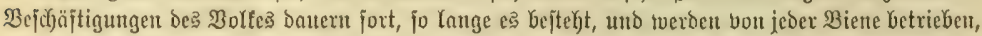

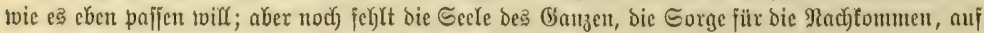

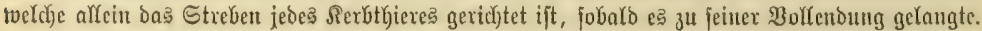

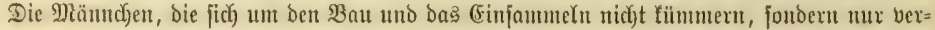

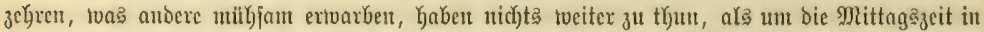

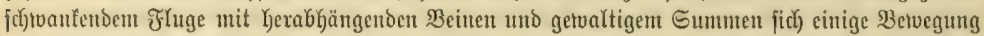

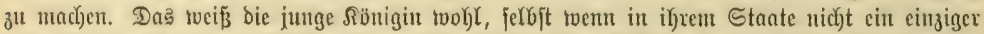

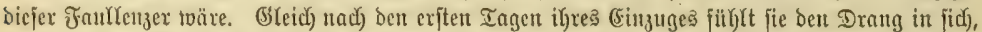

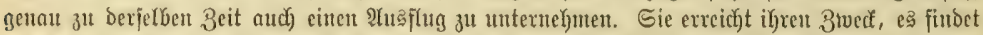

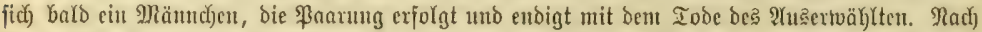

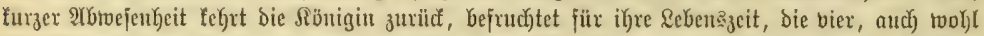

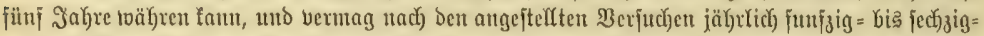

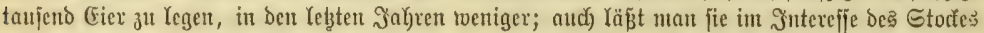

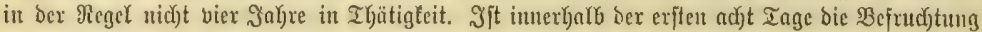

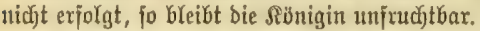

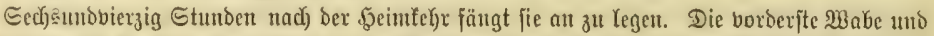

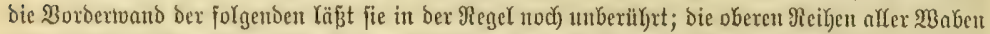

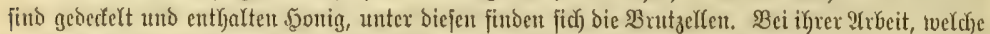

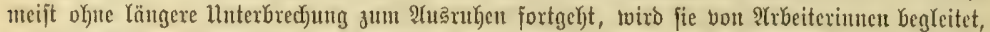

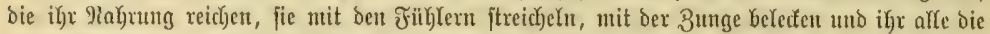

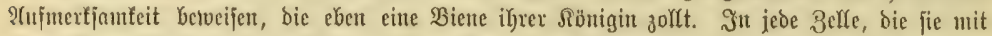

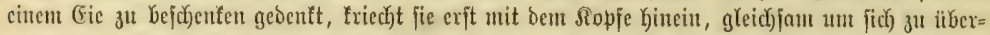

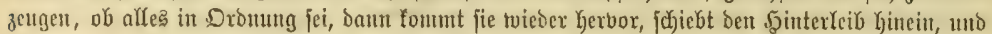
ijt fie tvieder heransgefommen, fo fieht nan Kinten zur Seite ber unteren Wanto unmittelbar ant

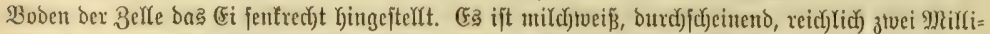

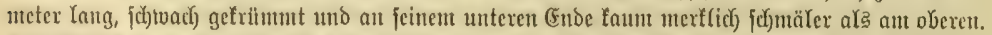

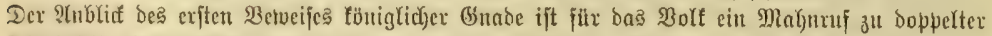

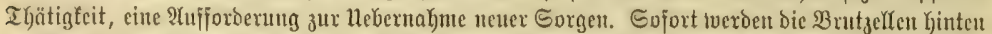

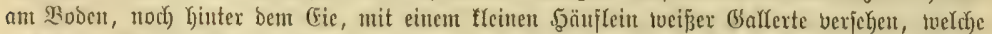

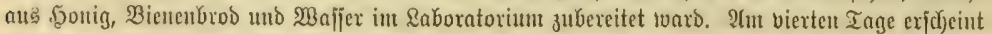

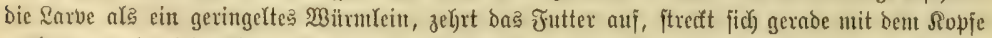

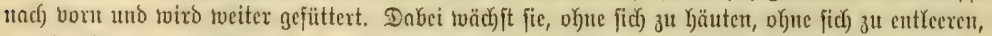

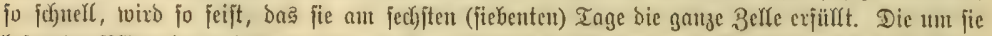

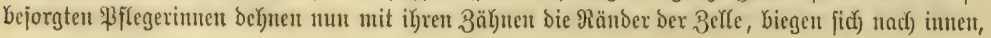




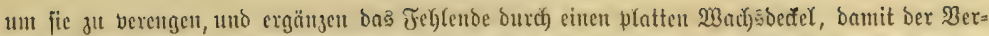

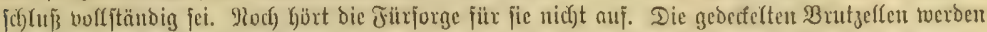

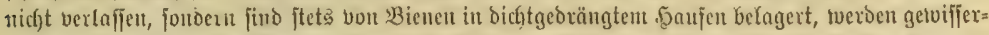

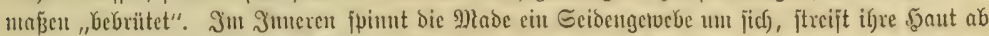
unto wiro zu einer genteifelten Puppe. 2(nt ciun

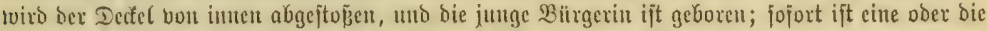

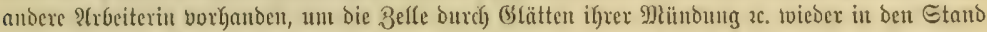

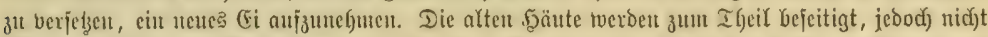

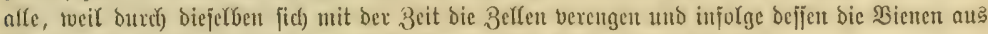

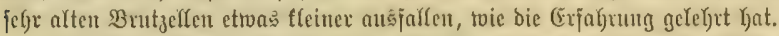

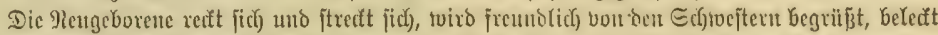

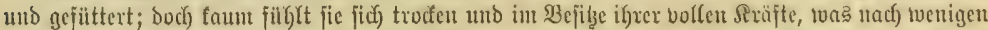

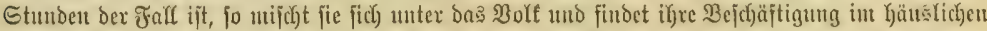

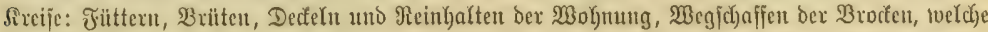

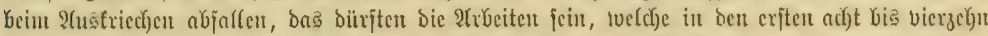

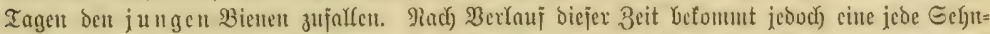

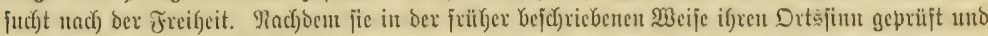

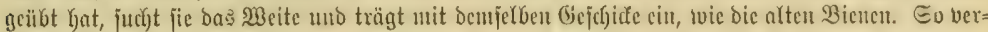

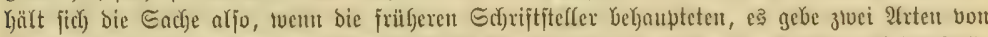

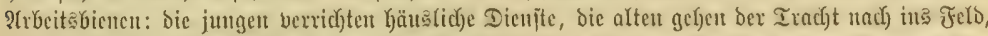

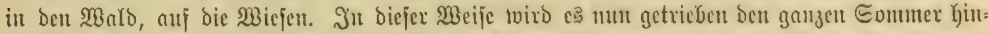

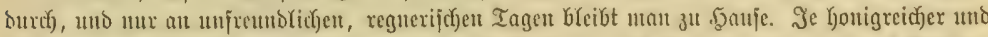

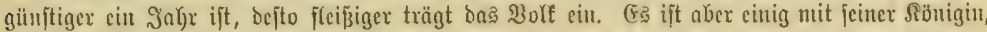

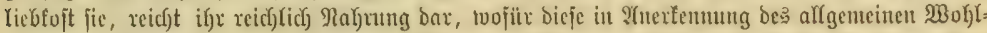

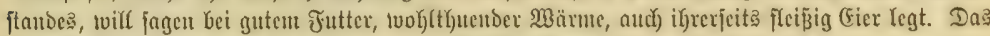

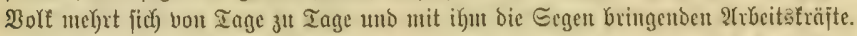

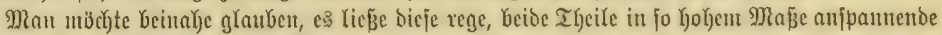

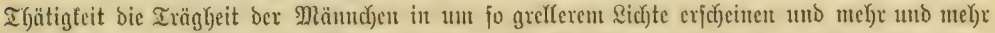

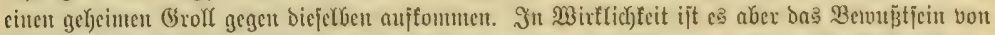

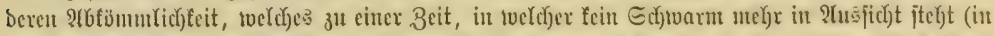

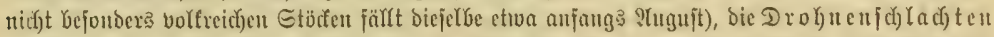

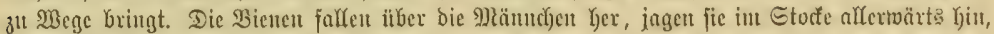
treiben fie in cine Edfe uno fperren jie bour Futter ab, jo on

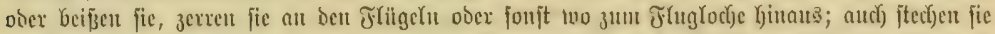

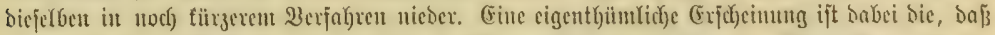

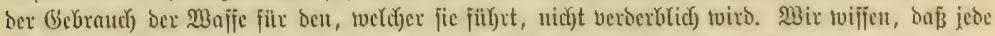

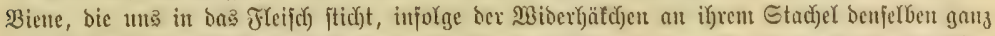

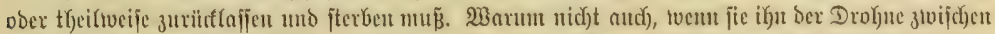

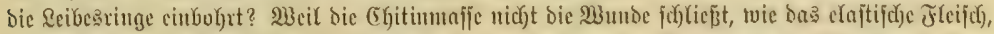

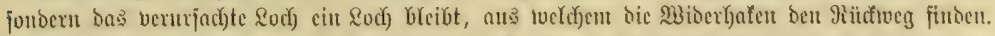

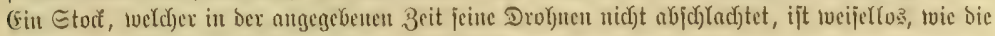
Bienenväter felgr wohl in (Exjahrung gebradjt haben.

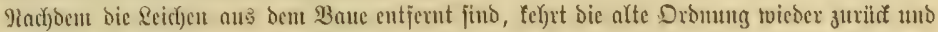

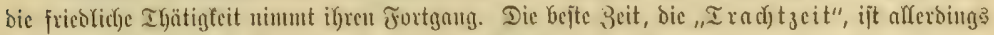

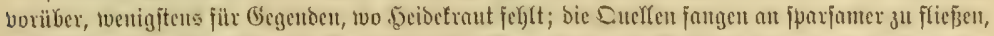

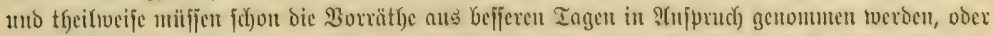

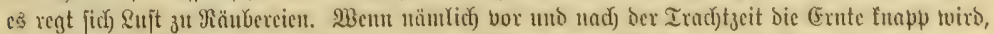

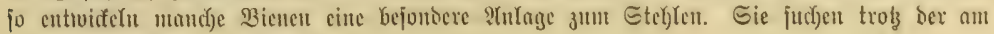

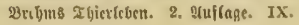




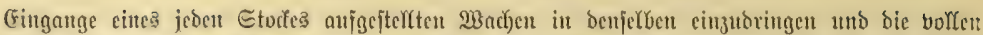

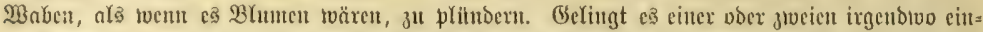

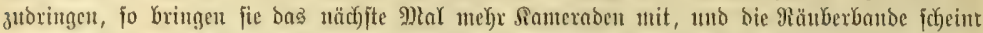

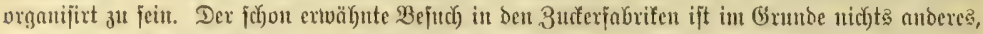

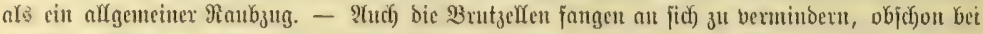

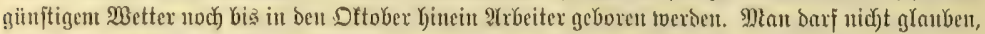
Баई

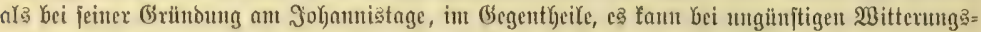

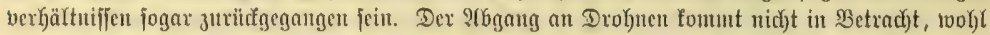

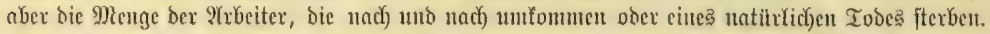

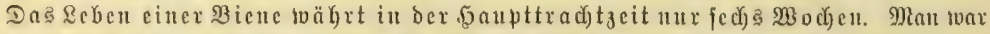

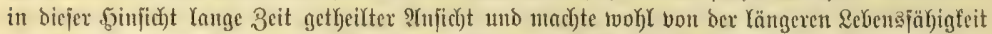
Der Sönigin einen Irugid)

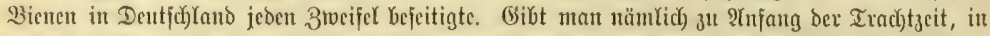

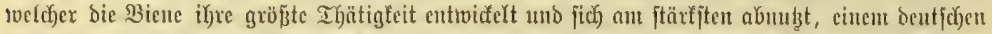

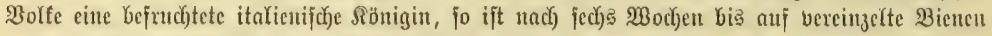

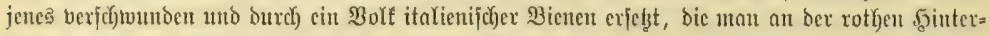
reibatuurzel obne Mühe bon unjerer nordifchen Spielart unterjacheibet.

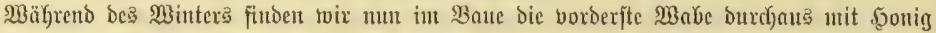

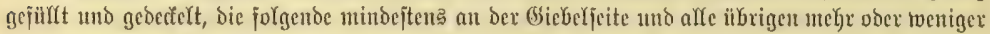

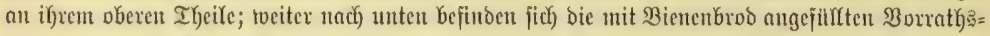

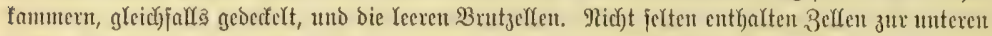

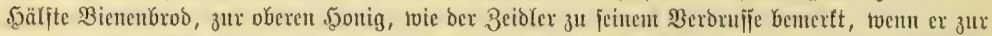

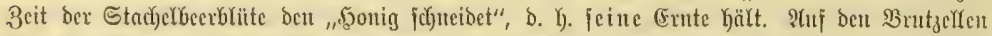

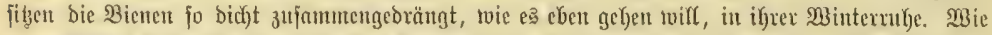

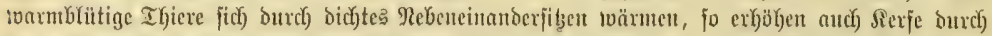

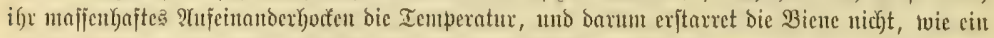

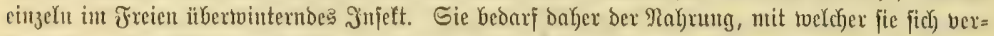

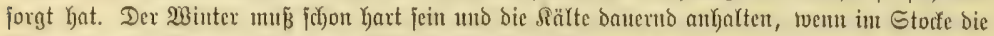

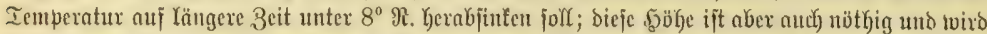

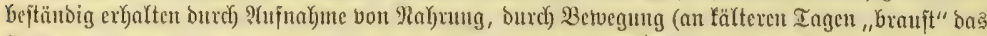

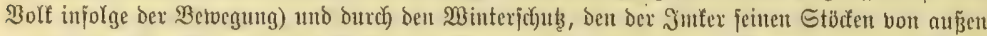

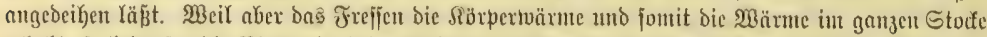

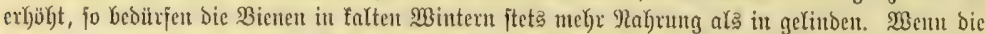

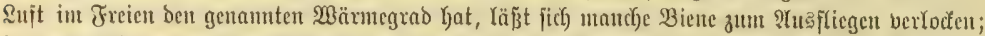

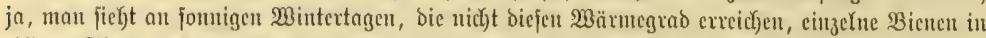

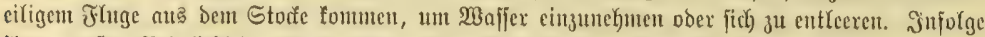

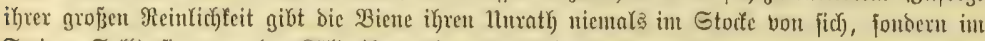

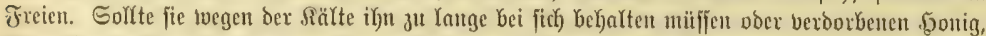

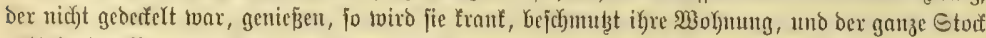

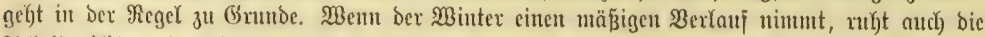

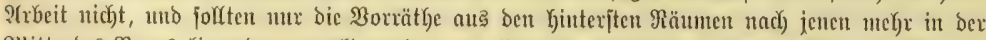

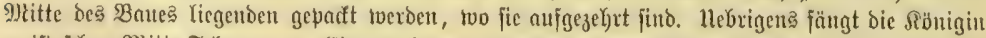

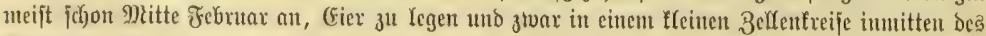
Minterfagers.

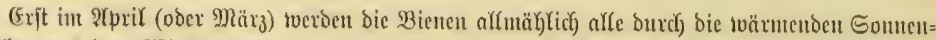

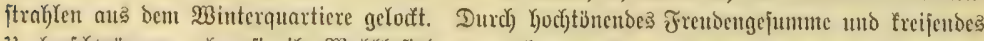

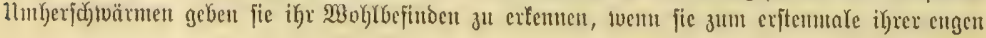




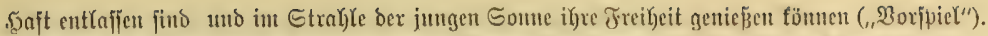

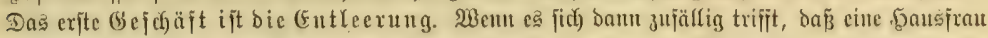

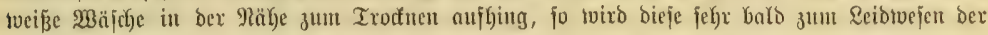

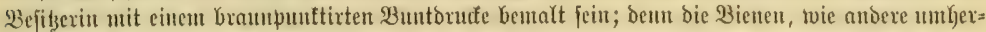

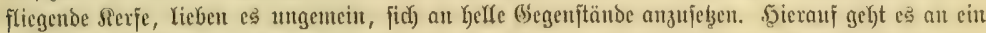

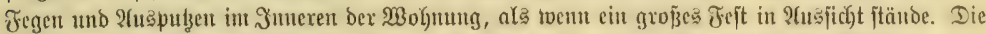

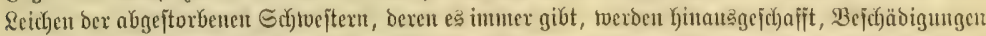
a

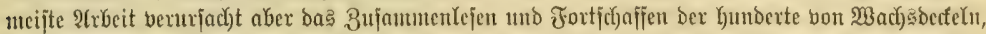

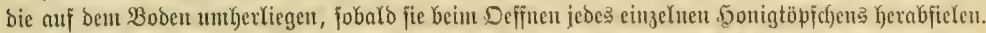

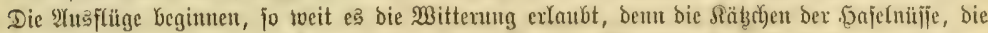

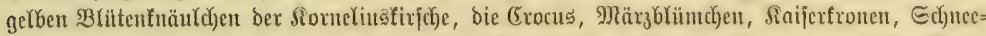

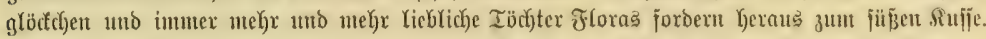

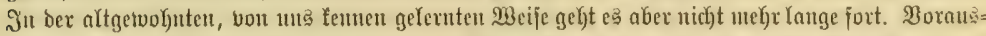

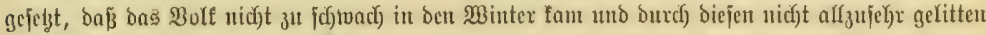

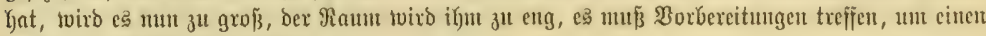

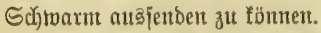

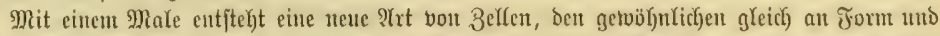
Sage, aber größer Dem Innenramue nad). In bieje legt bie Rönigin genau in Der frïfer

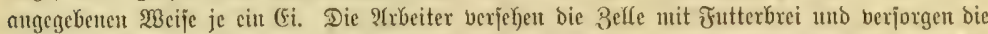

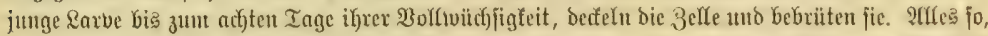

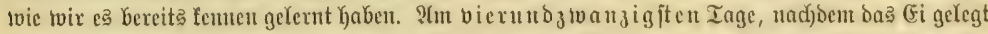

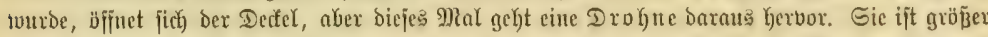

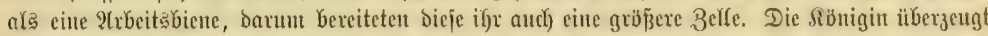

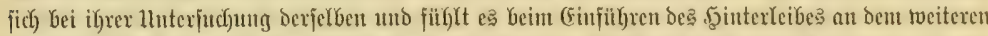

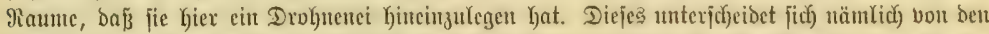

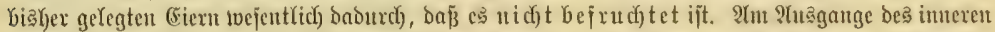

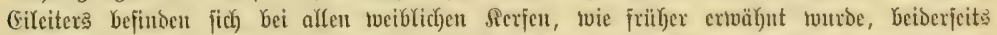

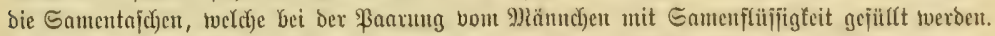

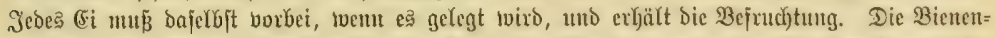

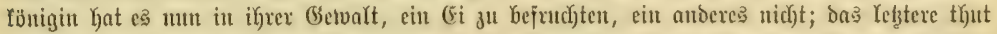
jie mit affen benen, toeldye in bie gerüumigen Drohnenzelfen abgejebzt tuerben. Fine tounderbare

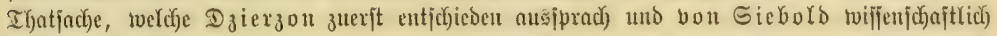
hegriindete.

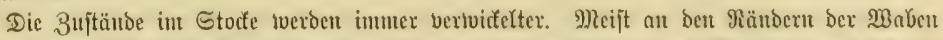

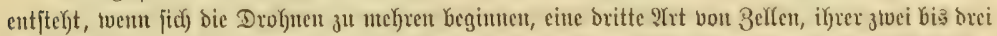

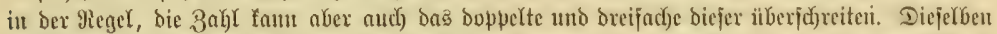

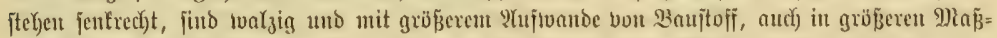

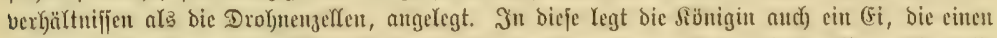

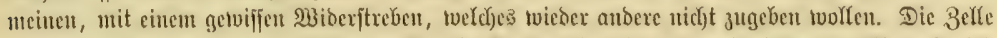

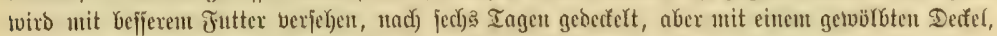

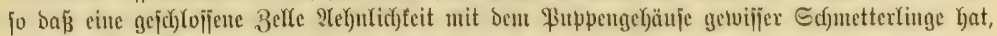

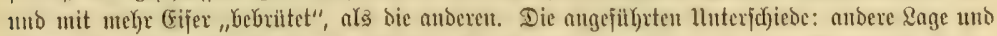

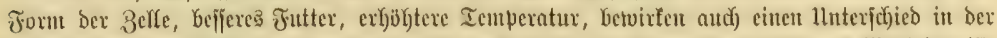

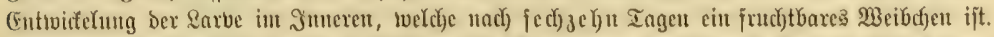

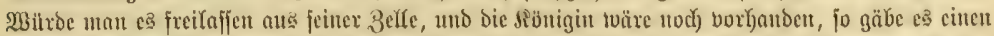

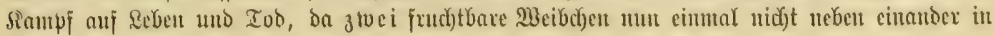

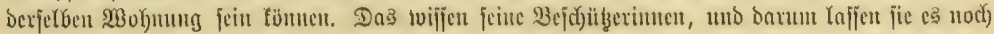




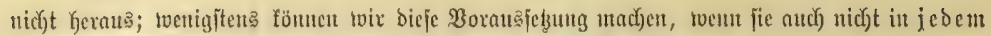

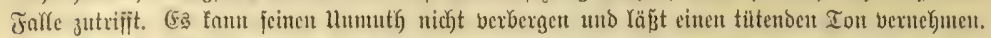

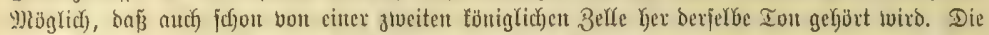

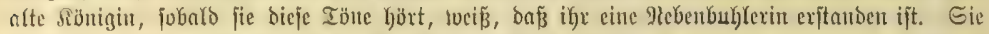

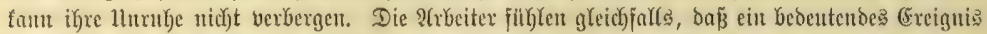

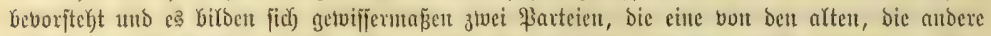

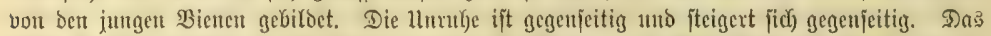

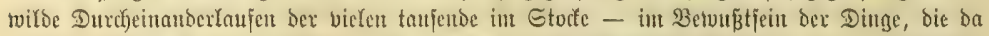

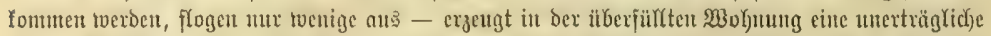

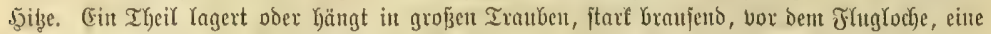

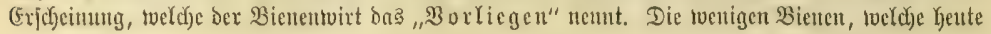

2

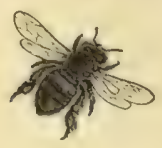

3

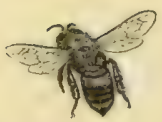

1

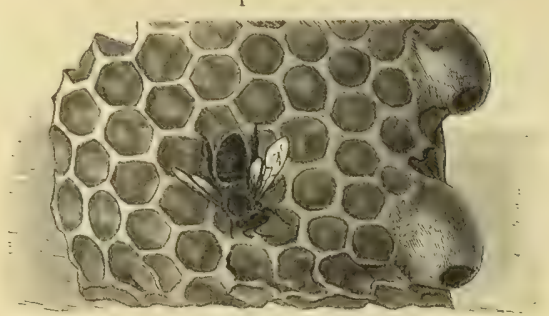

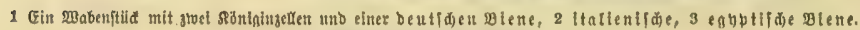
oftes in ratirlidec Gróge.

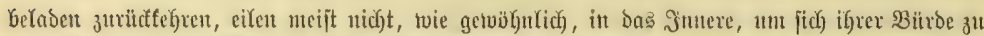

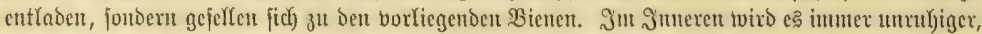

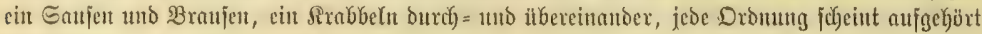
at habelt.

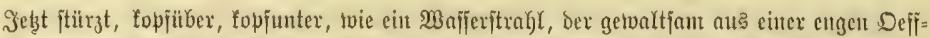

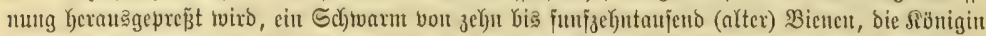

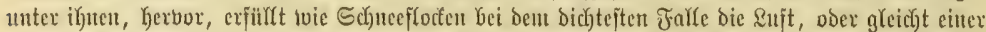

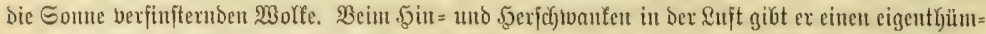

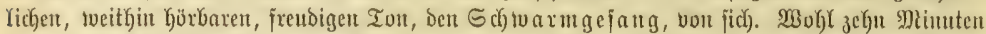

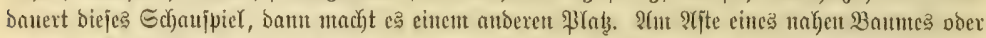

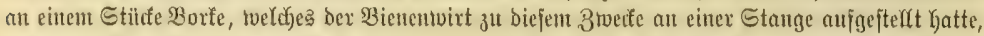

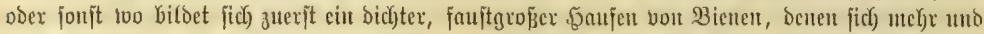

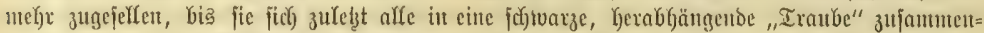

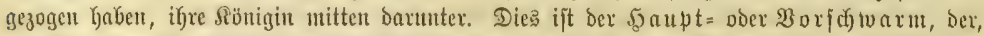

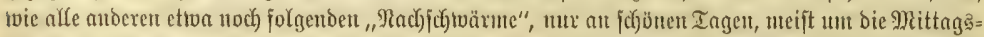

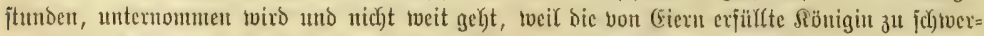

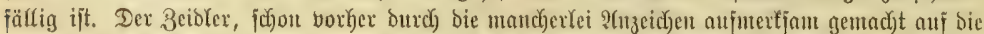
Dinge, die ba fonmen folfen, hat cinen ncuen Saften, cine neue WaYge, ober wie ex forfft feine

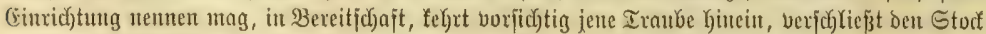

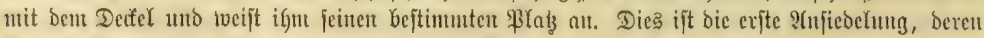

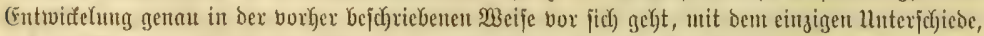

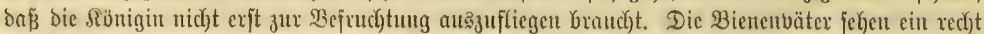

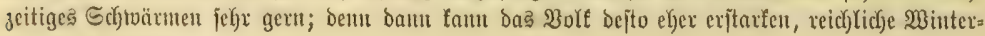




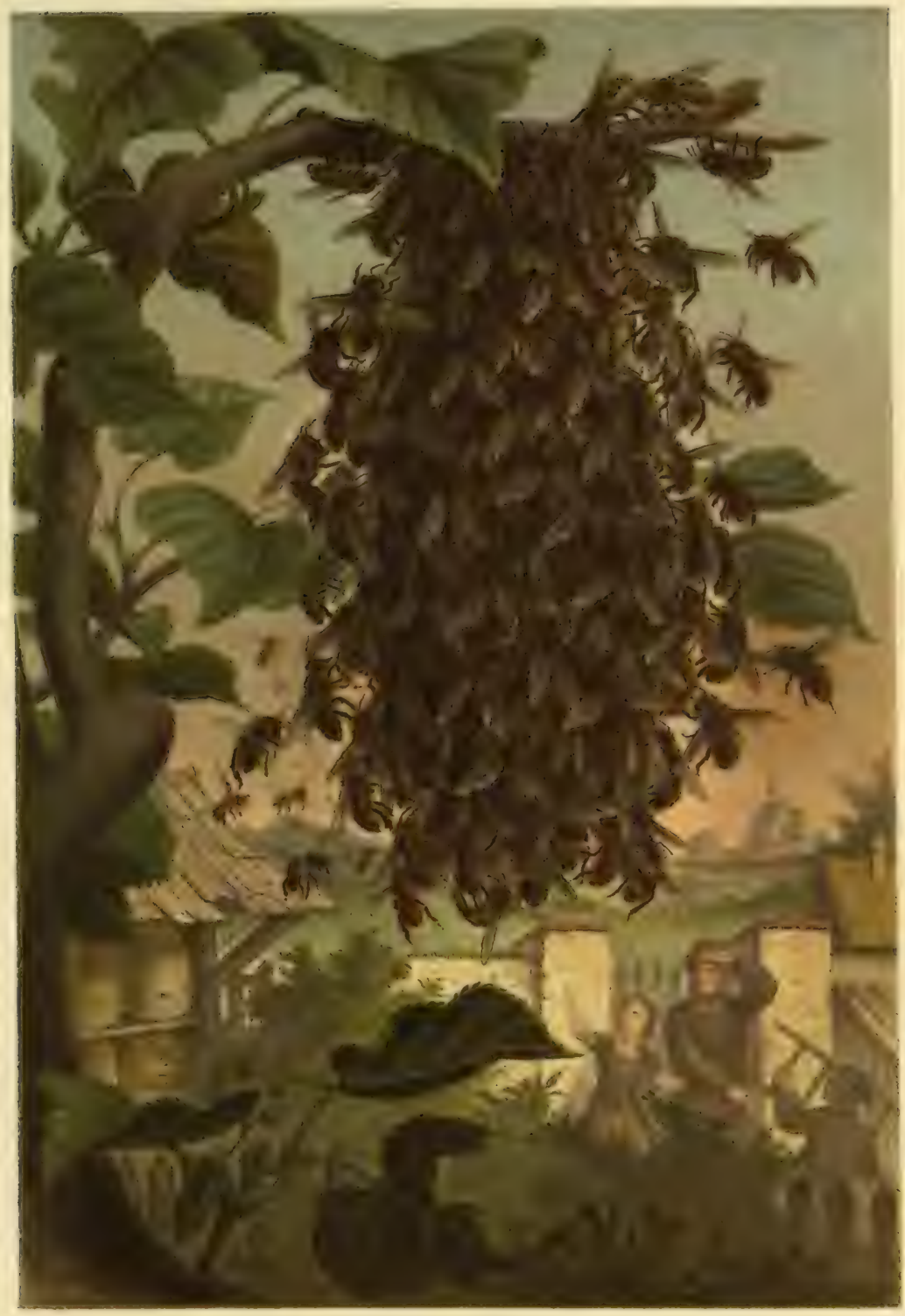

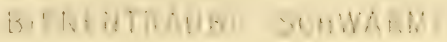





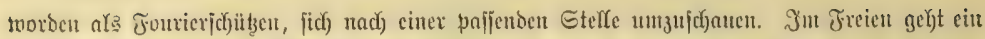

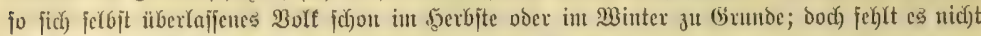

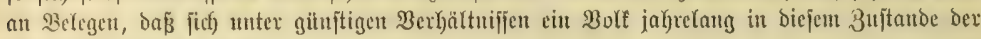
Berivilserung getjalten hat.

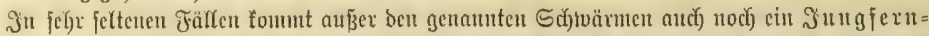

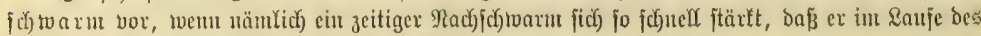
Eonumers cinen neuen Sdyromt abjtopen fant.

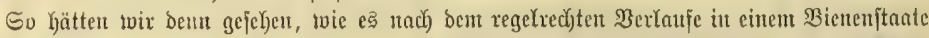

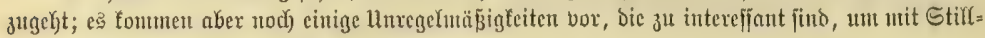
jütweigent Hibergangen twerden zu Dïrfent.

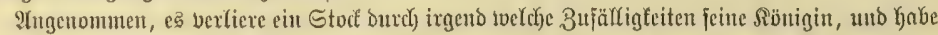

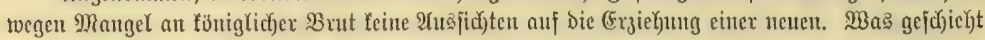

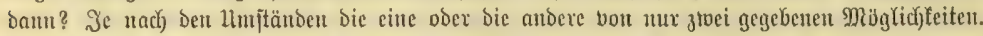

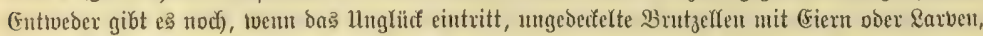

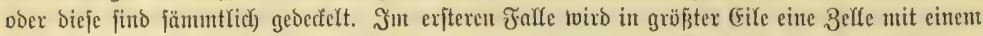
(Sie ober cinex jefhr jungen Mabe zu ciner föniglichen umgebant. Mlan trägt fie ab, entfernt bie

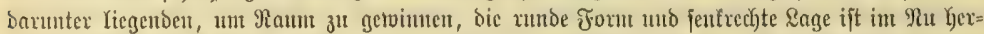

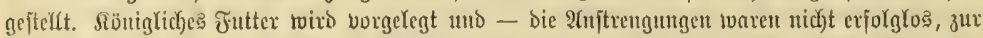

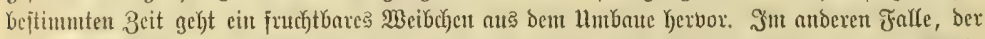
Dicję T)

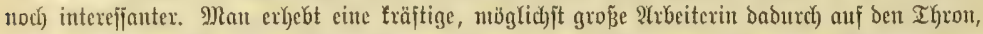

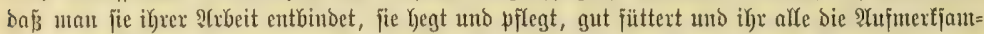

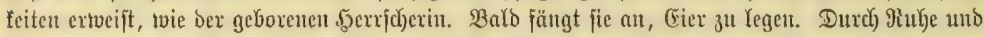
Bflege entwide

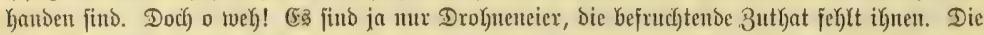

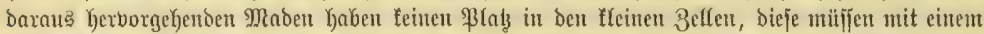

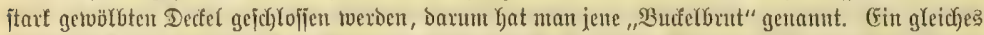

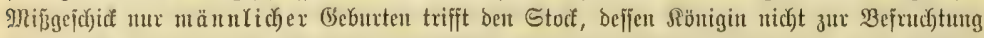

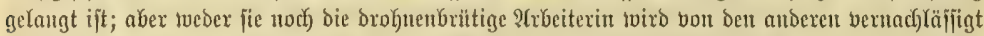

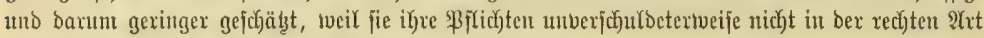
crfilluen fönter, twie von einigen behauptet toorden ift.

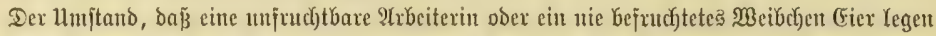

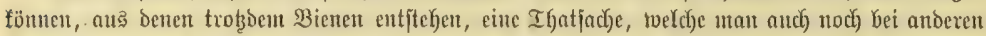
Rerfen, bejonbers bei einigen Schnetterlingen aus ber Eippe ber Sactträger beobad)tet hat, uno

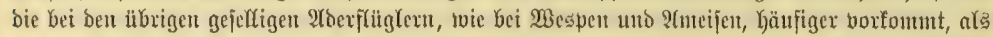

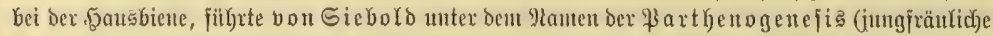

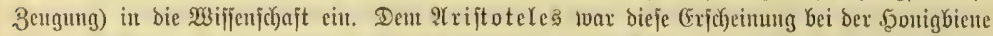

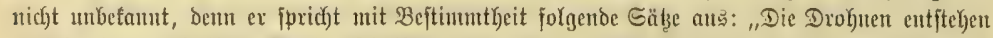

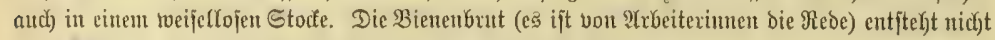
ohne Rönigix. Die Bienen erzeugen ohne Begattung Drohnen".

Slopjt man an einen Stod, toefcher feime Rionigin hat, jo bernimmt man ein fofort tvieder:

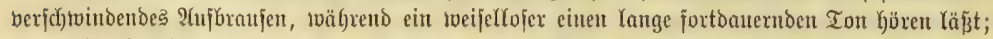

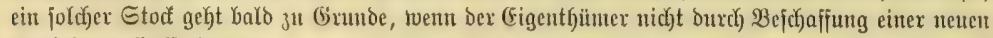
Sönigin zu Sullie fonmt.

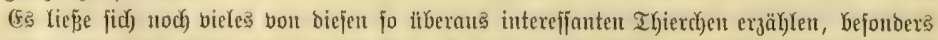

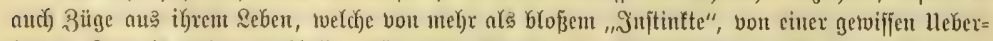

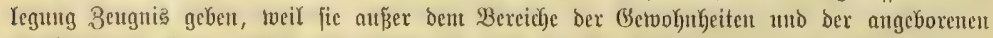

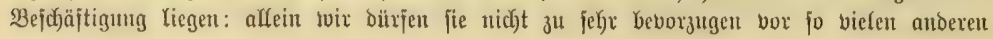




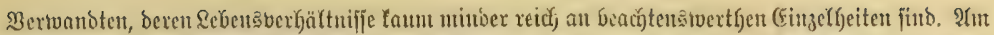

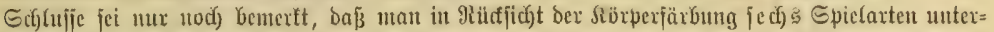

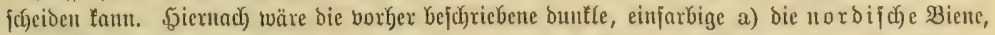

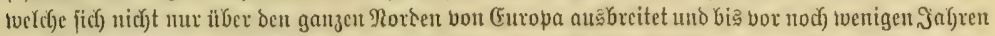

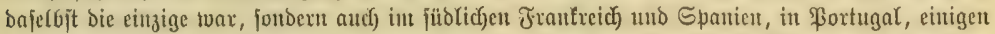

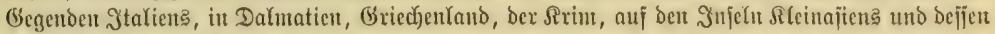

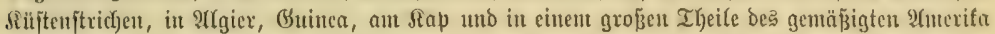

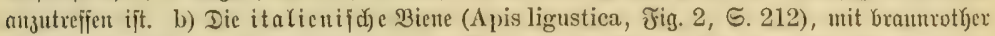

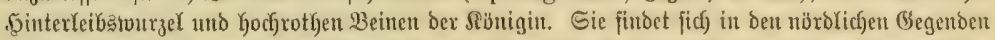

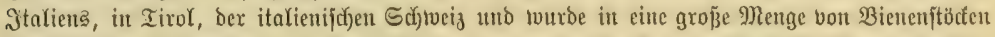

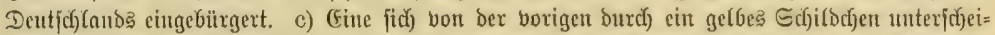

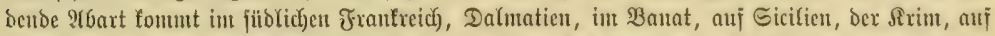

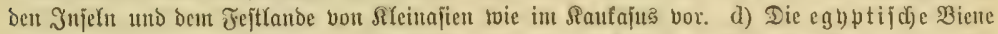

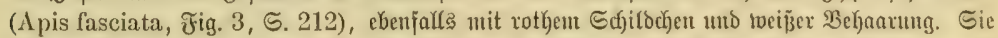

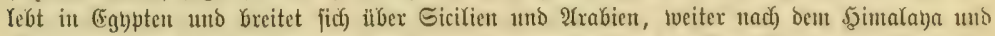

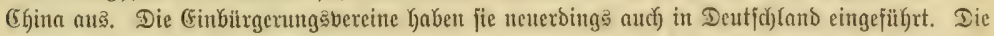

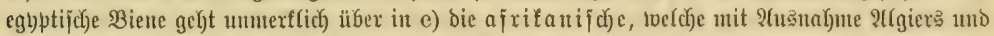

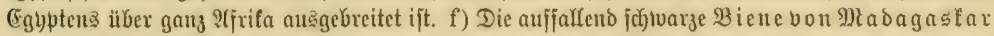

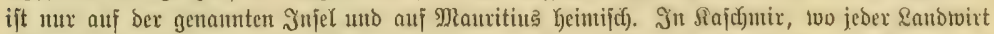

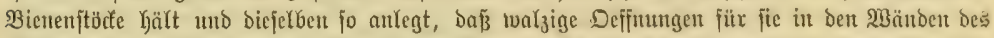

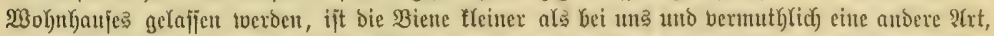

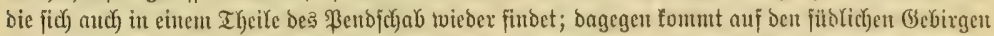

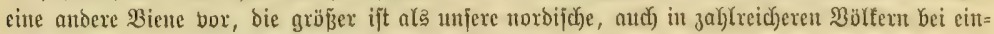

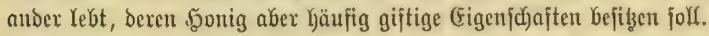

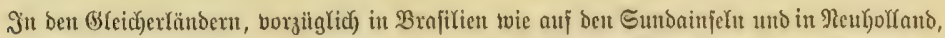

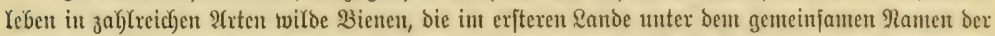

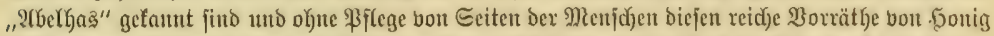

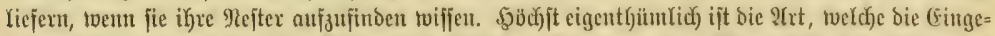

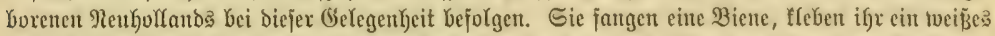

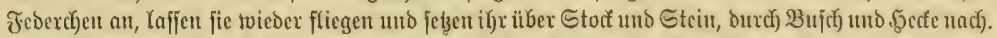

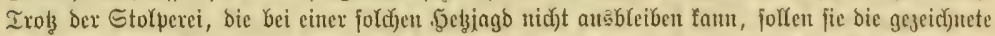

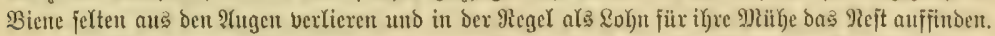

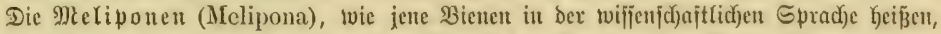

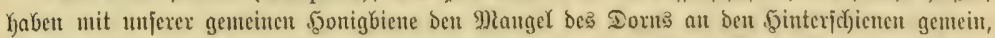

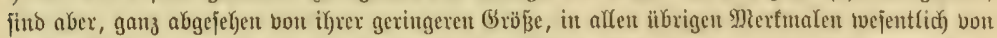

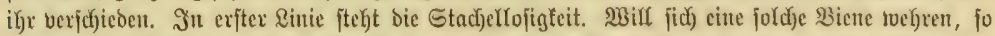

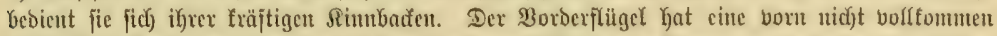

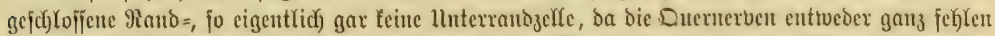

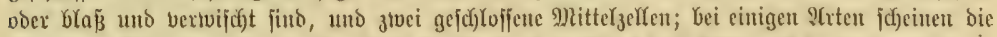

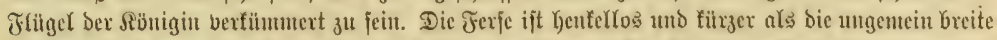

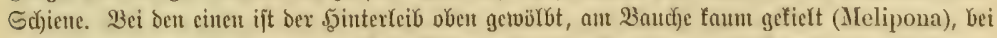

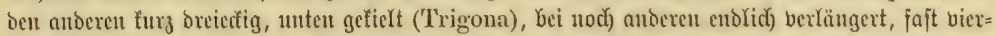

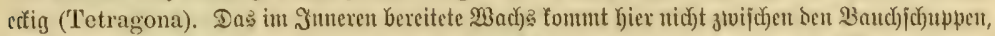

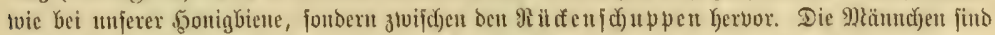

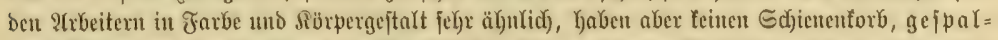

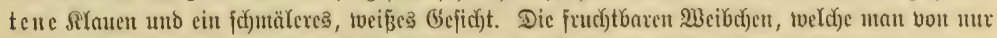

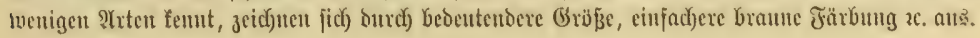




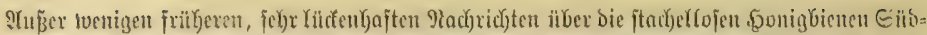

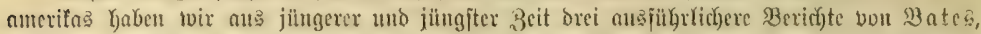

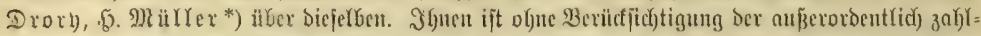

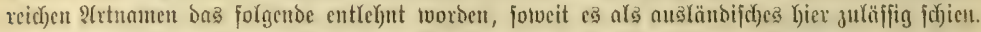

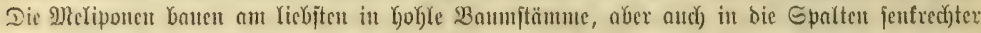

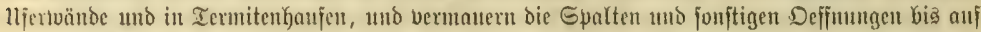

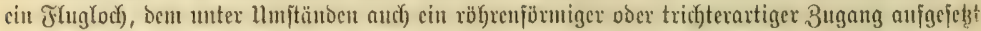

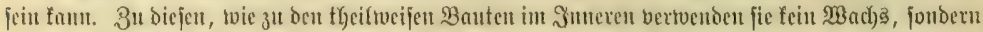

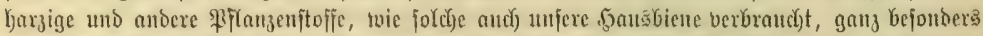

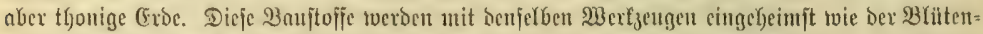

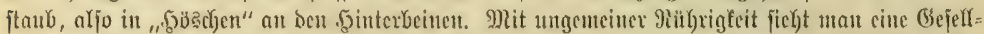

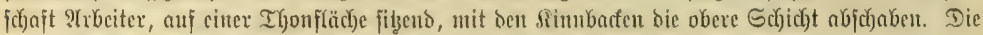

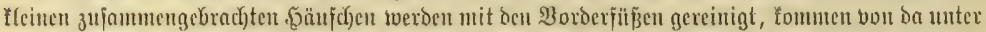

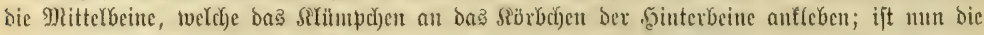

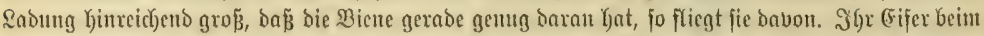

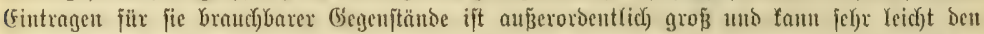

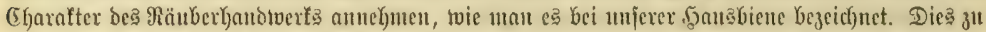

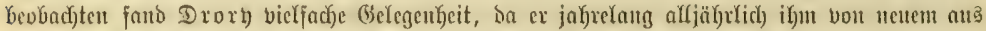

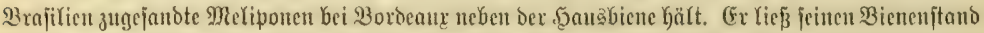

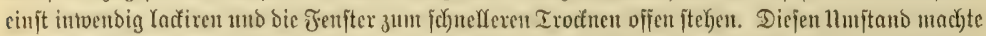

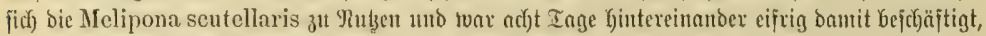

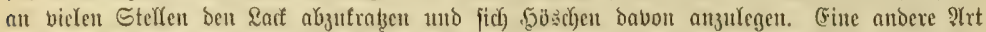

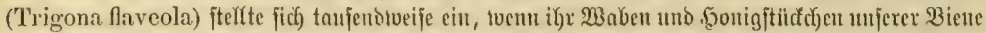
3ugänglich) เwaren, legte .

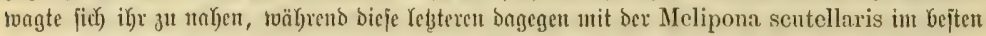

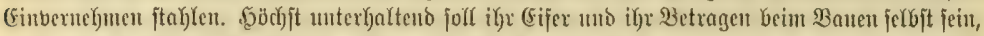

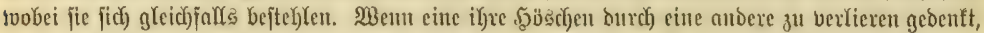

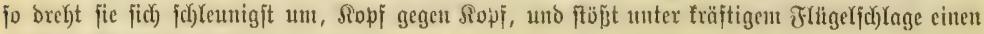

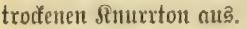

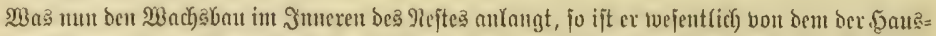

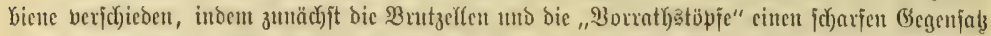

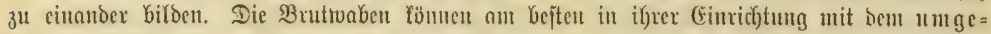

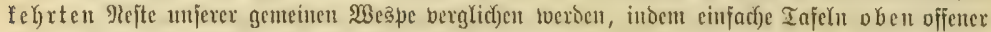

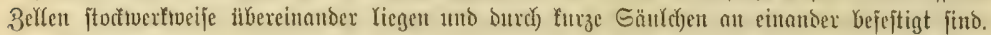

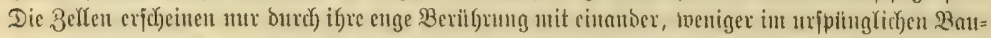

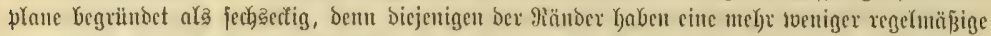

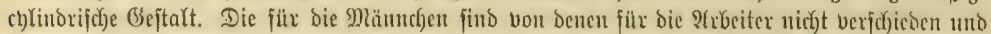

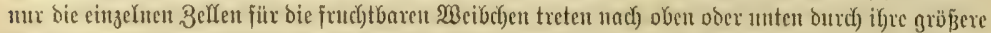

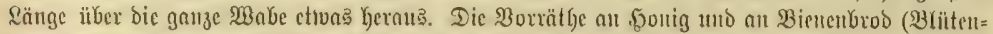

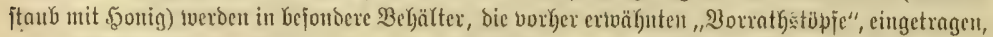

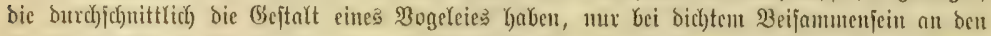

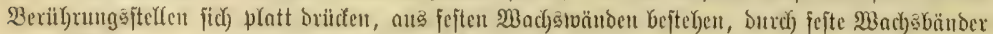

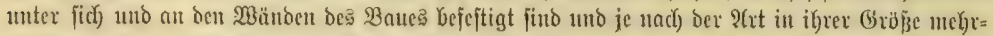

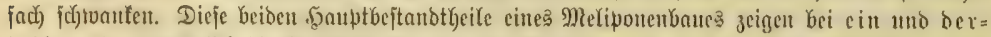

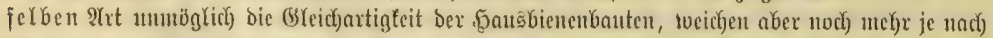

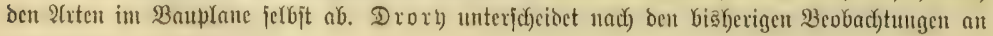

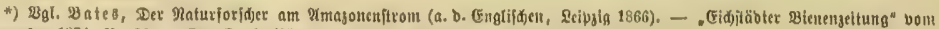

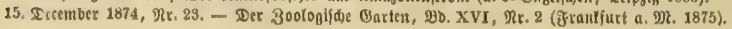




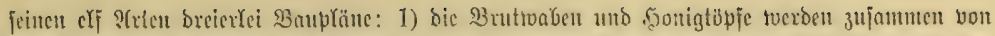

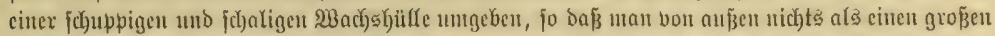

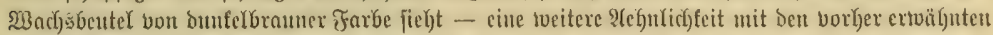

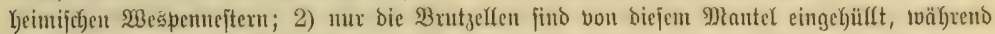

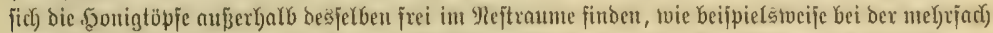

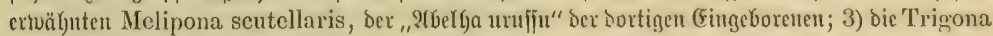

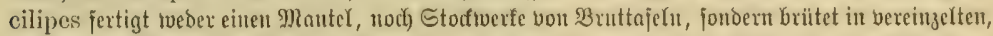
runden, wie bie Beeren ciner Weintraube burde Sticle verbundenen Beffen und untobt biejen

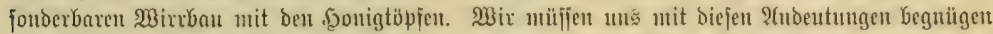

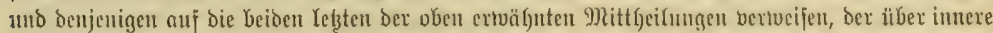

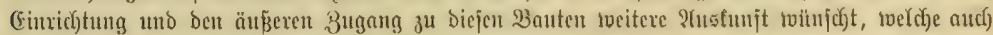

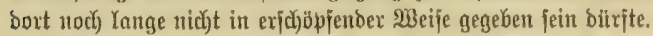

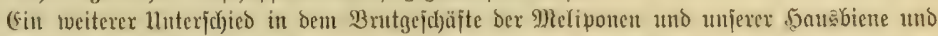
volftonmene 1lebereinjtinumung jence mit anderen "einjanten siunjtbienen", wie twir fpäter jeken

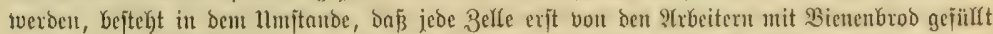

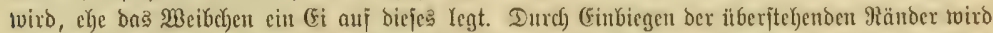

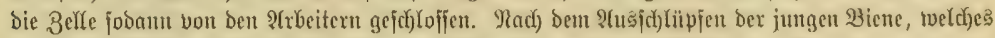

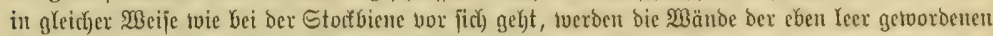

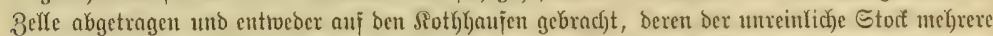

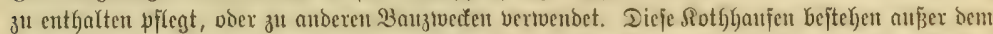

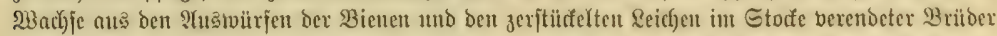

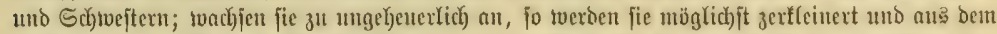

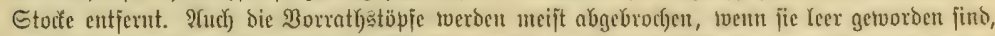

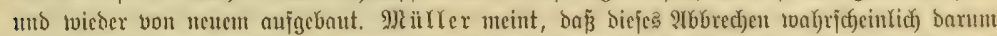

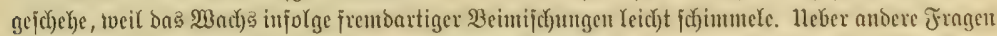

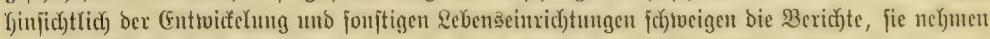

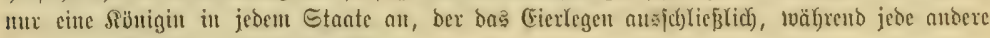
Bejorgung ben शrbeitem ankeim färnt.

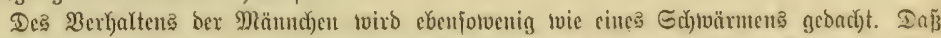

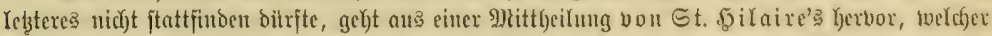

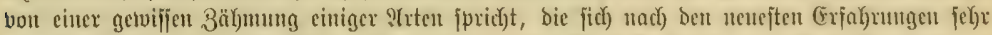

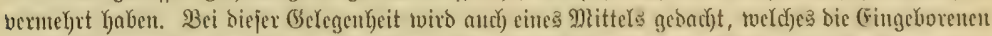

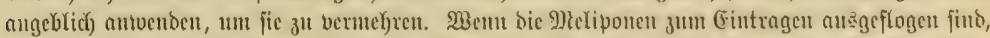

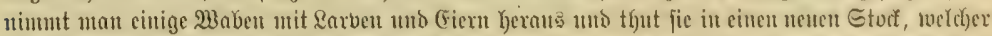

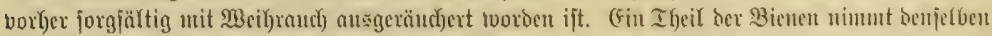

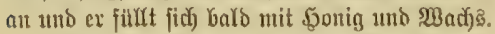

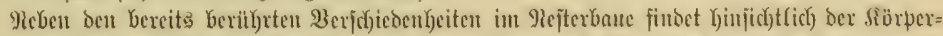

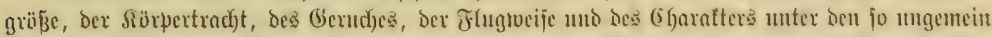

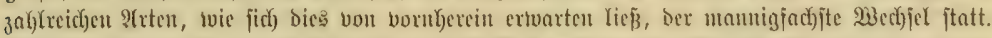

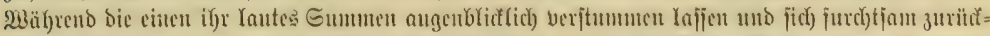

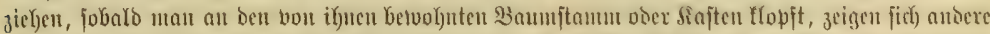

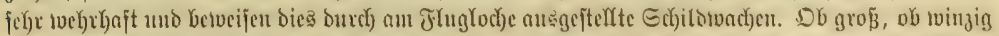

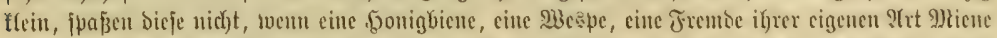

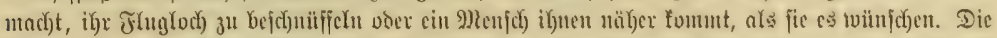

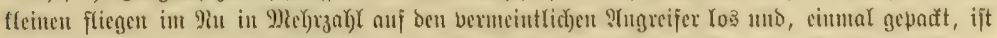

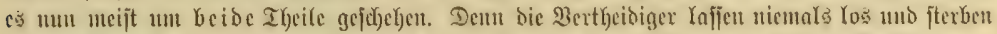

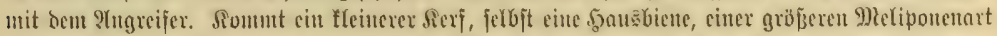

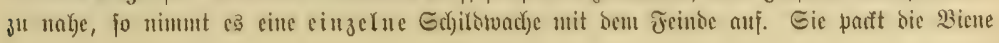




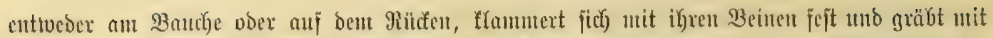

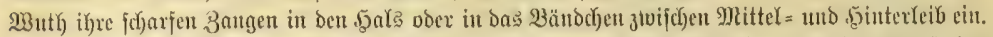

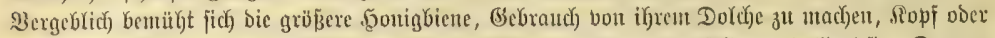

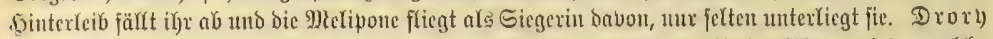

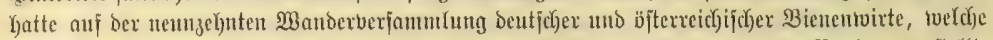
vom 16. Gia 18. Eeptember 1874 it .jaffe tagte, einten Saften mit Melipona scutellaris ausgefterlt.

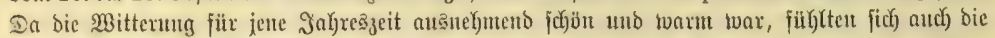

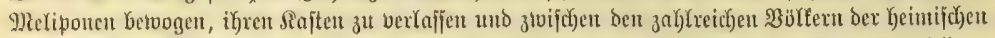

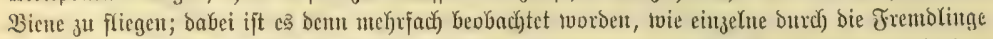

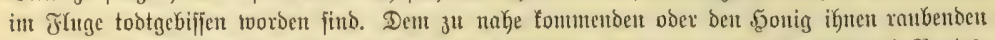

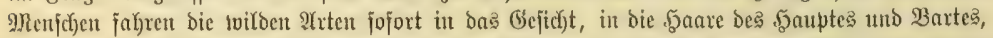

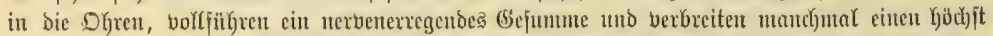

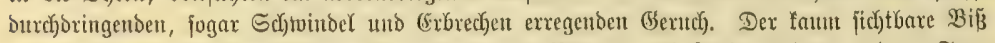

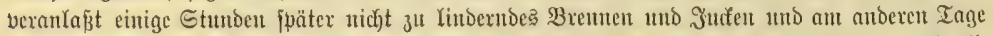

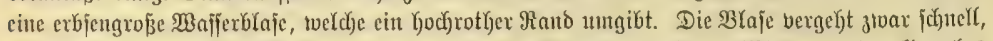

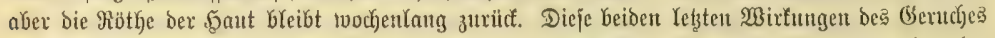

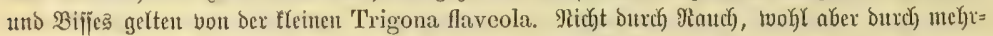

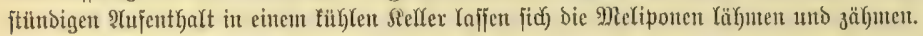

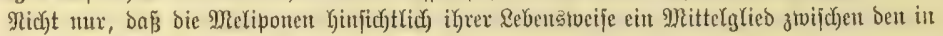

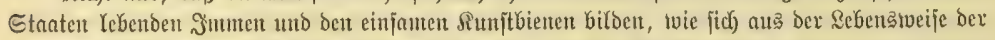

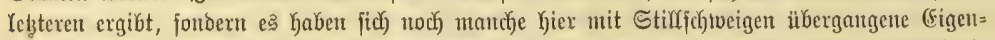

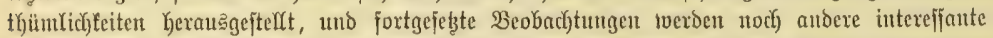

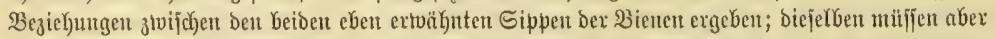
jenjeit bes Meeres angejtellt werben, ba nad) Der bisherigen (Exfaf)ung (Gntropa ben Meliponen

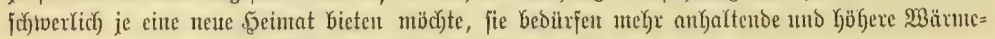
grade, als die europäifchen Witterungşverbältniffe getoähren.

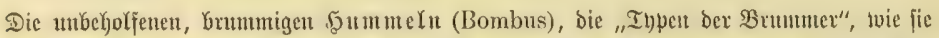

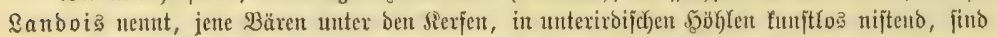

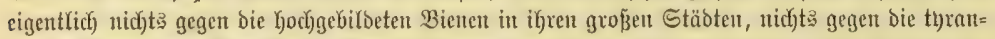

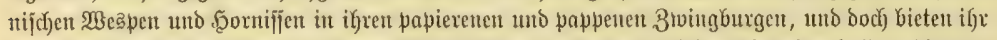

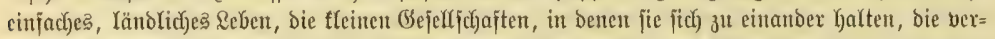

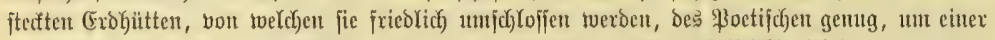

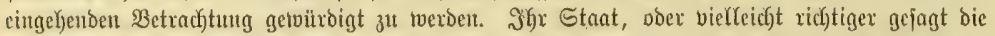
Fantilie, foll nod) zujaumengeję̧ter jein, als bei ben Şonigbienen, iubent man groß̌e uno fleine

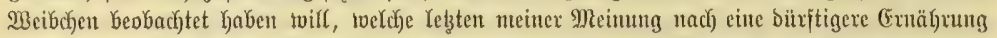

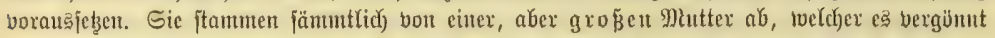

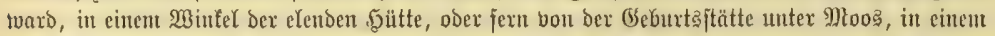

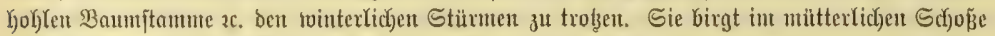

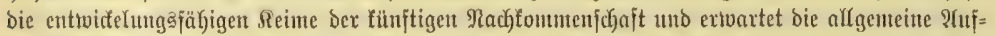

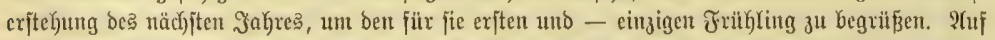

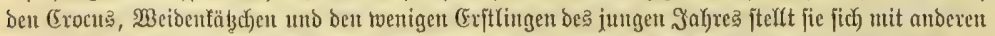

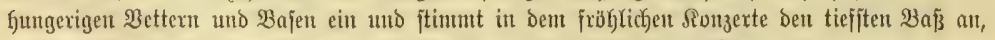

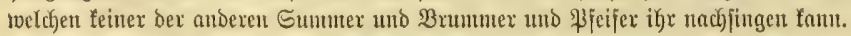

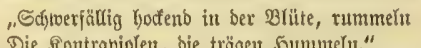

Die Rontrabiolen, bie träget 5̧ummeไn."

Dabei gert bie 2frbeit riljtig von jtatten. Dic 2frbeit? Sic feiert ja! Feiern und 9trbeiten

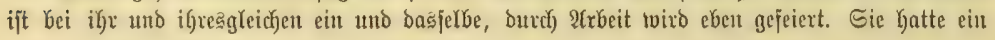




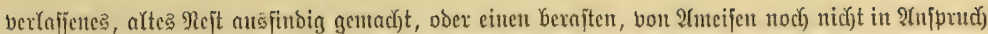

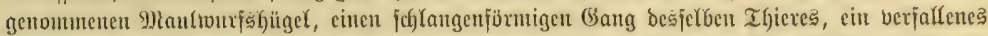

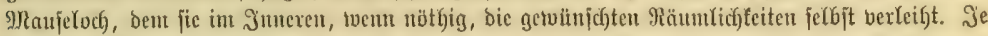

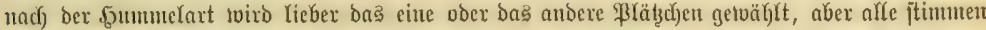

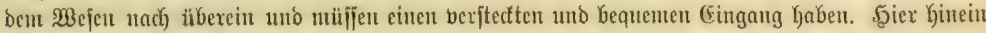

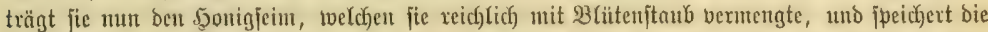

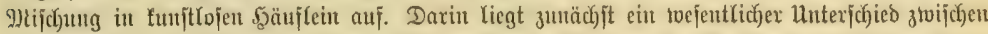

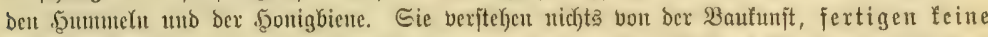

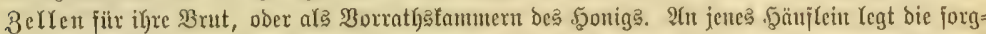

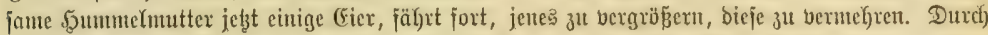

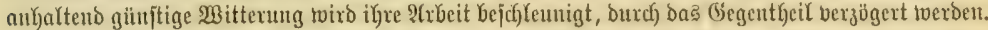

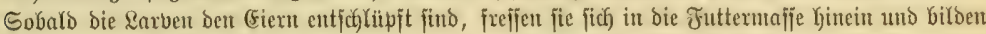

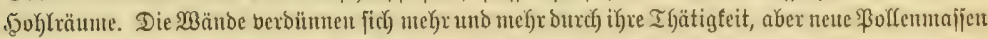

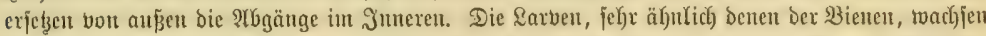

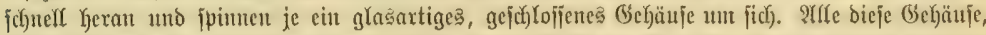

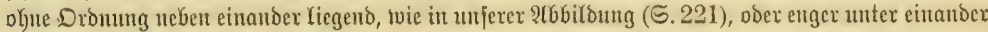
verbunben, je nach bex geringexen ober gröperen $3 a \mathfrak{h l}$ ber gleich alten \&arben und ifremt bant

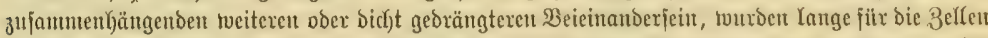

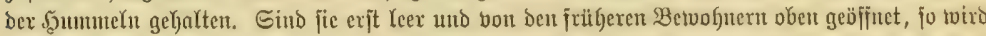

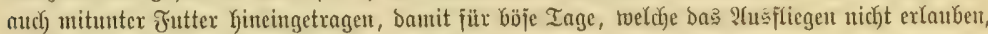

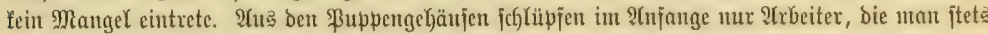
an ifrer bedeutenderen IIfeintheit crfent. Sie Geljen nun Der Etammmutter, Gringen Jutter herbei,

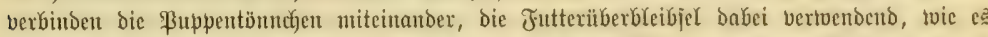

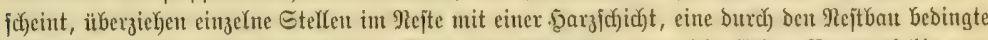

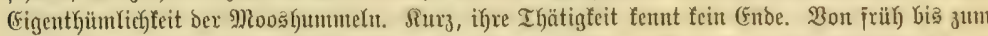

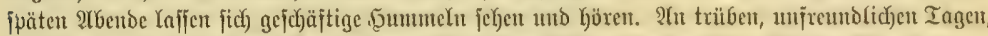

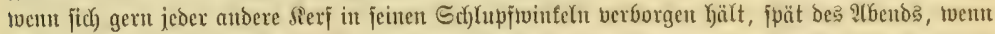

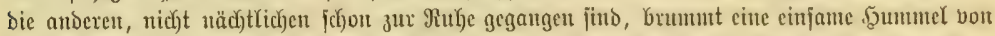

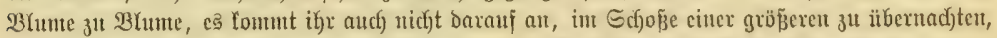

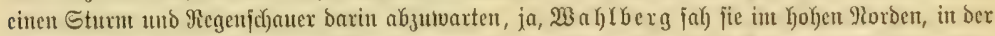

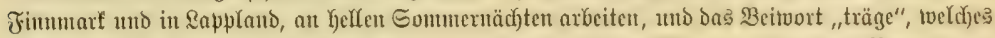

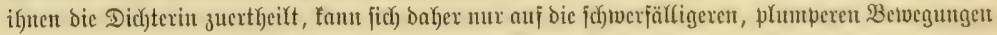

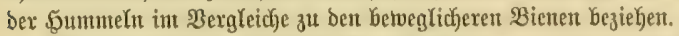

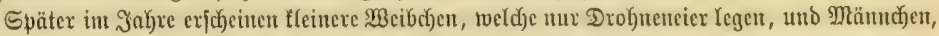

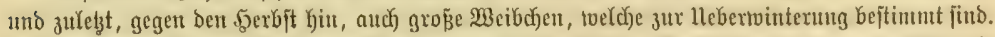

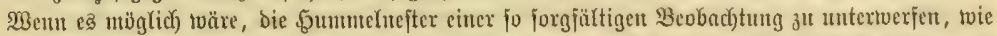

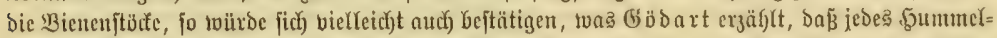

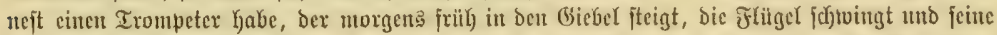

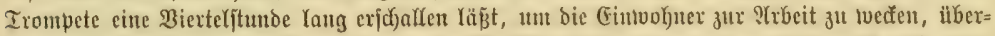

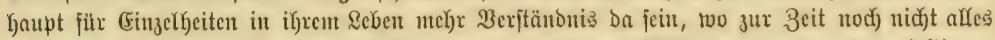

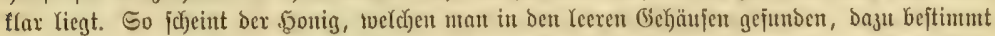

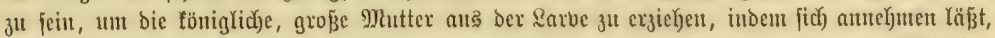

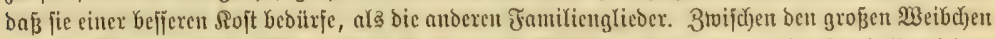
uno ber Stanmmutter jolfen anjüngfid) einige 3wijtigfeiten vorfommen, bic aber bald bei bemt

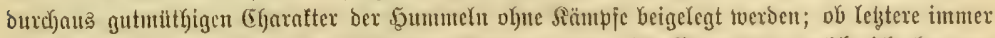

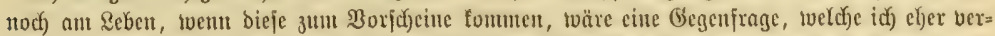

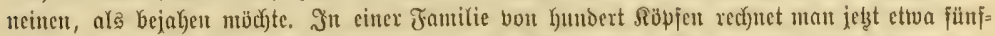

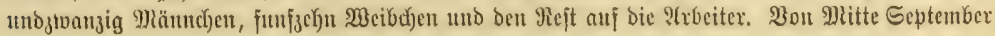




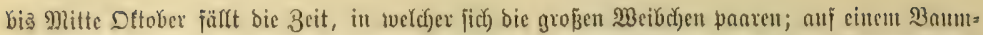
ftumpfe, ciner MRauer, obex cinct anderen, ctros crbjubten Stelle crtwarten fie im Goumenj

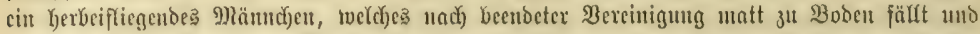

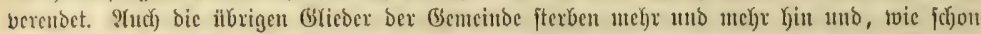

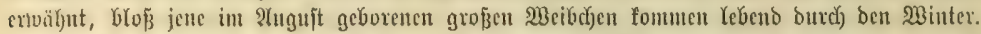

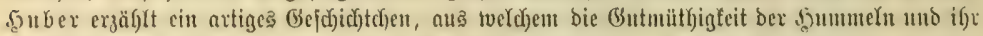

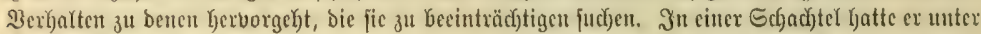

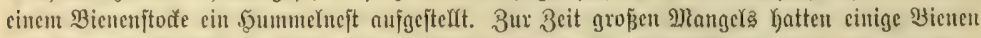

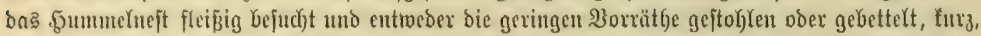

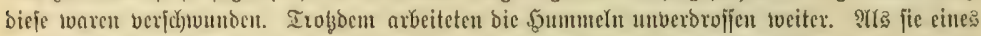
Inges heimgefefrt twaren, folgten ibuen bie Bicnen nad) und gingen uidjt cher bavon, bia fie

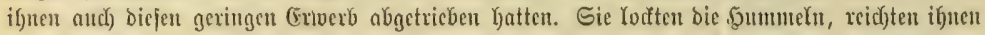

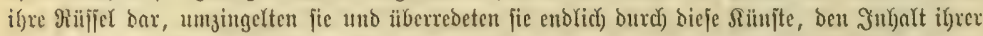

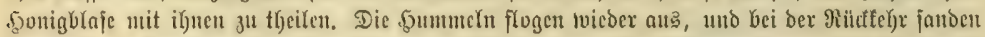

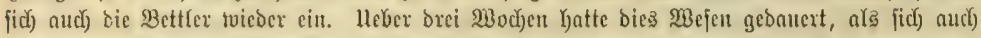

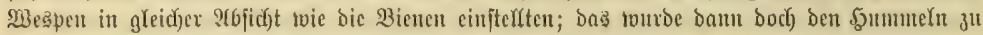

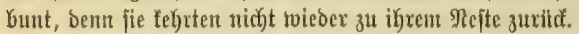

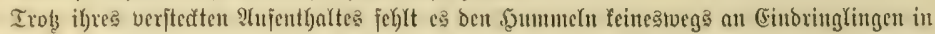

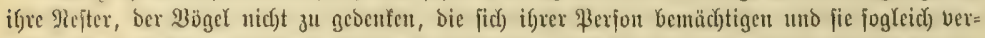

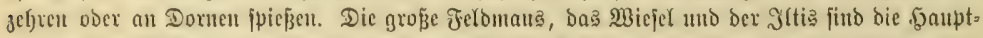

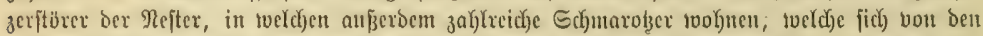

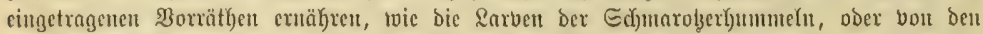

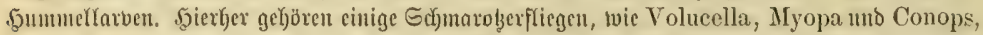
เoclche svir fpäter femen Yernen twerben, bic Spimenameifen (Mutilla), Die Delfäferlarben uno

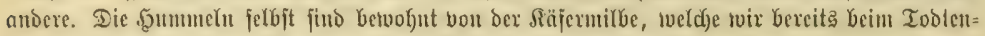

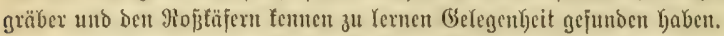

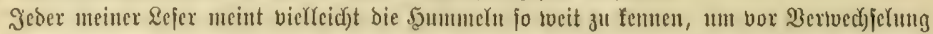

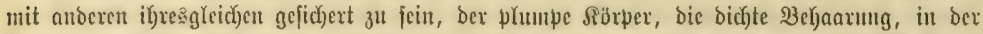

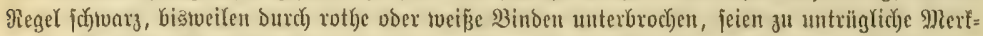

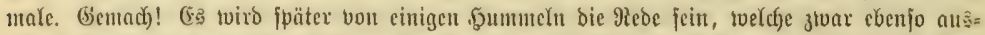

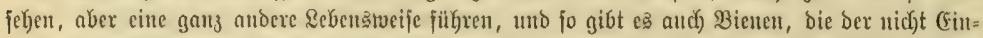

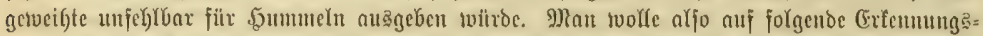

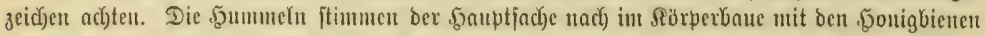

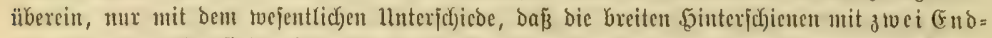

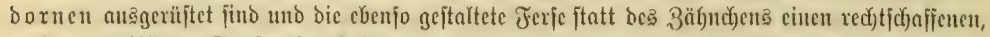

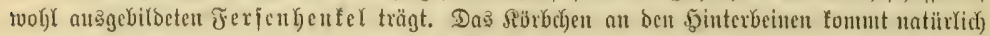
nux ben Weibe)

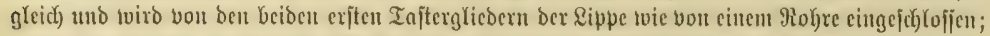

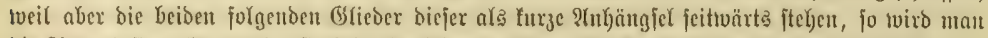
bie Sippentajter als zlveigeịtaltig bezeid)nen miljen; bie Sieferntafter ongrgen find flein und

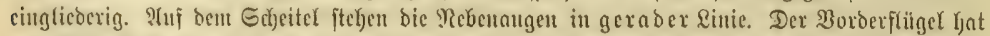

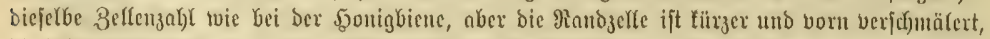

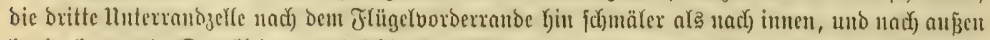

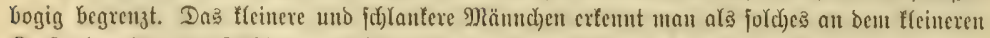

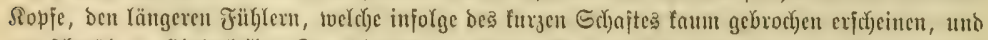

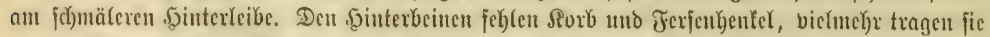

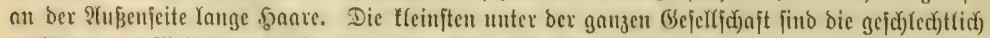

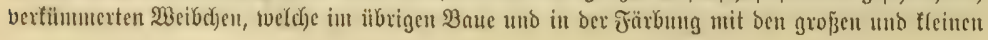




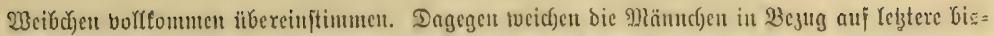

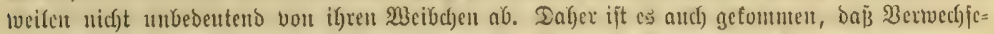

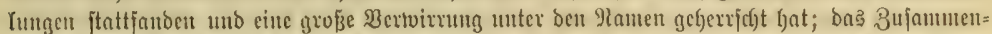

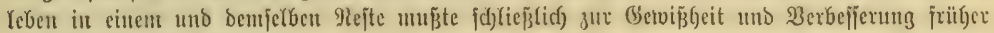
begangener Fegler fülgren.

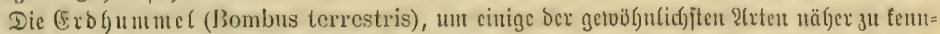

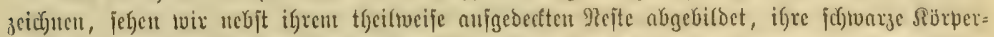

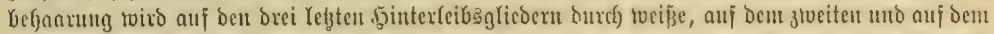
Jjalstragen binbenartig burd) getbe vertreten. Die brei formen ftimmen gennu in ber färbung

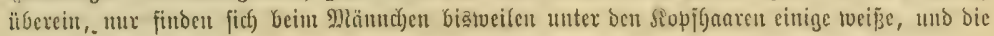

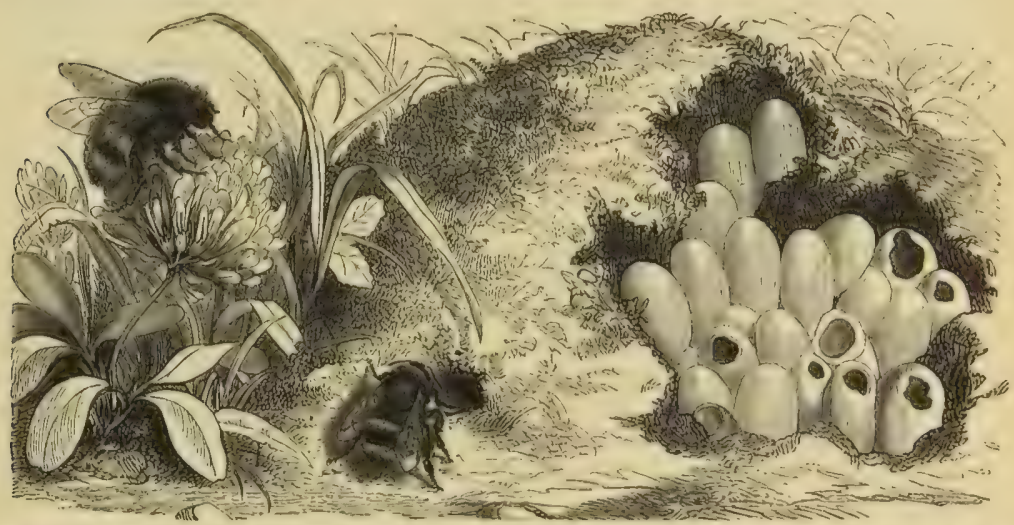

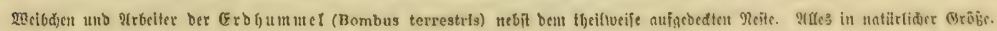

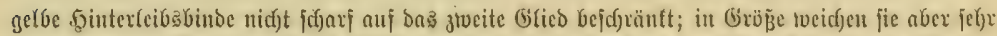

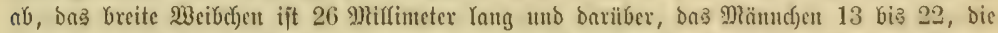

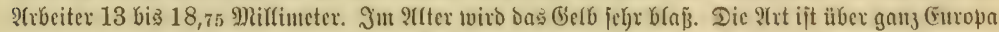

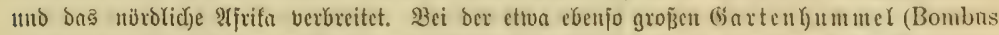

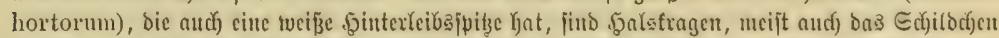

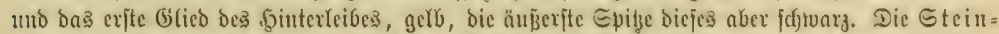

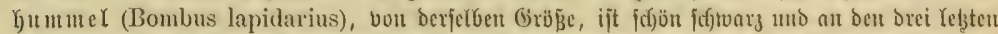

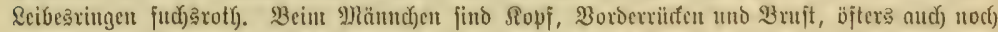

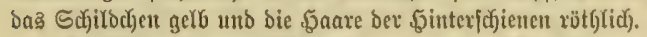

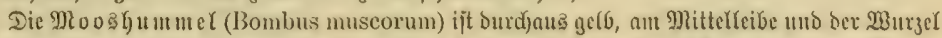

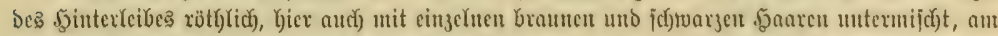

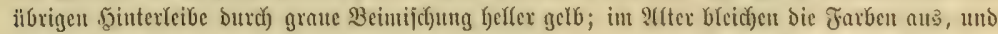

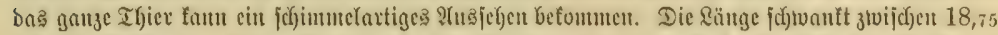

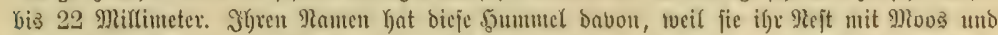

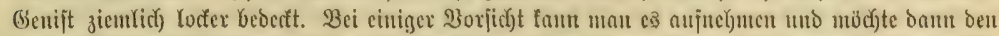

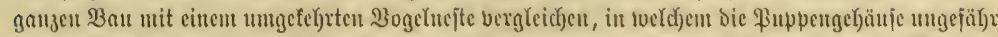

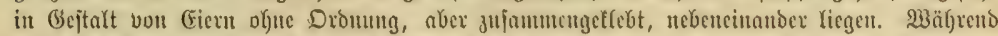

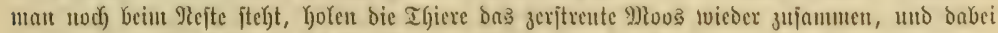

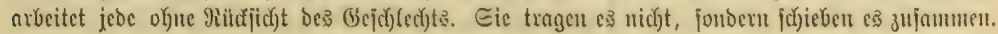


Sabei fteffen firy brei ober vier Ginter cinander, bie entjerntefte fapst ein Silümpchent mit ben Sie=

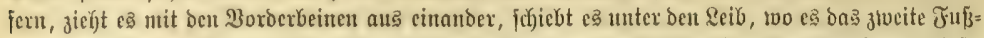

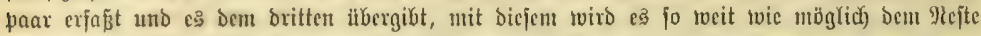

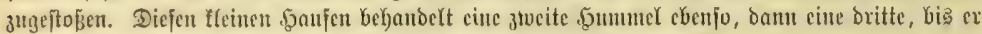

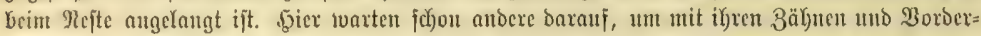

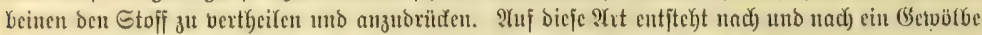

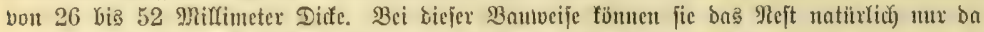

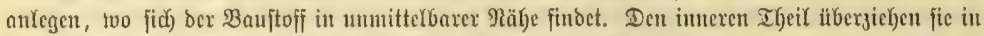

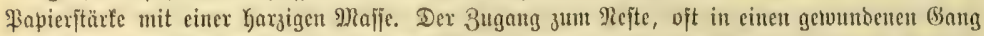

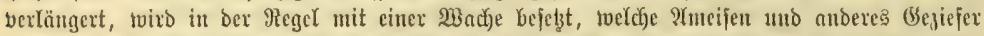

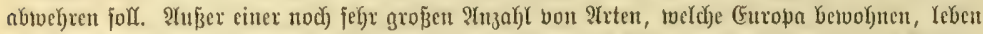

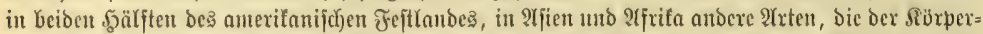

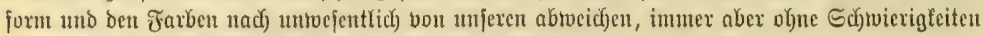
alş Battungeggenoffen erfonnt werden.

Den biäher betrachteten gefelligen Bienen fteben nun die mittela ber vorber erörterten Gammelwerfzenge eintragenden einjamen Sunjtbienen gegenüber. Diejelben Yeben mu pan=

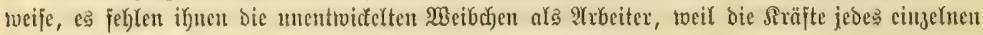

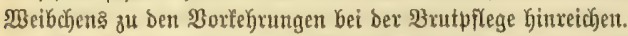

Die Schienenjannter (Podilegidae) ftimmen bei vielen hier mit Sting chweigen zu uber=

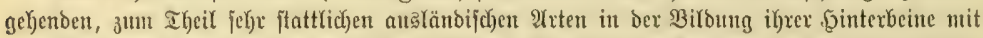

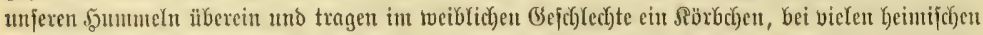

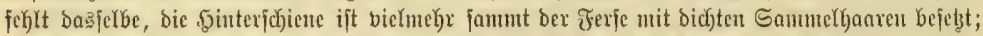
Yebstere innenjeitig zu Der früher bejprodjenen Butrjte getoorden. Die Rinubarfen fino gerabe, auf bex

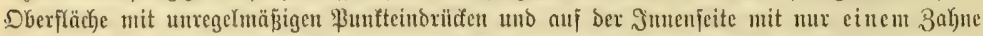

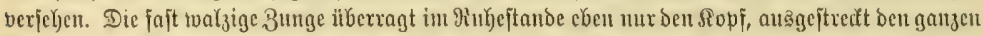

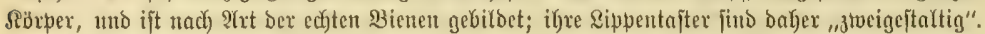

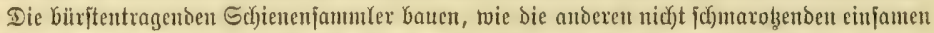

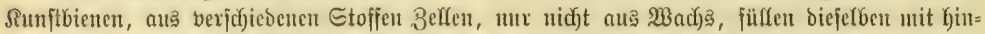

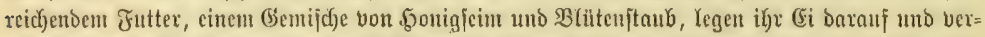

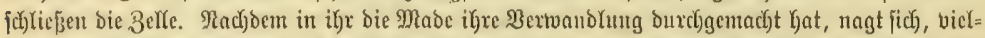

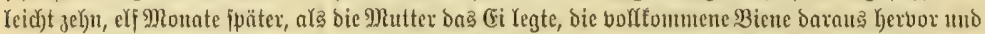

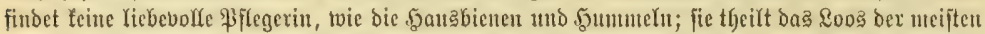

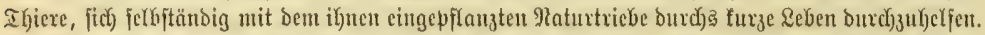

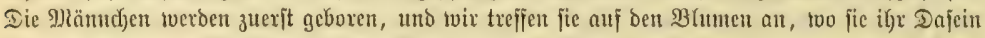

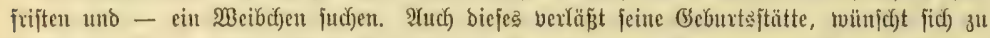

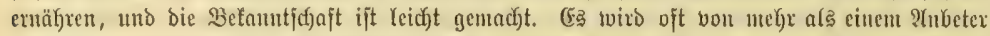

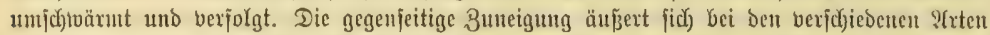

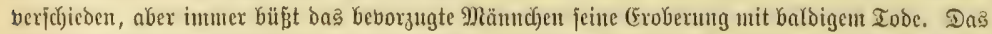

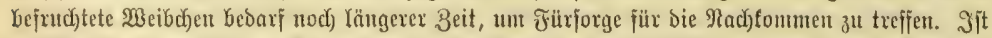

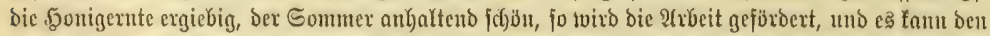

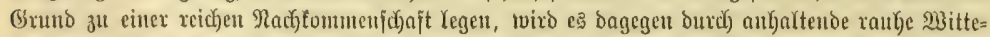

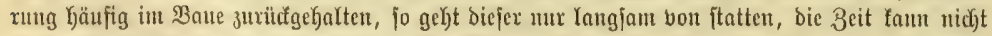

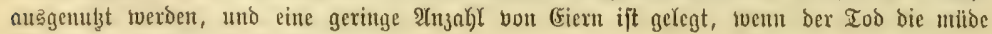
Filgerin für immer jur Muke bringt.

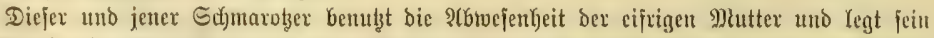

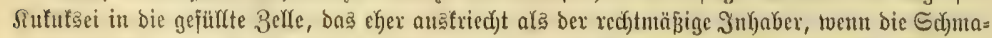

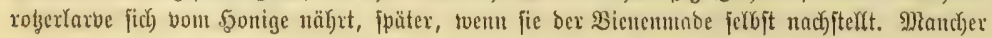




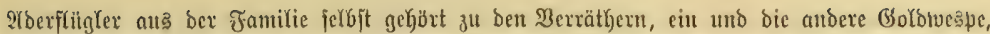

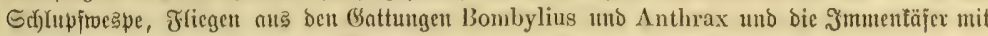
ifren Berwanbten (Trichodes, Silais).

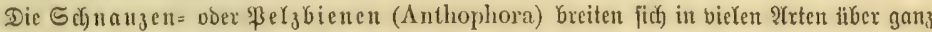

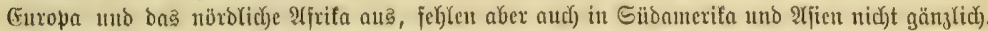
Su Borberftüget findet man bie gleidhe Beffenmenge, twie bei ben borkergehenden Battungen; eine

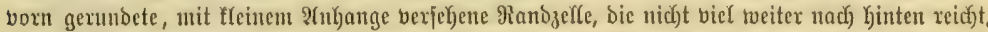

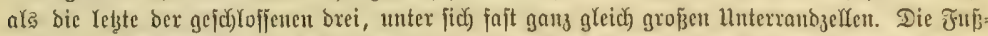

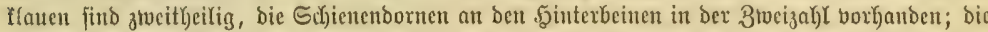

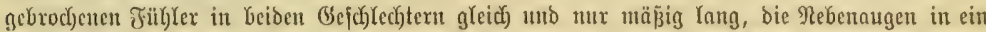

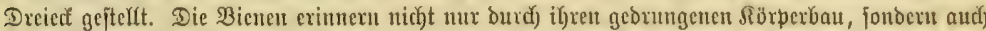

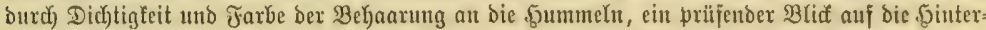

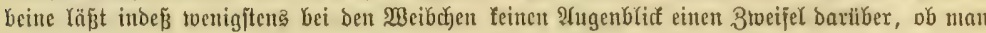

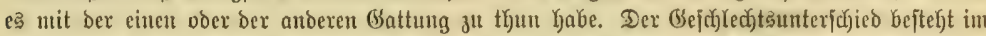

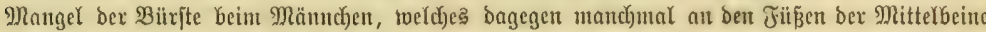

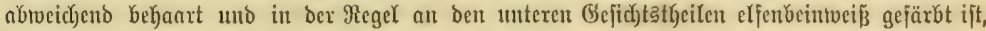

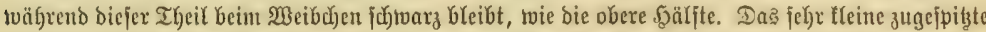

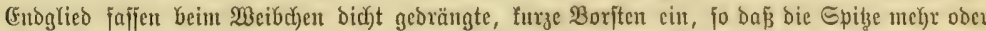

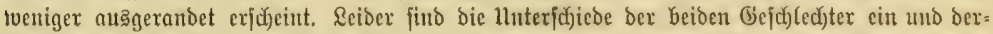

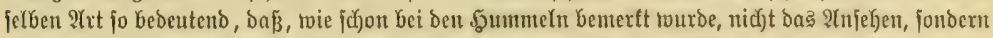

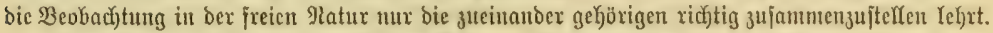

Die Schnauzenbienen bauen in ber (Frbe, in Mtauerippalten, Baunlöd)ern, Refyntoänden

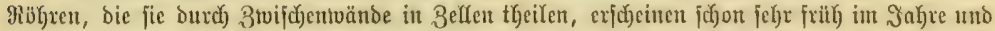

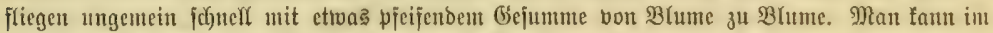

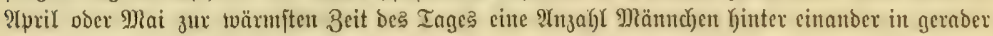

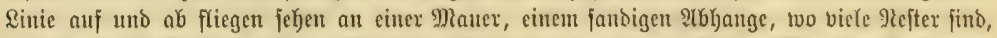

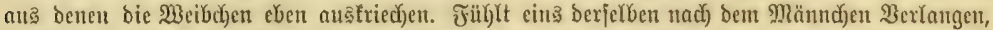

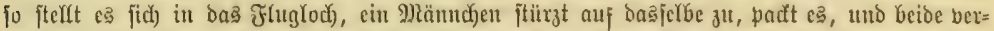

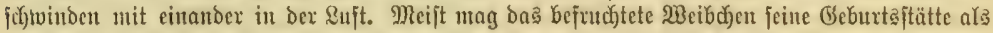

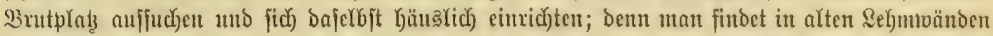

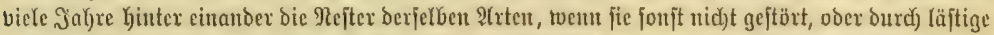

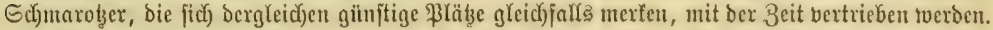

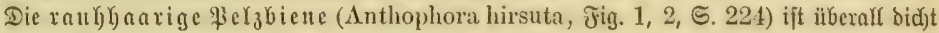

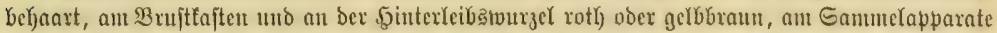

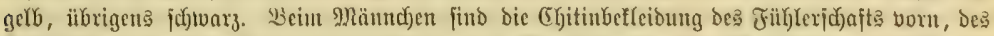

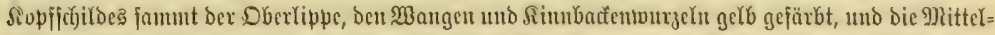

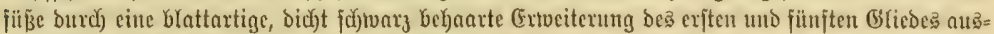

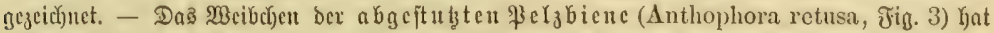

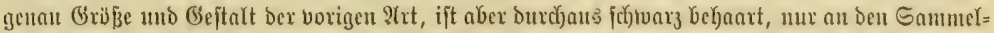

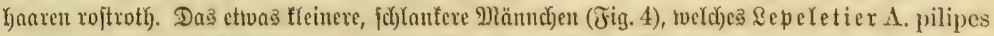

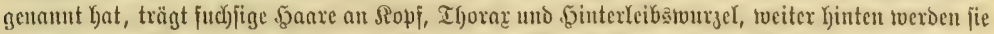

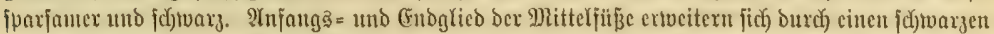

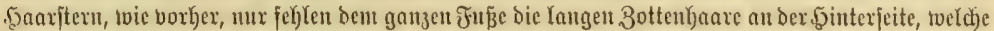

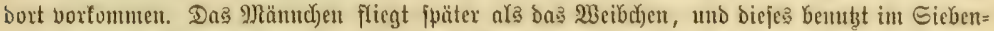

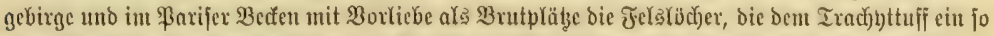

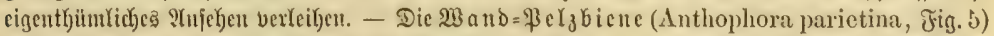

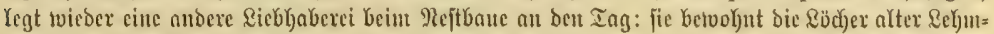

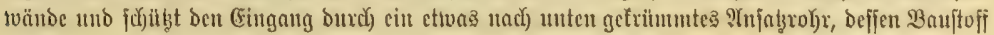




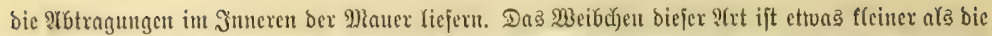

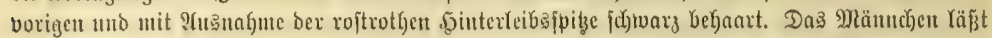

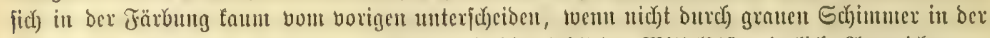

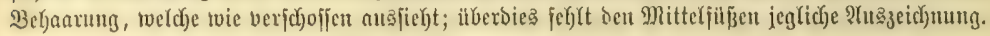

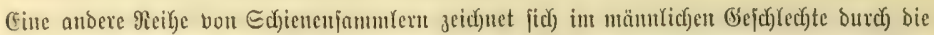

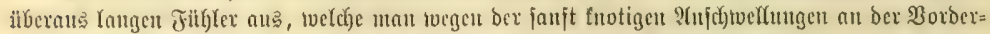

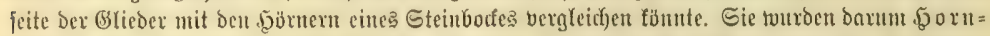

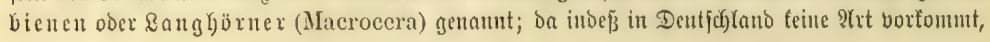

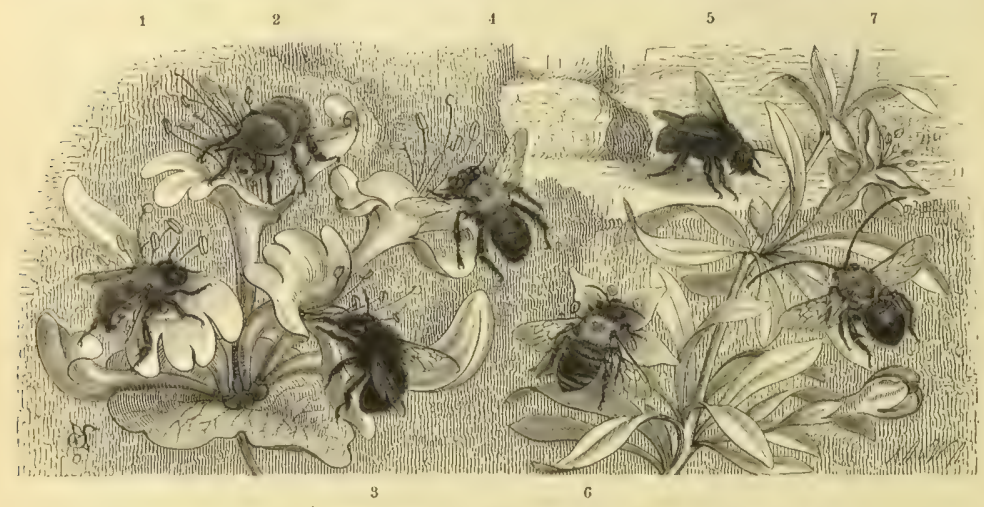

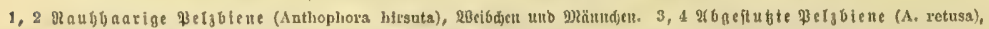

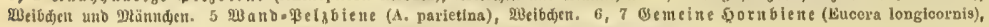

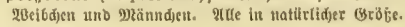

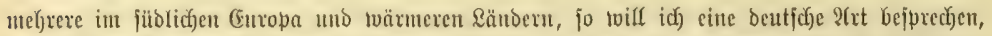

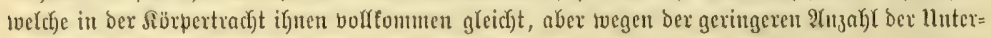

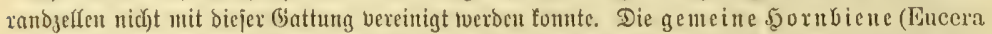

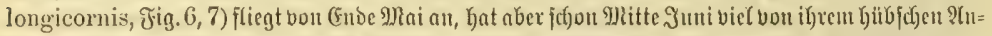

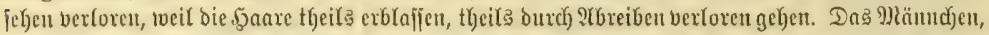

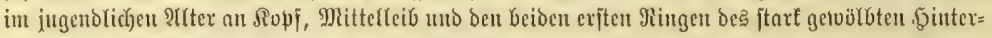

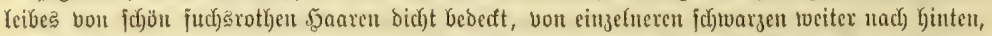

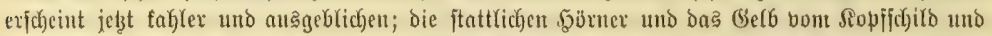

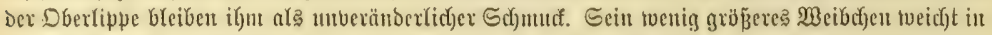

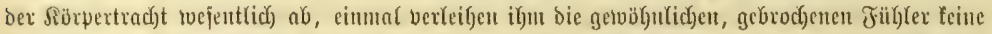

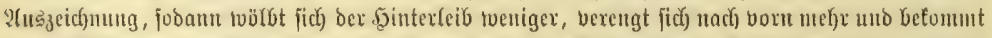

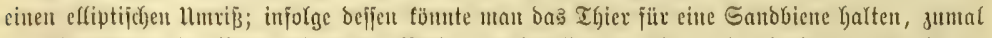

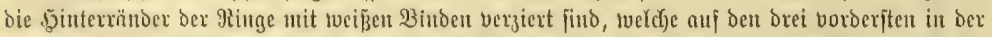

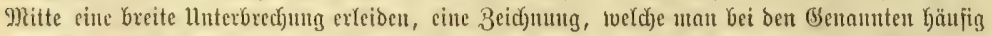

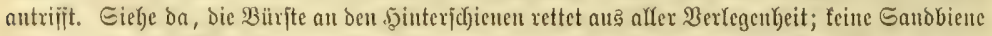

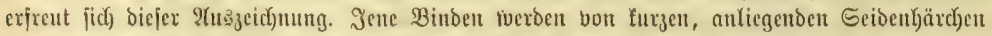

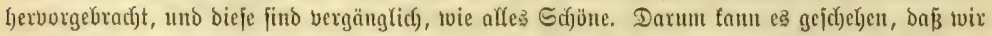

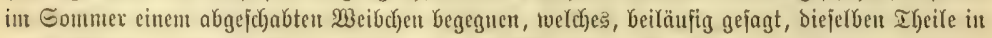

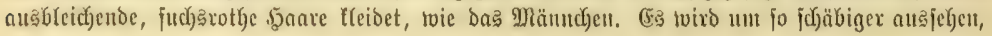




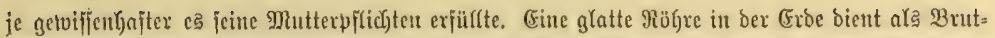

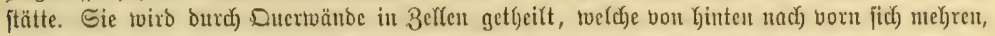

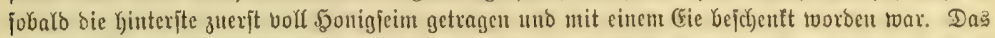

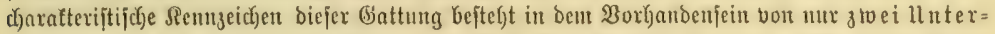

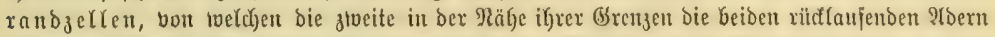
anjuimmt. Sonjt ftimmt fie mit Macrocera übercis. Die Rebenaugen ftehen gerablinig, und bic

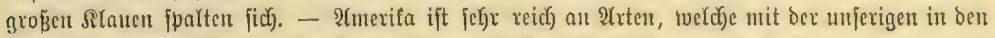

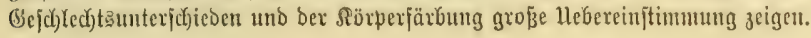

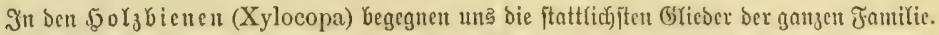

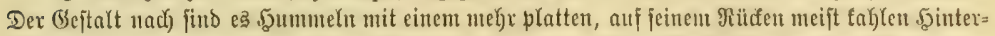

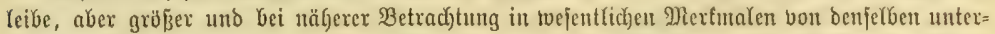

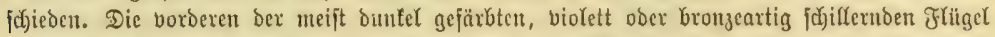

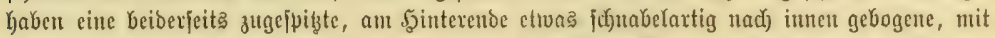

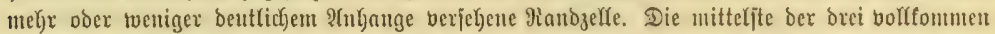

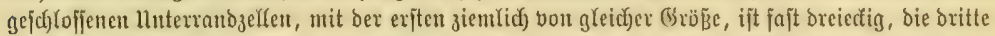
fo Yang, wie bie beiben exjten zujanmengenonmen; in oder Ginter ifrer Mitte mündet bie zrocite

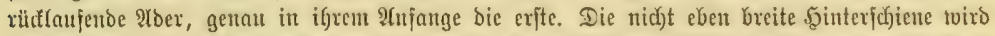

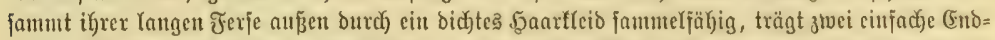

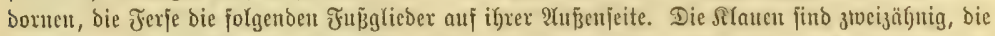

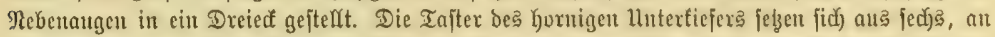

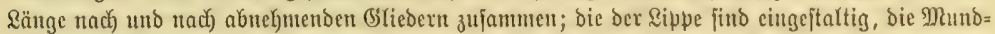

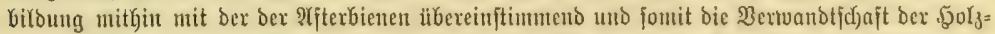

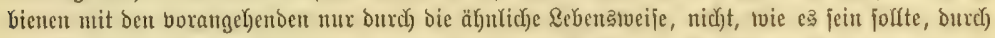

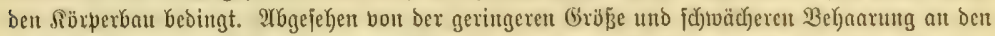

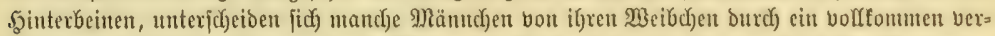

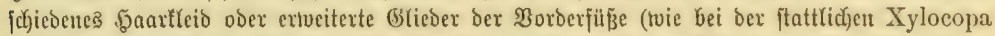

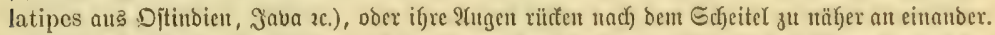

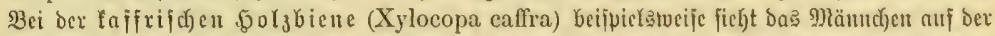

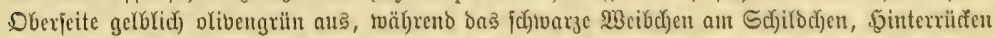

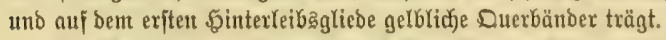

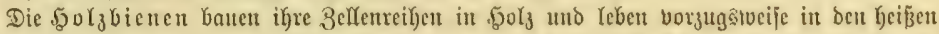

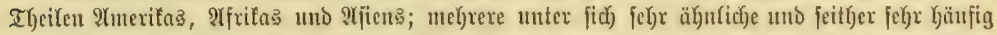

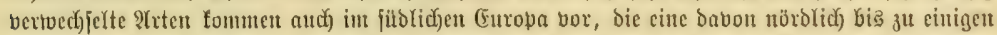

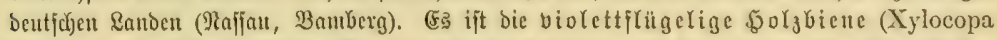

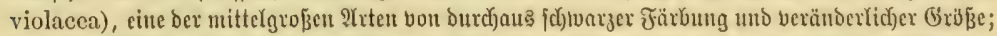
bas britte Jih ferglied ijt an ber Wutrzel ftielartig verditnnt und jo lang twie bie brei folgenton

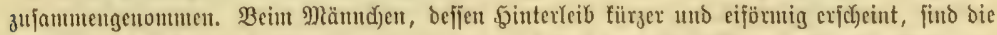

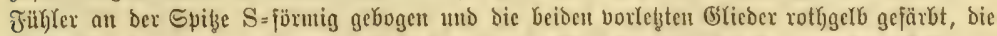

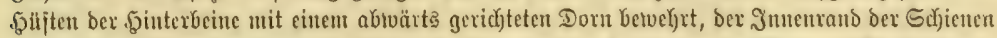

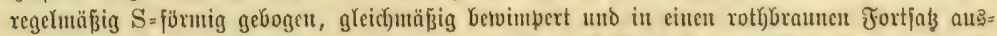

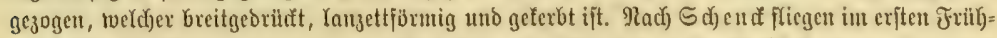
Yinge (bei Mcilburg) überwinterte Meibd)en; von Jüli bis it Den berbft fommen, bejonders

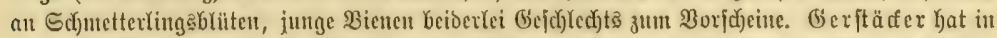

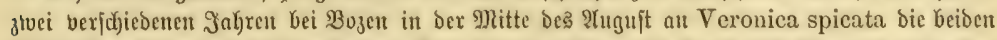

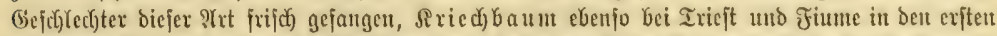

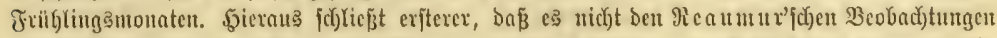

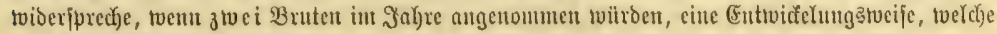




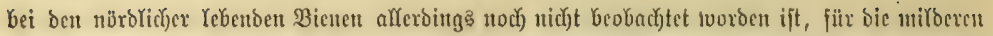

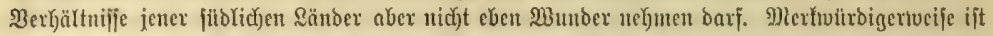

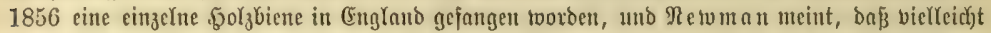

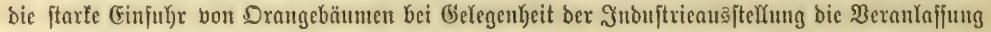
Dazu gegeben Kabe.

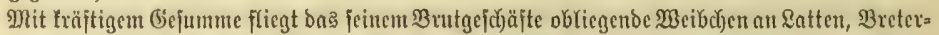

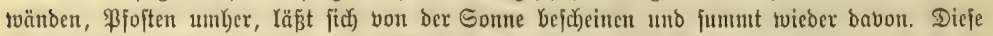

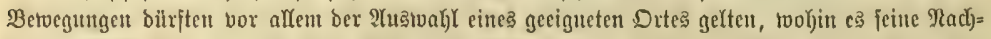

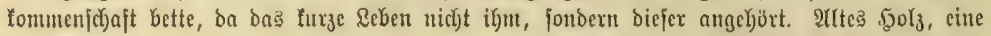

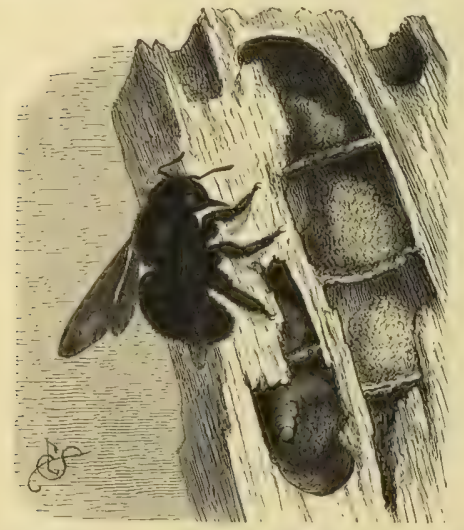

Bioleftitilgelige Solgbiene (xylocopa violacea) nebit blog.

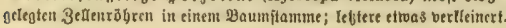
morjche Pjojte, ein mürber Baumitamm, bem jebzentweife bie $\mathfrak{B o r f e}$ judon jehlt, eiguet fidc) bazu an beften unb ermöglicht bie fadwere Fibeit. Mit (Eifer nagt bie Biene ein Rod) bon bem Ilmpange ifres Sibrpers, bringt einige Millimetex in bos Innere ein uno toenoet fick mun nady) untent. Бierzu bebarf fie eines

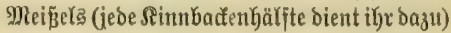
uno einer Bange, als jold de rirten beibe in (Bemeinjujajt. Die Späne twerden Gerats= gefdraffit, unb ticjer uno tiejer oringt bie Irbeit bor, bis eine gleichmäß̉ge Rofre ent= fteht, roelche eimundreiß̧ig (entimeter Yang fein fann und fich am (Enbe rieber etroas nad aufien biegt. Die forgjame Mintter gönnt fiç)

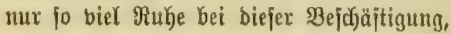

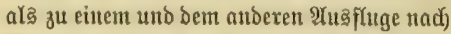
Blumen nòthig ift, two fie burch atujnatume bon \$ुouig neue Rräpte fanmelt. In ben

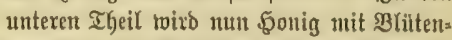
ftatb vermifat in einer gan beftimmten Menge cingetragen, ein Gi Darauf gelegt uno ctroa in

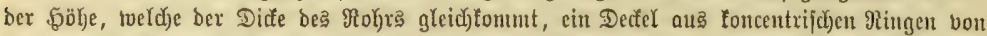

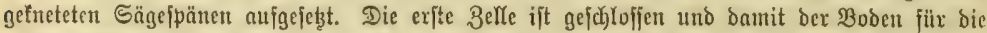
zrocite, hobjer Yiegende, gewonnen. Dieje befommt eine gleid)e Futtermenge und roieder ein (Gi.

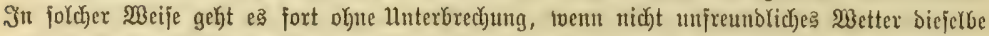

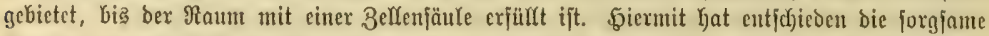

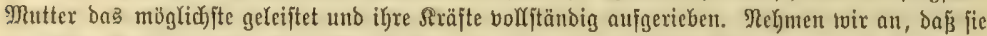

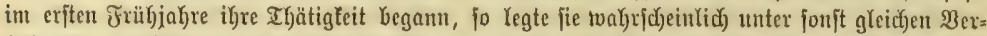

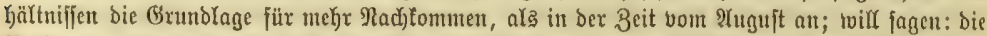

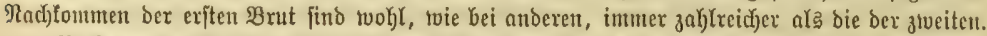

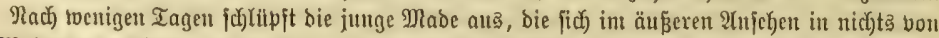
ben Maben unter[d)eidet, twie fie in ber allgenteiten Meberjicht zu biejer fantilie bejchrieben wurben.

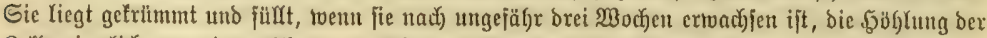

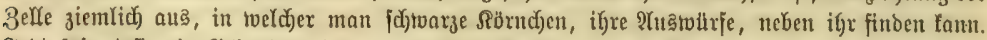

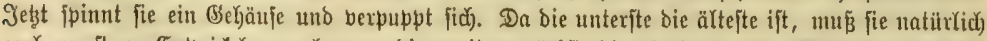

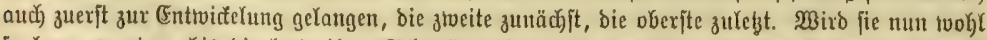

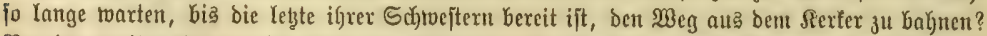

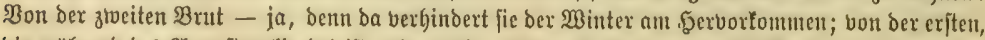

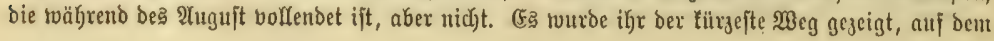




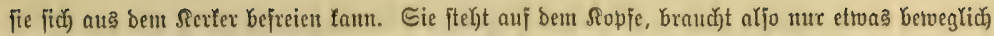

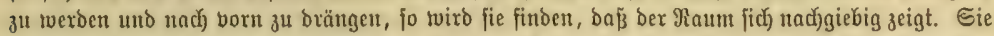
gelangt jo an bas Ende ber Biegung, welches mit Spänen loje gefülnt ijt; indent fie ifre 3angen injtinttmäßig lennt, prüjt fie biejelben zum exjtemmal uno nagt bie bünne Gdjidjt ztvifd)en fid

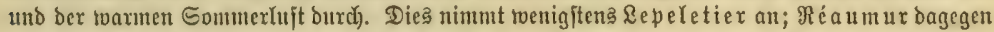

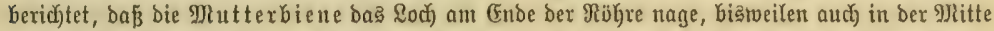

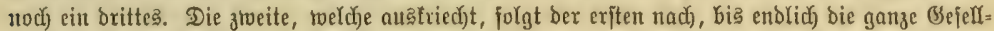

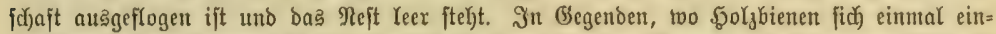
gebürgert Kaben, benubzen fie ofne 3roeifel jahrelang bie alten Butpläb̧e uno getwinnen bei fonjt

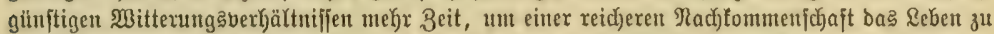

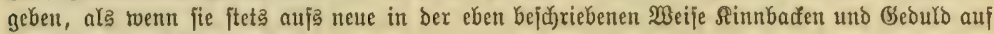
jo harte \$roben jtelfen milijen.

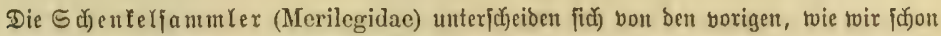

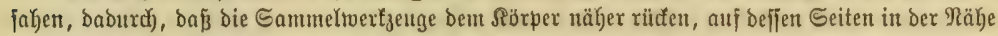

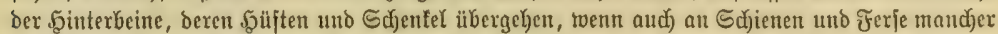
Bałen gelben $\mathfrak{B}$ lütenjtaubes Kängen bleibt. (Fingejtaltige Sippentajter tommen ifnen alfen zu,

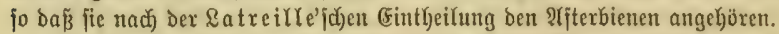

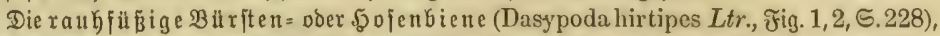

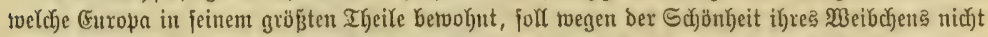

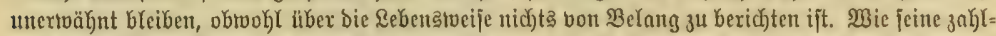

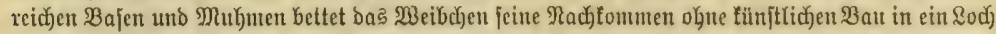

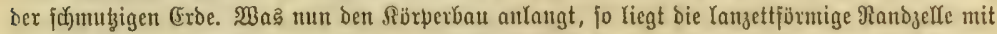

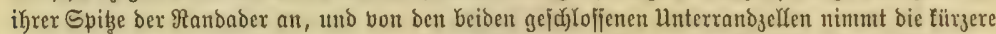

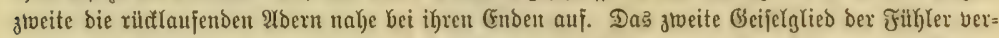

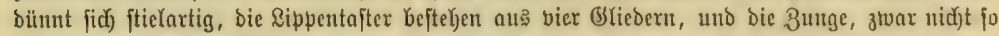

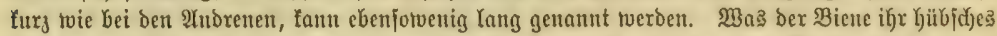

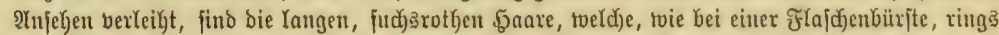

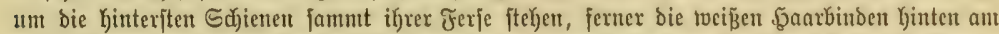

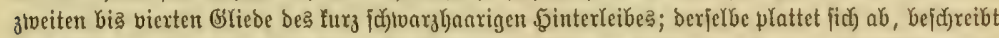

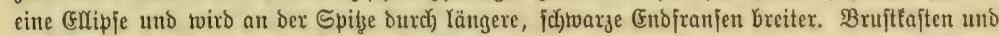

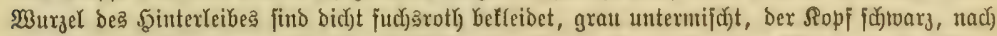

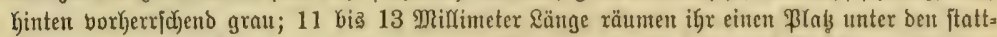

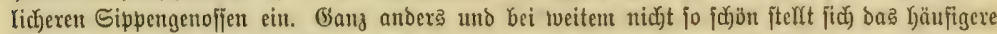

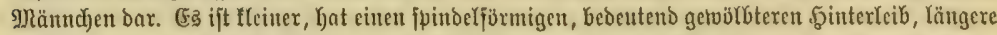

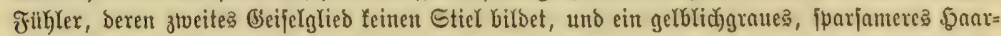

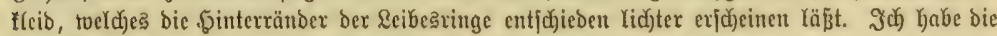
ฐojenbiene imuer nut bon Mitte Juli bis (Ende शugujt zu feben befomment.

Die E $E \delta$ = ober Sandbienen (Andrena) Yiefern mit ber folgenden Gattung 3ufammen,

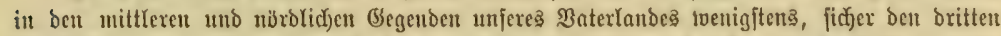

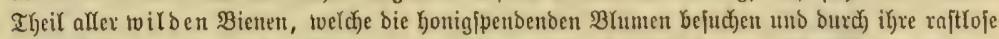

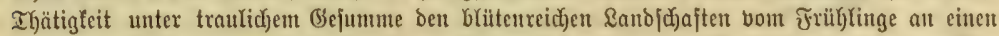

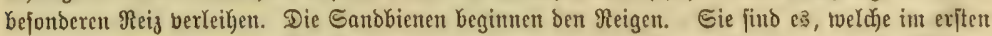

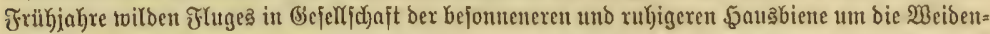

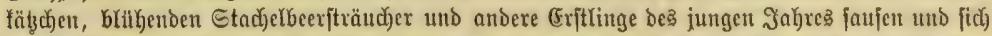

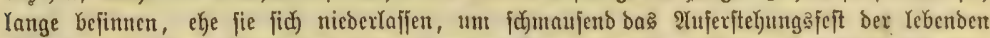

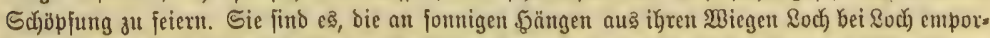

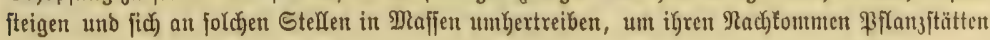




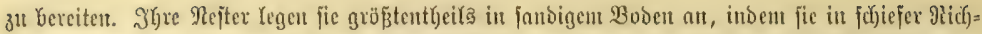

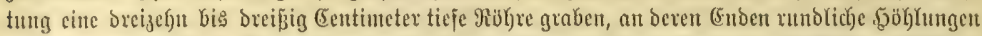

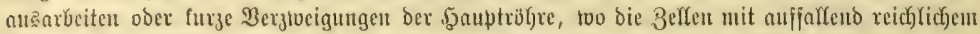

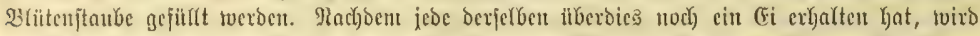

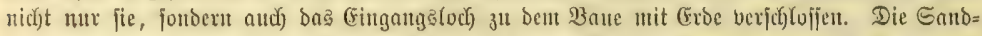

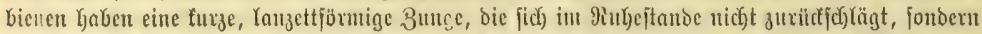

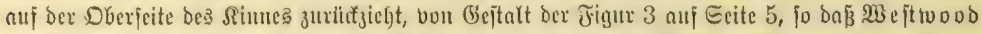

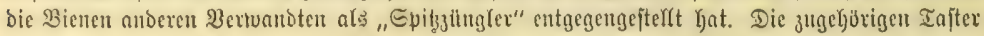

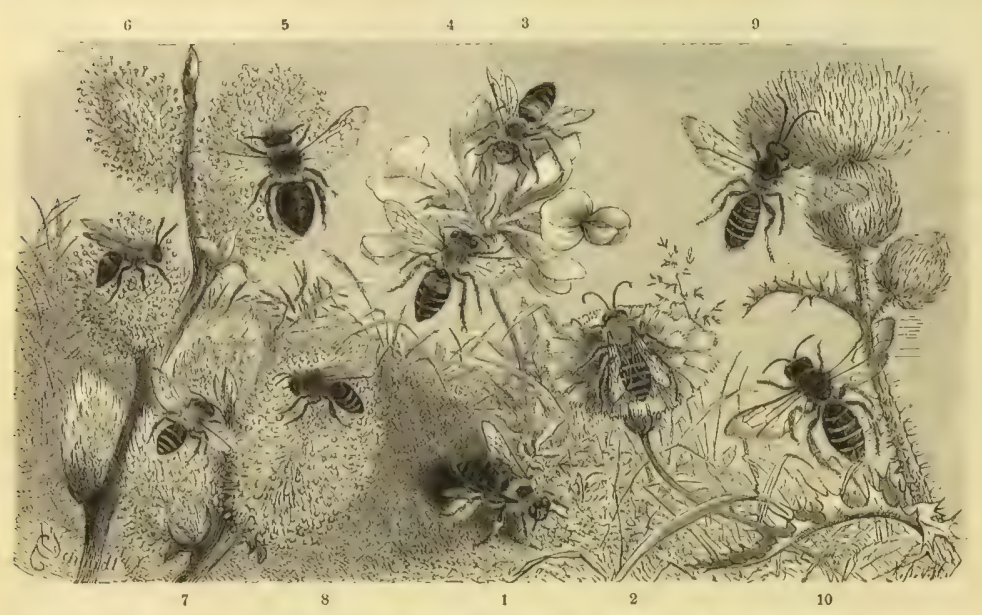

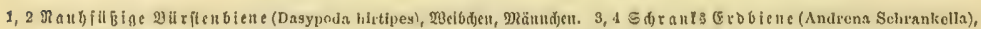

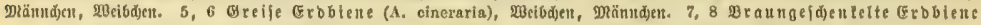

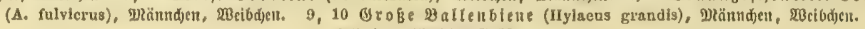
भlle in natiarlidicr Größe.

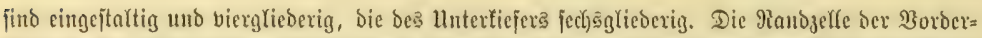

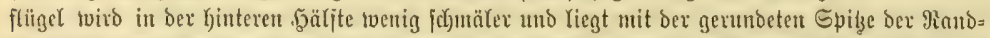

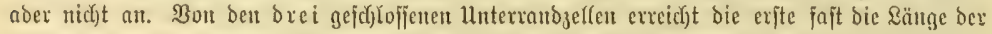

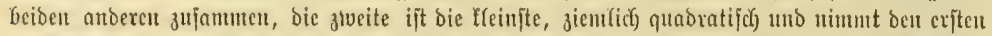

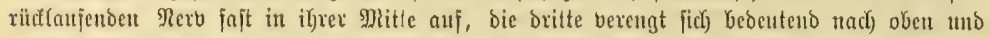

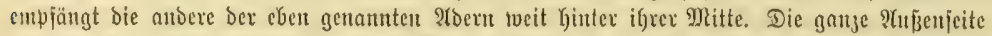

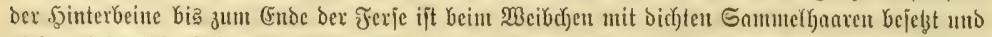

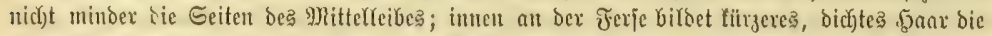

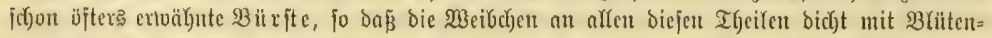

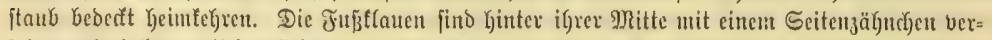

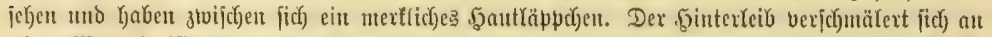

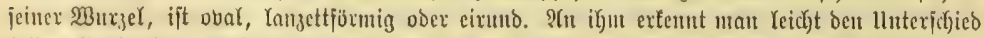

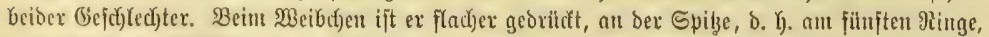

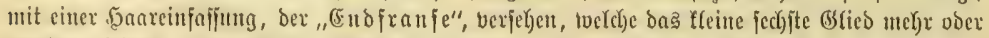

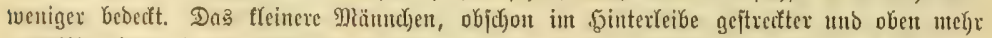

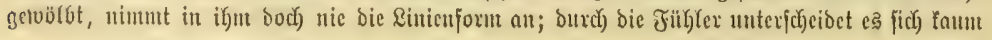




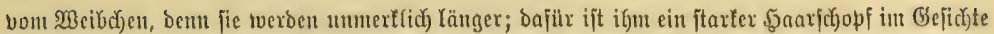

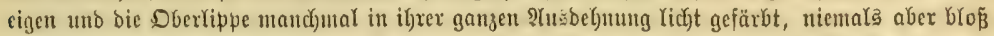

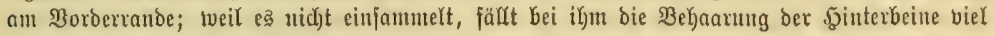
fparjanter aแล, als bcim æeibd)en.

Die (Evbbienen find reid) an Sdymarolzern, unter benen die fleinen Mespenbienen (No-

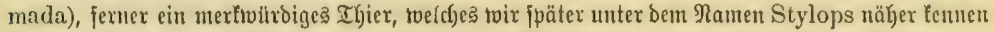

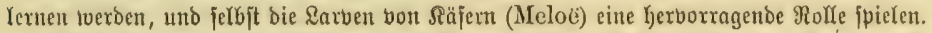

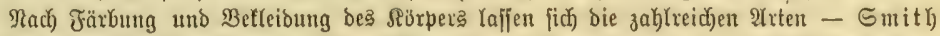

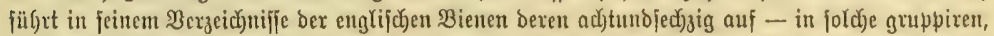

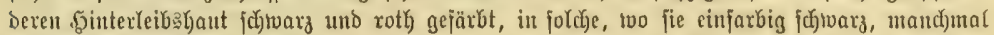

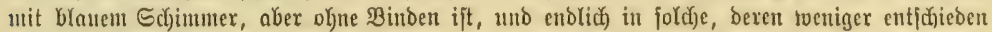

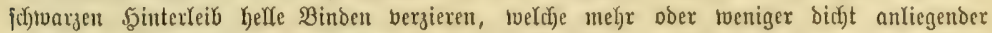

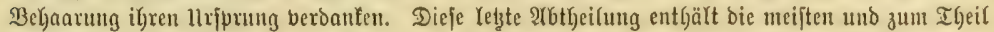

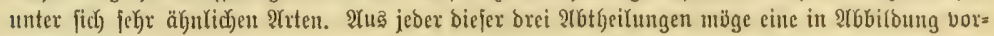
gefitgrt twerben.

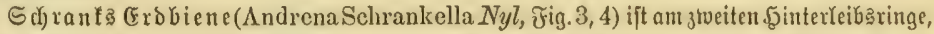

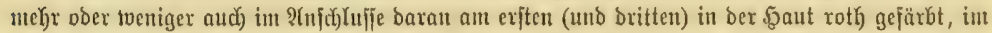

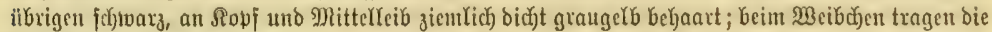

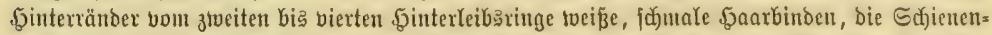

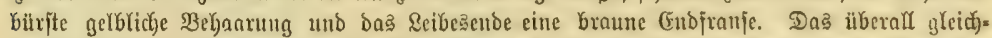

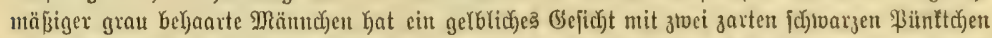

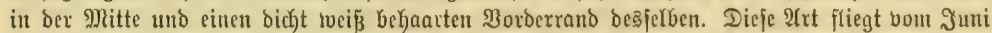
aל au blübenden Sträuchern und Rräntern, tvie Rhamnus, an Zauntebe, Sourntlee und anderen, fonmt aud) in ber Bajelex (Gegeno bor, therall jebod) nidjt häufig.

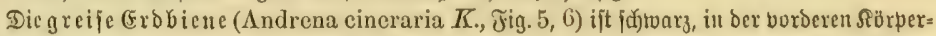

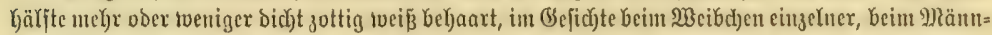

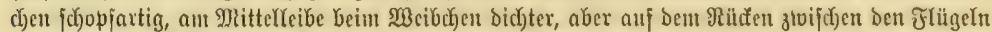

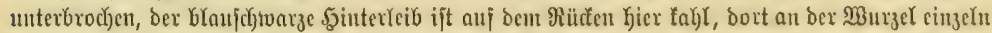

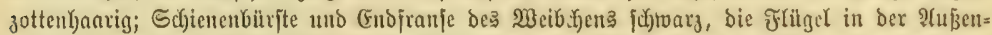

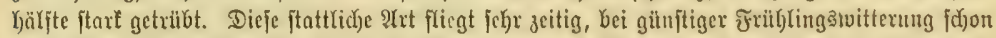

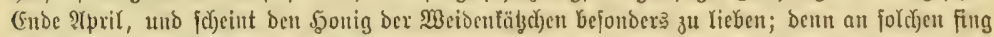

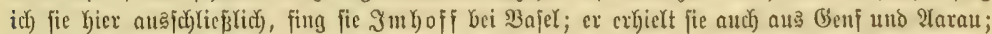

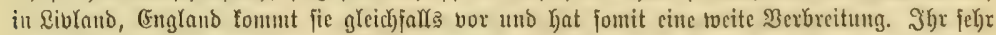

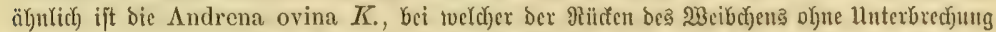

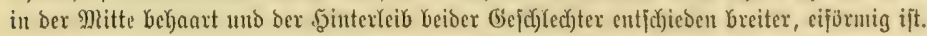

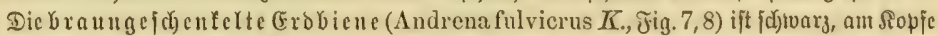

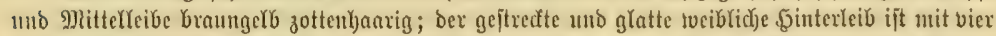

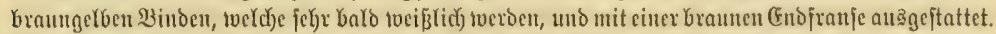

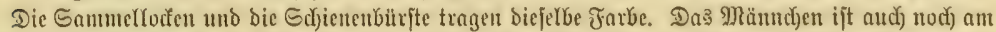

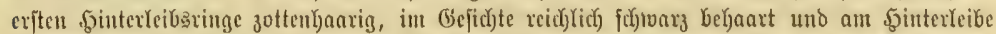

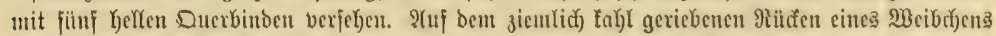

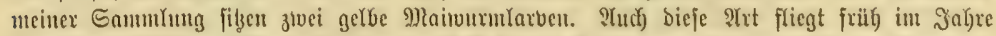

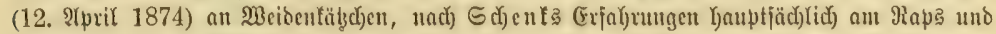

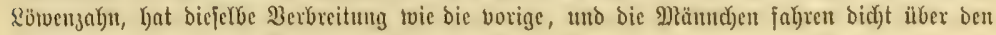
Boben Kin, twent fie bie $\mathfrak{B}$ eibdren auffuchen wollen.

Die $\mathfrak{B a r f e n b i e n e n , ~ S d y m a r b i e n e n ~ ( H y l a e u s ~ o b e r ~ H a l i c t u s ) , ~ w e n i g e r ~ r e i d f ) ~ a n ~ P l r t e n ~}$ als bie vorige Gattung, ftimmen in ber Rebense 


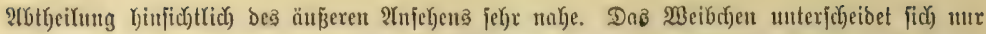
burd) cineu (glänzenden) fallen Reilfred mitten auf ber (Endfranje, ber f̧interleib

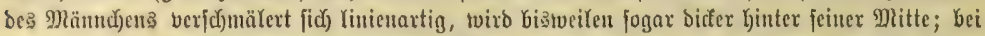

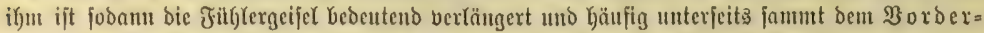

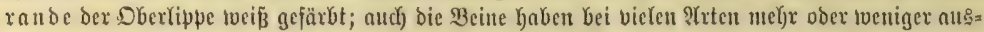

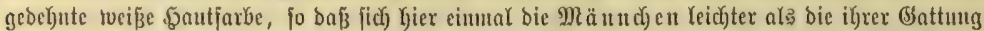

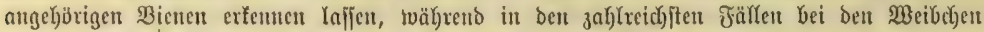

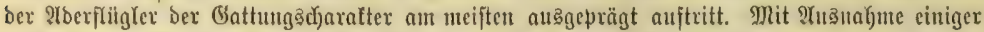

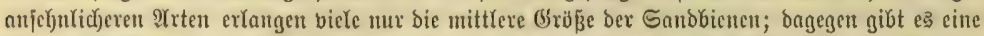
Menge feldr fleiner, twie fie bei ben vorigen mur feltener vortontmen. Die Sdjmalbienen erfdjeitent

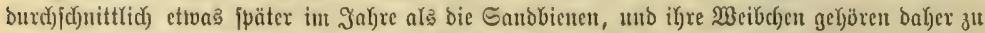

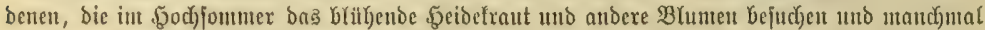

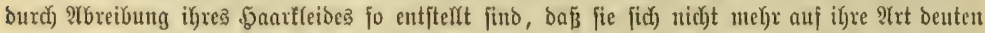
Iaffen. Sie Yegen ifre Butröbren an liebften in Garten Boden an. Daber find fie es, twelche

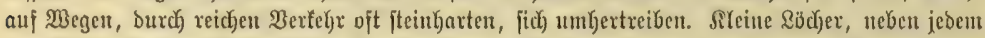

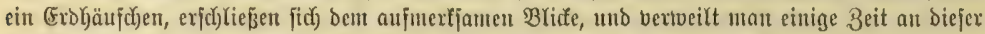

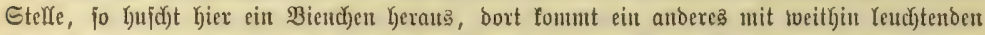

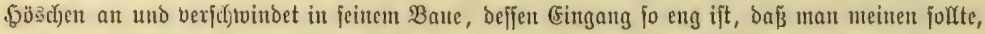

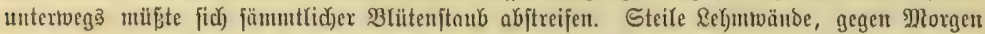

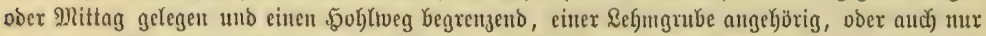

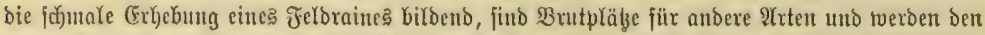

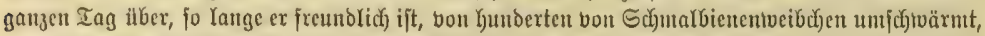
beren jebes nแล = und cinfliegt, nie fid) verfiegt, fondern unter ben Kunderten volffommen gleicher

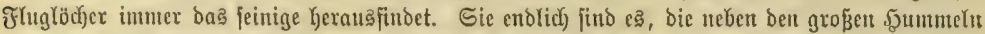

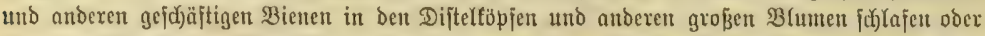

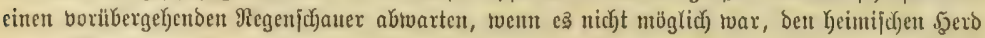
aน erreid)en.

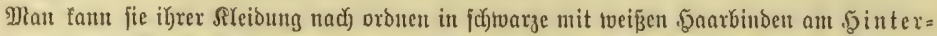

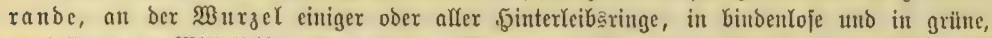

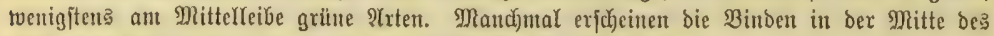

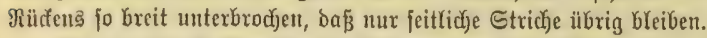

Die groß̧e Bałfenbiene (Hylaeus grandis, Fig. 9, 10), unjere ftattlidjite Art, twirb

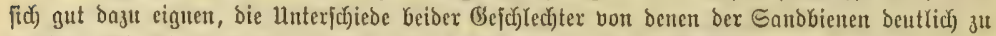

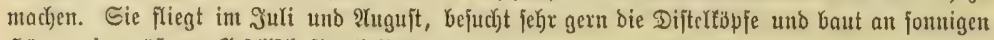
Sängen in größzeren Bejelfidjajten beijammen.

Die ranke Seibenbiene (Colletes hirta), weldye ben beioen borigen (battungen fehr

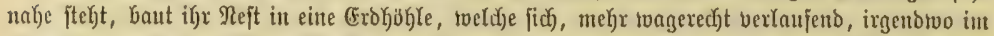

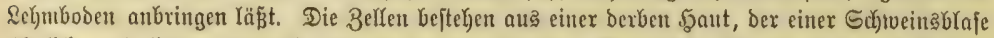

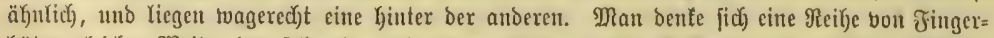
hüten gleicher Weite, Den folgenden mit feinen Boben in bie Definung bes vorigen gefdubben,

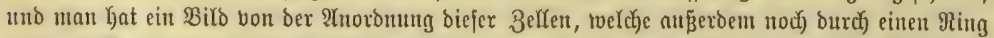
aus berjelben Mafie an ber Derbindungsifeffe je ztweier zujammengebalten werben. Der Duer=

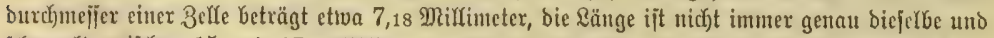

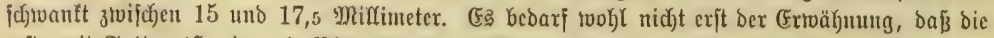

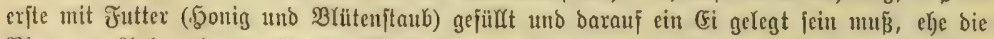

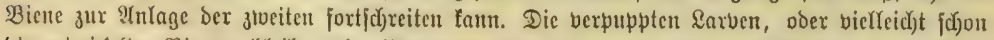

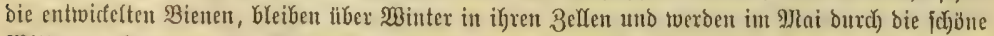
Witterung herborgelodt. Die Belfen, weldje id zu beobadjten (Belegentyeit lyatte, twaren an ber 


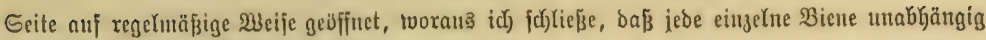
von ber anberen ífre Slauje verläßst.

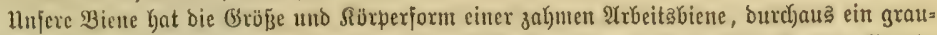

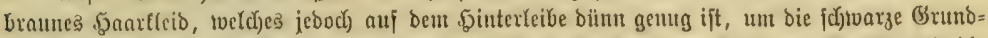

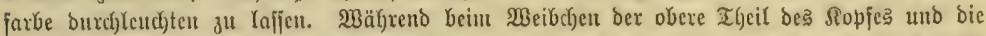

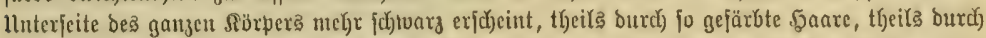

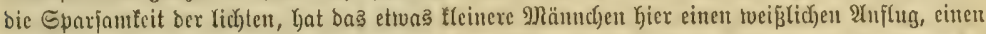

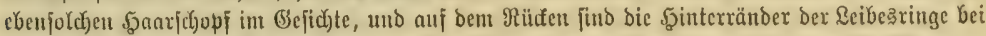

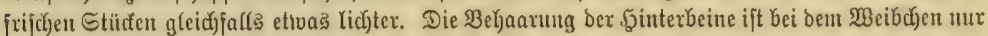

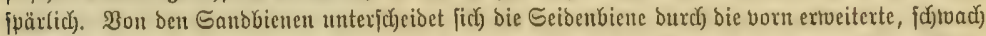

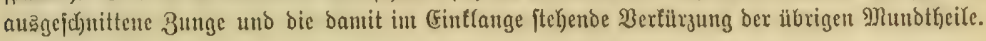

Die Märtelbicne, geneine Maurerbiene (Chalicodoma muraria), bem 2rnjehen nad)

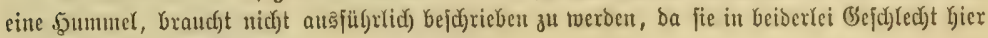
borliegt. (E⿱ jei nux bemertt, Daß̄ basె jibzende Weibchen burdjaus jujtoars auspliebt,

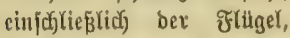
suerche nadj) ber Spiz̧e zu ettuag richter toerden, Daß bas

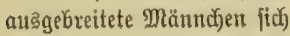

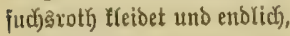
baß̃ die 3unge fergr lang, die zugebörigen Iajtex zreige= italtig, bie Riejerntafter zivei= glieberig und bie vorn ver= breiterten Sinnbacten vier= zäbnig uno vierfurdodig fino. Der şaud) ift gleidi) bent Milifel ftnif befjaart, unb jtwar beint Weibraten mit

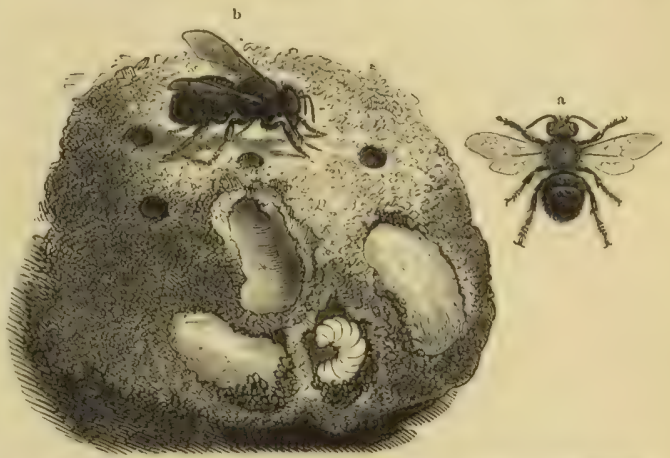

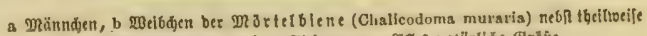
gedfinetem Refie an einer Eteinmauer. Mats natlitide Sröbe. mehr borjtigen, nach binten

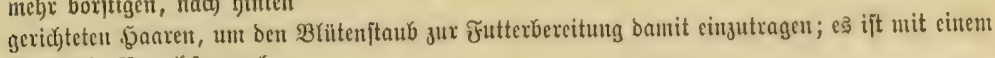
Worte ein $\mathfrak{B}$ aud (d) jammlex.

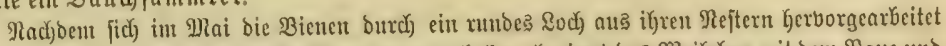

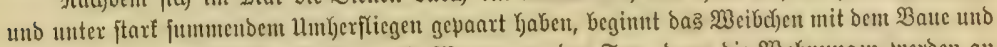

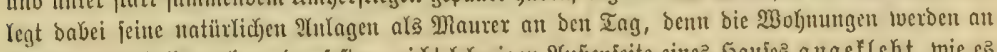

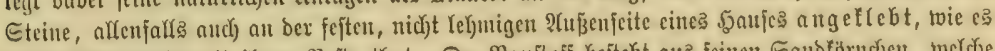

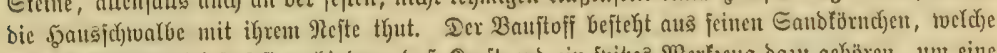

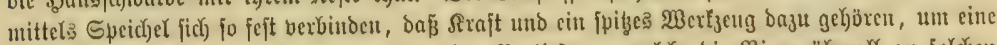
3elle zu iffuen. Jin irgento einer fodwad)en Berticfung, weldye bie Biene überall an foldjen

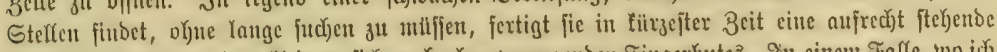

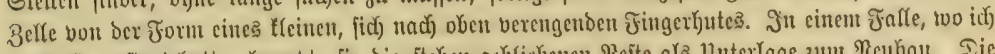

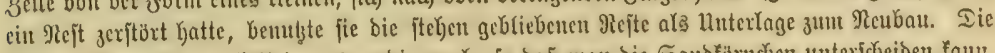

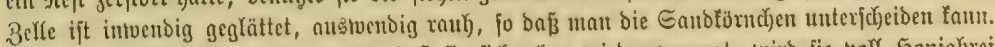

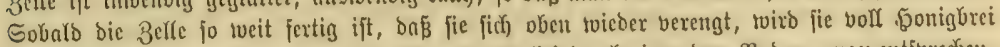

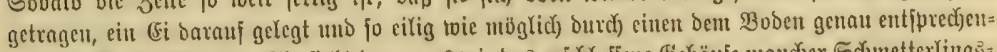

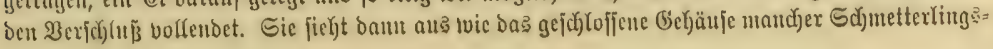




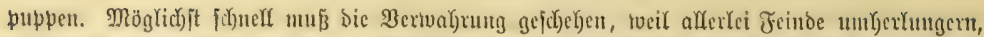

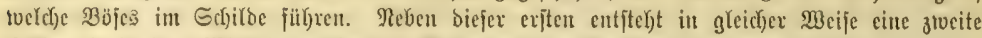

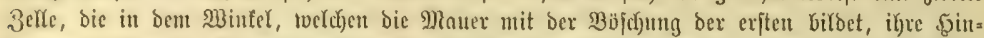

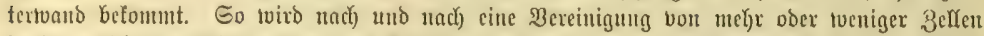

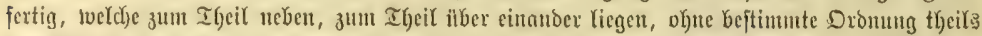

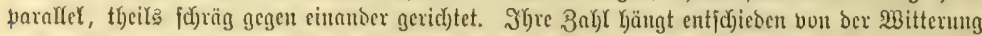

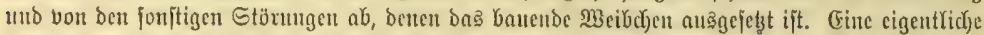
Socinat Yjat başflbe nicht; Denu ber frei gelegene Drt, wo ę bie 3elfen aneinander maucrt, bietet

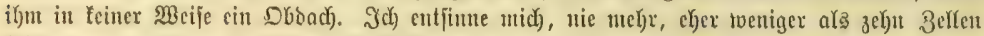
beifamunen gefunden zu Kaben. Diefclben tverben auf ifrer veltigen Oberfläche rob) geglättet,

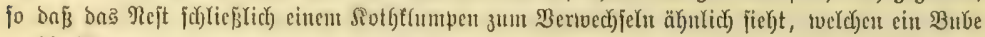
an bie Wano twarf, uto ber nun angetrodnet ijt.

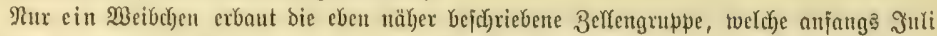

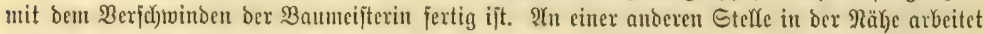

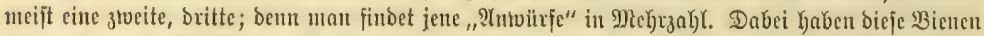

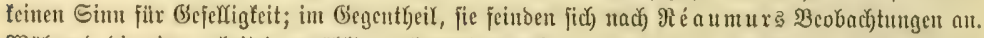
Währeno bie eine arbeitet, erzähylt er, foumt mand

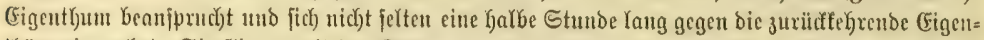

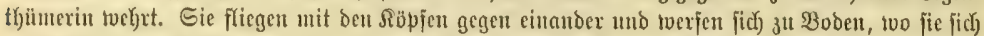

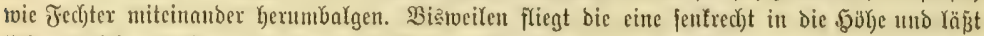

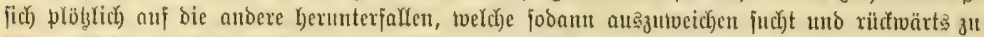

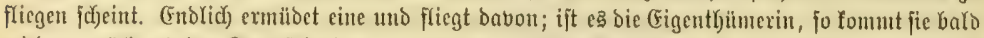

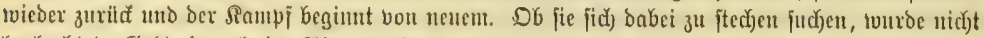

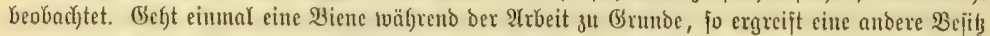

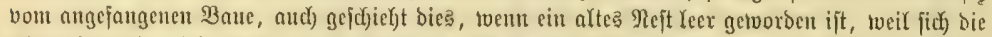

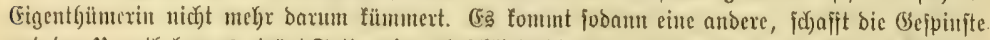

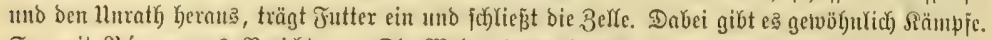

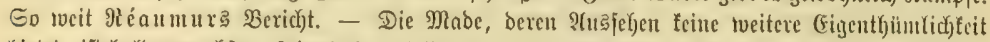

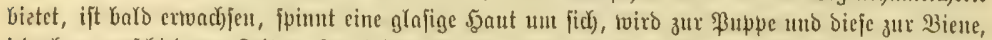

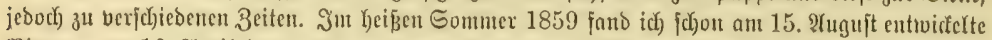

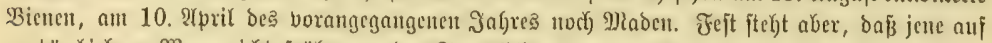

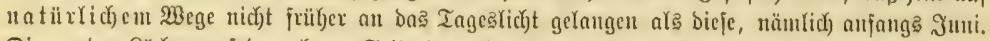

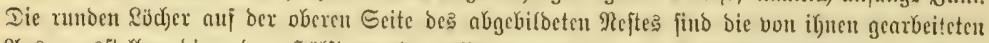

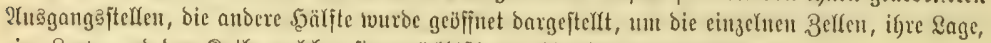

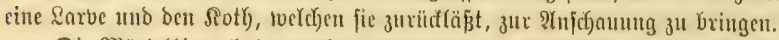

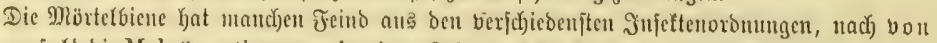
Fraucufeld bie Meloë erythrocnemis, cinen §äfer, und bie Irauerfliege $\Lambda$ rgyromoeba subno-

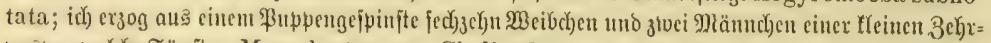

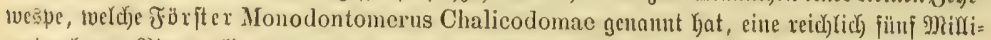

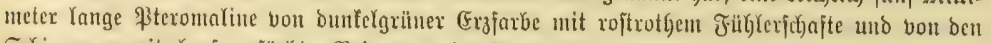

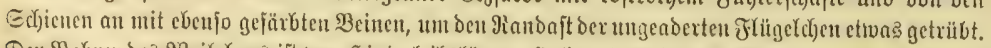

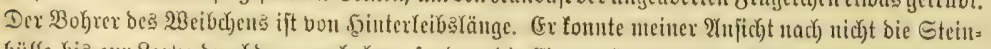

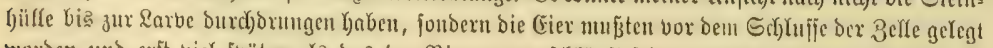

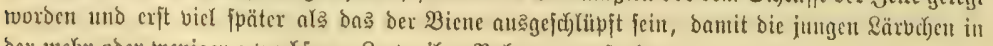

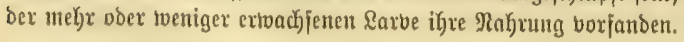

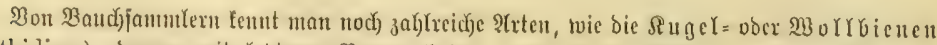

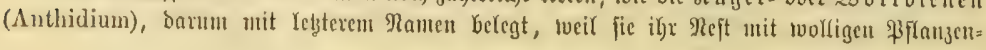




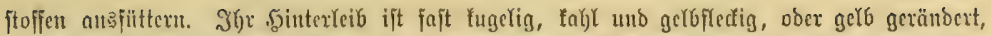
wą bei Bienen ponft ferten borfommt. Die Rauerbienen (Osmia) baben einen gleich)

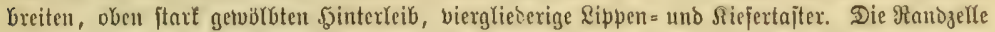

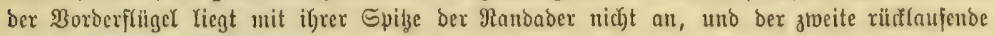

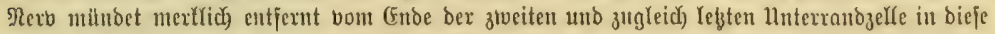
(Fig. 2, S. 201). Sie Yegen ihre Refter in Mauerlöchern an, benutzen bazu autch ben vcrlaffenen

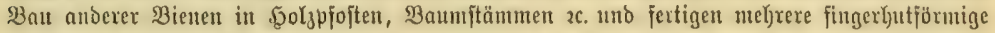

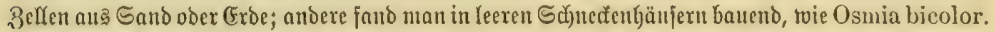

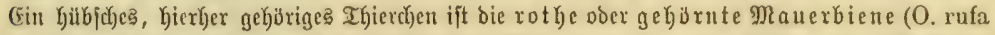

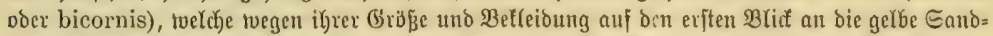

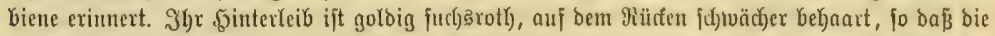

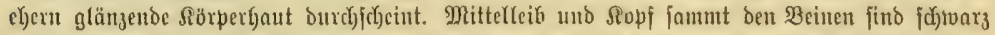
behaart, uno bein $\mathfrak{W}$ seibc)

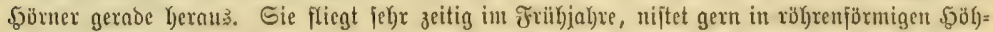

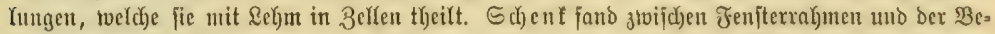

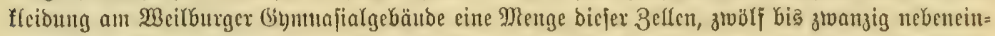

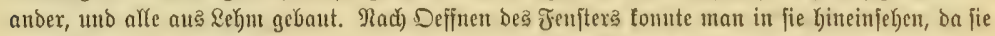

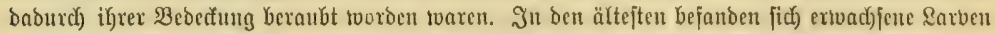
unb wentig ober gar fein Futter meljr, in ben folgenden twurben bie Rarben immer fleiner, bie

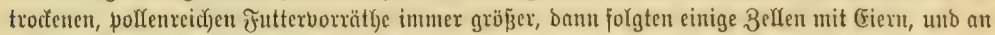

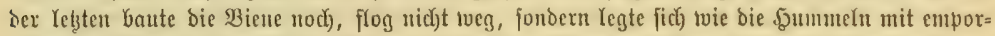

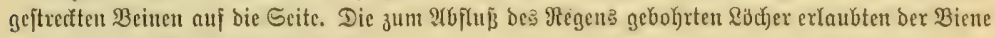
an bezeidjnetex \$auftelle Den Butritt.

Eefir nabe vertwanst mit ber eben befprodyenen Gattung find bie BYattjefneider ober

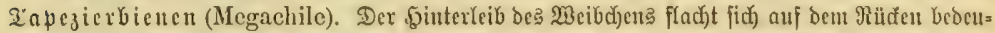

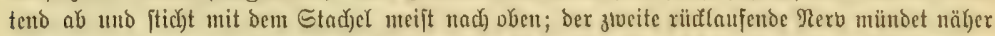

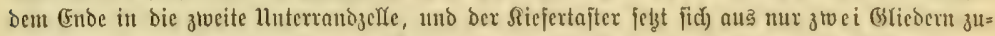

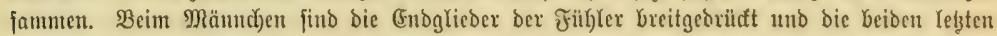

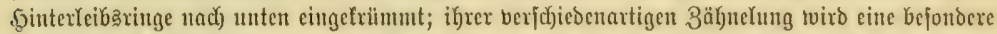

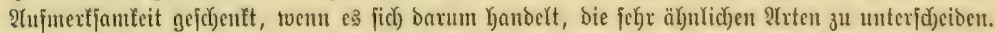

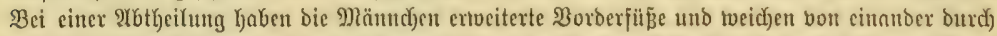

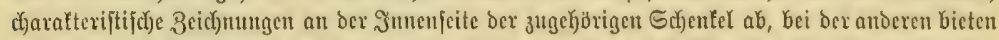

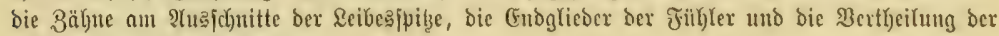

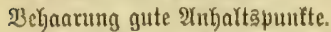

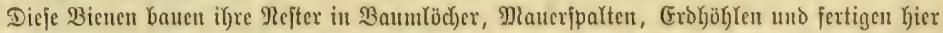

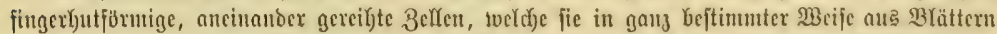

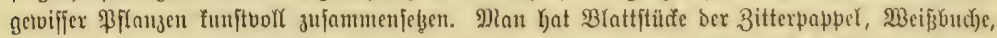

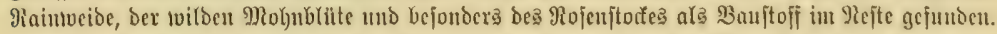

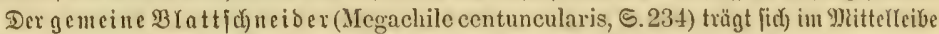

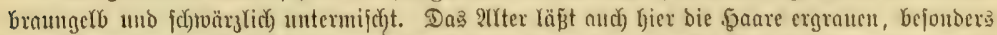

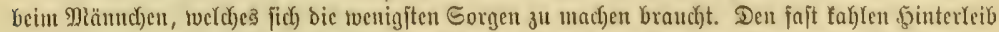

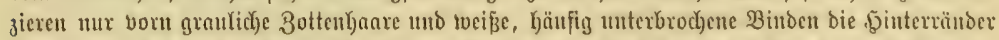

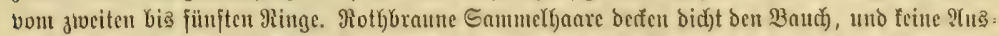

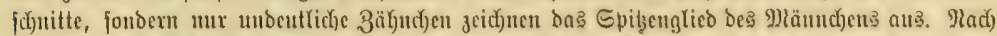

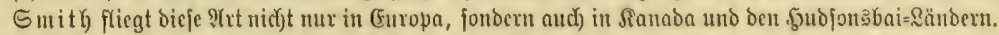

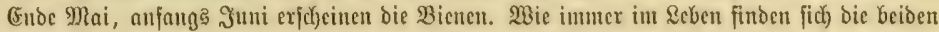

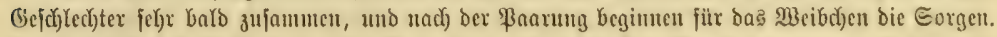

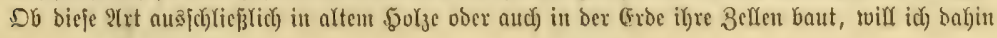


gefteflt jein Yajien, jedenfalfa find berartige Belfen fier und dort gefunben toorben und fönnen mög=

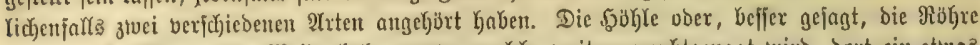

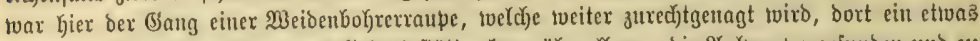

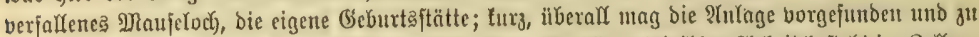

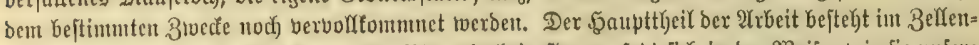

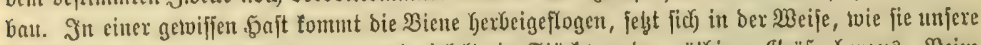

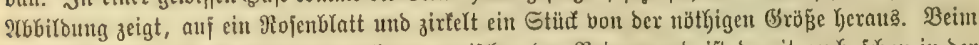

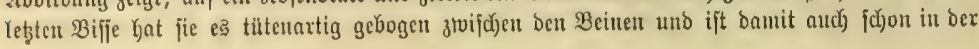
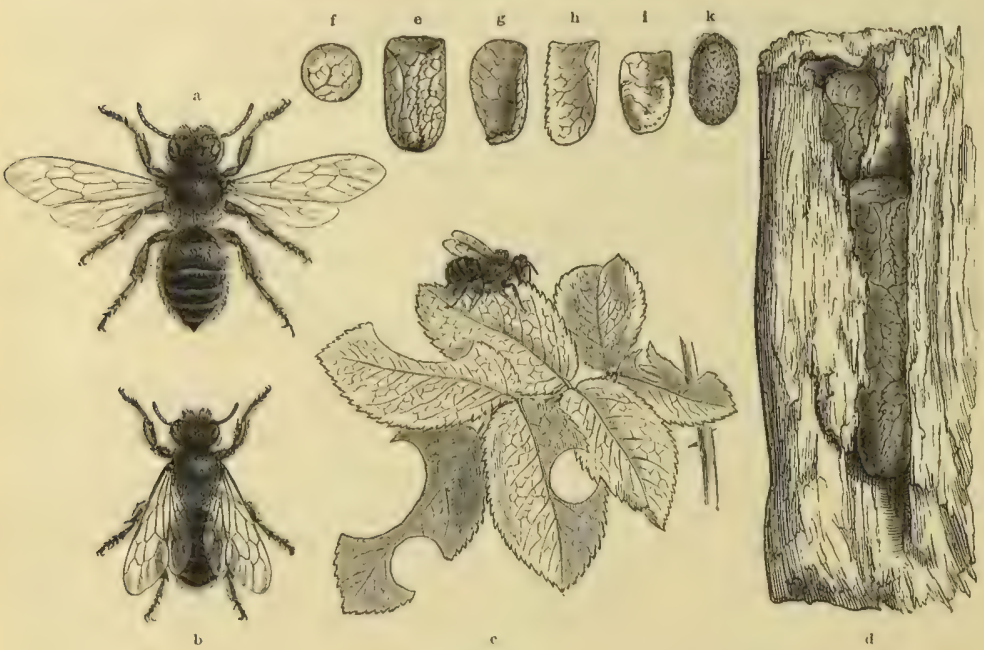

d

(9) eneiner Blattid nelber (Blegachlle oentuncularls).

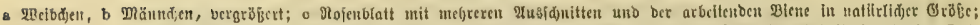

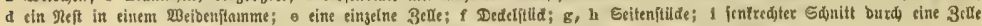

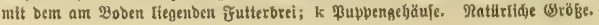

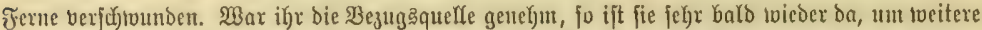

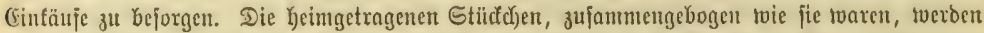

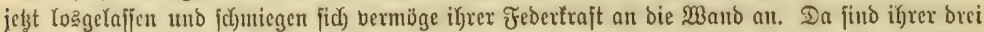

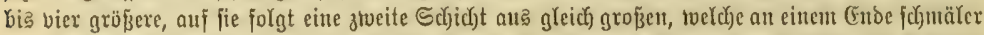

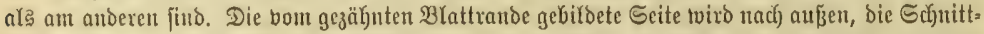
feite nad) intuen gelegt. In bicję Futteral bringt bie Biene ein britte aus abernals unter jict)

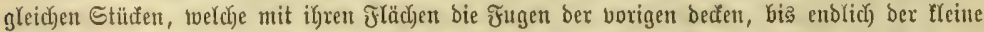

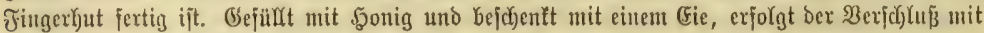

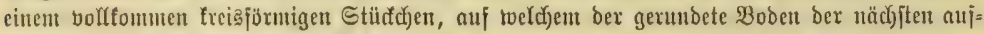

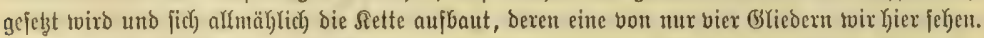

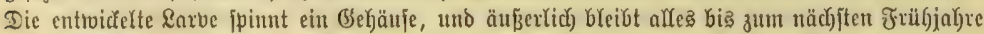

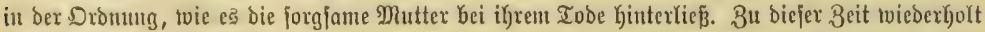

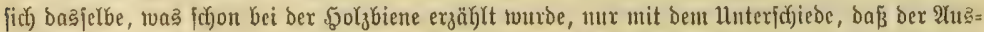

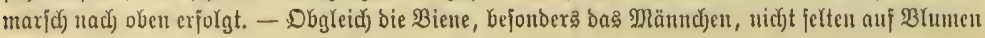




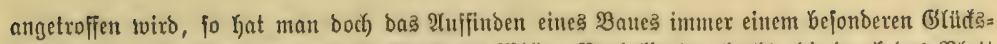

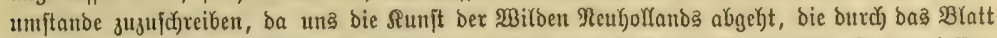

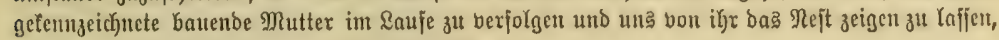
twie fid jene ben Meliponen gegenuber verbalten.

Die großje Denge zum Iheil recht artiger Bienen, beren Meibchen loeber an Den Beitten,

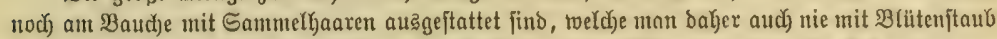

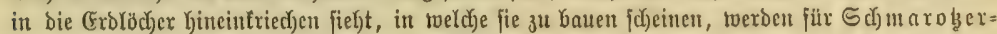

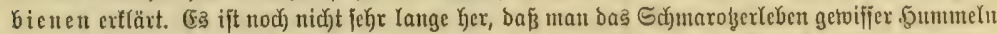
entbeitt hat; nach S miths Beobachtungen follen bie Bude lbienen (Sphecodes) feine Parafiten

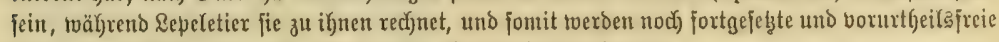

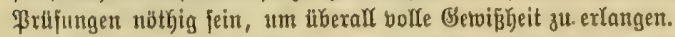

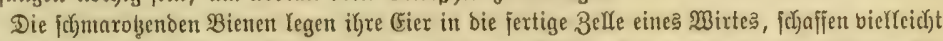

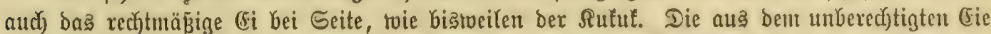

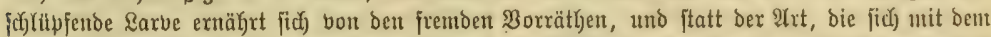
3effenbaue abgequält hatte, fommt ein bie Bequemlidjfeit liebendes anderes, teent and) vertwanotes

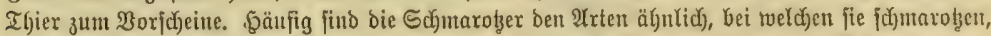

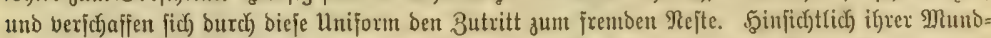

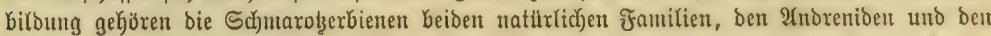

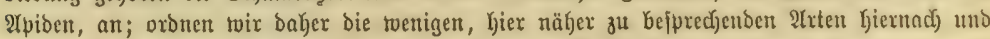
beginnen ntit ben langgungigen.

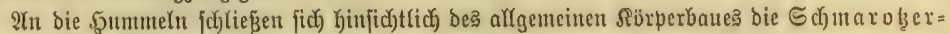

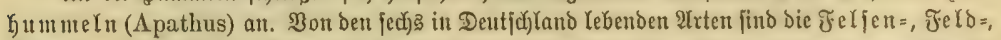

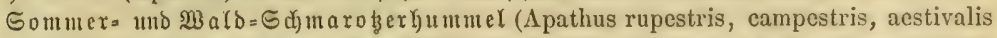

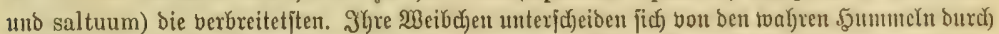

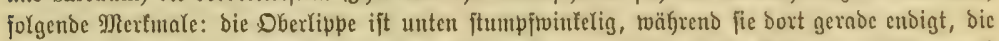

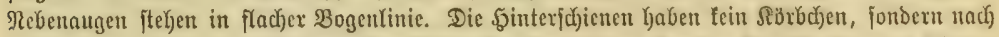

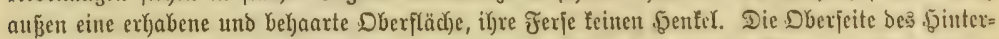

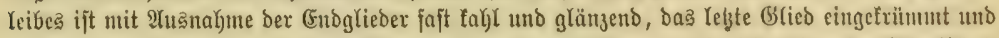

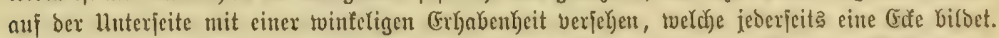

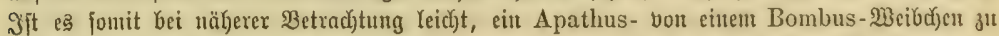

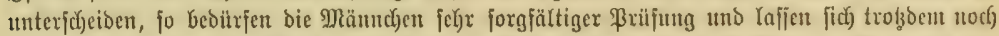

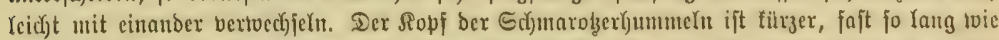

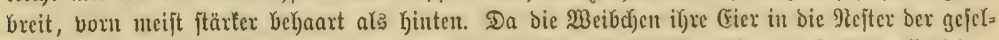

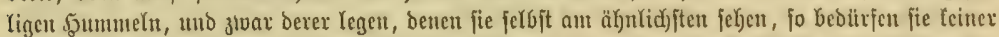

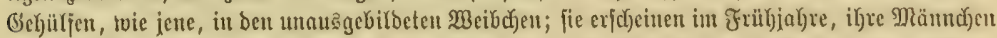

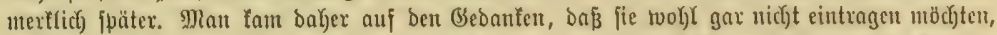

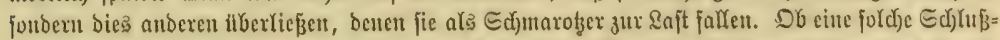

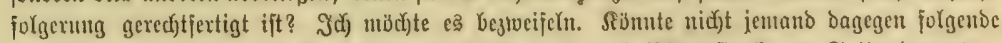

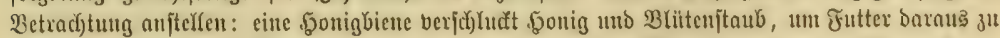

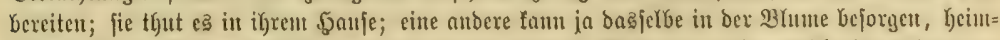

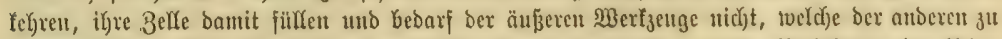
Gebote fteben. Die Ratur ift mamigfaltig genug, un aud) in bicjer Bejiebung eine ffeine Renderung anzubringert.

3u ben gemeinjten uno artenreid)ften Echmarolgerbienen gehjuren bie Weßpenbiencut

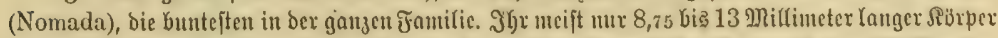

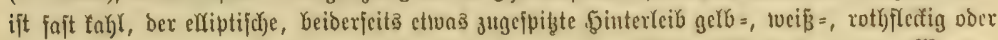

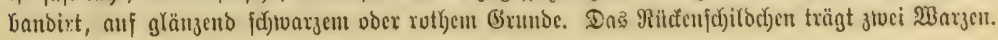




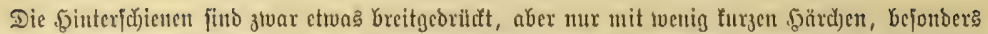

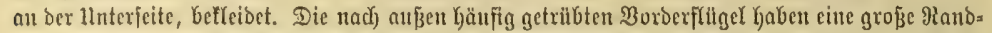

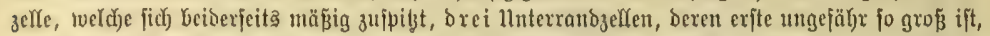

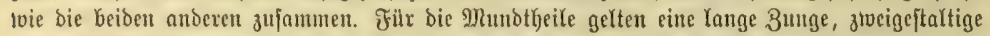
Sippen = unb fech)

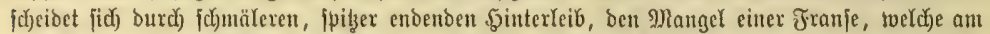

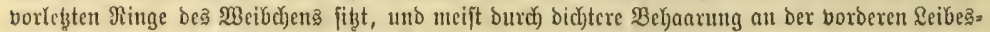

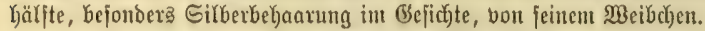

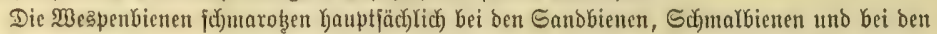

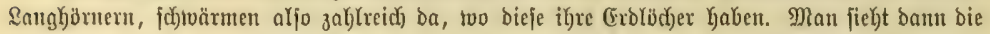

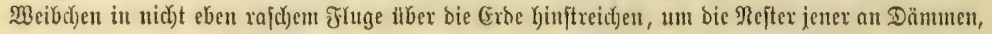

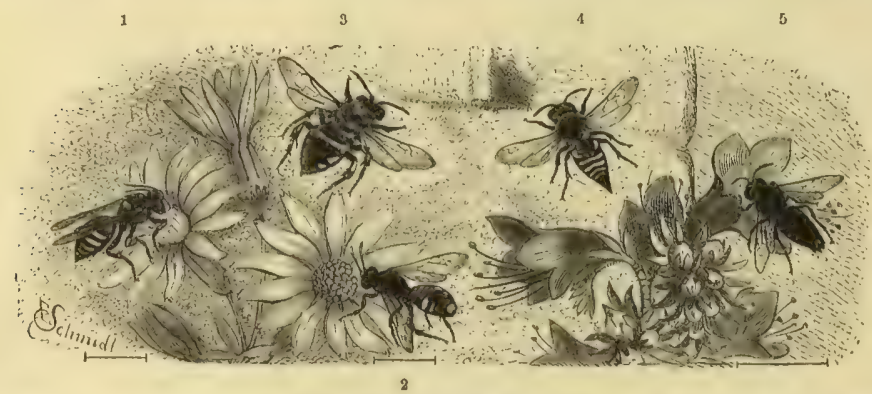

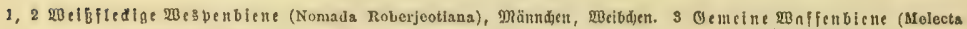

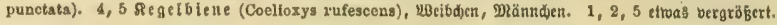

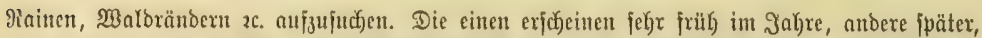

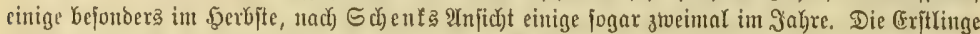

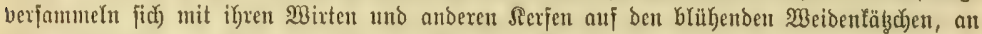

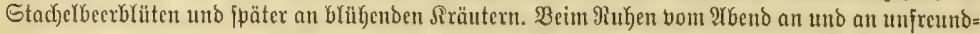

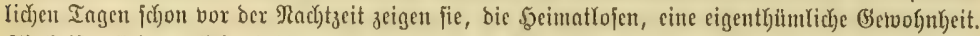

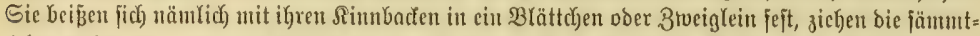

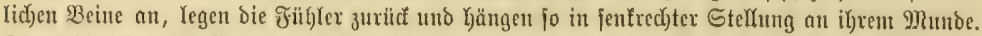

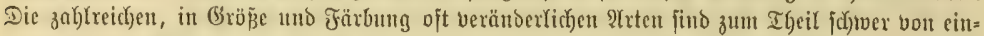

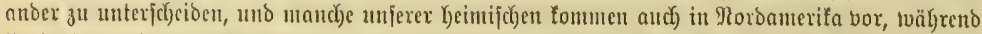
fie in ben heipen (eroftrichen burch) andere Formen vertreten find. Un ein Birb biejer jierfict)en

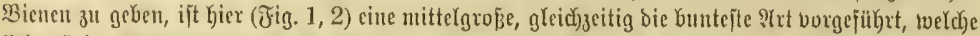

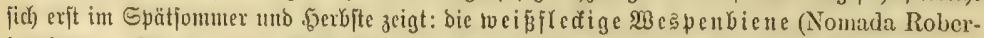

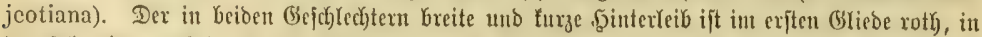

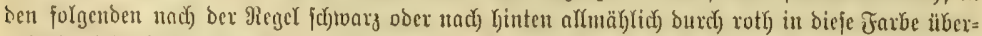

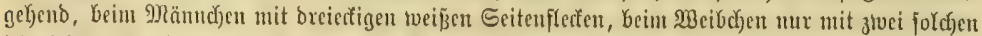

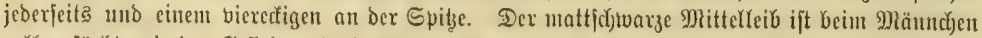

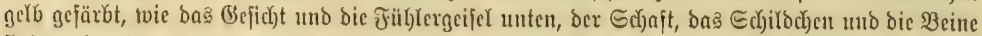

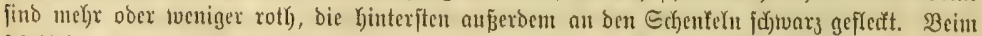
24 cibchen find bie hefferen 3eichnungen etwos jparjaner unb nur bis roth herabgebend.

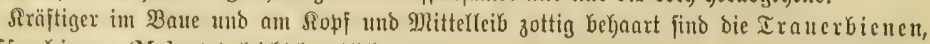

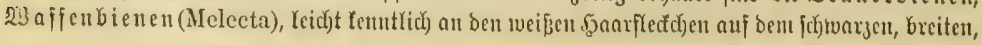




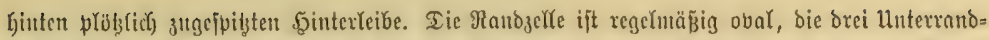

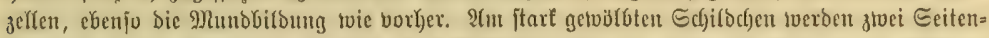

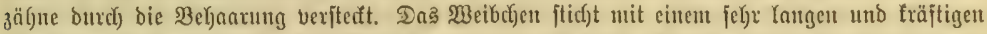

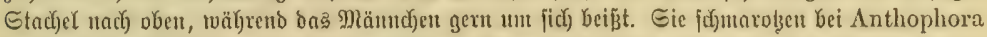

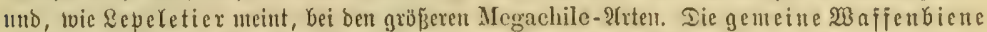

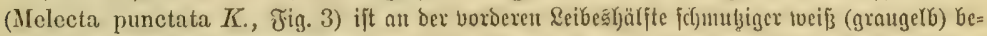
hant unto fdrmarobst vorherrfdeno bei Anthophora retusa. Die punttirte $\mathbb{B}$ affenbiene

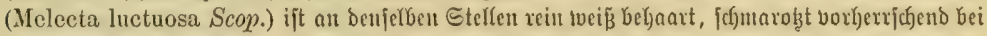

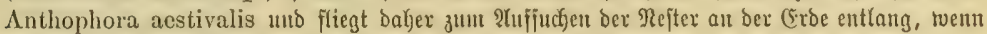

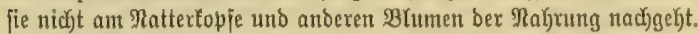

Sie Siegerbienen (Coelioxys, Fig. 4, 5), näd)ft ben Wespenbienen für unjere Oegenben bas

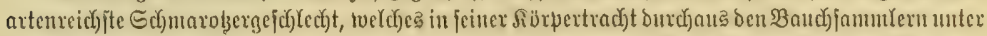

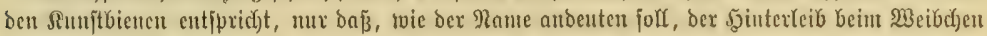

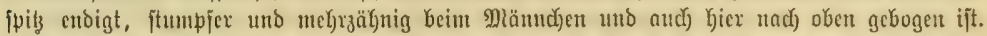

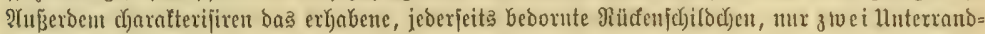

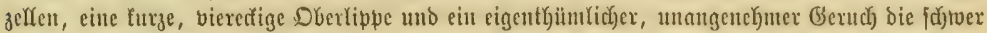

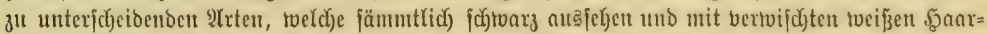

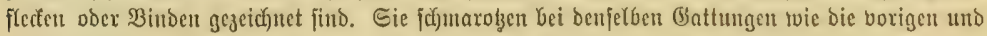
bei Saropoda.

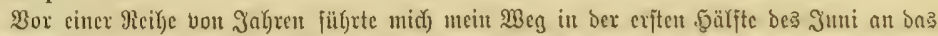

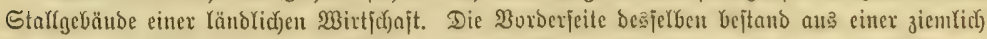

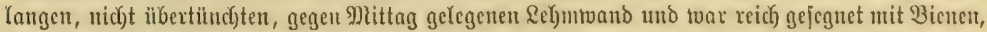

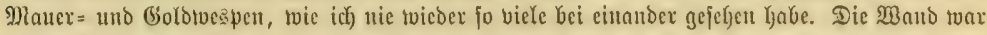
fajt fiebartig bur(f)(ö(t)ert. Bon ben Bienen herrjobten vor bie brei Gattungen Anthophora,

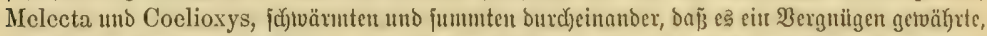

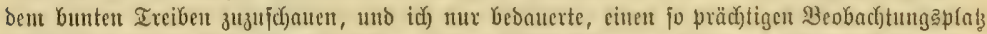

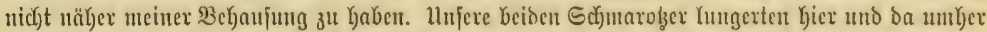

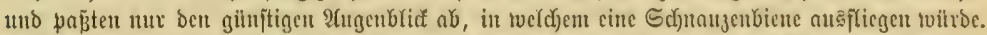

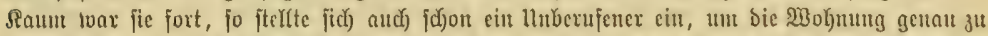

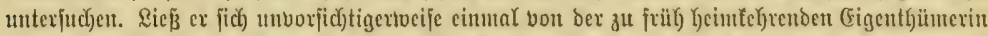

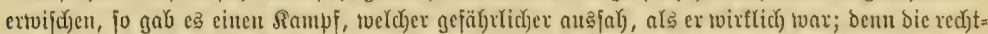

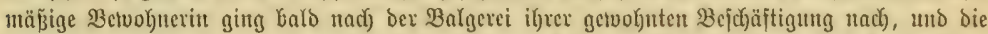

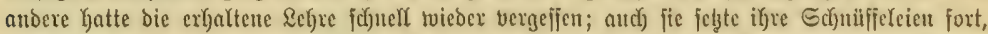
ge [र्d)

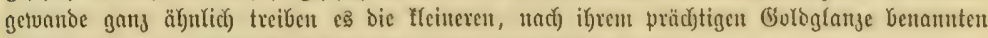

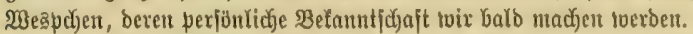

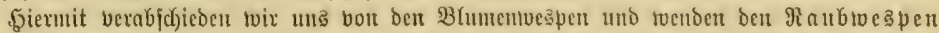

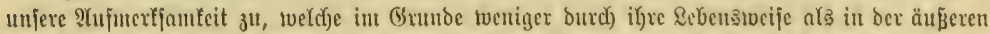

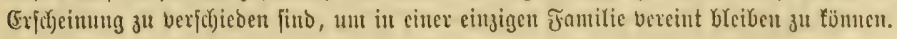

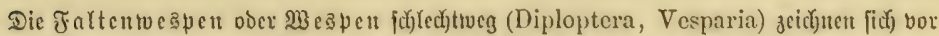

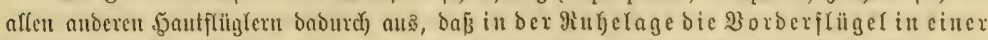

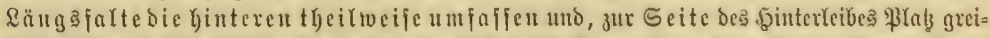

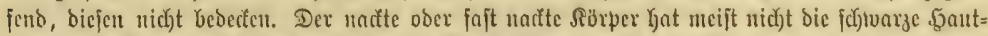

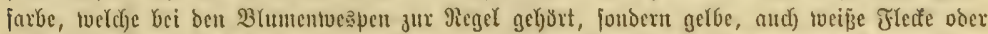

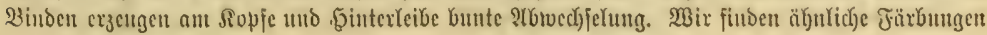




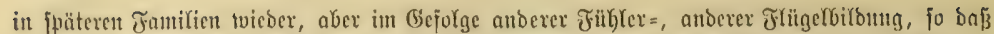

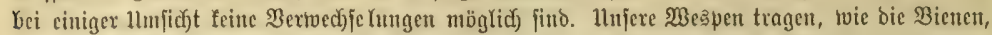

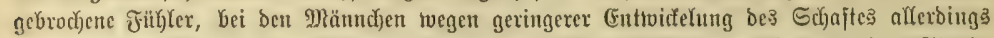

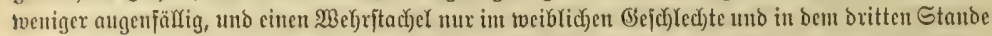

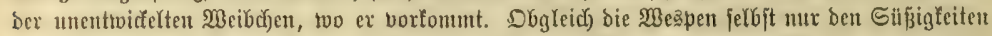

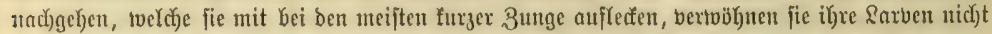

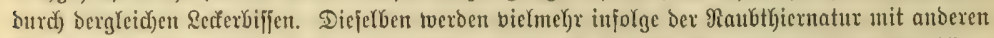

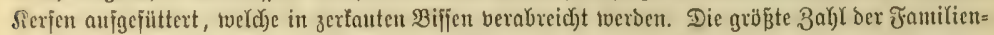

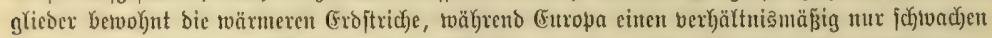

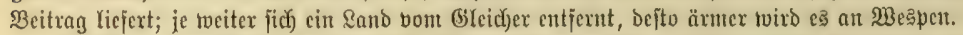

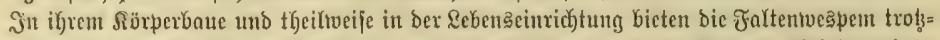

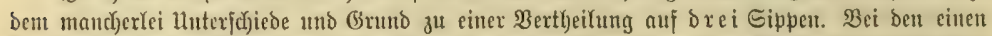

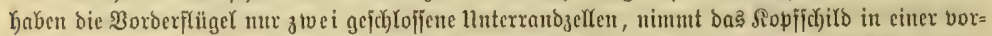

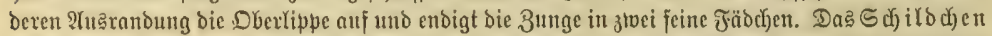

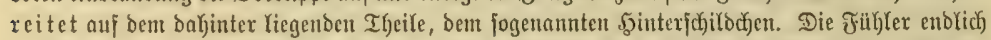

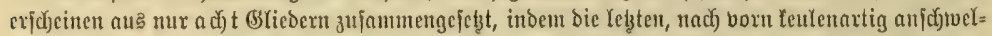

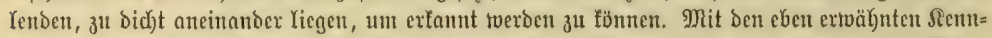

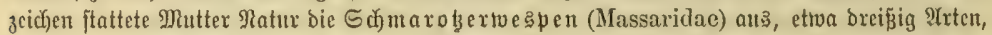
weldye in warmen \&ändern Yeben uno audd in ztweien, Celonites apiformis uno Ceramius Fons-

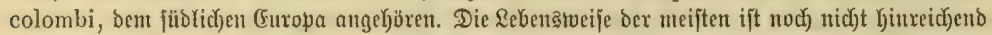
criforjoht, ba man fie aber bei einigen als cine jchmarotzende ertantht hat, meint man, bie ganze Sippe als joldhe bejeidynen zut Surten.

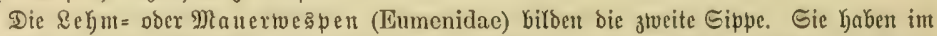

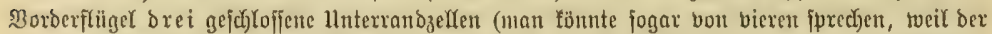

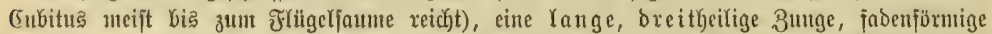
Injter, jechasglieberige an Den Riefern, vierglieberige an ber Ulnterlippe, ein hergförmiges ober

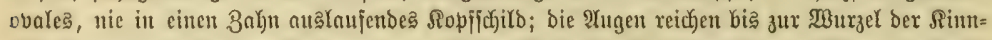

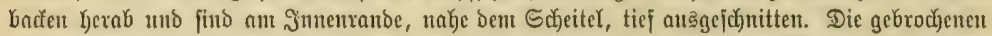

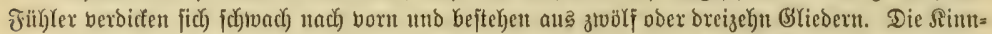

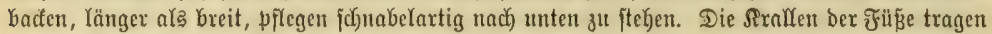

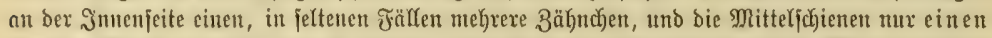
Eporn. Wie bie vorigen Keben fie einzełn, vorzugąweife in \&ehnnwänben, fteilen atbłängen fetten Eanbes, einige in trodfenen \$flanzenitengeln, in weldyen fie Beflenreihen von (Exde anlegen (Ody-

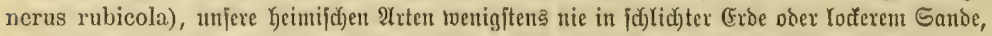

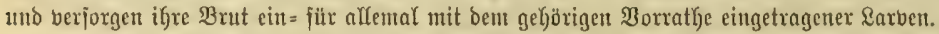

Die Papierwespen (Vespidae) endrid, Yeben zuneift gejellig, baben unjuchtbare

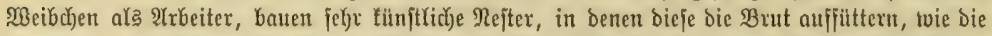

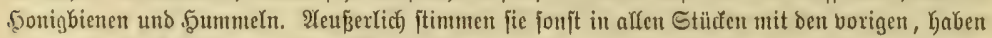

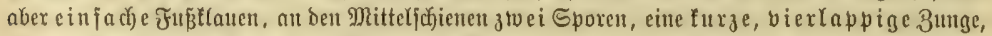

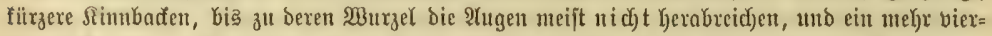

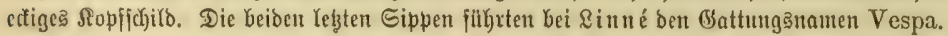

(Fin ungemein artenreiches, ïber Die ganze (Erde verbreitetes (Bejd)led)t ber Behmwespen, weldye die eine brunogeftalt bes Қinterleibes bergegentwärtigt, ijt Odynerus. Diejer nämlid)

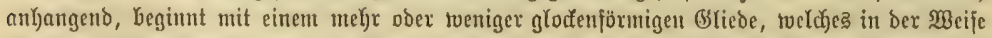

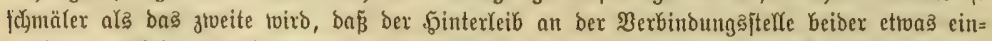

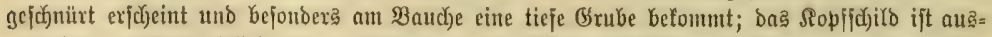

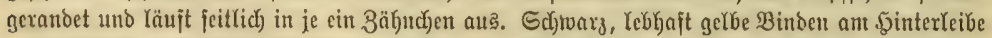

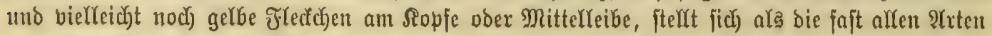




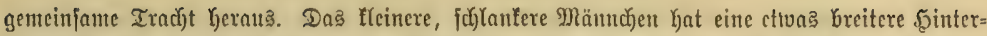

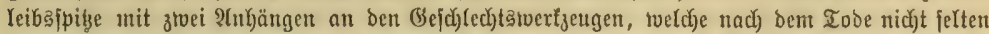
twie ztwei fleine Stadjeln, jeberjeits einer, aus jener Kervorragen; au[jerbent charafterifirt ę fich

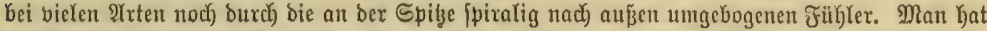

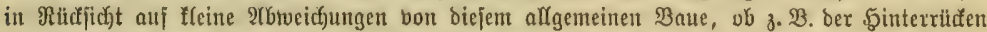

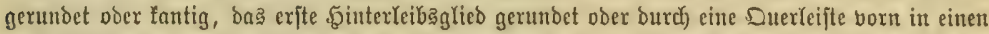
fteil abjalfenden vorberen und einen twagerechten hinteren Ifyeil geidjeden ift, ob bie Sinnbaưen

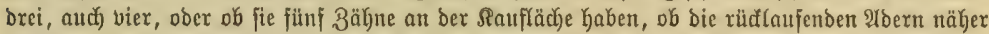

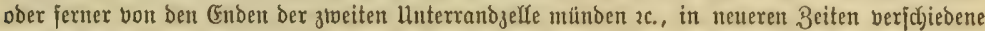
Oattungen babon abgetrennt, weld)e aber entjd)ieben vielfach ineinander tibergehen.

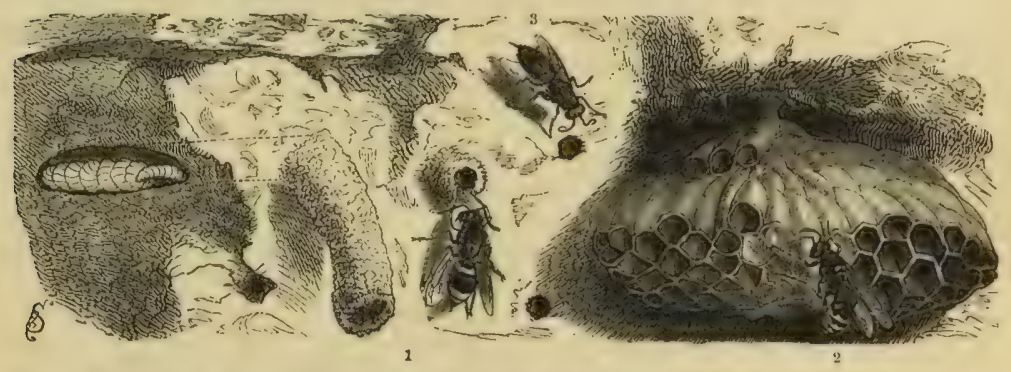

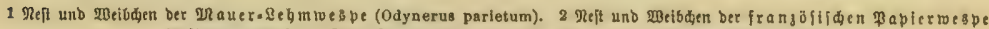

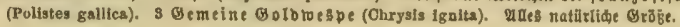

Die Ma uer = \&ehntwe spe (Odynerus parietum, Fig. 1) ändert in ber gelben Beichnung und der

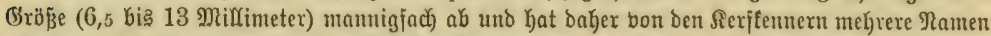

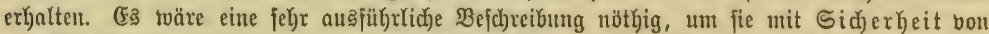

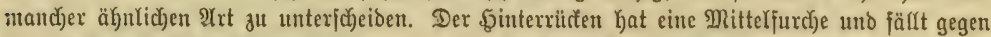

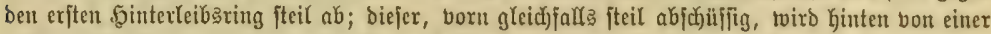
gelben, feitlich tweit vorgreifenden Binbe bejäumt, in ifrem $\mathfrak{B e r l a u j e ~ g l e i c h ~ b r e i t e ~} \mathfrak{B i n d e n ~ z i e r e n ~}$

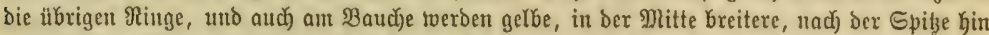

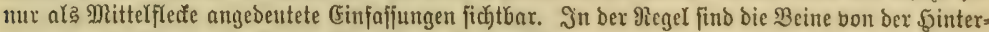

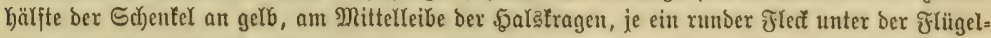

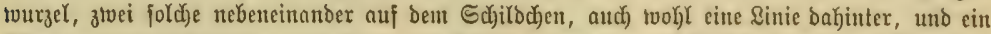

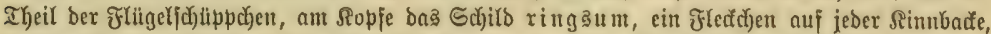

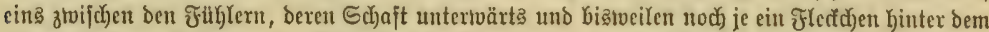

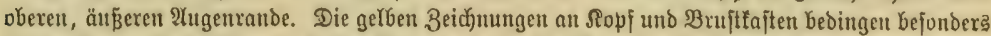

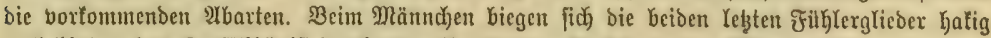

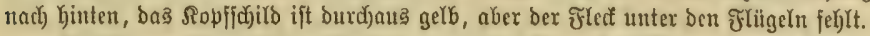

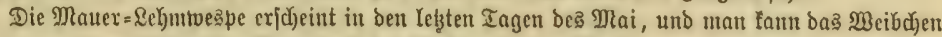

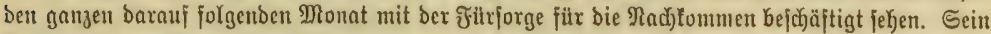

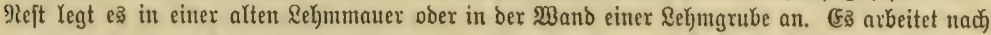

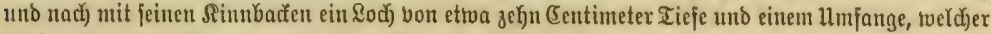

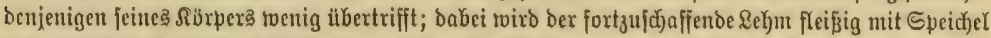

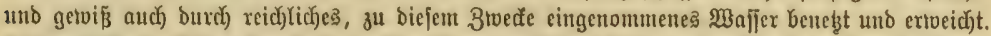

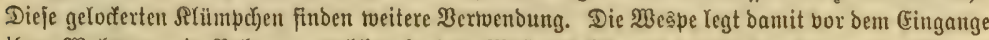

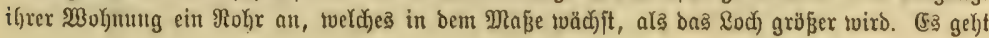




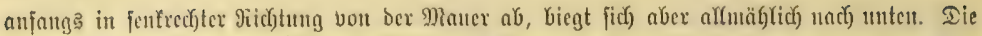

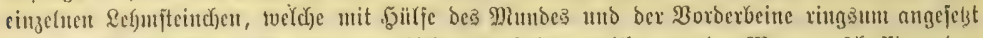

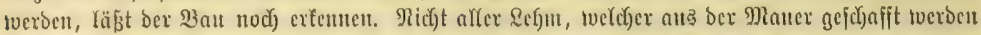

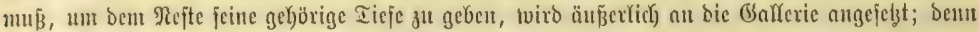

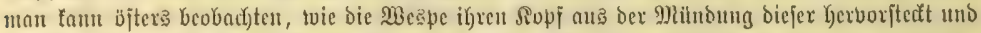

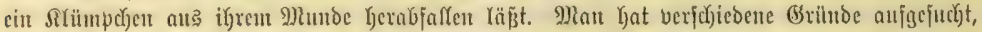

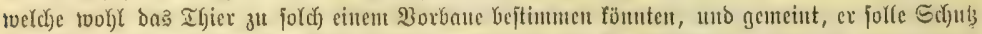

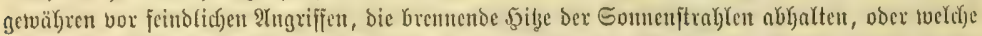

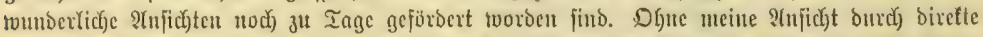

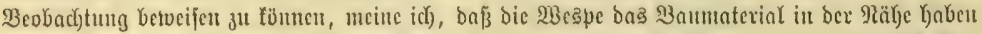

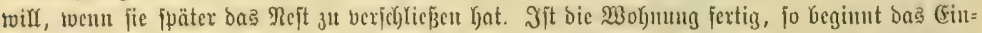

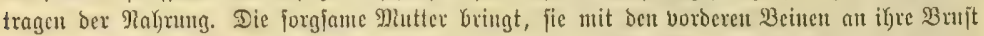

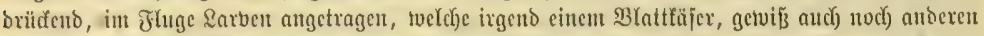
Serjen, suie fleinen Edjurctterlingen, angehjüren. Jit fie antgelangt, jo jaßjt fic bie Bente an Sopje,

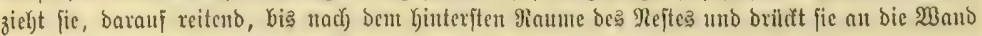

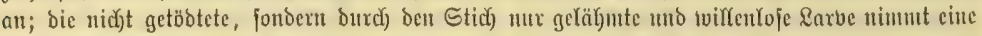

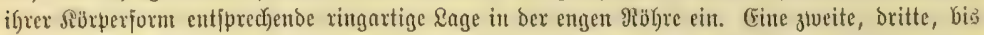

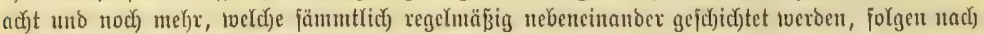

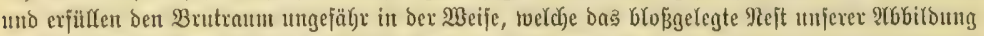

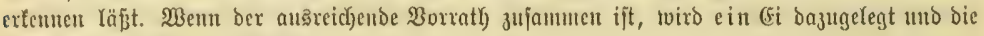
Deffunng mit Rebm verfid)lofjen.

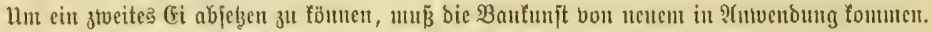

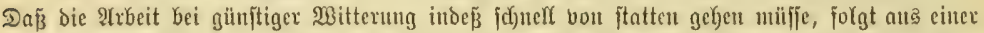

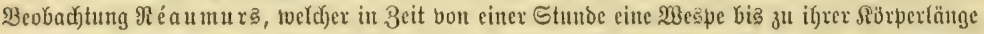

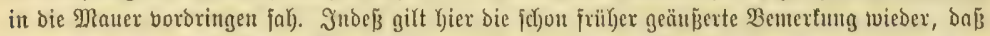

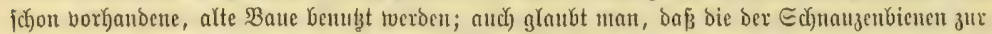

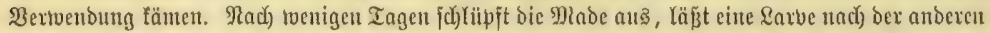

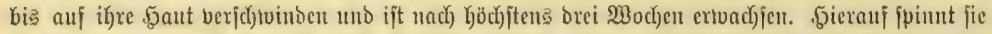

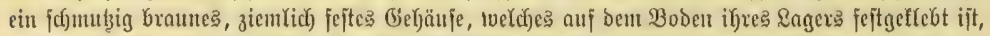

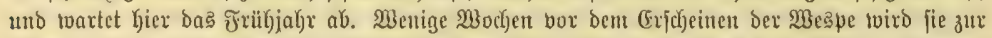

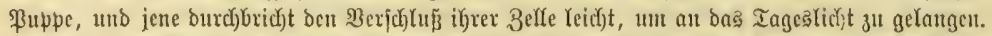

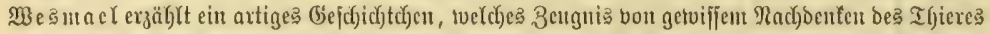

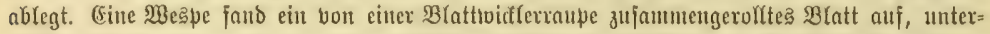

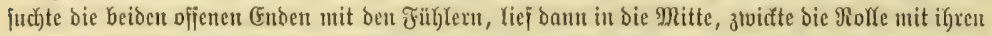

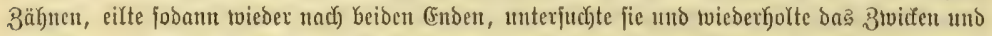

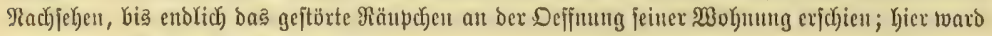

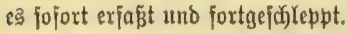

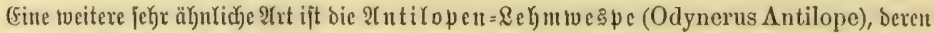

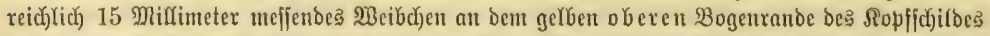

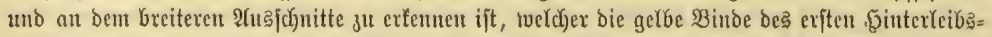
gliedes auszeichnct. - Die zahn

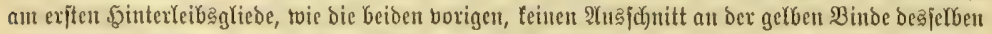

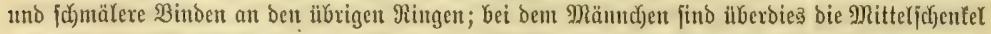

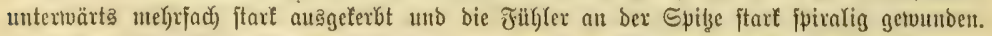

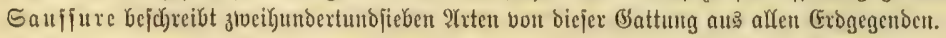

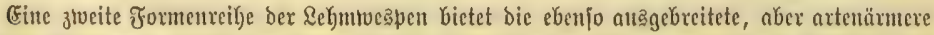

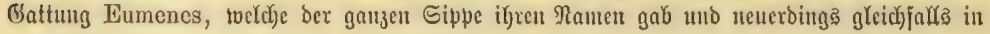




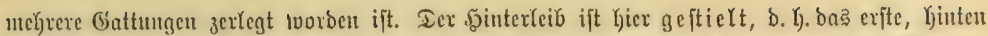

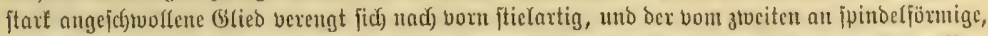

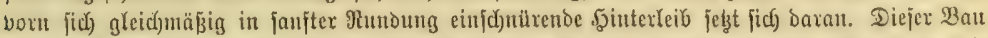

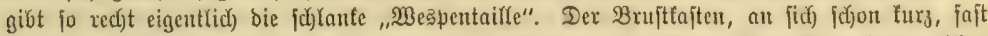

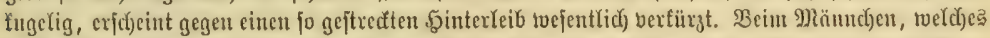

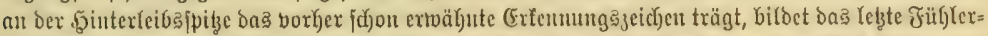

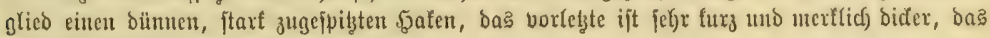
Drittrę̧te rächjit noch) mehr im Umfange.

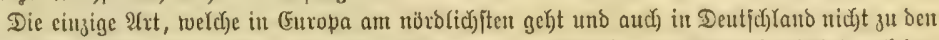

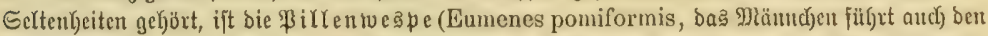

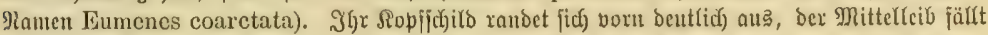

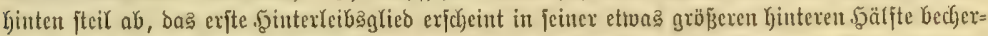

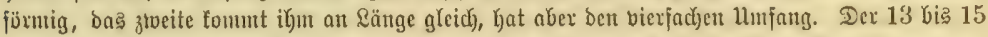

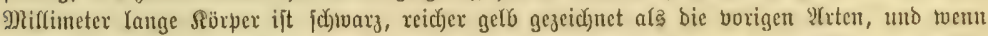

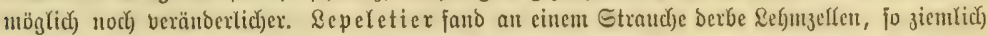

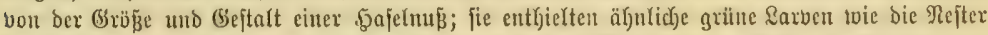

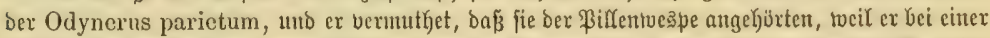

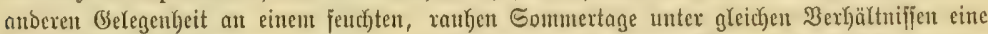

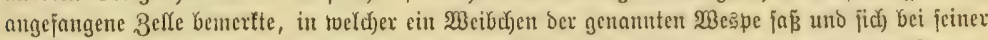

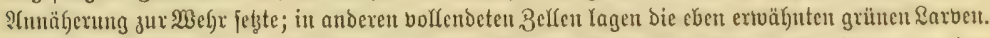

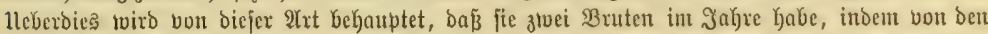

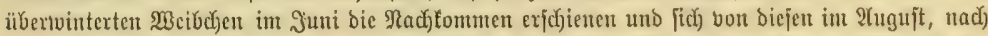

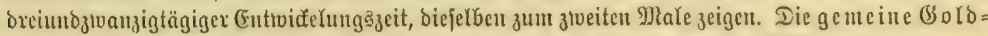

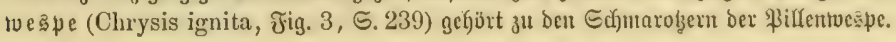

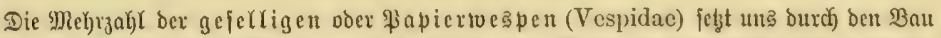

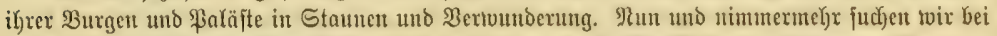

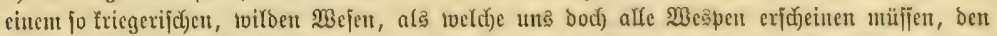

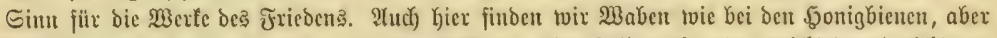

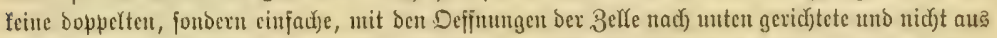

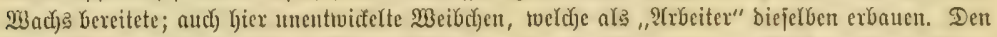

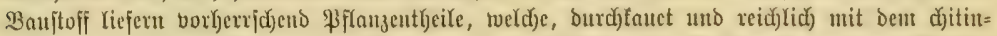
Y)altigen Speidfel gemifd)t, зu jenen fpröberen oder mefre febernden Sintiftwerten werden. Die jefjr

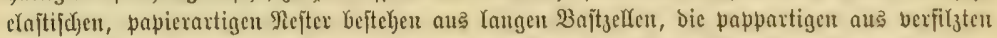

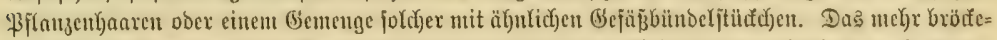

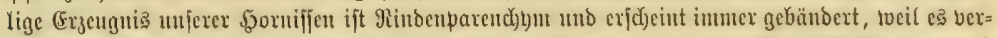

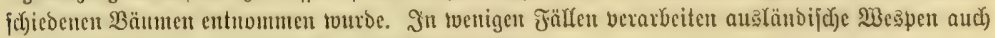
thunige (Exbe, ober ben Mijit pflanzentreffender Igiere.

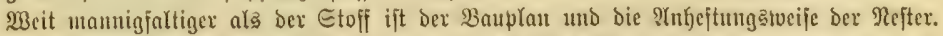

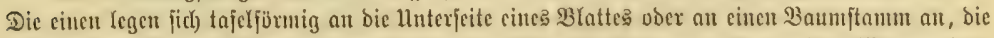

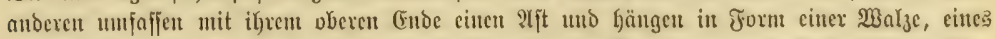

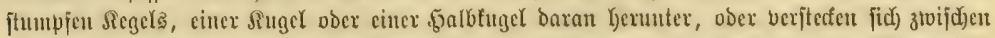

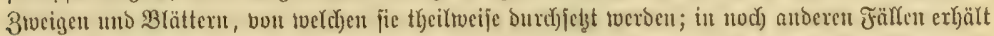

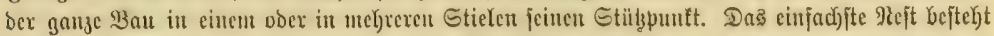

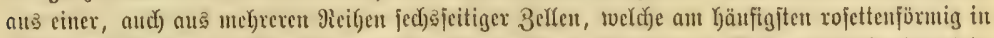

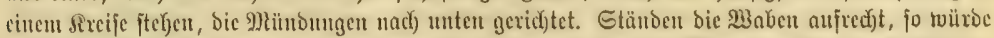

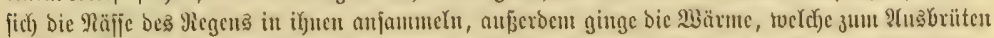

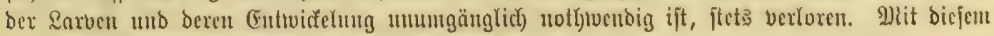

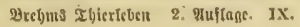




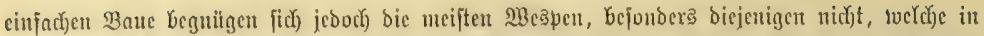

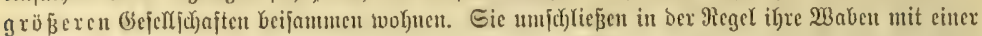

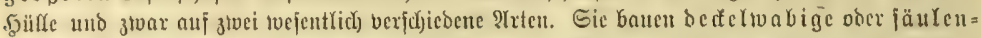

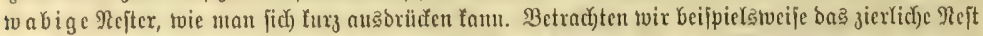

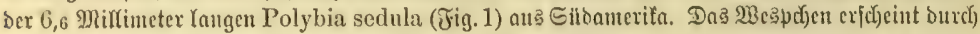
reid)(id) bla

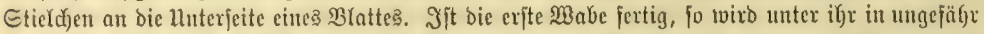

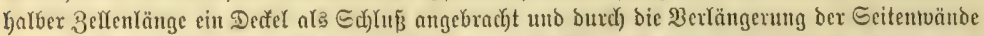

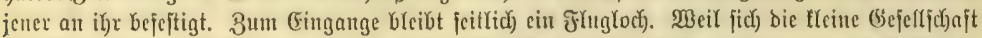

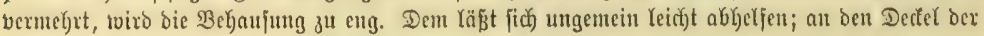

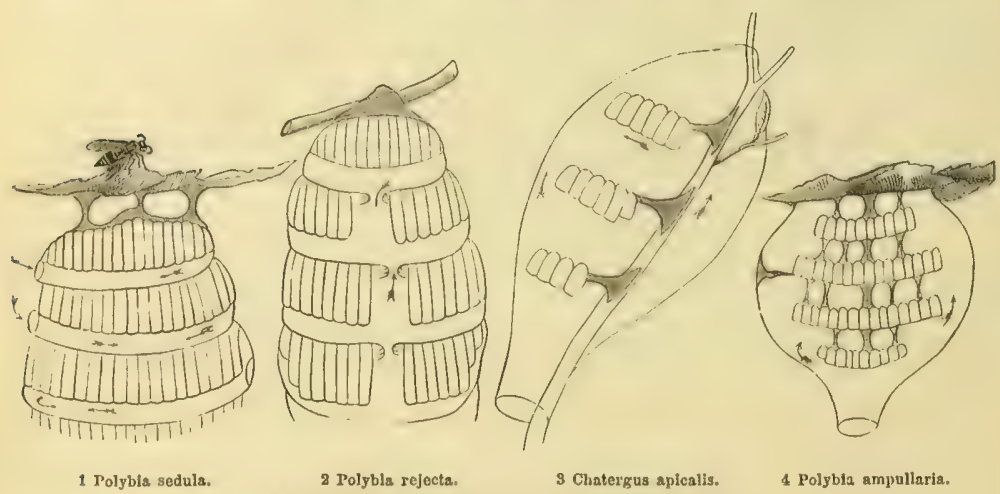

Sdematifide Darfeltug von bertieinerten gejtern.

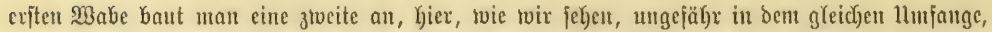

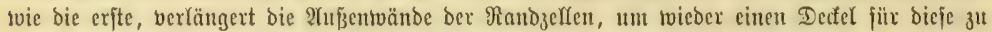

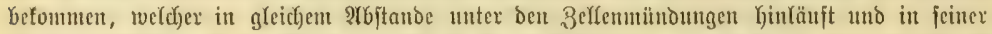

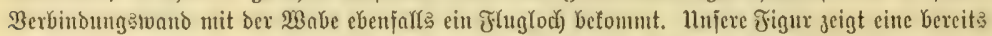

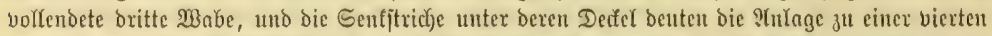

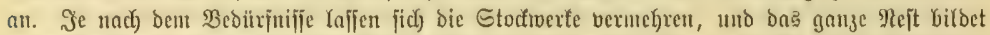

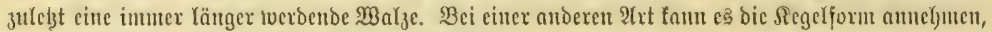
bei einer britten in ber 9]itte mehr anjichrollen.

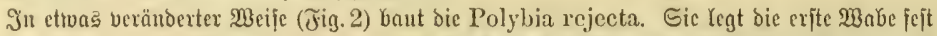

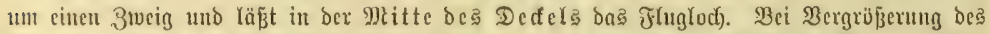

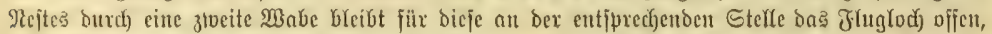

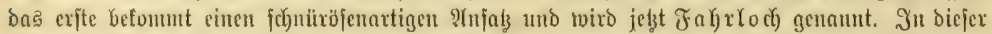

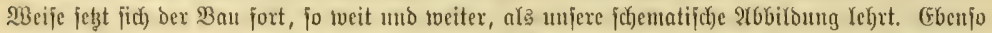

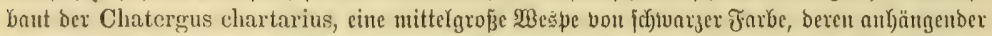

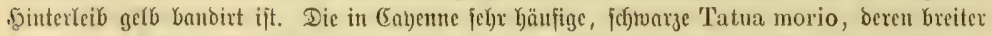

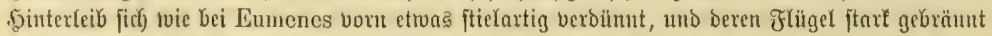

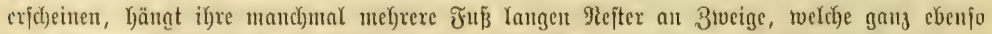

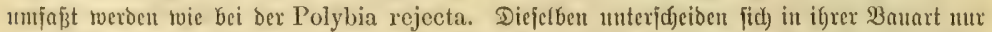

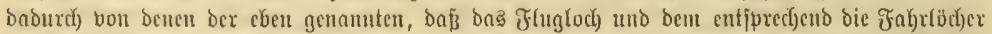

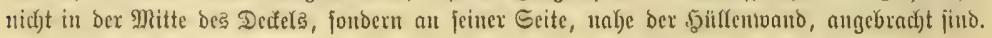




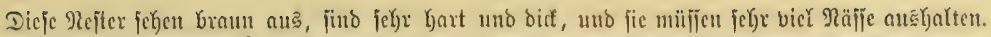

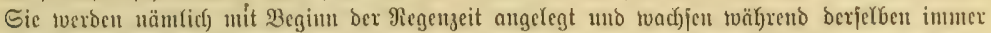

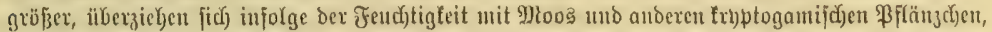

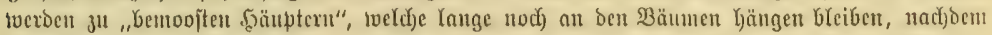

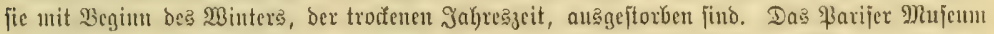

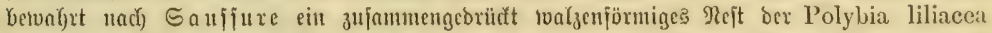

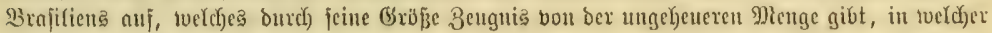

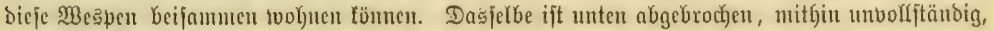

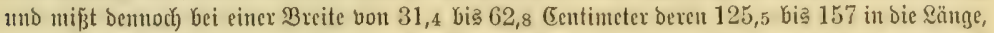
inden $e$ a a

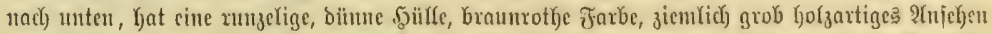

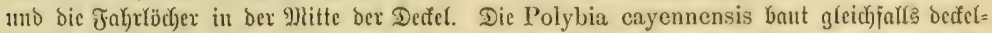

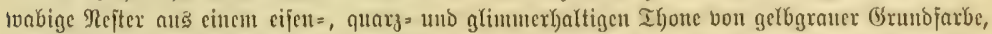

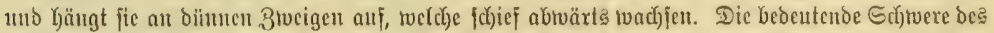

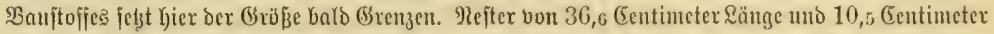

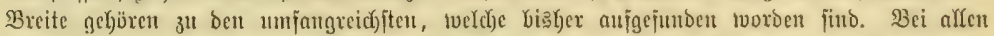

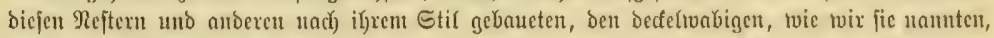

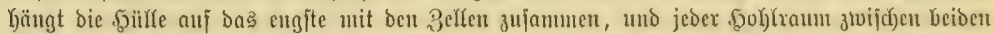

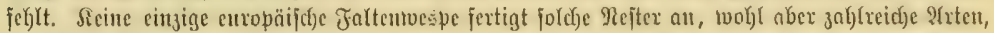
foldue in fitolidjen Amerifa Keimaten.

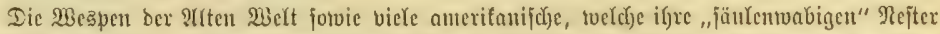

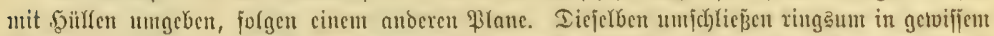

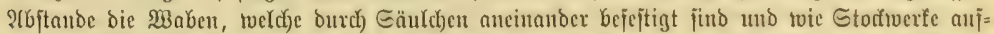

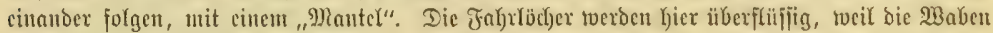

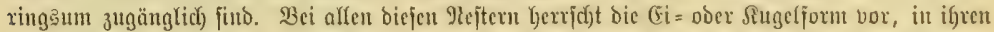

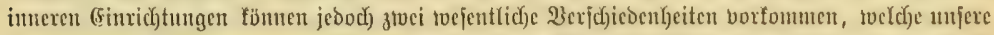

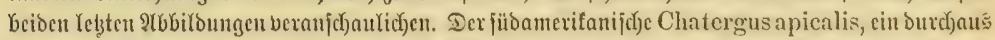

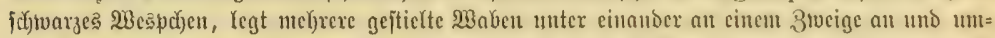

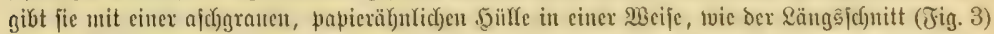

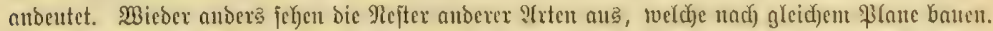

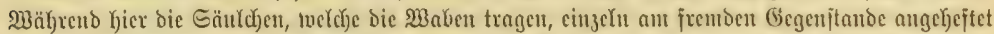

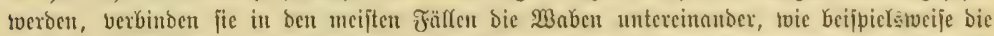

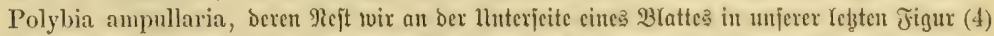

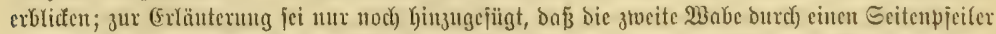

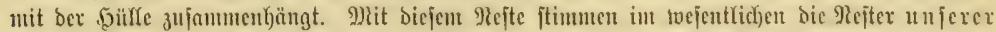

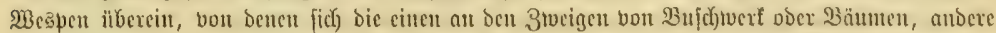

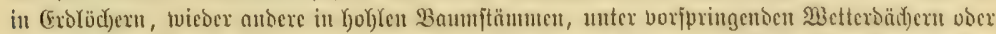

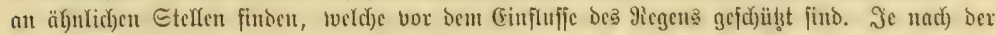

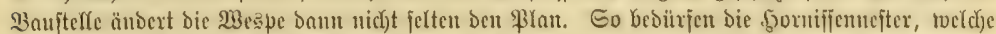

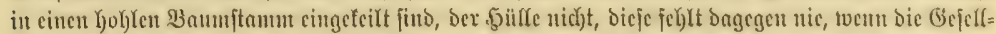
jớ)

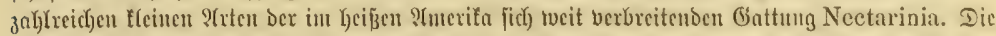

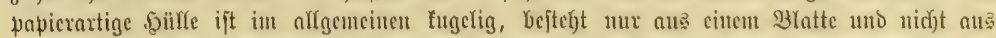

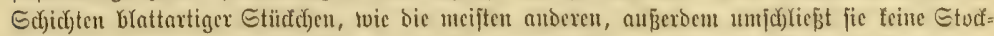

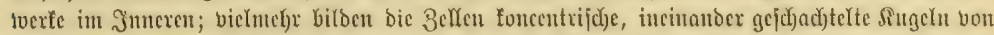

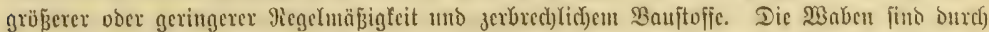

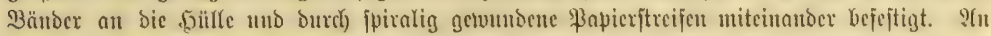

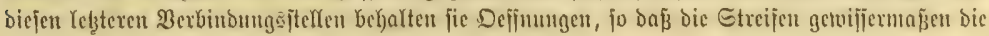




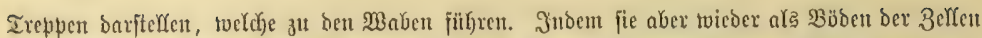

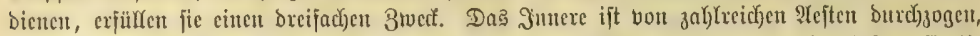

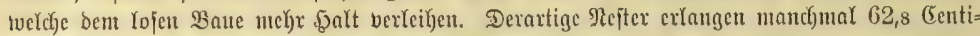

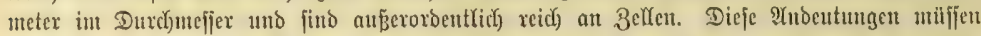

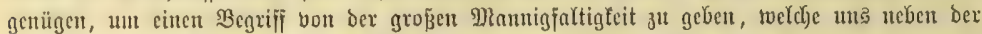

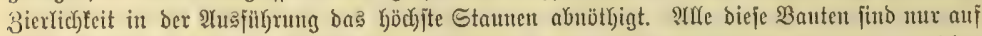

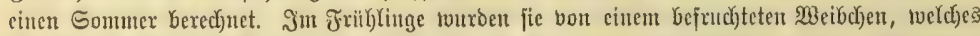

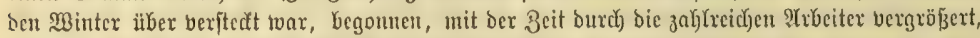
genau in bem \$lane, tweldyen bie Stanmmutter angab, unb tvent bie böje Beit Gerannaht, fint fie veröbet und bertajjen, gerabe jo twie bei ben ફummeln.

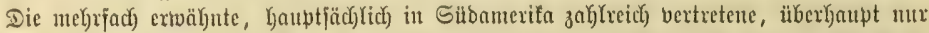

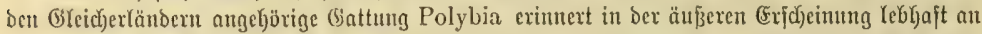

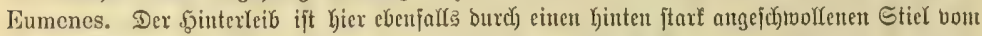

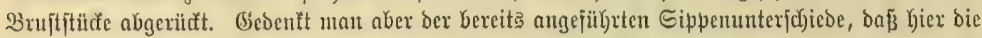

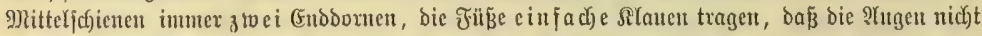

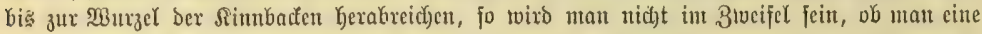

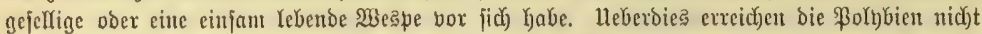
bie Gröbe vielex (Eumenesarten, haben vom zroeiten Biliede ab einen mehr ovalen ober fajt

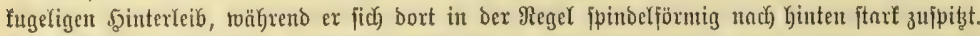

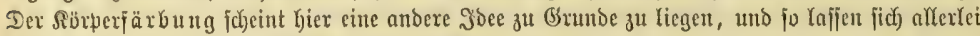
Unterjudeioungsmerfmale zmijđjen beiben auffinden.

Eine ztoeite, über alfe $\mathfrak{B e r t t f}$ eile verbreitete Gattung gefelliger Wespen Keif̧t Polistes.

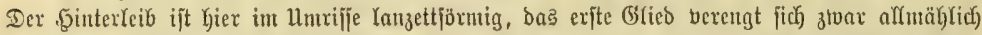

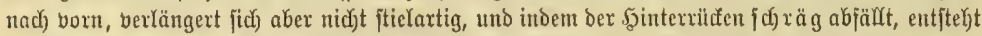

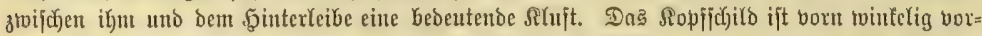

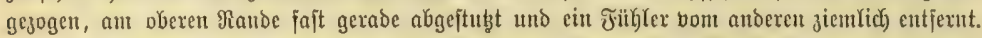

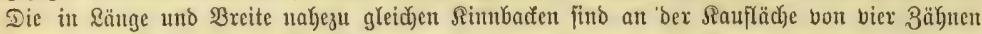

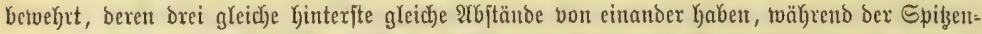

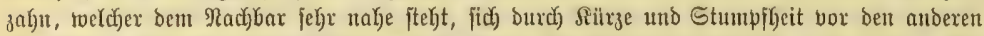

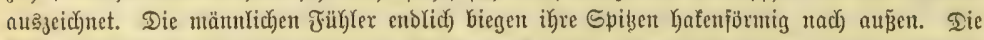

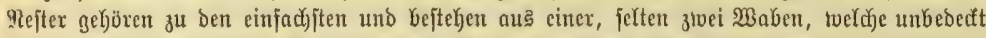

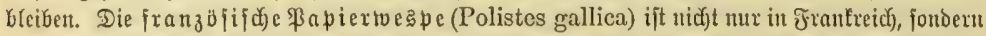

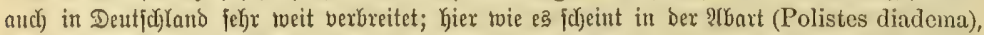
two nicht die Füh) (exjpitzen burchaus gelb, fonbern höchjtens an ber Unterjeite rothgerb gejärbt

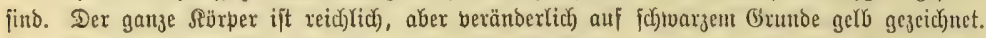

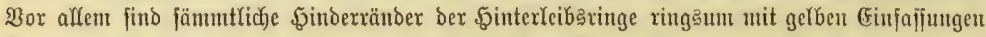

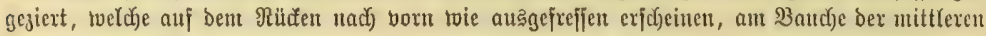
2(usłebłung entbehren.

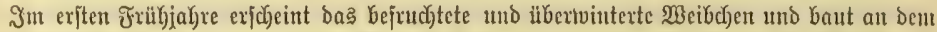

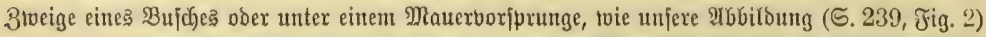
angibt, an cinem furzen Säuldyen einige wenige Belfen, welche mit ber Beit eine hülfenYoje Jiojette

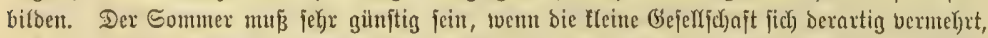

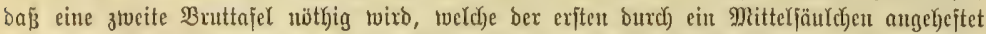

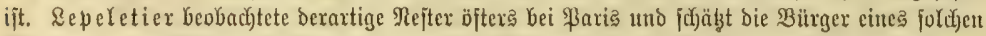

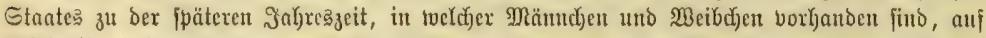

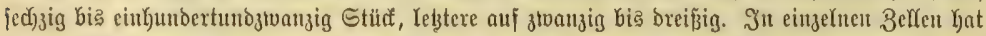

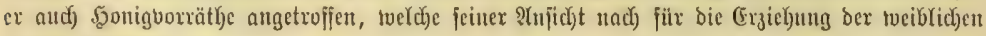
Sarven beftimmt find. 


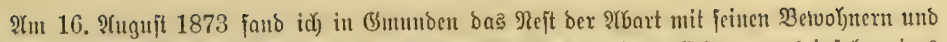

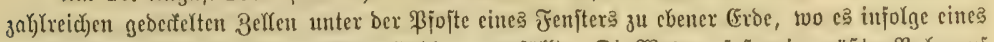

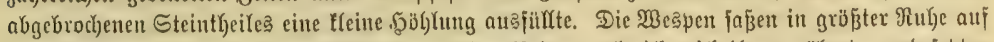

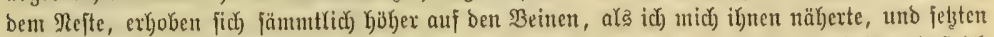

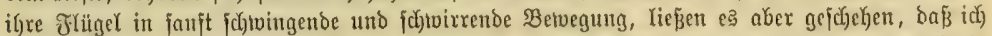

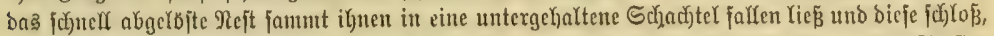

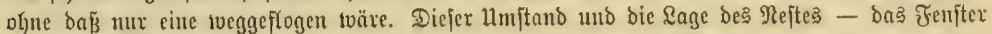

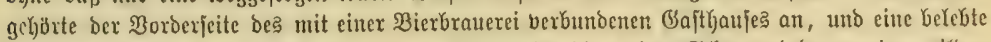
Fabritrabe füfrte ant bemfelben entlang - jpred)en für bie geringe Scheu und ben tveniger tvilden (Egaratter biejex :

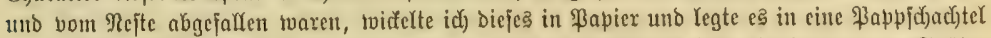

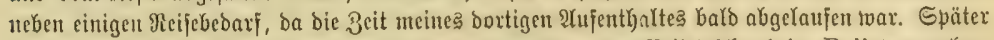

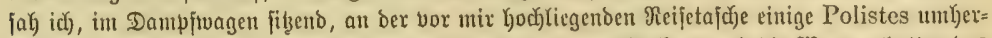

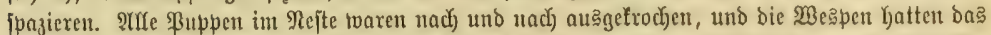

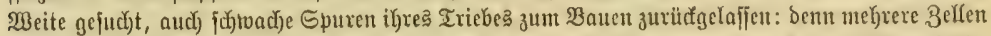

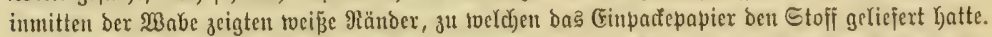

Meit interefjanter find bie Beobad)tungen, weld)e von Siebold an berjelben 2(bart ange=

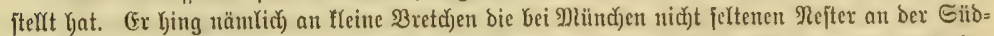

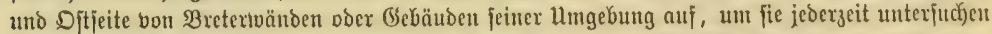

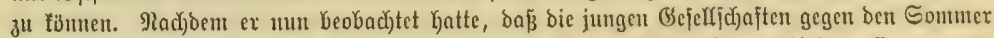

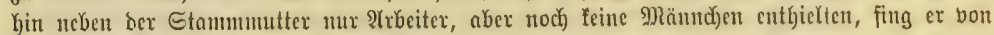

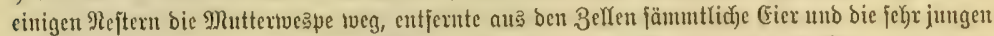

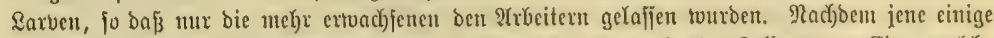
Tage von biefen verpflegt worben waren, fanben fid) in ben geleerten Beffen neue (eier, weldse

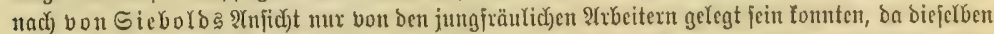

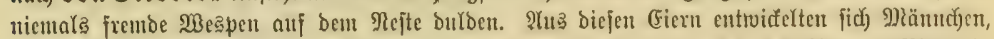

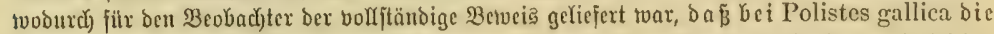

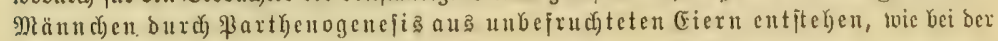

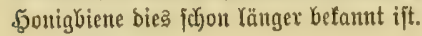

Dic Gattung Vespa begreift Geimifiche शrten von fo ïbereinftinmenden Fornten und Farben=

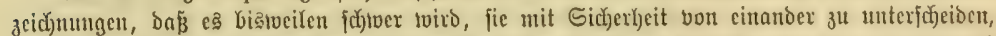

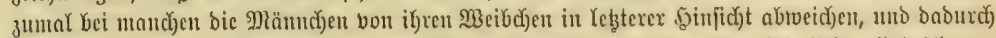

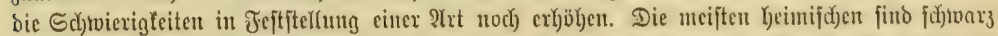

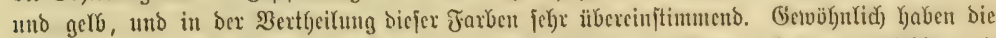

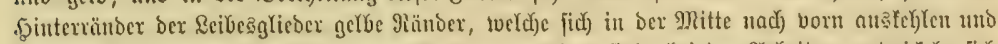

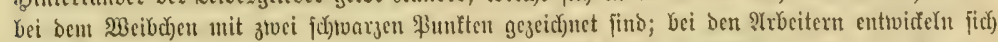

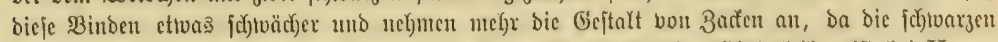

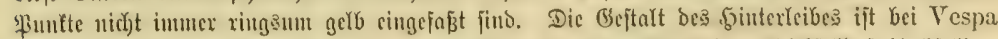

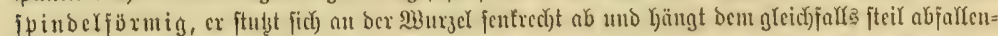

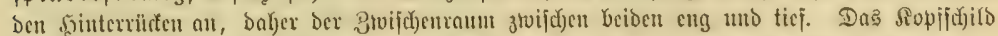

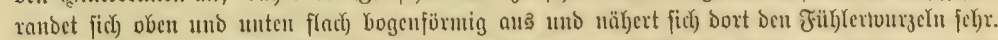

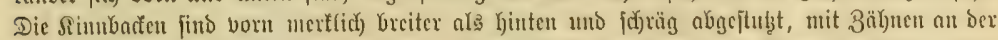

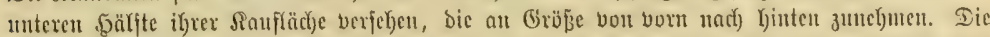

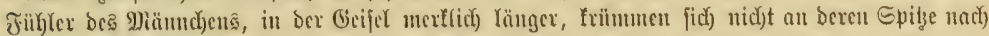

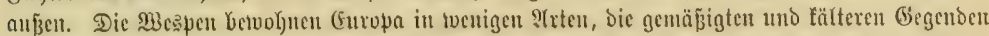

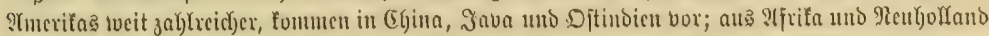

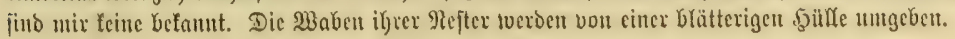




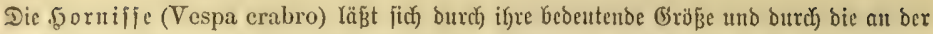

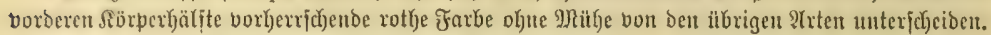
Sie fommt in gans (erropa und nörblid) bis Rappland yor.

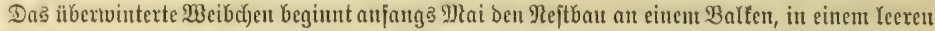

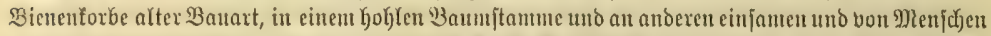

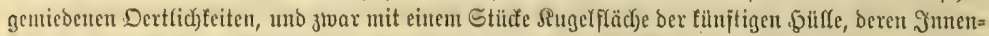
feite an einem fräjtigen Säulchen bie exjte Wabe mit nad) unten offenen, fed)

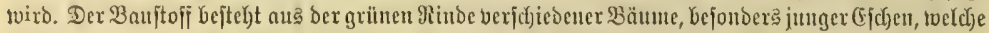

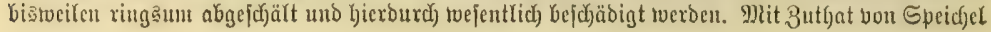
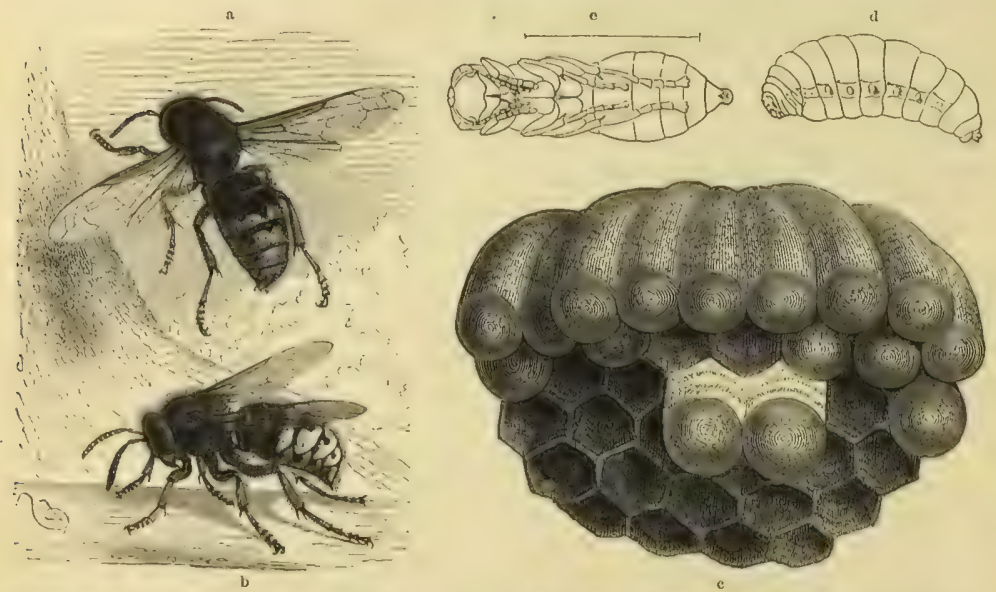

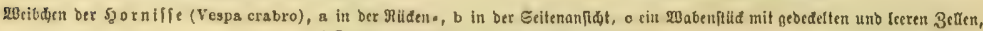
d Sarve, o \$uppe (d unb e etmas bergrögett).

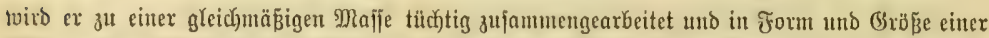

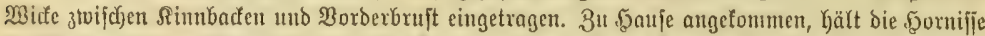

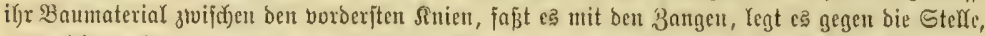

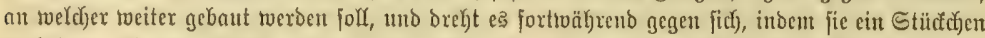

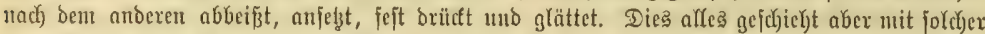

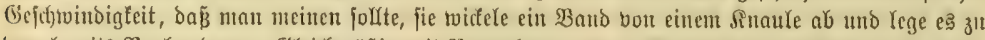

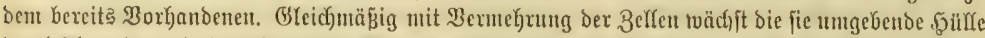

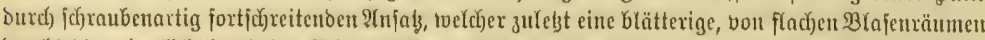

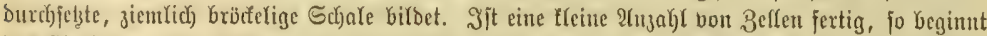

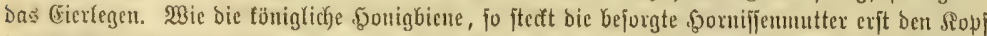

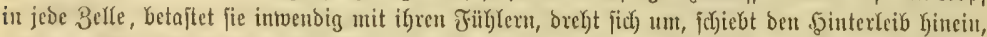

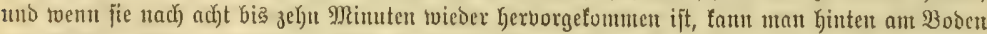

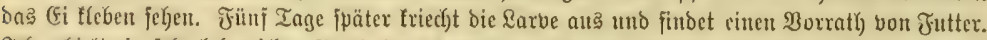

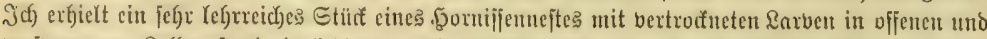

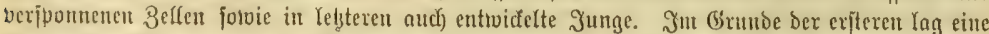

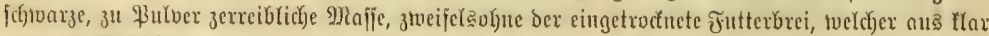

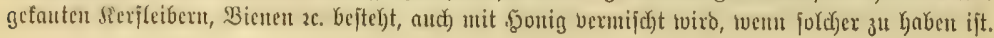




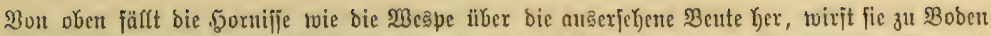

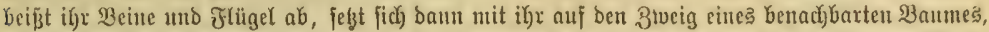

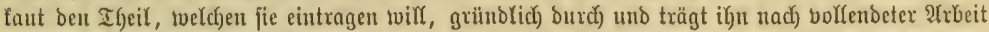

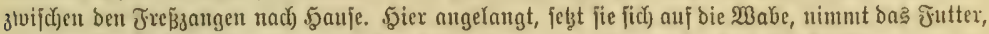

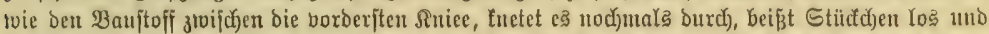

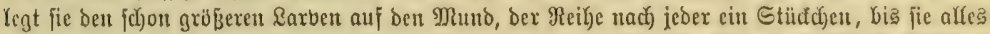

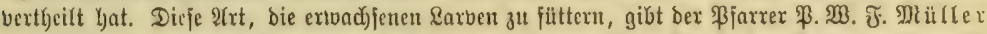

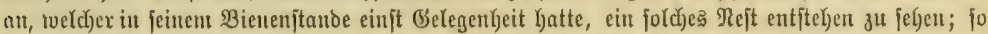

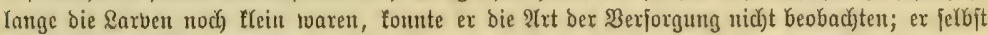

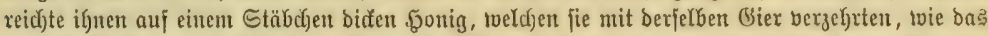

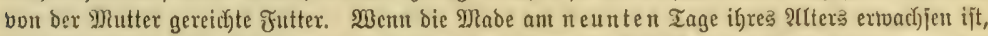

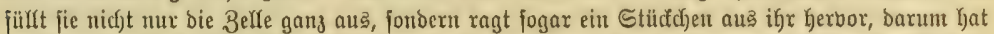

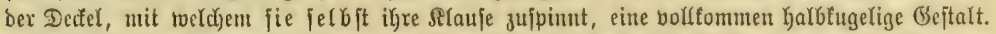

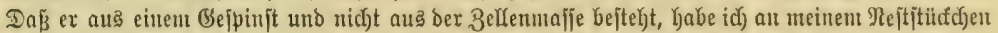

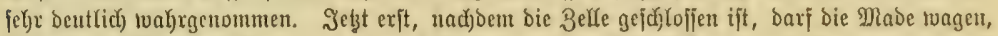

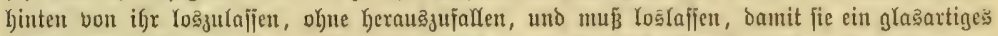

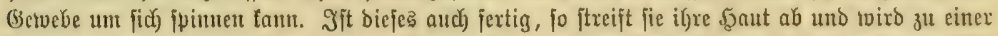

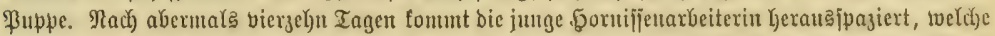

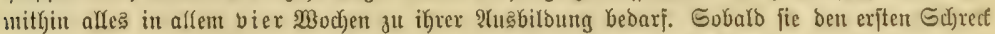

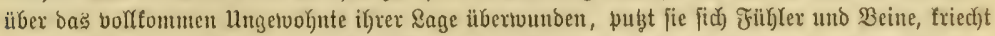

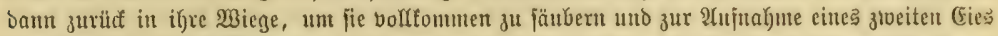

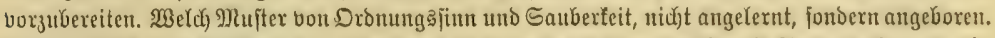
Findet fie fodjon Sdywejten bor, fo nimmt fie ber exften bejten, jvelche mit Jutter anfommt, ein

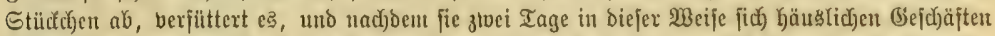

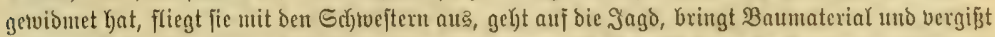

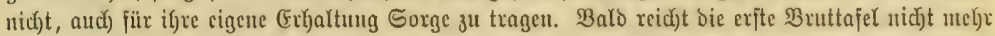

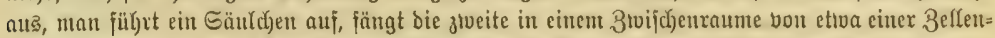

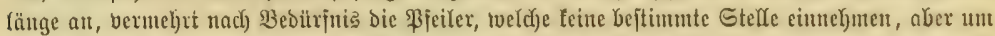

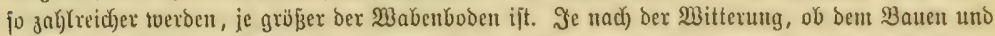

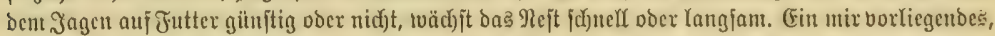

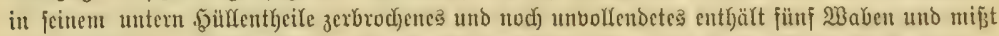

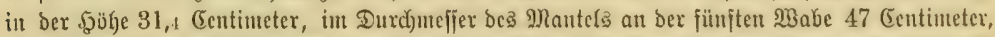

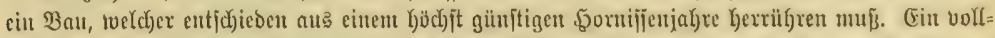

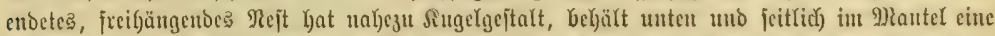

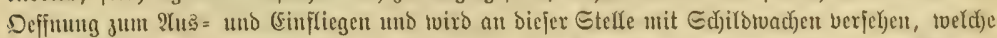

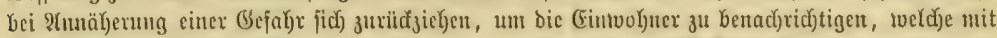

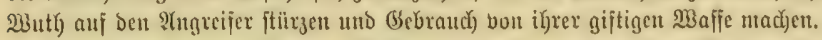

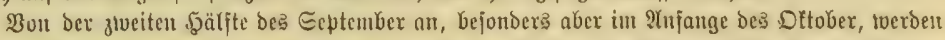

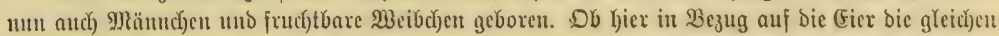

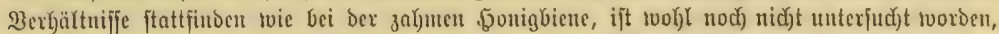

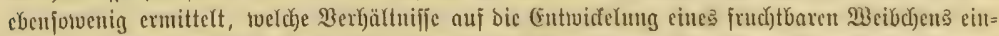

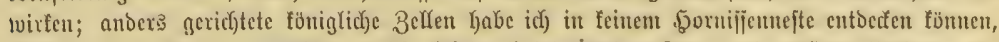

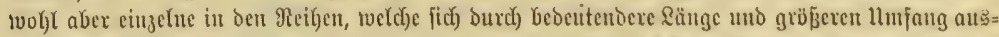

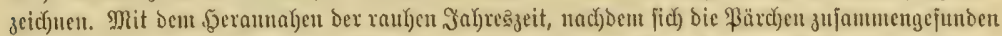

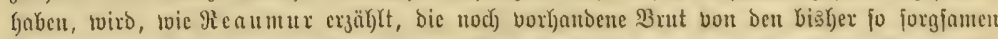

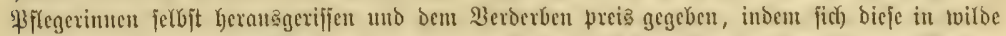

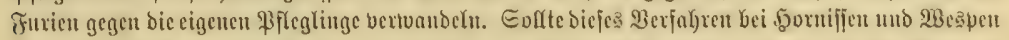

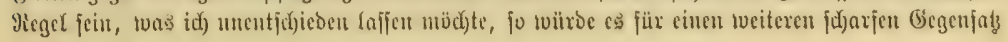




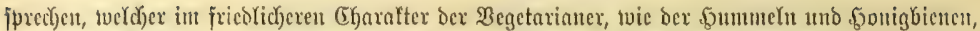

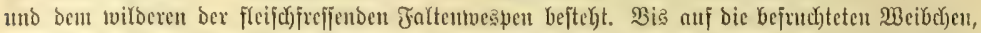

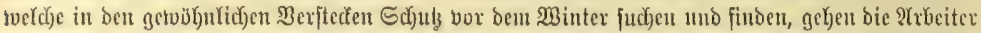

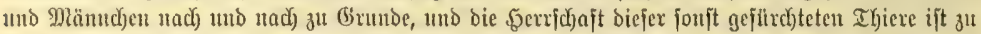

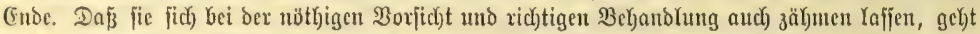

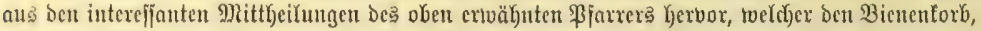

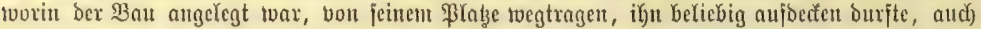

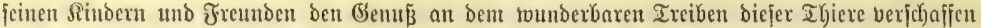
funnte, ołne je von Den joujt wilden uno unbändigen Bejtien beläjtigt zu werben. Der Staat,

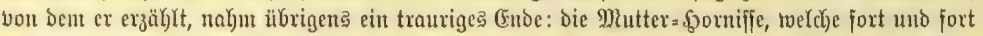

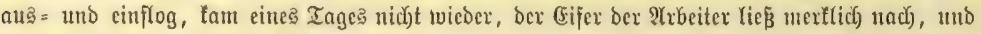
almäb)lid ftand bex ganze $\mathfrak{B a u t}$ bertwaift ba.

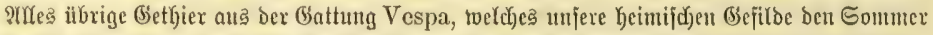

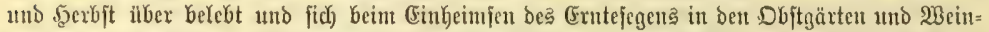

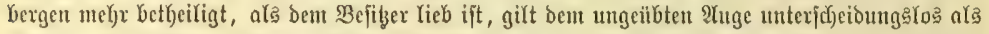

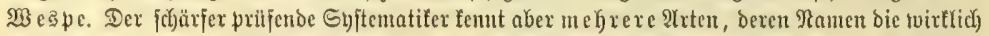

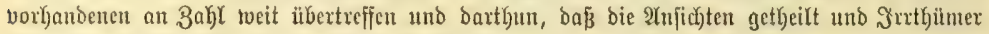

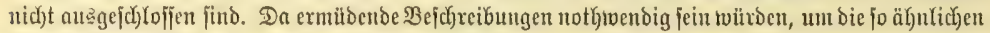

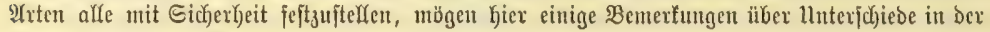
Sebeñ̄weife in ben Mordergrund treten.

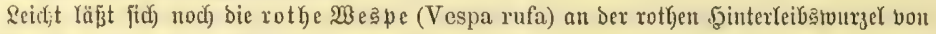
ben übrigen untericheiden. Sie fommt auch) in शtorbanterifa vor, bout unter ber (Eroe, Yeb̆t aber mur

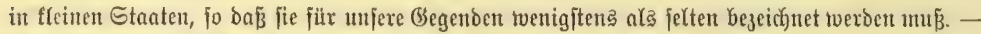
Ebenfalf unter dex (5roc Gauen die gemeine $\mathfrak{B}$ espe (Vespa vulgaris), welche auf Mabeira, in

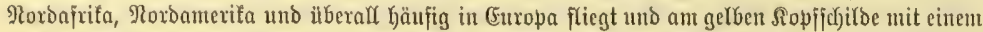

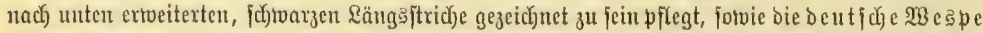
(Vespa germanica), meijt mit brei jobtwarzen \$untten an ber bezeichneten Stelfe bei Weibchen

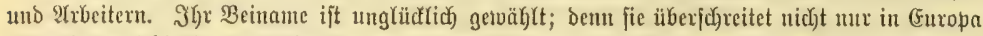

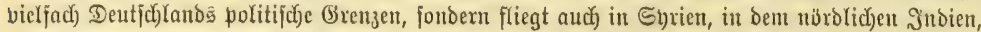

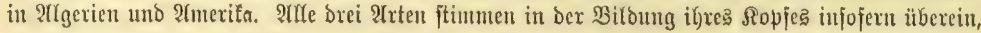

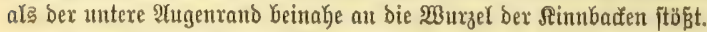

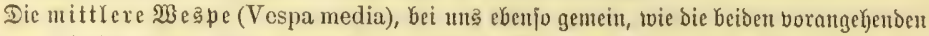
Irten, uno in ber gelben Järbung bes Jainterleibes getrïbter, mehr brantgelb, weniger rein tois affe itbrigen; die 2 ald twe 5 pe (Vespa silvestris Scop. ober V. holsatica $F$.) und eitige andere

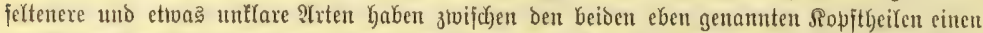

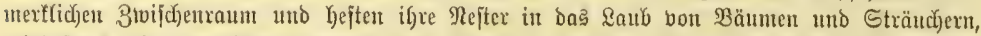

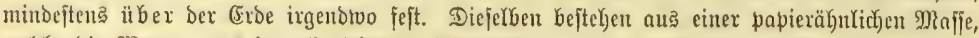

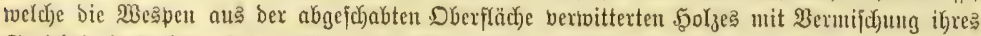

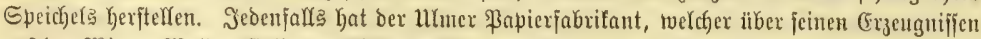

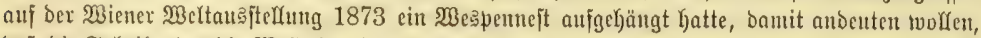

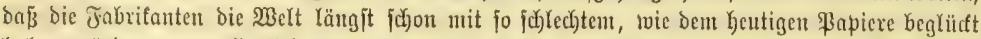

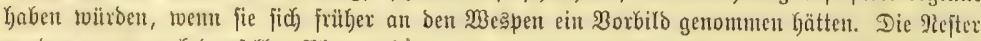

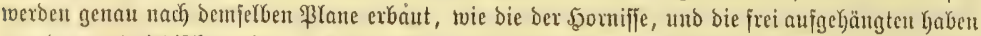

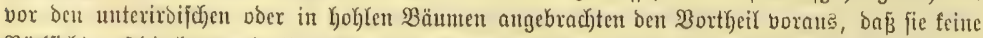

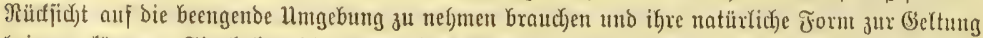
britgen tömen. Sie Kaben bie Jurm eine马 (Fie马 oder einet Citrone, an Der Eeite bea unteren

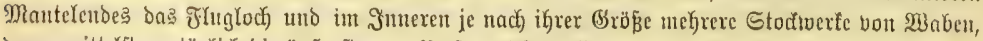

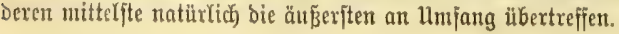




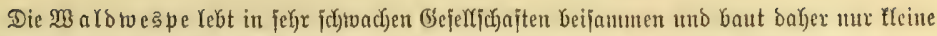

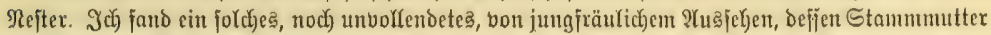

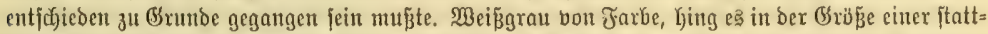

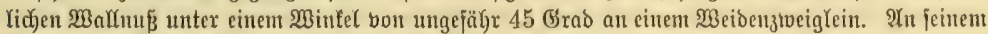

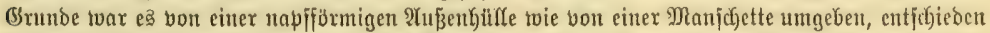

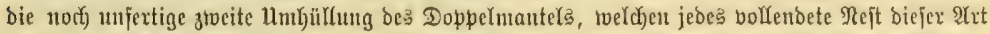

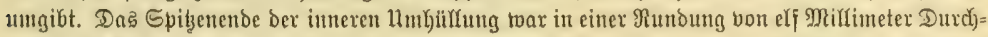

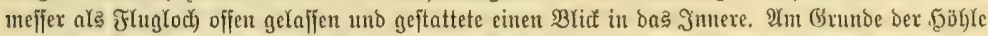

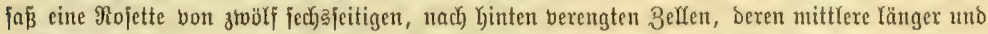

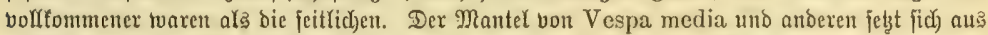

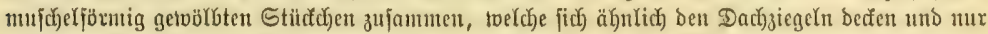

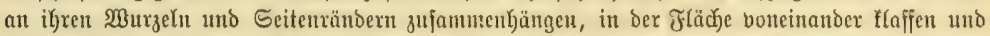

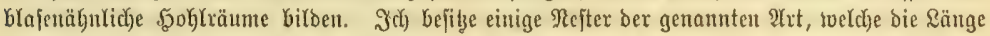

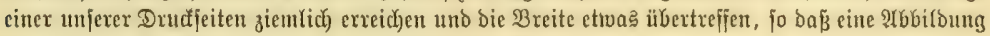

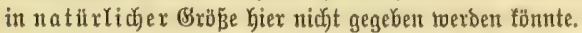

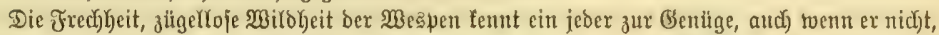

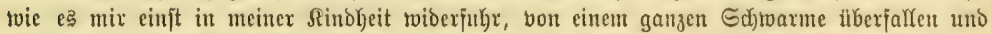

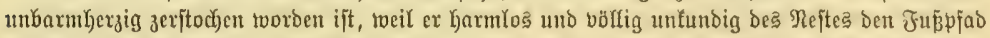

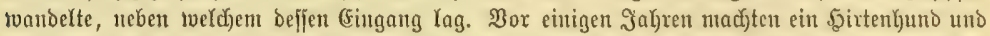

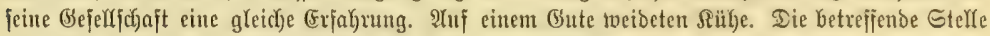

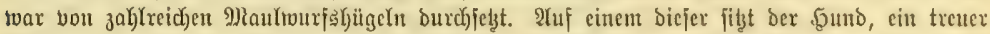

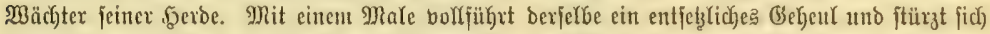

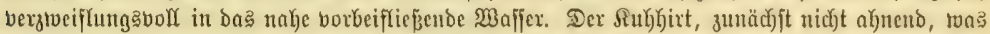

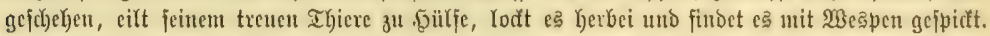

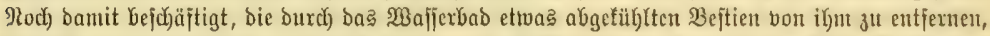

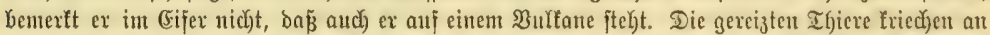

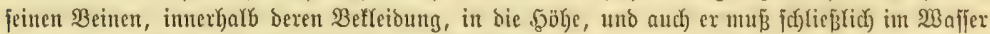

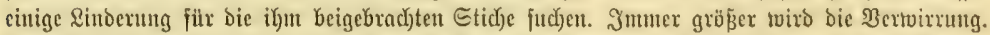

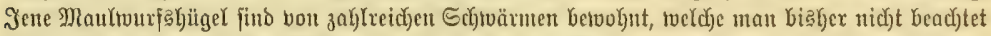

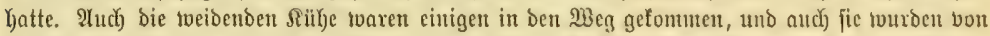

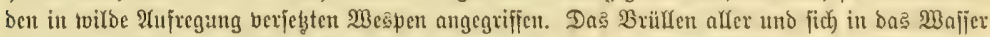

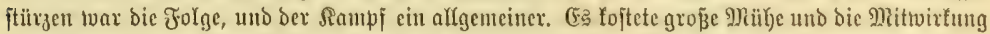

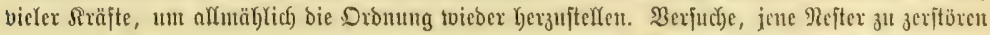

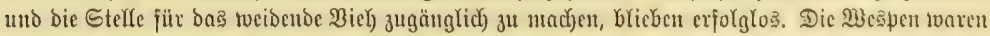

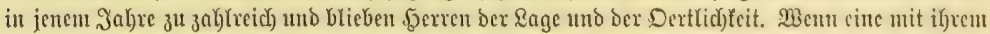

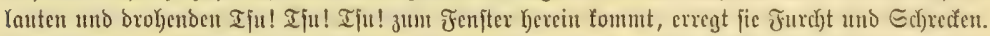

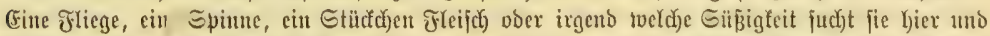

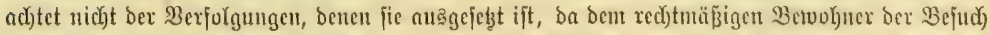

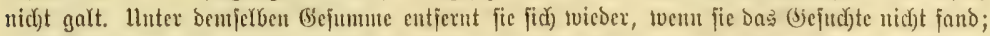

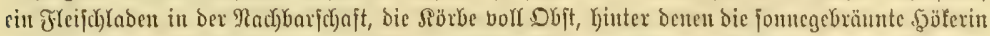

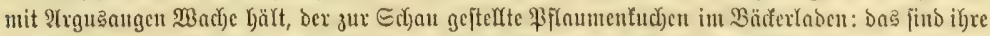

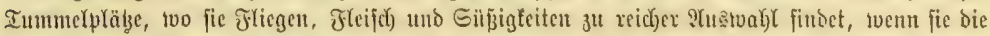

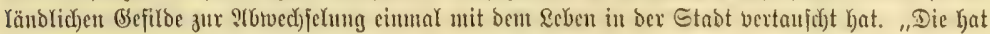

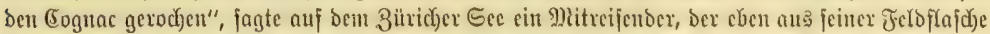

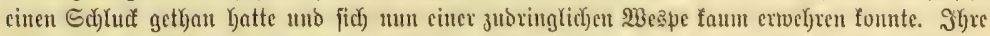

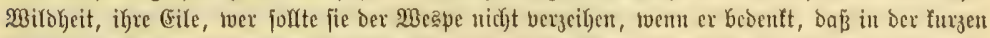

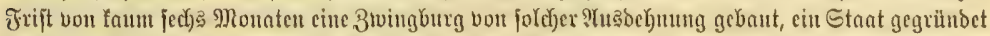

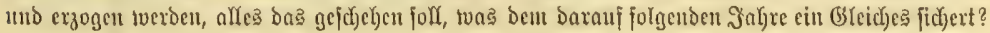




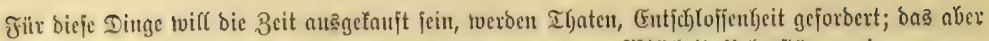

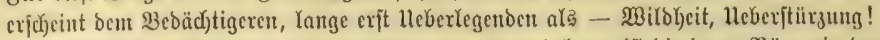

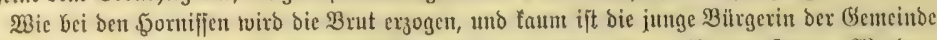

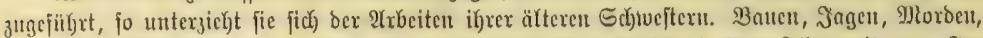

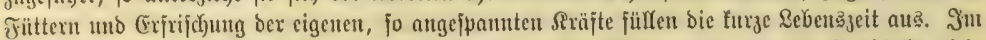

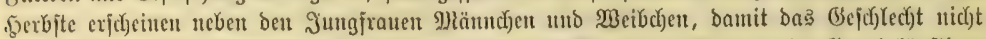

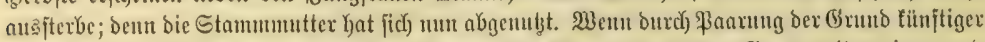

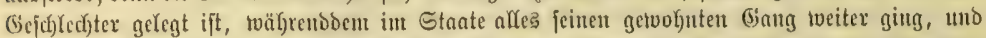

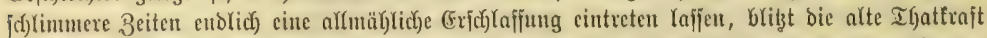

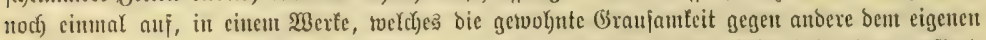

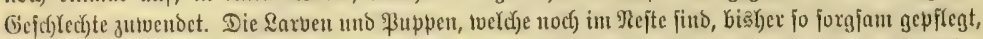
werben un unbarmberzig heransgerifjen und bem $\mathfrak{B e r d e r b e n ~ p r e i s ~ g e g c b e n . ~ E i t e ~ a l f g e m e i n e ~}$

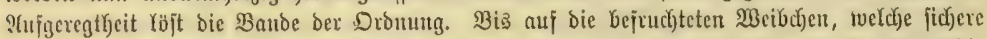

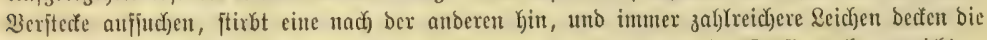

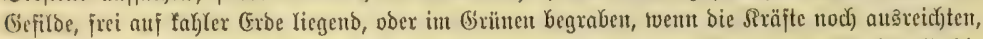

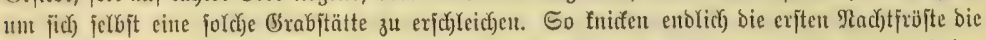

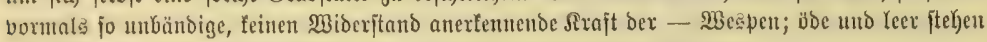

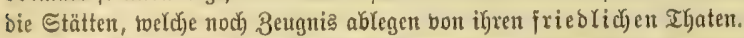

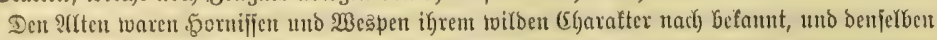

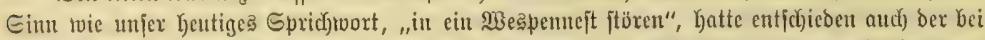

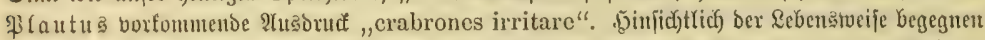

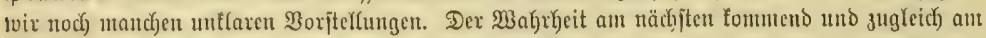

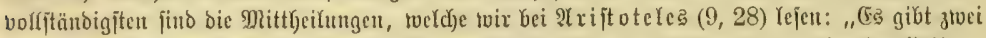

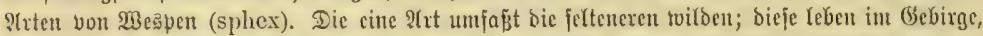

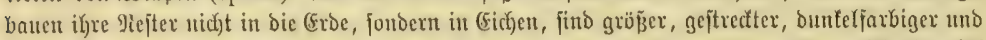

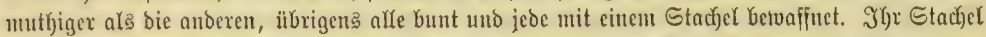

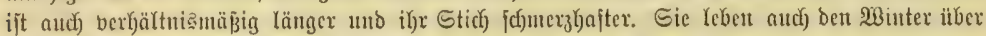

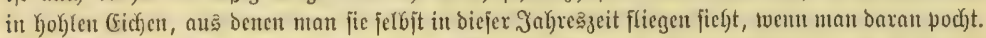

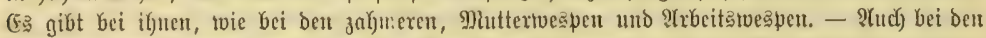

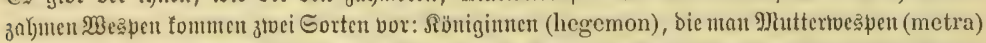

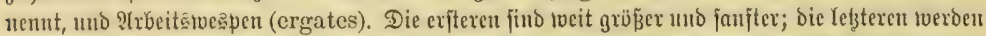
fein Salje alt, fondert fterben alfe, jobald ber Winter eintritt, suas man baraus jujliefen fann,

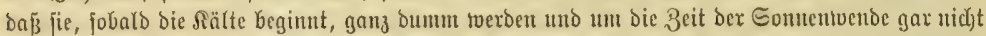

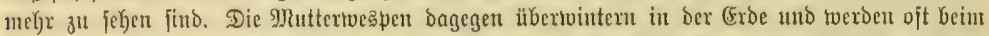
Graben uno ¥flïgen gefunden, nie aber 2rveitsuespen. Die Fortpflanzung ber Mespen geichieht

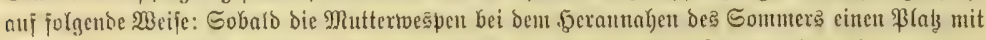

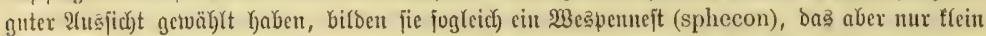

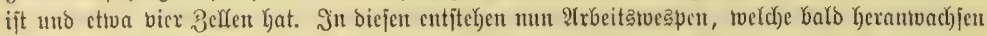
uno größ̈ere Echeiben bauen, tworin twicber Jünge gezogen uno bann rvieder uene Subeiben angelegt

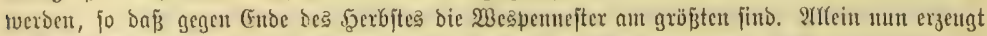

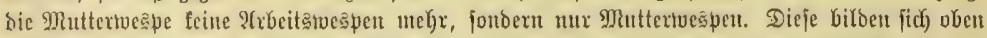

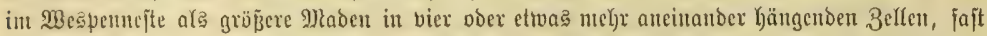

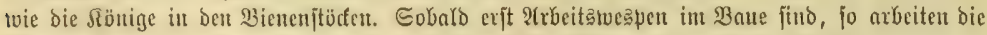

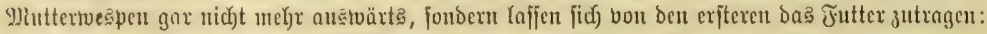

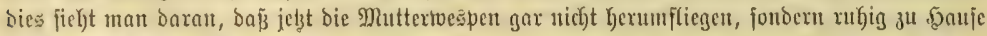

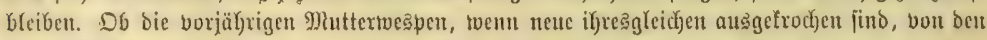

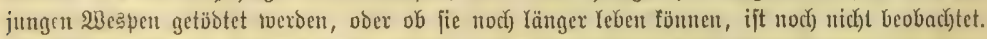

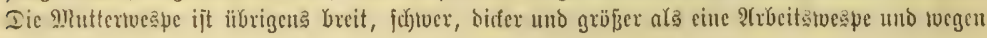




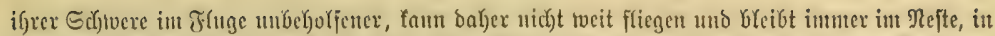

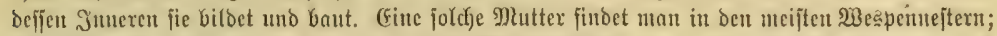

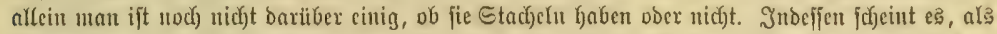

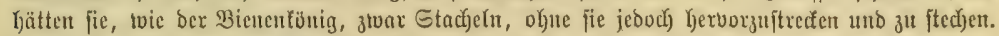

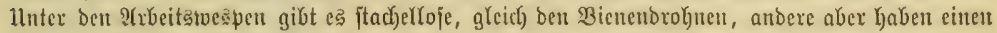

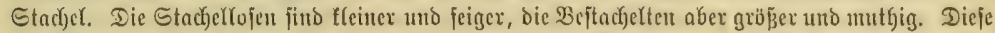

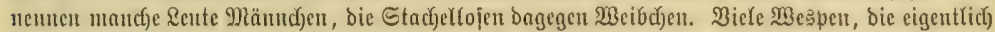

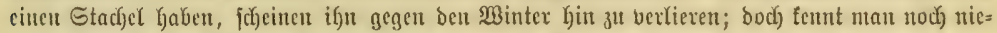

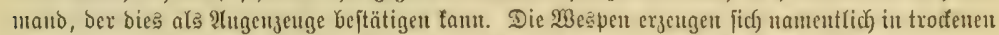

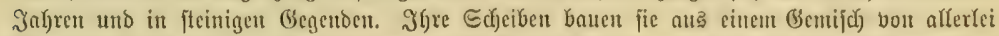

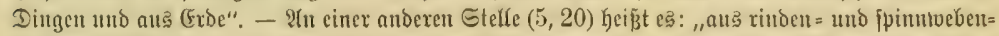

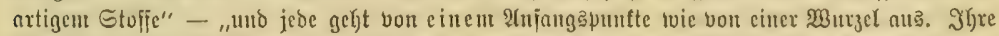

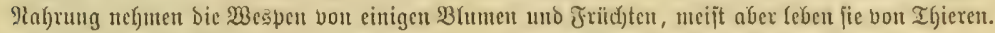

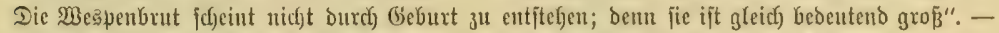

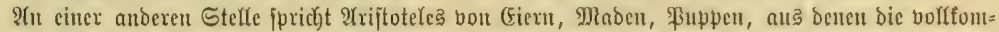

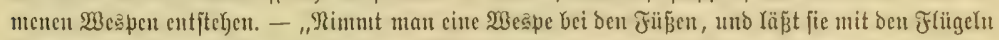

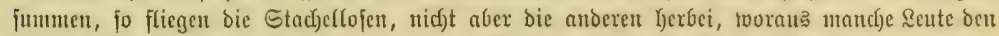

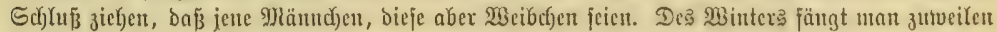

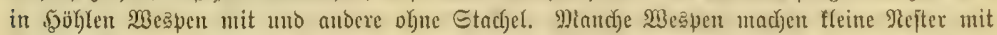

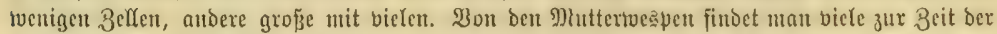

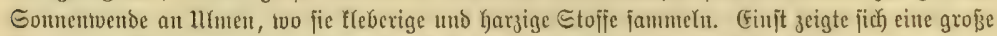

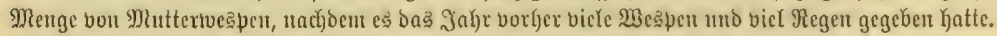

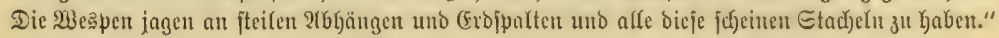

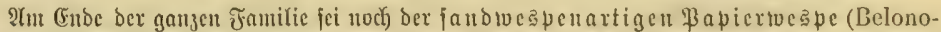

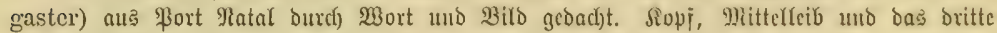

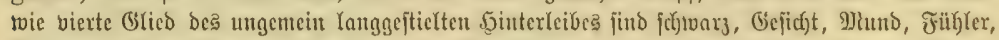

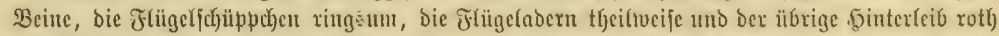

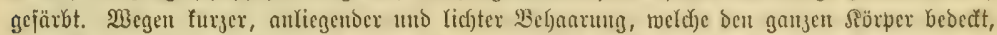

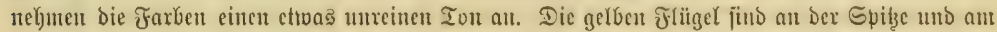

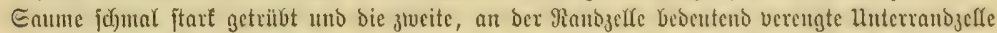

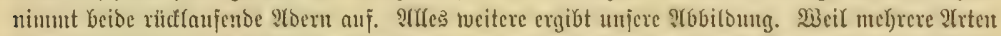

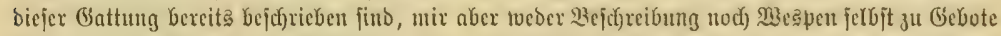

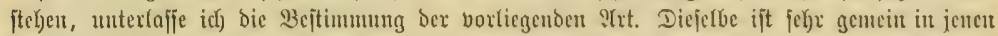

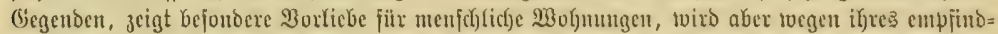

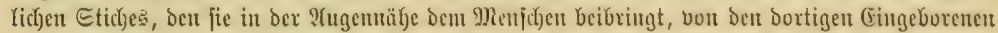

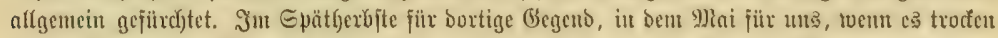

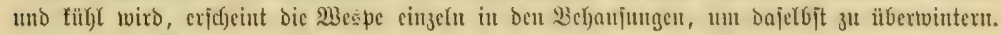

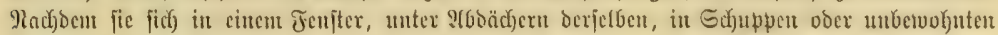

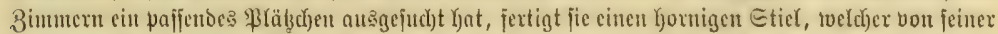

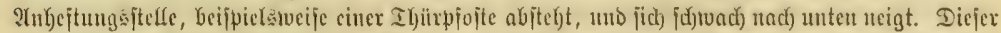

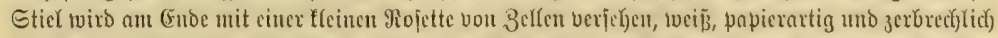

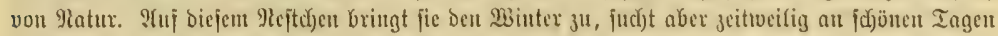

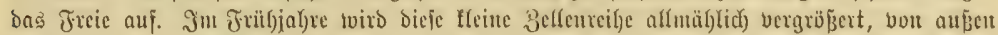

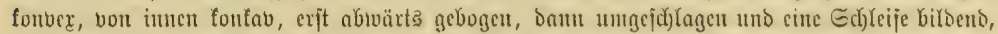

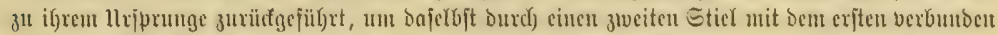

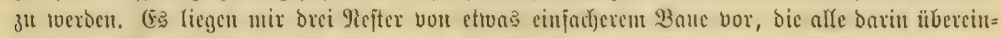

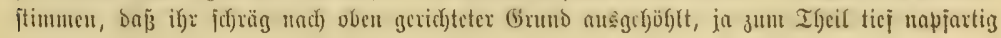




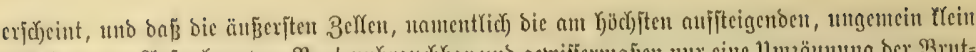

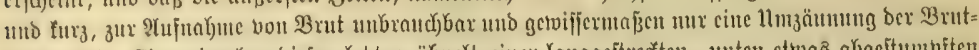

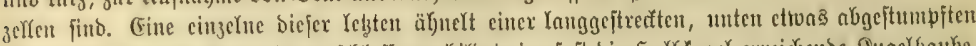

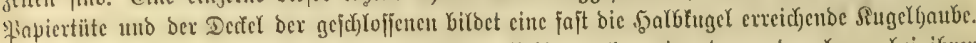

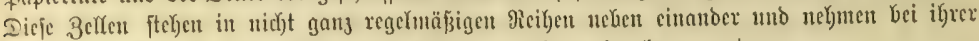

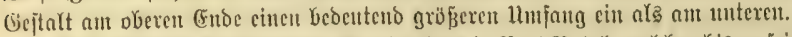

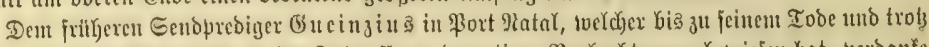

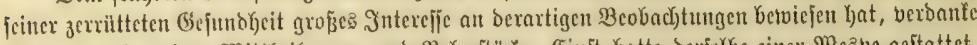

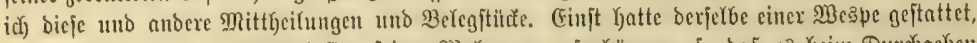

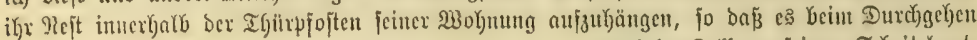

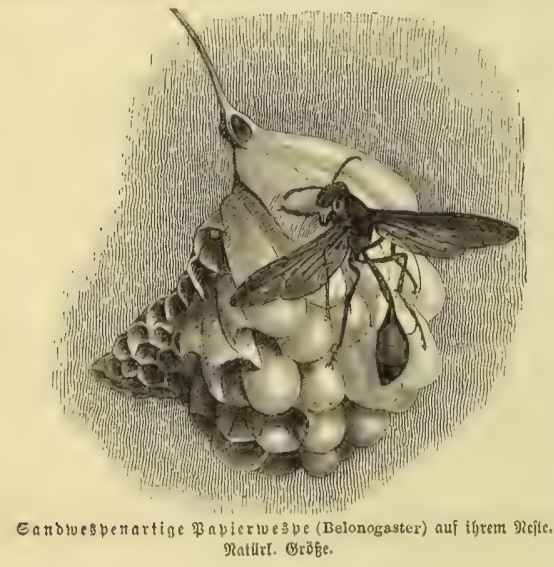
mur einige 3olf bon feitrem Sdjeitel ent=

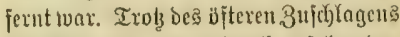
ber Iffïr und ber bndurd) erfolgenton

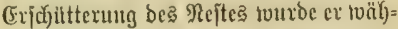
reno mehrerer Monate ber $\mathfrak{B a n}=$ uno \$rutgeit mux einmal bou ciuter jungen Meape an bex pben bezeidneten Stelfe gejtodyen, ward aber jür ben शैugenblict peiner Sime fajt betaubt. Sein תaffer

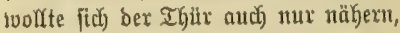
acichlveige burd) biejelbe gehen. Dic Wesิpen betwachen bas গejt forgfältig, rid)ten fick bei Innäherung eine? jrem= ben Gegenitandes alfe Kod auf, mit Den Ropjen nact) jener Seite Kin, uno jummen suter jtarfer Flügelbetwegung. Damu ijt aber ber Stugenblict getommen,

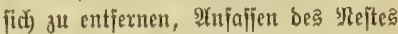

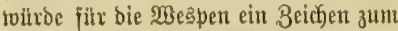

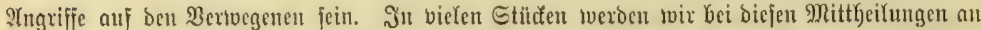

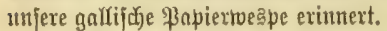

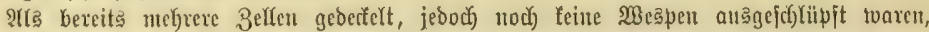

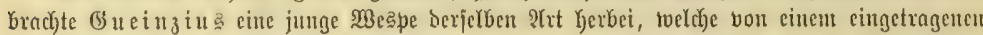

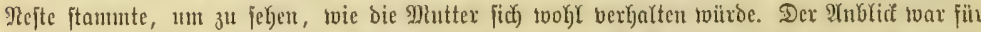

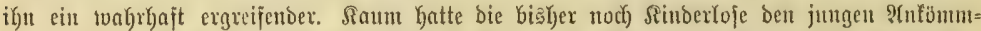

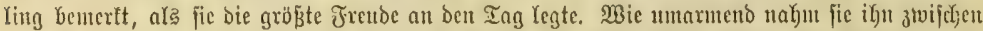

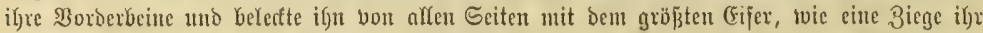

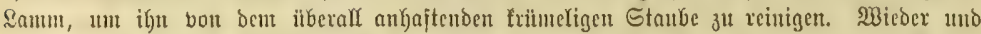

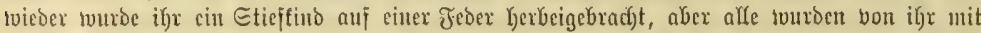
gleid)er Jrende begriiß̈t, mit gleidyer Riebe angenommen und in ber eben angegebenen 2Beije

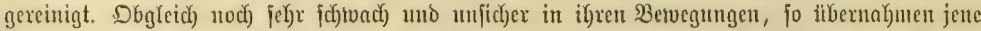

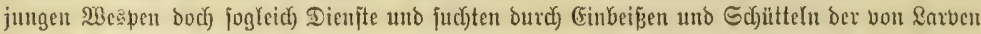

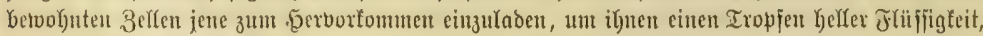

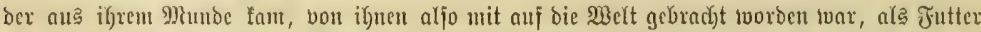

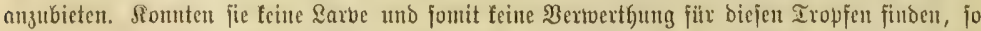

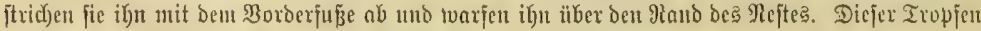

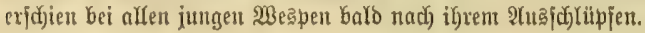




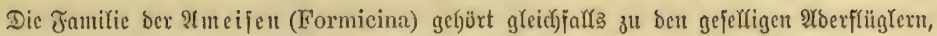

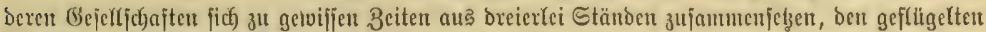

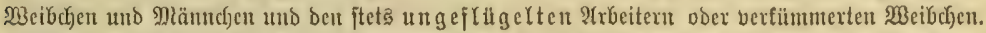

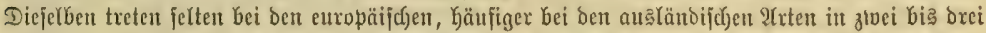

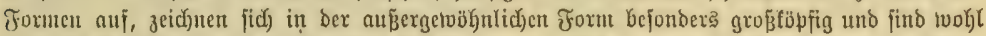

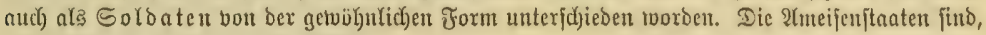
twie bie ber ફ̧onigbiene, melyriährig.

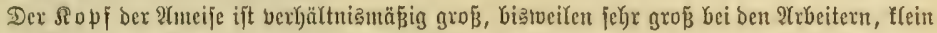

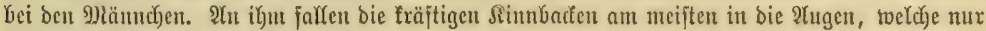

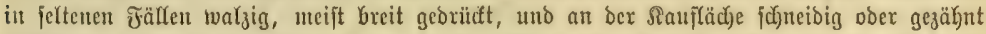

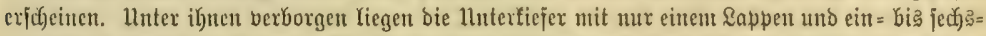
glieberigen, wargigen Tajtern. Die Rippentajter bejtełen aus zwei bis vier gleichjalls toarzigen Gliebern, unb bie 3unge gelangt nidjt zu ber Entwidelung tvie bei ben Hibrigen gefelligen Immen.

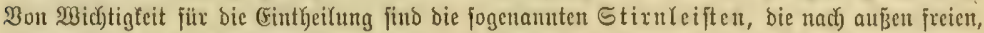

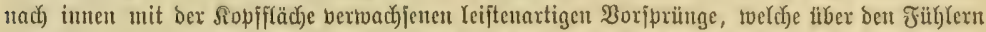
beginnen und nad) fjinten und oben gleid)=, auseinanderlanjend unb geraolinig ober S=förmig gebogen find. Dic Jübler gehüren ber gebrodjenen Jorm an, toen aud biątueilen bei ben

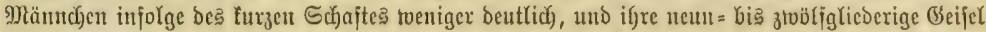

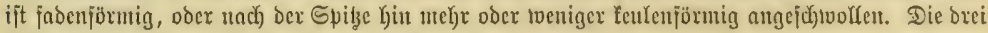

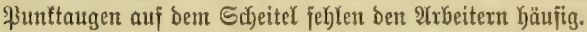

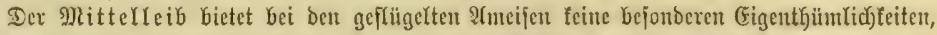

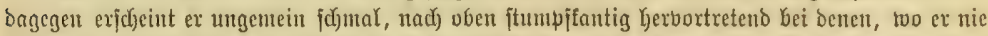

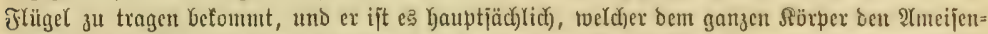

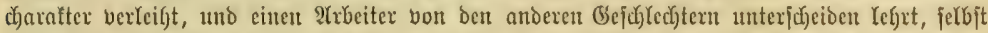

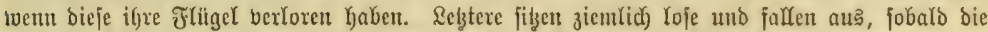

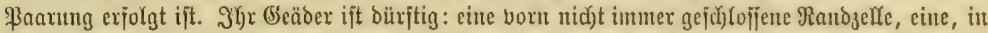

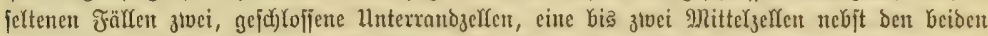

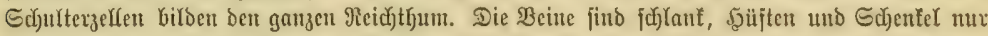

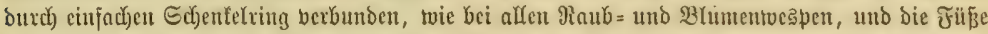

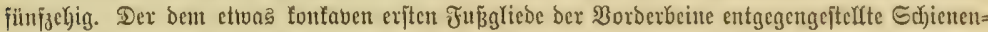
jporn ift innerjeits borjtig betwimpert uno bilbet jammt bem an gleicher Etefle betwimperten eriten

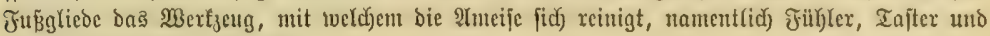
jonjtige Muntotheife abbitrjtet.

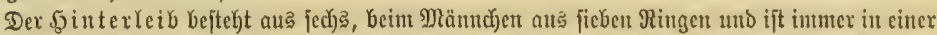

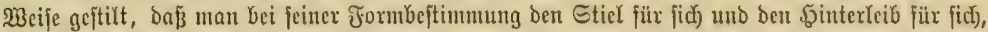

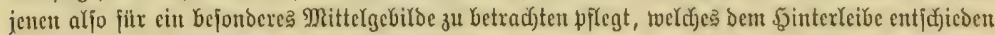

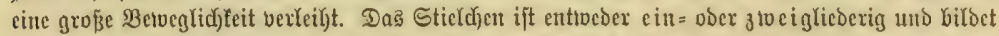

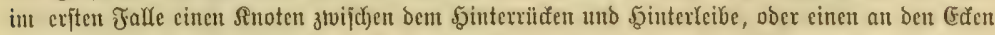

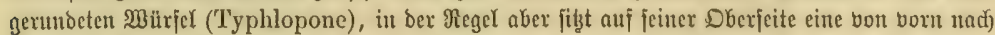
Ginten geridjtete viereffige, gerumbete, oben meljr ober weniger anfgeridytete Duerleifte, bie

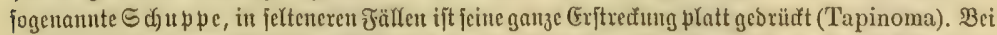

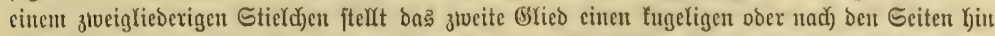

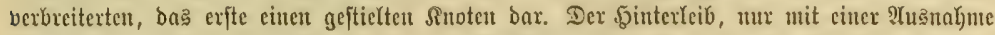
(Crematogaster) an jeitem Ilnterrande bem Etield)en angetvad)jen, hat cintu fugerigen, obalen,

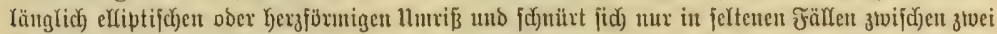

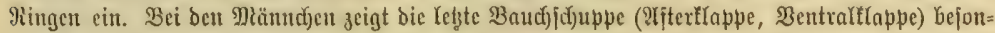

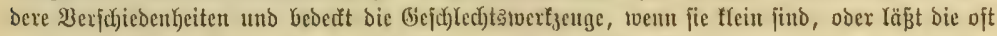

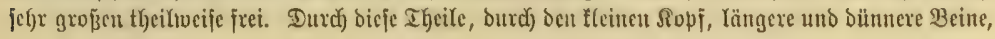




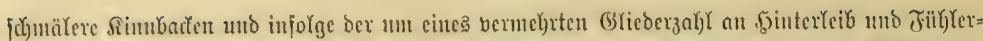

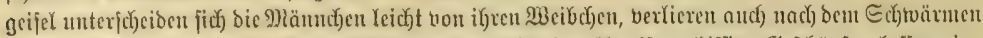

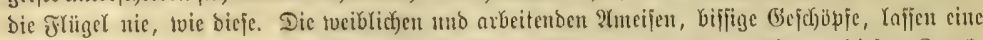

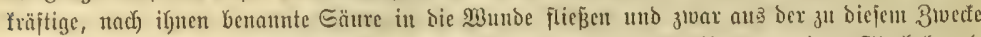

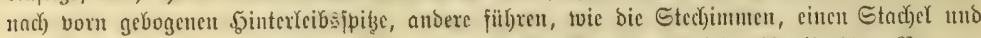

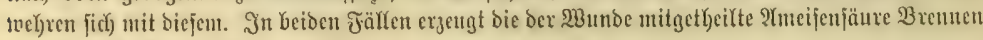
auto judroache (Entzilutoung.

Die smurmförmigen, juplojen \&arven bejtelyen aus zwöli nicht immer untericheibbaren

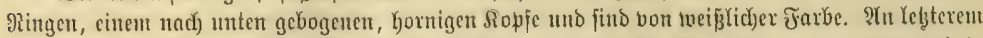

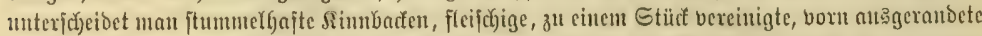

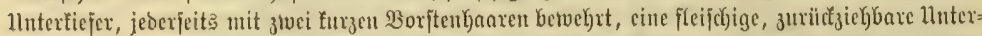

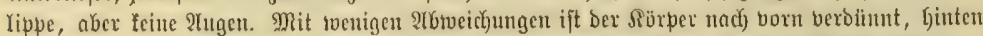

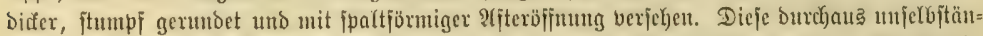
bigen Rnrven fönnen fich nicht von ber Etelfe betvegen uno müffen gejüttert weroen. Sic fint in

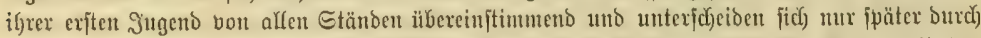

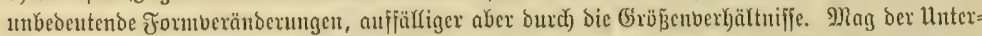

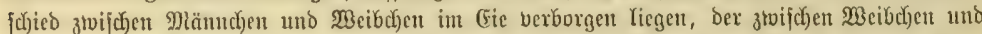

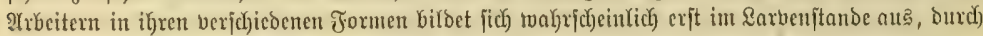

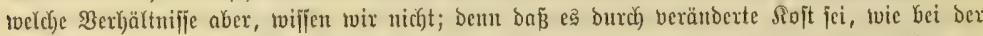

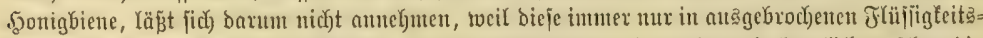

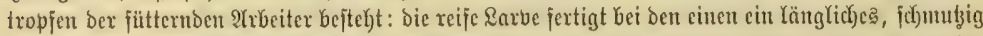

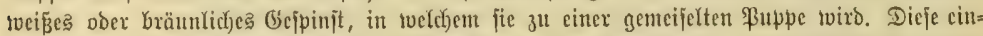

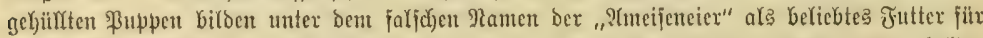

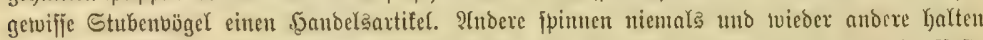

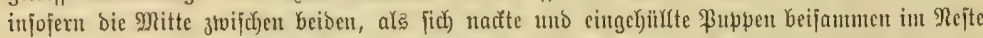

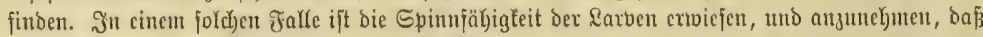

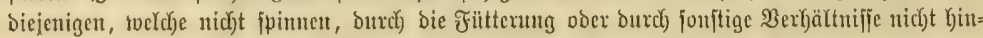
reidjenben Spinnjtoff in ifren Drïfen zur Entrvifelung bringen fonnten. Die uit ztweifnotigem

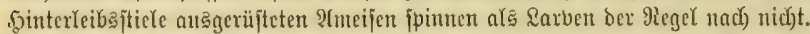

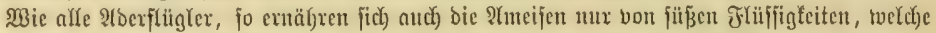

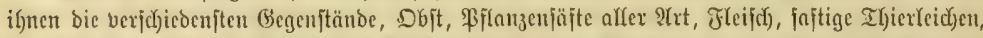

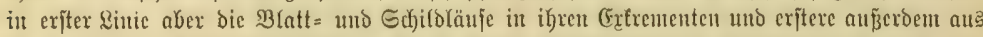

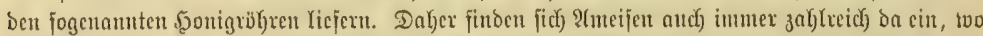

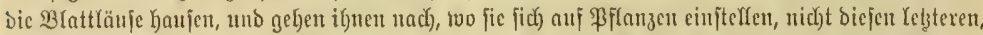

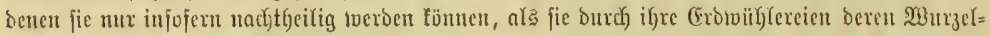

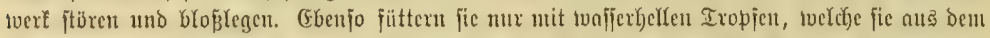

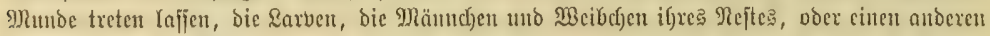

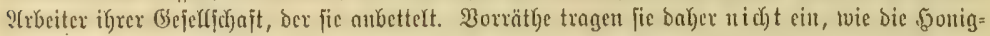

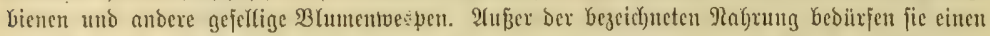
getvijien Fruchtigfeitagrad zu ifrem Gedcifen, und biefer beftimmt aud ben Drt ifrer Neftanlage.

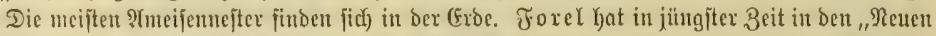

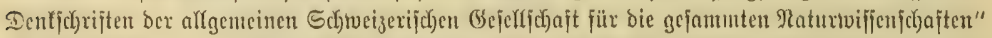

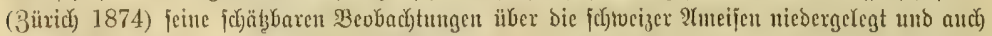

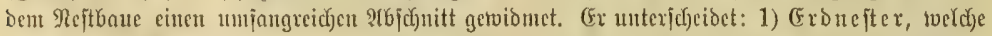

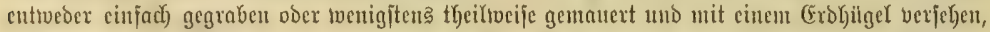

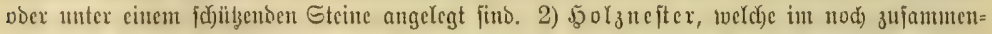

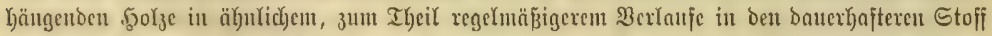
gentbeitet find, wie jene in bie feuchte (Exbe. Die fefteren Jahtestinge bleiben meift ala 23änbe 


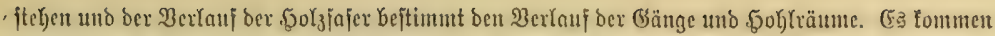

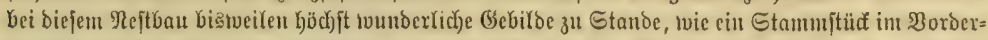

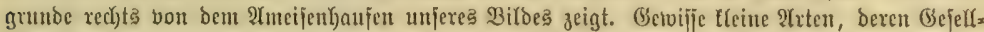

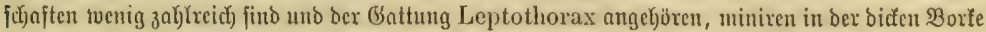

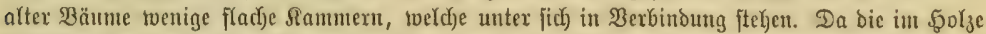

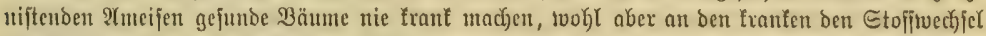

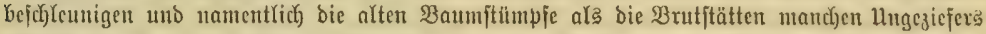

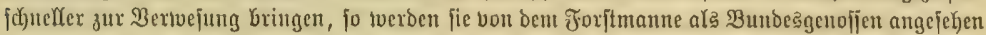

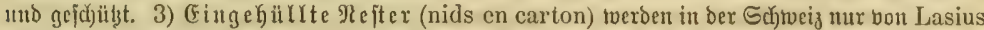

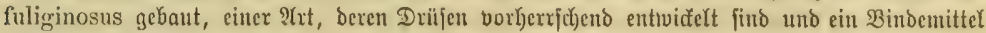

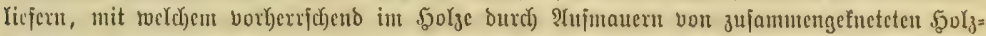

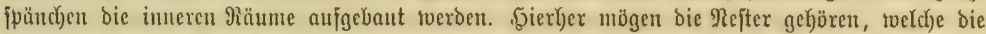

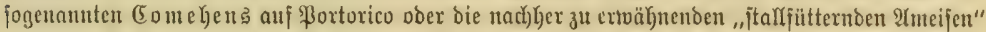

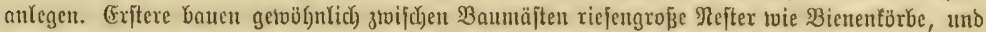

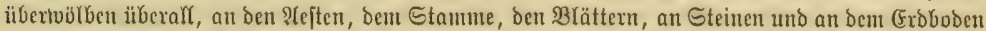

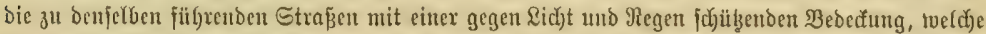

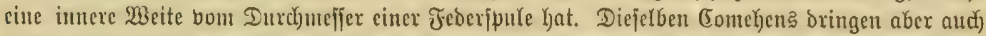

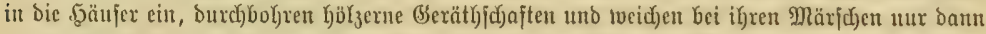

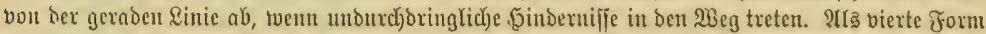
bezeid)net Forel bie Reftex von zufammengefetzter $\mathfrak{B}$ a uart, zu Denen bie alfbetonuten aus

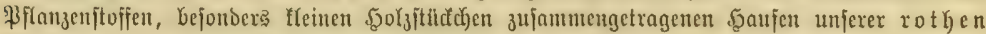

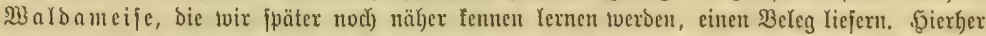

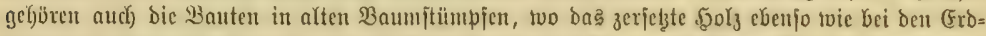

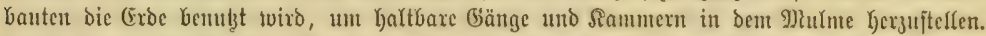

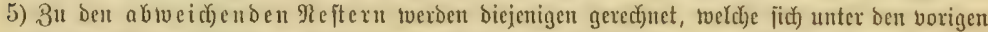
nicht unterbringen Infjen, wie biejenigen in Mauterilzen, Jels[palten, menjchlichen Moljunngen ac.

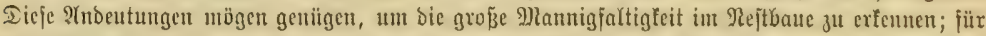

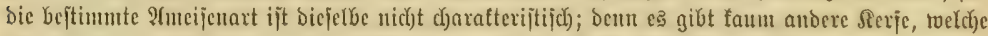

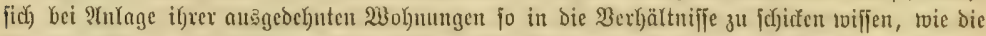

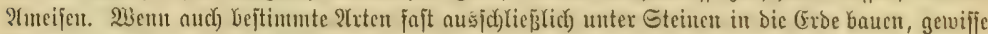

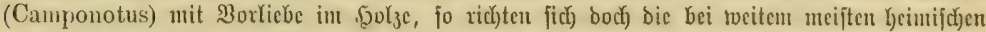

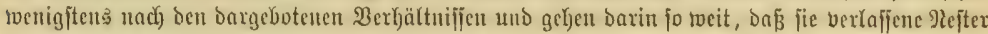

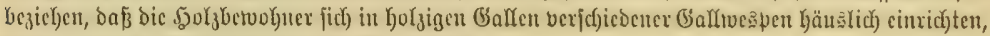
jobalo jene igre Bebaujungen vertaijen haben.

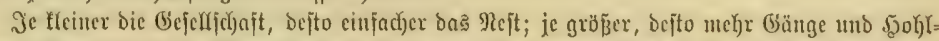

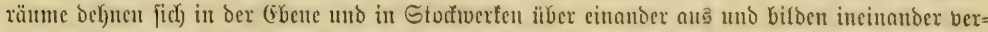

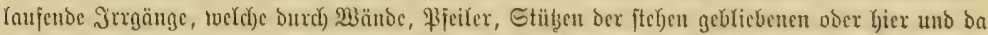

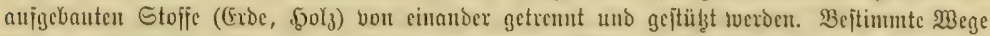

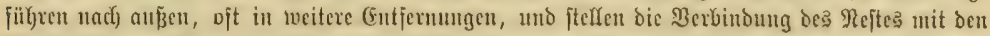

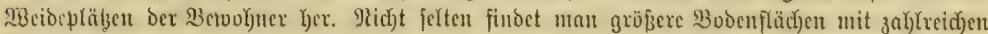

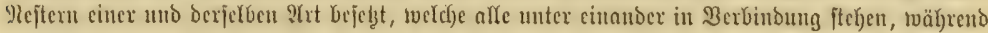

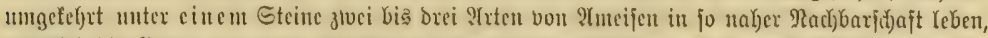

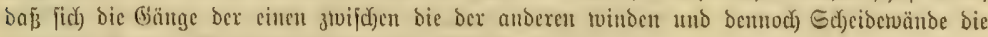

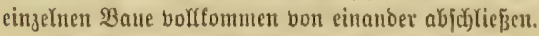

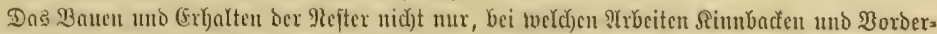

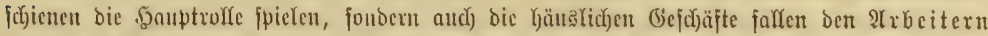

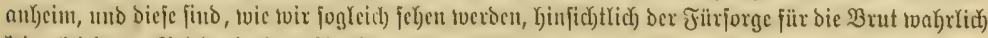

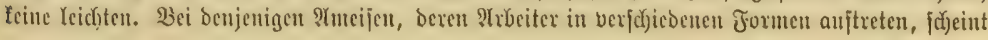




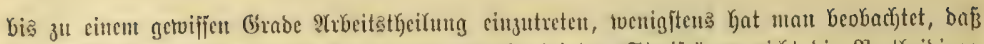

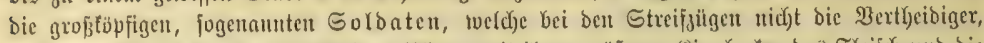

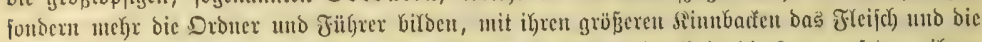

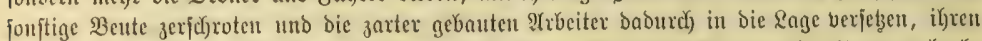

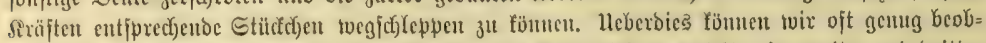

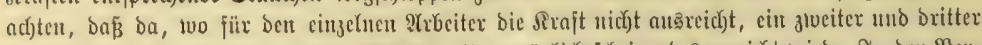

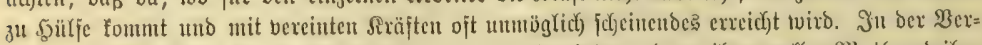

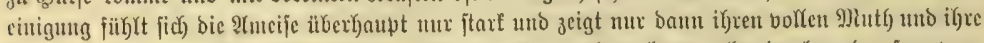

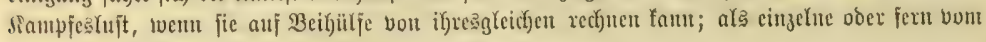

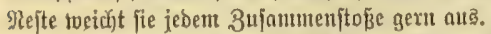

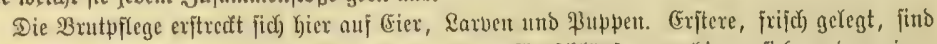

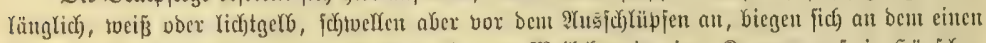

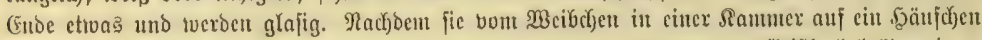
gelegt tworben find, twerben fie bon ben Arbeitern bieder nufgenommen, fleiß̄ig belecț, wie eక

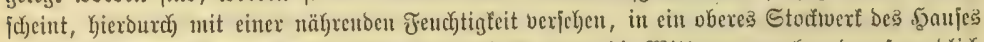

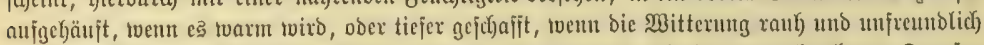

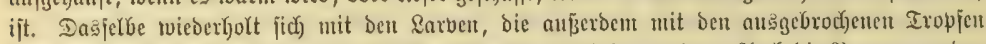

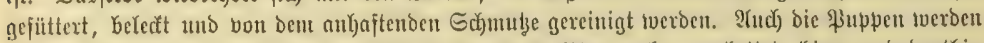

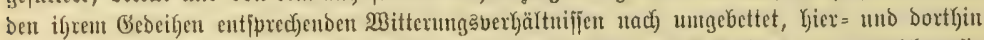

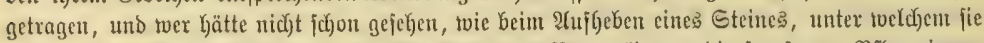

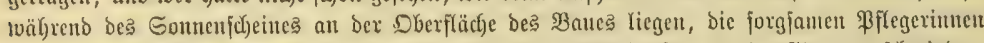

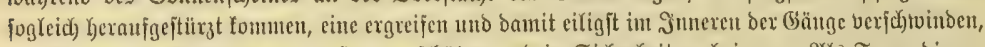

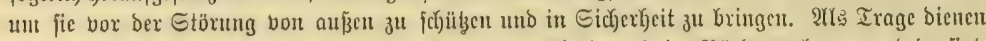

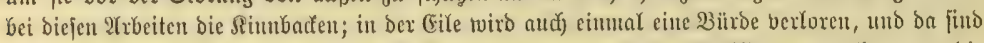

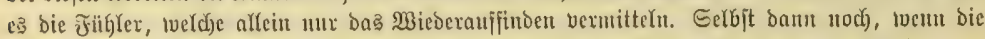

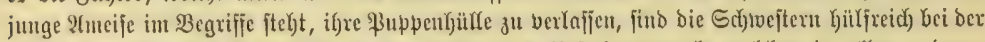

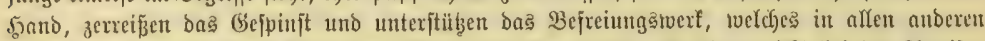

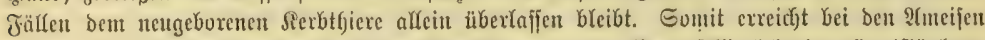

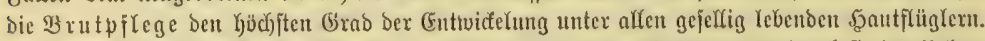

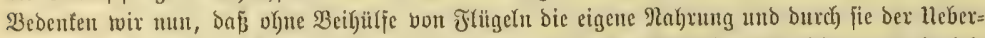

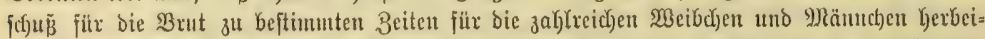

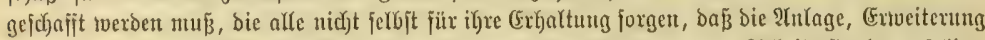

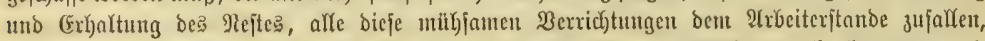

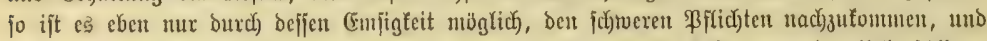

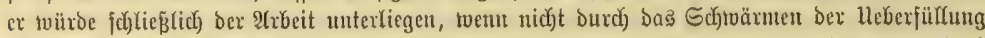

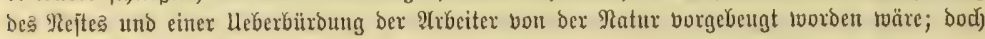
Giervon fpüter.

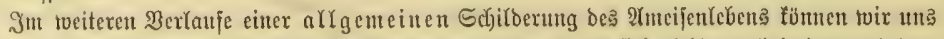

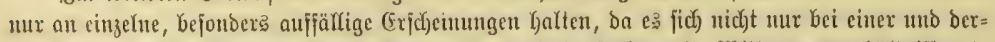

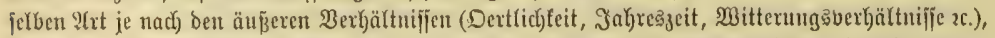

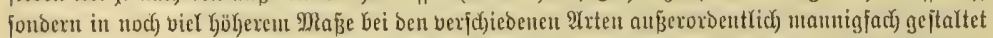

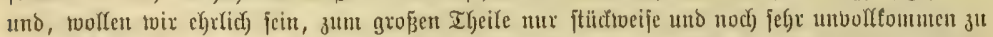

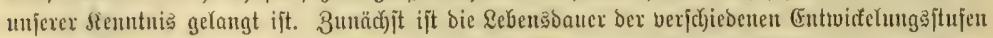

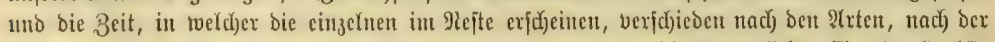

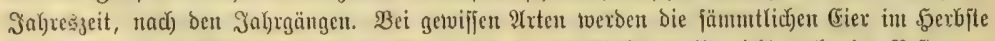

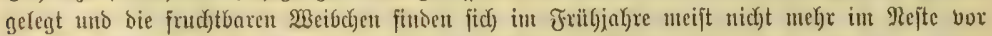

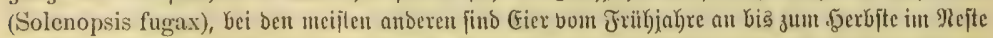

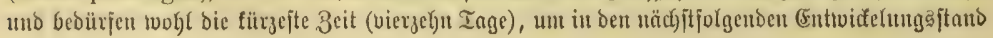




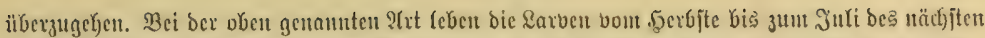

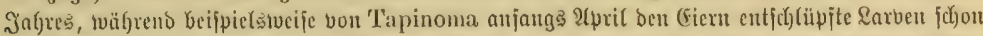

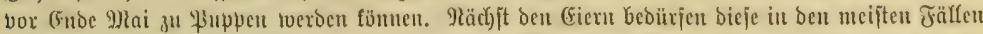

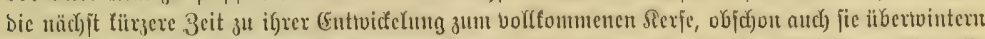

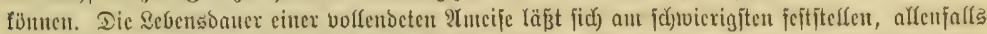

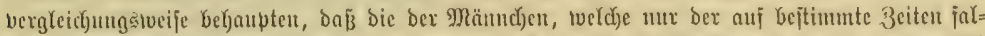

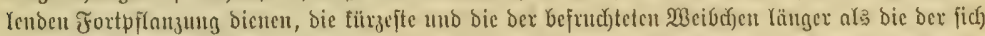

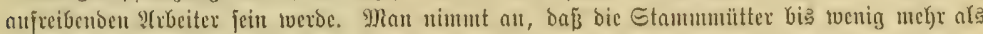

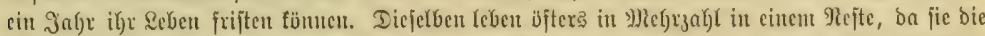

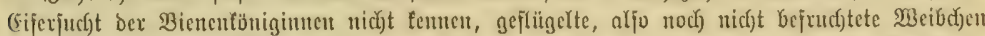

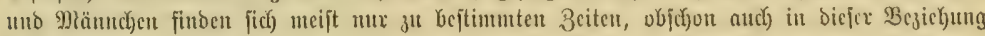

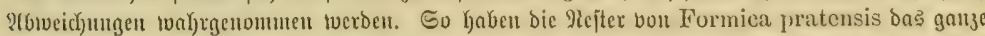

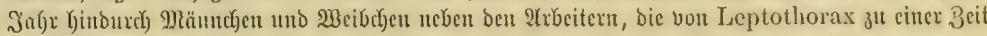

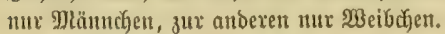

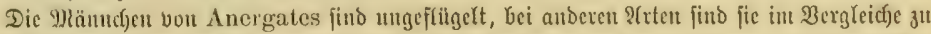

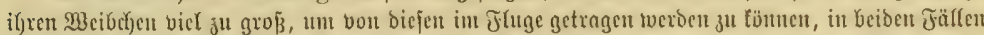

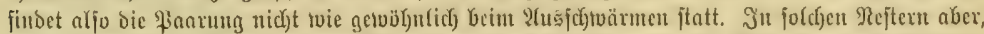

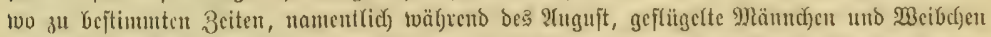

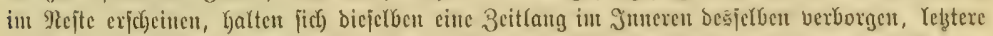

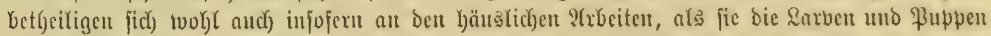

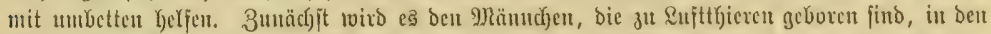

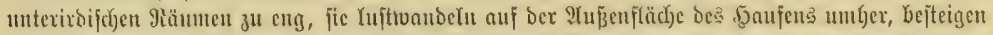

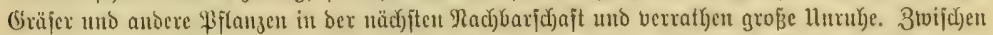

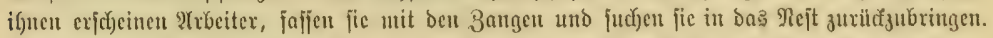

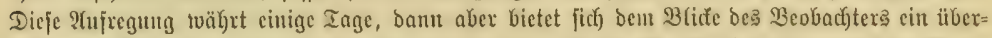

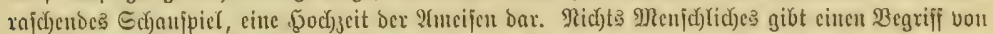

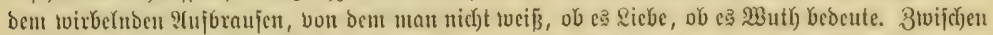

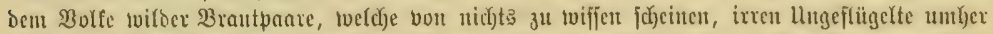

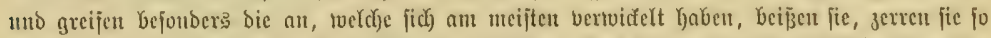

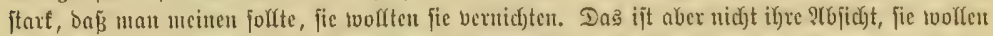

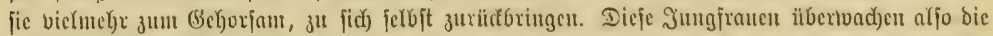

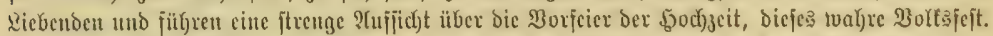

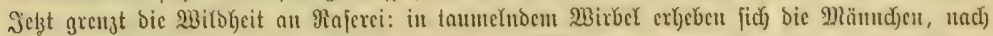

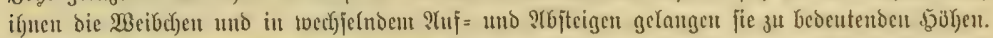

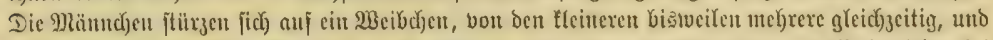

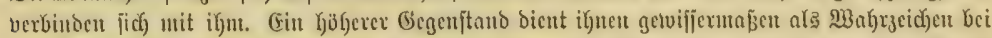

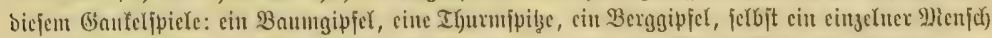

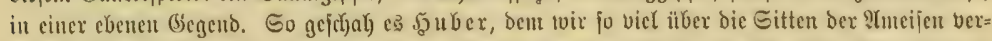

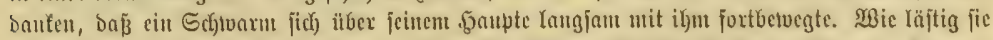

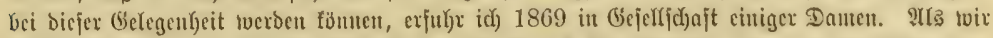

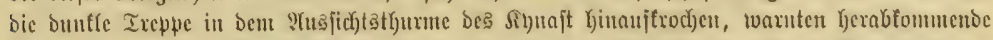

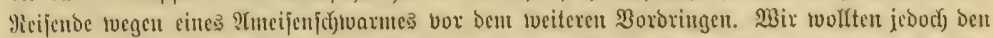

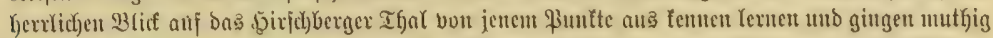

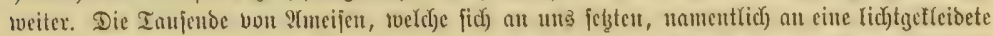

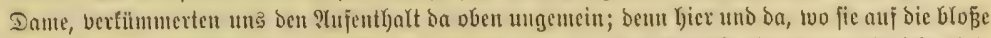

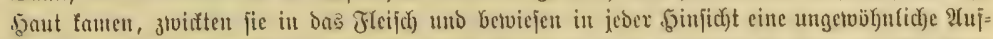

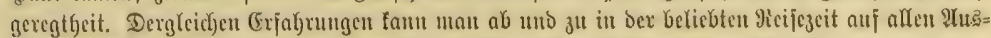

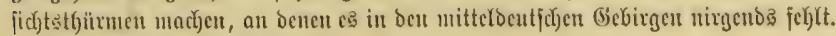

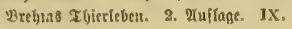




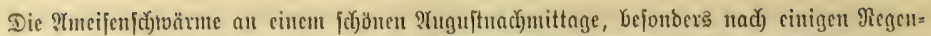
tagen, von Lasius flavus, niger, alienus, fuliginosus, Myrmica berf(f)iebener Irt, Sole-

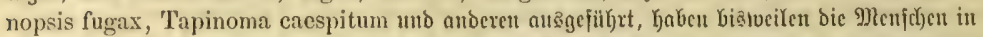

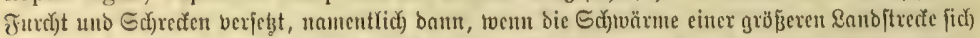

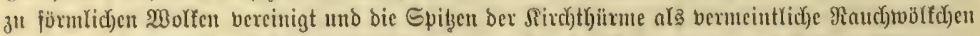

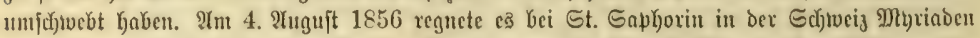

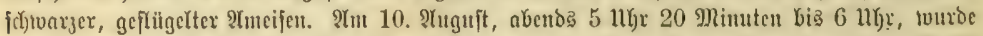

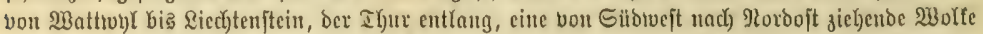

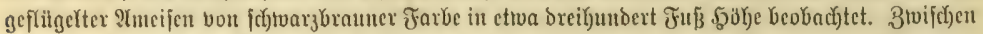

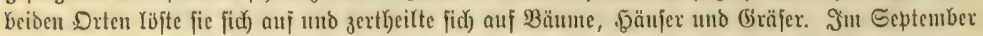

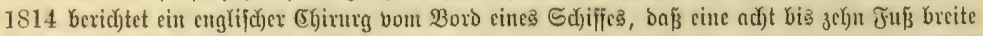

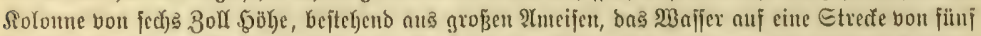

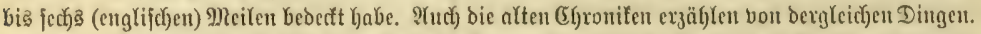

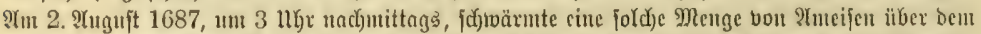

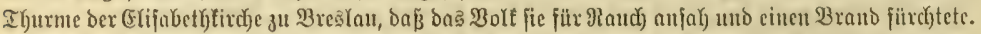

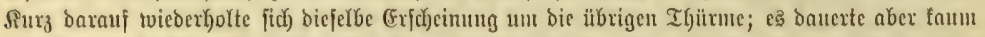

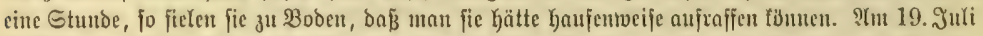

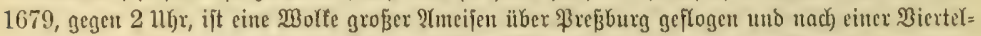

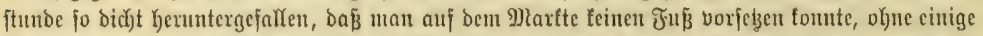

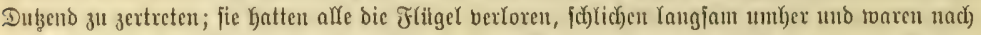

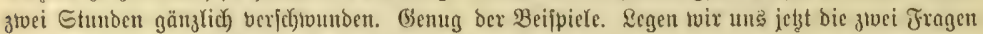

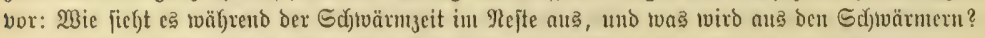

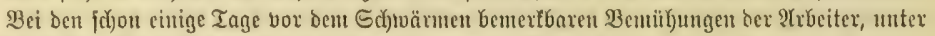

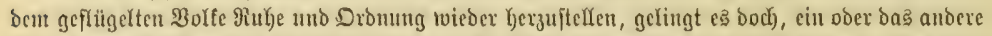

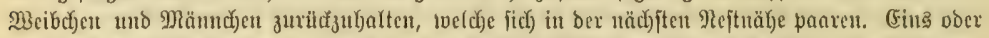

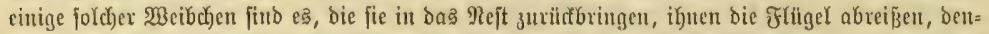

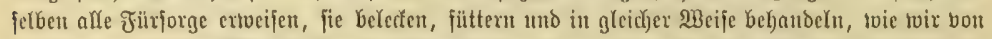

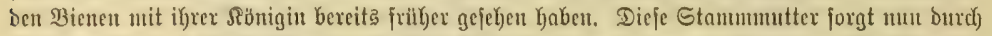

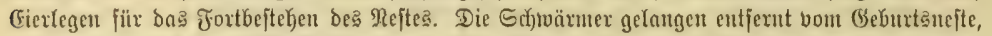

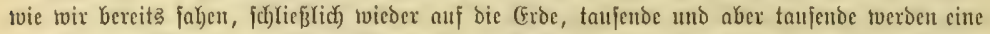

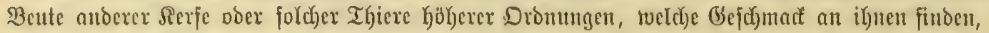

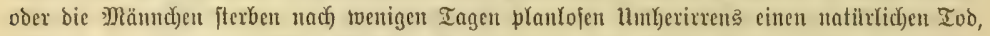

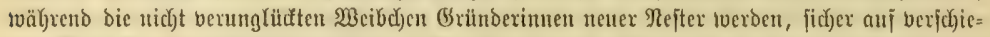

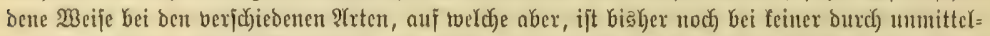

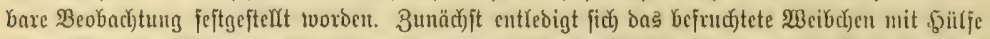

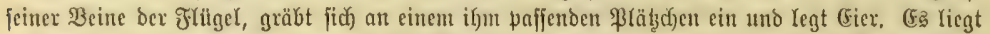
nun nahe, auzunefmen, baß

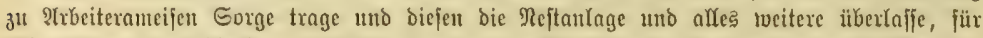

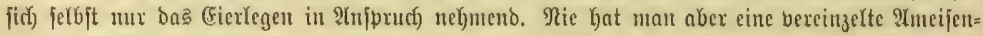
mutter mit Puppen, nidjt einmal mit extuadjenen Rarven angetroffen, fondern mux mit (Fiern obex

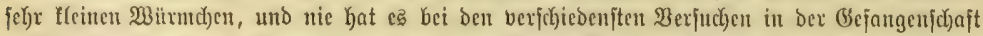

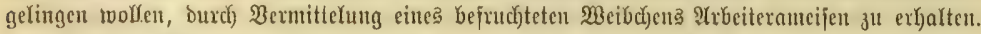

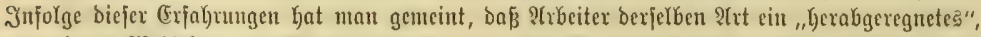

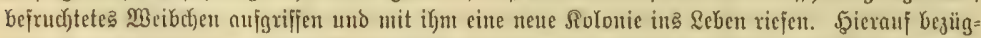

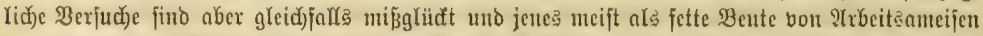

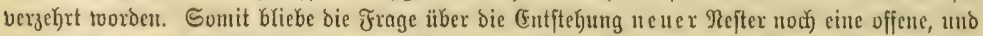
e⿱

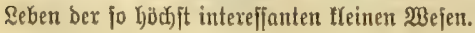




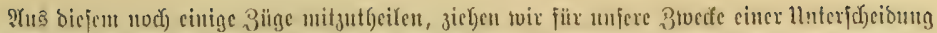

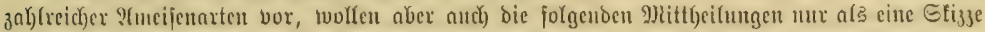

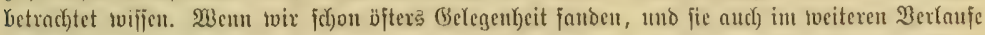

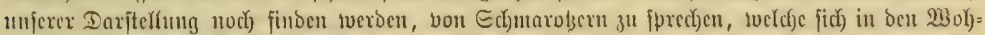

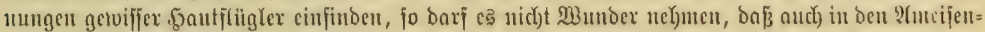

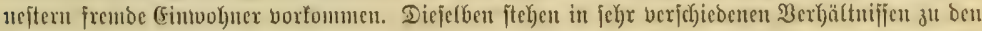

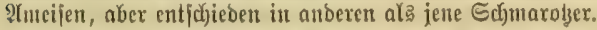

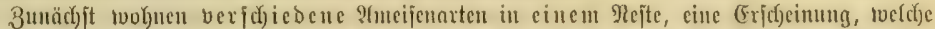

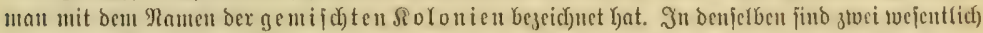

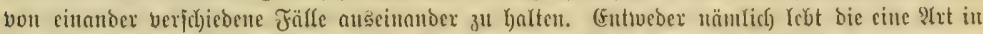

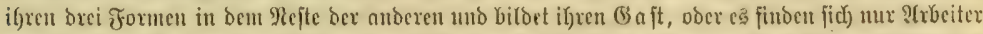

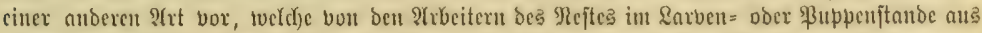

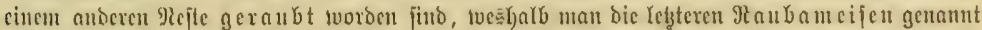

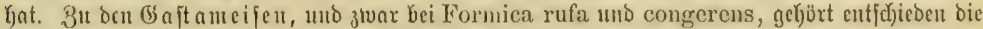
ffeine, getbrotg) glänzende Stenamma Westwoodi (cine Sententumeije), von welch)er man, weil man

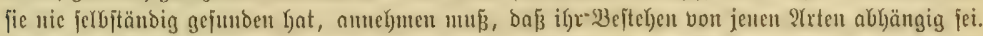
(Eine zweite Frt, Asemorhoptrum lippulum, ift gleid)faltä jür cine Baftamcife bei Lasius fuliginosus, brmeus und Formica sanguinea gebalten tvorden; von .5agens fand fie aber aud is

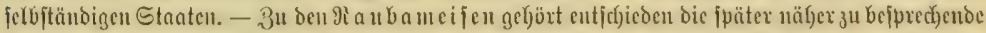

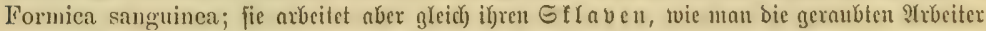

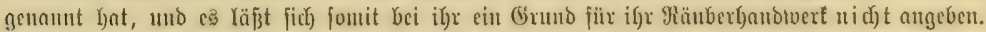

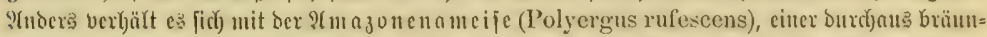

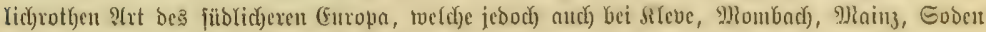
Geobachtet tworden ijt. Sic ranbt die Rarvent ton Formica fusca mo cunicularia unb zeigt jid)

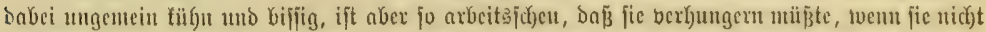

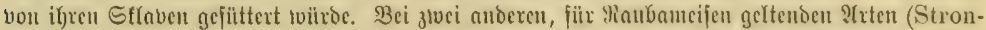
gylognatlus testaceus uno Myrmica atrata) fino bic Berbältnifie abermals anders uno nod)

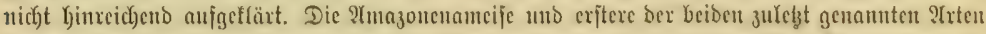

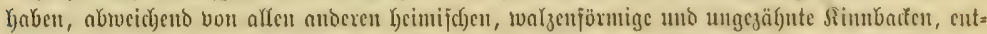

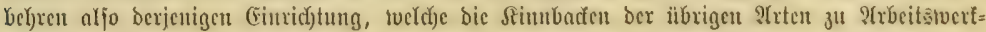
zeugen geitalten.

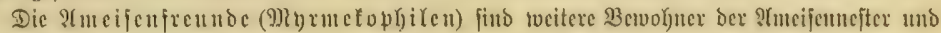

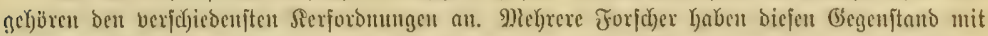

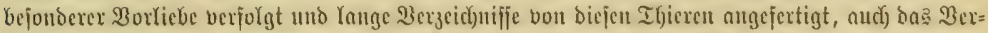

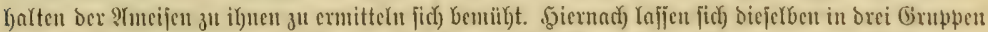

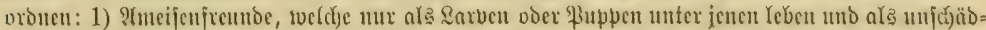

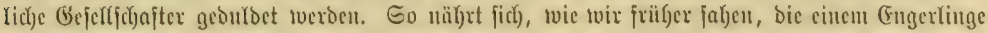

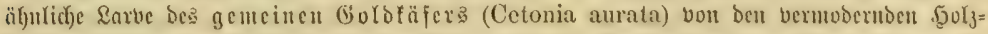

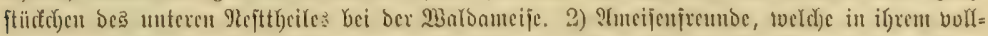

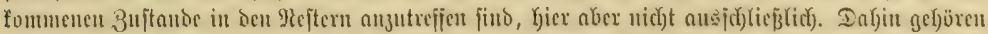

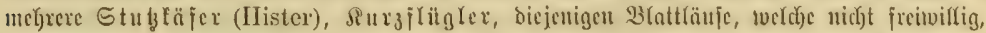

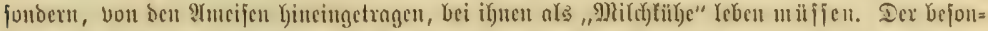

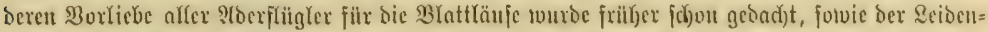

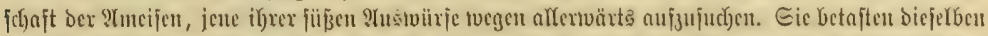

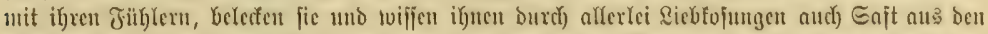

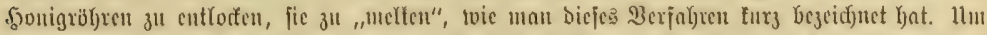

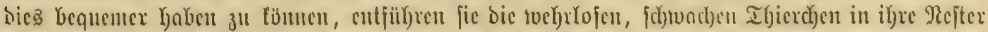

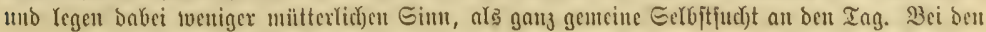




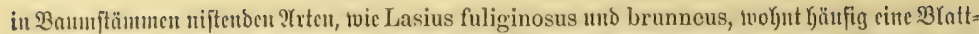

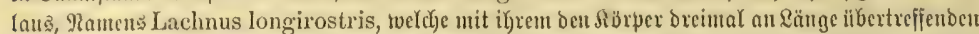

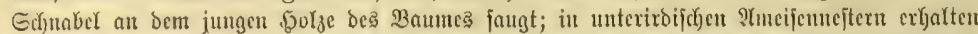

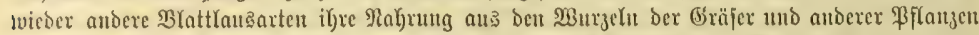

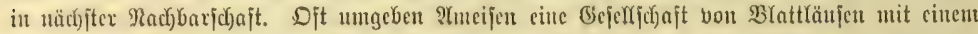

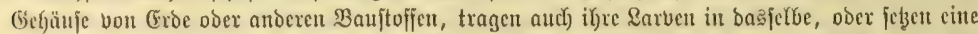

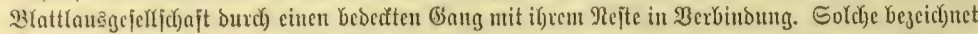

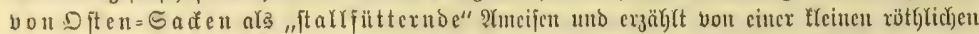

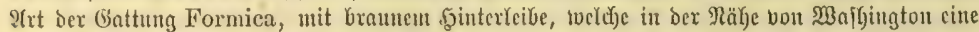

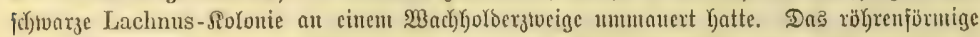

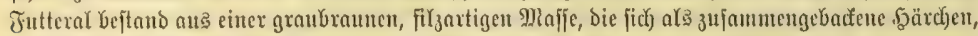

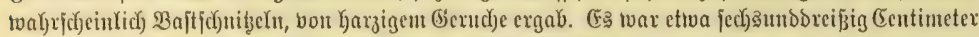

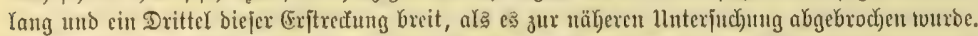

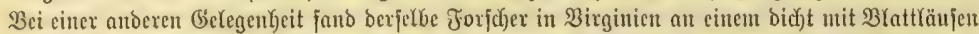

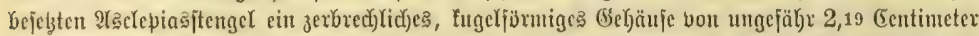

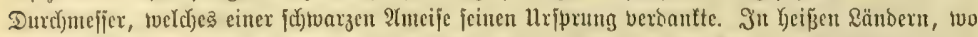

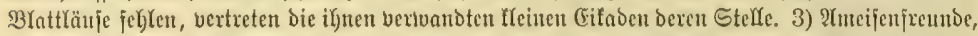
weldye auf allen ifren Rebenşfufen a

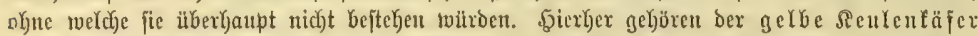

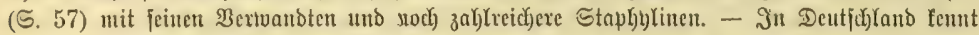
nan itber breifundent fiexjarten alfex Drbnungen, weไche zu einer ober ber anderen biejer brei

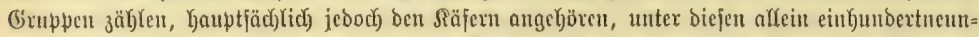

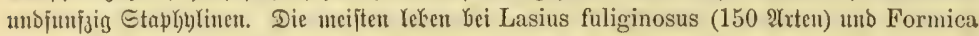

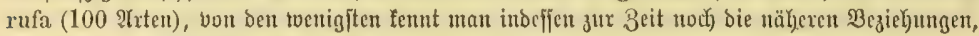
in soełden jie ju ifren Wirten jtelyen.

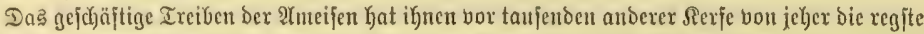
Theilnahnte berex abgenöthigt, tweldhe überkaupt Sinn für foldbe Dinge Kaben, wie uns bic

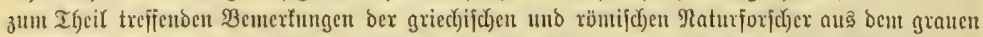

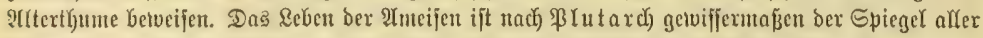

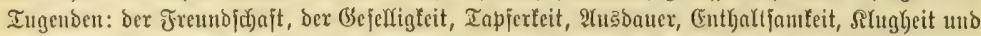

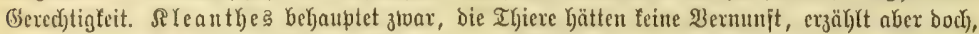

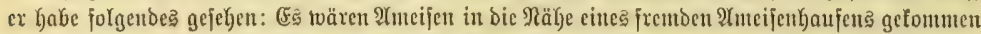

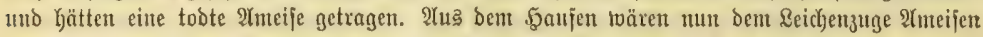

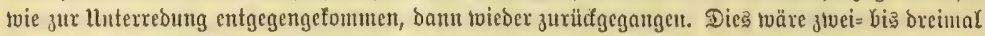

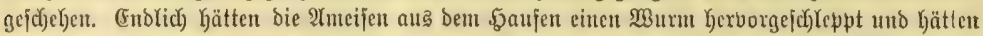

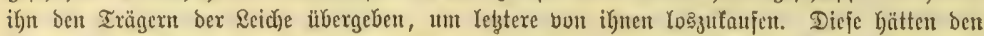
Wurm angenommen und bie Reiche bagegen abgelaffent. - Sebenfalfe bemerft man Hiberald bet jic) begegnenden Imeijen, twie fie bie Tugend ber Bejcheibenfeit üben, indem alle, bie leer gelyen, Den Belabenen autstocichen; wie fie ferner Dinge, bie nidjt gut fortzufd affen find, weis(ich)

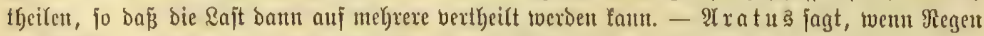

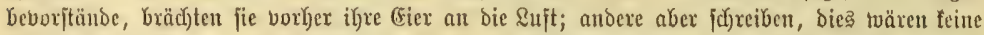

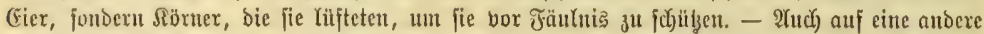

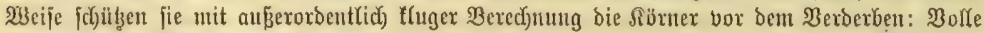

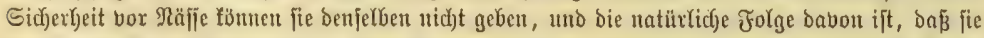

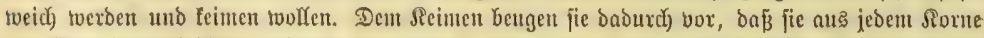

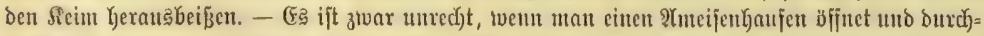

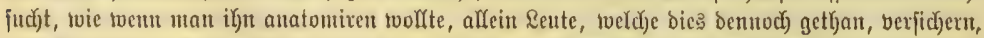

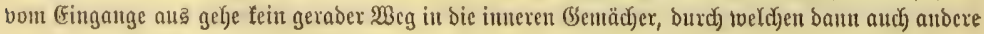




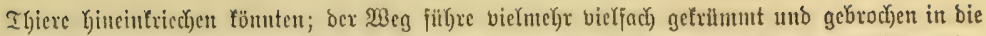

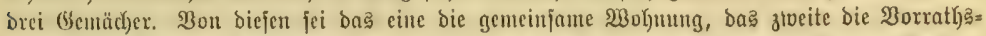

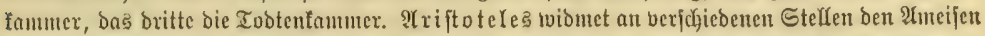

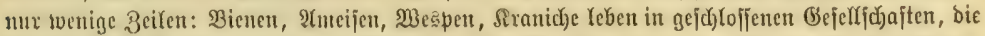
Siraniche uno $\mathfrak{B}$ ienen untex cinem Dberbantete, bie Anteifen aber nidjt. Sie fino theila gefliigelt, theila flügellow. Sie riech)en \$onig von toeitent. Bejtreut man ibre Wobnuntgen mit gepulbertent Edjwejel obex mit Doften, jo ziełen fie aus. Die Almeijen bringen Maben zur Melt, bie anfangక

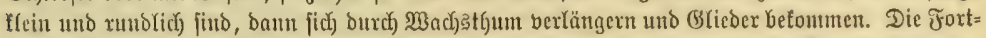

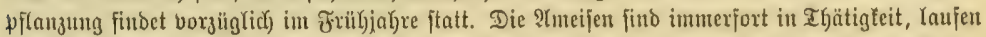

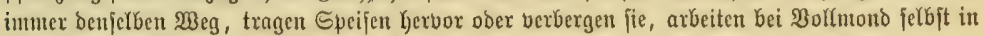
ber Macht. Gie jagen ztwar nidyt jerbjt, tragen aber zujammen, was fie finden.

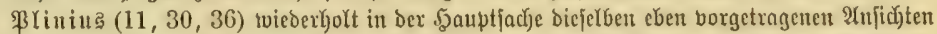

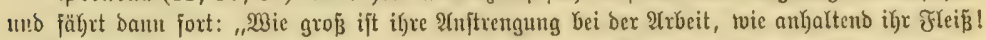

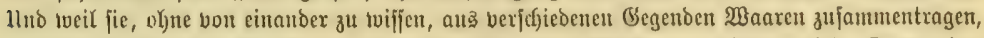

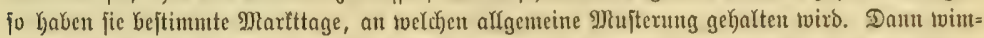

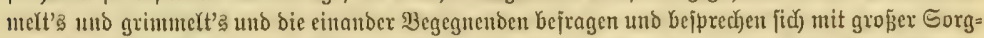

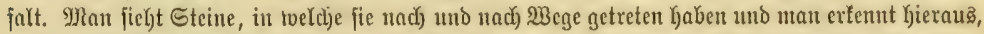

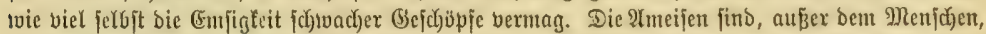

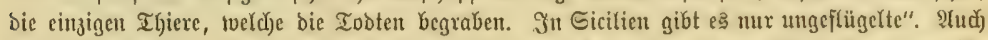

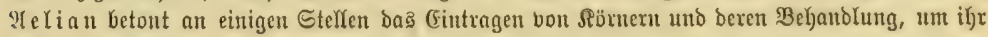
Seimen zи verlyindern.

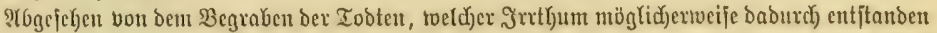

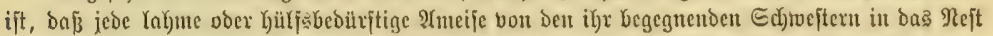

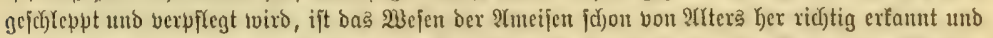

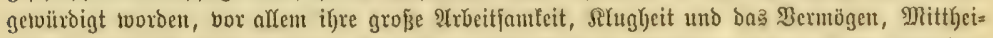

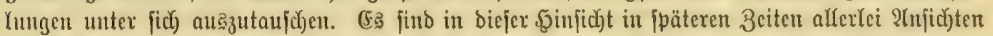
(ant getworoen, eitu Beidyenfprad) an vexf(d)

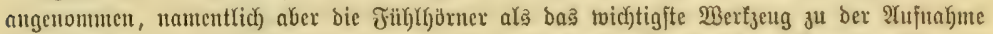

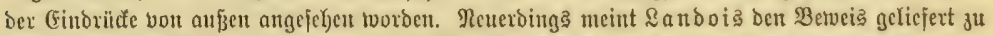

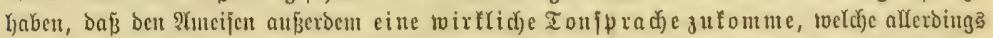

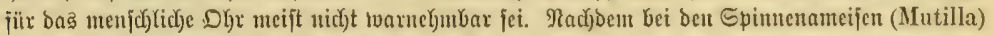

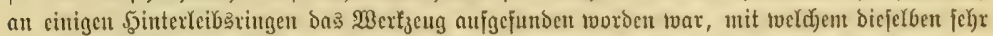

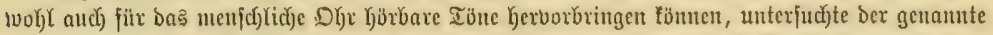

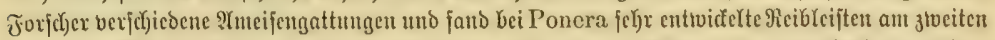

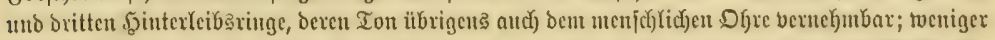

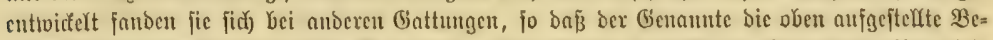

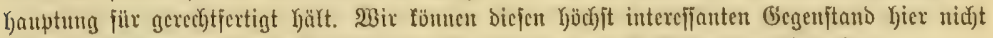

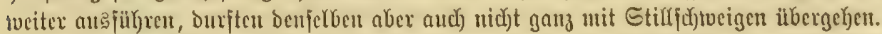

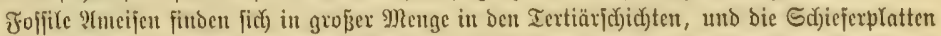

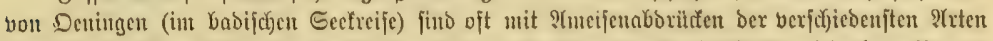

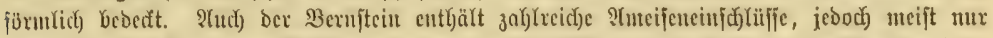

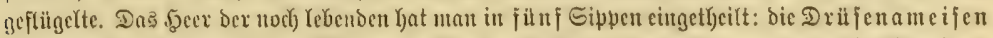

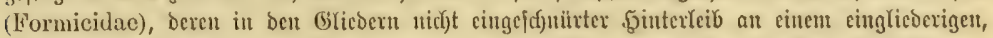
fdhuppentragenoen Stide fibzt; bic 3angenameifen (Odontomachidac) Gaben biefelbe finter=

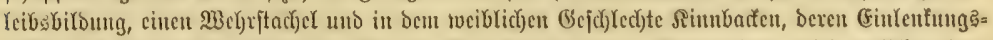

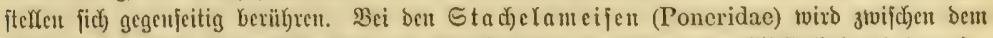

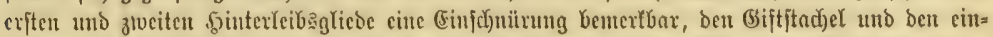
glieberigen Etiel haben fie uit bex vorigen folvie mit ber folgenden Sippe, Den Blindameifen 
(Dorylidac), gentein, two bie Weibd)en und 2trbeiter augenlos find. (Fin zneiglieberiger Љ̧inter:

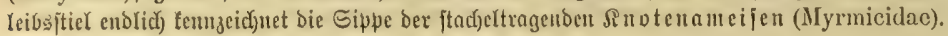

3u ben artentreichjten Gattungen ber Drïjennmeijeu gelürt Camponotus. Die S=pörmig gebogenen Etirnleijten, bie boun Ropfichilde entfernt eingelentten Jillyler und ber Mantgel ber

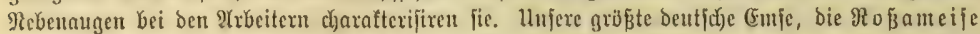

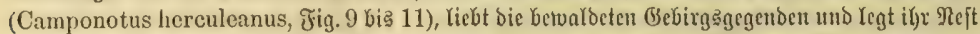

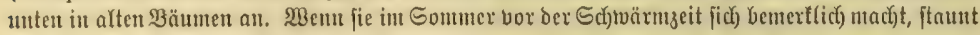

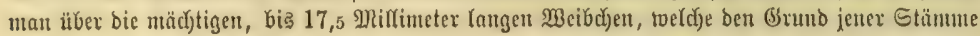
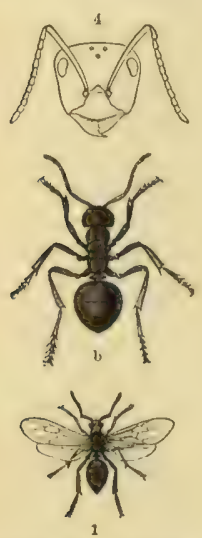
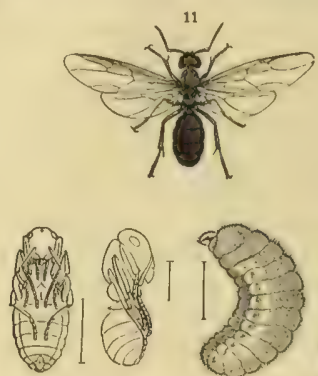

7

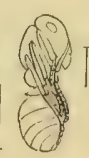

8

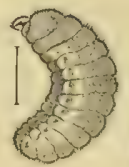

5

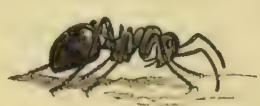

$2 n$
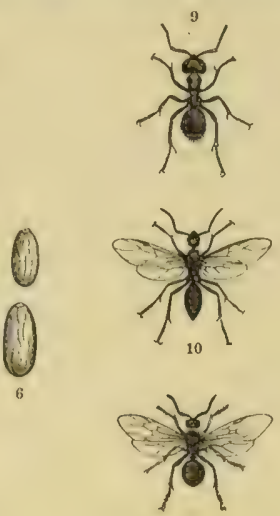

3

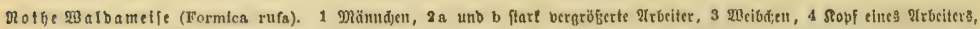

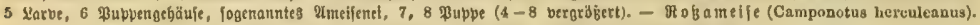

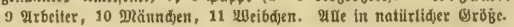

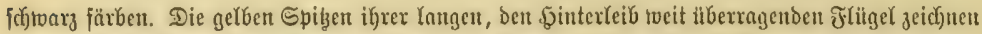

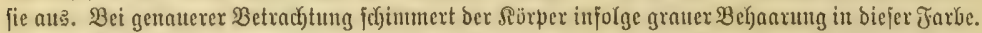

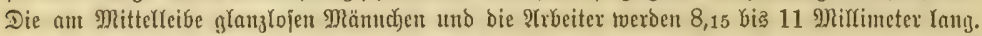

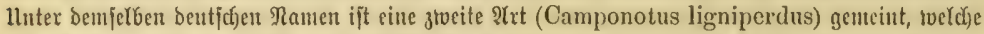

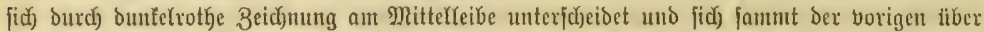

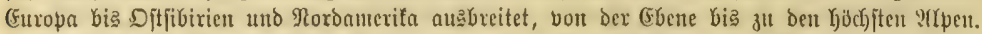

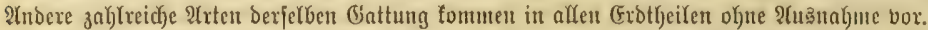

Die rotge $\mathfrak{B a l d a m e i j e , ~ 5 u ̈ ~ g e f a n e i ~ f e ~ ( F o r m i c a ~ r u f a , ~ F i g . ~} 1$ bis 8), bat ein uicht aus:=

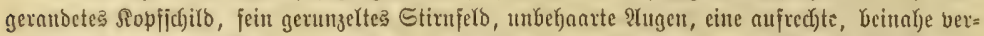

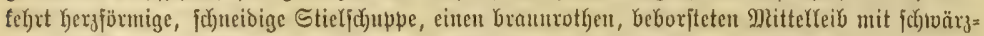

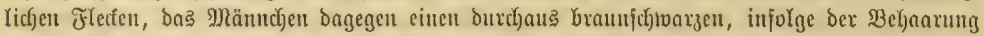

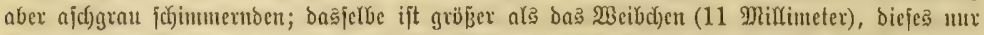

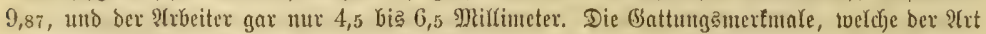

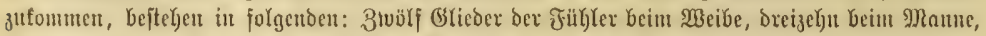

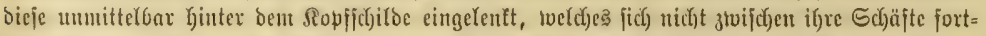

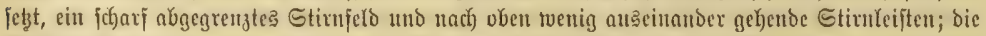

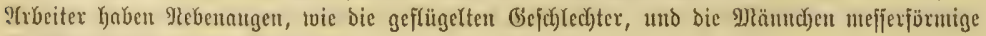
slappen an bett groéen Genitalien. 



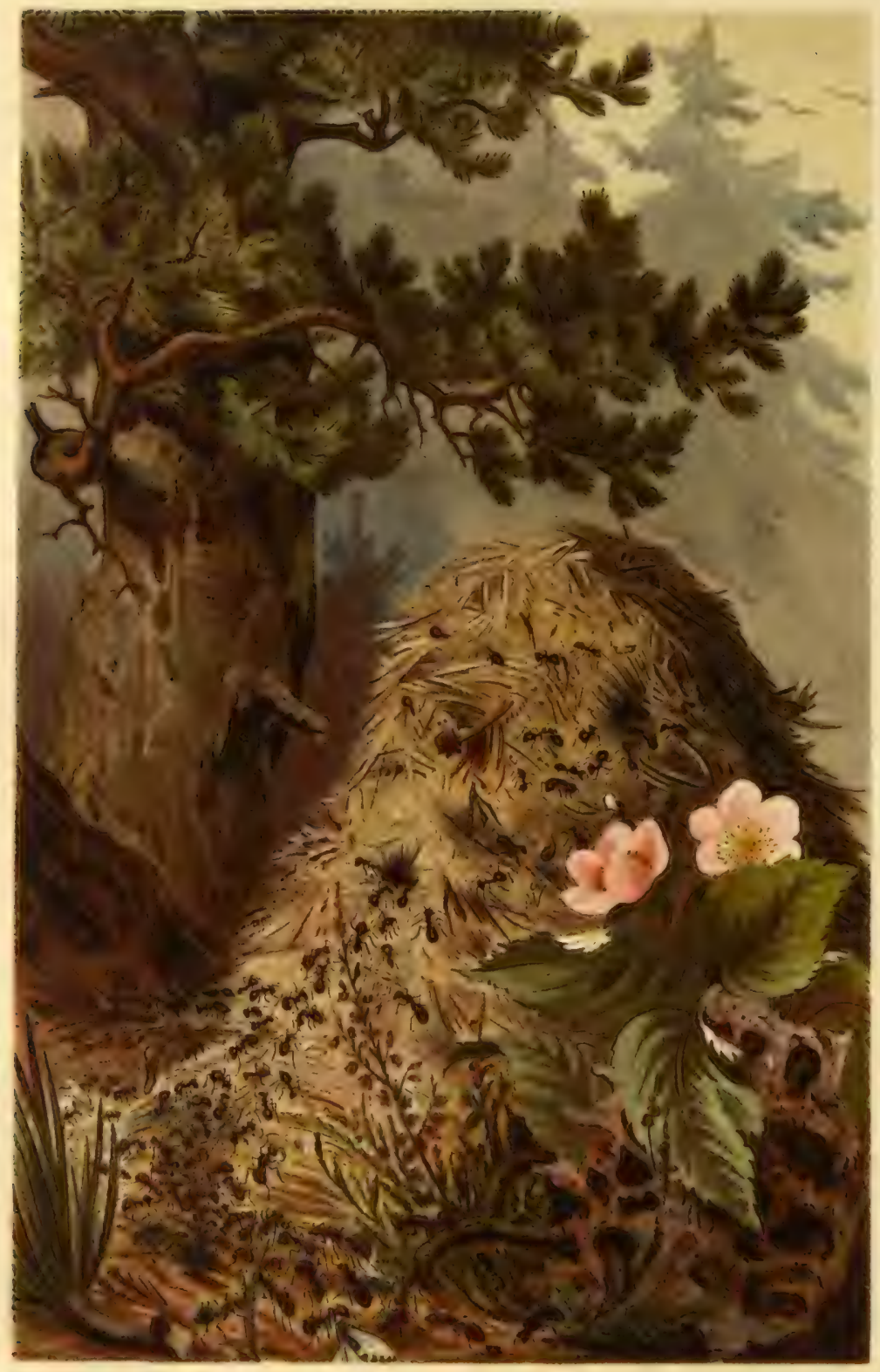

BUTHE WALGAULISE 


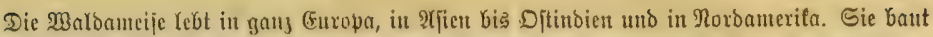

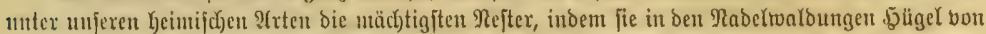

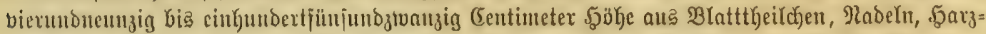

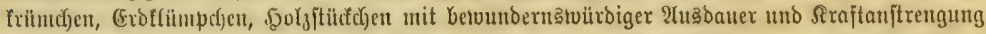

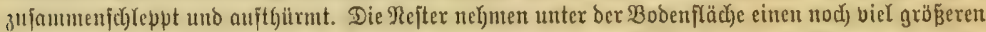

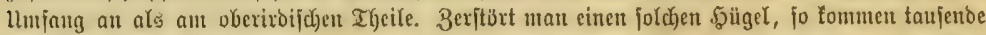

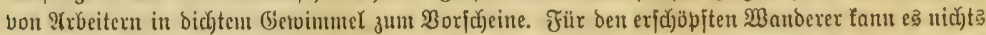

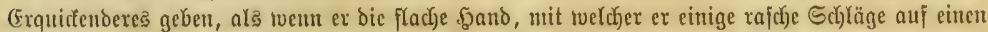

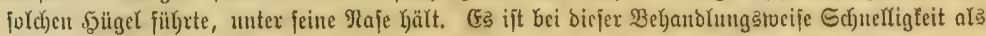

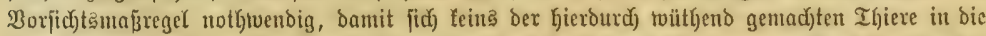

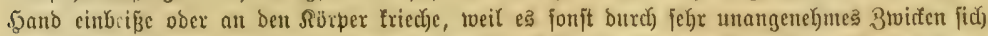

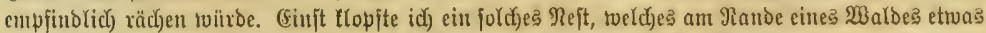
Yjoct) lag, und ztwar gennu bor ber in Sdjeiben begriffenen Eonne. Rachoent vir, meine mid)

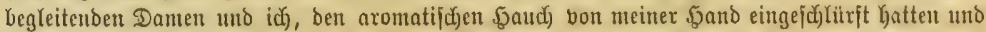

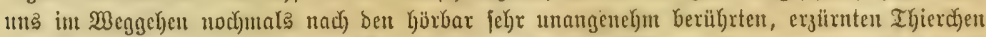

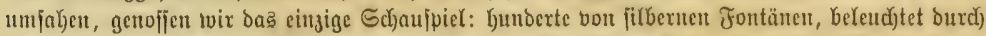

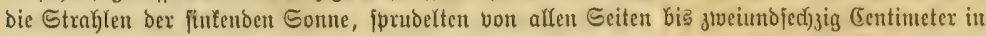

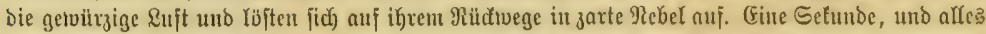

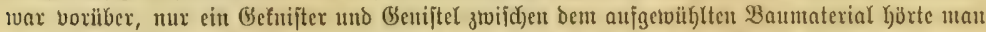

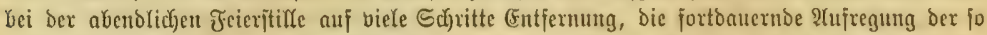

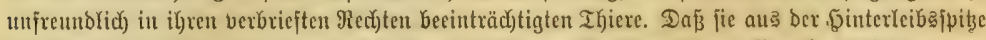

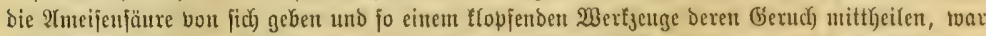

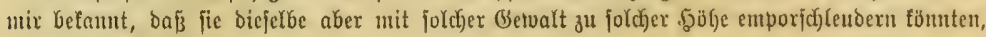
hatte idid) nidjt geabutet.

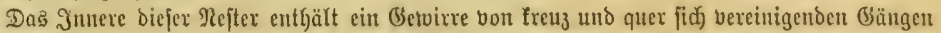

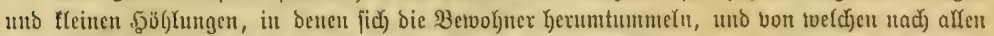

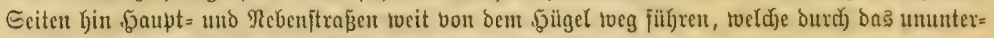

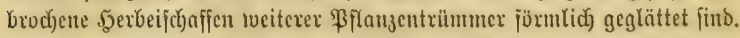

Die blutrothe Raubauteife (Formica sanguinca) ift ber borigen fefre äfnlid) uno frither

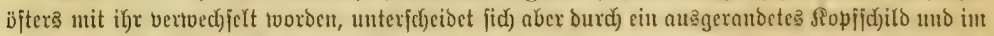

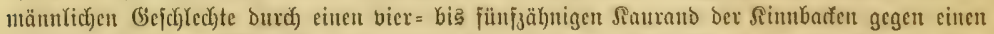

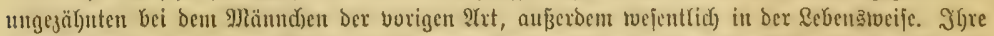

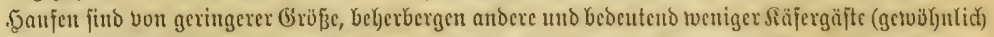
bie beiben Rumffüngler Lomechusa strumosa uno Dinarda dentata) uto bie Irfeiter vout Formica fusea, cunicularia uto feltener aud von Lasius alienus, tweld)e affe in Rarvenumftande

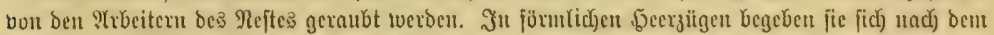

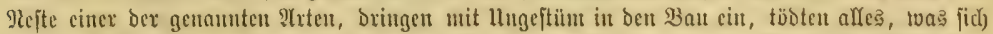

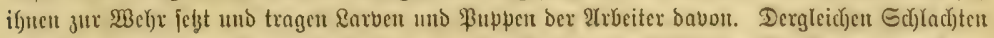

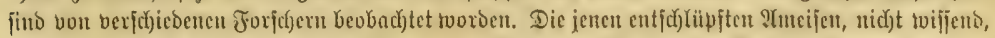

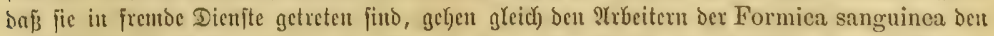

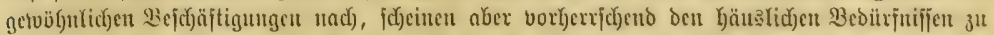

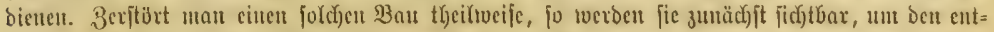

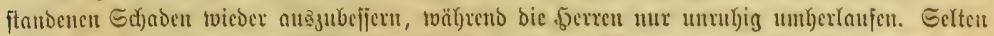

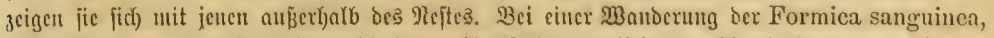

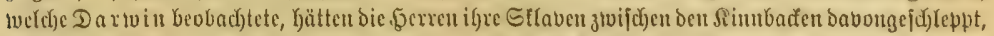

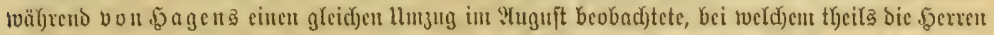

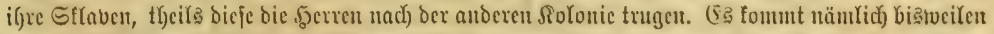

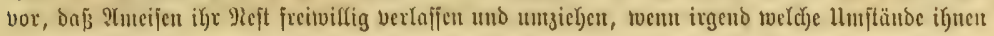




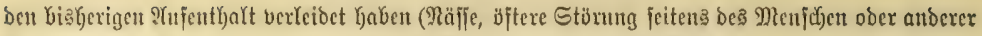

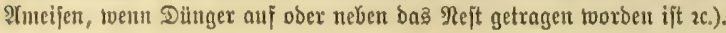

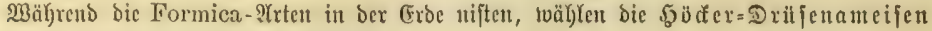

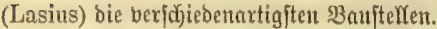

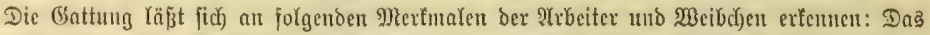

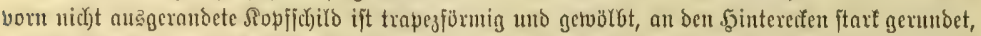

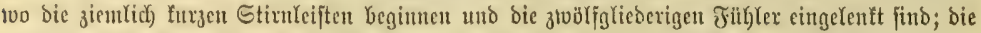

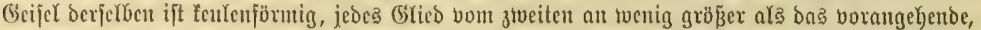

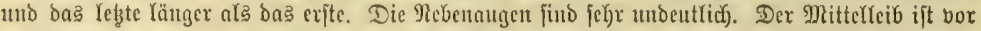

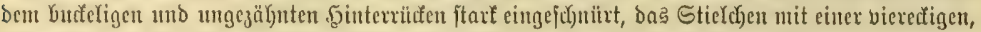

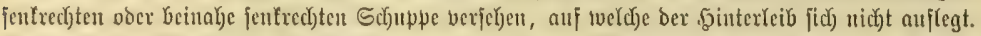

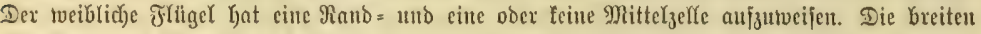

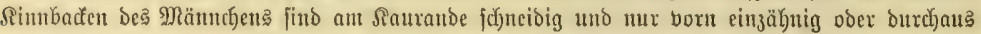

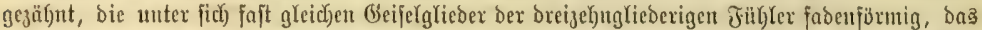

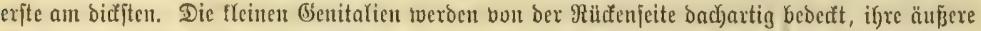

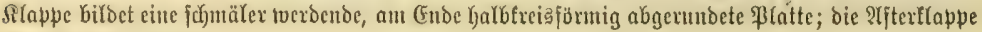
ijt nidht autsegejdynitten.

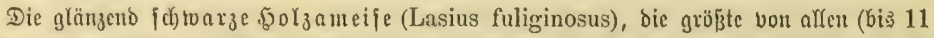

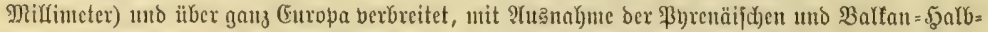

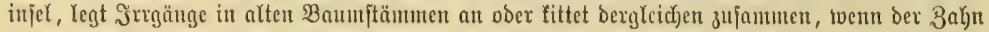

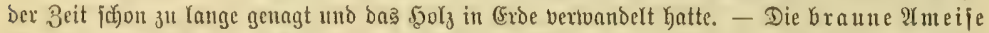

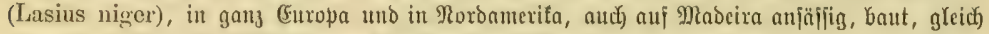

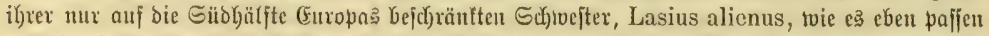

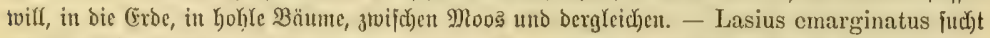
mit Borliebe bie Riz̧en in Gartemmanern auf. Die twegen ifrer empfindlidjen Bifje berüd)tigten

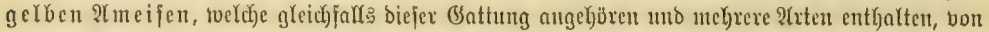
benen Lasius flavus am verbreitetften ijt, Gauen befanntlid) in bie (Eroe unter bem Sclube eines Steines ober eines ફ口itgels.

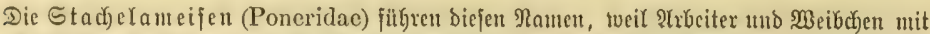

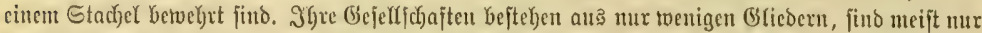
im 2trbeiteritande befannt und in Europa fparfam bertreten. - Die von \&atreilfe aufgeftente,

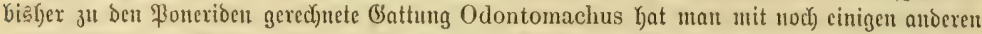

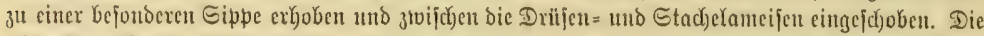

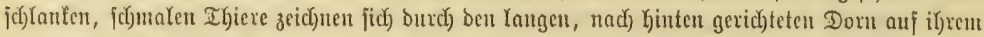
cinzigen Etielfnoten atta, folvie burdh bie ztwei llnterrandzeflen und bie brei s)littergeffen in ben

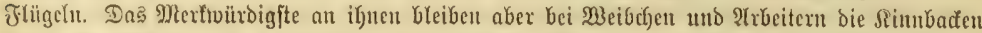

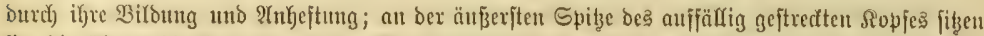

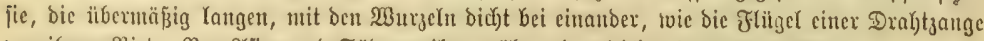

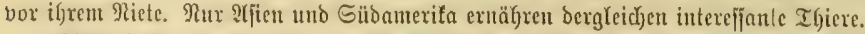

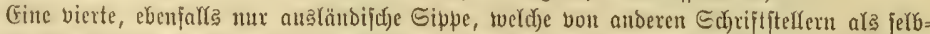

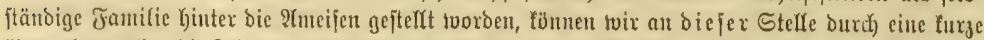
Wemerfung über bie \&ebenşberbältniffe einer Irt cinführen. Die Dory liben (Dorylus, Labidus,

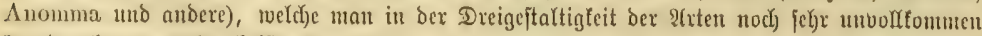

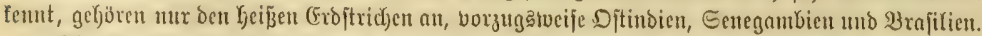

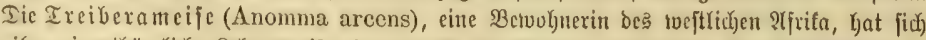

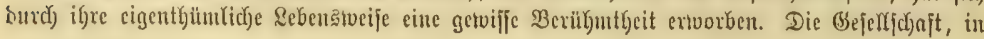




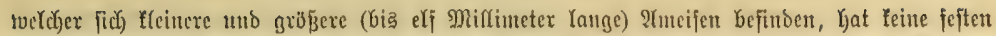

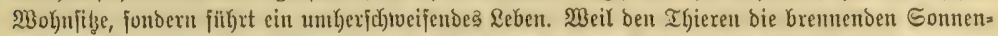

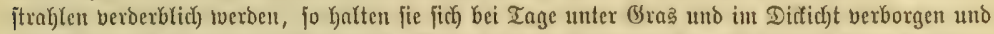

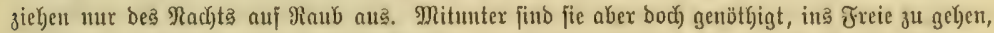

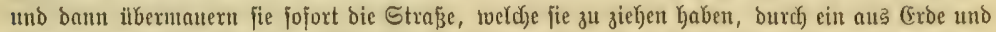

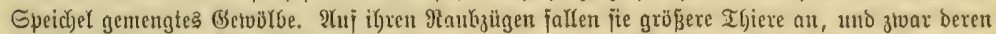

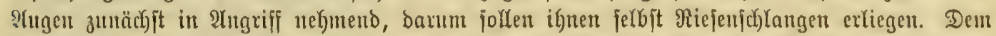

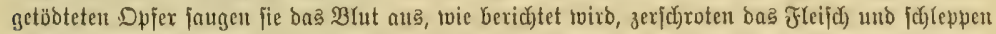

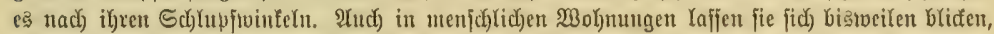

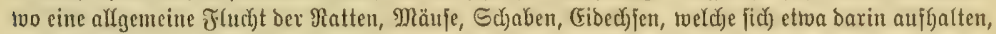

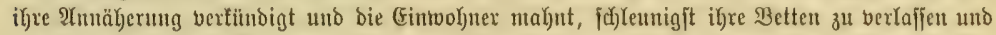

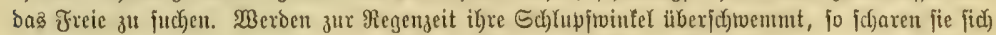

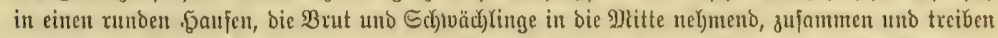

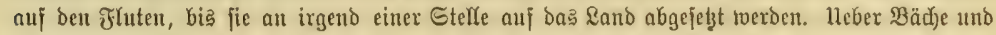

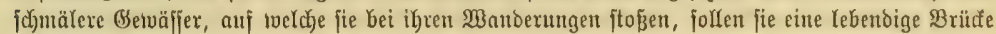

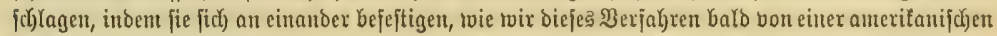
Prt näber expabren werben.

Die Rnotenameijen (Myrmicidac) bieten ben gröpten Jormenrcichtfum bar uno nöthigen bie Styjtemntifer, fie auj ungefähr ztveiunbvienzig (Battungen zu vertheilen, twełdhe bei tveiteren

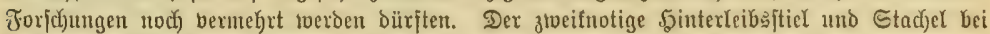
Meibchen und $\mathfrak{A}$ rbeitern bilden bie affen gemeinjamen Merfmale. Gattungen twie Myrmica, Eciton un $\Lambda$ tta, $\Lambda$ phaenogaster, Monomorium, Typhlatta uno andere, beren brei erjtere

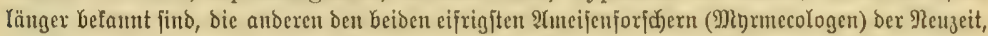
(5. Mabr in Mien uno Smith in Ronton, ifre Briundung berbanten, gehören hierher uno

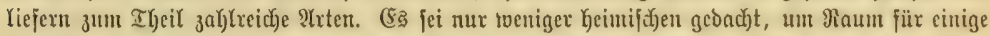

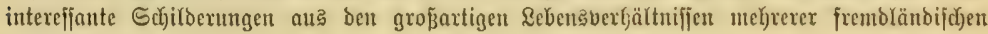
zit getvinnen.

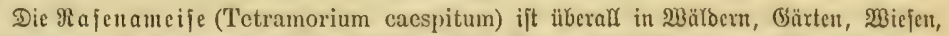

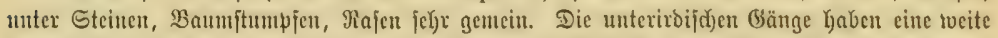

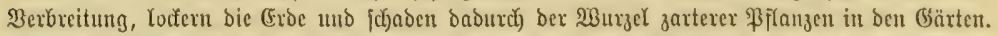

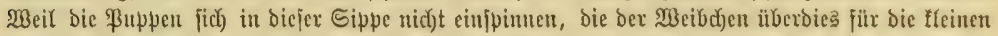

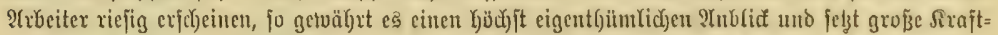

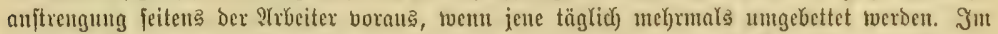

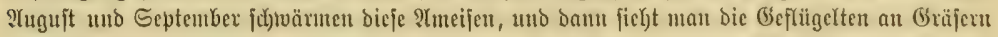

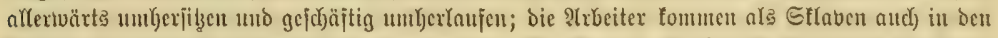
ఇejtern von Strongylognathus testaceus vor. Die Gattung ift d)arafterifint durd) cin hinten

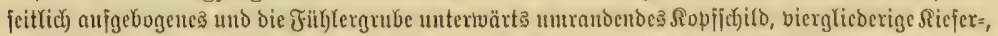

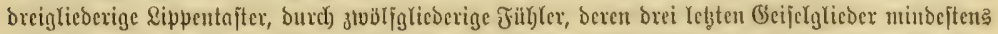

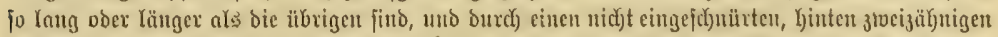

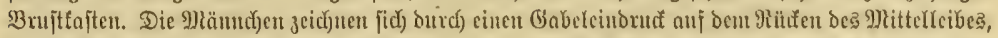

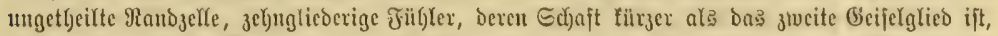

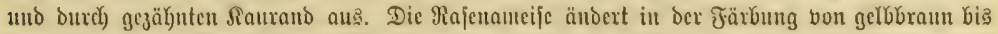

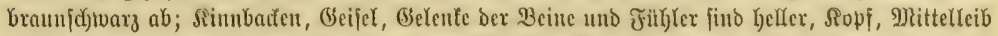

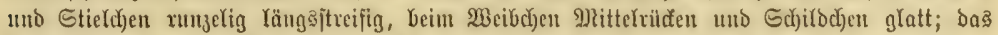

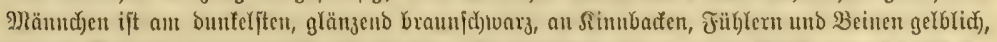

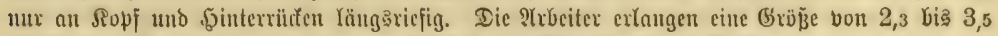

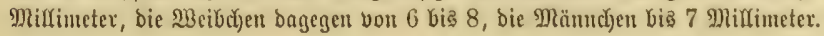




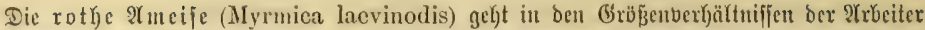

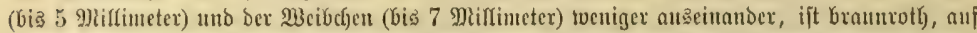

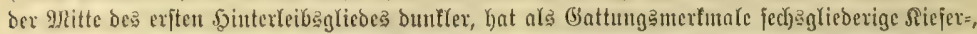

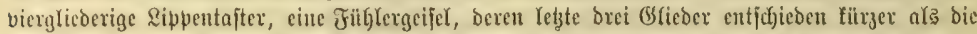

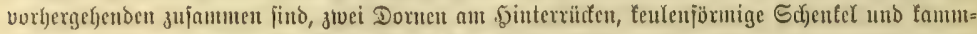

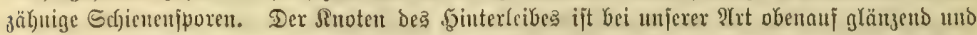

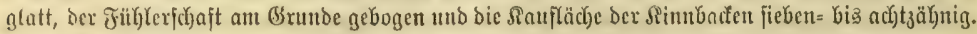
Dicfe ?tut lebt ebenfo twie bie vorige uno tonnt in gleidjer alfgenteiner 2erbreitung bor.

Die a dérbautreibende 2 neife (Mrymiea molificans) ift Gegenftand eineb Berichte getuviden, weldyen Darwiu an bie Linnean society in Soubou auf Grund ber in Texą vou

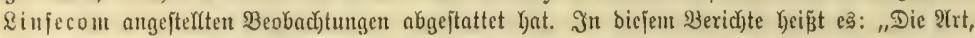

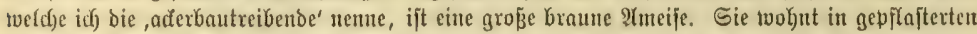

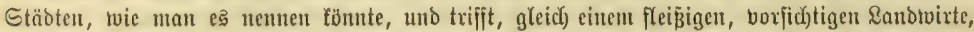

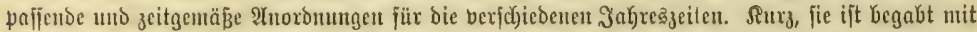

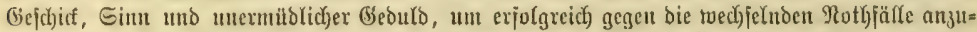

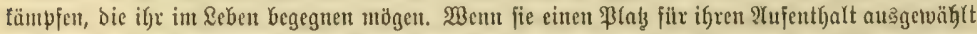

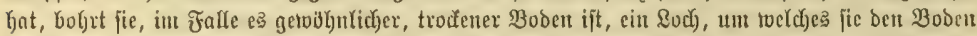

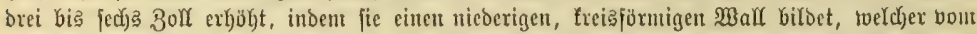

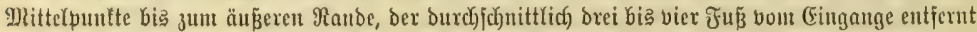

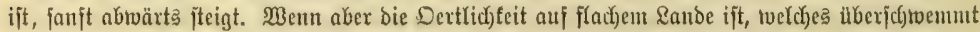

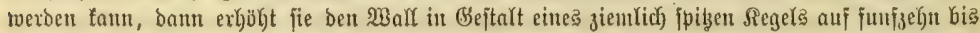

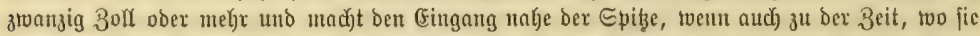

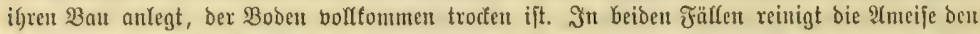

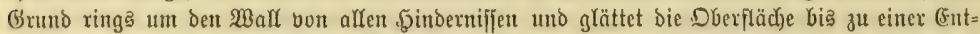

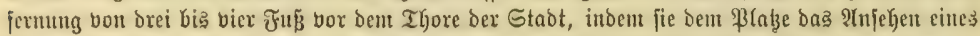

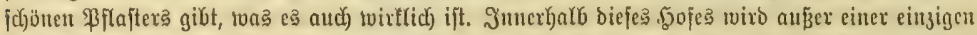

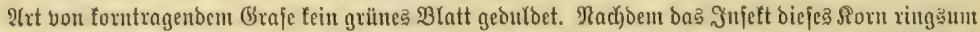

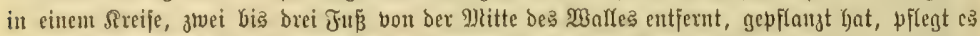

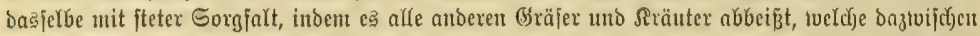

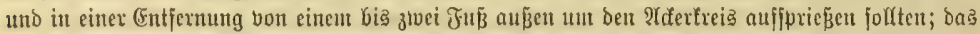

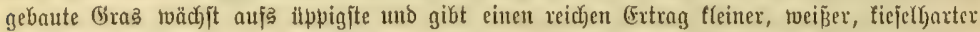

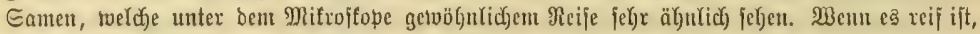

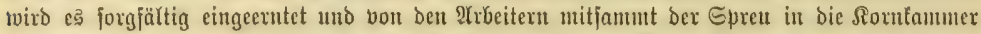

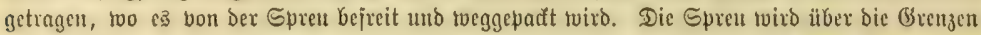

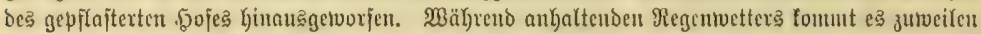

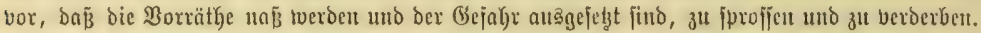

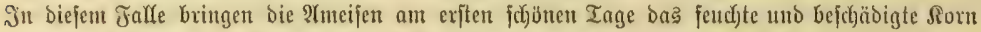

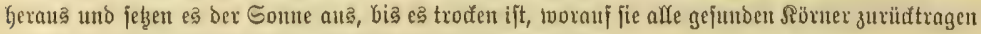
unb toegpaden, während fie bie fprofjenden umtonmen lajien".

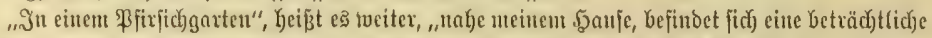

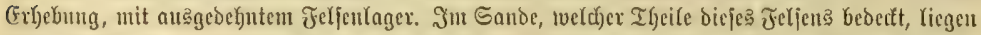

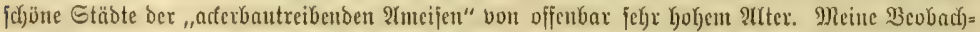

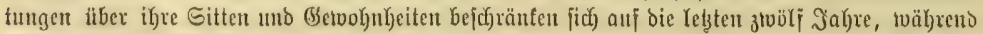

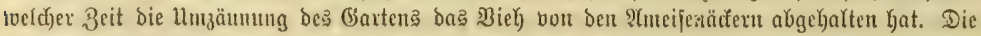

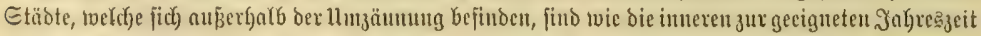

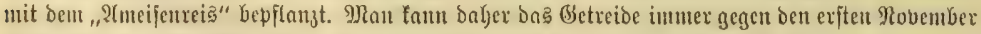

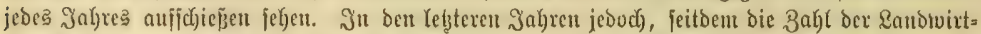

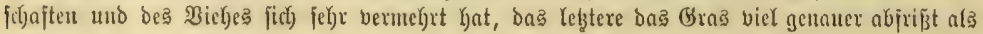




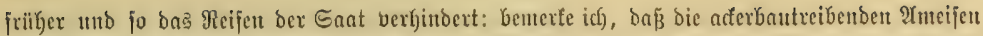

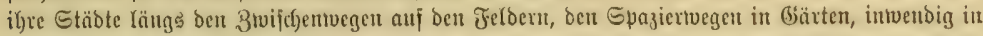

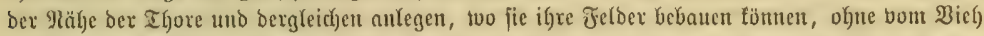

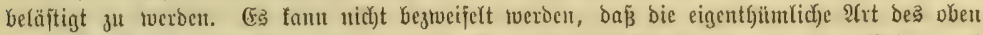

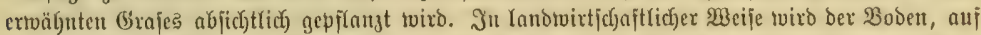

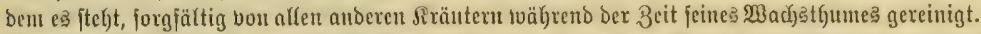
Wen bas Sern reif ijt, twiro bajür Sorge getragen, bie trofene Stoppel abgeidunitten und fort=

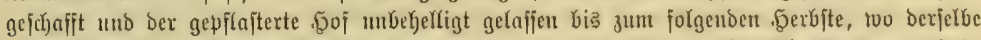

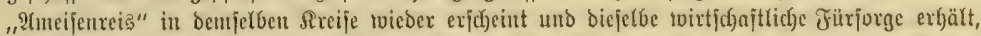

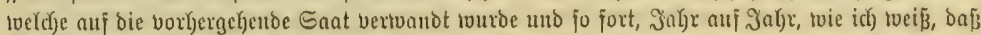

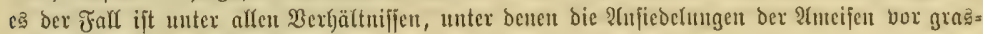
freffenden Ijieren gejulib̧t find."

Die (Eciton

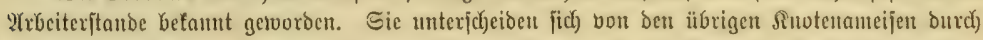
jrveiglieberige Sicjex =, und breiglieberige \&ippentajter, burd) eine (brube fïr bie zrobliglieberigen

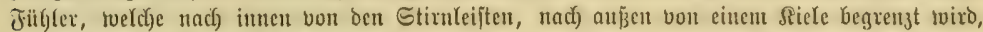

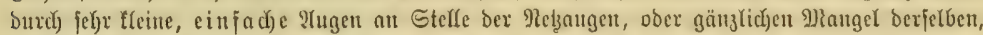

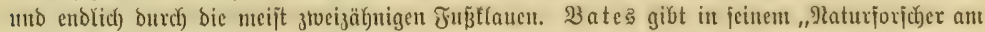
2(majoneniftrome" büct)jt intereffante (Eingelfbeiten über bas Reben biejer von ben (Eingeborenen "Touóca" genamuten Iljiexe, loeldye wir ben folgenden MRittheifungen zu Grunde Yegen. Die

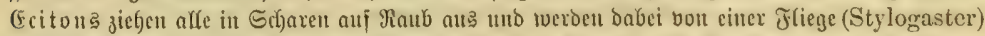

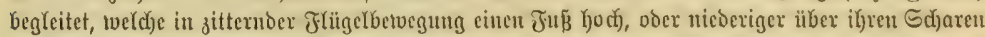

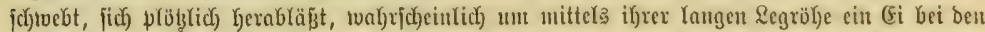

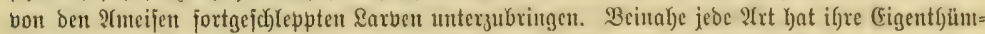

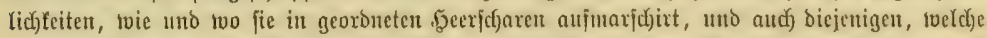

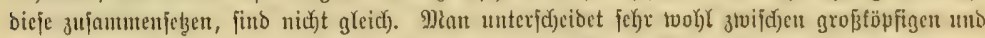
fleintöpfigen \&rbeitern, toefdye aber nux bci cintigen 2trten (Eciton lamatum, erraticum,

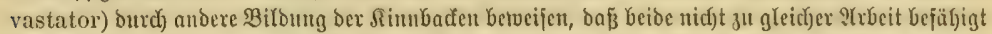

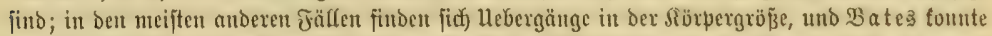

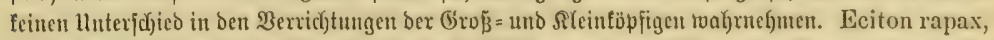

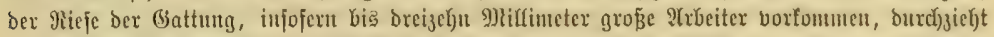

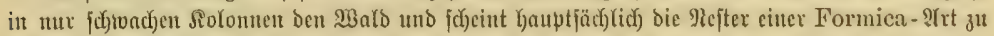

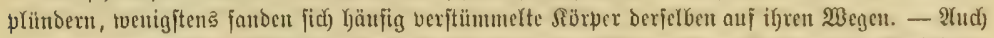

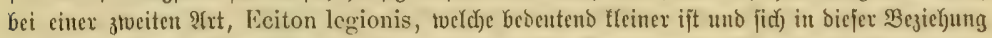
twie in Farbe wenig bon unjerer europäijd)en rotben Sinotenameife (Myrmica rubra) unter=

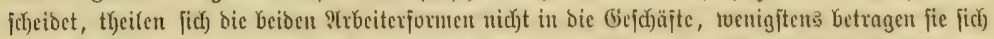

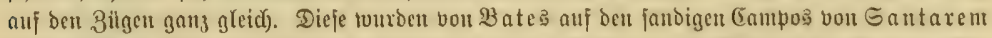

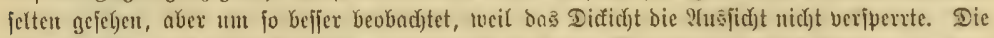

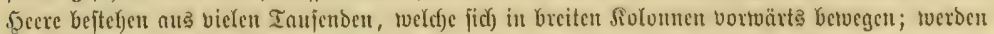
fie babei geftört, jo greifen fie ben einbringenden Gegenftand mit berfelben Muth) an, lvie bie

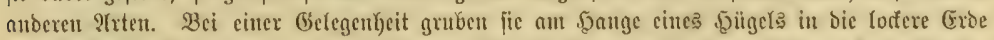

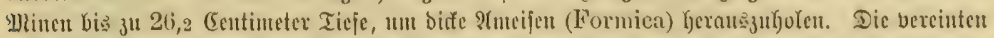

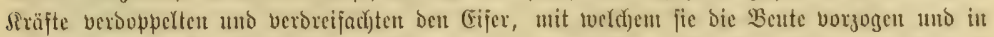

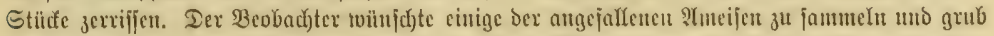

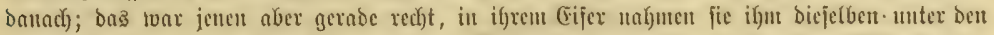

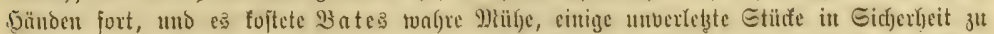

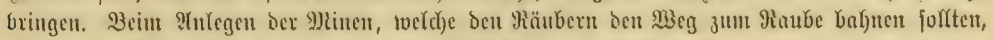
f(b) 


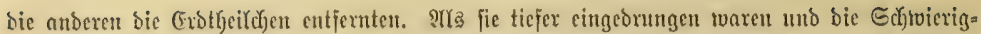

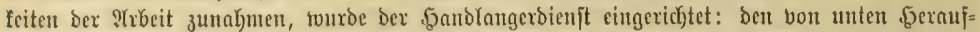
fommenden nalymen bie Sameraben, weldhe fie fdjon oben am Ranbe erwuateten, bie Bürbe ab

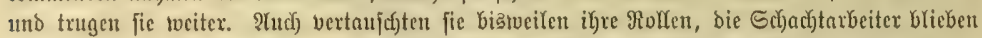
brauken und jene fuljren cin, un bie Erbe bis zum Rande zu fürdern. Sobald aber crft bic

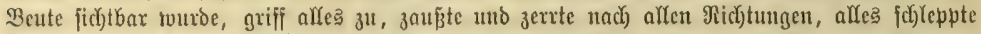

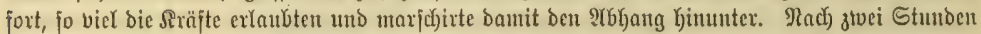
twaren bie 9tefter fo zicmlich ausgenommen, und in einzelnen Bügen betuegten fich bie Sieger ben

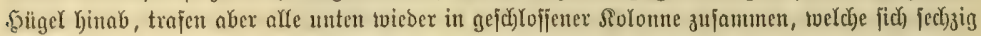

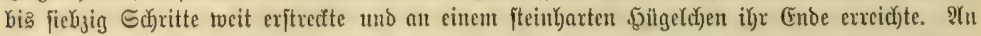
biejem ging ber Etrom hinauf. Sicle, bie bis bahju leex mitgelaufen twaren, halfen mun ihren

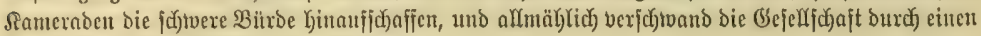
Dheren (Fingang in bie Tiefe bes $\mathfrak{B a u t e}$.

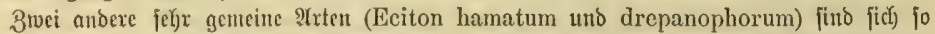

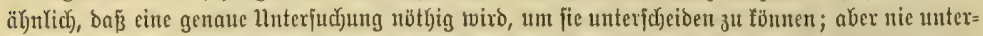

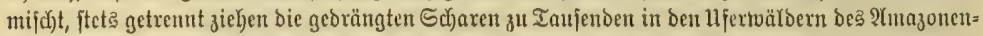

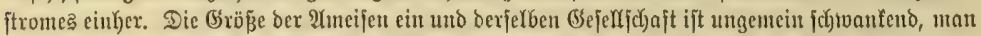
fann 3lverge bon einfiüntel 3olf neben einen Kalben 3oll Iangen groptöpfigen mit ungeheucren

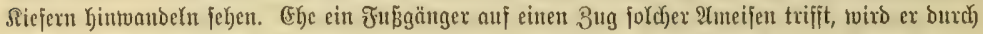

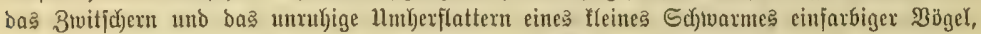

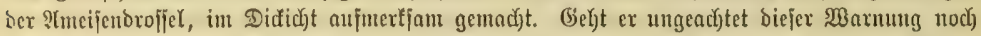

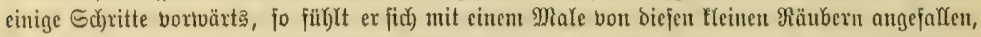

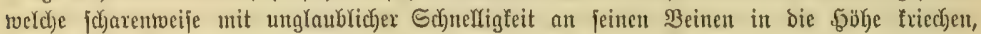

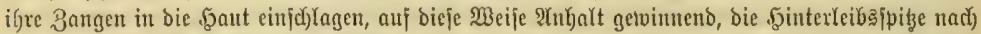

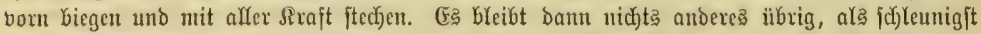

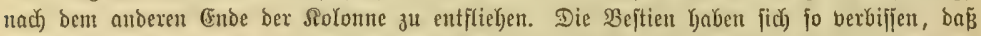

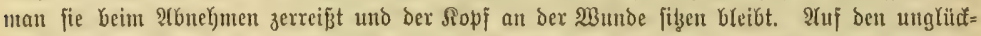

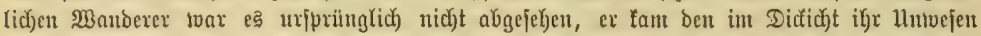

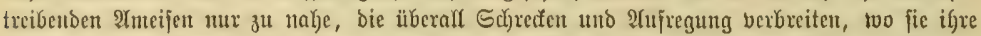

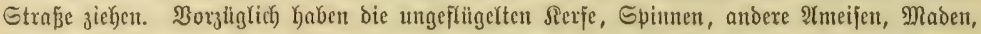

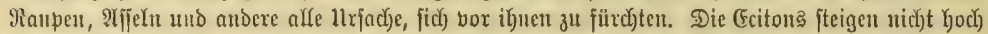
an Den $\mathfrak{B a ̈ u n e n ~ K i n a u j ~ u n d ~ G e l a ̈ j t i g e n ~ b i e ~}$ Bogelnejter baher twenig. Bates meint folgende

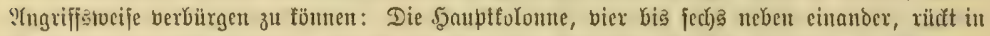

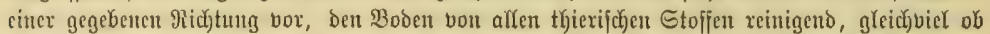
Yebendig oder toot, twobei jie hier und ba eine fleite Geitentolonne abjenden, tweldye an Den Flanten Sex 5auptarme fourragirt und baun twieber in ben \$antzug cintritt. Wenu irgendotwo in bex

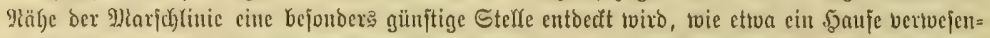

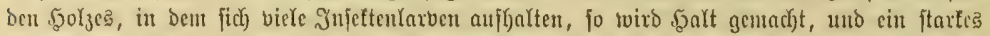

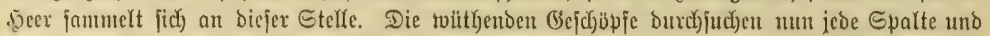

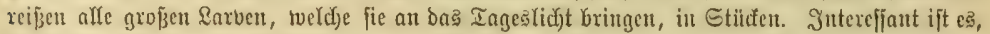

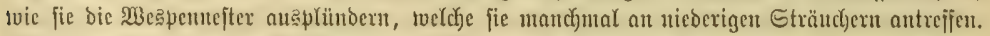
Eie nagen bie papiernen Decfe! von ben Bellen, un zu \&arven, \$Hppen oder fodjon entivitelten

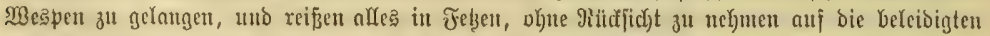

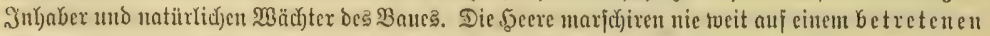

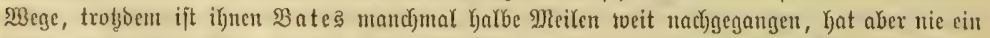

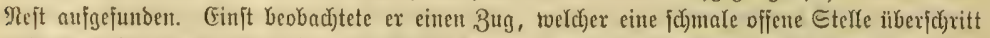

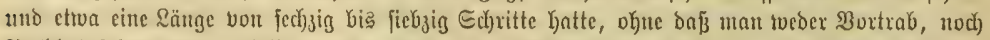

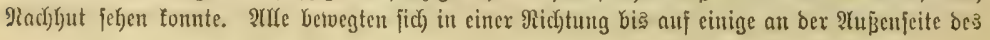




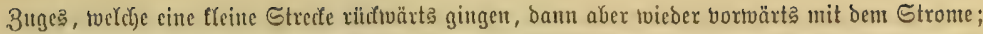

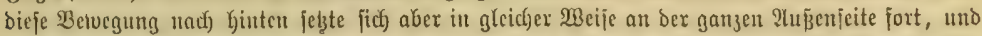

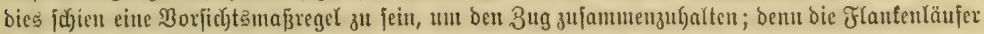

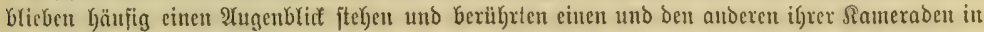

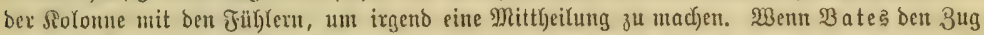

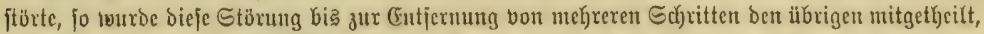

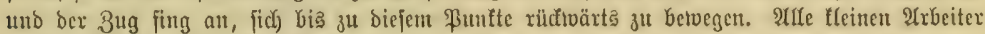

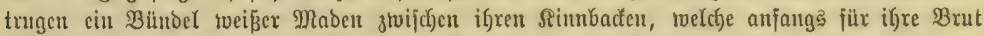

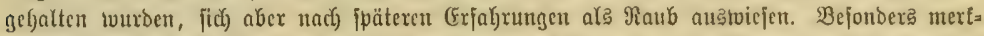

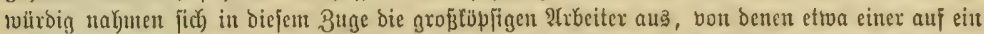
Dubchl ber fleinen fam, und beren feiner etwas trug, fonbern afle liefen leer uno aufertyalb bes

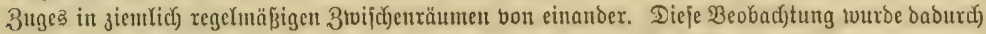

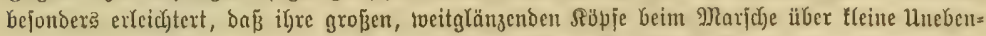
Geiten vor ben andeten auf = und abvogeno herborjahen. Daß fie bie Bertheibigung ber anderen übernomunen Gätten, tvie man nad) ber ifnen gegebenen Benemung „Eolbaten" ertvarten millß̈te, fonnte nicht Gemerft iverden; ber $\mathfrak{B a u}$ ifrer Simnbarfen berbietet ifnen übrigens auch, fich) in einen

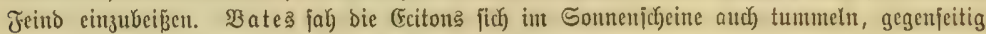

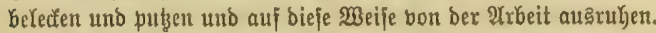

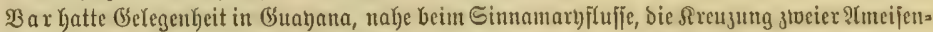

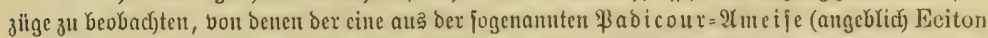
canadense $\left.L t r_{.}\right)$, ber anbere aus ber $\mathfrak{B} i$ itenameife gebildet twube. Jene waren auj ber

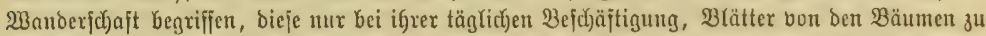

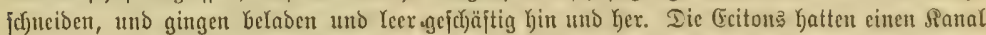

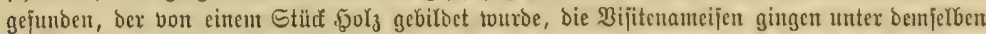

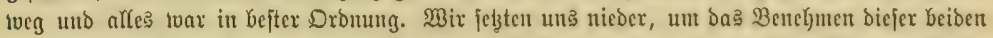

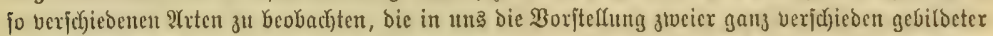

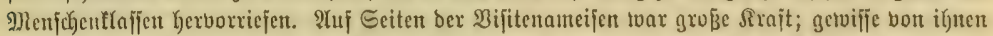

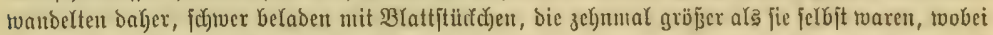

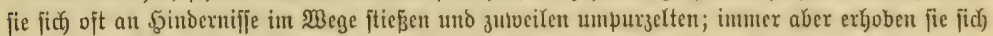

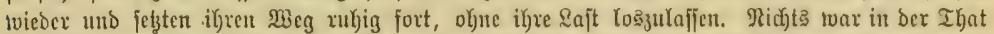

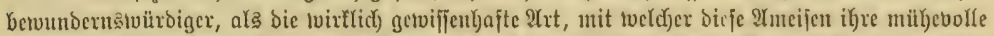

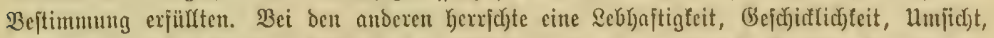

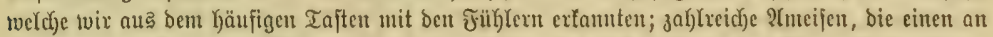

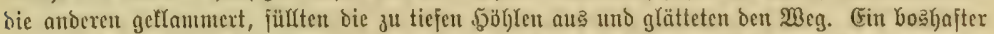

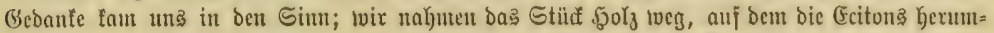

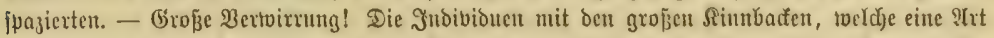

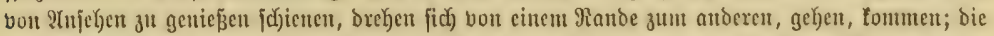

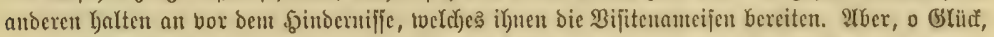

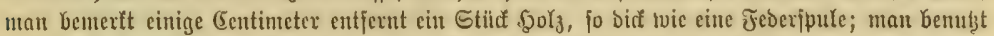

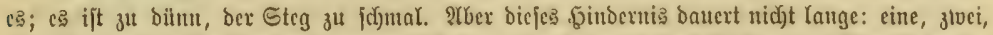

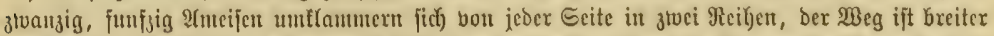
getworocn, bie Rolonne überid)reitet bieje lebenbe Brilđe, lange 3eit ohne 3tweifel, bem bie

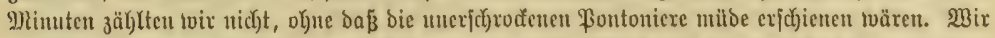

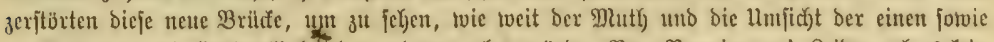
bie $\mathscr{A}$ :

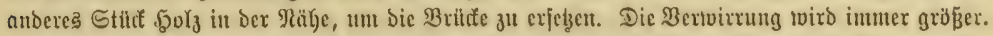

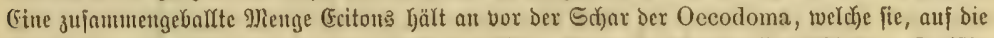

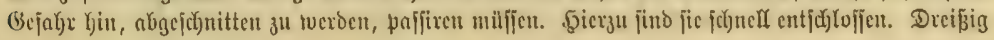




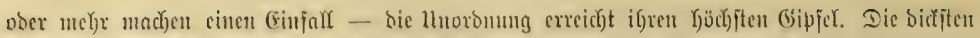

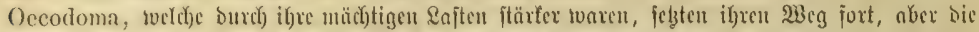

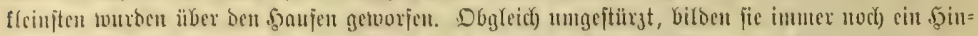

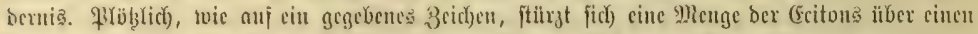

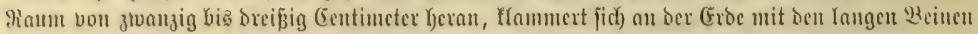

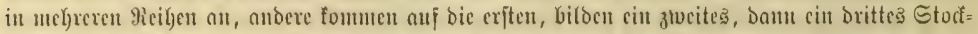

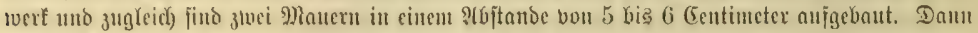

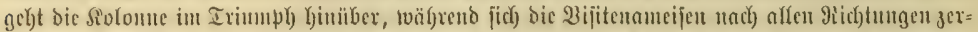

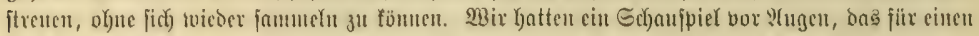

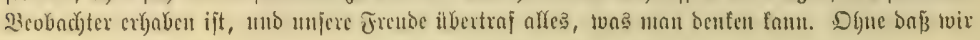

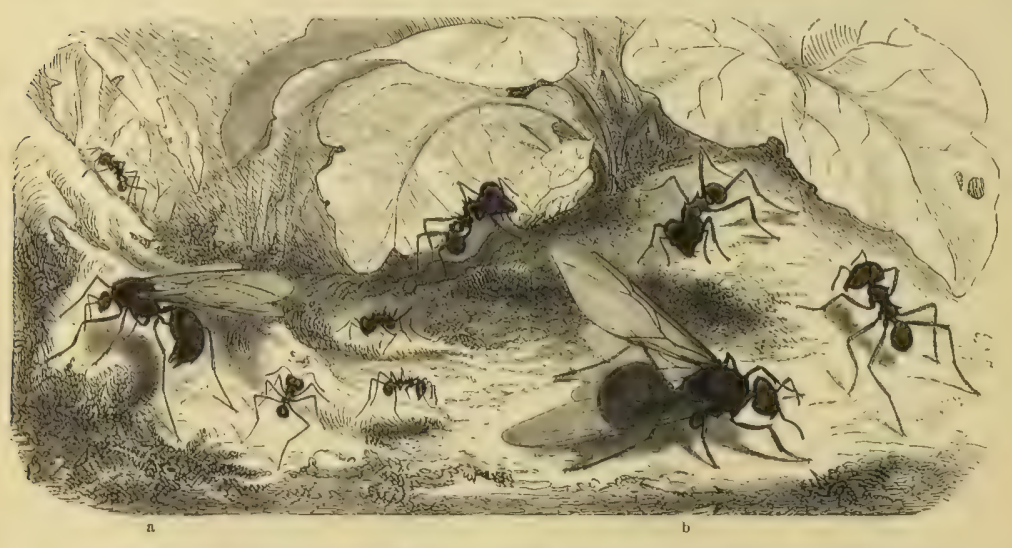

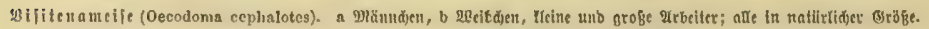

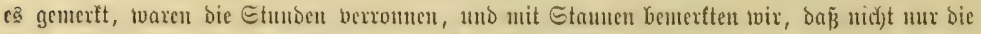

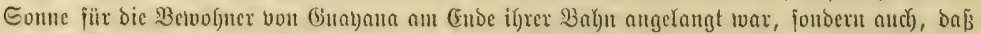

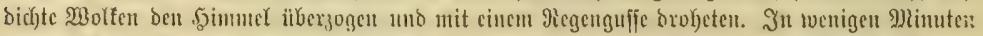

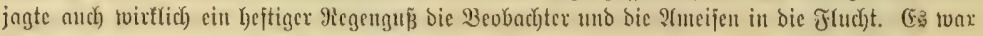
SRacht, als toir unjeren Sdyouner exreichten.

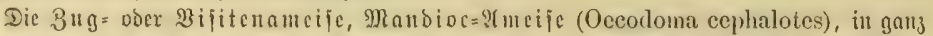

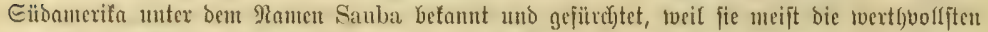

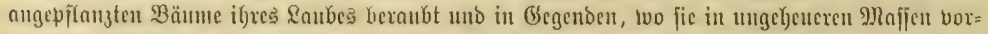

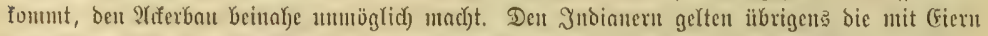

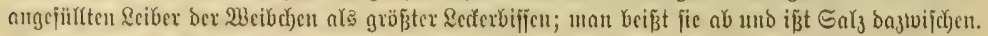

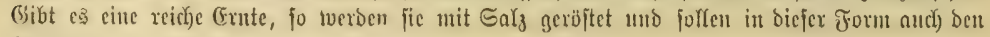
Guropäern munden.

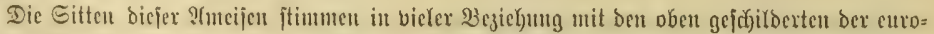

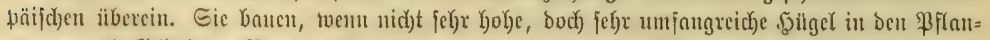

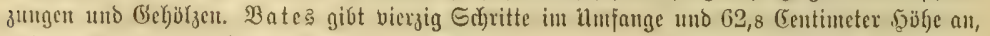

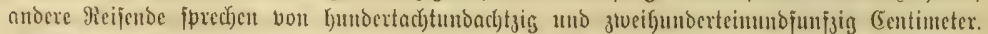

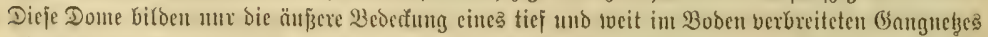

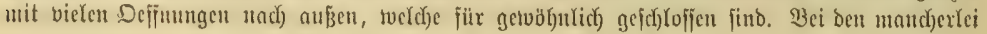




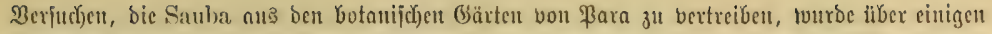

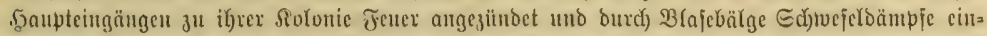
gefüfrt. Bates faly aus ciner Mlenge bon Deffunngen bie Dämpie ausjtrümen, unter benen cinc fiebzig Gefritte bon ber (Einfiifrung

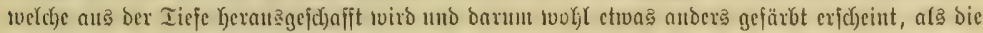

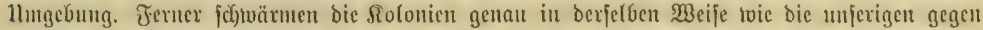

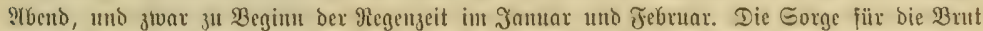

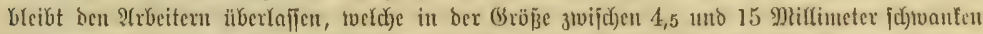

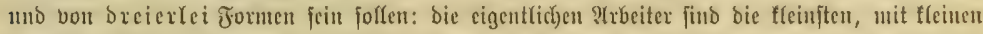

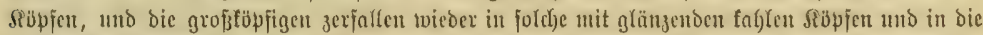

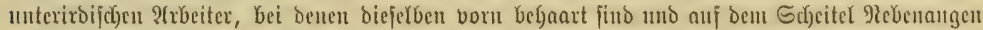

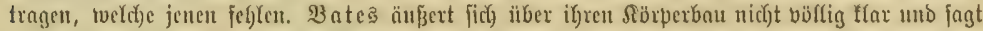

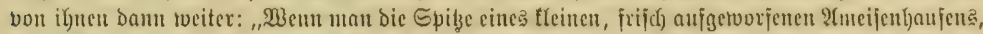

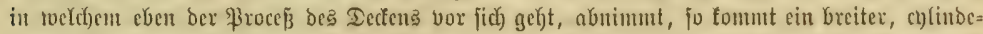

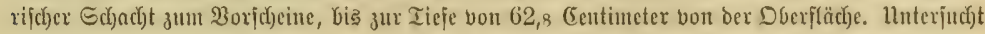

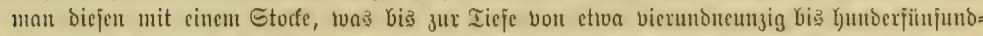
3)

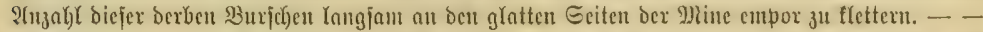

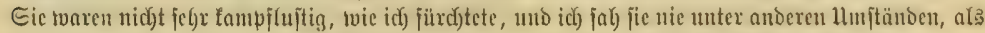

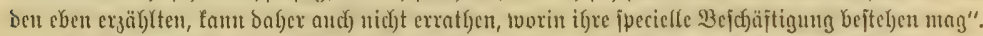

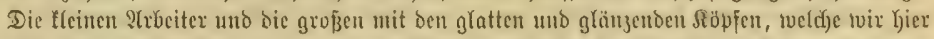

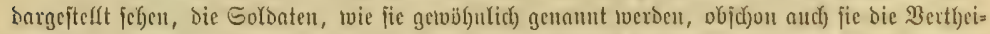

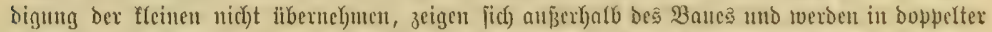

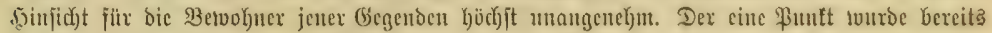

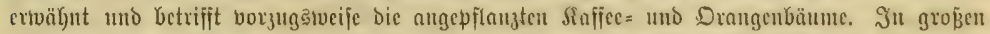

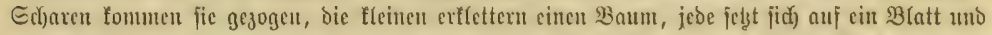

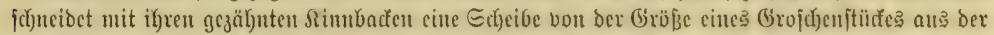

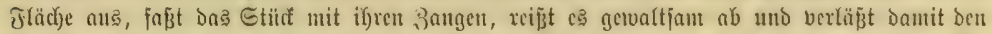

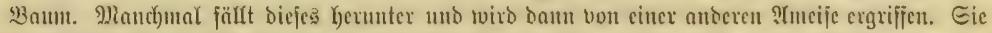

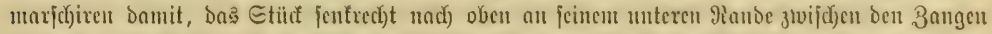

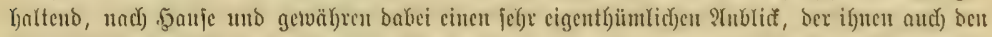

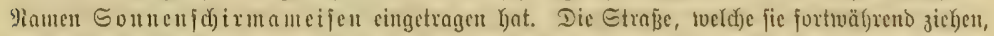

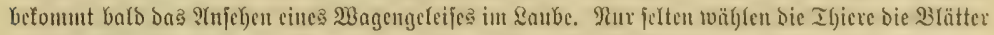

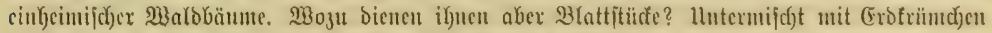

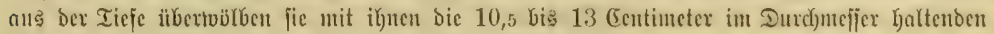

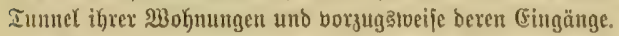

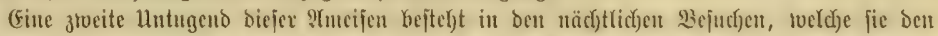

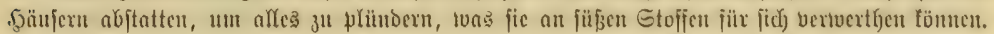
23̧em von

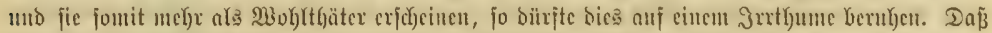

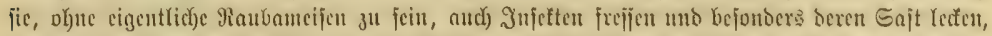

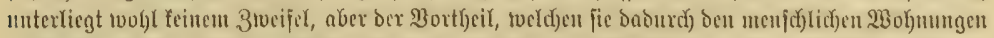

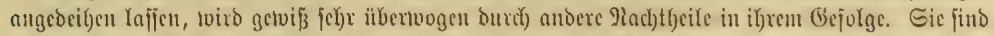

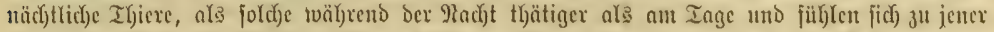

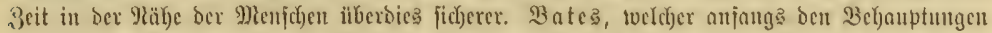

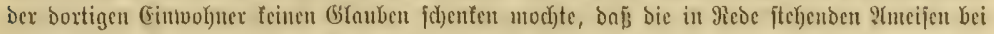

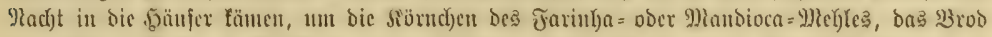

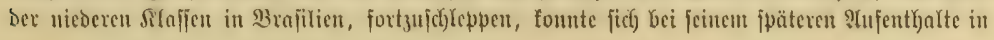




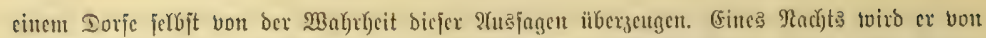

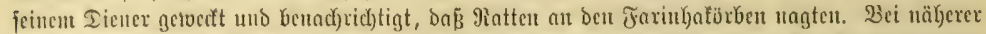
llnterjudjung fand fid) cine Rolone von bielen tanjenden unjerer शneifen. Die Rürbe mit oent

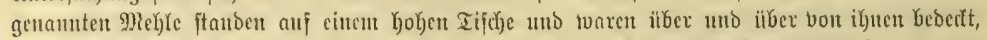

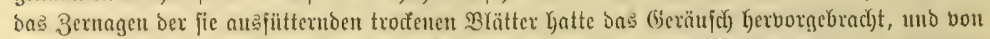

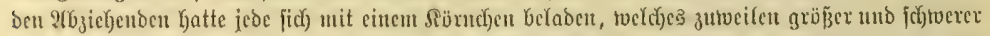

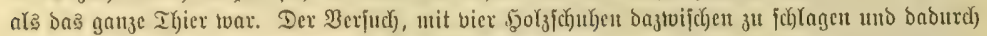

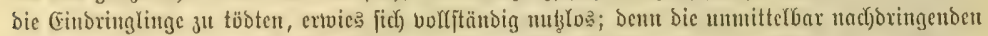

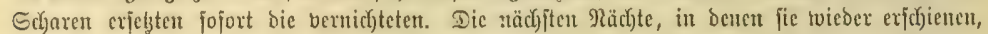

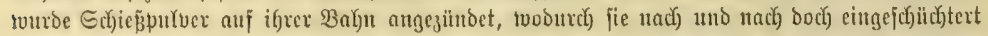

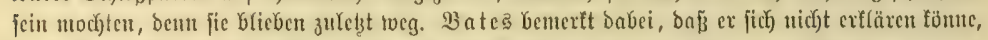
woju fie bie Diandiocalörucr, weld)e viel Jajerjtoff uno feiten sleber cutfalten, aljo afs

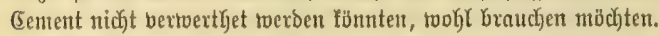

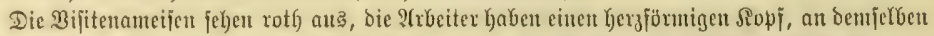

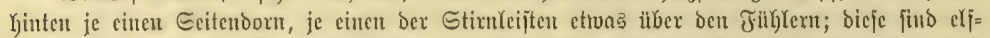

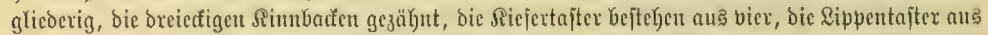

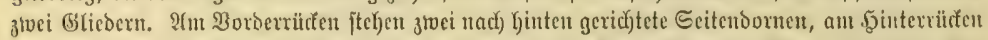

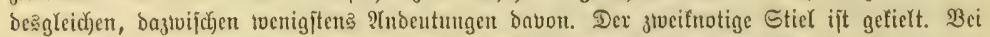

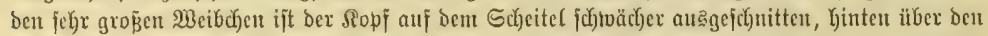

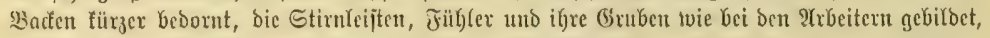

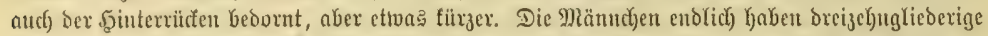

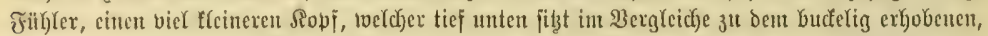

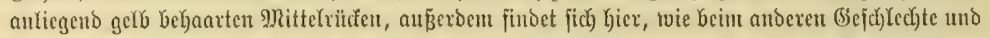

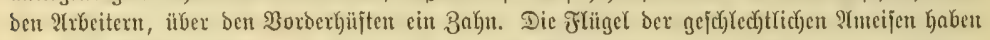

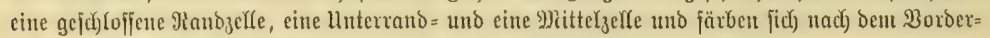

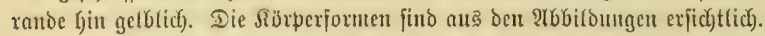

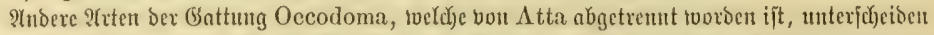

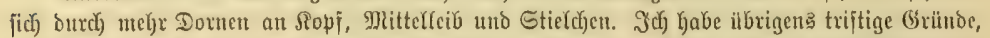

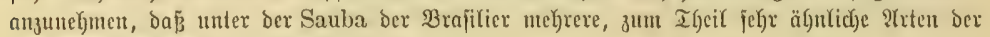
europäif̧̧en serftentuer begriffen jind.

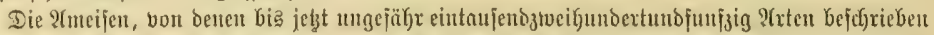

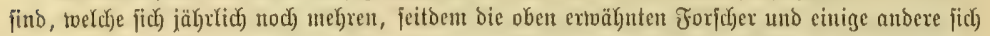

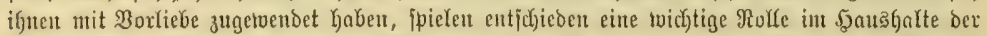

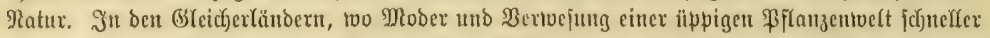

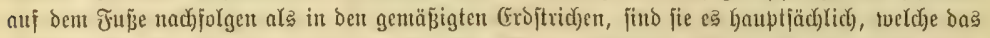

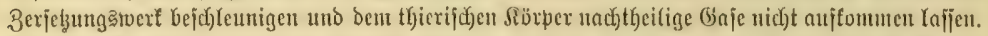

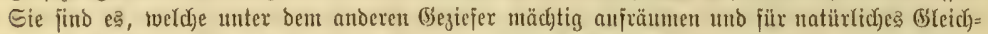

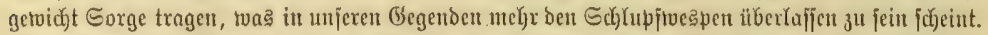

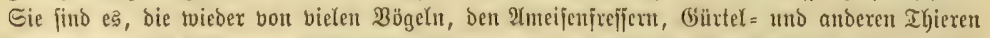

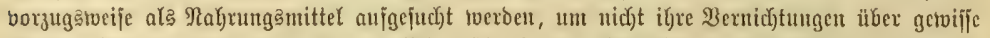

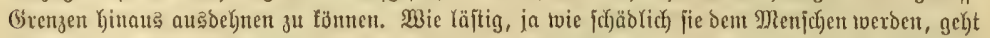

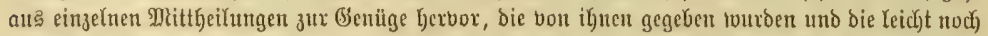

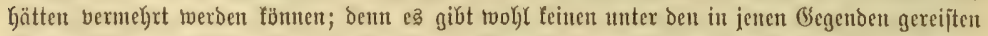

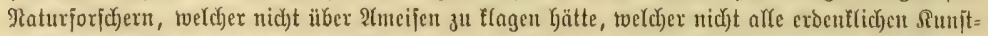

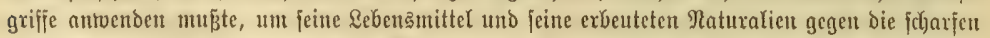

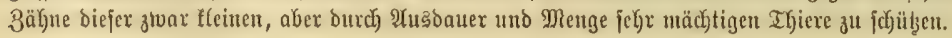




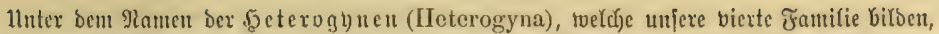

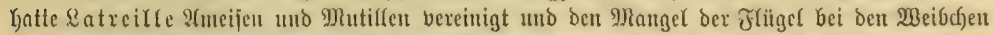

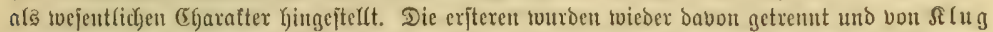
burd) Die If f extof

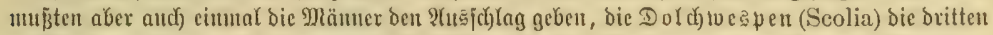

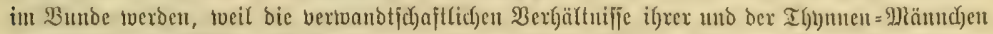

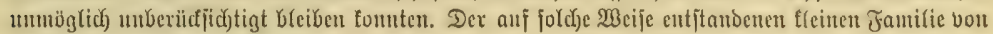

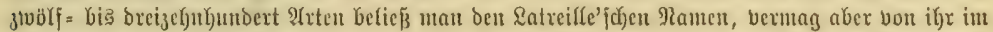

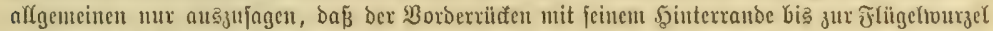

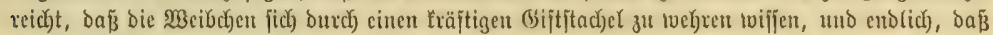

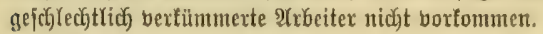

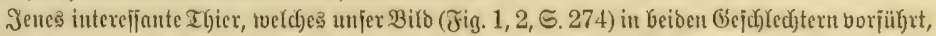

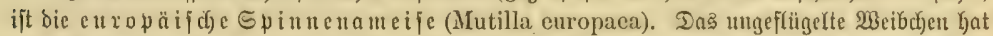

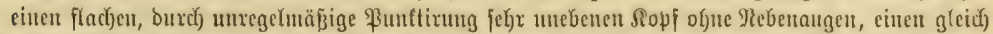
ranben 9]

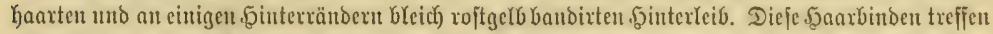

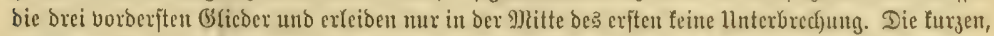

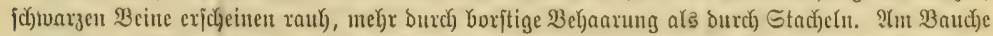

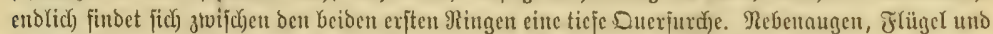

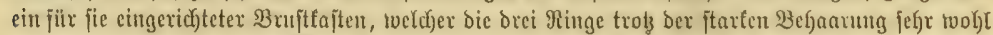

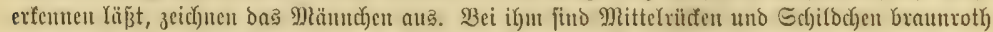

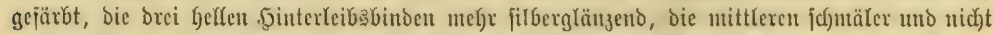

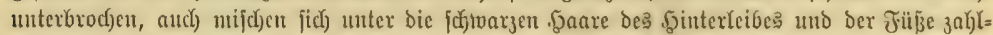

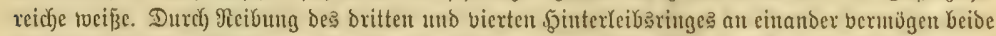

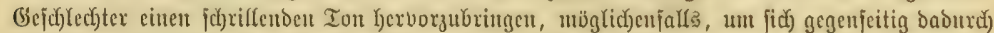

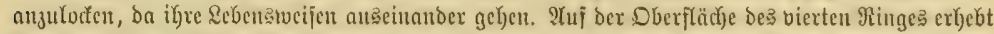

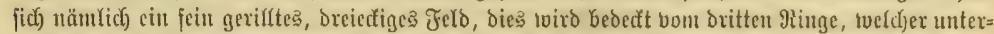

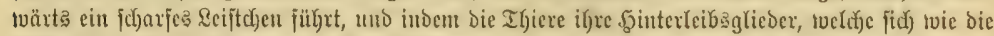

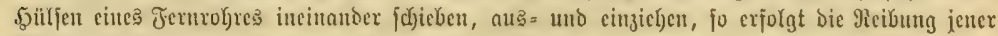
Ifyeile an einanoer.

Die Weibchen fieht man im Sonmer auj fanbigen Megen uno .5äıgen inmer vercinzelt

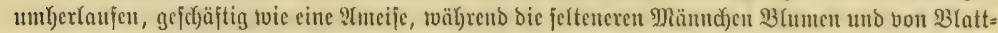

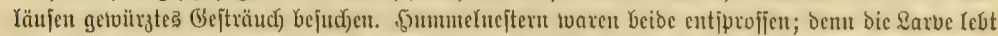

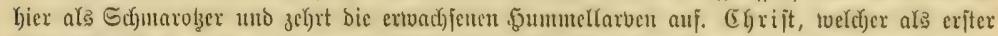

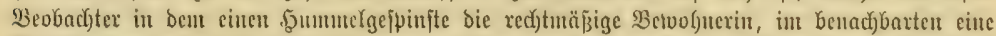

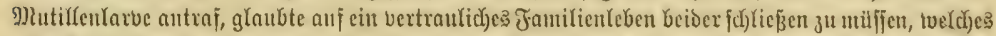

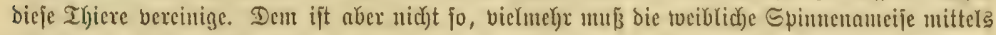

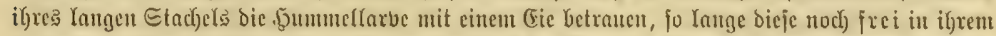

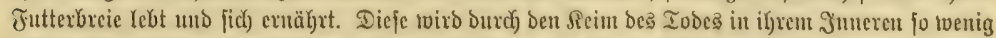

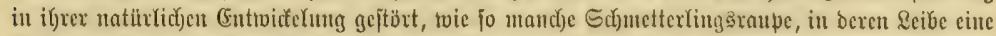

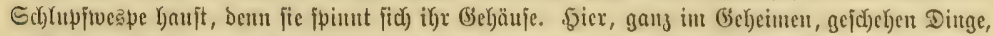

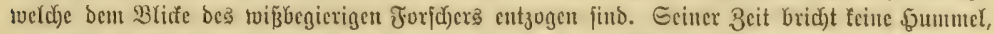

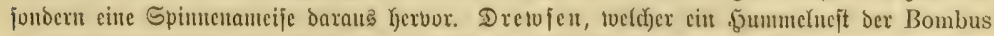

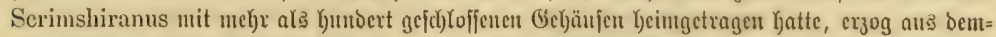

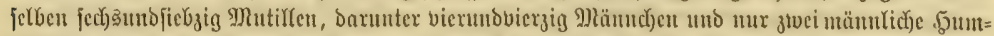

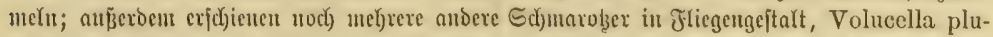

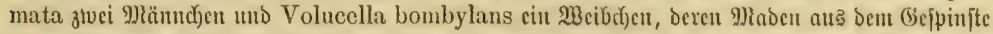

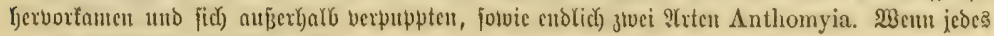




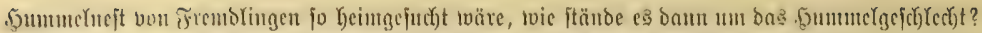

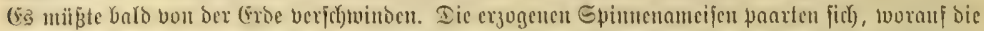

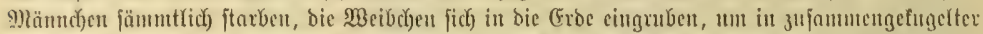
¿age 3!

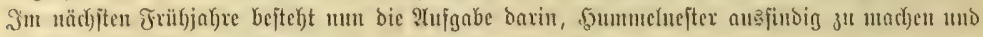
bie (Fier bajelbjt untergubringen.

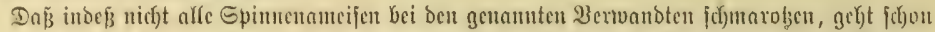

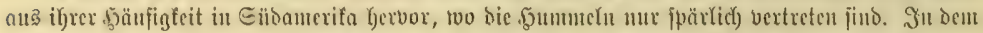

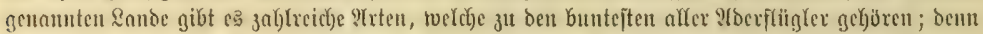

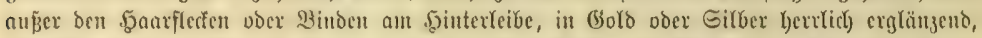

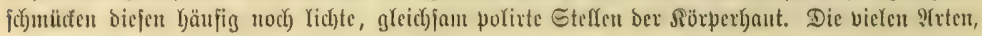

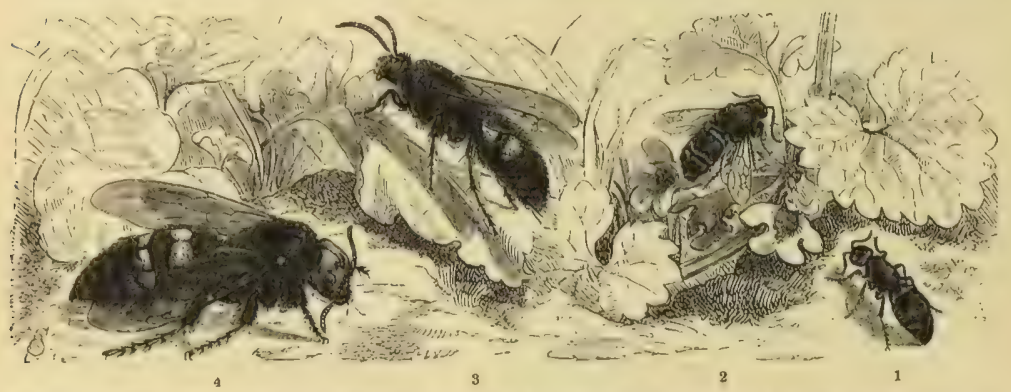

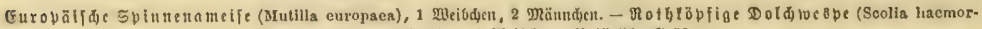

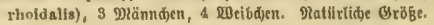

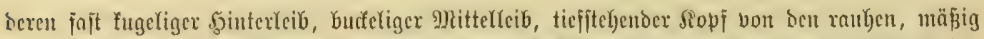

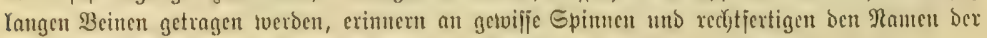

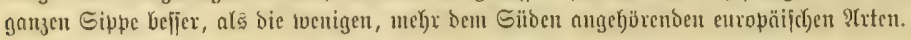

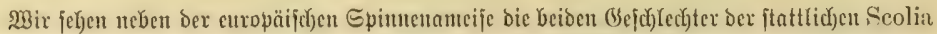
haemorrhoidalis, zu tecld)er Scolia erythrocephala alb Weibchen gehört, uno twollen fie unter

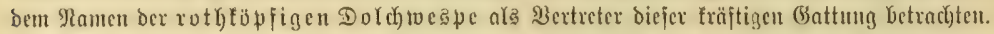

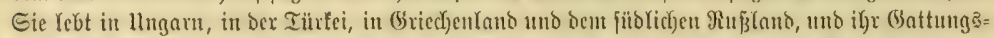

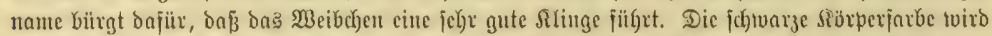

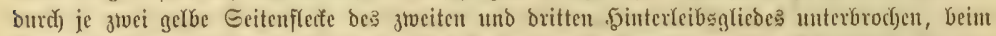

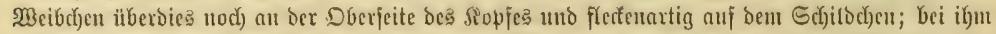

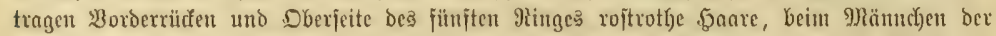

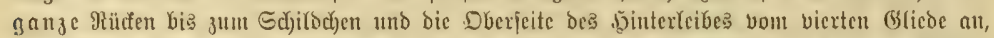

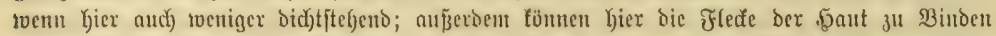

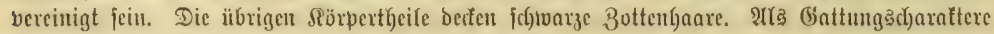

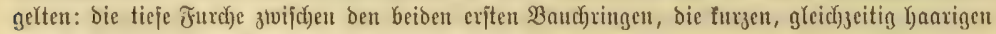

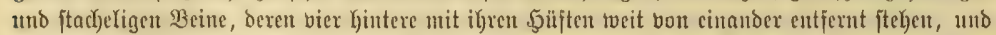

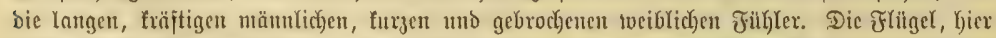
beiben (beju)(ed)tern zuertbeilt, zeigen nicht minoer wie bei ben mämulidjen Spinnenameijen dą

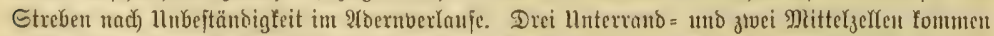

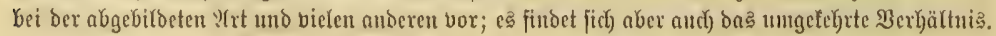




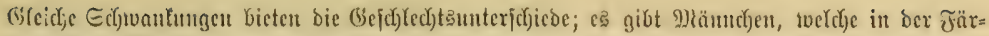

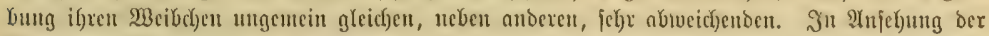

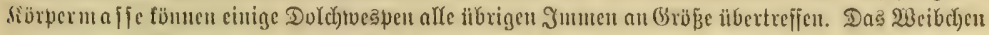

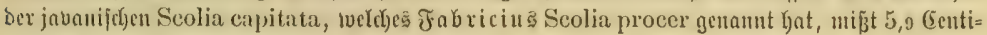
meter bei reich)lict) 1,3 (Eentimeter Sinterleibabreite.

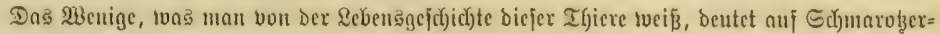

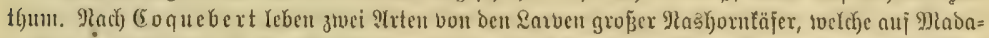

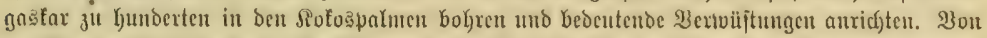

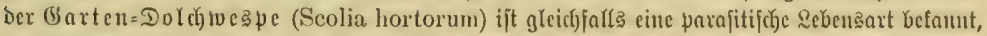

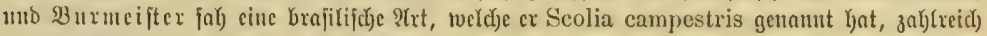
aนs ben Meftern Dex $\mathfrak{B i f i t e n a m e i f e ~ f o n m e n . ~}$

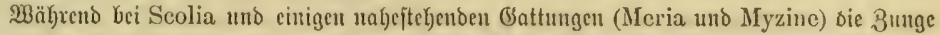

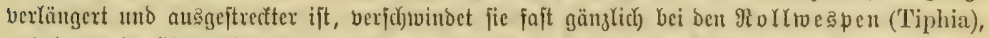

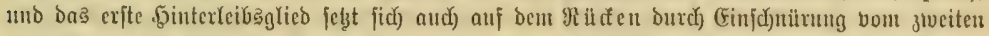

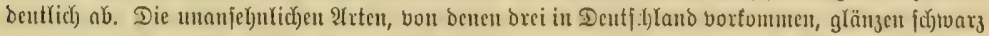

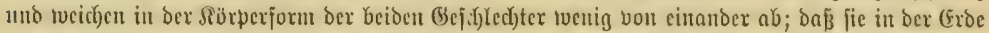

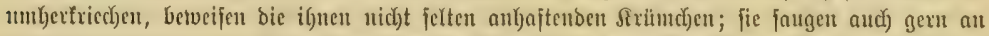

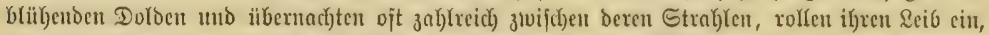

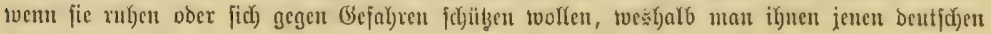
3amen beigelegt hat.

Somute für bie vorige Fantile feine bentfdye Benenmung anfgefunden werben, ba bie lleber=

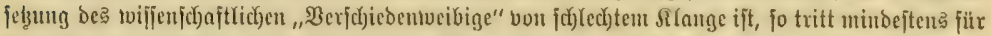
bie mu folgende teine 2 erlegenlyeit ein. Eeiber feblt es nod) bei Den meipten biejer Iffere an

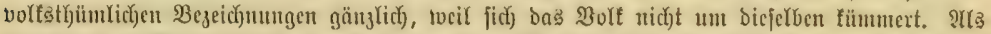

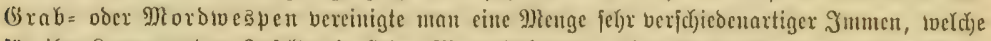
fïr ifje \&arben andere Jinjeften in (

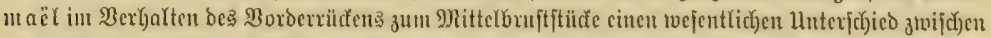
cinex 2 (nzagl berfelben auffand, weldyex cine Iremung in jtoci Fantilien zur Folge Yjatte. Die

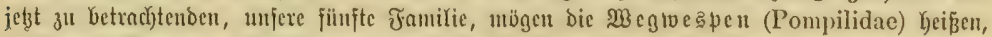

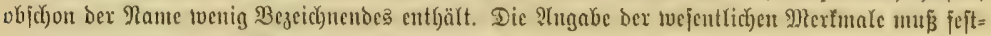
itellen, weldbe bon den झ̈örbern Kier gemeint jeien.

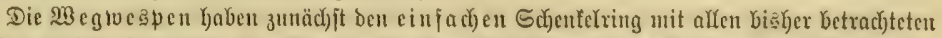

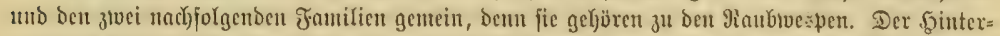

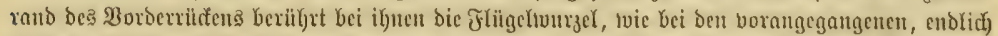

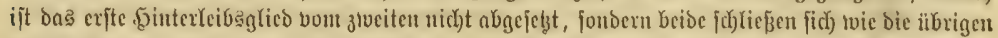

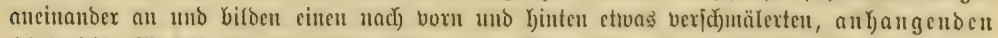

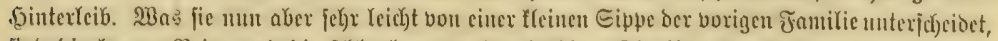

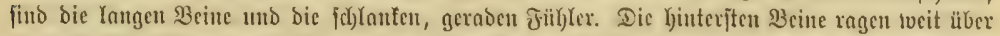

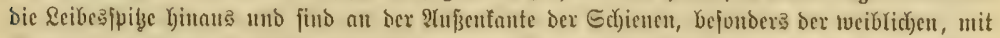

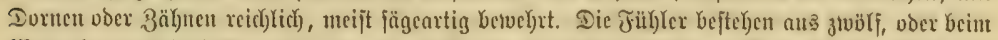

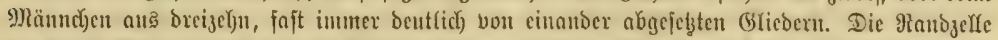

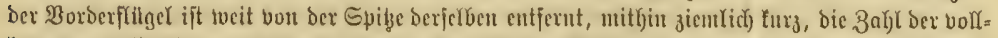

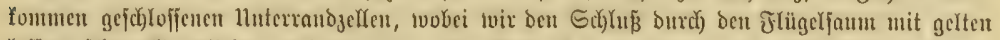

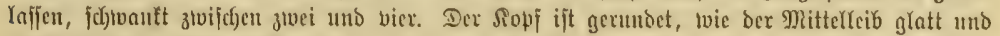

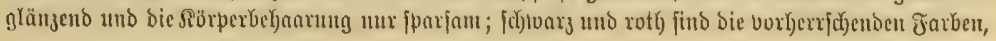




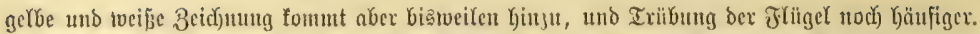

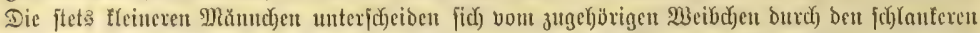

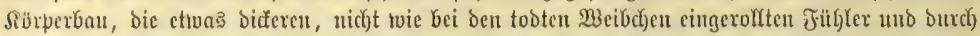

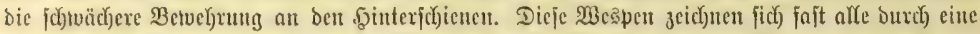

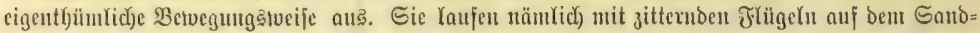

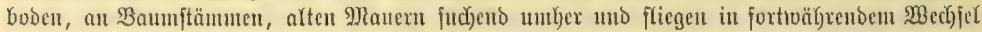

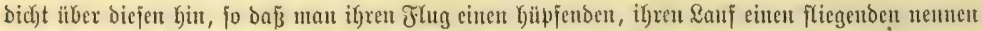

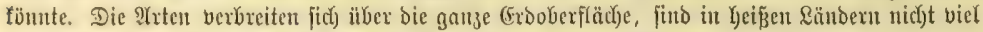

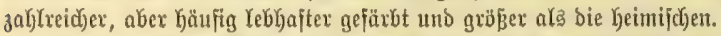

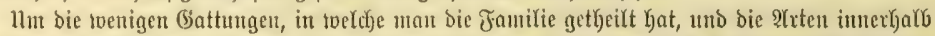

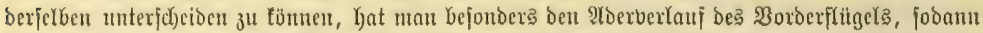

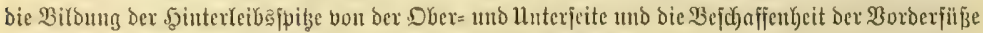

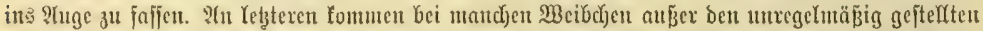

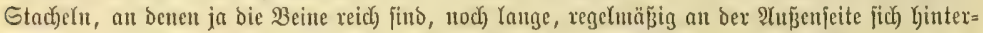

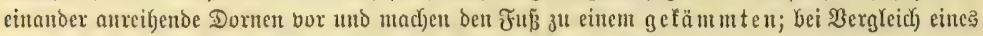

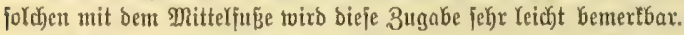

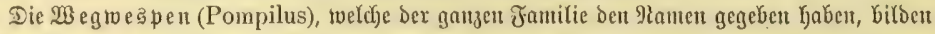

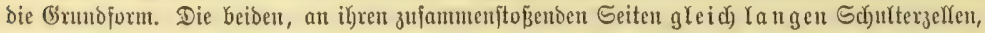

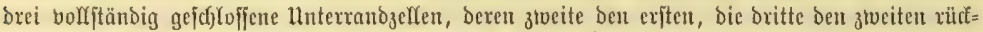

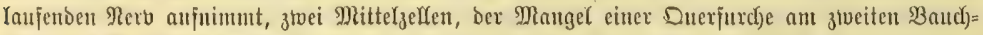

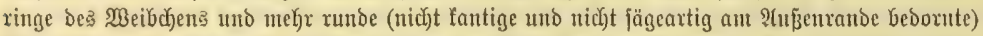

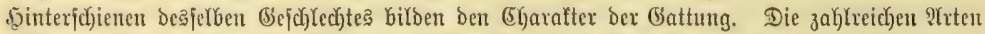

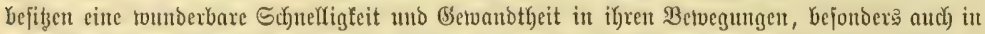

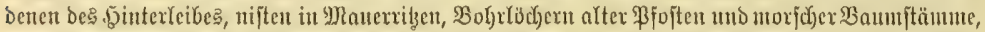

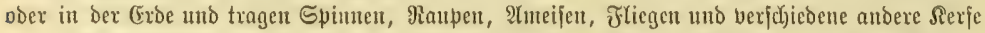

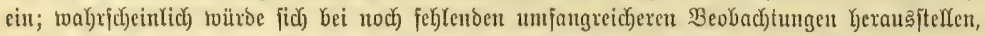

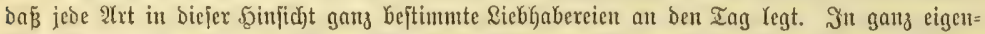

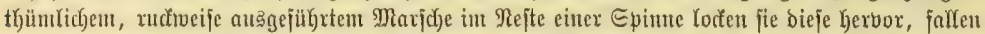
über fie her unb betäuben fie mit einem Sticke, ohne fid je in jenem fejtzuremen. Die Spinnen=

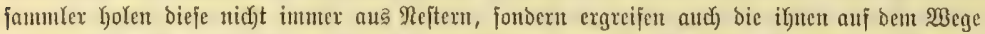
begegnenden. So überliftet dex Pompilus formosus eite in Texab häufige Bujujpintue (Mygale

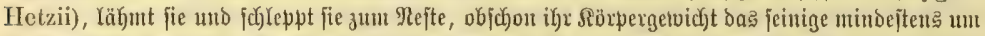

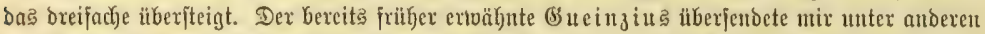

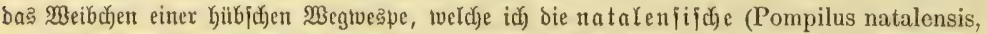

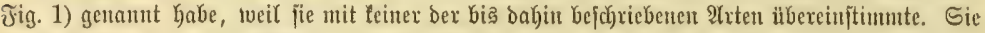

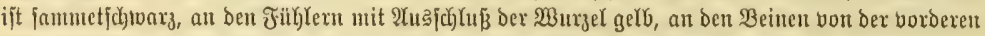

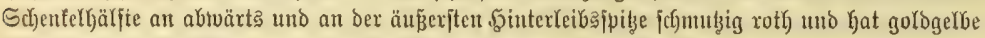
Flüget mit bunfler Murzel und Dunfler Epitze ber vorderjten. Das Snterefje an biefer ftattlichen,

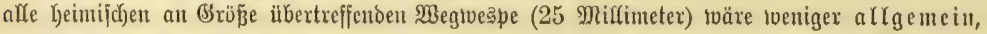

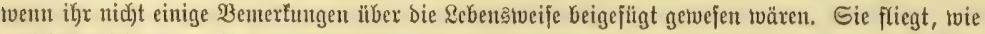

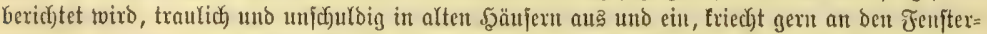

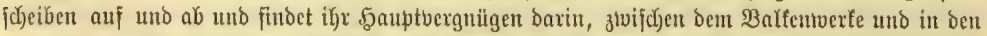

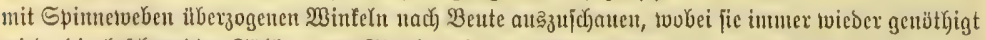

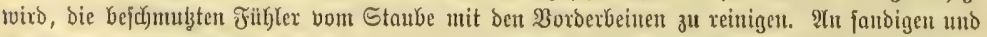

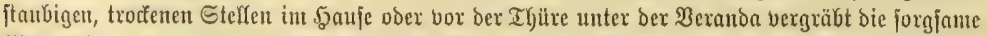
IJutter bie gejangenen uno burch) einige Stidye geläl)nten Spinnen und Yegt ein (5i an bieferbent;

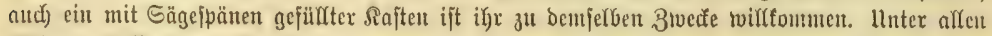

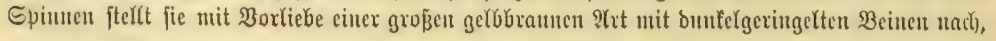




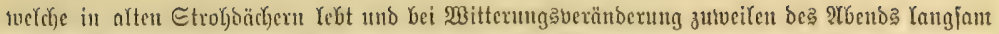

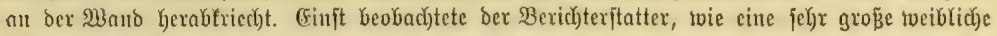

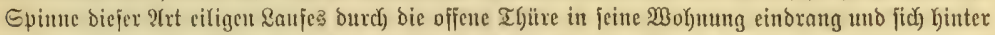

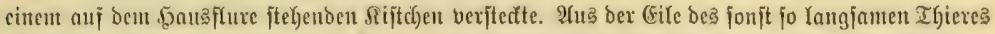

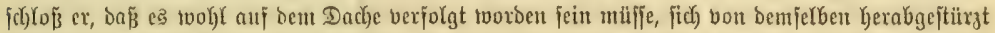

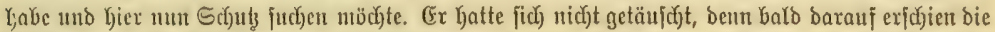

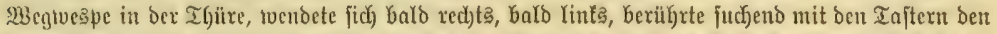

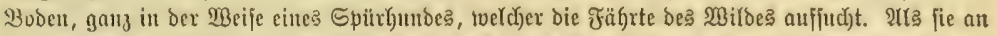

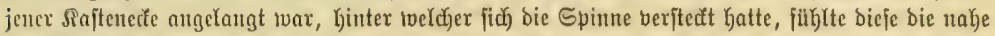
Gefabr, ftürzte bon ber anderen Seite unter berjelben herbor uno fteuerte nach ber TGüre zurüă.
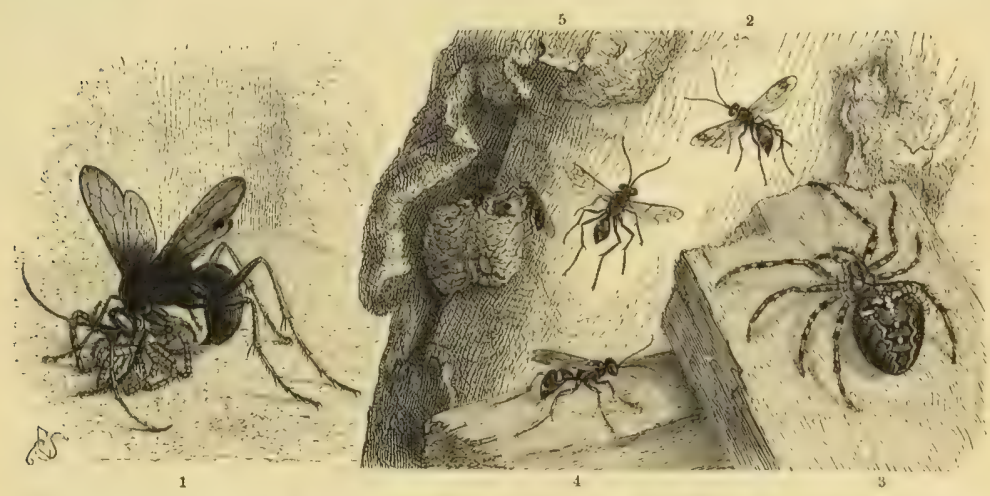

1 Ratalenflidie mentuespe (Pompilus natalensis). 2. Pompilus trivialls. 3 Ecine Larbe, an einet Epinue faugent.

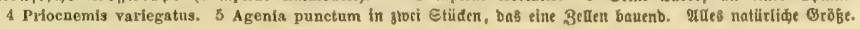

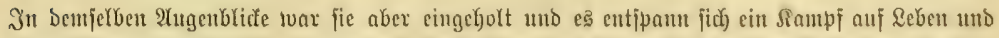

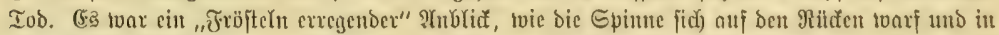

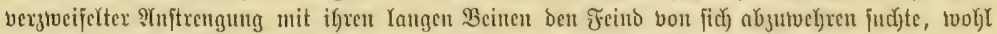

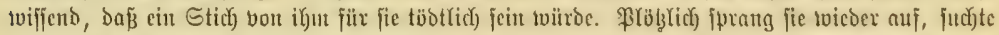

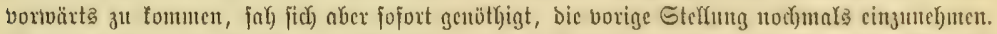

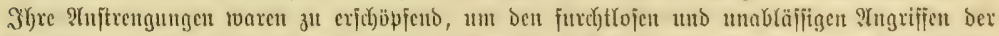

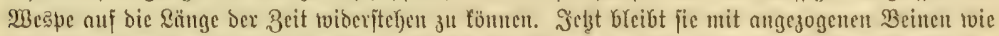

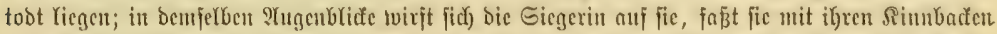

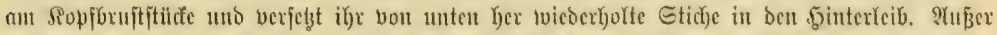

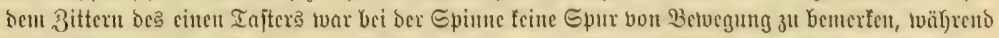

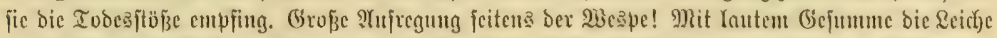

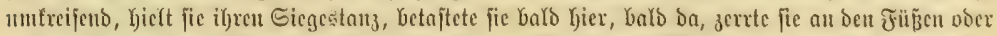

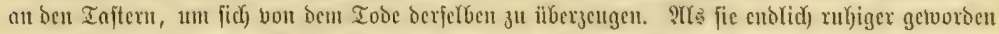

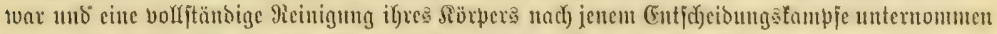

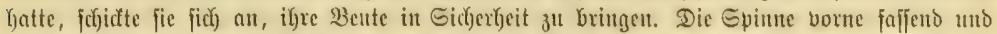

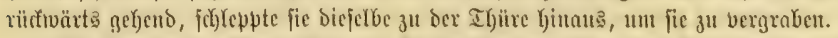

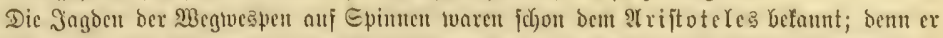

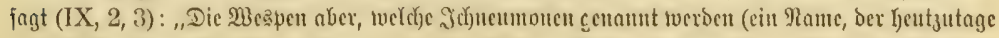

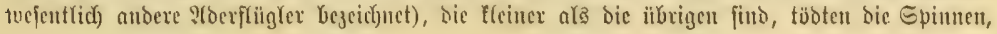




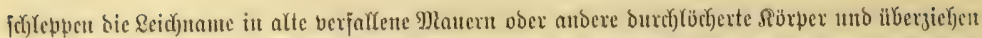

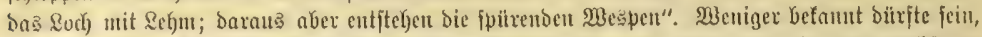

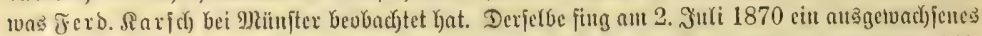

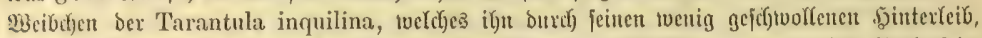

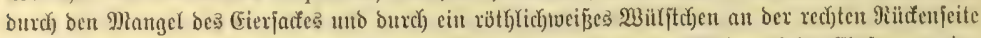

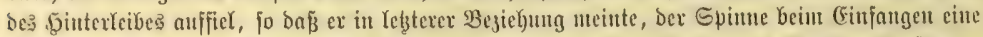

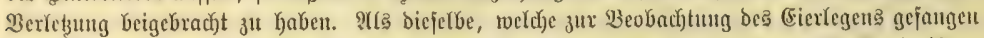

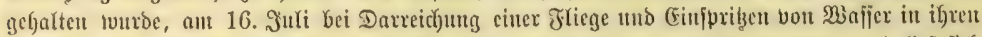

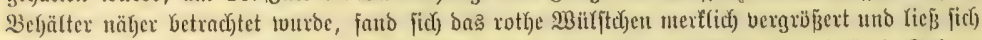

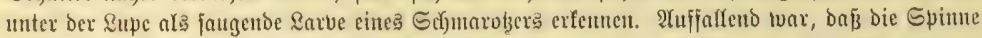

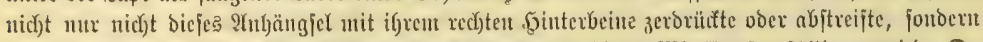

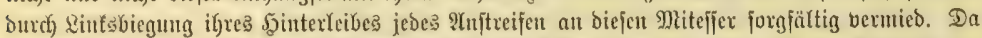

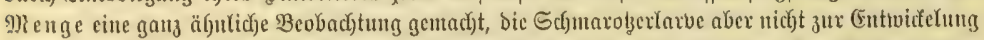

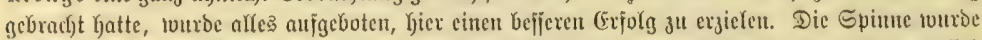

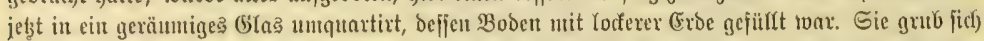

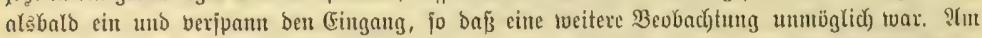

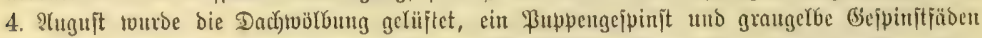

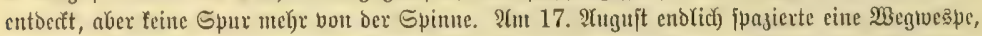

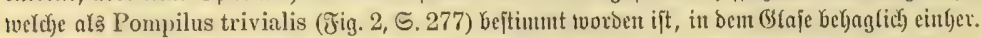

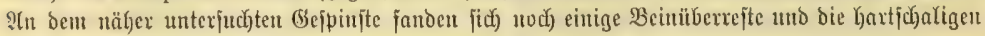

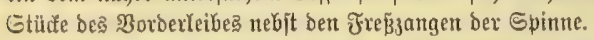

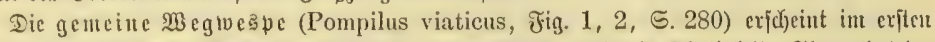

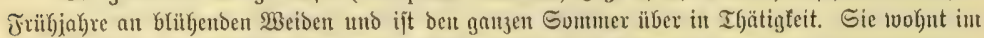

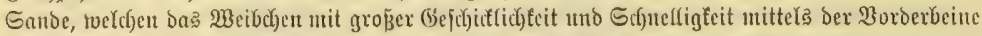

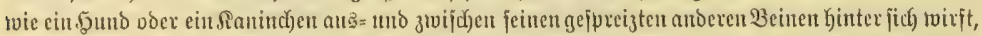

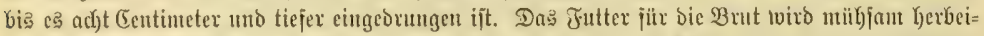

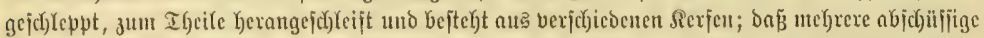

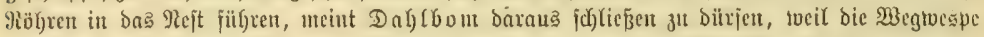

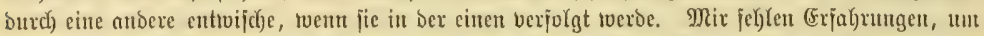

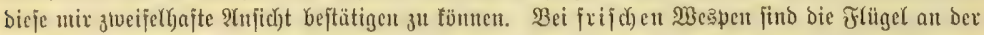

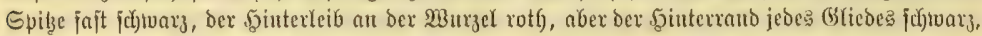

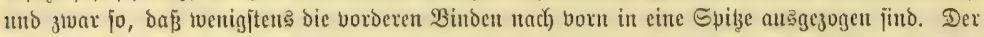

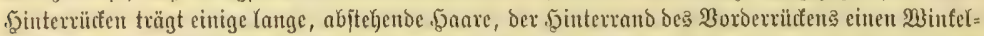

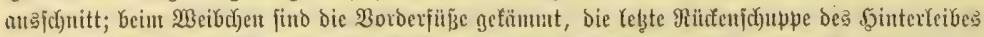

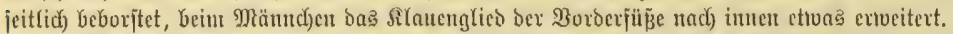

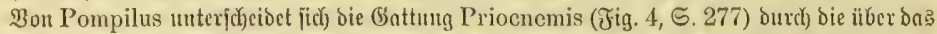

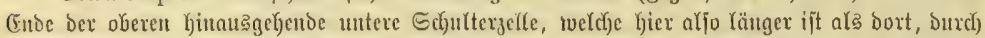

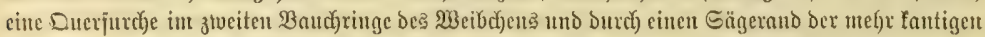

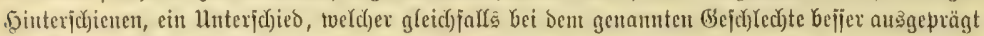

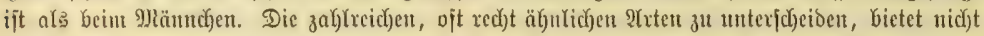

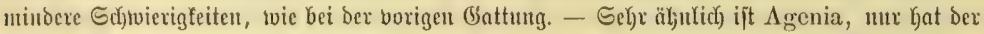

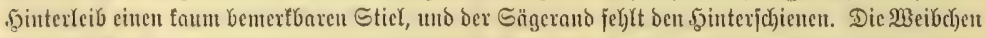

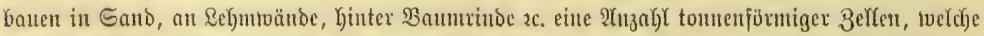

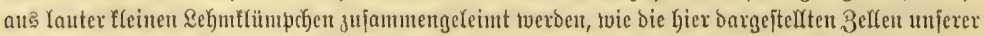

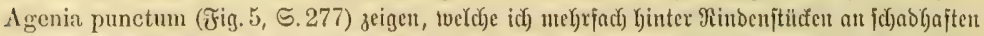

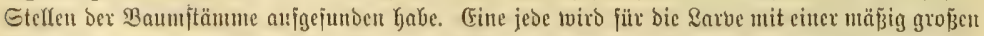
Spinte verjorgt, ber vorfer bie Sbeine abgebijen roorden find. Giseinzius entroirft von einer

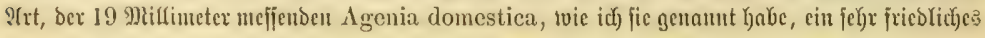




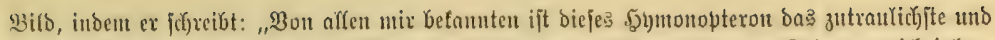

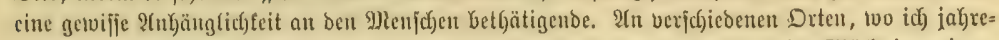

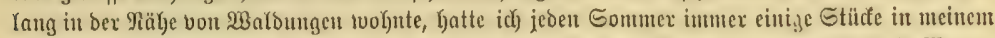

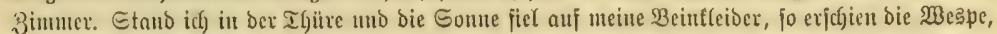

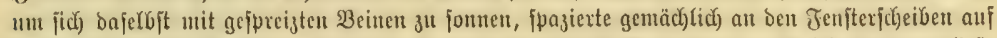

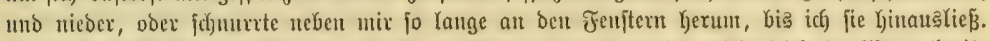

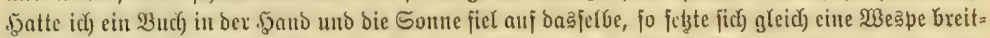

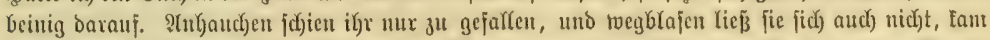

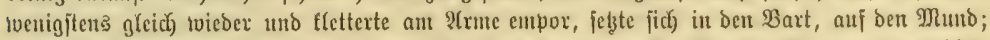

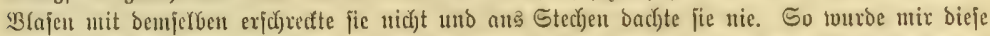

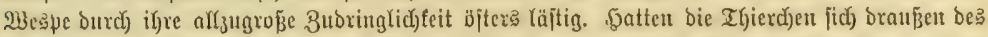

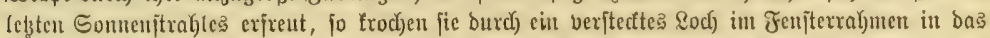

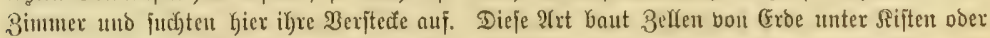

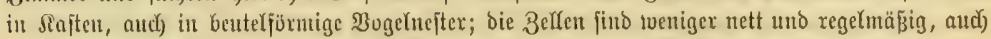

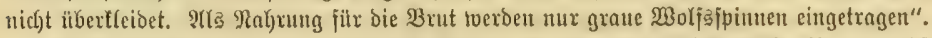

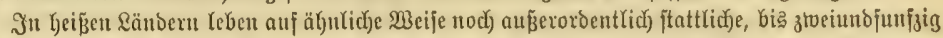

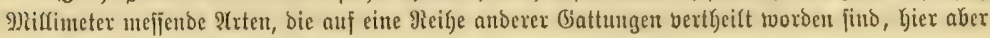
uicht tociter erörtert weroen fönnen.

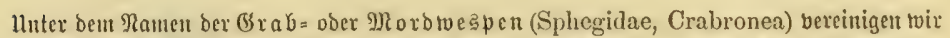

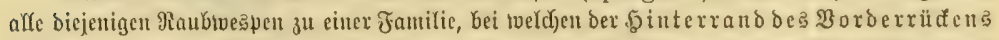

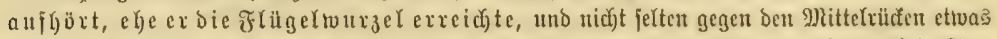

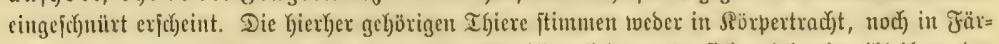

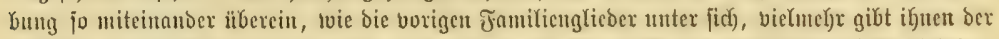

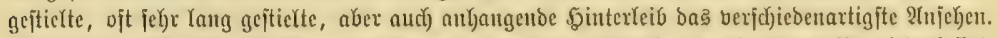

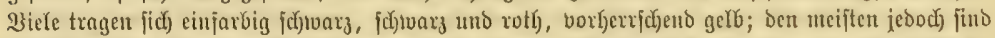

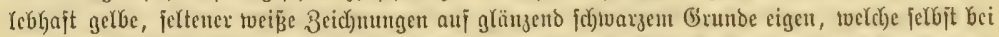

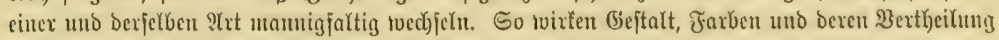

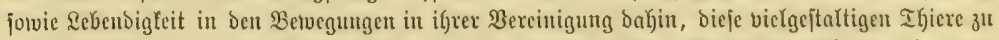

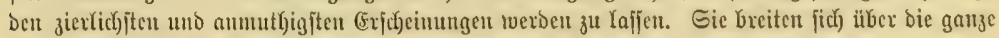

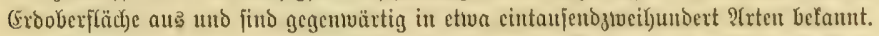

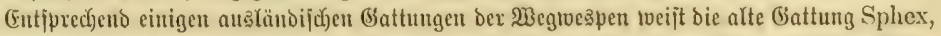

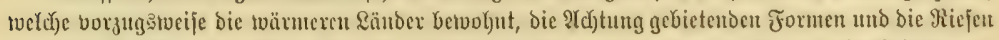

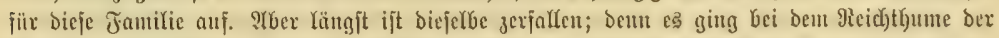

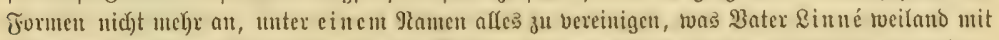

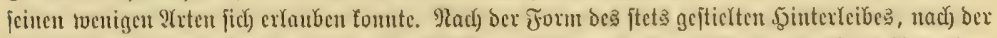

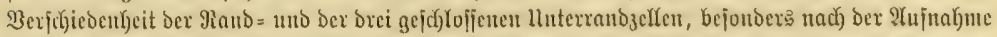

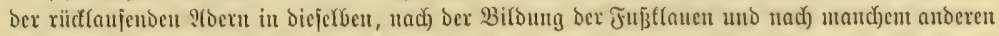

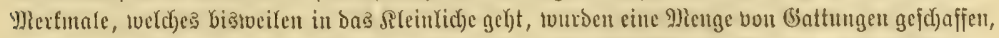

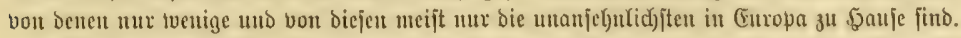

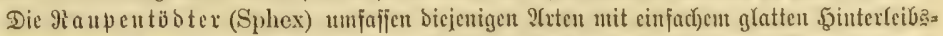

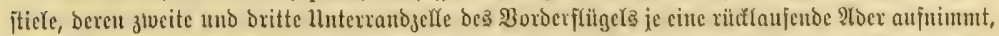
beren ,̧interf(b) (Sphex maxillosa) fdjeint in (Juropa an tveitejten und) Rorben vorzufommen. Bon zroei

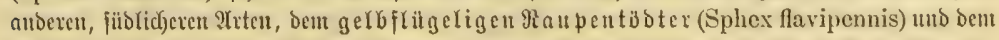

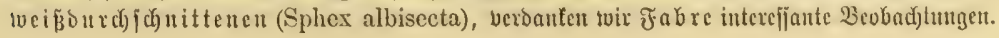




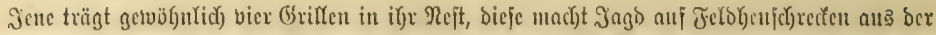

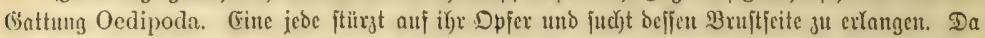

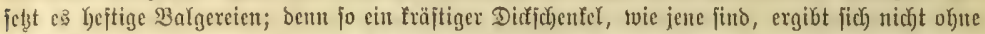

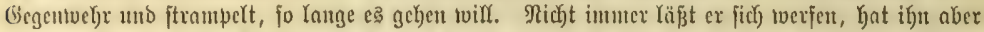

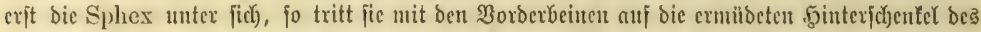

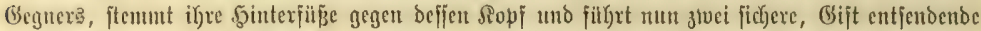

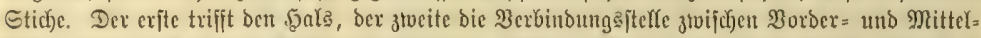

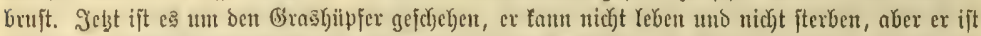
wilfenlos. Müffjam jod)leift ign bie Sphex nad) ifrer (Erbbüble, Yegt ifn bavor nicoer, un fidf) exft

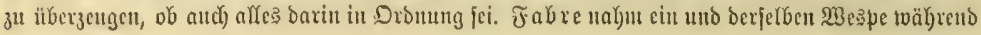

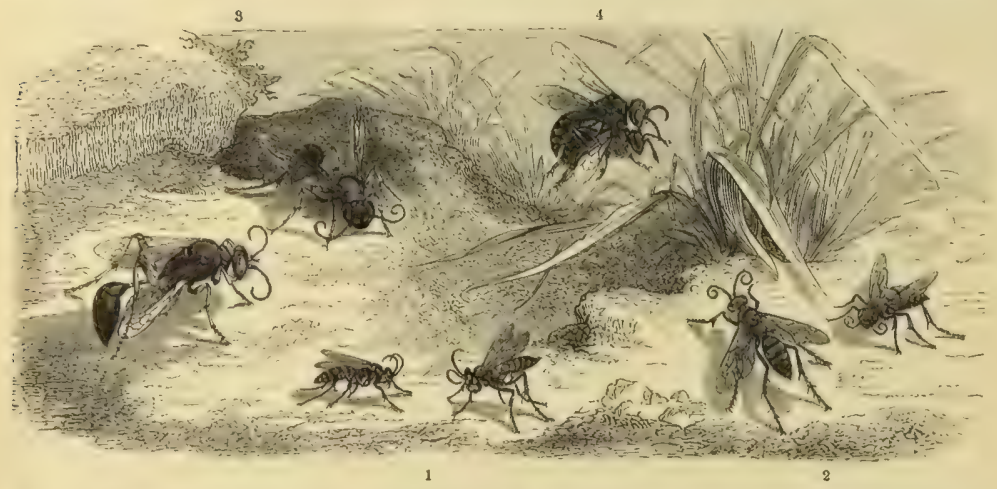

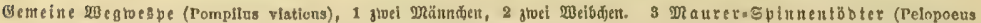

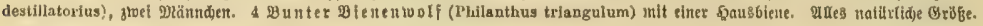

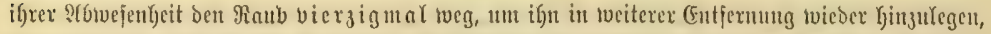

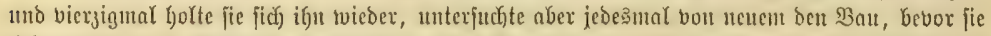

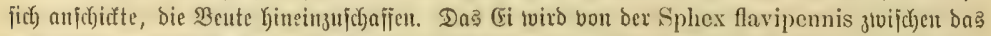

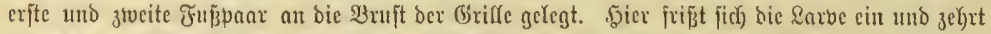

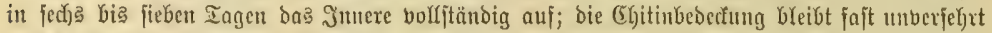

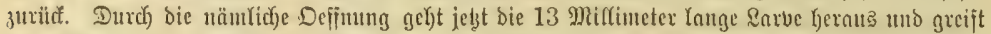

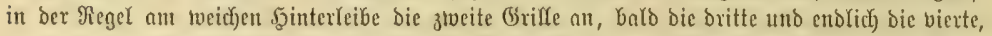

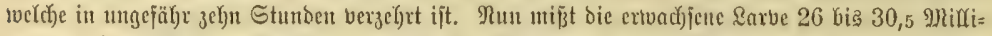

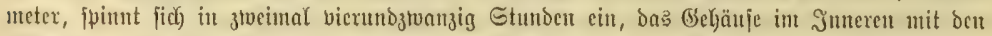

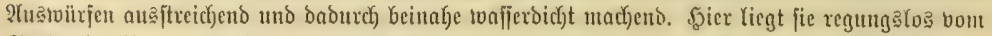

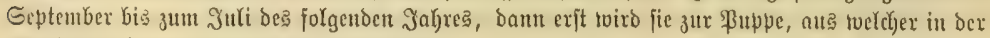

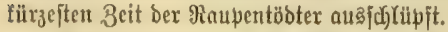

Genn von derfelben Bejtalt find die Spinnentä oter (Pelopocus) und vou ben vorigen un:

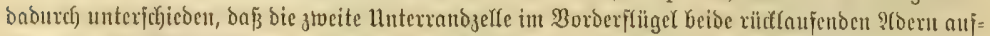

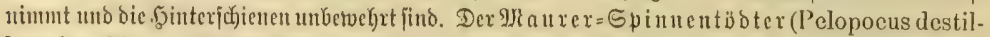

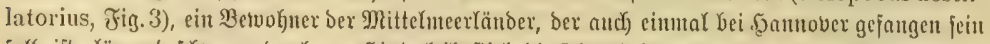

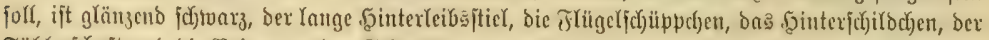

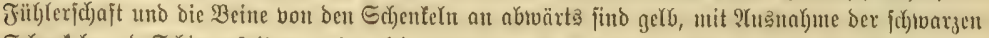

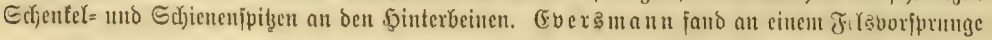




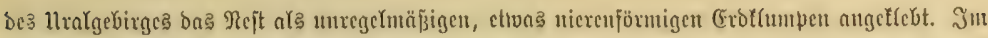

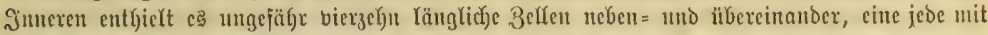

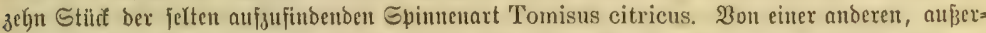

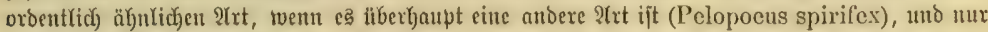

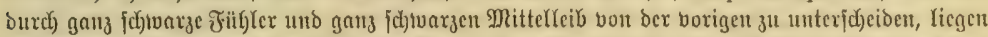

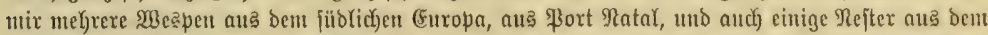

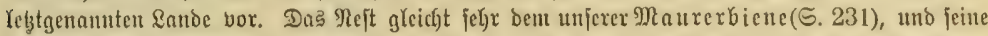

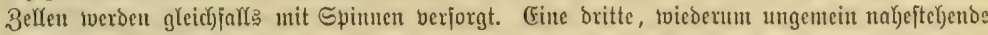

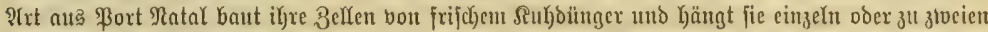
an Binjenhaluen auf. Sein \&andżman, der blaue Epinnentäbtex (Pelopocus chalybeus),

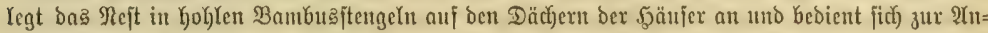

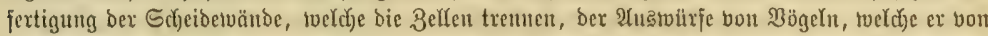
Den $\mathfrak{B l a ̈ t t e r n ~ a b j a d ) a b t ~ u n d ~ m i t ~ E p e i c h e l ~ b e r m i f a c h t . ~ D e r ~ p f e i f e n d e ~ S p i n n e n t o ̈ b t e r ~ ( P e l o p o e u s ~}$

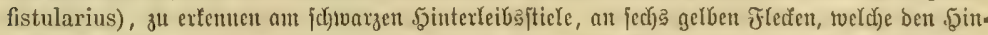

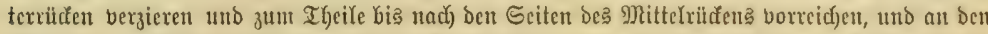

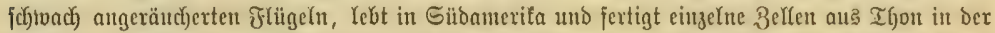

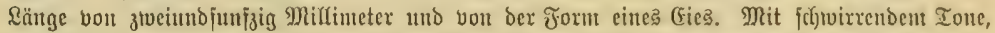

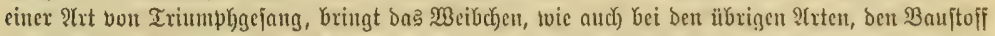

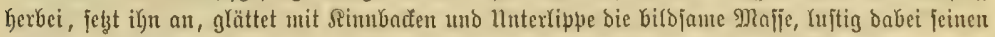
Gejang fortiełzend, betaftet von auß̄en uno innen mit ben Beinen bie ganze Wano uno - ver=

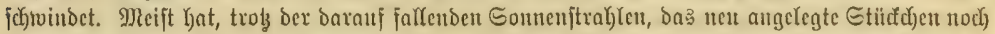

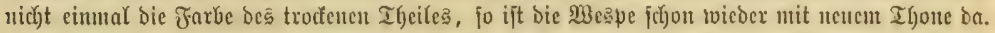

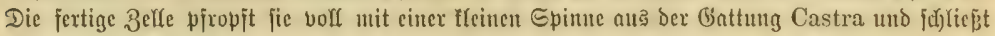

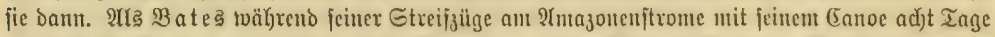

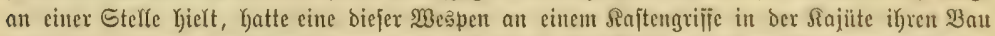

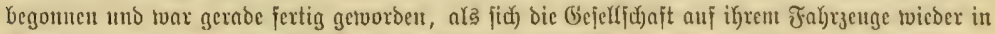

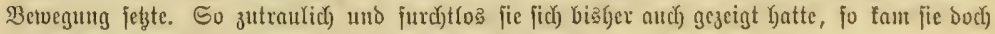
nicht vieber, objdyon rangiam an llier Kingejabren tourbe.

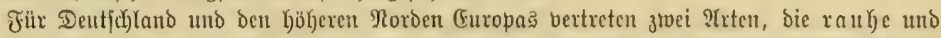

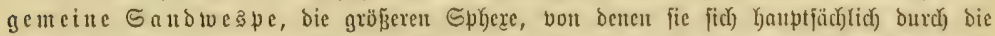

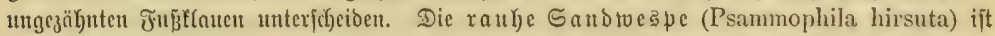

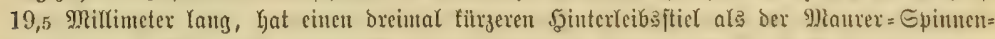

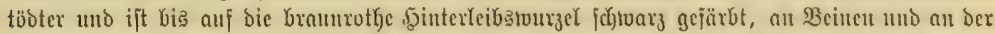

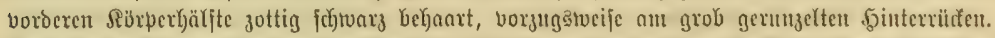

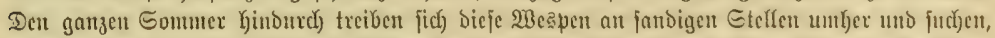

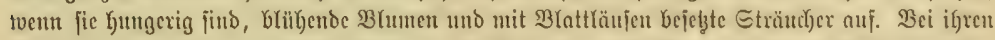

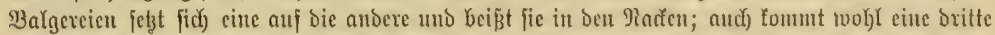

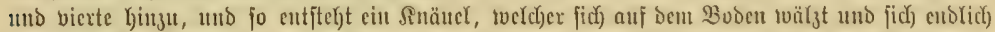

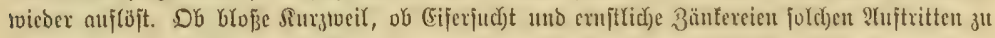
Grunde Yiegent, twer foll es errathen?

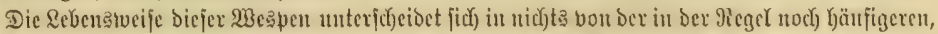

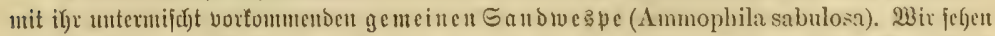

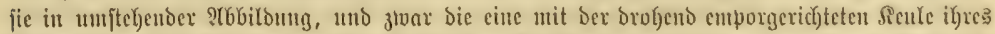

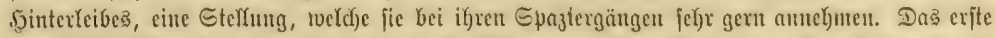

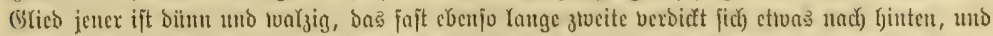

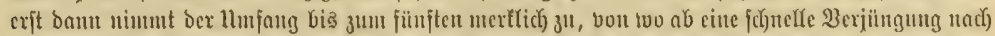

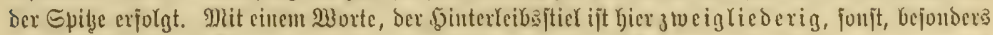

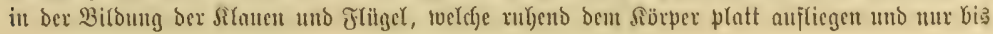




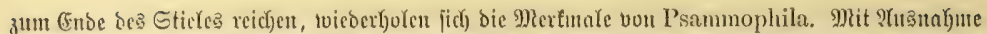

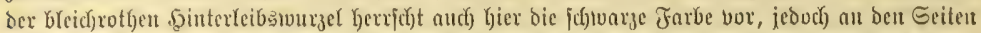

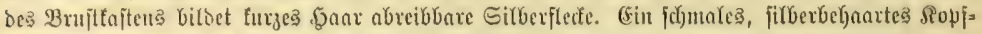

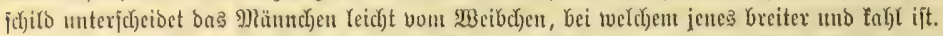

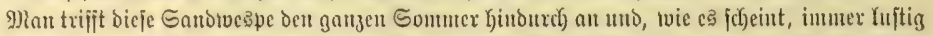

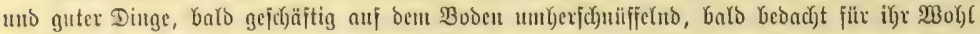

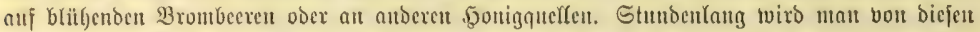

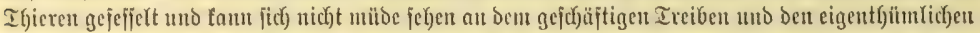

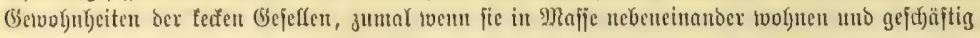

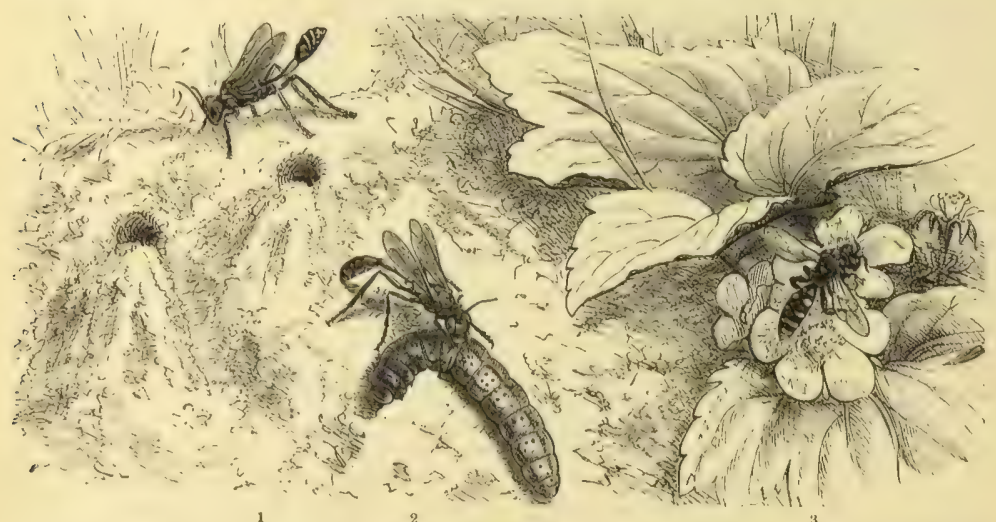

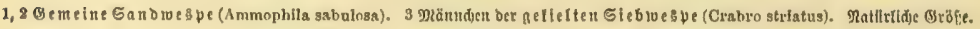

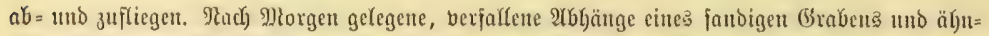

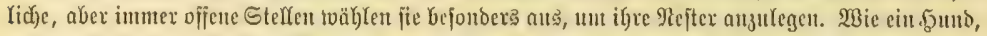

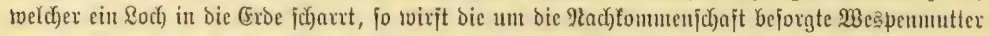

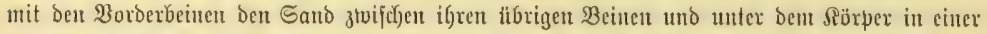

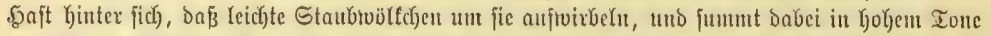

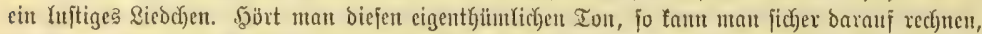

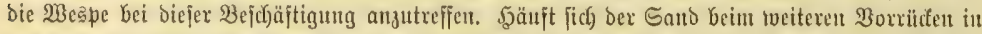

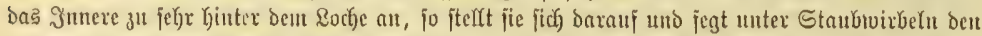

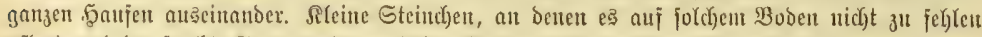

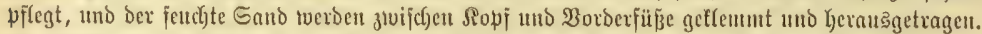

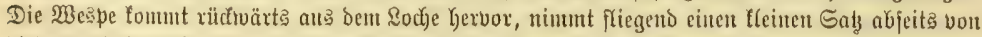

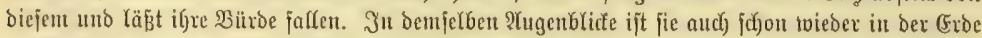

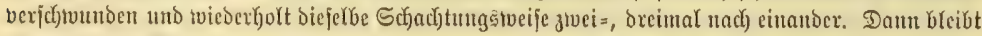

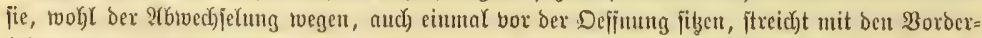

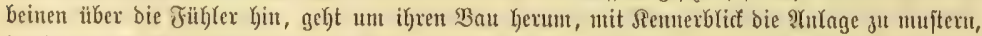

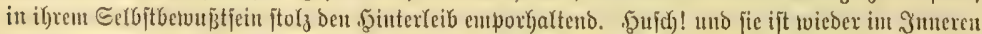

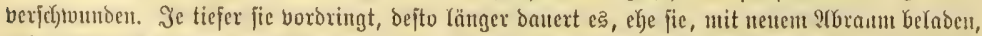

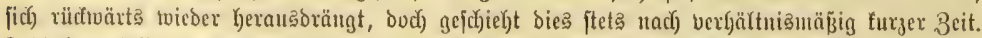

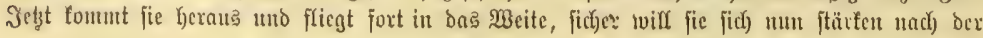




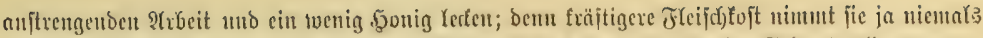

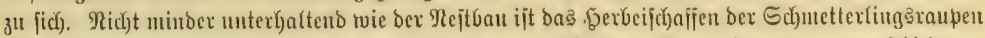

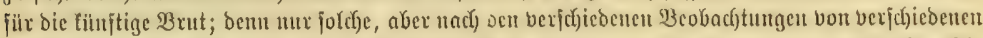

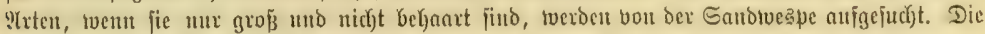

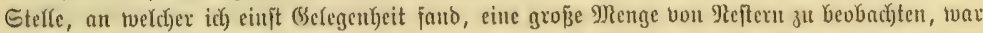

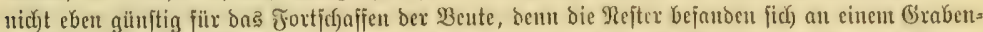

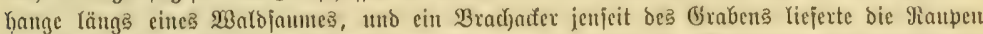

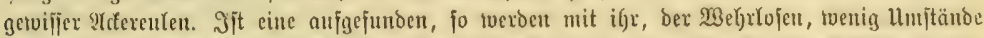

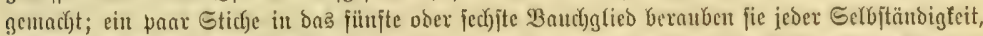

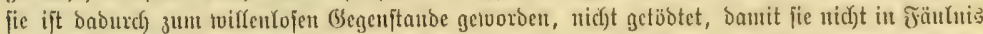

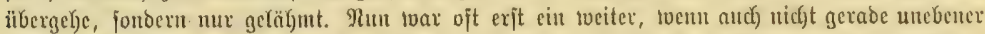

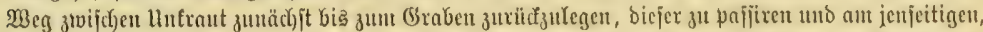

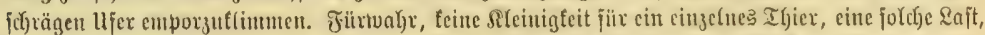

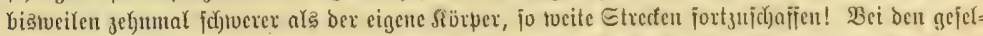

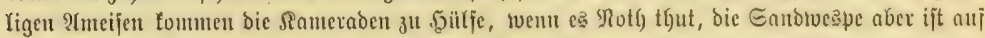

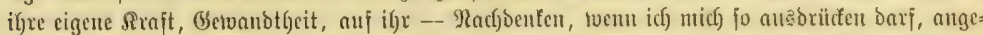

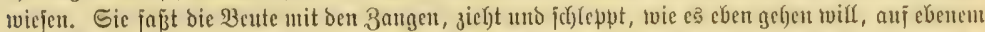

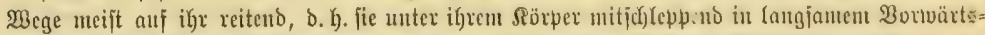

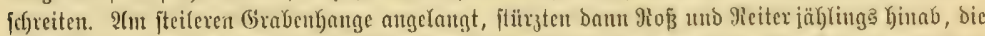

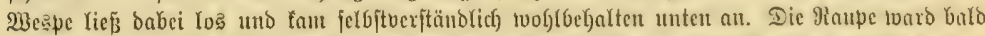

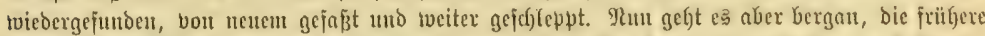

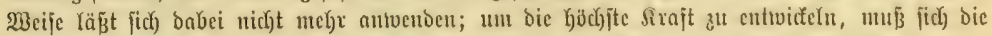

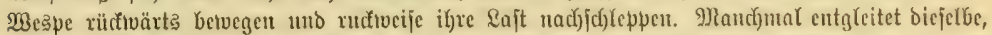

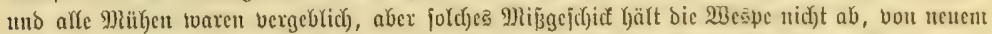

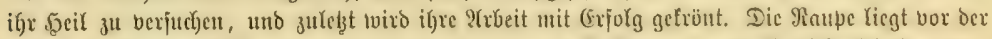

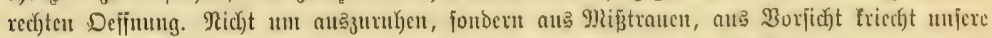

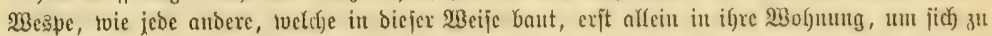

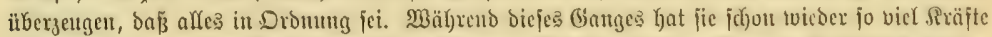

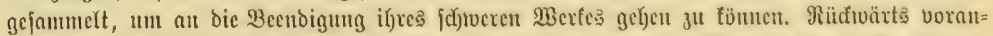

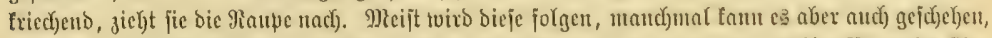

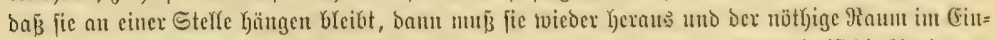

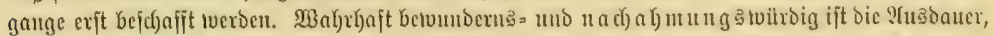

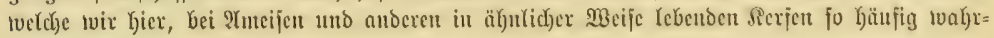
nełumen tömen!

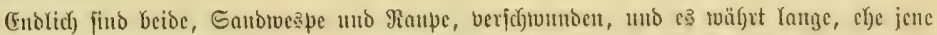

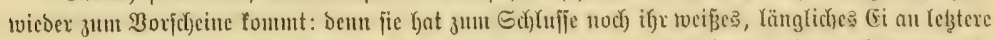

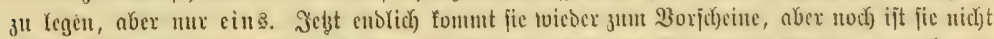

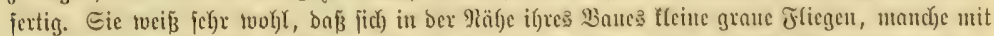

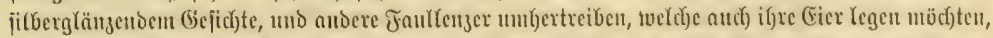

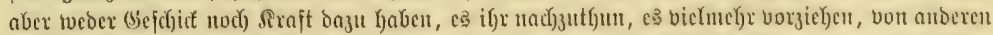

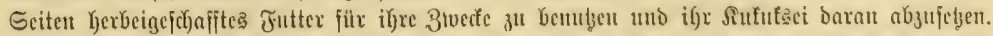

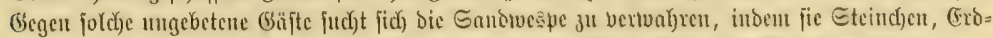

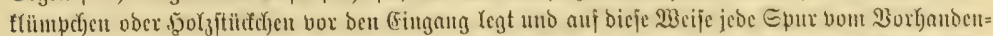

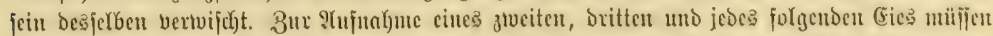

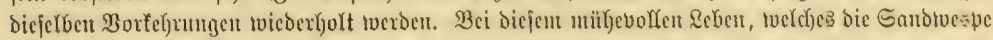

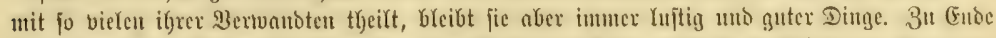

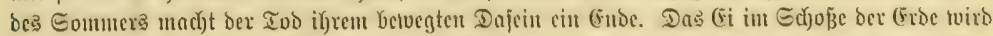

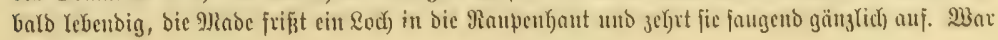




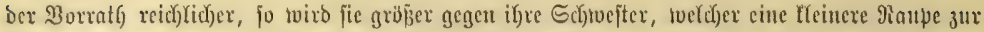

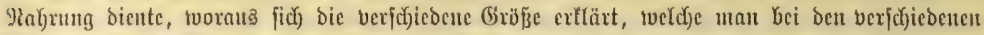

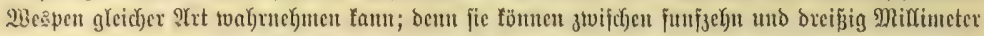
in ber Ränge fótruanten.

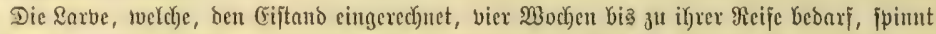

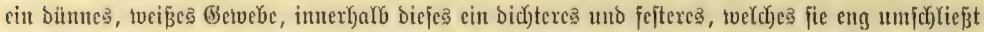

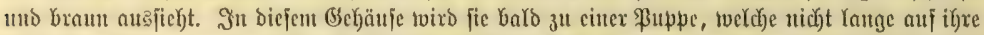

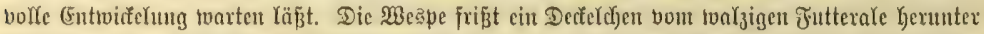

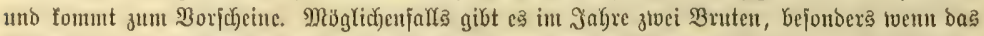

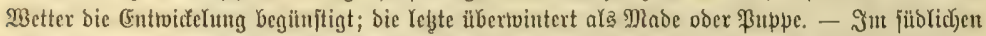

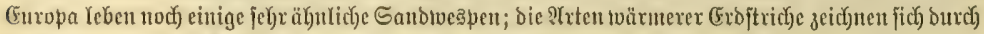

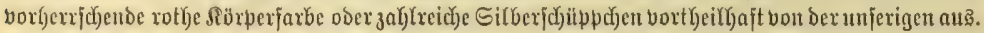

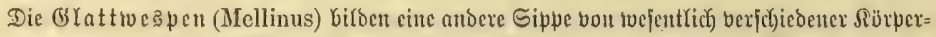

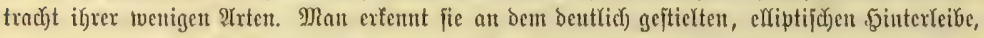
Der antjangrojen Ranozeffe uto ben brei gejchlofienen Unterranozellen, beren erfte ben erjten, bie

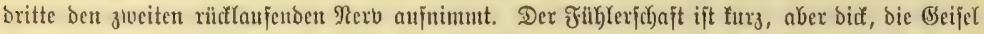

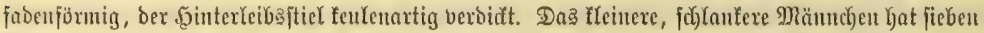

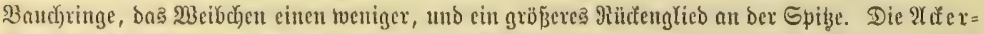

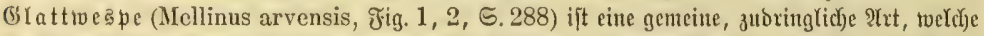

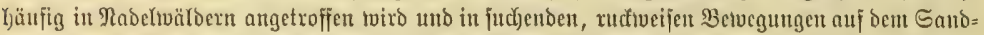

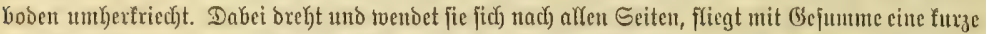

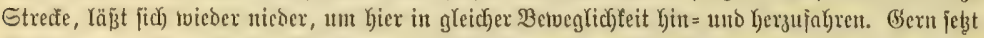

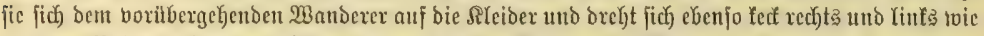

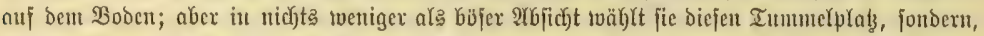

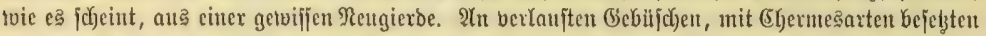
sitejern zeigt fie fid gef)

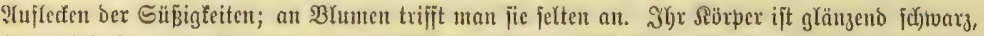

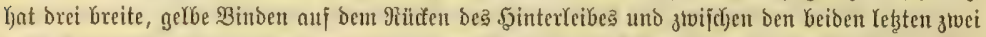

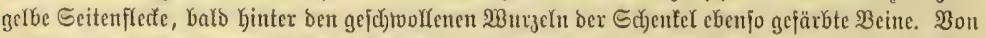

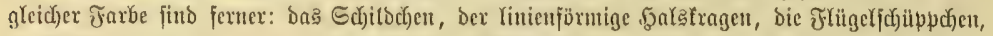

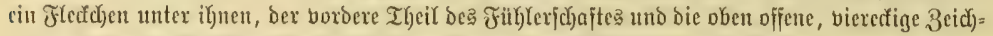

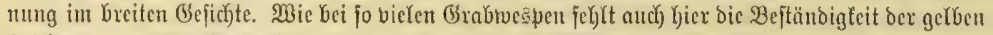

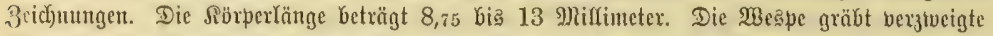

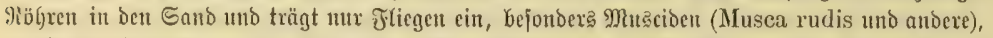

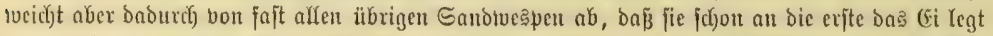

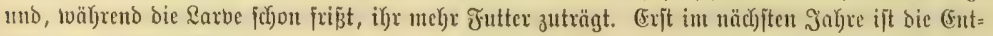
widełung biejer bollenoet.

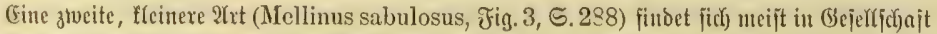

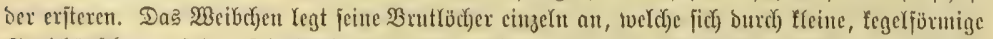

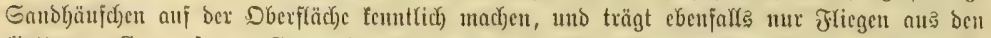
Gattungen Sarcophaga, Coenosia, Anthomyia, Lucilia, Cyrtoncura und Syrphus cin. (E⿺

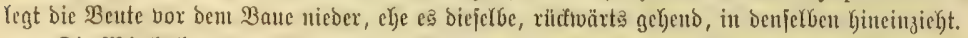

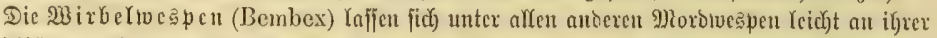

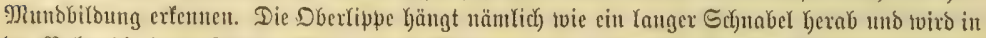

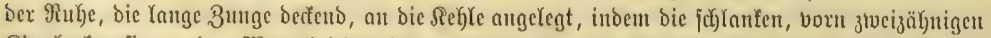

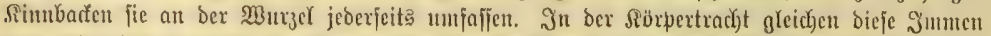

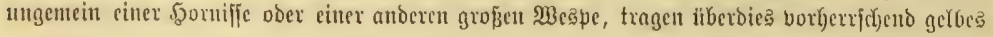




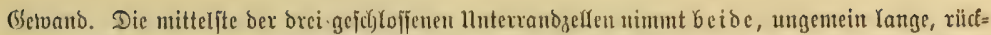

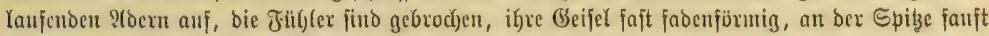

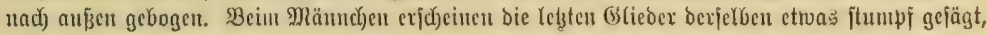
uno ̈̈berbie

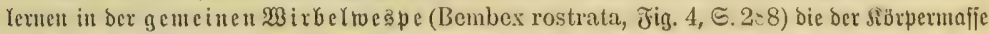

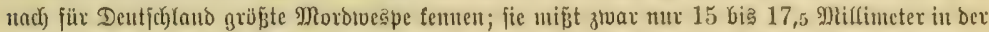

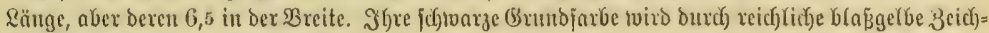

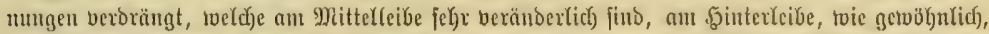

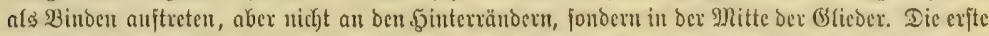

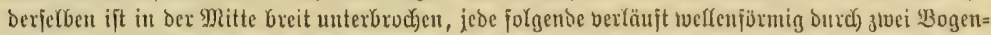

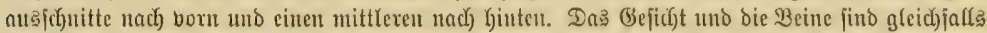

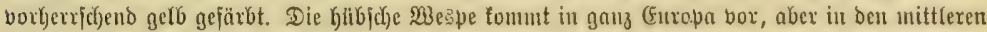

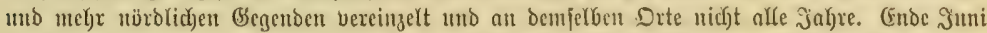

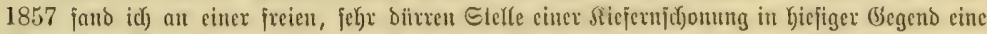

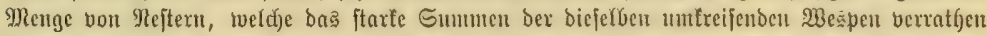

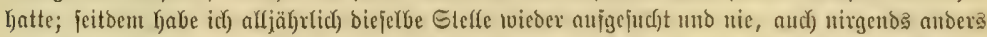

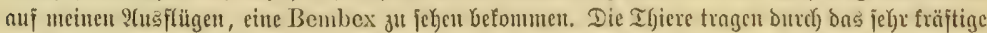

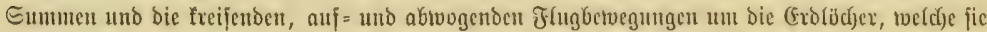

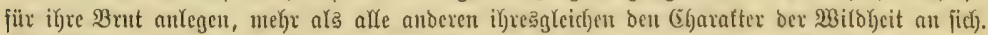

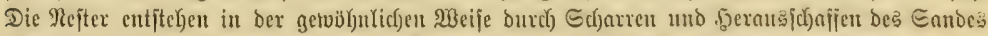

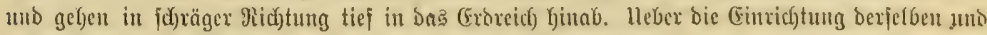

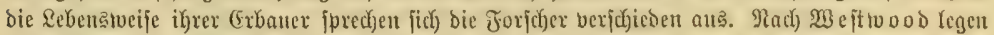

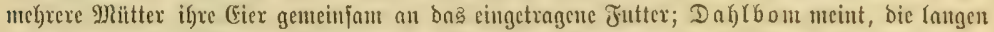

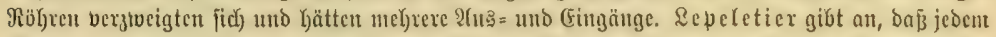

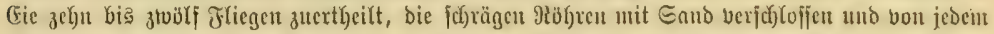

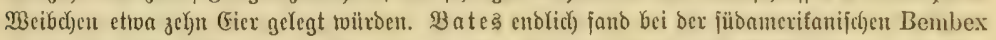

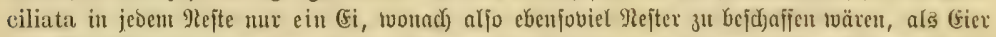

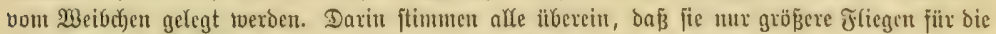

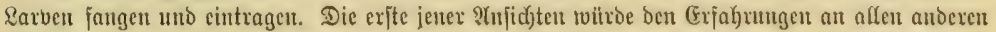

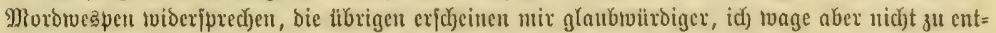
jocheiben, weldhe bie alfein ridhtige jei, weil mir bie eigenen Beobad)tungen fehlen. - Lic Mirbel=

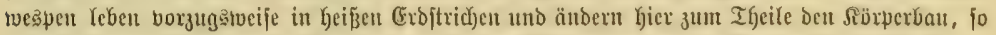

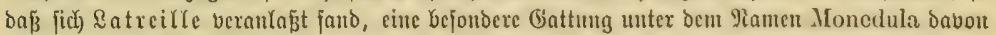

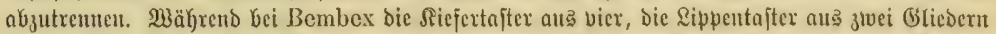

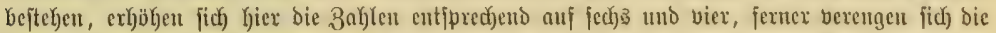

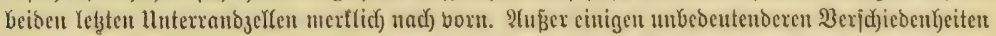

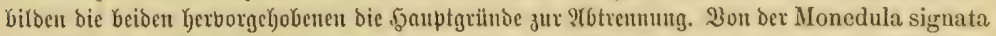

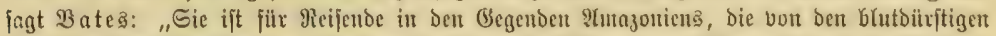
„Mutúca" Der Eungeborenen, Hadans lepidotus ber Fifiegenteuner (Fipterologen), geplagt jinto,

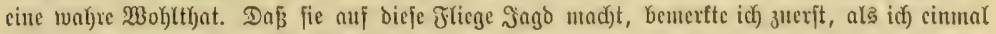

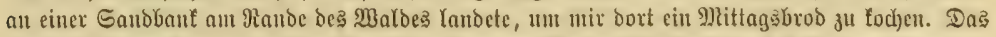

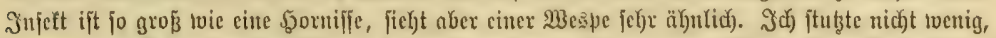

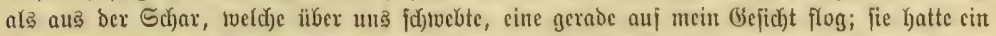

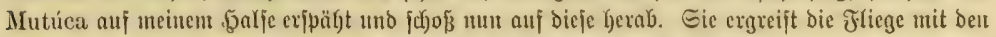

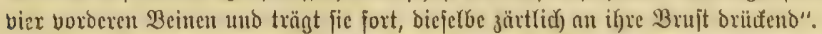

Dex bunte Bienentuolf (Philanthus triangulum, Fig. 4, 5. 280, Jig. 5. 5. 288) ift

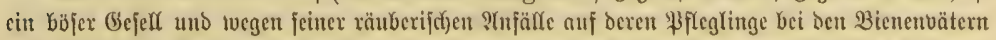

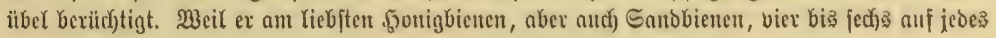




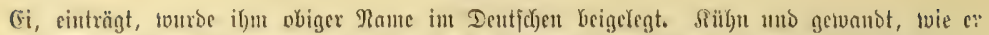

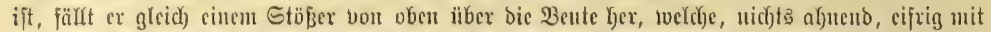

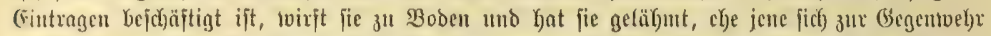

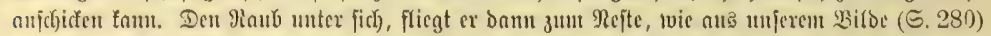

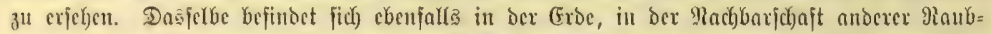

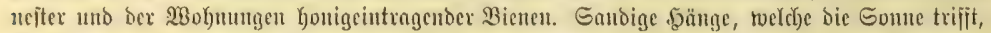

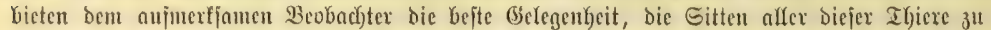

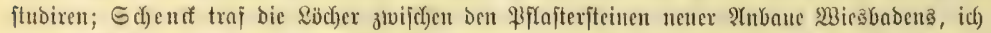

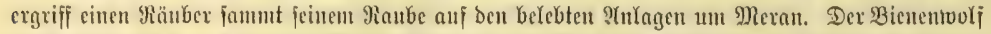

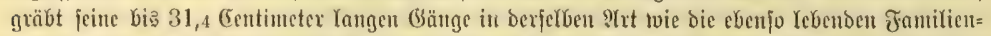

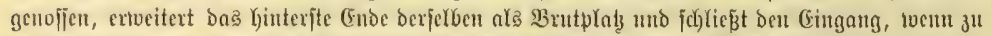
Den cingetragenen Bienen Dą cine für fie beftimme Gi Kinzugefonmen ift. Go viele Eier er abjebzt,

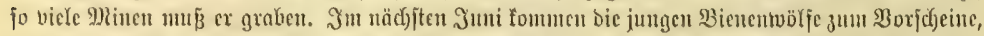

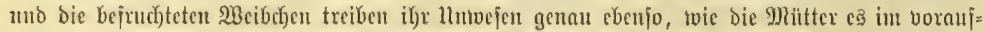

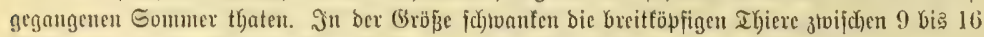

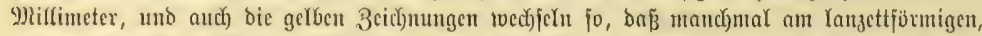

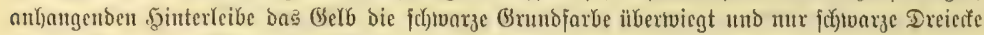

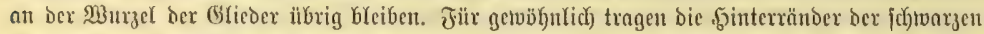

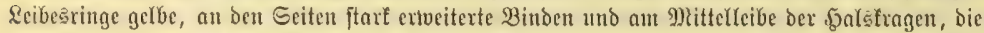

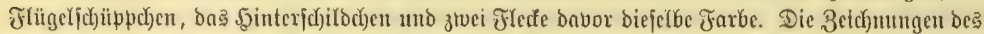

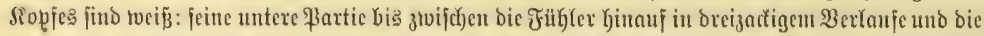

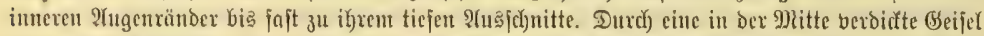

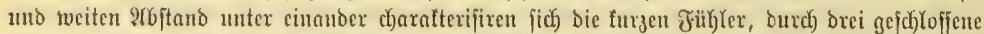

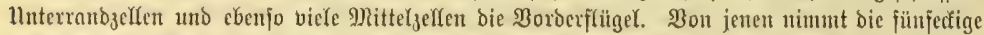

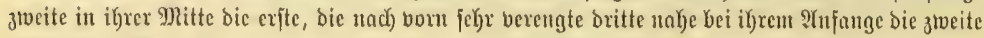
rüăfaufende शtoer auf.

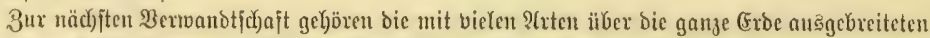

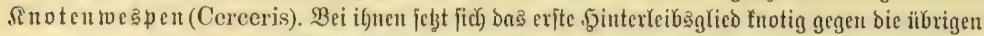

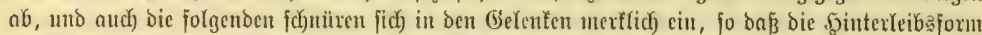

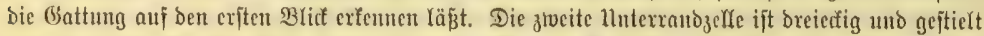

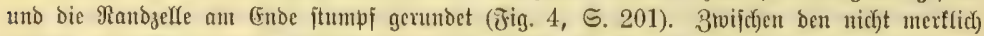

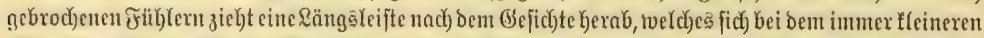

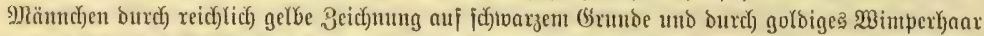

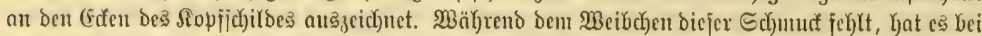

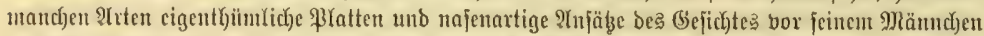

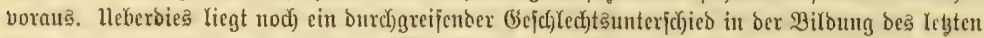

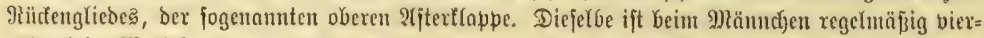

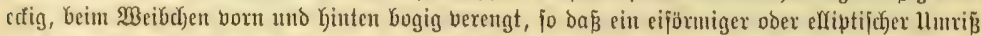

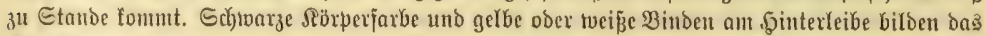
Sileio ber meiffen Snotenwespen, in ben roärmeren (Evoftrichen finden fich aber burdfan roth ober

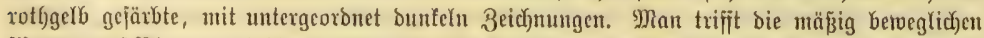

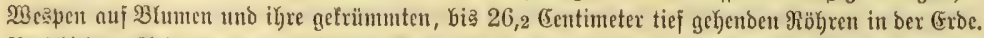

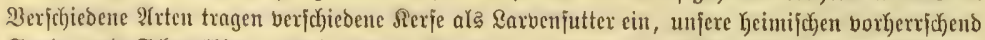

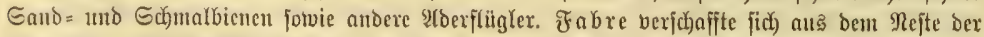

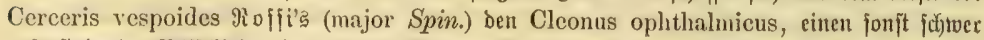

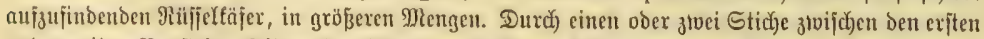

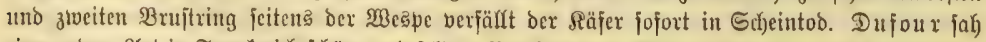

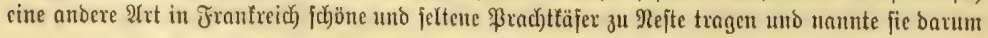




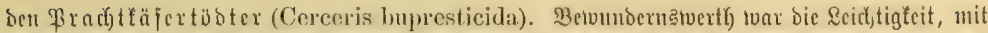

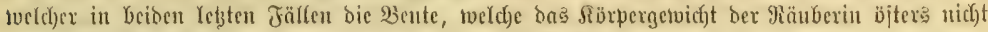

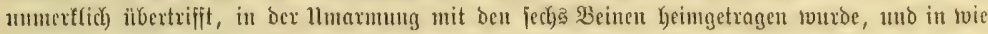

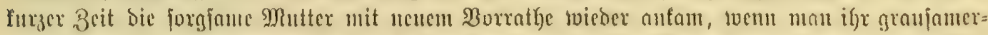

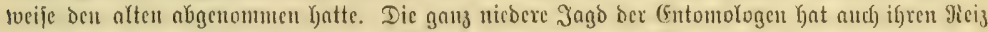

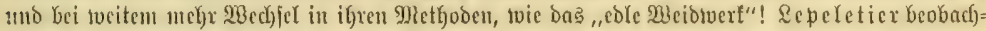

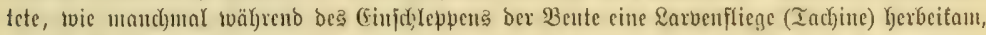

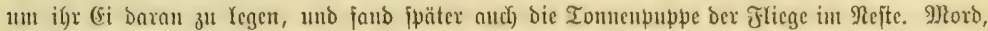

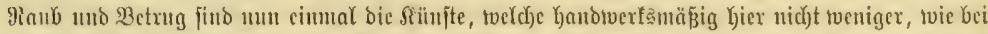

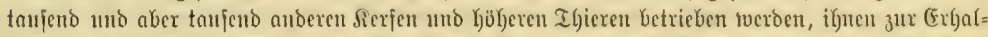

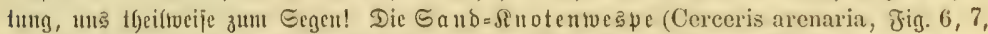

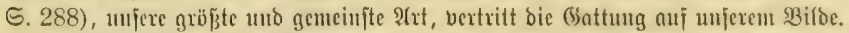

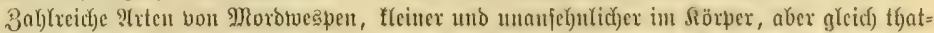

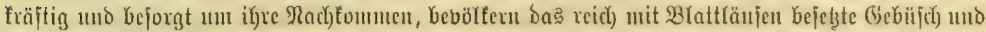

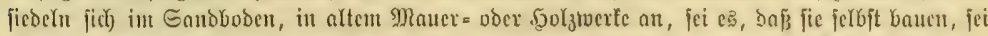

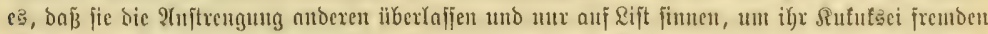

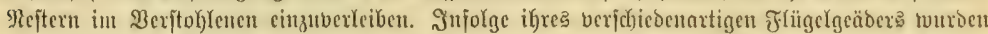

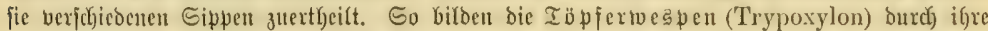

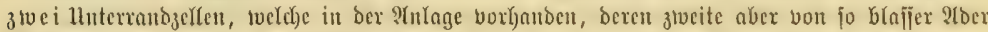

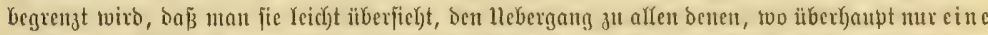

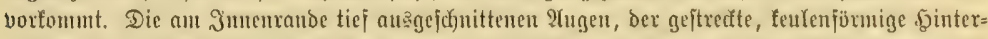

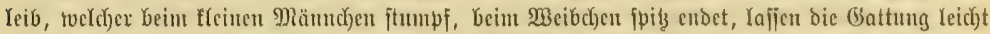

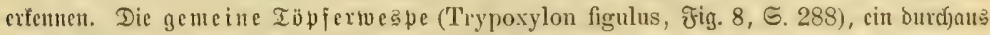

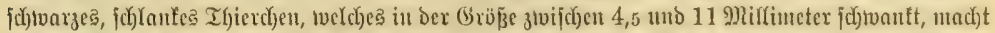

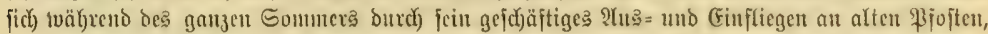

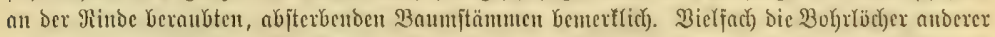

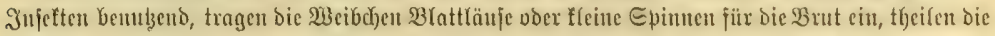

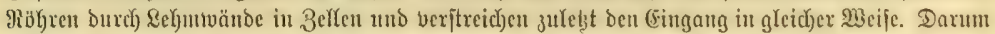

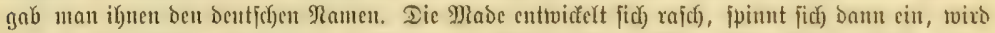

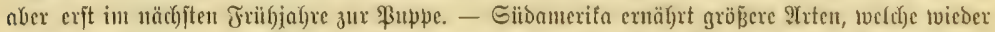

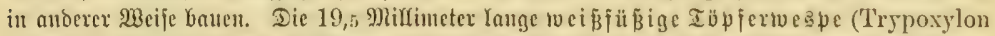

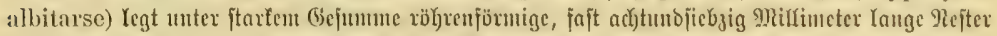

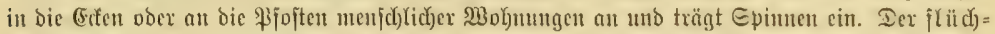

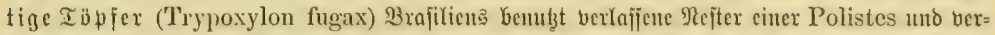

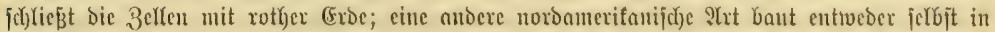

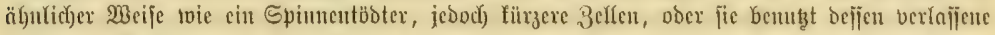

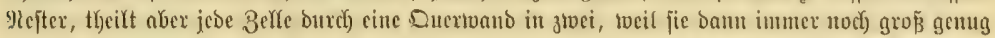

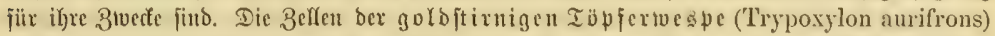

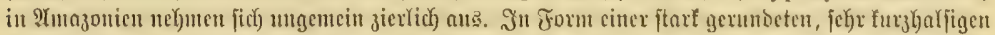

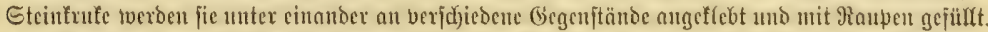

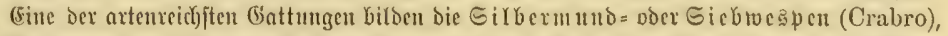

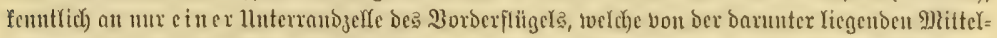

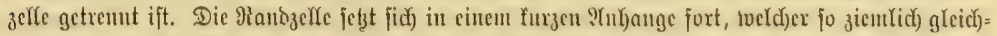

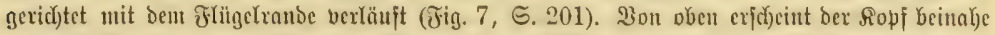

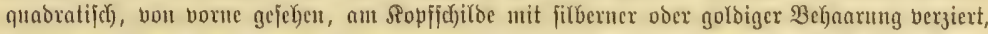

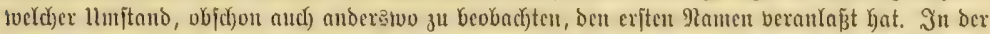

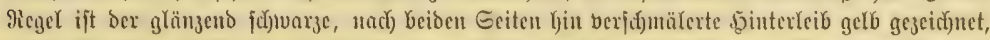

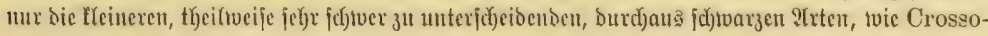




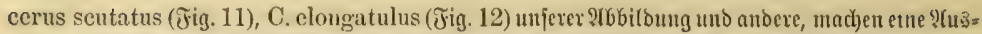

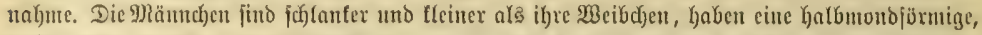

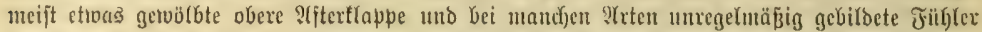

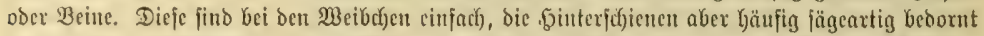

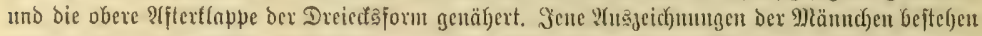

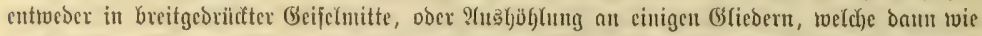

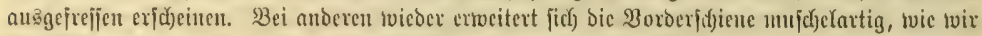
(ङ. 282) auß ber auj bex Bromberbliite fibemocu, gefielten Gicbuespe (Crabro striatus)

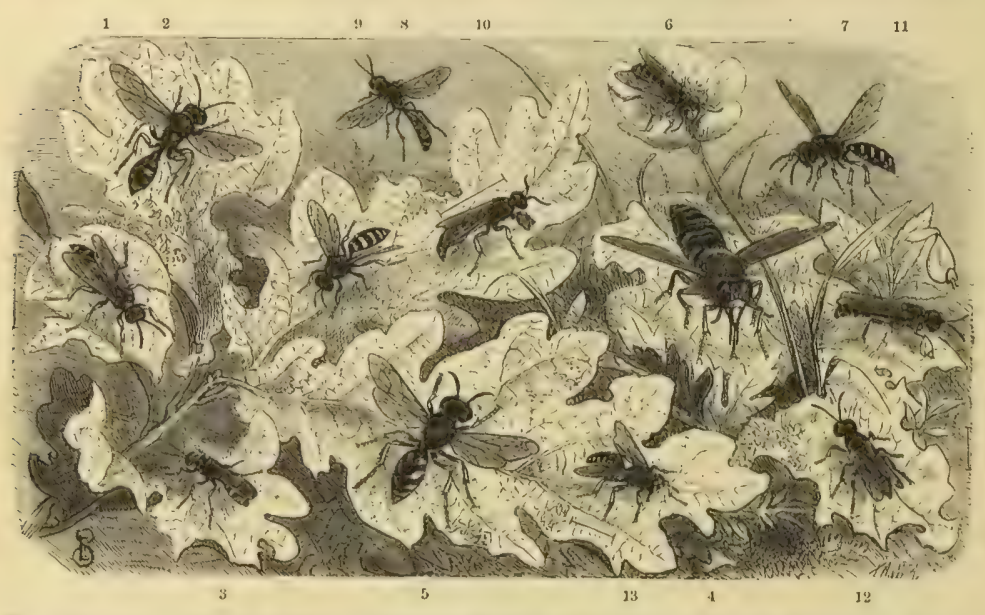

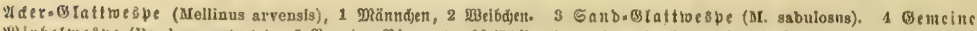

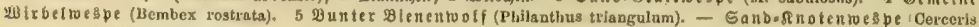

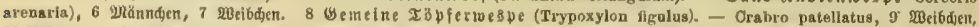

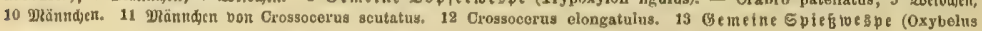

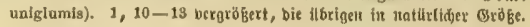

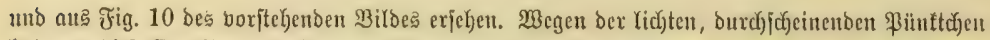

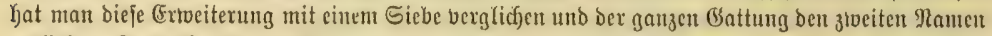

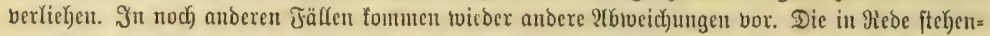

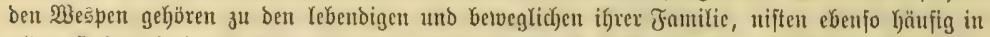

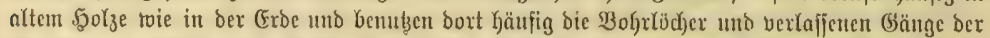

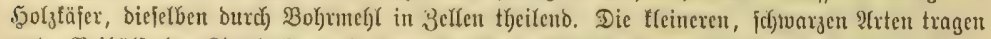

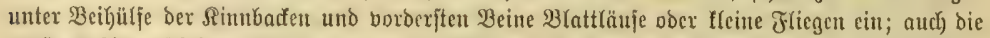

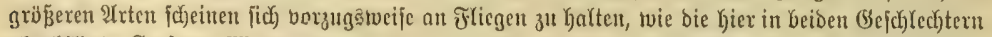

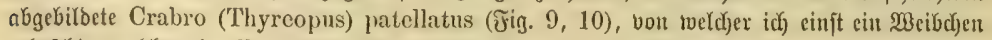
erfajd)te, tweldyes eine Regenbreme (Hacmatopota pluvialis) cinfjeinifte.

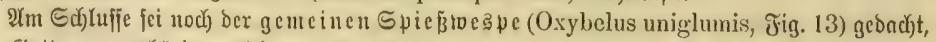
einer (battung angebörig, weldye man Keicht an bem meift rimenartigen Dorn erfennt, in velchen

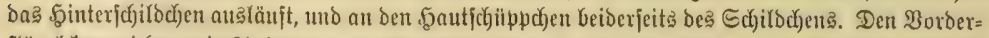

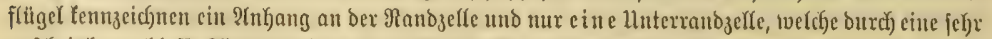

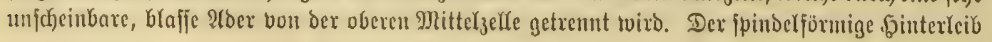


Fäugt bem .̧interrildent an unb läuft beim Mämud)en in cine vierectige, ebene Ifterflappe,

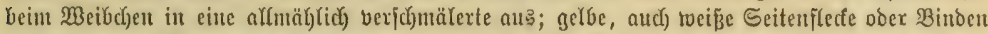

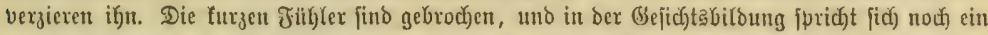

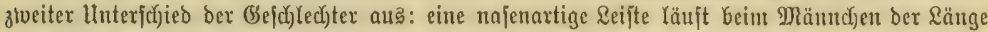

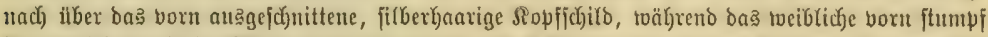

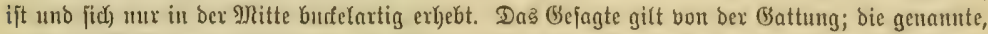

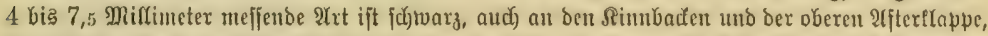

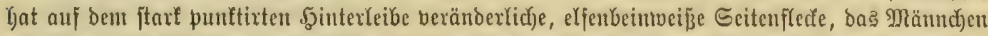

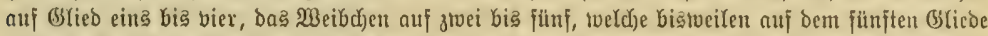

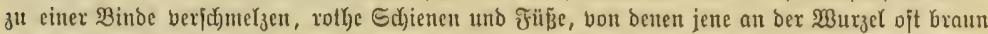

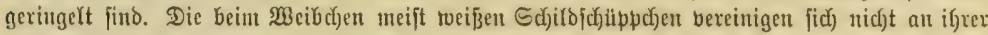

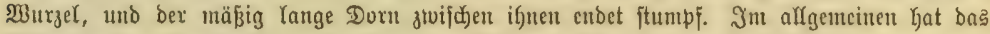

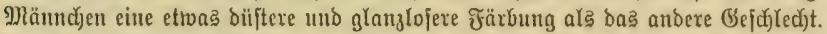

Das befrud)tete Weibd)en gräbt an fonnigen Stelfen einen fünj bis neun Midrimeter langen 6ang in ben Sanbboden, für jebe Larbe einen, beginut bamit im Mai und fälnt fort bis gegen

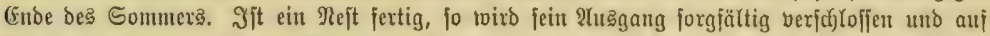

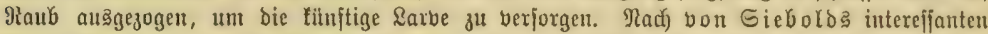
Mittheilungen über biejen Gegenjtand finden fid in bent Refte ffliegenarten, in jeben meift un

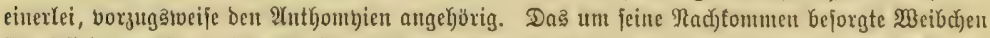

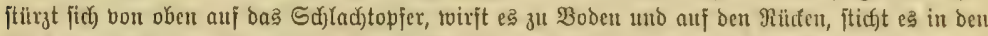

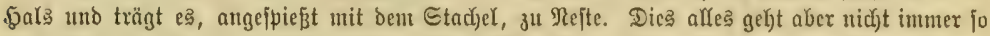

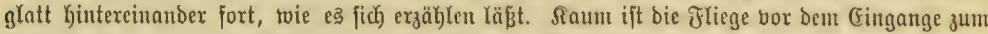

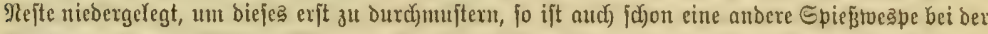

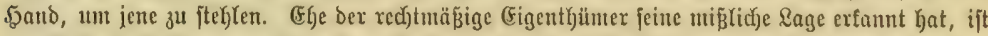

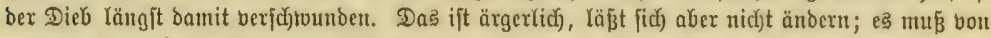
neuem auf bie Jagob gegangen toerden. Dann gibt ę eine fleine fliege, Miltogramma conica

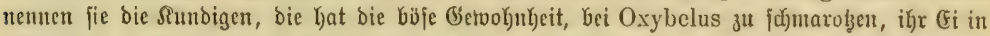

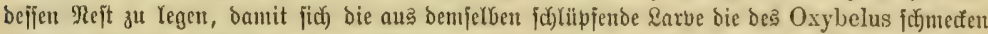

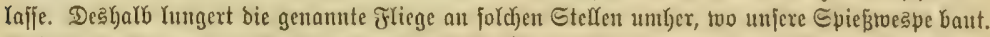

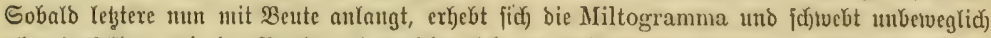

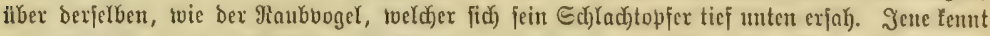

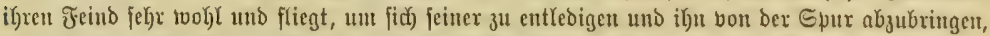

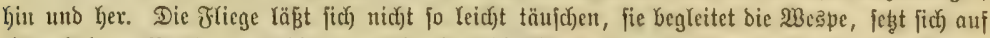

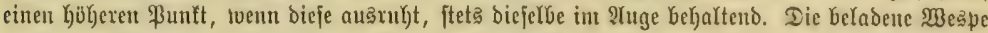

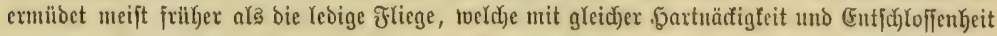

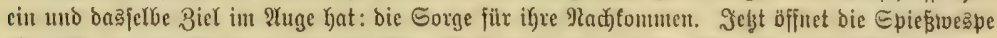

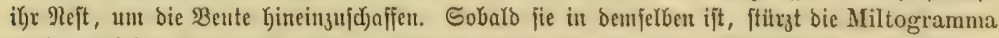

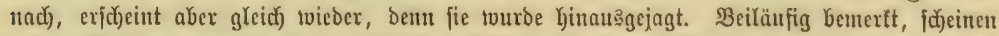

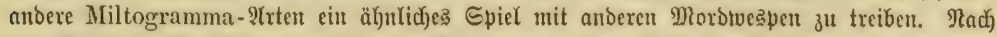
von Siebold 3 Bcobadjtung wird bic rauke Eandivespe durd) Miltogramma punctata berfolgt.

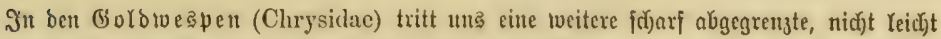

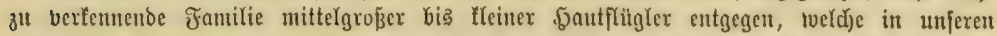

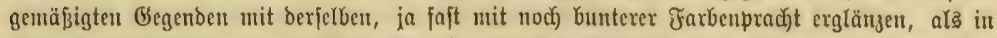

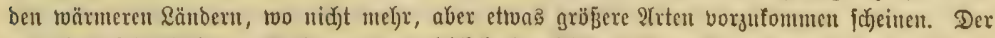
auf feiner Oberfläube nu Sopfe uno bem gleid) breiten Wlittelleibe mefr ober wentiger grob, an bem 


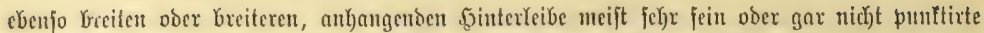

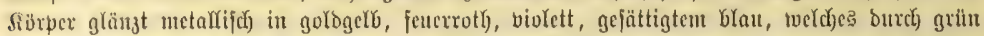

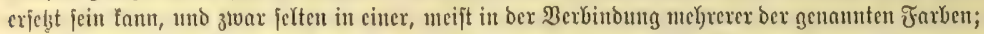

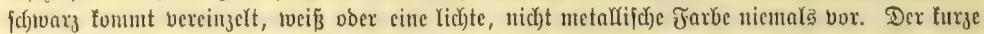

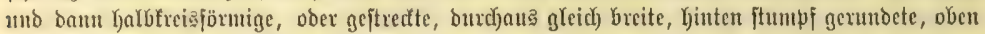

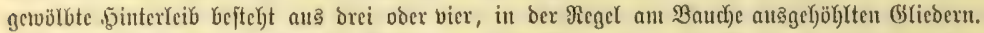

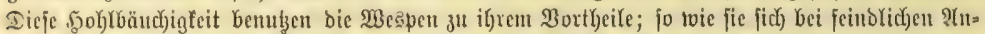

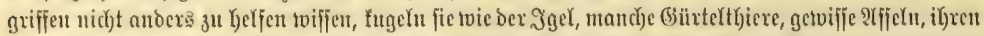

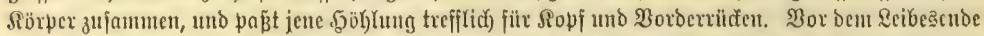

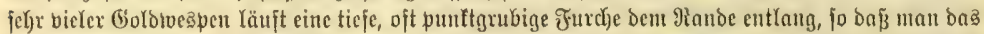

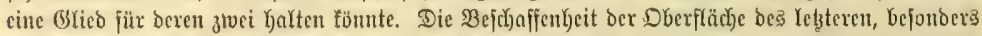

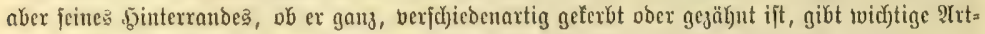

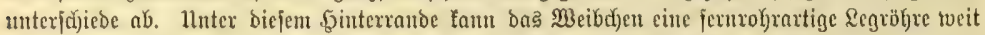

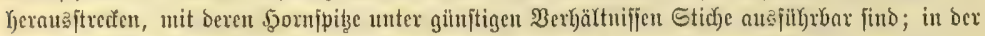

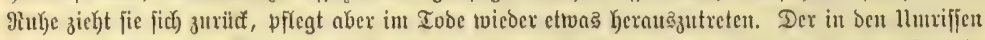
jo ziemlich bierectige Mittelfeib tritt an ben f(f)arfen Sointereffen mefro ober wentiger zahnartig

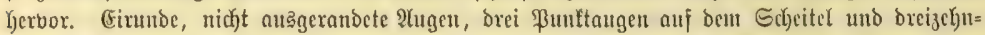

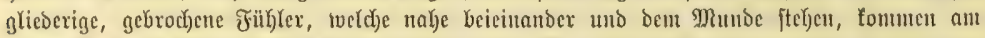

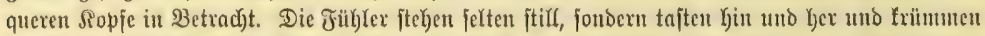

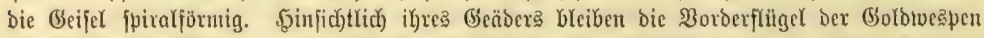

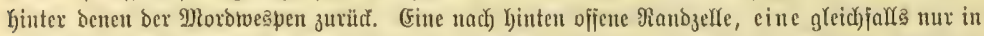

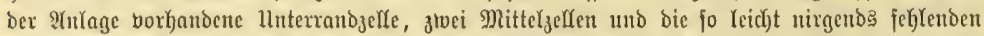

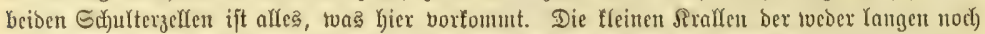

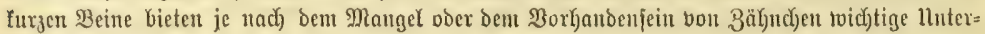
jheibunģmertmale.

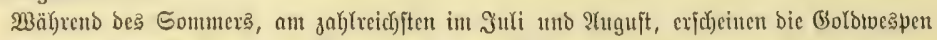

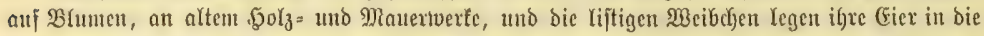
Sejtex anberer, bejonders grabender Sumuen. Osmia unter ben \$ienen, Odynerus uno Eumenes unter ben frnltenuesper, Philantlus, Cereeris, Trypoxylon, Crabro, Bembex unter ben

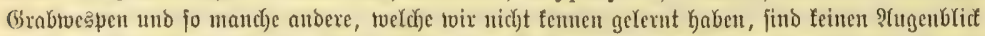

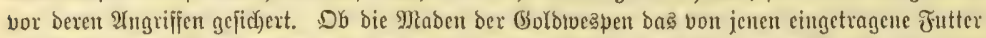
svegfreffen ober fich mitunter aud an ben Sarben ber Mirte bergreijen, ijt nock) nich)t bei affen

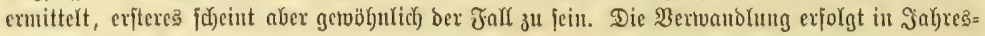
frift nur cinmal.

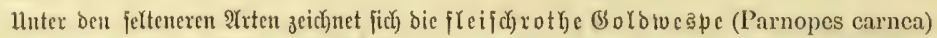

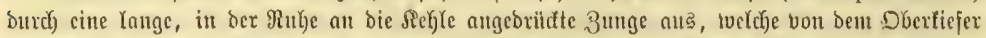

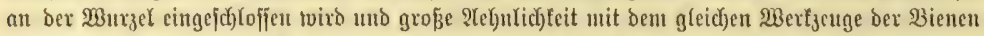

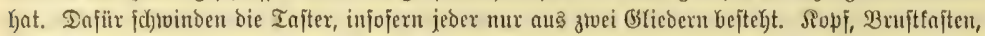

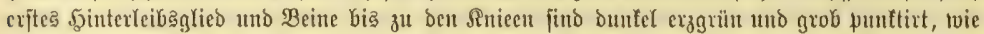

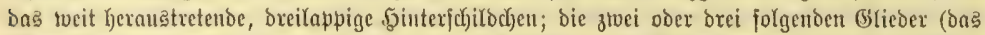

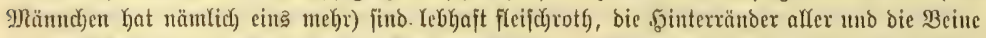

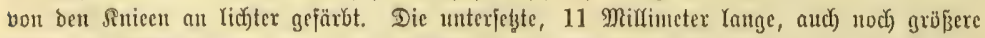

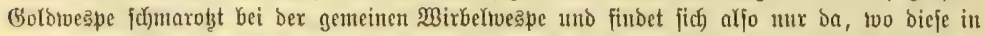

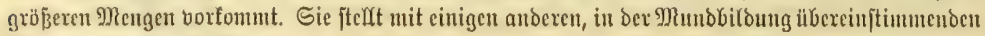
Irten eine bejondere Sippe bar.

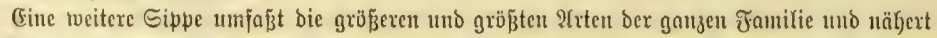
(id) burch ben langgejtredten Rärper ber vorigen, burch bie mäßig Yange Zunge, ben itberlyautpt nicht abroidyenden 23au ber Munotheile und burd) bie cinfad)en Fußflauen ber folgenden Gippe. 


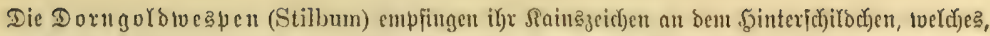

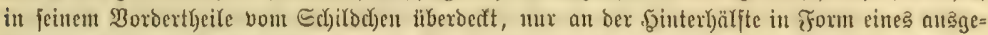

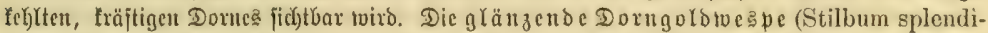

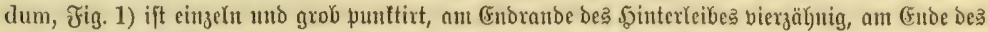

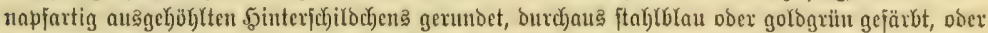

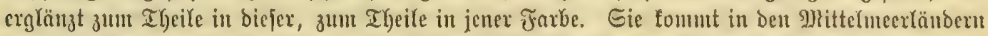

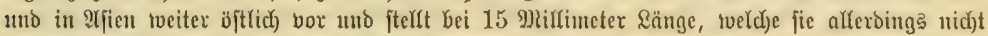

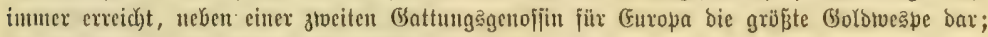

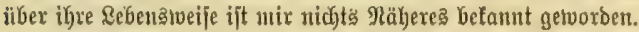

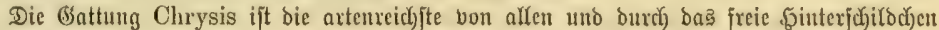

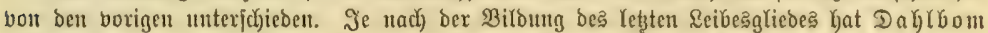
acht Bruppen angenommen, bei benen in Betracht fonmt, ob bex Şinterrano gans uno glatt

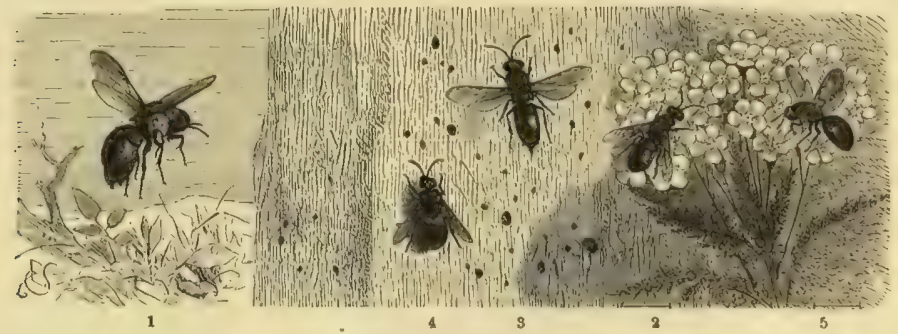

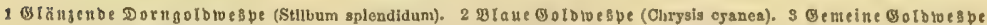

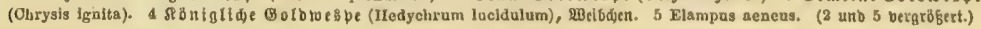

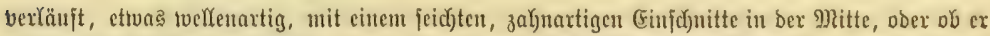

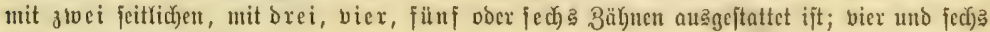
finden fich an häufigiten.

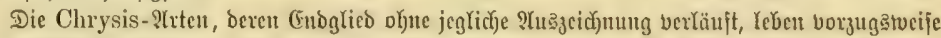

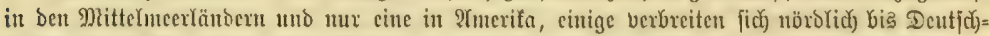

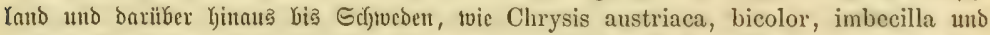

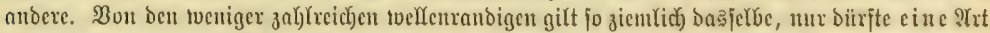
(Chrysis elegans) bis Deutich)land und cine andere (unicolor), felten nürolid)er, in Edjucdent borfommen.

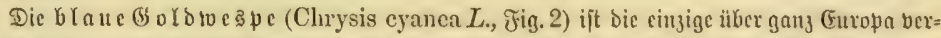

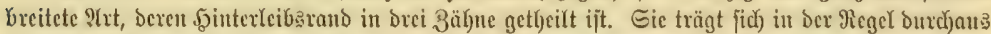

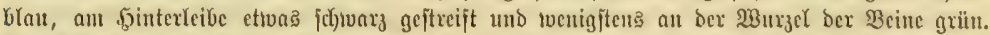

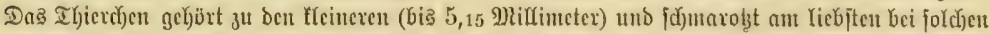

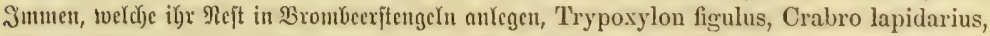

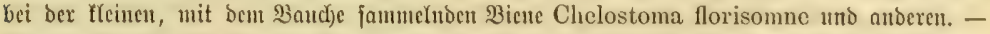
Chrysis fulgida ift cine bon ben tvenigen am Einterranbe viexzähnigen, über ganz Europa

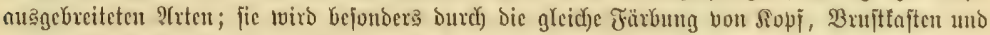

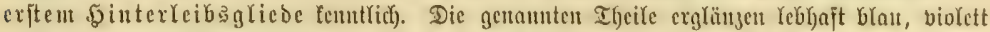

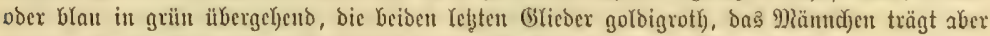

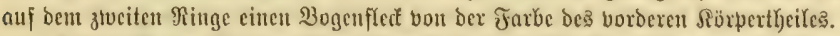

Dic gemeine (Solbuc spe (Chrysis ignita, Fig. 3), Die berbreitetite uno bäufígite vou

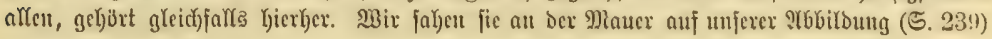




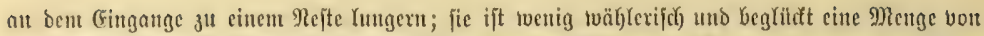

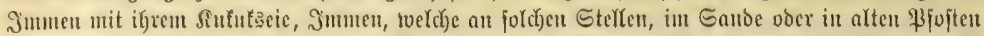

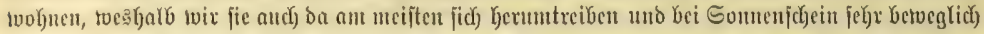
feren. Philanthus triangulum, Cereeris ornata, Odynerus parietum, Antilope spinipes,

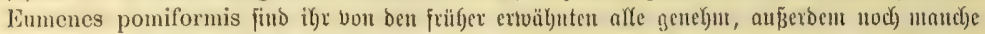

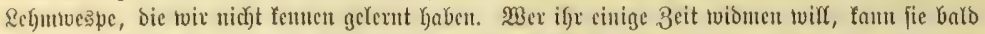

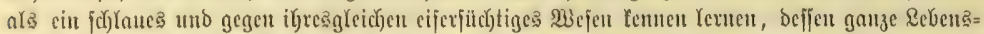

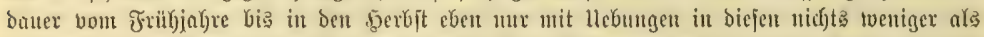

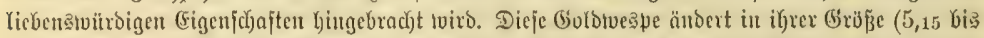

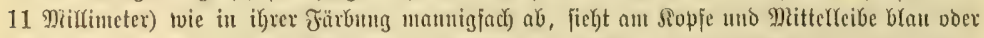

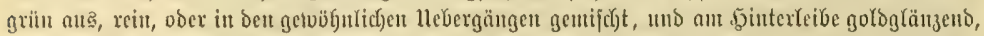

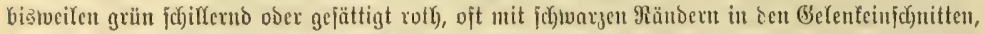

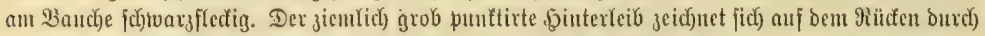

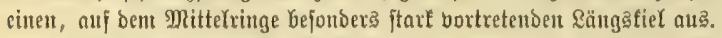

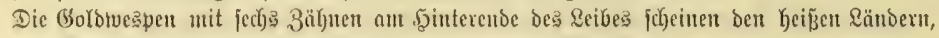

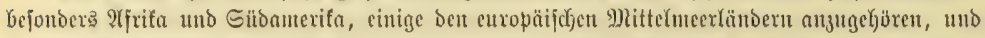

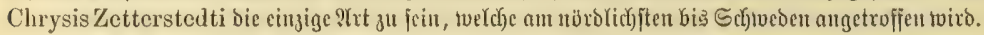

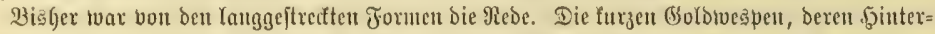

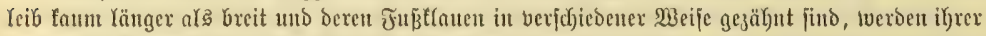

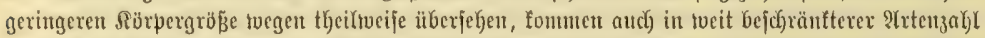

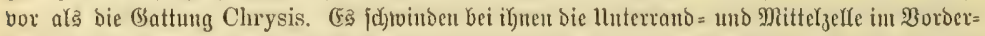

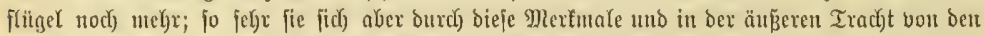

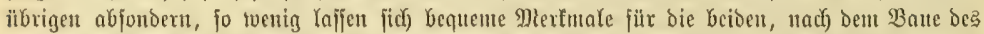

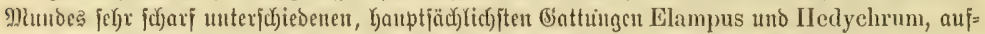
fteffen. Erjtere ftinunt mit Chrysis in Der furgen, fegelförmigen, rełtere nit Stilbum in ber ver=

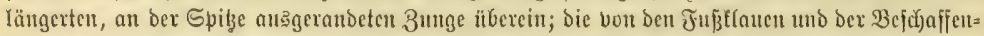
Yyeit des (Enogliedes hergenommenen llnterjchiebe, weld)e jut tweiteren Spartungen gejübrt haben,

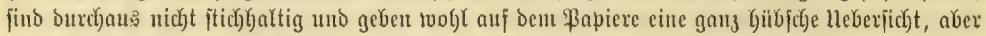

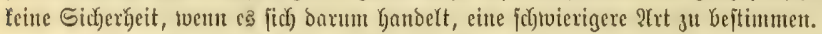

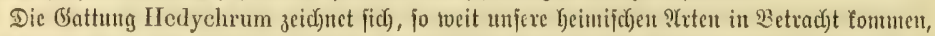

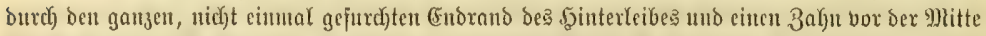

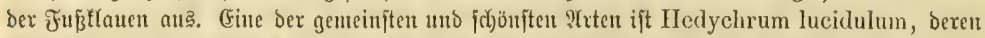

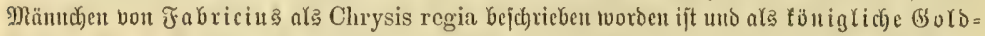

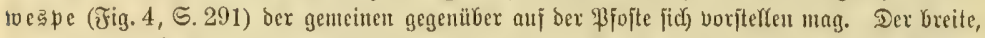

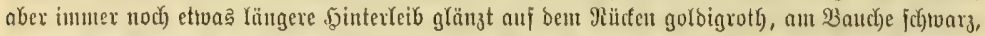

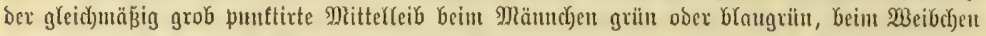

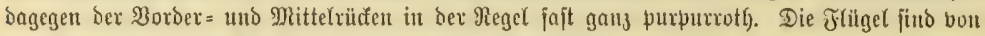
Der Mitte an getrübt. Die \&änge beträgt 4,5 bi弓 8,75 Mtiflineter. Mant Gat biefe शrt bei Osmia

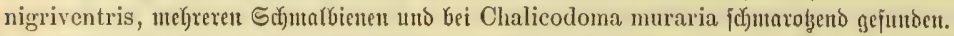

Die rojige Ooforvespe (Iedychrum roseum, auch Chrysis rufa von \$anzer benannt) twirb ourdy igren ungemein bid)t punftirten, barum utten, zart ro fenroth gefärbten Sginter(eib

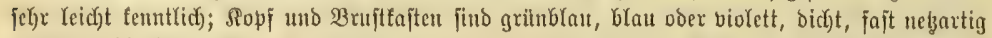

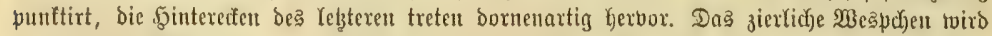

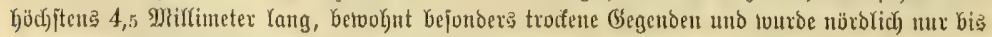
gegen ben fechzigiten $\mathfrak{B}$ reitengrab hinauf beobarjtet.

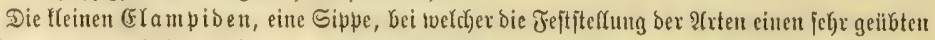

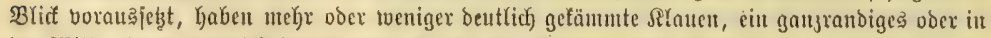

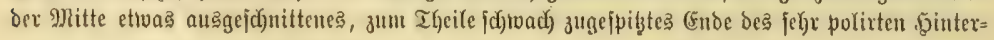




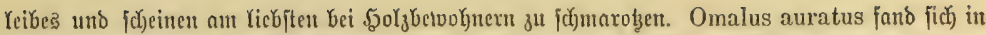

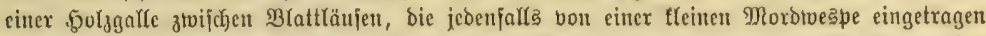

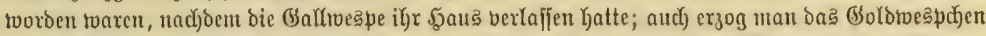
aute bem Refte von Cemonus unicolor, einent fleinen Pemphredonioen (Morbtwespe) aus Brom=

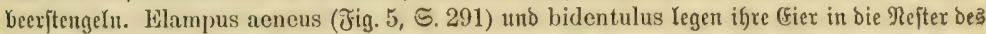

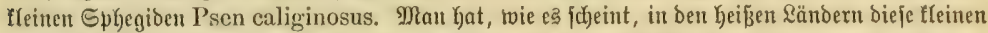

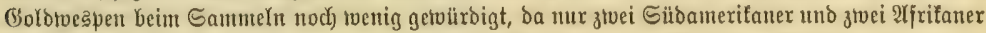
betannt find; bie \$(el)zzah)l, etwa ztwanzig, Geobadytete man in ben Mittelmeerländern und einzelne babon in ben weitex nad) গorben reidgenden Theilen (Europas.

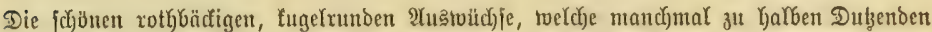

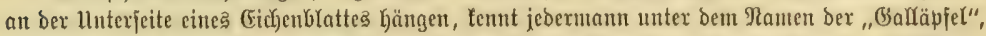

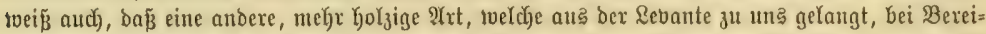

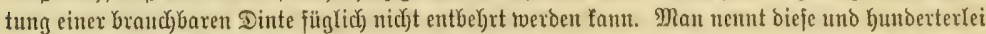

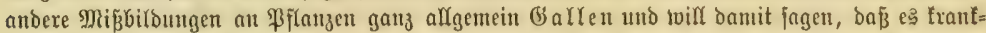

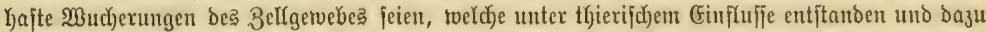

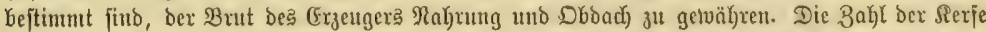

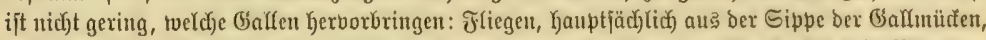

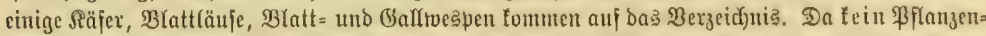

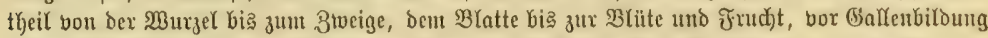

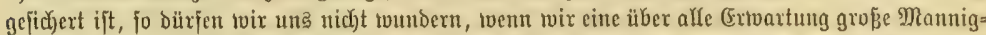
faltigleit unter biejen (bebilden finden. Der interejjante Gegenjtand, nod) lange nidjt hiureidjend

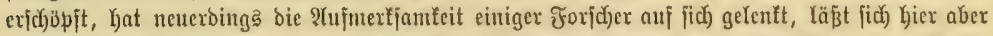

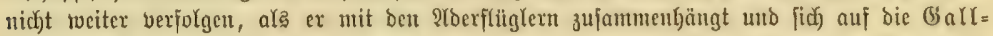
toespen (Cynipidae), eiuer bejonocren Familie ber gentannten Jujettenoronung, bejięjt, toeldye bie volfonmenjten (Balfen erzergen.

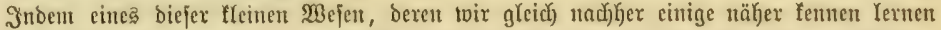

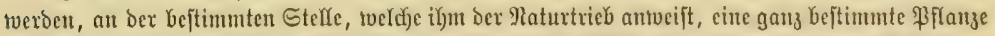

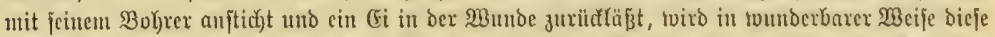

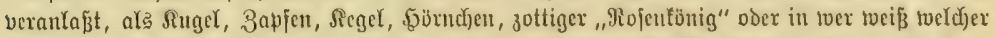
Form auşรutwad)

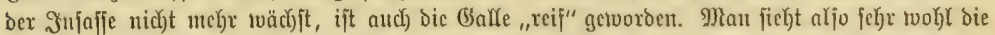

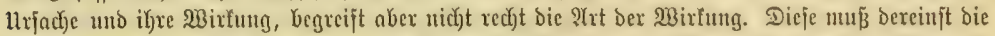

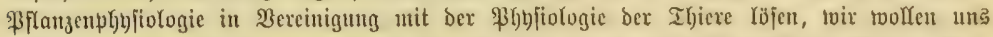
3unäc)jt nur bie Bedingungen vergegenwärtigen, unter denen eine Galle zu Etande foumen fann.

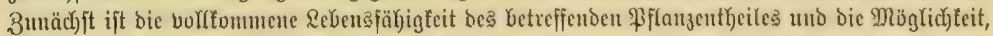

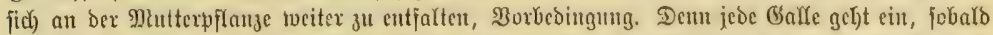

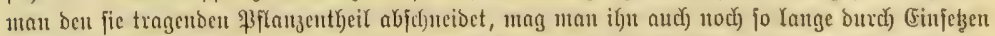

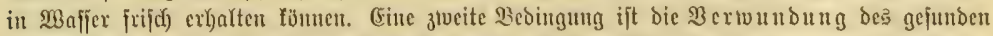

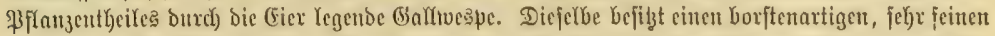
B3okrex, Der in Reibe berborgen ift, aber toeit vorgeftectt und in Den Pf(anzenfürper eingejtodjent

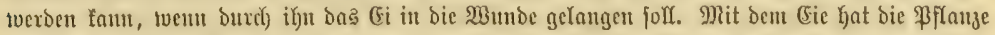

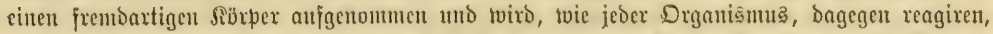

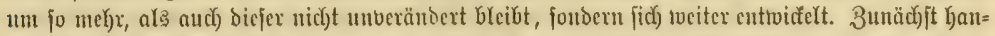

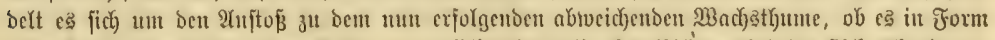

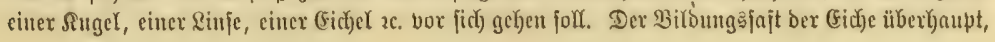




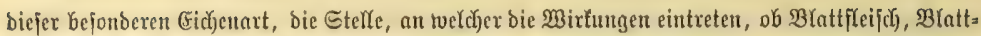

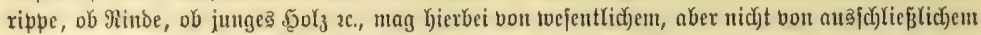

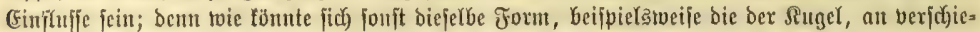

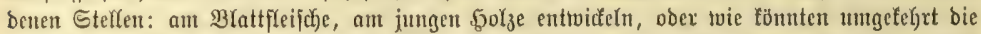

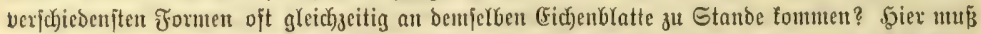

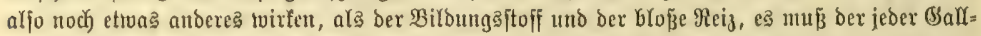

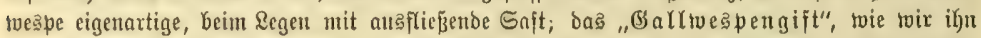

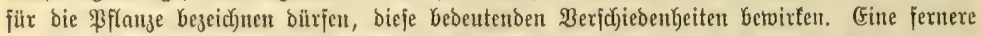

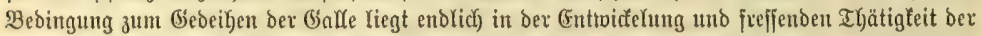

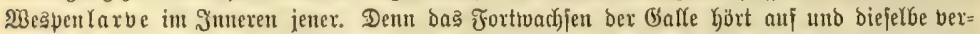

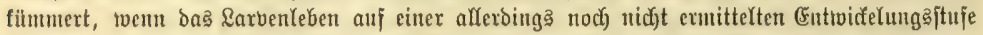

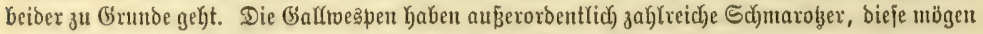

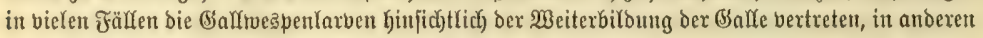

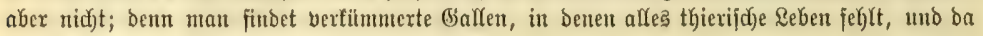
twurbe eక zu zeitig für beren frortbiloung getobtet.

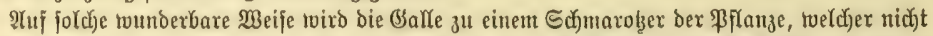

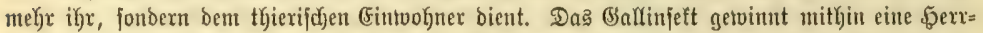

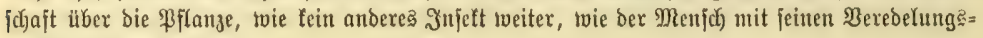
berjuden nimmermeלx.

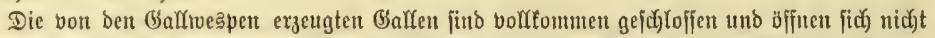
vou felbit, wie viele andere Ballen, jondern twerden bon ben volfendeten Mespen durchnagt,

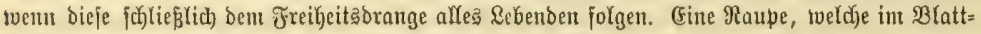

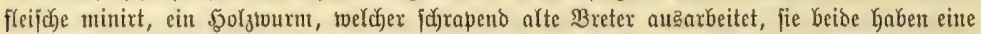

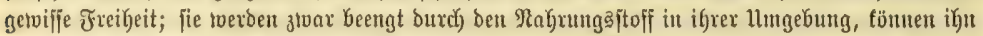

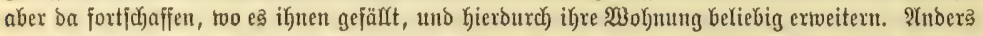

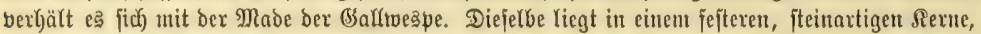

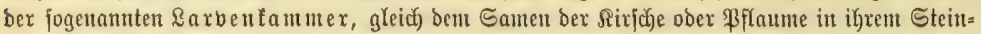

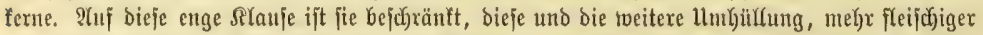

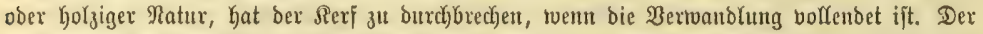
genteine Balfapjel enthält in feinem Mittelpuntte mur eine Sarbentanmer uno gehöut baher zu ben

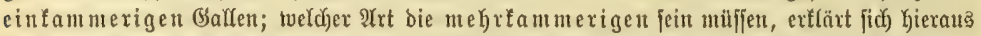

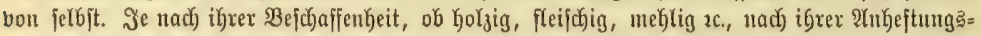

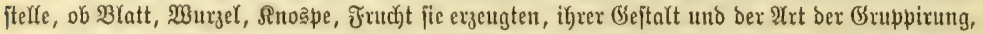
went mefrere beifamunen fint, gibt ę eine Menge bon näberen Beseicionungen für bie Balle,

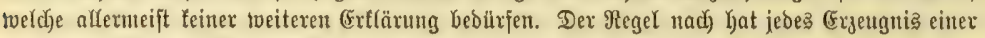

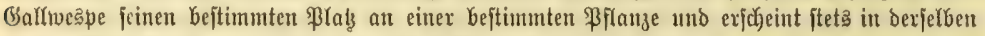

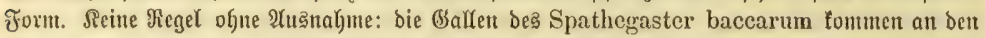

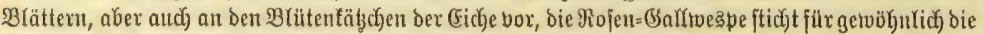

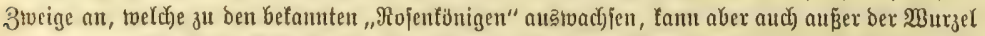
jeben anderen Theil bes Rojenjtrauches beglüden. (Eine interefjante ungeflitgelte Ballwespe, die

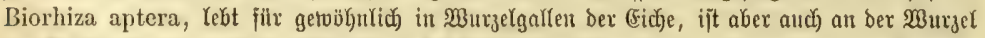

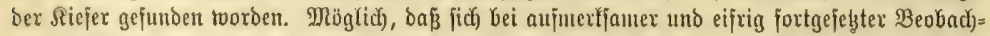

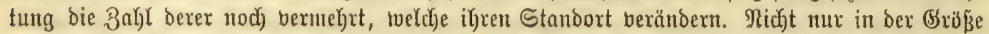

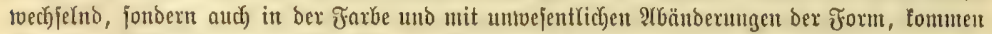

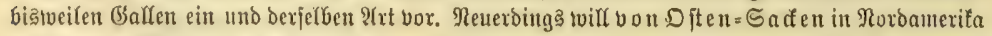

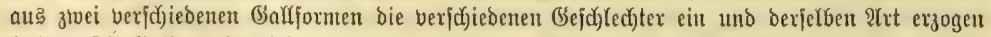

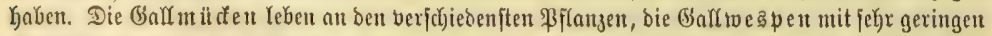

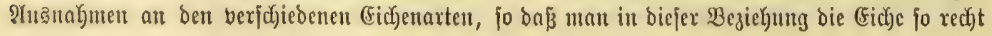




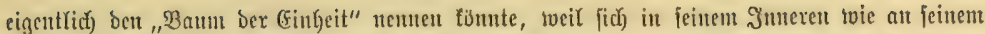

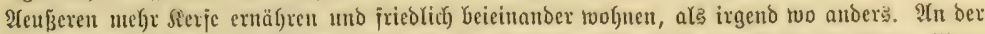

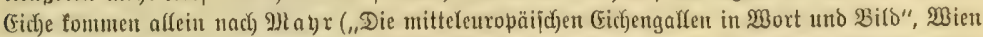

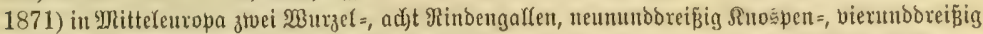

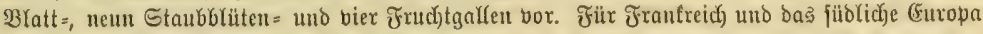

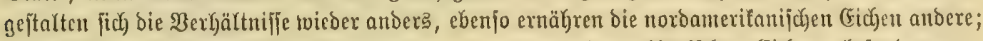

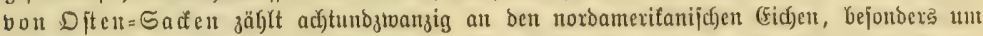

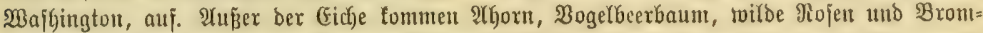
beeten in Betracht. Bou frautartigen Pflanzen find in biejer Beziefumg faum ber Rebe tuertf)

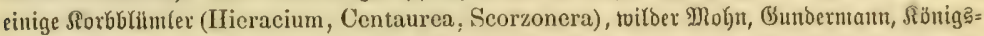

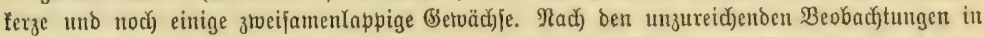
außereuropäijchen Sänbert, tweldye über biejen Gegenftand befannt getworben find, jef)lt es jton

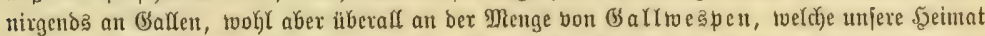

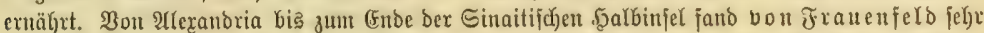

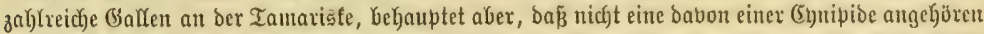

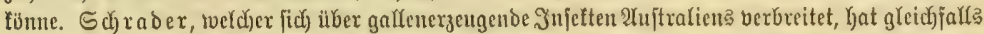

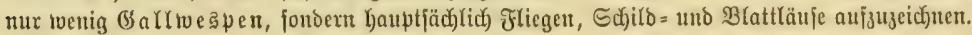

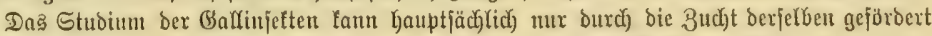
merben, weldye aber - Gebuld exforbert, vornelylich aus zroei Grilnoen. Sammelt mant bie

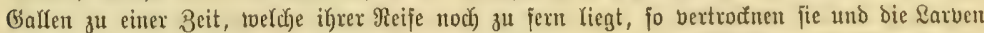

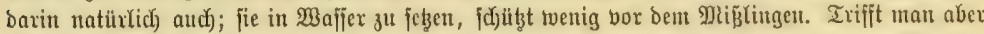
ben günjtigen 3eitpuntt ber Reije, fo folgt noch) lange nidjt baraus, baß man mun auch) Betamt=

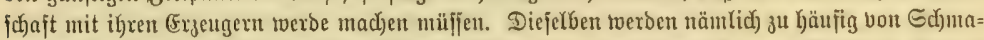

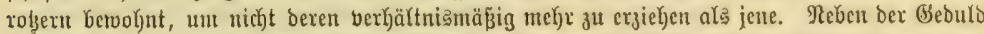

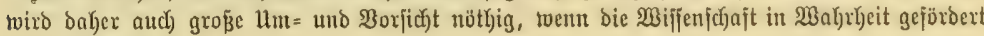
twerben foll.

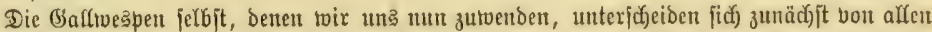

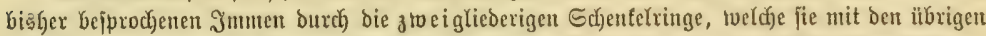

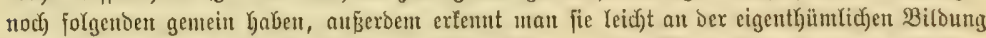

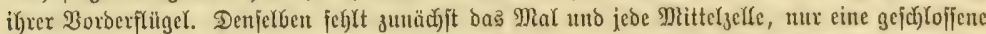

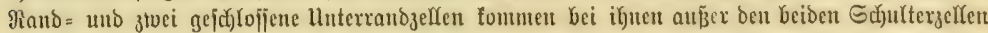

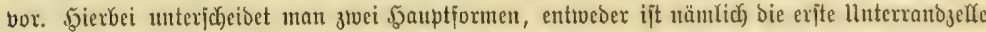

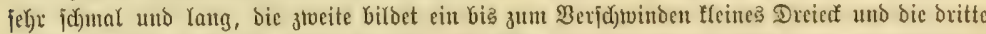

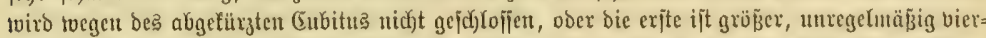

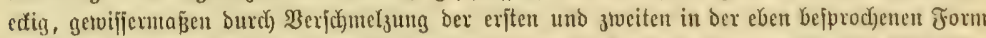

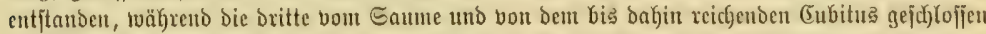

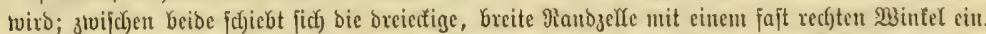

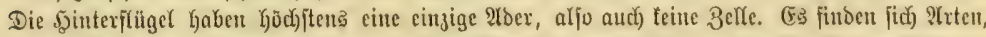

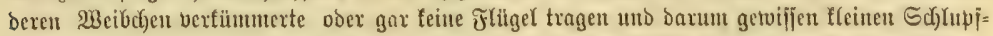

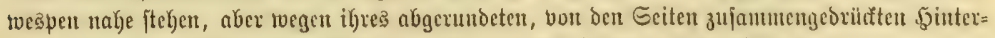

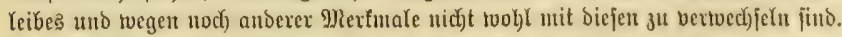

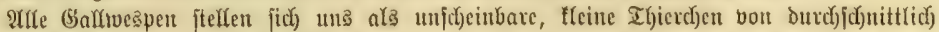

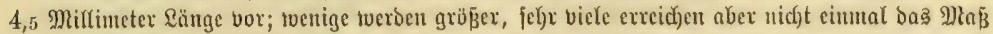

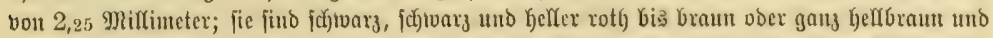

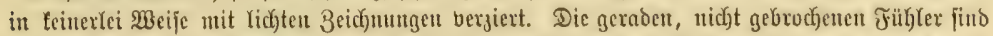

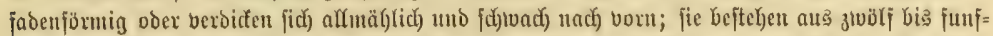

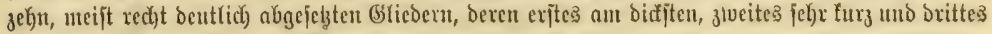

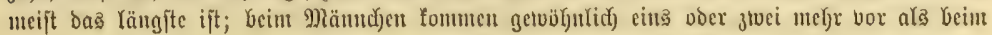




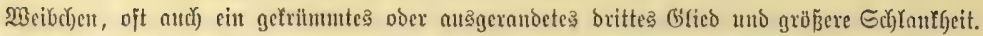

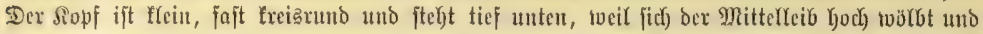

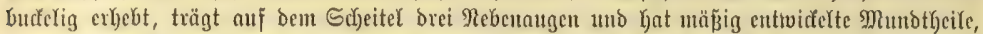
sine fel)r f(eine Dberlippe, Łurze, meift ztveizähnige finmbacten, am Ende verbreiterte unto gejranfte llnterficfer, cine breite, nicht ausgejonittene lluterlippe mit jebr furger 3uttge und faun vor=

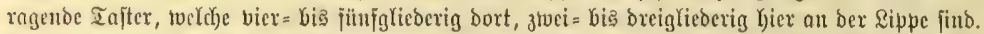

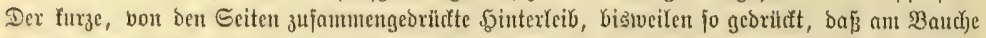

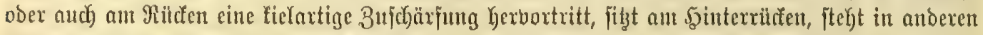

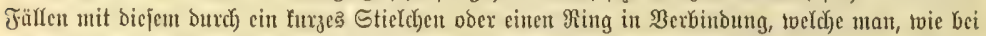

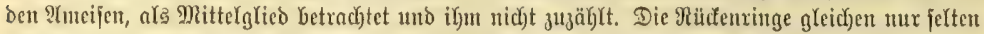

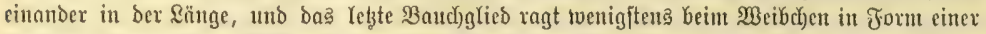

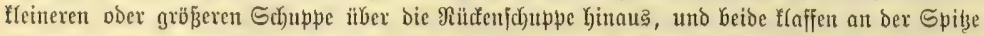

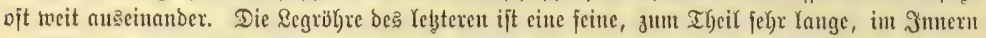

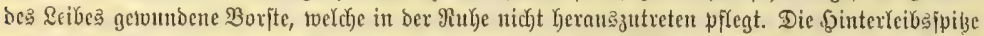

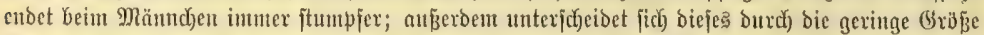

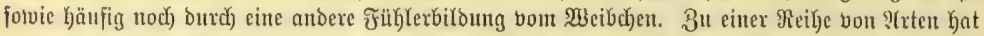

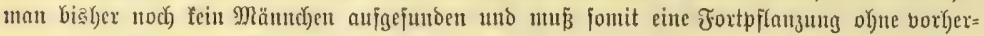
gegangene Bejudututig (

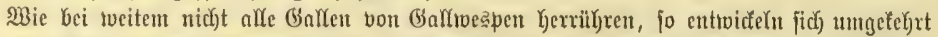

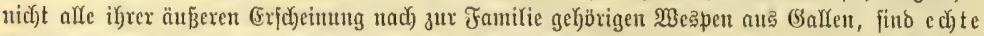
Gaflwespen, fondern ein gut Theil berfelben Yegt jeine (Eier an bereits borhandene, junge Galfen,

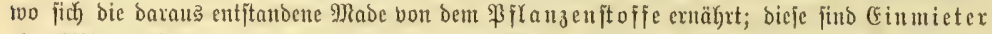

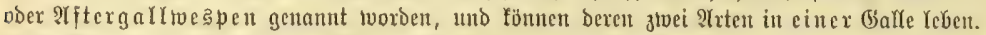

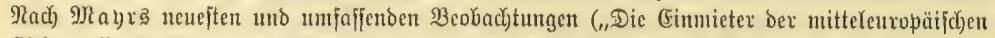

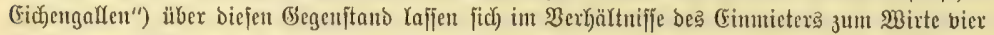

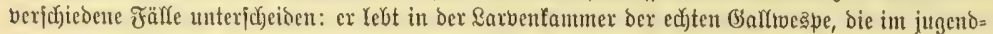

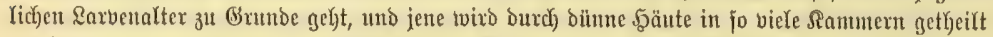

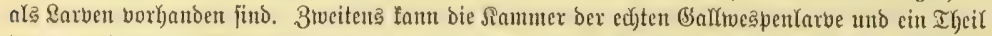

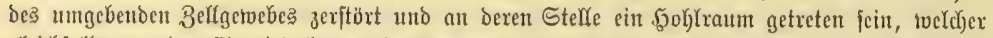

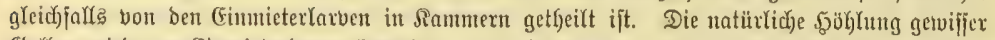
Galfen twird bon (Cimmieterlarben beivolynt und auch ertoeitert, ohne baß bierourd) ber urfprïng=

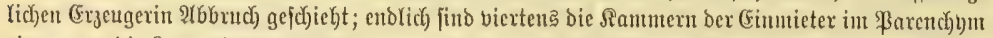

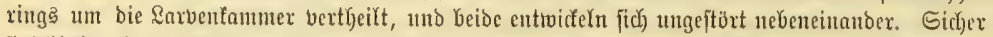
fino biather die brei Gattungen Synergus, Sapholytus und Ceroptres als (Einmieter erfannt woroent.

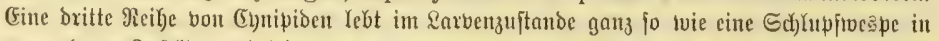

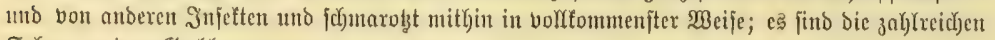
Schmarotzer= Siartroespen.

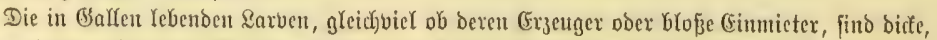

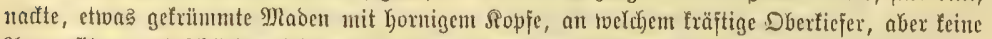

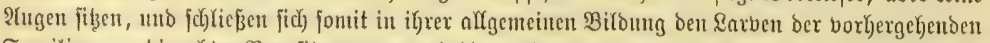

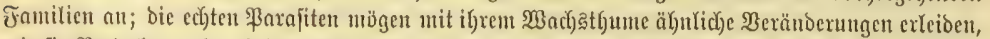

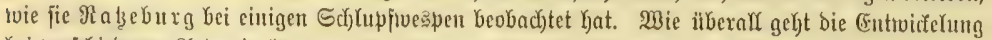

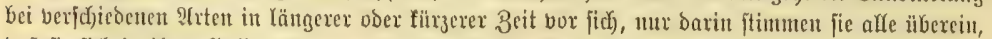

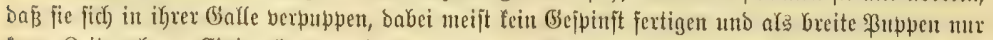

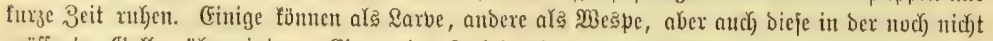

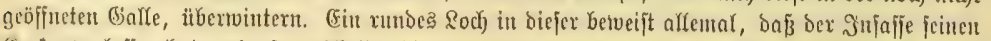

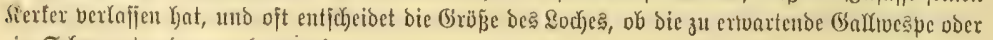
rin Schmarolzer Daraut hervorging. 


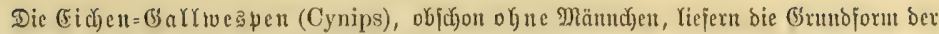

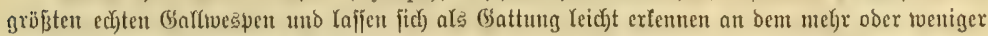

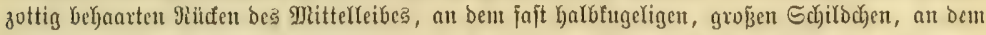

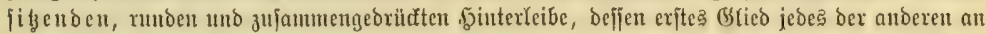

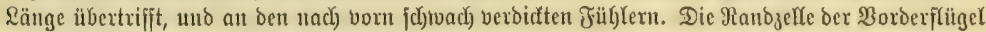
ift geftrecit, bie ziveite lluterrandofelfe fehr flein und breiectig und an bem Grunde jener gelegen. Die Siefertajter werben von finl, Die Rippentajter bon ztwei Bfiebern zufanmengefebt. Reuerbing

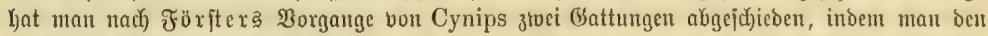

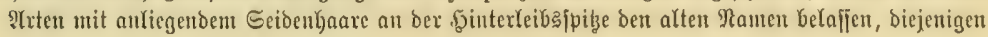

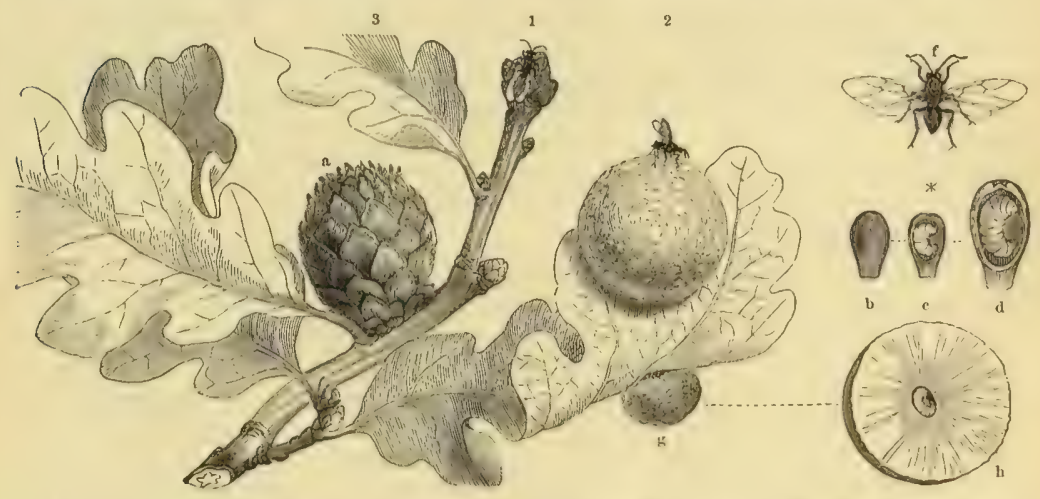

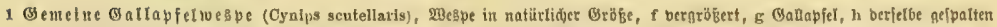

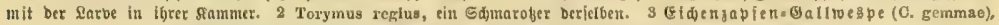
a. Balle, is acidoloficue, e geüfincte Rarbenfammet mit ber Laroe, d lebfere bergröbert.

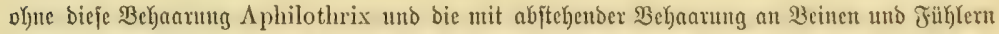
Dryophanta genaunt hat. Dicjer Spaltung ijt bei Beneunung ber wentig bejprodfenest Ifrten Gier feine ßechnung getragen worben.

Die gemeine (Gallapfeltocape (Cynips scutellaris Ol., Fig. 1 uno f) ijt die Berjertigerin

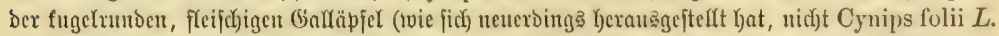

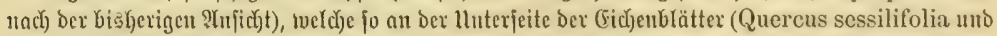

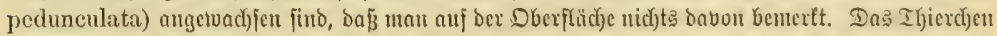

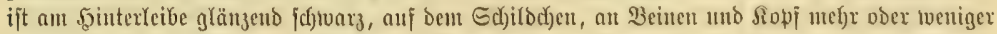

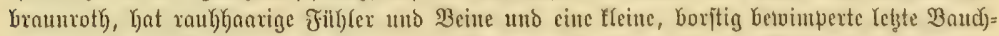

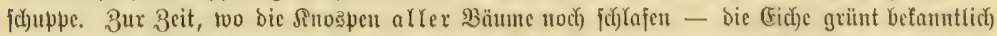

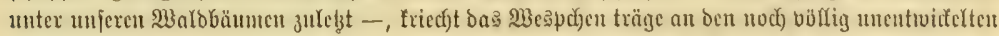
Sinospen untyer und fiticht cine unb bie andere an, un bei jedent Stidje cin Ei zu Yegen. Jït jeine

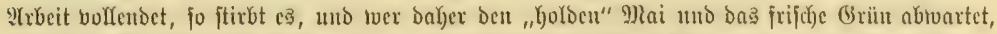

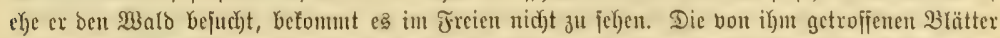

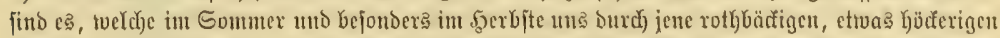

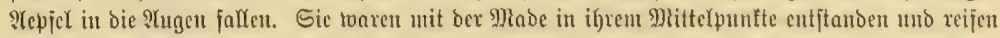

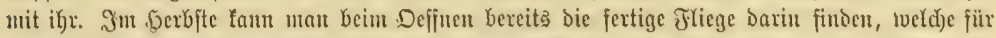

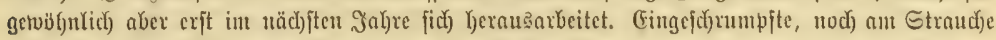

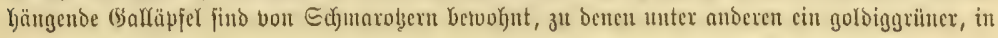




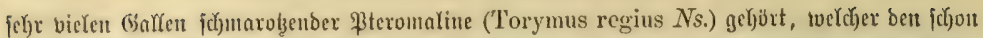

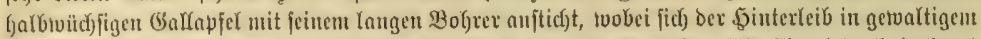
Bufel erhebt und bie đedzte Baud) bie Irt Drei: Synergus pallicornis uno Tschecki jotvie Sapholytus connatus.

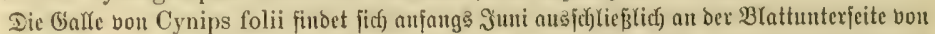
Quercus pubescens, ijt glatter uto, auggewadfjen, nแx von (5rbjengrübe. Cynips longiventris crseugt die ganz ebenjo bejchaffenen, aber roth uno gelbgeftreiften Gaflen an ben Blättexu Dex Eticfeicfe (Quercus pedunculata). Die oft mafjenthajt an Den Seitemippen mjerer beibent

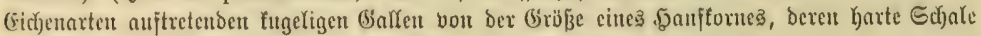

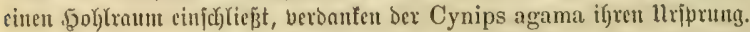

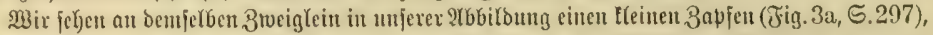

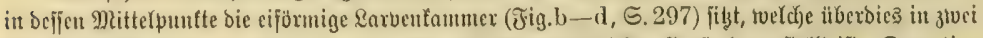

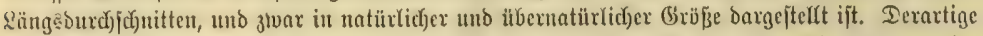

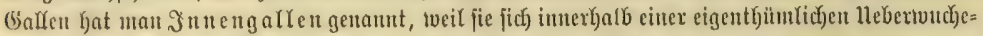

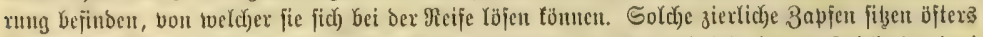
in gröferer Menge beicinanber an Den Spiben oder in ben Blattwinfelu junger Iriebe ber brei

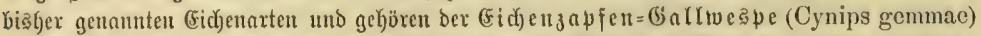

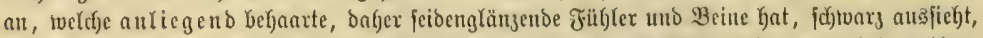

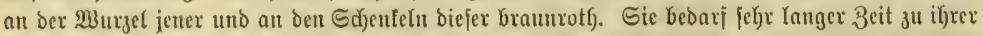

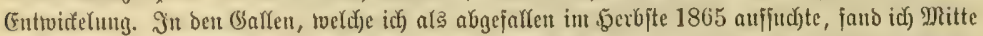
Sttober 1867 noch Yebende Earven, bie nie jur (Entrvidelung gefangt find. Bei fritleren Budf)t=

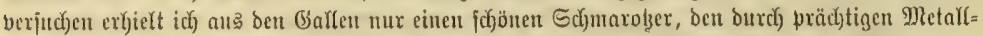

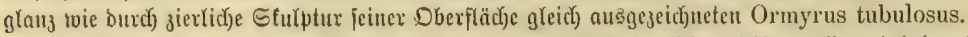

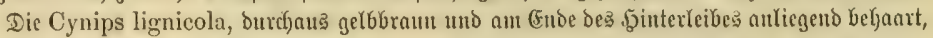

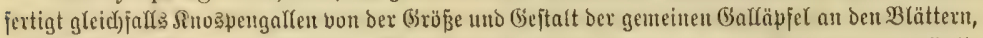

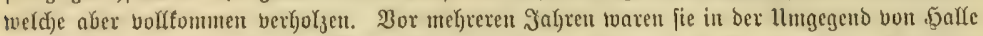

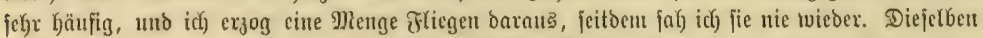

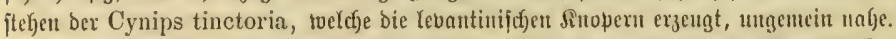

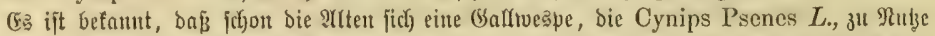

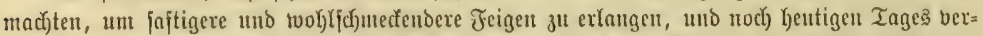
renoet man in Griect)enlano groß̈e Gorgfalt baranf, Die "SRaprififation" Der Feigen an ben ber=

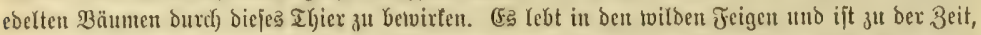

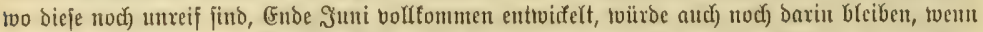

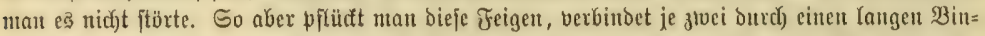

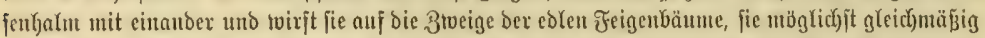

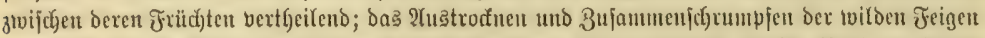

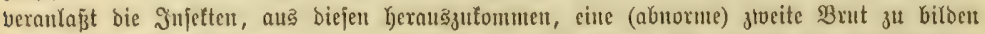

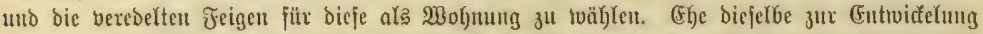

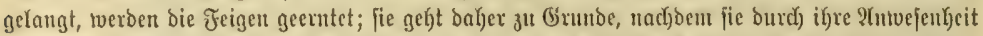
ben Eajtreidythutm der Frutcht vermefyrt Kat. Reueroings hat diefer Rerf Den Raunen Blastoplaga

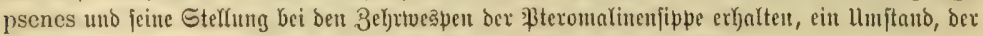

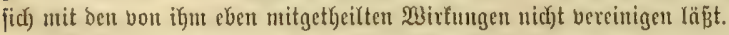

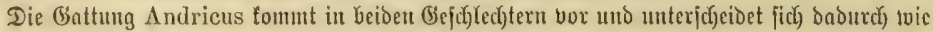

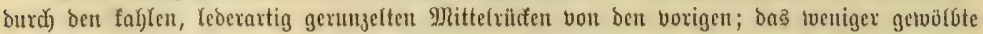

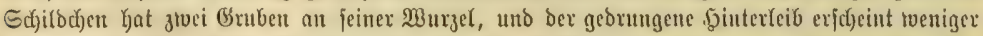

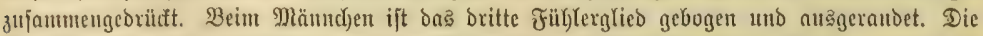

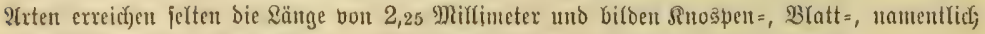

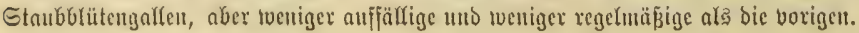




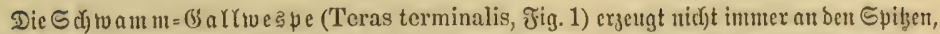
swie ber Beiname bejagen foll, fondern aud) an ben Seiten ber (Eicfenzlucige bie vielfantmerigen,

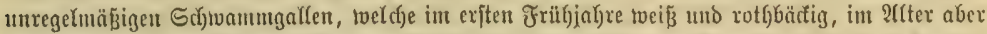

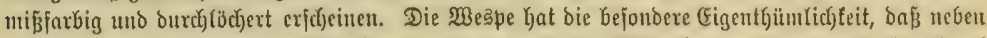

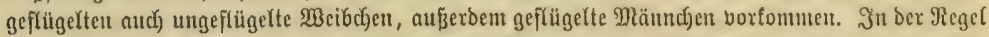

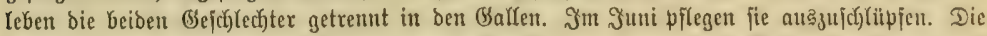

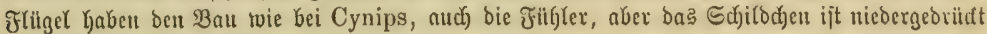

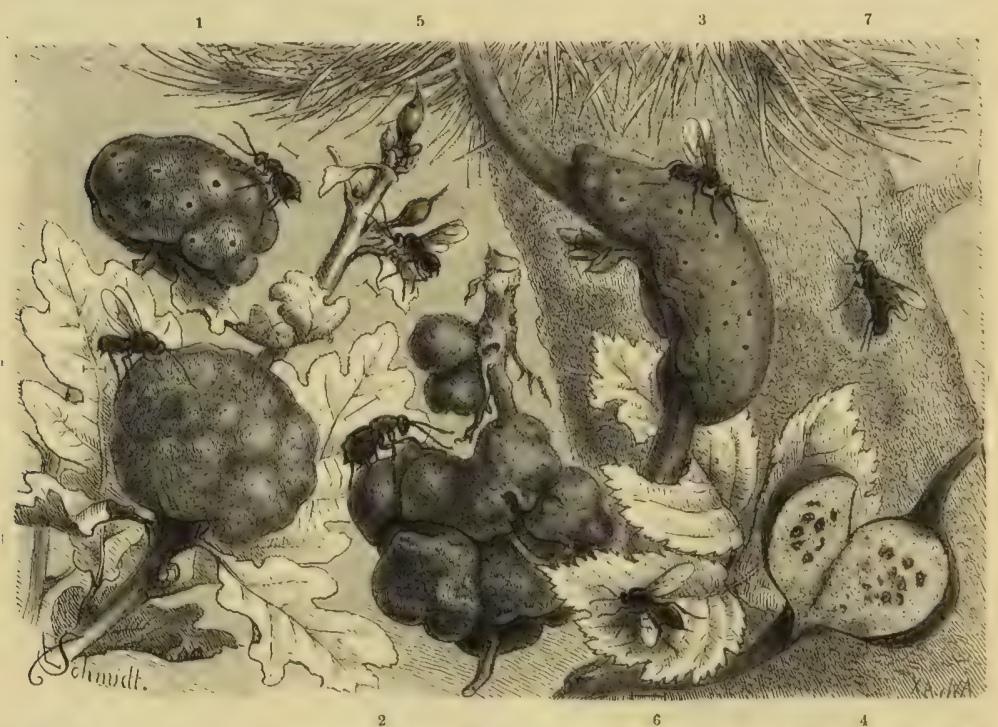

1 S

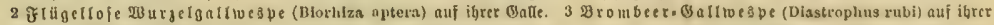
Galle. \& Eline bergleiden, Gatle burdidnitten. S Synergus facialis bel Gallen bon Oynips solitaria. 6 Figiteg scutellaris.

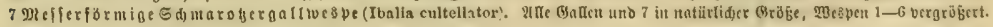

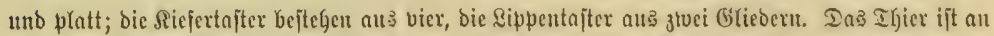

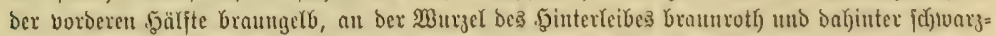

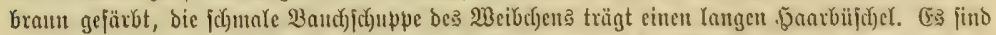

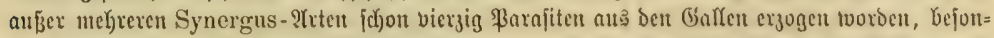

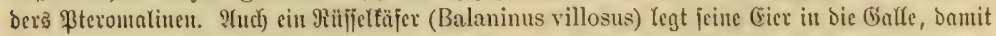

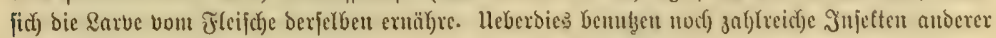
Dronung die alten Gallen, un Gier in bex Jugent eit Sbbach) ju findent.

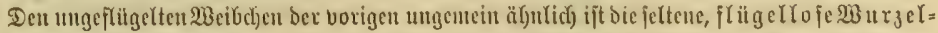

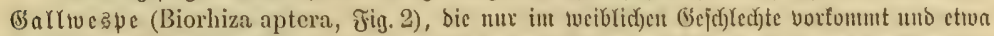

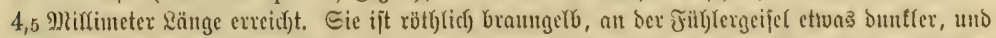

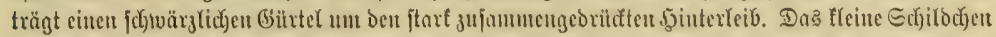

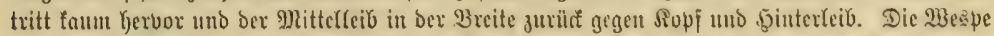

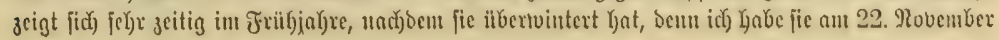




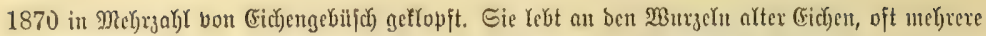

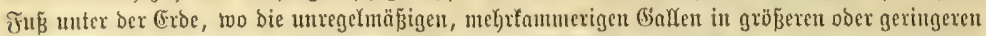

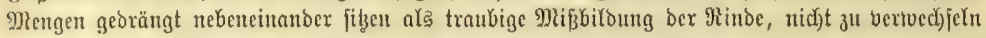
unit ben fartoffelähnlidjen, mebrtammerigen (baflen ber Cynips radicis.

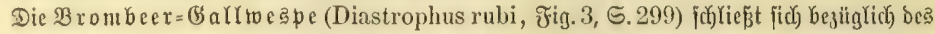

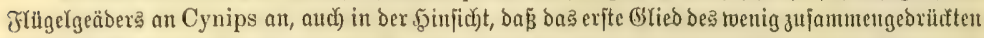

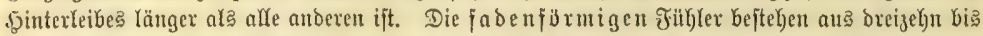

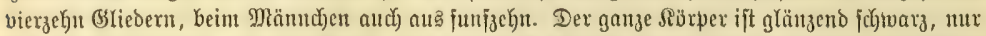

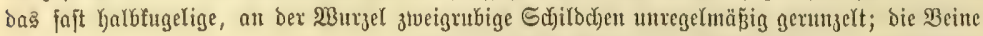

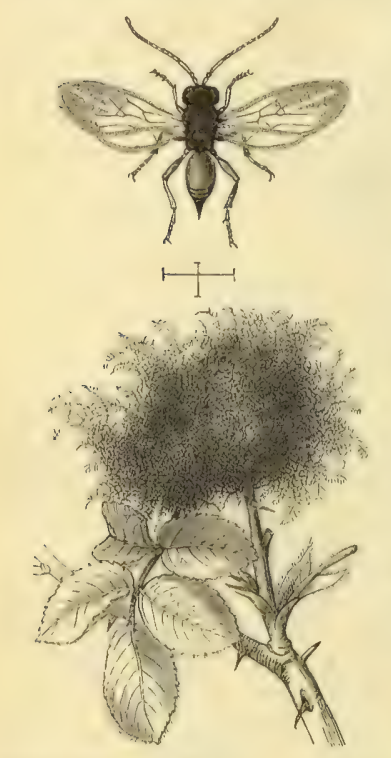

Rofen = (5) a frues ve (IRhodites rosae), bergrobert, und ifjec balle. jino braumroth Doer Kelfer. Dieje gedrungene Baffwespe crzeugt an ben Stengern ber Brombeeren ftarfe, oft wuns

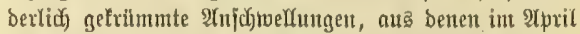

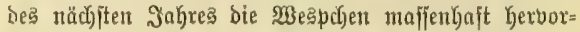

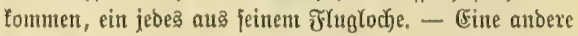
Irt, die Bundermann= Sarftoespe (Diastrophus glechomae), ift am vorberen Bruftringe befaart, an

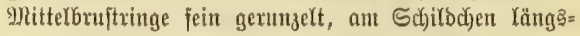
tunzelig, aljo entjchieden toeniger glänzento ala bie vorige Axt, von weldher fie fich in ber Färbung nicht unter: fidjeibet. Sie erzengt an ben Bundermanue (Glechoma hederacea) jơbon roth gefärbte fugelige, eintanmerige Gallen mehr fleifudiger Ratur.

Die gemeine Rojen=Osarrwespe (Rhodites rosae) uno ifre ivenigen Battungsgenofjen verbinden, went ber $\mathfrak{B a u}$ ber $\mathfrak{B}$ orderfliigel in $\mathfrak{B}$ etrad)t fonmt, bie beiden oben ertwähnten Formert miteinander, injojern eine breite oreiectige Ranozerfe uno gleidjzeitig eine breiectige, unter ifrer Wurgel jtehenoe groeite Unterrand=

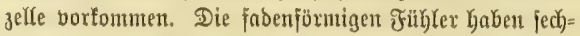
zehn twarzige Brtieber, bie Riefertajter ihrer vier, bie Sippentajtex nux zwei. Der Sopf ift breiter als Der Mnit= telleib und nich)t jo tiej Gerabgerüctt an bicjent, twie bei Cynips, twelcher (Sattung bieje hinfict)tich ber alfgemeinen

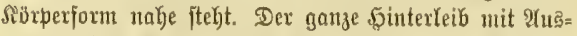
nalyme feiner Epitze uno die Beine find braumroth), alles

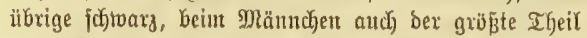

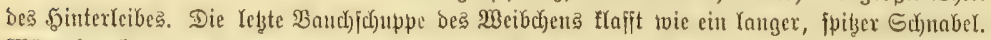

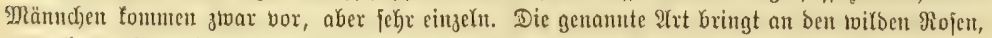

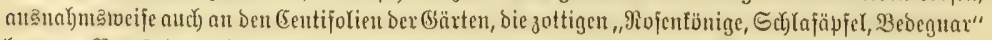

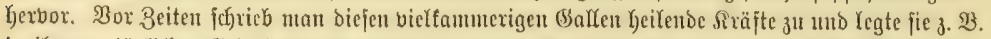

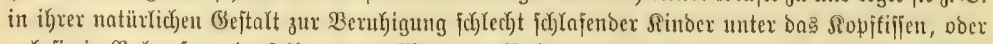

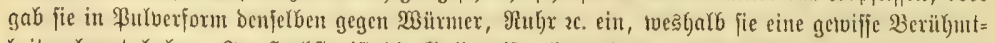

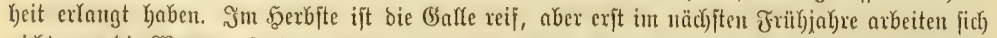

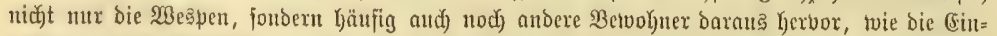

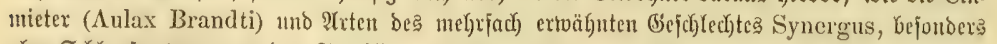

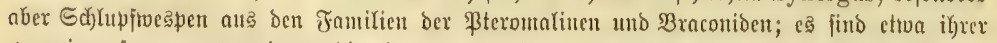
ztwanzig zufammen, von benen bie einen bor, andere nad) und nod) andere gleichseitig mit bem

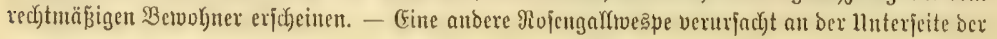




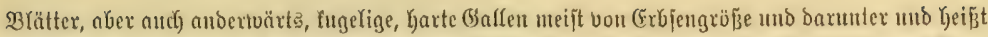
Rhodites Eglanteriae. Diejelbe ift ber vorizen jef)r ähnlich), Gat aber Geflere frlïgel, ftatt bes Drei=

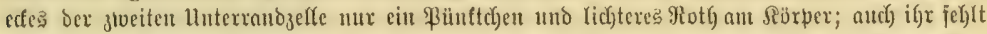

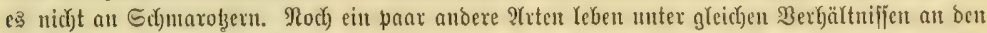

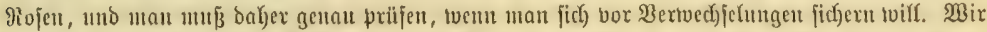

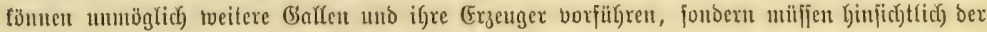

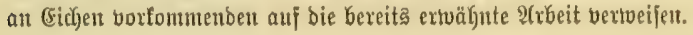

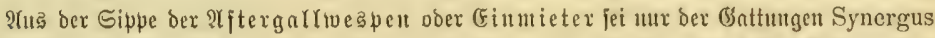
bon ben brei oben bereitz genannten und einer ztweiten Aulax gedad)t, beren beiber flügelgeäber

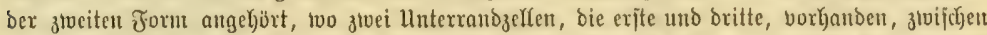

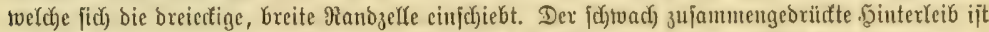

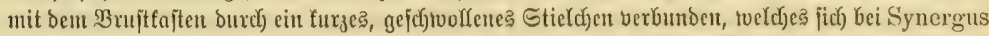

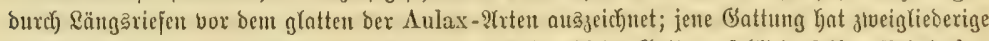

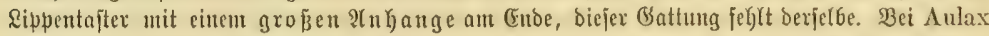

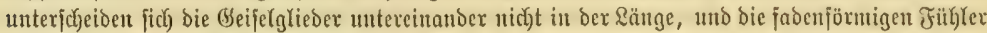

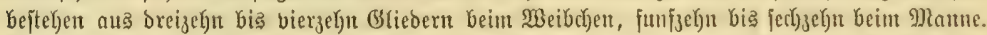
Der neben ber Bfaffe von Cynips solitaria bargeiteflte Synergus facialis (Fig. 5, 5. 299) lebt als (Eimnieter in biejer Galle, bei Cynips glutinosa, albopunetata, Teras terminalis, Spathe-

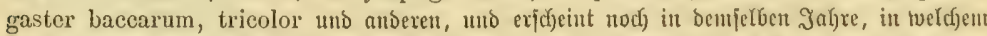

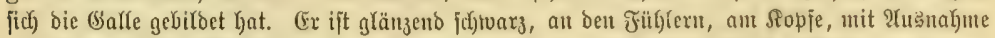

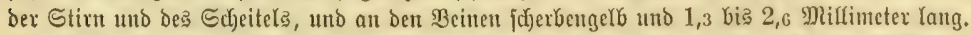

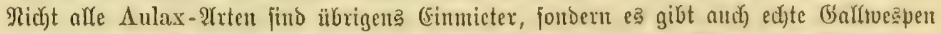

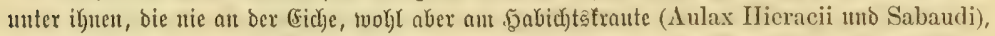

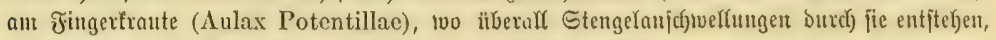
an Mohne (Aulax Rhocadis), und zivar in ben Sapjelt, Yeben.

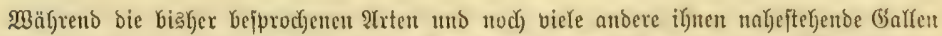

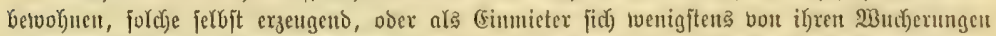

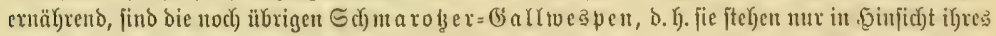

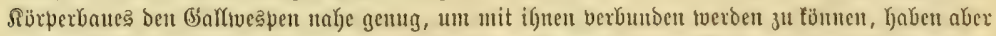

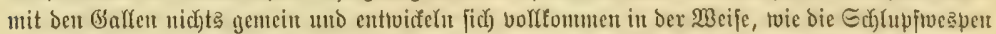

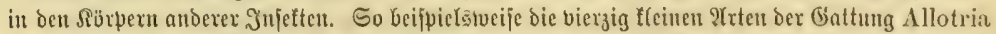

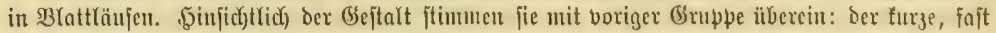

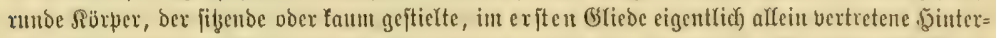
Yeib uno bie jueite Fritgelform fommen Gicr tvic dort vor; bie polirte Dberfläct)e des fleinen

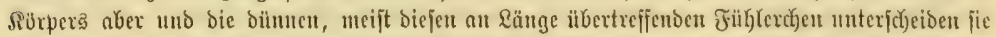

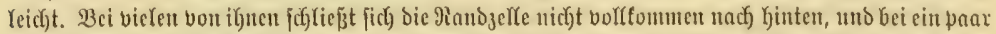

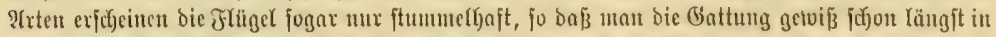

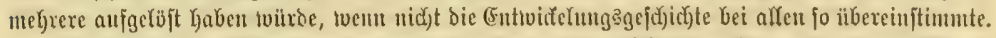

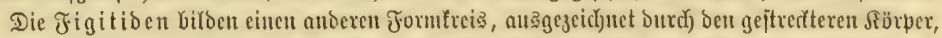

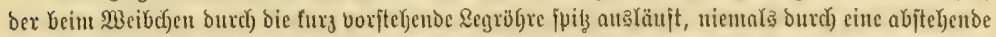

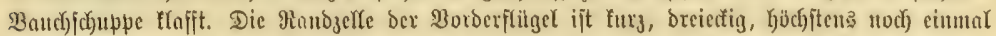

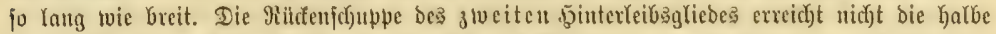

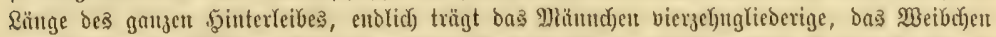

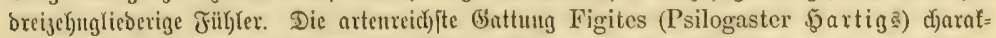

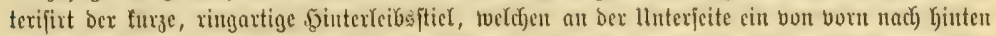

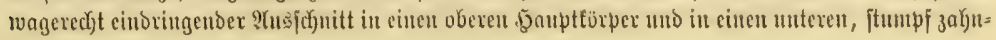




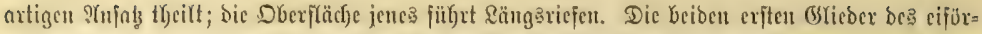

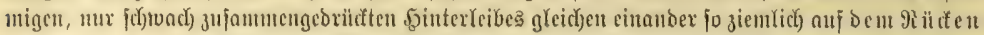

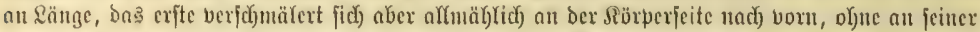

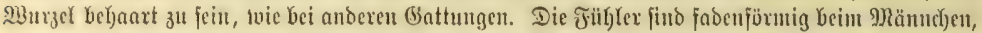

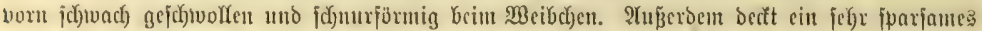

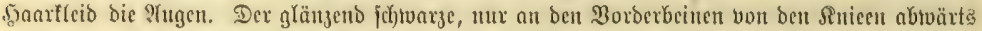

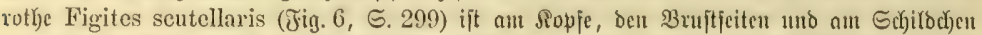

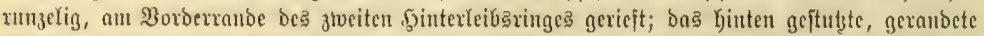

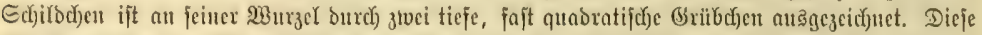

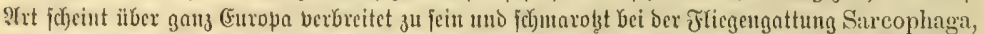
tvie iiberhanpt alfe Gippengenoffen, fo weit man biejelben biăber erjogen Kat, von Fliegen= Yarven Ieben.

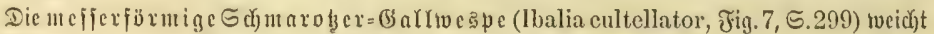

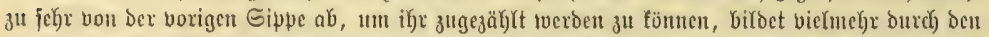

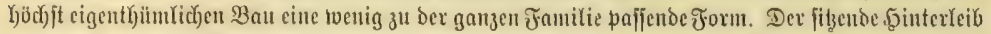

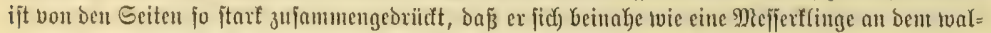

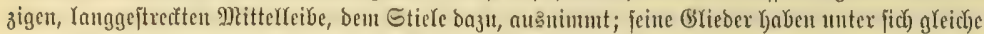

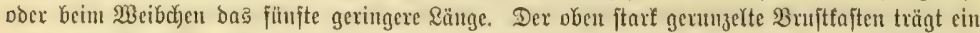

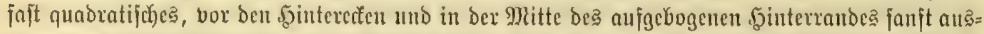

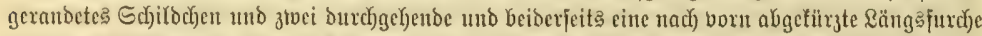

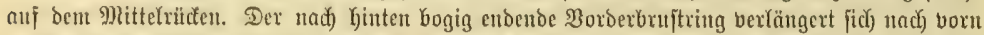

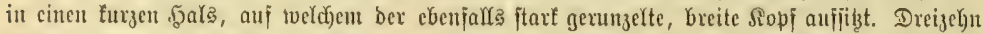

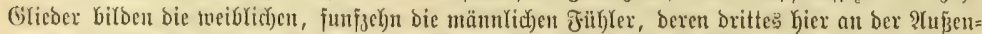

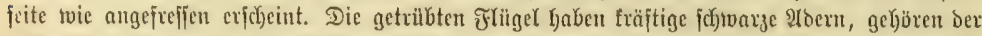

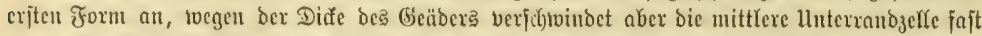

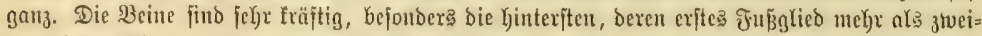

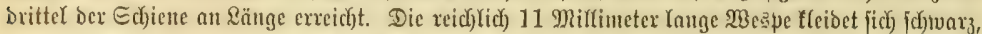

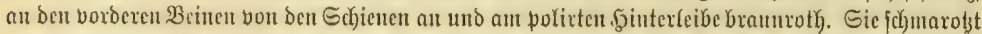

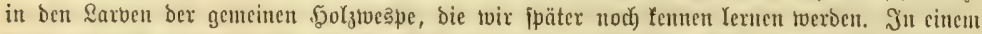

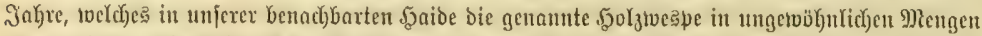

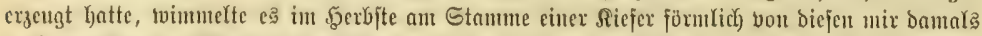
nod) unbefaunten Sdymarolzergalftuespen, namentfic) beren Mämnd)en. Seitben ift fie mir in

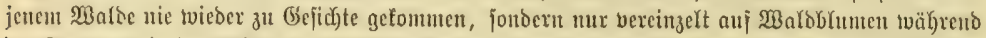

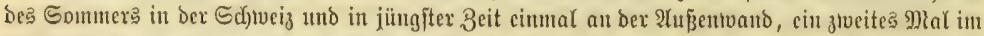

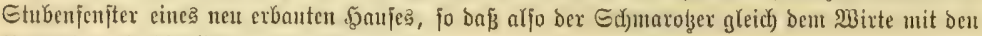
2łauljörgern in bie Gebäube beridjleppt wiro.

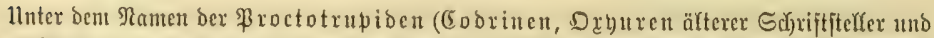

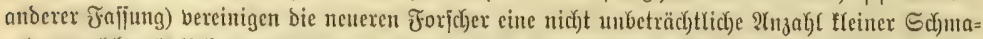

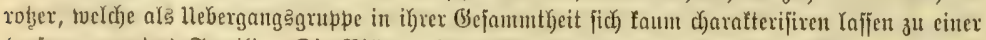

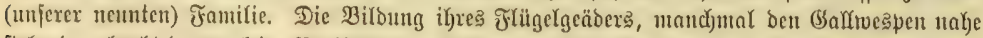

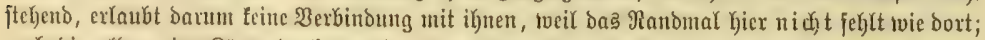

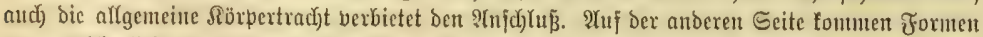
vor, welche fich bex jolgenden Fantile zuntigen, wie bie gebrodjenen Fühler, ber Mtangel jeber

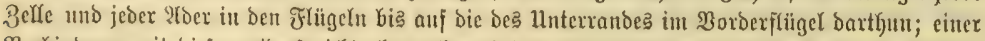

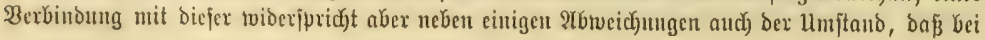




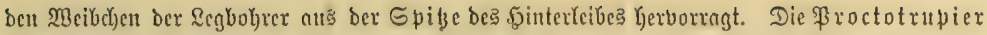

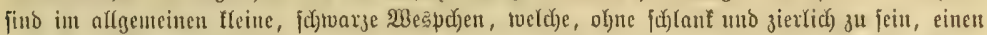

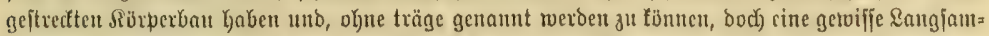

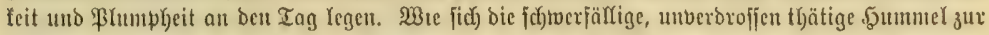
svilberen, fahrigen, in allen ifyren Betwegungen rajacheren Eandbiene ober zu anberen Biencuarten verhält, jo bie \$roctotrupier zu ben (É)alcioiem. Sie bemerfen einen Gerannahenden Jeinto nicht

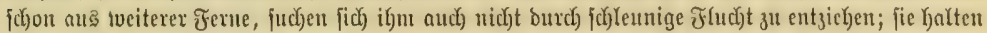
fich) ant riebjten an feuchten Etelfen, unter abgefallenem \&aube, in bent unteren Schichten bidyter

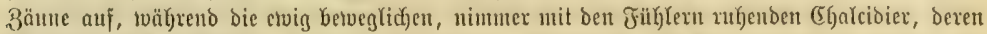

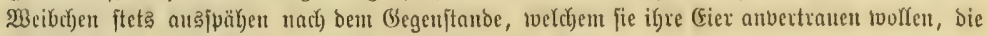

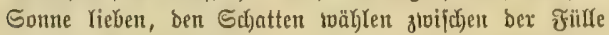

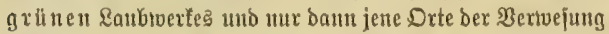
auffuchen, twenn fie genöthigt find, bei Kerannahentent Minter ein jickjeres Sager zu bezieken gegen befijen verberb=

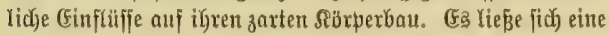
Reike ber jiertidyjten Formen borjübren; bod) too toäre ba

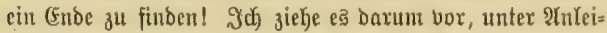

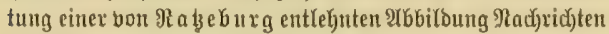
iiber bas Betragen eines biejex Thierchen zu geben uno gleidyzeitig eine Form borzuführen, weldye Yebbait an bie folgenbe Fanilie erinnert und zu ifyr überfeitet.

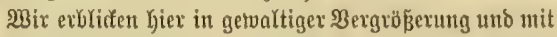
auşgebreiteten Flügełn die weibliche (Fiertoeąpe (Teleas

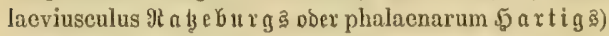
und in ben llmxiffen ber fiłsenden Figux ben ungentcin ähn=

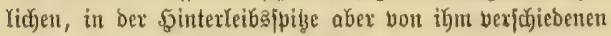
'l'eleas terebrans, 2eibe Wrten und nod) ztvei andere, welche Rabeburg babon getrent rifjen vill, haben cine glänzento jodwarze, an ben \$ilpten uno Schenteln brauns f(c)twarze Färbung unb eine Sörperbildoung, weldye unfer

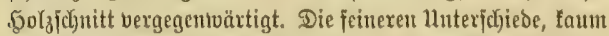

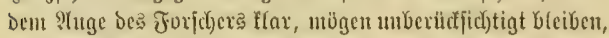
ftaft Derfelben curige Bemerfungen iiber Die \&ebensistocife

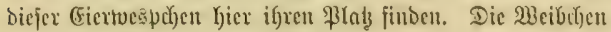
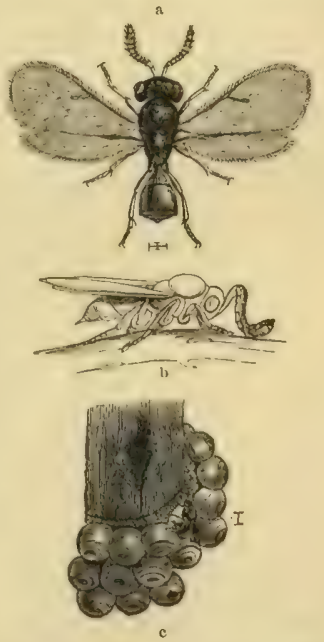

a (Eierioespe (Teleas laeviusculus), b Teleas terebrans, c Fier bes oingcifpinners, toclaje cin Teleas anjifidjt. 2utues ftart vergröfort. Yegen ifre Fier in bie von Epinnern, uno zoar bas erftere

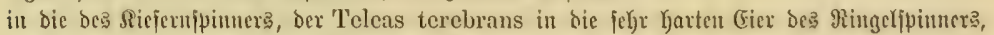

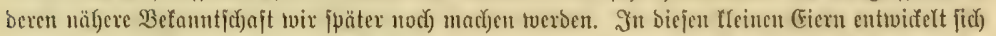

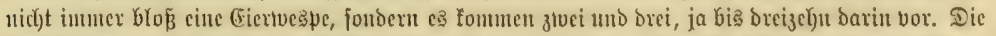

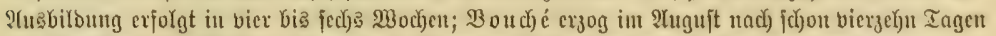

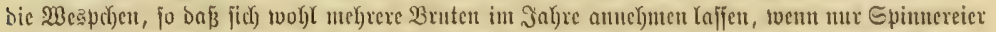

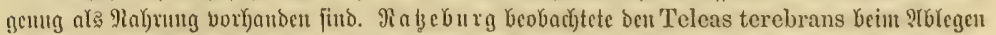

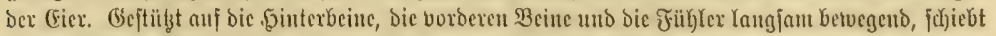

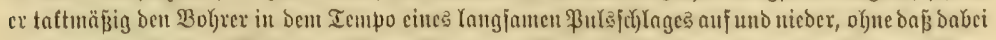

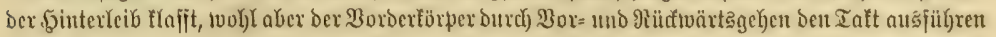

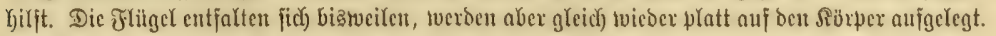

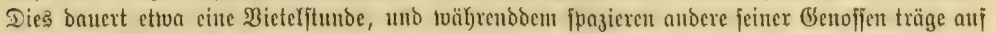

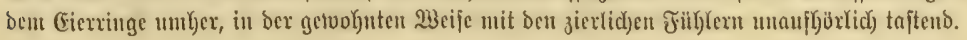




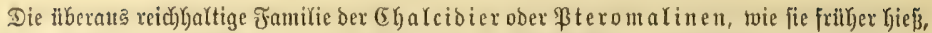

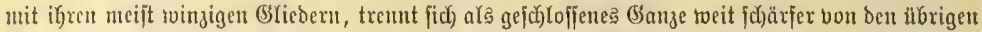

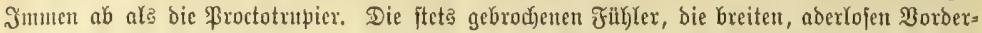

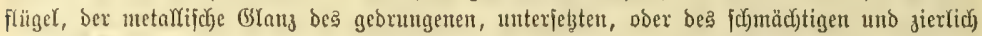

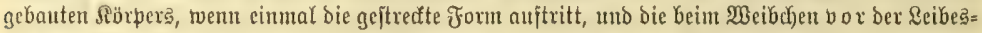

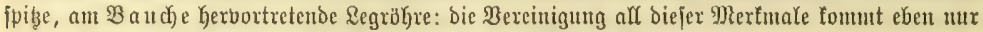
hier bor uno anteridjeidet bie (SGalcibier von ifren nädjiten Bertwanoten.

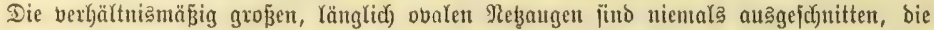

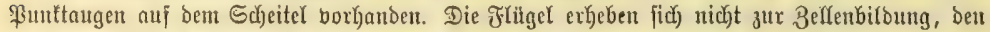

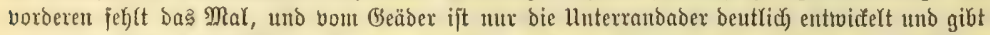

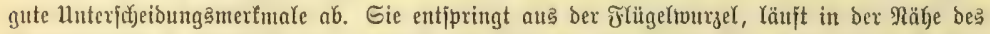

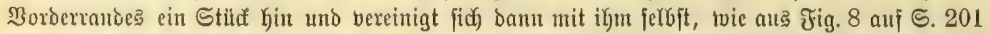

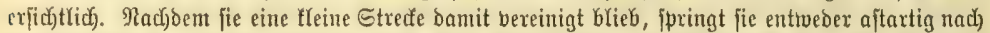

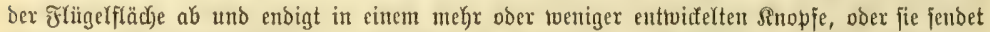

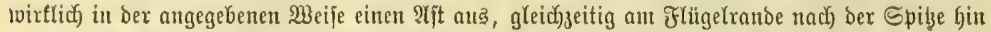

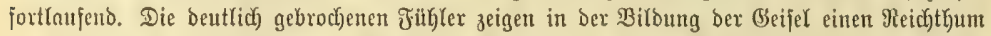
an Formen und mand)

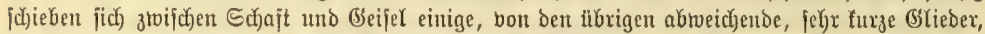

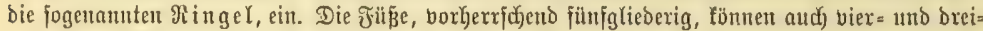

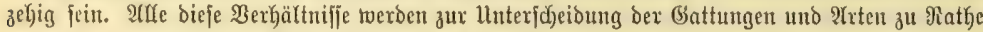

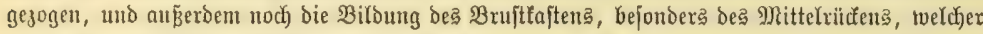

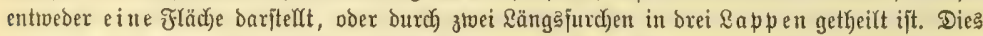

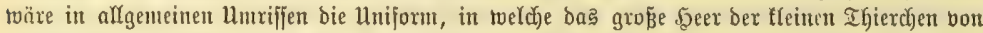

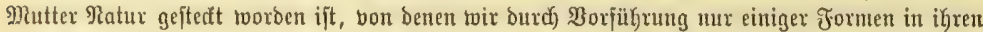

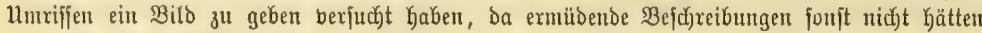
vermieden twerden fönnen.

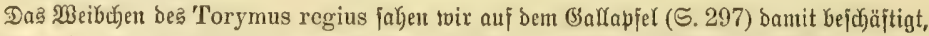

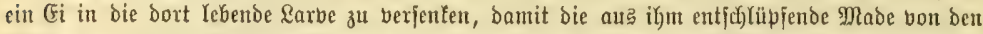

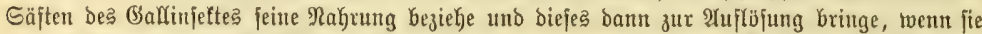
feiner nicht mehr bebarf. Dabei berlyart es ruhig iu der angegebenen Stellung mit flaffender

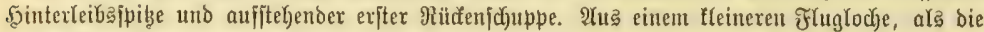

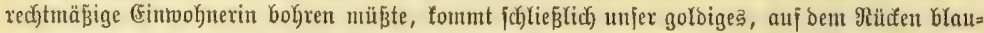

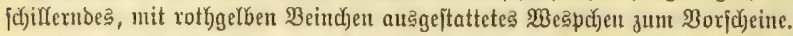

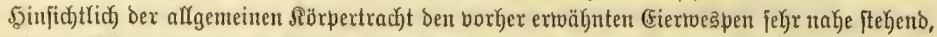

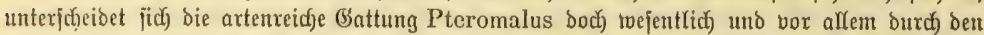

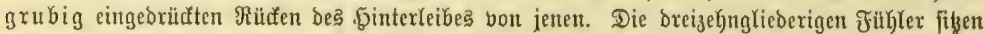

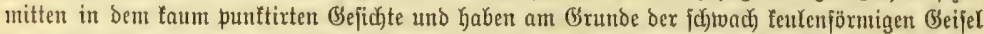

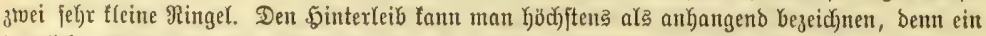

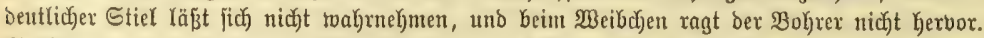

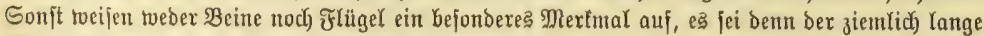

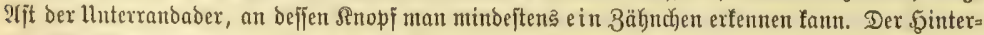

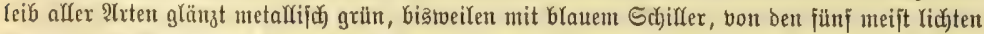

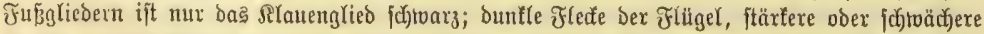

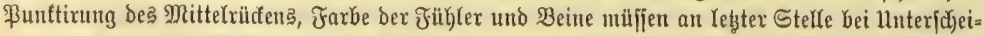

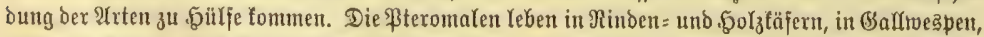
einige in Sdyild = แnઠ $\mathfrak{B l a t t l a ̈ u j e n , ~ F l i e g e m m a b e n , ~ u n \delta ~ b e r ~ j e f ) r ~ v e r b r e i t e t e ~ P t e r o m a l u s ~ ( D i p l o - ~}$ lepis) puparum, Fig. a, it ben Puppen mefrerer Tagiff)netterlitge, wie in Deten ber (Effalter uno

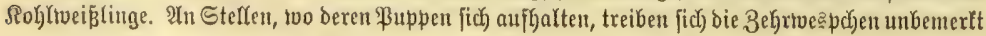




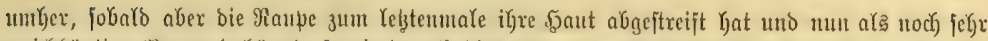

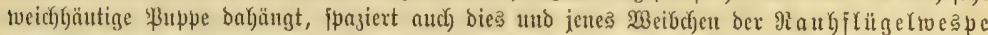

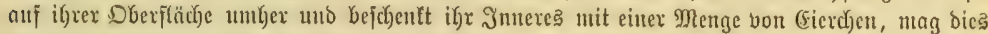

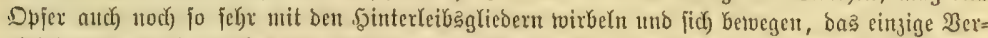

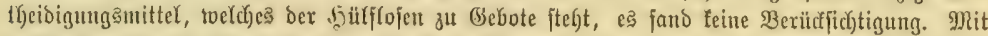

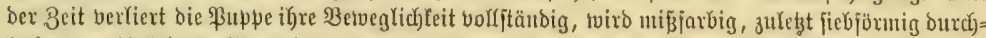

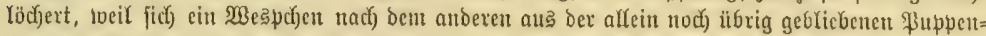
haut heraubbohtt, fobalo jeine Beit gefommen ijt, b. h. jobalo neue Ed)(ad)topjer für die legendent

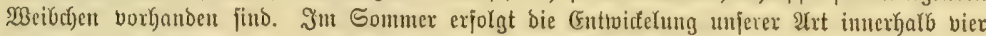

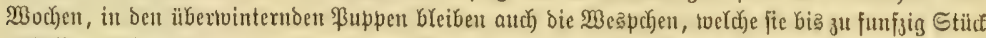

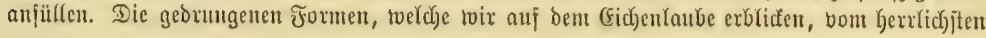

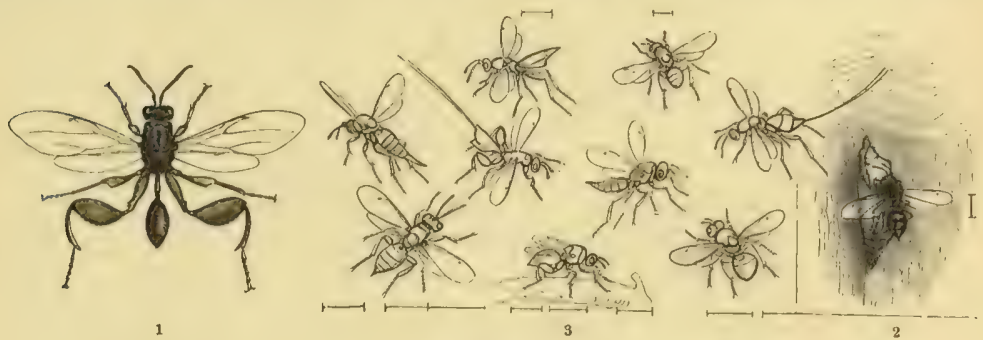

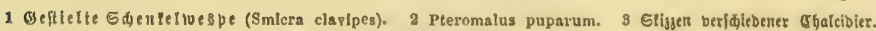
2uts bergröfert.

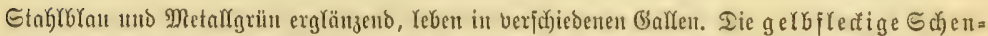

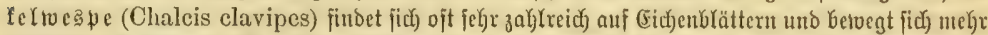

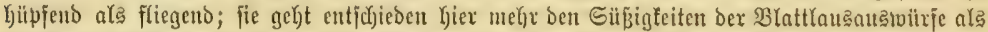

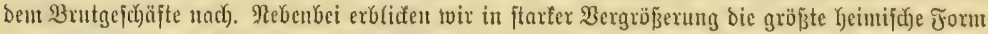

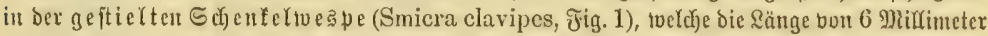

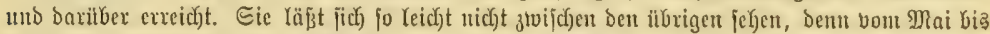

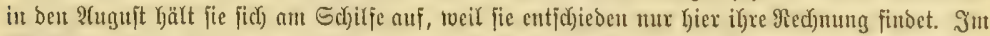

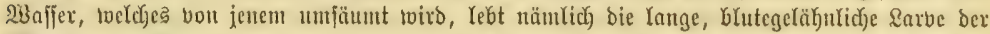
23affenfliege, arbeitet fid zur Berpuppung aus Dem Wafjer Keraus und judjt feudjte (Erde auf.

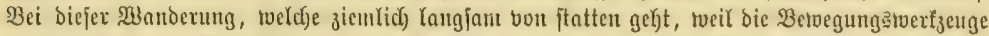

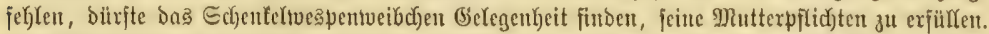

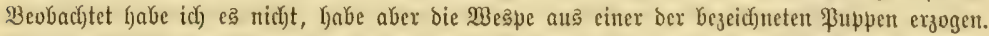

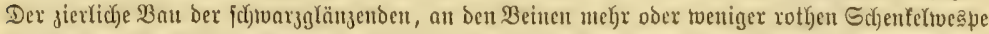

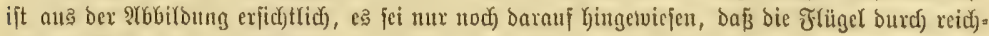
ficheres (Seäber von ber (Einfad)feit ber ilbrigen Jamiliengenofjen abtweid)en.

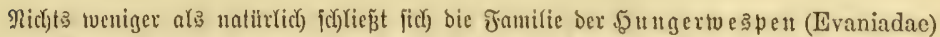

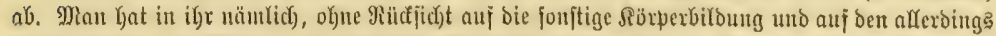

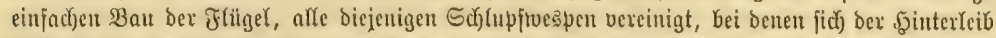

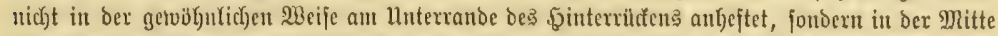
ober über benifelben, und noch einige andere ?rten Ginzugefïgt, weldje fonjt fein llnterfommen finden formten.

2brebns suicrleben. 2. Tuflage. IX. 


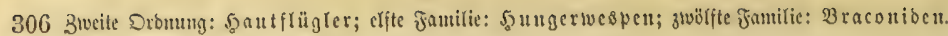

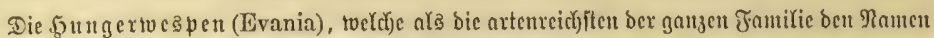

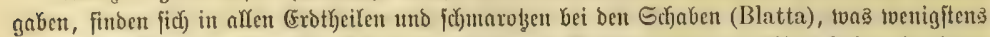

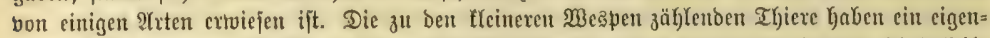

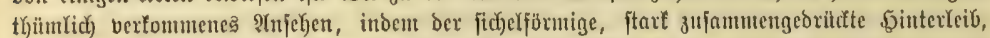

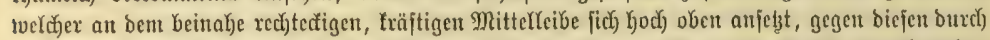

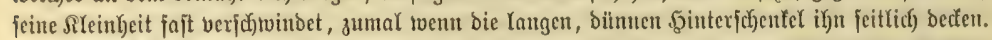

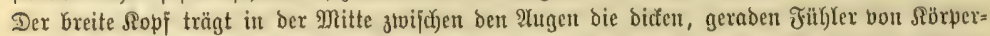

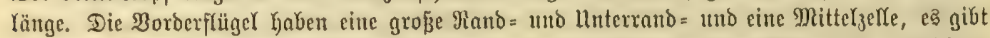

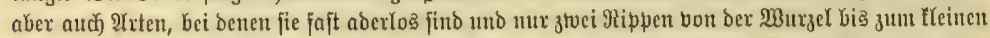
Flitgełmale aujanweijen haben. Dieje trente man unter bem bejonderen Stamen Brachygaster yon Evania uto mußste unter anderen bie fleiue \$ungerıespe (Br. minuta oder Iyptia

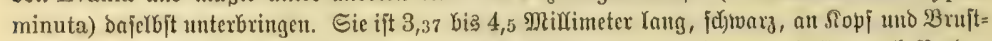

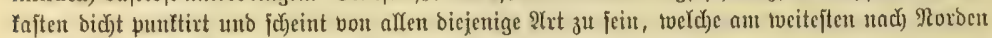

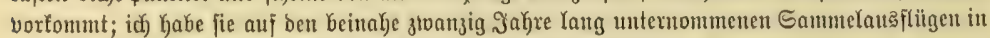
ber llmgegeno bon .5alle exjt cin einziges Mal (16. Puguft) aut einem fanbigen Brabenrande gejangetr.

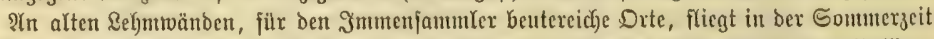

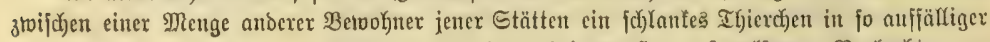

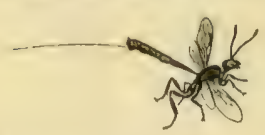

Pfeilträßer (F̂̀nus jaculator), natiirlidje (\$röge.

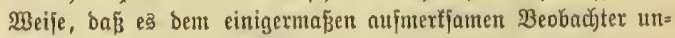

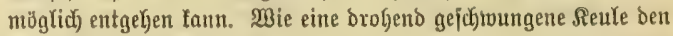

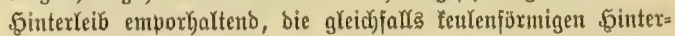

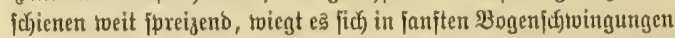
Gart an ber Mauer und wiro faum mübe; denn nut jelten jiebt

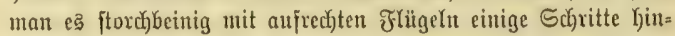
wandeln. (Es tit bie bei mauerbewobnenden Jautflüglern jod)ma=

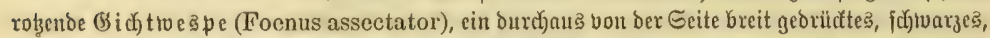

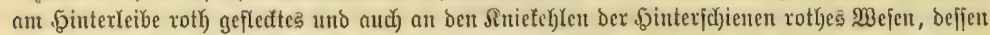

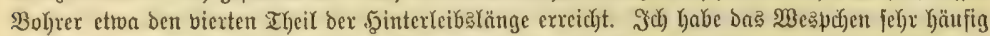

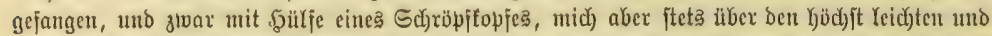

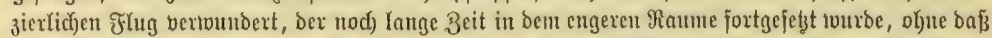

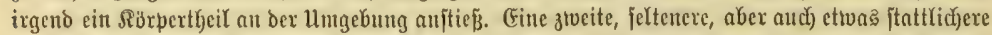

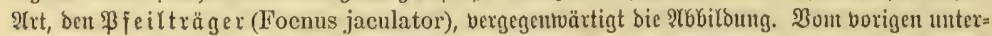

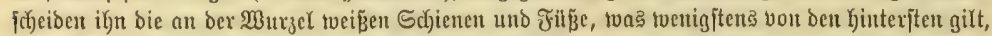

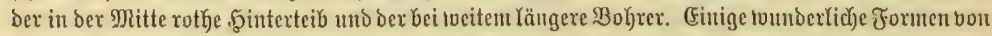

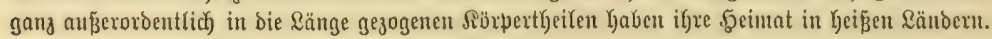

Die Sch) Iupfrespenvertuanten, Braconiben (Braconidae), unfere zwülite fantilie,

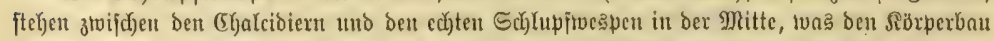

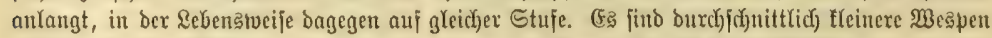

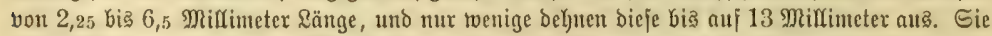

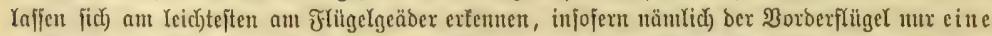

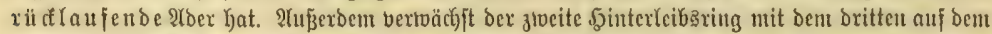

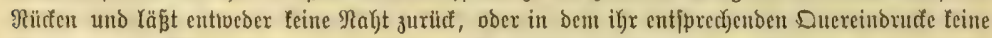

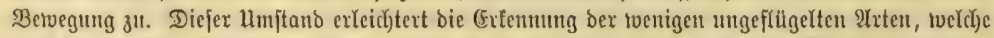

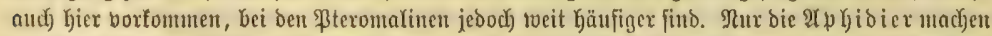

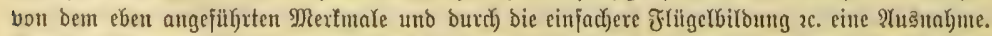
(Einzelne jeltenere Fälle abgered)net, find bie geraben Füblet oer Braconiben faben = ober borften= 


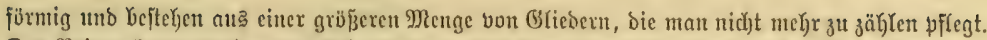

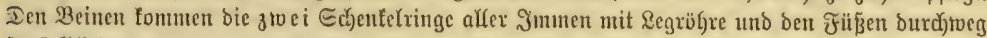

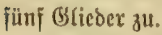

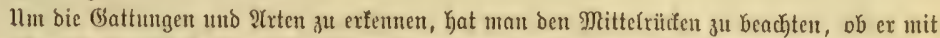

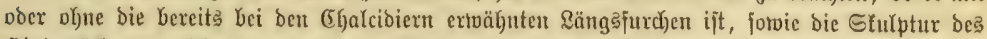

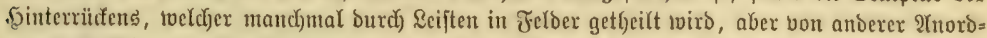

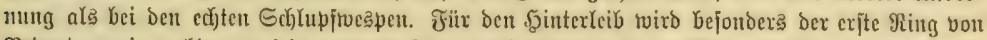

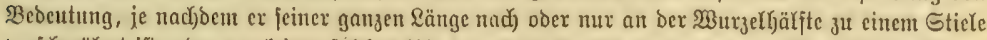

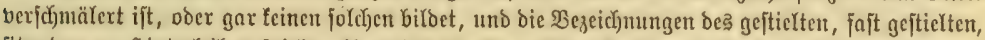

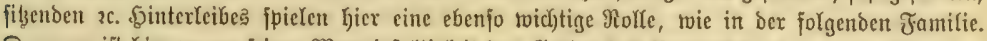

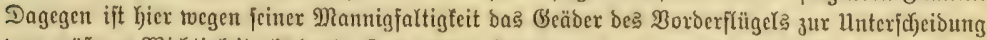

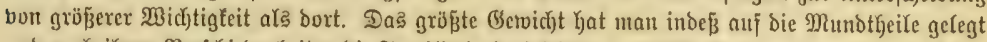

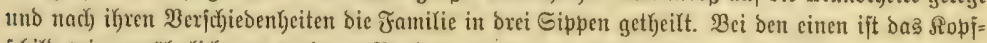

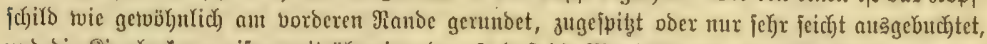

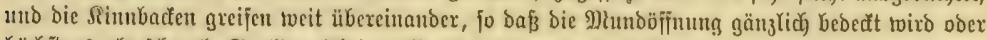

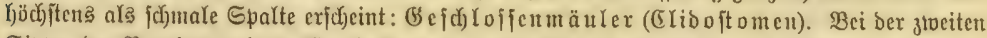

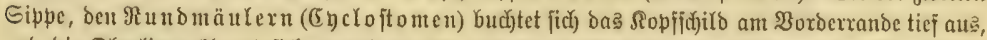

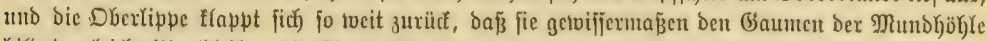

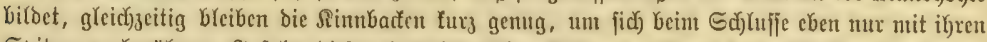

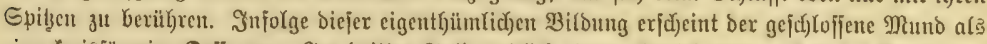

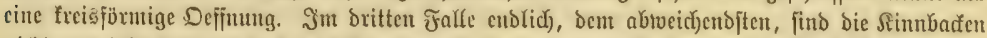

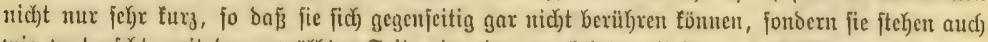

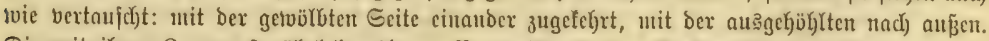

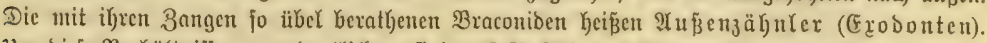

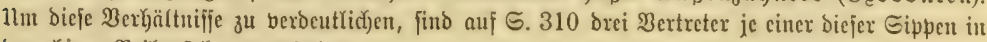
ber obigen Reifenfolge borgefüfrt.

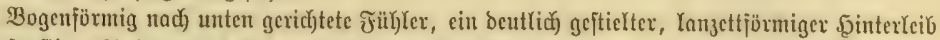

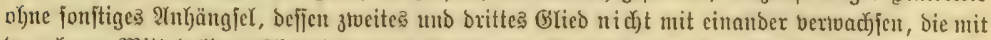

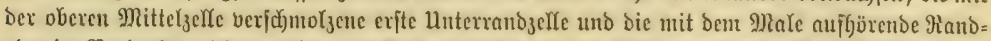

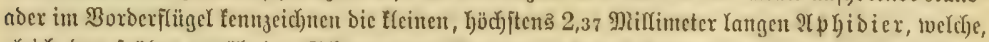

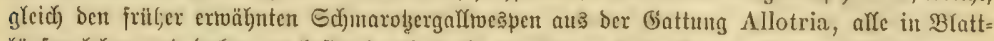

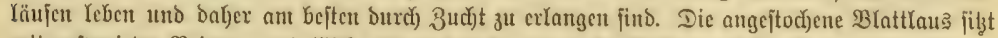

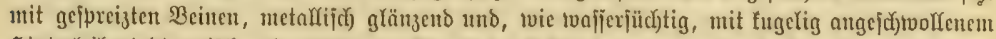

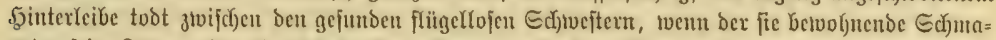

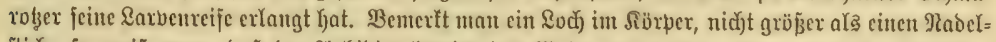

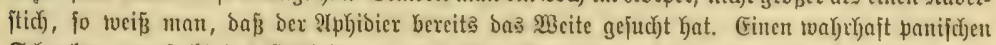

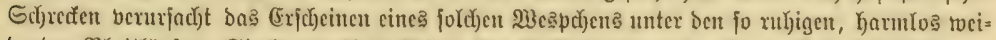

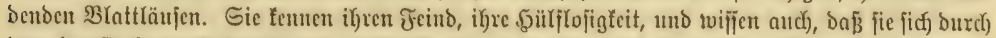

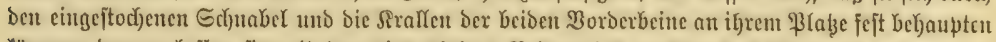

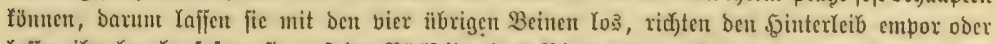

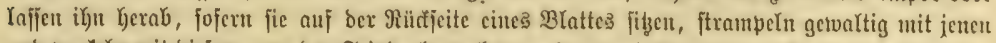

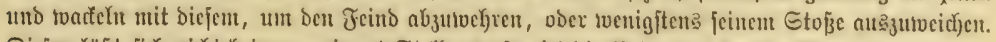

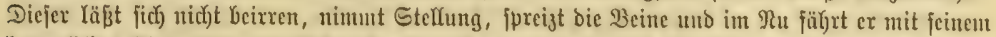

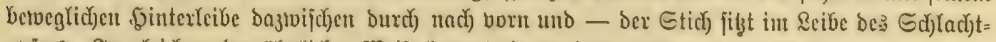

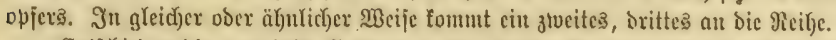

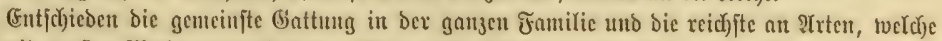

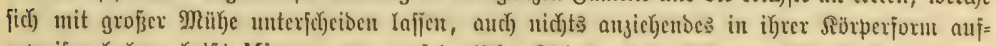

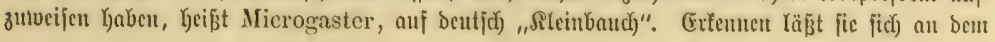




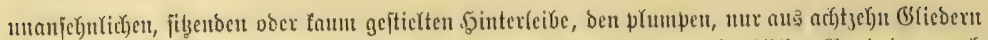

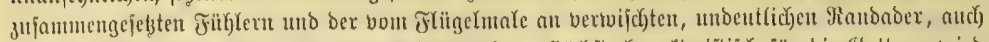

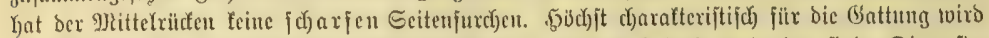

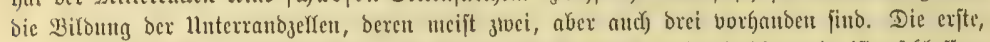
unregeไmäpig ject)

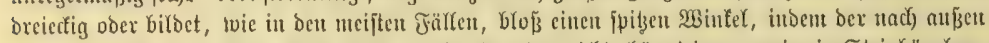

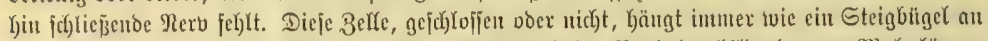

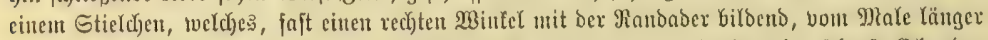

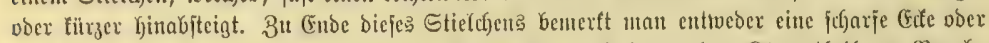

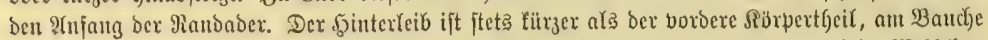
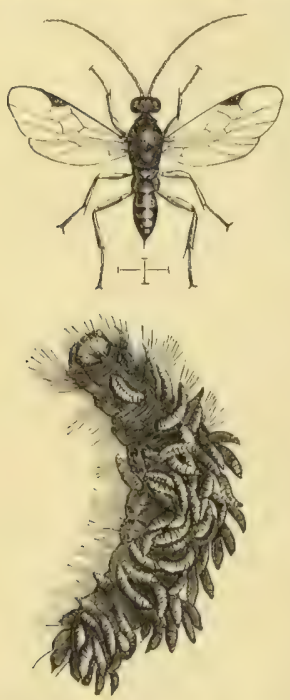

Meibdict bes Mllogastor nemorum bergröfert, unb feitue aus ber Maupe bes Stefertipituers vorbringenibe Larbe. meift nach ber Spibe Gir zujanmentgebrïct, uno bein Meibchent

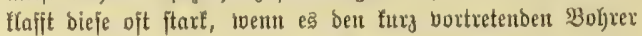
gebraudyt. Die ziemitich groben Rebaugen jind meift beutlid) bebaart und bie \$unttaugen auf bent Scjjeitel fidjtbar. Die

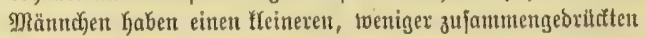

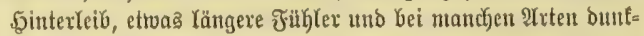
rere Flexfe ober Streijen an ben Beinten, burdid) twelidje jite (iid) von ben Weibchen untericheiben.

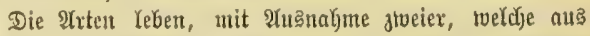
Spinneneiern unঠ BYattläujen exzogen tworoen fino, in Sd)met= terłingşraupen, ben haarigen mehr als ben natten. Sie ferbjt toerben aber im Rarbenjtande twieder von fleinen \$teromalinest betwolynt. Bur Beit ifrer Reije bolyren fich oie MicrogasterLarben aus ber Raupe Keraus, pinnen aber jofort ein gejichlofic=

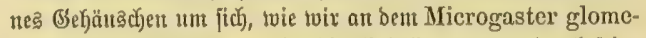
ratus exjeben tönten, tveldher bie Weipling graupen burdy jeine gelbłiçen \$üppchet - bie verneintlichen Raupeneier für ben= jenigen, weldyer bie Sache nicht befier berjtegt - weich bettet, und an bent Yjer vorgefübrten Microgaster nemorum, einent

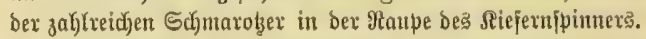
Die jduneemeifen ßuppengejpinjte bringt die Keimgejuchte

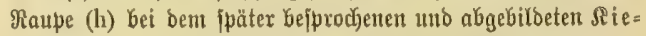

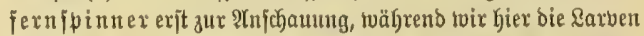

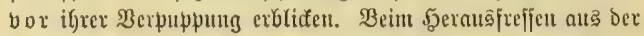
Raupentyaut fangen fie an zu fpimnen, jobald fie zur \$äljte mit bem sionpex jrei find, uno braudjen teine bierundswanzig

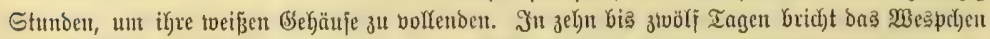

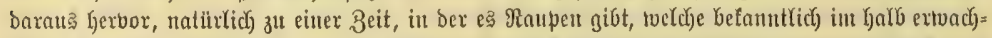

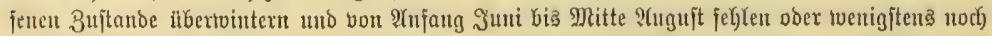

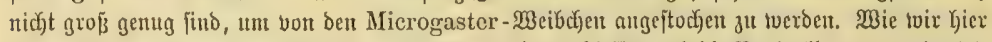

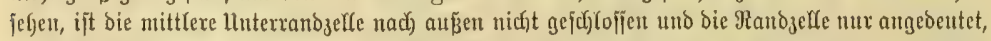

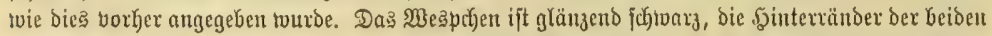

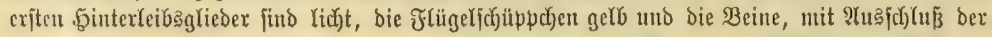

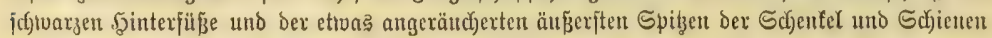

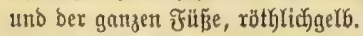

Der S. 310, Jig. 1 abgebilbete Macrocentrus marginator, einer von etron zroblf anderen

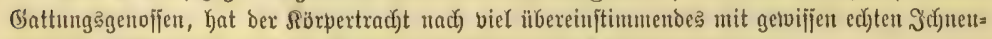

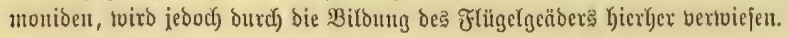




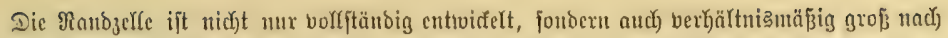

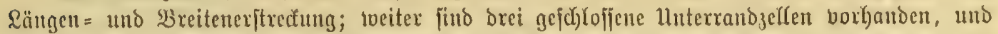

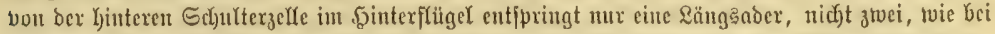

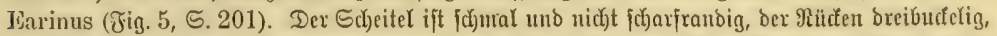

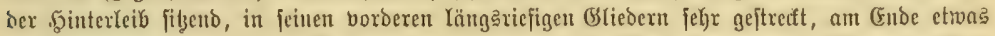

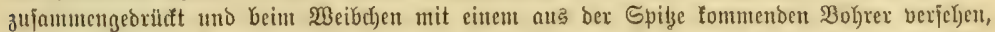
twetçer mindeftena die Ränge bę ganzen Sërpers erreidyt. So weit bie Battunģmerfmale. Dic

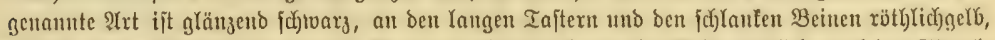

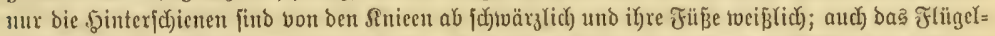

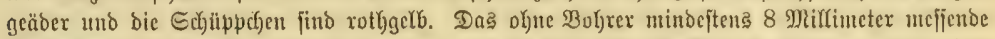

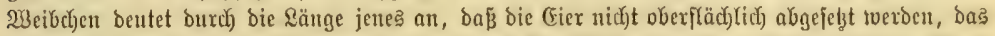

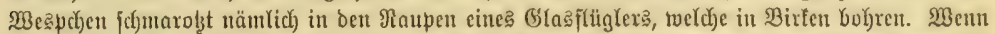

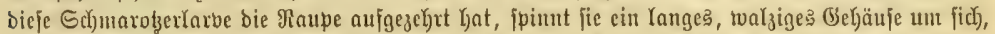

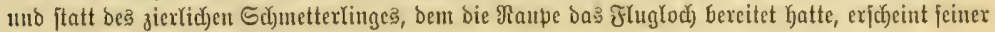
3eit bie fochntäd)tige Bespe.

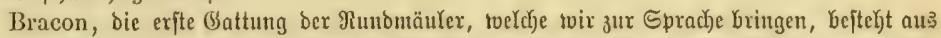

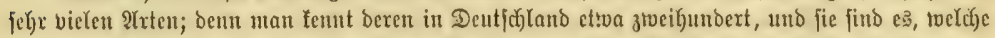

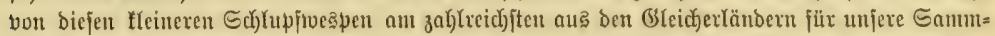

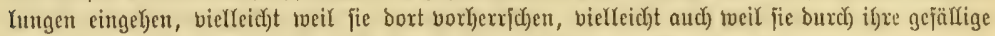

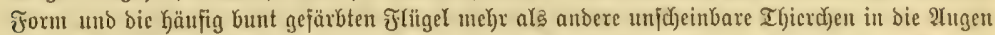

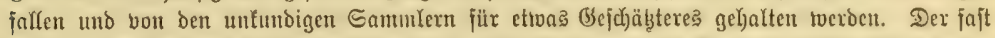

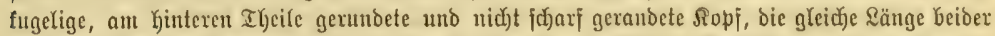

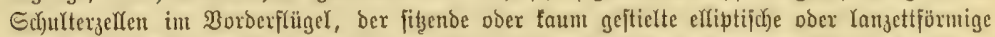

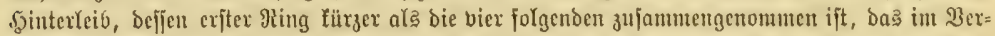
gleiche zun zroeiten längere britte Fühlerglieb und bie oben bejafricbene Mundbildung djaratte=

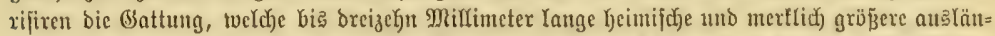

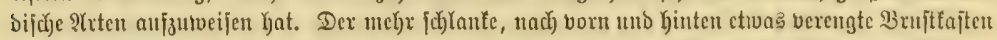

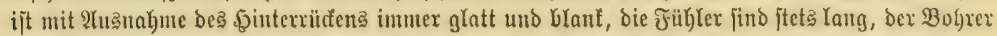

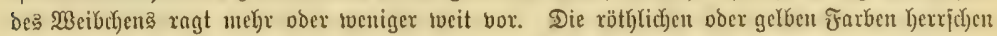
meift an ben Beinen, am ŞinterYeibe uno wentiger am Siopje vor, zu ben EcYtentheiteu gefjören bic

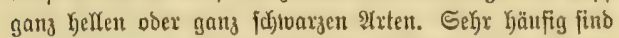
bie frlïgel, Deren voroere übrigens ztoei ober brei Unterrano= zelfen Kaben fönnen, ftarf getrübt, bis faft fdctward, unb bei

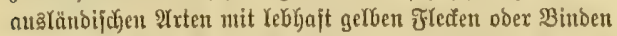
gezeidfutet. Die Braconen facheinen borgugstoeije in ben=

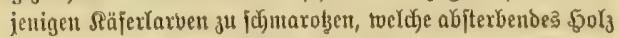

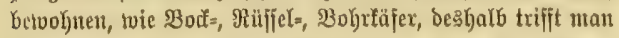
fie aud aut meiften auf altem \$olze an, toenn fie nicht auf B(umen bem 5outigjajte nach)gehen.

Wix gebeu hier in bem Bracon palpebrator cine $\mathscr{U}$ xt, welche vou $\Re$ a bुeburg in beiben (Bepdy)(ed)tem zah)(reich) aus Sirfernfnitppełn erzogen toaro, bie mit Pissodes notatus,

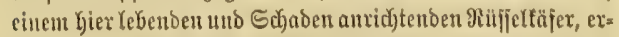

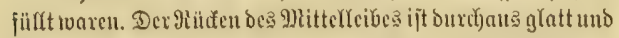

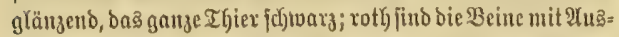

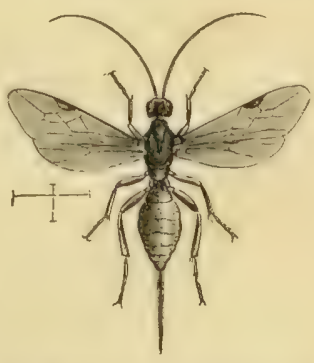

2Bcibdicu bes Bracon palpebrator, ftarl vergrǫ̈̈ert.

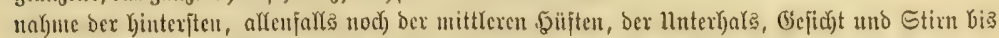

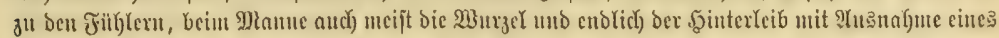

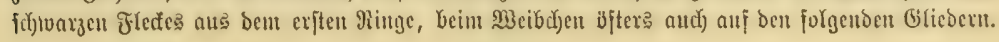




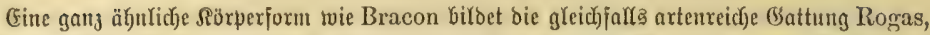

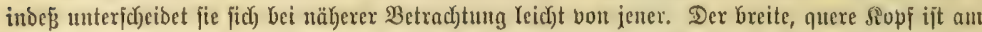

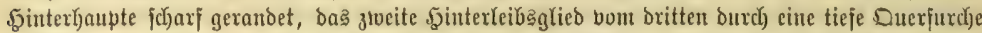

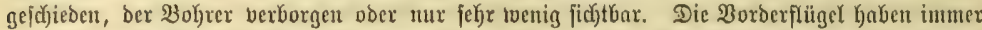

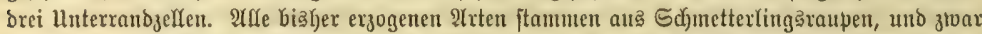

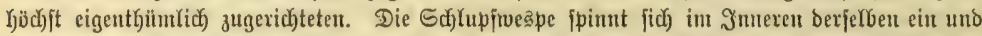
verfteinert jie geroiffermapen in getürster uno verfrüppelter Forn. Man findet dergleidjen Mumien,

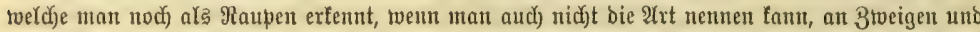

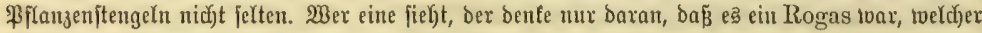
iły biejes anthat.

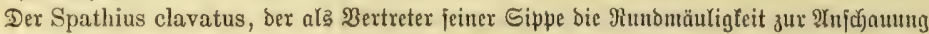

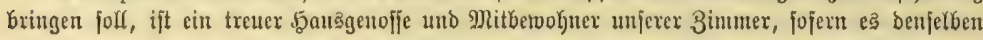

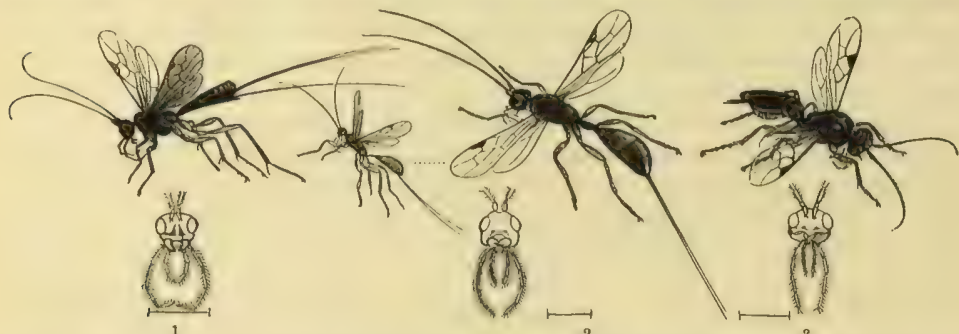

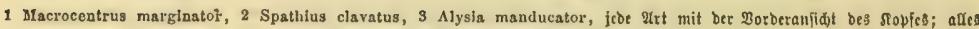
verbröbert, bis auf bas Iteinere Stüd bes Spathius.

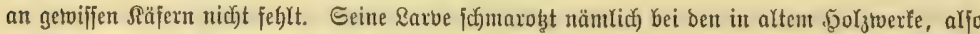

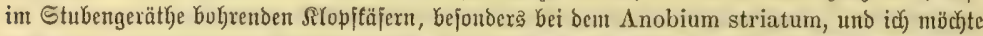

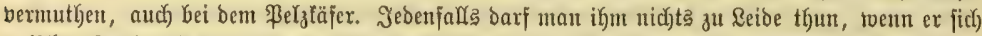

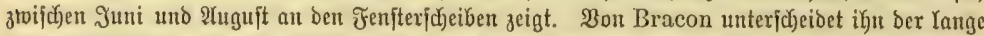

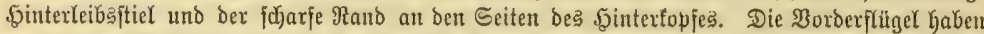

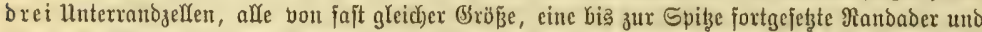

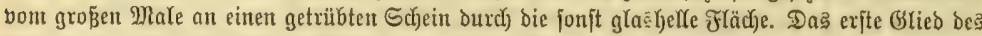

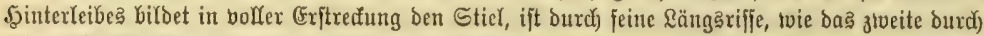
jefr bidyte \$uttirung matt, bie folgenden glänzen und alle cinigen fíd) zur Reulenjornt. Unter

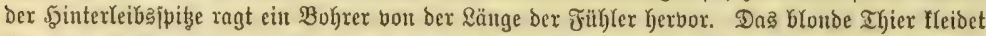

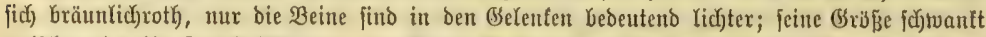

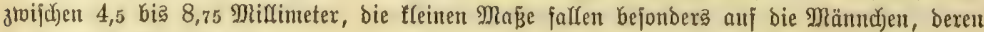
Fithlex noch fachlantex find.

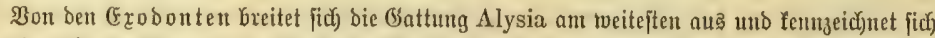

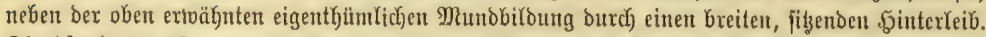
Die Alysia manducator hat breite, an ber Spize breizäbuige Sinnbaden, weldd)e, went fie flaffen,

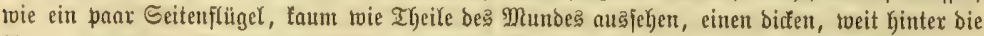

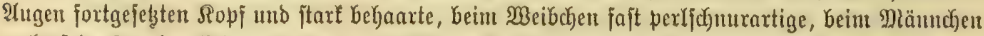

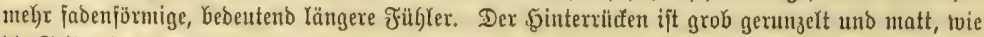

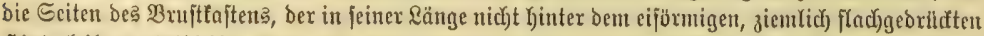

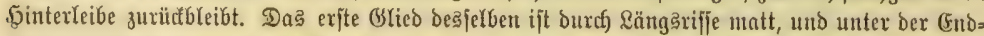

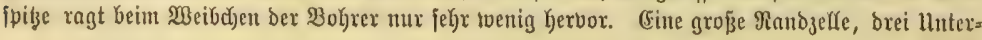




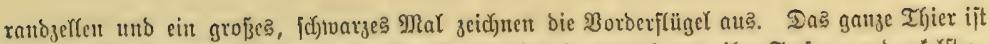

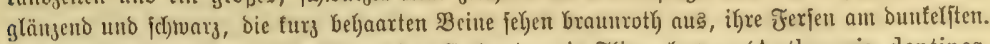

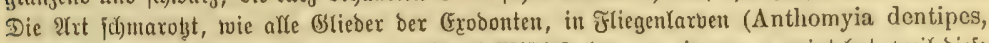
Cyrtoneura stabulans uno amberen), uidjt bei Mifftäferlarven, wie ntan genteint fot, weil bieje

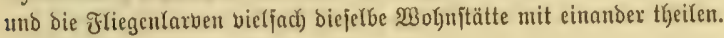

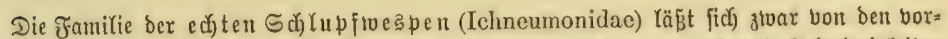

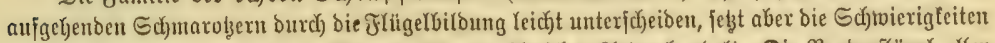

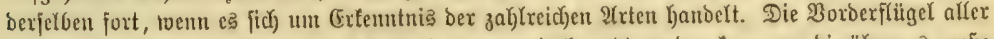

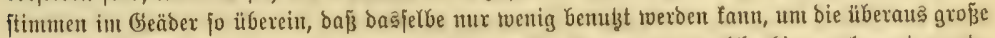

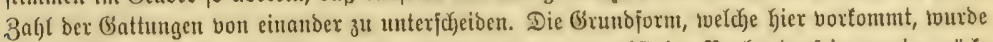

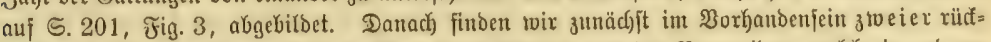

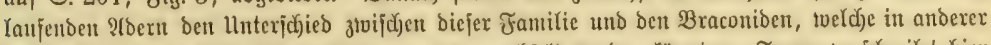

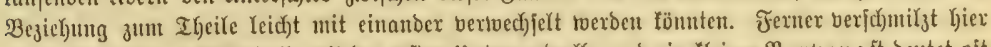

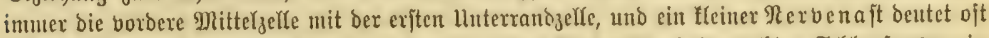

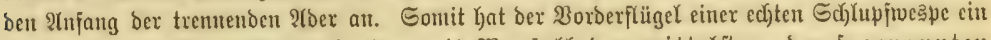

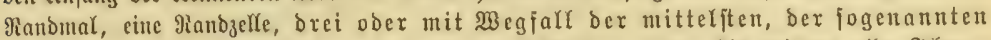

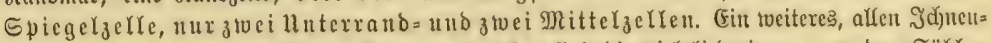

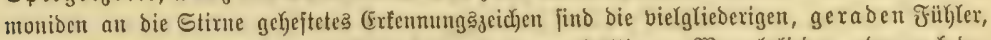

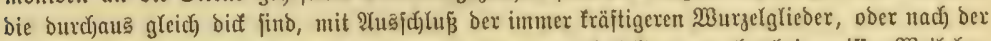

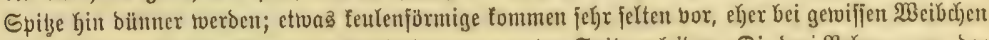

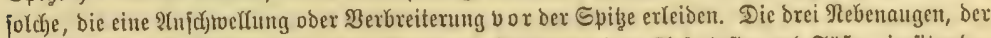

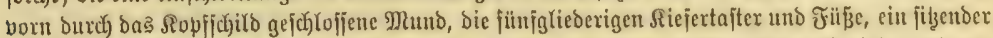

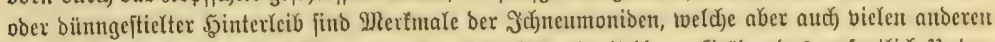

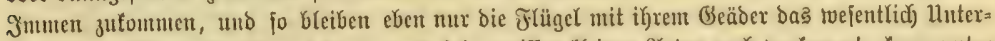

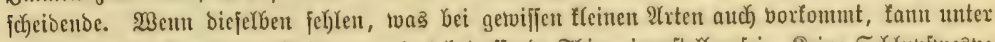

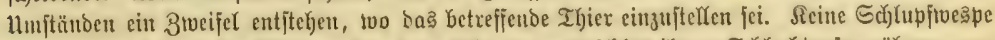

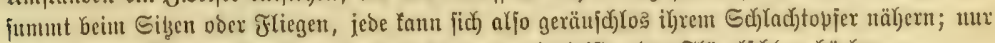

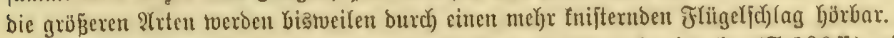

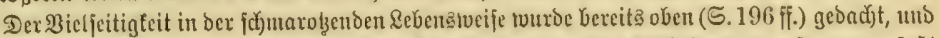

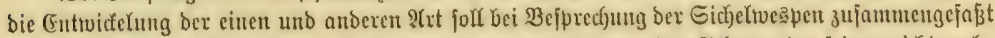

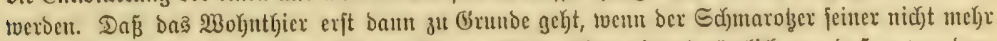

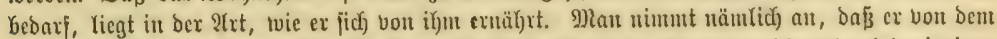

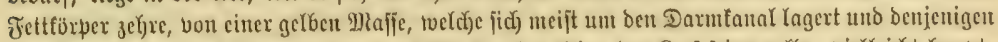

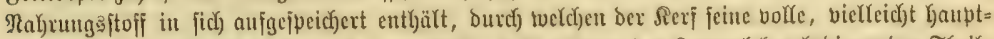
fäch)(ich) feiue gef

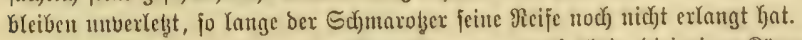

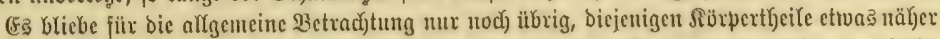

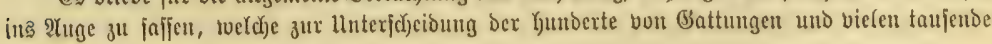
von Frten bienen.

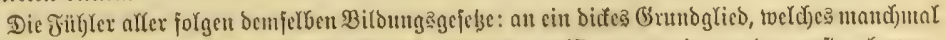

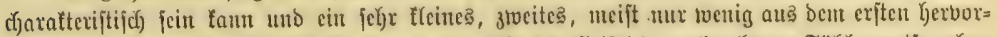

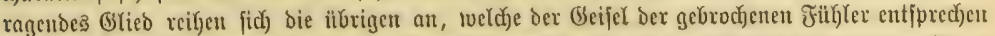

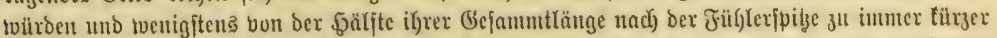

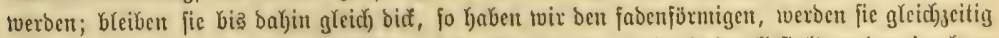

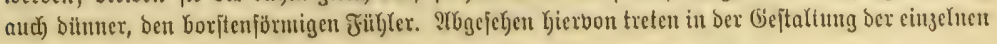




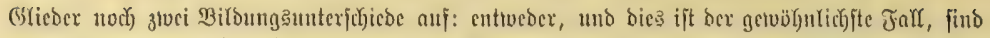

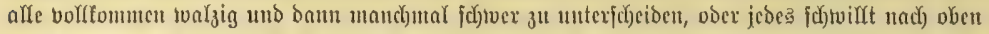

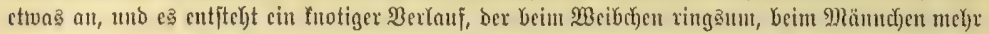

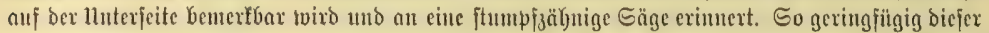

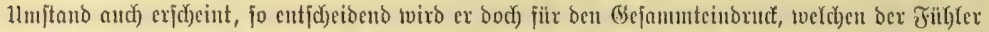

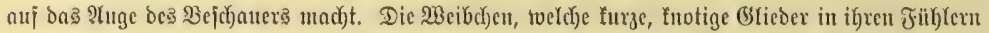

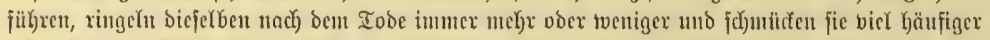

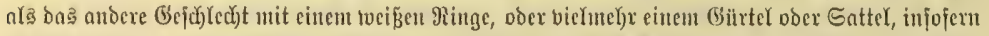

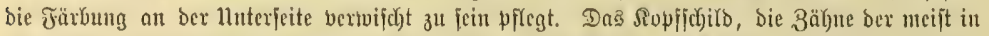

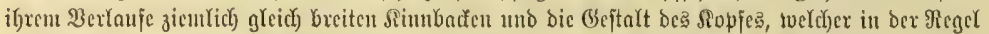
breiter als lang, aljo quergejtellt ift, fonmen melyrfach in Betradyt. PH Bruptfaften verbient

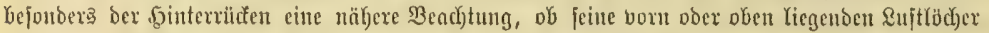

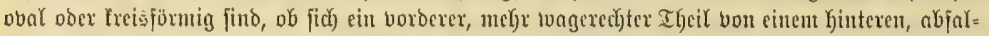

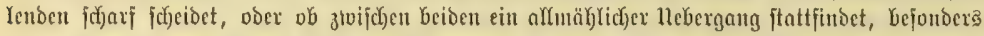

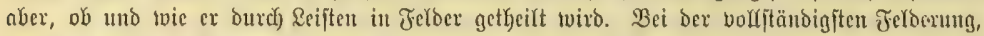

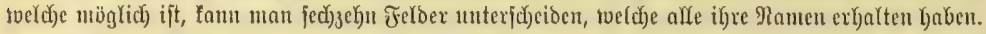

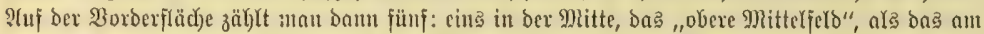

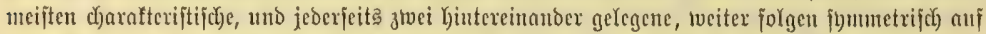

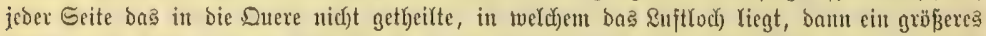

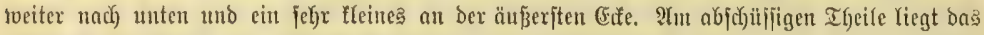

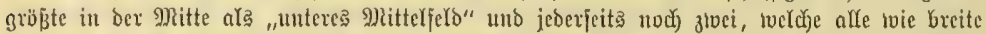

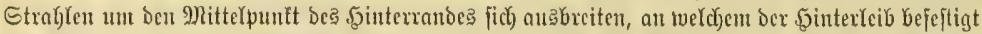

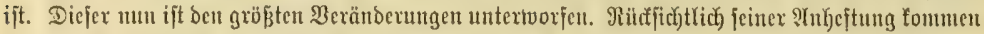

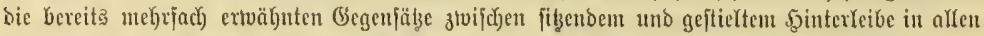

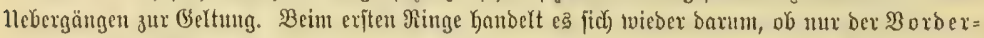

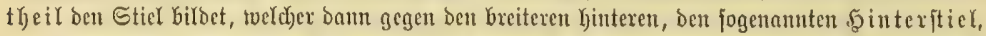

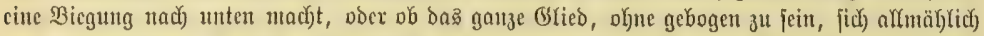

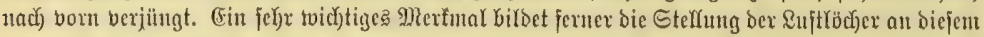

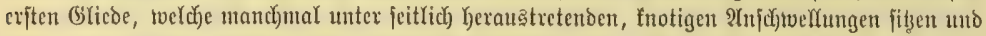

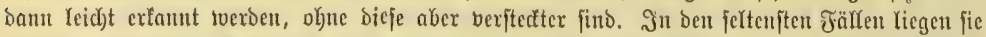

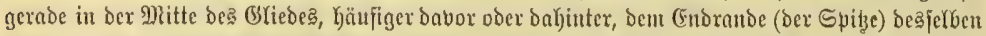

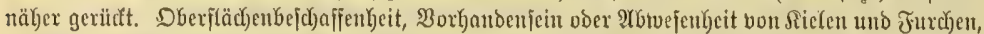
bie Frt, wie Gointerftiel uno Stiel bein Hebergange ineinander fid in ber Eeitenlinie verbalten,

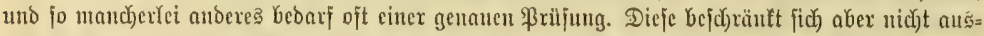

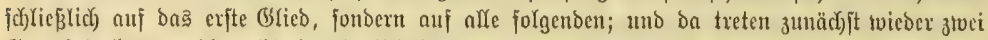

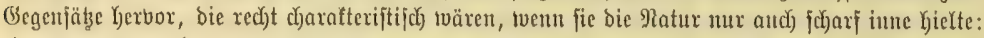

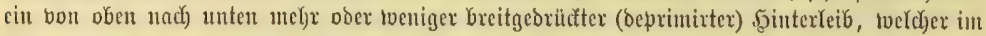

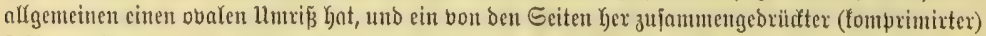

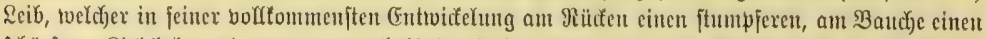

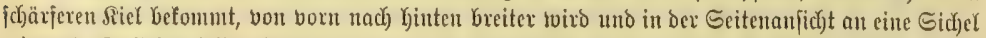

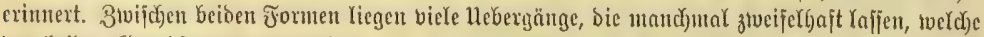

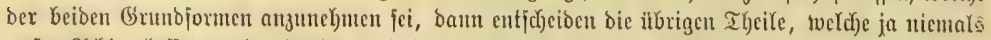

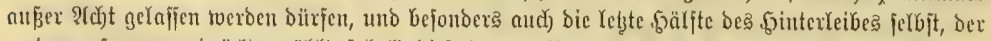

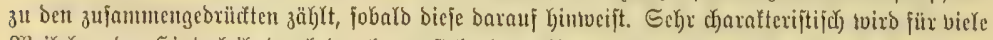

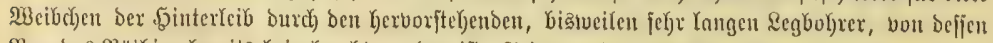

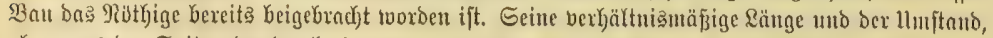
ob ex aus ber Eppize ober Durch eine Eparte am $\mathfrak{B}$ aud be beim (Bebrauche hernustritt, wiro bei ber

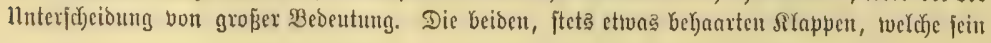




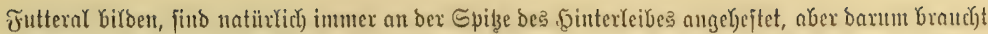

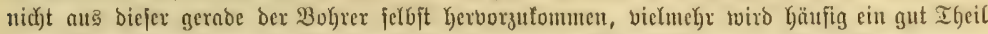

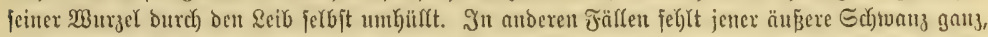

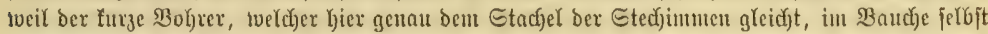

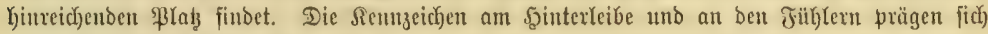

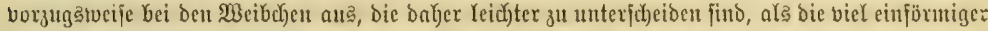

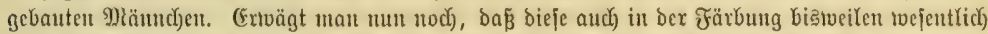

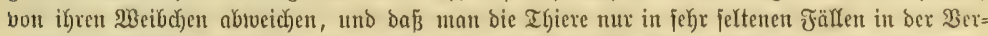

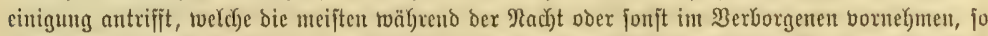

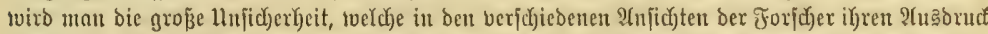

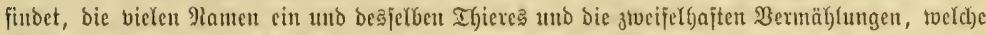
nIt tobten Stücten in ben Sanuntungen vorgenommen tourden, leid)t begreiflid) finden. (Śteid)zeitig

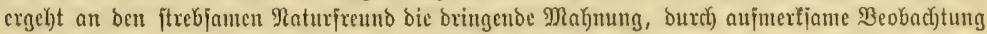

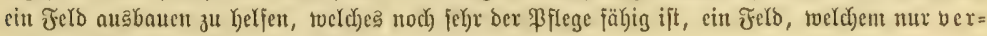
cinigte Sräfte twirf(id) eriprieß̧lidyes abgetvinnen tönnen.

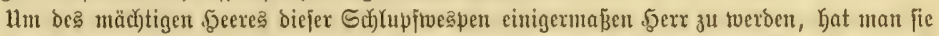

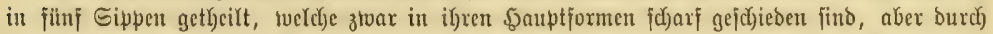

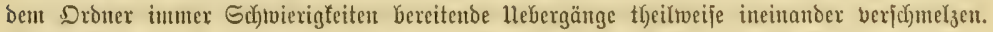

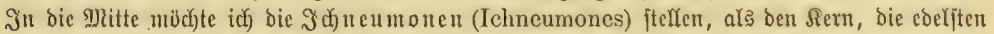

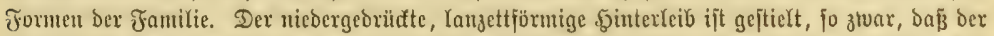
Sintertheil bes erften Ringes mit den übrigen höber fteht ala bie $23 u r z e l$ bes Stieles. Die

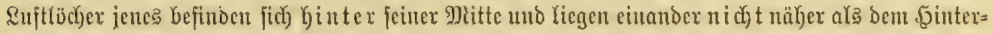

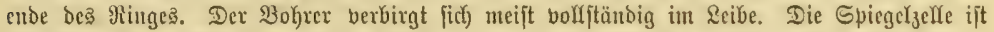

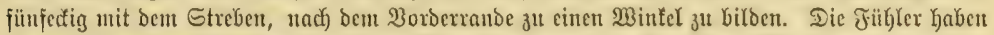

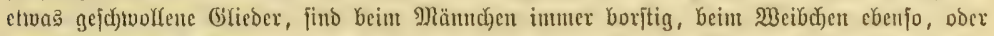

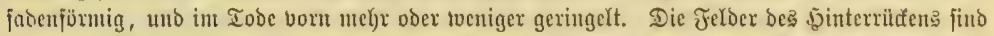

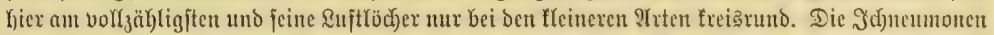

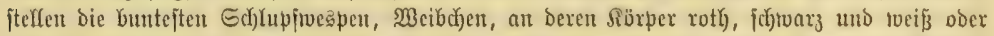

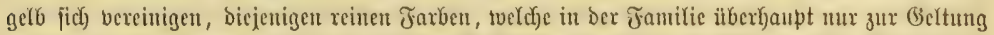

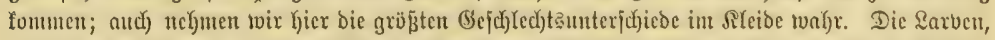

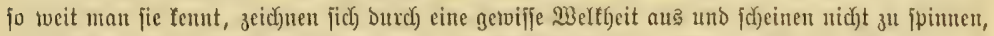

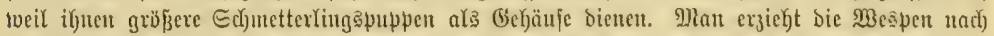

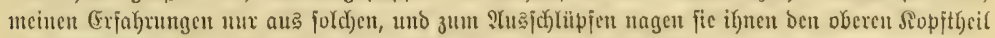
tweg. Das Weibdyen bejchentt bahex bie Raupe nur mit einent (5ic.

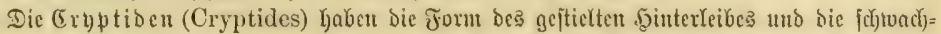

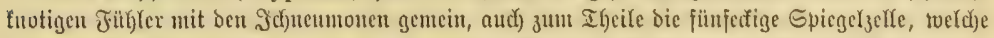

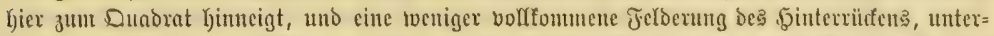

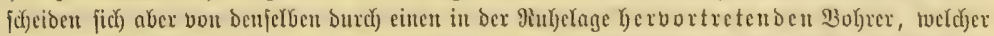

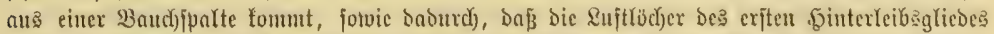

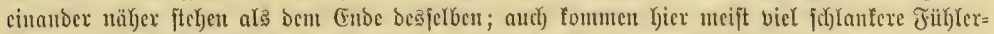

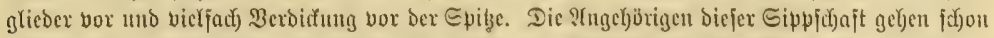

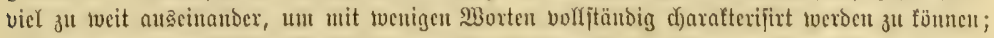

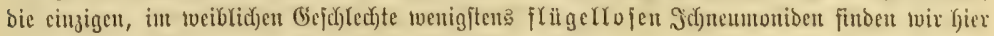
in ber Battung Pezomachus von Braventyorjt vereinigt.

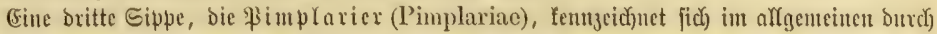

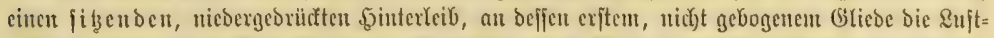

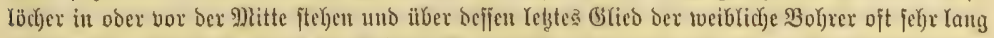

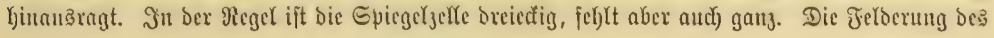




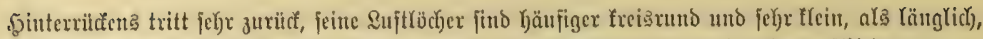

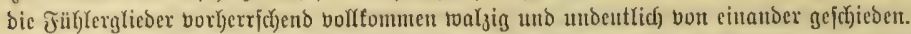

Dic Sid) ltwe apen (Ophionidac) ftimmen in bem meift getaofticligen, bon ben Seiten

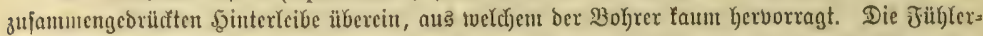

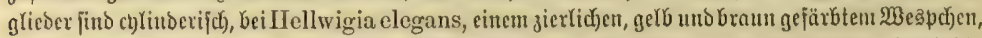

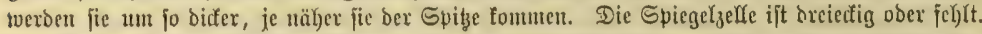

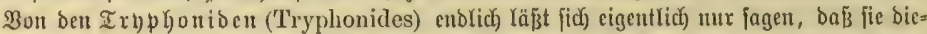

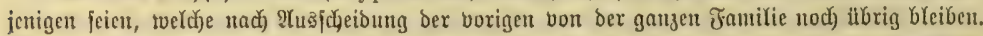

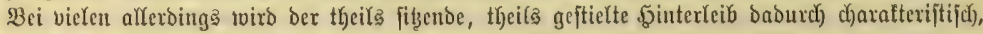
baß er brelyrund uno bon born narf) Yjinten etwas bicfer, aljo folbig vertäuft uno ben Bohrev

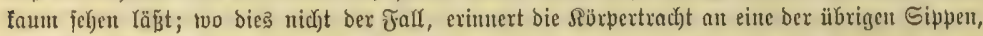

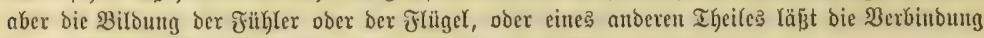

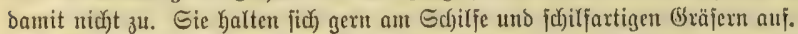

(Fin genteiner Irbphonibe ift Dex 11 Miđlmeter Yange Exenterus marginatorius (Fig. 1, 5. 315), fenntlidf an ben gelben इintertändern ber \$interleibsringe, veränderlich gefber

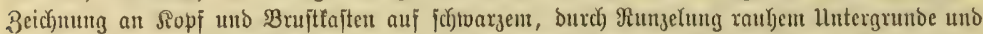

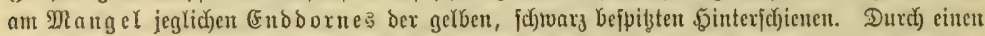

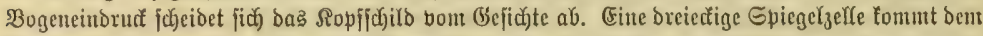

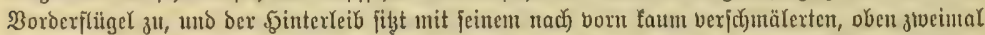

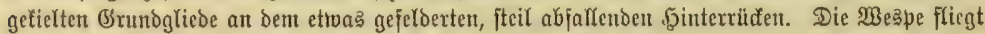
borzugetveife in Riejernväldern, tweil jie Yier für ifre Sarve in ber gemeinen Riefernblattruespe

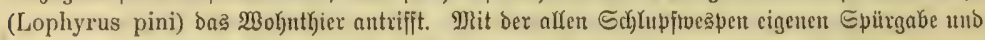

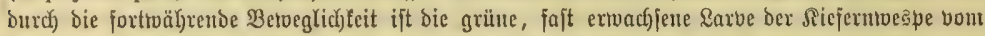

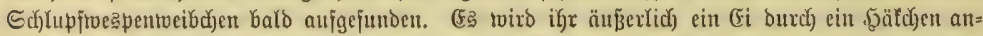

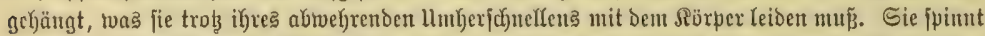

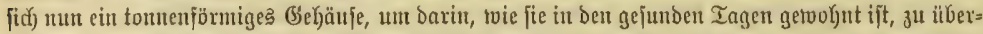
wintern. Das Sdjunroberei fried)t aus, bie Sarbe bleibt äußerlid) fiben und jaught ifren Wirt

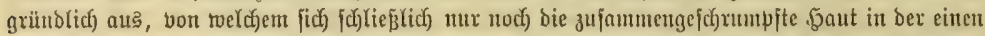

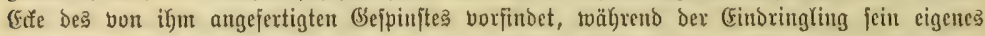

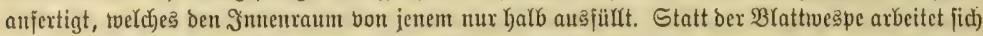

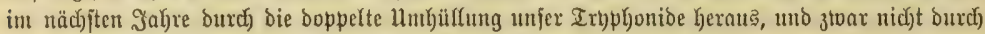
einen am Scheitel abgenagten Dectel, wie es bie $\mathfrak{B l a t t w e}$ spe getfan Kaben witrbe, fondern burd)

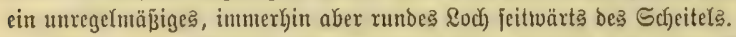

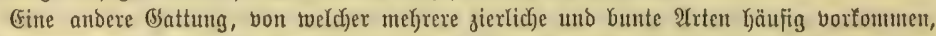

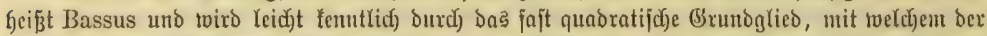

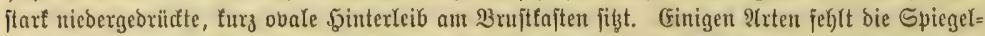

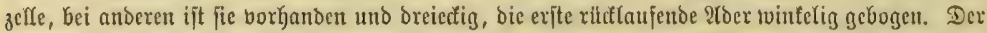
Bassus albosignatus (Fig. 2) hat feine weiteren (Entbefungereijen anzutreten, wemn er feite (Fier

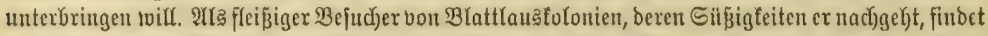

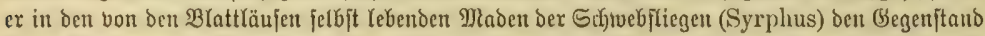

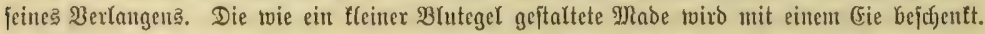

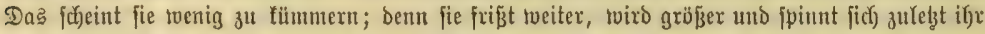

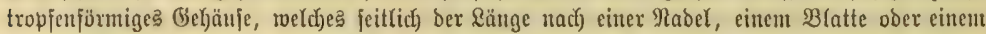

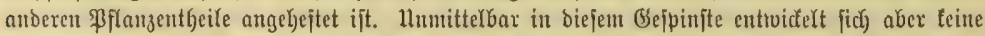

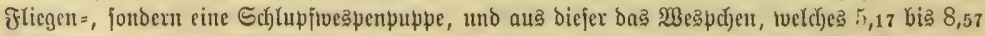

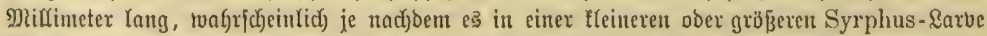

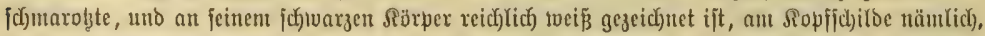

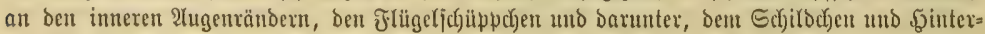




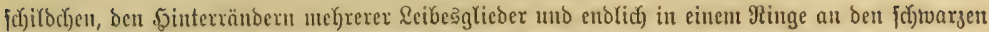

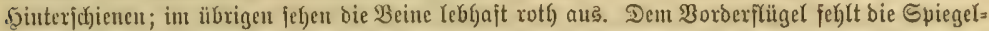

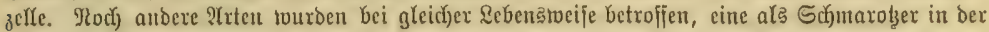

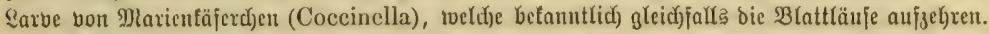

Der Banchus falcator, Dej]en Weibdjen Fabricius jür eine andere 2rt fieft und Banchus

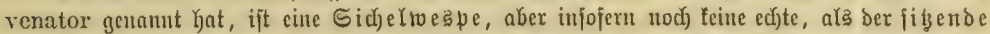

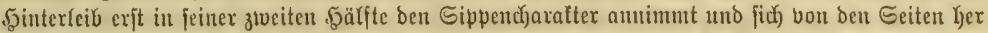

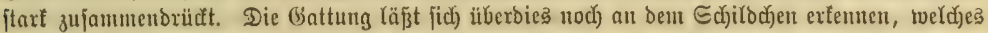

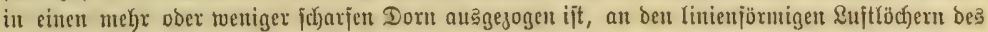

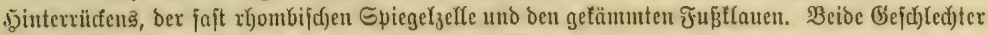

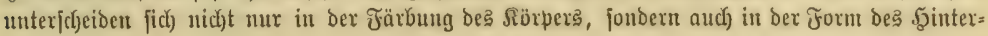

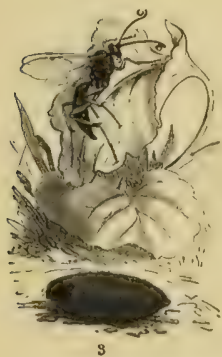

1 Exenterus marglnatorius.

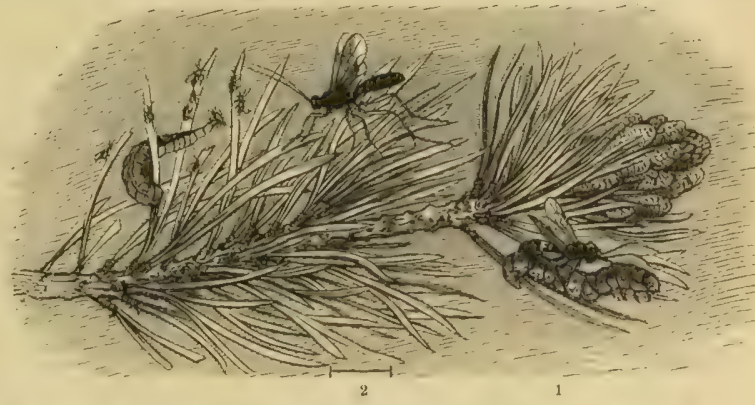

2 Bassus albosignatos, auf eine Surbbustarbe cindringenb. 3 Banchus falcator unb fein

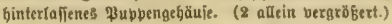

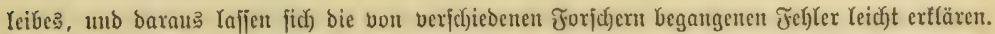

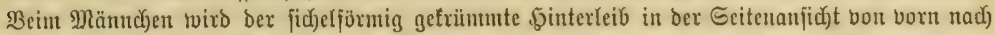

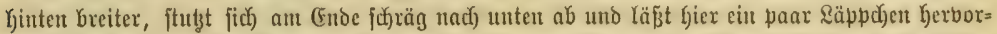

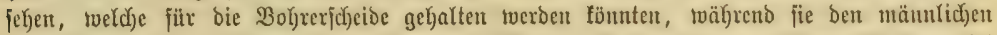

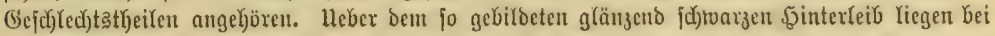

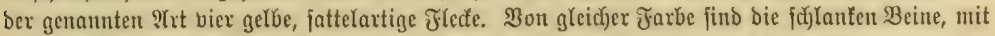

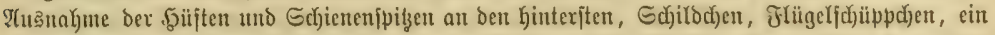

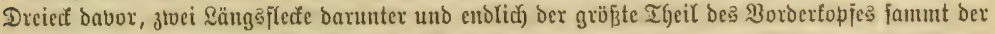

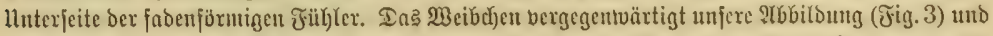

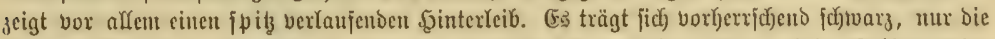

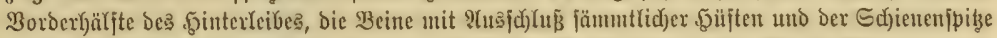

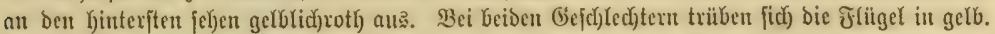

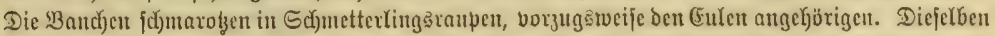

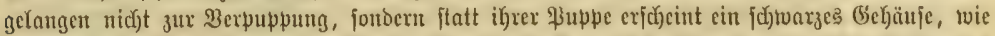

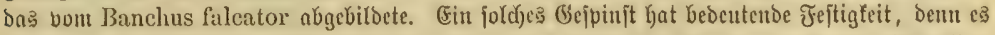

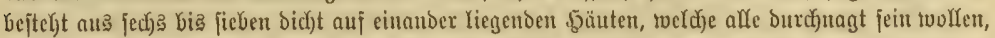

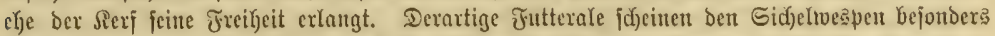

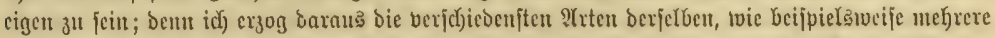

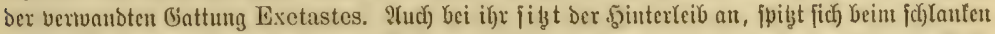

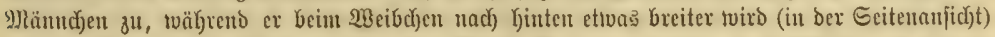

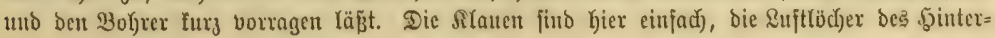




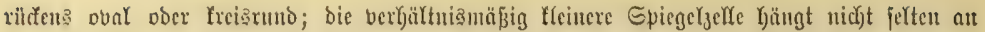
cinem Stiełdyen.

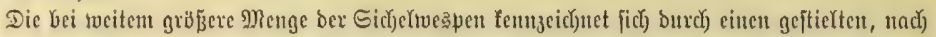
Kinten alfmäblich) breiter toerdenden finterteib nub cine Sörpertracht, wie fic bas Anomalon auf

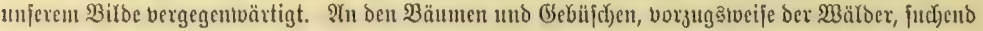

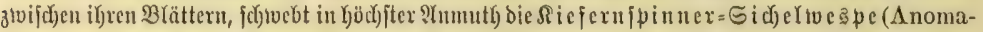

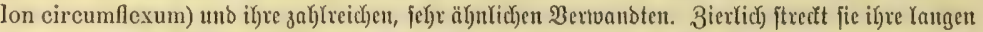

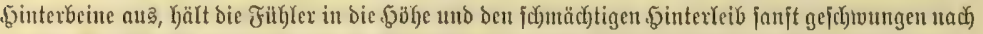

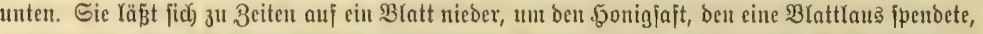

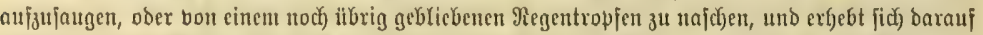

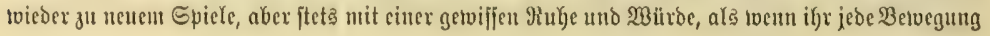
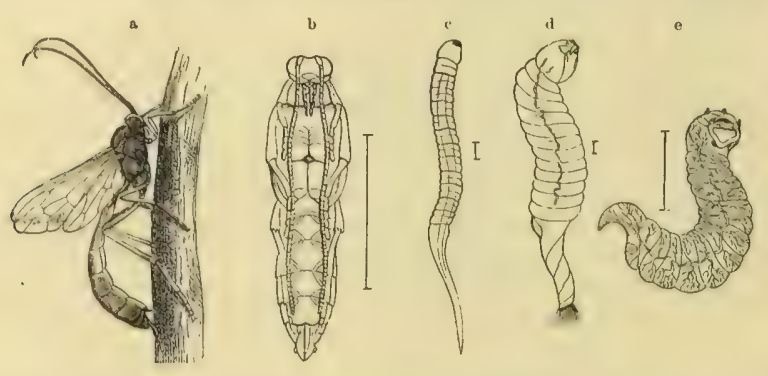

f

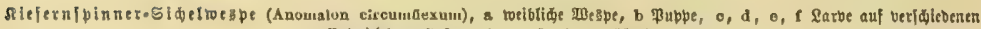
Entividelungsilufen. (b-e flart bergröbert.)

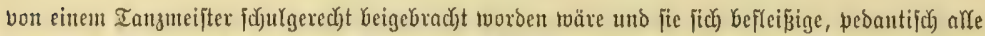

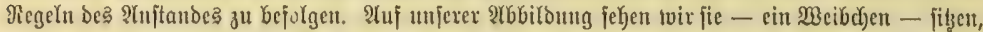

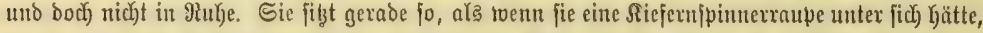

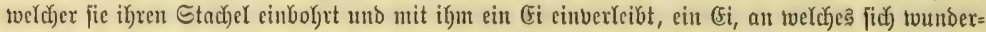

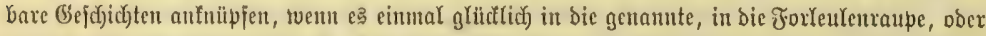
in biefe und jene andere gelegt ift. Die ifm entichlipjte Rarve Yebt frei in ber Ranpe, ift 2,25 Milli=

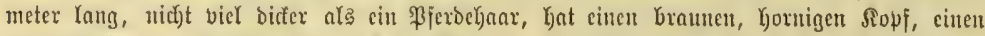

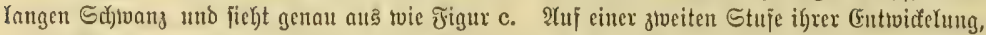

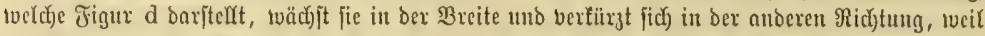

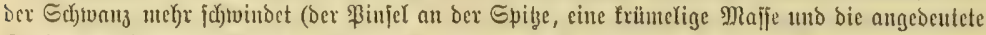

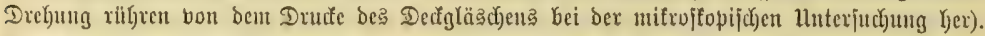

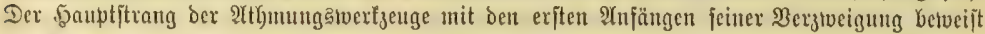

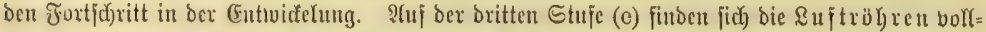

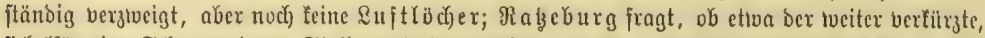

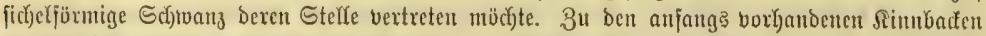

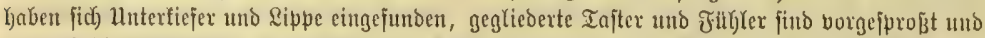

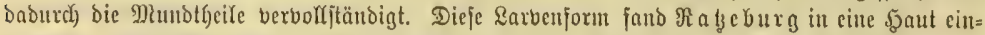

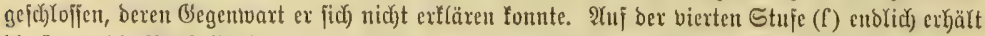

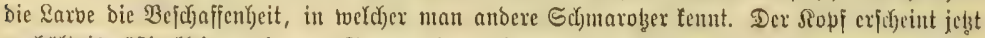

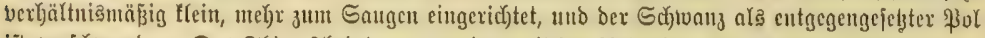

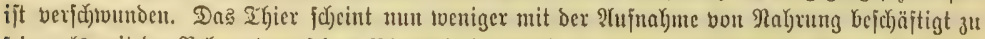
fein, ala mit ber $\mathfrak{B}$ K) 


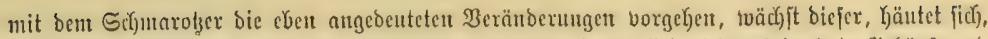

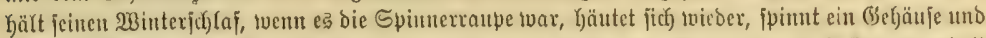

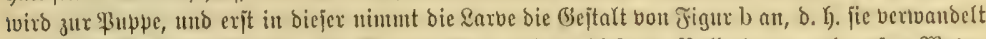

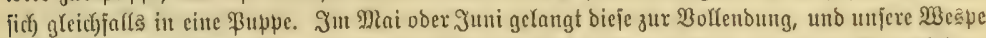

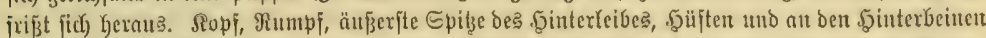

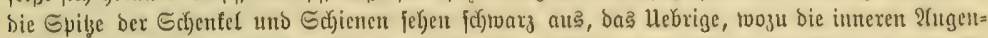

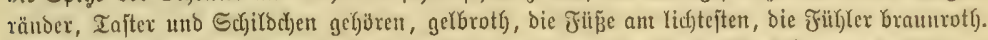

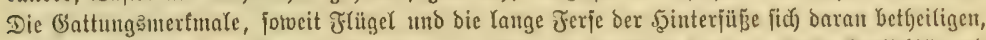

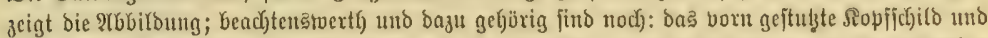

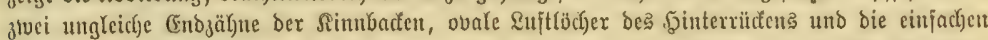

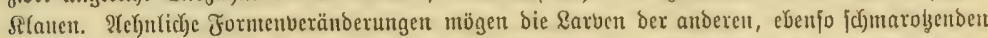

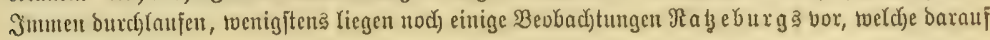

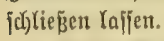

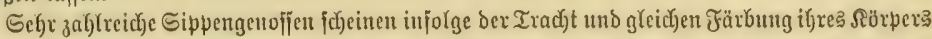

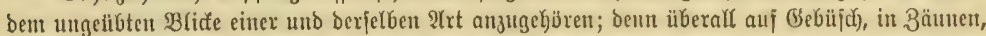

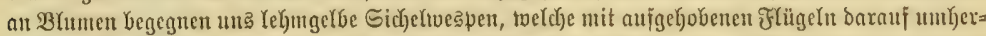

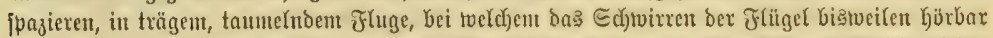

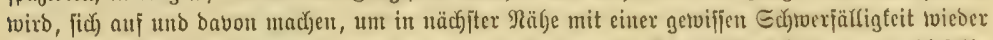
nicber zu gehen und zu fuchen, was fie vorker nicht fanden. Dieje Igieve haken gennu bicjelbe

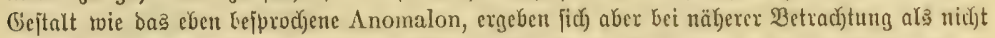

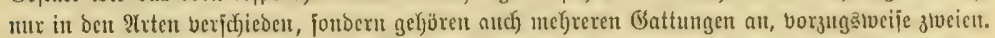

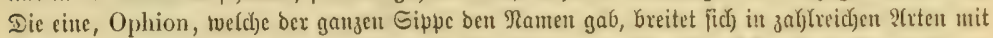

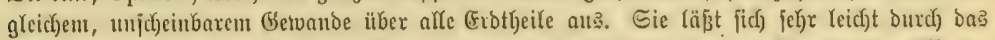

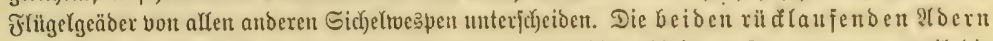
wetoen hier nämlict) von ber exjten lluterranbjelle allein aufgenommen, wcil bie

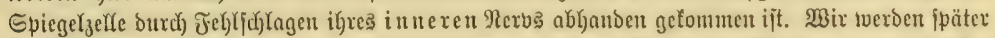

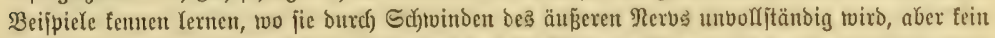

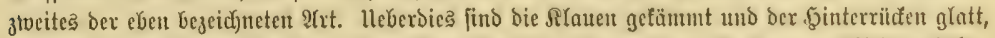

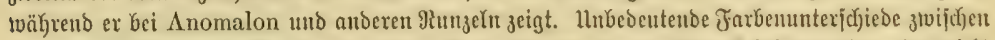

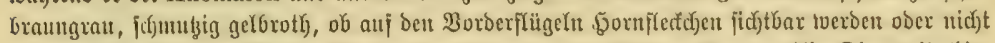

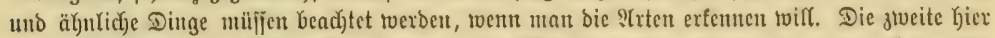

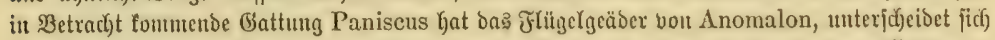

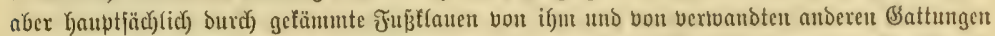

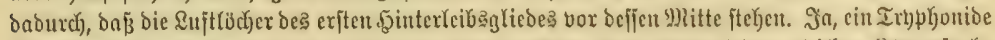
(Mesoleptus testaceus) faun jelbjt von einem geibten ?luge wegen feincr gleicfen siörperfarbe

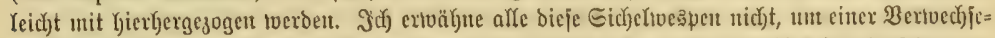

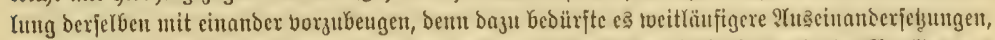

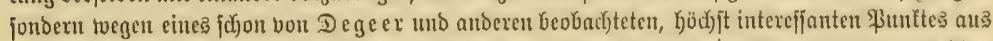

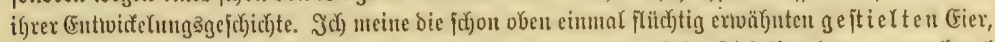

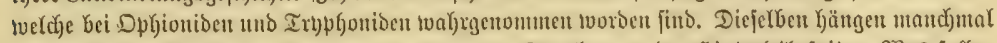

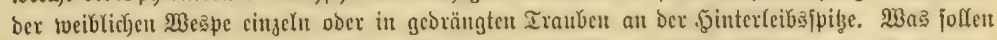

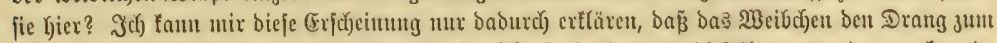

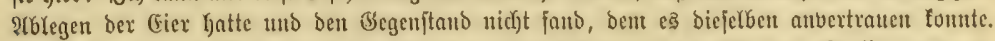

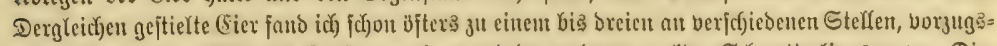

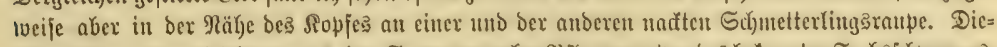

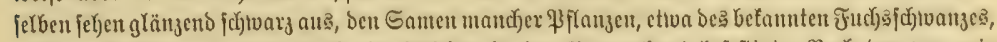

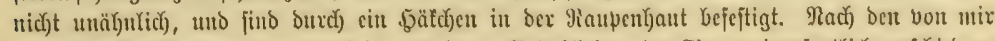

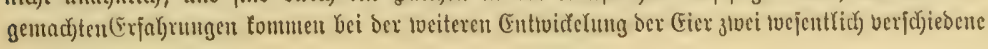




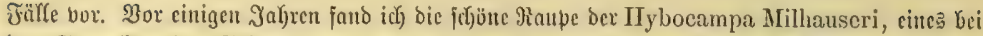

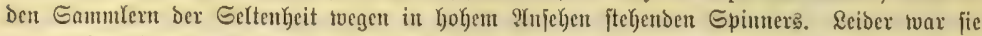

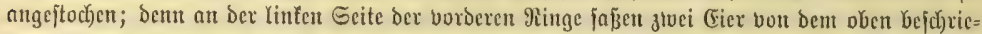

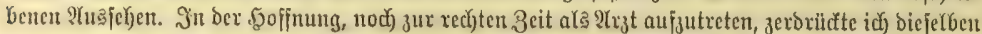

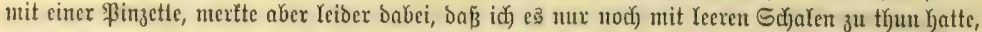
Der Jnlyalt aljo ficjon in ben Raupentörper cingebrungen fein mupte. Deffen ungeachtet waro bie

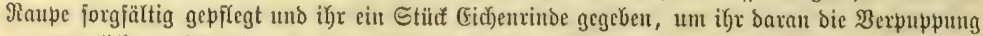

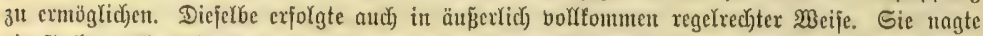

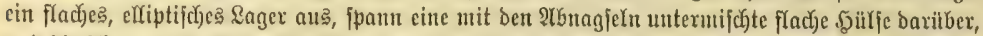

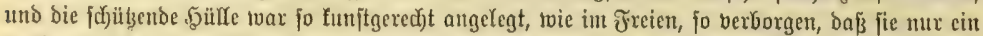

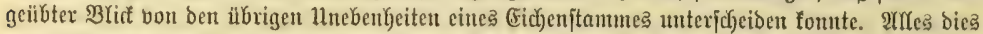

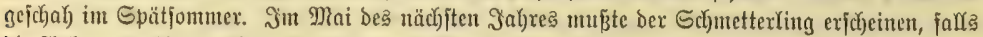

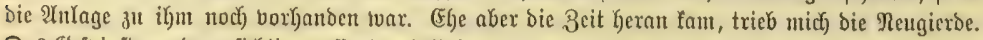

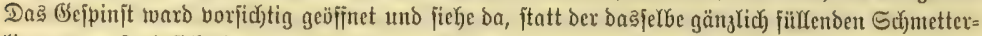

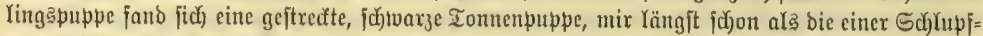

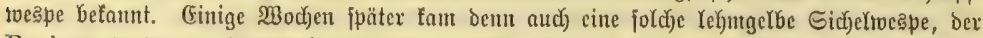

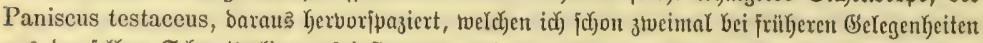

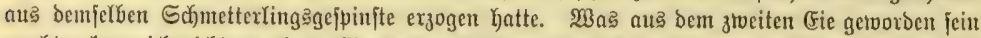

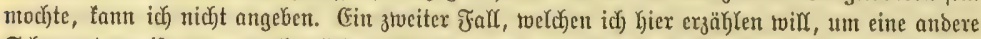

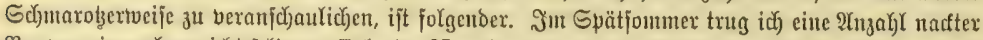
Raupen einer eben nich)t jeltenen (GuYe, Der Naenia typica, ein. Sie waxen nod) jiemlid) jung uno

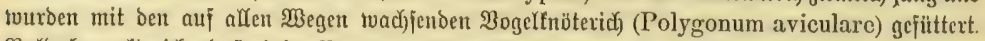

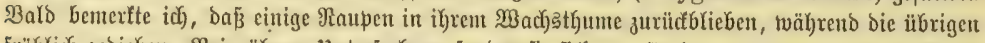

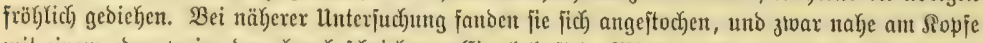
nit eitent oder zweien ber oben befdriebenen (Fier behaftet. Mit Denjelben Yjatten fie fid), wie bie

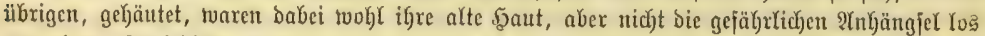
getoorden. 3roei biefer franten Raupen nakm id) unter meine bejondere Prufficht, brad)te fie mit

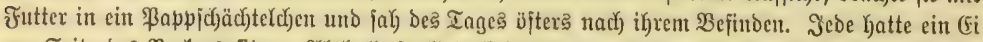

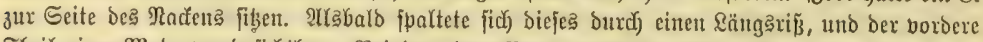

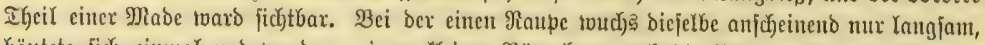

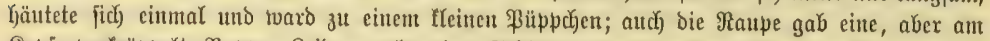

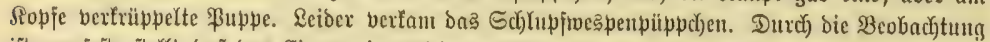

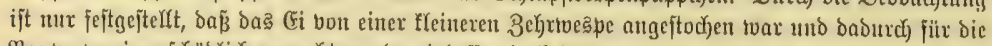

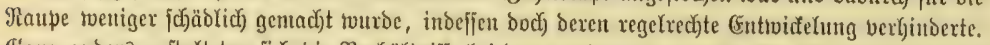

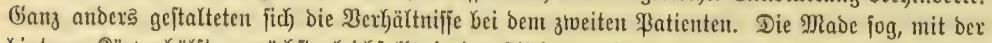

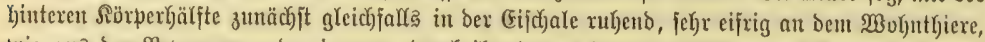

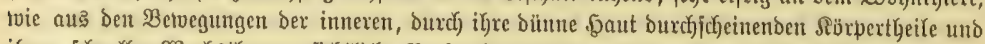

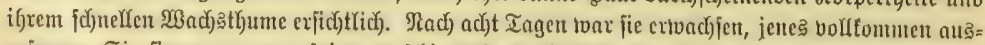

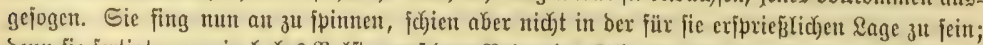

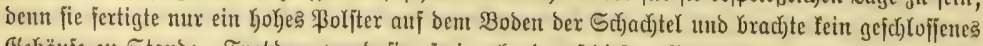

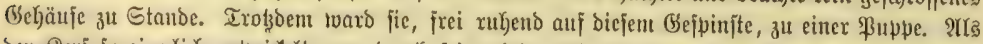

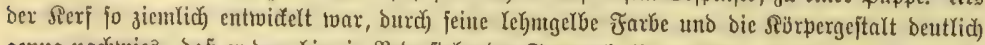

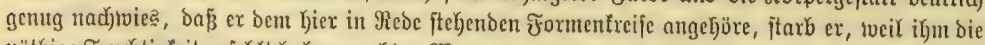

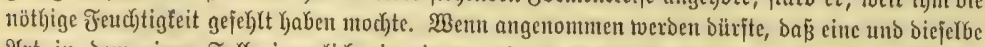

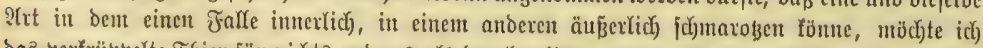

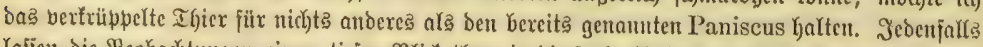

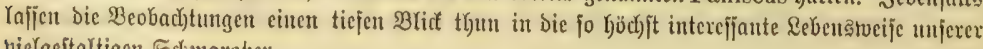
vielgeftaltigen Ed,marober. 
(S) ra ven Gorft befol)rieb 1829 in feiner "Ichncumonologia europaca" unter ber Gattung

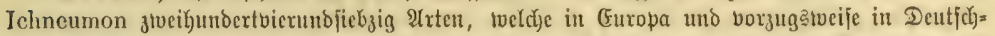

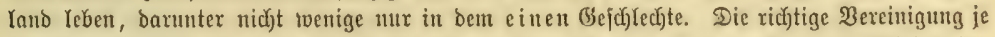

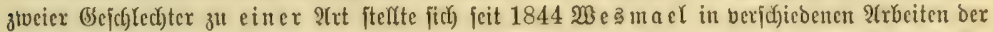

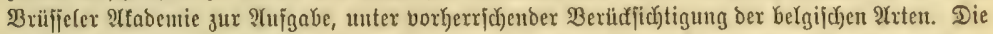
Babl) ber (battungen und llntergattungen hierbei vermebrte fid nid)t unbedeutend, burd) weitere

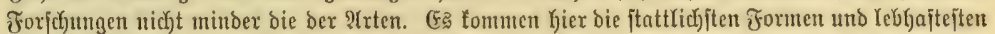

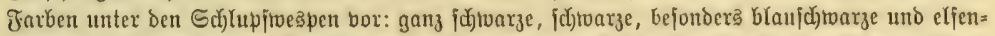

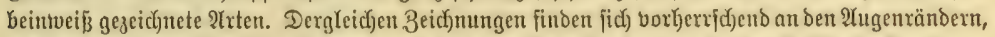

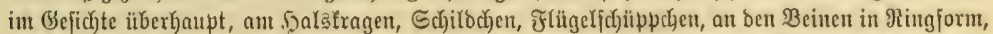

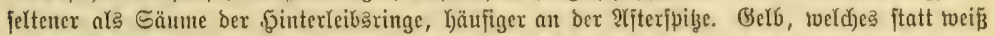

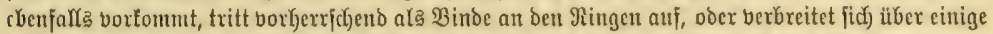

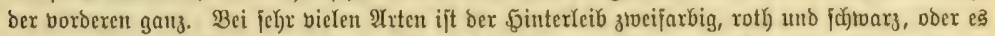

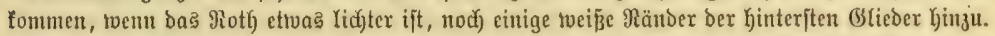

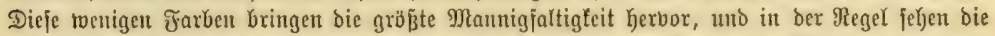

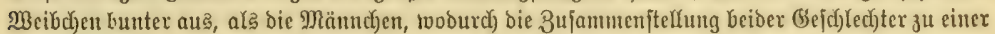

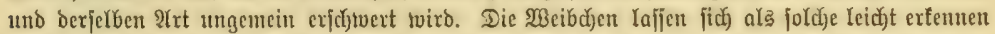
an ben etwas fnotigen, im Tobe immer melgr ober tveniger getwundenen, faben= ober borjtenjërmigen

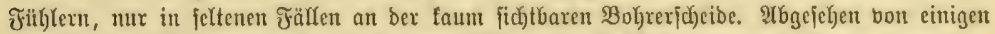
unter Moos ooer in mürben Baumftänmen überwinternoen Şd)neumonen, befoumt man bom

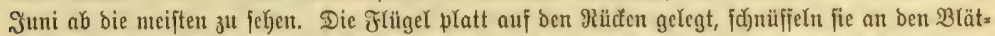

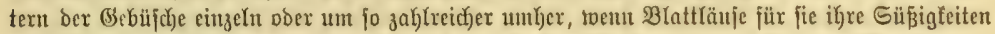

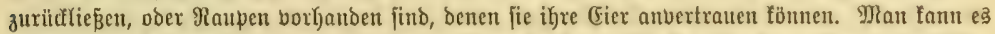

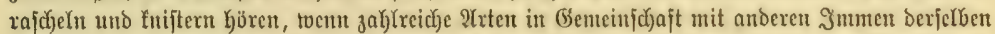

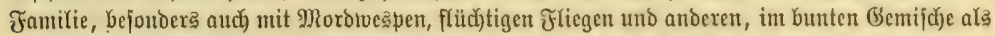

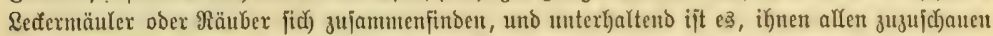

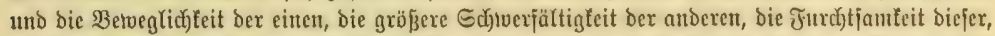

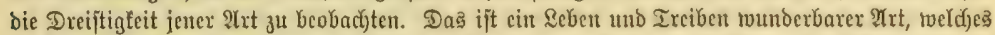

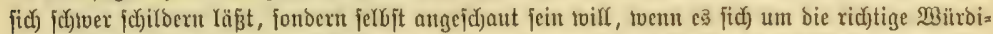

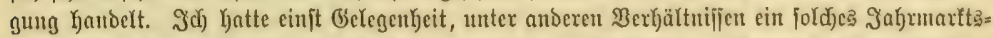

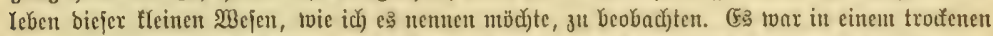

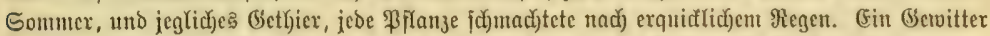

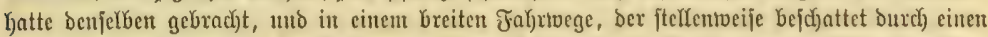

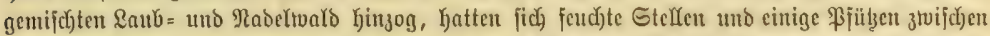
(3rątvuct)

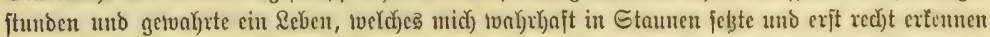

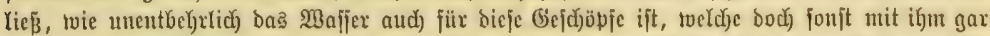

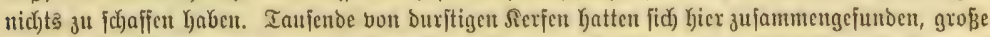

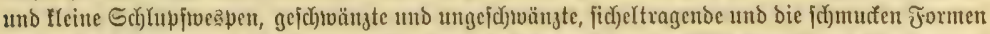

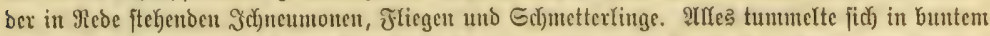

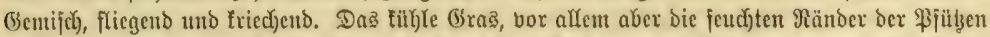

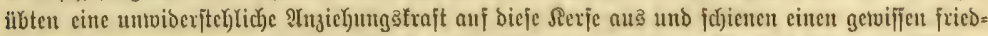

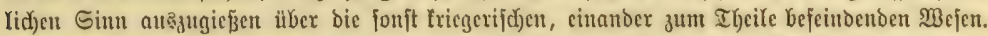

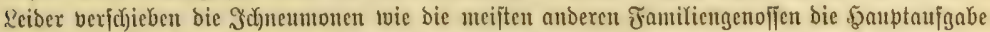

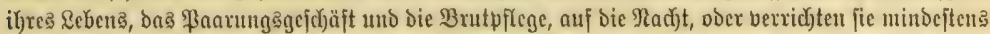

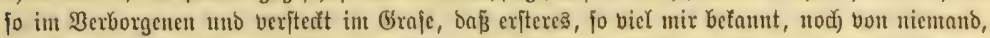

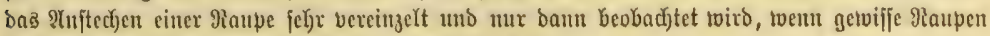
vorübergeljent in verheerender झlenge vorkanben fino. 


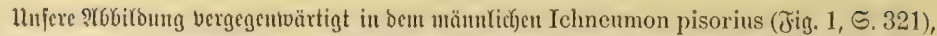

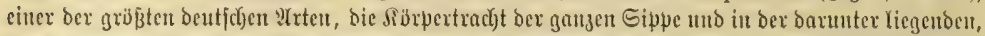

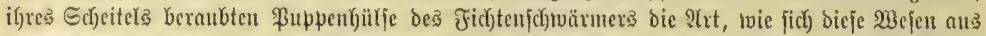

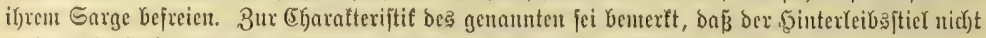

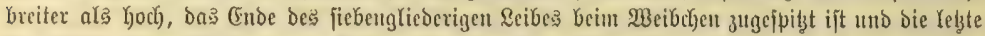

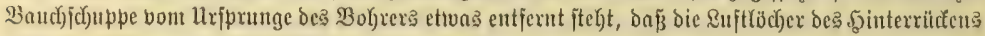

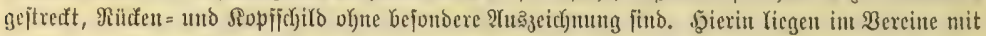

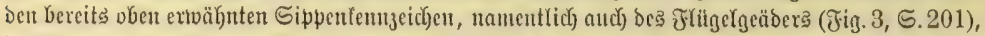

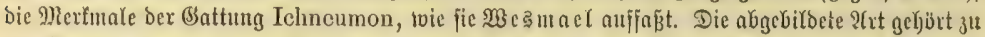

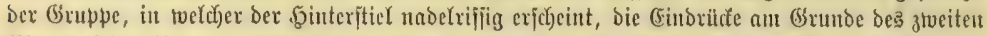

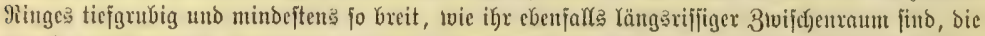

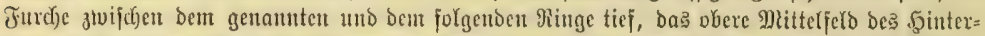

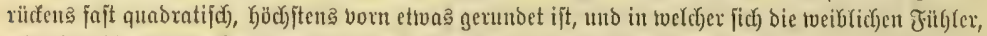

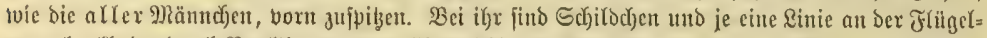

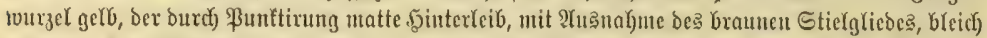

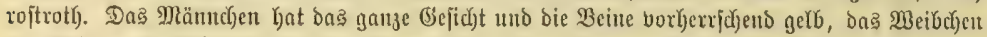

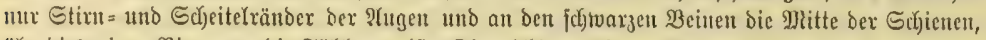

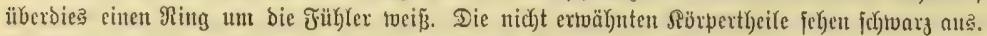

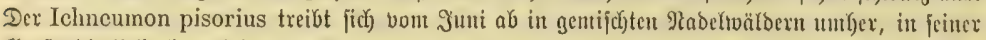

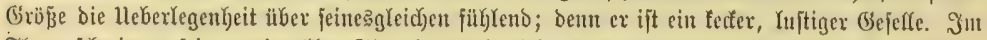

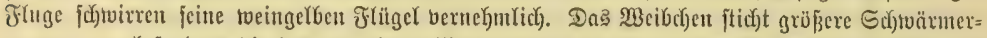

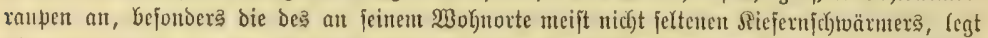

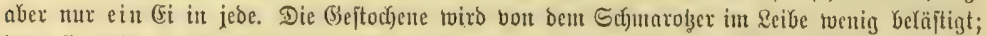

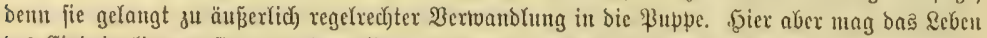

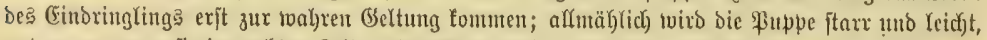

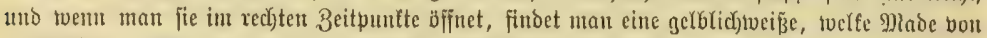

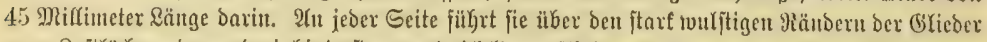

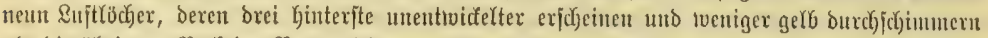

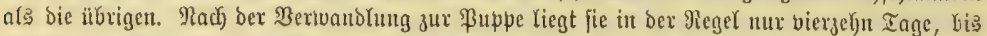

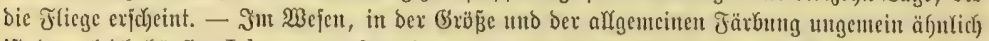

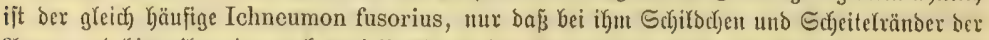

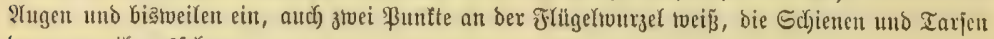
bagegen roth ausijeben.

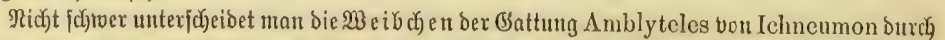

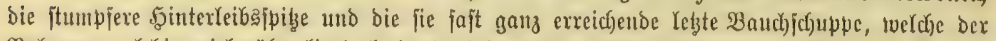

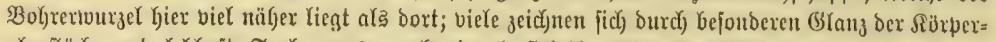

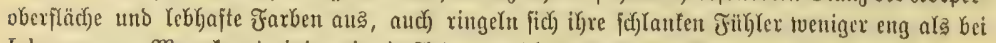

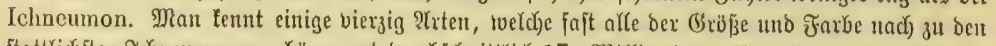

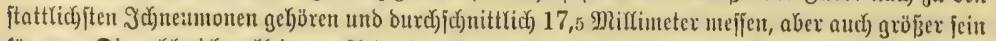

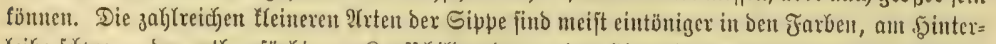

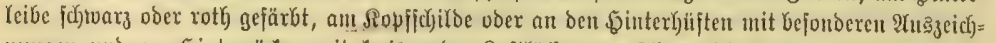

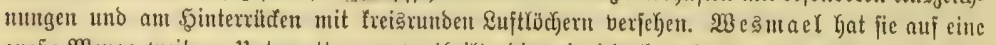
groß̧e Menge weiterer Hntergattungen vertgeilt, bie twir jebod), twie jo viele andere, mit ticjent Stiflfdyweigen ubergeten milfien.

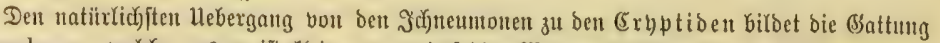
Phygadeuon, weld)e aus meijt fleineren, unterjebsten Wespen bejtcht. Die weiblidfen JübIex

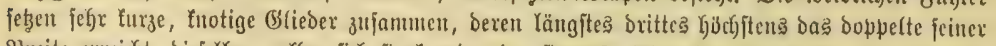

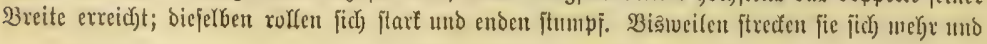




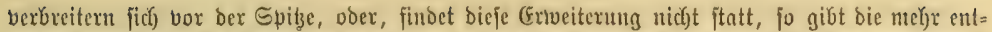

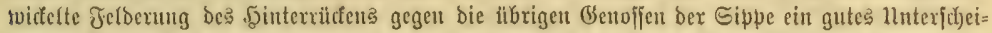

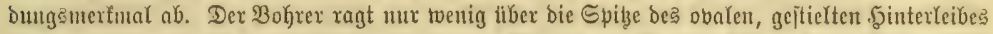

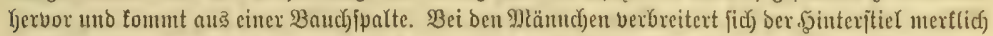

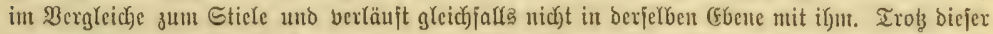

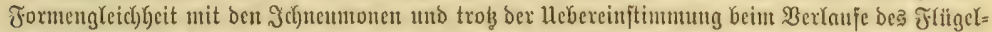

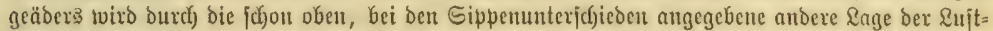

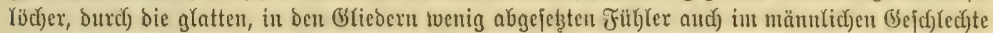
zrvifchen beiben eine unberfentbare Grenglinie gezogen. - Zu ben größ̈eren uno gemeinften Prten,

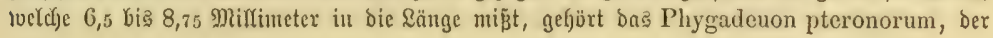

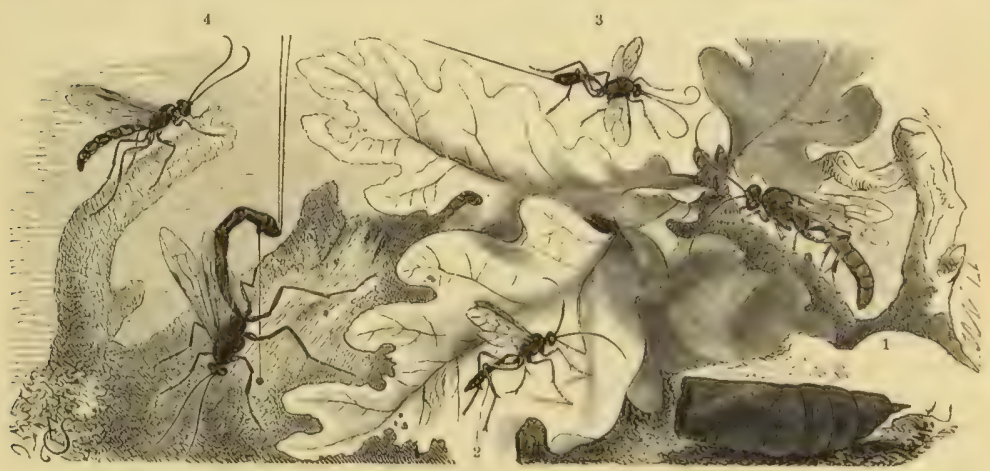

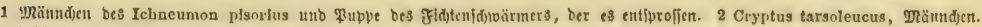

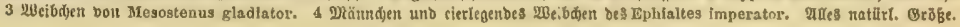

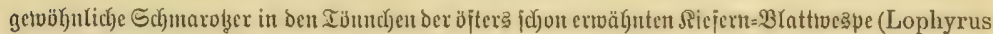

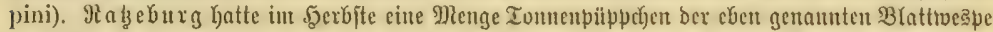
unter Moos gejanmelt and in bie twarme Stube gebrad)t. 2Im 24. T(pril bes jolgenden Jahreß

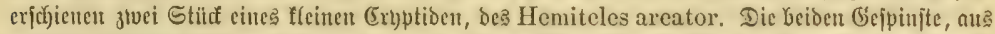

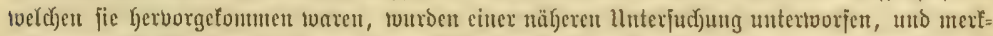

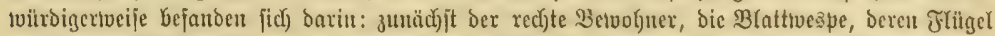

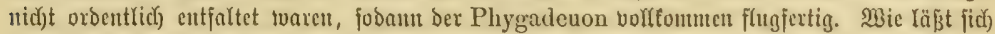

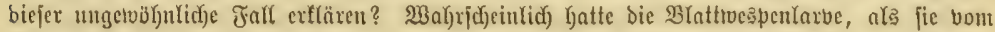

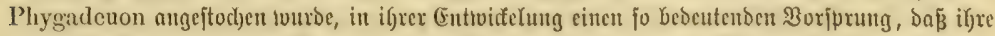
regelred)te Berpuppung uno (Entwiffelung nidft mefgr verfindert tuerdent founte. Die Phygadeuon-

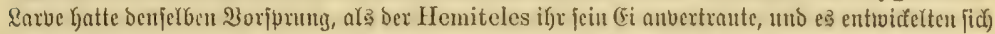

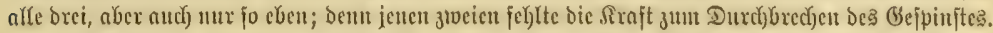

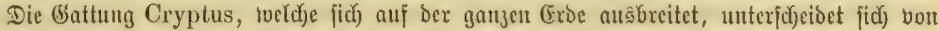

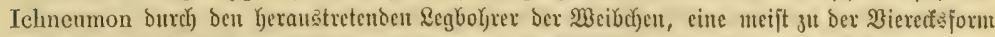

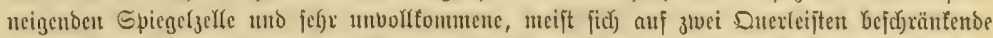

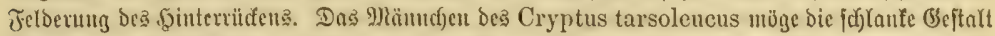

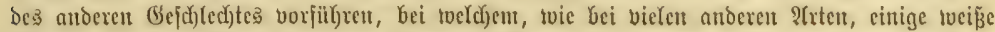

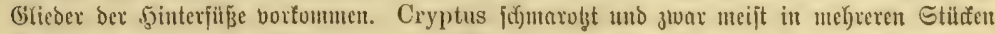

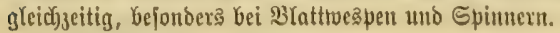

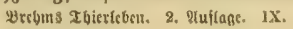


Wix feken über bem Cryptus tarsoleueus cinen weibrichen Mesostenus gladiator (Jig. 3,

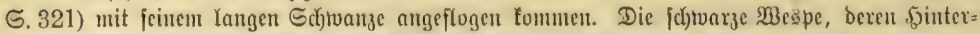

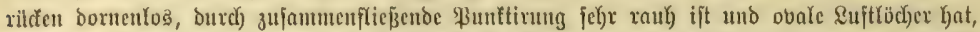

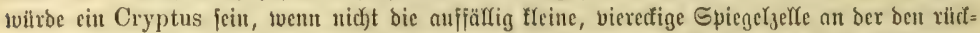

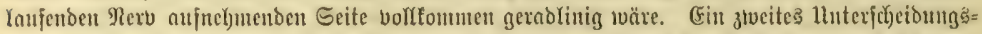

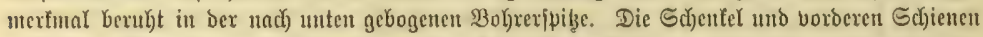

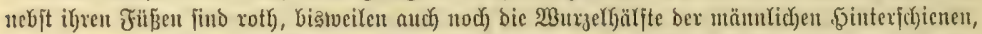

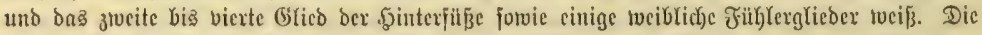

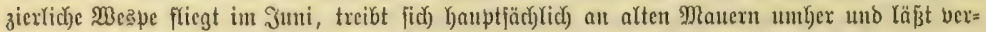

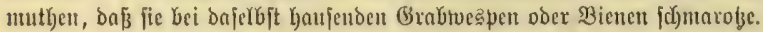

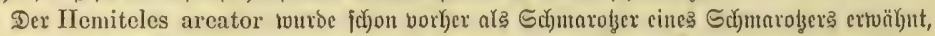

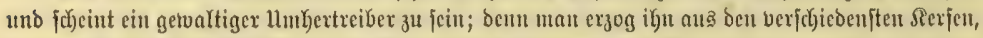

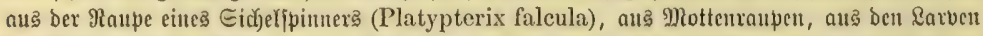

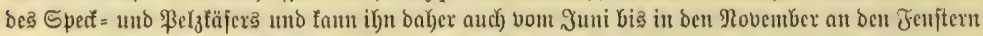

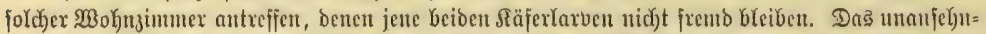

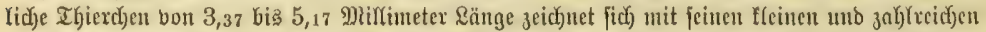

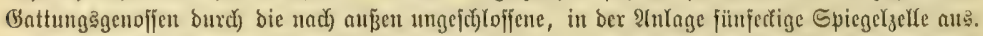
Dex Sinterriäfen ijt bidjt punttirt, und wegen ber anf ben vorkandenen Duerifeiften ftelyenden

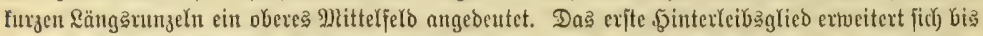

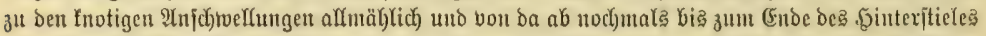

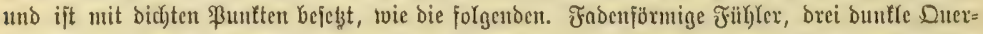

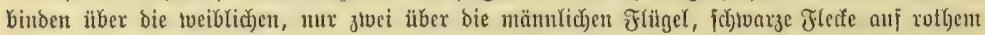

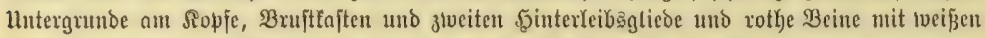

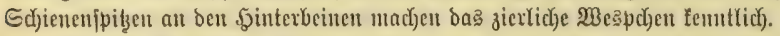

Wie bie (5rbptiben "Sdyuanzwespen" mit gejtieltem .jinterleibe find, jo bie noch übrige

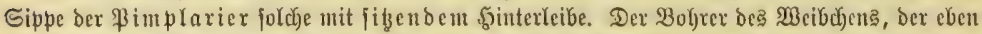

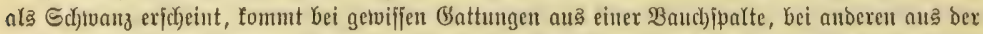

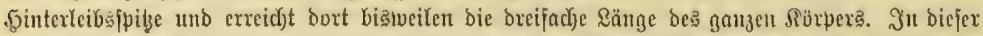

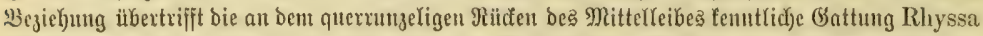

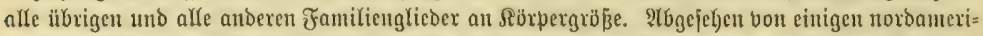

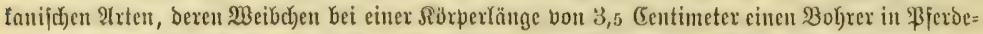

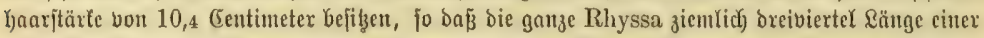

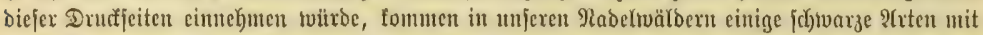

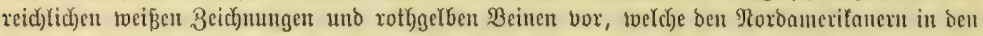

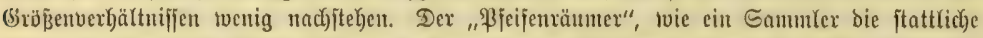
Geftalt zu bezeichnen pflegte, Rhyssa persuasoria ber Gelehrten, fochmarobzt in ben Rarven ber §oł

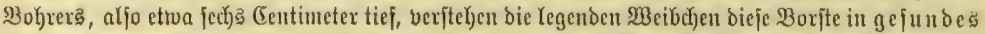

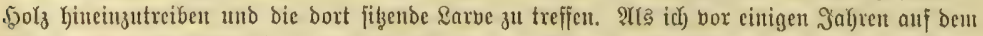

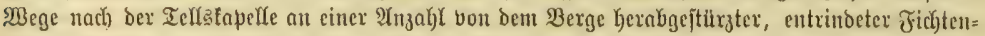

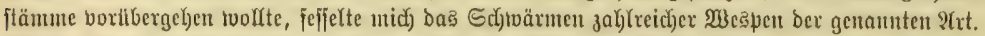
Die eine hatte fid feitgebohnt und zrwar bis ju ber Tiefe, welche fie aiberhanpt erreichen fonnte;

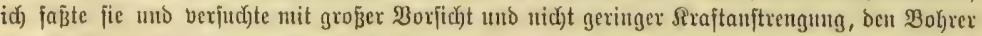

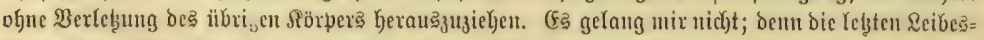

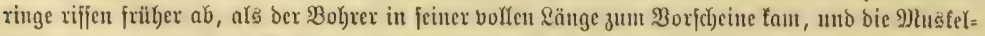
betwegungen in ben abgeriffenen (stiedern bauerten nod) einige Beit jort.

Man fteht hier ftaunenb vor einer räthjelfajten (Exjcheimung. Jene federnbe, pferochanartige

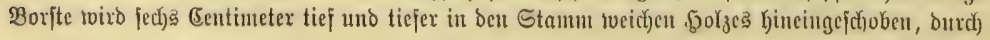




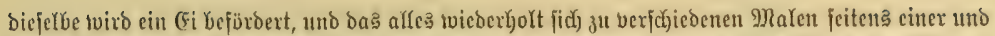

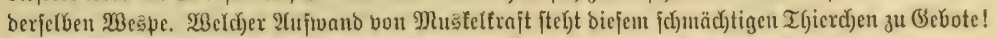

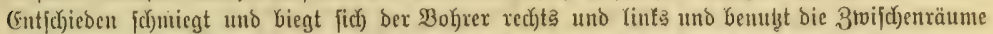

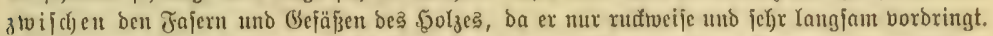

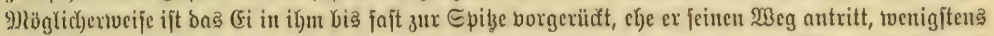

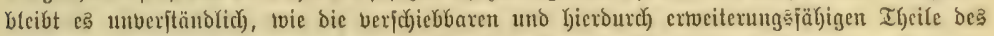

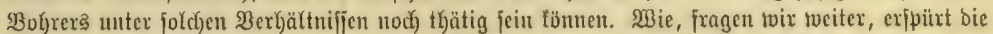

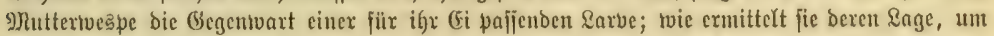

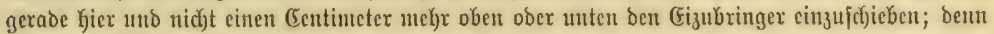

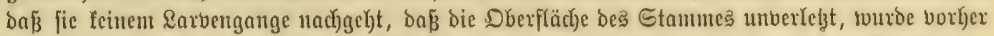

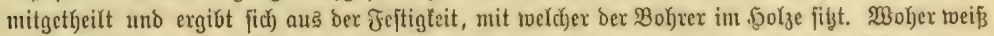

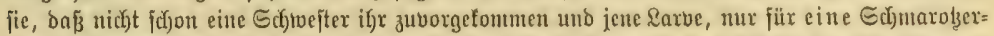

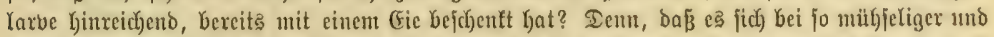

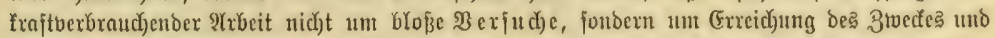

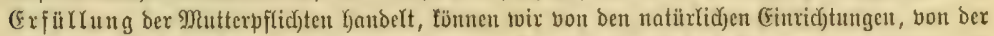

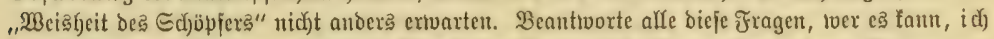

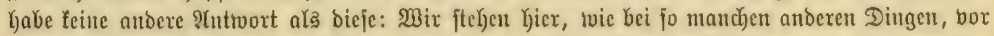

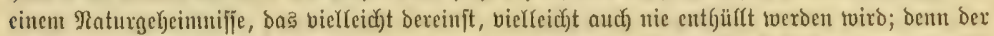

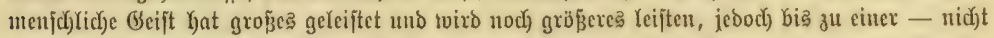

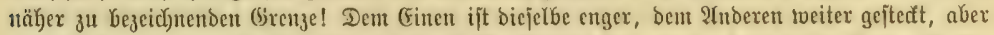

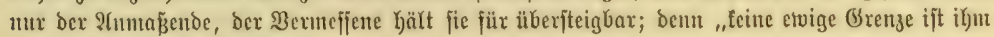
geiebst, aber etwig eine Brenze".

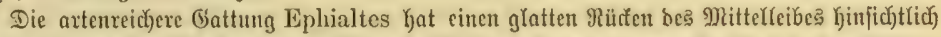

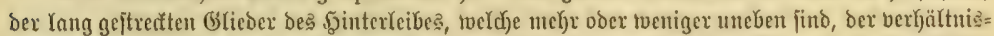

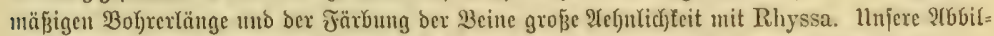

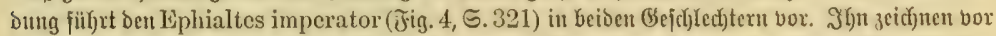

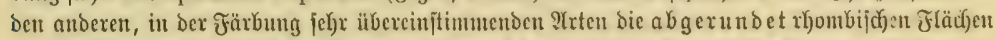

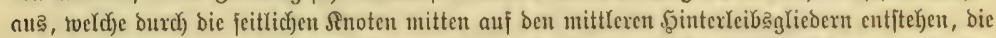

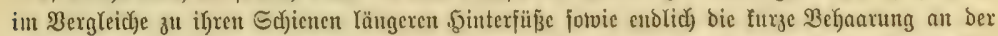

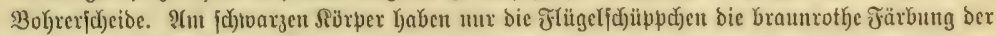

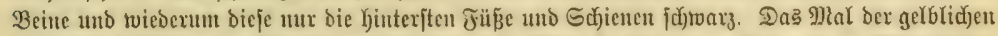
Flügel ift Dunfelbraun, ifre Epiegelyelle breterfig. Wie alfe Ephialtes-2Irten in ber Sïrperlänge

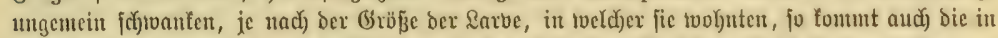

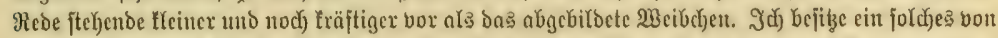

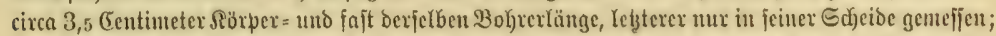

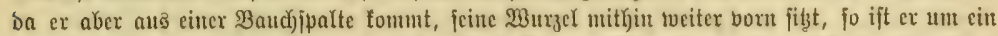

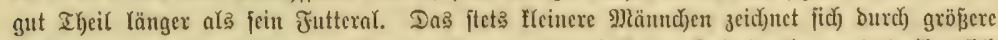

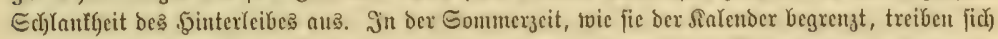

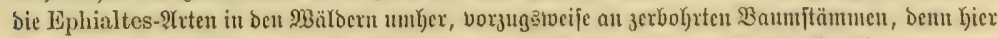

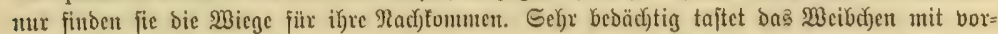
gejtrecten Frih)

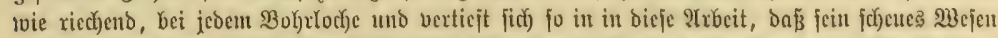

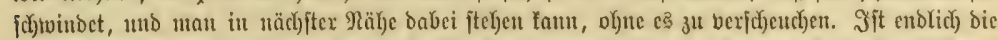

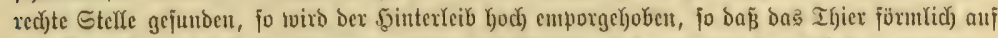

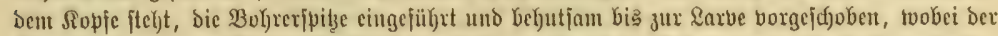

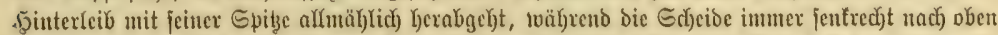

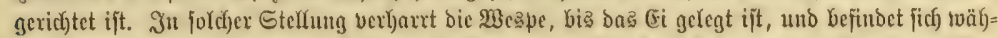

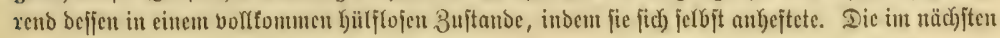




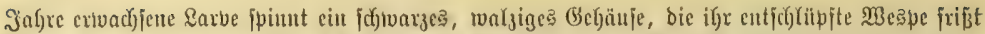

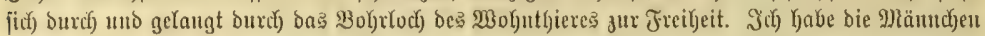

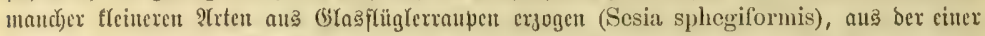

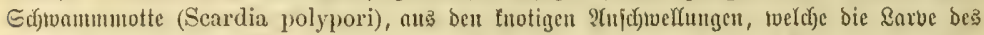

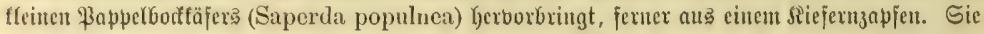

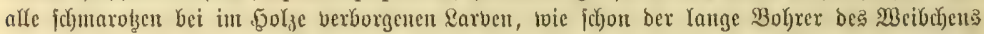

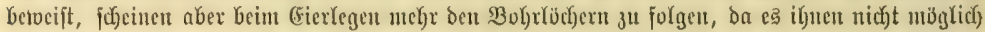

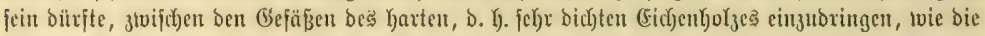

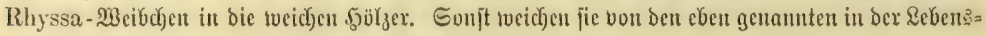
tweife nicht ab.

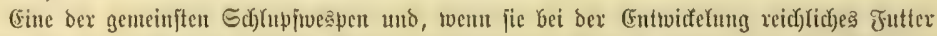
hatte, cine ber gröperen heintijon Sippengenofien ift bie Pimpla instigator, cin jodtwarzer Gejefle, Der lebrajt gelbrothe Sdytenen uno Füp̈e an bent vier vorderen SBeinen, an ben Ginterjten

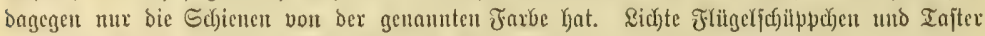

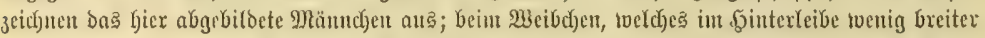

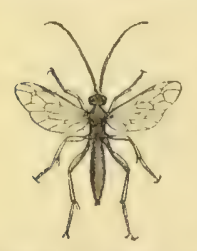

2Räindijen bon Pimpla instI gator, matüri. Bröbe.

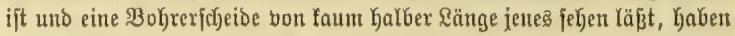
jene bunffere Järbung. Dá̧ bie Ruftlöd)ex bes breiten und rauben

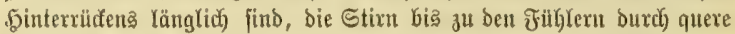
Mabelriffe rauly viro, bie Btieder biejer an ifren Epizen etwas an=

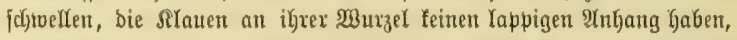

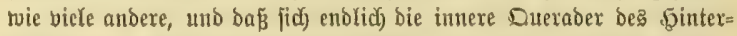

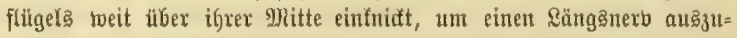
fenden: bas affes find Dlerfmale, weldye twoh) beadjtet jein twollen, un

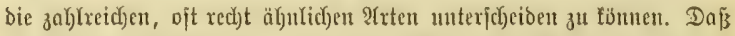

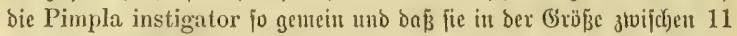

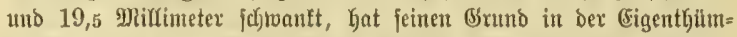

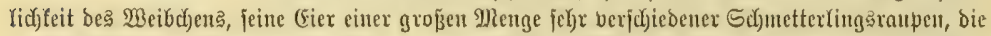

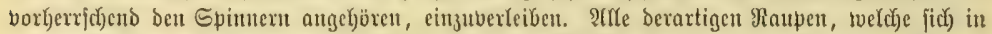

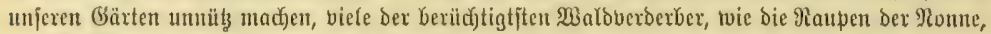

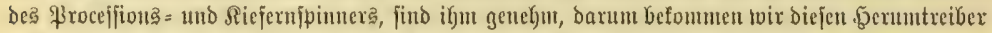

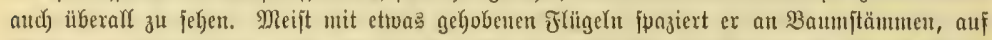

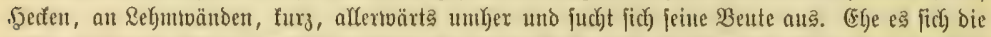

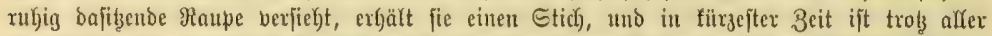

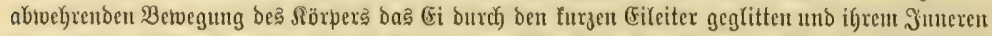
cinberleibt. Mit twippendem Fluge ift bie Uebelthäterin verjd)wunden, treibt ifr Ulnvejen in

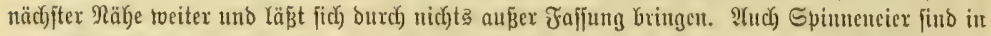

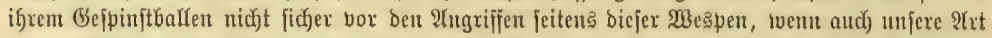

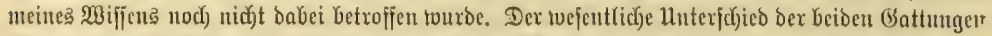
Pimpla unb Ephialtes beruht im gebrungeneren seorperbaute jener: oie Sinterleibsglieder find,

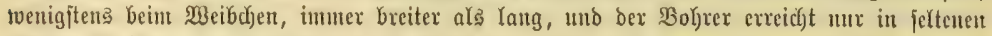

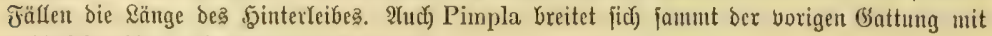
zah)(reid)en $\mathscr{A}$ rten über bie ganze (5xoe aus.

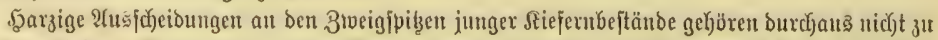

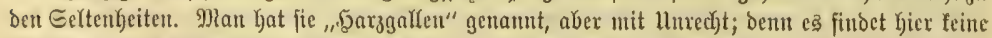

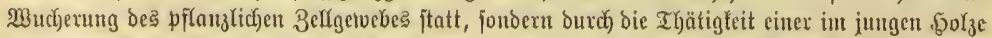

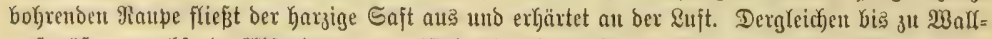

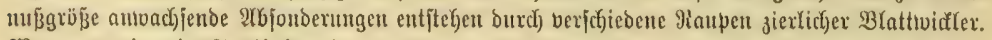

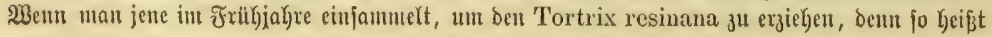




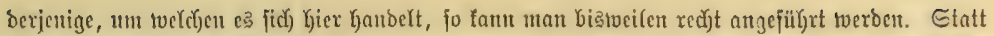

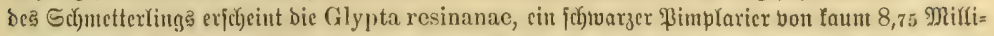

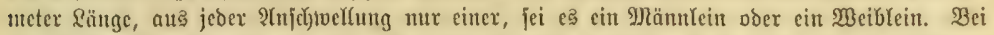

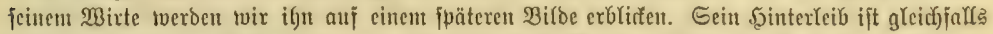

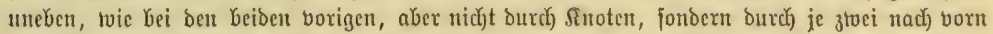

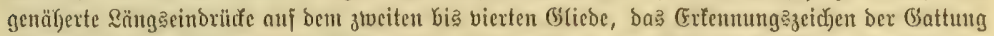

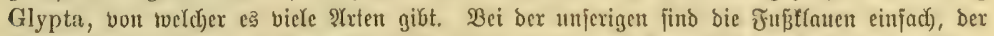

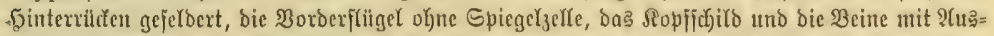

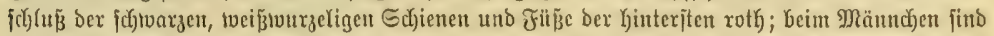

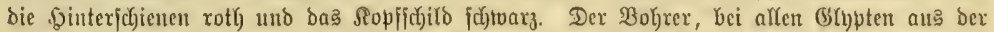

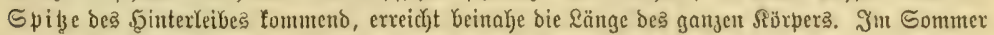

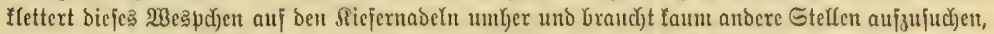

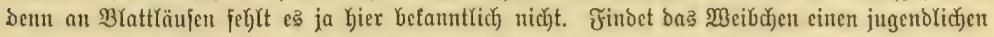
Қarjat:

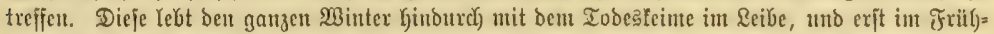

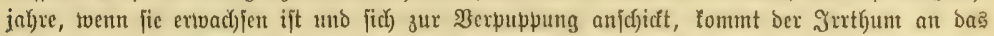

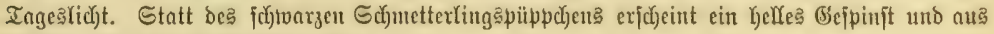
biejem alşbalo bie beja)riebere Glypta.

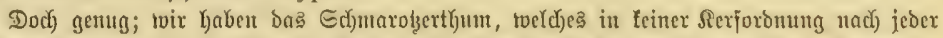
bentoaren Ridjtung in jo vollendeter Weije auzgebilbet ijt als bei ben इautflüglern, Yjinteicheno 3ur Spradje getrad)t, un ciuen (Einblid in bas gel)eine Walten bes fo

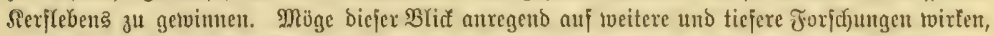

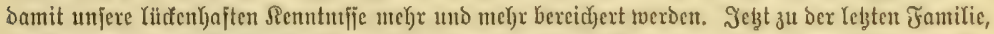

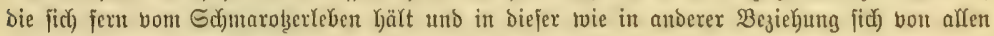

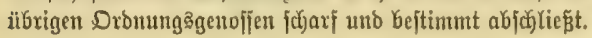

Die Familie der $\mathfrak{P f}$ fanzentuespen (Hymenoptera pliytophaga ober Phytosplieces)

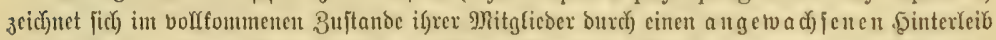

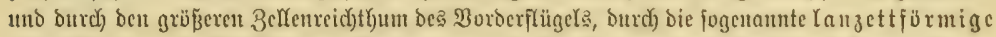

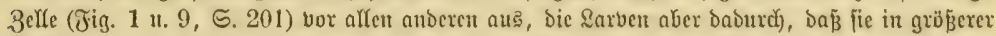

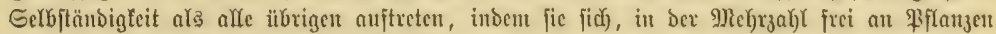

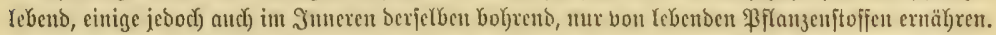

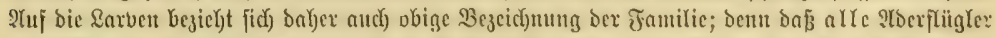

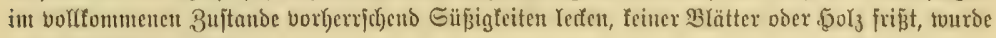
bereiț frither extoülunt.

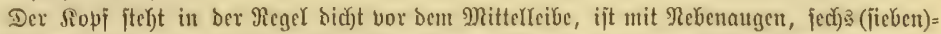

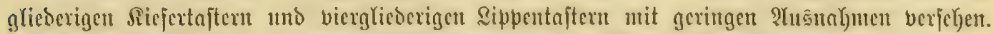

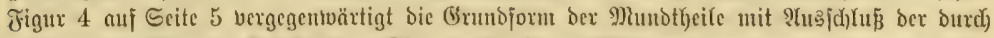

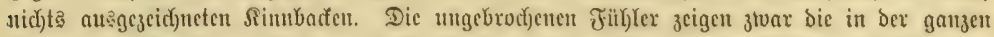

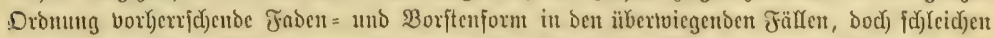

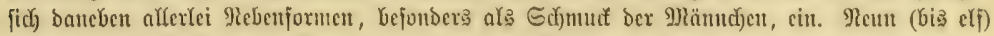

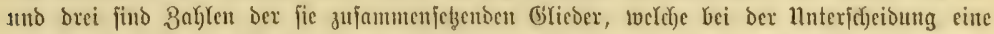

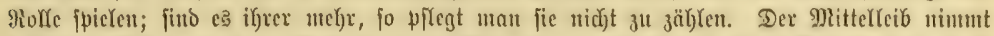

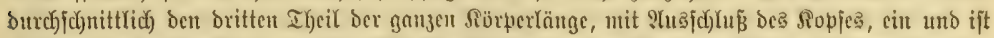

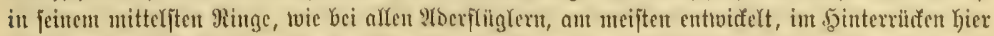

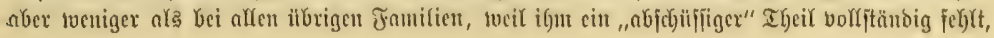




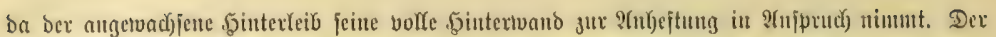
furze Theil, als borberex bon ben abjchiifijigen bei beut nnoeren Jamilien unterfojieden, zeichnet

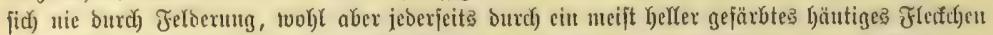

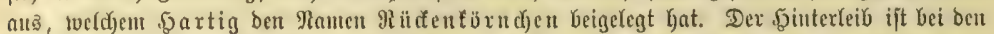

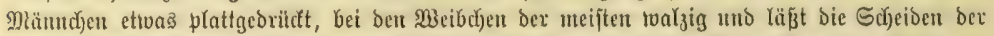

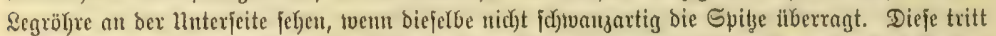

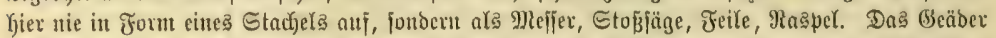

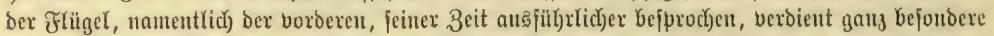

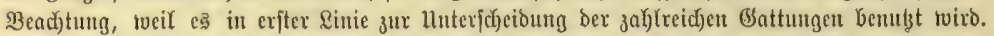

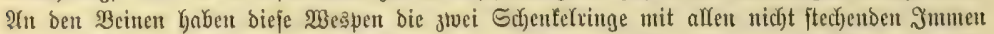

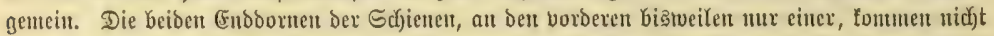

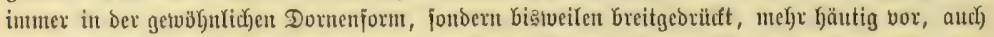

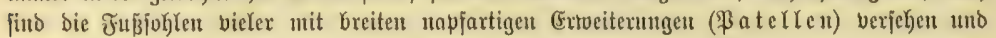
bie Slauen zroizăbnig.

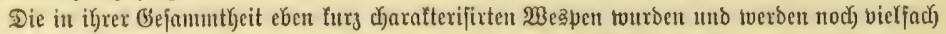

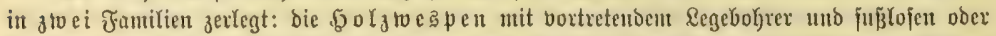

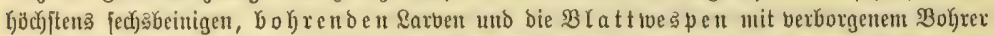

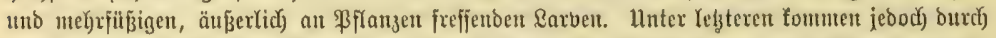

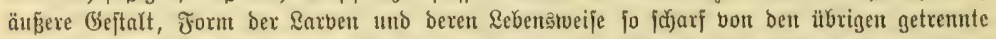

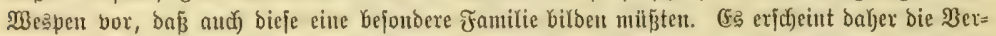

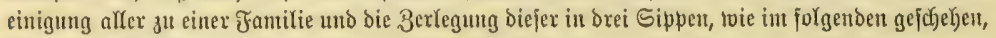

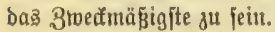

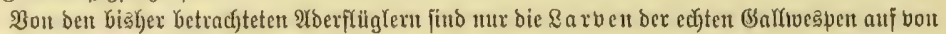
ifnen felbjt ju erreid)ende Pflansenunhrung angetwiejen, aber injojern volfonument unjelbjtänoige

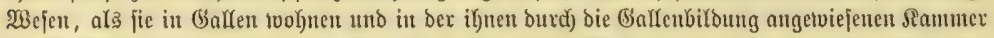

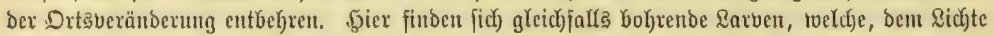

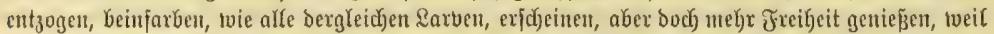

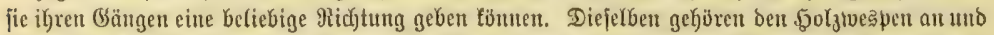

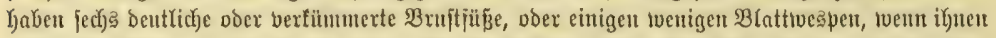

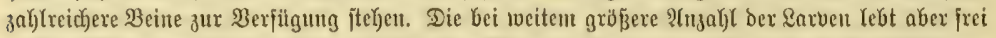

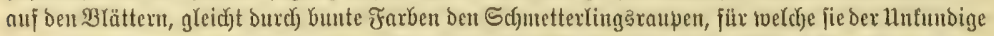

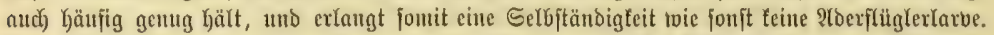

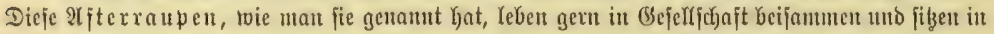

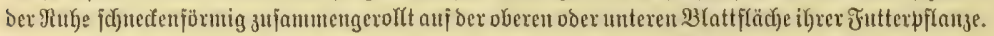

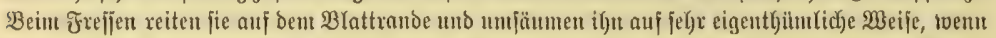

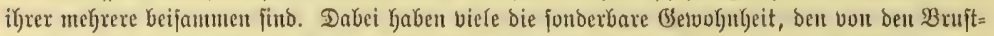

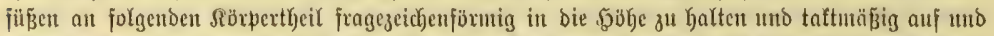

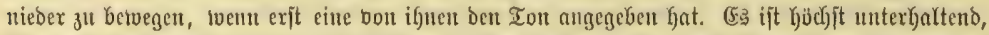
biefe tvippenden Fragezeid)en zu beobad

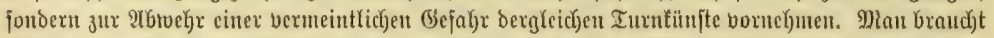

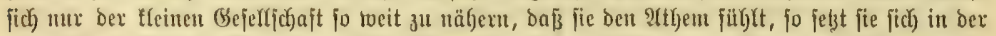

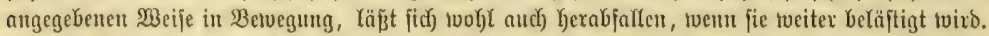

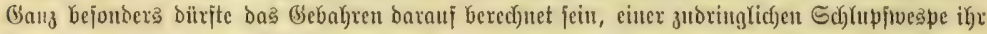

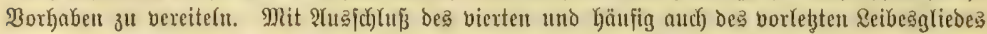

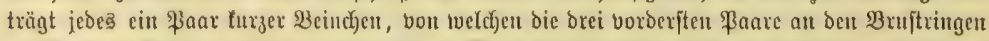

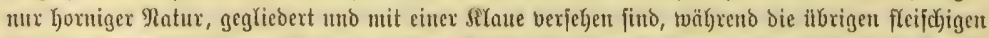

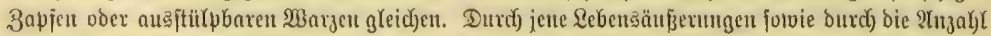

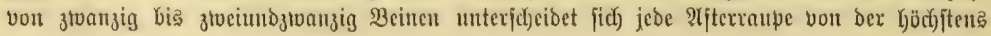




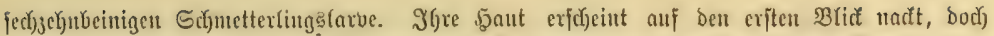

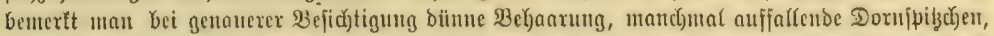

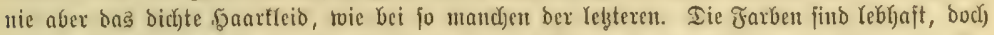
nicht ntantugfaltig, un buntlere ffedte auf helfem (Brunde bie getwöhulichen 3eichnungen. Die

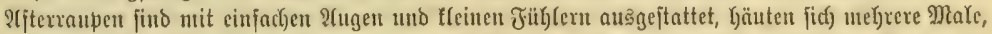

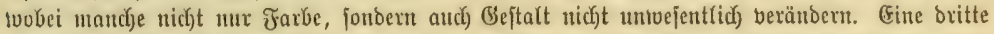

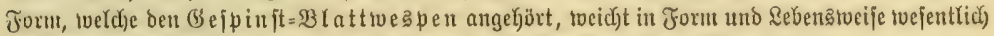
won ben Iijterraupelt ab, wowon weiter unten bei Bejprechung biejer Sippe.

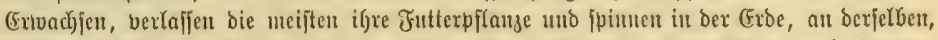
unter bitren \&aube ober Moope, mitunter aber aud) ant Stengel anderer Pfifanzent ein tomment=

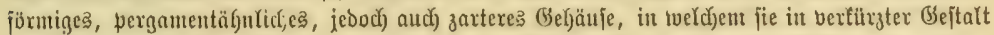

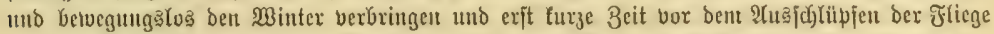

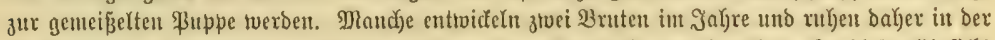

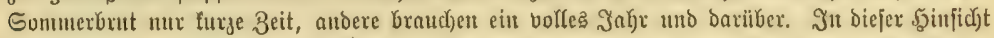

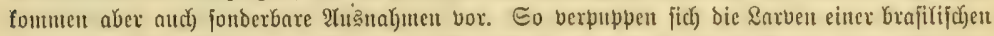

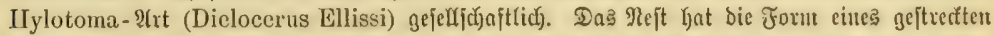

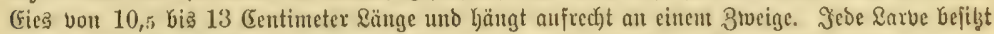

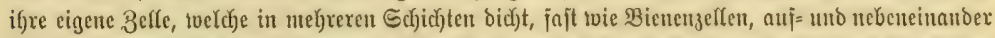

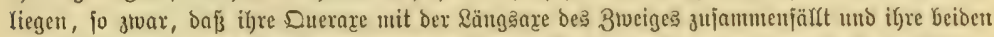

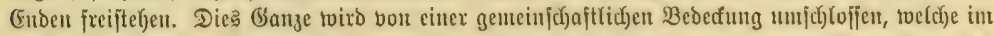

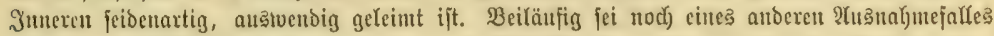

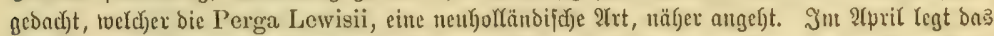

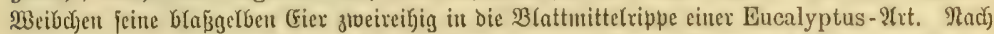

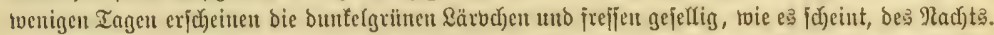

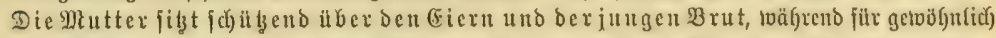

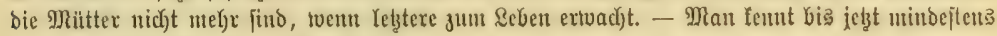
taufeno verifdjiebene Gitieder ber Fantilie.

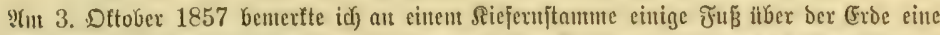

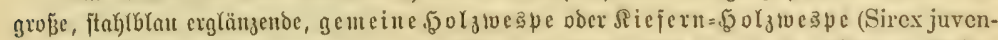

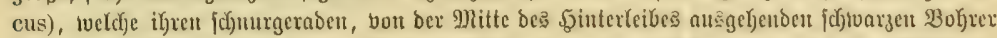

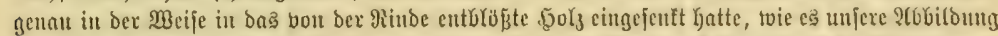

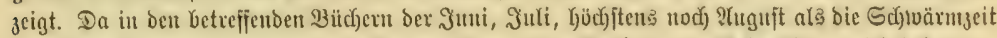

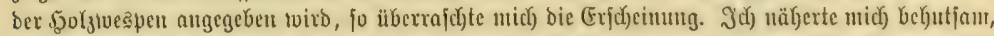

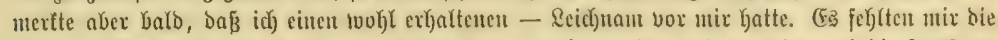

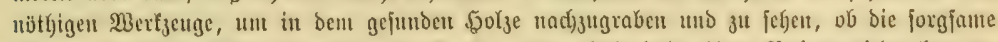

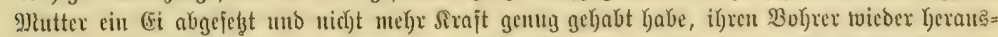

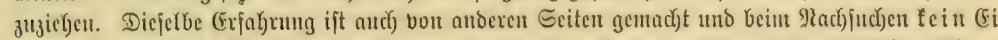

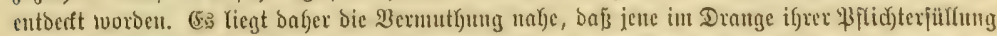

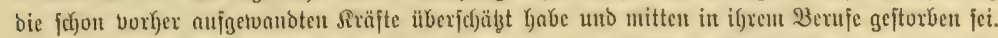

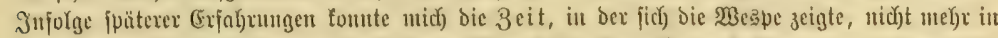

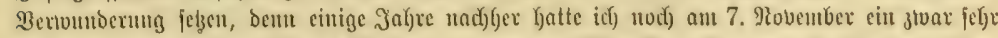

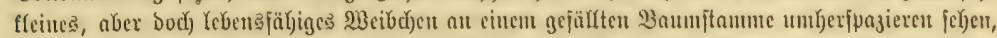

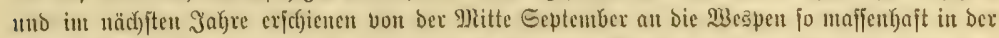

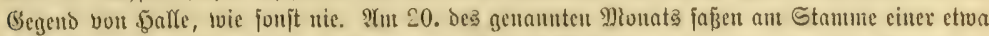

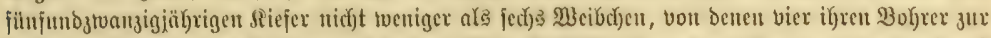

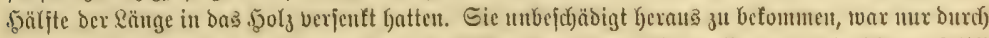

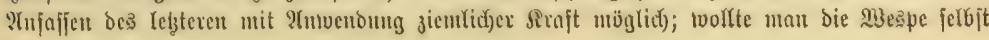




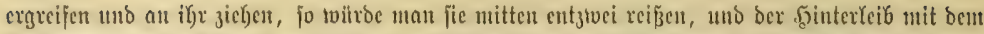

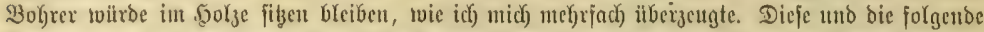

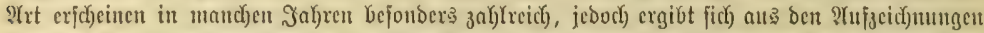

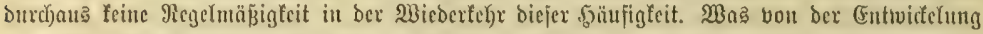

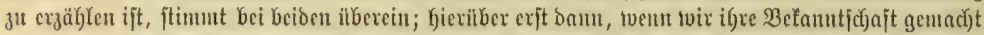

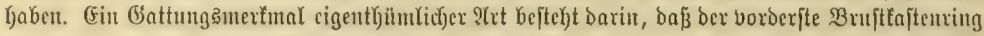

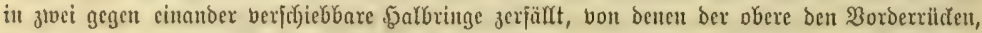

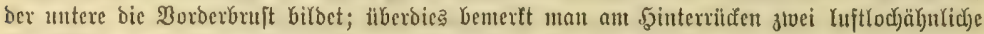
Epaltöfinutgen uno am Munde Leiue Siefertafter. Der ŞinterYeib endet in einem, Gei ben ver=

6
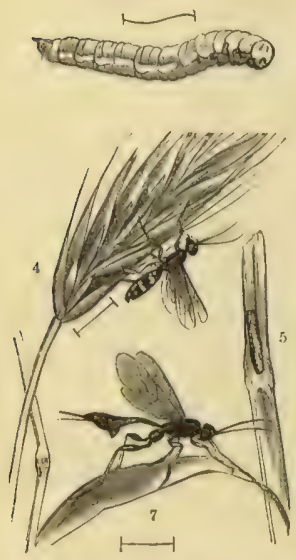

3

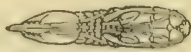

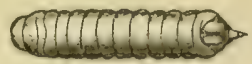

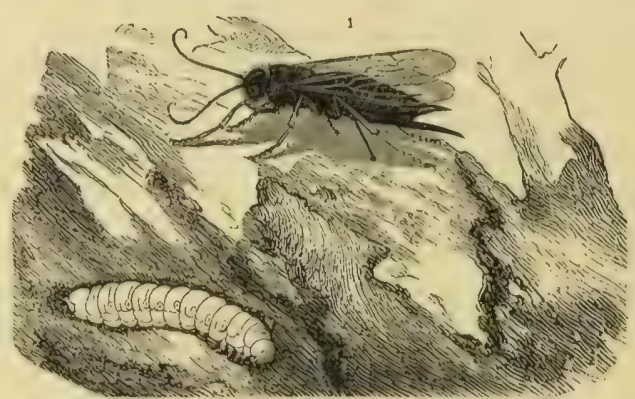

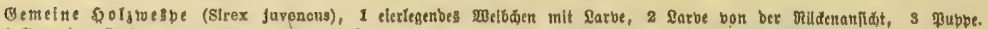

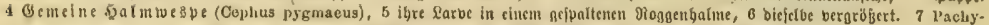
merus calcitrator, eine bei ihr idjmarobende Sidjctroghe. $\{4,6,7$ betgrobert.

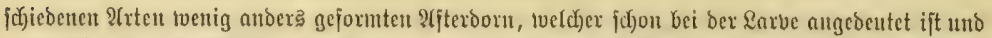

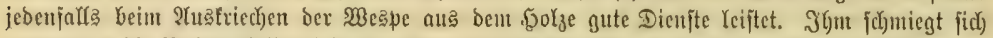

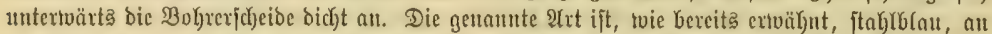

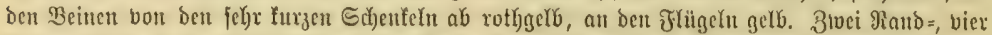

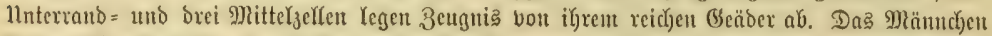

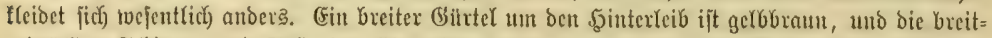

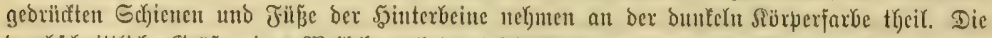

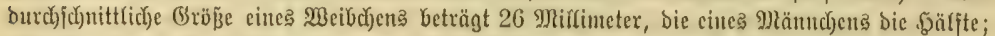

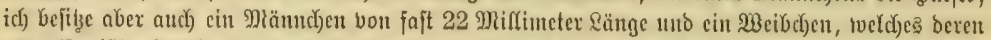

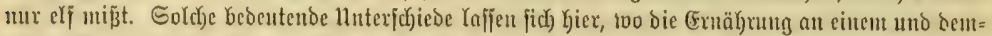

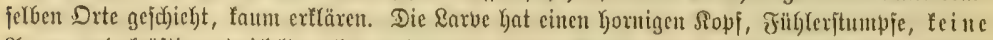

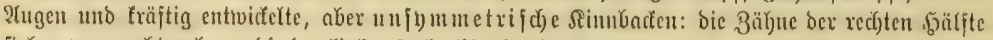
ftehen toagered)t neben =, bie ber Yinten jentrecht libereinander.

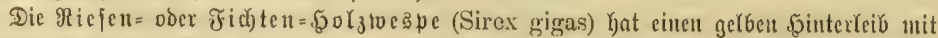

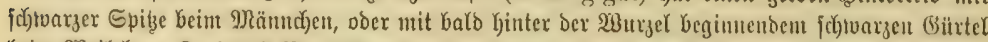

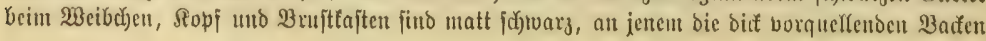




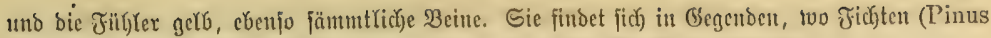

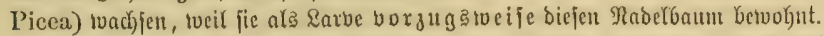

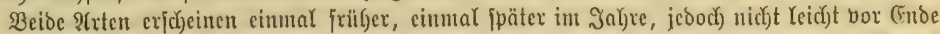

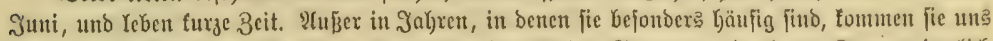

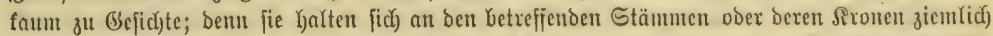

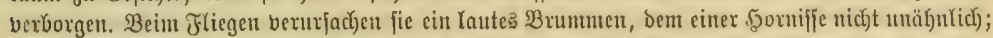

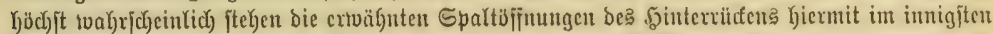

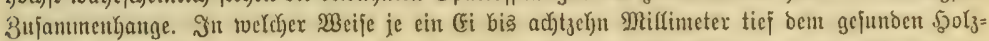

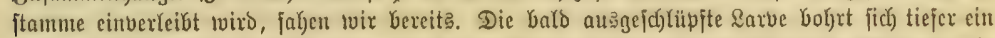

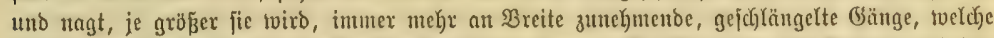

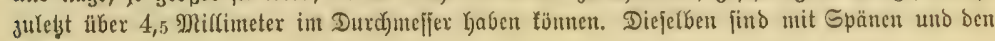
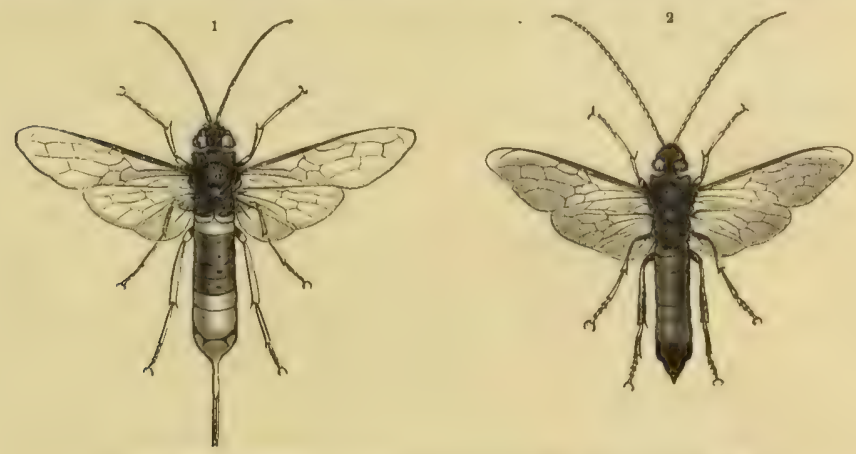

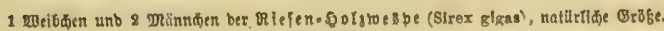

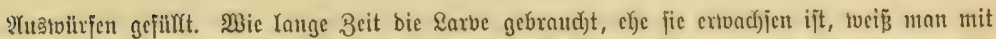

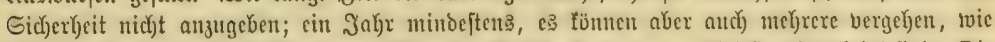

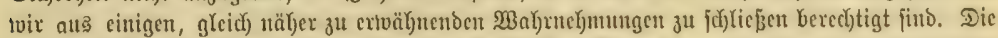

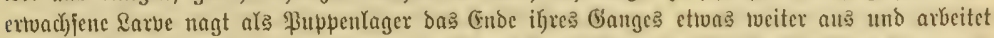

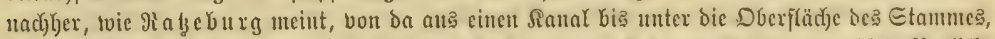

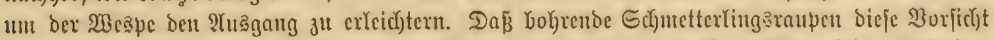

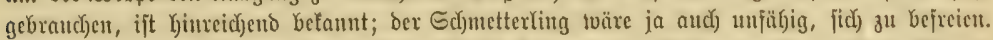

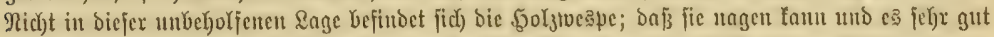

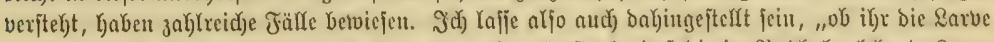

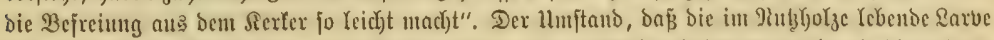

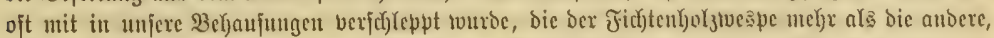

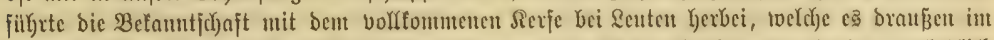

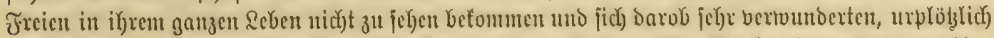

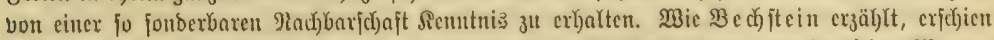

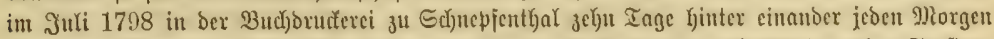

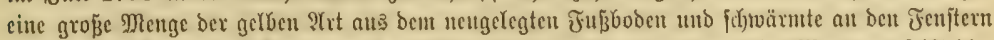

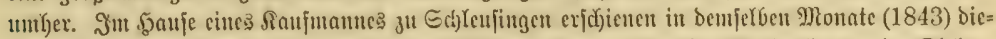
ferben Wespen mafjenljaft, aber auß ben bas Jahr vorber cingebrad)ten lluterlagen ber Dielen;

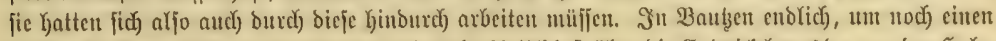

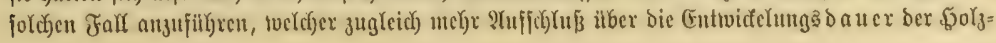




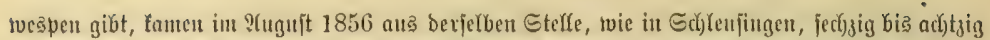

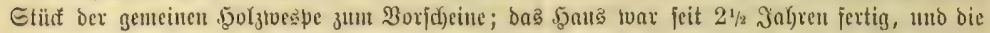

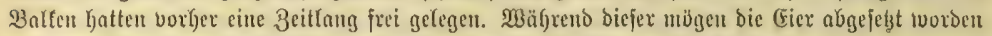

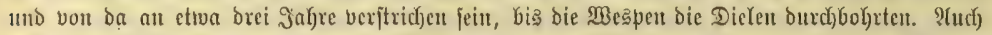

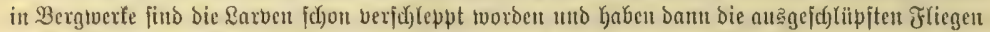

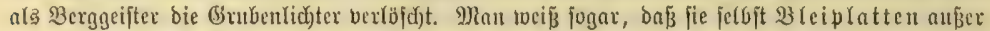

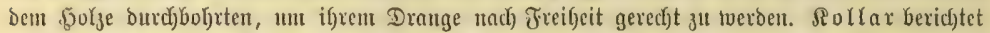

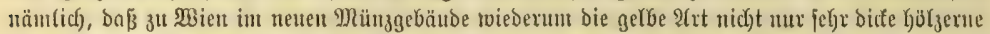

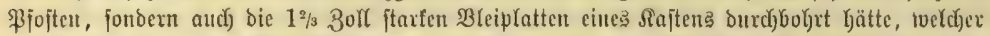

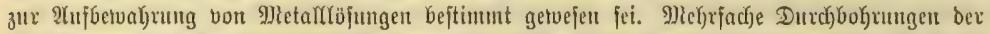

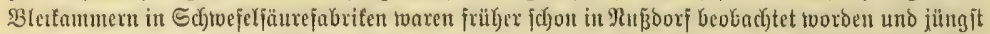

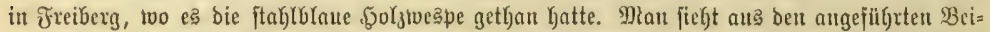

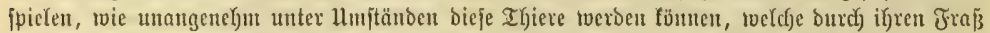

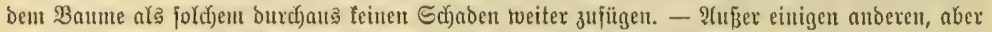

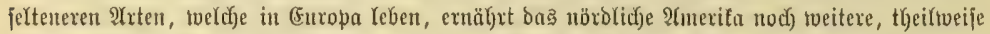

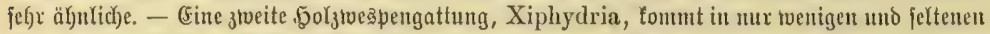

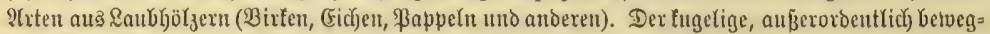

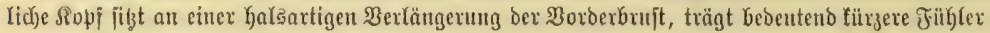
und an Munde brei= ober vierglieberige Rippentajter, twie bei ben vorigen, aber audic) Riejertafter,

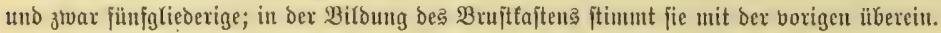

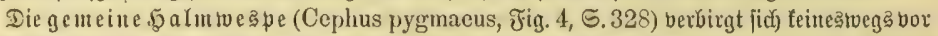

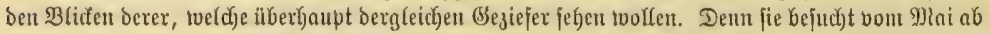

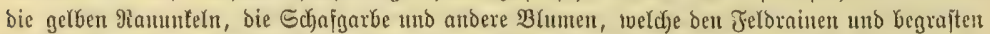

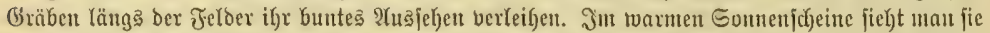

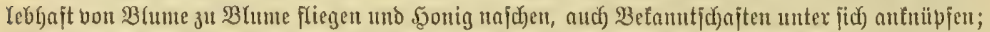

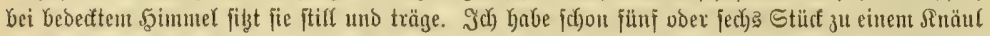

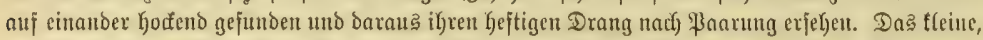

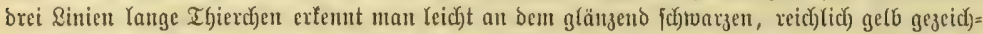

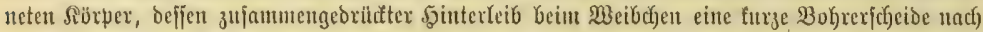

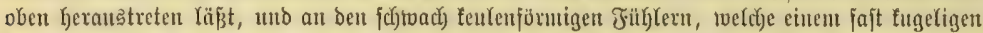

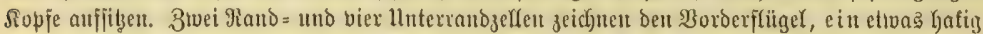

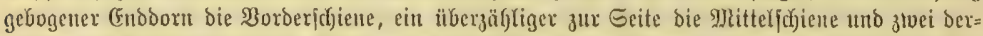

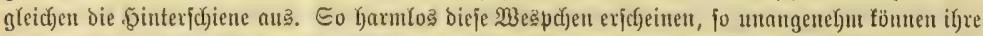

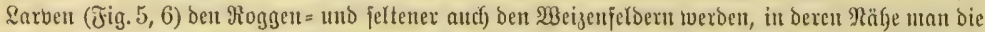

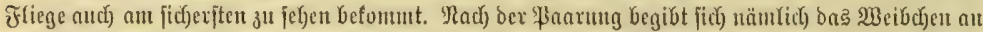

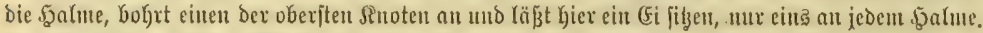

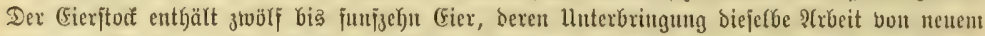

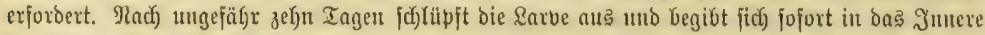

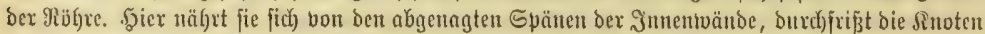

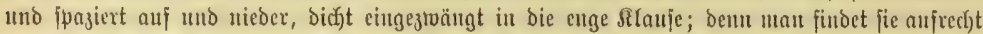

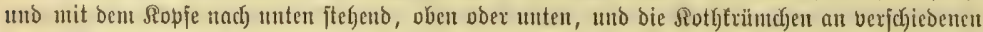

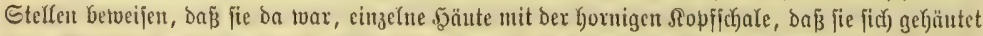

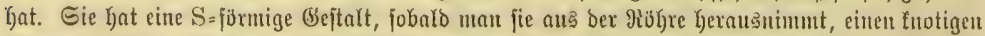

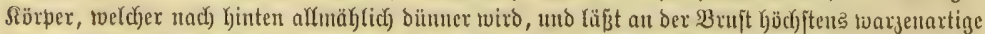

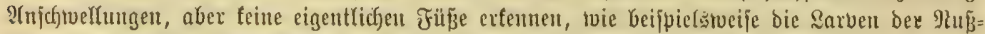

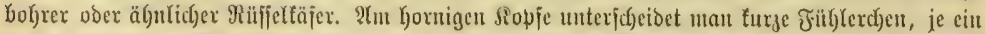

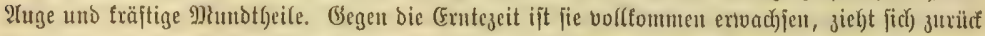

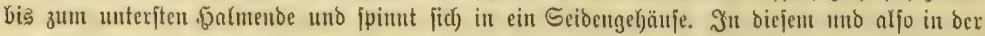




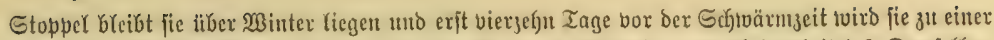

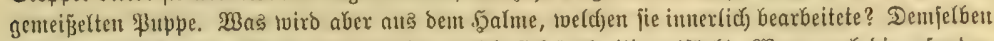
fieht man nid)

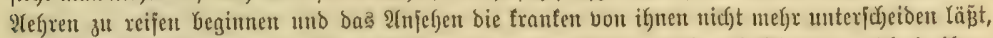

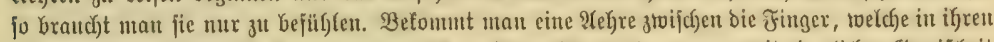

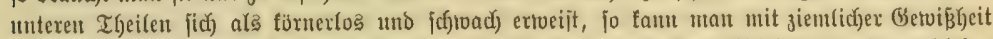

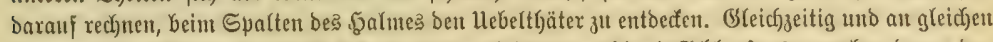

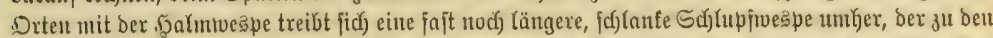

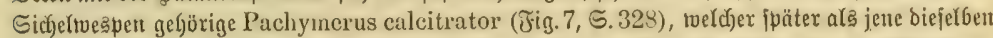

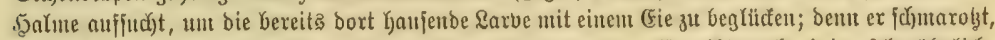

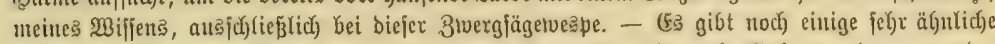

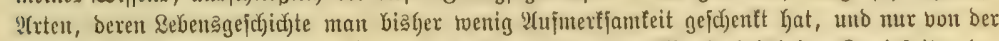
cinen (Cephus compressus) tweís man, baj jie als ¿arbe bon Marfe einjägriger Broeigipitzen ber Bixnbäune Yebt.

Die Gefpinft= ober breitleibigen Blattwespen (Lyda) bilben in ifren zah)lreid)en,

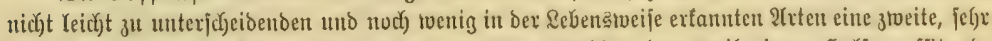

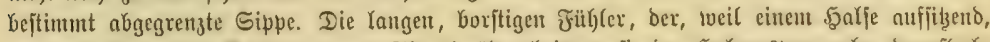

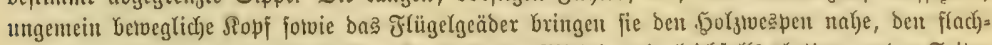

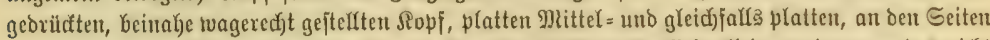

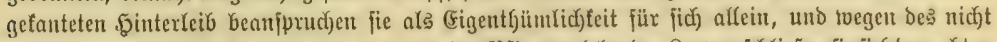

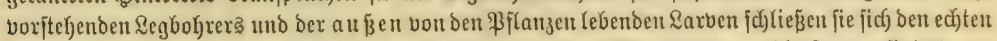

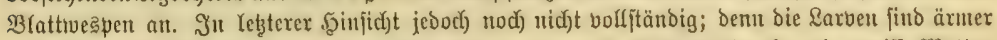

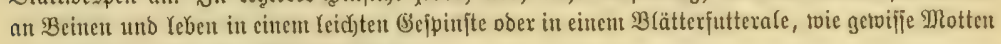

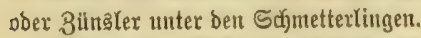

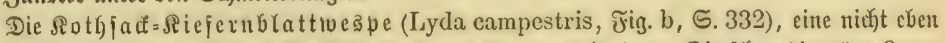

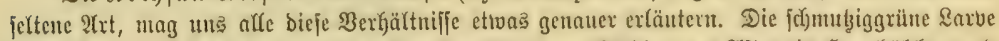

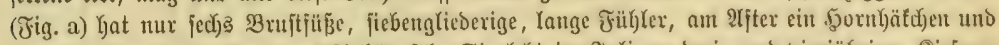

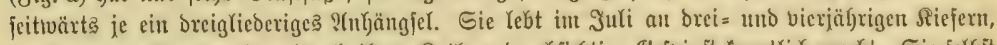

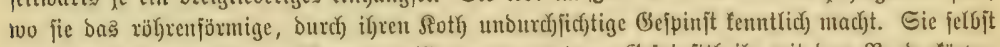

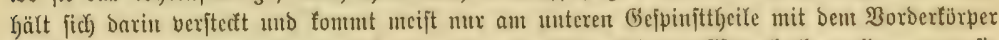

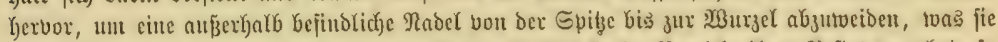

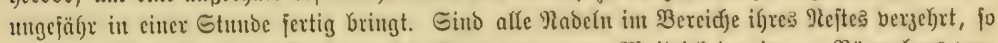

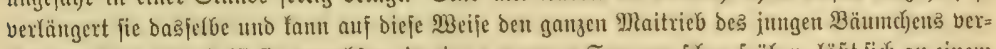

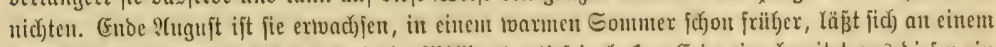

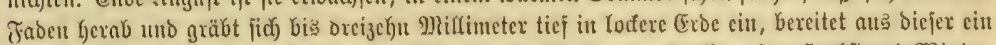

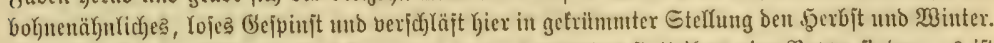

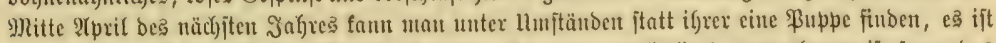

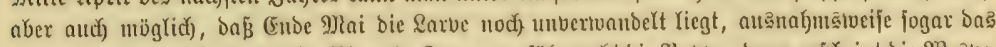

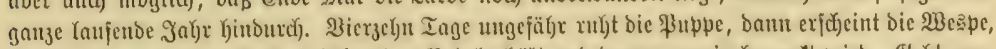

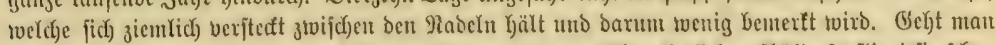

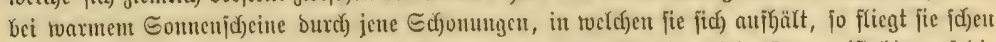

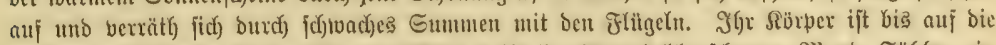

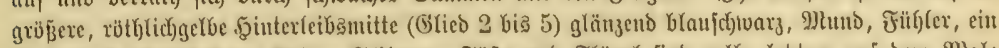

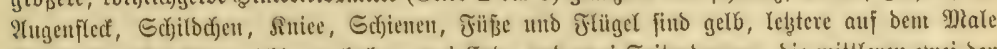

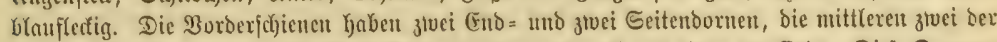

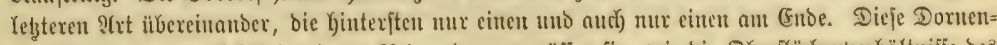

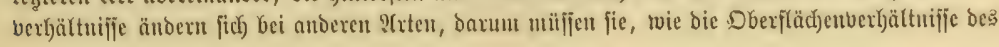




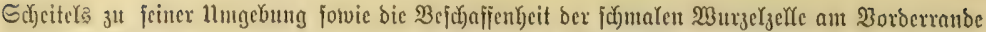

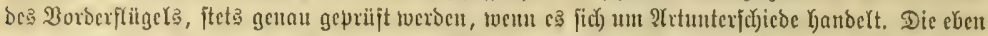

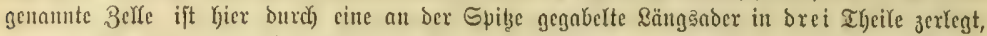

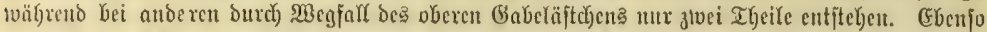

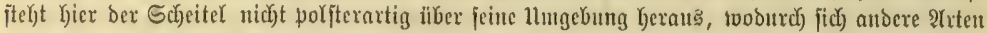

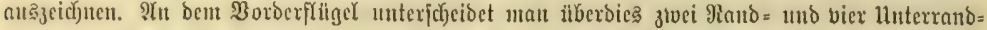

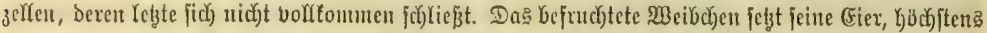

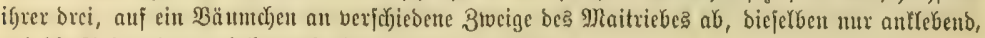
und bie Folgen babon Kaben twir bereita femen geternt.

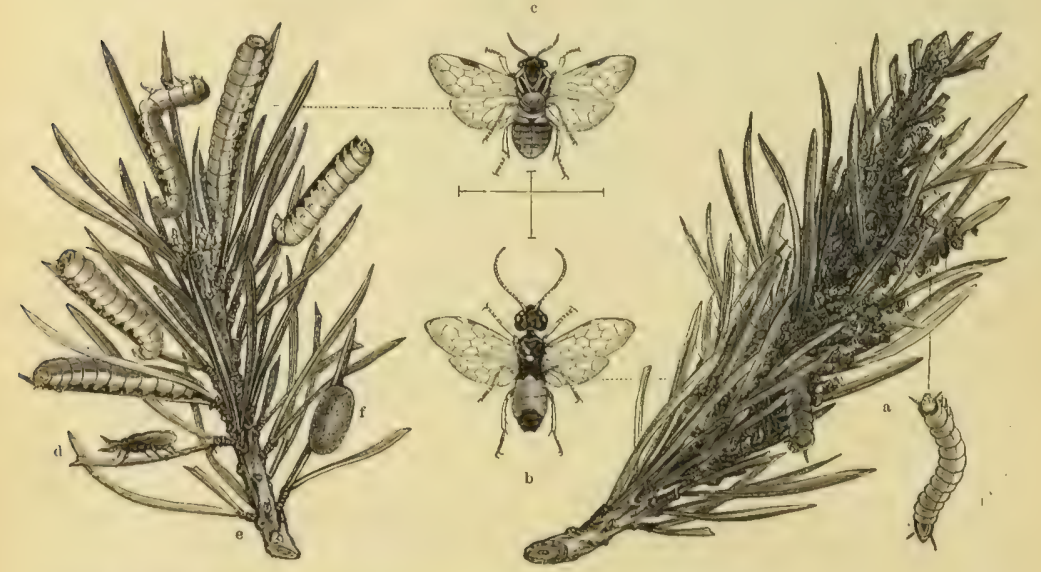

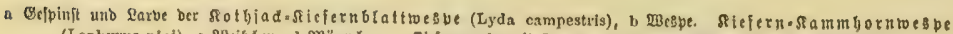
(Lophyrus pini), o 2Beibden, d Pännden, o Siefernstorig mit Iarben, f Puppengebäule. (Nur o vergrobert.)

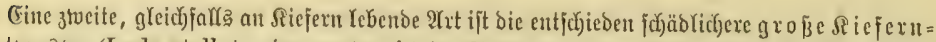

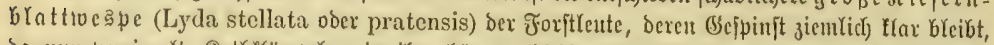

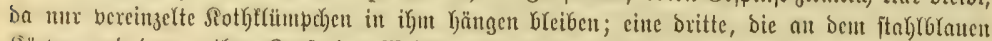

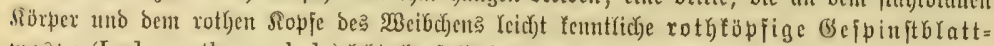

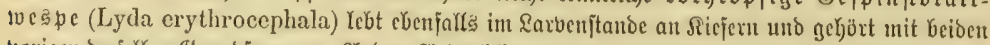

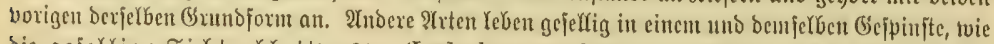
bie gejerrige Fidjtenblattwespe (Lyda hypotrophica) an funjzchu= bis zlvanjigjälyrigen

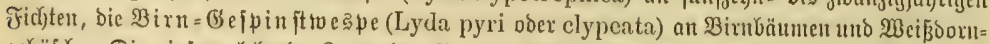

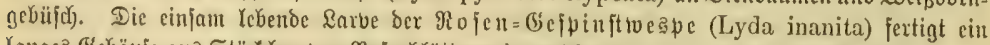

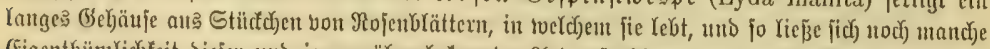

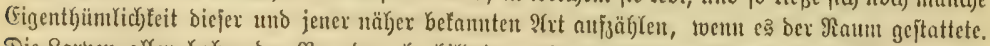

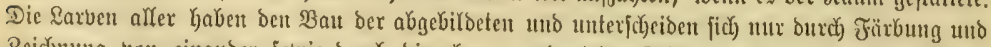

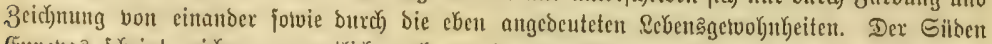

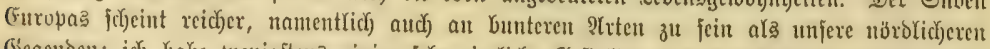

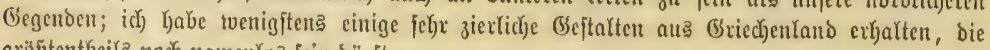
größ̄tentbeils noch namentos fein büriten. 


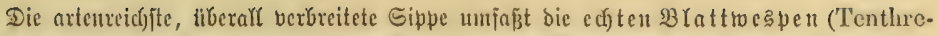

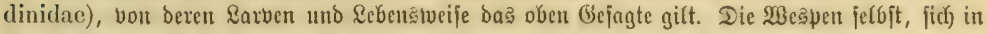

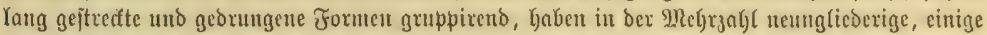

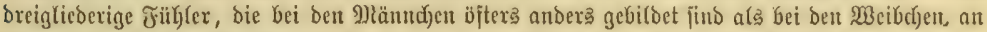

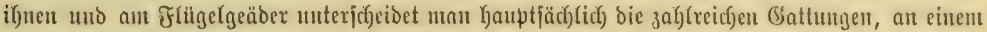

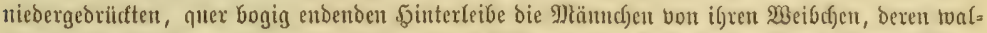

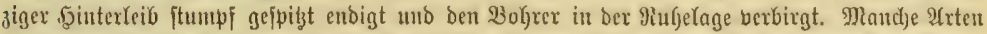

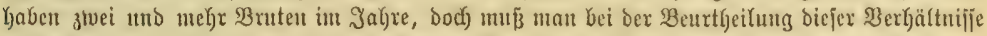

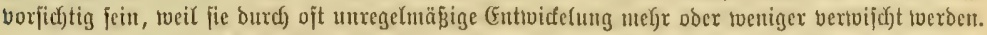

Die $\Re$ icfern= $\{$ a mulyorntue

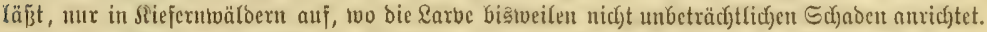

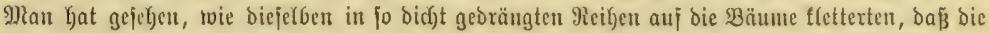
Stänune gelb gefärbt twaren, wie fie oben bie 9adeln volfitändig bedeffen un in Sinäulen von

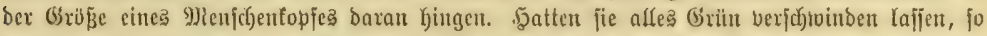

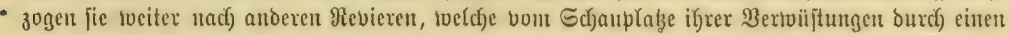

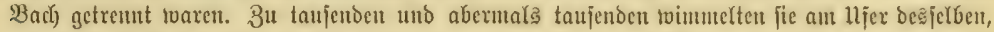

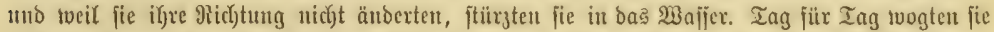

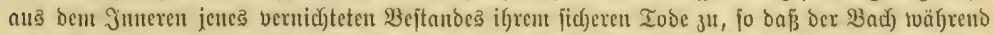

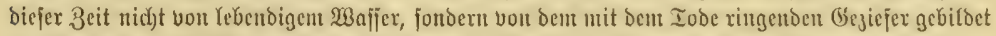

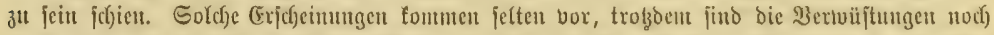

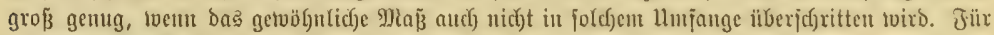

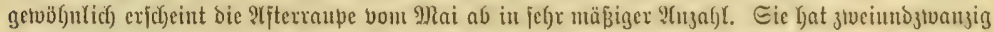

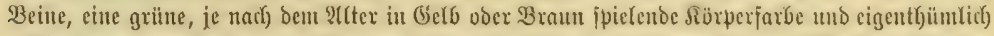

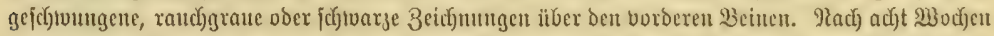

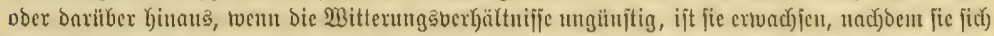

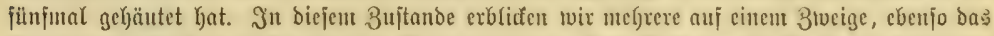

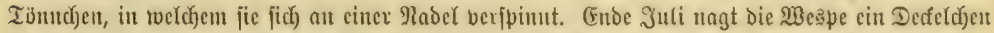

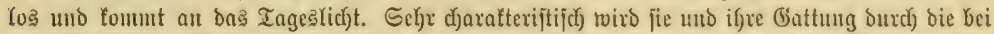

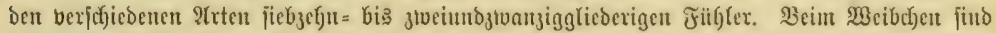

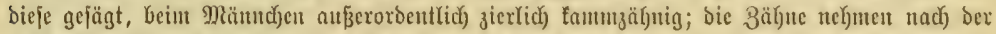

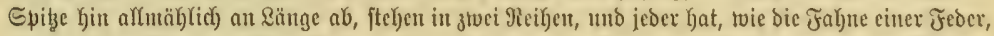

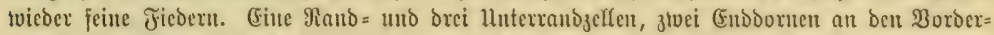

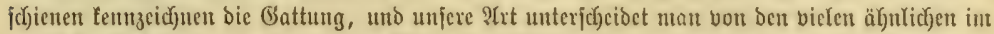

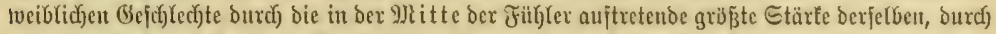
Den bidjt punttirten Sopj uno Mittelfeib, bie Gier uno ba in flciuen Streffen autageblicbenen Jlitgel=

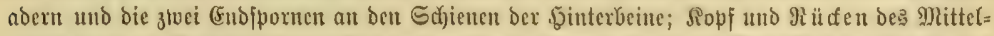

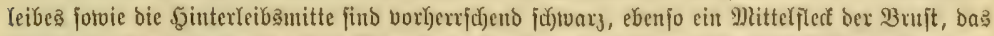

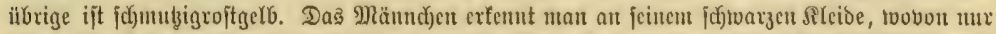

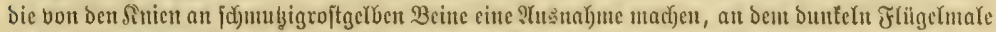

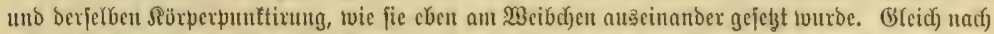

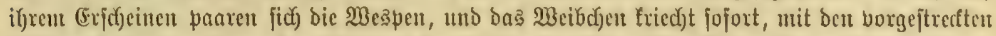

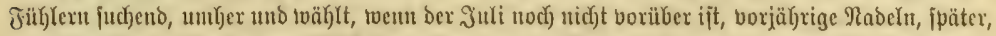

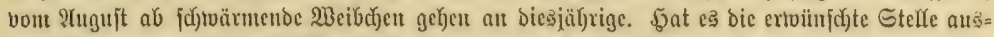

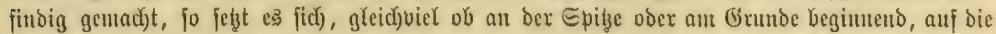

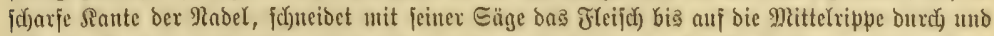

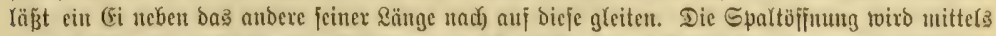

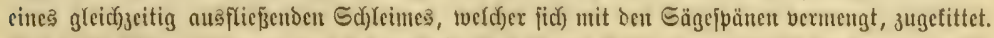

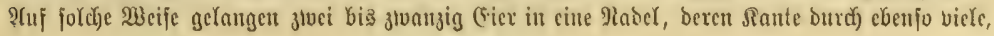




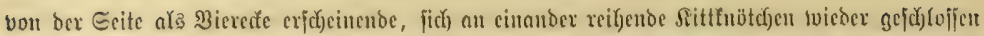

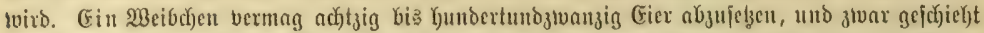

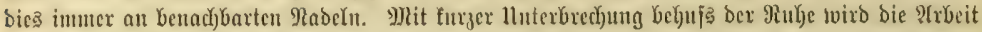

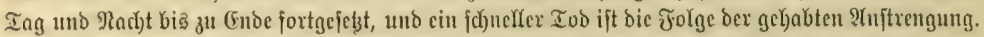

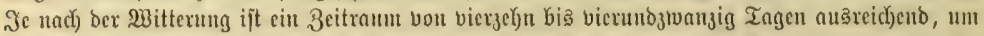

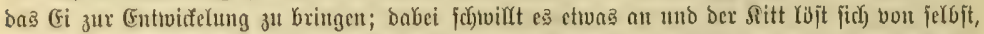

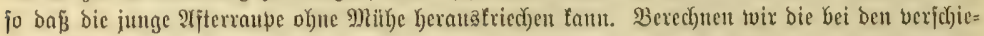

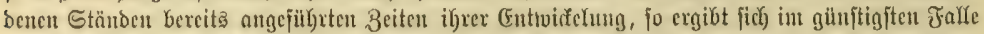

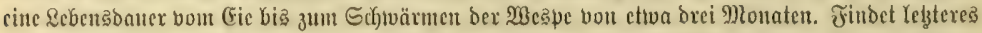

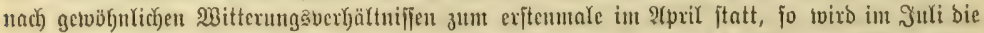

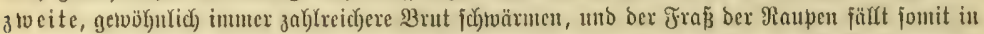

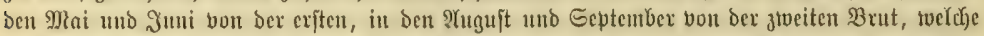

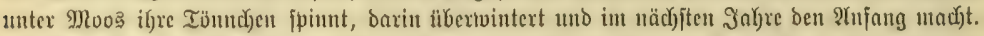

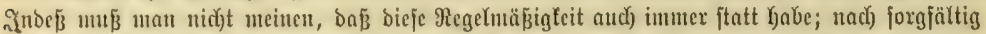

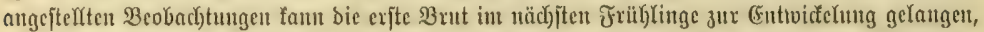

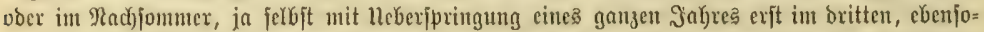

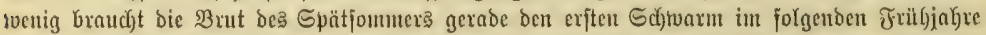

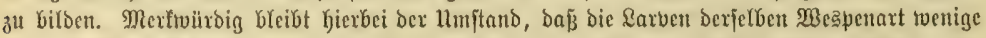

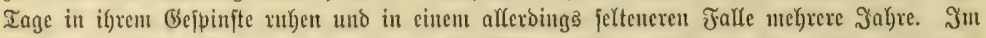

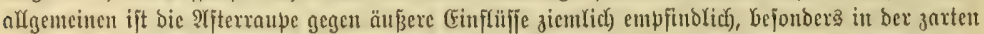

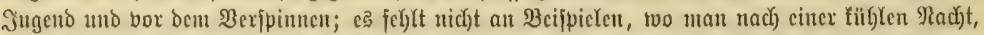

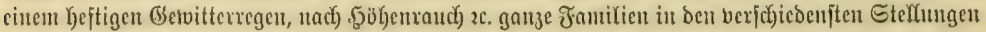

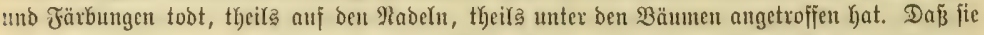

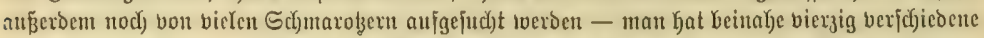

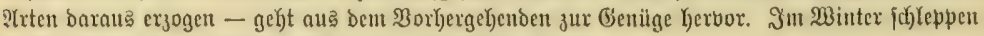
Die झläuje gern bie Tönchen zujammen und jrefjen fie aus.

Nematus ift cine fefre verbreitete Gattung, Deren Arten wegen ber grop̧en Uebereinftintmung

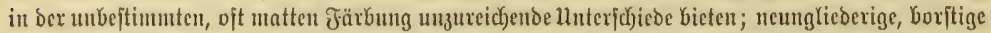

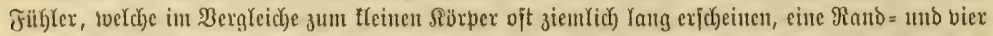

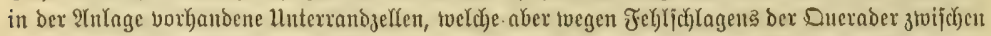

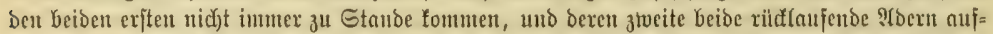

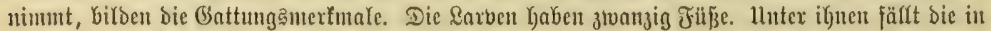

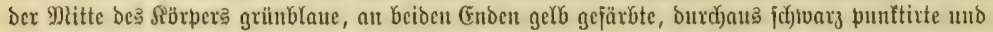

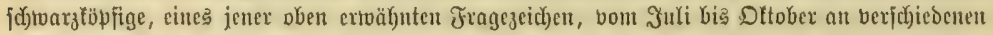

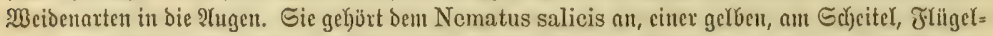

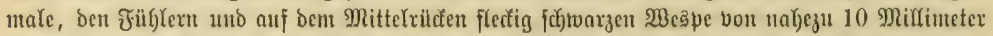

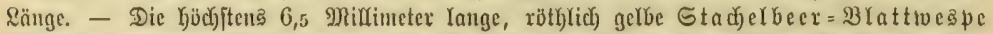

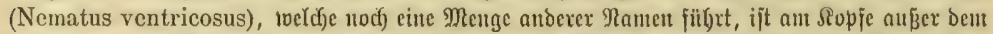

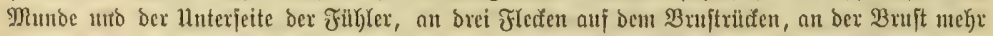

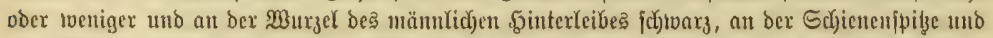

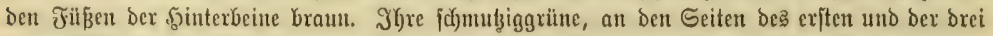

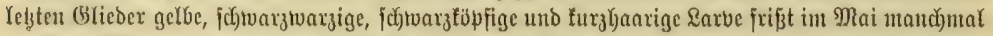

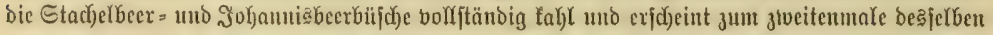

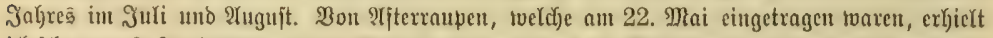

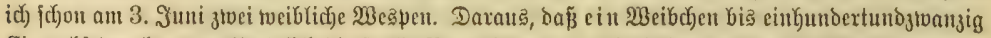

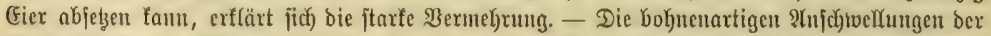

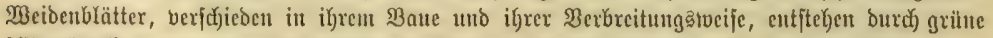

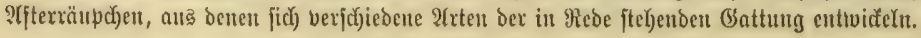




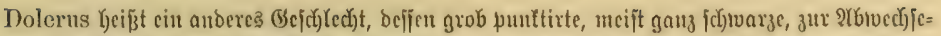

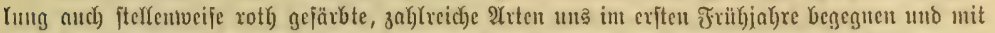

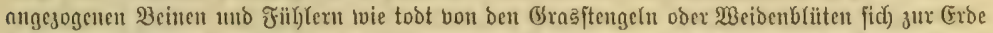

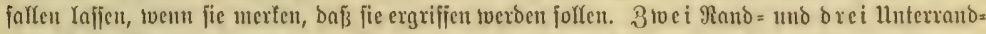

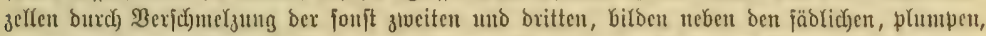

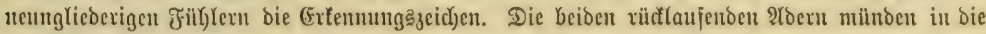
mitteljte Ilnterranogelle.

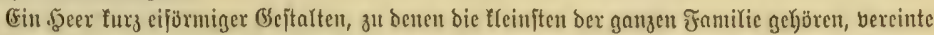

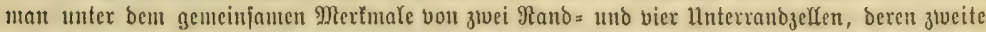

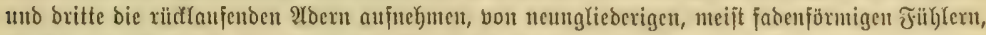

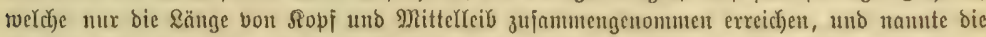

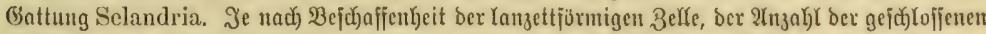

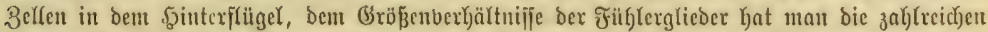

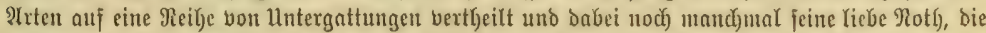

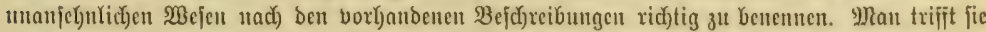

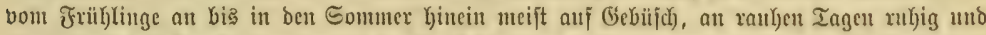

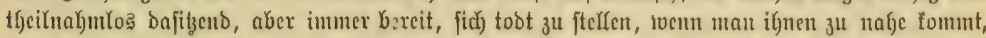

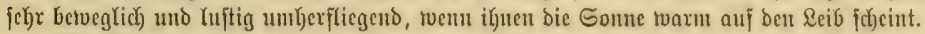

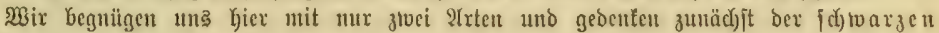

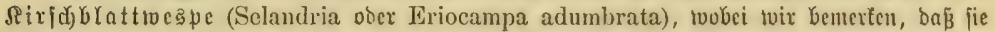

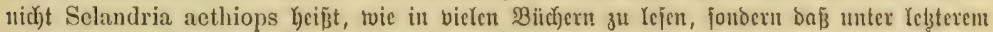

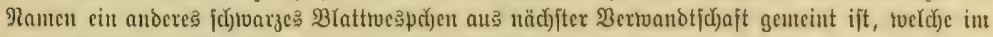

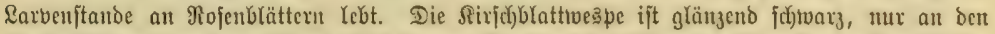

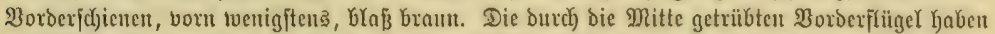

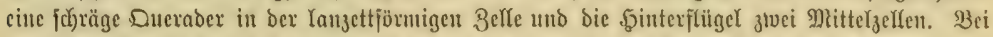

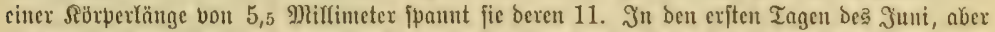

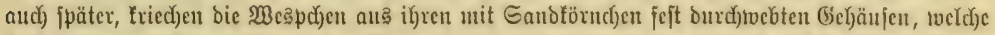

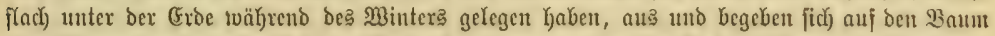

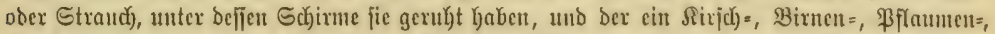

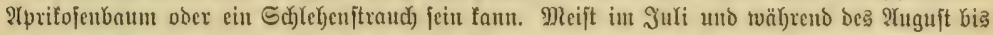

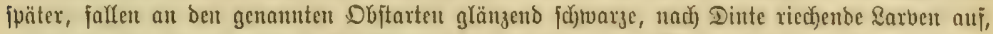

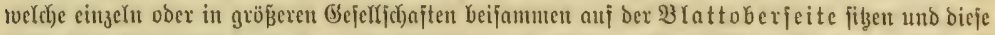

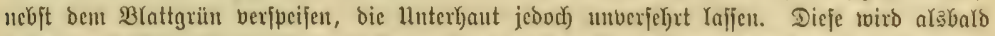

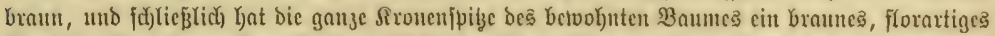

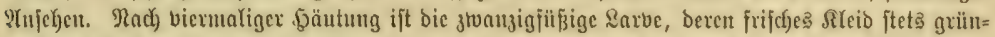

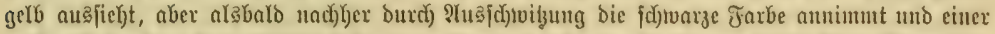

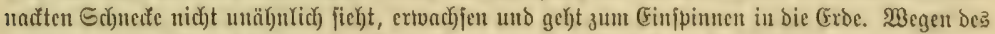

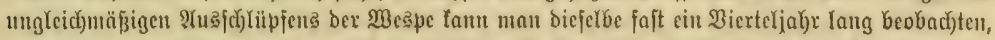

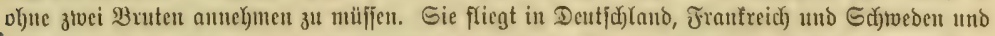

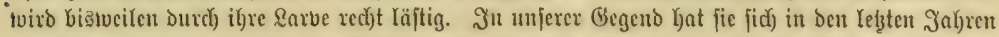

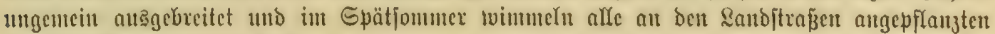
Sauerfirjocten bon ifrex Rarbe.

Dic PfY a u ue = Sägetoespe (Sclandria ober IIoplocampa fulvicornis) hat cine in ber

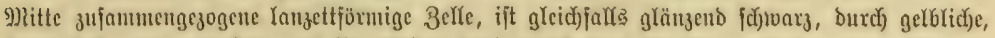

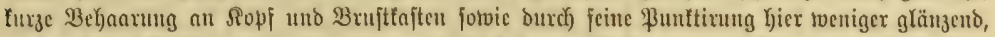

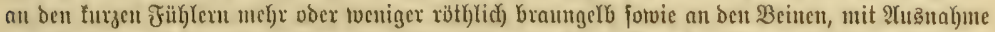

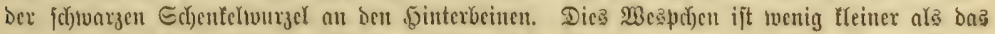

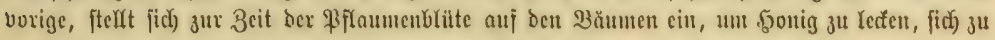




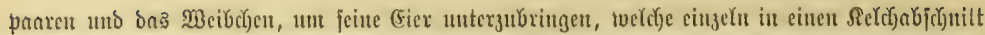

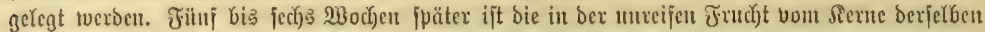

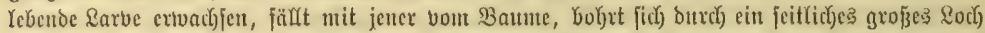

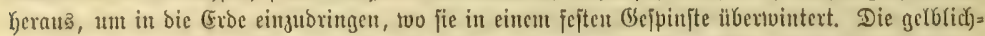

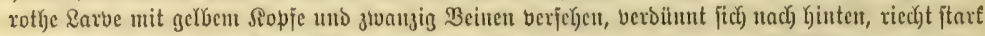

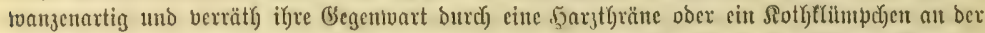

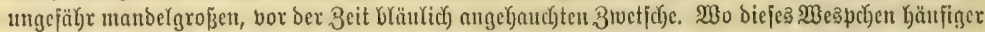

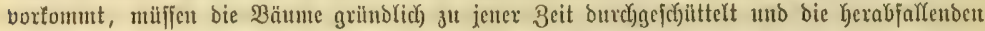

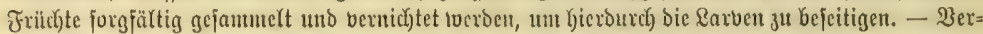

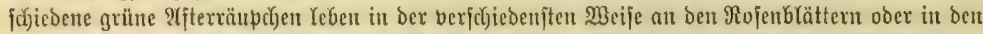

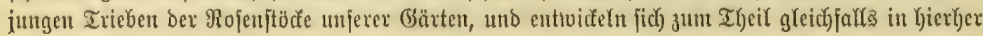

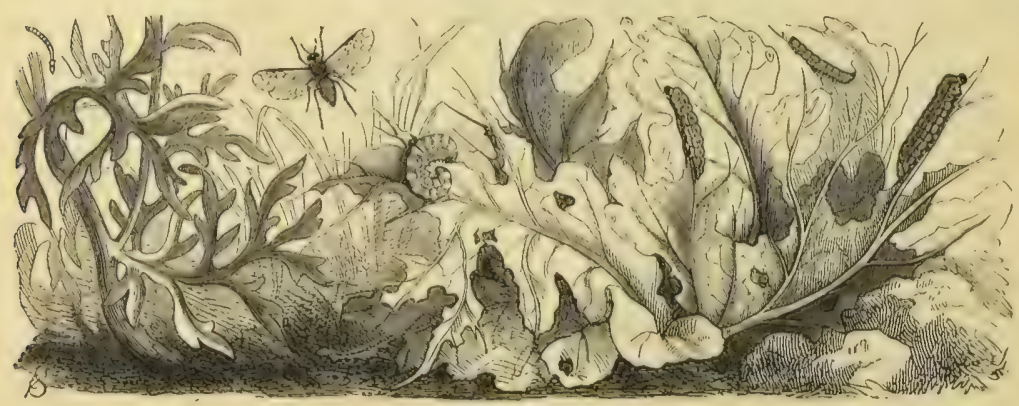

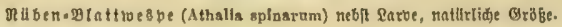

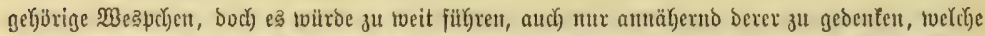

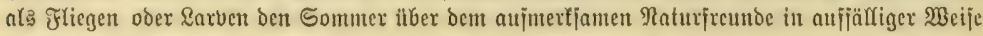
begeguett.

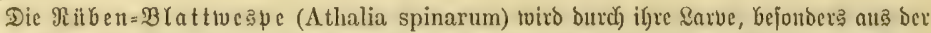

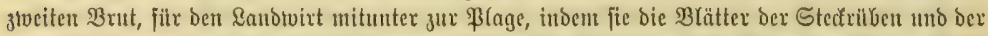

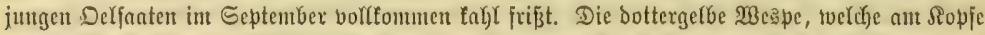

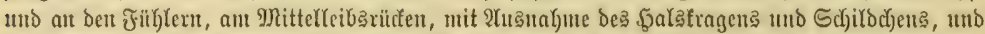

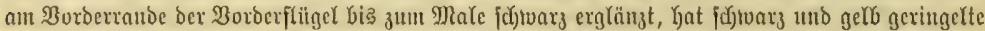

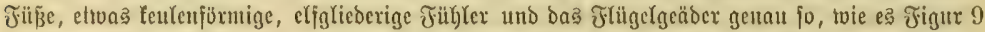

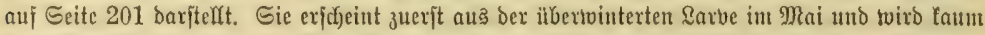

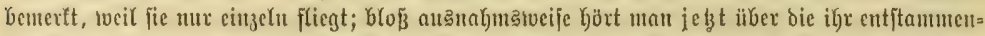

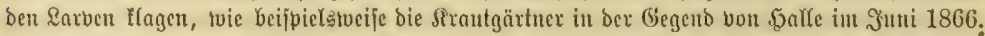

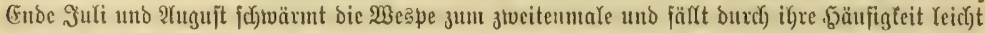

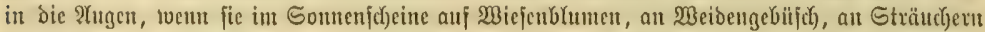

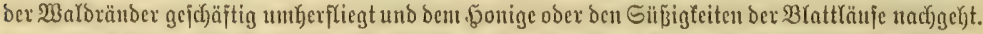

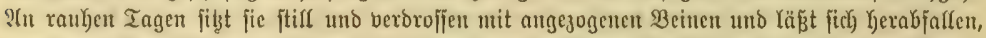

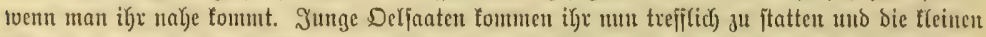

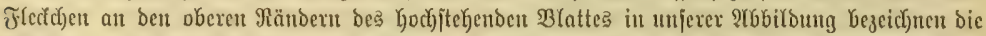

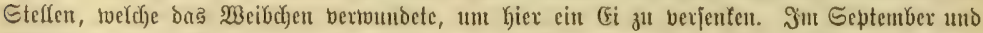

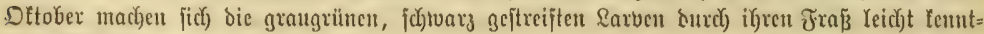

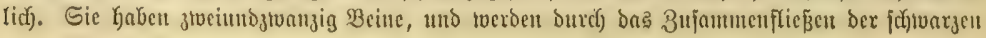




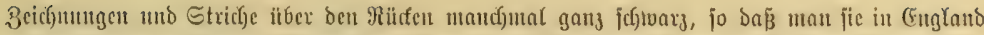

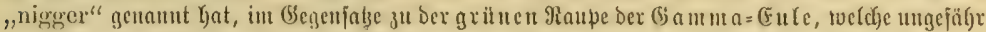

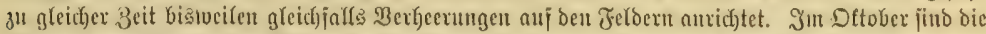

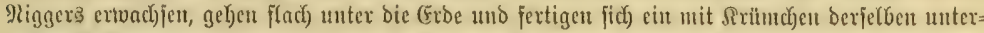

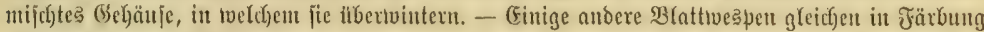

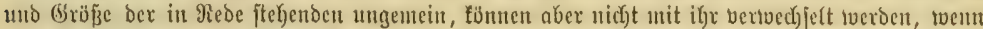

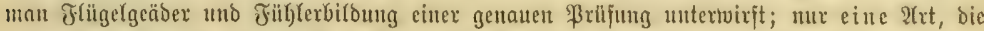

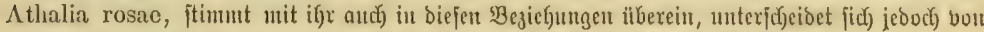

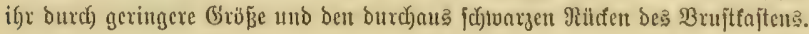

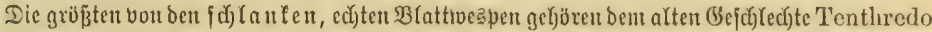

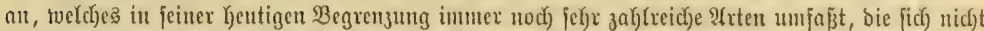

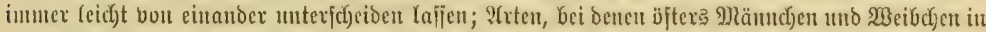

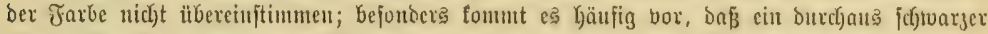

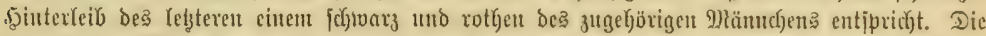

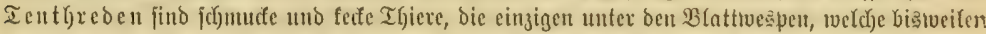

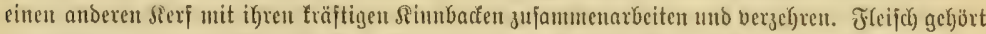

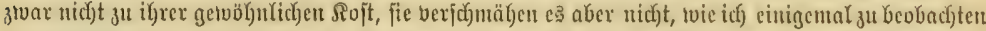

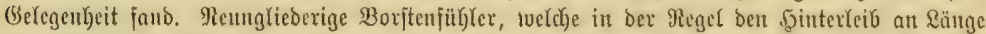

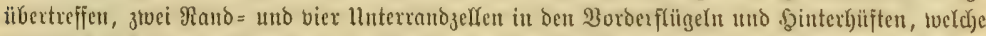

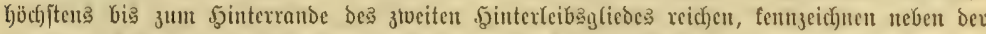

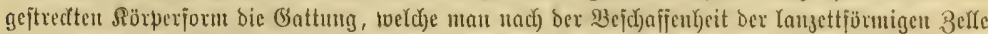

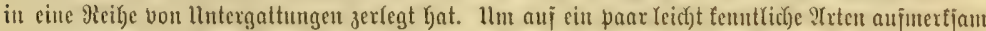
glt madyen, bei benen bie Ianzettï̈rmige Beffe von gexabex Dueraber getfeilt virb und in ben

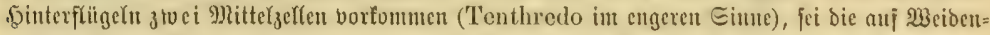

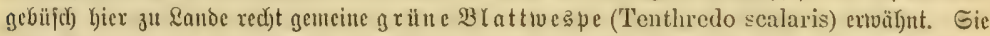

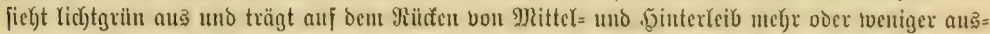

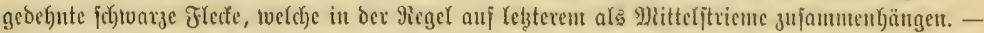

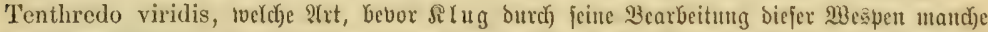

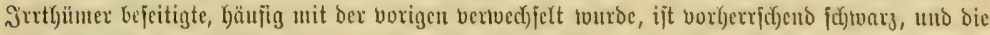

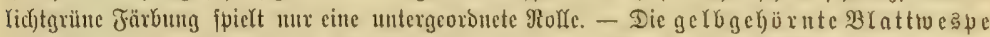

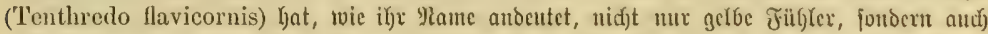

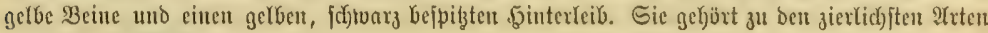
und mint 13 Milfineter.

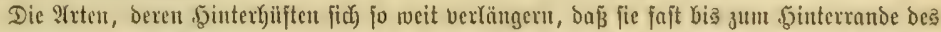

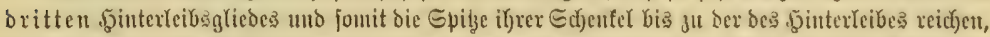

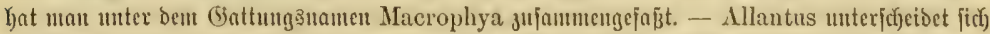

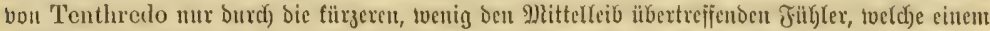

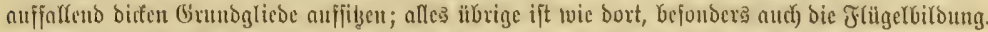

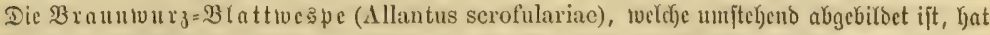

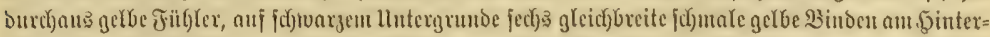

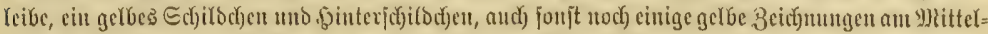

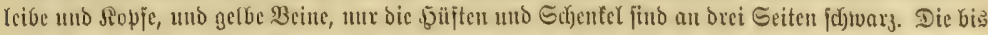

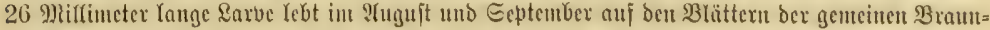

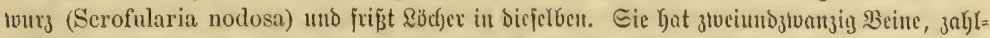

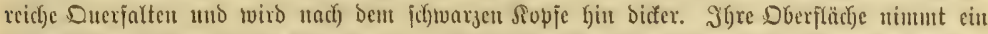

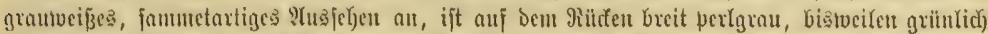

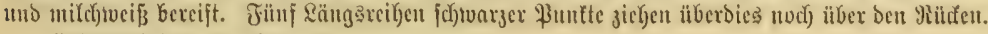




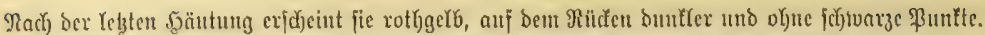

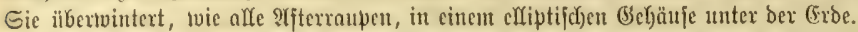

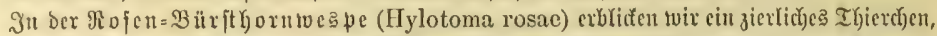

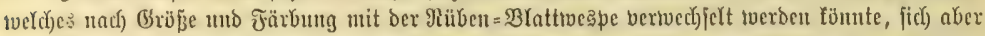

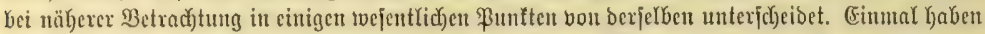

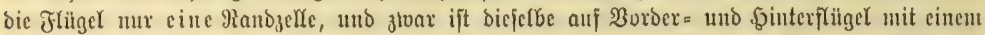

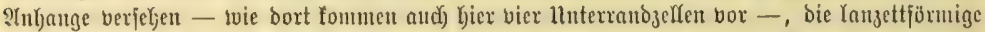

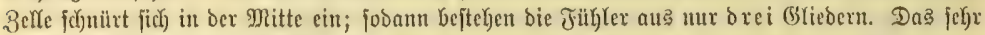

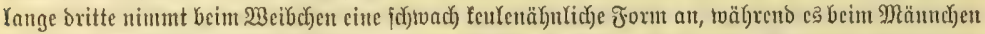

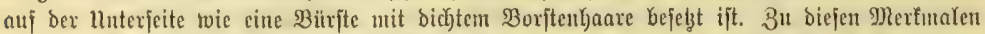

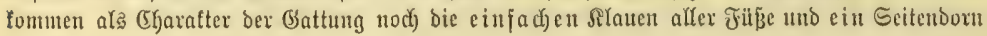

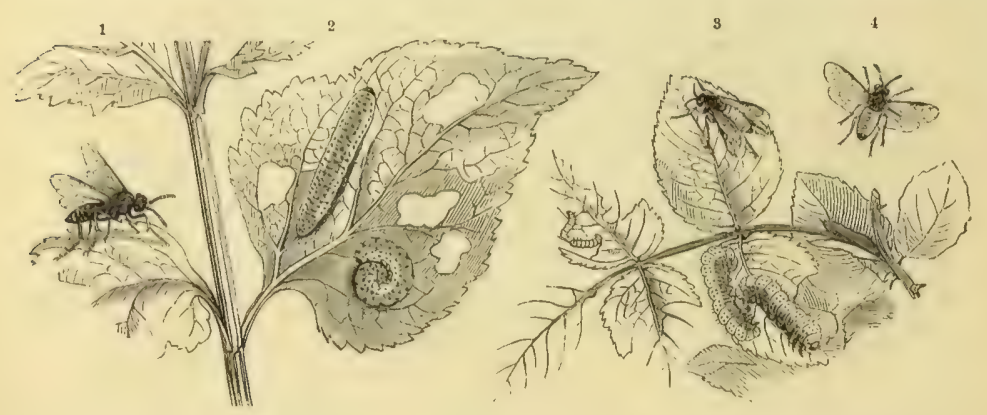

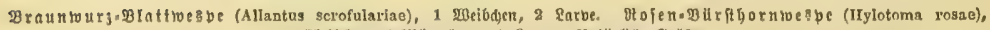

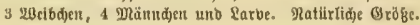

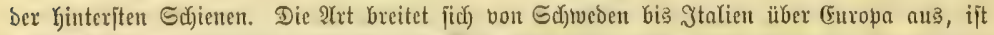

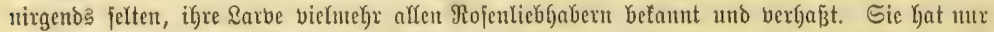

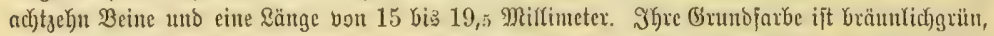

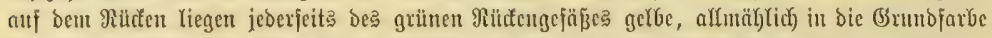

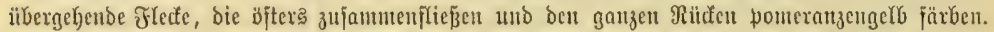

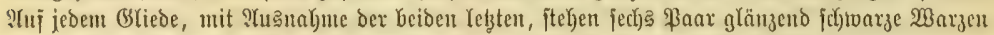

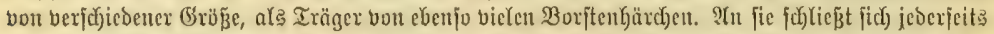

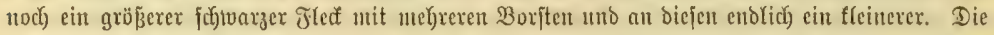

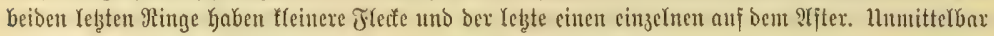

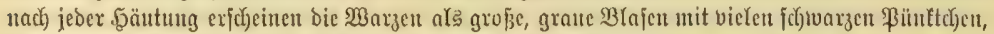

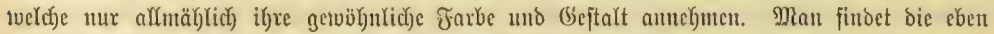

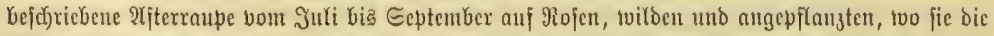

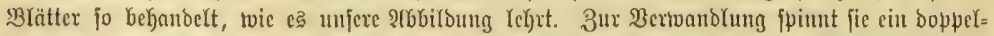

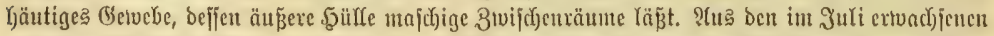

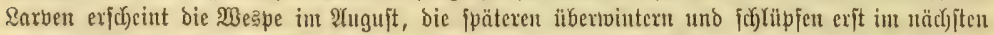
Safre aus. Şier tommen aljo tvieder ztoci Bruten vor. Da: Weibdyen fägt in bie jungen 3tucige

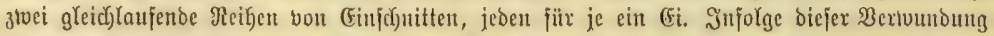

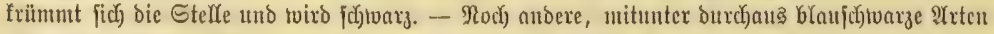

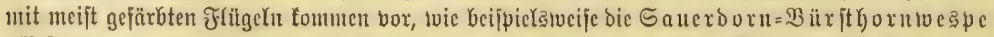

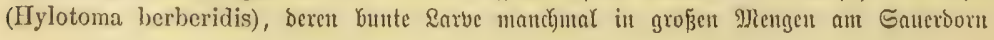




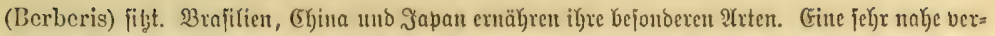

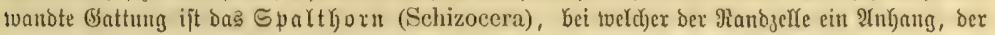

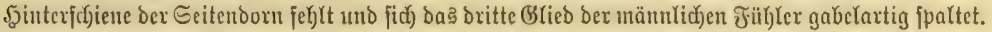

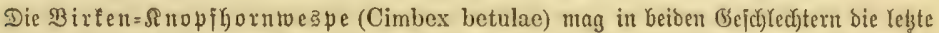

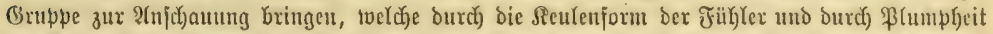

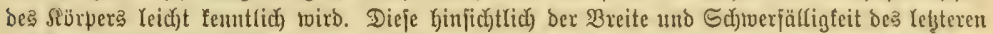

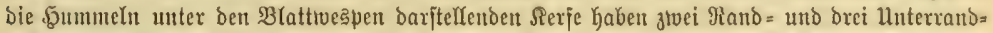

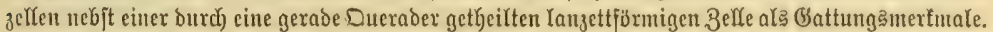

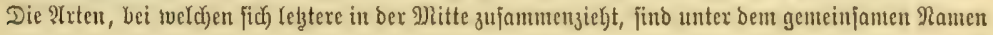

a
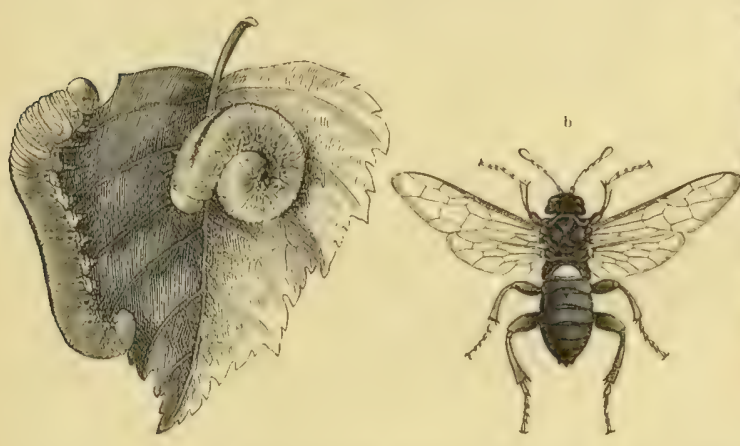

c

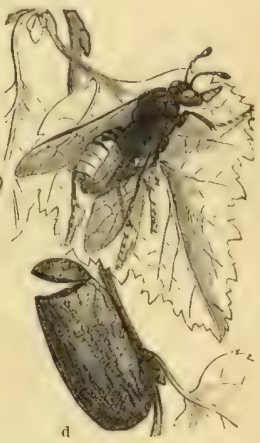

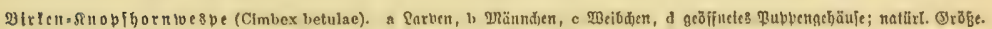

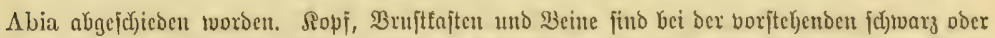

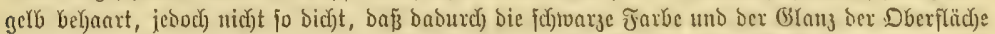

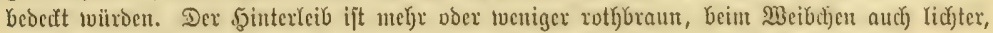

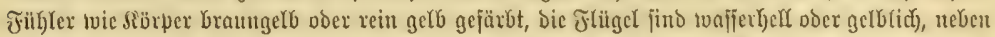

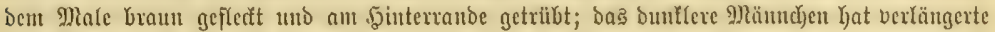

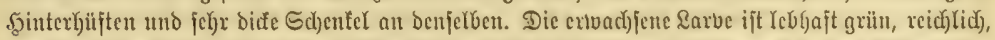

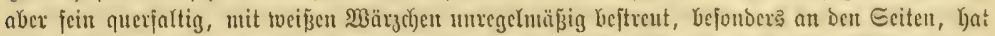

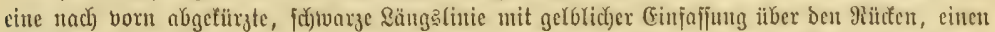

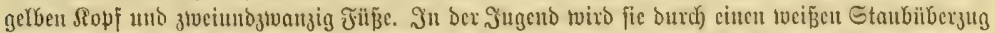

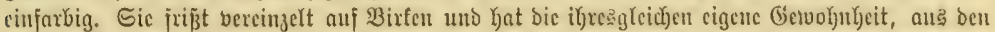

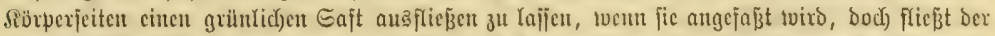
Gajt midyt fo reich)(ich), svie bei anderen. Beim Эiuben an Inge pflegt jie zujammengerolt an ber

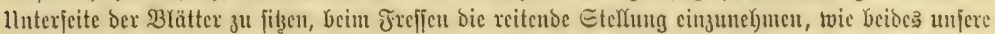
S(bbiroung vergegentwärtigt. $23 e m$ fie crivad)jen ijt, fo fertigt jic an einem 3tueige cin pergantent=

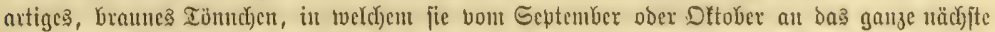

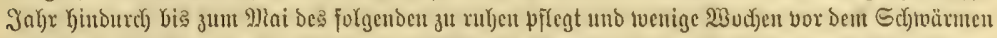
ber Friege zur \$upe wviro. Dic biejer cutjchlüpjte Me

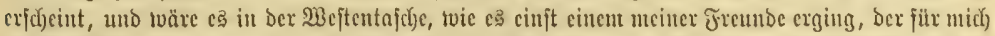

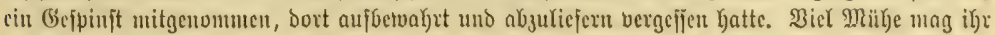

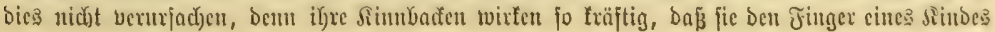




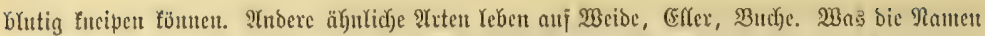

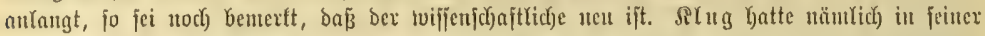

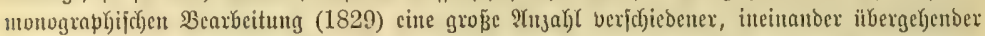
Formet, weld)e bie fribliberen Edyriftiftelfer als Cimbex femorata, C. sylvarum und andere aแf=

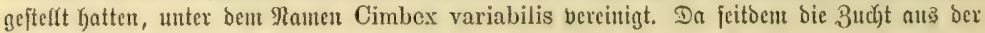

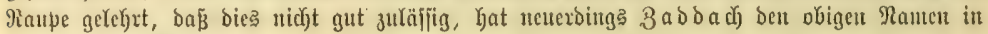
2utwenoung gebracht.

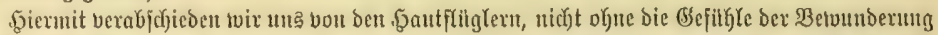

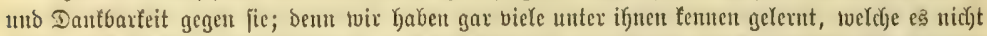

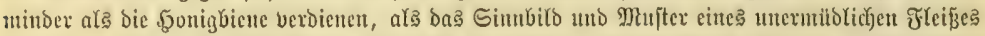

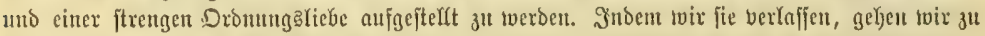

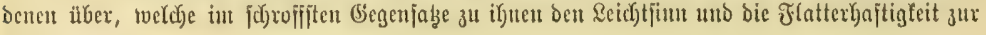
Scjau tragen. 


\section{Dritte (Drinung.}

\section{Dic Edimetterlinge, Falter (Lepidoptera, Glossata).}

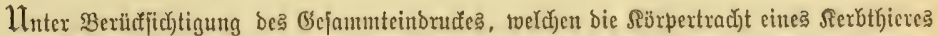

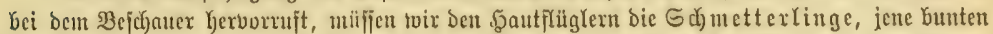

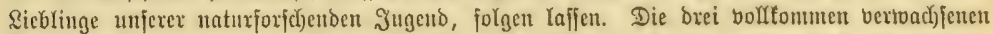

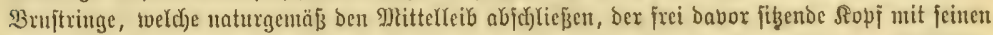

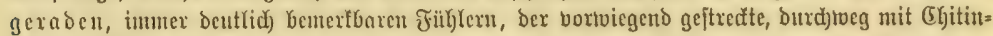

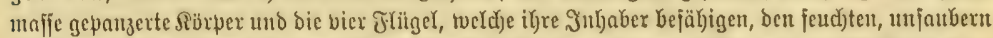

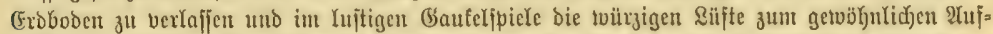

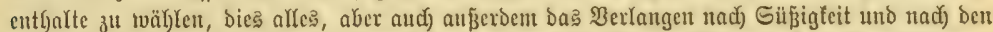
अerten be

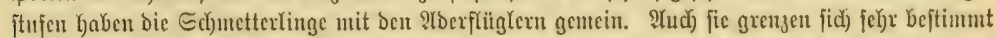

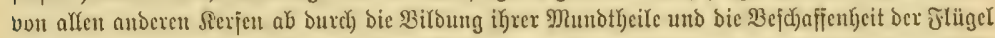

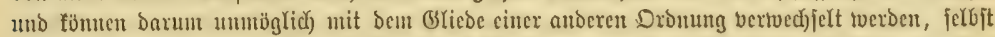

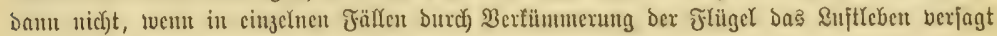
toorben ift.

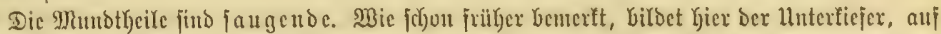

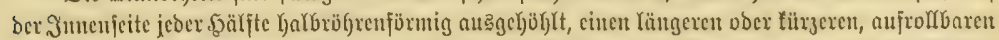

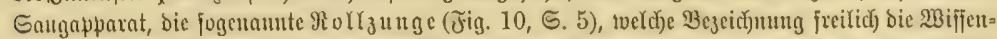

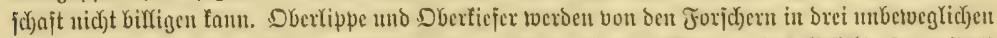

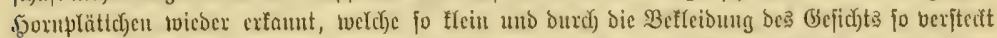

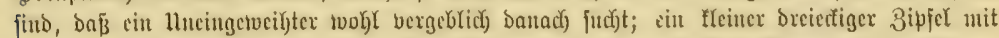

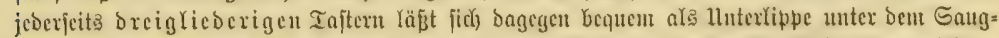

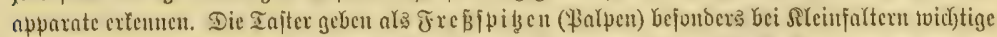

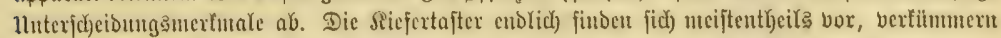

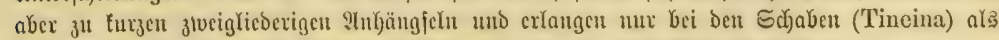

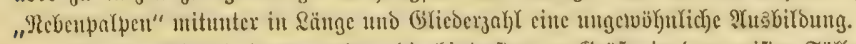

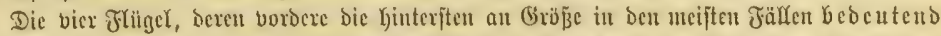

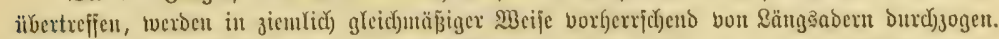

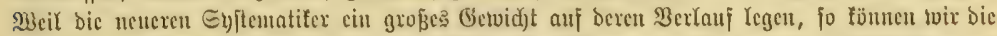

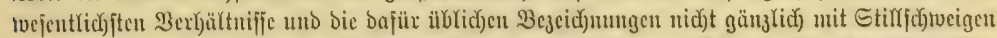

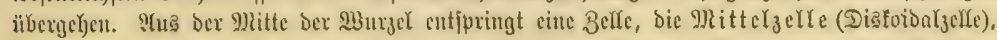

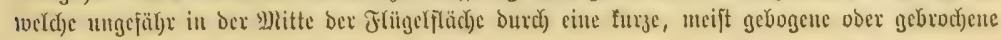




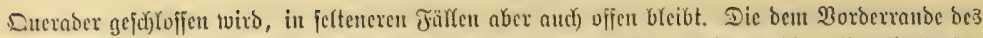

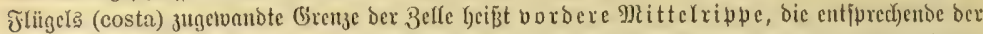

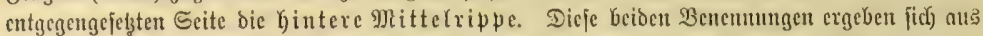
berjenigen Rage ber Flügel, veld)e man ignen zu geben pflegt, um ben Schmetterling in ciner

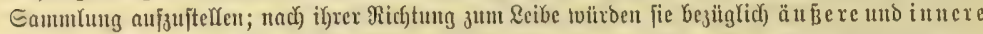

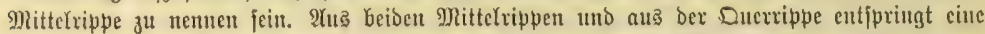

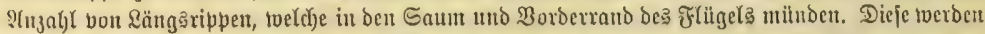

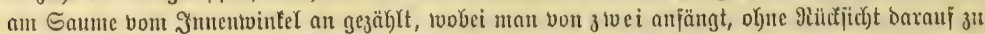

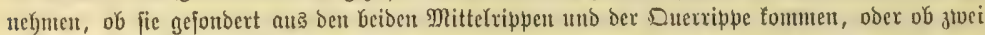

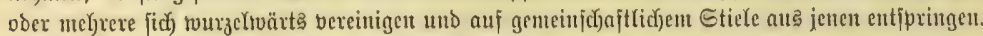

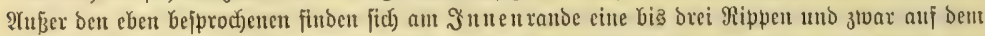

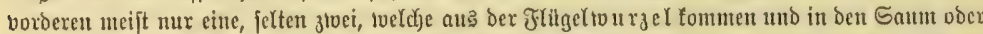

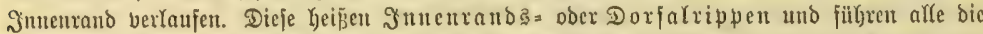
3ah) 1; two mefrere vorlyanden fint, unterid)eidet man fie bon ber Muzel nad bem Eaume, aljo

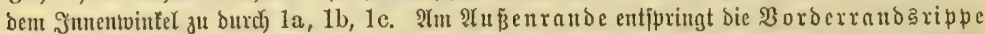

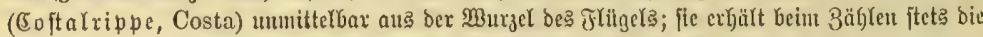

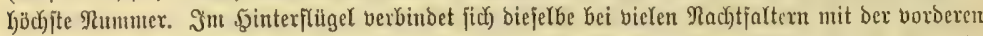

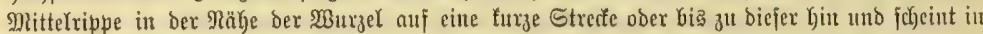

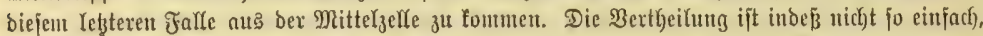

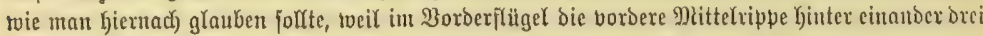

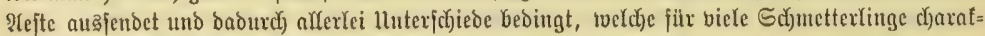

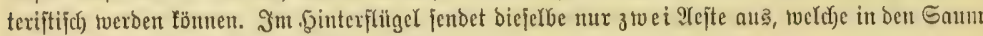
verłaufen uno gröpere Meberetnjtinumung zeigen.

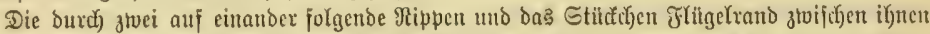

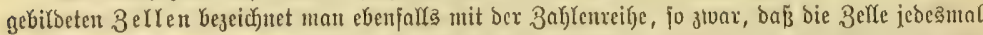

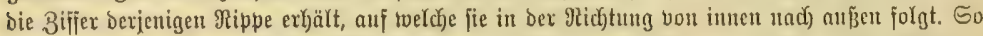

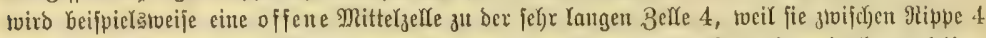

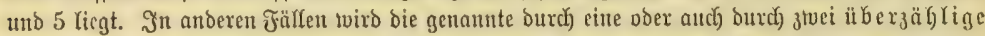

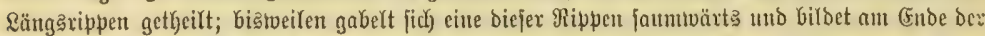

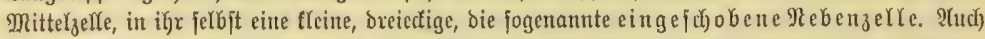

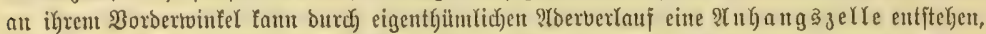

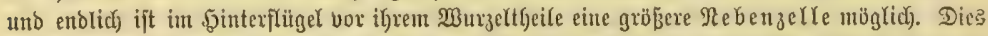

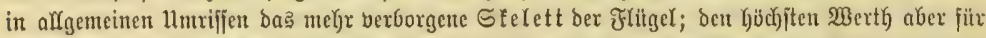

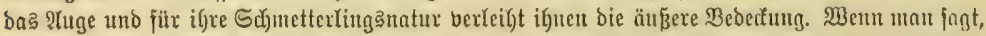
bie Sc(f)

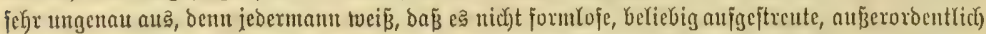

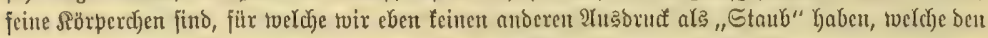

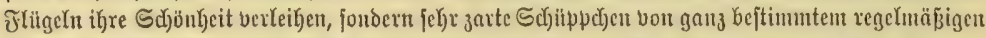

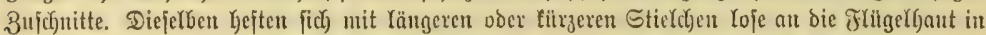

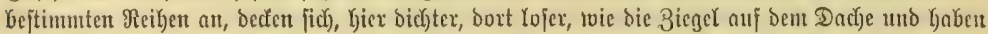

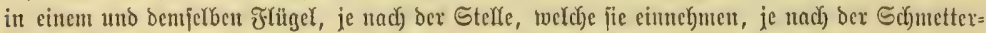

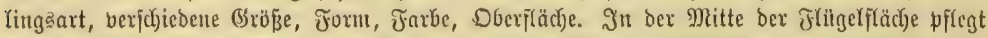

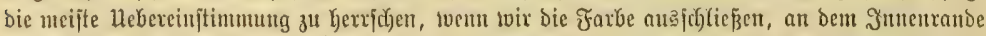

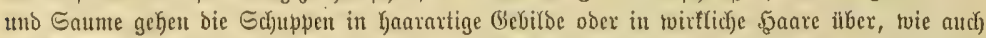

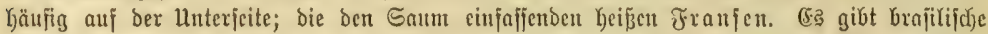

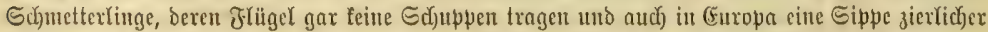

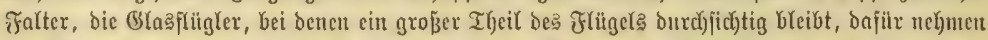

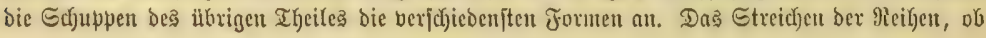


fie gerabe ober gebogen, bas jeftere ober Yojere, bişweilen fogne fenfrechte ?tufifiben ber cinzefuen

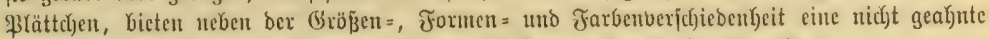

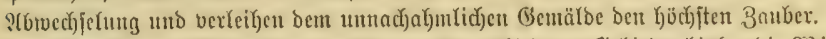

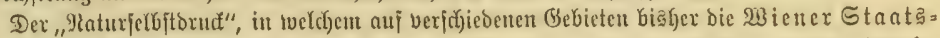

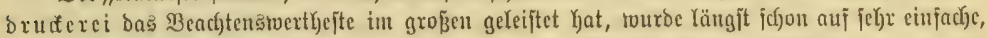

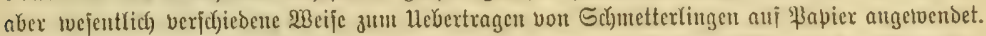

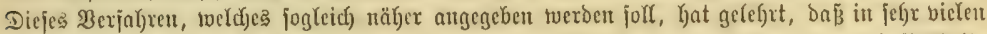

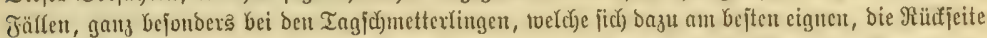

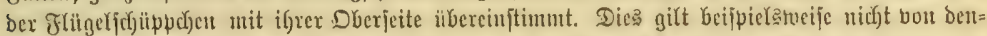

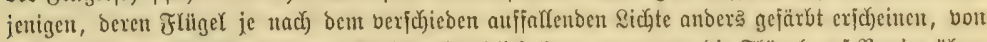

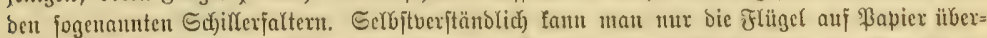

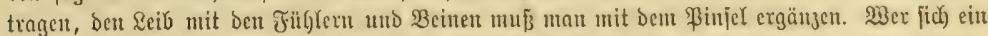

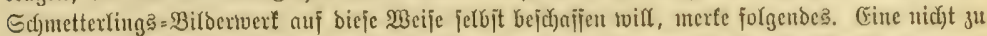

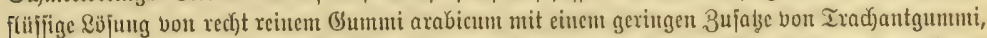

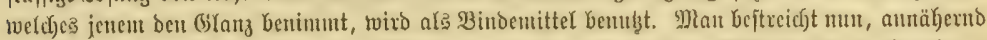

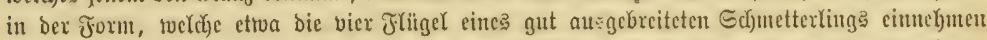

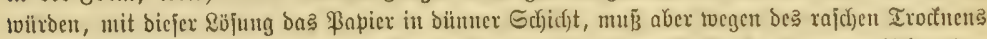

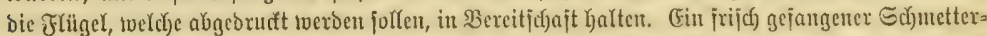

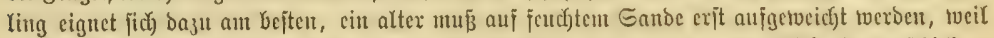

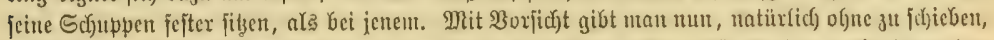

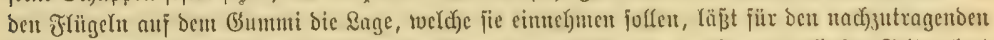

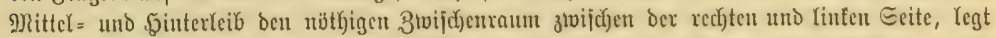

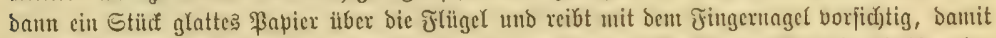

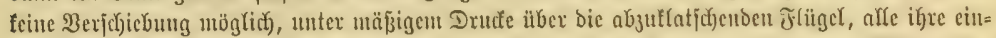

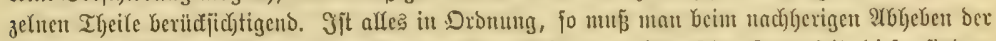

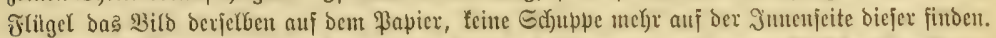

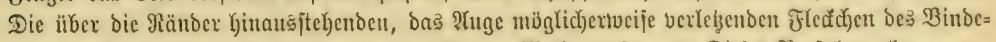

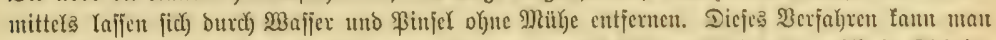

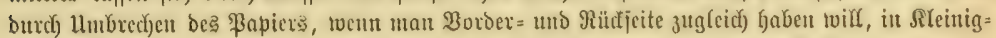

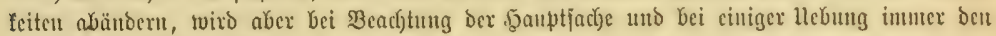
getwiunjudten (Exjolg haben.

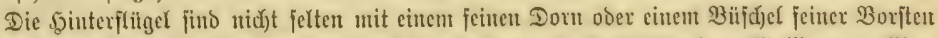

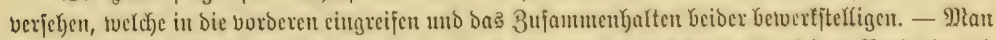

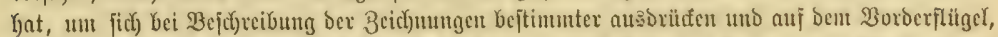

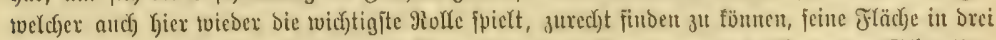

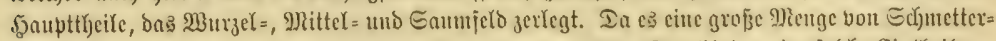

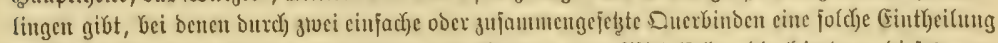

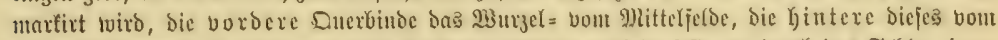

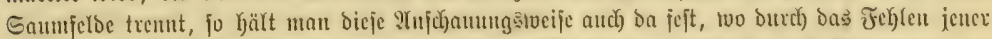

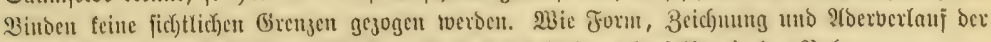

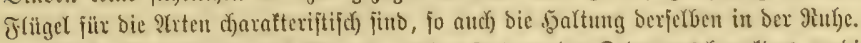

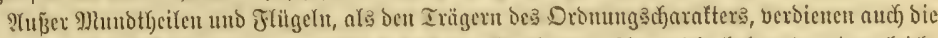

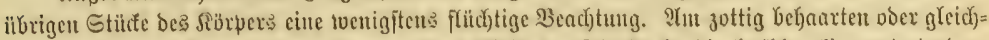

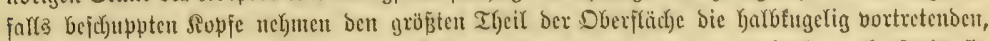

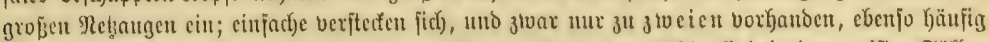

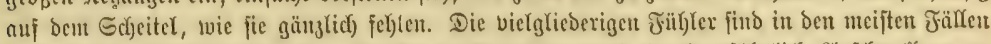

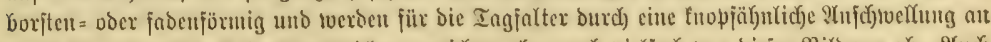
ber Spize zu chten (Extenun 


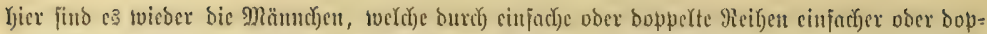

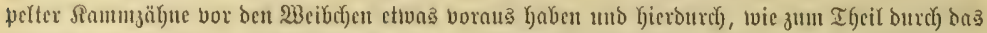

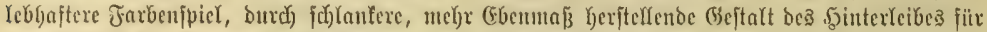

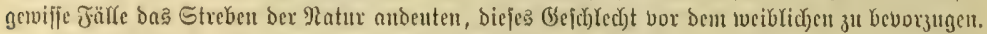

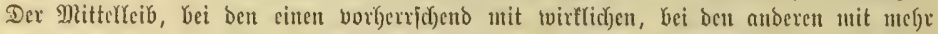

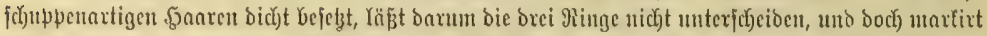

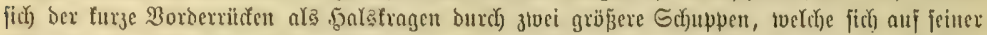

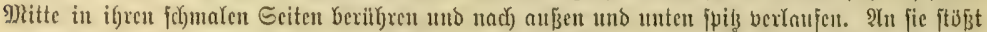

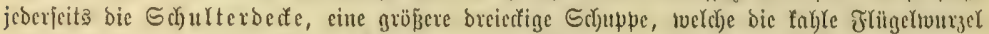

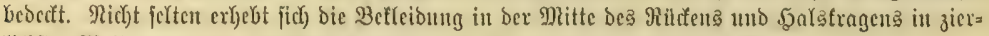

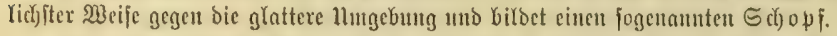

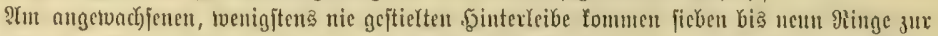

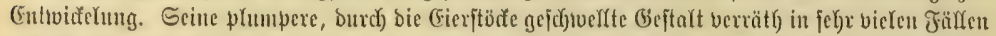

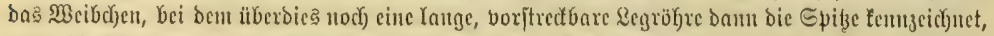

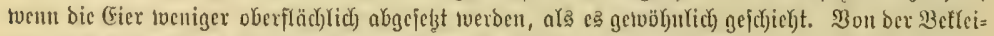

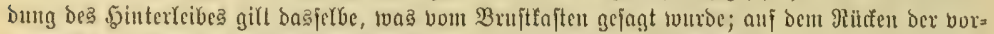

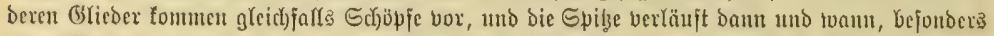

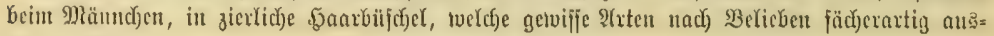
breiten fönten.

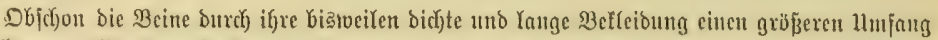

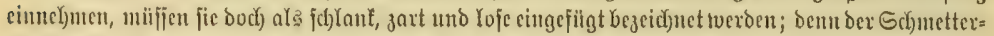

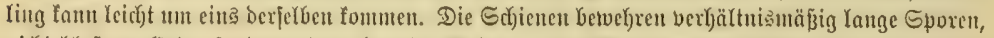

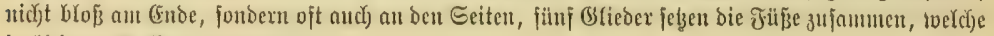
in fleinen Sralfen auşroufen.

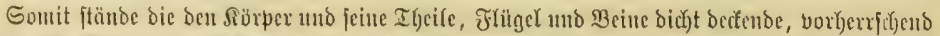

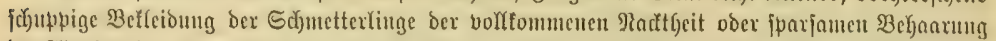

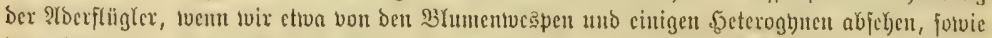

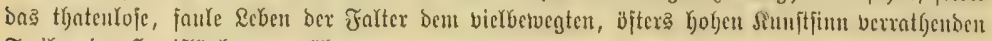
Treiben ber Şautflugher gegenüber.

Die Rarven ober Ra upen ber Schuetterlinge fennt man volftändigex ala dicjenigen irgend

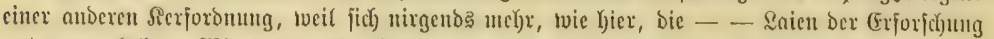

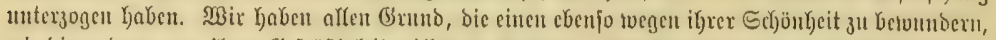

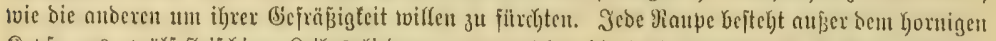

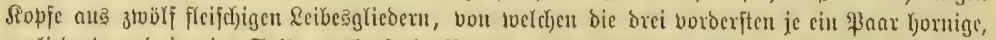

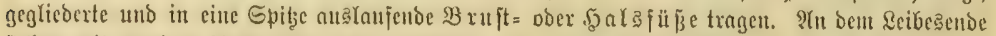

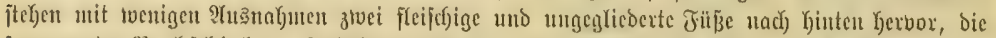

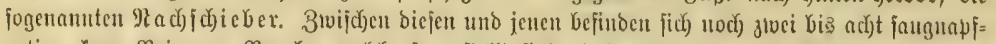

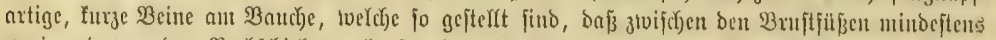

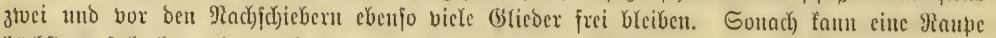

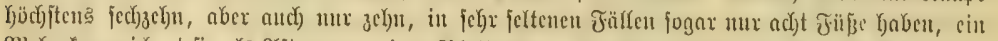

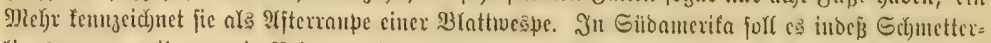

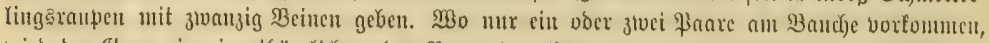

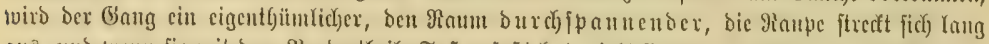

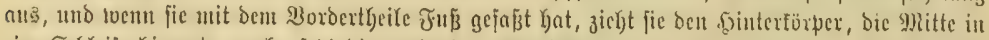

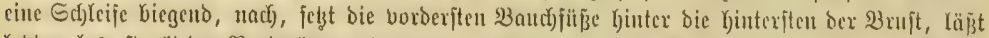

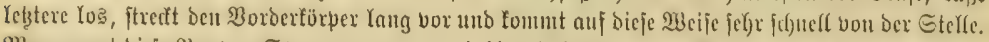

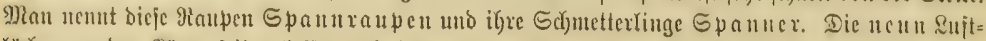

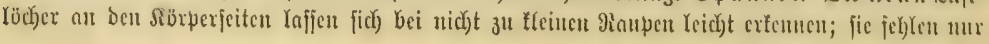




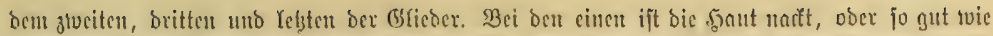

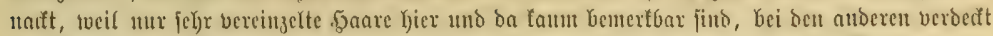

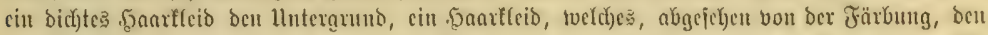

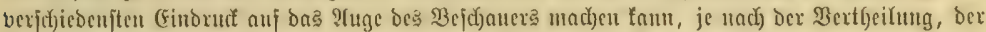

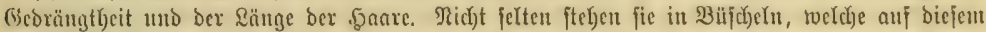

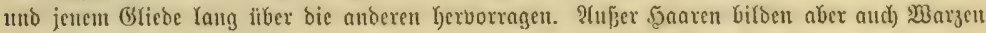

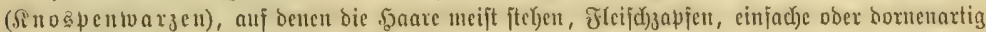

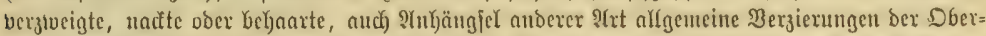

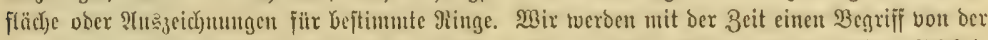

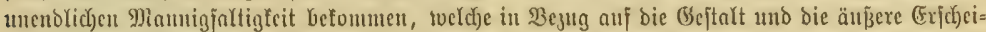

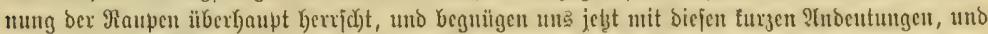

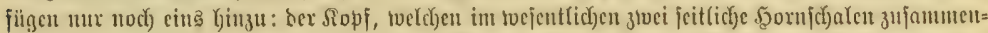

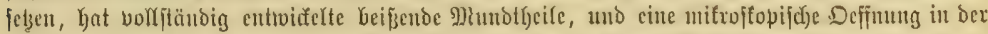

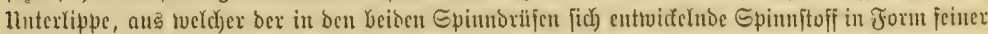

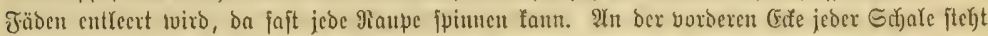

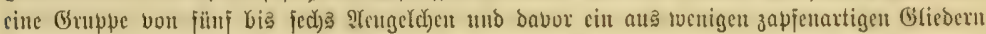

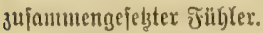

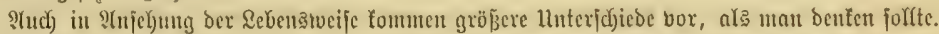
Die cinen finden fich) inmer nux cinjeln, weil bie (Eicr vereinjelt tuntoen, bie anderen für fürzere

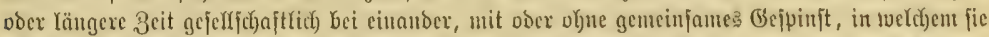

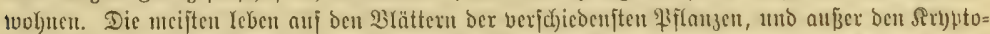

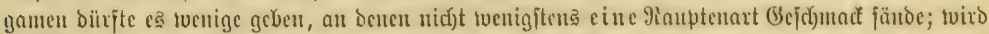

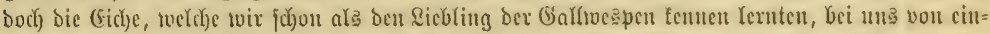

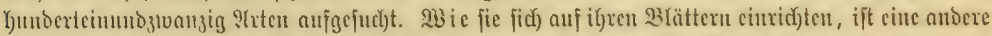

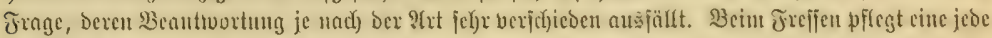

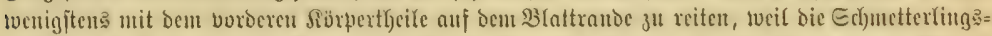

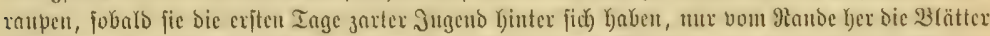

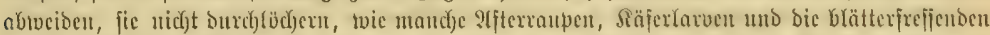

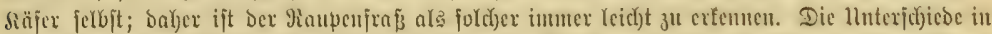

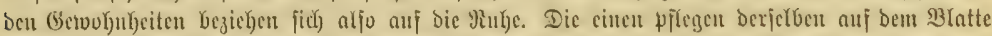

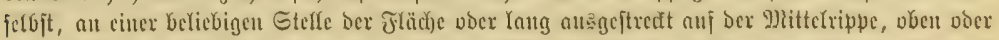

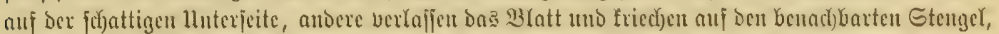

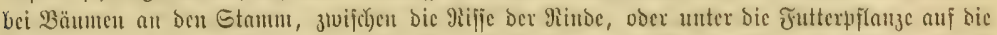

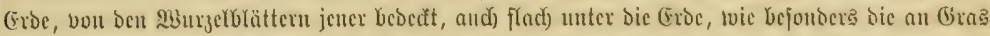

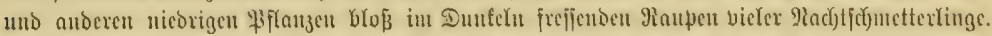

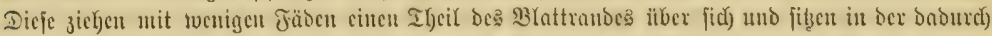

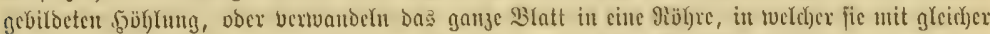

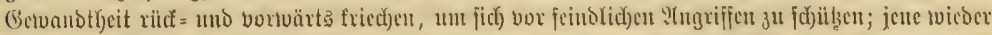

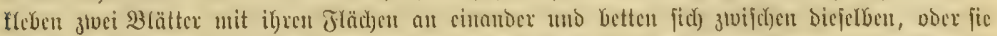

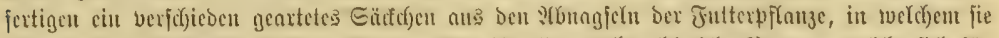

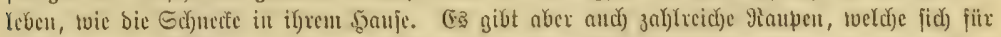

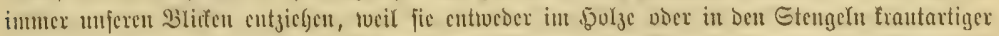

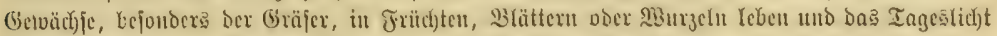

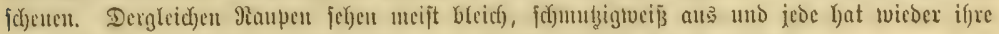

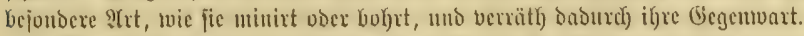

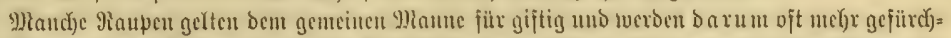

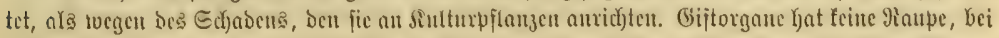

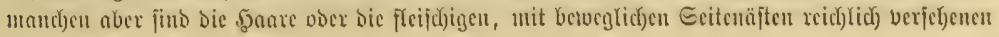




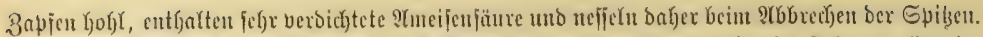

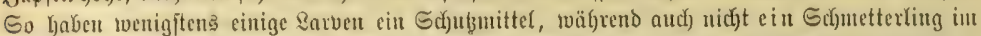

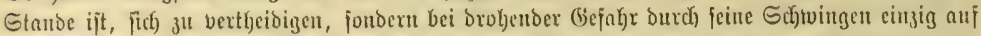

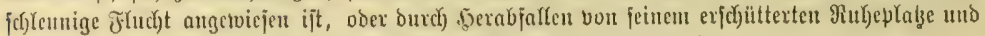

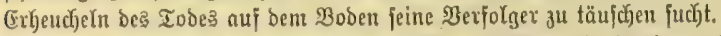

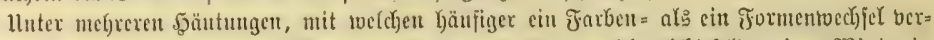

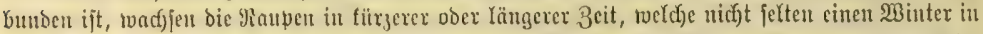

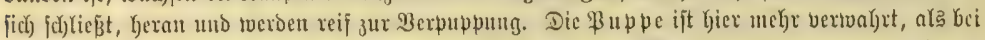

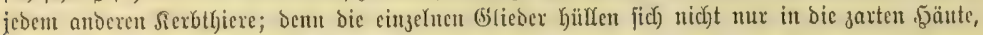

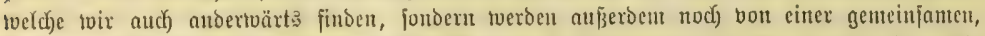

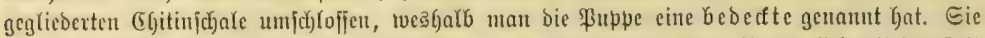

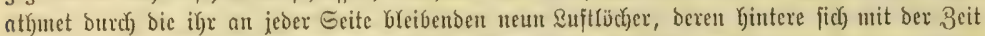

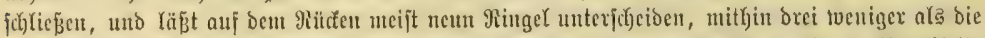

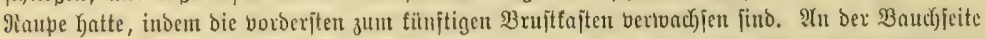

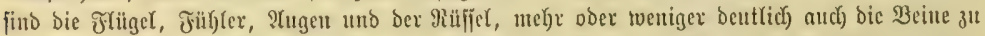

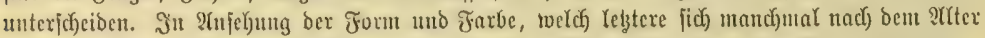

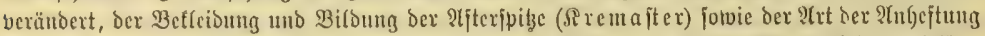

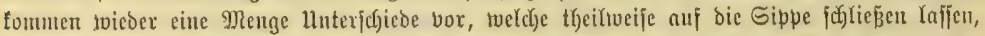

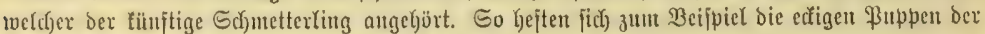

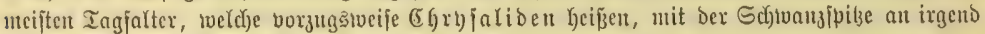

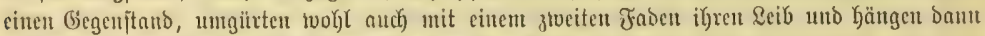

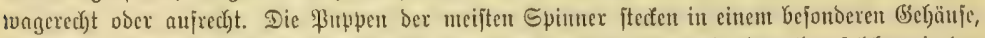

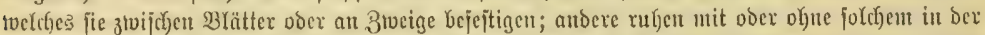

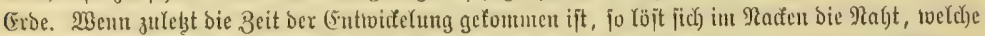

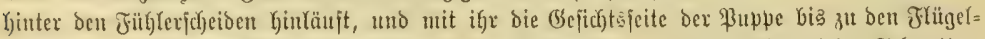

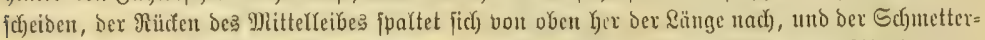

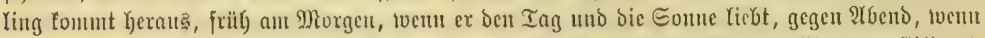

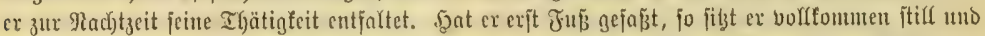

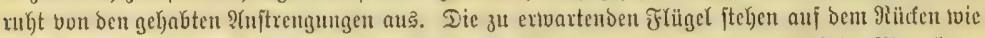

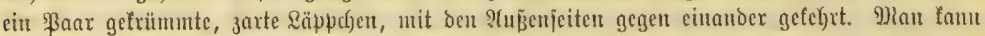

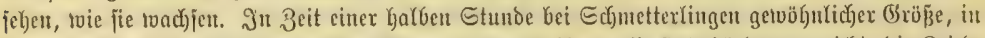

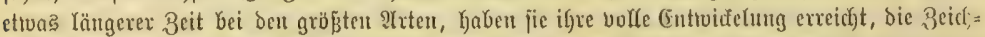

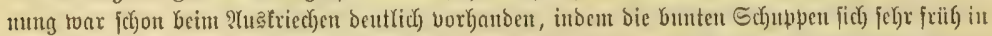
ber ßuppe entroicfeln. Die Flügel berbarren noch furze 3eit in bicjer \&age, Dann bringt fie ber

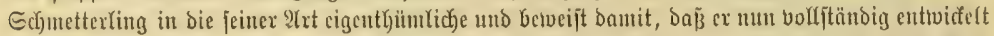

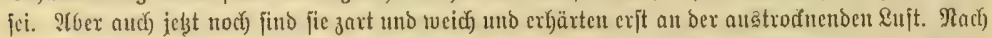

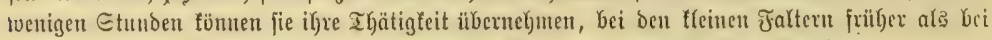

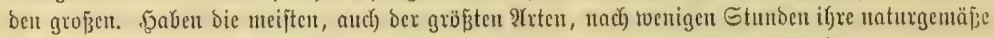

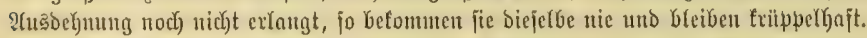

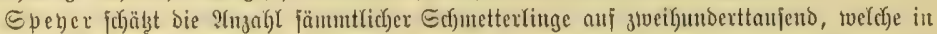

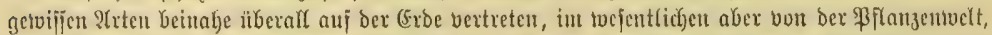

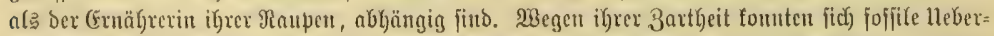

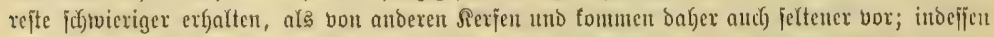

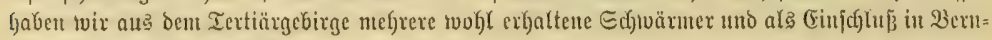
ftein fleinere und zartere Formen.

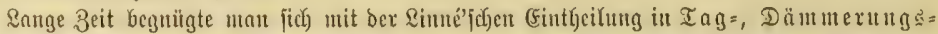

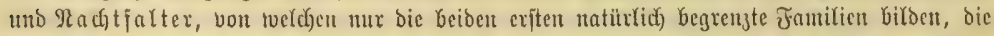

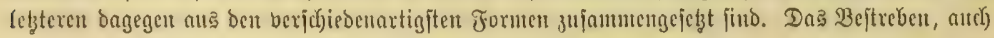




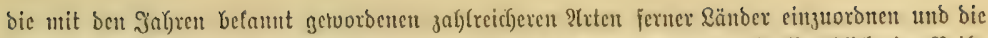

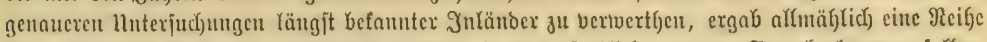

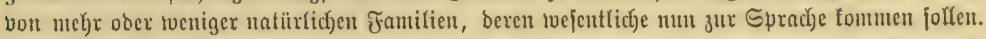

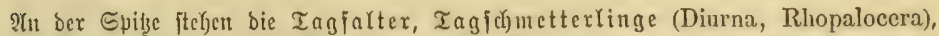

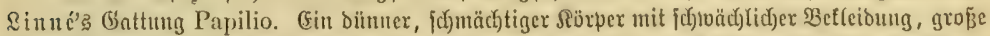

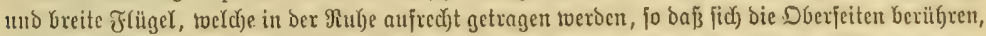

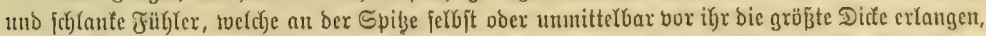

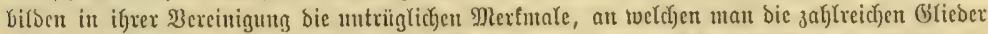

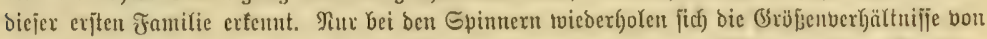

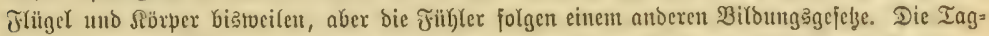

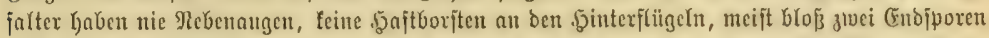

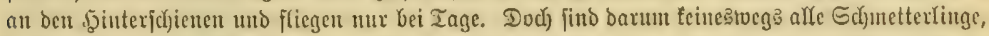

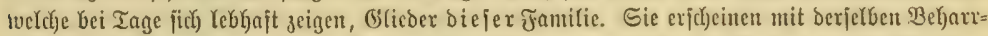

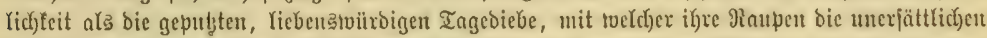

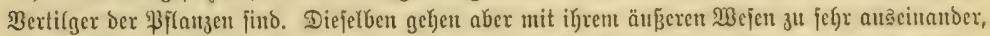

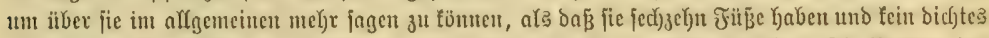

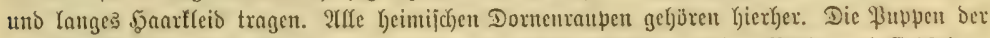

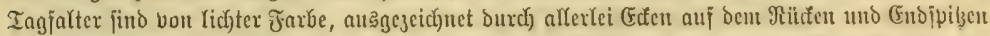

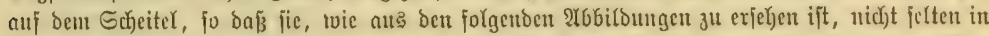

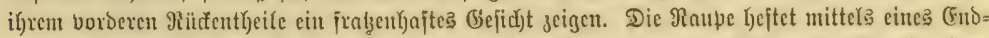

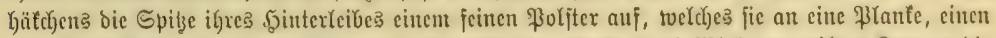

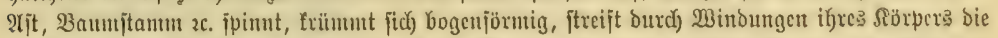

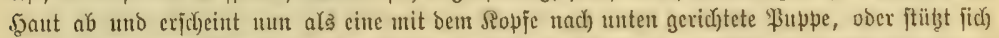

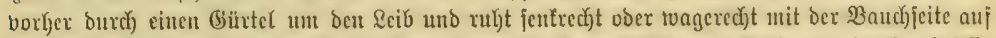
ihrer Ilnterlage; in jelteneren Fällent findet man bic \$uppe aud) unter Etcinen, nie aber hat jie

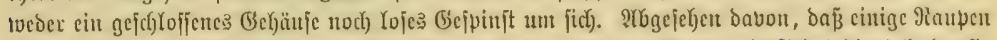
in ifrer Singeno ein 9lejt fertigen, tvelches ignen bejonders für ben Minter als Schubz bient, Yaben fie

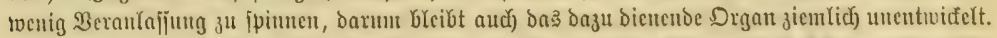

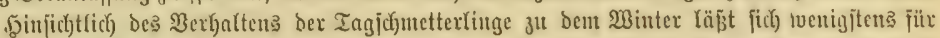

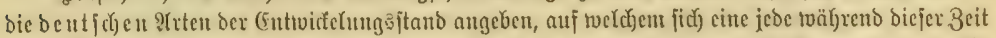

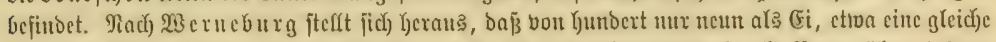

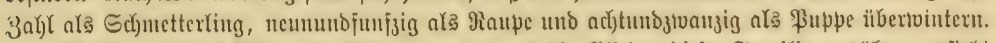

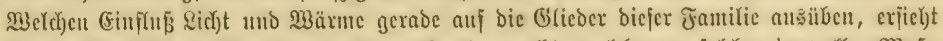

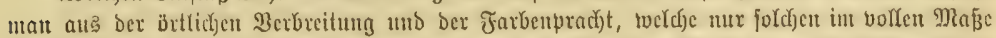

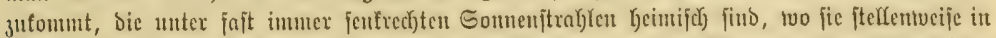

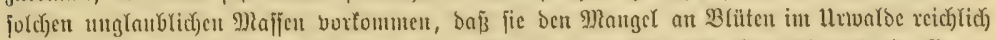

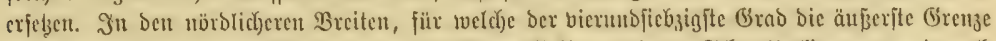

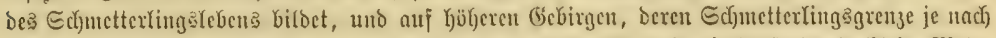

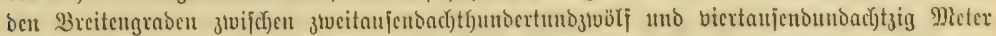

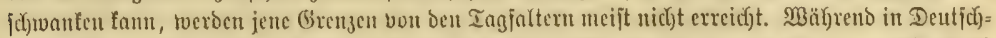

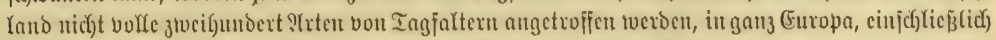

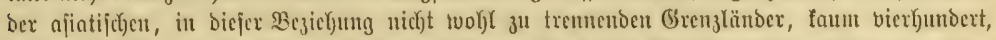

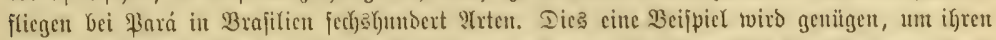

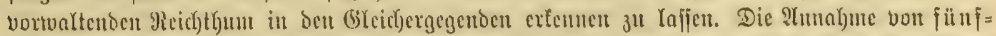
ta uf

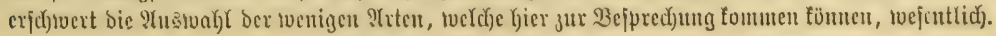




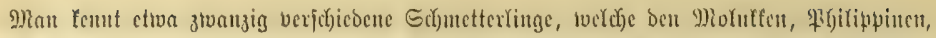

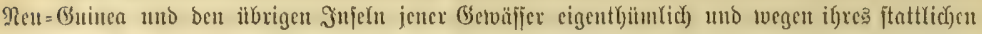

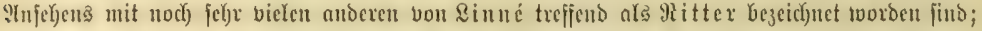

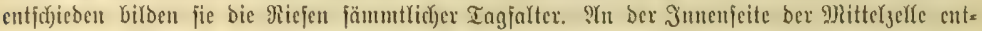

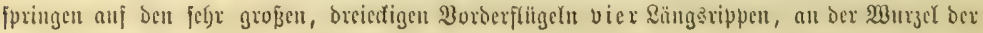

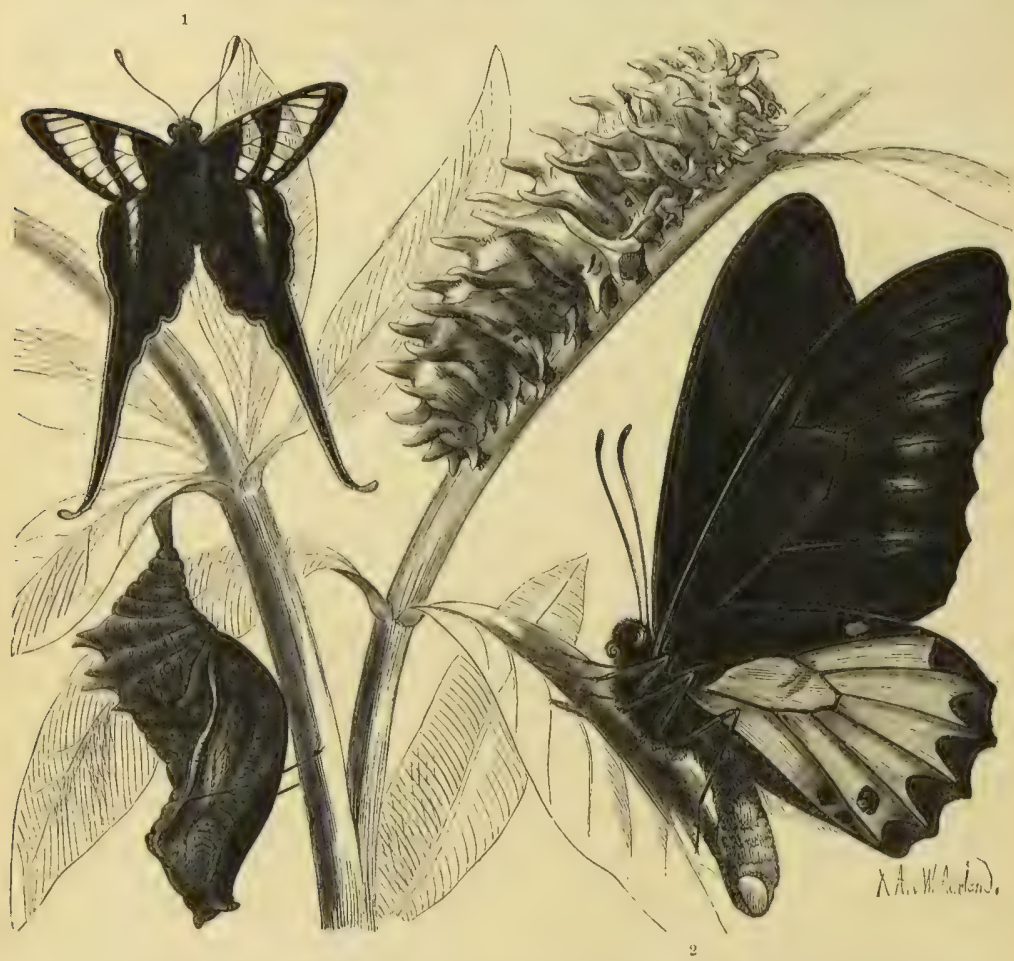

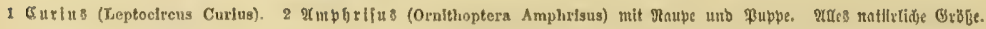

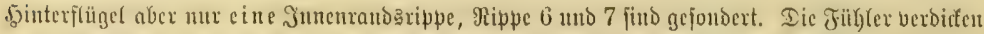

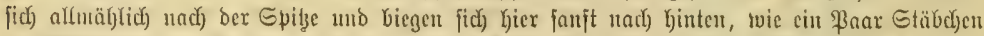
von Fijubrit zieren fie ben nicht eben groben fiopf. Ier hier abgebifoete 2 mphrijus (Orni-

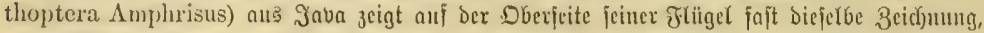

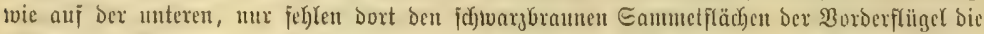

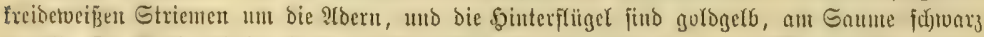

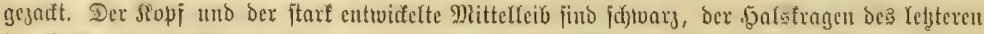

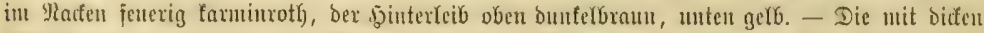

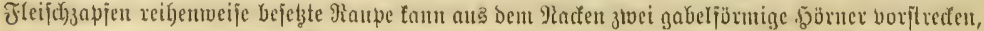

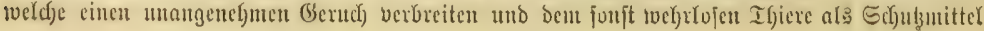




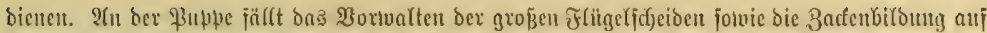

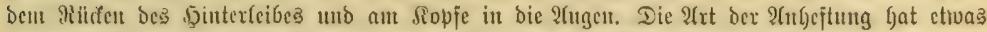

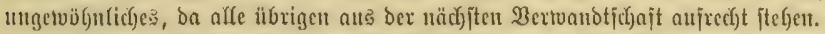

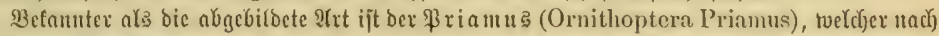

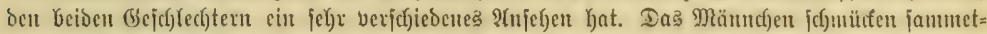

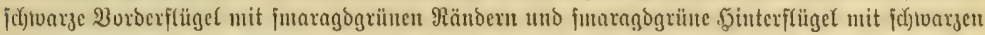

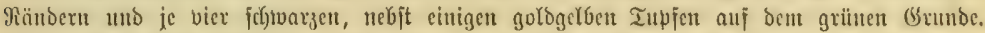

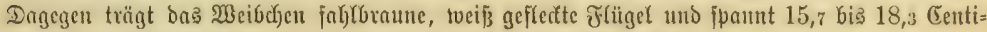
meter. Der Şinterleib ift bei beiden (Bejd)led)tern gologelb gefärbt.

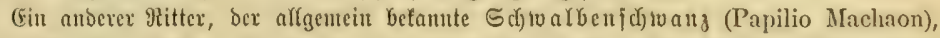

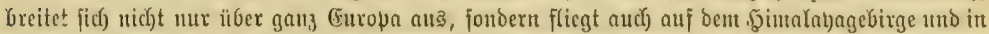

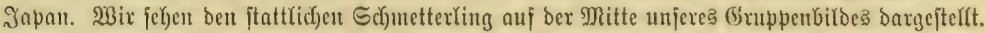

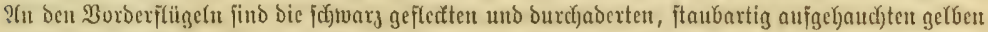

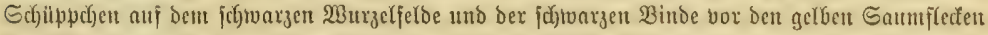

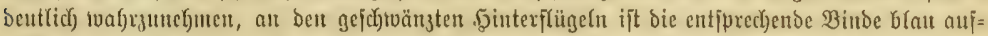

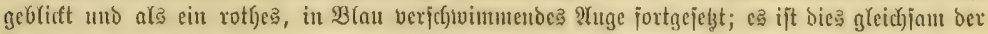
Drben, twe(t)en bieje Ritter tragen. Die Ilnterieite hat jajt biejelbe Beichnung, mur matter uno

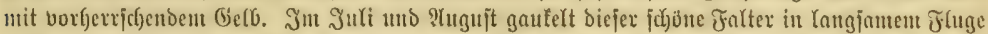

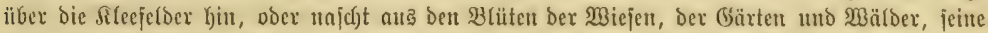

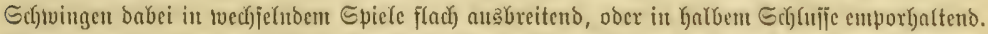

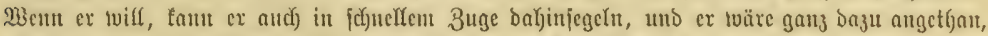

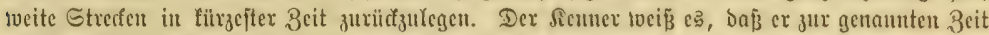

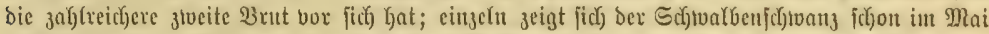

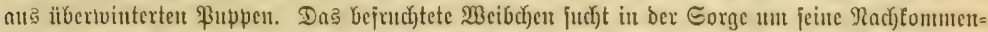

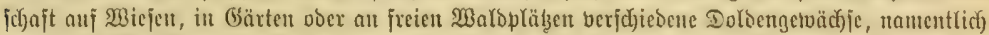

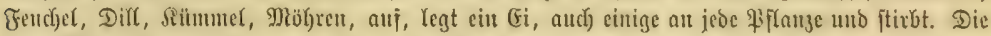

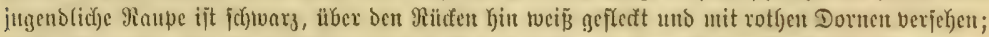

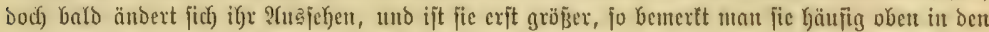

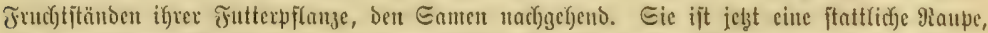

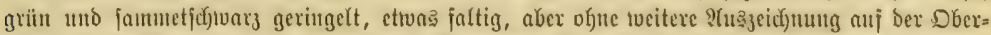

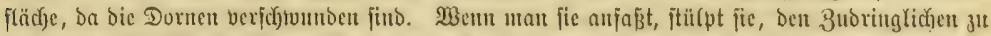

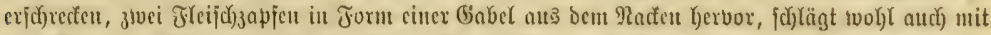

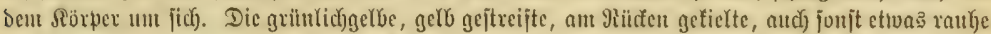

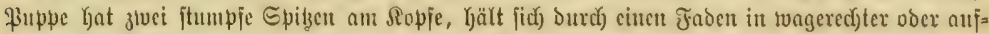

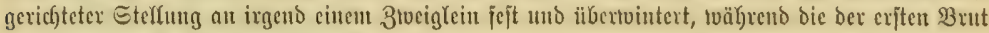
nach) ivenigen झodjen zum Sdjmetterlinge tviro.

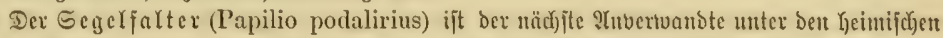

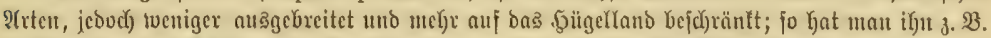

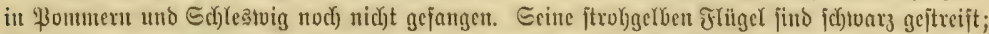

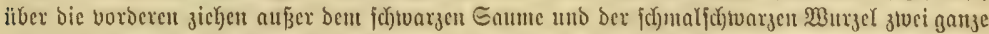

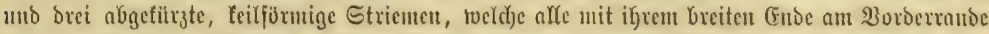

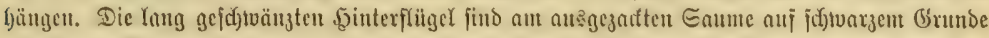

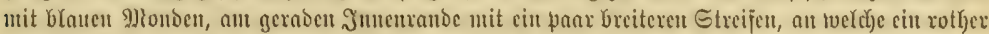

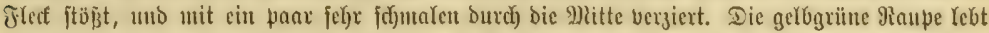

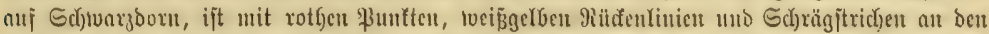

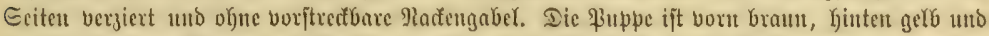

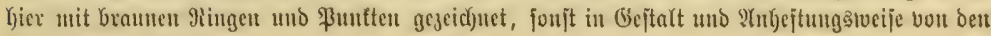
vorigent nidgt unterjchieben. 


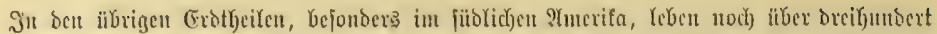

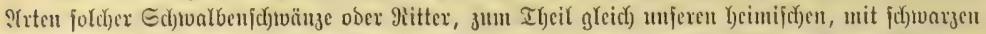

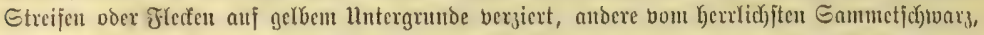

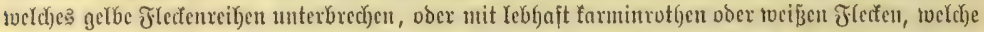

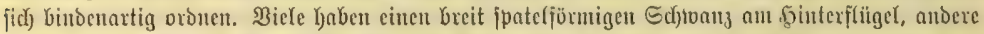

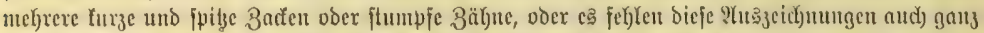

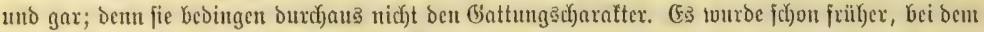

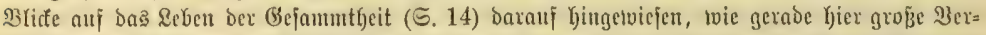

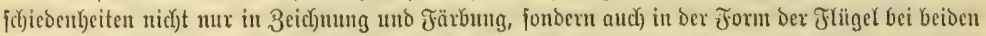

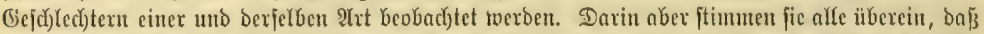

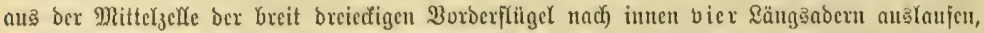

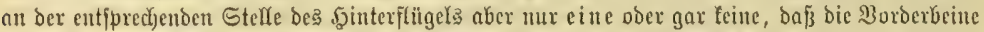

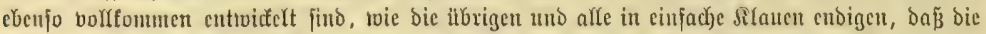

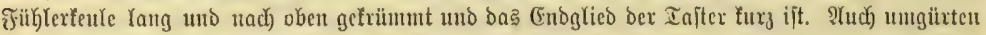

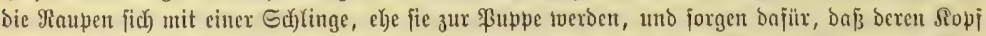

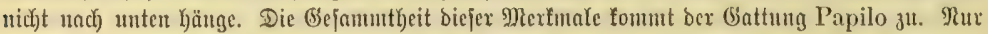

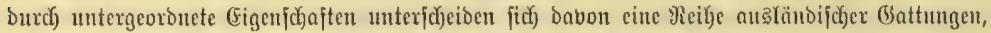
bon weld)en ber gleid)falfs auf unjerem Bilde prangente (5uriug (Leptocircus Curins) bie

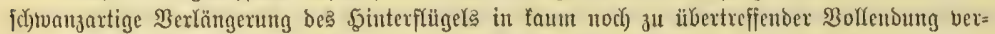

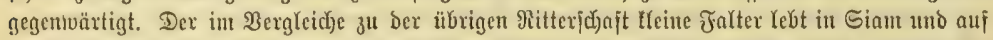

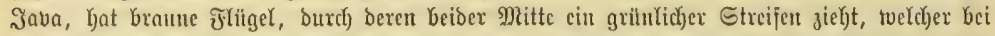
bem Meibd)en beinake farblog ift, tvie ber breitere, glashelfe in Saumpeloe ber Borderflitgel. Eit

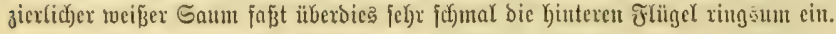

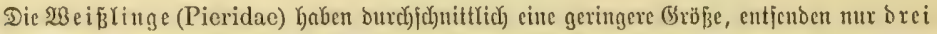

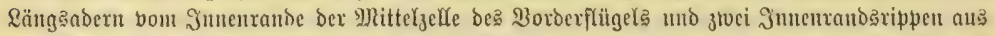

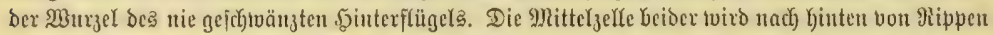

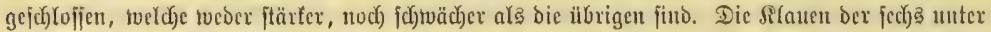

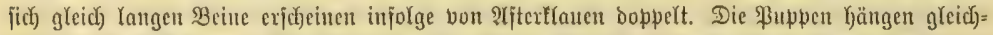

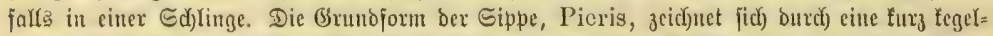

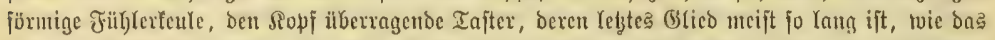

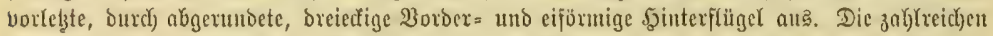

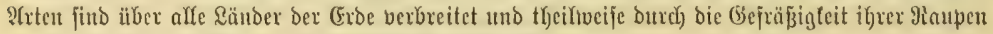

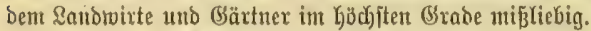

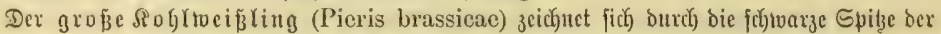

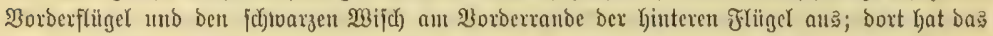

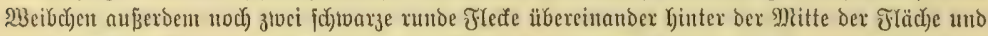

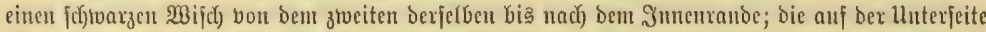

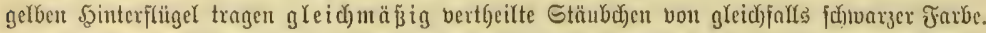

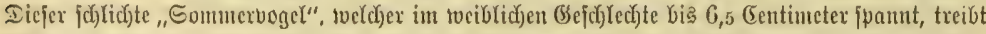

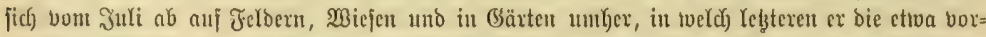

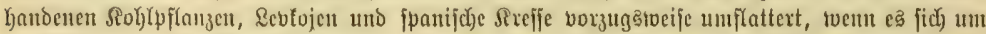

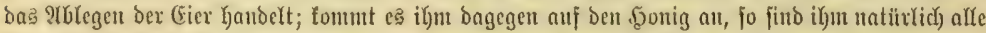

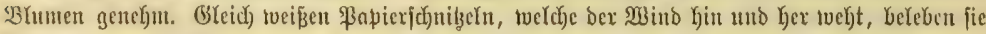

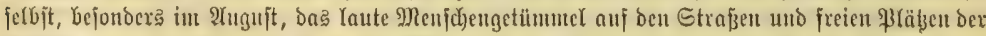

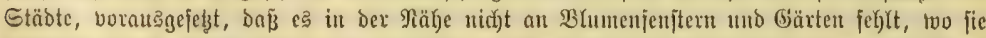

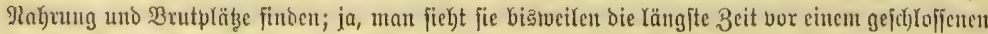

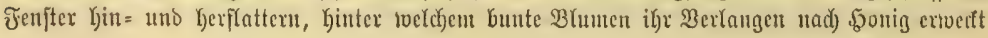




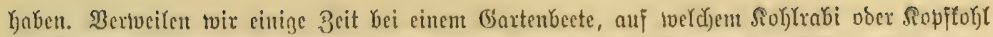
wächft, uno feben bem munteren Ireiben zu, aber voruntgeifafrei und unbefümmert um ben

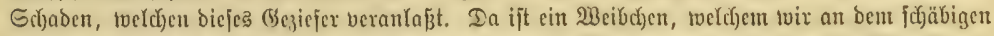

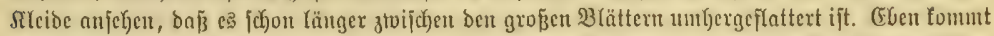

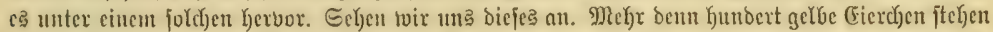

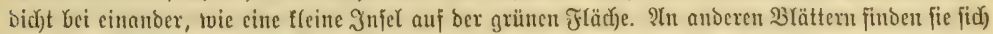

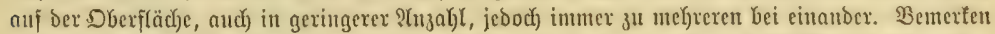

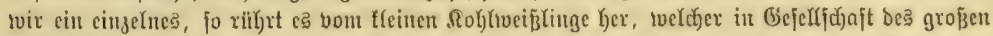

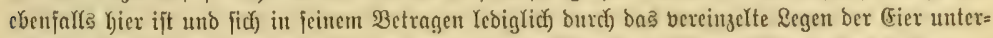

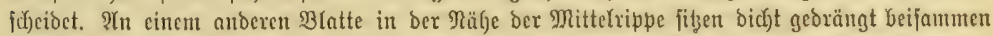

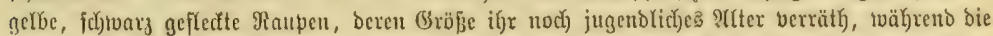

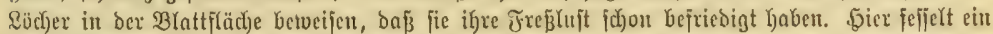

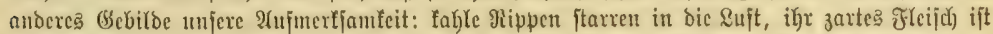

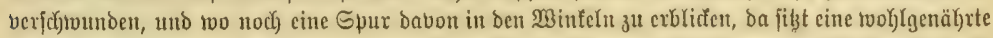

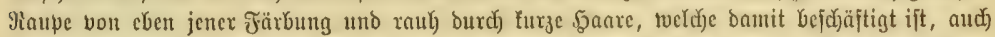

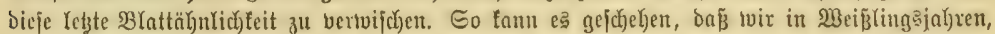

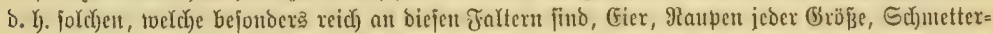

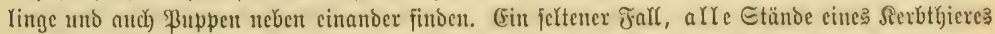

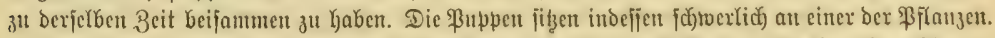

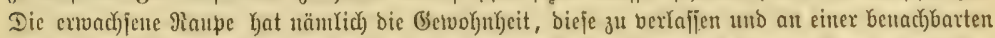

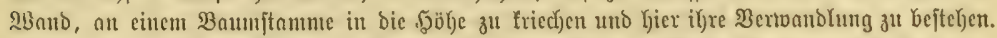

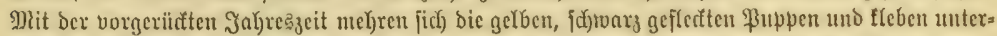

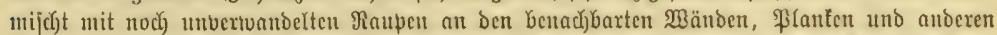

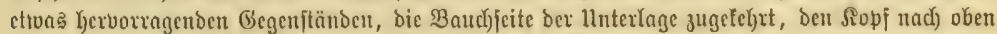

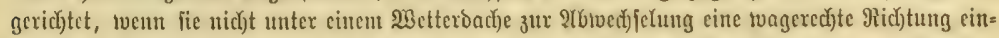

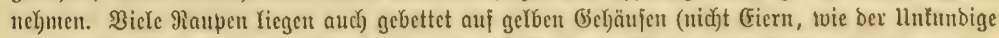

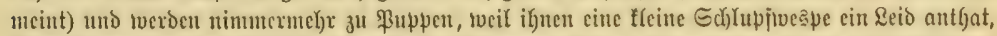

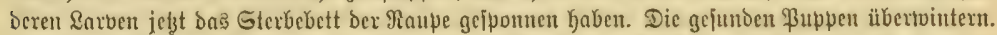

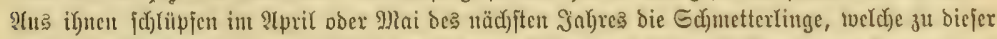

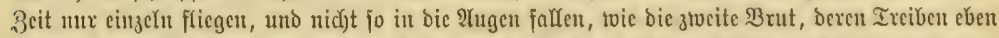

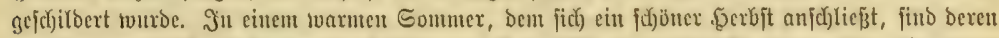

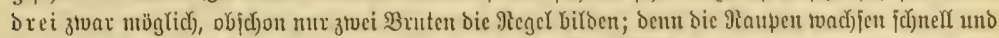

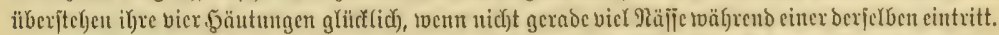

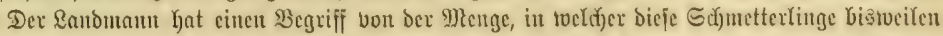

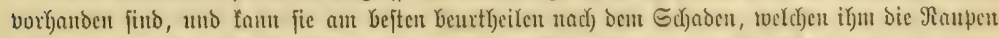

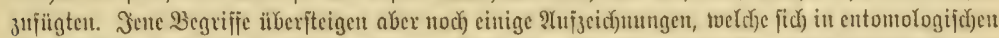

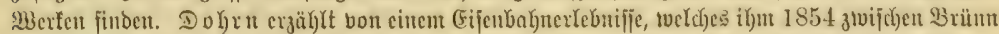

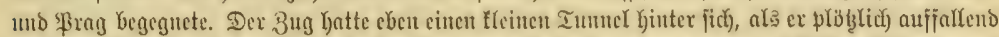

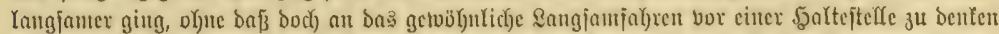

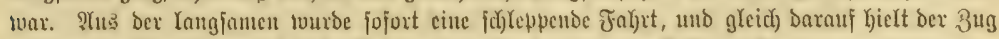

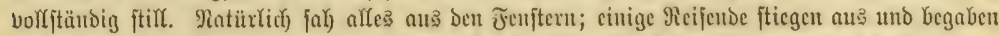

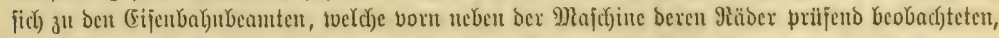

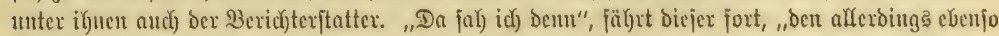

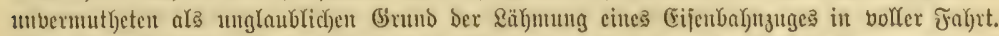

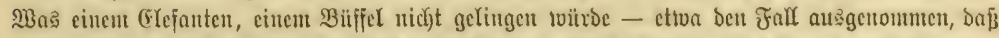

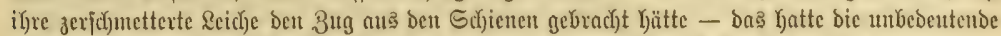

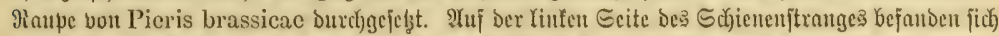

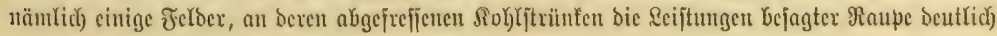




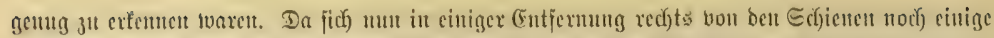

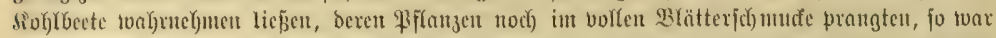

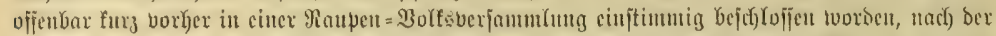

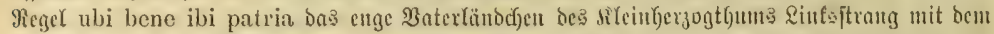

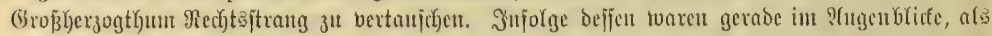

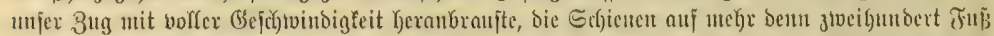

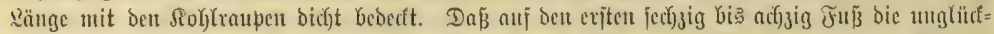

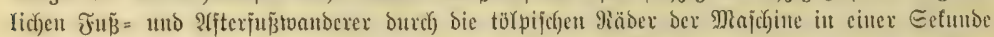

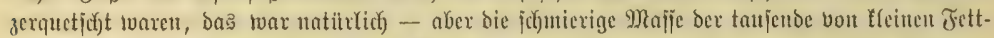

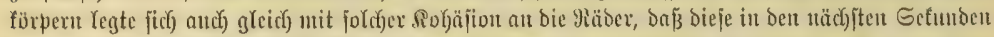

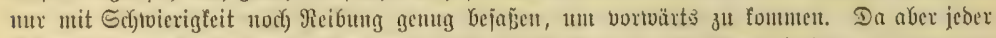

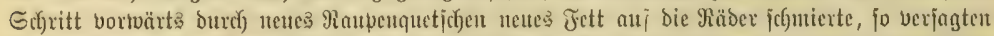

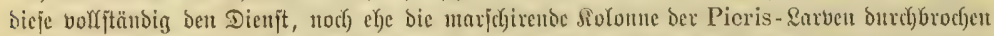

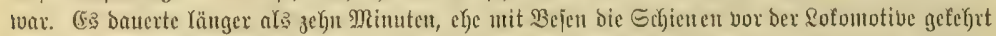

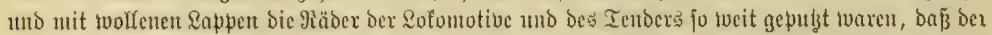

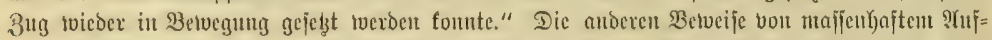

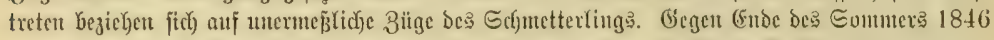

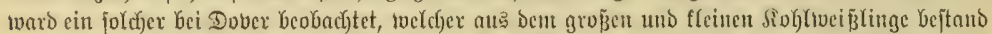

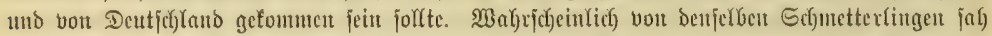

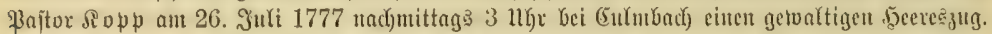

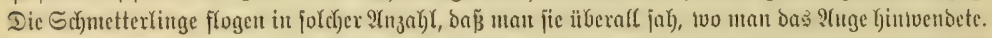

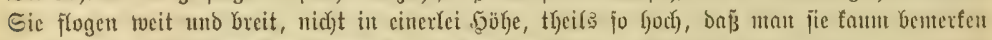

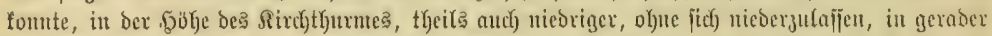

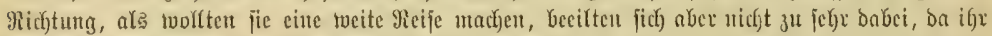

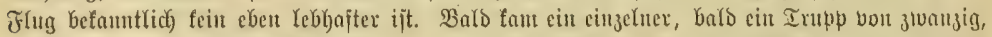

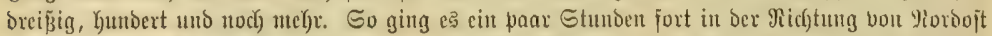

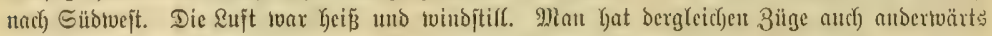

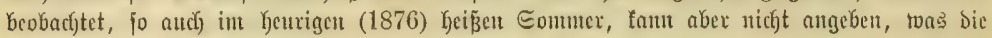
Schutetterlinge baju veranläst haben mag.

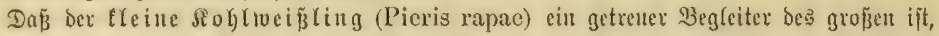

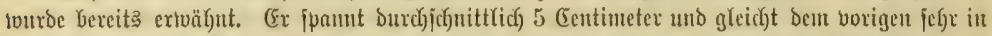

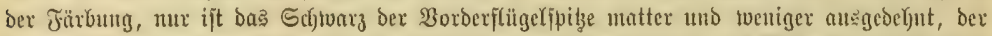

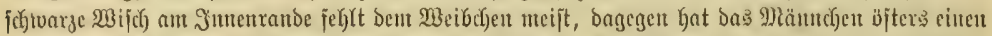

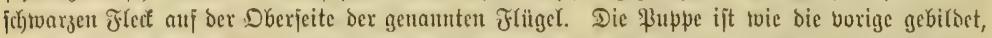

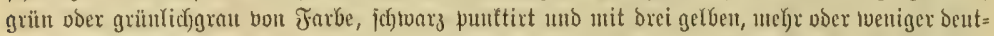

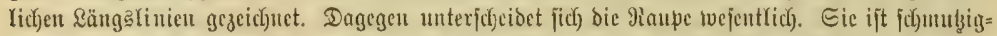

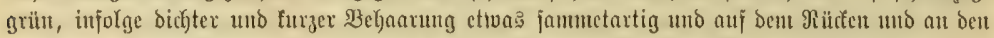

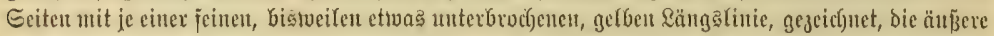

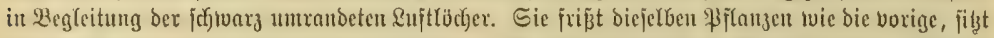

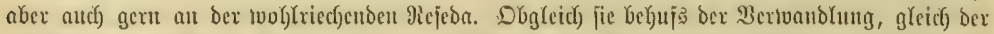

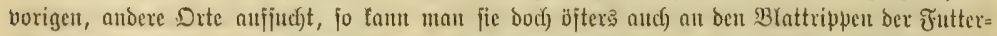

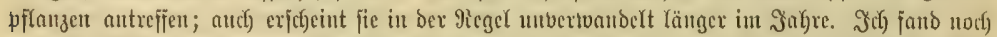

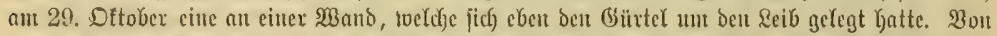
cinigen anjangs Geptember eingejanmelten, ber ßerpuppung fehr nabe ftehenden Ranuen, Yiejerten

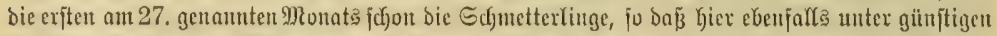

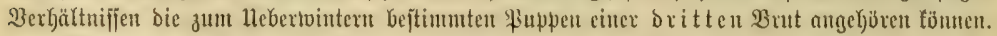

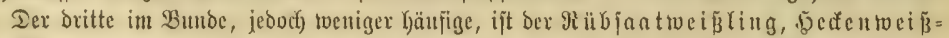

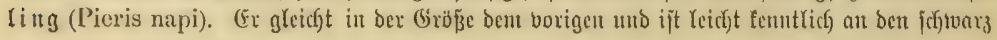




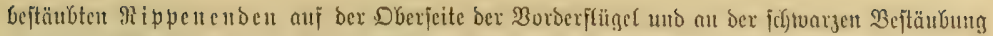
ber ganzen Kippen auj ber getb angeflogenen Unterjeite ber Ginteren. Eeinte Raupe ift ber be马

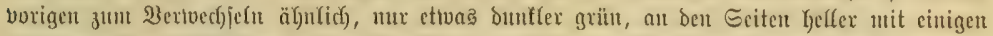

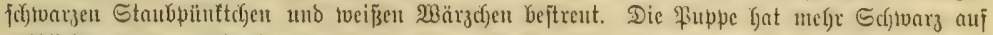

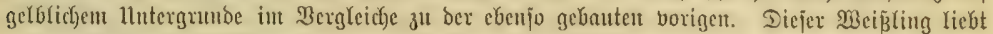

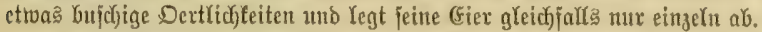

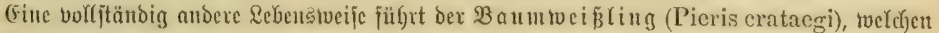

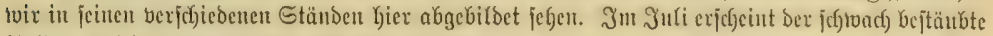
Falter, toetchen jeine jodytwargen Rippent und bie

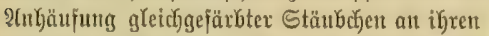

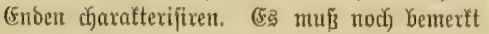

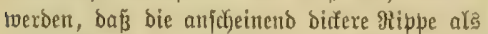
Galbe Srenze Der Mrittelzelle int Borberflitgel von ftärferer Beftäubung herrïhrt, uno då̄ jie ber Regel folgt, welche borker bon ber Sippe angegeben twurbe. Das Meibd)en Yegt alabald

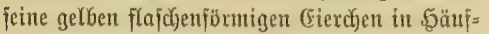
Yein, größjere ober fleinere, wie wix fie auf ben

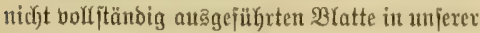
Beicfunung erbłič̃en, an bie Błätter ber ßflan= men= uno Sirnbäume, be马 vertvanoten Sdytvarz= Doms, am jeltenjten toogl an ben Straudj, sweldyer bem Faltex jeinen miffenifichaftlichen

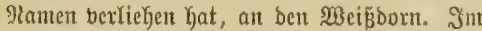

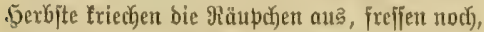
ipintuen aber gleidid ein paar Blätter an ibrem 3tweige zujammen und an biejent jeit, bantit fie beim Raubfalfe fiben Gleiben. Int biejen jeiden= gläıżenden Gejpinjte ilbertvinteru fie. Wenn die Bäume iłr \&aub berforen haben, falten bieje "fleinen Raupentejter" Yeidyt in bie 2tugen. Gobalo in nächjten Frübjałre die Snospen

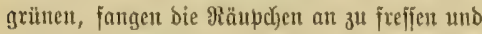

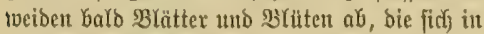

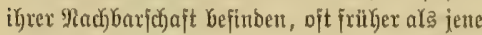
3u iłrer (Entwidelung gelangen fonten. Menu die Raupen größser getworden find, verlajpet fic ifre gemeinjome Wobyung und zerjtreuen fidd. Die cruachfene Raupe ift feijt uns glänzent,
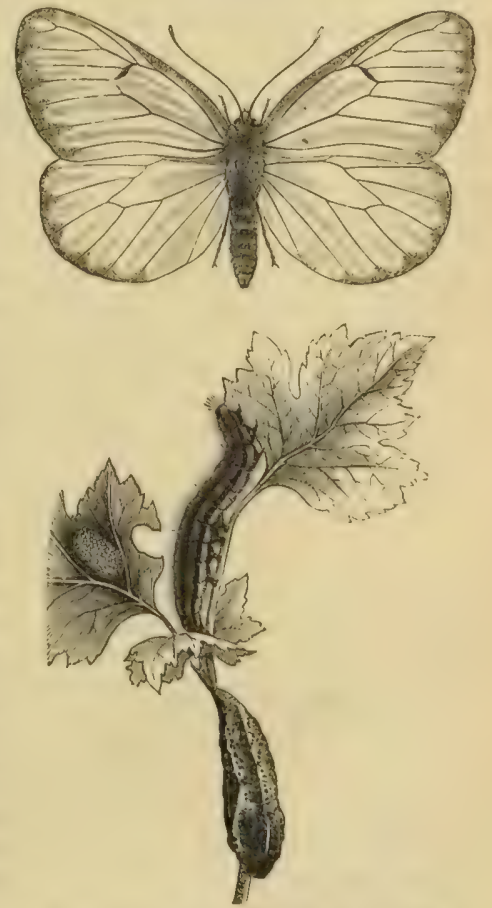

Baumroeffing (Plerls erataegi) mbit Fiern, Raupe unb

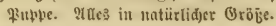

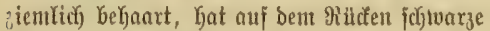

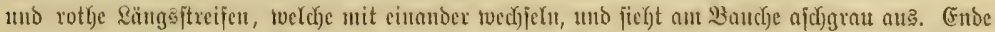

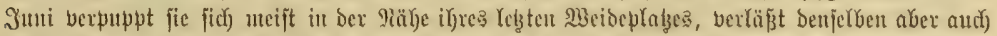

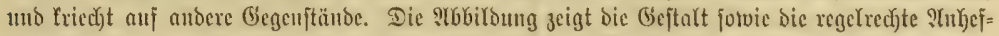

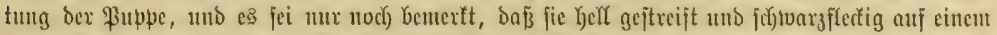

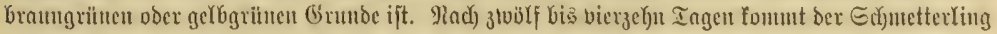

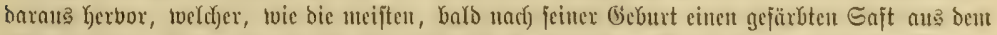

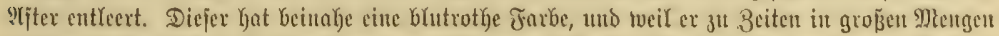

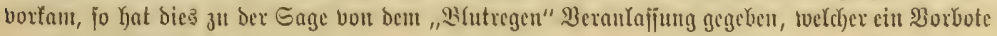
Erebuns rgierteber. 2. थuflane. IX. 


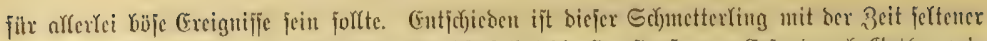

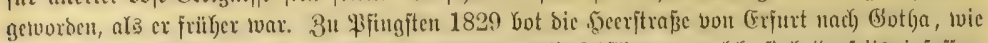

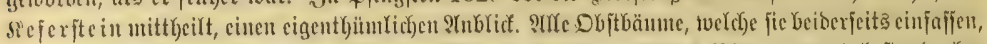

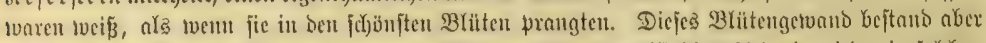

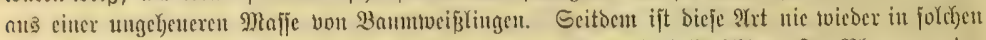

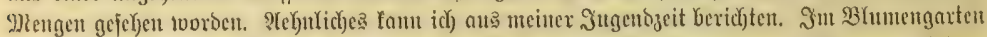

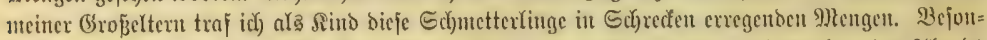

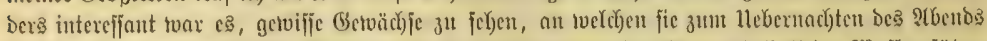

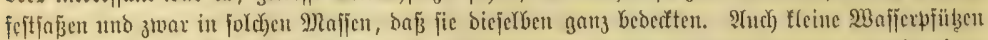

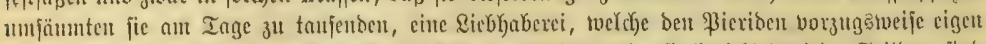

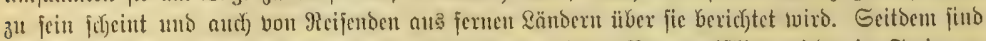

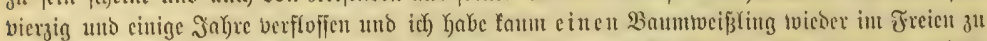

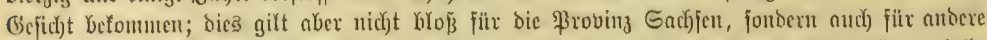

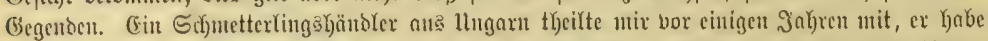

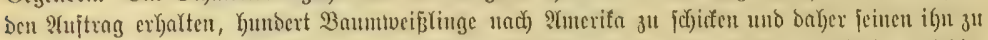

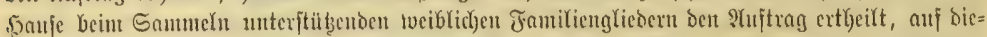

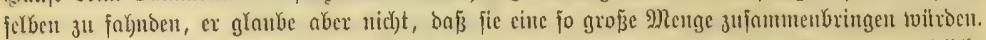

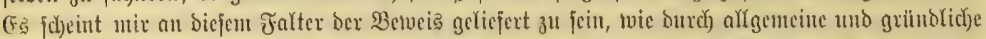

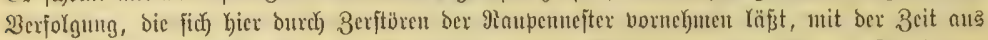

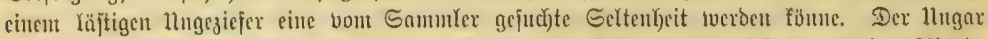

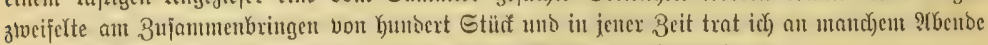

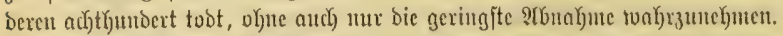

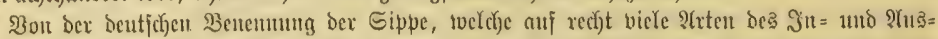

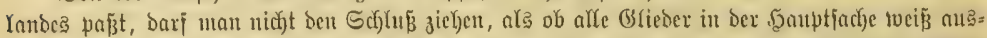

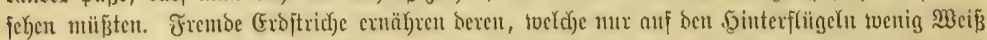

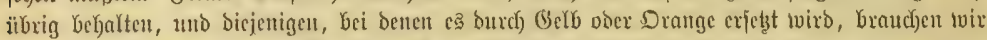
nicht in ber Ferne zu fud dyen. Der übernus zierliche ?turorafalter (Anthocharis cardamines)

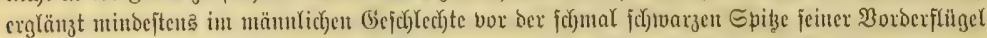

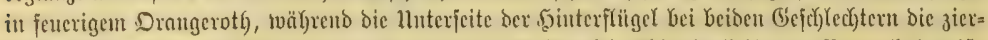

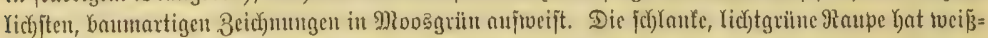

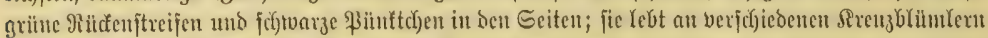

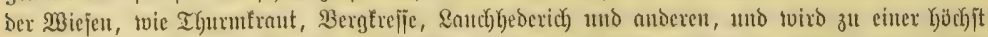

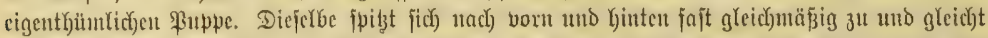

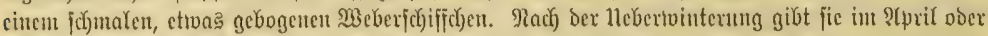

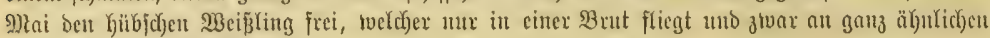
Stelfen svie ber Sectentweiß̄ing.

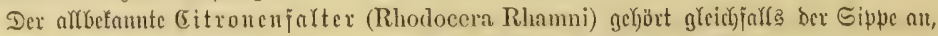

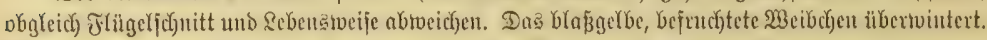

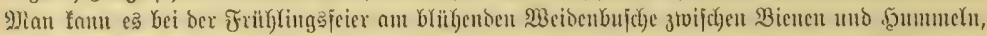

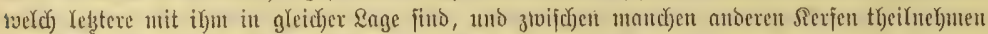

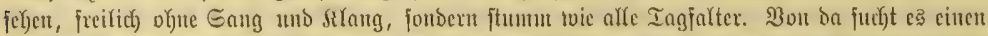

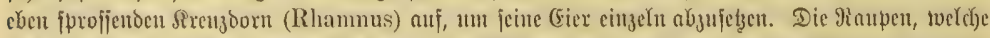

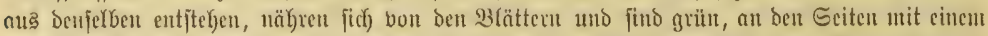

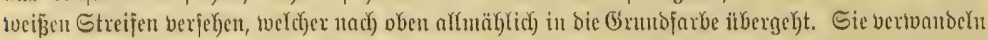

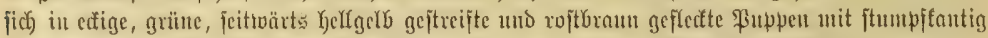

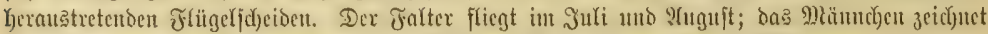

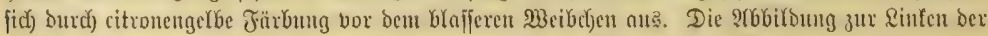

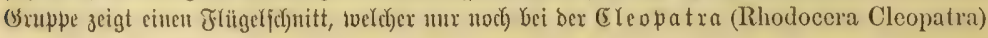




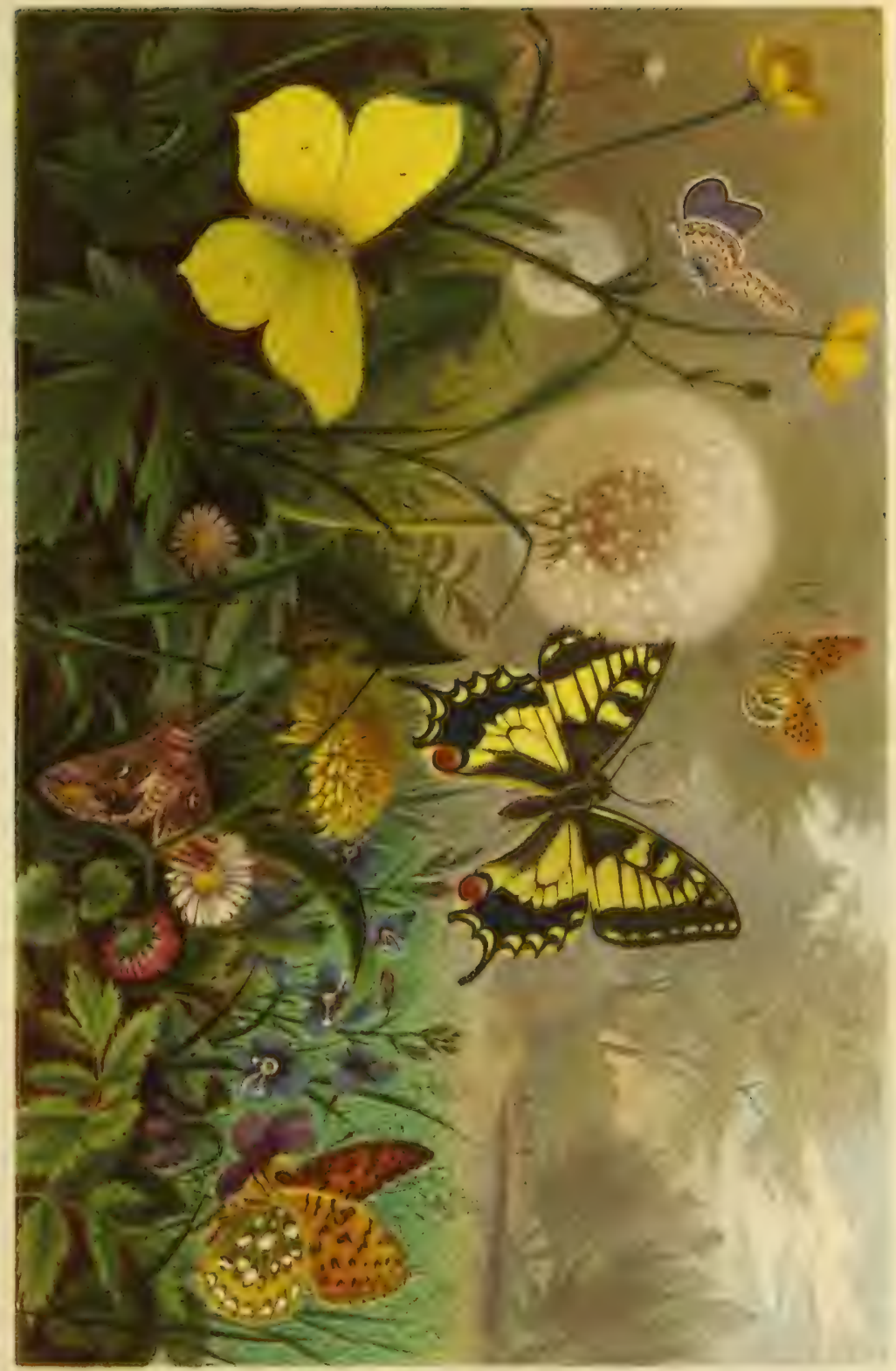





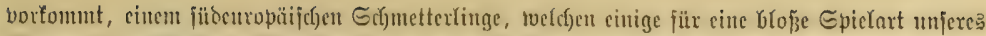

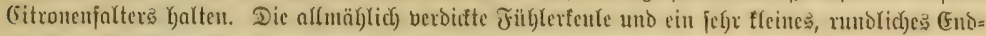

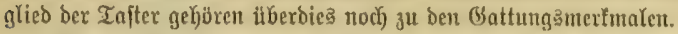

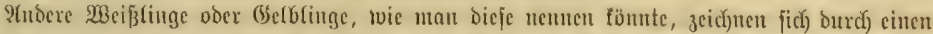

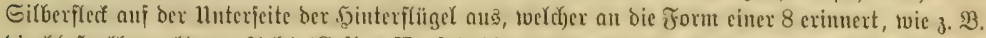

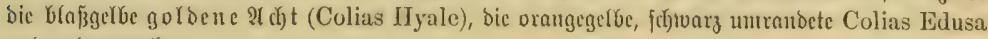
und andere metgr.

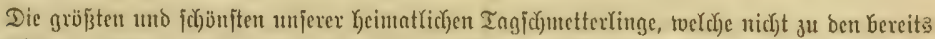
befprocbenen gehören, haben mit nod) vief zablreicheren aus(änbifd)en Prten bie zu fogennunten

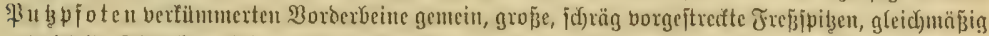

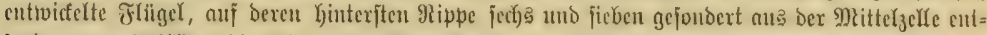

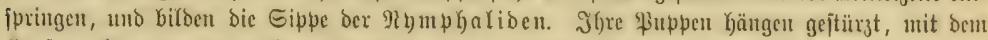

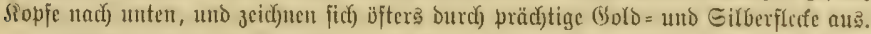

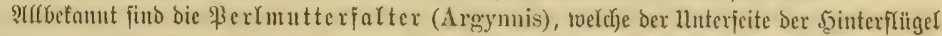

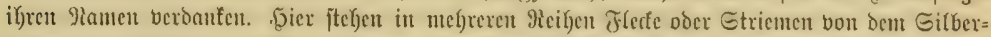

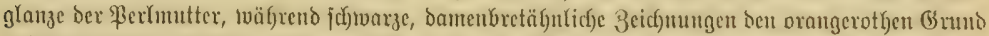

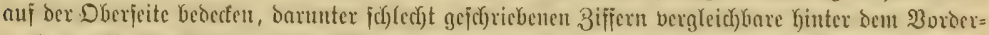

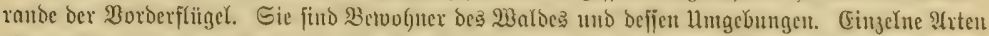

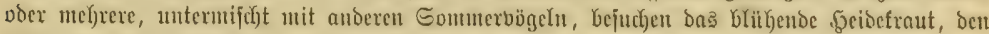

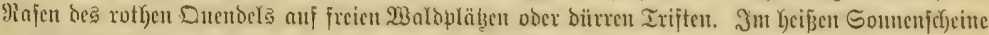

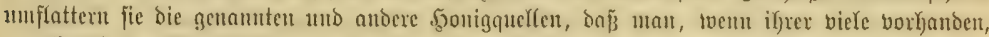

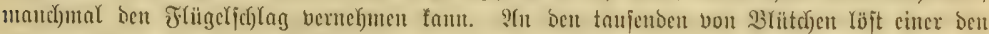

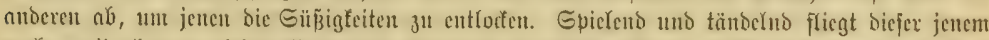

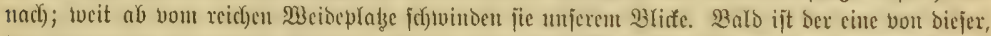

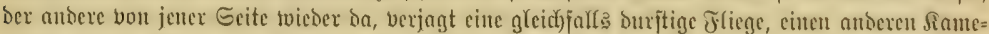

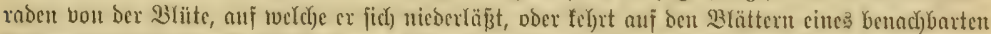

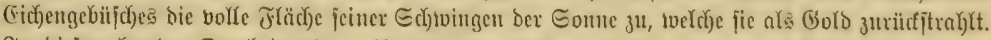

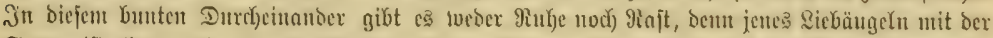

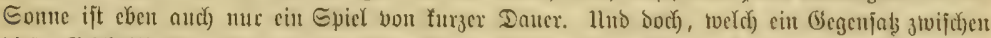

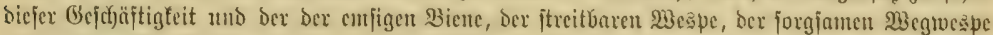

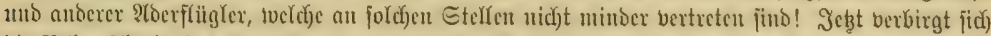

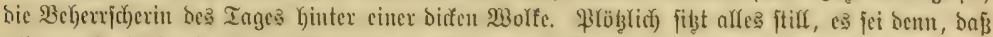

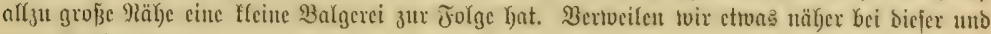
jenter (Exjdgeinung.

Ulujex gröp̈ter Berlmutterfalter ijt Der Eirberftriç) ober Raifermantel (Arogmis

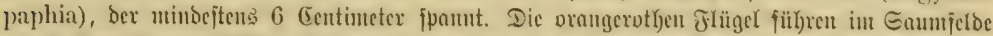

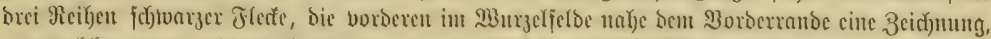

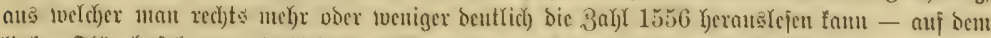

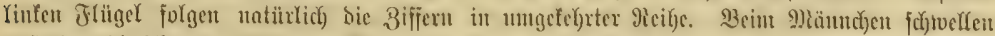

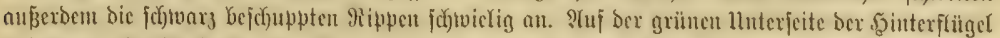

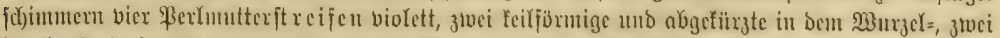

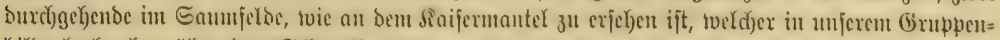

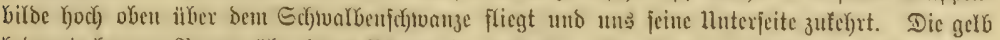

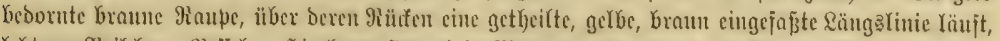

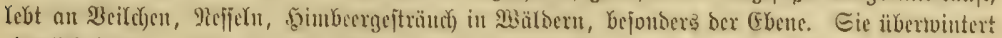

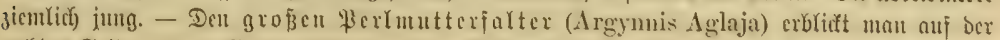

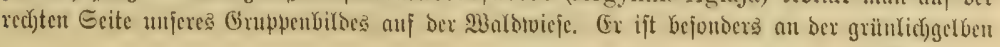




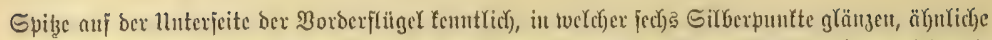

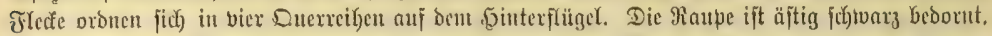

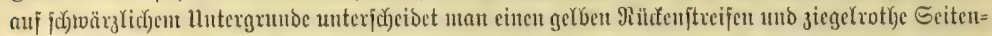

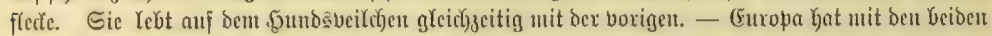

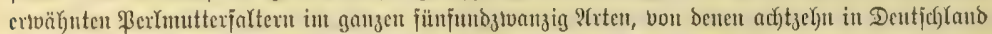
vorfonmen und Tamen twie Piobe, Daphne, Rathonia und äbnliche fithren; in anderen

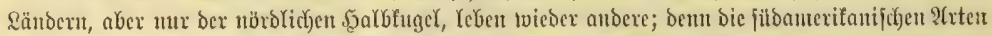

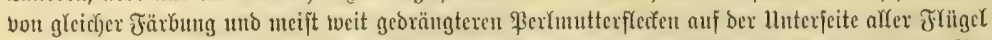

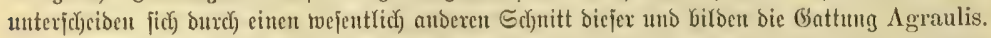

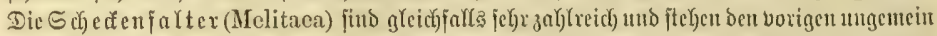

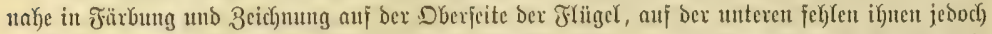

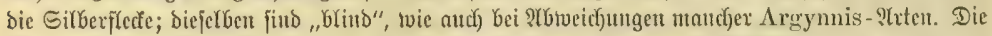

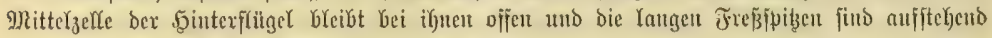

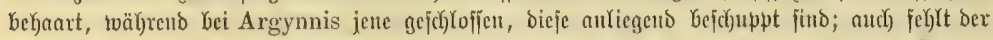

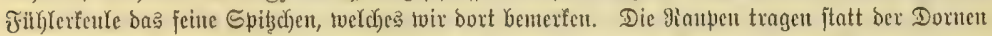

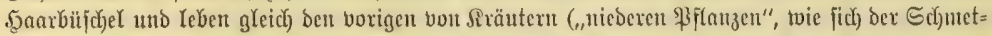

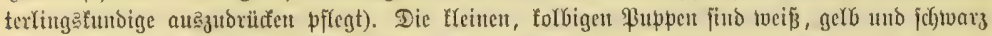
getigert, ohnte Metalfglanz. Warbrviejen uno offene Stelfen ber Wälber Gicten ben Echunetter=

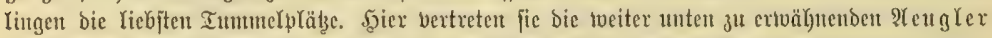

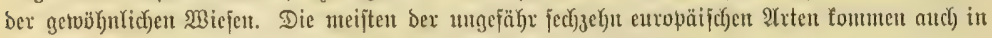
Deutjchland vor, mandje bon ifnten in nicht unbebeutenden Spielaxten.

Die (Edfrügler, exflügeligen Faltex (Vanessa), gehören zu ben meift verbreiteten,

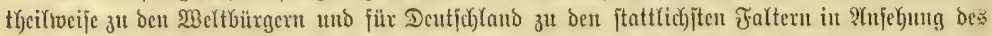

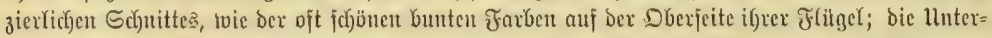
jeite ift meift buifter gejärbt, wie mamorirt. Dic IUgen fiuto ftarf beljant, Die Fithferteulen

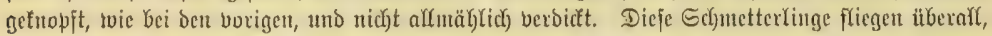

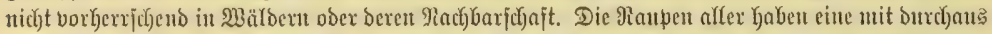

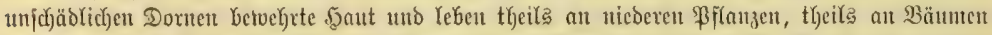

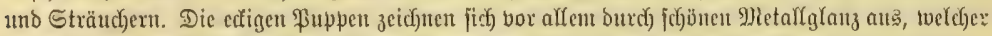

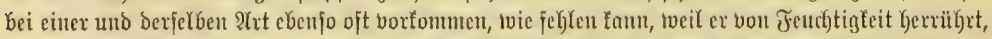

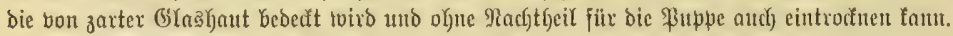

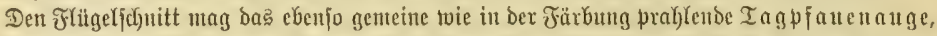

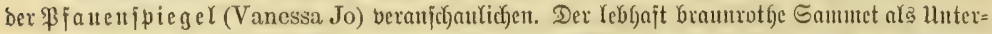

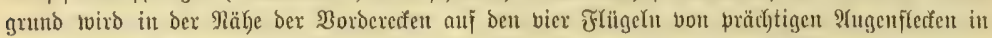

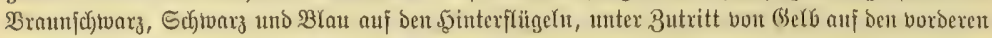

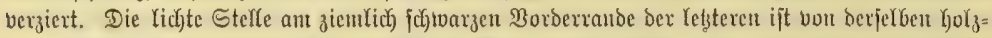

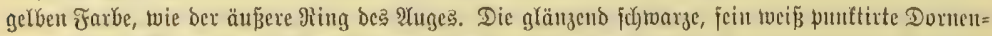

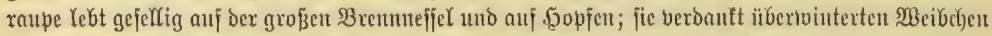

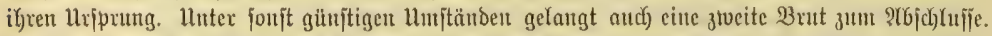

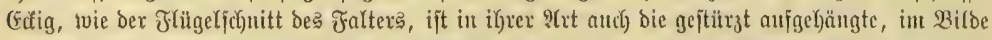

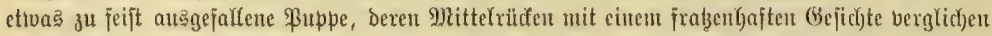

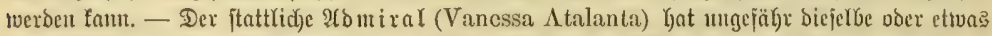

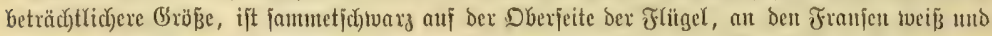

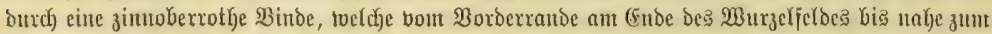

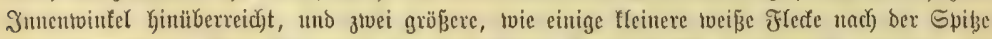

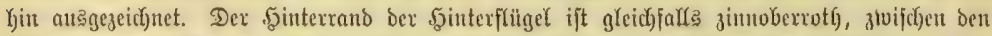

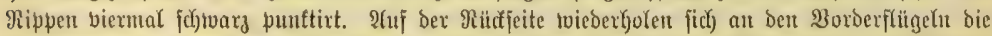
3eidjuntgen ber Dberjeite, mur matter, Die Sinterflïgel Dectt Yeb̧ajter Marmor in gelben Tünen, 


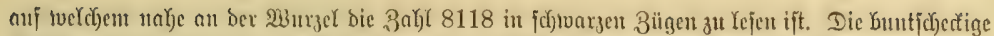

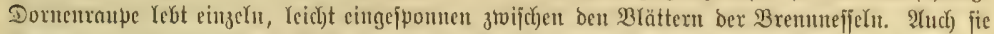

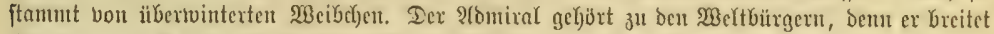

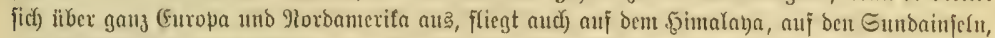

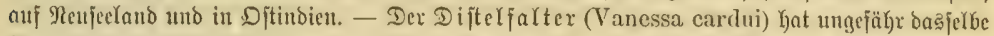
23erbreitungägebiet tvie ber vorige, Yebt im Raupenzujtande in gleidyer Meife an Difteln, auch) an ben gebauten $\mathfrak{F}$ (xtifdjoten, und twirb baburcty jo recht zum Segler uber Feloer uno :Bege; aud in ber 3eid)mung fteht er bem ADmiral am nädjften,

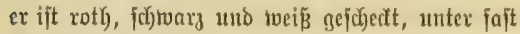
gleidjmäß̧iger Betheiligung Der beiben erjten ₹arben.

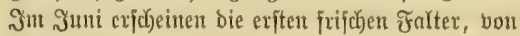
benen häufig noch eine zweite Brut zu Stande foumt. Befuchtete Weibchent Überwintern aud Yier. Bistweilen fliegen bie Diftelfalter in außzer= orbentlicher Mnenge, wie von unviberfteglicher Manderluft getrieben. \$revojt beobachtete an 29. Ditober 1827 in Frantreich einen zebn bis funfzelyn Fuß breiten $3 u g$, weldyex ztwei Stunben Yang bon Süben nach Forden flog; Bhilian i ebenfalfa im füblidyen Guropa an 26. Tpril 1851 einen anderent frifó) aus̈getrodfener Falter, unto weitere ähnliche (Exfdyeinungen finden fid in ben

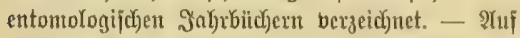

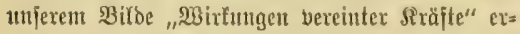
blicfen bix einen Ixauermantel (Vanessa An-

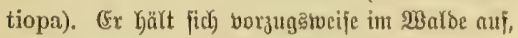
bent jeine Rautpe exnäbrt fiç an Yiebjten von ben

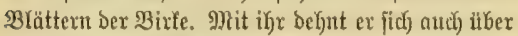

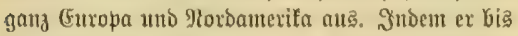

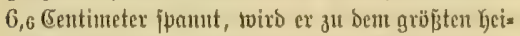
mijoben Eiffalter. (Fine breite licbtgerbe (Einjajpung

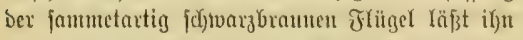

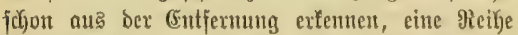

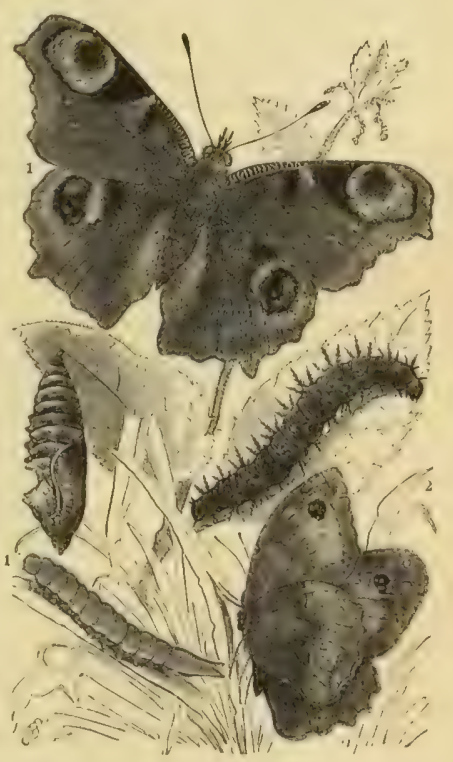

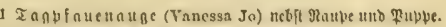
2 Niscibd)et bes Sanbauges (Eineplede Janira) neb/t

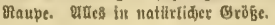
blauer Fłecfe vor ber Rante ijt nur in ber gä̌̉e

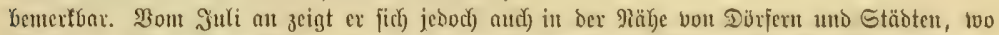

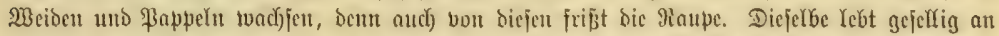

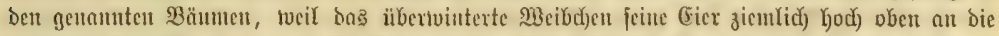

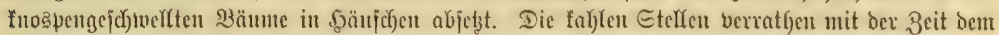

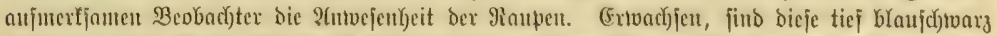

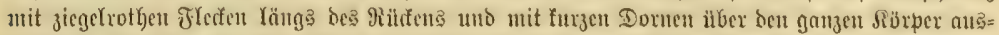

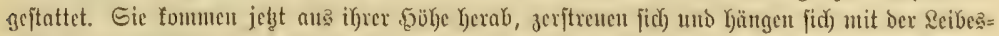

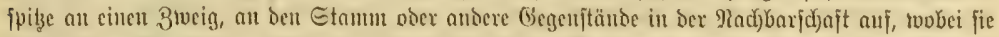

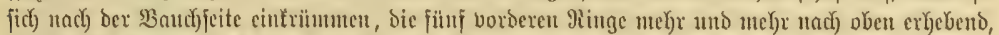

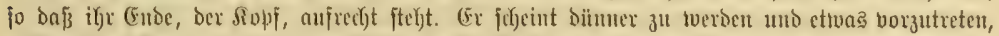

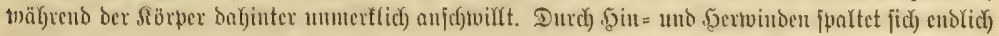

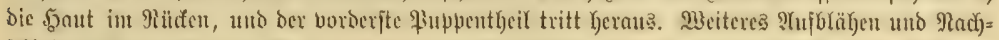

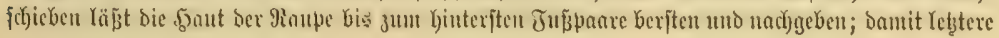




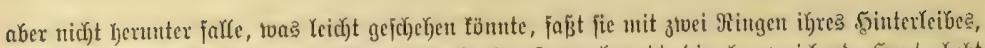

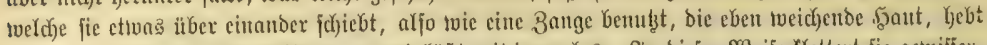

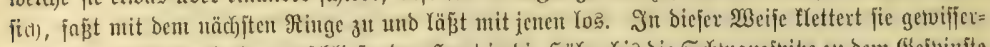

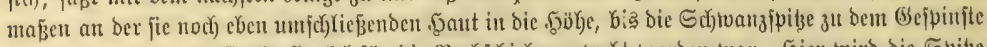

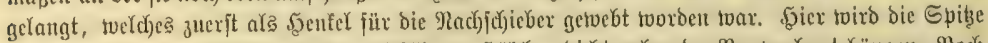

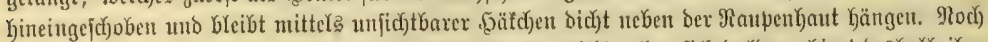

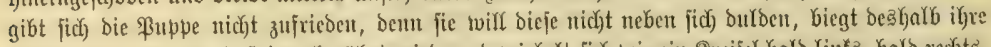

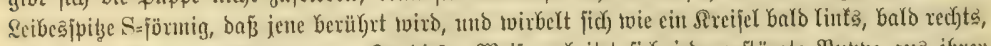

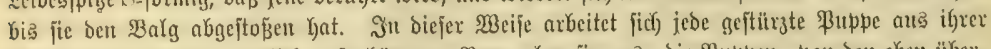

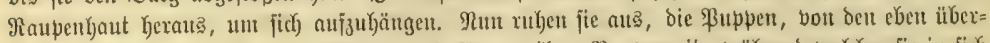

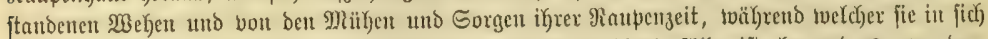
ankäuften, wa

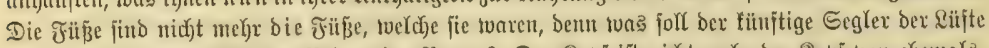

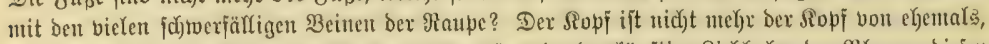

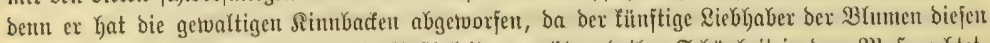

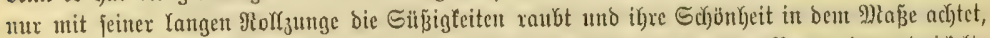

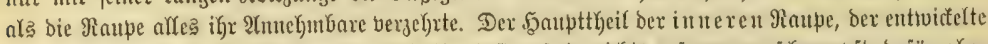

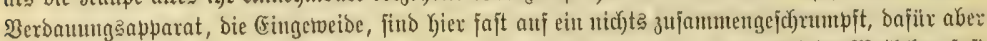

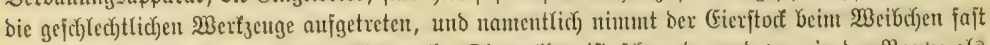

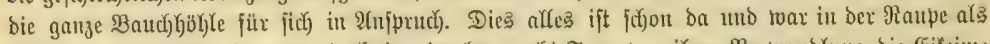

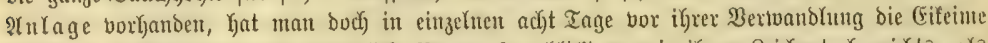

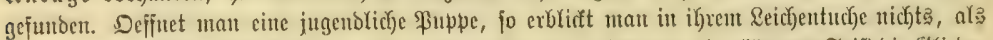

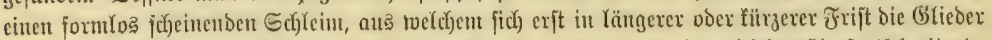

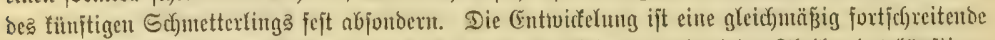

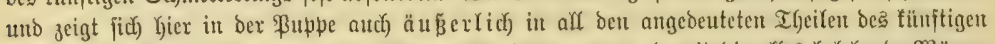

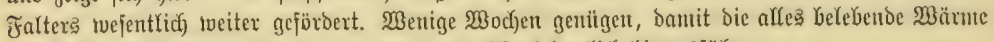

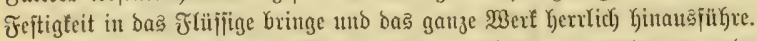

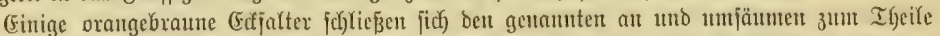

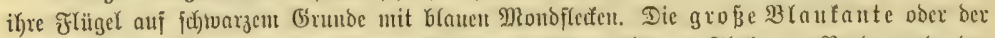
groß̧e Frud)

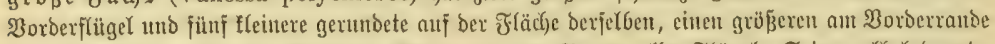

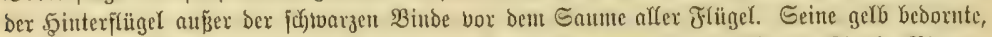

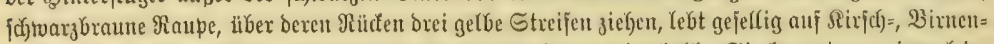

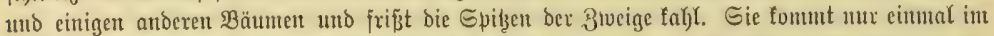

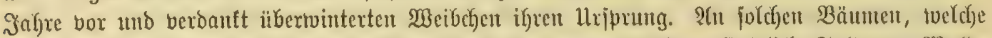

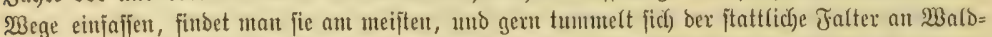

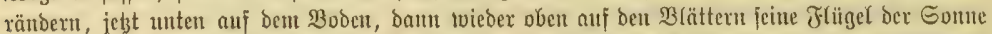

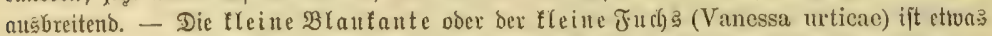

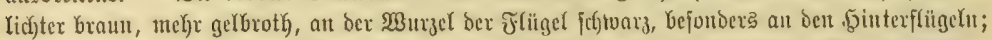

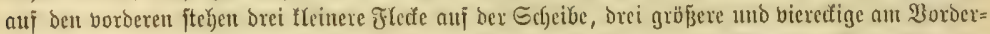
rande bon gleid)er Jarbe, und ztvijchen bent Ginterjten biefer mb ber j(f)twarzen Saumbinde cin

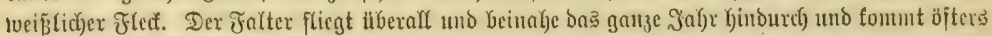

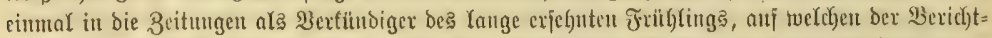

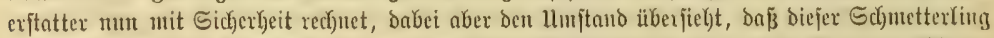

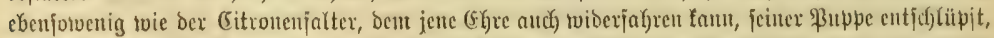

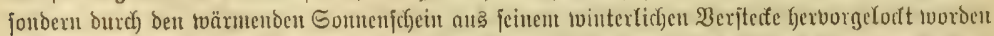
ift. (Stindfidsertweife ift $\delta$ ex ffeine Fnd

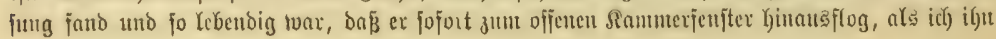


eirfangen worfte, von cinem 3eitungaberic)terftatter nicht gejeben toorden, fonjt Gätte unt biejer

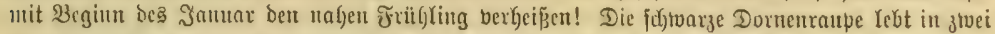

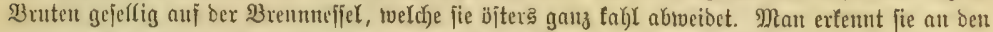

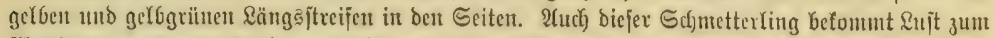

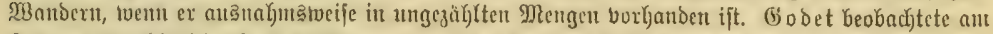

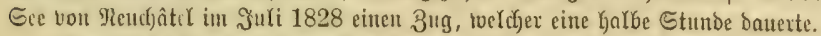

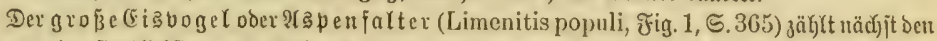

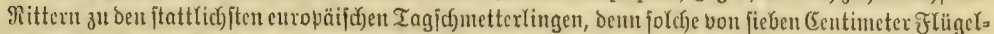

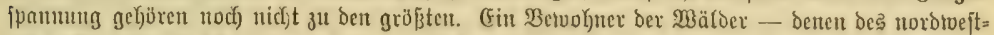

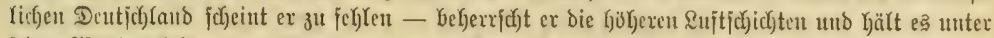

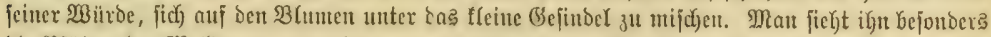

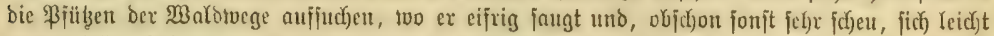

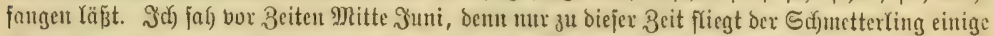

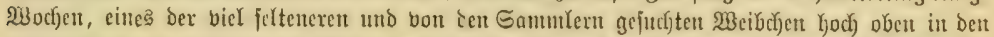
Buiften über eine Rich,tung in Walde herbeigeflogen fomuten und ucben cinen Bache förmlich) ein=

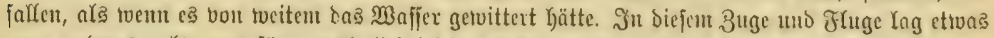

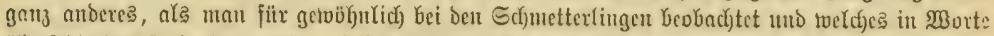

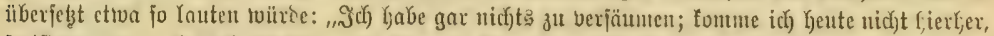
jo ift morgen aude) nod) cill Ing, uno fomme id) utorgen nidyt, fo lisgt menig Daran, bas Wofiu

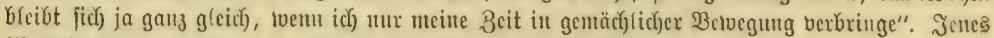

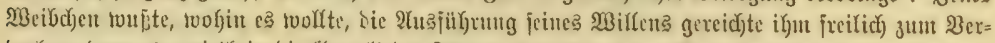

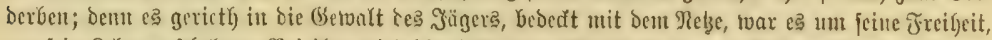

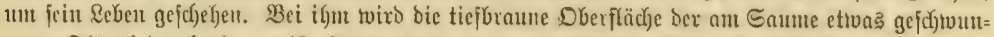

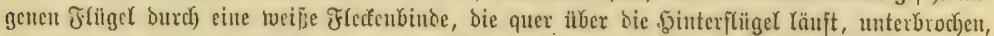

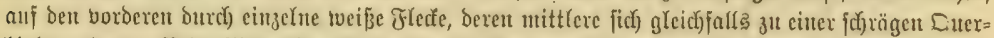

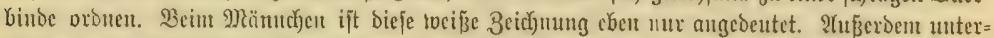

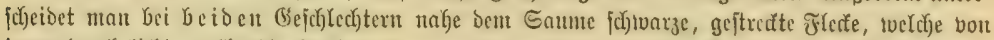

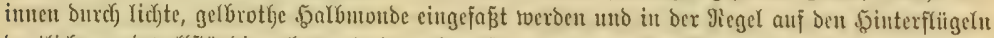

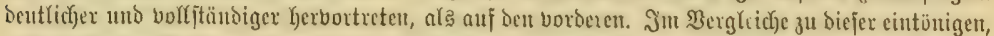

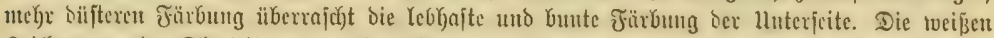

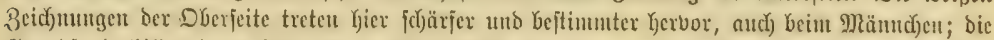

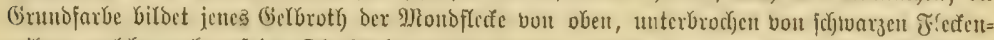

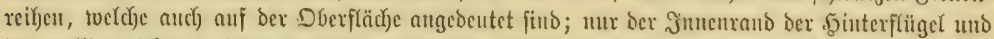

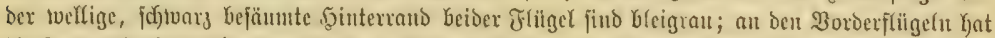

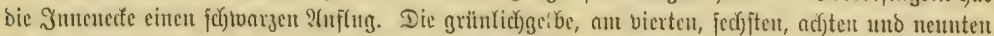

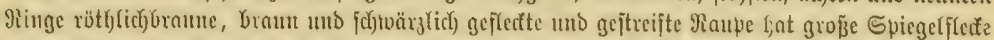

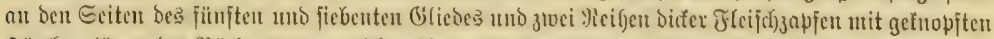

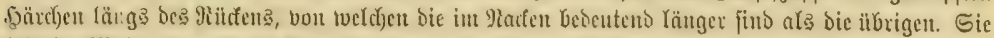

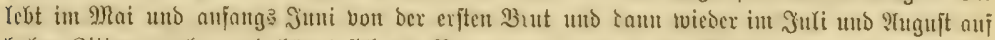

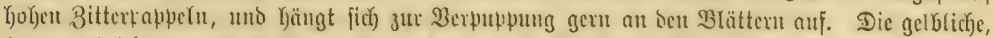

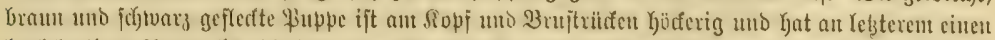
Yenfelantigen? ?(s)und)

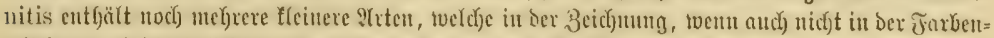

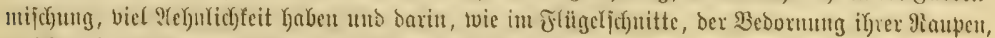

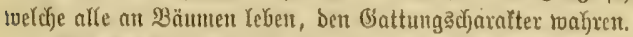

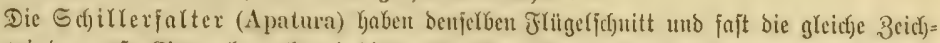

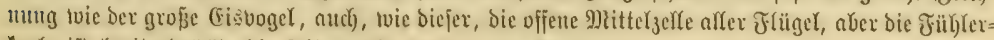

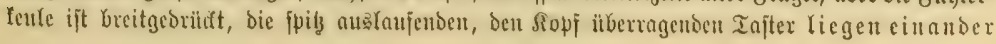




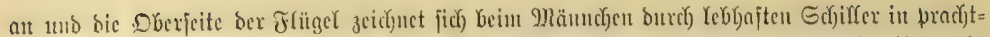

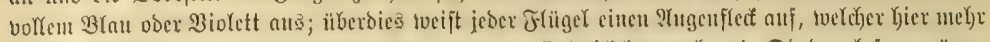

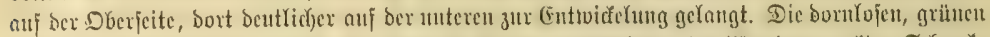

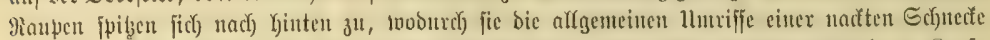

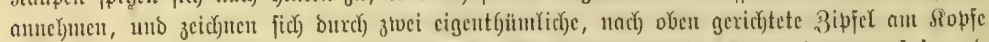

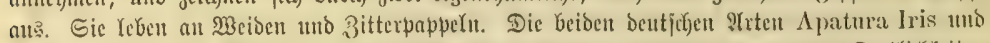

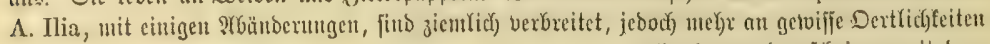

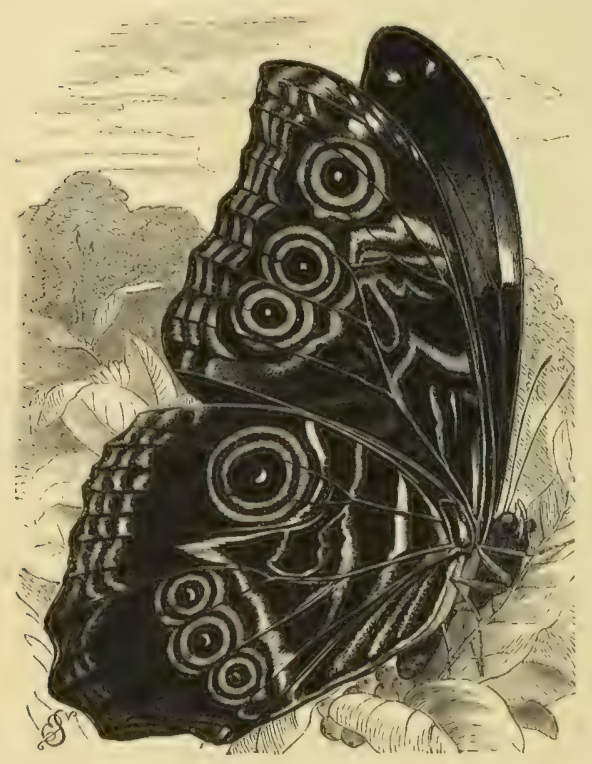

Reoptofemus (Borpho Neoptolemes), nallirlide Grỏ̧e. gebunben mis erfocheinen mit bem

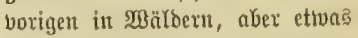
Yängere Beit in Săhre. Ein fteter,

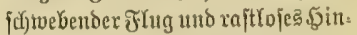

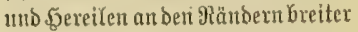

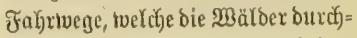

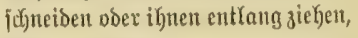
zcidunt fie auts.

Die riefigen Mtorpfiden Silbamerifas fimb Falter von glanz= boller Färbung, weldye hod, oben, meift nicht unter fechs giketer (Ent= fexnung vom (Exoboden in Den \&ict)=

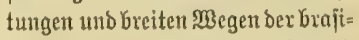
Yifjchen Wälder fid tummeln uno Dem Bejudauer einen itberrafdchenden Inbliç getwähren. Wemn bie groß̌en

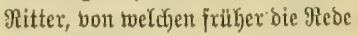
war, burtc bie Strañen der Stäbte fegetn, in bie Bärten, ja zum offe= nen Fenjter Kineinffiegen, too fie BYumen erbficten, fo Iaffert fitc) unjere "trojanifdent Ђyelden", ein pradjtbolf biater Menelaus, oder cin T'elemachus, ein Hector mit min Glauem Duerbande von mat=

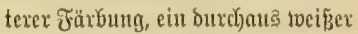

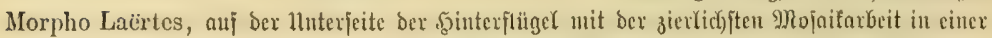

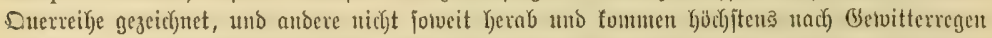

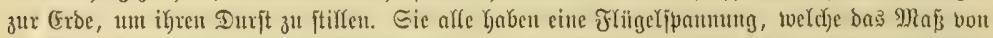

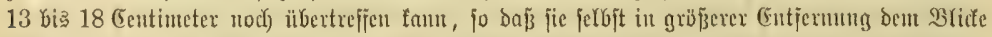

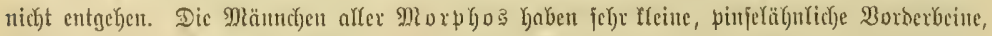

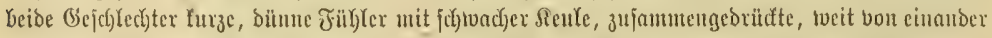

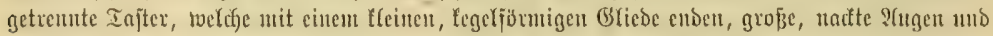

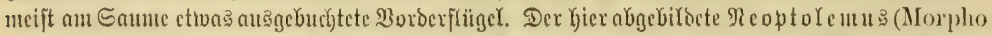

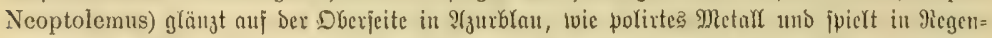

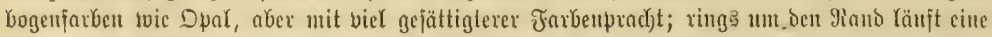

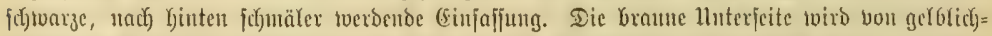

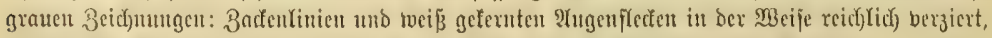

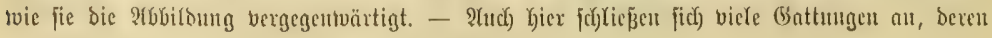
zaflreidje Frten tiber bie Gifeidfergegenben berbreitet finto. 


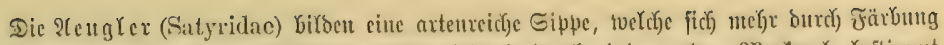

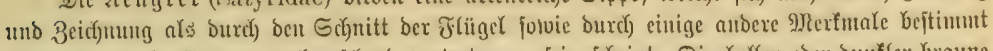

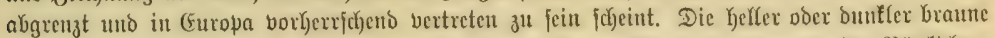
Dberfeite ber Flïget faun jajt cinfarbig jein, wirb aber meijt yon cinzelnen runben Püntt(d)en,

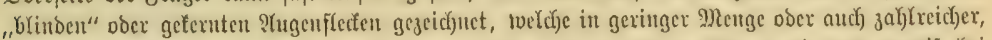

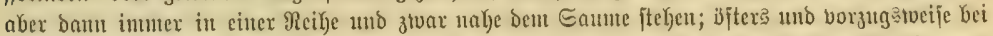

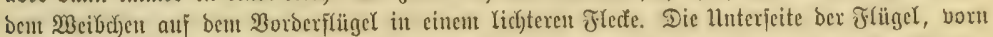

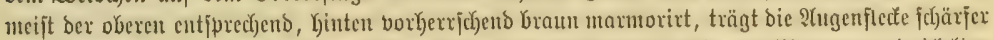

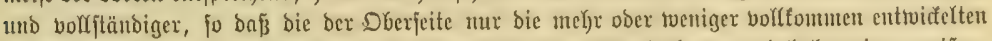

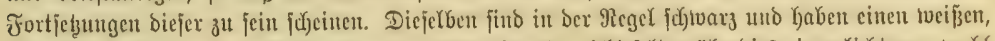

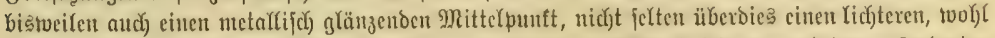

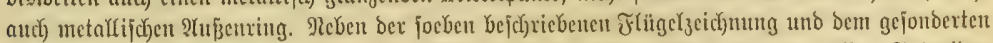

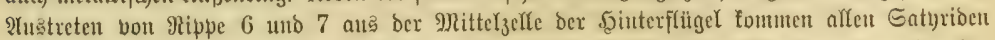

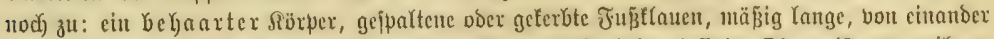

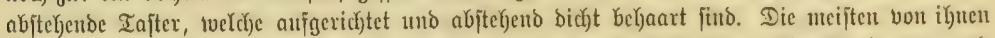

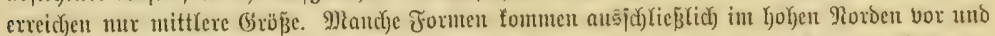

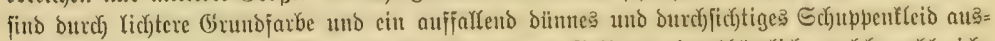

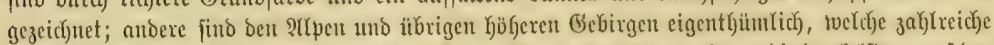

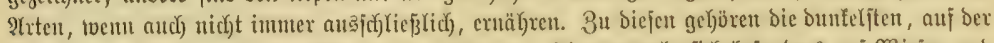

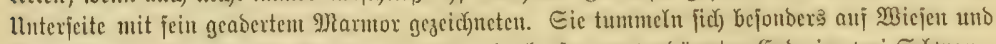

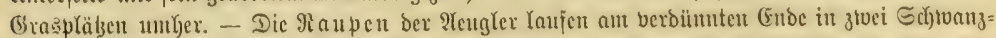

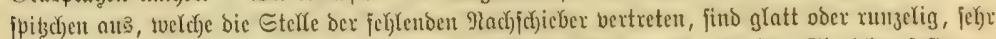

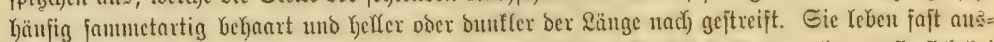

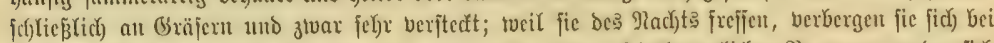

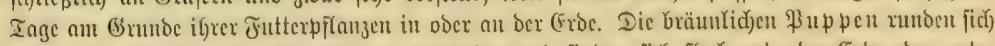
mef)r ab, als bie ber meijten übrigen Ingjalter mb finden fich flact) unter ber (Erbe ober unter Steinen, andere aujgehängt.

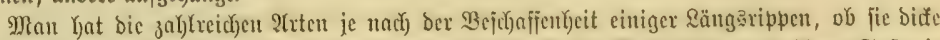

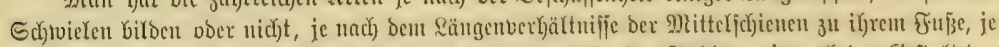

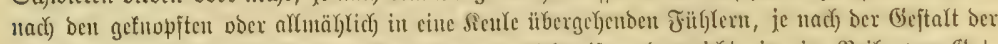

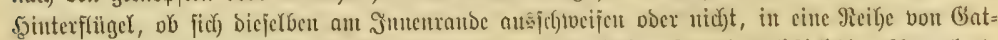

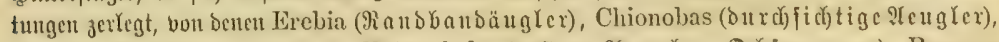
Satyrus (Breitbandäugler), Epinephele (büjtere sfeuler, Dedjfeuaugen), Pararge

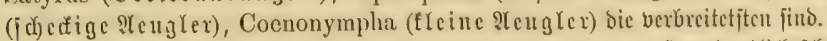

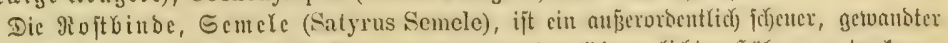

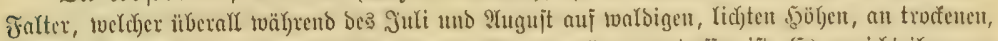

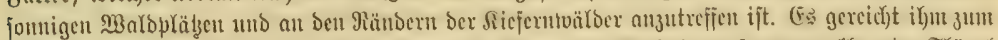

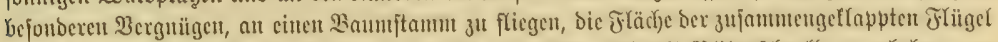

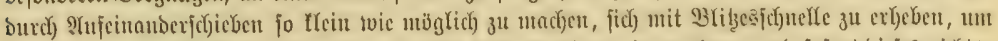

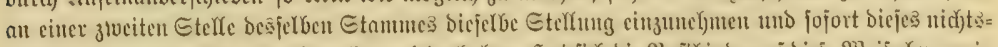

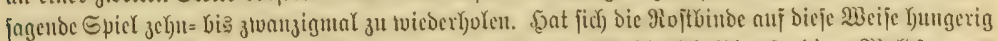

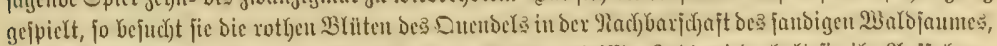

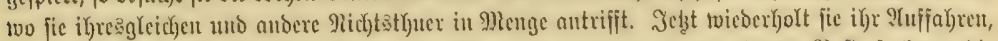

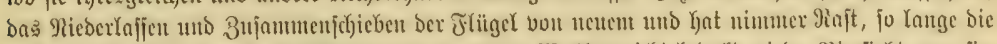

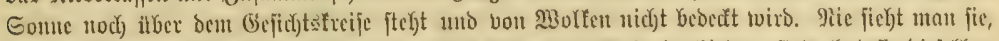

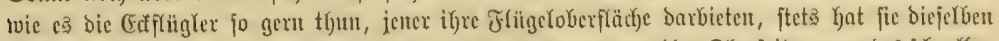
ॐ

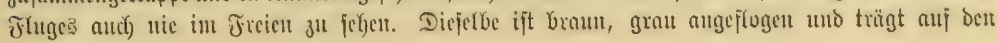




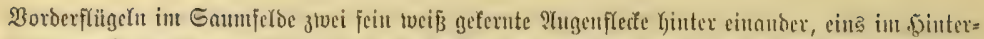

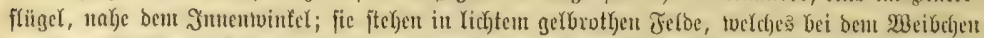

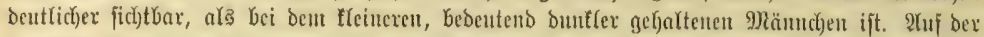

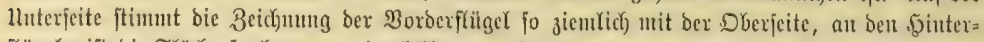

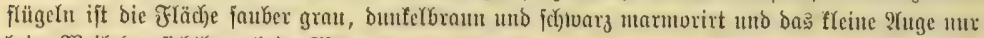

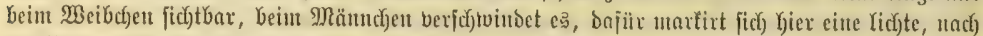

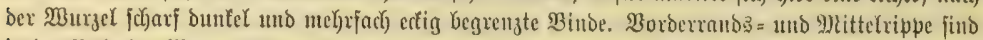

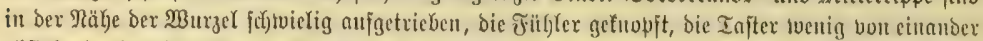

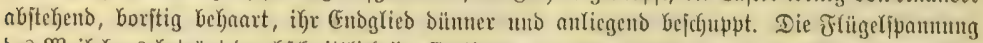

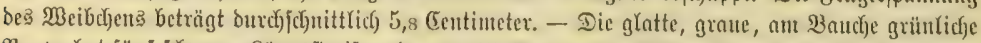

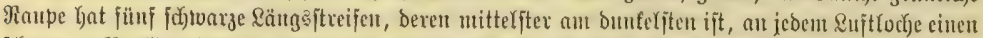

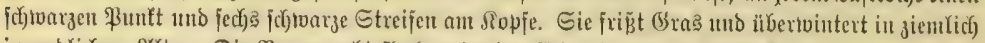

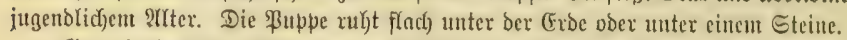

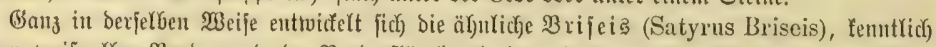

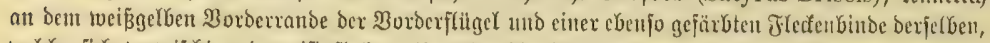

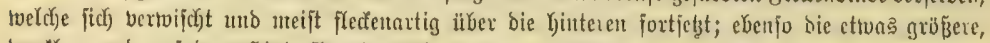

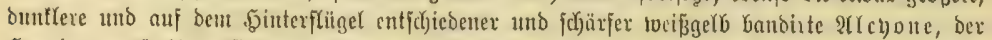

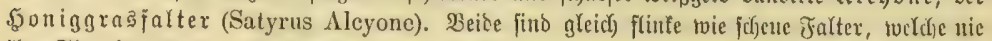

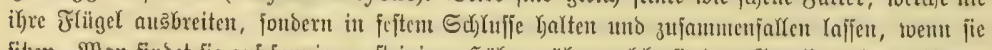

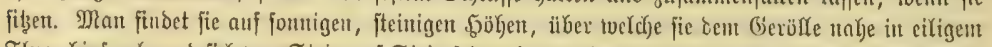

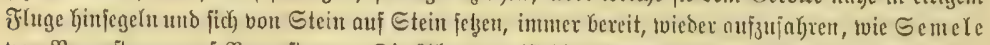

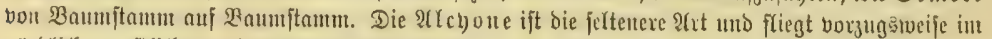

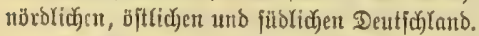

Der Ђirjengrasfalter, Grasfalter (Epinephele ITyperanthus), ift ein edfter Miejen=

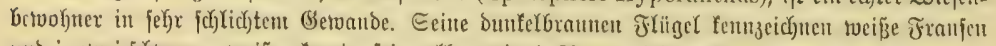

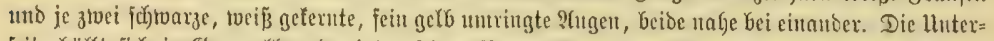

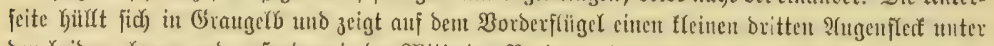

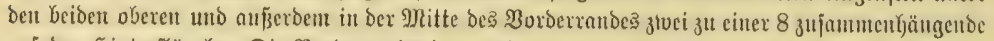

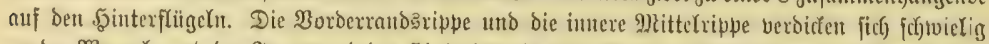

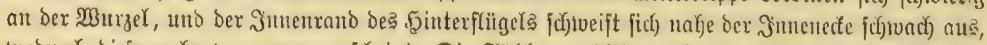

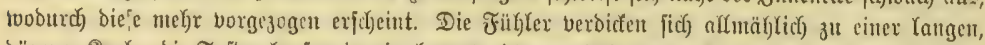

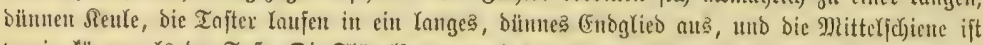

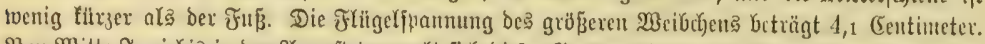

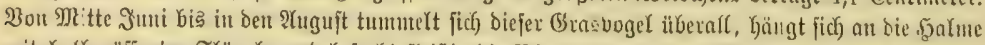

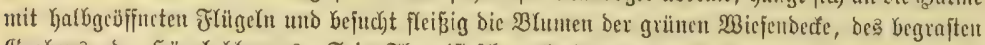

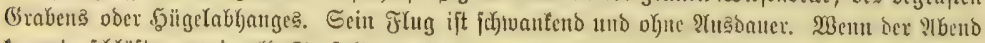

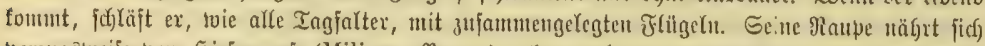

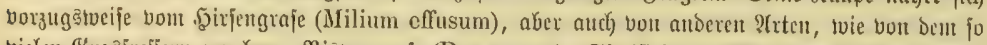

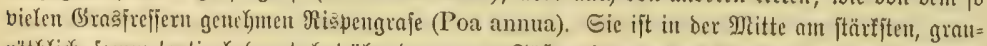

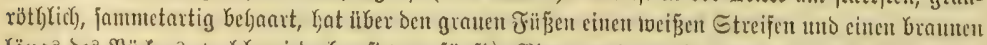

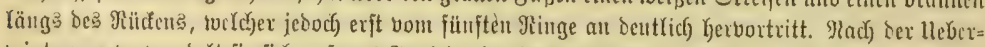

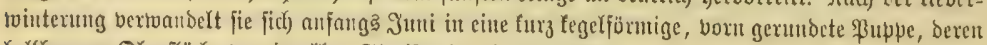
Gellbraune Dberflälfe bon Dunflen Etreifen burd)zogen tviro.

Das grobe Defjenauge, Sandauge, ber Ricbgrasfalter ober gemeine Miejen= vogel (Epinephele Janira), belveift burch feine vielen Nanten, baß̧ er cinex ber gemeinften und

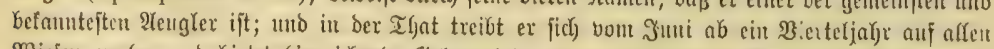

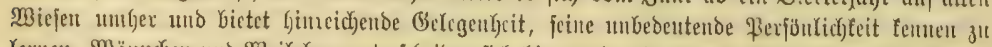

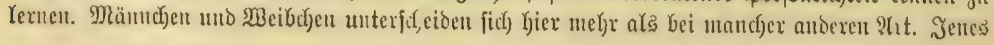




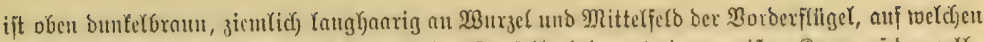

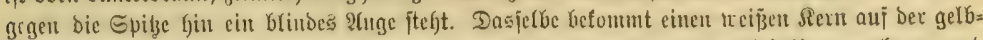
rotgen, riıgsum gevräunten lluterfeite. Der angenloje Siuterftügel trägt ficf) Gier graubraun uno

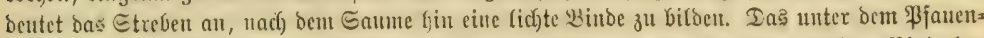

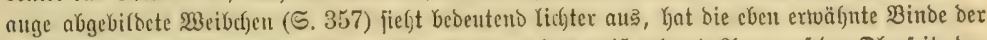

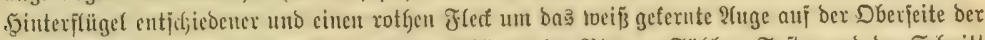

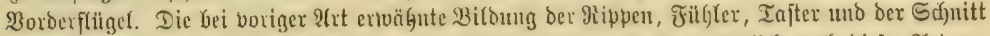

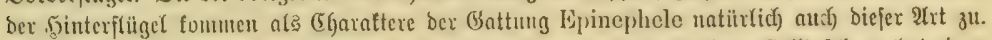
Die grüue voex gelfficf)grïne linupe, beren Oejtalt wir gleidjaffs bargejtelft feljen, hat cinen

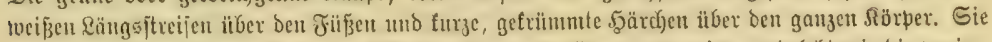

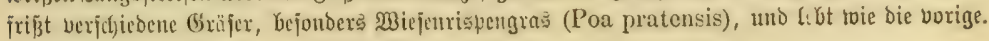

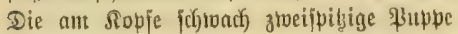
zeichnet jich burch melyreve bräunlicf biolette

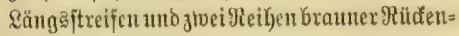
puntte au grinulidjent Untergrunde aus.

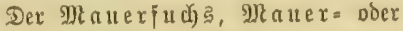

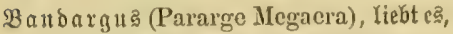

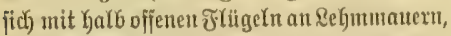
at fteile Mände ber פohtroege ober Gräben, in Steinbriidje ober auf bie nadte (Erie ju

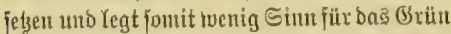

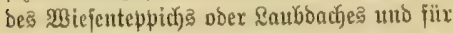
bunte $\mathfrak{B}$ ไumen an ben Tag; benu ex fliegt

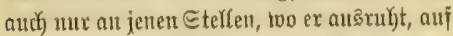
uno ab in for) Yaffer 5ुaltung feiner rotfgetben,

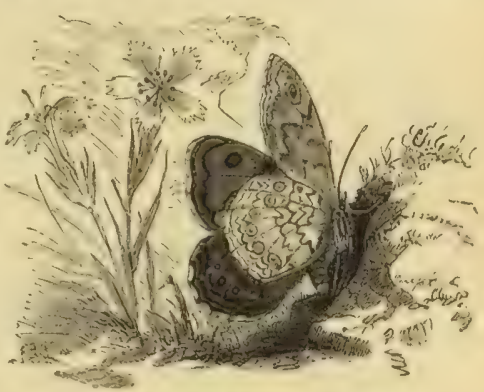

Ma uefutis (Pararge Meraera), natilitide Brobe. jd)wary Ganbirten unb gefledten Ed Givingen

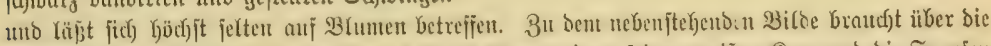

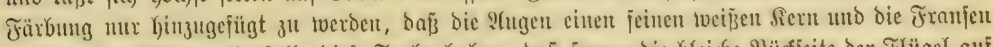

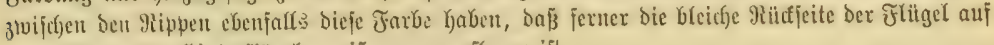
Den gelbbrautnen .5interflügełn tweiß̈grau angeflogen ift.

Dic Gehaarten P(ngen unterfucheiden bic $\Xi$ (f)edenäuglex (Pararge) von ben $D$ d) fen=

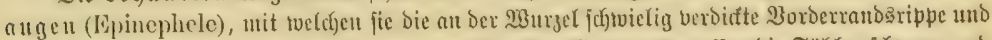

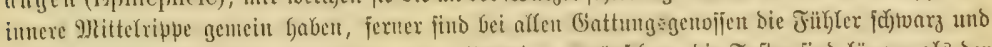

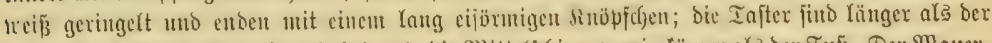

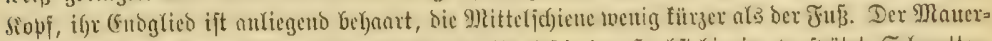

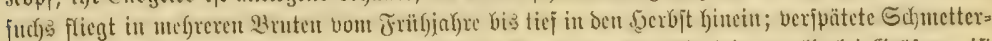

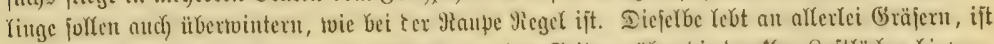

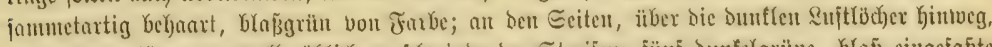

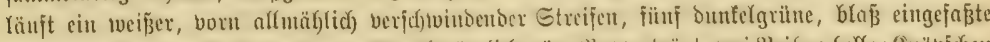

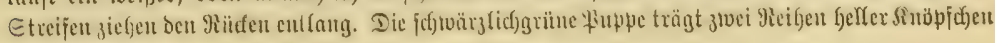

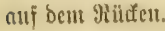

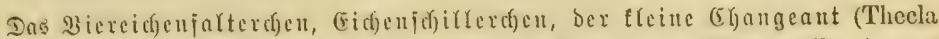
querens), füllt in Freien weniger in bie IIngeu ale bie meijten anberen Sippengenoffen; benu er

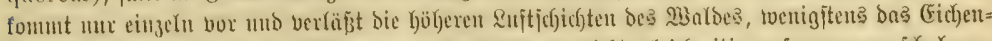

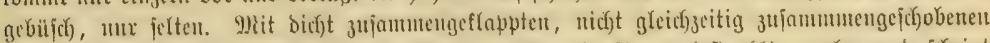

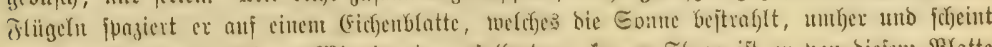

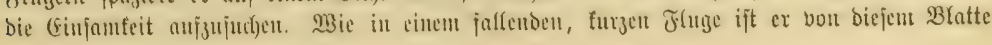




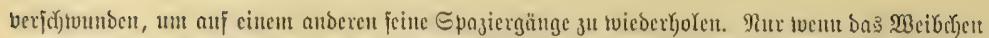

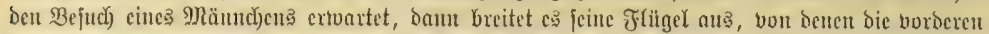

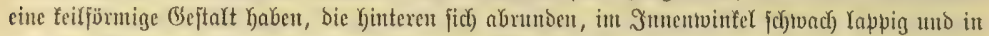

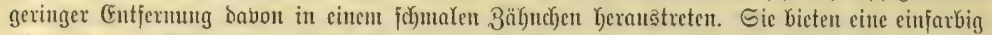

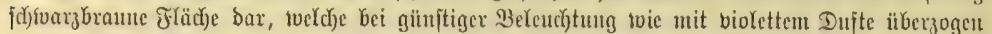

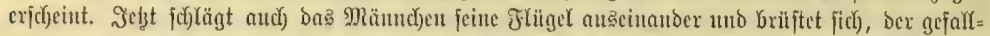

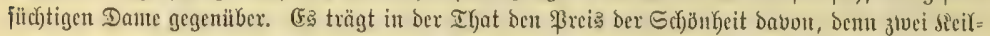

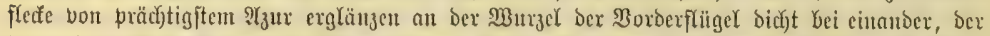

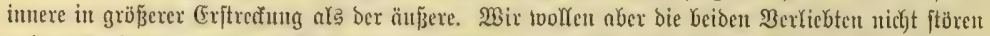

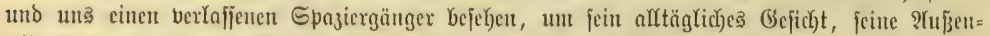

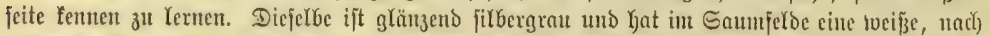

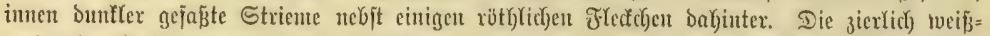

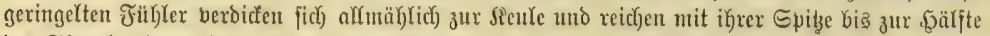

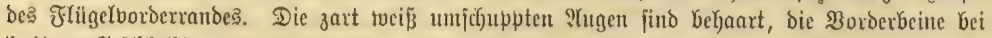

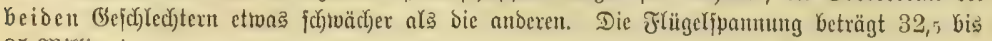
35 Mrillimeter.

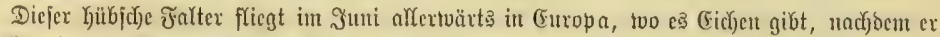

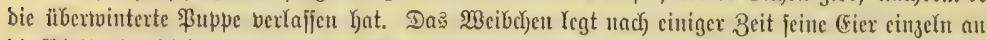

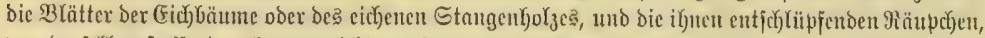

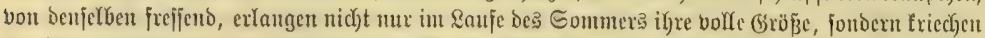

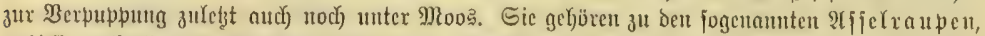

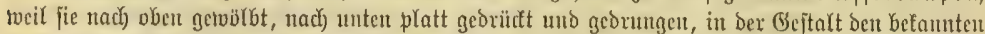

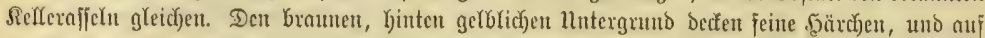

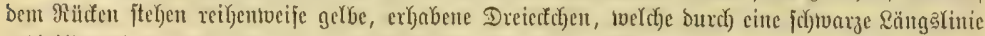

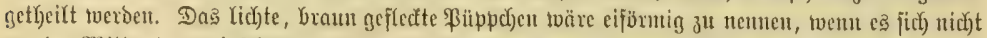

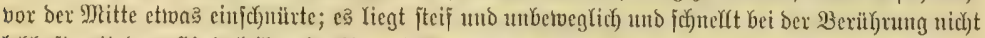

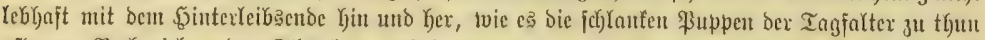

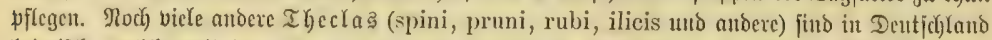

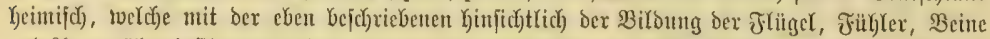

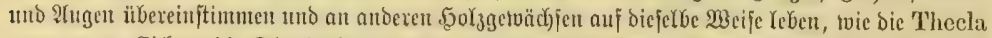

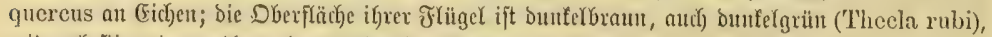

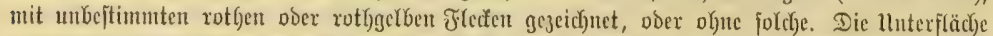

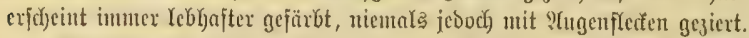

Der Feueroogel, Dufatenfaltex, Goloruthenfaltex (Polyommatus virgaureac,

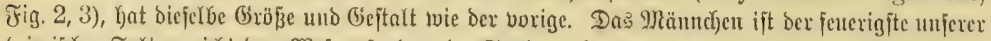

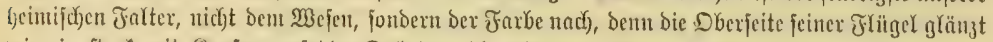

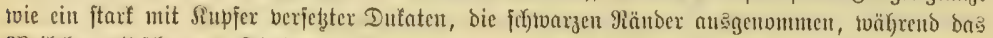

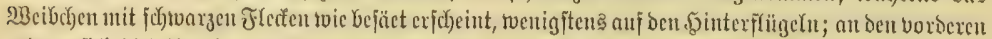

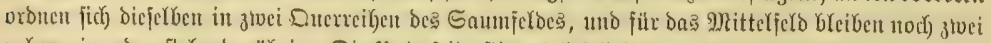

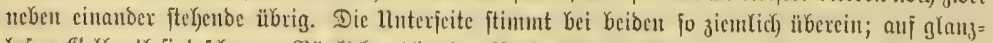

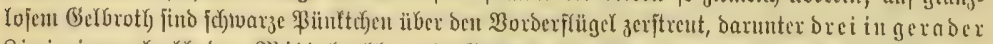

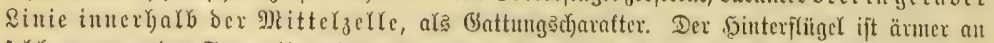

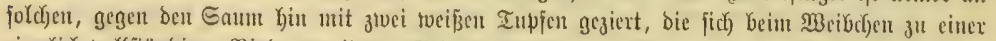

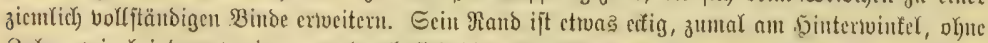

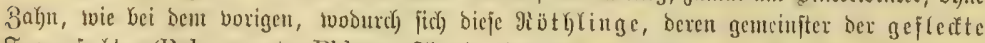
Feuexfaltex (l'olyommatus Phlaeas, Fig. 4) fein bürfte, von der borigen (Śntumg unterfdeiden.

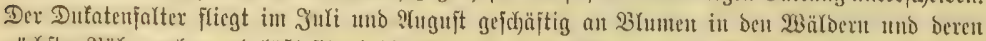

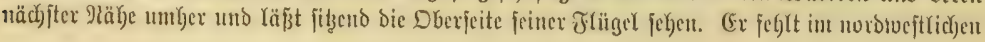




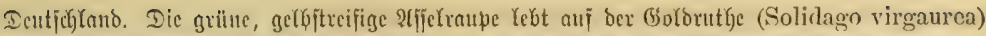

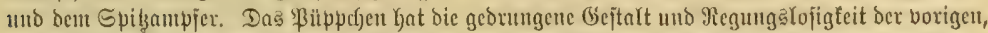

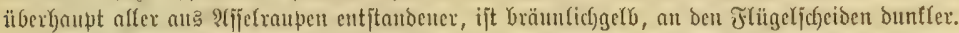

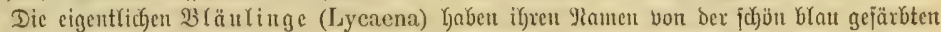

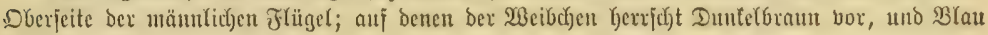

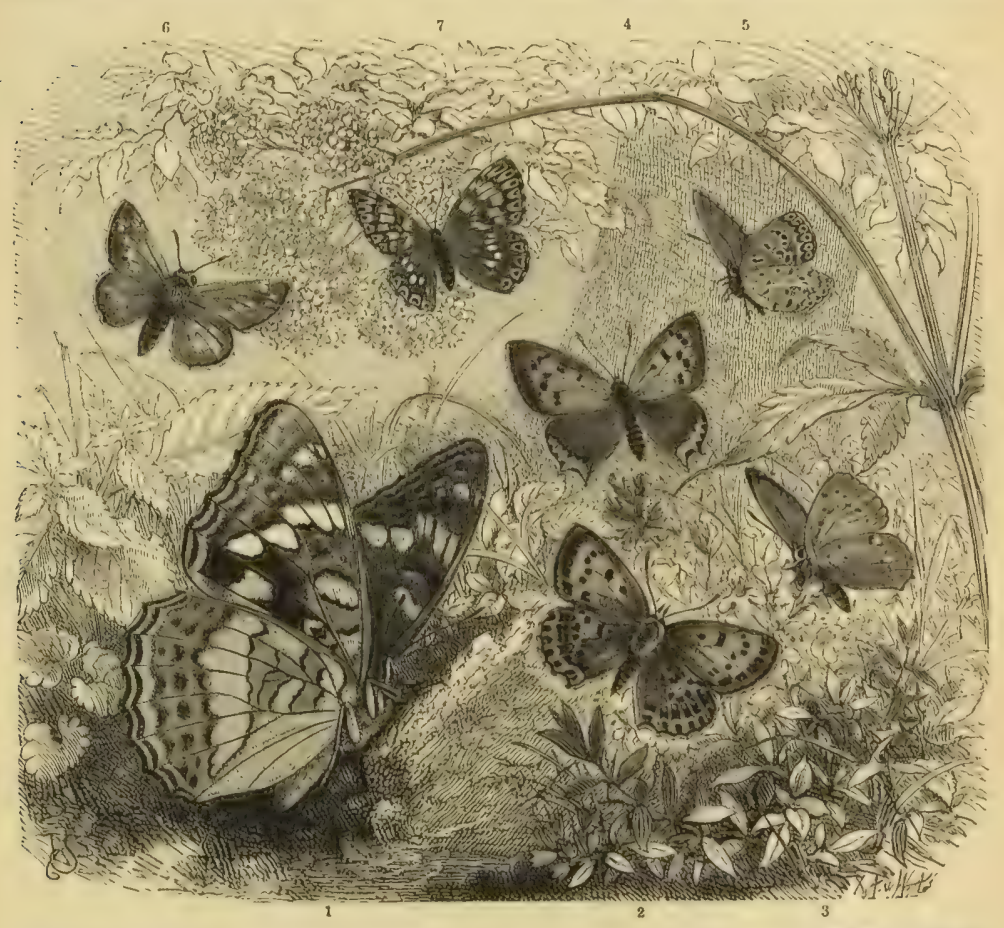

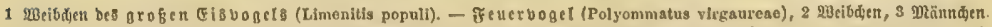

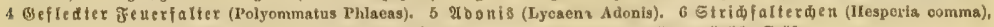

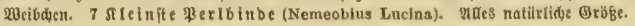

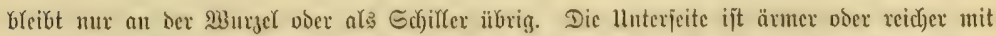

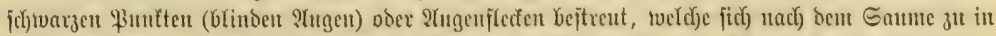

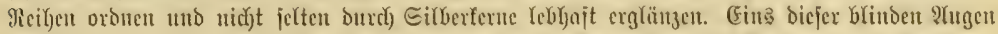

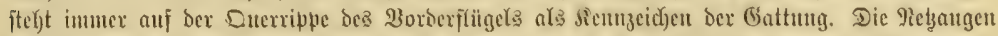

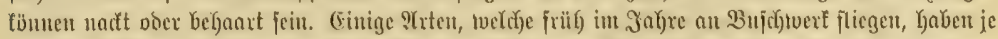

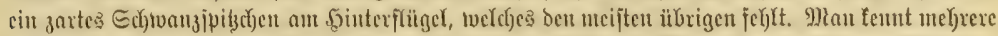

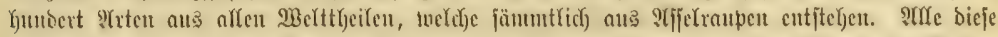

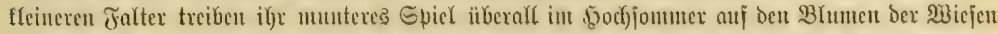

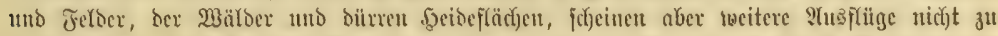

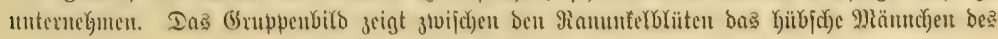




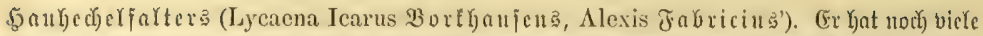

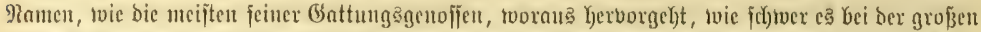

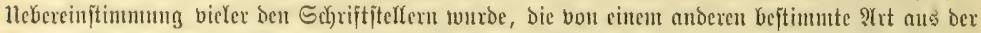

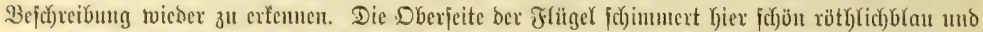

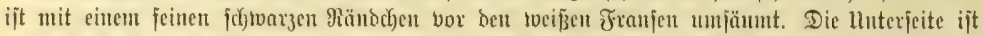

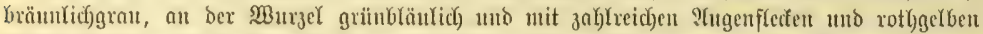

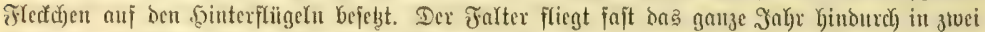

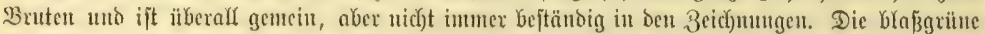

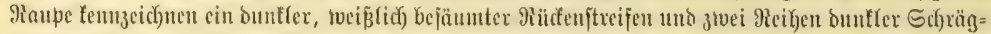

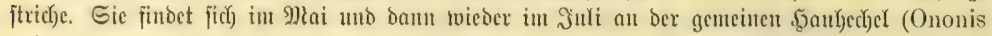

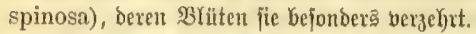

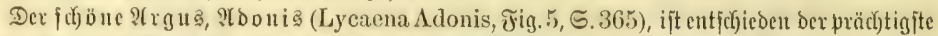

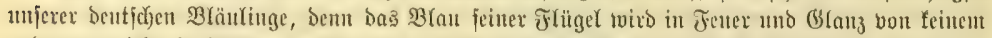

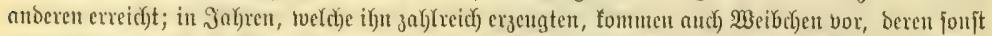

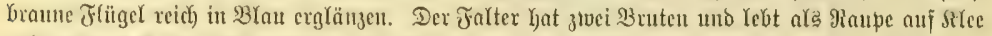

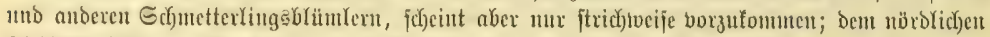

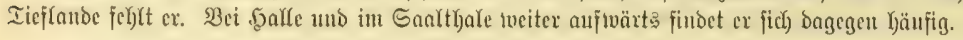

Die Didfüpje (Hesperidae) untericheioen fich Yeicht von allen antoren Iagfaltern burch)

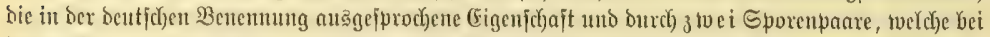

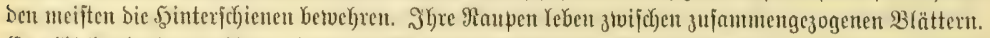

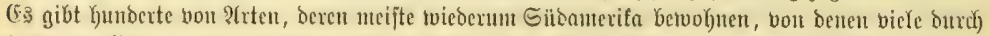

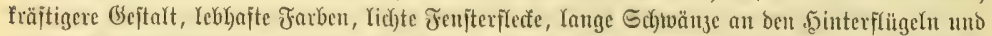

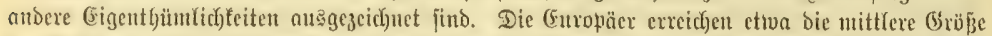

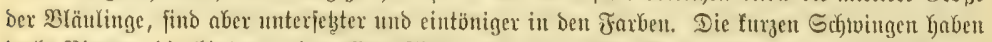

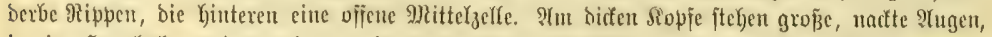

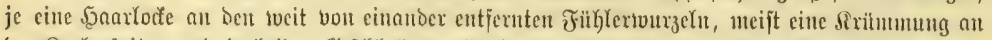

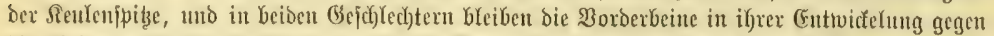

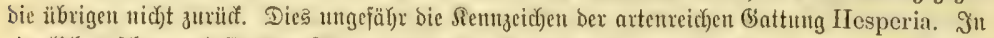

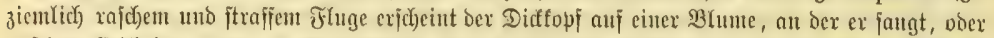

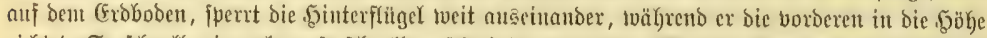

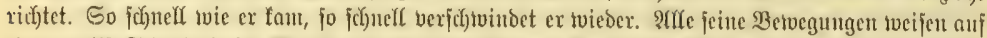

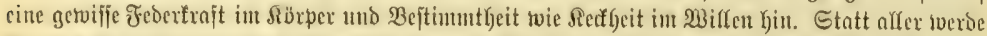

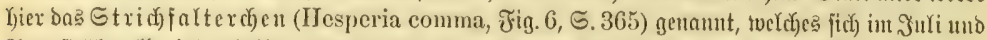

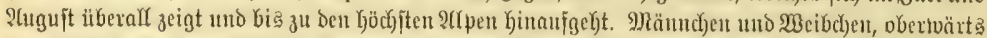

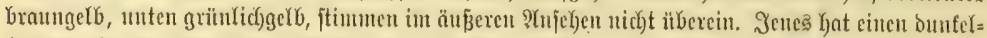

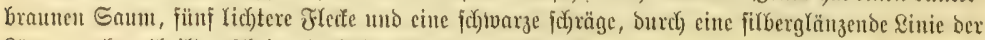

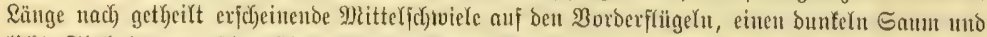

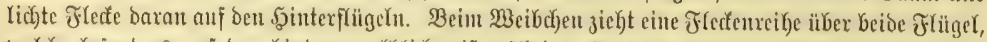

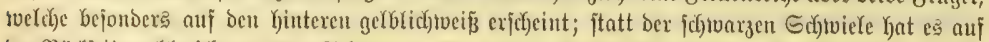

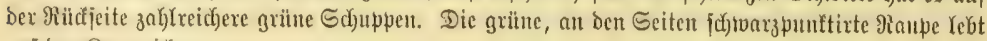
auf ber Sitontwide.

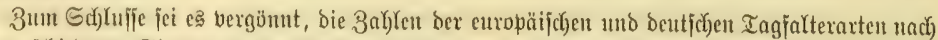

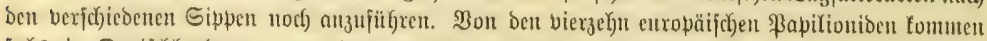
ject)

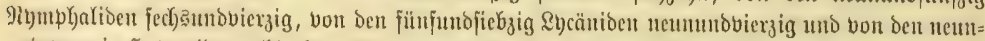
undzwanzig Jae auf Sicifien als einziger Danaibe in Europa und in ber fleiuften ßerlbinde (Nemeobius 


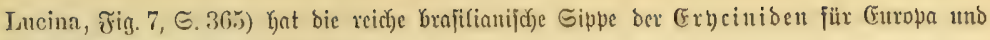

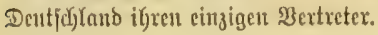

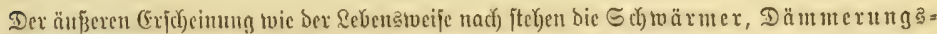
Farter (Sphingidac ober Crepuseularia), ala ztweite Edfmetterfing

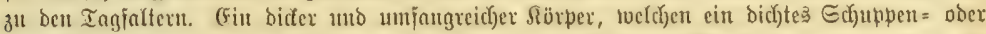

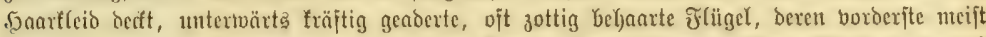

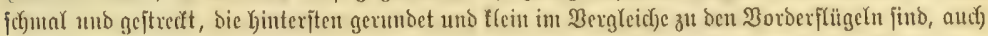

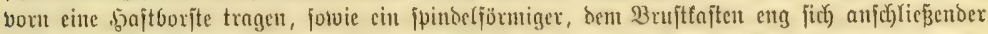

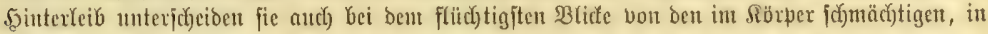

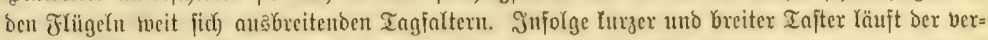

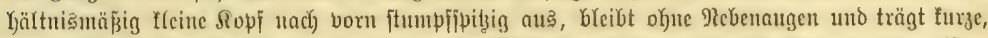

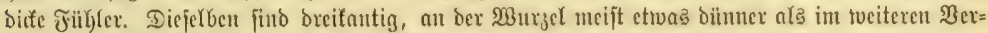

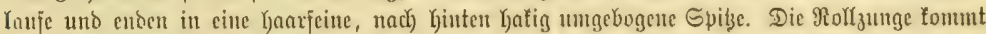

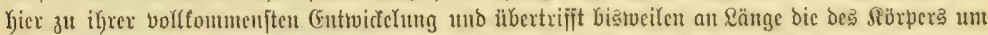

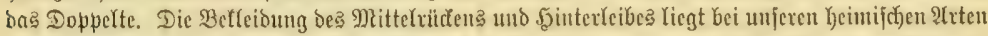

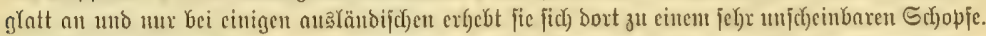

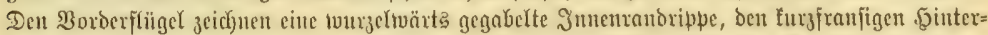

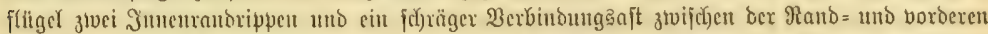

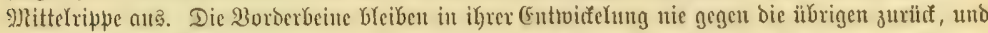

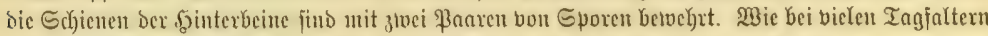

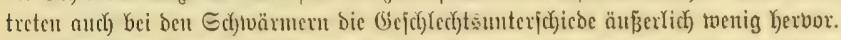

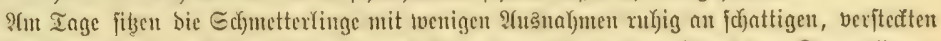

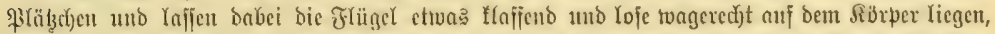

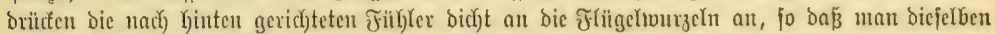

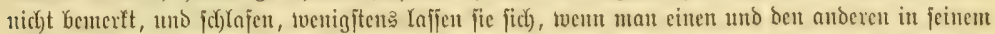

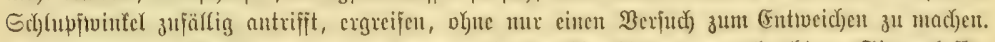

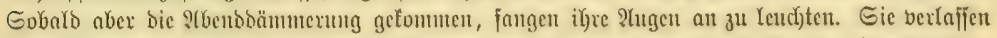

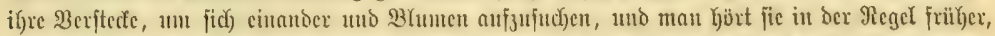

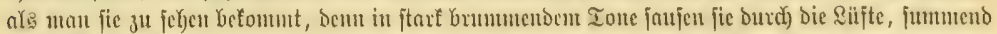

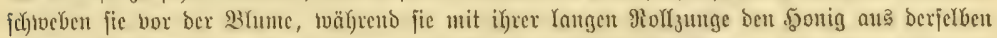

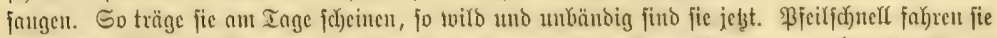

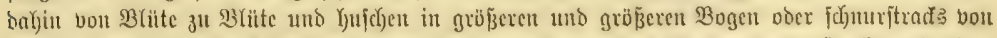

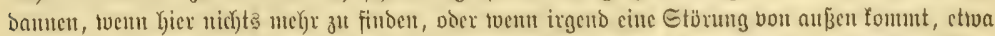

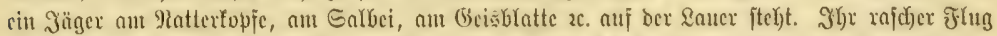

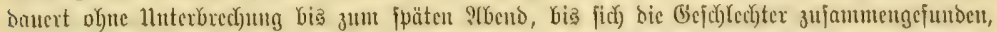

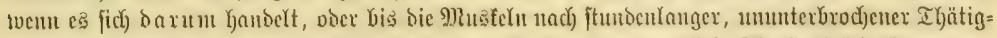

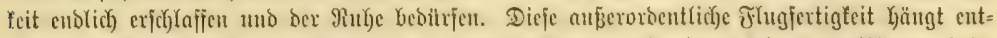

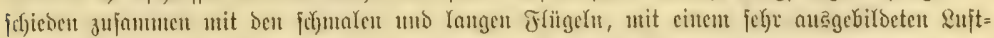

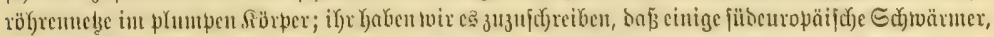

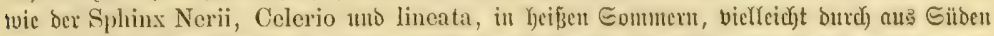

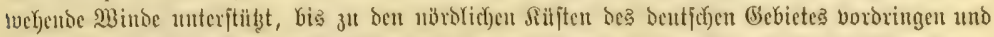

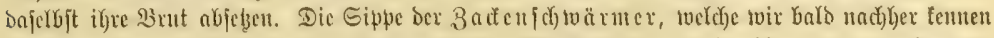

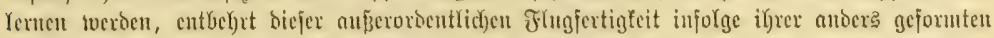

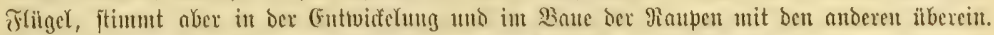

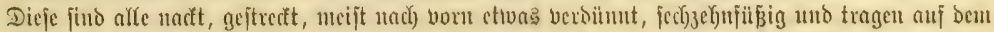

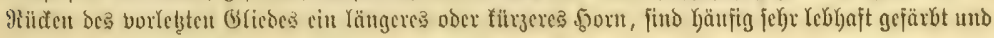




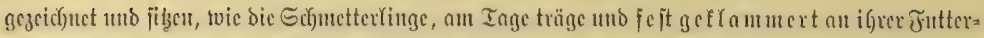

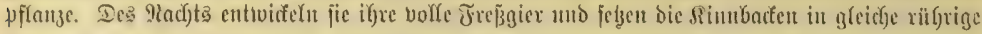

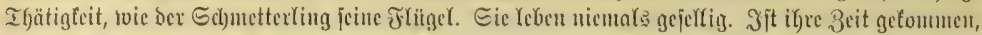

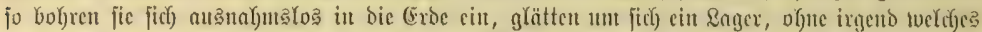

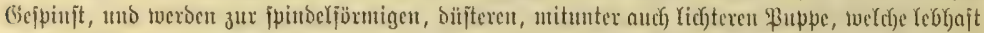

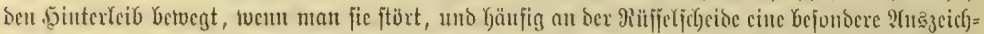

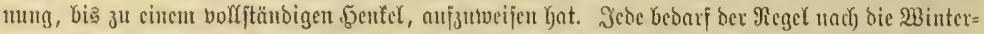

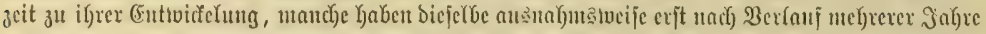

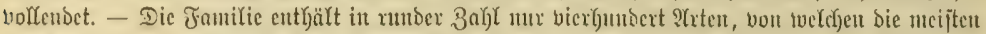

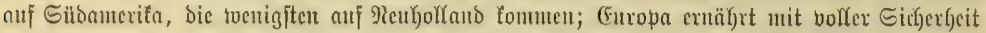
nux fïnfundorei

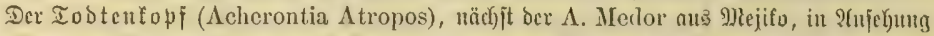

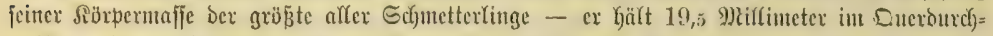

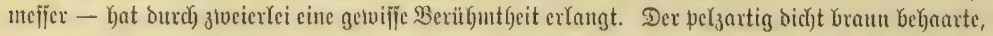

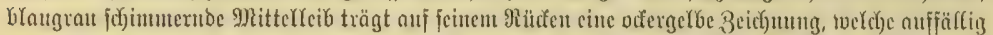

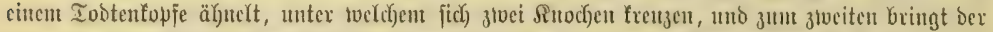

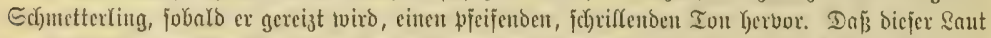

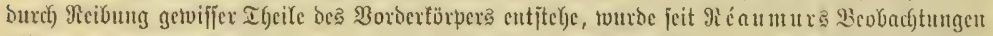

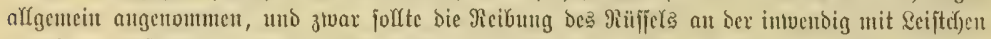

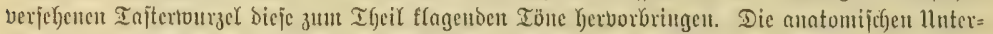

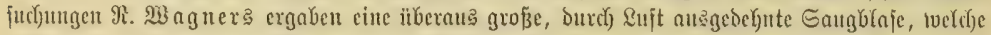

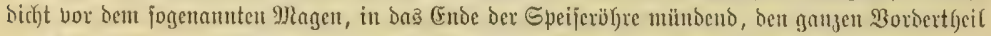

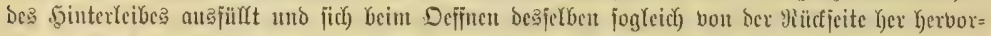

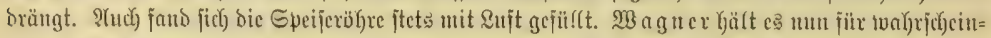

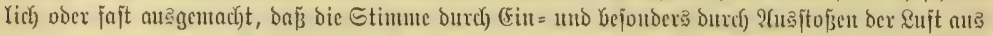

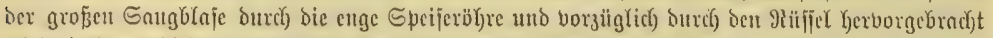

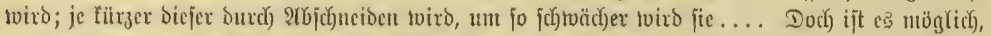

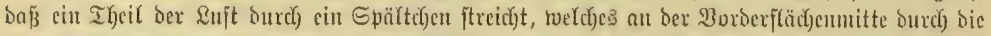

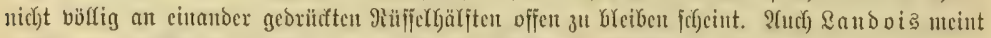

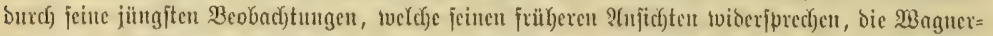

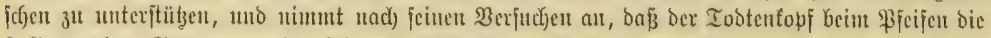

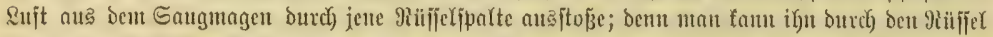

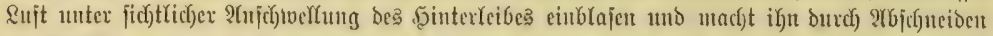

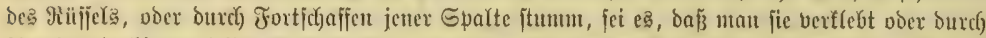

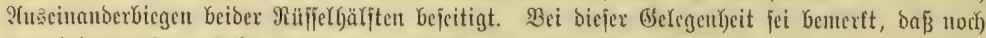

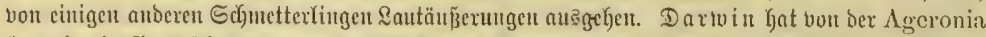

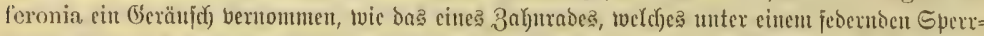

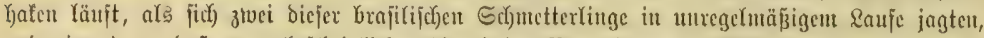

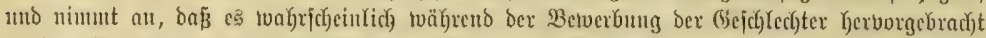

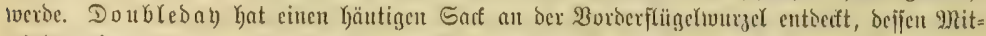

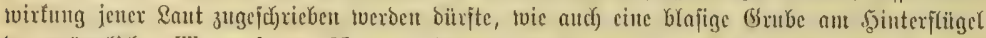

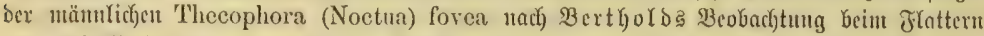

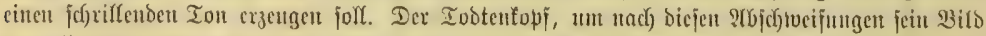

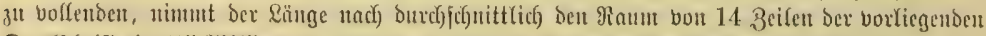

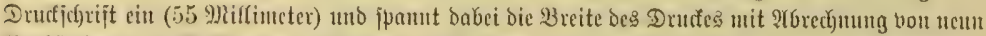

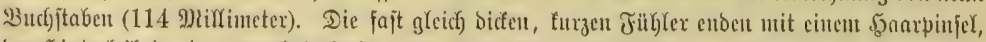

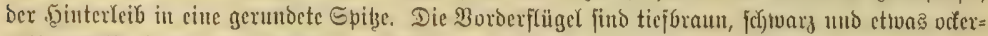

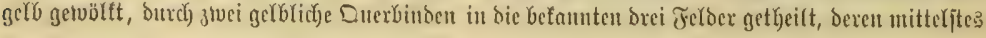




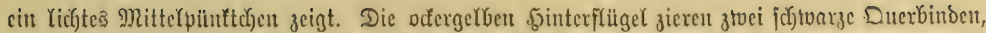

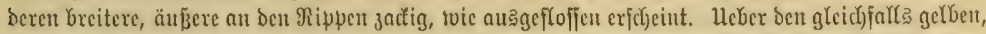

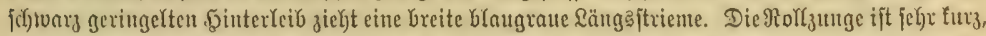

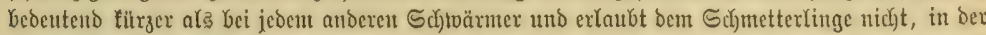

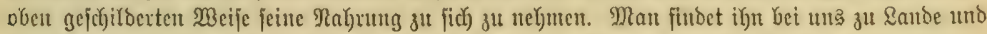

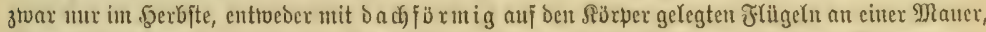

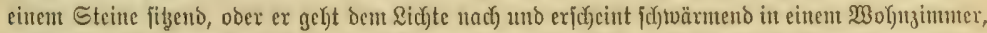

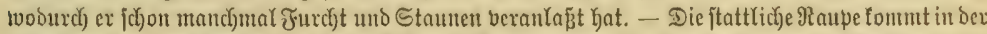

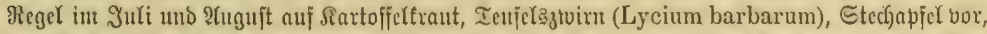

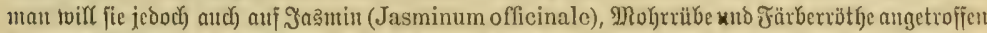

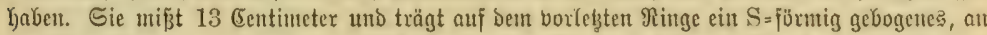

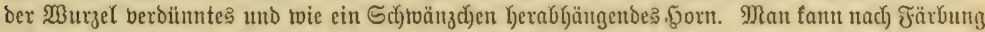

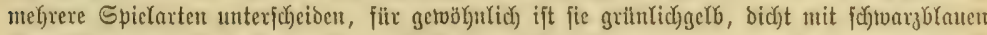

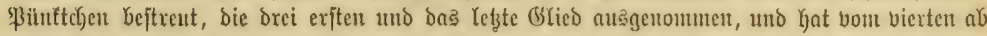

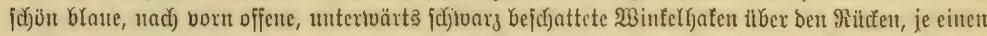

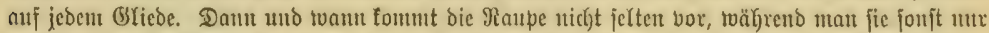

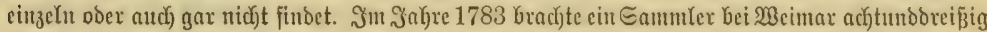

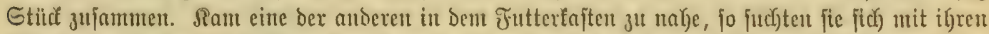

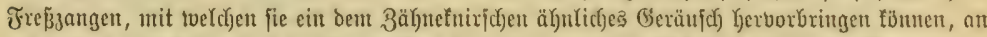

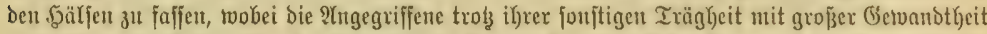

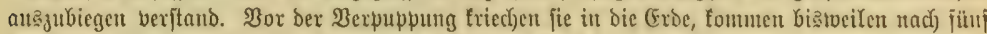

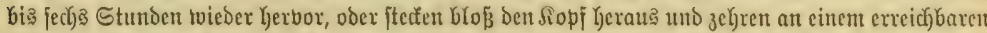

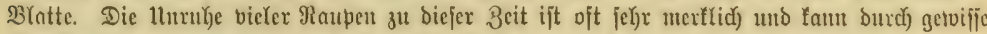

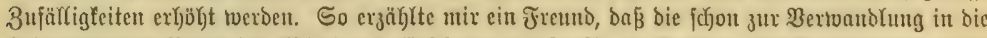

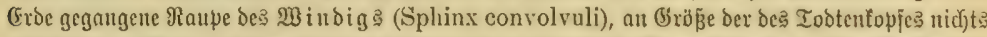

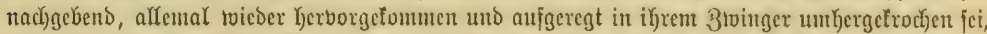

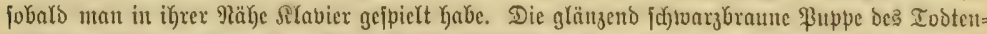

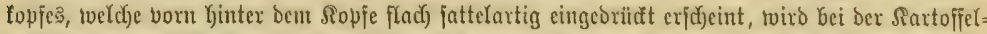

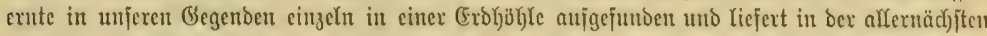

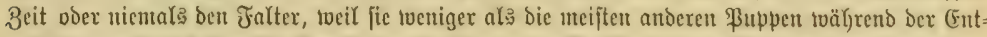

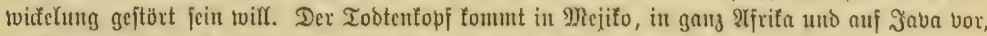

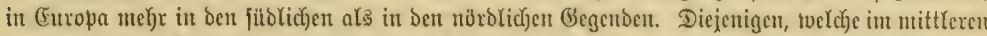

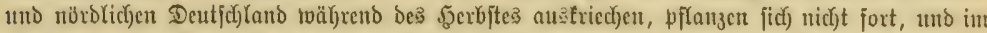

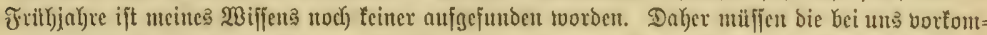

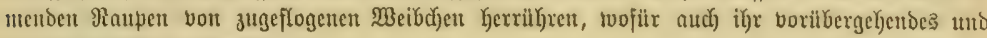
örtfiches (Exidjeinen ipridid.

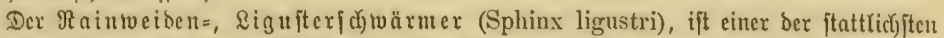

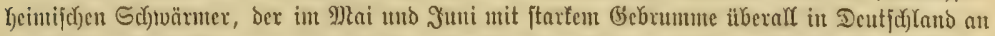

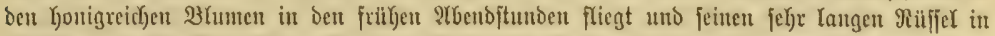

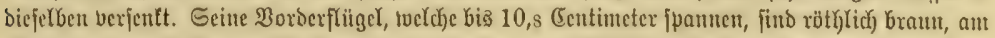

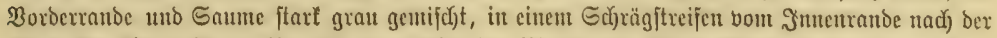

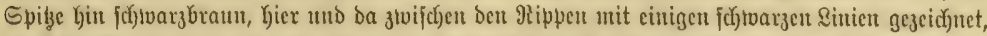

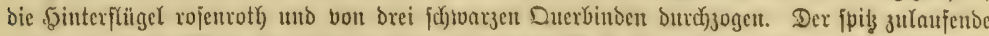

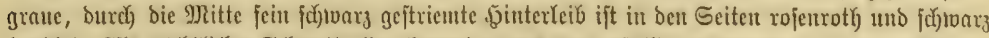

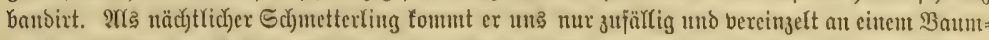

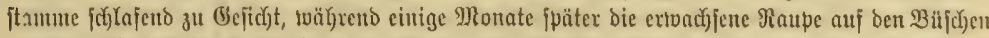

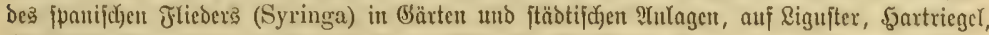

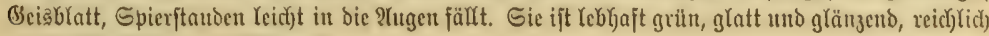




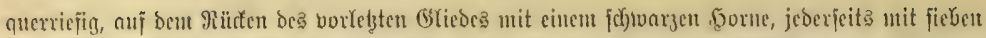

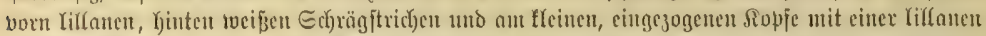

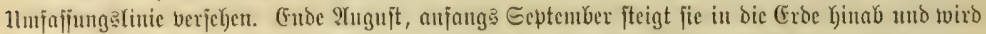

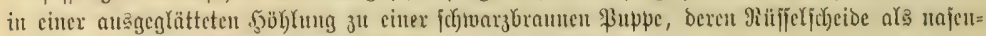

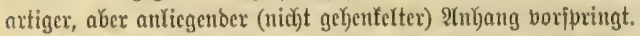

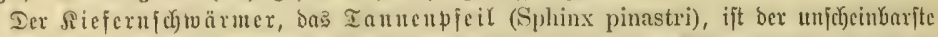

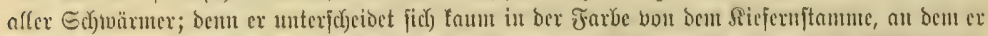

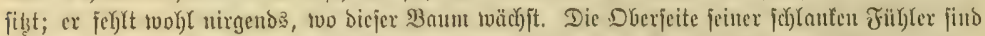

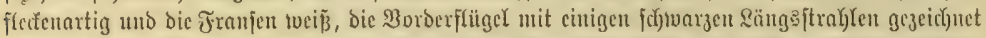

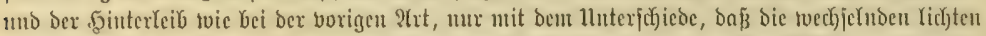

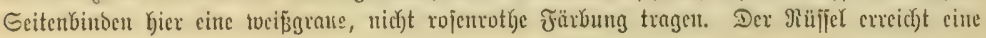

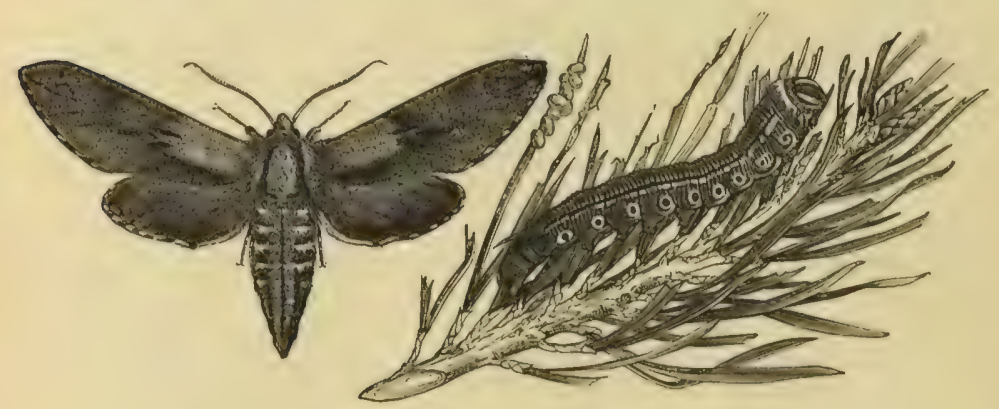

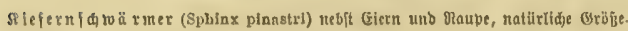

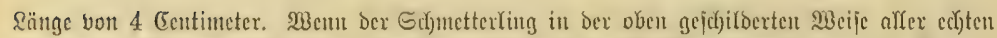

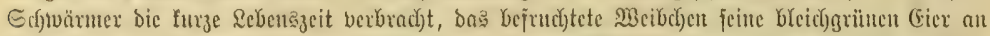

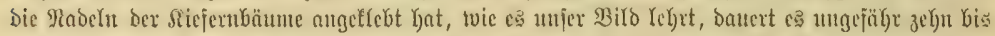

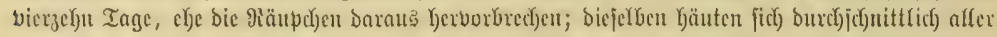

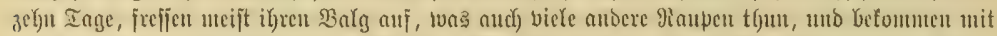

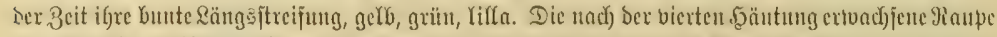

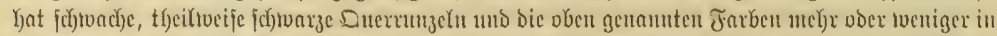

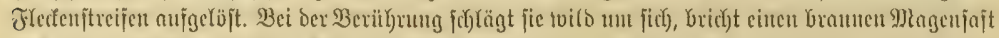

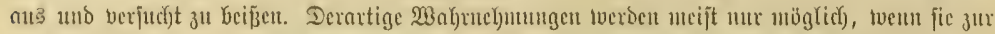

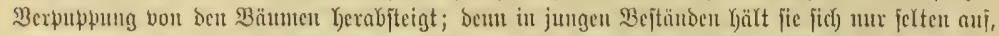

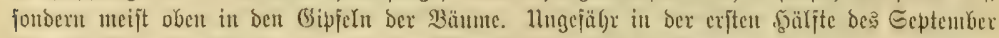

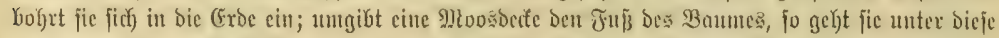

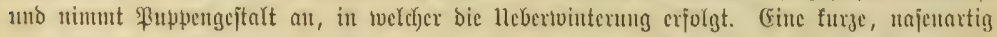

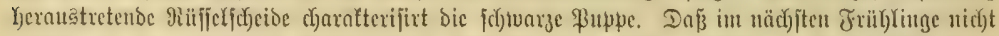

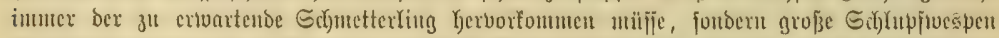

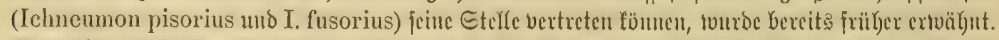

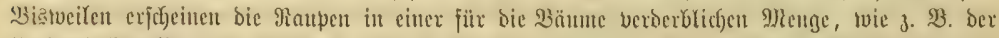

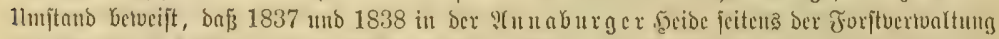

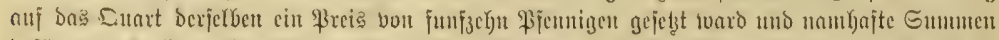

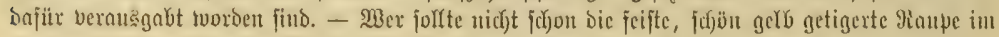

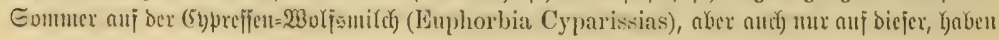




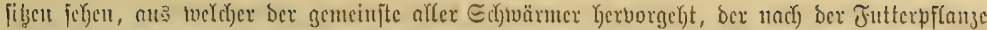

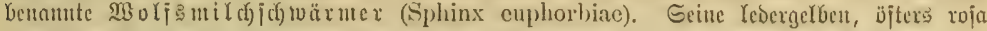

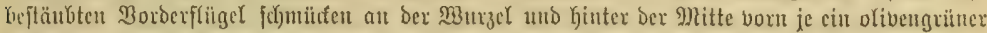
Jfert jutuic cine feiljürmige Etrieme von glcicher Farbe vor bem ruthen Eamme; bie Yjuteren

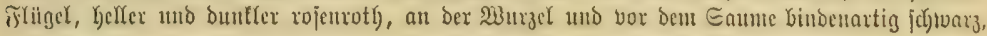

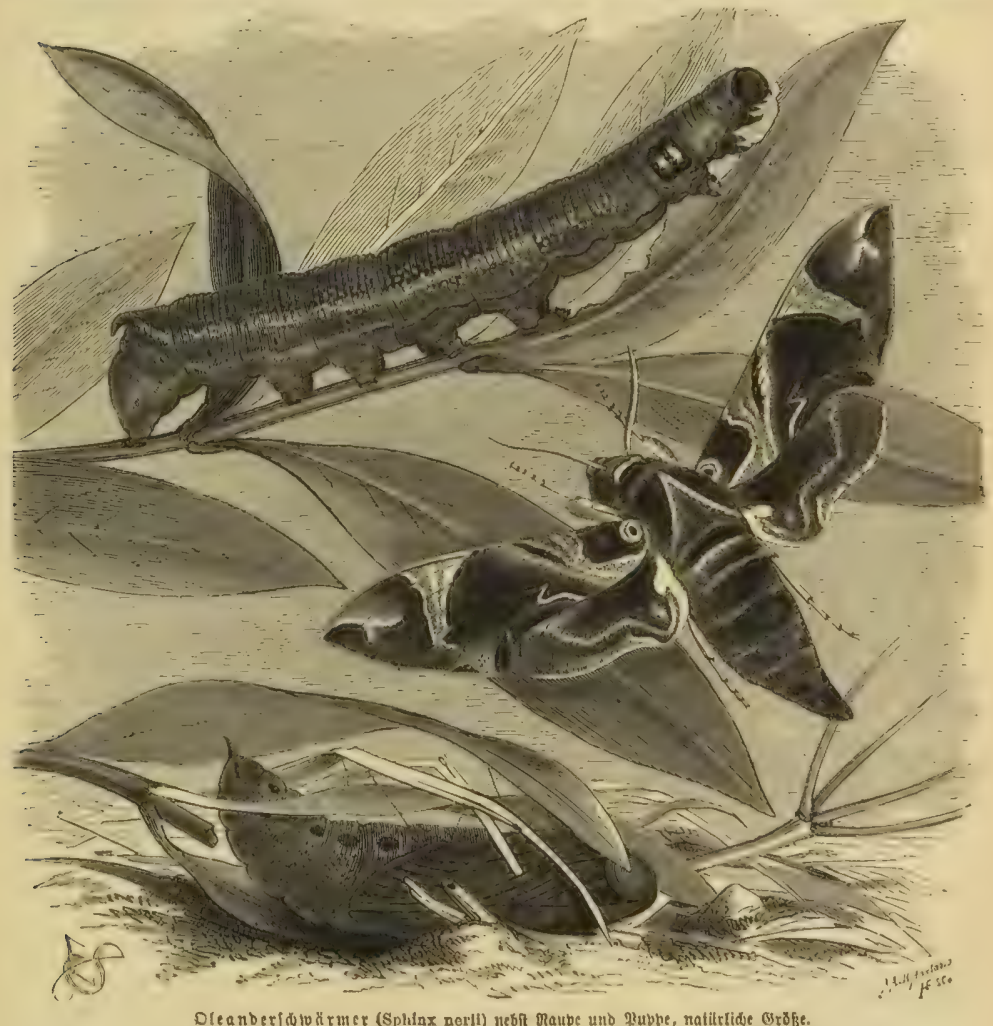

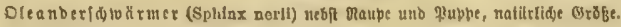

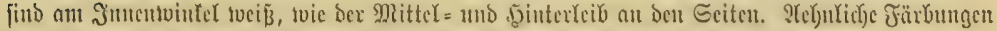

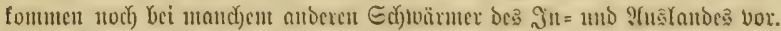

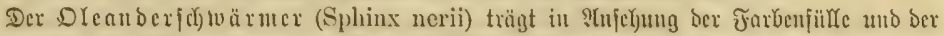

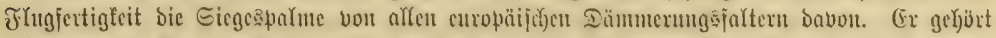

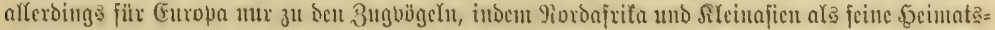

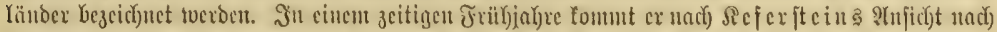

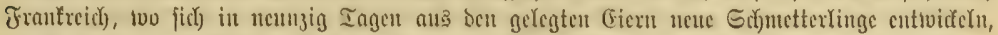

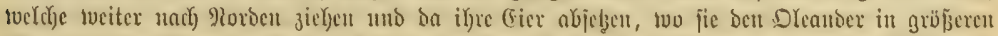

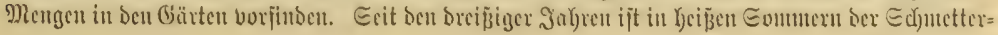




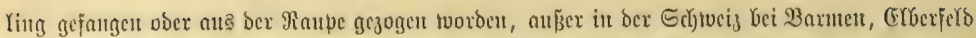

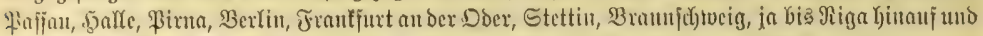

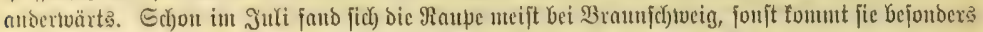

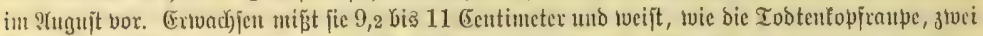

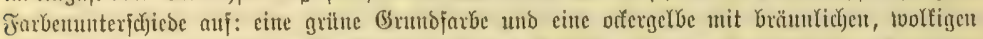

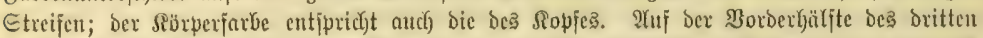

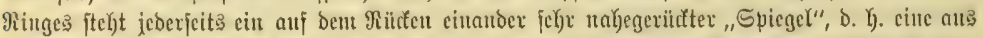

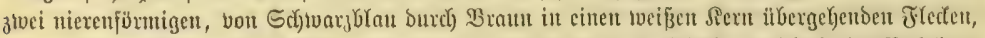

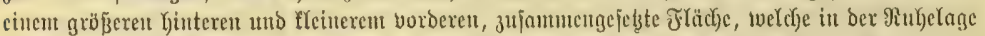

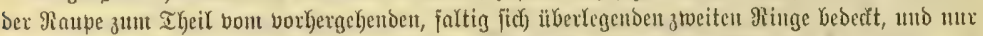

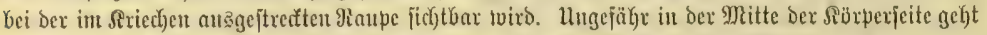

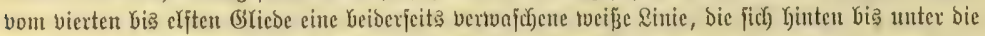

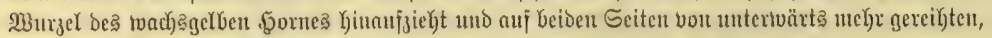

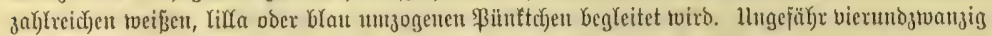

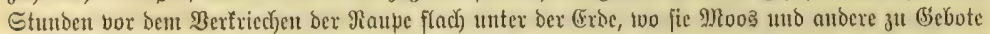
ftefyende (Scgenjtände ber Bobendecfe burd) einige Bejpinjtfäben fejt verbindet, ändert fie iłje Farbe

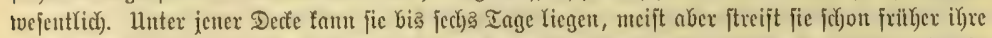

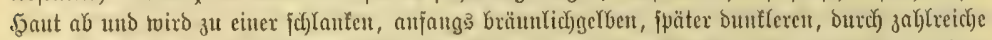

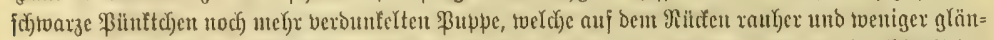

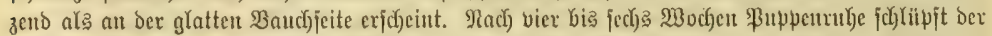

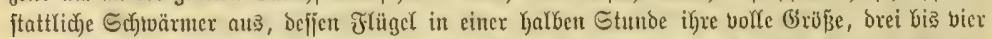

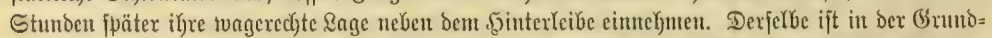

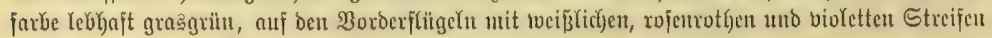

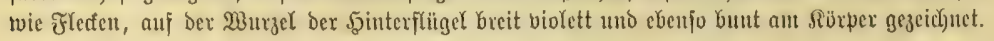

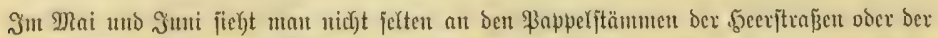

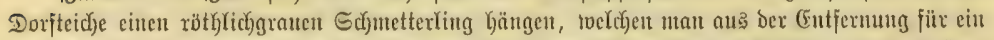

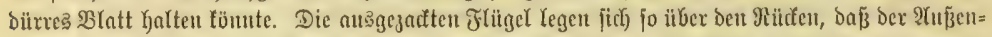

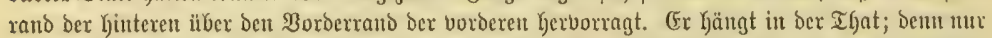

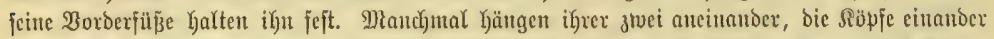

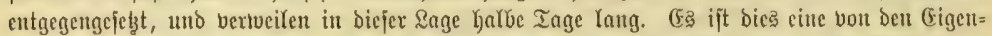

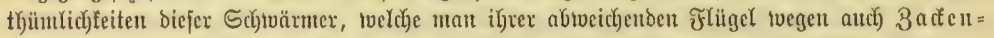

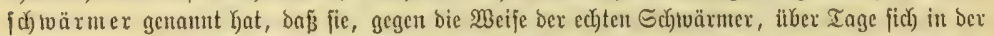

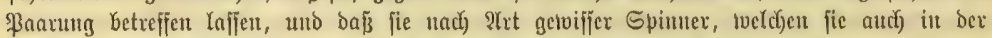

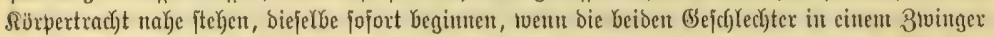

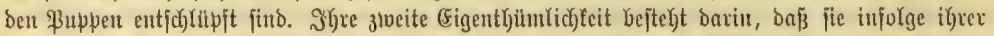

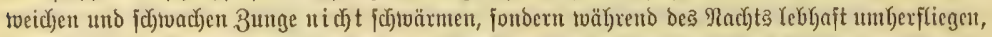

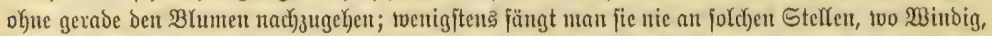

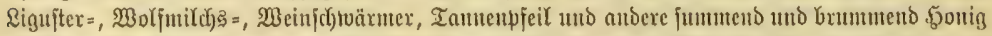

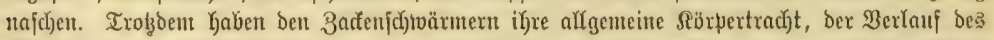

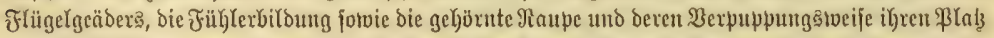

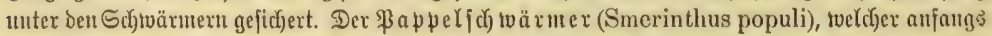

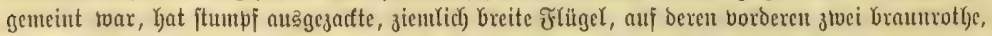

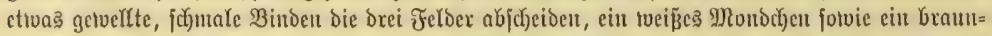

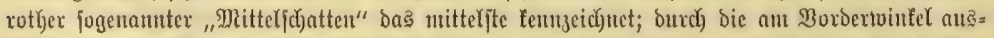

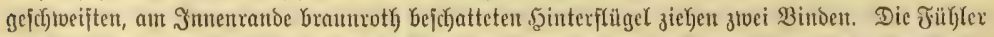

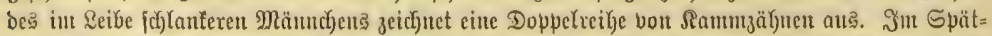

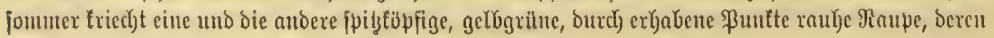




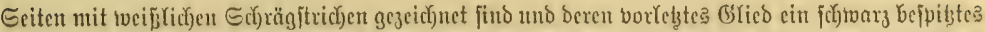

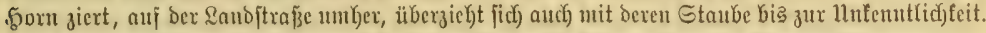

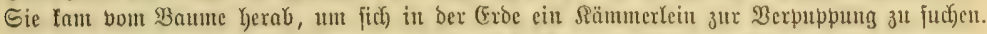

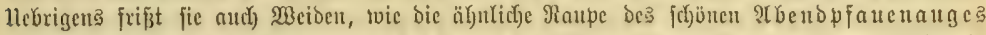

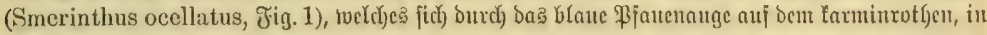

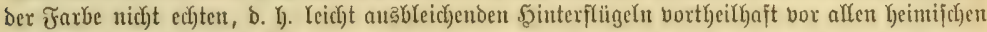

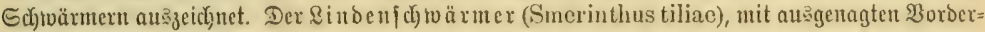

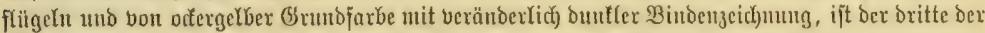

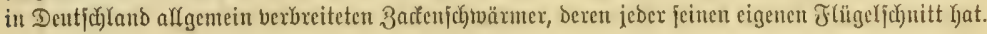

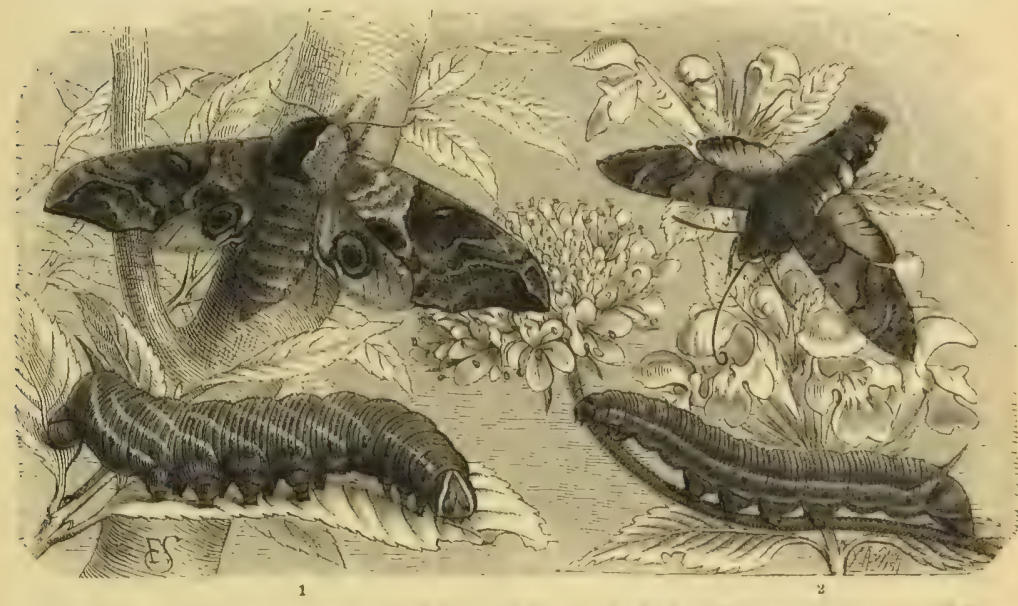

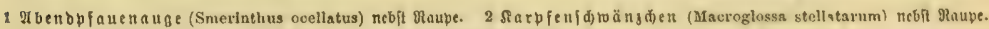

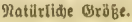

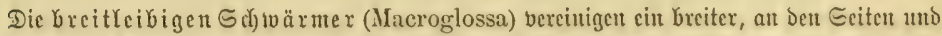

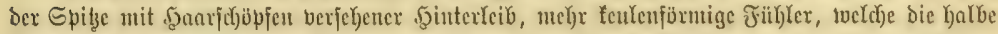

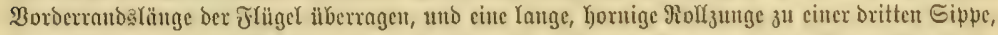

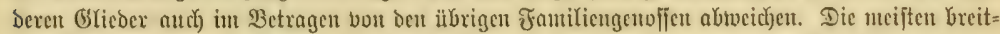

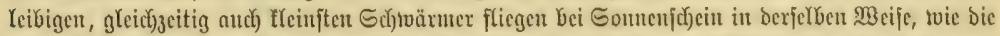

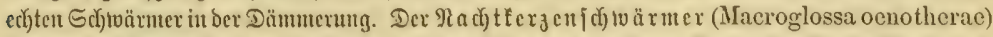

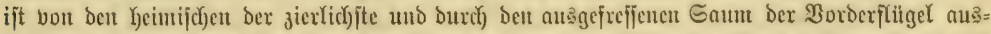

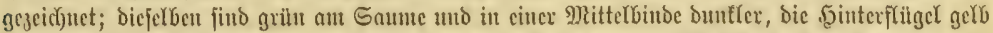

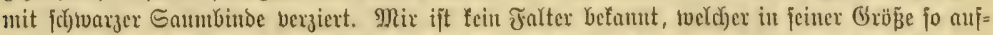

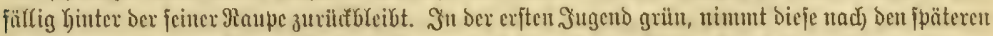

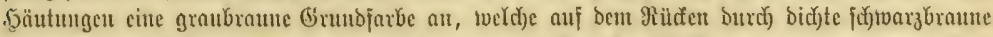

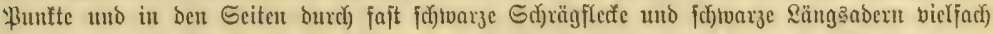

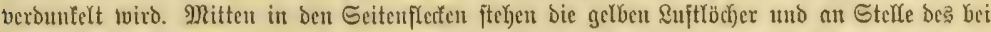

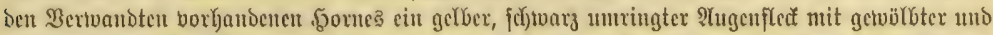

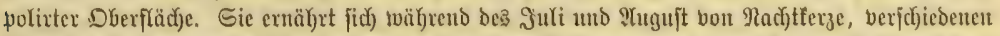

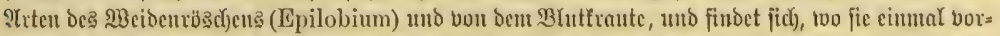

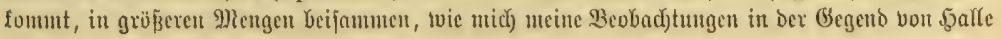




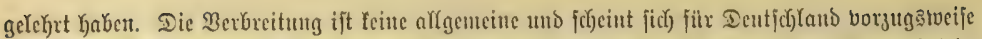

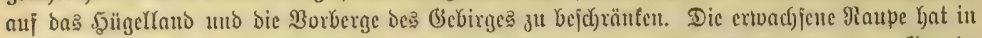

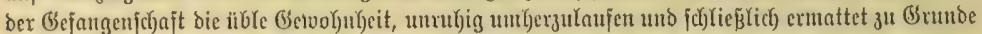

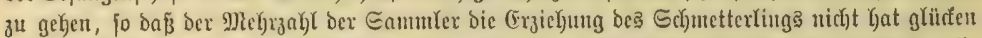

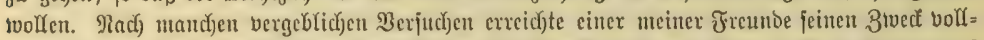

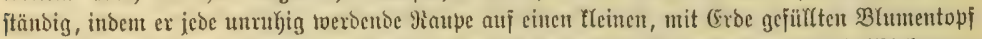
fetzte, bicjen mit einem (5) ber Eonnenjtrahlen zu erhoben, Denen ber Topi preis gegeben toard. Jebe Raupe verfügte fich

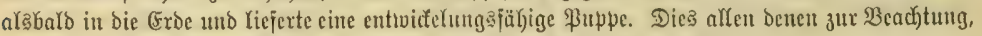

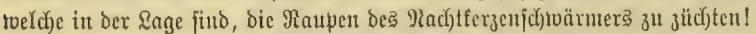

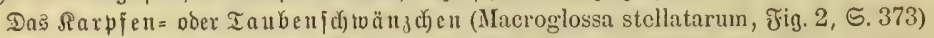

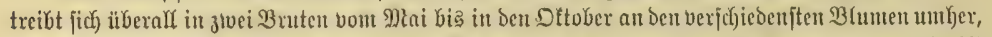

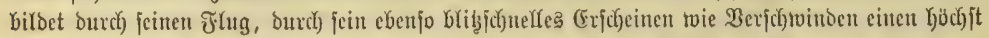

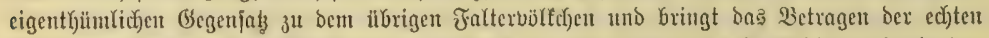

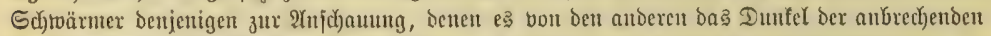

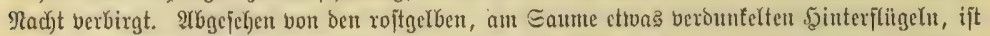
biefer Echıärmer graubraun gefärbt unb auf ben Borberftügeln mit cinigen bunfleren, binden=

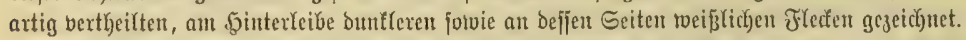

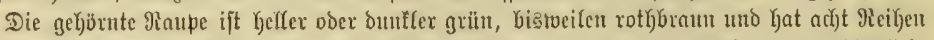

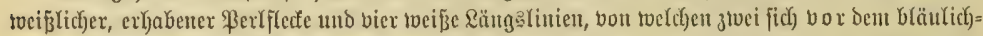

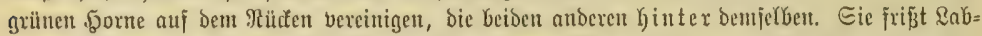
frout (Galium) und Fïrberribtge (Rubia tinctorum). Die graubraute, rauke łuppe hat eiuen

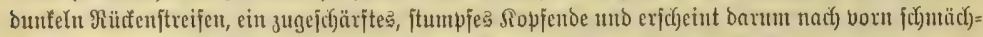

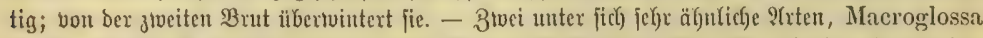

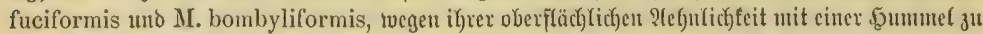

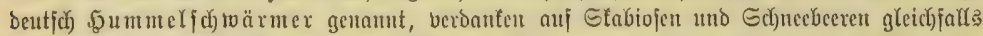

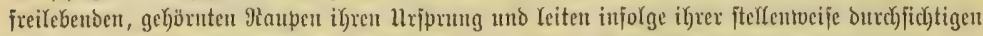

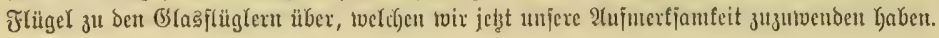

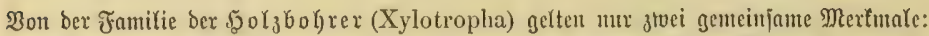

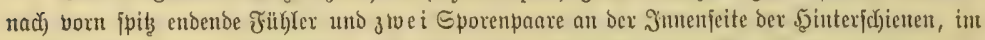

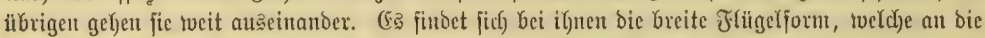

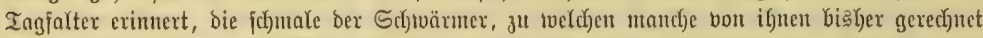

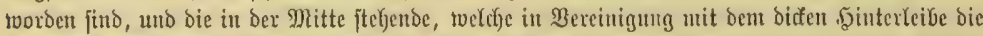

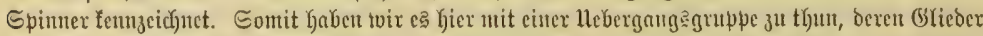

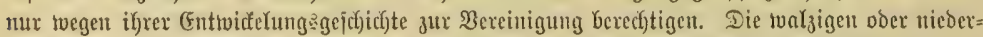

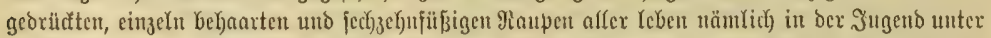

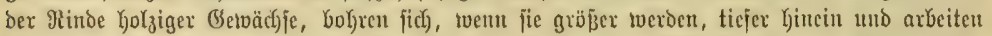

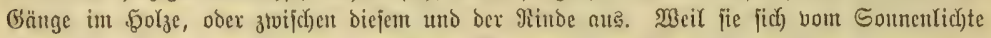

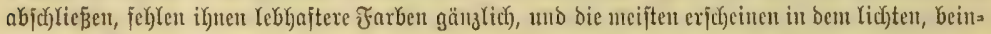
farbenen Getwande, wełches ben cbenjo Yebenden anderen Serjlarven cigentfÿ̈mlich ju jein pflegt.

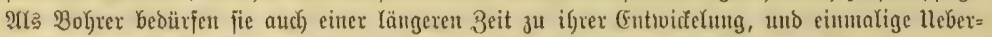

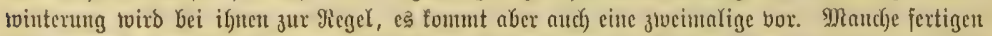

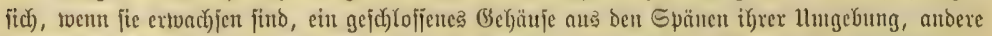

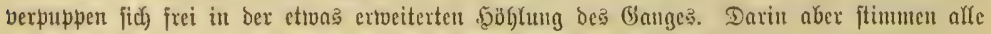

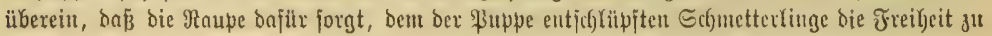




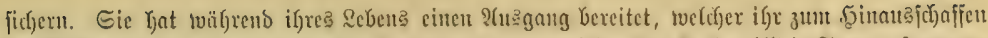

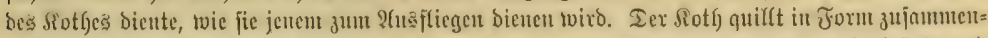

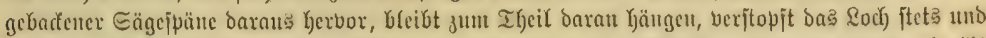

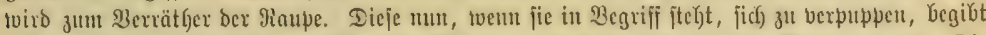

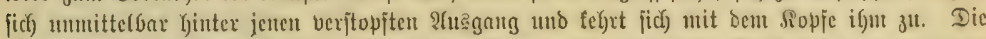

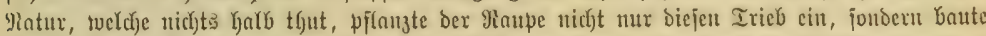

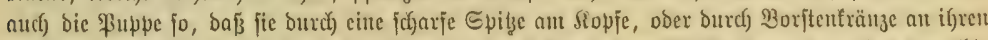

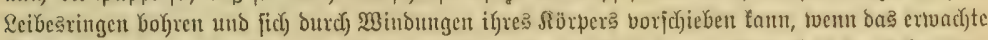
Gdfuctterling

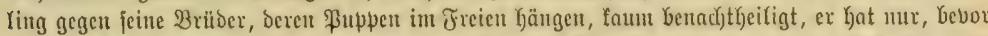

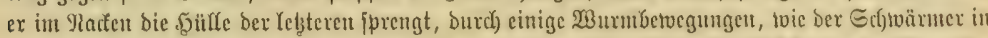

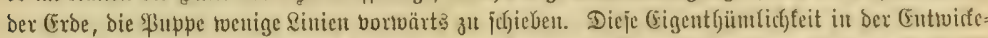

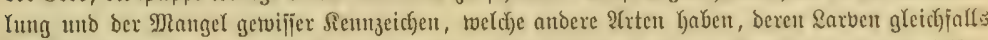

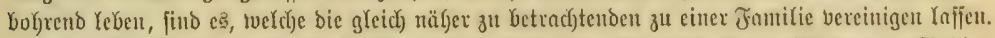

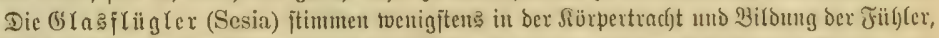

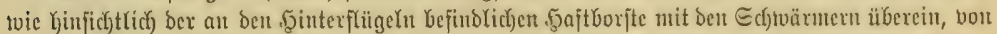

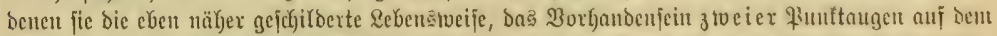

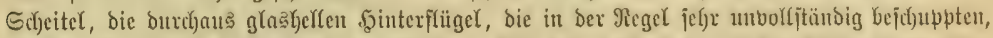

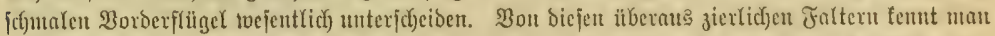

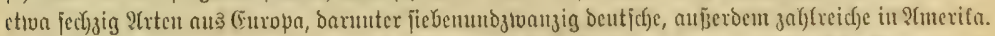

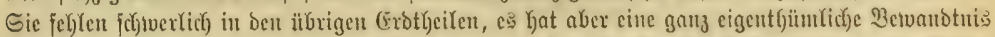

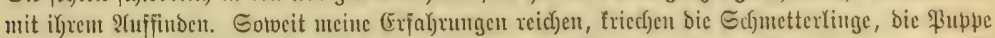

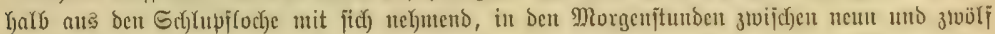

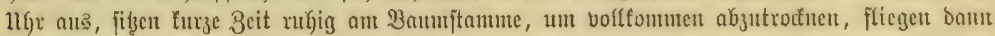

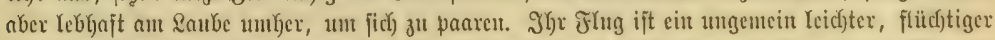

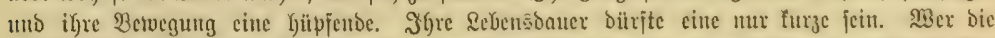

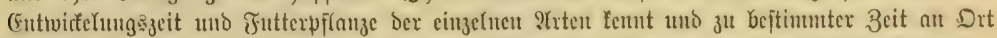

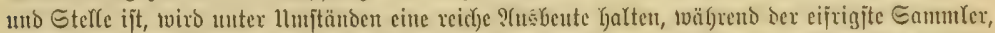

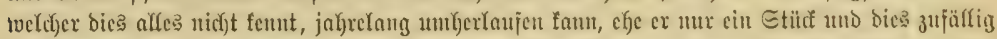

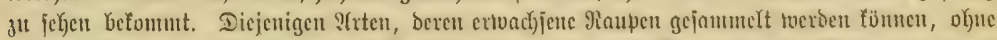

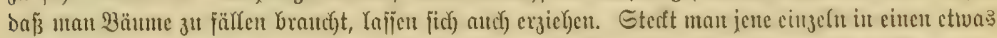

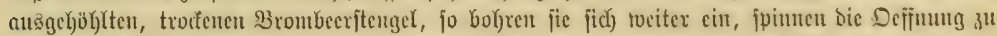

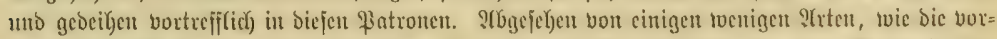
Yerridgend getbe Sesia empiformis Esp., S. tenthrediniformis Ochsenh., beren gaupe in bem

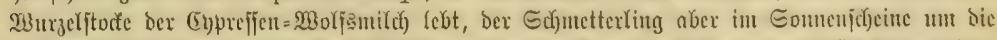

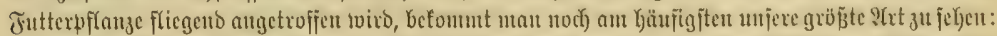

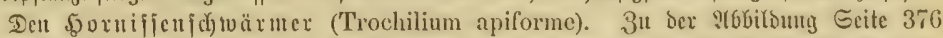

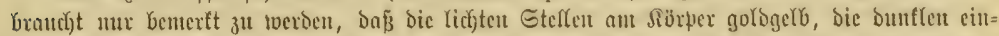

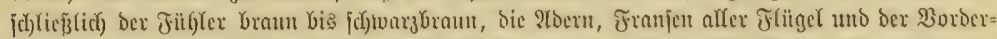
rand ber borberen nebjt ben $\mathfrak{B}$ einen roftgelb (Gronzejarben) fint. Die Raupe Yebt unten im

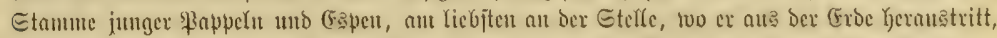

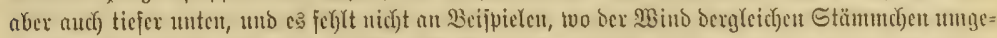

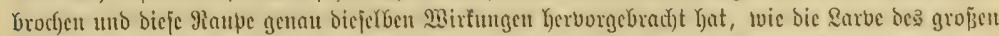

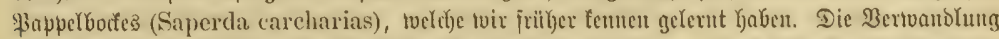

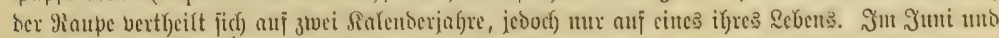

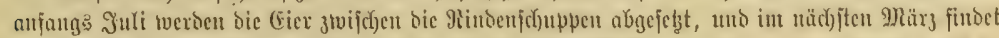

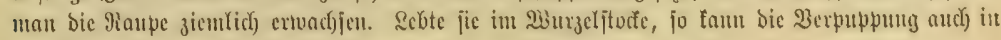
Dex (Evde, nake ber Dberflädje erijolget. 


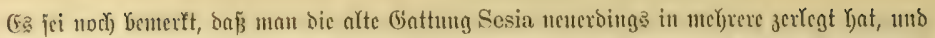

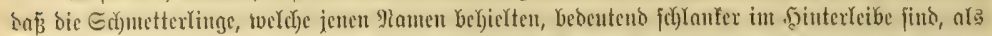

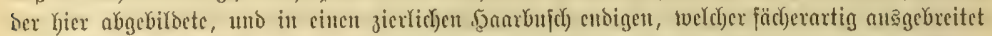

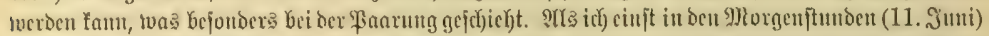

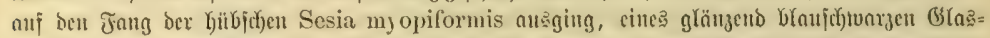

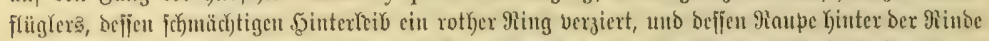

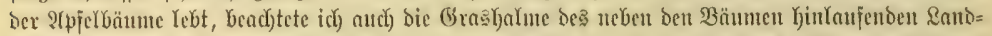

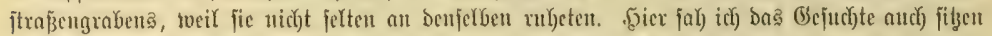

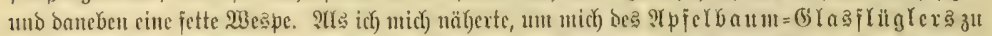

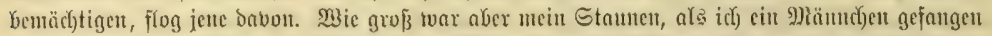

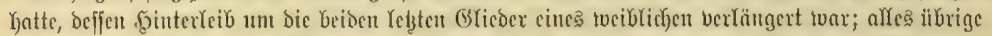

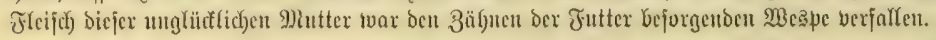
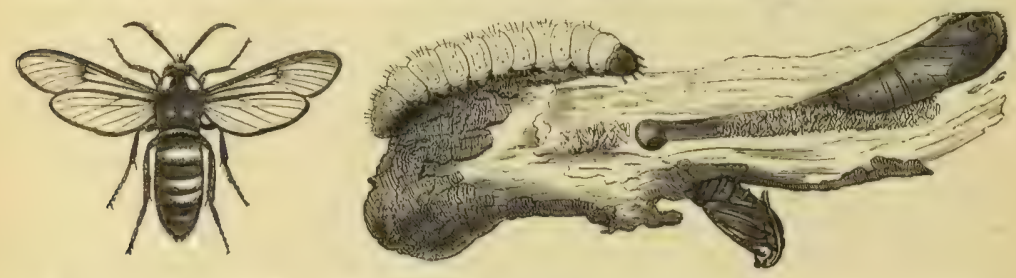

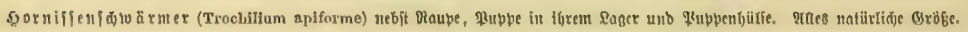

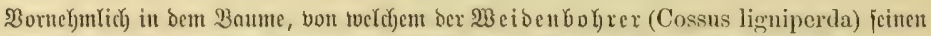

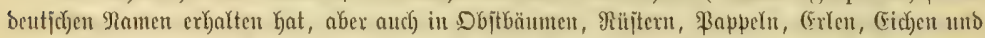

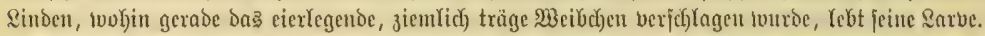

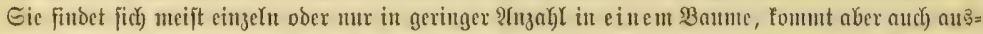

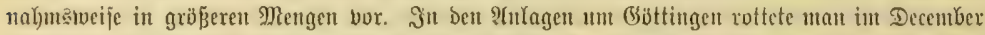

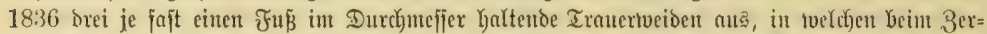

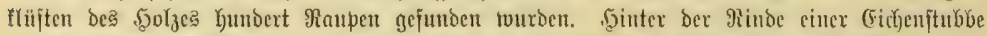

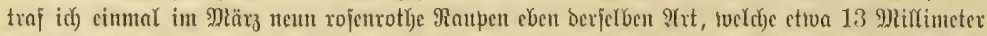

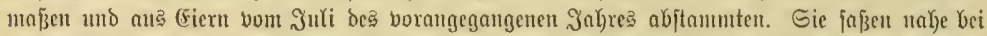

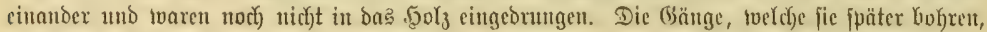

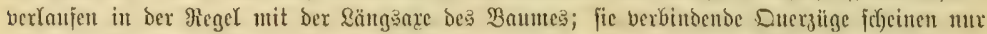

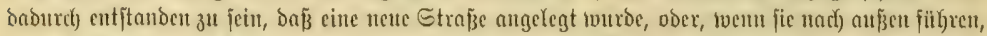

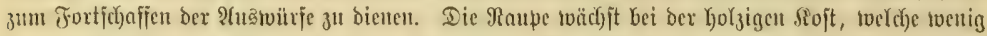

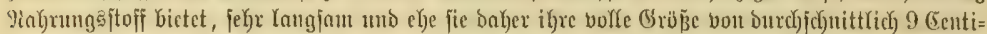

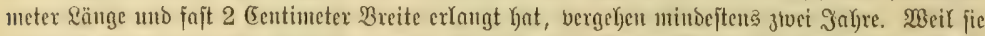

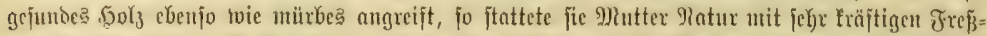

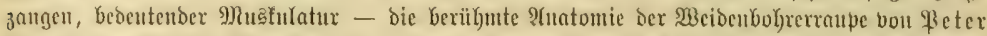

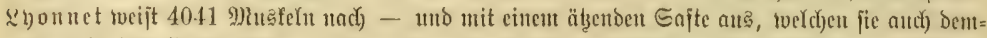

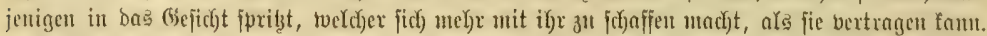

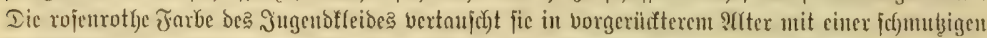

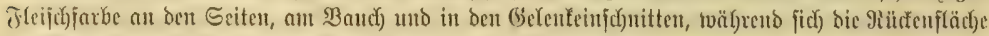

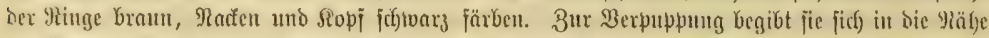

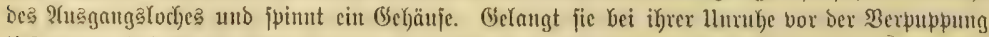

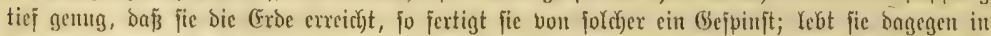

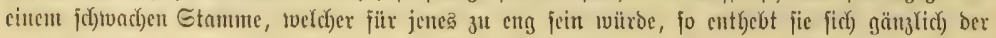




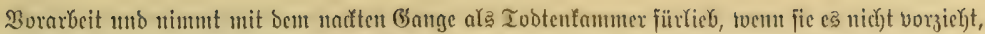

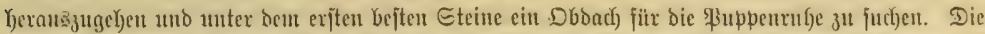

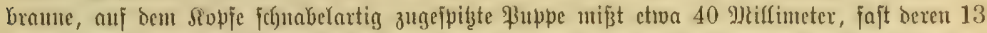

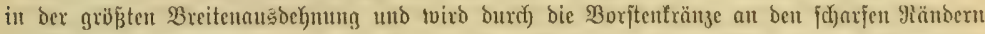

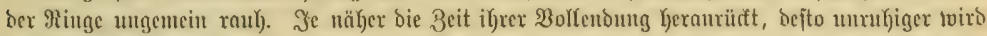

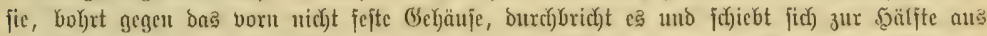
Demjelben heraus, ja, fie verläß̈t

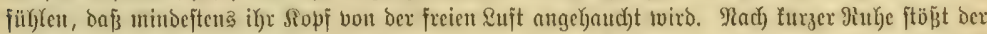
naर्d) weiterex Freifeit ringende Falter gegen ben vorberen Theil, uno bie bünte Schafe fpaltet fich)

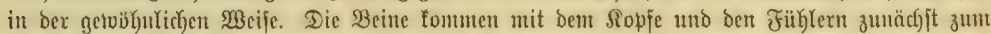

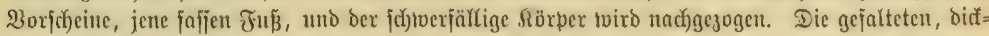
rippigen Frïger wad)jen in berjelben furzen Beit, tvie bei anderen Foltern, nur bedürfen fie länger

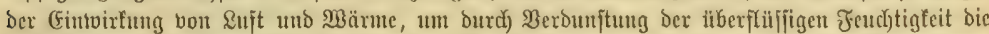

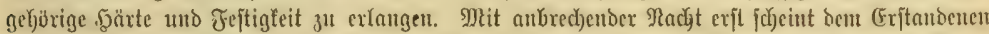

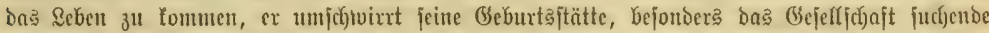

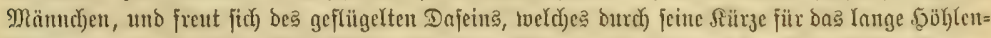

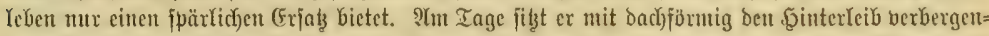

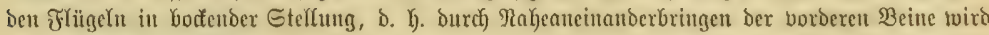

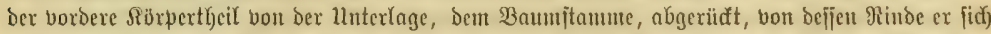

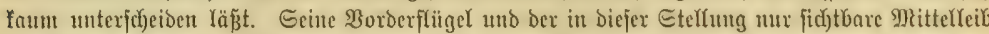

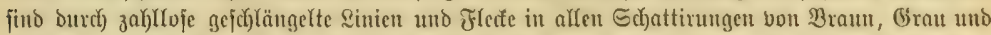

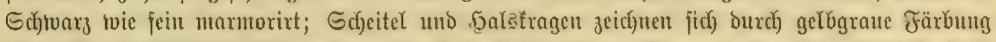

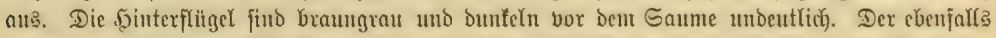

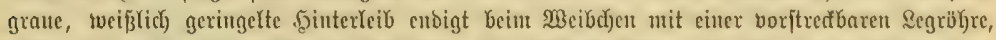

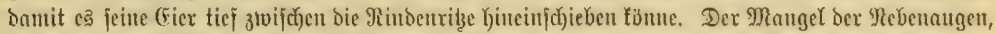

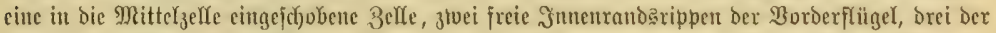

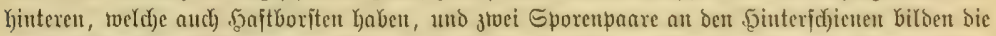

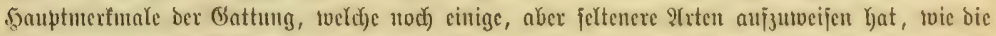
Sippe nock) verivanote Gattungen.

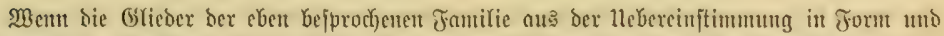

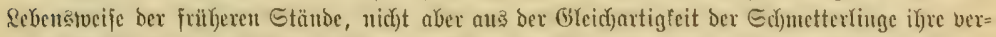

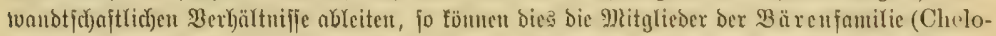

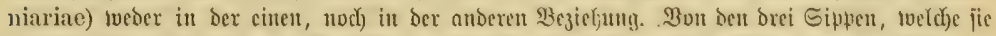

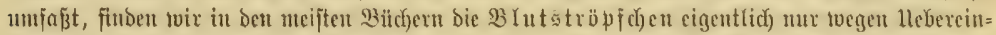

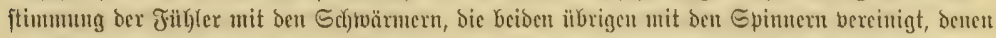

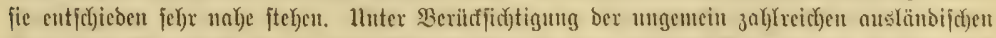

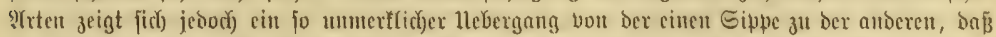

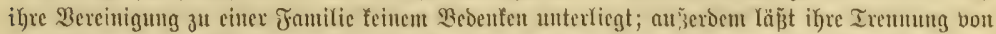

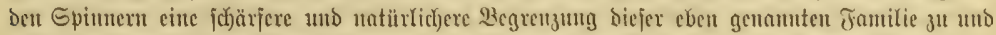

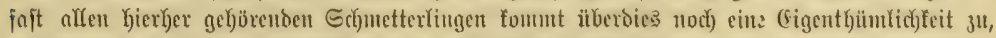

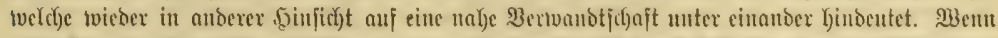

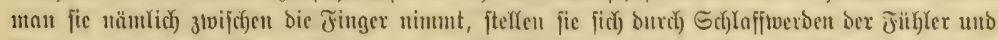

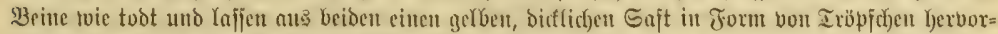

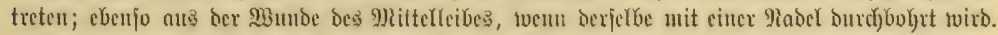

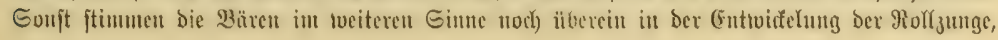




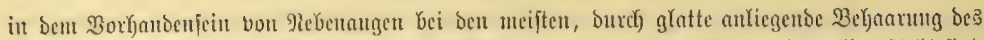

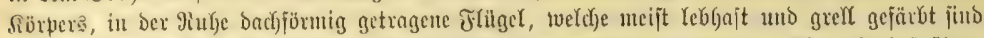

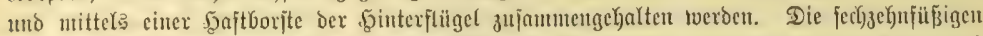

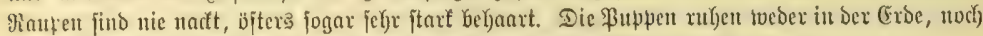

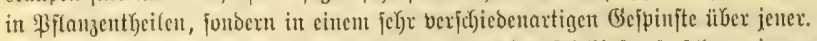

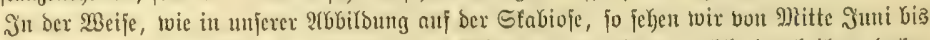

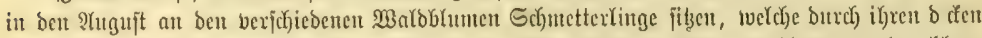

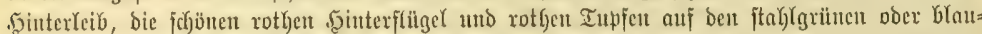

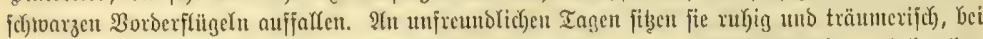

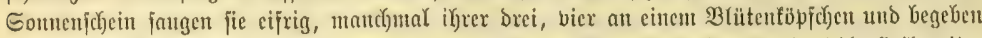

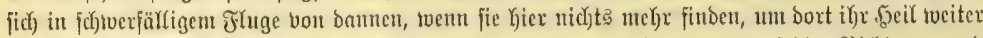

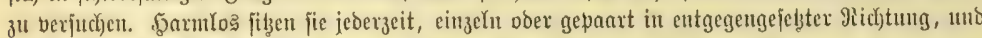

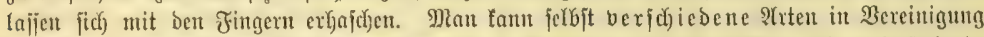

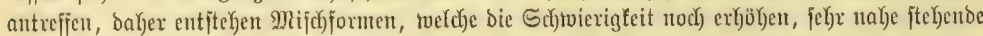

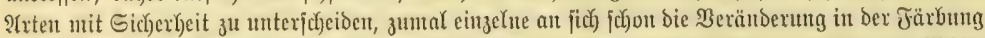

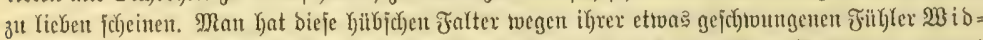

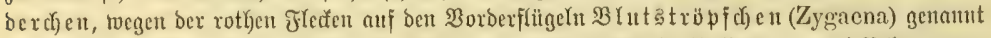

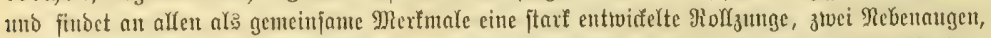

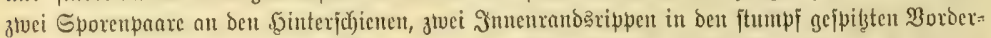

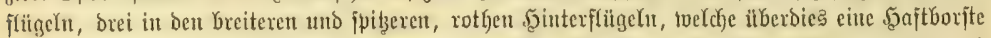

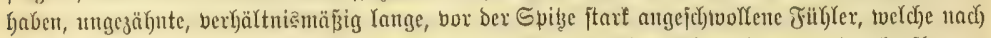

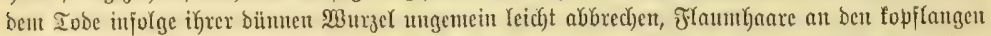

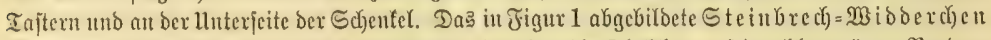

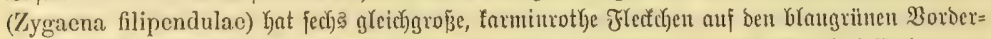

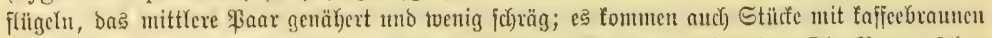

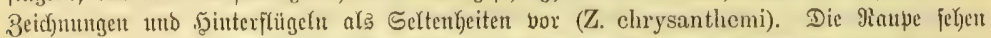

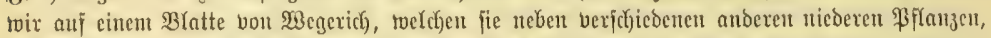

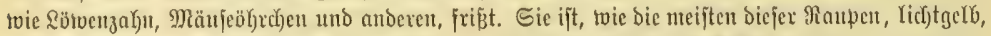

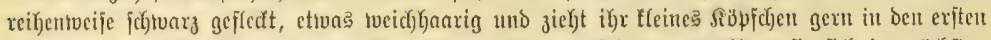

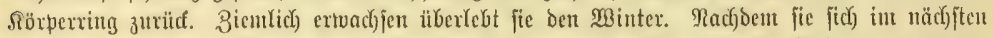

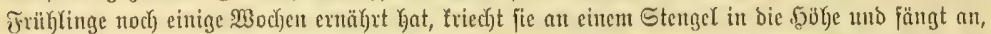

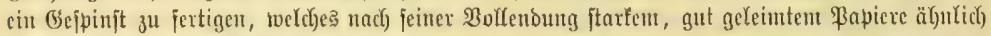

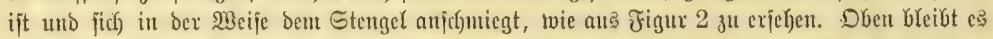

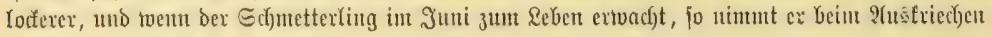
die Puppe halb mit herau?.

Das Weipflect, Den Riugelidftuärmer (bie Siebeubriber, Syntomis Phegea),

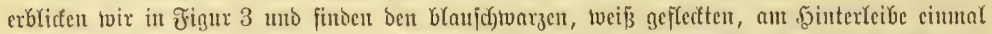

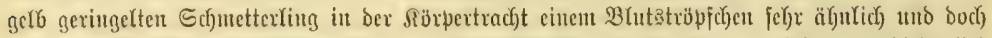

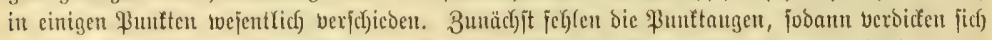

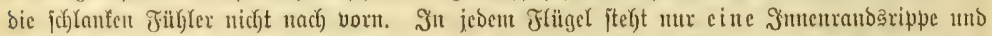

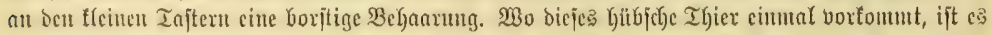

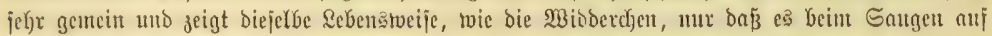

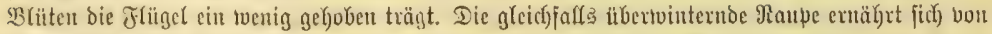

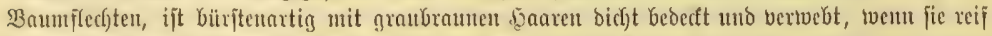

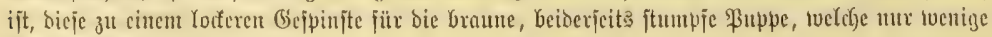
झुochent rufft.

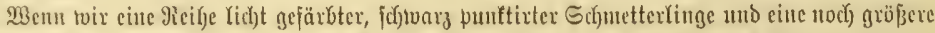
in jelye Iebgajten Jarben prah) 


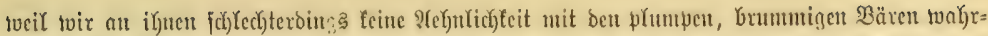

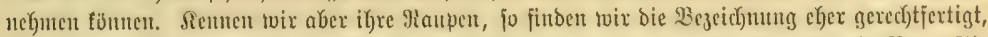

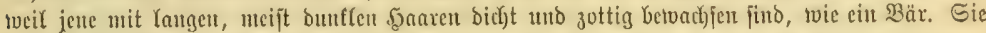

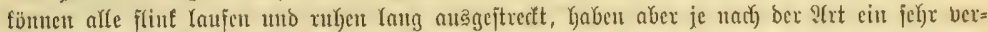

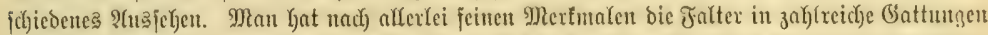
vertbeilt. (Einen ber gemeinten, Den $\mathfrak{B}$ raunen $\mathfrak{B} a ̈ r$ (Aretia caja), jehen wir hier janme jeiner

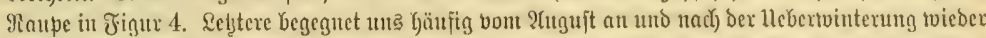

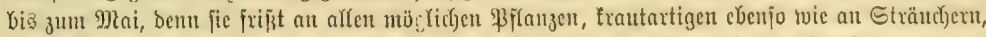

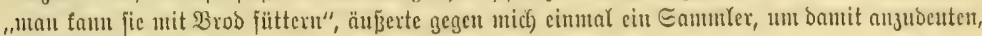

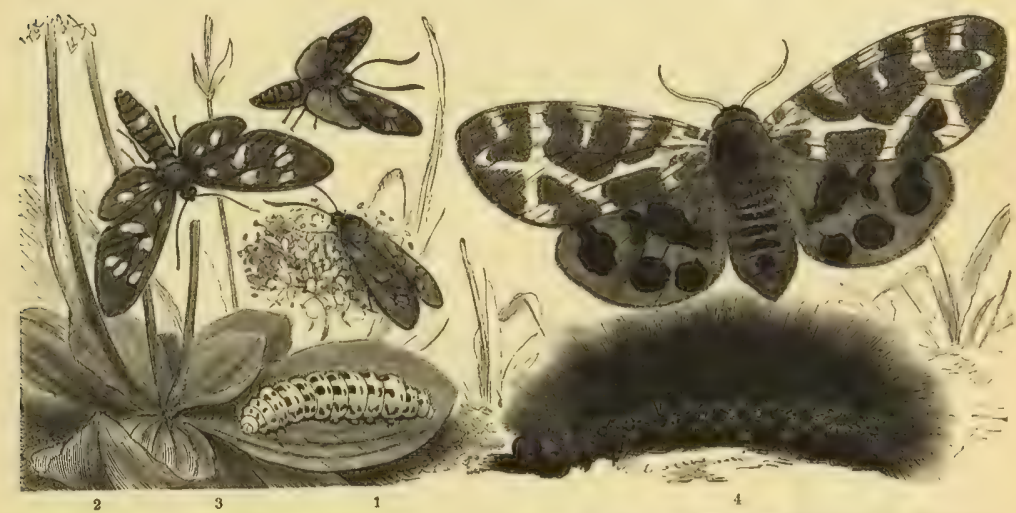

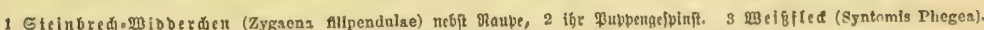

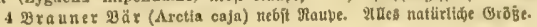

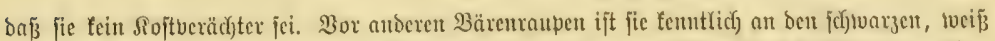

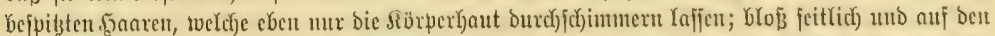

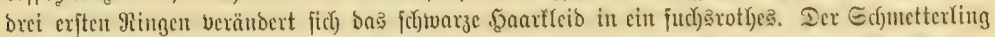

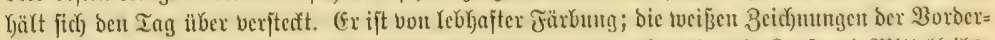

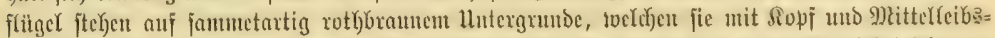

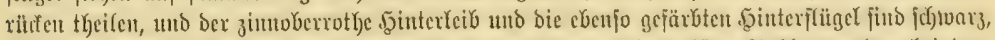

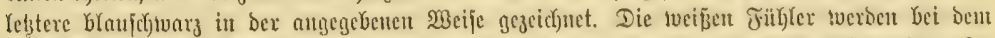

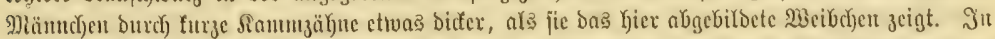

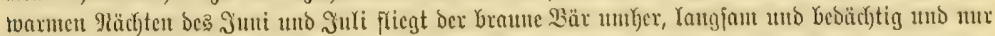

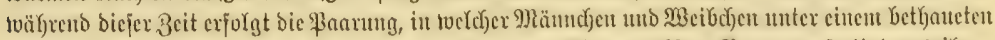

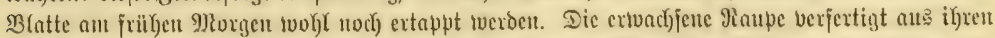

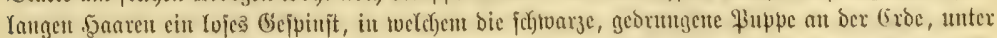

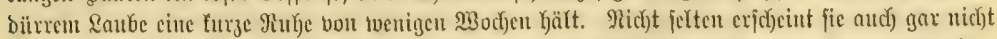

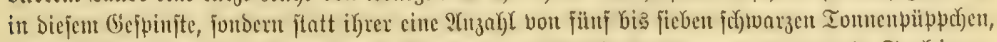

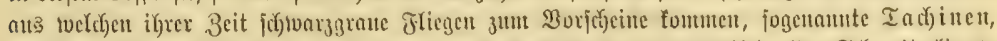

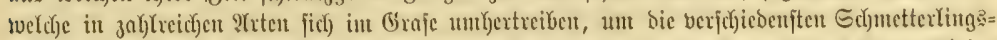

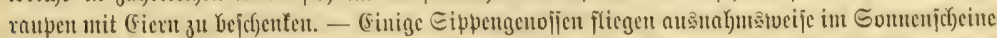

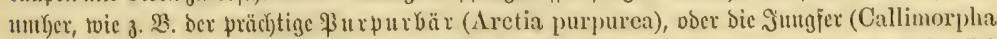

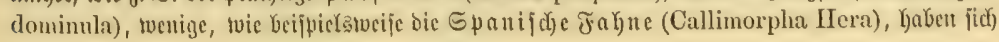




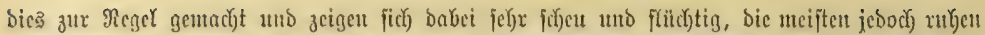

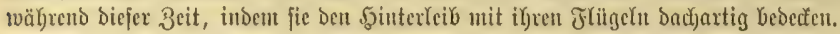

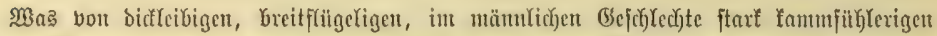

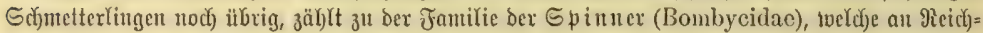

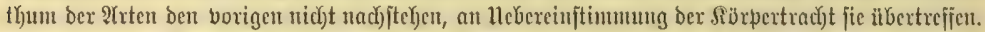

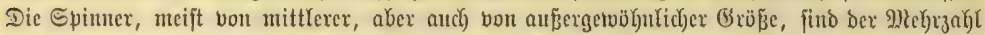

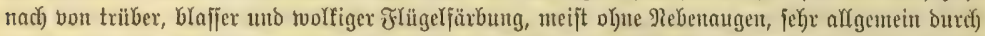

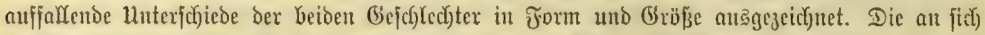

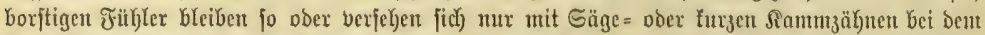

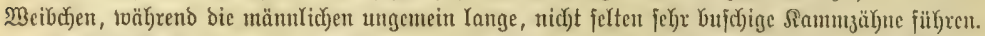

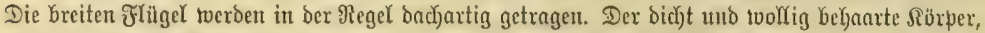

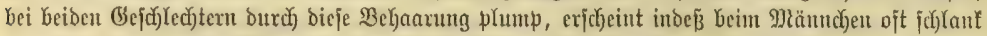

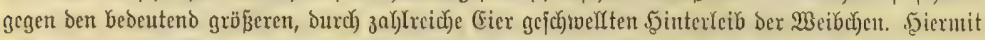

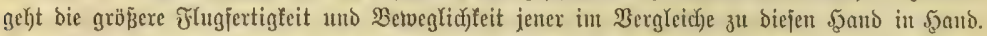

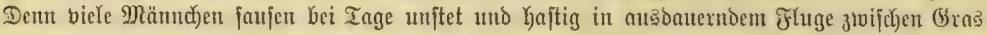

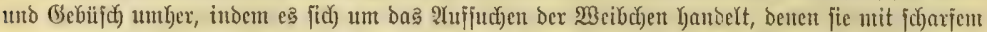

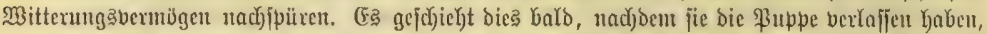
fobald fie, nicht hinter ben Dhren, fondern an ben Filïgeln trocten getooroen füb. Die Weibchen

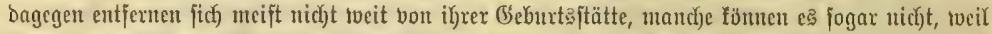

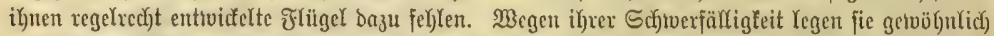

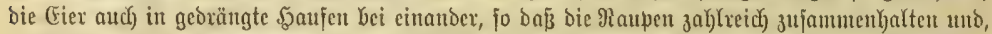

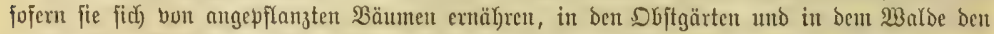

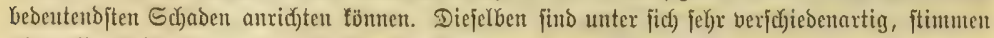

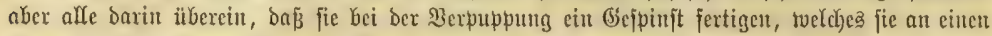
Gegenjtand ifyer Umigebung ankeften; baker ber Fanilienname.

Wie Ornithoptera und Morpho für bie Iagfalter, Sphinx für bie Gctyärntex, jo ift bie alte Battung Saturnia ber Stolz Der gauzen Familie, ja Der ganzen Dronung; Denu unter Den

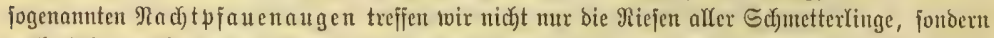

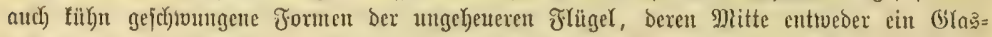

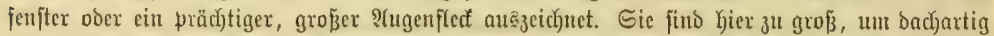

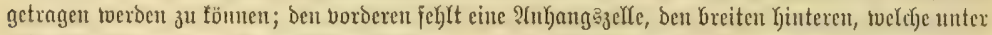

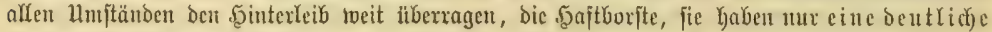

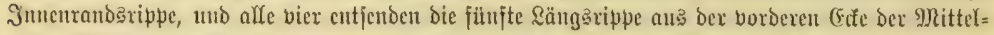

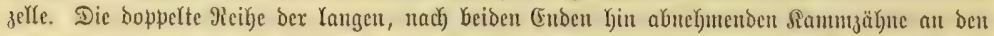

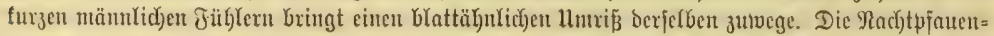

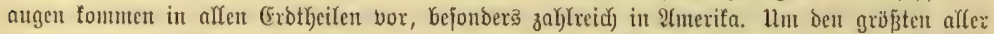

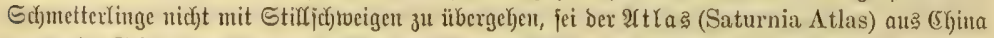

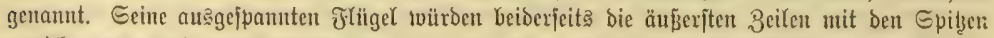

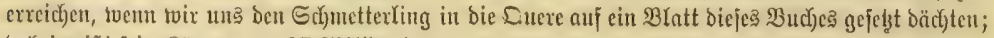

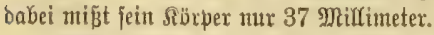

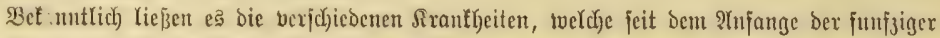

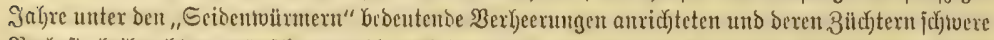

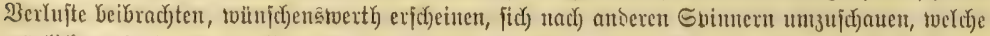

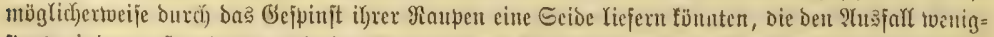

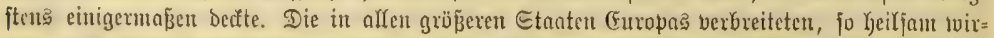

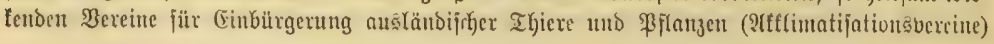




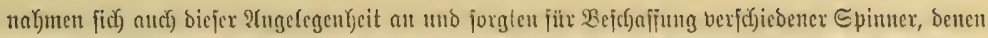

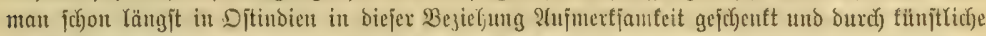

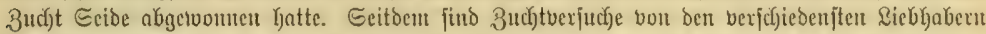

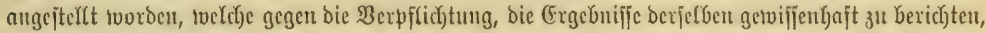

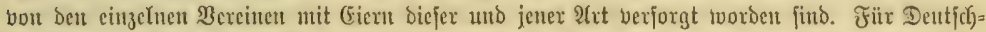

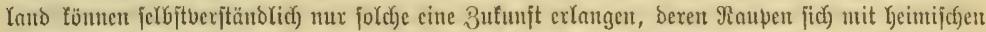

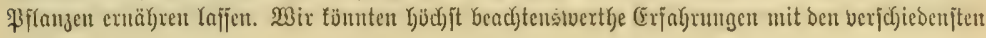

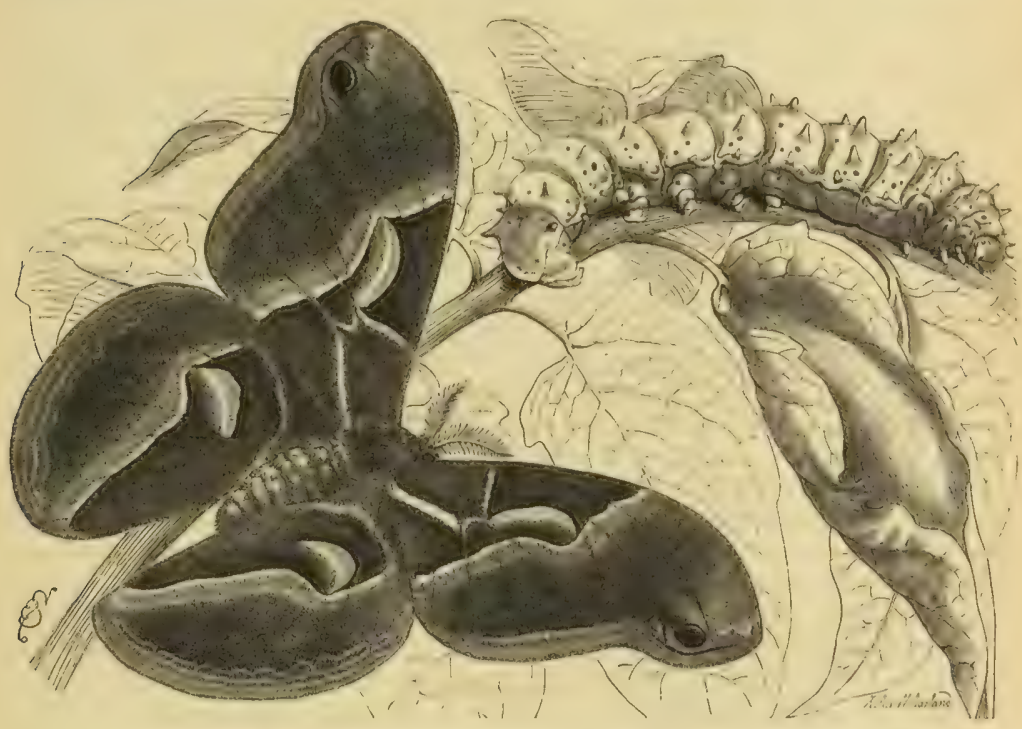

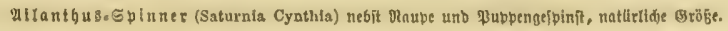

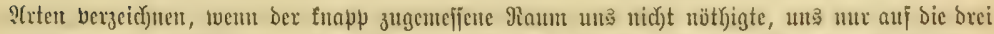

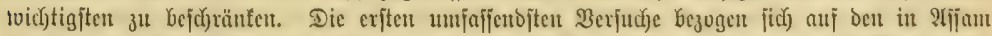

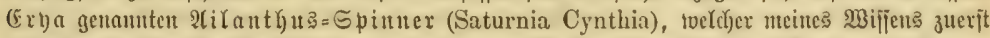

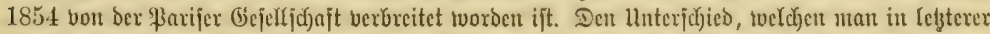

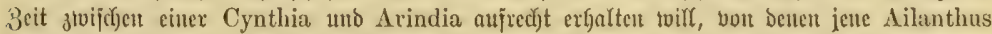

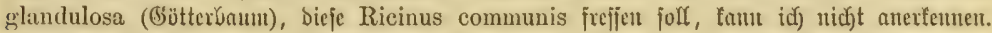

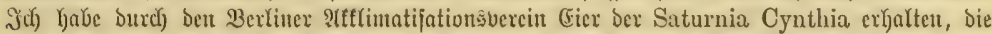

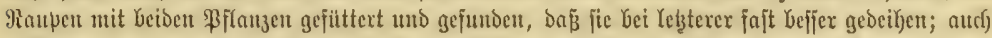

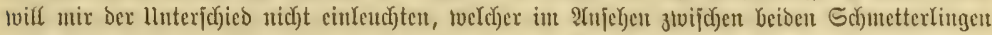

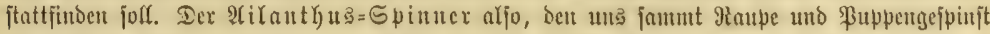

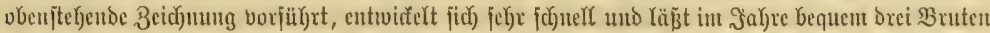

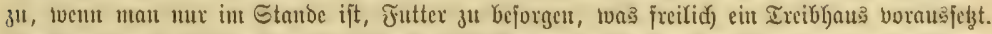

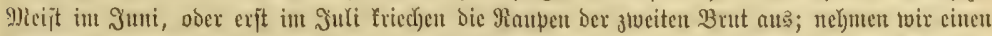
ipüteren 3eifpunt, ben 14. Juli an, fo erfolgt ben 19. Die erjte, an 28. Die ztweite, ben 8. Tugujt bie britte uno an 14. Die vierte goüutung. Dicje Beitpuntte find ermittelt, follen aber mur bie 


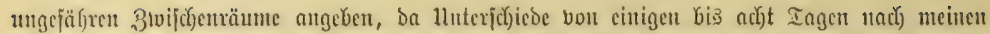

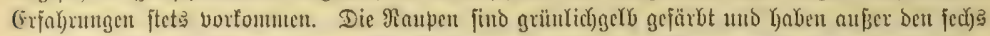

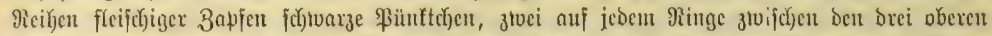

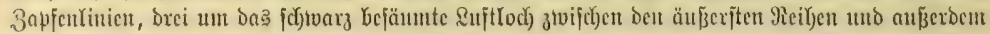

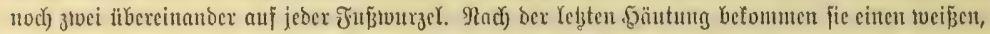

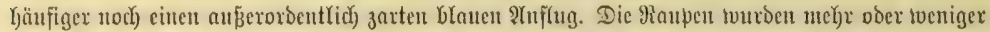

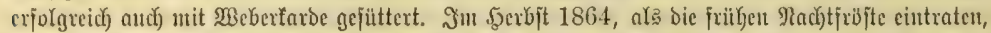

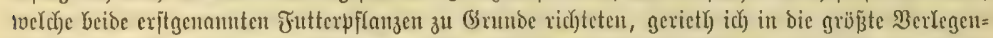

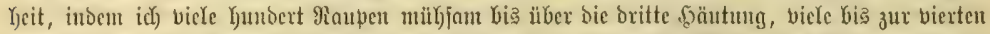
gebradyt Yjatte. Die Yedzteren liefen fich theiltweife Durd) Die B̉ättex bes Eifingaumts (Rhus typhina),

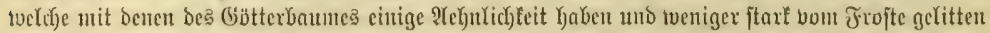

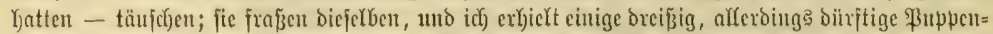

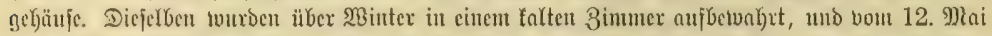

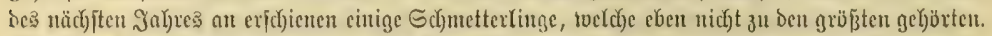

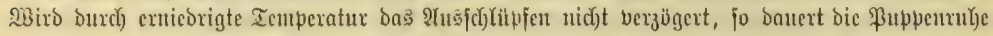

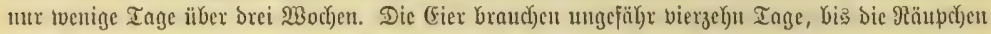

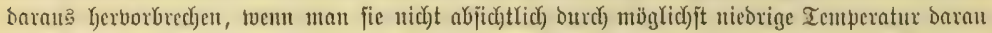

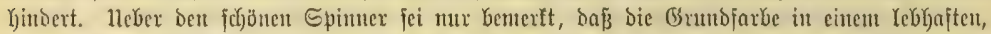

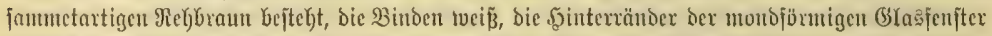

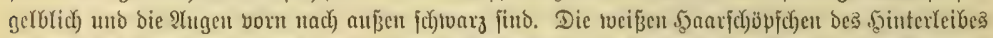

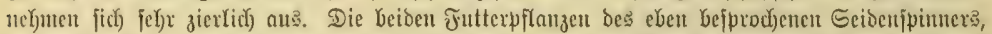

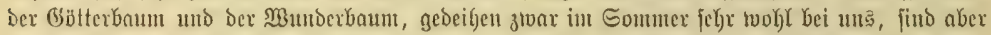

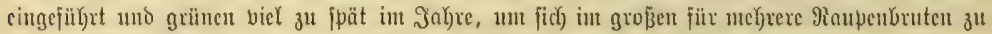

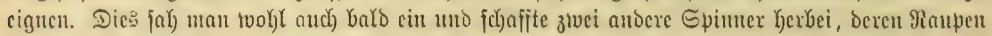

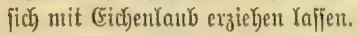

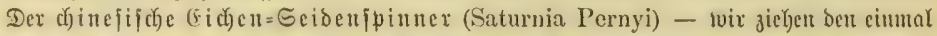

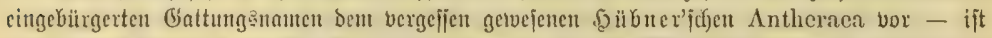

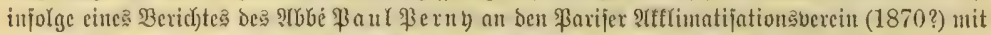

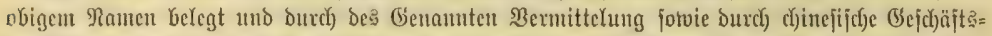

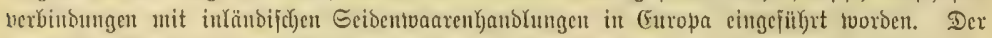

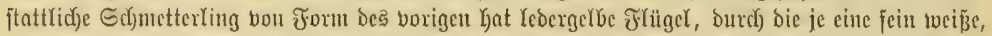

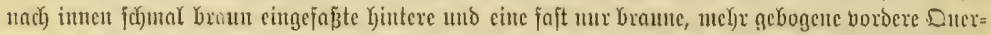

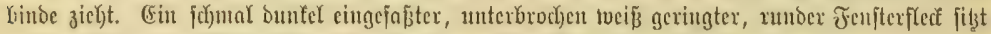

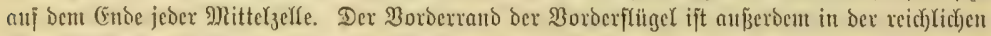

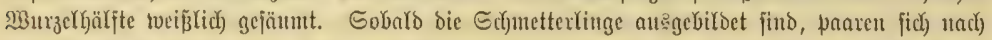

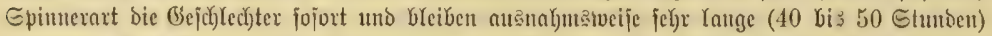

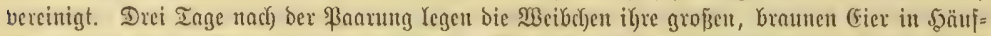

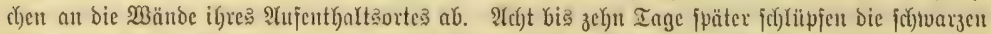

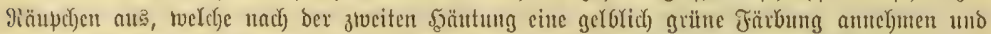

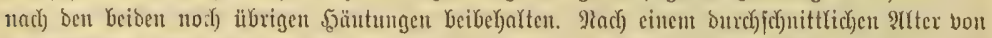

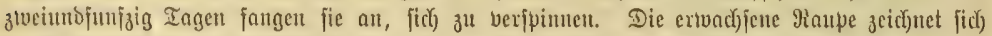

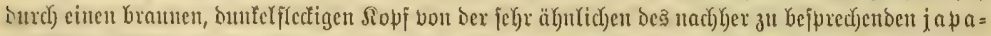

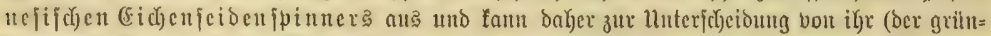

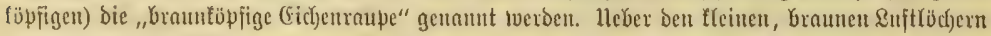

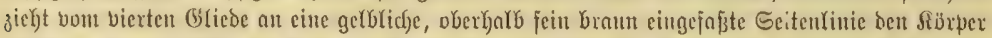

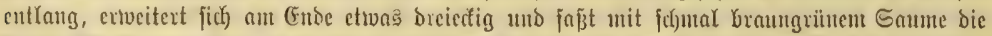

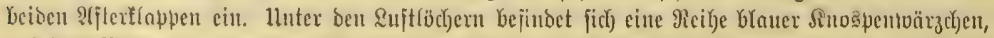

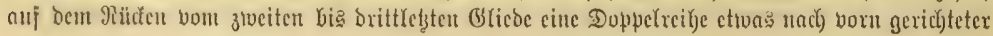




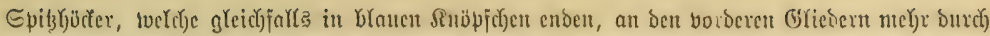

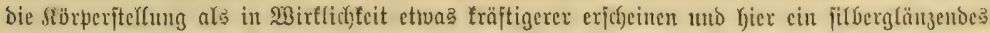

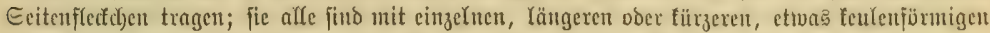

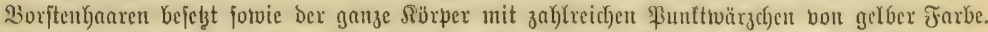

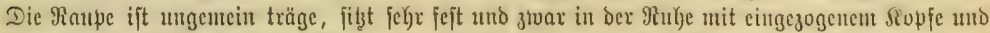

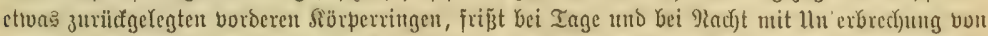

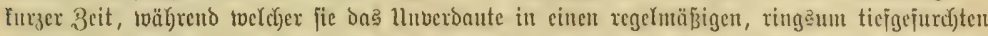

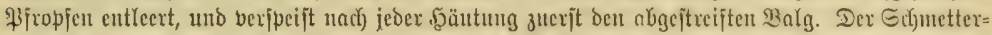

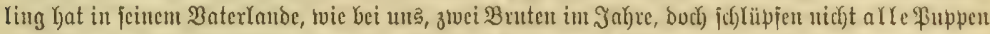

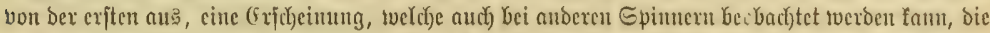

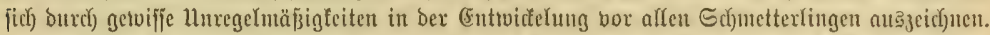

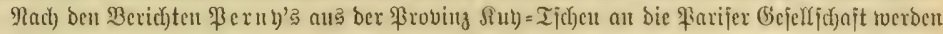

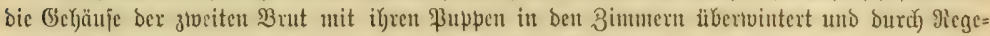

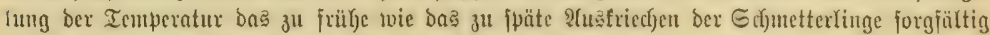

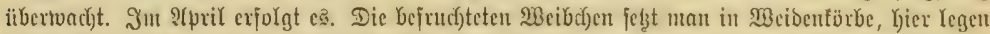

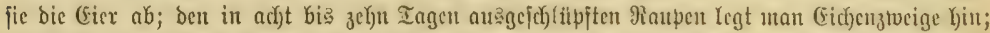

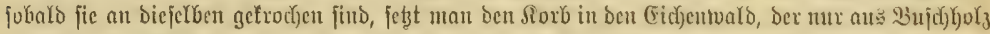

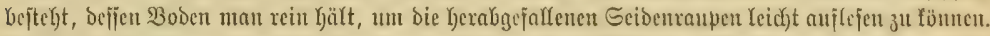

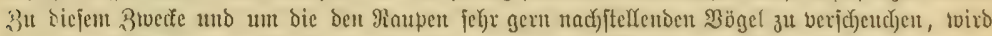

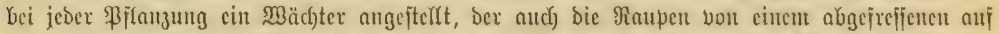

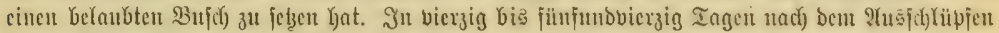

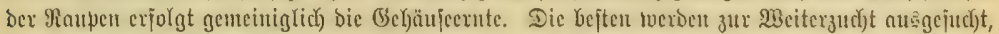

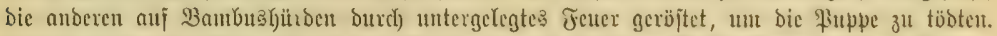

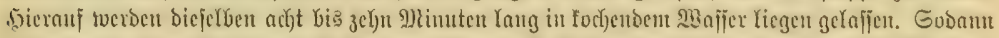

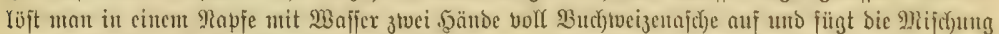

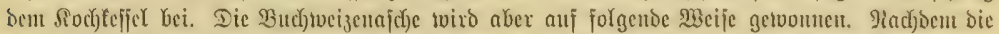
Siöner gecrntet fint, trochnen bic (5hinejen bic Stengel an Der Eonne und zünden bic aufgebänjten

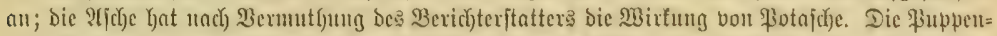

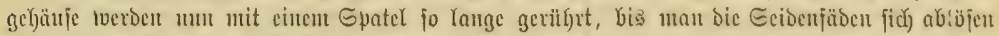

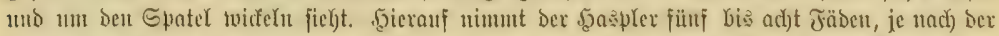

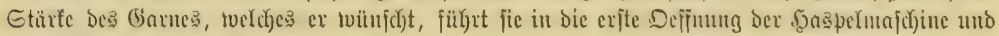
Gaspelt bic Gebäule ab.

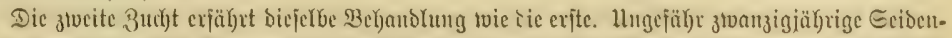

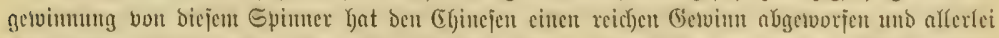

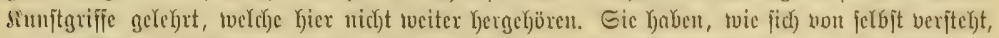

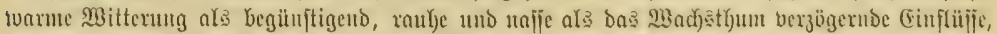

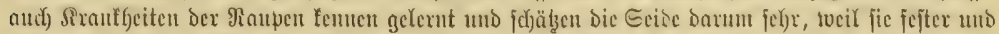

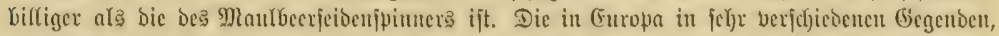

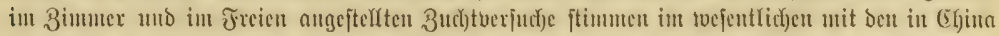

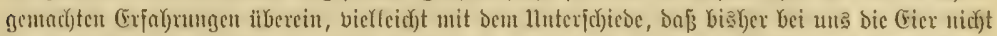

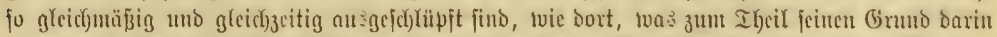

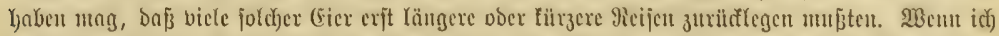

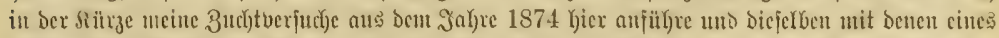

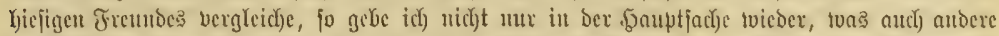

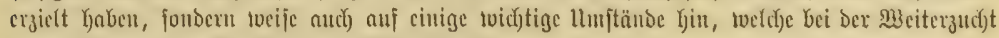

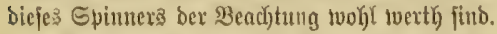

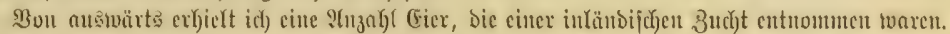

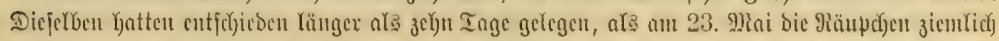




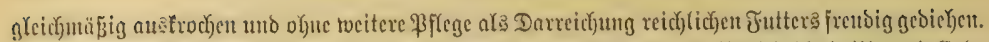

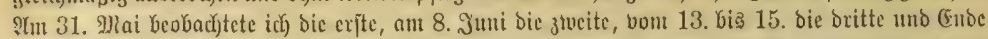

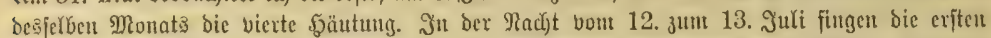

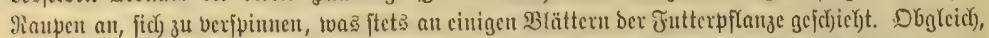

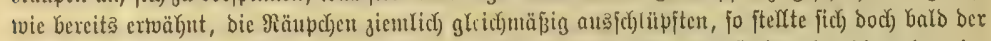

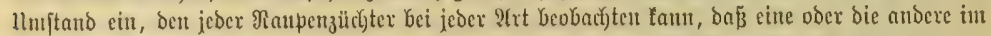
23ach)

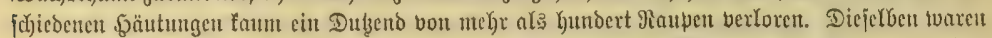
anfang

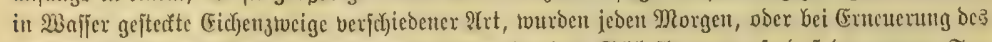

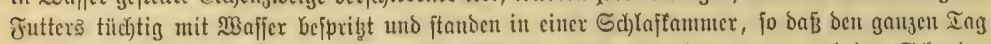

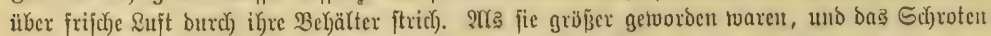

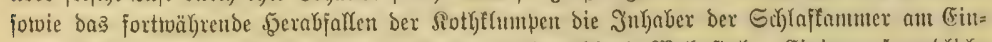

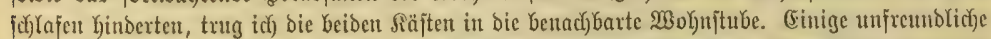

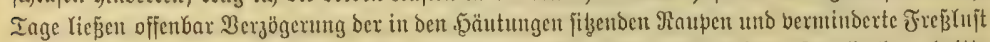
ber geputoen twahrnchmen, und jene Iage werden bie Bentertungen in meinem Ingebudge: "britte

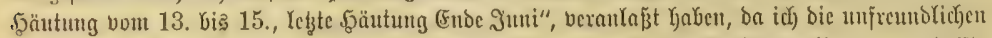

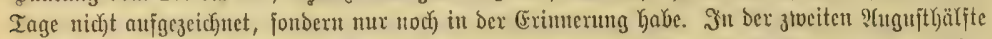

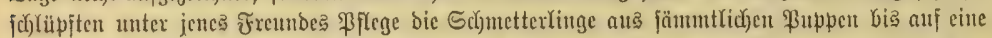

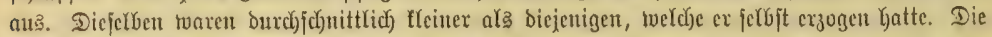

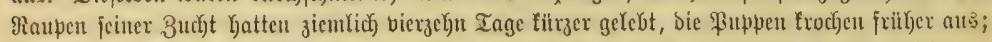

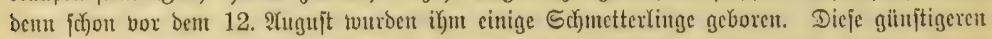

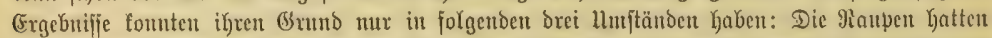

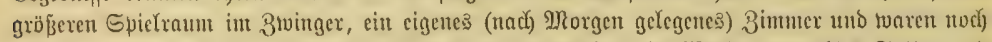

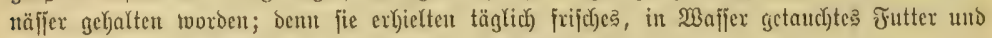

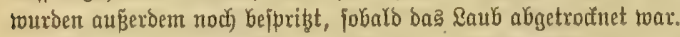

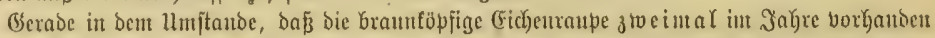

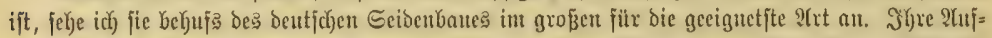

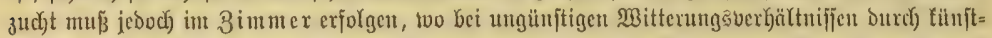

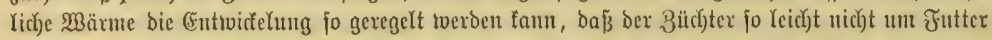

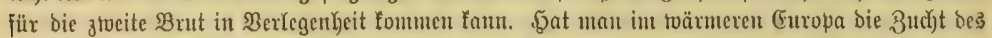

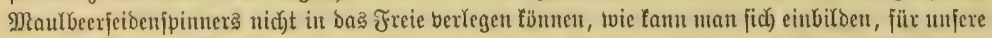

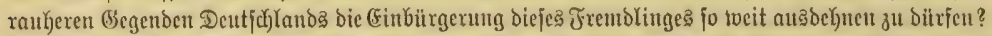

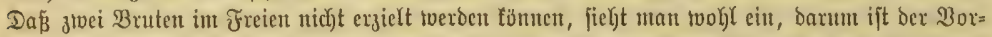

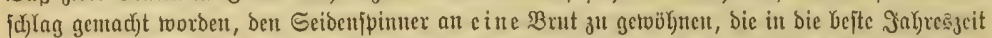

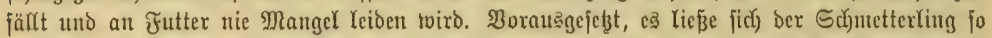

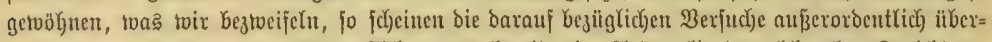

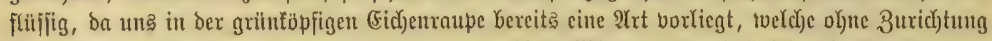

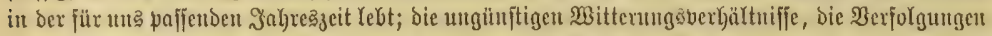

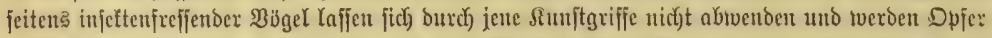

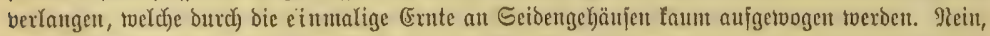

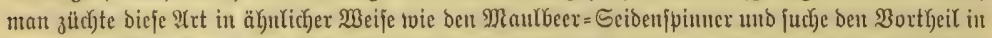

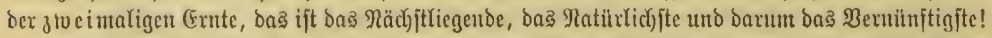

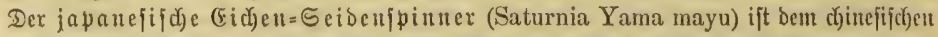

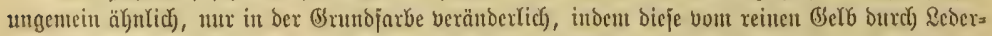

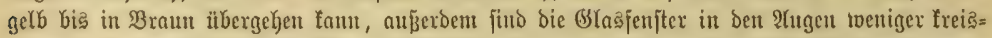

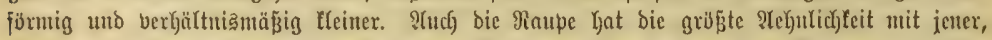

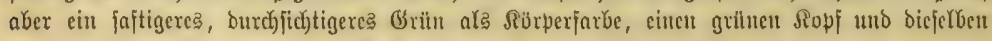




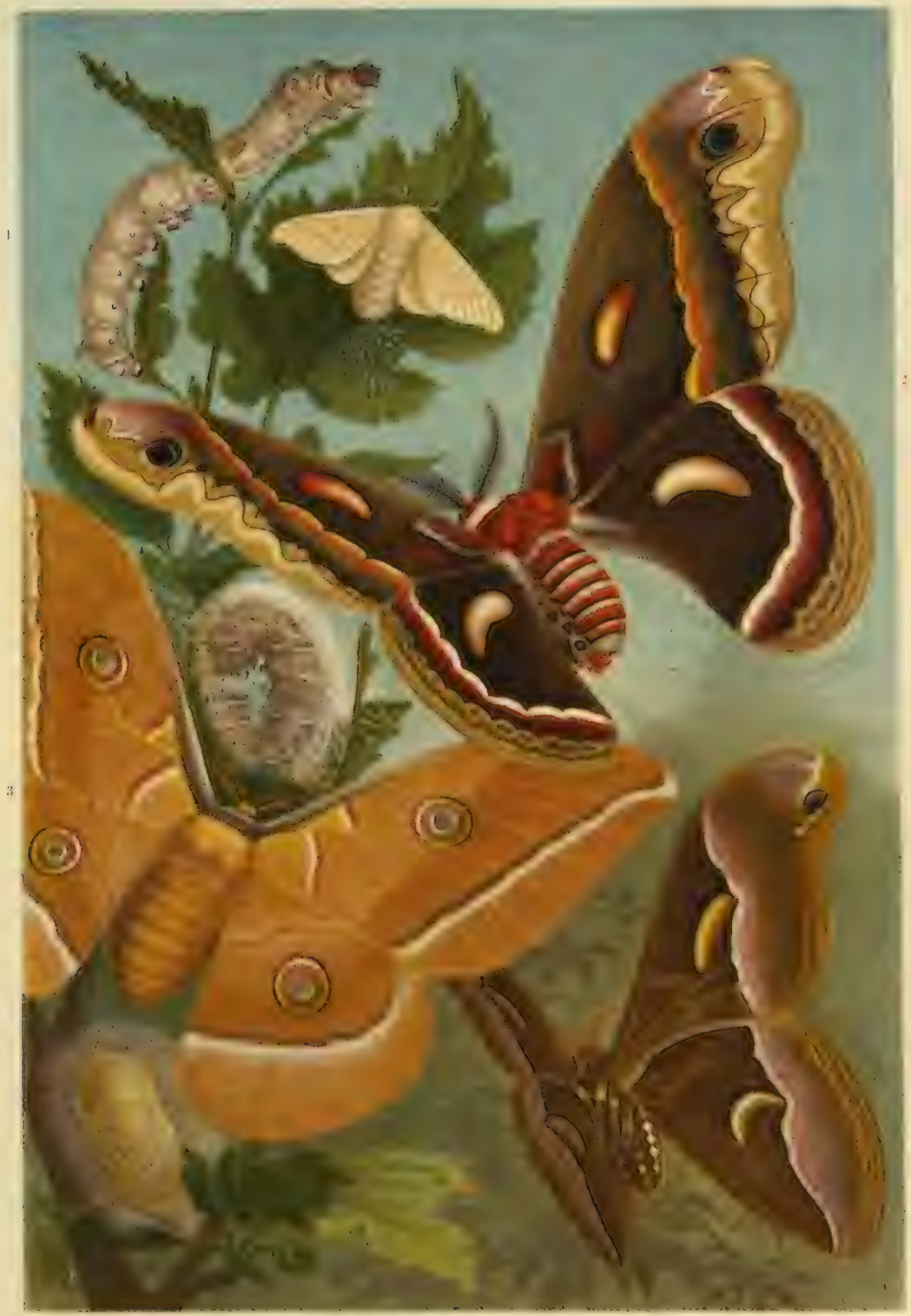

SEIDFNSPINNER

1. MAULBEERSPINNER WESI LAUPE UND GESPIN. TEA 2. SUDAMERIKANISCHER SEIDENSPINNEF

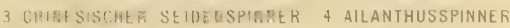





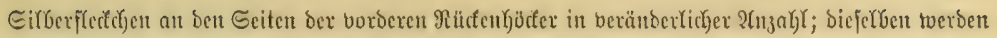

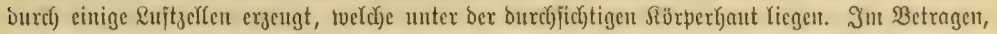

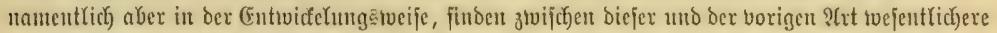

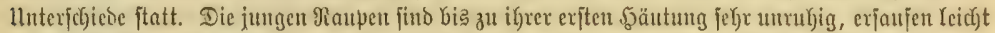

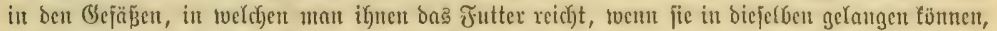

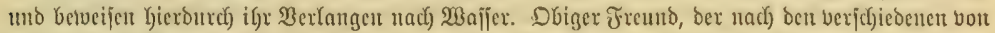

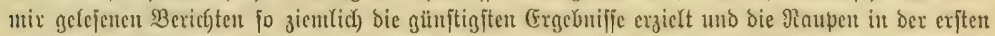

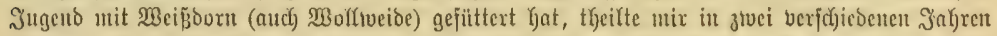

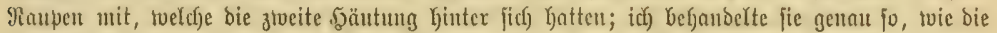

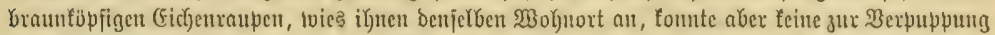

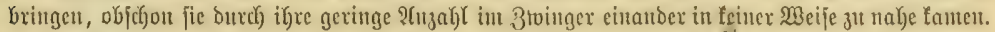

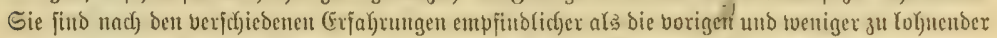

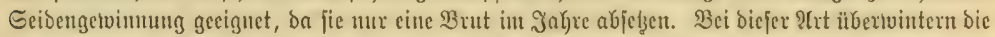

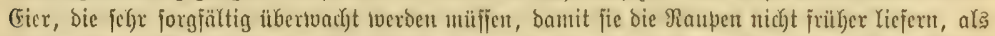

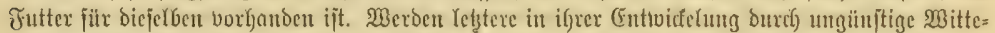

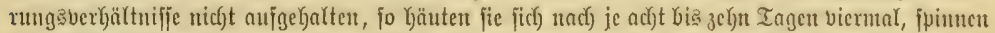

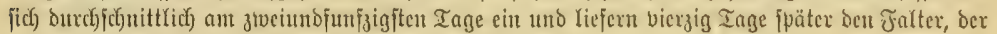
tweit fitrzere Beit in Der Paarung berkart als ber borige.

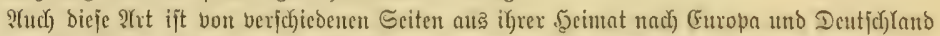

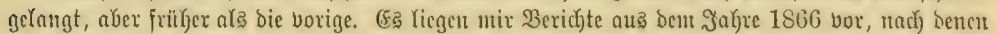

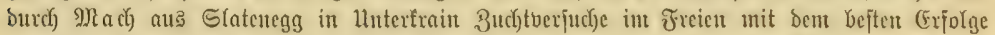

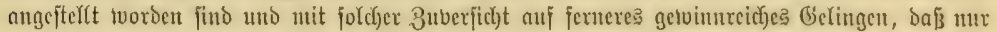

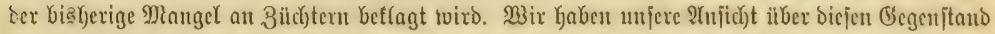

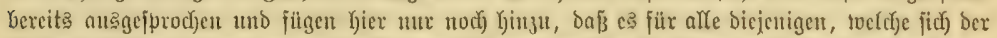

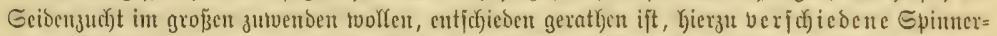

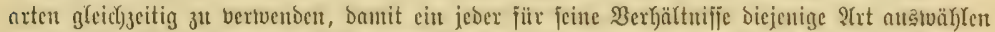

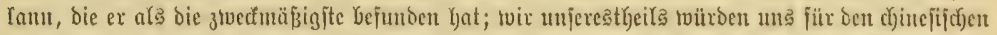

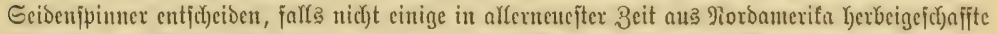

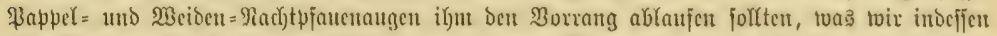

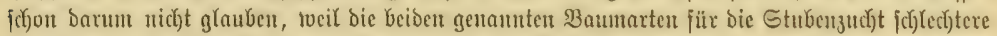

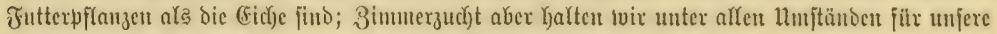

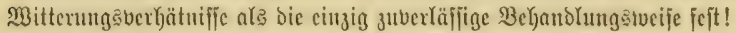

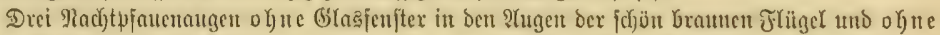

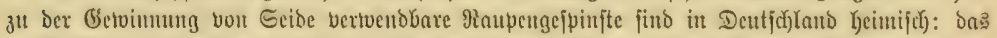

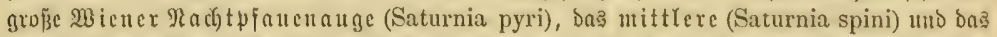
gemeinjte bon ifuen, Das flecine (Saturnia carpini). Sl)re grünen Raupen tragen tweniger auf=

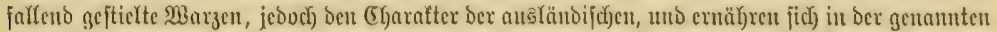

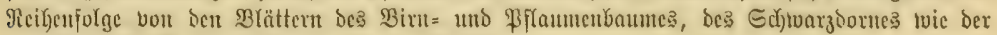

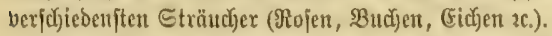

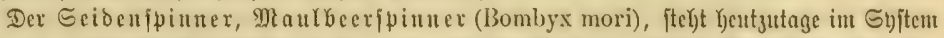

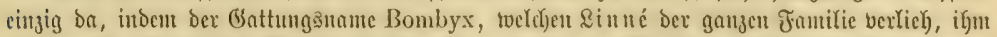

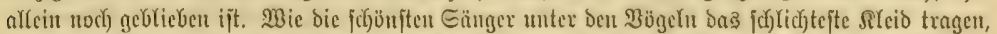

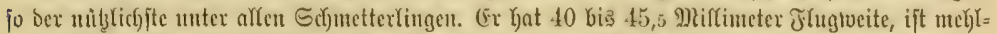

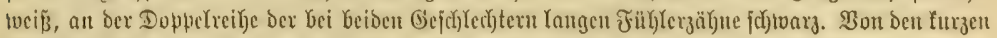

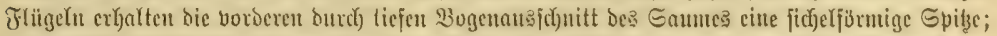

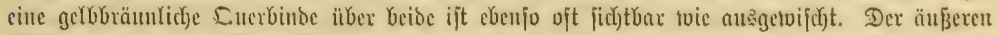

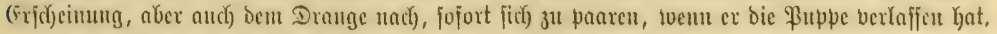

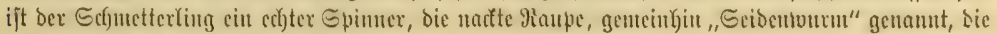




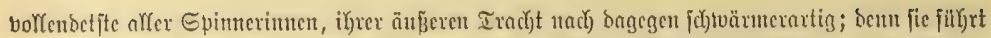

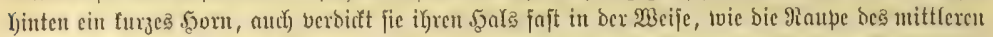

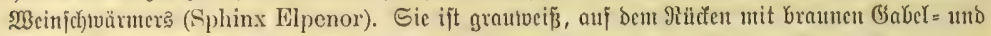

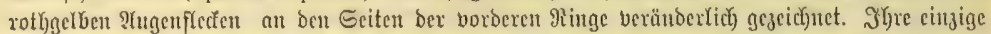

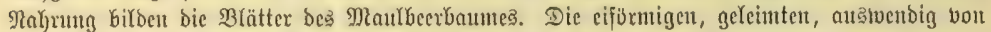

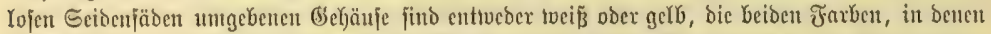

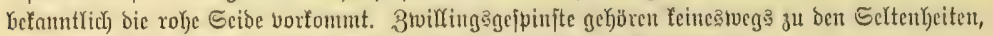

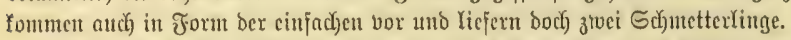

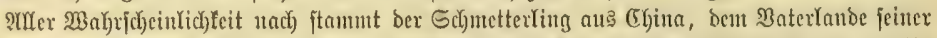

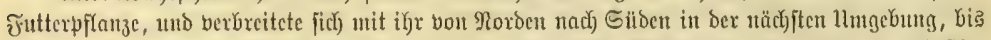

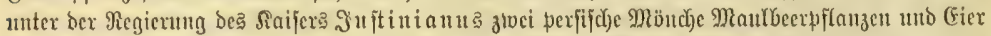
(Öraine

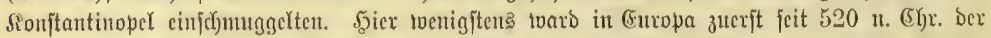

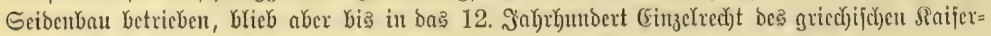

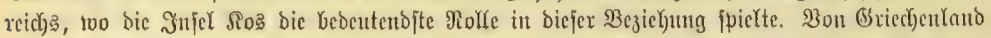

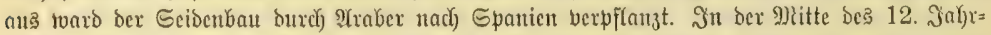

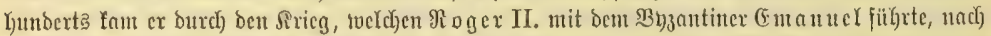

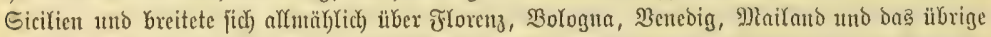

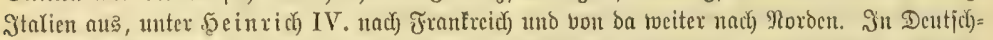

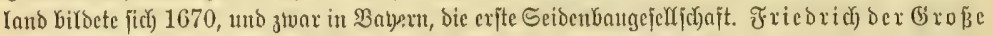
nahm fich) biefes (Erwerbsztweiges in jeinen Rändom auf bas twërmite an, mo fo fant in ber

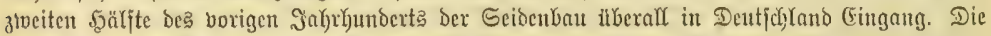

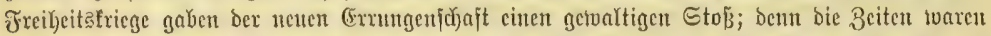

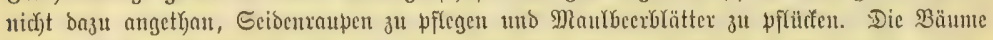

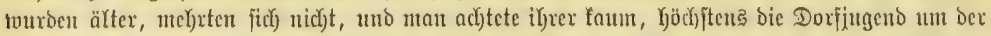

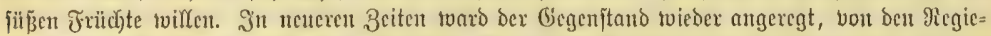

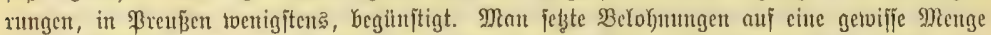

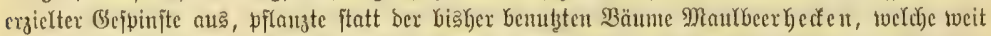

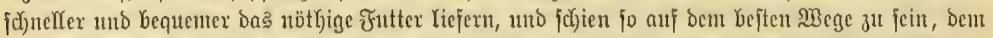

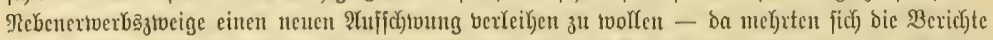

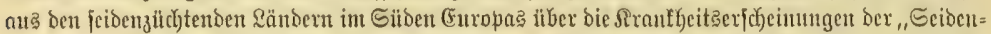

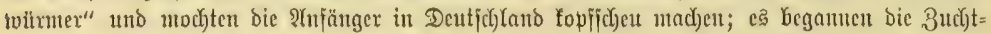

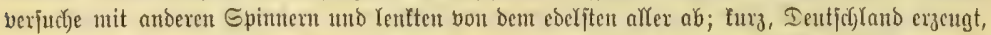

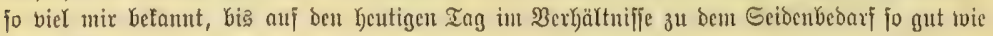
leine Seibe!

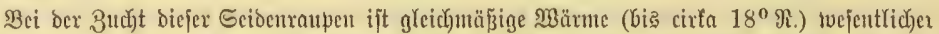

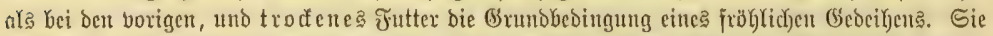

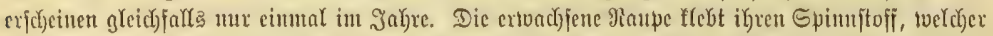

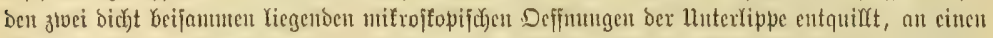

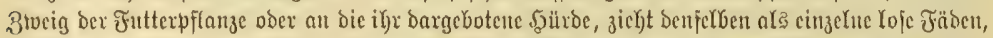

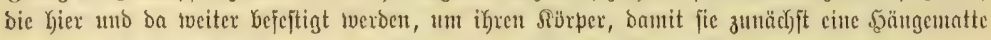

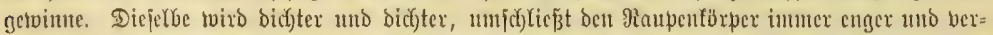

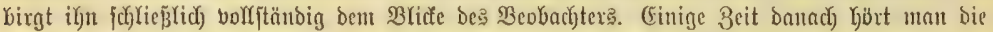

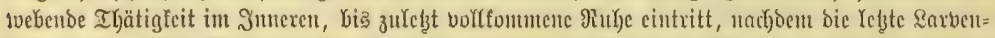

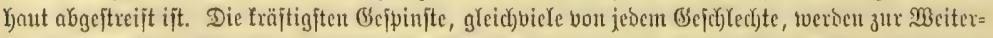

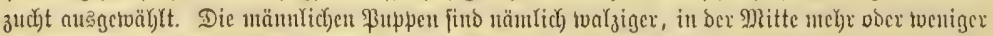

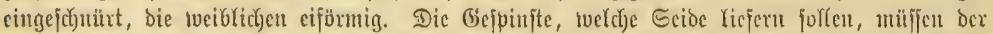

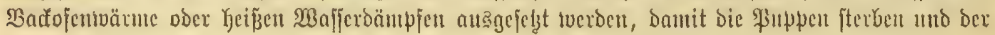




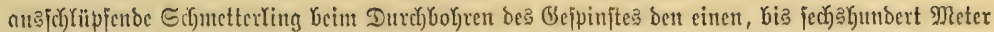

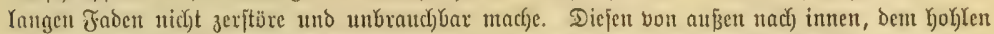

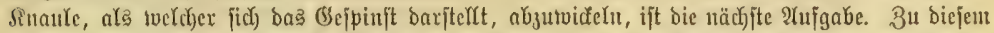

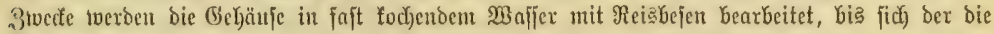

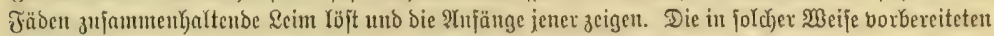

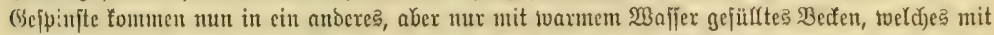

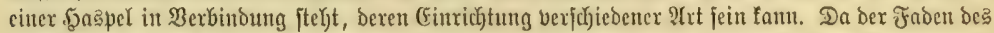
cinzefuen Gejpinjtes zu fein jein wihrde, jo Kaspelt man beren, je nad) den Bebürjnifjen, brei bis

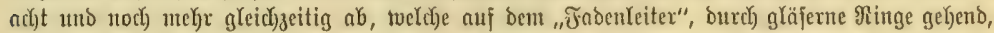

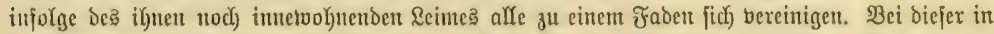

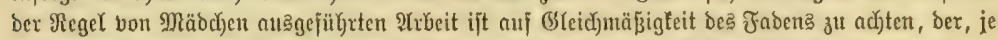

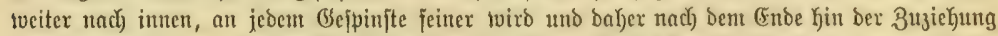

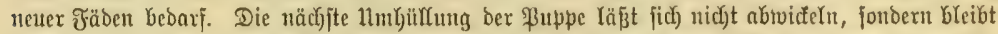

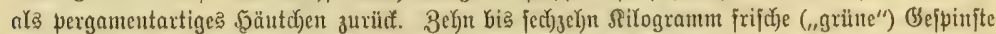

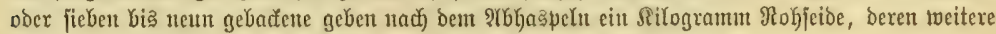

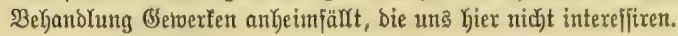

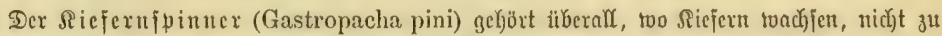

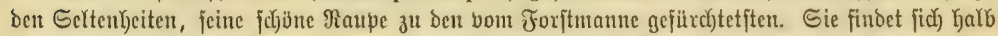

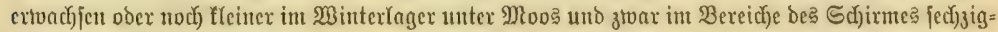

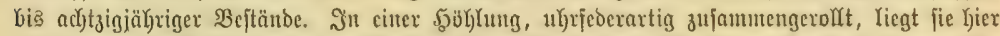

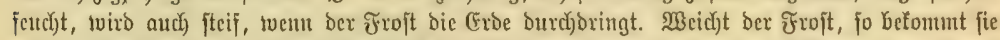

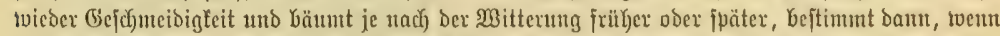

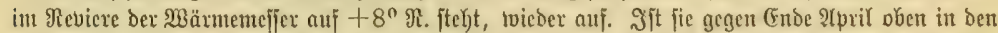

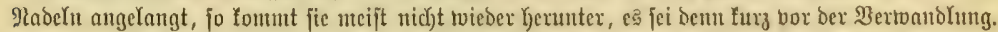

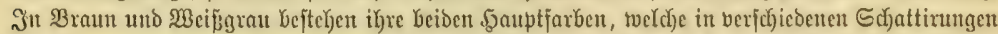

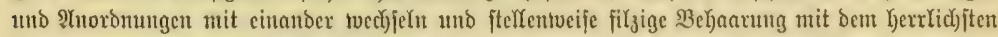
PerYnmtterglanze tragen. Die (Einfichnitte Des zroiten und britten Ringeß bilon jogenannte

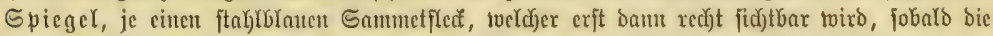

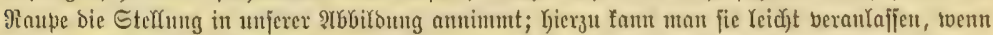

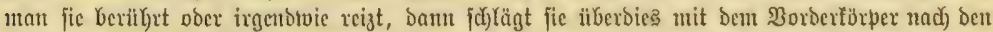

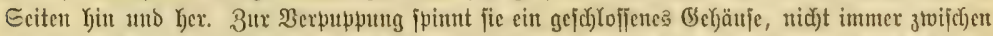

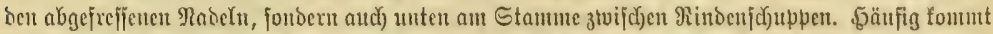

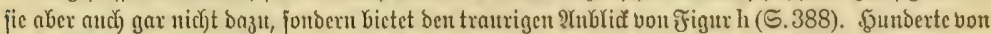

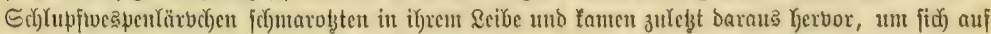

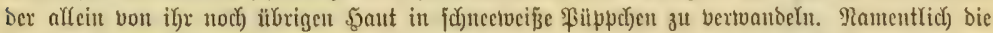

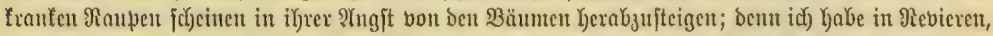

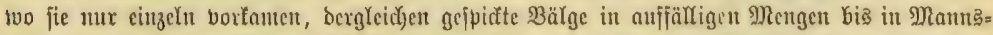

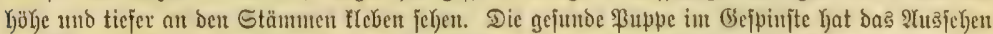

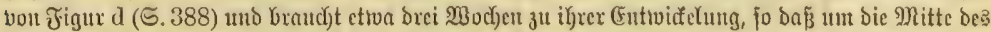

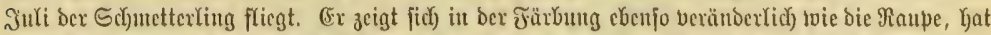

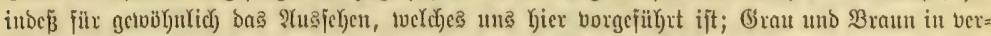

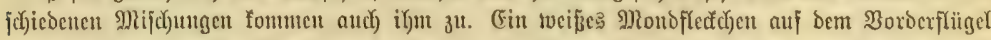

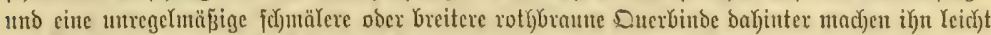

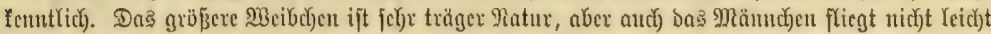

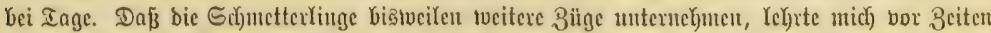

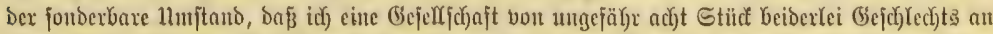

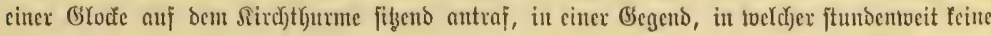




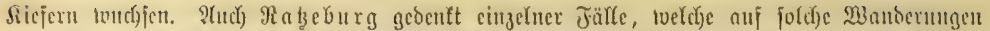

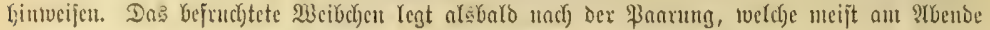

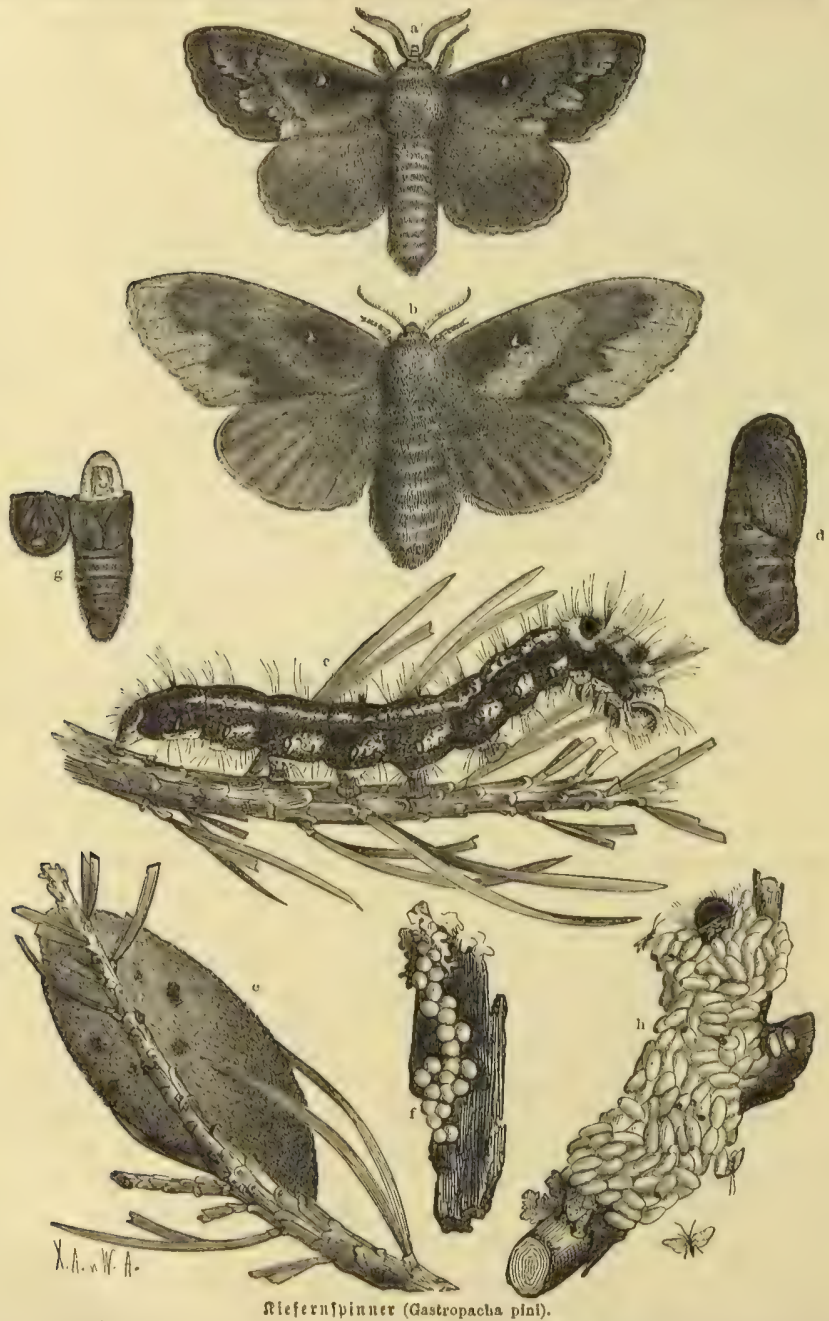

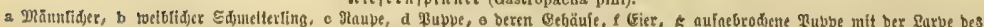

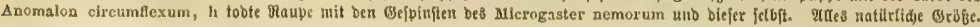

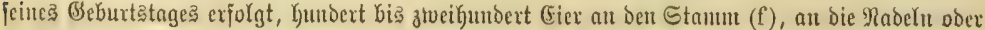

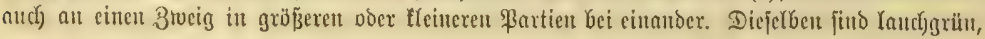




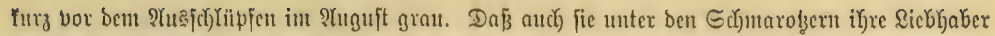
finten, haben wir bereits früber erfalyren und in einem 'T'eleas ben einen bavon fentuen gelernt,

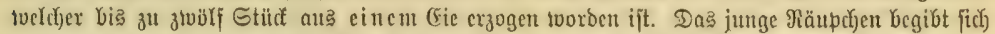
fofort auf bic ?abelu, bejchabt biefelben zuerft, fann fie aber bald mit Stumpf und Stiel ber=

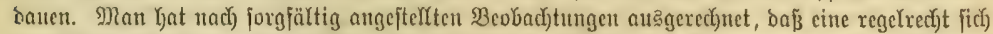

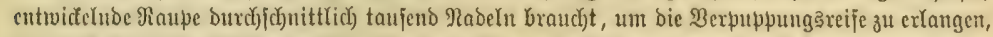

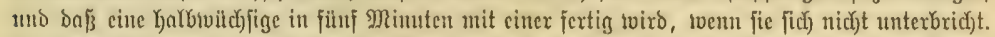

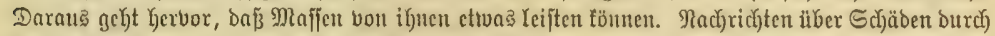

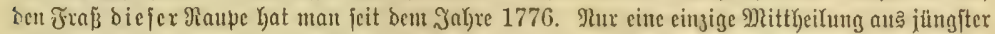
3eit, tveldec mix von einem Forjtbeanten zugegangen ift, mag ben Betveis Yicjern, in weldyen

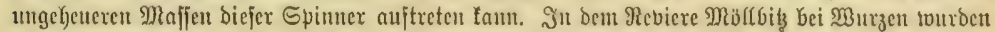

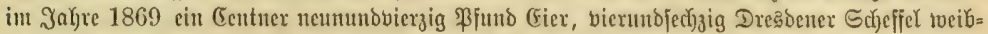

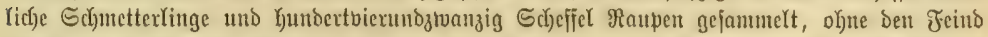

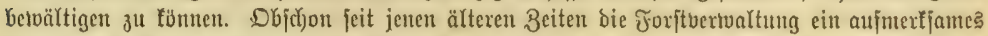

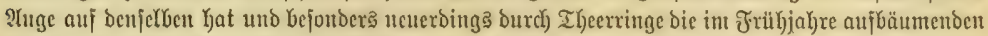

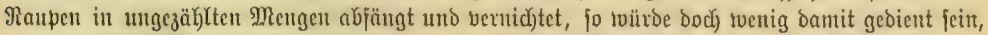

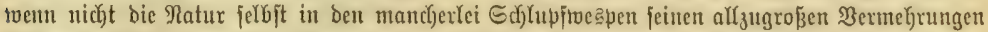

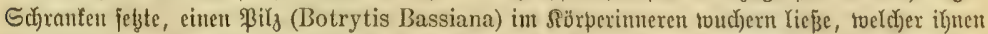

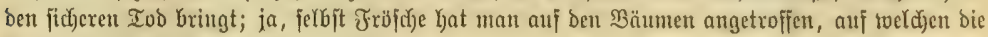
Raupen in berbeerenden Mengen faß̧еn.

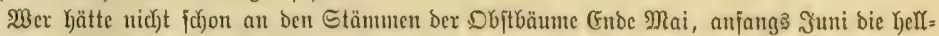

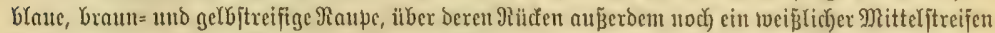

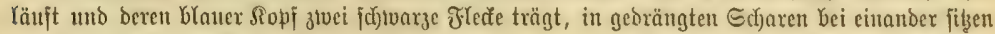

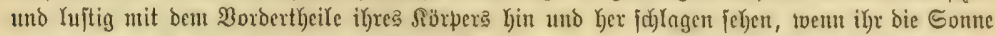

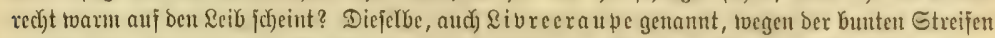

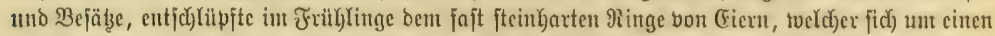

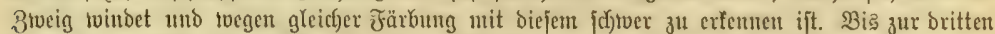

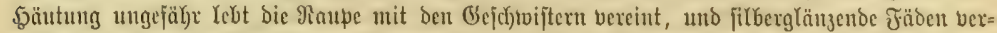

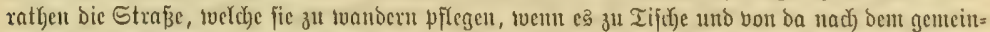

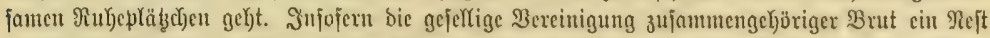

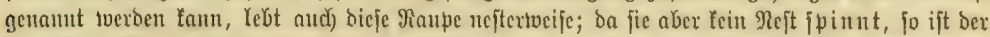

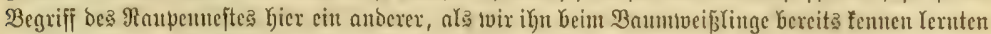

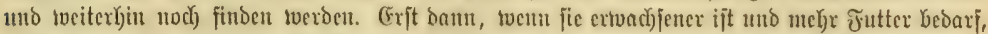

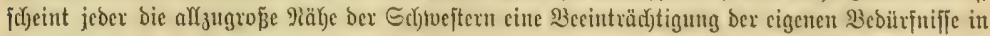

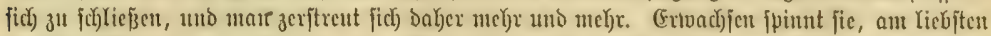

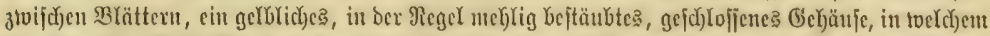

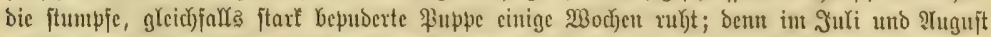

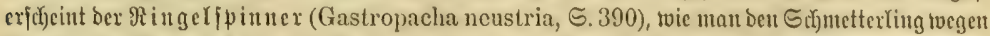

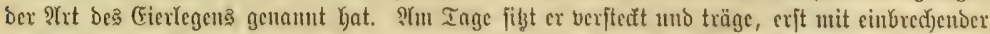

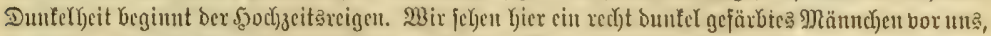

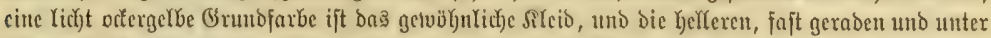

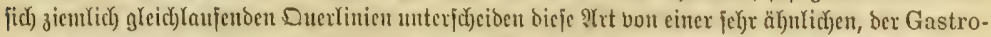

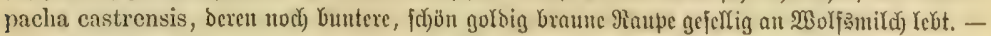

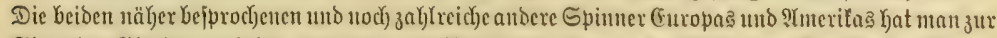

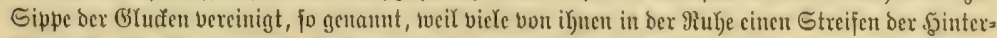

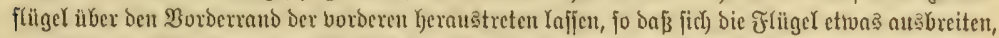

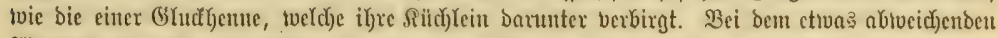

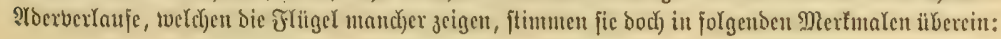




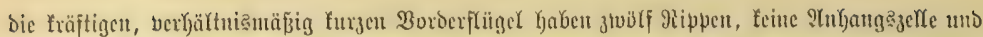

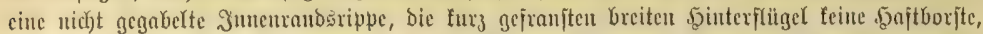

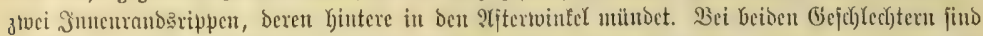
Sie Jih)

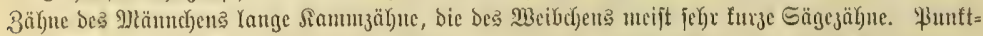

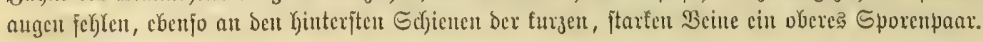

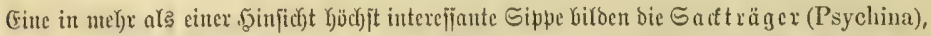

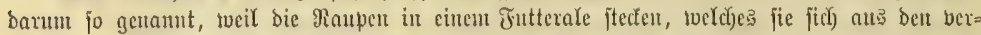

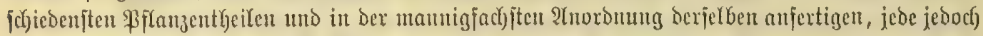

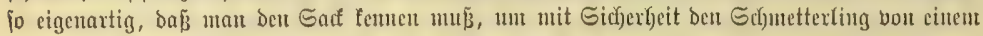

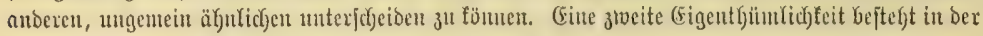
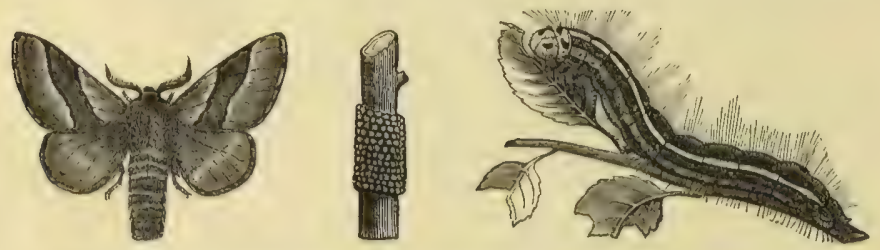

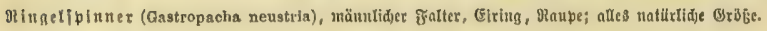

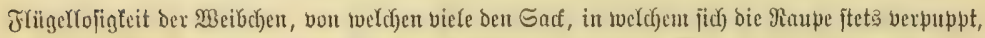

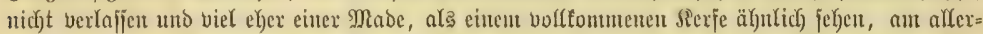

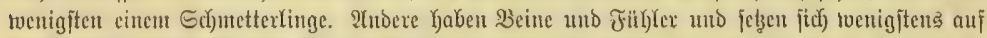

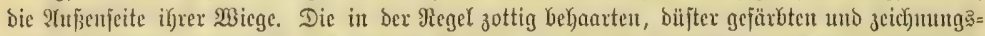

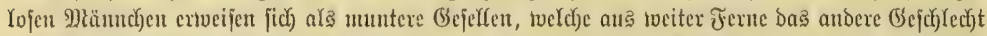

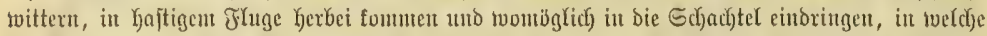

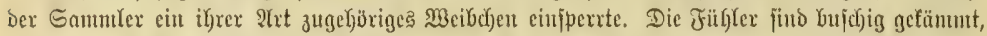

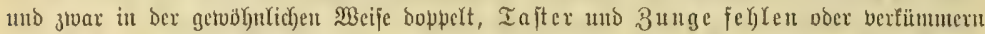

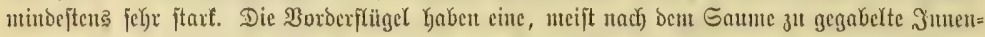

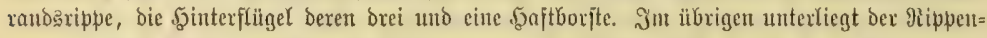

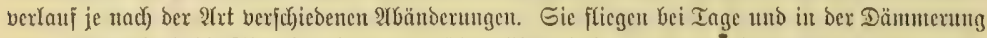

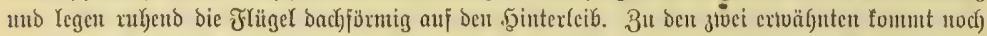

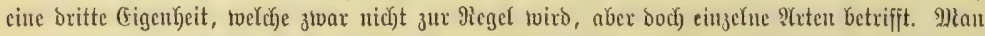

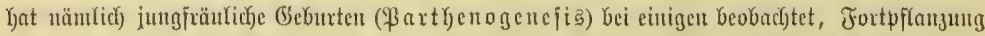
ol) the vorangegangene 3ejrudjtung; ja, bei citter, ber Psyche helix, tweldfe aus Santöornditen

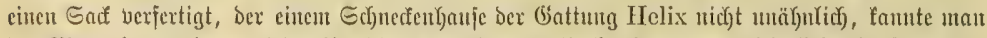

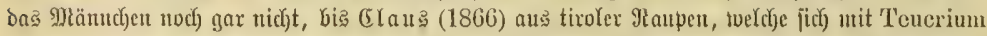

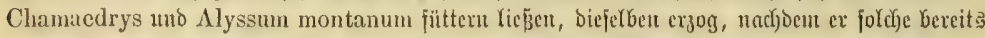

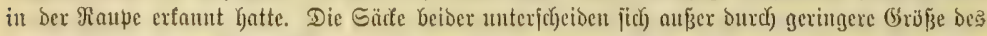

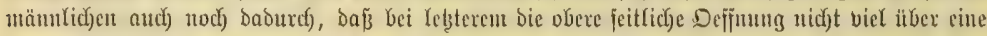

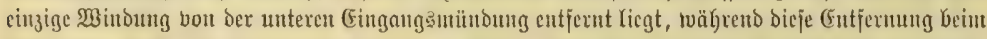

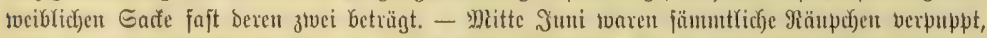

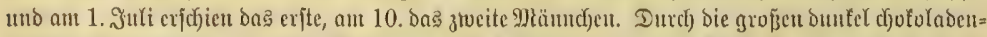

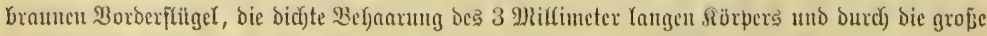

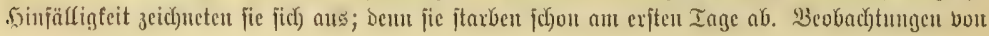




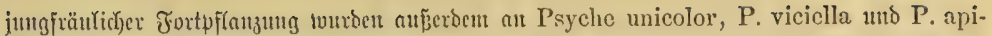
formis, an ber Talaeporia nitidella, Solenobia lichenella, triquetrella fotvie vereinzelt und auşnalmatweife an einigen größ̄eren Spinnern angejtelft.

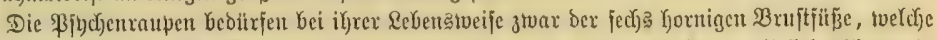

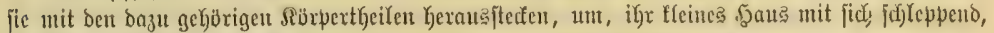

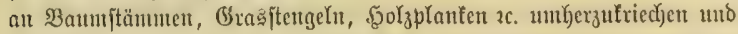
fid) Jutter zu fuchen, bie übrigen Fufe find überfluffig uno bafer zu

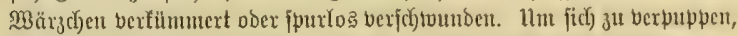

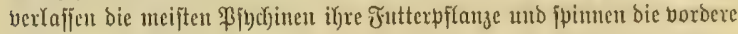
Mitndung ifrea Sactę an einten $\mathfrak{B a u m i t a m m , ~ c i n e n ~ B r e t e r z a u n , ~ e i n e n ~}$ Steit und bergleidjen fejt. Sobann fefyrt fich bie Raupe um, mit bem Sopfente gegen bie Ginten freie Münoung. Die beiberjeite ftumpf

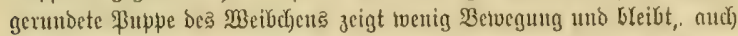
wenn ber Sclymetterting auştriedbt, am Grunbe Des Behäuję licgen,

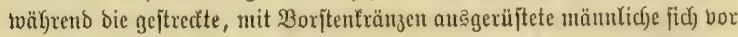

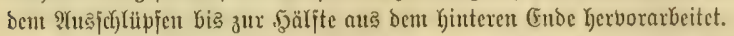

Der gemeine Sa fiträger, Mohrentopf (Psyche unicolor ober graminclla), mag als bie verbreitetfte $\mathfrak{A}$ rt ein $\mathfrak{B i l}(\mathrm{b}$ bon biejen inter=

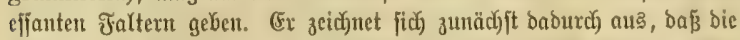
Raupen ber verjodiedenen (Bejd) (ed)ter verjdyiedene Säde fertigen. Der

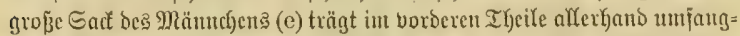

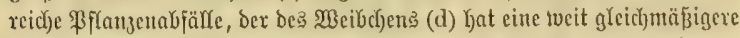
Oberfläd)e uno tviro nie jo Yang tvie jener. Da bie Raupe vibertvintert,

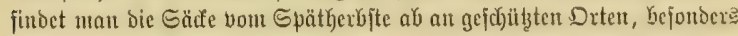

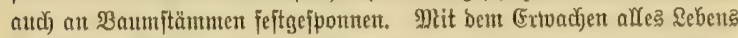

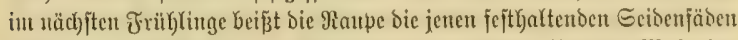

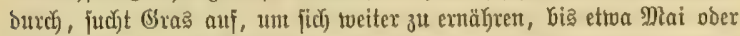

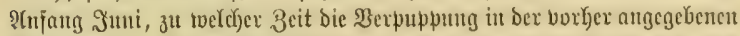

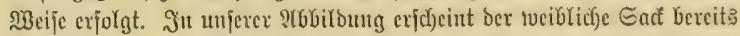

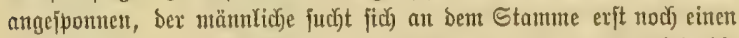

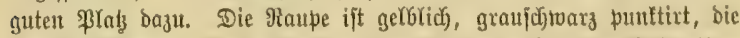

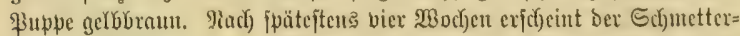

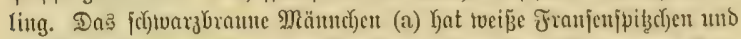

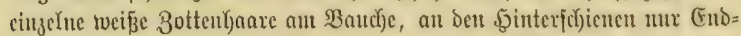

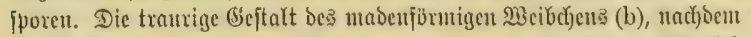

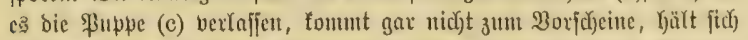
aber an Kinteren offenen (Enbe bes Eades auf uno toartet in Demuth)

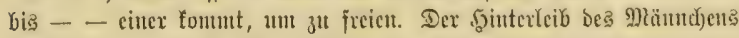
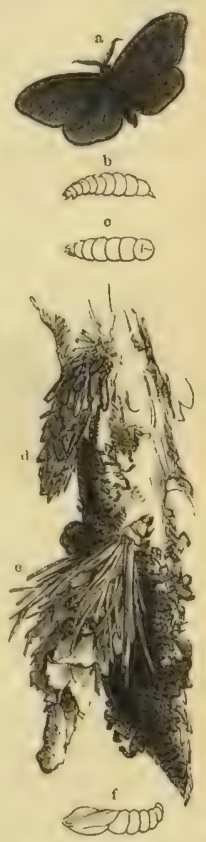

Gemsiner Eadträger (Psyche uniculor).

a Païnndyen, b פBcibdyen, o tociblidge Puppe bon unten, d tuciblidjer nngipounener Ëad,

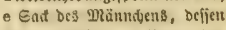
Raupe fidtoar, \& Buppe bes

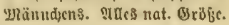
befibt eine ungemeine Strectbarteit und fant belyufa Der \$aarung tief

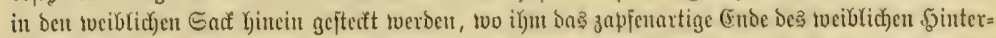

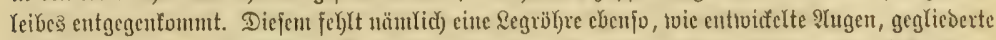

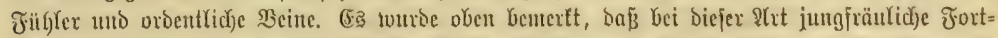

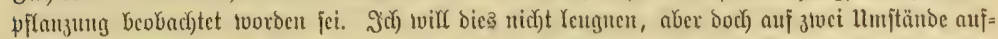

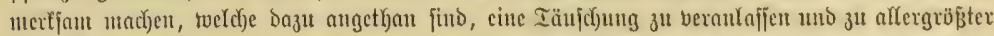

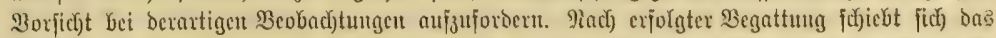

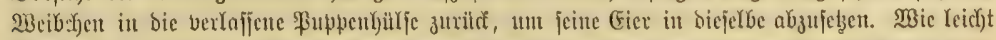

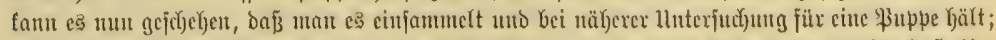

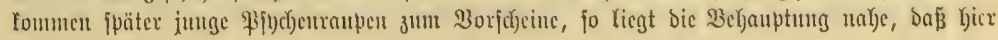




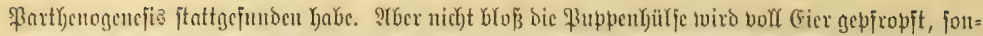

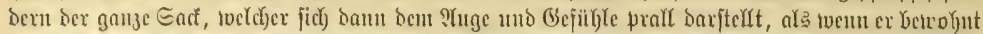

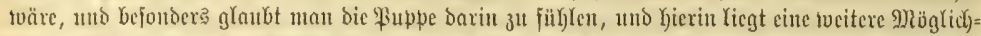

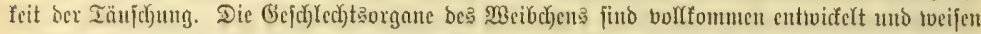

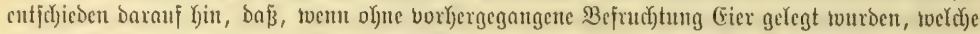

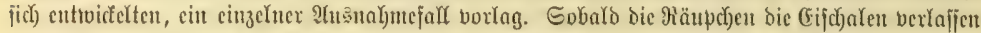

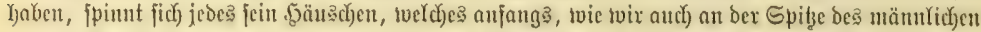

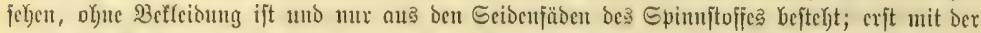
inurd) bas 23 d)

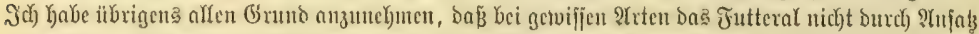
vergrößjert, fondern aufgezelyrt und burch) cin größeres, neues erjelzt twiro. Range Beit bient ber

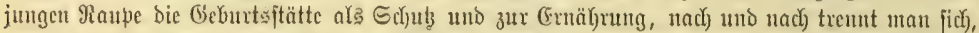

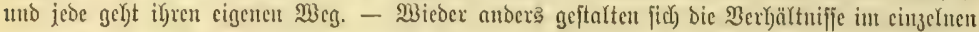
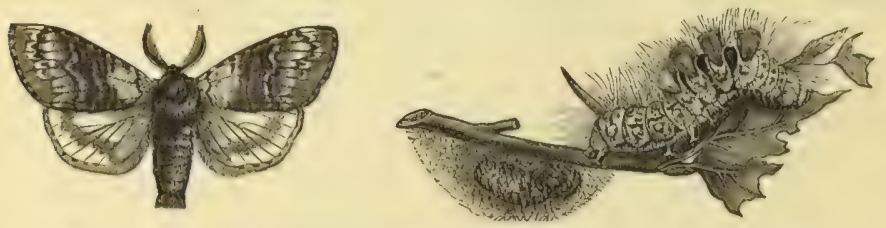

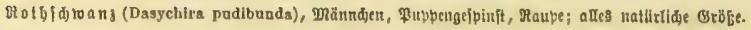

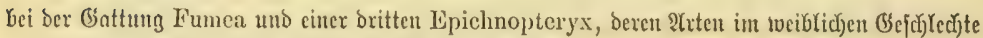
ctivas melyr entroidelt jino, als bie ber Gattung Psyche.

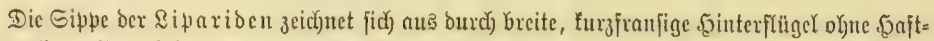

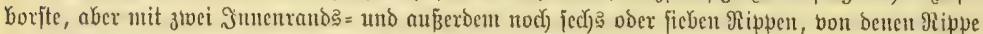

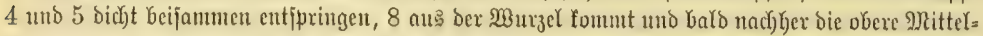

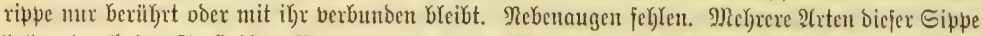

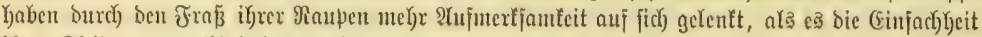
ifres Sitcibes bermocht kaben toürde.

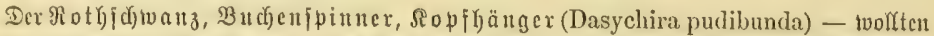

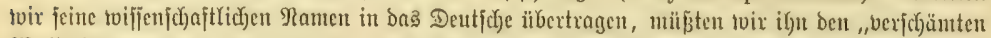

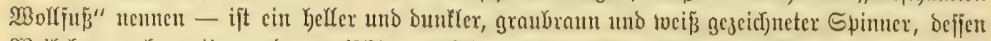

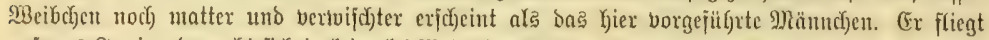

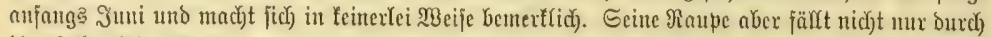

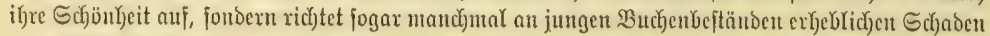

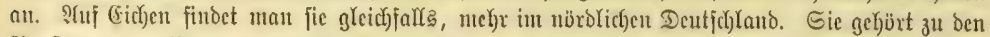

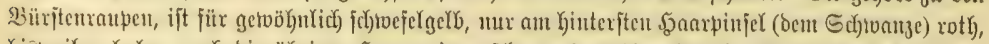

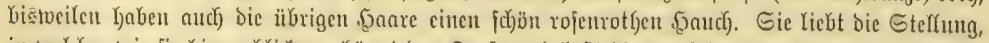

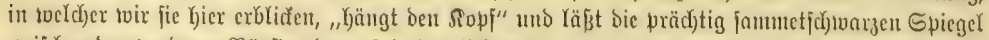

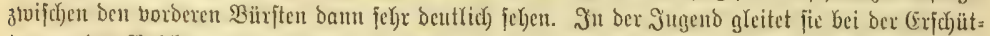

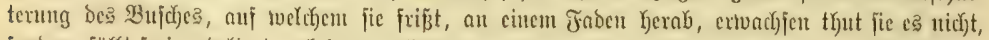

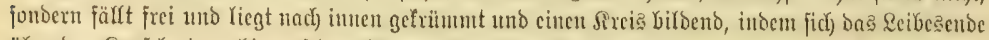

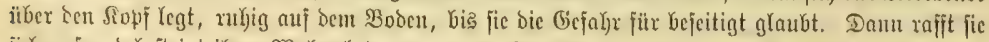

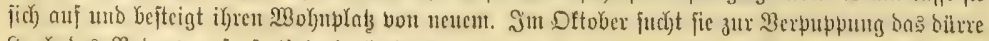

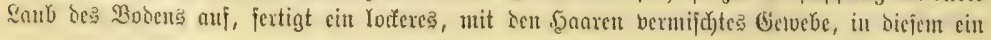




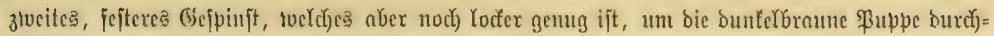
jajeinen zu Yaffen.

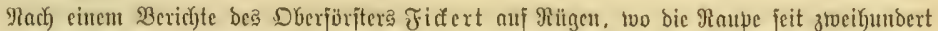

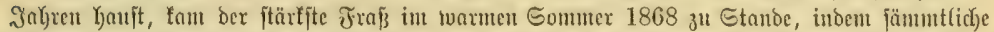

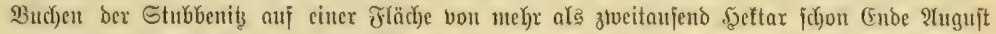

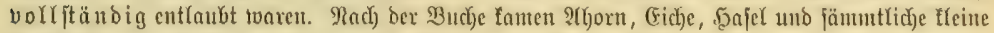

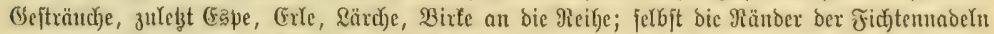

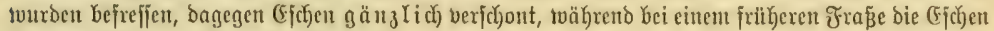

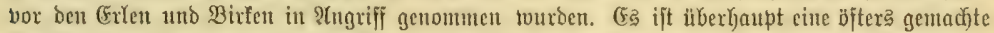

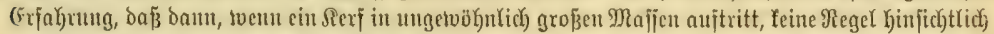

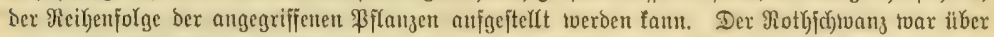

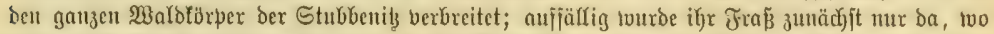

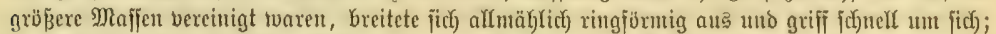

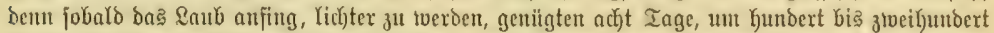

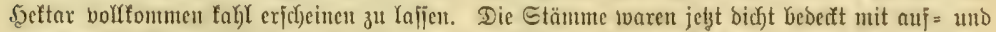

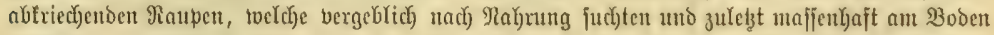

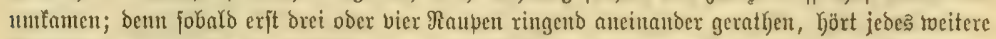

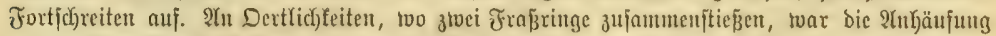

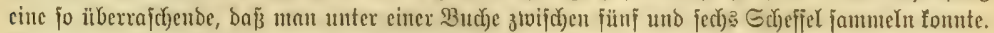

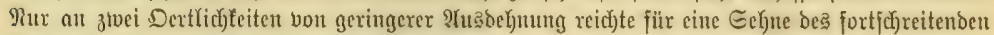

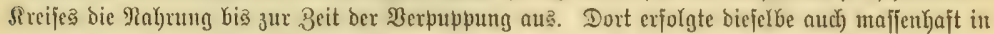
bem Bobenilberzuge, bent oben aufliegenden \&aube und an ben bemoojten Stämmen.

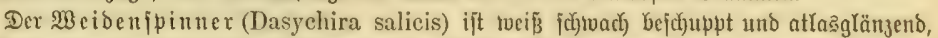

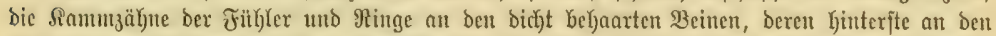

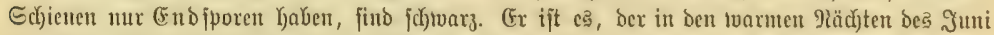

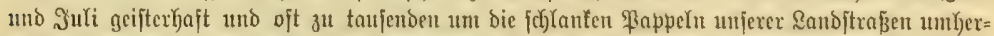

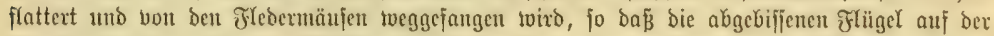
Etrape ausgeftreut Yiegen. Fu Tage crglänzen fie nuß tveiter Ferne an ben Stämmen, falfen

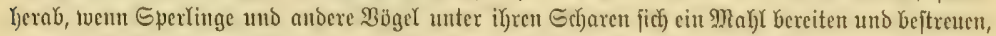

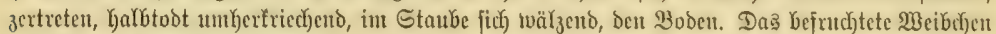

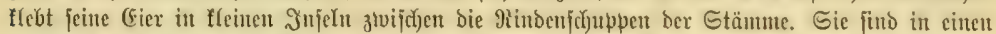

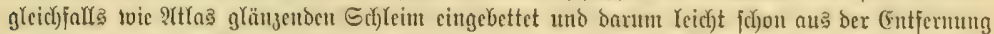

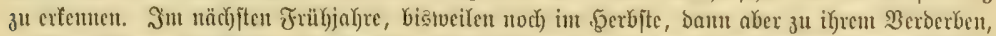

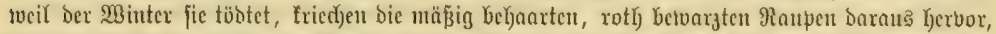

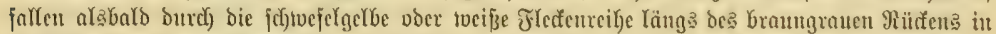

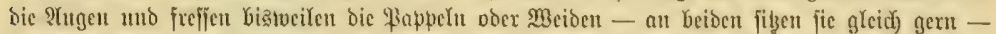

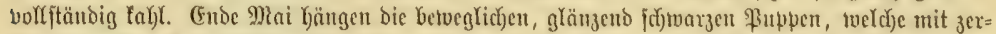

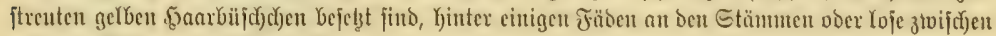
twenigen Blättern ber Futterpflanze.

Der Golbafter (Po:thesia chrysorrhoea) ijt gleid) dem borigen eimfarbig weiß̄, aber an ber

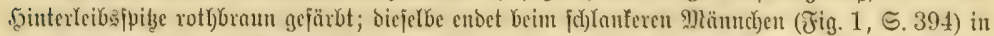

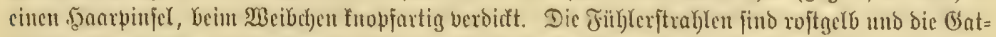

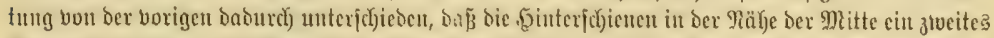

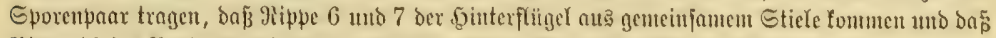

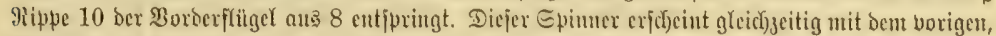

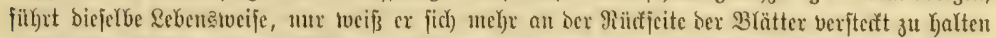

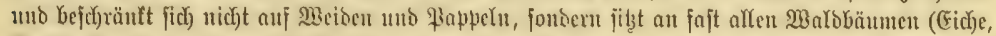

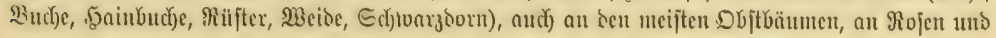




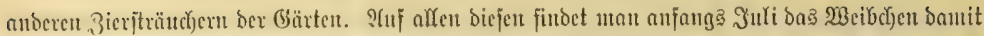

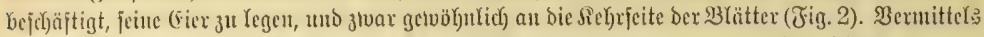

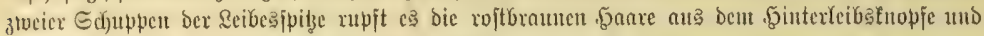

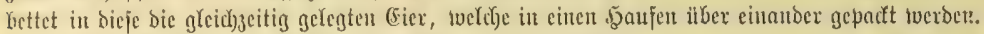

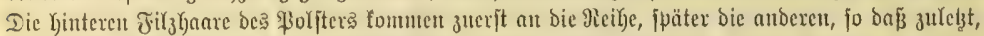

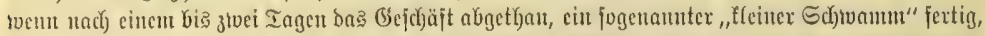

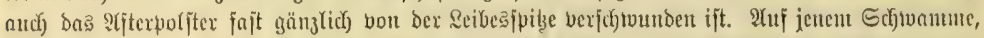

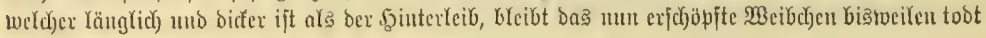

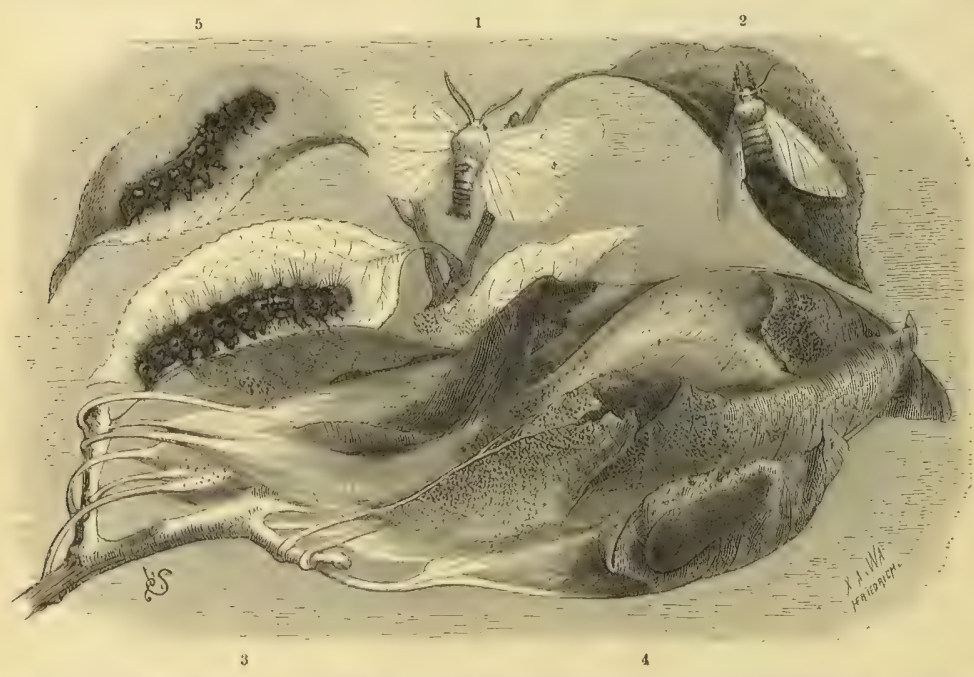

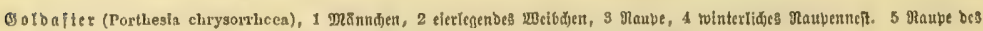
ङ d)

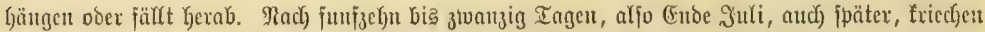

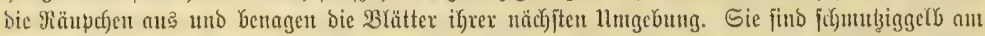

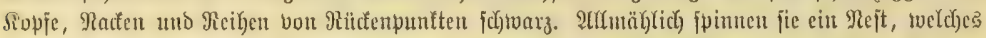

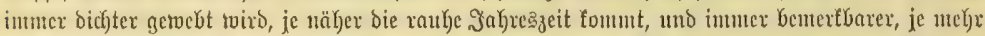

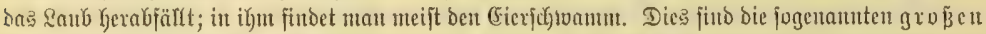

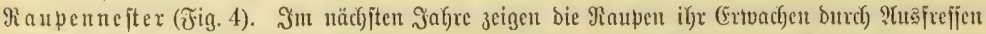

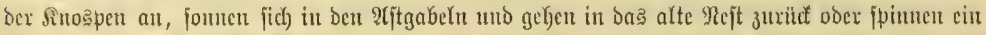

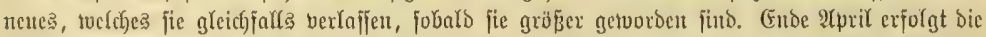

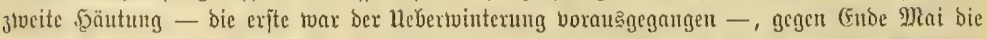

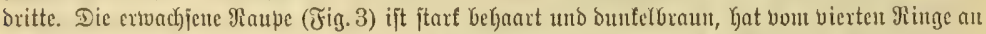

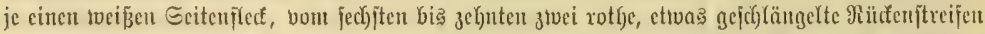
und je cine ziegelrothe $\mathfrak{B a r}_{3}$ mitten a

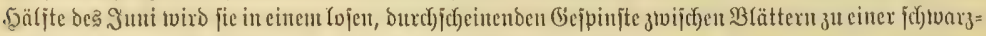

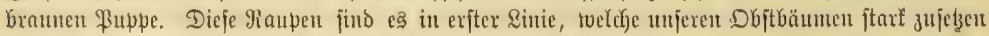

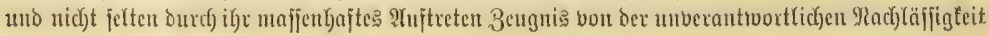




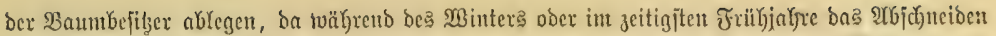

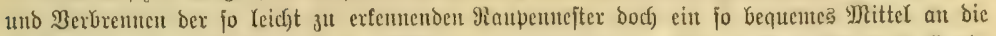

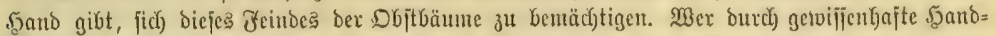

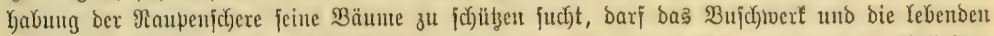

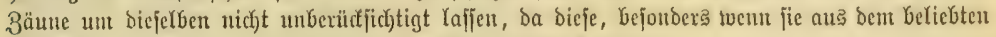

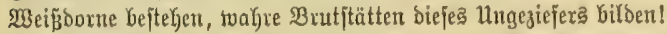

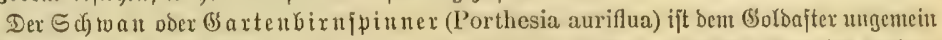

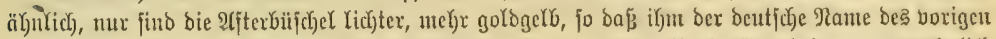

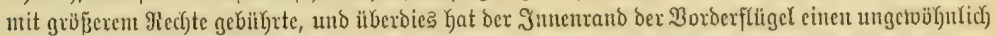

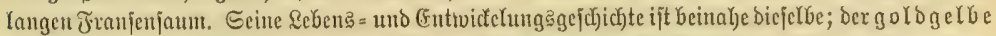

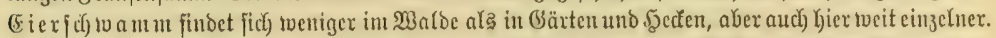

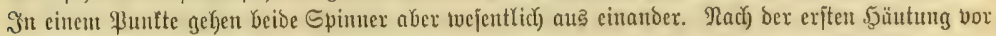

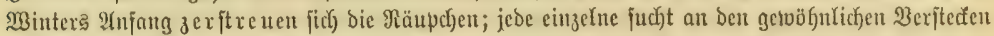

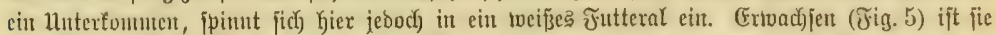

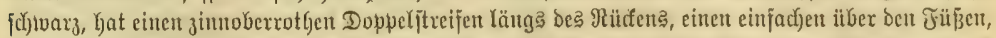

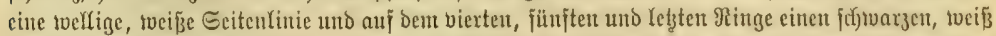

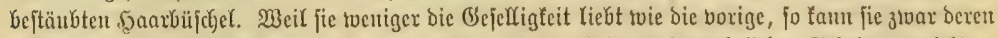

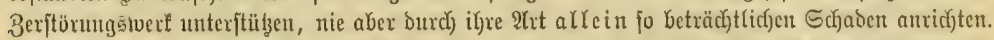

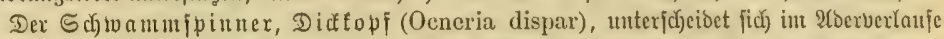

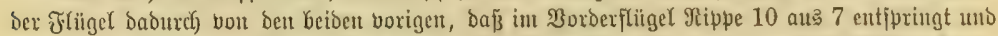

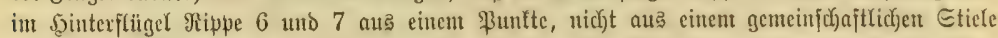
fommen. Die vier Sporen an ben Sinterfobienen Gaben beide (Sattungen mit einander gemein. Den

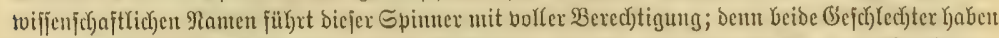

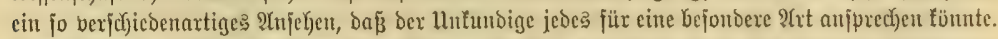

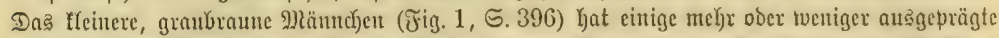

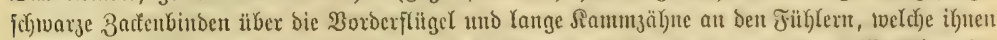

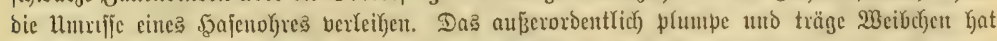

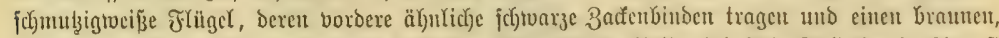

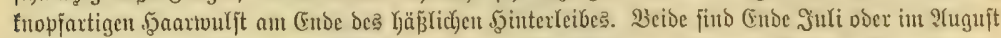

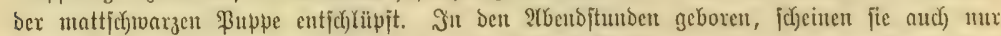

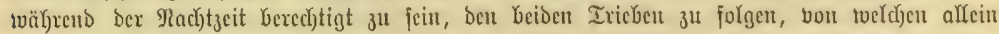

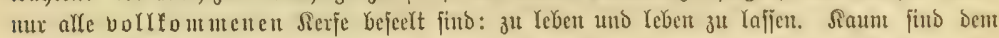

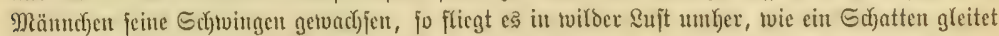

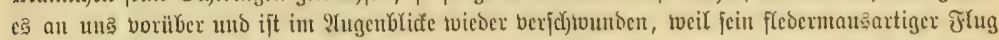

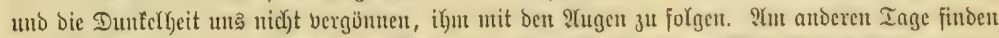

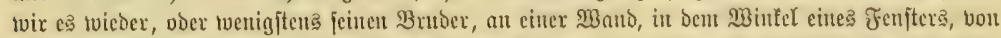

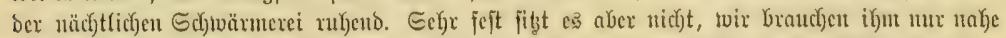

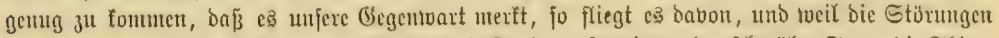

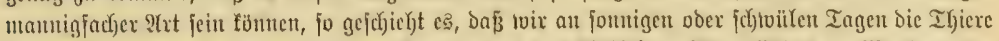

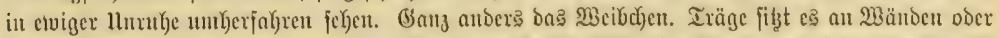

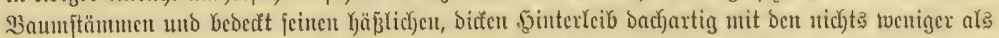

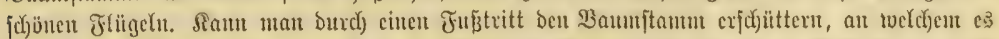

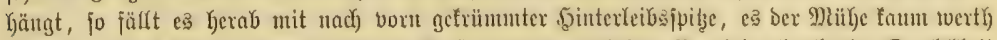

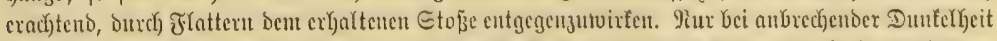

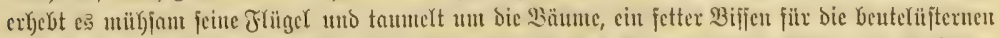

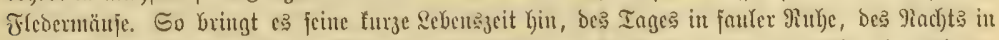

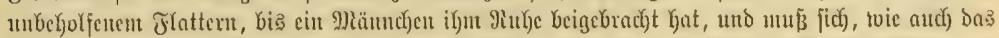

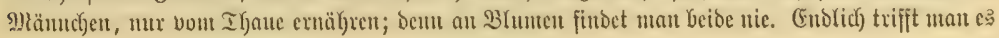




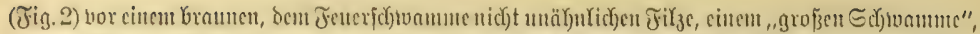

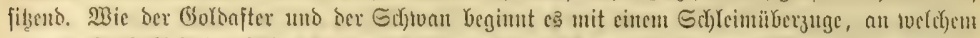

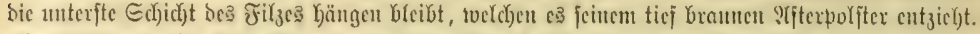

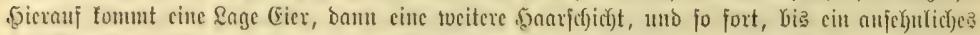

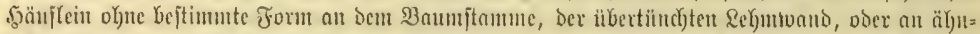

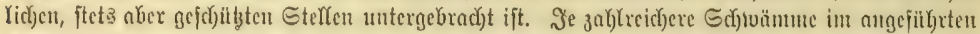

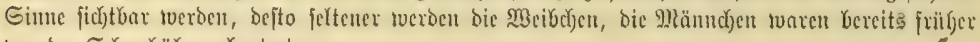
bon ber S(j)aubithne abgetretent.

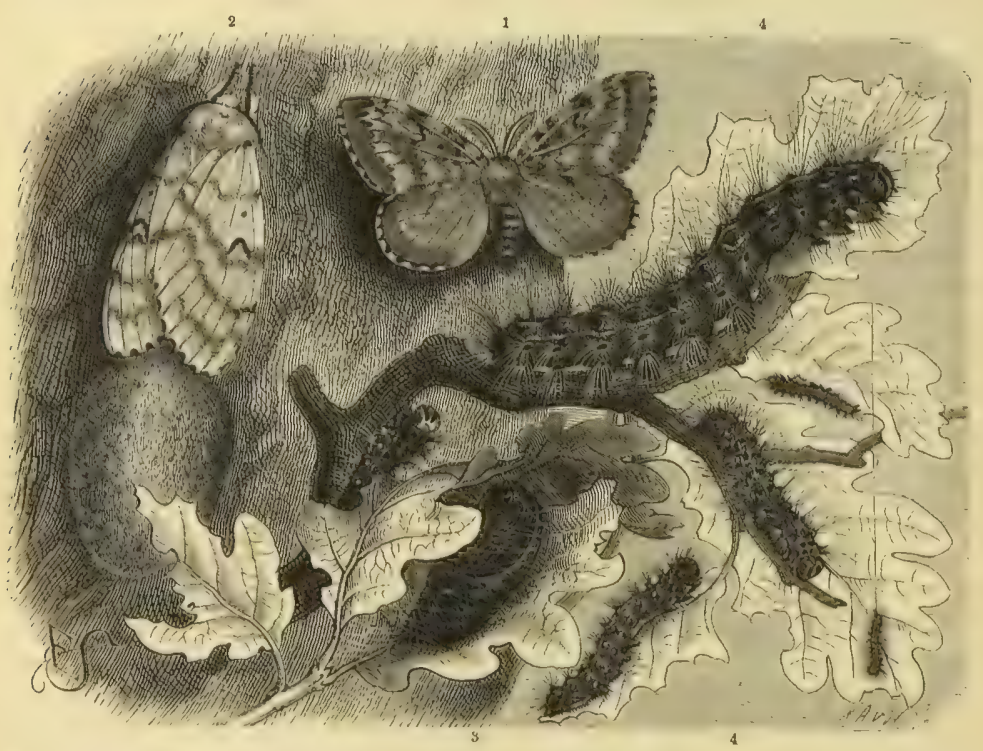

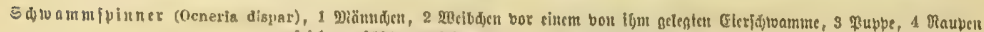

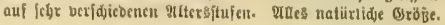

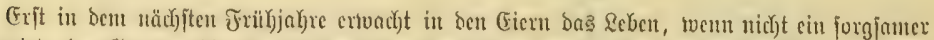

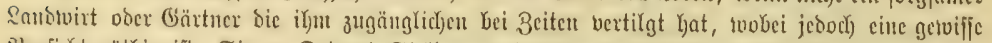

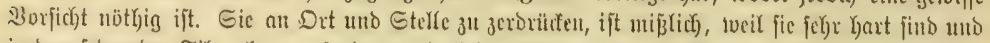

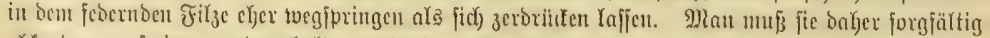

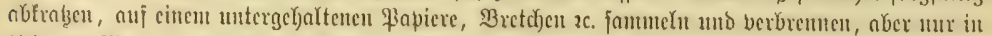

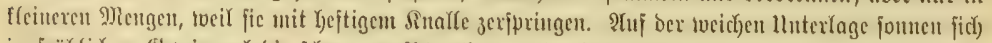

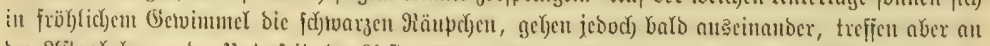

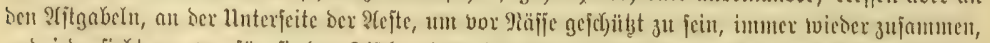

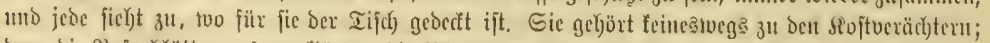

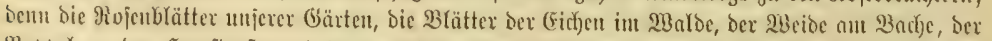

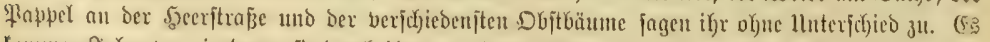

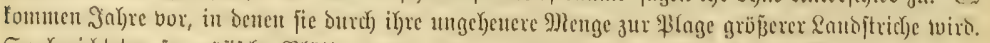

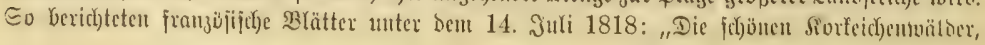




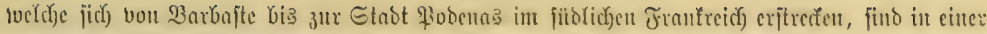

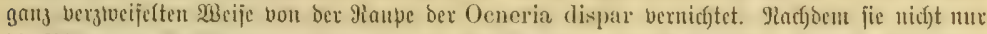

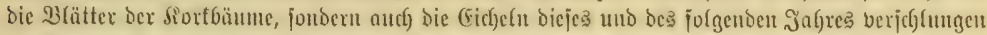

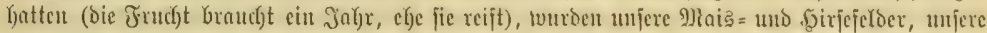

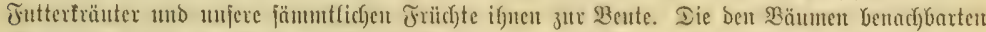

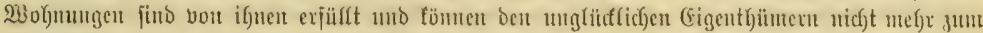

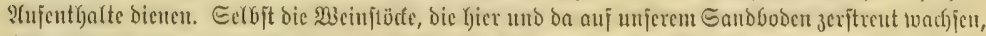

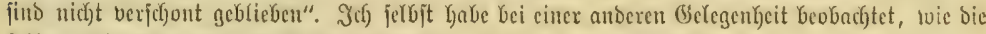

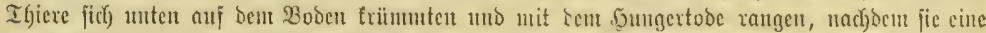

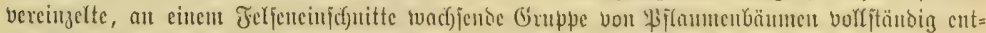

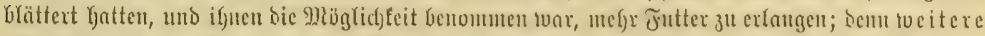

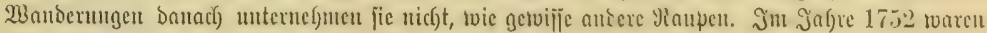
fie in Sachjen fitharentueije borkanben, fo bap fie in ben Gegenten von 2trtenturg, Beił, Raunburg, Sanger= haujeu nicht uur alfe Dbjtbäume, jonbern zum Iheil ganze $\mathfrak{B a ̈ l d e r ~ f a b l ~ a b g e j r e f f e n ~ K a t t e n . ~ D i e ~ F i g u r e n ~} 4$

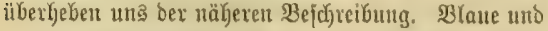

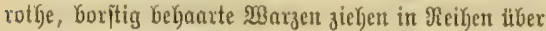
bett graubraunen Sörper, uno wenn bie Raupe exjt

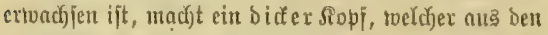
bichten Borjten herborjieht, fie Yeicft bor bent ilbrigen lingeziejer fenntlich. Bur $\mathfrak{B}$ expuppung jiełt jie einige

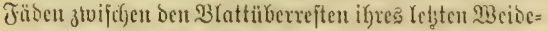

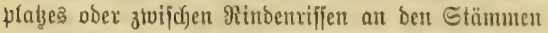

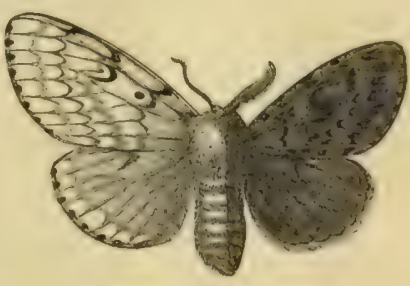

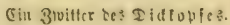

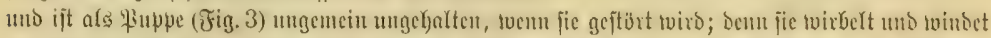

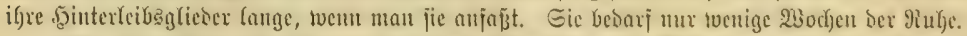

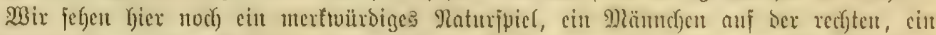

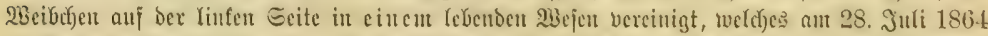

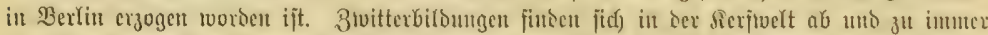

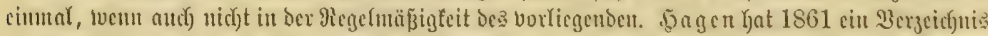

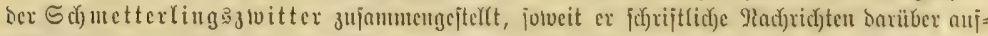

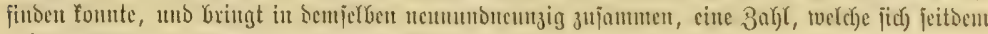
vermełrt hat, twie fochon ber borkiegende Fall Gelveift.

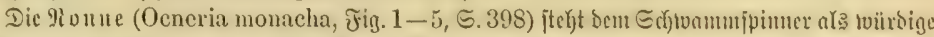

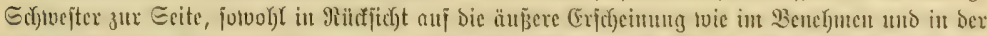

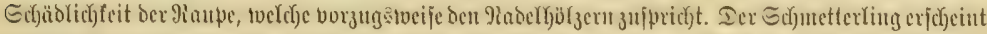

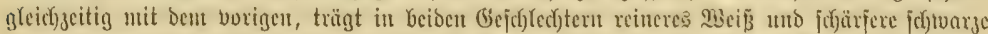

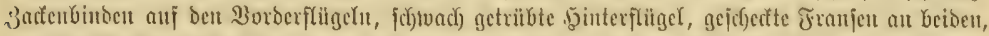

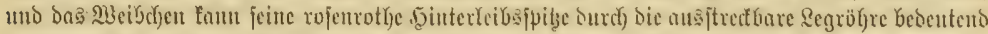

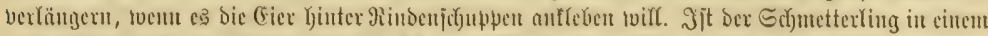

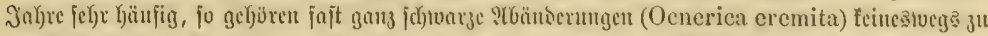

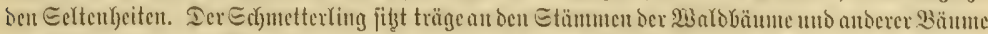

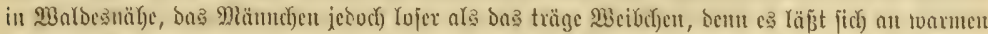

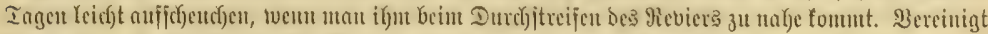

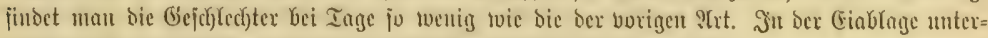

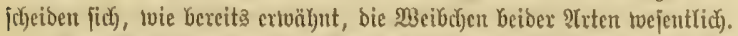

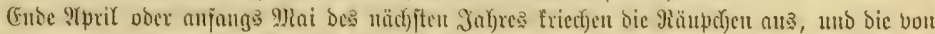

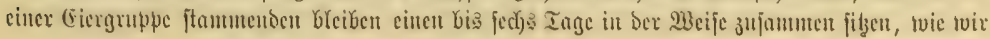




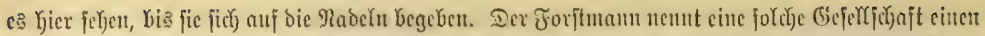

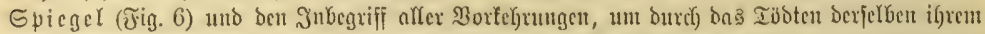

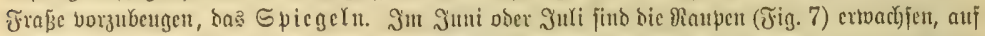

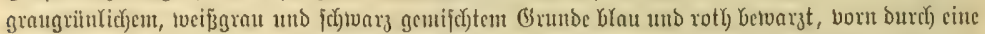

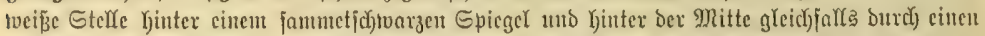

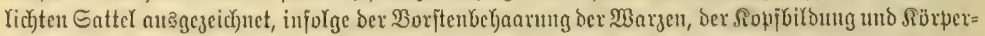

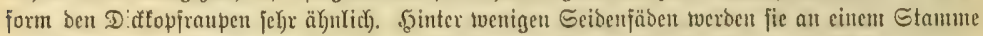

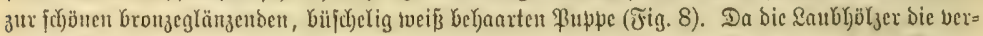

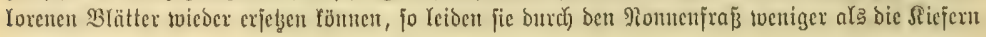

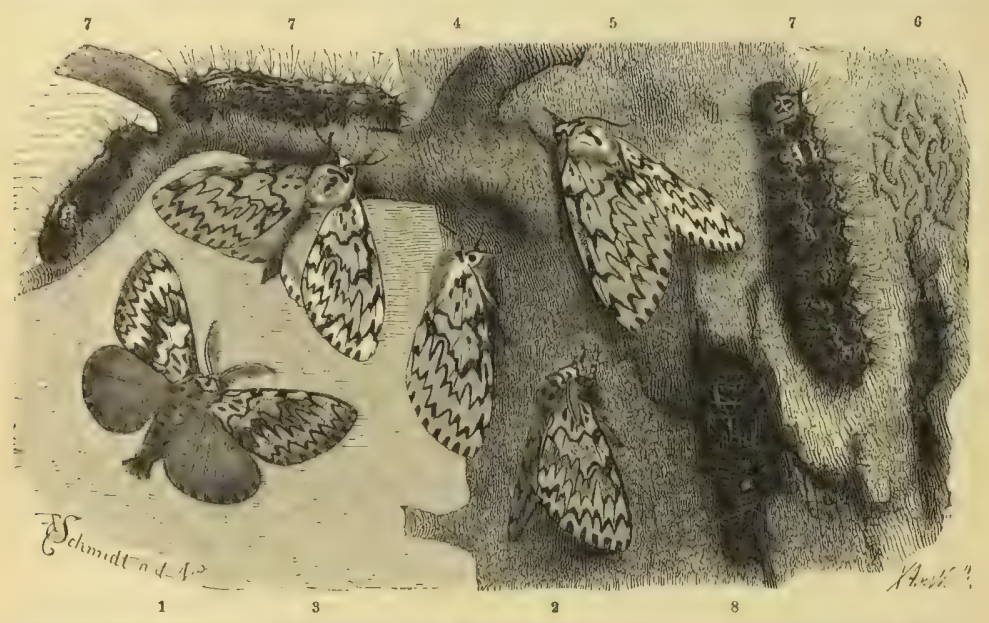

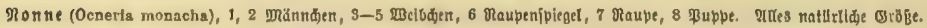

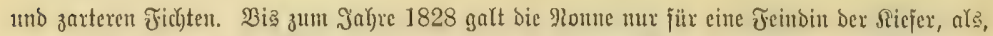

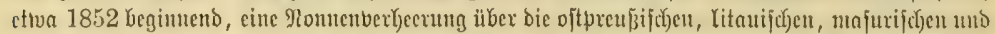

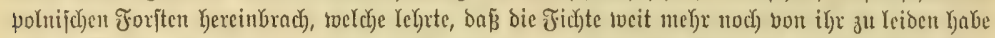

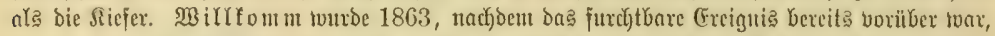

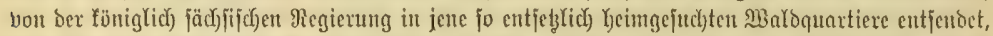

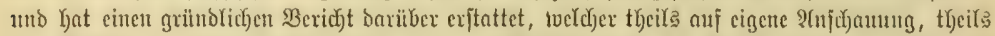

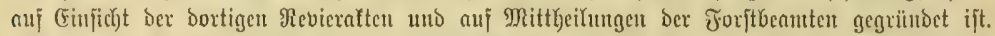

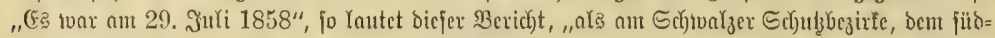

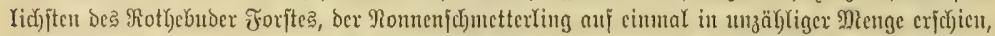

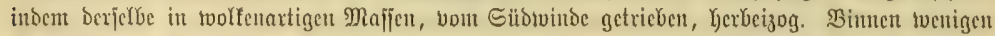

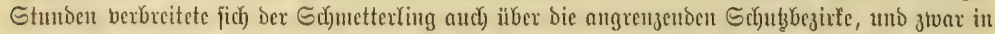

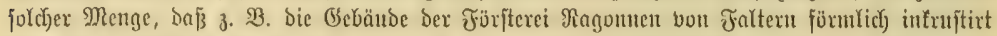

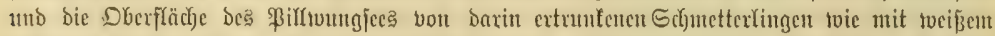

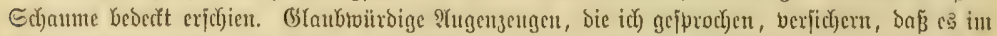

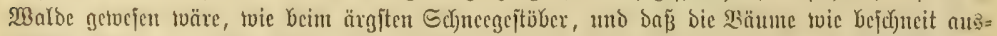

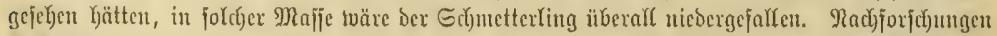

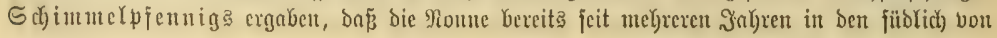




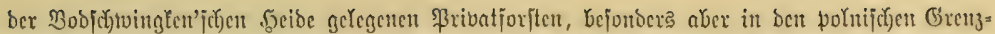

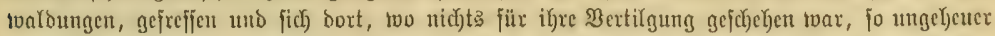

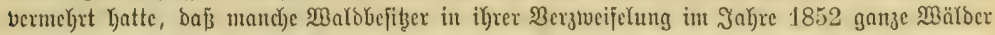

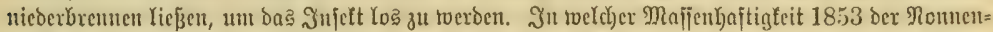

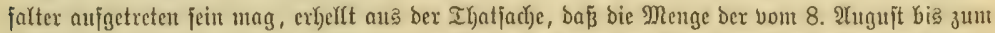

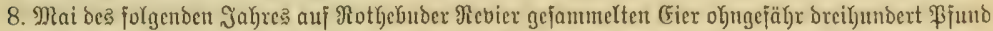

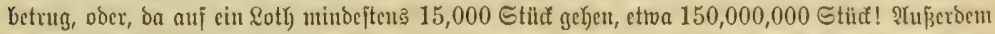

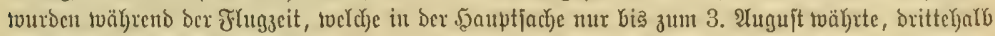

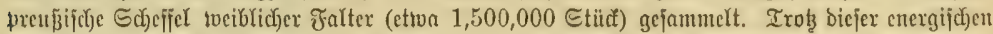

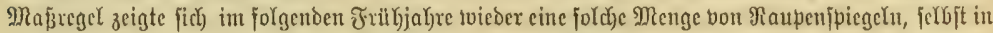

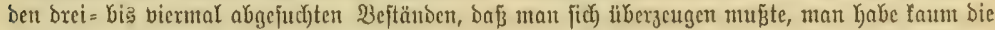

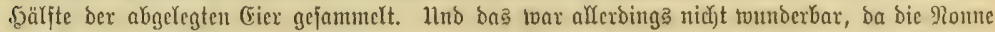

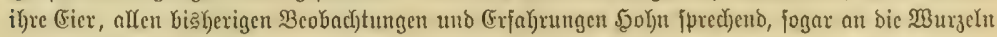

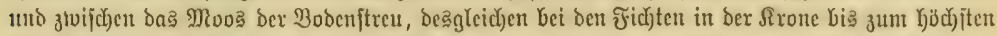

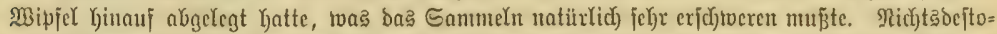
sveniger toaren in fajt allen Forjten, two ber Schmetterling fid in Menge gezcigt hatte, int ganzen

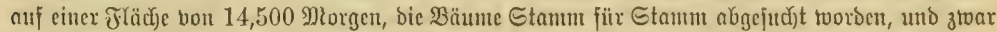

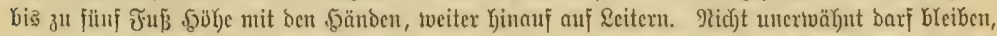

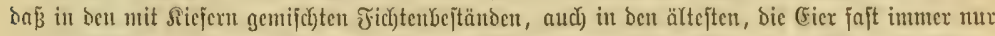

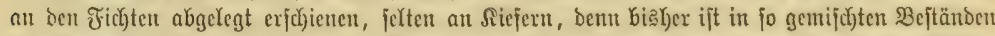
bas (Segentheil beobnd)tet wordon. Die meiften (Fier fand man imuner an alten jtarfen Jid)ten

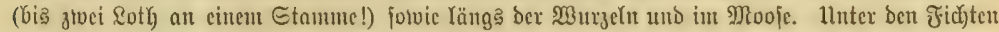

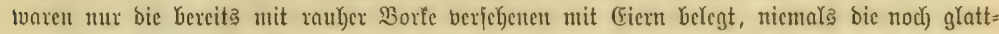

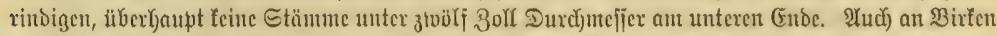

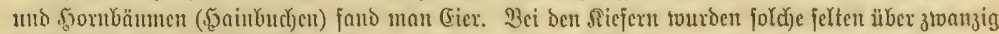

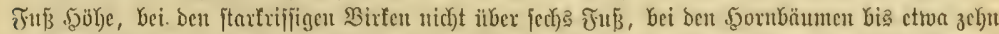

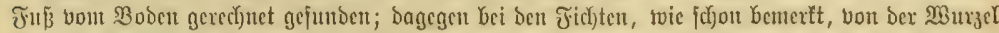

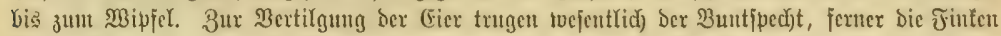

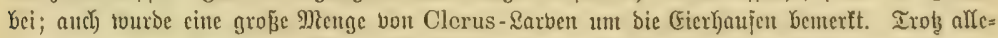

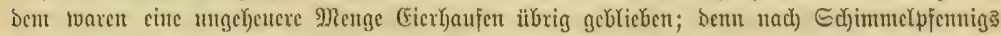

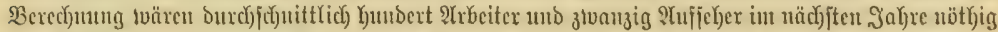

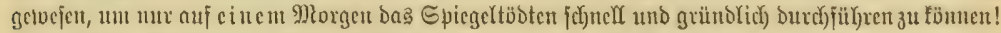

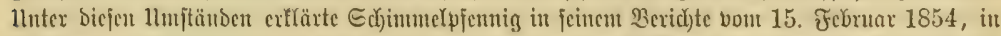

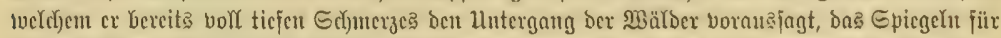

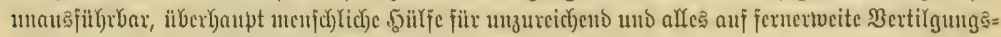

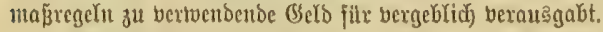

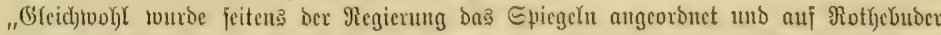

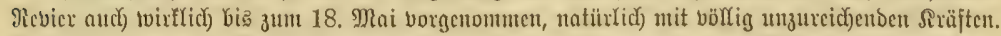

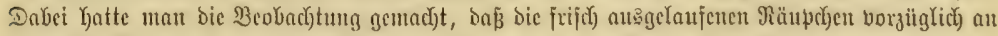

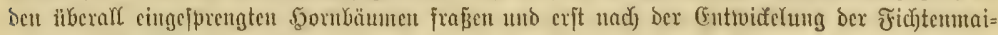

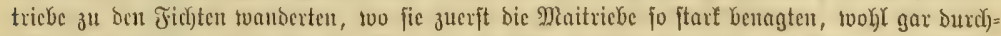

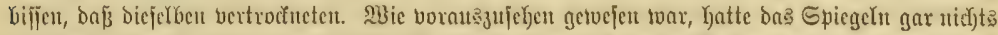

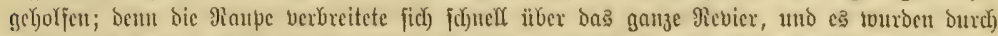

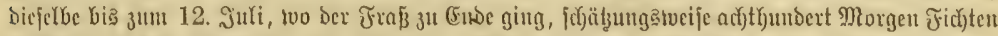

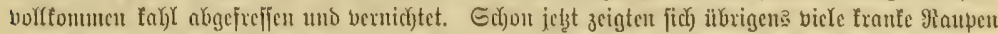

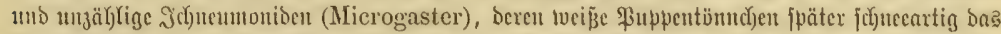

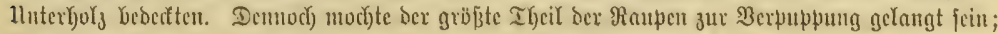

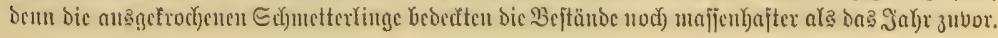




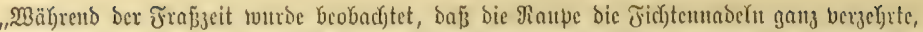

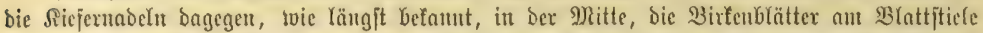

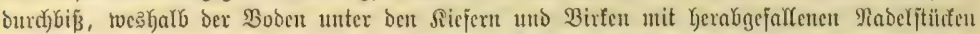

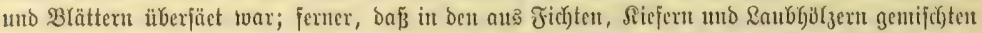

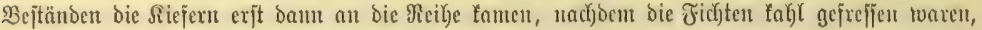

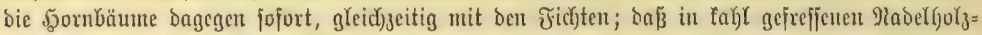

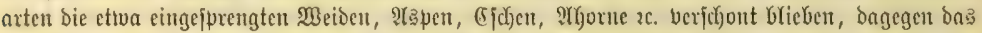

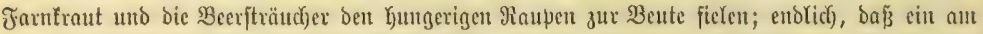

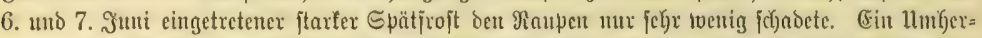

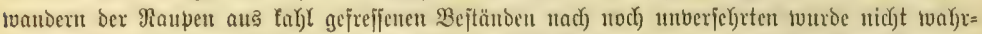

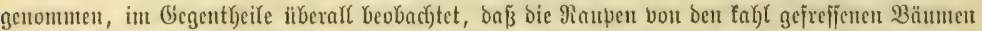
crmattet herabjtüraten uno fich) unter Deren Ec(jirmfläd)e anjanmelten. Bicle Derjelben mögen uicht

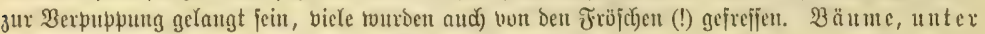

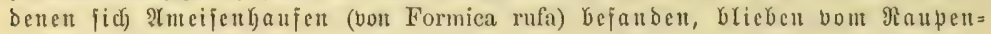
jraje verfactont.

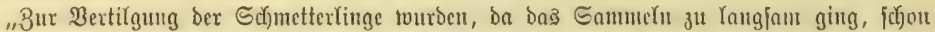

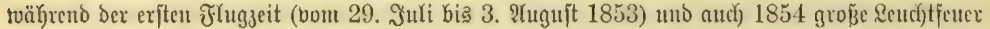

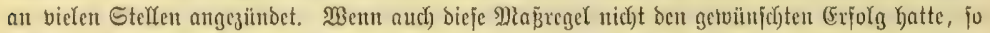

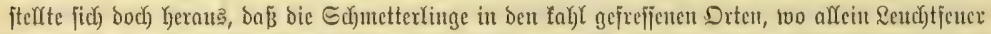

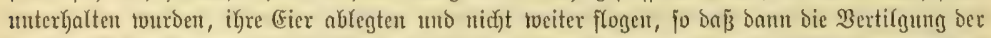

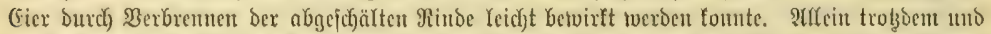

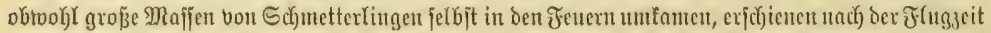

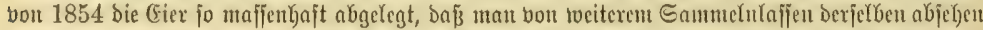

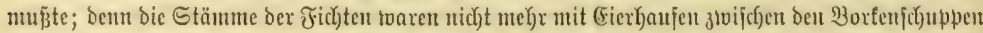

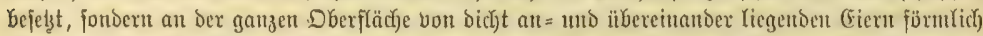

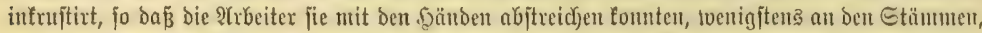

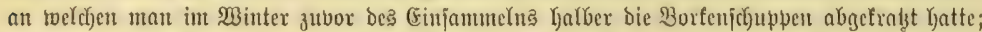

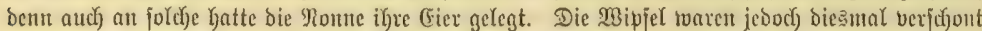

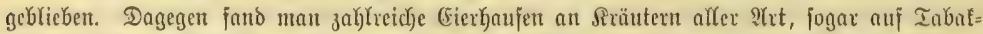

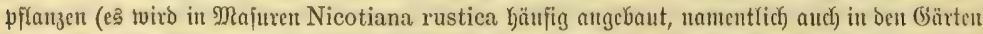

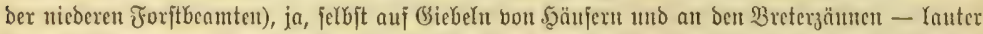

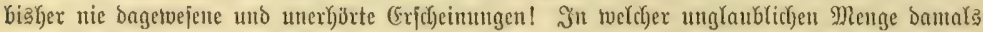

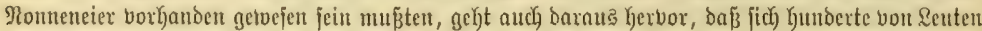

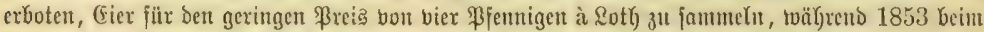

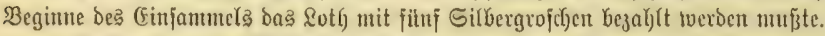

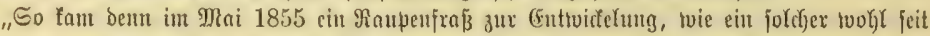

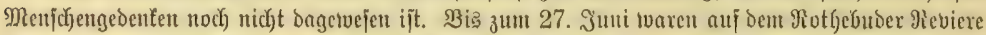

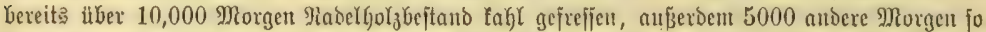

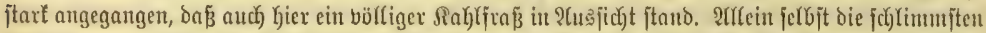

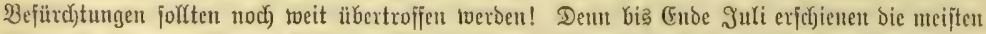

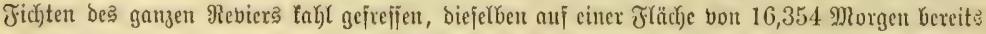

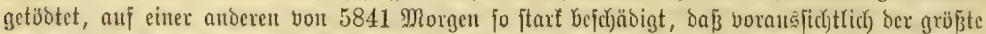

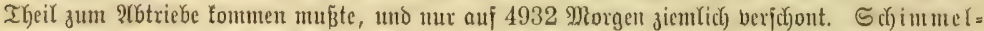

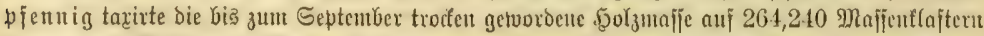

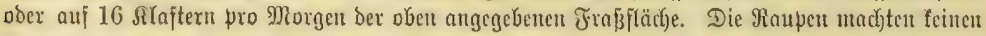

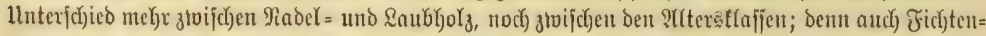

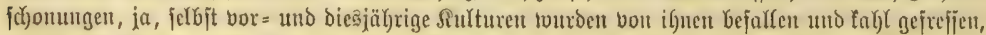

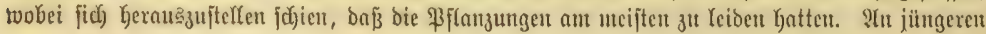




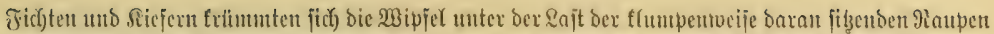

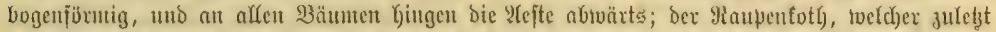

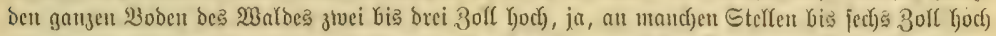

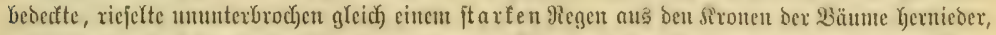

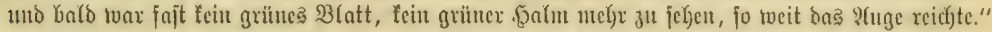

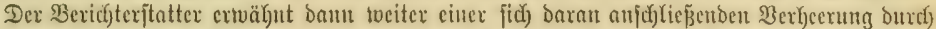

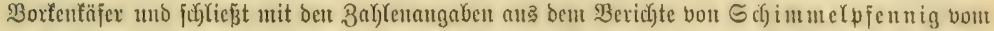

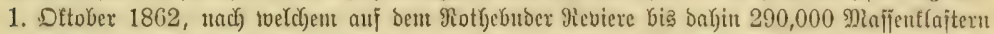

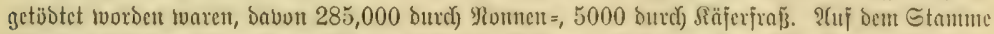

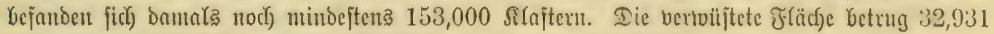
Drorgen uno Gatte fich jonit beinabe über bas ganze Revier erjtrect.

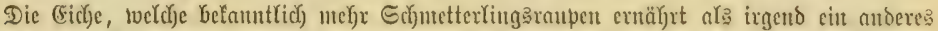

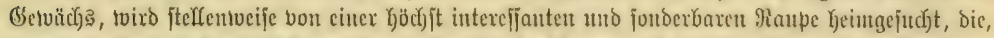

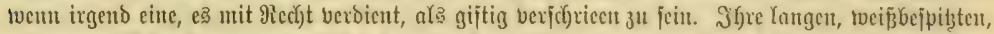

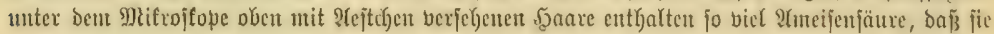

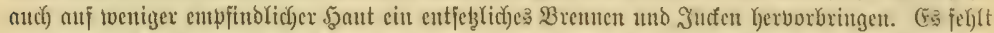

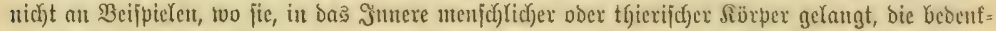

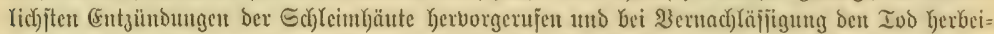

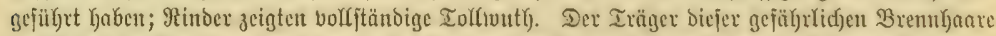

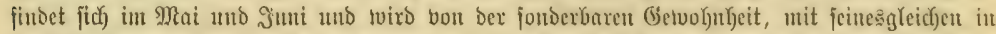

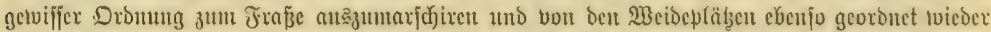

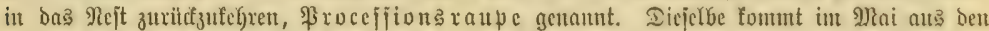

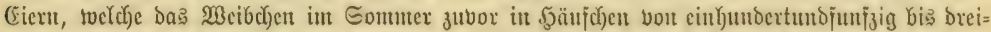

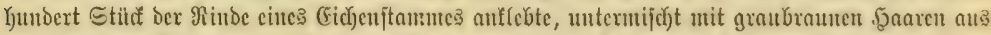

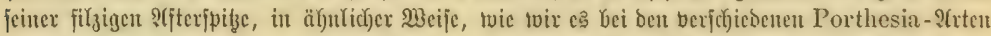

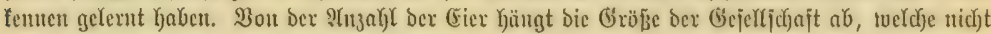

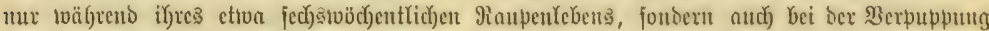

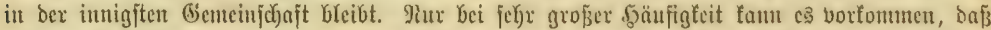

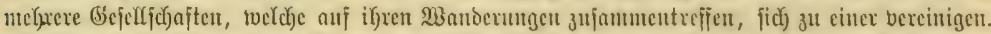

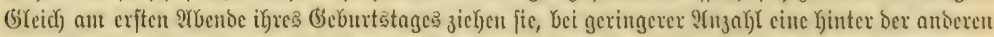

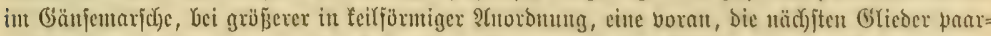

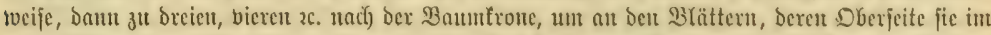

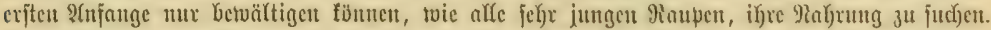

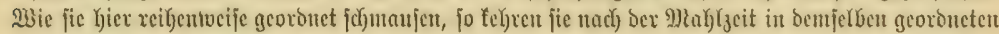

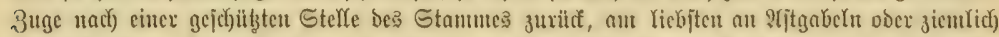

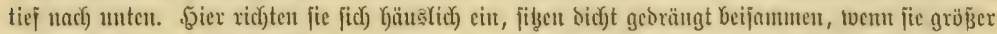

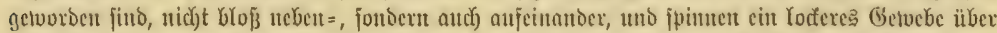

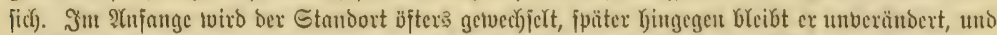

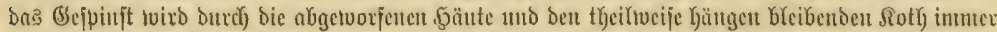

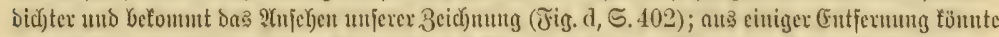

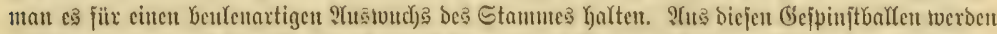

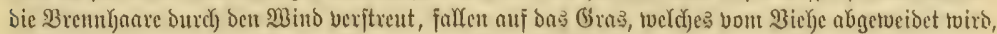

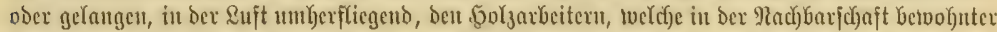

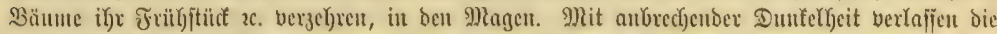

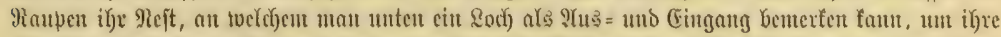

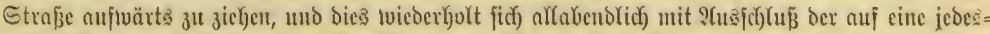

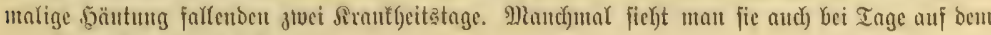



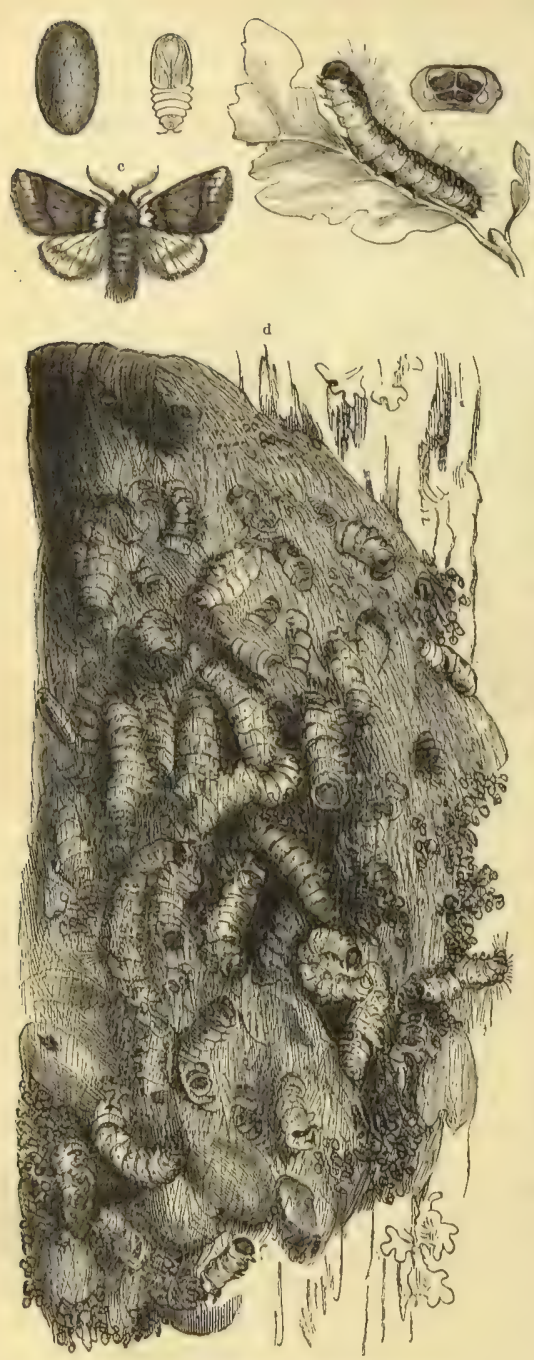

(E) d en: Broceflionsfpinner (Cnethocampa processionea).

a Vaupe, bancben ein Vilidenidito. b ßupve nebit Gschöule. c Edimetterting. a Etila eises getifes nads einer ber Icsten

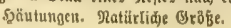

Boben Ginzichen, vielfeicht irgenonie uno

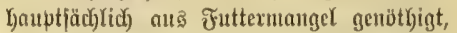
ifren Saum uno ibr Meft ju verfaffen. Der Bug getülfat bam einen höbjit uberrajd)en= Den Intblid; twie eit bunftes 2ano, eine

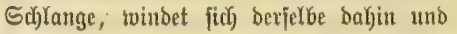
fonment nur Iangjam bon ber Stelfe. Die Raupe (Fig. a) Gat cinten breit Glaufichnarzen

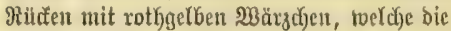
Saarfterne tragen, und veiphliclye Seiten. (Ertwachjen 39 bis 52 Mlintinteter Yang, beo

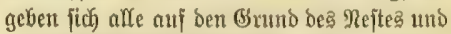
bereiten Reiben bon (Seppinften (Jig. b), wehiter nit eitem ifrer (Enden unter rechten $2 B$ infel anf ber Stammoberfläcje fteben uno fejt mif einanber verfunben find. Sic eximtern in

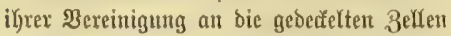

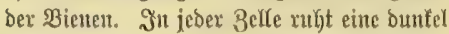
rothbraune \$suppe (Jig. b), Deren \$auth) ringel ¡djarje giänoer haben.

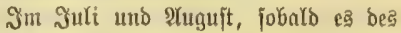
abenos з bämmern beginnt (nac) acht Uhr), tomunen bie Schmettertinge aแs jenen Ker. vor, beren Mtänndiden burody baldiges Davon= fliegen ihre 20itokeit zu extennen geben. Sđd) jabe bie Iflete oft gentg erzogen, mert, twitroigertweife in Freien aber fein cintiges зи Befichte befommen. Das jochlichte, bröums

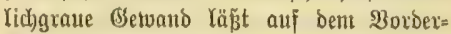
flitgel einige dunflere Duerlinien, beffer bein

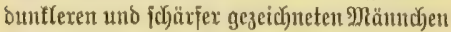
(す̛ig. c) als beint Weibutyen, erfennen; ben

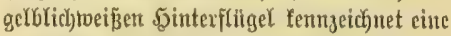
vertwifacte Querbinde, fieben Rippen ipan= nen ibn, und eine Şaftborjte bereint ifu im Fluge mit bem vorderen, tuelch)er bon zroblf Rippen burdyzogen toiro. Bei beiben $\mathfrak{B}_{\mathrm{C}}=$

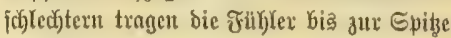

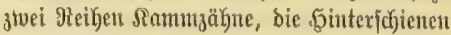
nur (EnDjporen; von einer Rolfunge iit nichts zu bemerten. Die $\mathfrak{A}$ rt verbreitet fick im jublidjen uno nordwejtrichen Deutjod)= land, in ber (Ebene melyr als in Gebirge, utb exreidyt nach Speber bei fgabelberg ifre Polnagrenze.

(Fine andore felfre äbulidide 2(rt, ber Riejeru= Brocejfionspiuner (Cnethocampa pinivora), treibt ibr $\mathfrak{W}$ ejen ebenio, 


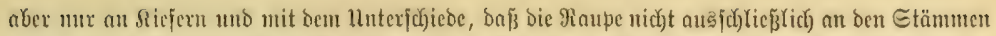

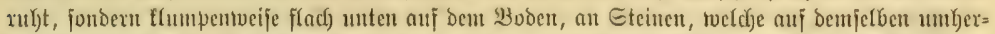

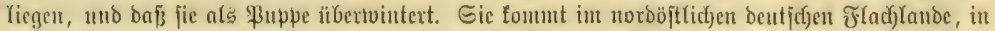

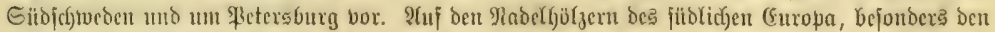

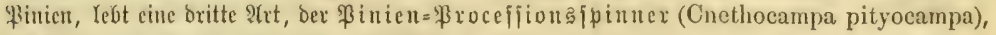
weldye in ber Rebenstweife ber borigen jefre nahe jteht.

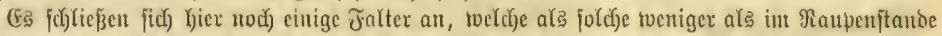

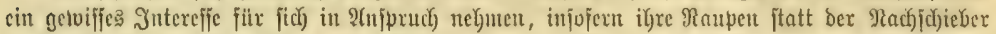

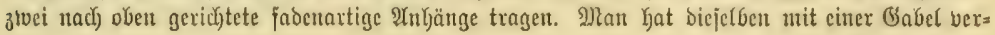

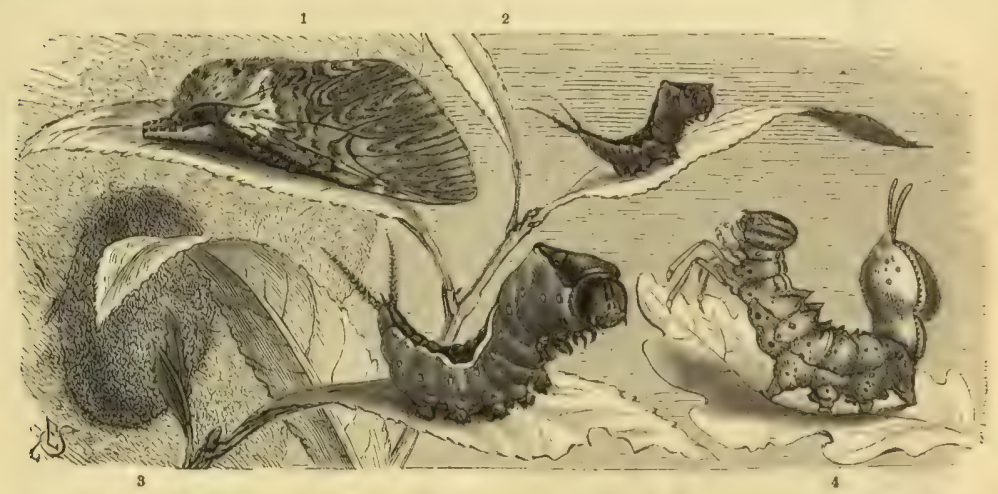

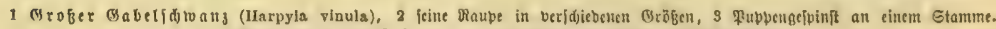

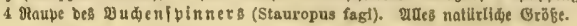

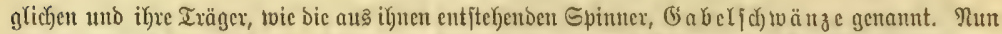

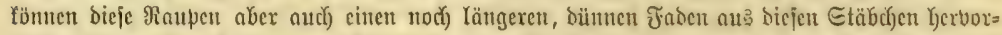

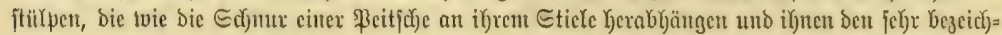

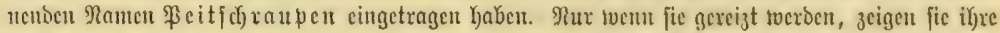

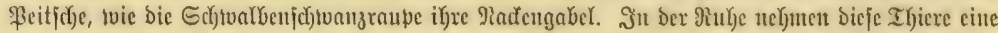

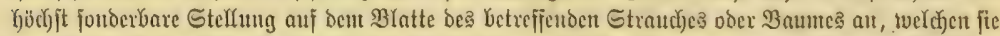

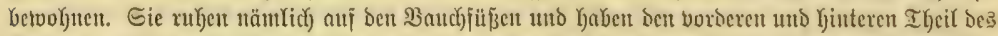

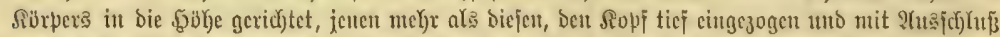

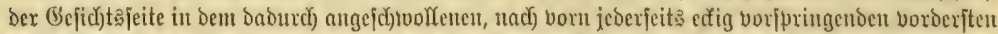

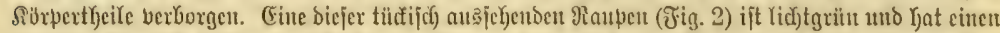

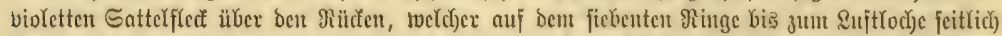

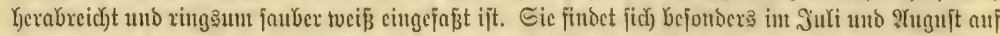

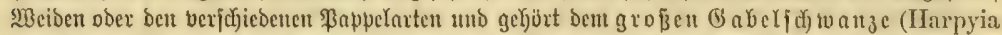
vinula, Fig. 1) an. Bur Berpuppung benagt fie ben Gtamm ifyer Jutterpflanse uno fpinut ityer Do

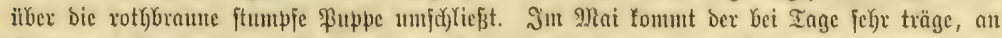

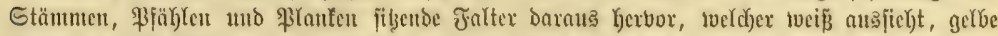

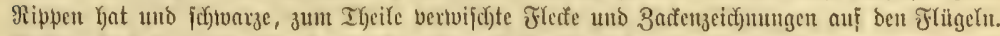

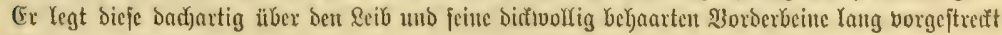
bidet neben cintander. 


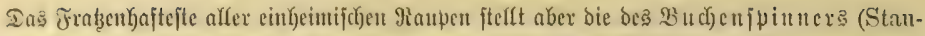

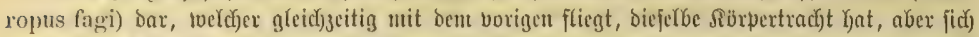

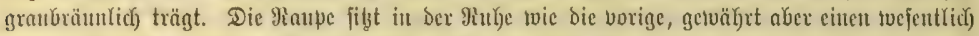

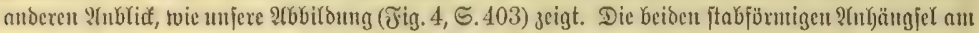

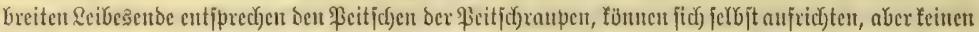

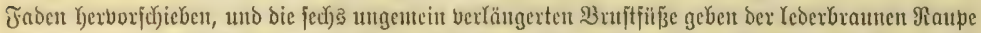

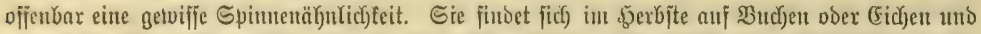

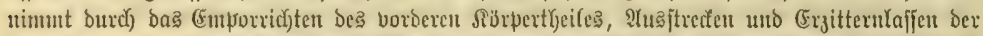

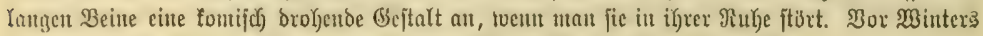

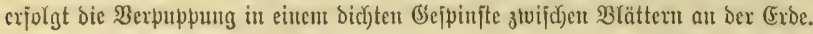

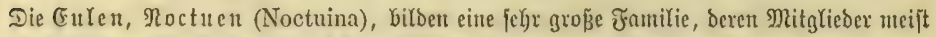

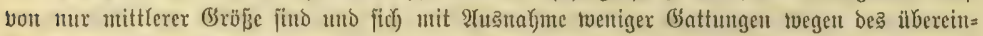

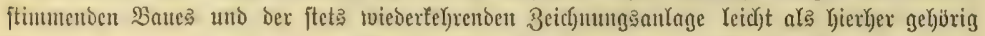

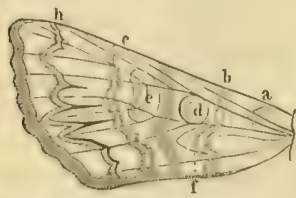

Cusmalifher Borberflilght ciner Guls. a Satbe, b borbece, o fintere-Quertinie, d Dins=, o 9ticren=, i 3apjenfted. l. 2 teflentinic.

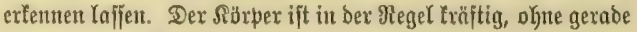

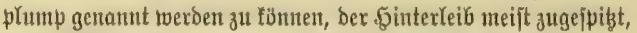

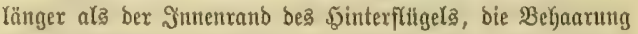

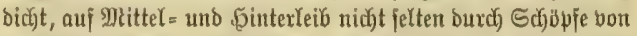

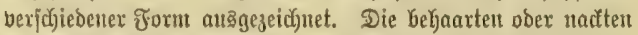
2ugen Yeudsten im Dunfeln, গRebenaugen nabe ben zufaumen= gejęzten fehlen mur in feltenen FäLen, futo aber unter ber bid)ten Belfanung verftect. Die Gorftigen Füh)(er fito etwas länger

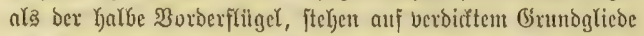
und tragen in Der Neget Mimperboriten, bei ben Mänuthen tweniger $\mathfrak{A}$ rten Rammzähne ober pinfelartig betwimperte Säges

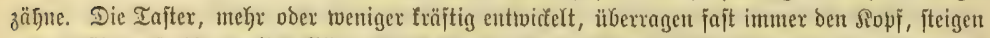

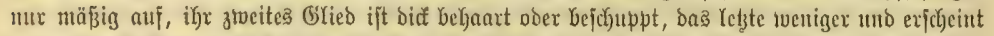

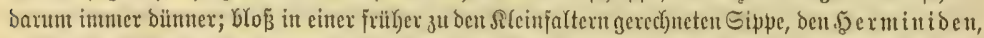

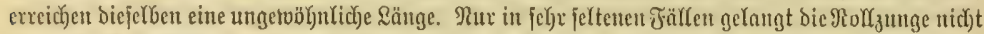

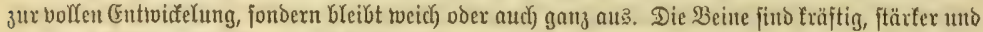

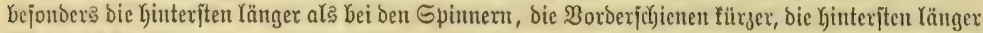

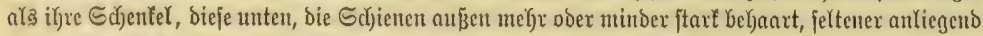

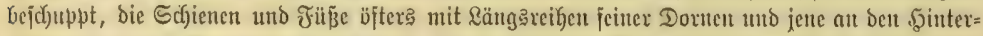

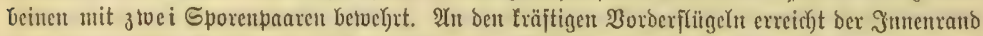

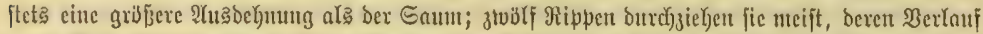

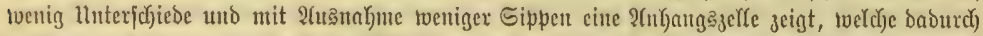

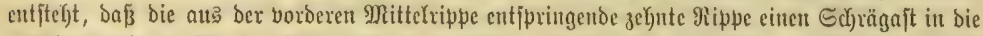

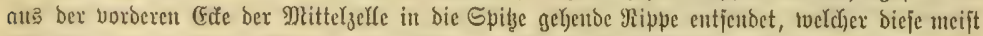

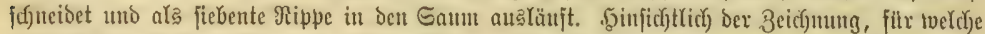

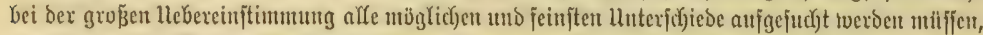

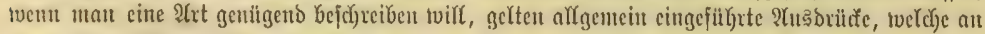

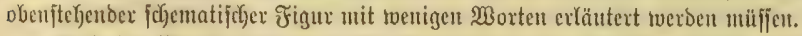

Malje der Wurgel zieht bie Galbe Duerlinie (a); bie beiben ganzen, bie borbere (b) und bie Gintere (c), tourden f(c)on öfters ertoälynt, uno tvix tviffen, Daß̧ fie bna Mittelfelo begrenzen.

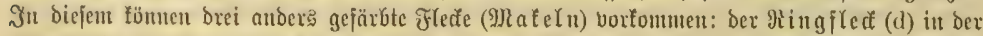

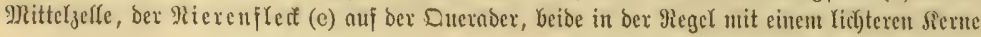




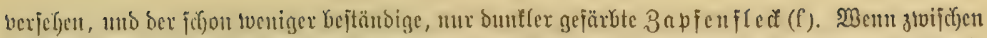

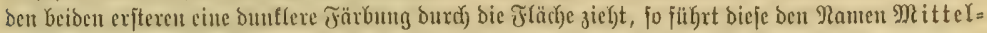

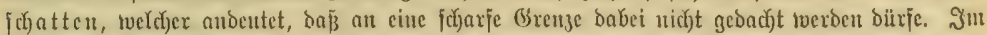

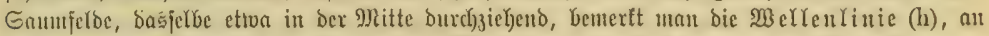

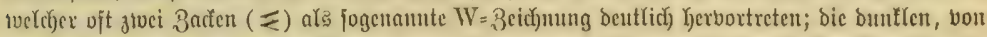

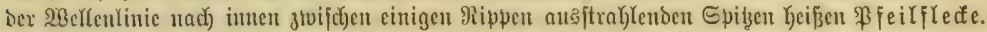

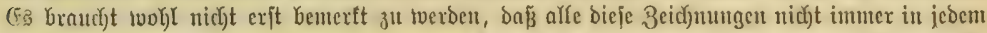

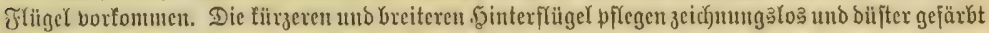

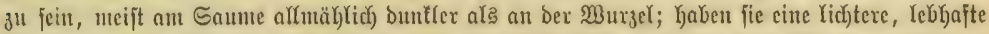

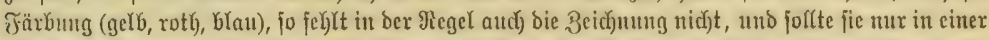

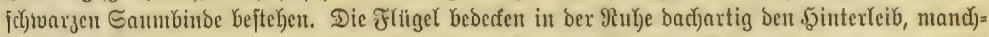

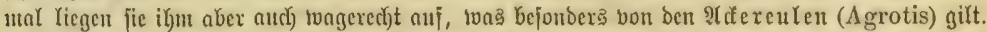

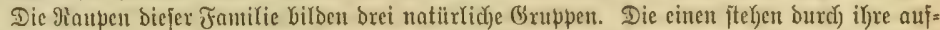

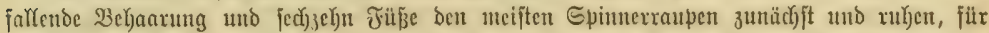

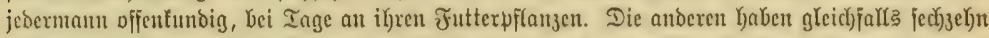

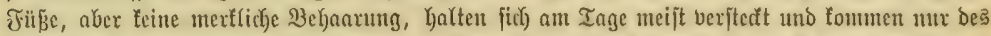

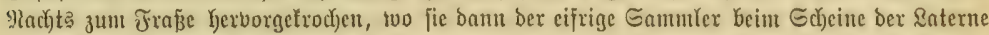

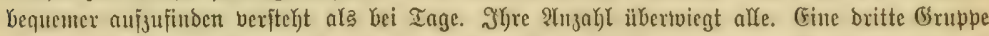

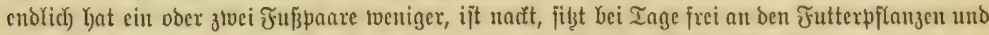
bant in ifyrex erjten (Sigenjichaft ben (Enlen bic Brilde zur nächjten Famiłie, ben Epannern.

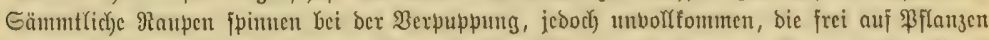

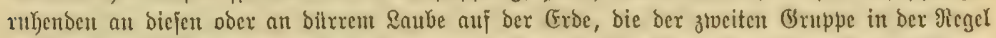
unter ber (Eroe, beren Situmd)en fie mit verweben ober mit ifren Speid)el mux Yoje zujanmenteimen.

Megen ber grojen llebereinjtimmung ber Gulen find bie Sippen bei ciner Gintheiłung von

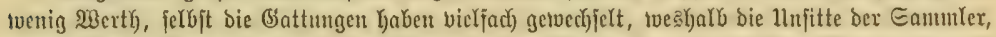

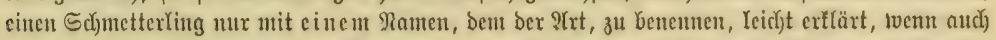

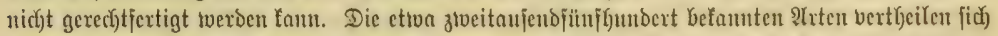

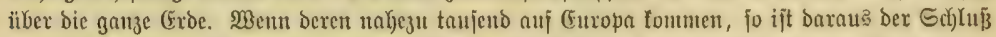

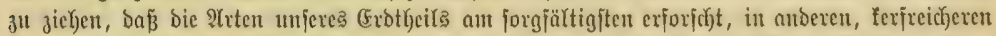

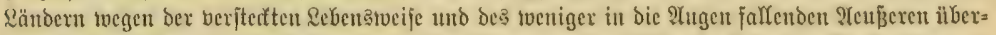

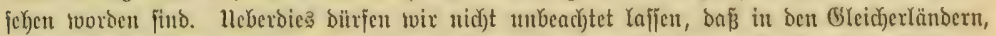

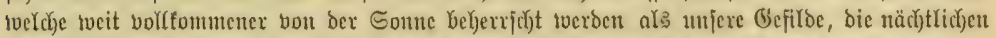

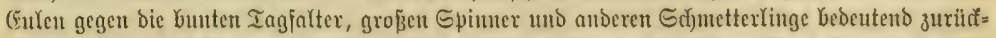
treten uto in an fid geringerer Frtenzalj

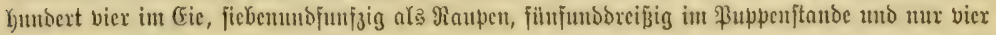
als Sdjuttertinge.

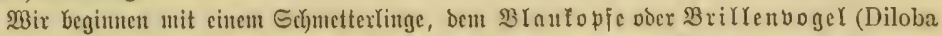

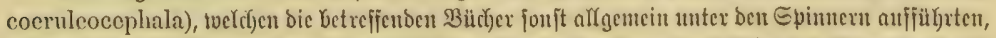

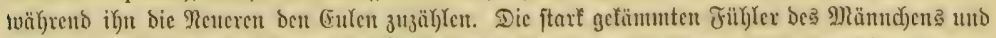

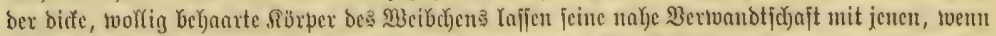

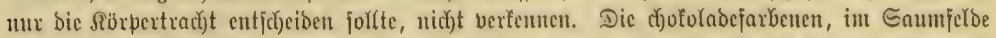

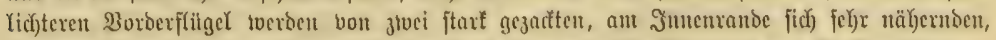

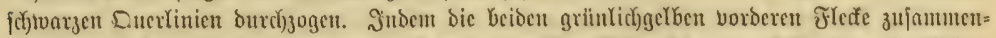

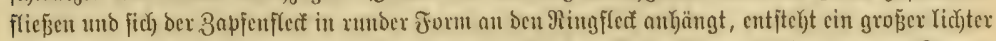

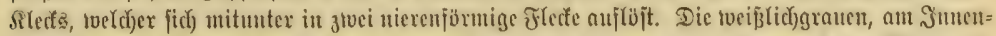

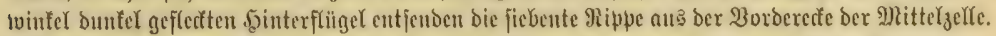

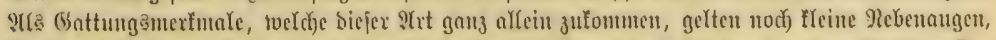

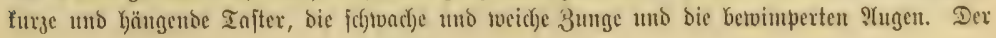




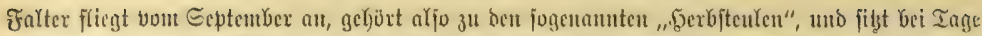

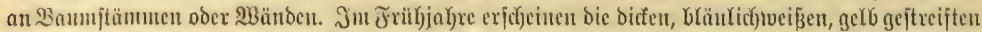

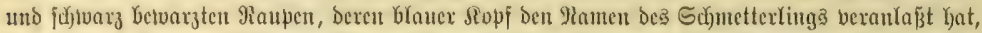

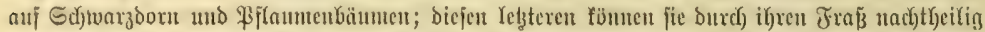

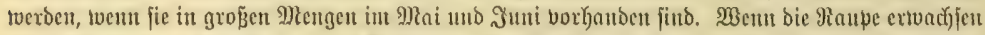

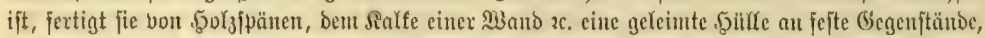

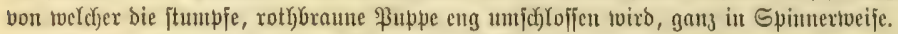

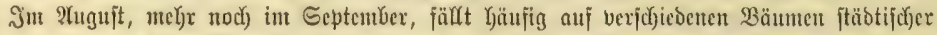

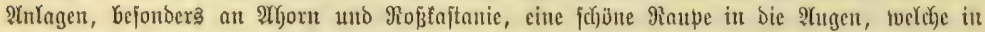

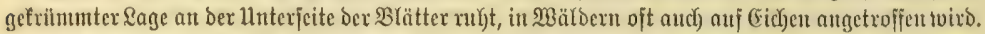

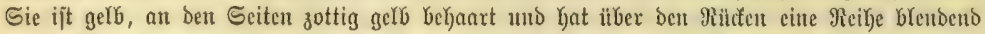

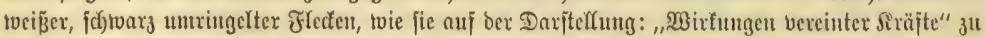

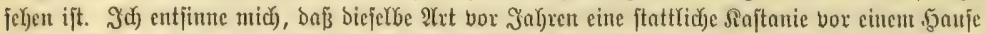

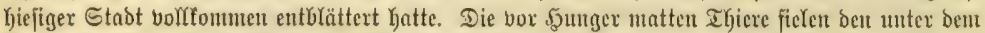
Baume vorübergełenden \&euten auf bie Rüpfe. Der aus ber ïbertvinterten \$uppe im Mlai oder

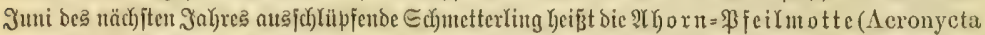

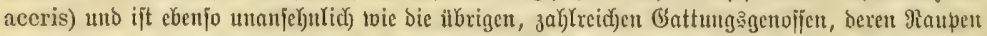

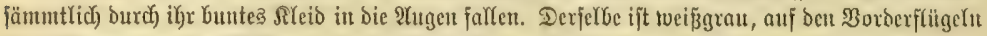

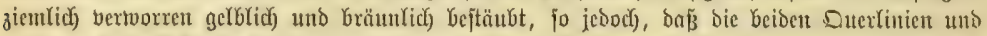

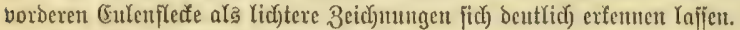

Den Drion (Moma Orion, Fig. 1), einen ungemein jauberen Falter, fünten tvir iut Mtai ober

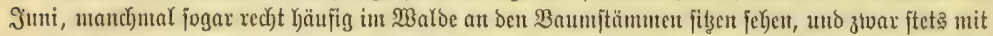

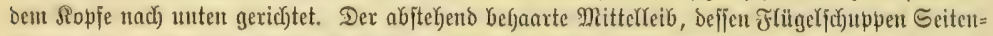

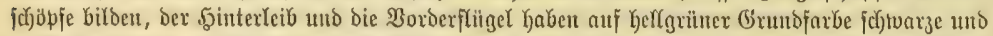

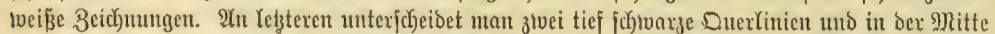

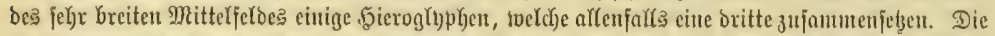

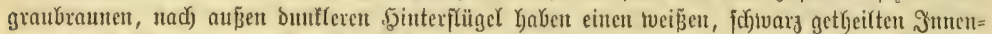

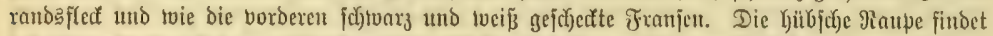

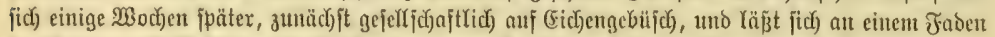

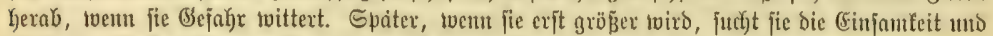

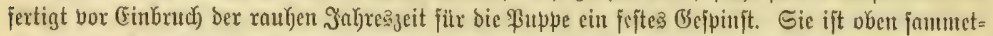

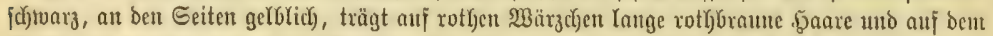

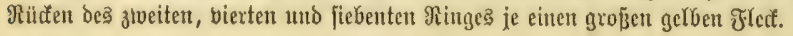

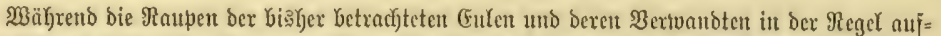

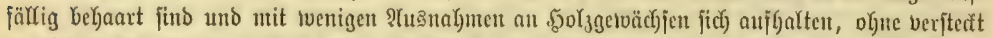

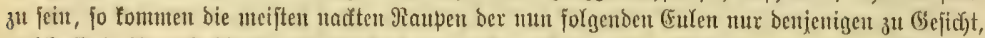

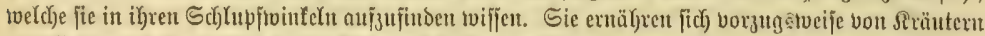

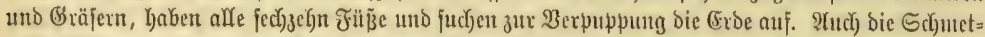

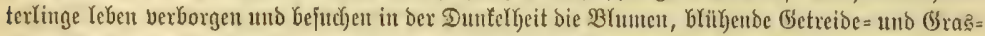

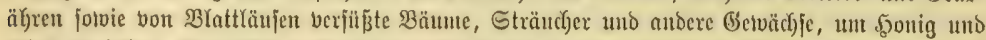

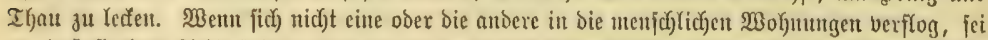

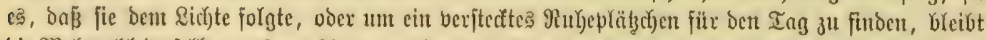

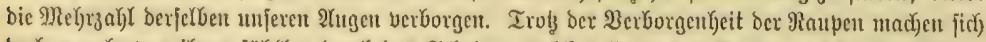

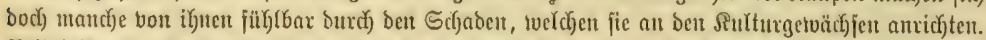

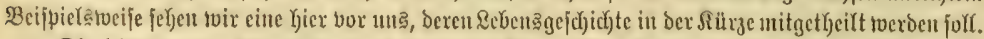

Die leberbraune, bientweilen etwas grau angeflogene Ducieneule (IIadena basilinea) Kat

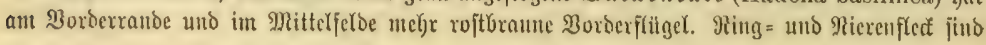




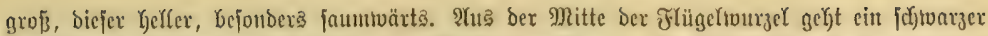

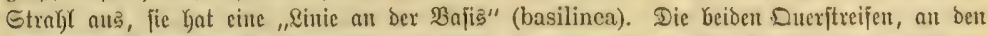
zugefefrten Seiten bunfer cingefaß̧t, bie Mellenlinie, ber Bapfenflect, fie alle find bentfich) zut

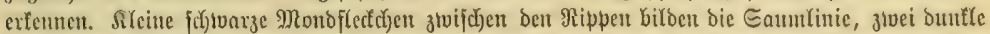

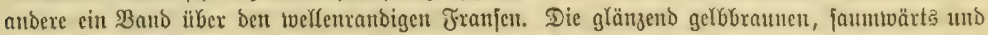

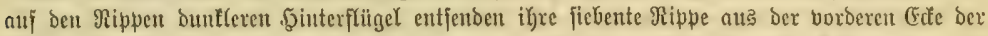
Mcittergefle. Die Augen jino naitt unb unbetwimpert, bie 3unge ift ftart und bie Tafter enden mit

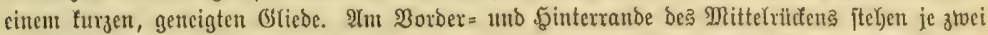

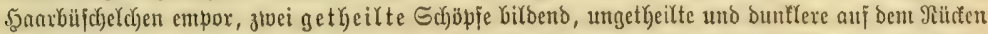

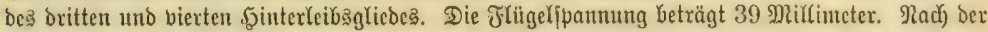

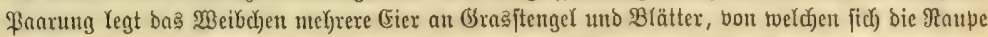

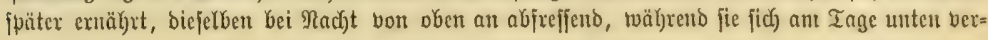

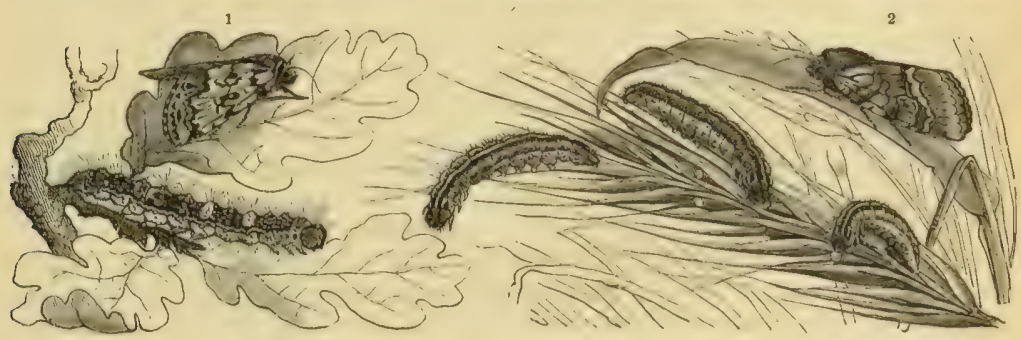

1 Drion (Noma Orlon) nebit Daaupe. 2 Duedeneule (Hadena basilines) nebft Daupen. Raturltae Gröbe.

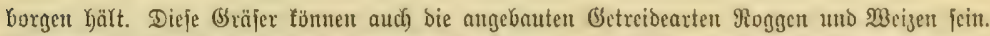

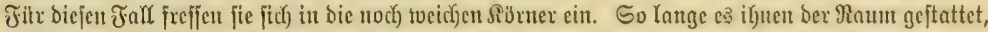

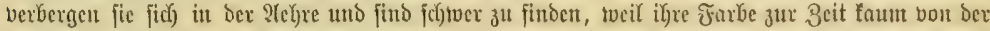

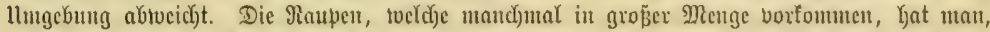

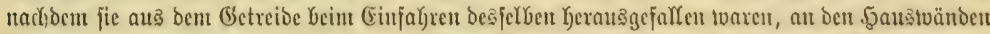

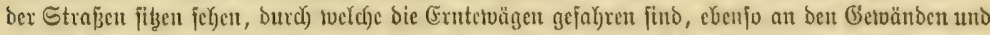

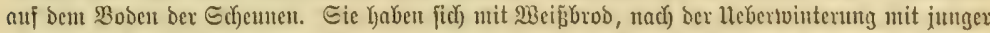

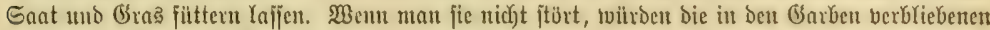

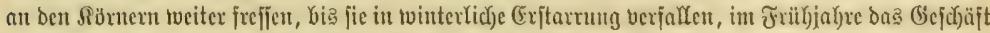

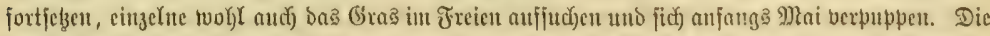

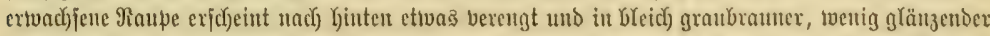

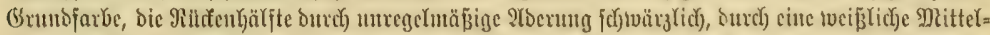

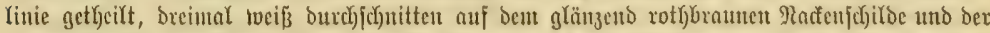

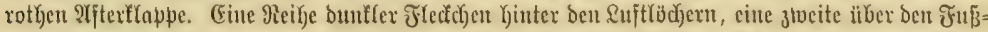

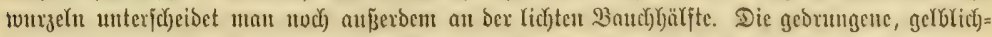

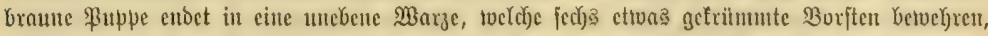

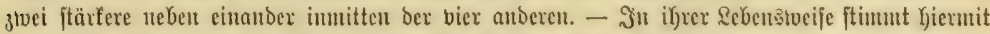

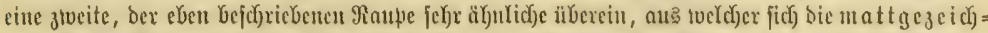

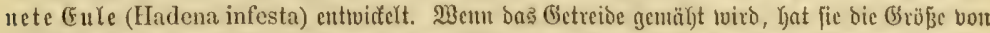

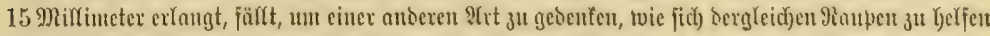

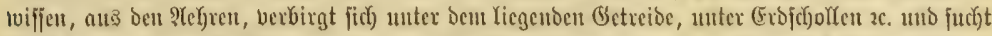

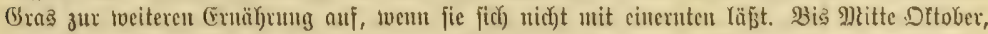

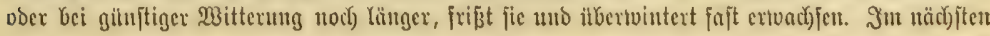




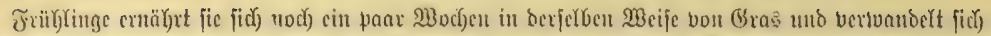

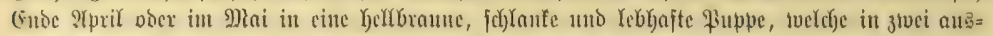
wärt ge gebogene Dornen endigt, bie boit einigen $230 x$ ften ungeben find. Die gelbgrauen, bräunlid)

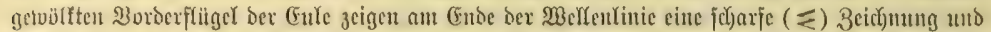

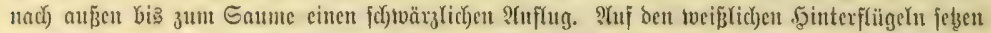

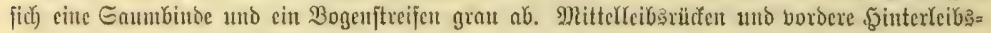

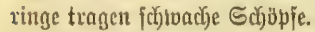

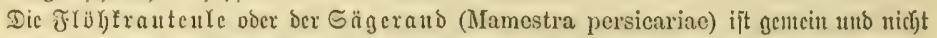

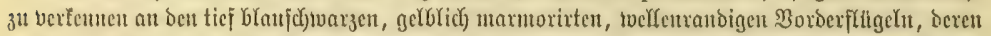

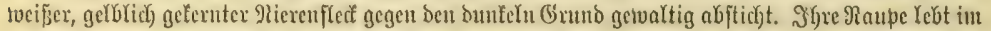

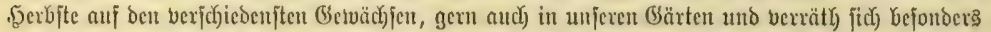

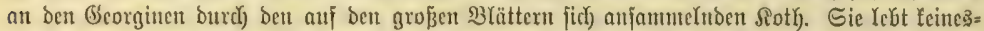

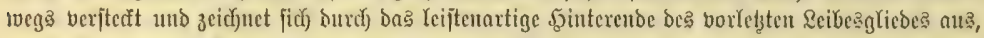
bon tweไd)

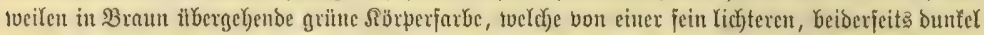

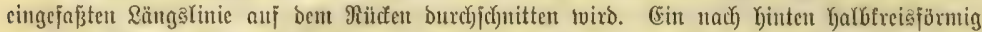

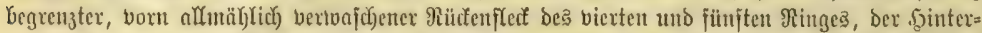

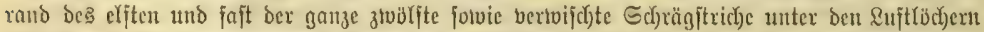

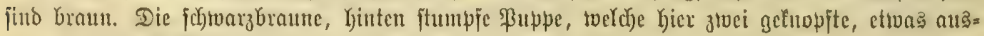
einander jtelgende Gabelipitzchen trägt, überwintert in ber Erbe.

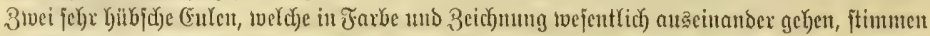

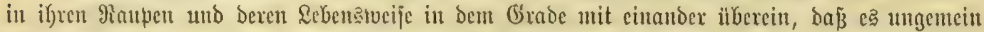

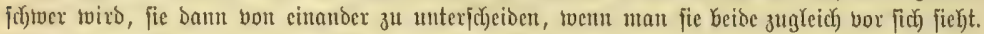

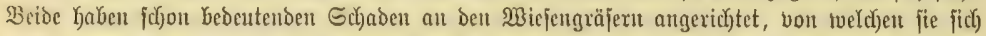

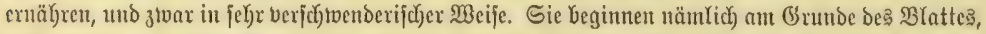

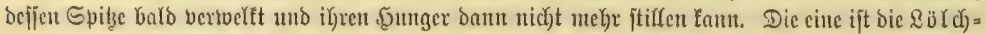

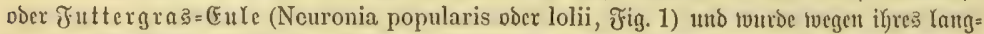

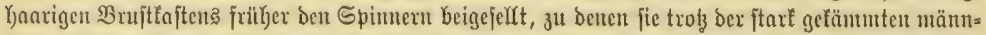

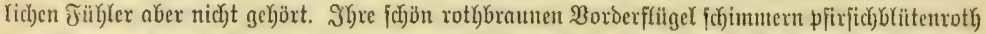

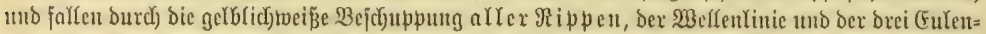

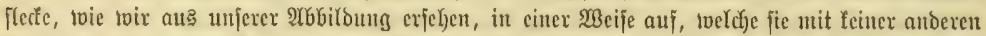

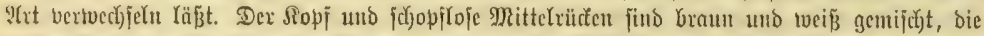

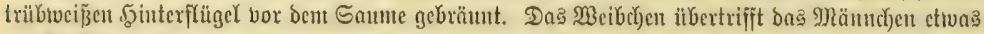

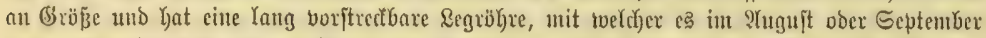

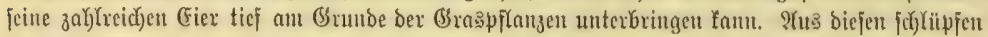

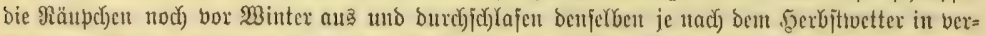

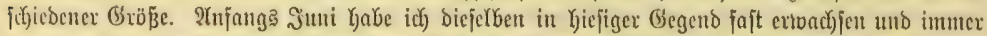
mur cinzeln unter Stcinen gejunden, wo jie in ber Kier abgebildeten Steflung ruben. Der feifie

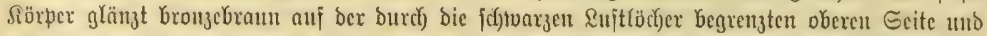

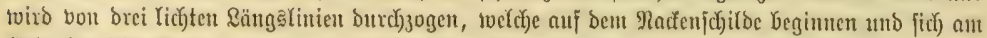

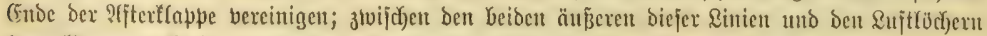

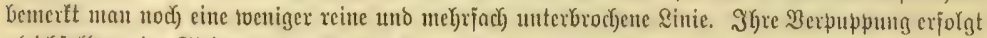

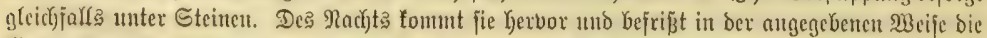

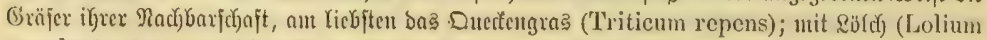

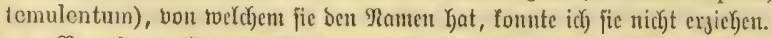

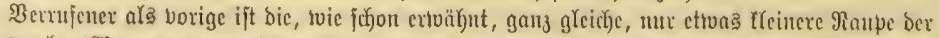
(5)a

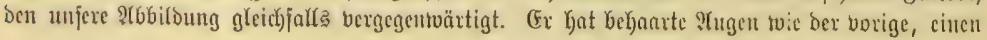




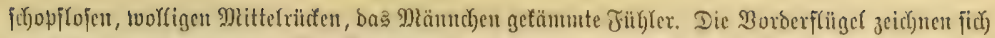

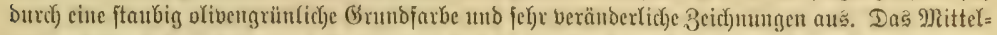

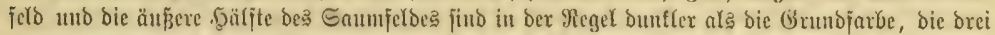

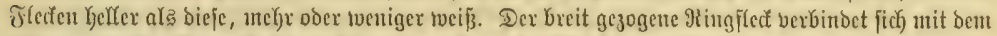

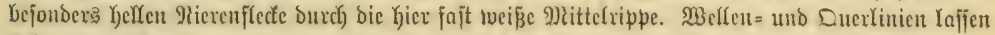

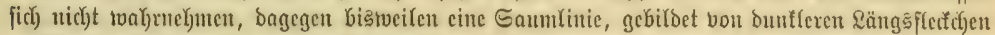

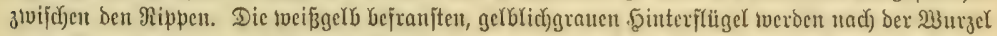

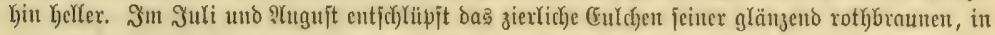

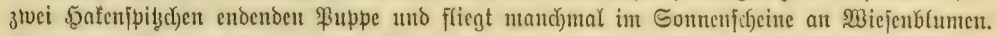

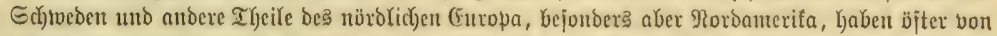

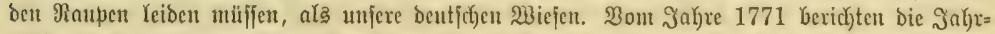

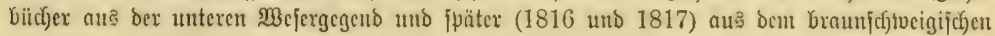

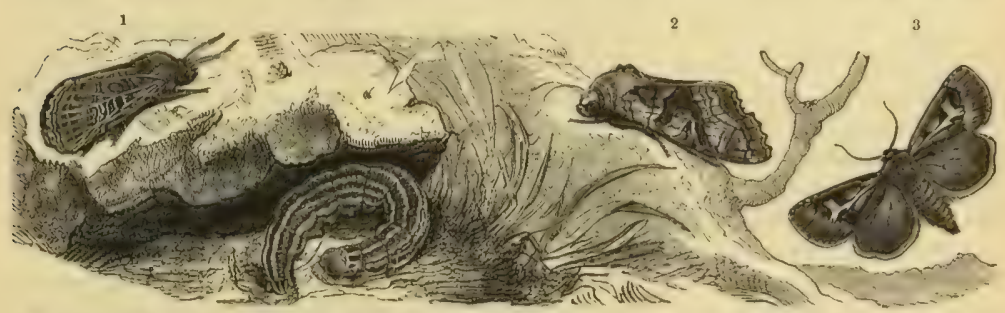

1 Futtergras. (EuTe (Neuronia populoris) nebit Daupe, 2 Dangotbeule (Brotolomis meticulosa). 3 (5) ta sute (Characag

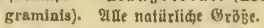

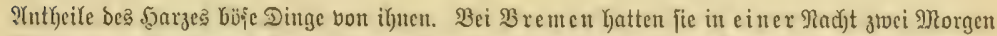

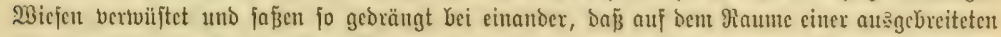

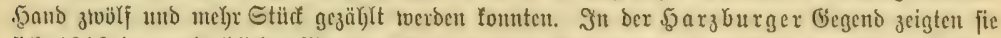

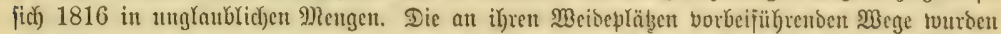

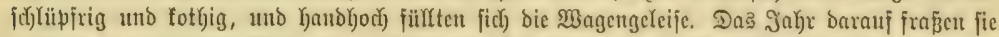

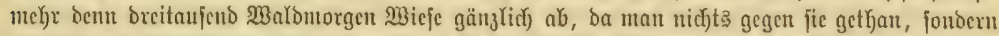

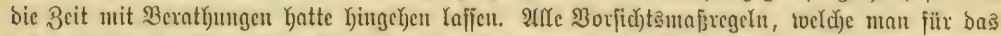

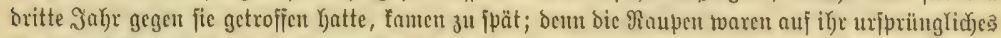

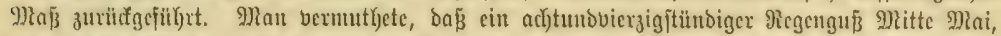

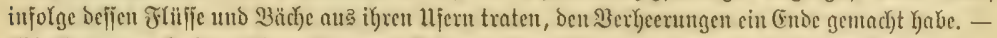

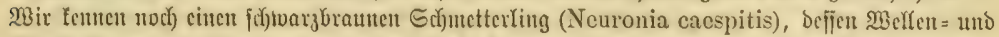
Suertinien twie bie llmjüumumgen ber Flecte fein gelb herwortreten. Ex ift biel feltener, feine

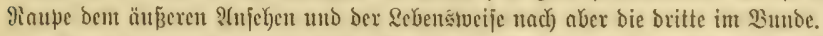

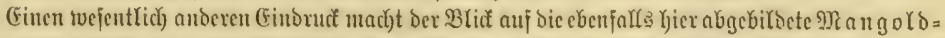
cule, ober beu Thatbogel (Brotolomia meticulosa, Fig. 2), bei tweldyem fict) ber Saum ber

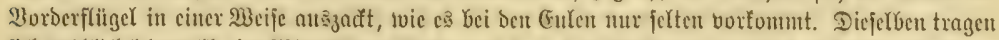

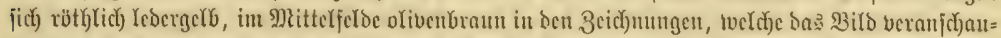

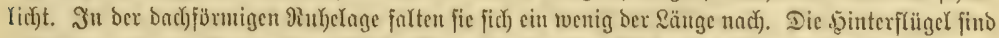

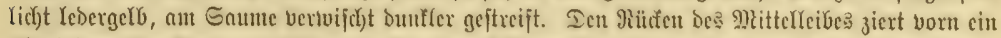

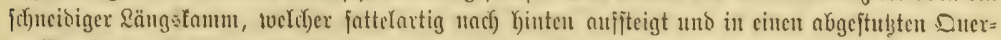

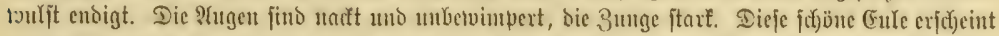

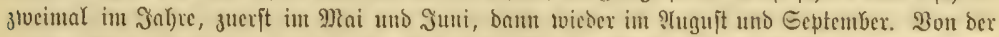

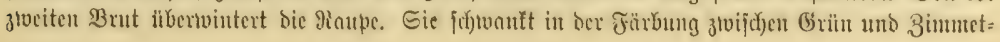




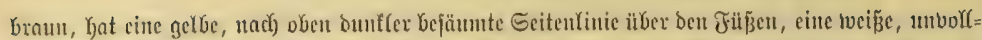

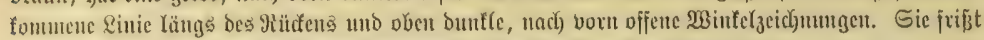
alfertei niebere

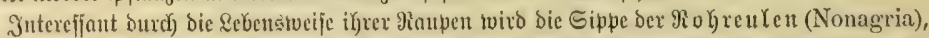
zedid)mug

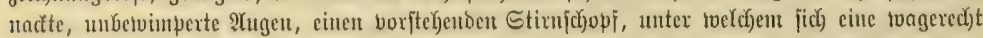

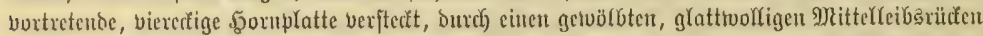

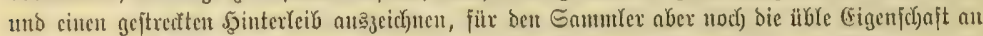

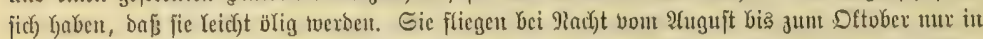

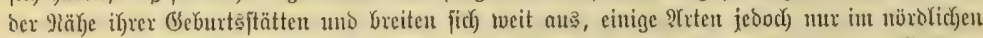

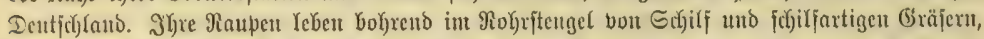

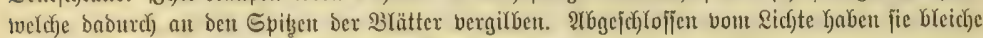

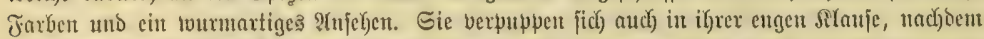

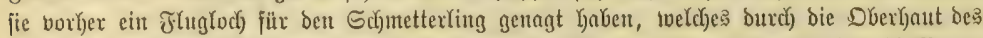

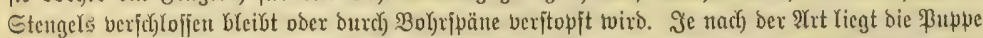

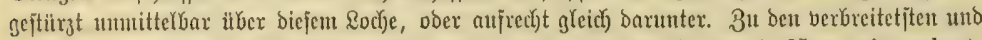

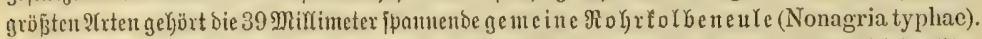

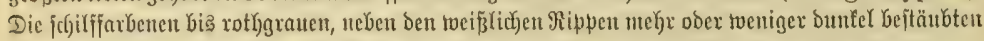

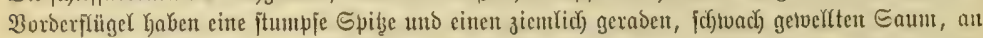

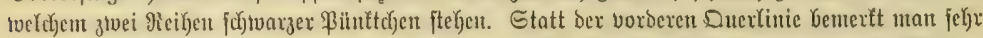

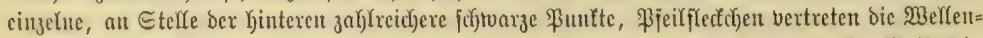

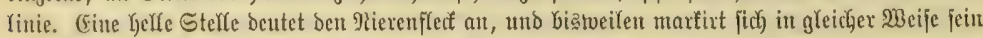

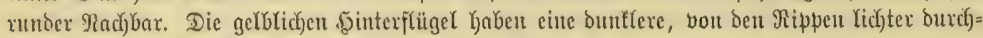

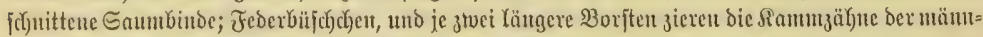

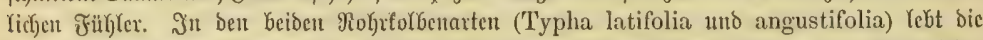

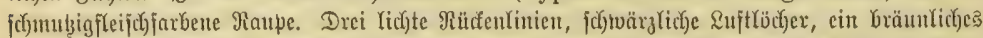

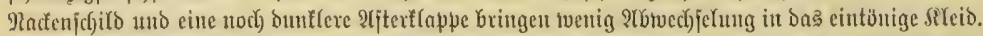

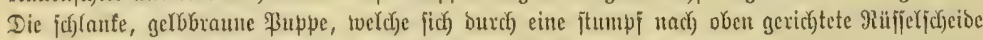

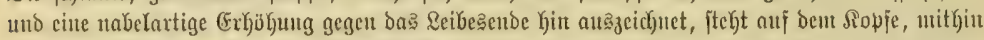

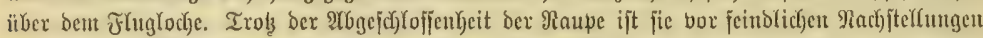

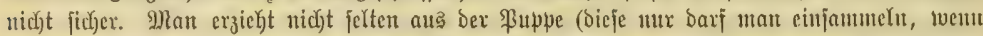

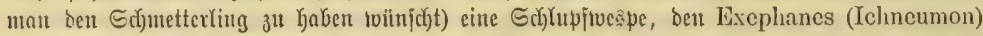

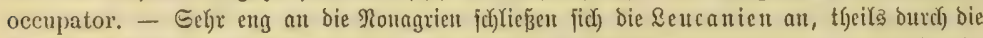

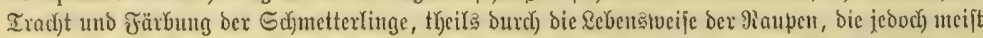

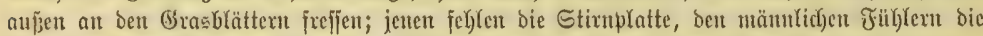

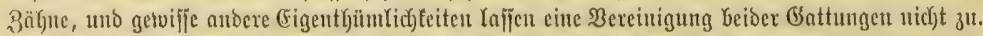

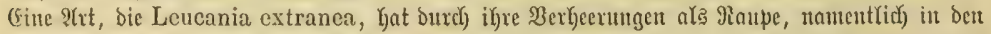

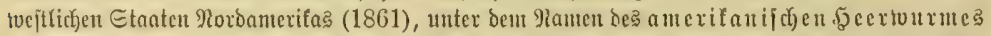

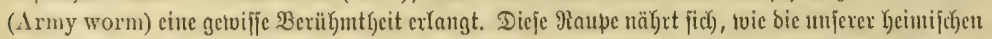

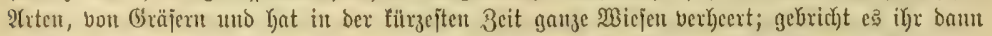

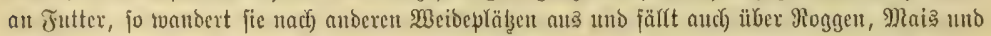

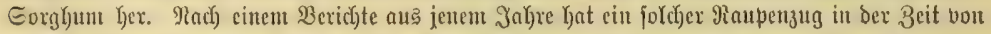

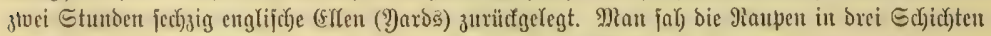

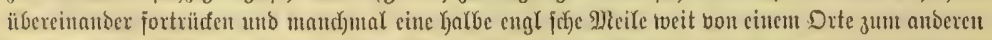

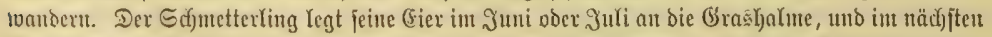

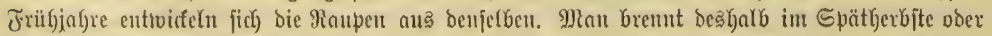

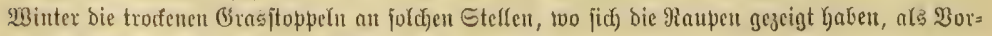
beugungamittel gegen weiteren Schaben ab. 


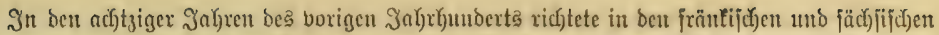

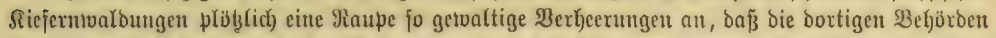

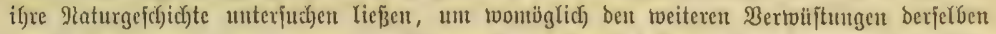

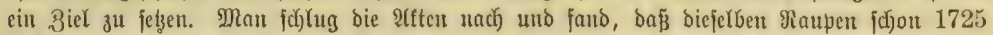

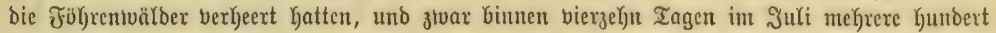

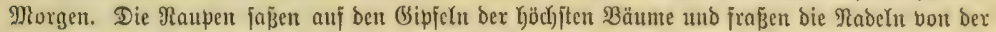
Epize an ab, bis jene in furzer Beit fahl und tvie berbrannt außjahen und - - nach einigen

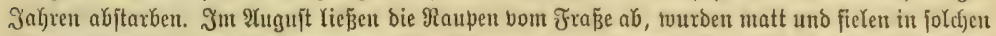

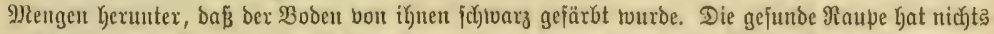

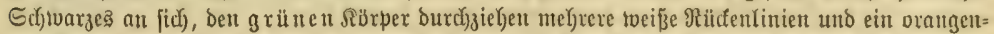

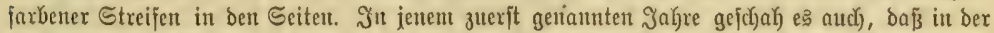

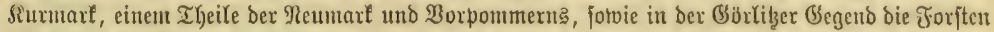

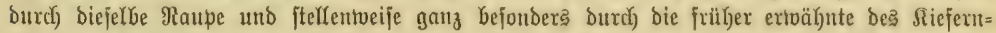

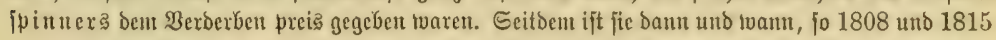

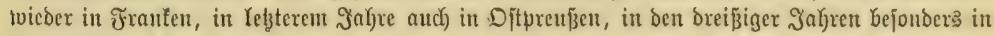

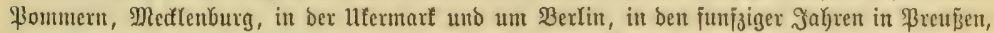

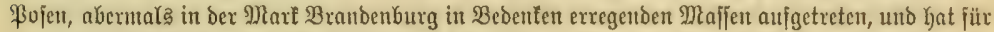

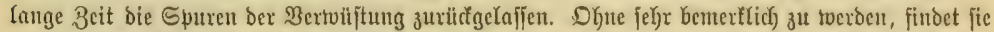

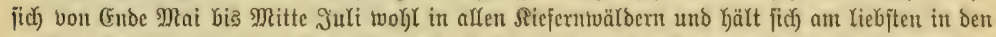

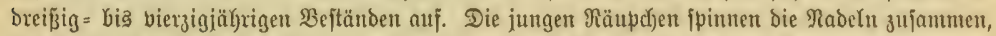

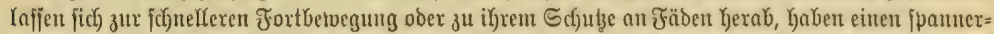

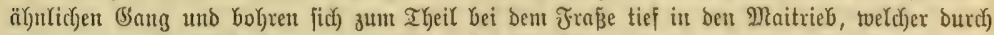

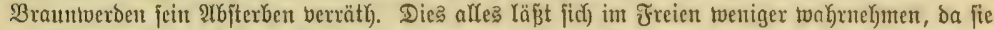

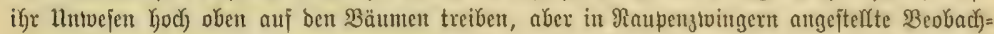

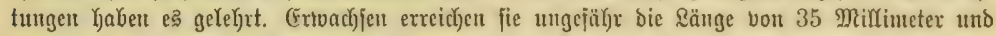

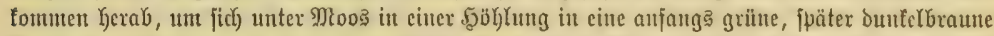

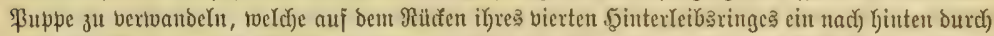

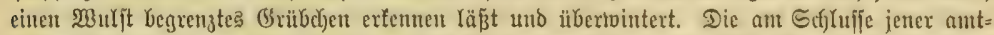

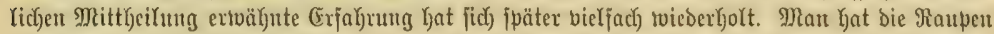

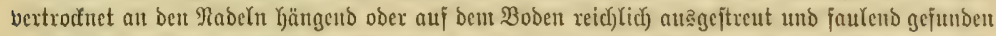

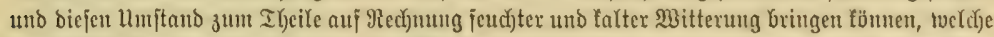
gerabe bicfe Raupe wenig vertrïgt, зun Ifyeile aber aud für eine unter ifuen ausgebrod)ene (Epi=

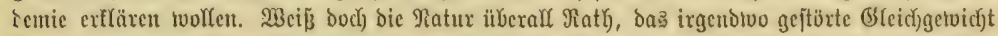

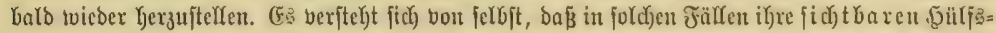

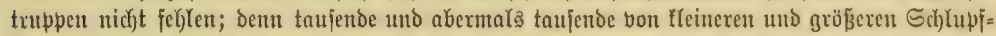

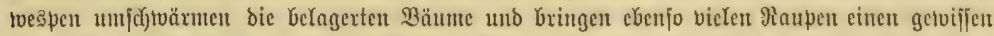

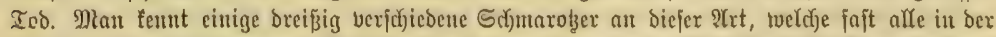

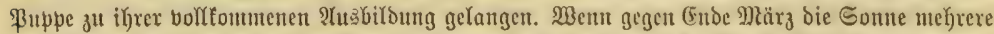

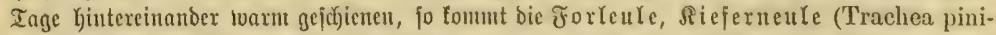

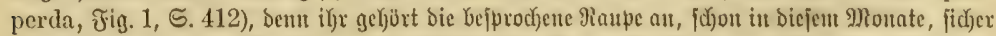

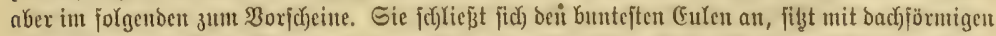

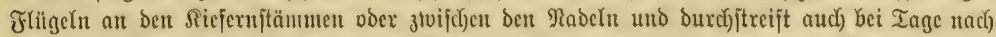

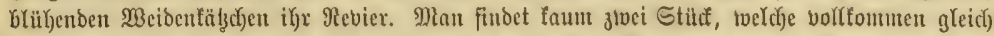

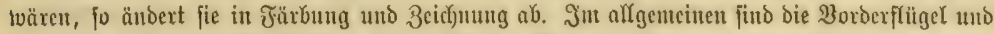

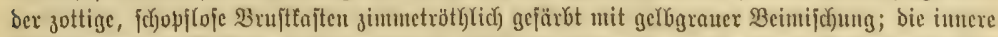
Befichattung ber Welfenlinic ift rotybraun, jeder ber beiden gropen vorberen Jilefe weif3; eine

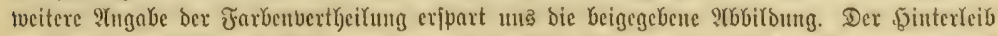

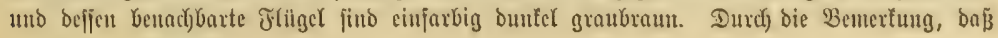




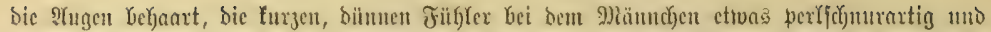

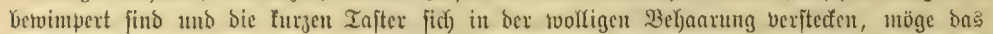

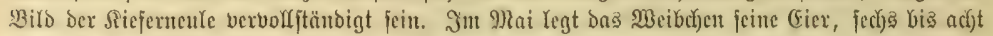
gereifet, an bie Mabeln.

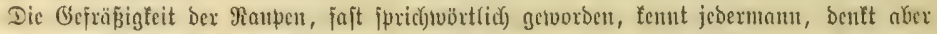

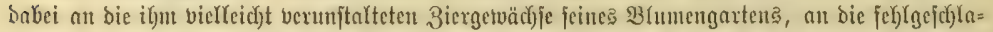

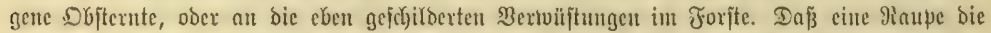

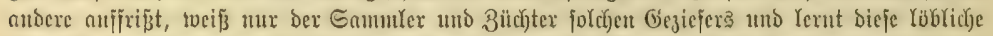

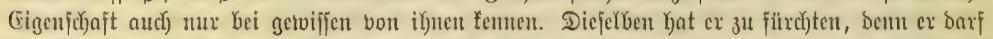

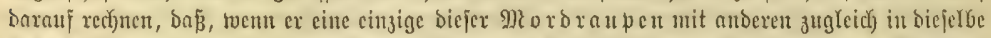

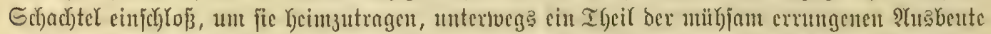

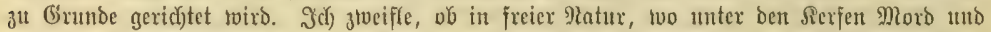

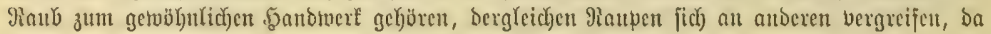
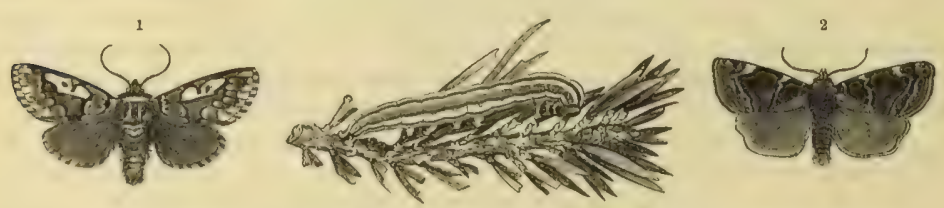

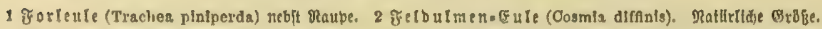

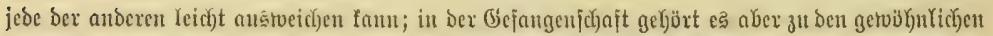

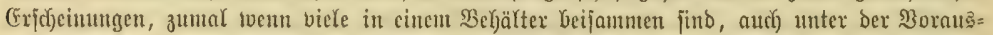

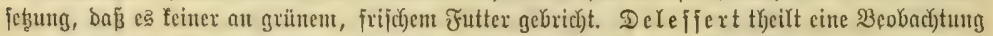

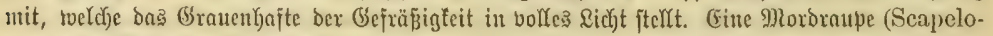

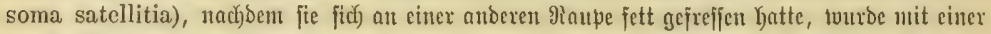
ztueiten Mordraute (Cosmia trajezina) 311 fammengejpert, von biejer an ber Geite angefreffen,

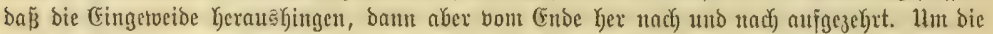
Rebenezäfigfeit bicjes Spjers feitzuftelfen, twurben ifm bie cigenen Eingetweide borgelegt. Die

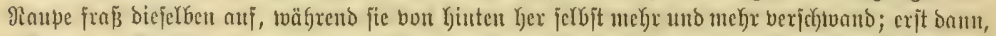

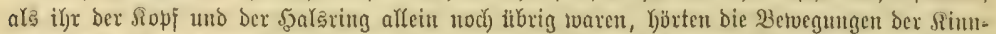

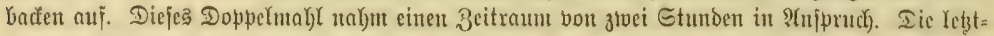

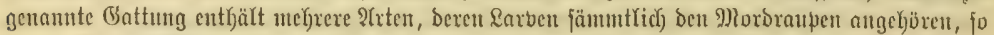

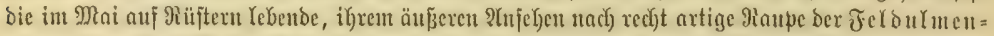

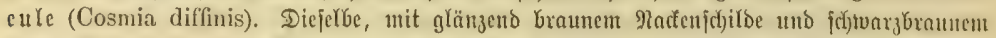

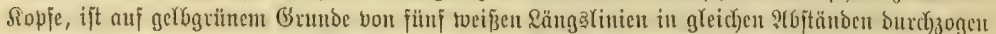

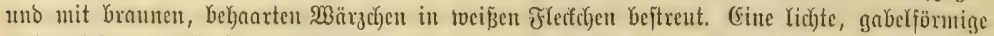

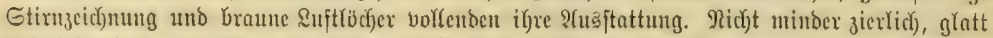
unb fajtanicubraun glänzento, rotggrau aigeflogen, befonbers am Jumentande, nimmt fich ber

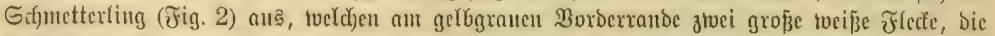

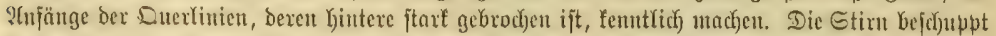

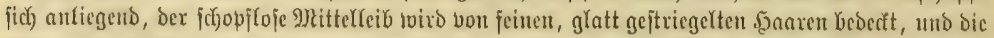

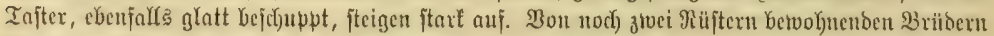

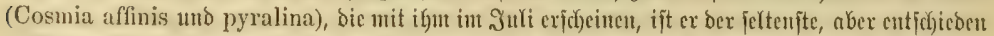

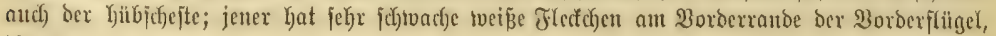
biejer gar teine. 


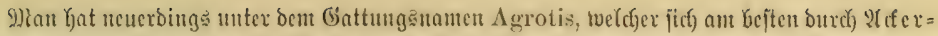

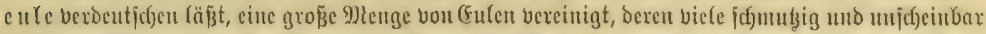

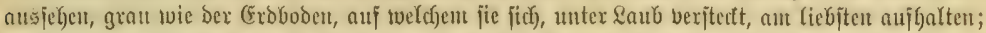

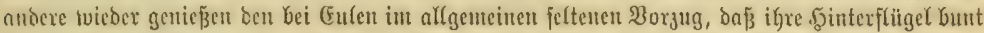

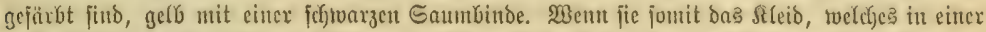

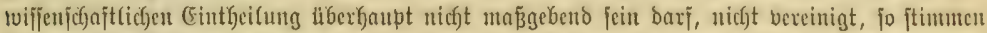

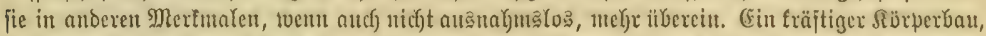

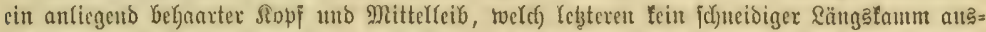

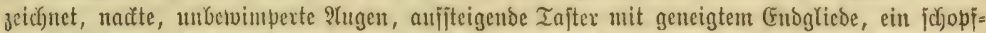

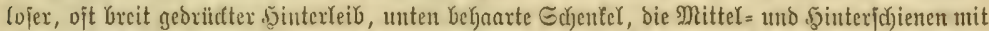

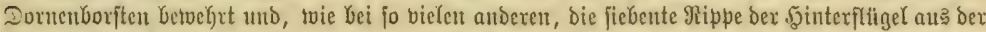

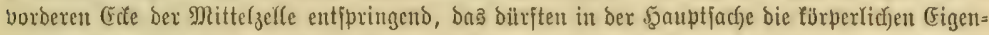

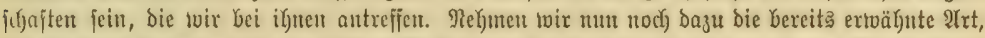
ficf) bei Tage zu verbergen, bie auj bem Füden va gered)t übereinanber gelegten Flügel, twenn

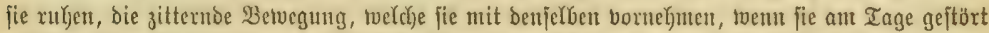

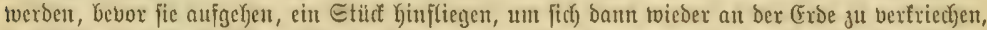

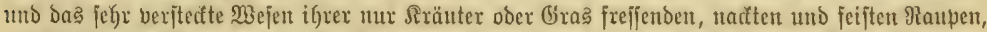

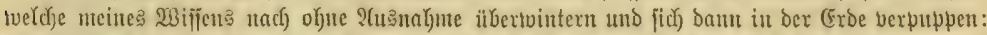

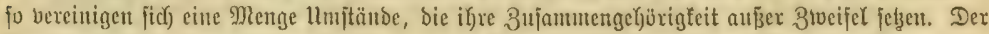

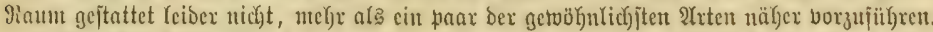

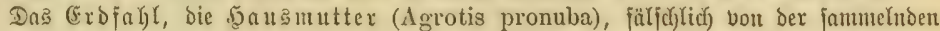

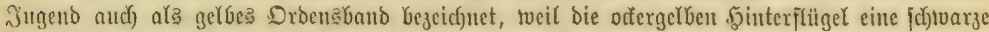

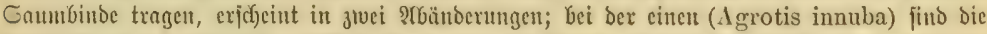

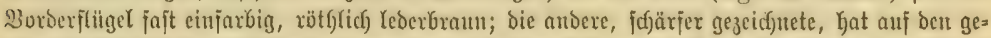

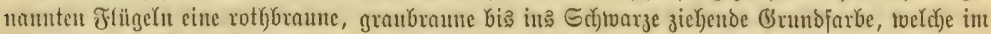

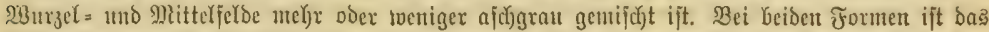

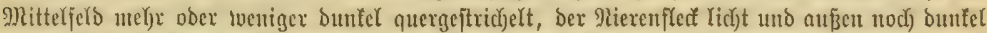

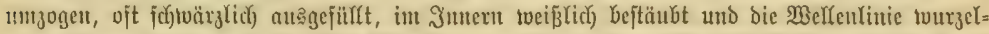

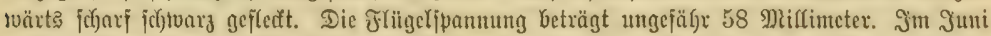

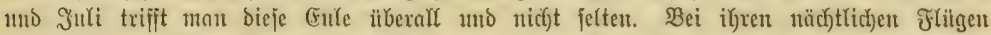

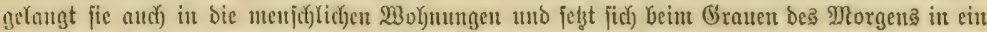

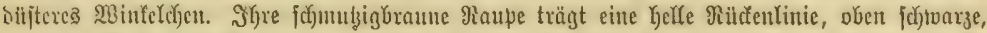

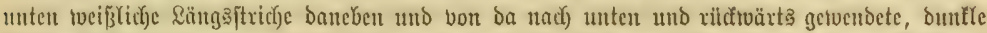

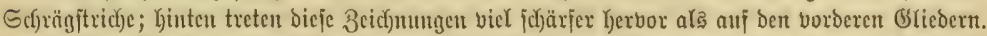

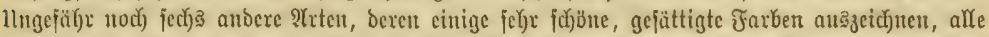

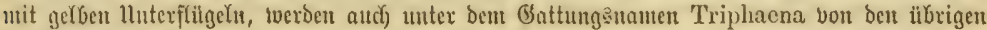
nUgejchiedent.

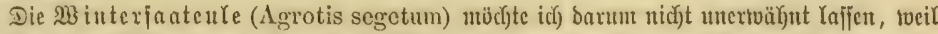

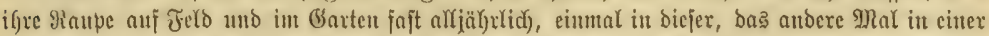

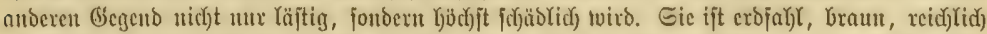

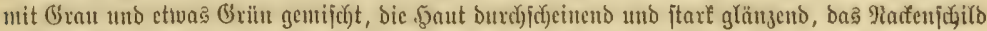

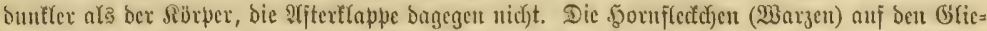

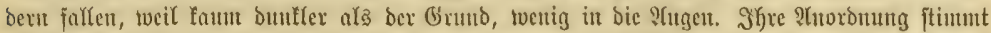

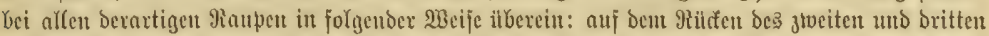

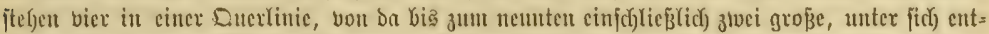

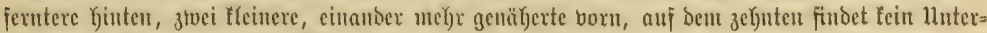

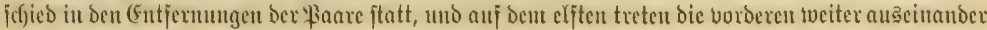

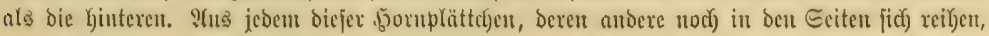




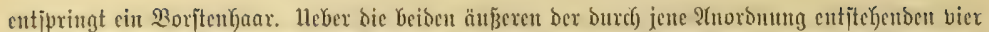

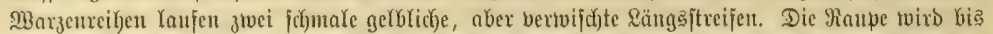

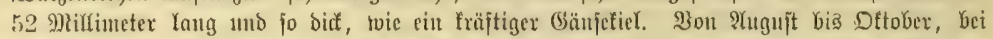

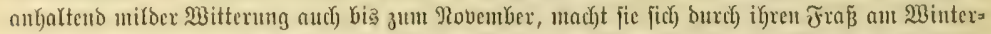

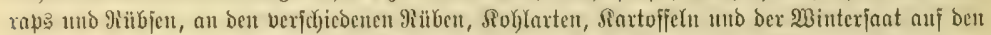

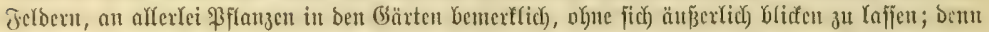
fie verbirgt fick bei Tage unter Steinen mo (Erojd)offen ober, wo bieje fer)len, flad) unter ber

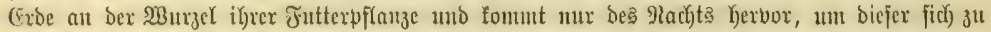

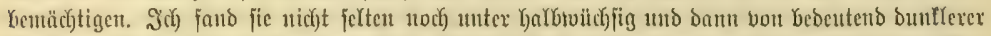

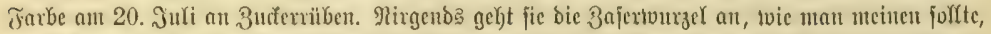

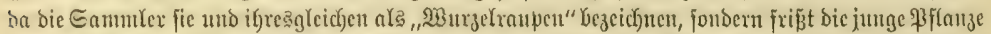

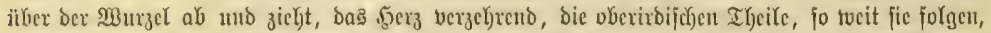

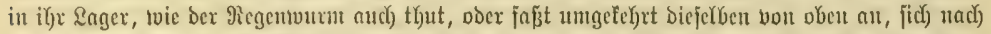

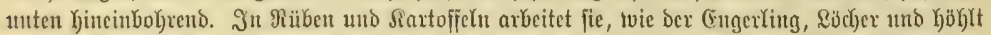

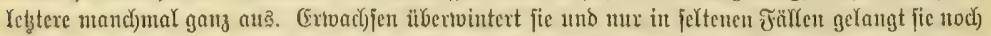

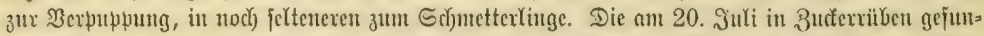

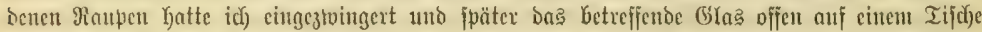

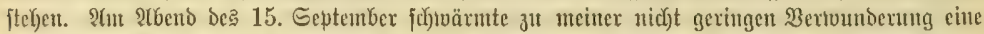

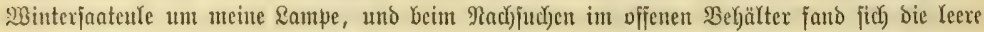
\$uppenbulije.

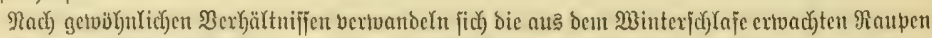

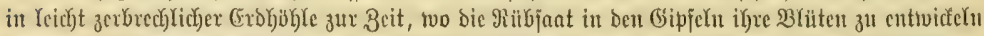

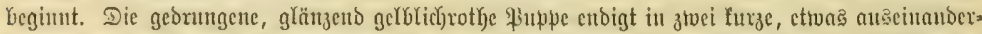

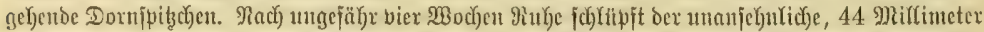

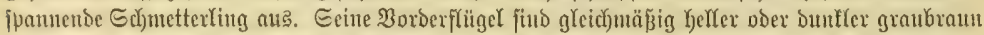

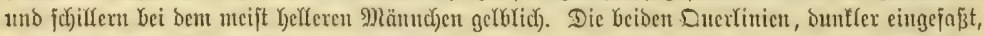

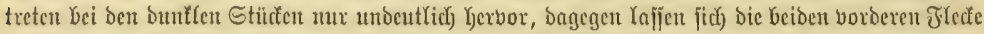

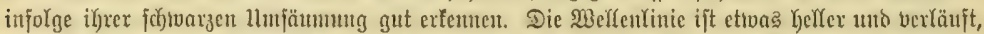

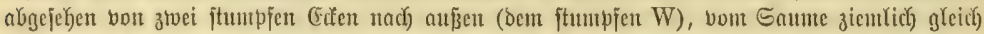

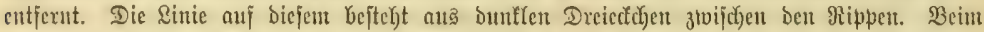

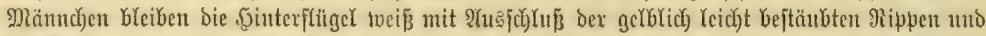

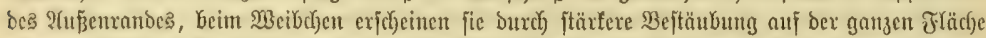

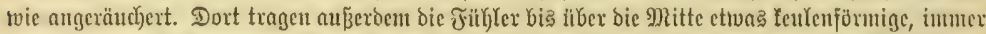

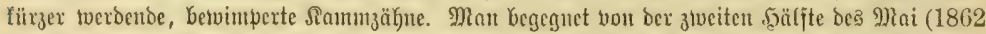

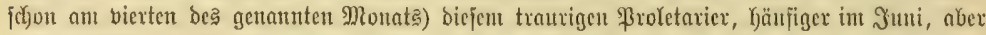

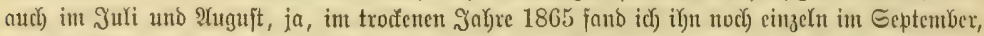

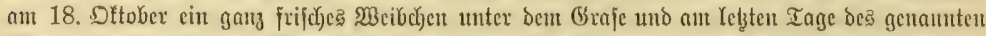

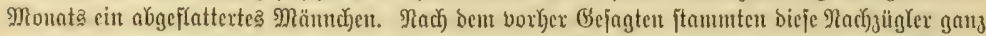

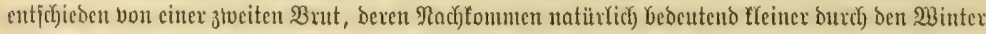

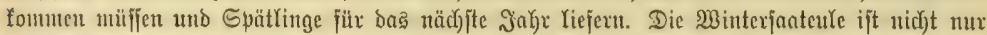

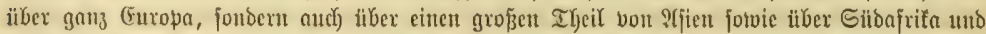
Sorbamerifa berbreitet, gehört aljo entjojyieden zu ben Weltbürgern.

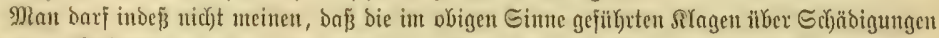

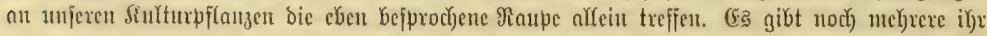

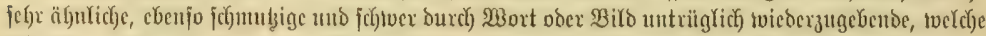

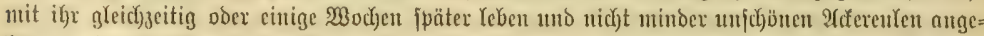

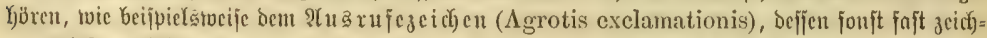

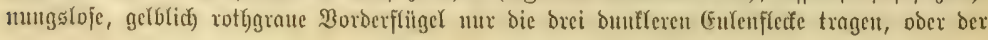




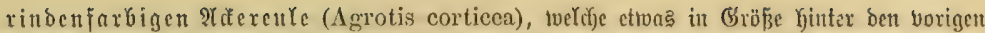

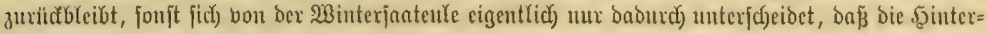
flitger in beiben (Bejd)led)tern braun ausjeben.

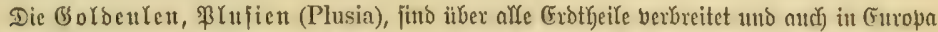

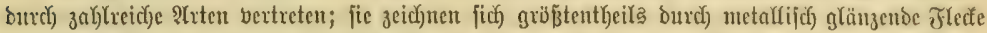

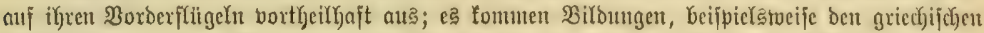

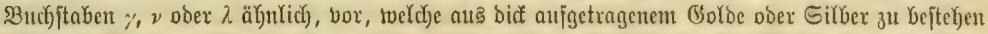

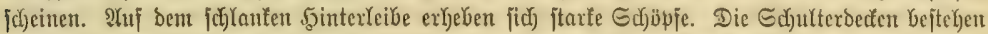

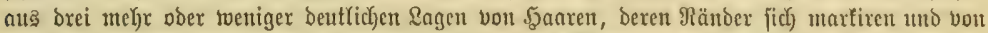

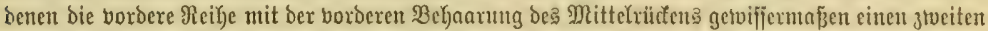

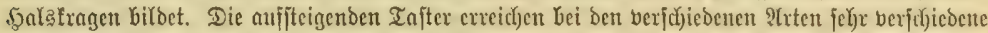

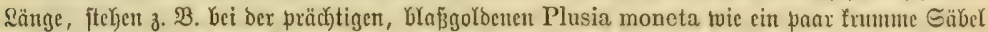

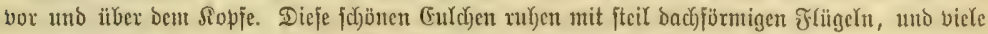

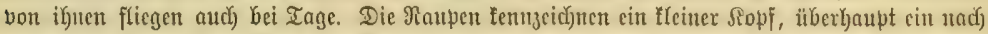

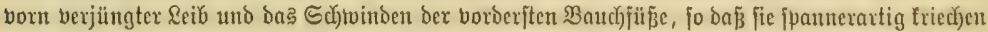

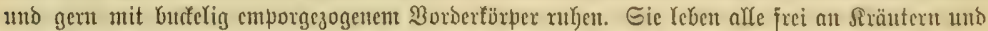
fertigen meijt an ber Jntterpflanse ein Yocteres Gejpinft jür Dic \$uppe. Dieje hat cine ftarf ent=

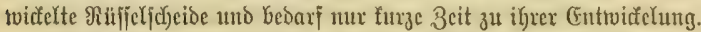

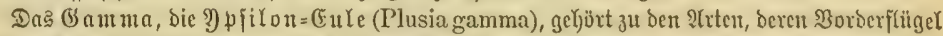

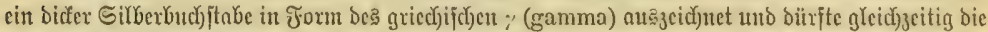

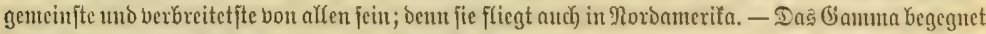

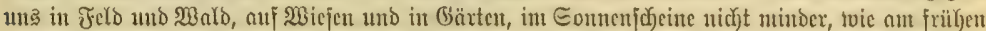

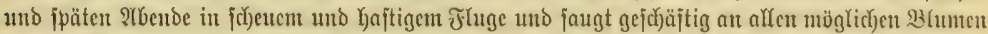

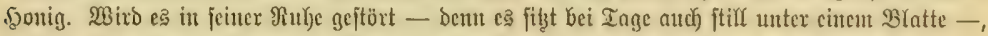

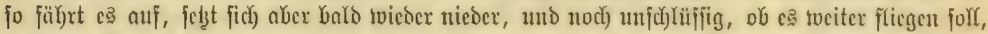

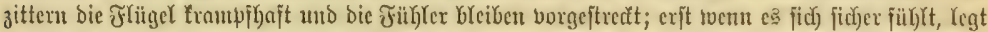

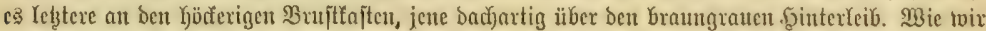

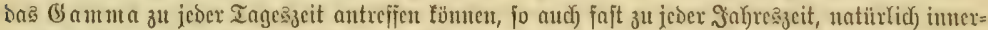

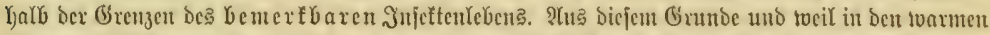

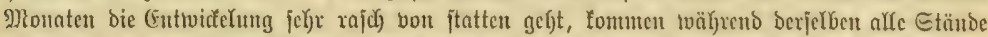

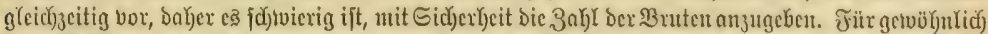

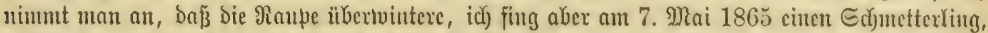

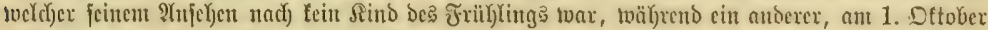

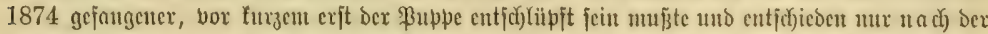

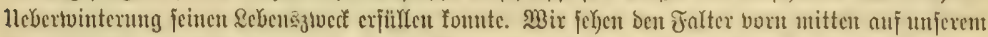

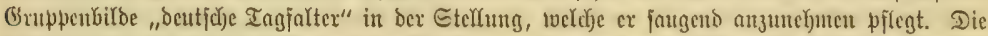

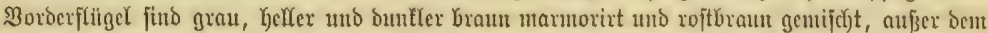

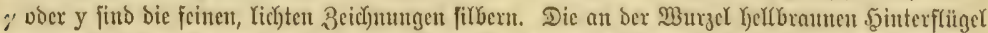

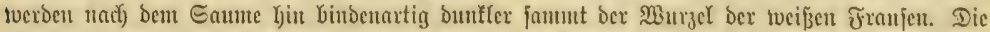

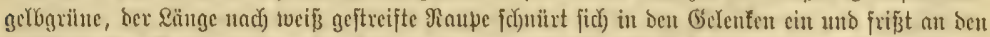
berfochicbenjten Sinätern, mand)

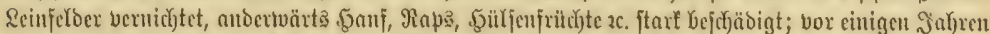

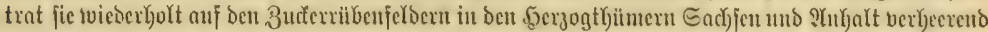

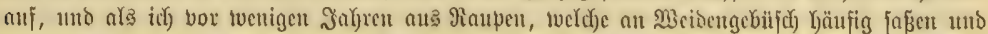

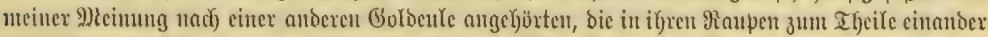

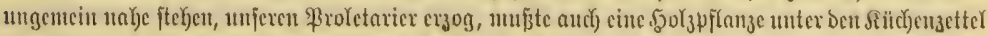
feiner Raupe aufgendmuten tverden, twas biaher neu twar. 


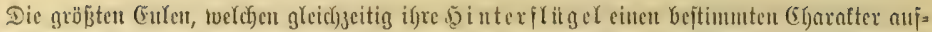

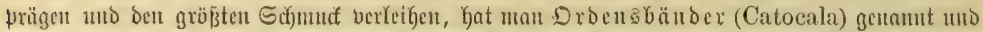

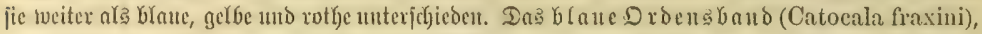

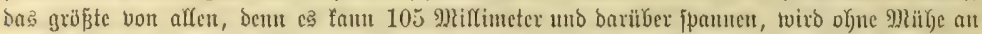

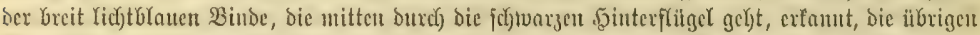

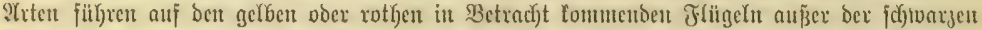

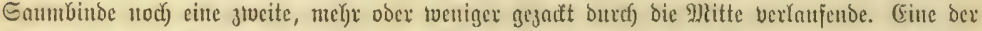

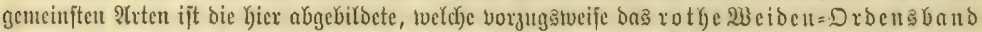

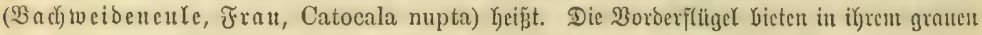

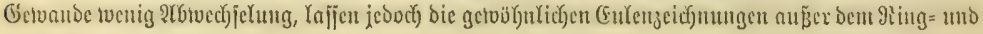

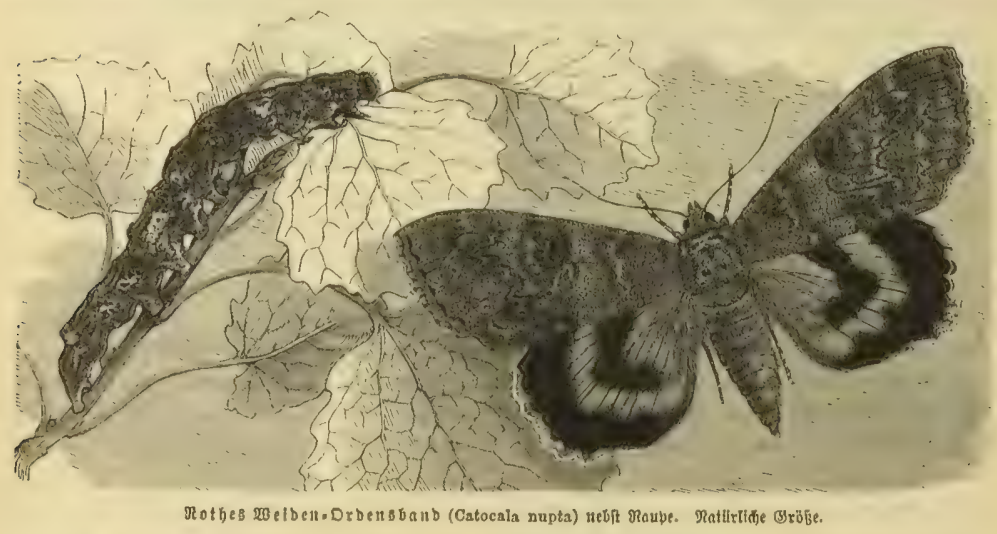

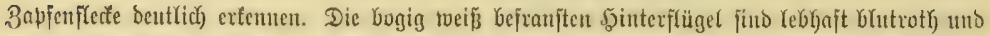

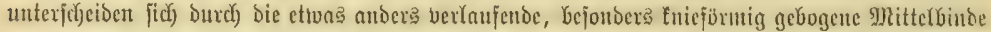

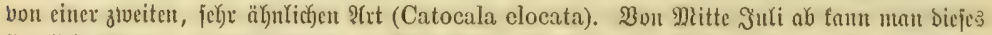

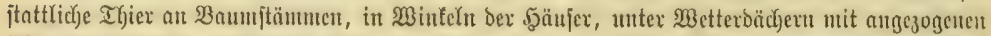

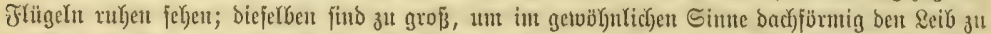

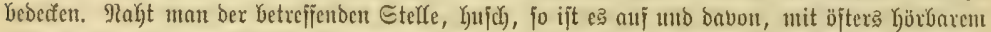

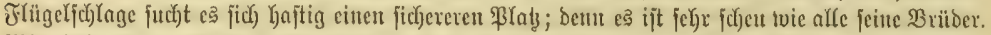

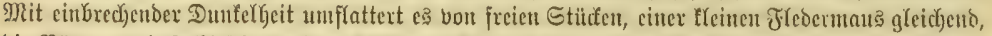

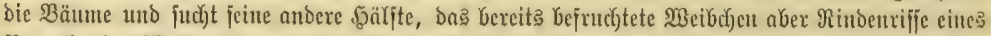

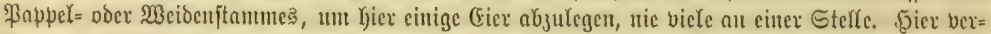

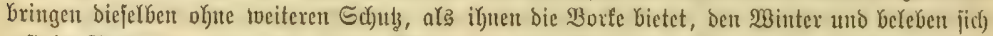

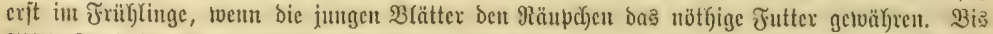

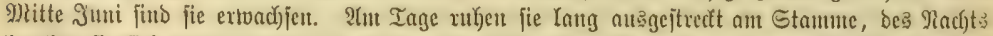

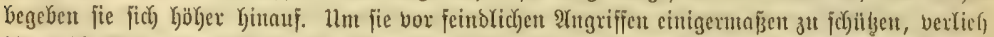

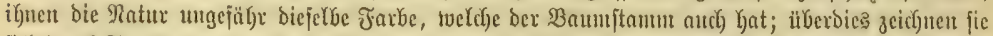

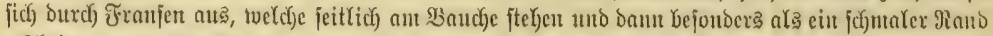

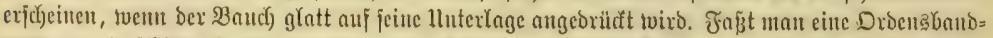

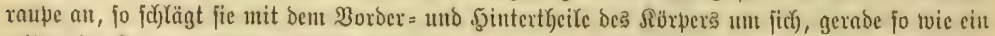

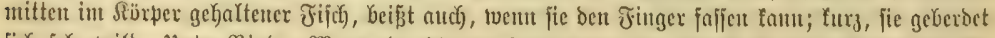

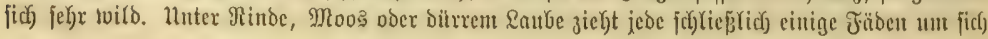




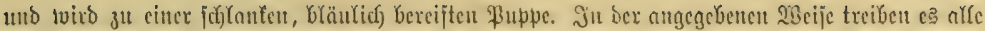

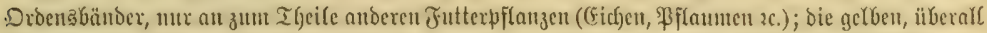

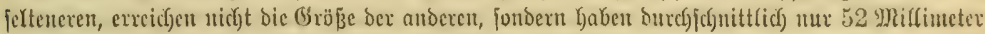
frligelppanumg. Norbamerifa enährt gleichjalla vicle itrten.

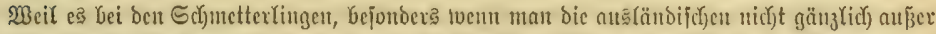

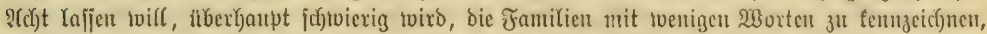

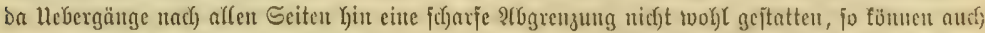

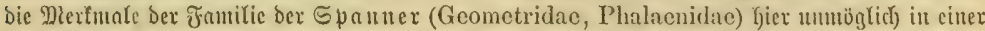

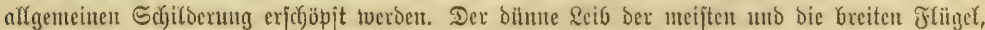

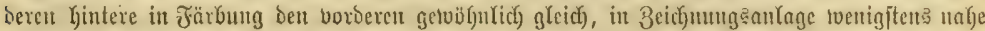

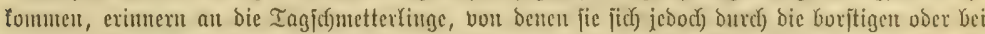
mand)

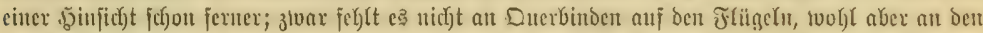

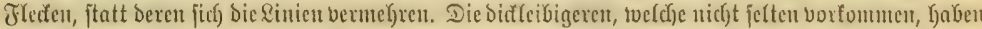

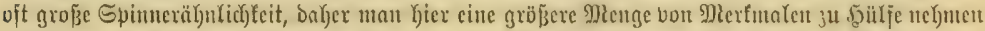

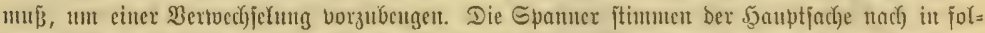

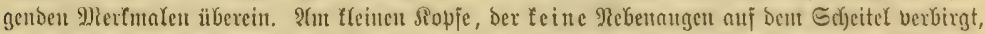

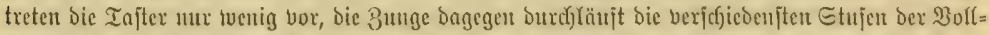

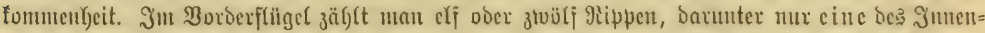

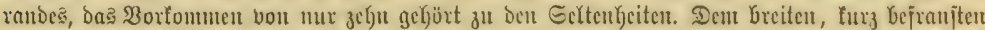

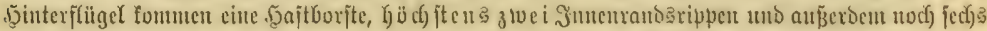

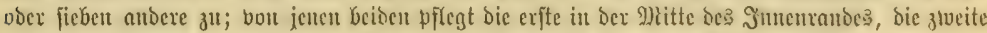

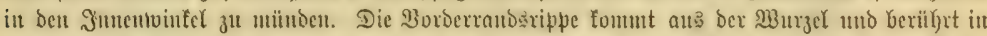

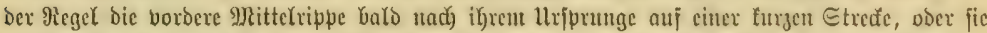

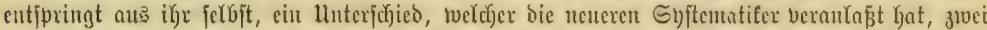

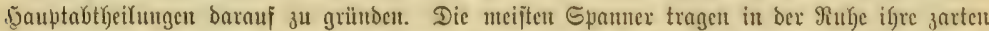
Frligel etwas an agebreitet, tvent aud nidy)t fo soeit, twie tvir fie in Eammlungen feben; cinige

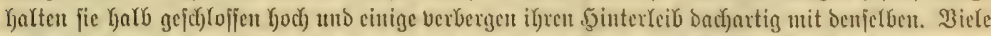

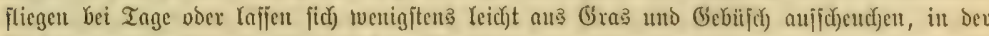
Hadatzeit zeigen aber bie meijten größ̈ere Rebendigteit.

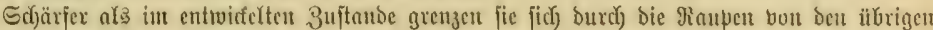

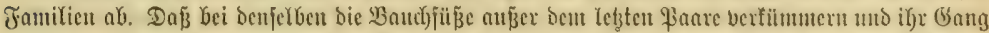

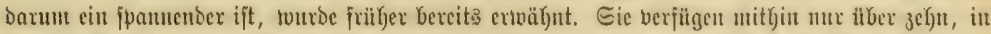

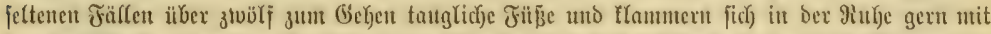

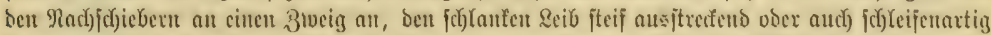

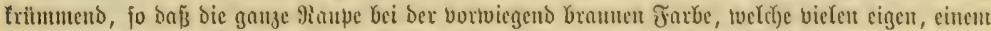

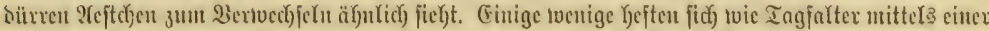

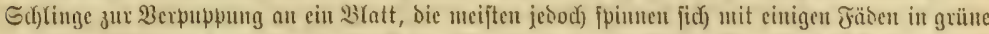

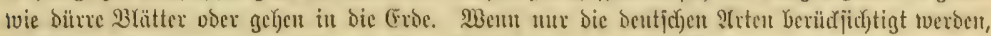

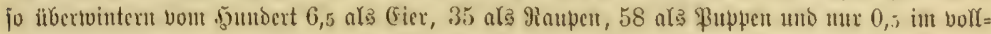
fommenen 3ujtande.

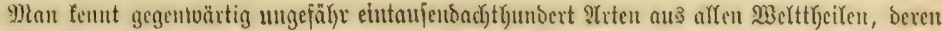

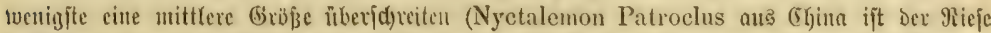

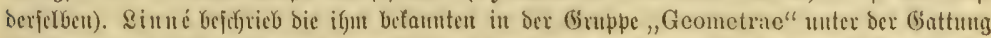

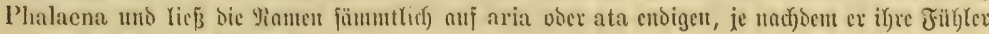




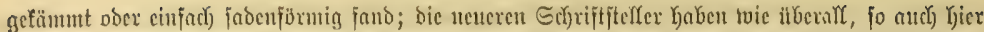

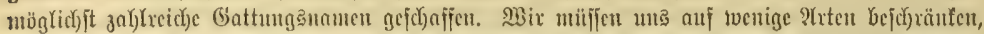

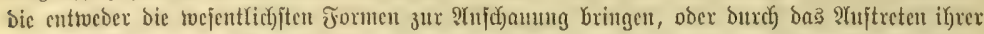

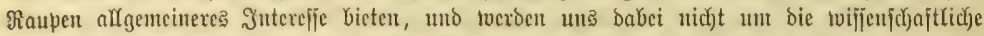

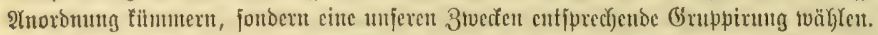

Der Birfenjpanner (Amphidasis betularia, Fig. a) getbört jeiner R̈̈rperbejchaffentheit

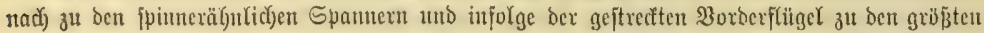
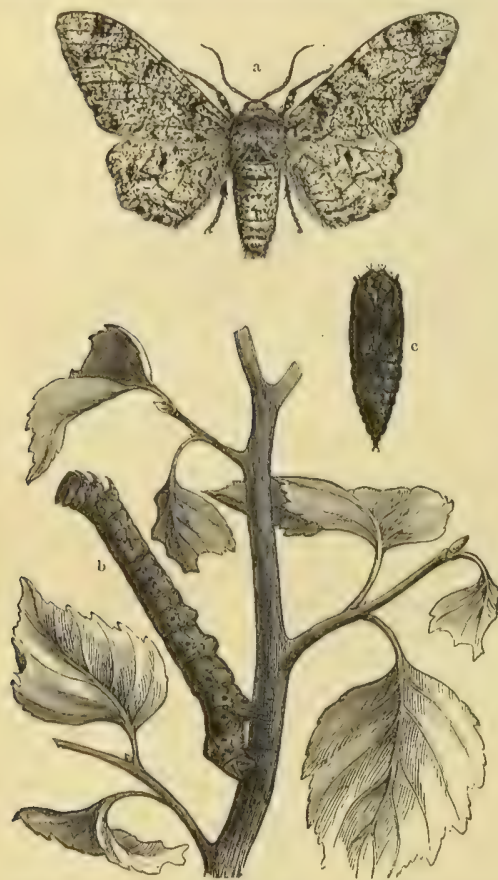

Birfenlvanner (Amphidasis betularia), a melotidjer Enanner,

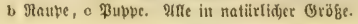

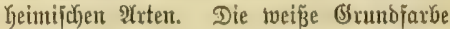

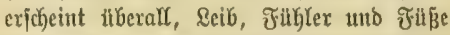

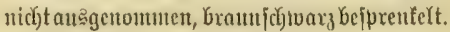
\$iełe punttgroß̧e Sprentel flię̧en hier uno

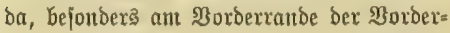
flügel, zu Flecten und Rinien zufammen.

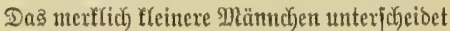
fich) burch einen fichlanteren Seib uno, mit

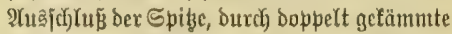
Jühler vom Meibchert. Die Raupe (Jig. b) ift überall gleich) bict, am Scheitel bes fleinen

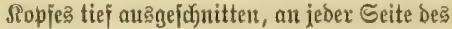
acyten BSliedes mit einem twarzentartigen Snötçyen bexjeken, uno berändertiç) in Dex Jarbe, twie eక jadjeint ie nad) Dex Futtexpflanze,

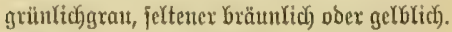
Sie fibzt zivar an Bixfen, Eberefod)en uno anderen Raubhölzen, jujeint aber bie (Fidje

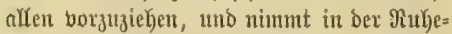
lage bie biełen Epanterrautpen cigene 2ijt=

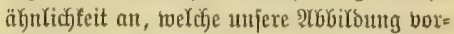
fulfyt. Som September ober Dftober hat fie ifre volle Gröpe exlangt uno geht in Den Boden, um in einer . Winter zur \$uppe (ðig. c) zu werben. Sm

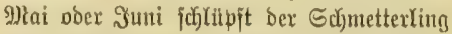
aแs, weldyen man nie bei Tage fliegen, wegen

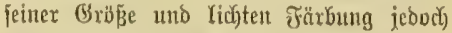
ijterą nit Lalb flaffenden Flügchn an einem

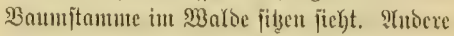

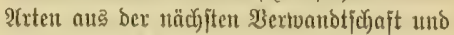

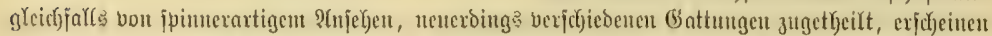

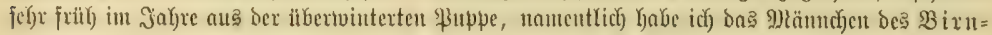

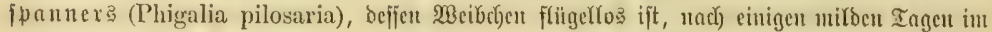

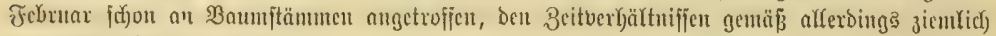
regutgs = und theilnahmlos.

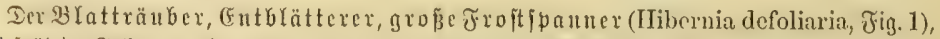

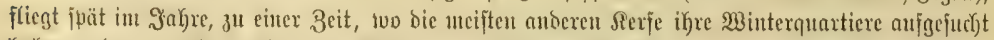

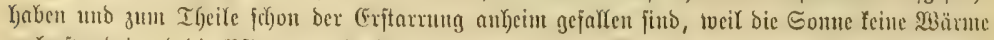

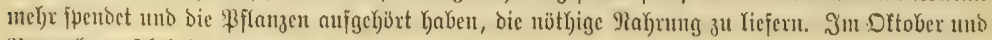

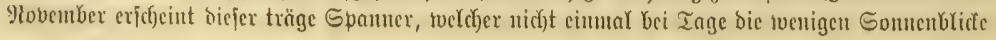




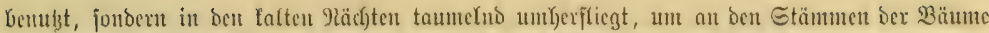

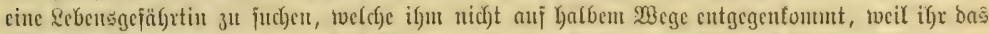

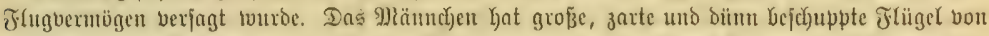

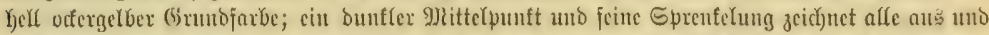

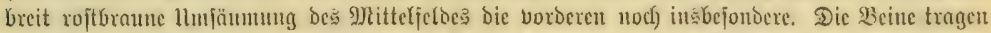

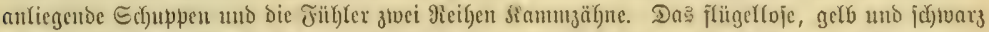

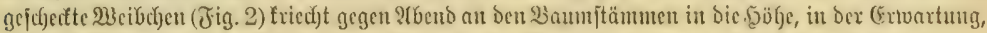

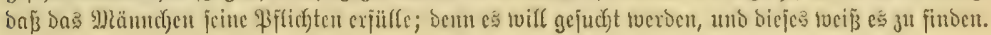

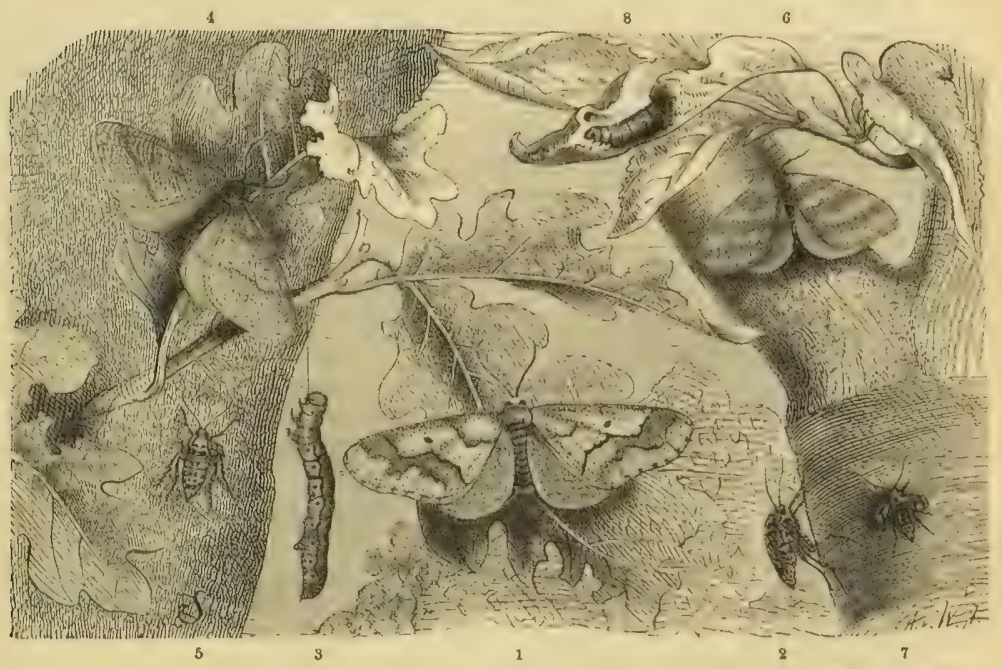

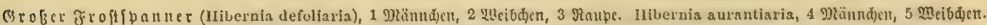

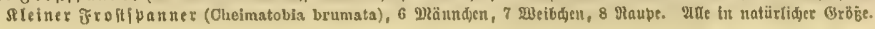

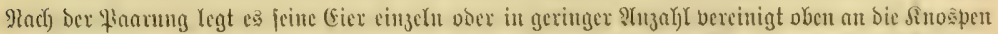

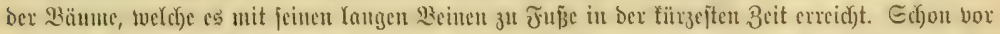

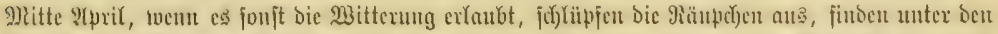

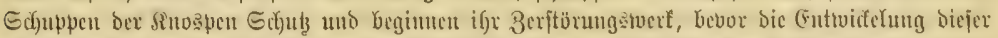

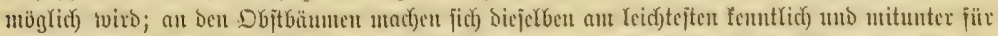

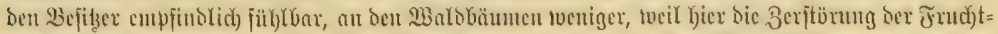

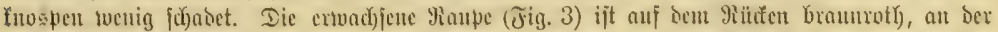

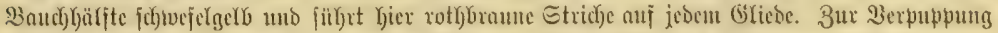

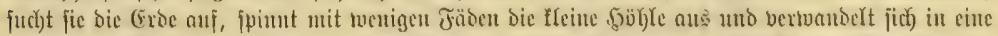

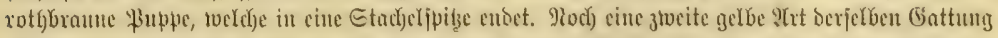

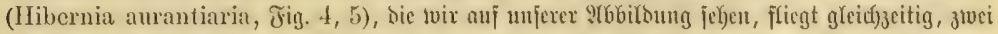

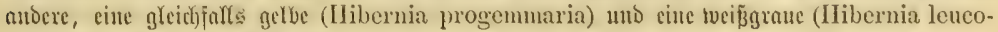
phacaria), im cxften frühjafje.

Dex freiue Frojtipanuer, Wiuteripanuer, Epätring (Cheimatobia brumata,

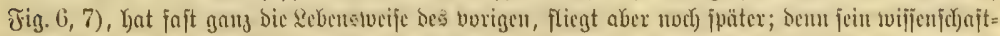

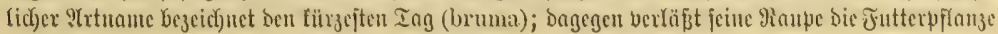




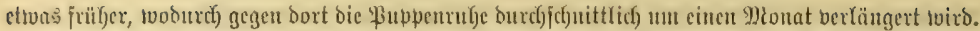

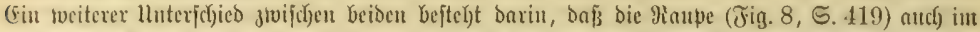

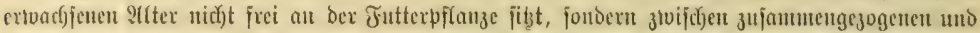

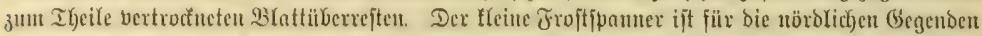

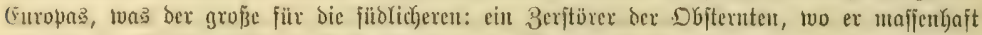

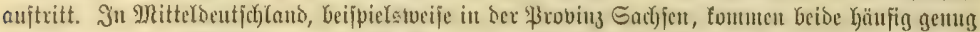

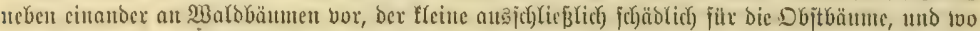

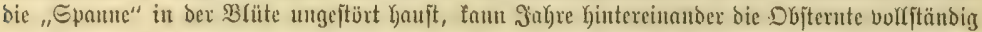

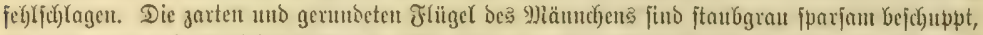

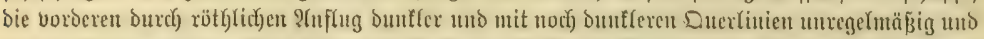

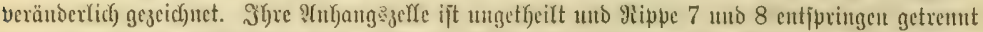

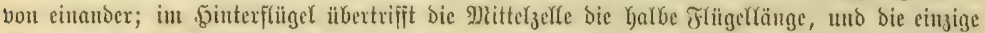

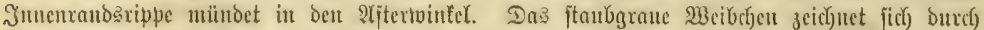

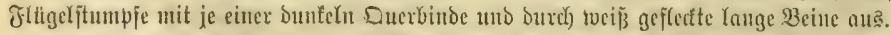

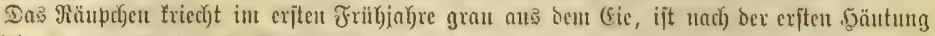

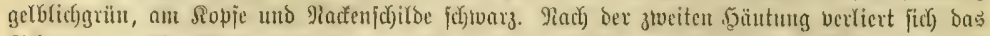

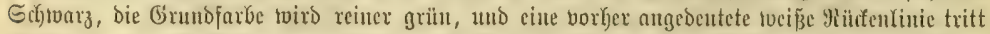

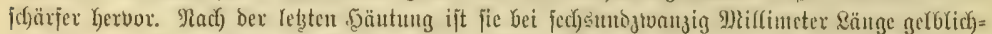

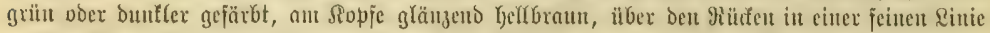

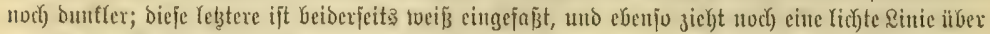

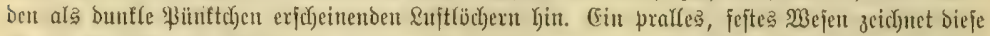

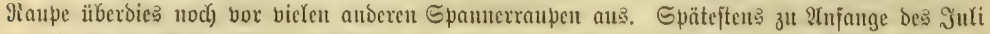

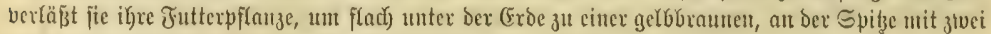

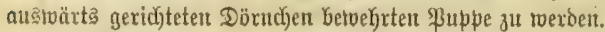

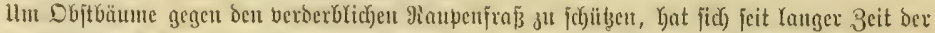

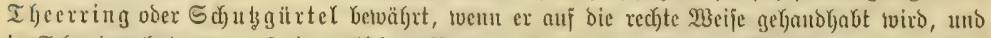

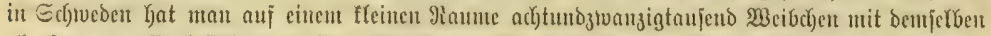

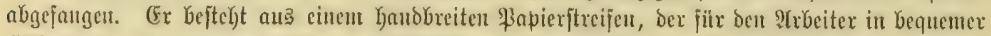

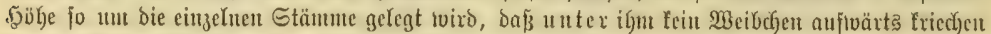
fant. Diejer Büurtef twiro mit einent Silebejtoffe bejtrichen und fleberig ergalten, fo lange

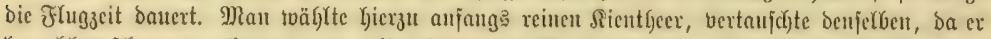

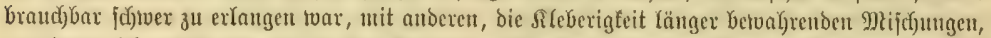

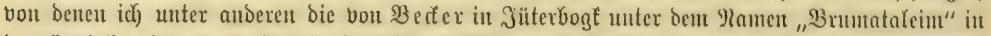

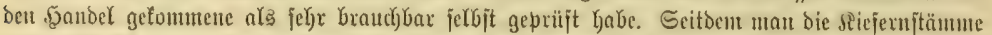

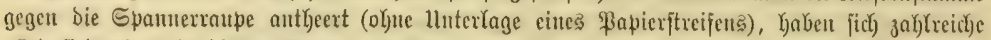

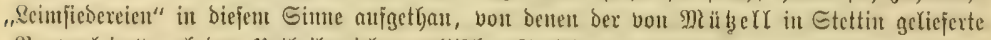

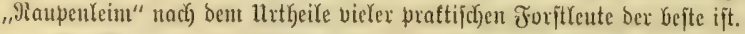

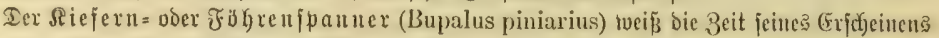

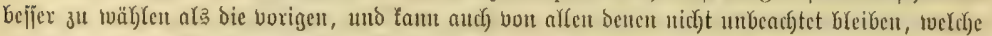

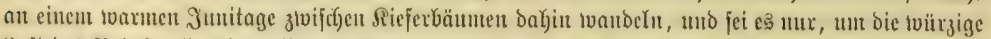

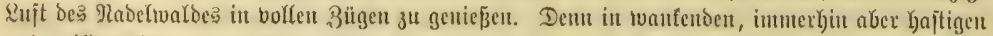

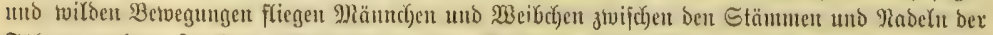

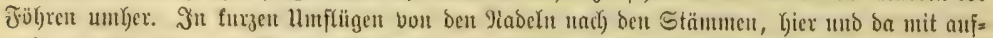

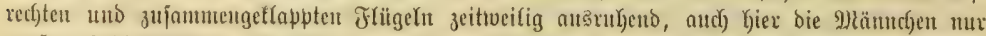

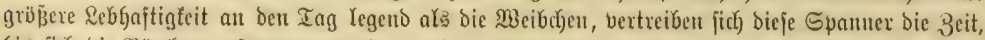

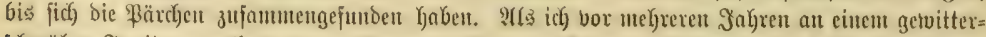

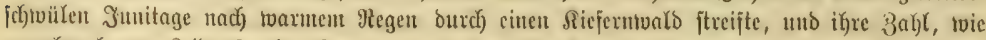

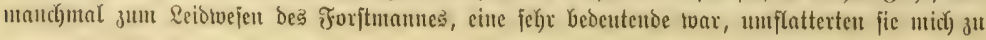




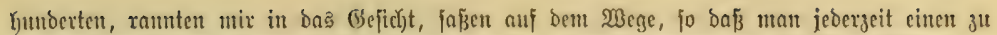
zertreten fürd)

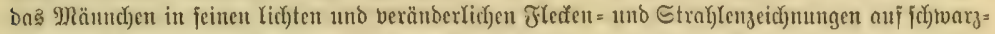

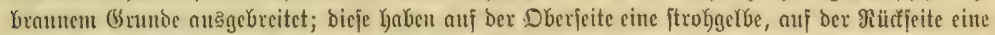

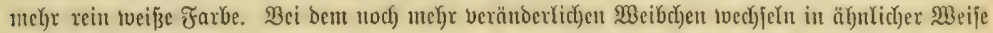

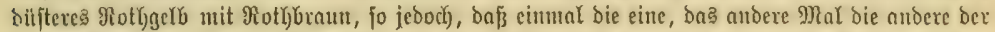

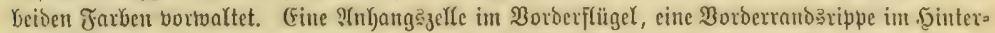

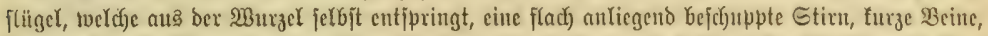

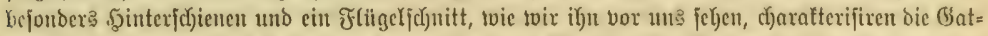

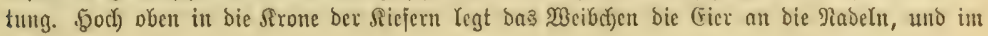
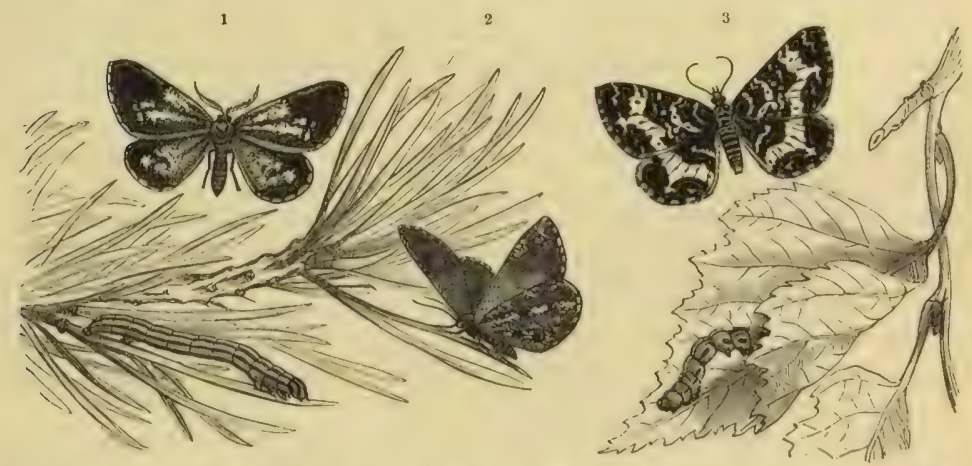

Siefernfpanter (Bupalus pintarlus), 1 Männdyen, 2 20eibden unb Raupe. 3 Gplebुbano (Larentla hastata) nebft Raupe Rte in natiurlidjer Gröbe.

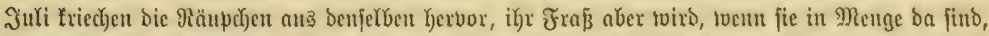

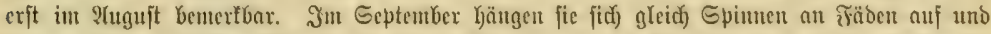

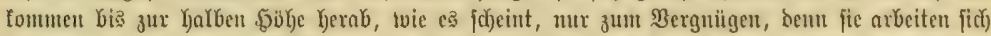

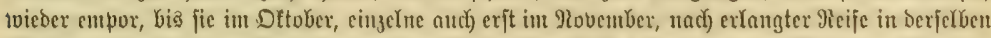

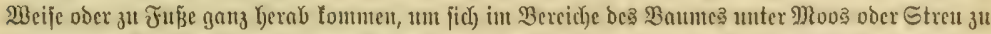

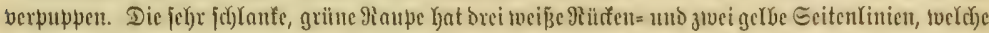

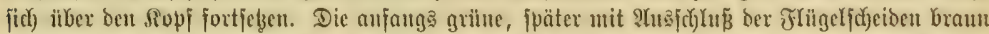

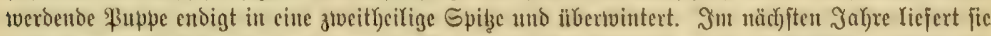

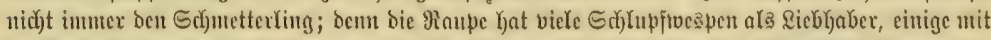

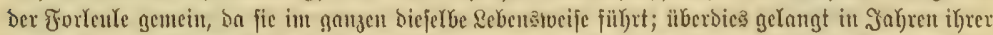

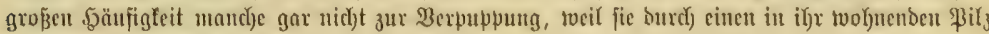
(Botrytis) getubtet tworden ift.

Die artemreid)e Epanuergnttung Isarentia geljört ciner Gruppe au, bei beren Ǵliebern bie

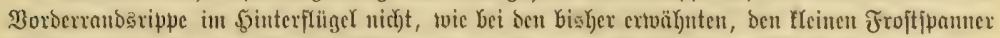

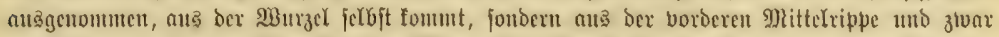

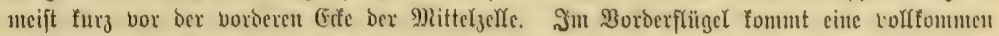

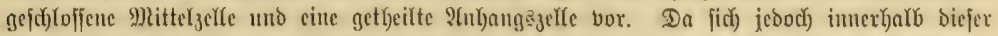

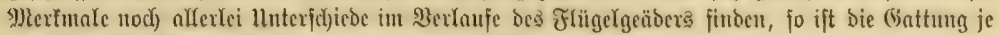

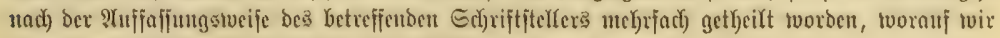

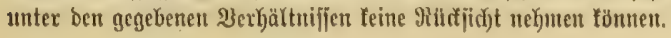




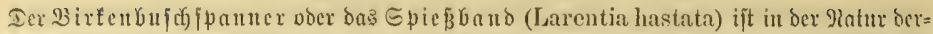

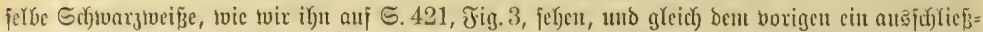
(ic)

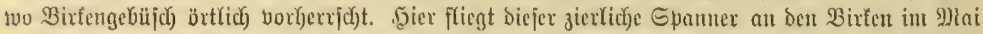

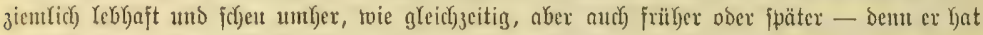
zuei SButen - ber faft ebenfo gezeidyncte, aber minder groje Iraucrfpanter (Larentia

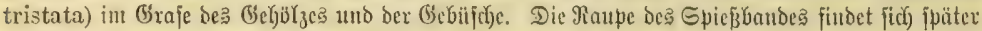

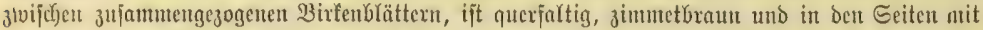

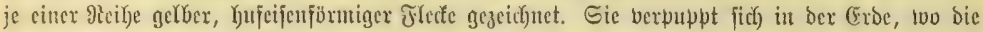

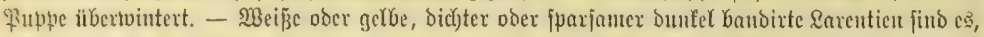

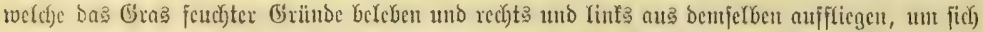

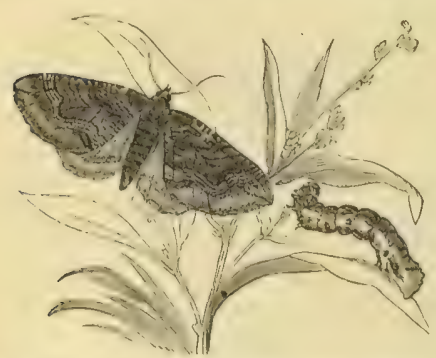

(säniefubfpanner (Tarentia chenopndiata) nebft Plaupc. Ratuitidie (Brobe.

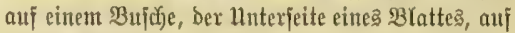
cinem $\mathfrak{B a u m i t a m m e ~ b a l d ~ w i e b e r ~ n i e b e r z u l a f f e n , ~}$ oder bon nettem im Braje ein Beriteif zu jurtenen, wenn man in einer für jie etwas verdächtigen $\mathfrak{B}_{\text {eije }}$ joldje Begenden burdajtreift. Man mertt ignen an,

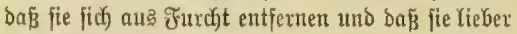
bie Dunfelgeit abtoarten, un aus eigenem Intriebe unt im Dienjte Der Ernährung uno Der Fortpflan= zung lebendigere Ilmflüge zu kalten.

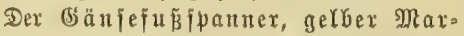
mor (Larentia chenopodiata, auch) Cidaria clienopodiata), rjält jich an älynlichen Dertlid feiten, bejonders in ben Dorïgärten und ocren

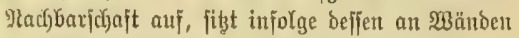
bex Stallgebäube, an Etämmen und nidjt im

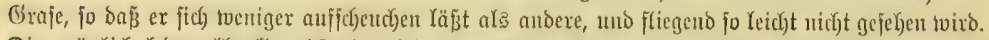

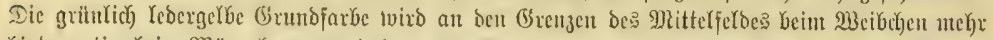

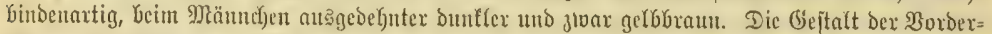

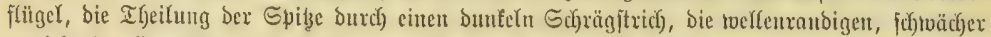

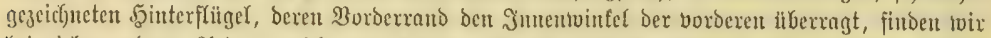

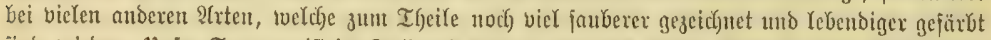

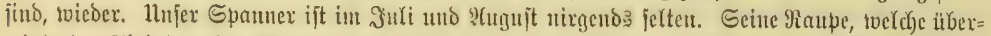

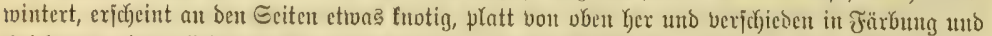

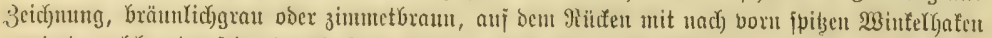

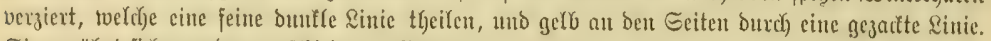

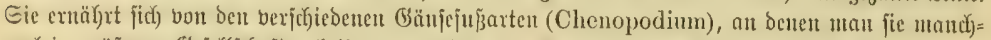

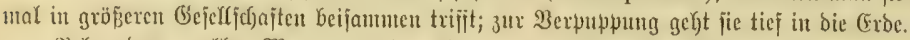

Meben bem "gelben Marmor" feben wir ben .jarlefin, Etack) elbeeripannex (Abraxas

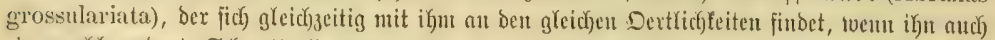

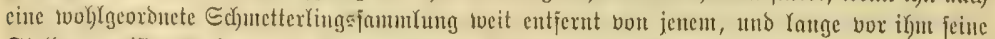

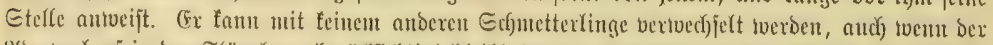

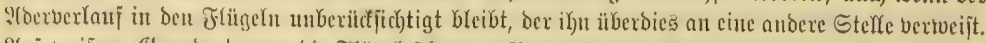

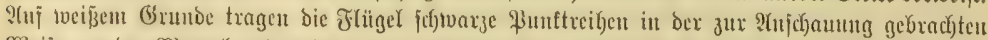

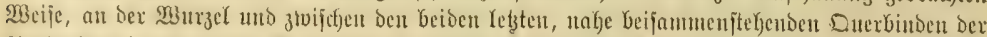
Dorberflïgel jorvic an Den Sibrperieiten fommt bie bottergelbe als britte Farbe Ginzu. Bei Iage fibt

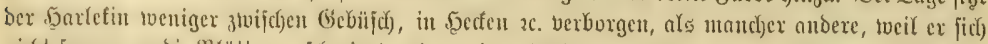

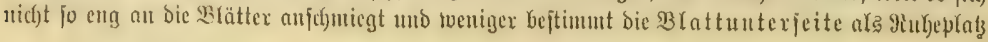




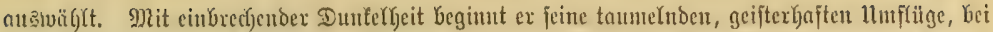

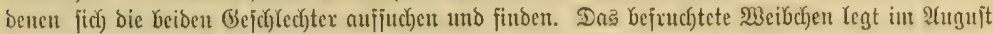

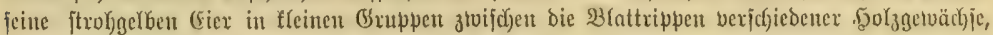

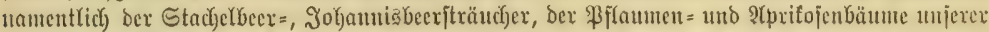

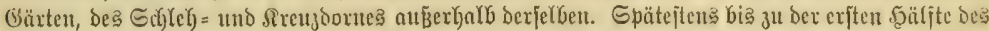

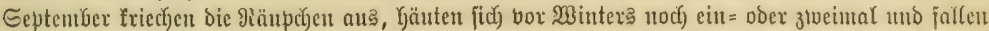

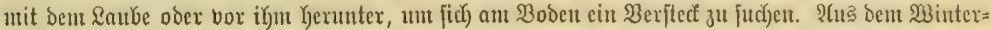

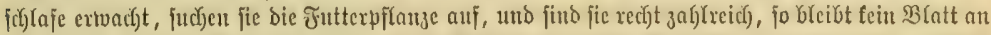

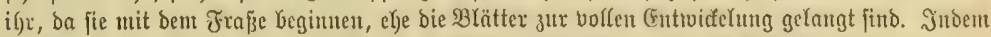

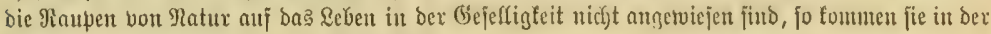
Meget aud nur bexeinzelt bor. Sie liefern

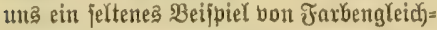
Keit zivijchen \&arbe unb volffommenem Serfe. Sie ift in ber angegebenent Weije fochnarz=

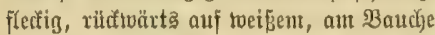
auf Dottergelbem Untergrunde. Mtit $26=$

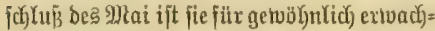
jen, jpinnt fich mit einigen fäbett an ifrem Yebten Weibeplabe odex in bejien ?ähe feit unb twixd hinter benjelben zu einer glänzent

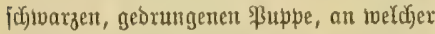

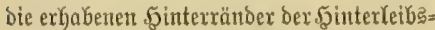
glicoex bottergelo gefärbot fint. Dieje zier=

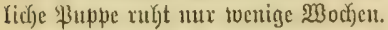

Jinjolge ber llebereinjtimmung in Farbe

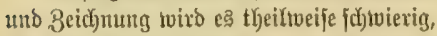

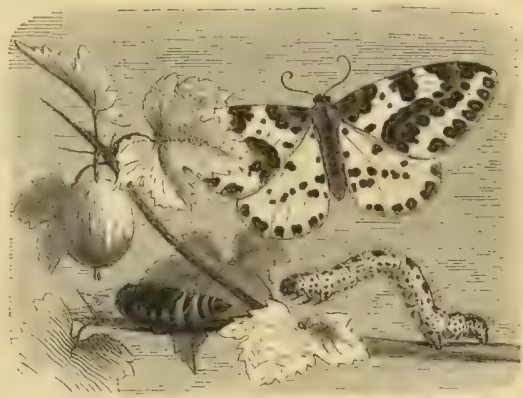

Saricfin (Abraxas grossulariata) nebft Raube uno quppe. Ratïrtibe Gröge.

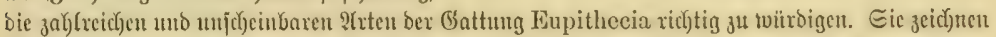

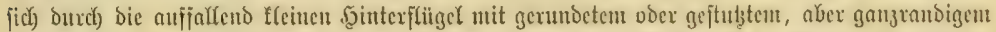

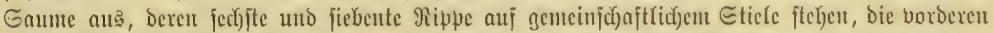

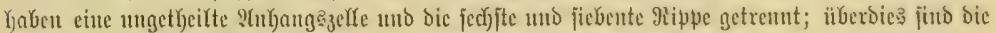

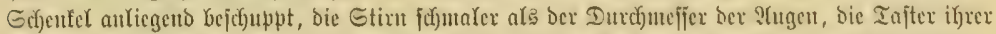

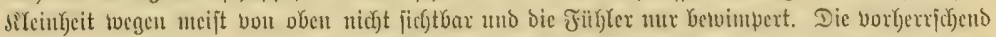

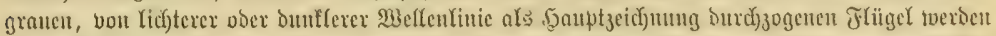

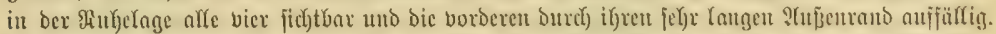

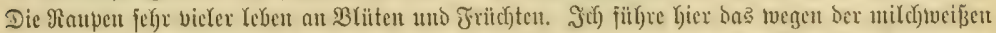

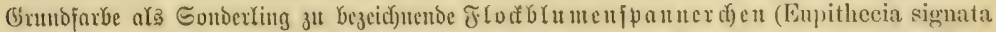

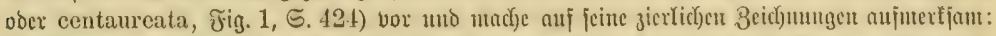

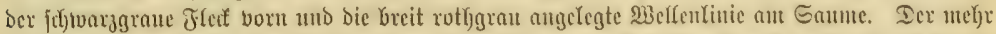

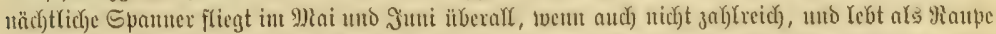

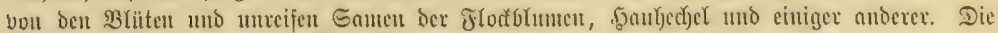

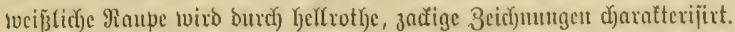

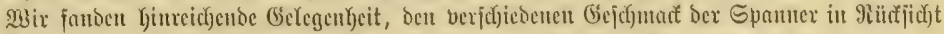

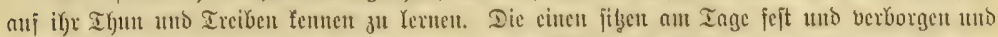

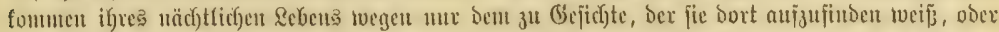

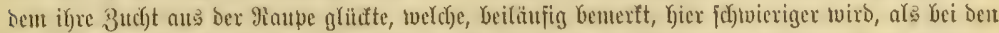

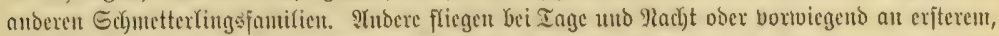

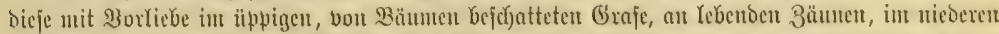

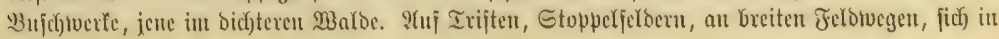




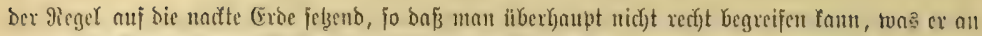

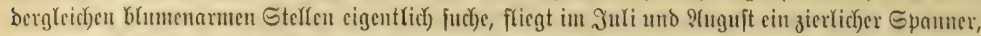

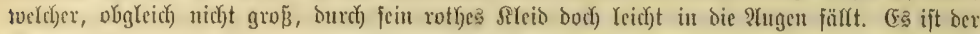

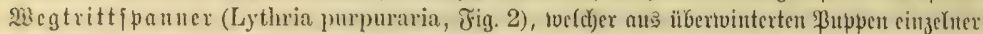

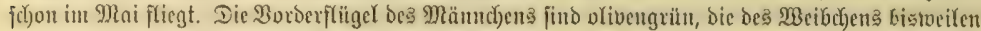

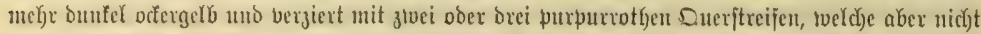
immer in gleicher פolffommentyeit ausgeprägt find, injofern bejonbers ber Gintere ben maunig=

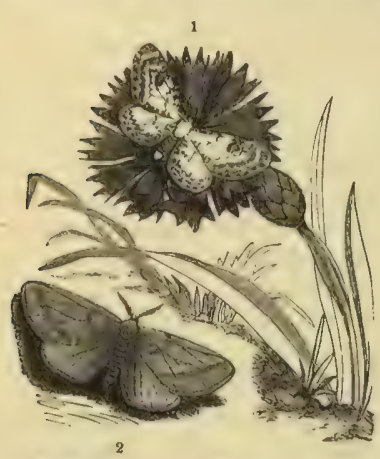

1 frlodbrumenfpanuer (Euplthecla sigata). 2 23 estrittipaner (Lythia purpuraria). Matiirtide Broble. faltigften शbänderungen untertoorfen, einfach, roic wir ifn in ber abbildoung jeken, ober boppelt, ober nur vorn gabelartig getheilt ijt. (5ine purpurne Gaumlinie und ebenjo gejärbte Franjen fommen nod) Ginzu; audo bie Dunfel vofergetben Dinterfliggel, beren purpurrothe Mritterbindo bon unten auj Der Dberjeite nicht jelten ourchjichimmert, unijäunen mit den bor= Deren gleidjfarbige Franten. Die ungetheilte श्tu=

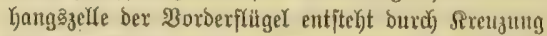

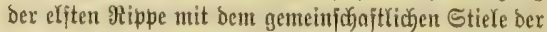
fiebenten und zebnten, welcher bor ber (Ecfe aus ber

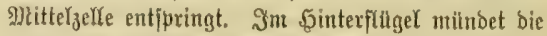
cine nur borkandene Imtenxnoşrippe in ben 2ijter= vinfel, bie fectjite uno fiebente find gejtielt, uno bie Drittelzelfe zeidfutet jich burd) ifre Rüze aus. Sange

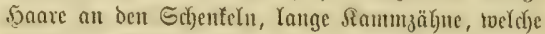

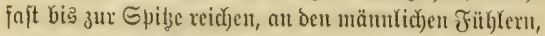
uolfenden bas Bild biejes bie Iroctenkeit Yiebenden

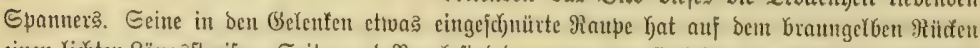

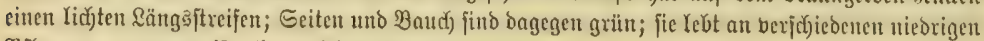
Pflanzen, vorzugatweife aber anf bem fleinen Sauernupfer.

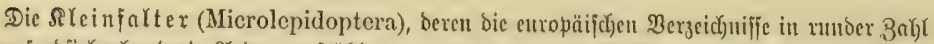

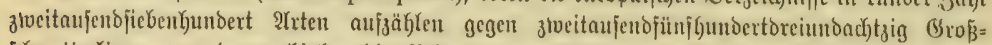

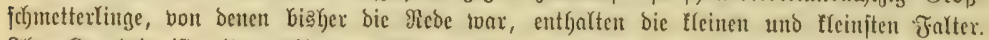

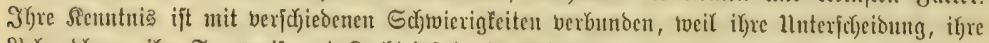

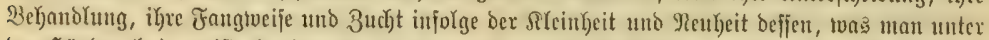

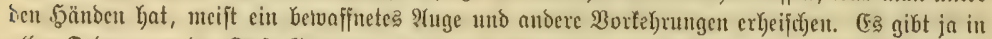

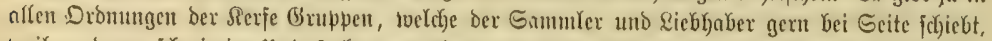

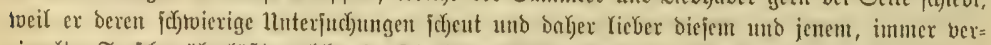

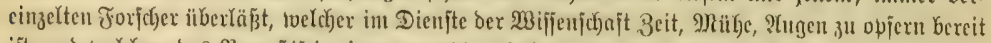

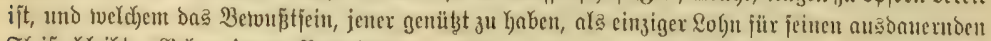

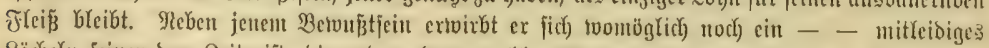

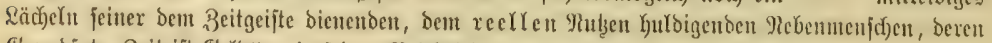

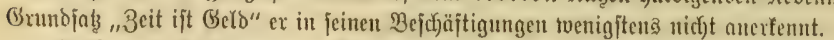

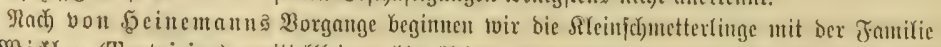

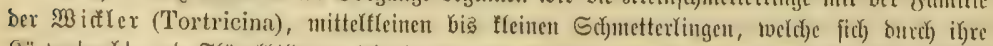

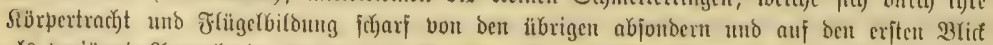

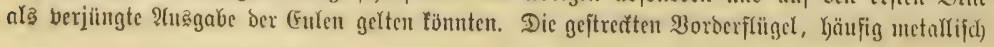




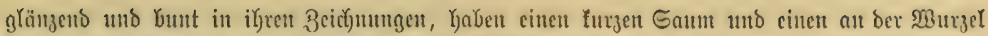

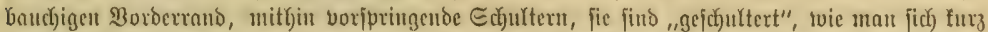

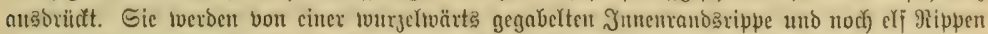

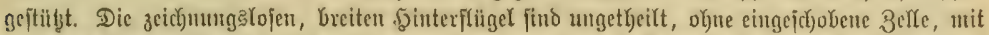

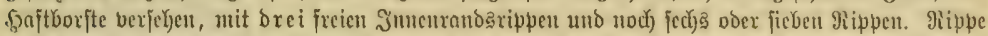

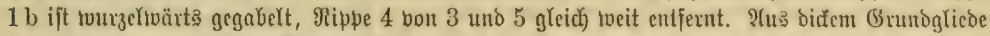

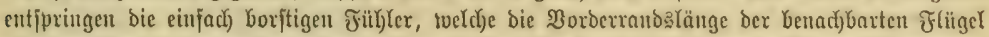

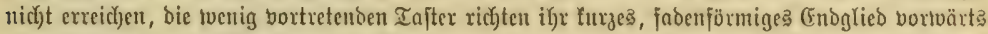

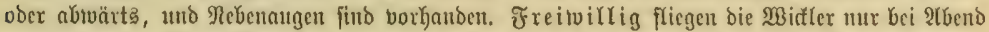

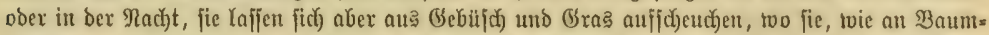

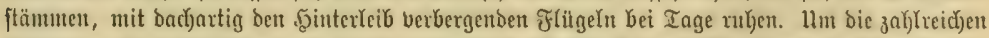
Ginttungen zu unterjociben, in tweldse neueroings bie alte Battung Tortrix zerfegt worden ift,

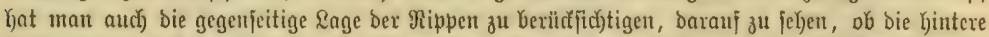

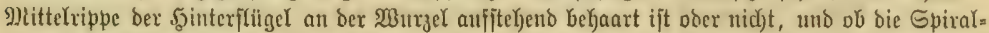

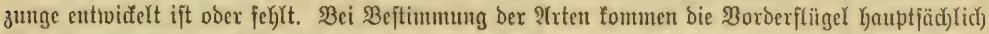

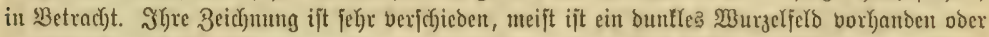
benigftens burd) feine Segrengung angebeutet; bahinter fontmt ein Yeflerex, oft bindenartiger oder

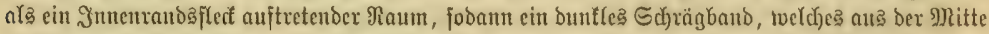

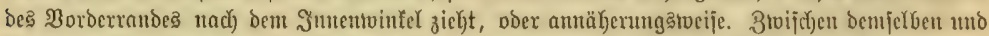

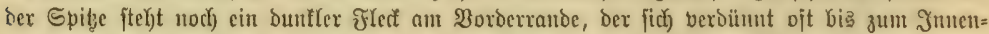

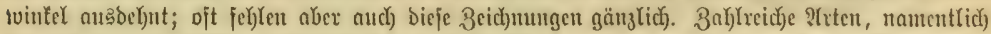

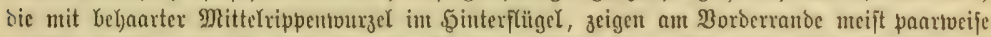

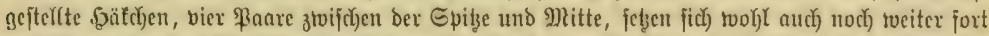

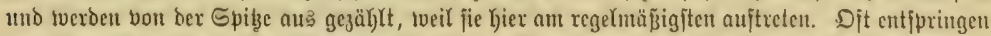

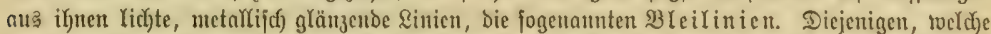

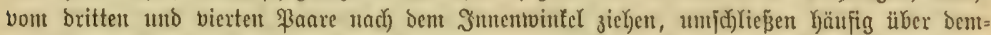

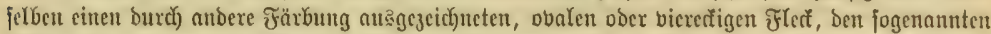

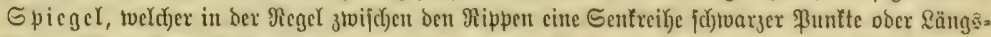

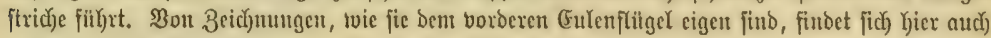
nicht bie Yeifejte Inbeutung.

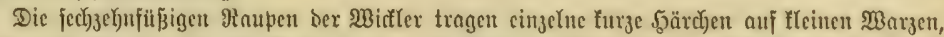

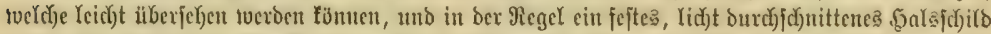

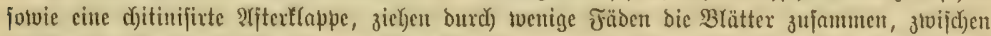

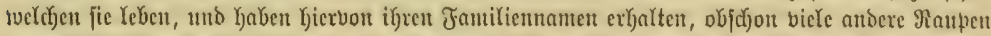

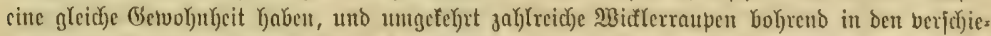

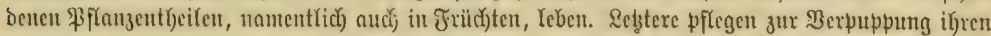

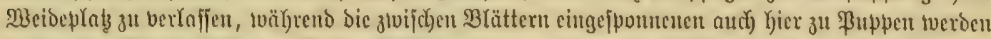

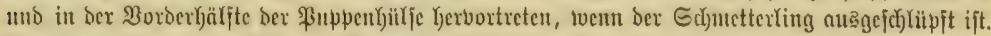
Mur bei roenigen 2 rten find gtvei Bruten beobacktet tworden.

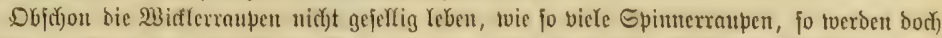

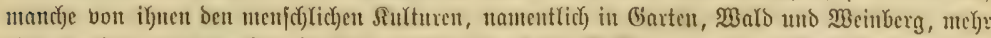

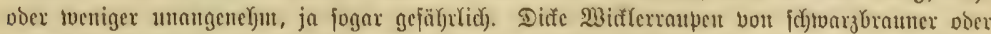

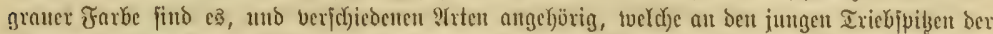

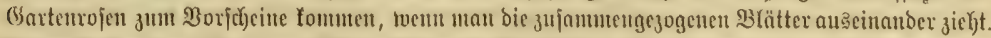

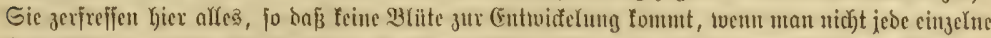

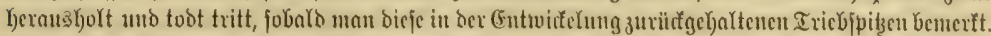

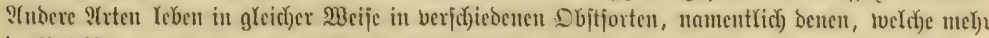

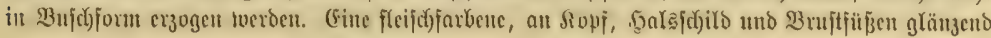




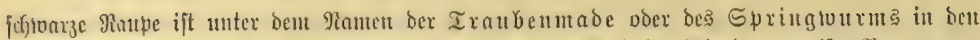

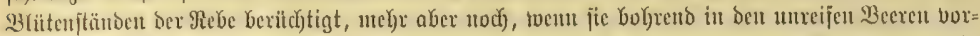

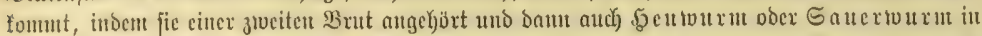

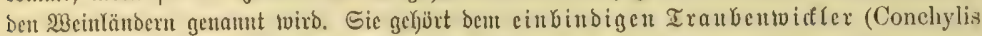

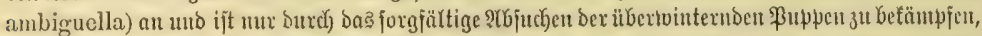

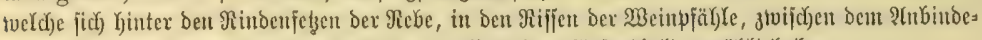

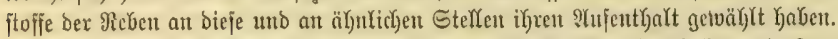

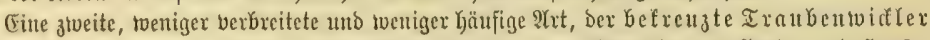

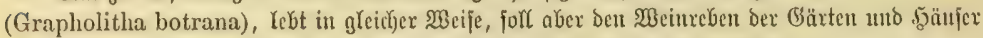

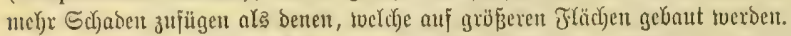

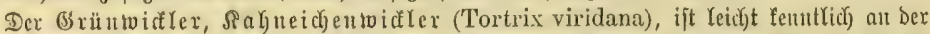

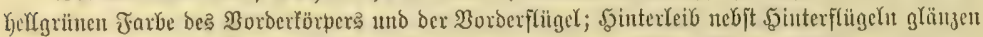

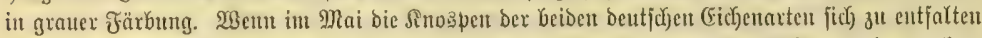

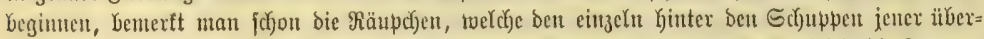

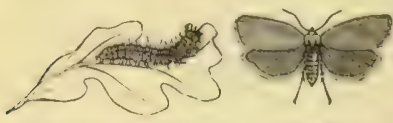

(S) riluwidler (Tortrix viridana) neof? Raupe. Malilitidje (Sröß̨e. tvinterten (Eiexn entjproffen find und ficd in bie Rnospen

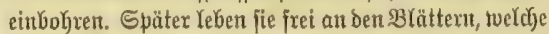
fie befpinnen, audj etwas zujammenzieben, jo baj

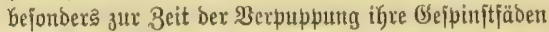
vou ben Bäumen เvic Spintenveben herabłängen. Dic gelbgrïne Raupe ift am Sopje, ant Sointertande bes

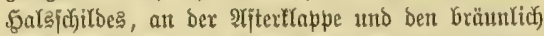

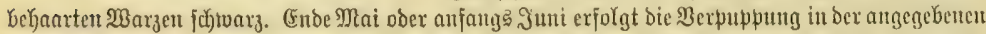

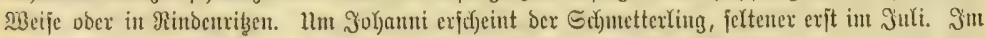

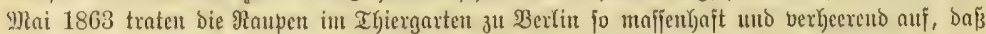

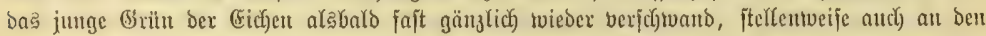

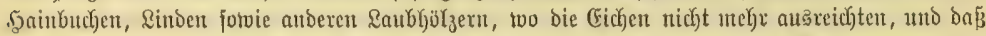

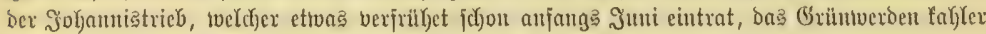
Bäume zแm zrveitenmale borjübrte.

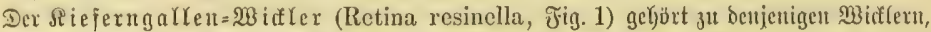

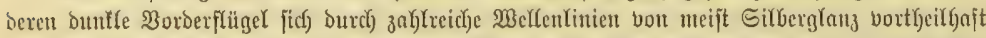

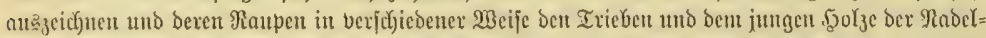

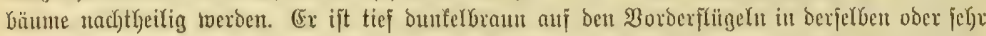

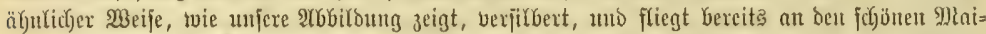

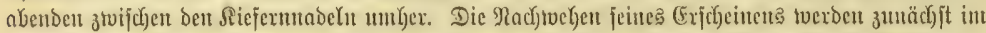

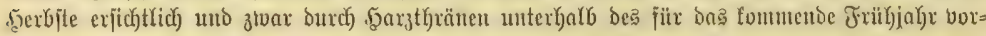

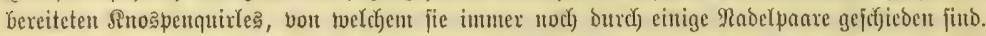

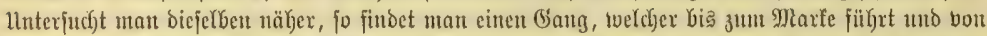

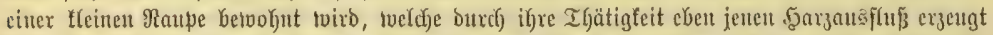

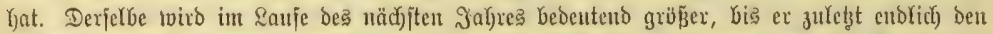

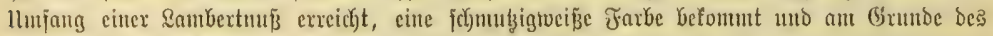

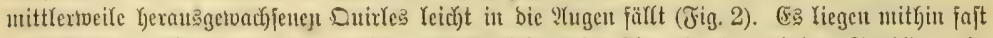

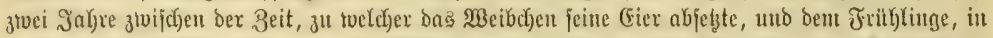

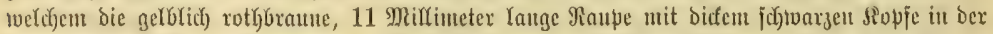

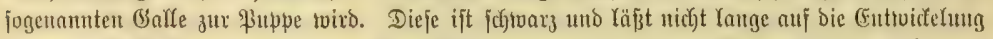

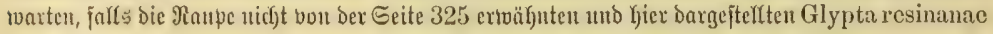

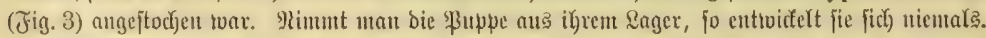

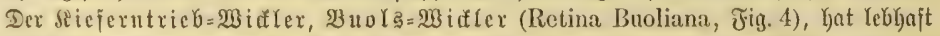

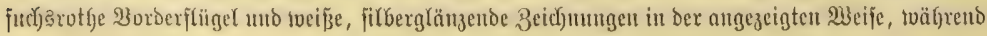




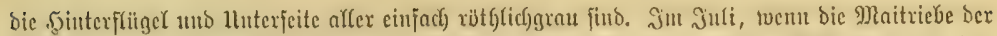

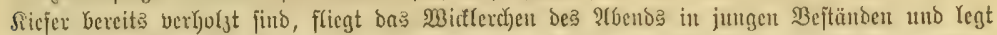

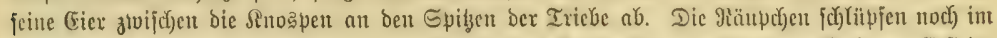

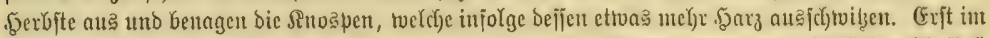

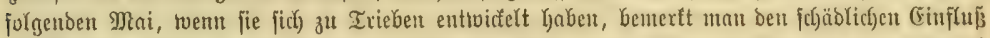

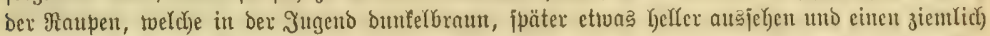

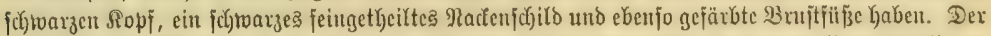

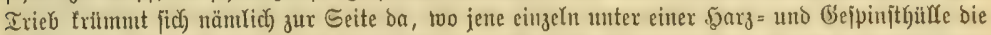

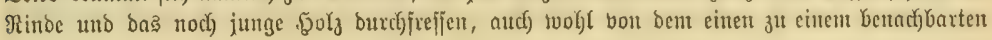

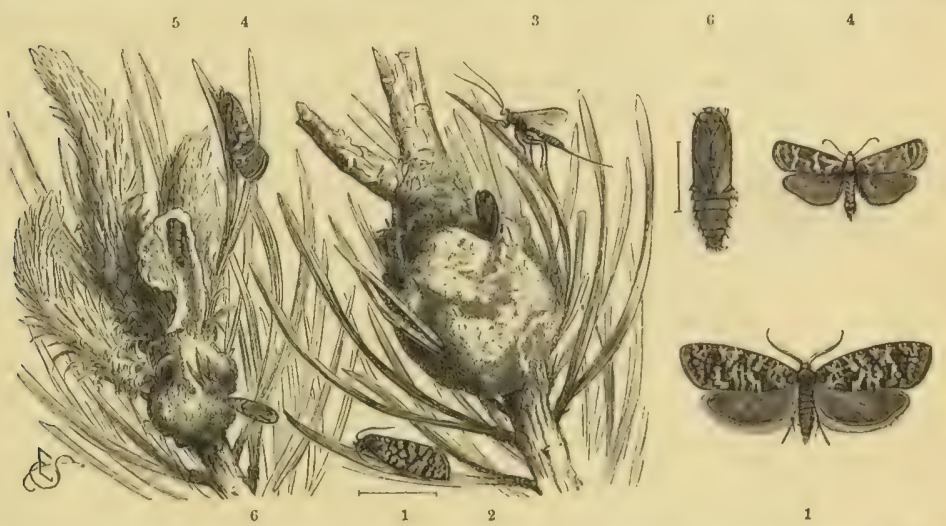

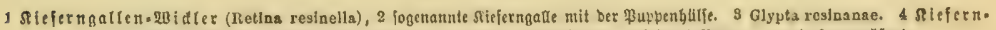

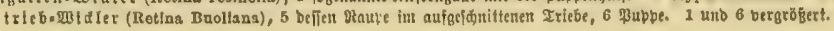

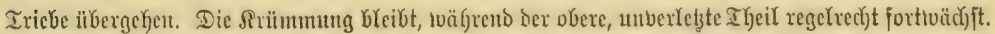

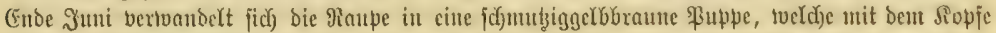

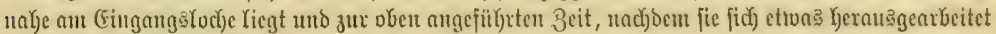
Gat, ben Sdymetterling entläß̄st.

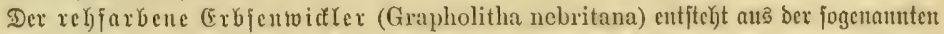

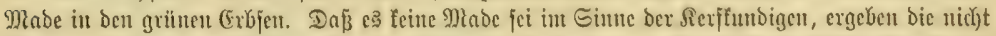

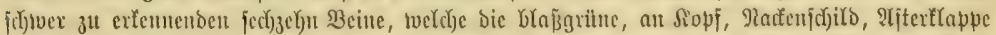

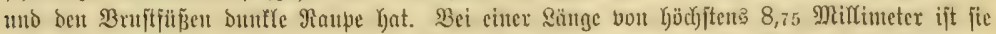

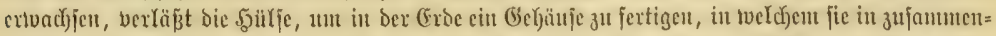

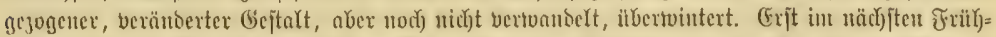

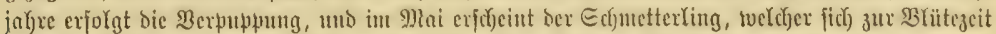

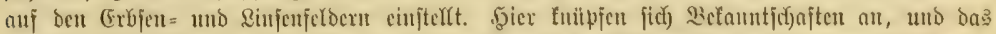

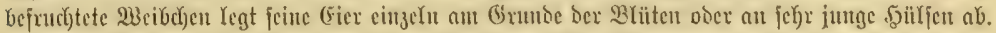

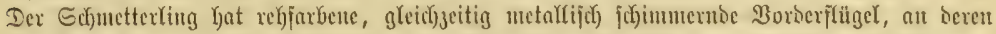

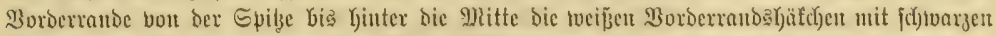

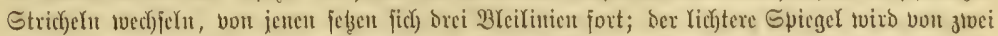

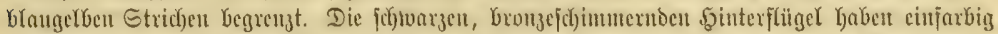
weißje Franjen. Der mu uffecfige (Exbjentuidfex (Grapholitha dorsana, S. 42S) Yebt ganz

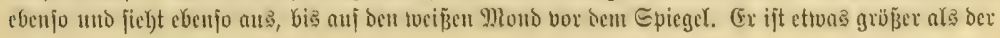




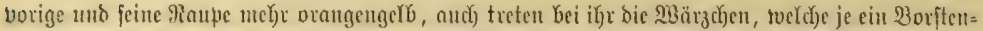

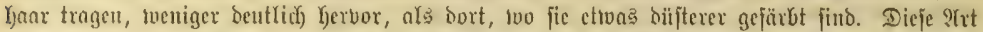

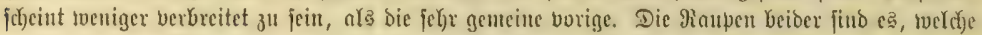

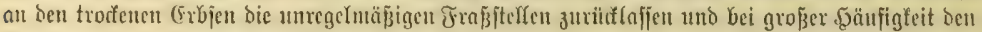
(Enteertrag berjelben toejentlid) beeinträrdtigt Kaben.

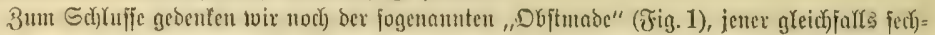

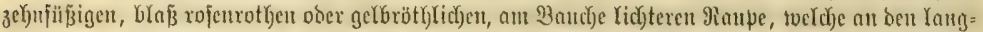

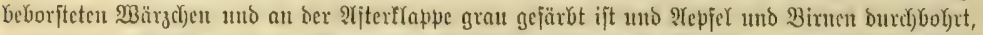

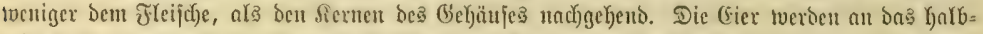

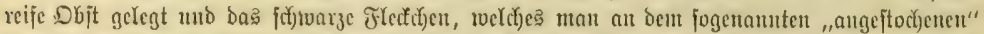

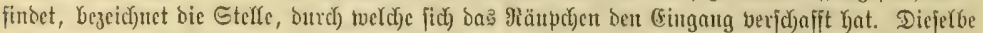

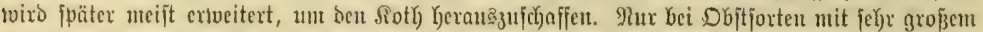

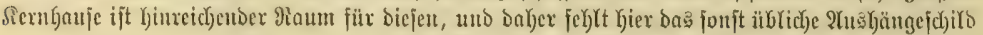

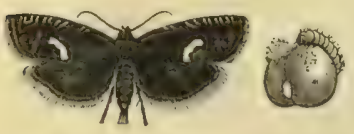

Donoftediger (Exbienvid ler (Graplunlitha dorsana), vergrobert, nebf gtaupe.

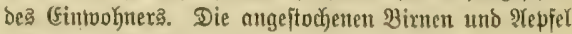
erlangen befanntlich eine etwas fruibere Beife uno fallen aucd) theitweife noch) unreif von ben $\mathfrak{B a ̈ u m e n . ~ श ( u ~ b e n ~}$ frïferen Sorten geht die Raupe meijt zu Grunde, toeil fie beim Derbraudjen bes Objtez gefunden uno Keraus= geworjen toiro, bevor fie volffommen ertwachjen, mit bem

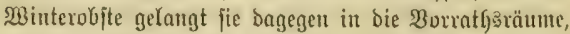
arbeitet fick) Yjier burd) Das (Finganga

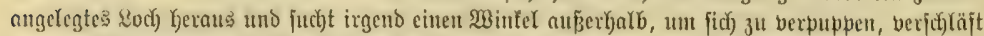

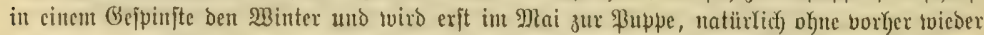

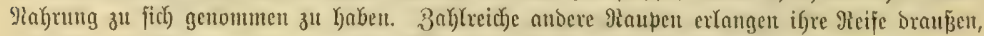

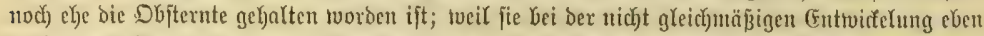

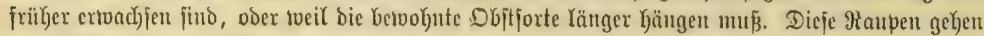

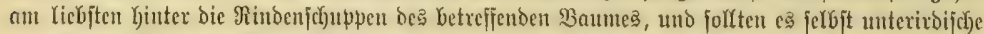

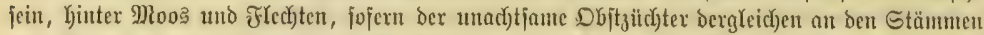

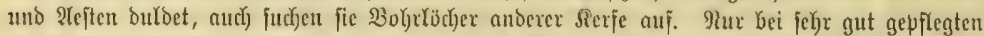

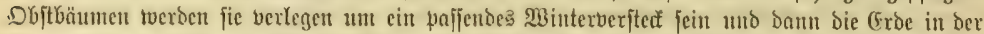

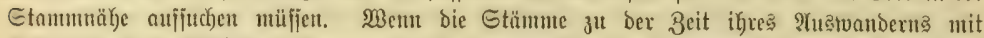

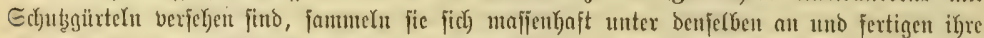

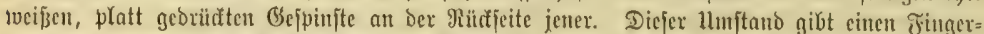

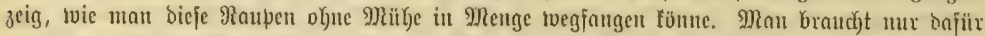

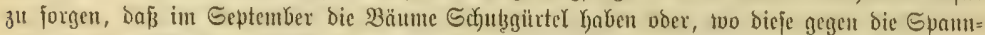

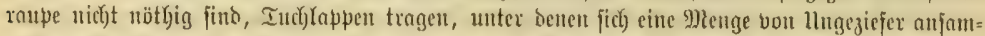

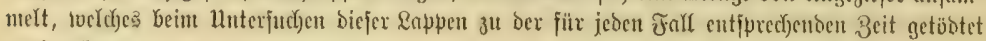
werben fann.

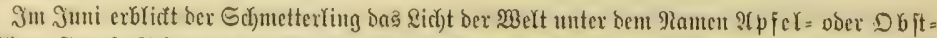

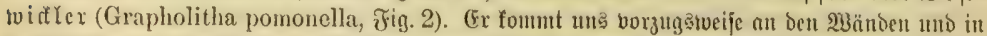

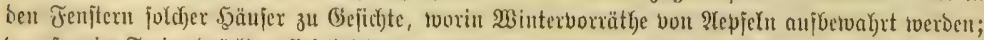

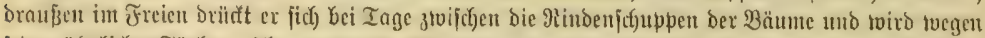

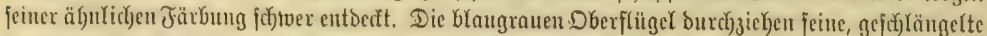

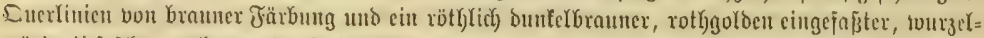

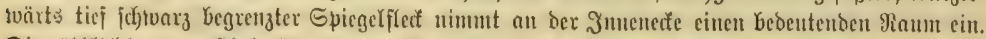

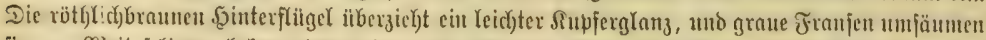

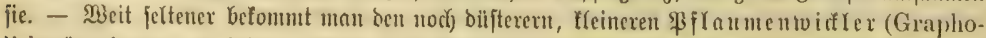

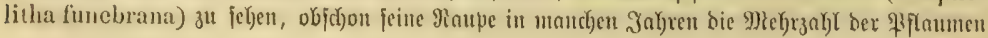




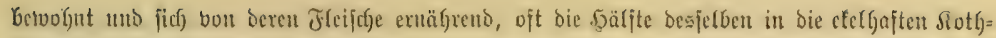
frümeln bertonatoelt.

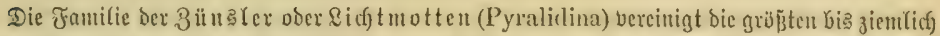

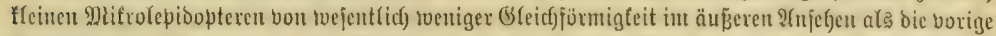

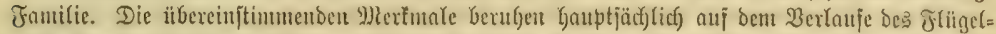

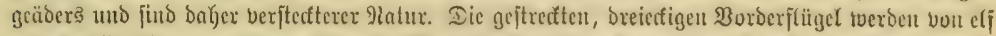

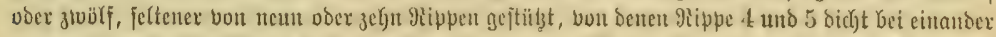

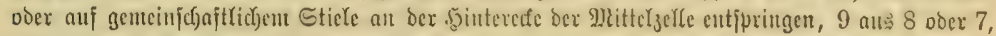
jelten gan fehlend, nałe ber vorderen (Ecte. Dieje ungleiche $\mathfrak{B}$ ertheilung bon Rippe 3 bis 8

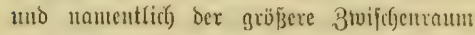

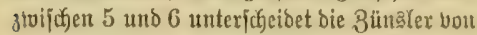
ber vorigen und von ber folgenten Fanilie.

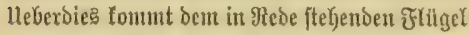
cine ungetheilte פglittelzefle зu. Det inme: breitere 5interftügel ift ungetheilt, olyne eiu= gefdjobene Belfe, mit \$ूajtborfte, brei freien

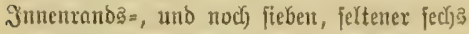

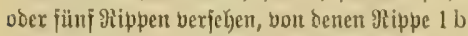
nicfit gegabelt, 8 auf einer strecfe mit 7 ber= cinigt ift ober minoejten nake baran bertäuit. Die Fühlex jino boriftenförmig, bie 2Tugen naăt Itto meijt ftart holblugelig hervorgequolleu,

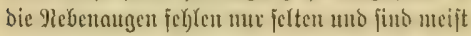

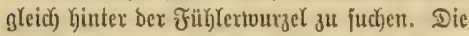

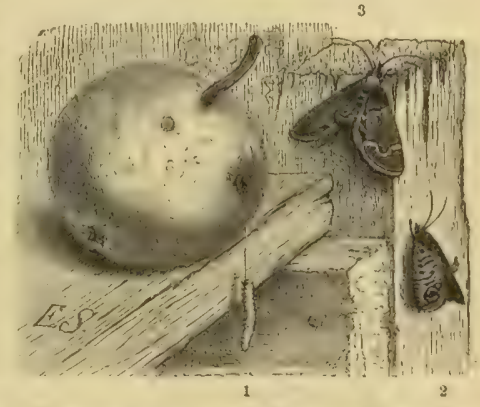

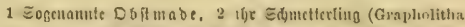

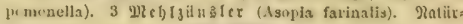
lide Gröte.

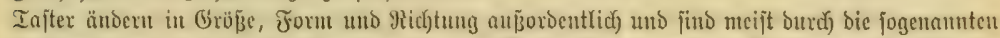

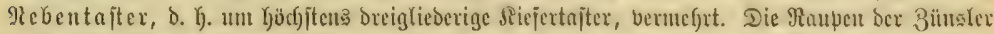

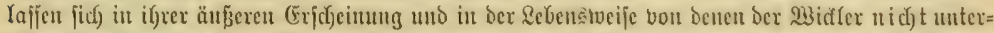
fcheioen; fie find eas, twelche in ben weitans meiften fäffen ïbertwintern, mur felten gilt bieș von

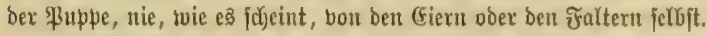

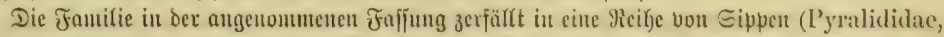
Botidae, Chilonidac, Crambidae, Phycidae uno Galleriac), beren eine voer andere wir mux an twenigen $\mathfrak{B e r t r e t e n t ~ e x l a ̈ u t e r n ~ t o ̈ n n e n . ~}$

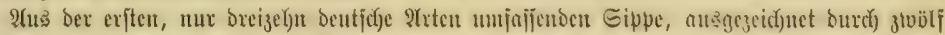

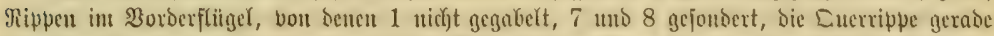

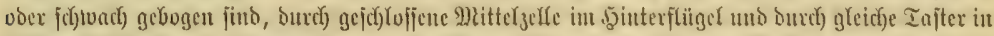

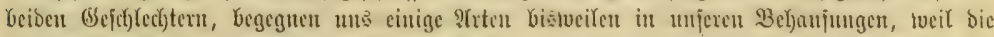

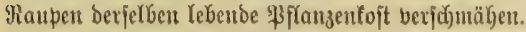

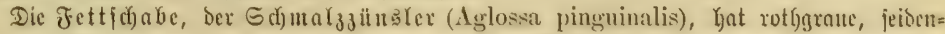

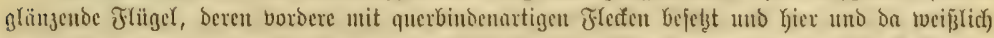

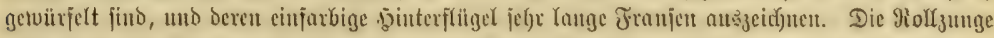

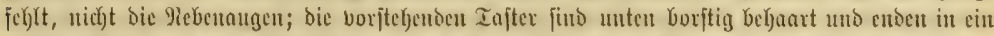

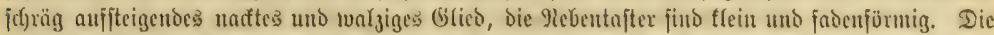

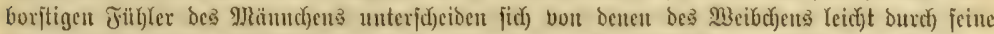

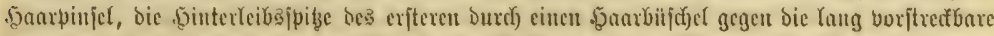

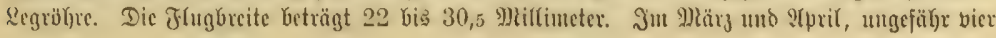




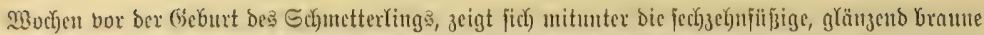

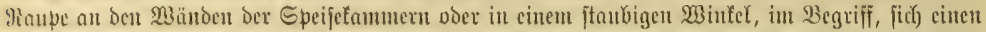

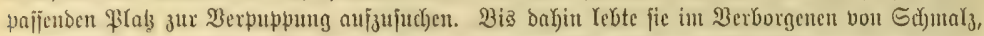

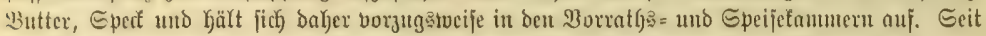

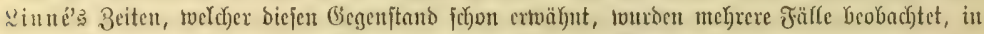

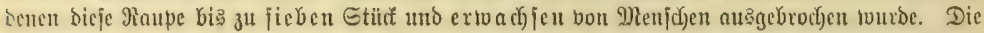

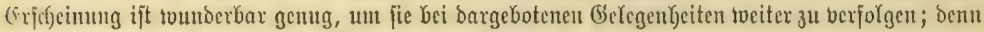
cine annelymbare Extärung berfelben fonnte nod nientand geben.

Der Melylyün

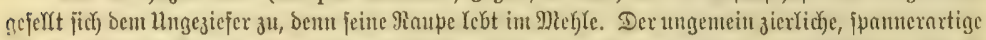

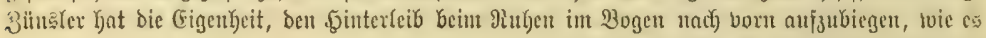

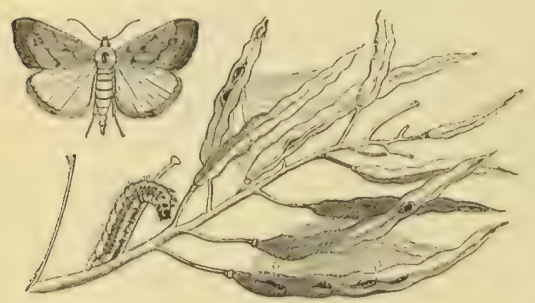

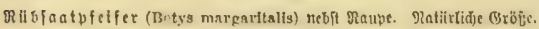
audi) ein treiper, braunbindiger Spanner (Cidaria ocellata) thut, ben man an ciner $\mathfrak{B a n t}$ gleichjalla bei Tage in biejer Stelfung ruber jehen fann. 3roei zart toeiß̌e, unregełmäfig verlaufende Duex= linien grenzen auf ben olibentbraumen $20 \mathrm{O}=$ derflügeln ein breites, mehr gelbes 2)tittel= felo ab; auf ben grauen. finterflitgeln jino

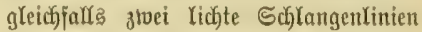
angebeutet. Die aufiteigenden $\mathfrak{I} a j$ ter jind anliegento befuluppt und enden faben=

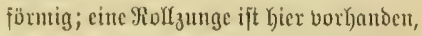

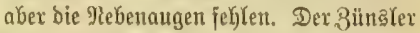

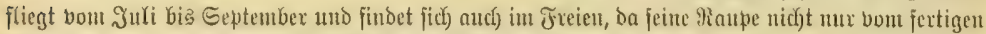

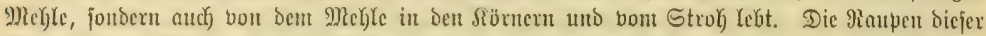

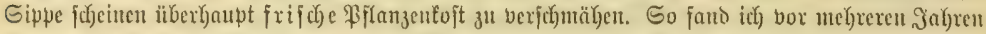

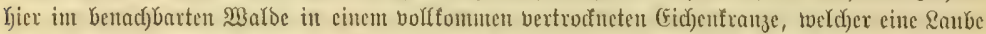

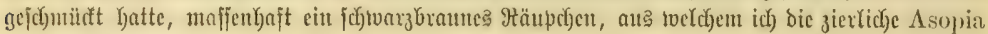
glaucinalis erzog.

Ulm bic ungenicin artenrciche Gattung Botys, bie allein über Kunbert (5uropäer entbält,

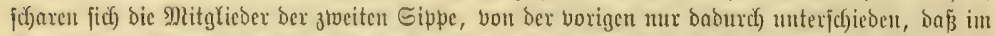

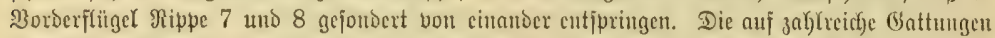

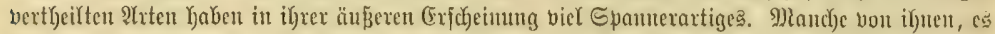

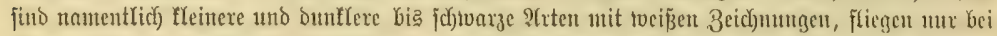

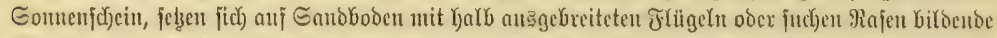

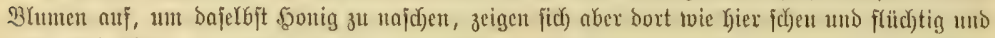

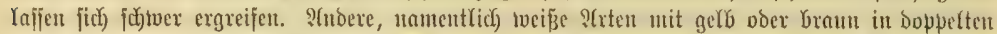

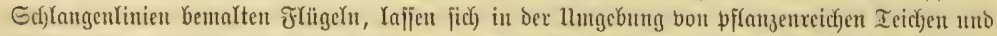

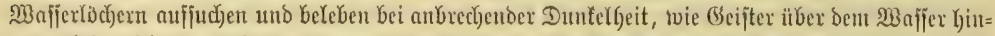

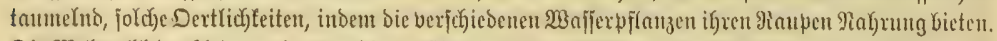

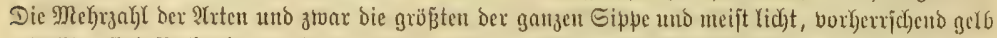

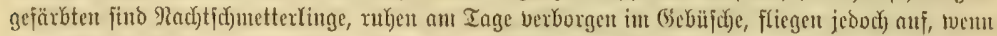

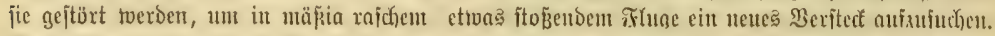

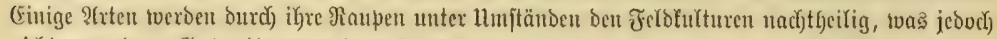
richt bon bem (Setreidezitneler. (Botys frumentalis) gilt, twie man ans feinem Panen

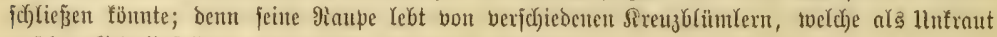
auj ben (betreidejeldern, namentlich) im Weizen, twachjen. 
Der Mübjatpieifer (Botys margaritalis odex Orobena extimalis, wie ifn bie neteren

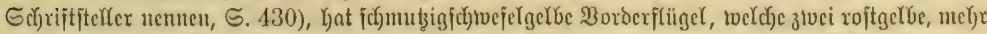
voer weniger beutlicke und zum Ifeife unterbrod)ene Duerbinden, cin roftbrauner Echrägittrich) nus

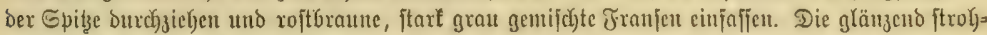

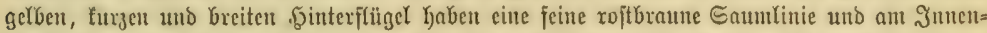

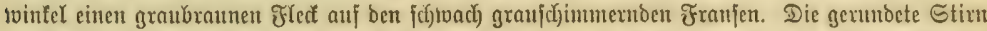

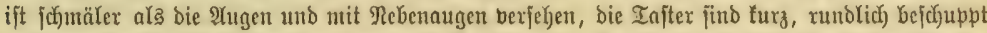

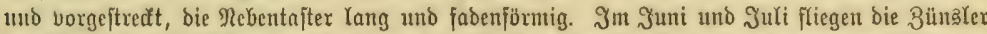

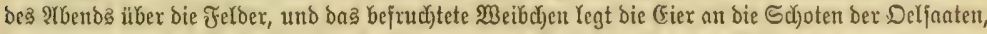

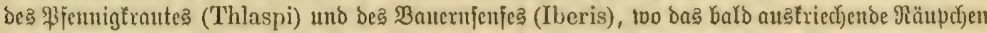

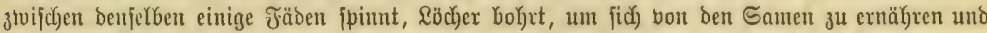

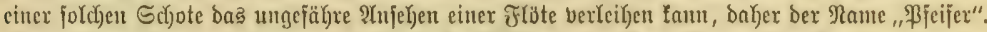

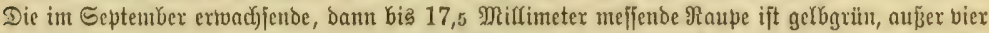

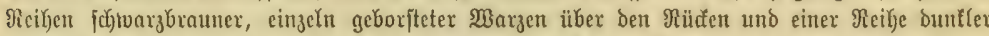

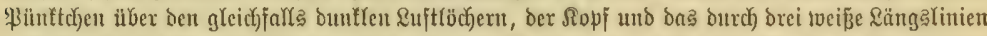

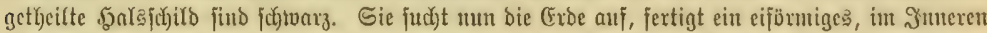

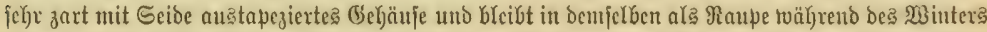
lirgen. (Exjt cinige Mod)en (26 Iage) bor bem (Exjd)einen bes Edfmetterlinges, aljo im Marai,

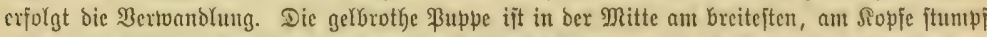

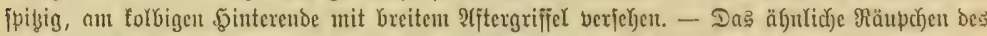

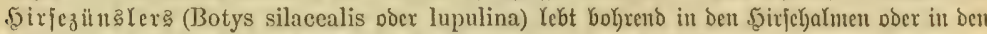

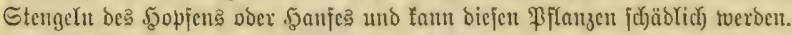

Die Rüjelnotten (Crambidae) beleben ben ganzen Gommer Gindurch die Miejen und

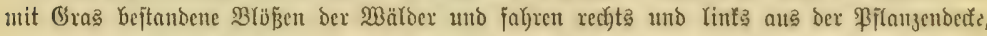

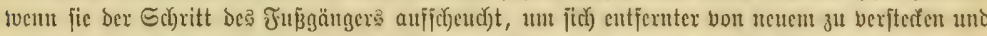

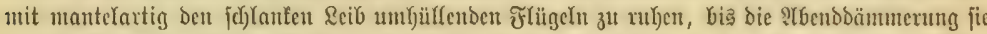

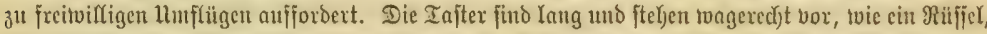

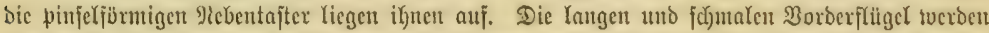

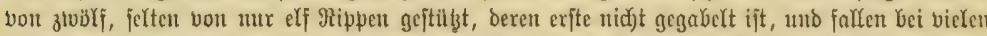

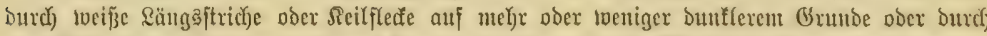
metallif(d) glänzende Rinien, befonders Jranfen des Saunes auf. Die felyr breiten, einfarbig grauen

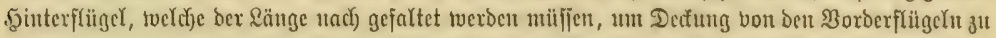

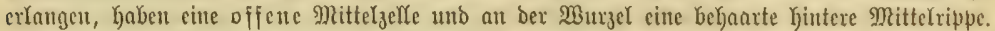

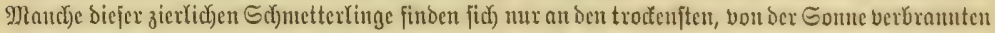

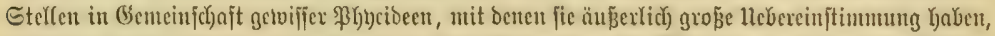

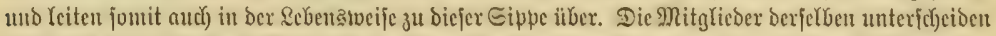

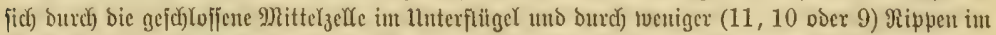

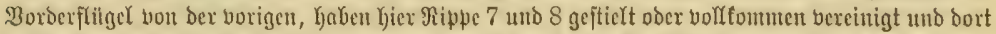

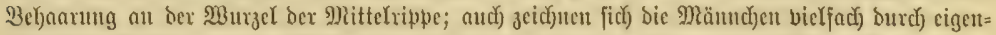

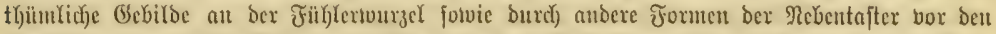

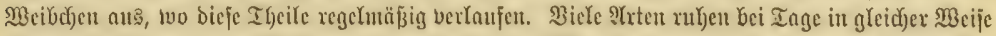

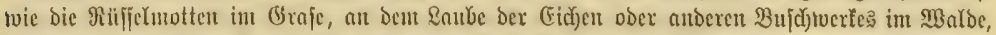

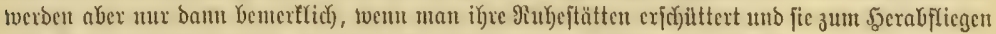

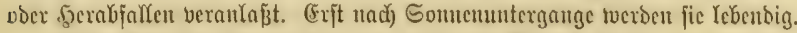

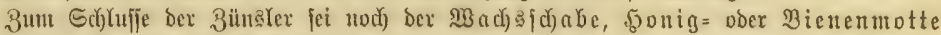

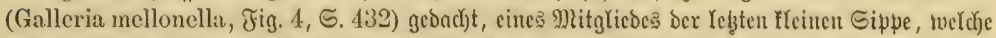

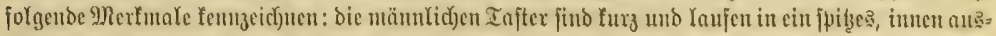

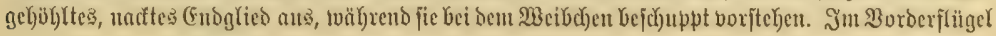




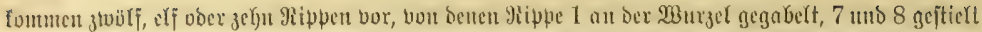

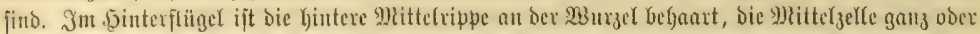

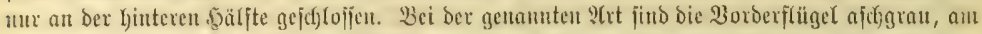

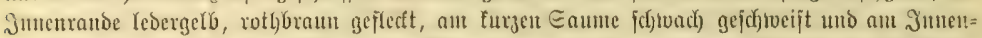

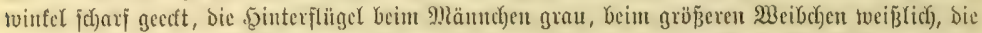

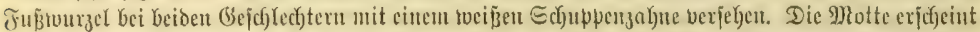

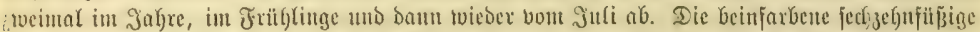

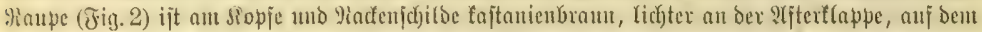

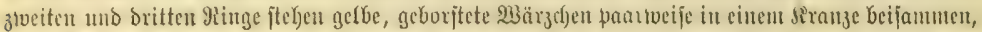

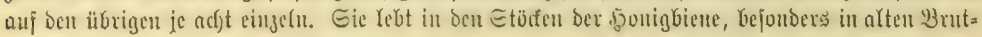

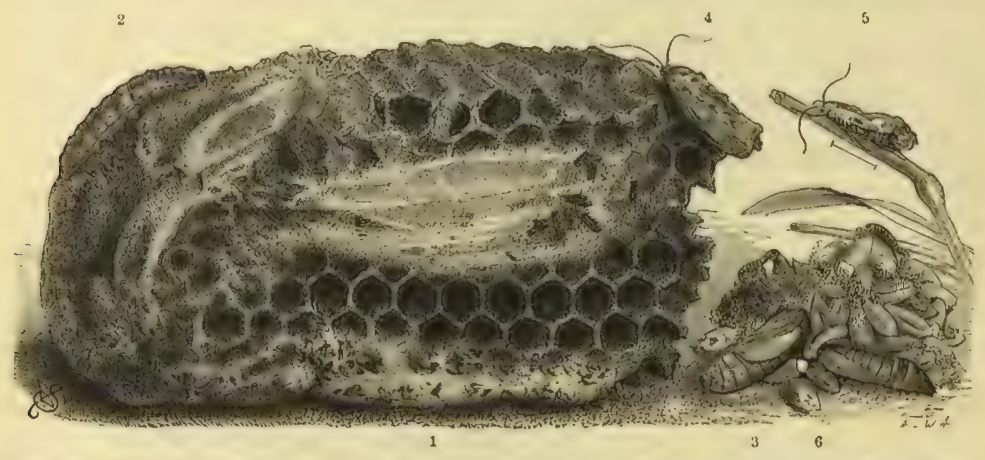

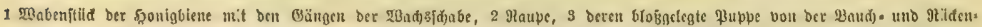

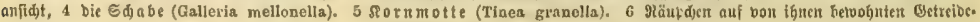

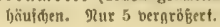

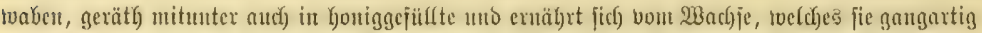

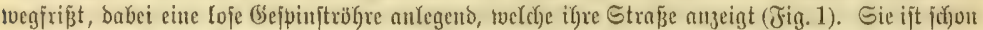

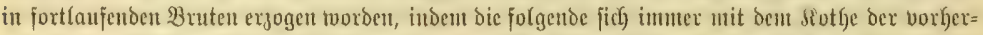

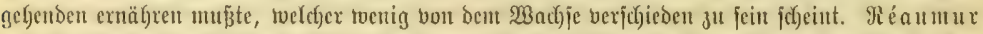

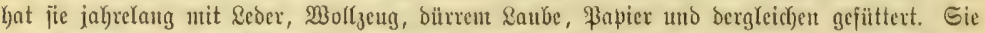

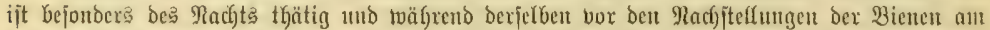

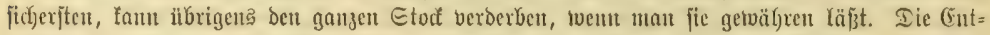

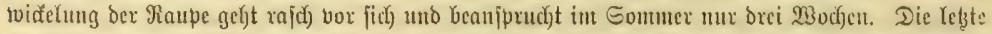

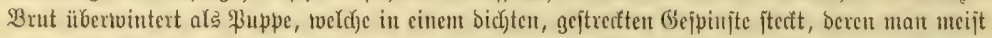

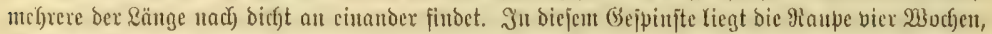

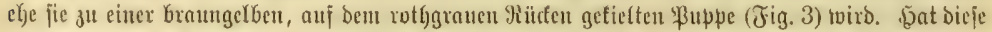

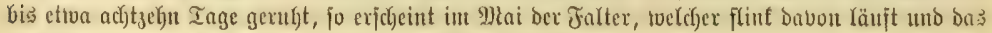

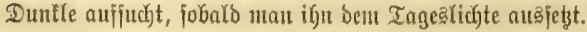

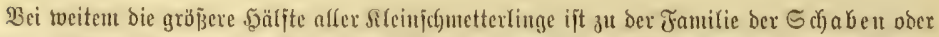
Motten (Tineina) bereinigt worben, bic jeboch eine allgemeine Ecfillorung teegen bes grofen

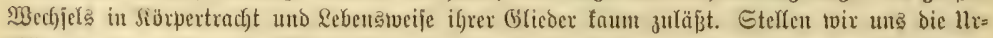

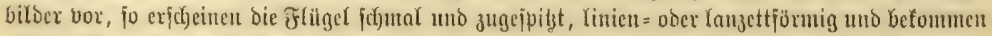

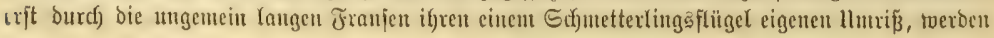




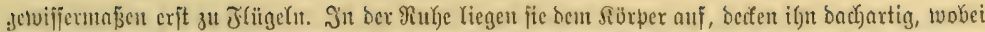

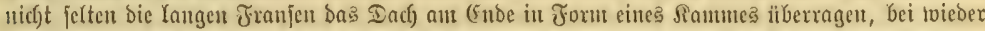

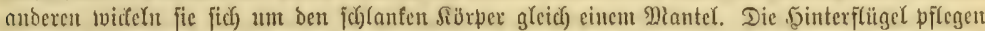

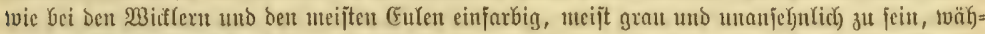

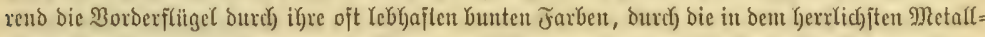
glanze ftrah)

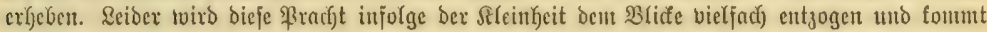

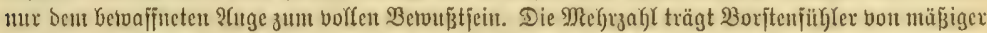

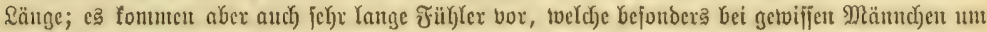

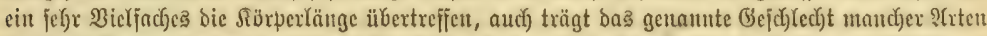

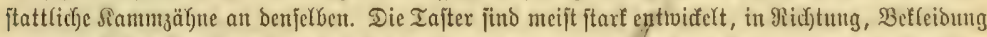

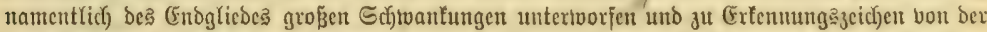

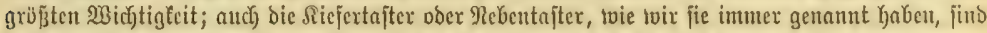

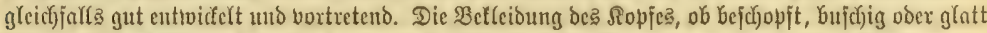

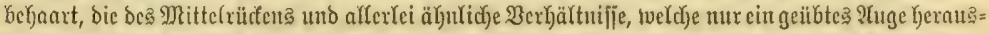

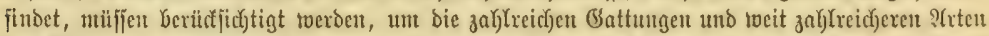

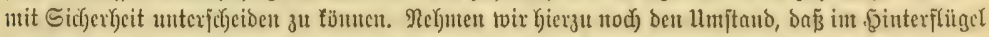

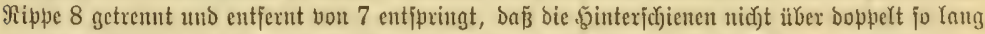

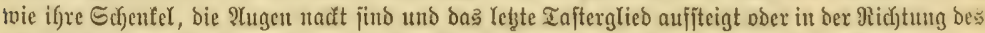

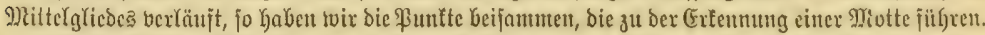

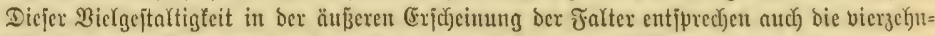

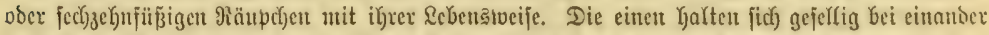

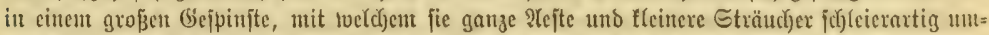

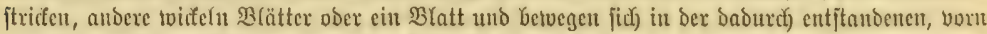

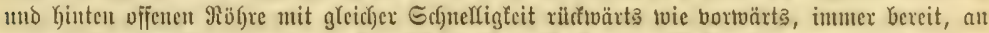

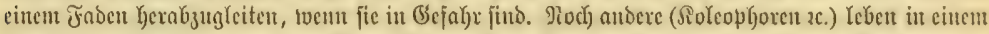

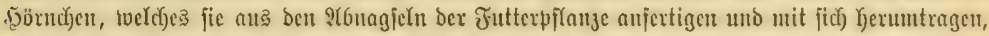

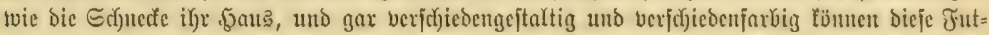

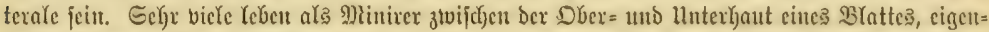

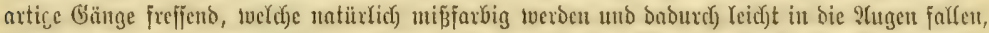

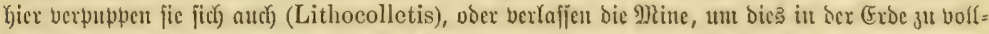

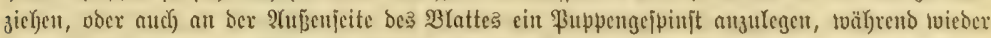

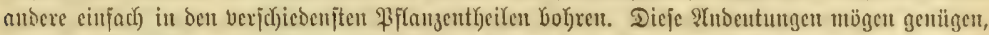

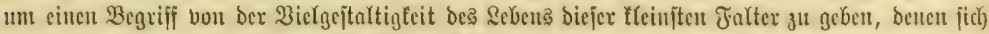

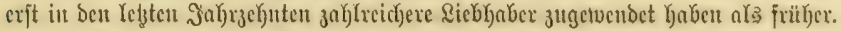

Richt cimmal auf bie (E)arafteriftif e

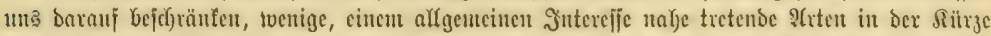

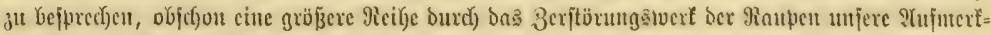
fanteit auj fich zu lenten bermag.

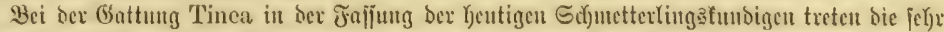

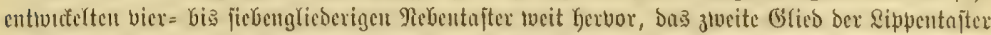

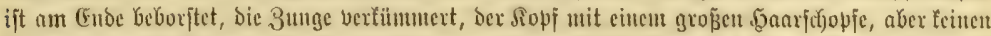

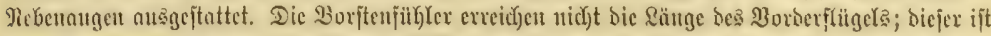

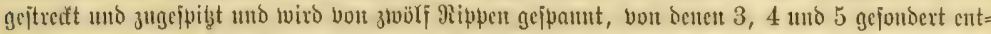

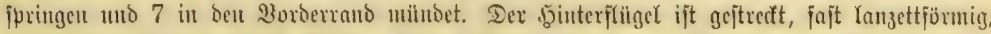

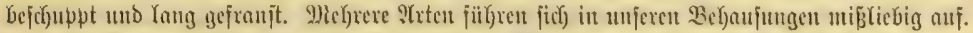

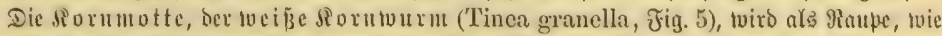

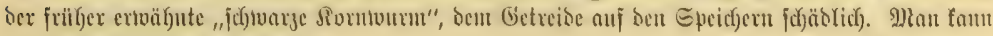




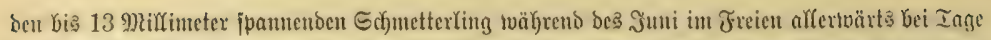

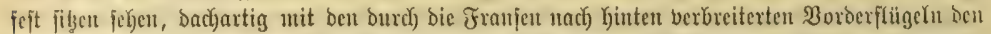

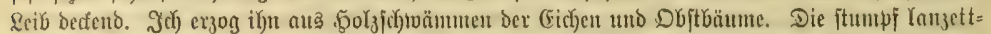

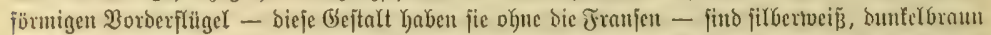

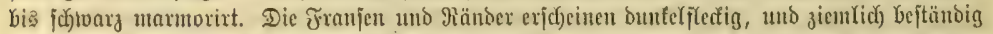

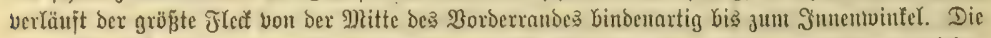

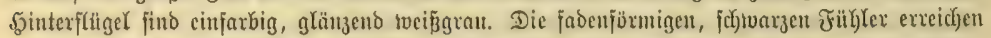

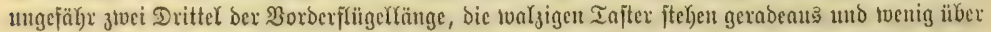

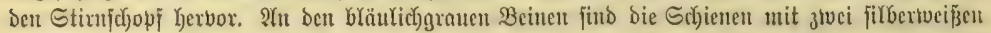

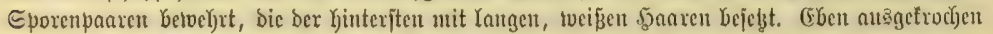

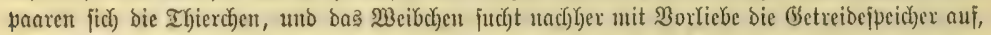

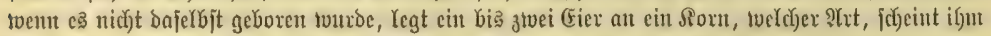

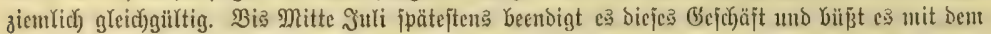

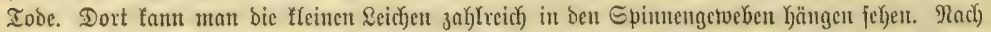

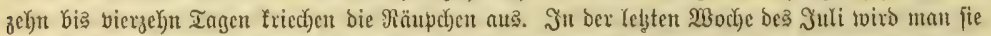

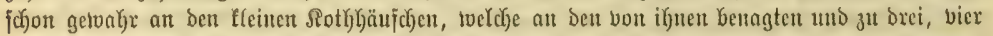

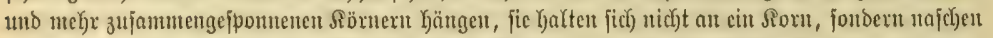

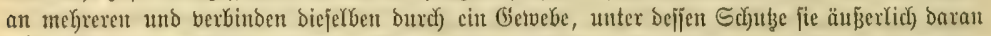

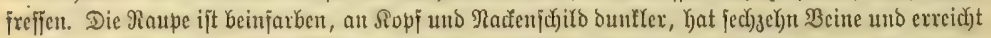

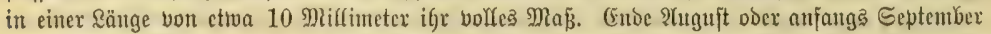

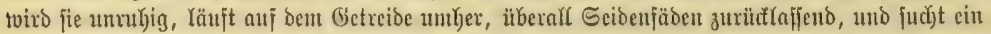

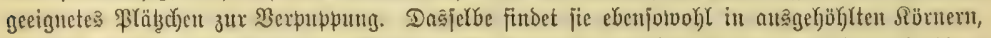

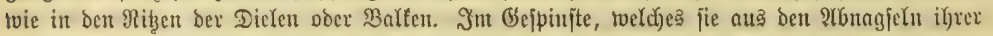

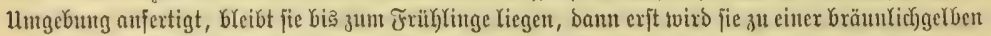

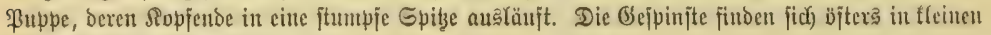
Bejelficjajten beijamment.

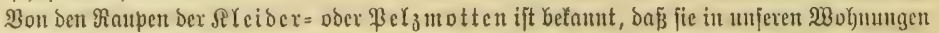

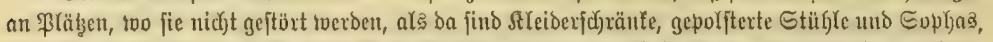

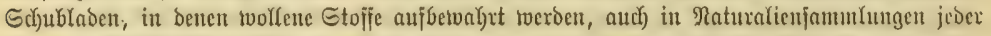

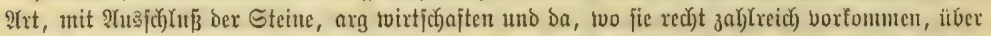

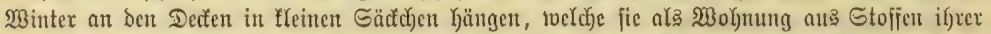

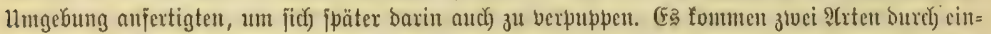
ander vor, bie Tinea pellionella, gerblič feibenglänzend, Borberftüget mit einem ober ztoci bunften

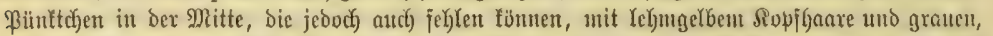

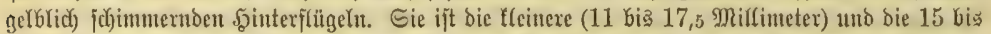

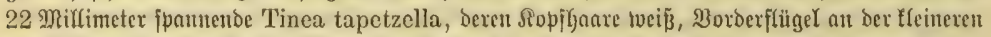

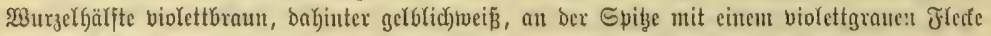

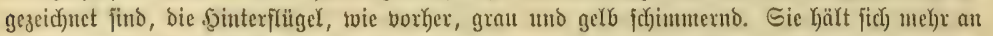

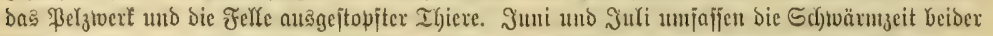

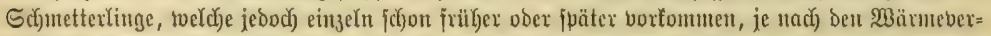

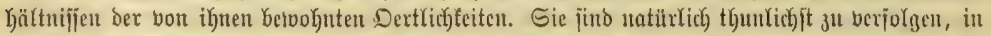

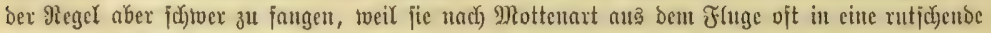

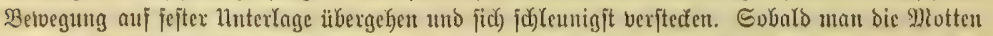

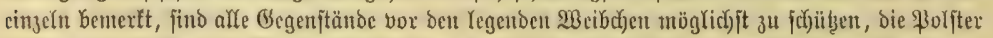

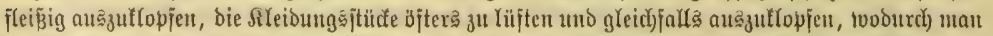

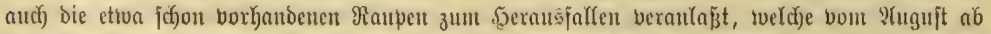

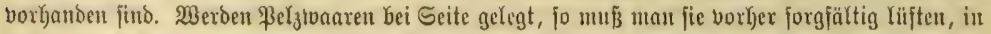

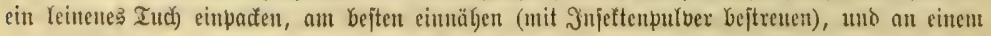




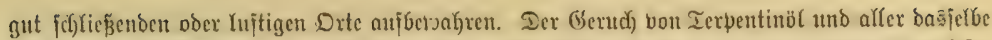

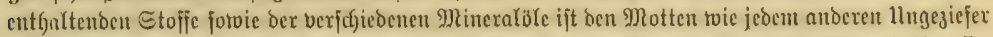

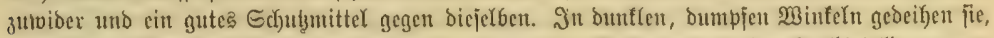

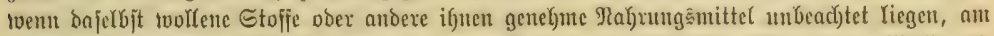

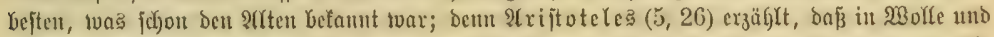

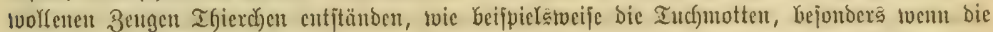

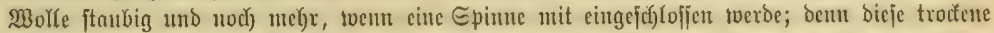

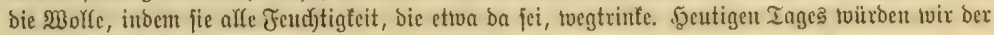
Mteinung fein, baß̄ bie Spinne bie 2Rotte ausjauge.

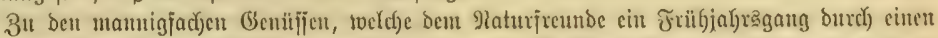

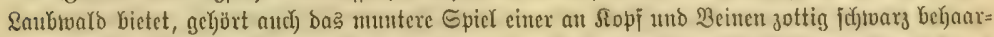

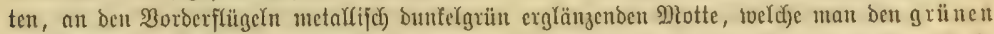

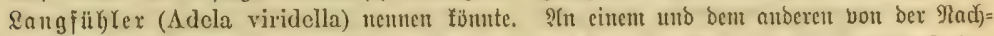

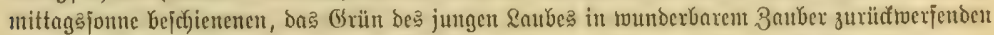

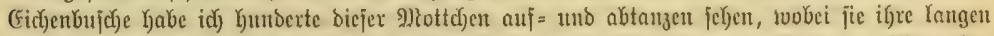

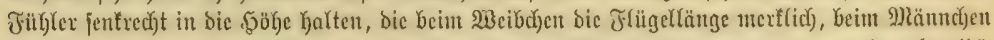

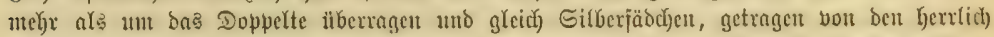

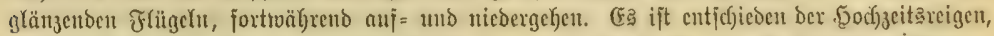
weldenen biefe IGierd)en in Yautloper Etilfe nux nad) ben Iafte ber Farbentöne auffübren;

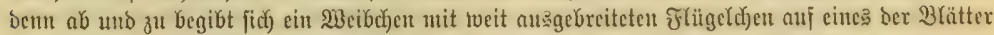

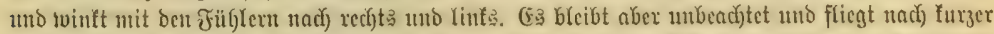

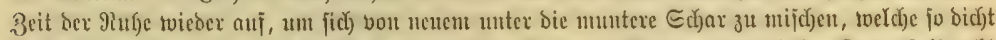

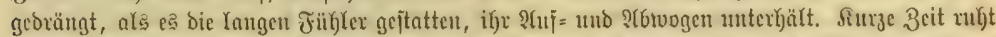

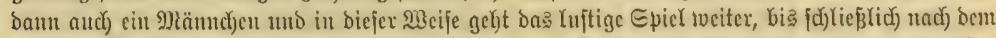

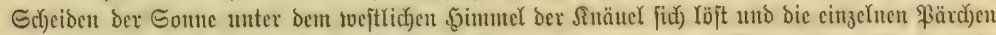

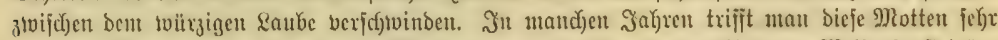

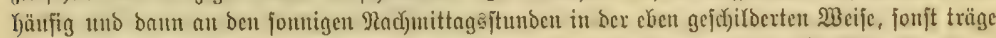

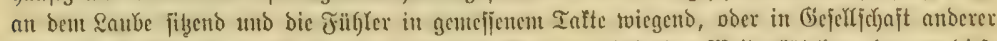

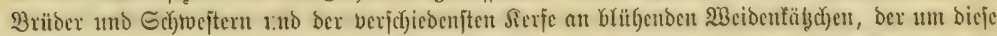

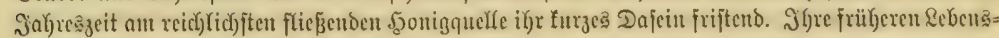
verbältuifje find mix unbefannt.

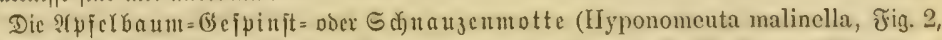

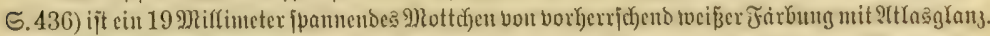

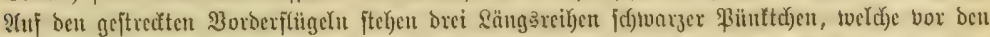

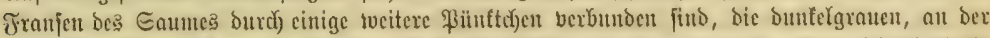

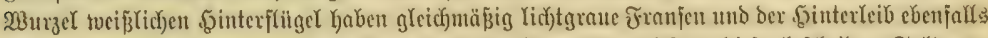

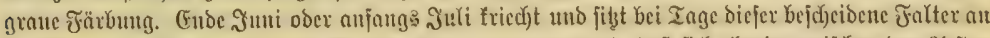

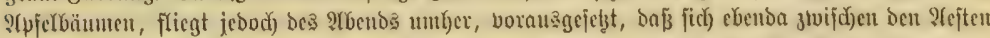

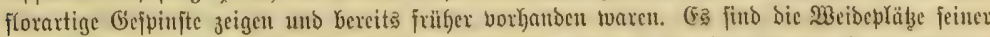

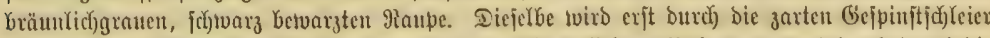

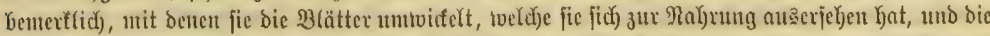

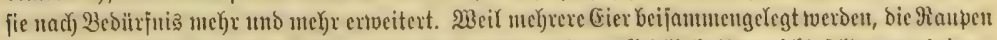

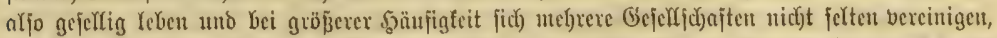
jo faut es gejef)efen, ba

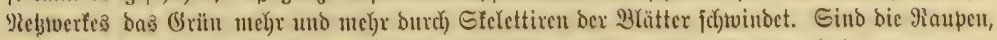

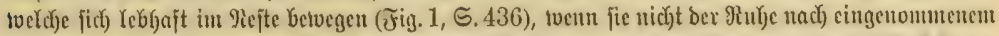

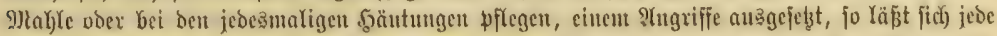

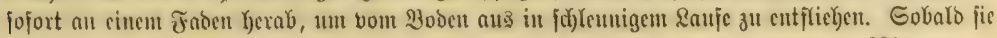




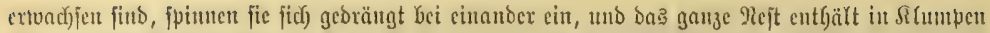

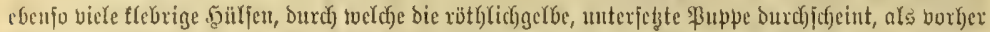

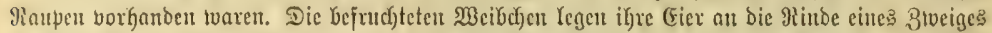

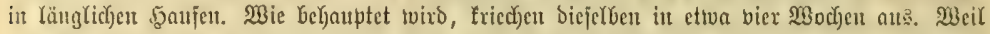

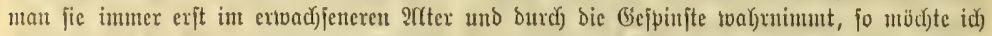

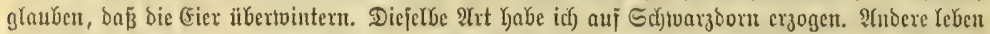

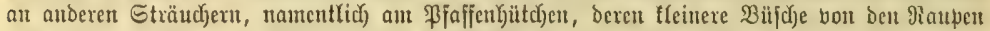

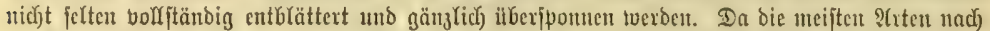

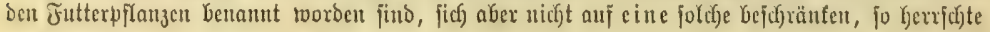
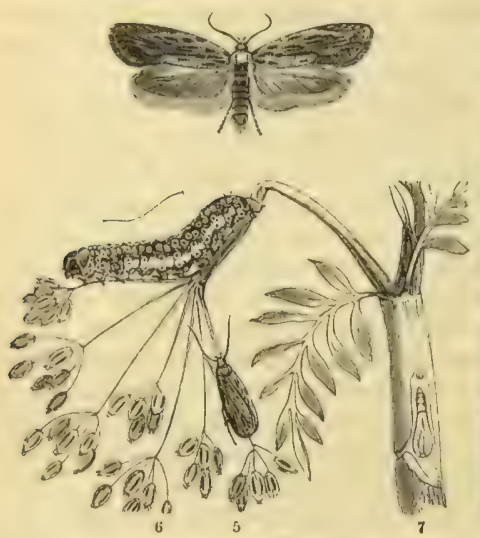

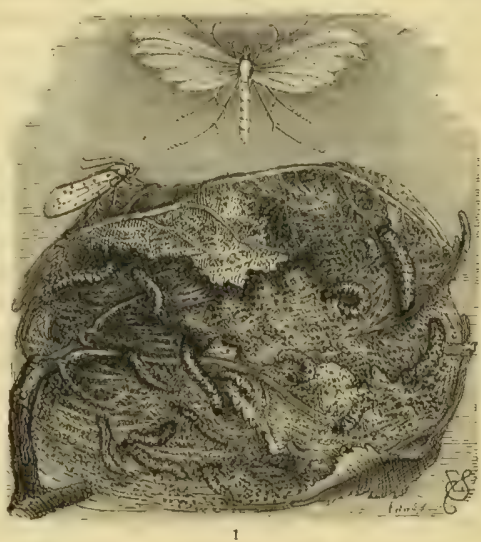

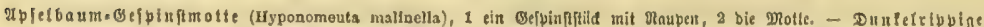
Se

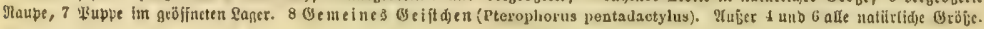

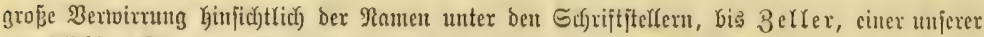

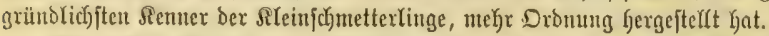

Die Afereulenmotten (Depressaria) bertreten unter ben Ed)aben bic (Eulcugnttung

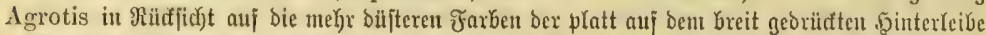
aujliegenden Flügel, beren vorbere breit, hinten ftart gejtulzt ober gerunoet jinto, woägrento bie

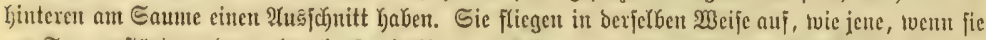

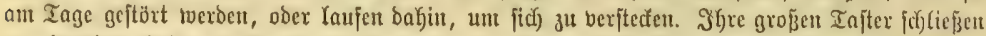

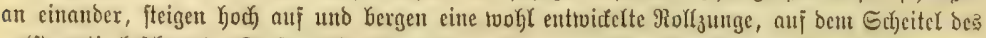

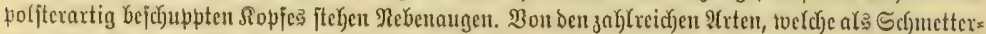

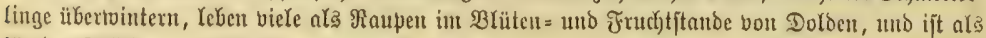

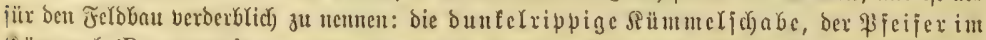

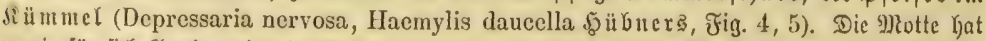

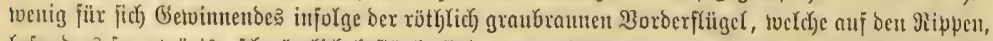

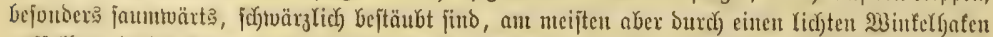

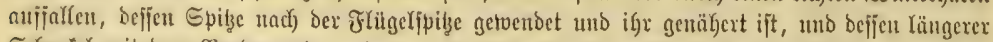

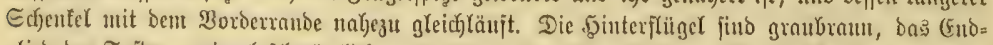

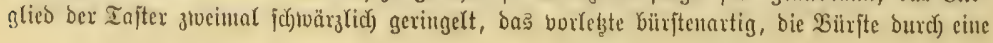




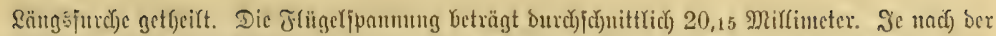

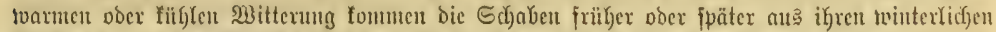

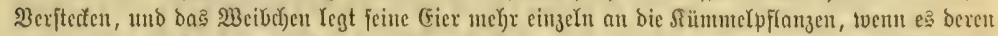
Yabbaft twerden fam, wo nid)t, an andere Dolden, unter benen Oenanthe aquatica (Phellan. drium aquaticum) unb Sium latifolium neben nod) cintigen noberen gentannt weroen. F(n fiummet

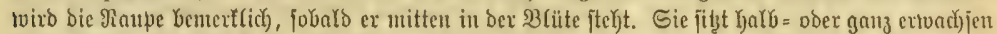

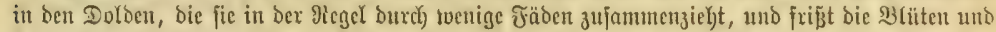

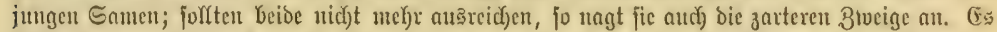

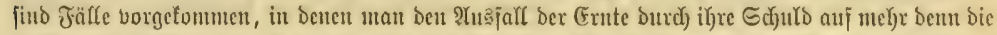

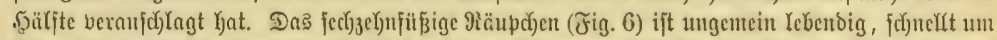

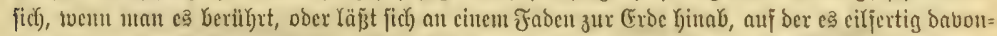

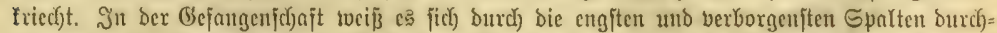

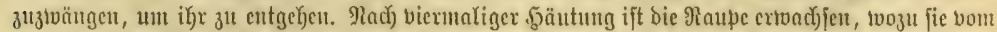

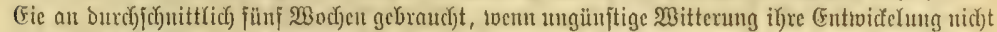
aufjält. Gic ift ctıa 15 Miłfimeter Yang und ziemlich bunt gefärbt: cin breiter orangener Eciten=

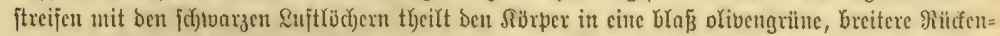

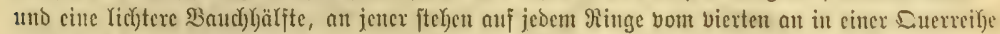

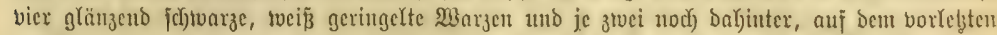

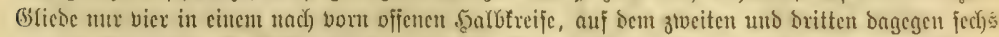

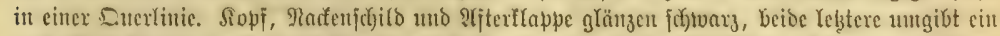

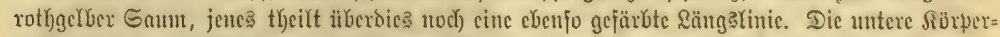

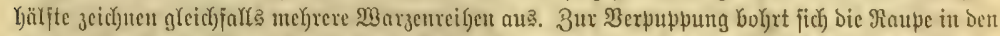

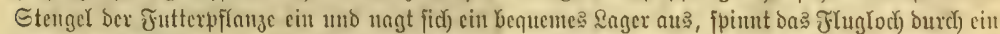

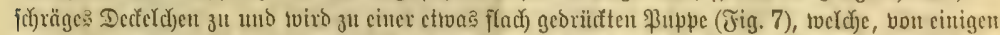

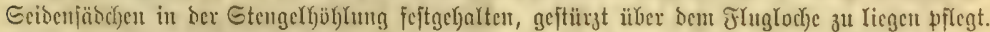

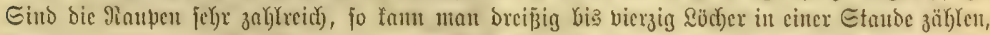

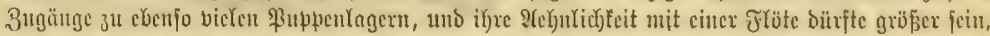

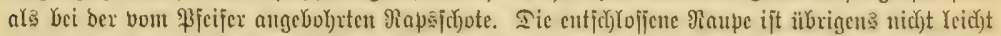
berlegen, twie idé) an gefangenen beubachtet Yjobe. Sgat fie feinen gecignetent Etengel, fo berpuppt

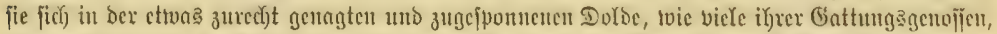

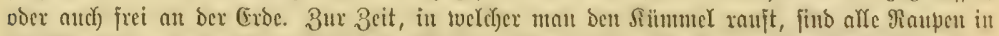

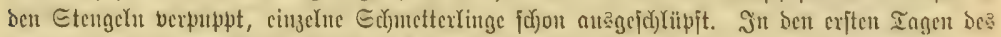

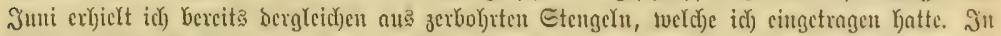

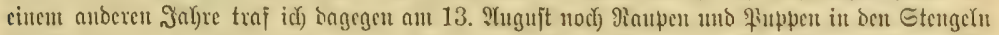

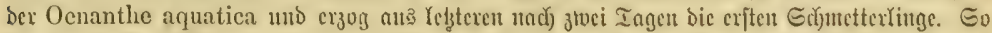

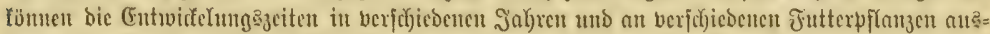

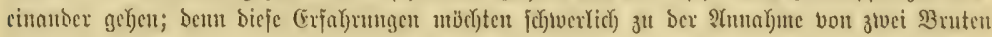
berechtigen.

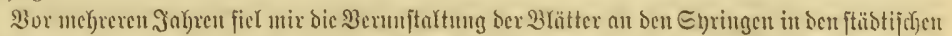

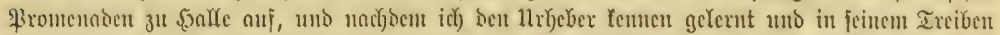

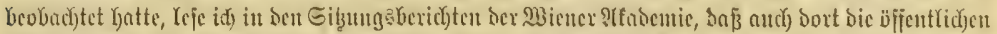

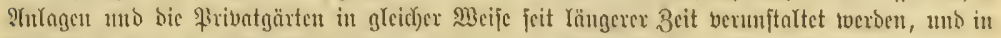

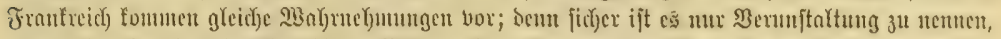

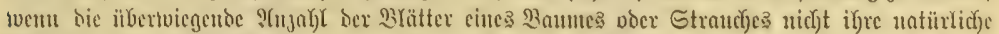

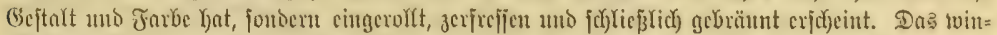

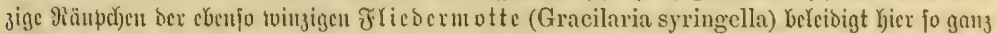

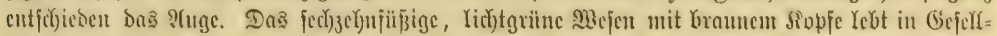

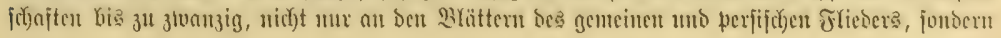




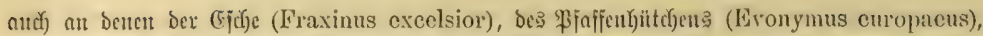

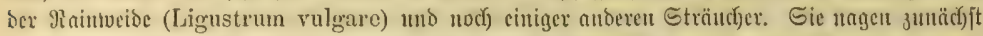

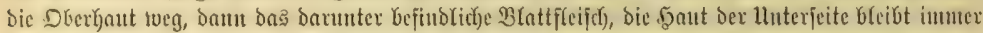

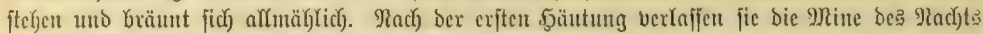

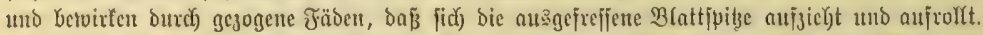

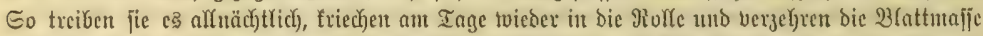

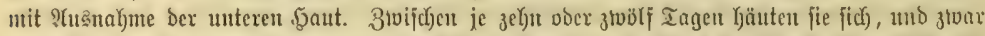

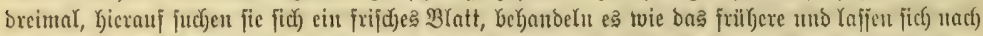

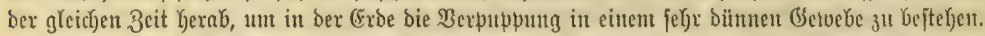

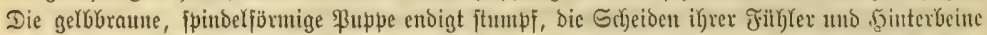

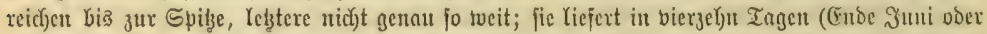

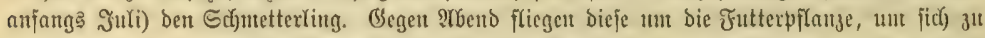

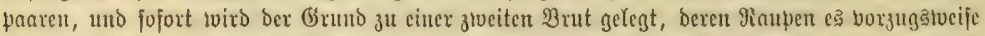

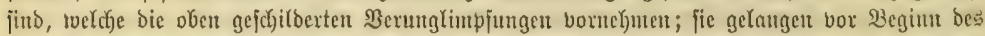

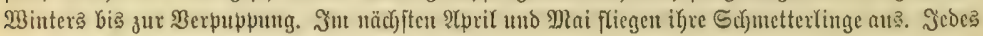
Meibchen tant burchjidnittlich Gundert (Eter Yegen.

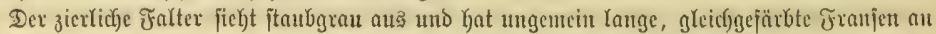
leinen Fltigeln, bejonders an Jintentuinfel ber borberen, bie twie cin hoher Rantm herbortreten,
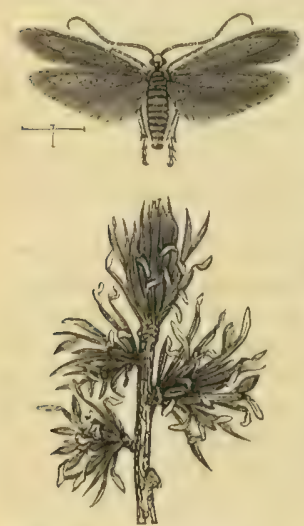

Lärçen.Dintrmotte (Coleophora larieinella). Sergröferter Edyntterling unb Iricbfuife ber Särdje mit ausacirelferen Rabclititen unb anljaftenben Eäddjet. wenn fie in ber Ruhelage bachartig Det Reib verjteden. Die

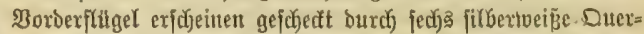
Ginden, beren brei hinterfte feiner und unbollftänoiger find als bie vorberen. Die grau uno weißß gexingelten Fithler exreicyen

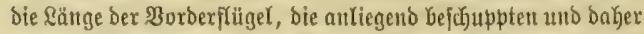
Dünmen Rippentafter ftehen fojuertförmig vor bem glatten,

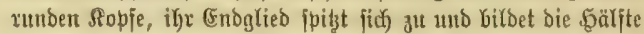
ifrer ganzen Ränge; Siollzunge und Riefertajter find Deutlid). Eire intereffante Stelfung nimmt bas Dtottchen an Inge ein,

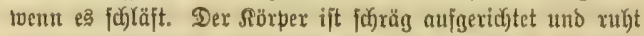
auf ben beiben Iangen Borberbeinen, Deren Sniee in einer F(udh)t= Iinie mit Der Stirn liegen, bie Fithe greifen weiter Ginten

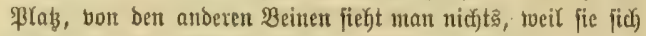

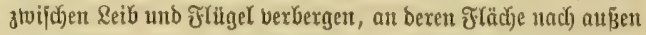

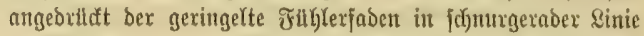

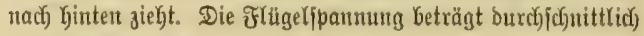
11,5 Mrinimeter.

Die Rärd) en= Miniruotte (Colcophora laricinella) ift feibenglänzeno ajchgrau, an ben Franjen ctıvas ntatter. Dic

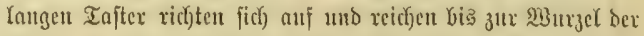

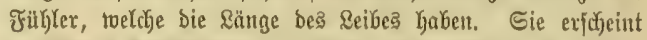

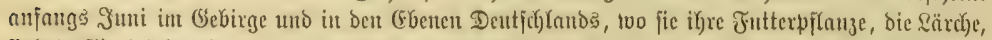

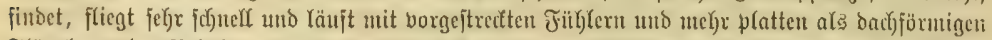

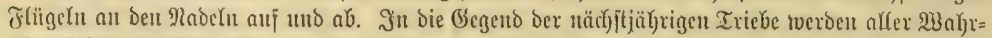
f(c)

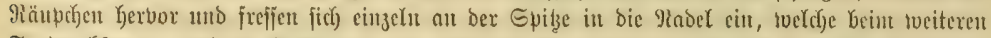

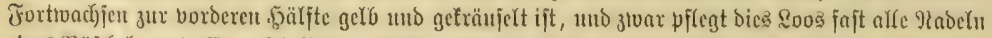

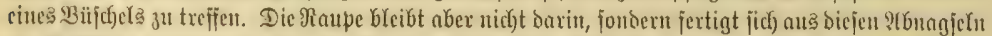

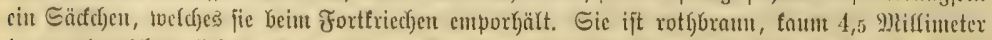

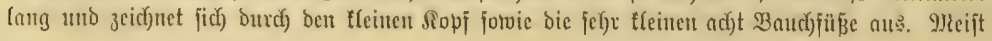




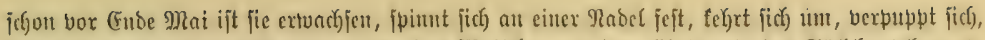

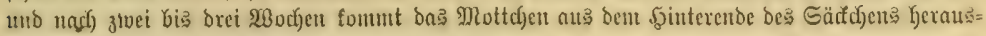

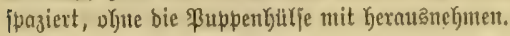

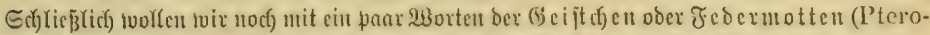

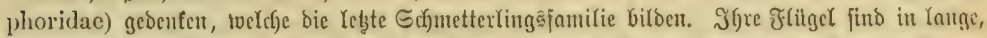

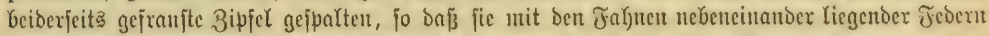
verglichent tuerben fönnen. Die 2̧orderflüget pflegen fick) in ztwei, bie Yjinteren in brei voer bei

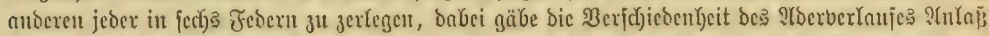

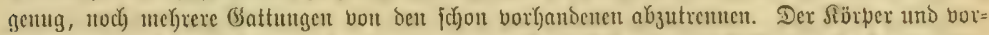

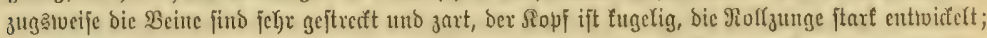

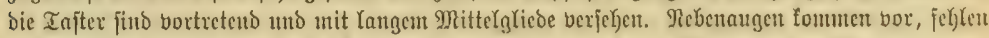

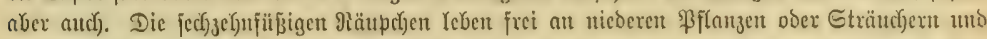

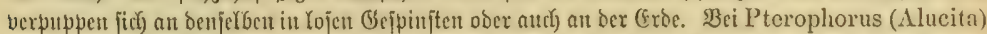

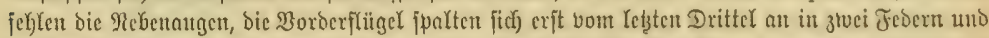

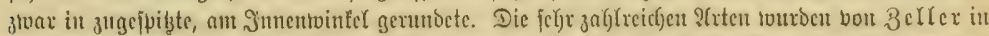

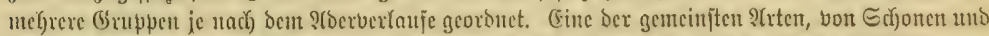

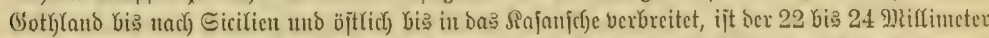

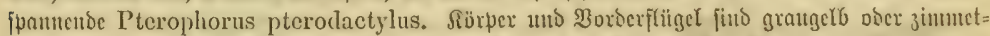

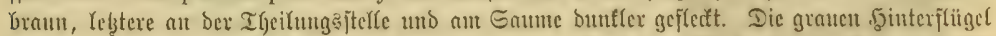

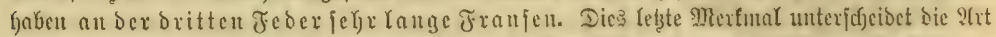

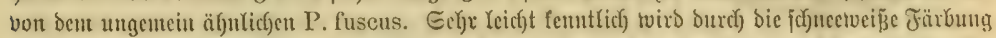

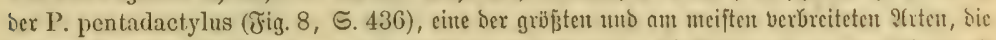

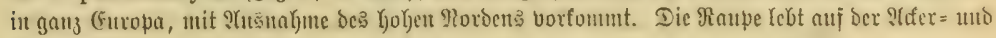
3auntwinbe.

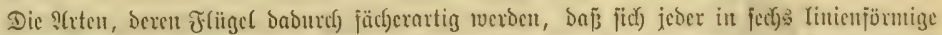

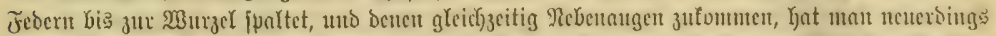

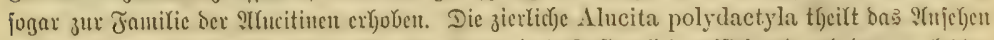

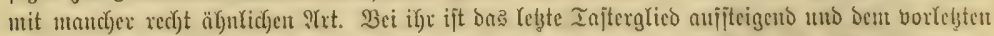

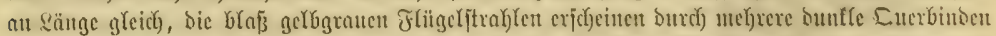

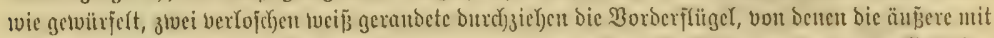

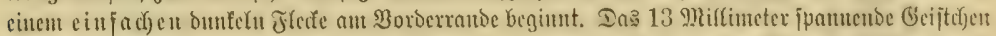

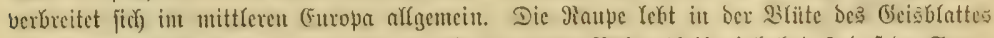

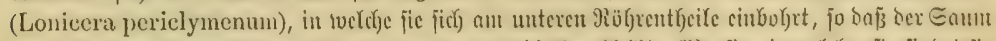

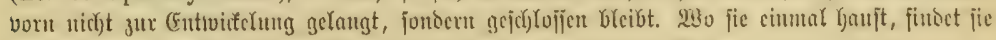

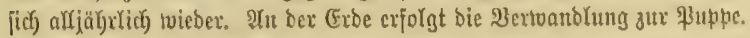




\section{Đierte (1) ronung.}

\section{Dic 3 we iflülct (Diptera, Antliata).}

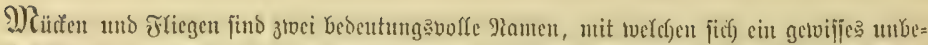

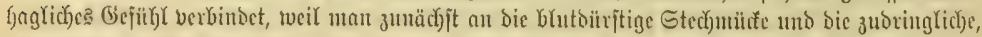

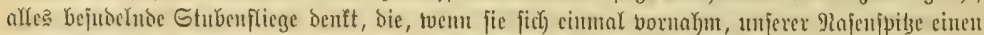

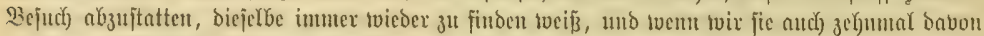

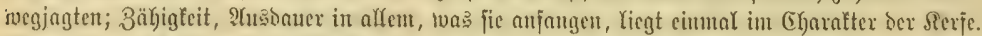

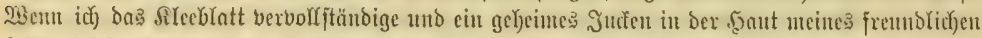

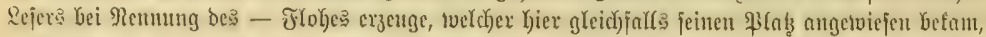

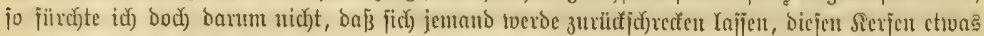

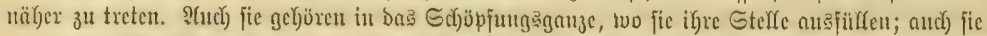

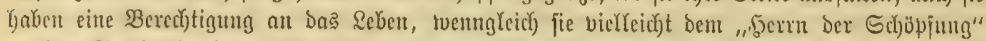

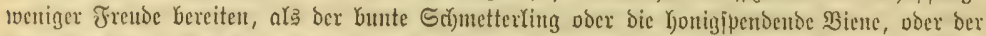

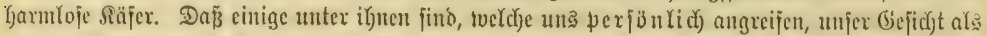

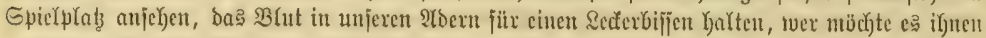
sou ibrem Standpuntte aus beroenten?

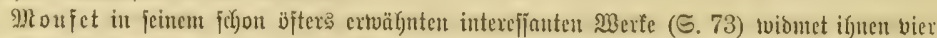

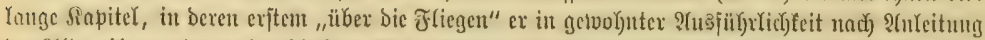

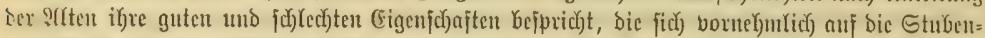

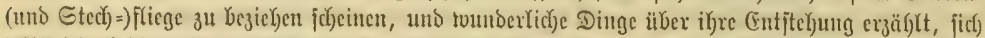

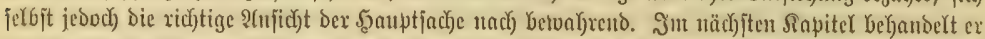

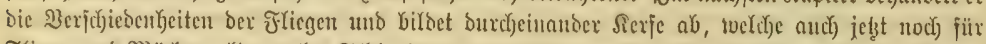

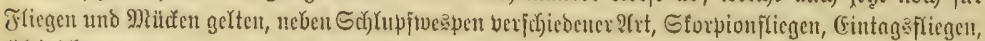

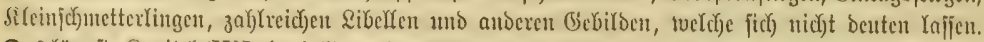

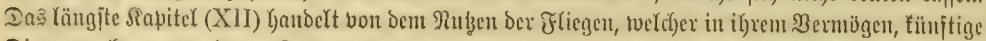

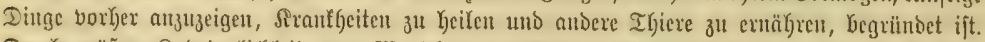

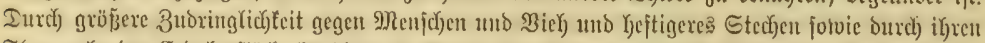

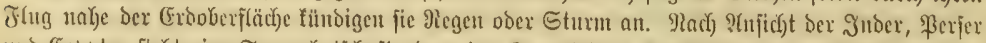

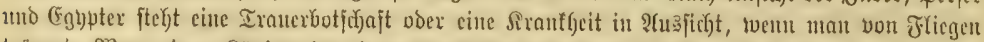

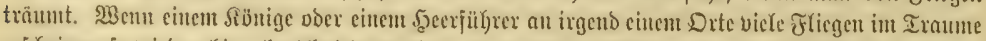

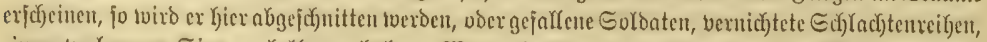

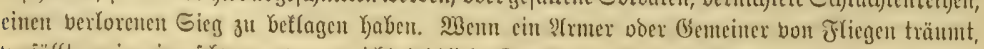

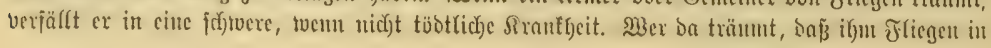




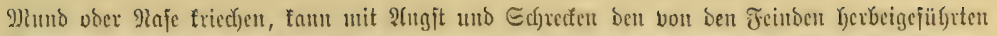

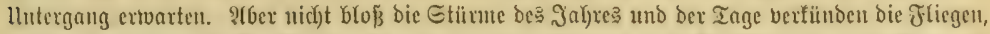

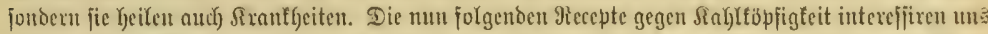

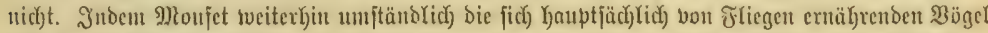

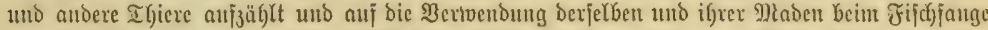

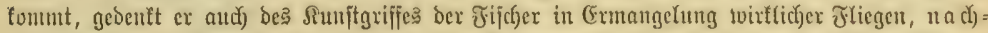

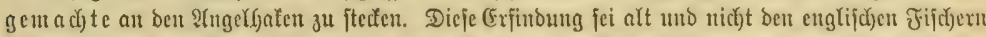

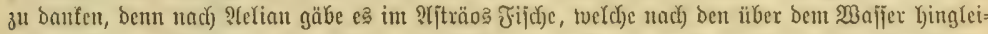

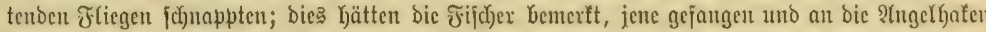

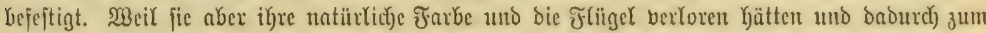

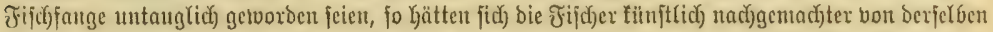

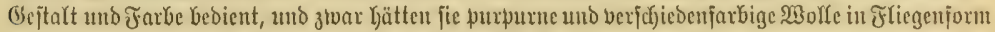

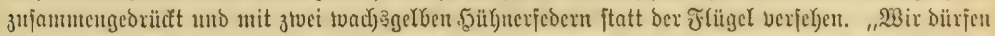

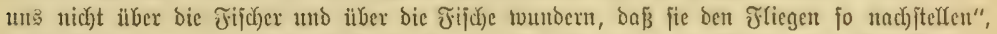

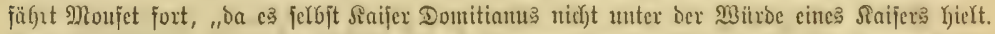

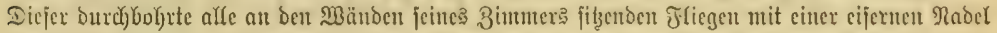

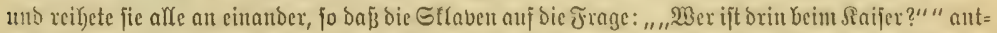

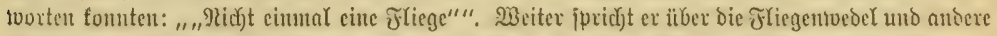

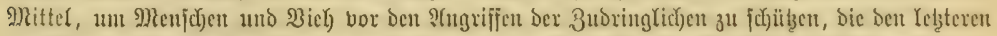

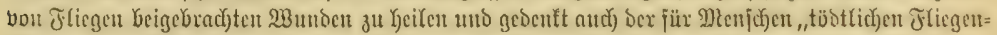

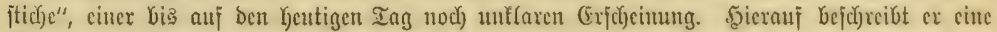

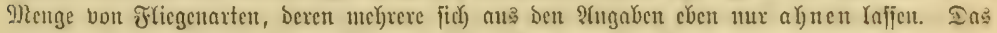

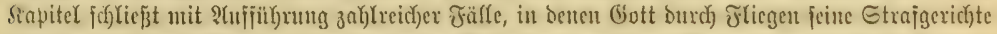

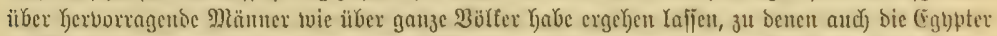

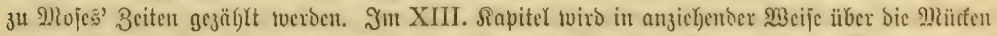

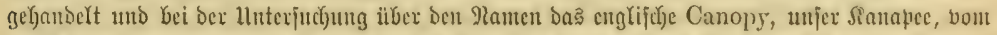

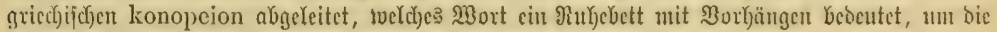
9Rư (konops) abzuhalten. Dod) genug ber शrbichtweifungen!

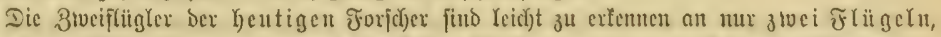

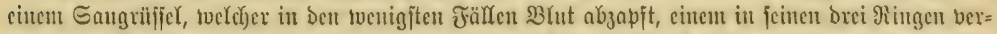

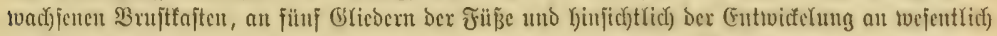

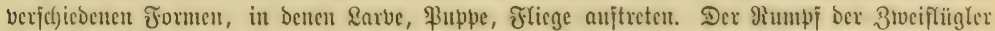

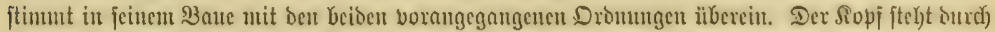

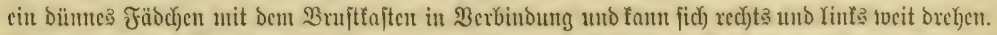

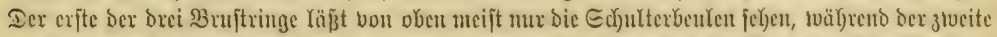

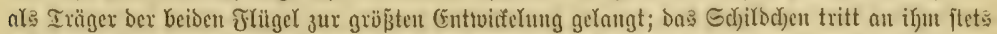

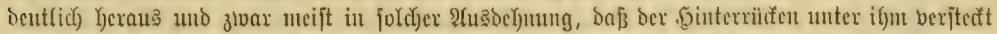

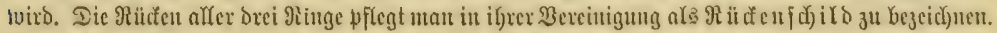

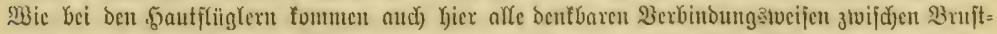

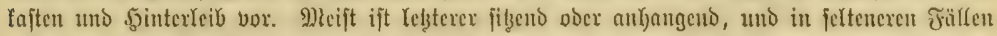

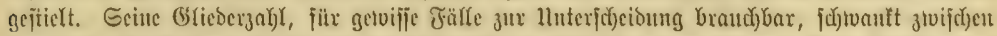

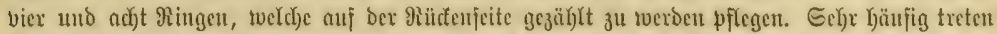

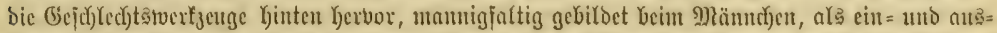

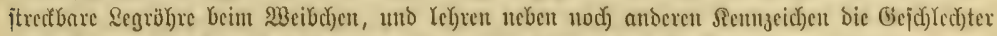

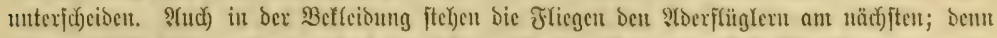

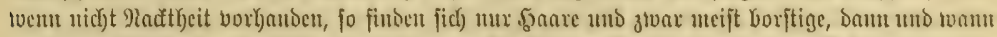

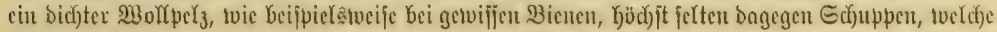

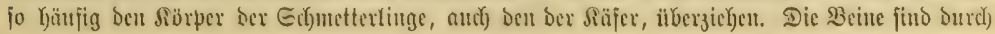




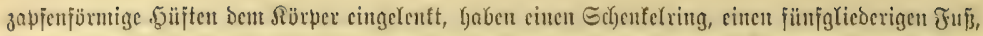

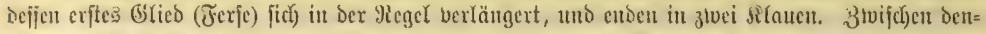

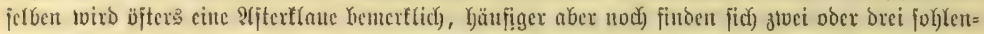

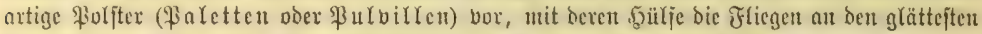

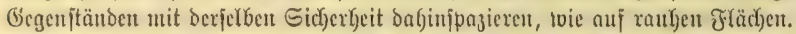

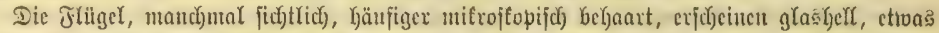

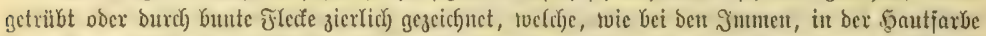

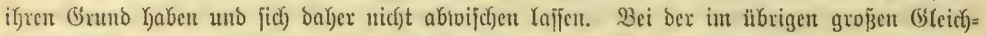

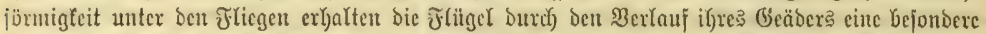

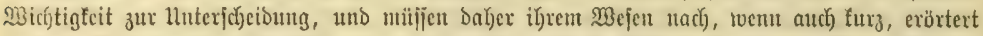

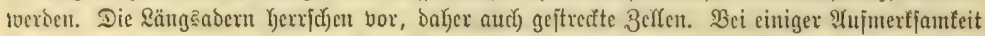

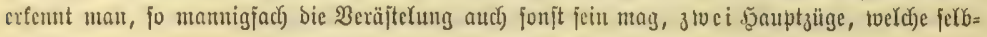

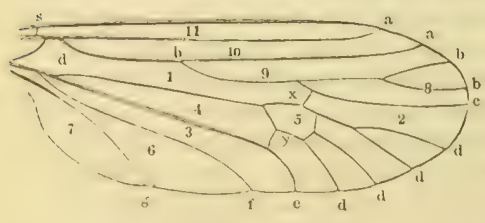

Mudenłtüget.

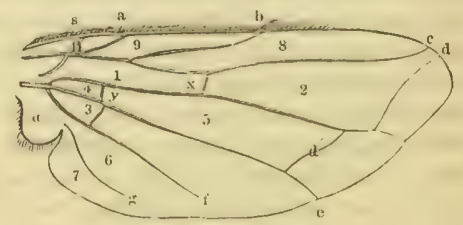

Museibcufräncl.

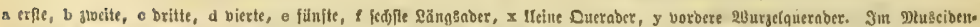

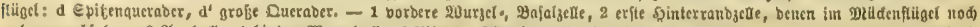

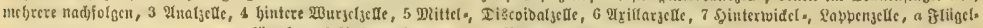

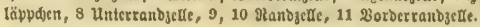

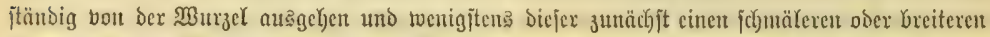

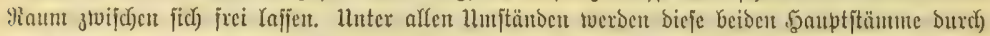

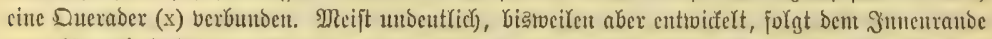

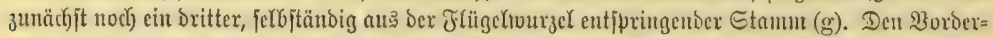

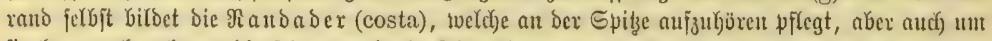

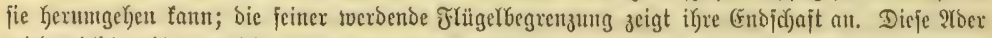

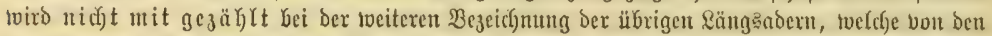

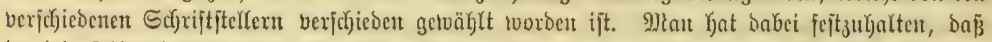

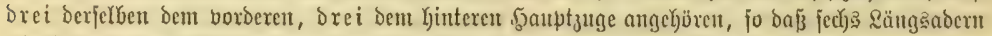

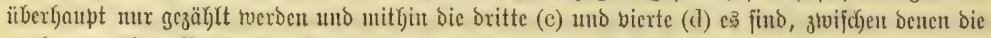

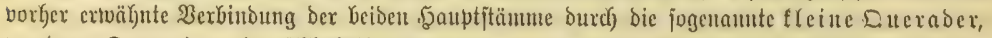

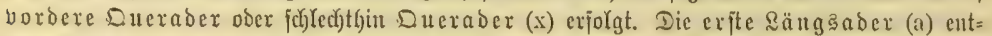

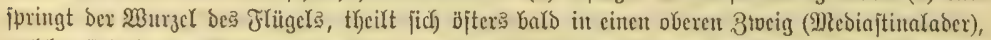

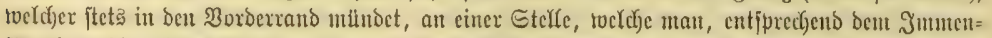

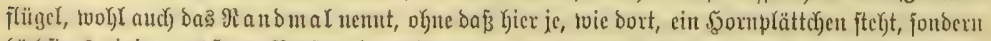

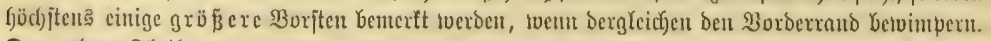
Icr antere Ifeif, vorzugencife exjte \&äuggaber (

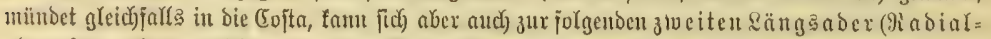

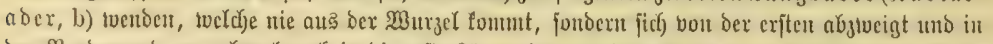

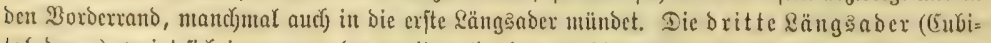

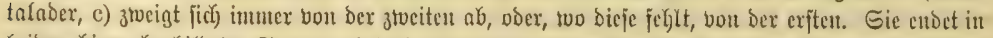

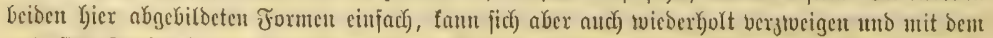

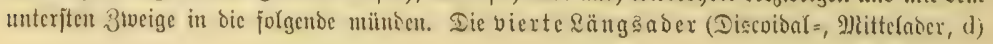




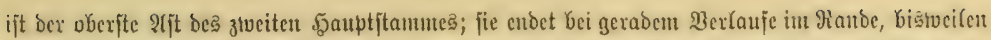

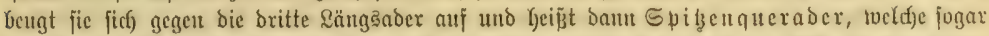

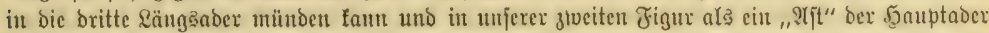

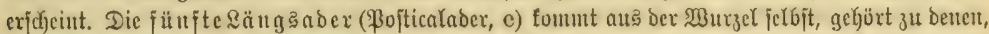
told d)e uie fer)

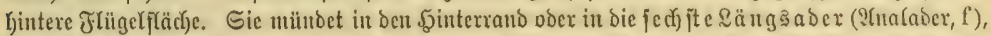

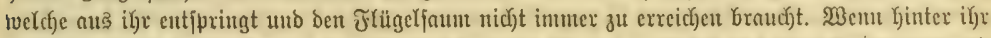

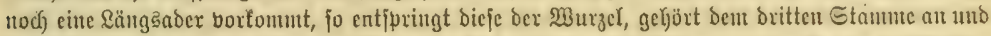

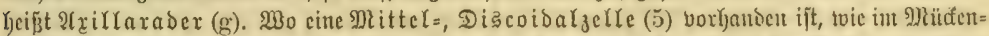

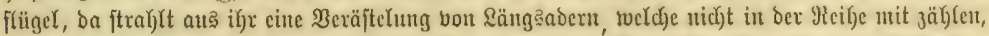

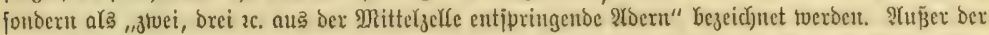

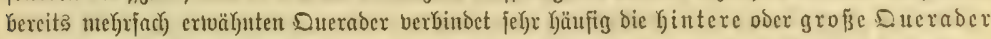

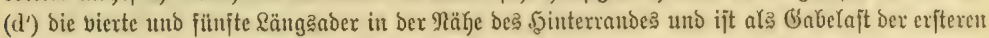
nach Ginten, twie bie Spibenquetader nach) vorn, zu Getrad)ten, bie vorbere Wurzelqueraber

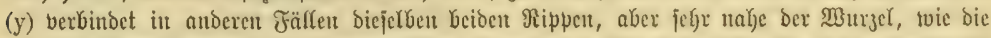

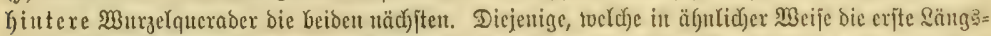

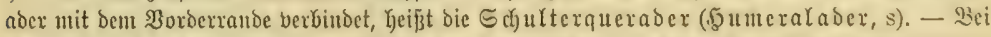

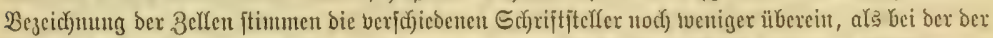

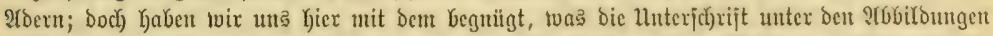

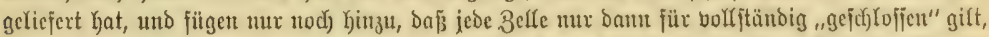
went fie ringsum bou Iroern begrengt tviro, für "offen", fobald von ber einen Eeite ber Jfïgel=

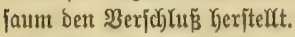

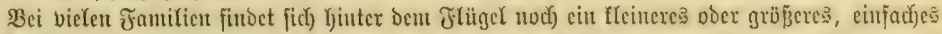

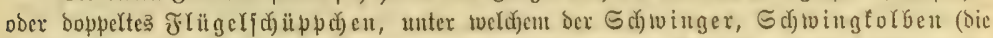

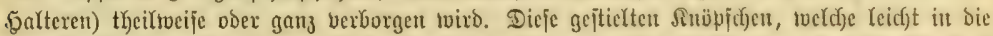

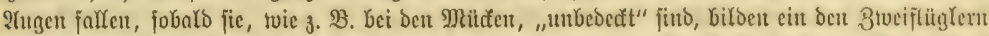

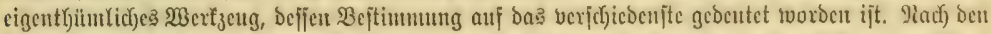

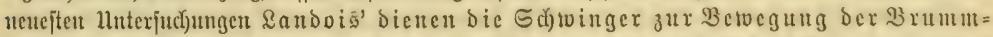

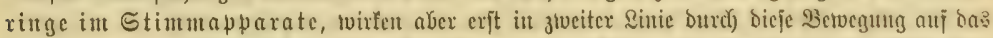

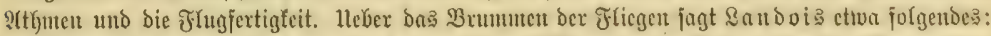

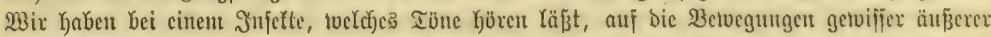

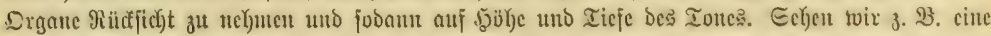

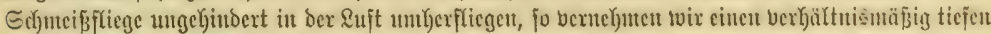
Eumunton unb benerfen bie hejtig zitternben Betuegungen Der Fltïgel twie ber Edftwingforben.

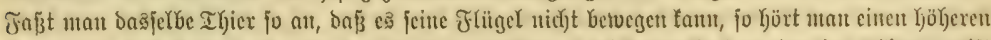

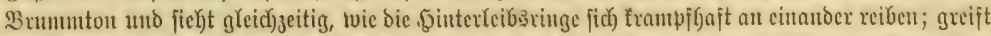

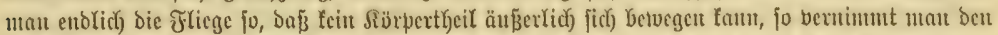

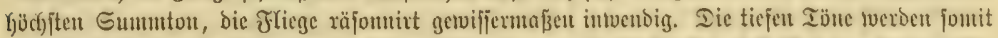

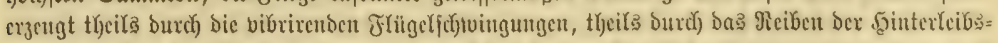

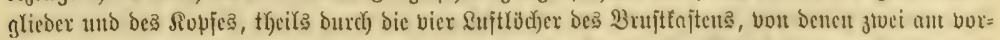

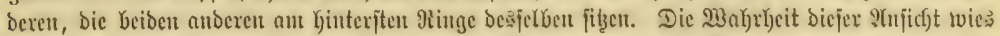

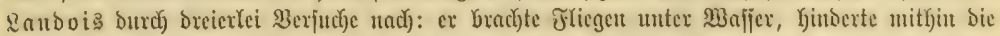

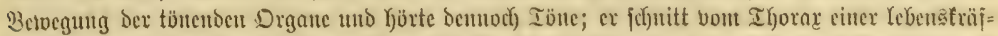

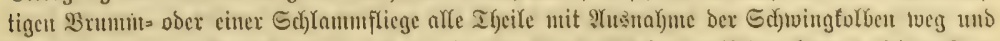

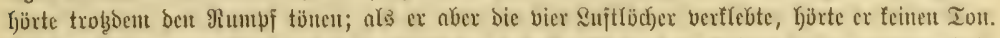

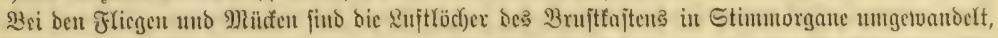

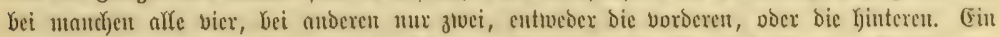

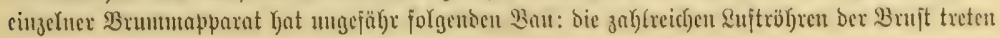




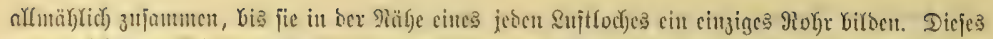

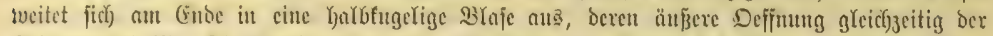

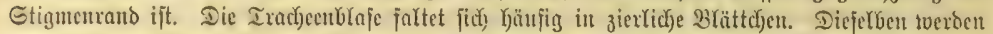

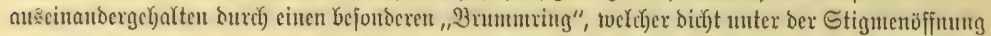

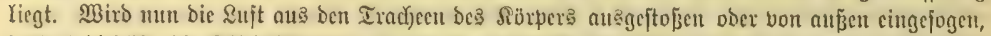

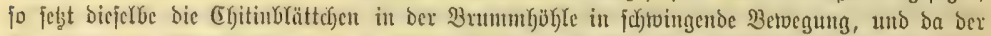

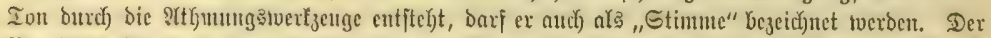

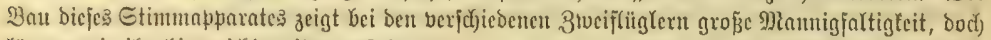
fömen tvir ifu Gier nicht tveiter berfolgen.

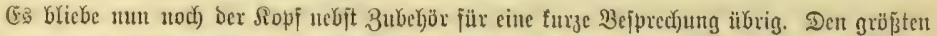

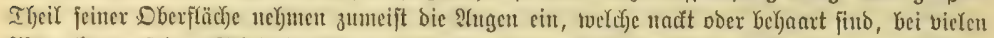

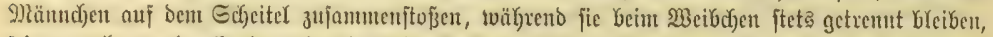

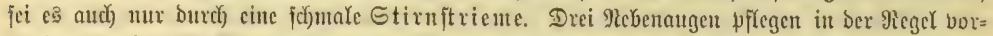

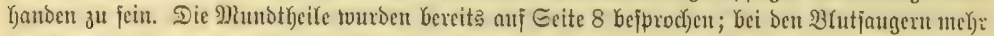

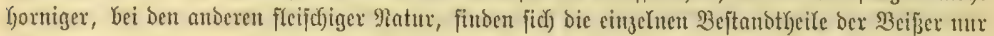

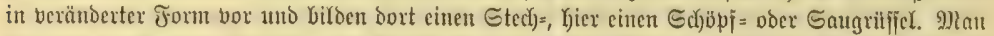

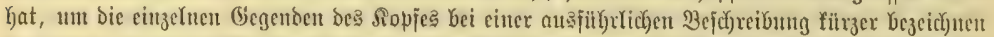

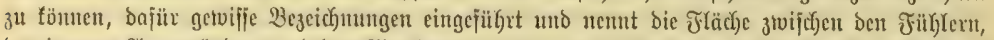

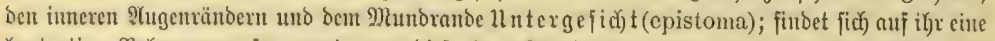

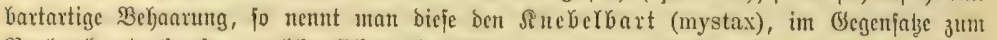

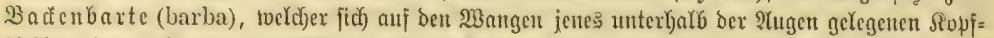

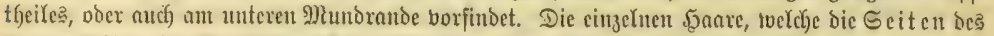

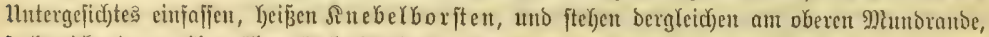

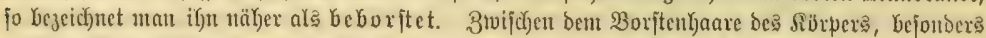

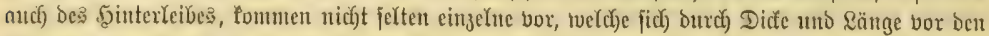

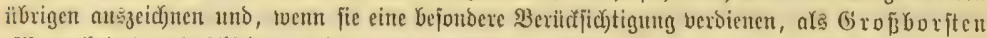

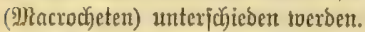

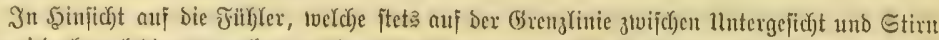

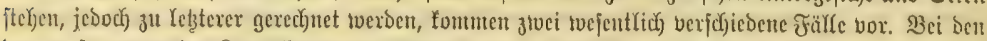

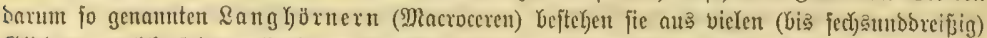

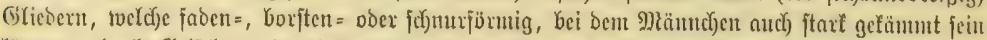

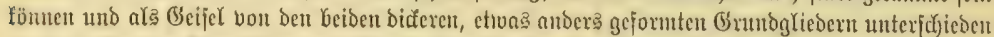

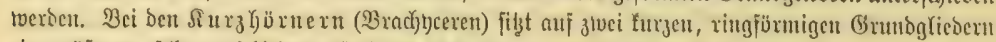

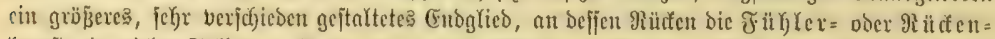

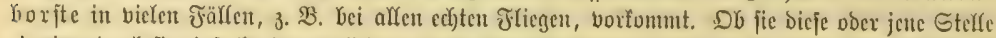

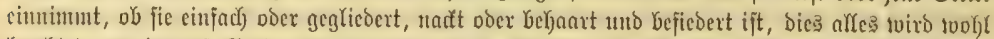

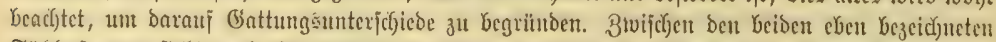

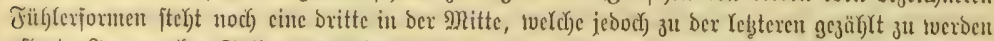

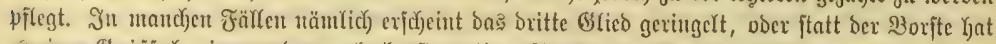

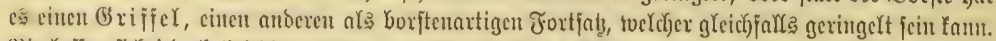

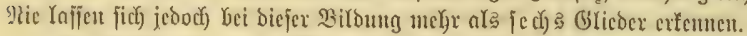

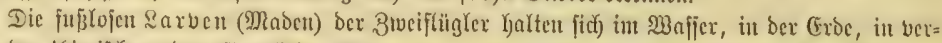

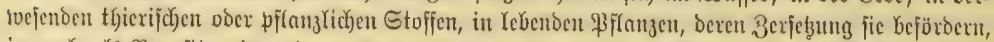

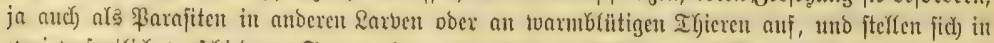

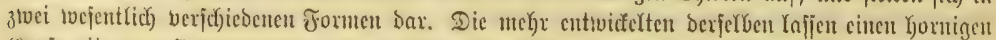

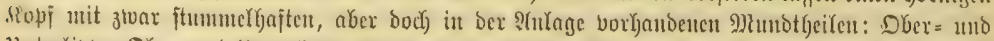

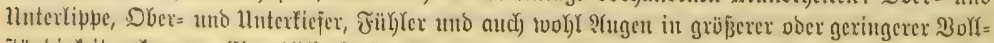

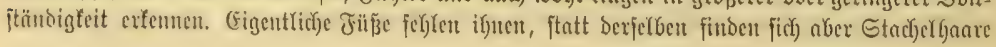




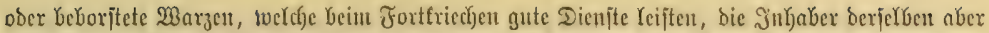

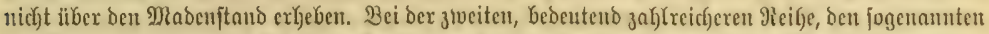

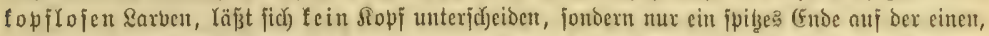

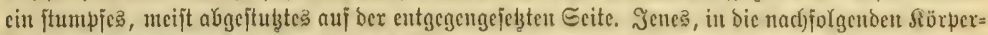

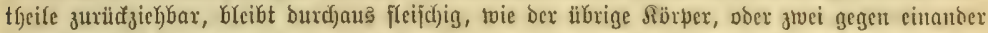

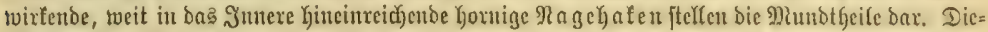

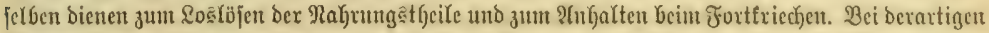

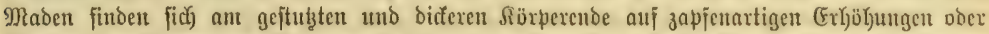

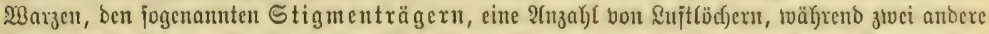

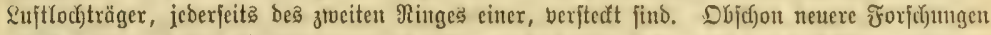

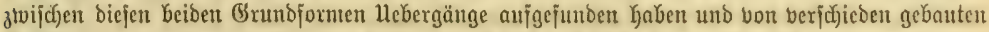

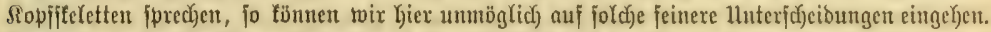

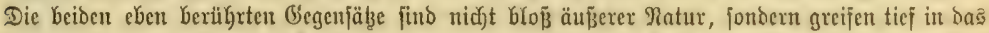

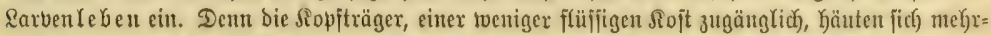

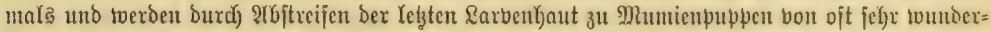

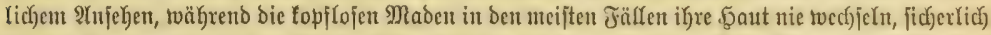

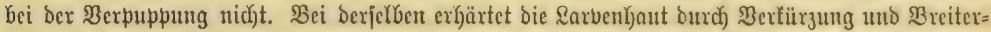

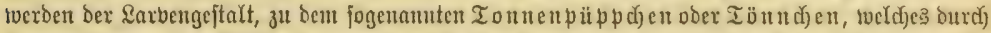

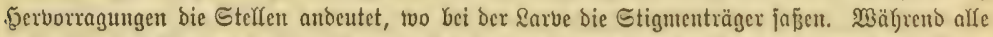

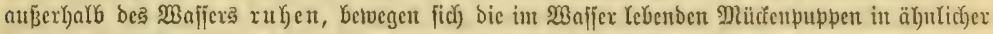

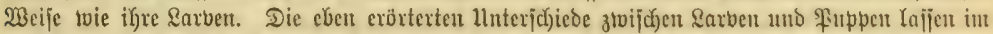

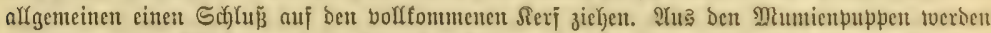

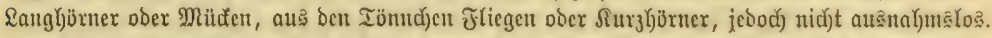

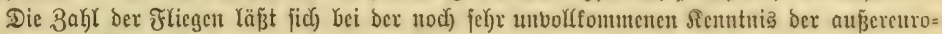

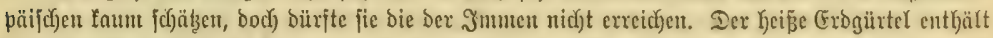

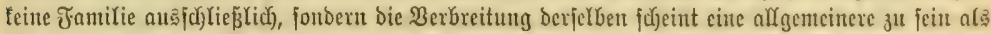

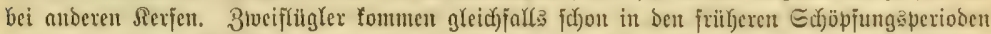

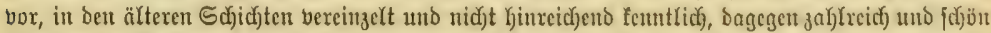

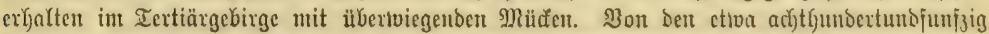

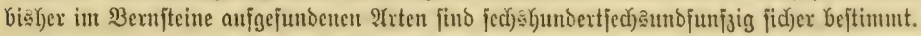

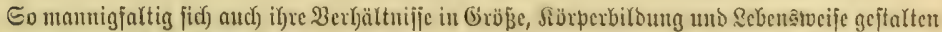

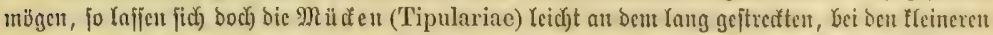

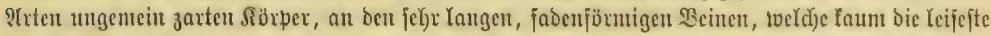

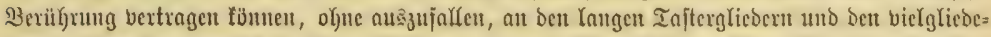

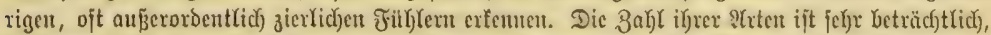

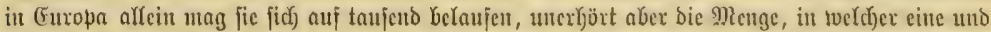

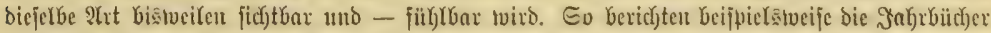

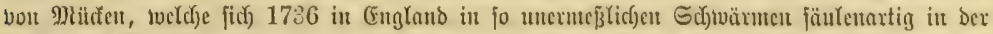

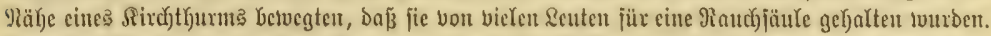

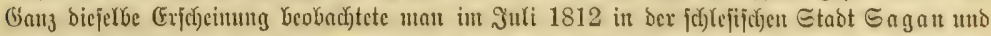

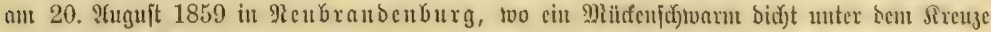

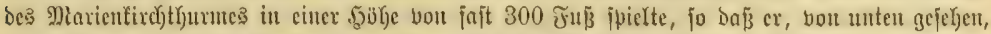

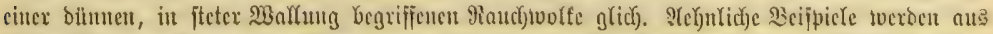

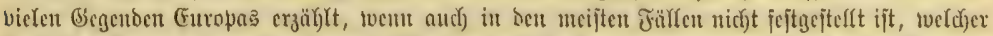

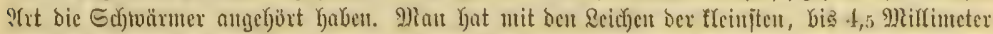

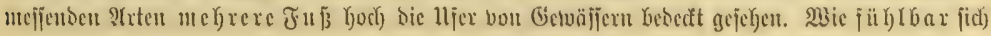




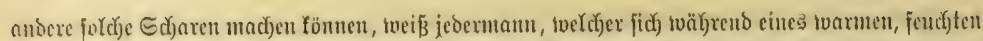

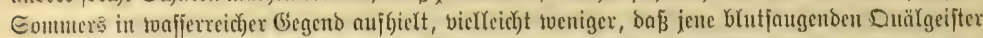

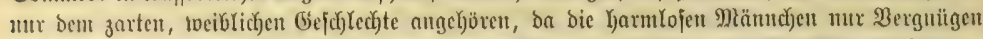

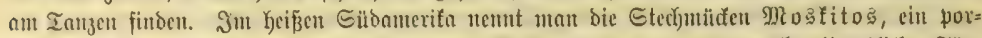

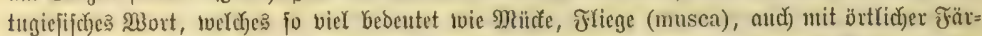

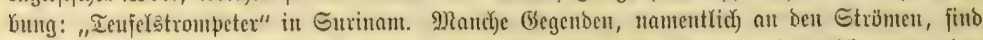

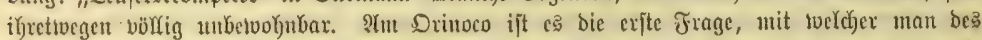

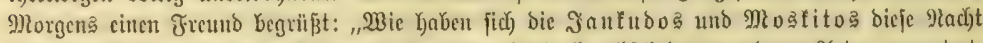

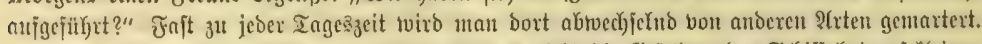

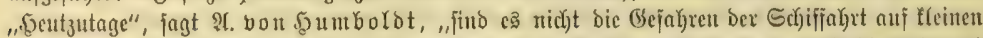

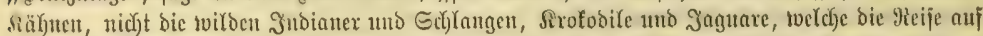

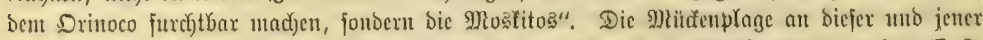

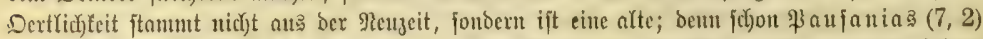

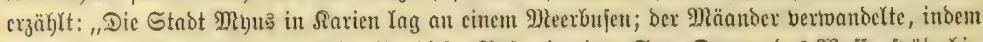

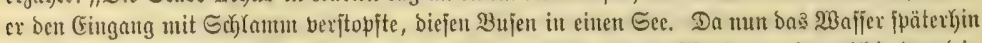

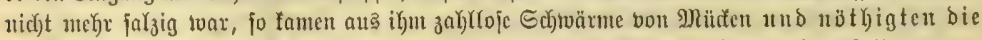
(Eintwolner, bie Stabt zu verlafien. Sie zogen nad) Milet, und zu meiner Beit war won

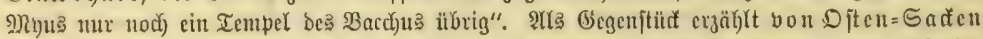

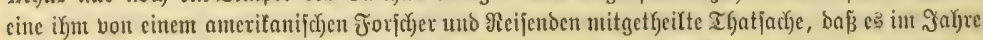

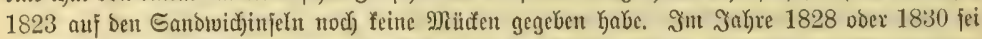

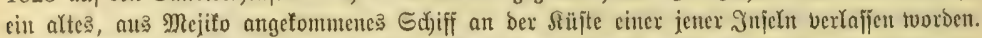

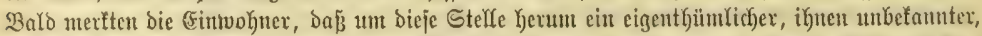

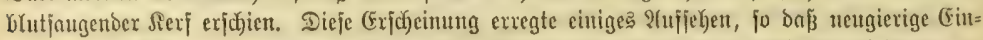

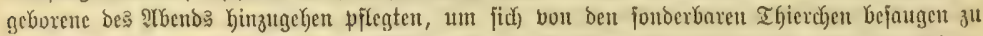

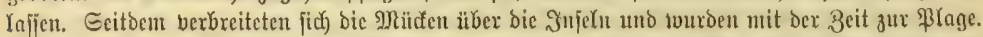

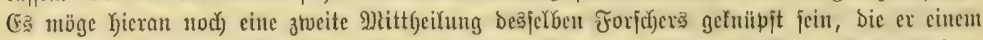

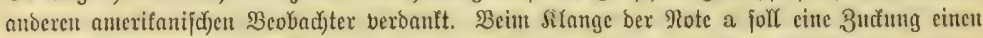

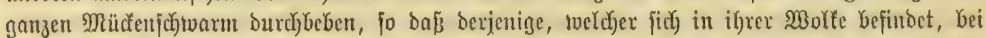

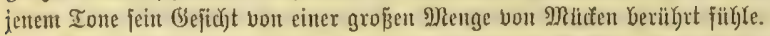

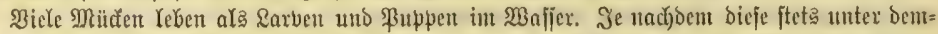

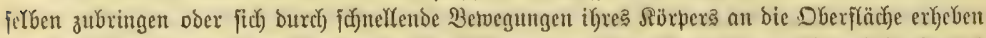

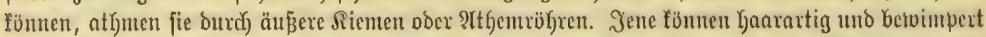
Doer bInttjörmig jein und pflegen, twie bieje, am exjen uno Yeşten sörperringe z" fitzen.

Die geringerte Stech)mü te (Culex annulatus, Fig. a) mag bie Sippe ber (5uriciden

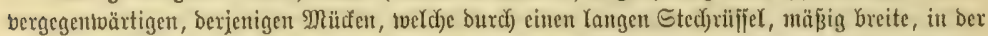

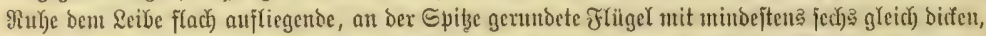

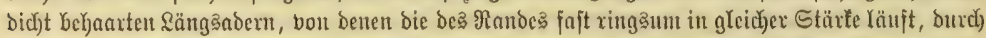

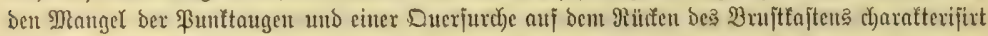

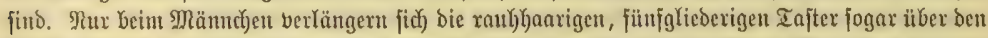

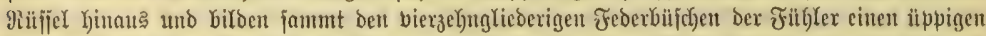

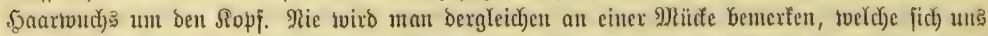

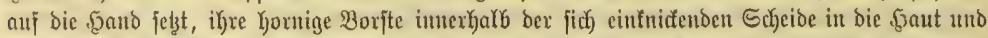

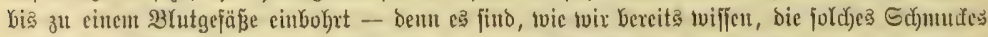

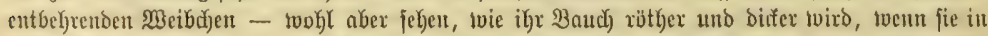

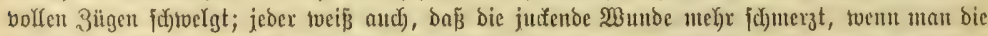

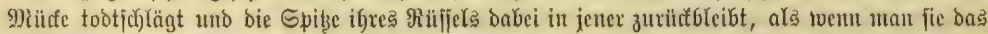

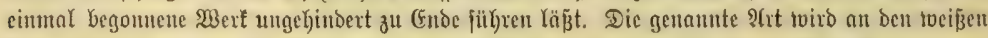

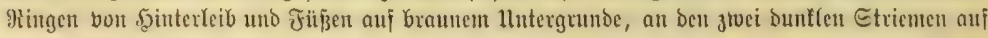




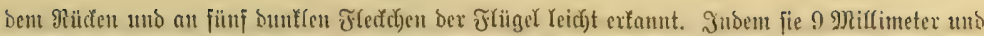

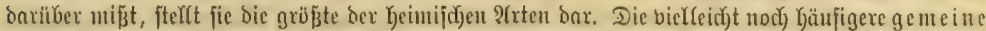

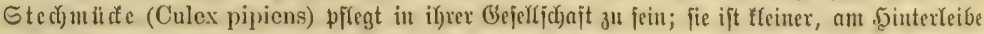

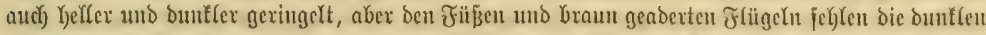

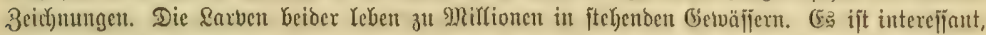

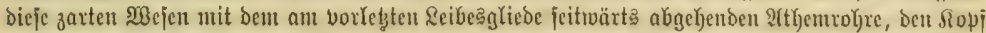

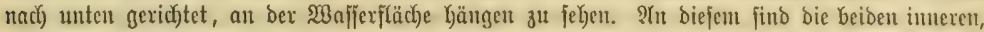

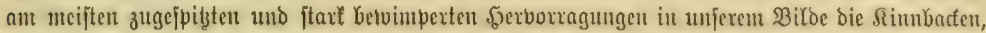

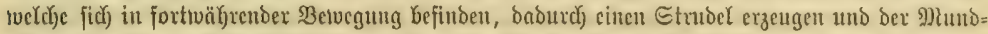

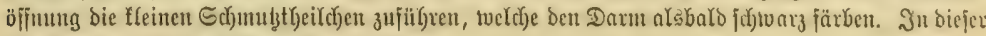
Weife, poer mit Dem Borbertörper fich er: hebent und mit bem anderen ßaare ber $\mathfrak{2}$ !ns Kängjel, ben điihlern, umlyertajteno, Kängen bie Ifiere bie Kange Beit ba, uno mur twetut bas eine bem anderen zu nake fommt, zaujent fie fid tookj audich an bent Siopfen, ohne

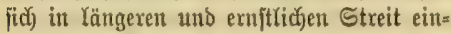
zulajien. Die Keijejte Erjobütterung bes Wajpers aber läp̄t fie von der Dberfläche verfătuinben, in fát Kangentartigen 2 indungen

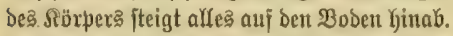
Бier Kalten fie jeood) nidjt Yange aus. In Dexjelben खeije, lvie fie untertaud)ten, tomunt balo eins ttach bem anderen twieder Kerauf uno hängt mit bent शithentrohre an ber

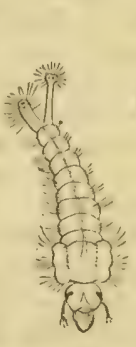

$\mathrm{b}$

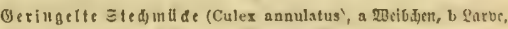

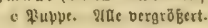

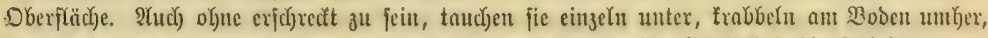

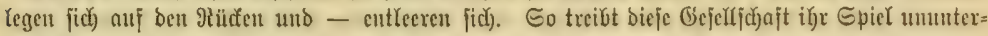

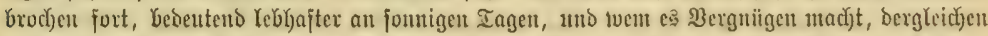

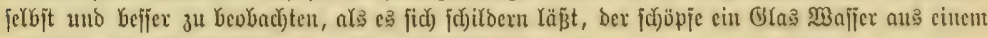
bon ifnen bebilferten Iroge, aus einem \&bjojtulbel zc.

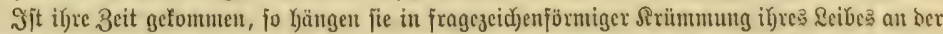

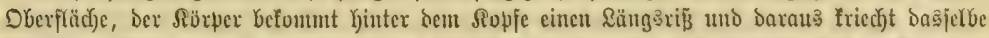

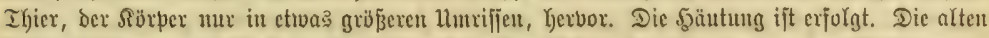

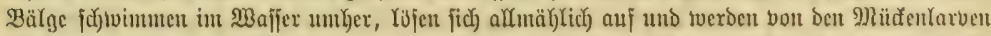

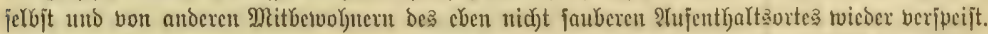

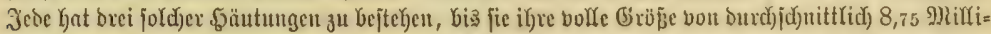

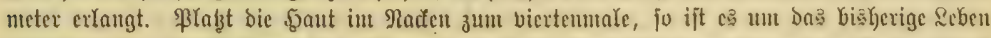
gejud)

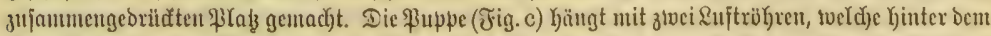

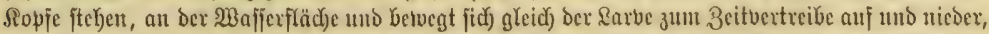

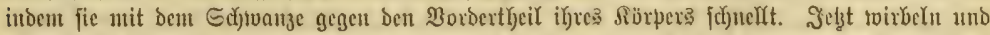

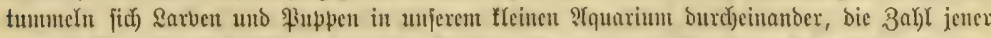

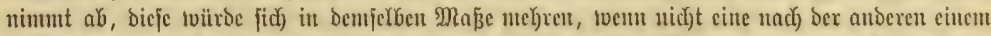

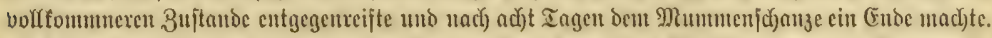

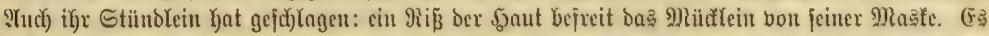

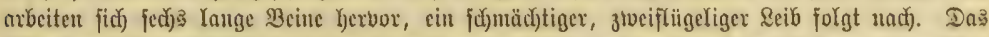

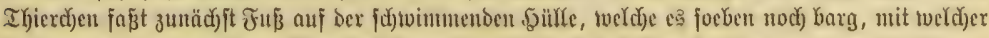

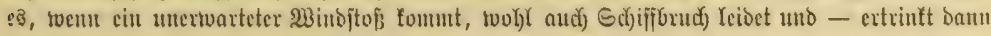




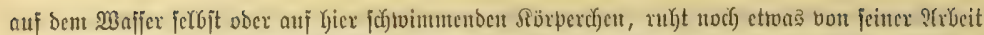

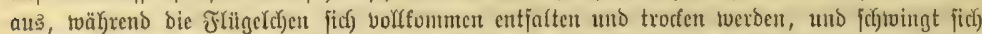

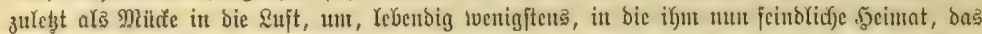

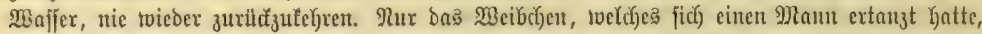

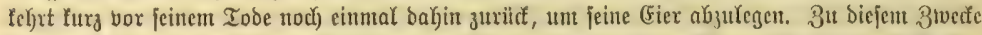

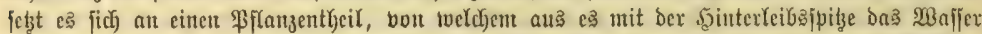

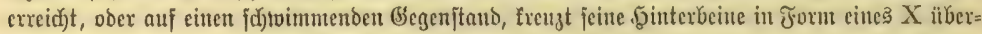

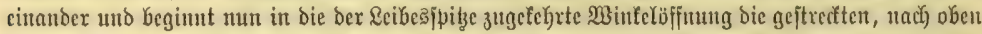
Bcjpizzten, nad) unten breiteren (Fiex zu Yegen, weldye mit ifyrer flebrigen Dberfläche jentrecht aut cinanber Kaften und ben WinfeL nad) und nad) ausfüllen. Jit bamit exjt ber STnjang gentacht, fo

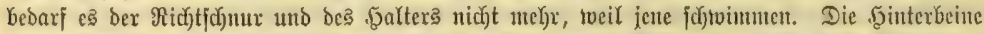

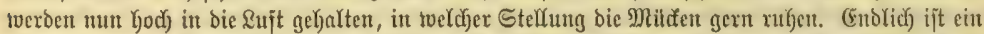

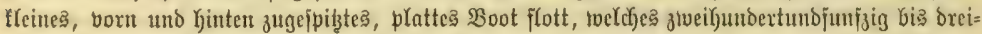

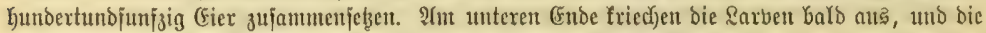

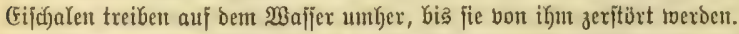

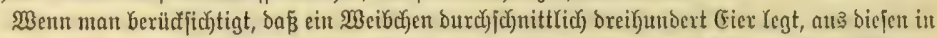
bier bis fün ’

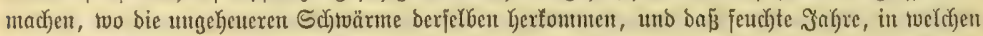

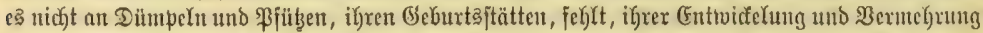

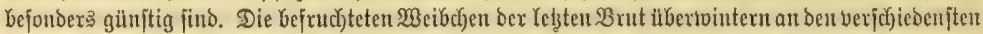

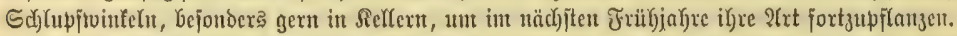

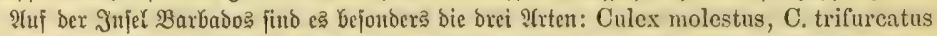

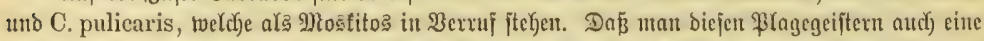

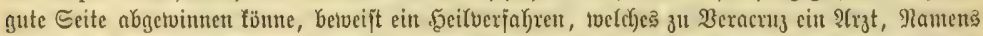
Delacoux, nit einer Dame cinleitete. Dieje lag injolge ener Gébirnentzünoung jeit zmölf Etunden

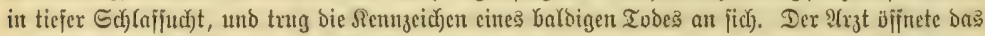

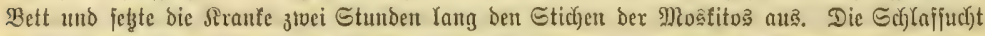
Kürte injolge befjen bald auj und bie Sirante bejand fidc an anderen Inge nicht nur nod) unter ben Rebenoen, jonbern audich um vieles beffer.

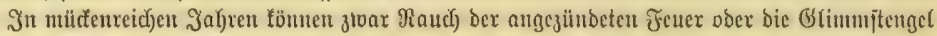

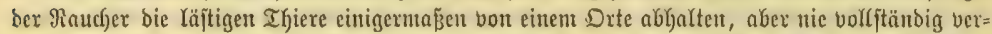

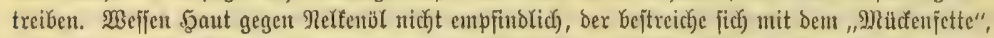

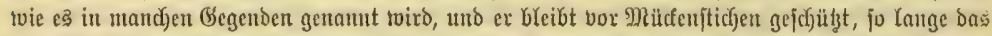
flüd)tige Del nod) Berud berbreitet. Betupfen ber verwundeten Stelle mit Saluniafgeift befreit

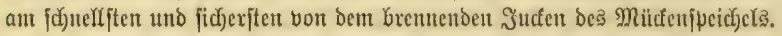

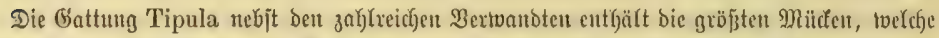

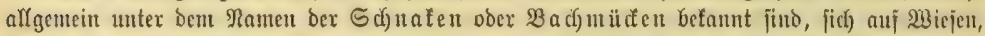

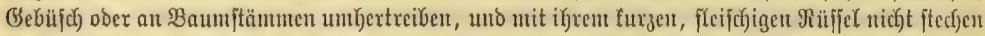
fönnen. Man erfennt jie an ber beutlichen Duerjurche bes MRittelrüufens, an ben viclaberigen

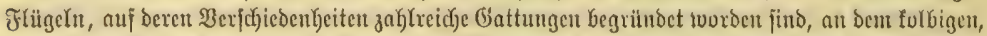

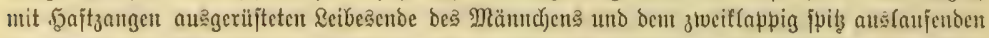

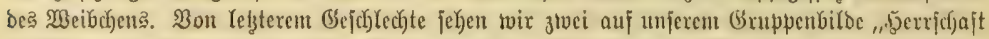

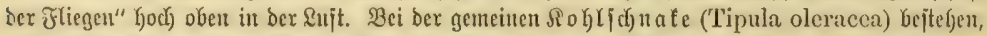

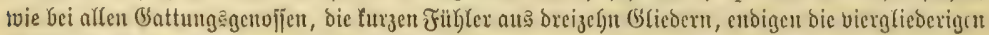

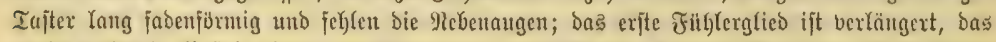

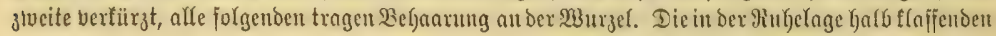




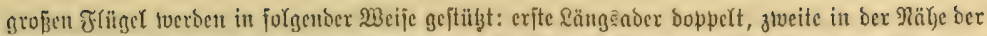

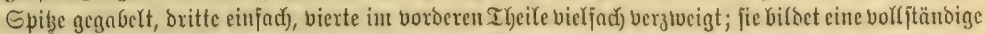

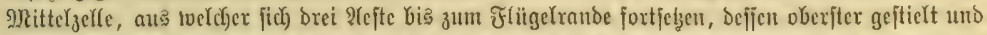

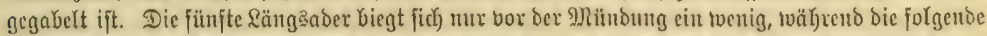

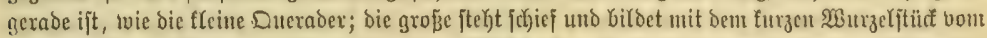

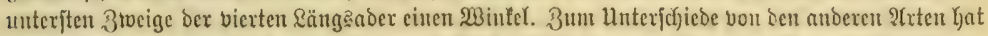

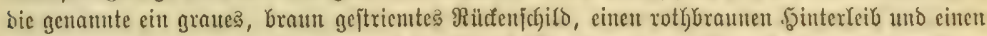

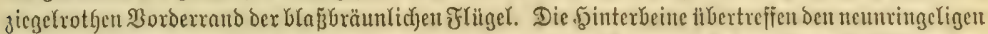

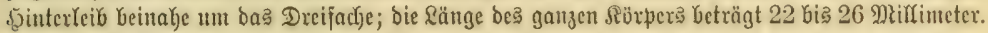

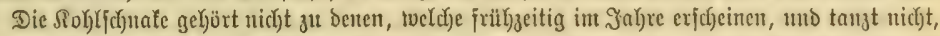

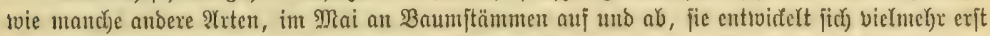

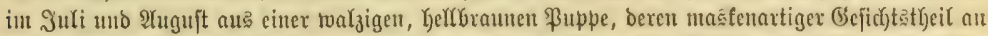

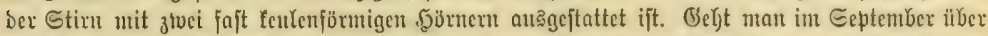

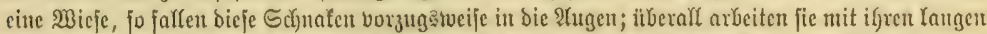

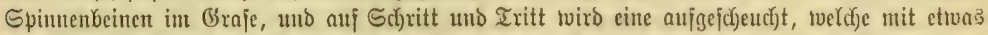

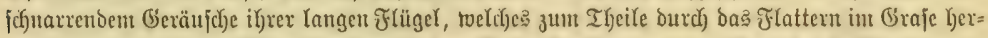

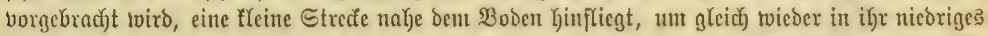

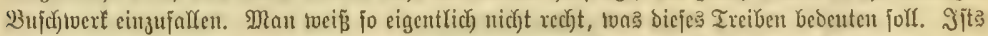

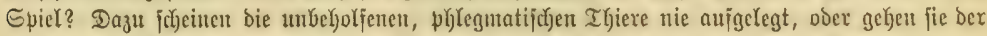

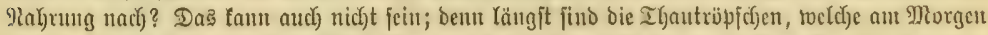

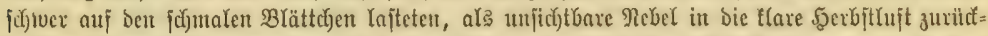

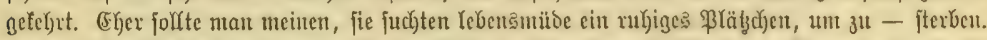

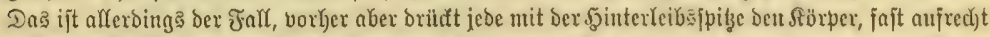

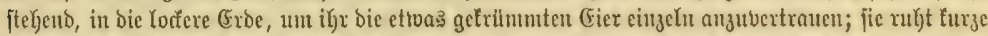

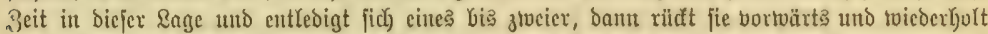

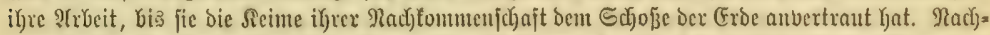

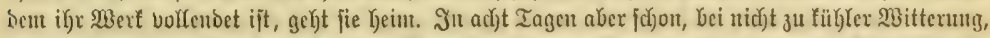

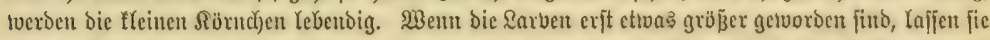

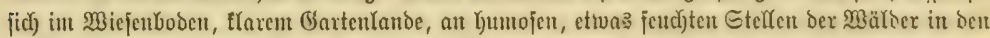

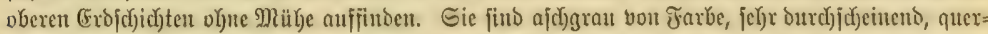

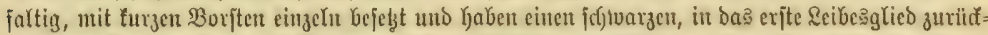

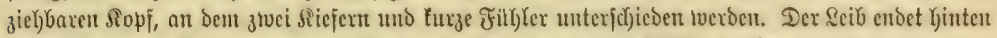

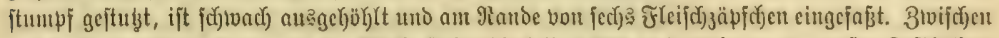

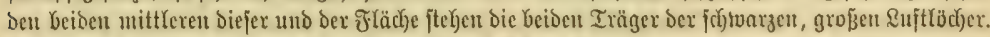

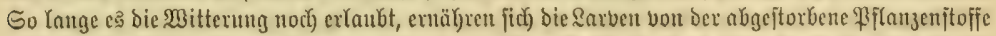

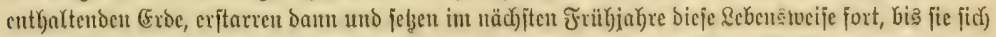

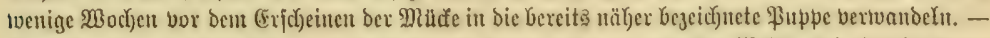

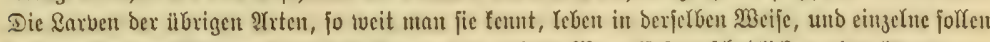

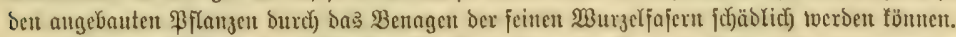

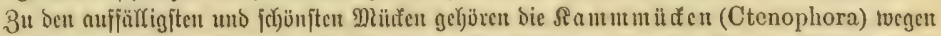

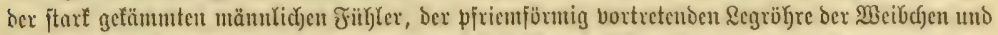

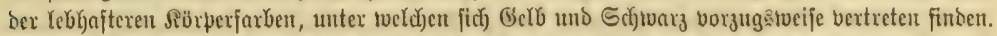

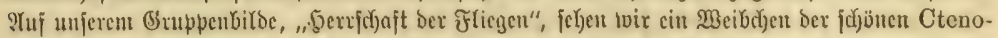

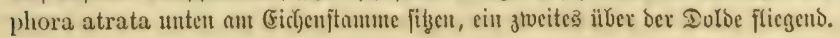

Uluter ber Fanilie Der fleinen, meift lid)t ge(btid) gefürbten Milden, Deren Maben zah)(reid) in Pifzen leben (\$ir

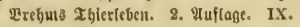




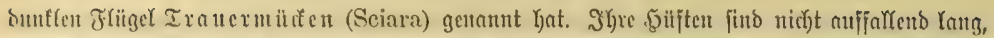

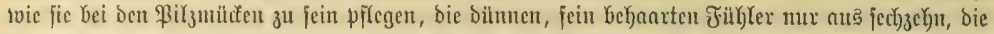

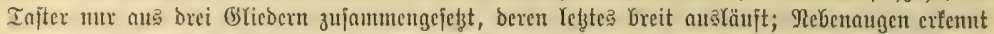

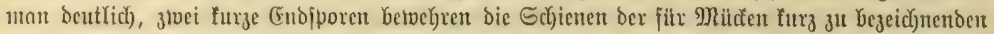

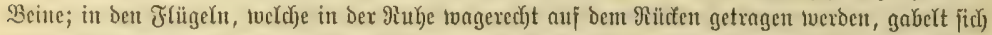

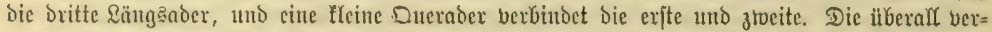

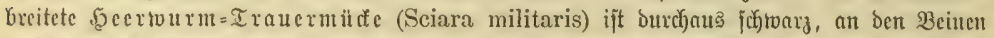

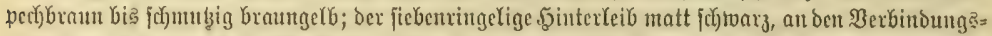

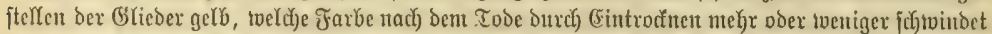

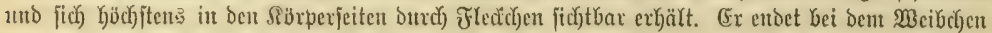

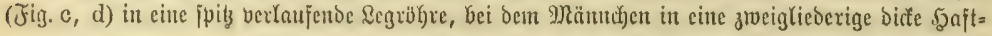
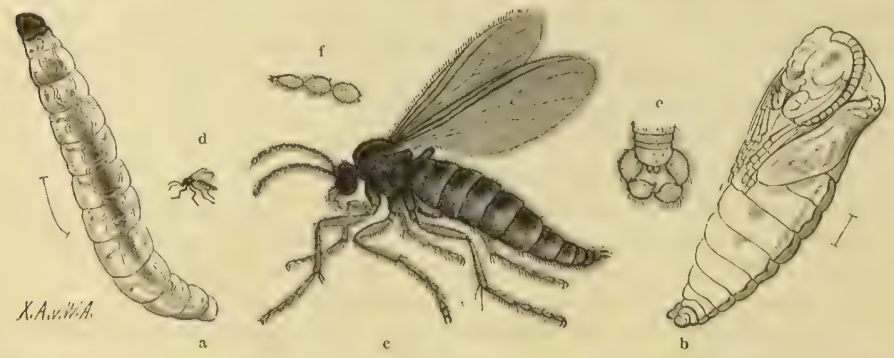

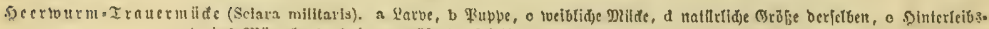

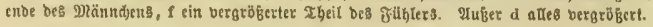

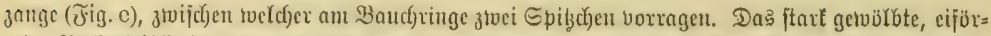

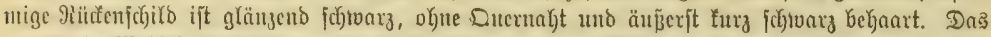

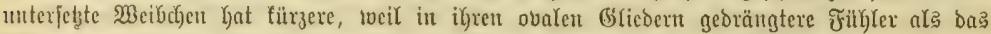

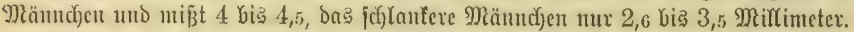

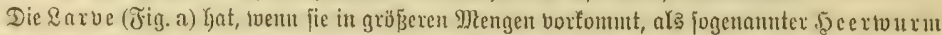

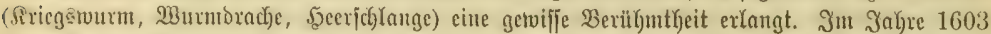

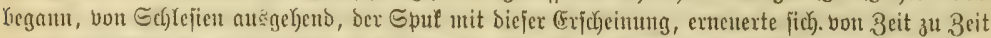

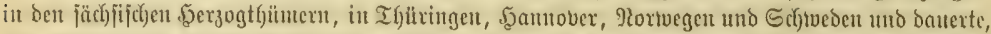

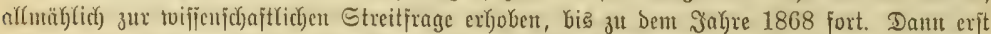

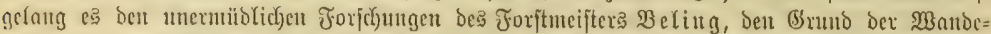

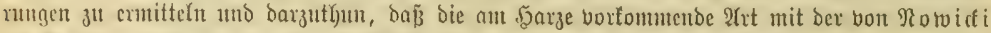

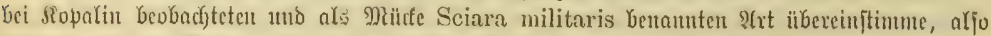

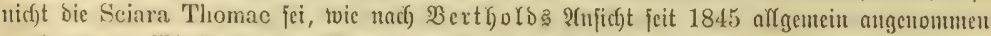

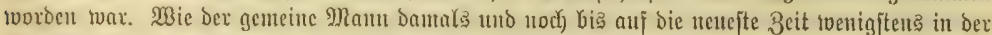

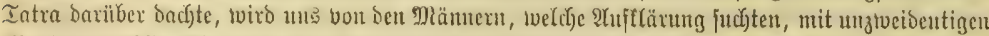

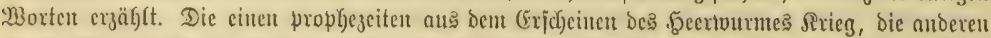

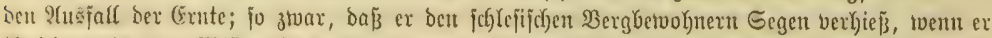

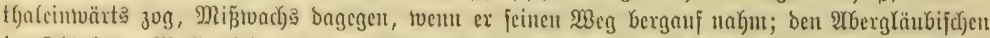

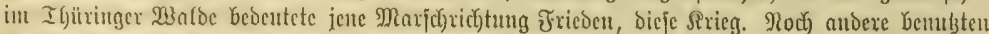

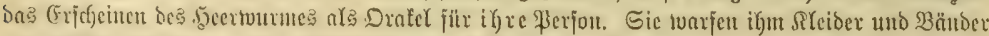

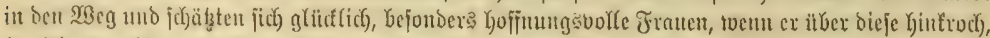

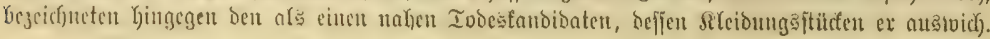





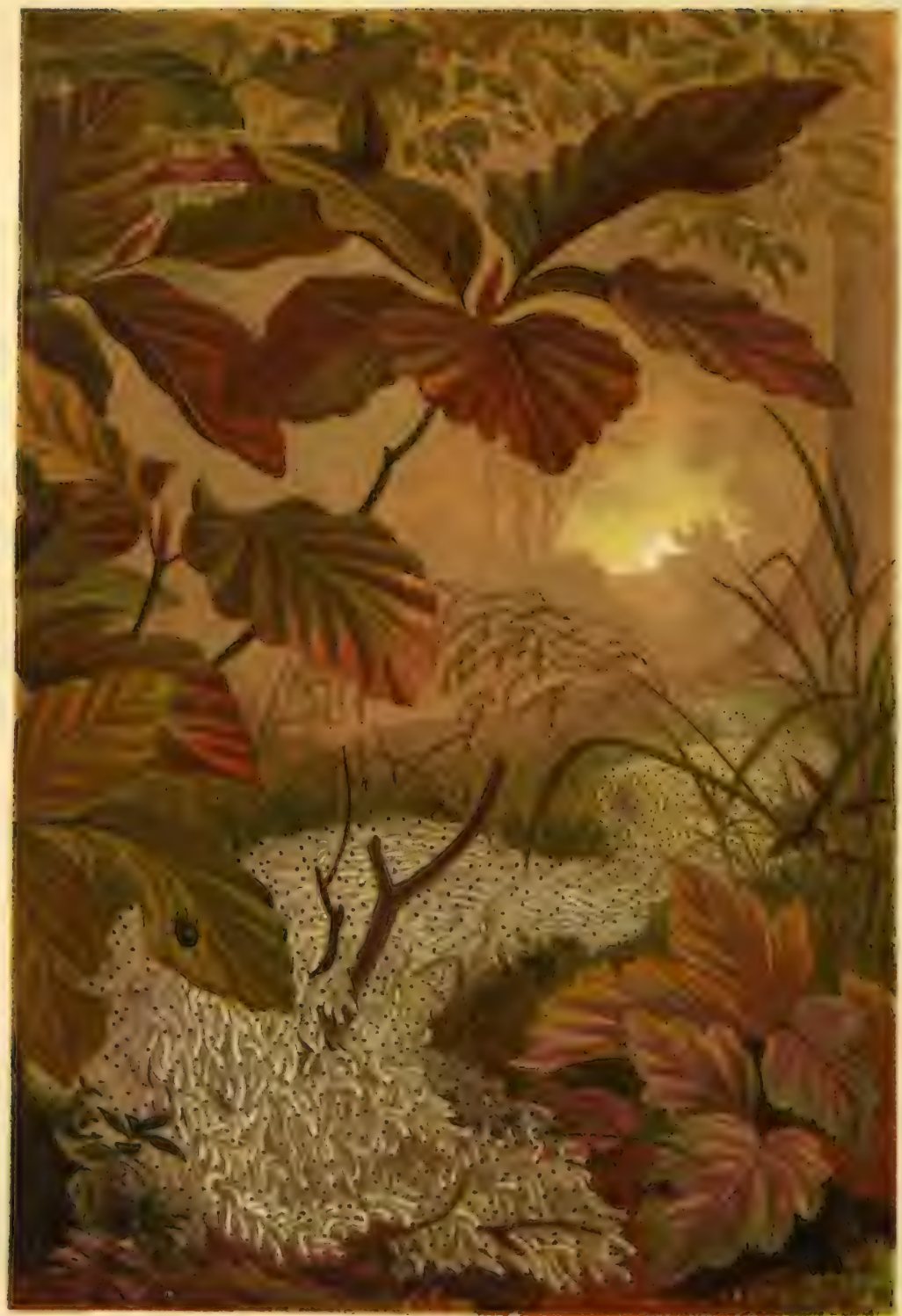

III HWom 


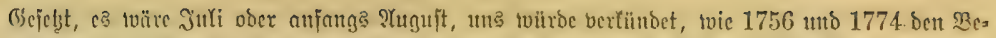

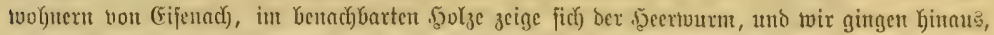

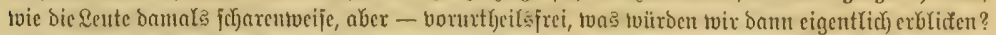

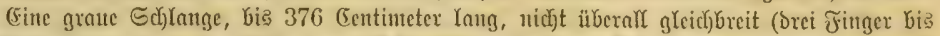

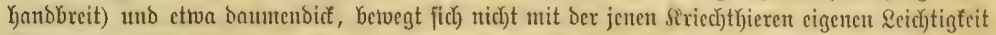

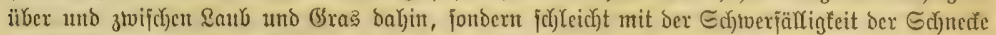

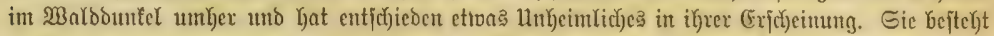

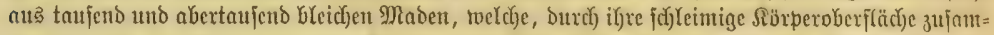

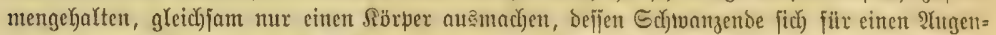

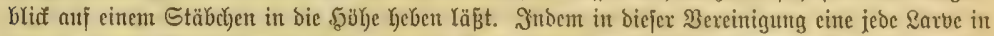

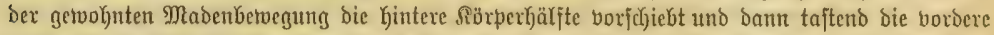

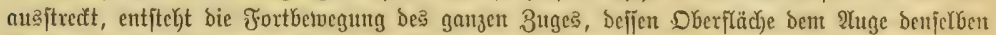

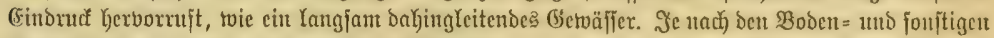

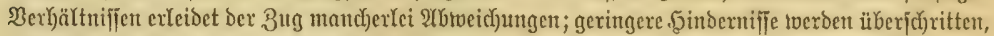

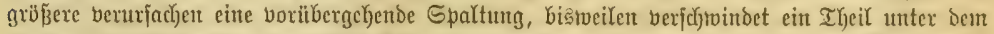

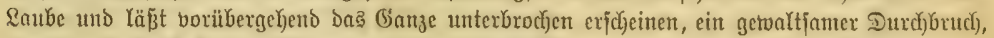

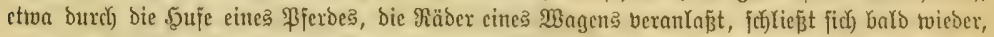

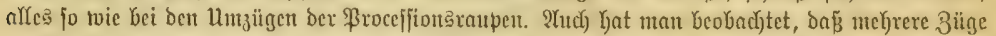

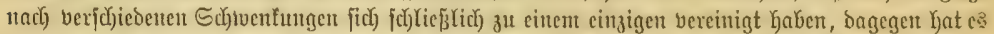

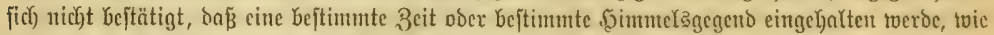

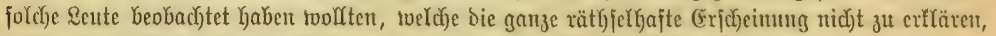

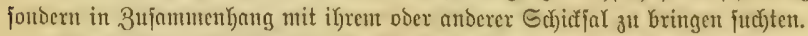

Sorgfältige uno jabrelange ßeobartytungen in Freien tvie bei Buchtverfuthen itt ber Gejangens

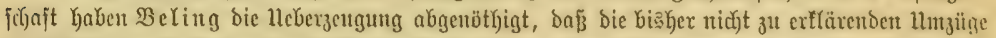

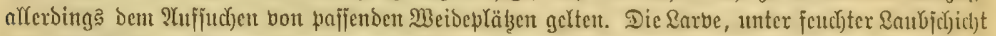

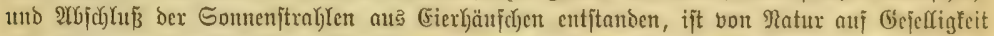

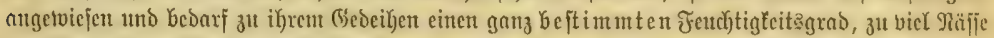

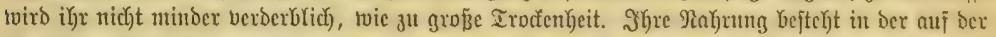

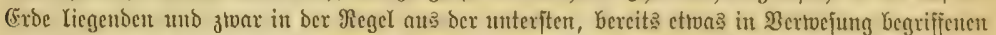

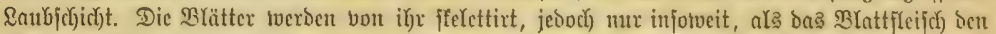

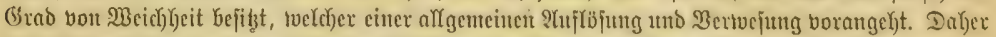

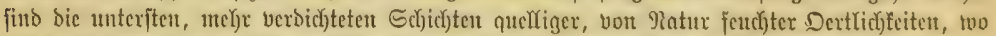

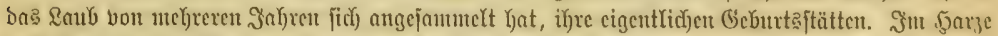

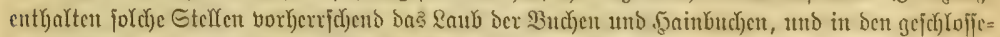

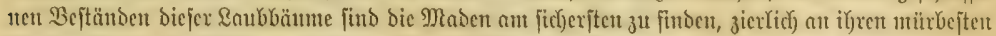

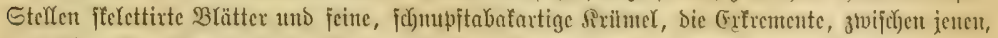

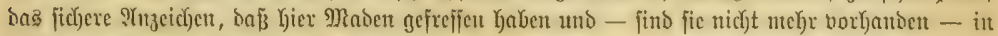

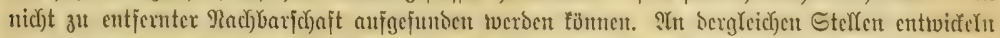

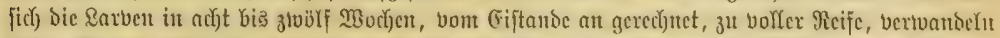

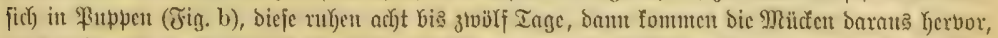

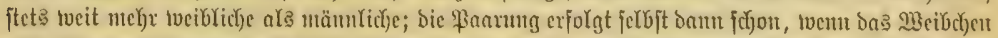

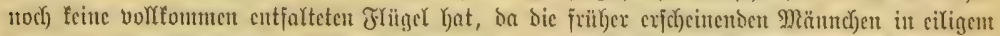

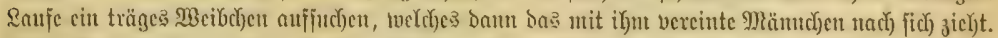

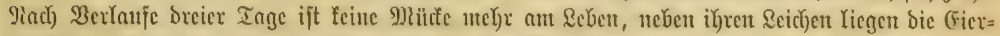

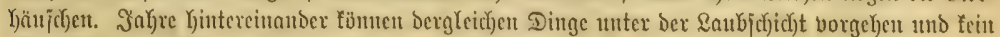

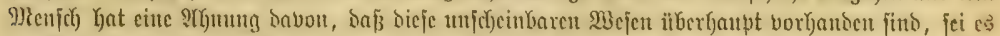

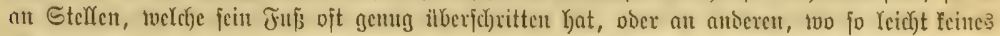

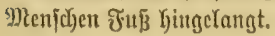




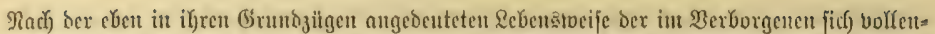

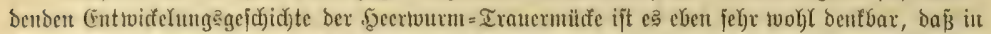

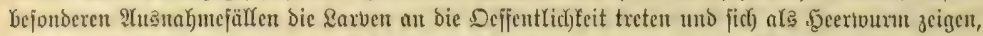

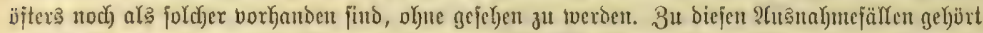

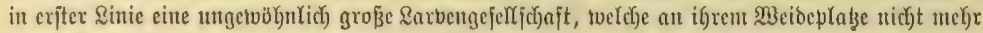

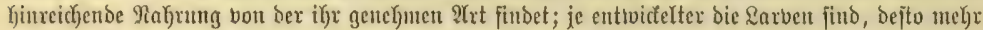

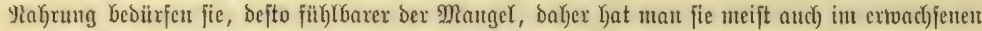

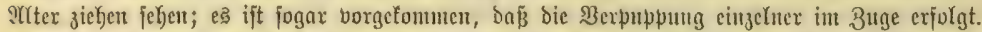

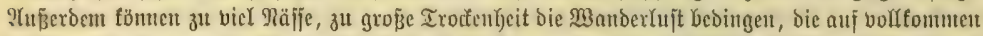

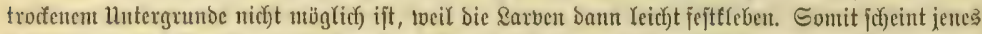

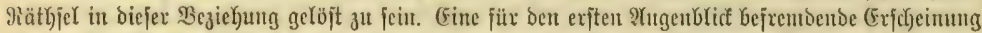

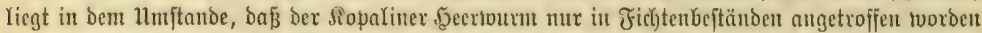

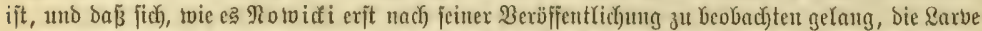

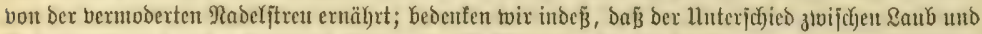

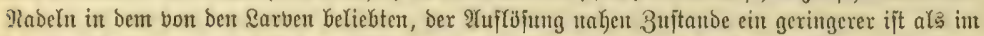

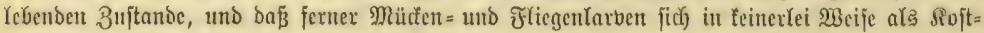

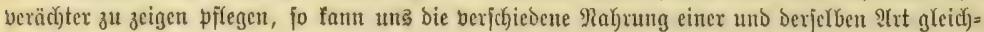
jalls feinet weiteren 2Hnjtoß geben.

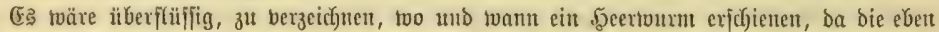
Genanten, Beling im "3oolonif(ben Garten" (IX, X), bie anderen in bejonoeren Ed)rift ftüăen

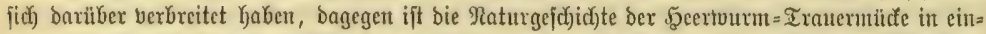

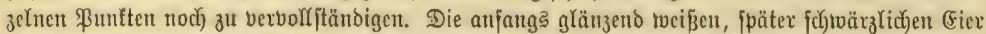

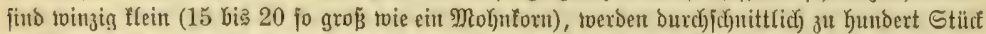

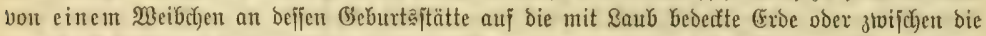

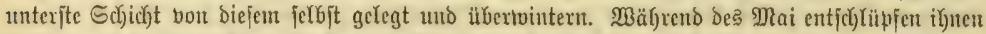

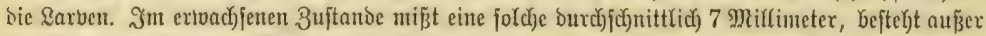

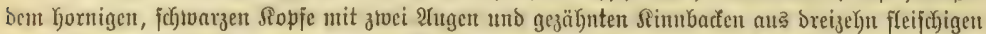

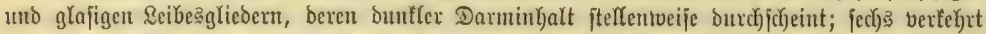

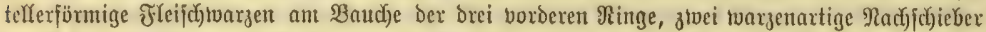

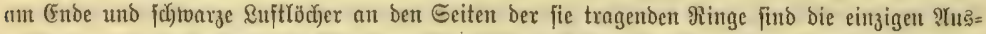

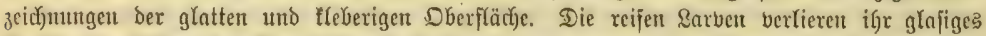

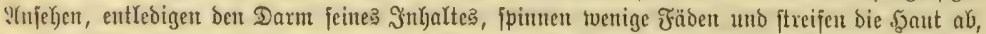

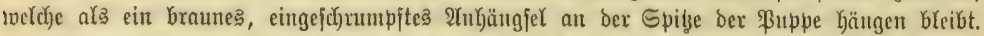

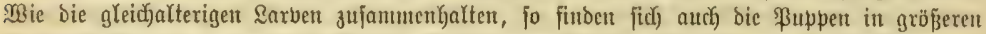

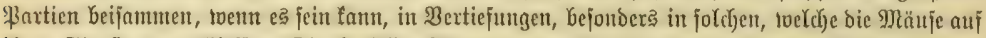

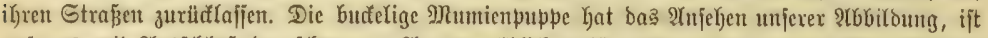
anjangs mit $\mathfrak{A}$ (t)

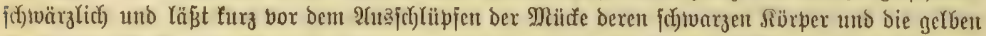

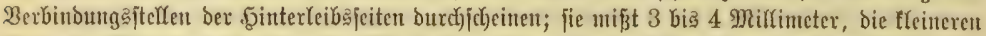

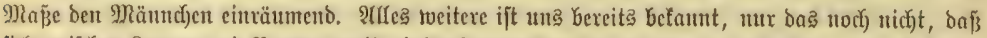

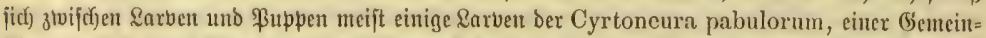

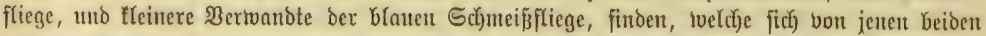

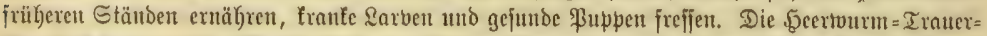

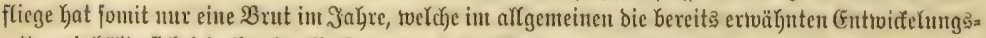

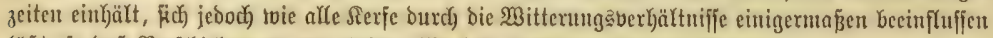

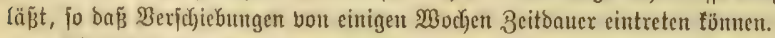

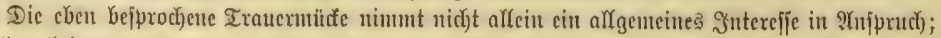

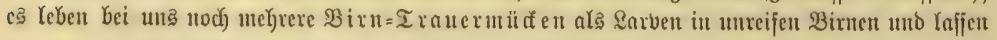




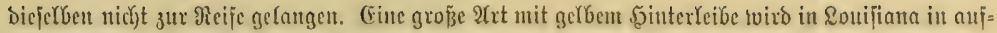

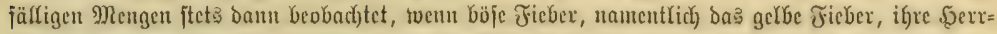

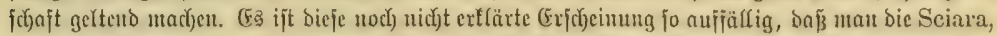

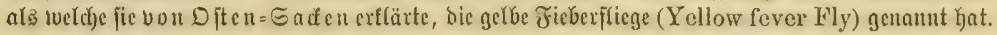

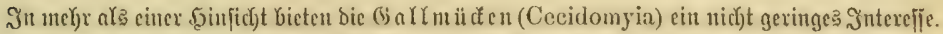

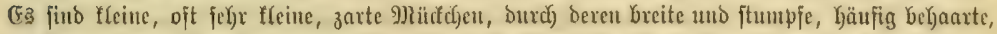

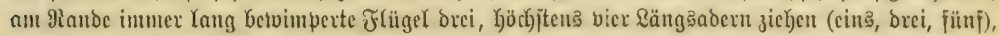

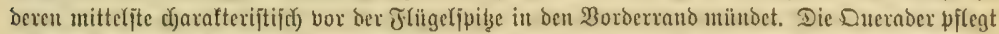

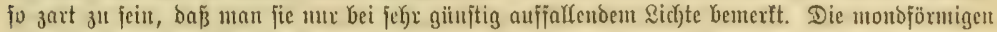

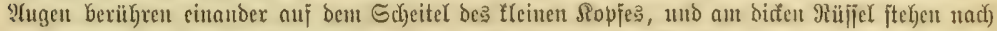
imen bie vierglieberigen Injter hervor, beren Enoglied in ber Pegel an längiten ift. Die perl=

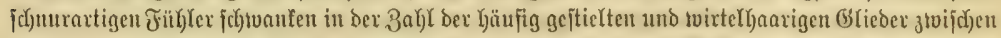

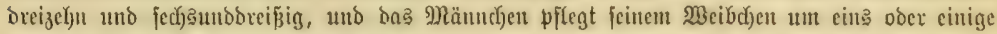

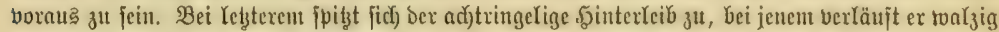

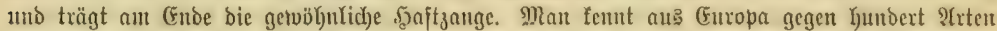

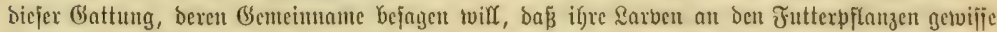

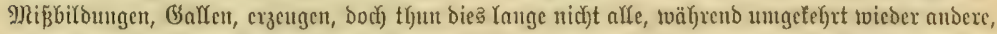

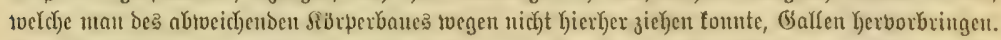

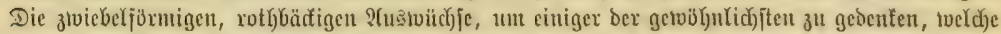
nuf ber Sbericite ber Butchenblätter fiłzen, entjtelyen burd) ben Etich ber Cecidomyia fagi, bie

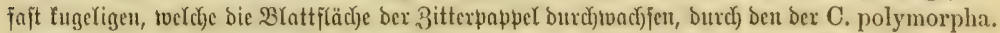

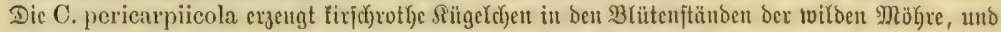
jeber anbere Pffanzentheil fann won toieder anderen Frten betoohnt jein.

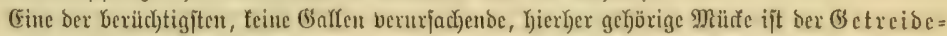

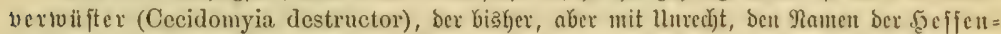

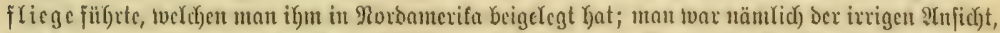

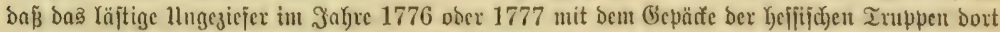

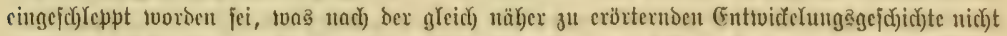

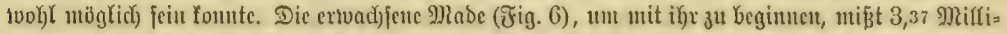

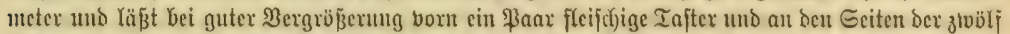

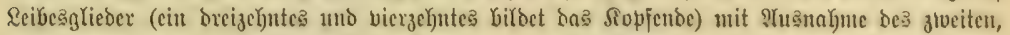

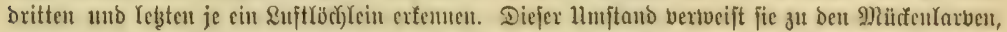

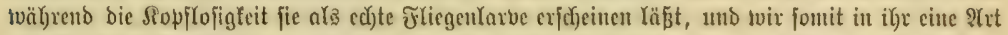

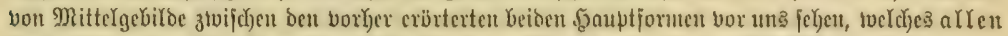

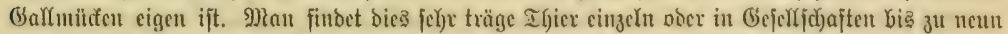

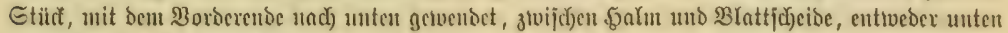

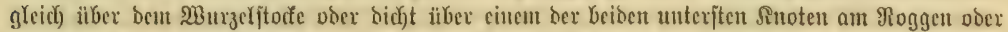

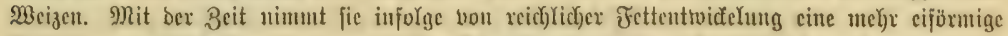

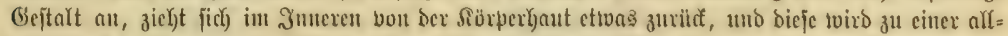

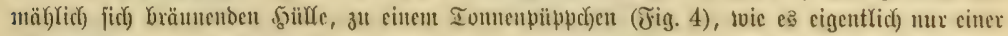

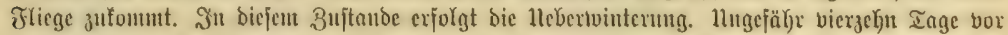

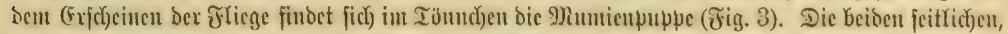

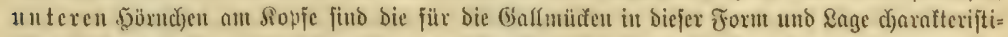
f(d)en P(t)

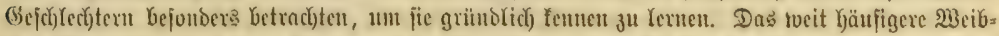

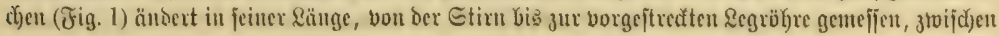




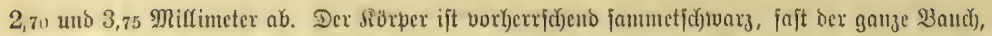

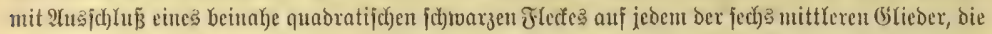

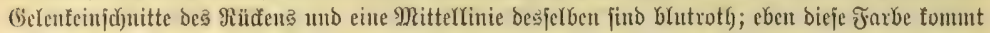

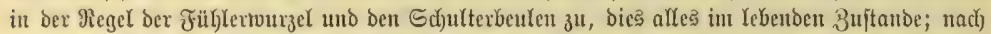

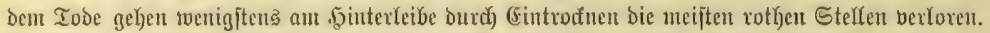

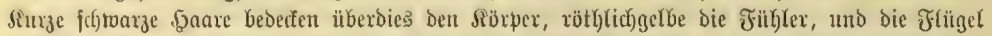

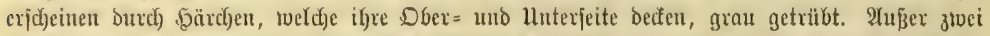

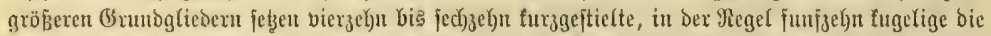

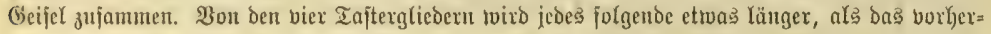

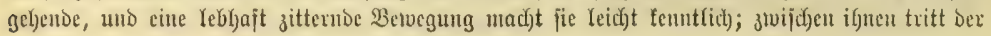
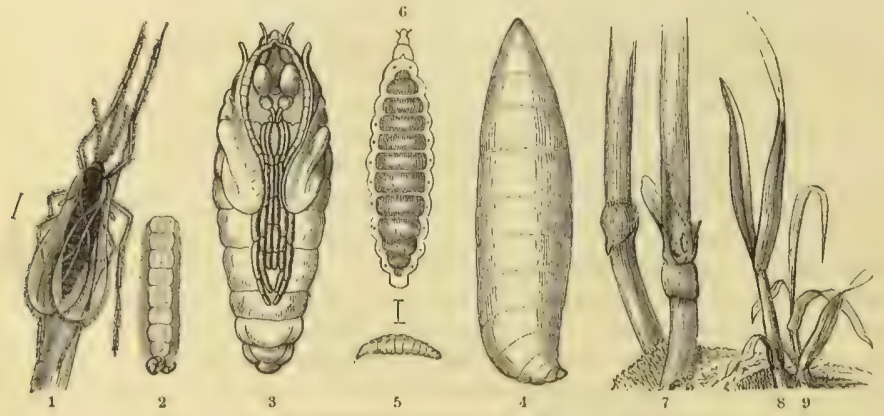

(3) treibeberwilfer (Cecidomyis desteuctor).

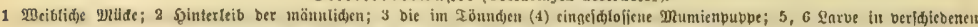

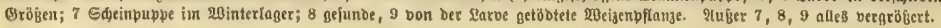

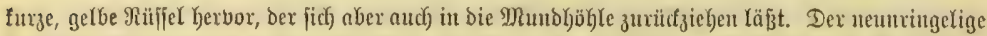

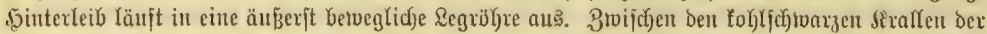

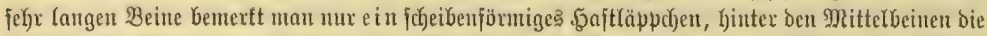

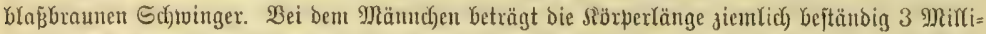

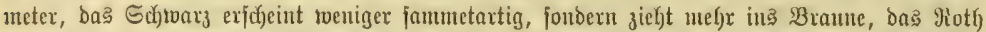

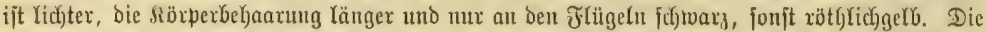

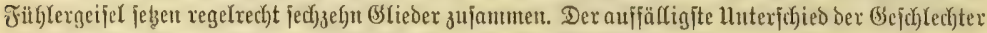

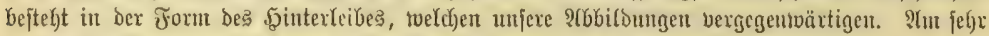

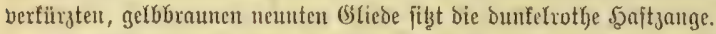

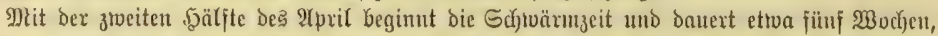

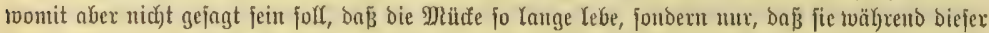

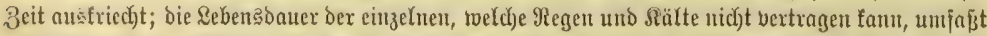

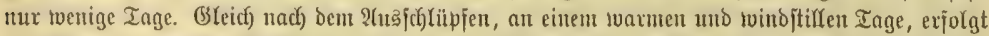

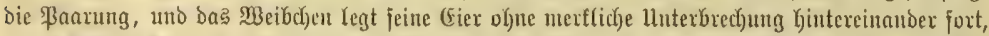

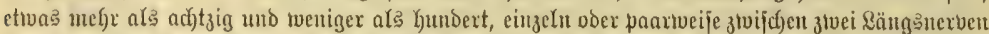

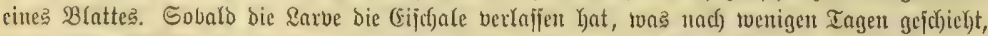
gleitet fie am $\mathfrak{B}$ latte Ginab uno gelangt hinter defjen Scheide, no jie fid für iumer feftfebst. War

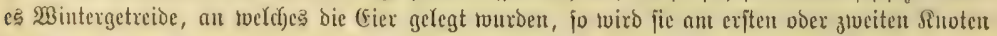

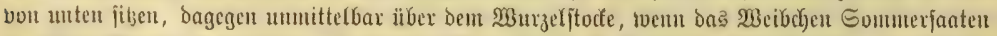

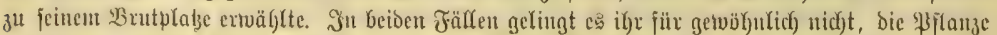

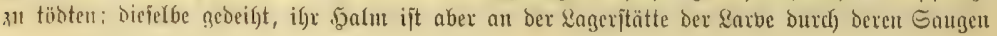




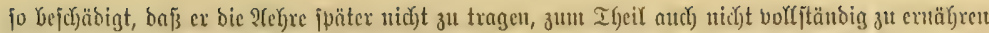

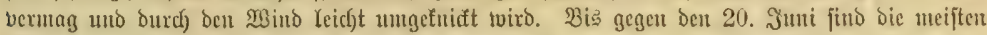

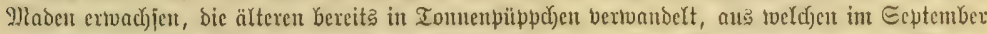

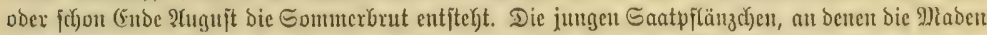

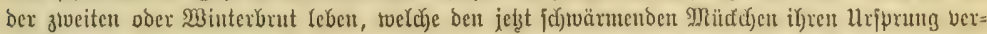

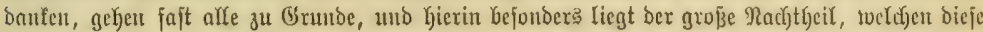

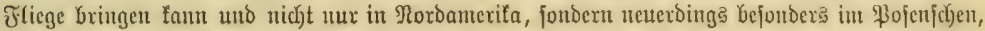
in Sch)

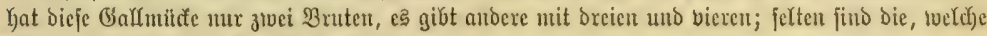
แux eine im Jahre zu Stande bringen.

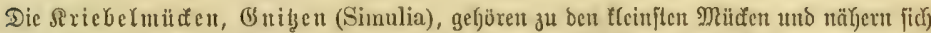

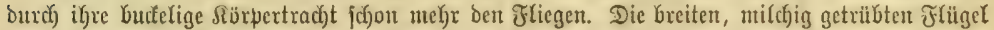

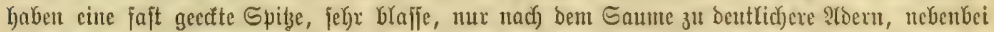
gegabelte uno ungegabelte Falten; an ben meijt gejdyecten Beincu madjen fid bicfe Edjentel uto

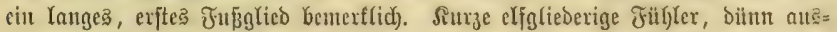
laujende, vierglieberige Infter, eine fieic, bold)artig zugejpizzte Oberlippe, cin zum

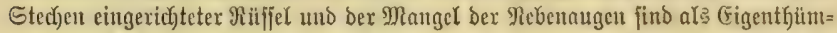

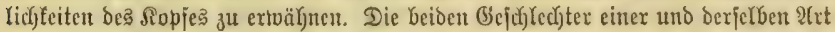
unterj(c)eiben fich oft toejentlich) in ber Färbung unto andertucitig. Die Onilzen

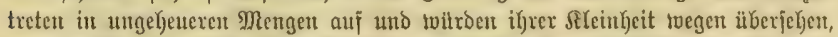

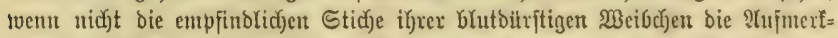

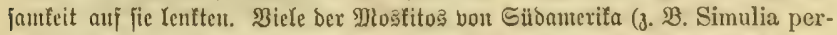
tinax) gełören zu bicjer Óattung. Die হarven uno Puppen Yeben in Mafjer, two

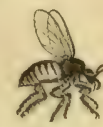

(columbatfdict 2lil de (Simulia Columbaczensis', bergröęcrt.

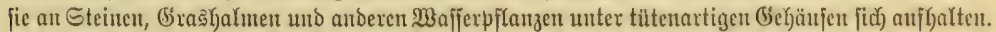

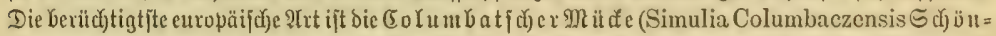

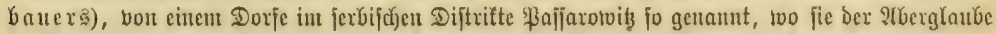

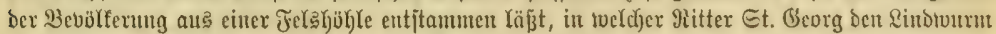

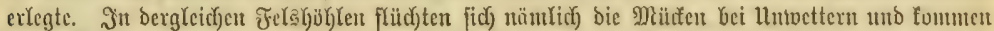

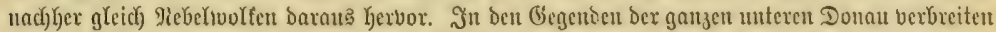

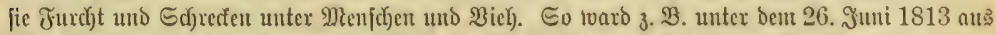

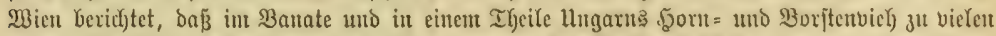

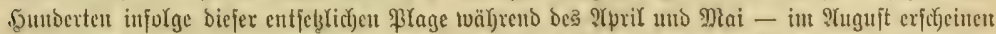

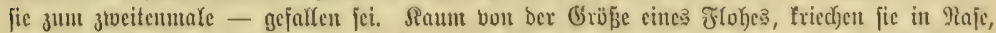

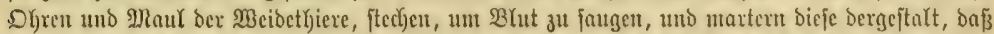

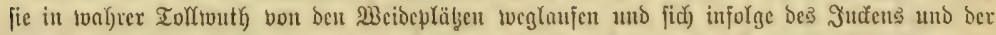

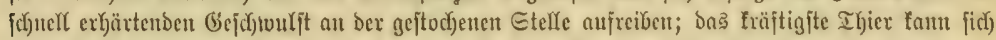

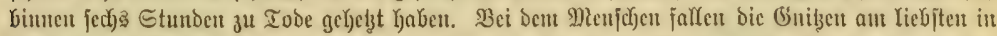

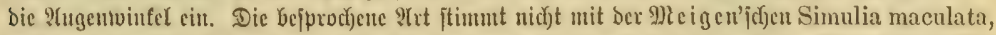

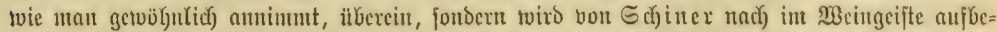

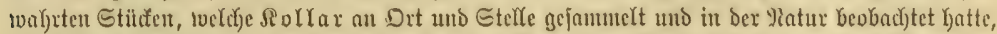

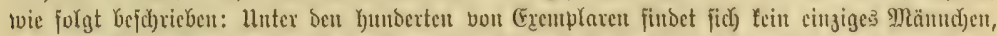

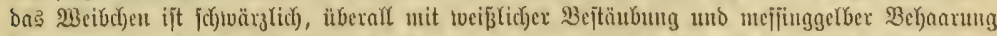

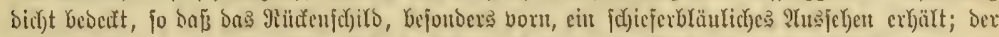

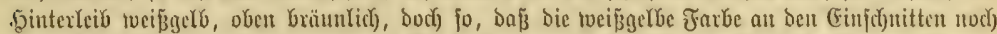

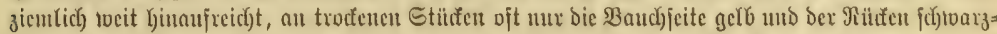

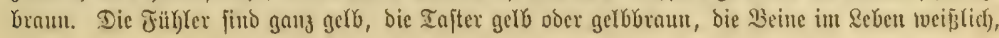




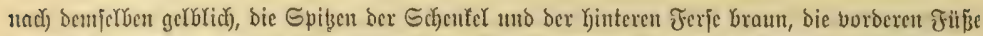

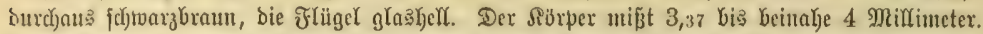

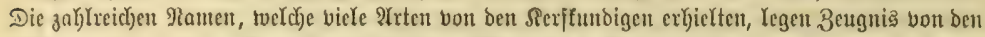
Gdjuierigfeiten ab, weldye mit beren ridytiger Erfennung verbunden find.

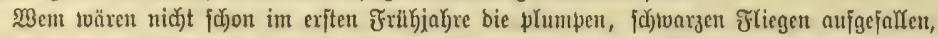

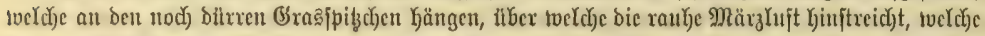
träge an $\mathfrak{B} แ j$ djwert umberfried)en, bejonders ba, wo jich bie Blattläuje zu zeigen begiumen, aber

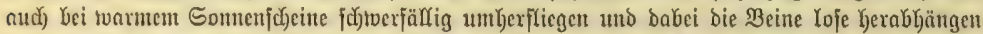

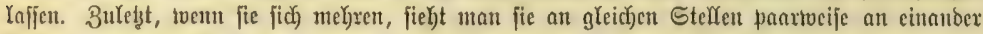

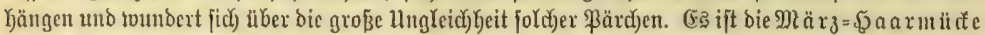

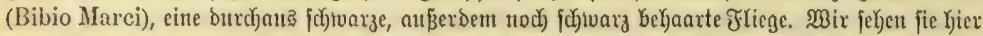

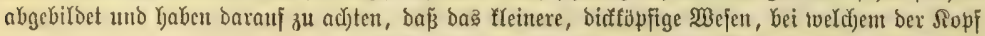

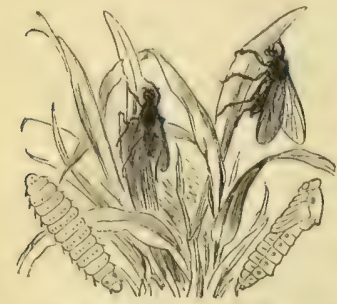

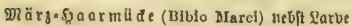
und quppe; bie peiden lefteren bergrobert.

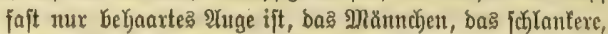

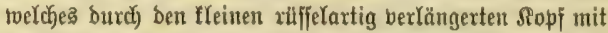
ben fleinen nadten 2(ugen nod) ben Ptildend)arafter betwahrt,

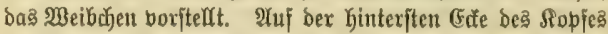
Yafjen fich brei Rebenaugen erfennen, am entgegengejetżten

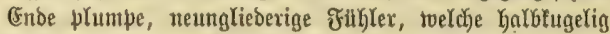

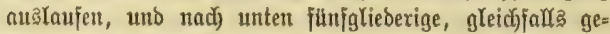
brungene Tajter. Das ftarf getoölbte Rütenjajilo marfixt jeinen exiten Ring als zlwei jcharje Santen, tweld d)e einen

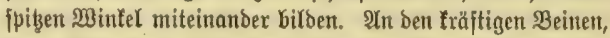
beren hinterfte die längiten, falfen bie Schentel burch thre

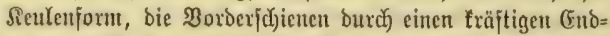

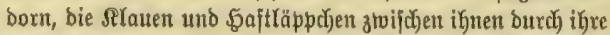

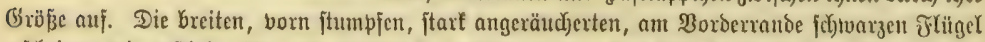

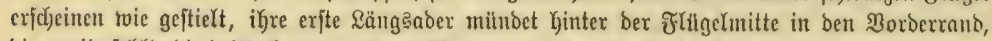

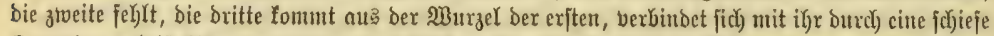
Ducraber und ift bis zu biejer bebeutens ftärfer, ałs teeiter hin, bie ziemlich) gerabe bierte viro Kjinter

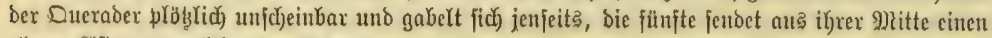

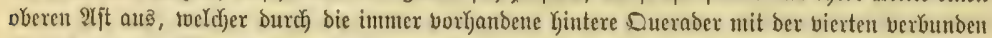

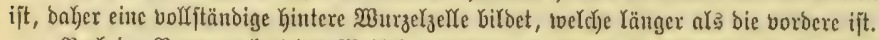

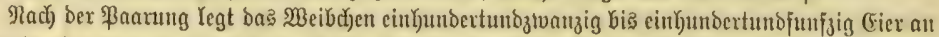

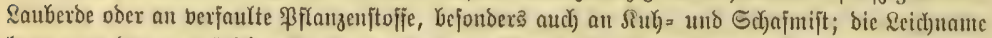

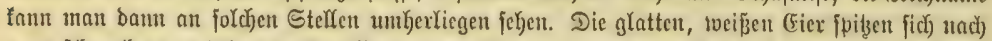

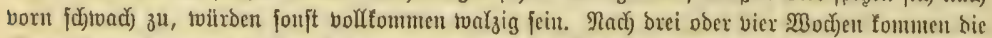

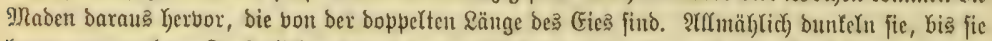

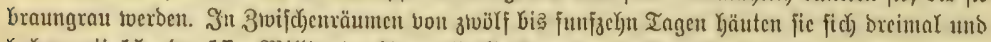

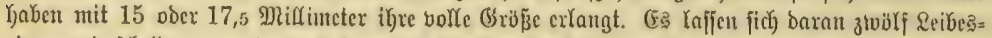

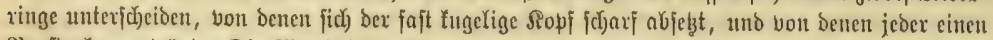

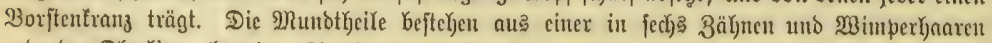

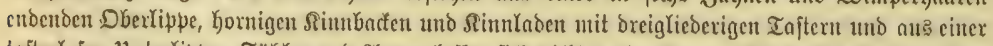

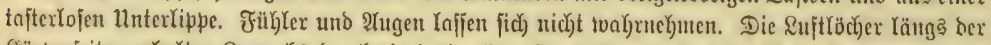

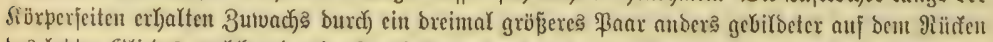

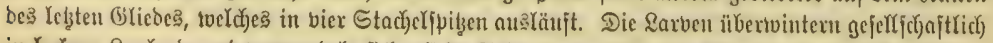

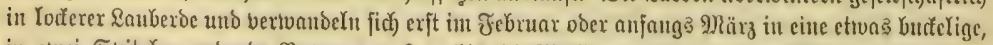

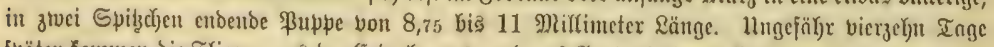

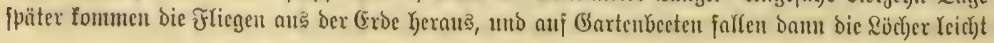




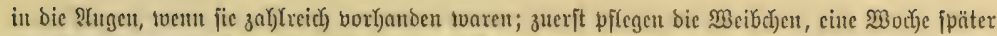

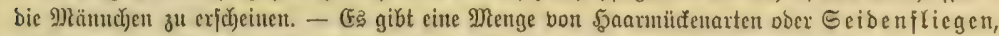

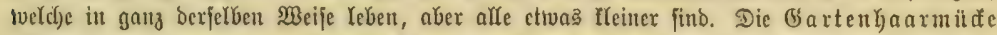

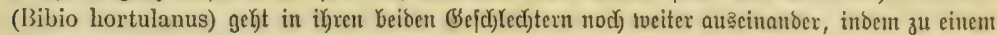

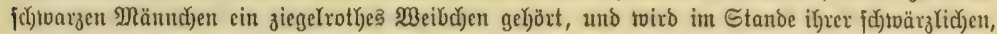

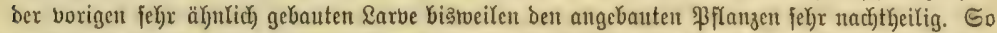

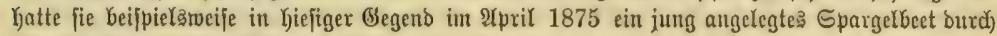

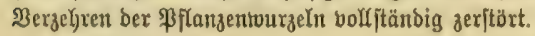

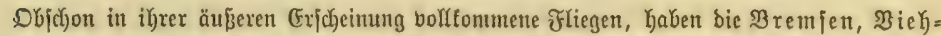

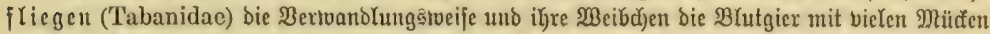

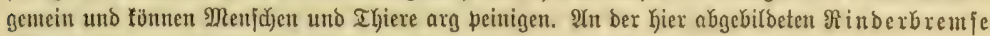
(T'abanus bovinus), einer bex gemeinjten bex vier = bis fünfbundert

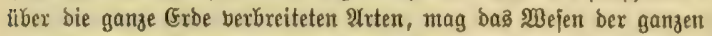
Familie erläutert toerben. Förpertradjt und Form ber cinzelnen Theile

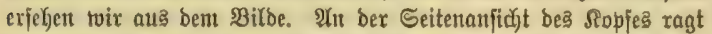

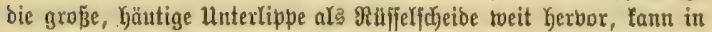

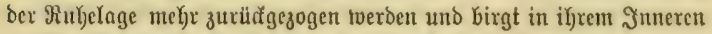

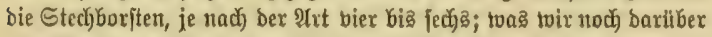
bemerten, fint bie alweigliederigen Siejertafter. Die vorgeftreatten, an

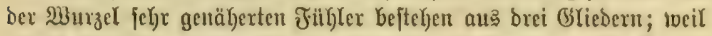
aber baß britte manchmal geringelt exjod)eint, tönnte man auch) von

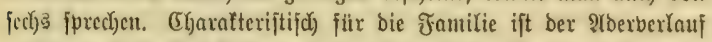

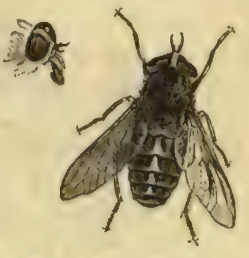

28 ciblide Finderbremie ( $\mathrm{Ta}$ banus bovinus), mit Ecituan!l(d)t

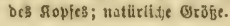

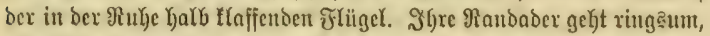

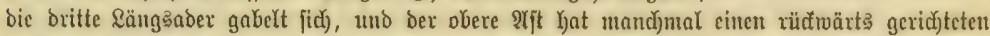

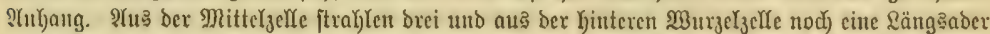

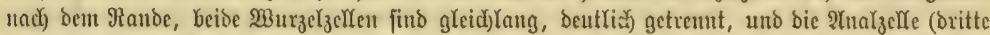

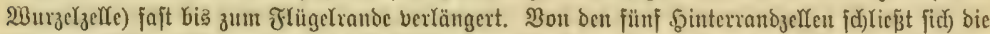

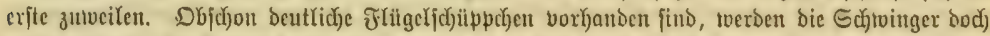

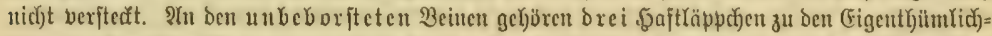

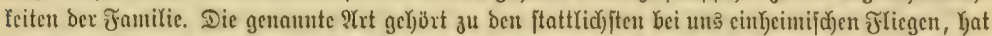

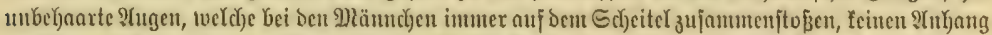

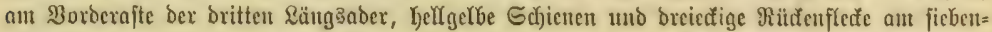

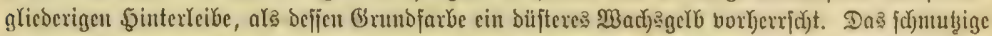

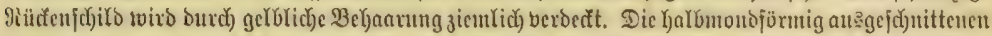

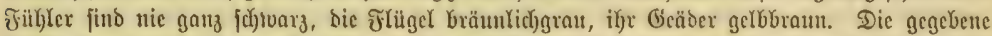

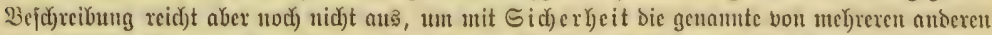

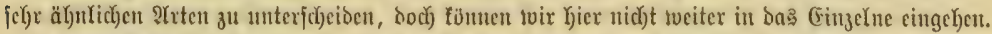

Durc) fräftiges Gejunme verfündet bie Rinderbrenfe, wie if)re anderen Gattungegenoffen,

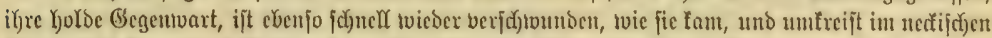

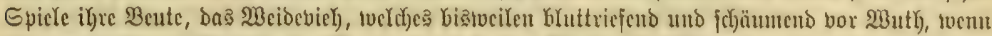

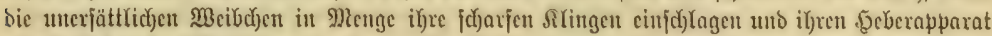

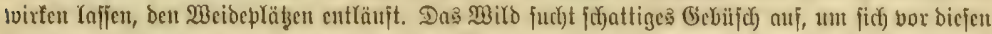

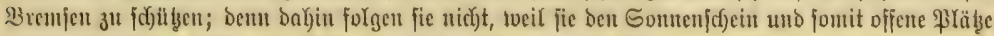

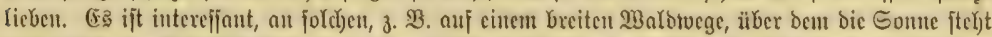

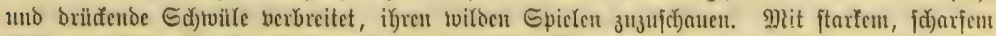

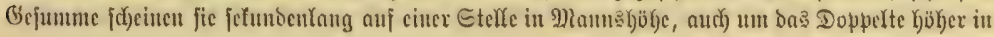




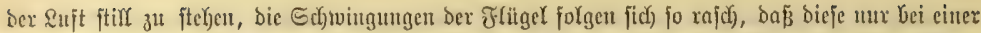

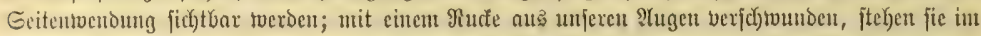
un̈d)fen ?ugenbficte twicber an ciner anderen Steffe. Mit bicjem tumberfichen Tanze verbintoct

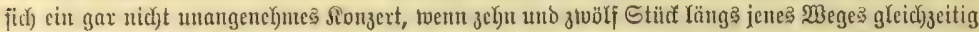

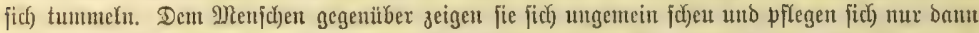

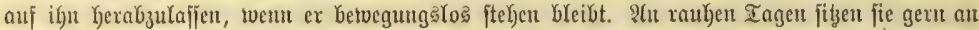

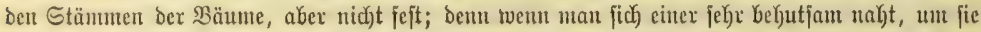

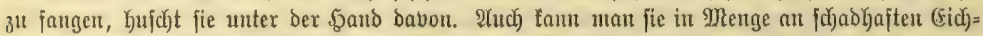

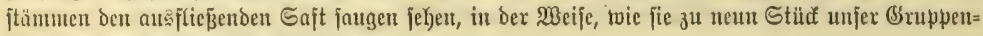

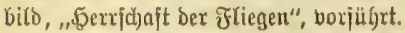

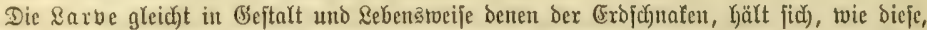

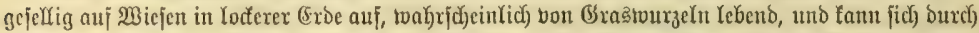
श)เ

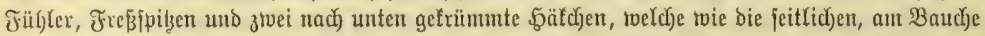

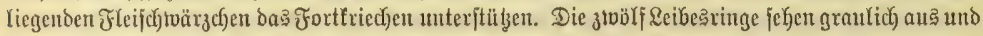

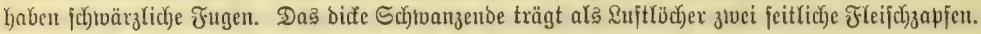

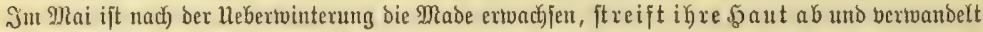

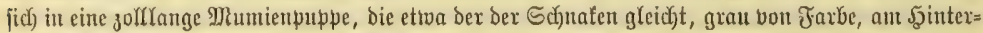

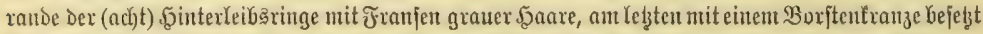

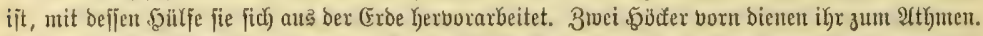

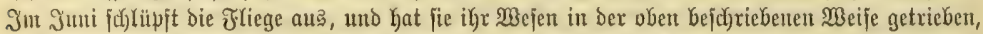

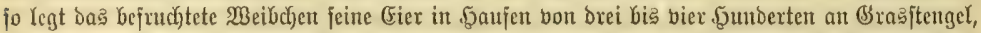

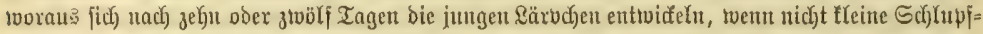

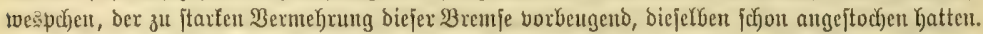

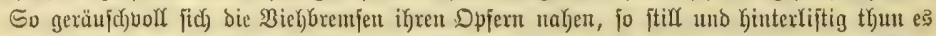

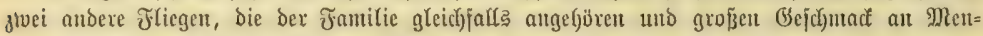

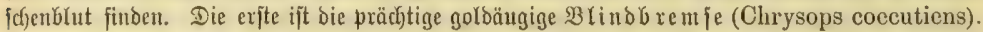

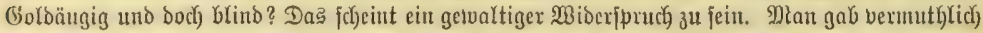

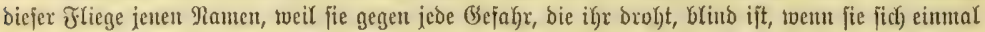

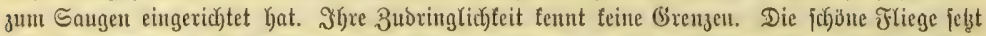

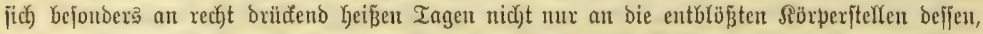

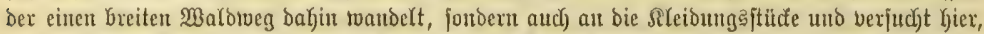

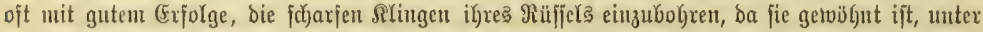

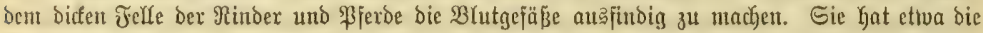

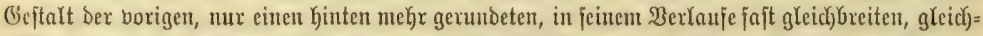

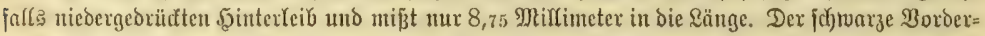

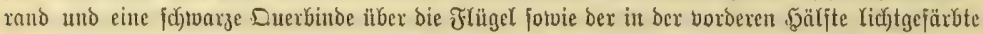

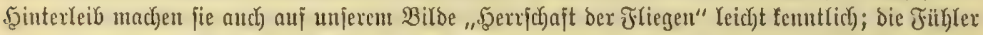

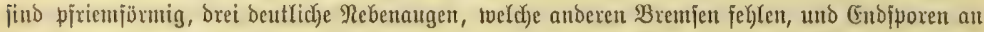
ben Sinterjd)ienen unterfdeiben bie Battung von ber vorigen. Man finbet biefe Fliege uno cinige

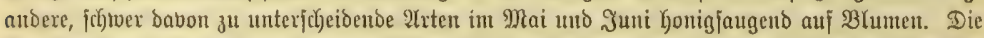

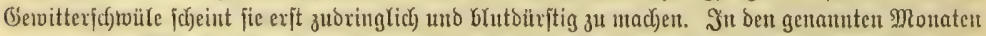

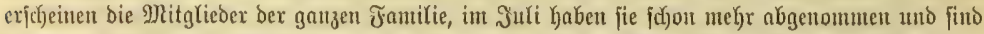

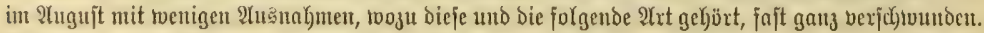

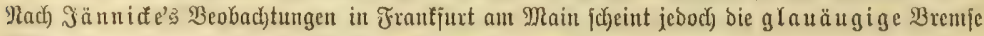
('Labanus glaucopis) nur int ફerbfte zu fliegen.

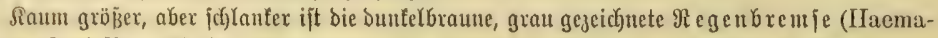
topota pluvialis). Sie hat jufwarggraue, helf matmorirte flïgel, in bex oberen \$älfte purpurn 


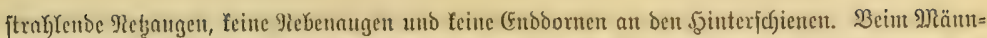

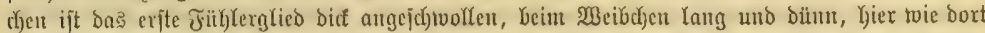

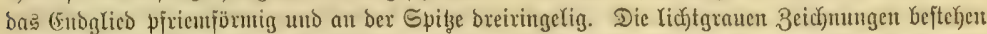

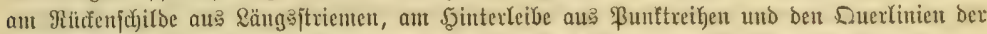

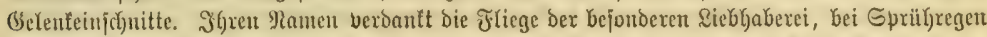

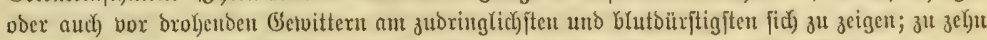

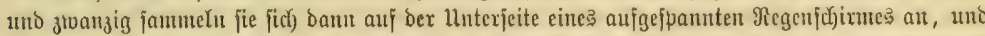

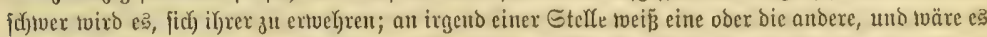

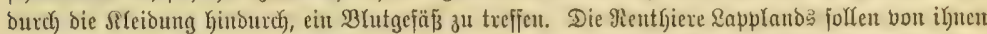

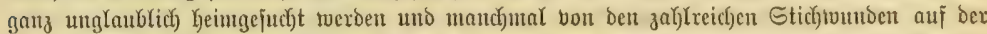

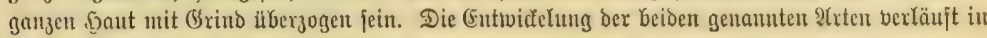

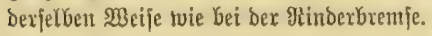

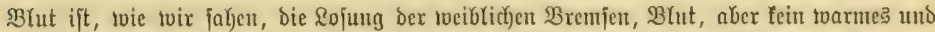

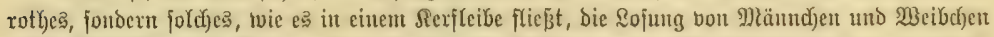

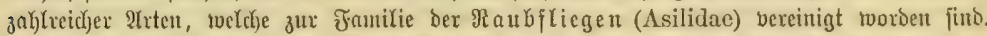

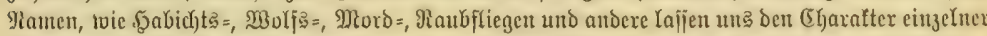

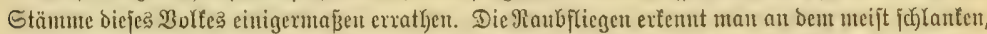

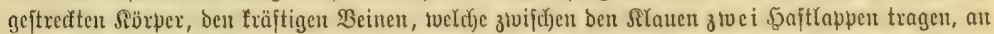

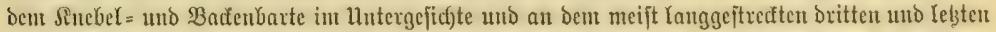

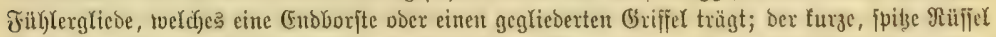

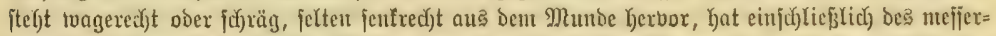
förmigen lluterfiefers mur vier Borften, eine verlyonte Unterlippe unt ein = Gis ziveigliederige

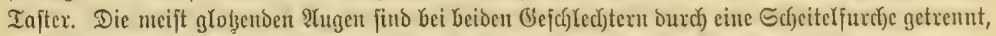

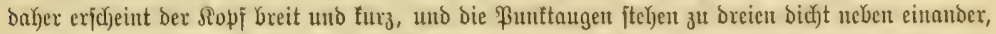

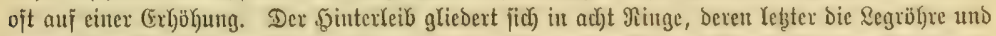

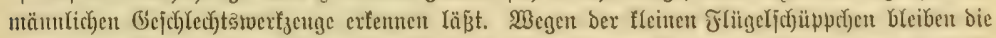

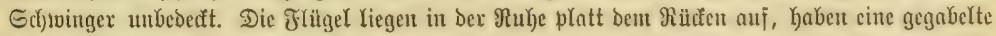

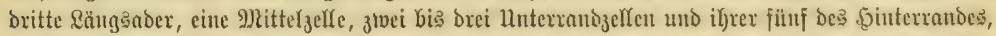

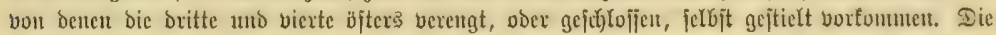
S)

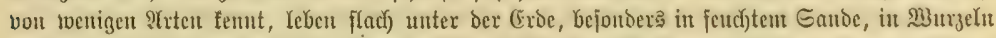

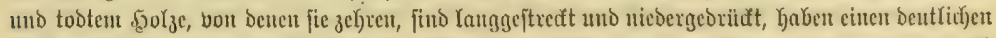

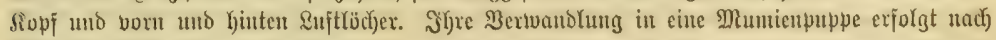
Xbitreifen Der Yeßztert \&arventyaut.

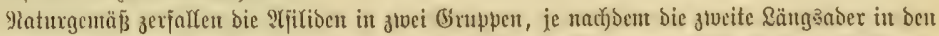
Friigelrano (Ieptogaster, Damalis, Ceraturgus, Dioetria, Dasypogon) ober in bie erjte \&ünge=

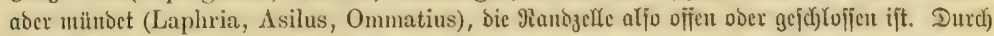

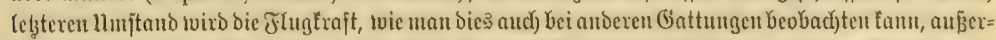

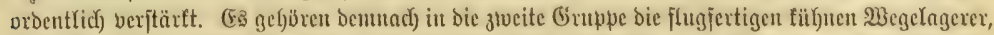

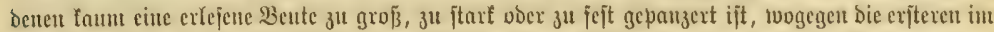

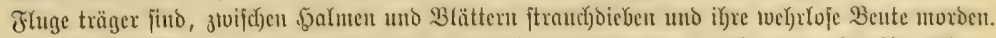

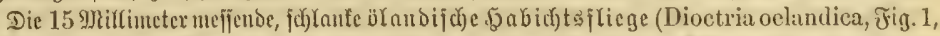

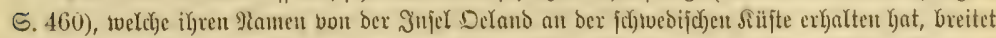

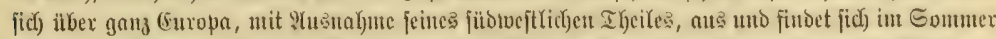

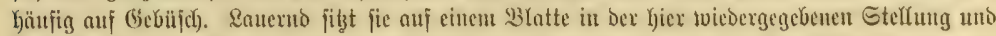

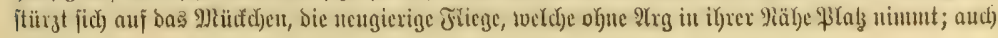




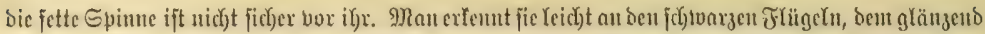

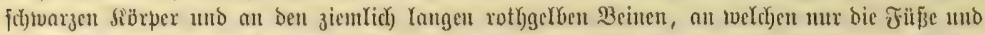

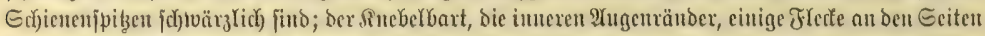

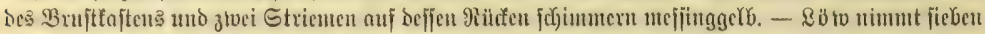

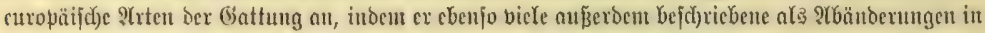

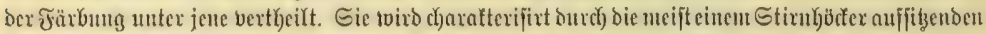

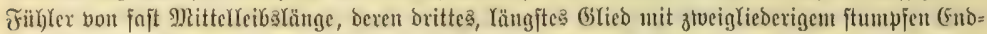

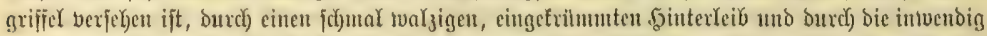

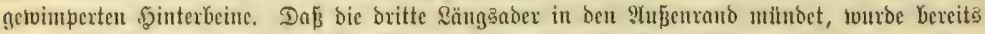

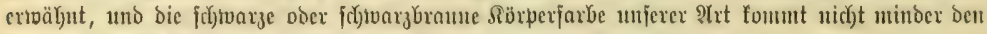

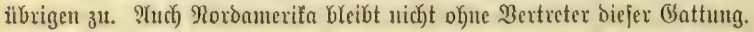

Die Steifbärte (Dasypogon) find unterfebte fräftige Sobichtęfliegen, Deren Jüb)ler it cinen

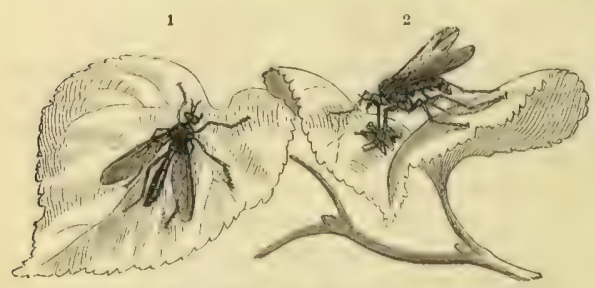

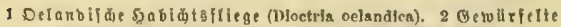
Gdu nevfenflege (Fimpis tesgellata). Natirtidje Grëge. ipizen (Sriffel enden; ein ftatt= richer Sneberbart und ein Endbafen

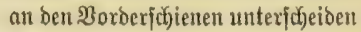
fie toeiter bon ben borigen. Dif

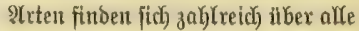
(Erotfyeile verbreitet, in Deutfich)land uidjt jelten ber 15 bis 17,5 MRilli= meter Yange deutiche Steijbart (Dasypogon teutonus). (5x ijt glänzento fochivary, an. Schienen, Schenteln und Fiiblern rojtroth, am Brujtrüdén braun geftriemt,

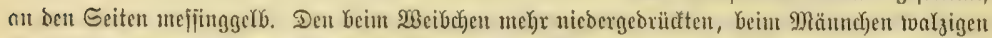

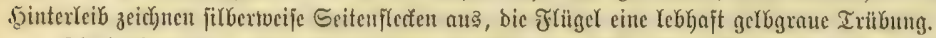

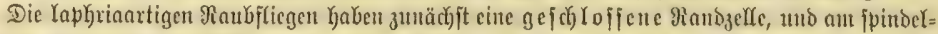

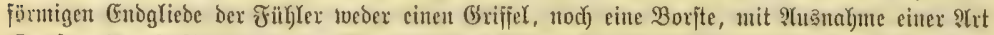

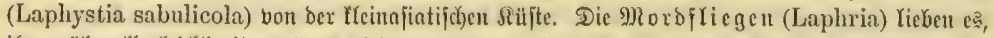

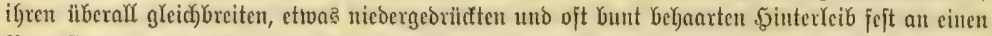

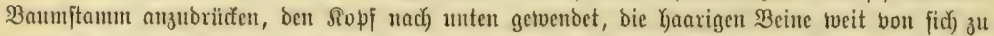

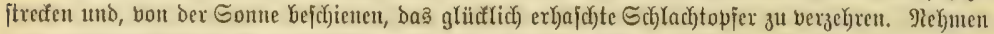

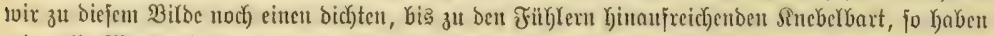
wir nlle Mertmale vereinight, twe haje bie Gattung femzcichnen. Bei den cinen breibt bie erfte

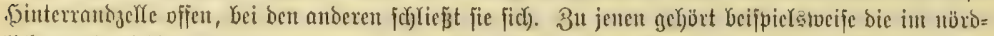

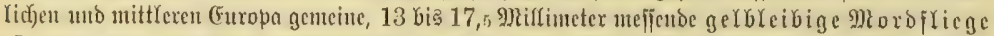

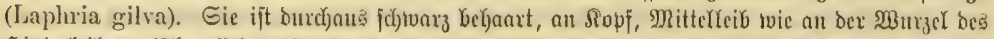

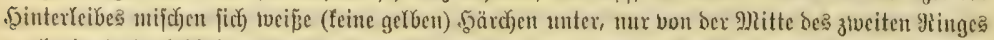
an beginnt cin Yebryajt roftrotger şaarfil

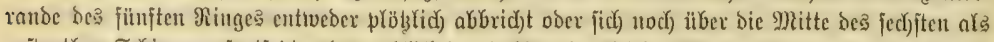

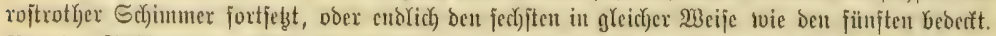

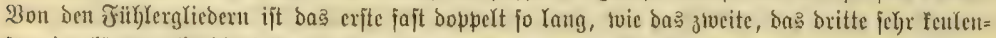

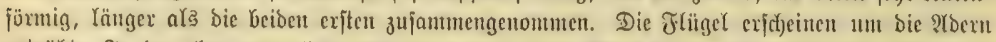

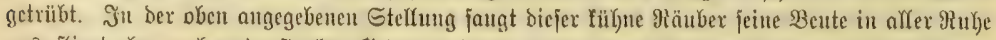

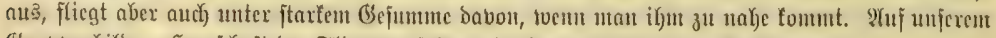

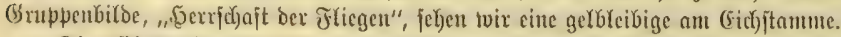

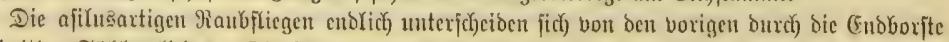

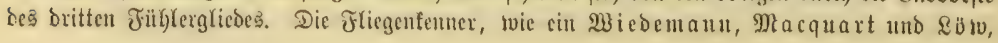





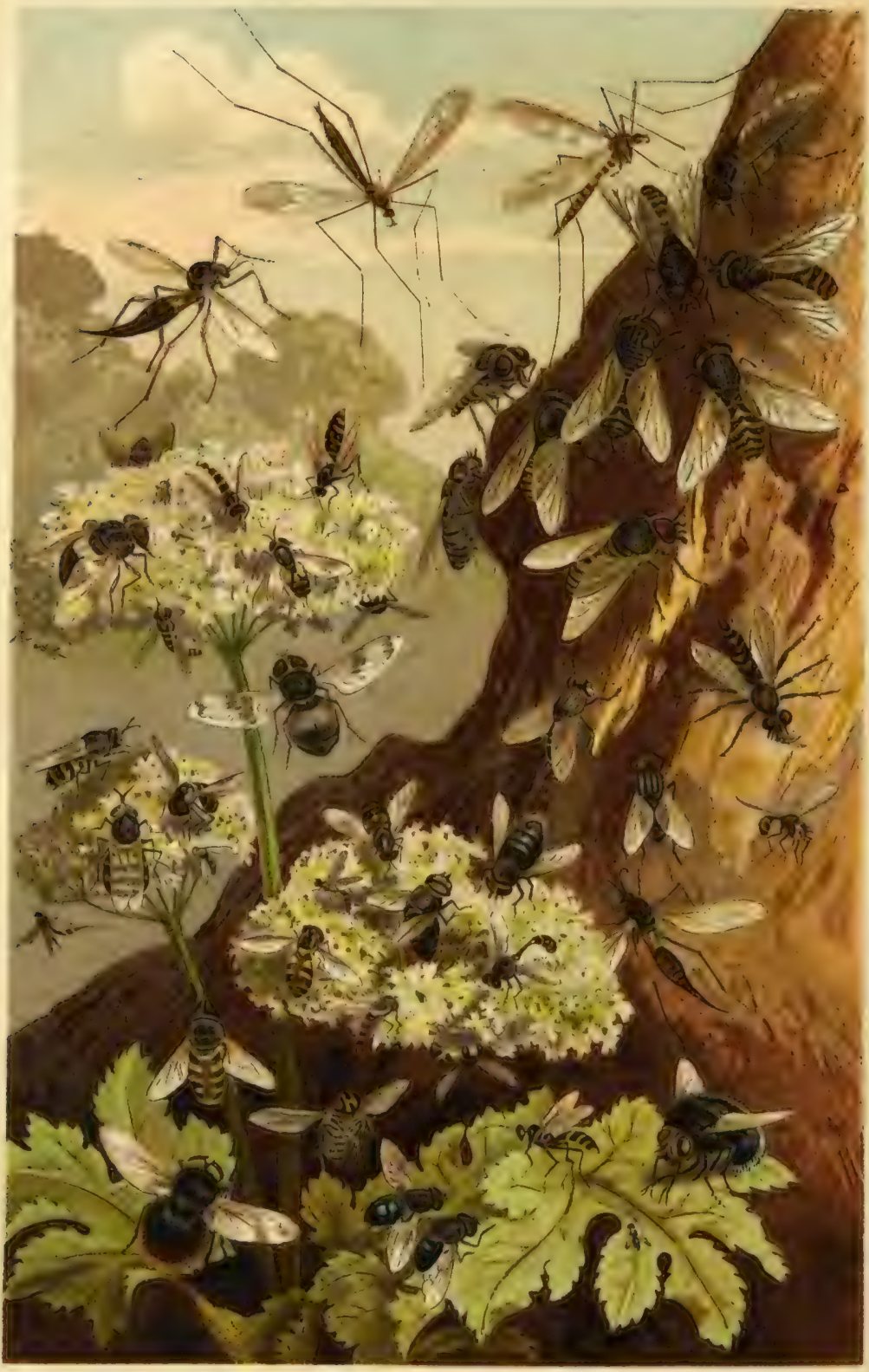




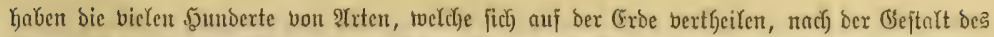

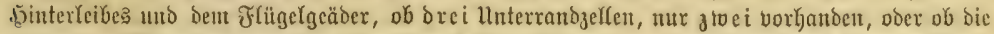

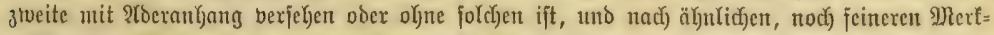

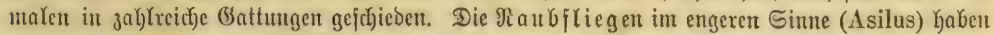

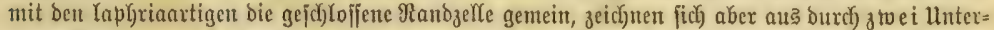

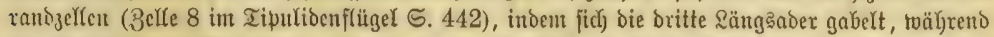
bic ztucite feinen Proerankang hat; ferner burch bie nacte Fühlerborfte ober, twie man jagen

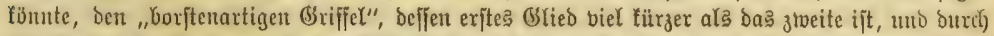

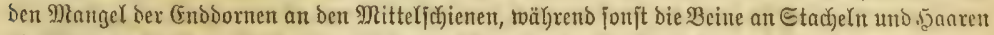

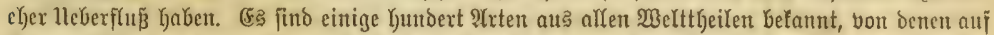

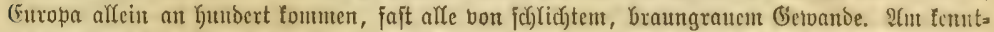

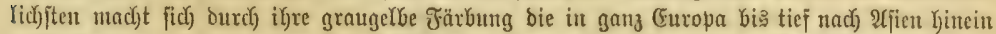

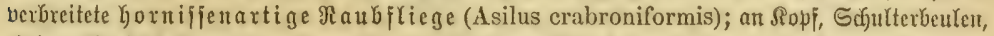

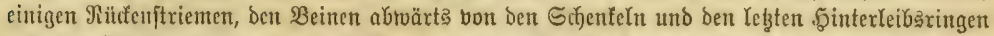
geht bie Grundjarbe it reineres Gelb tiber, und an ber Wurzel bes \$interleibes tweidjt fie einem

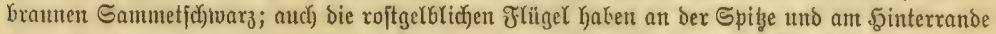

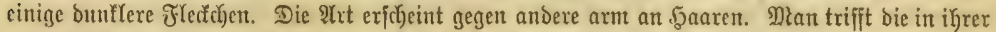

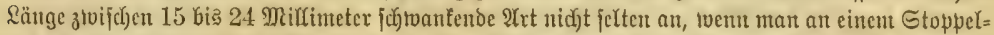

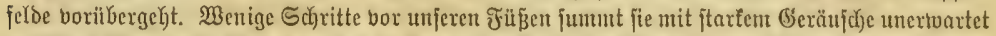
in jäfem Fluge auf, flach) Hiber ben Boben hit und jucht E(t)ub vor etwaigen Ingriffen an ciner

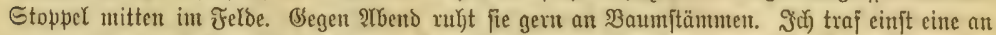

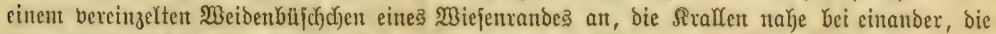

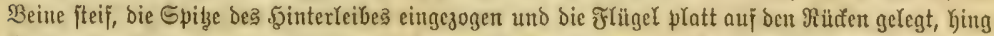

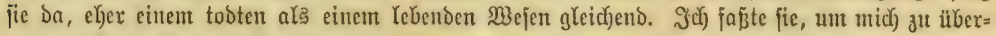

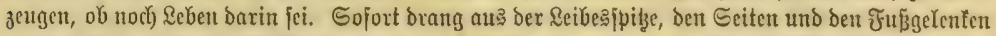

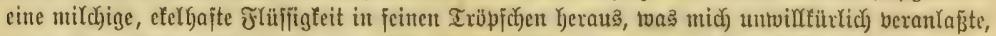

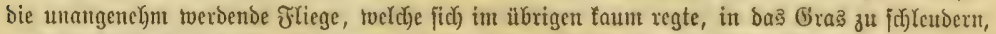

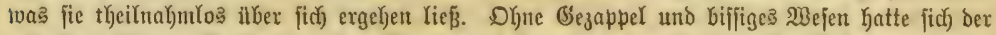

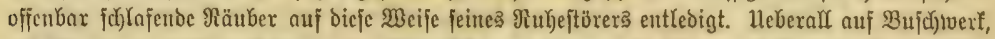

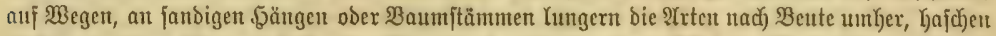

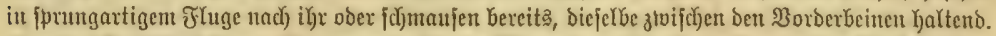

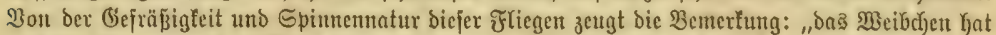

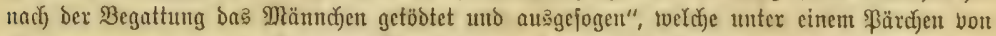

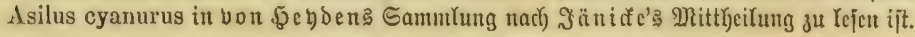

Die Ianjiliegen (Empidae) bilden eine bon anteren ztoar jod)arf abgegrenzte, unter fict)

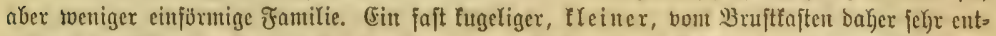

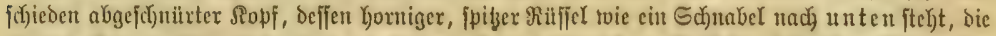

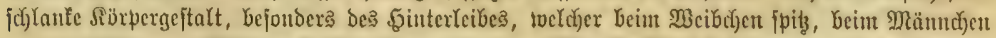

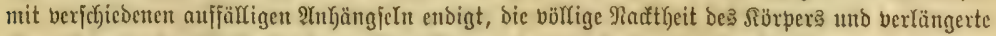

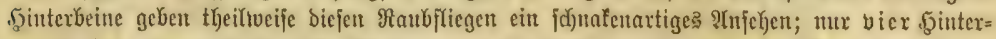

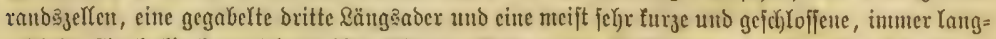

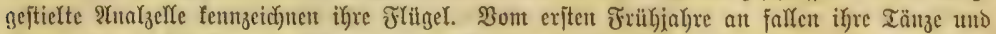

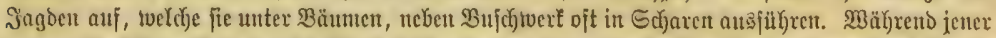

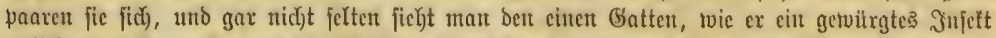

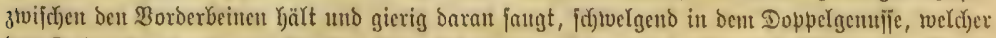

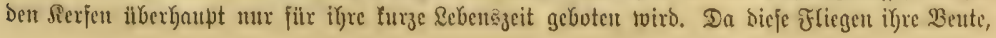




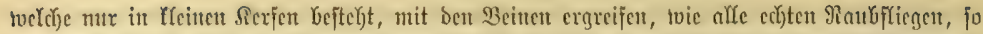

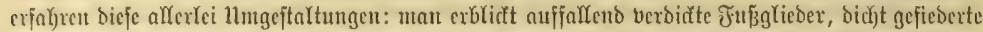

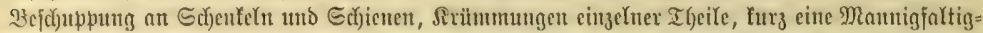

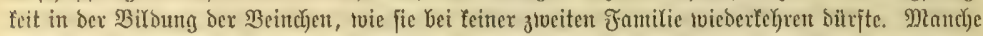

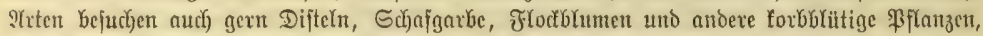

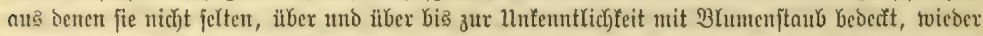

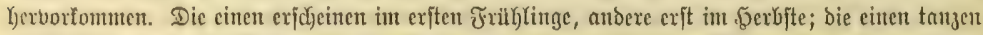

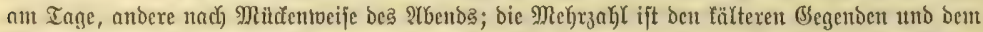

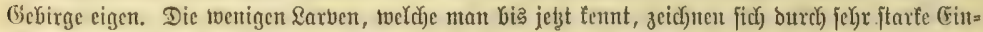

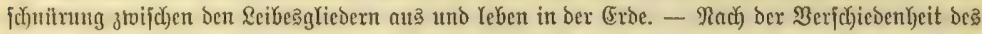

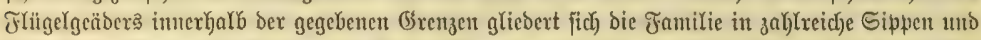
Dieje in cine Mettge von Battungen. Statt affer möge cine unjerer gröften Arten, bie geto il xịclte Gdi)nepfenfliege (Empis tessellata, Fig. 2, 5. 460), Den Familiend)arafter berfintichen.

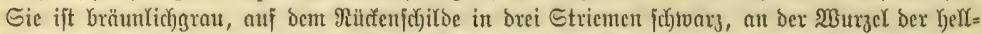

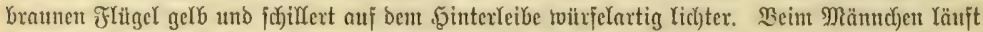

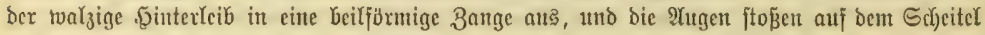

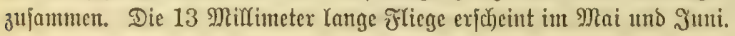

Der gemeine Irauerjodyeber (Anthrax semiatra ober morio Sinne'?) ift butrdyan

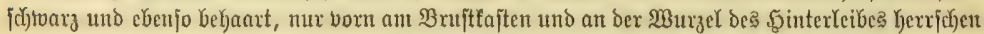
futchs

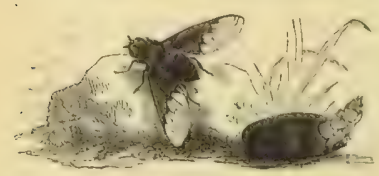

Irauerfolveber (Anthrax semiati:n) nebif bem \$uppengchäuje, in bem fie famarobt bat. Matitr lide "sröbe.

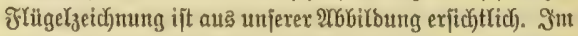
ilbrigen charafterifiren bie (battung nod) folgende Mext=

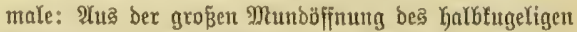
Ropjes ragt ber fpiłze Rulljel mäß̈ig lang herbor; bie toeit

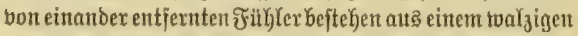
exjten, napfähnlichen ztweiten, zivicbel= ober fegelförmigen britten OSliebe, befjen Enogriffel wieberum zroeiglieberig

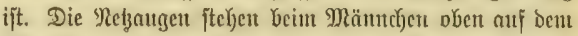

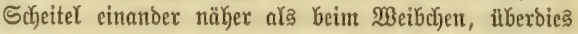

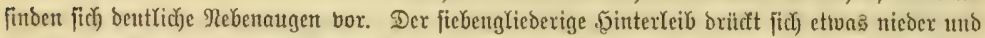

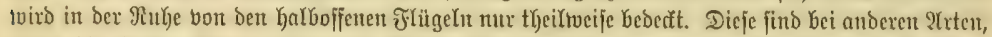

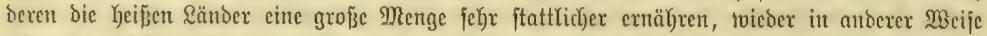

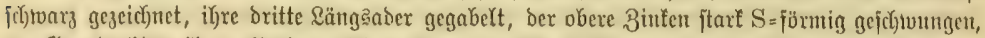

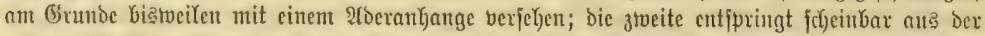

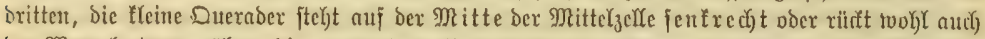

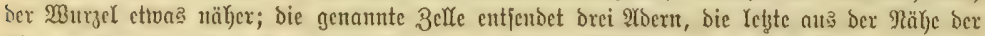

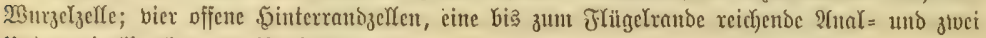
llnterrandzellen fommen bier in Betracht.

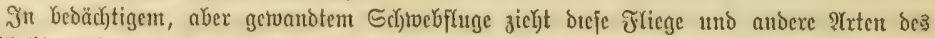

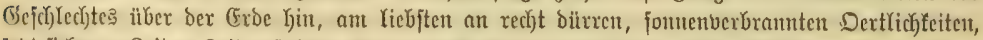

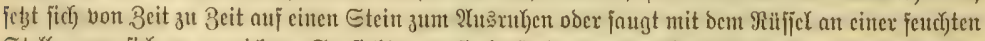

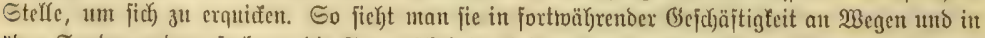

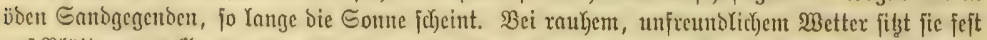

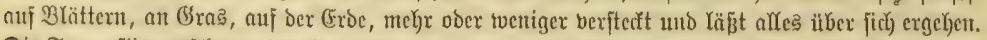

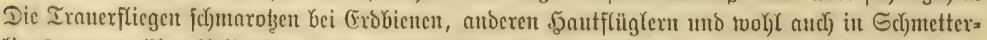

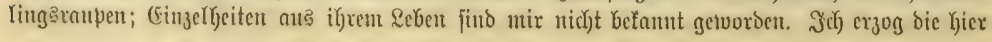




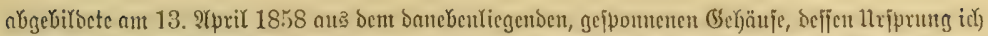

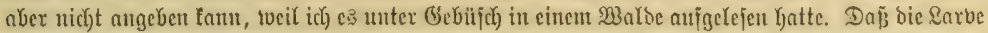

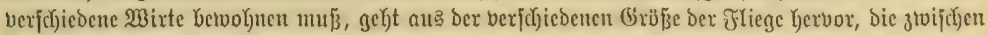

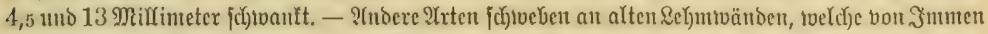

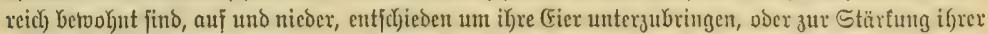

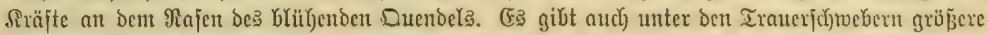

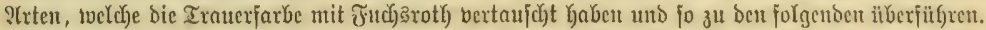

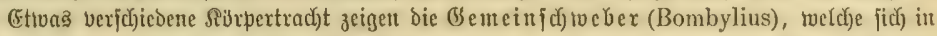

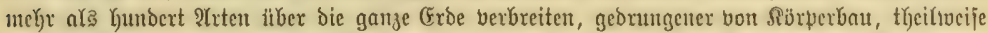

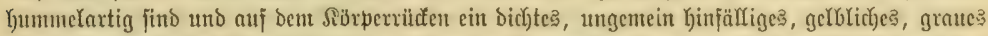

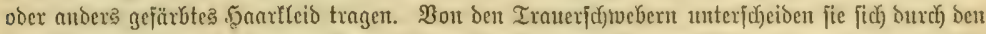

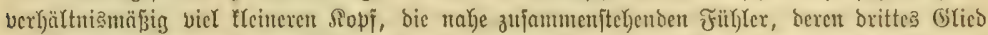

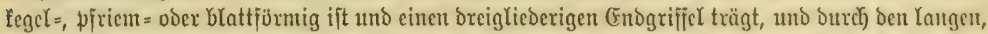

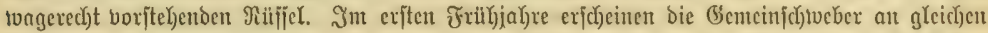

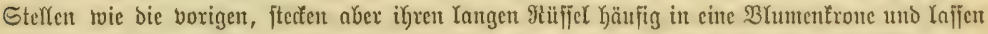

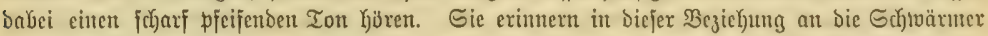

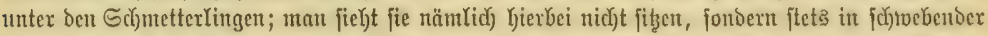

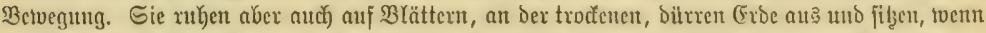
bie Sonne nidyt focheint, an glcidjen Stelfen regungerlos fejt. Der Bombylius venosus ftecft anf

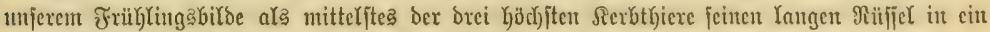

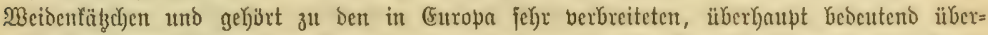

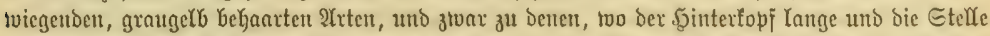

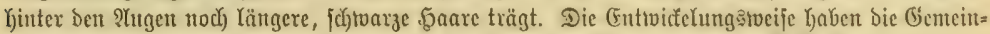

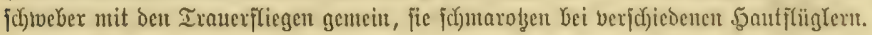

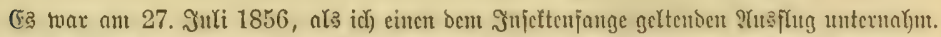

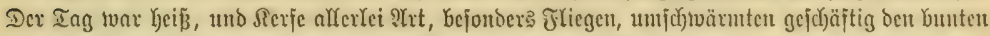
I

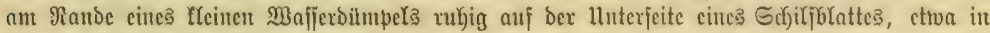
झू.

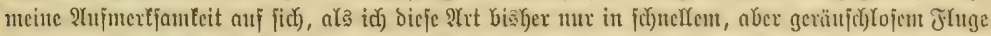

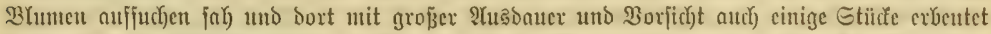

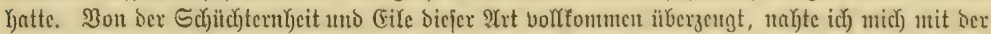

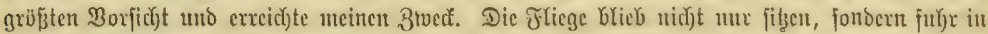

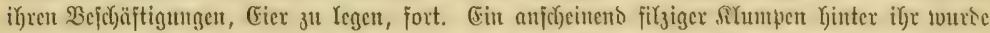

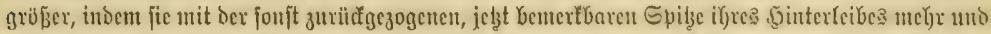

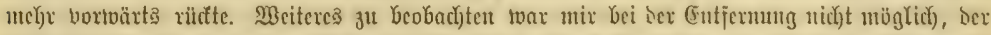

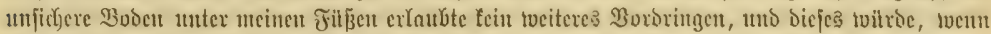

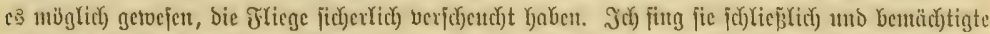

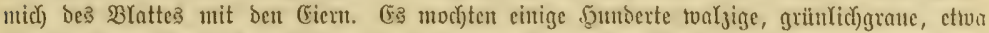

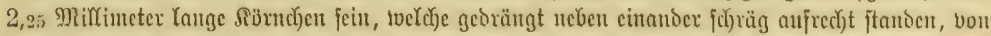

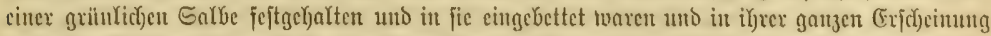

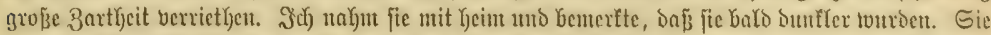

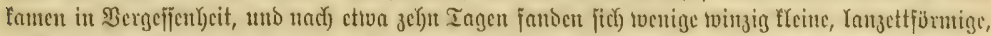

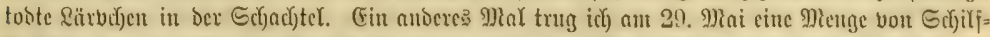

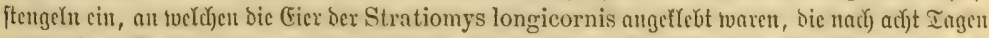

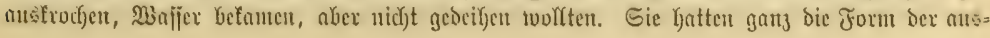




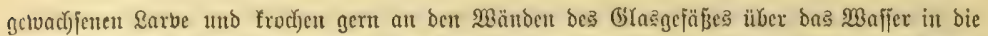

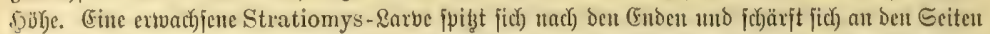

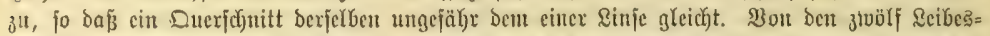

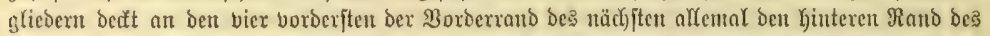

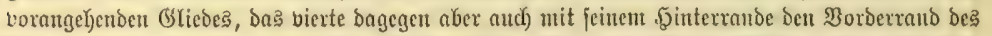
jolgenoen, und in biejer umgefefrten Weife geht es bis an bas (5nde. Wifl man ben Ban bes

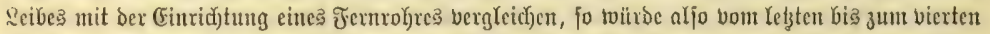

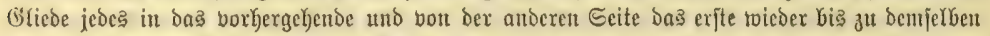

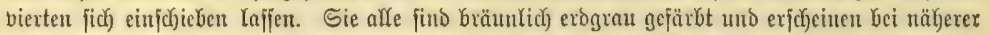

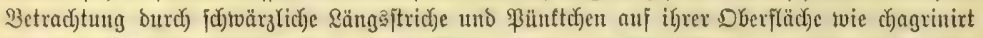

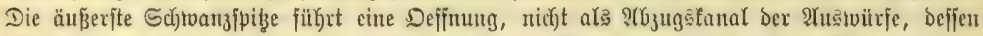

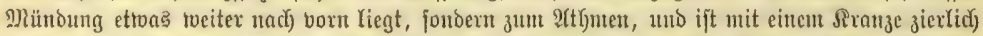

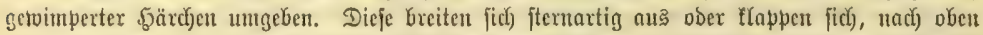

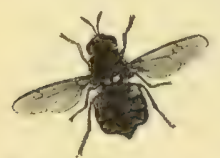

2Beibuen ber bemeinen 28 offenfliege(Stratiomys

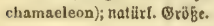

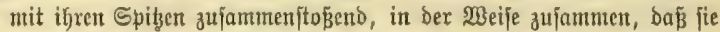
einen hohlen, fugelähnlithen Raum einjor)ließen, weil fie Bogenlinien barjtelfen. Sn ihren Betvegungen Gaben biefe Rarven biel Pebulichteit mit ben oben erton̈hnten \&arben ber Gtechmitufen. In $S=$ und $C=$ für $=$ migen Mindungen, Das Schtwangende nad) oben, Den Sippf nact) unten,

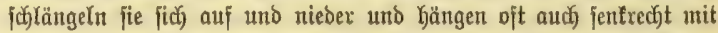
auşgebreitetem Scftwanjiterne an bex Dbexfäc)e. Sobalo jie unter=

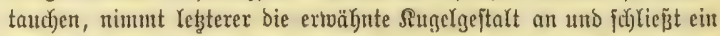

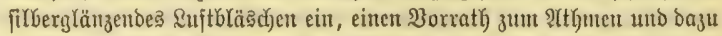

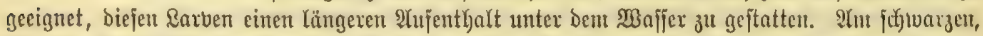

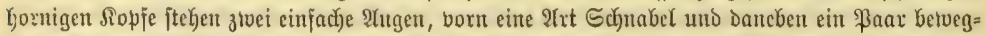

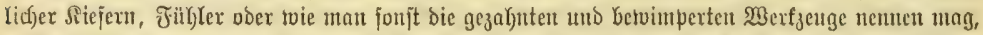

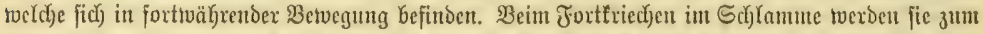

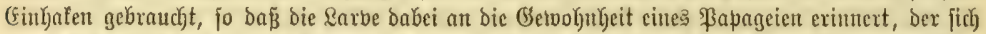

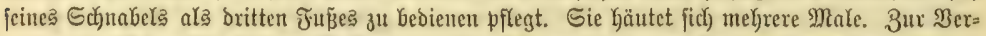

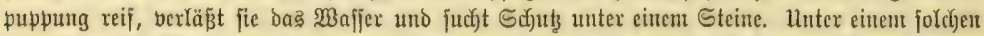

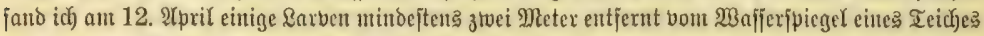

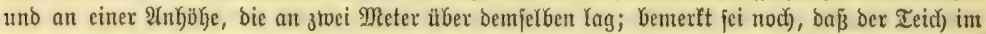

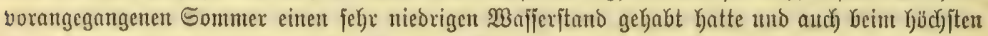

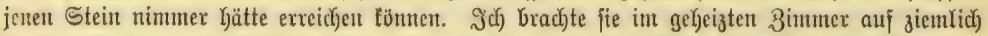

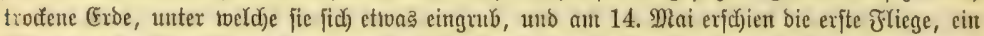

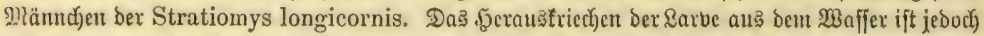

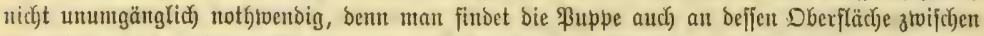

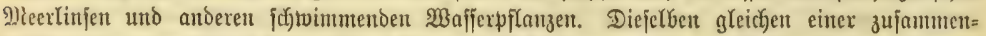

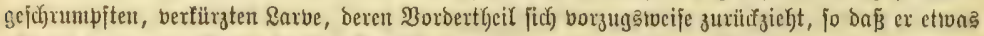

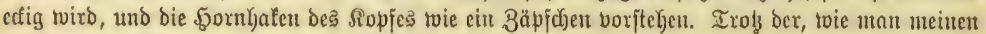

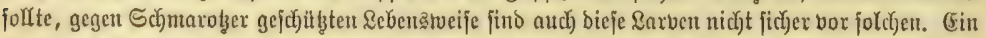

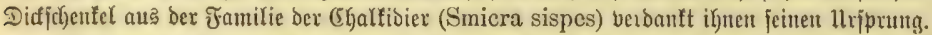

Wa

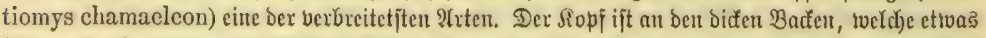

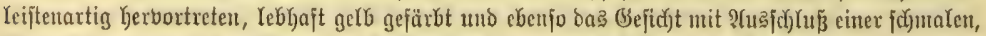

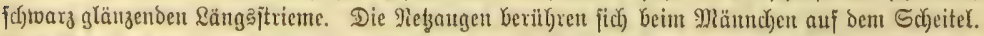

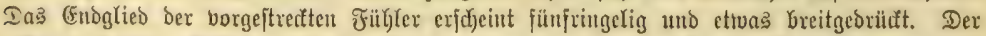

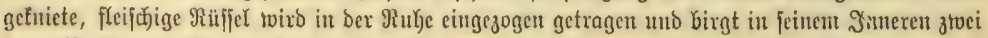

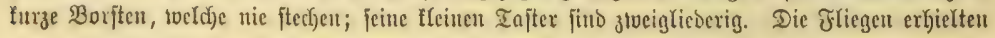




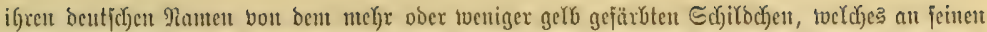

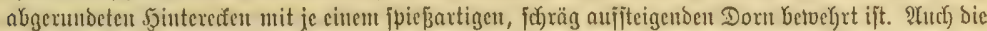

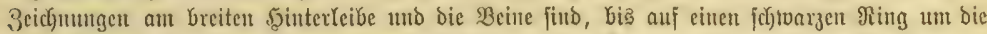

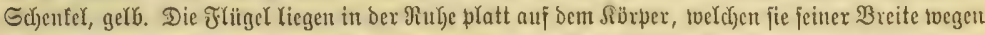

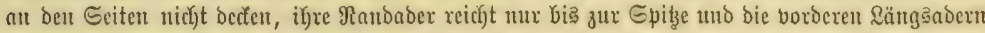

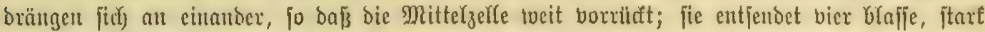

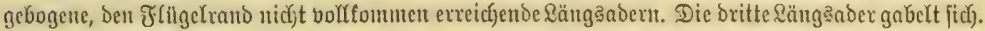

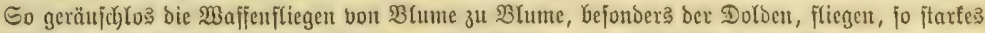

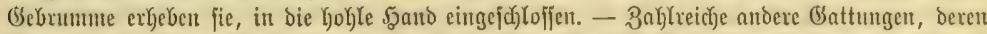
Larben meijt niçt in Waffer leben, reiben fich) noch ber itber affe (Etotgeife verbreiteten Fantie an.

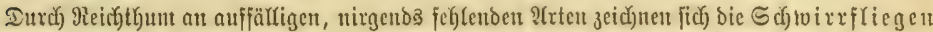

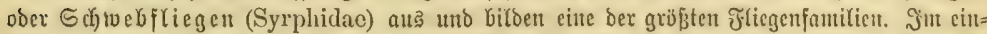

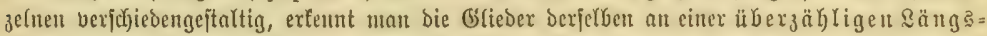

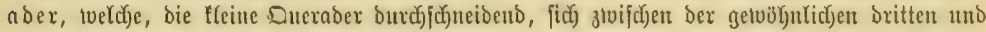

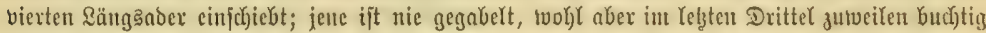

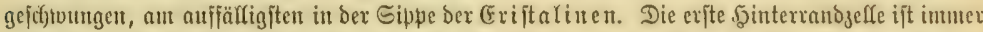

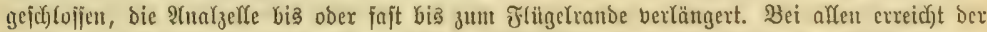

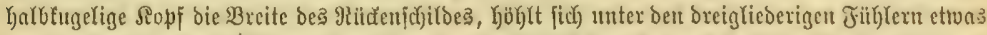

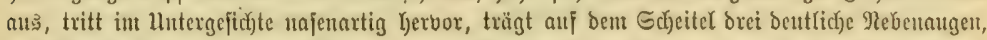

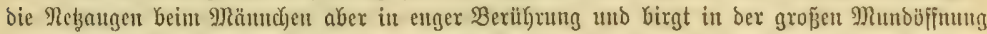

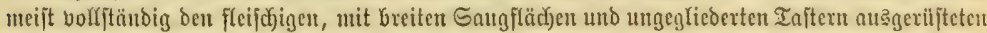

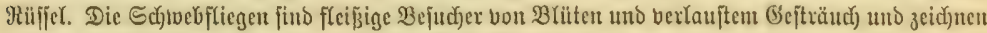

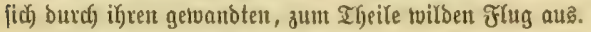

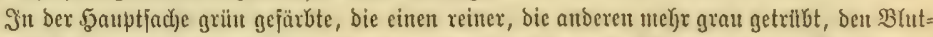

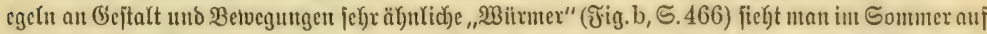

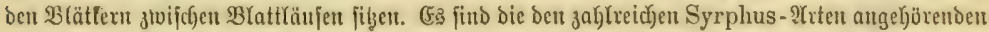

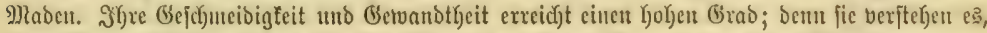

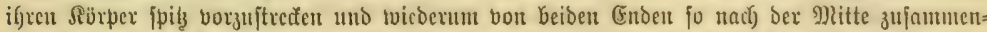

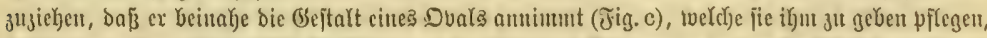

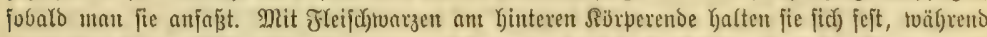

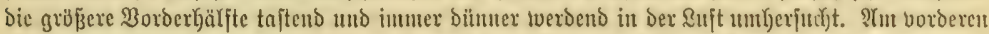

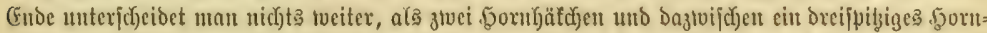

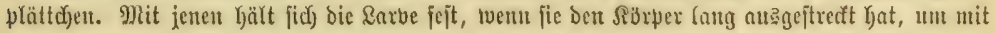

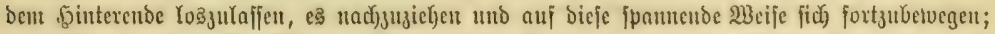

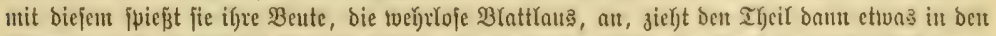

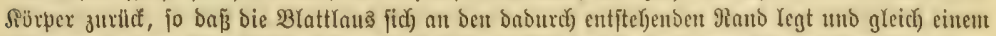

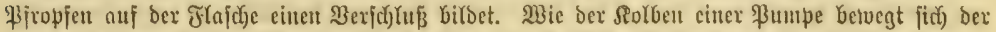

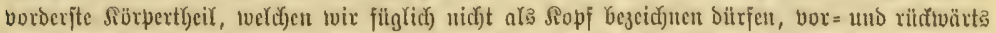

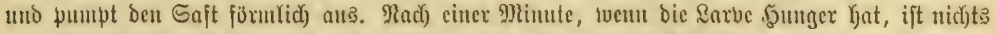

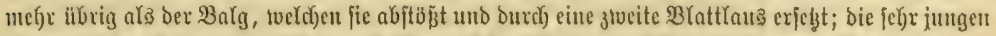

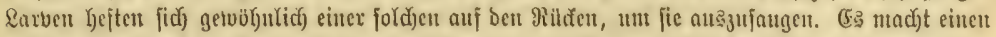

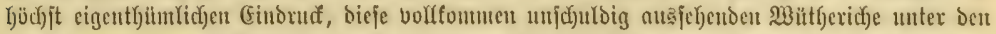

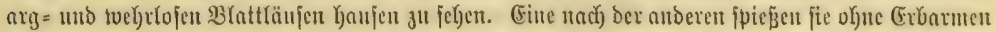

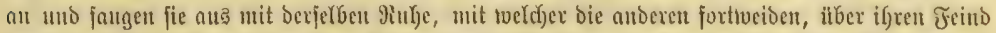

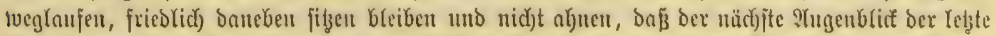

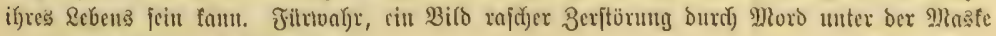




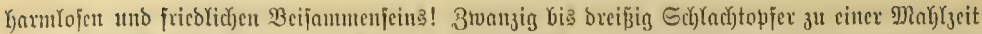

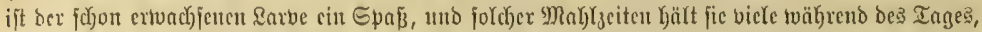

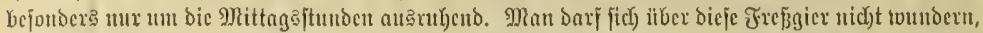

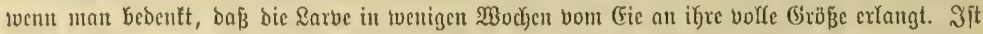

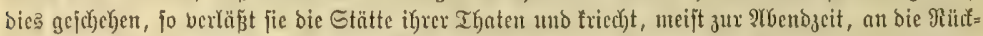

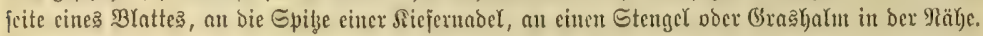

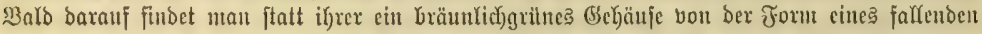
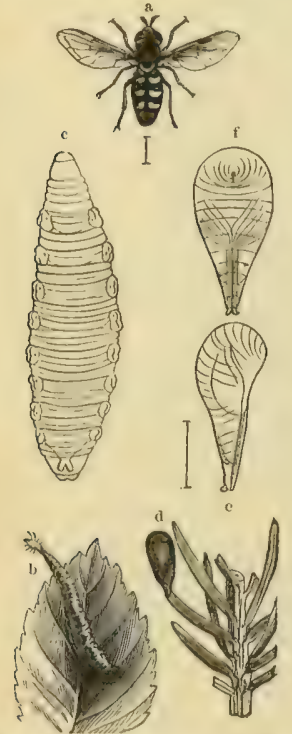

Monblictige Gdituitilene (Syrphus scleniticus). a Flicge, b ausgeitredte, o jujammengezoncire Ĺarbc, d, o, 1 Wuџbe, Iote bon ber Eandifite. e, e, $f$ vergröbert.
Iropjens, eiuer Thräue (

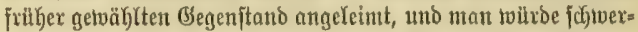
Yid) geneigt jein, biejen Sörper mit der Made bon vorgejtern in Эerbindung zu bringen, twenn nicht bie gemad)ten (Exfalyrungen

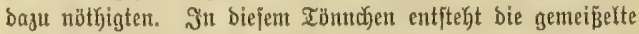

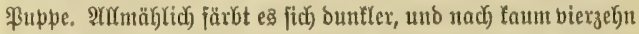
Iagen hebt fich) vom bicteren (Ende ein ffeiner Dectel ab, um

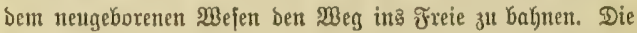
monoflectige S d) twixxfliege (Syrphus seleniticus), tweldye auj bieje Meife bas \&idat bex Melt erblictt hat, ift au Siopf und

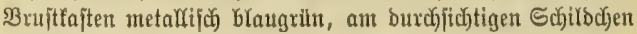

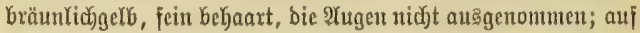

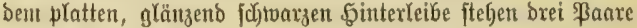
tweiper IJtondflectchen - bei einer jehr ähulichen, faft nod)

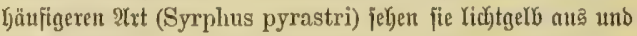

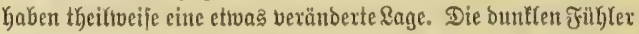
enden mit einem obalen Srliebe, weldyes an ber Wurgel eite

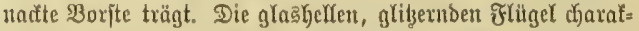
texifixen, twie bei affen Battung genoffen, eine fajt gerabe, britte

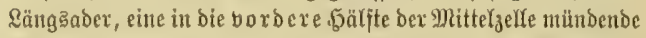
fleine Dueradex und eine offene Ranozelfe. Die Mittelzelfe hat fajt die \&änge ber exjten finterrandzelfe, beren oberer

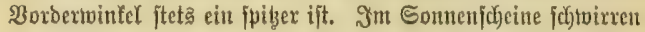

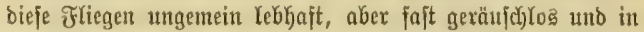
cinter Weife, welche alfen Elspljiben eigenartig ift. Sie ftehen

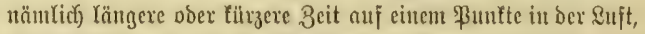

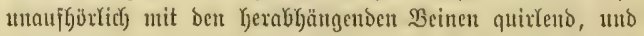
\aijen fid

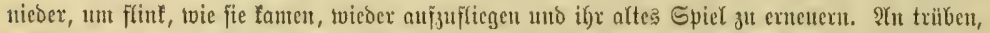

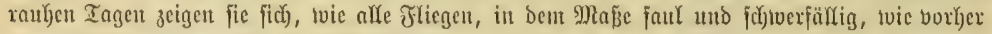

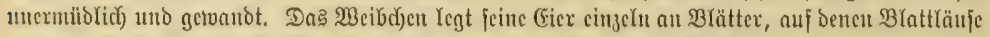

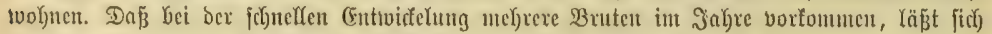

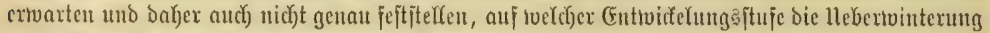

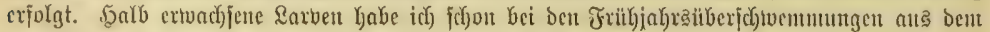

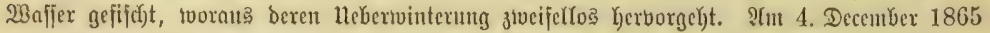

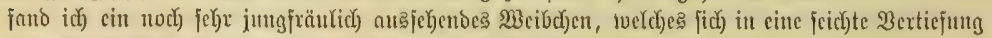

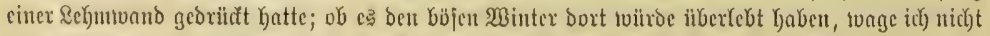

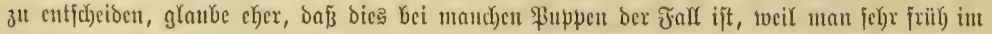
Jabre ojt frifoch ausgefrod)enen friegen begegnet.

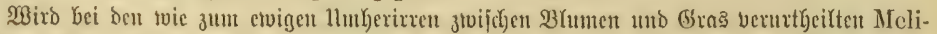
treptus-?rten, Gejonders Melitreptus scriptus, M. taeniatus uno anderen, Der Sërper f(d)on 


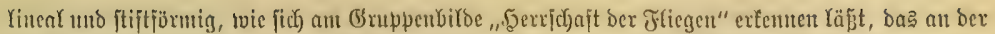

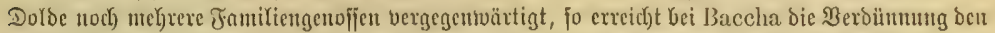

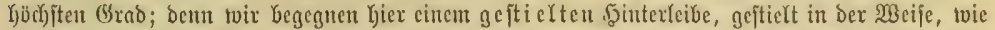

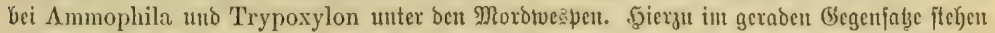

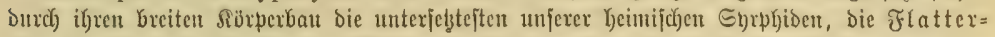
friegen, Jeber (eidftjliegen (Volucella), beren melyrere burch bic ftarfe Bebantung einer

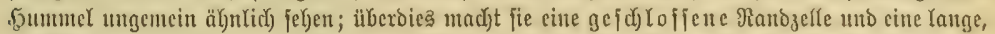

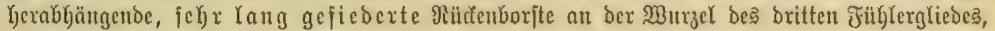

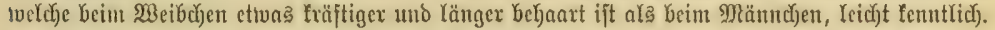

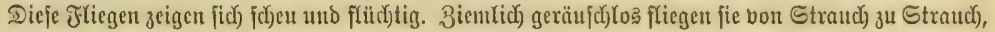

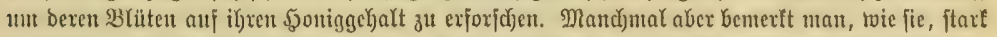

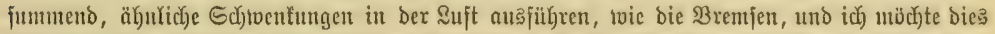
(Gebahren für tvilde Tänze zur Feier ifyrer. Joc(j)zeiten balten, tweldde fie an red)t fonnigen Iagen ver=

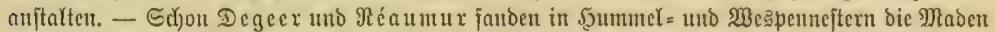

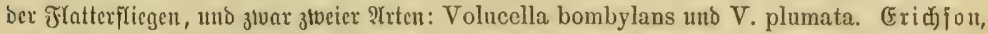
in Bejibe von Ueberganga formen, jweifelte bereits bie 2Yrtrechte beiber an und Gielt bie Yebztere mur

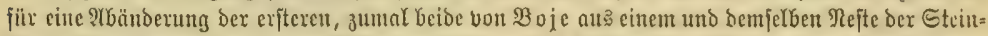

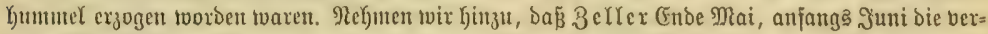

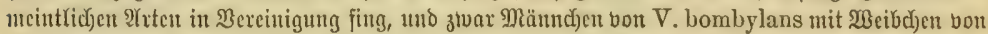

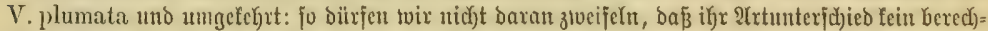

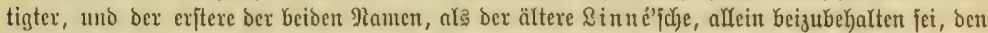

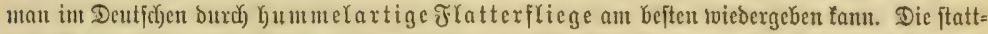

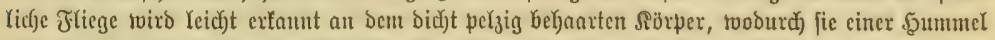

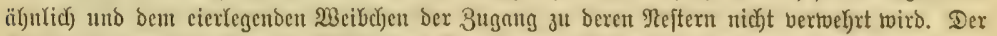

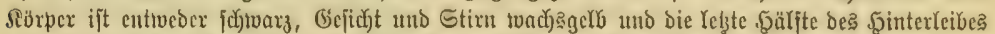

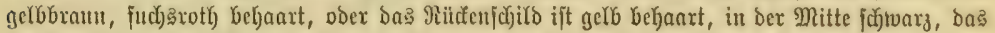
Edjilbchen gelb in ber Grumbfarte; ber .jinterleib hat an ber Murzel gelbe Seitenflecte, gelbe

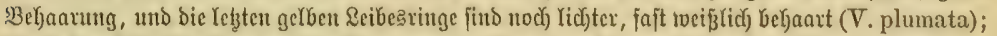

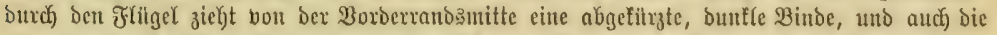

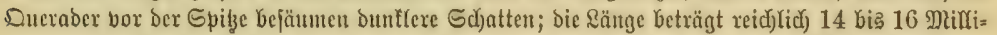

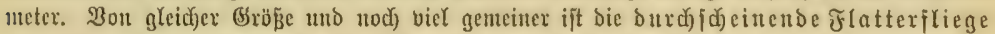

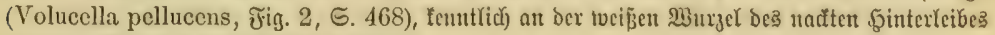

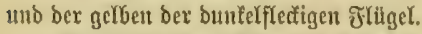

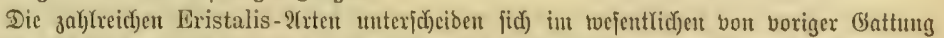

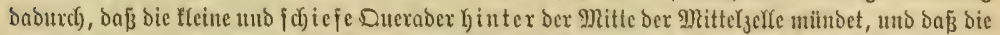

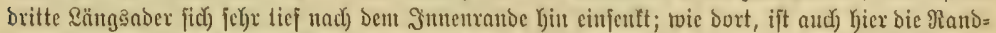
zeffe gefdh)

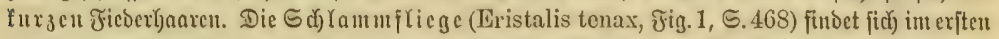

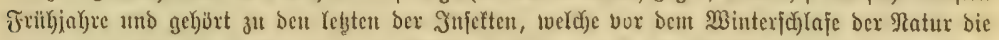

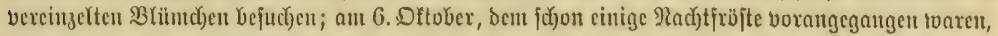

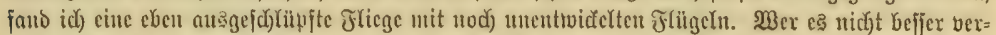

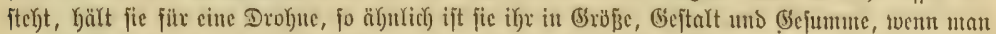

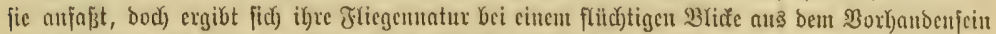

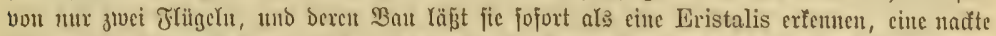

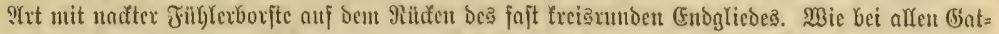

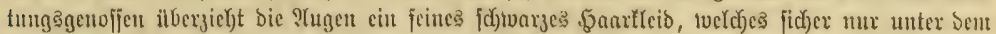

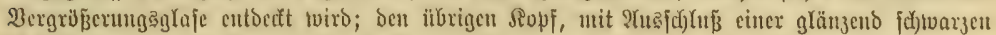

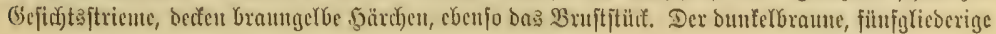




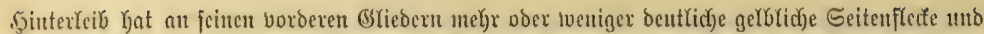

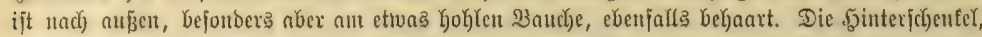

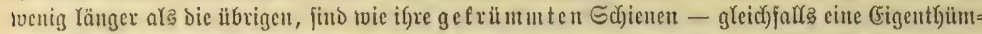

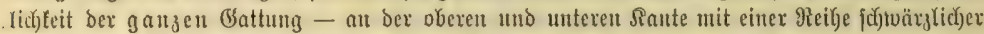

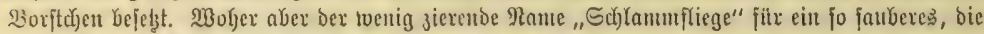

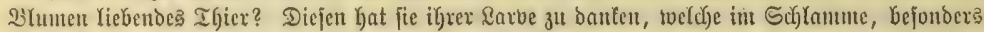

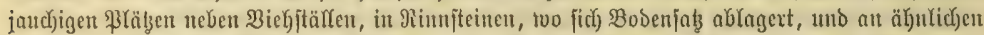

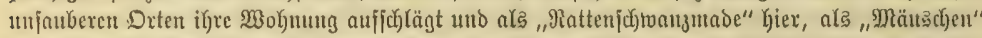

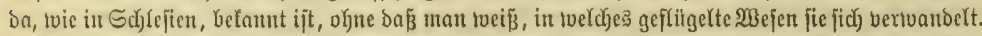

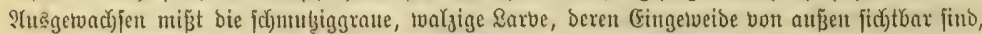

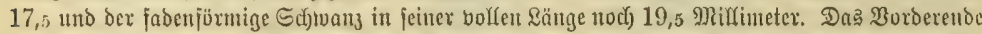

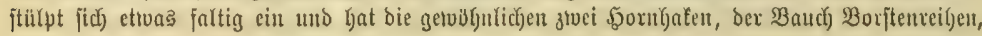
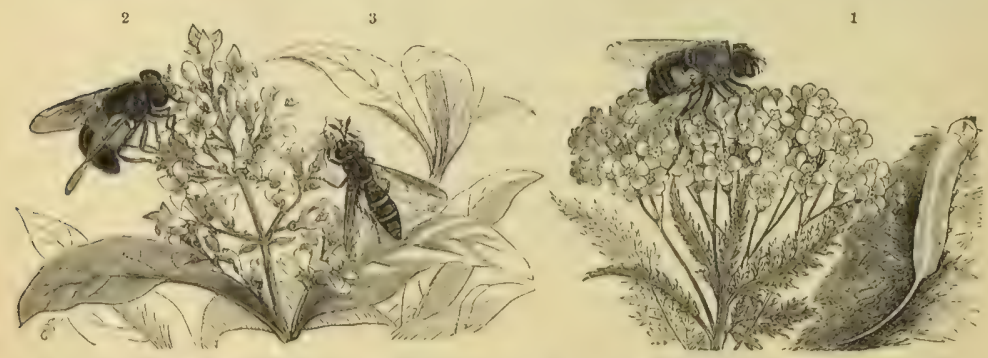

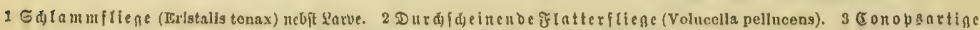

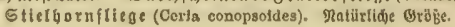

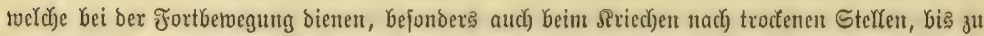

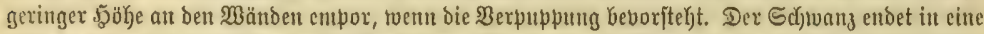

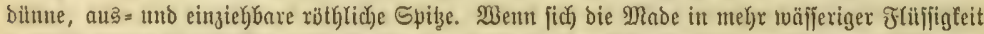

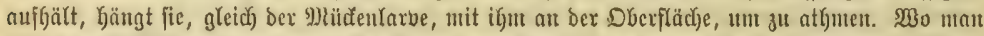
viele biejer Maben findet, zeigen fid jpäter, und grwar an trofeneren Stellen, erhärtete Gebilde,

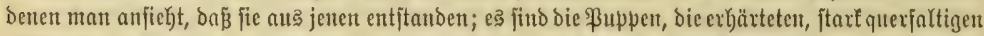

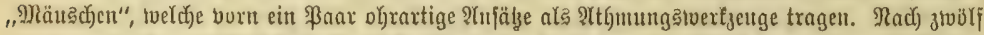

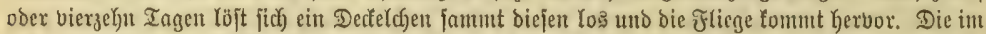

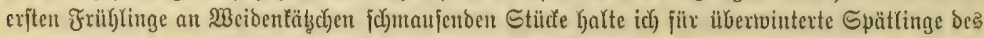

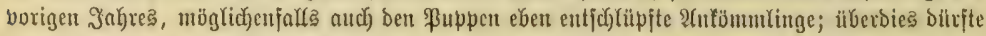

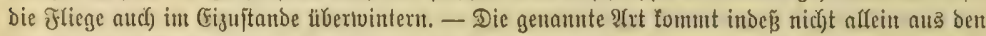

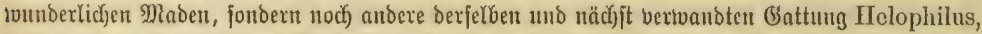

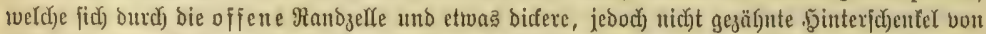

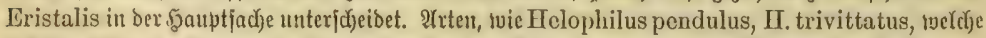

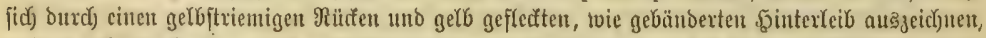

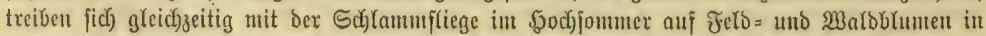

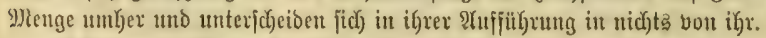

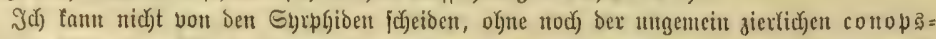
nrtigen Stielgornfliege (Ceria conopsoides, Fig. 3) zt geذenfen, tweldye man oft ucben ben

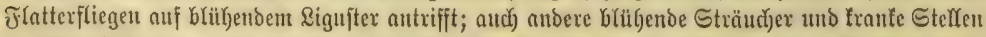

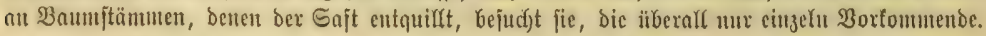




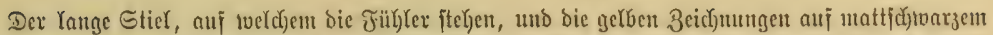

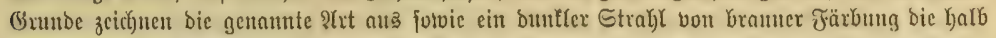

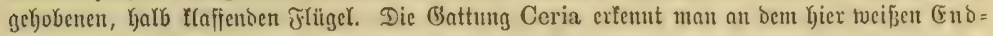

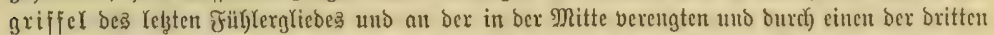

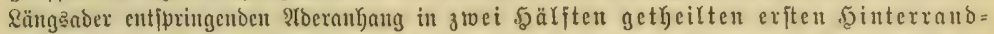

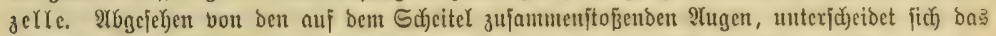

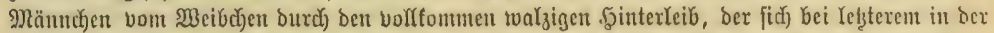

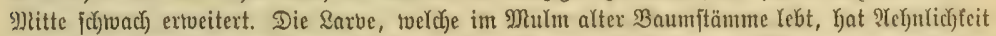

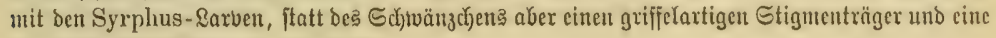
tvie burch Döndjen rauke Oberfläche.

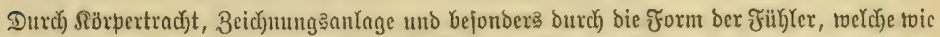

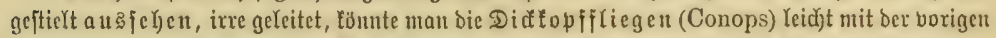

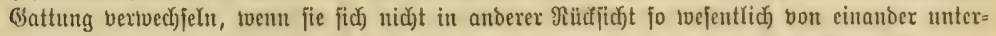

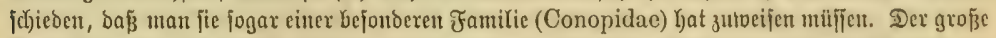

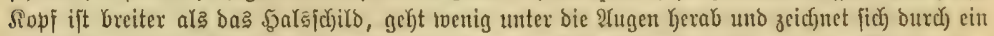

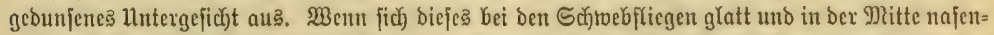

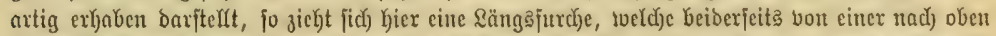

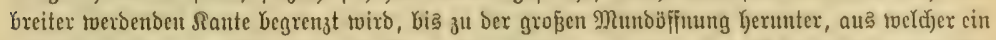

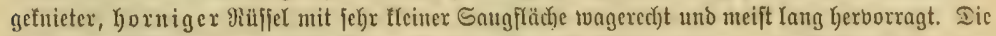

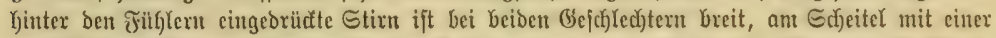

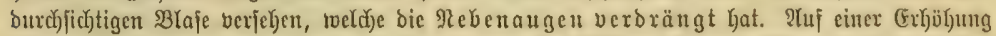

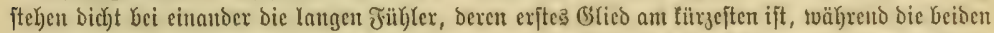

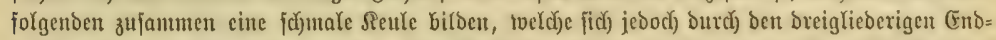

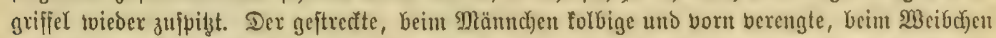

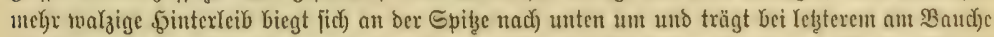

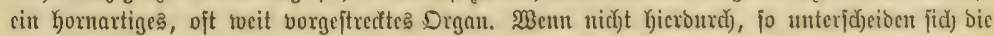

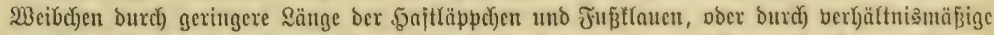

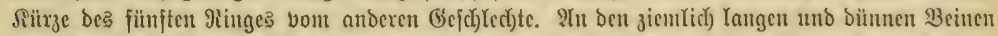

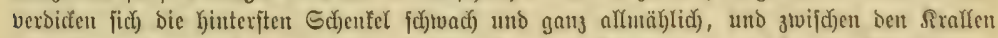

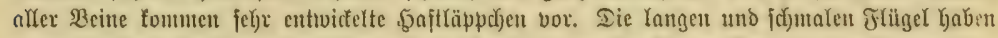

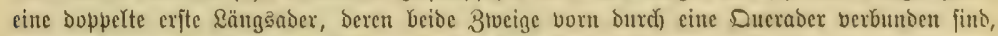

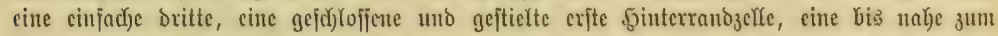

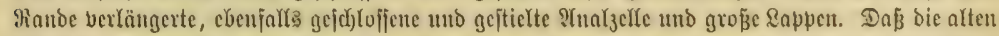

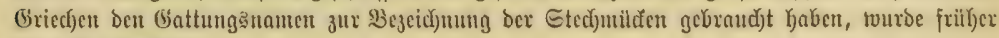
bciläufig ertwähnt.

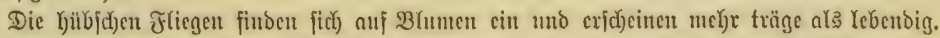

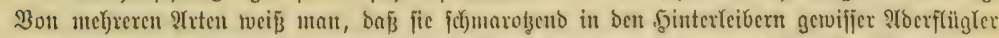

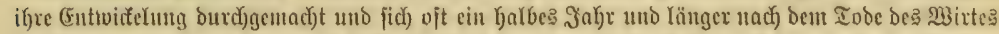

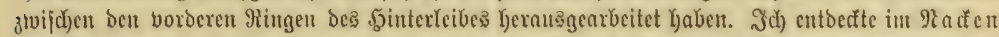

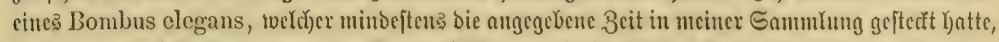
ein Sod) mit Yjalb herborragender Puppenhullye, und in bemferben Sajten bie Reiche bes Conops

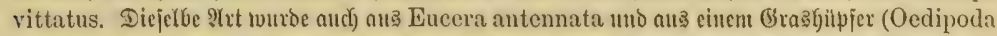

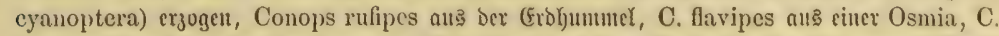

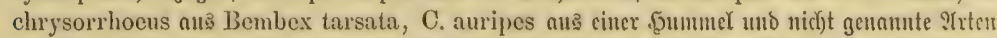

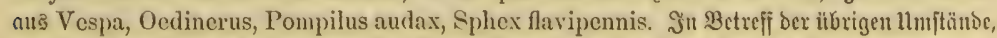

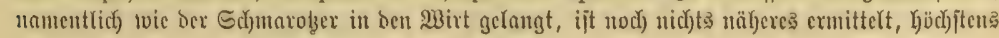




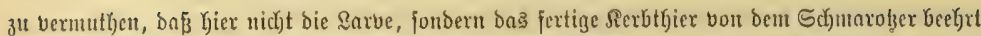

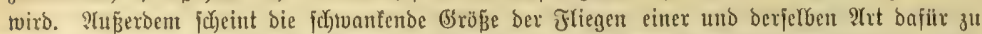

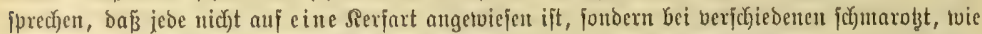
bie马 von ber geftreiften Did fopffliege (Conops vittatus) bereitß nad)getwiejen tworden ift.

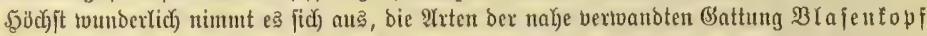

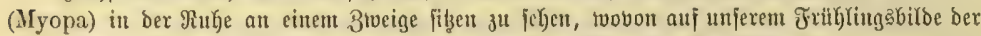

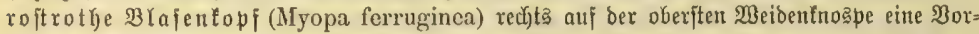

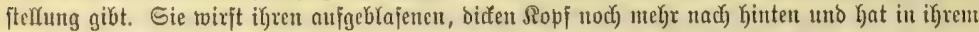

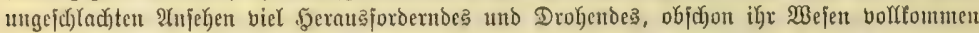

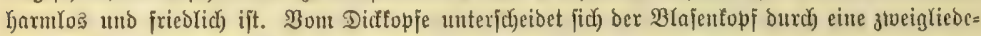

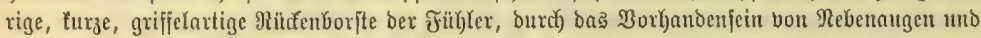

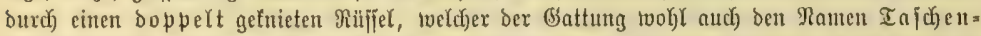
mefferfliege eingetragen Kat. Die genante Irt, eine bon einigen ztwanzig (Furopäent, ift

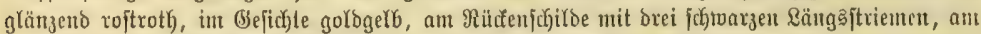

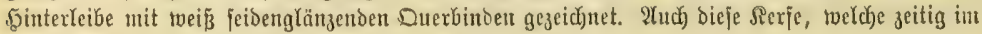

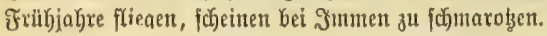

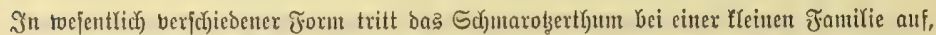
weldye man Daffel=, Bieģliegen ober Bremen (Oestridae) genannt Gat. Die Arten fuchent

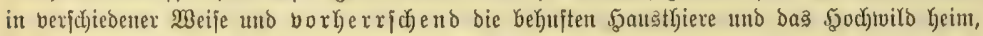

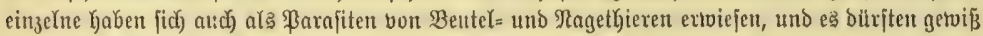

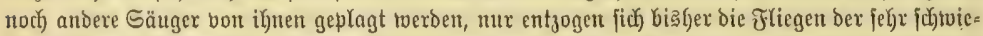

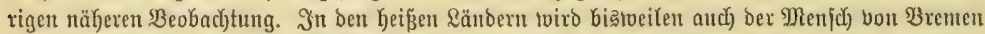

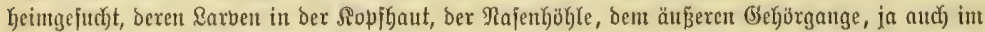
Magen gejunden toorden find, in Brafilien Ura, in (Ea)enne Ver macaque, in (5ojtarica Torcel,

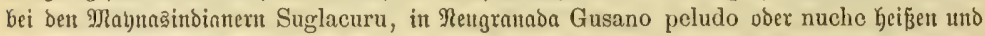
einem Menfchenöftriben (Oestrus hominis) angebüren folfert. Dem ift jeboch) nicht jo, fondern

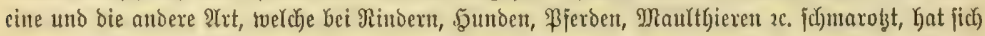
in ben vorliegenden fälfen eimmal zu einem Menfichen verirrt.

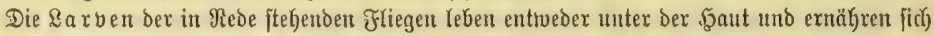

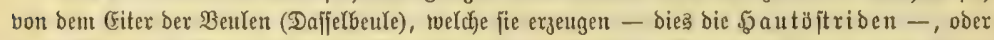

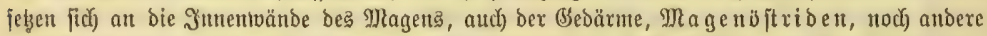

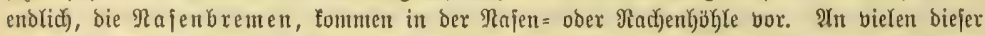

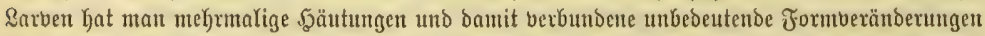

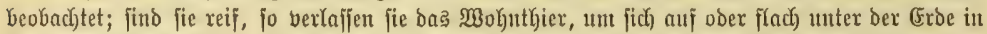

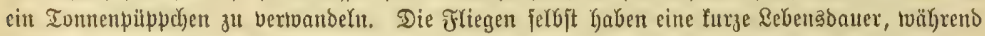

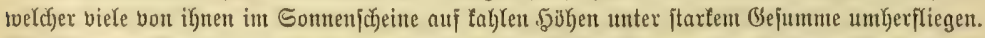

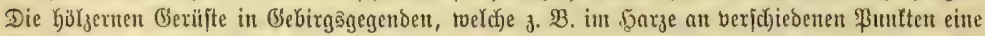

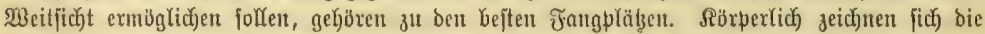

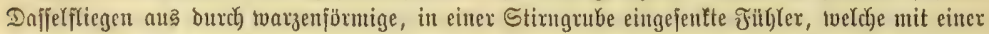

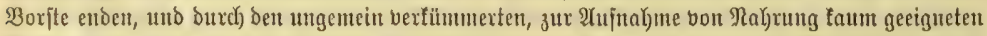

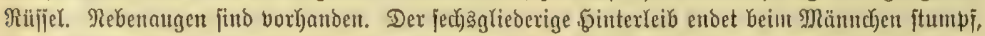

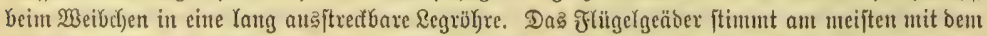

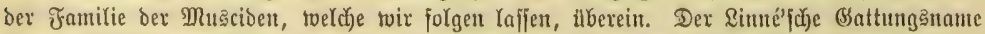

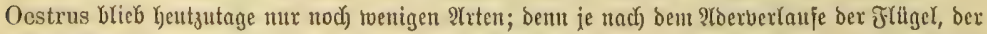

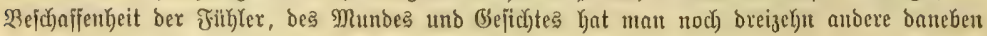




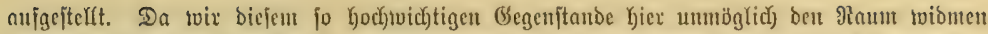

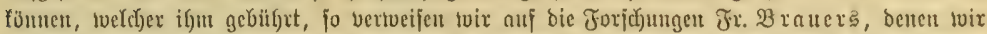

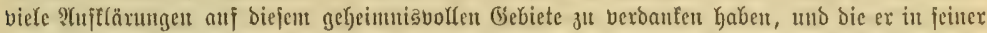

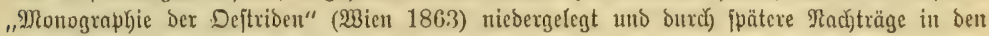

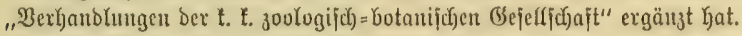

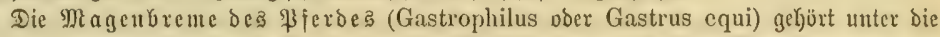

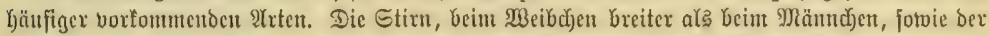

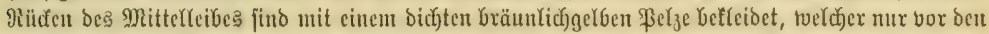

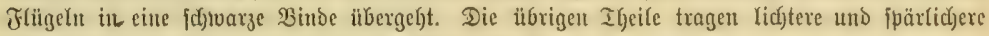

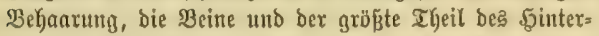

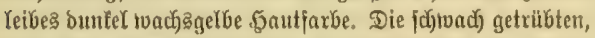
mit cinex berwifichten butferen Duerbinbe und einigen Fleafd)en geseidjueten Flügel find bon einex bolfonmen geraben viexten Räugsaber burdfyzogen uno haben tweber eine Spitzenqueraber, nod) eine verengte ober gejojlofiene cxite Ginterranozelfe. Die 13 bis 17,5 Mifimeter lange

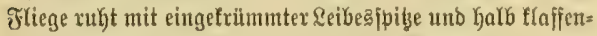
Den Fłügeln. Sat fie in ben exíten Mtorgenịtunoen an einem jodjonen Tage ein Dedfeldyen bout Der Tomenpuppe

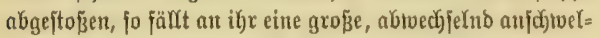
lenbe und zujammtemintende Błaje auf, toeld)e bie gantze Stirn bis zum (Benide bedeçt und burd)fidytig ift. Maat meint, bieje B̧aje, weldye man aud bei Tadjunen uno anderen Mlusciben im Sugenbarter toahrmehmen fann, Yeijte beint 2tbjtoßen be马 Decfela gute Dienfte. Mlit Dem boll=

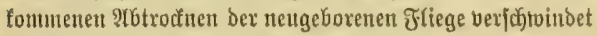
Diejelbe, und bie Breme fliegt nun unter Bebrumme aus, unt fich zu paaren. Sie gehört zu benen, twełdje hoke

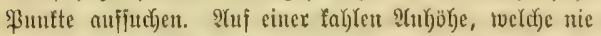

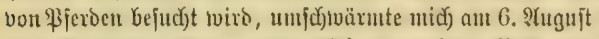

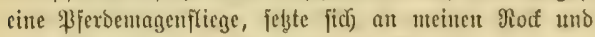
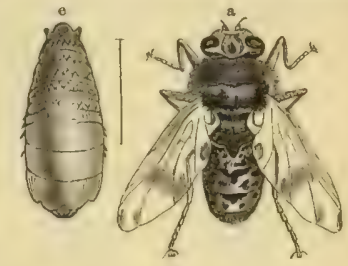
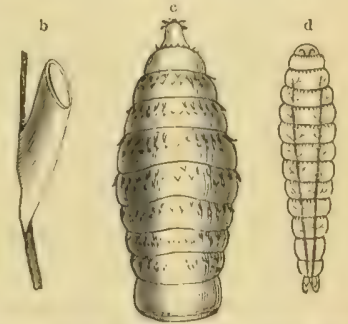

mageroreme des Pferdes (Gastrophilns

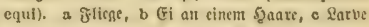
auf ber Ietsten, d auf ber crịtent Entwidelungsituje, o ₹üunden; alle vergrobert.

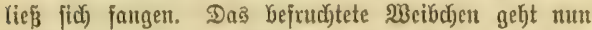

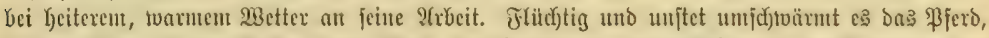

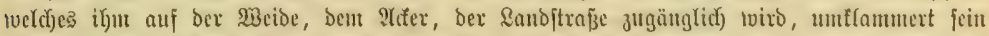

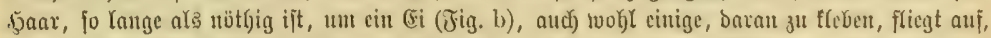

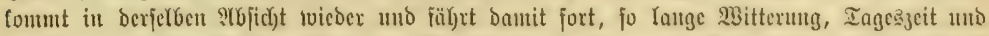

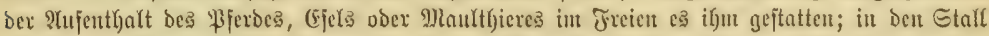

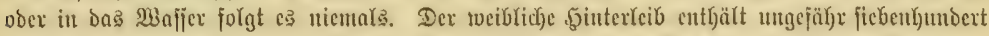

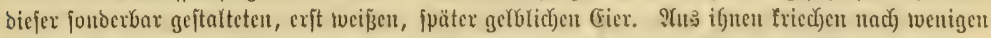

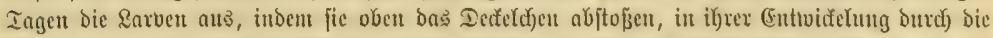

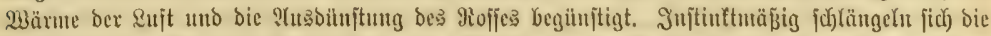

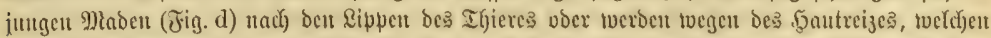

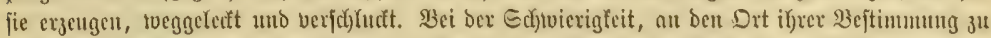

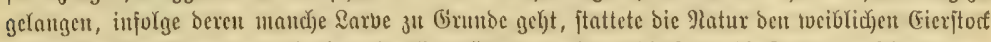

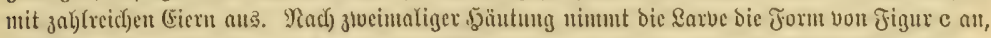

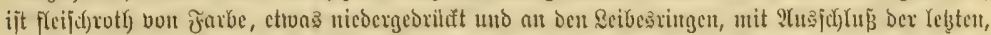

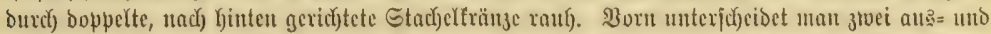

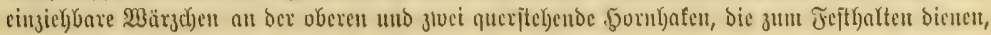




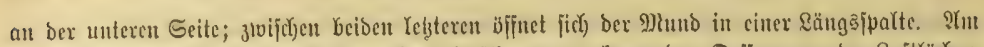

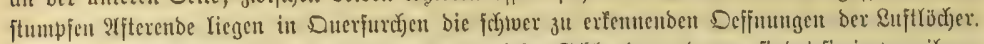

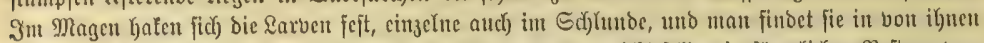

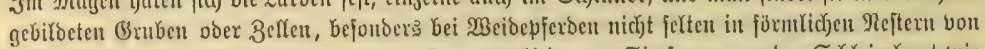

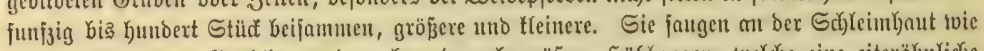

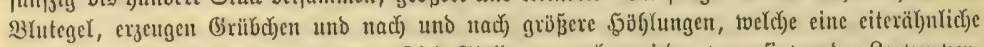

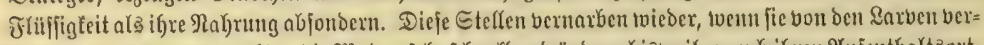

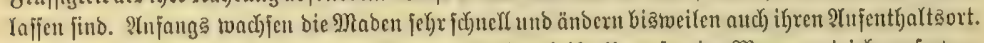

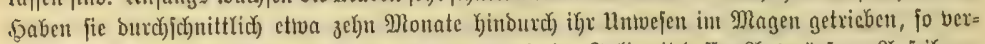

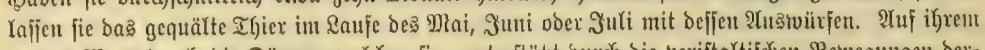

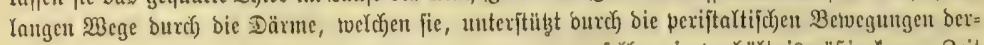

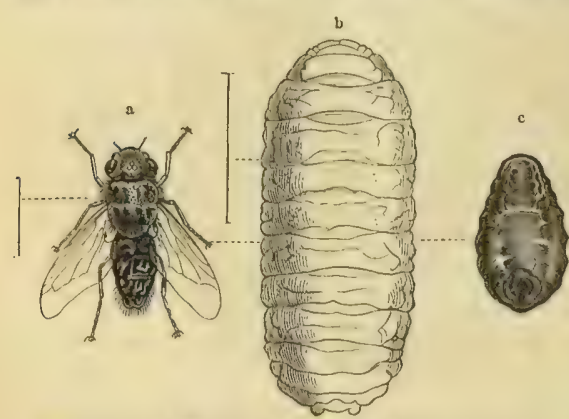

Rajenbreme bes $G_{\text {d }}$ afes (Oestrus ovis). a Ifiege, b Satbe bon ber Miidenjelte, c Puppe bon ber Baudjeite; alle bergröbert.

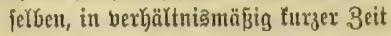
zuritidtegen, ficheinen fie ibre Yelzte (Ent= tvidelumg st exlangen, twenigiteno hat es̉ in nux äuperft jeltenen früfen gelingen twollen, aus joldyen sarven

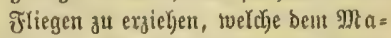
getl zu Orunbe gegangener Pierde

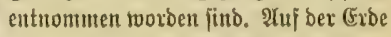
angelangt, gräbt fich bie Rarbe fent= recht in biejelbe, bis bas (rnde be? Lcibes babon bedectit ifit, febrt fitch um, forrumpit ein und wiro zum harten

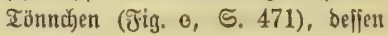
vordere 2tthmungatvertzenge toie zwei

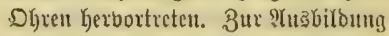
Der fliege find bei einigermaß̧en gin itti=

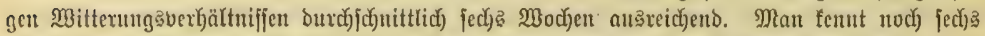

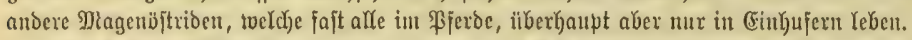

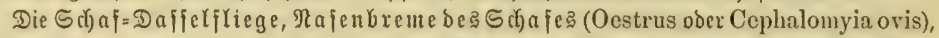

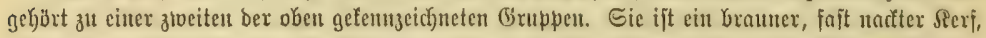

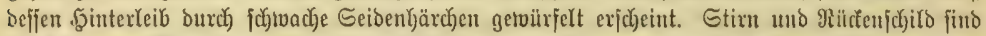

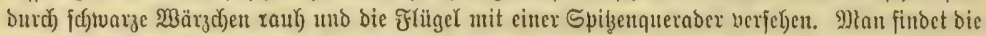

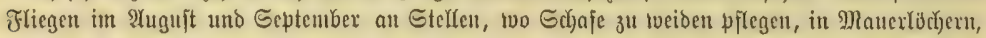

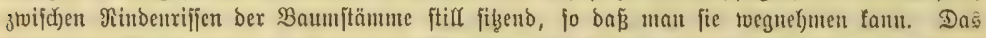

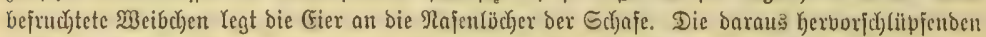

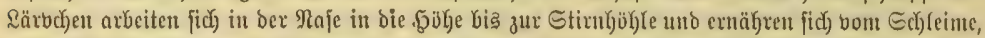

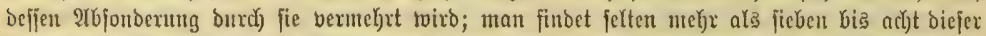

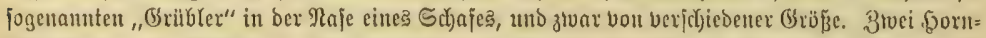

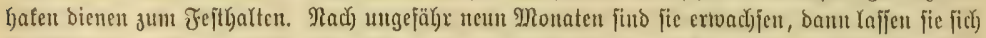

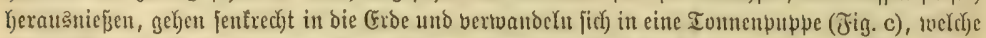

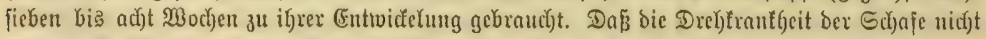

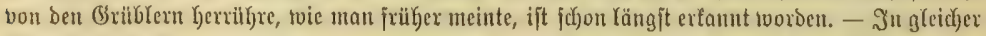

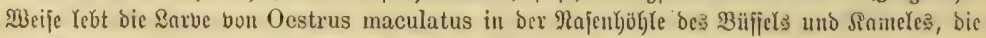

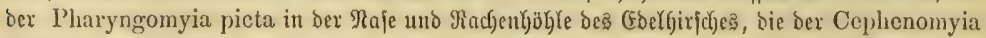

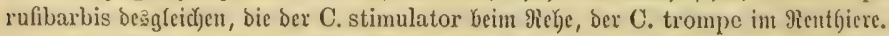

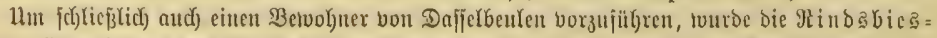

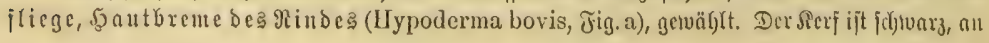




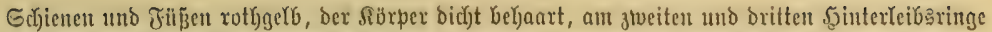

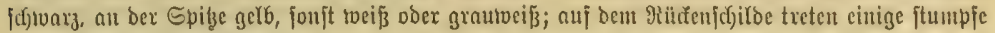

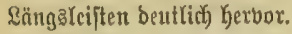

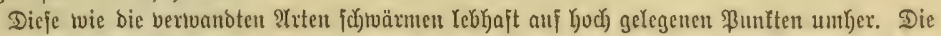

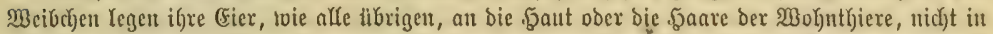

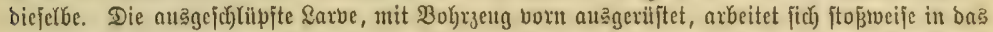

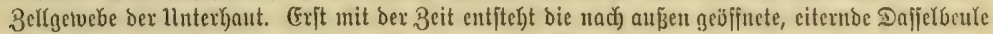

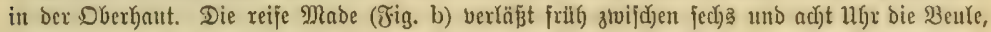

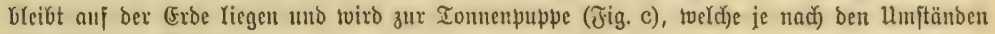
vier bis ject) зи ifrer (Entroidelung Gebarf. - EGenjo Yeben die Rarven von $\mathrm{Hy}$ poderma Diana uno H. Actacon, jene am Rehe, Dieje am Đirjotje, H. tarandi in Dett Dajjelbeulen ber Rens thiexe. Art bie cine oder andere Meife twerben Die genannten Thiere

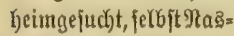
Gorner und Elejanten tverden won ihnen nidjt
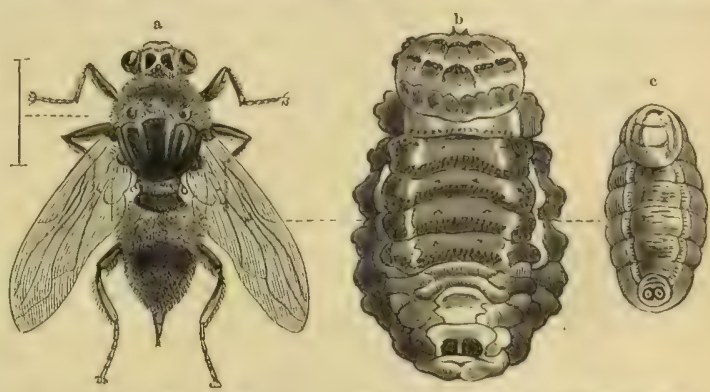

Sautbreme bes RInbes (Uypoderma bovis). a Fllege, b Rarbe, o Puppe, belie von ber פoudditite; alle bergröbert.

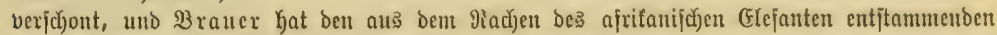
Pharyngobolus africanus befadrieben.

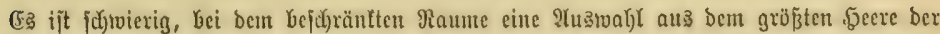
Fliegen zu treffen, tveldye bie Gyjtematifer zu Der Jamilie Der Bemeinfliegen (Muscidac)

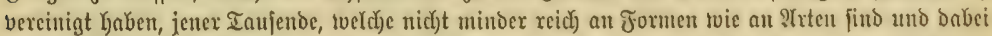

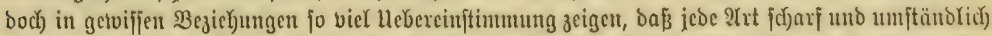

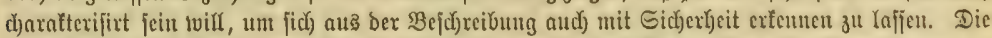

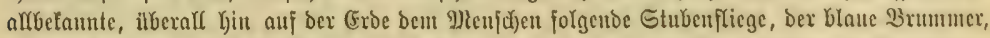

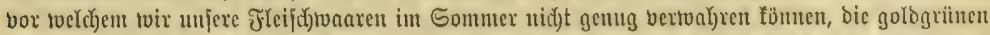

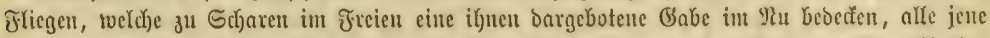

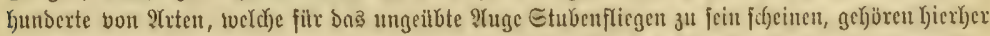

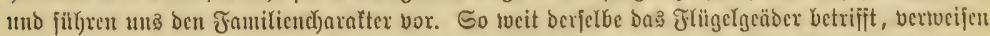

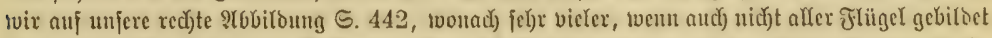

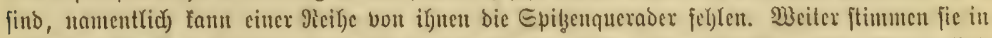

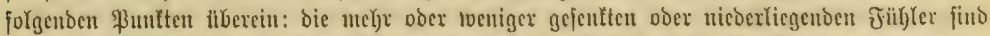

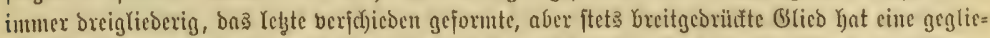

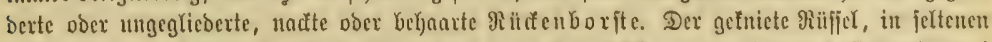

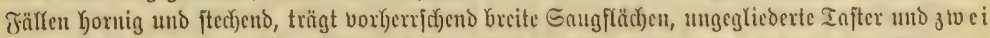

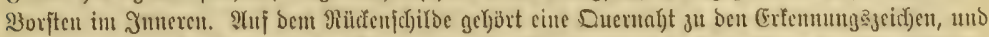

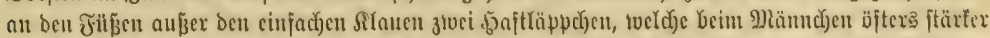

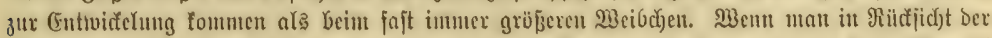

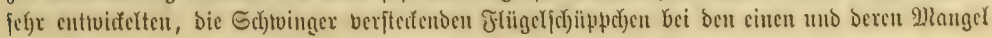




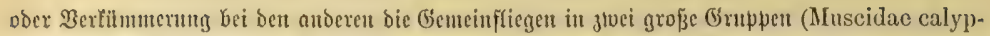

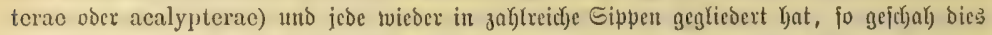

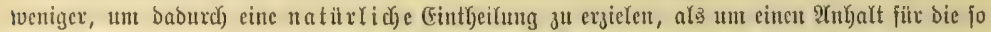

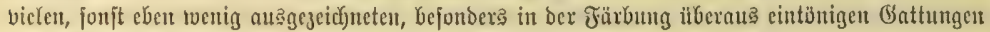
und $\mathfrak{2}$ rten gu getwinnen.

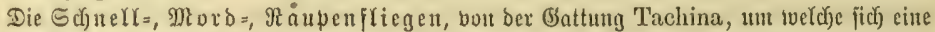

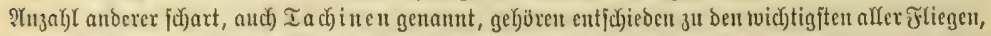

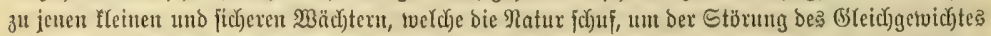

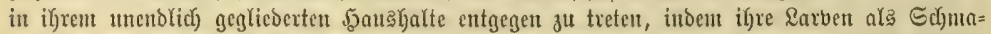

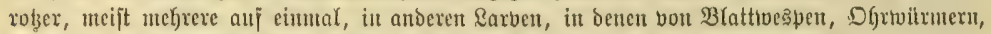

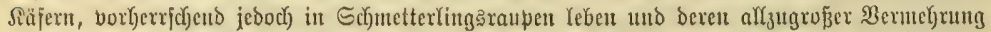
vorbengen. Darum falfen un bie fleineren bou ihnen wenig in bie Thgen, bent fie fdhtüpfen,

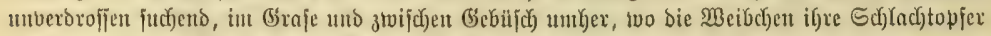

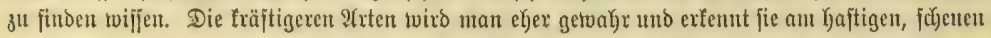

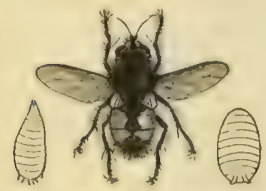

20ttbe Daupenflicge (Echinomyia ferox) nebit Sarve unb Bubpe. natiirlid)e (Sröbe. Fluge, an ihrer Milbgeit, toorauf ber erjte jenex beutjchen Manen unt bie siffenjichaftlichen Benenungen, tvie Echinomyia ferox, E. fera uno andere, Gintweifen. Dą $\mathfrak{B e r f}$ alten ber Larben zum

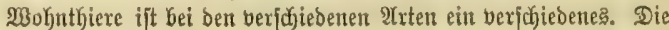
cinen bohren fich aus bem Raupentörper uno gehen zur ßexpuppung

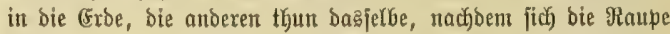
berpuppt hat, nodi andere bertuandeln fidf in ber Sdimetterting

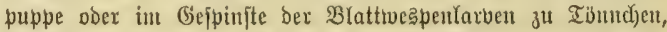

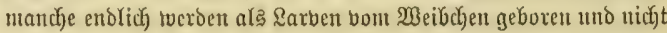

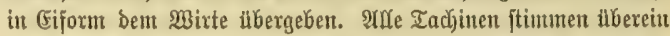

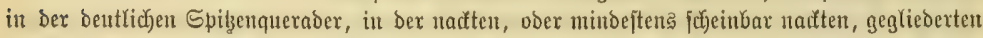
Fithlerborjte uno in Dem vier ringeligen, furz eiförmigen, fegeligen, felten walgenjörmigen Şinter=

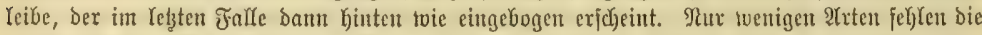

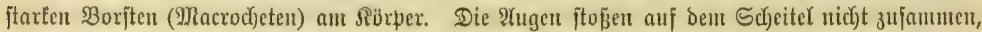

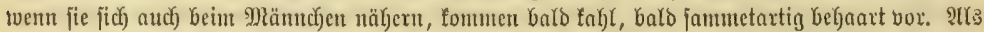

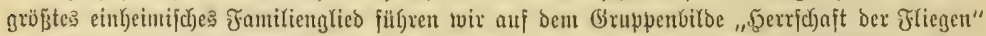

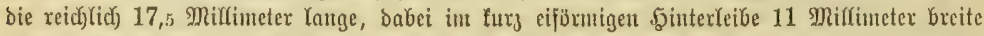

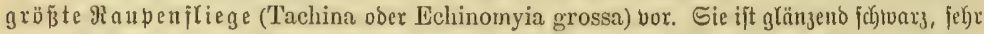

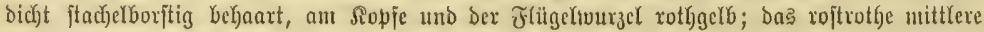

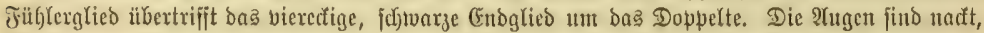
23impern ben llutergefichte borentgalten. Die Tachina (Eehinomyia) ferox vergegentuärtigt att

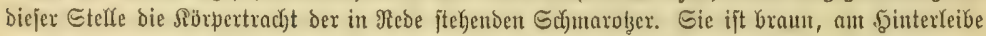

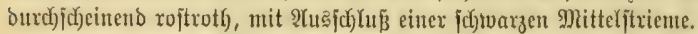

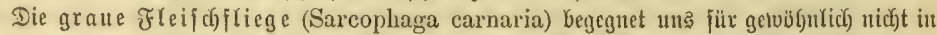

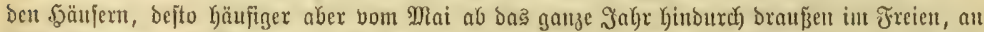

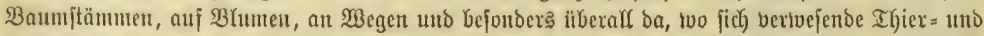

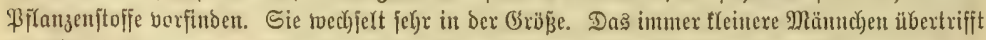

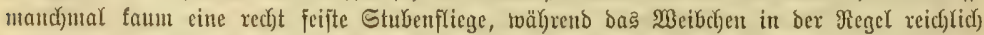

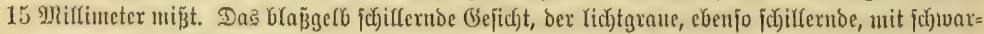

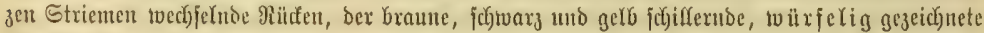

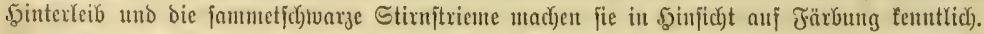

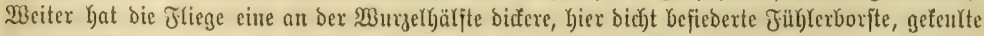

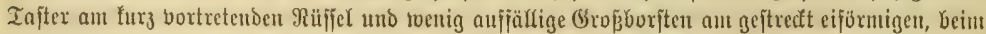

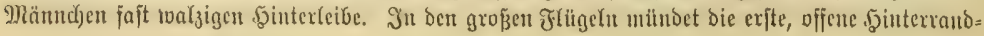




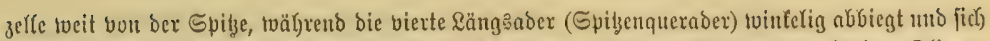

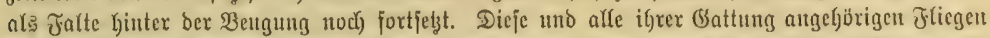

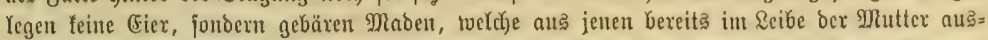

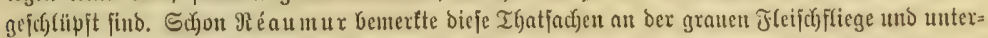

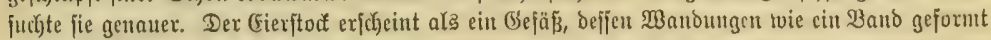
uno jpiraljürmig jujantntengerollt find. Witfelt man eines auj, jo ergibt fitch cine \&äuge vout

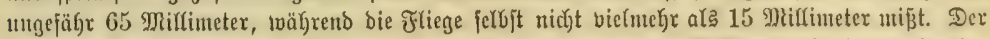
Breite nach Ciegen ztwanzig Maben uno auf einer Ränge bon 6,5 Mifrimeter Yumbert nebentein=

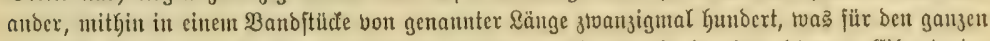

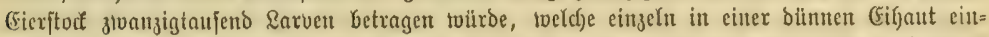

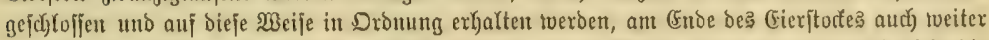

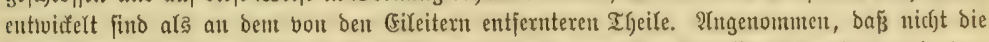

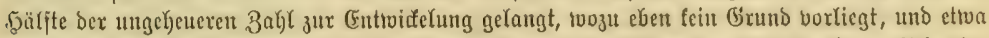

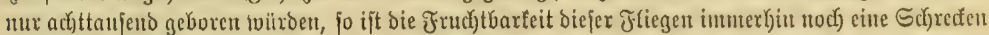

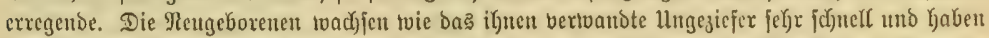

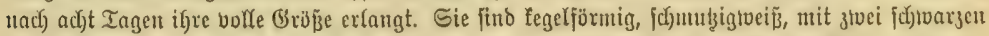

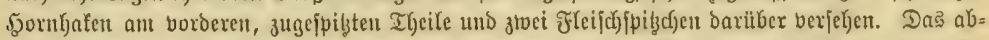

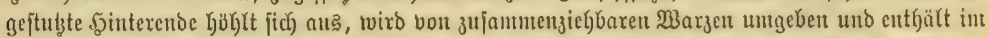

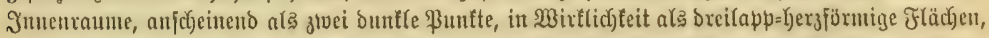

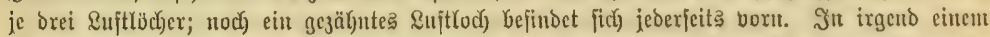

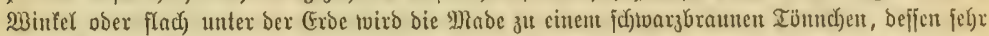

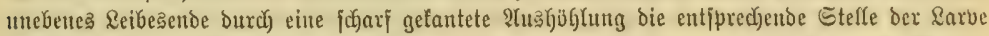

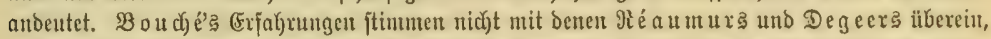

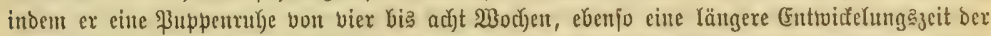

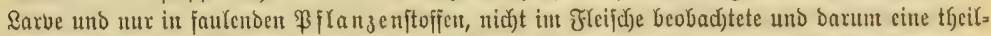

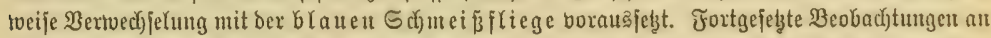

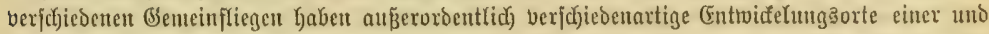

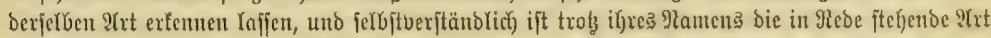

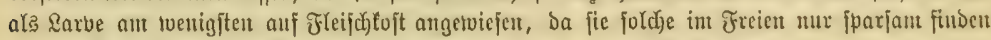

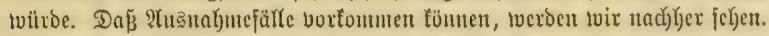

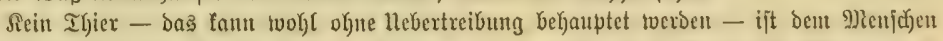

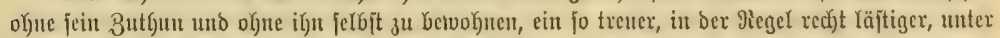

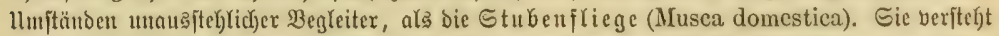

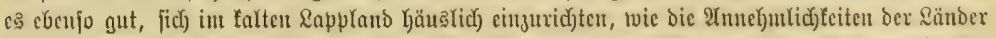

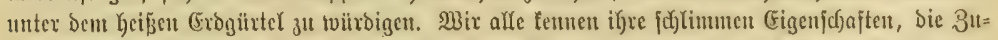

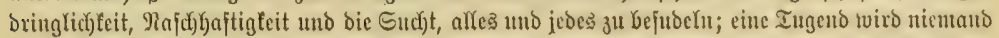

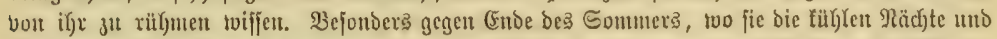

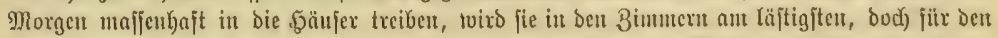

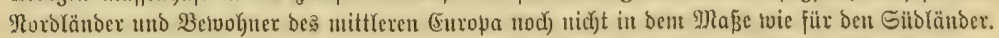

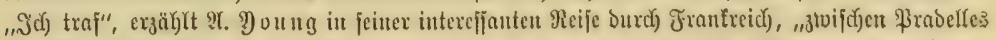

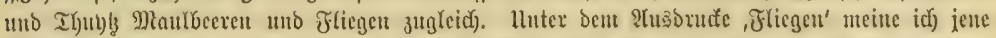

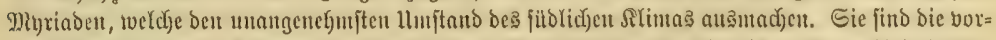

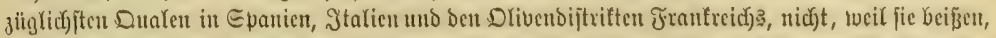

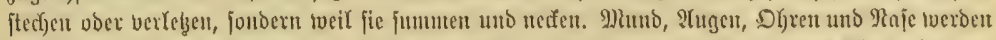

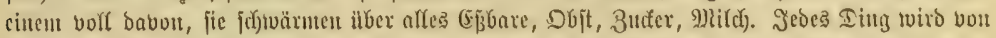

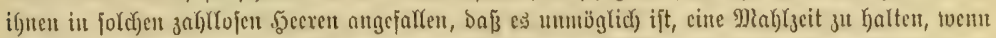

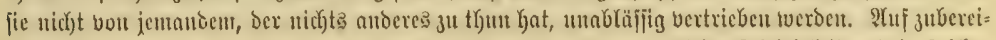

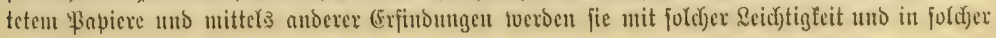




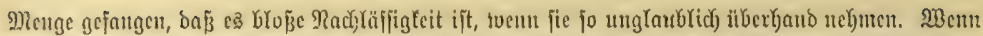

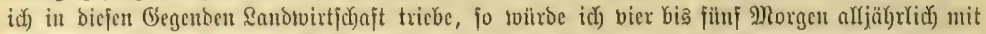

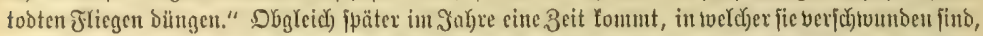

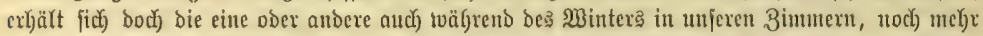

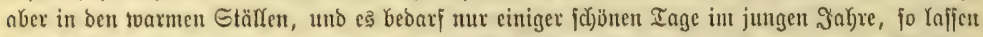

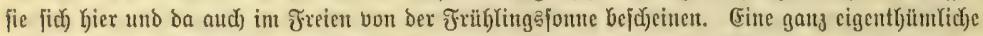

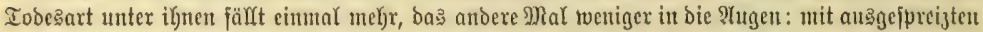

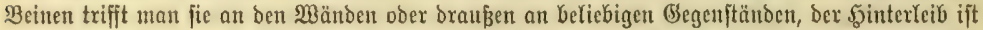

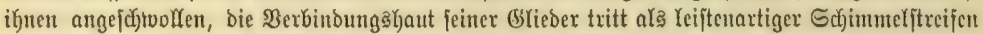

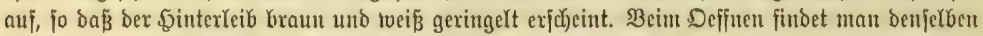

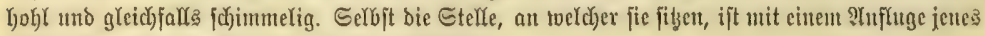
Pilzes iberzogen, weldider ben Reichnam jejthält.

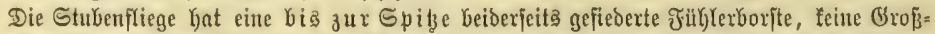
borften auj Den Shüfen ber vier Gintertcibaringe, eine wintelig zur britten aufgebogene vierte

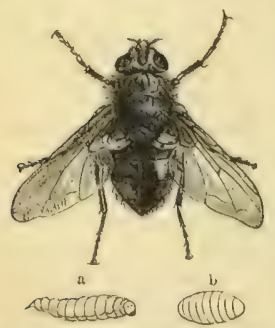

Sdineiffllege (Muses romltoria) nebjt a Larue und b pappe; If bte beibe in natiirlidec Gröse.

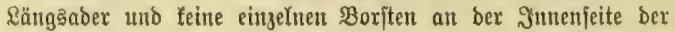

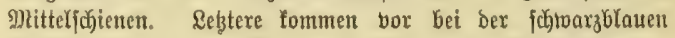
Sd)meipffiege, bem Bruntmex (Musca oder Calliphora vomitoria). Schwarge, roth behaarte Baden, vier fobtwarze, nicht eben

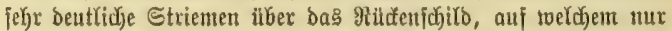
Borjten, feine Şaare ftehen, rothgelbe Tajter, judjwarge Beine mb

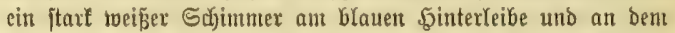

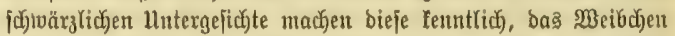
Hiberdies noch eine jehr breite fidnarze, an ben Seiten grau jojil=

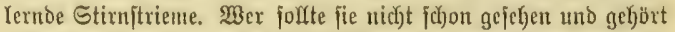
Gaben, jene grofe $(8,75$ bis 13 झtilluteter meffende) Bummfliege,

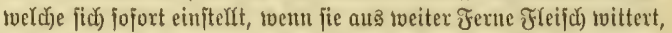

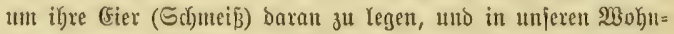

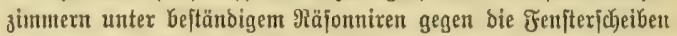

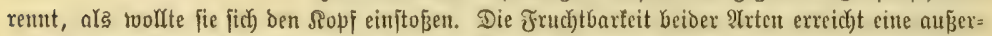

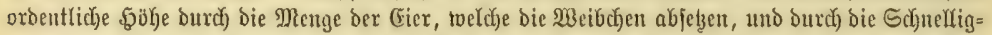

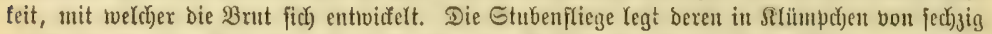

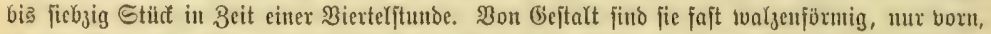

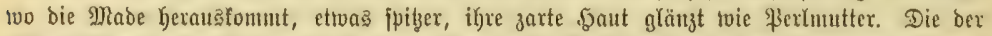
Edymeifflicge haben bie etras gefrümnte Form einer Burte und an ber eingebogenen Seite cine

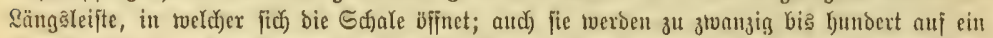

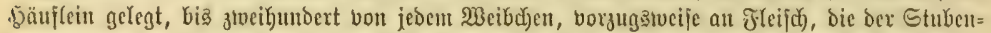

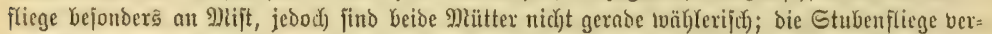

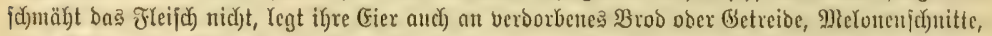

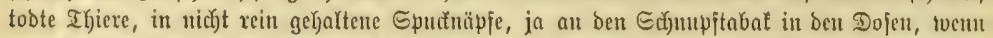

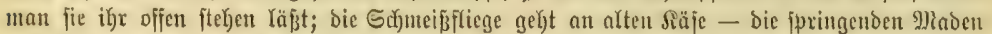

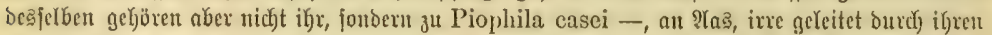

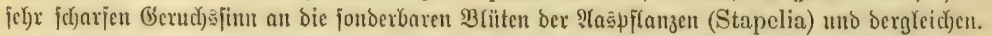

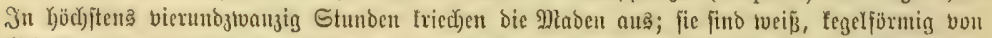

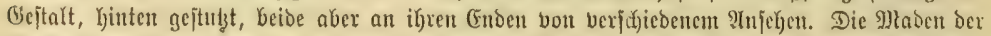

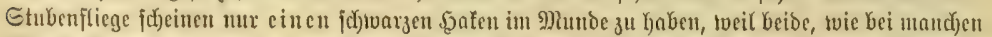

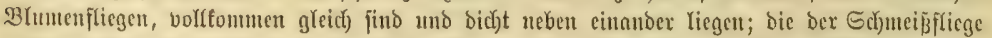

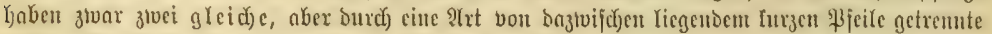

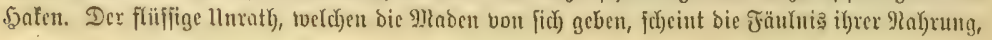




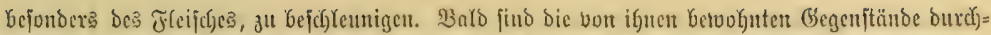

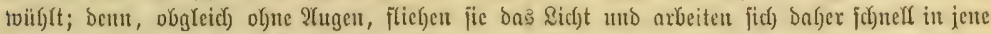

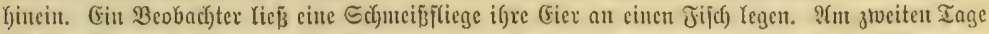

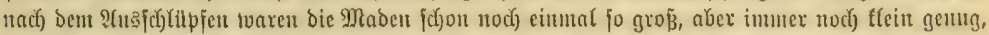

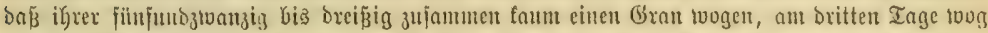

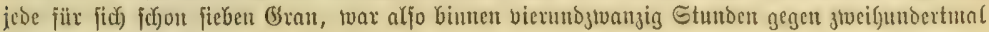
ichtoerer getwordett.

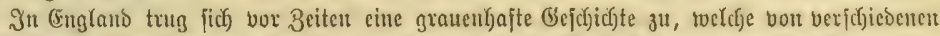

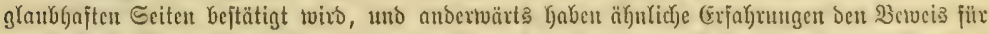

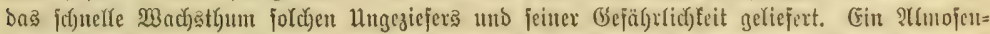

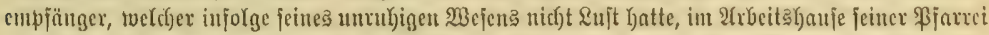

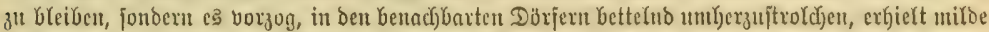

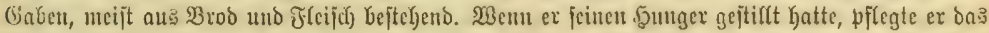

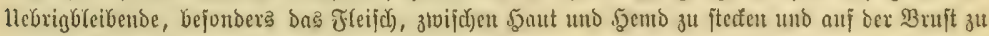

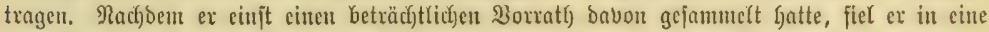

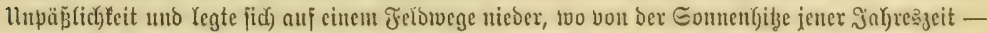

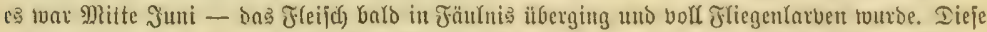

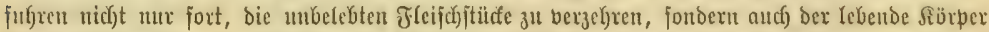

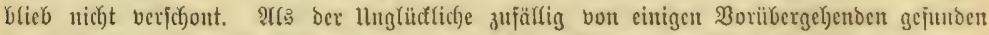

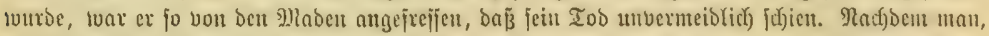

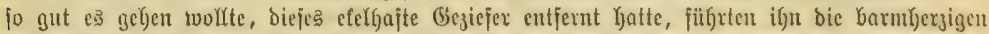

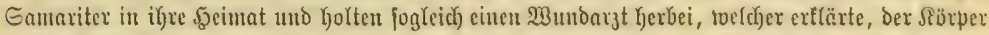

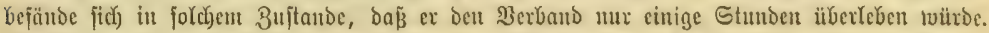

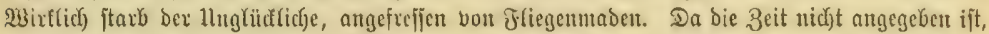

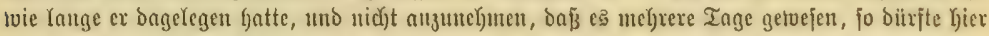
feine Dcr beiben Musca-2frten iu Betrackt fomuten, fondern eine lebendig grbärende Sarcophaga.

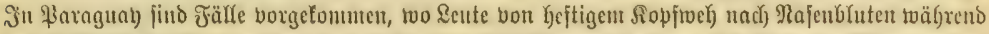

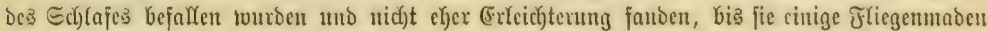

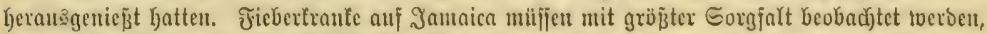

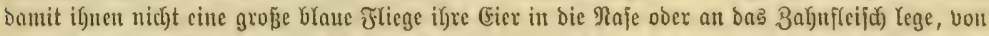

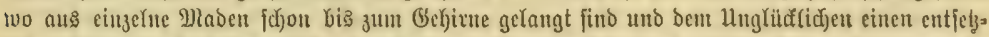
(ichen Iod gebradyt haben. Rafjen wir bahintgeftelft jein, ob bie verberblichen Fliegenlarven gerabe

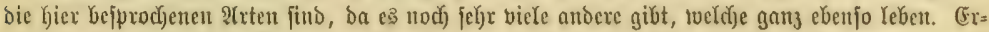

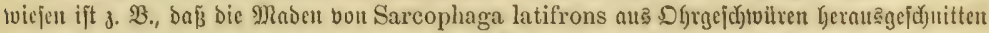

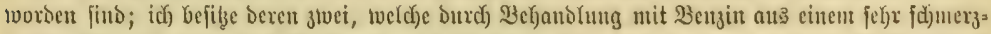

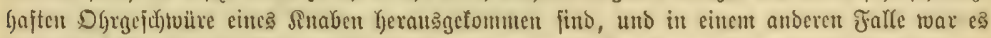

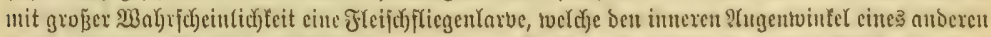

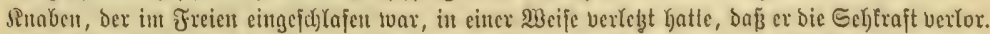

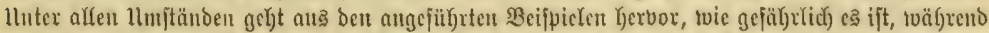

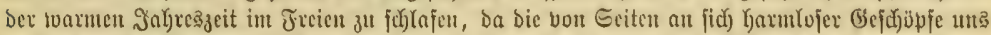

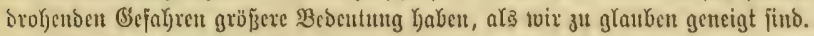

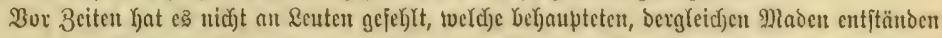

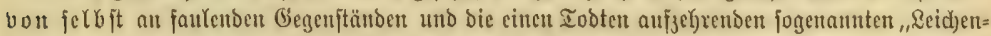

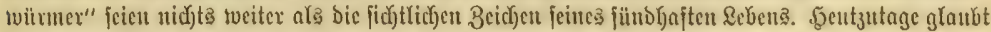

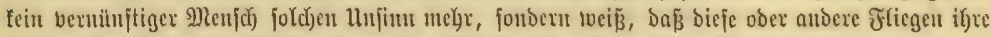

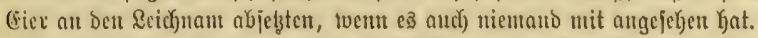

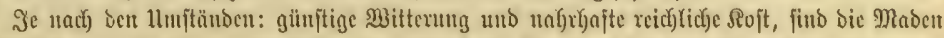

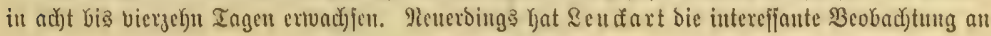




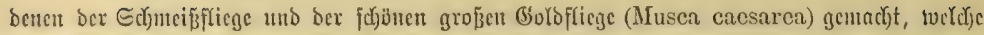
fd)on bei ben Deftriben und ben bald zu extuähnenden Pupiparen angefterft worben waren, bnß

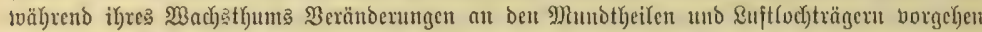

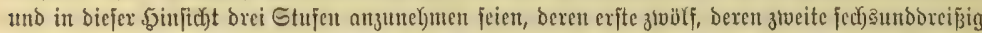

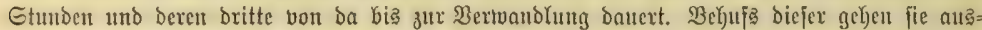

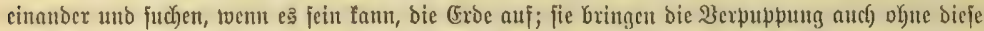

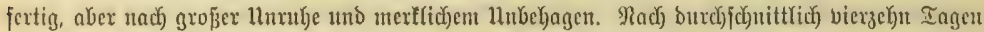

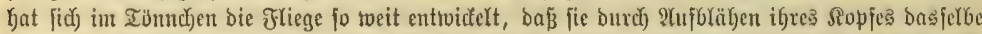

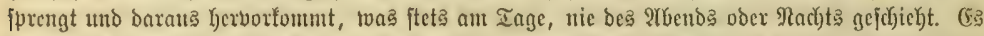

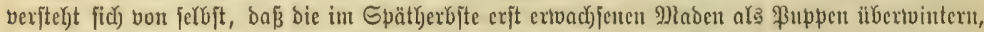

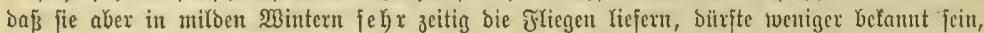

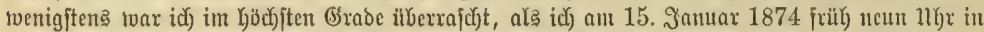

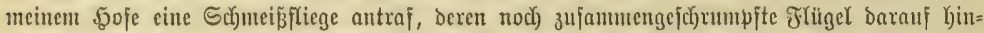

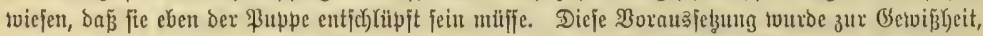

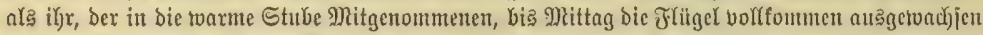

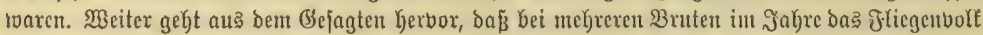
3u einer unermeßj(id)en $3 \mathrm{abj}$ herantwad) jäjîig toüren.

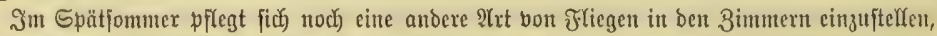

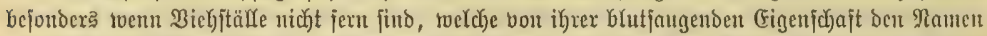

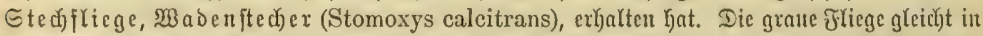

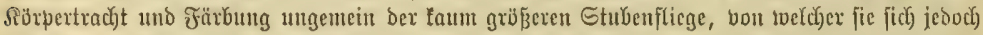

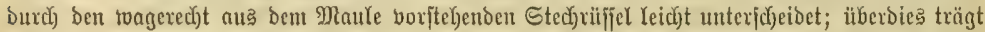

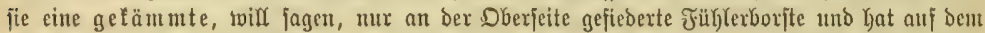

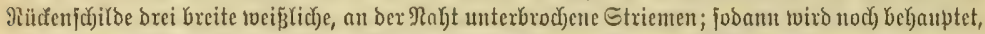

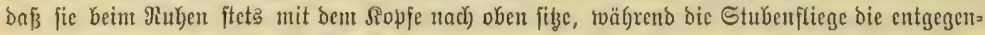

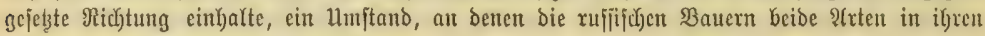
3immern Yeicht au interjidjeiben svijien.

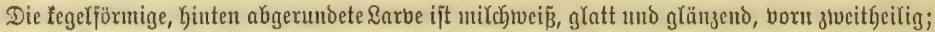

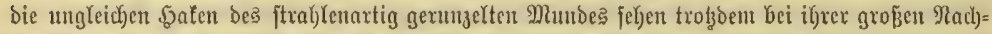

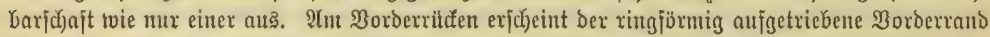
\{charf, bie gelben, mujudelfärmigen Stigmenträger zerfallen in je jectģ feulenförmige Theile, bie

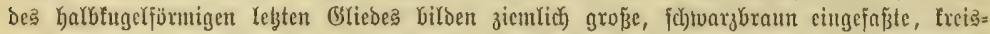

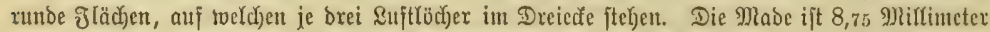

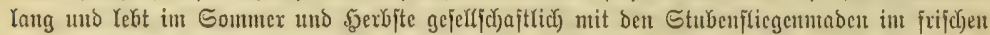

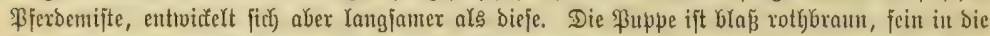

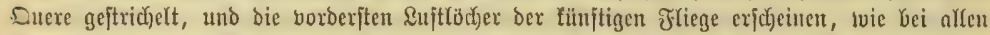

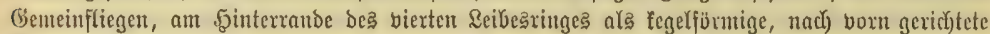
इörnchen, toälyrend bic Ginterften Da liegen, two fie bie Mabe lyat. Die \$appenube Dauert vier

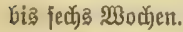

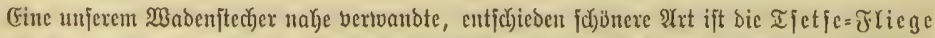

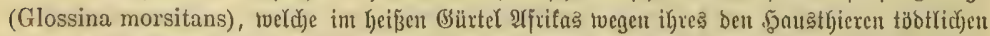

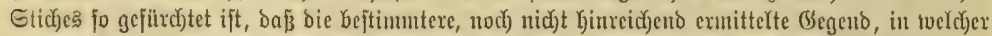

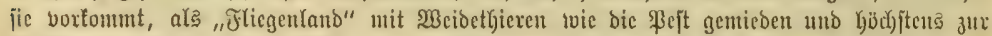

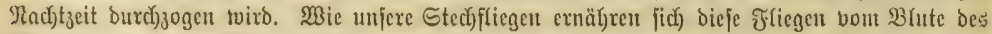

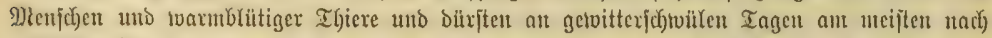

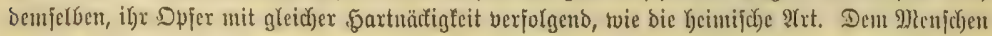

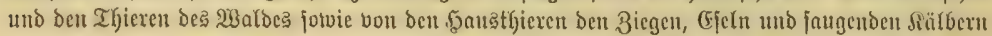




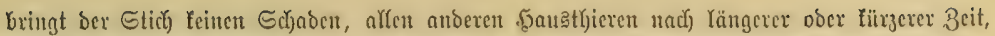

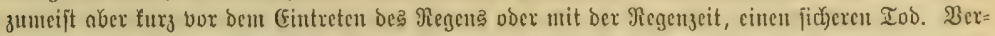

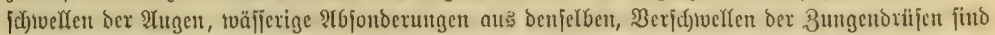

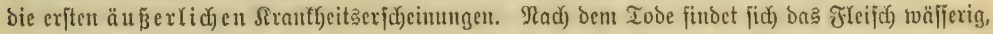

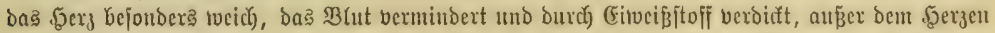

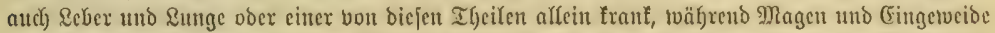

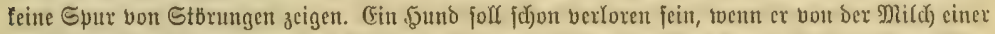

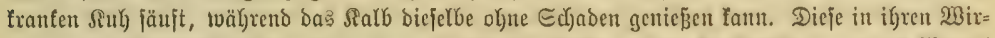

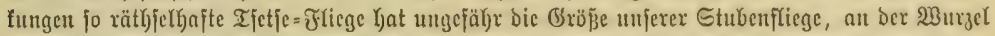

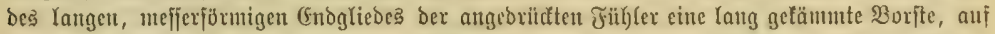

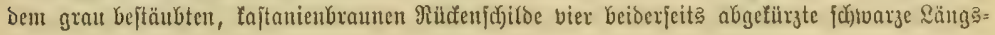

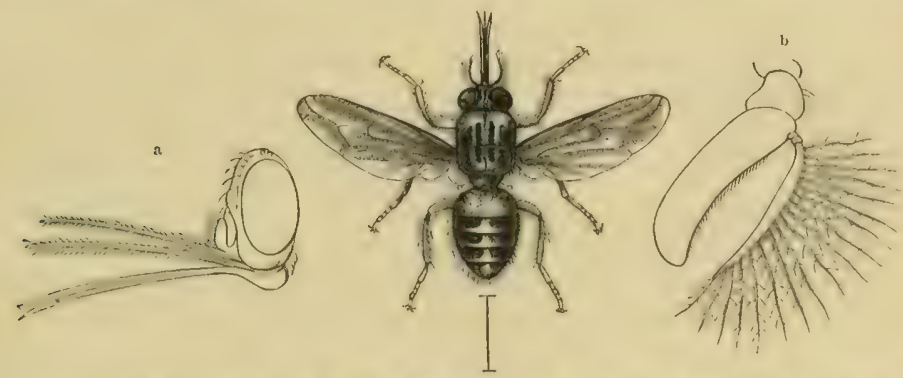

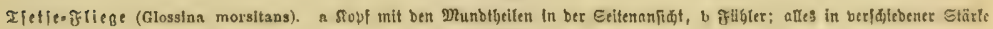
bergrósert.

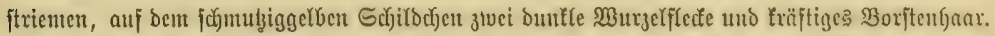

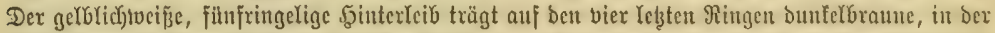

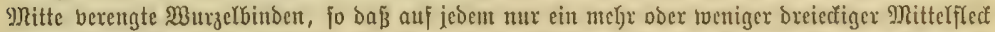

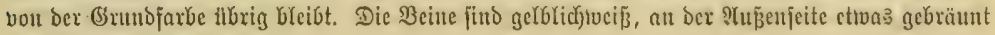
uno bie frtügel angeräud̄)ert.

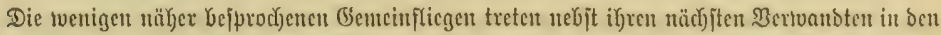

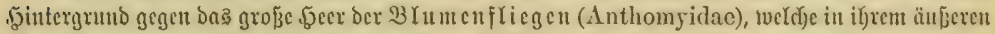

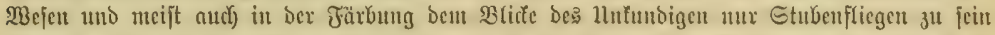

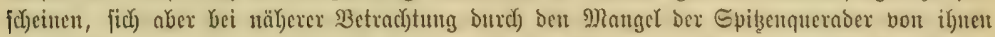

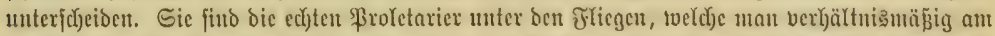

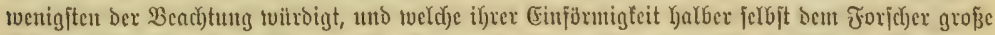

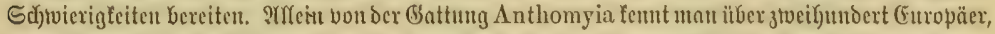

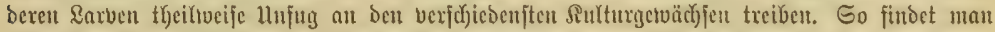

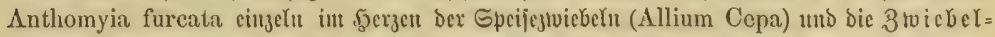

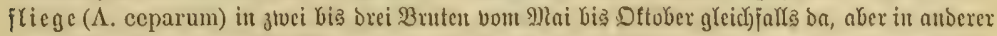

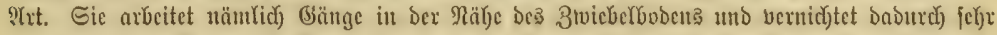

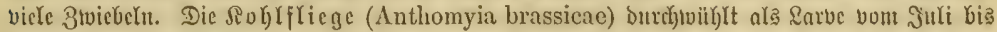

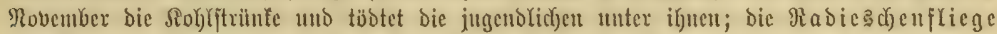

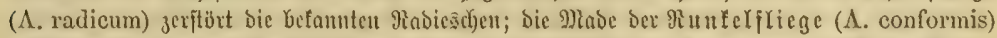

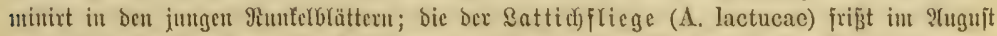

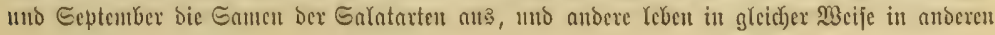




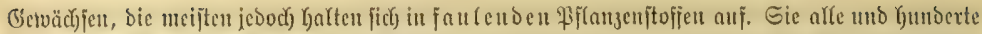

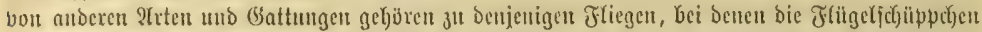

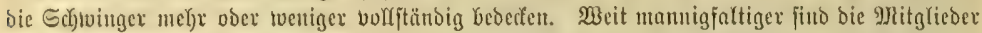

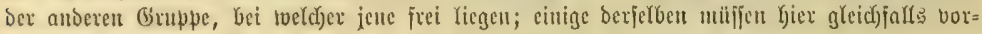
gefülyrt twerdent.

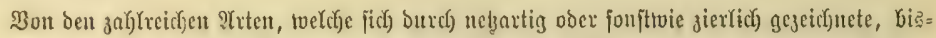

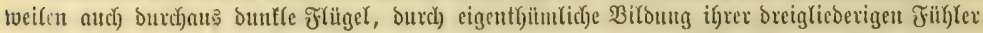

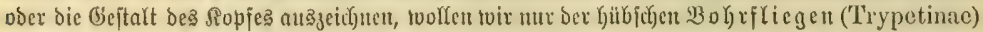

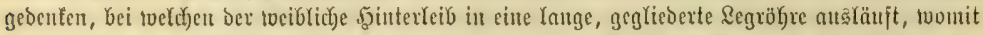

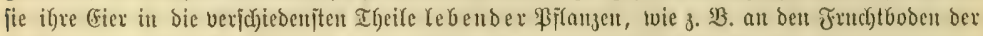

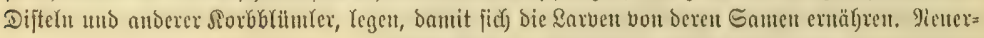
bing hat bie Made der Spargelfliege (Platyparea

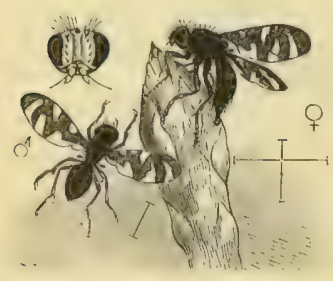

Evargerfliege (Platyparca poeclloptera),

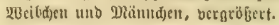

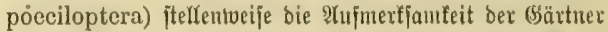

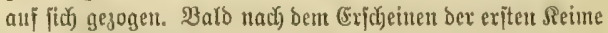
gentannter \$flanse, aljo anjang Slai, ftellt fich bie Fliege

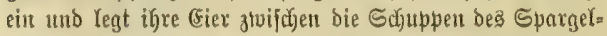
fopfes. SRach vierzebn bis eimundztwanzig Iagen, je nach ber

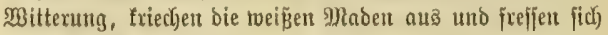
bon obeu Gerab burch) ben Stengel bis auf beffen unteret Golzigen Theil. Dieje Manderung ift nach etwa bierzetn Tagen beendet uno bie Mtabe Daun in Der \&änge von 6,5 1 lltlimteter

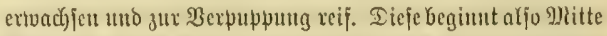

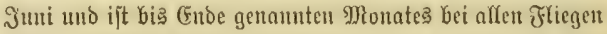
exfolgt, Deren bis acht und mehr in einem Stengel piben fömen. Die von Mtaden betwohnten Spargelpftanzen zeigen jefyt bald ein frilppelfajtes, meift vben

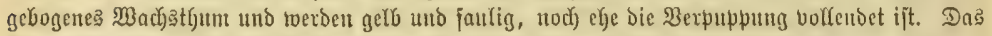

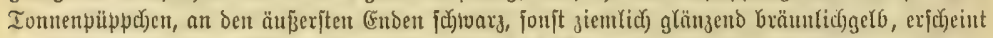

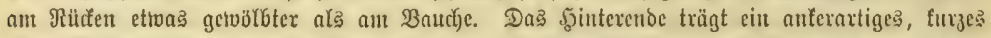

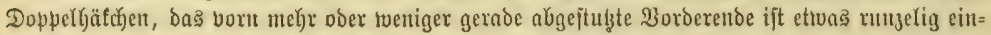

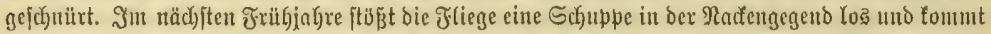

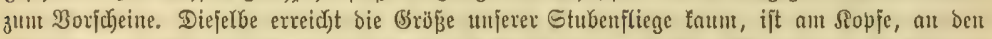

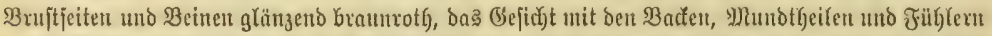

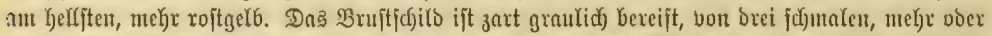

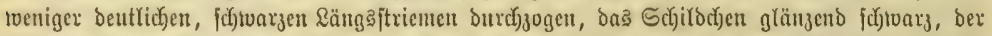

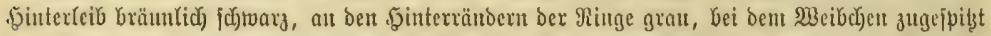

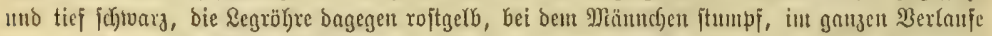

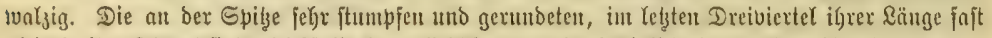

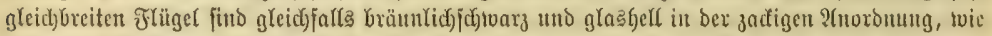

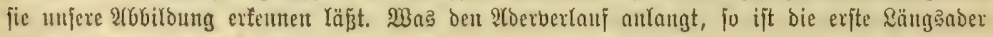

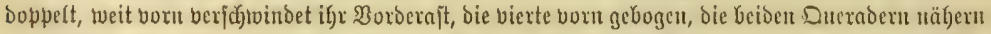

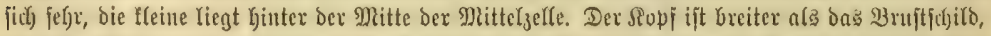

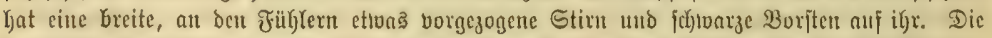

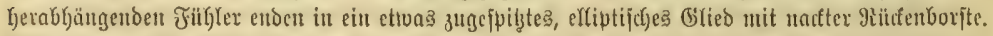

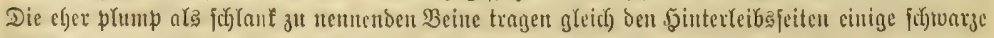
Borjtenfaare. Die \&änge beträgt 4,5 bis 5,17 Millimeter.

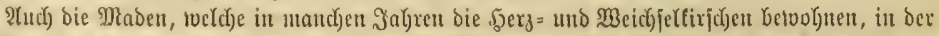

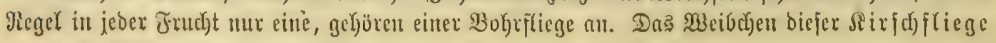




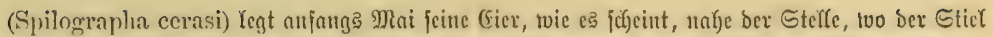

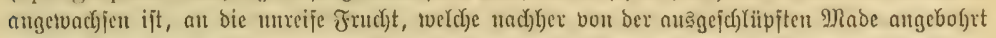
wird. Diefelbe Gat jich jedod) aud) nod) in ben Frïchten ciniger Geizblattarten (Lonicera

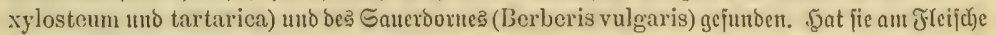

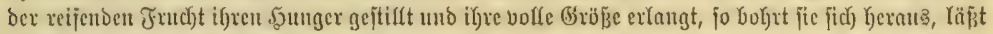

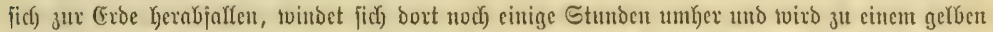

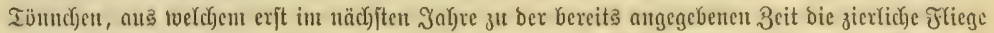

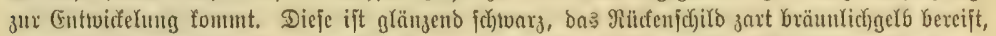

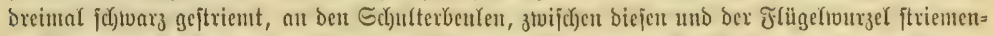

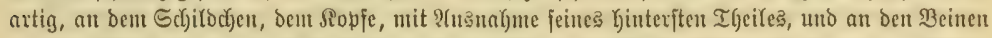

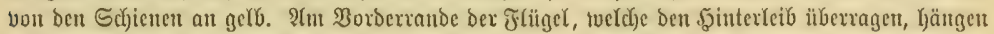
Drei bunfle, fajt głeid)laufende Duerbindent, bie Geiben exjten gefïrgt, bie oritte aber bollitändig unઠ born zu cinem gleichbreiten, biș tvenţ

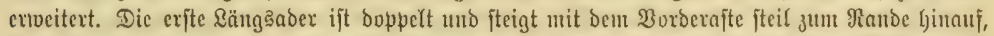

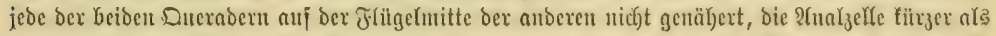

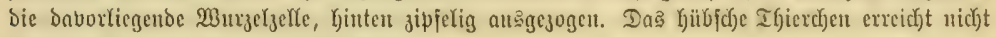
gan bie (Stüßje bex Epargel= Bohrfliege.

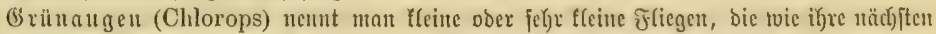

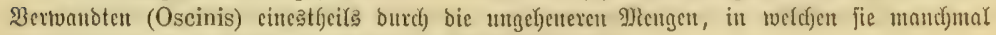

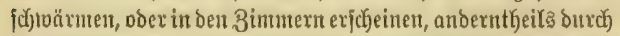

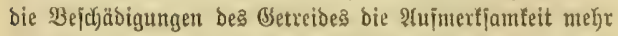
auf fich gelentt Kaben, als wohl fonit fold fleintem (be=

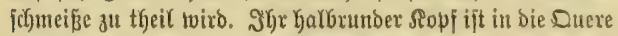
gezogen, bas twentig zuxildiveidjende llntergefidjt geht unter bie nadten, зน Rebzeiten ber Fłiegen jd)ön grünen Iugen Ginnb unb trägt feinen Snebelbart. Die Stim ift bei beiden

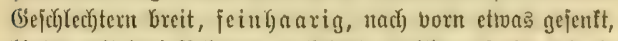
Ginten mit brei Rebenaugen bejelzt, toełdye anif einen brei= ectigen, jdhtwarzen Flecte (Scheiteloreiect) ftehen, if naci)

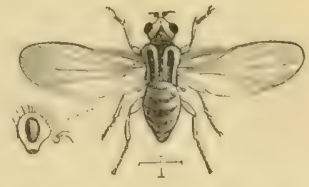

Baubfll giges of rilnauge (Chlorops trenlo. pus), Danchen Sopf in ber Ecitenanifit)t; beive vergrȫ̄ert.

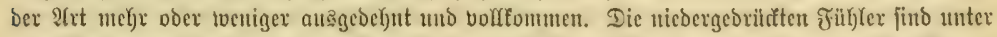

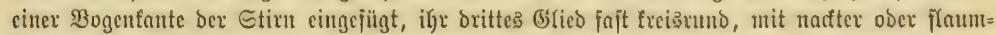

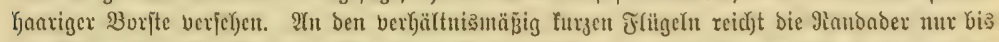

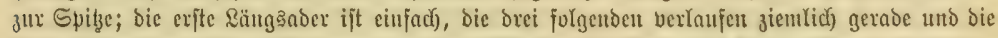

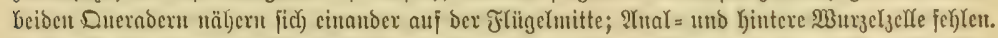

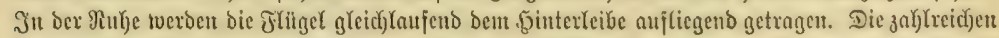

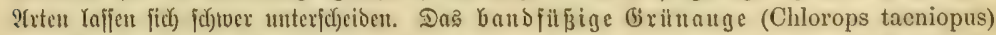

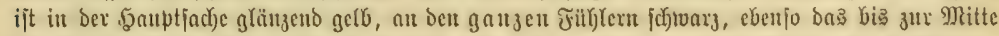

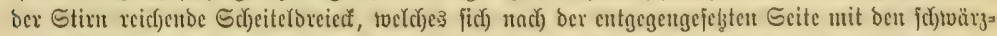

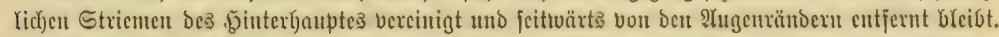

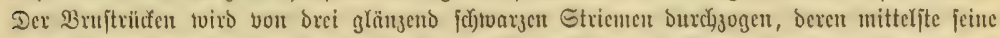

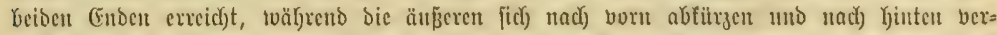

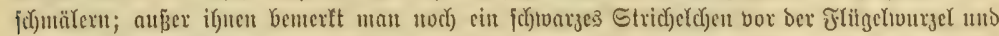

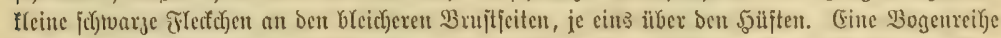

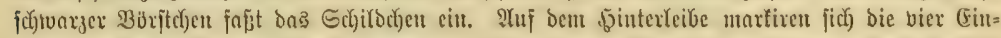

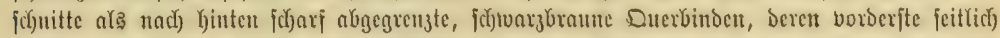

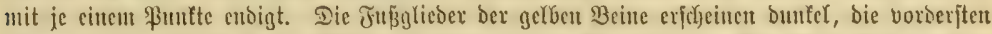

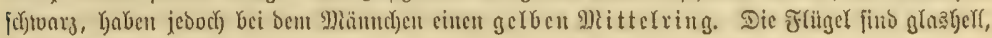

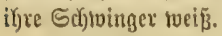

Probms sbierteben. 2. 9fuflane. IX. 


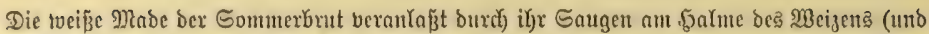

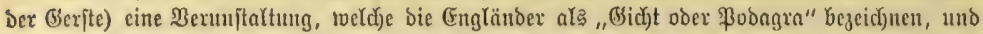

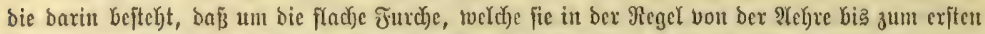

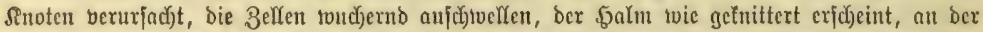

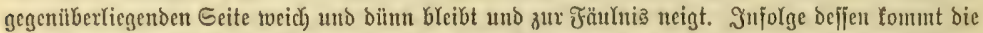

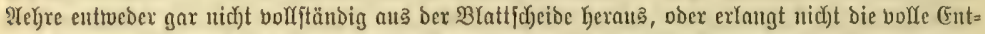

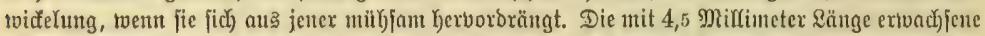

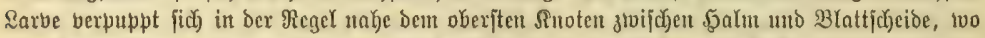

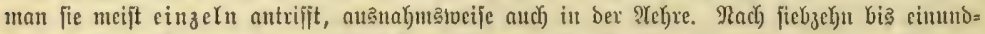

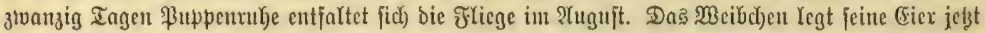

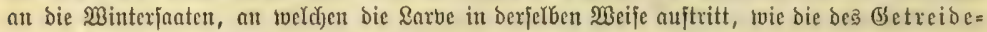

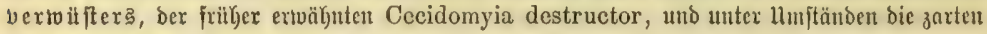
Pffanzen nody vor Binter

Die Fritfliege (Oscinis frit) ijt eine faum 1,7 Milfimeter mefjende, genau eb̌njo gebaute,

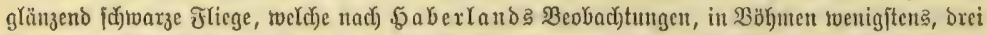

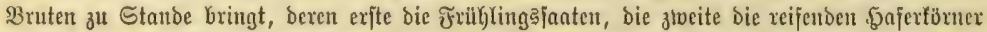

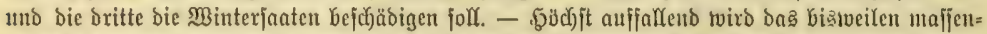

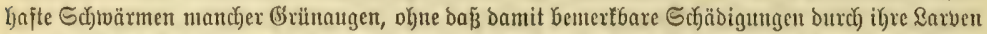

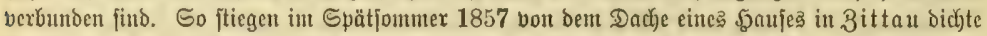

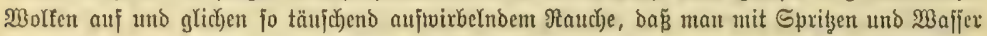

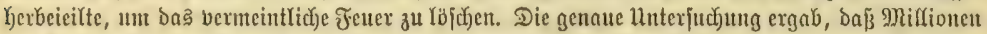
Der fleinen Chlorops nasuta aus eiter, Durch einen abgebrochenen Biegel entftandenen Dad)(iide

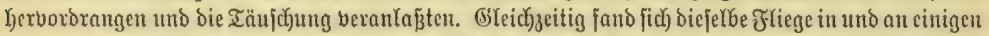

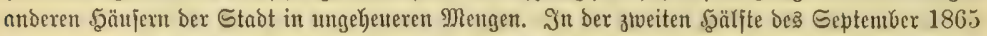

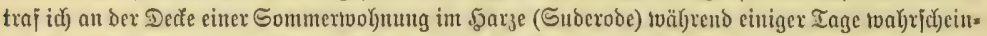

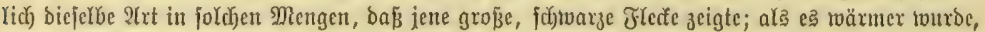

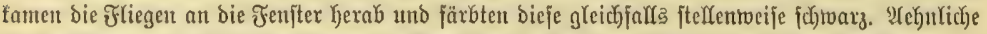

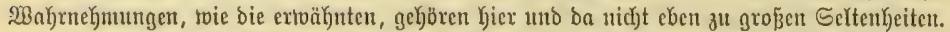

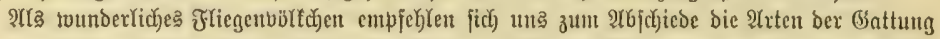
Phora utio ihre nädjften פertwandten. Die ffeinen, Gutefigen Thiere remen mit einer getvifjen

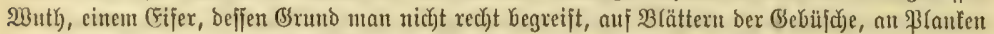

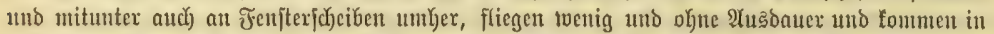

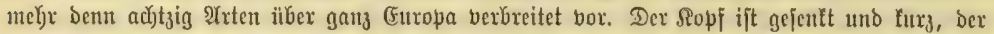

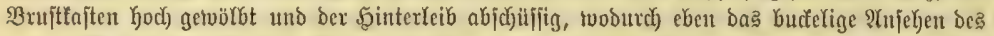

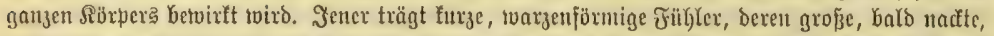

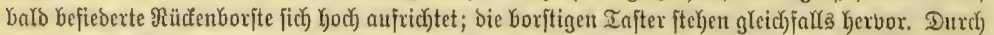

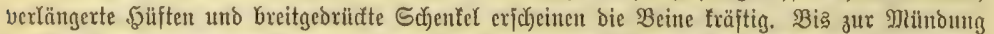

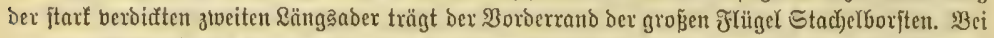
genauerer Betradjtung hat man bie eben gentannte शrber fïr bie britte anzujeken, welche fich) vorn

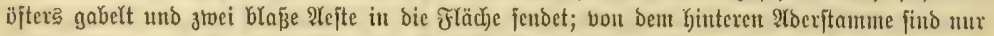

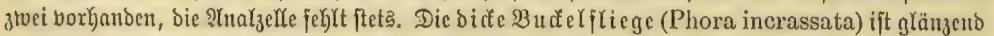

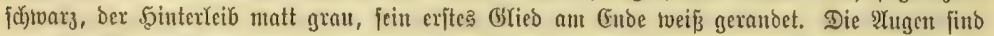

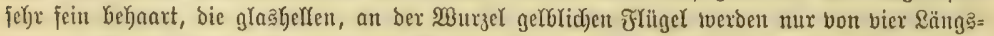

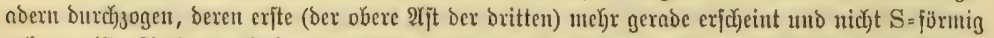

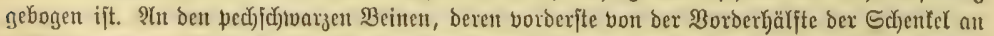

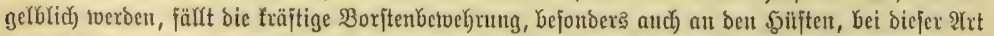

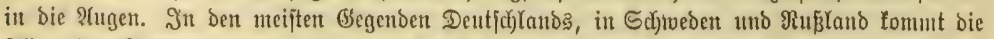

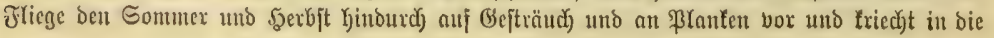




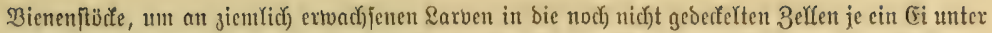

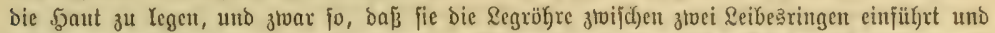

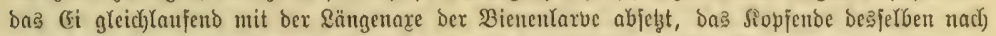
Dem Sopjende biejer gelegen. Die Made nuß im Eie fodjon fajt volltommen entroidelt fein,

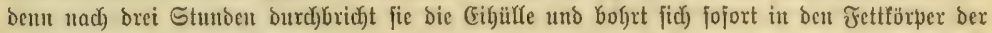

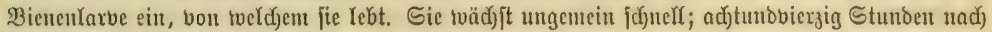

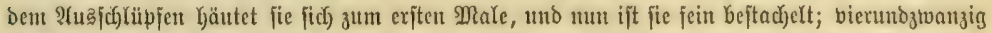

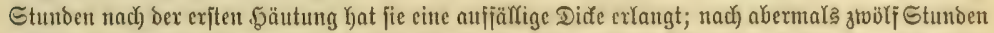

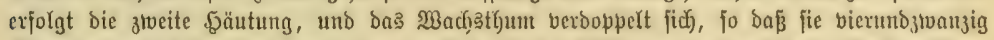

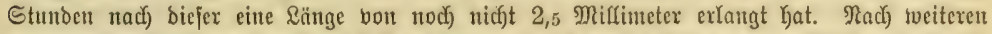

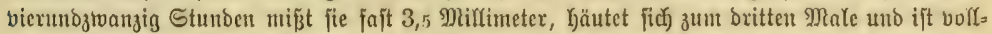

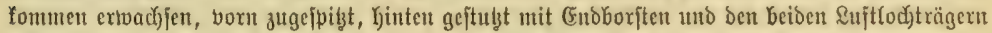

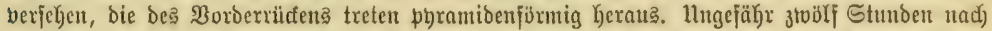

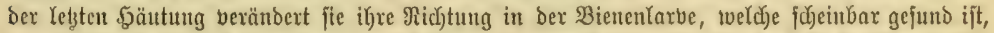

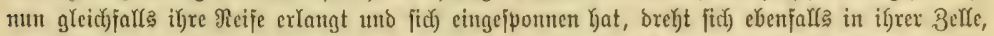

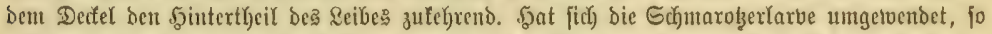

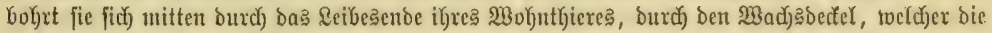

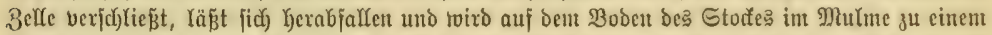

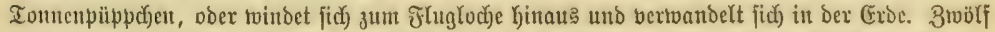

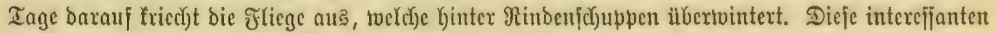

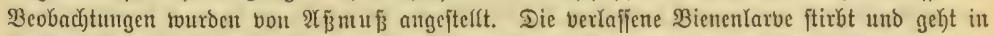

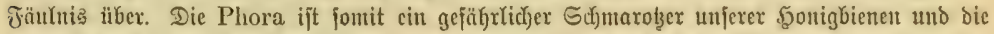

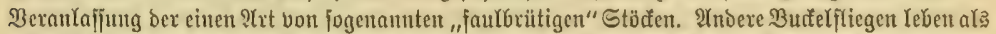

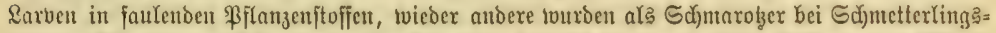

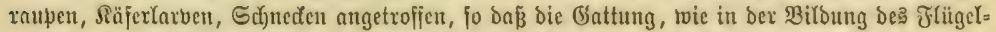

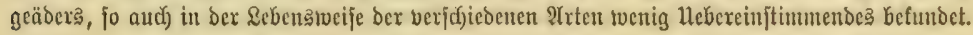

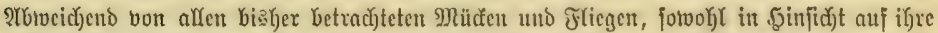

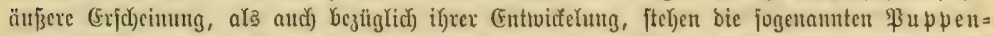

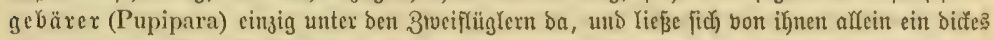

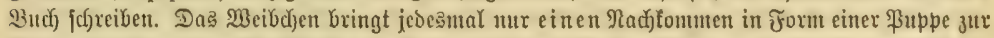
Welt, eine Rarbe, weldxe fid) bis zur \$uppenxeife im Reibe ber Mutter cutwidelt hat uno bei ber

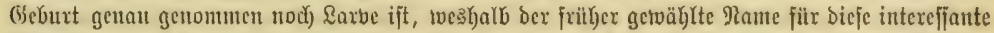

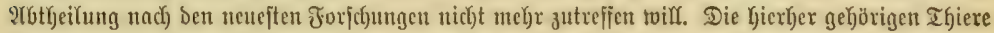

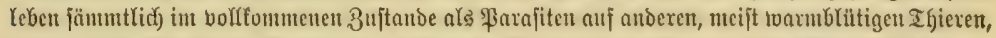

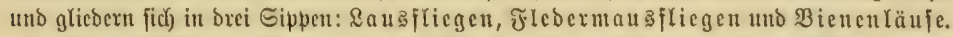

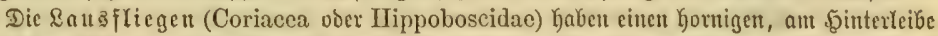

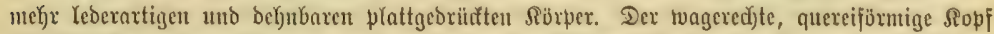

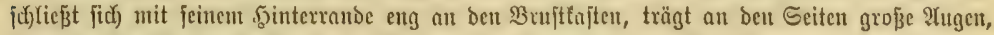

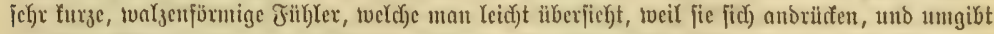

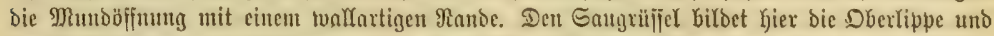

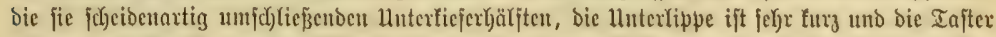
feb)

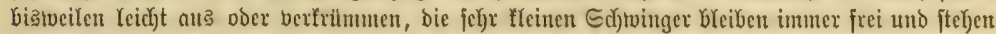

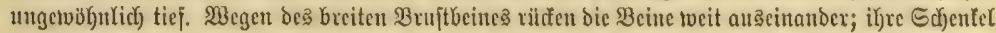

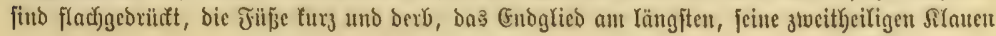




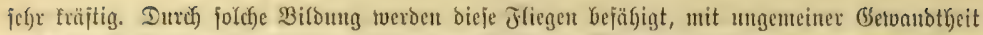

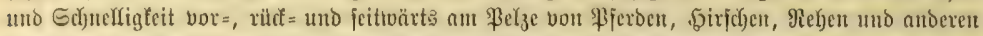

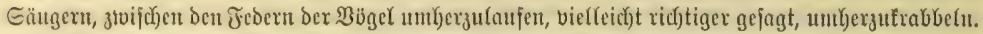

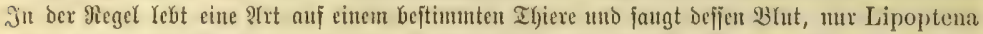

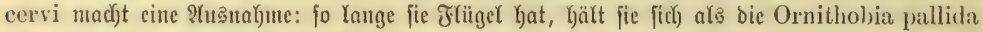

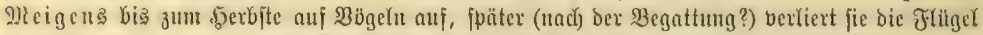

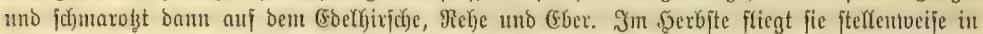

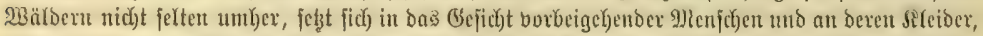

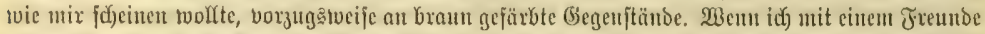

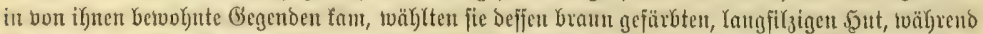

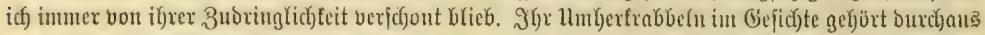
uidat zu ben angenehmen Empfindungen.

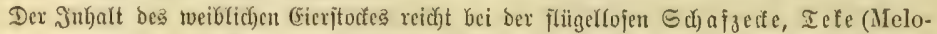

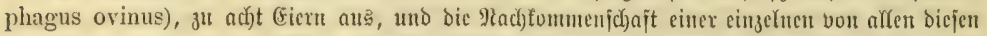

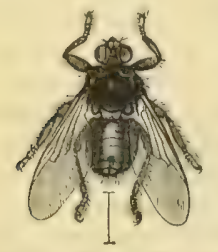

Pferbetaus tiege (IIlppobose equina), vergröbcrt. Fliegen bejchräntt fich auj eine nux fehr geringe 2 (nzobl. (Eine gropere, Gaumartig berztweigte Dritje jonbert eine Flitjifgteit $a b$, weldye bie in Der (Entridelung begriffene Rarve gierig auffiaugt. Went jie geboren tviro, ftelft fie einen glatten, obaren förper ohne jede BStiedenung

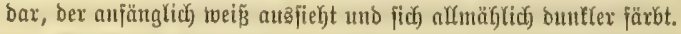

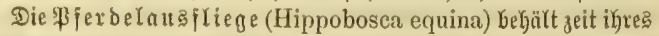

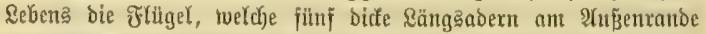
fentreidrnen; bie exjte ijt boppelt, bie ztweite und oritte fino einfad), lebstere fommit fajt in ber Flügchuitte aus bex jtweiten und trifft

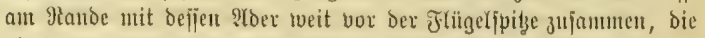

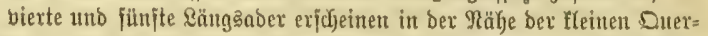

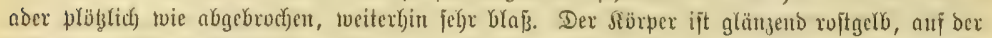

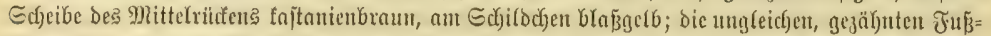

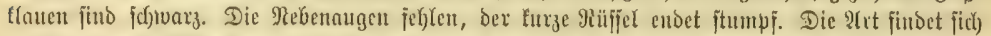

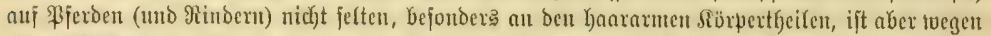

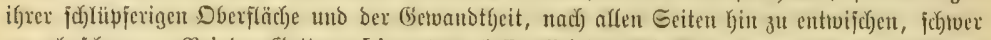

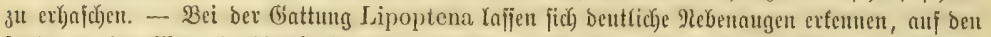

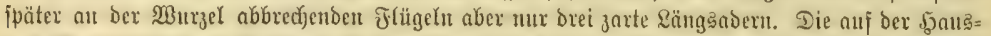

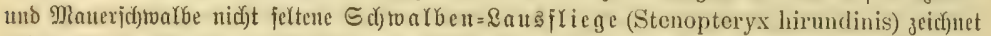

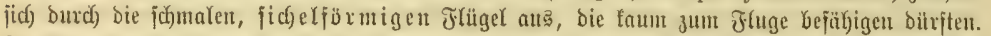

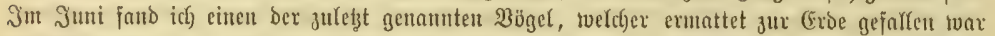

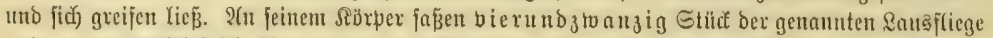

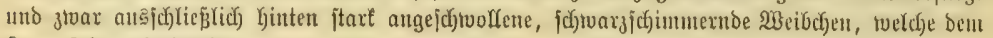
Regen jehr nahe ftanden.

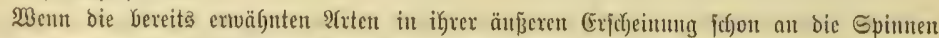

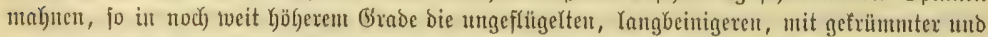
vertängerter Jerje berjebenen Fle berm a u

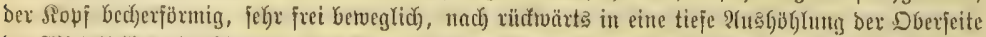

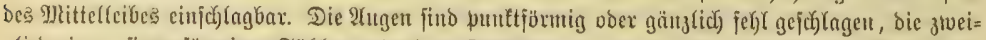

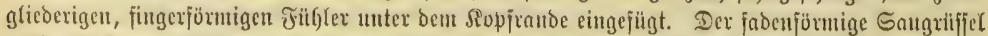

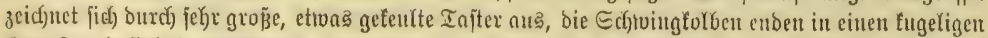

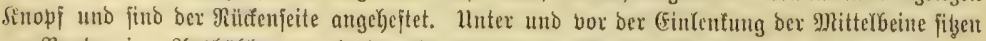

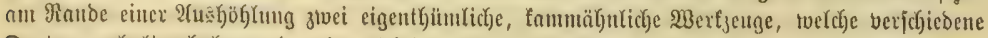

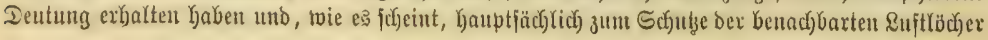




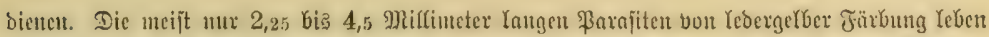

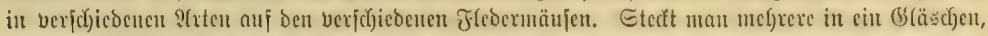

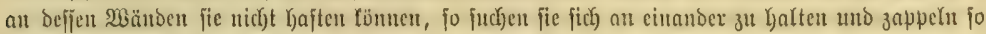

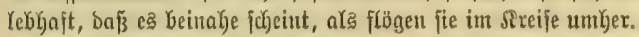

Die verfdhiebenen befprodyenen Sonderbarteiten finden fich an aufaflenoften bei ber flügrl=,

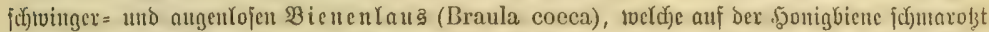

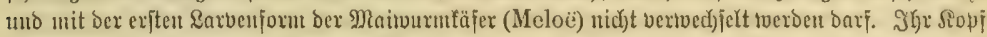

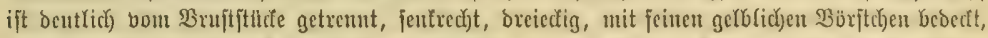

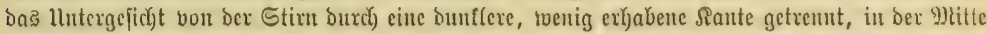

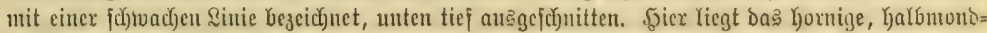

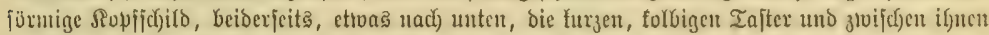

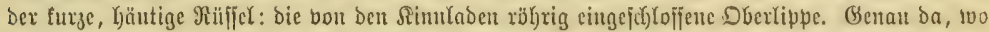

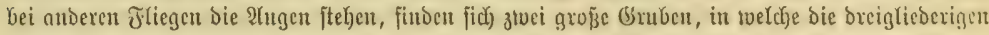

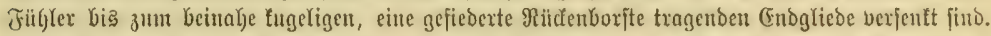

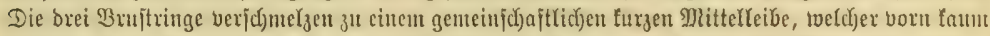

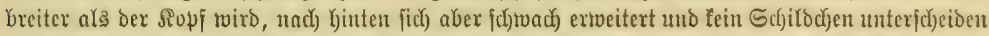

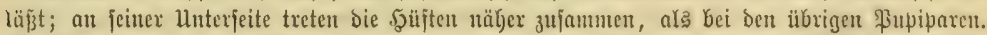

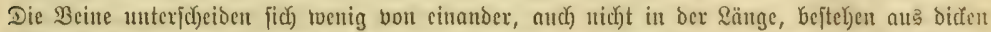

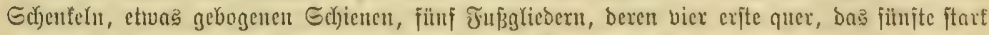

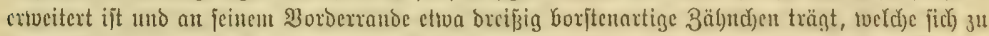

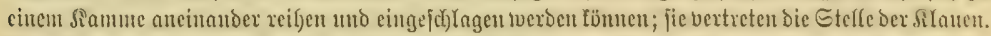

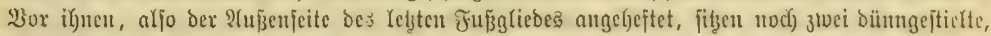

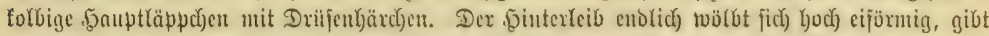

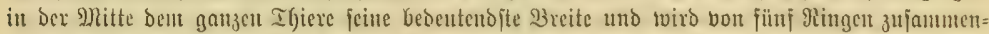

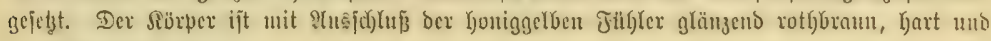
1,5 Mlifimeter lang.

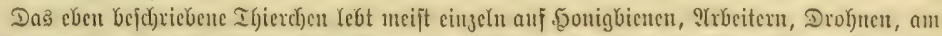

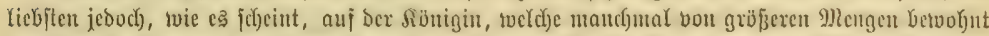

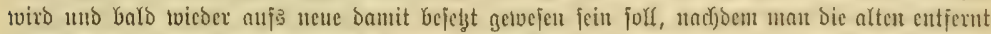

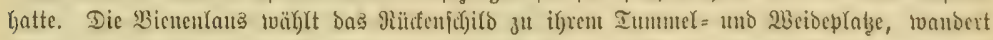

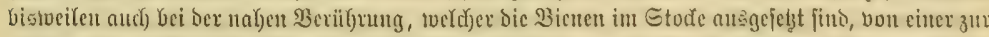

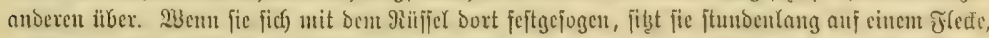

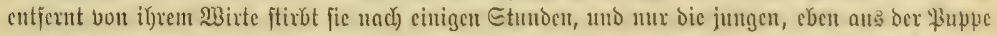

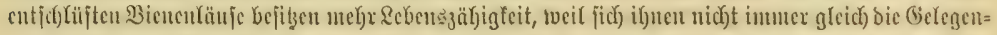

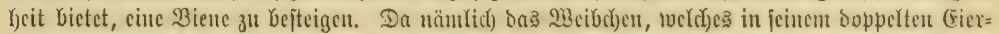

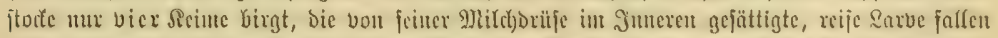

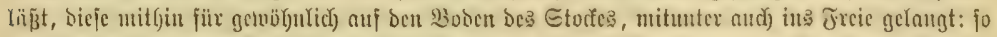

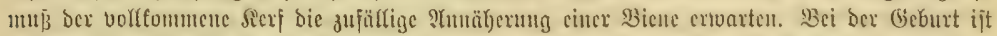

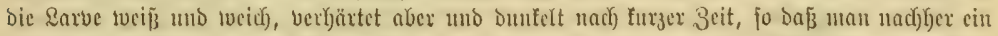

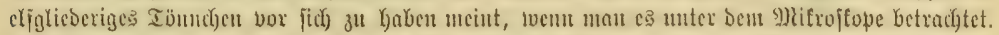

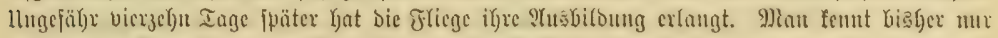

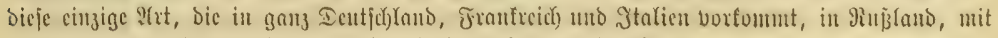

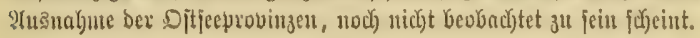

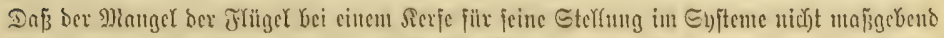

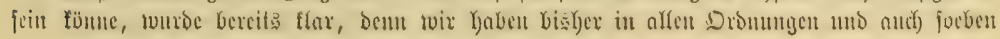


bei ben Fliegen cinzelne ungeflügelte fennen gelernt und tverben and jerner bergleich)en begegnent,

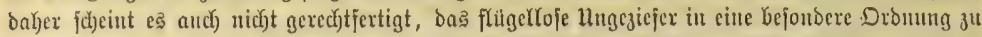
bereinigen, svie ntandje Forjcher getwolft Kaben. Die Ratur Kat eimal fein Syjtem, fondern

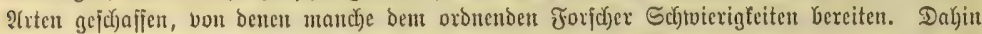

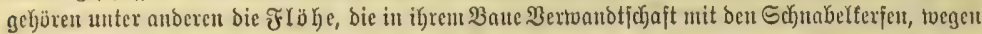

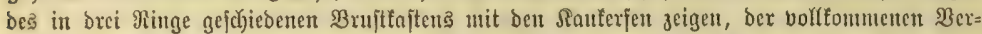

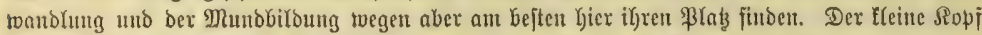

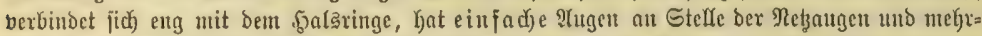

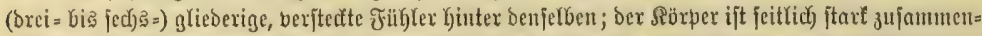

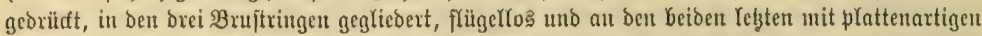

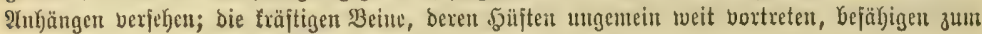
Springeu.

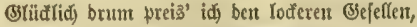
Pulex, ber Turner in brauten Tricot,
V̧⿻上丨 ex in Sprüngen, berwegenen, jdjnellen,
Şimumelgod) jaudjset frifd, fromm, fret unb froh!

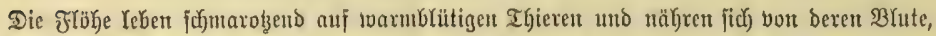
ilyre Rarben bagegen von afferlei faulenden Stofjen, Gejonbers bom Mifte. Früher rech) mete man

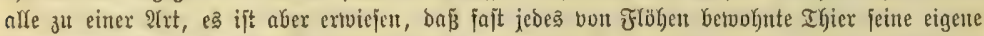
beberbergt. Der nebenftełend ałgebilocte gemeine Jlok (Pulex irritans) bes Menfichen ijt

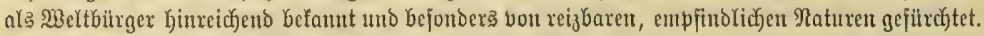

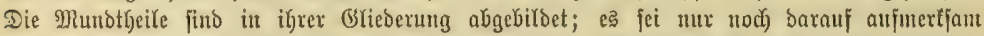

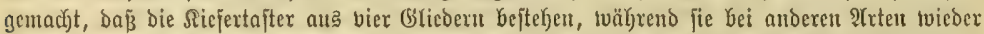

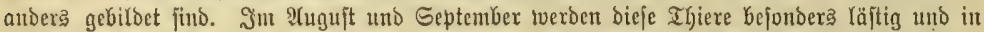

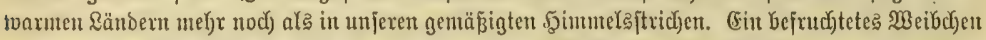

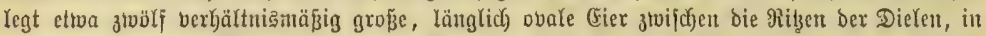

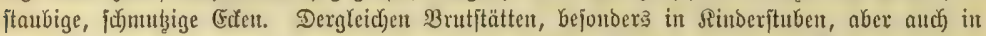

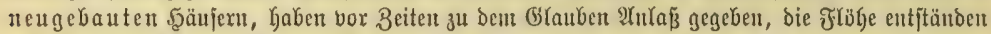

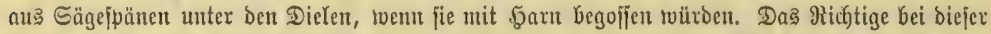

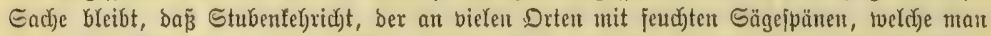
borker zum Eprengen gegen ben Staub antvendete, gemengt ift, eine befondere PYuziebungefrajt

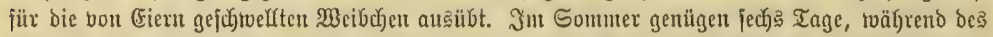
Winter in gefeizten 3 immer bie boppelte 3eit, un im (Fie bie \&arbe (Fig. f) zur Cuttwidelung

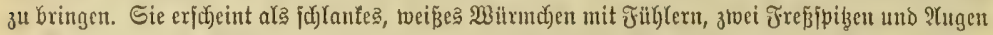

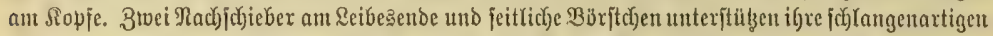

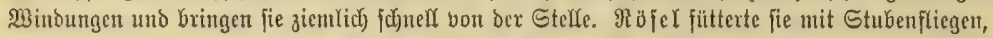

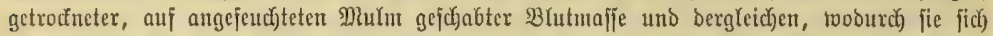

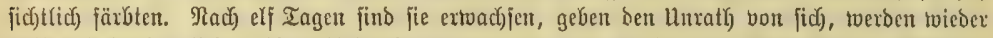

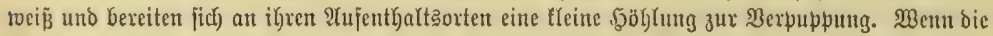

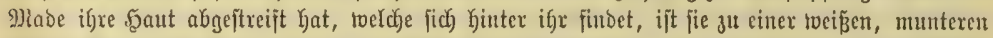

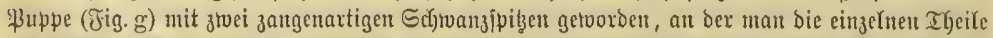

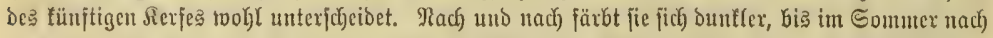

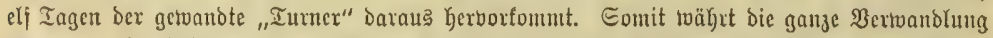

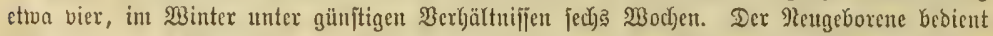

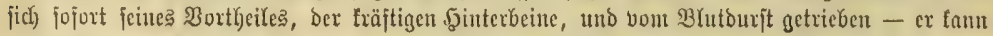

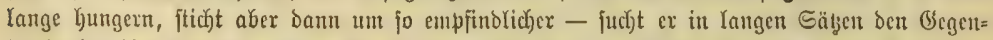

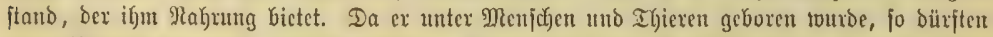
feine Benübungen bald belohnt weroen. Mit meijtergafter Fertigteit bohrt er feine fpitzen 


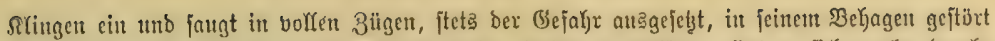

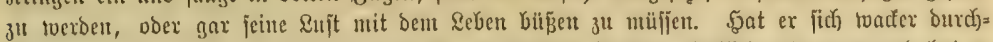

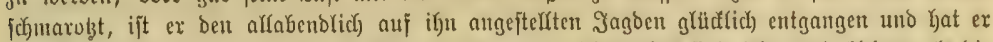
Den (begenjtand feiner thierifachen Ricbe gejunden - bie Männot)en find bedeutend tleinex ala bie

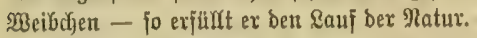

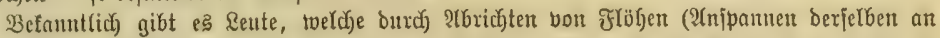

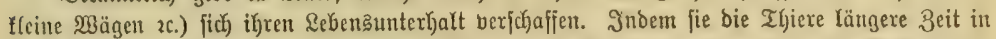

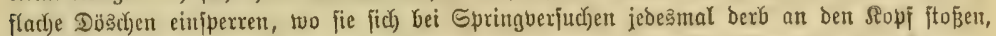

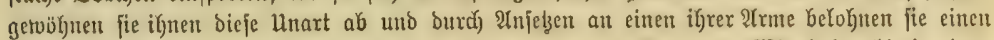

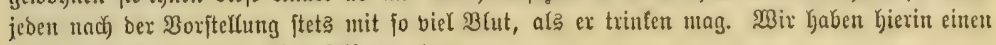
neuen $\mathfrak{B e t v e i s ~ d a j u ̈ i x , ~ D a ß ̄ ~ b e n ~ T h i e r e n , ~ d e n ~}$ unbedeutenoen Rerfen, eine getvilje Yjöhere gei=

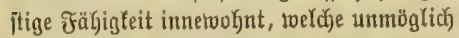

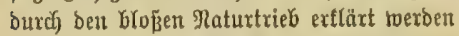
fann, twie von getwifien Seiten berjudyt twirb.

2rbgejełen von ben biełen anberen Irten

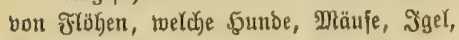
5ühnex зc. betoobnen uno nod) nidjt genau gejchieden toorden find, gibt e马 einen jübames ritanijichen, ber für ben Menjaden unter um= ftänচen hödjit gefäbrticf tocroen fann unঠ

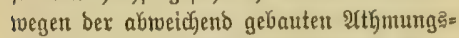
rextzeuge, Der bexjjiedenen from Dex finn= raben uno ber tajterartigen शtulyänge ber ztweippaltigen Unterlippe ben \$ulexen entrüat und zu einer bejonderen Ǵattung erfoben tworbenift. Der Sandiloh, (cid)ao, Jiger,

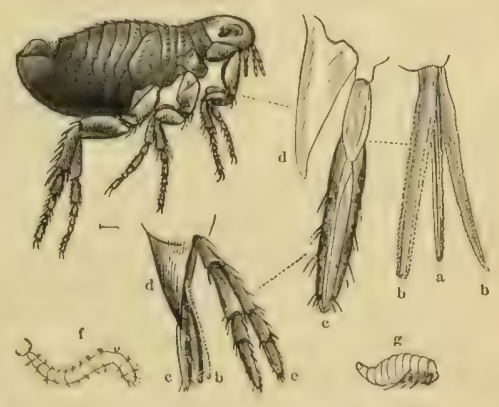

(5emeiner Flob (Pulex Irritans), a Dberlippe, b Simbaden (beides bie Eled)lverfjeuge), c Iafter ber Unterlipbe, a Dicle felbit, - Iajter ber furzen, nidit fidjtaren sinnlaben, f Iarbe, g łuppe. थHes berbedsert.

Rigua, $\mathfrak{F}$ id) o(Rhynchoprion penetrans),

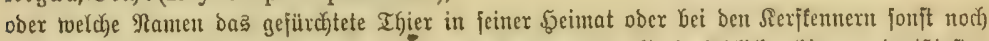

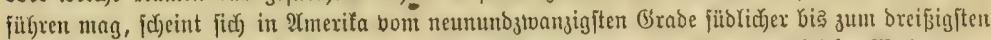

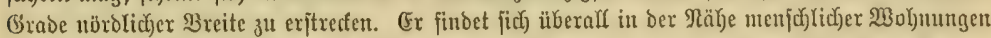

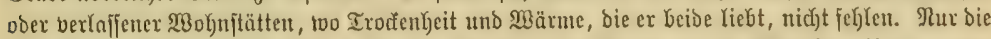

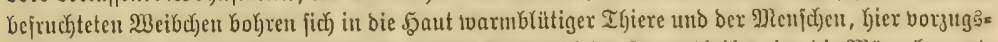

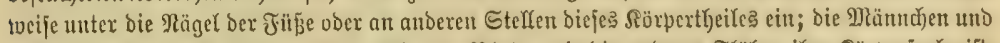

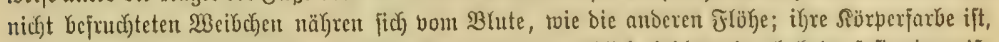

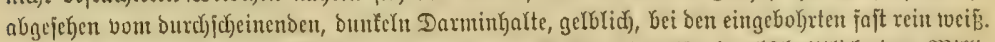

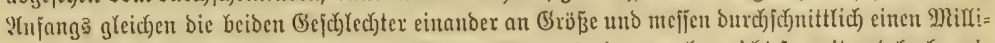

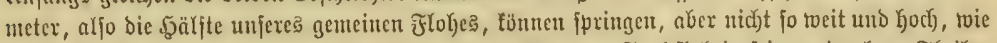

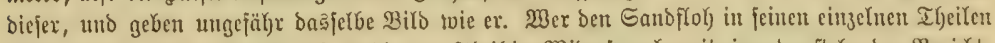

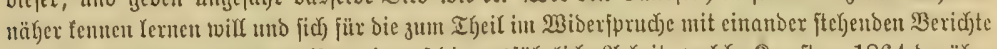

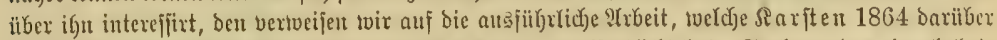

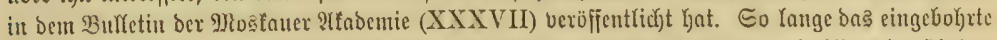

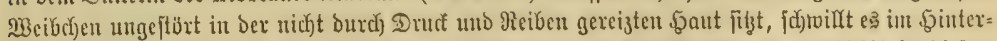

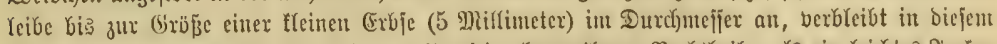

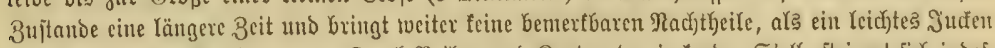

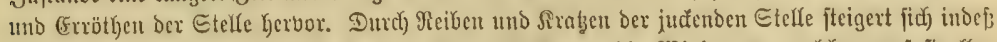

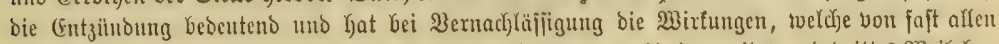

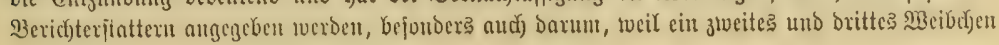




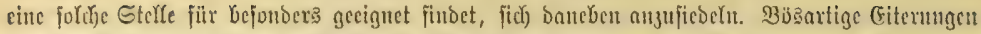

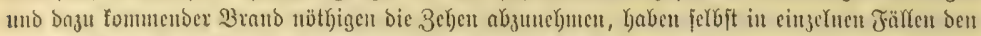

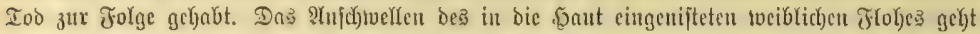

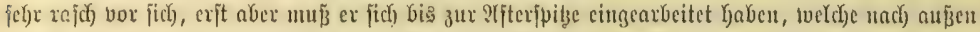

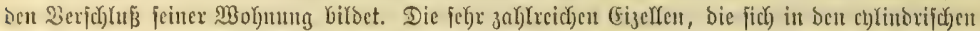

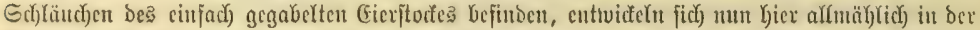

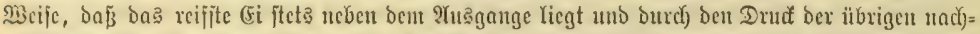

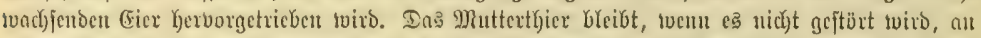

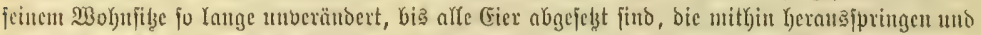

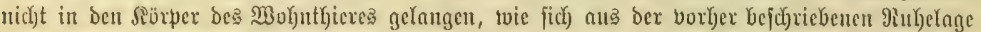

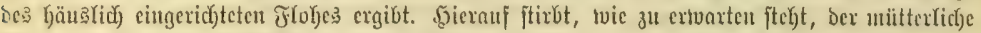

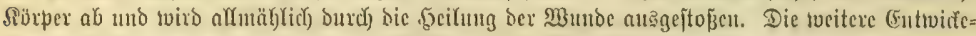

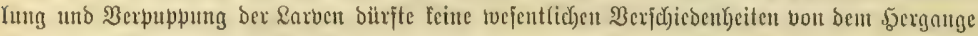

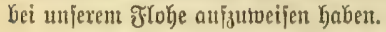

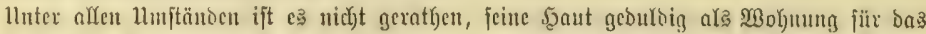

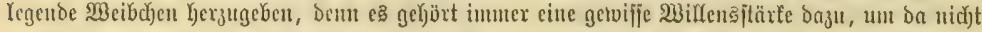

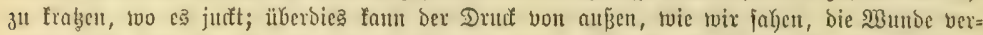

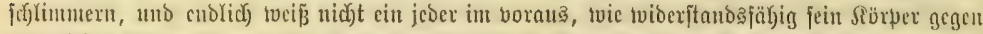

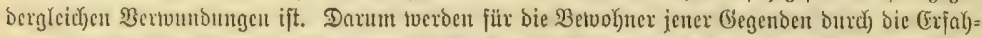

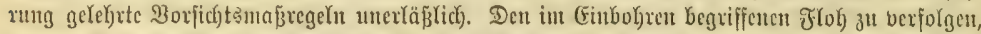

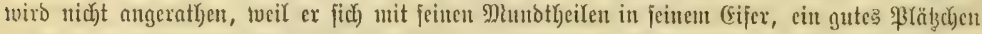

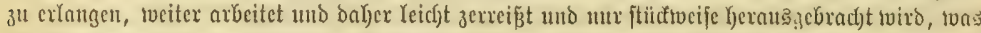

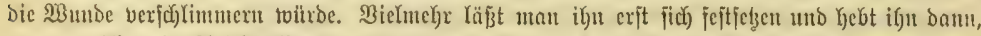

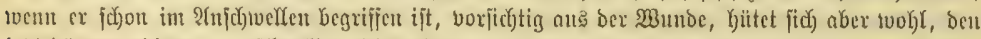

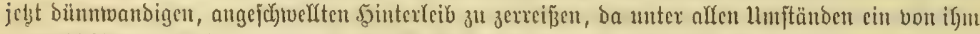

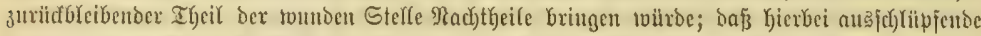

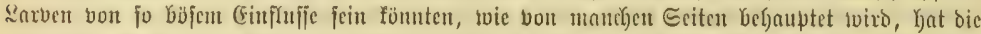

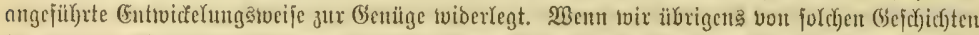

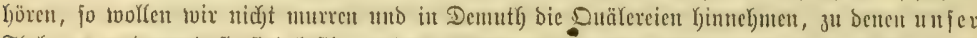

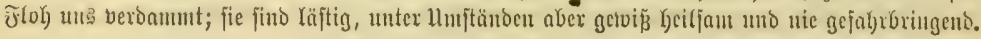




\section{Tiinfte Oronutu.}

\section{Dic Nich= oder (Sitterfingler (Neuroptera).}

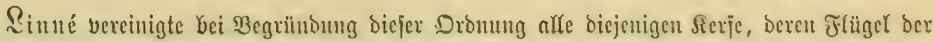

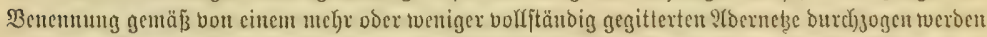

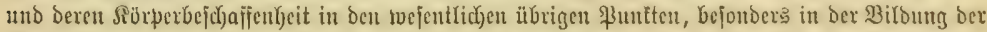

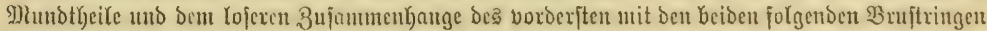

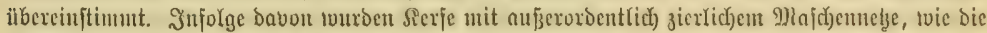

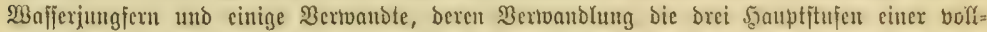

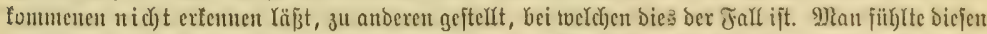

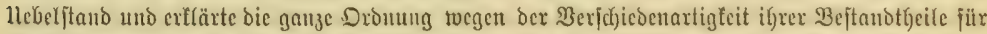

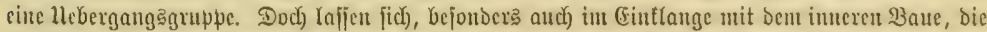

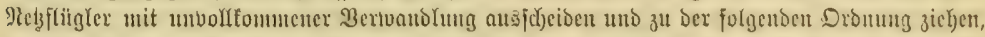
swie bies Kier nad) (Exid) fon

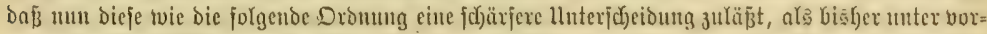

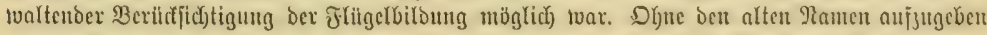

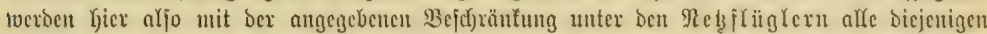

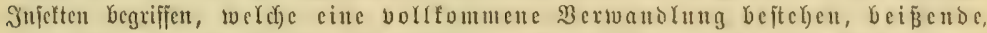

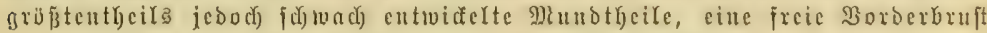

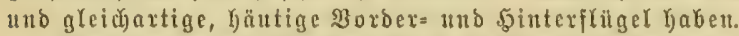

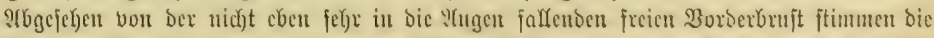

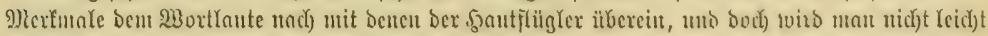

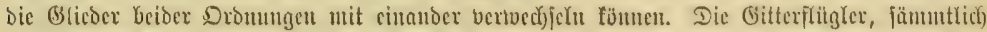

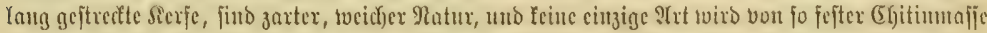

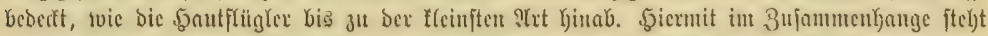

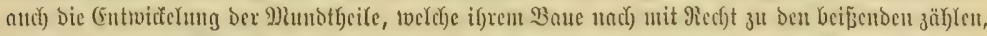

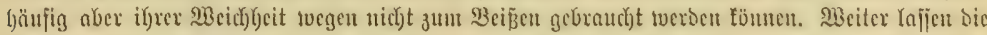

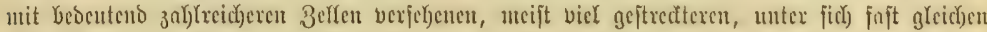

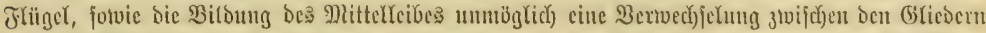

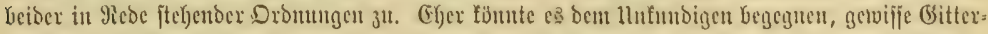

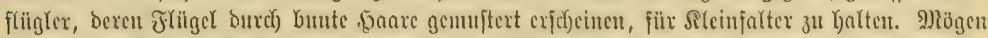

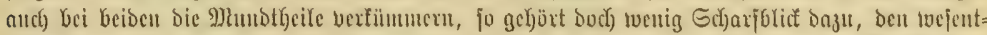

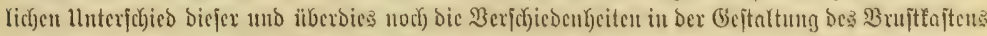

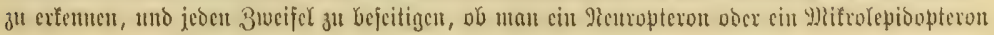


vor fick Gabe. Die volfommenen Jnjeften biejex bon ber folgenden Dromung allenal mit Sichers

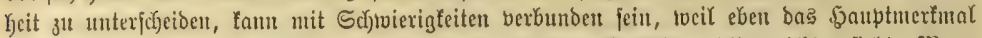

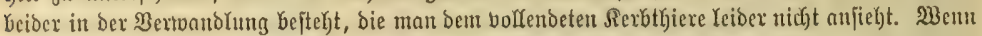

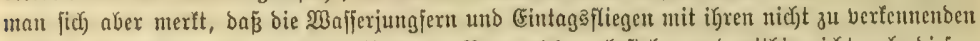

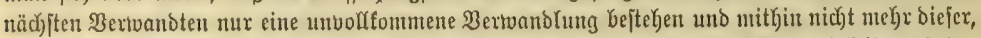
fondern bex jolgenden Dromung beigezäh)lt werben, jo jubrvindet aud bieje Schtoierigteit, und ber

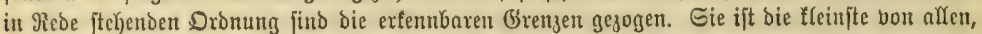

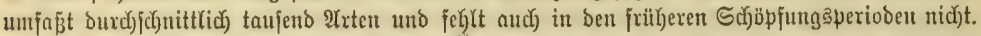
§n ben älteren Sdyidjten treten bie berjteinertên lleberrefte nur fparjăan auf, was bei ber Zartheit

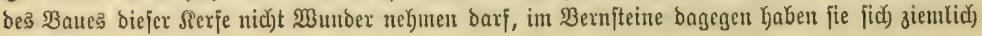
zaljlreich erfalten.

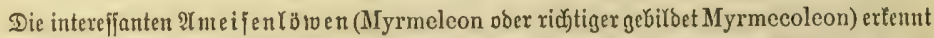

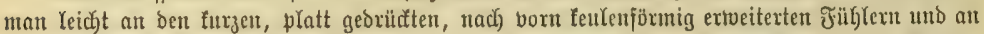

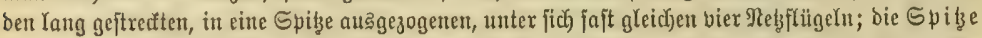

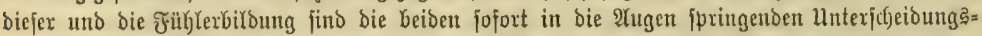

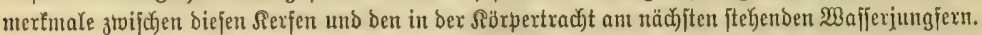

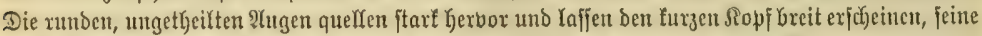

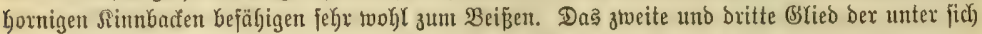

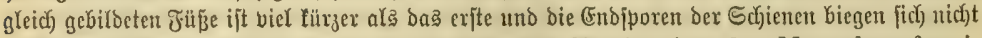
Gatig un. Bein gemeinen $\mathfrak{X}$ meijenlötven doer Der $\mathfrak{A}$ meifenjungier (Myrmeleon formi-

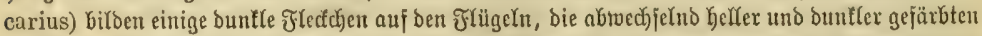

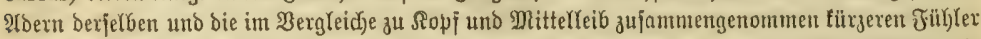

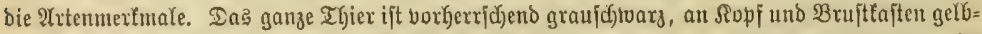

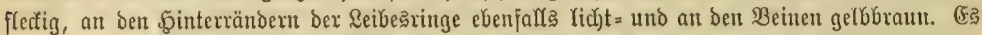

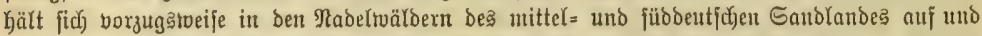

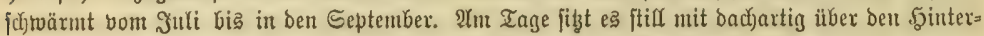

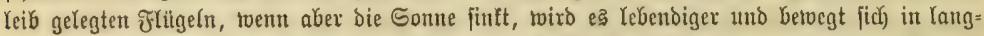

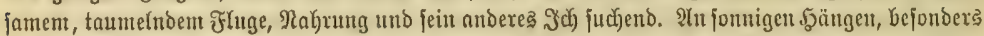

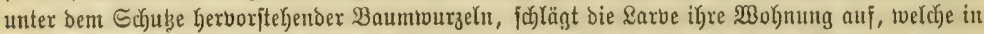
cinem fleinen Trichter befteht, in Deffen (5runte fie verjtedt, mit emporgeftrcten Bangen auf Bente

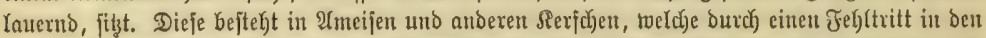

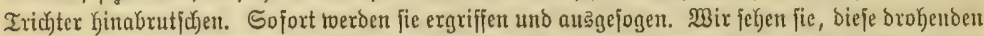

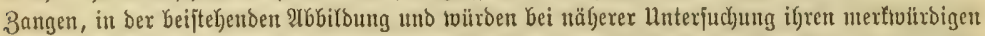

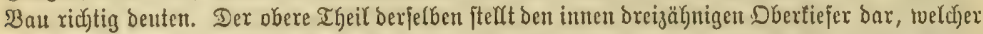

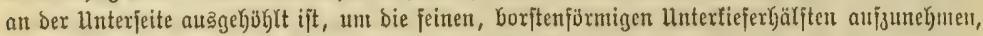
mit twelchen zujammen bas ভaugwert hergeftelft ijt. Die Tajter an Kełzteren jeblen, bie ber \&ippe bagegen beftehen aus einem auffallend grofen, elliptijuchen osrunogliebe, bem brei fleitere, chliu=

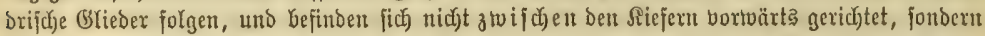

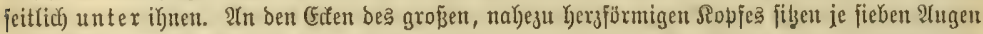

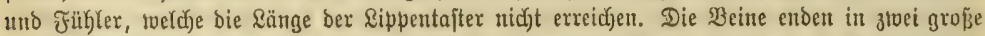

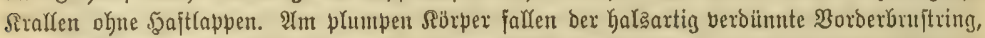

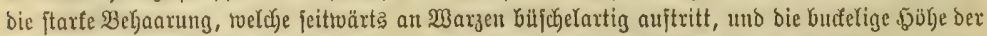

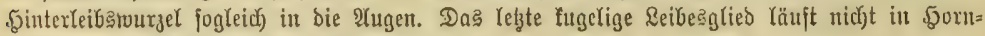
plättçen, joutoen in beborftete Wargen aus.

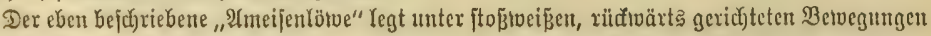

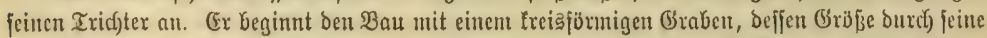

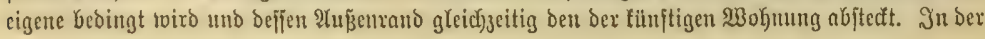




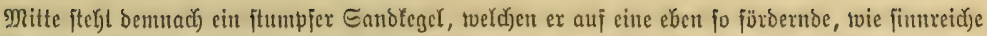

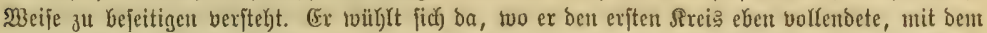

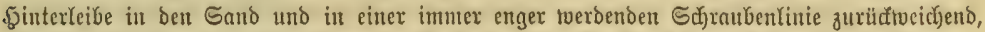

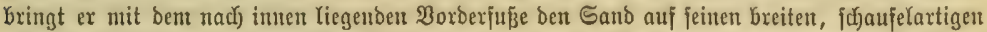

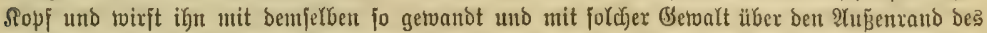

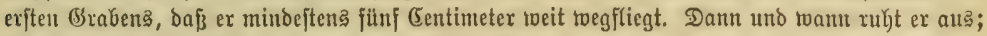
ift er aber bei ber Irbeit, fo ergeugen bie flinten Betvegungen einen unuterbrod)enen Sandregen.

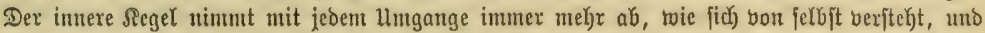

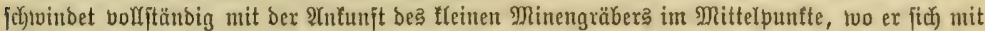

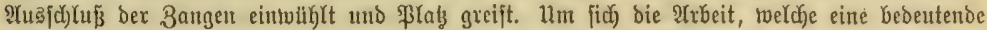

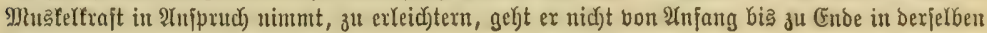
Richtung, fondern brefyt fich bon Zeit 3u 3eit um, bamit eimmal bas linte Bein Şanblangeroienj:te verrichte, wenn e马 bisher bas rechte gethan hatte. Sium= men gröbere Sanofürnex in ben $\mathfrak{W e g}_{\text {, }}$ trasె nicht auğbleibt, jo twerben fie ein= zelı aujgelaben, noch größere, twelch)e fid) nidjt rerjen laifen, twohl gar auf

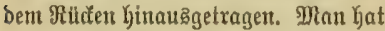
beobachtet, daß̄ in biejer ફminicht

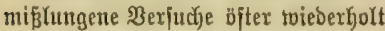

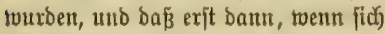
alfe Bemlihungen exfolglos zeigten, ein

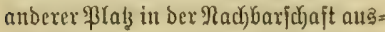
gejucht wurbe, um hier bie शrobeit in

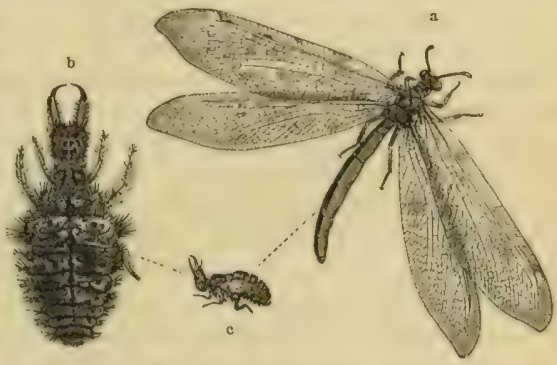

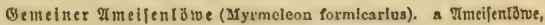
b, c Larbe; mur b ftart bergröbert.

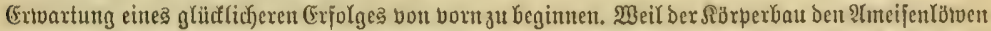

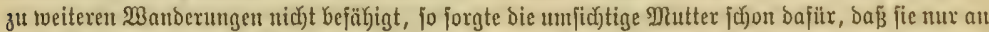

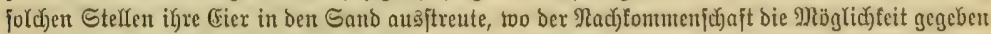

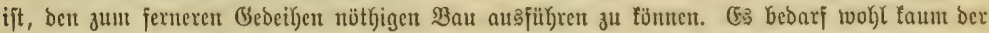

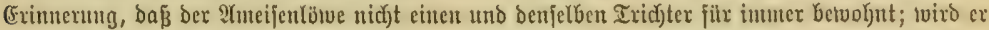

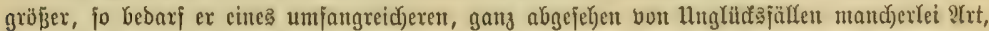

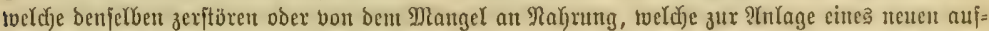

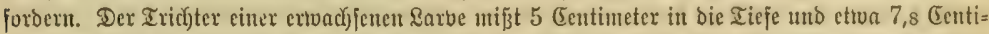

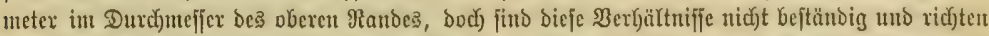

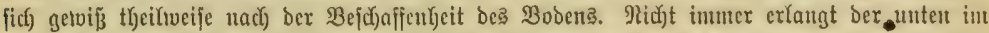

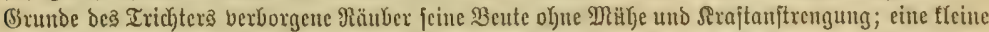

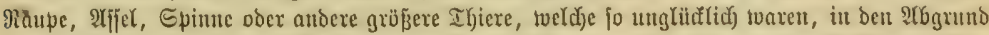

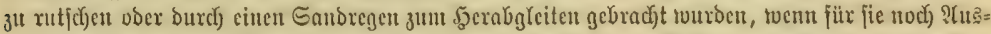

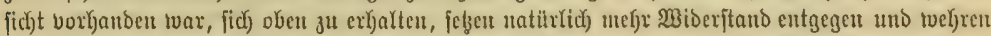

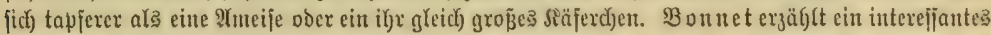

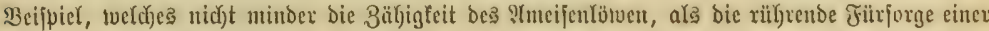

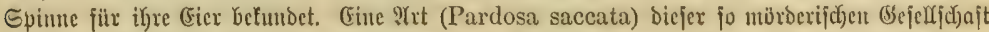

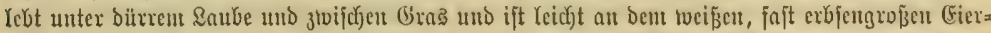

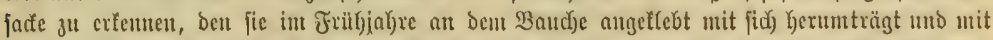

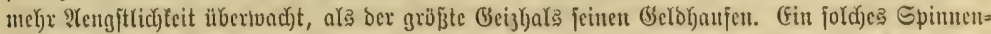

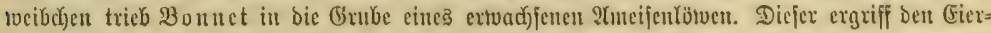

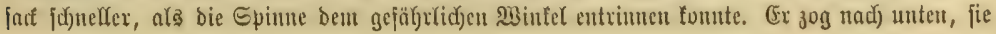




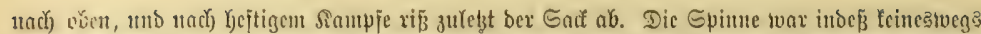

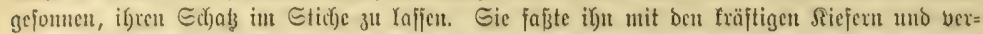

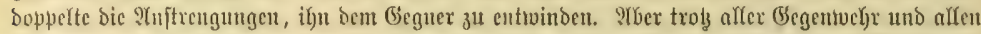

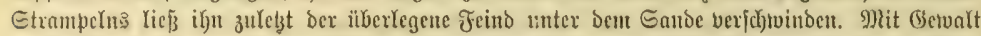

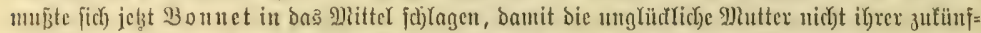

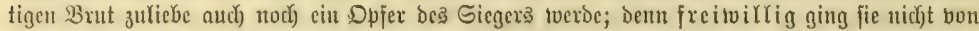

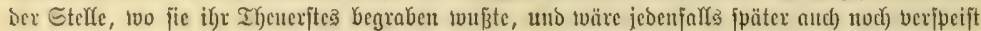

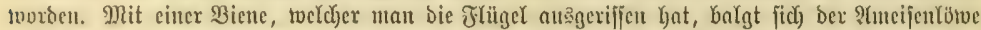

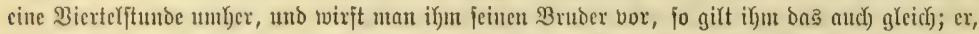

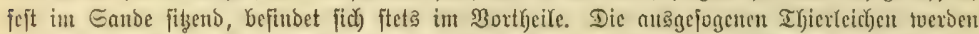

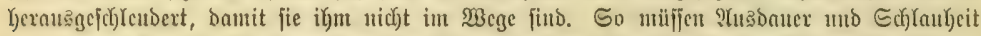

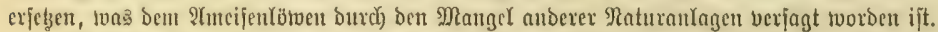

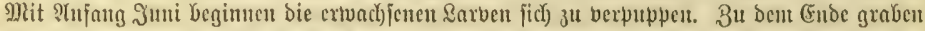

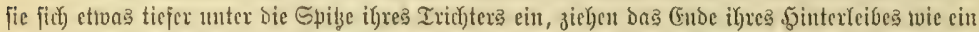

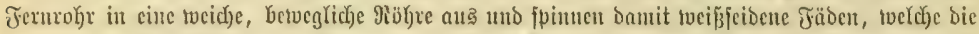

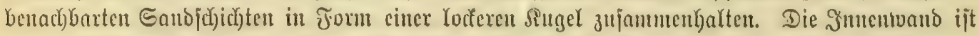

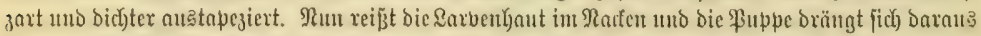

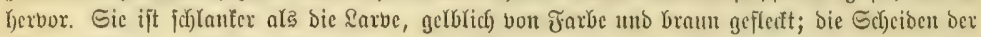

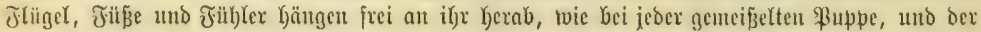

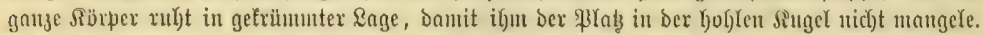

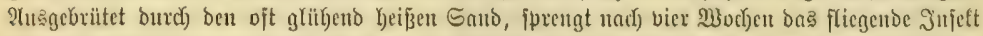

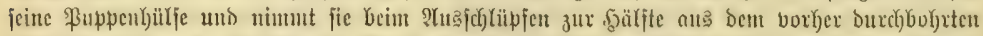

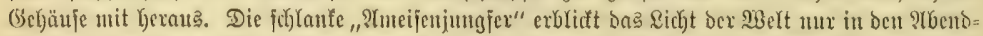

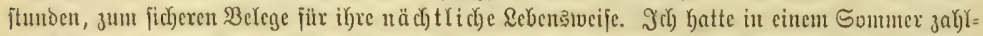

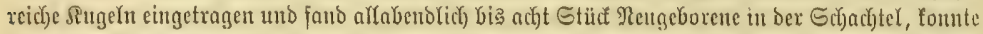

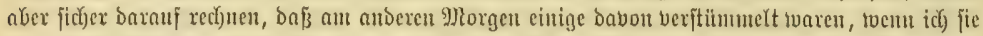

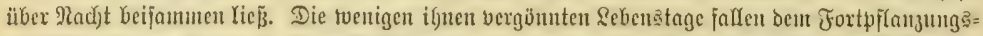

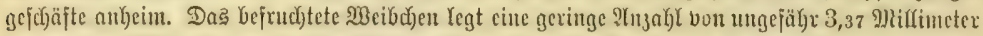

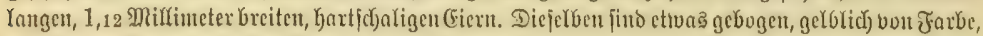

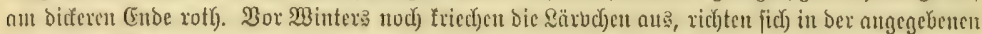

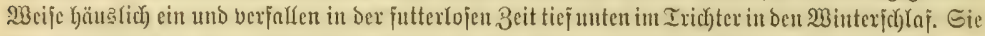

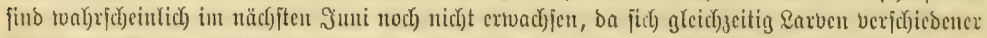

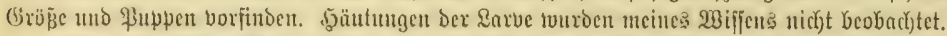

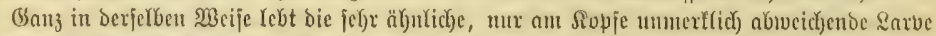
ber ungefledten ? Tmeijenjungict (Myrmeleon formicalynx), weldfe mit ber vorigen ?(ut iu

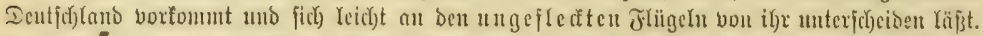

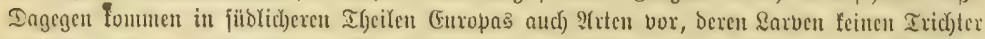

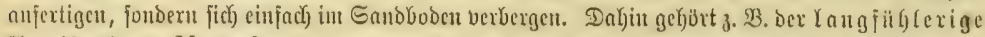

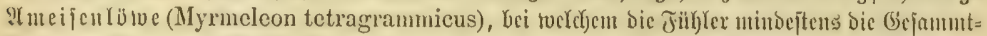

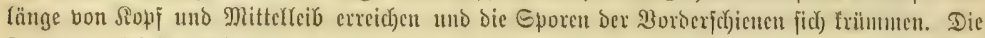

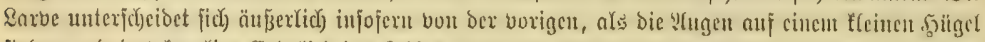

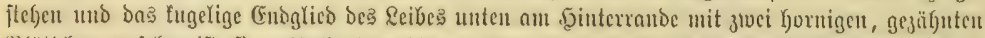

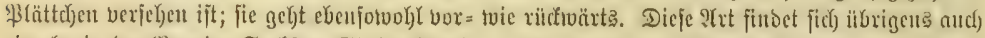

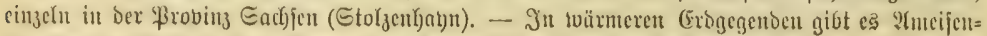

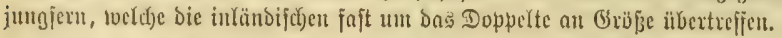

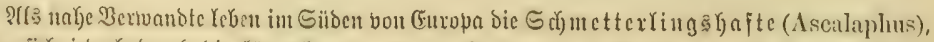

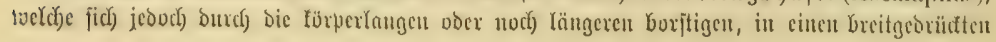




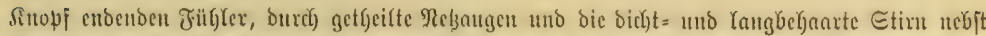

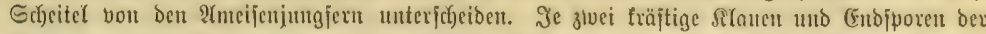

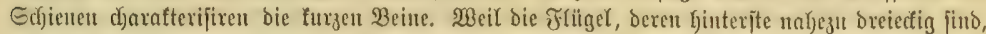

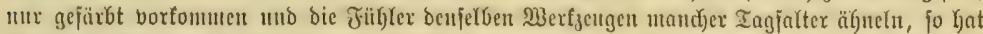

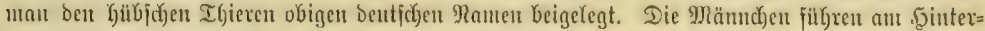

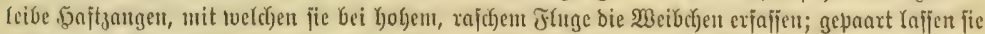

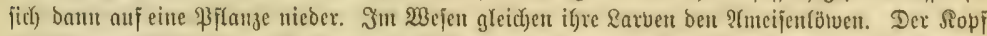

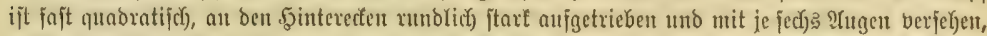

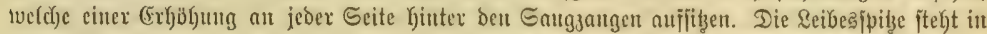

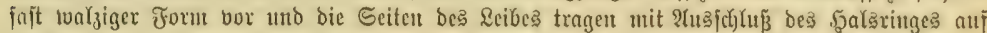

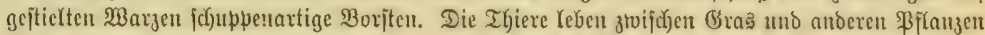

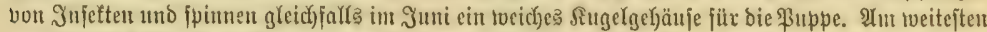

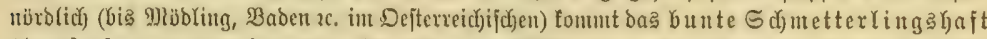

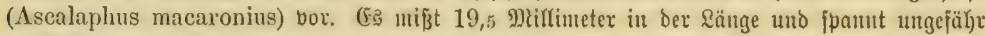

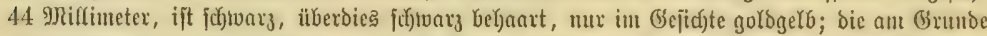
breit gelben Borberflïgel zieren ztvei großje braune Flecte auf bent angeräucherten Saumfelde, bic

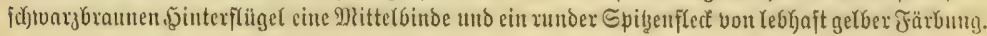

Die Florjleget, Blattlaugflegen, Borbangen (Chrysopa), fino treinere Reb=

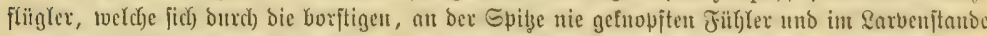

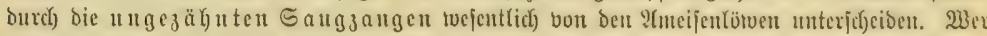

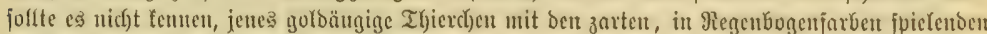

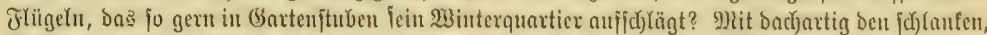

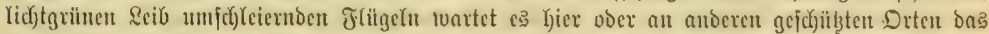

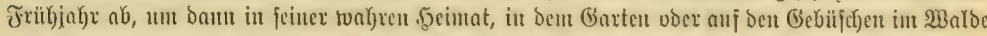

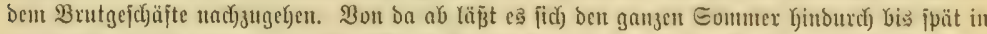

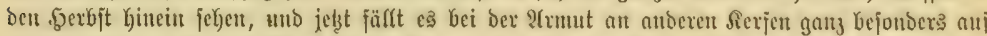

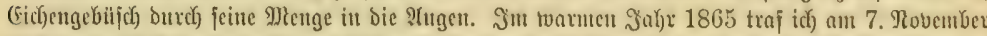

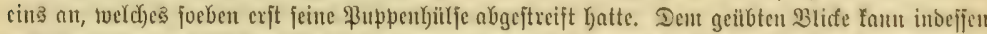

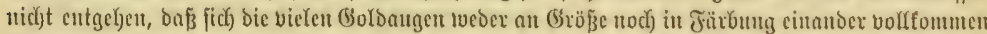

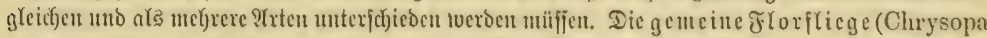
vulgaris, Fig. a, S. 494), von হinué mit Beinifdung nnberev \$rten Hemerobius perla

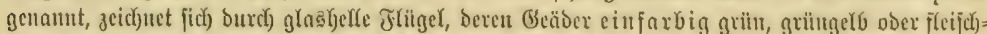

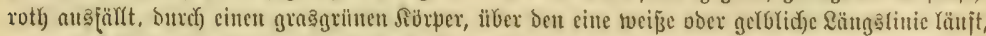

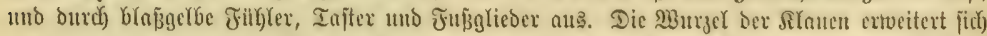

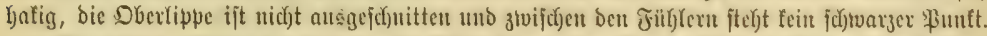

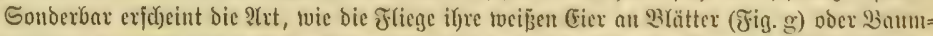

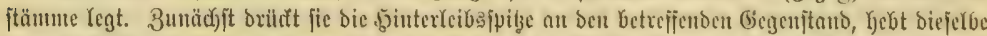

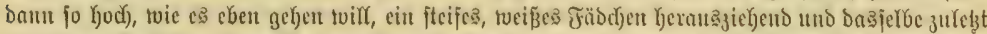

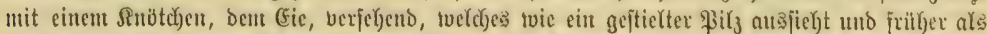

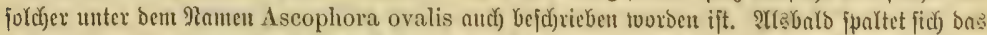

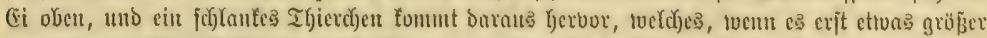

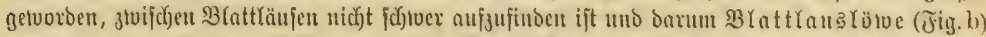

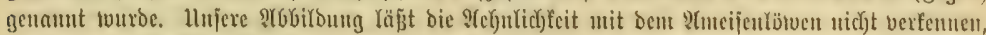

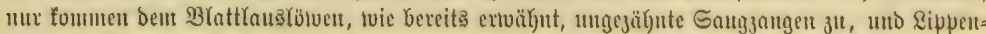

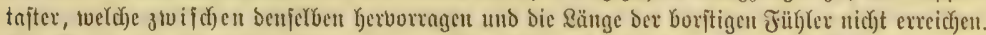

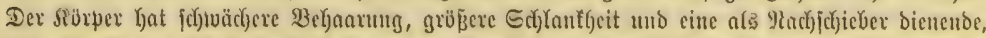

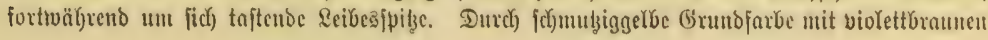




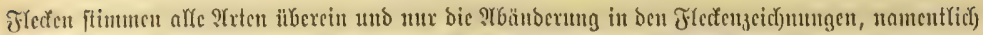

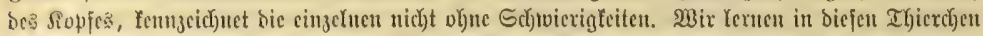

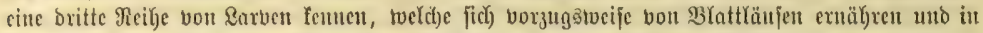

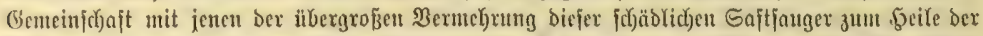

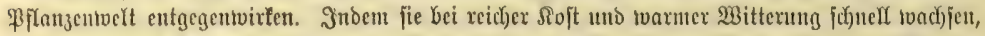

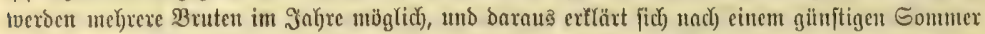

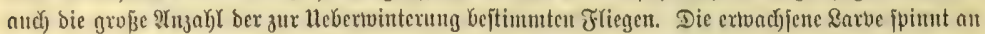

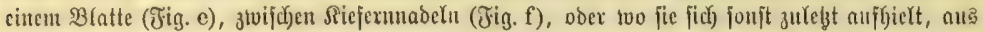

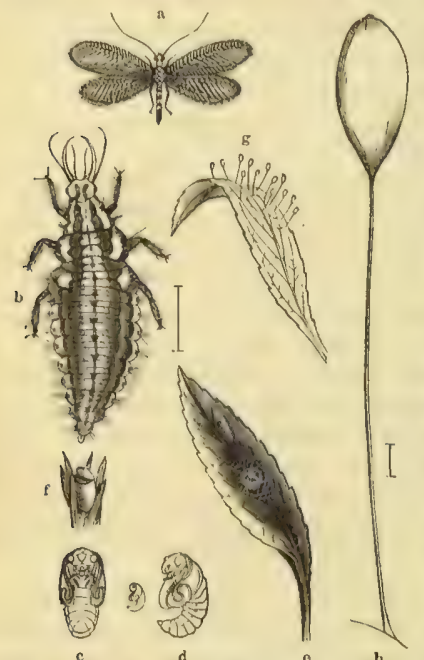

Oemeine frorflicge (Chrygopa vulgaris).

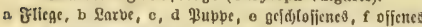

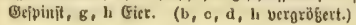

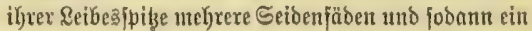
zienrich fejtes, jaft fugeriges (Gehäuje utm jich), worin fie zur \$uppe twirb. Beibe bebltrjent teiner weiteren Erörterung, jonbern nur eines $\mathfrak{B l i d f e s}$ auj unjere

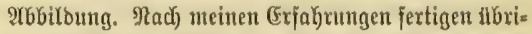
gens nicht alle $\mathfrak{\text { Yrten ein }}$ Bejpinjt. Die gemeine Florfliege ift itber gant (5uropa nusgebreitet uno fommt aud am Sap ber (Suten Foffmung vor, andere Irten Yeben in Europa und wieber andere in ben übrigen Crotheilen.

Man twürbe die \&andjungfern(Hemerobius) faljud beurtheilen, toen man infolge bes twifjenjchaft= licken Namens iGren Trten eine nur eintägige

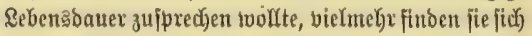
mit ben Bolbaugen zufanmen, nur nidjt fo zable

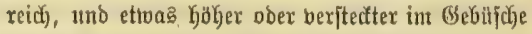
und zur llebertwinterung bereit. Dic Thierchen tragen ifre breiten, Käufig geffectten oder ১urd)aus gejärbten

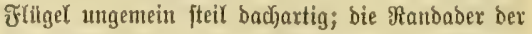

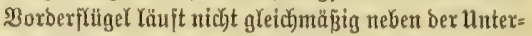
randaber hin, jondern bildet tahe ber 23 urzel nad)

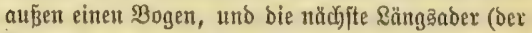

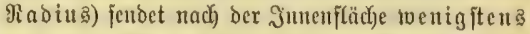
zloei unter fich) gleid)(nufende Plefte (Settoren) aus.

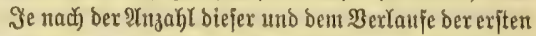

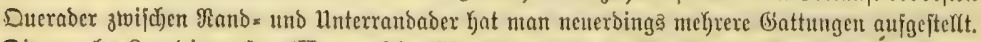

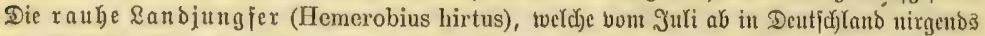

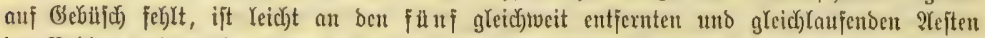

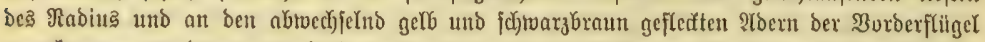

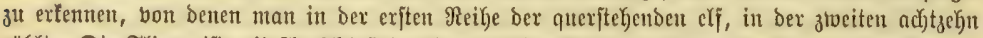

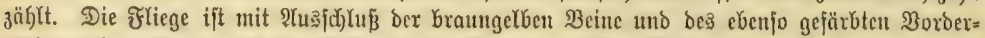

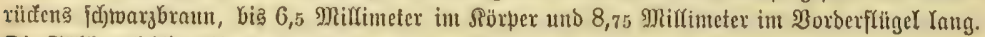

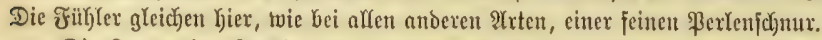

Die Rarben ber Randjungjern ähneln den Blattlauştötoen, Deren Rebensitueije fie fitfren,

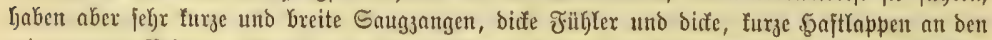
gebrungenen Beinen. Manthe von ifnen Gjitfen fich) in bie auşgejogenen Bälge ber berjpeijten

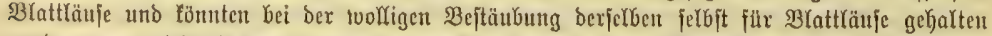

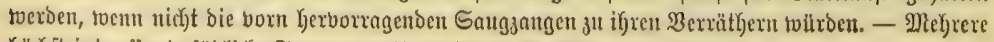

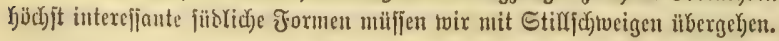


Die Sameryaläfliegen (Rhaphidia), wegen bes geftreften, fefor betweglidjen exften Brujt=

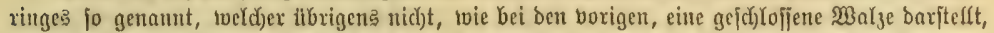

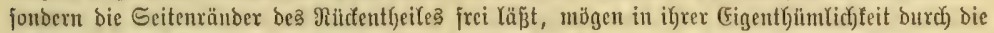
bicefit hy rexige Samergalafliege (Rhaphidia ober Inocellia erassicornis) hiex borgejülyrt werbet. Der Mlangel bex Rebenaugen und ber Dueraber in bem bunfel rotgbraunen Male ber jout glt fie bei jeiner monographifid)en Bearbeitung biejer Bruppe zu einer bejonderen Gattung a erbeben.

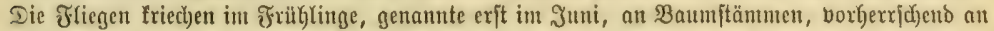

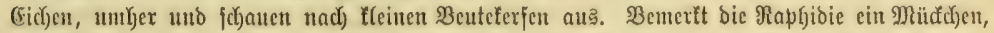

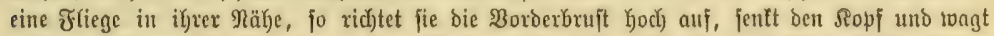

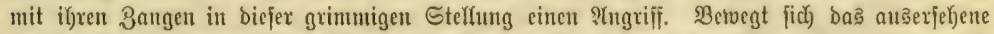
Echladjtopfer in biejem Plugenblide, jo prallt fie twohl aud exft cinmal zurüct, ehe fie zupact.

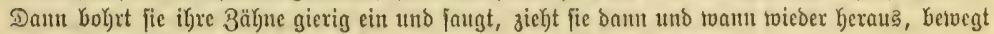
fie rajich gegen cinanber, als twenn fie biejelben tweben rooldte, und fährt

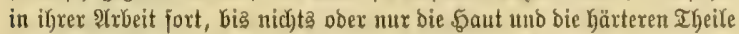
nod) übrig finto. Şält man ifrer gtwei in einent Raume gejangen, jo

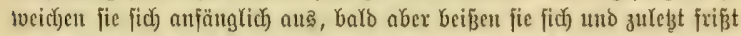
bie ftärfere bie fochtoächere auf, tvenn nicht für andere Sojt gejorgt tworden ift; cine cinzelne fann ntehrere Modjen faften. Shr Kinten Kaläartig ber=

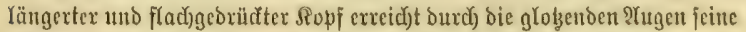

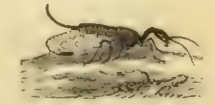

Didfublertge samel. b) cornis). Ratütlidje Oróge.

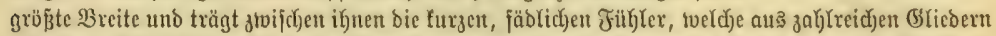

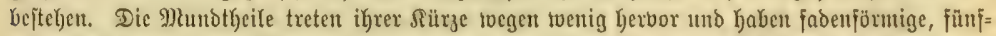

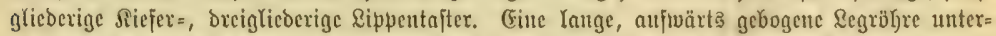

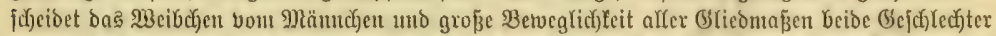

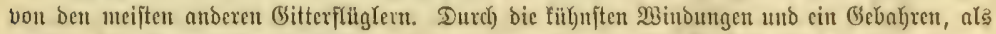

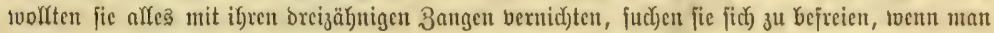
fie łıviłchen Den fringern Gält.

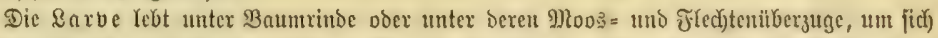

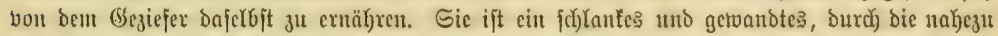

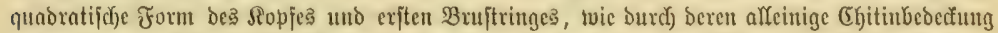

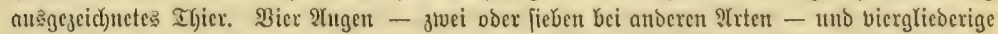

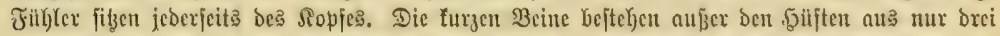

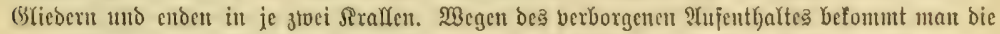

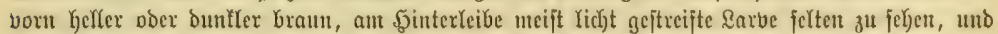

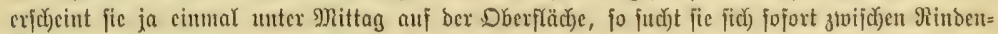

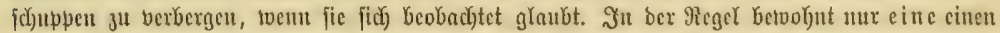

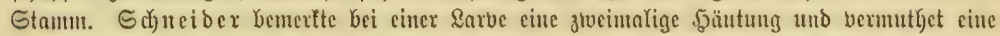

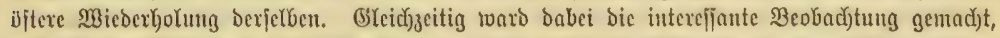

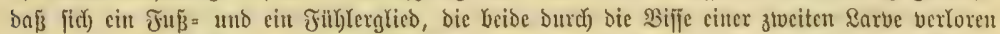

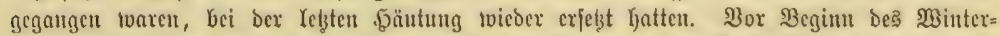

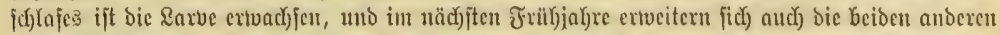

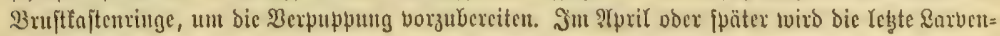
Gaut abgelegt.

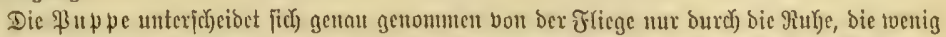

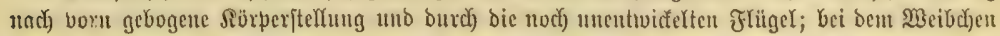

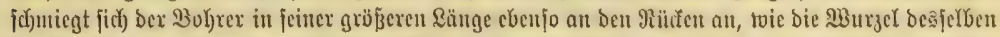

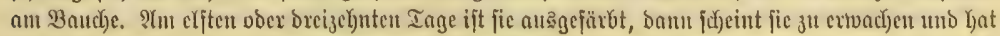

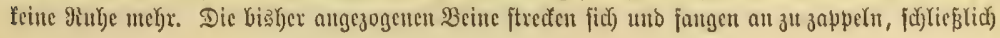




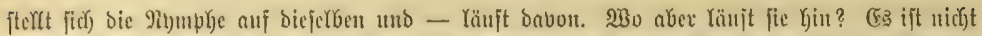

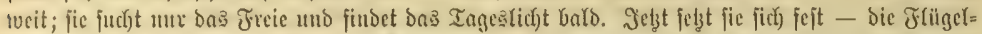

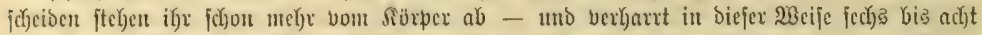

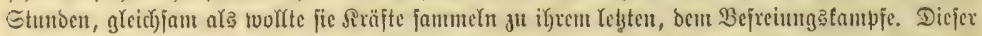

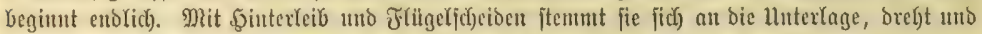

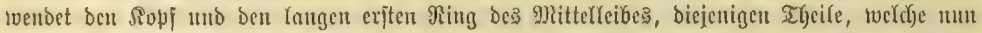

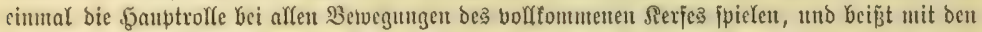

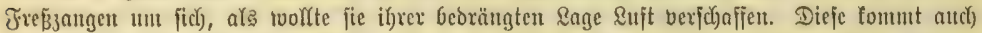

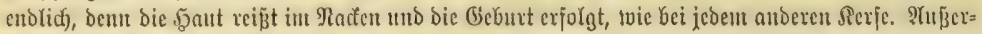

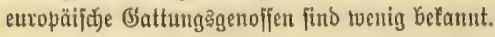

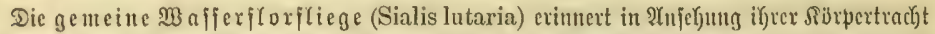

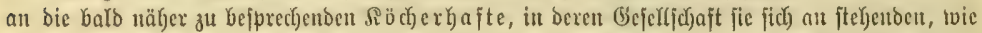

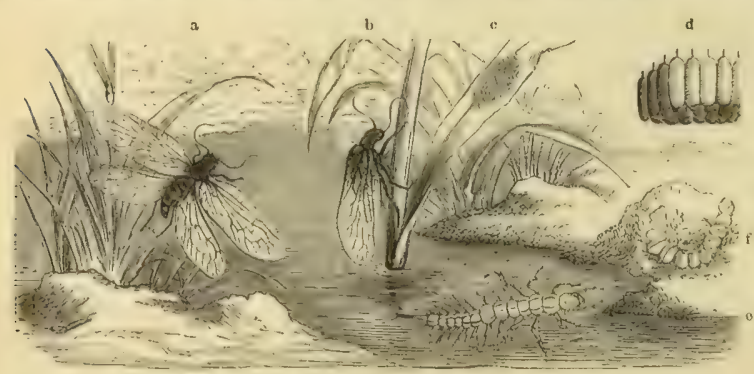

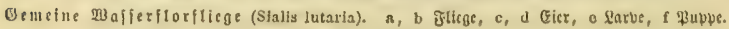
(d, e, f vergrobïert.)

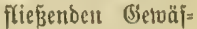
fern umbertreibt, it Den Stellungen toie tvir fie Gier feryen, an

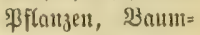
ftämmen, \$(anfelı, Mänoen rulyt oder

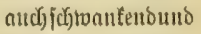
fưftoerfäntig fliegt, boun fie botr dell Strablen ber Soll= ne hiergu ertwärmt 10iro. Dbictyoll fie au[erden mand)= mal eine Etrerfe voit

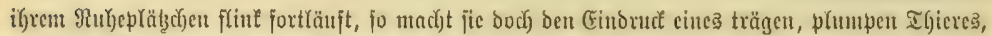

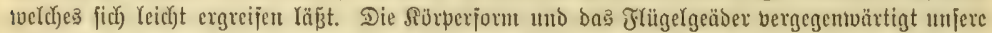

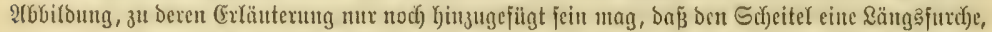

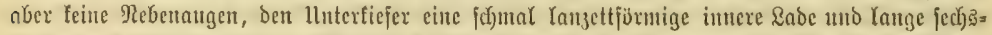

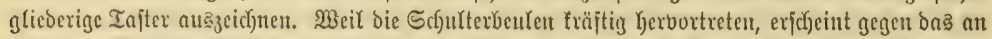

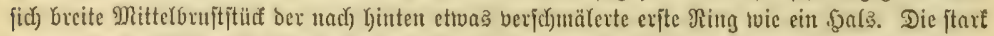

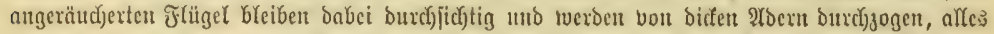

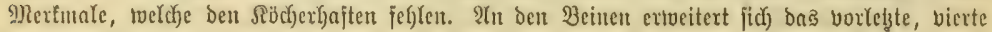

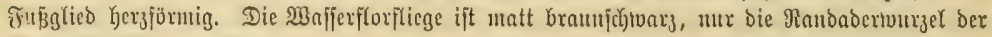
3orderftitgel braungelb.

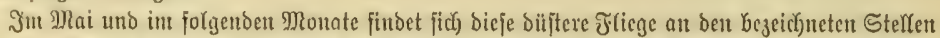

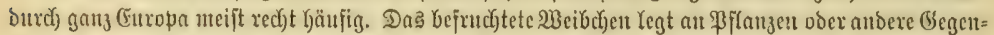

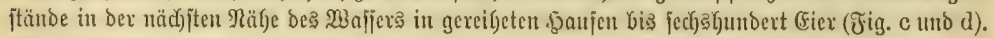

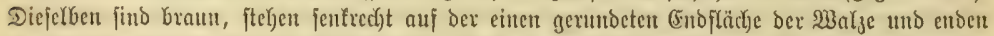

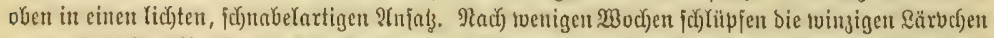

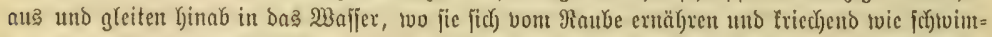

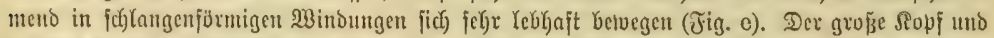

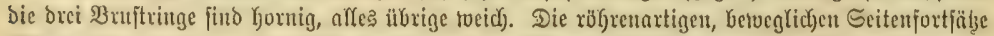

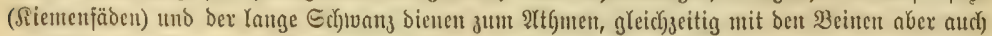

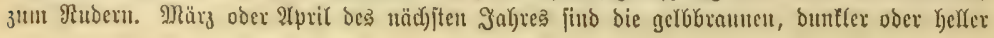




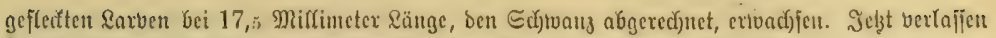

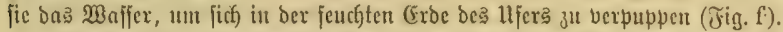

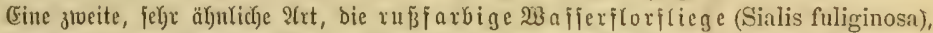

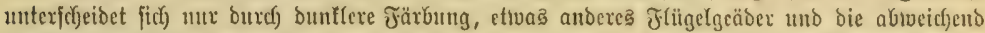

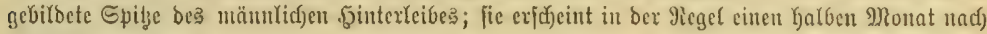
ber vorigen.

Einen abermals anderen Fomentreis eröfinet bie zemeine Storpionfliege (Panorpa

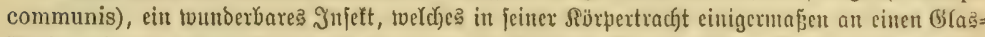

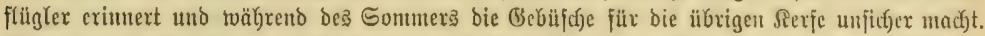

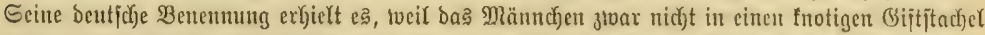

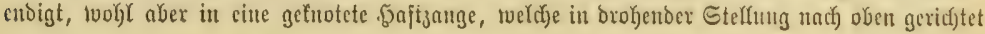

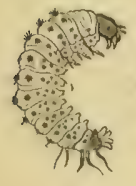

e

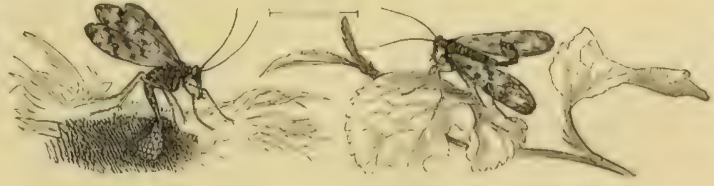

b

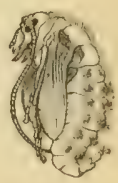

d

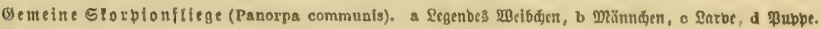

(a unb b taum bergröbctt.)

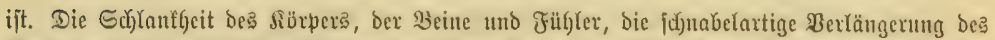

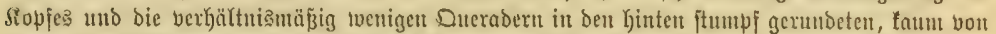

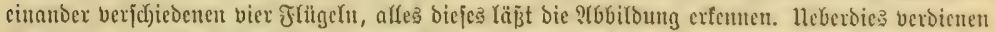

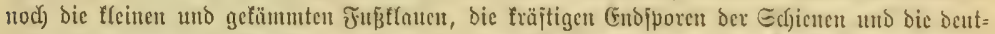

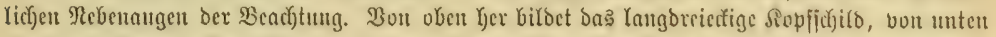

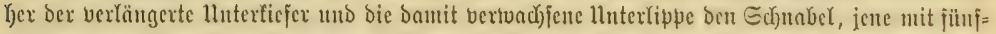

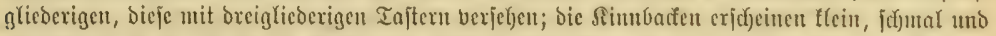

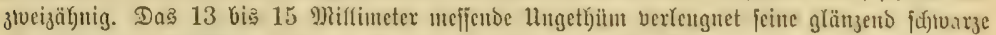

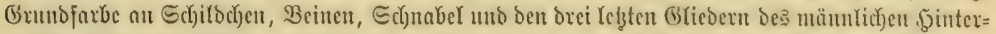

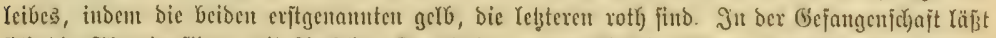

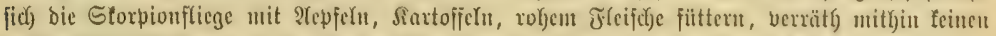

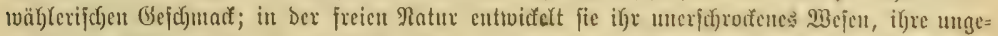

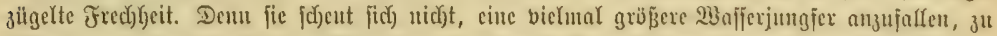

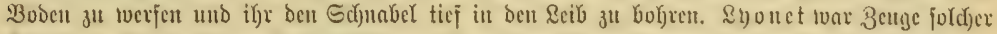

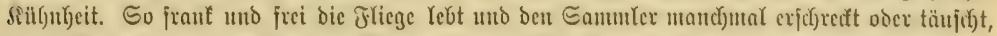

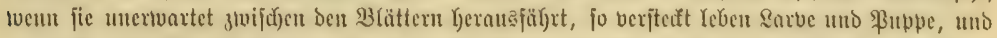

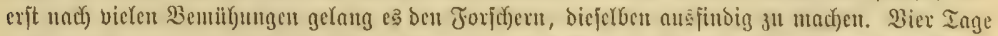

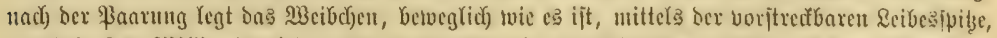

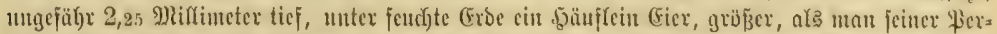

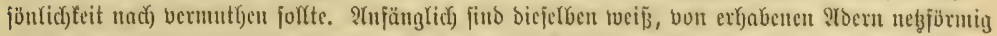

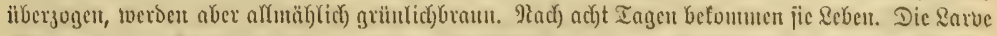

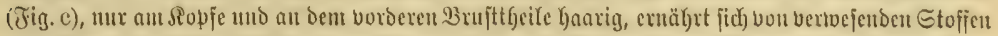

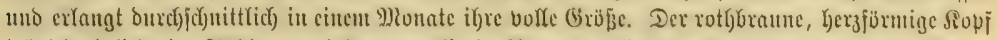

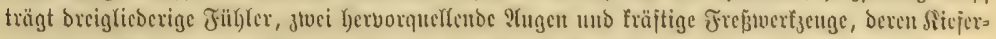

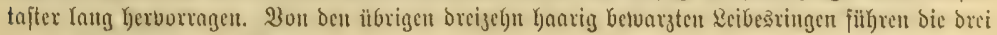




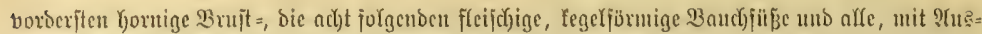

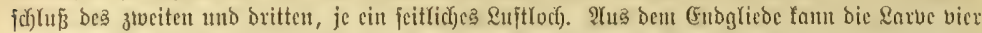

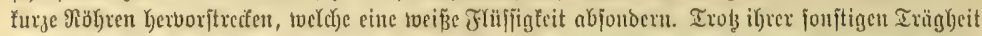

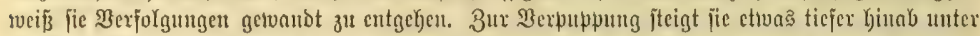

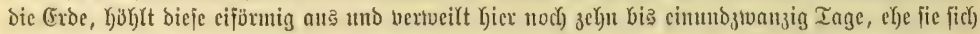

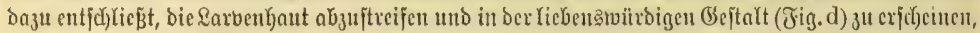

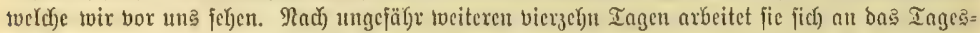

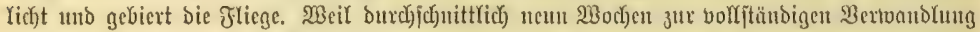

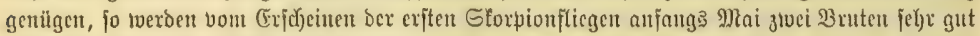

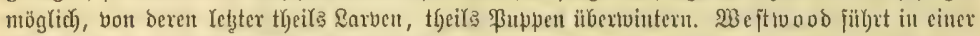

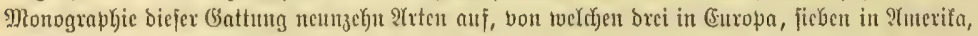

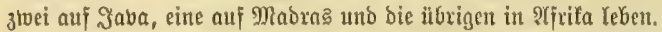

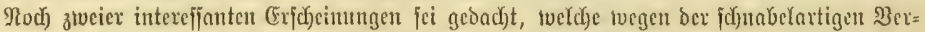

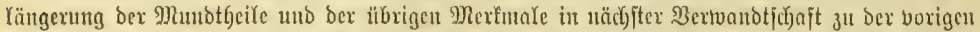
fteren. Die müdenartige $\Xi_{\mathcal{d}}$ nabefjungfer (Bittacus tipularius) Des fiiblict)en (Europa,

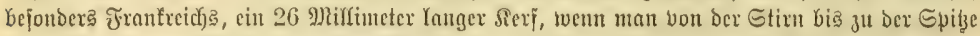

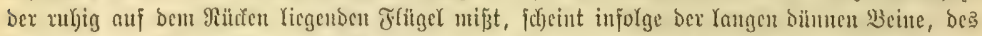

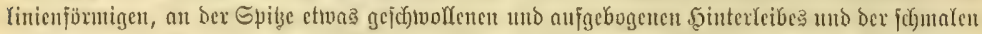

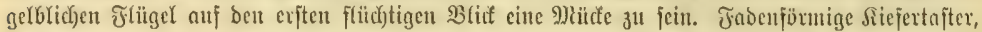

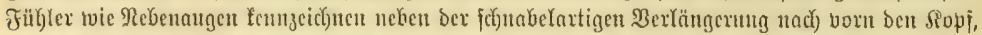

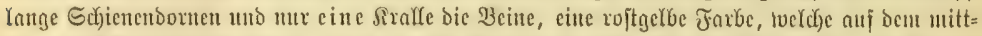

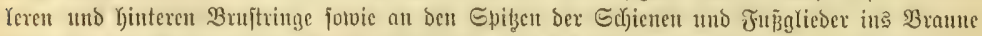

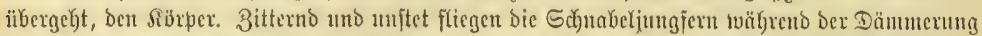

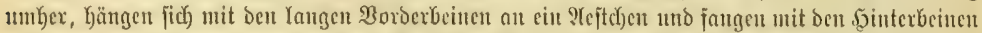

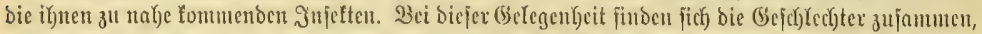

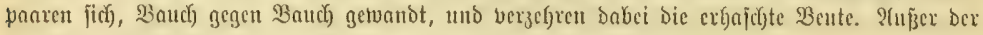
eben befprochenen fent man nod) einige antocre 2rten vou ?luftralien.

Die griflenartige Echuabeljungfer, Dex (bletjd)ergaft (Borens hiemalis), cin uur

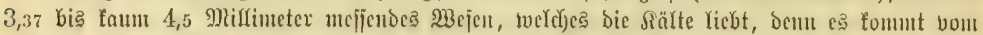

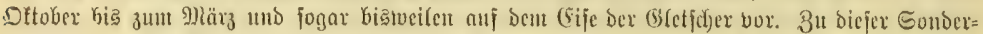

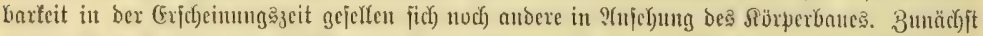

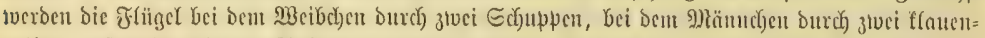

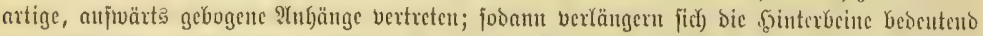

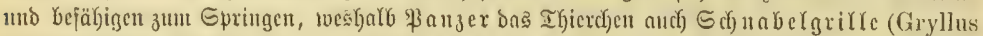

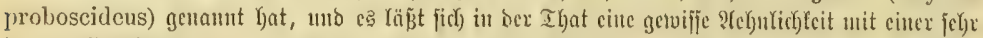

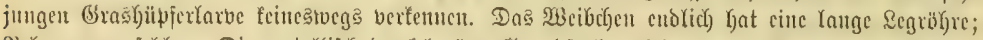

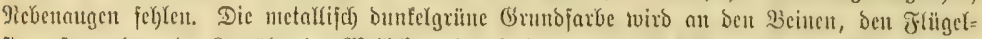

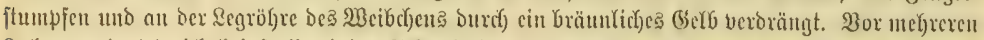

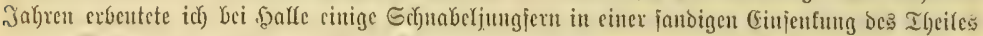

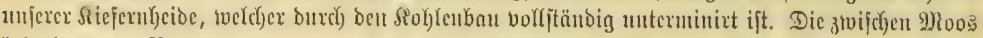
lebenoen, зur Bexpuppung trocfene (Erbe auffuchentoen Rärvet)en follen benen ber Eforpionfliege

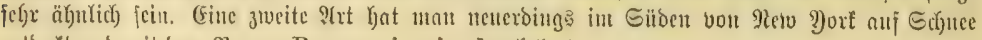
entbeatt und mit Dem ?amen Boreus niroriundus belegt.

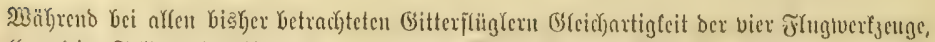

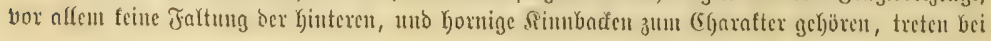




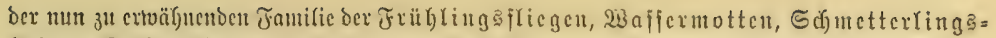

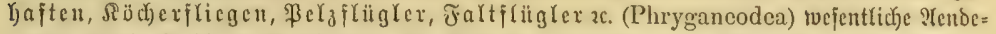

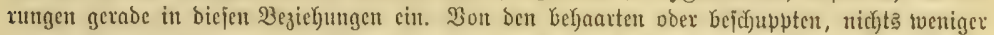

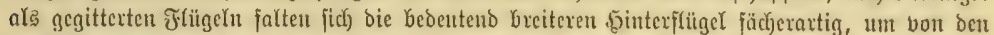

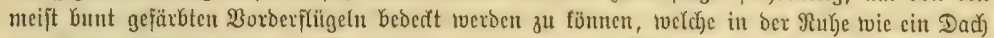

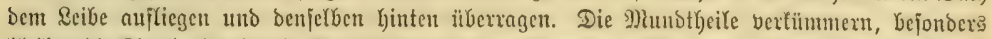

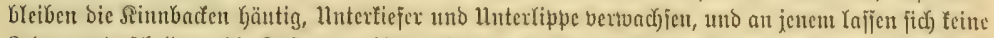

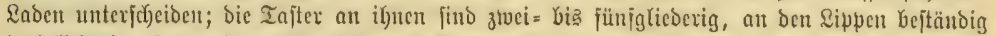

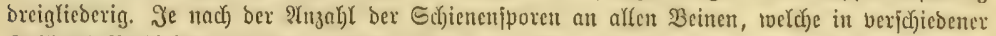

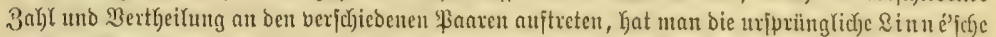

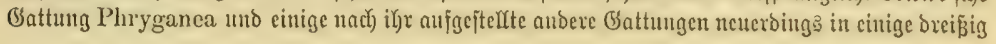
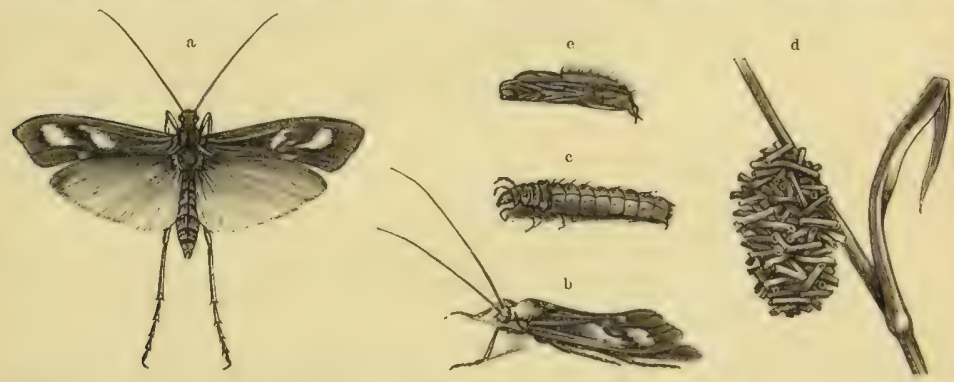

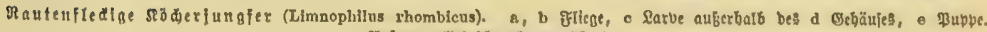
2uber o alles folwa bergröbert.

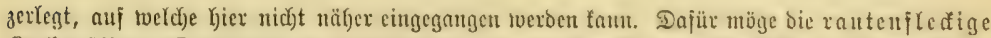

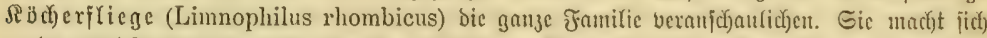

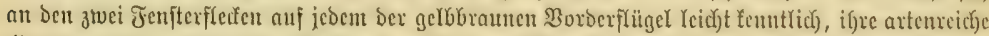

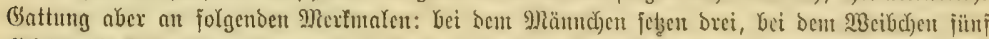

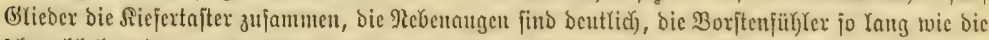

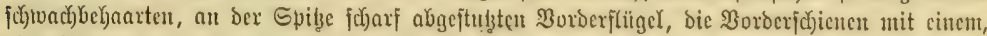
bie mittleren mit brei uno bie Ginteriten mit biex Eporen betwehrt.

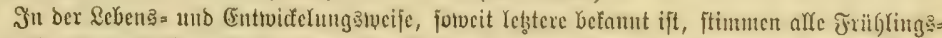

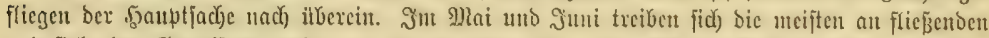

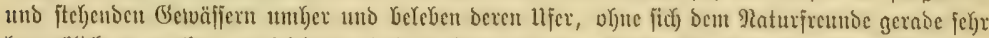

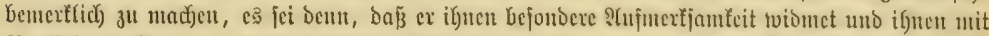

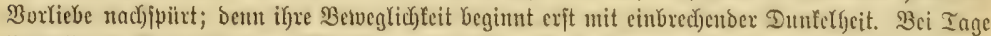

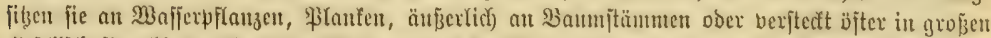

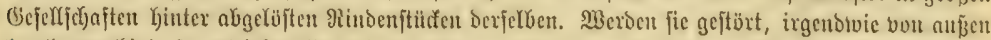

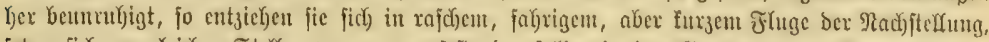

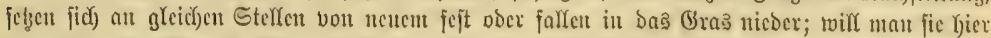

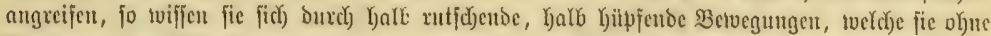

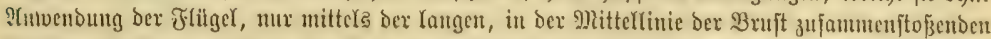

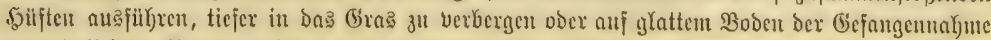

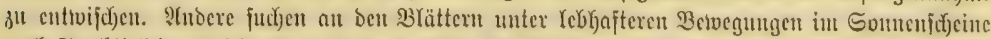

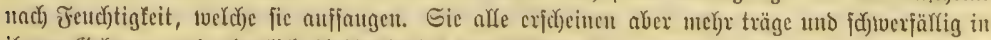

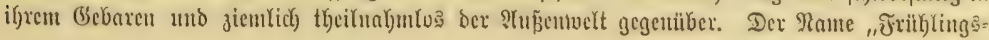




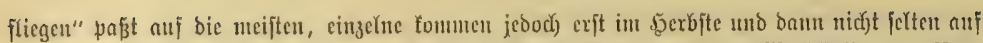

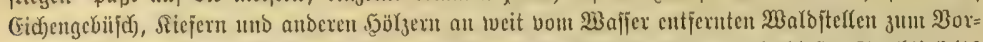

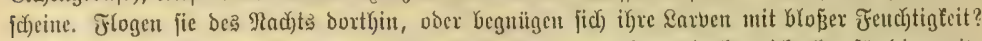

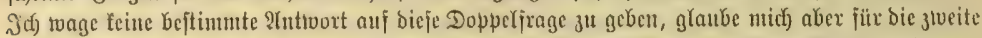

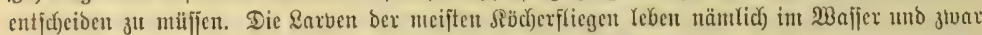

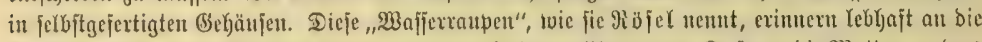

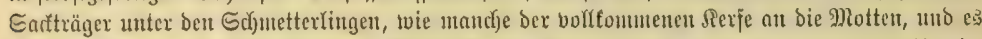

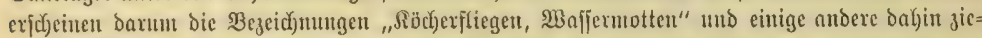

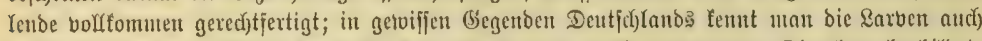

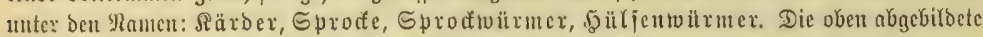

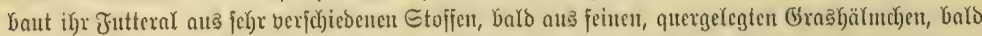

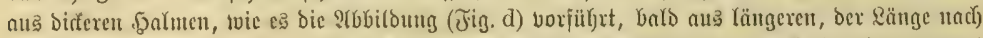

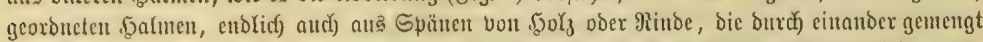

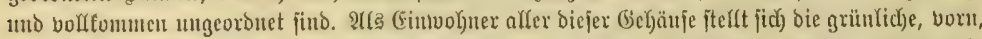

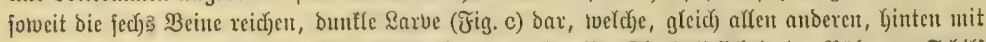

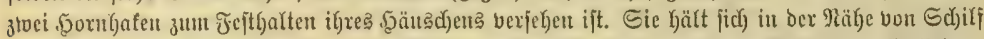

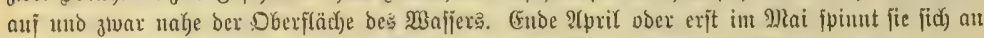

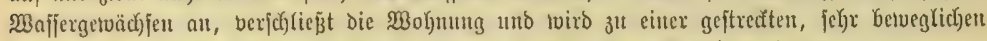

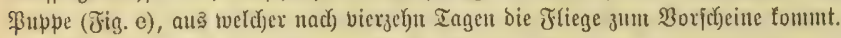

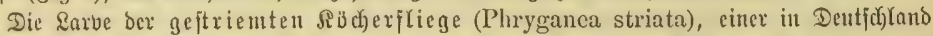

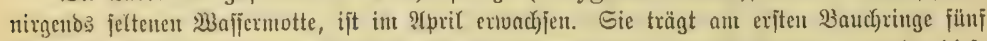

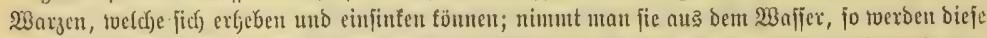

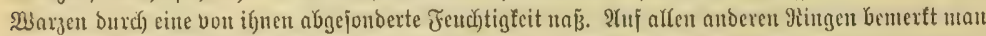

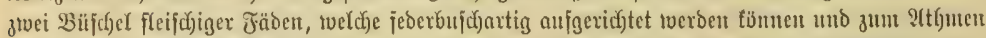

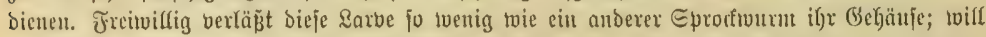

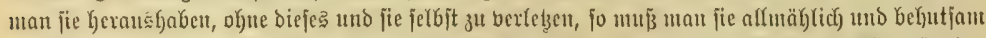

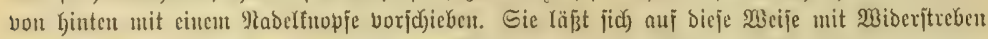

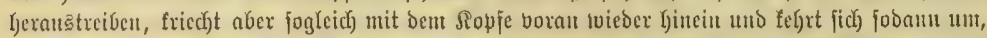

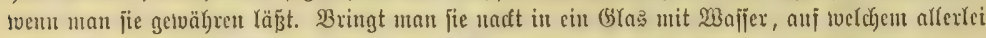

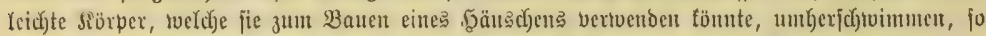
betwegt fie fich jtundenlang unter Denjel(ben unt)ex, ofjue fie zu verwenden; twählt man aber Stücff(yen

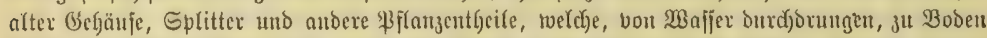

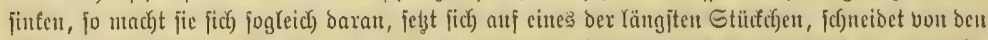

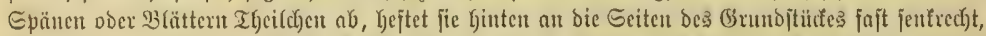

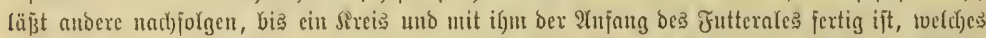

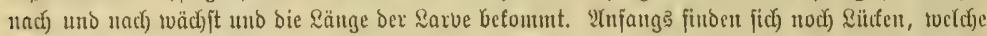

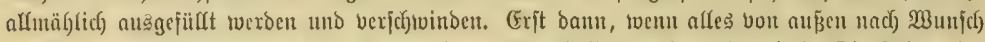

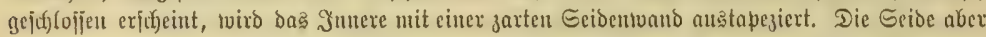

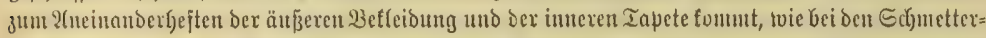

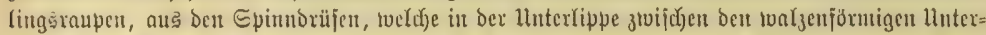

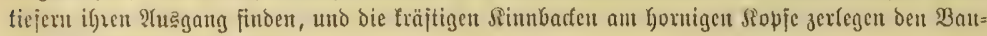
ituff, jo ojt bię nöthig toiro.

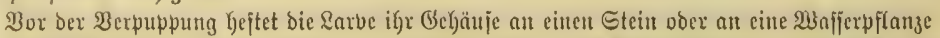

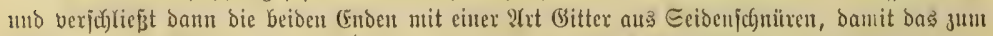

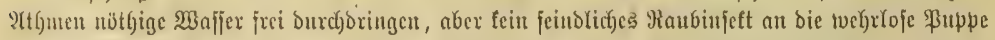
gelangen tönne. Da man f(d)on im 9lär

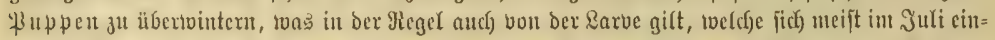

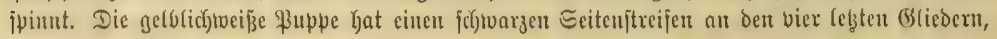




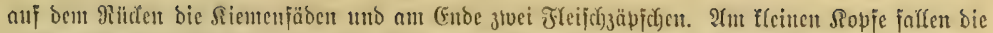

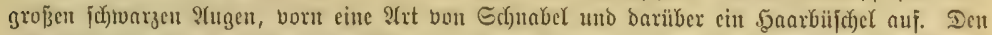

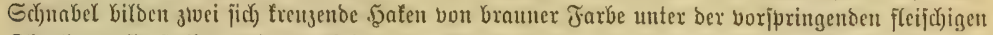

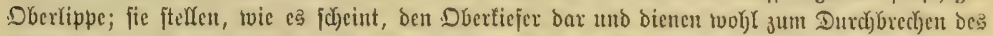

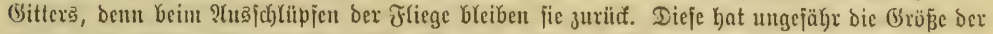

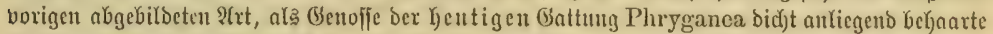

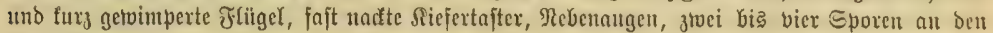
Echienbeinen, von bem vorberiten Pante an gerechnet, unb ben Kinteren 2ijt bex llnterranbaber

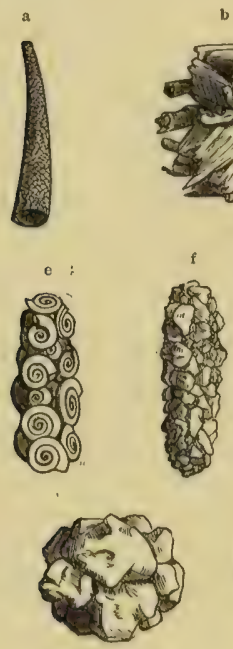

h

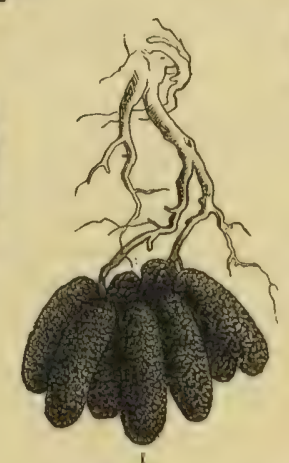

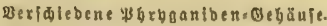

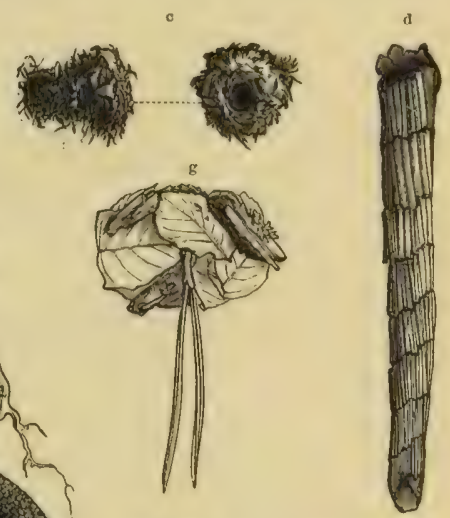

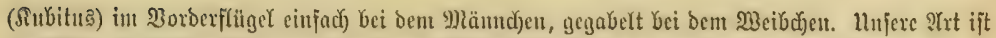

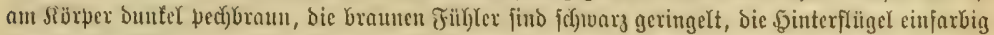

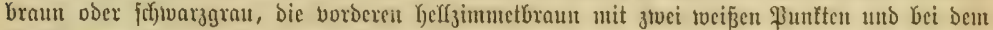

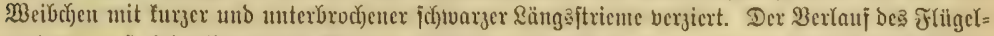

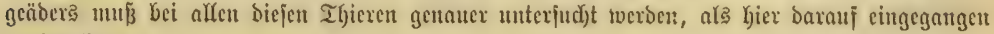
twerben farm.

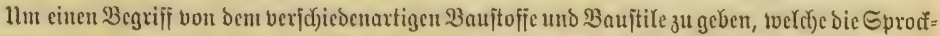

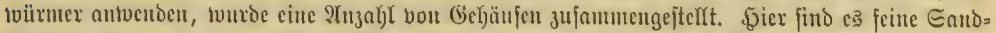

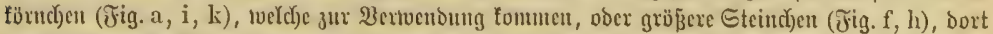

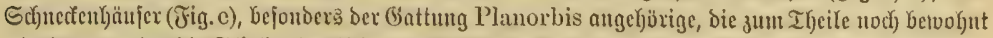

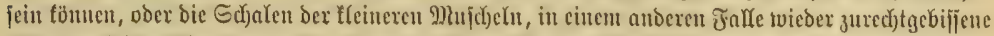

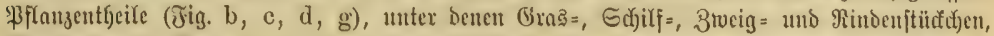

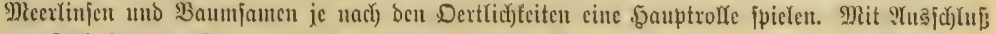

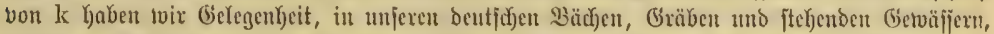

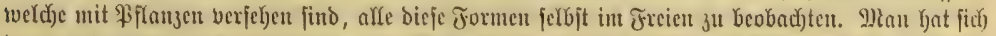

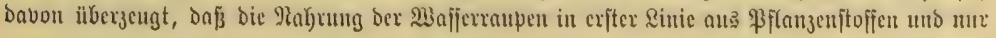




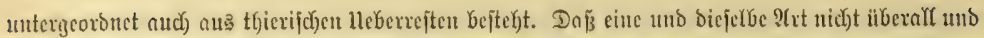

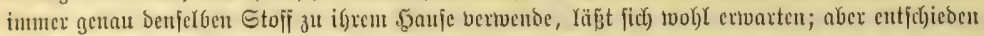

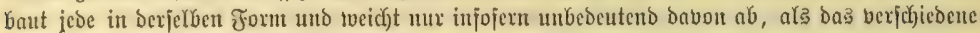

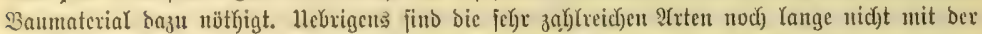

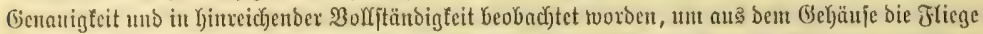

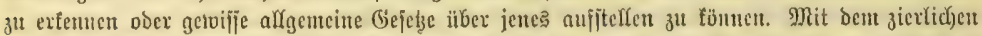

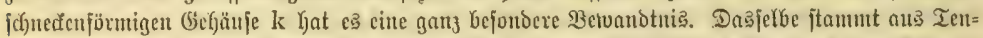

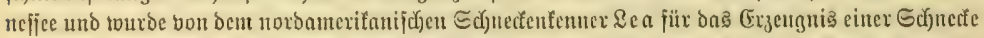

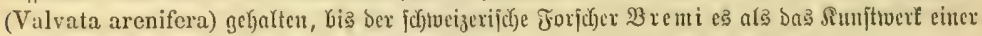

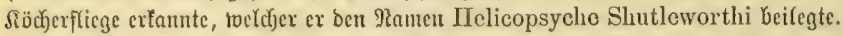

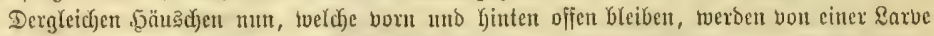

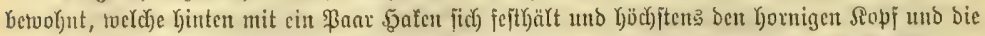

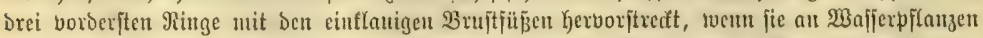

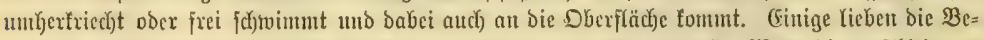

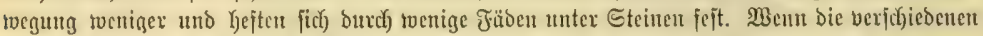

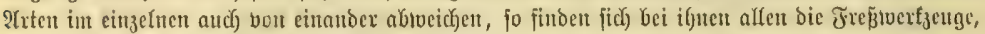

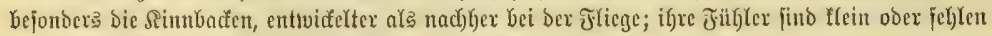

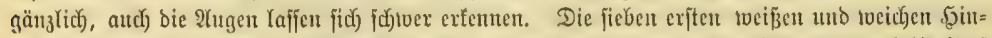

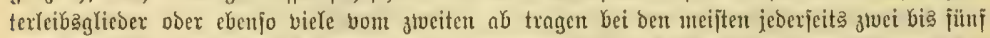

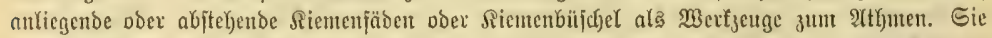

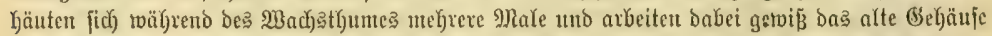

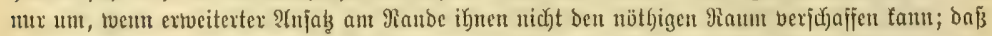

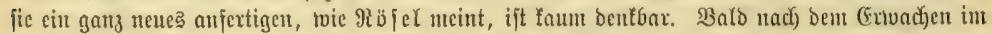

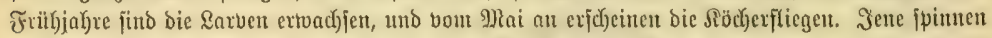

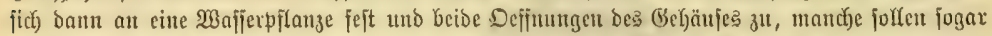

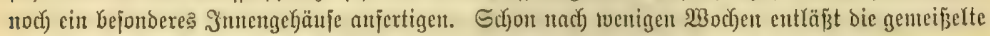

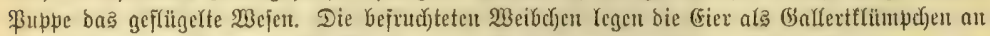

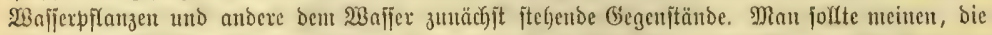

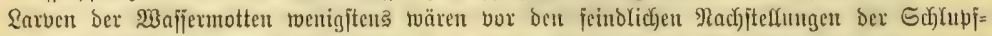
wespen gefichert. Dem ift aber nicht fo, tvie bie überrajchende Entbecung bon Sicboldo

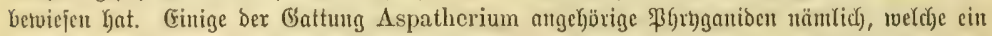

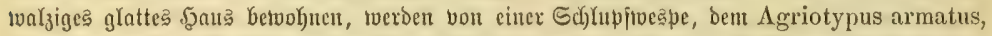

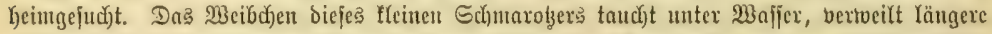

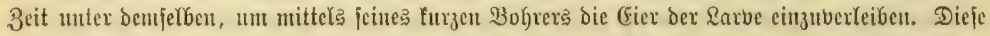

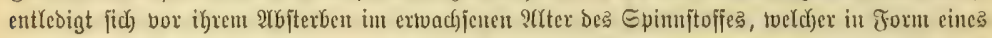

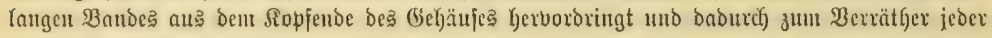
angeitodjenett Rarbe toird.

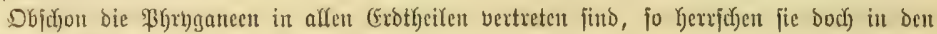
gemäpigigten Güütełn vor.

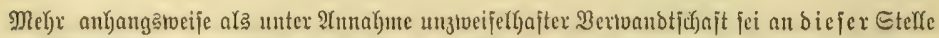

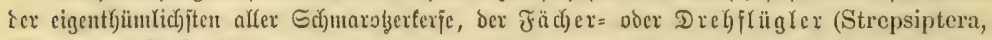

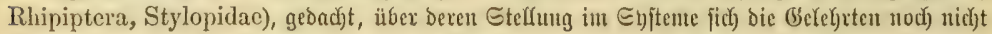
cinigen tonnten. Die cinen, Gefonders bie Engländer, wollen fie an ciner befonderen Dromung

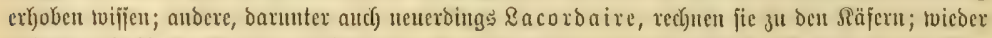

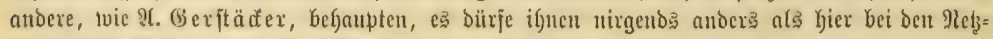

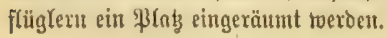


Dic Etrepfipteren wntron lange Beit แn von ben (Englänbern ber näGeren Betrachtung

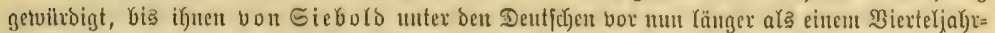

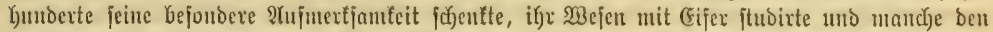

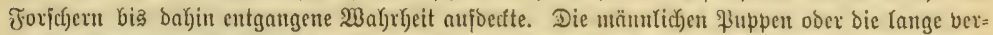
fanten toum

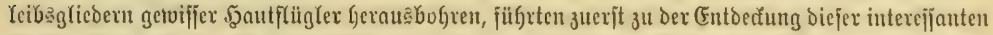
Serfe. Bei Andrena, Ifalictus, Vespa, Odynerus, Polistes, Sphex un Pelopocus jano maı

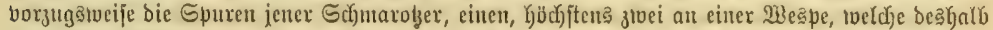

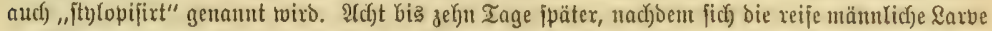

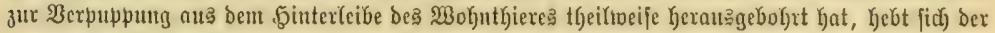

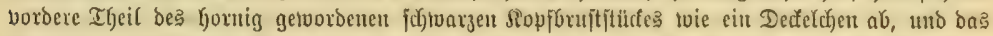

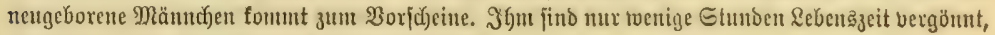
toeldye auf basె Begattungågejdyäft bertuenbet werbent. Mährend biejer furgen Frijt befindet e

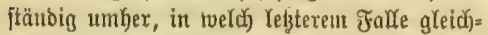

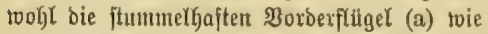

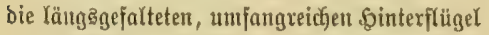
it jteter 23ernegung bleiben. Beim Fliegen fteht Der Särper jentrecht, mit ber Spike nad) oben gebogett, jo baß fich eit zierliches $\mathfrak{B}$ ildodjen in Iragezeichenform barjtelft. Fud beim Srieçen halten fie, toie fo häufig bie Staphy)tiuen, bie

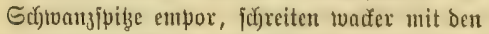
vier vorberen Beinen auล, während bie hinterjten,

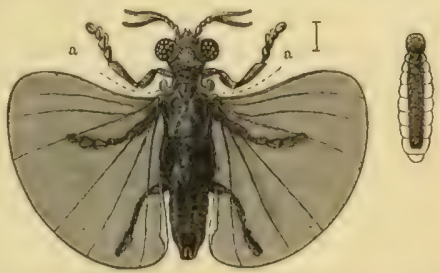

Vănnden bon \$eds 9 mmenbreme (Xenns Peckll), a bie

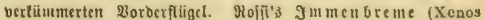
Rossii), 28cibđgen vout oer Baudjfcite. Weibe ftarl vergröbert

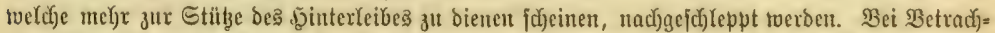
tung biefer jonberbaren Ibiere unter IInleitung bes abgebirbeten Xenos Peckii falfen bic unber=

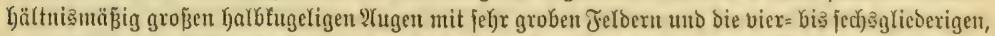

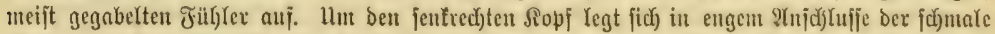

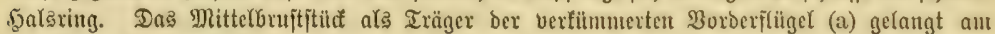

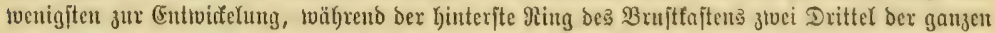

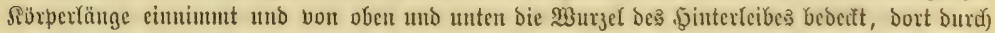

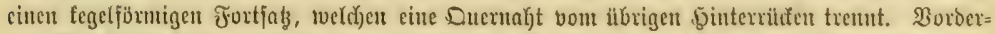

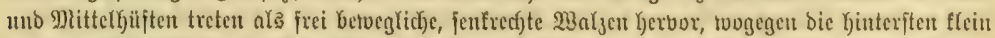

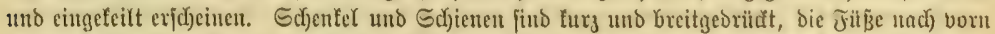

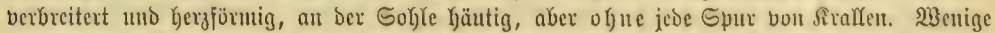

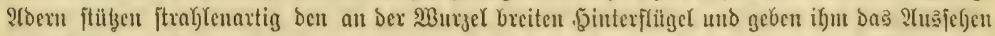

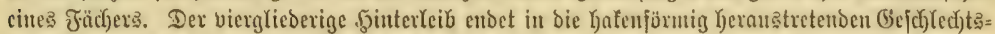

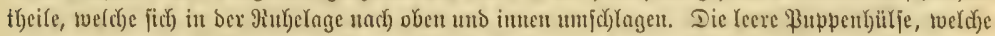

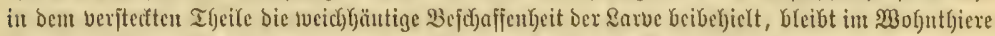

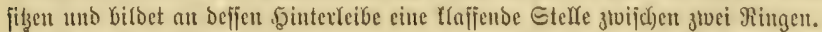

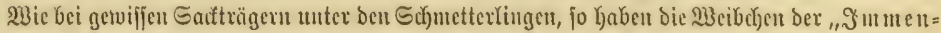

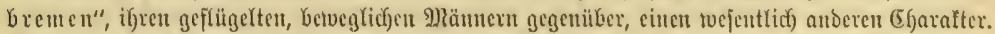

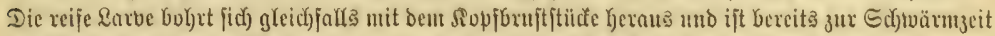

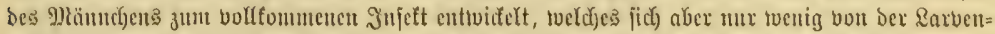

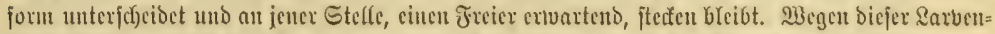

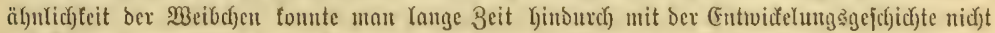

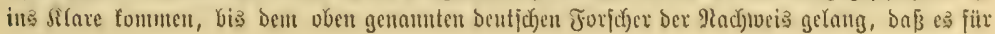




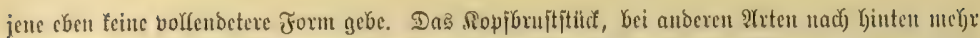

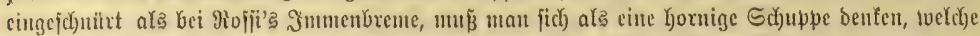

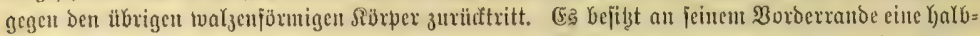

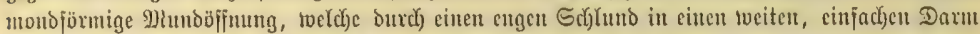

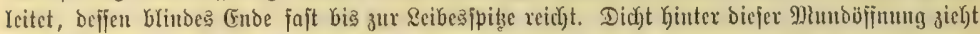

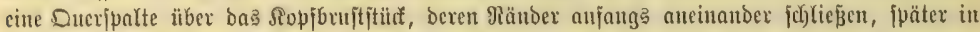

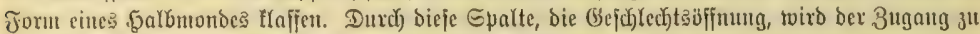

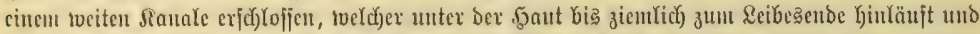

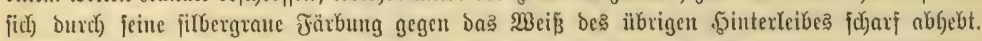

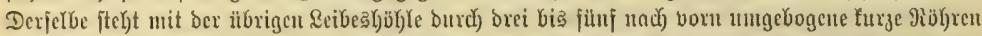

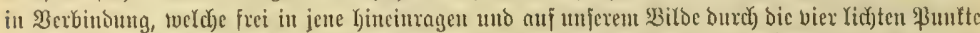
angebentet weroen; vou Siebord hat ifn ben Srutfantal genamut, veil er fpäter bie Brut auf=

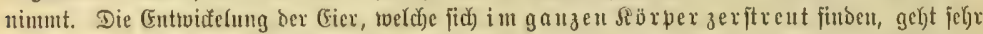

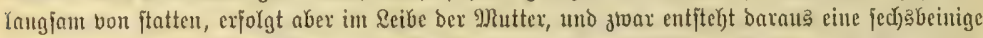

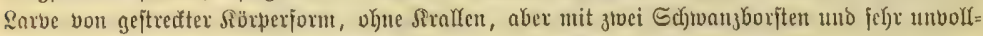

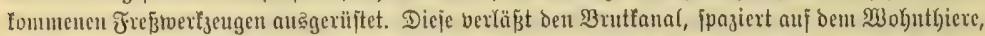

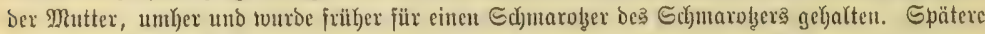

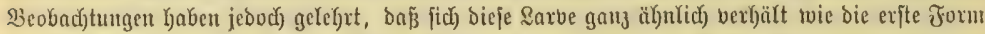

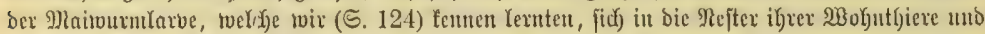

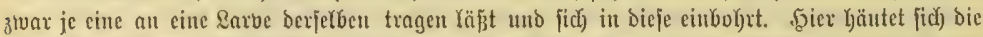

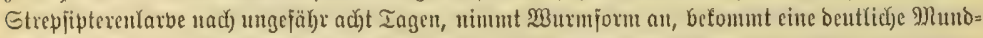

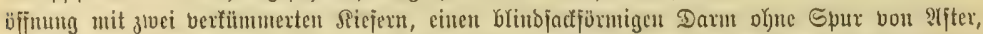

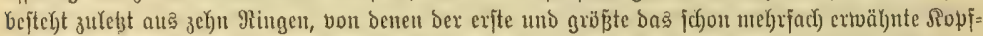

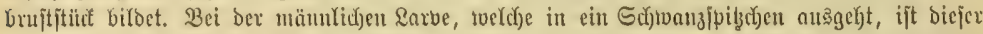

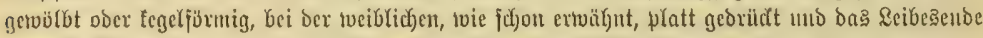

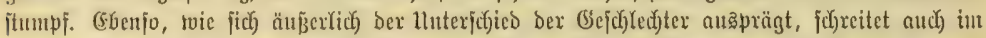

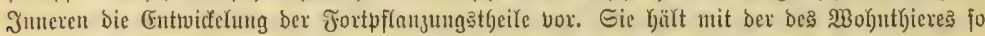

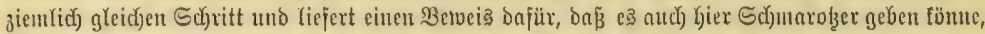

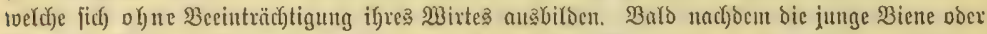

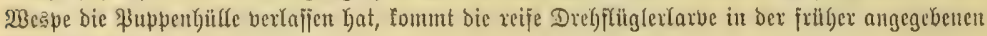
Mcije herbor:

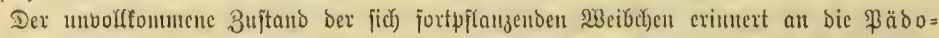

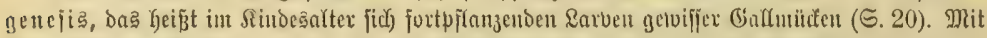

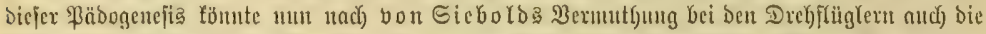

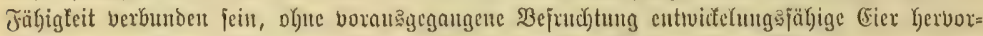

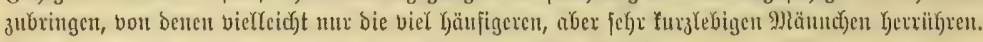

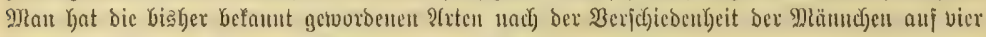
Gattutgen (Xenos, Stylops, Halictophagus, Llenchus) vertfgeilt. 


\section{Sedfe (0romung.}

\section{Sinuferfe oder (Sicrabflingler (Gymnognatha, Orthoptera).}

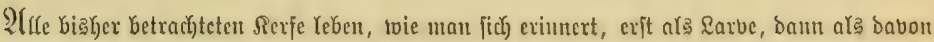

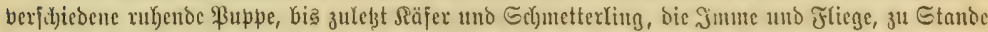

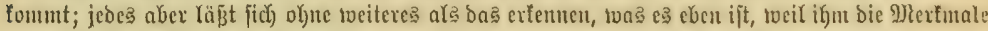

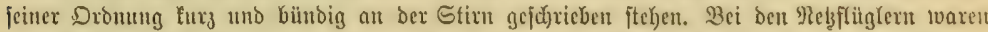

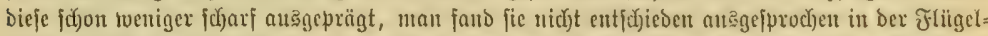

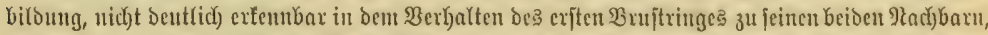

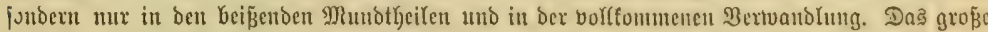

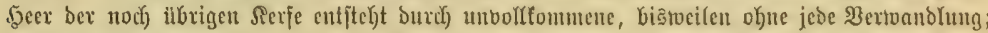

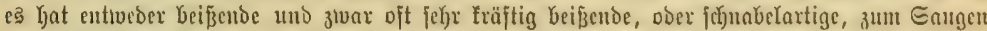

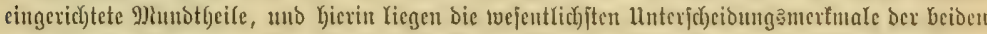

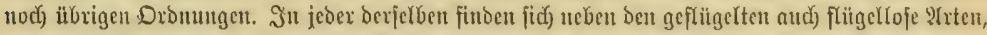

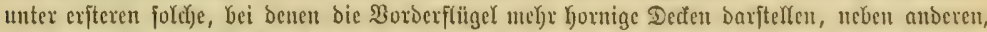

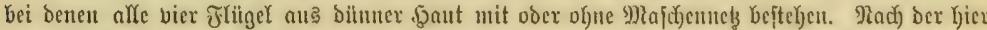

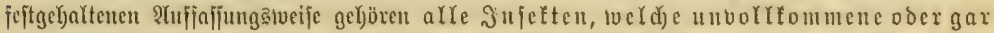

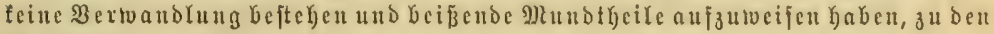
Seaterfen.

Tußzer biejen ztuei alfen Drthopteren gemeinjamen Merfunalen zeigen fie in Ser Biloung

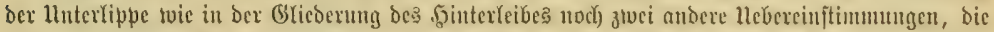

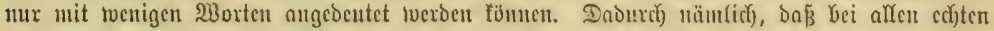

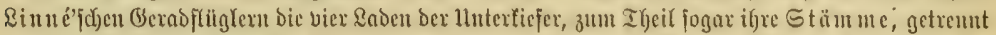

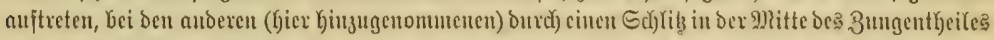

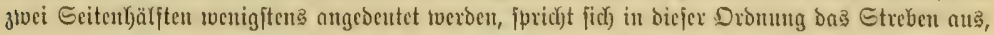

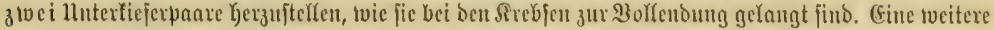

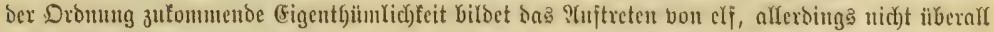

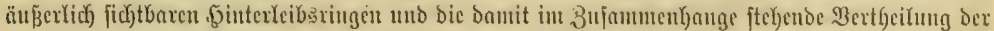

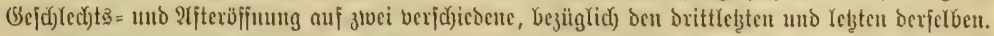

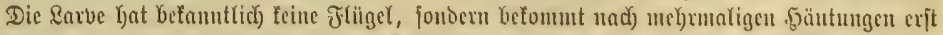

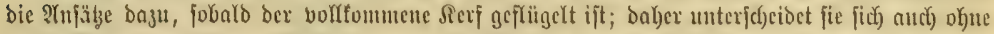

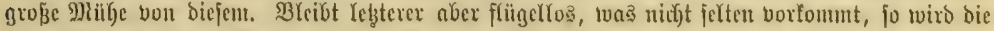

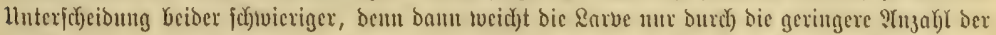

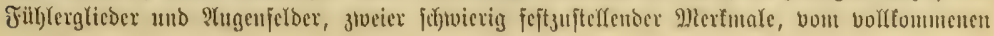


Snjefte ał. Mand liegen, während Gei ber Rarve bie umgefehrte Rage ftattfindet.

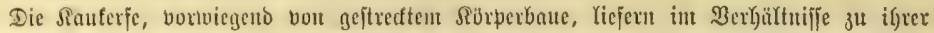

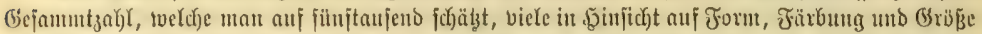

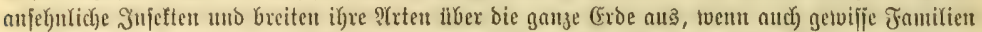

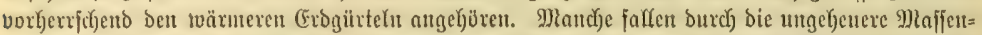

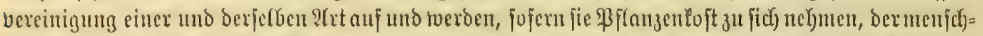

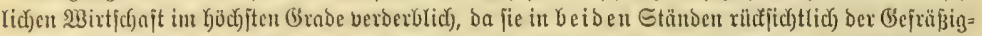

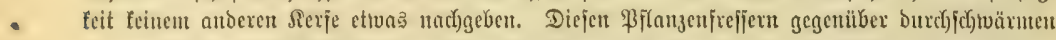

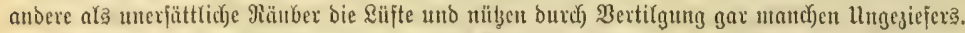

Beriteinterte lleberrejte fommen bereits in Rog)(engebirge bor, too fie affe anberen übertoiegen;

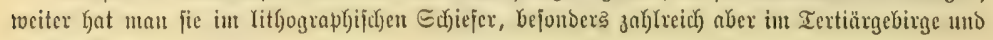
im Bernfteine aujgejuben.

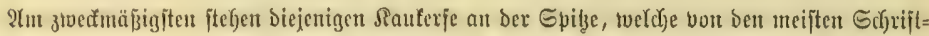

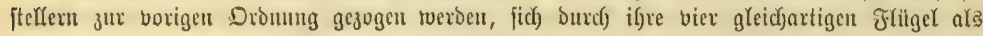

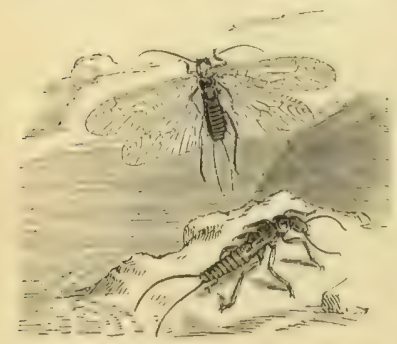

3tveifduängiße ttferfliege (Perla bicaudata) nebit ertuadjefer l'arbe. Santïr(idje (Gröbe.

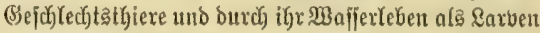

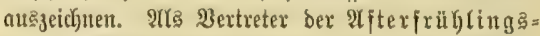
fliegen (Perlariao ober Scmblodea) jei junäd)ft bie J heifuchtoändige uferjliege (Perla bicaudata) genamt. Sie hat einen braungetben, zrweimal buntel= geflectten, burdid bie slitte bunfelgejtriemten uno ebenjo eingejap̆ten 2borderrilden, einten rothgelben Sopf und am übrigen Sürper eine mełhr braungelbe Färbung. In ben gelbtichen Beiten find bie Spilzen ber Schenter

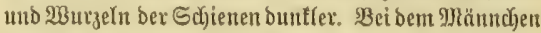
biegt fich bie gejpaltene, flache neuntc Ritifenplatte

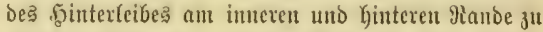
f(r)utalen Reiften auf, bei bem $23 e i b d j e n$ theift fie fich bagegen burch feichte (Bribchen tvie it brei säppdjen,

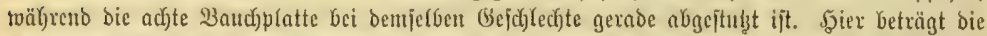

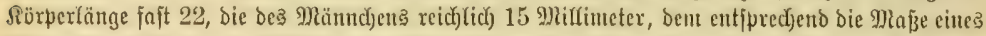

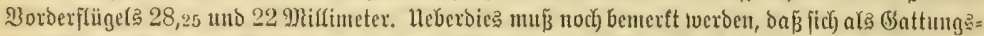

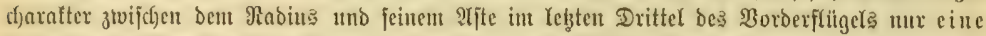

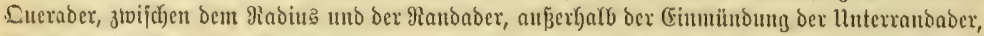

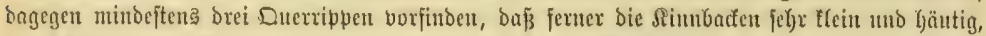

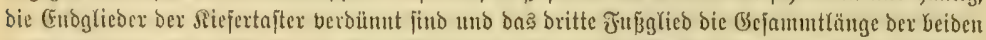
vorfergef)enoen übertrifit. Unter Berïcfichtigung aller biejer Merfmale rviro man bic gentunte

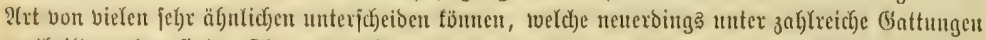

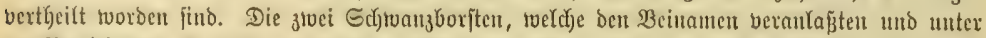

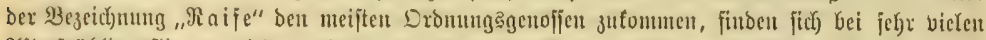

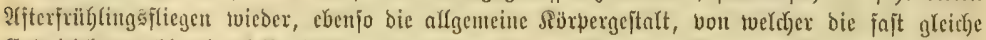

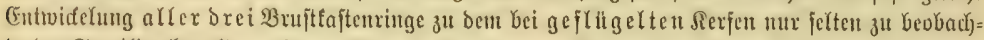

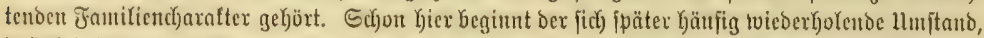

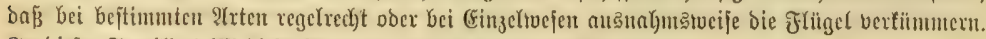

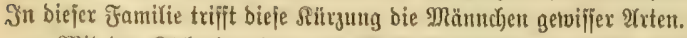

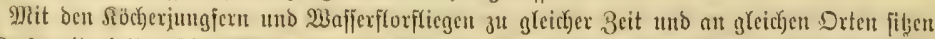

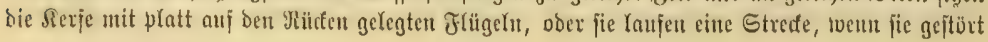




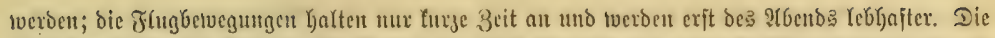

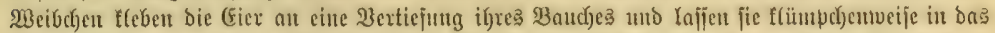

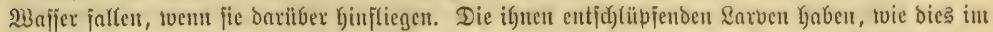

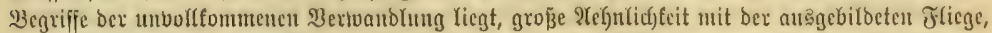

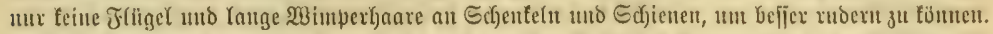

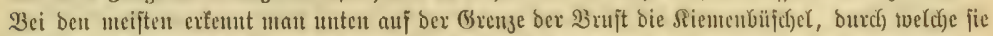

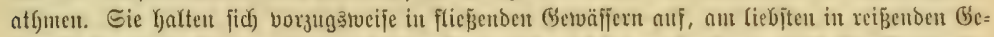

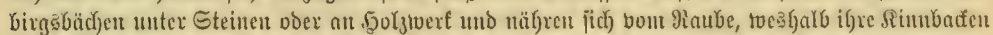

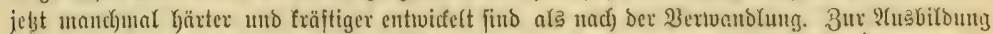

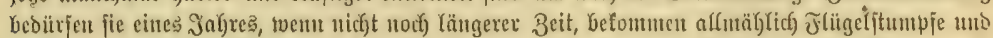

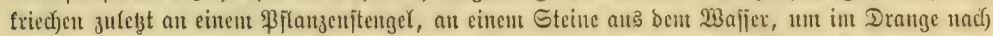

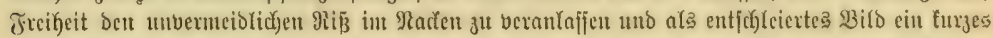
Dafein zu jriften. \$ictet bearbeitete 1841 biefe Familie im bejontoeren unb tviontete ber frülyeren

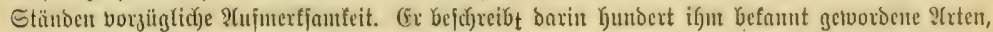

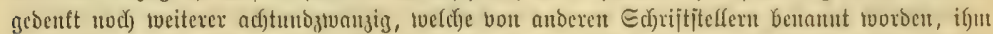

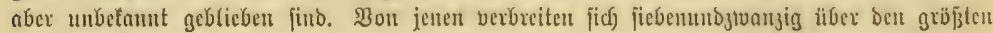
Ifeil (5uropas.

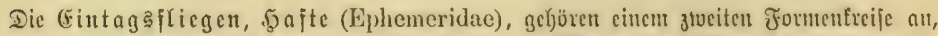

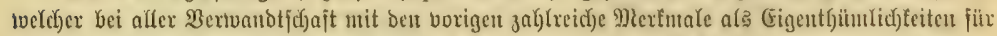

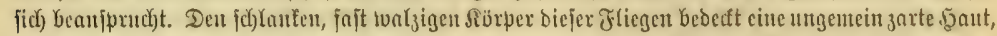

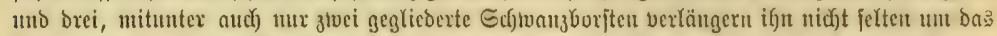

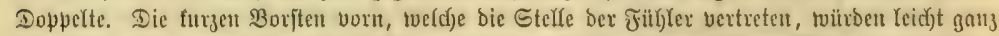

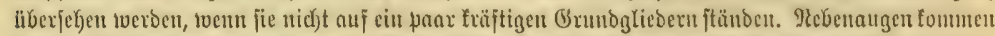

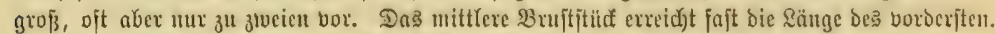

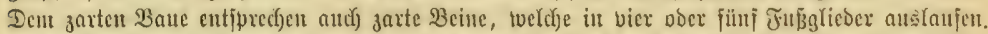

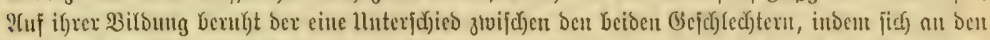

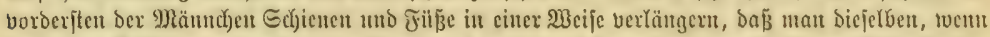

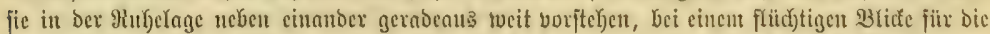
Füf)(ex halten müchte. Die vorgequolfenen, beinafe ben ganzen Sopf cimehmenden ?hgen geben

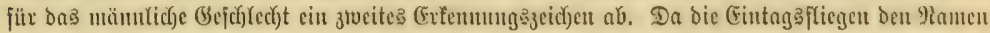

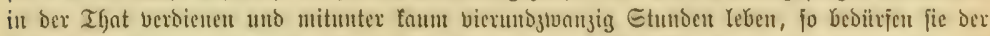

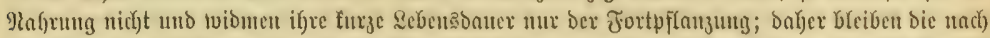

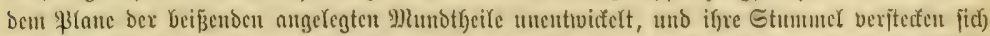

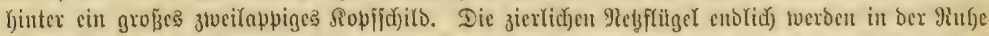

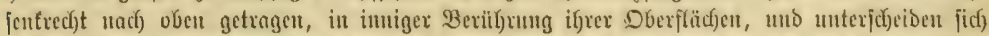

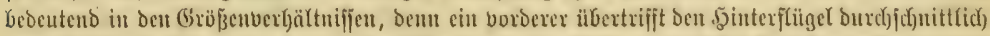

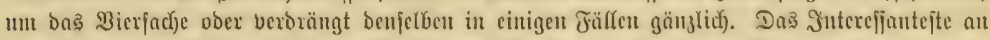

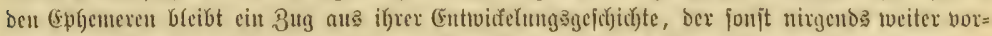

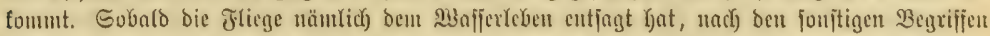

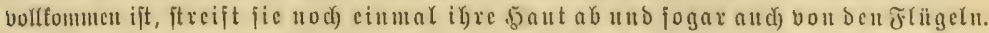

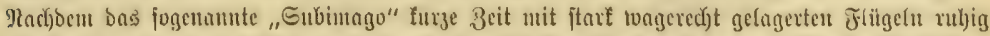

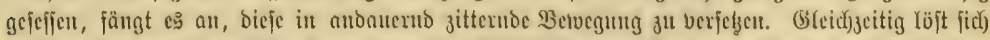

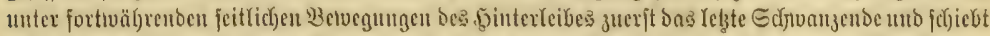

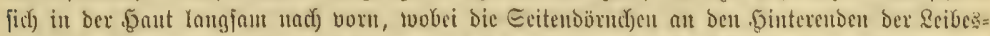

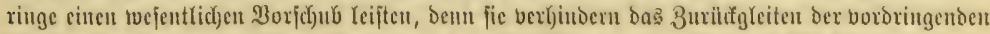

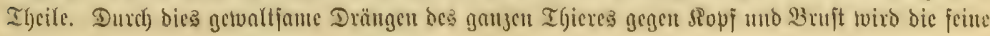




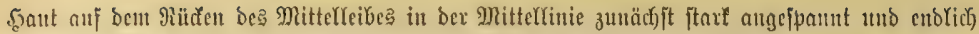

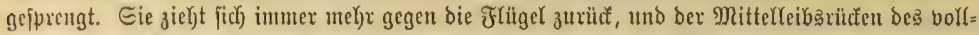

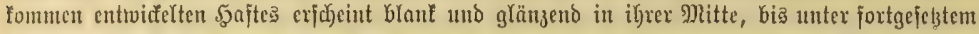

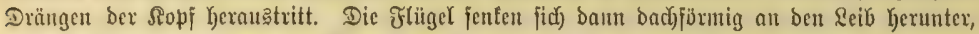

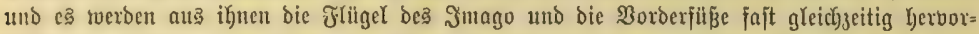

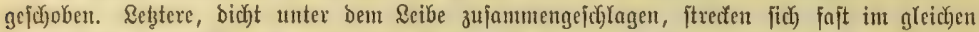

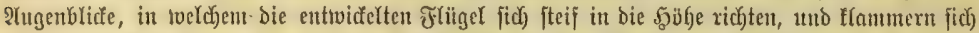
feft an Den Begenitand, auf tweldhem Das Subimago fiģt. Nun ruht bas Thier cinige Gefunden

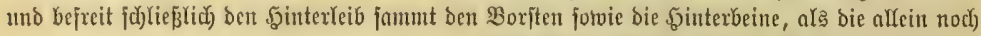
umichlofienten IGeile, pust ben Slopi uno bie Fiblex

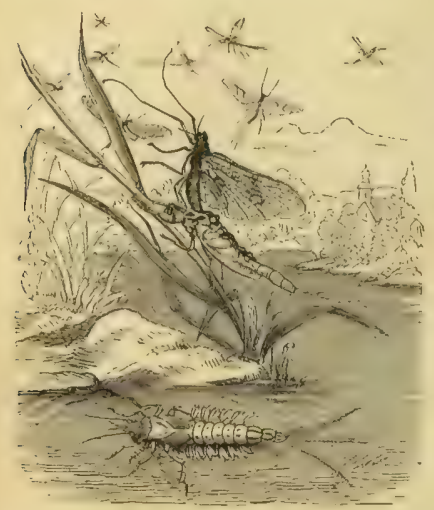

(5) neine Eintagsflicge (Ephemera vulgata) bei ifres

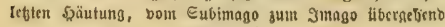
nebit ibret Sarbe.

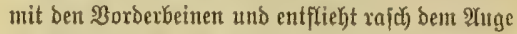

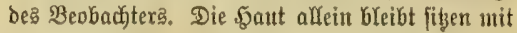

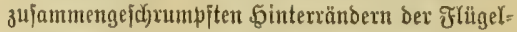

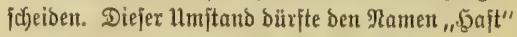

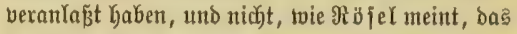
Rlebenbleiben an frijach getheerten Subiffen. Mix ijt aus meitue \$ัugenozeit, too id bergleichen Dinge

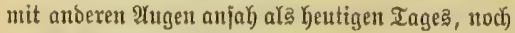
in bex (Eximexung, eine joldhe ફäutung in ber \&ujt

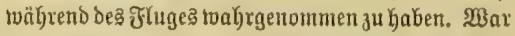

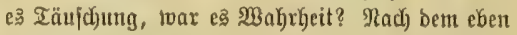

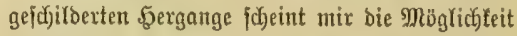

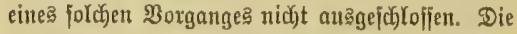
Beridiedentheiten ztwijhen Subimago und İmago

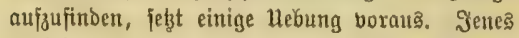
exjcheint tvegen bex joblotternoen fant plumper; feine Bstieber find bicfer und türger, bejondera bie mämulichen Borberbeine, bie Färbung ift unbe= fitimmter uno jodmutbiger; bei biejent treten alle

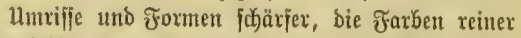

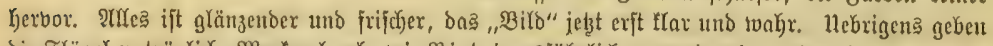

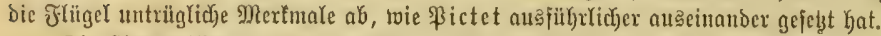

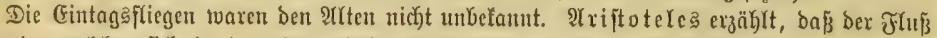

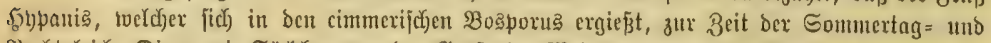

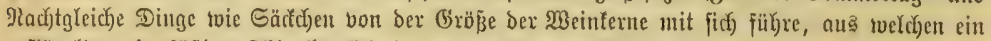

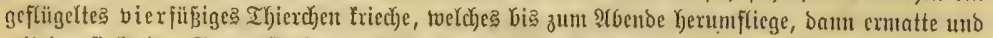

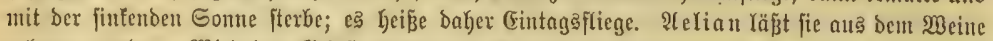

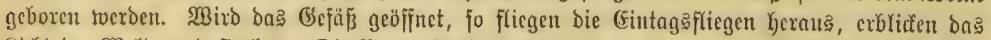

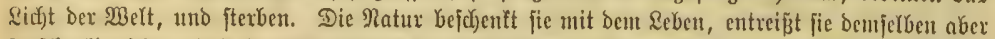

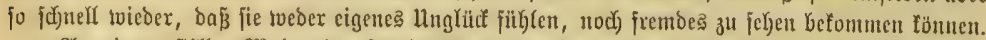

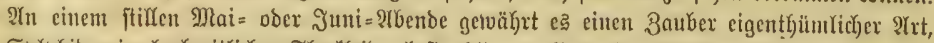

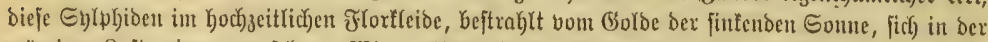

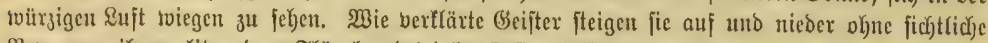

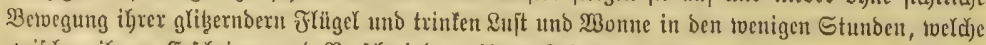

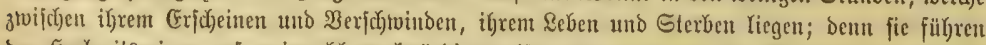

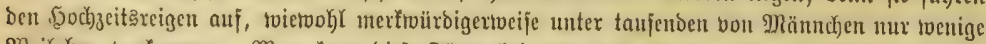

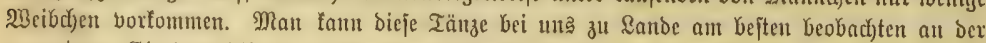
gemeinen Eintaggjliege (Ephemera vulgata), tweil fie bie gröjte ift, aul häufigiten in 


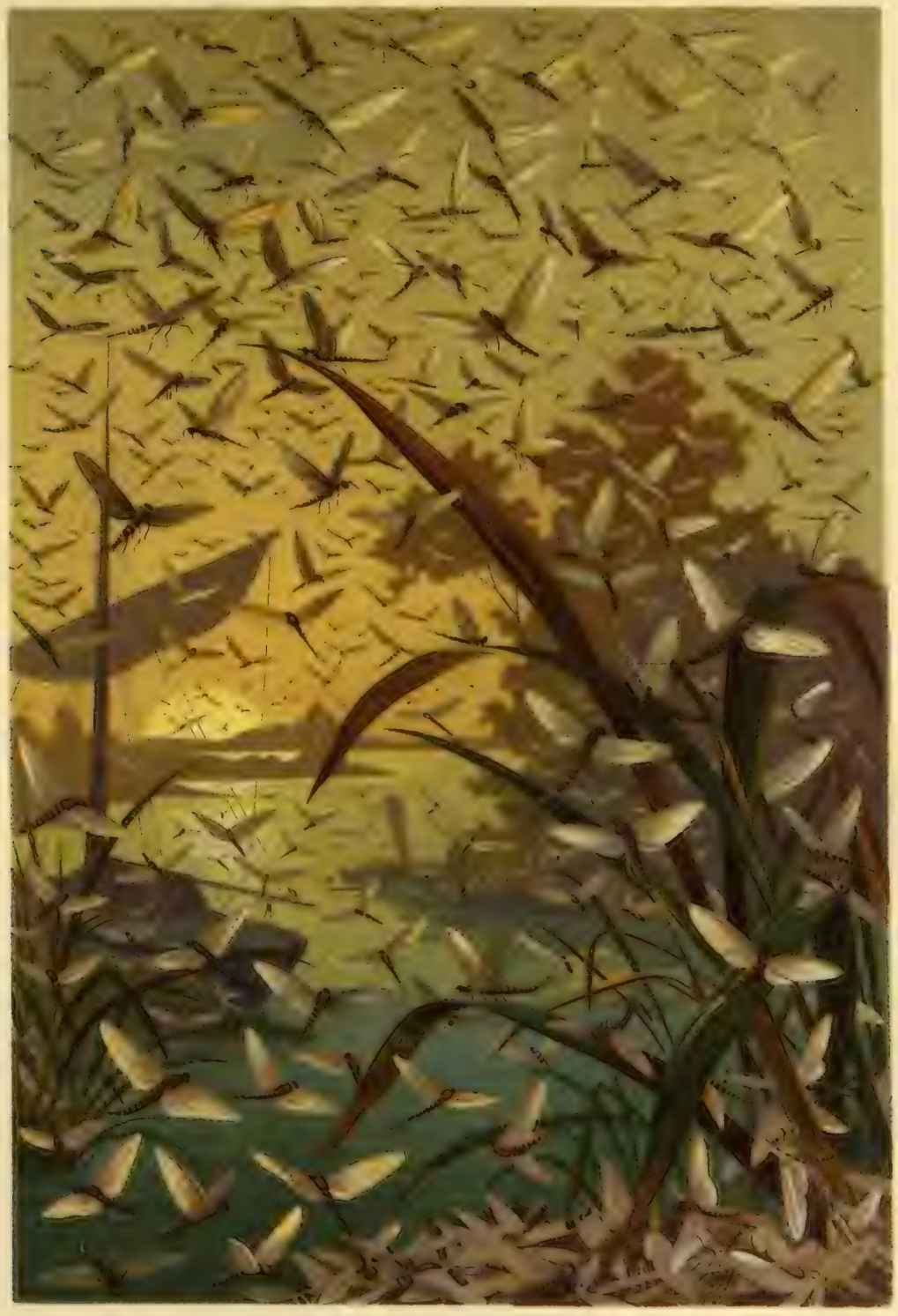





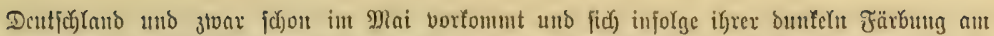

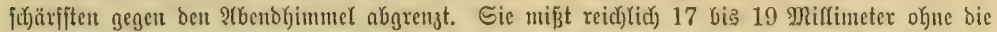

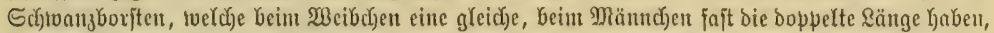

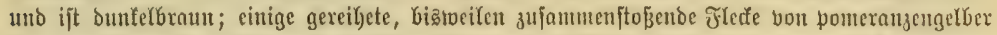

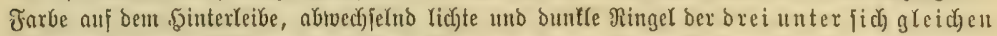

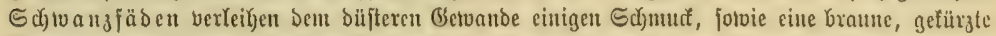

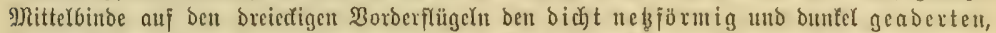

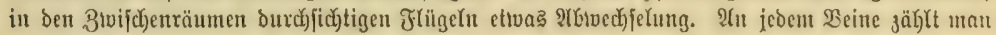

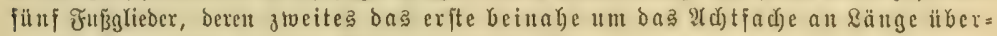
trifit. Die gejperrt georucten Dertmale fommen aflen Txten Dex Oattung Ephemera zu, bie neueroing马 in mehrere gerlegt toorden ift.

Fragen toir mun, too fommen fie her, jene epfemezen (Exid)einungen? Sie entiteigen, gleid) ben borigen, Dem

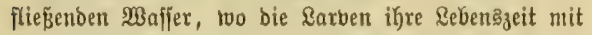
Raub verbrachten, nachbem bie Meibchen bie Eier in başjerbe ausigeftrcut Katten. Die geftredte Rarbe unjerex 2rt hat auf jeber Seite bes f̧interleibes fectso Siement= biifichel ober Duaften, feine Sitementblättchen. Der Sopi \äujt born in zroei Spitzen aนจ, trägt jein behaartc Fübler und Yainge, fichelförmig nad) Dben gefrümmte

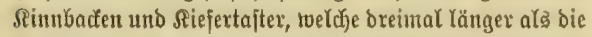
Sippentajter fint. Die einflarigen Beine find glatt uno besvimpert, Sdjenfel und Schienen ber borberiten ftärter und zum (6raben eingerichtet; benn fie arbeiten mit î́nen in bie fandigen 1 fer, ber Bäche Yieber als ber frtüfie,

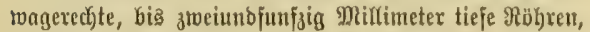
meift grei bidjt neben einanber. Die jadmale Sibeibetwand

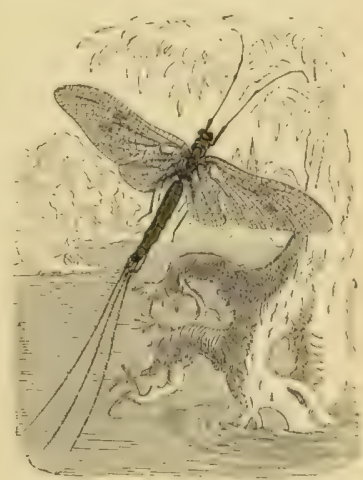

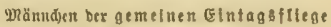
(ipphemera vulgata).

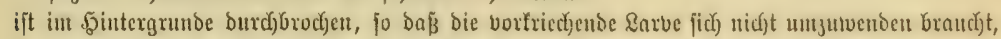

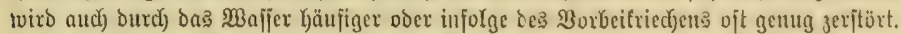

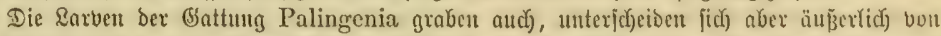

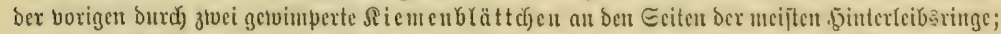

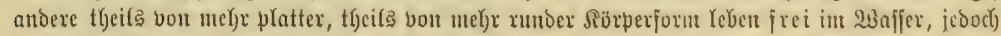

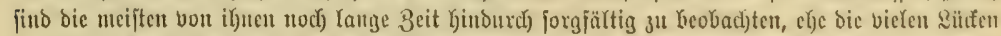

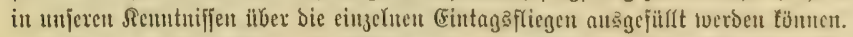

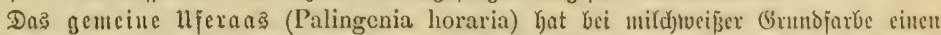

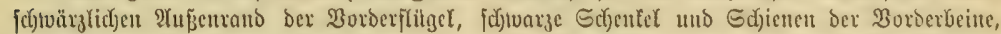

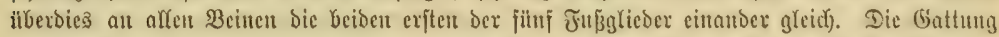

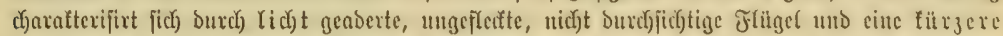

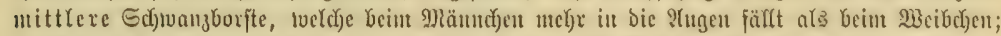

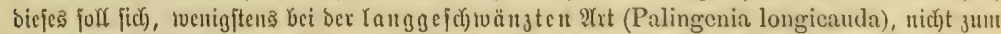

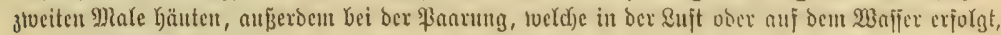
auf Dem Mräındjen fiżen.

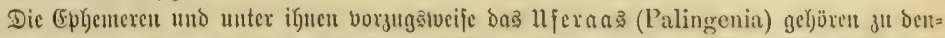

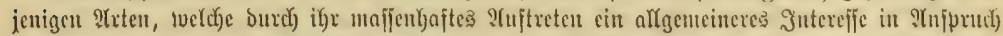

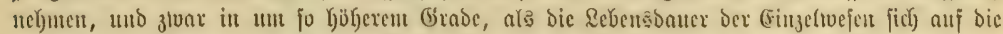

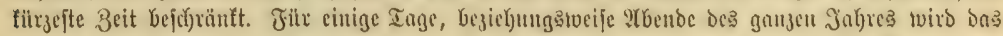

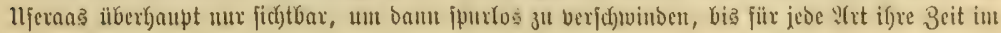




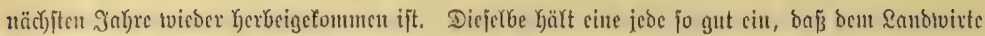

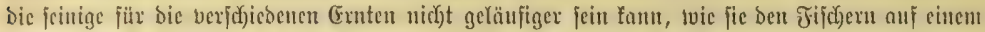

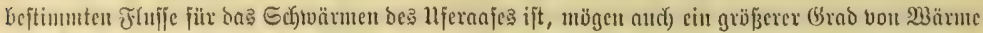

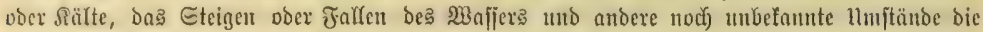

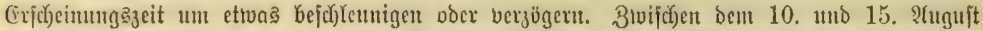

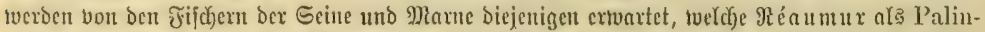

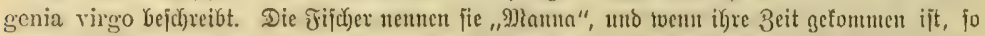

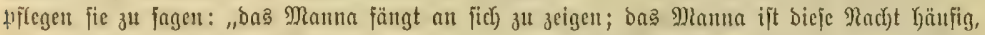

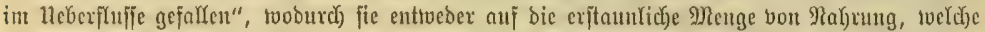

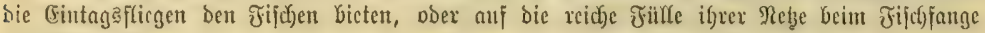
anppiełen toollen.

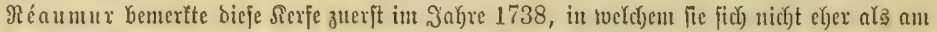

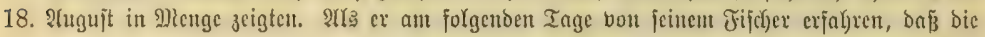

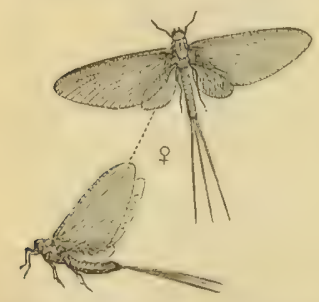

Metbijen bes semeinen liferaajes (Pallngenia horatia). đ̛liegent exjochienen twären, ftieg er brei Stunden vor Sounen=

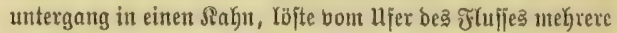
(5romalfen, weldye mit Rarben angefitut waren, uno jeste fie in einen groben Suber mit Wajfer. Wra biejer bis

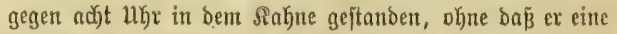
beträdytlidje Menge von நaften geboren hatte, und ein

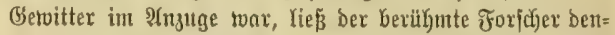
felben in feinen Barten bringen, an weldyem bie Marne bor=

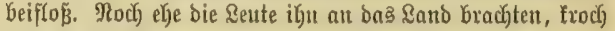
cine grope Menge von Ephenteren aus Demiflben herbor.

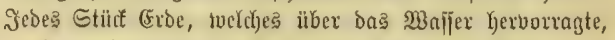
ronto bon benjelben bedectt, indem einige ifren Echlammfits зน verYaffen begannen, einige $3 \mathrm{~mm}$ Fłiegen bereit uno andere Vercits in fluge begriffen waren; ïberall unter ben 20 afjer fonnte man fie in einem höberen

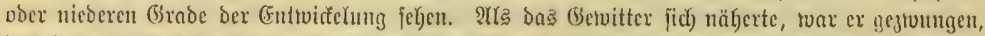

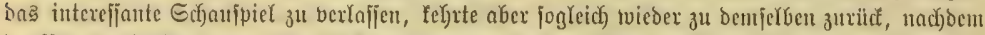

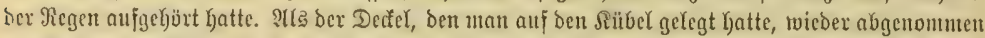

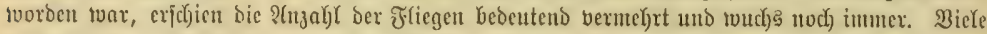

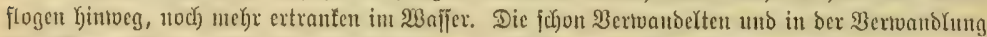

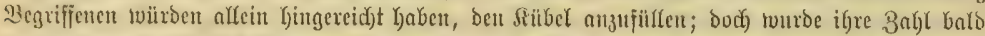

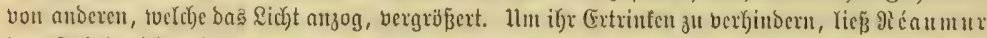

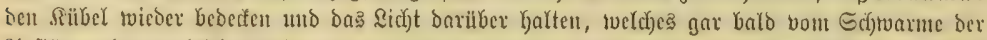

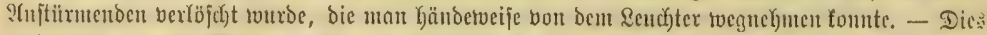

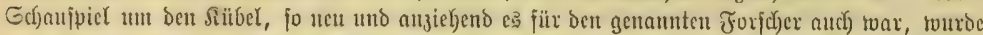

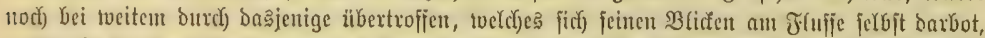

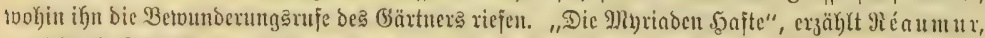

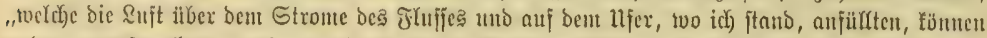

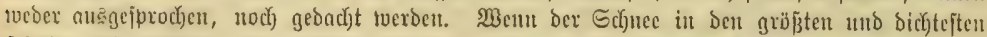

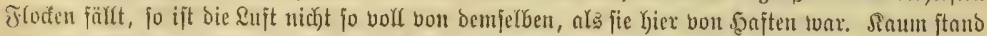

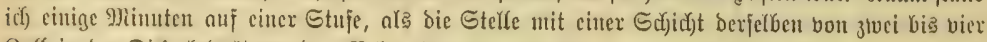

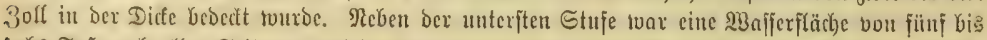

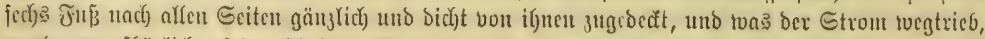

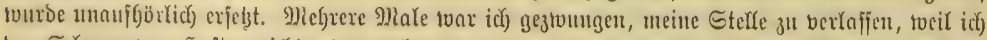

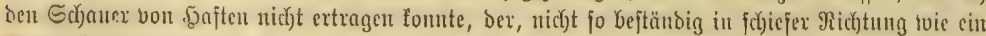

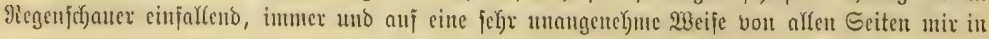




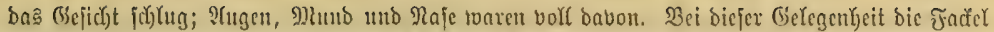

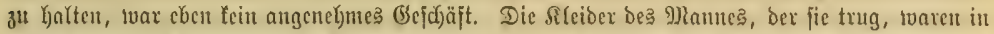

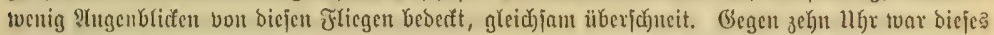

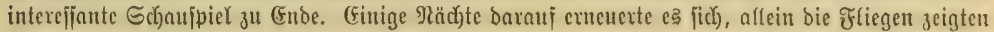

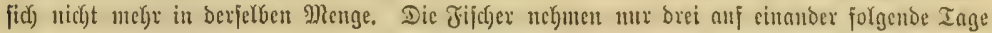

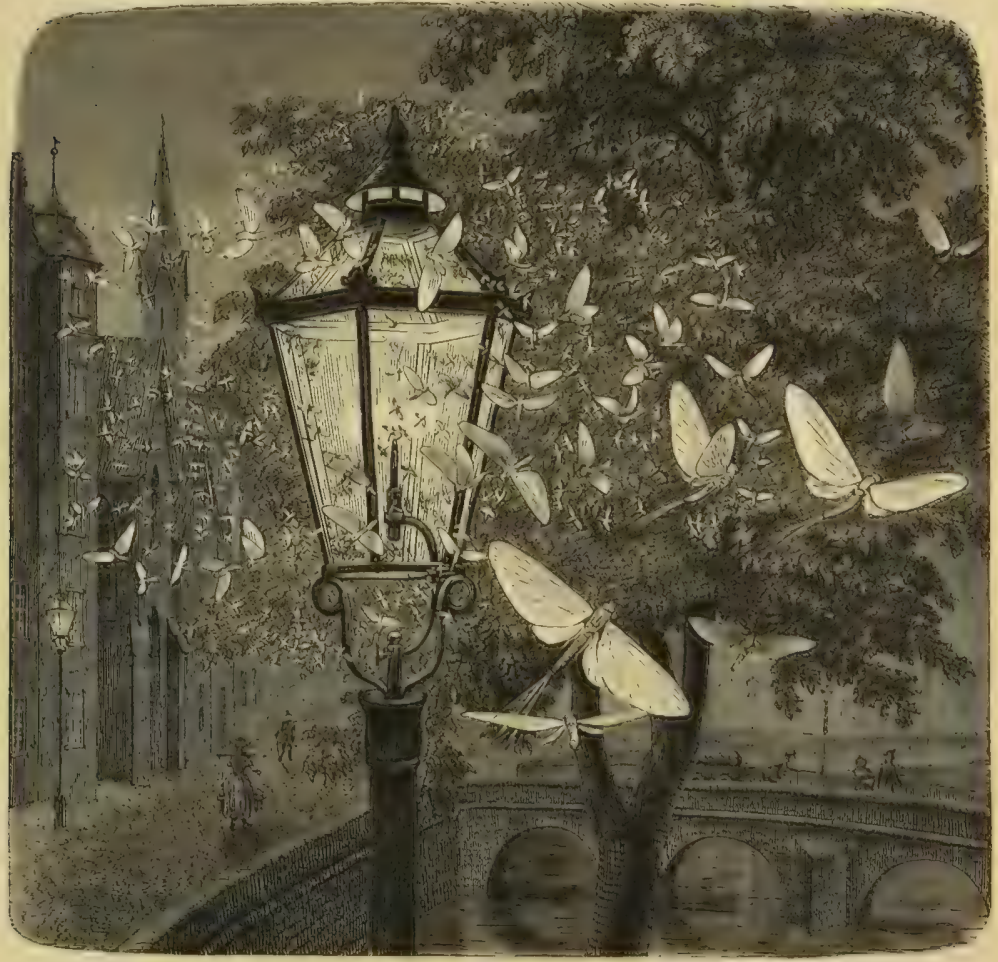

(6) melues 11 iera a \& (Palingonia horaria).

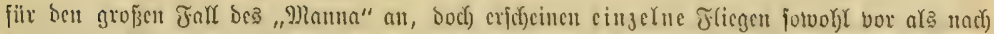

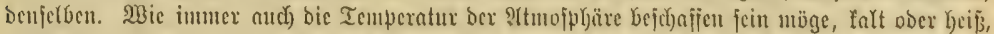

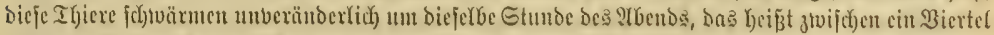

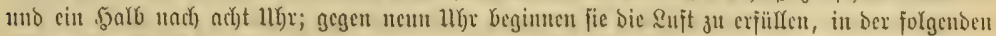

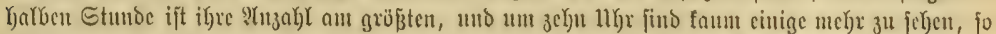

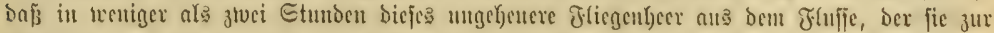

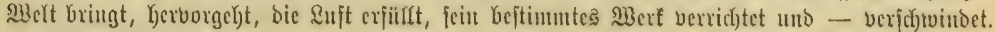

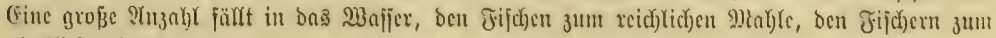
glilithict)en Fange." 


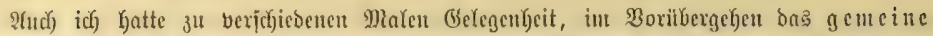

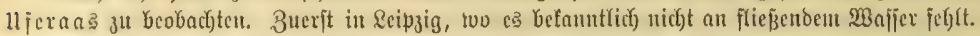

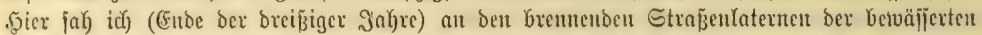

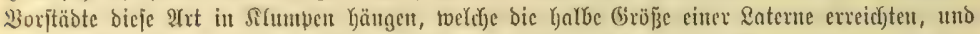

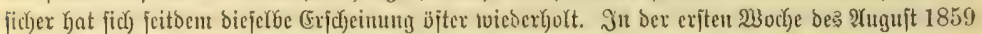

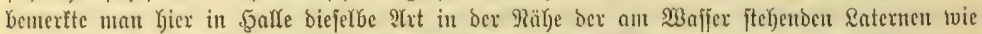

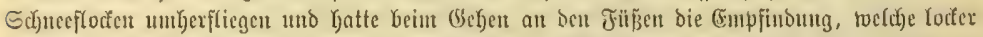

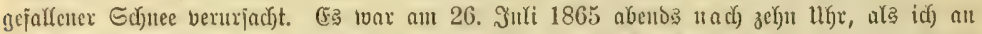

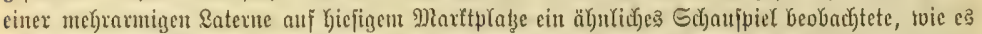

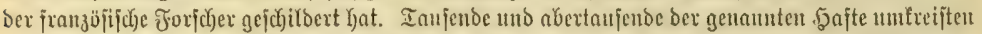

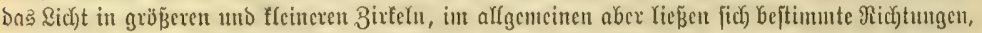

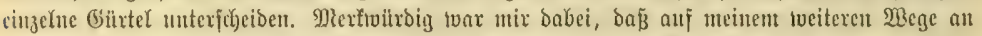

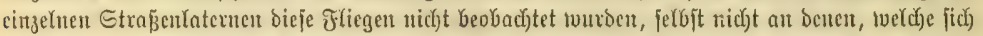

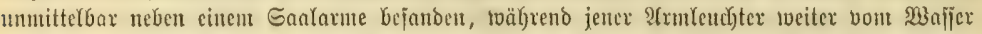

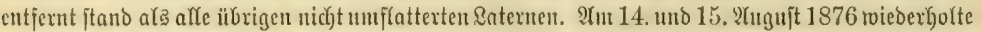

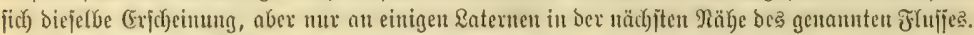

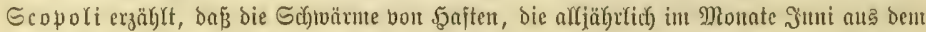

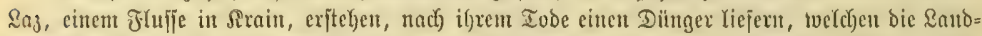

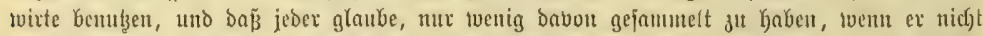

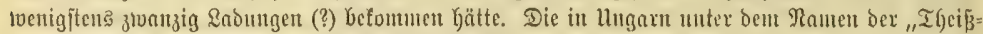

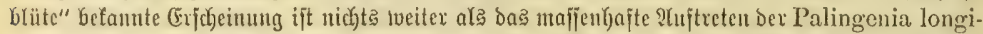

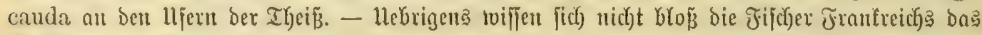

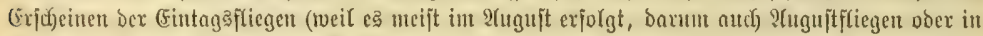

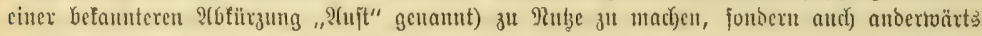

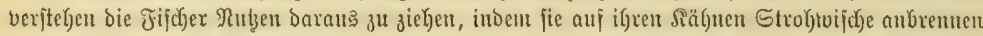

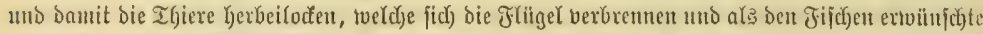

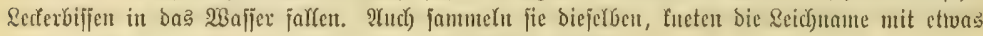

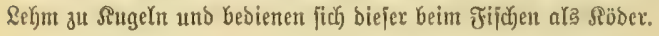

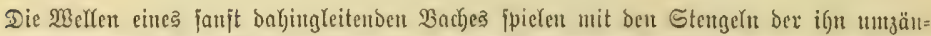

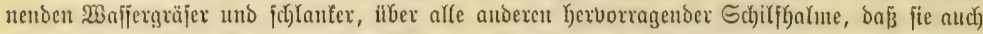

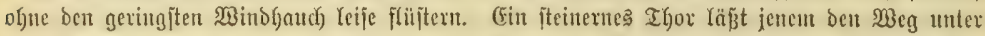

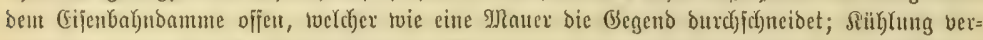

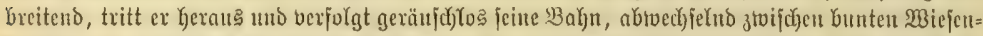

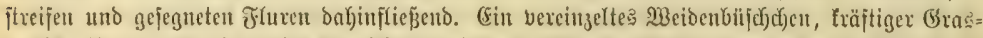

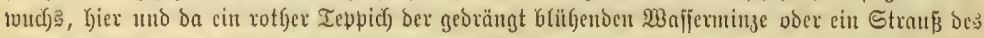

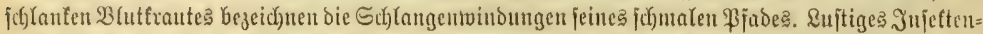

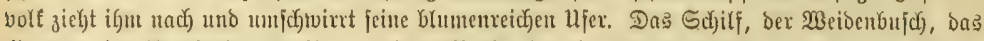

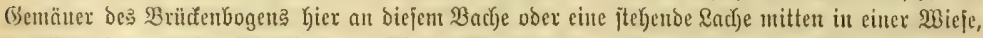

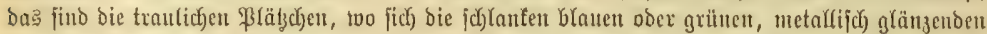

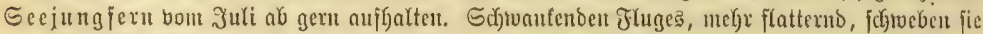
bon Etengel zu Stengel, wiegen fick anf biejen Blatte ober f(anmern fick an jenem fejt, svem

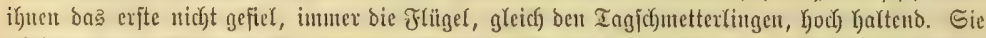

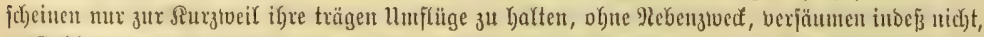

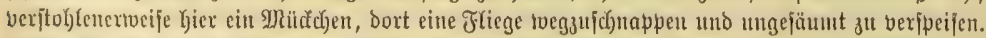

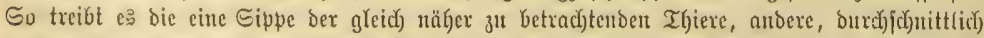

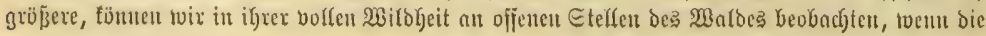




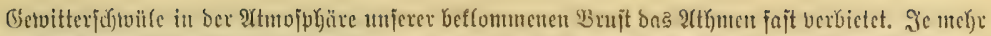

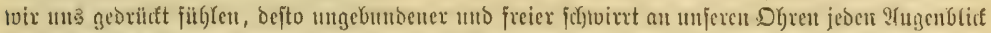

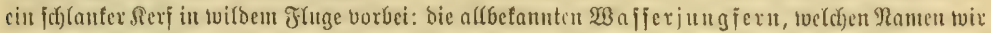

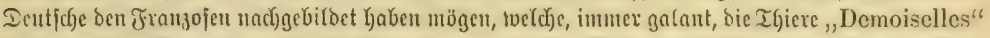

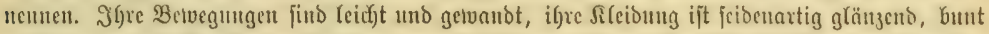

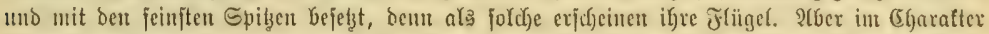

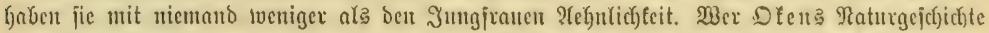

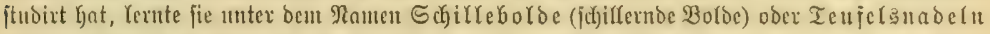

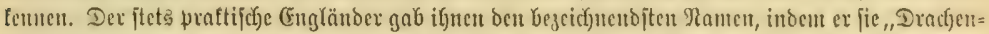

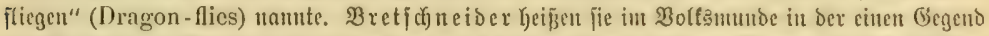

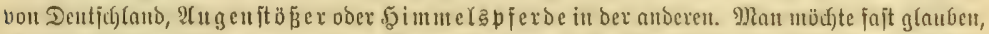

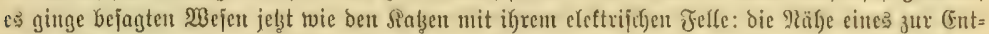
fabung fommenden oder mindeften brobenden (Setvitters rufe in ifrem Drganiämus eine nich)t

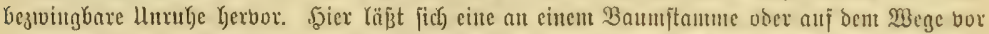

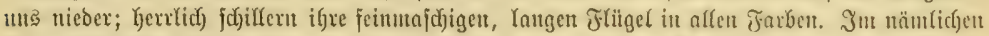
Iugenblicfe fäbrt fie ebenfo tvilo auf, twie fie fich nicocrgelaffen. Dort jtürzt cine toie ein ginub=

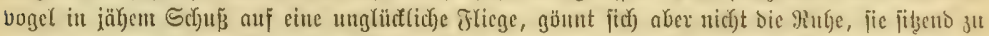

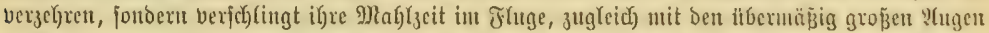

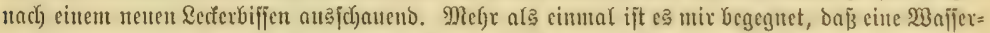

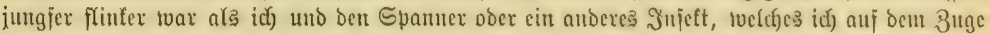

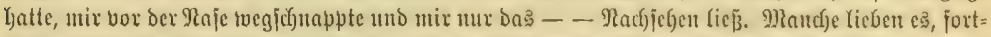

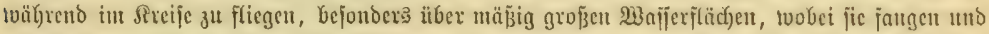

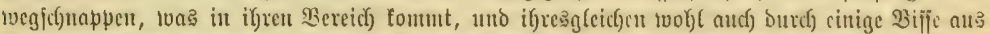

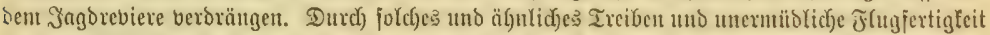

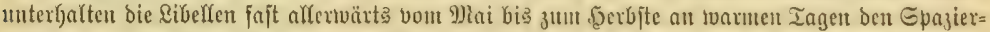

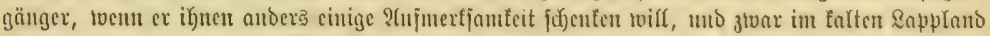

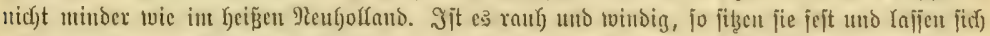

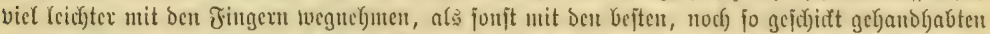

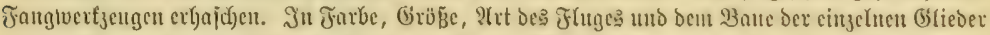

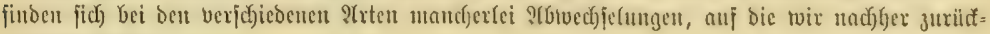
fontutet toerden.

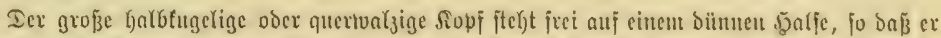

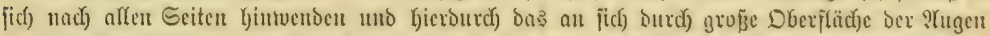

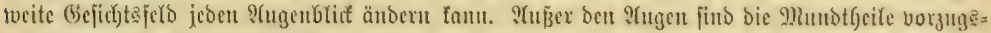

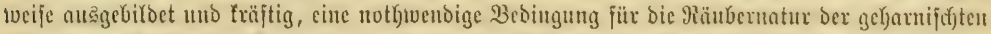

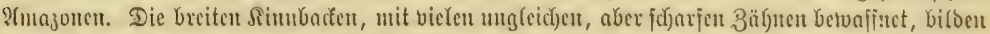

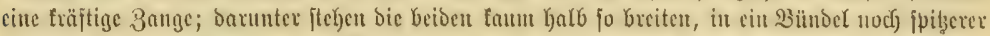

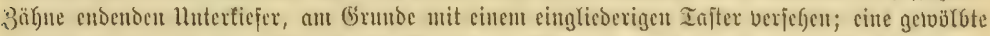

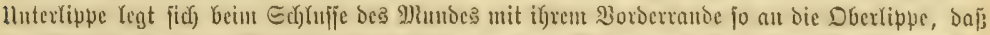

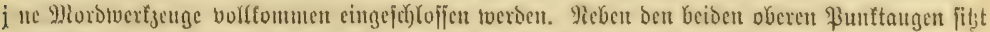

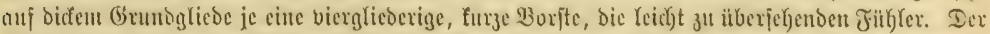
9)

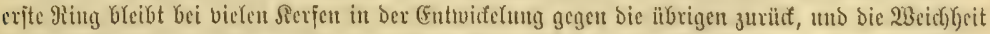

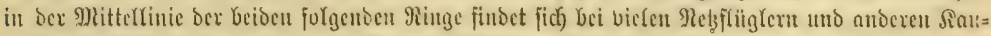

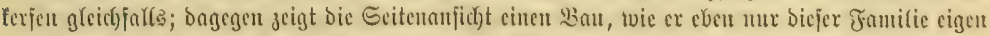

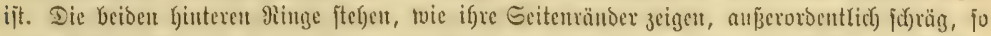

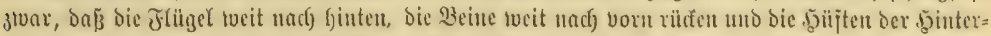

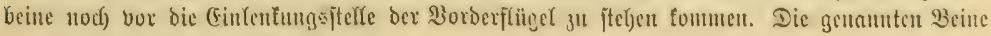




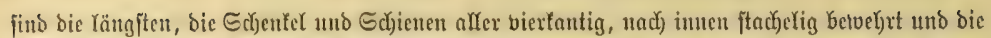

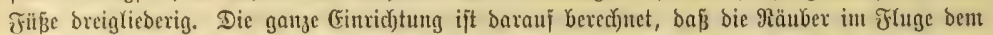

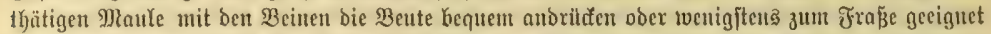

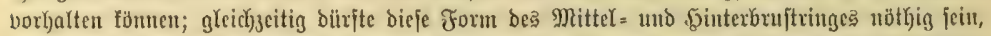

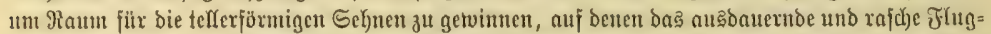

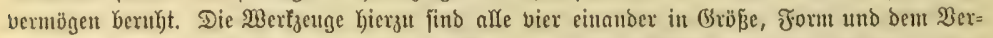

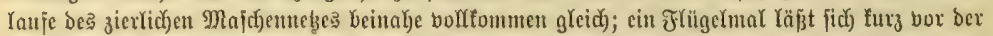
Epize jajt inmer beutfich) erfennen. Der elfglicberige Şinterleib, an borleb̧ten Ringe mit zыvei

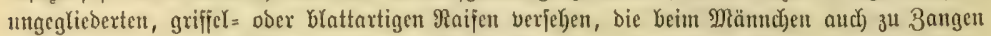

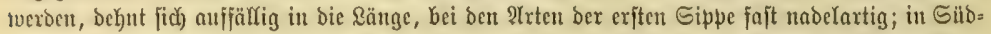

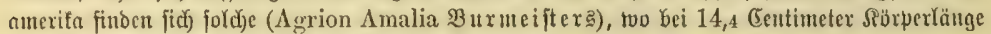
nuf ben Ginterteib alfeiu 12,2 Gentimeter fommen. Uebrigens bereitet er bem Sammler nidyt

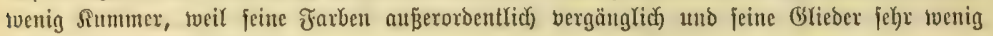
anlyänglidu an einanoer fino.

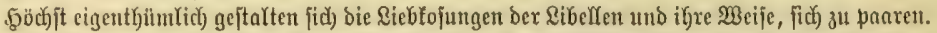

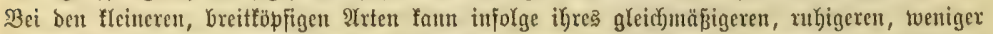

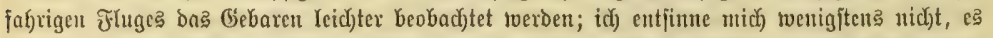

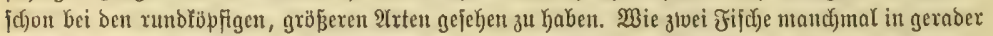

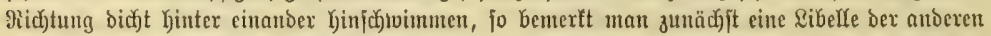

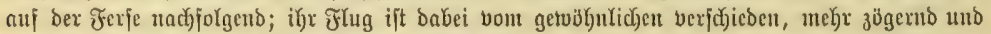

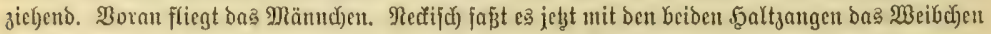

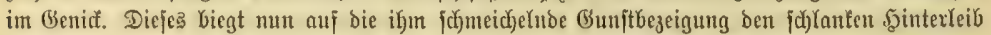

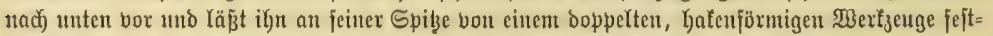

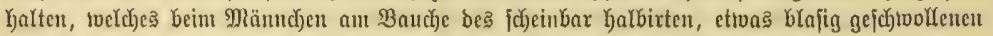

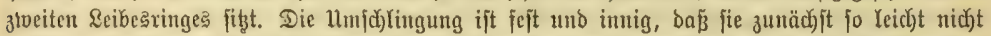

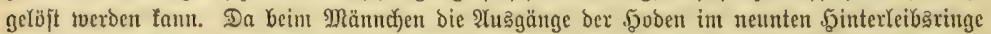

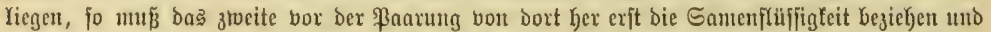

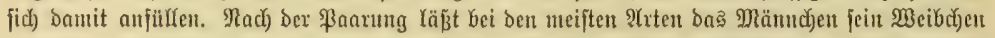
bieder frei, und bieję tanjt entweder in aufredjter Stelfung über bent Wajper, oder fodueioet mit jeincr furzen Regröhre Wajferpflanzen an, unt jeine (Fier unterzubringen.

Die Rarben ber Ribeflen leben im Majjer und fint in Seen, Teidyen und Sumpfen wie

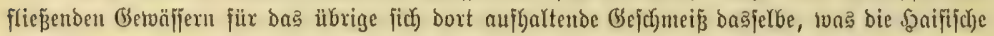

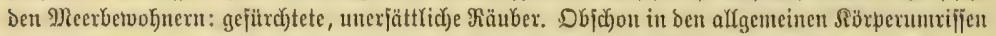
bem bolffommenen Serfe zu vergleichen, tweidjen fie bod), abgejeben von ben fleineren Ilugen,

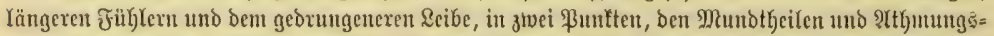

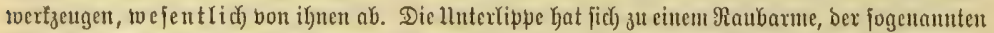
隹a

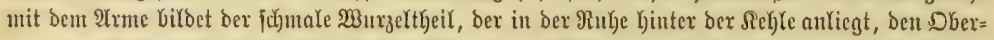

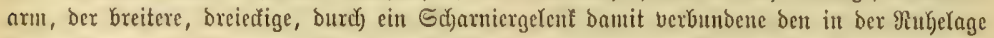

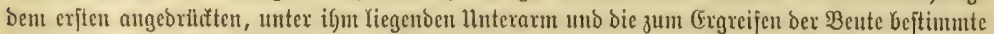
3ange bie Sand. Weil bas Ganze aber an ber Stelle ber llnterlippe ftert, fo Yaffen fict feine

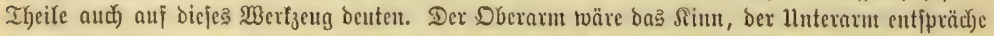

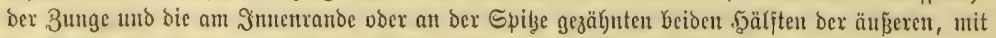

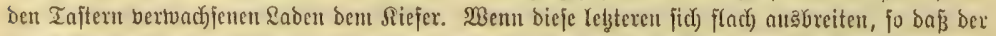

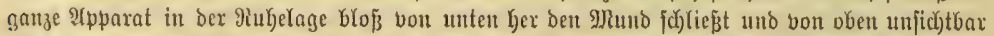

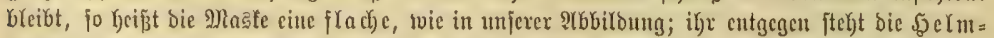

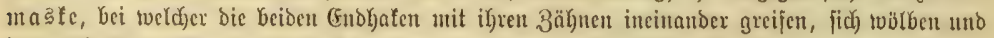

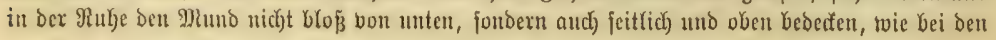


Bnttungen Libellula, Cordulia, Epitheca. Menn bie Rarbe auj Raub auągełst, fo fdjnellt jie

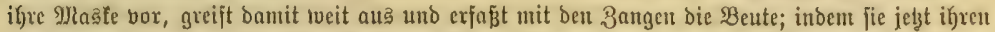

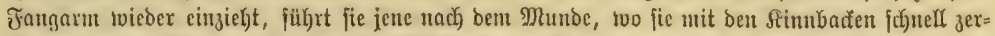

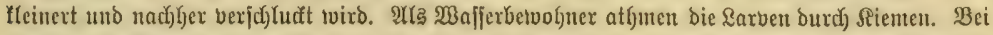

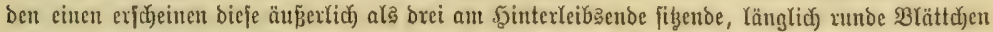

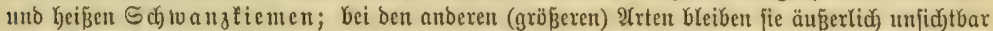
und weroen von ber Stelfe, an ber fie angebradjt find, als Darmfiemen bezeidynet. Sin ben Mänben bes Majtbarmes nämlich, weld)en ztwei bünnere श(tf)menröbren jeiner ganzen \&änge nad)

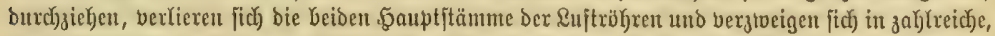

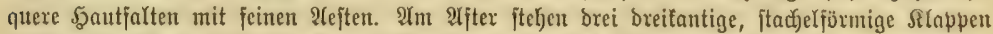

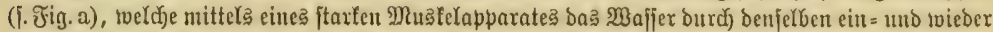

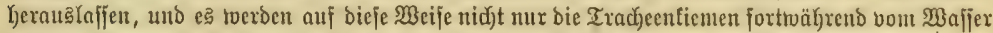

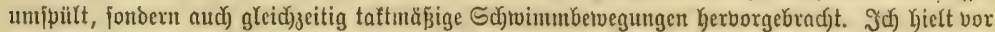

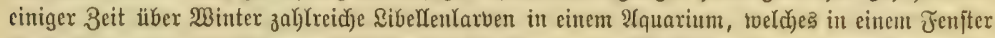

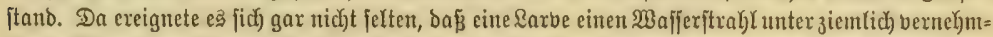

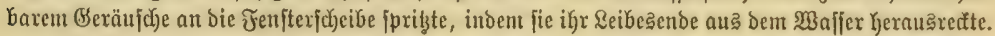

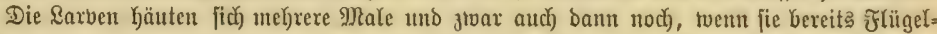

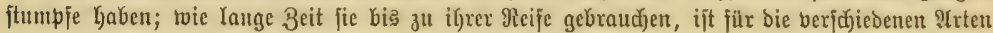

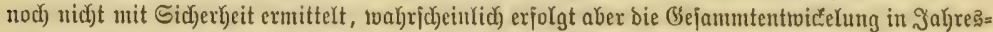

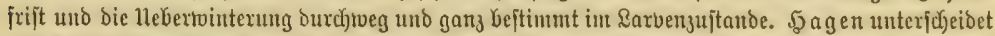

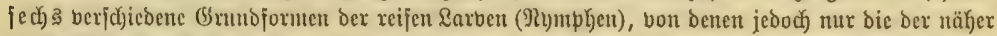

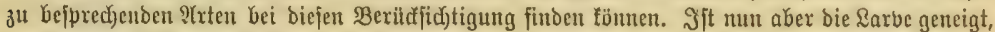

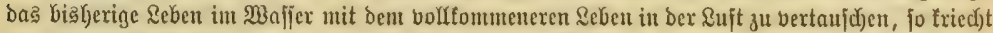

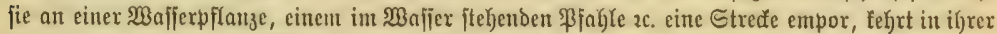

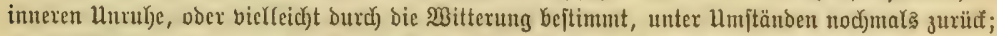

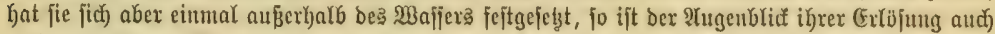

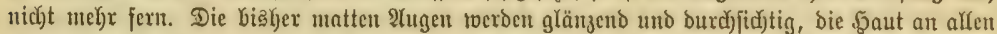

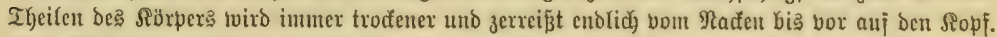

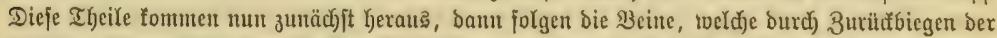

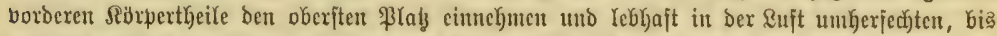

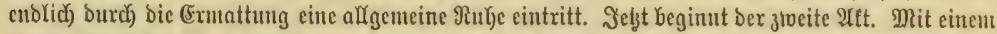

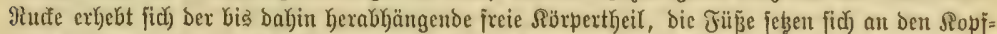
theil ber (eer und baburd) Gelf getworbenen (baut feit, und nun twirb ber nod) berborgene \$interteib

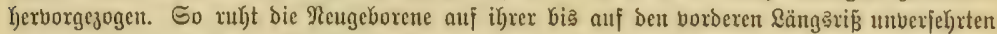

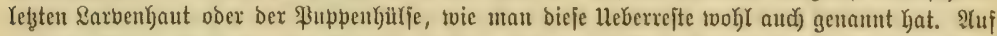

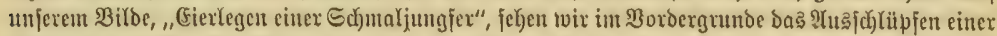

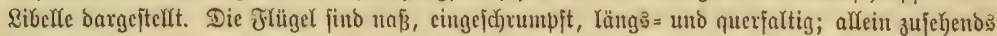
glättet fičd) eine Falte nach) der anderen, und in faum einer Galben Stunte bängen fie in iGrex bolfen

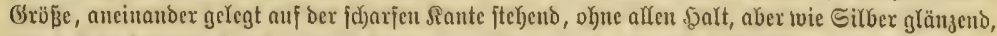

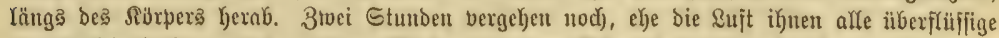

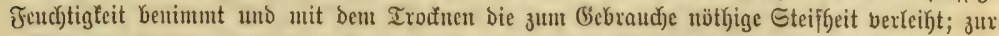

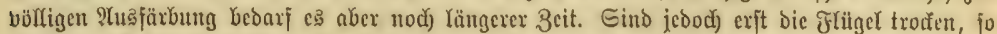

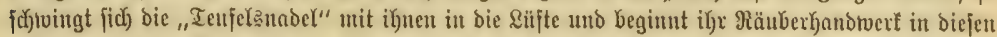

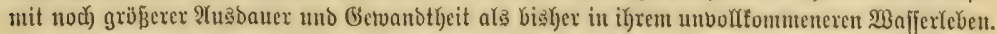

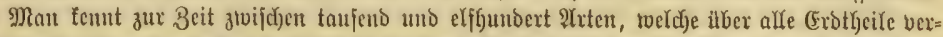

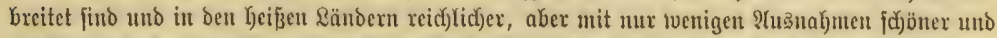

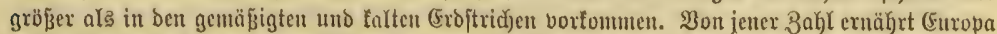

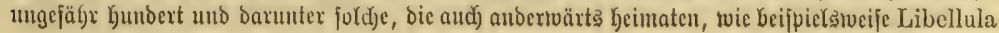


pedemontana in Eibirien, Aeschna juneen in Iranstautajien, Anax Parthenope in ?firifn;

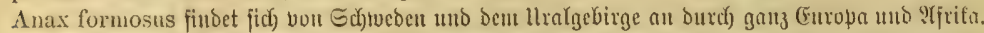

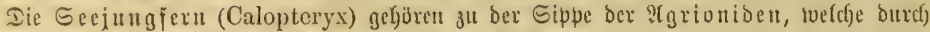

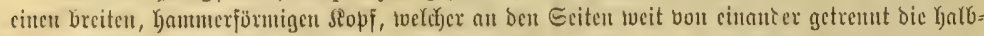

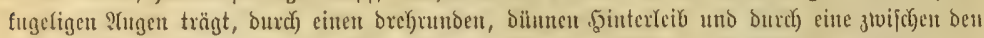

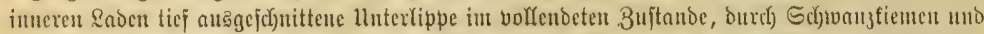

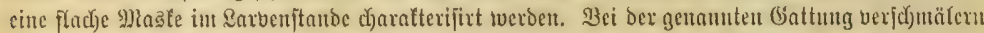

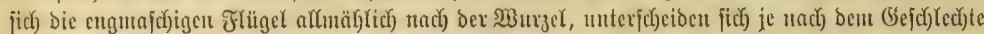

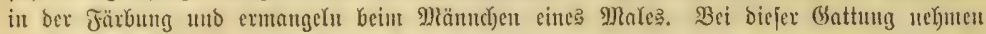

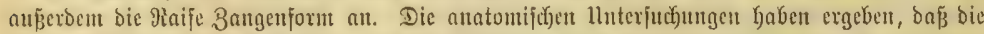

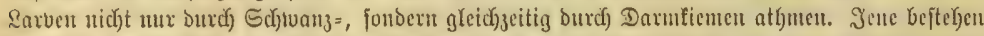

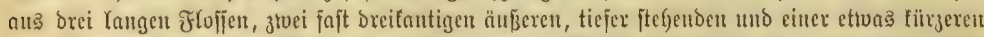

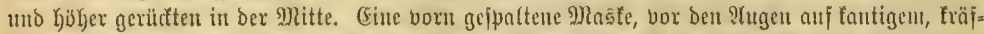

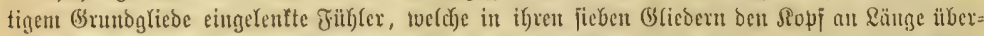

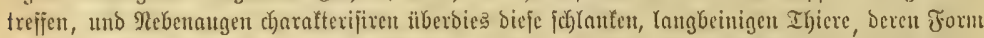
in gleid)er झeife bei feiner anderen Gattung vorfummt. (Fine ber häufigiten unto verbreitetiten

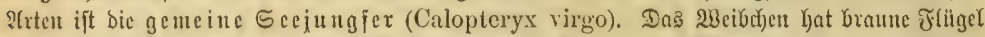

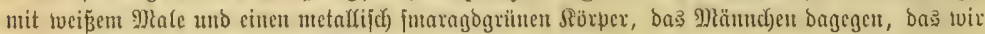

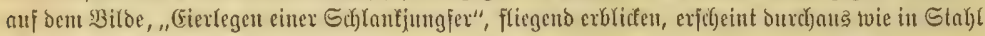

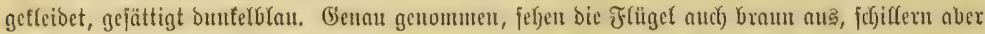

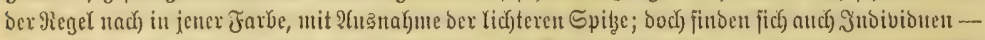
man hat fie "unreife" genannt, Calopteryx vesta (5 garpentierz-, bei benen ber Silfiffer volfitänoig wegbleibt un๖ die braune Grundjarbe zux Geltung foumt. Die Sörperlänge beträgt

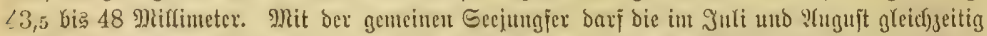

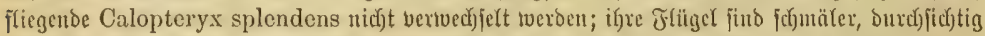

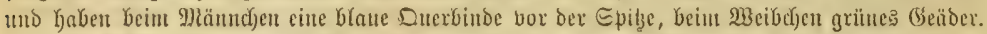

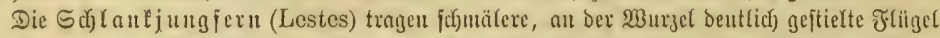

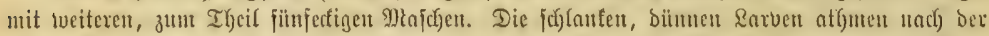

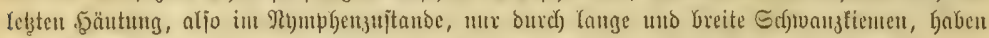

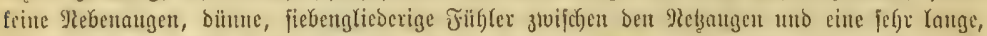

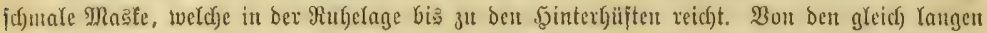

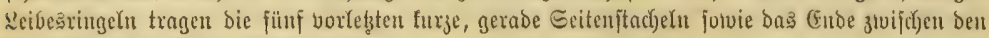
Drei Flofien fün furge Sdjtwantipizen.

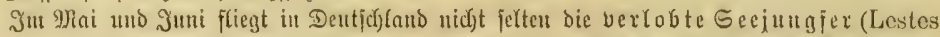

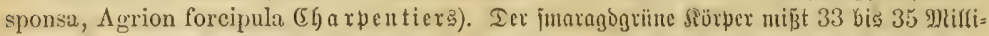

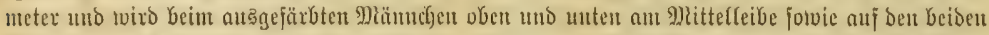

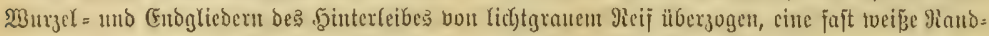

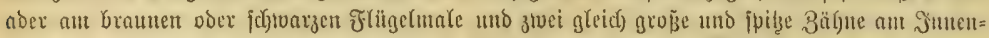

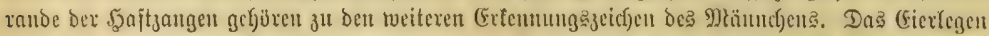

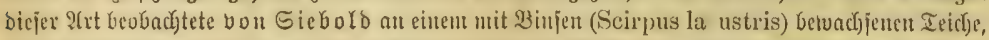

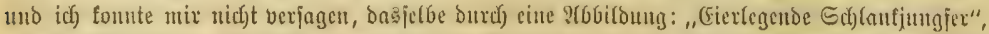

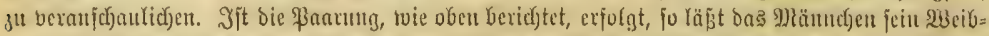

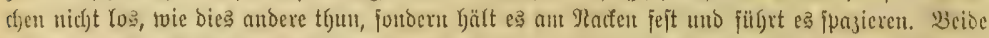

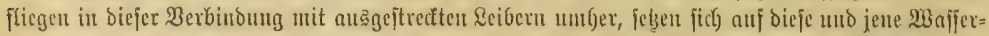

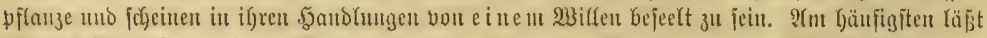

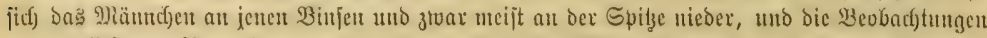

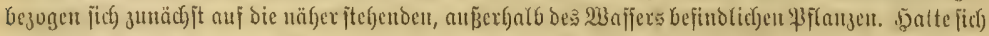

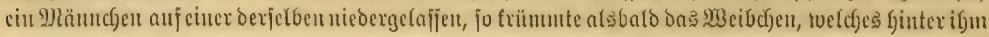




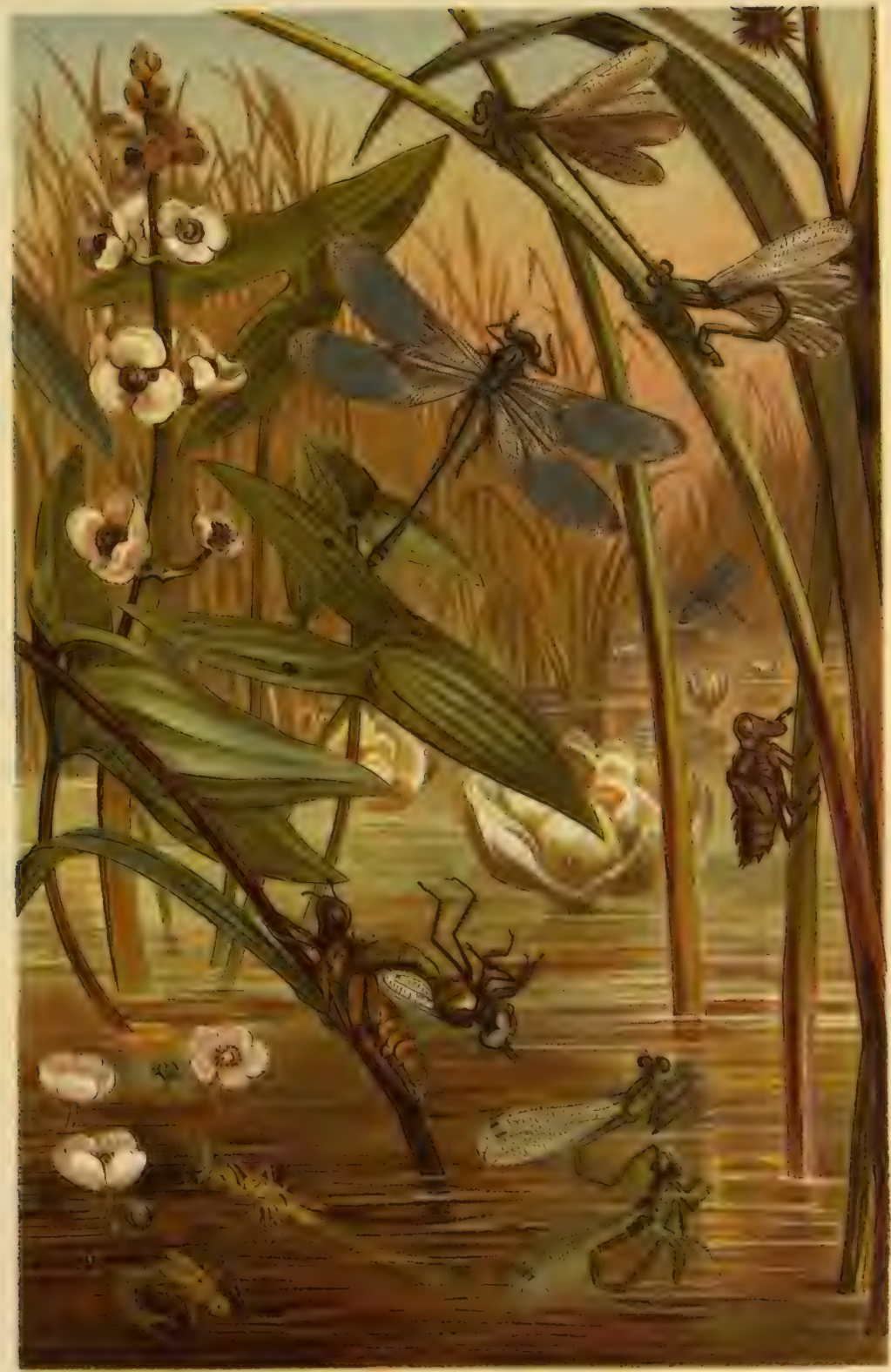

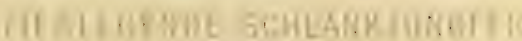





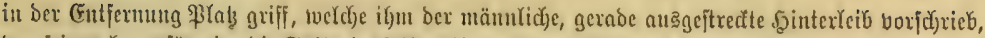

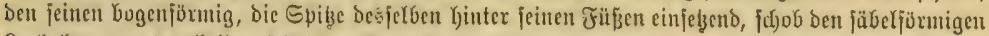

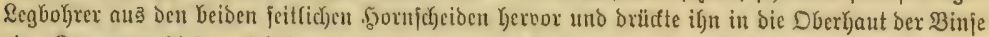

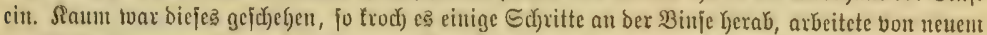

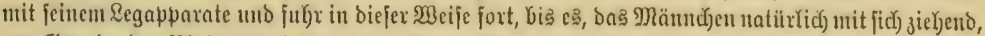
nut Grumbe ber $\mathfrak{B}$ inje angelangt tunt. Dant flogen beibe bavon, um alt eiuter anderen bnajelbe

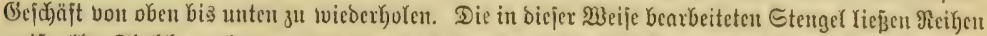

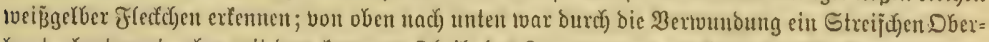
hout abgetremt, aber mit bem fonveren Theiłe bes Regapparates, nadjocm berfelbe heransagezogen

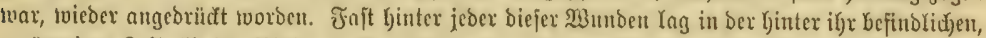

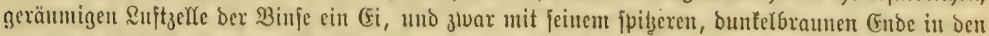

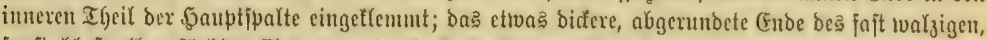

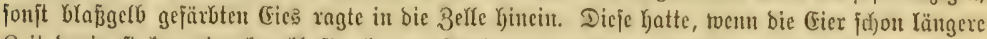
Beit barin ftafen, cine franfgafte, brante Farbe angenommen. Mand)

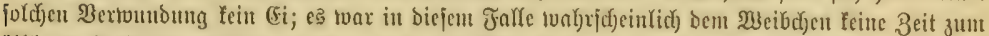

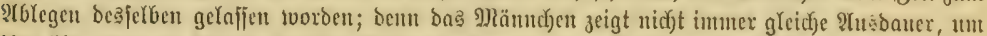

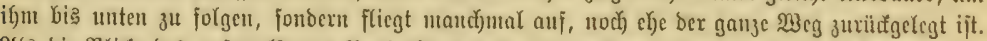

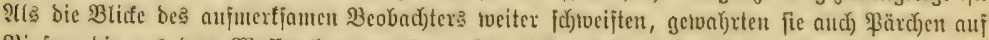

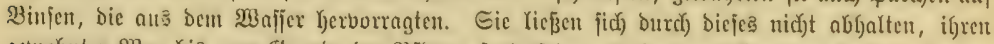

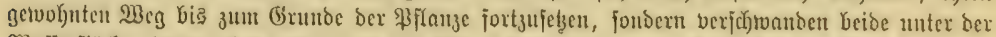

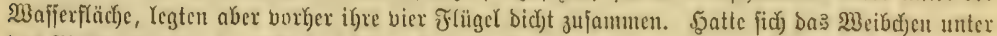
Dంకె :

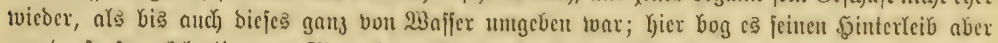

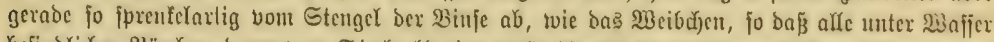
befindrichen \$ärdyen, beren von Giebold cine grofe 2 (nzah) beobad)tete, mit ihren \&eibern cinen

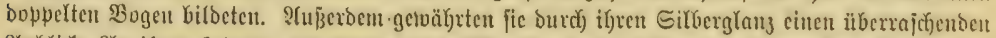

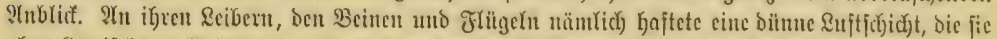

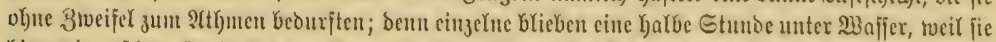

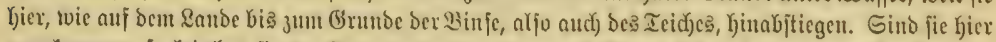
angefommen, fo friechen fie an Stengel svieder empor mo fliegen fojort bavon, wenn fie iiber bem

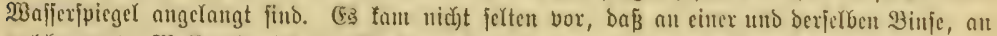

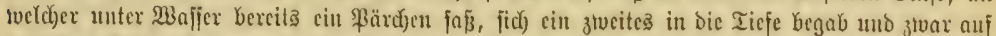

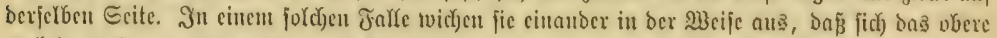

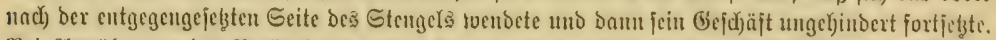

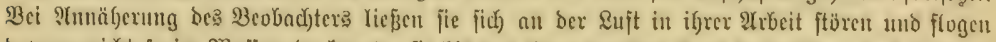

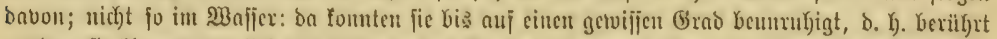

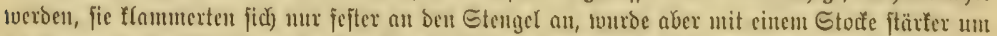

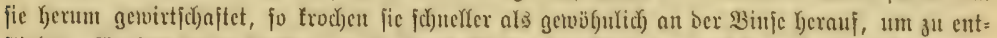

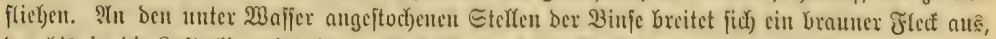

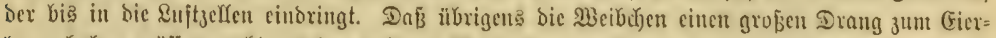

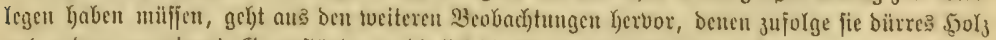

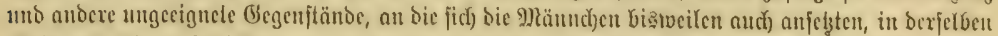

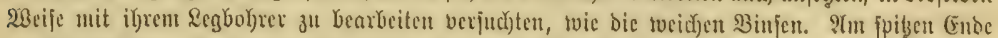

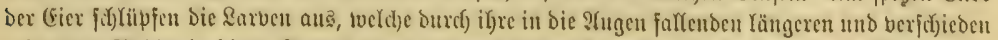

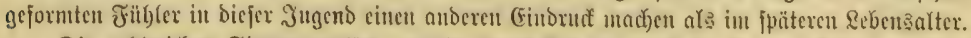

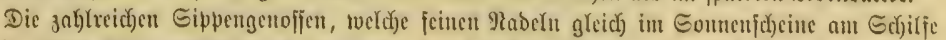

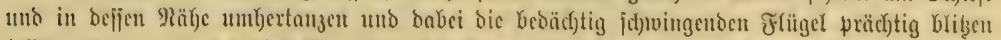

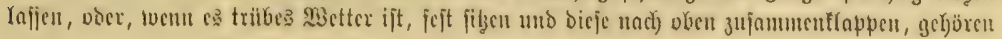




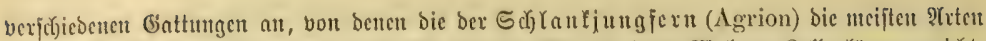

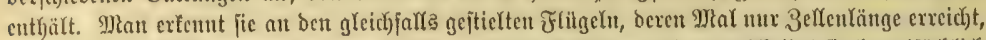

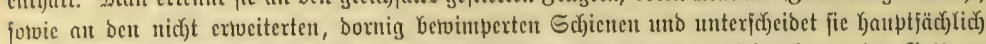

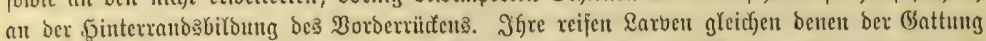

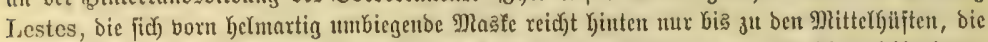

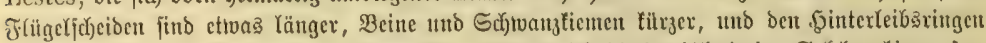

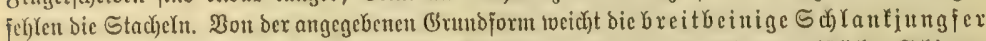

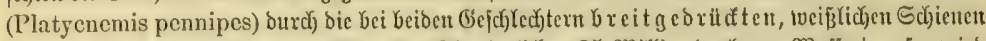

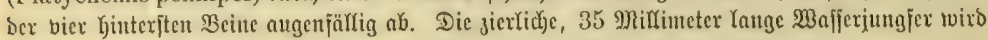

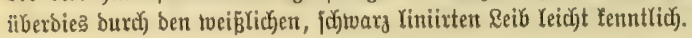

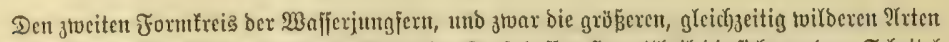

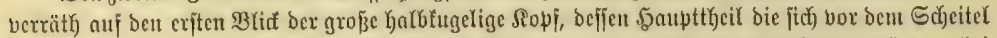

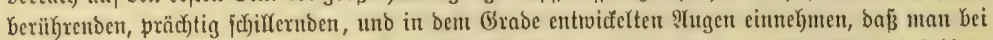

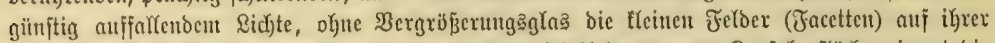
gewüloten Dberfläche erfenten fann. Den britten Theil bex ganzen Ropfoberfläche niumt bic

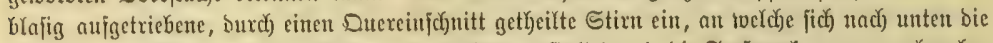

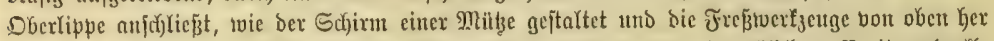

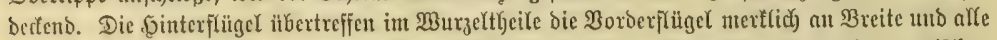

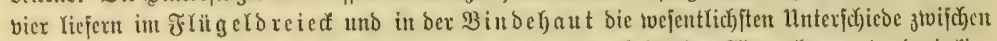

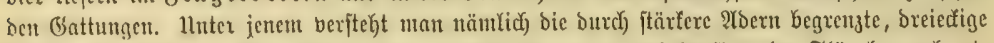

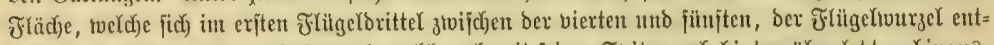

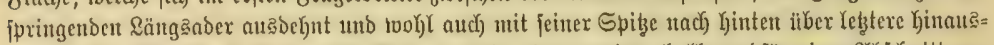

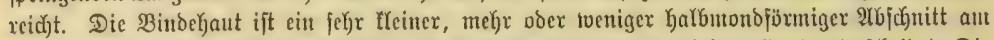

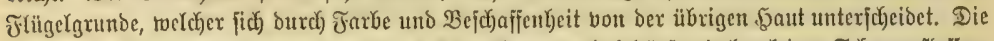

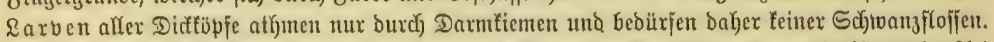

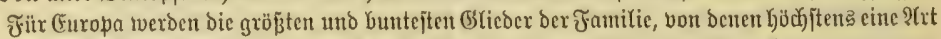

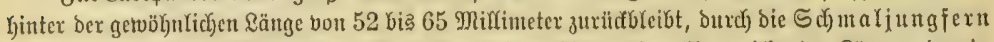

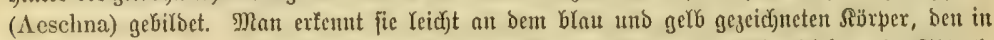

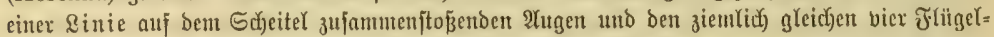

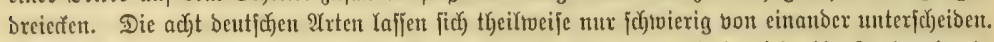

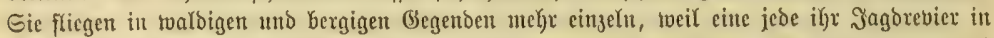

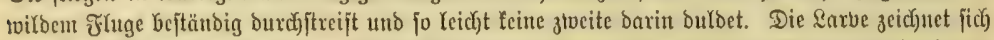

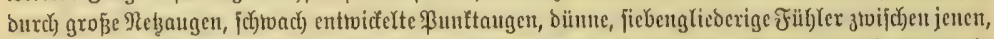

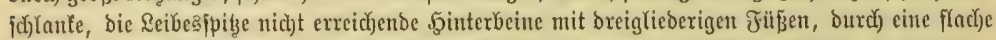

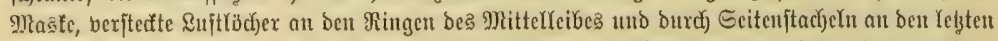

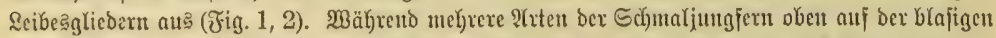

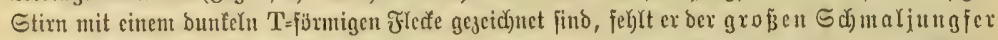

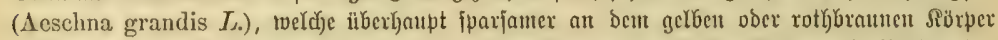

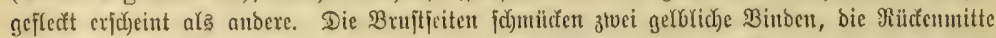

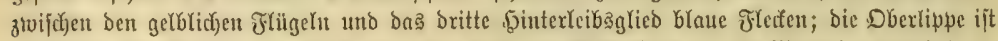

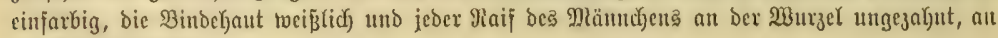
ber Epibze gerundet.

Der geme ine Plattbaud (Libellula depressa), gelbbraun bon Farbe, an bent Rändert

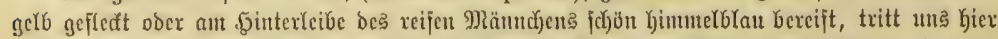

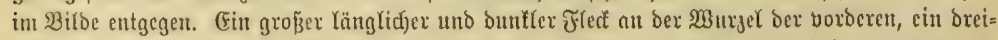

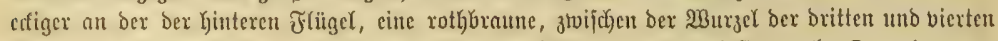

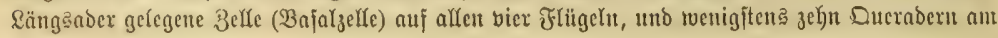




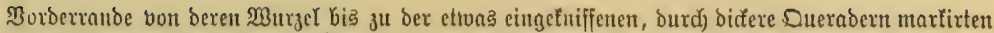

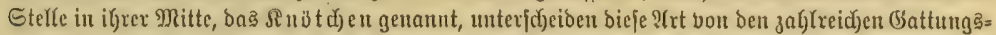

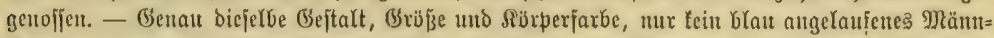

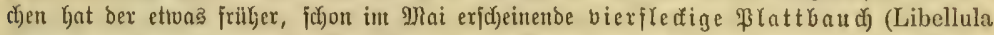

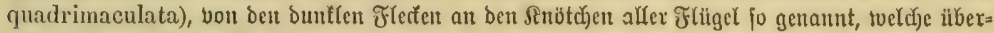

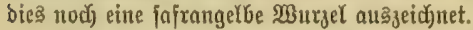

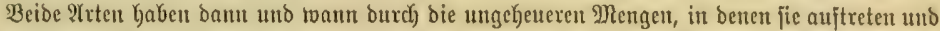

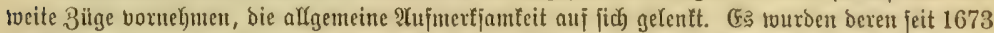

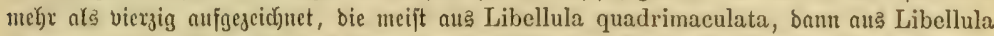
depressa unb auck eimual aus einent $\Lambda$ grion bejtanden. Der bereits oben ervöbute, nicf)t mur

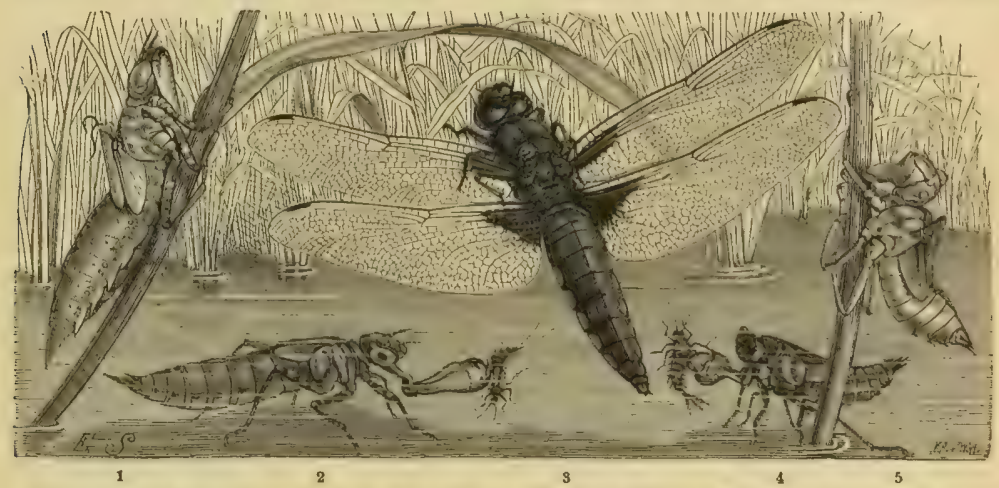

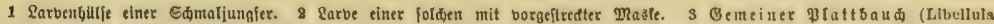

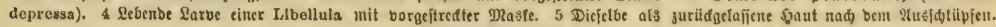
Ratürlide Orỏise.

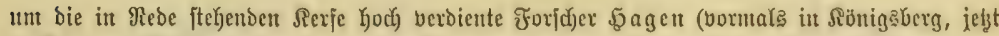

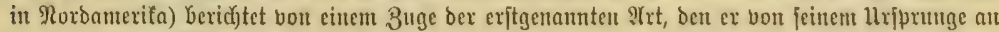

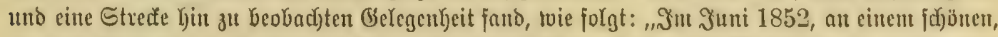

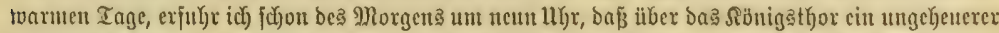

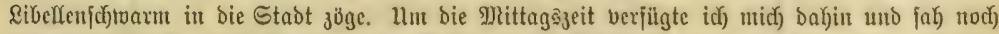

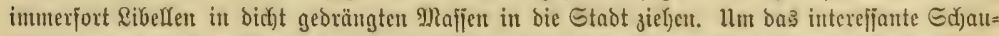

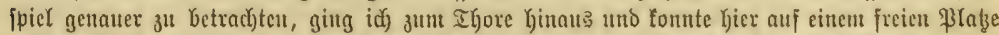

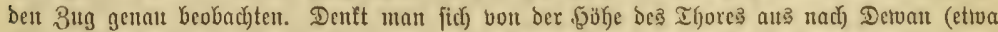

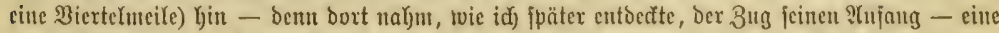
gerabe Rinie gezogen, fo gibt fie bie Richtung genau an; ant Thore tuar cr ctua breiß̄ig đuß itber

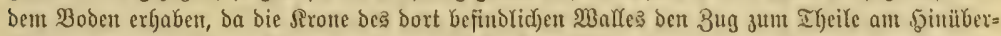

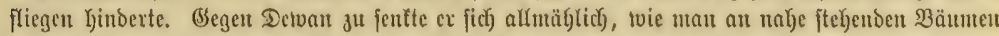

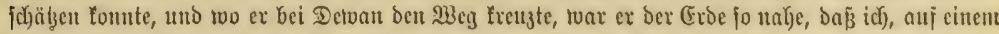

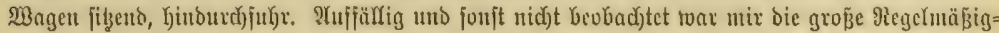
feit bes 3uges. Die Ribelfen flogen bidyt gebrängt Ginter = unto übercinander, ohne bon ber bor=

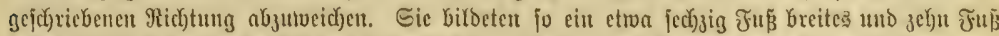

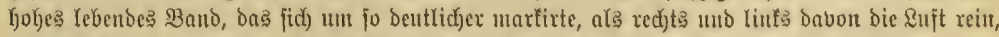

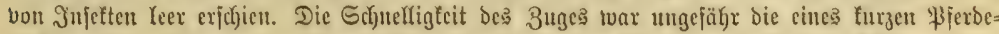

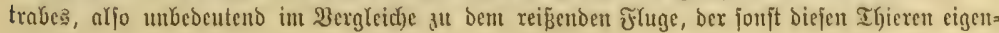




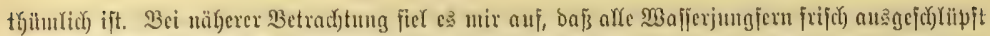

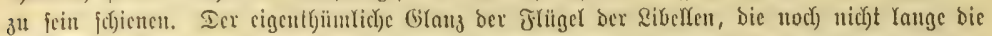

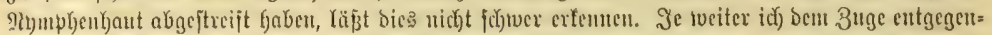

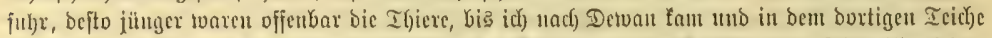

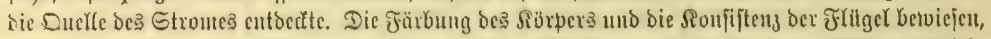

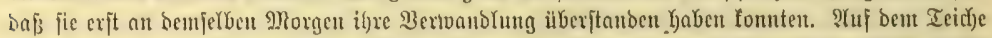

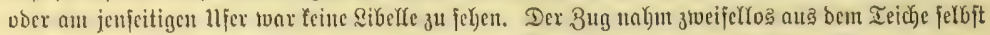

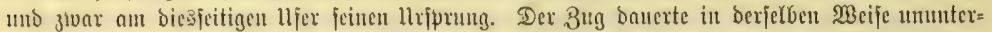

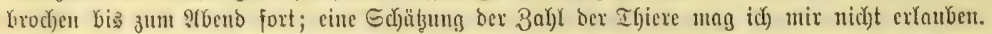
Sllertwüroig genug übemach)tete ciu Igeil besfelben, bn bie Ribeffen mit Sonucmuntergang zu fliegen

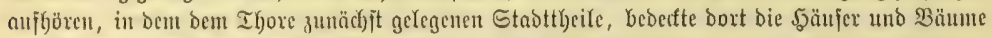

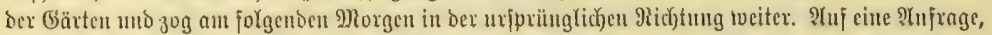

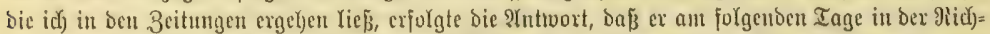

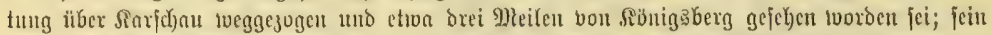

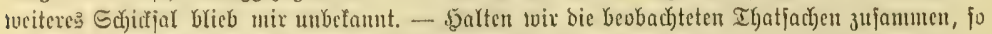

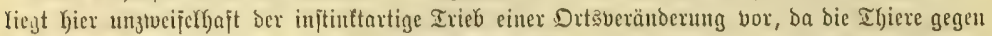

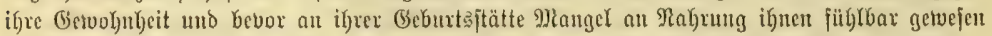

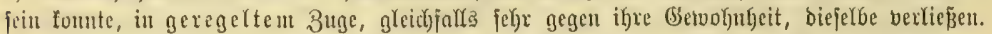

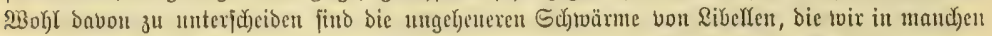

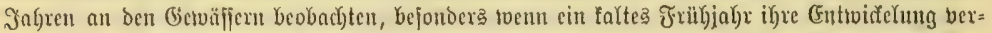

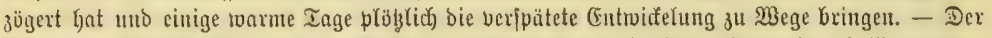

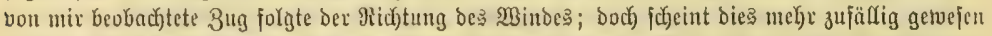

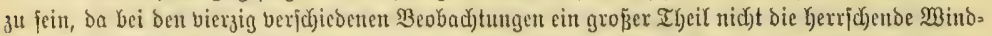

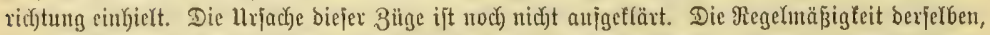

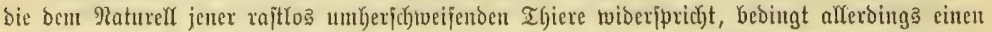

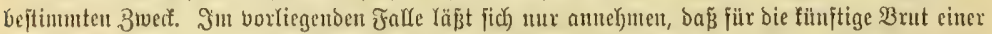

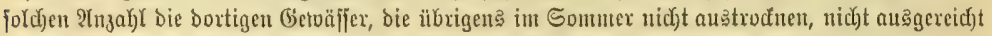

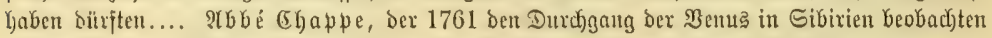

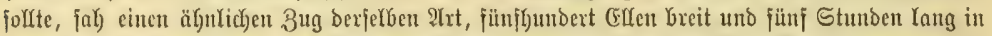

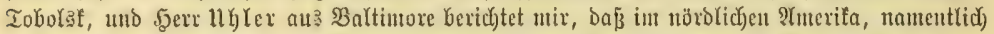

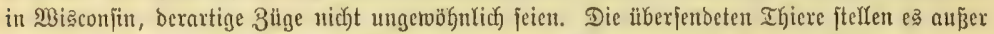

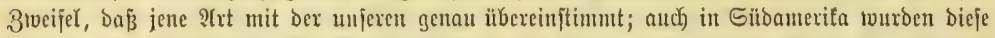

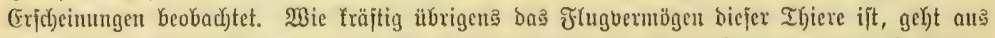

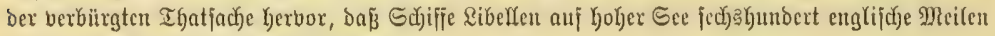
bom \&ande fliegend angetroffen Kaben....."

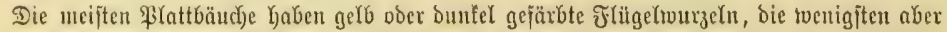

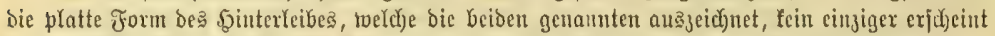

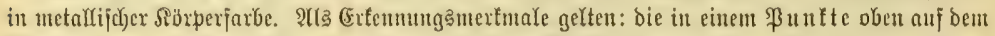

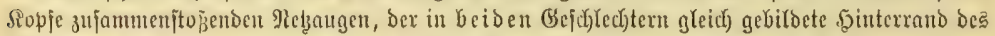

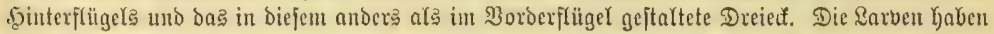

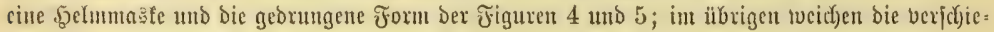

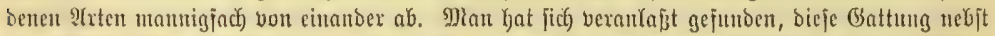
ifren Bertononoten (Epitheca, Cordulia, Polyneura, Palpopleura unb andere) als britte Sippe

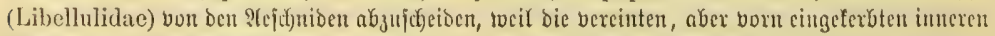

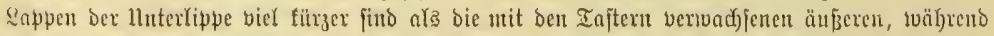

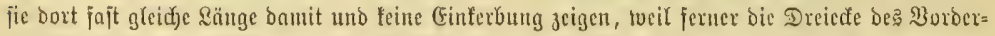

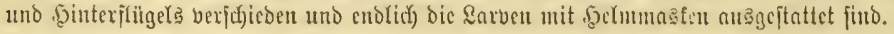




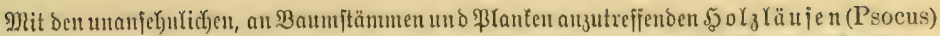

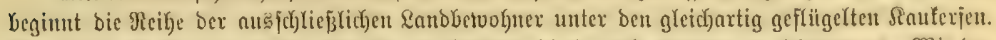

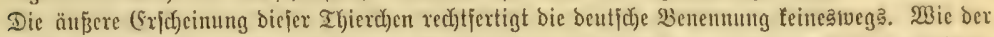
Siopf fich) burd) cine blafig aujgetricbene Stim nad) voru, burch) globende Augen feiflich ertweitert,

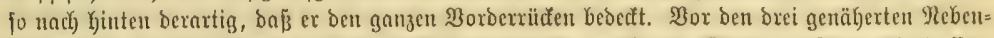

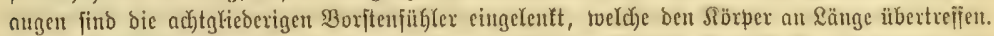

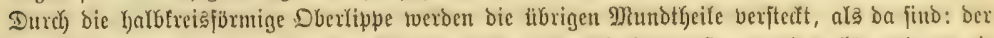

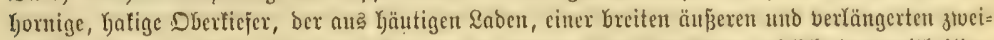
¡pibigen imeren, uno vierglieberigen Injtem zujanmengejebzte Hnterfiejer, cnolid) cine zlocitheilige,

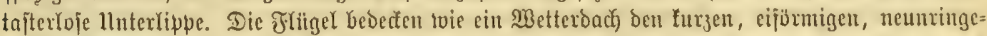

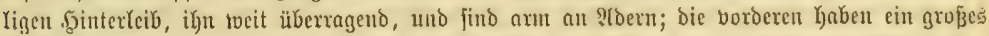

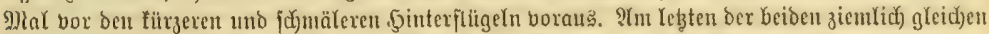

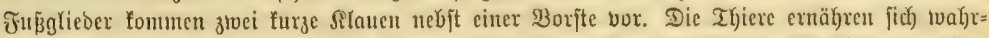

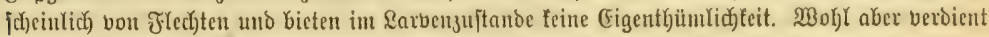

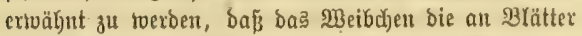
gelegten Gier mit Fäben auล jeiner Dberlippe ziberipinnt, jebe 2 rt auf ifre Wreife. So birgt z. 23. Die bierpunt= tige \$olzlaus (Psocus quadripunctatus) bie ifrigen,

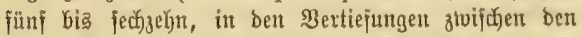

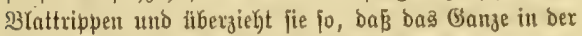
Entjernung Das Tnjeben einex Jijodjodjuppe annimmt. Wir Yernten früber dasె Spinmen einiger Maffertäjex zu

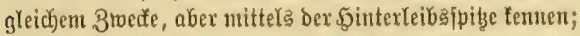
unter ben bofffonmenen Sinjeften ift mir fcins weiter befannt, toeไd)es mit dem Maule fpinnt.

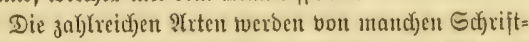

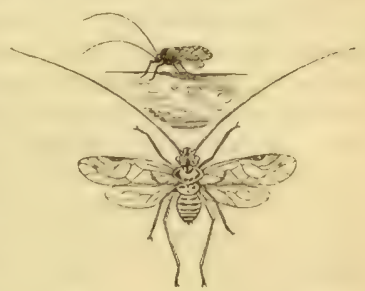

Sinitrte \$oljโa $\$$ (Psocus lineatus), brcimal verßrötert. fteffern auf mefrere Battungen vertfeilt und Yaffen fich

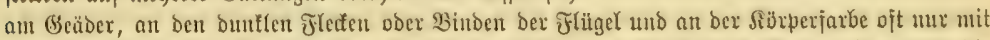

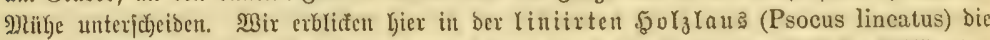

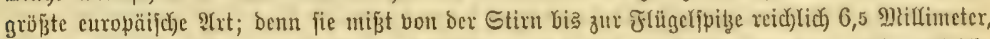

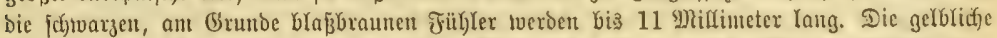

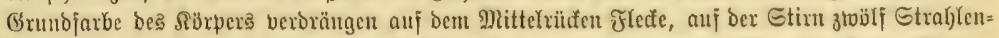

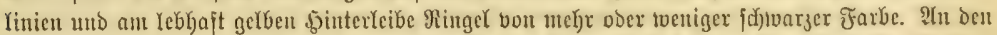

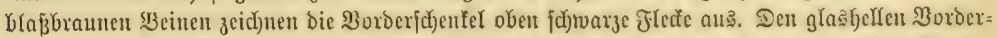

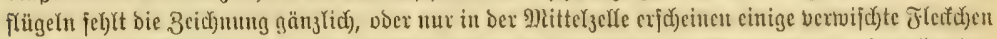

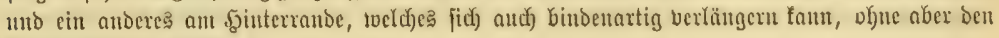
\$ुorberrano 孔u exreidjen.

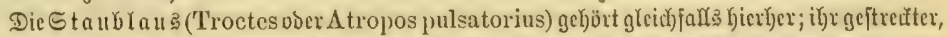

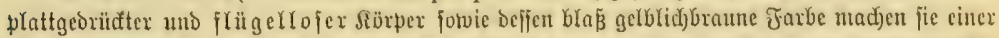

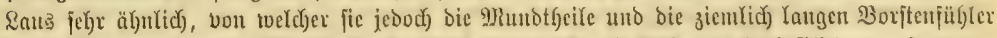

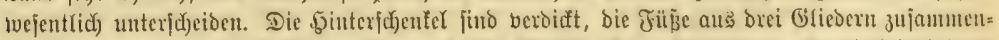

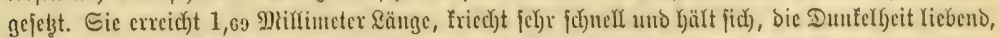

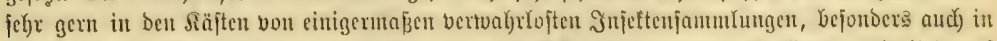

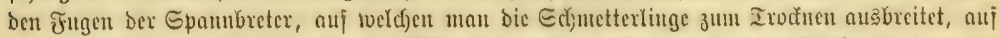

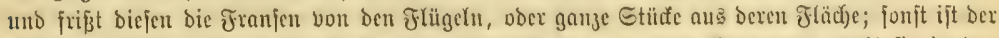
Eeffoben, welden fie in Den Eammlungen nurid)tet, von wenig sedocutung, weil fic in seu

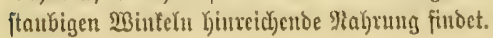


Dic Iermiten, llnglü ä

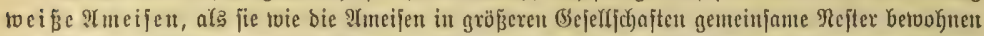

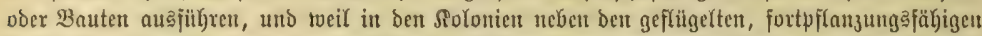

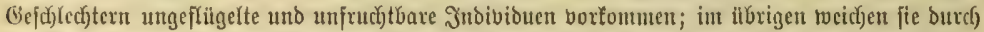

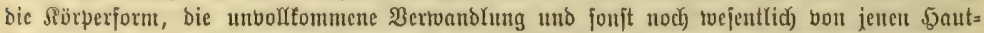

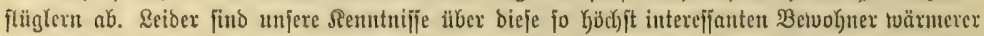

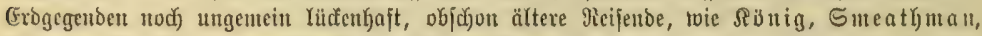

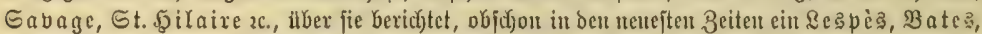

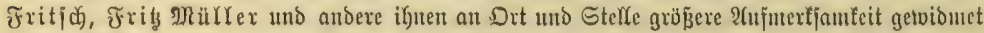

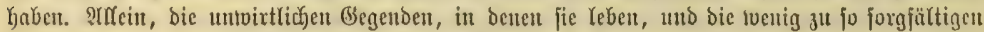

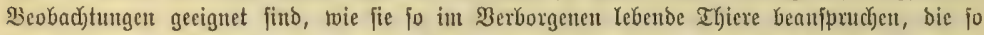

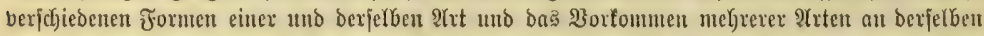

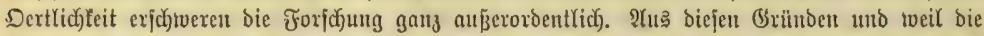

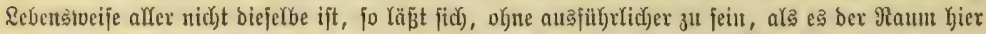

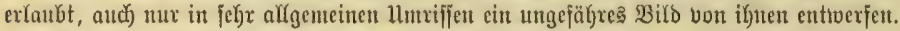

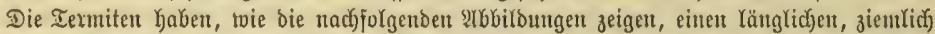

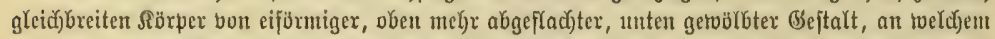

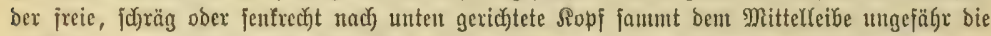

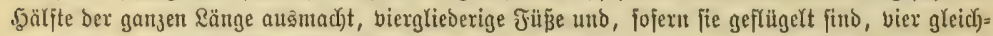

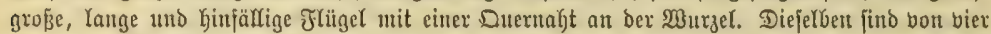

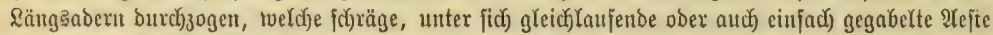

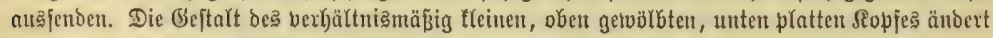

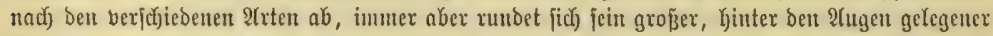

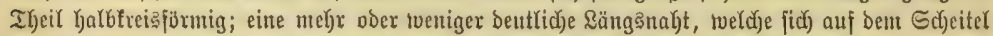
gabelt, theilt ihn in brei fajt gleiche Theife. Die meift grofen Irugen quefren Kerbor uno grenzen jeberjeits uad) innen an ein Nebenauge, beren im ganzen un ztwei bortommen, gar feine bei

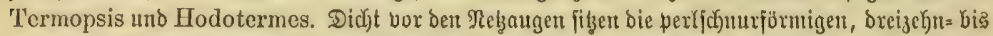

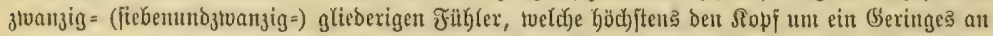

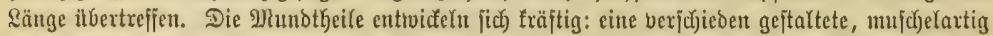

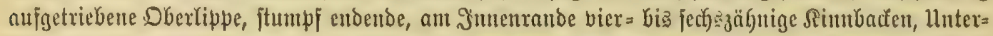
fiefer uno Unterlippe; jenter aus einter łoeizähnig endenden interen, einer Yjü̧ger liegenden, fäbel=

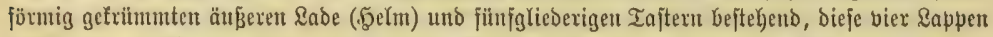
baritellento, tweldye von ifren breiglieberigen Iajtern twenig überragt werden. Die brei Ringe bes

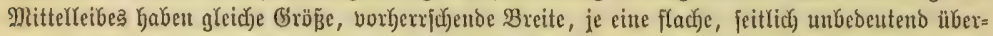
ragende (Shitinplatte als Bebedung, Derent borberjte fich) von ben übrigen einigermajen unterjucheibet

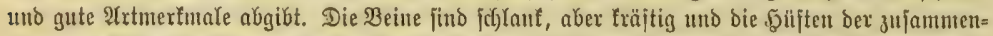

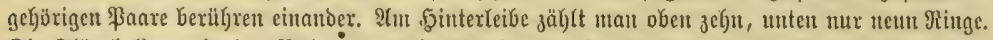

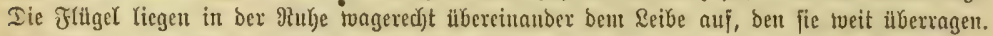

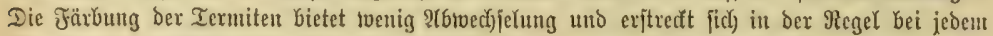

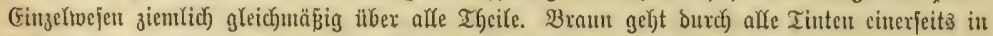

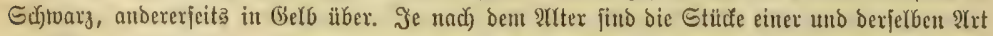

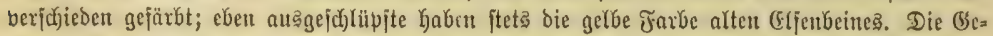

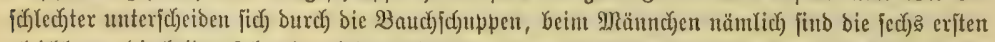

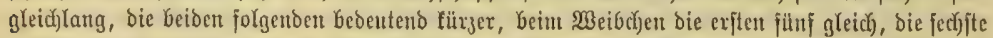
größer, je nach ber 2frt anders gejormt, bie beiben folgenoen verfïnutert; bie neunte erjicheint bei beiben (bejchlechtern berfümmert uno getgeilt.

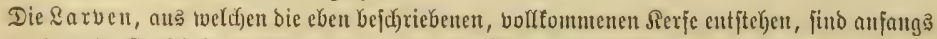

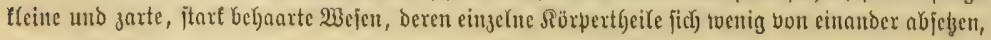




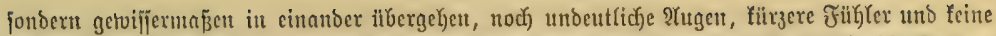

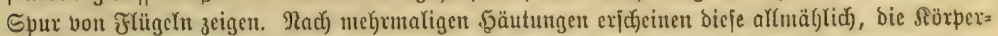

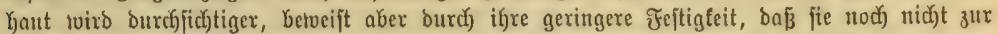

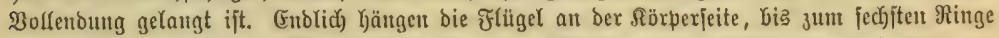

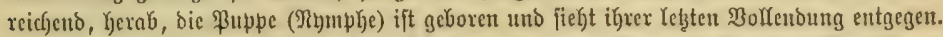

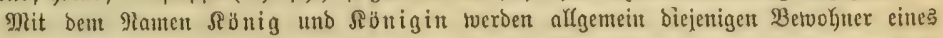
Temitenbaues belegt, tveldfe bie Fortbflanzung zu bervirfen haben und entjodjieben gepaart getoejene

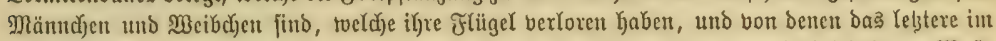

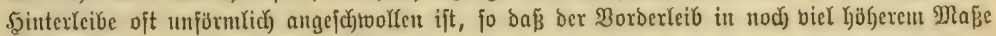

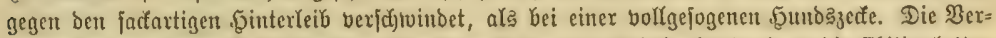

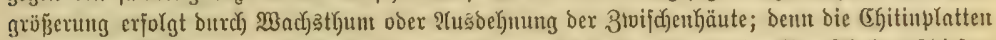
ber (b́lieber felbft verändern fich nich)t, fondern liegen als weit entjernte, buntlere Fleffe auf biefen

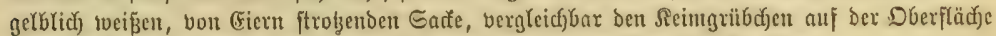

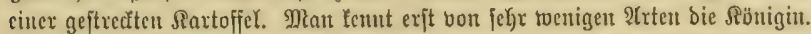

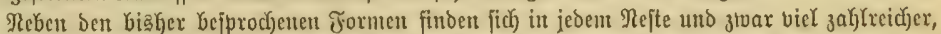

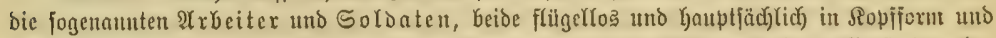

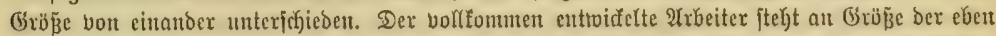

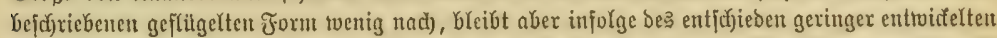

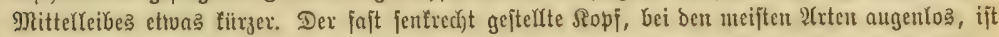

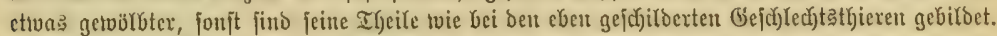

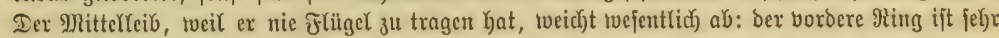

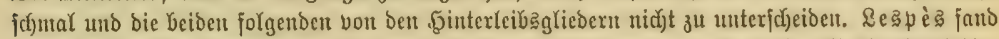

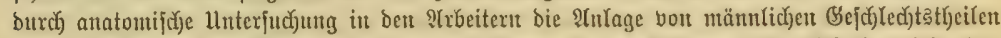

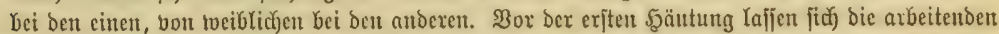

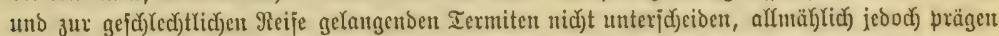

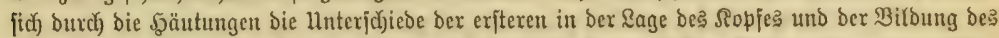

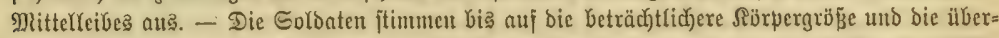

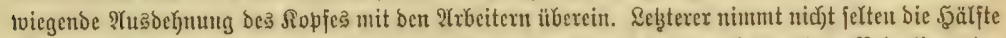

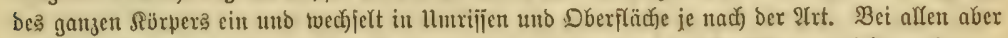
treten bie Simubacten broheno Gerauz, inbem fie ben britten Iheil ber Sopflänge erreichen, mitunter jogar bie ganze Sopflänge nod) übertrefjen, ıogegen Siunlade und Ilnterlippe fajt verfïmutern.

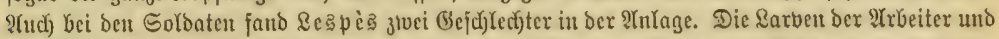

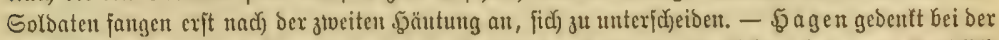

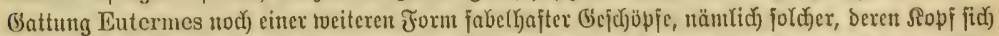

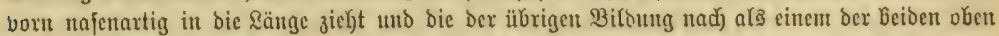

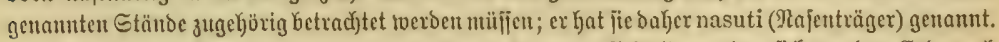

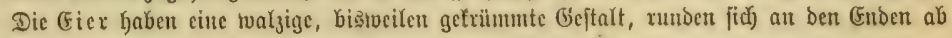

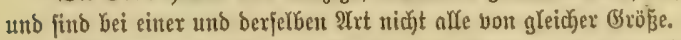

Was mut bas Reben uto Ireiben bex Icrmiten int alfgemteiuen anlangt, fo jtegt fejt, baj

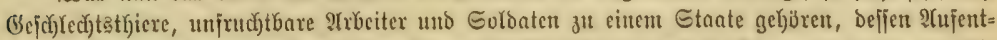

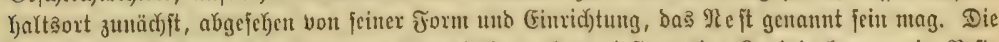

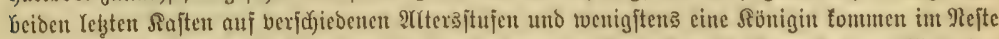

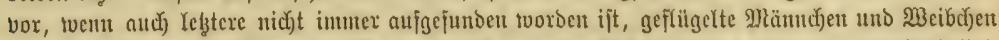

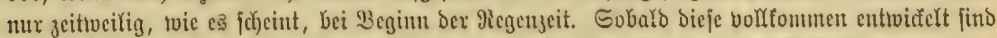

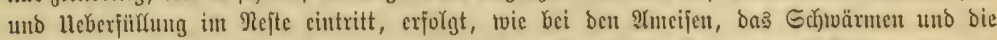

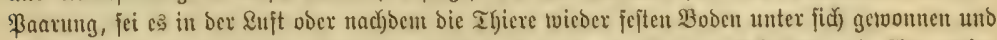

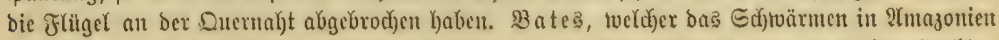

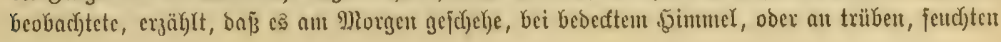




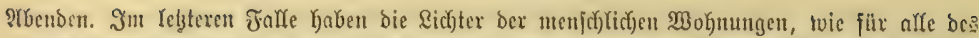

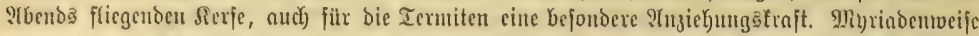

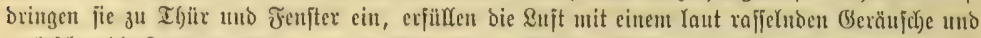

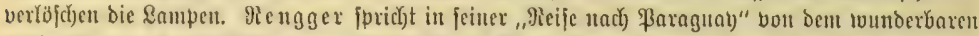
Cinorude, ben Der शublid cincr "Säule" biejer Tfiere ferborbringt, bie aub ber (Groe auffteige

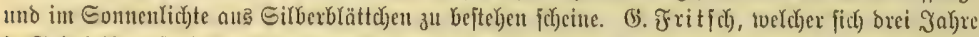

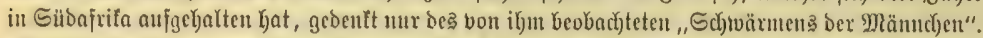

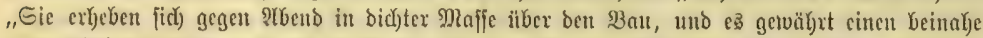

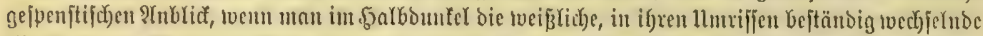

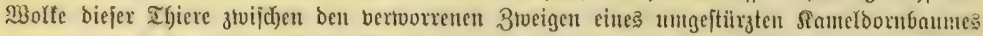

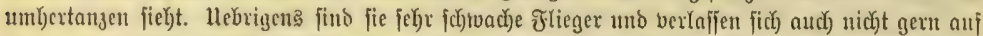

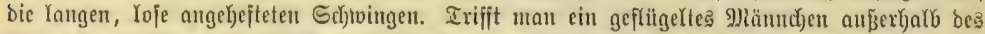

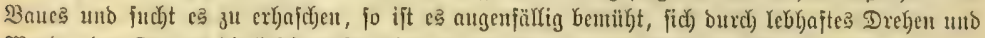

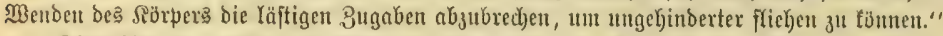

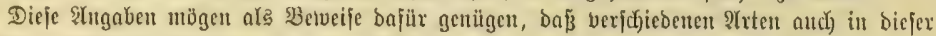

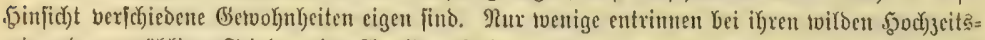

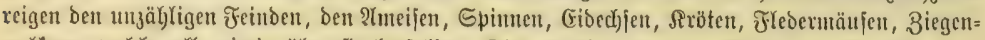

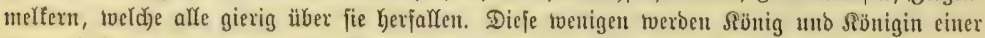

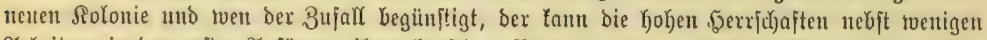

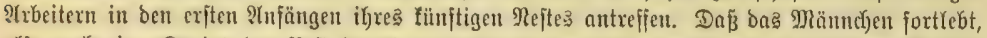

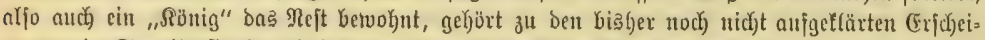

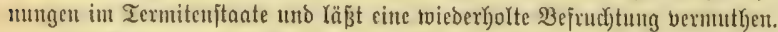

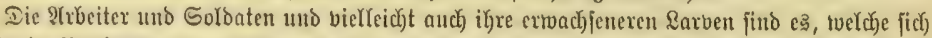

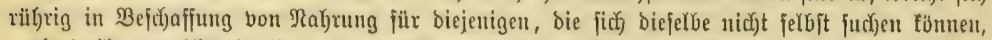

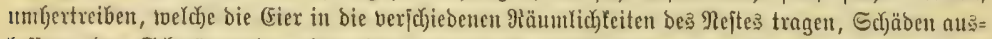

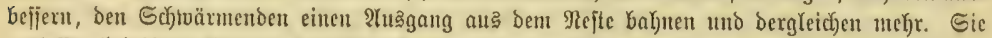

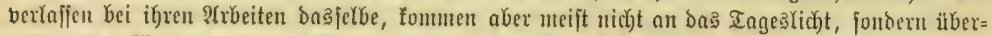

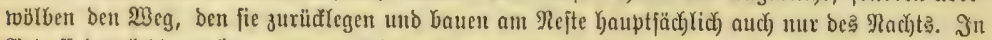

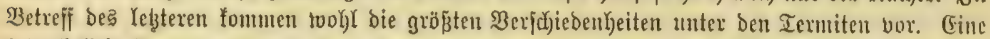

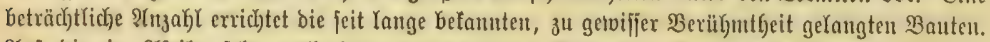

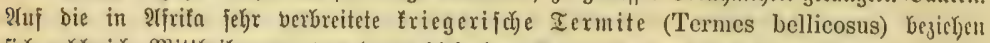
jid) zab)Yreid)e Mittheilungen, bon benen biejenigen Smeathun ragenbem Werthe fino. Die Bauten beftehen hiernad) in auß̌en unebenen, mit vielen Soerbor=

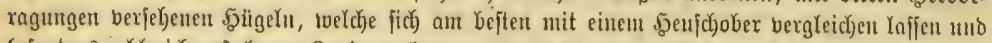

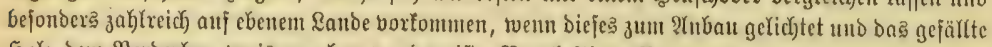

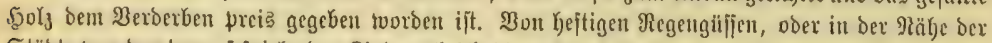

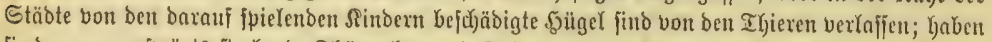

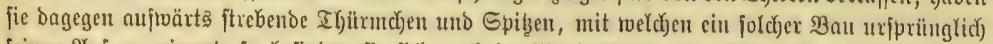

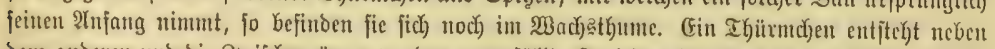

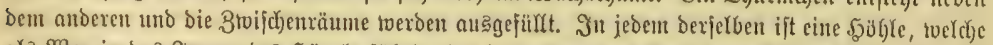

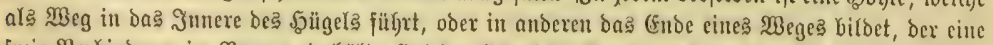

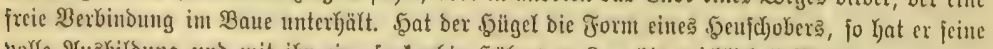

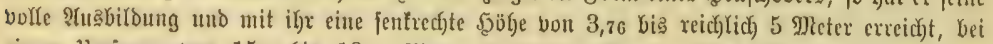
cinem llujange bon 15,7 bis 18,83 Meter an feinem Grunde. Das Material befteht vor=

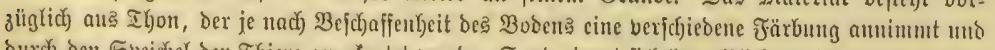

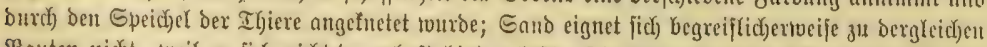

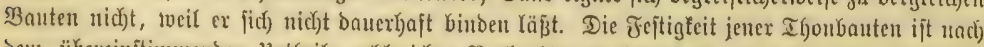
beu 


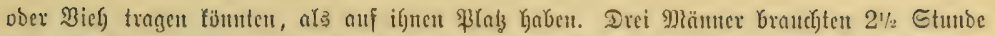

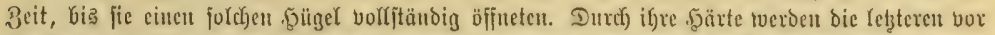

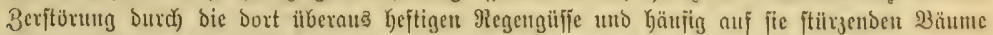

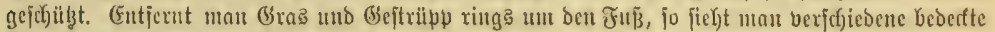

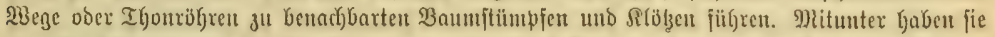

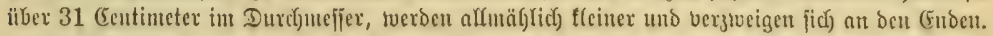

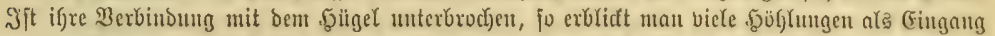

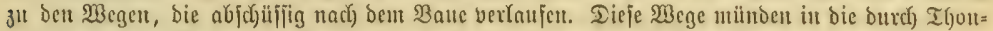

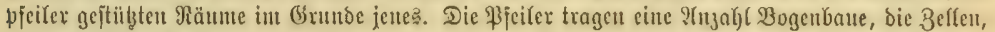

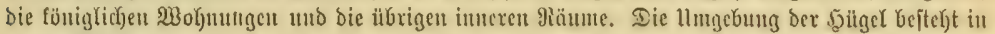

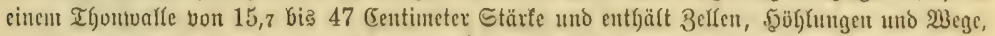

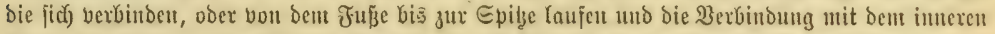

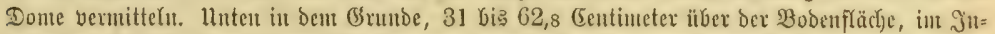

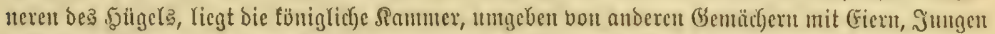

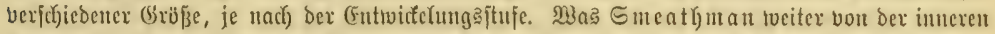

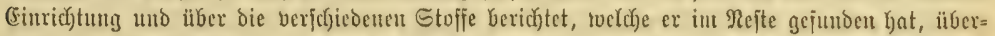

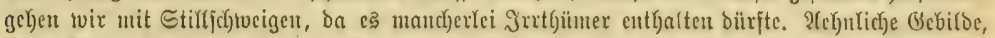

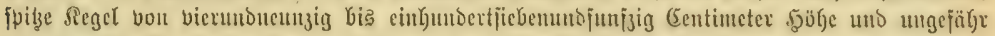

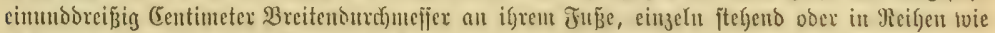

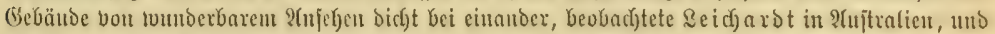

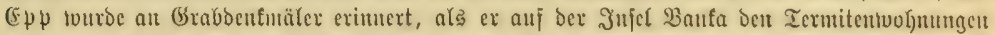

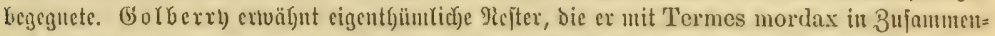

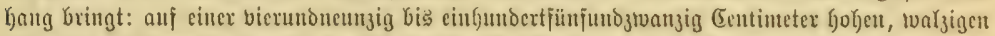

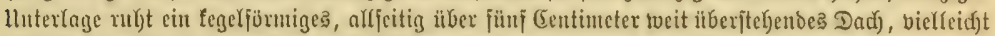

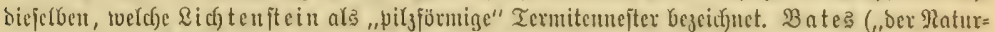

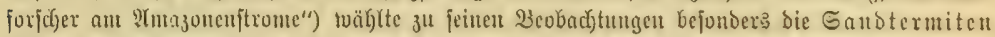

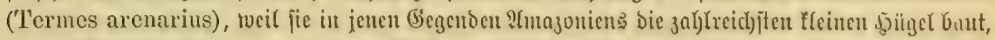

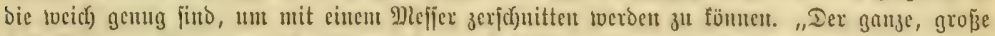

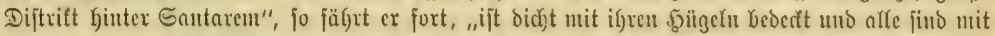

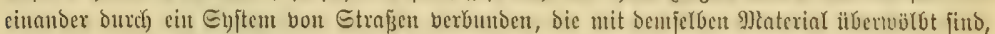

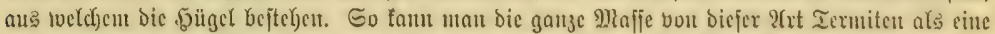

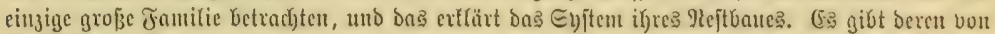

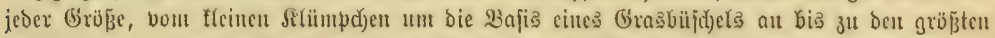

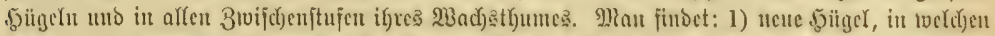

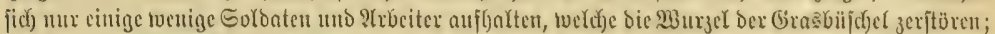

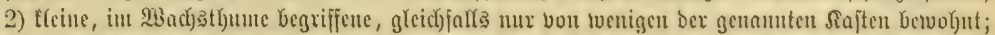

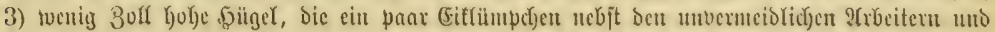

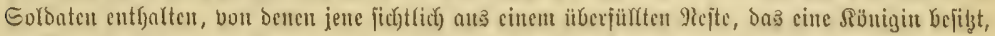

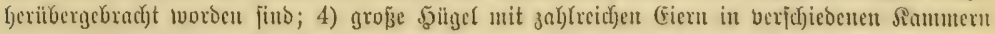

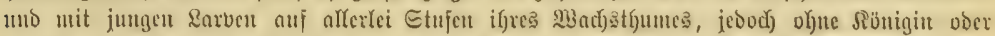

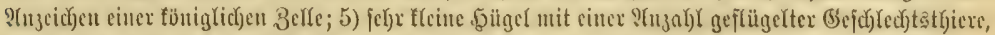

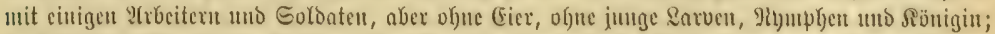

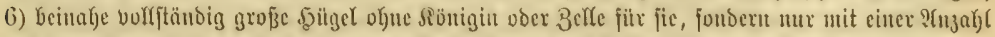

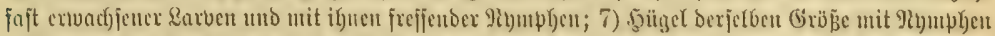

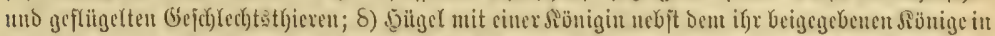

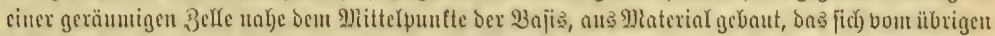

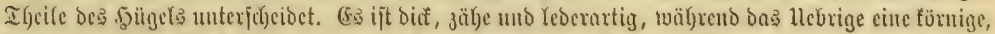

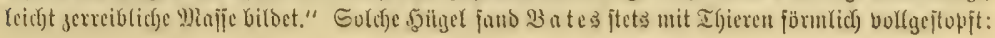




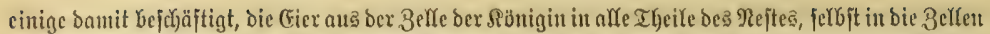

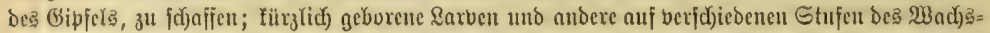

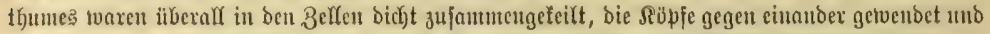

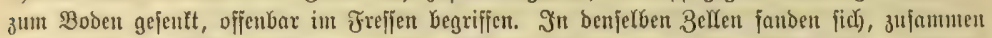

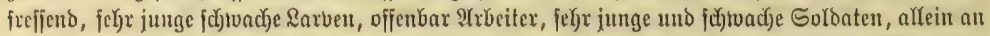

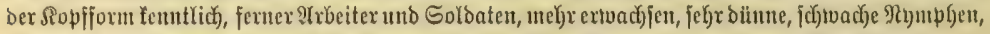

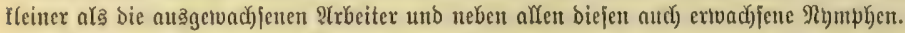

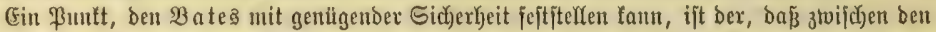

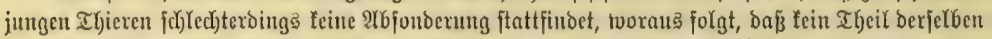

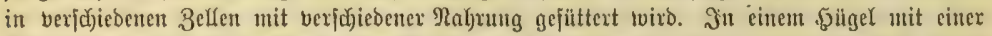

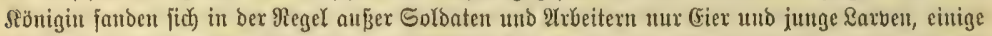

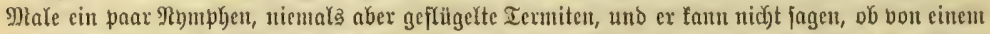

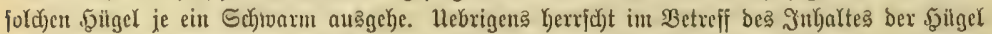

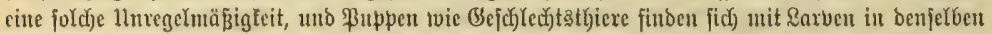

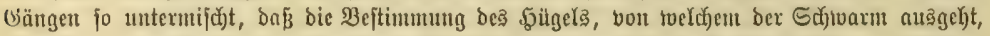

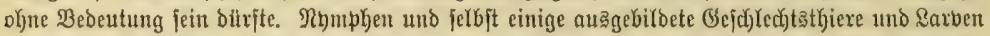

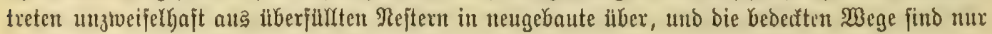

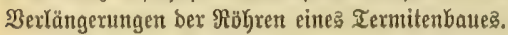

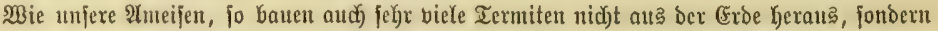
Gleiben it ifgr verborgen, fitzen unter Steinen, begeben fich auf unterirbijad)en (bätgen nad) bem

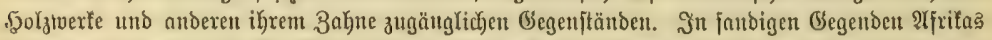
hat man tief unter bex Dberflädje rülyrenartige, erbärtete OGänge aujgefunben, ben jogenannten

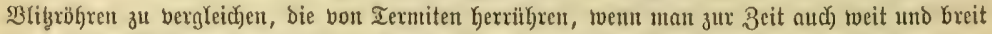

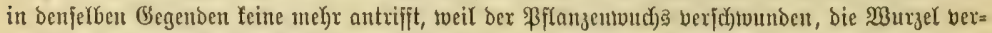

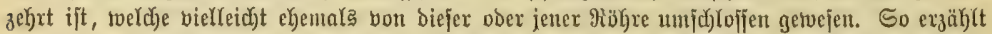

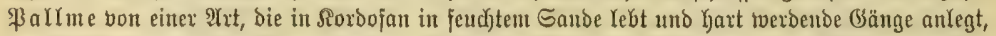

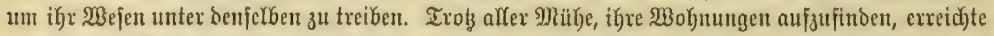

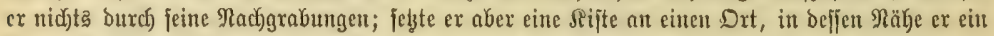

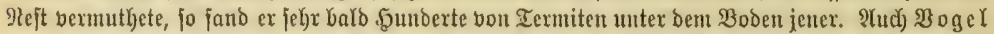

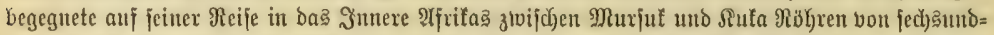
zwanzig bis achtunofiebenzig Millimeter int Durd)meffer, weldye meift fenfredht bis fiebenutovierzig

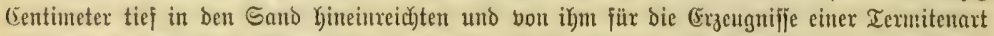

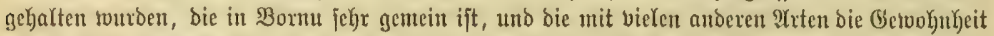

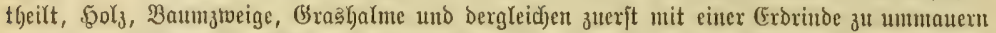

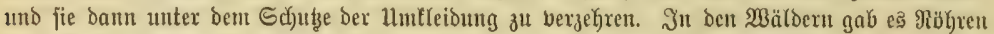

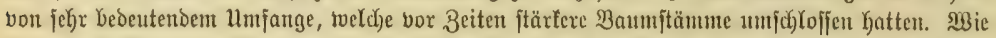

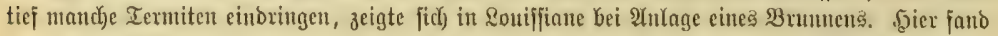

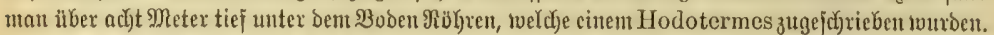

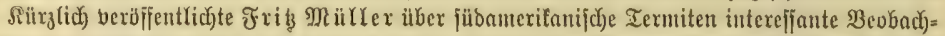

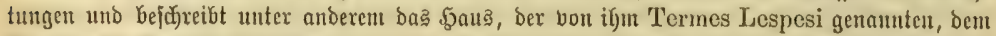

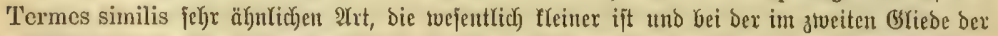

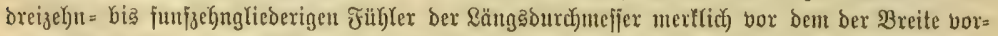
twaltet, it etwa folgenber Meije. Die Bauten getjören wie bie bon Emeathmant gejchildoerten ber friegerijd)en Termite zu den merftuitroigiten. Sie Gaben bie Gejtalt ciner bicfen, etton panunenlangen

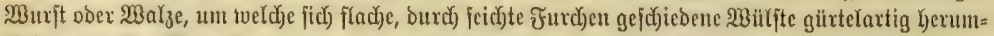

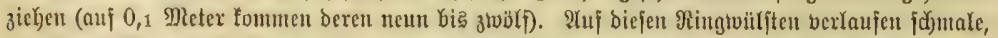

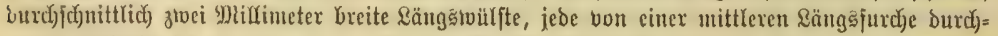

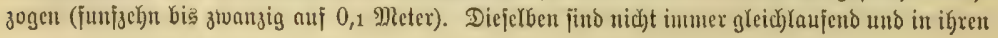




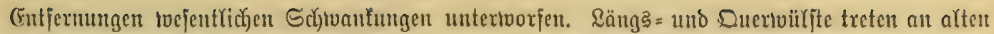

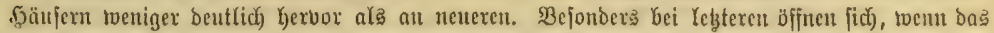

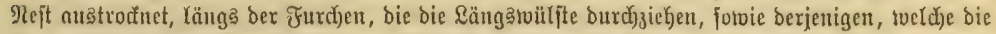

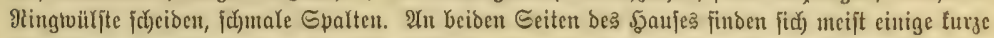

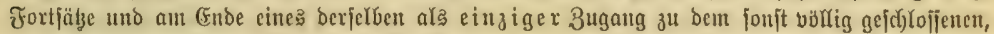

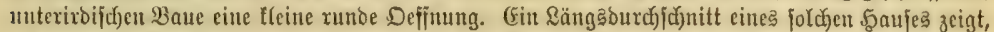

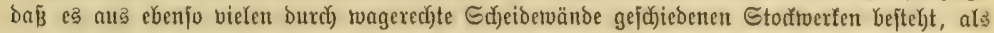

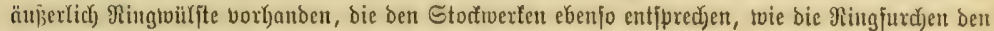
S(f)eidetwänden. Die Rijie, welche Geint (Fintrod̆nen ent=

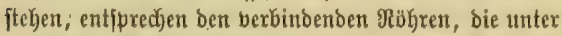

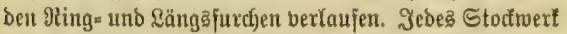
hat bie Geptalt einex flachen Schadjtel mit baudjiger

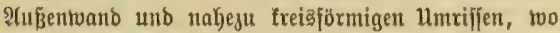

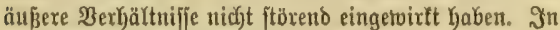

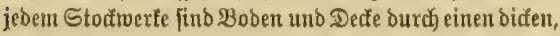
oben und unten verbreiterten \$Feiler berbunden, Der balo bie Mitte einnimunt, Gald mefr ober benigex bem Un=

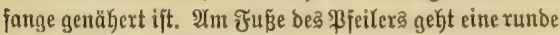

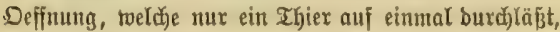
johief burch Den Boden in bas nädjpte Stodtwert. Seht

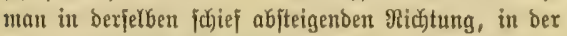
man in biejes Stodtwert eingetreten ijt, an befien \$ieiler tveiter, fo gelangt man ureift zu bem am Fuß̧e beşjelben

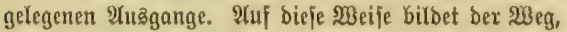
wer(d)er bout oberften bis unterjten Stodwerfe burd bie Sdjeidervänbe bindurdi) und an ben Pieilern entlang fübrt, eine Sdyraubentinie oder eine Mendeltreppe, die man fich twegen bex Stelfung ber Pjeiler unt ber nicht

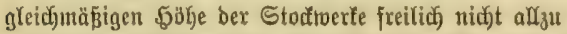

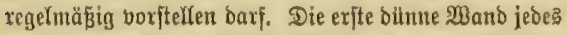
neuen Stodivertes beftebt fajt immer nux aus bem reinen Sothe Dex Iermiten, biffere \&agen bon reiner (5rbe pflegen fie bejonters in ben bon ben \&ängąring=

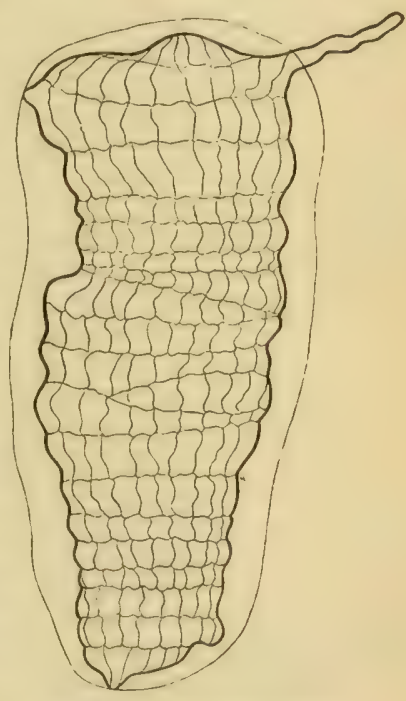

\$aus bon Termes Lespesi; berflcitert.

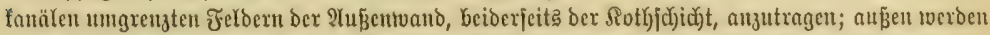

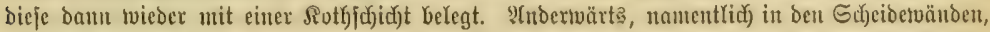

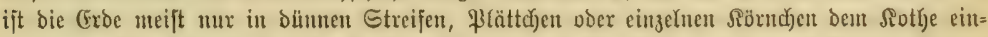

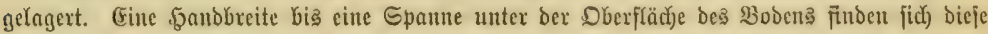

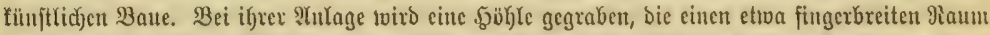

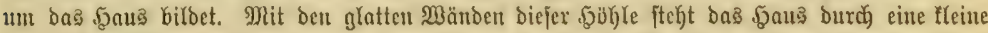

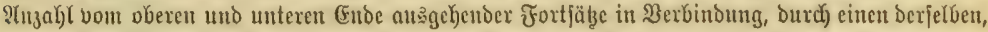

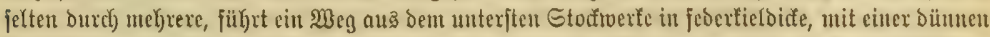

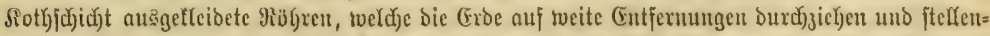

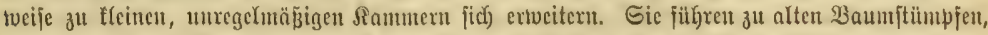

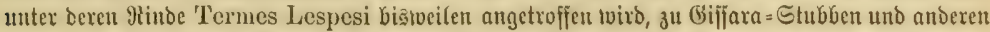

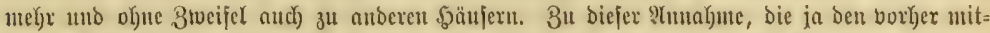

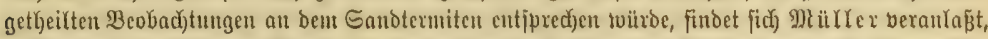
sveil ex bie berjofiedenen Stände nic beifammen traf, felten eine Seünigin und noch feltener (Eicr unt junge \&arven in beren \$tïhe. 


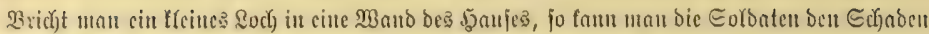

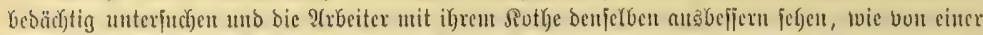

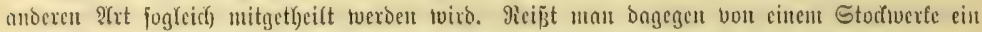

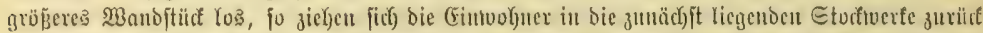

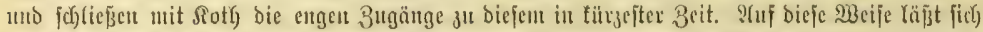

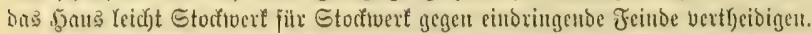

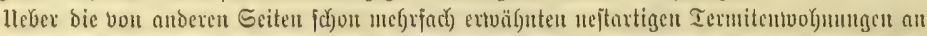

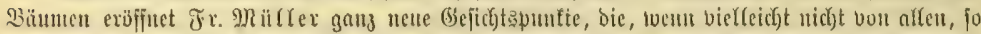

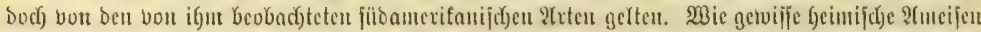

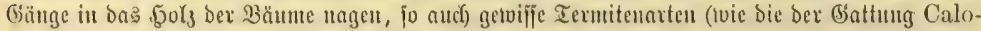

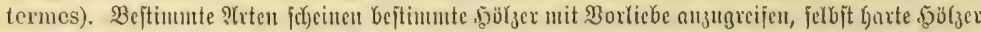

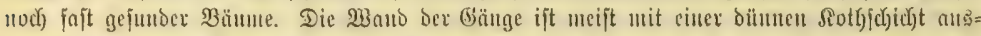

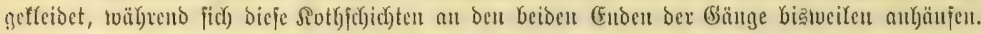

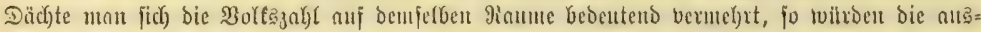

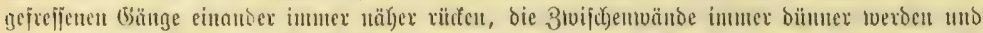

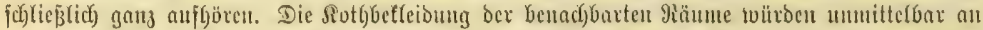

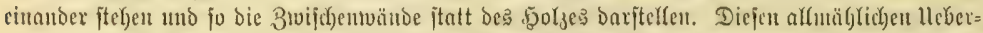

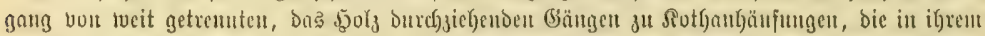

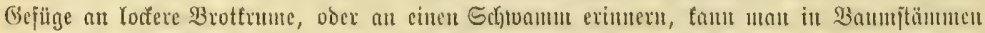

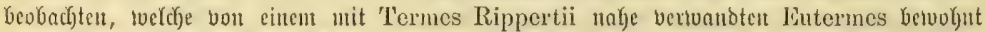

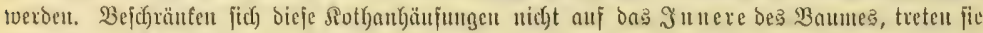

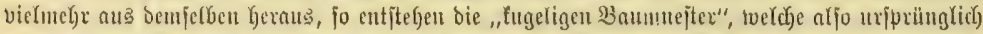

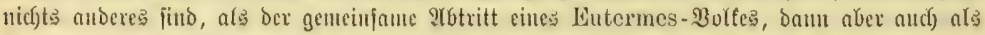

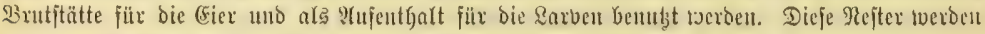
aljo auts bem Baume herauts nticht an benferben herangebaut.

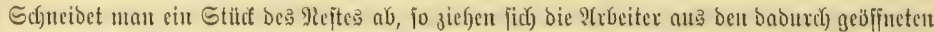

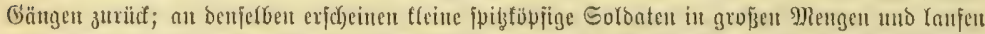

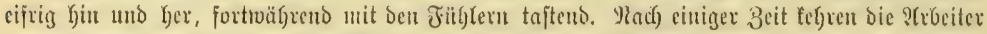

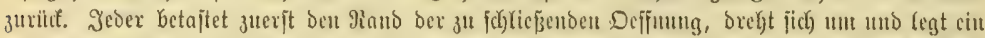

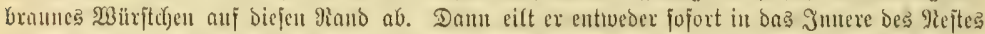

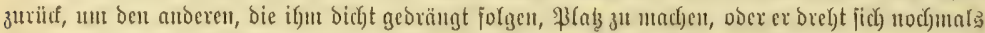

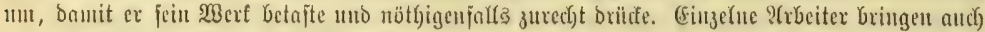

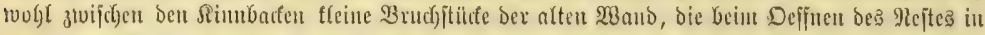

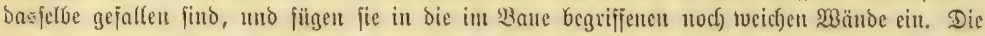

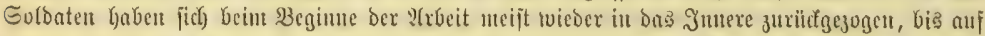

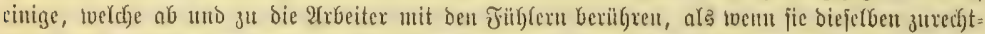

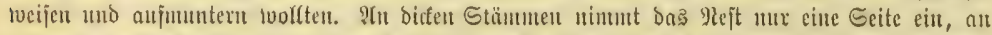

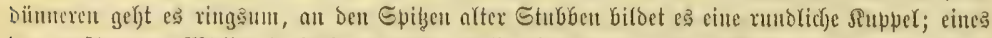

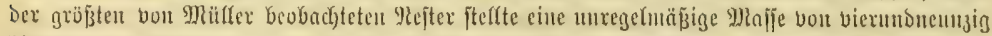

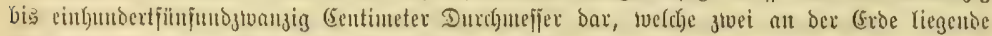

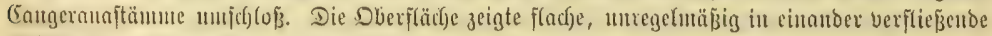

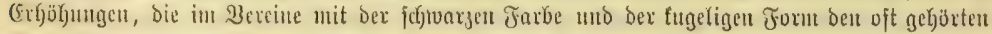

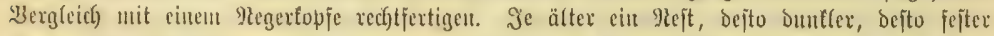

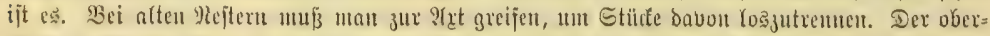

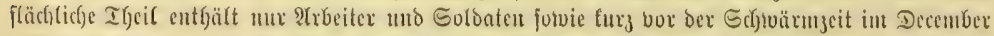

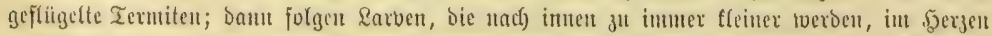

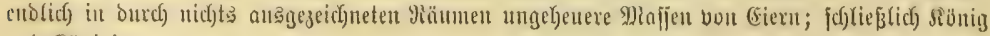
uno Sönigin. 



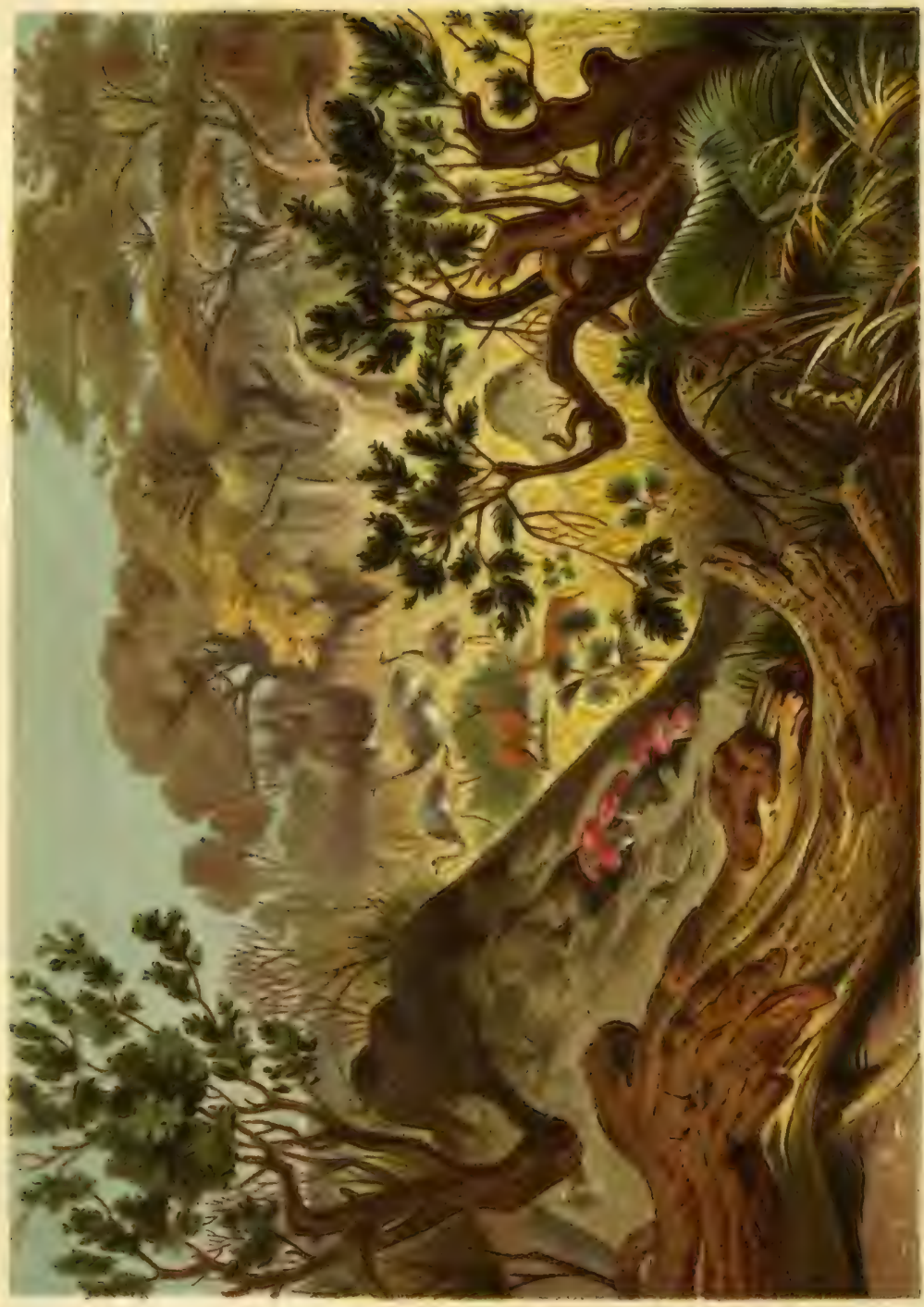




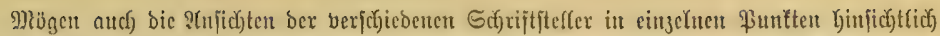

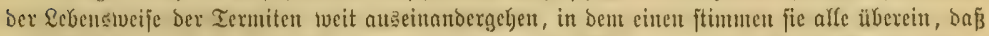

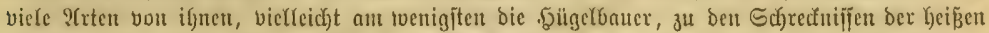

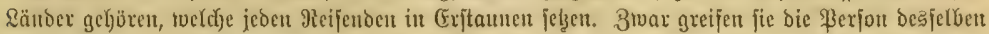

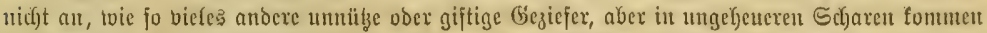

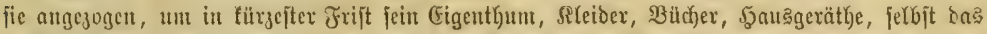

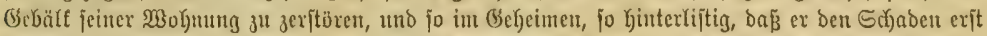

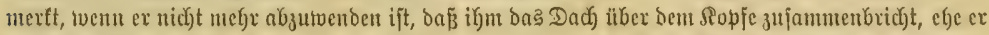

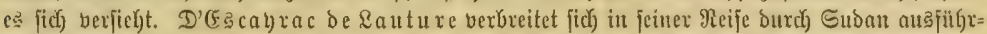

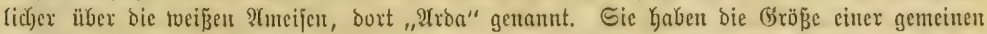

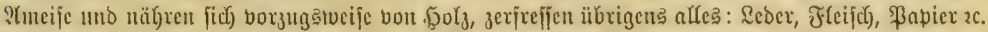

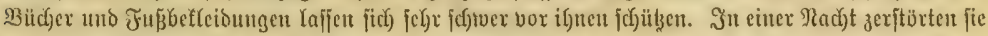

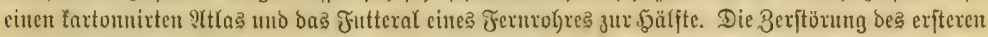

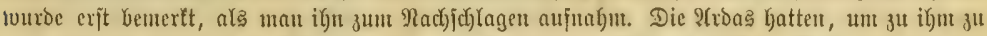

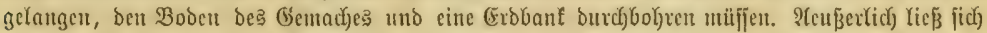

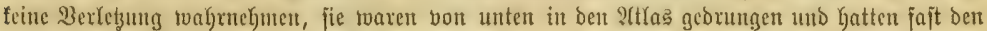

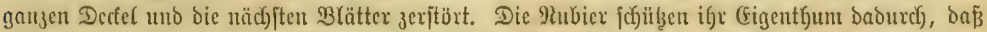

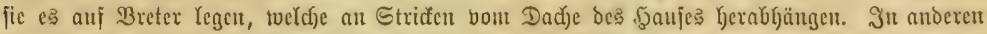

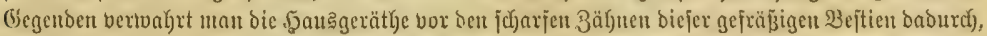

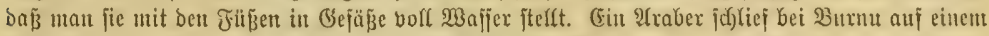

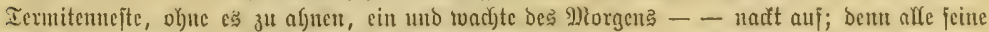

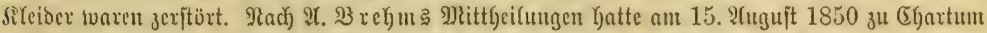

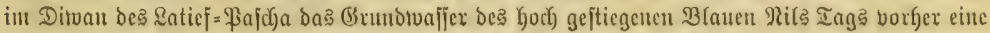

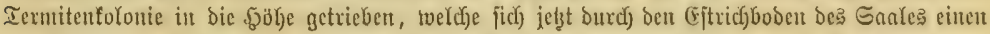

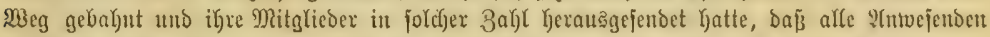

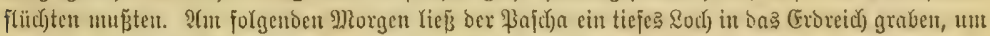

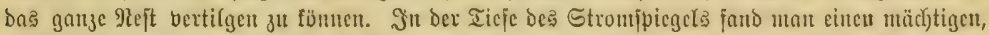

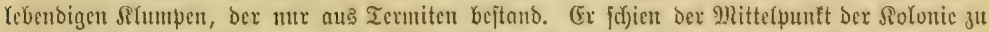

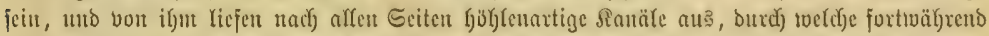

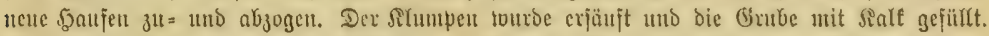

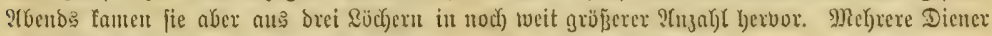

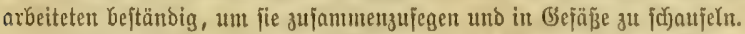

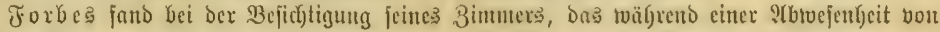

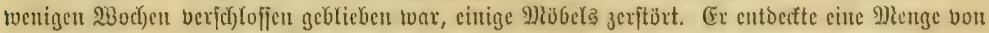

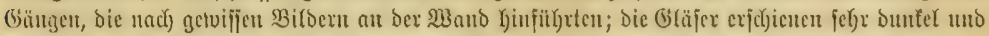

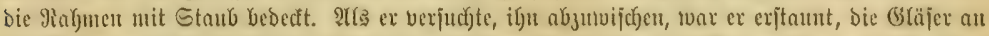

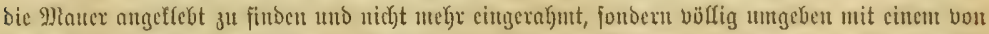

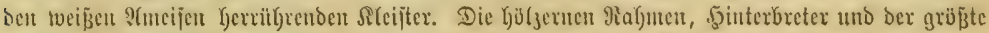

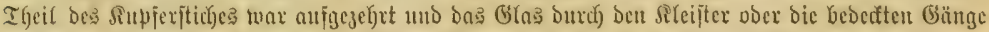

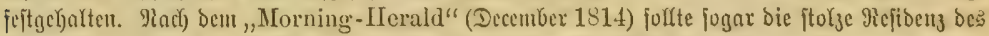

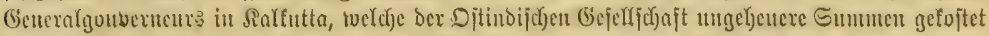

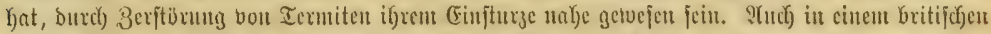

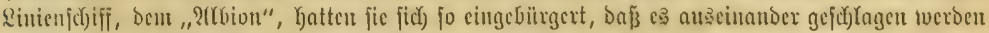

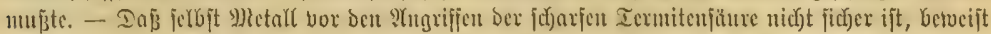

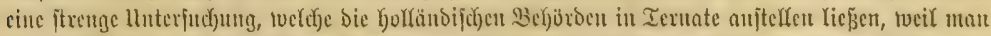

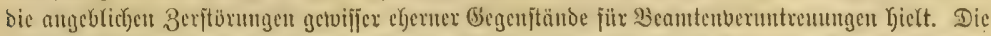

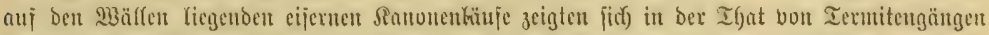

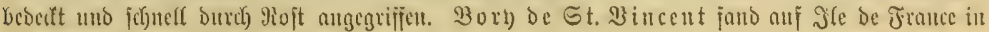




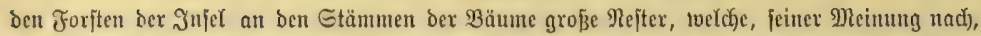

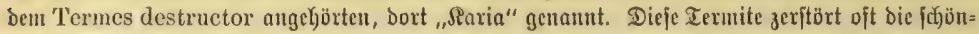

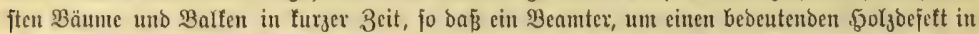

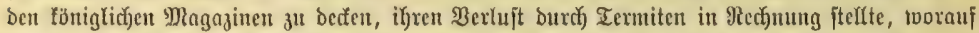

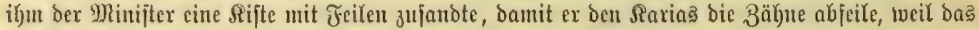

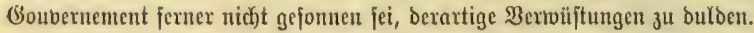

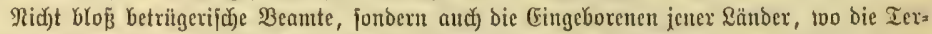

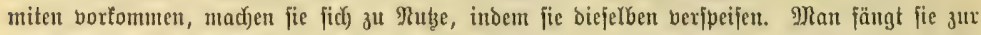

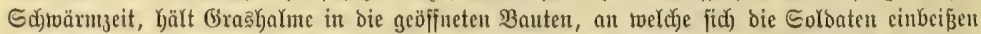

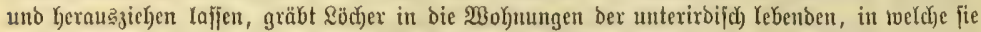

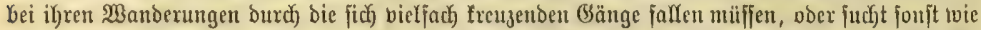

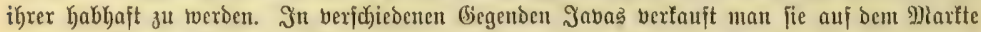

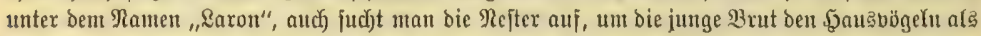

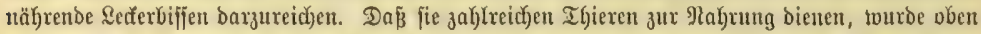

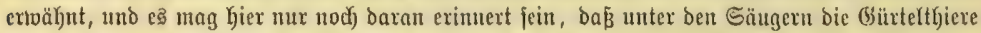

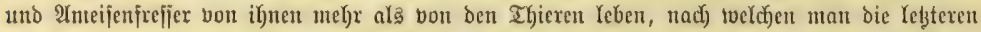

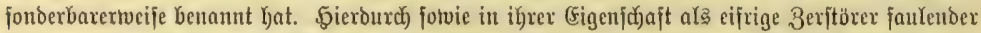

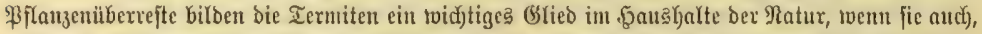

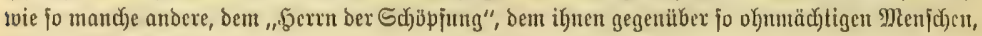
nicht gefalfen mögen.

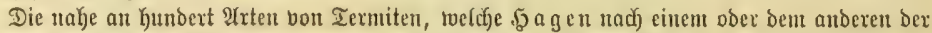

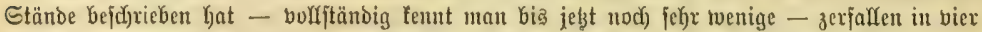

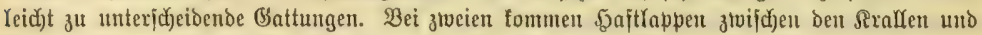

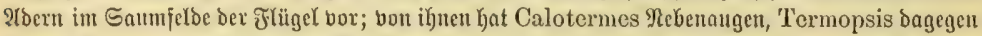
feine. Şierbon unterjod)eidet fich Hodotermes burd) Den Mangel ber f̧aftlappen uno bie bei wei=

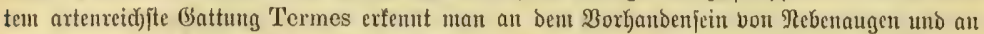

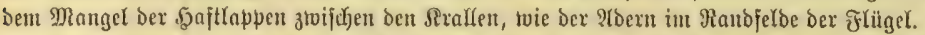

Die gelbhalfige Iermite (Calotermes flavicollis), als Betwohnerin ber mittelmeer= Yänoer cine ber beioen im fïbličen (Europa vorfonmenton ?trten, fenut man nur im geflügelten

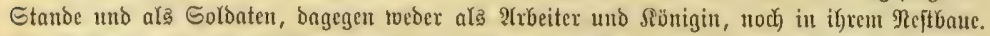

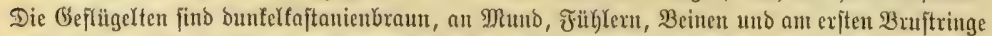

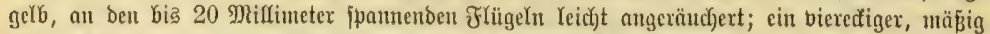

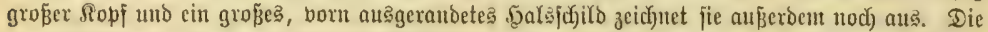
un 2 Millinteter längeren, 7 bis 9 Millinter mejienden Eoldaten d)arafterifint ein auffallen

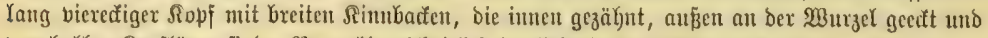

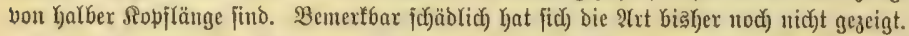

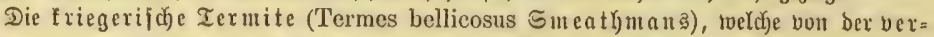

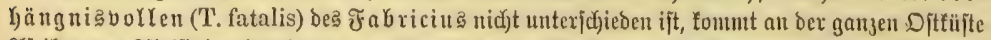

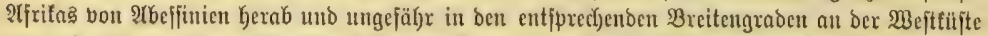

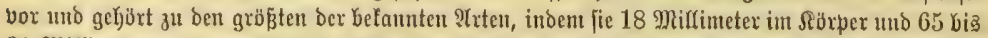

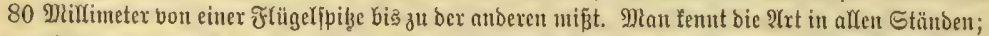

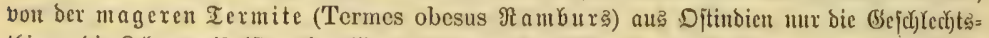

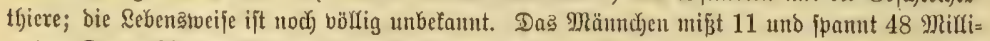

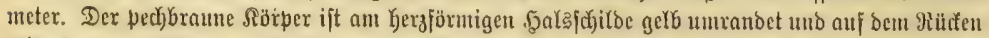

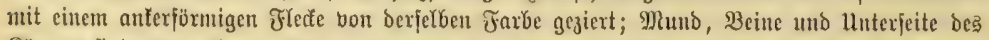

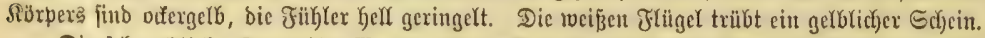

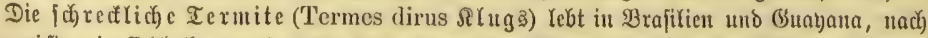

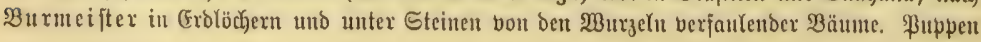




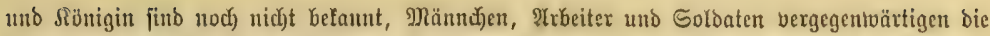

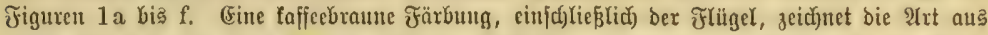

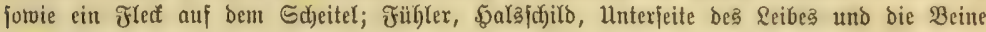
finto gelbroty.

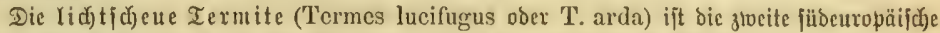

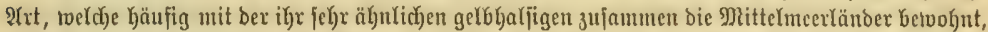

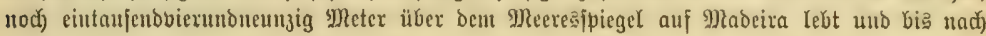
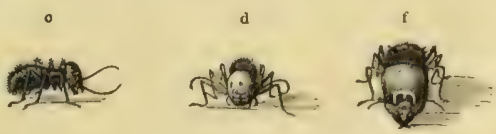

e
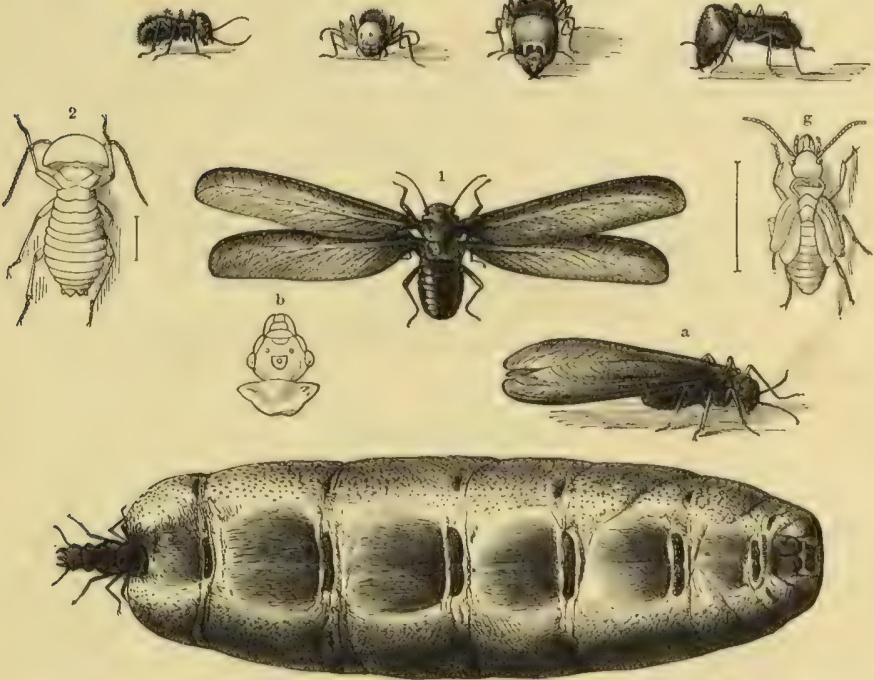

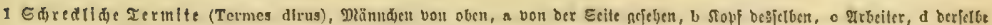

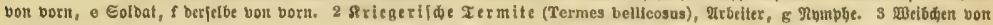
termes regina, (b, 2, g vergrögert.)

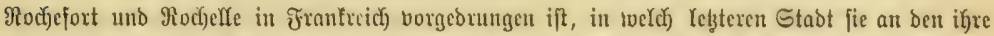

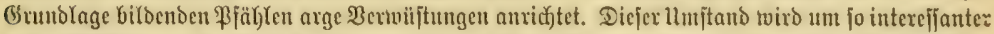

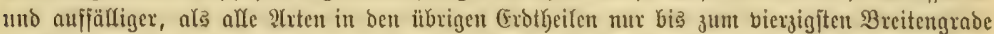

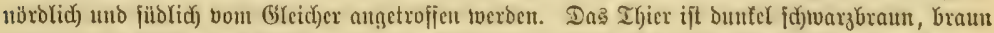

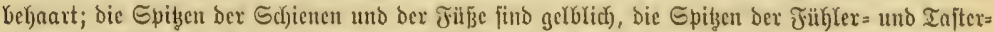

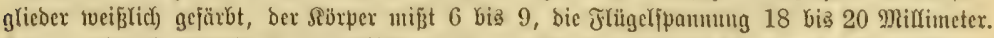

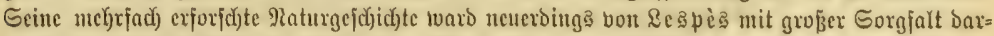

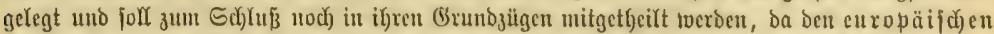

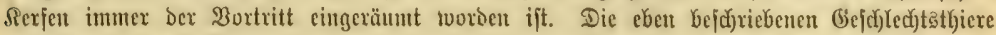

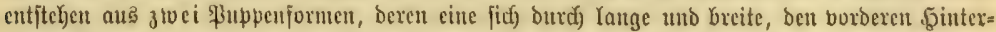

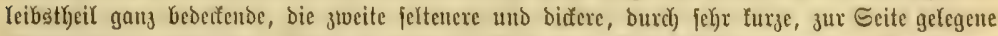

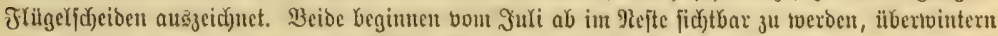

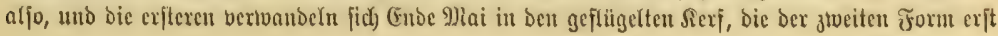




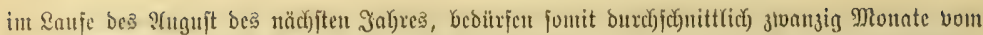

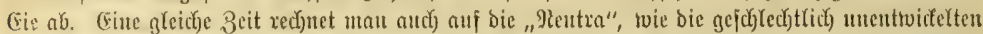

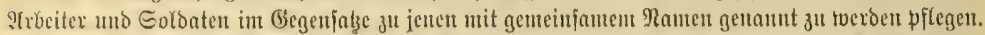

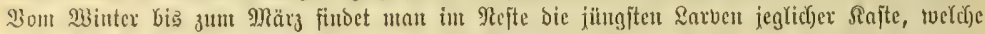

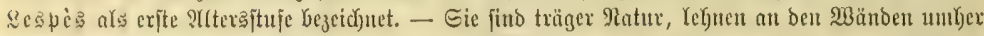

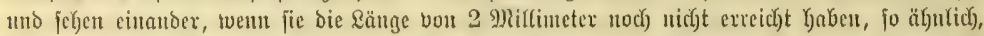

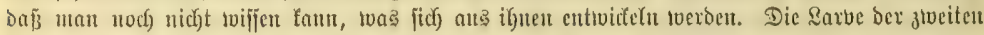

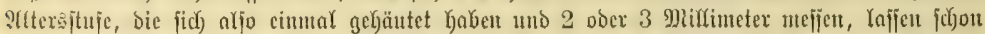

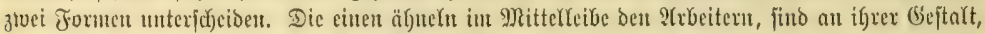

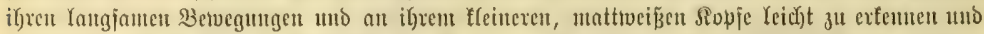

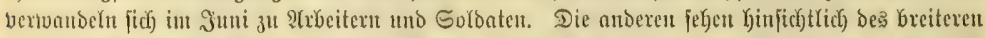

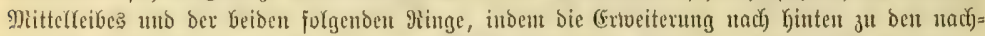

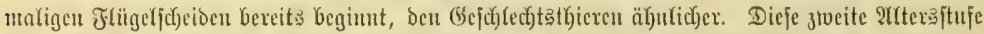

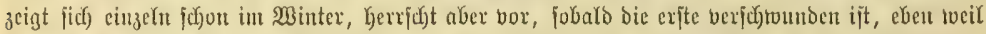

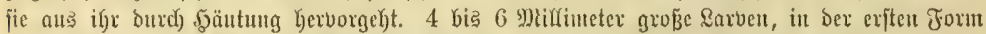

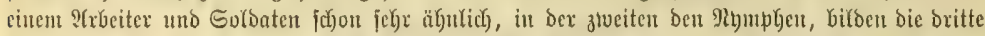

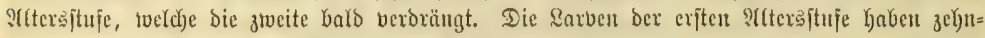
gliederige, bie ber ztweiten ztwülf = bis viergehnglieberige, bie ber oritten ject)jebuglieberige Füh)(er.

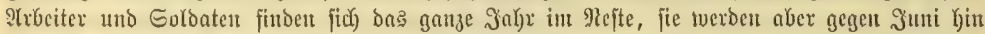

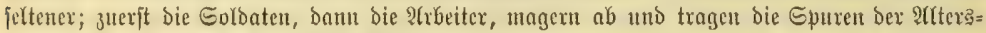

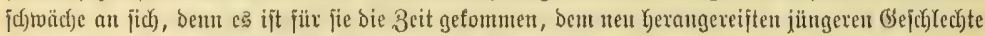

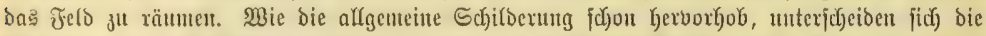

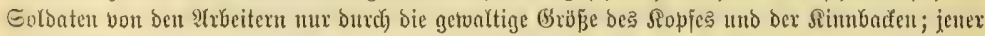

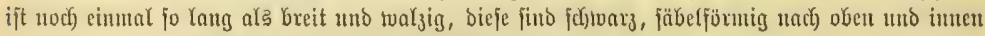
gebogen, inten ungezähnt unb vou Galber Sopflänge.

Die Rrbeiter, auf Denen fait affeit affe Gorgen un ben Stant Yaften, haben bie Getwohnyeit

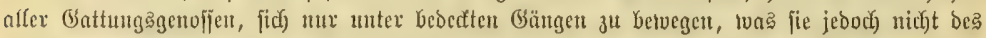

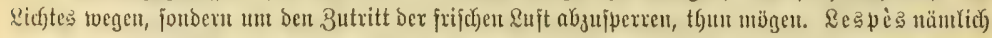

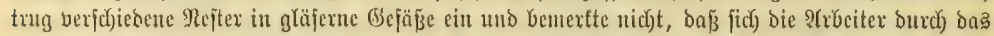

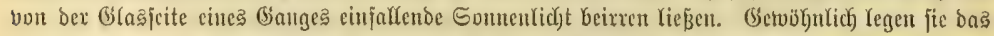

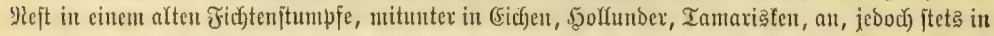

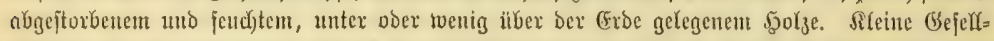

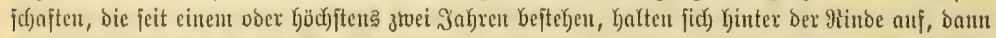

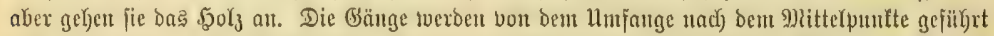

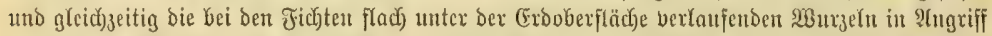

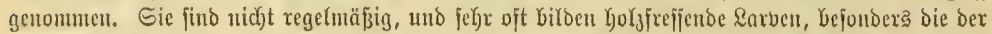

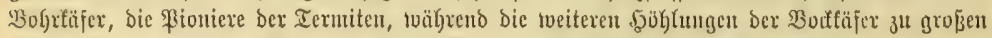

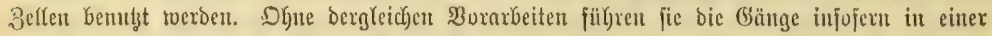

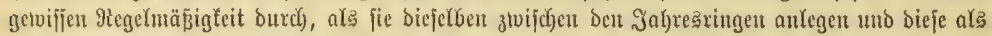

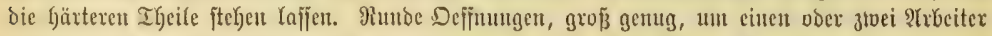

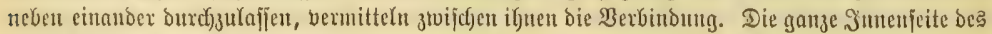

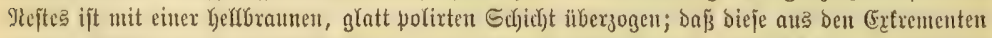

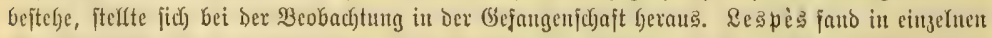

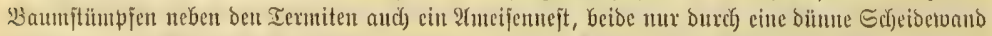

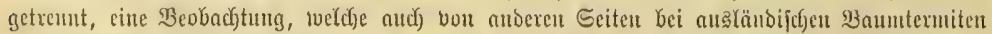

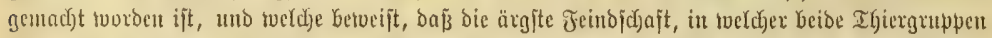

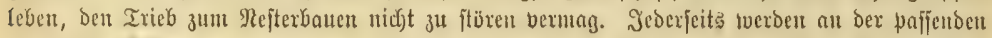

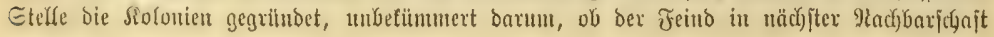




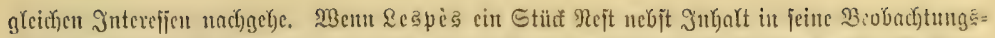

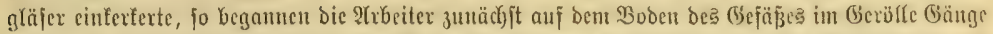

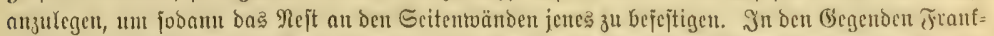
reid)

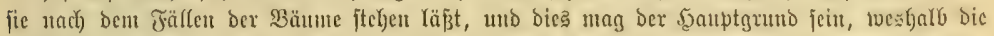

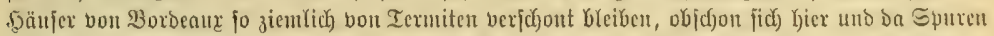

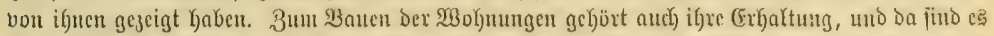

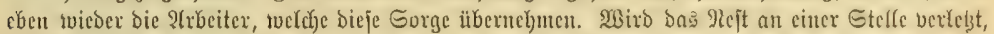
Dem 3utritte ber freien \&uft preis gegeben, fo holen fie bic verjohiebenten Gegenftüube ans Der

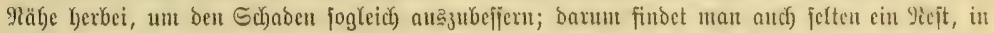

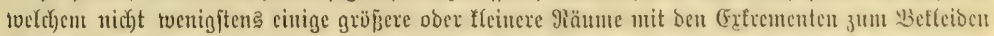

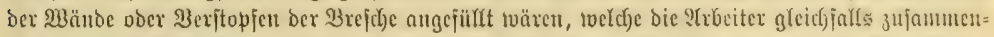

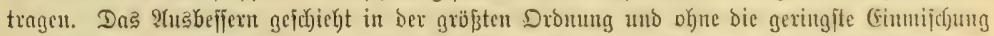

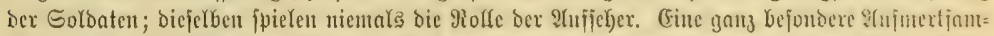
feit lafjen die Irbeiter ben Eiern zu theil werben. Deffnet man eine mit bicjen gejütete 3efle,

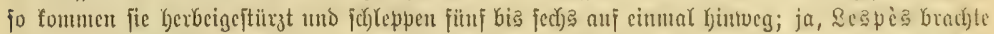

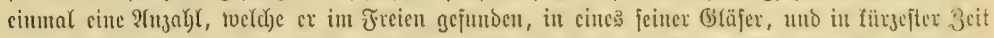

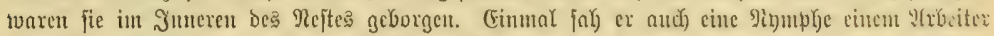

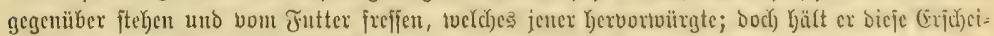

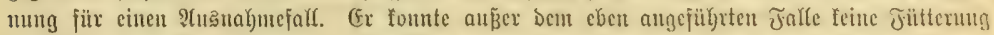

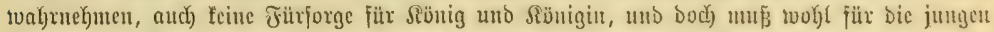

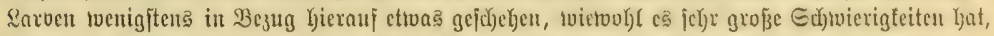

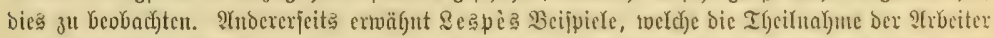

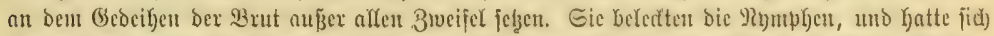

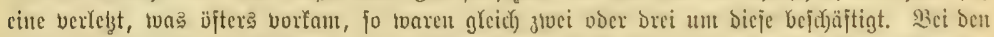

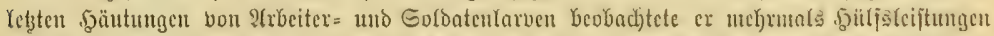

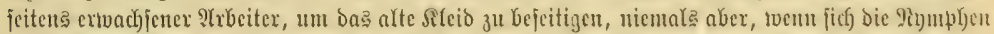

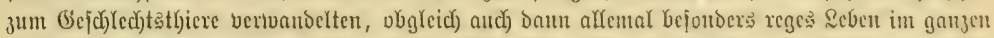

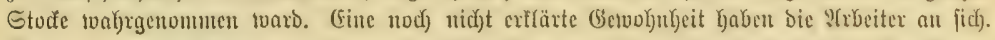

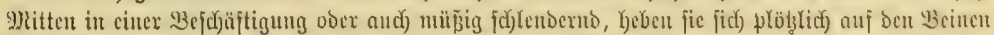

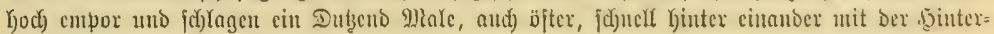
Yeibajpitze auf ben Boben.

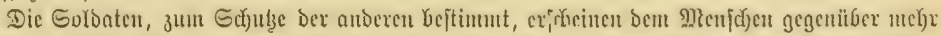

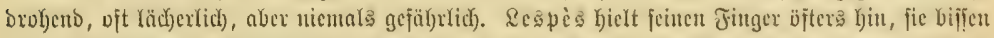

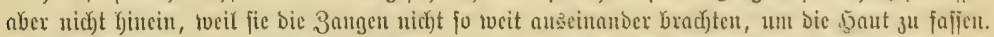

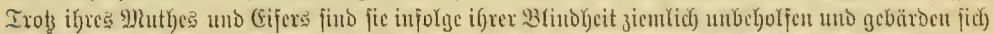

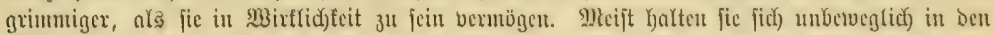

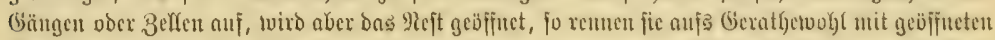

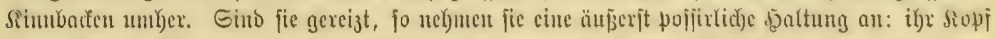

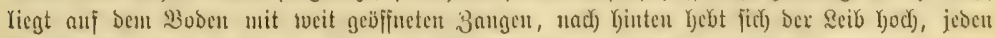

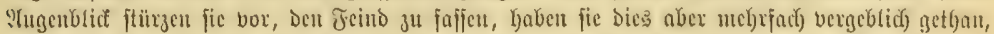

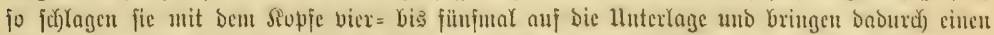

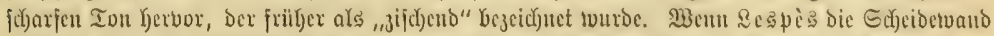

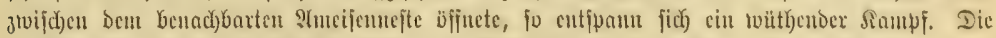

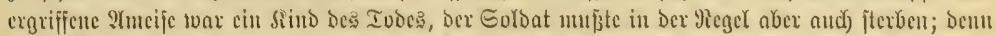

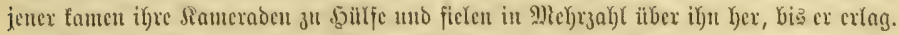

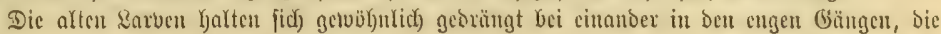

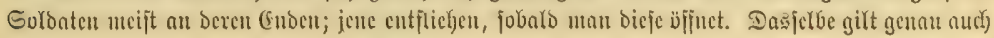




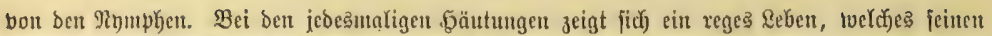

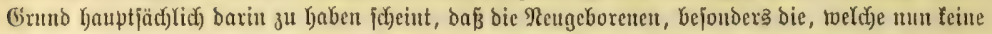

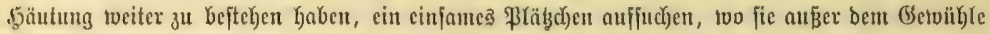

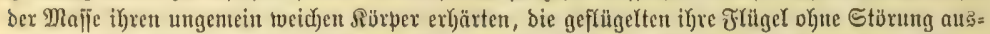

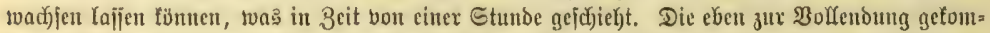

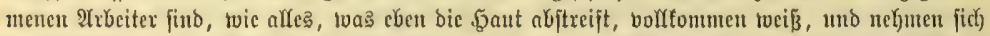

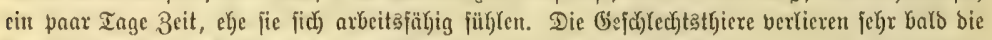

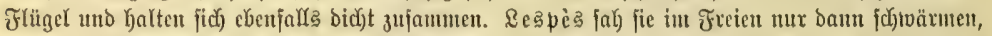

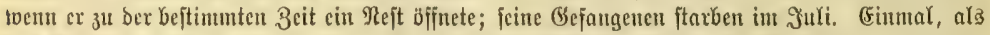

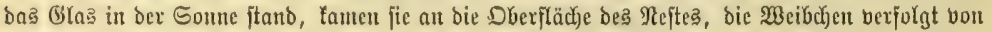

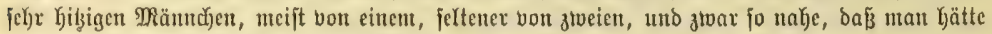

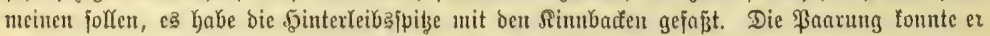

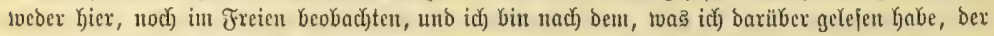

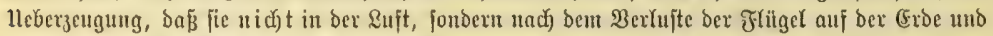

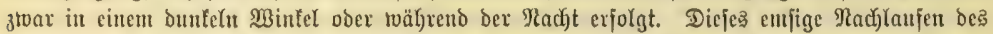

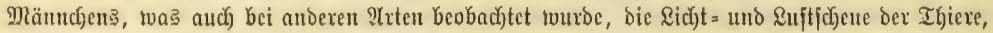

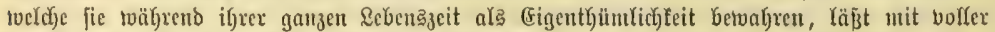

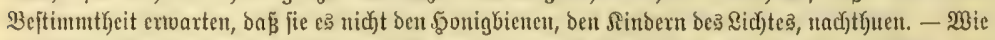

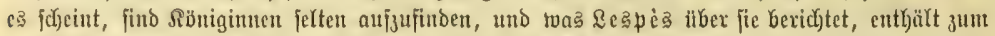
Theil Wiberfpritc)e. (5r traf wohl (sier, affemal in Slumpen vereinigt, an, niemale aber eine

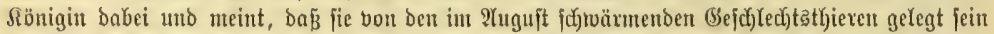

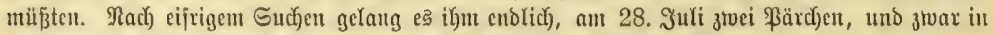
cinem und bemfelben Baumitumpie, anzutreffen, jebes aber in einer befonderen Beffe, bie beibe in

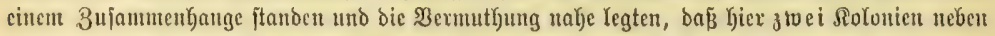

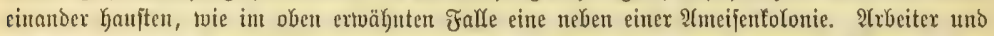

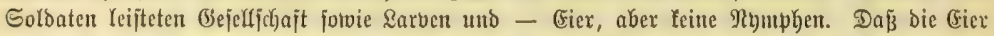

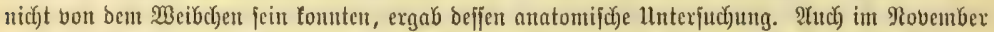

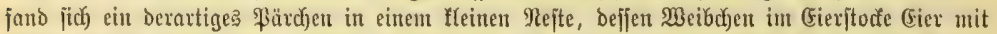

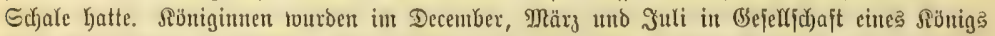

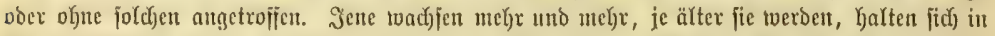
feiner befonderen Beffe, fondern mur in einer tiejer gelegenen Gallerie mit bem fehr lebjajten

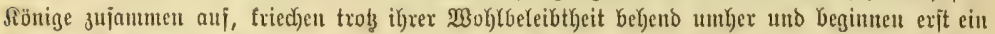

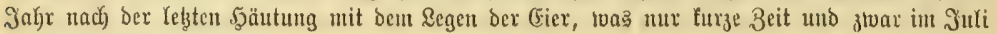
gejdjeken bürite.

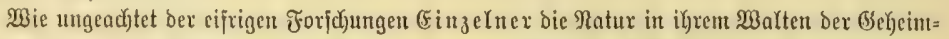

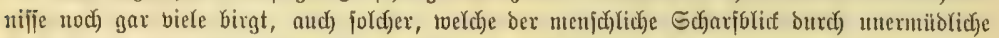

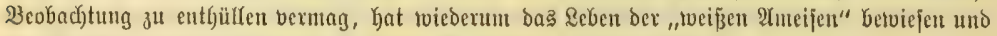
ben Maburuf an alle Strebjame erneuert: Sudjet, fo toerbet ify finden!

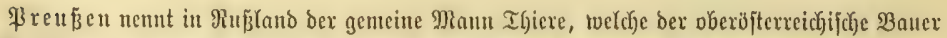

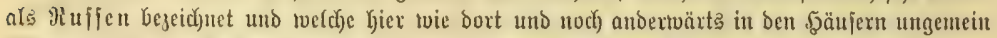

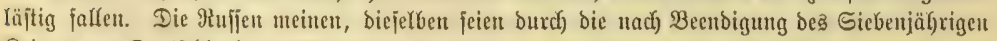

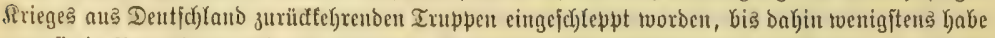

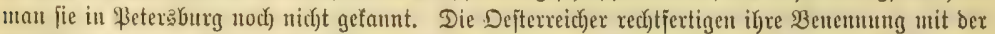

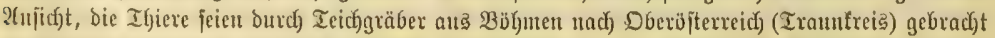

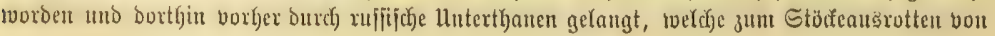




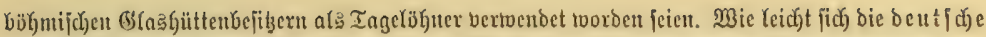
S chabe (Blatta germanica), um tweldye es fich bier handelt, von einem Drte ju einem anderen

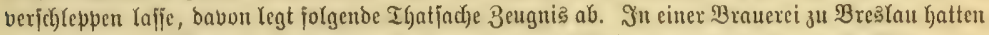

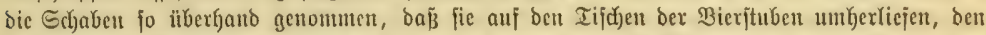

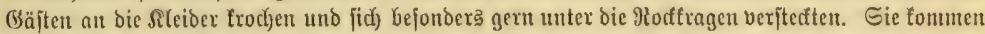

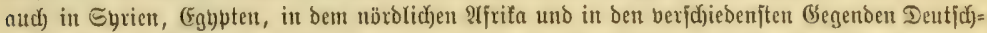

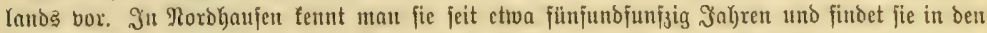

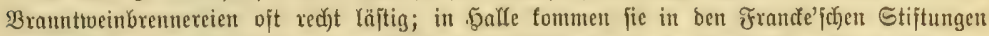

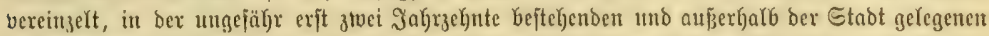

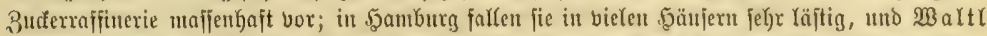

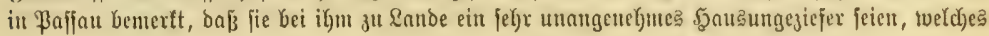

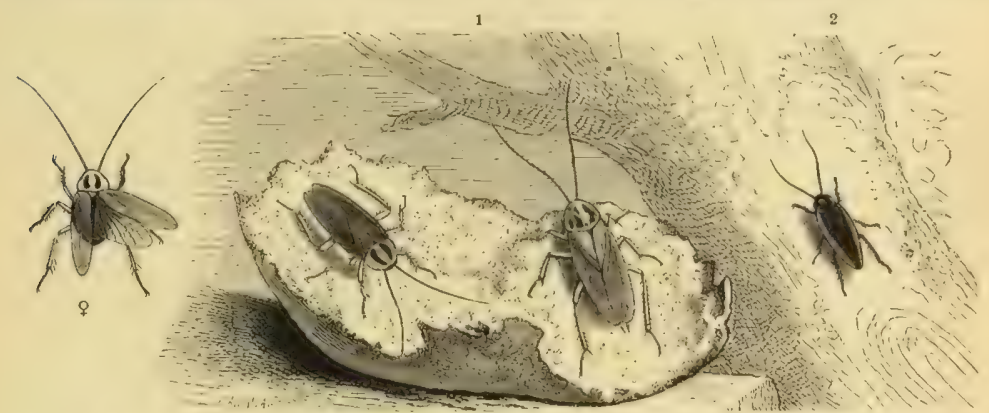

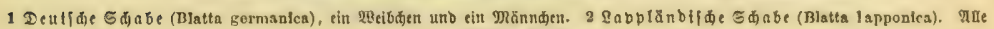
in tatürliçer Grōbe.

nicht jelten bie Reute zแn शIı

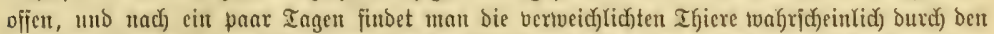

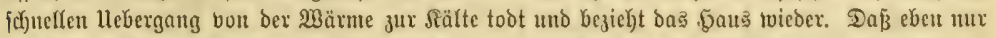

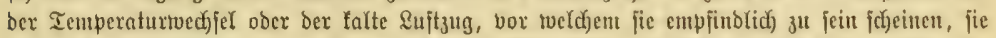

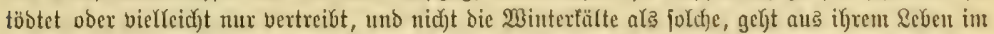

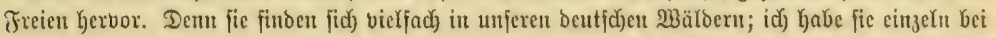

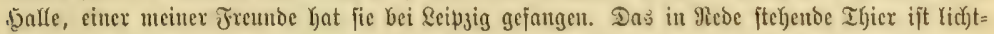

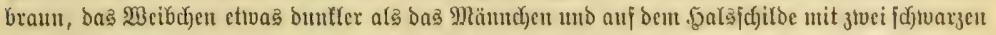

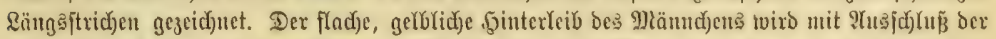

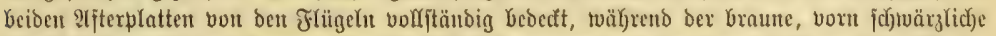

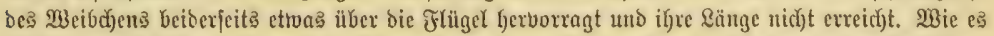

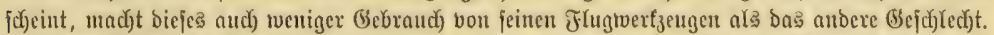

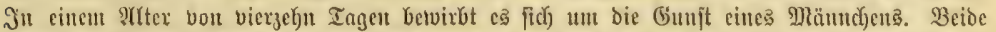

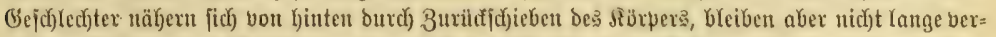

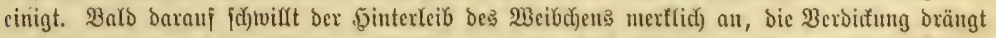

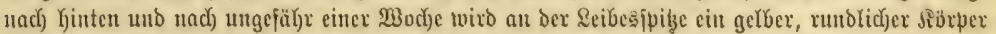

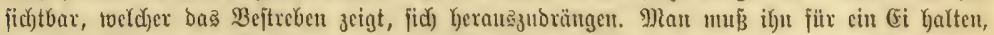

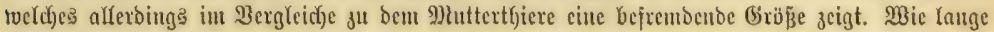

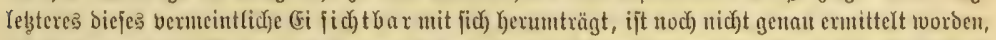

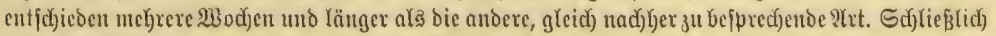

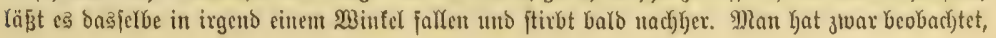




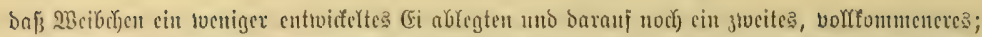

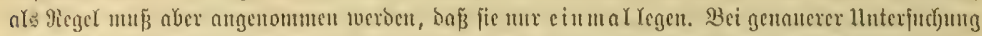

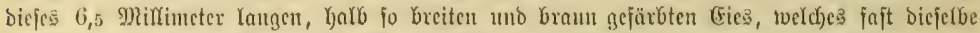

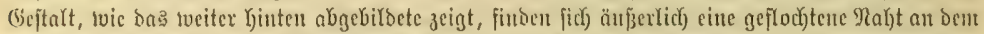

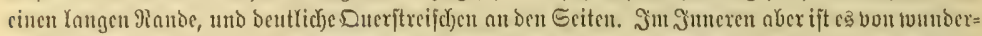

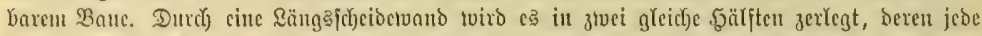

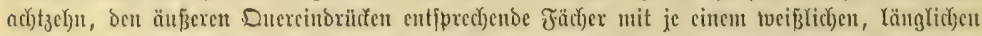

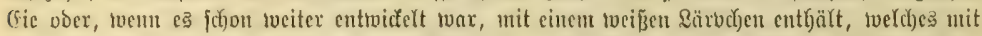

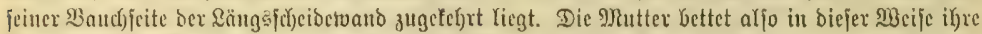

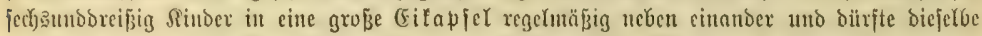
unx furze 3eit vor Der (Entwiffelumg Der Juntgen folfen Yaffen. Diejclben arbeiten fick), tocun fie

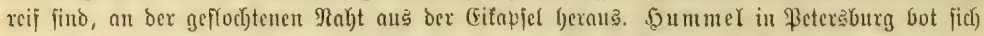

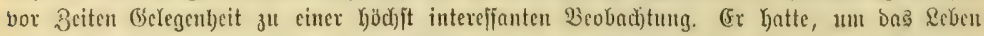

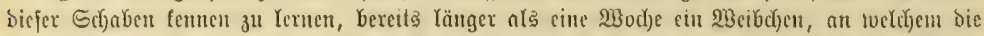

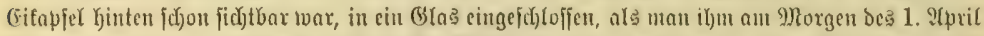

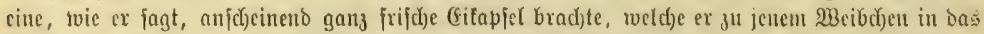

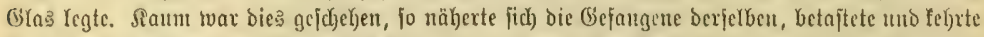

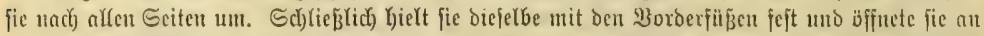

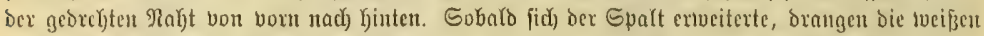
¿ärbchen Gerbor, beren imuter ztwei und zwei auf einnonder gerollt waren. MRit ben Sicjertnfteru

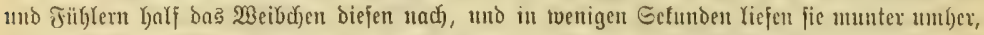

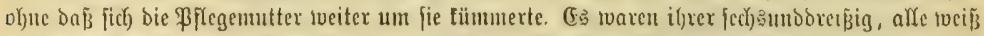

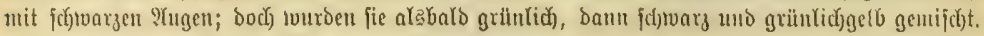

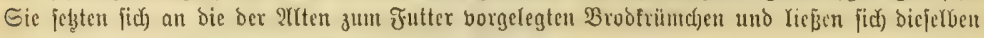

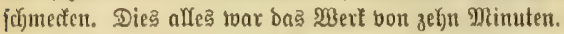

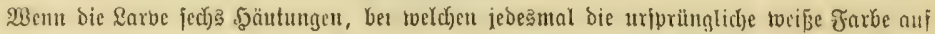

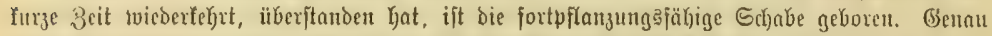

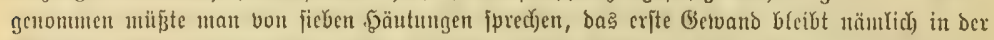

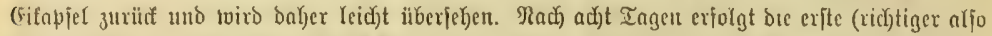

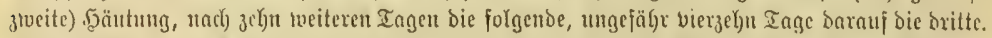

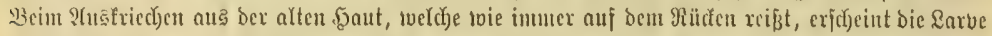

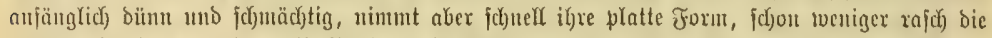

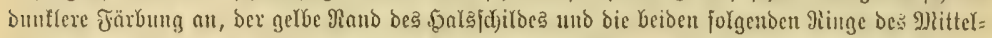

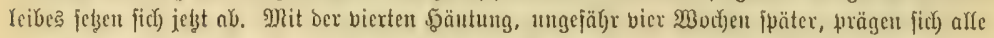

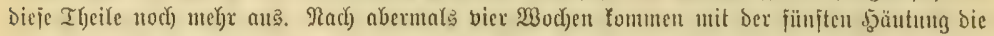

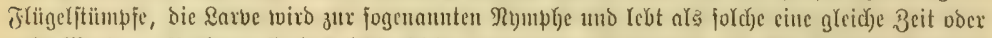

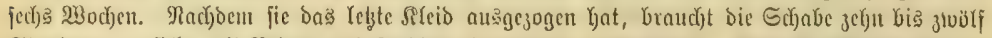

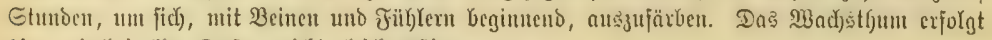

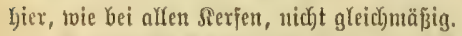

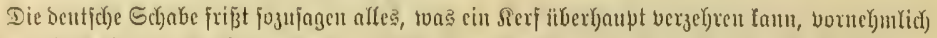

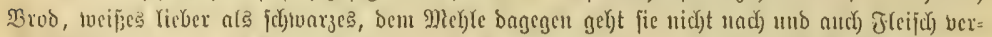

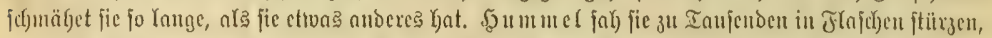

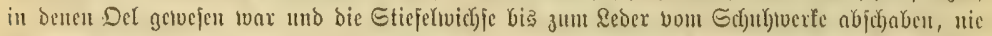

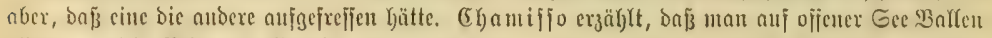

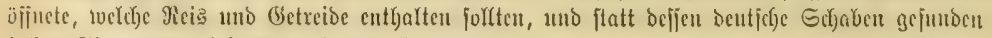
gabe. Sie tönnen itbrigen aud lange Kungern.

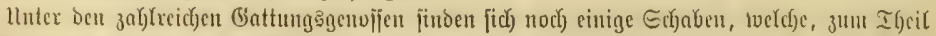

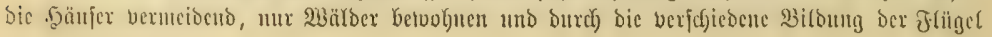




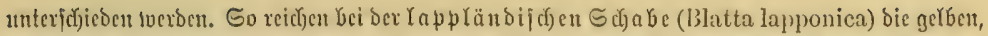

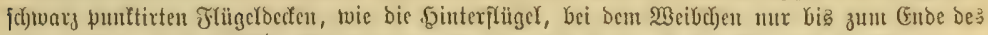

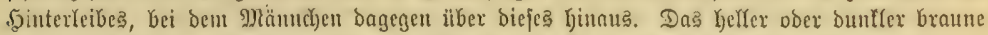

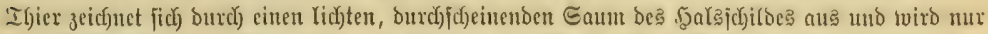

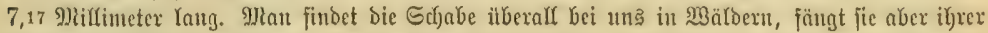

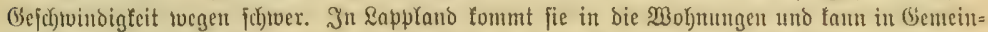

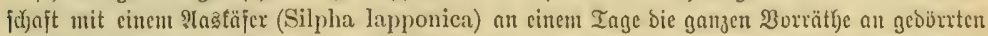

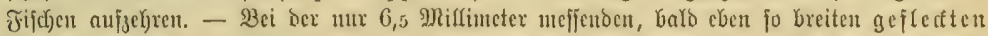
Gchabe (Blatta maculata) breiben bie Şinterftügel merflid) fïrzer alz bie mit ber \&eibeäpibe

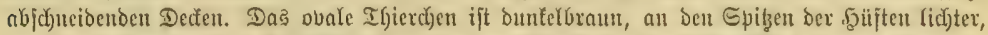

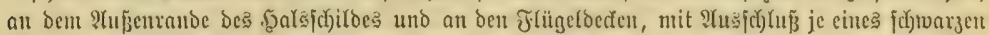

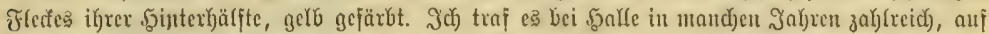

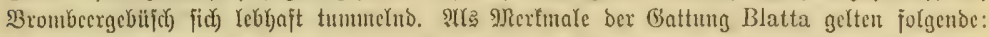

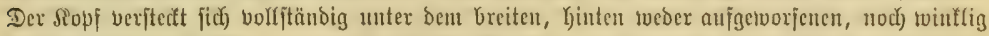

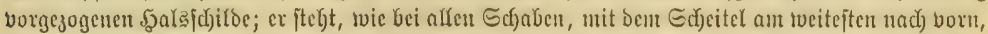
mit Den Tre

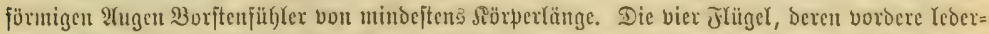

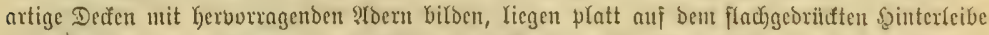

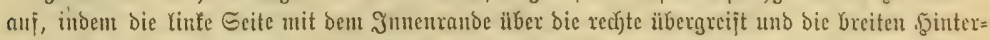

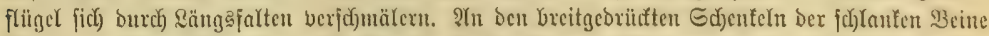

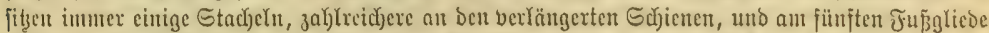

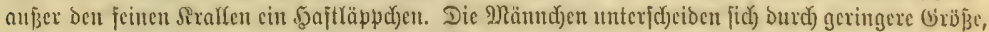

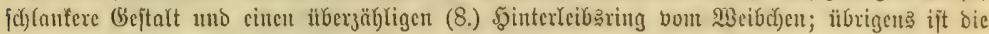

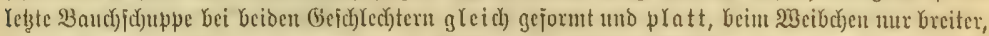

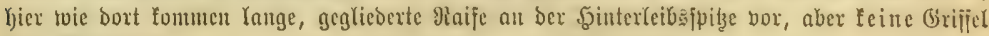
bein গภännd่en.

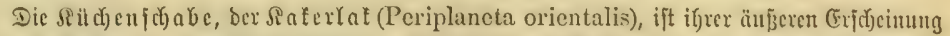

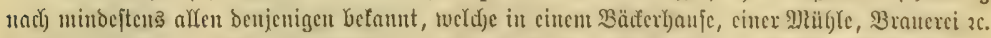

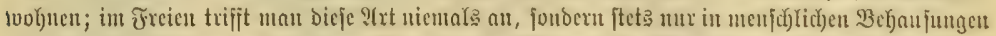

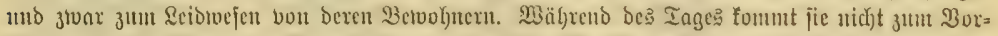

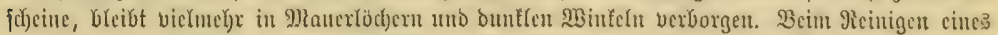

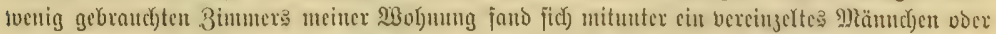

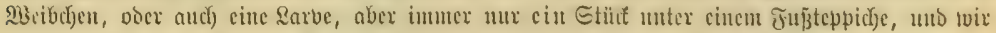

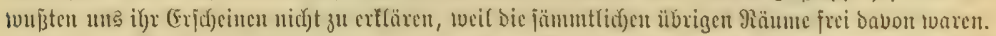

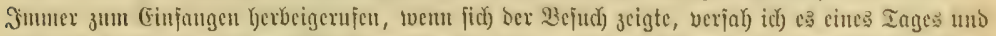

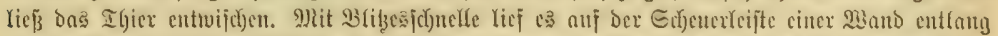

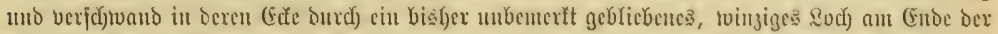

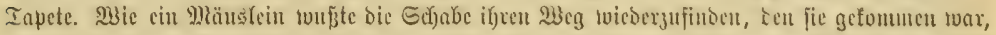

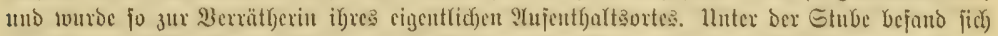

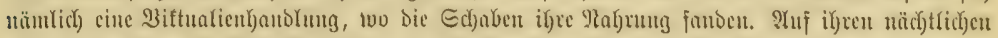

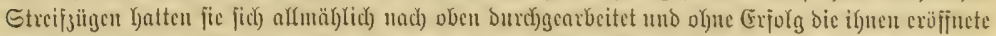
Etube Durdjirrt, einige waren jogar bariu verfyungert; benu brei = bis vicrmal fanb fick eine tost

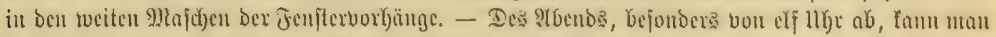

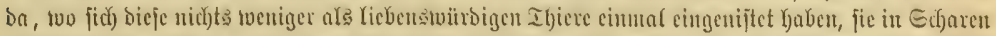

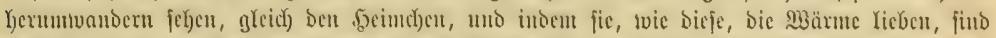

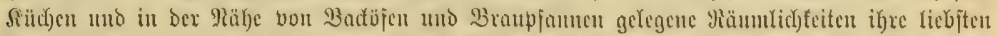

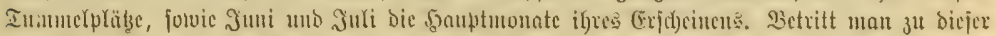

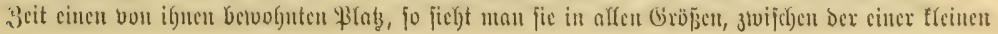




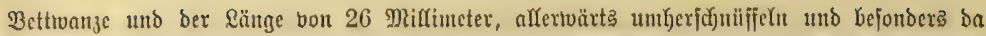

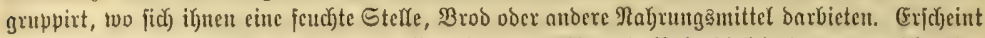

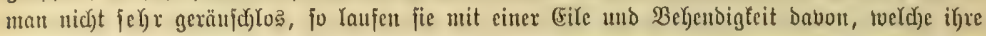

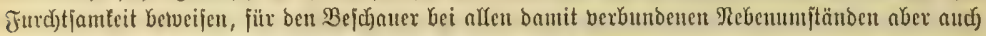

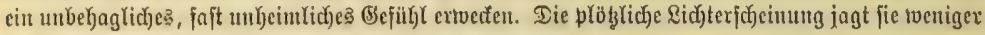

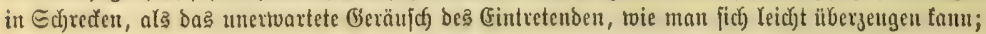

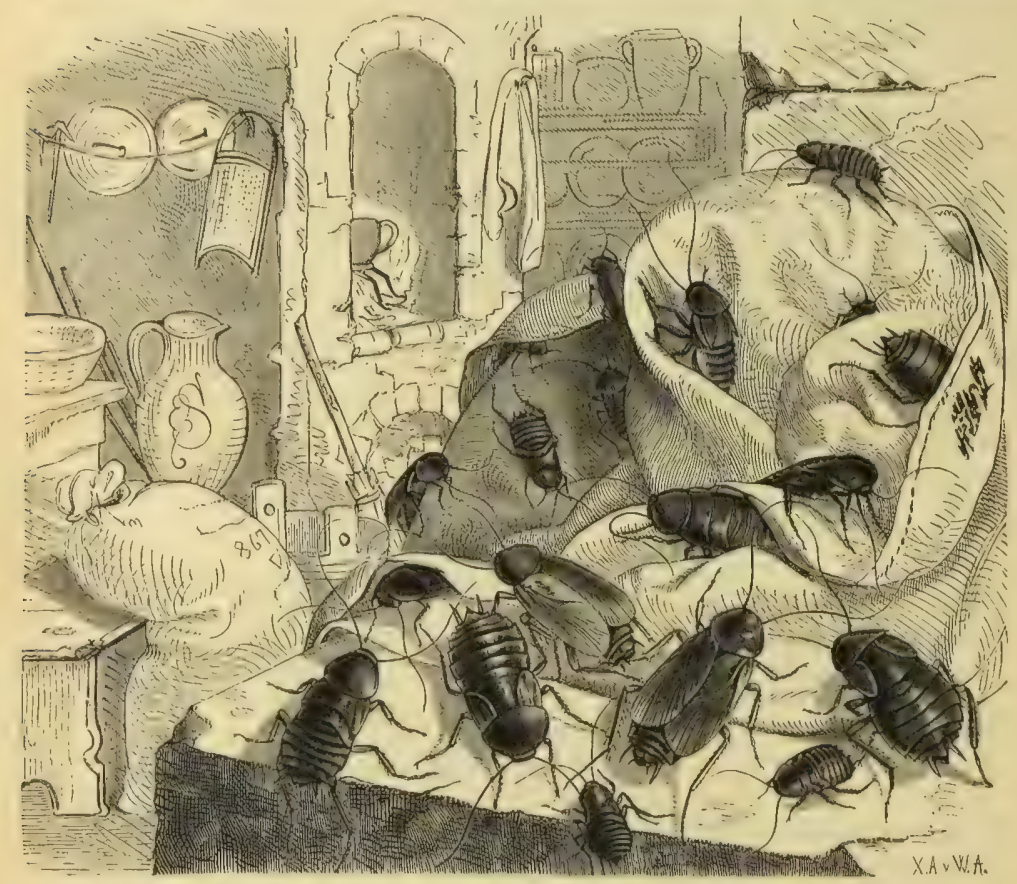

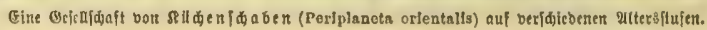

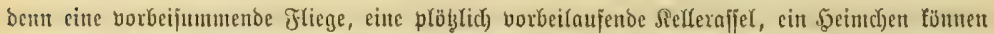

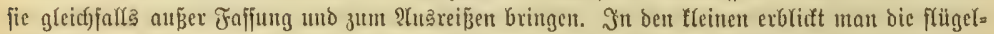

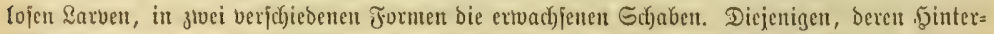

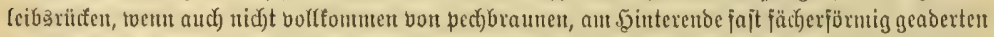

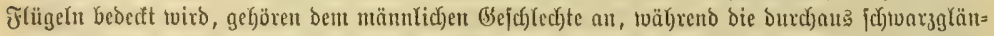

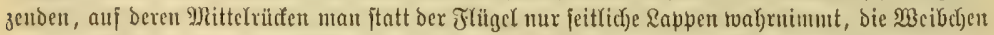

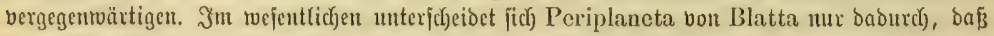

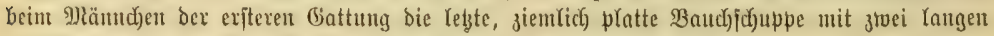

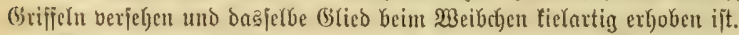

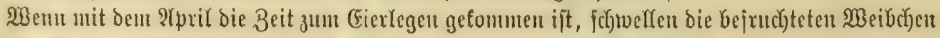

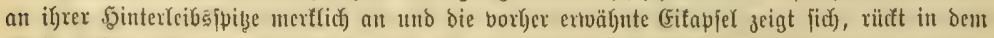

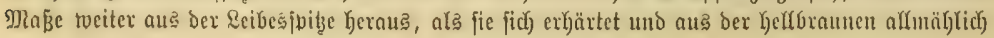




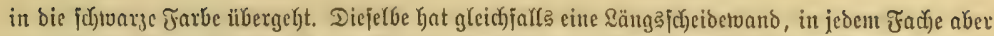

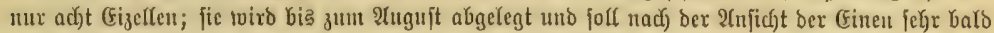

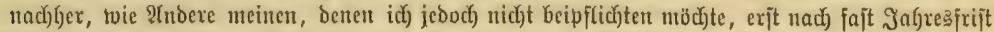

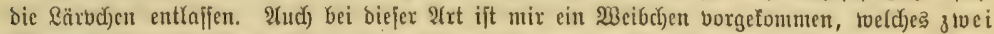

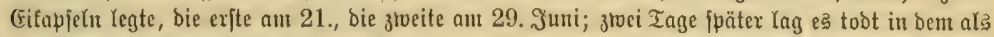

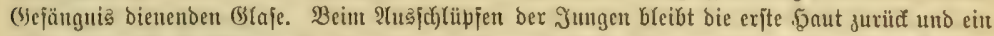

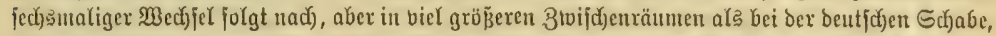

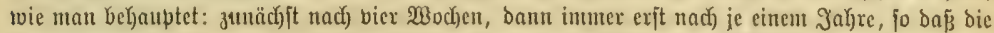

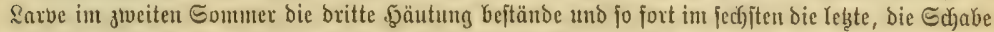

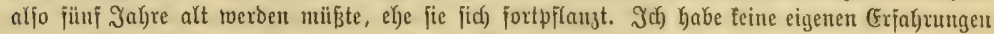
bariiber angejtelrt, finbe aber bie angabe bes artex̧ etroas jebr hoct).

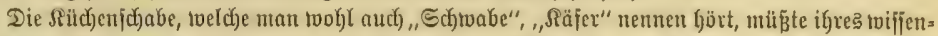

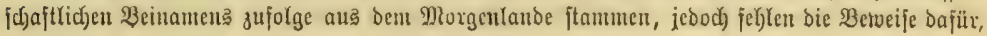
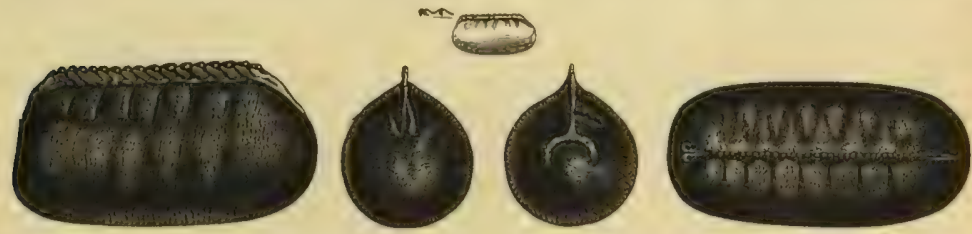

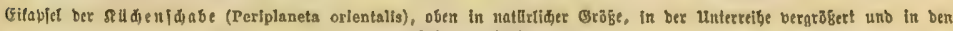
berjdiebenen थnfidten.

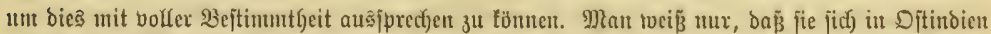

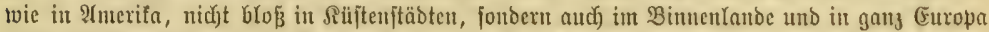

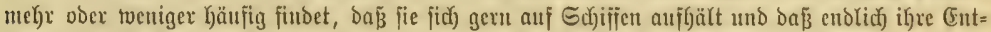

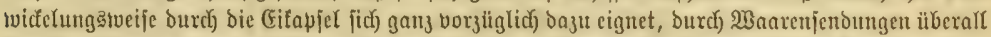

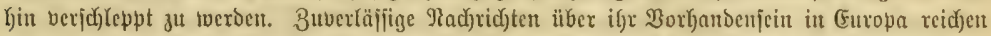

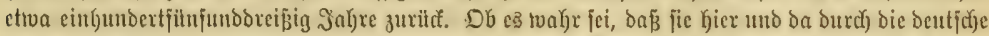

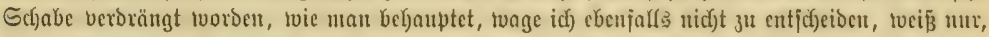

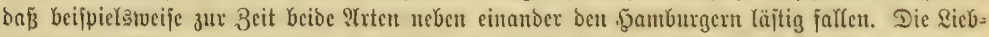

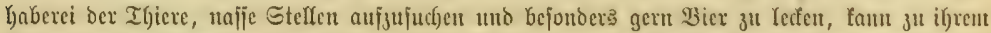

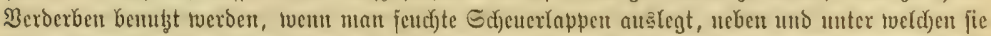

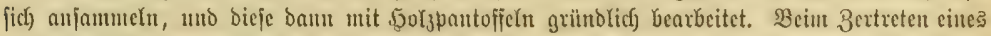

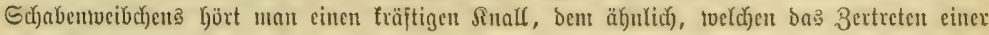
fleinen Fija)blafe exzeugt.

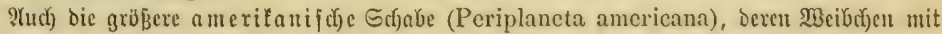

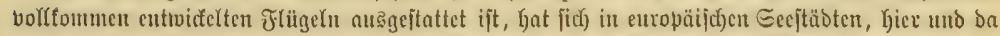

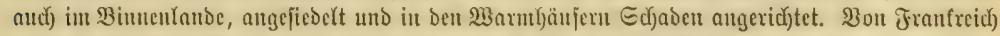

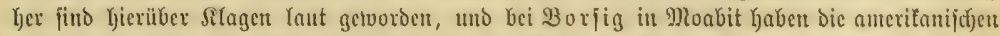

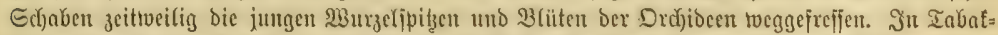

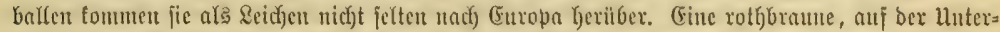

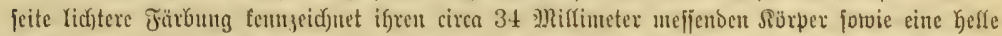

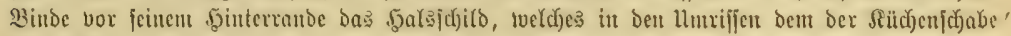
rake jteht.

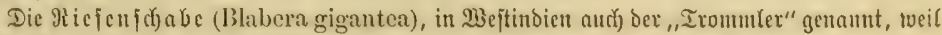

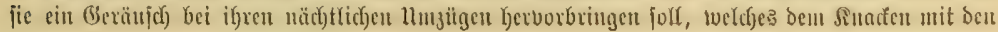




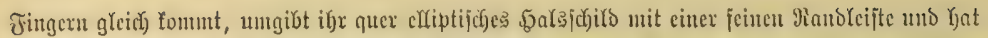

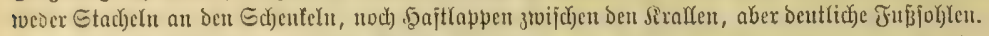

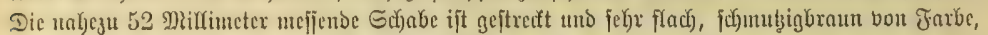

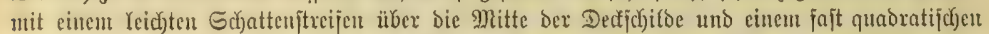

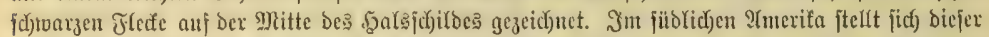

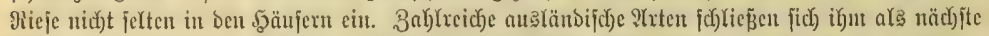

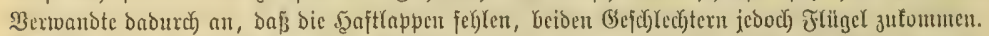

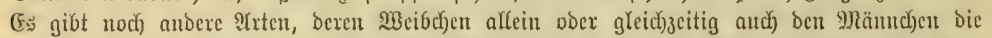

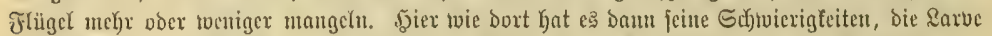

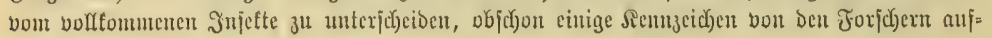
gejunden tworden jind.

Die Gejaumtgeit ber $E$ d)aben ober Seaferlafe (Blattina) geburt gleich Den Iermiten,

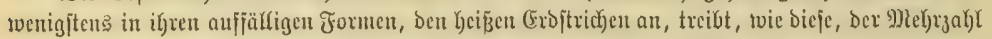

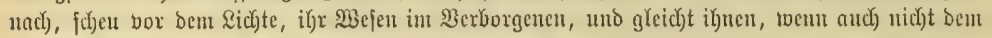

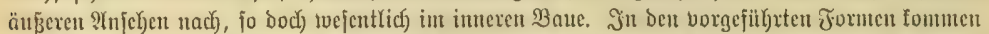

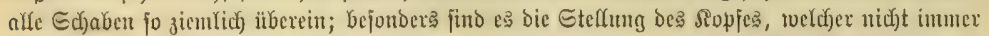

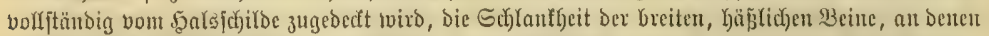

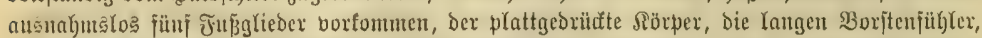

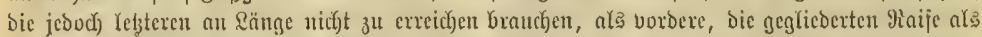

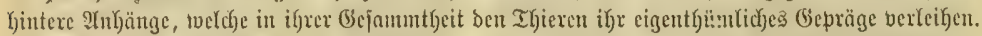

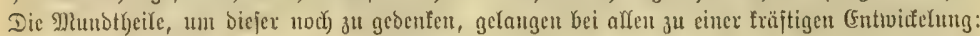

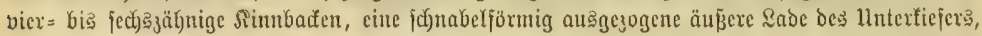

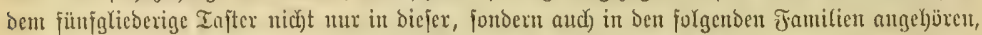

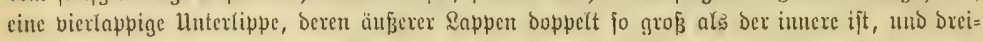
glieberige Tajter tennzeichnen bie Seaterlafe als Senterfe exften Pange日.

Die Gotteganbeterin (Mantis religiosa) gebürt ifrer äuß̌eren (Erjochemung nad) ent=

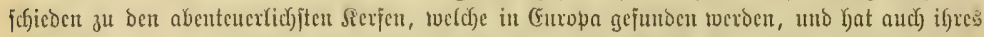

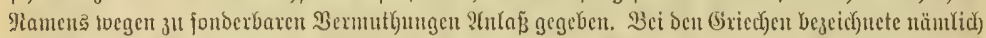

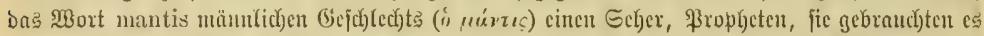

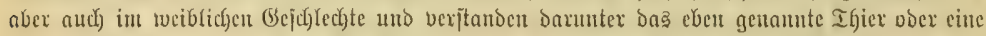

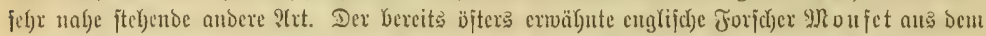

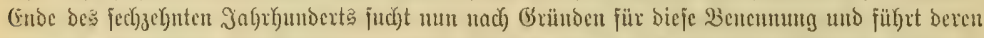

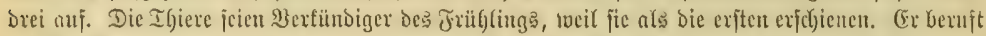

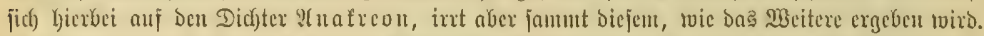

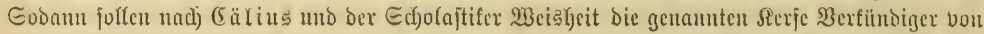

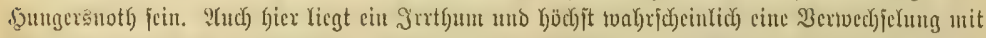

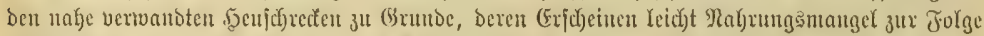

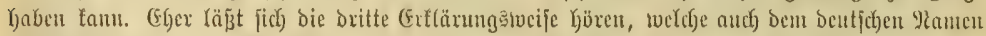
"(Gottešnnbeteriu", Den Bezcich)ungen Der provençałijchen Banern préga-diou (prie-dieu), Dent

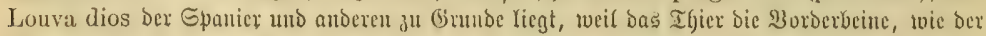

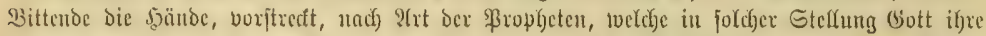

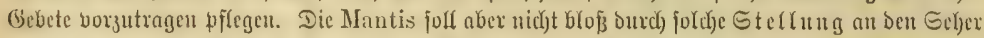

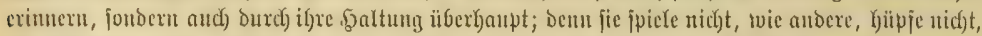

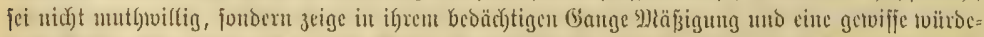

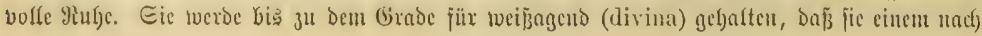




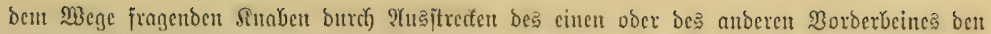
ridjtigen zeige und jeltent ober niemalg täujoj)e.

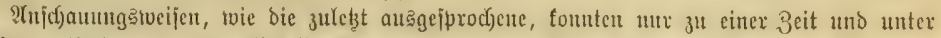

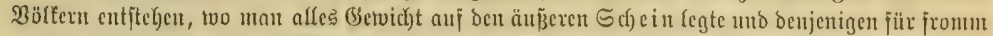

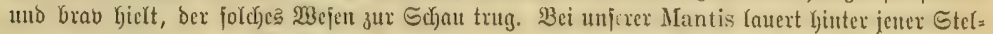

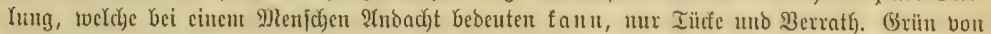

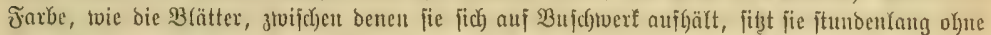

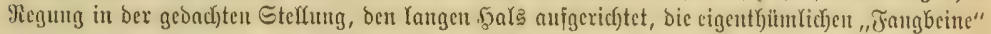

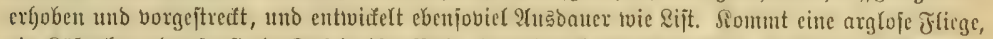

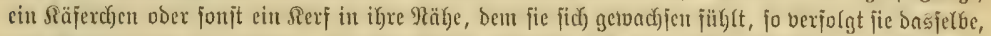

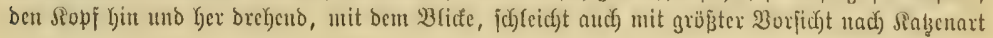

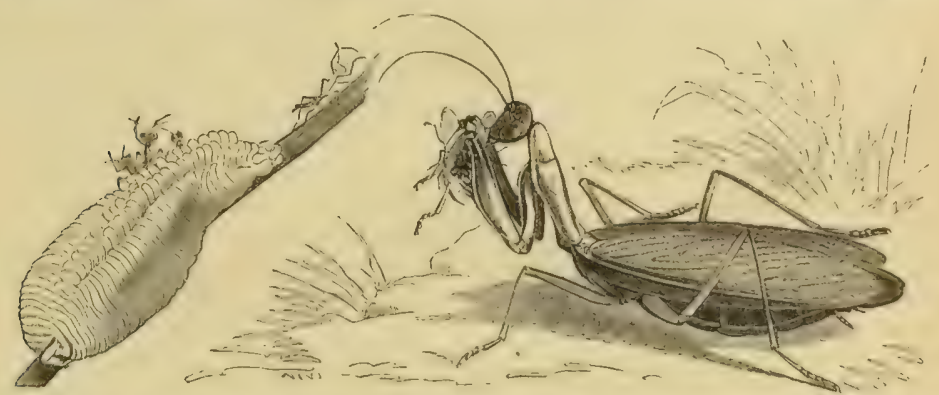

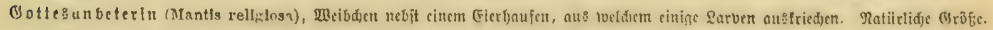

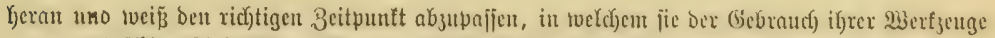

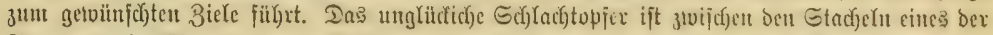

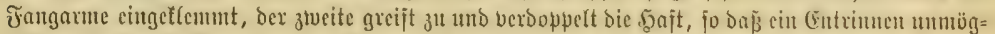

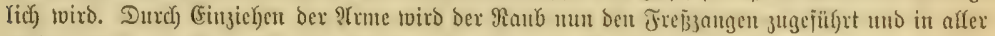

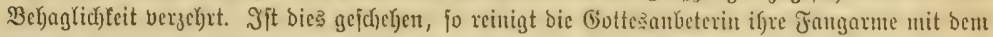

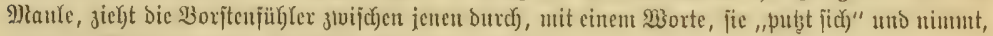
auf neue Bente Iauerno, bic frühere Steflung twieder cin.

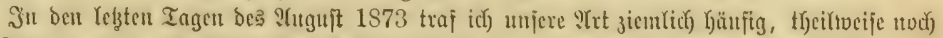

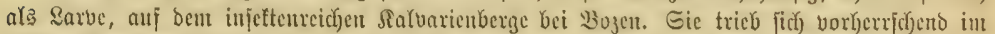

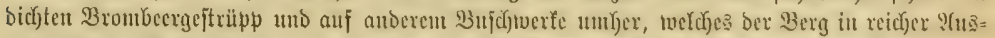

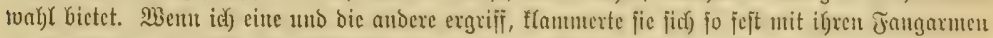

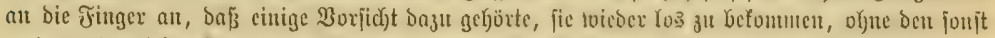

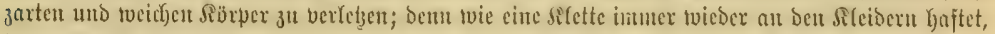

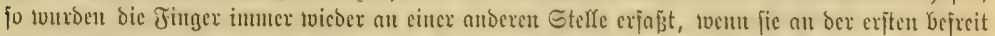

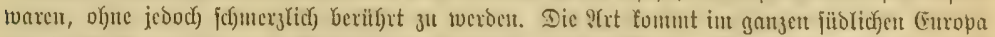

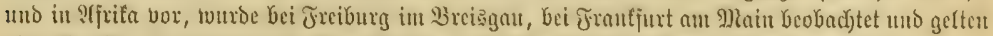

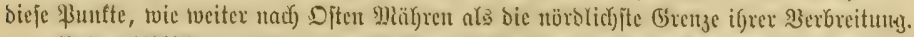

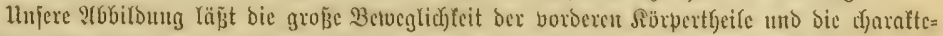

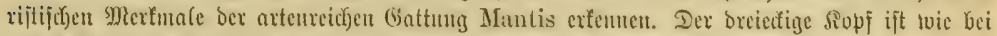

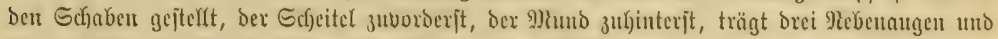

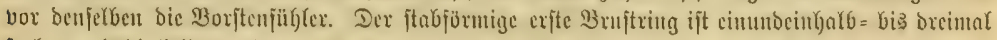

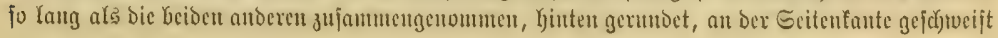




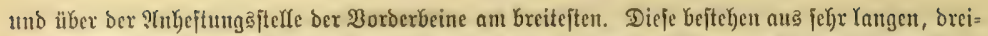

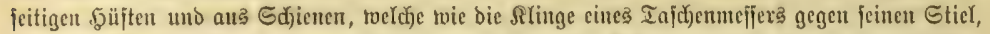

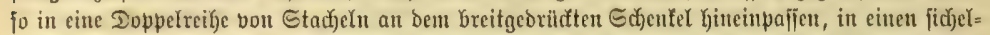

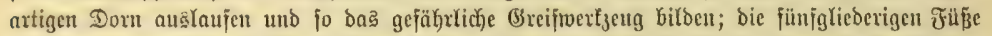

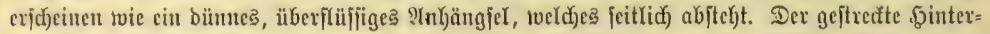

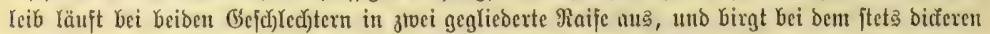

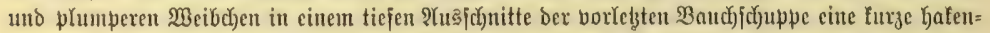
järmige Regröhre, toährenb beim Mä̈nd

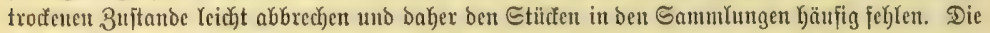

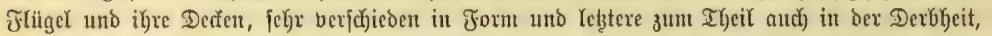

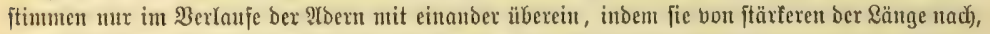

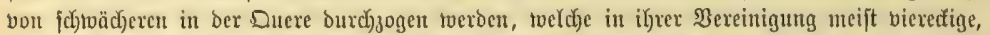

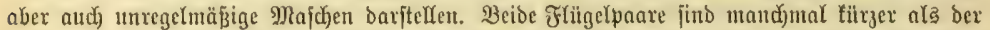

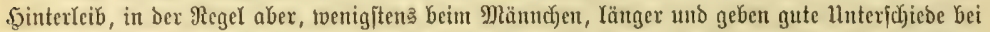

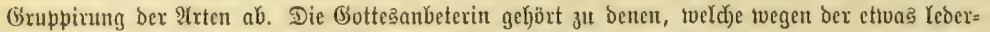

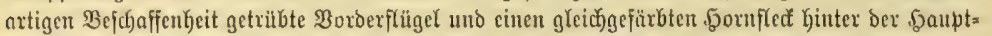

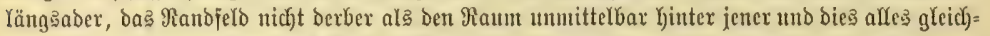

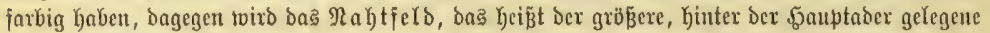

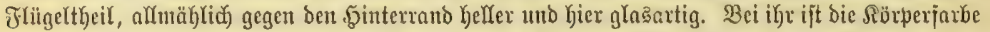

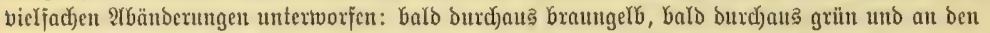

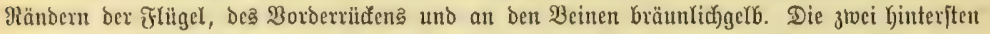

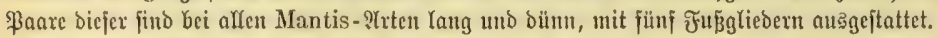

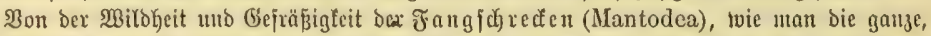

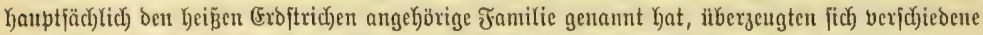

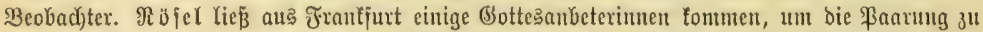

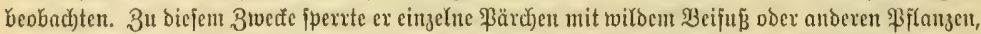

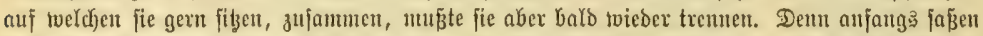

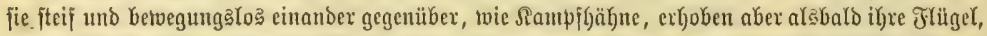

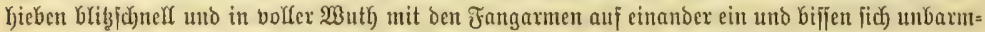

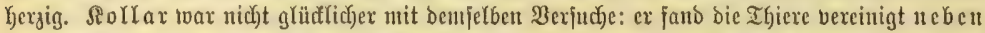
cinnonder fitzend, twie es bie Sforpionfliege autd thut. Sierauf aber verfpeifte bas Weibdjen bas

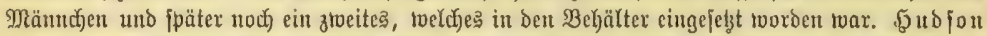

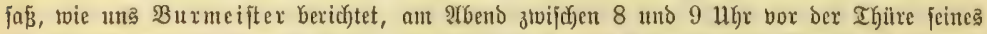

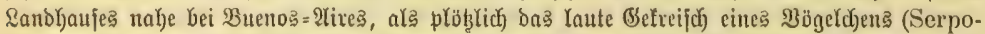

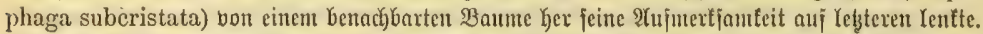

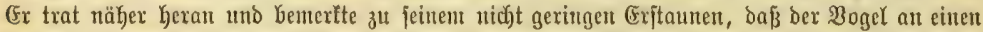
3tweig angeflebt zu jein jchien uno Keitig nit ben Flügeln flatterte. Mm bei ber (5ntfermung uno

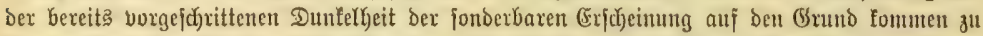
tönnen, hatte ฐubjon cine \&eiter herbeigeholt uno jah nun, wie fid eine Fangidjecte mit ibren

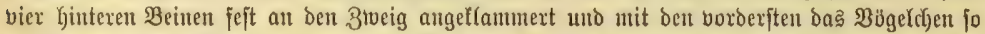

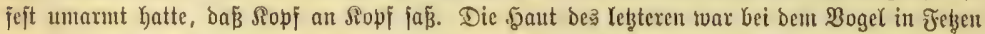

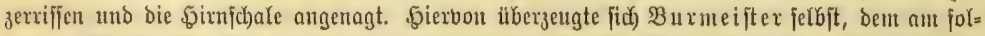
genden Morgen beibe Thieve von \$̧

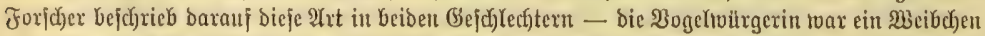

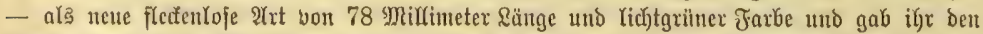

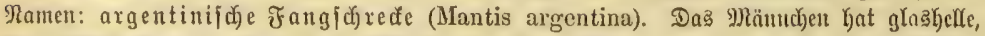

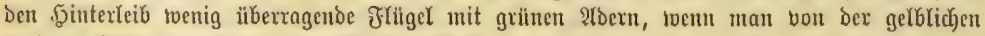

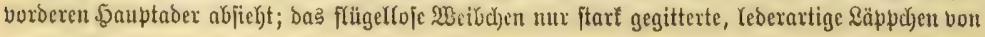


26 Miffimeter Sänge an Stelle ber Decten. Dieje Mittheilung ftellt aljo bic Ihatjache feft,

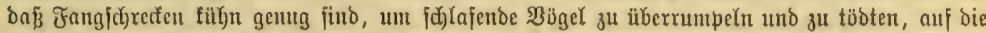

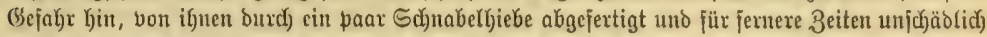
gemacht zu werben.

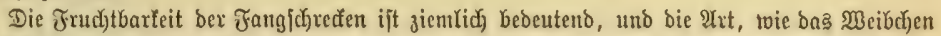
fecine jehr lang geftredten (Gier in flcinere ober größ̄ere \$afete an einen Stengel oder an einen Etein

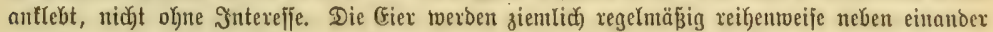

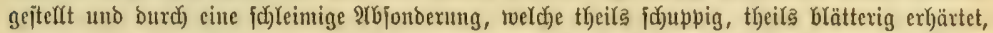

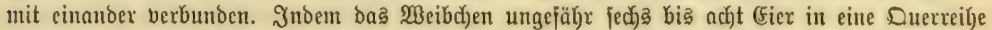

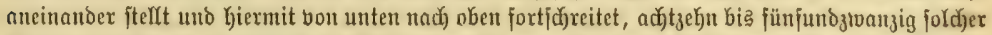

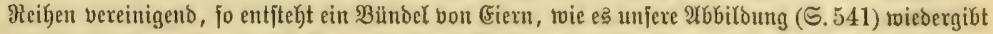
und in tweldhem fämmtliche (Fier mit ifren Ropjenden nad) oben oder roenigitens nad) aujen gerid)tet find, und bie in bem berbindenden Sdyteine wie in einem fad)werfe fteden. Die mel)r

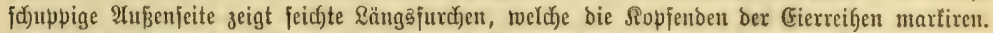

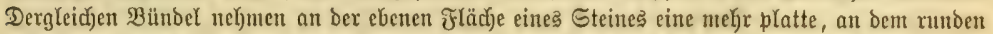

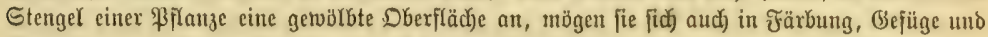

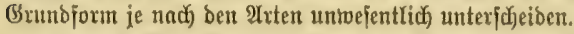

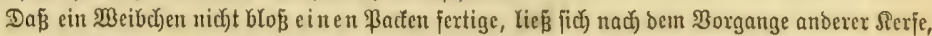

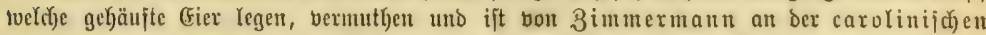
Fa

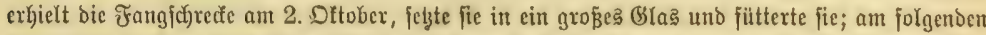
Tage legte fie (Eier, ftarb aber nicht, twie er ertwartet hatte, fonbern berzebrte nad) voie bor täglid(

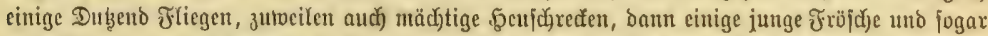
cine (Eibedfje, weld)e breimal jo lang als fie jelbjt mar. Mas fic cimmal bein Frefien verlafjen

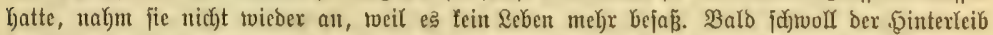

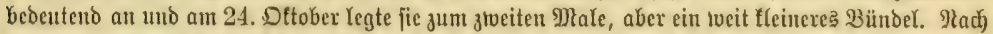

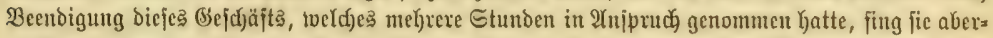

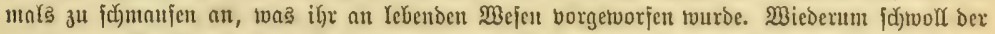

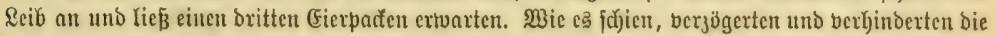

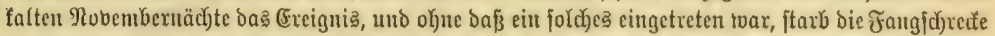

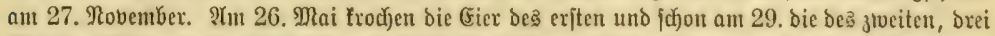

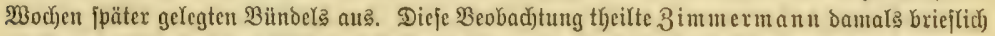
an $\mathfrak{B}$ urme

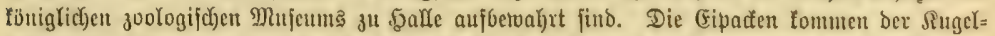

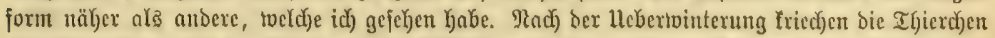

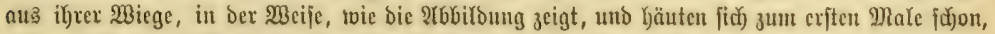

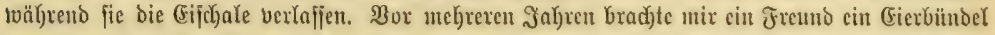

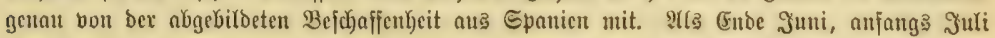

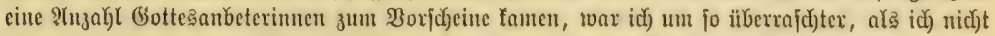

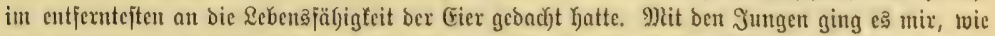

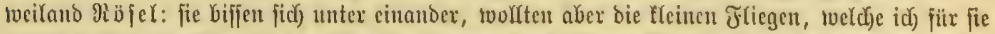

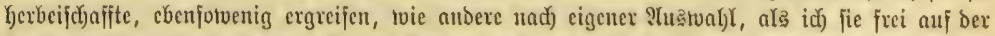

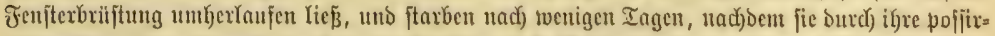

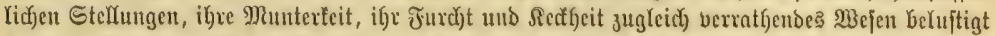

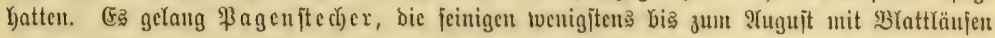

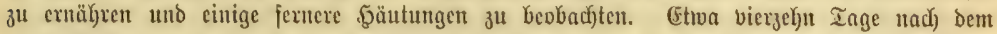

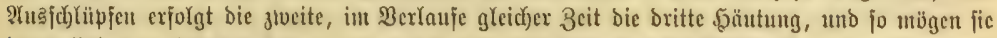

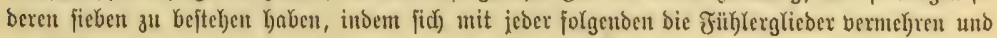




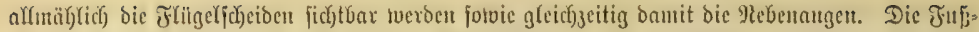

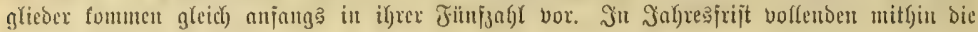
Fangidyreden ibren Rebentslaui.

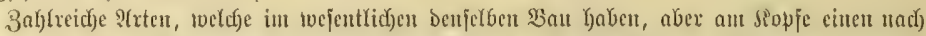

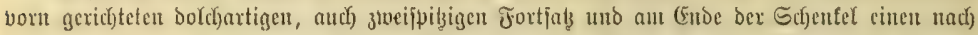

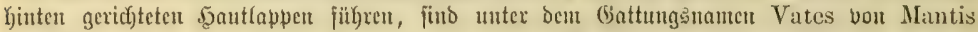

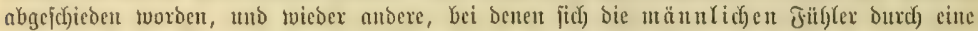

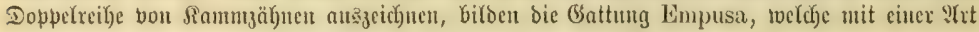
(Limpusa pauperata) aude) im iüblidjen (europa vertreten ijt.

Dic Gejpenftichreffen (Plıasmodea), mit ben vorigen imnig verbrübert in ben Gebunden=

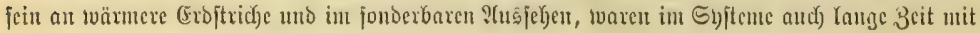

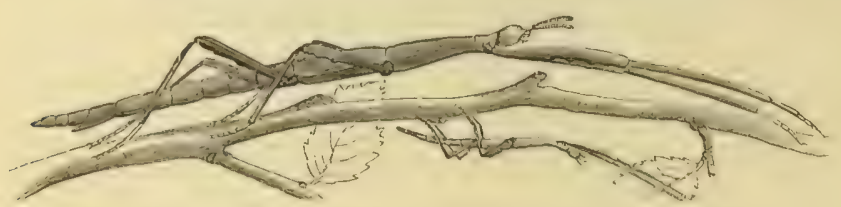

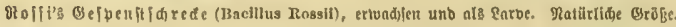

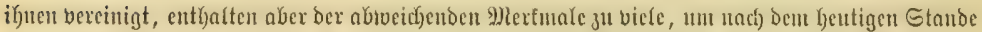

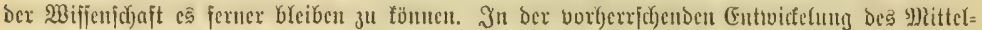

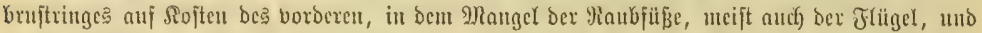
in Der ftabjörunigen Gejtalt ber meiften oder ber Glattjürmigen einigex Yiegen bie obue Iveiteres in

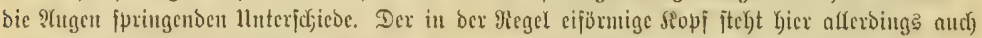

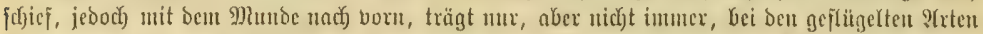

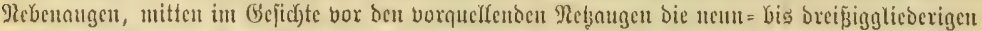

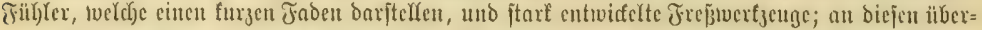

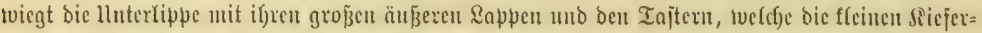

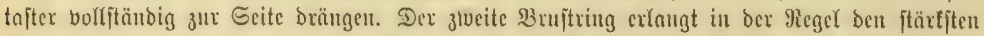

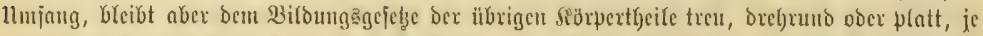

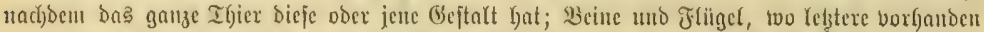

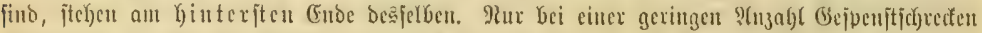

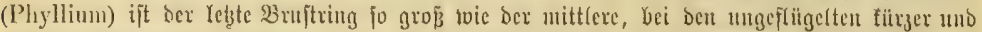

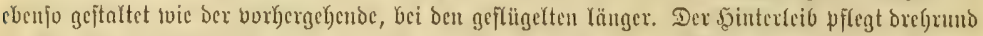

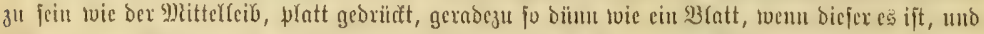

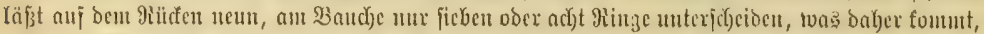

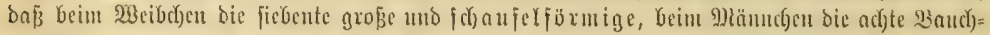

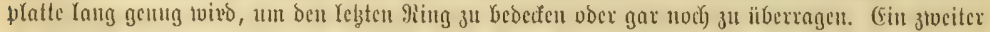

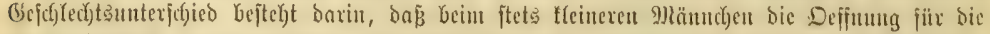

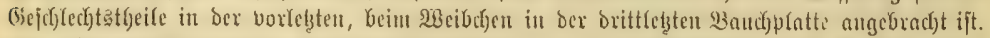

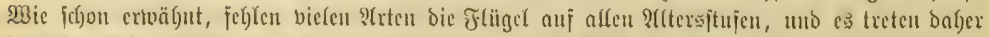

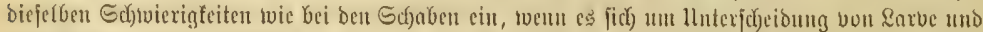

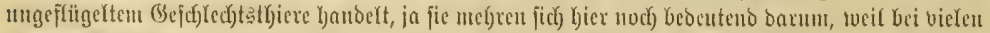

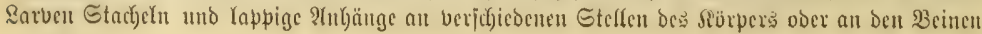




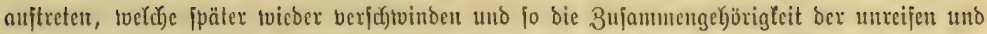

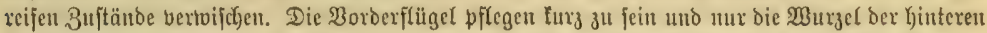

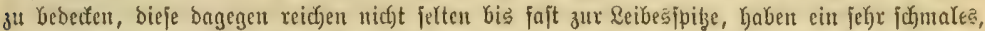

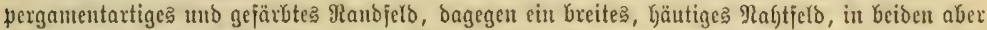

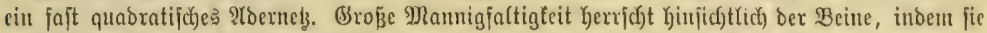

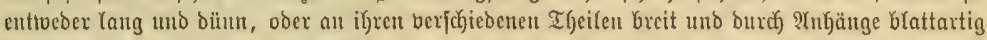

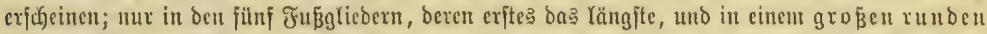

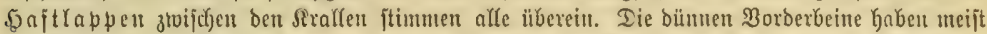

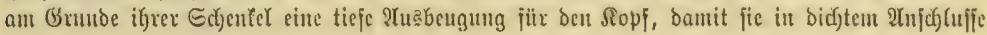

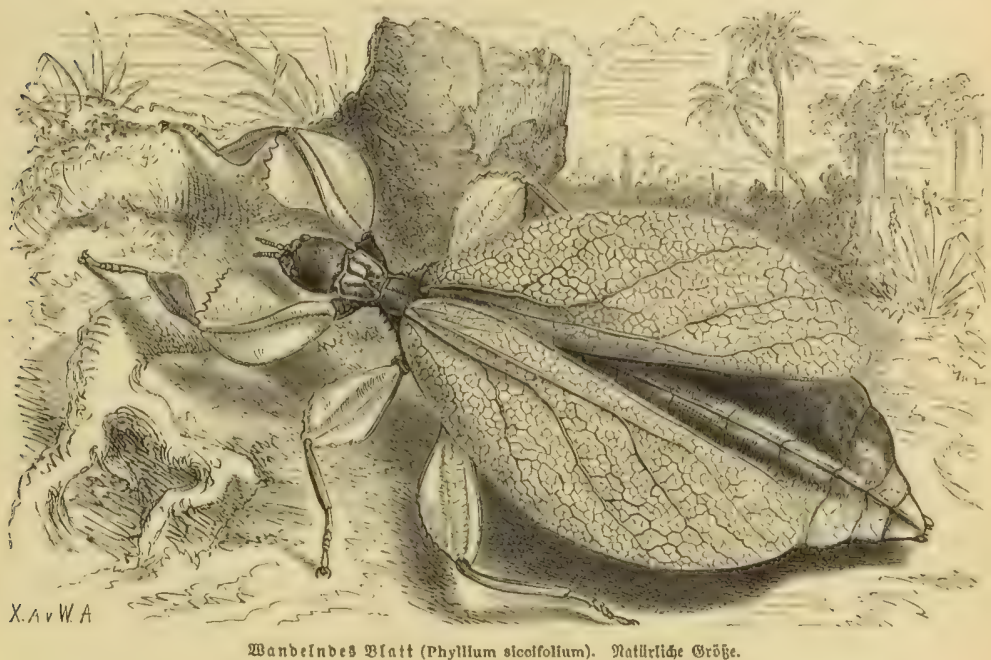

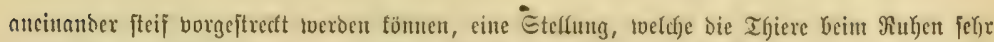

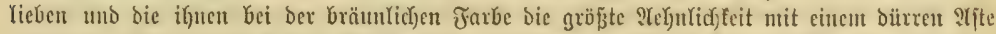

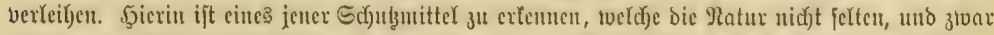
vorzugstweife bei Dex đeinde zu verbergen.

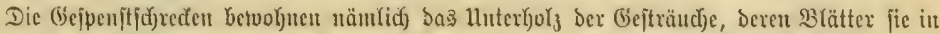

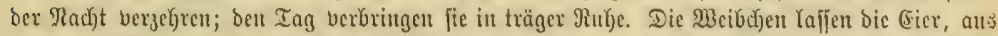

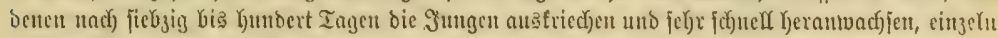

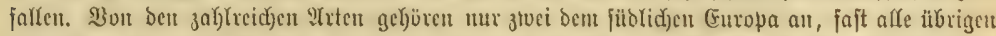

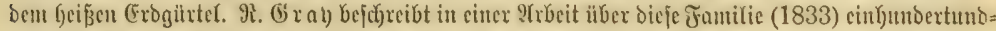

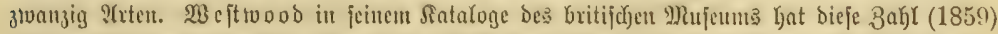

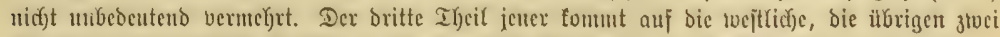

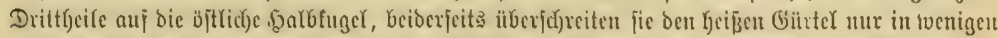

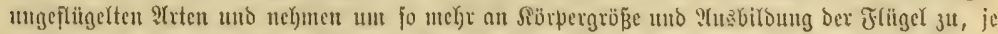

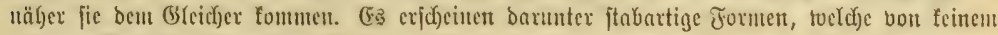

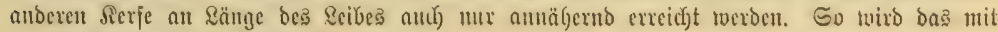

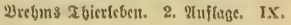




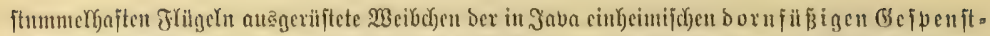

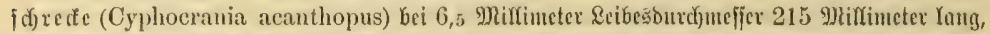

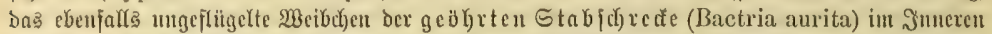

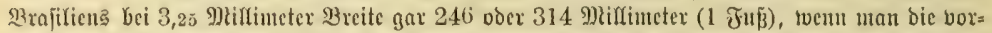

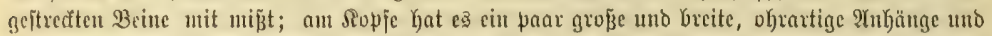

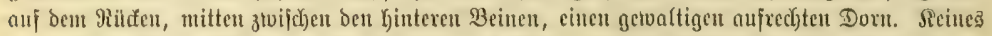

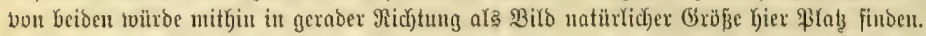

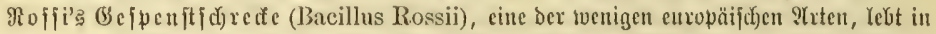

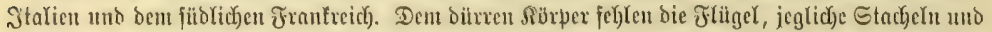

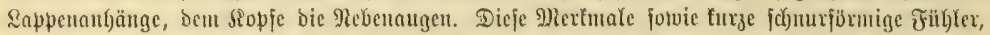

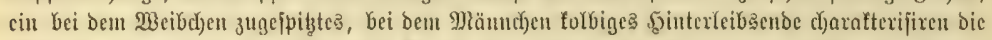

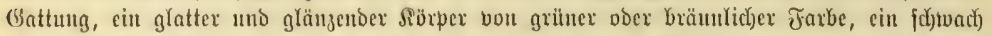

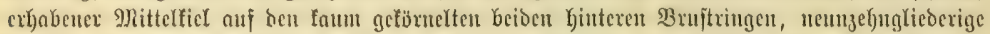

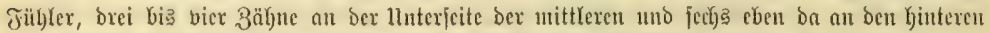

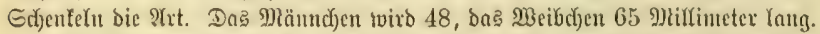

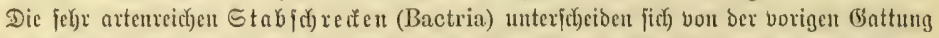

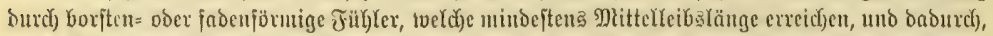

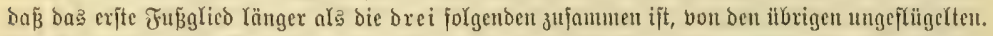

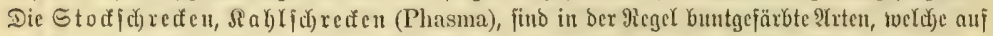

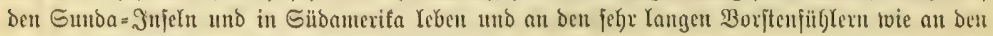
unter fich gleid Yangen Flïgeln erfannt werben.

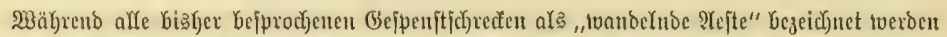

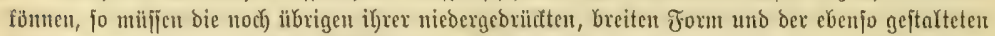

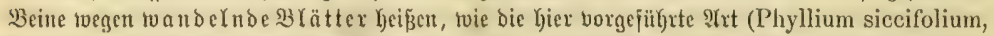

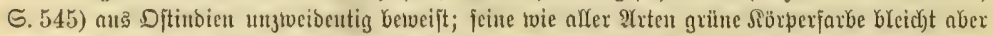

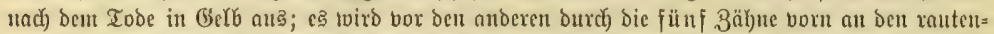

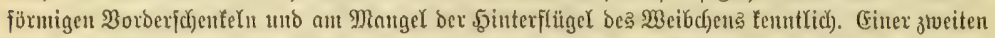

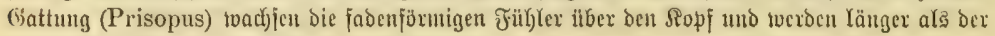
yalbe sittelleib.

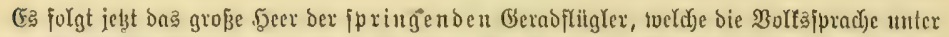

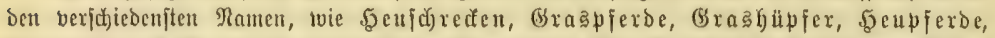

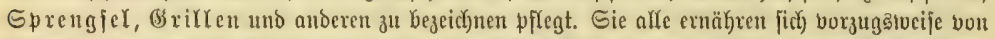

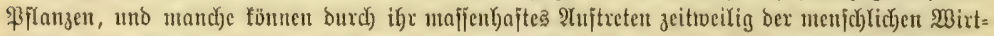

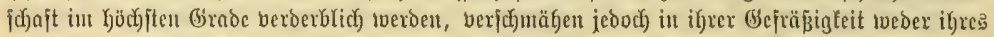

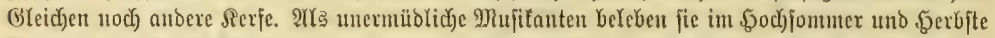

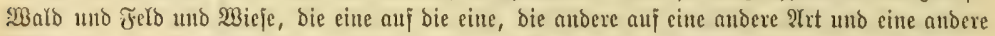

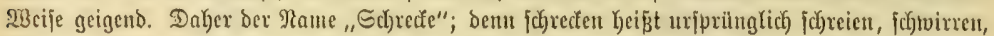

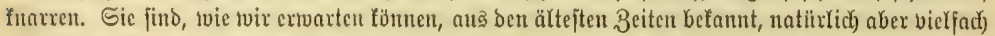

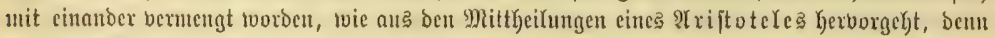

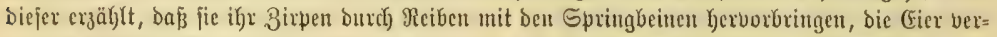

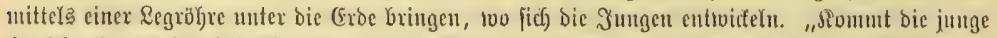

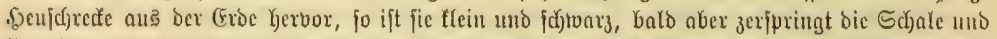
fie wirb größer." Die heutigen (Entontologen bertbeilen afle Schrefen auj bic brei Fantifin ber

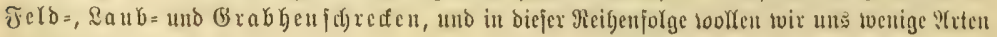
jelzt genauer anjeken. 


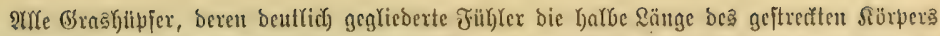

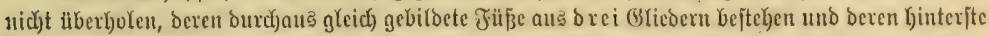
Beine infolge bes verbictten Echentels und ber Ynugen Schiene zun Spunnge befähigen, gehören

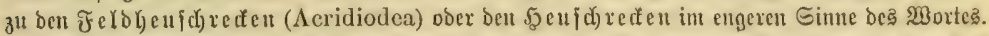
Eie find bie beften Springer in ber Familie und f(h)tellen fid

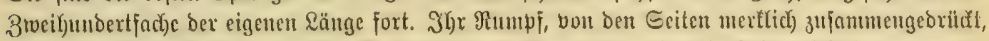

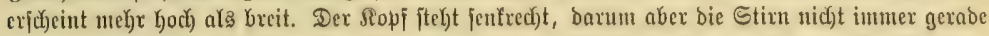

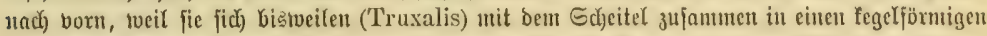

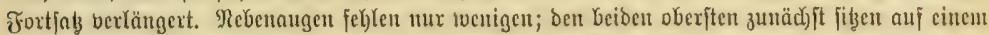

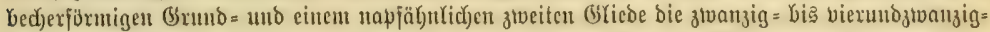

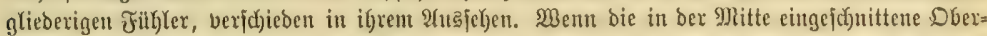

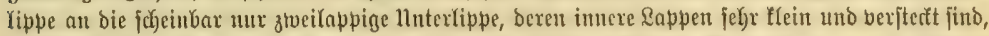

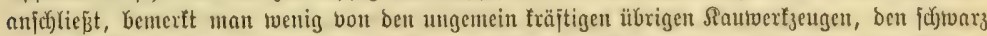

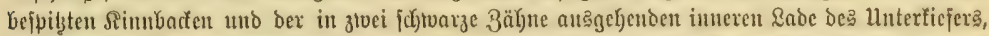

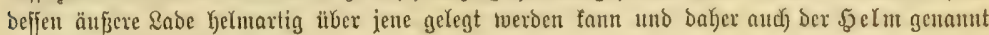
worben ift (S. 4, Jig. 8).

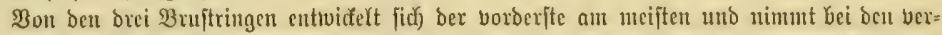

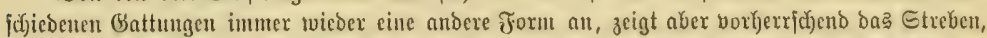

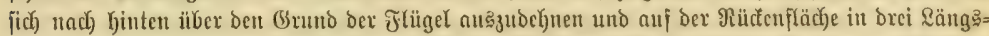

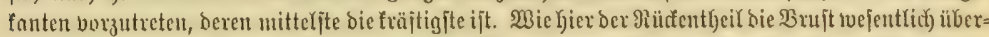

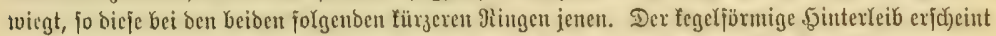

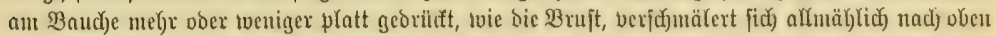

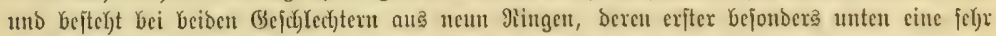

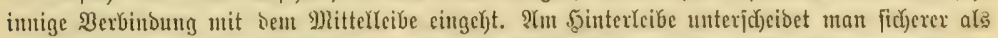
alloet

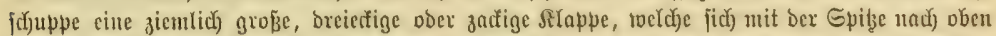

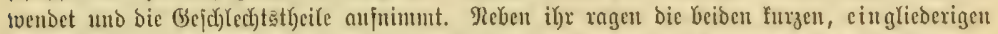

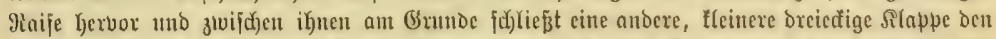

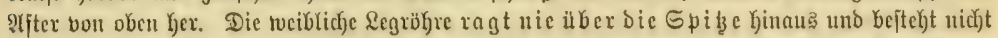

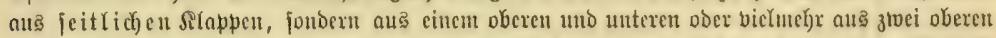

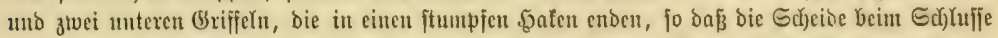

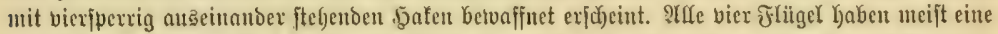

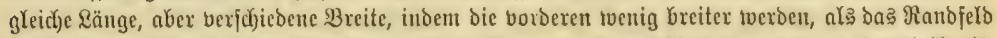

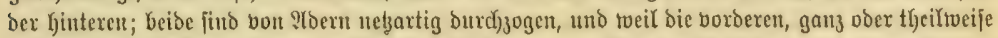

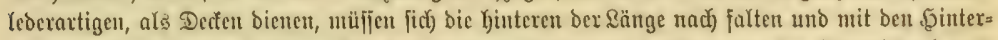

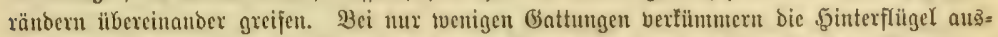

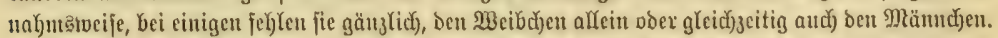

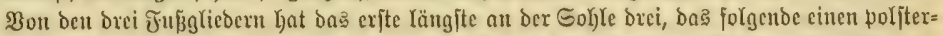

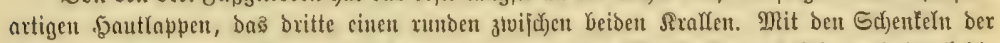

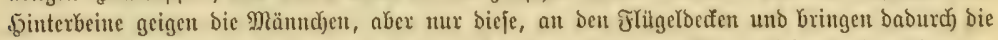

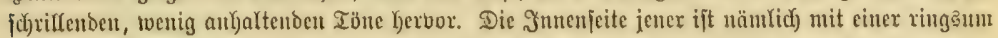

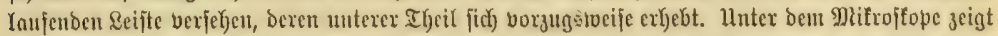

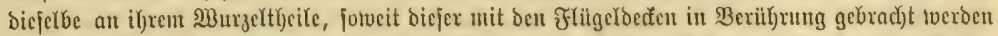

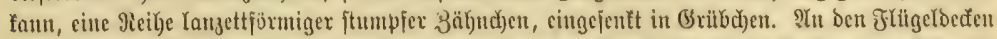

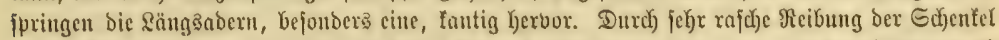

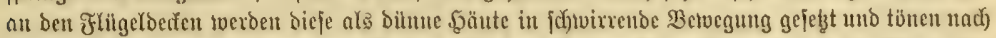

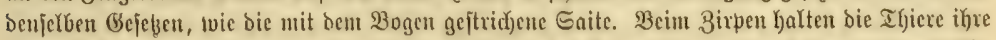

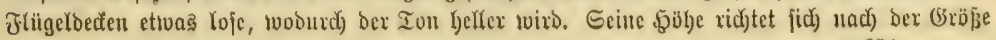




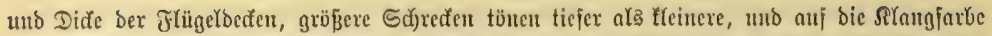

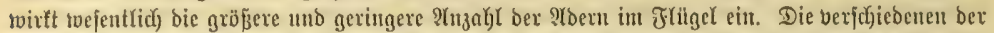

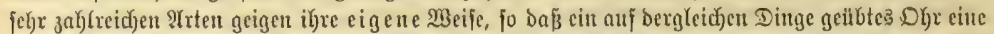
uno bie andere wenigitens, bejonbers bon bex Gattung Gomphocerus, an igrent Geigen ertent.

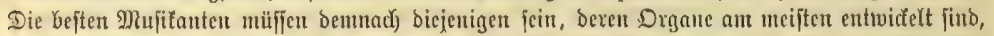

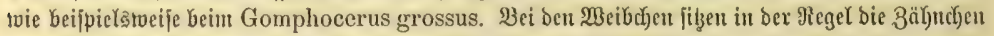

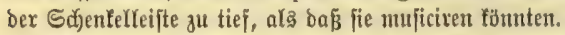

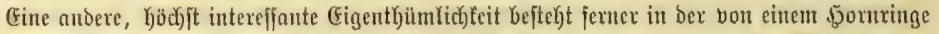

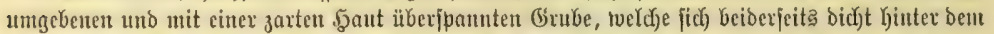

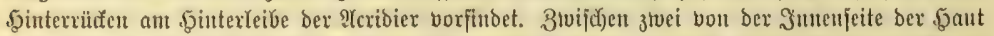

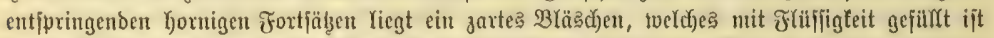

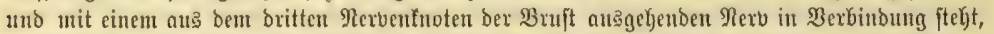

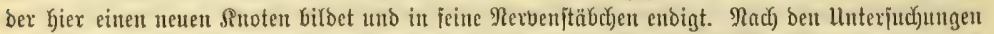

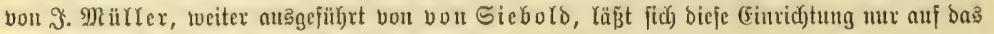
- - Geyörtoerfzeug ber beufdrecten benten.

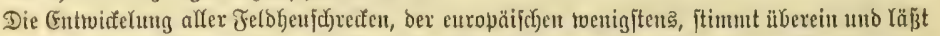

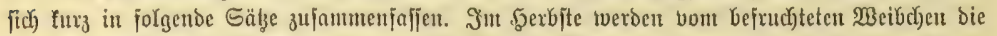

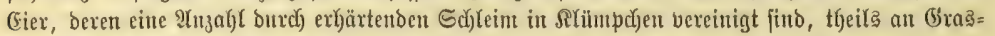

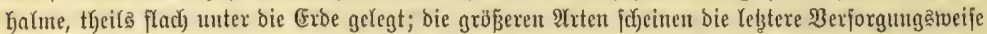

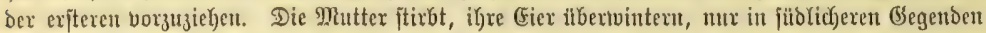

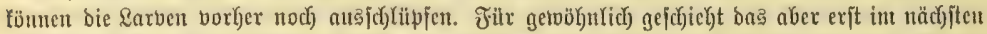
Frülinge. Durdy unbeftinmte Farben, Den Mangel ber Flihgel und ctroas plumpere, türzere

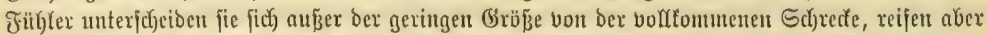

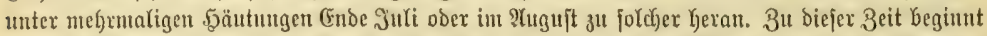

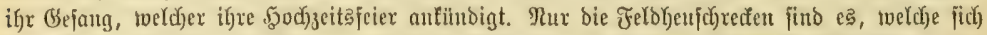

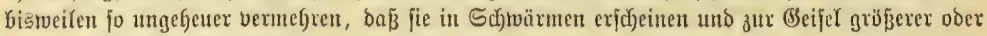
tleinerer \&änderitreçen mexoen.

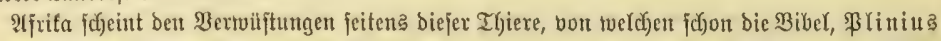

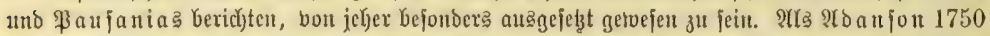

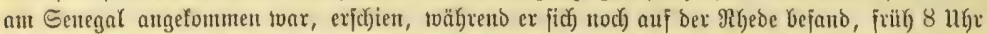

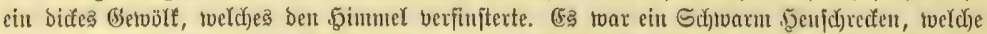

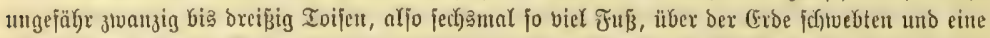

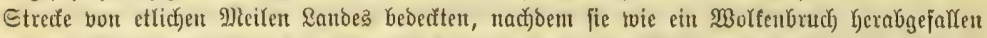

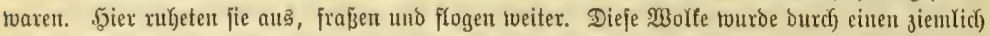
ftarfen Dftwind berbeigefïgrt und jog den ganzen Mlorgen in Der Gegend umber. Itadjben bie

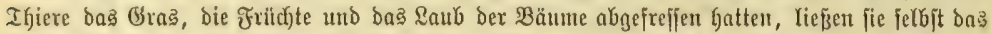

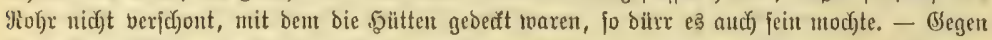

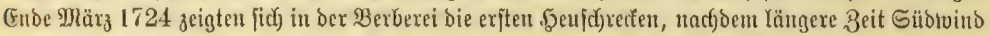

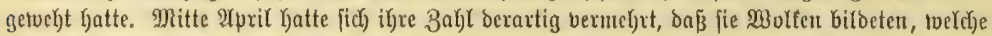

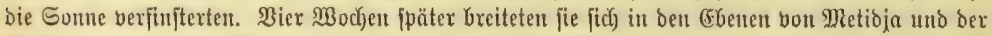

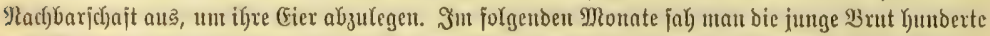

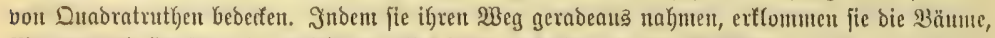

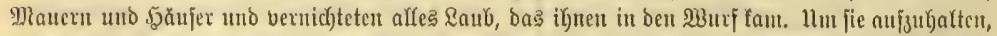

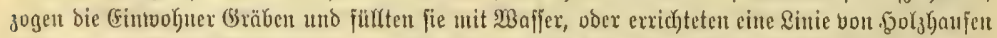

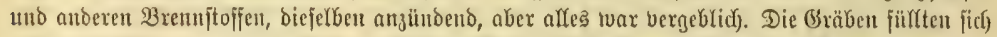

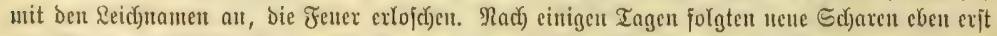

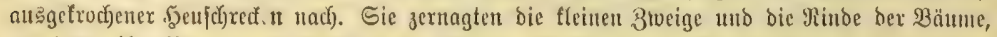

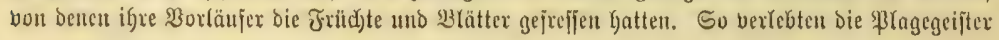




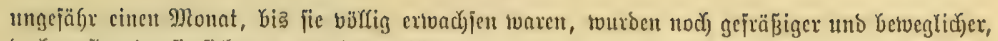
bod) zeritreuten fie fich un und Yegten (Fier.

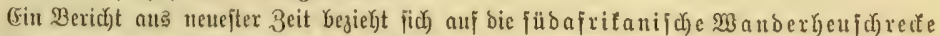

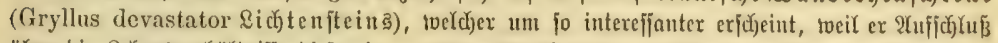

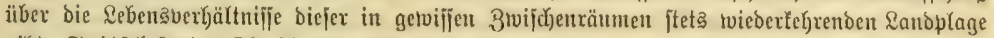

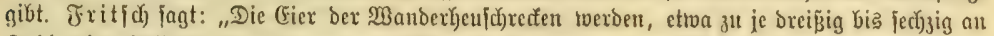
3agl, eingeljüflt in einen braunen, majojigen Meberzug, von bem Weibdjen in fleine zunbe Ero=

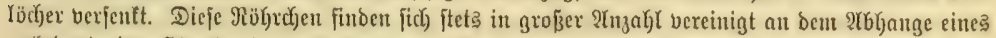

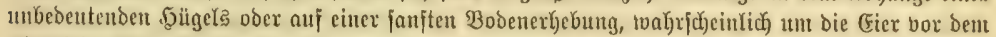

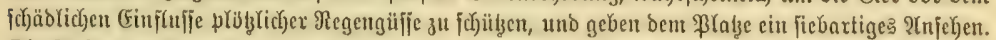

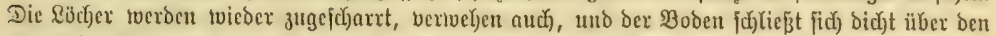

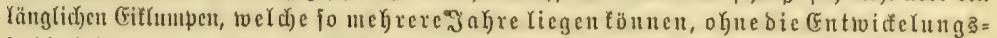

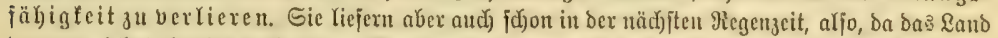

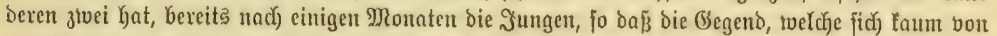

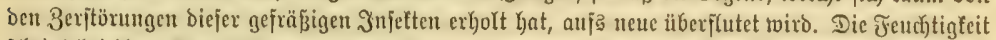

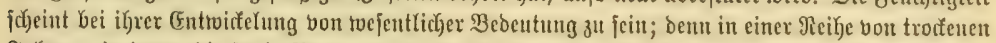

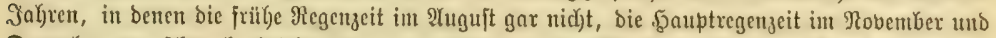

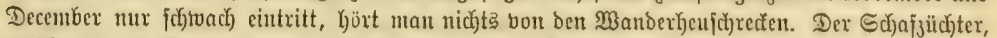

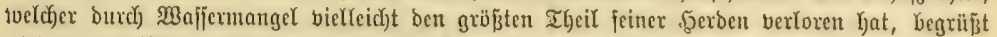

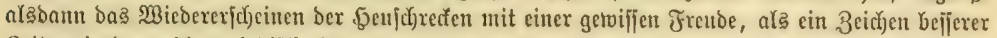
3eiten, in benen bie periodijd)e Trodenlyeit borïber ift, unb opfert Yieber ben geflügelten \$lünderen feinen fleinen, milbjan gepflegten Garten, twenu nur bie ఏerben gedeiłen und bie verfiegten Quelfen Der farm roieder herborbrectjent.

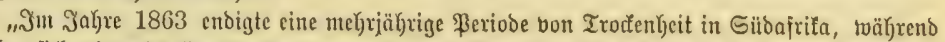

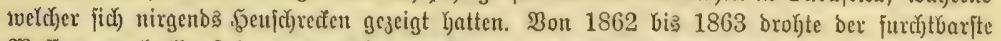

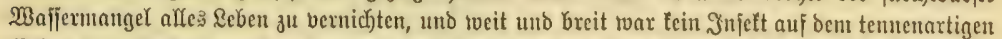

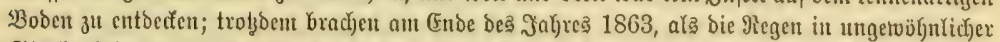

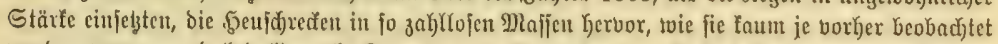

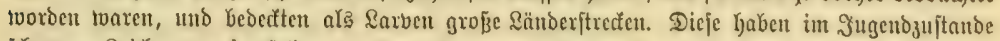

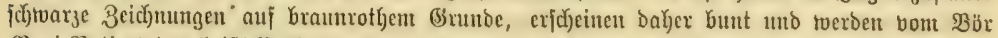

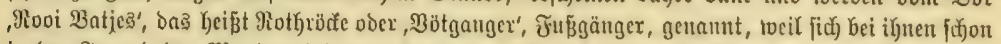

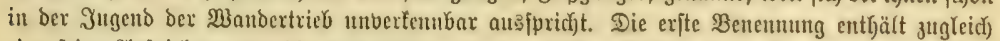

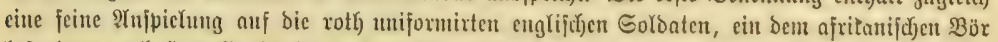

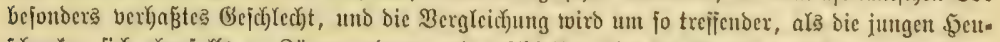

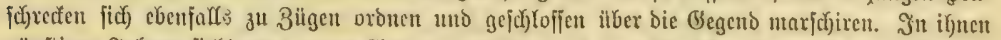

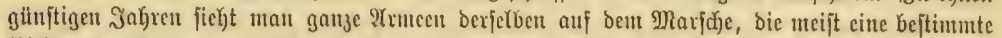
Ridytung cinfjalten unb bicjelbe nicht gern aufgeben. Sommen bie Thiere an ftelyendes Bafjer,

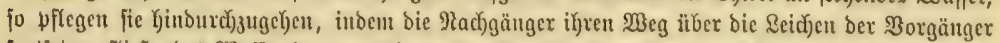

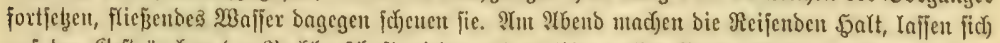

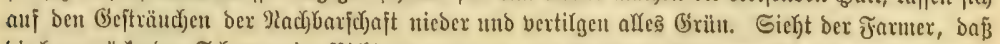

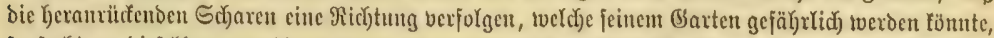

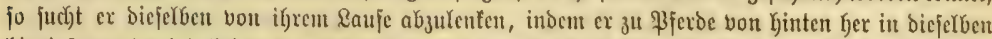

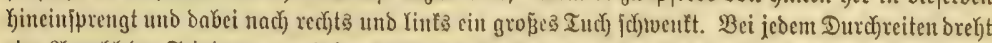

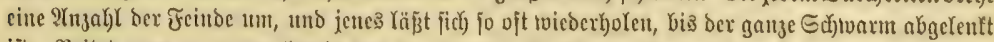

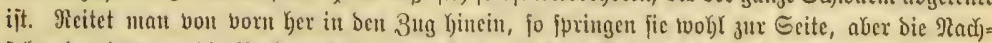

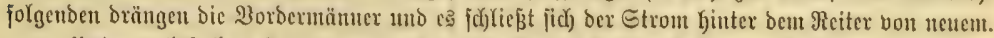

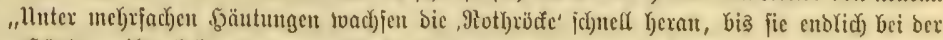

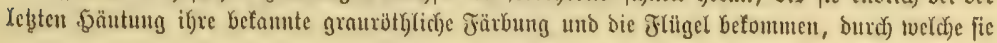




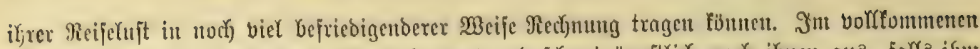

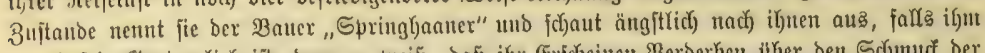

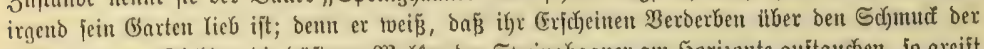

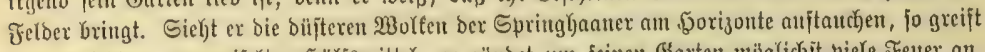

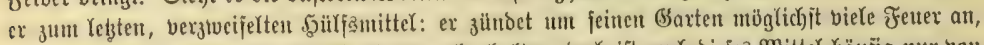

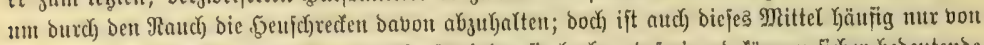

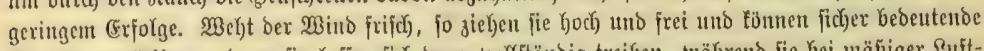

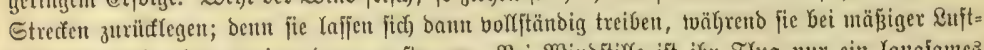

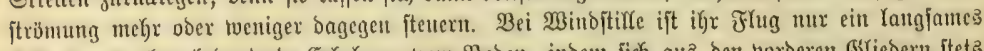

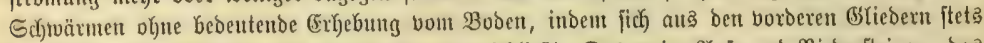

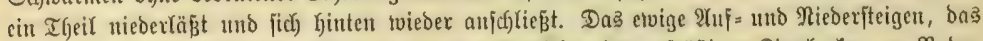

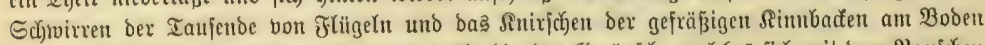

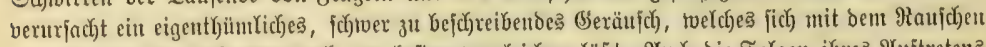

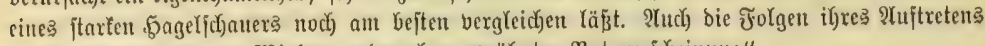

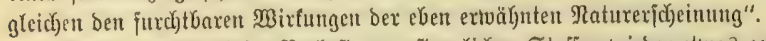

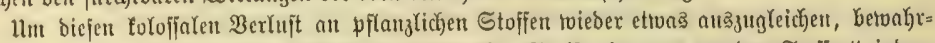

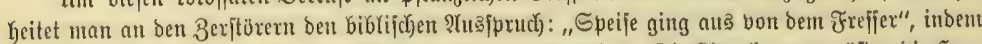

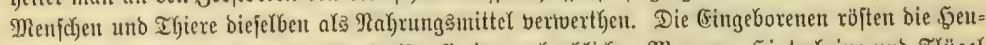

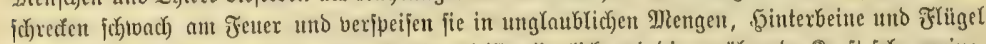

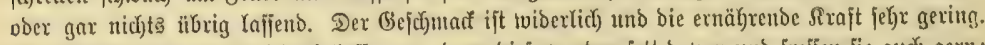

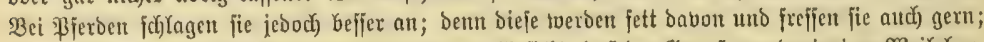

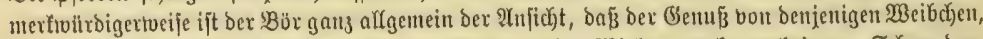

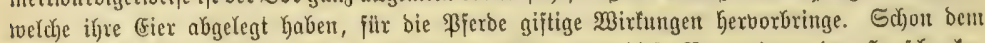

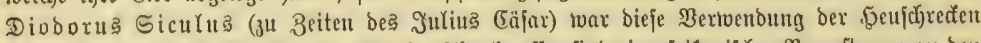

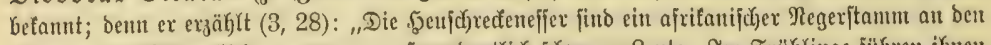

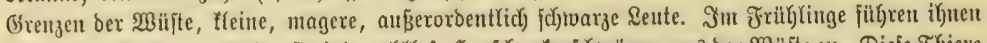

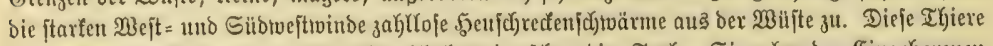

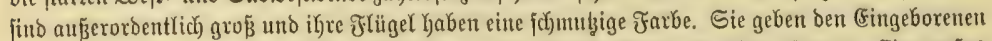

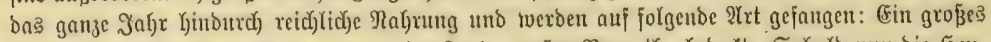

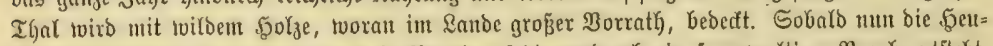

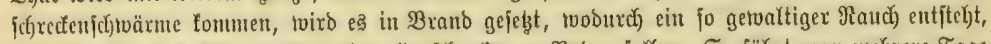
১aß̧ bie

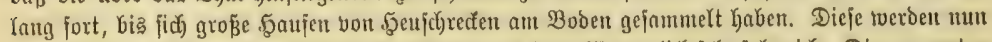

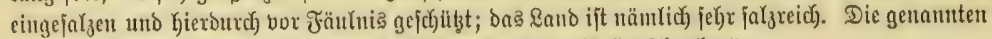

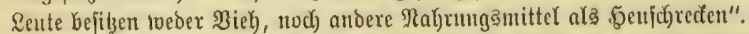

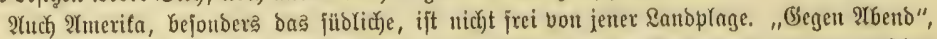

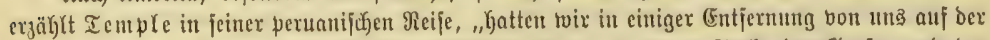

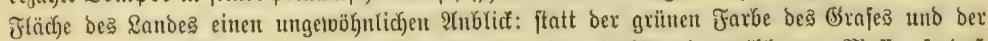

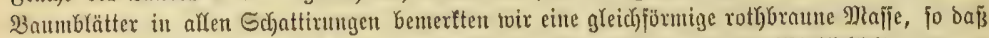

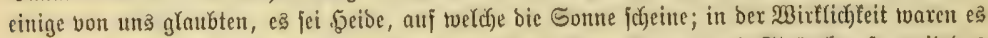

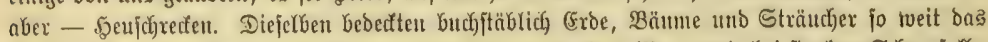

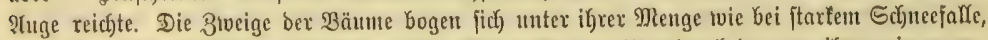

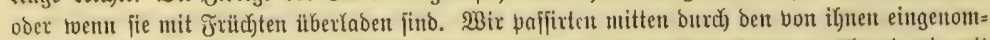

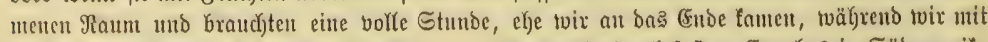

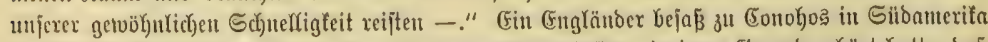

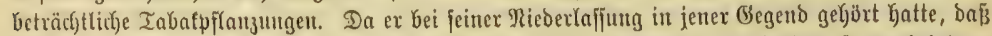

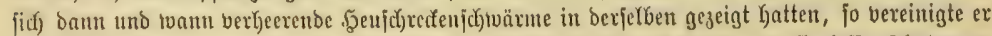

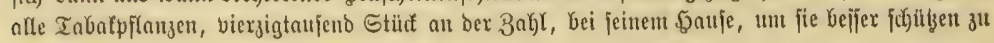





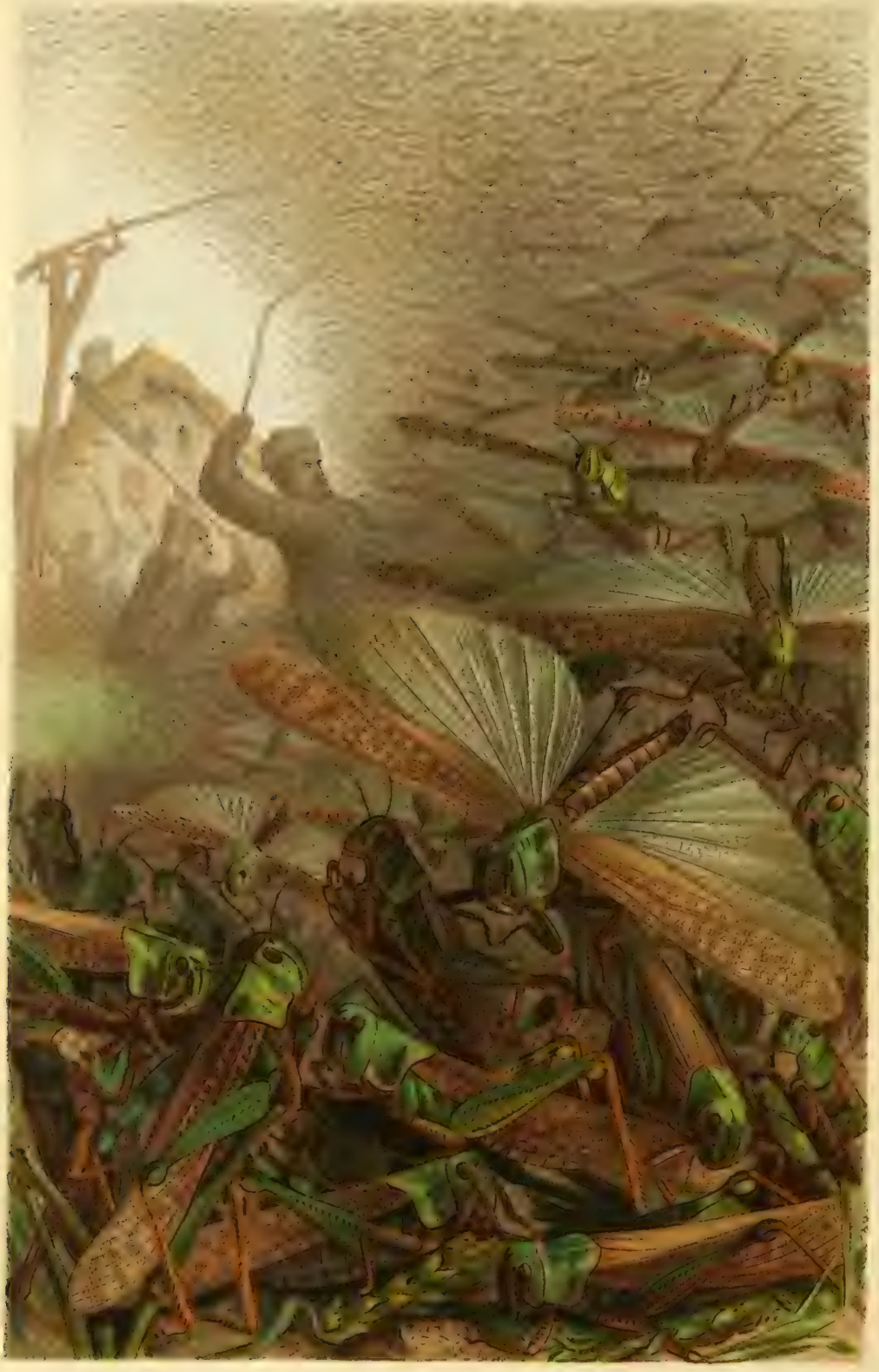




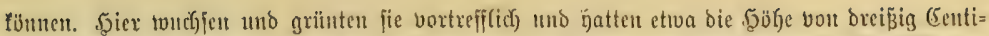

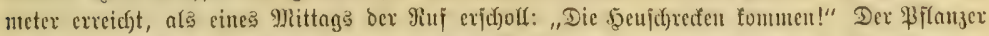

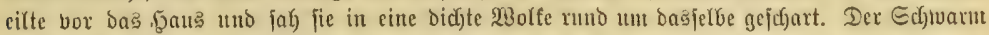

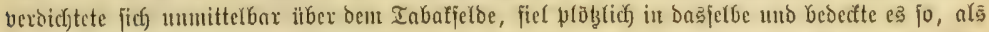

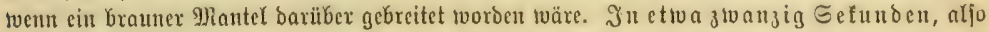

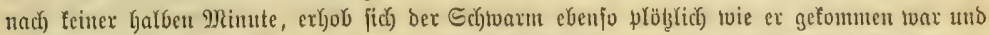

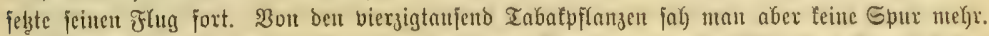

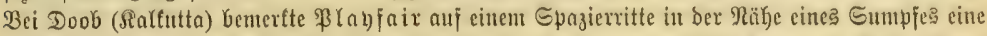

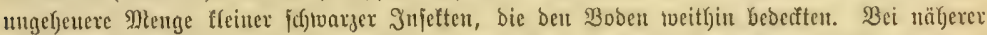

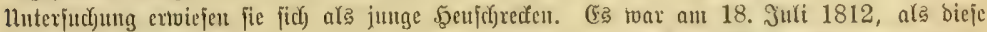

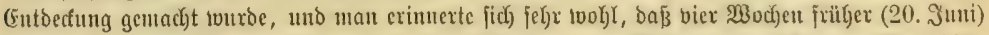

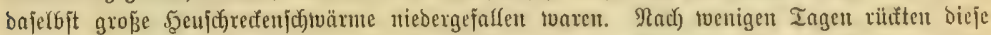
jungen, ungeftügelten Thiere gegen bie Stabt (5tatvel) vor, zerftörten bie Fluren und twurben balo

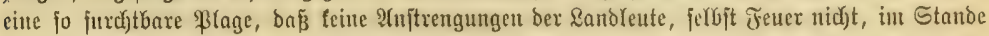

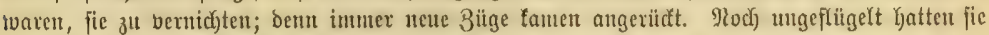

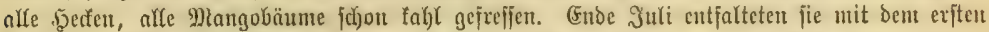
Megen ifre Flitger, bie Röpfe färbten fich) buntelroth, uno jie beganten in Schtwärmen unther=

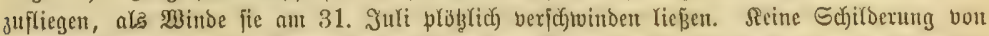

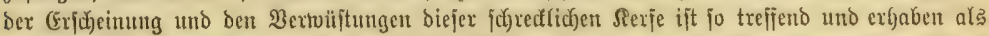

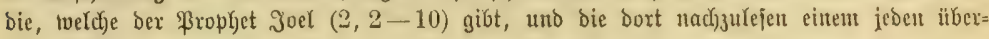
rajjen bleibt.

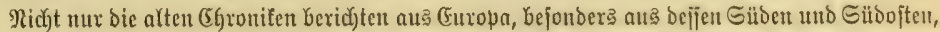

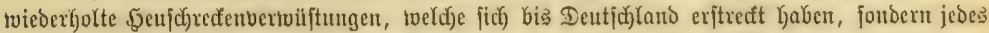

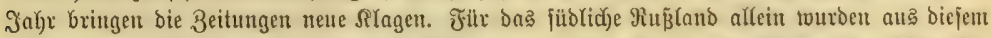
Jahrbundert jolgenoe J゙ałre angenertt: $1800,1801,1803,1812-16,1820-22,1829-31$, $1834-36,1844,1847,1850,1851,1859-61$. Heberall fpiclt fier bie $\mathfrak{W} a n \delta$ er $=$ oder $3 u g=$ heufd) xefe (Pachytylus migratorius oder Oedipoda migratoria) bie ฐauptrolfe, als beren

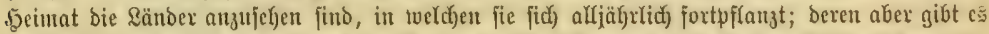

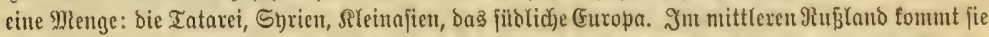

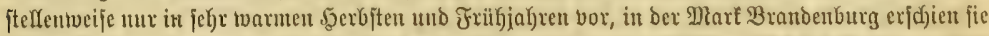

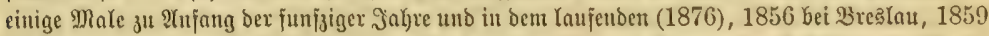

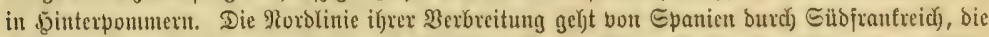

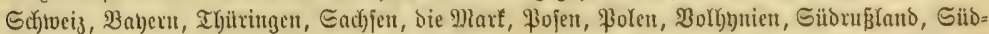

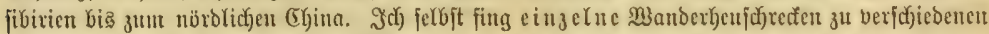

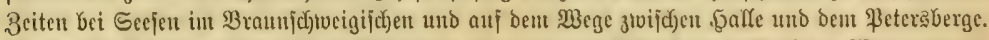

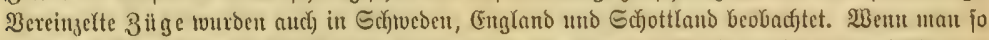

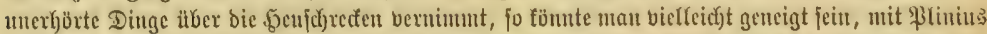

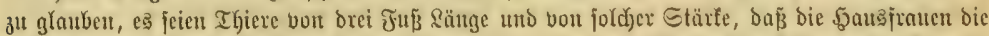

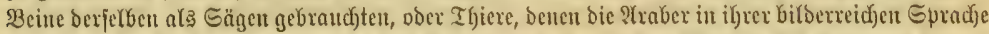

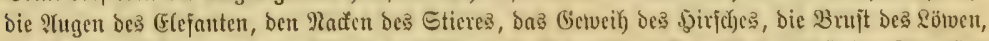

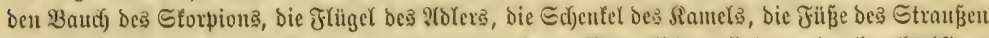

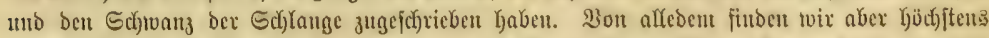

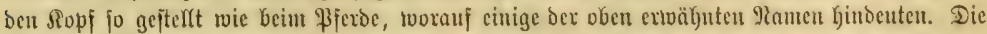

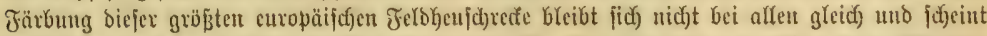

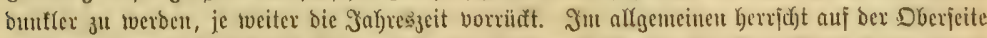

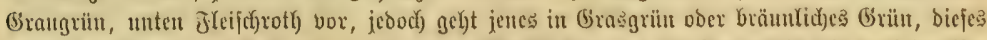

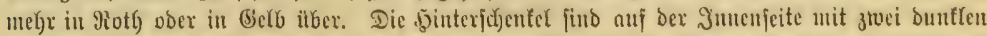

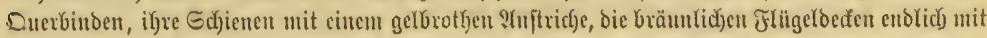




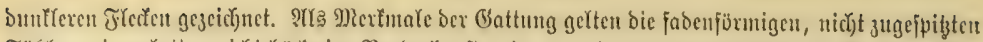

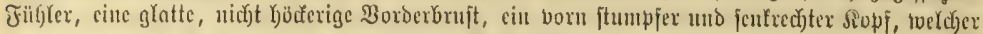

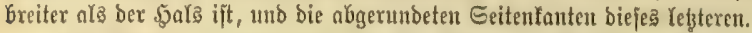

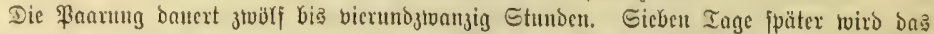

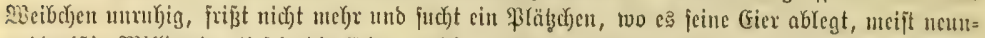

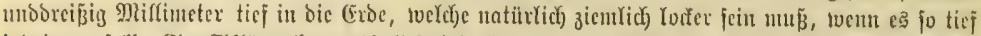

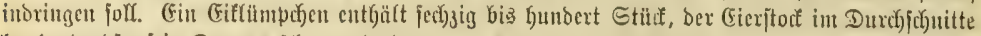

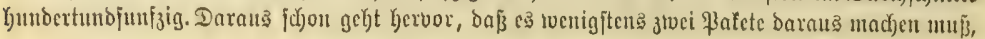

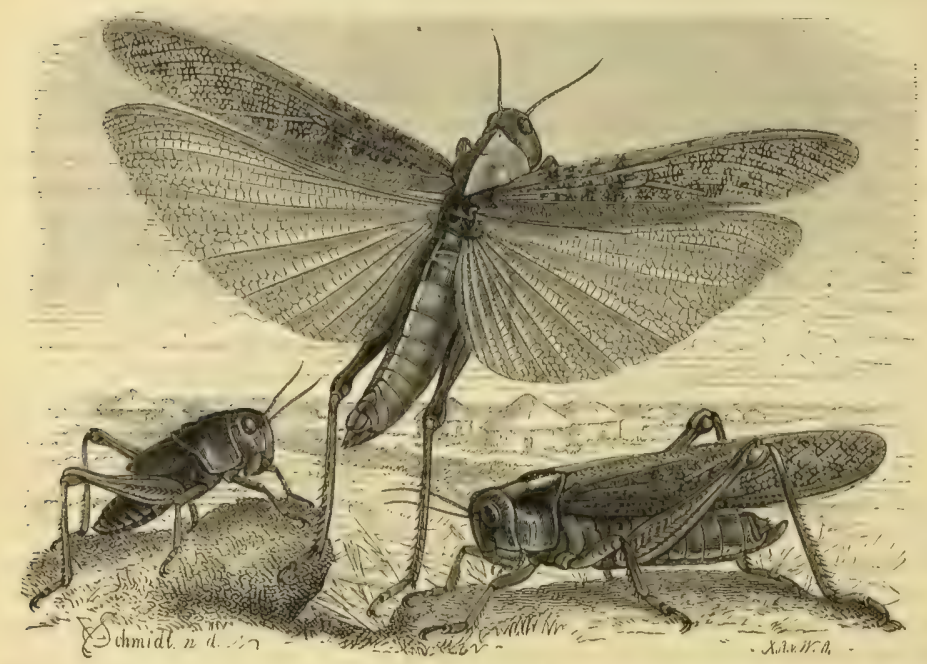

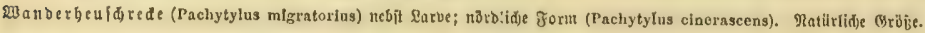

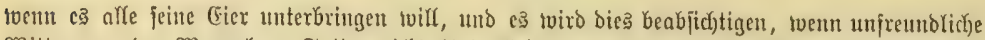
Witterung oder Mangel an Futter nidjt Kinderlich in ben Weg treten. Man beobachtete cine

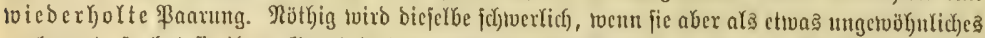

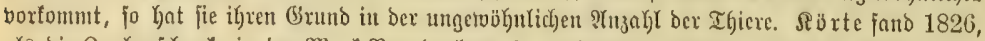

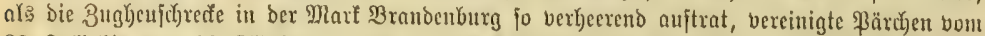

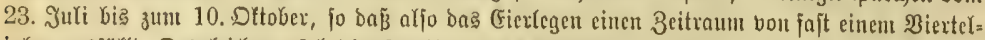

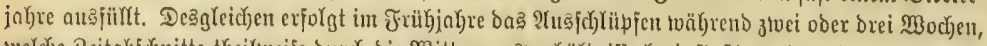

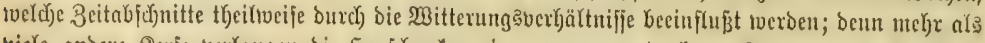

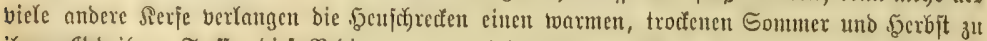

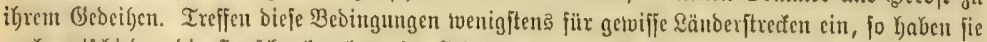

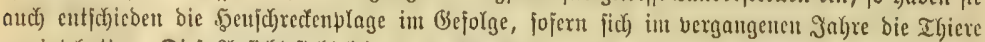

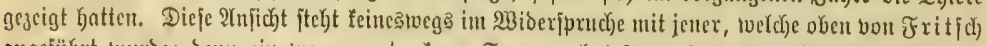

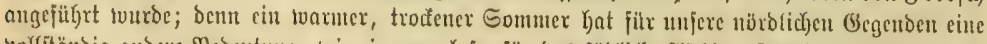

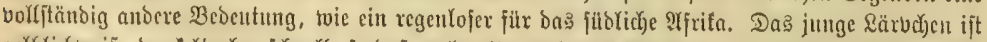

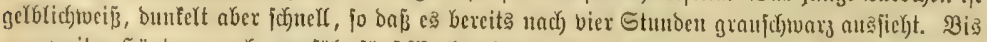

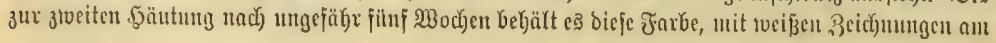




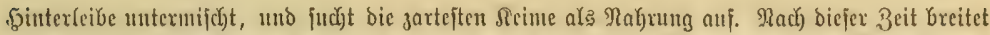

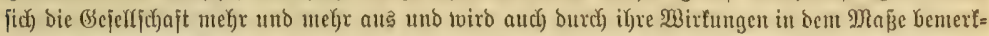

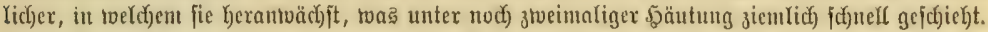

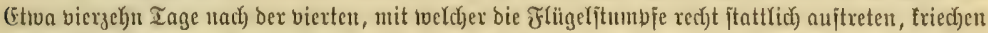

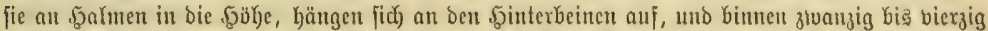

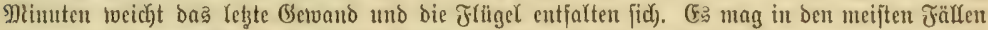

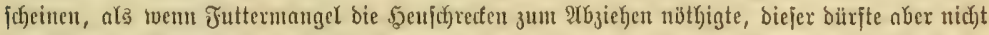

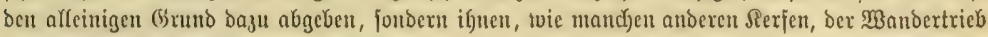
aus nod) unertlärten $11 \mathrm{r}$ jad)en angeboren jeit. - Fine f(cinere Frorm, weld)e, für eine andere Ift gebalten, Pachytylus cinerascens genannt twurbe und borherrjc)end in Ifrita, Epanien,

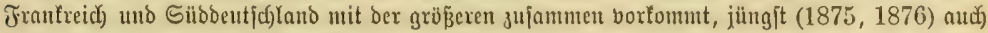

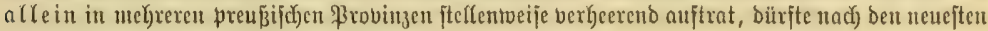
Beobad)tungen feine jelbjtänoige Trt fein.

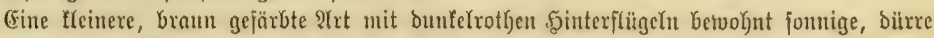

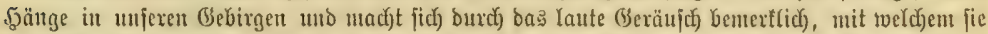

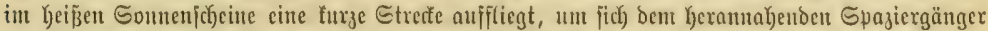
3t entzichen; man hat fie beâhalb bie filapperheujchrede (Pachytylus stridulus) genanut.

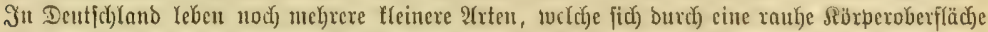

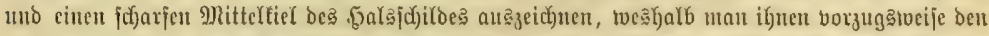
3tweiten ber oben genannten Gattungghnamen Oedipoda gelnffen Kat. JGre fdetwarz bejäunten

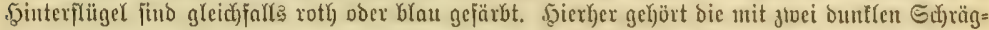

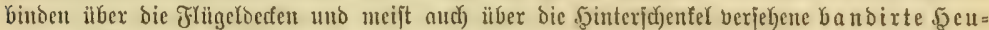

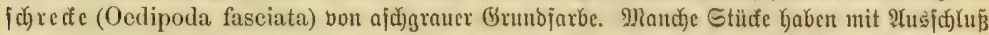

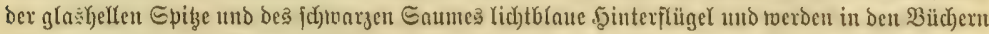
alfgemein unter bem Ramen Oedipoda cocrulescens aujgejübrt, andere find in nid)ta anderem

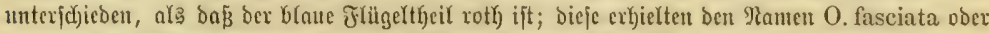
germanica. NGgejełen bon ber jonjtigen llebereinjtimumug fint beide oft genug gepant angetroffen

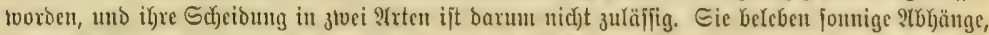

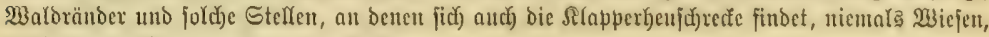

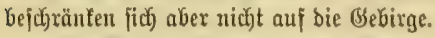

Die Gattung Gomphocerus (Stenobothrus $\widetilde{F} j \mathfrak{d}$ ) Miejen uro Graşpläbze belebenden F(rten. Sie Gaben cine platte, niemals raulge oder tief puuttirte

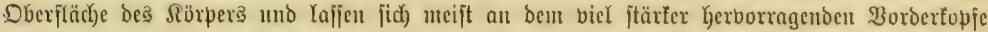

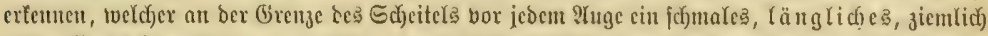

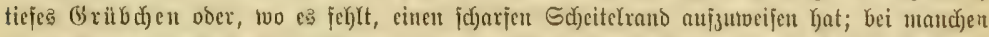

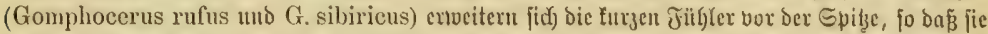

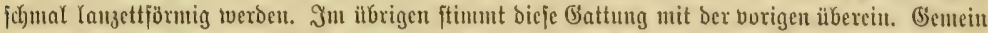

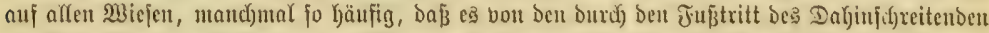

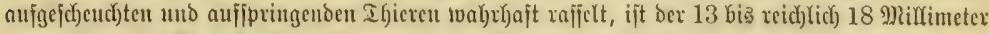

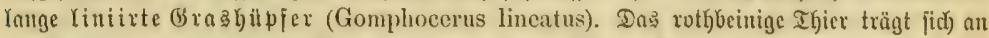

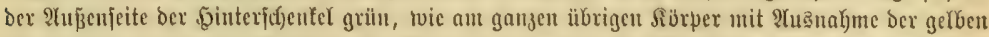

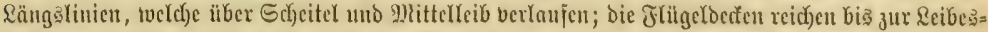

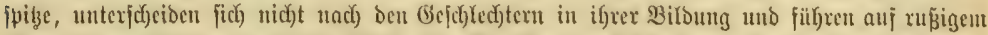

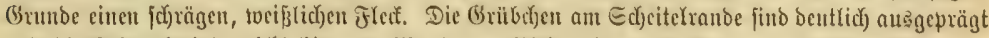

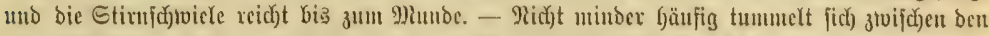
cben befdyricbenen auj ben Wiejen von ganj Guropa ber bide Graghüpfer (Gomphocerus

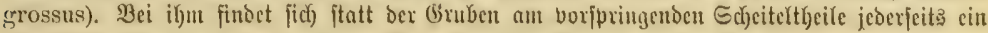

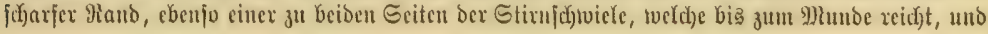




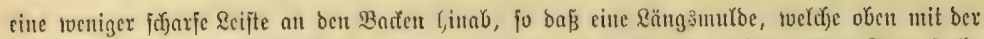

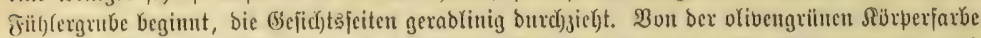

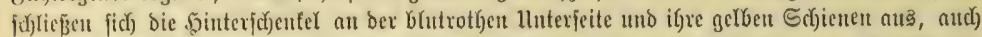

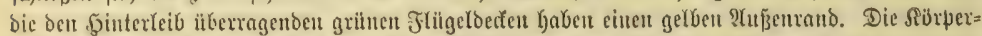

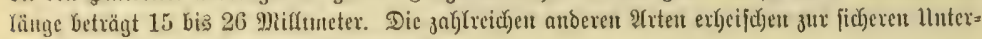

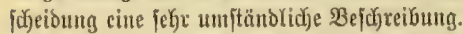

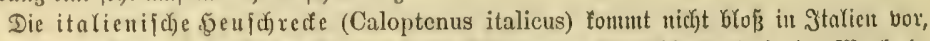

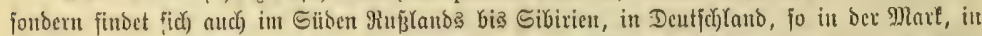

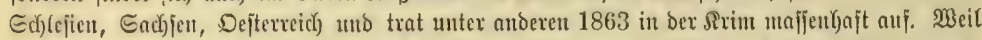

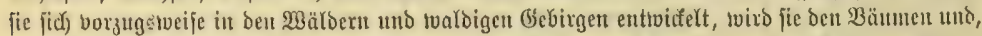

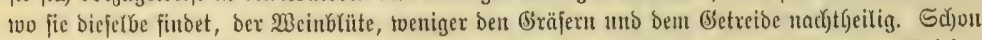

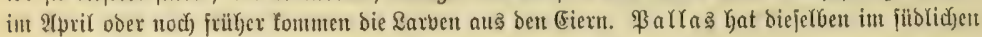

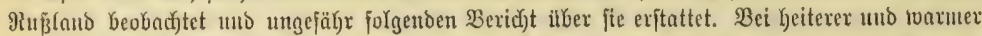

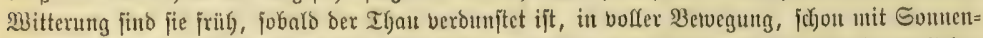

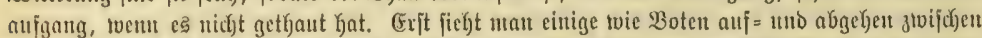

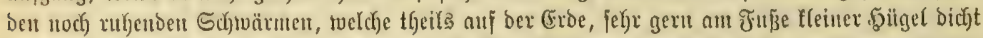

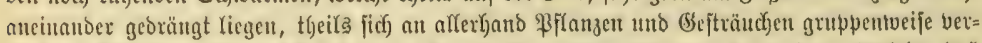

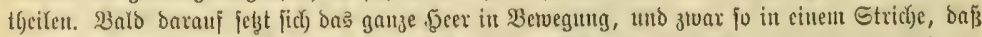

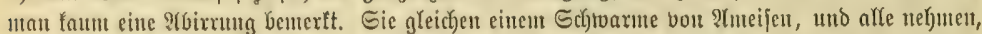

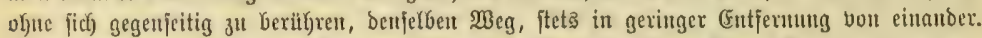

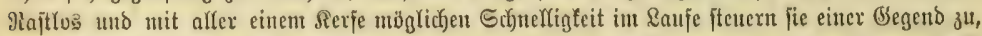
whye zu jpringen, aujer in Dem Fafle, two fie berfolgt werden. Dam zerftreuen fie fich, aber bald

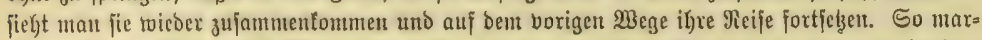

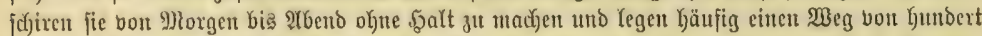

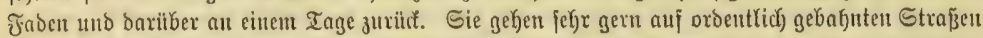

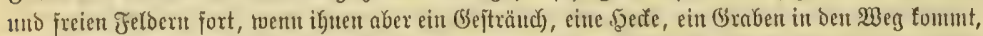

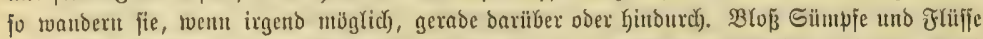

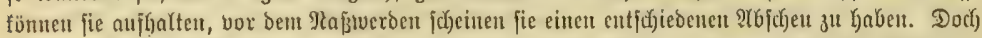

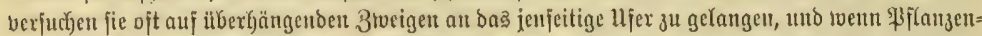

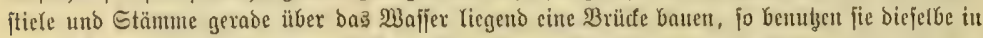
bichten Rolonnen. Sit fieht man fie barauj ausrulyen, als ob fie fich an ber Siüblung bes Wafjer:

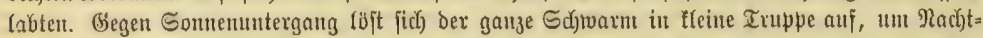
quartier in ber gewornten Beife zu nebuen. An falten, reguigten Tagen toandern fie nitut. Die

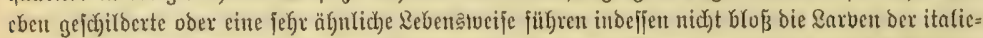

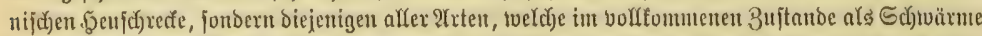

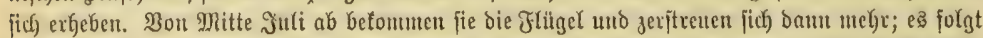

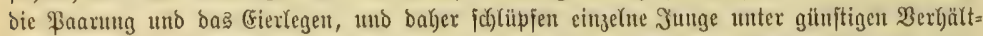

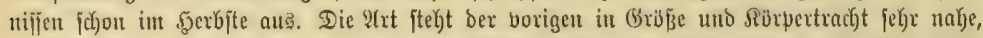

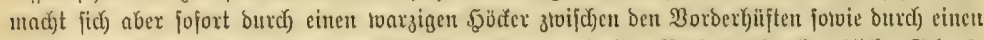

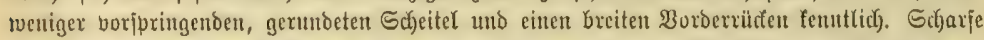
3äGne an İnenrande ber stimbafen und ber inneren Rade bes lluterfiefers nebjt einer fuge=

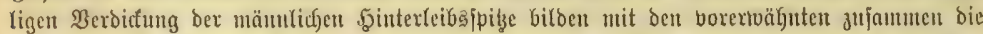

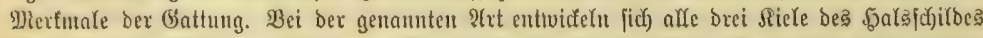

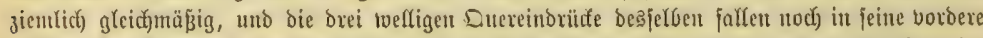

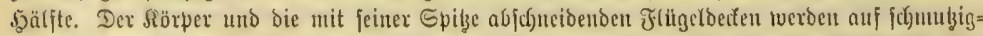

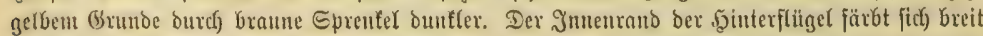

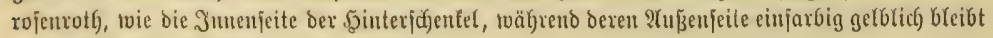
ober nit bunffen $\mathfrak{B}$ inden gezeicustet ift. 


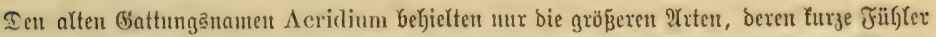

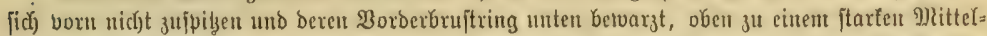

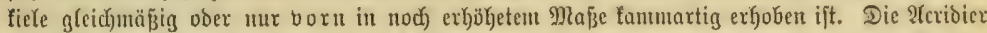

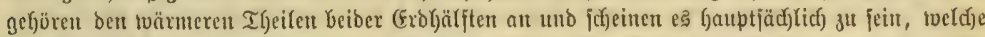

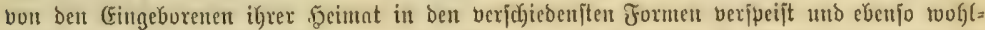

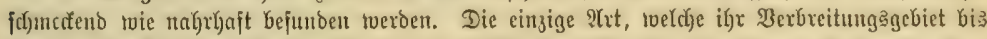

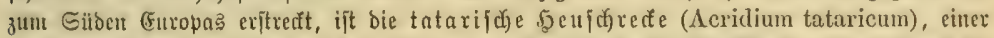

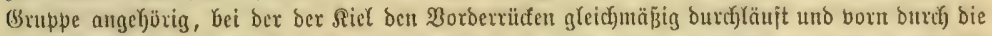

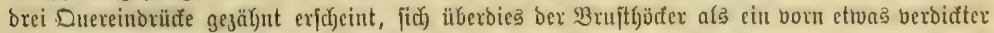

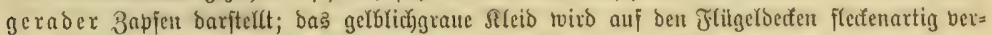

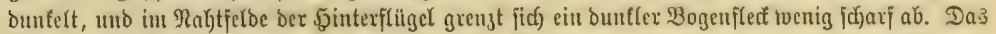

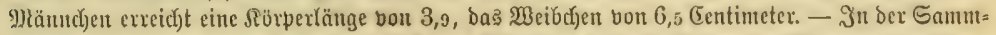

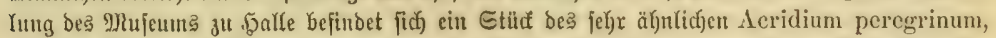

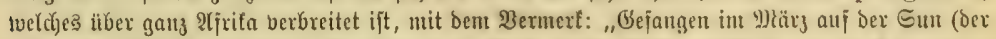

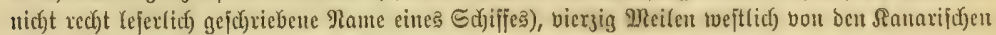

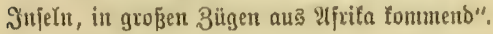

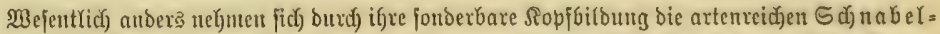

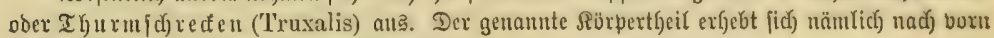
uno oben mełr oder toeniger hody in einen am bipfel breiectigen und an ber oberen Fläcje entweeder ausggebübrten ober ge= toblbten Seger, weldfer fid feitlid) tief einjentt uno Gier bie platten, oreifantigen,

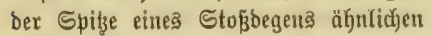
Fühler trägt. Diefe fehren ifyre breitejte Iläche nach oben, bie jobmalite nad) innen. Dex Rörpex exjodjeint fớtoäd)(id) und gुe= ftredt, bie ihn überragenden flügel jpikgen fich an (Fno zu und bie getonteten \$inter=

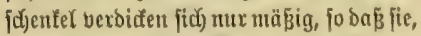
toie affe angegebenen Merfmale bas Э̧rige baju beitragen, bie Sdjuabelfochred̆en be=

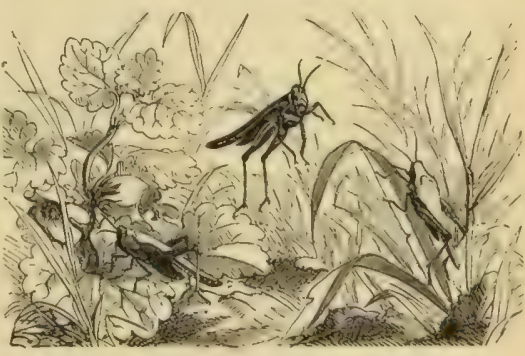

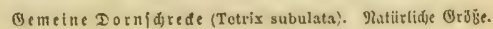

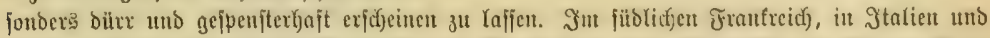

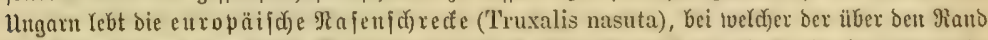

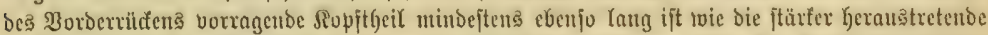

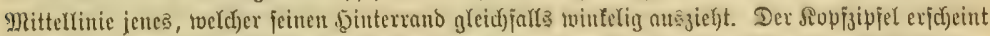

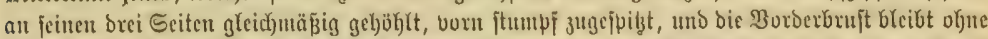

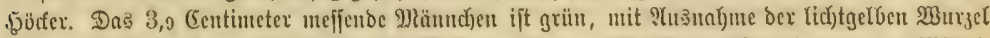

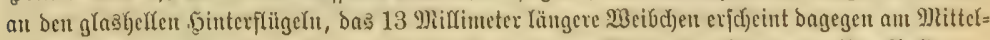

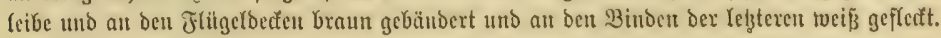

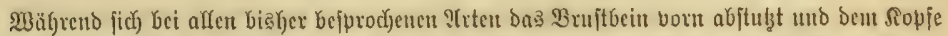

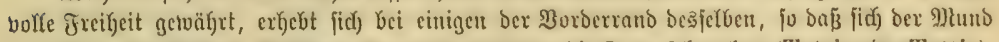

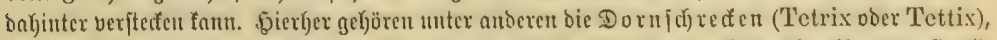

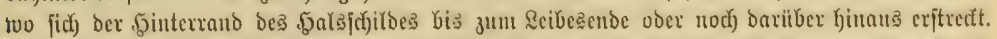

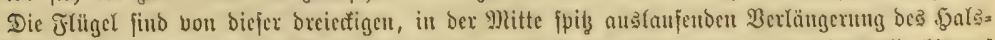

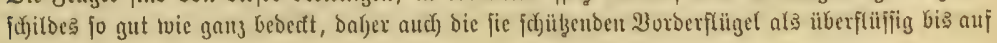




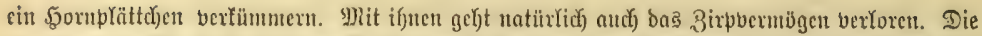

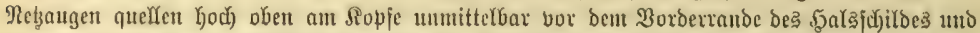

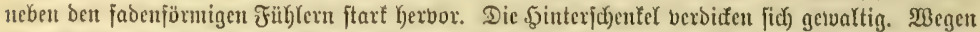

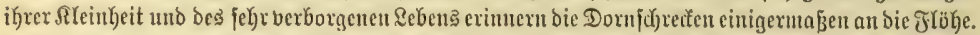
Die gemeine Dornjd)rede (T'etrix subulata, S. 555) ift unter den beutjdyen nod) bie größjte

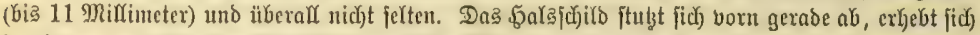

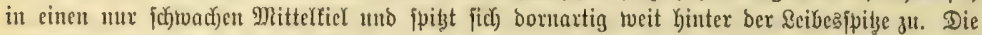

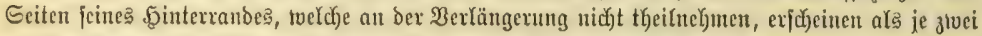

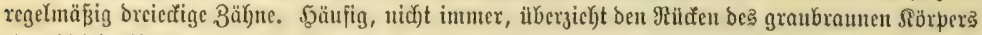

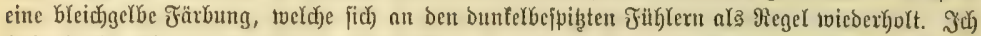

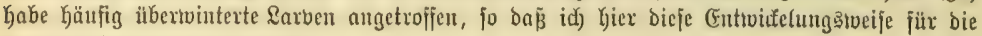
getöbynliçje anuehmeu möctste.

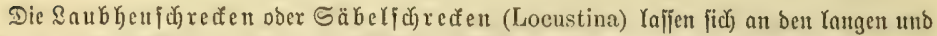

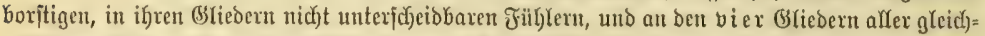

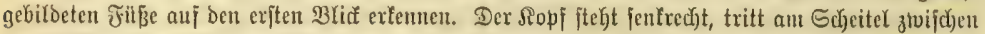

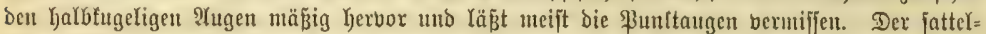

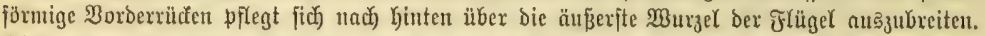

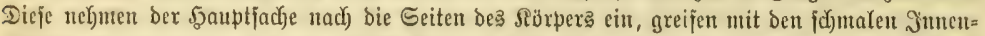

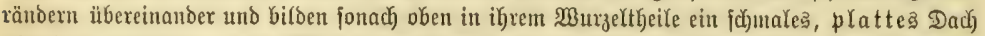

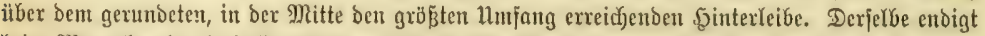

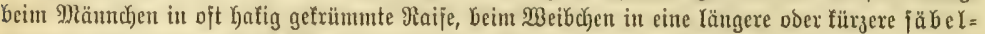

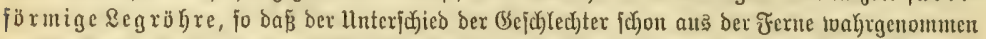

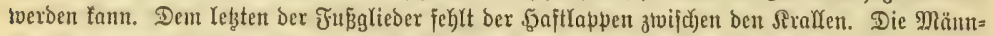

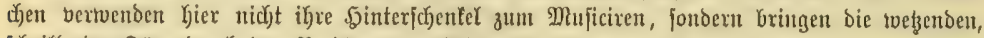

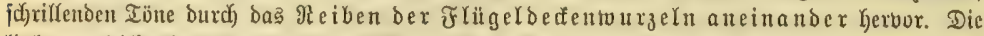
liute, zugleich obere Fliigeldedfe enthält ant igrem Grunde eine fräjtige Queraber bon nabezu ber

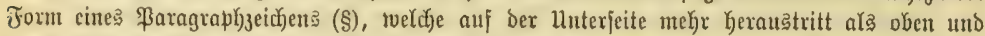

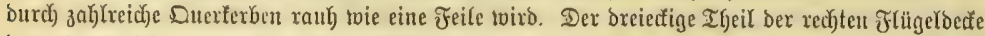

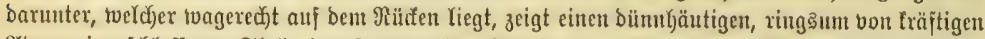

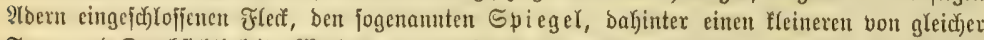
Form und Durdjithtigteit. Werben nun bie Decfen beim Zixpen gefoben und mit Den Gdjrifl=

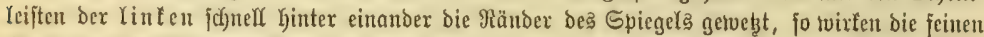

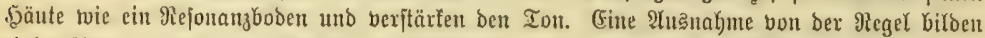
cinige $\mathfrak{A}$ ten mit blajig aujgetriebenen Flügeldecfen, bei benen auch) bie Meibchen Yocten fömen uno bie gegenfeitige \&nge ber Deden eine burdjaus gleich)gültige ijt. Für bie Gäbelfdbrecten Gaben

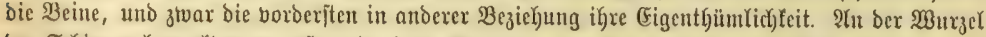
ber Scfienen bemerft man auß̧en ein tiejes Spalten = ober Grubenpaar, weldyes im Inneren bou

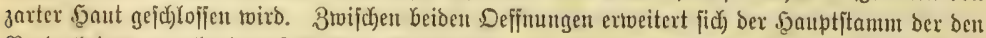
\$orberbeinen angebörigen \&uftröfren Glajenartig, und ein aus bem eriten Mlarftnoten ber Bruft

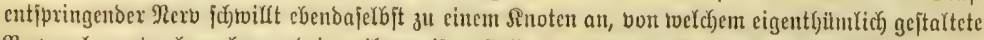

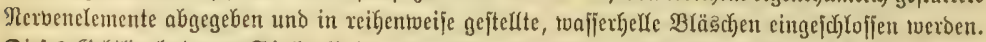

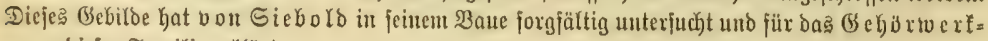
ze ug biejer Familie erflärt.

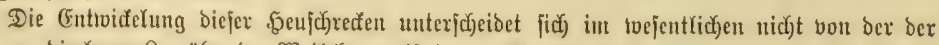

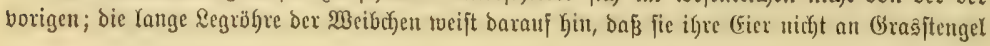




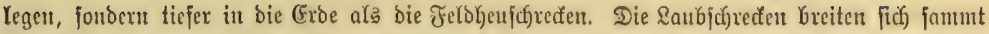

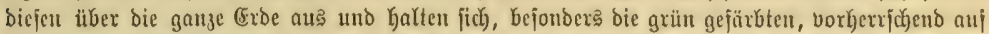

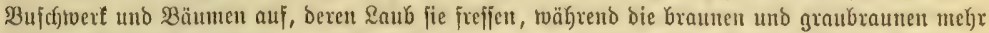

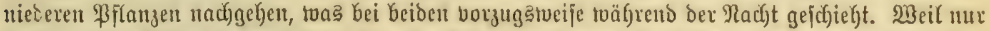

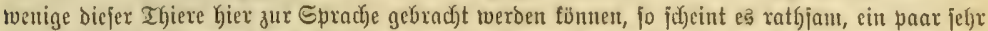

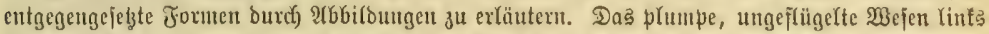

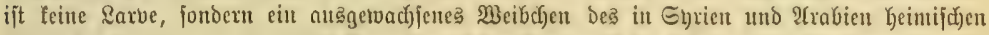

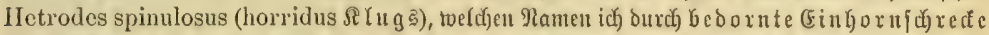

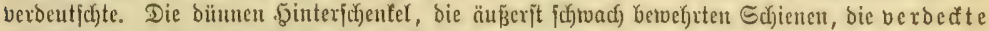

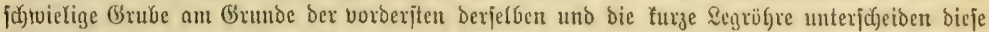

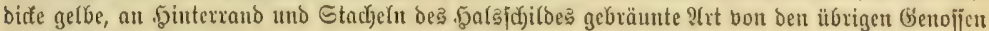

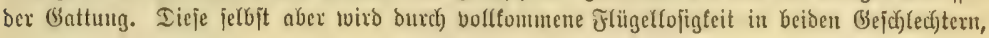

1

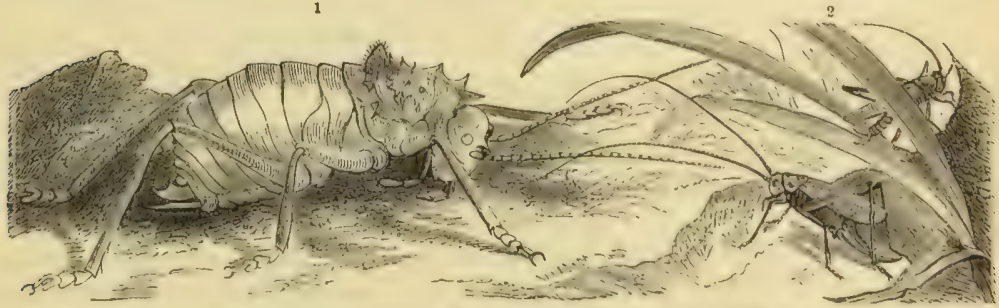

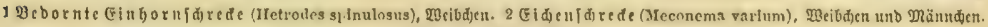

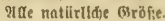

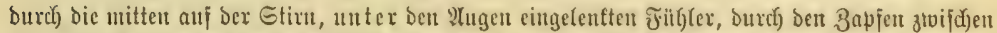

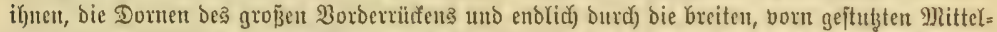

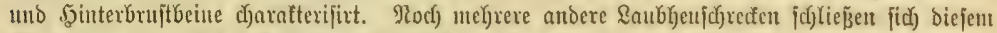

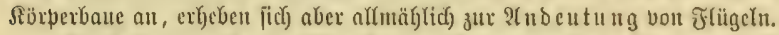

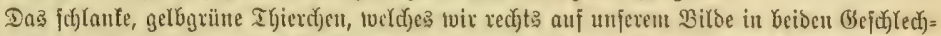

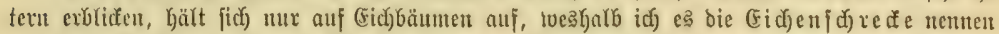

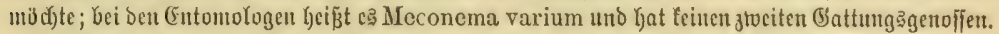

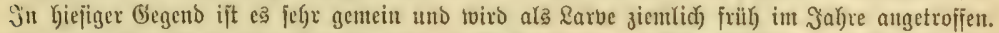

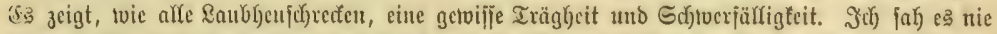

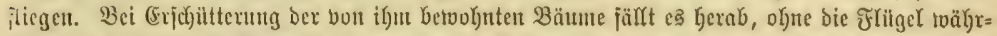
: vben iu grïnelt \&aubdadje thun mag, häufig genug tried)t ę aber an Den Stämunen auf

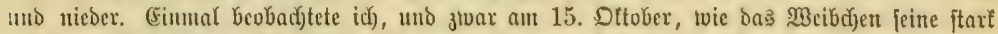

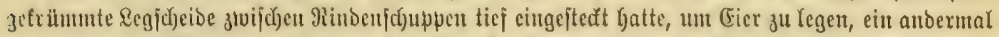

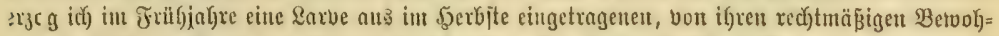

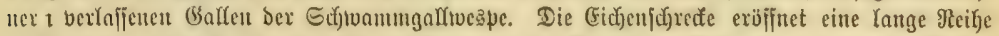

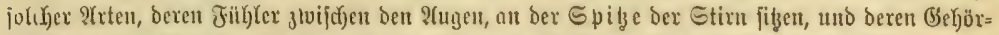

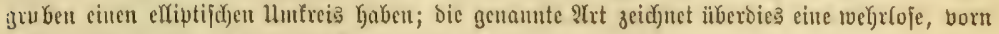

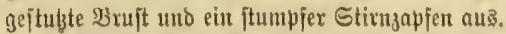

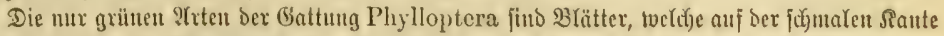

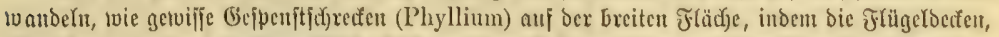

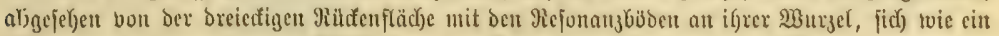

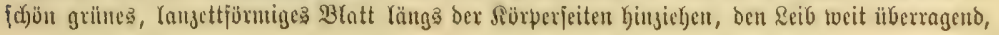




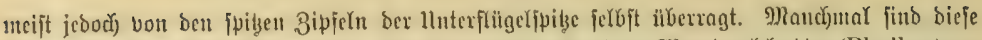

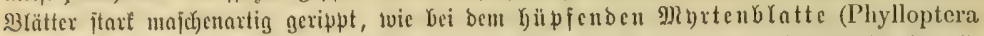

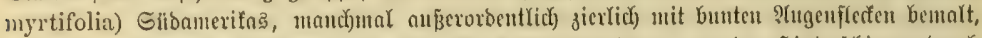

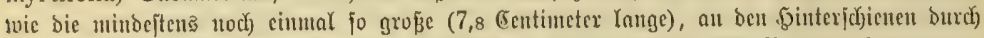
Dornentnoten nod) bejondere betuchute gefenjterte Blattfod) xede (Phylloptera fenestrata)

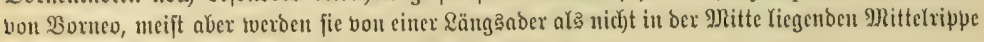

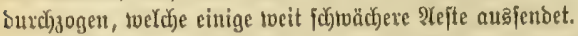

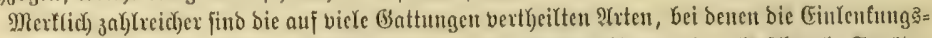

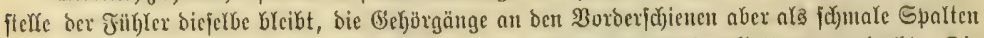

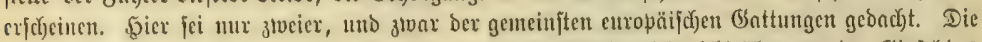
cine, Decticus, crfenut man an bem ftumpfen, Das erjte Fith)lerglied nicht überragenden Gipjel Des

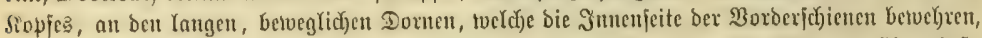

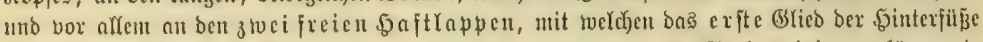

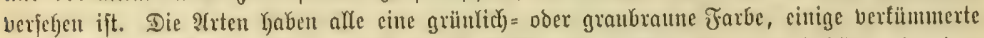

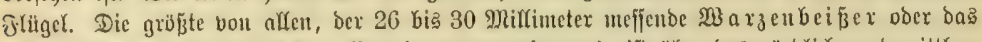
grope braune 5eupferbd) en (Decticus verrucivorus), ift über bas nörolicke unto mittlere

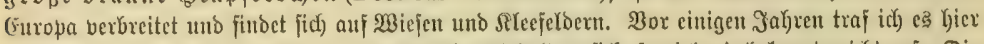

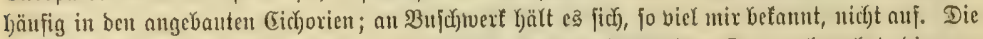

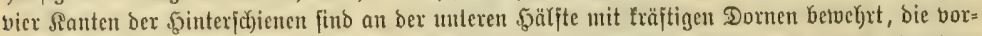

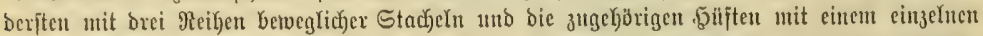

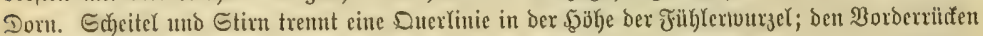

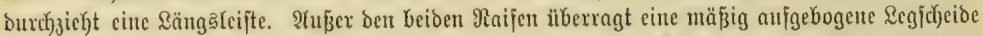

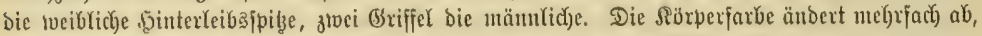

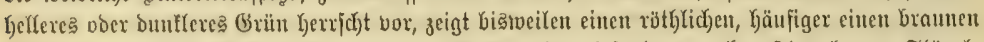

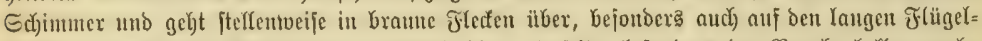

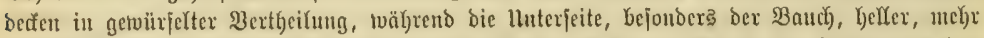

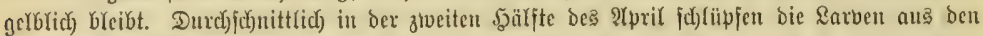

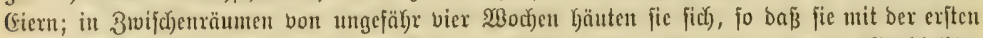

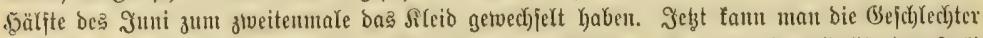

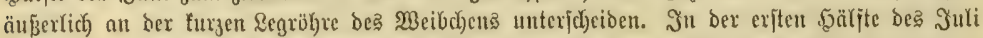

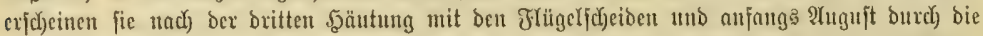

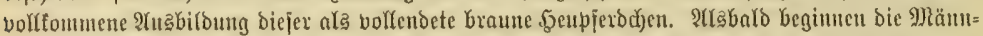

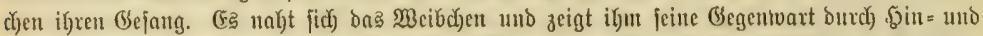

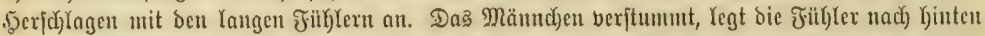

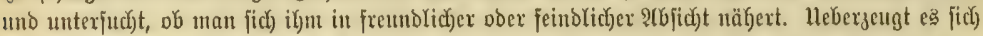

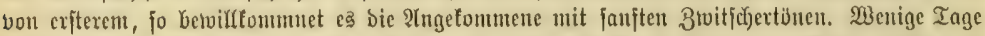

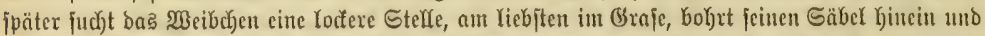

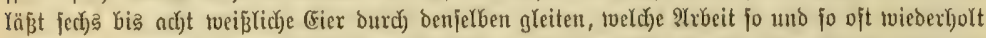

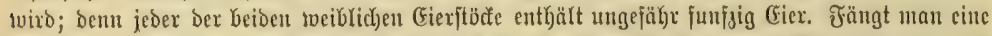

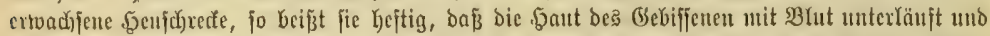

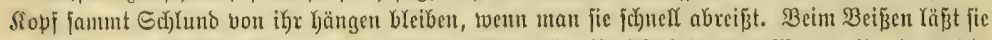

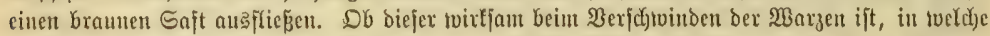

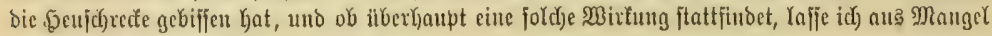
an jeglicher (Erfabrung Daljingejterlt jein.

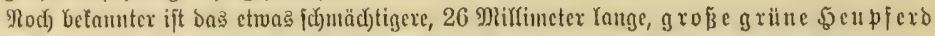

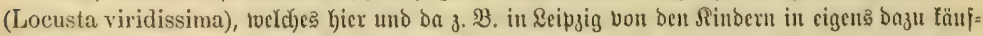

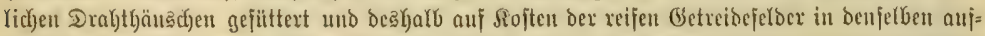

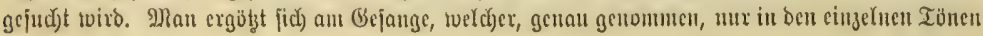





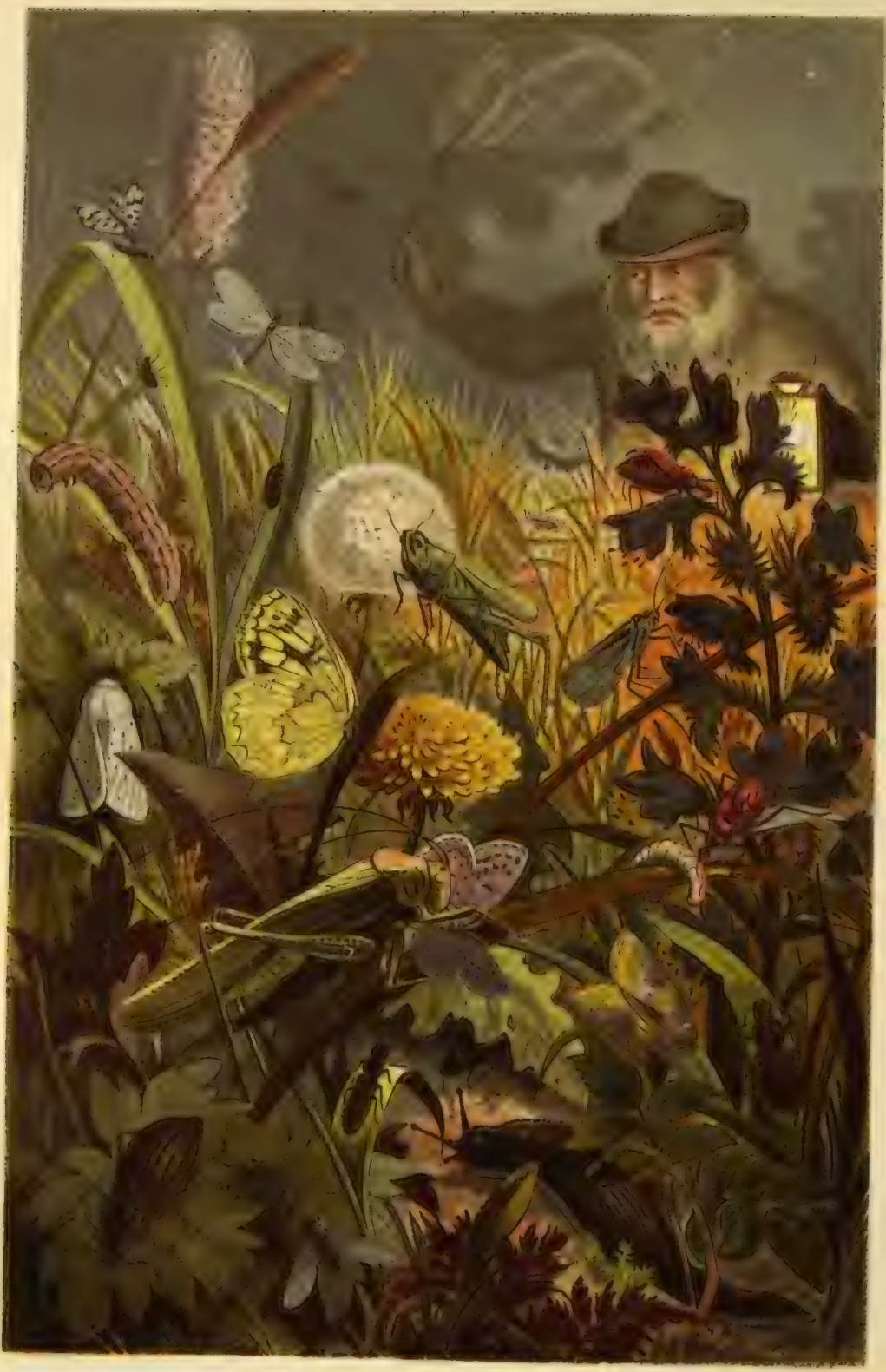




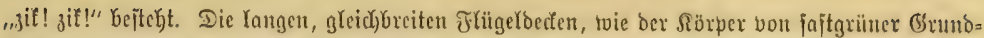

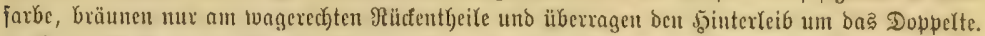

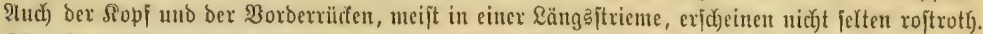

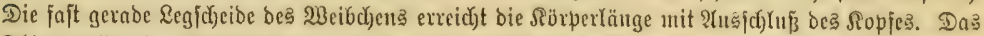

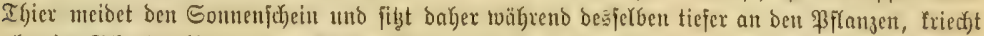

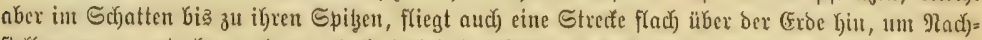

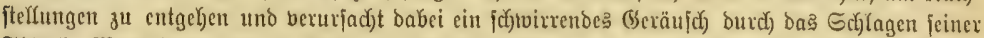

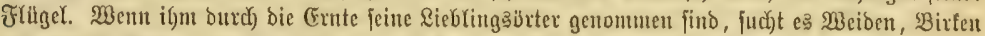

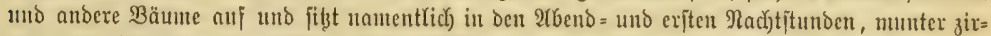

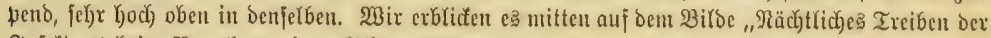

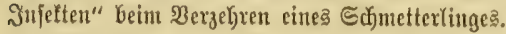

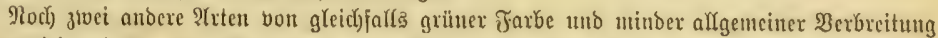

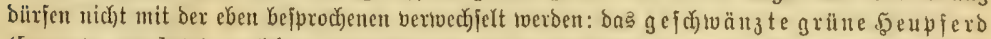

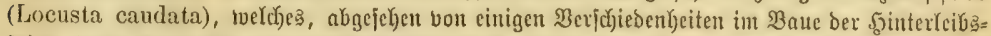

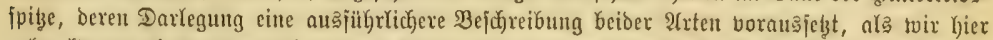

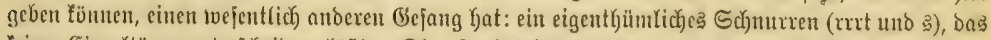

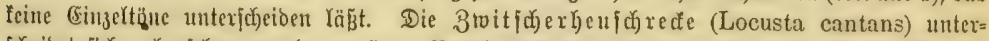

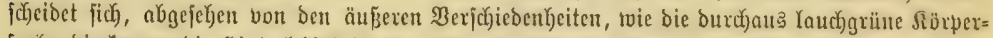

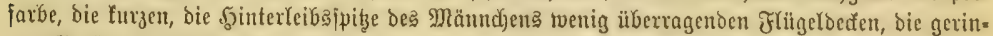

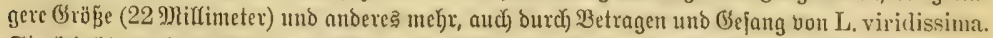

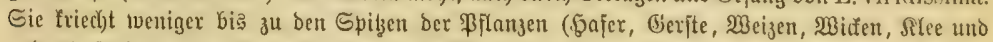

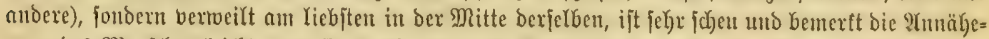

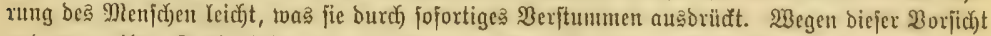

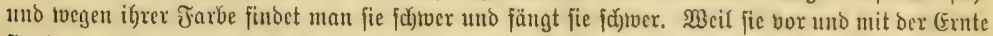

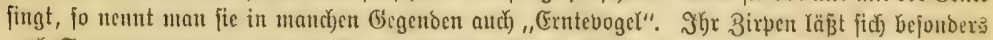
unch) Sonnemuntergantg uno vor Somnenauggang bören uno findet ojt fein Ende. Die Iüne folgen

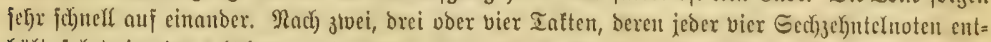

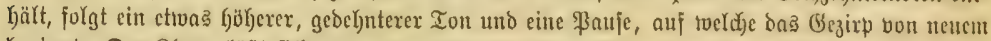

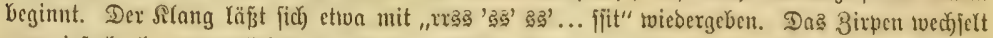

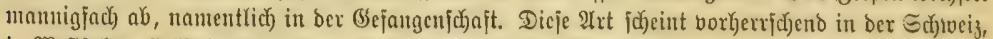

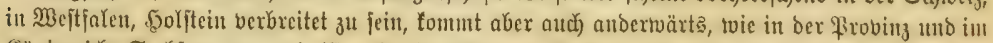

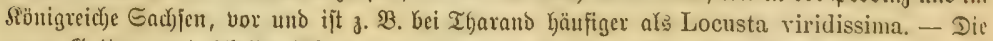

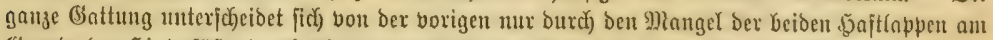

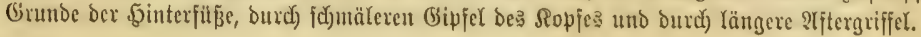

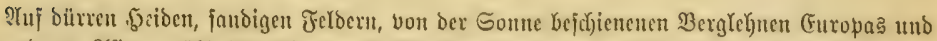

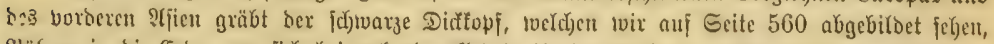

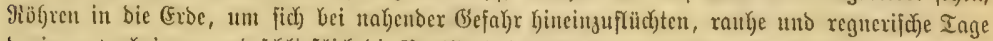

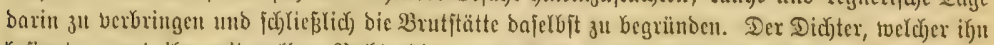

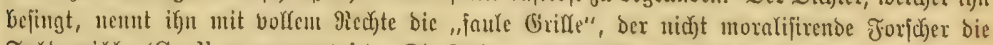

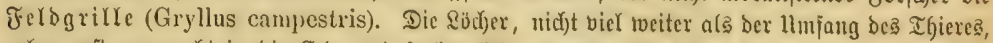

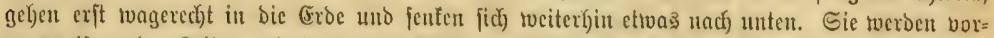

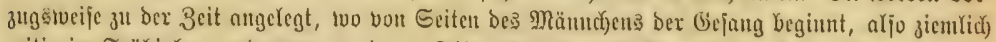

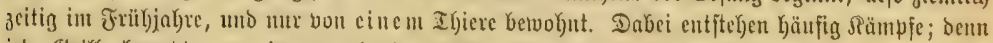

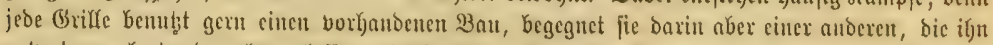
entweber anlegte ober als verlafienen fribjer bezog, fo weicht feiner bon beiden Ilgeilen freituilfig. 


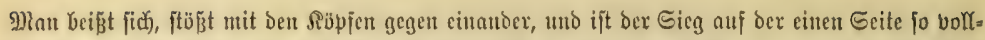

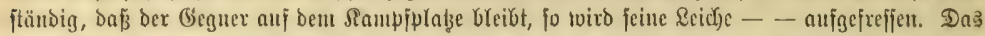

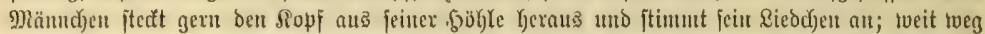

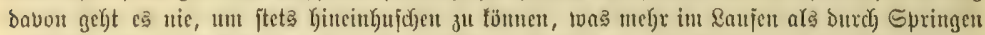

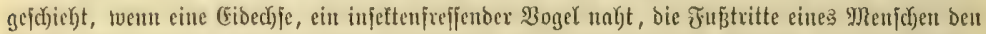

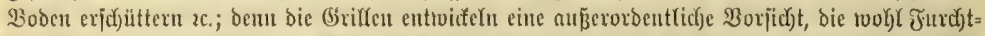

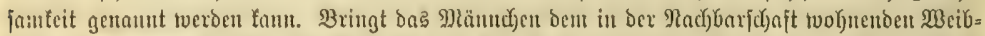

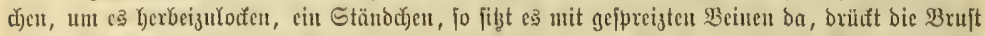

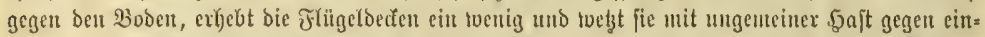

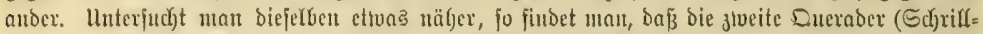

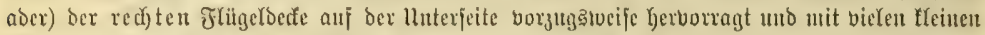
Etegen querïber bejebzt ift; Diejelben teerben gegen eint nabe Dent Smentande gelegene rocr Der

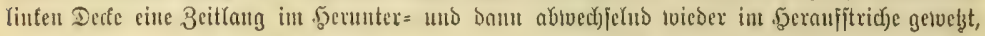

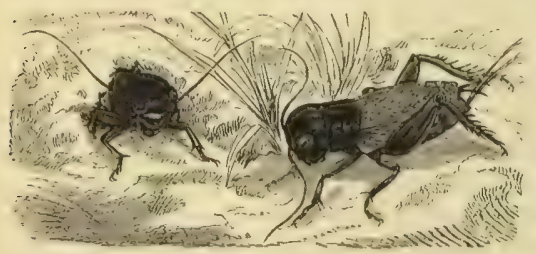

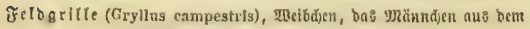

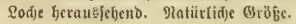

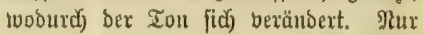
twent die Briffe anffyourt, Yegt fie bie Decten zujanmen, ber Widertyalf, twetuden bie

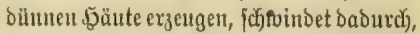

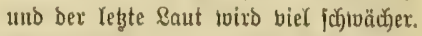
(Es findet fich) fonit biejelbe (Einxidbtung, twie bei Raubfeupichrecten, nur bertaujdyen bie beiben fringerbeten ifre Rolle, weil hier bie rechte, bort bie Yinfe bie oberjte

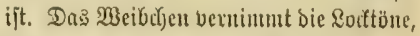
twounit aber, tweip man noch niç)t, oa bic

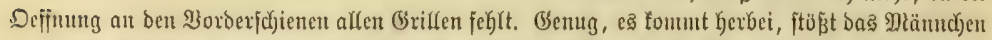

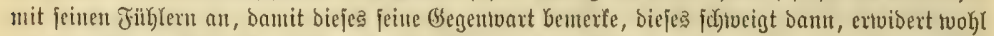

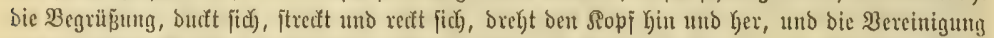

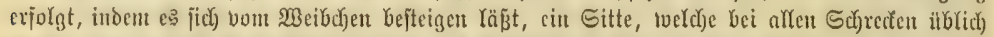

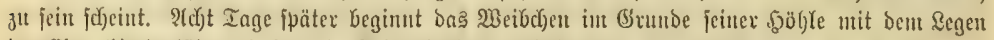

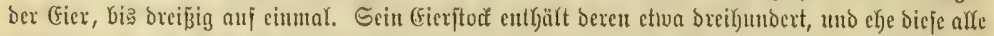

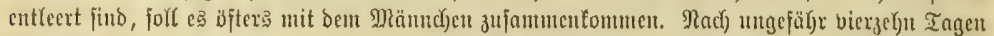

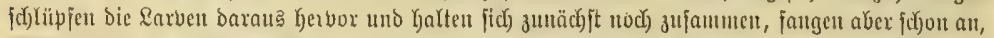

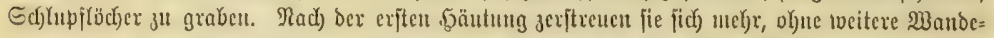

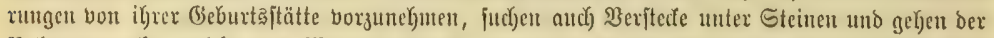

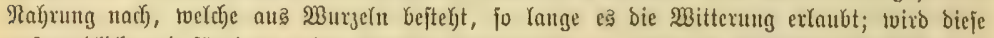

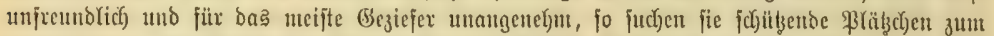

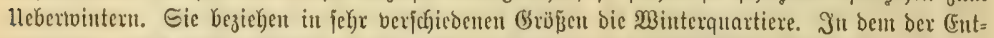

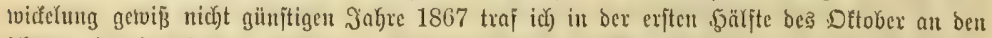

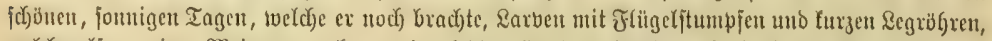

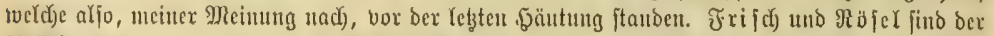

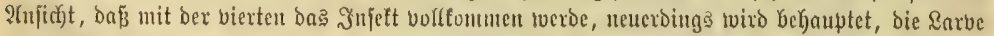

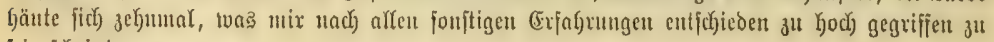
jein lâjeint.

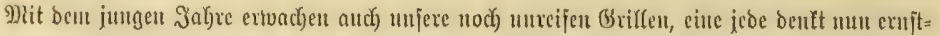

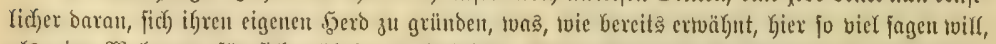

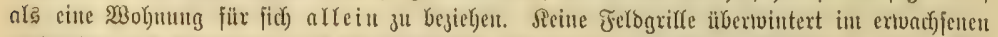

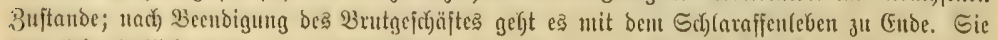

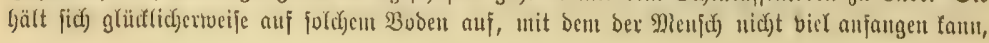




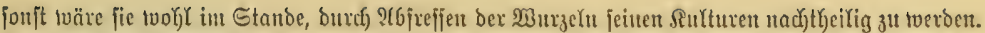

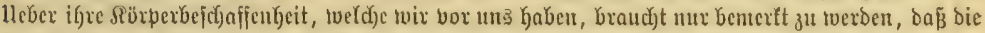

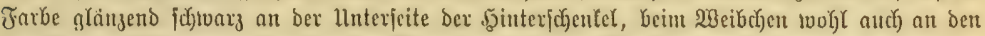

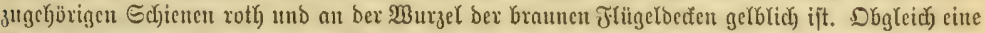

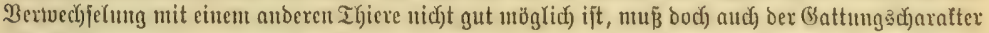

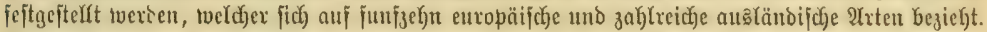

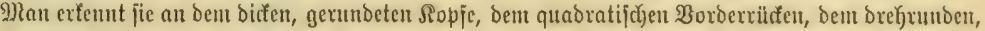

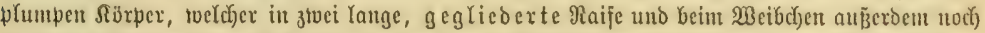

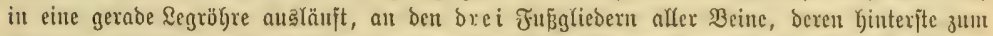

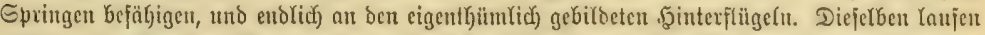

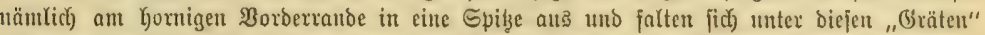

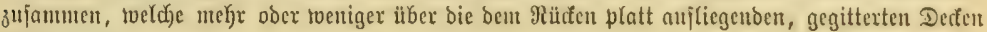
Y)inauștagen.

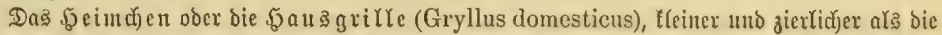

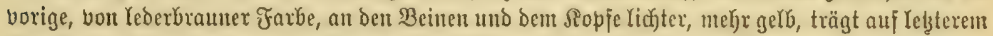

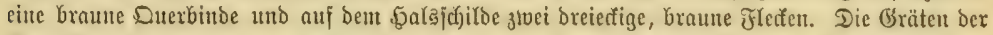

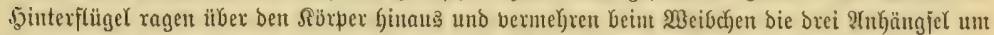

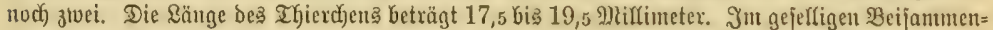

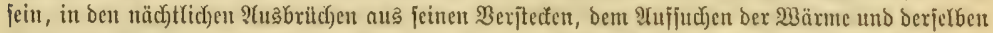

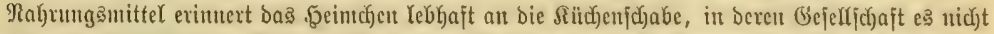

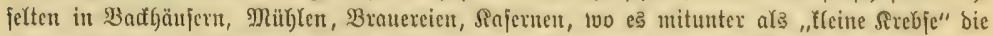

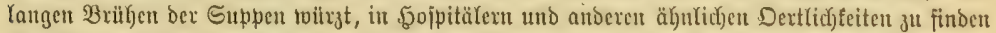

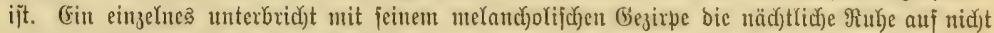

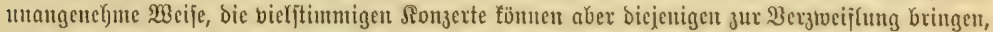

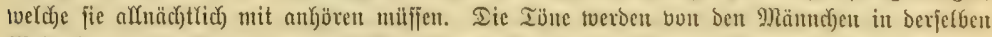

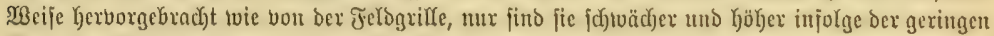
Größje bes Muficirenoen uno ber bichter ftef)enden Etege an ber Schriffaber.

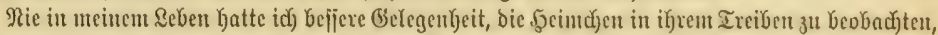

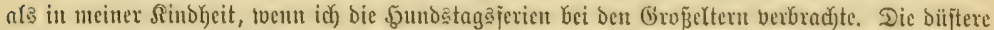

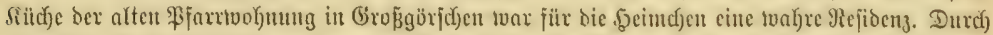

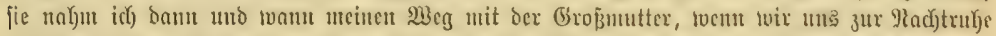

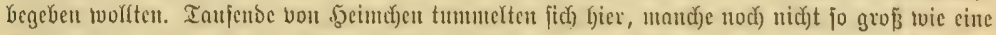

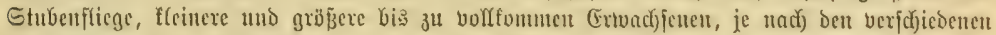

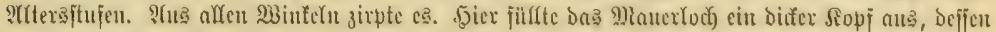

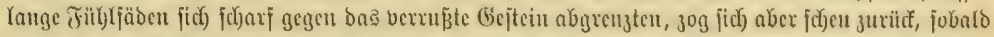

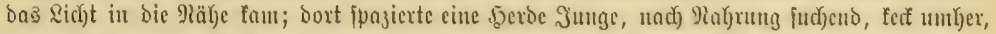

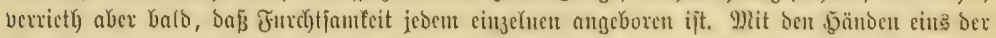

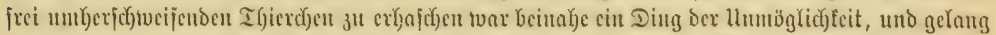

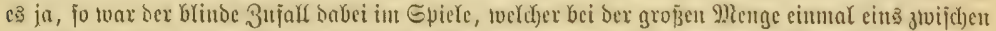

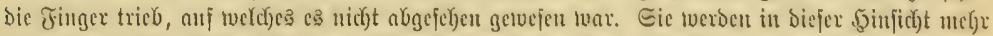

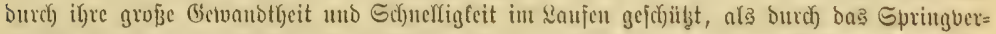

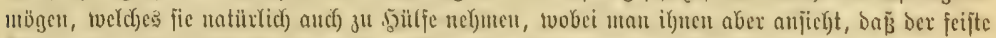

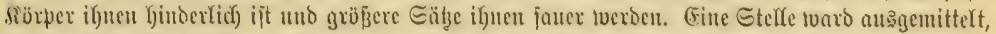

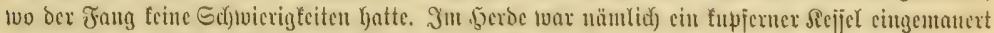

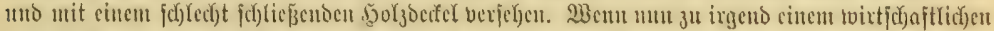

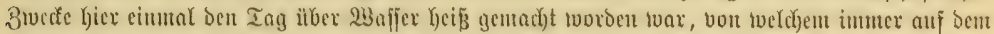

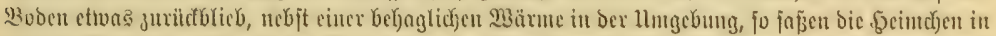

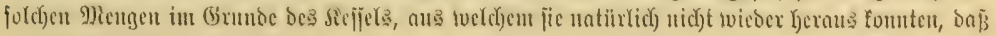




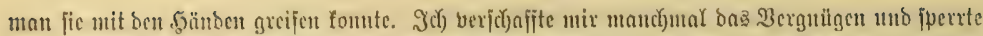

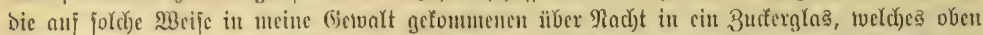

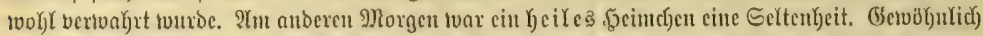

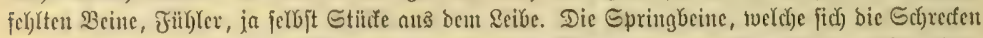

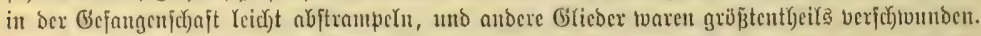

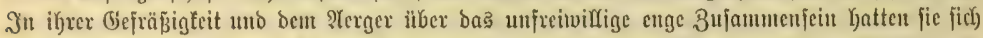

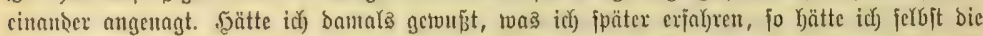

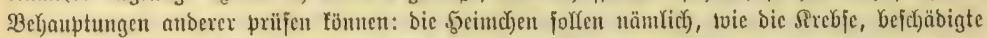

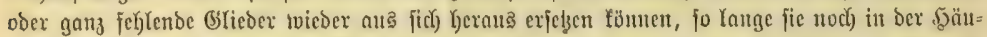

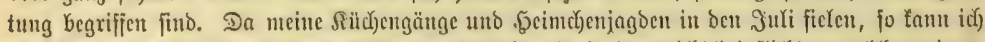

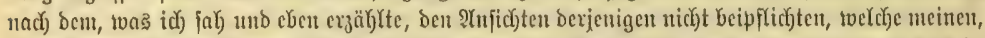

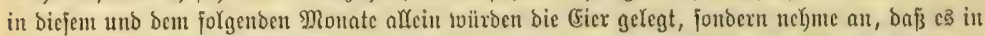

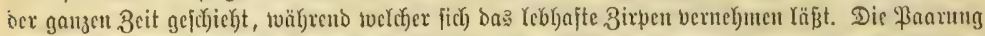

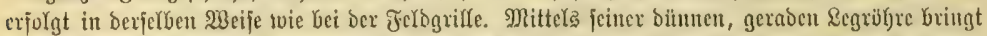

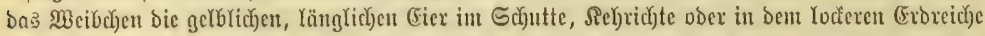

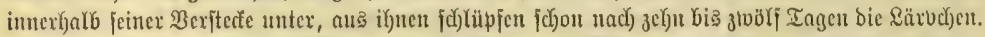

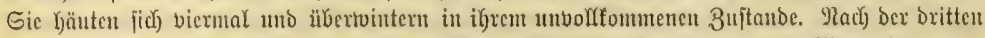

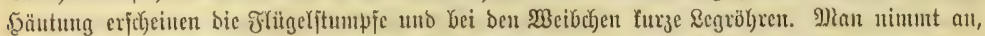

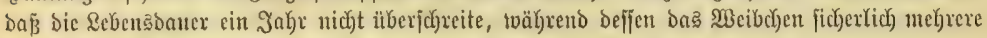

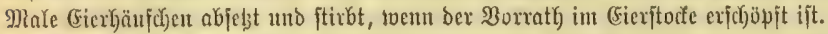

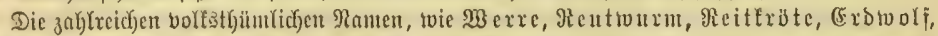

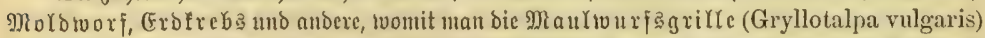

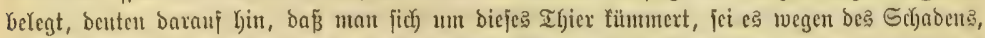

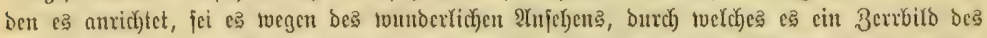

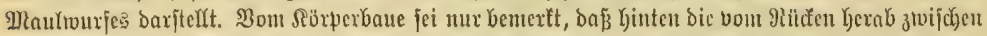

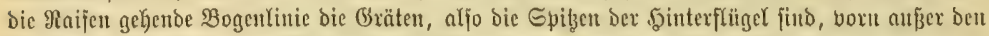
Filf)

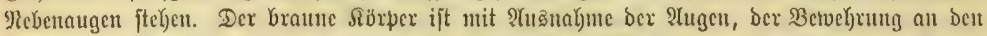

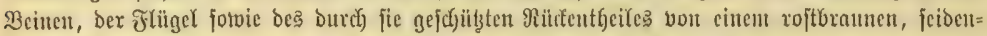

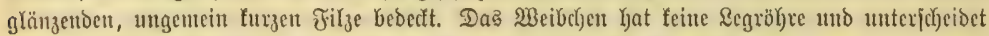

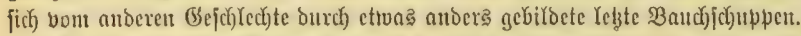

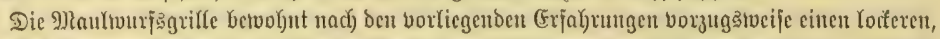

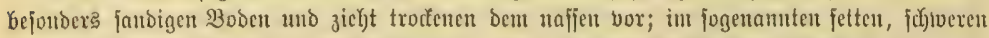

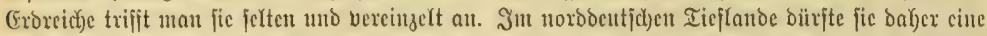

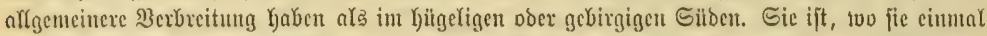

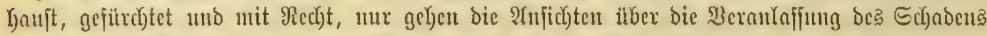

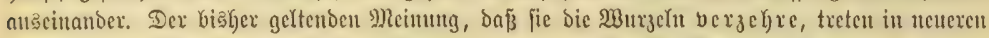

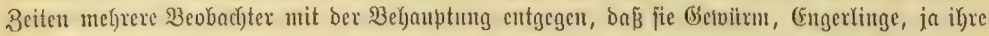

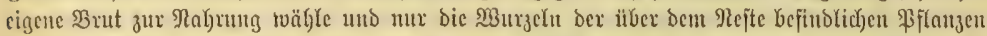

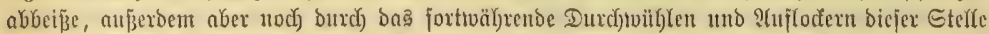

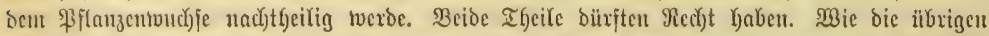

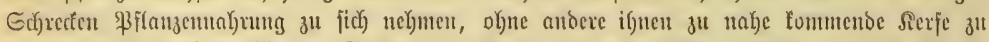

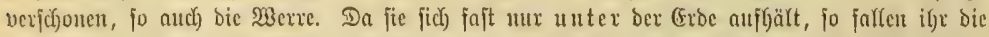

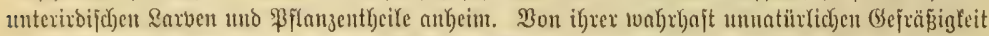

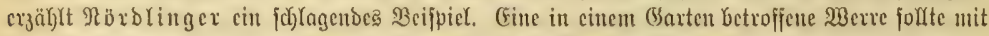

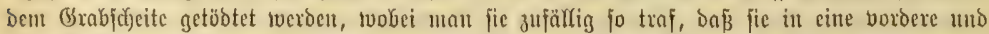

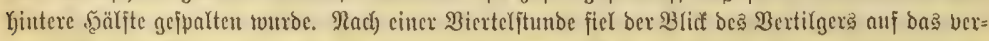

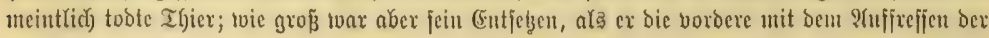




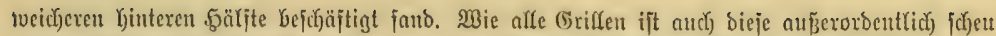

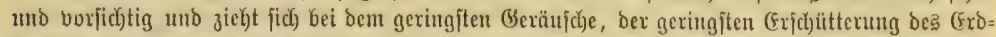

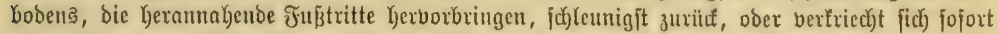

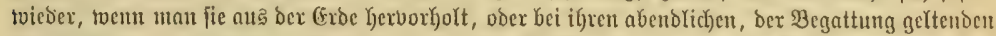

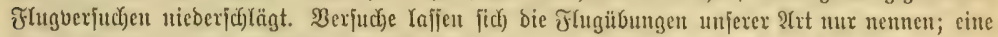

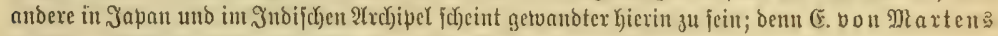

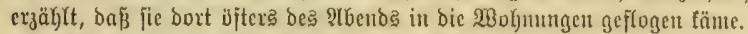

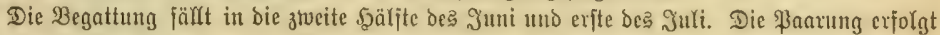

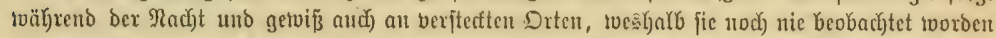

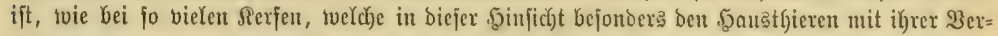

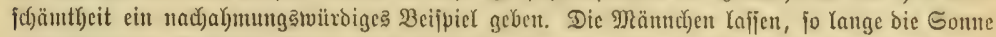
nicht über bem Jorizonte fteht, eiuen leije zirpenden Ion hören, ben man nit bem entjernten Sidtuirren Desె Biegen= melters (Caprimulgus curopaeus) berg(ichen hat. (Steich) nach bex \$aa= rung Geginnt Das $\mathfrak{B}$ rut=

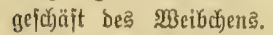
Ulm jeine zahlreidfen Gier abzulegen, bereitet $e^{B}$ cin

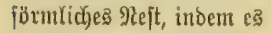
cinige fơduectentörmig ge= twunbene Bänge und in ber Mitte berjelben, bia etroa 10,5 Bentimeter unter ber Grobe, eine ફ口blung bou

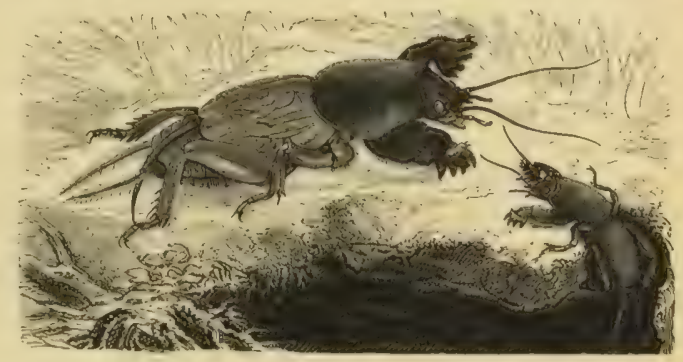

Daulrout sిßrille (Gryllotalpa vulgaris), ertoadjen unb als Larbe.

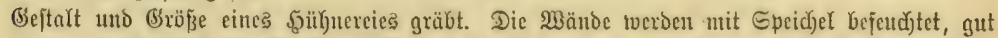

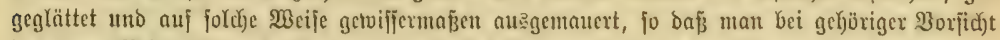

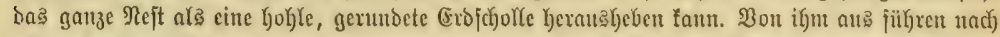

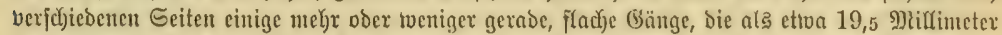

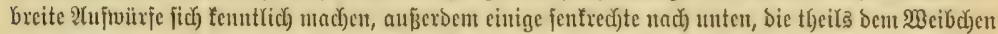

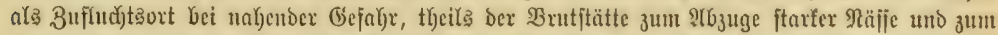
Irofentyalten bienen. (Fin foldjer Ban tviro an einer offenen, unbefd)atteten Stefle angelegt und

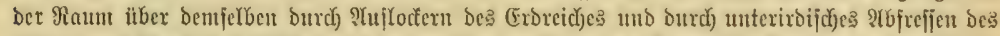

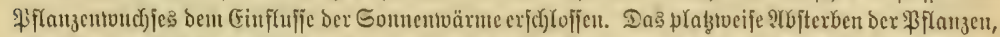

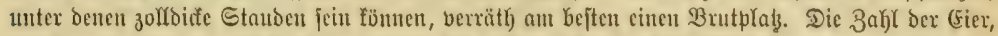

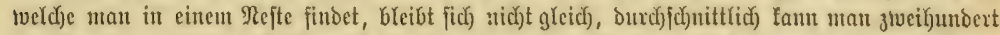

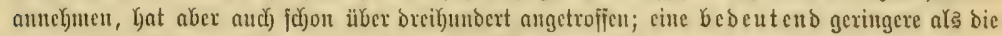

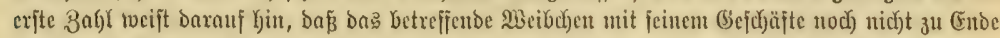

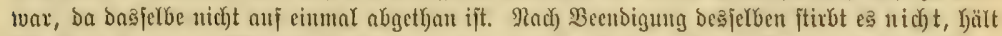

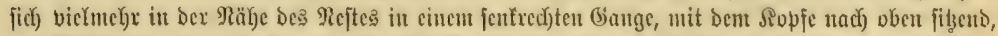

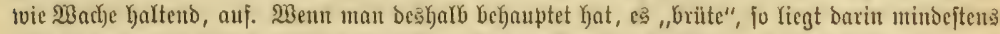

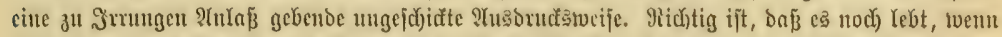

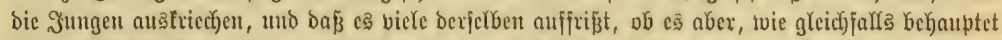

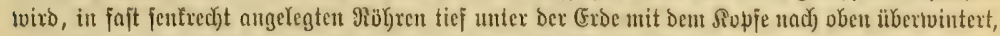

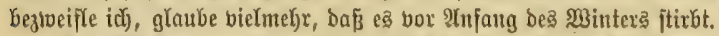

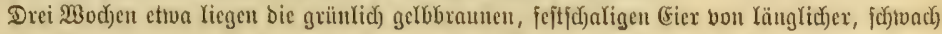

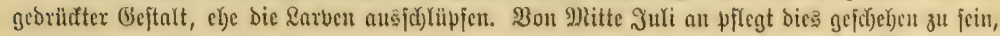




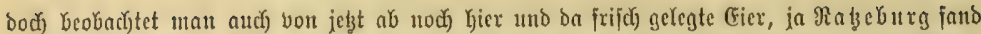
joldye einmal nod) an 6. 2Tuguft. In ben erften brei bis biex Wodjen breiben bie Jungen beifanunen,

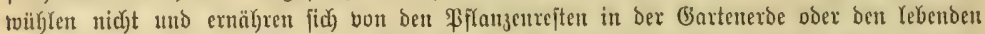

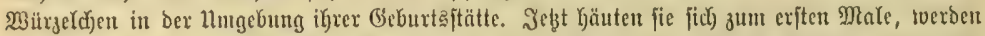

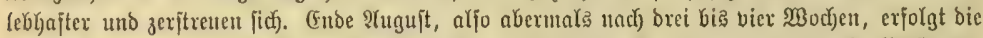

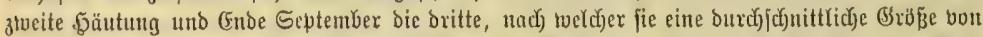

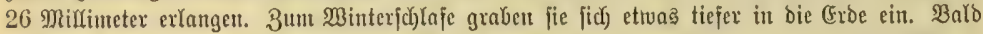

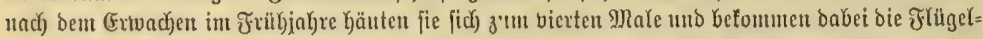

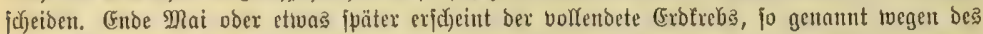

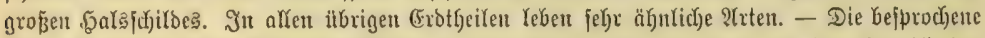

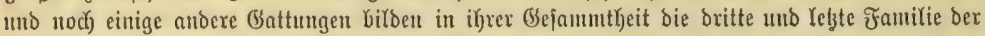

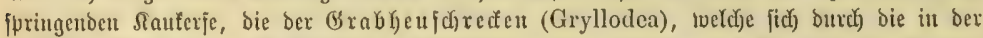

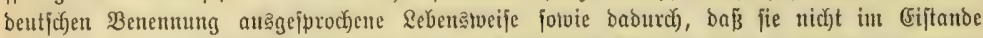

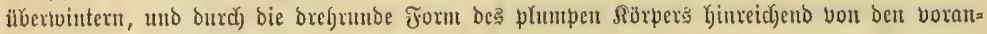
gegangenten untexjodjeiben.

Der groß̧e Ohrtwurm (Forficula ober Labidura gigantea) von 11 fis 13 Millimeter

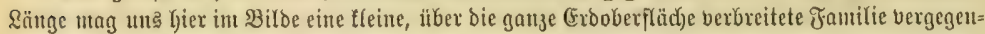

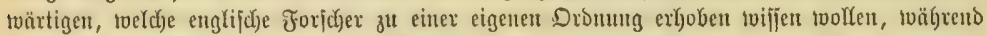

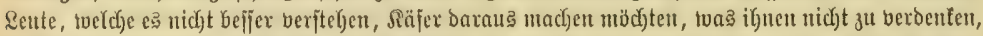

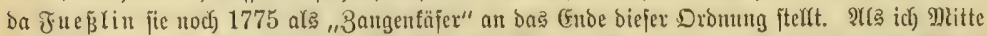

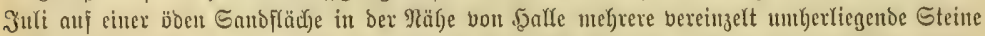

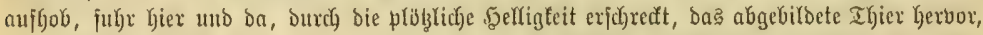

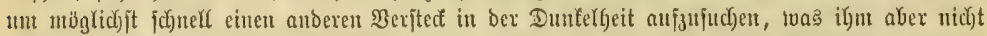

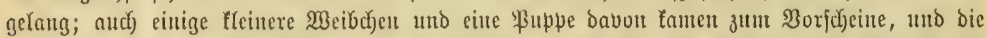

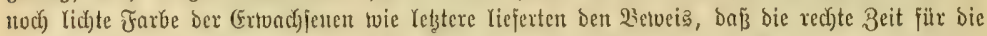

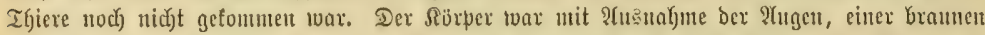

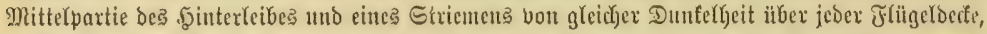

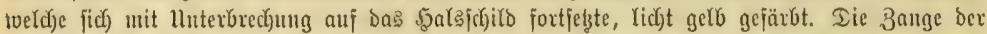

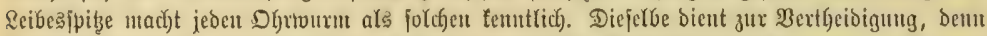

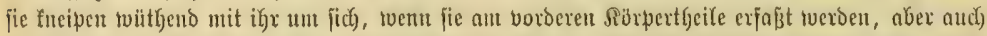

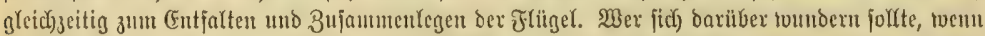

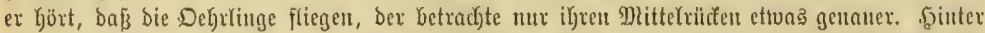

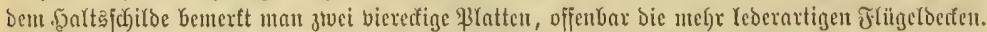

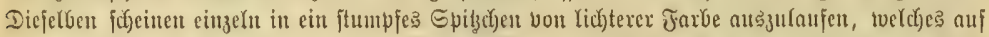

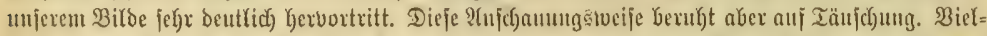

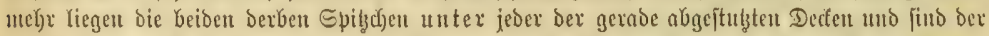

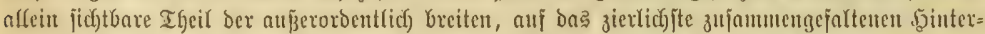

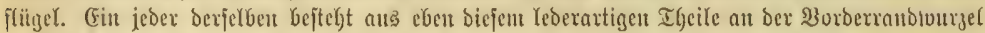

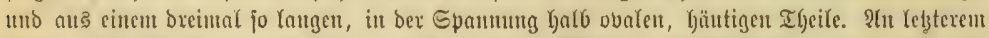

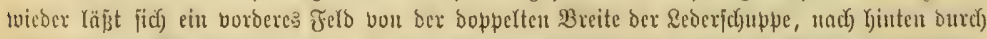

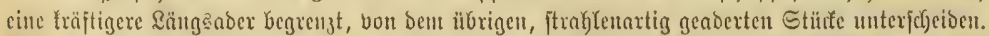

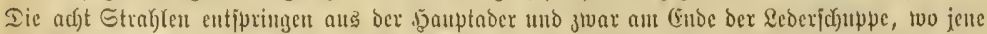

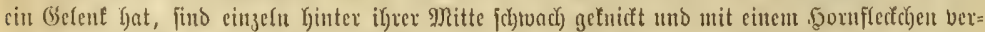

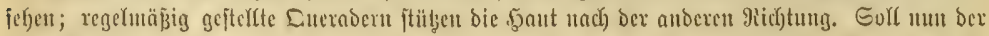

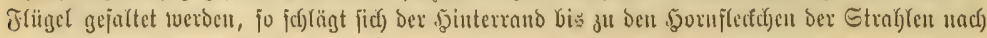




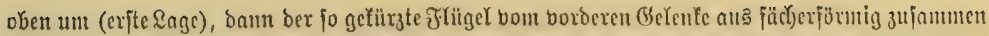

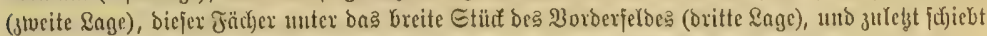

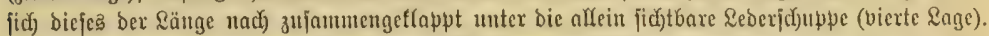

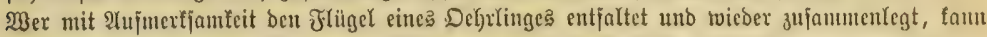

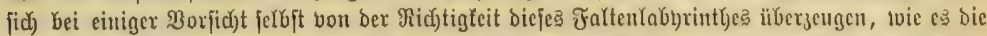

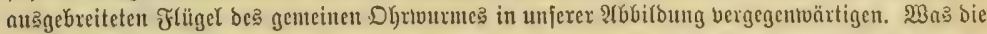

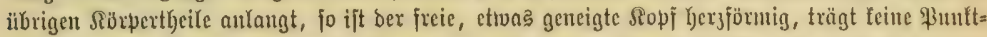
nugen, an ben Geiten aber runbe Rebzaugen, unter benen ficd bie zroblf = bis vierzigglieberigen

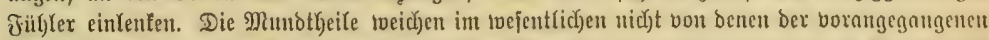

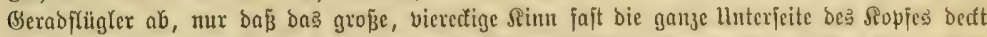

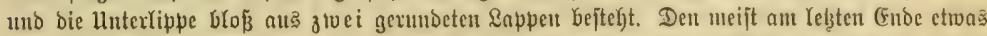

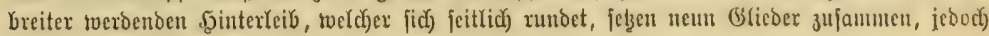
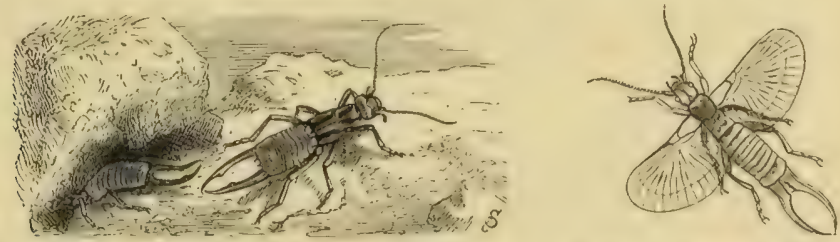

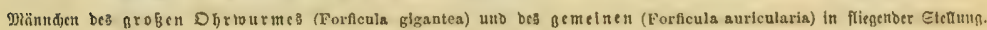
Ratürfidge Gröbe.

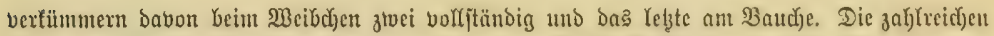

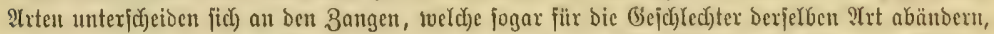

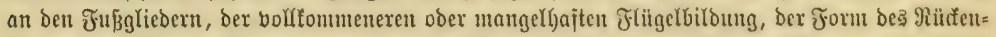

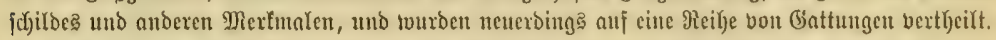

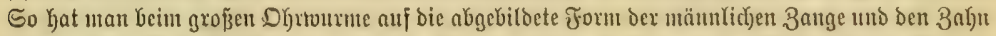

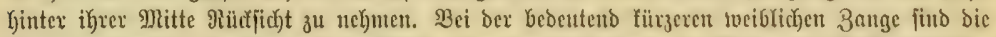

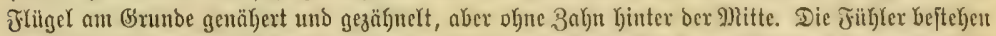

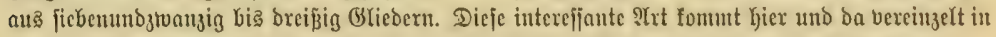

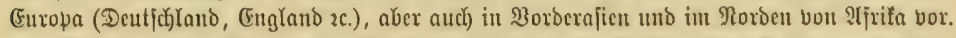

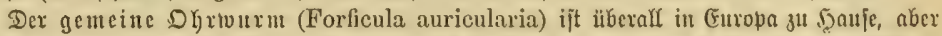

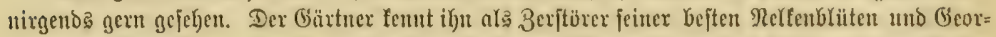

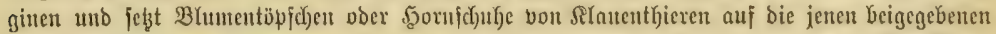

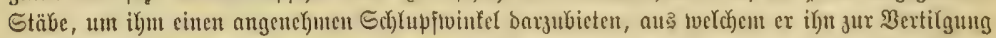

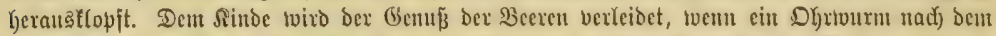

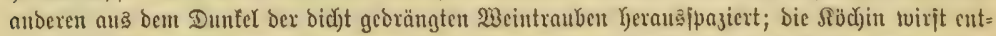

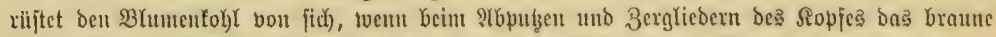

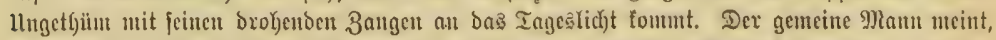

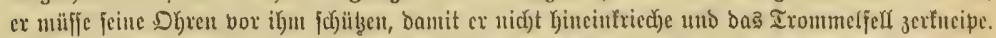

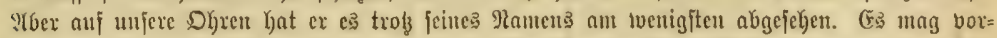

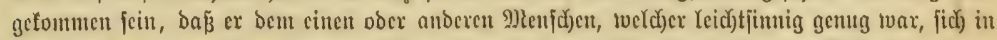

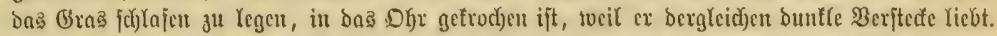

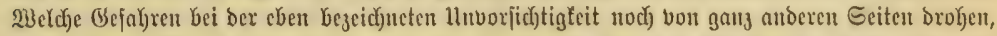

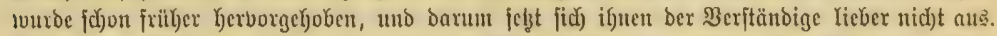

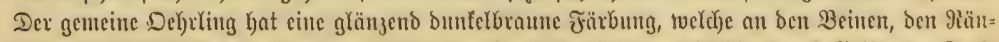

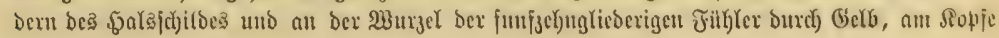




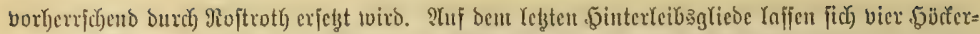

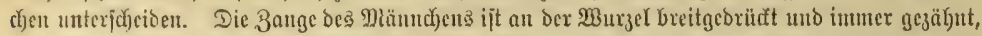

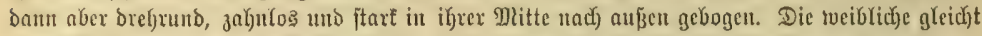

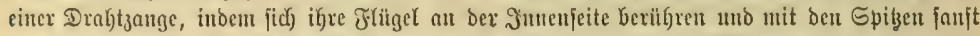

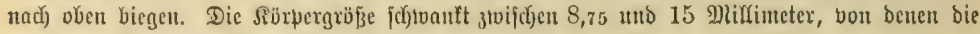

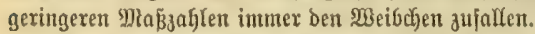

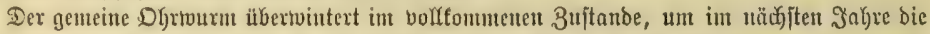

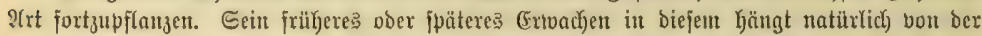

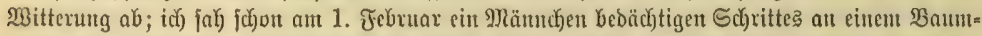

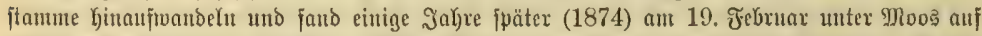

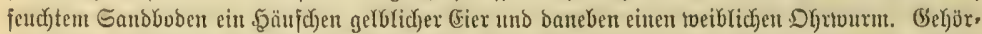

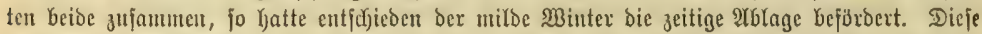

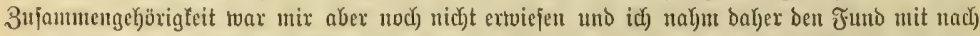

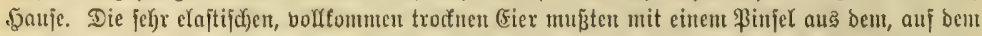

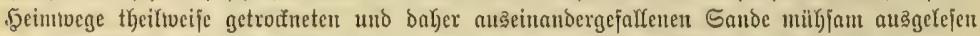

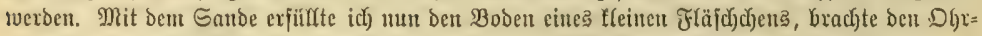

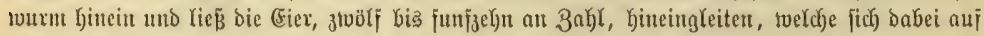

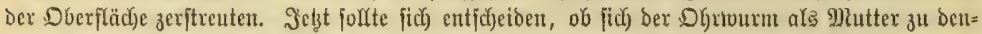

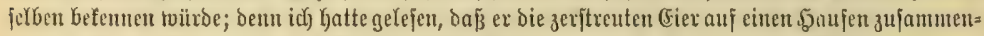
trage. F

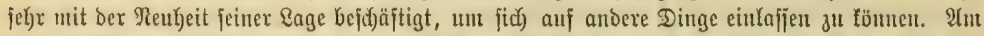

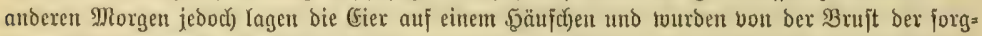
jamen MJutter bebectt. Jin biejer gleichjan brütenden Stellung ließ fie fich fajt immer betreffen.

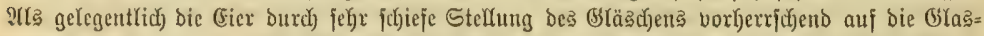
twant gerathen twaren, bettete fie diefetben nad ber andoren Geite in eine borfjer auf bem Sande

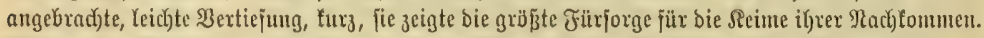
Gollte ctwa Belecten oder fonjt toeld)e Beciuflufjung auf bie Cicr bertu Entwidfelung bebingen?

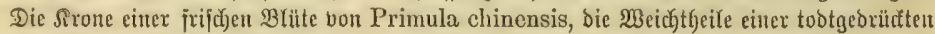

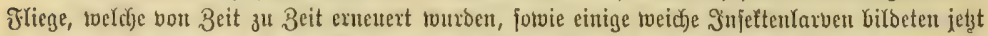

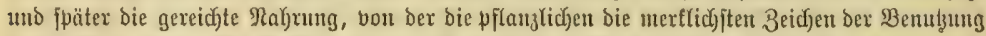

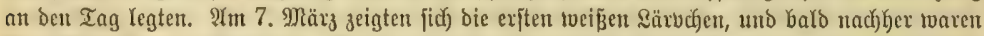

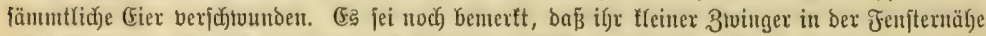

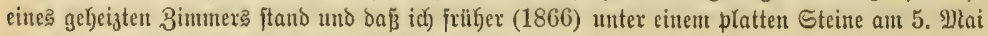
eine Arte mit igren Jungen im Jreien angetroffen Gatte.

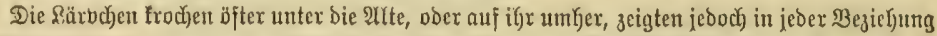

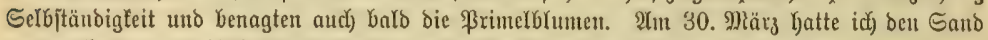

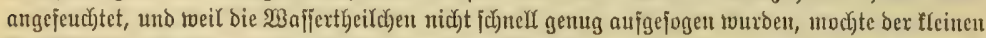

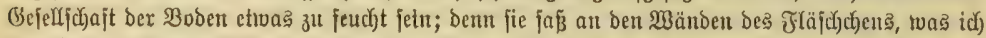

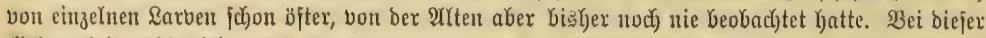

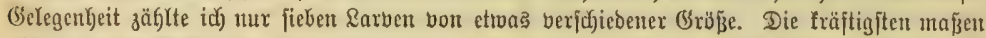

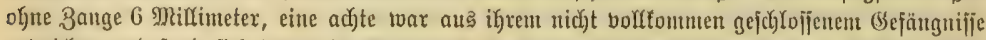

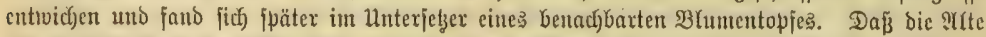

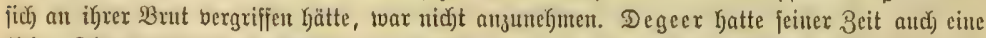

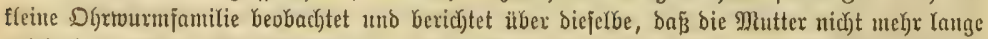

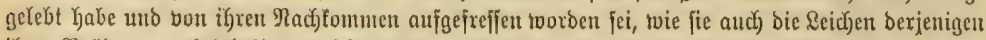
ihrer $\mathfrak{B}$ rilber berzelgrt Gätten, twelche zufällig geitorben twaren.

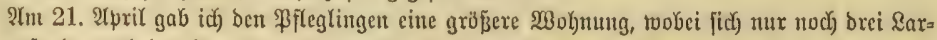

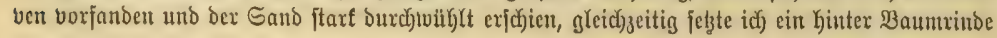




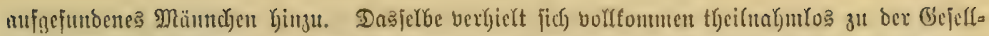

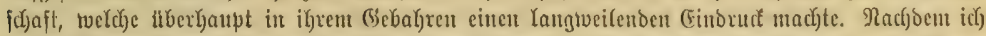

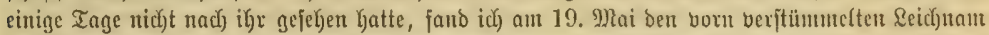

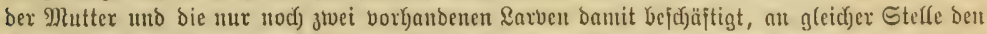

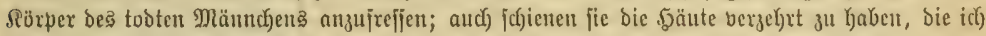

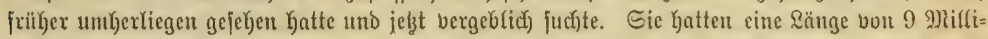

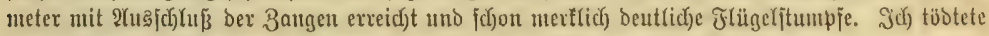

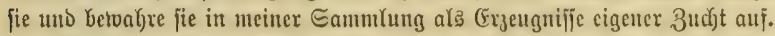

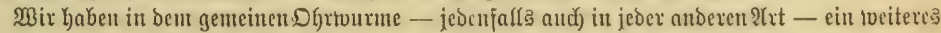

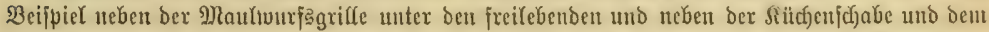

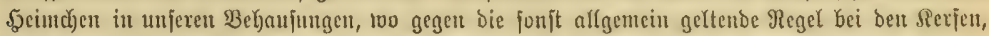

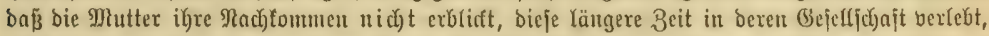

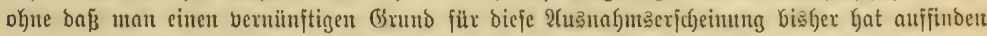

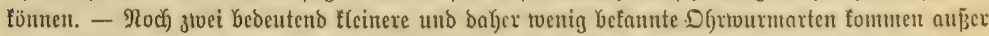

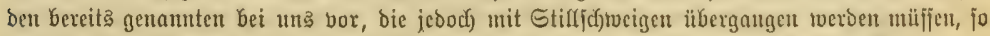

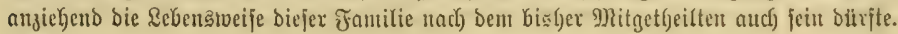

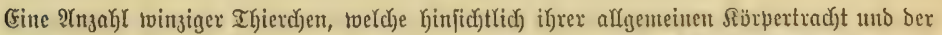

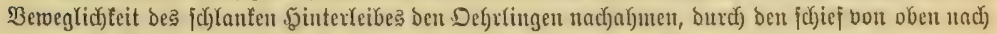

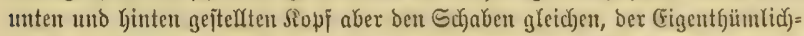
feiten jebod) fo viełe haben, baß̉ fie tweder mit den eimen, nock mit ben andoren

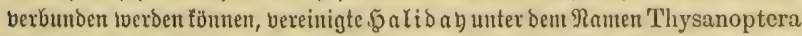
(Jranjenflügler) zu ciner bejonderen Dronung. Die Deutjdjen (Entomologen ber

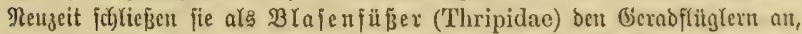

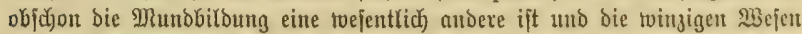

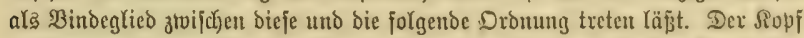

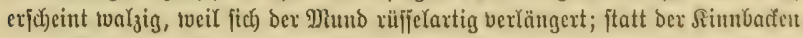

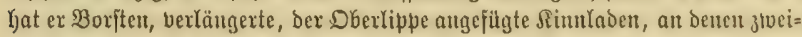
ober breiglieberige Tajter fiben, und ztweiglieberige Rippentajter. Sie jaugeu

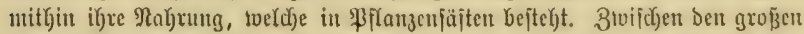

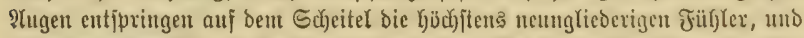

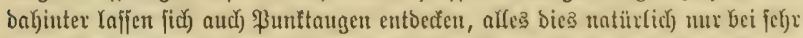

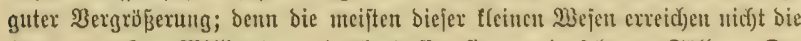

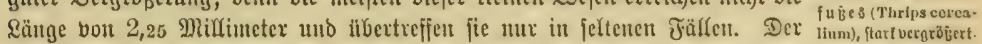

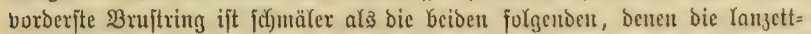

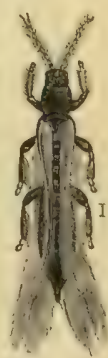

Meibden bes (5) etreide : 9 [a [en.

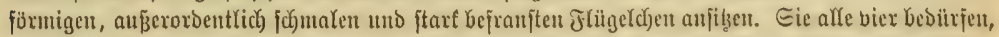

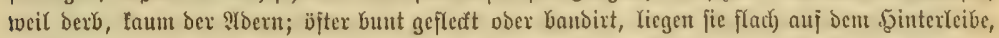

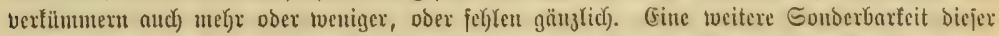

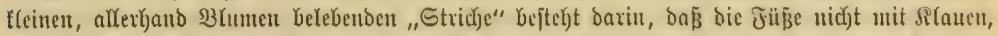

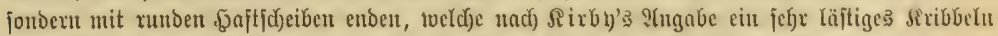

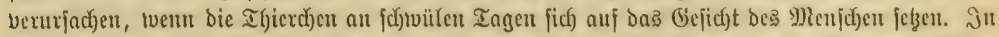

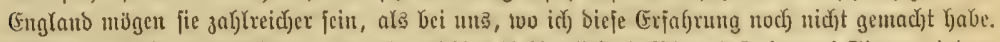

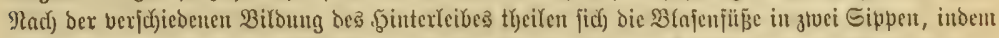

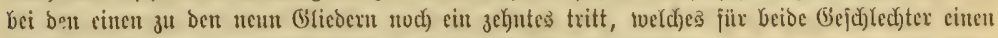

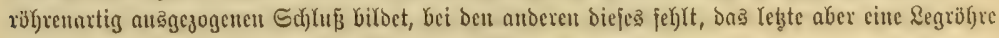

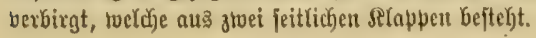




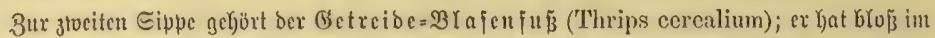

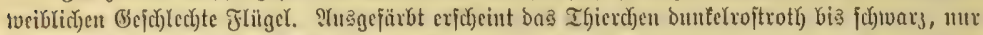

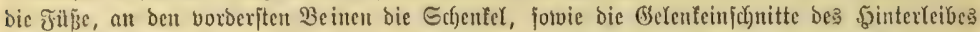
Yaben cine ftrokgelbe Färbutg. Die Rarbe ijt Yebraft orangegelb, am Siopic, an cinem Theile bes

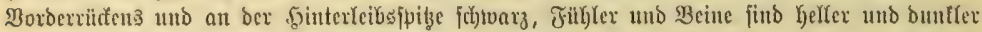

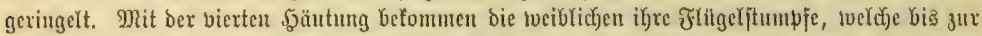

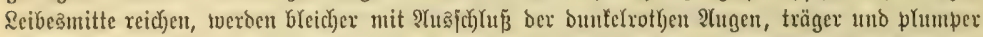

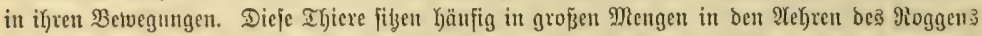

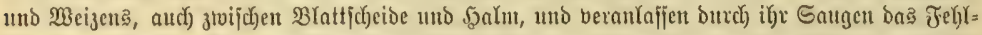

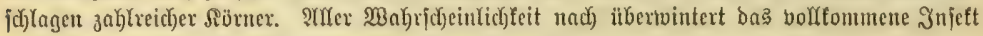
uno febst im fribjabre an ben genanten Drten jeine Eier ab.

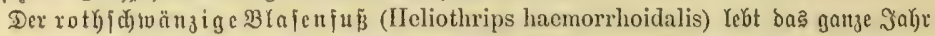

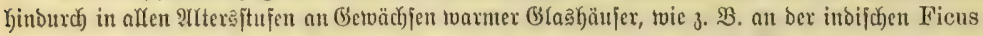

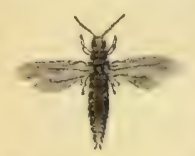

Mänutăt bes roth. 元他ängigen 3 Iafen, fu B E S (IIeliothrips haemorhoidalis), ftat? ber grögert. retusa unt an Begonia cebrina; er fiłt an ber Blattunterjeite jungex

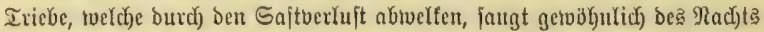
uno paart fick and zu biejer 3eit. Das bejuchicte Weibchen legt feine

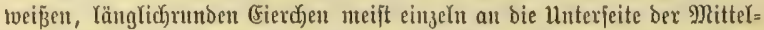

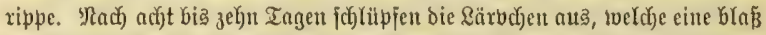

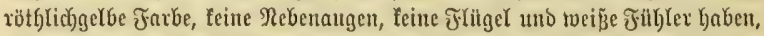

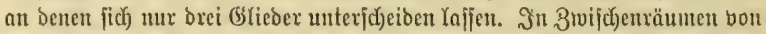
gleicher Dauer bäuten fie fič breimal, betommen bei ber Yeb̨ten ફ̧äutumg Flügelftumpje und find in biejent ifren \$uppenjtande jelyr toentig betweglick),

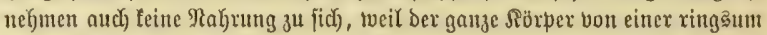

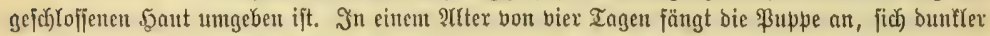

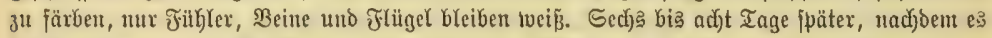

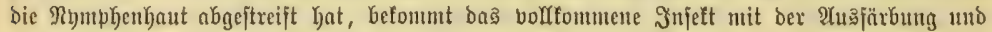

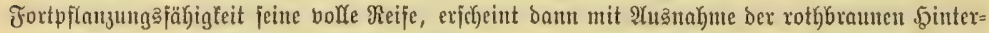

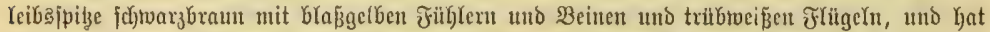

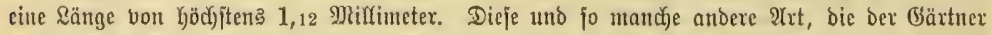

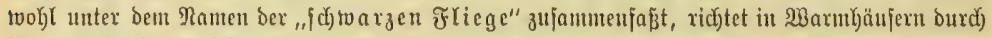
ifre §äufigfeit oft nicht unbedeutenden Sdjaben an.

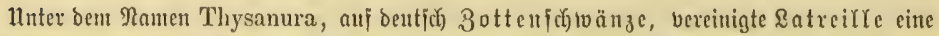

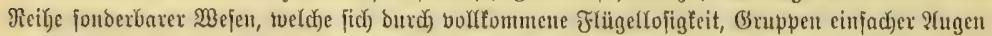

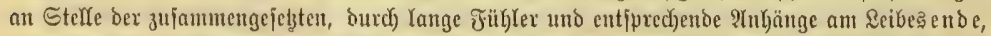

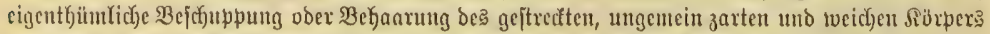

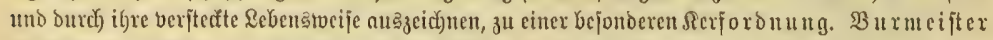

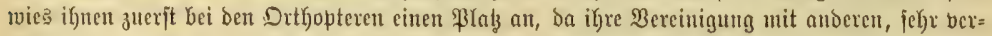

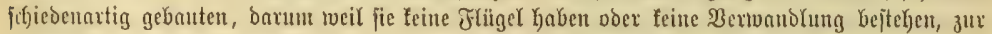

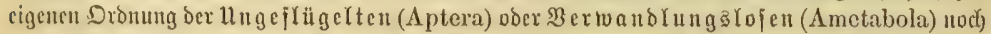

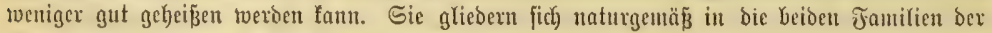
Boritenfơdroänze und Springidy wänze.

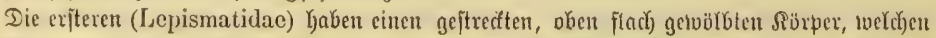

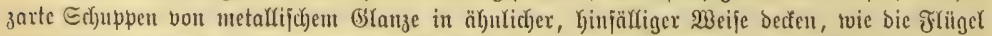

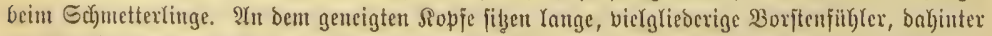

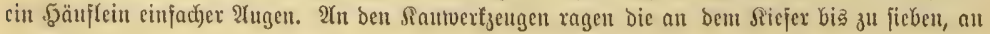




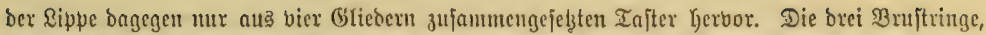

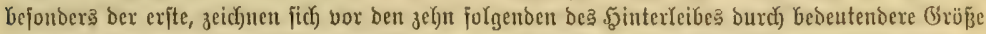
nuछ uno crisnem, tvie bie Bilbung ber Beine, an bie Schaben. Die Schentel jino bid, bie Gefienen

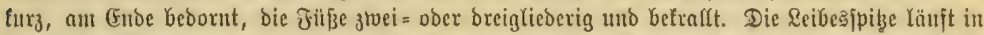

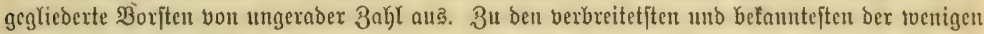

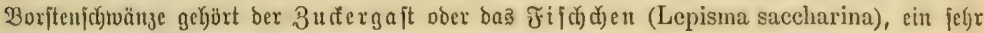
flintes, oben fitberbejchupptea, unten, an ben scinen uno

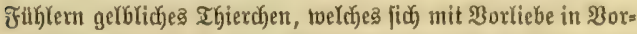

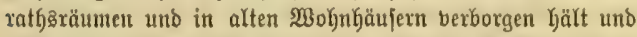

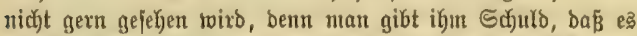
gleich Motten Molle, aber aud \&einenzeng, Papier, felbit \&eder annage uno burd) jeine berborgene Thätigfeit fojäblidj) tverbe.

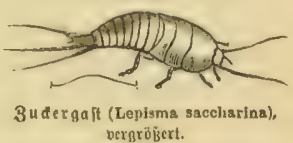
perpröjert.

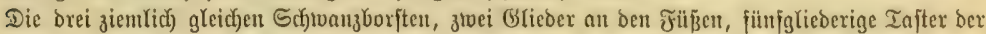

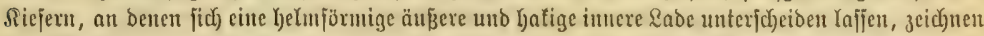

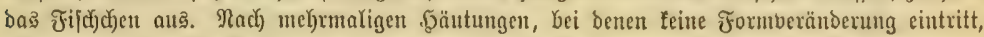

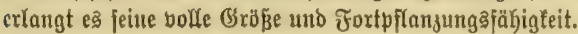

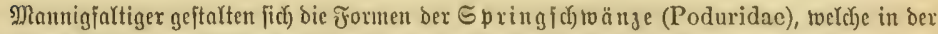

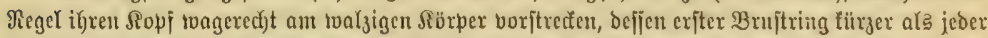

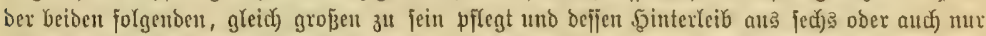

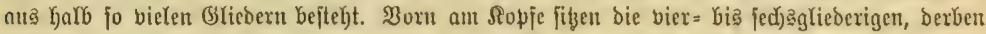

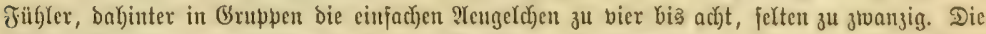

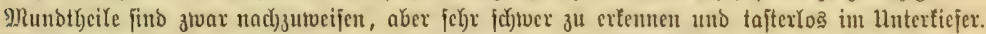

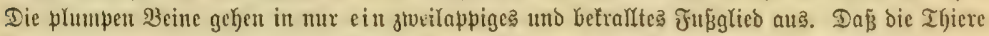
fełr gut hod) und weit fpringen fönten, verbanten fic nicht jenen, fonbern bent gabelartigen

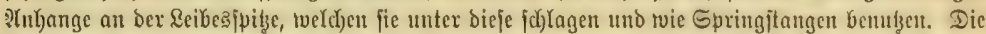

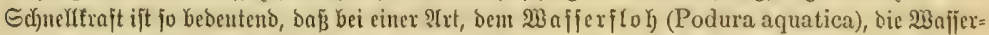

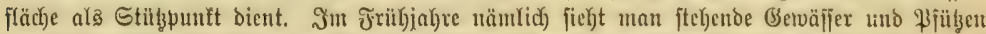

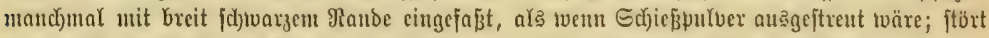

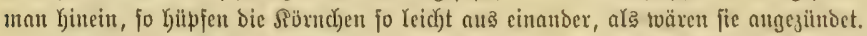

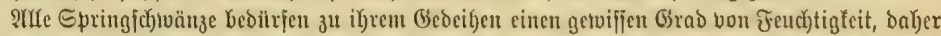

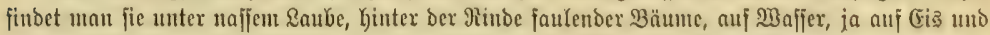

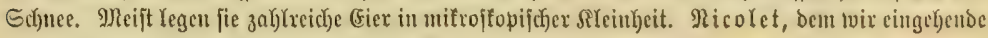
Unterjuchungen liber bicje intereffanten झejen berbanten, fand bei einem Mcibchen eintaujenboreifyutoertundfectyig

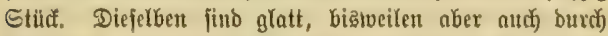
Bef)anung rauh, obal, länglid) oder fugetrund. 3uerjt

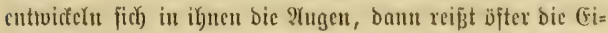
hant und breibt in einer vorderen und hinteren bälfite an ben betrefjenden Theilen besె nod) unentwidfelten Seines hängen.

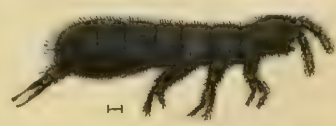

(9) If vergrübert.

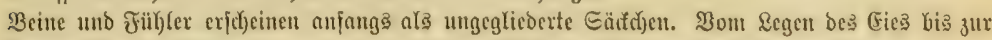

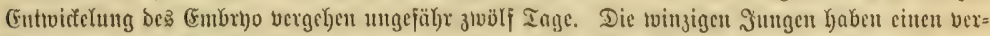

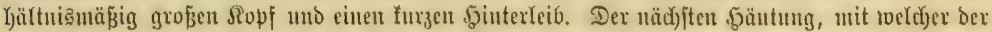

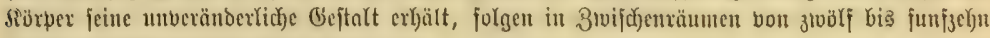
Iagen zablreidje toeitere §äutungen nad ).

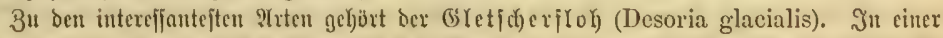

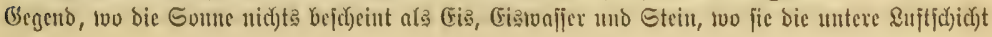




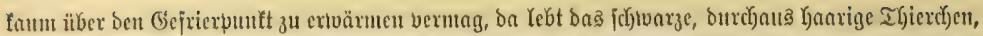

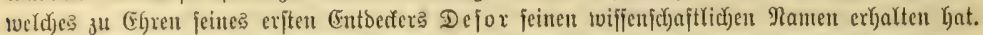

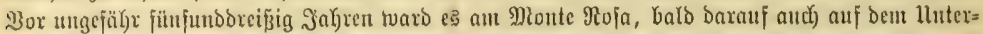

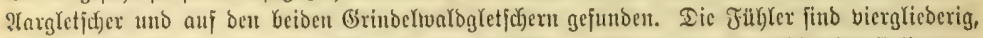

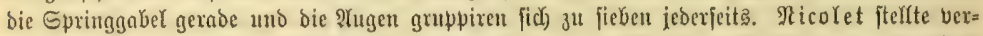

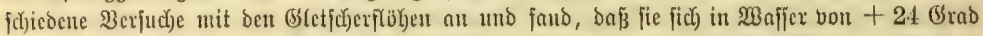

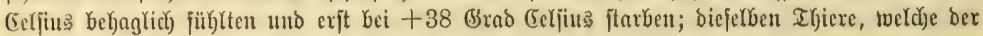

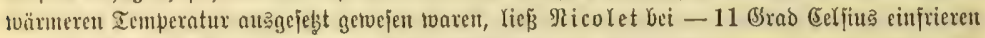

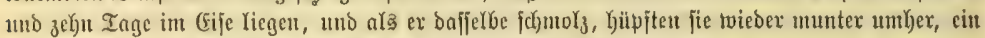

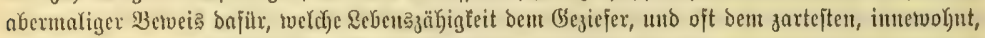

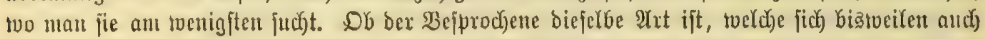

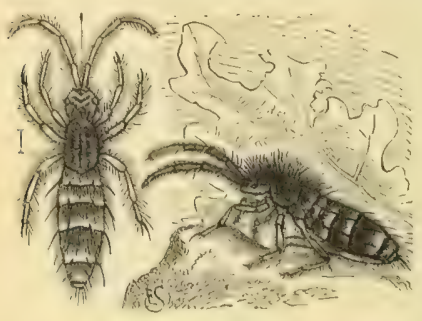

3ottiget Eprinßld)toang (Podura villoga), vergrögert

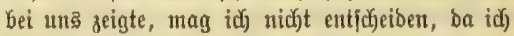

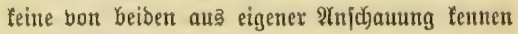
gelernt yabe.

Der jottige Springidronan (Podura villosa) gehört ju ben bunteiten, indem ben gelb= rotfjen Siörper [chrwarge SBinden bebecfen; ex Gäl̨t fich gern in (Gebuild auf, unter bem herabgefallenen Raube in Gejelfidajt bes breigrauen Epring= ¡ch) wanzes (Podura plumbea), beffen Siorper

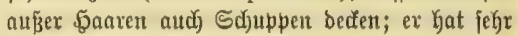
Yange, twent auch) nur bierglieberige Futhler, eine Yange Springgabel uno ein auffüflig verlängerte

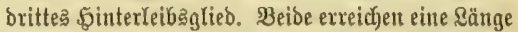

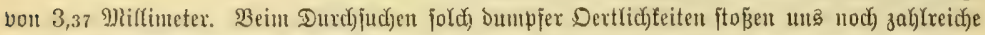

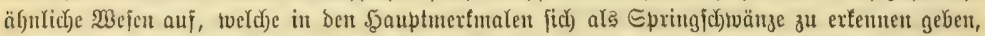

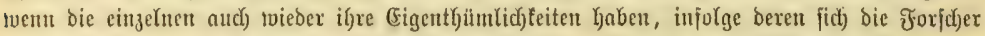

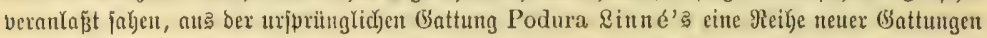
zu billoen.

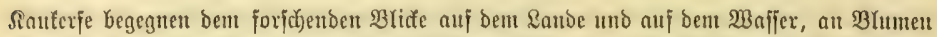

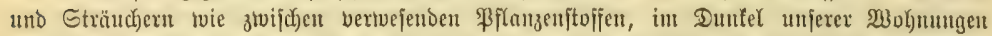

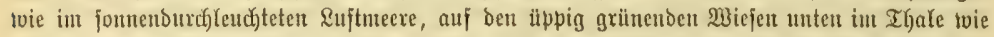

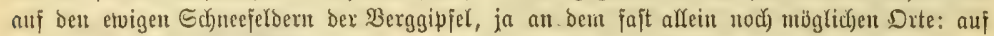

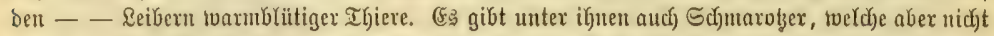

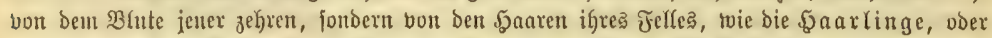

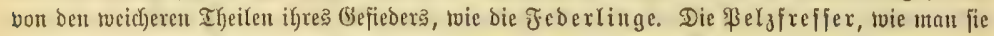

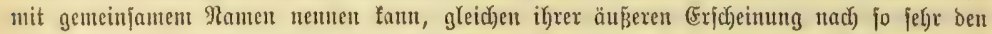

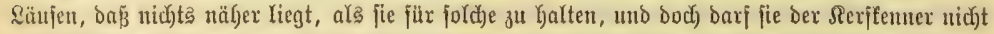

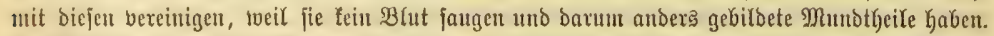

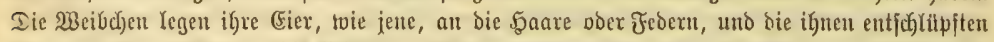

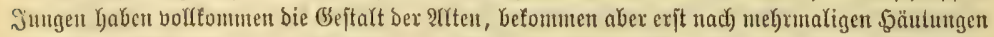

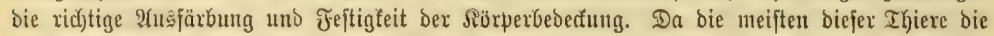

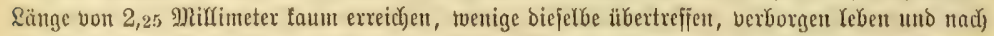
ben Iode ifyer Mohnthiere dicjelben zu verlaffen pflegen, fo fonmen bie meijten mur demjenigen

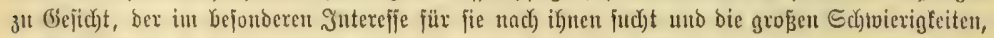

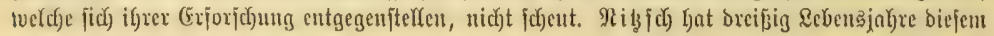




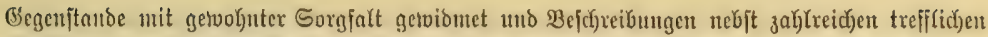

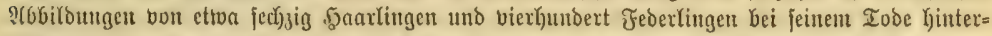

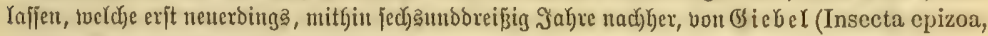
Seiłjig 1874) veröffent(id)t toorben fitto.

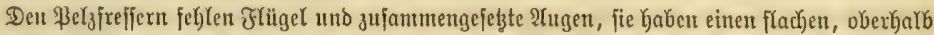

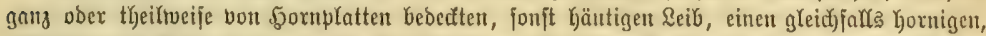
f(c)iloförmigen Ropf, tweldyer twagerecht borjteht unb bie Mtunotheile an Der Unterjeite trägt. Die

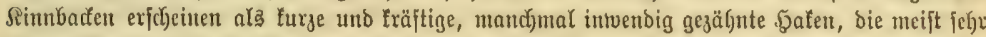
fleiten Sintlaben Kaben bei ben einen fcine, Gei ben anderen bierglieberige Tafter. DVer = uno

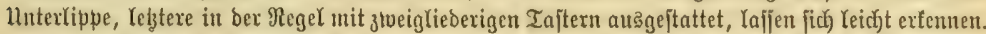

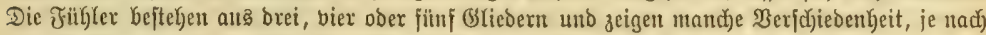

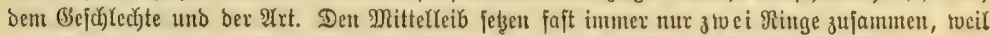

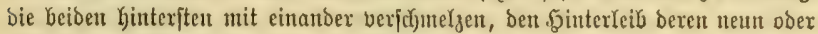

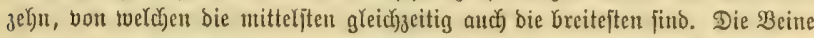

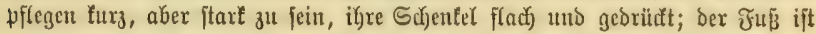
zweiglieberig uno enoigt in zrvei tleinen Seraffen bet ben Feberlingen, in einer

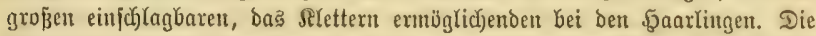

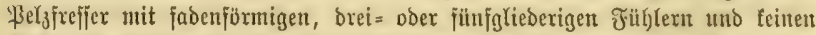
Siefertaftern bilden bie Familie ber Fe berlinge (Philopteridac), im Gegen=

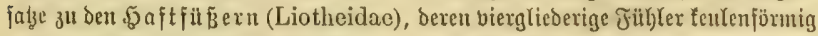

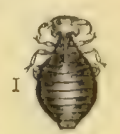

Pfau= Feber $\operatorname{In} g$ (Gontodes faleicornis), vergrö̈̈ert.

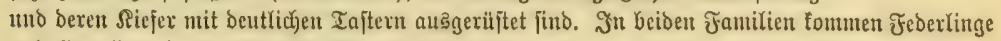
und Saarlinge in ber obigen Fafiung bes $\mathfrak{B e g r i f f e}$ vor.

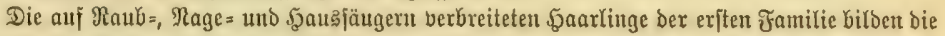

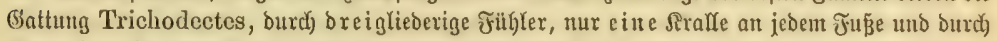

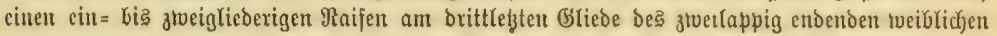

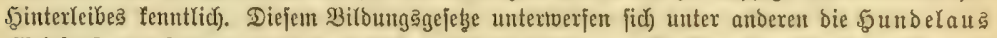

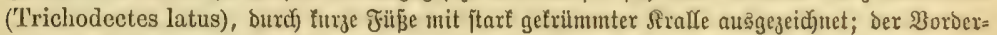

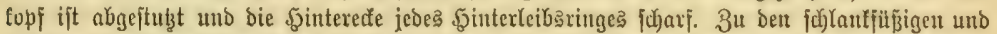
jajt gernofralfigen 2trten gehỏrt bie Biegenlaus (Trichodectes climax), Deren fiopf born breit

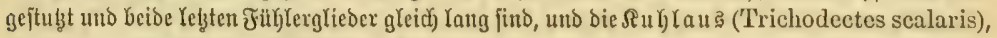

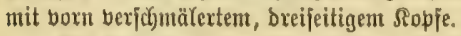

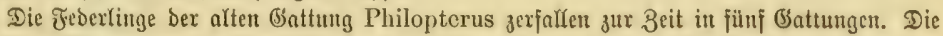

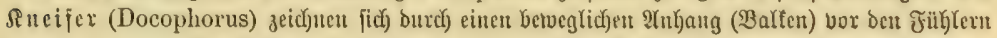

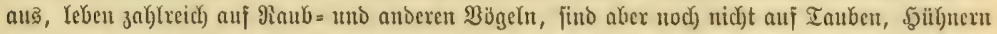
uno Ranfü̈gełn beobadjtet tovroen. Dagegen Yeft Der Éänfefueifer (Docophorus adustus) an

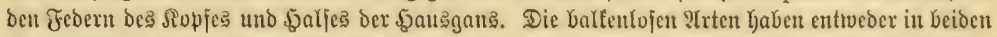

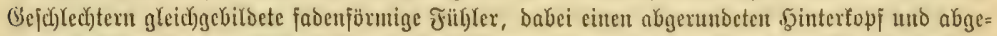

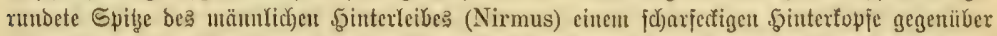

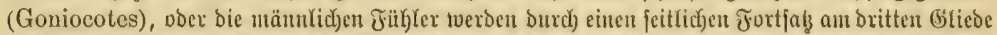

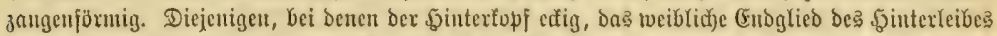

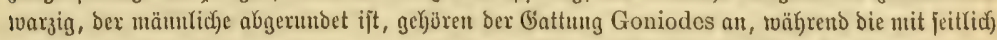

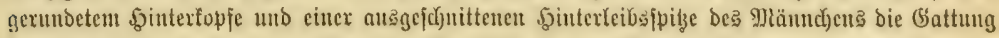

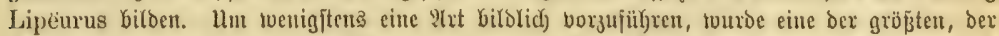

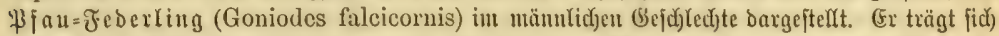

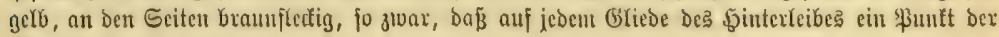
3rumbjarbe treu bleibt. 


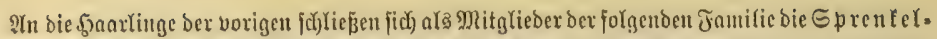

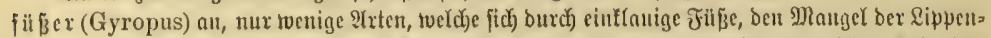

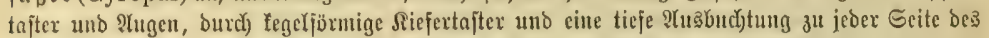

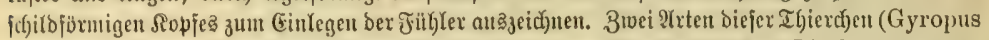

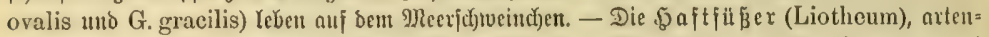

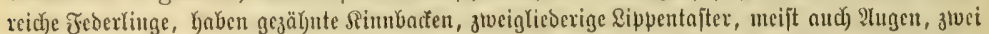

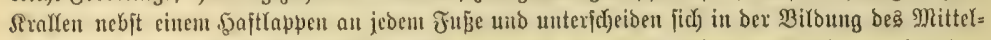

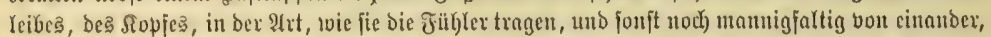

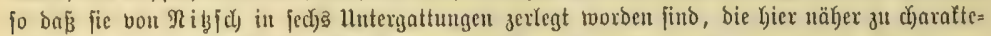

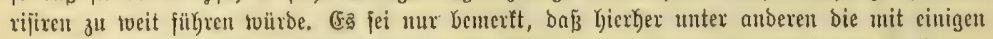

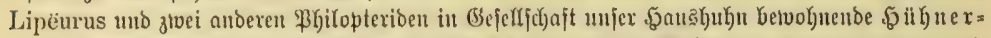

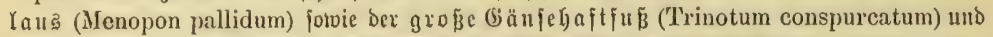

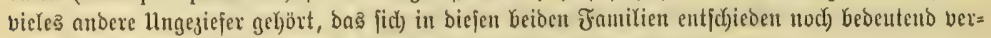

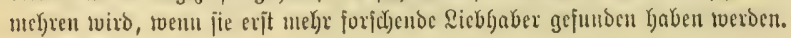




\section{Siebente (Brimung.}

\section{Die Edhuatelferfe, 5anlludeffer (Rhynchota, Hemiptera).}

Sie die vorkergehende, fo vereinigt aud bicje Dronung ferbthiere, weldhe in ihrem äแneten

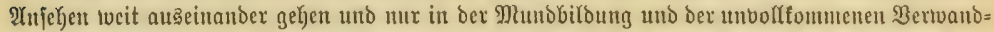

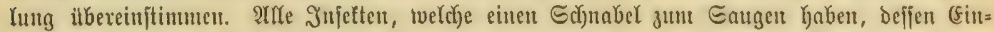
ridjtung bereits auj Seite 8 gefdjildert twurbe unb beren Rarben fidf nur burdf ben Mangel ber

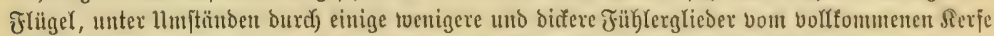

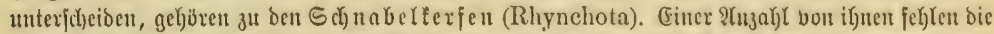

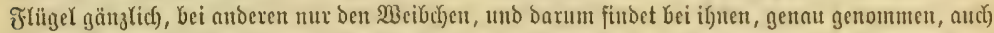

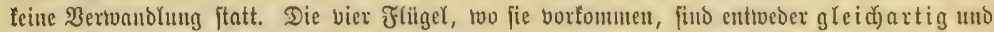

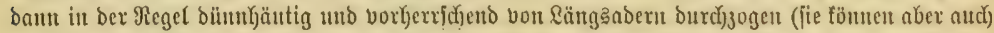
in felteneren Fälfen affe viex von berberer, melgr Yederartiger \$aut gebildet jein), oder fie find

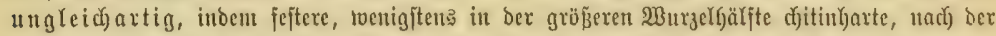

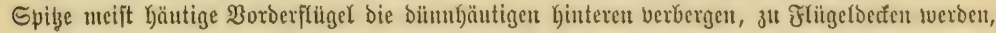

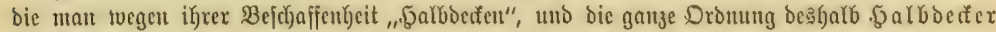

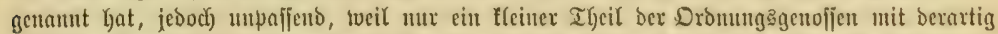

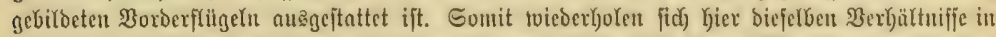

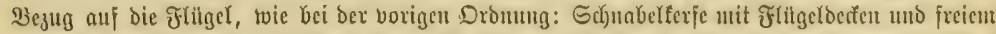

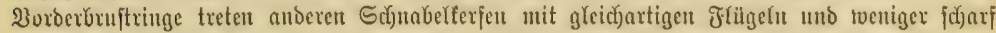

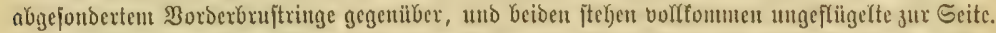

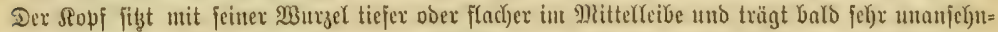

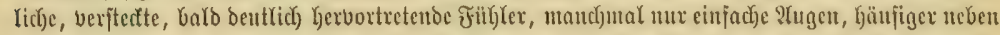

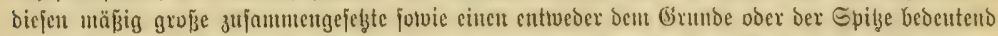

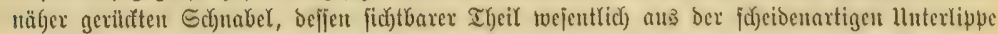

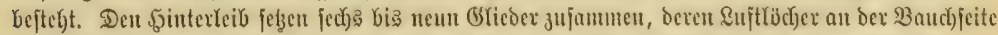

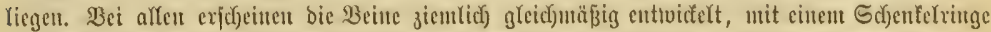

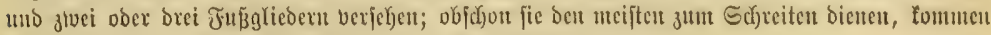
baun unb roant aud) Faub=, Spring $=1$ mo Schtoimmbeine bor.

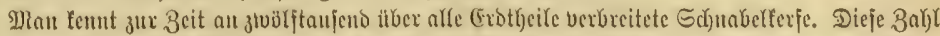

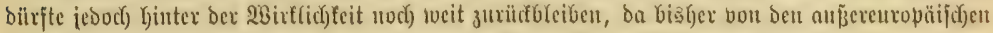

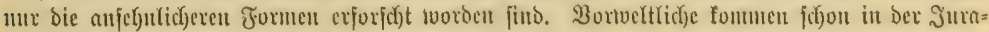

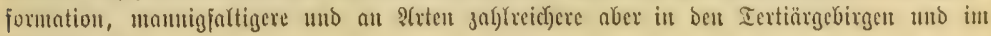
Berufteine vor. 


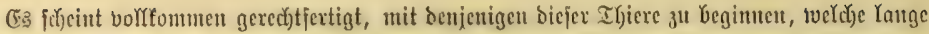

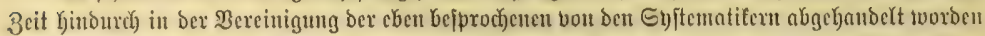

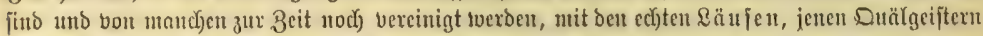

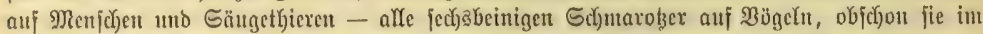

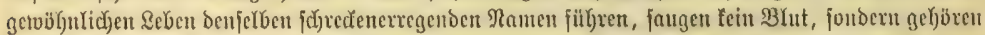
Den Jebertingen an. - Dic \&äufe (Pedieulina) Kaben feine Flïgeł, fabenjürmige, fün fgliederige

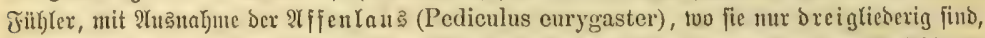

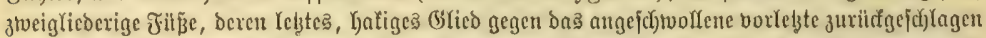

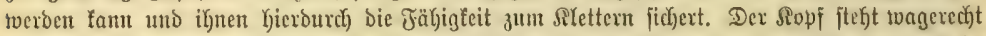

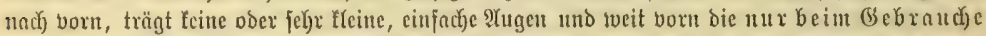
¡i chtbar werbenden Mun

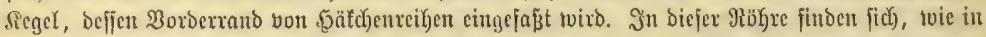

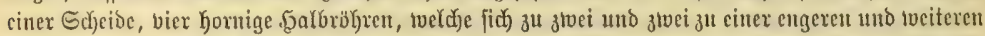

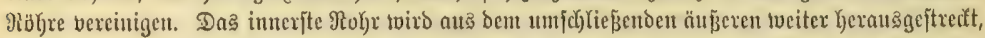

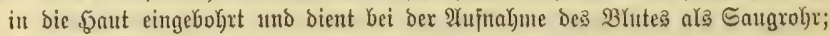

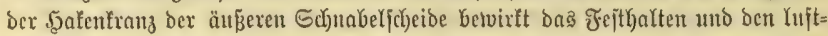

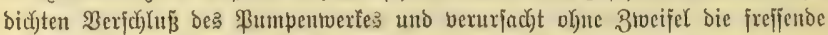

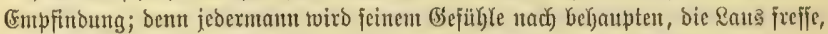

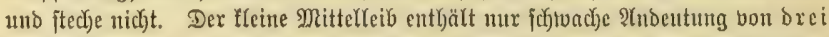

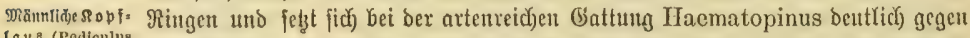

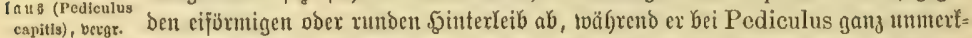
lich in benjelben übergeht. Der in Den Ilmrifjen meift eiförmige Dinterteib räß̈t

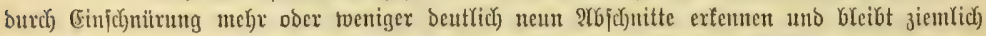

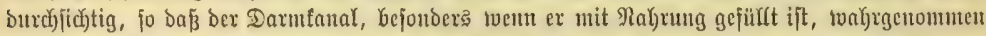

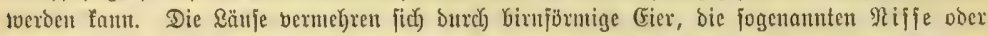

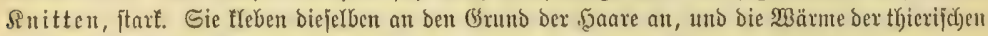

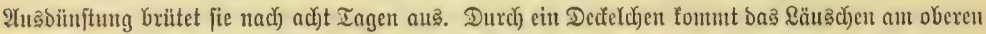

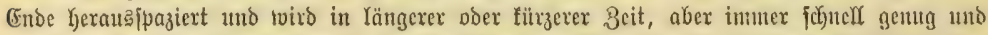

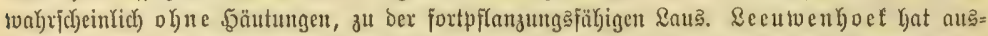

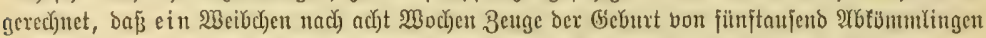

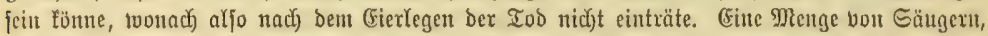

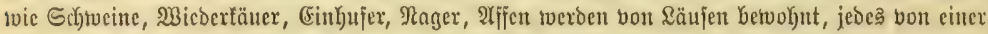

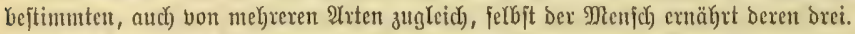

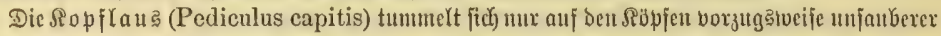
Sinder. Gie ijt grangelb bon Farbe, an ben Rändern ber ફsinterteibighteder bunfler und hat

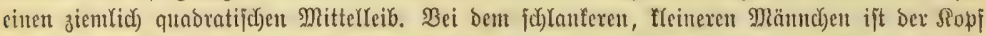

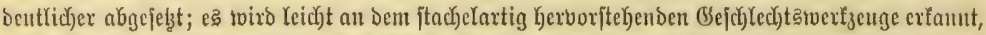

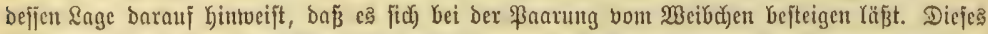

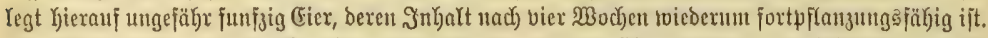

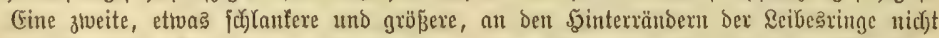

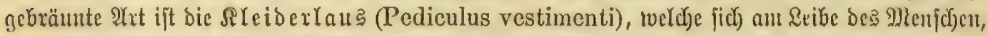

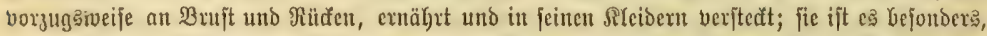

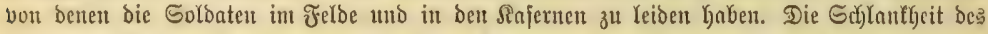

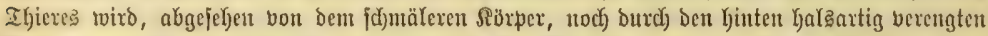

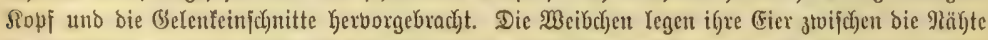

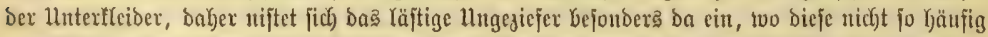

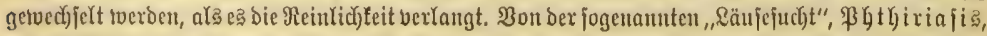

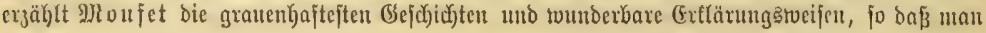




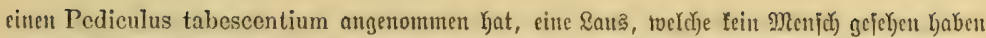

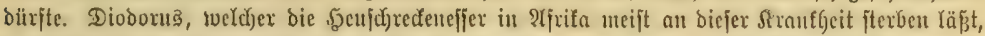

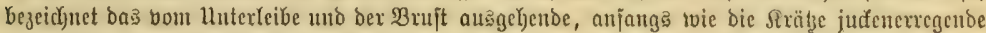
Ilngeziejer ała "geflilgelte \&äuje". Da bejagte Strantfeit feit sen Beiten nie wieber aujgetreten ift, in

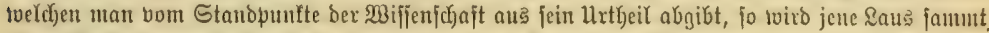

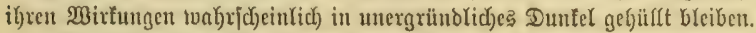

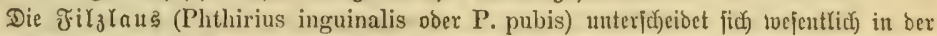

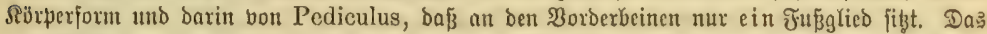

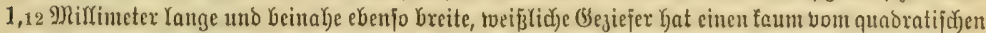

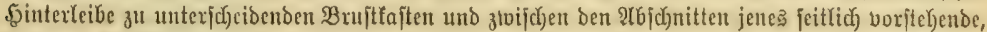

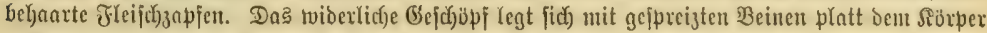

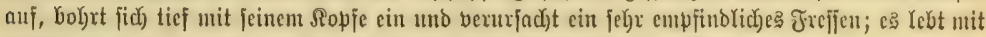

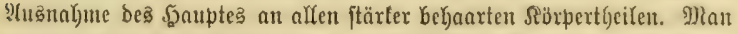

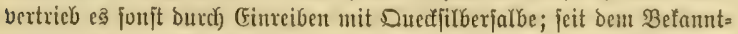
toerben mit ben Mineralölen erreid)t man burdy bieje benjelben 3rwed, ohne feine eigene ફaut wechjełn zu müfien.

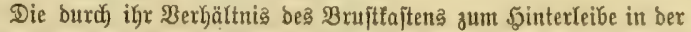

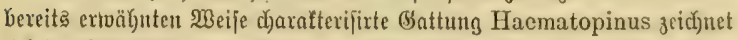

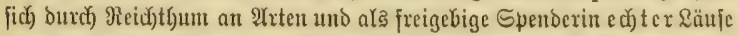

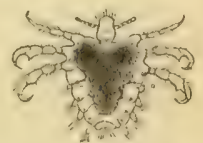

f̊latcus (Phthirios Ingulnalis), bererö fert.

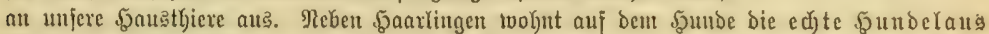
(IIaematopinus piliferus), auf ber 3iege H. stenopsis, auf bent Gdjtveine ber ftattliche

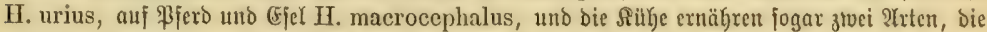

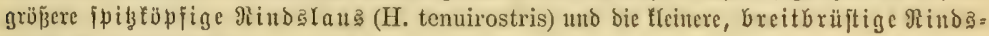
laus (H, curysternus).

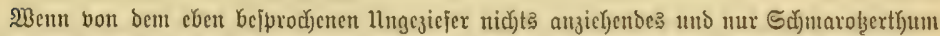

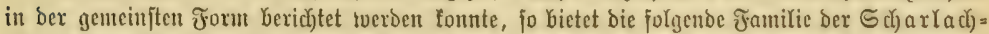

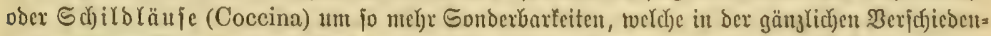

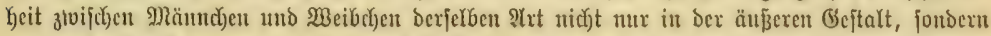

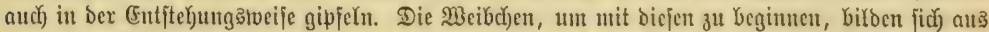

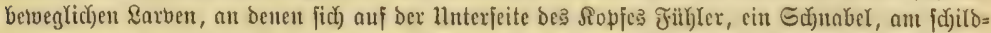

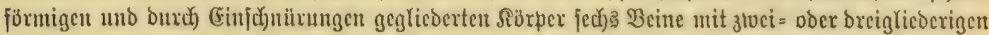

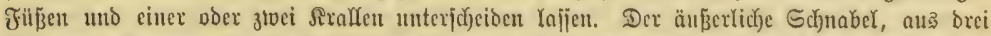

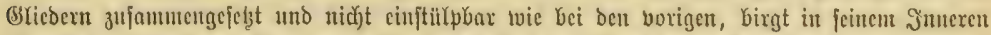
cbenfalfs bicr Borjten. Dieje entfpringen an Sopje, itcigen tief in ben Sïrper Yjincin, bitben Yjier

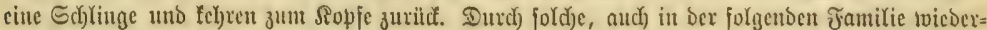

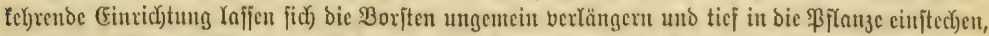

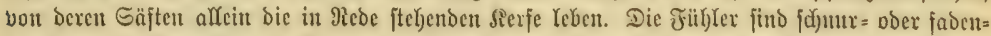

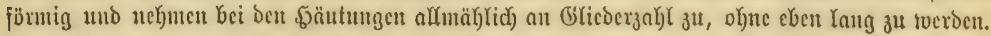

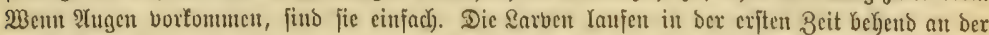

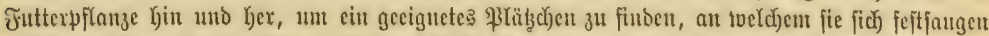

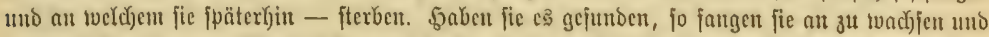

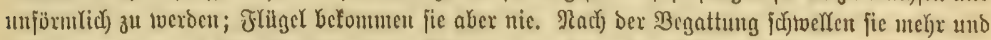

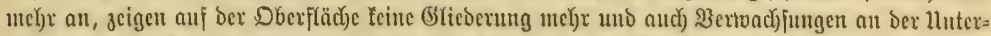

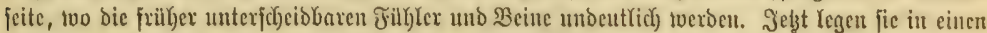

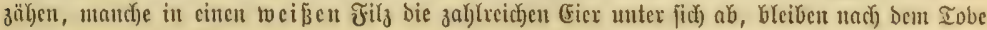

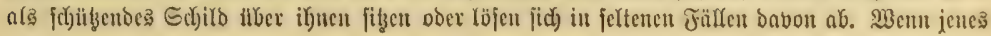




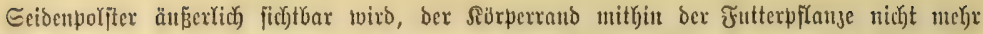

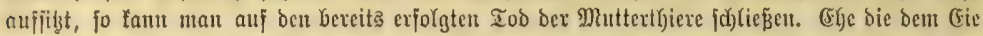

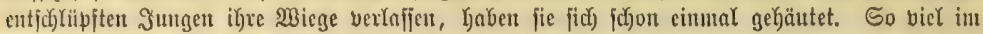
affgemeituen boun Weibdyen.

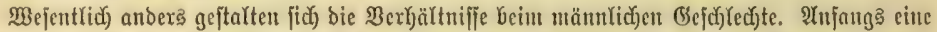

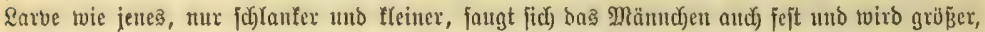

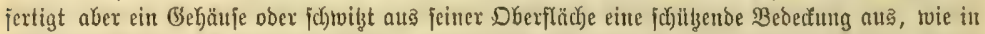

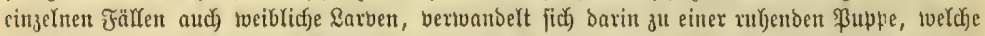

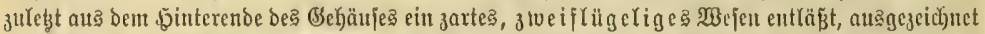

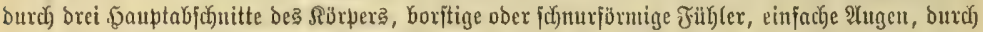

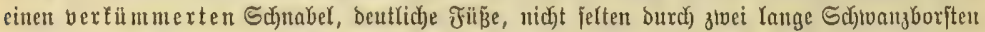

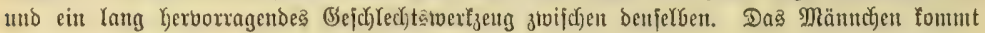

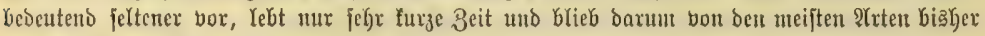
noch) unbefannt, ja, feblt einigen vielreidb) gänjliç).

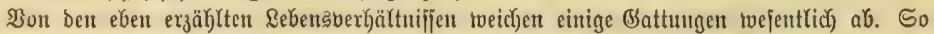
greid)en fich beifpie(ștweife bei Aleurodes beibe (bejd)

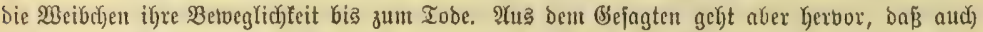

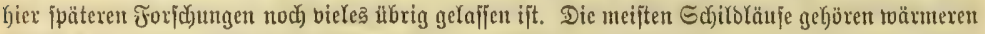

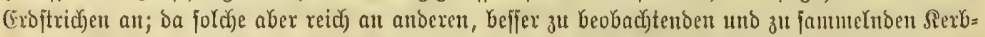

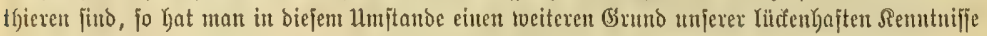
yon biejen unjadjeinbaren, aber höchjt interejpanten wejen ju juchent.

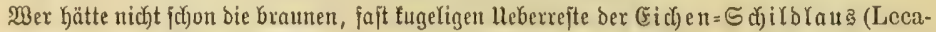

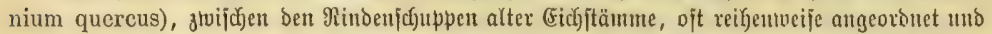

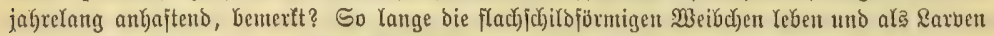

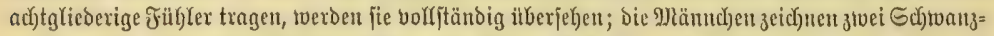

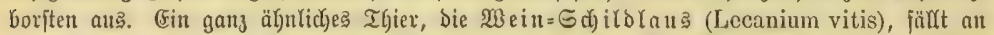

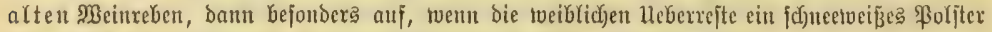

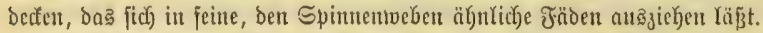

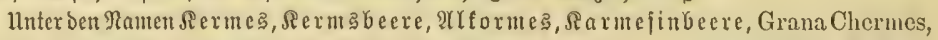

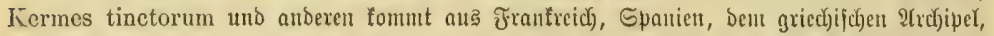

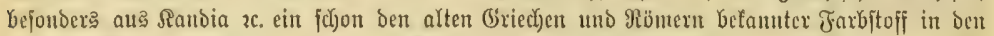

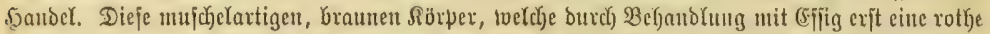
Farbe geben, mit ber bie Sopjbebectungen ber Briechent uns Iürten häufig gefärbt fund, gełören ber fierme

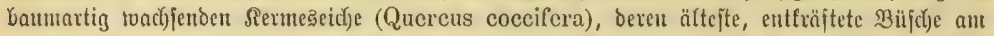

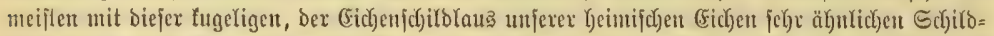

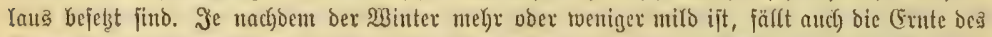

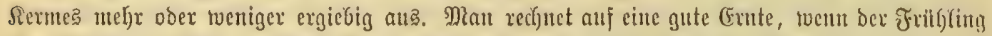

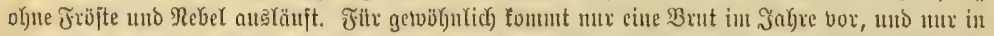

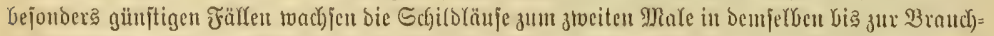

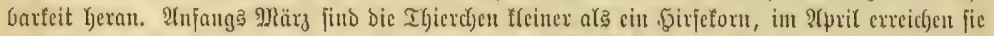

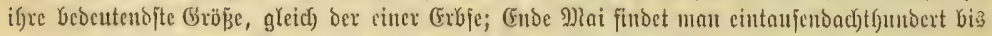

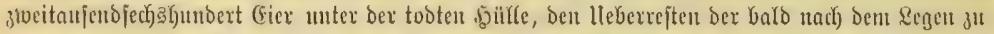

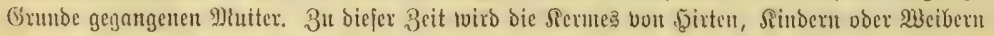

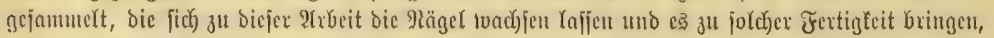

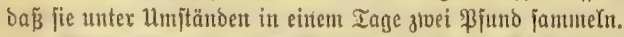

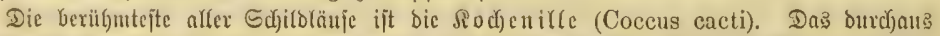

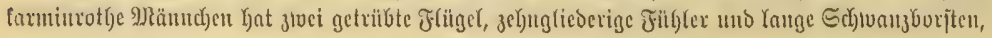




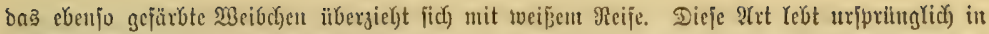

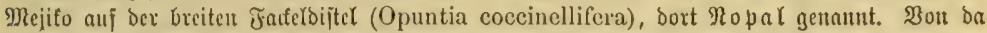

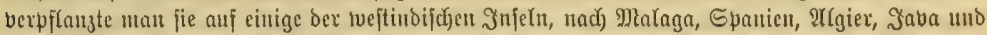

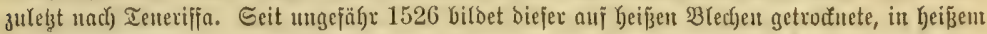

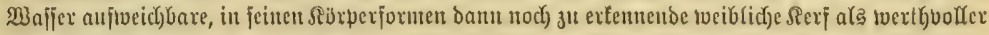

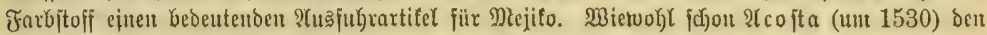

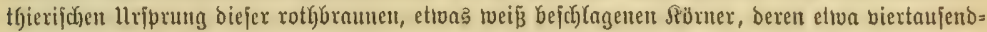
cinfumbert eine lluze tviegen, nadggetviejen und andere Forjdyer benfelben bejtätigt hatten, Glieb

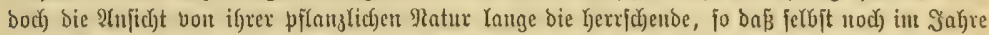

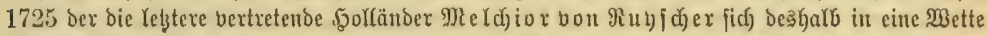

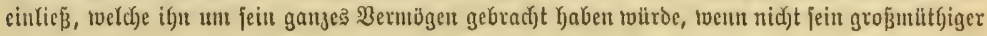
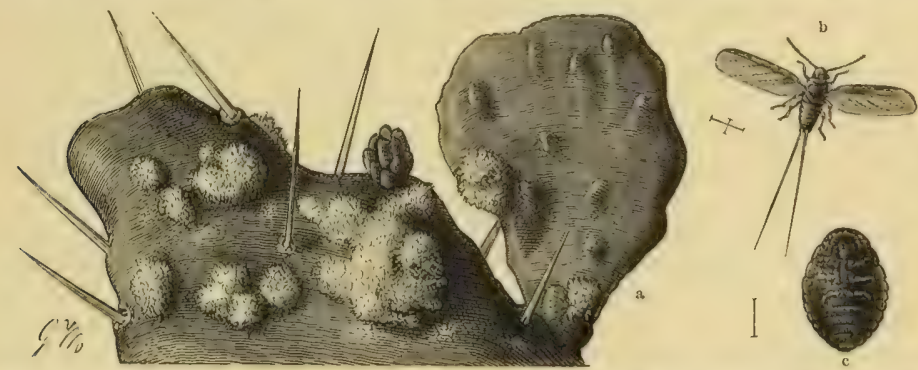

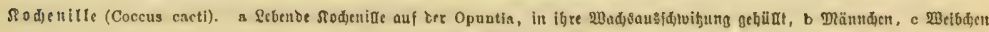
nob her \&audifeite; vergröbert.

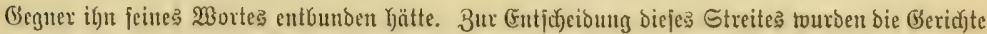

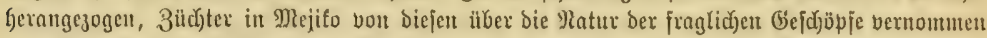

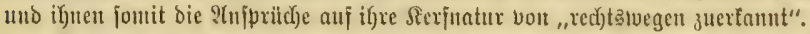

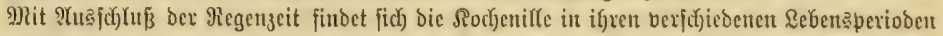

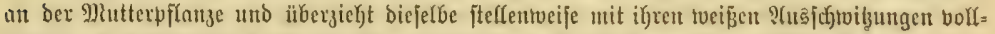

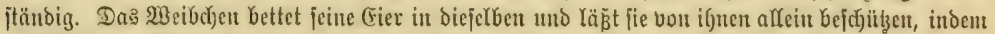

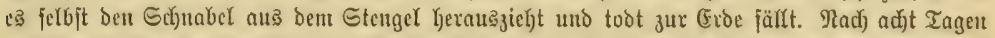

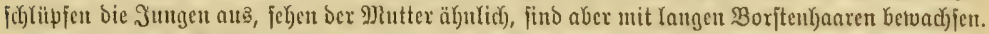

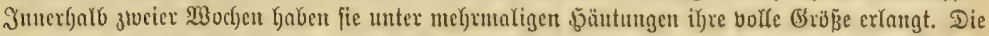

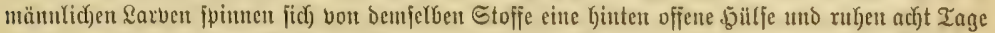

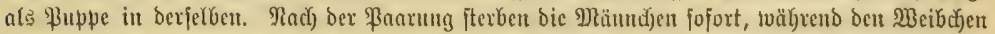

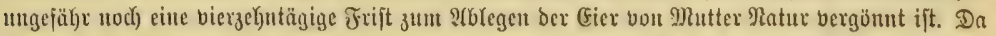

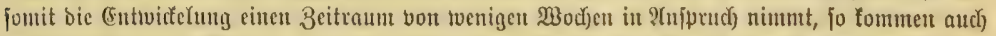

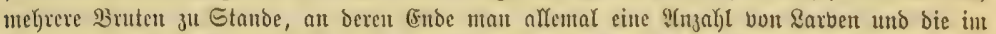

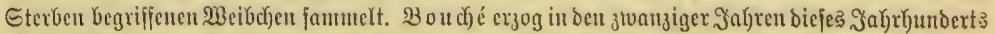

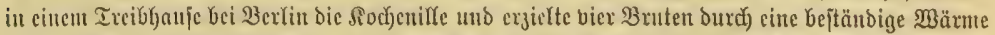

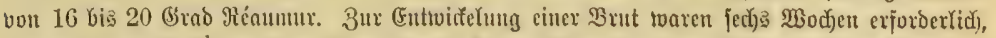

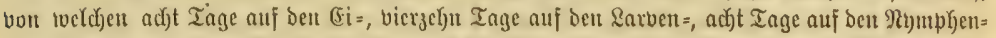

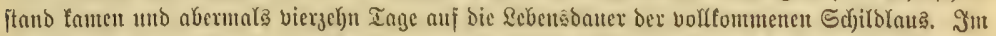

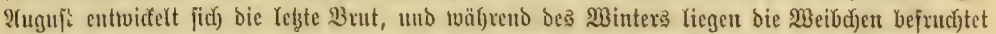

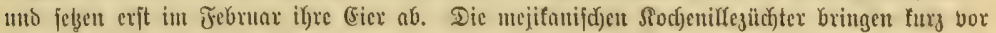

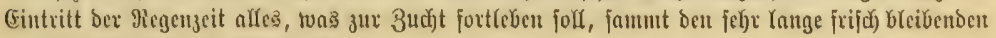




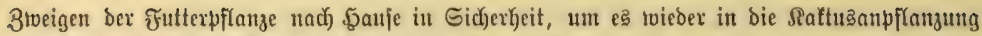

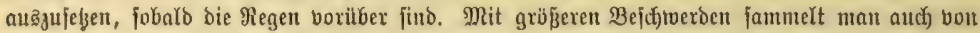

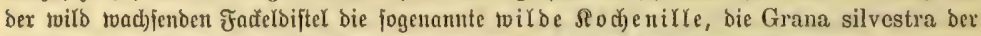

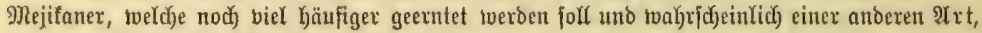
nidgt einer bloß̉en $\mathfrak{A} \mathfrak{b}$ art ber vorigen, ange jört.

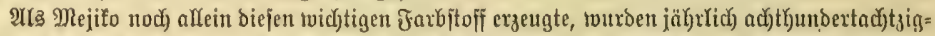

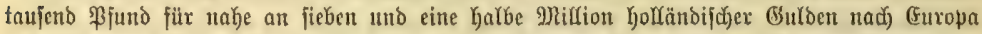

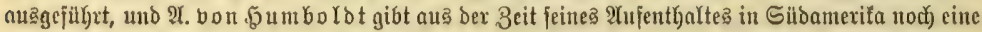

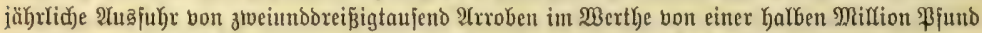

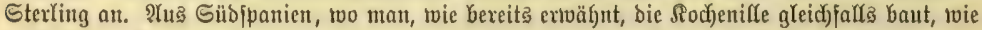

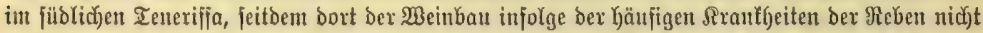

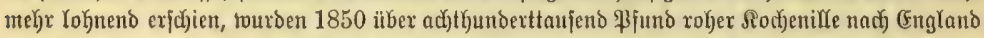

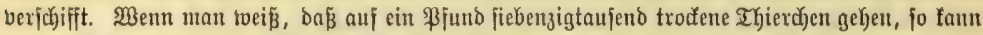

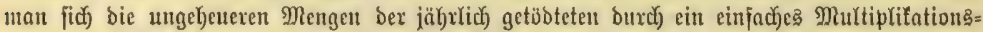

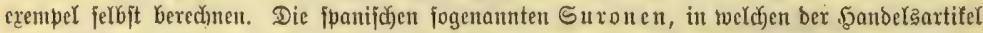

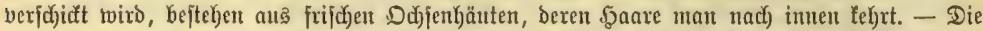

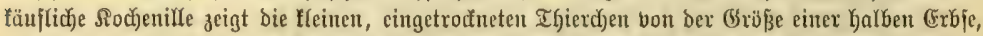

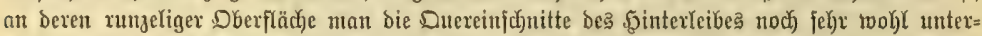

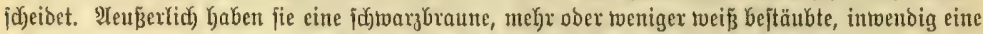
Duntel pupurrothe Färbung; auj bie 3unge wirfen fie bitterlich und etwas zujammenziehenठ,

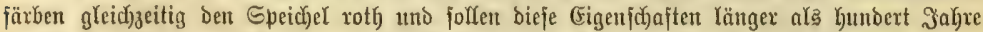

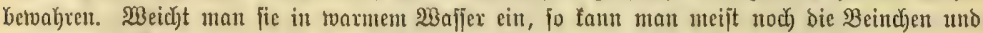

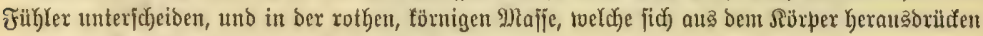

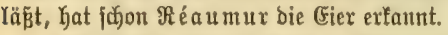

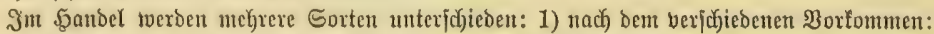

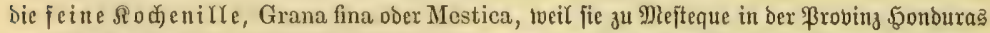
gezogen tviro, uno bie or binäre, Grana silvestra ober Capesiana, tweldeje aủ ctivas ffeineren

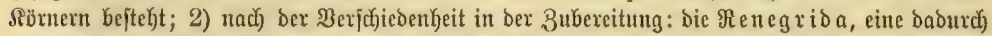

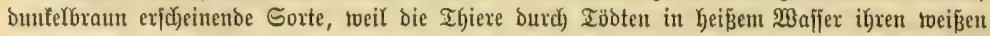

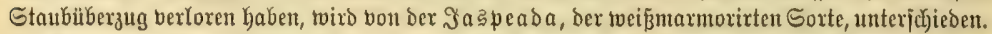

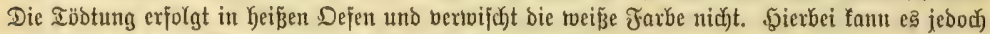

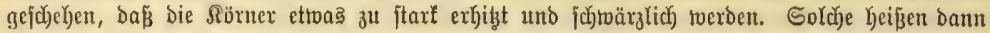

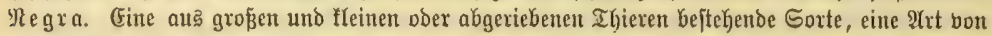

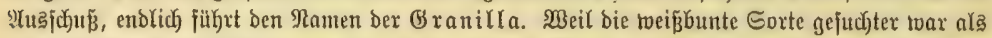

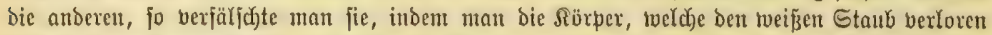
Gatten, viertmozmanzig bis achtunovierzig Stunden an einen feudgten Ort (in Den Reller) brad)te

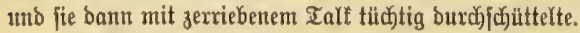

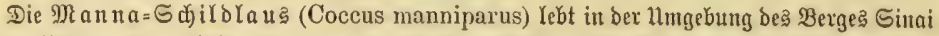

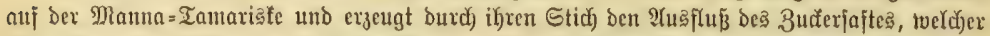

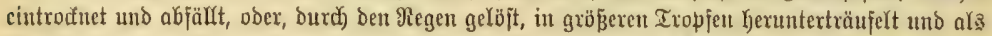

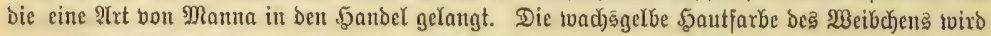

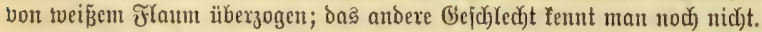

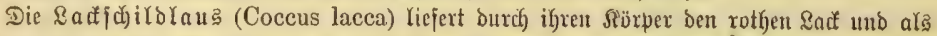

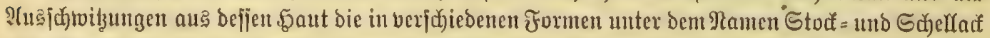

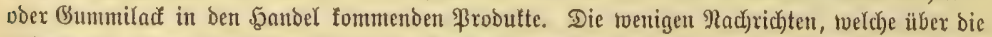

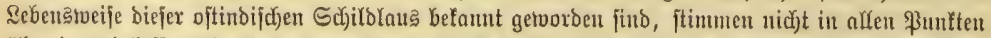

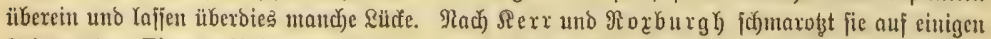
Feigenarten (Ficus religiosa und indica), auj ber \$lajo (Butea frondosa) und brei verjuchiedenen 


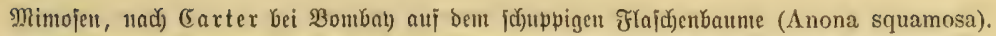

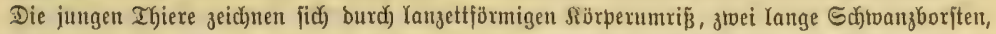

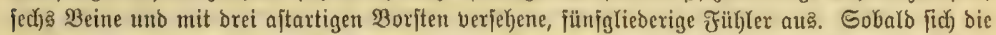
Weibd)en angejogen Kaben, fobroelfen fie an uno befommen unter Berłujt ber Fübe und Jüh)(er citte birn = ober faft fugelförmige (Sejtalt, in letsterem Falle jedod) am vorderen (Fnde eine bemertbare

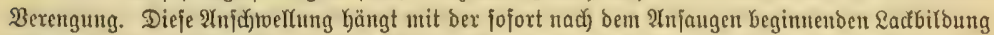

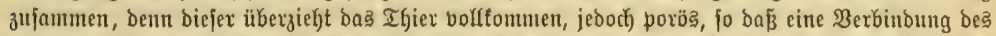

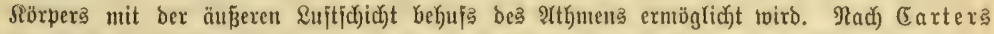

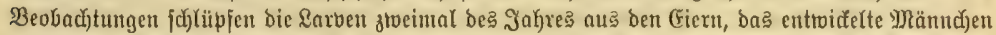

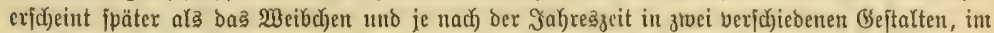

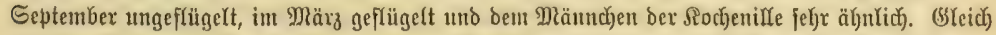

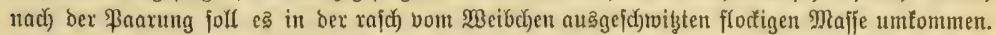

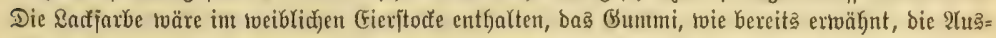

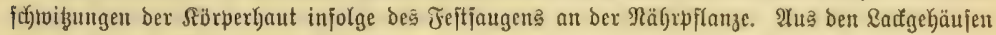

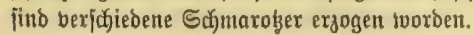

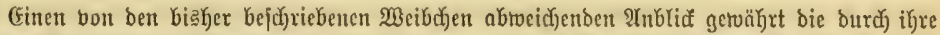

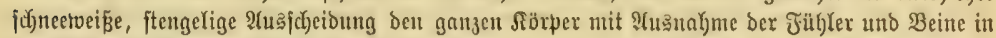

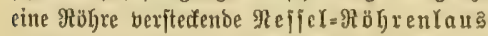
(Dorthesia urticac), weld)e fick nie jo fejt jaugt, Dä́ fie auj berfelben Stelfe fïzen bliebe. Der in bem manjobettenartig nack binten bejpibten Salädjilbe fibende siopf trägt adjtglieberige,

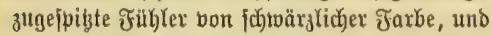

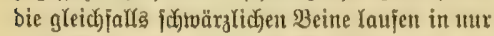

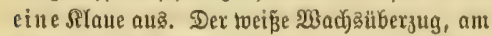
Baud)e eine \$latte bildono, biegt jicd hinten

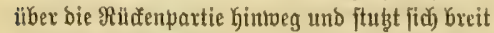

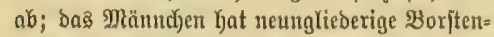
füh)(er, gef)äutjte uno barum förnig erjacheinende

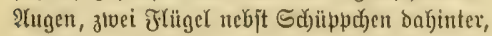
entiendet vom Endo bea obalen Sinterteibea einen.

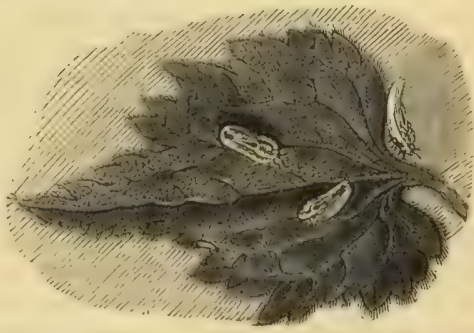

Reifel- Rõbrenlaus (Dorthesia urticae), Weibden. Ratïrlide Bröbe.

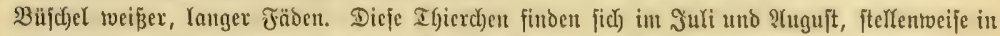
Deutjchlanto nidjt jelten, an ber großen \$rennmejpel.

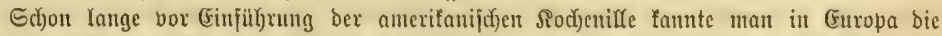

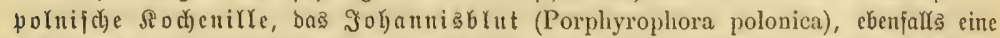

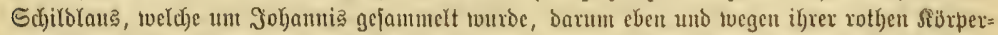

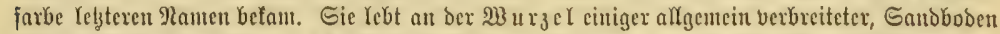

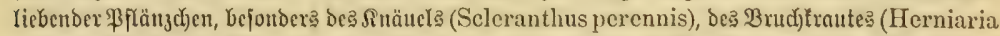

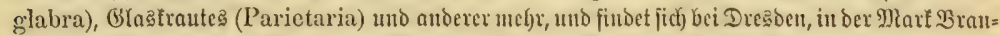

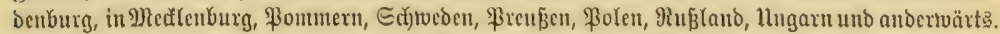

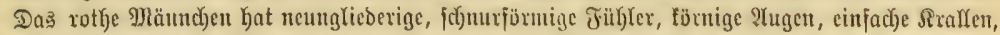

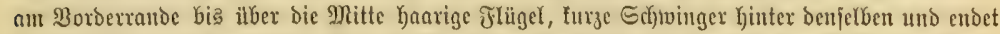

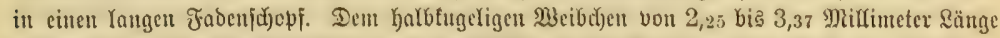

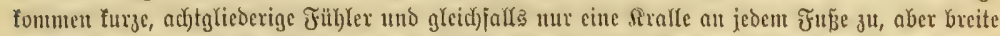

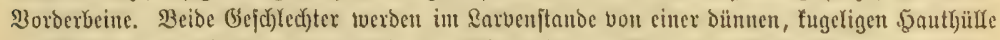

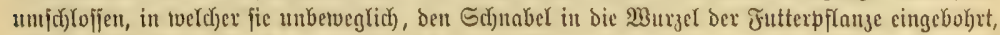

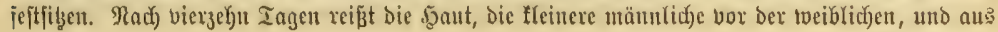




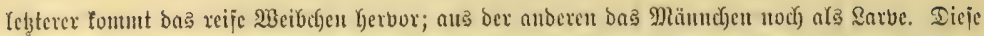

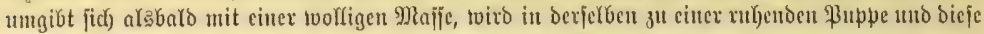

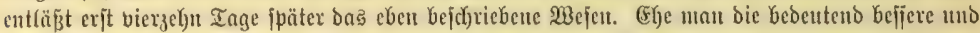

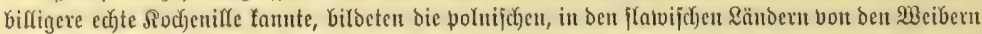

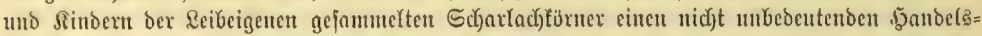

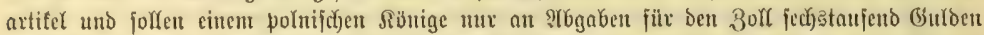

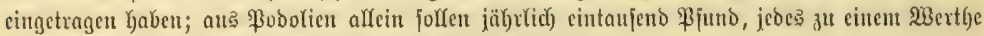

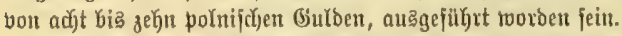

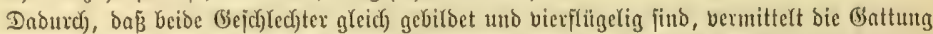

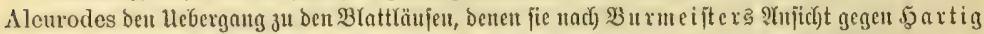

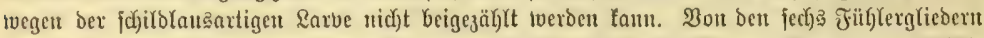

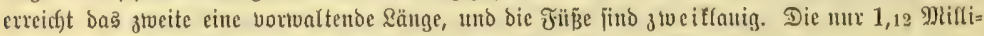

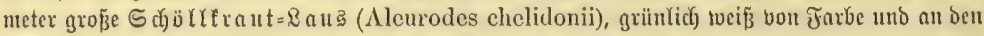

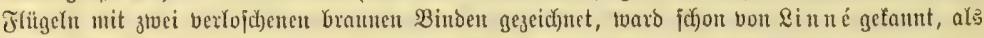

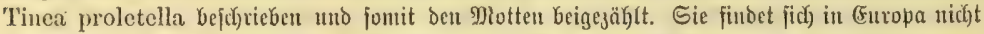

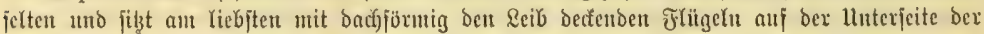

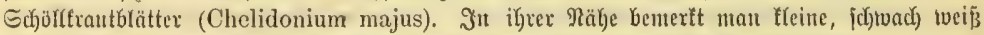

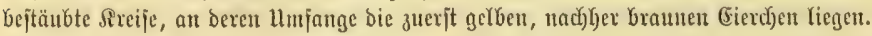

Einige twenige Ginttutgen, Die man mit Der folgenden Fantilie zu verbinden pflegt, müget

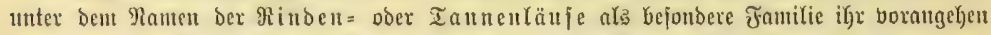

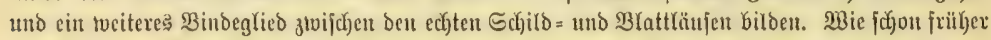

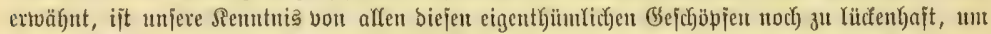

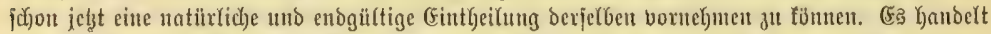

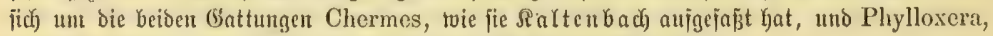

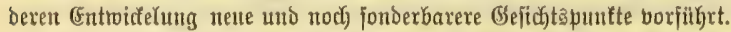

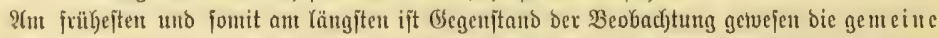

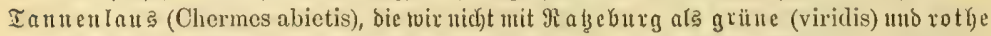

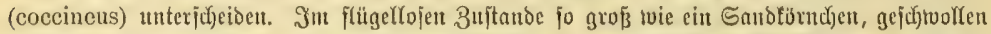

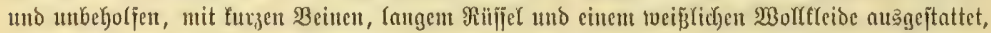

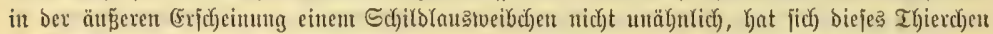

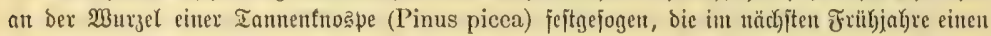

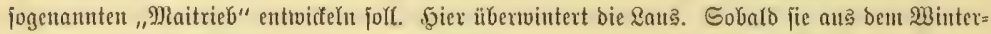

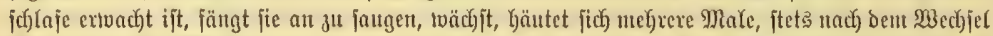

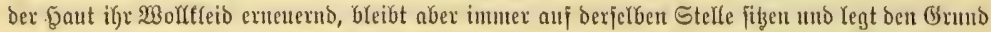

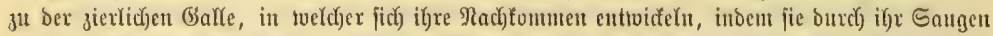

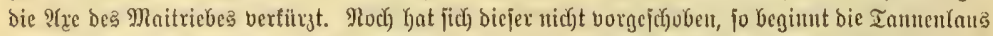

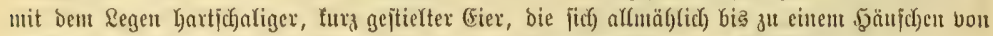

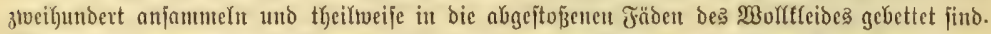

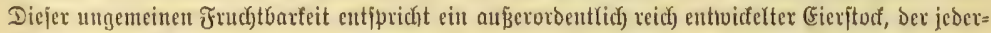

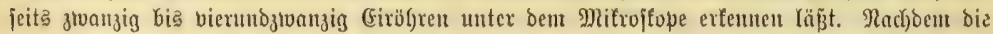

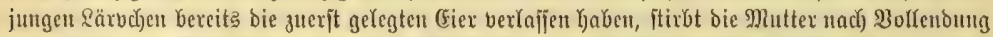

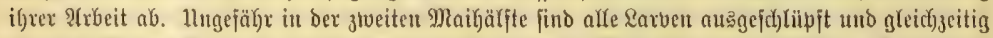

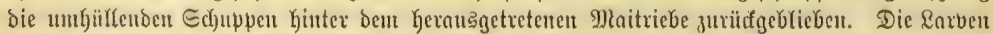

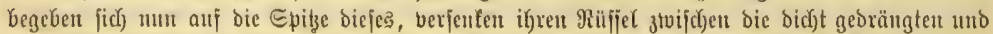

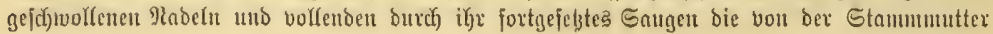




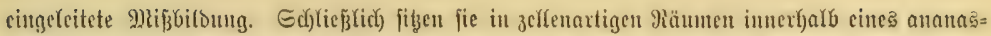

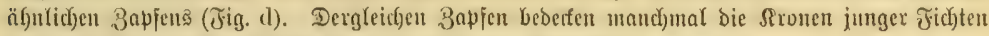
క̈ber uno ïber uno beeinträchtigen beren regelrect)te (Entrviđełung getwaltig.

Die it ben Balfen Yebenden \&arben (Jig. a) find fdylanfer als ilyre Etammuntter, betveglid)er

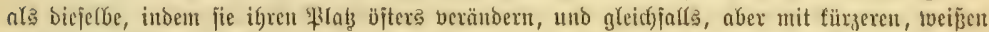

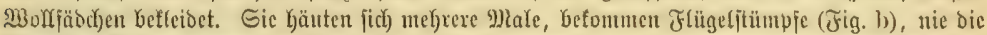
(G)

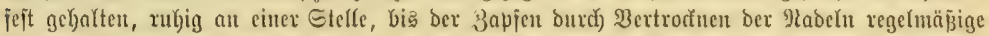

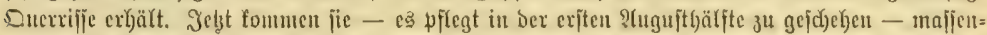

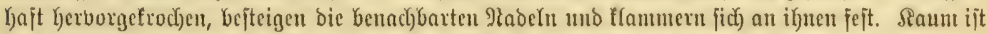

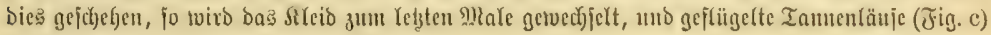
jiken gebräugt unber, zerjtreuen fich aber Gald, von ifrem Flugbermögen (bebraud) machent, in alle Minde. Skach twenigen Tagen fonn man eingelue in volftontmen untüricider Stelfung, aber - toot uno

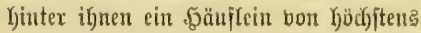
ztwanzig Giem antrefien, toełddye genau ben (Einbruaf toie bie von ben ïlferwinterten

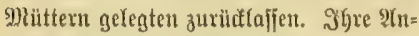
zah) ift eine wejentlid geringere, weil $\mathrm{e}$. atch bie ber Giröbren in Gieritode ift.

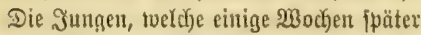

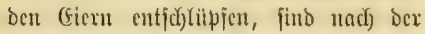
llebervintermag bie Etammunitter, mit Denen unjere Darfteffung begaum. Irokz Dex jorgfältigiten \$eunifungen hat $\mathfrak{e}$

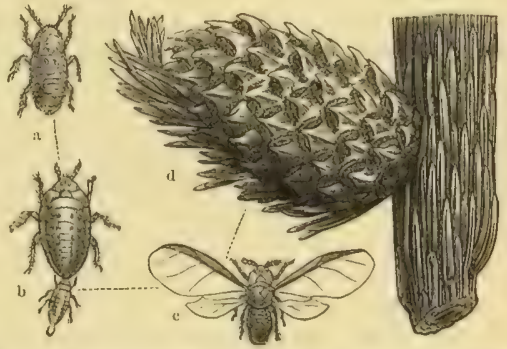

(1) cucine Tannculaus (Chermes abietis). a ?arve, b cben gerjättctc

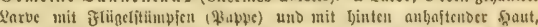

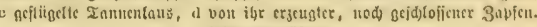
शues tergtiget'.

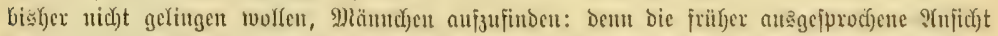

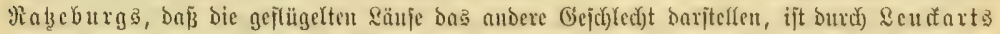

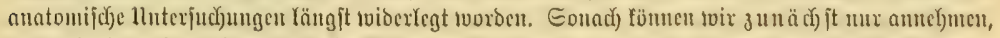

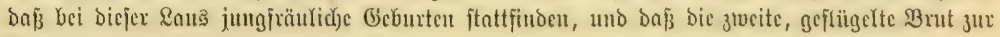

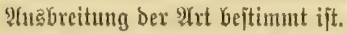

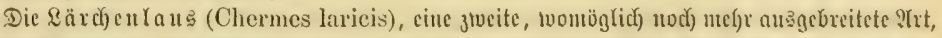

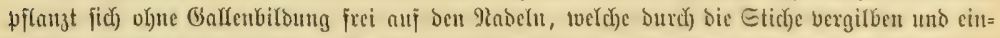

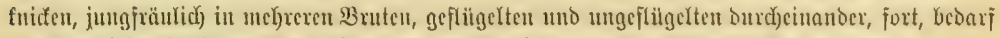

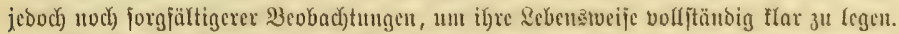

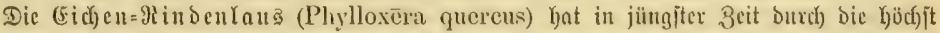

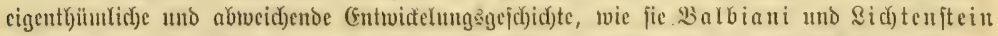

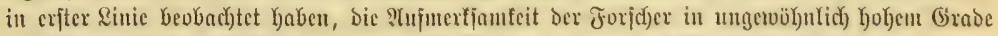

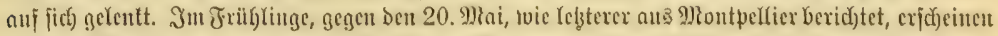

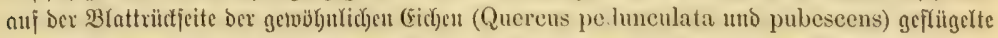

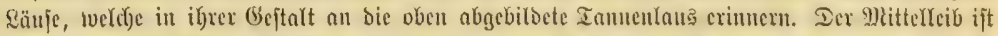

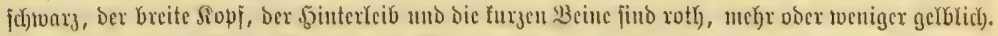

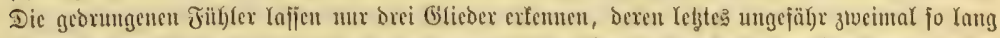

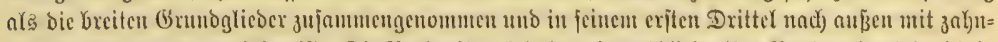

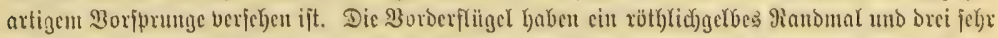

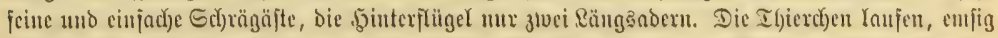

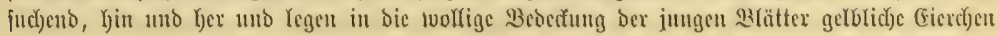




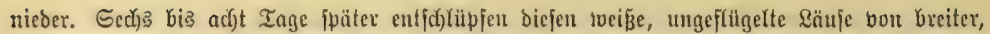

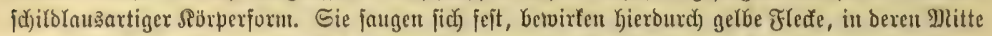

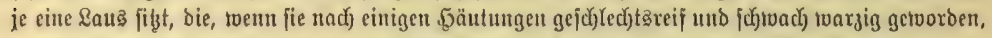

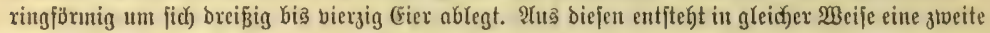

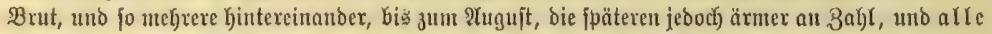

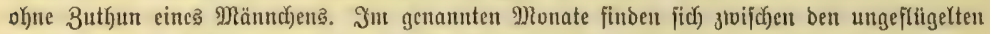

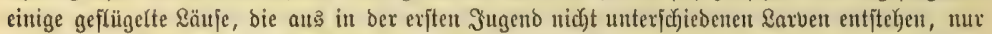

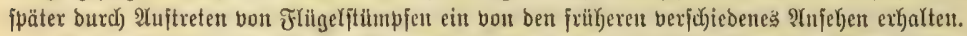

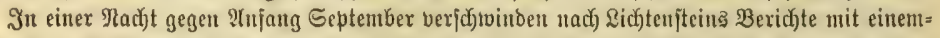

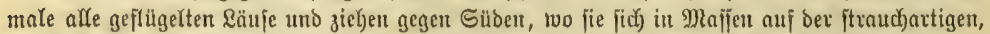

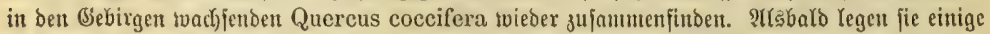

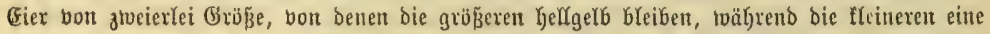

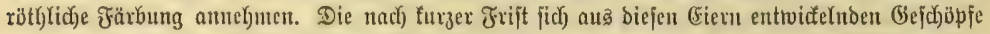

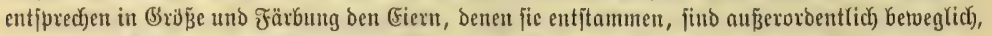

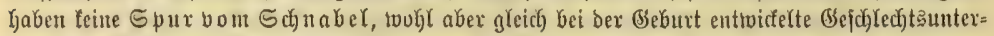

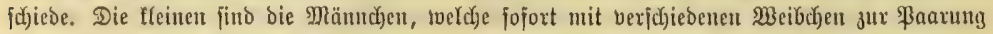

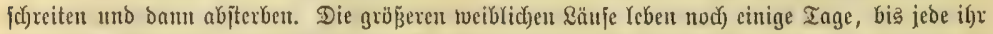

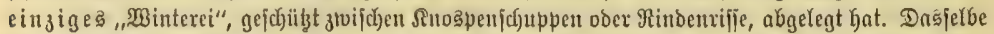

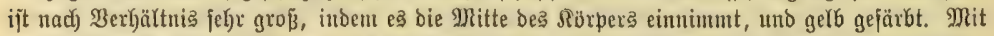

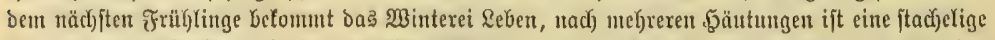
Menttertans borkanden, die in ben erjten Maitngen an ben Stengel ober bie MIattunterjeite ber

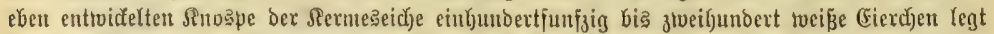

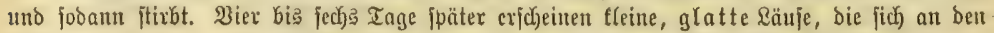

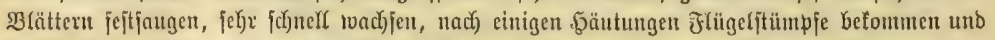

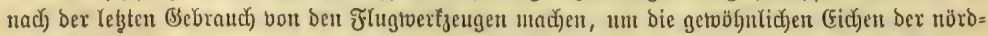

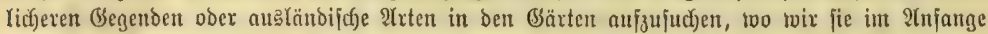

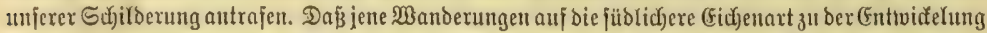

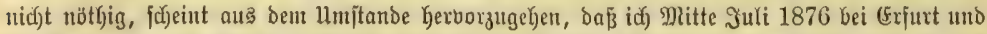

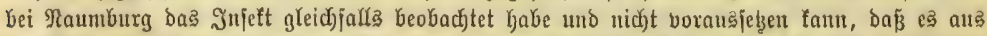

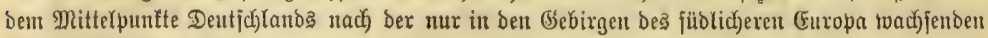
Sermesąeidje fliegen jollte.

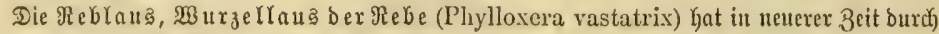

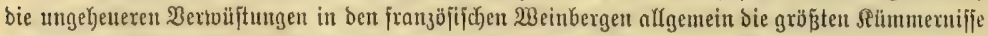

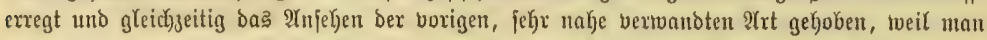

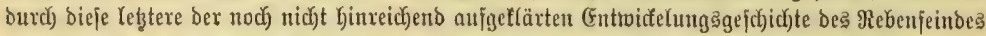
nuf bie Spux zu fommen Goffte, was in jüngiter 3eit rvirflid) gelungen ift. Sdjon länger in

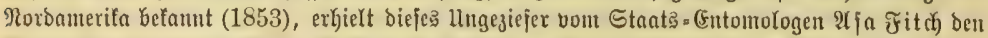

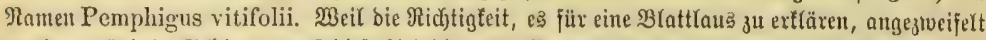

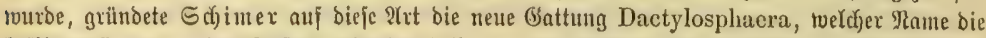

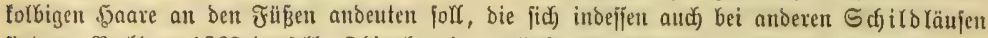

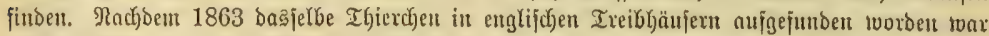

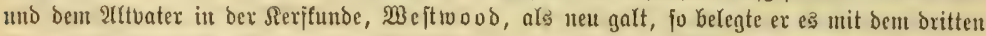

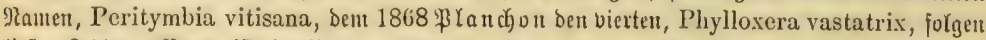

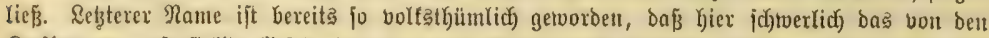

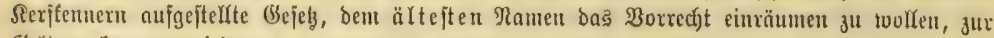
Geltung fommen toiro.

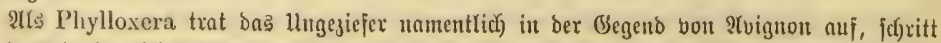

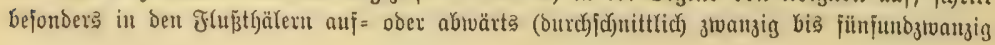




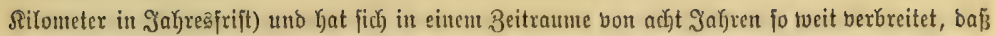

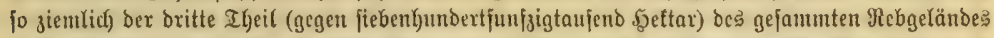

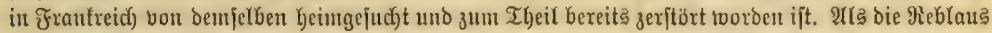

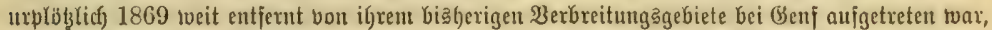

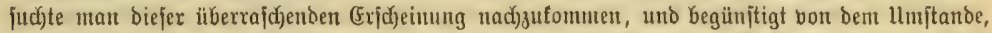

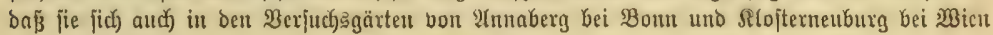

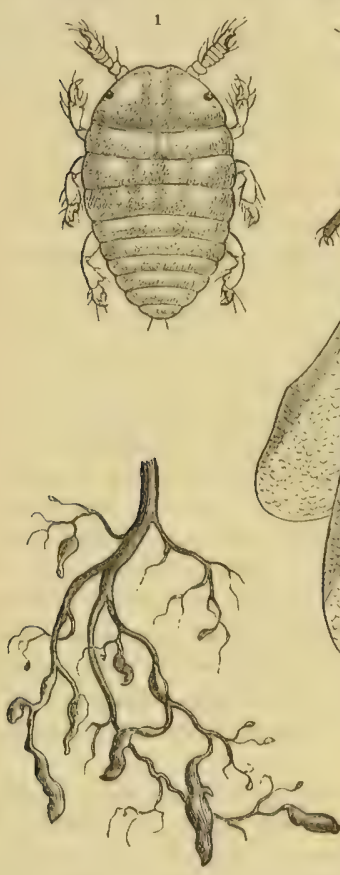

6

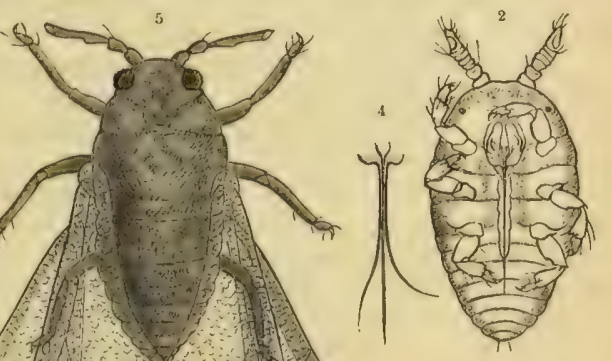

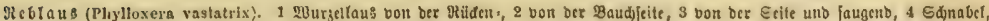

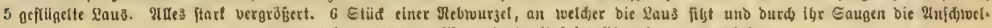
lungen exzeugt baf; 7 ätterer $2 B$ urgelffod mit bei 8 ubertwinternben Läujen.

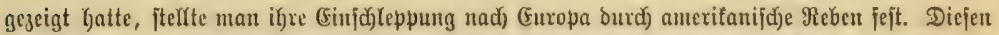

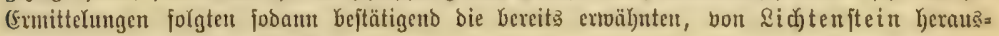
gefundenen über die Ramengebung.

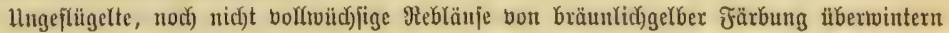

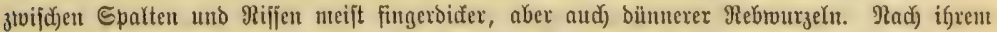

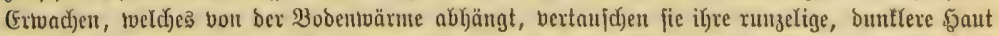

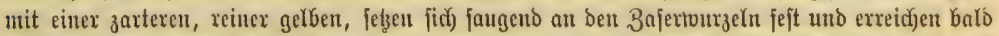

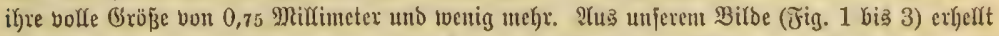

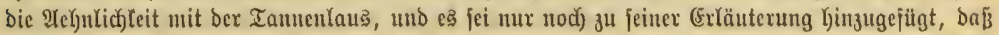

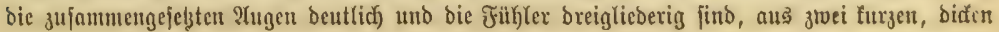




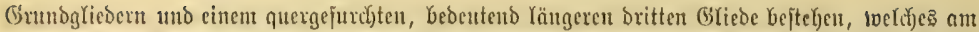

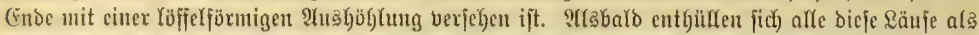

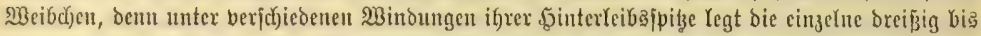

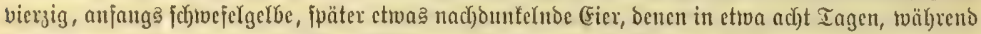

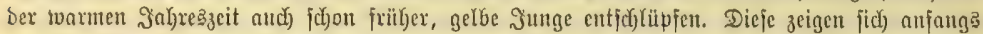

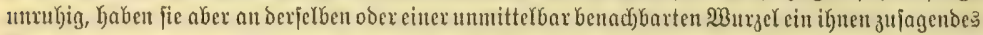

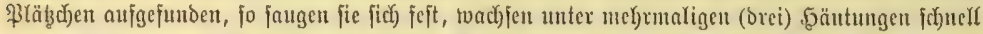

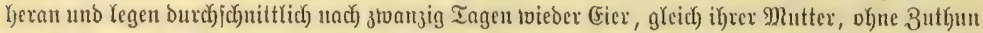

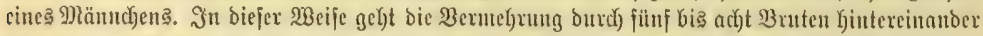

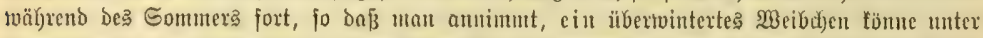

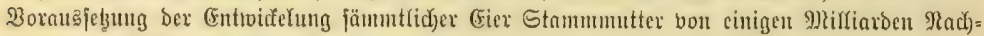
fommen in Raufe cinez Sommers twerhen.

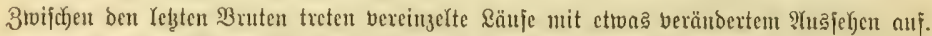

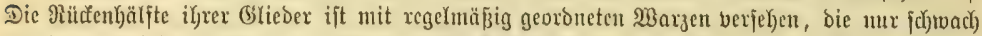

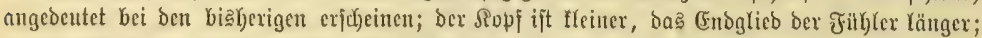

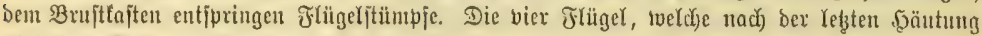

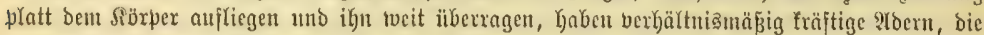

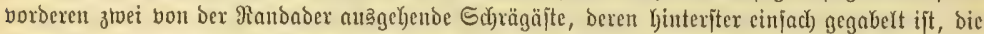

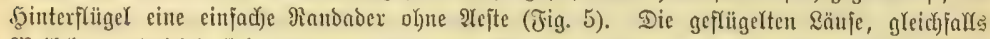

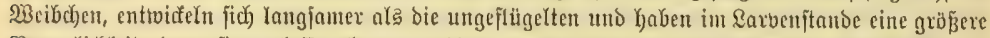

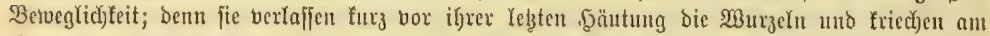

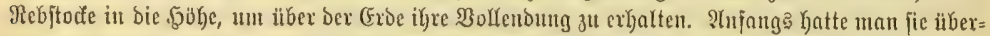

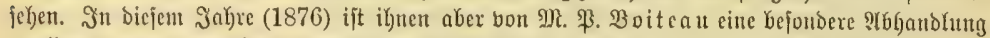

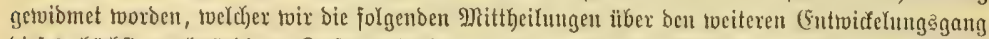

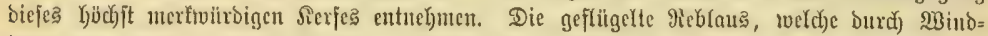

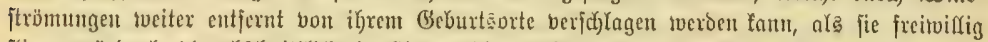

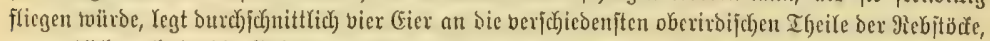

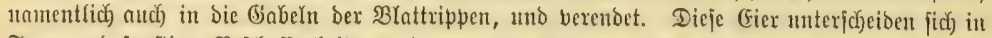

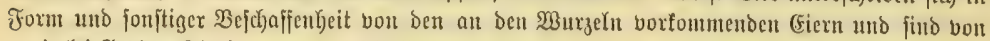

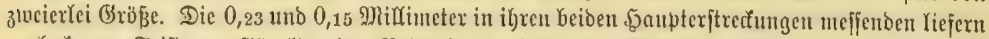

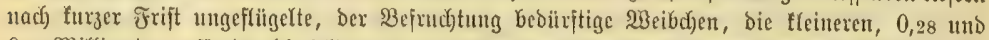

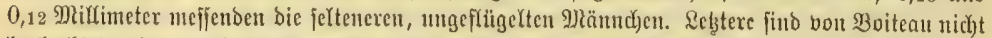

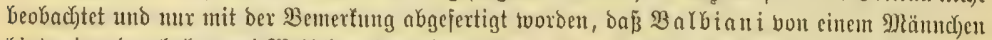

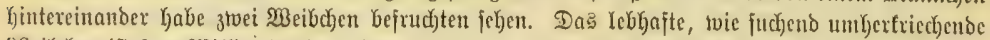

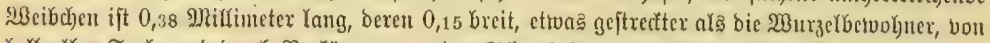

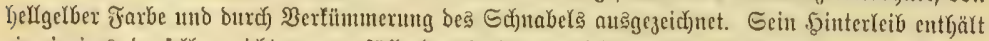

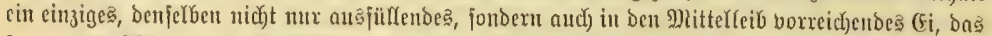
jogenannte Winterei. Daşfelbe twiro im Kinterften Theife berjenigen Gänge abgelegt, weldje au

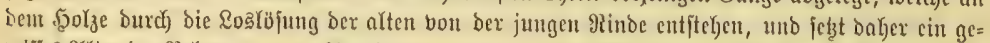

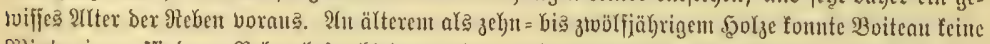

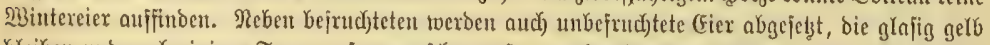

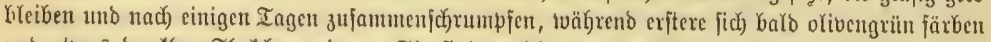

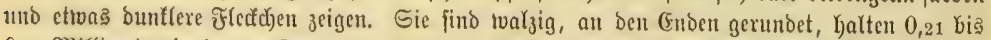
0,27 Miflimeter in ber grösten, 0,10 bis 0,13 Mrifimeter in ber fleimpten Erftreffung uno fino

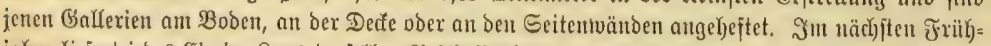

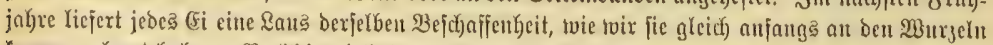

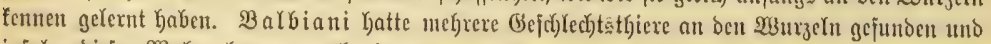

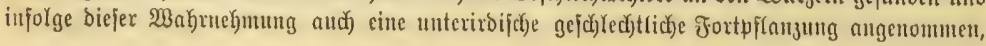




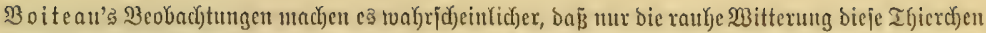

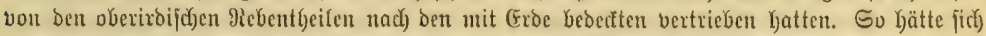

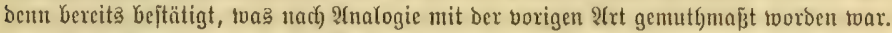

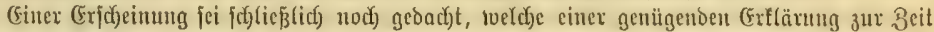

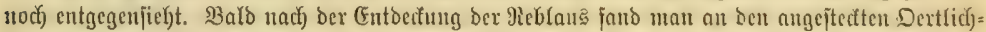

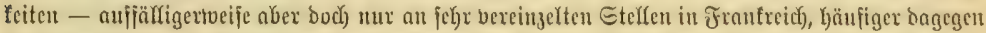

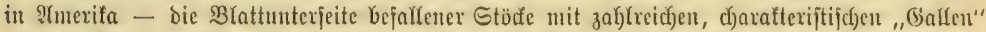

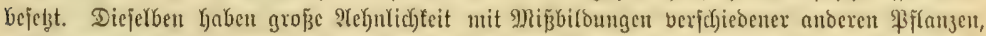

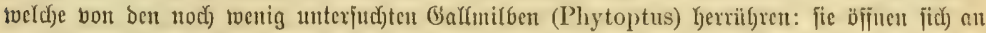

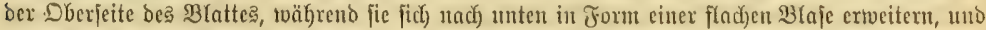

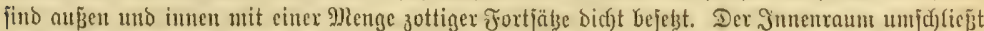

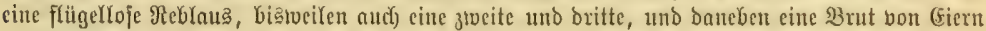

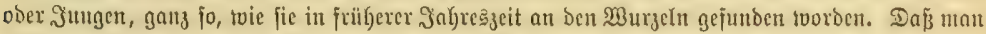

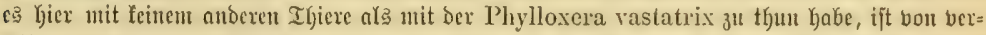

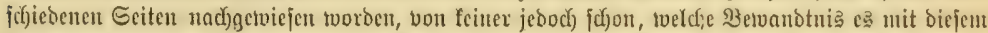

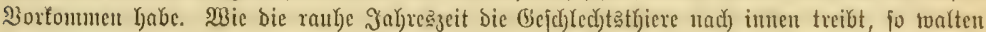

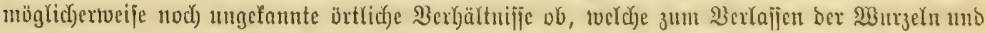
зun Injiedeไn auf Den \$rättern treiben.

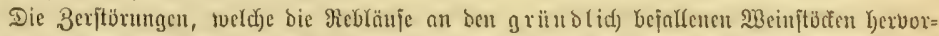

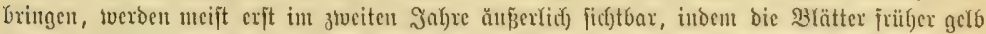

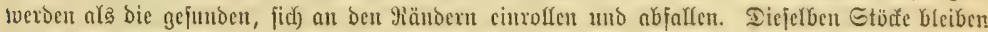

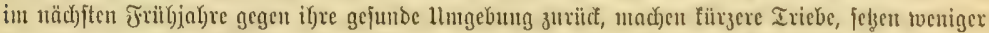

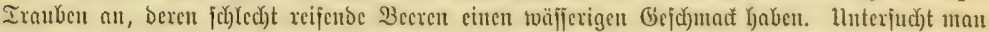

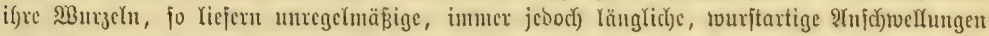

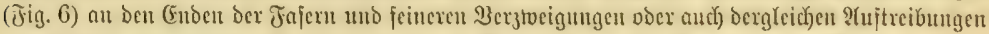

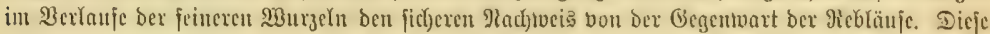

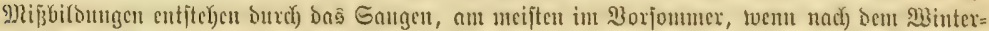

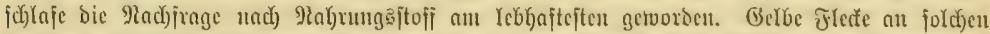

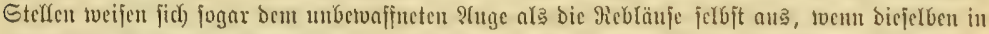

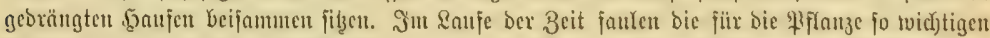

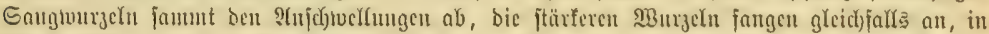

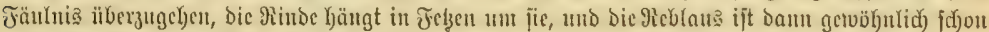

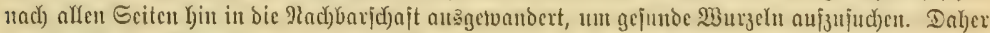

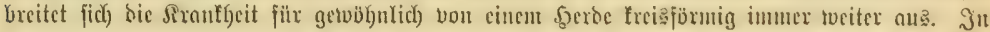
bem Bermögen vicler ancrifanif(c)

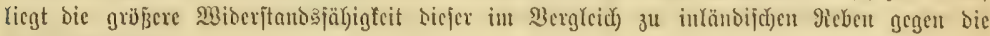
Ueblaugtrantheit.

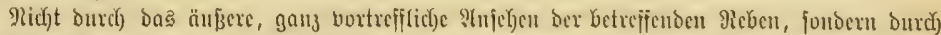

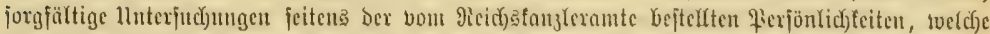

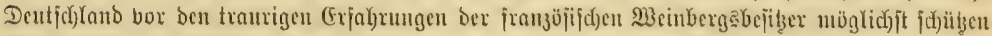

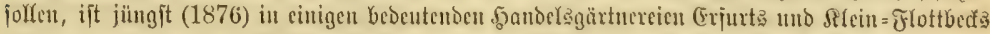

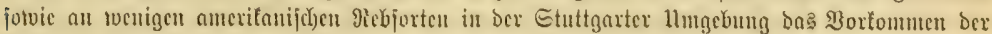

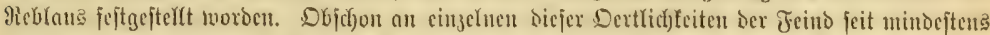

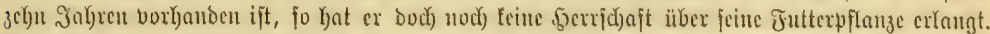

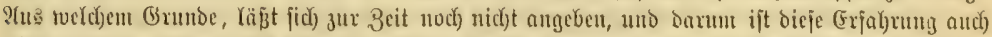

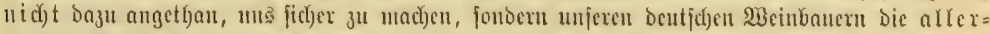

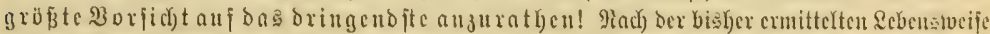

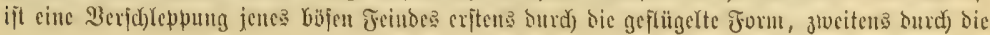




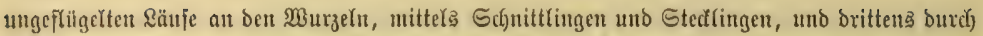

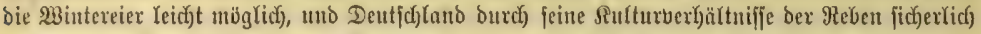

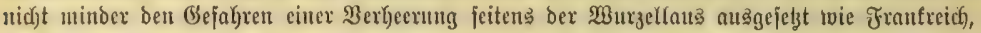

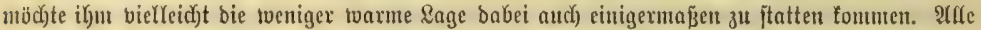

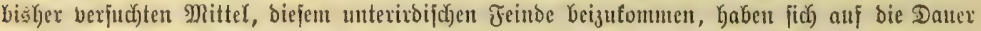

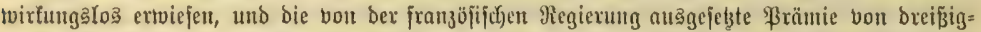

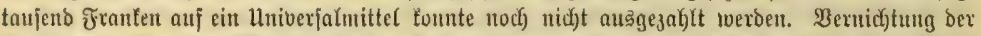

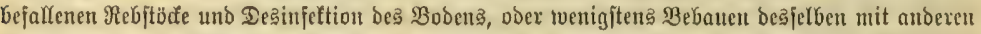

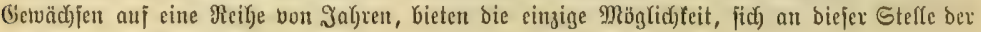

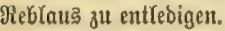

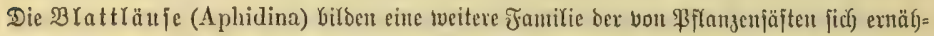

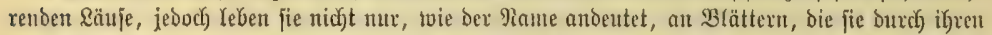
Stich) oft verunfalten, fondern ebenjo hänfig an Den Spitzen junger Iricbe, an Rno spen, an ber

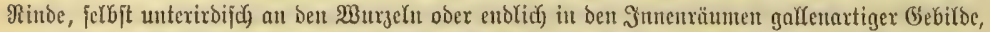

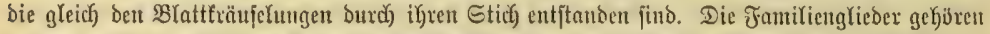

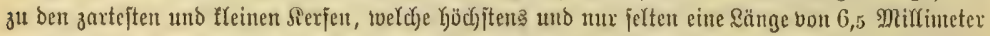

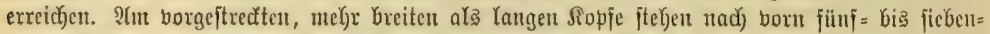

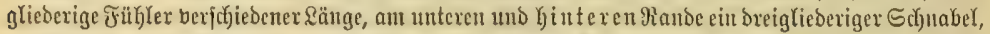

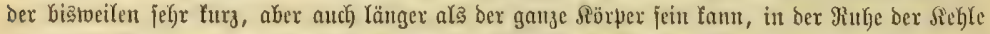

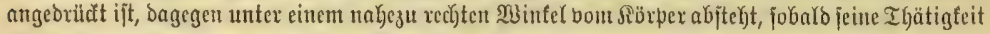

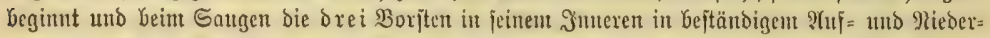
gange begriffen find. Seitlid) am Sopje quellen bie Netzangen ftarf herbor mo Yajjen in ben meijtent

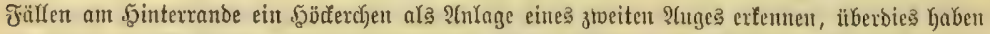

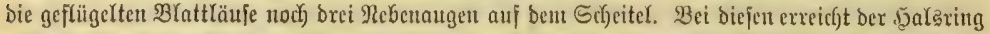

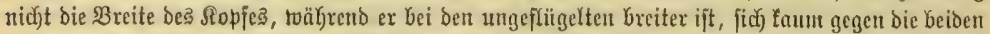

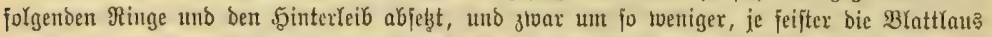

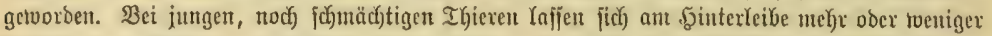

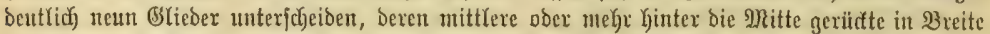

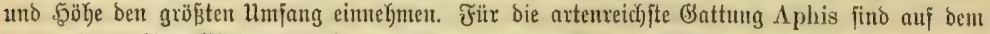

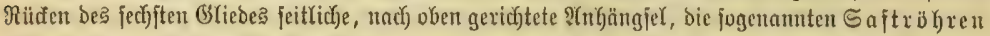

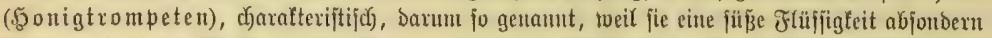

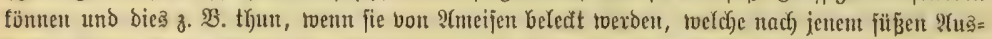

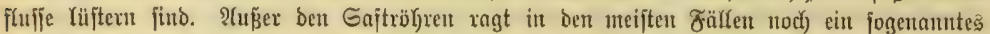

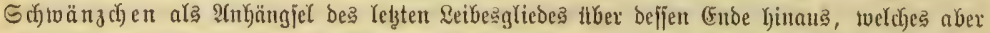

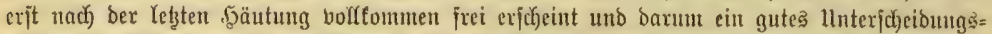

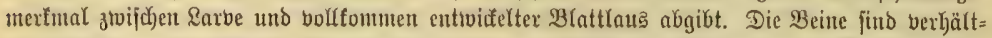

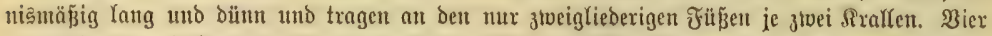

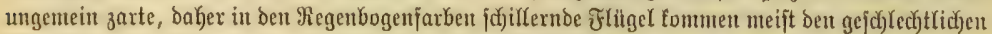

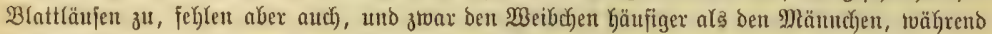

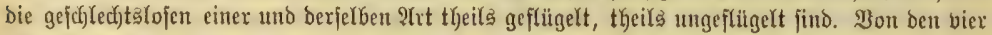

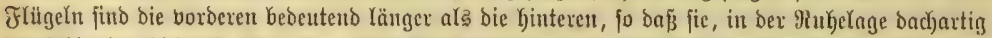

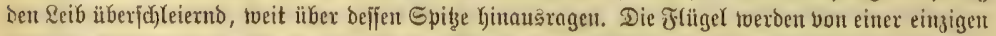

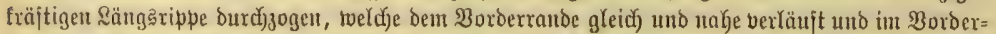

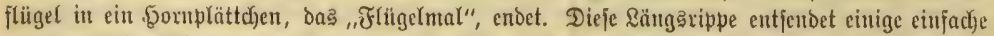

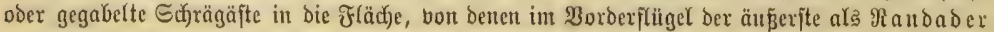

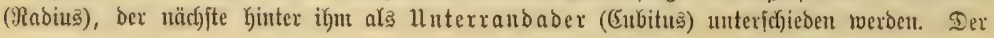




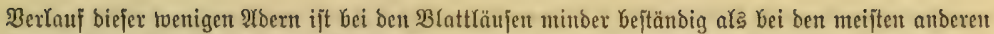

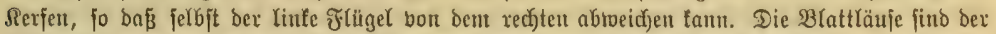

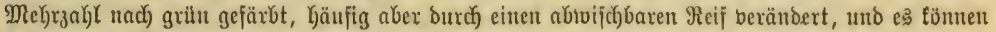

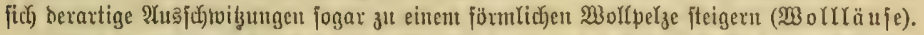

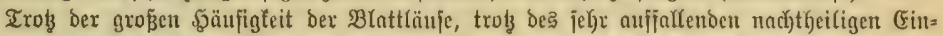

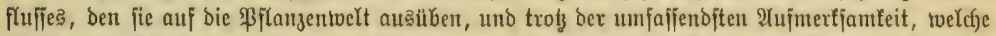

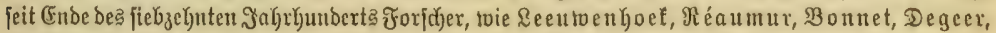

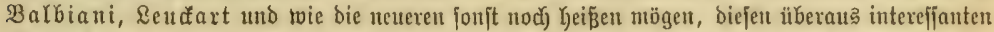

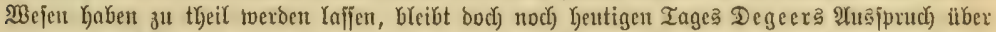
biejelben in Beltung, wenu er jagt: „Diejelben furb vollfonmen baju angetlyan, bą ganze vermeinte

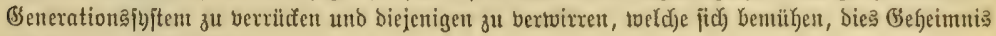

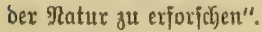

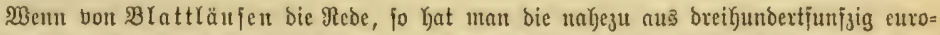

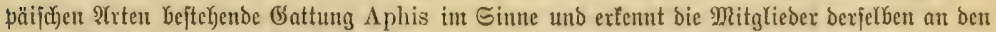

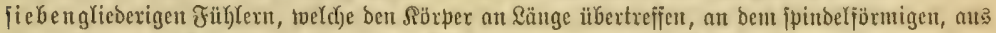
feiner Mitte bie Randader entjendenden Flügelmare, an ber breitheiligen llnterrambaber jorvie an ben Saftrühren und meijt einent Schwänzchen des .̧interleibes. Sic fizzen an ben Iriebjpiz̨en,

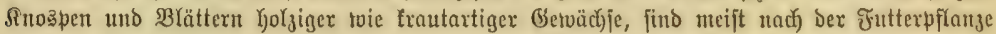

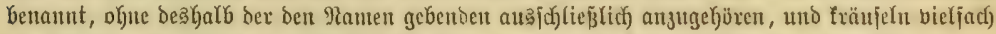

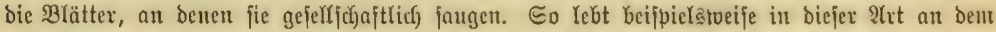

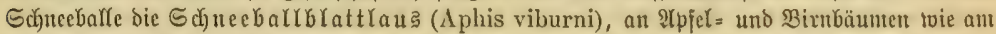

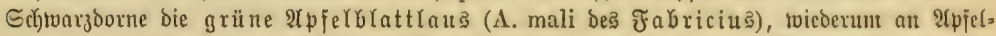

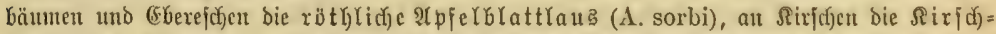

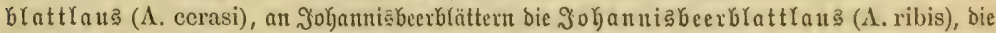

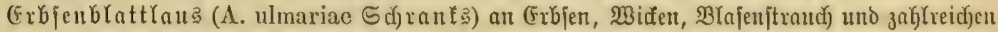

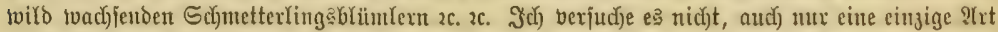

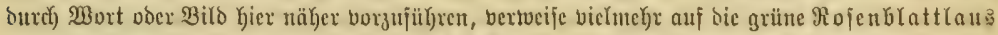

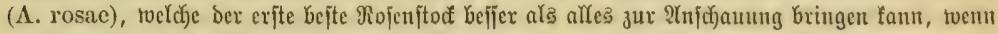

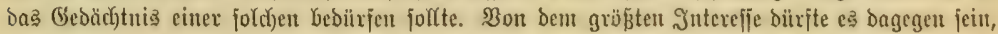

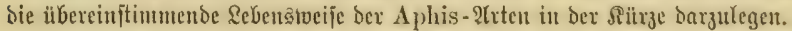

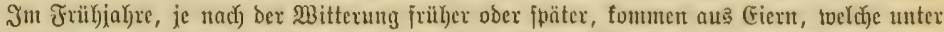

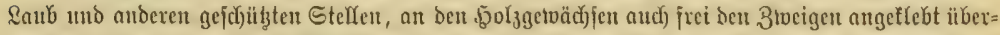

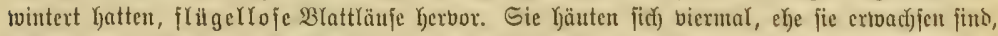

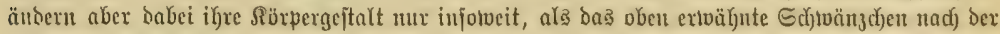

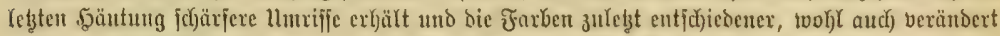

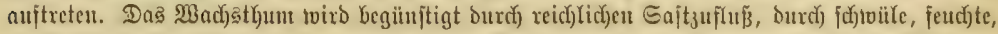

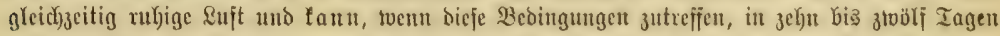

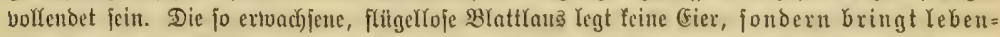

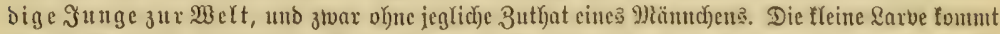

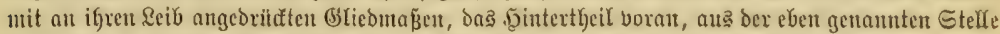
ifrer Mutter hervor; aber nod) ift ber Ropf nicht frei, fo ftreft fie Yebrajt bie 23einchen von fich),

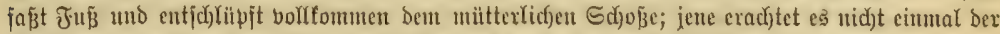

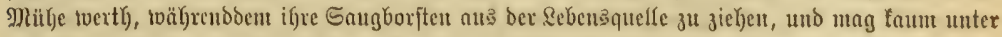

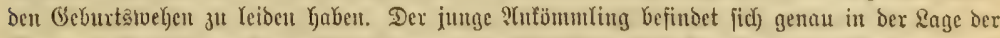

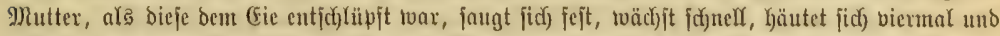

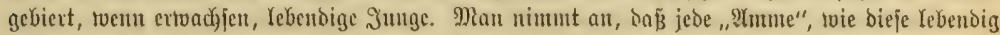

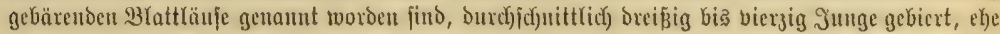
fie jtirbt. Fehlen zeitweilig dic oben näher bezeichneten \&ebenzbebingungen, fo berjögerut fich 


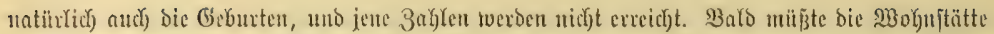

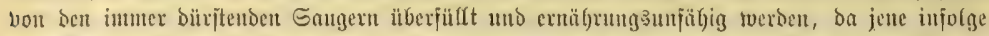

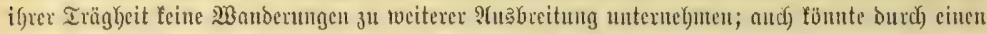

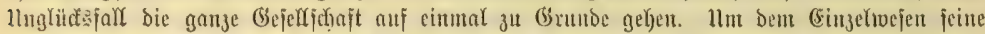

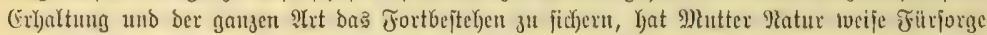

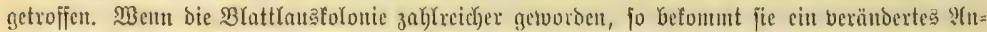

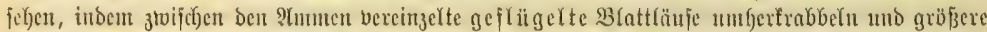

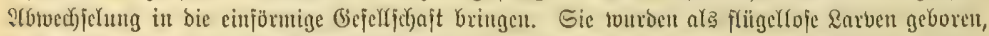
Gefamen mit ber 3eit bie Flnglwertzenge, bie ihnen anfang in Form fuzzer Stäbrhen an ben

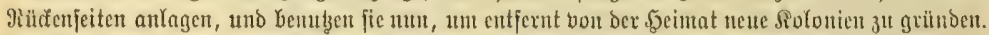

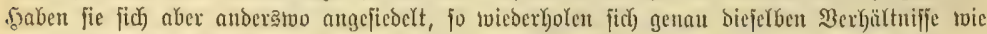

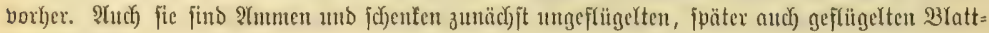
läujen bą \&eben.

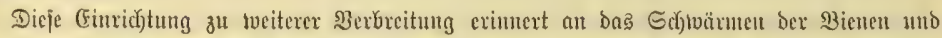

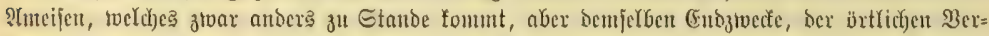

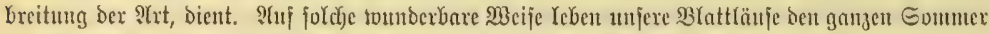

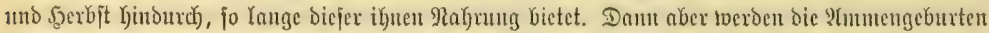

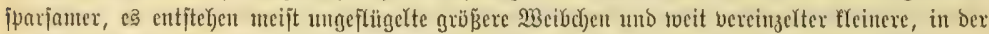

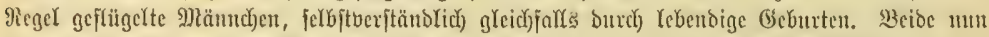

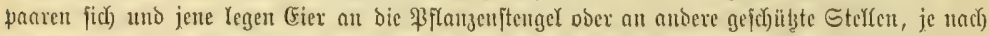

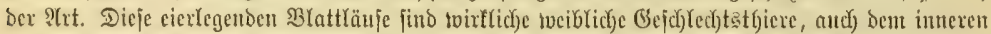

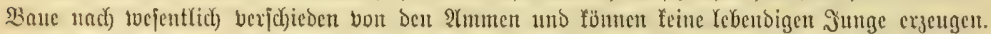

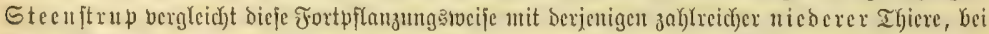

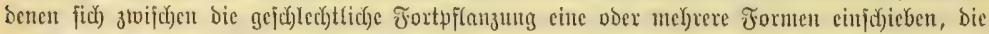

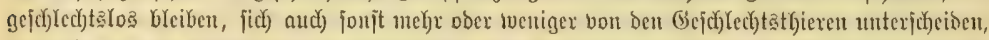

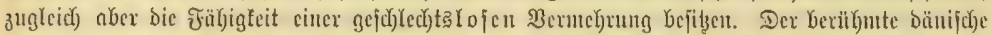

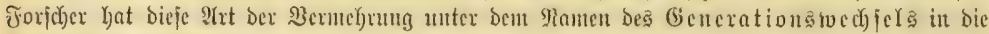

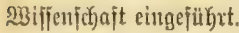

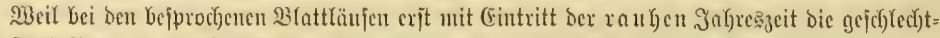
Yich) Forfpflanzung butch (Eicrlegen ftattfintoct und nach) fo und fo viel vorangegangenen unge=

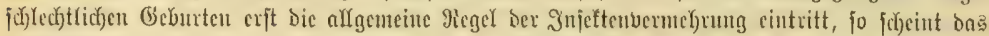

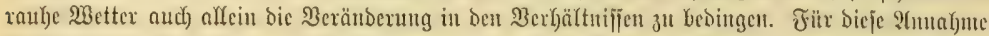

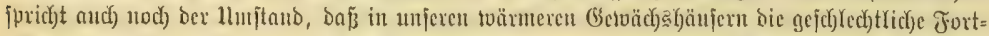

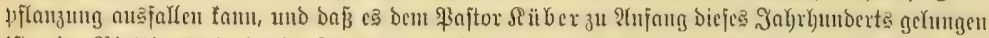

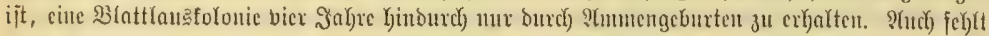

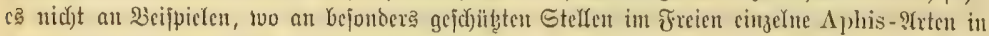
cinem andoren als beu (Eiftande bibertointert Yjaben.

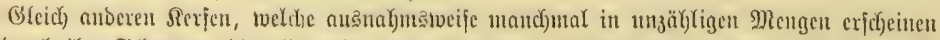

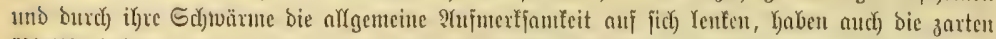

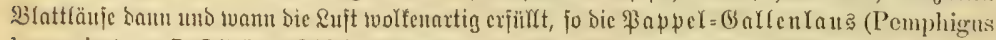

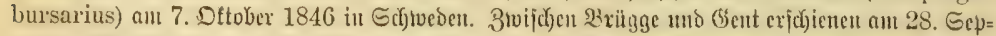

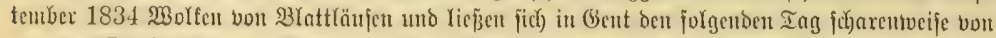

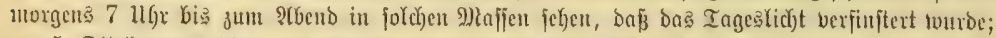

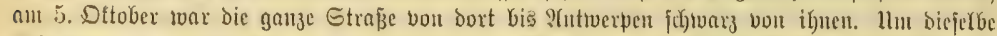

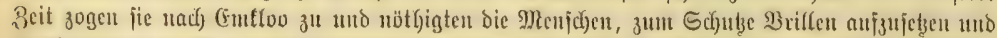

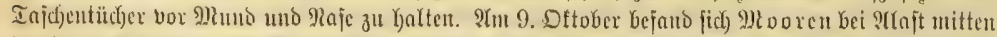

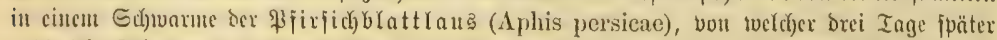

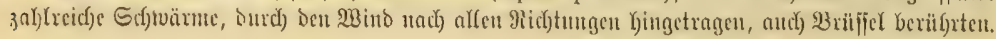




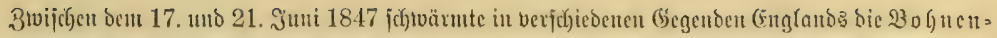

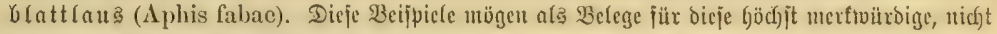
Joeiter zu ertfärende (Exjud)einung biencn.

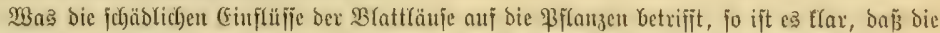

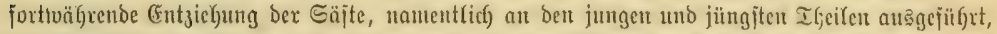

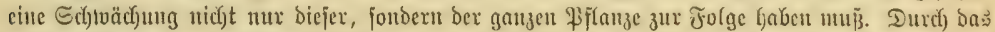

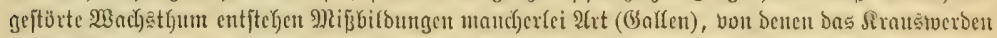

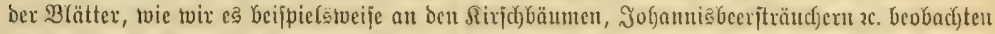

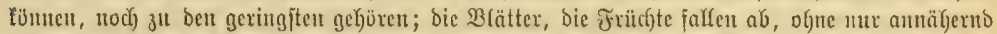

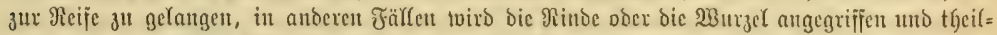

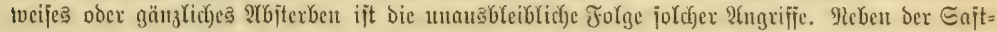

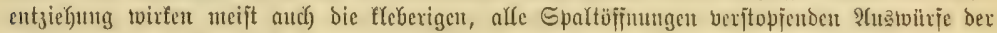

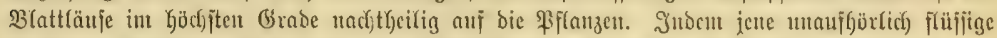

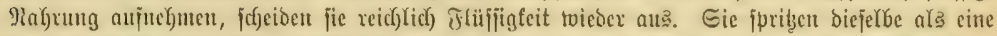

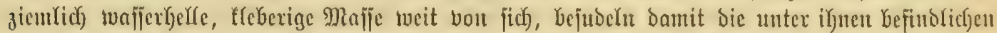

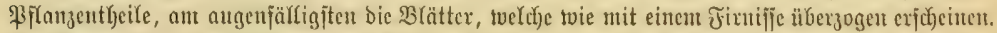

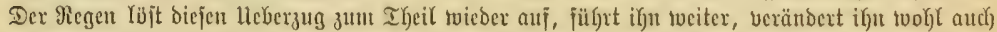

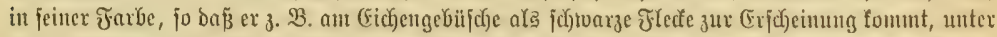

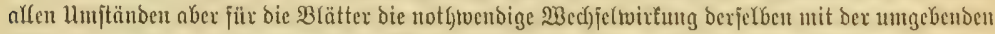

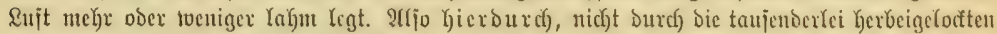

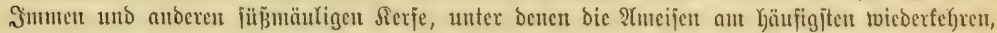

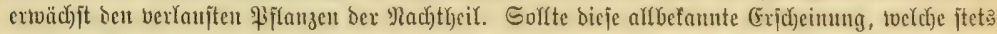

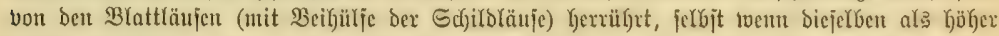

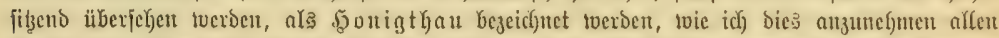
(6)

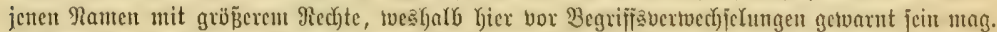

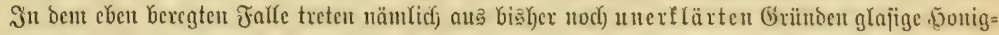

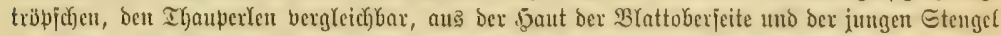

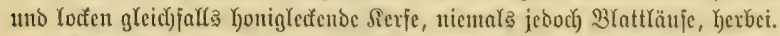

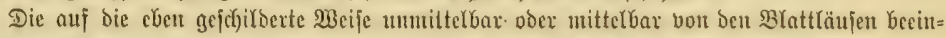

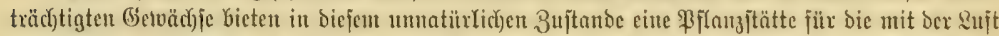

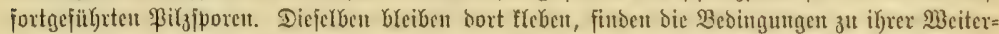

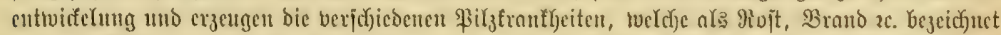

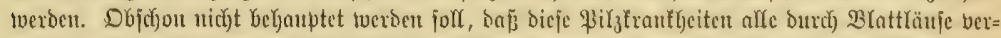

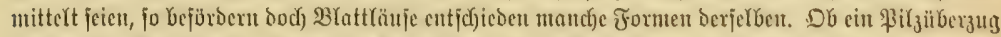

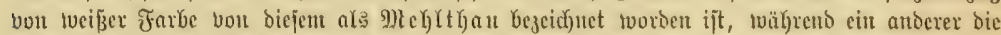

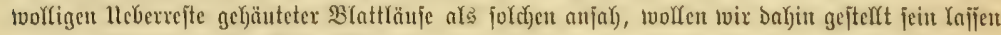
uno aud) bei biejem Begrific vor Bextvirumg toarten.

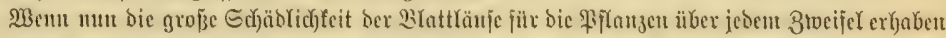

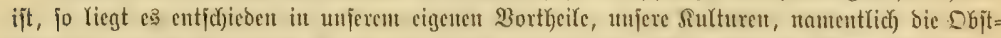

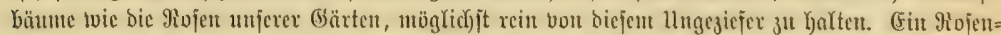

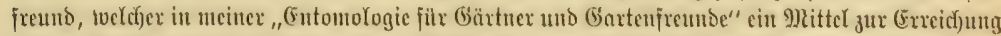

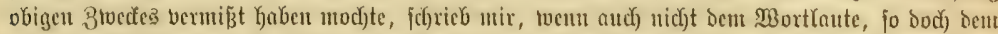

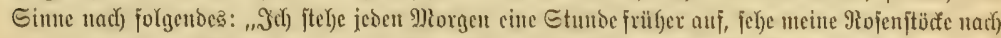

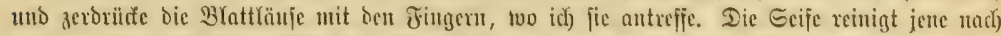

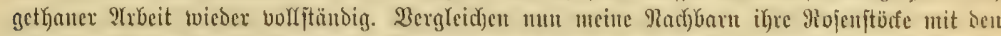

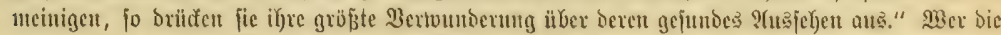

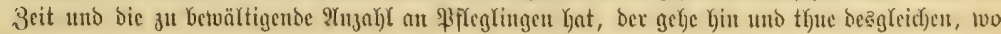




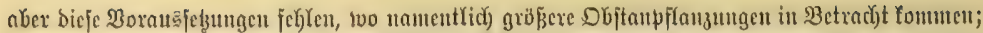

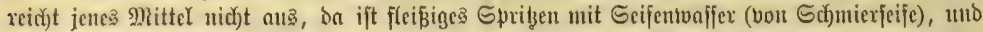

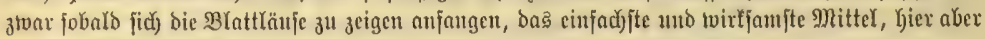
nicjt der Drt, Dem (Begențtande näher zu treten.

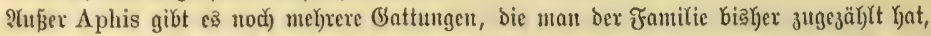

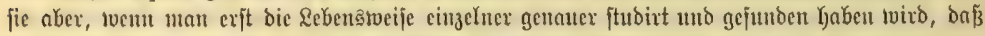

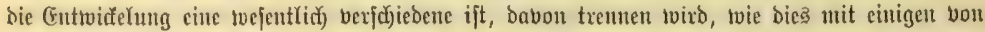

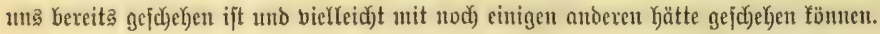

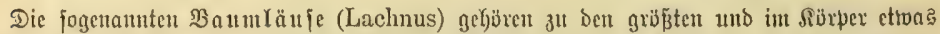

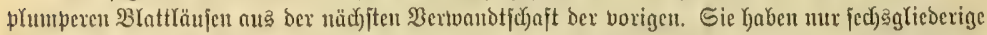

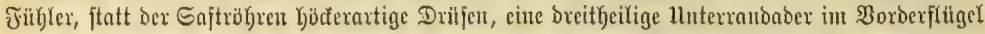

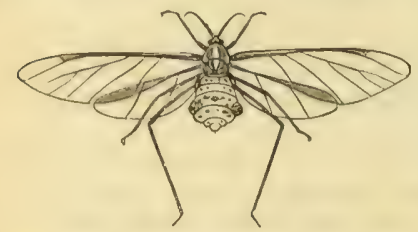

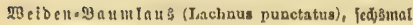
veţröbet.

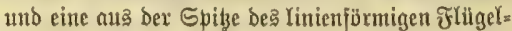
małes austretende Randober. Bon ben adjtzehn

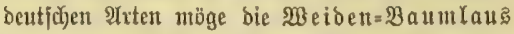
(Lachnus punctatus) bie ganze Battung bergegen= toärtigen. Diejelbe ift ajd)grau gejärbt, an ben

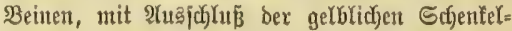
twurgeln, braun; iber Den Sinterleib Yaufen eime Reike jodtwarzer, fammetartiger \$utte. Dieje \&au

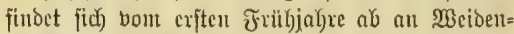

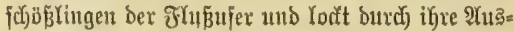

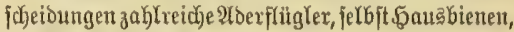

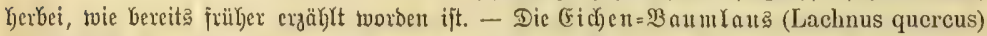

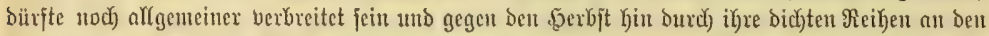

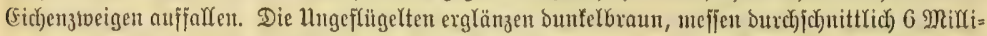

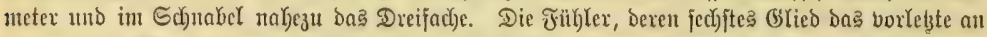
Qänge übertrifft, Kefinden fich) in fortwuähreno tajtenden Bervegungen. Die um 1,12 Mrifrimetex

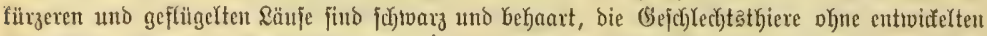

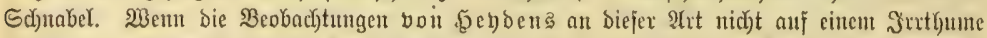

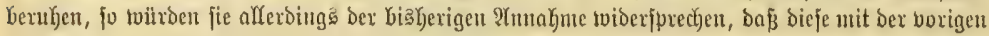

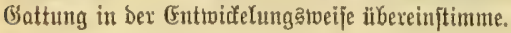

Die (Sattung Schizoneura, Durd) fect)

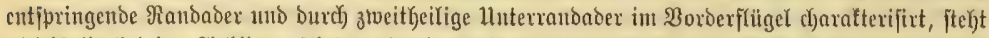

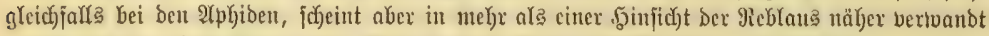

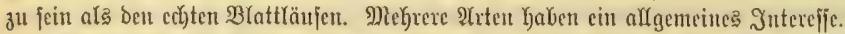

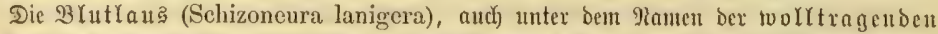

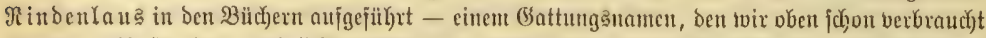

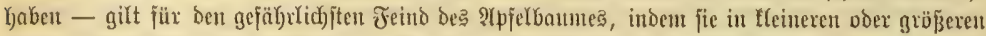

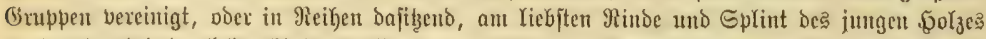

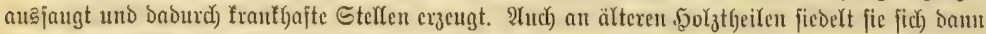

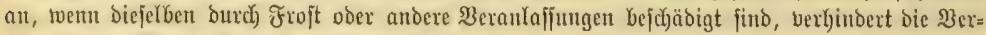

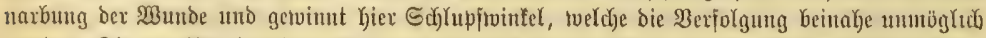

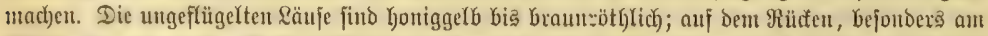

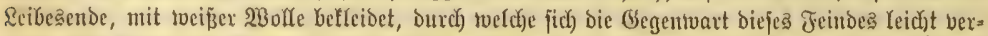
räth. Die Stugen find ftein, bie furzen Fühlex blajgelb, bie Beine an ben Sinicen am Dunfeljten. 


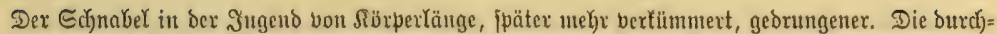

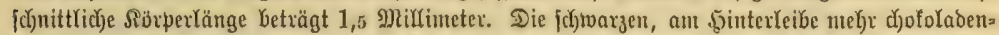

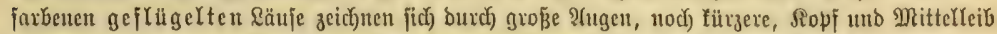

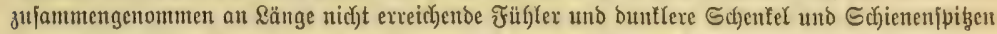

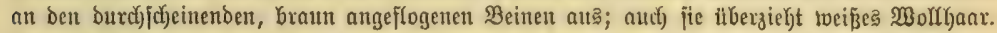
Weil bie Thtere beim Berorüden cinen Glutrothen Fled hinterlajīen, Iegte man iłnen paffend obigen

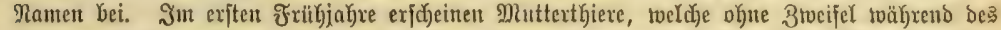

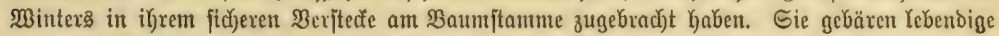

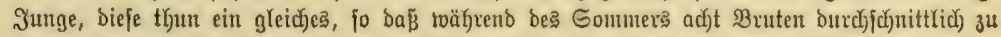

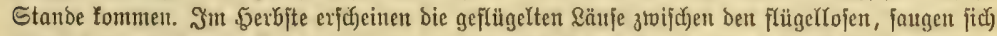

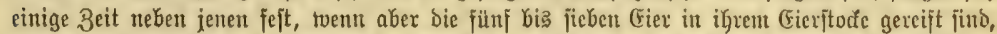

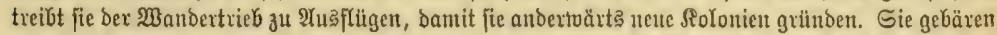
baut ztweierlei groß̋e, ungemein zarte \&äuje mit bertünmerten \$unotbeilen, nach) ber Pnalogie,

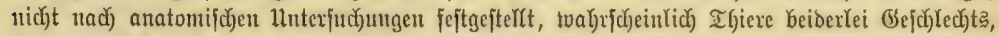

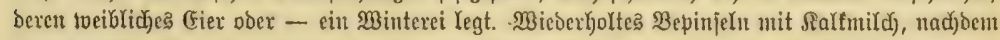

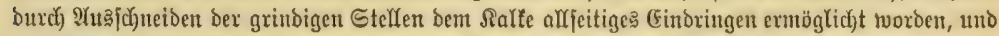

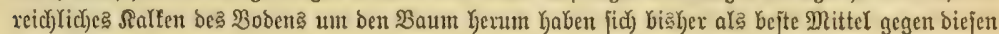
Göfen J̃eino Getväljut.

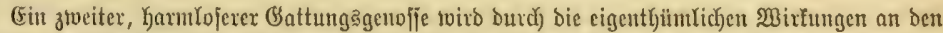

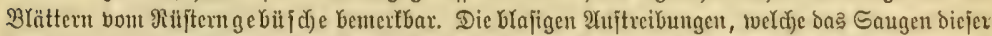

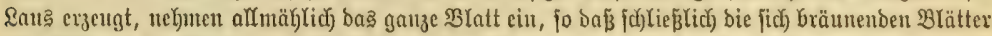

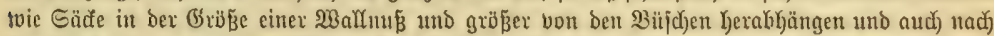

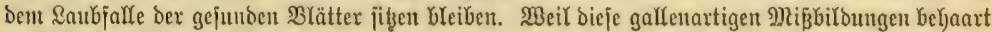
find und auf ber Brattoberfeite besfelben Baumes aud glatte Oalfen borfonmen, fo ift bie

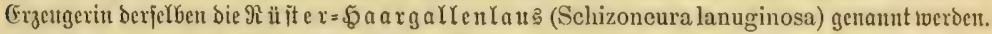

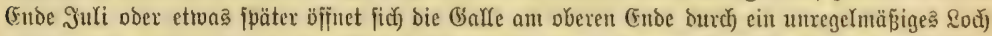

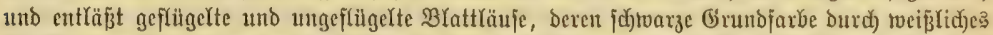

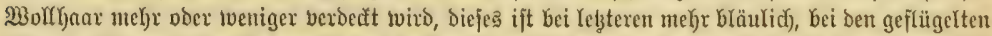

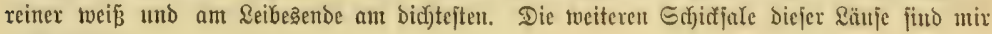
richt betanut.

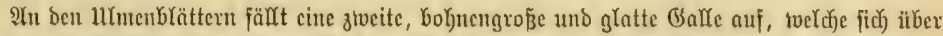

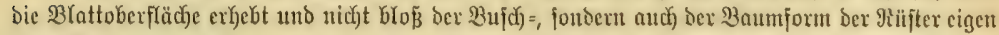

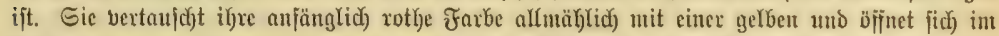

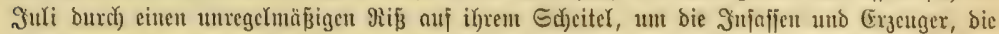

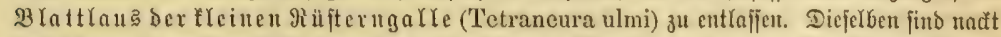

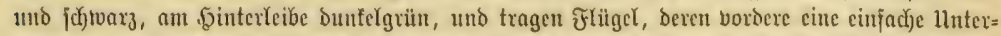

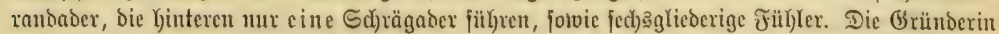

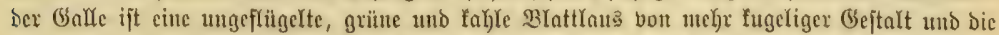

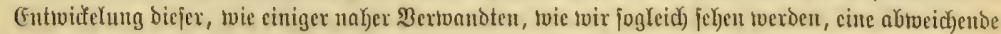
von ber ber Aphis-2reten. Zu biejeu ßertwansten gehört:

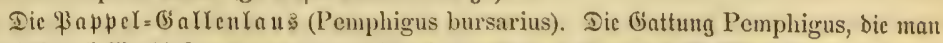

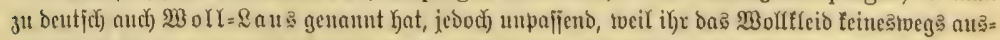

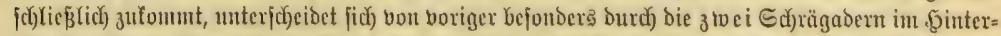

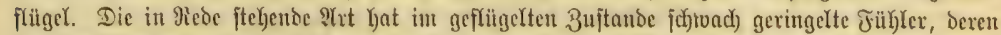

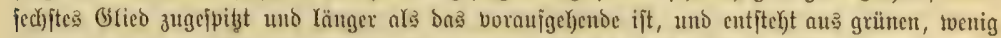

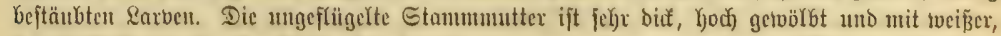

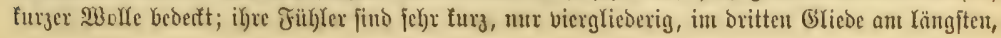




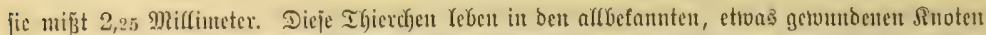

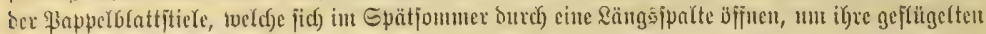
(Fintwolner zu entrafien.

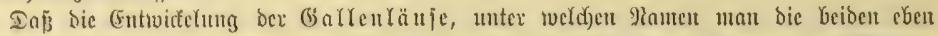

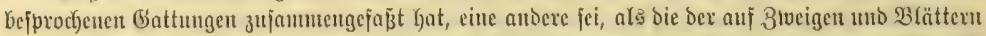

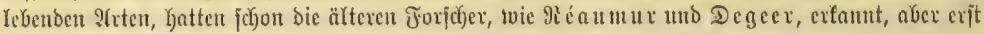

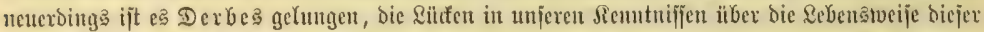

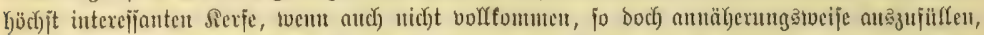

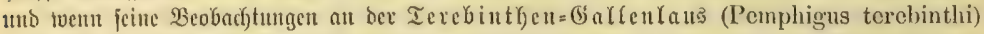

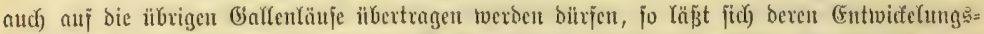

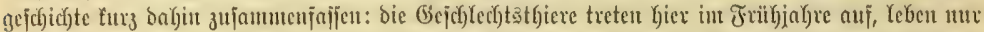

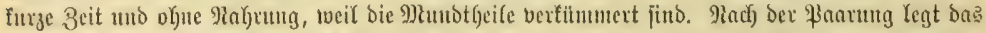

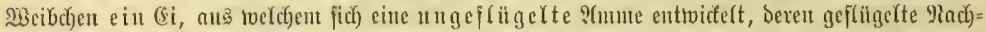

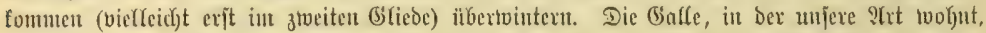

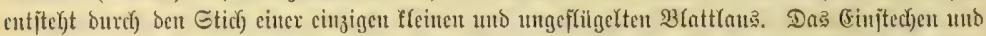

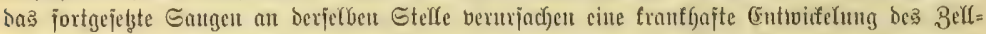

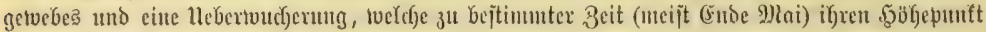

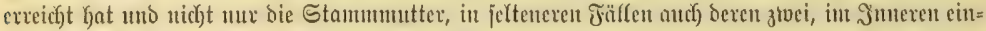

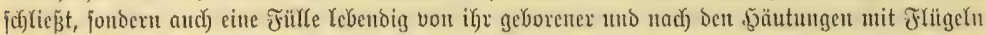

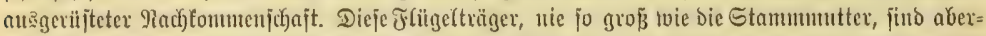

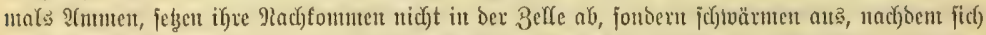

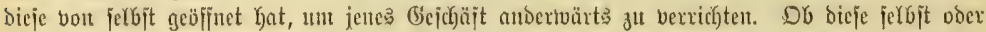

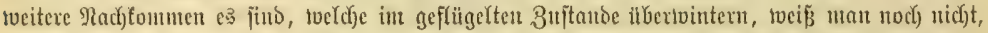

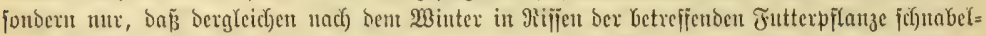

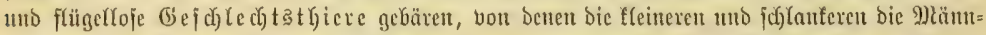

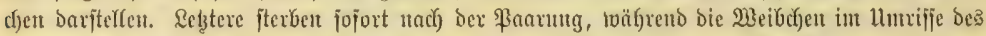

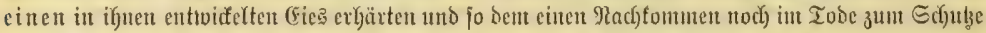

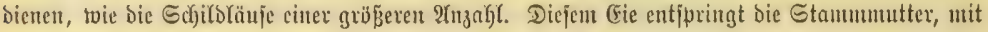
bex unjere Edjilderung begant.

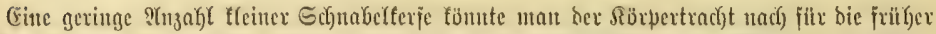

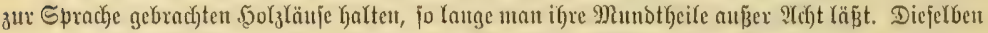

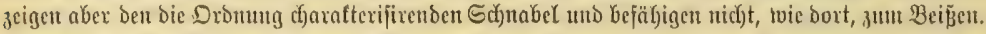

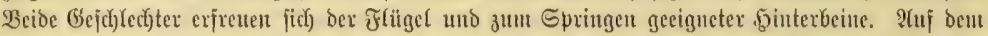

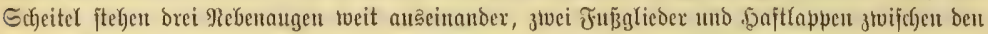
Silauen fennzeichnen bie nux mä

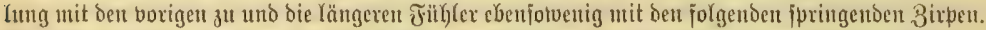

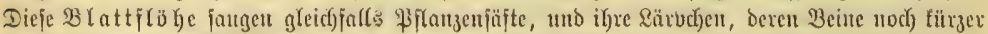

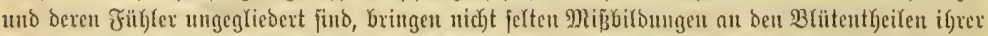
Jutterpflanze hervor. 2(m verbreitetjten finden fick bie beiben Gattungen Livia und Psylla.

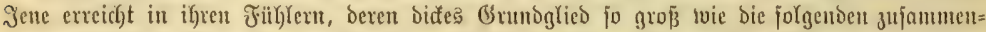

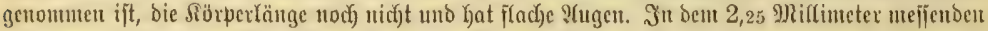

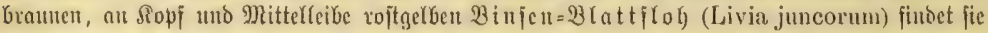

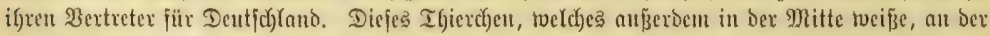

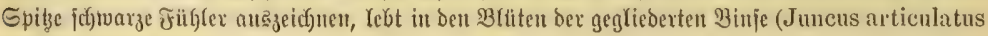
oder lamprocarpus). 


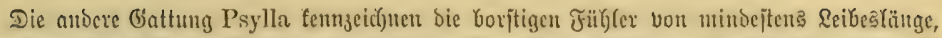

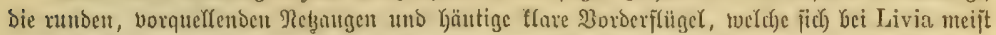

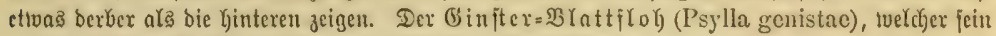

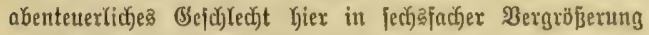

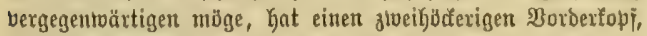
bräunlidje Streifen in ben Fłtugelfeldern uno eine lidjtgribte Sorperfarbe; er lebt, wie ber Rame andeutet, aut bem Binjter. -

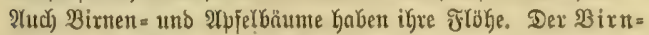

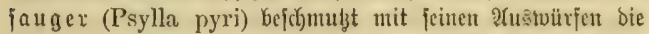
BYattitiełe und 3roeige twie mit einem von İneijen gejuchten,

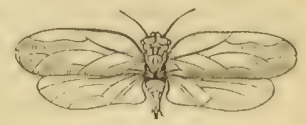

(5) infter. BIattfloh (Tsylla genlstae), ied)ỏmal verñöbert.

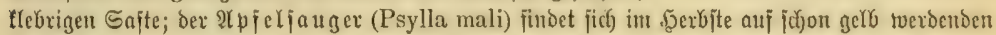

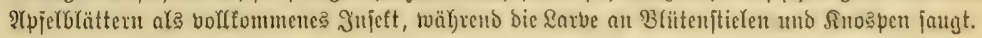

Die nächjte Reihe der Sifynabelferje, bie Birpen ober (Eifaben (Cicadina), cmpfing, fo

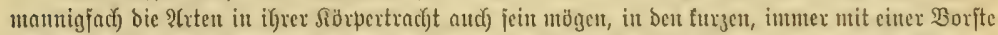

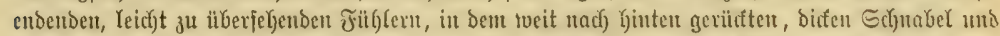

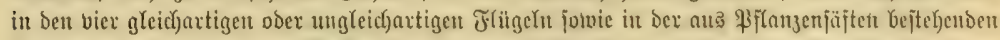

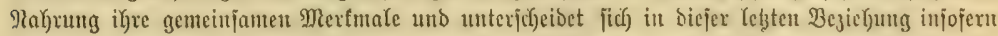
twejentfich) von ben bişgerigen Dronungagenofjen, afs jie nie burch) Jejtjaugen cine und biejerbe

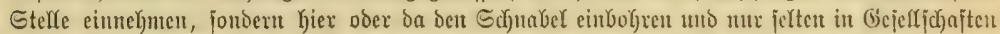

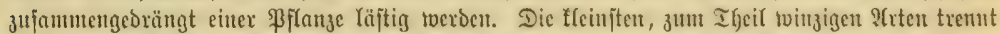
man von ben übrigen ala bejondere Jamilie ber Sileinzirpen (Cicadellina) unter jolgenden

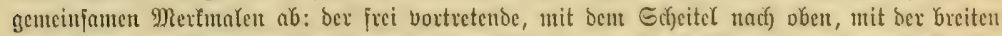

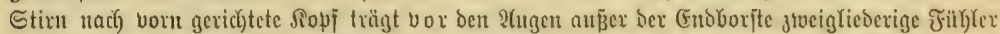

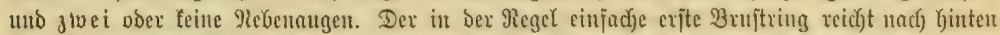

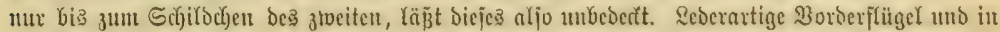

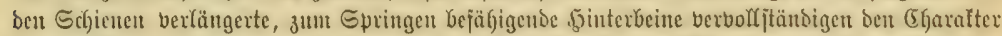

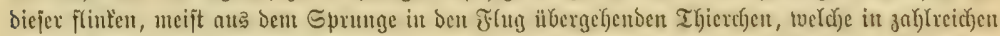

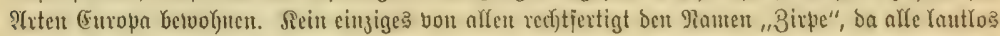
ifre furze Rebenezeit verbringen.

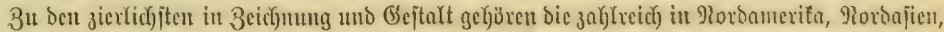

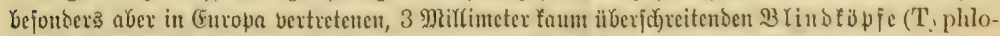

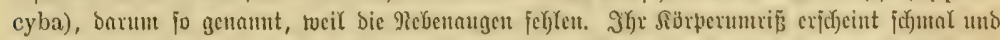

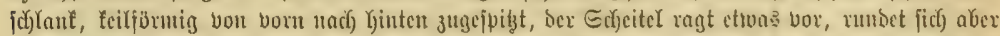

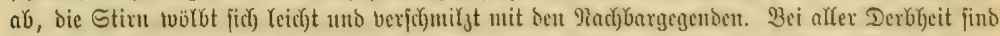

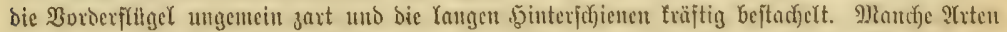

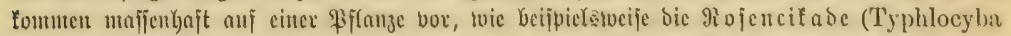

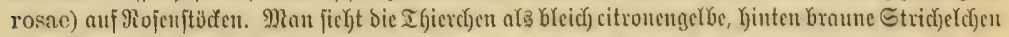

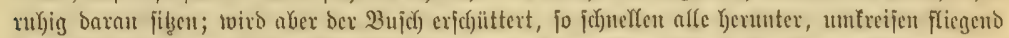

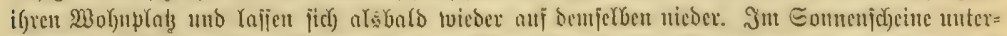

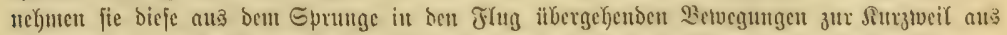

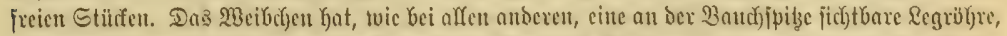

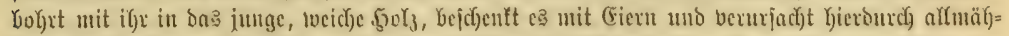

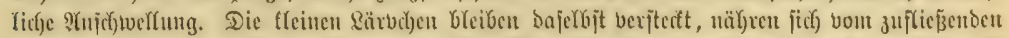

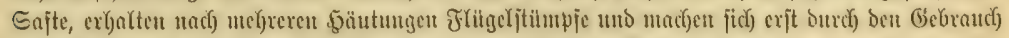
ber volffounten cutwide

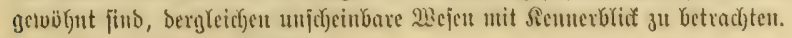




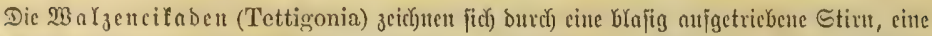

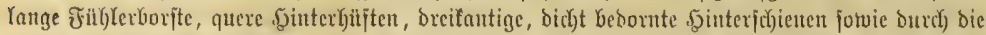

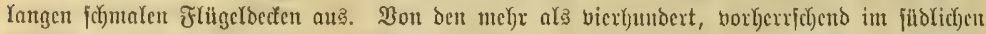

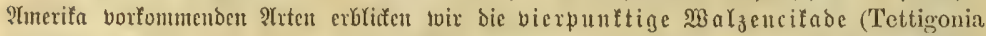
quadripunctata) nad) innen auf bent Blatte unter Dex Paffionsblunte unfereß (Stuppenbiloes

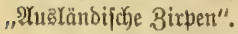

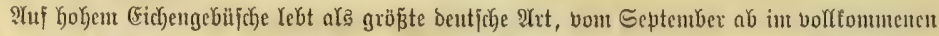

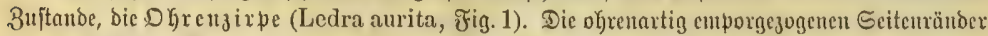

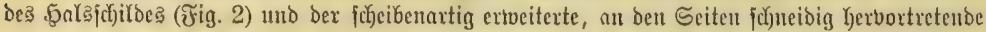

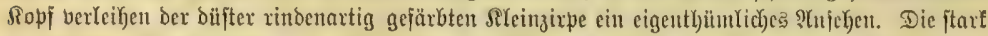

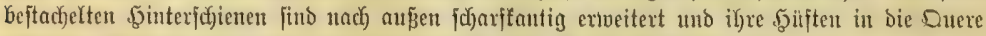

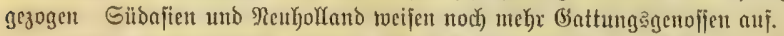

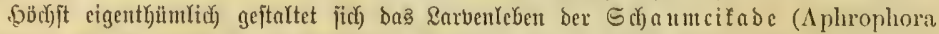

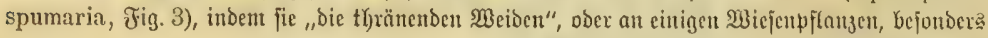

1
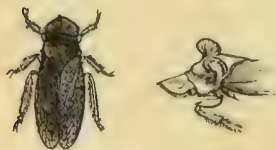

1 Dhrengixpe (Icdra aurlta), 2 Dorbertörper bon ber Eeiten.

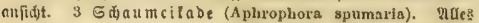
vergrö̉izert. ber Rututa = Richtnelfe (Lychnis floseuculi) uno Dem Bofţ̧

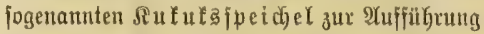
bringt. Im 5erbjte hatte Das (5ifabentweibd)en mittels feiner Yangen, in einer Saudjpalte ver= borgenen \&egicheibe bie (Fier zivijd)en Pintontibe,

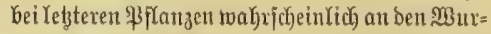

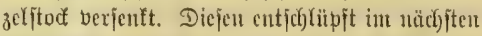

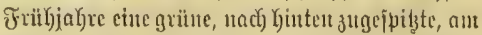
Bauche abgeplattete Rarbe, tveldye bie betreffende

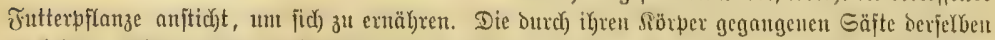

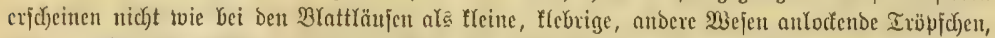

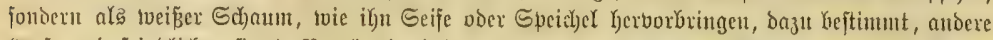

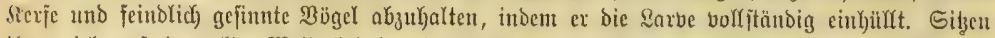

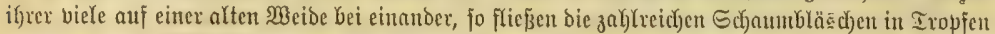
311

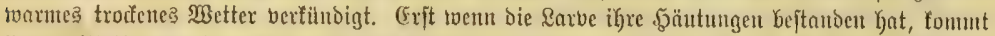

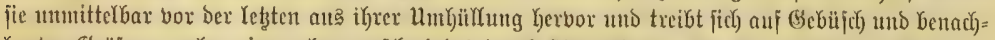

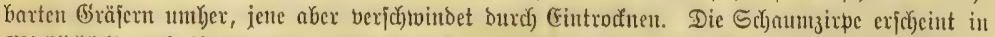

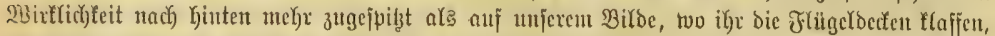
bon Farbe gelbgrau, mit श1!

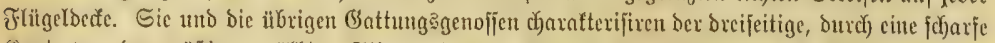

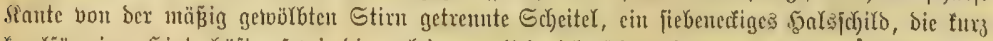

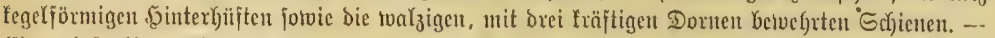

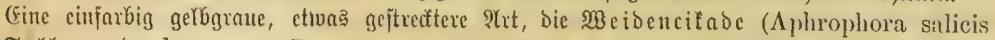
Farlen

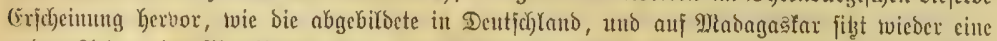

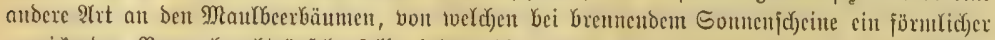
erquictentor Regen Kerabträufelu folf, indem bie Rarben ffuntpentweife rund um bie ftärfiten

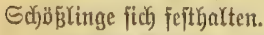

Bei ben Stirnzixpen, Schnerrzirpen (Cereopis), greift bie aufgetricbene Etim n̈ber den

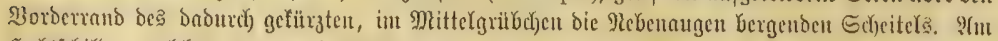

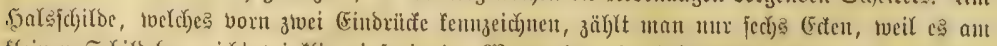

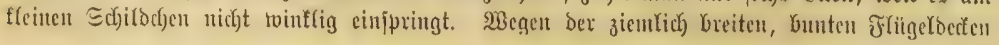




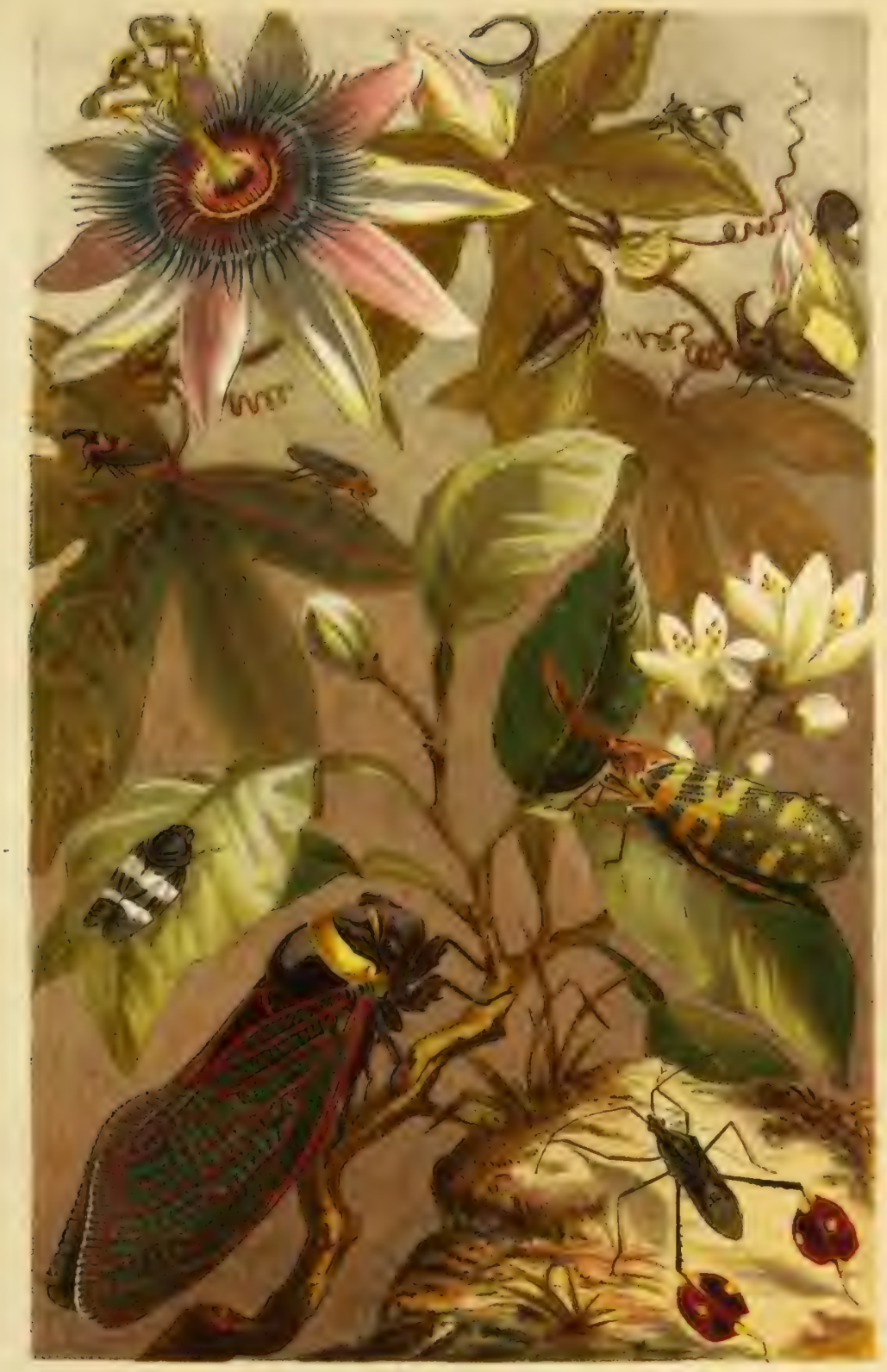

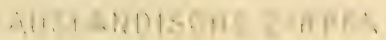





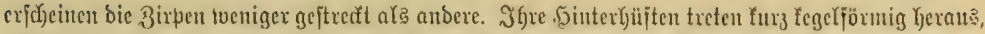

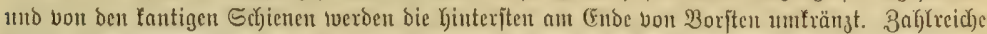

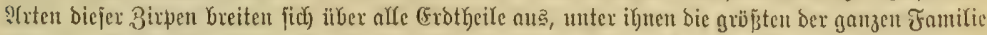

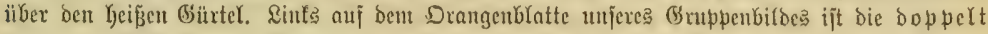
bandixte Stixnjirpe (Cercopis bivittata) aus Jaba bargejtellt. Eie ijt glänzend fobruarz

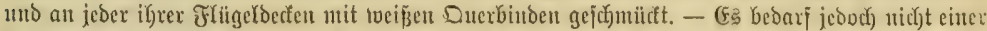

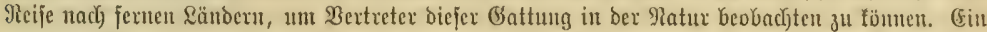

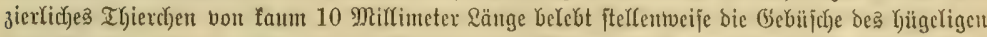

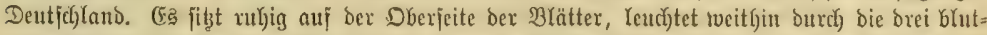

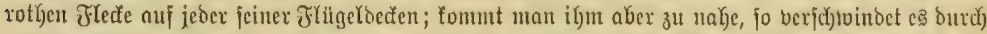
cinen ntächtigen Eprung und ztvar um fo ciliger, je fidjüner fein Getwant in ber Eonte erglänst.

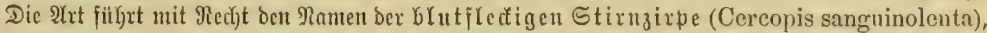

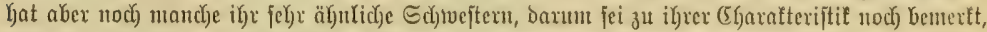

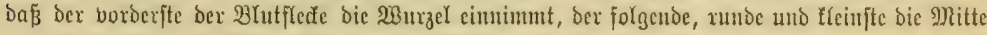
uno ber hinterfte alą Binde uiber bie ganze Fläche reidyt.

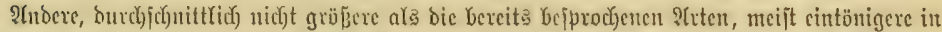

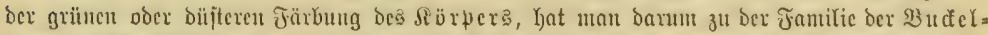

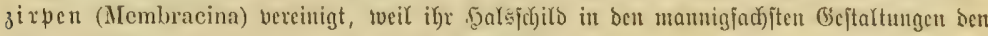

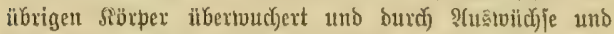
S)(nbängiel, ojt Der fonderbarfen Sfrt, alb ber an meiften

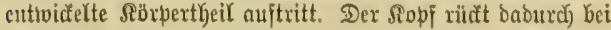
alfen nach unten, eine jocharie Sonderung zivifdyen Scheitel uno Stixn, toie bisher, fält tweg, indent beibe mit einanber

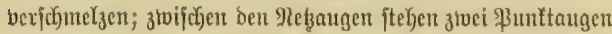
und Die fehr furzen Fibler verfteden fich unter dem Etirn=

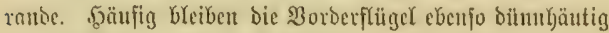
mo Durchjlidatig toie bie binterflügel, entjchieben inmer ba,
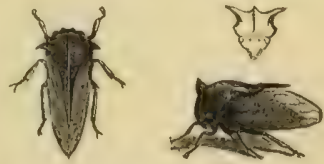

(6) cbornfc Dorngirpc:Centrutus cornutus), von vorn unb in ber Eeitenanfidjt. Tturs ber. gröpert.

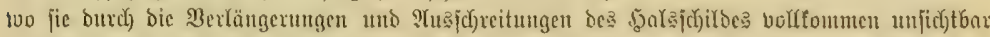

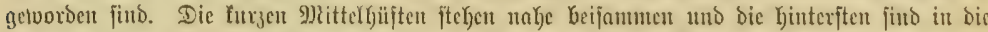

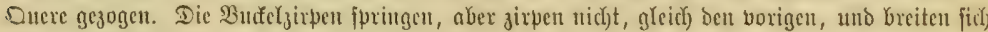

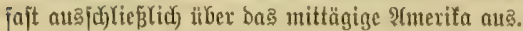

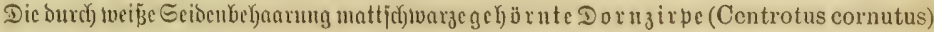

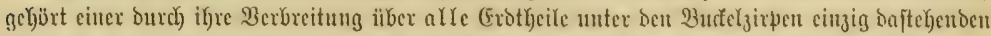

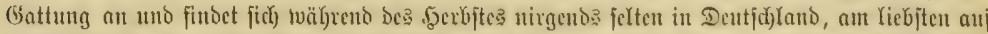

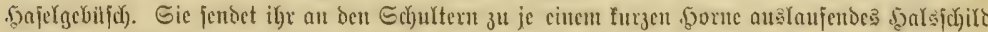

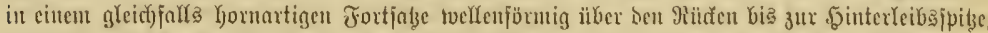

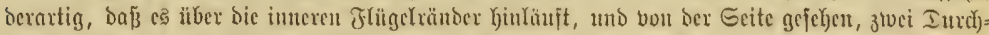

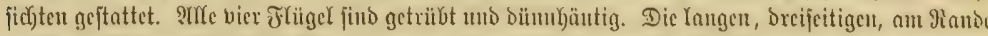

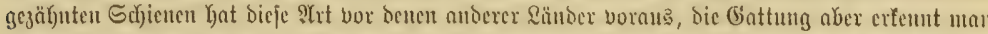

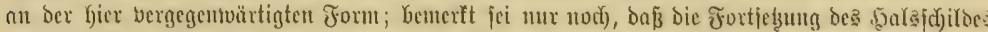

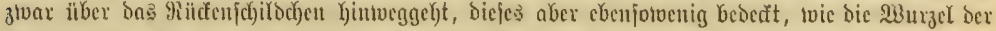

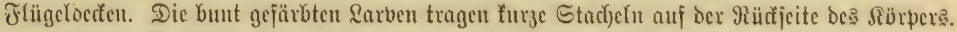

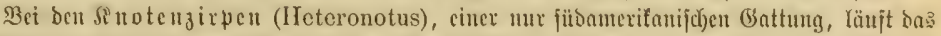

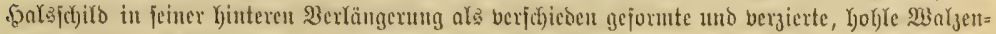

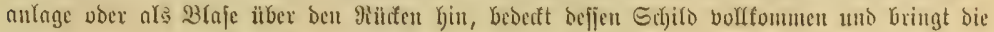




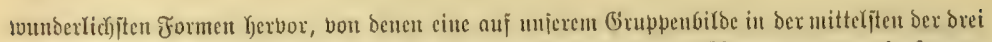
oberiften Finuren vorgefïfrt ijt. Dic uckzaberige finotenzirpe (Ieteronotos reticulatus),

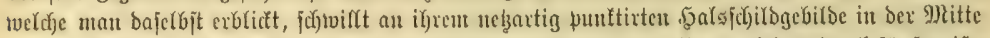

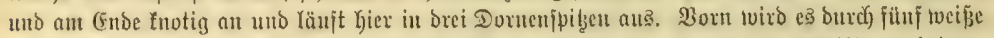

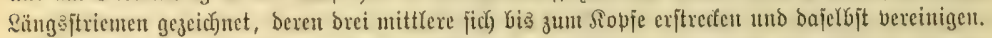
Die cinzelnen Sinoten fiibren einen in ber Mitte unterbrochenen Dueritric) uns bie brei Donten

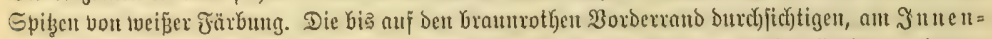

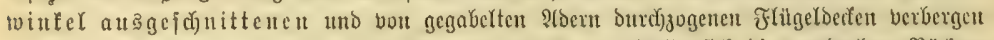

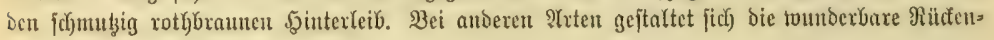
verzierung twieber anders.

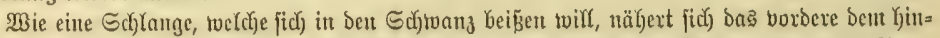

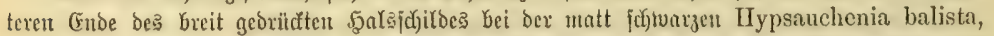

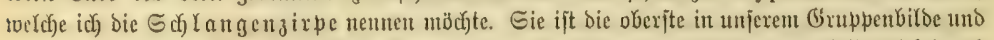

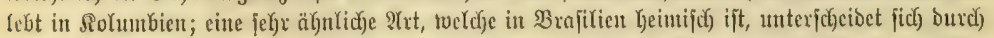

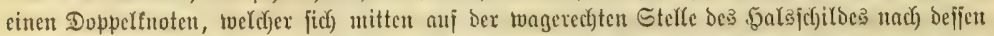

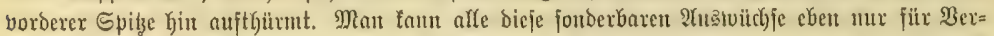

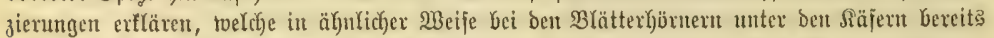

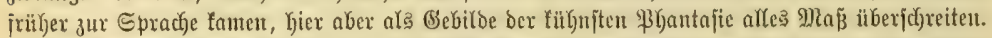

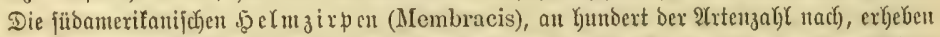

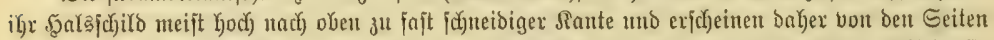

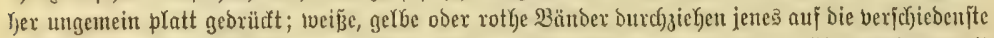

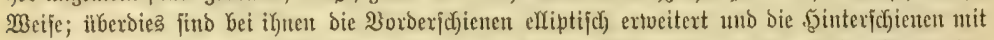
ftarten Dornen betwehrt. Wir fehen auf unjerem Gruppenfiloe, oben rechts, auf ber Stnoape ber

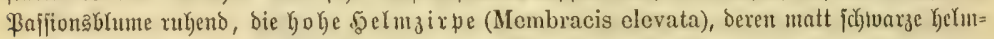

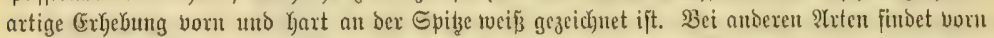

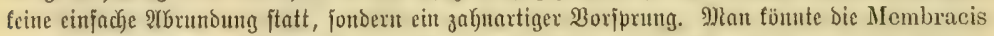

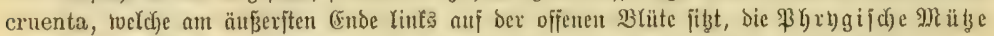

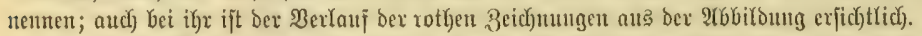

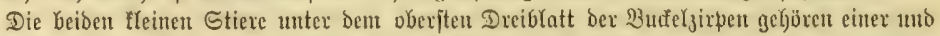

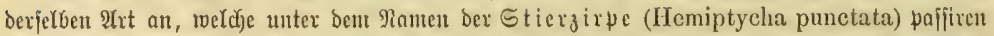

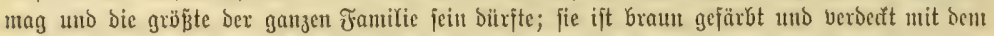

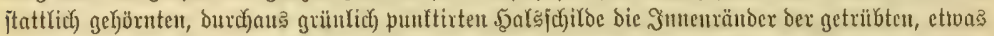

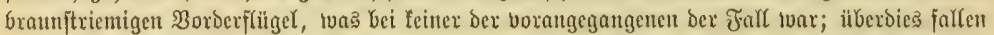

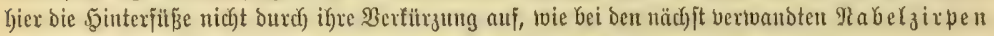

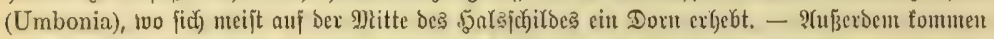

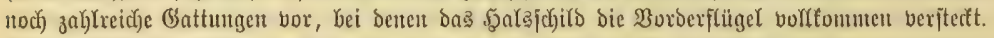

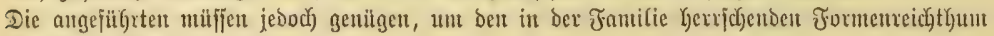
ahnen zu lafjen.

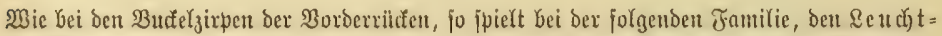

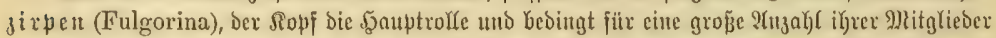

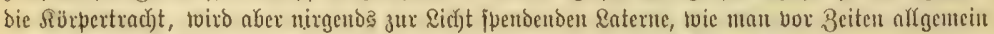

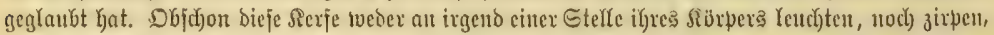

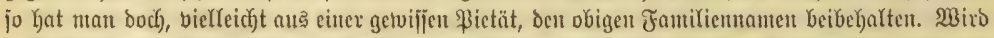

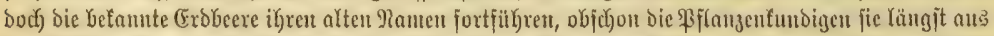

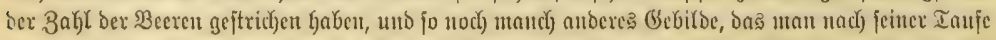

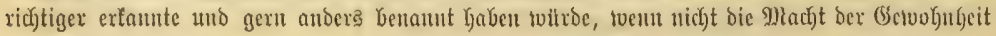




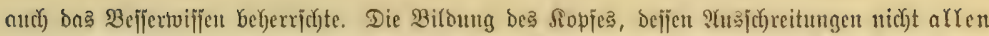

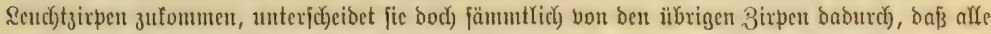

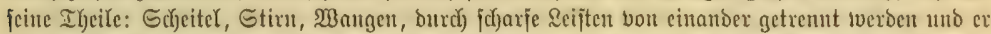

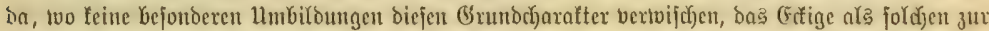

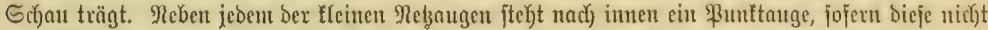

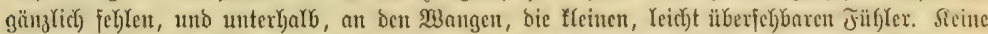

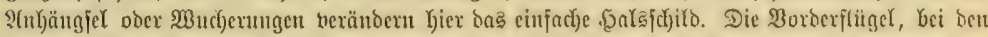

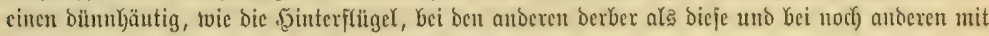
ibnen zugleidf) Yederaxtig uno bunt gejärb̧, fino an

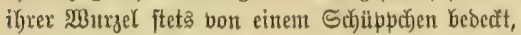

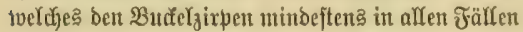
jehlt, two bas .5alsjichild beren Wurzel oder ganze Fläd)e Gedectt. Die verlängerten Mittelyujten jtełen toeit auseinanber, affe Sifienen find oreifantig, häufig beoornt und die hinterjten mit einem Stadjel= franze an ber Spiz̨e gefrönt. Niele Reudjtzirpen

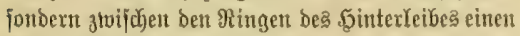

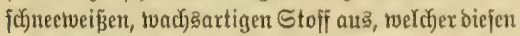

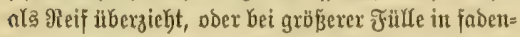
jömigen Strängen einen (Enofichopf billdet, fick aud) svieder erneuert, toenn ex abgerieben toiro, toie fol=

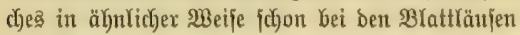
zut Sprache fan. IYud bie Reudjtzirpen gebören

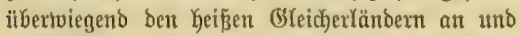
swexben burdis nur twenige, zwar zierliche, aber int=

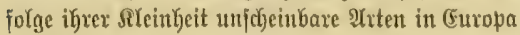
wertreten.

Dakin gehört bie gexippte Minircifabe (Cixius nervosus, Fig. 1), eit 7,17 9) Rillintetex

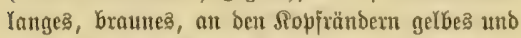

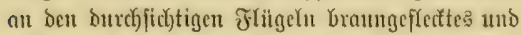
punttirtes Ifierchen. Der fochmale, mit Jeben=

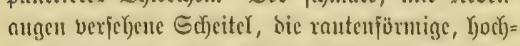

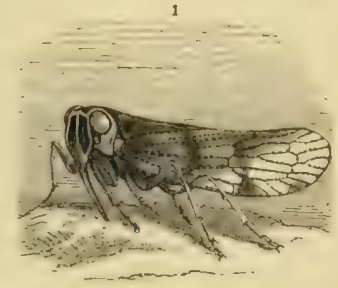

2

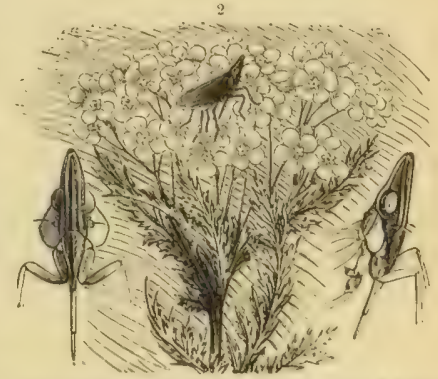

1 (Scrippte Minircitade (Cixius nerrosus). 2 (Eแro. Wäifder Laterneuträner (Pseudophana curopaea),

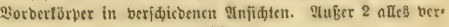
gröbert. umrandete und von einer \&äng

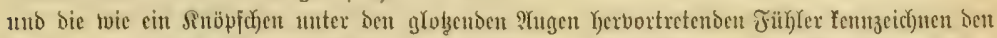

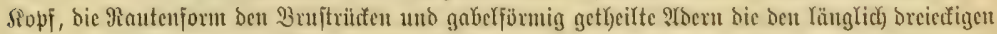

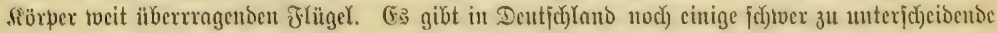

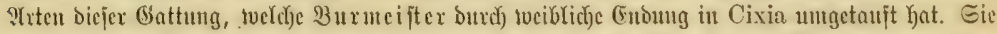

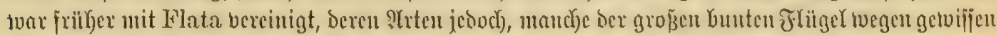

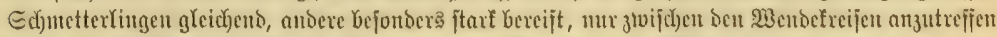

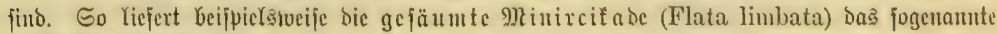
weip̉e (5Ginatwadj).

Der europäifde Raternenträger (Pscudophana europaea, Jig. 2), cin 8,75 9̧7iffi=

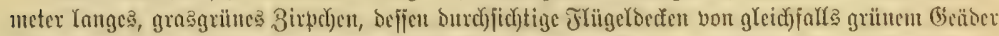

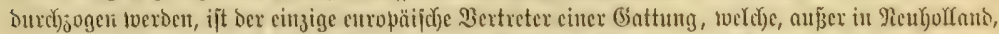

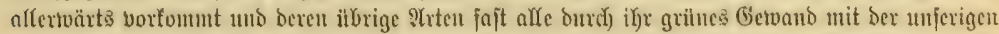

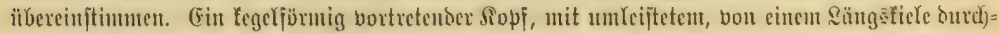

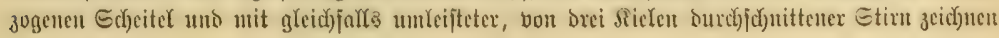




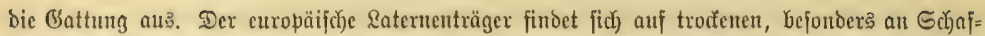

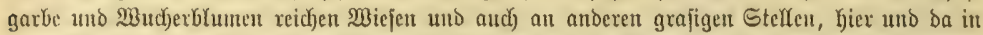

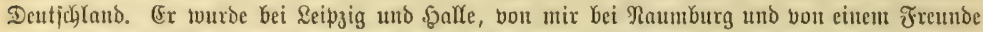
an ber norobjtlidyen (Sienze ber Proving Sachjen einzeln aufgefmoen, fommt aber tweiter nad) Sulben häufiger bor.

Die Battung Fulgora Yiejert bie anjelynlidjpten uno vollenbetiten Formen, einen din in ejifdyen

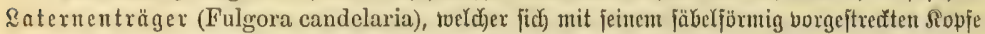
red)t

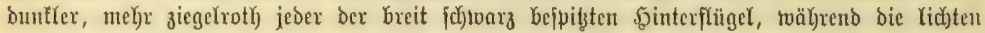

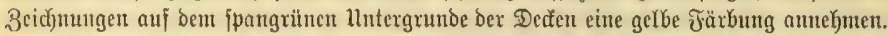

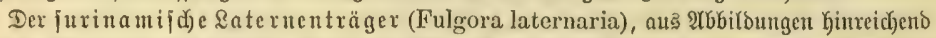

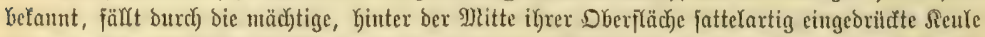

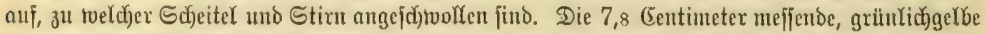

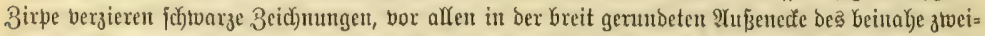

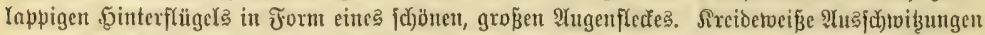

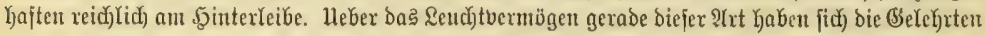

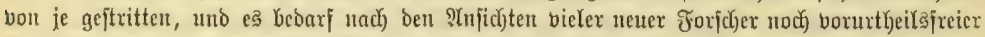

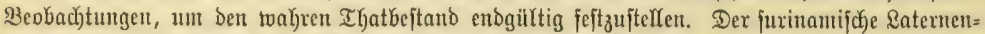

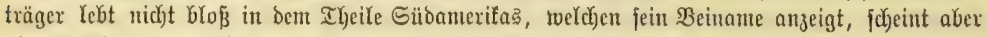

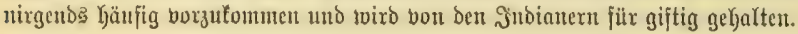

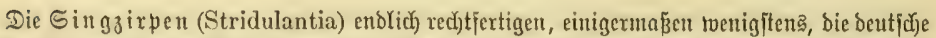

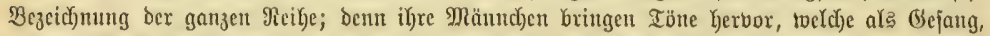

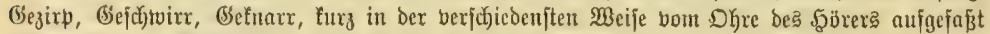

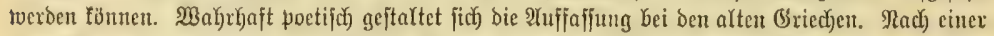

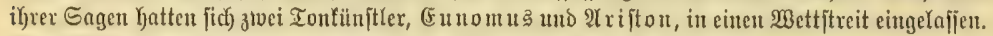

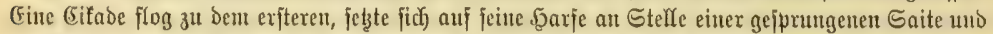

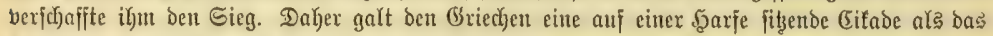

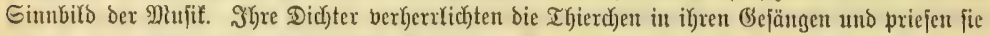

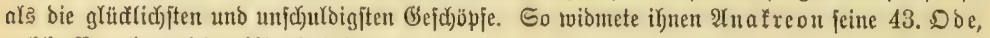
tweldhe $R$ amler twiedergibt twie folgt:

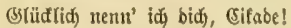

Daß̧ bu auf ben Gÿ̈dften :Bäumen,

Bon ein venig Thau begeiftert,

Aefnlid) cinem Rönig! fingeft.

Dein geböret all' unb jebes,

$\mathfrak{W}_{a}$ bu in ben felbern foducp?,

Was bie Jabreşzeiten bringen;

Dir fino Freuno bie \&nnbbeivolner,

T3eil bu feinem lebit zu Reibe,
Ins bie Sterblidjen verebren Dith, bes Sommers folbent Boten;

ln' es lieben bidj bie Mu[en, 1lno es riebt bid) Pbotbos ferber; Er gab bir bie flare Stimme; Aud) bas 2(tter bid). nidjt bränget, Seber, Erogeborene, Sänger, Seibenlos, ohn' Blut im ileifde Sdjter bift bu ben Gotterm ăbutiō! ex jagt:

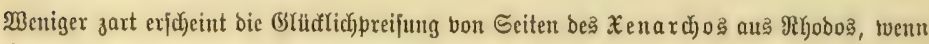
(3)üălid) Yeben bie (sifaben, Denn fie laben ftuntme Weiber.

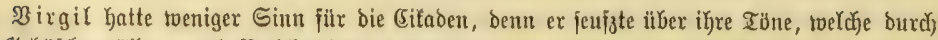

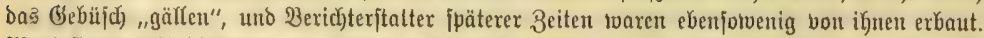

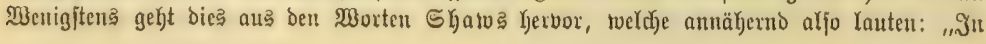




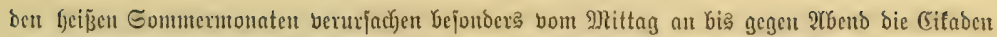

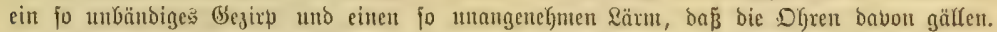

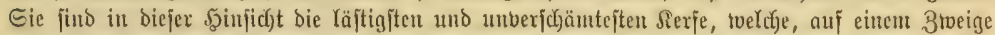

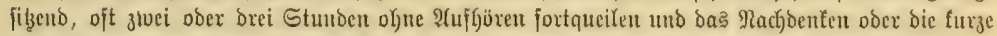

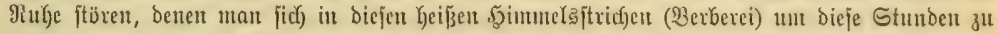

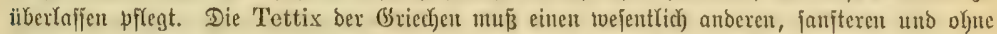

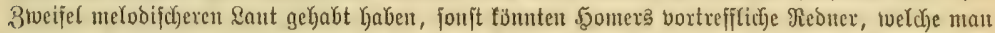

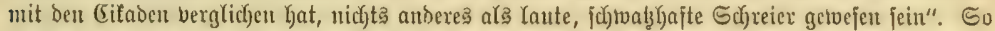

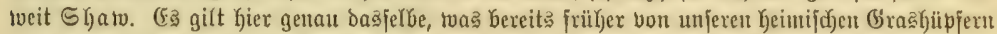

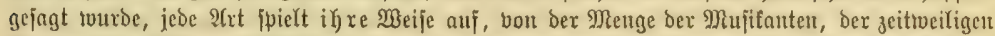

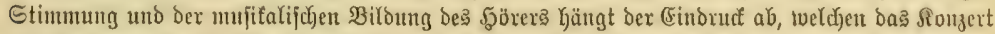

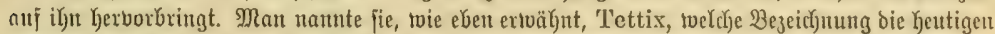

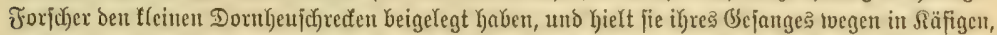

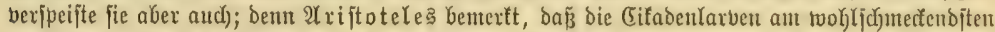

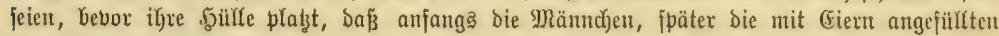
Weibchen bej̈er joumedten.

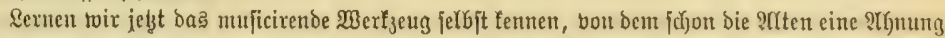

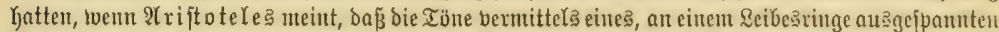

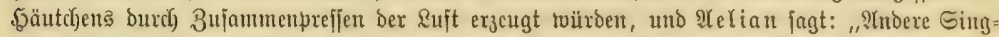

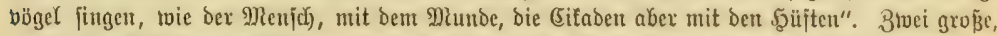
Iederartige Schuppen, toeldhe bem Şinterbrujtbeine ohne Eiulentung angetwachjen find, nefmen beu

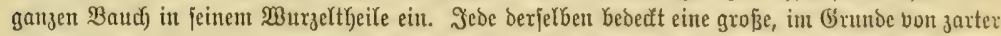

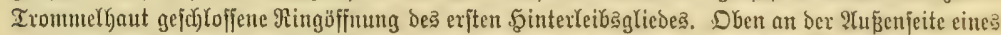

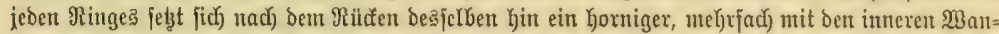

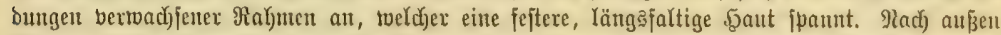

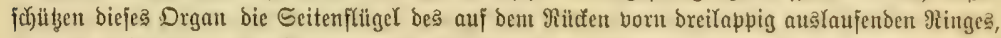

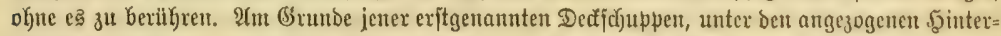

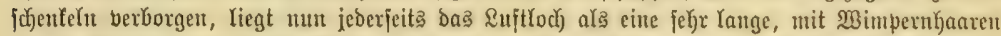

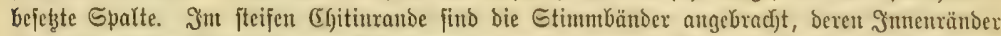

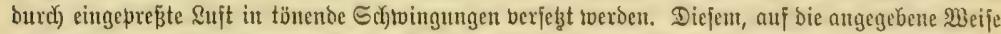

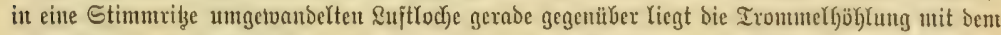

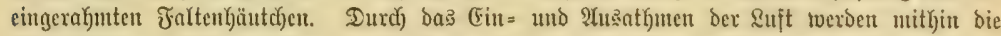

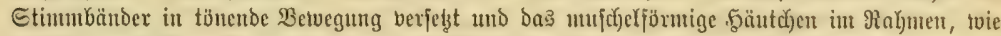

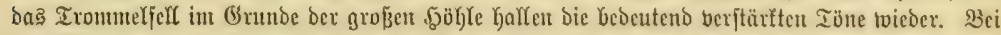

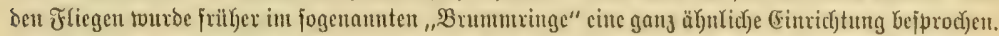

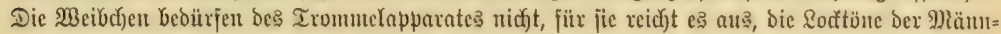

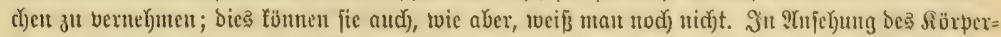

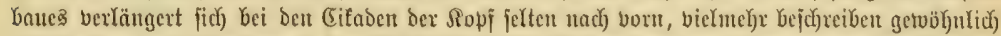

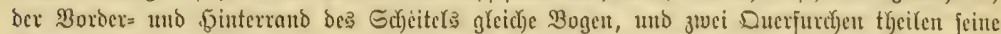

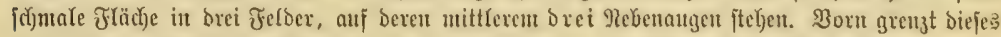

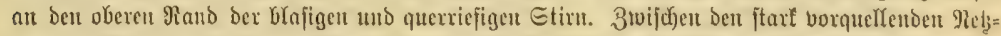

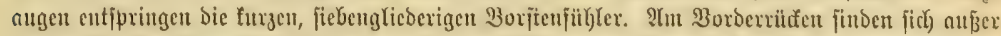

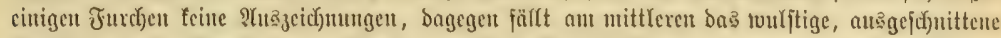

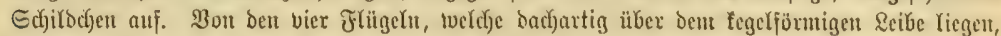

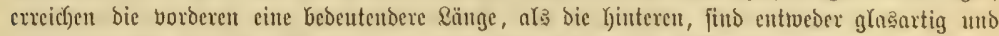

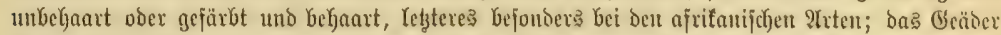

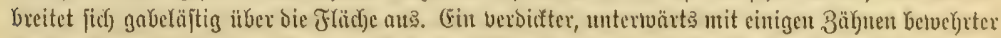

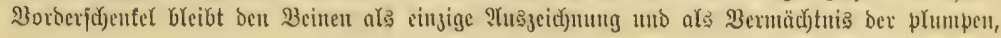




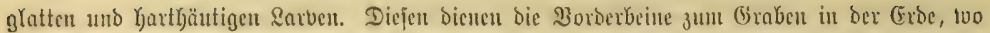

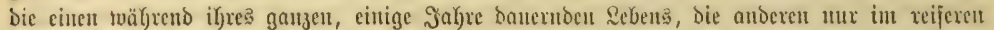

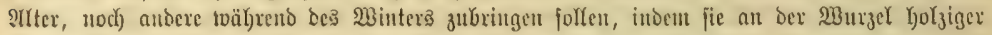
(Betväd)le jaugen.

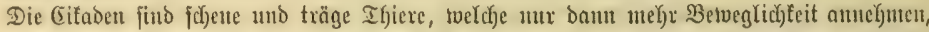

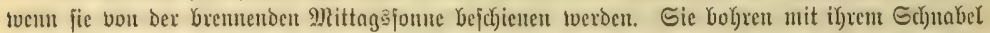

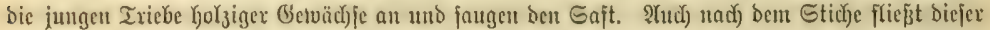

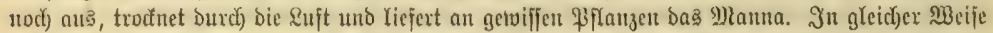

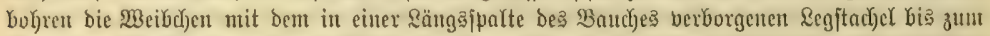

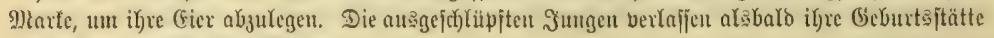
uno jaugen äuperliç, am ?3aume.

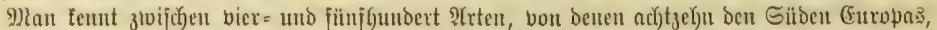

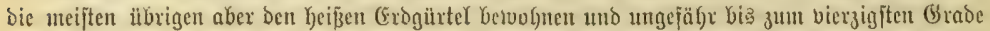

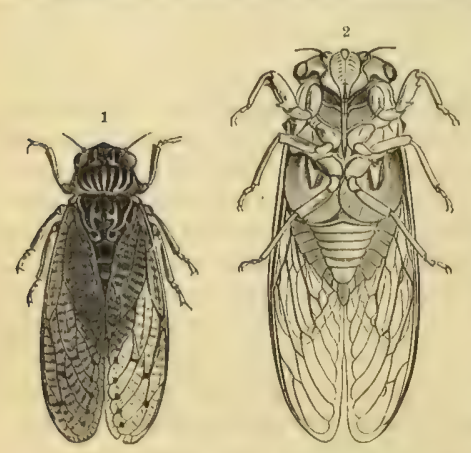

1 Dauncilabe (Cleada oral). 2 demeine Ginncllabe (Oicada plobeja) bou ber Baudifite. Ratiltidje Gröbe. füblidyer ß3reite, nad) গtorden jeboct) in einzelnen Trten bedeutento tweiter veichen. Die Gattung Cicada, von İabricius Tettigonia genaunt, twurbe neueroing in zahlreiche, Gier nicht tveiter зu berüafijigtigende Untergattungen jerYegt. Daß beigegebene Orruppenbilo jührt linta im \$oroer= grunde in Der prächtigen Singaixpe (Ci-

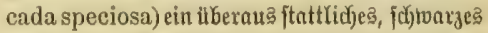
Ifier vor. (Fin fleinerer Fled vorn uno eine

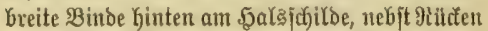

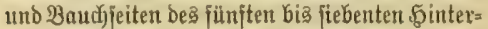
Yeibagliedes find gelb, bie Reiften Des s)littel=

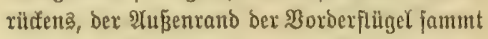
bem Geäber Głutroth, ber äuß̄erjte Đinterranঠ biejer uno ber ganze Saum ber ફinterflügel tocí̈. Die Kelfen Duerzeid)unngen in Den Beffen Der Flügel beuten bie Fältḑyen bex niçt ftraff

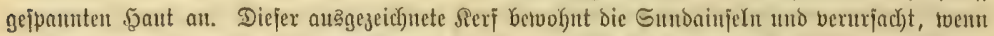

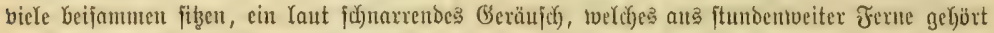

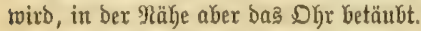

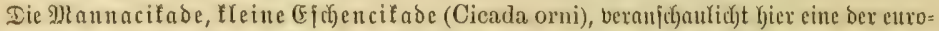

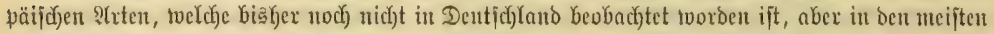

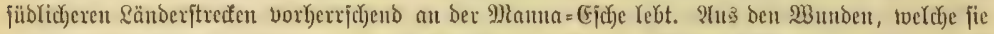

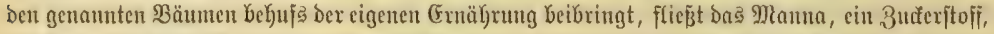

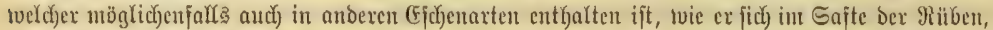

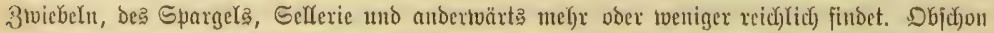

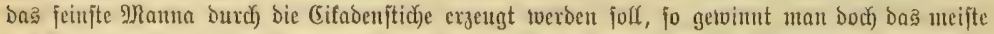

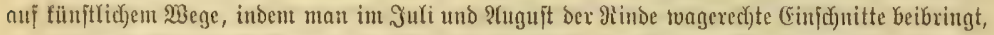

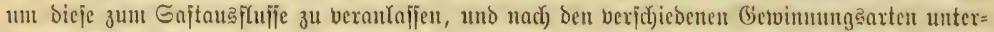

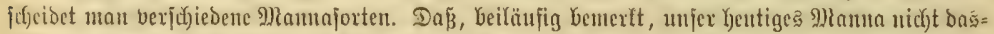

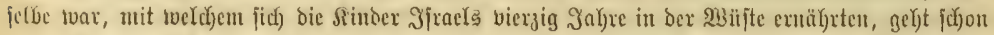

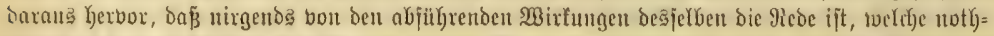

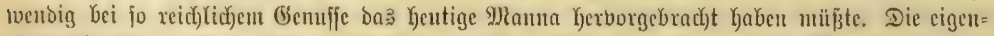

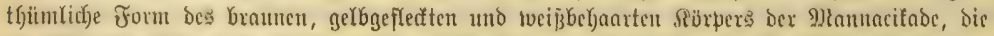

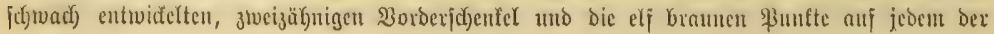




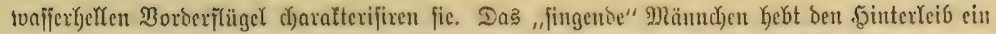

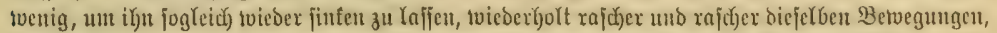

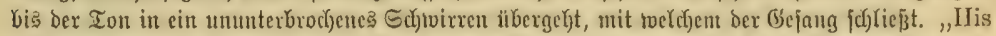

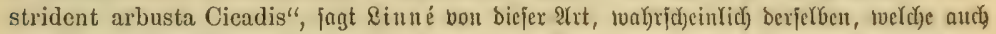

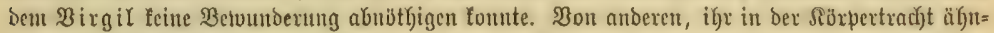

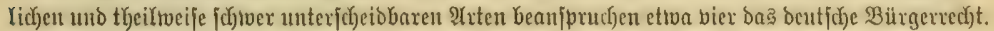

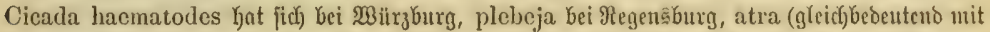

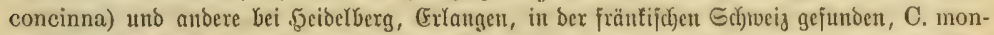

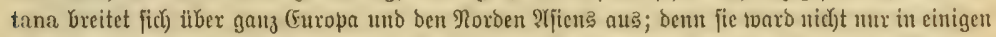

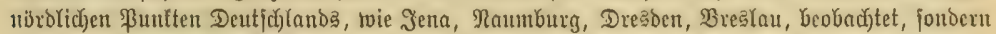

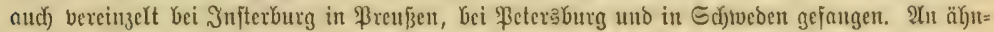

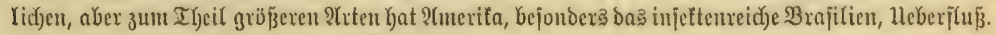

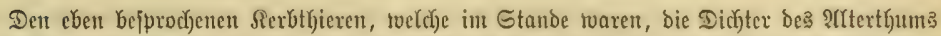

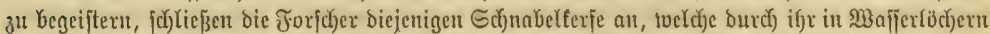

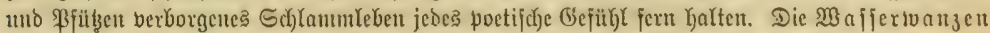

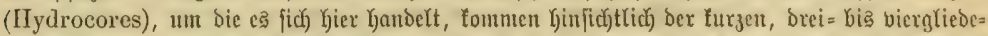

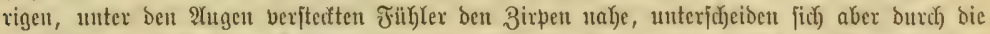

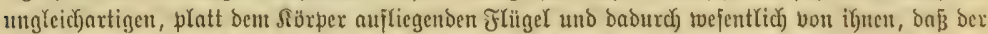

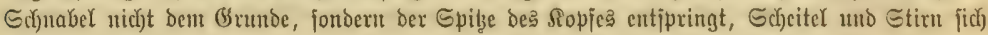

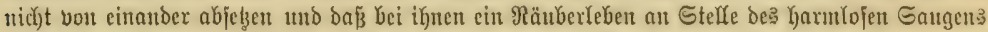

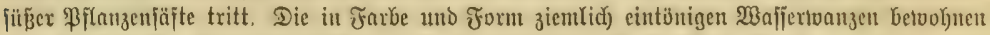

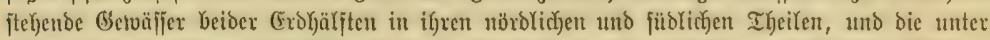

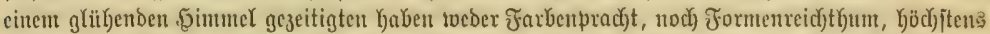

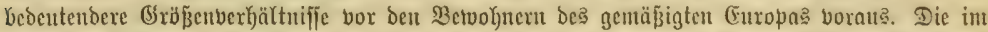

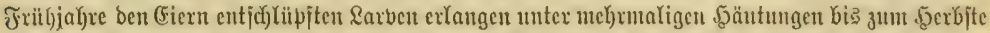

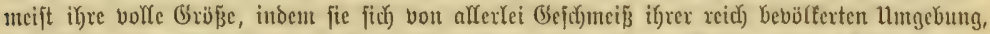

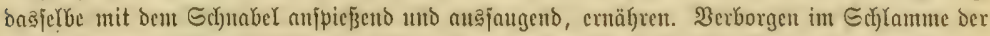

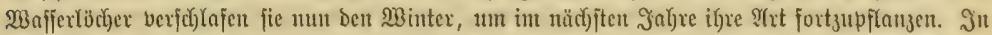

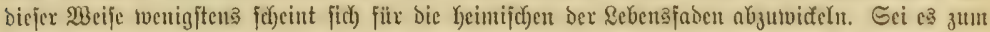

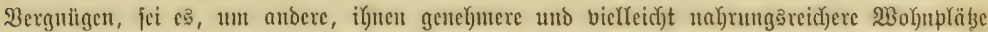

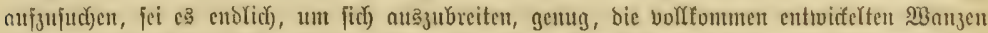

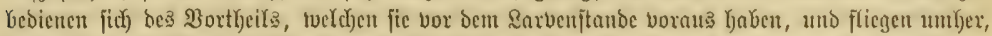

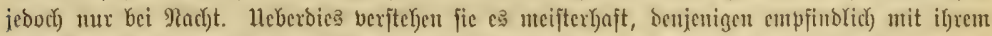

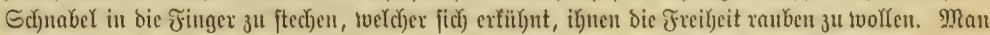
Gat bie Mafjertwanzen in brei Fnntilien zerlegt.

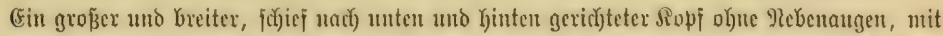

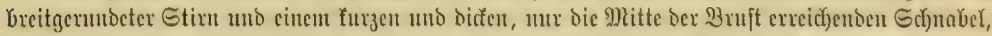

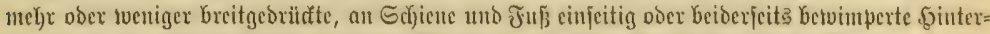

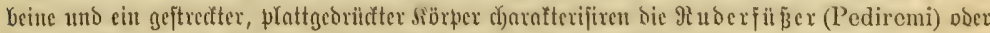

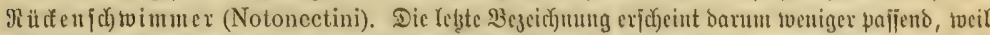

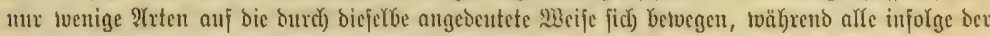

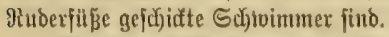

(Geoffroy's Mindertuanze (Corixa Geoffroyi) belebt in ber Dreizahl, uno ztuar auf ber

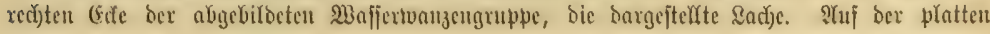




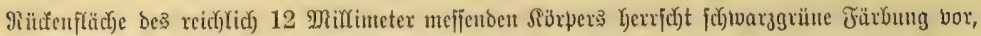

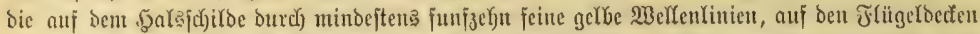

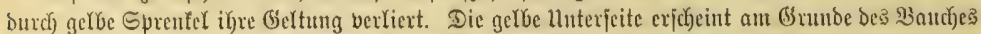

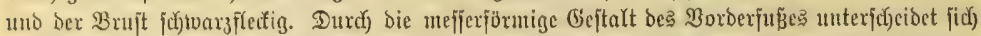

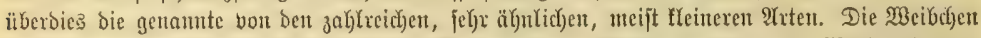

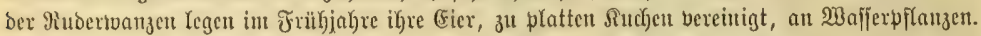

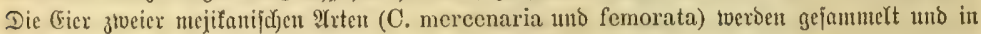

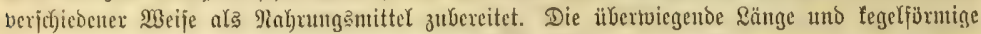

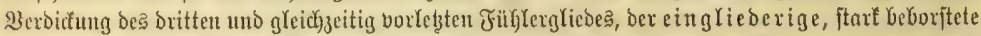

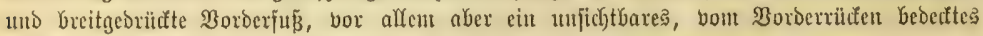

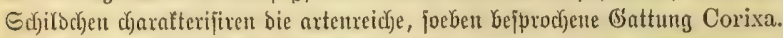

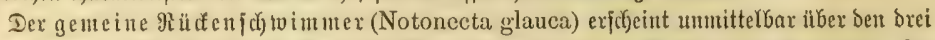

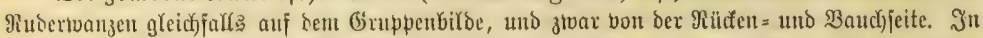

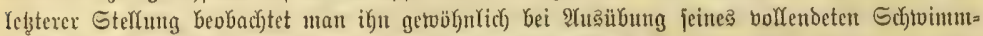

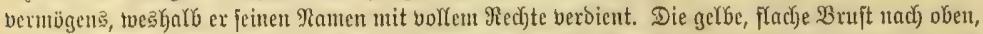

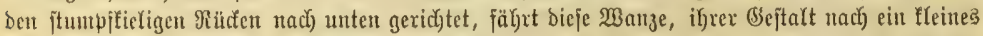

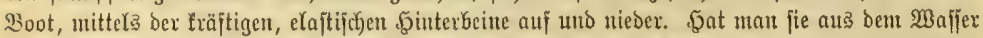
auf bas Tructente gebradyt, jo jodnelfen eben bieje Beine Den Siörper in ben unterhaltendften

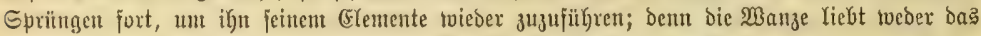

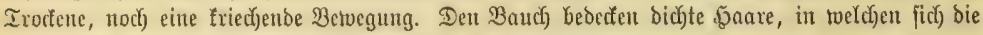

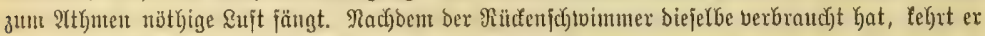

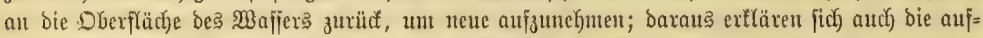

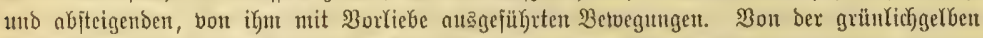

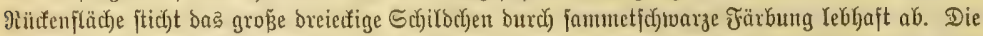

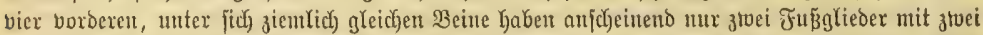

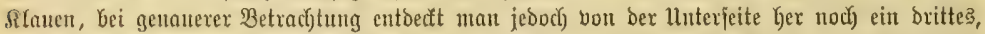

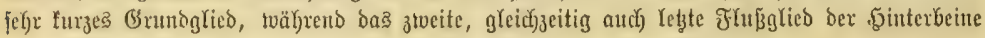
olyne Rlaue endigt.

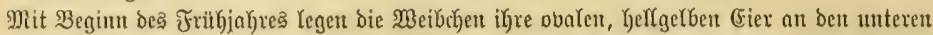

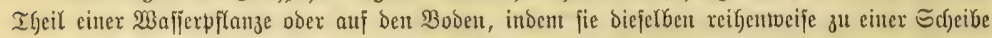

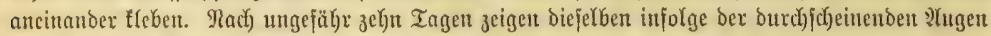

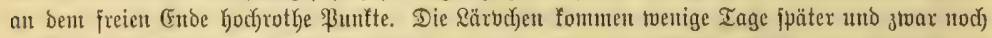

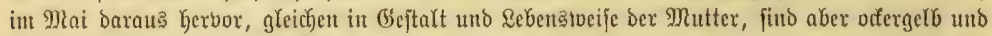

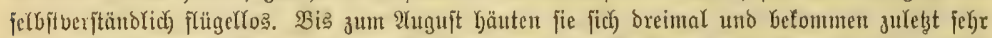

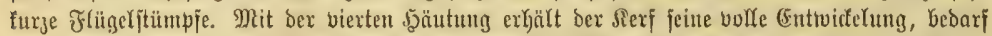

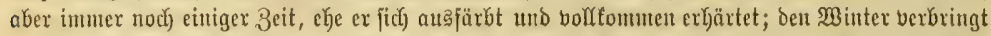
er in critarten 3ujtande unter Sdy)(amm. Simpjon will im September 1846 einen fïmi=

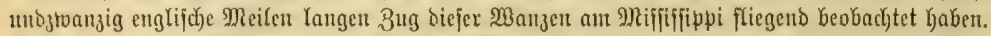

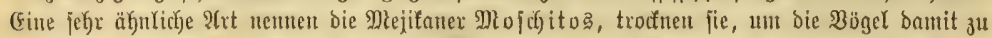

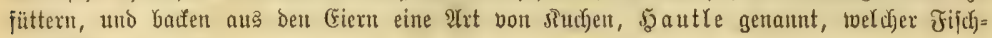
gejdymatf haben joll.

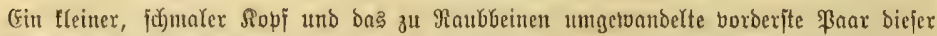

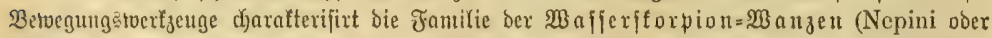

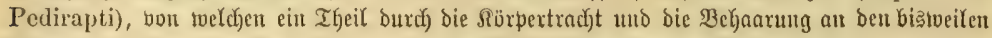

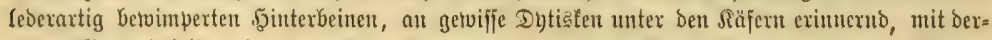
jelben Getvandtgeit, wie bie borigen joftwimmt, ein antoerer IGeif bagegen an bem flachen 


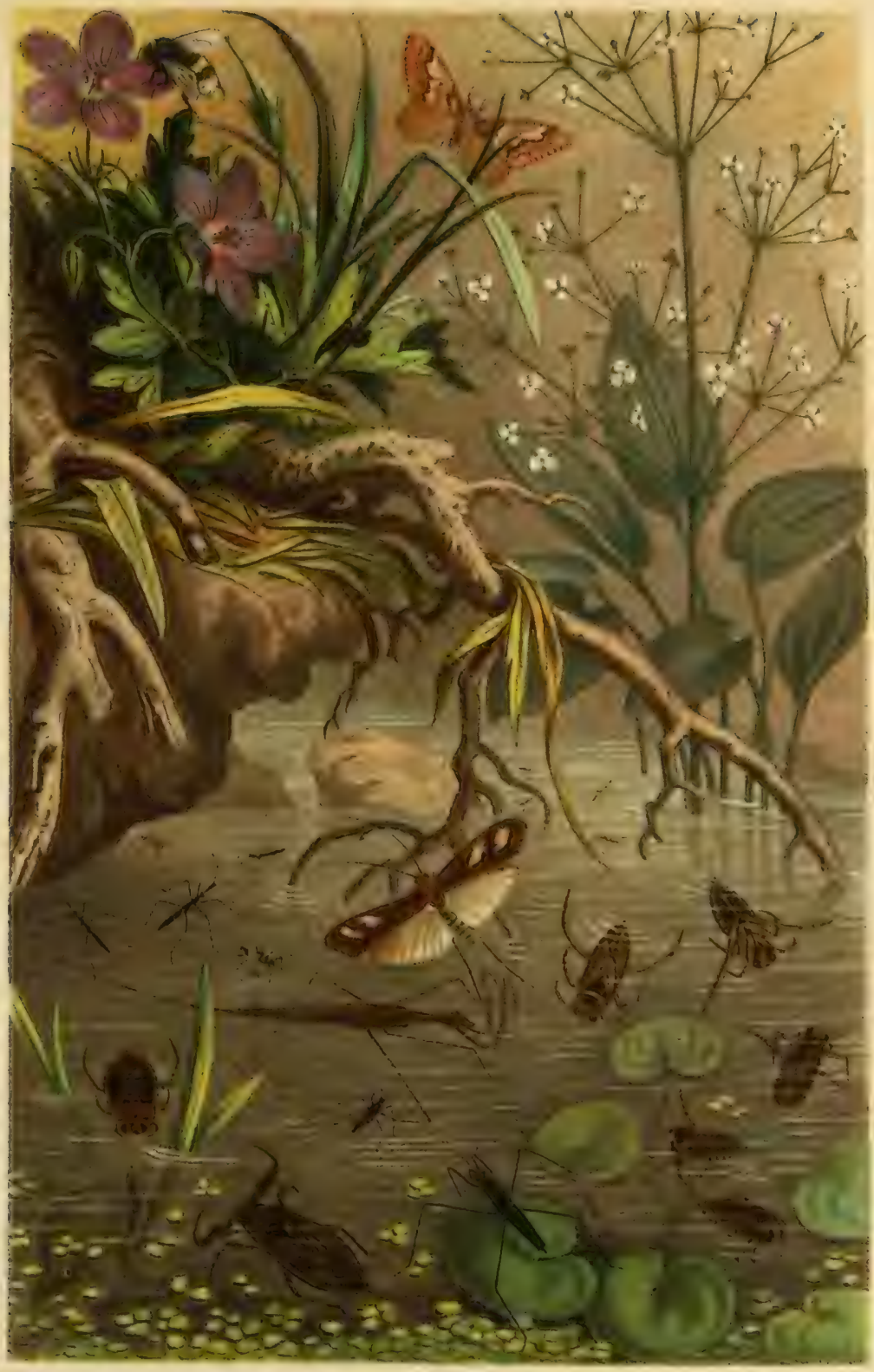





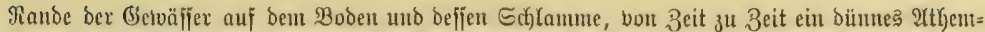

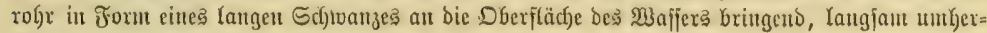
iriecht. 3u exjteren gebört:

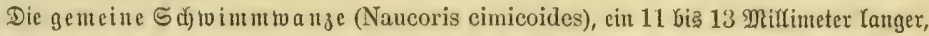

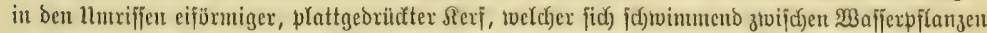

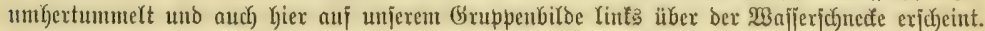

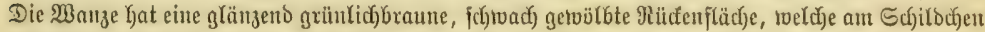
und an ben Flügeldecten an bunteliten aujtritt. Die furgen, in ein flauenartiges Fupglied

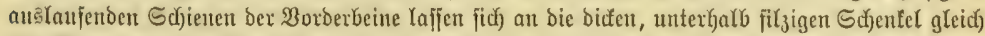
ber Nitinge eines Tajohenmeffers an ifgren Etiel einlegen und bilden bas Fangiverfzeug jür ben

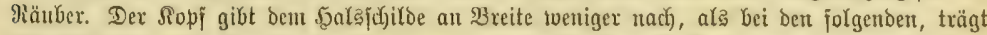

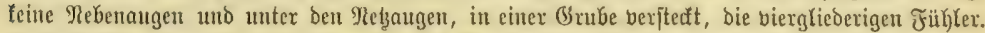

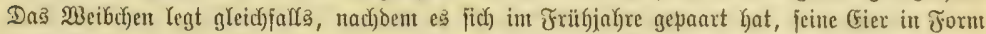

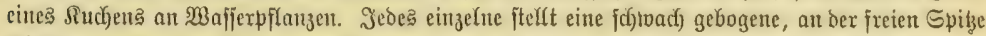

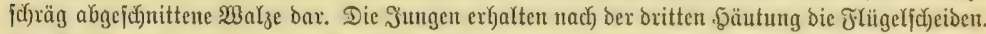

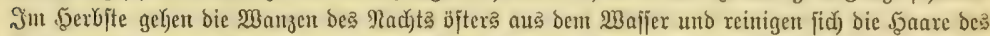

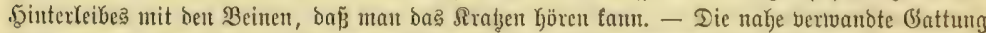

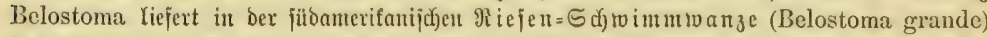

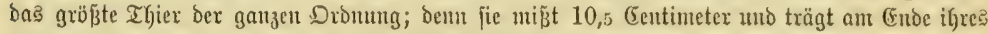

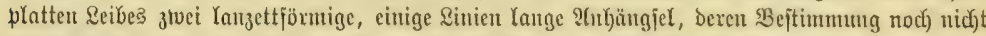

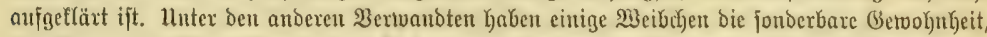

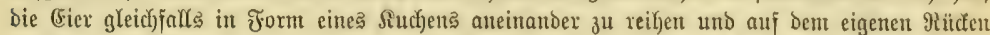

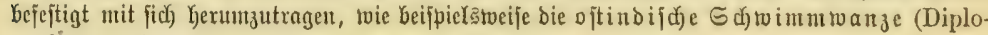
nychus rusticus).

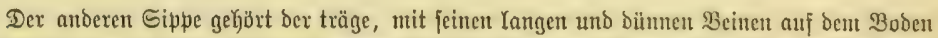

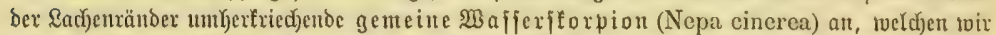

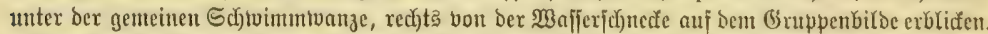

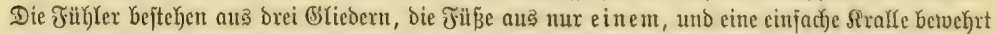

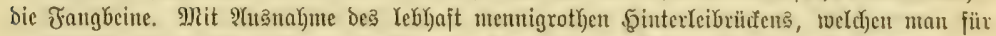

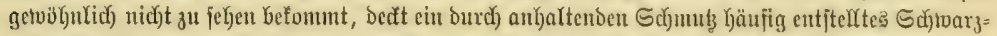

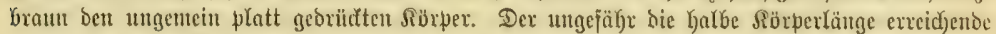

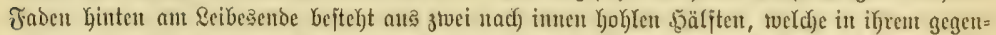

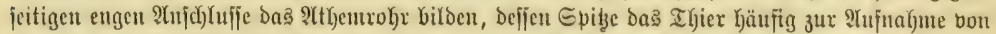

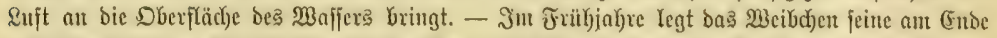

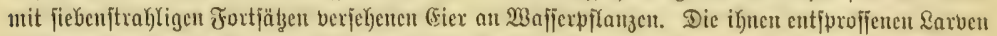

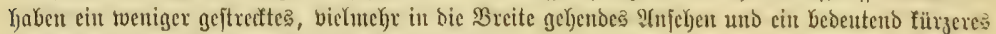
Ithentrohr als bie volftonmen entruidelte Manze.

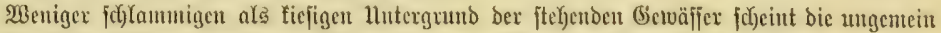

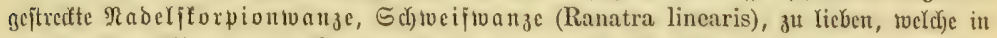

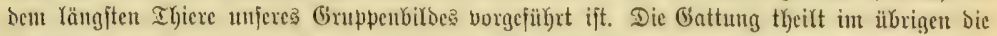

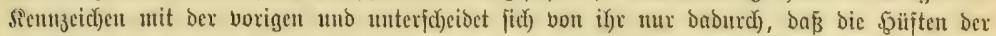

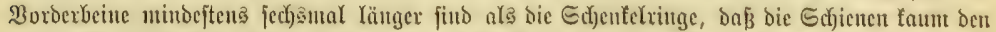

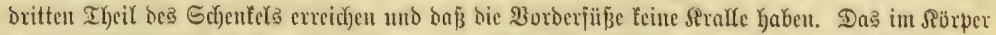

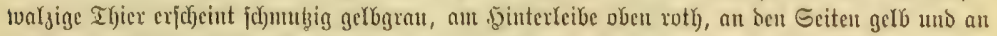

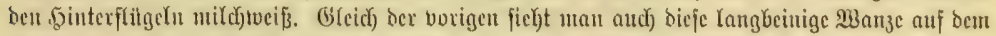

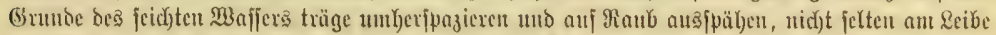

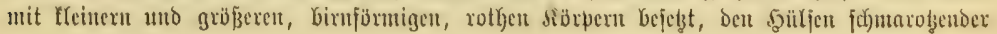




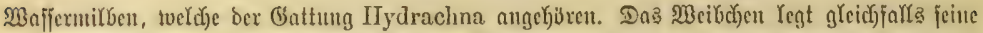

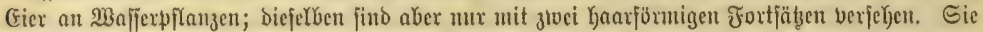

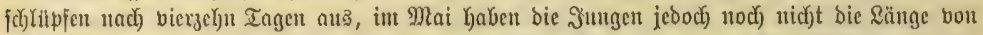

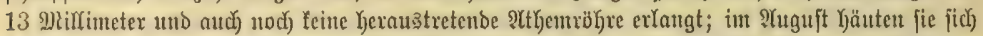

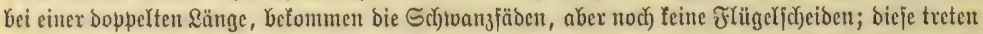

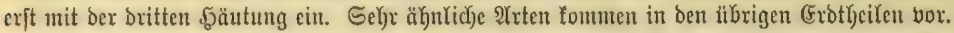

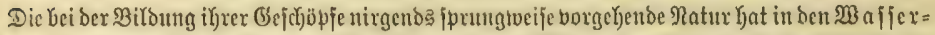

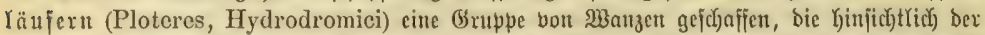

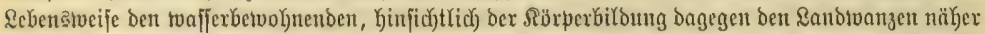

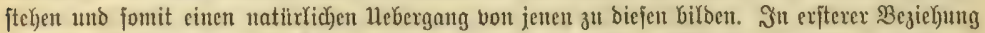

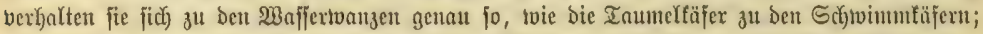

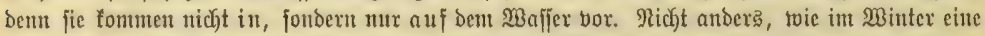

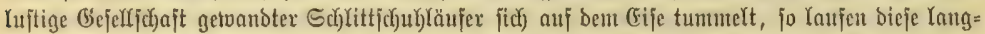

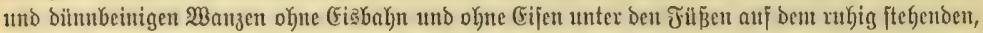

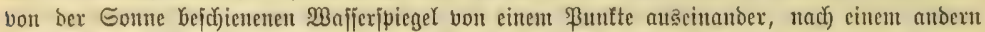

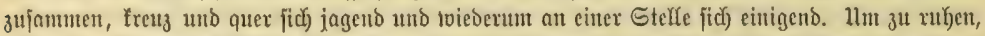

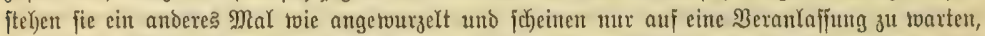

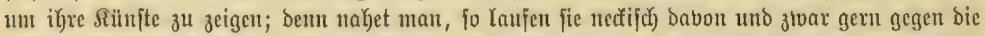

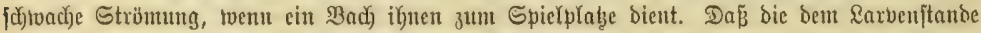

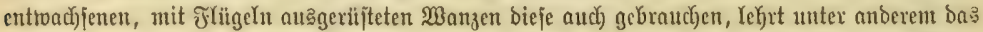

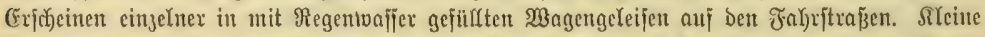

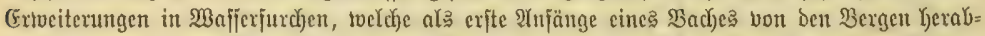

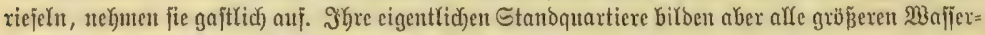

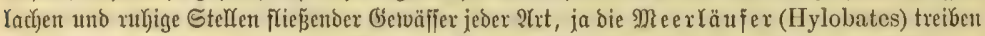

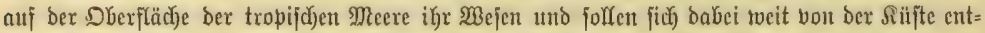

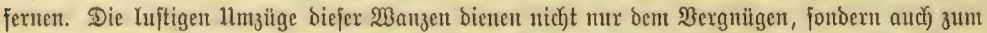

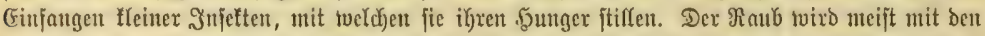

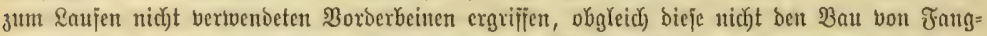
beinen Knben. Bei ben verfachiebenen ESattungen folgen bie fed)

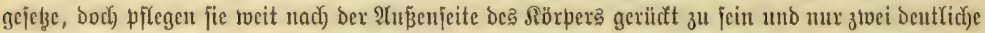

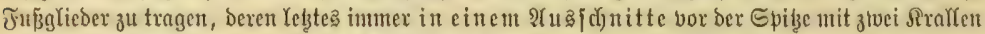
verjelyen ijt. Bei allen erreicht ber Sopf faft bie Breite bes borberen Buftringes, aus weldenen er

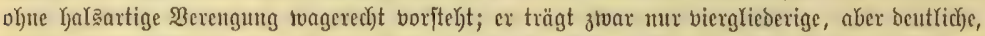

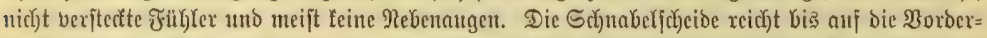

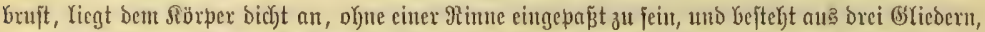

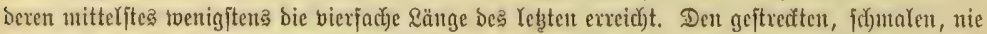

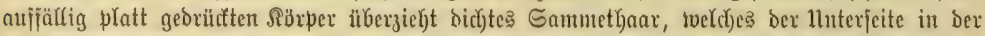

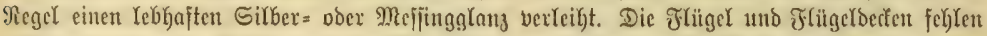

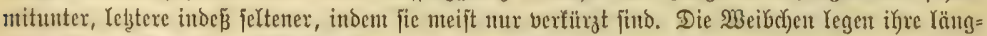

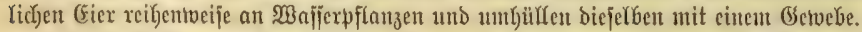

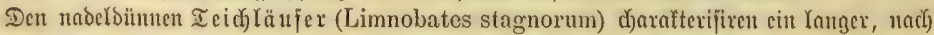

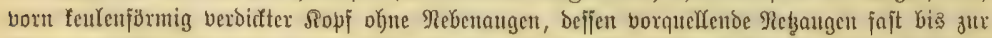

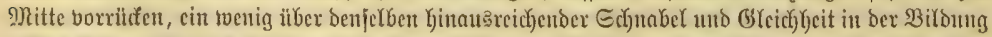

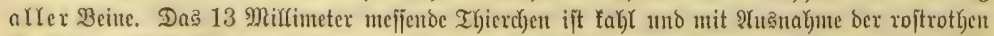

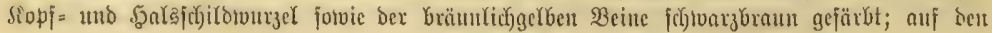




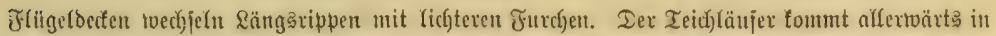
(5uropa vor und zeigt fid) unter ben borfpringenden Wurgelu unjeres (Gruppenbildes in פlef)rzah).

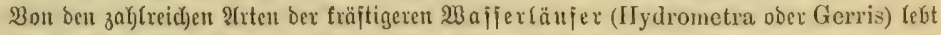

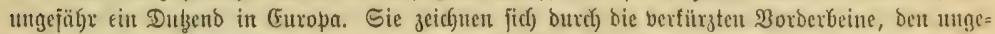

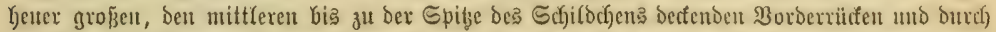

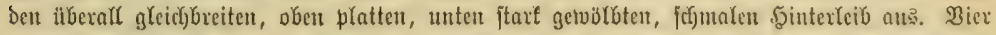

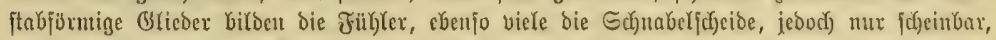

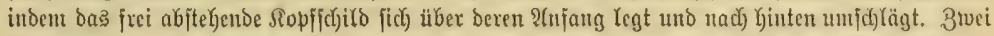

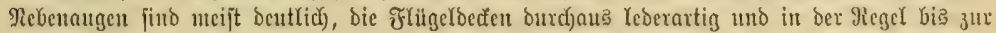

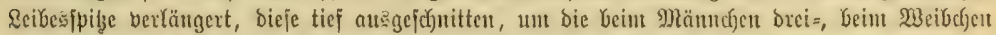

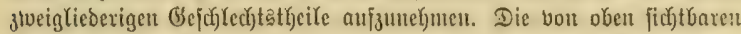
Ђulften ber bier Đinterbeine veranlafien an ber betreffenden Sörperịtelle cine merffidje Berbreiterung. Die Rarben unteridyeiben fid) von ben aue:

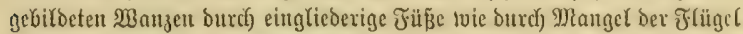

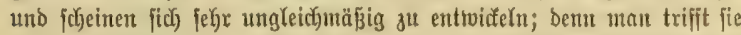

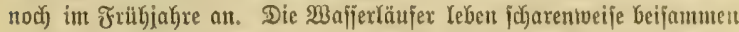

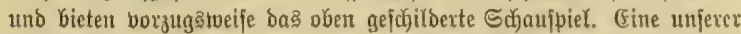

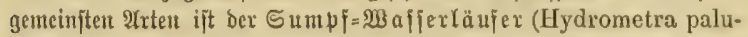
dum), fenntlich) an ben Quexrunzeln auj bem hinteren Theile bea breimal

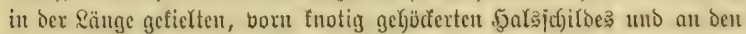

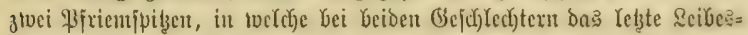

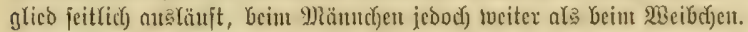

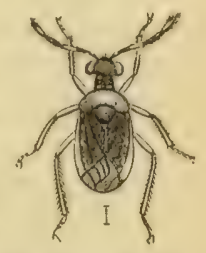

Bierlider liferläufer (Salua elugautula!, adjtual vergröğert.

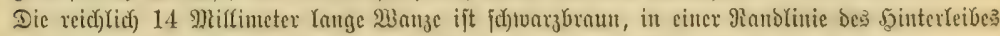

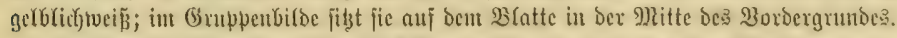

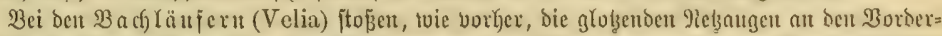

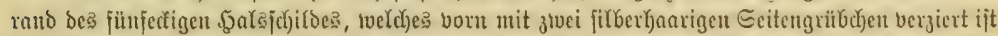

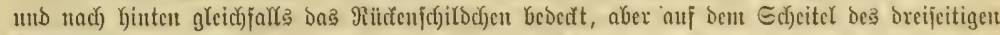

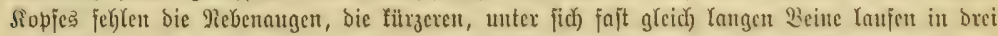

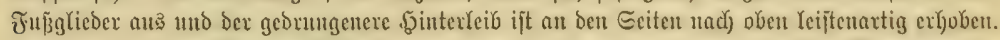

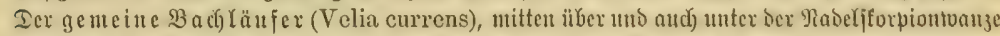

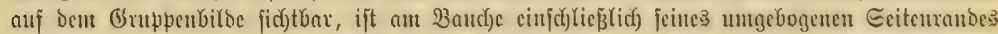

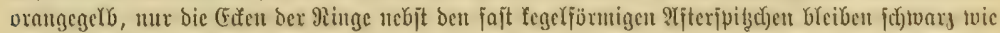

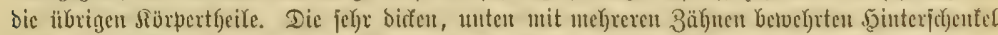

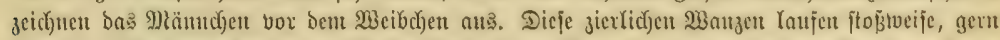

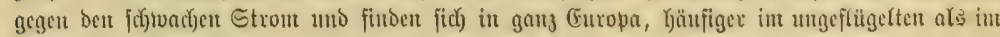
volftommenen $3 u$ tando.

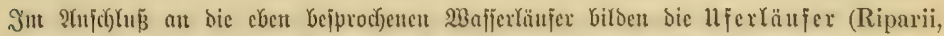

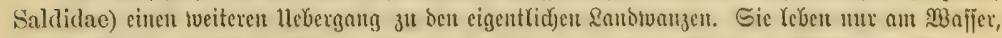

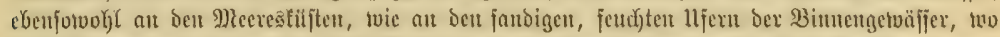

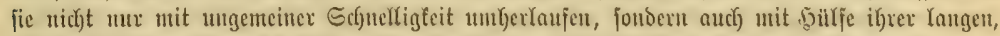

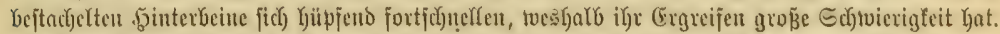

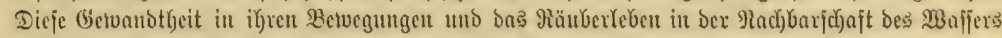

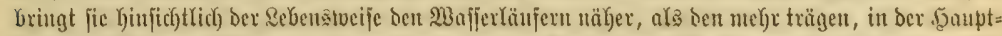

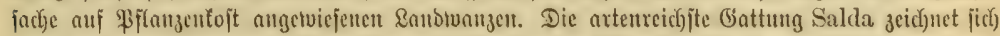

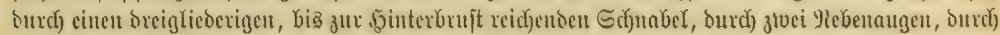

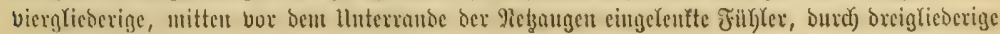




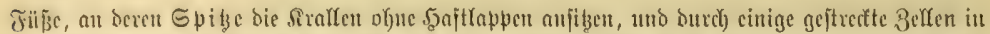

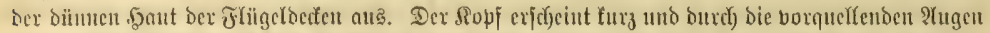

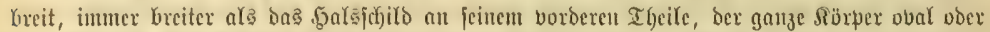

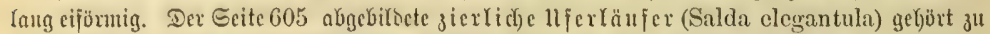

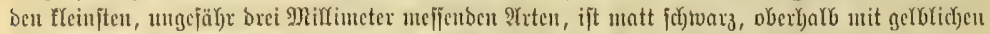

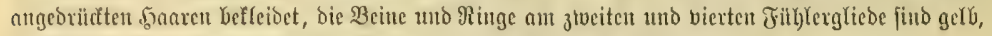

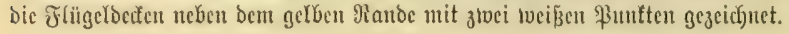

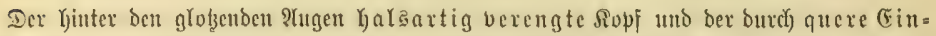

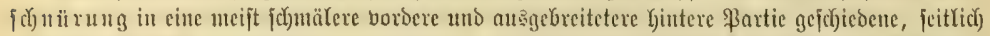
getundete Borberbruftring Gilden bie beioen in bie ?tugen fpringenden Sennzeidjen ber Sef)reit=

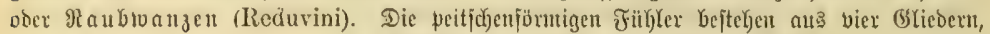

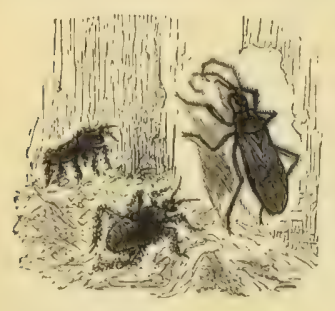

Sotbluanje (Redavius personatus) nebift Sarve. Ratilitidic (Stöp̆e.

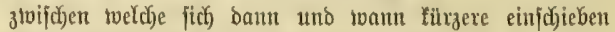

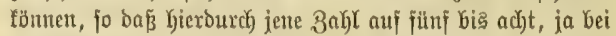
einer Brattung burd) Berfalfen ber Sauptgrieder auj Dreifig antwadyfen fanu. Sinter eintex Duerfurchye trägt ber Sdjeitel

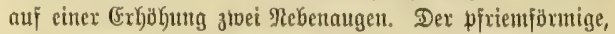
meift furze uno oreiglicoerige Schuabel jteht jrei bom Rörper

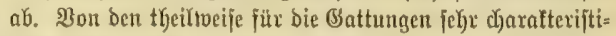

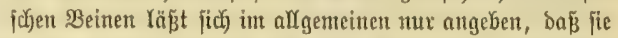

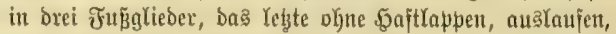

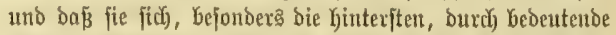

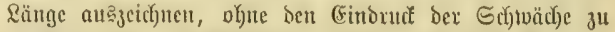

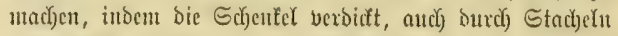
mannigfach betuebrt zu fein pflegen. Die fänmtlichen

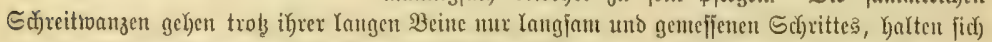

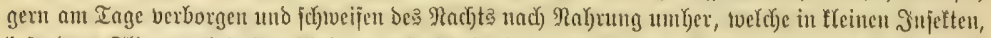

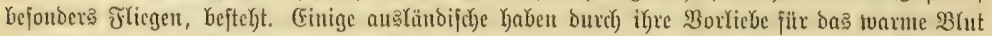

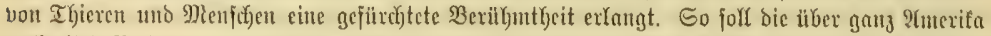

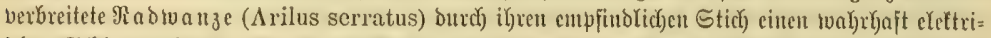

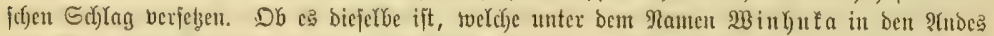

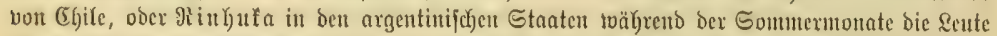

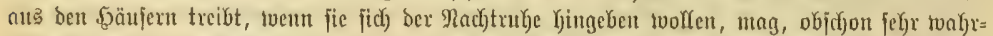

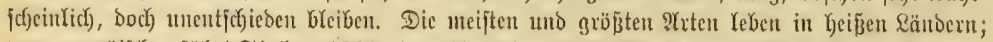

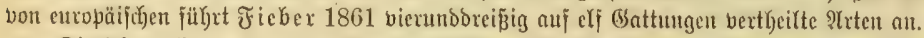

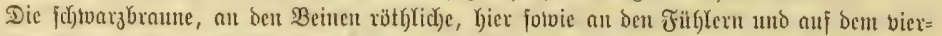

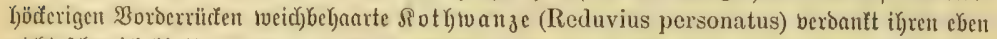

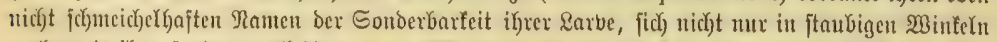

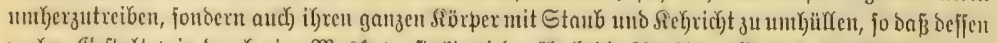

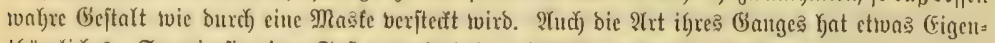

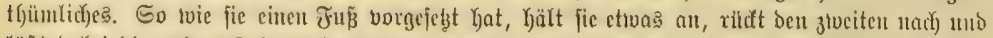

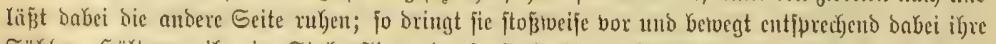

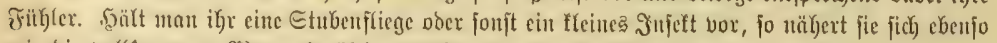

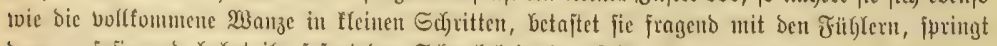

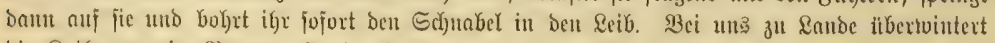

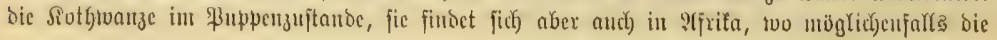




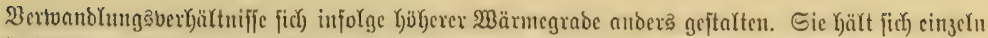

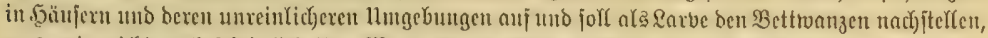

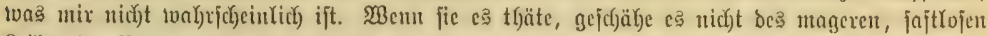

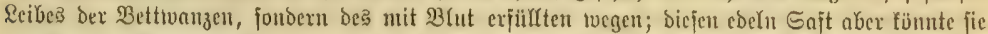

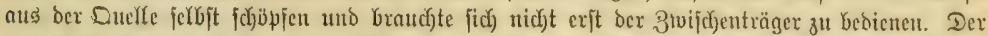

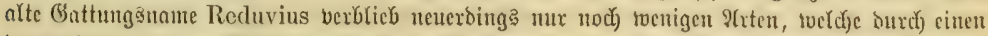

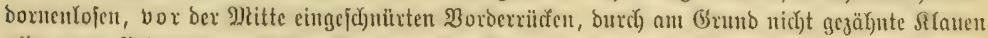

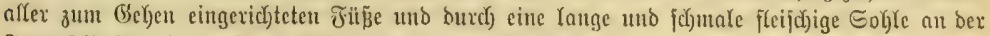
Jumenjeite ber vier voroberen Schientripiber ubereinjtimmen.

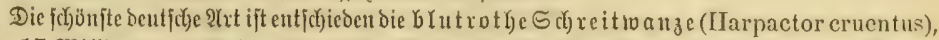

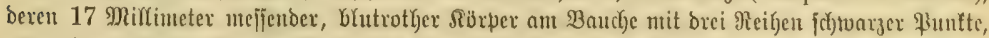

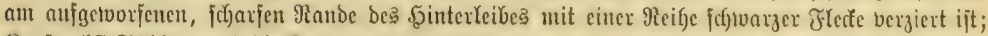

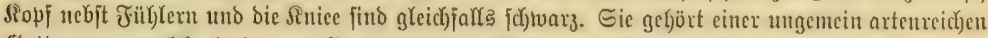

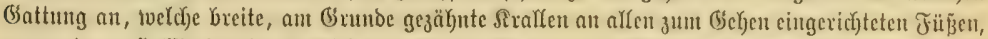

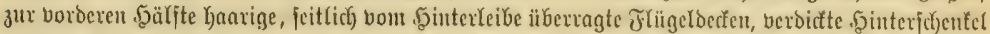

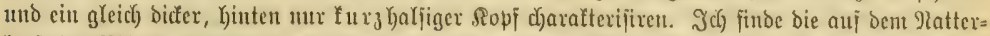

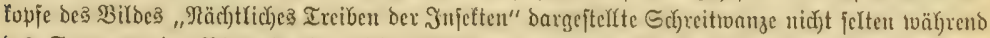

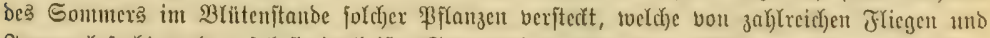

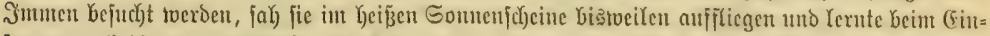

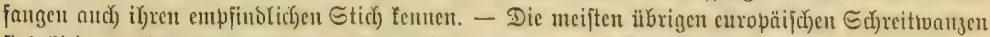

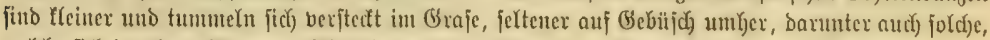

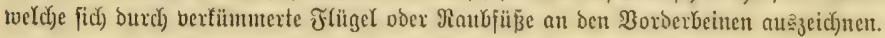

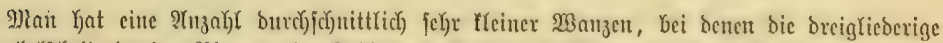

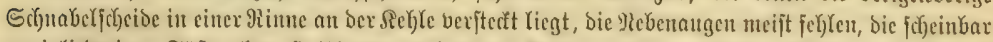

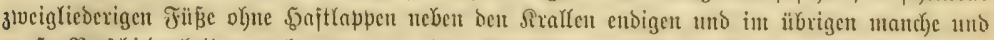

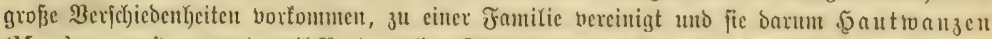

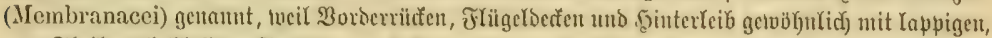

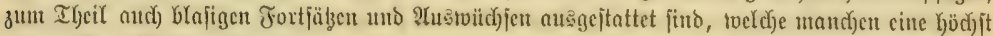
muntorbare Gejtalt verYeiben.

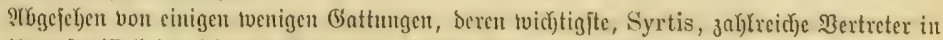

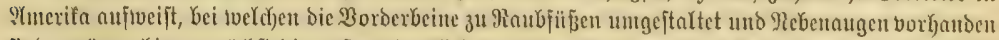

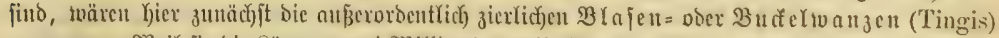

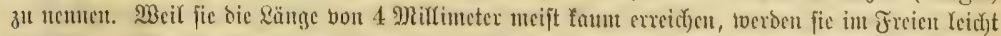

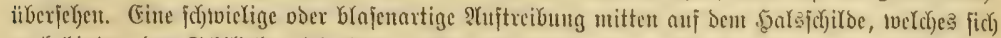

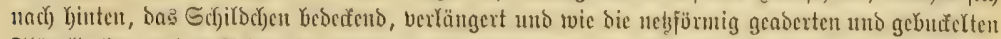

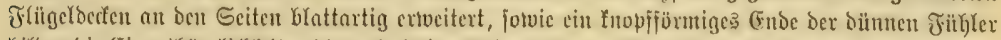

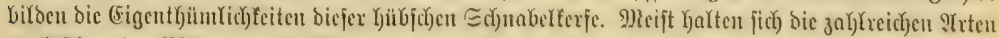

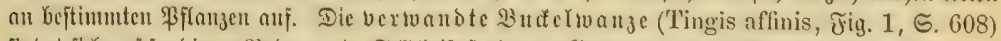

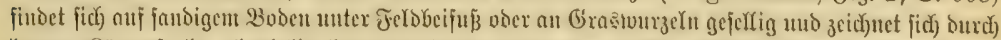

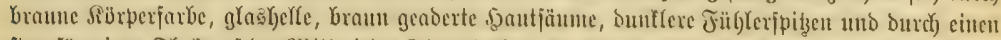

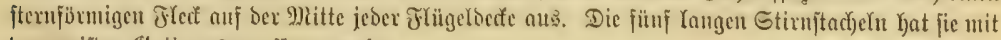
Den meiften Battungągenoj]en gemtein.

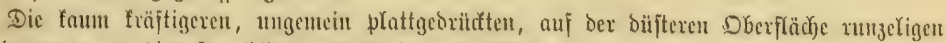

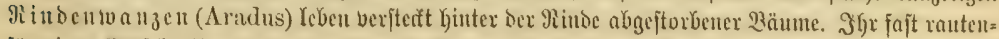

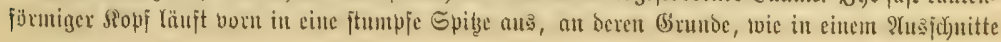




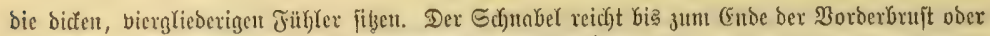

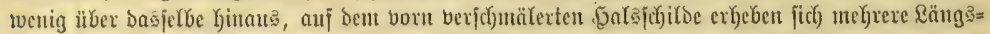

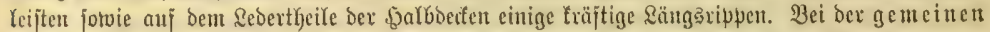
xinbentoanze (Aradus corticalis, Fig. 2) Kerrf(r)t bie f(r)tuarze Sörperfarbe bor, nur bie

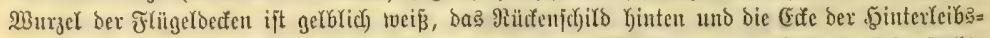

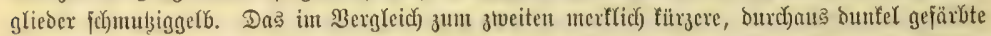

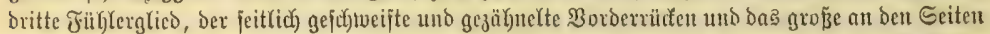

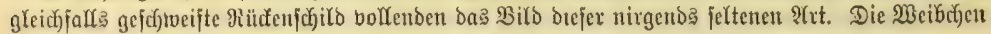

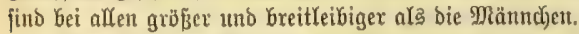

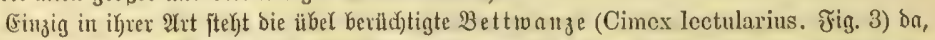

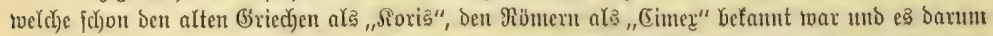

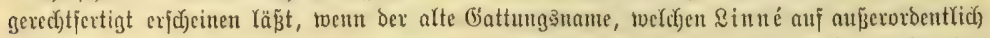

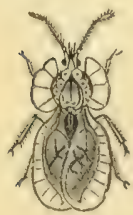

1

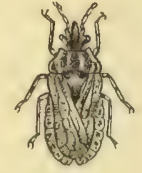

2

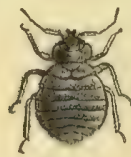
biele, in ben Formen fehrr weit auseinander gehende Ifrten übextragen font, ibr alfein berbleibt.

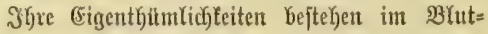
jaugen, in bex Flilgeflopigfeit, in ben borjtigen, vierglieðerigen Jüh)Yern, Dem einex Rehlrinte antiegendent breigliederigen Sd)tabet und bem Mangel ber Đaftlappen an Den Sraflen. Dex un= gemein platte, minoejtens 4 Millimeter meffende

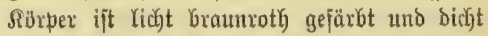
gerbliç) behaart. Die runden Räppctyen an beiben

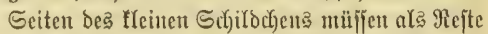
bex Flingeldecfen gelten. Dab Meibdyen lent im

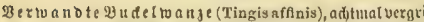

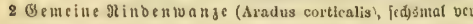
grögert. 3 bettiva nge (Cimex lectularlus), ftart vergröbert.

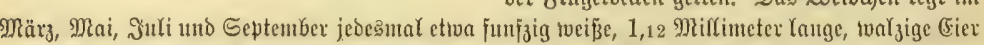

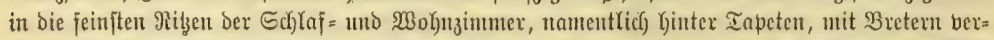

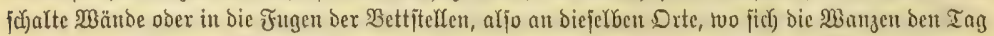

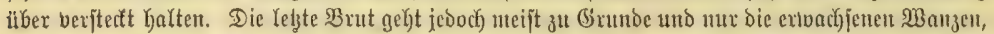

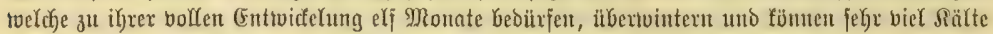

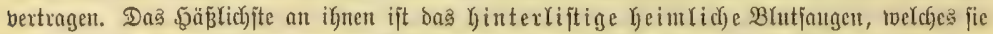

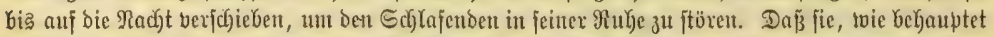

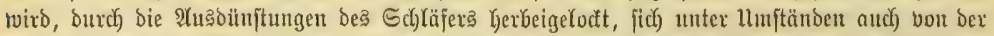

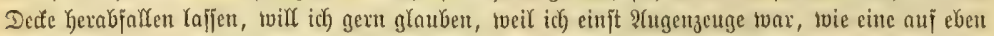

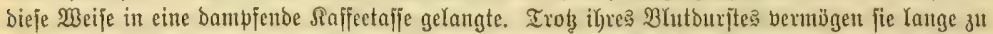

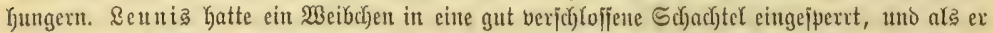

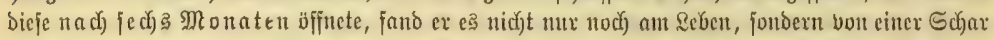

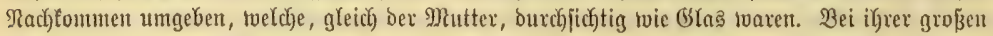

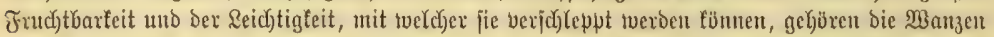

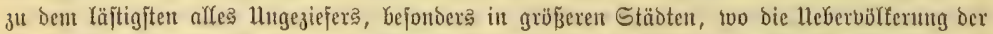

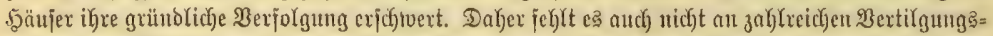

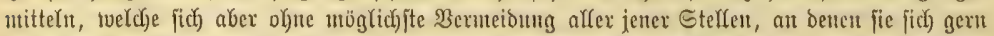

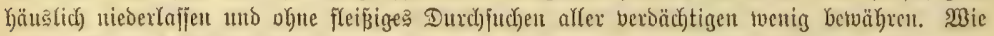

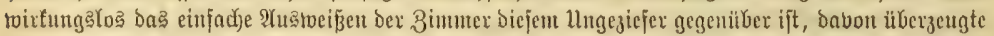

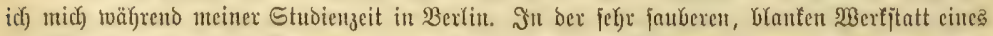

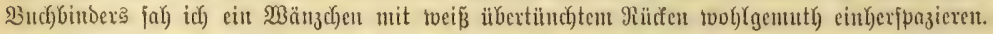

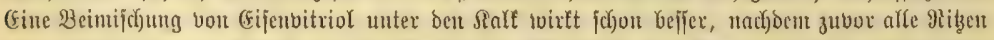

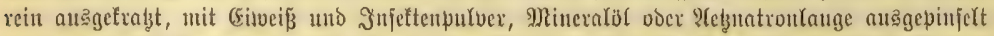

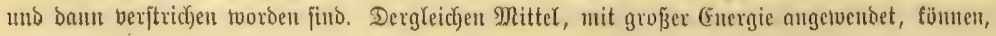




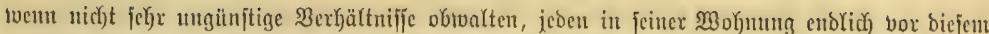

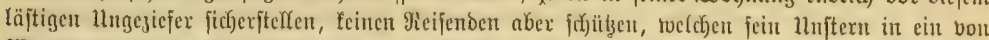

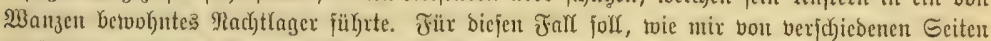

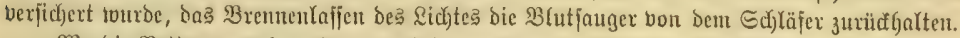

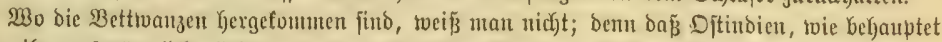

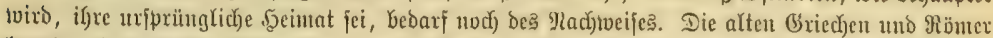

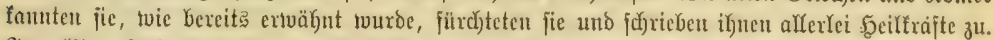

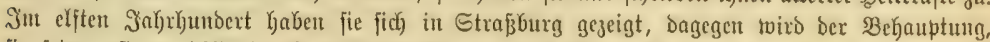

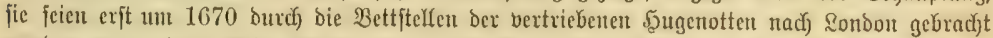
worben, von anderex Seite widerjproct)en, tweil fefjon 1503 dafelojt cin paar ablige Damen beren

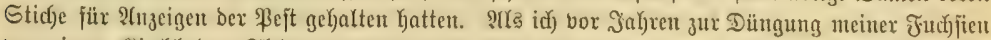
bou einem Sirch)boben Flebermausmijt jelbjt herabgeholt lyatte, wax idf nidyt toenig exftaunt,

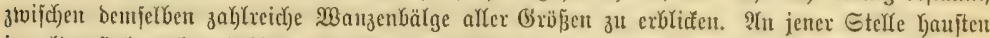

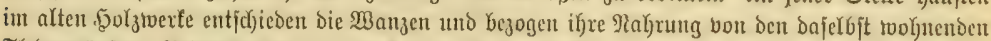

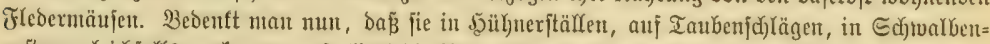

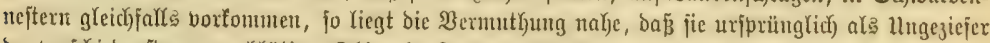

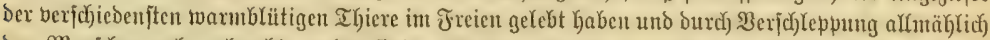

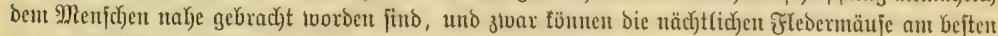

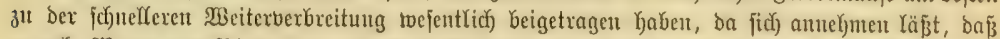

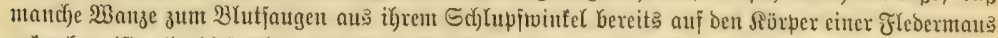

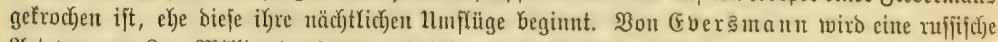

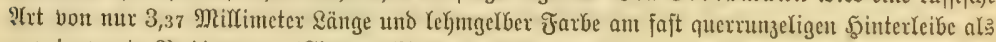
getoint perte 3 et troanze (Cimex ciliatus) unterjudieden.

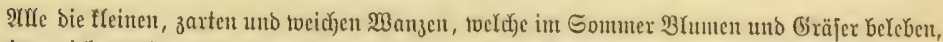
mit einer biclen anderen Dronungggenojīen fremoen Betweglidjfeit uno fortwährenden Bereitjd)aft

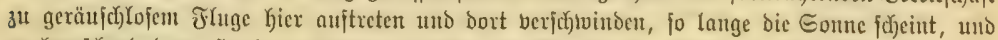

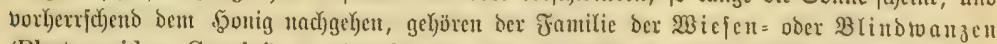

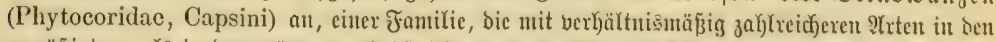

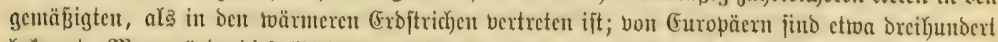

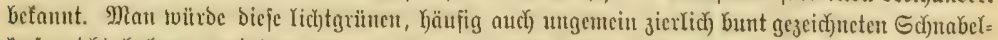
ferfe nidgt haben bereinigen fönnen, went fie nicht aud) in fiorperbaue mit cinander überein. ftimuten. Sie haben cinen breicatigen Ropf, seffen breifcitiger Ed)eitel nur bei einter Gattung (Miris) bon ber Etim getremt, bei ben übrigen Kerabgebogen und mit ber nad) vorn getwendeten

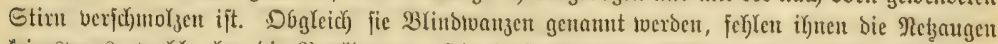

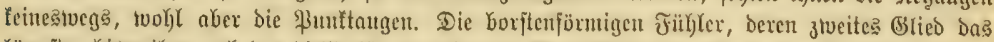

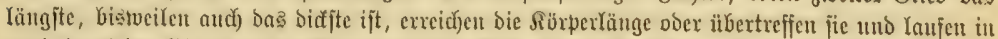

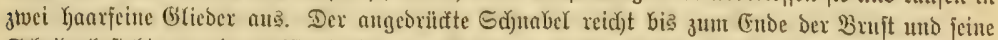

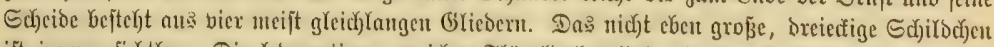

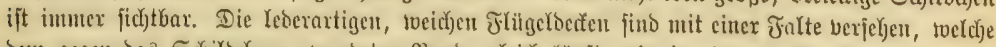

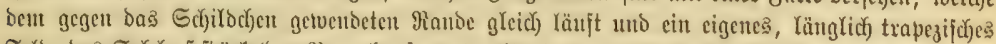

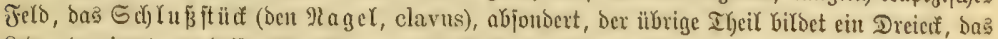
Reber (corium), an beffeu fürzefte, gegen bic Epilze gerid)tete Ecite cin Durd) ciute Jalte abgejejter,

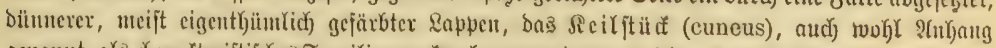

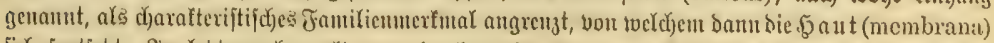

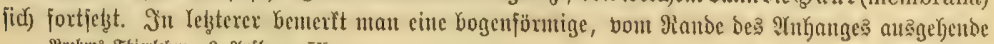

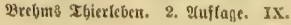




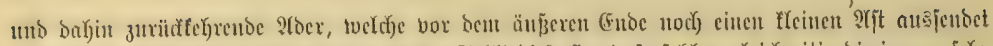

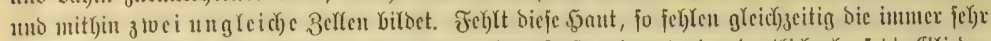

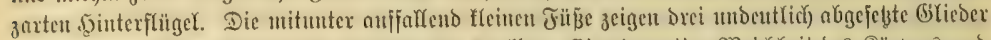

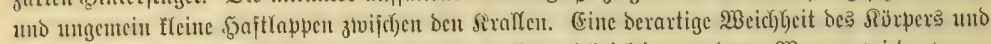

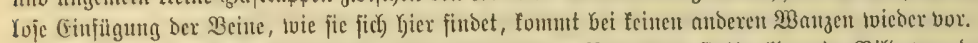

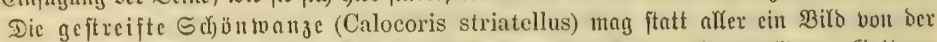
in Rese ftehenden Fantlic geben. Eic gebjüt Dex neuerbing vielfach) gefpaltenen (Battung

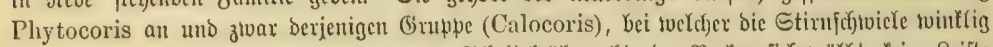

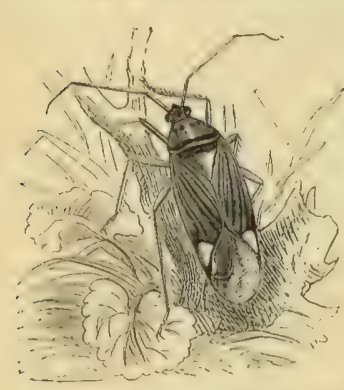

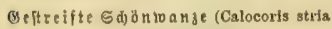
tellus), bergrö Gert.

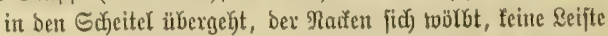
zeigt, bas Julhlertwurzelglied den fajt fünfectigen Sołf über=

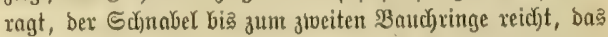
trapezijobe, vorn Yeijtenartig gerandete इarajchito an ben

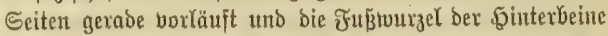

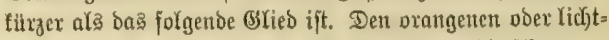

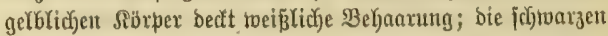

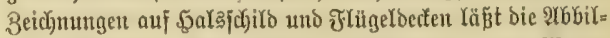
bung exfenten. Die reid)lick 7 Milfinteter Yange $2 a n z e$ findet fich auf Schimblumen burdy ganz Curopa. - Dic jodyfanten, fdumubiggrünet $\mathfrak{B}$ or fit entwanzen (Miris) zeid)= nen fick bor ben anberen burdi bejondere Sctymalkeit unt

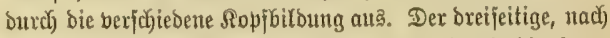

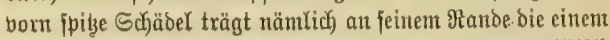

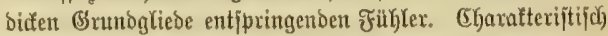

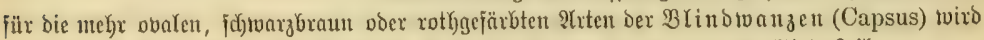

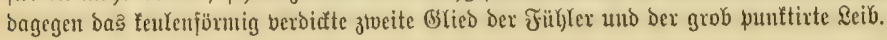

Bon ben jogenannten \&angtwanzen (Lygaeodes) Yeben Die meijten unter Steinen, bihrem,

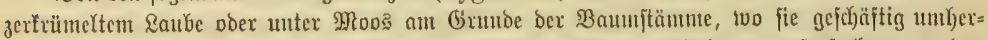

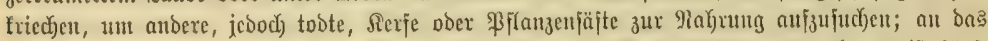

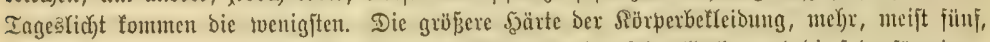

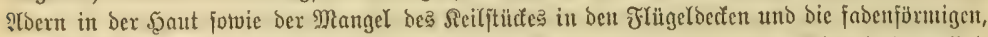

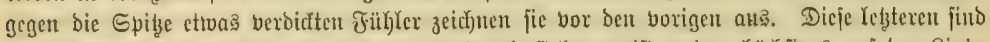

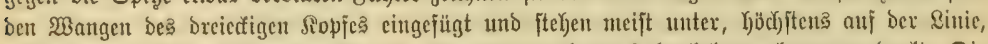

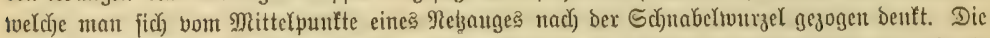

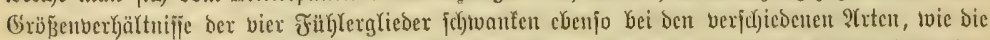

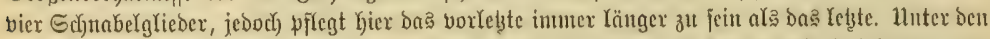

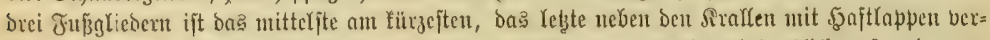

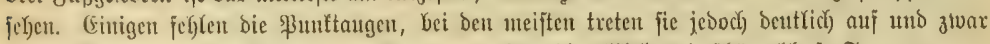

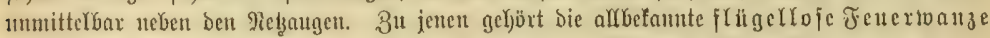

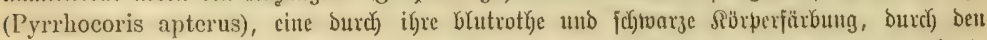

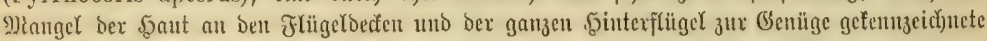

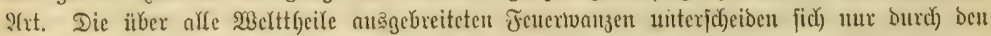

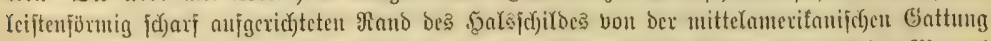

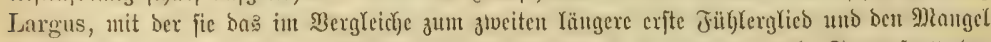

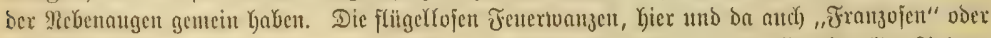

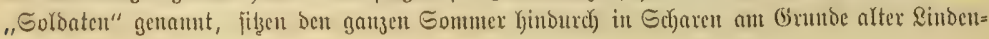




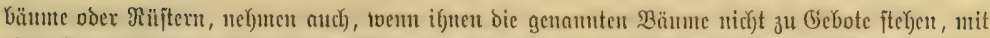

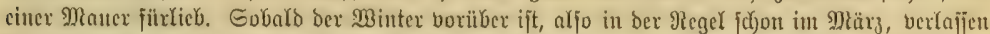

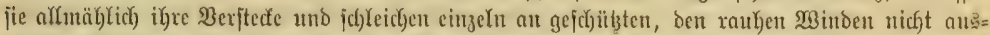

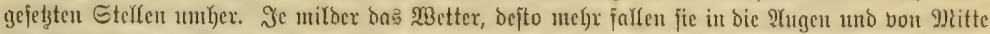

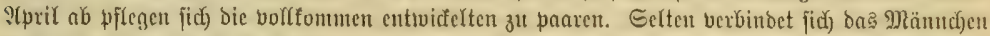

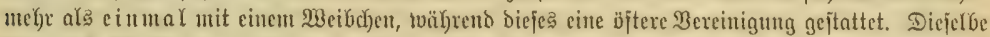

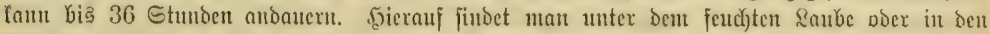

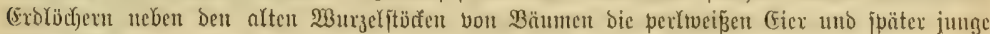

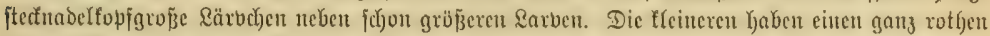

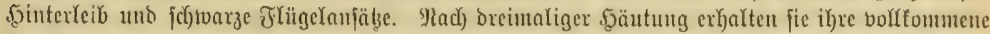

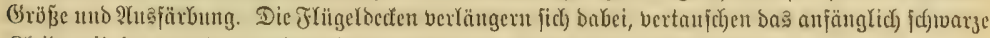

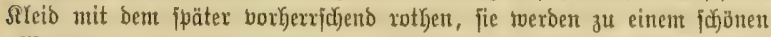

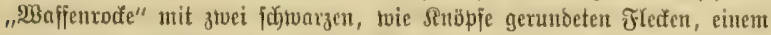
breiteren ober fdummäleren fớtwarzen Saume ant (Enoe und cinem fod)twazzen

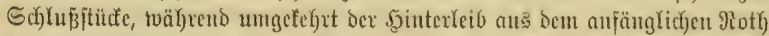

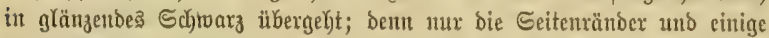
Duerbinden ant (Ende bes Bautjes behalten bie uriprüngliche Farbe bei.

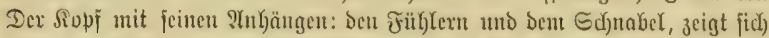

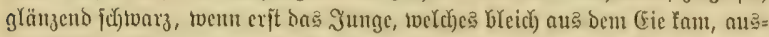

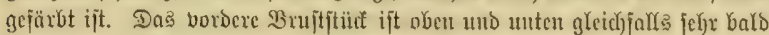

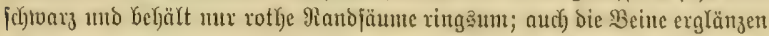

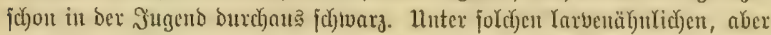
volffonmen ertwachjenten Jeuertwanzen fommen in jüblidyeren (begenoen bei 1 th traf ich) nod) feine an - cinzelue geflügelte bor. Dic erivad)jencu

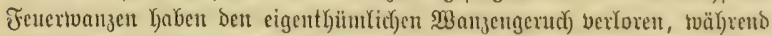

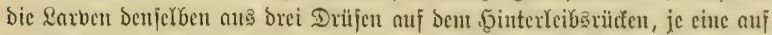

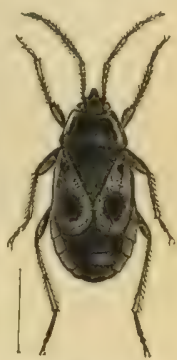

Itngeflügette ซeuer, uarise (Pyrrhocoris ap. teruy), orcinal ocrgröfert.

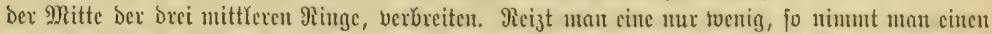

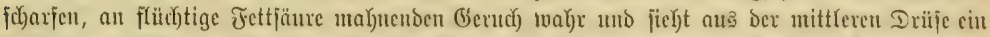

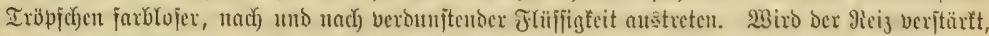

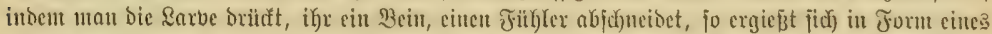
fleinen Etrah)

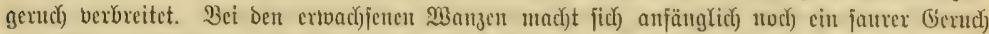

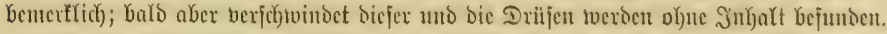

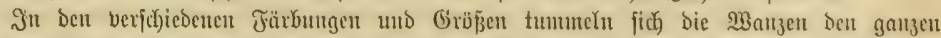

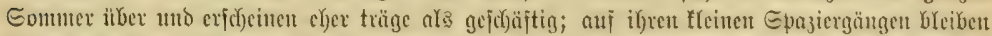

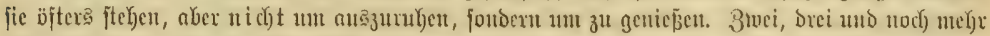

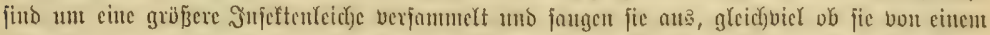

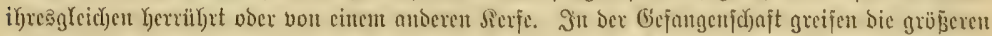

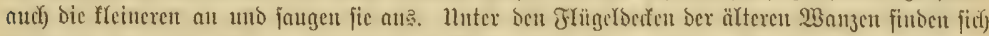

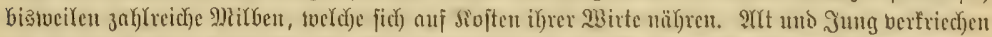

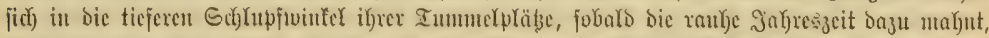

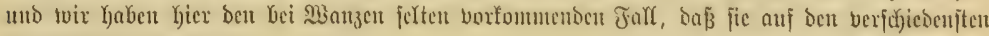

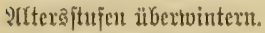

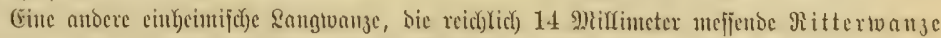

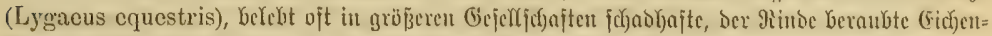

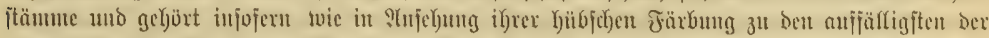

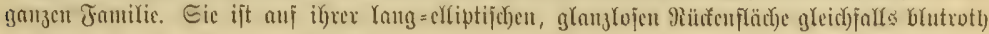

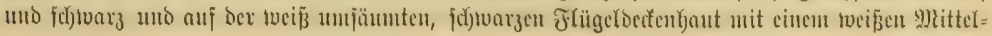




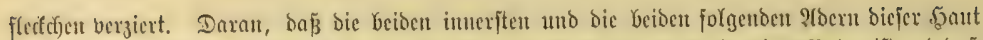

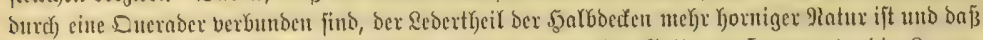

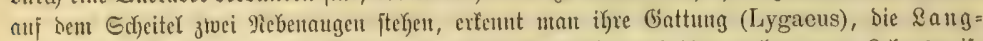

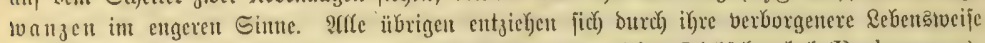

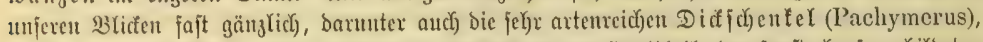

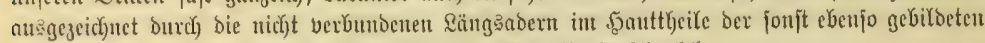

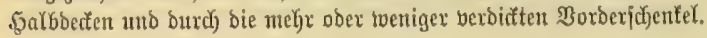

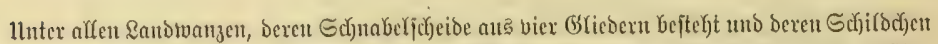

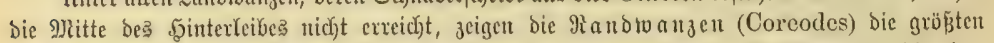

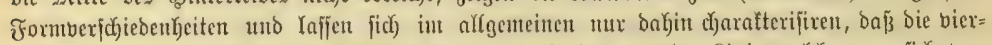

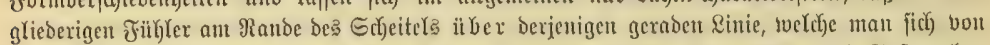

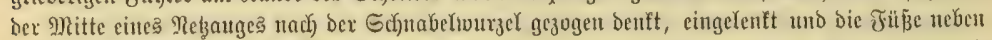

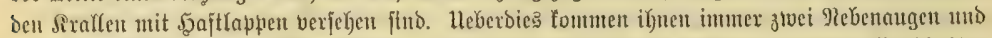

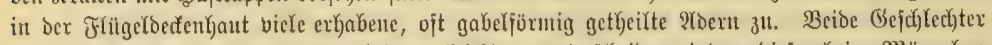

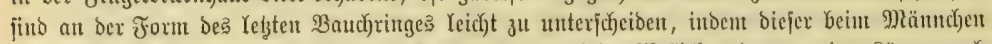
verbicft und toie bon unten mit ciner Rlappe bebectt, beim Weibdjen bagegen der \&änge nach)

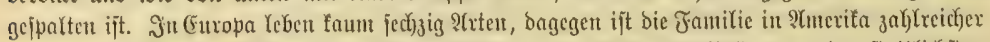

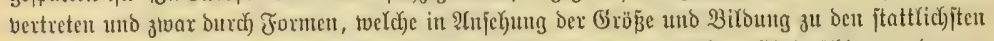

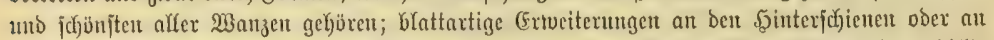

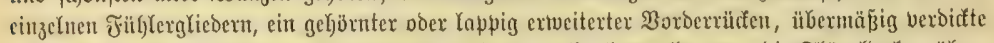

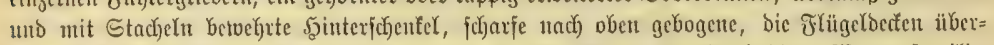

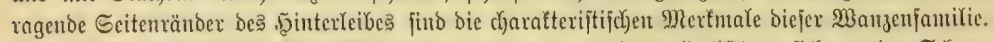

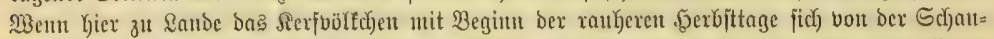

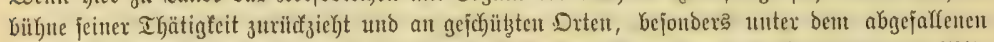

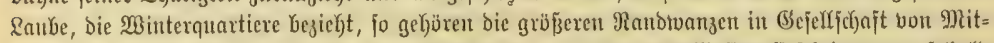

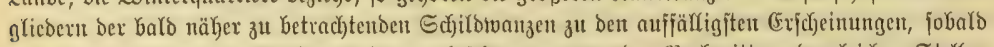

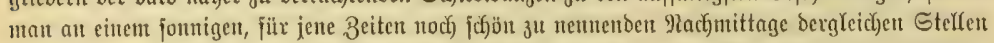

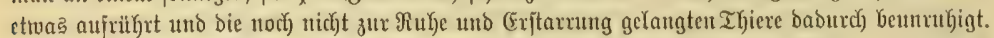

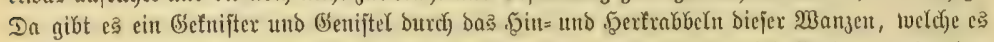

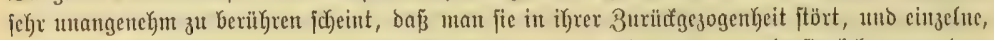

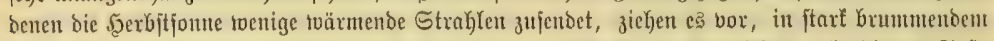

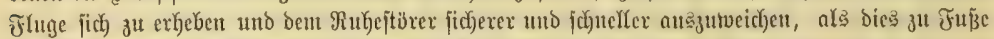

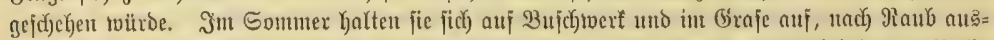

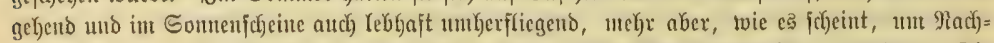
jteffungen zu entgeben als bent inneren Drange nack jolder Betuegungsiveife łu gentigen. Eie

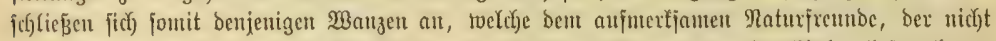

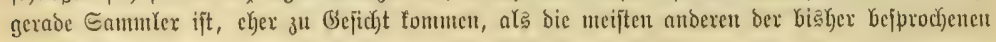
Franilier.

Die Jauptgattung Coreus ift Yeutzutage it utelyere aufgelojt, von benen Syromastes ntit

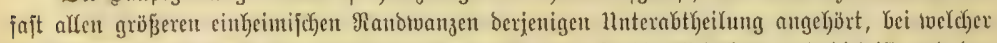

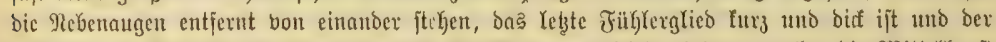

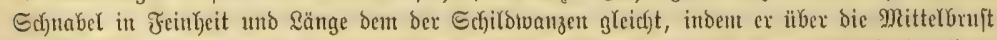

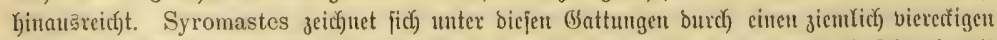

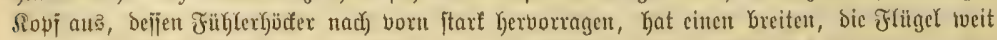

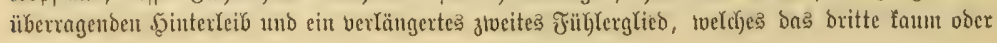


nur twenig an Räıge iibertrifft. Bei ber $\Xi_{n}$ um to anze (Syromastes marginatus, Fig. 1) erlveiteru

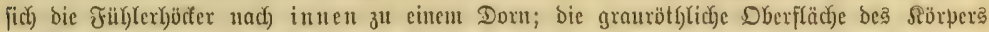

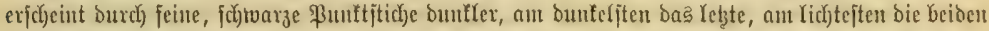

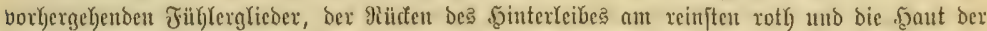

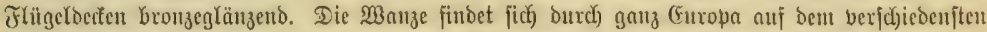

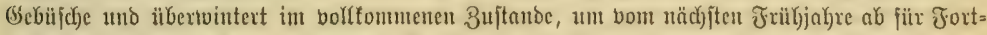
pflanzung ihrer Irt Sorge zu tragen. Die Rarbe (F̂g. 2) zeigt, tvic man bię bei allen Wanzen=

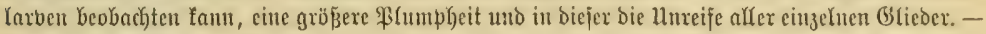
Die rantenförmige Randranze (Verlusia rhombica oder Coreus quadratus bes $\widetilde{J} a=$

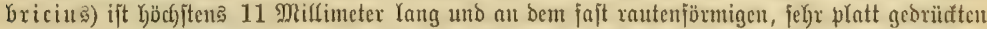

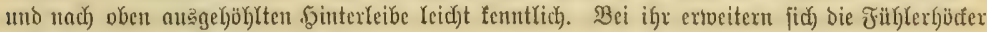

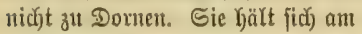
Yiebjten in Bräben läng ber Stiejer= walbungen auf, two fie an Gras= ftengeln und anberen Pflatzen bei Eomnenjedjein emporftiecht, voer ohne biejent mit einer getwifjen (Gil= fertigfeit und Furdetst, toem bas fie bergende Raub aufgejtìt toiro.

Bei Betradftung ber $S_{\text {(f) }} n a=$ tentwanze (Berytus tipularins), jenes ungemein jólanteu und zart= beinigen Ifyerchen (Jig. 3) von Yidjtgrauer Färbung, welç̧e an Den

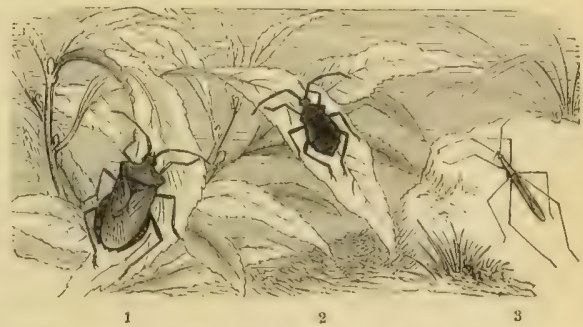

1 Ea umsuanje (Syromastes marginatus), 2 ibre Rarbe. 3 Eøuatentoanje (Berytus tipularius). Matïrtidic Gröbe.

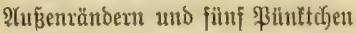

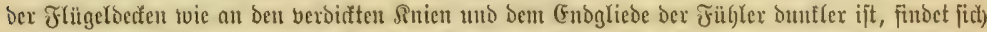

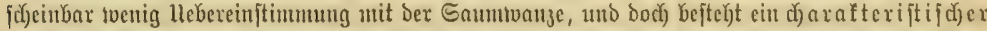

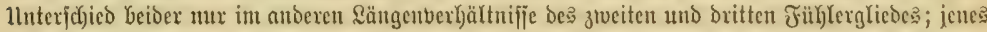

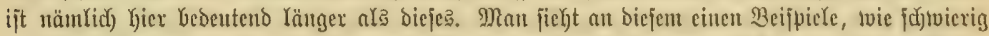

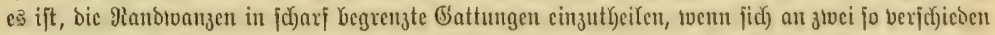

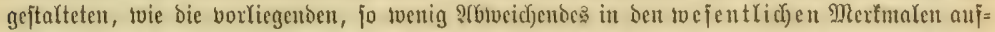

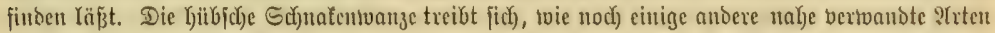

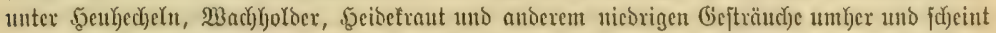

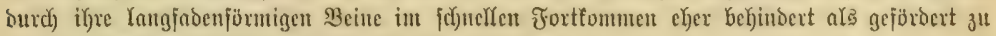
toerden; benu fie if̣t träge uno läpt fich Yeidjt exgreifen.

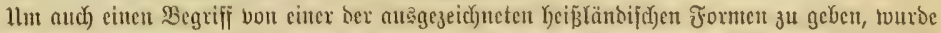

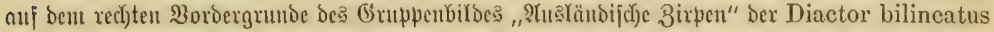

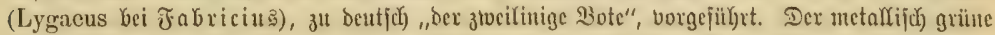

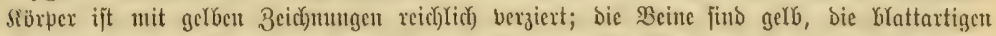

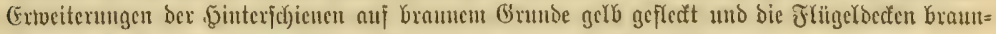

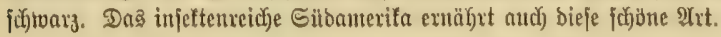

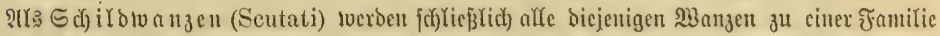

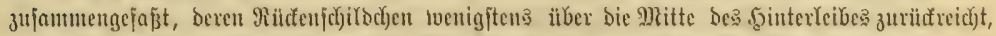

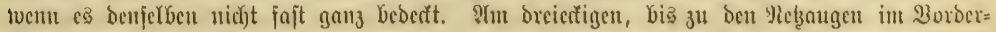

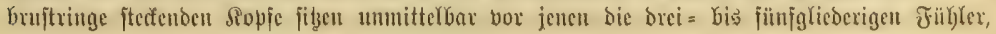




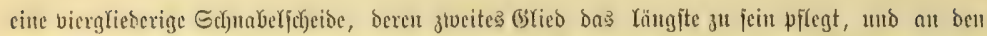

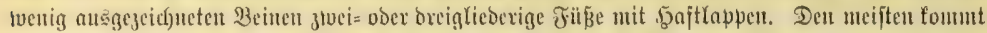
cin beutlicher (E)

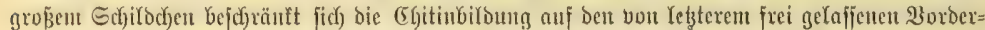

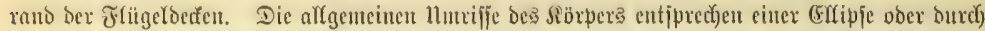

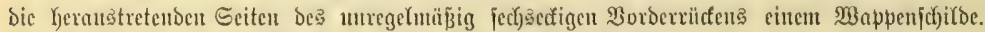

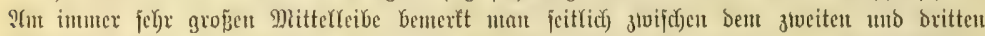

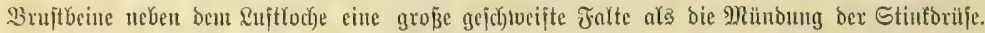

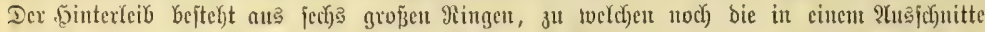

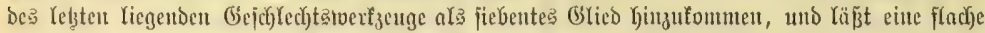

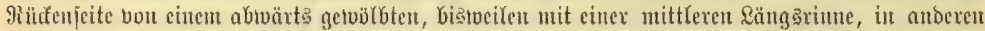

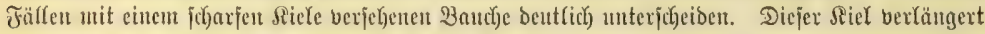

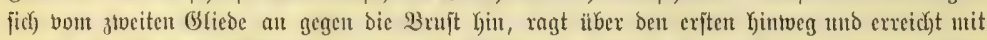

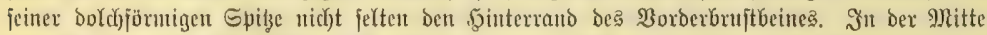

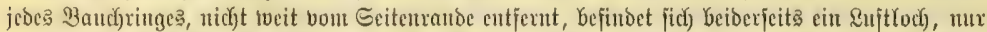

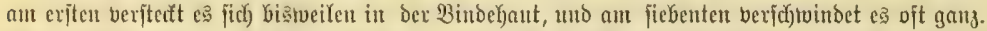

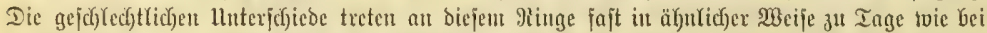

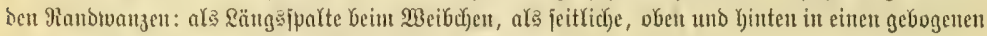

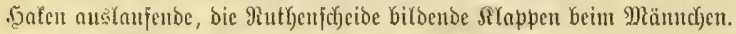

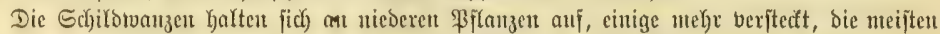

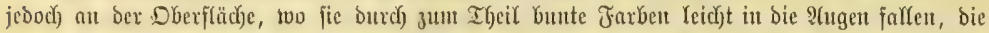

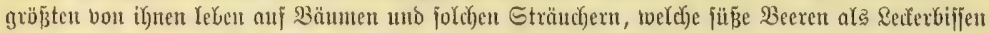

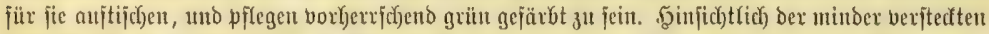

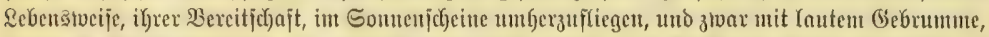

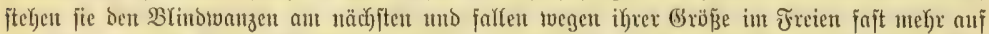

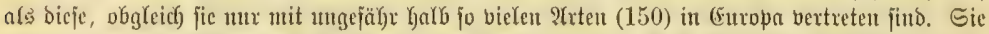
jiberinintern im volffonmenen 3ujtande unter bürren Raube. Das Gejuchtete Meibchen legt 孔u

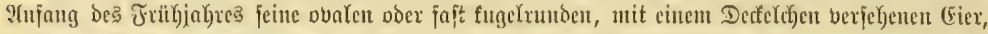

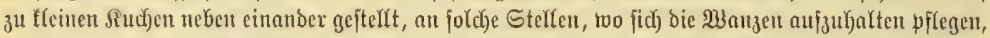

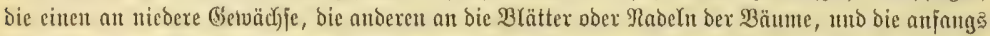

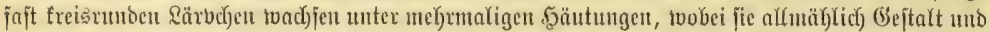

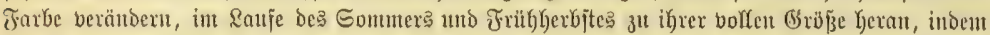

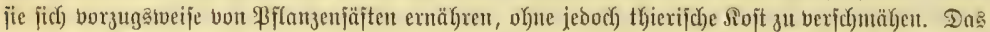

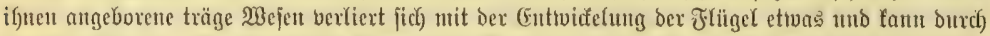
bie Etrableu ber alfe belebenden Eonue zeitweilig jogar in bas Gegentfeil ungetwandert merben.

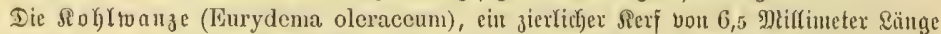

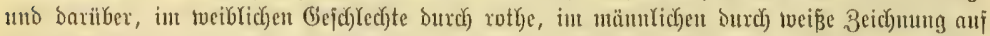

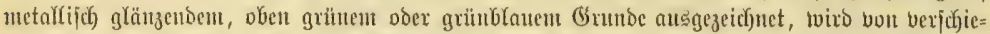

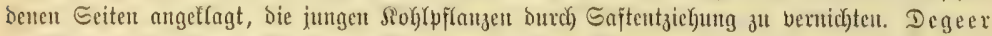

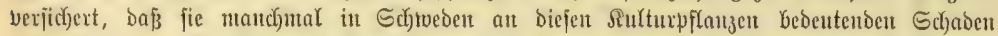

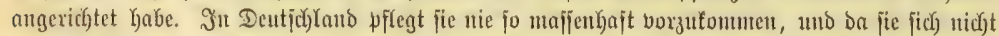

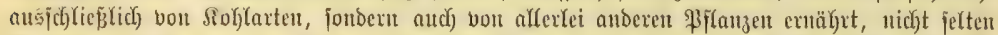

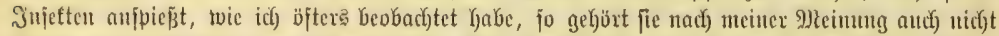

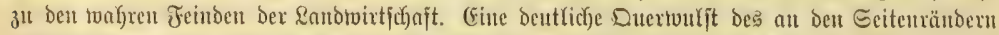

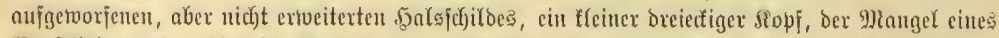

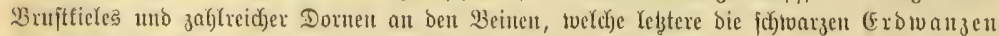

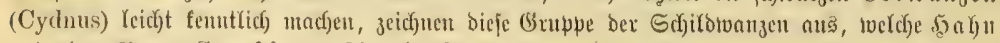
unter bem गamen Strachia bon Rinnés Cimex abgetrent Kat. 


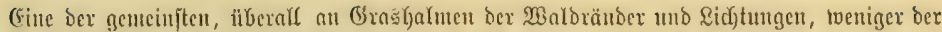

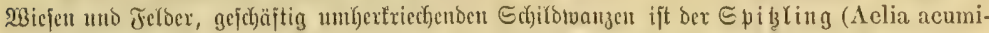

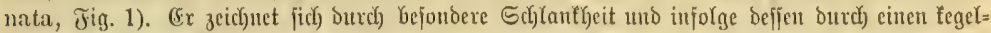

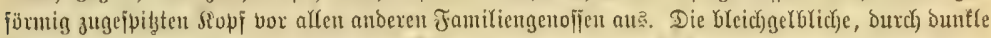

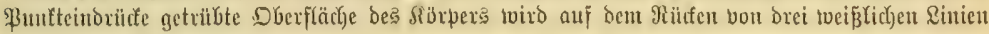
Der \&änge nad burd) 3 ogen.

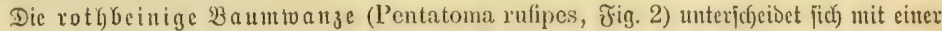

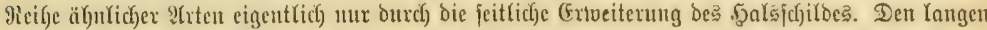

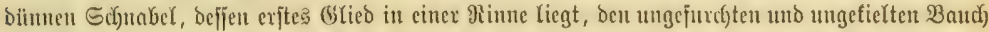

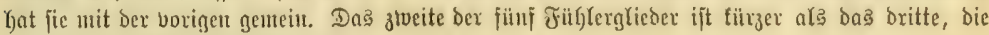
Dberf(äche deș Robrperse eingeptod)en j(c)tuarz punttirt, gelblict) ober rötl)= (ich) Graun mit Bronzefofinmer, Der

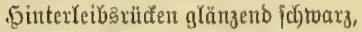

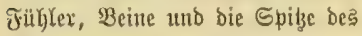
Sifjilodjent find mebr oder tweniger auşgeprügt roth. Dieje gemeine Fit Yebt geru auf Birfen, aber aud) nut anberem Gejträudje, friedjt an Baumjtämmen umber uno jolf fich

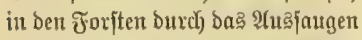

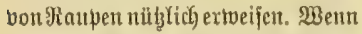
man eine Birfe burety einen fräjtigen Stoß erjidjittert, um bas barauf befinoriche Gieziejex ju Falle ju bringen, jo pflegt untere 2(ut nich)t Gerabjutfalfen, twie mandide andere, fonbern unter Tuabreitung ifrer Flügel fummeno herabufliegen.

(Fin anderer Bewolyuer junger

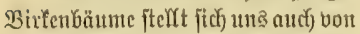

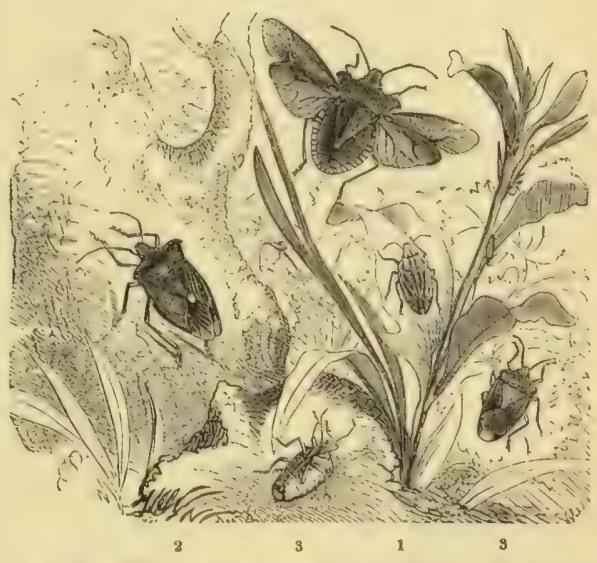

1 Spiblinn (Aelia acuminata). 2 Mothbeinine 2 aumbange (Pentatona rufipes), triedjend und fiegeno. 3 Gejähnte Gtad)elruange (Acanthosona

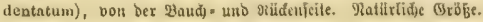

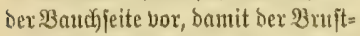

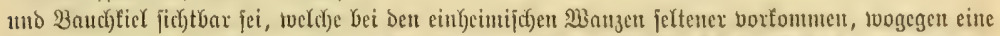

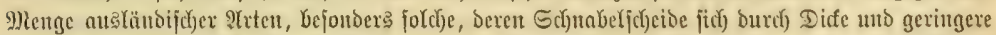

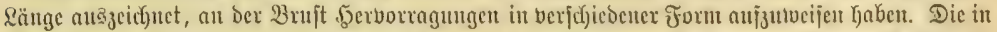

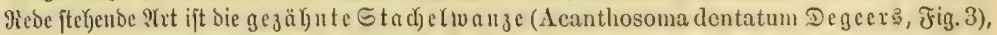

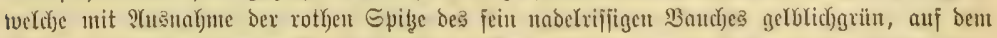

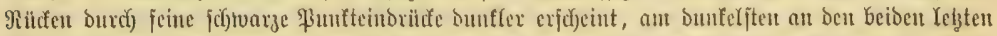

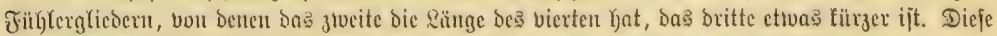

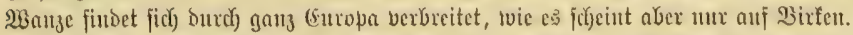

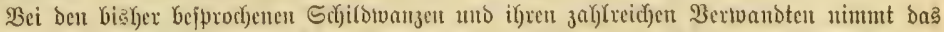

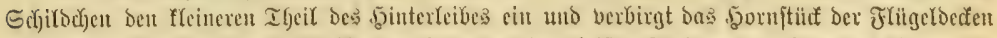

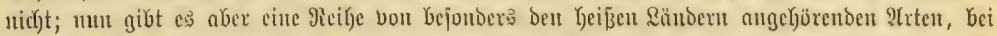

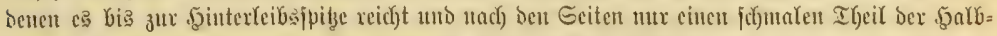

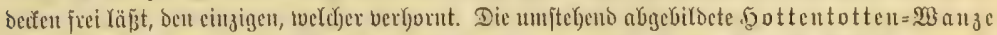

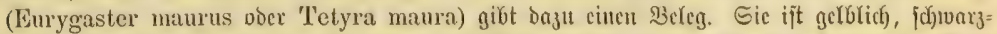

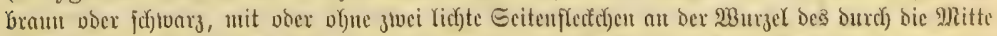

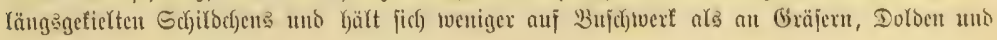




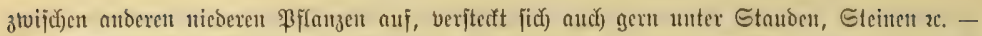

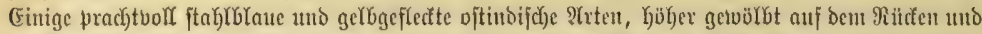

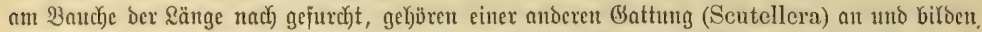

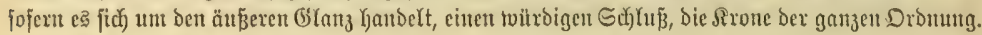

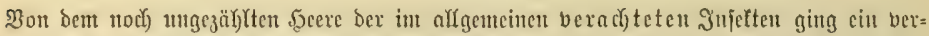

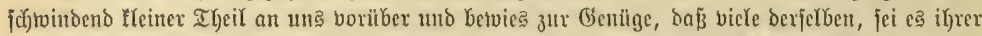

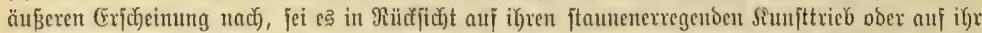

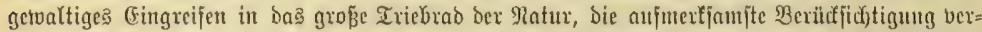

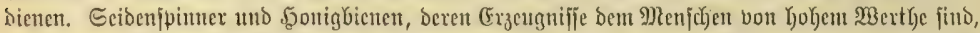

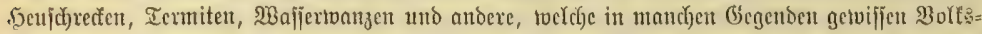

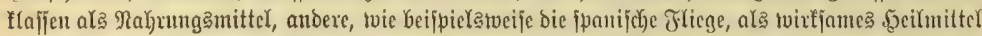

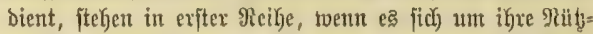

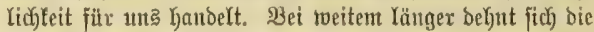

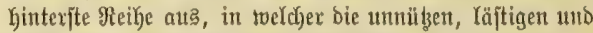

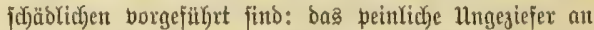

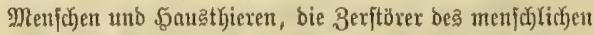

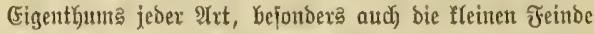

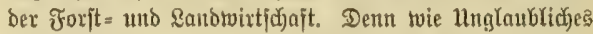
bie an fich toinzigen und anbedentenden Ifierchen ourd)

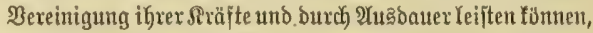
betweifen nicht nux bie Berkeerungen auf Felo uno Mieje,

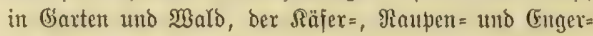

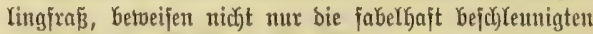

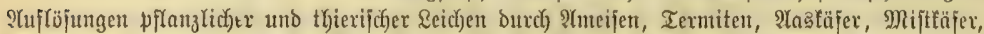

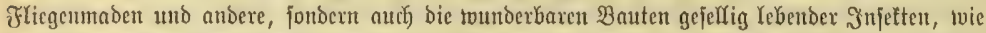

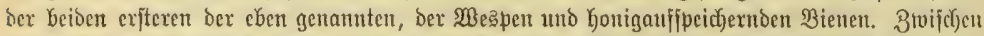

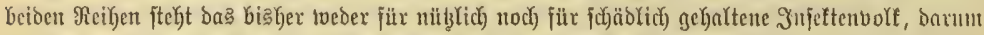
als eit neutrales, weil es un

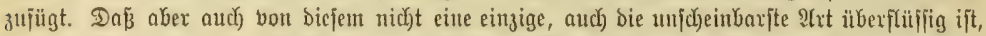

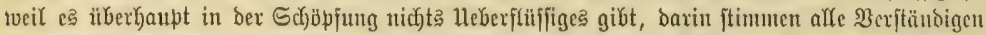

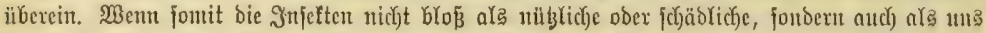

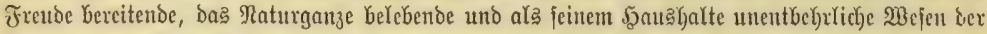

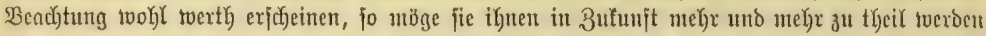

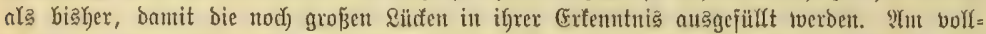

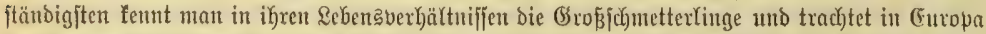

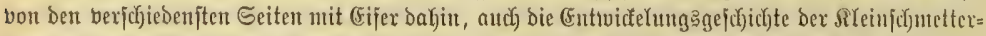

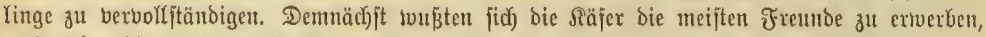

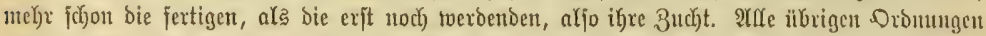

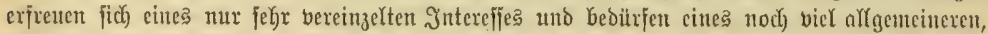

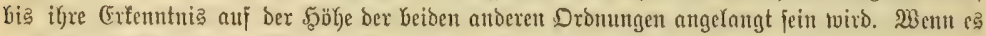
aud immer fochtoicriger fällt, für (Europa nod) einen neuen Sierf zu entocden, fo fent man aus

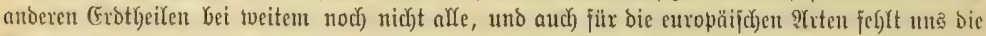

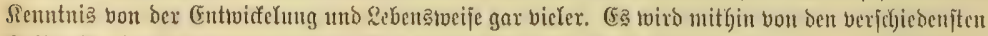

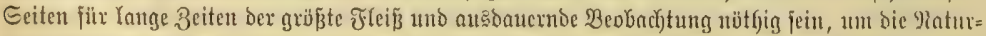

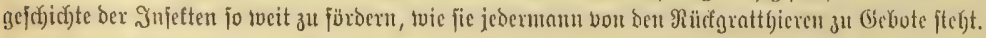




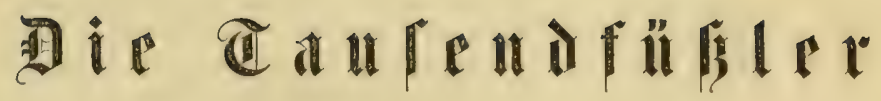
uno

Spinnentliers. 



\section{Die Cantendfürler (Myriopoda).}

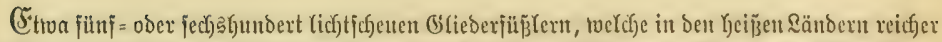

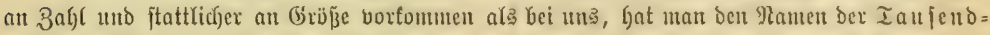

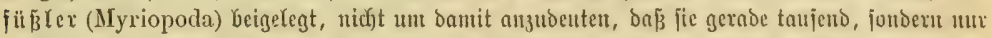

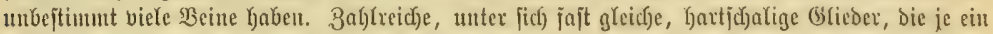

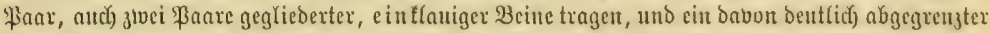

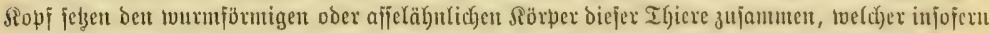

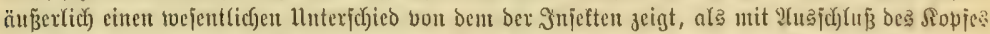

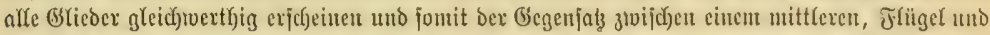

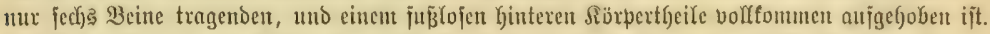

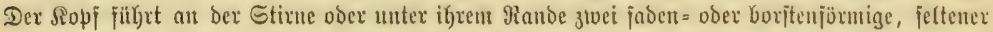

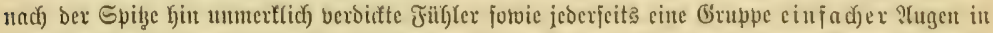

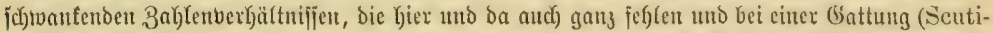

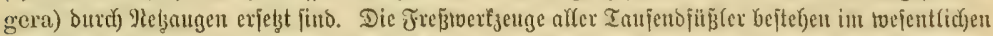

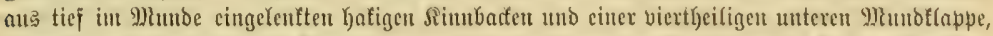

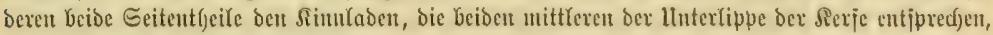
fämmutficd) aber bex Tojter ermangeltr.

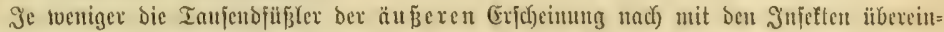

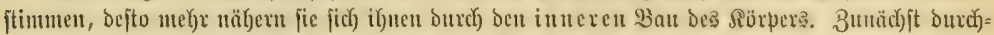

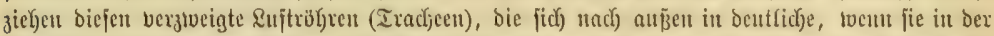

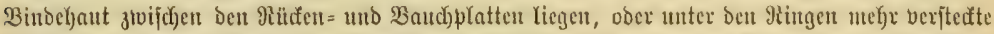

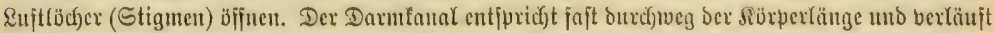

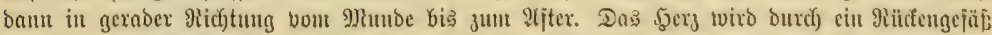

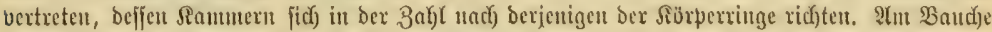

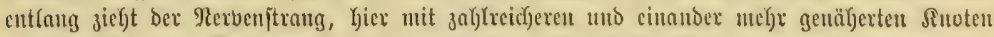

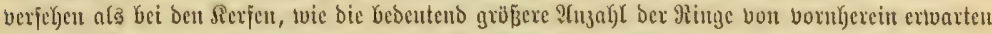

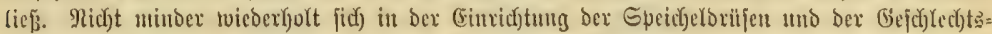

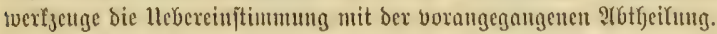

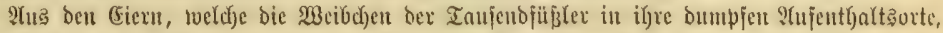

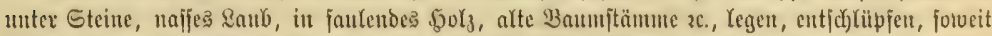

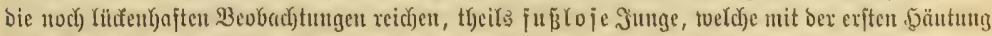

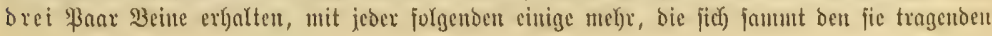




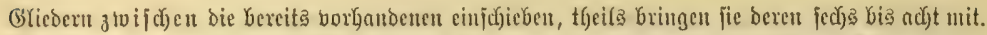

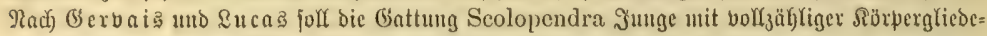

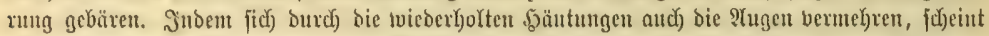

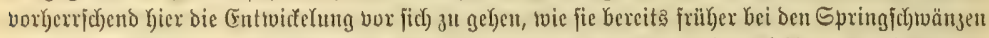

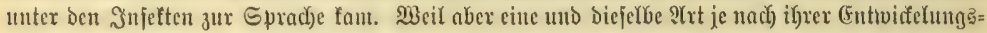

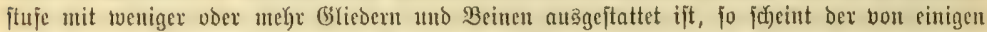

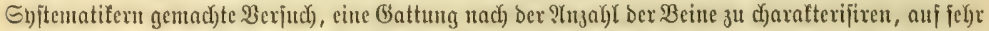

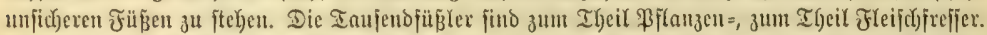

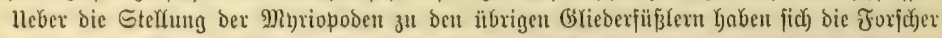
nod) nidgt cisigen fönnen. Die cinen verbinten fie nit ben Serebjen, indem fie bie Karte Rörper=

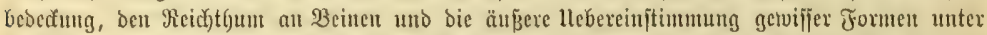

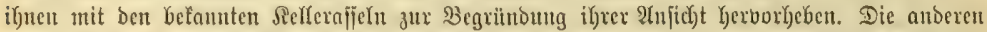

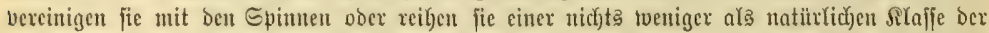

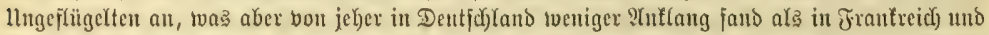

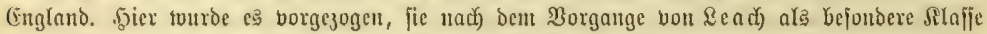

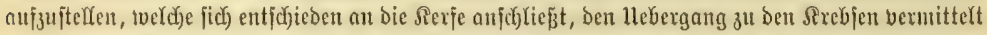

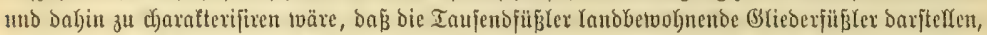

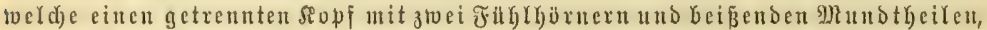

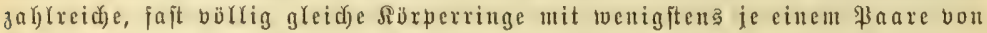

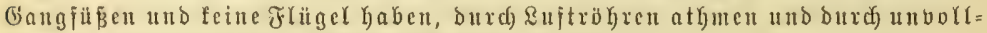

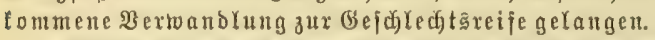

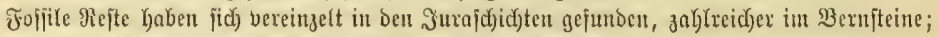

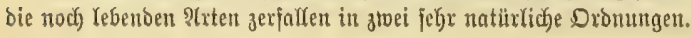

\section{Erfte (1) rinung.}

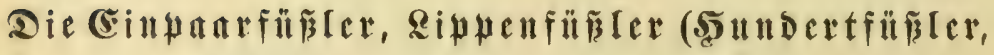 Chilopoda oder Syngnatha).}

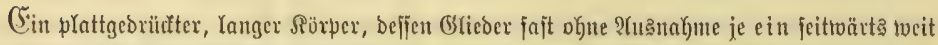

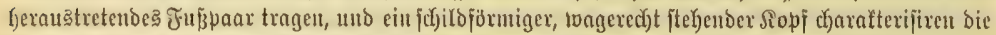

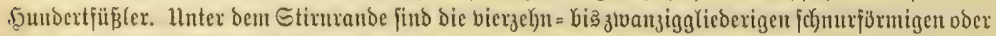

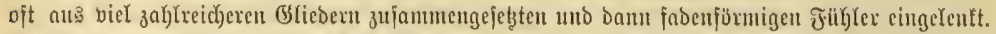

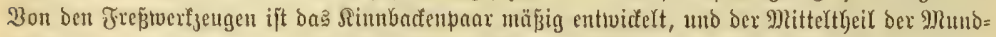
flappe auj ztvei fleine, nebeneinander ftehende Stämnte bejuchräntt, twäh)rend bie feitrichen IGeife

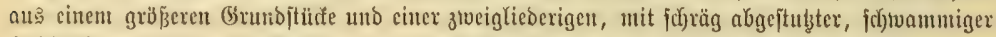

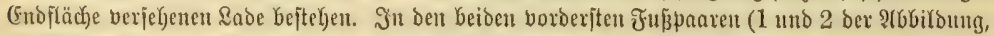

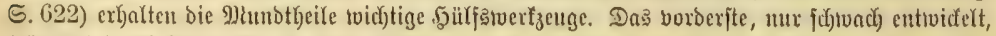

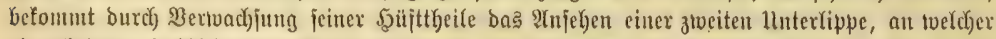

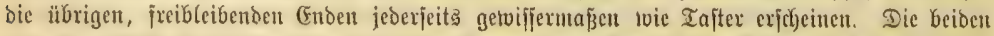

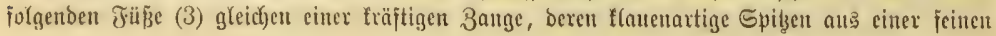




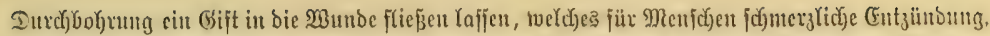

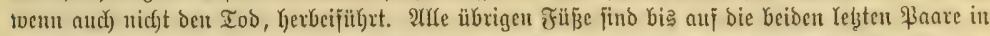

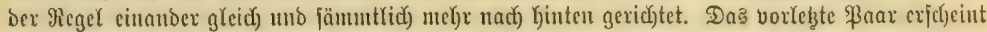

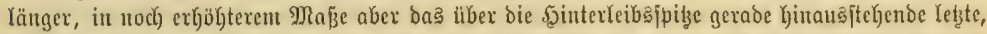

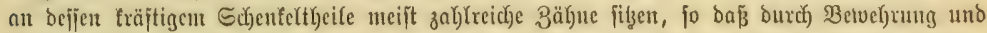

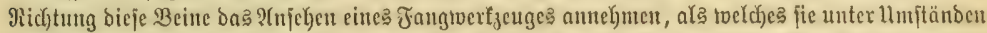

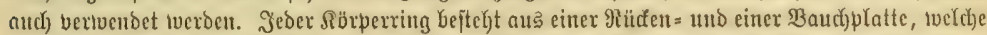
beioe an ben Eeiten butch eine tweid)e Jyaut, bie gleidyseitige Trägerin für bie Beine, uno an cincm

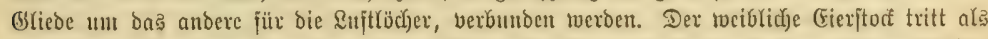
eiuzelner, fehr langer mo barmartiger Echlaud) auf, bem bald cin, bald ztuci furze (Eifcites

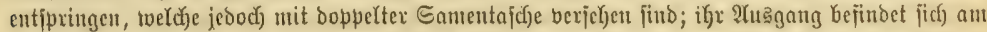

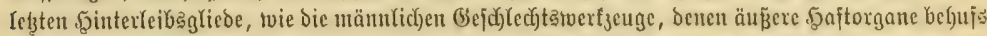
ber łaarung feblen. (Fine foldye exjolgt nach Fabre's Beobachtung auded) nid)t, fondern bie

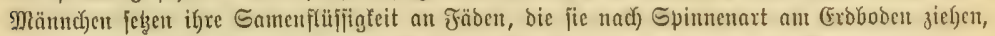

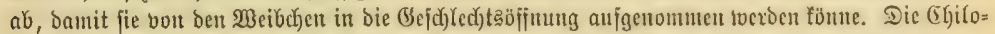

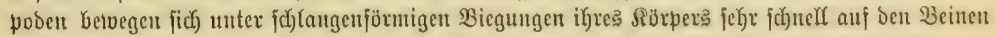

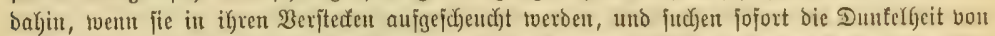

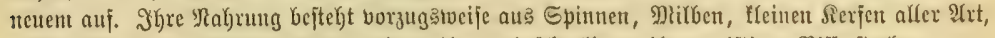

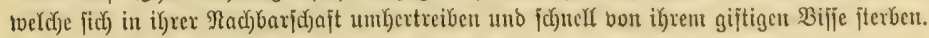

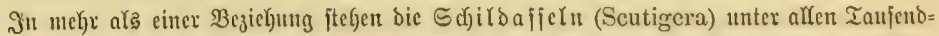
fiißß̋

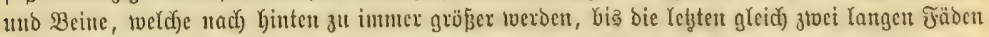

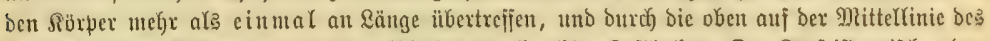

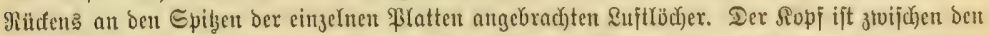

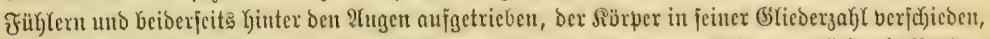

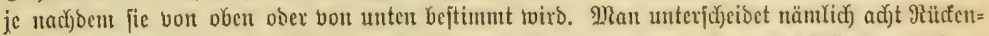

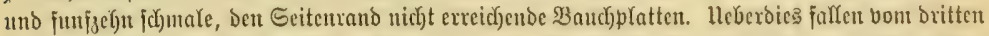

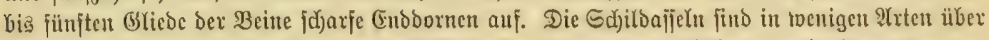

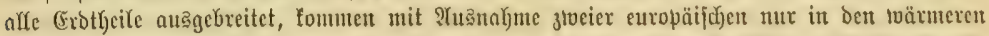

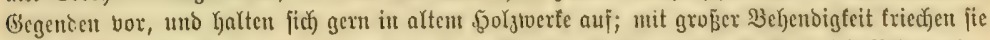

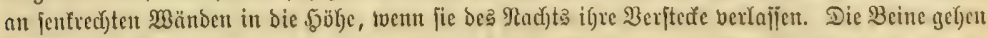

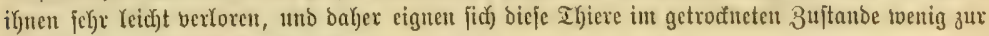
Iuffetwabrung it ben Sammlungen.

Die fpittuenartige Schildaffel (Scutigera coleoptrata ober Cermatia araneoides),

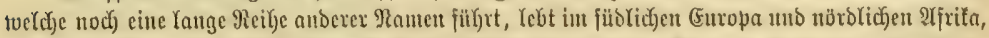

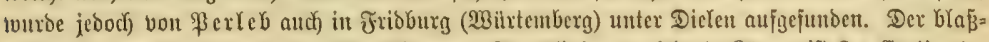

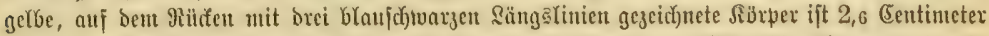

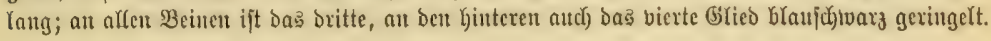

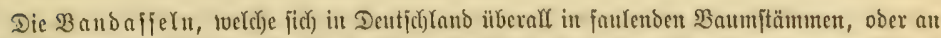

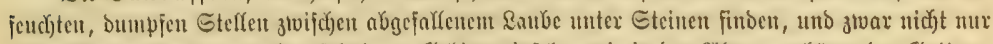

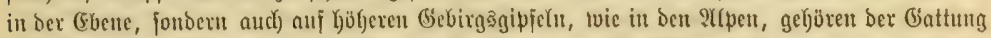

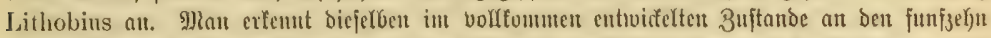

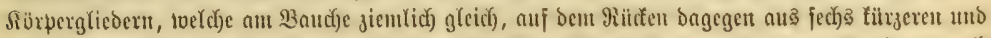

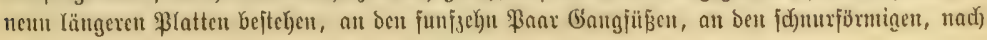




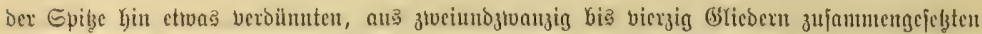
Jiih)

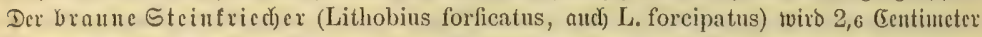

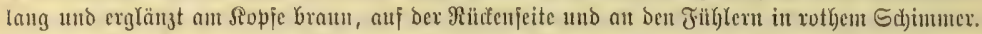

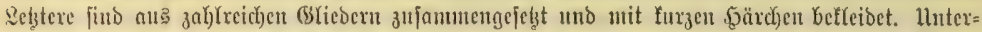

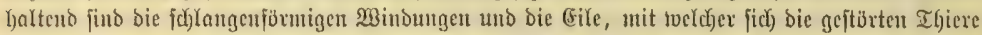

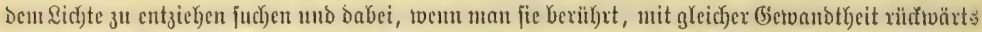

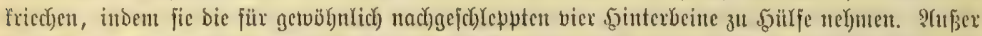

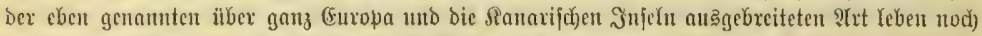

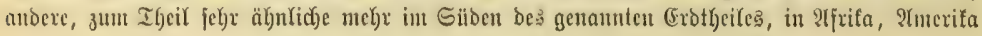
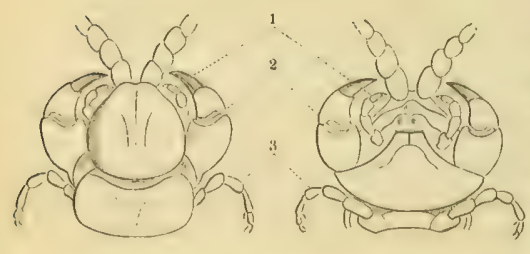

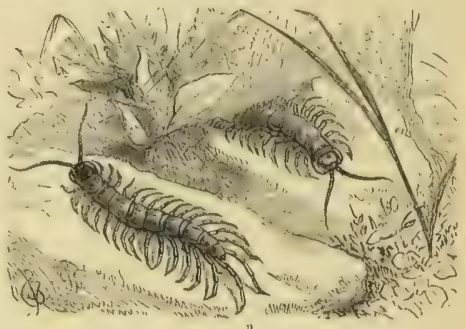

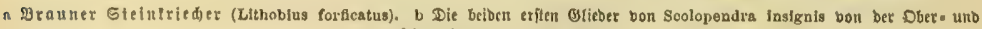
Unterjeite. Mates natilutiđe Grỏe

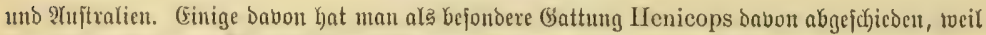

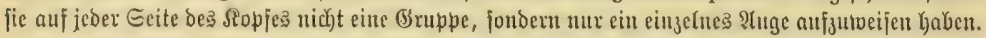

Bangenaffeln, Efolopender, Banbaffeln (Scolopendra) in engeren Ginte nemt

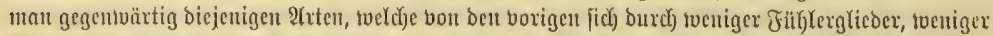

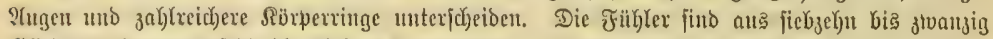

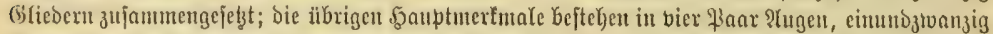

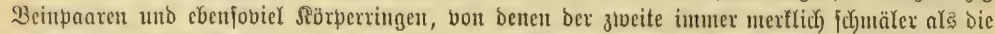
jolgenben ift. Die (Bijtzange entruicfelt fich) bei ihnen fräjtig. Sm einzelnen bieten bie felyr zah)=

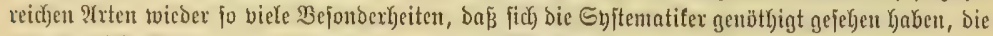

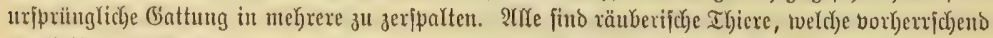

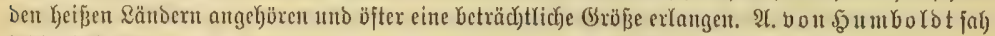

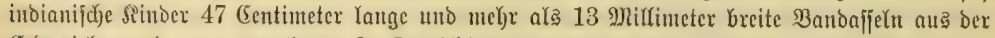

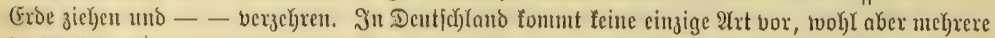

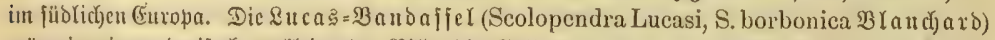

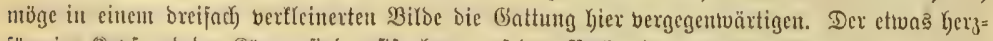

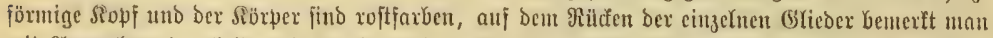
utit IuEn

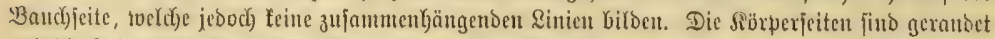

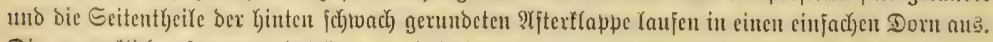

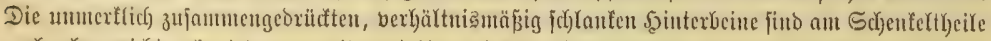

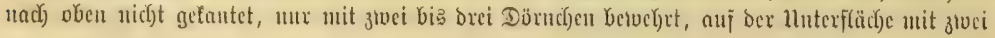




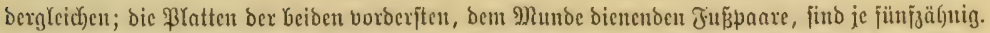

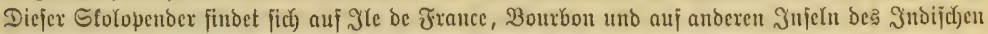

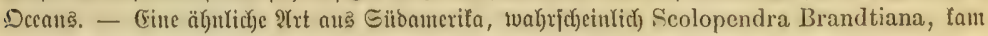

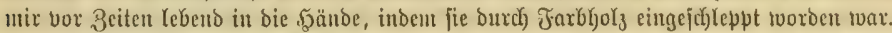

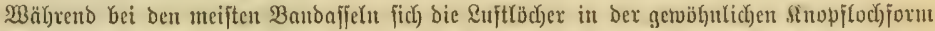

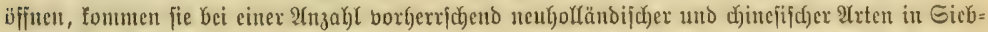
form vor, weไche barum von Gervai unter ber bejonderen Gattung Heterostoma vereinigt

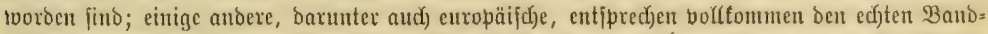

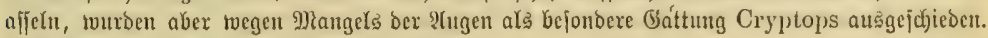

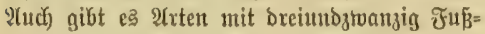
paren, jo bie $\mathfrak{B}$ and a fjel bon $\mathfrak{B}$ a fia (Scolopendropsis bahiensis) mit vier 2 (ugen jeber= feita, bie xothe $2 B$ andaffel (Scolopocryptops

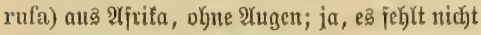

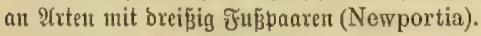

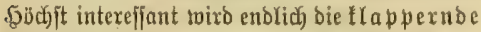
Bandajfel (Eucorybas crotalus) bon Port

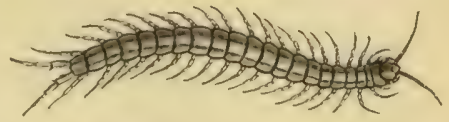

Iucasi. Banbaffel (Soolopendra Lueasl), It breifader Bertleinerung.

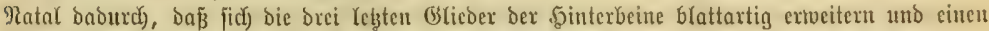

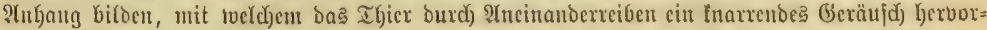

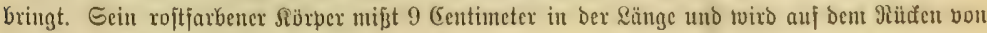
fieben Rängáfielen ১uxchjogen.

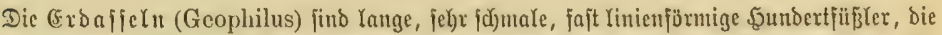

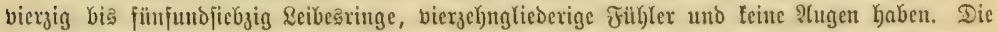

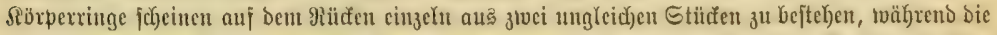
3auchplatten einfach GYciben. Das Yetzte Fuppaar enoct in bem einen Jafle in Siralfen, in Dem

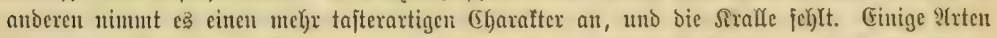

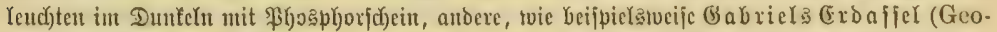

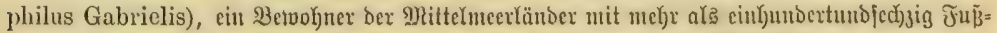

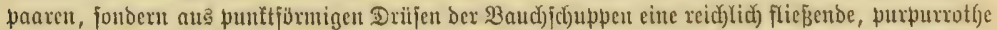

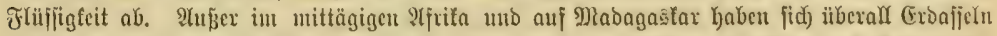

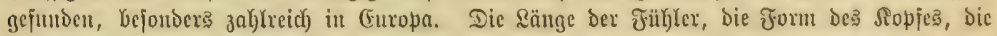

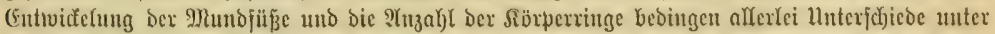

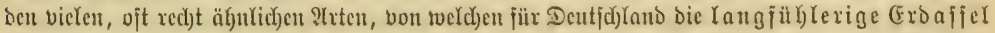

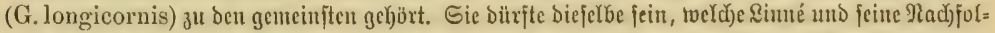

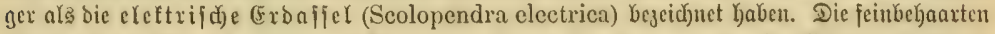

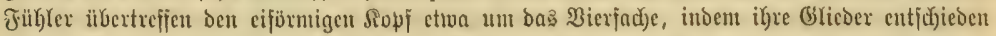

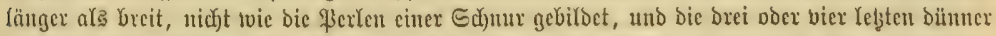

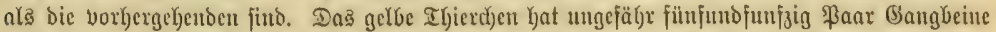

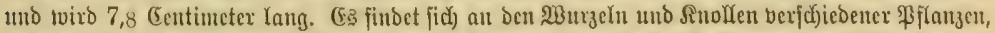

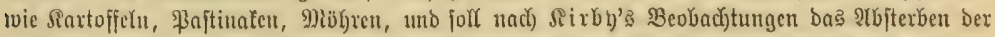

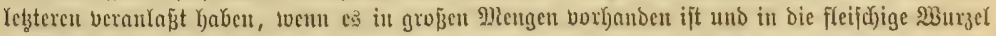

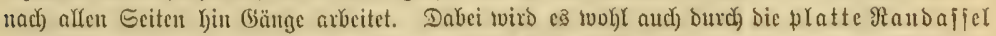

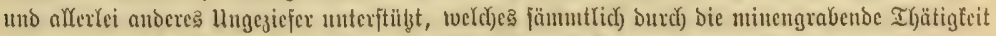

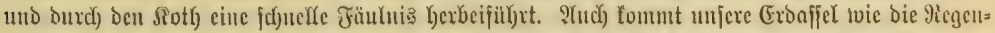

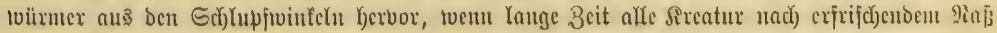
ge 


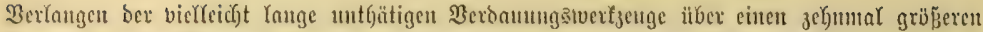

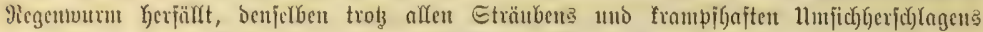

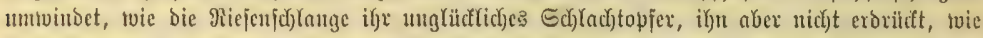

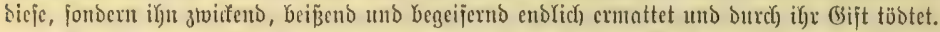

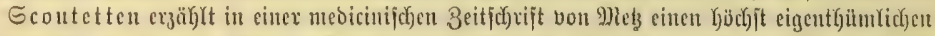

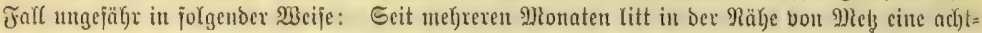

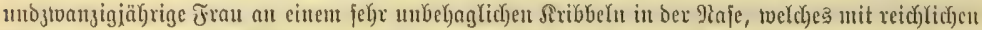

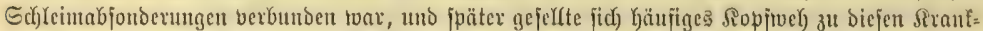

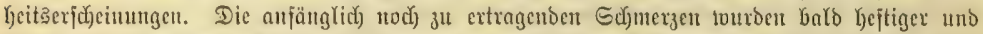

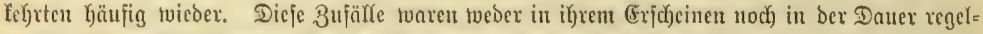

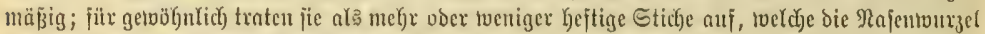

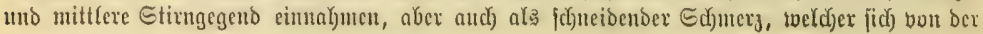

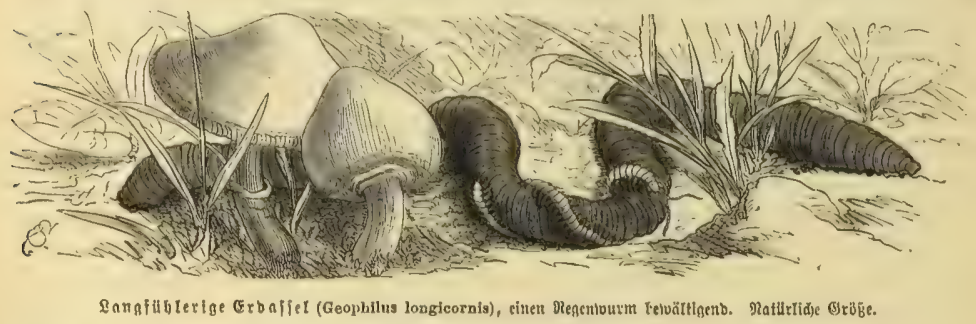

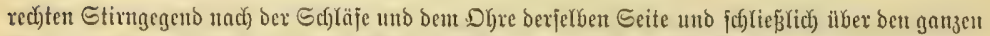

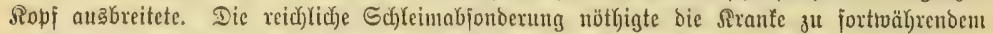

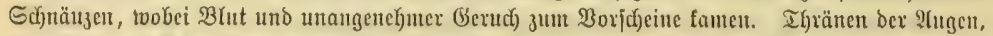

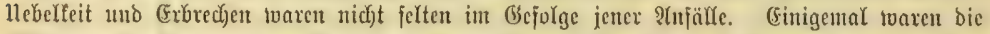

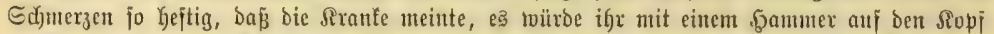

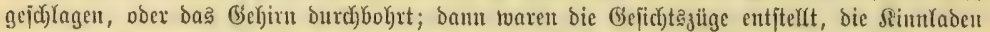

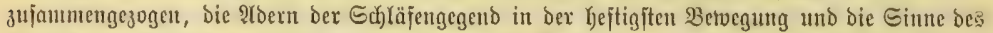

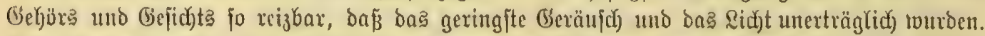

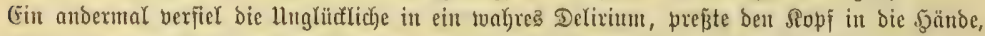

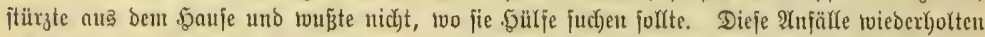
jich) fün $=$ oder fect) smal, bei Iage ober in ber ?tacht, einer berjelben hjelt fogar nit geringen

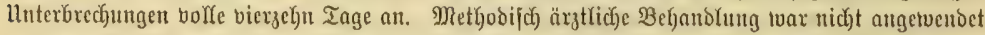

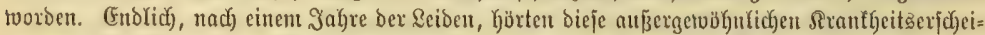

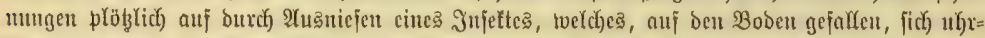

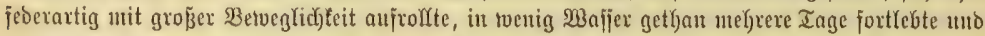

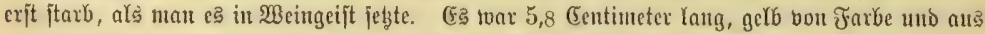

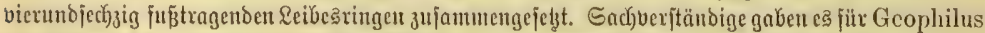

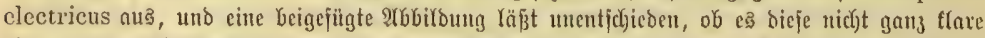

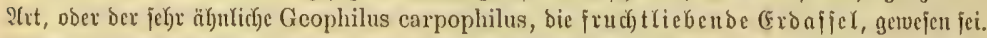
Beibe aber unterjudetoen fich von ber vorher bejchriebenen Iaugjühlerigen (Erbafjel burd)

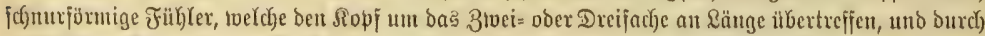

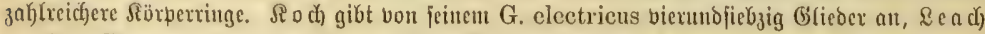

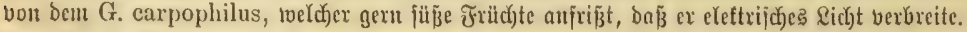




\title{
3แ1
}

\section{Dic 3 weipar $\mathfrak{f}$ fỉ (Diplopoda, Chilognatha).}

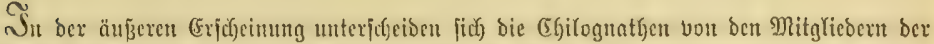

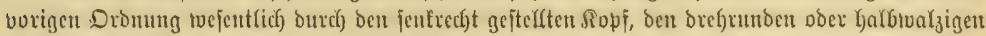

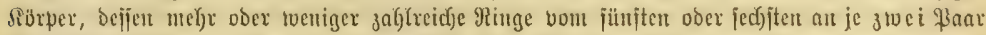

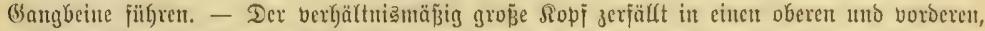

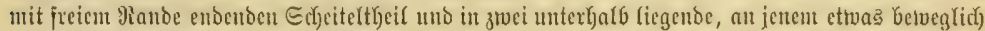

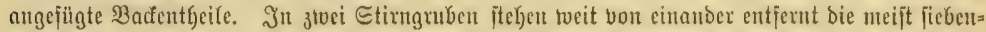

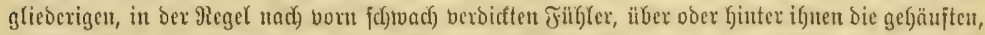

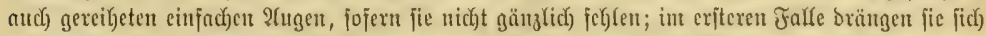

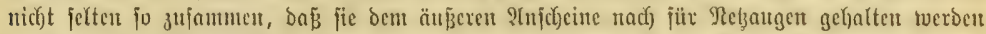

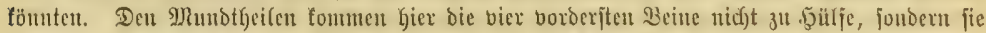

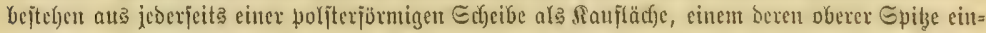

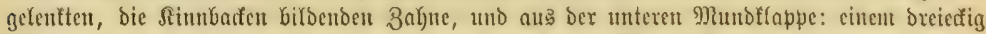

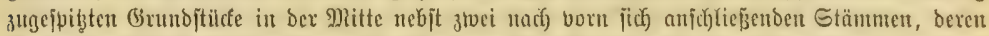

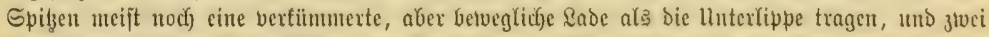

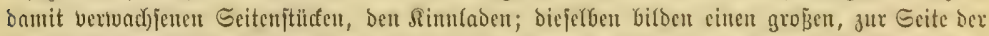
Ilnterlippe Gerabjteigenden Gtanm mit zwei vertïnmerten \&aDen am vorberen, Greiteren Enoe.

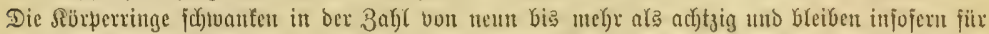

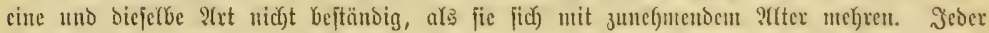

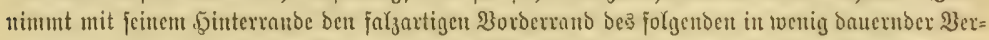

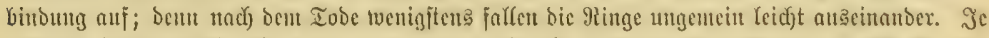

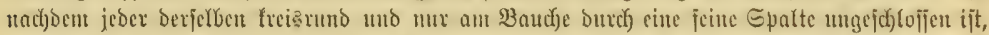

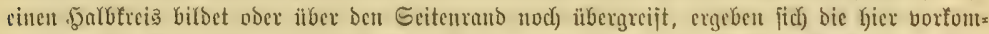

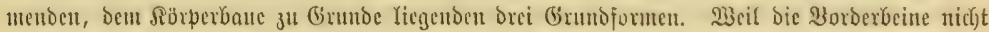

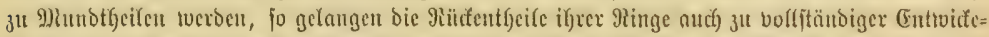

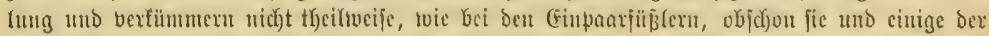

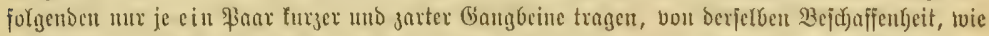

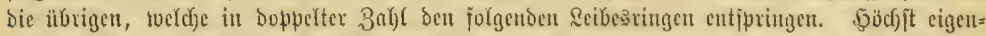

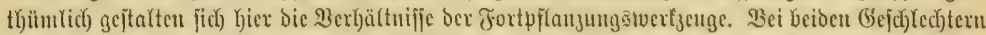

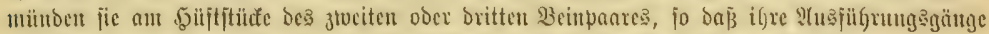

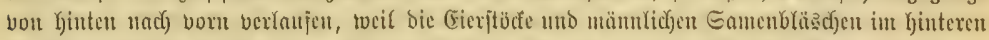

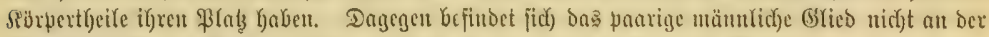

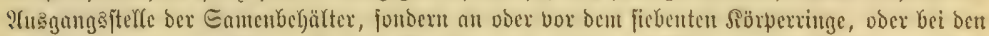

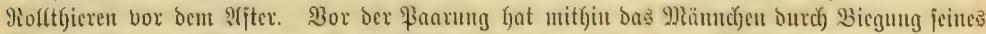

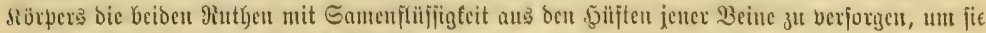

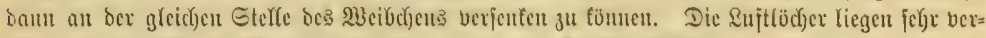

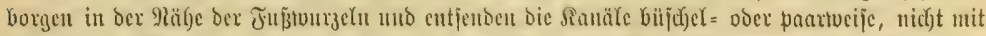

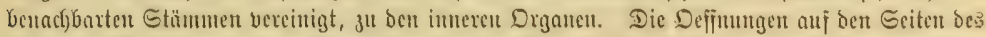

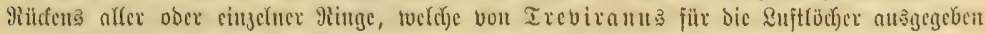

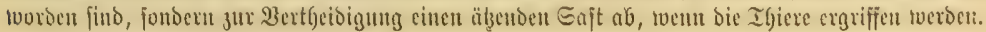




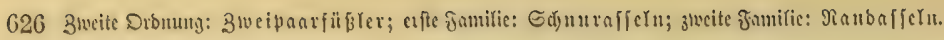

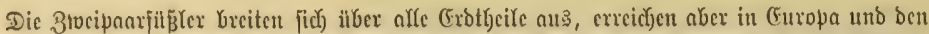

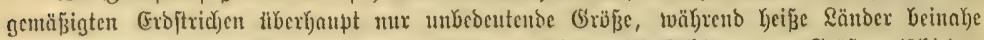

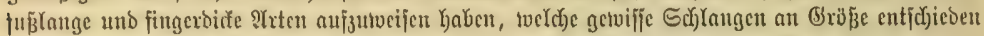

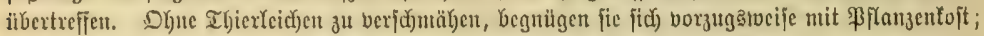

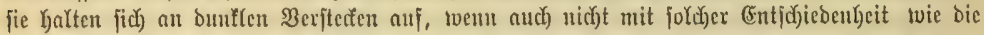

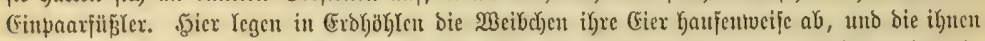

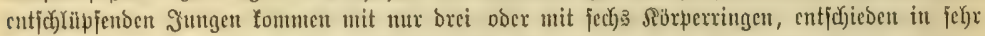

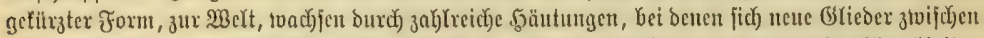

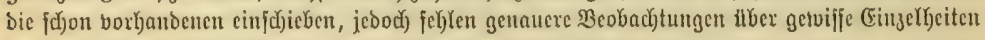

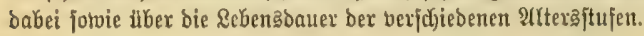

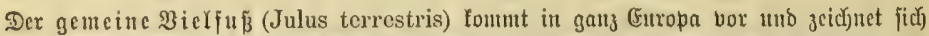

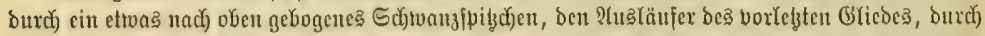

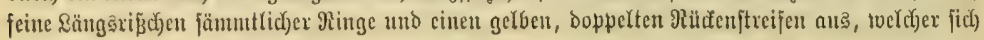

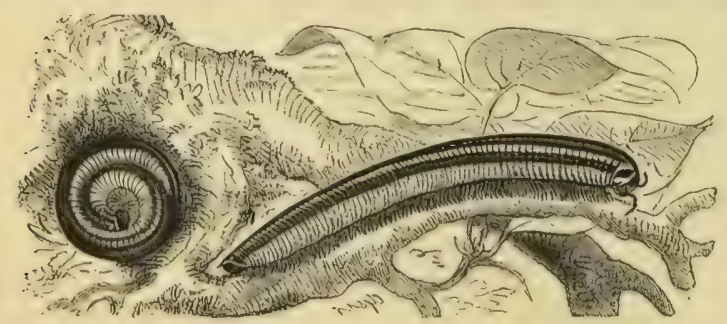

Oemeinex BieโfuB (Julus terrestrls), bergrōbert. von ber heller ober buntfer braunen $\Omega \ddot{b}=$ perfarbe Deutrich $a b=$ Gebt; die achtundziwan= zig $\mathfrak{T}$ ugen jeberjeits bilben ein Dreief und fteben in fieben ßeifjen. Wenn idy (snde Frilf)= jaโroె unter Steinen auf cinem fahlen, bitrien Эerge radj अaupen fuctite, fand id bie Seichen biefer Ifiere

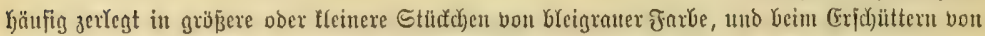

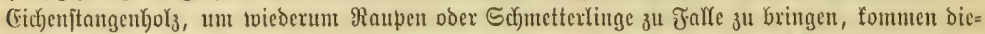

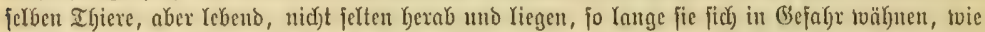

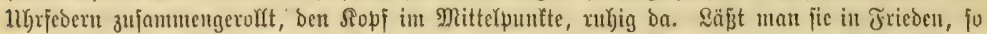

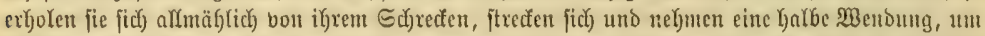

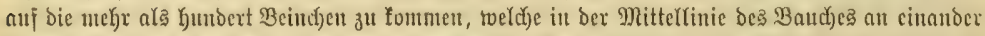

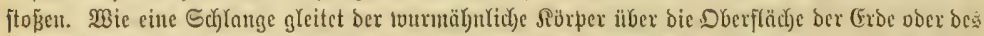

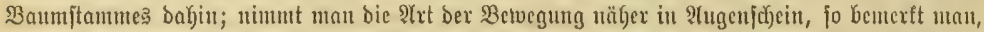

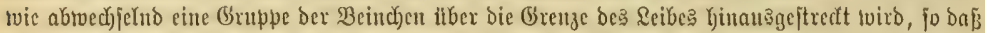

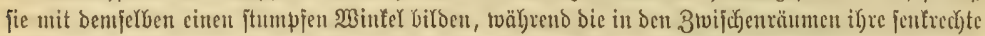

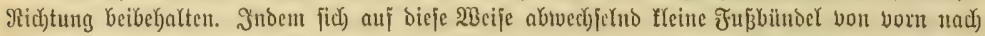

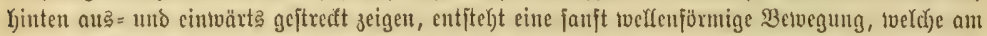
Siopie beginnt und nach mo nach gegen ben Ed)wanj hiu fid) bem ganzen Siörper mitibcilt. Die

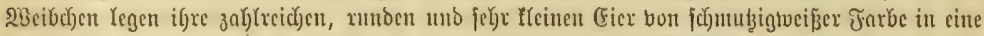

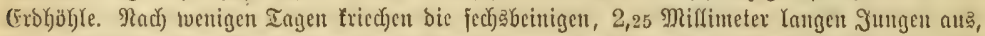

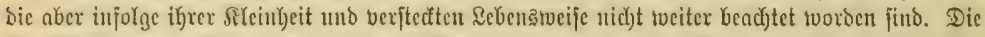

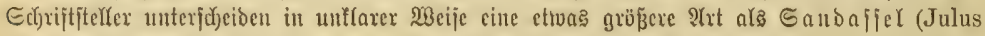

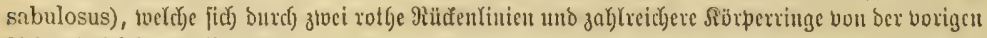
श्रt untericheiber foll.

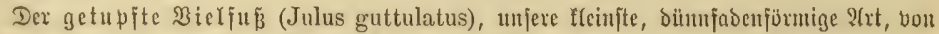

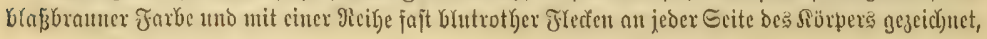




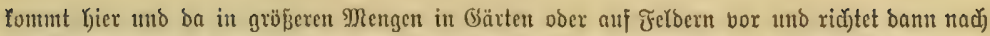

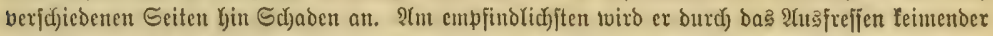

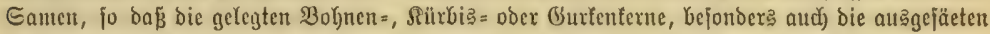

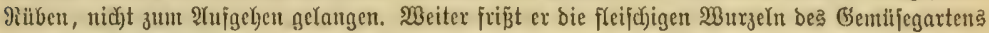

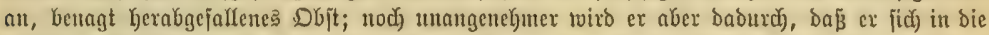
xcifenden Grobeeren, uto ztwar bie gröperen Sorten, jehr gern cinbolyt und bon bem fajtigen

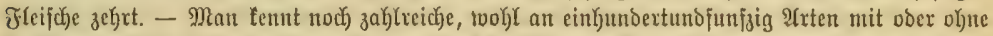

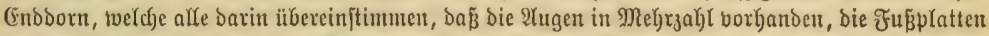

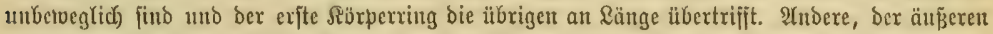

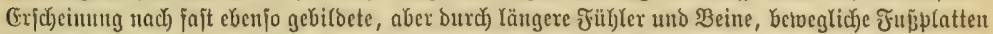

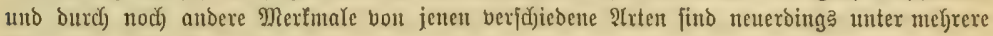
Gattungen bertheilt toorden.

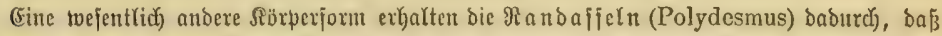

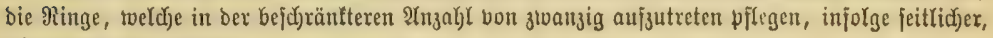
plattenartiger शนตื= Greitungett uns Ranten Den brefrunden UmríB aufgeben, und baß̃ bie Beine nidht in ser Mitteltinie des $\mathfrak{B a u =}$ d)es zujammenjtoß̄en, mitfin aud an ben Siöperfeiten beuttider fid tbar twexden. (5) vais beobachtete neu= geborne pratte Rand = a fieln (Polydesmus complanatus), ofne

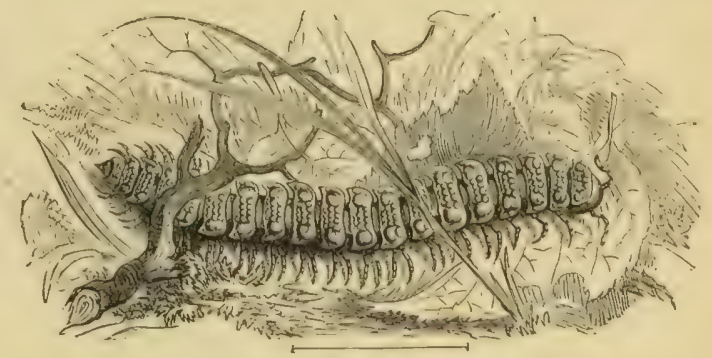

Biatte Ra rbaflel (Polydesmus complanatus), bergribert.

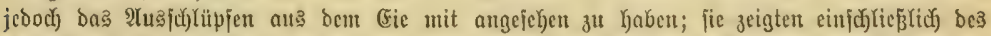

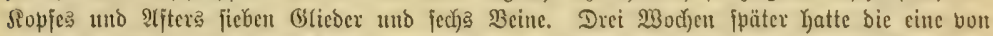

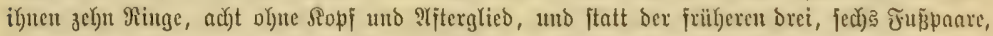
je eines am exjten, ztweiten uno britten, ein biertes und fünftes am folgenden und bas ferdjte uno

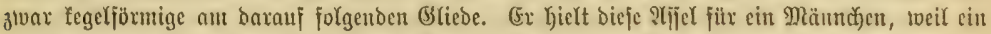

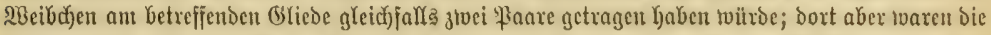

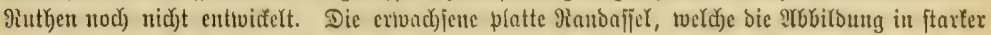

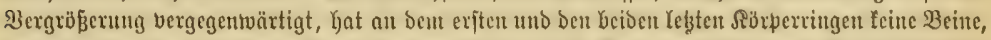
an jebem ber brei auf Den exjten folgenden gringe je cin Paar, tveitertjin zlvei \$aare und teine

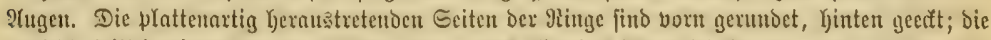

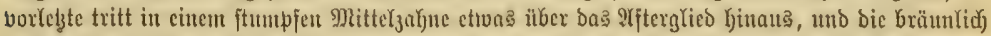

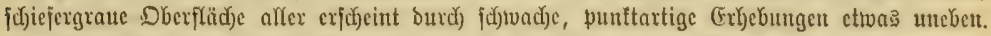

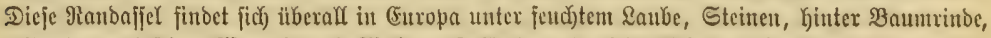

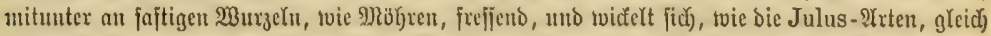

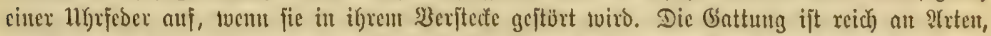

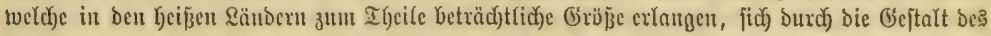

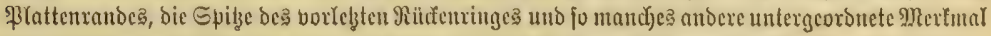

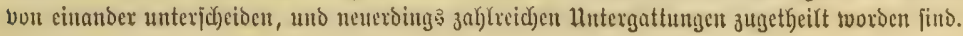




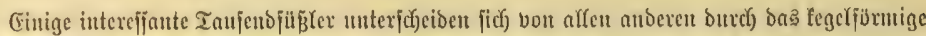

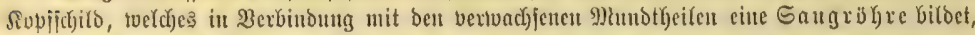

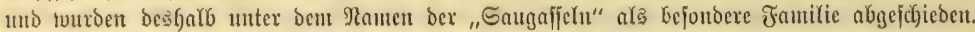

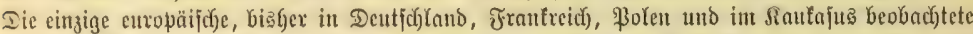

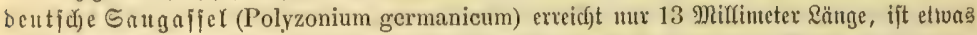

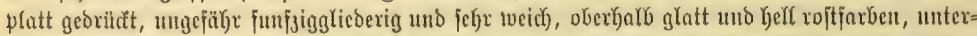

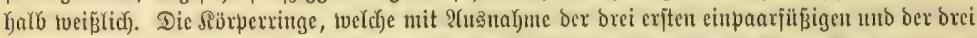

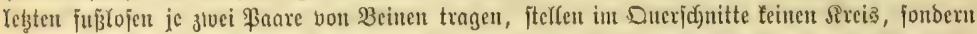

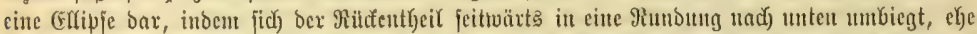
cr an ber (Einlentunģ⿹弓冫

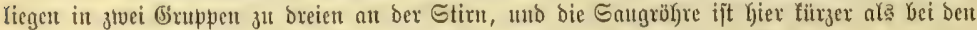

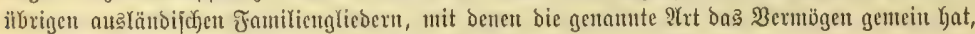

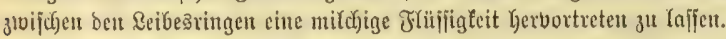

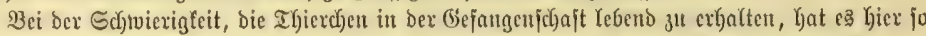

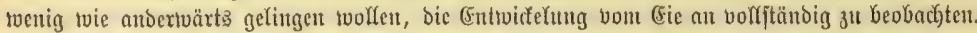

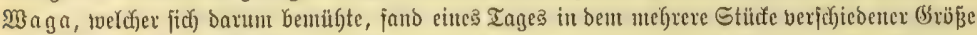

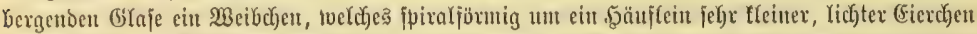

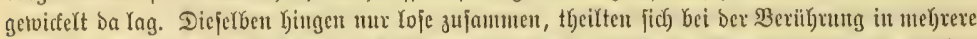

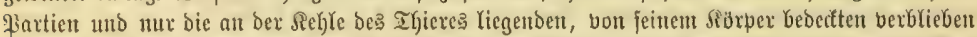

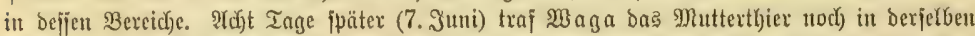

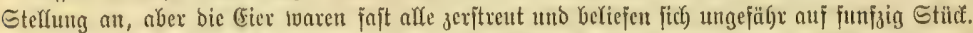

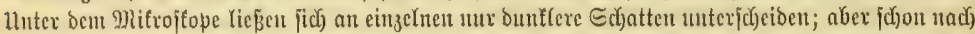

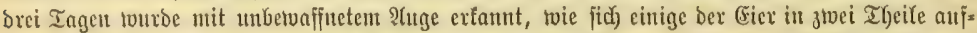

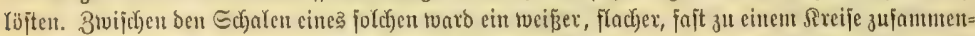

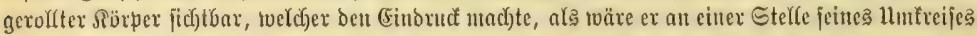

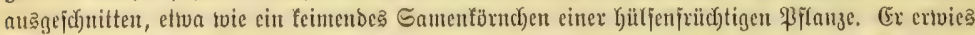

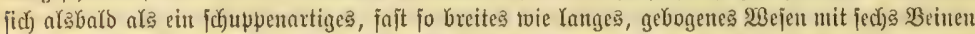

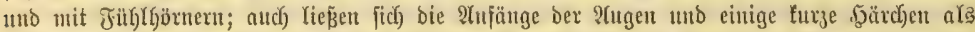

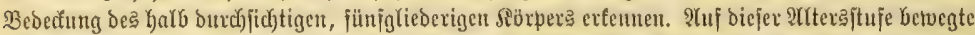

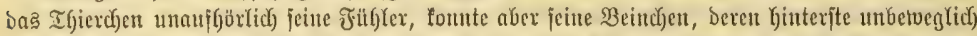

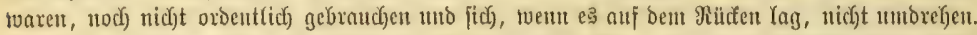

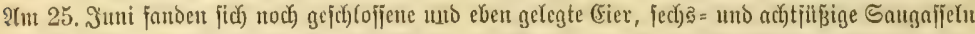
in bent GLaje vor; Da biejes aber zufälig in bie Sonne gerieth utb berjelben auj längere 3eit

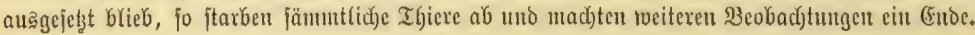

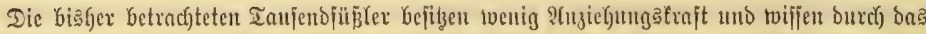

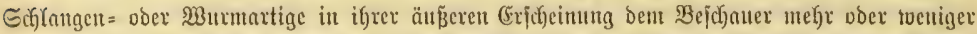

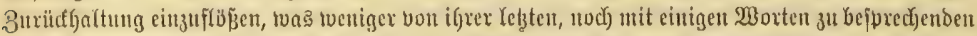

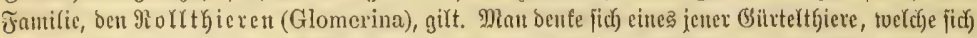

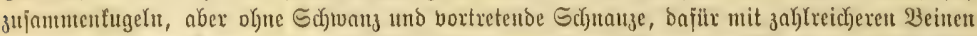

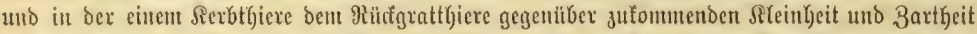

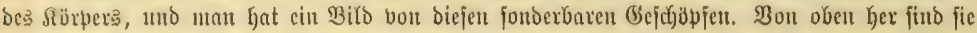

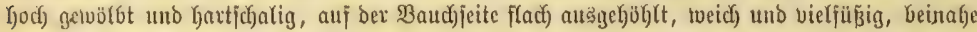

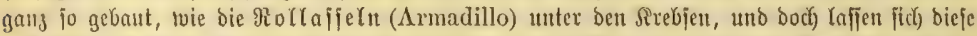

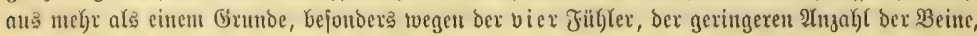

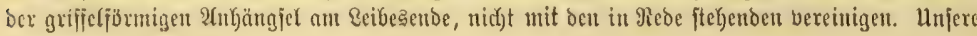




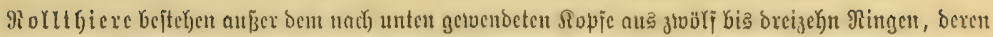

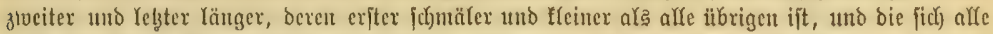

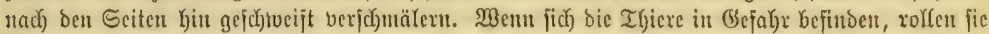

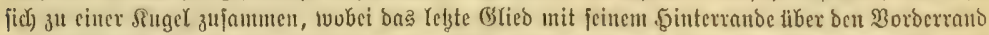

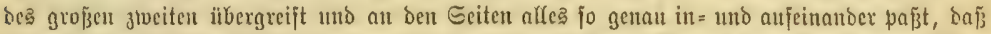

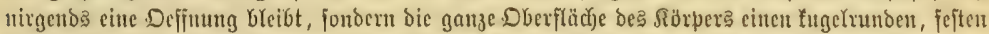

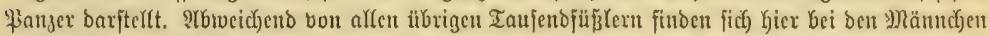

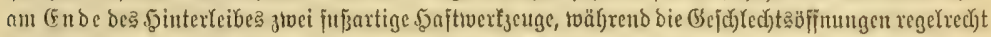

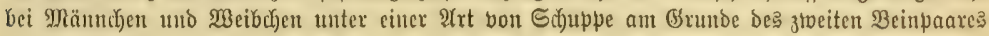
angebracht jino.

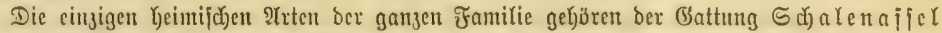

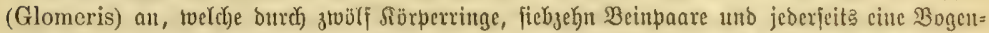

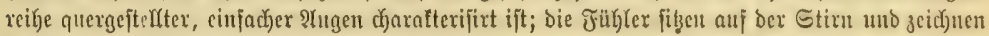

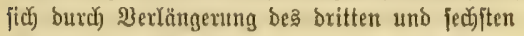
OCiebes aus. Man findet bieje vollfonmen harmlojen Schalenaffeln eistzeln ober in tleinen Gefelle

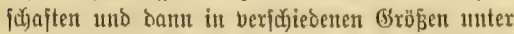
Steinen, abgefalfenem \&aube, an fenchten, reidj)lid mit Dammerde berjehenen, unbebauten Drten, aljo borberrfichend in ben $\mathfrak{3 a ̈ l d e r t . ~ ( 5 a g ~ f i n d ~ u n g e m e i n ~}$ träge I Ifiere, weldhe meijt jujanumengetugelt in ifren $\mathfrak{B e r f t e c f e n ~ r u h e n ~ u n o ~ z r o a r ~ i n ~ e i n e r ~ \$ o ̈ h l u n g ~}$ Dex Locferen (Exde, wełche sine ober mehrere zufanmen

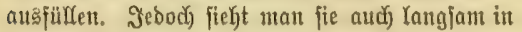

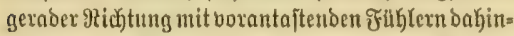

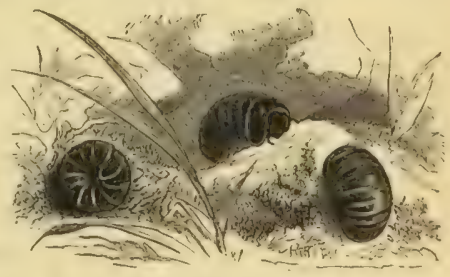

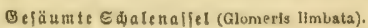
Ratürtiōe Bröbe.

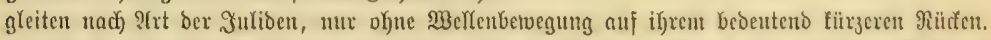

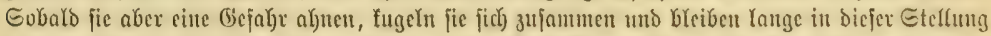

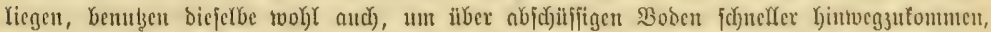

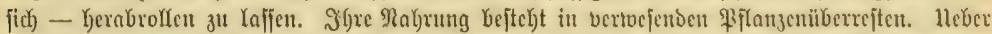

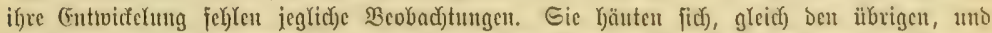

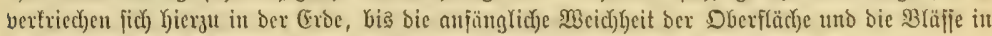

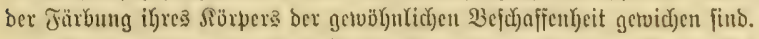

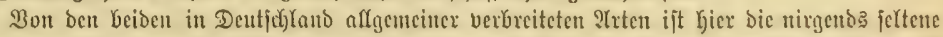

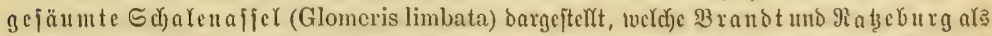

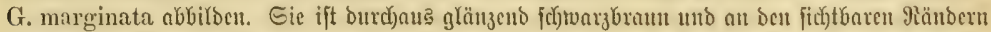

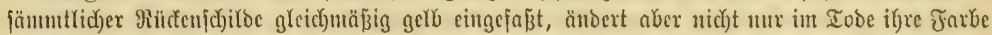

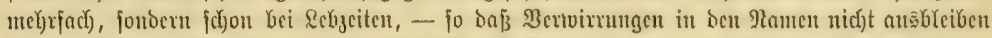

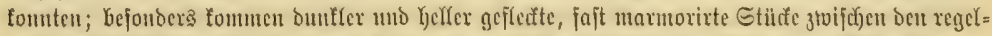

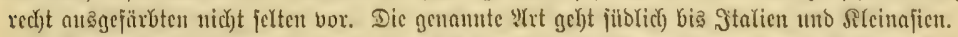

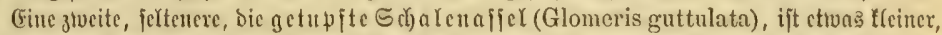

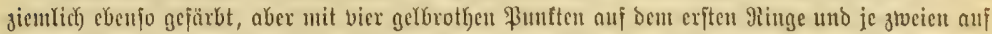

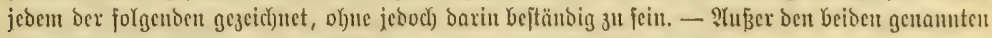
fonunt nod) cine unb bie anbere शrt bereinzelt im jublicfen (Europa vor.

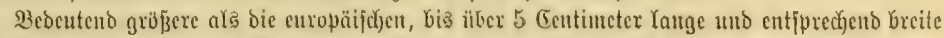

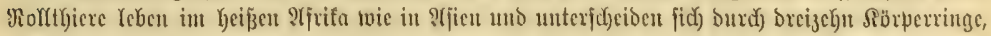

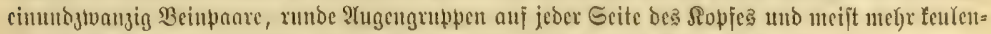
förmige Fiil)ler. Gie geljören ben Gattungen Sphaerotherium, Zephonia uno anduren an. 


\section{Die Spintentliere (Arachnoida).}

$\mathfrak{B}_{\text {ei }}$ ben Serfett glicbert fich, twie friltyer gezeigt twutroe, ber Söbper in brei veridjiedenartige

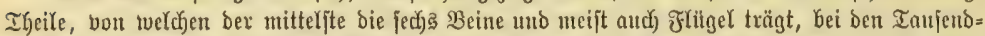

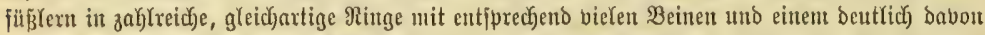

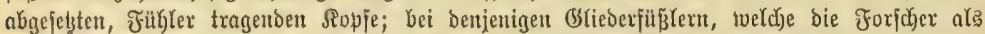

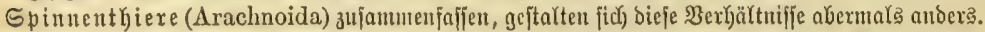

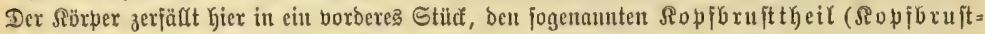

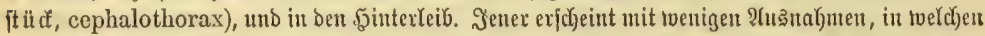

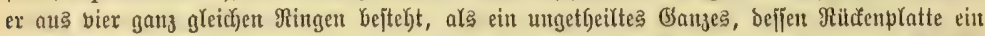

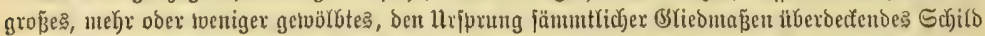

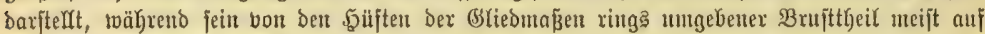

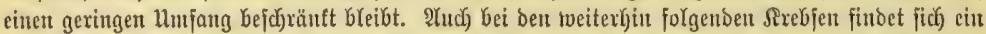

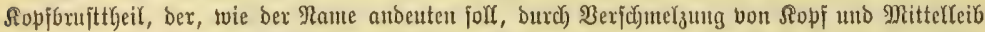

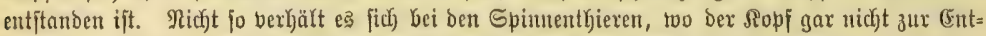

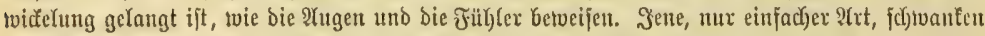

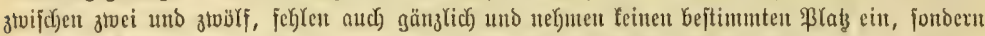

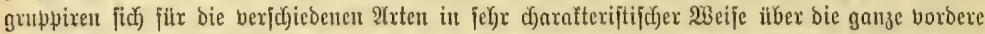

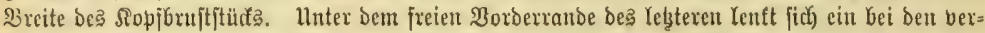

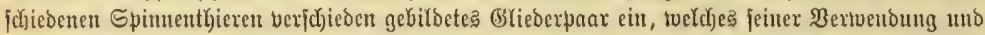

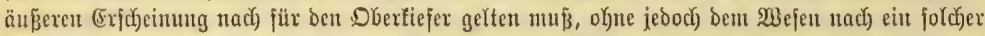

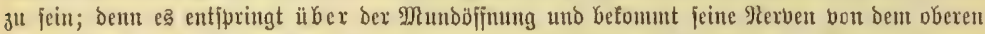

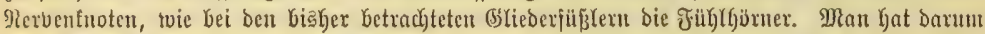

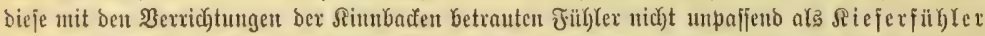

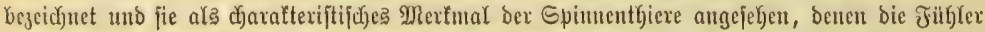

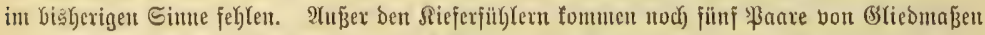

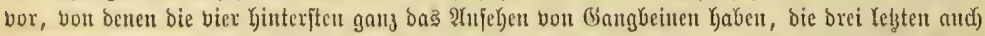

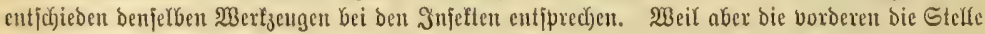

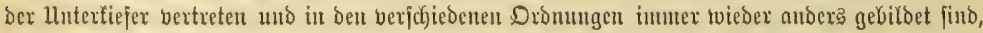

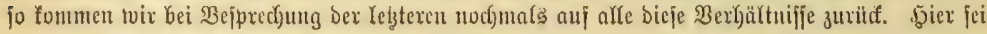

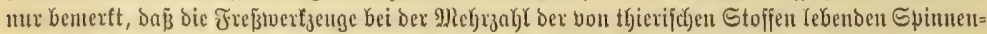

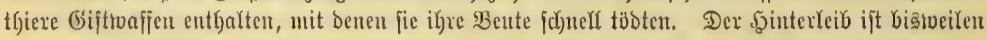

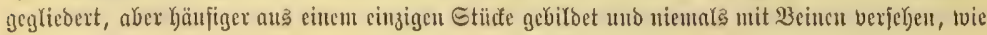




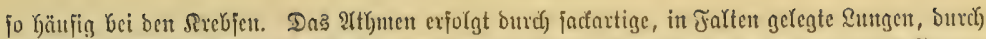
Eujtrübren, doex auf ber niedrigiten Stuje burch bie Jant. Somit Gegreifen wir, un bas Gejagte

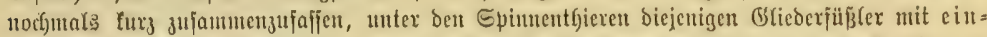

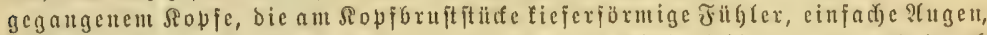

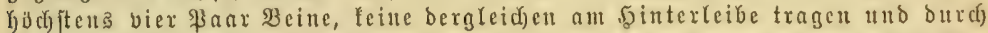

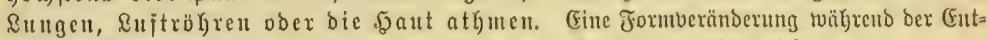

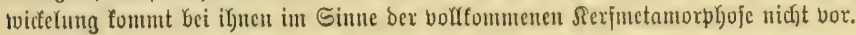

\section{Erfte (1)}

\section{Die Glicberipinnen (Arthrogastra).}

(Ein bentlid) geglicderter, meift in feiner ganzen Breite bem Ropforujtitüide angetoachjencr,

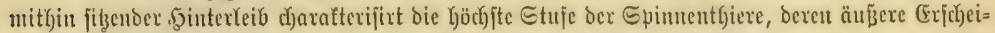

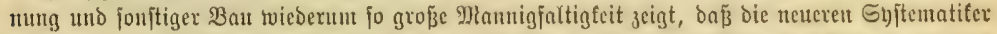

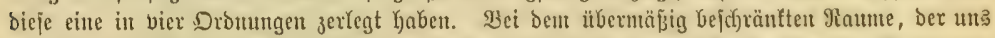

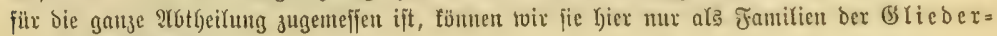
ipiunen befandeln.

Die $\mathfrak{W a l}_{3}$ enfpinnen (Solifugae ałz Drbunng, Solipugae als einzige Jamilie bezeidunet)

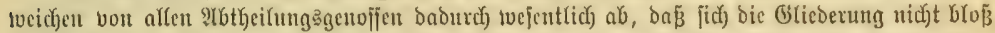

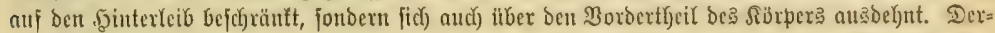

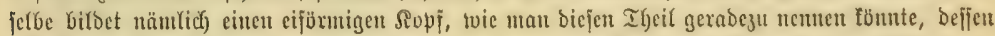

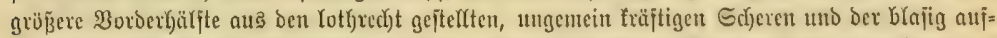

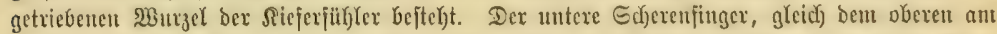

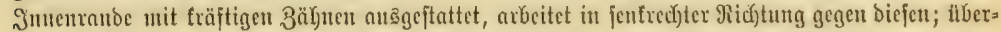

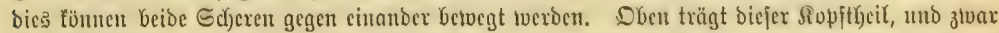
mitten an \$orberranbe, bie beiben ?lugen, an ber lnterjeite bie fralfenlojen, in übrigen wie bie Beine gebildoten beiben anderen Siteferpanre, poer rifftiger beren Injter. Jeoes ber edyten, in

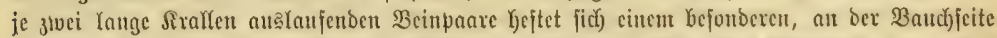

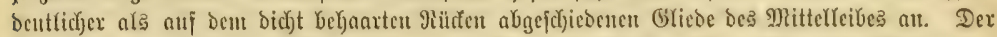

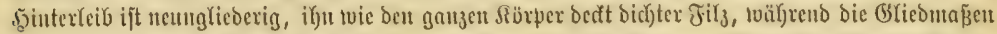

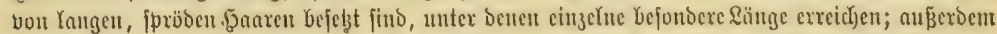

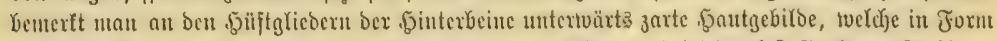

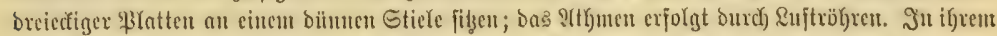

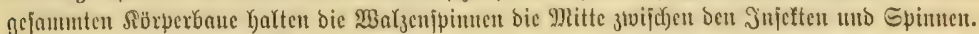

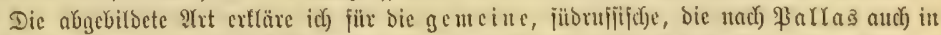

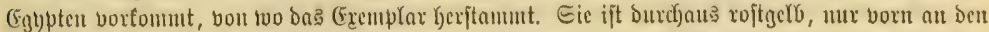
Sif)eren braun, ant bुinterleibe rojtbraun und an ben auj ber llnterfeite mit ftarten Stadfelit

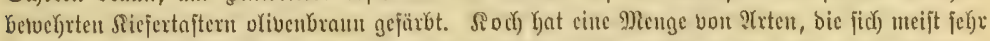

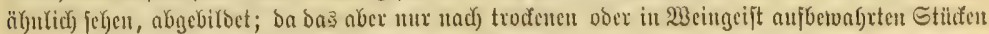

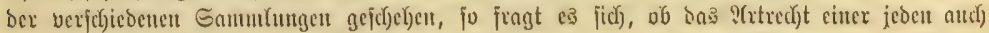

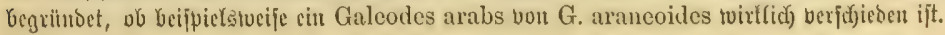




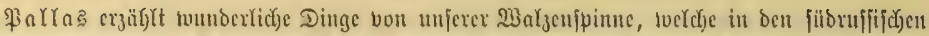

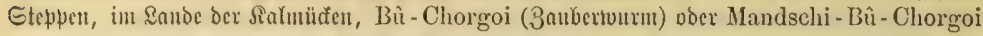

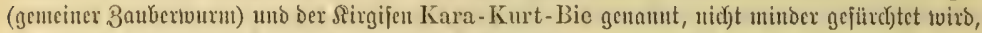

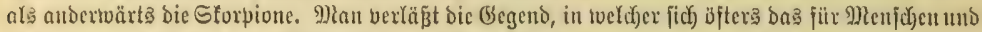

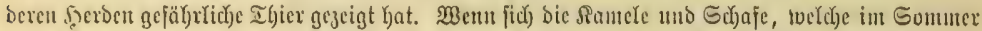

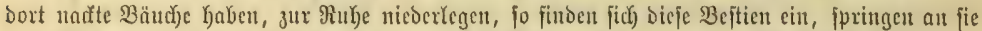

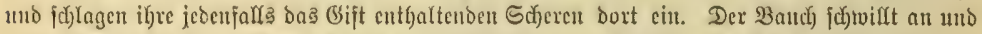

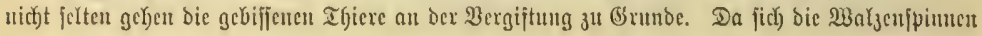

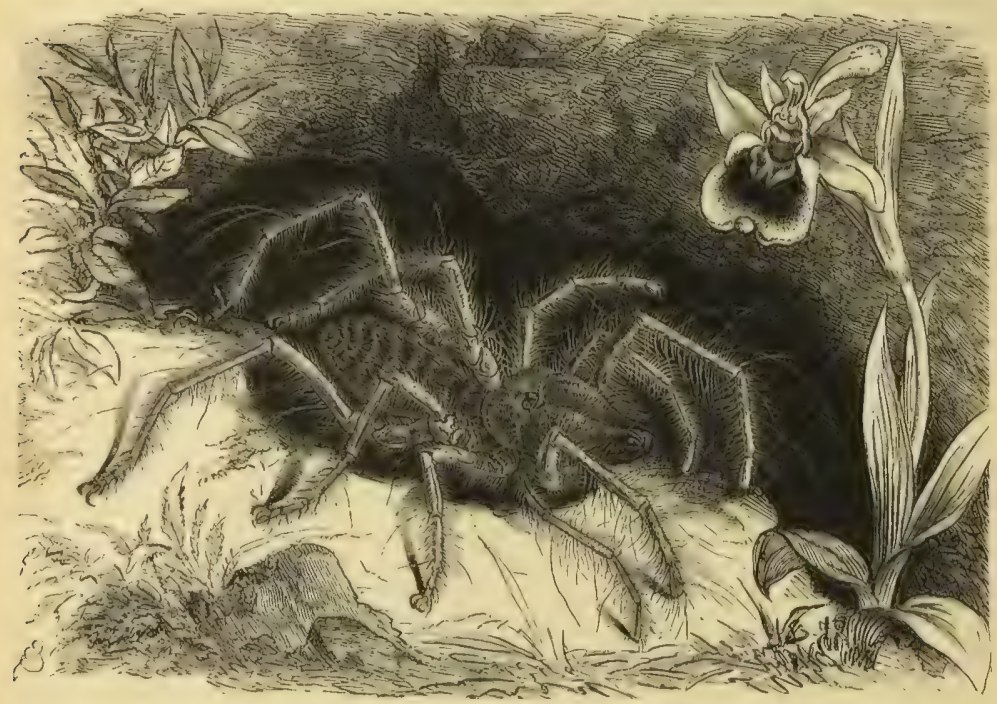

Bemelne TBalzenfpinne (Solpuga Doer Galendes araneoldes). Natilitide Grobe.

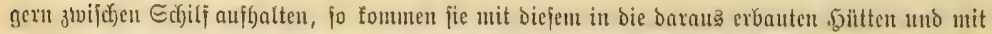

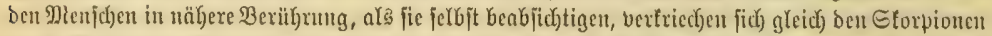

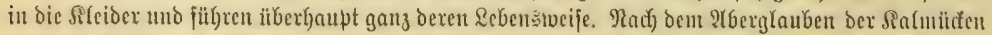

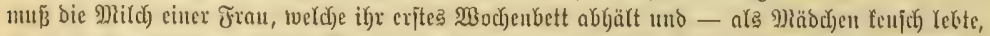

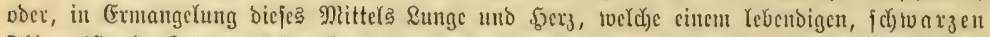

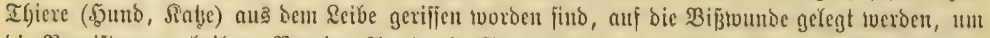

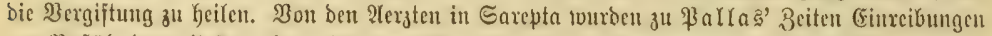

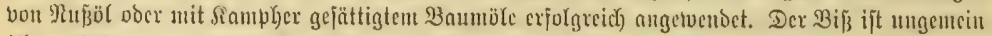

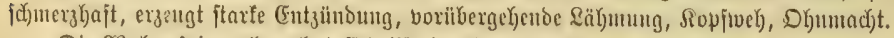

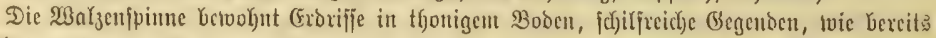

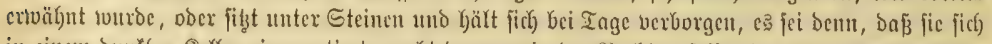

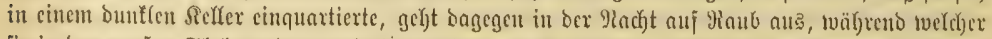

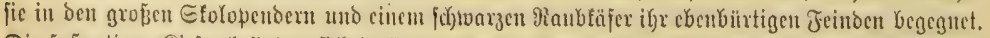

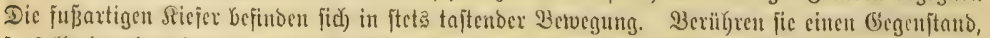

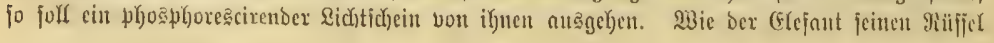




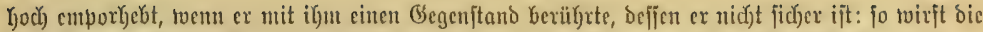

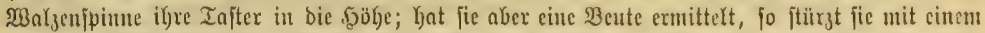

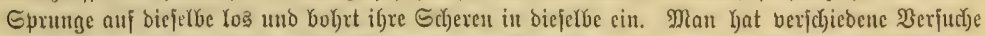

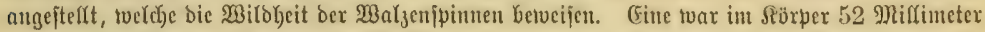

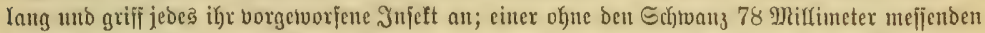

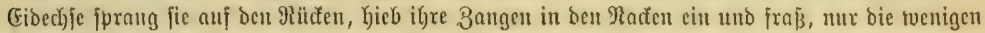

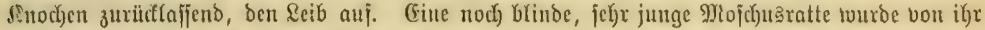
getubset uno in furzer 3eit volljtänoig bertilgt. Weiter Yieß̧ man fie gegen cine einfundertunofümị

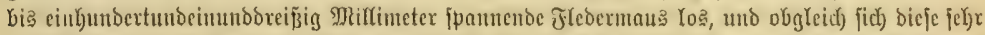

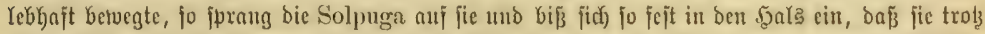

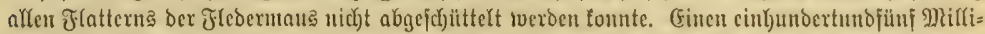

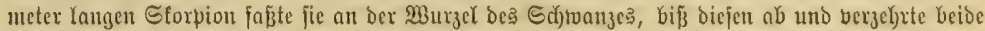
Iheile, bod) twar biejer Sieg mur ein zufürliger; benn einen gtuciten Eforpion, mit bem man fie fpäter zufammenbrachte, griff fie bon vorn an, wurbe aber von bejfen Echeren crjaßst, mit ben

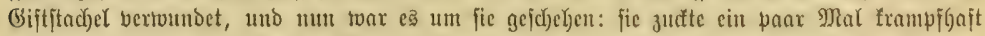

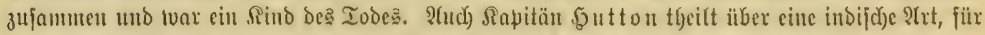

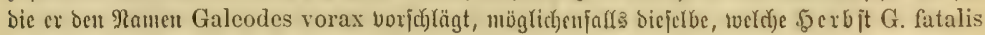

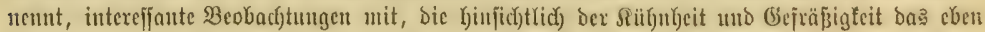

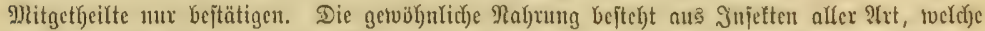

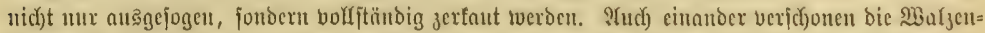

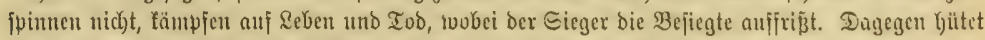

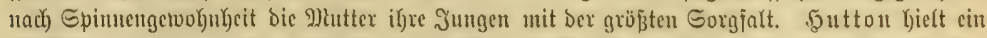

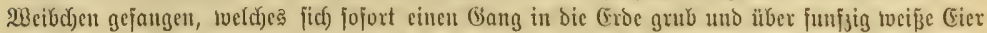

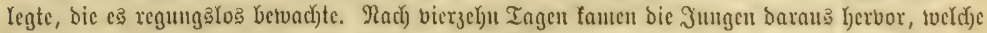

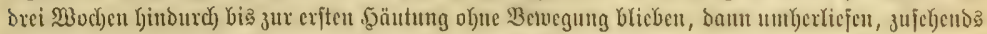

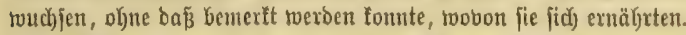

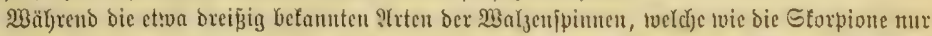

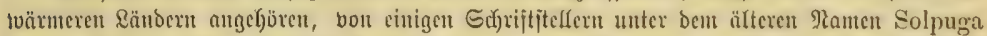

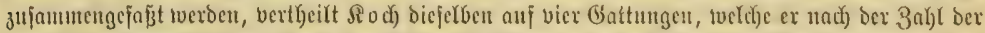

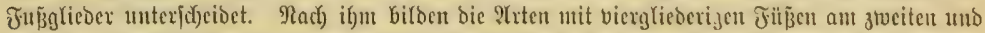

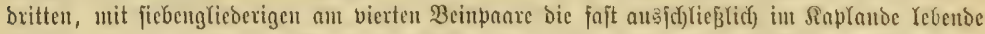
Gattung Solpuga, bie in entjpred)ender 23 eipe jwei= uno breiglieberigen bie Gattung Galeodes.

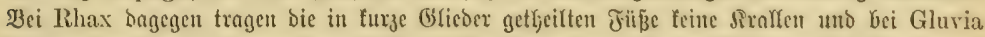

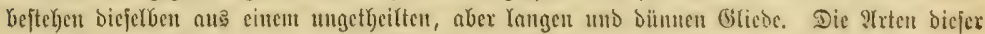

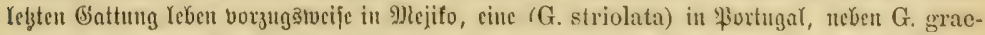

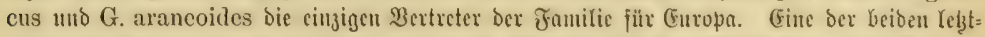

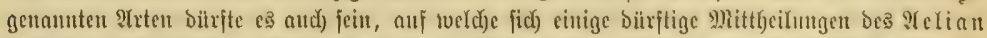

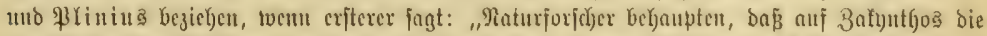

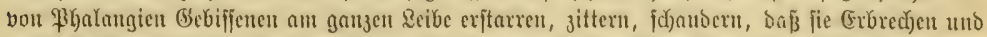

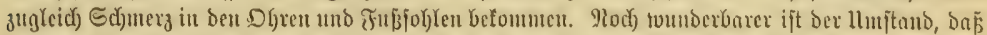

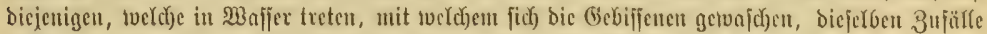

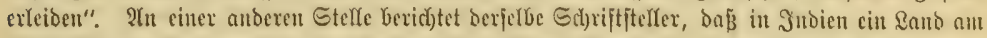

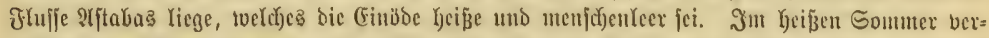

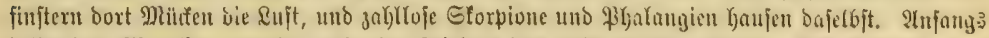

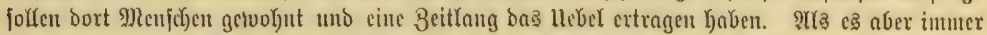

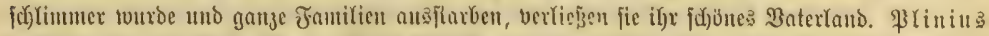

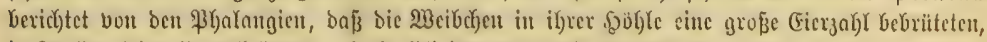

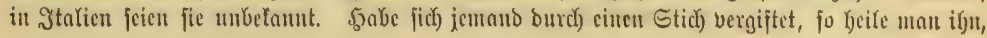




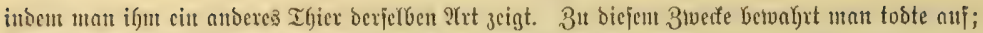

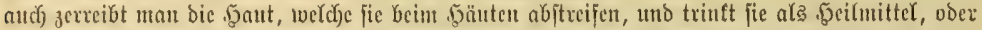

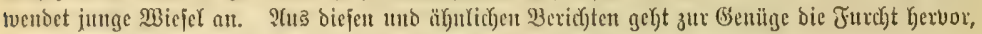
tweldye man von after: her gegent berartige Spinnentbiere hatte.

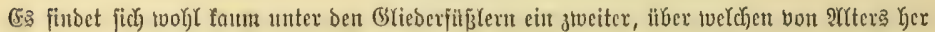
jo biel gefabelt toorben ift, wie tiber ben Storpion. (5x ift feinem ganzen Mejert nach unftreitig

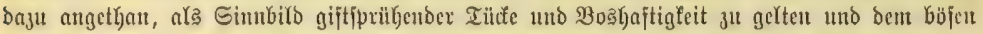
Genina Iyphon in ber altegyptijdyen Mnthologie jur Seite geiteflt ju werden. (Einige ber grie=

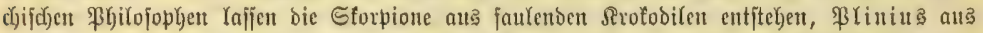

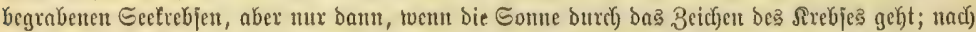

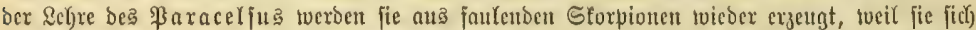

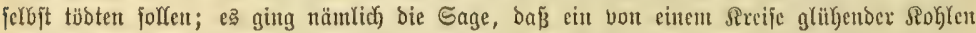

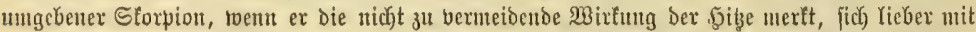

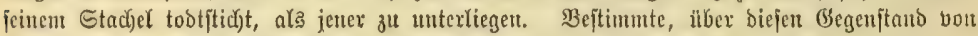

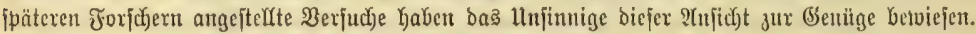

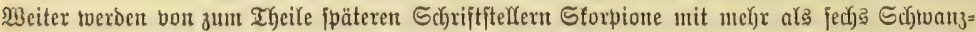

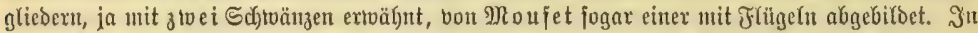

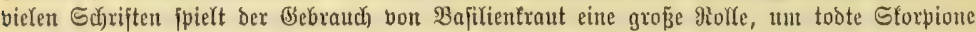

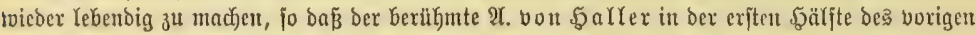

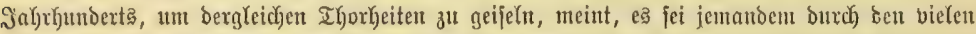

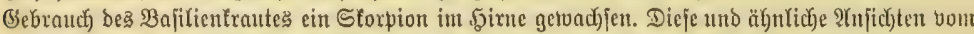

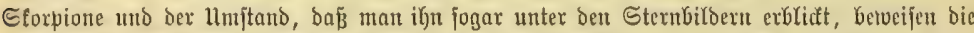

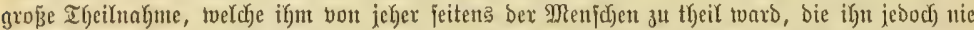

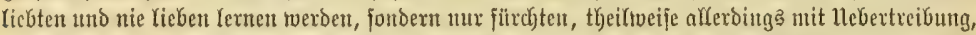

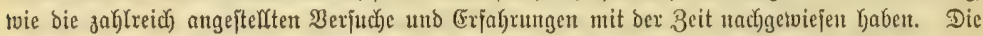

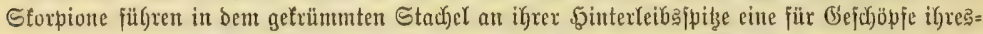

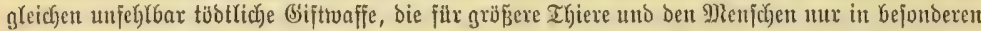

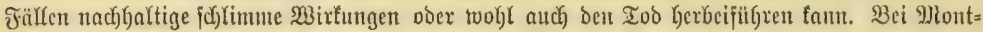

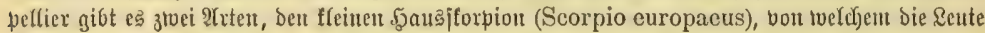

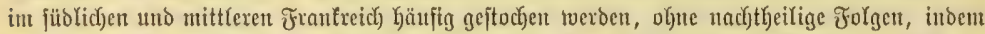

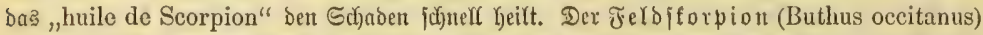

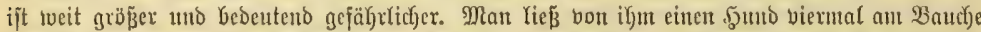

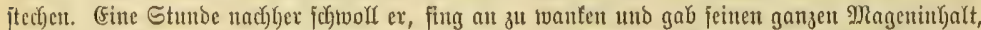

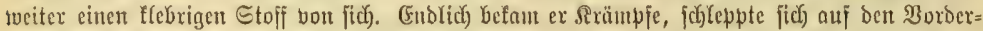

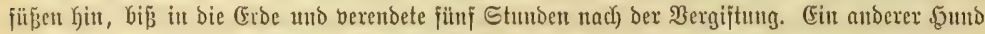

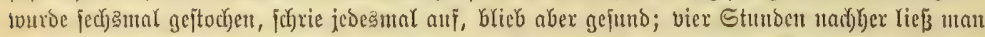

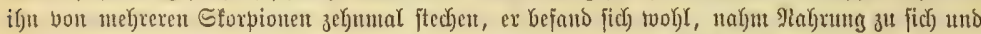

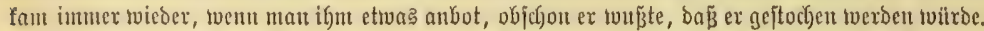
Bei cinem tociteren Berjuche brachte man orei Storpione mit einer Maus jujammen. Sie twaro gejtochen, quifte, biß bie Eforpione toot uto ftarb - nicht. Sn einem anderen Falle war ein

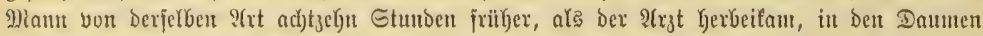

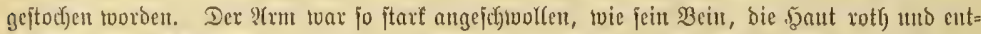

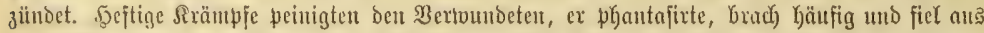

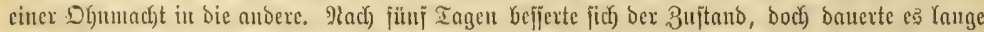

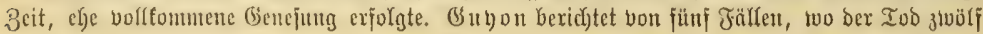




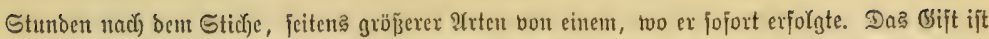

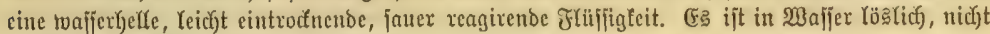

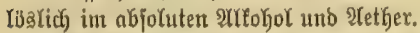

Die Sforpione Kalten jid) twie bie Taujenbfüpler unter Steinen, in jaulen Soorze, in Mance=

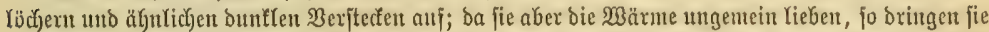

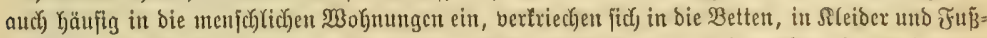

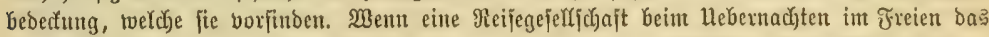

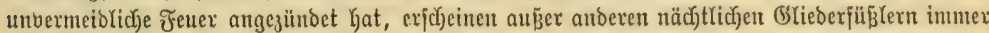

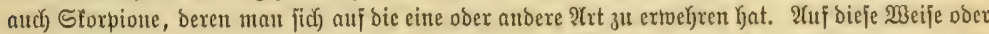

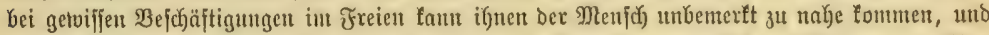
bann pflegt ein Stich ifrerjeits unvermeiblich zu fein, benn fie meinen fid) vertheibigen zu mitfen.

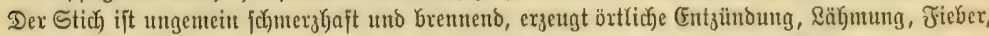

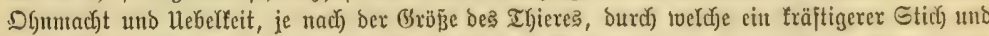

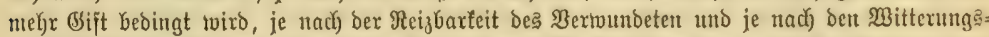

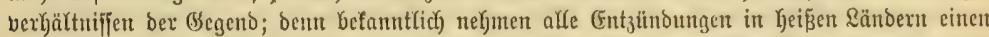

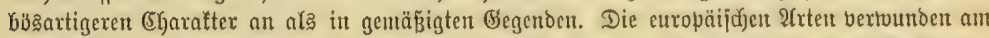

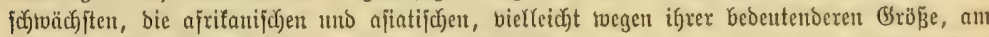
Geftigiten. Sonjt pflegte man bas jogenannte Sforpionül, Dlivenöl, toorin man einige Storpione

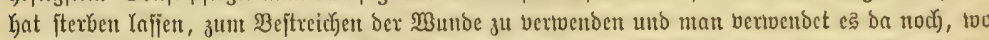

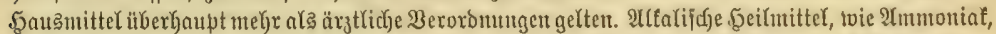

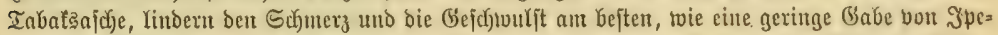

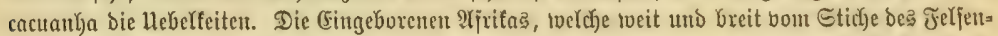

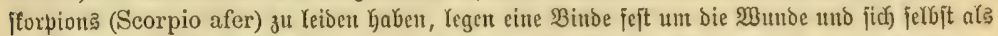

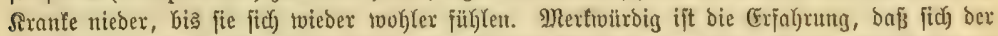

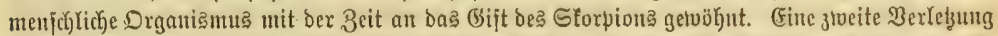

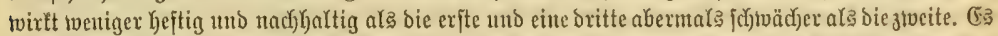

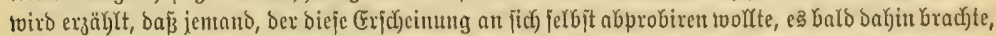

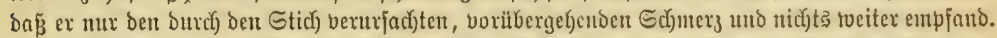

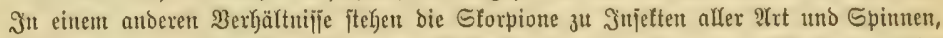

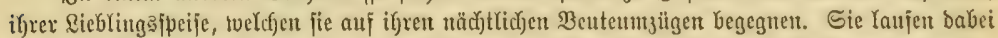

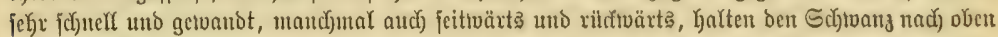

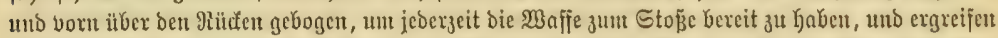

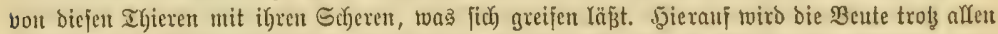

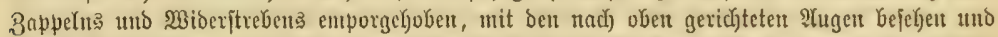

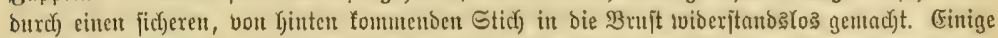

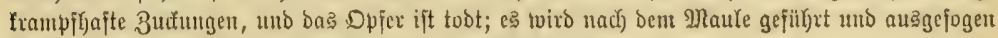
Doer unter Umitänoen aude) zerfleinert und voljtänbig verzefrt.

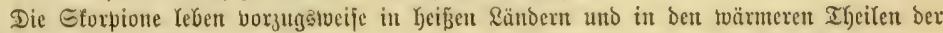

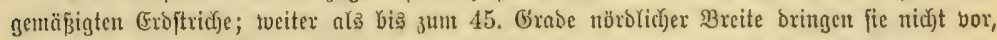
feblen baher in Deutjochland gäntzlict.

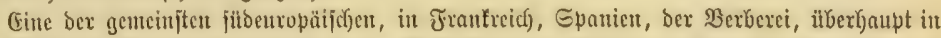

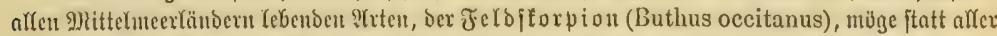

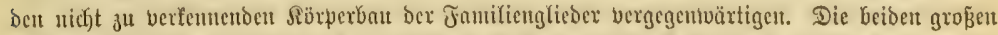

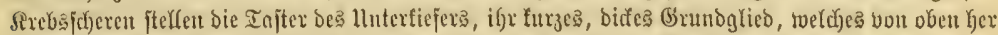

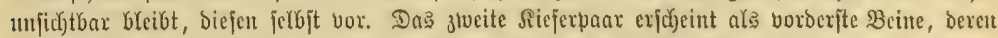

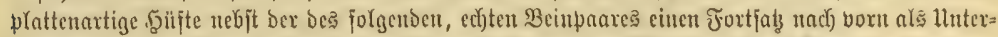

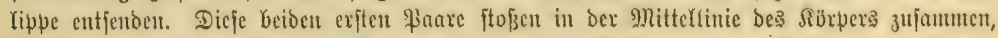

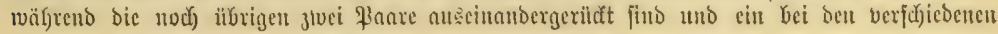




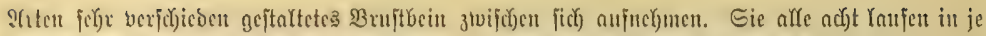

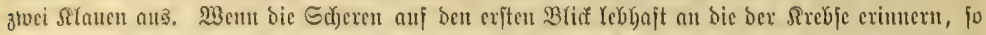

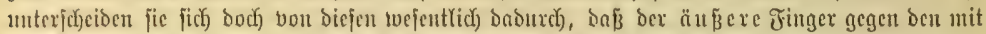

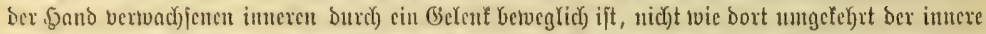

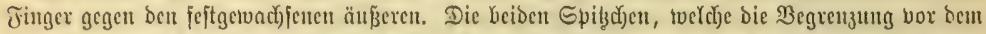

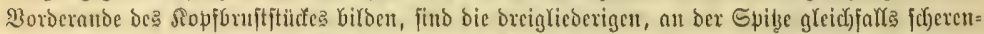

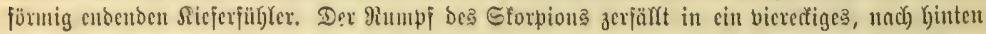

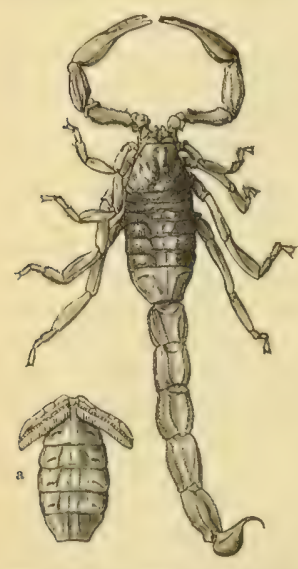

శeloftorpion (Buthus occitanus).

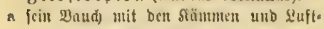
lödern. Patilutidje Brö̌ce. etwas Greiter twerdendes ungetheiltes Sopfbruitititic uno in

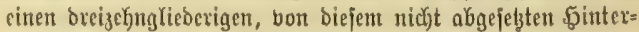
Yeib, bejien ject) Yetzten Minge einen fnotigen, in ben gebogenen (Giftitadyel auslaufenden Sdjwans Gilden. Die Doppelte Diff=

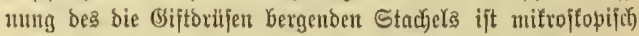

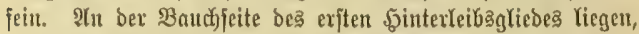

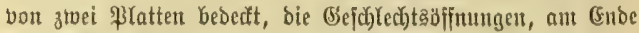

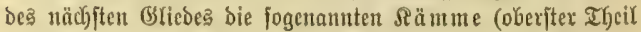

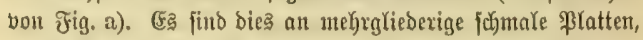

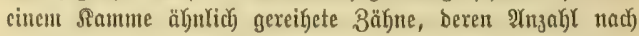

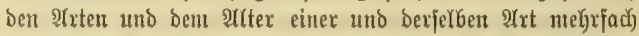
fótwantt. Diefelben enoen am änzeren Panbe faugnapjartig uno find an ober ztwijdjen ifren Wurzetn aus = uto intuendig

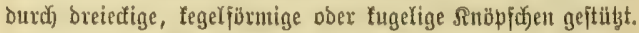
\$̧re eigentliche Sebeutung fenut mant noch nidjt; bon ben auf= geftelften $\mathfrak{N e r m u t h u n g e n ~ K a b e n ~ b i e ~ G e i d e n , ~ f i e ~ m o ̈ c h t e n ~ b e i ~ b e r ~}$

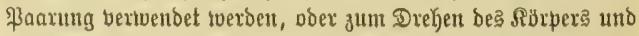
zum Jeftgalten an fteifen, glatten Mänden, fonit zux Unter=

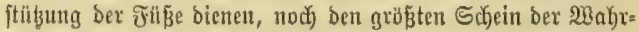
Yeit fïr fich. Sointer ben beiben Siämmen, toeld)e feinem Stor=

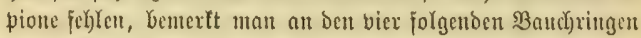

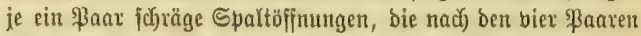

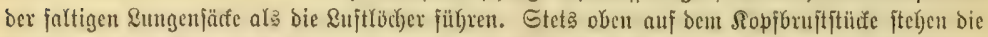

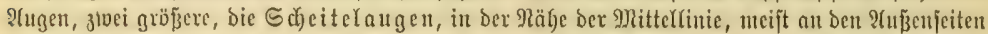

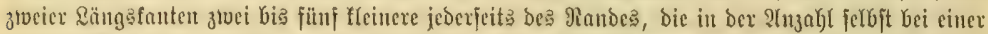

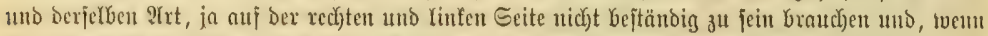

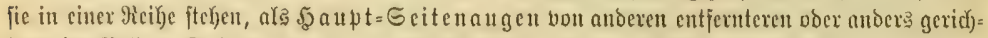

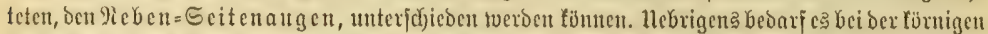

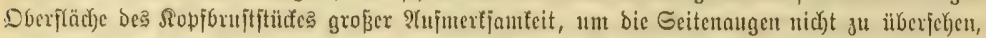

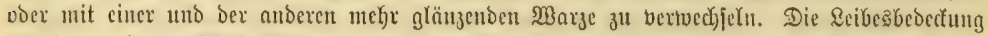

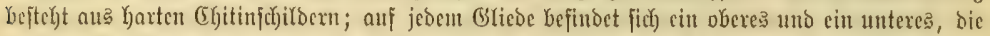

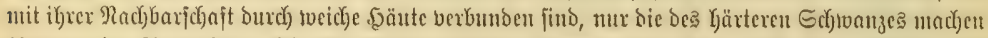

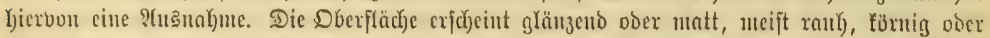

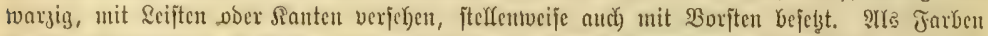

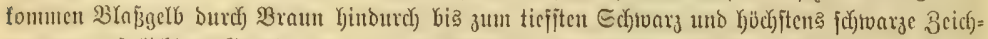

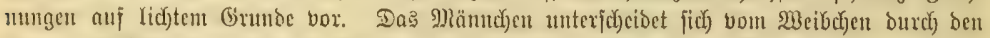

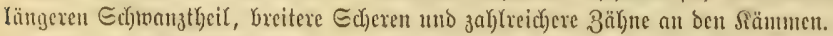

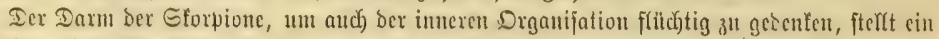

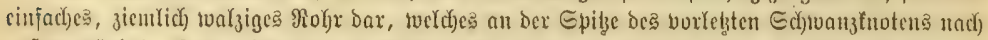

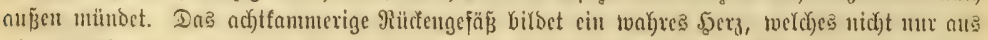

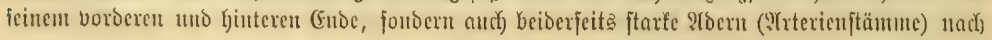




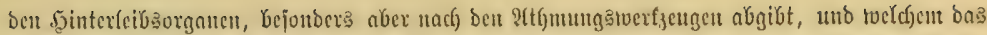

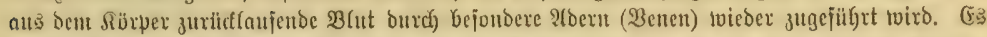

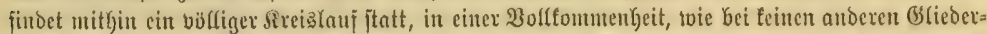

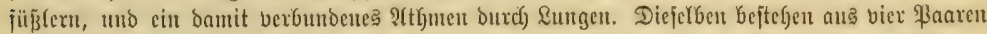

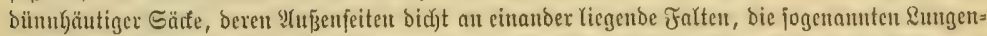

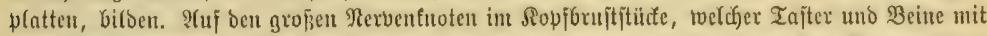

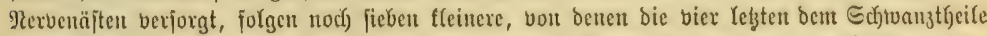

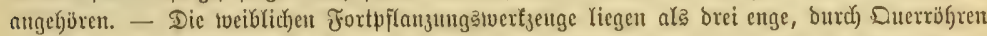

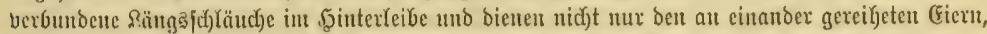

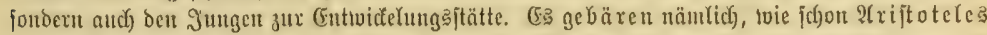

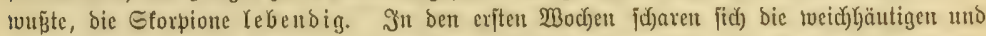

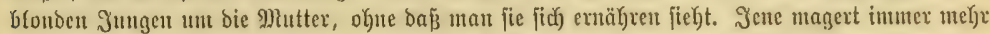

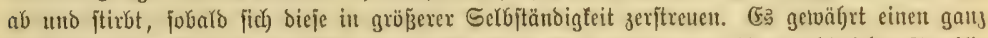

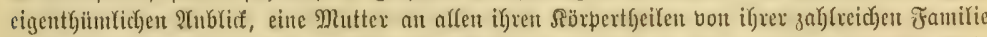

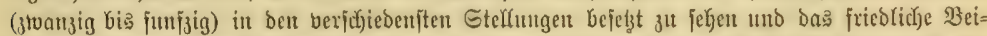

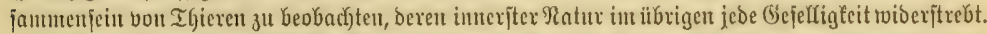

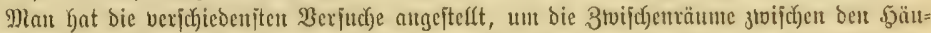

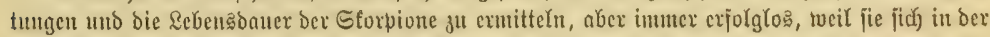

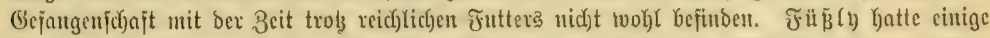

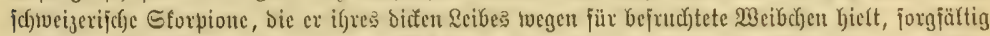

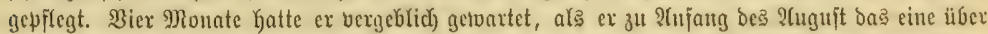

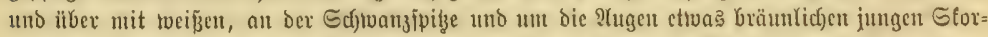

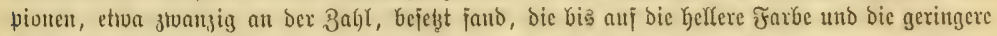

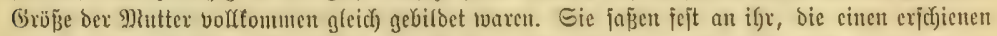

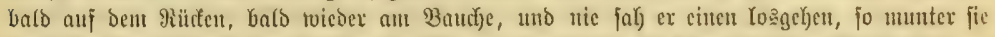

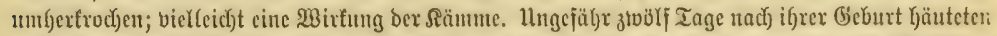
fie fich) zum erjten פ)

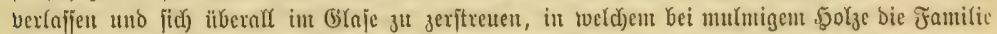

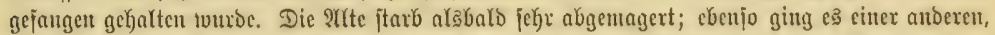

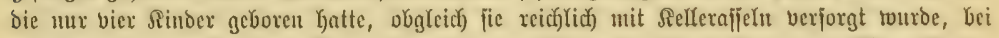

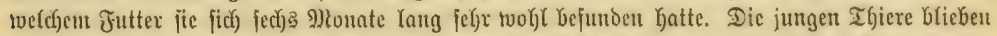

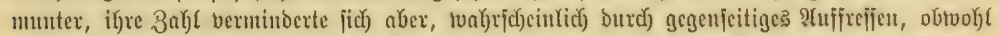

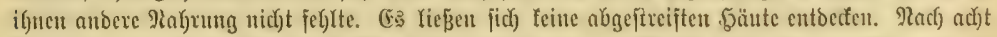

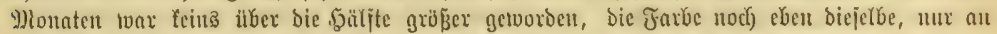

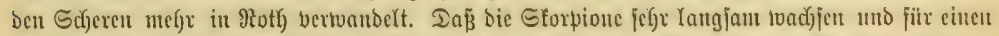

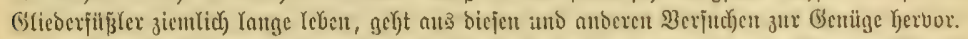

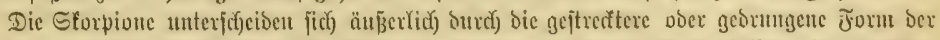

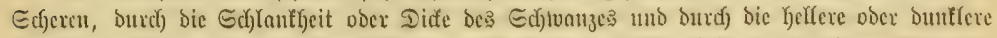

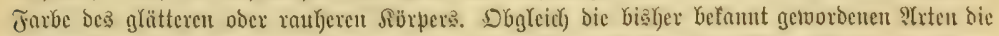

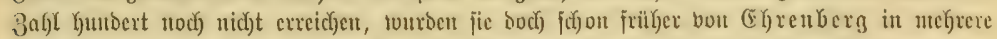

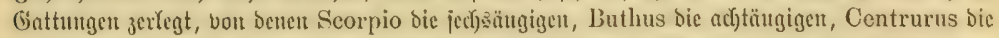

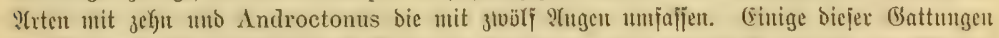

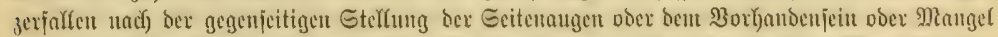

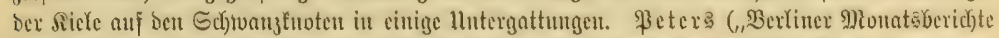

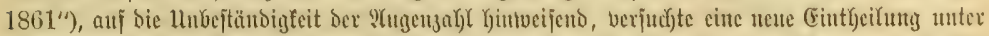

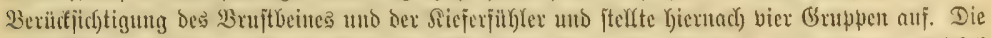

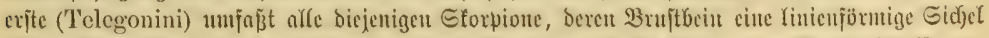

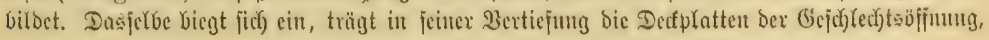




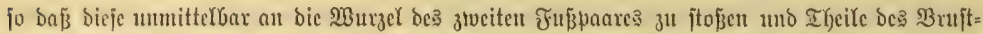

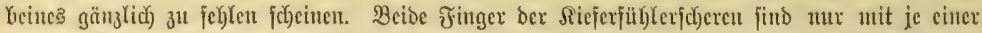

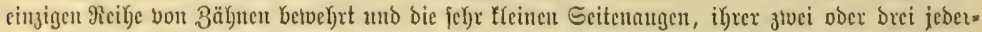

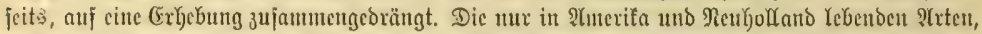

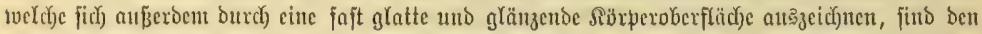

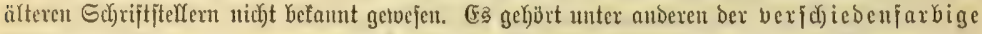

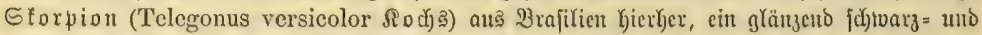

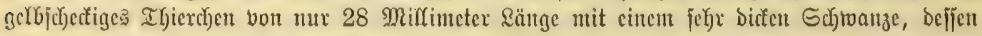

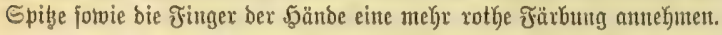

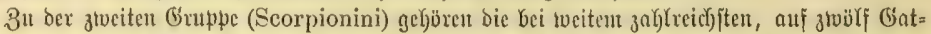

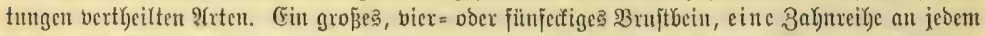

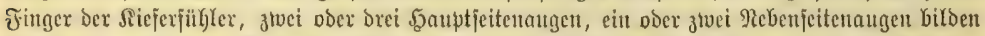

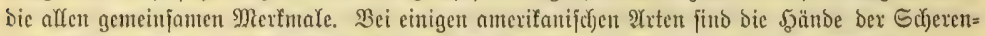

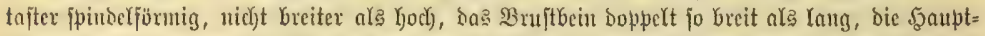
jeitenaugen zu ztveien, Die Rebenfeitenaugen einfad) ober partweije borłandent. Gie bildont bie

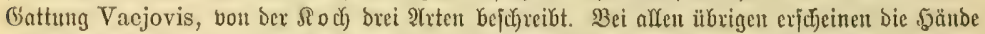

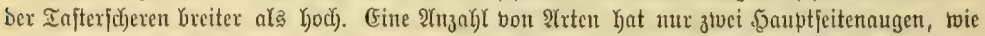
ber Yängit Gefante, bunfulbraune, an Bauche gelbe Mokren= Sforpion (Brotheas maurus).

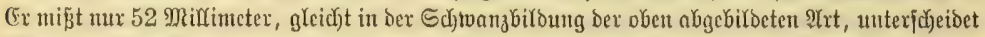

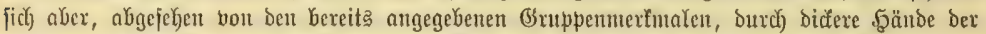
Echeren. Die Echeitelatgen ftelyen bor ber Mitte bes Sippibruftitüces, wälyrend fie bei dem fehr

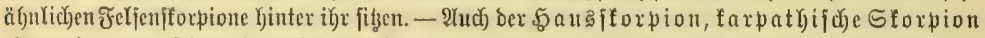

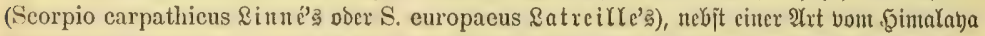
(Scorpiops Hardwicki) unb eine von Reuhollano (Urodacus hollandiae) gehjüren Yjiertyer. Der

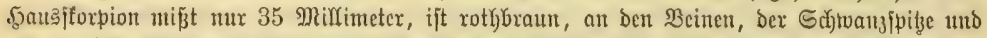

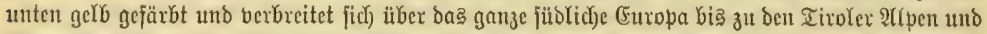

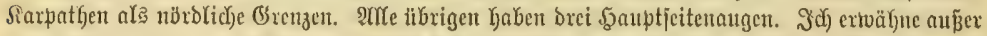

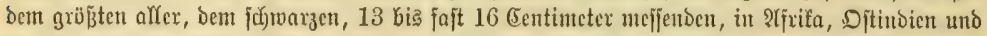

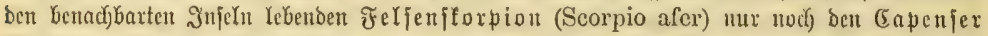

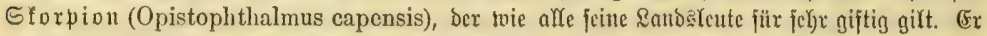

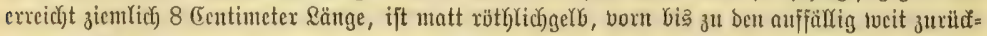

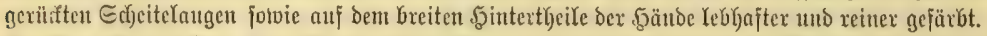

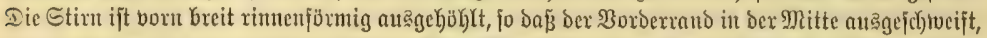

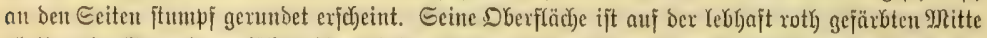

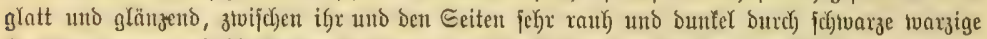

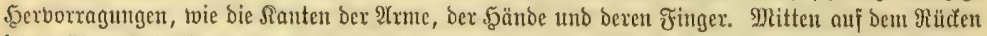

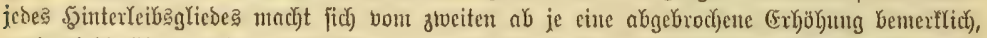

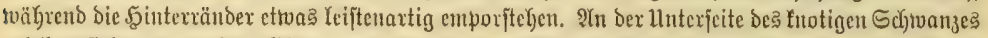

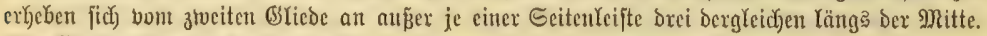

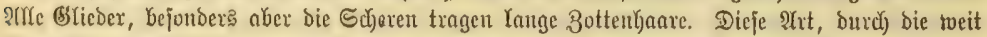

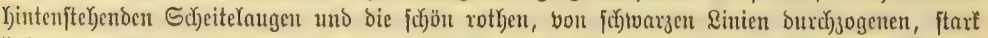

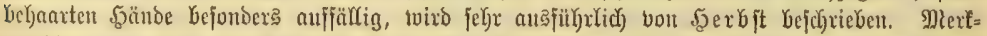

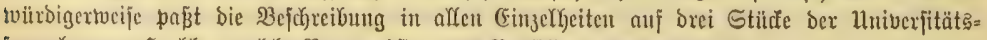

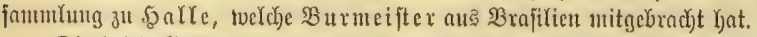

Dic britte (Suppe (Centrurini) vereinigt folgende Mertutale: cin Heines breictiges Brujt=

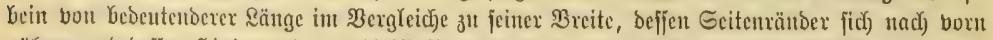

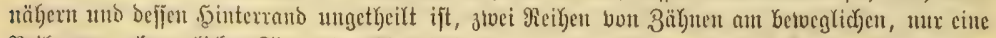

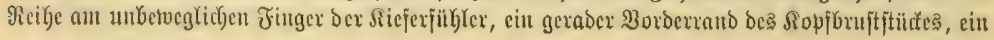




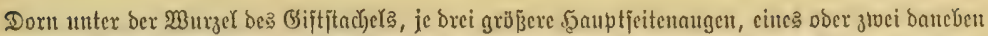

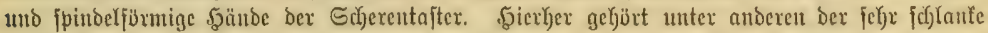
a merifanifde Eloxpion (Centrurus americanus). (Ex ift in alfen feinen Ǵliebmapen büm,

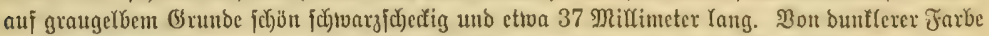

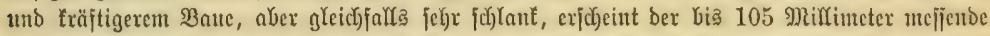
Sottentotten= Storpion (Centrurus hottentottus).

Der oben vorgejiifrte Felofforpion (Buthus occitanus), tveldyen Jerbft audi) unter

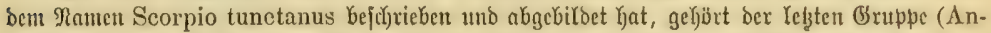

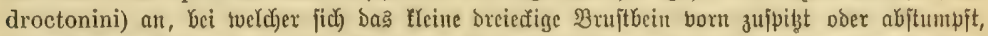

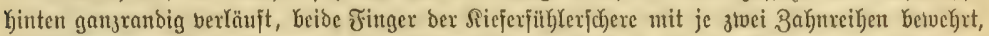

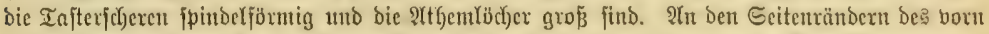

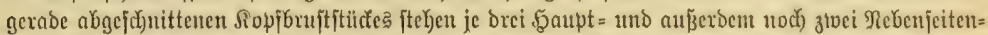

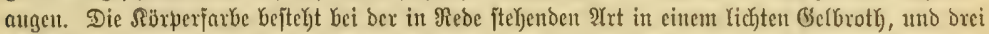

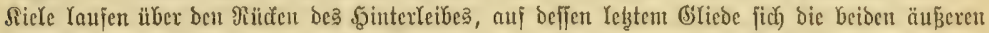

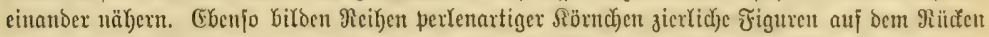
Des BordorYeibes, bejonderes zwoci von ber geraben, Yeijtenartig aujgebogenten Etirn bogenfïrntig

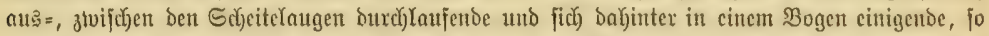

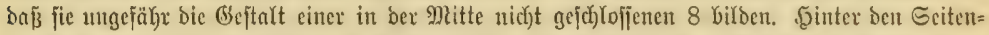

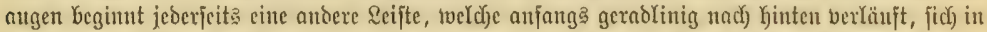

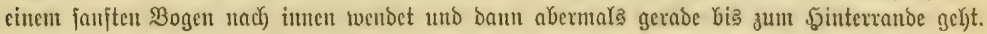

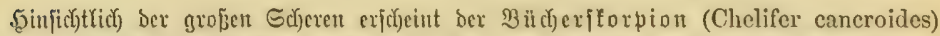

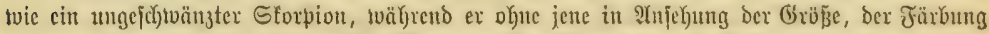

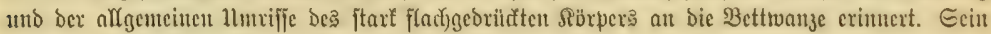

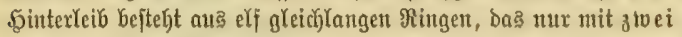
Fugen verjeberre Ropfbujt titid erjodeint querjurdjig, bas Iafterpaar ber: Untertiefer als getwaltige Scheren, bagegen fino bie Sitejer= filf)(er vertünmert, nidjt junt Rauen, fondern ur zun Saugen cingeridytet. Richt nur Der Mangel Der Rämme am Grunde Desె Bauches uno ber Gifftoriffen an irgeno einer Stelfe ihres Siörpera

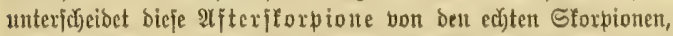
fonocrn autch ber alferbing

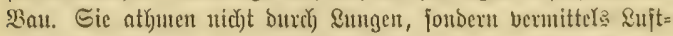

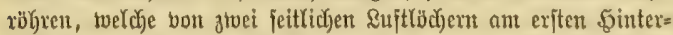

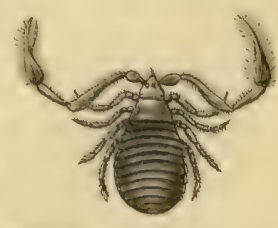

Plid)erftorpiou (Chelifer can. croides), flarł bergrögert.

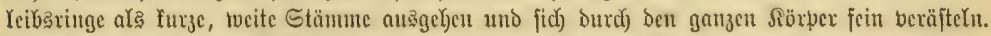

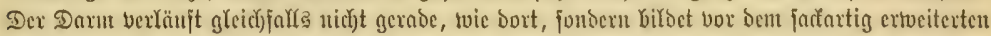

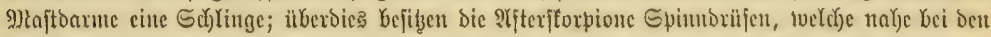

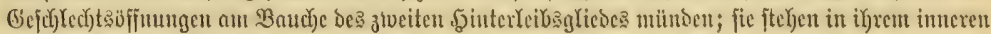

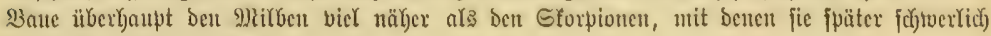
verbutuden Gleiben twerden.

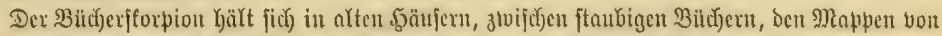

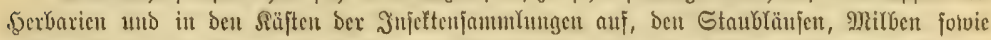

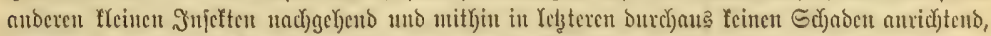

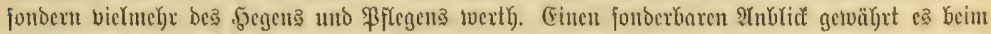

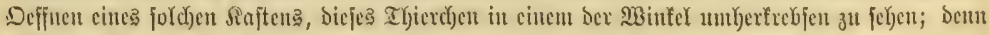

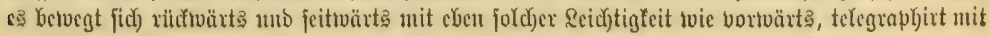




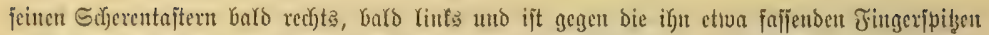
bollfomment twelyrloä. Da: Weibdyen legt ungejäbr zroanzig (Fier.

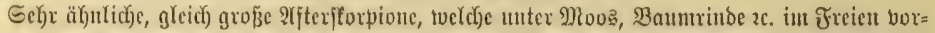

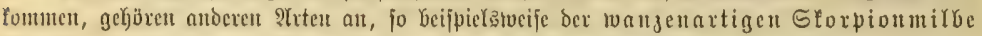

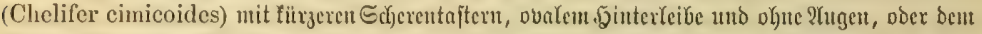

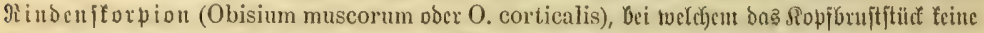

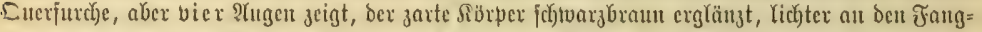

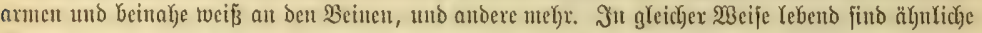

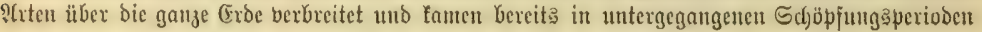

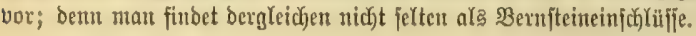

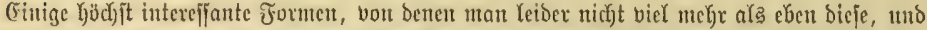

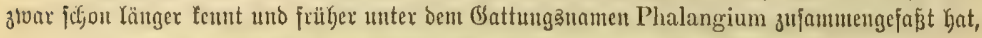

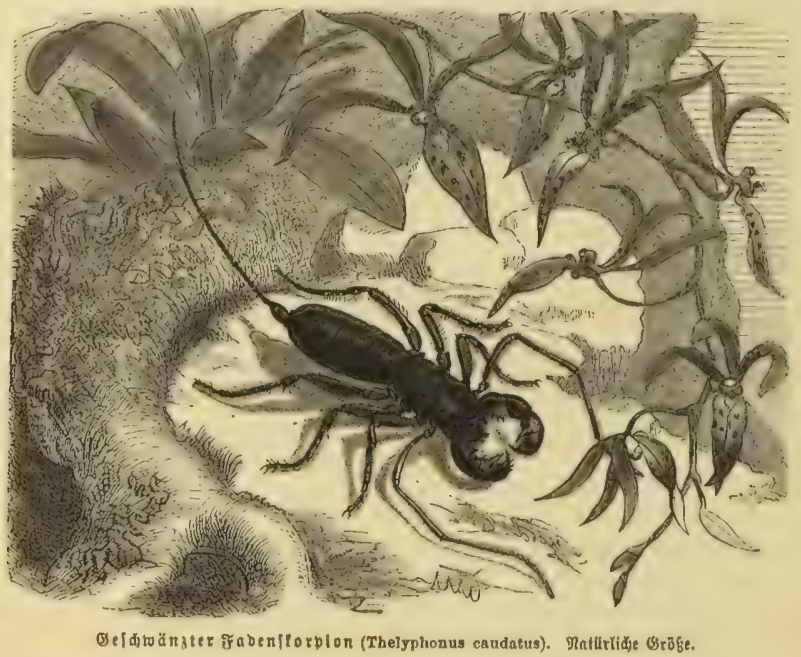

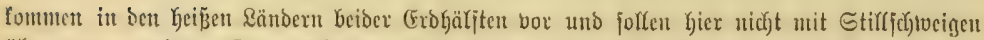
iibergangen twerden. Der gejd) twänzte Jabenjforpion (Thelyphonus caudatus) voer ber

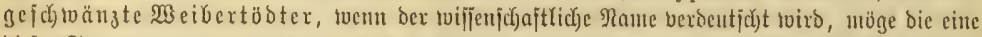

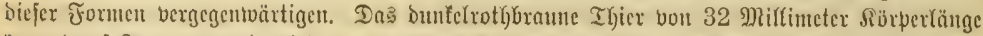

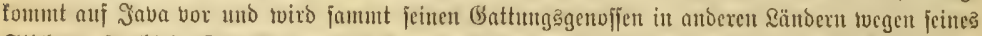

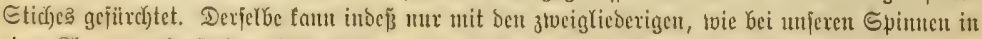

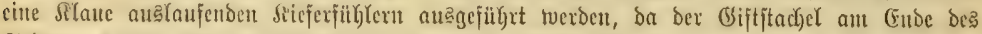

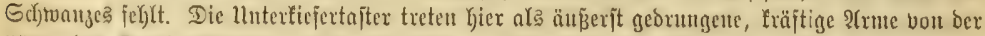

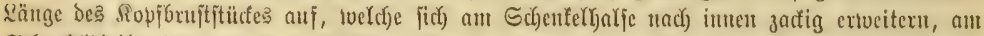

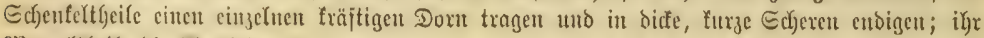

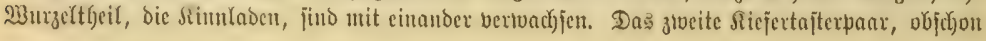




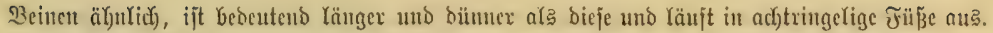

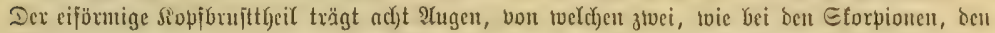

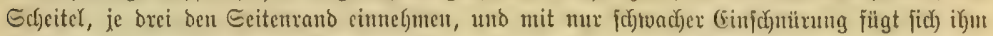

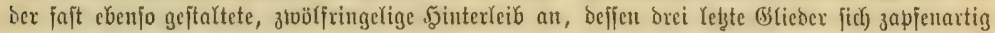

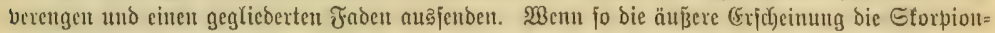

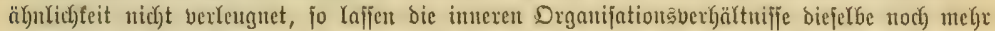

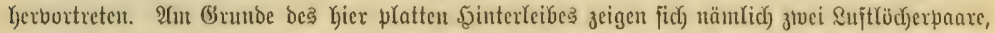

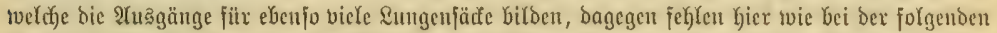

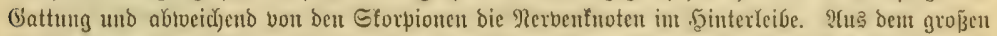

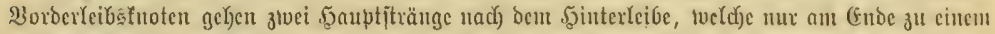

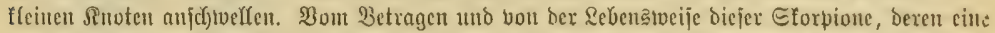

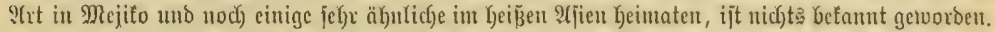

Der langarutige Iaranteljtorpion (Plirynus lunatus) vergegentuätigt bic andere,

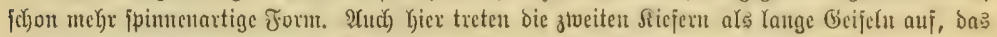
exite \$aar ałs Yängere ober fürzere, mehr ober tweniger bebornte $\mathfrak{A}$ rme, weldue in

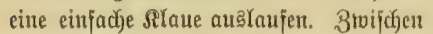
Dem die Rinnladen Gildenden Wurzeltheile beiber AYume fiteft ein betweglidjer Sinus born, bie Siejerfübler enden gleidjjalls in eine einfache Slaue uno bergen twaht= fdyeinliç) bie Biftorilfen. 2 m beinahe nierenförmigen Ropjbrujtitüice bertheilen fidc) Die IHgen, twie bie bergröberte Figu: zrijachen ben Oseijeln anzeigt, ztoei ftełen vorn, je orei toeit onbon entjernt uno jeit= twärta. Daburd), baß̄ ber elfgriederige Jainterleib vorn eingejochnitut ift, entiteht

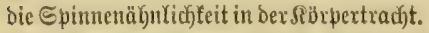

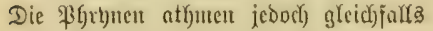
Durdid) Rumgen, weld de an ber Banudytumizel

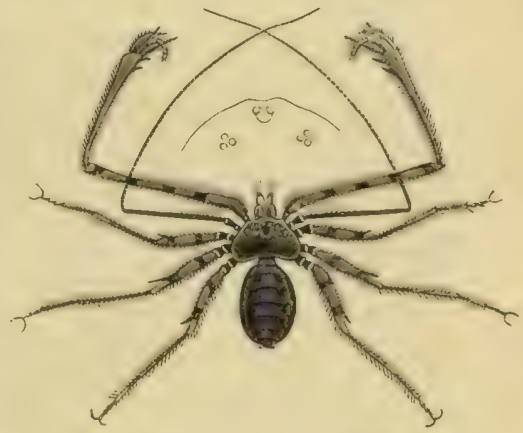

In nariger Tarantelftorpion (Plirynus Inatus). Matürlidje Gröice.

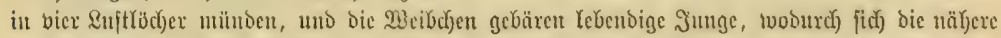
Berwanotjchajt mit ben Gforpionen befunbet. Bei ber Yjier abgebifocten fah) braungelben $\mathfrak{A}$ t,

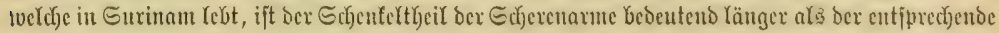

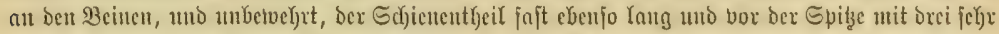
Iangen Dornen berjeben. Ilnbegreiflidfertueije bildoct Gervais bicje Tht unter bem Tamen

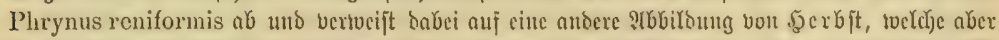

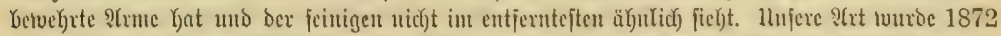

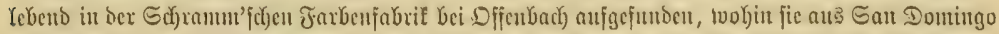

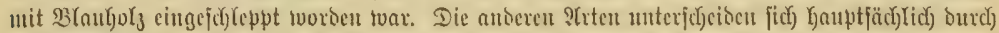

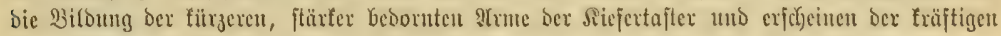
Dornen toegen noch brokenter:

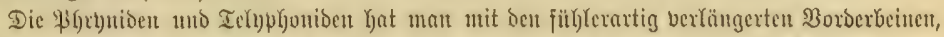

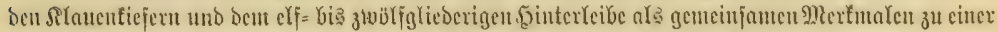

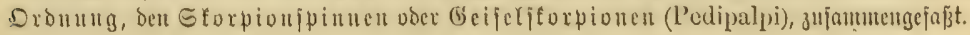




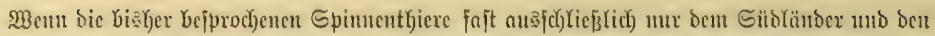

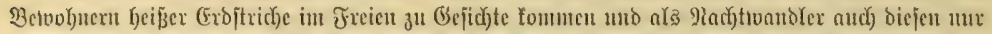

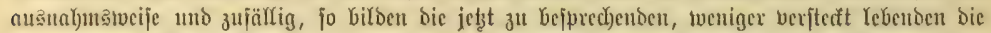

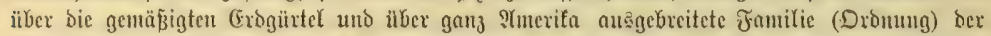

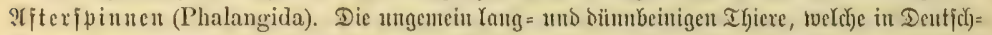

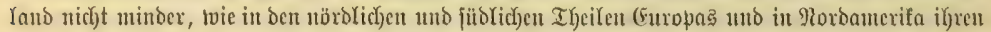

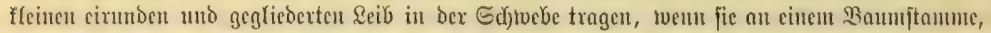

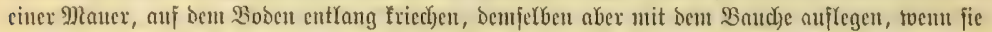

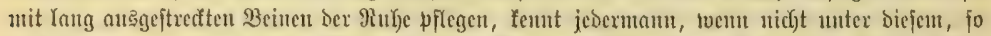

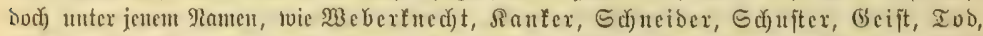

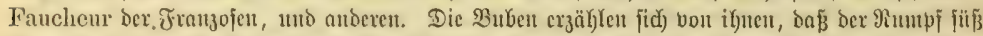

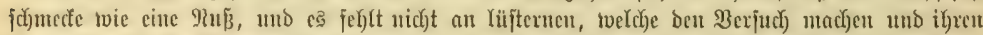

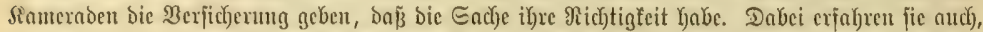

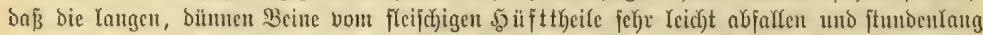

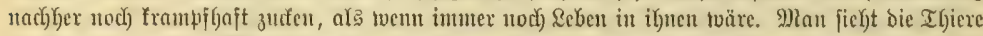

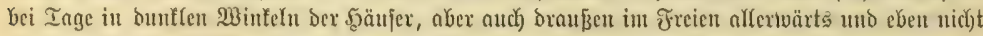

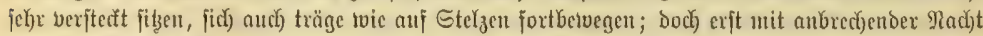

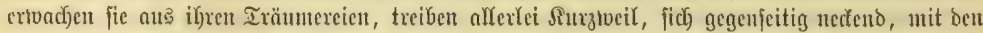

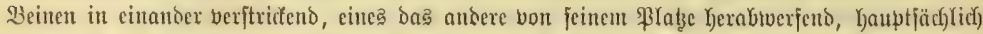

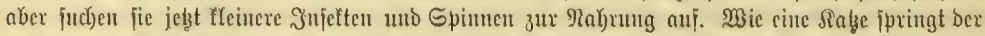

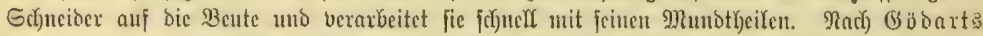

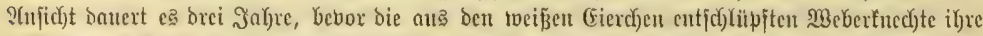

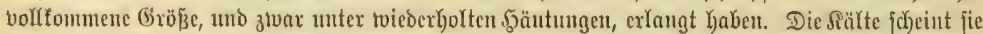

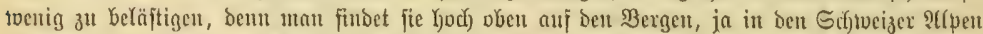
beobad tete mau den (Ei

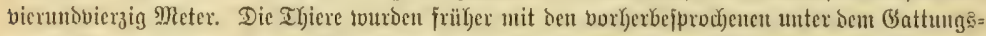

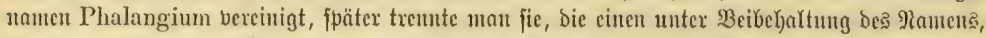

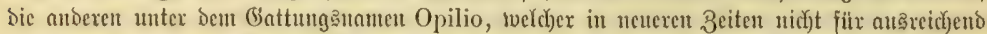

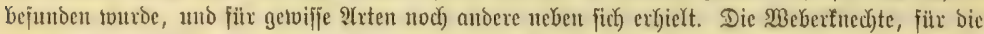

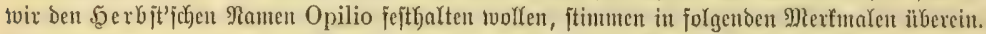

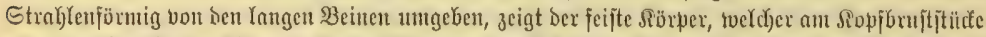

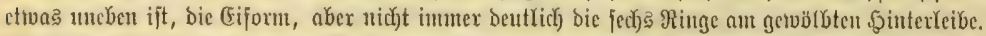

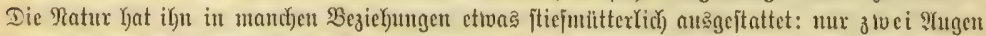

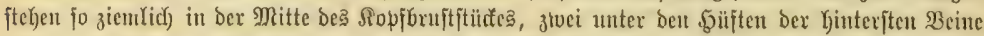

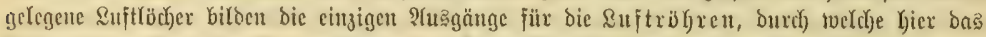

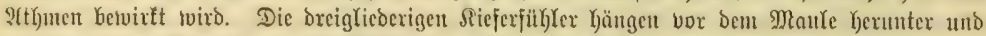

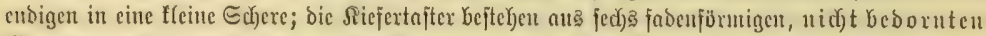

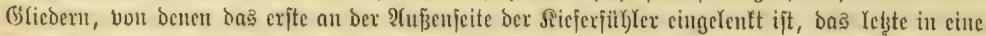

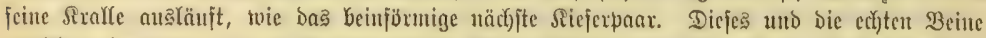

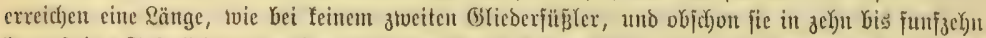

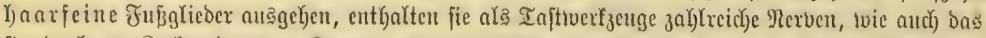

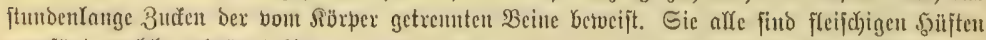

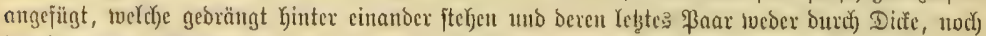

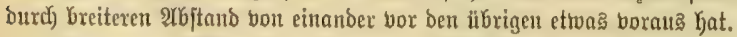

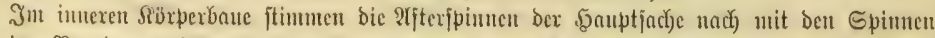

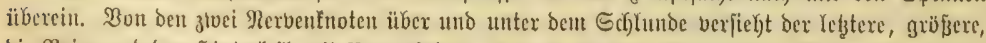

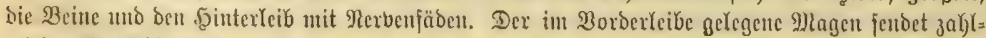

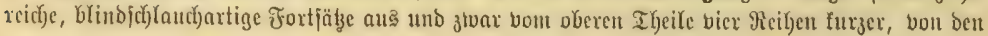




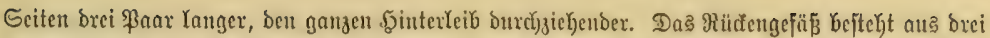

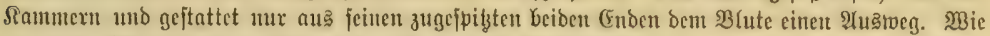

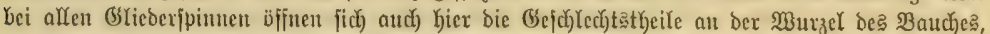

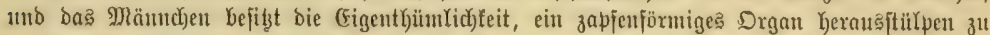

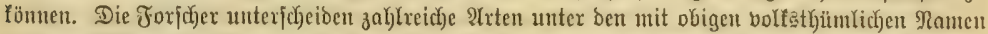

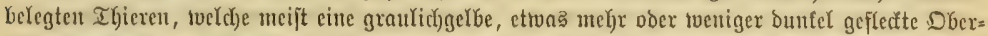

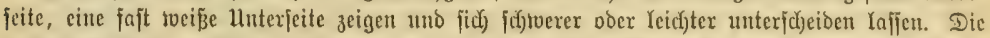

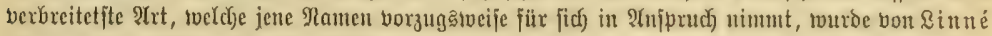
Phalangium opilio, von foexbit Opilio parietinus genaunt, mift in grauen ober graugelben

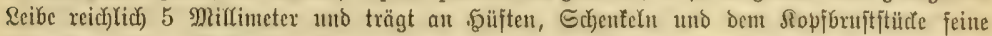

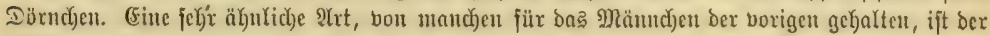
Opilio cornutus, nuşgezeidyuet burch einen hornartigen

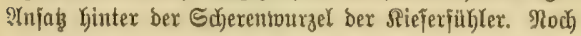

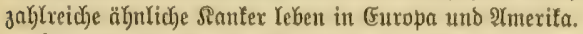

शnoere शrten, bon benen jeboch feine eimzige in

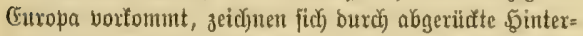
beine mit beroicten Schenfeln, breitgebrü rite Tajter ohne Stadje(borften uns burर्fi) einen gegen ben vieredigen 3orberleib jebr in Den Sintergruno tretenden, fleinen Sinterleib auts. Sie gehöien ber Gattung Cosmetus und einigen zunächjt vetwanotett an.

Die jonderbarften Fantilienglieber foeift aber Sild= anerifa it ber Gattung Gonyleptes aū, wie ber hier $a b=$ gebildete Gonyleptes curvipes betweift. Diejes , Rrumun= bein" ift im braumotyen ßumple ein jajt ganz Kartjoda $a=$

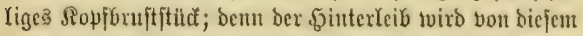

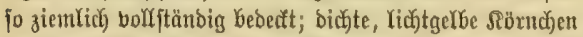

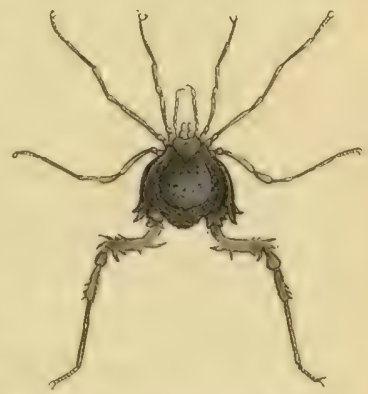

Dtănuducn bes frummbinigen Olonylepte (Gonyleptes curvipes). Ratiirlide Oröbe.

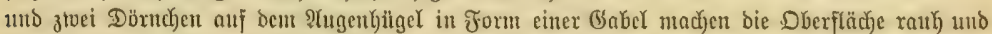

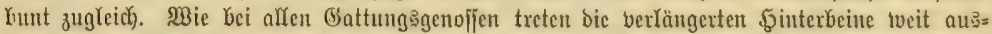

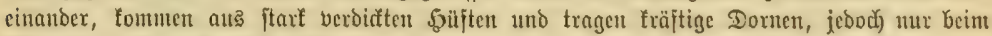

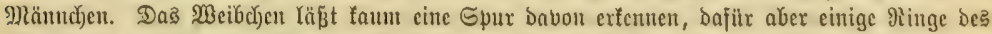

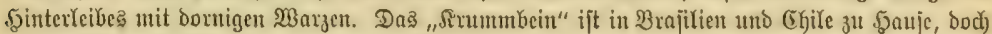

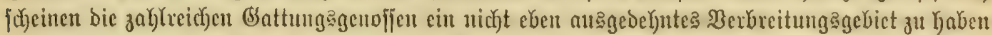

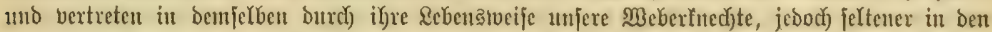

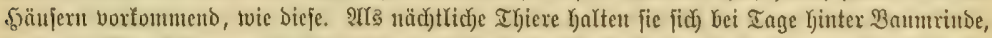

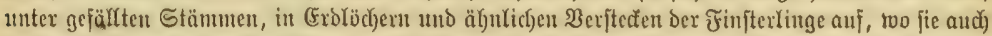

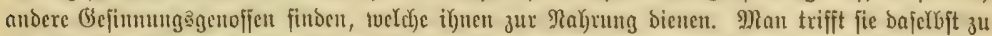

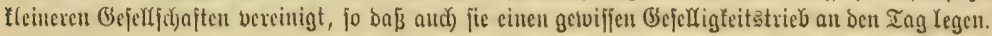




\section{Bucite (0ronung.}

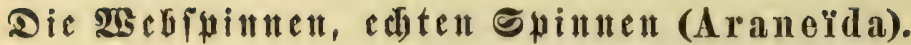

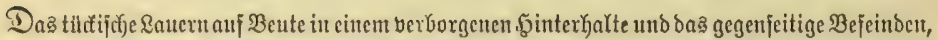

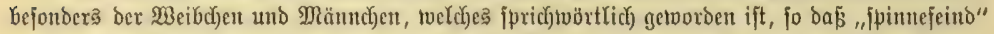

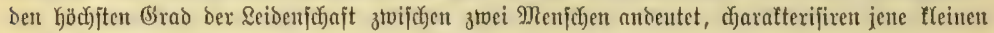

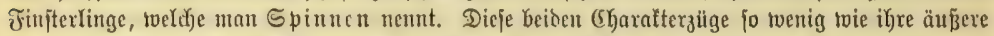

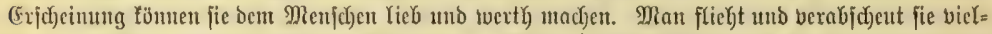

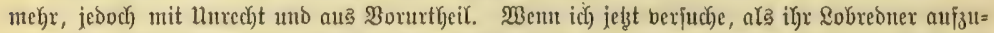

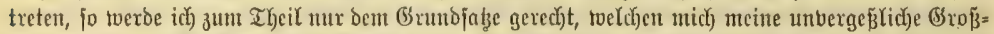
mutter Iehrte, als id) nod) ein Snabe twar. Diejelbe ging von ber 21njtcht auts, baß man bem

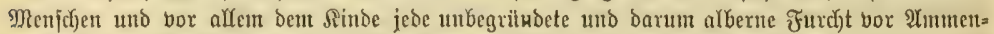

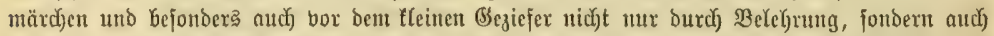

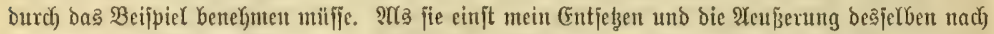

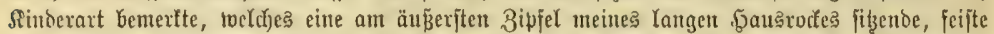

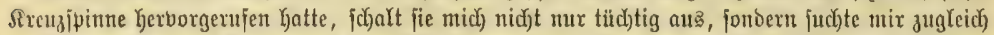

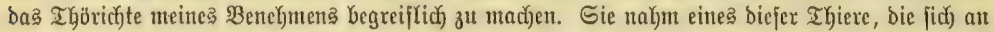

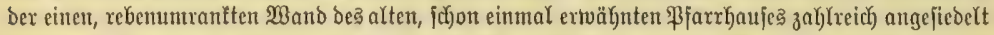

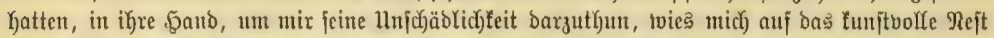

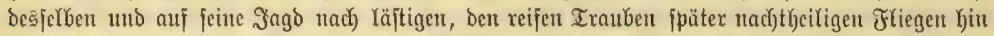

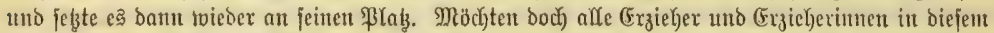

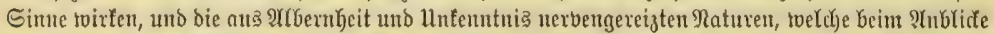

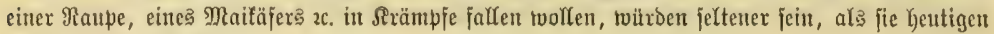
Iagę Yeider noch find!

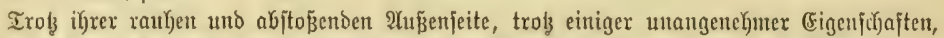

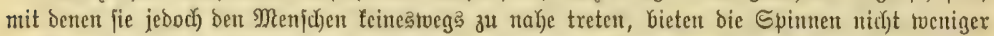

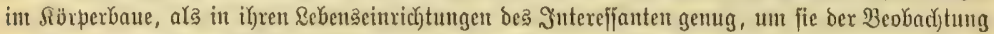

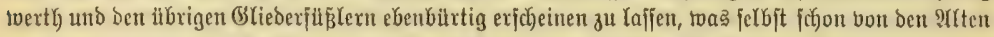

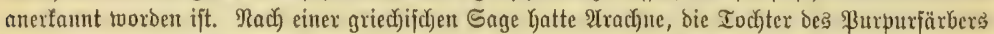

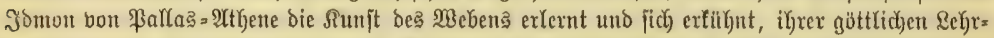
meijterin eiuten Wettjtreit anzubieten. Umjonjt mahnte bie Bsöttu in Gejtalt einer alten Fraı

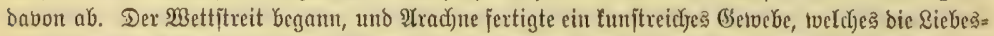

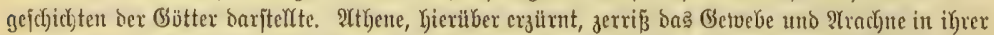

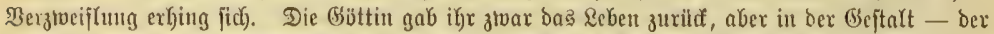

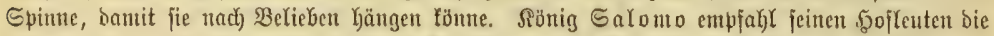

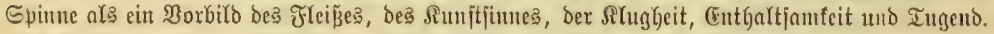

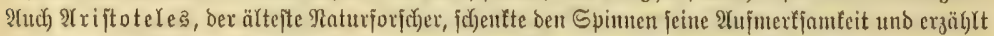

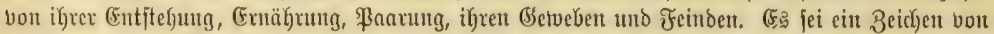

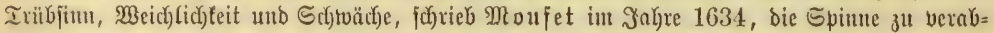

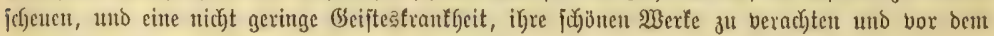

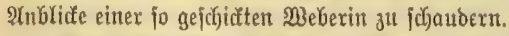

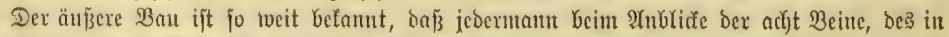

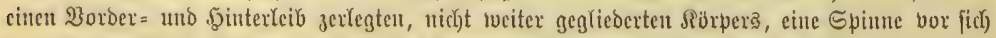

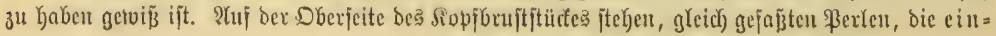


fach)

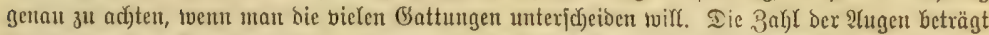

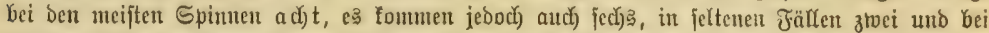
cinigen \$öblenbetwołnern (Anthrobia mammuthica, Stelita taenaria, Hadites tegenarioides)

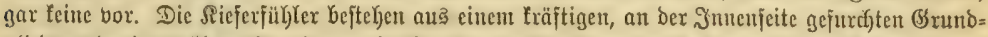

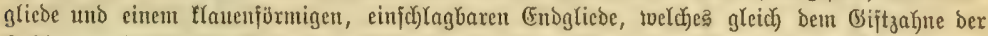

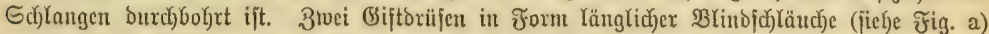

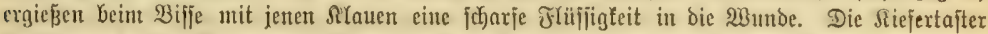

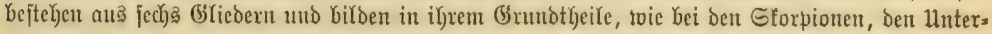
fiefer felbit. An biejen Iajtem fomm die eine (Eigentfümlidjeit ber ganjen Droumng zur

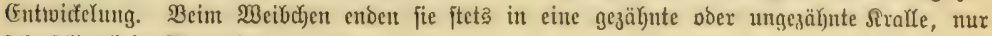
feryr felten beim șännuchen, too fid bas (Enoglied bicłmeł) allmäbliç tolbenartig berbicft und mit einer

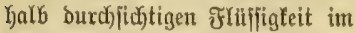

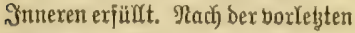
Ђäutung entitehen Gier bie ber= ¡chieben gejtalteten Hebertragungas= werffetrge bes Samen uno treten nad) Dex Yehzten burcic) Spaltung ber

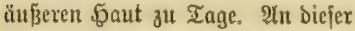
Ilntuand gekente Gried buxch Injats bon Borften, Stadjełn, 3ähndfen uno anderen hornigen(Sebilsenumebrober weniger Ifycil. Meld (x) Betwandtuis e马 mit Den eben genamuten Wert=

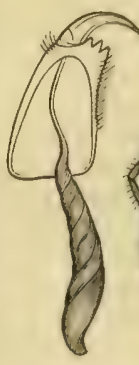

a

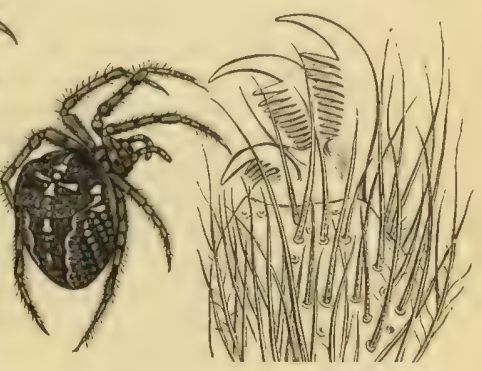

b

a. Ter tinte Sieferfibler ber Strujipinne, an ber Esile aufgeldutiten, bamit ber

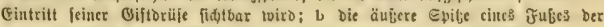
Sgaugfpinne; o tociblid)e se reugipinne (a und b ftart bergröbert). zeuge hat, twiro gleich) gezeigt weroen.

Das näd)ite Sicierpanx endigt tvie bie eigentlid)en Beine in ztwei tanmartig gesälynte Silauen,

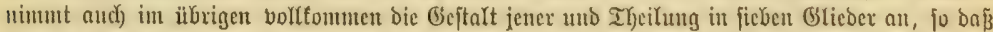

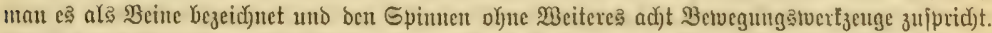

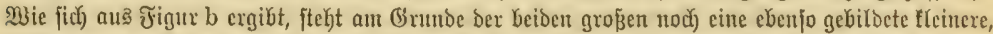

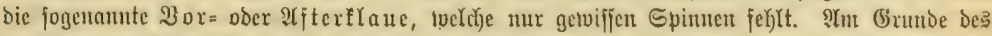

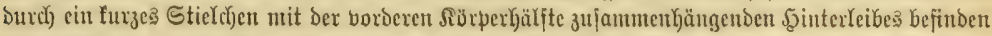

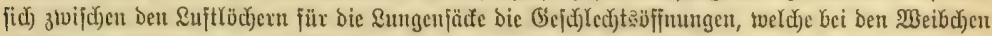

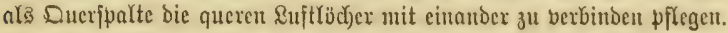

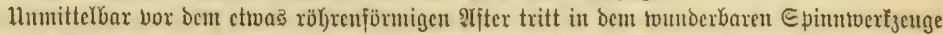

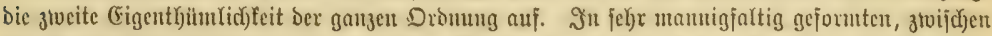

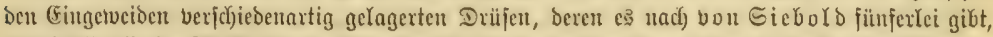

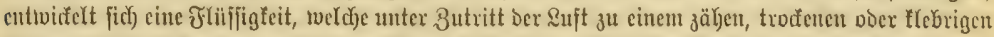

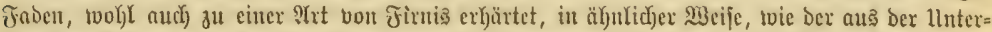

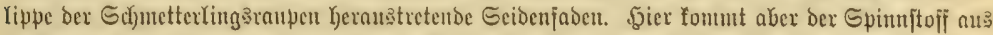

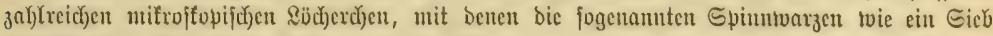

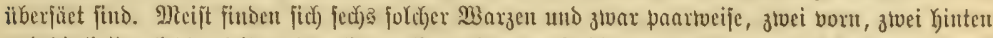

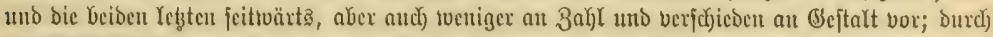

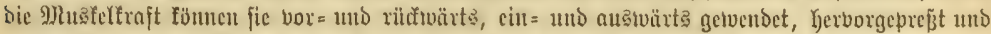

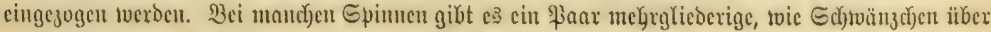

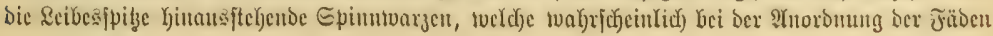




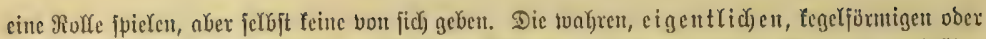

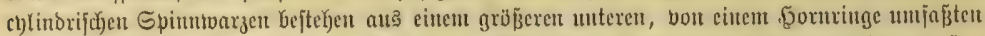

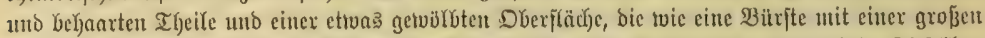

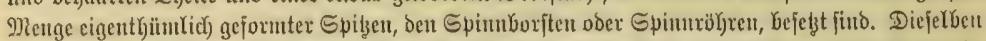

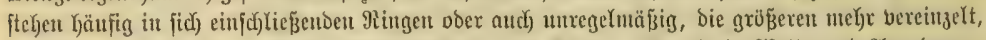

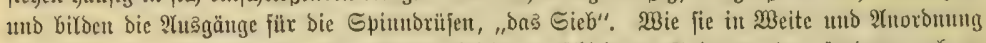

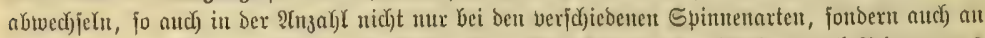

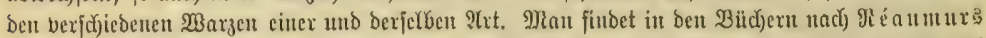

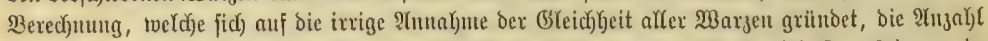

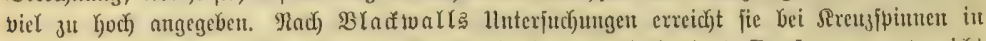

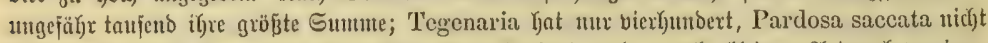

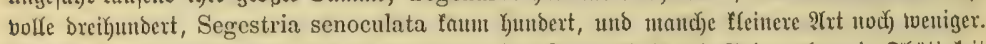

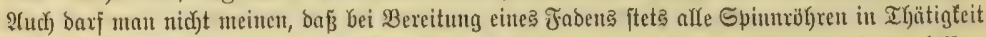

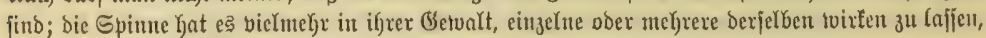
je nad্d)ent ber Fraben biejem ober jentem 3twecfe bient.

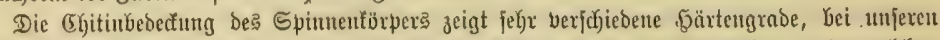

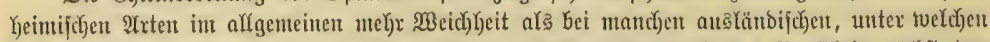

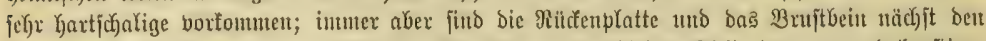

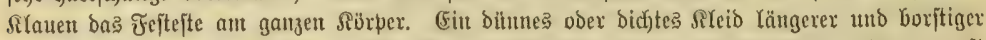

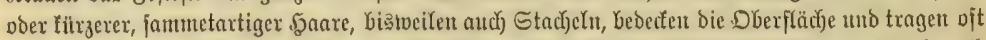

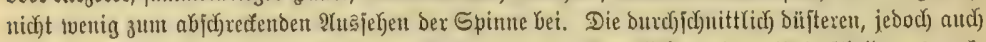

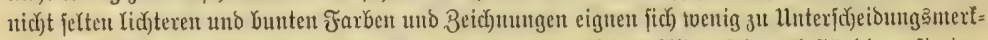

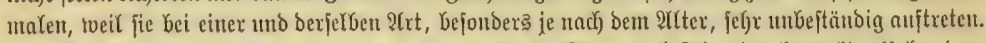

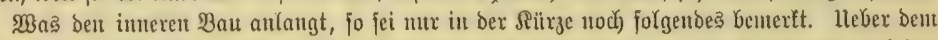

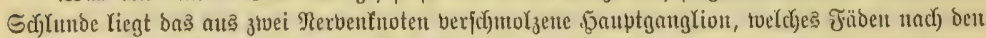

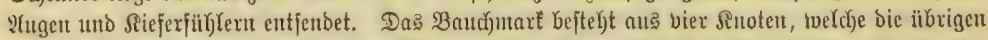

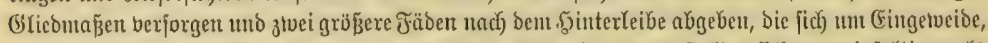

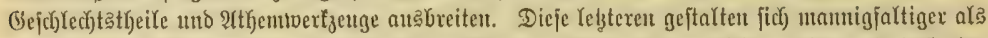

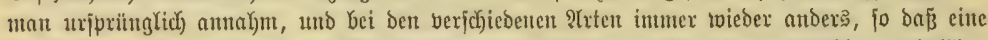

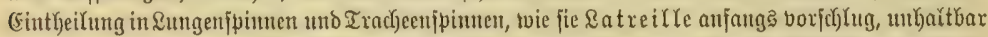

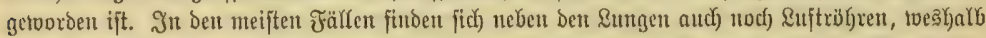

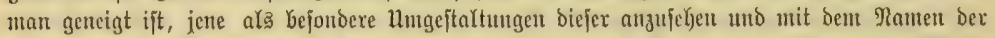

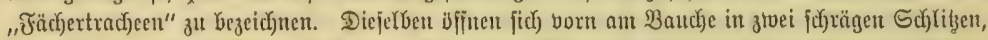

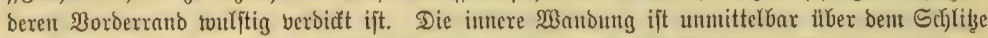

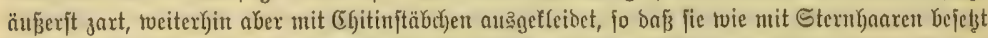

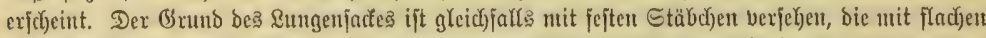

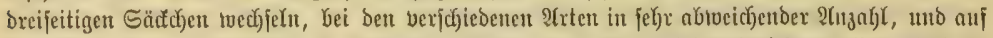

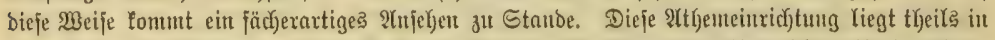

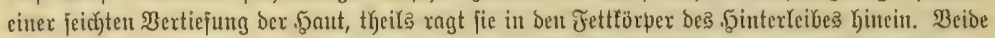

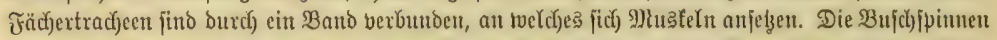

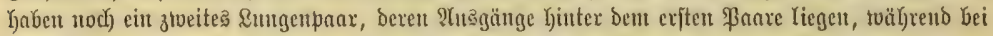

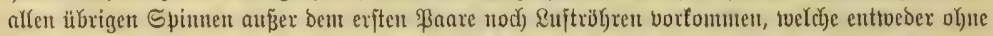

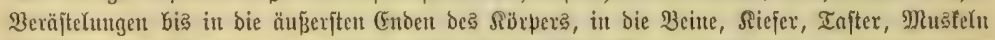

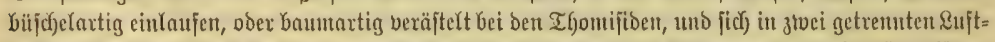

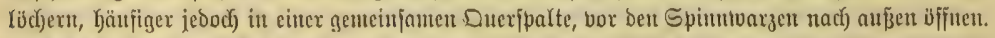

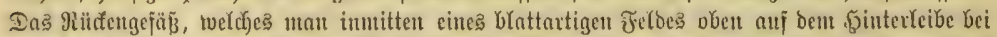

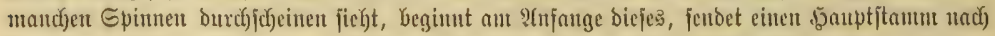

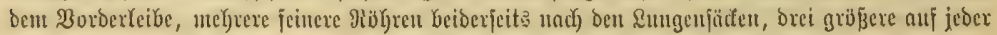




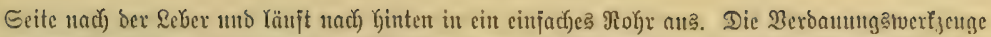

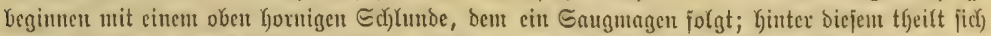

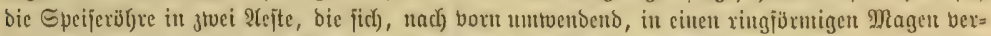

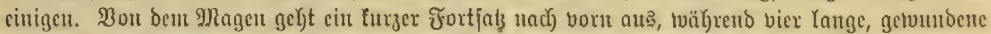

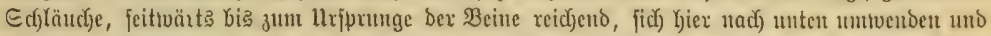

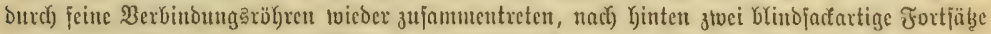

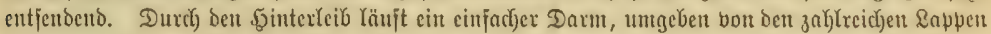

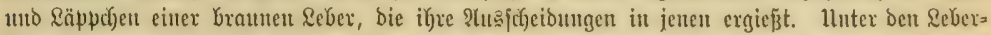

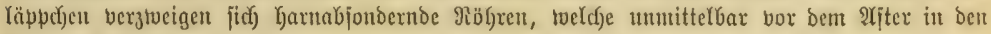
Blinojarf münden.

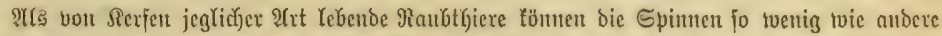

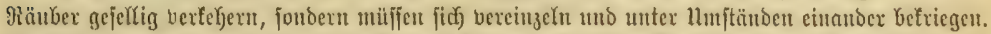

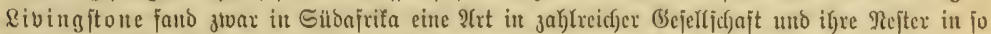

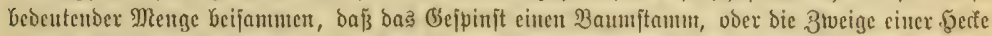

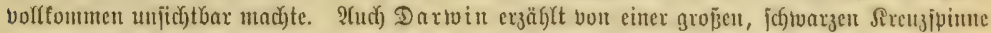

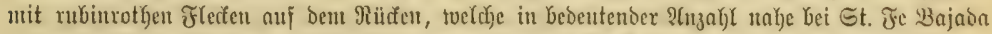

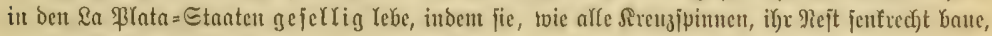

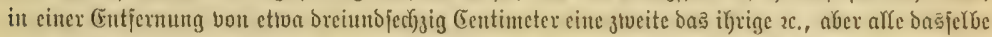

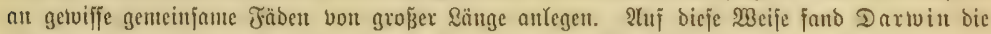

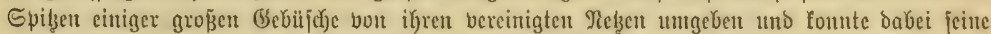

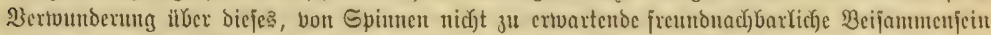

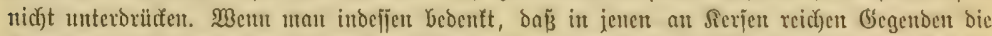

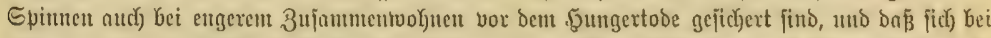

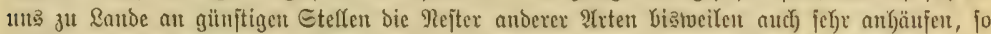

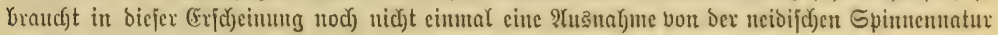
erfannt jut toerdor.

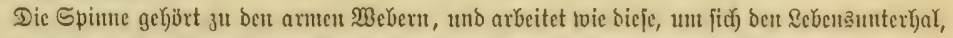

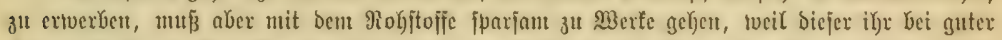

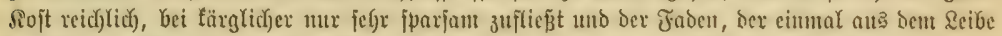

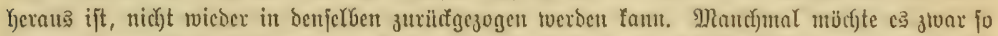

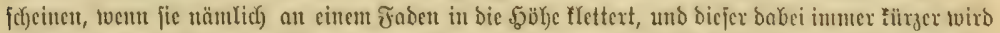

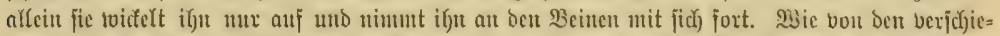

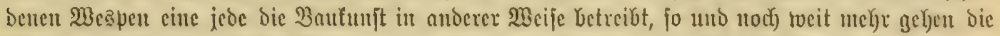

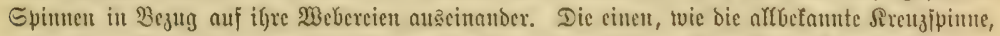

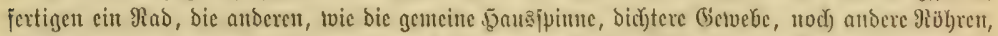

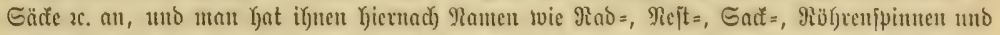

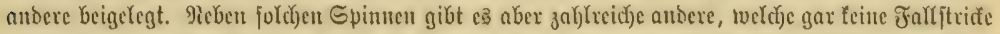

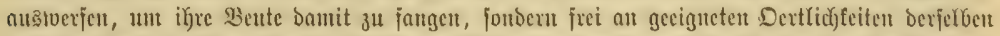

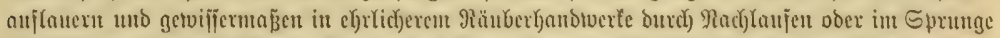

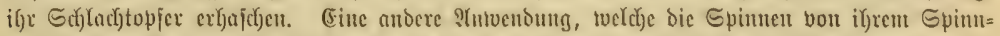

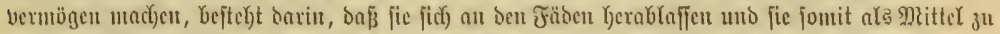
cince Drtäveränderung bertuerthen; ja, mand

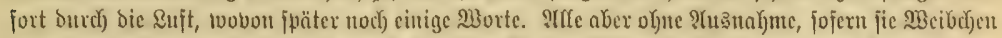

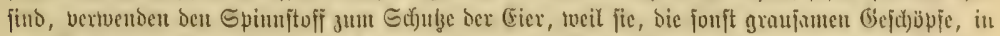

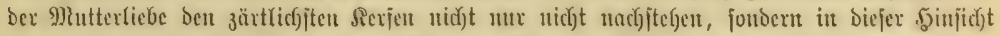

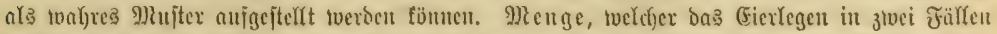

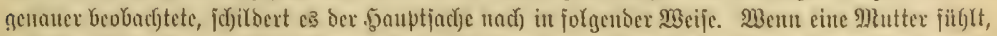

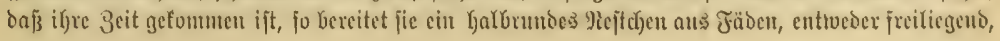




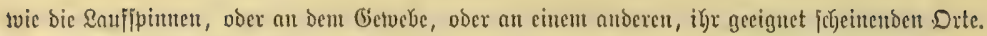

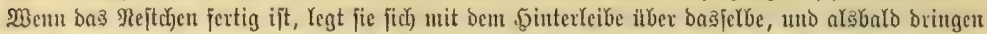

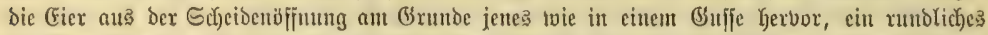

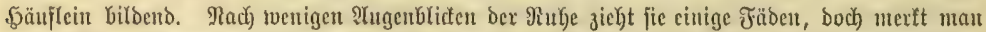

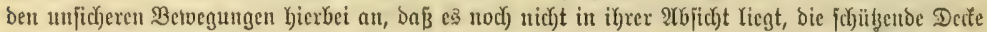

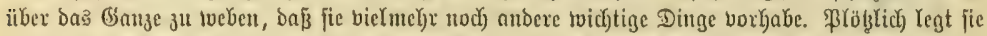

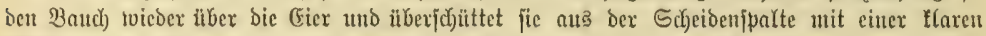

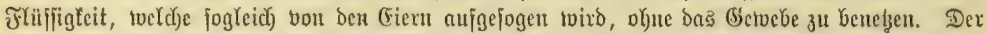

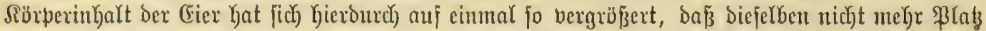

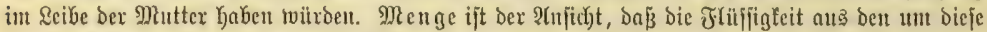

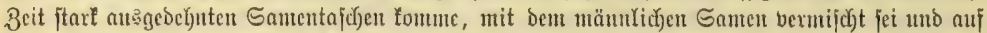

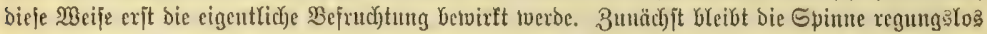

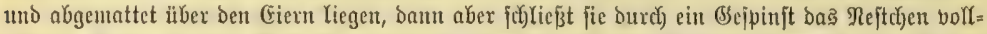

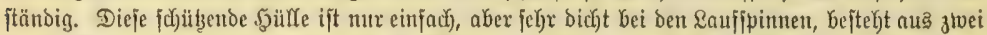

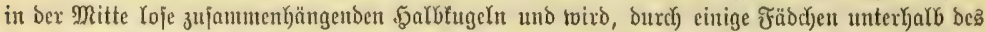
Leibes bejejtigt, bon ber Mutter mit unthergetragen; nux venige graben cine Frobjhłung, in

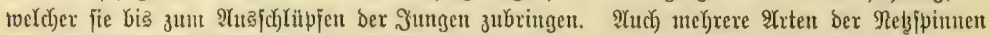

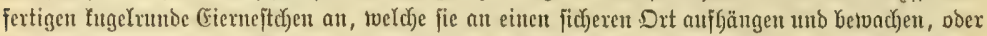

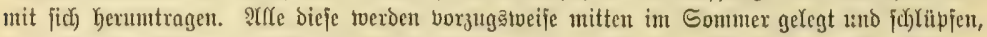

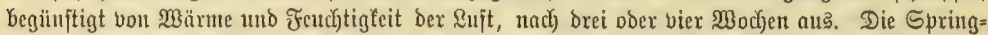

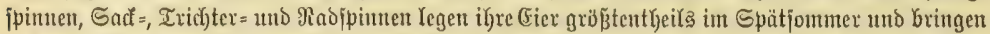

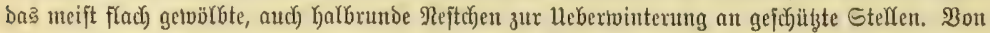

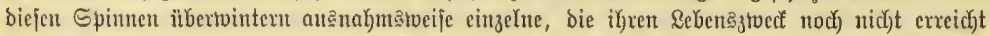

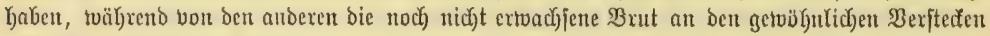
crjäart ben Winter jubringt.

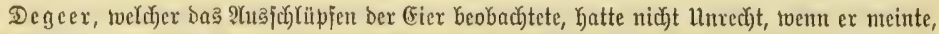

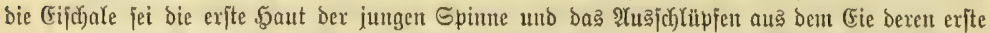

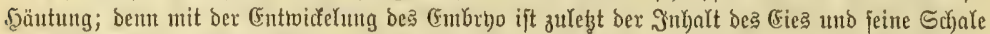

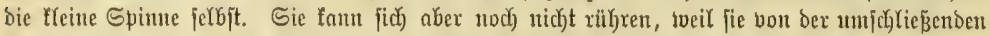

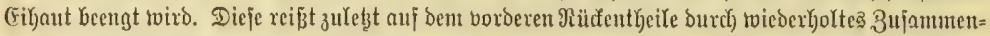

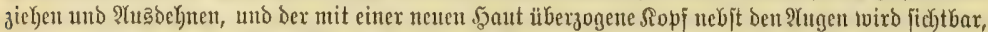

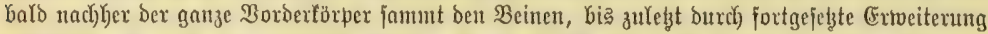

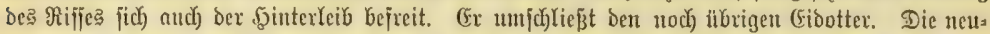

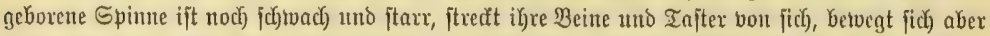

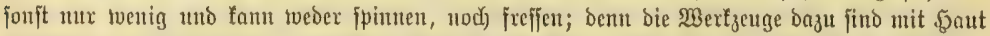

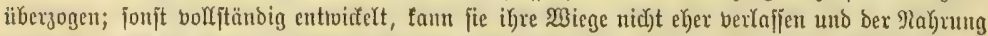

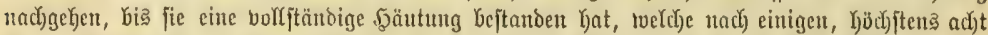

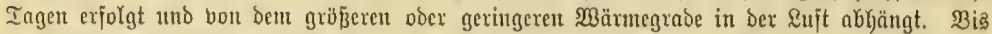

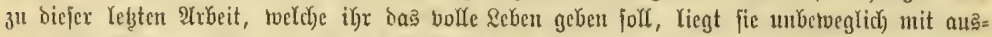

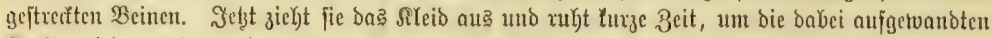

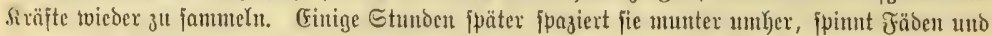

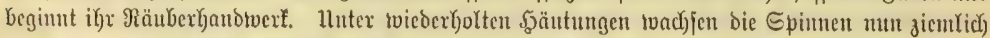

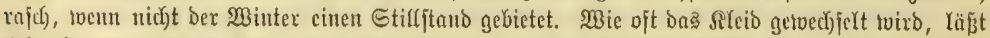

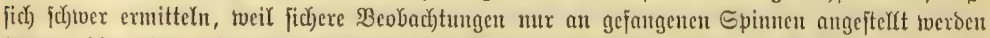

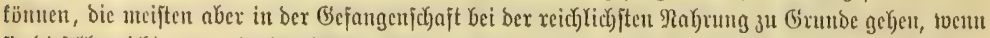

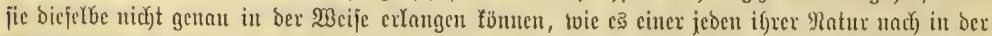

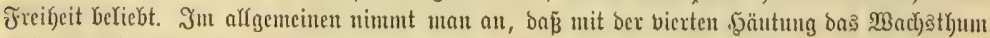

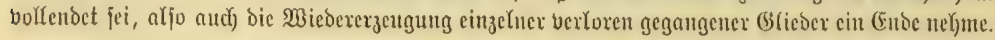





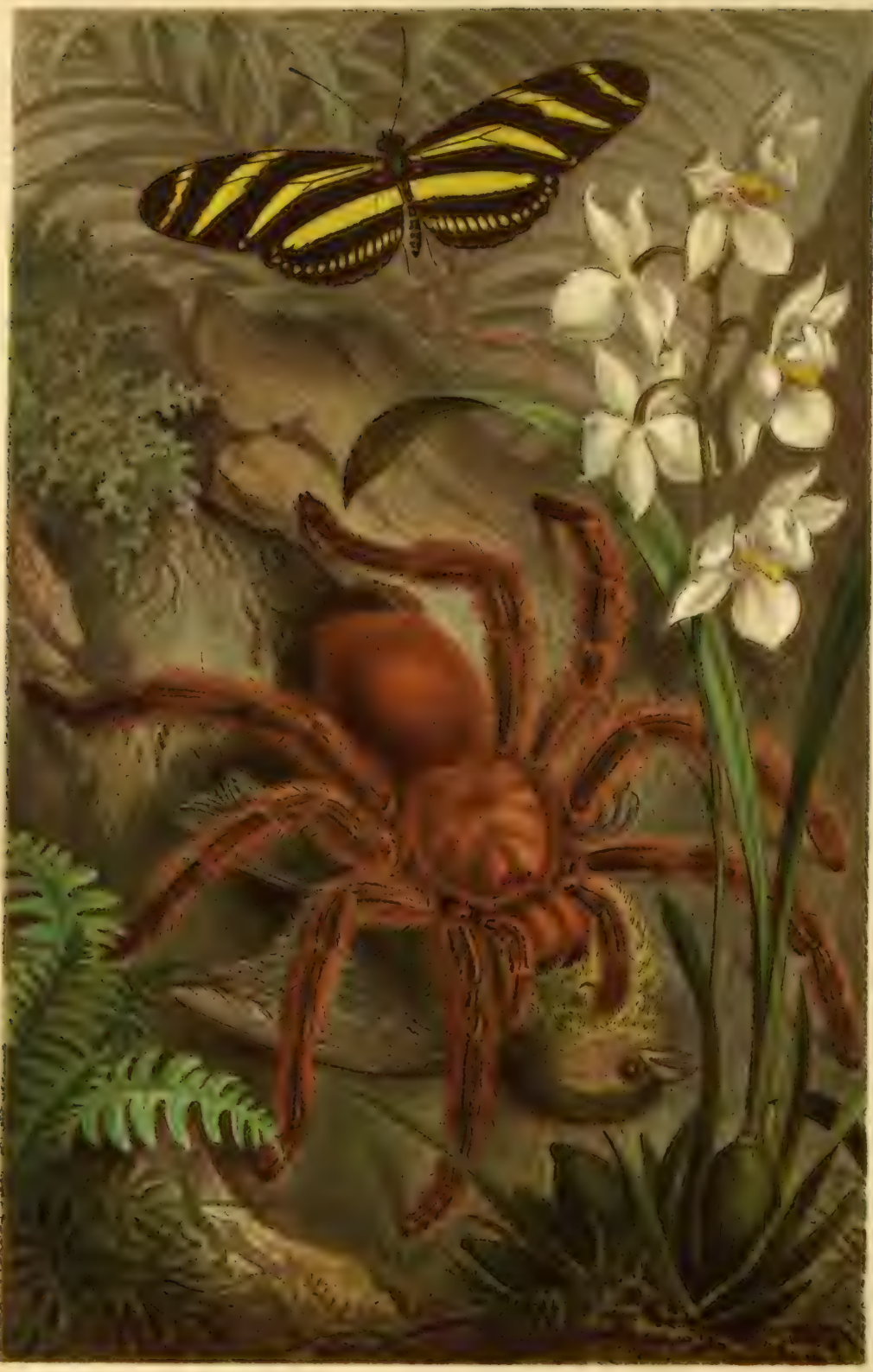




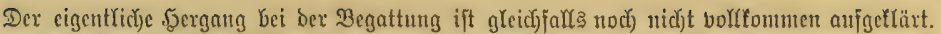

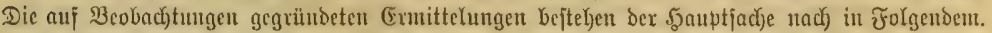

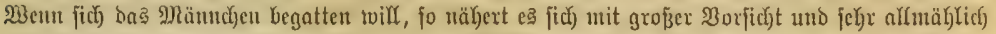

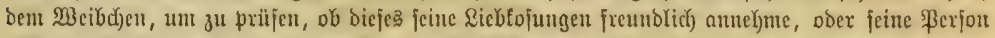

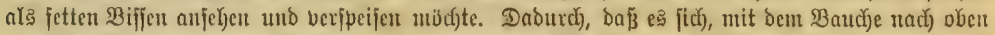

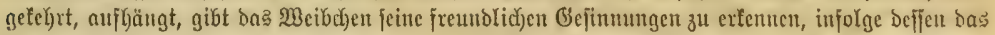

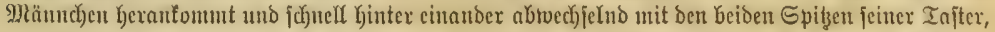

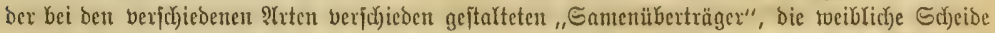

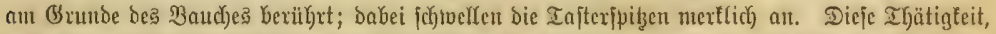

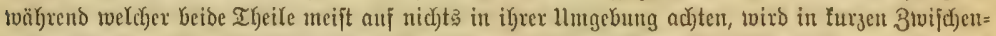

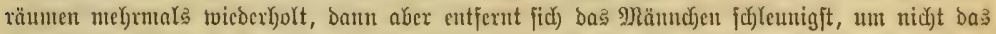

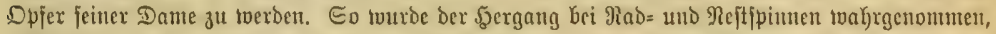

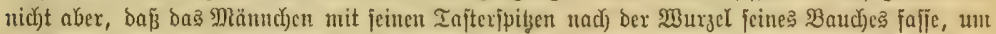

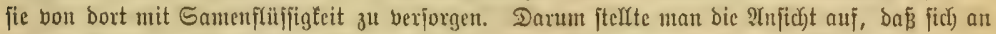

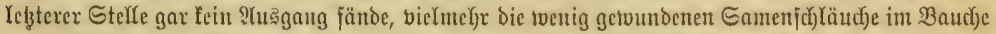

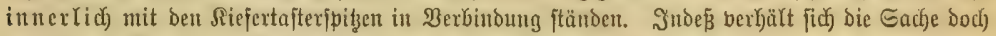

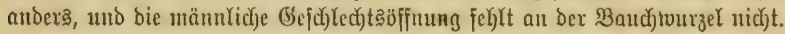

Man fennt zur 3eit cinige trujento Epimmen, tweld)e über bie ganze (Exbe berberetet futo uno in cinzeluen $\mathfrak{A}$ ten (Lycosa blanda, Melanophora blanda uno anderen) bis gegen breitaujend=

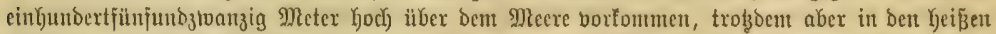

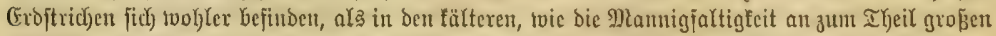

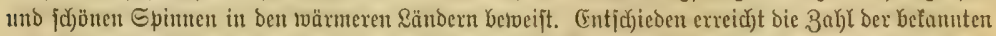

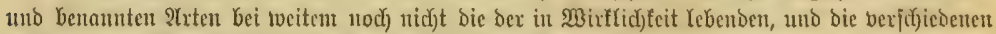

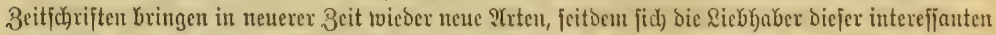

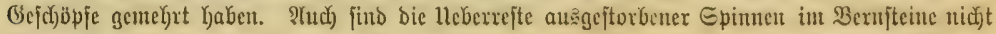
unbebeuteno.

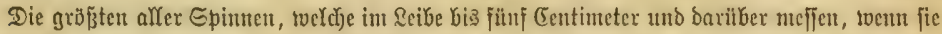

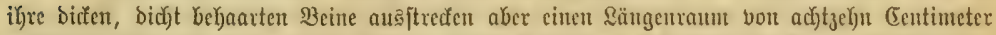

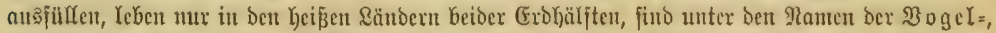

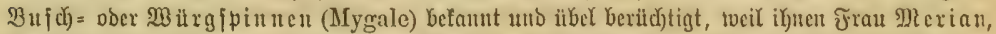

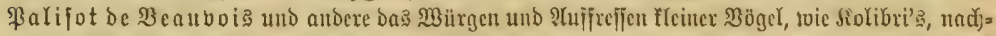

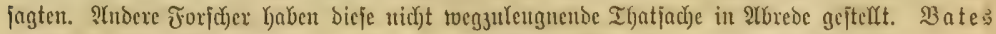

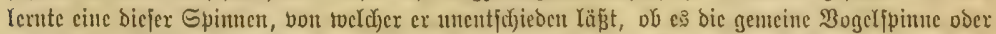

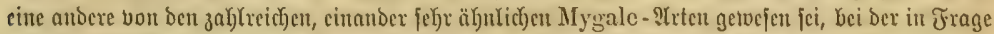

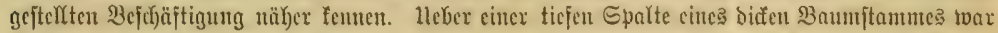

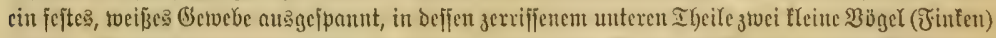

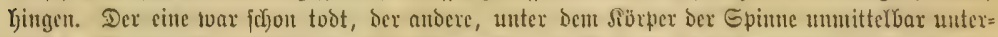

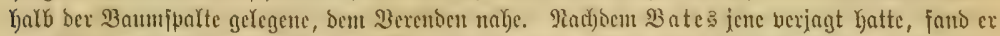

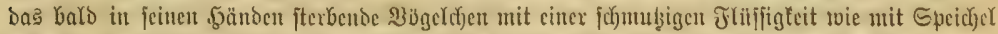

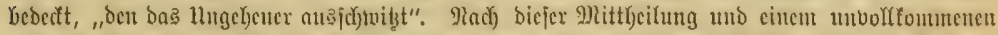

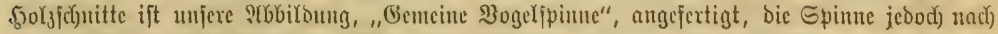

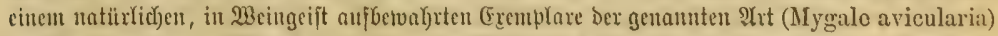

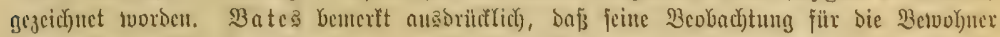

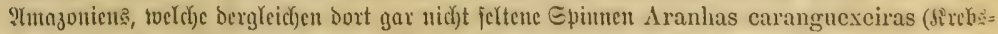

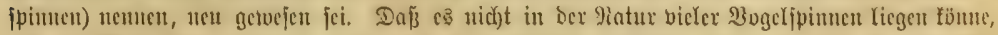

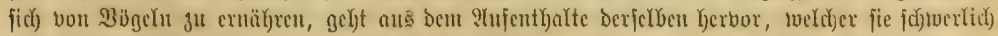

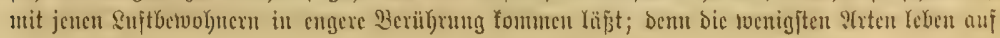




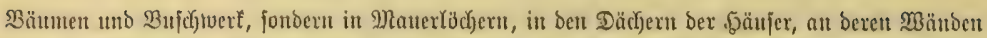

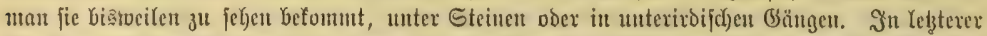

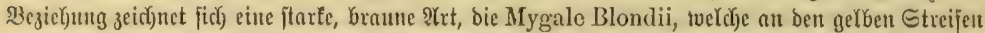

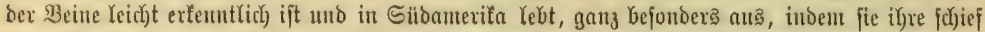

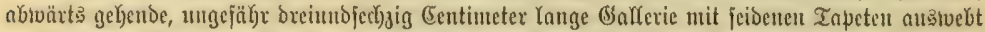

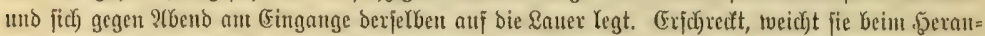

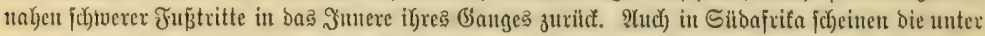

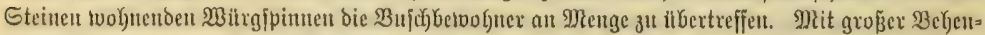

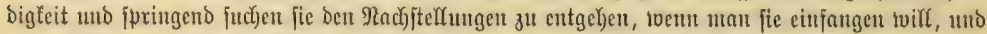

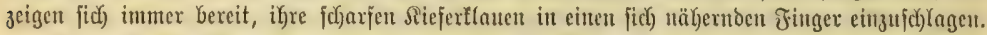

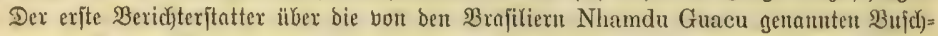

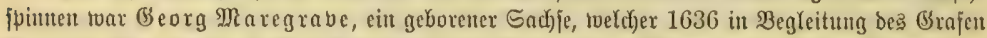

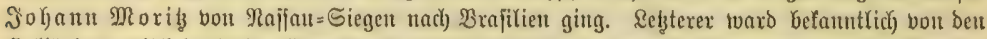

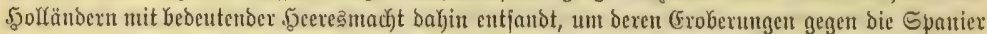

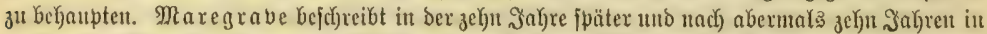

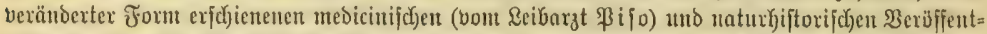

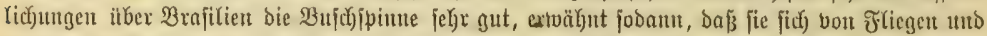

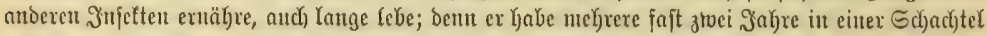
gehalten, tov fie fick zu bejtinmten Beiten häuteten; ber Balg aber fteffe eine Spinne dar, indent

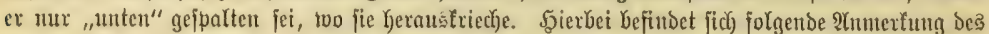

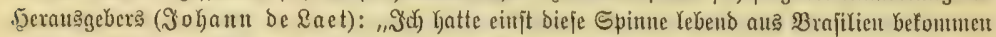

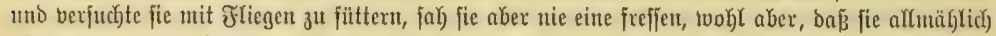
abmagerte uno nadid einigen Monaten ftarb; il bem Bebälter fonn fie nie, jobalo fie aber bei

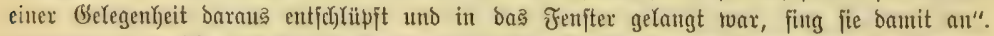

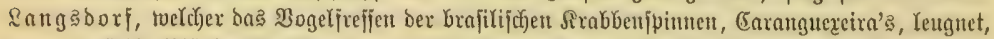

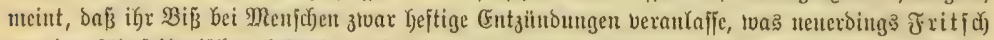

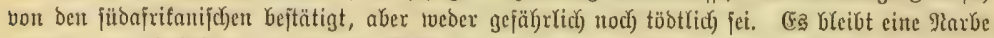

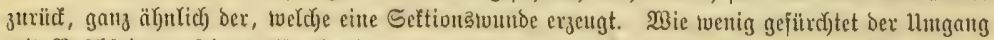

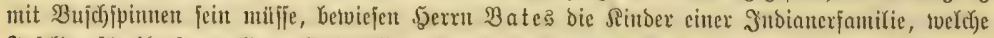

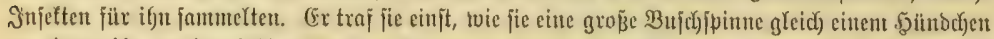

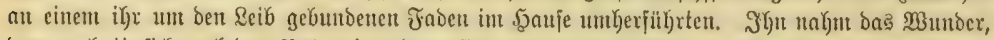

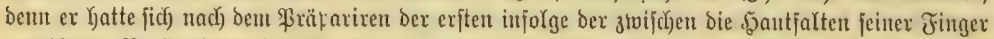

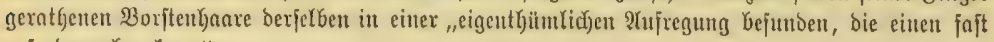
rajent madjen fam".

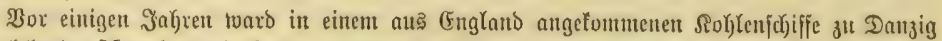
eine Yebende Mygale avicularia gejunden unt nut 10. September 1862 bent Dberlebrer

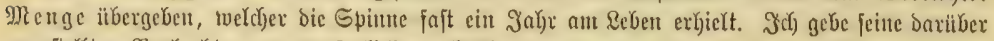

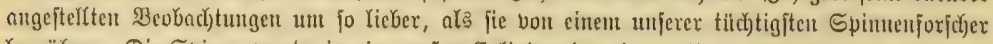

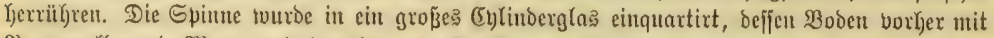
Bauntwolfe und Mloos und barilber mit Stüfen vou Fidytentinde belegt worden war. Sie

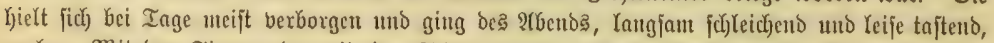

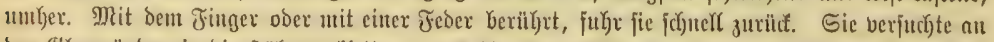

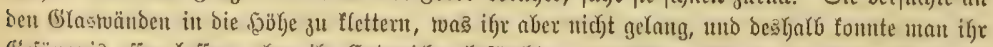

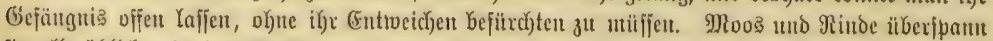

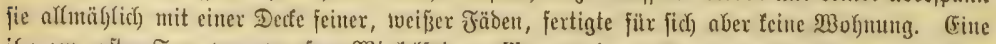

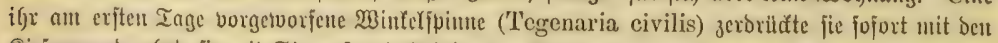

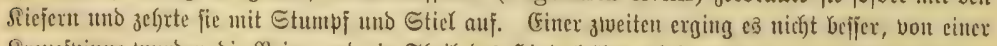

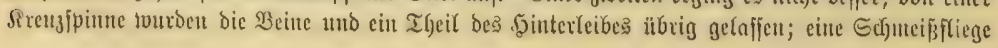




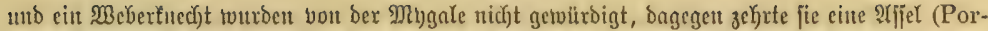

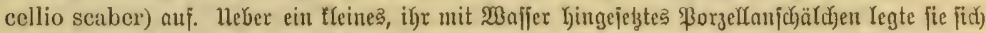

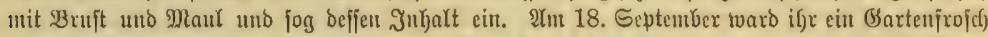

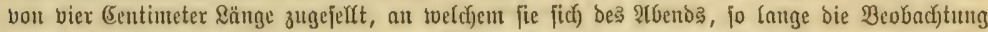

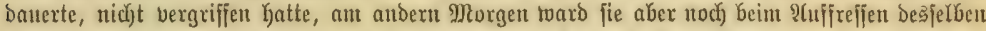

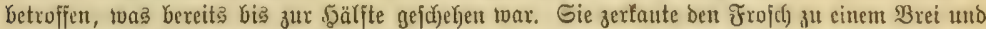

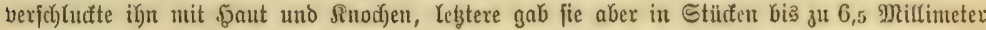

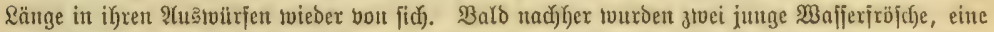

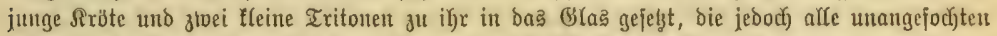

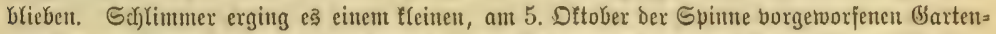

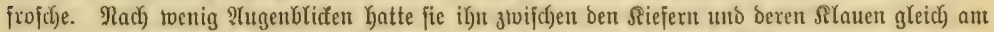

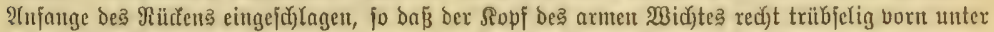

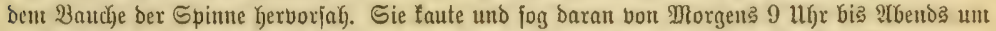

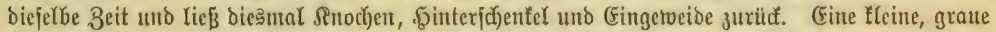

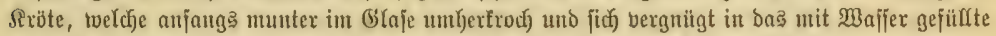

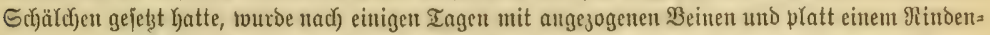

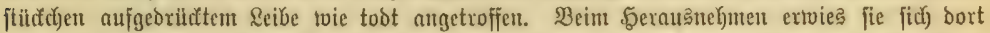
Feftgeiponneu und infolge einiger Bifje bem Tode nahe. Wenu fich die Spinue fatt gefrefien hatte,

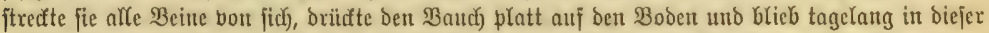

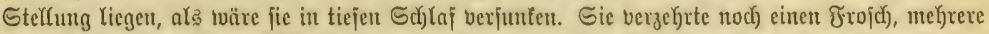

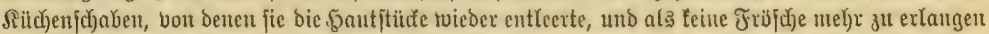

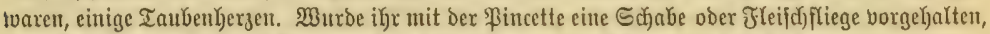

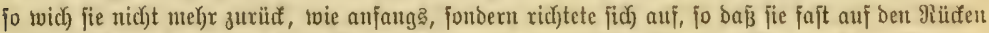

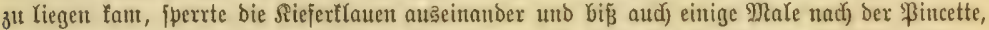

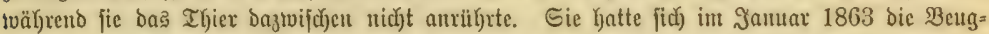

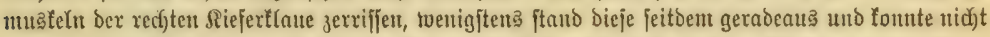

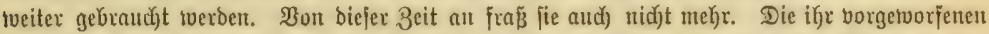

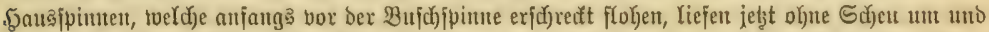

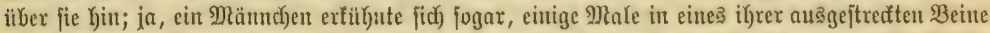

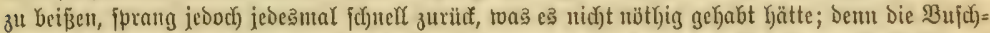

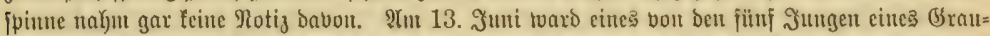

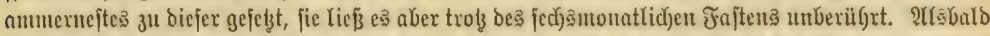

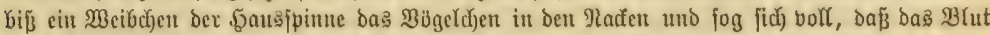

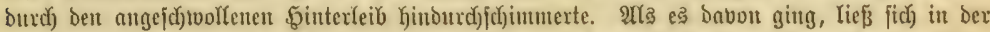

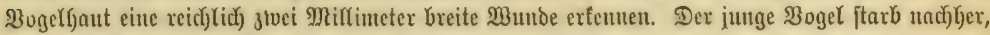

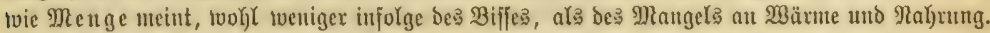

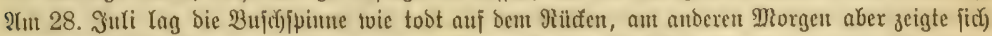

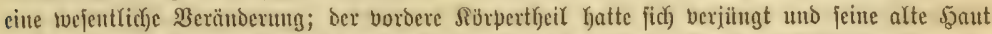

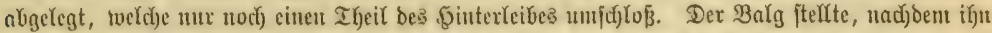

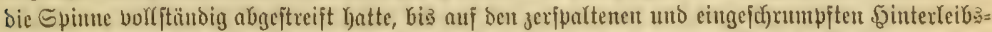

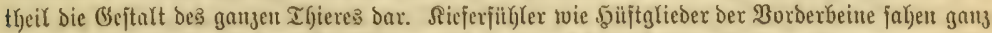

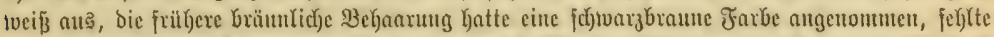

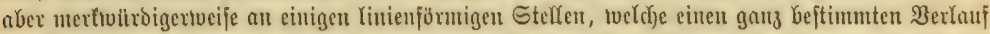

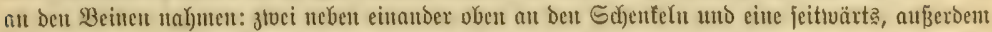

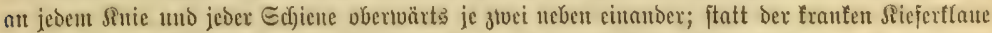

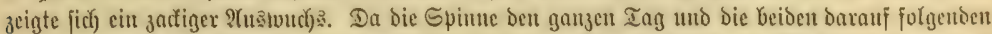

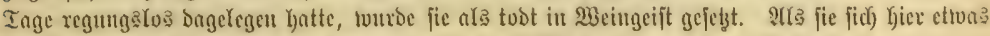

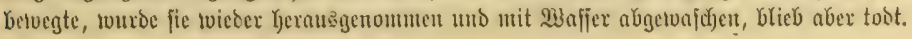




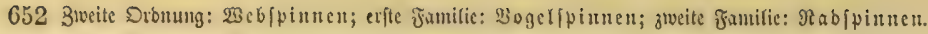

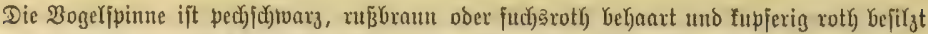

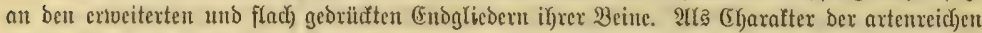

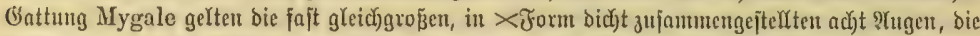
berben, lang uno biçt Keljaarten Beine, beren vorberjtes ßaar oft jajt fo lang als bas Yängite

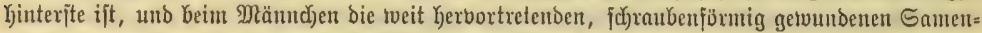

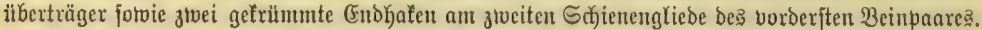

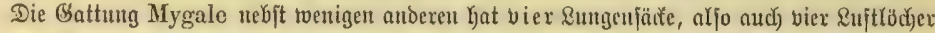

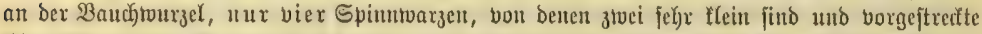

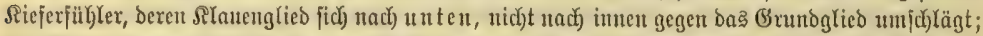

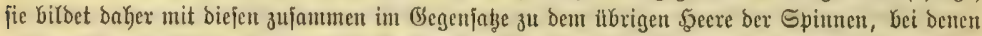

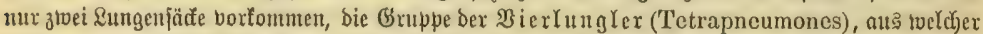

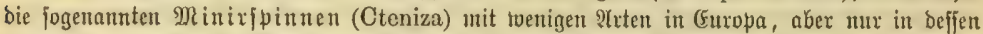

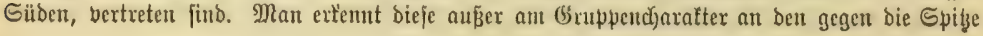

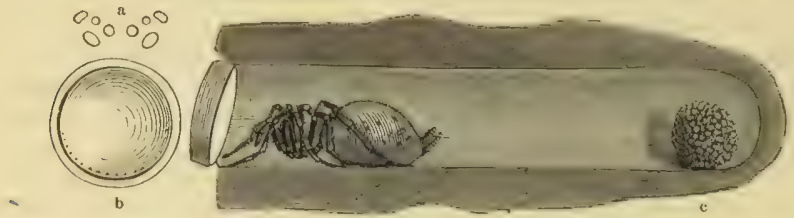

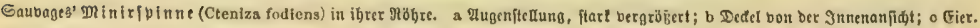

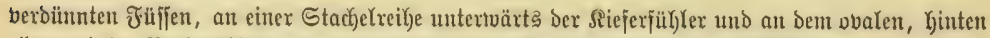

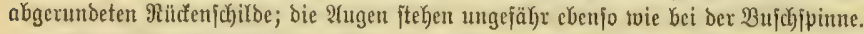

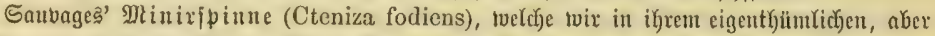
vertürzten und von ber Seite gebffneten Baue Yiex erblifen, hat einen rothyraumen, fajt nacten

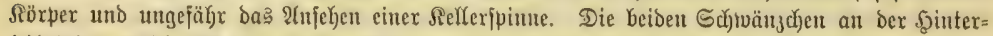

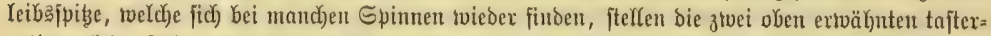

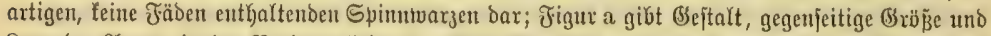

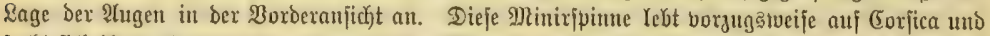

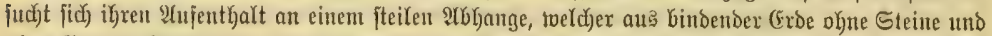

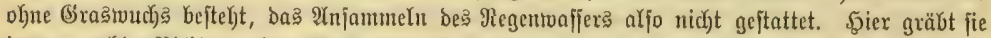

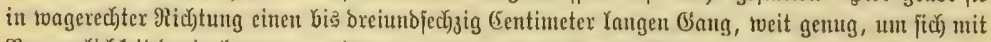
Bequemlichteit barin betwegen zu fönnen, uno tapeziert ifnn nit Seibengervebe aus, bamit ex nickst

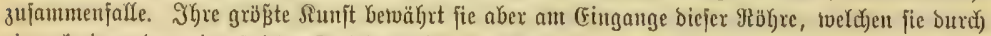

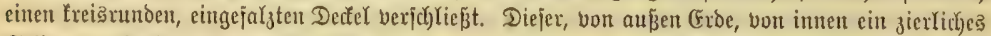

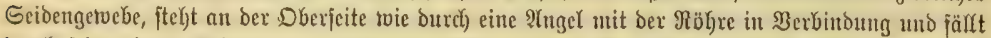
burd) feine eigene Sdytuere zu, wenn ex gejffnet toorben ijt. Was foll biefe Thuir, weldye fich)

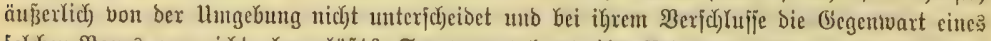

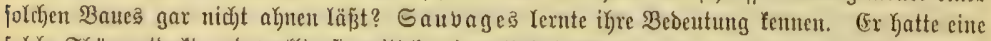

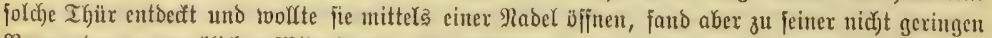

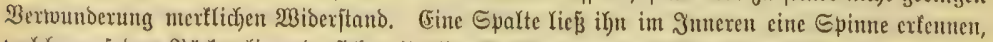

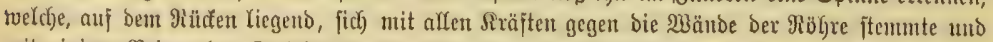

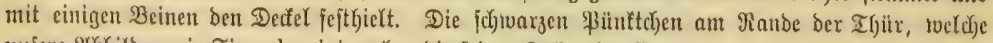
unjere शrbbildung in Figur b jeigt, geben bie feinen \&ücher im Getwebe an, toelche zu biejen 3weife

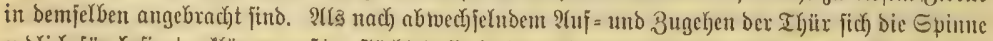

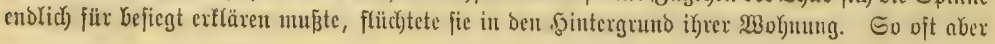


wicber Betbegungen mit ber Thür borgenommen tourben, fprang fie herbor, um fie von nettem

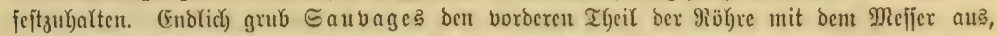

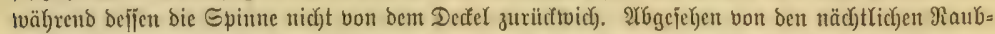

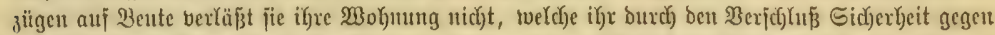

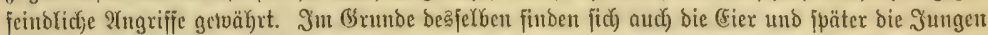

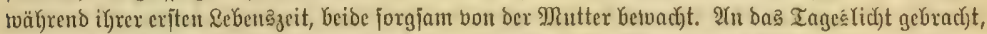

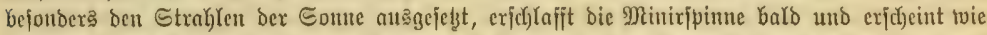

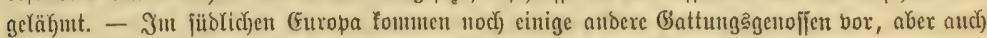
tweiter nörolich) uno in Deutj(t)(anto berbreitet, toenn aud) jelten, ein (Ślieb biejer Familie in bes: ped)braunen פorbipinne (Atypus picens) ober Sulgeripinne (A. Sulzeri), ciner

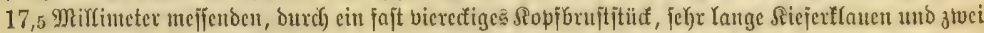

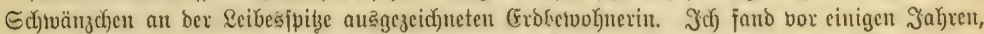

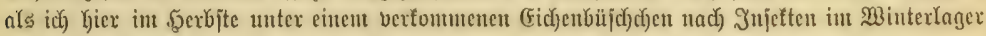

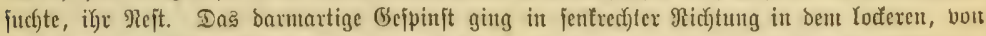

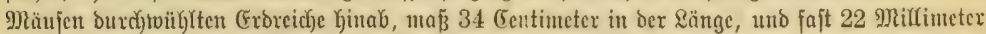

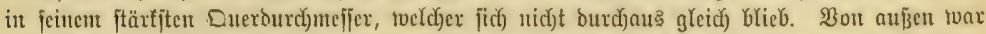

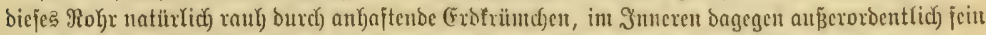

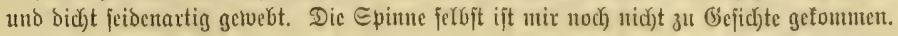

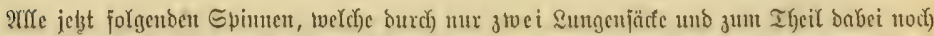

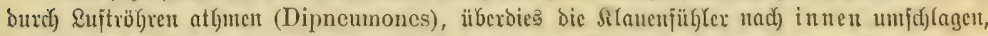

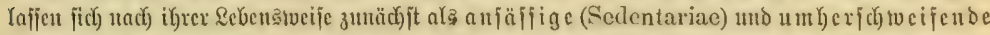

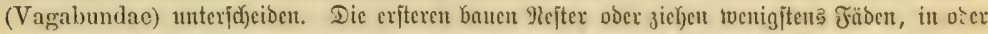

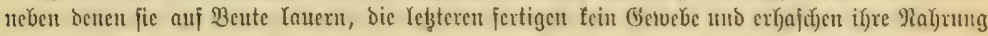

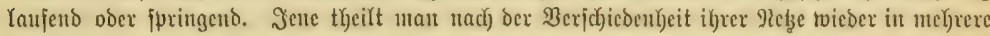
Jamilient.

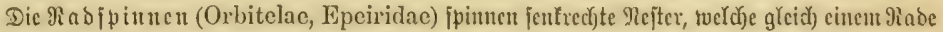

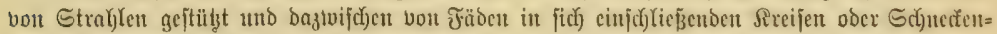

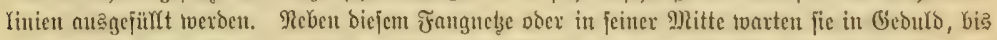

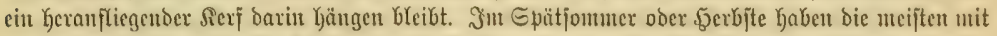

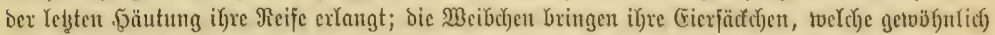

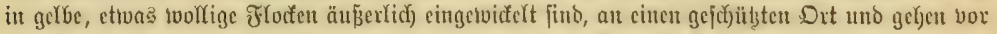

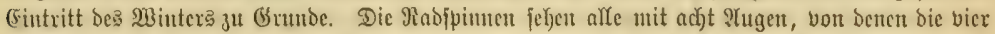

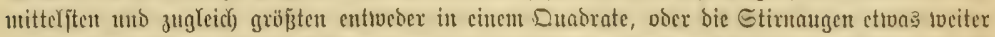

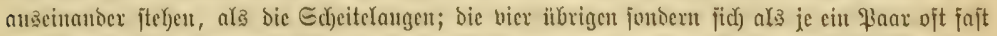

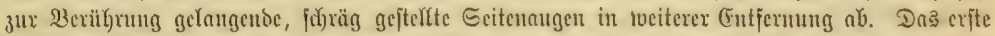
Honar ber ziemlide) biffen Beine übertrifft alfe übrigen an \&änge, bam folgt in biefer $\mathfrak{B e z i e f u n g ~}$

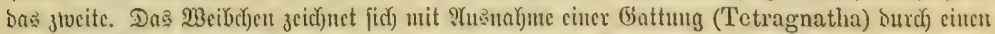

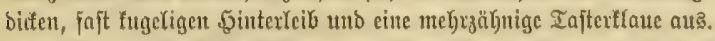

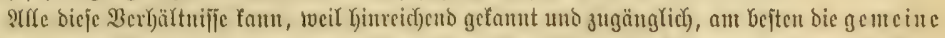

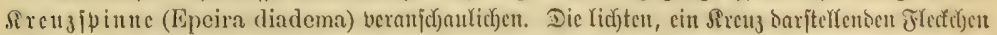

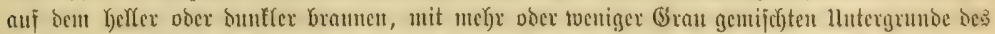

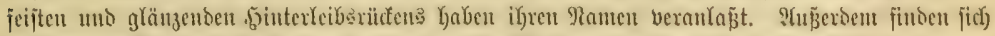

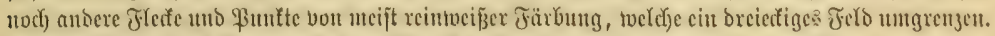

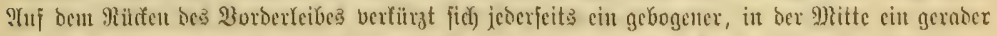

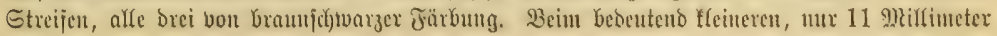




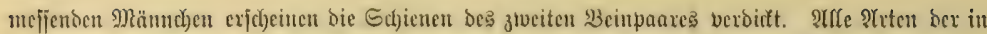

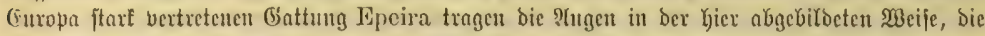

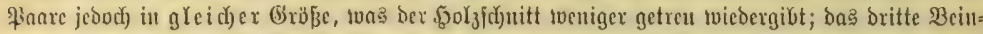

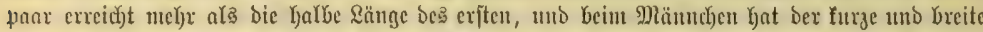

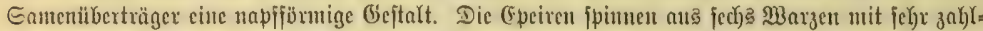

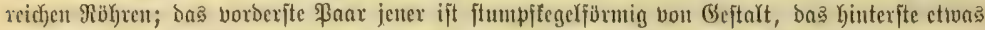
fïrzer uno mit bem Siebe nad) imen gerid)tet, bas breiedige mittlere von ben Geiten zufammen=

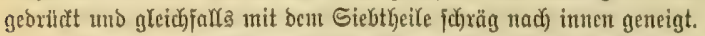

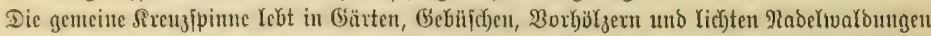

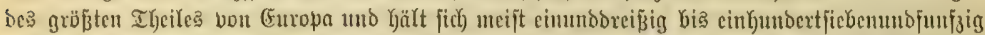

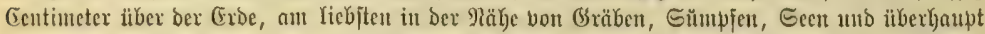

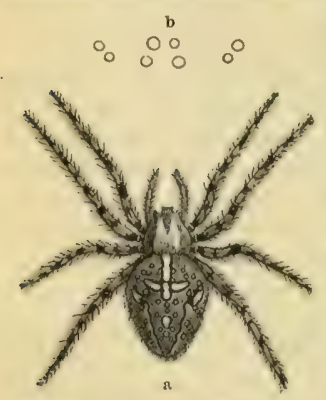

a 23 cibuen ber genteinen Steugipinte (Epeira diadema), 6 Die शrugen von vorn sciehent unb vergröbert. an foldyen Drten auf̈, twelche einen reichen Bujprutch bon

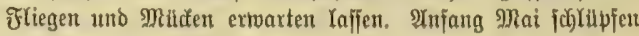

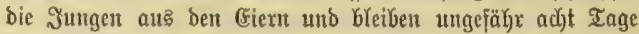

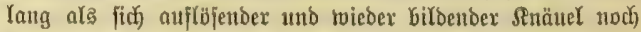
Geifamnten, Gis bie exjte f̧äutung exjolgt ift. Bunädjt fino fie an Sopf und Beinen Kalb burdffididtig uno tveiß̧, an Kins

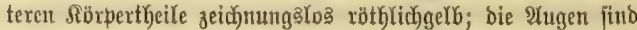

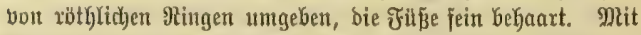

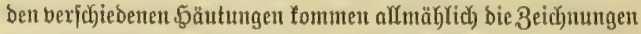

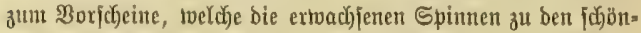
fiten unjerer Begenden machen. Sobald fid bie jungen Sireuz=

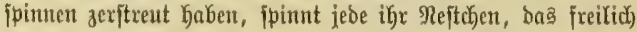

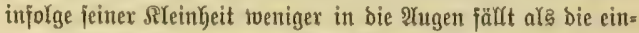

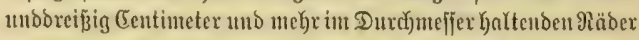

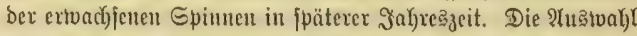

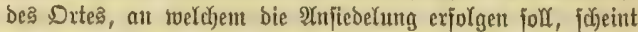
ber Epinne cintige Gorge zu bereiten; benn fie läuft Yange an Den Begenftäntoen hou uno her, ełhe

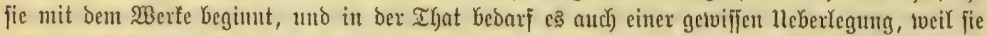

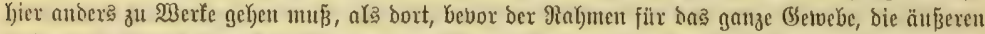

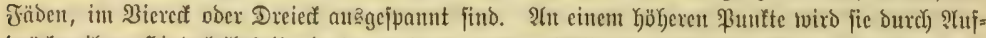

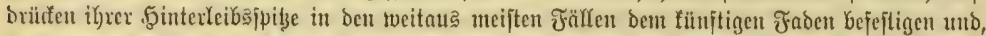

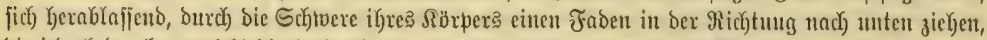

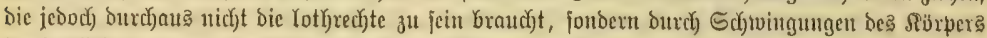

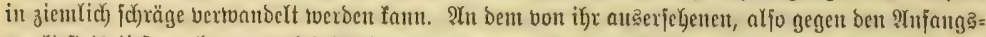
puntt jtetß tiefer gelegenen toirb ber ftraff angepannte Faben befeftigt. Bon Gejonoerer Wichtigfeit ift ber vberjte Duerfaben; um ifn tvie ein ftraffes Seil anzufpamuen zivifichen zlvei, vielfeich)t vicr= unoneunzig Eentimcter von cinander entjernten Riefernftänmten ober in ber Eiffe ciner alten, nicht

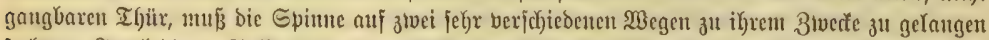

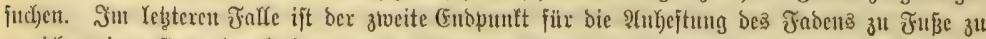

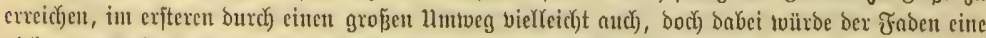

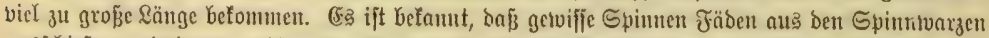

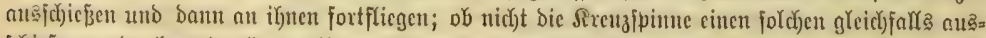

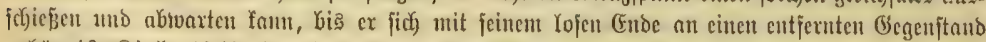

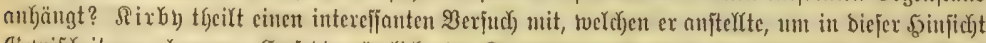

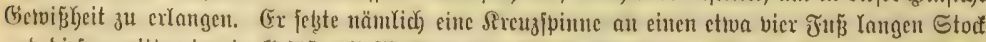

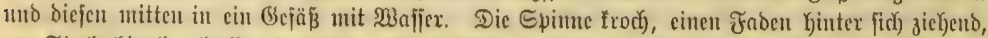

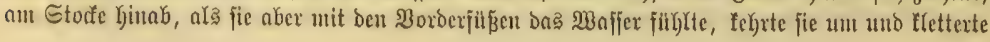




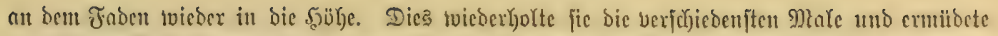

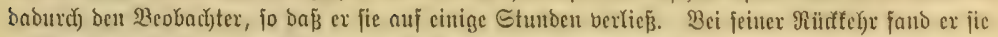

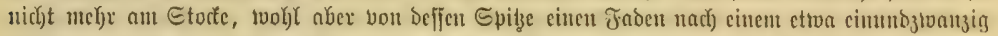

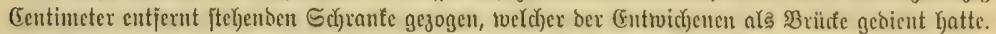
Rir

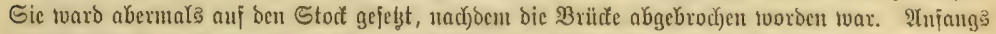

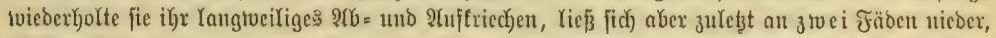

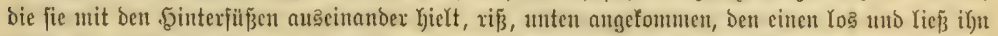
flattent. Sirby, weld)er ę nicht bem Bufalle anlycim geben wollte, bis biejer loje Faden

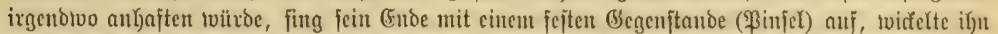
cinigemal um bemfelben uno zog ihn jtraff an. Die Epinue, tueldye inbeffen toicder an Siopfe bes

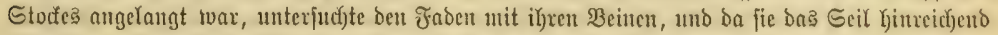

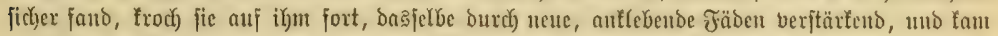

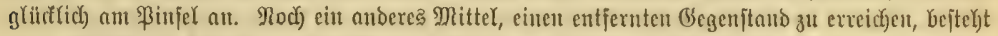

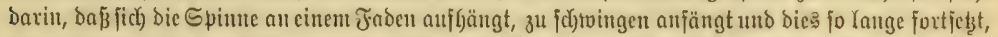

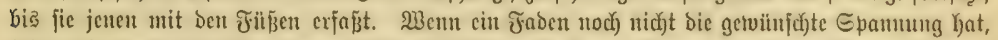

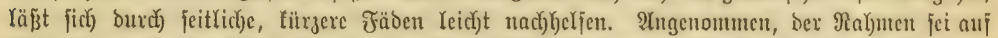

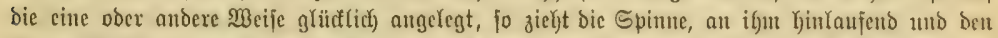

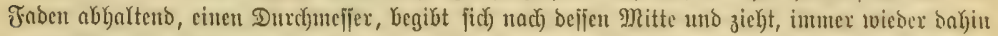

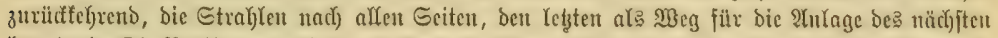

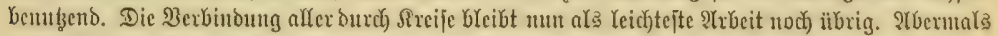

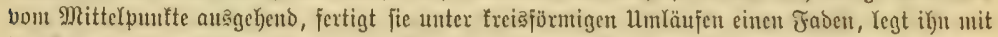

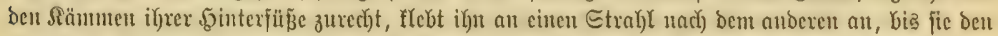

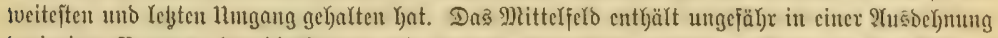

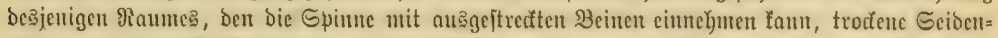

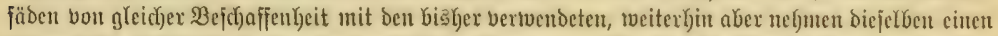

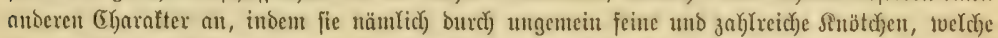

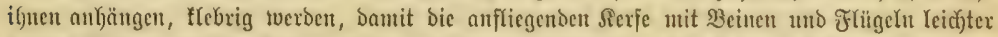

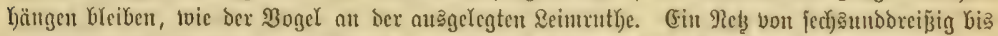

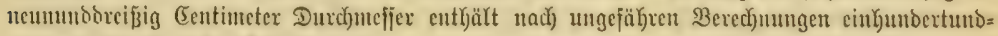
3twangigtaujeno fold

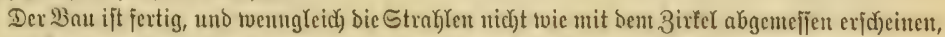

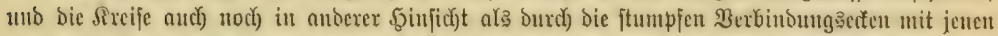

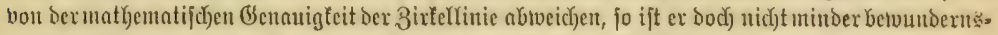

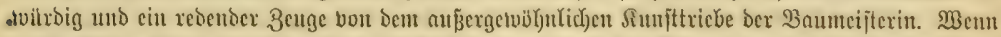

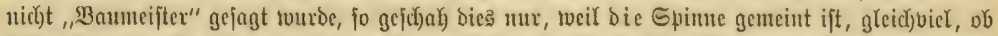

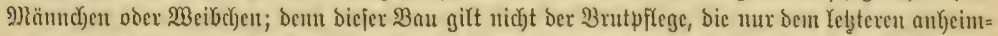

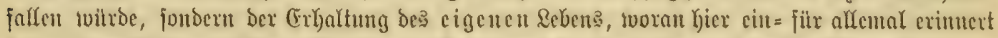

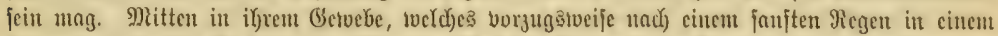

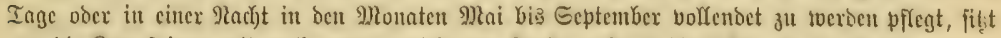

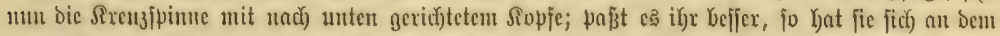

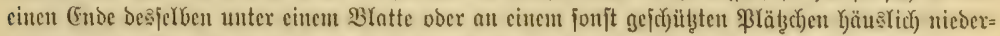

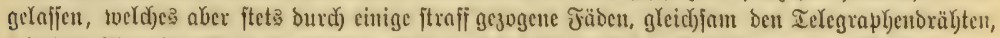

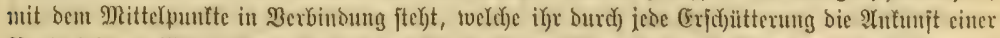

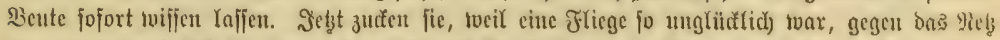

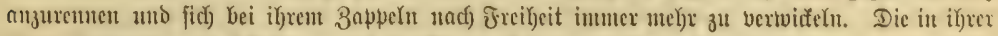

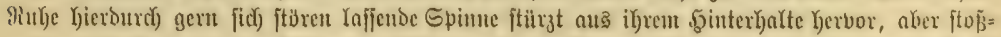

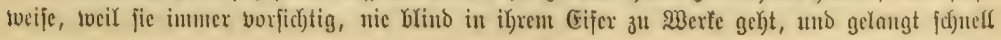


bis zut Mitte. Bon hier begibt fie fick nad) ber Stelfe, wo bie Fliege getonltig ftrantwelt unt

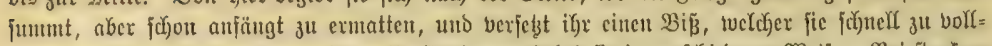

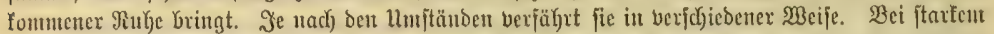
Sunger geht fic fofort an bie Maf)(zeit, oder jie legt cin breites Band von Fäben un bic J్liege

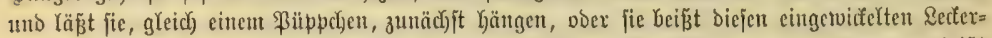

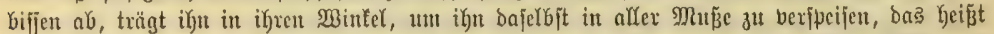

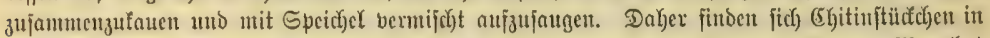

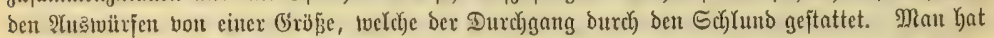

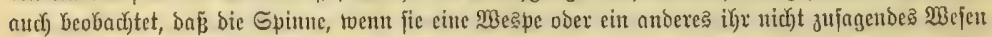

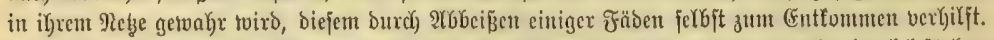

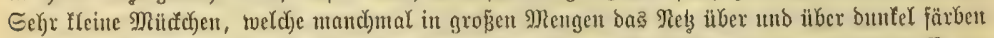

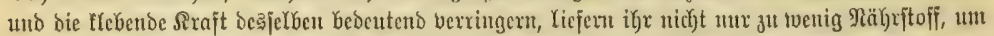
fie zu bertoertyen, jondern nöthigen fie jogar, ben Ban zu verlafjen unb eitten anderen anzulegen.

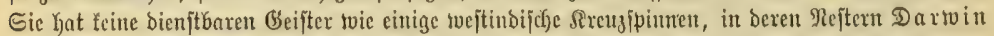

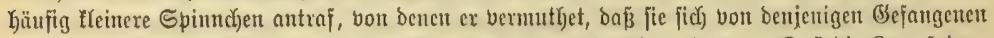

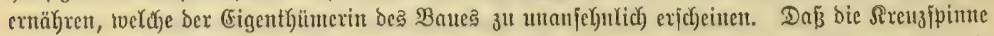

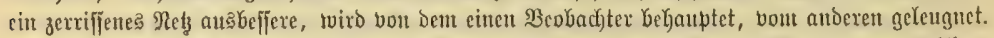

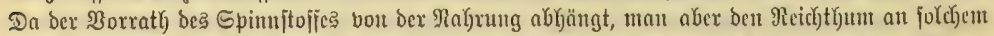

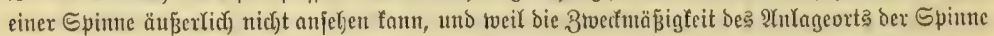

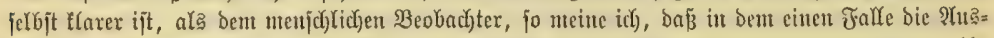

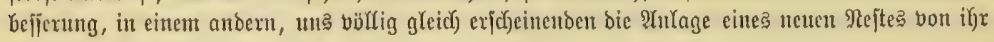
vorgegogent twixd.

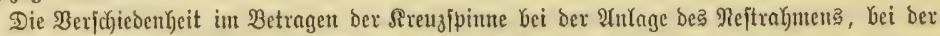

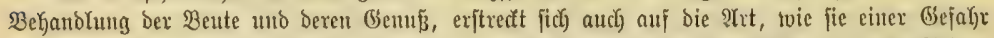

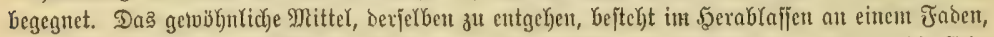

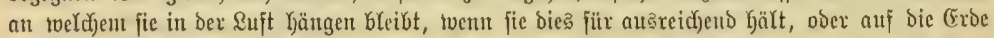

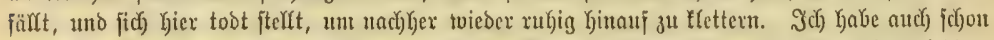

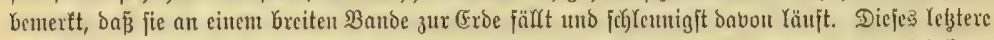

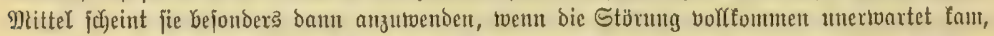

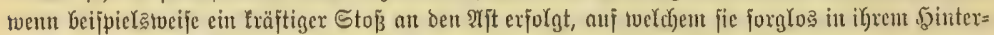

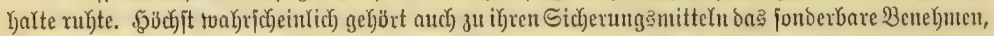

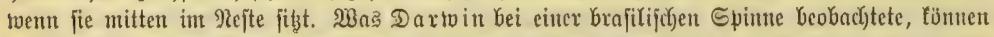

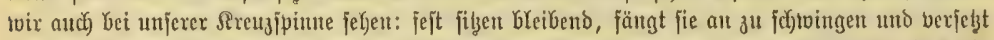

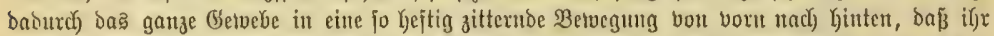

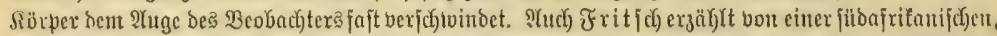

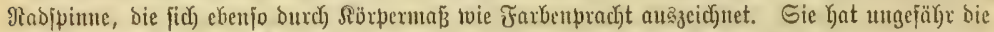

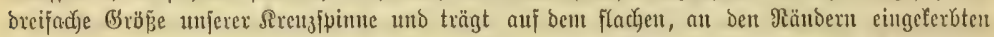

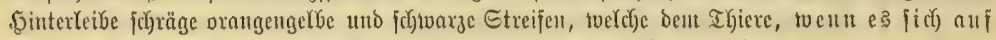

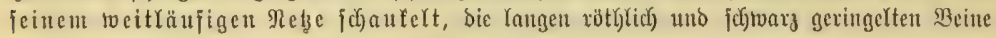

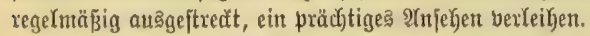

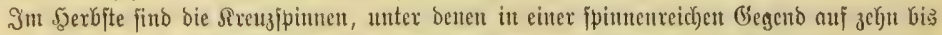

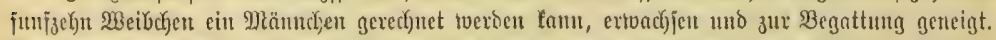

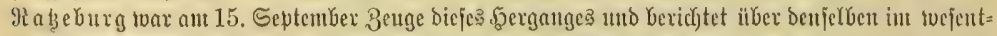

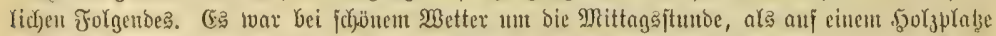

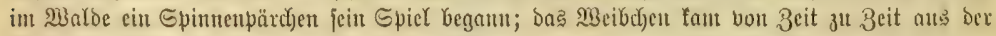

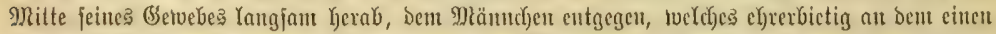

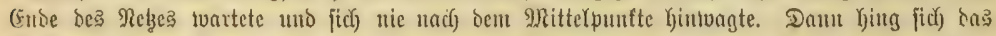

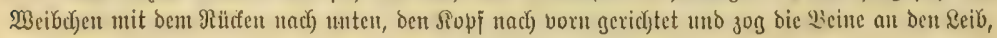




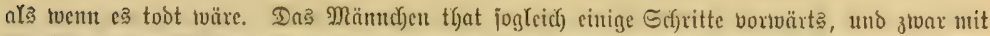

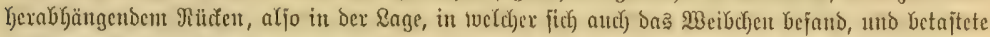

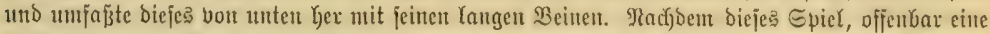

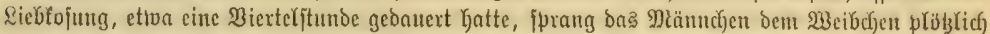

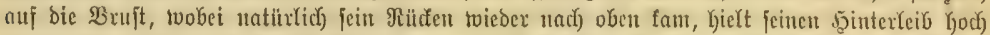

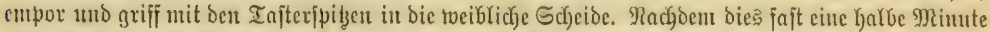

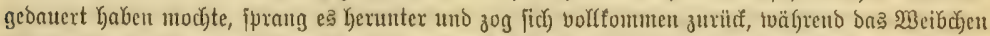

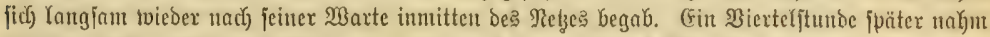

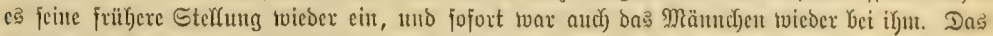
Betajten nahm jeinen 2Yrfang wie vorker, auch that Dab Männdyen aberntals cinige Sprünge nad ber Bruft

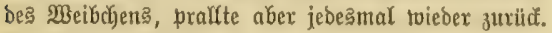

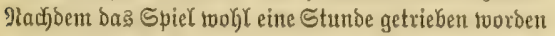
war, ging bas Weibchen anf jeinen früheren Stand. puntt zurỉa und bas Männchen in jein benadjbartes

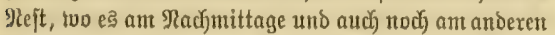

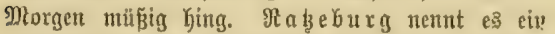

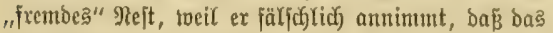

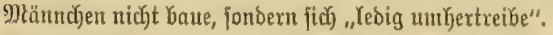

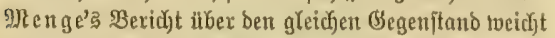
in Rebenumitänden wieber etroả von bem oben gege=

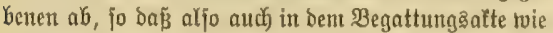
in bem übrigen $\mathfrak{B e t r a g e n ~ f e i n e ~ j e f t e ~ \Re e g e l ~ z u ~ g e l t e n ~}$

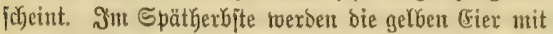
ifrem fejten Säcfochen an einem gejodjübten Dite ă lleberwinterung aujgehängt, uto Dex Đinterleib Deढ

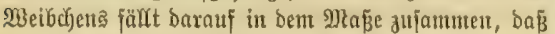
man es foum twieder erfennt. Ghe ber Winter fonmt, ijt es Gingetwelft. Die unter Baumrinde ober झloos fortfebenden gemeinen Sireusiphuten, bie fich) nux jelten finden, gchören unertoadjenten Spätlingen an.

Bon Epeira gibt es nod hulbidje uno ebenjo grope शrten in Europa, andere, meift fleimere, find

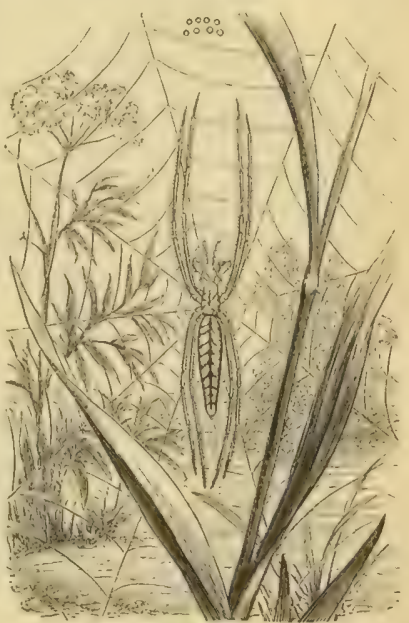

2)änud)et bor gefiredten Striderivinue (Tetra-

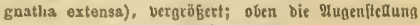
bout bintenber gejebert.

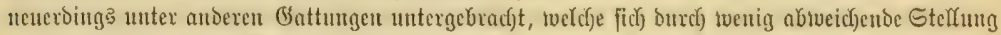

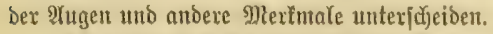

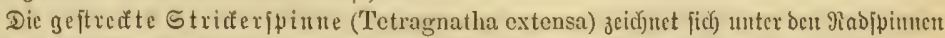

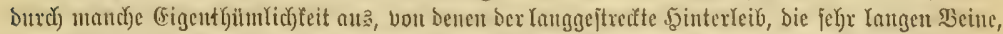

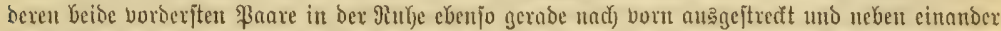

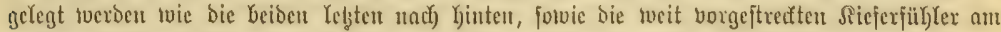

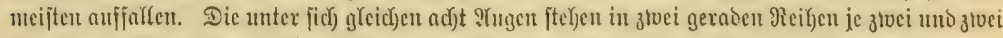

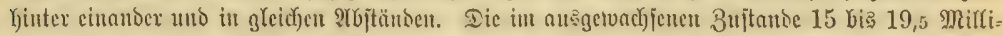

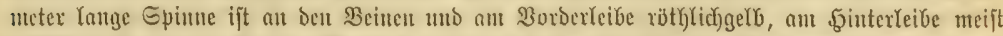

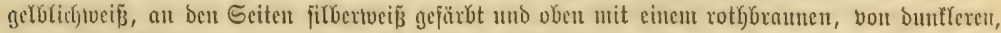

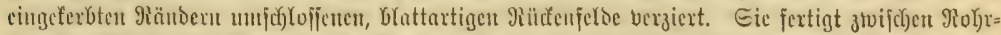

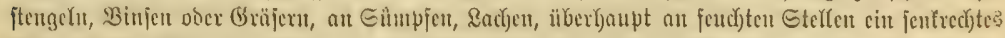

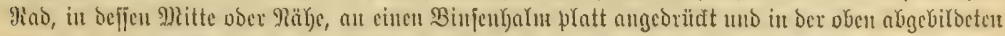

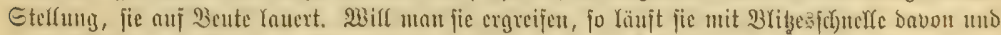

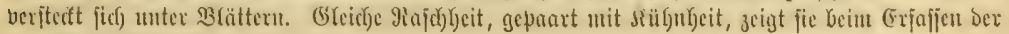




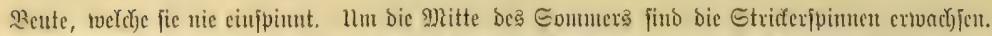

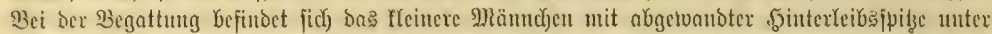

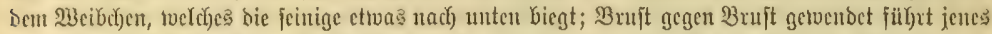

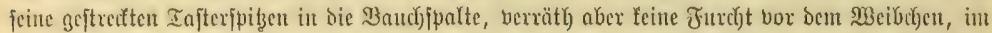

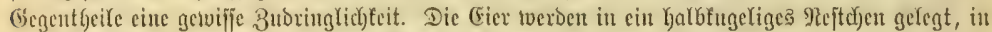

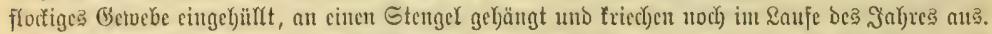

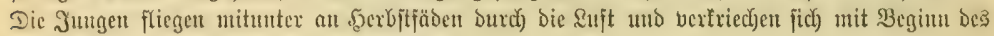

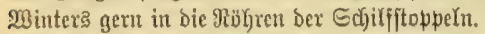

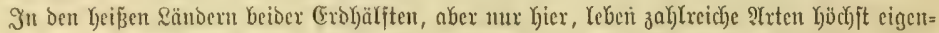

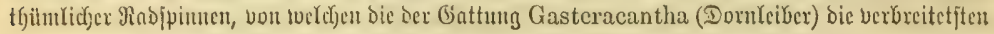

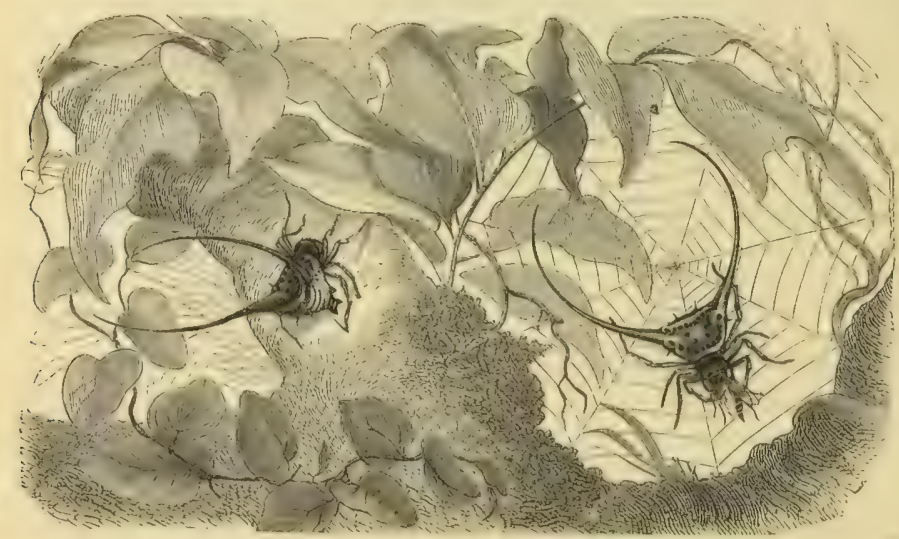

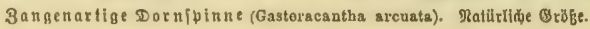

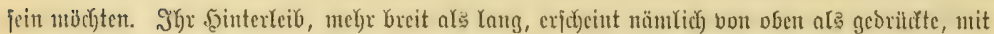

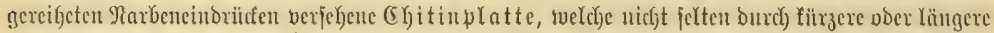

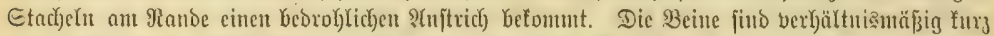

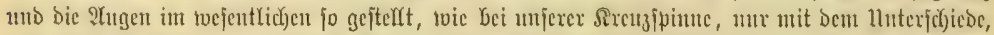

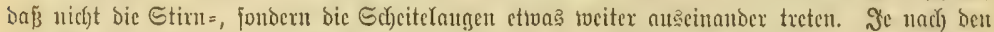

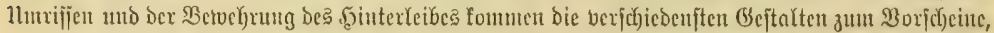

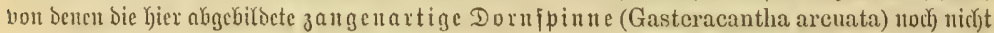

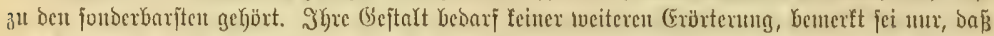

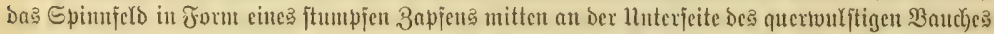

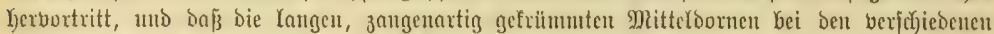

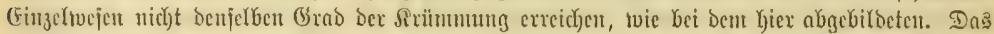

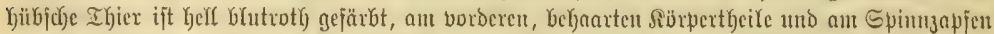

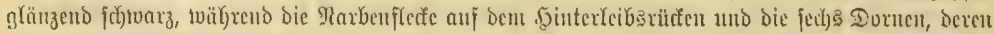

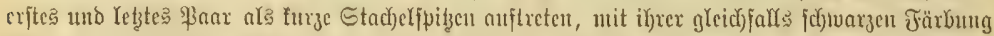

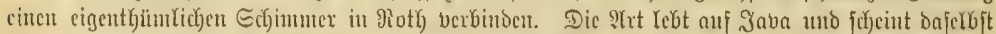

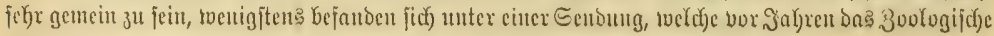
פ) 


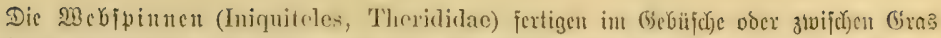

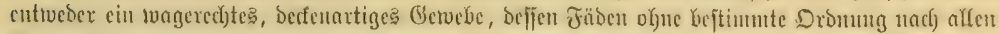

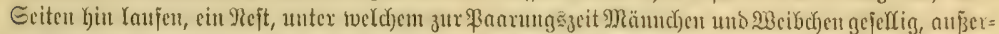

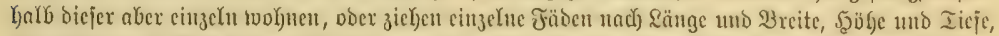

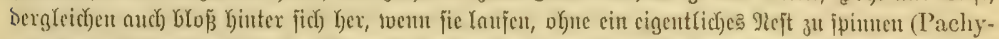

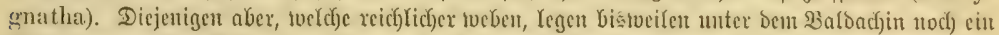

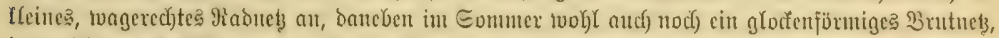

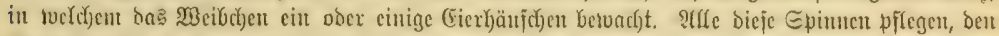

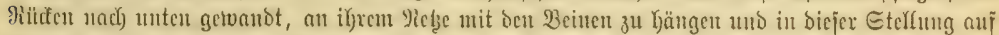

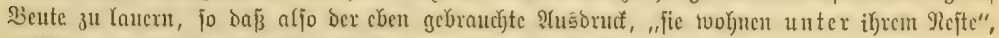

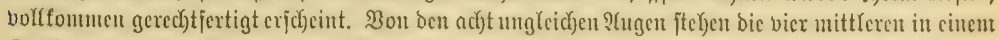

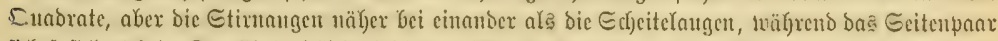

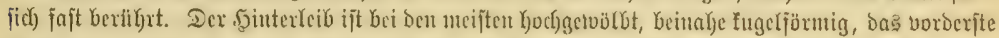

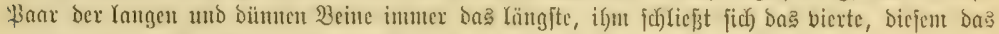
ztweite und endlich bas britte als tüzzeites an.

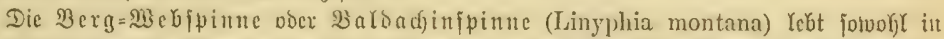

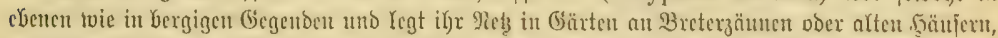

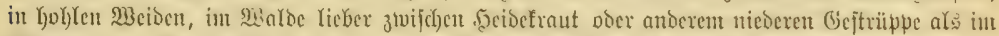

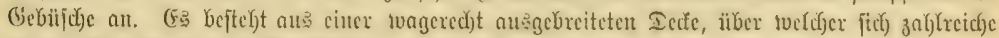

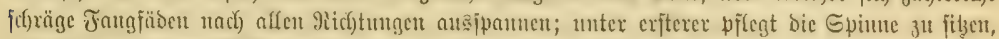

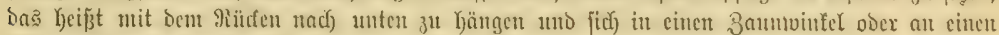

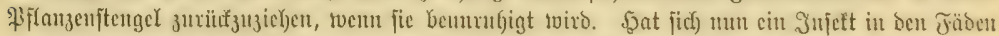

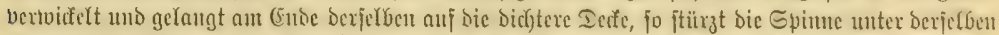

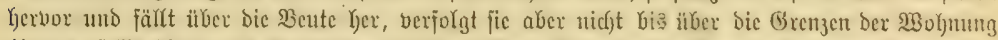

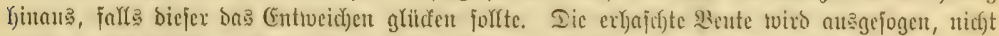

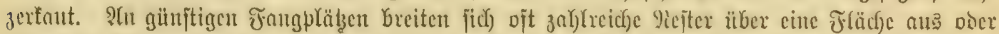

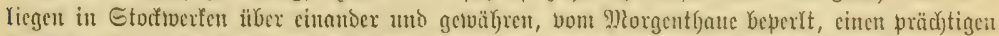

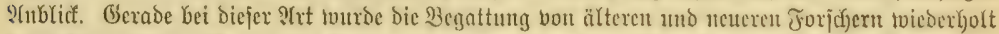

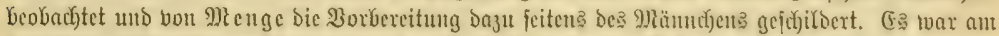

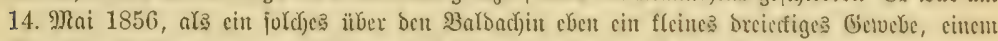

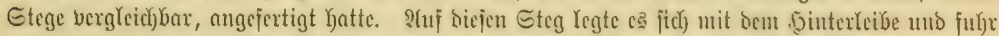

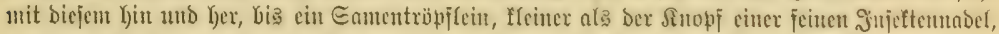

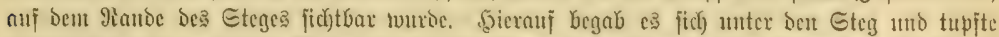

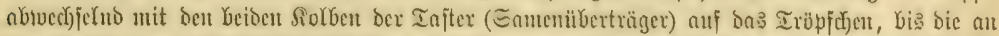

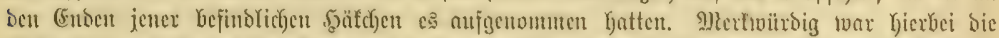

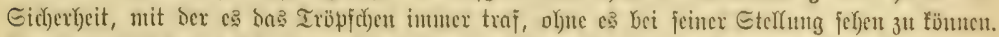

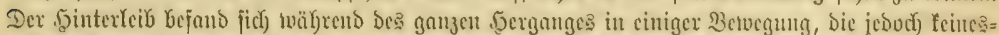

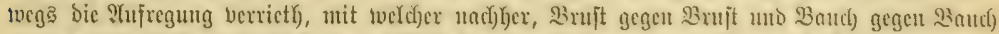

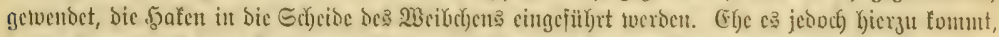

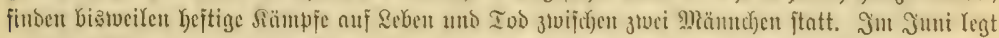

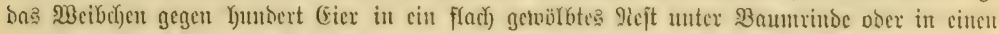

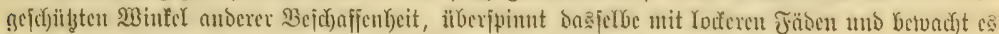

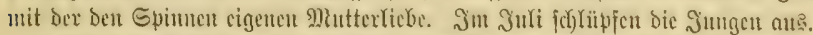

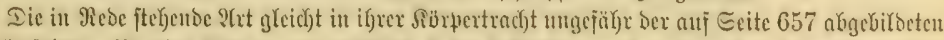

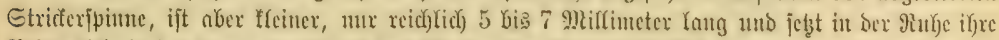

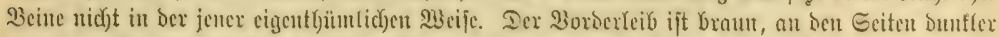

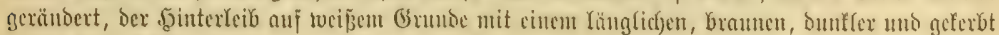

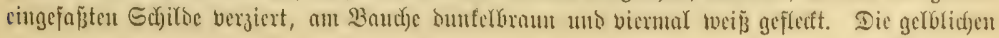




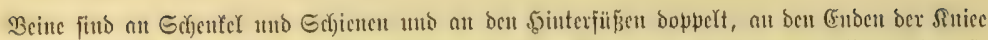

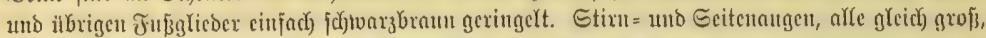

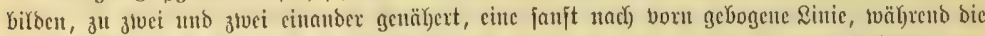

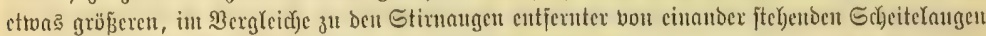
ntit ben Kinterjten Eeitenaugen beinalje in geraber \&inie jtełen.

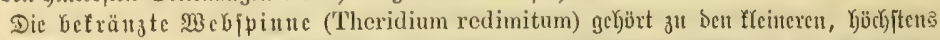

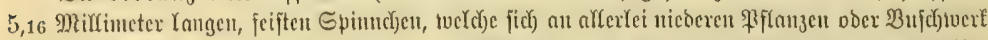

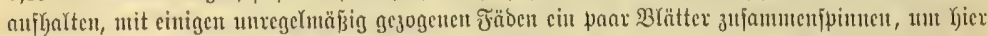

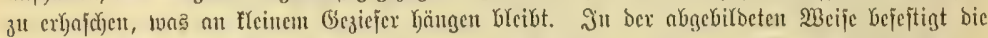

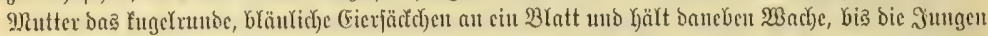

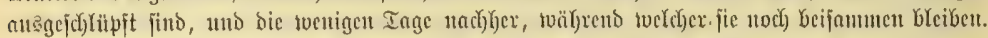

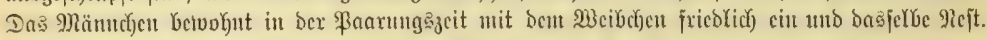

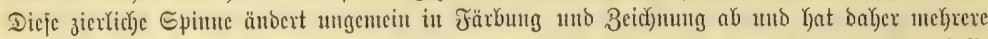

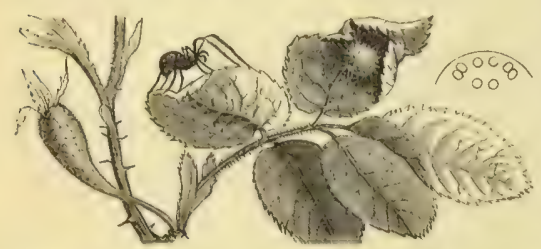

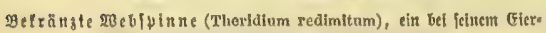

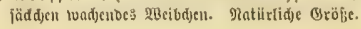
Sianten betommen. Ş zarter Jugeno ijt

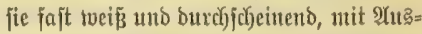

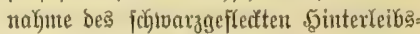

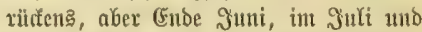
शuguit findet man an bexfelben Stelfe ourthaus bYapgeltbe Spinnen (Theridium lineatum) ober joldye, bie auf bent ફinter= leibe mit einem rojenrothen Sirei ('T.redimitum), Dder eitten obalen Flede ftatt bes freisförnigen ( $\mathrm{T}$. ovatum) vergiert find,

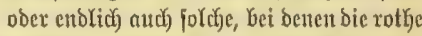

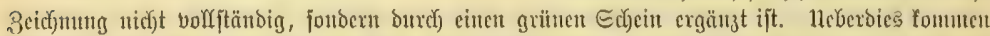

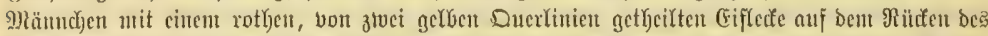

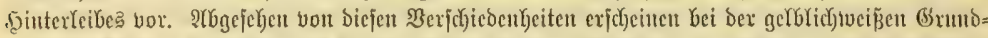

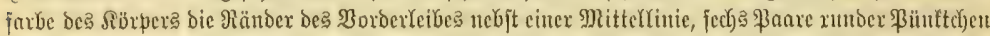

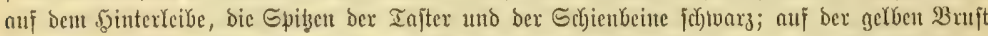

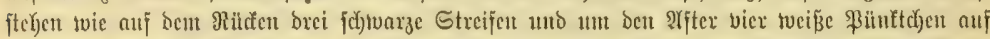

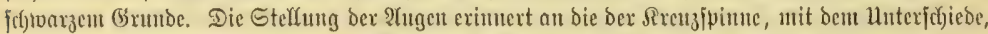

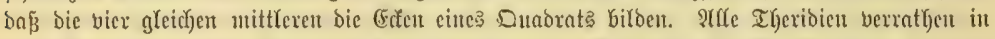

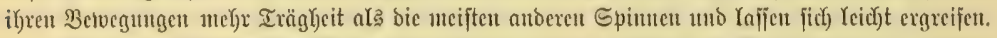

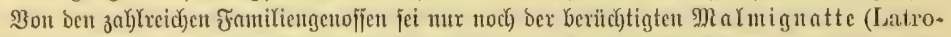

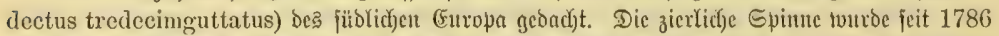

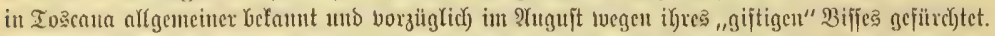
Jit Spanien fiel fie exịt feit 1830 auf, weil fie bamals in Satalonien it groper Menge erfichicu,

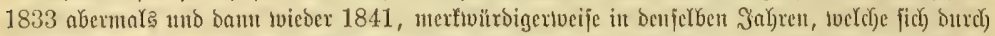

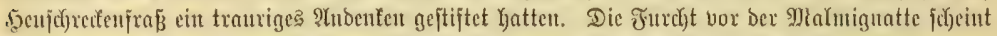

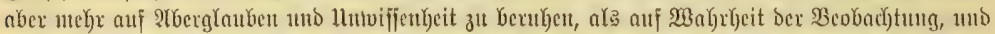

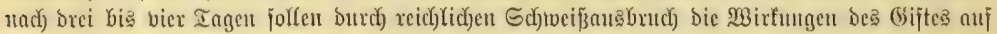

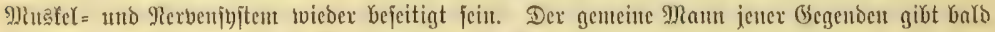

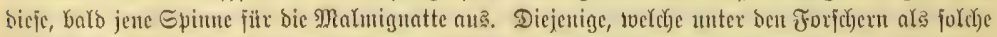

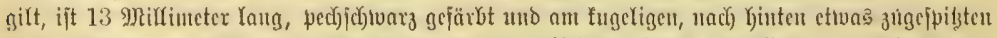

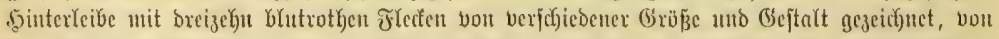

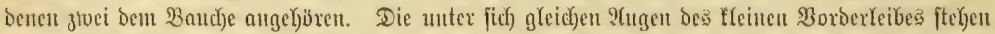

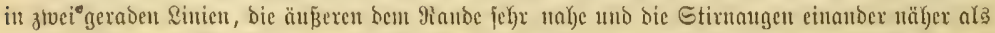

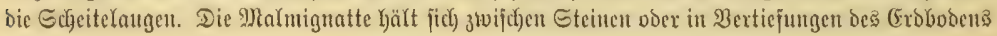




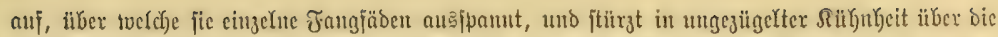

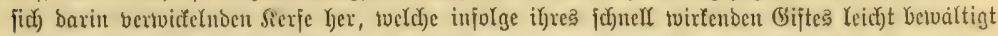

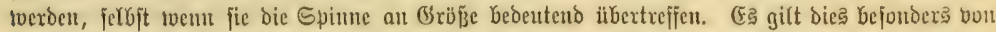

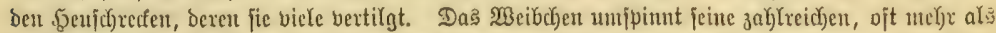

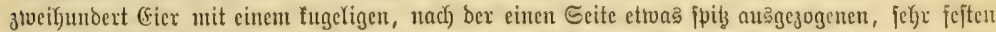
(bebäufe von helffaffecbrauner Farbe und breizebn Miflimeter Durd)uteffer. Die (Eier find uicht anteinander geffebt, aber auch nicht frei, fondern burd) unfichtbare Jn̈ben berfunden; Denn tucun man an einem berjelfen zicht, jo folgen andere gleid) ben Perlen auf einer Schnur nach. Iotti

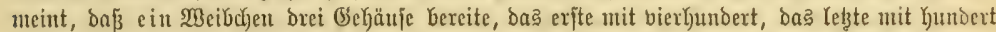

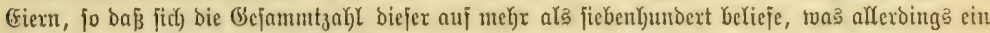

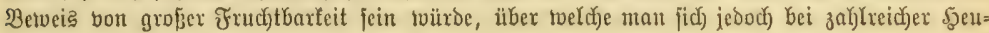
fic)rectentoft nidjt eben zu rounbern braudjt.

Die in ben Minfeln von Etälfen, Sdyeunen, Sird)en uno überhaupt von affen nid)t Djter ben

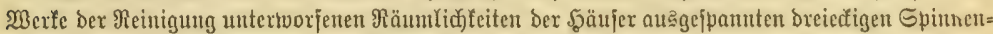

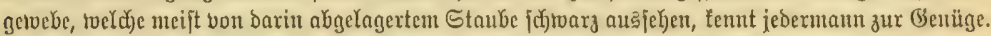

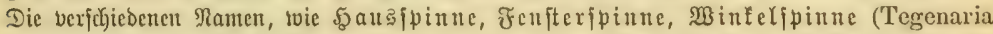
domestica), welche ifre (Exbauerin führt, beuten auf beren Iujenthalt ljin. Eie breitet fich) nidjt

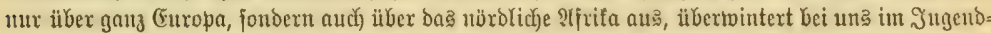

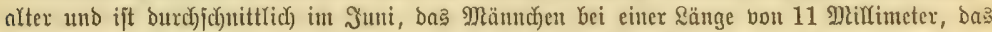

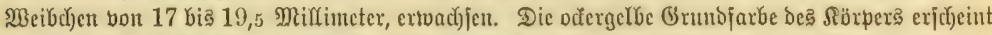

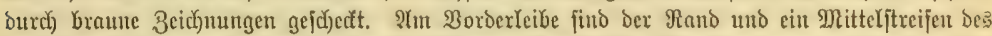

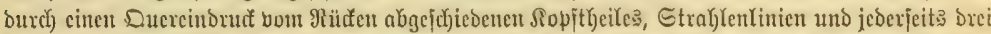
Mondflecte auf biefem bunfler, am Đinterfeife cine Mlitteltinie roftroth) ober branngelb, cinc

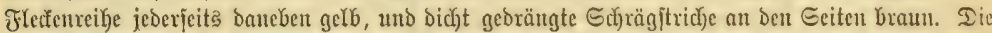

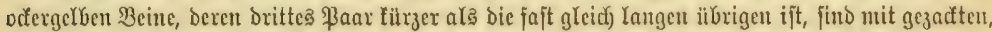

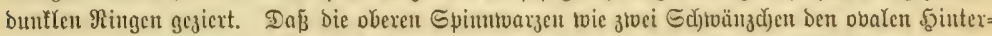

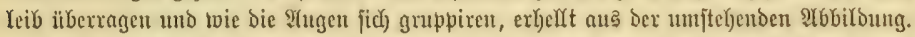

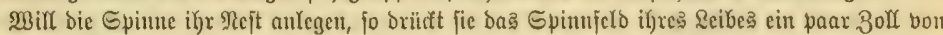

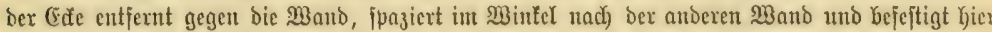
etrua in bemijelben ?tbitanto ben ftraff angezogenen Faben; er toiro als ber äuperfte und wichtigite

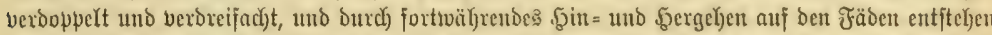

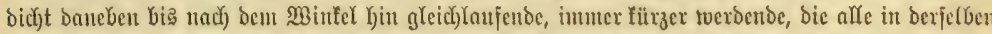

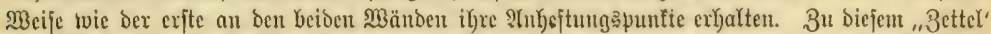

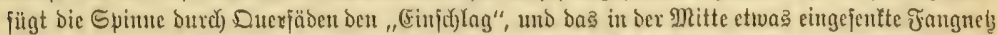

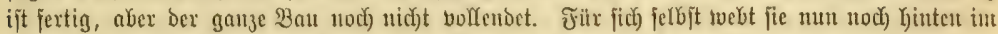

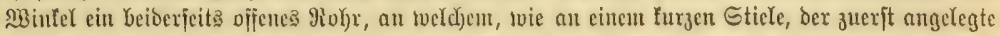

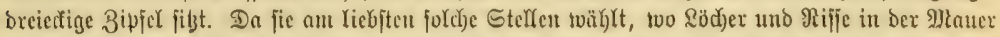

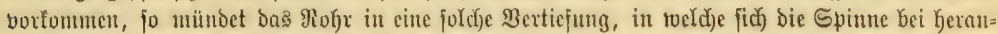

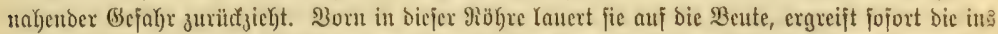

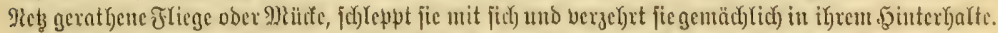

(E⿱

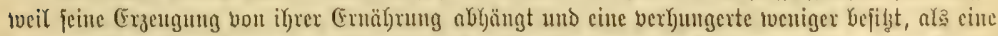

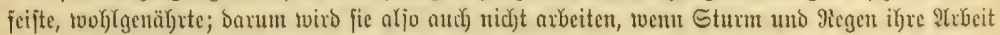

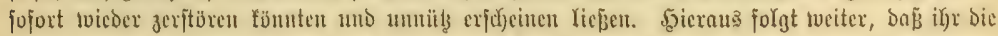

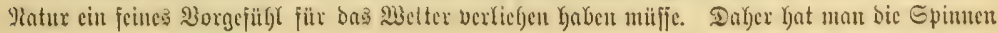




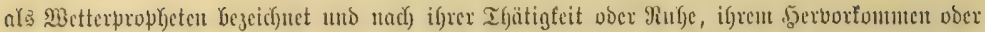

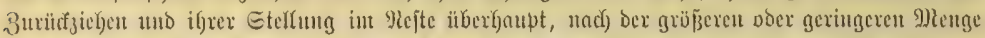

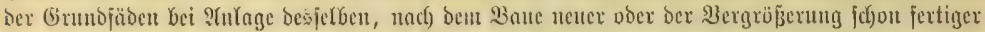

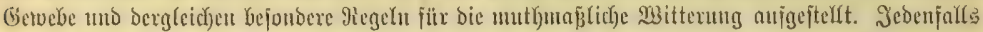

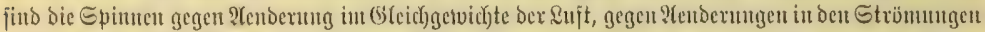

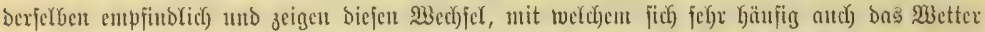

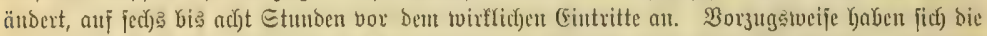

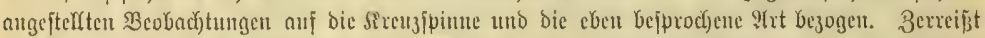

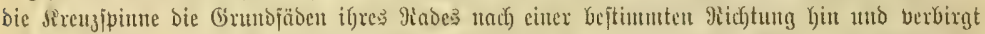

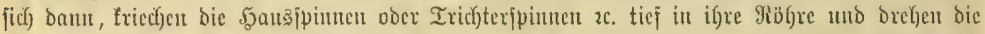

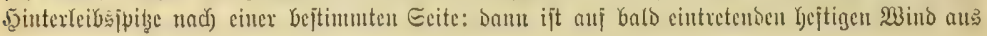

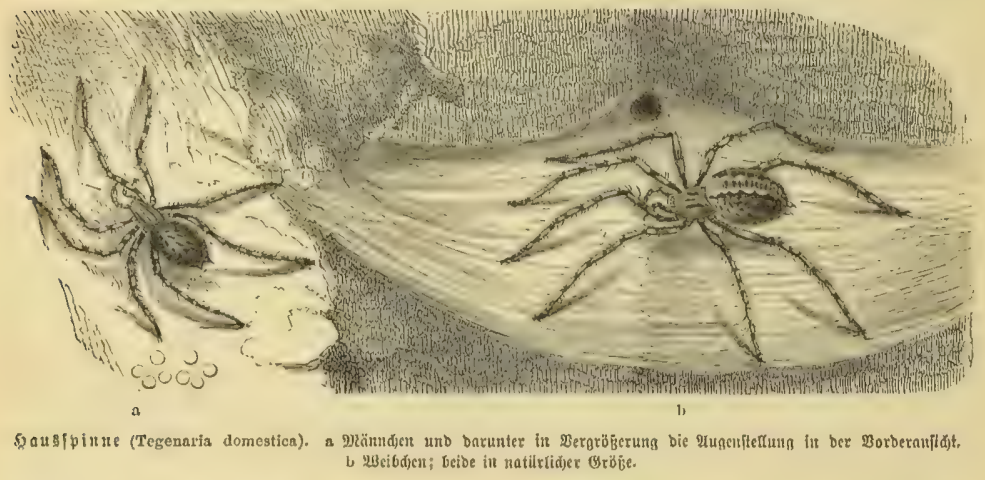

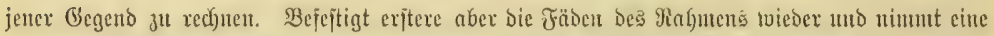
wartende Stelfung cin, fommen Yelztere mit vortuäts gerichteten Ropjende aแn Gingange Dex

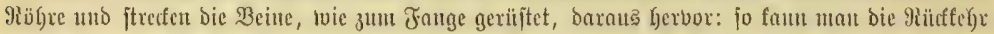

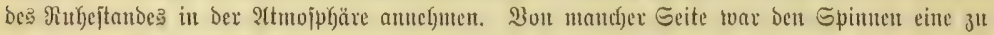

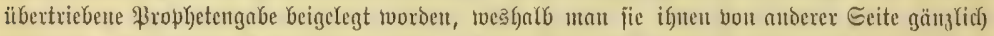

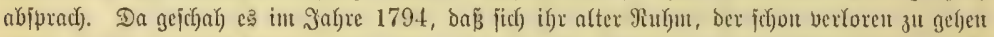

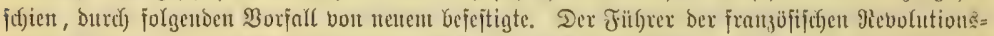

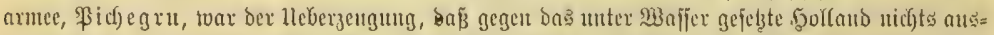

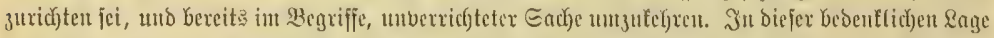

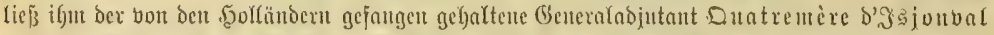

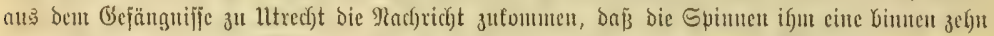

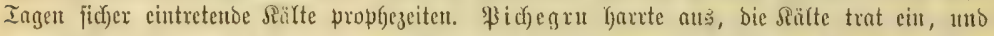

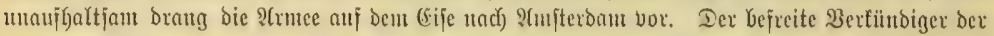

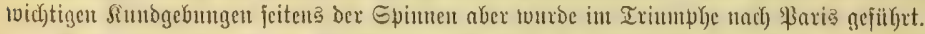

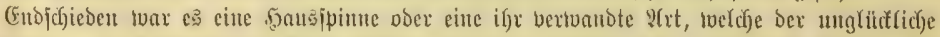

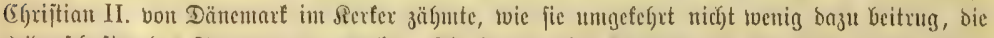

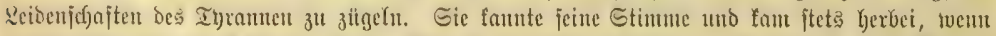

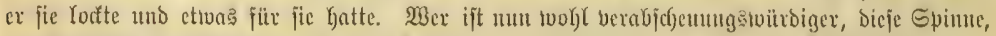

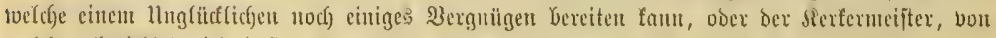

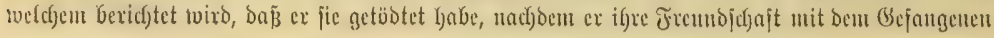




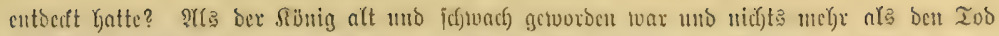

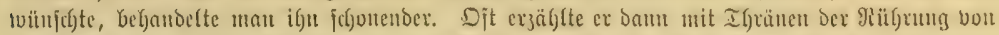

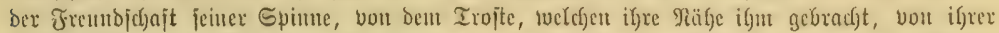

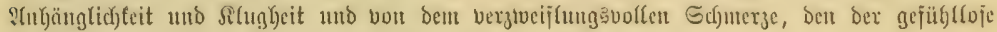

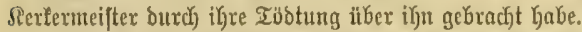

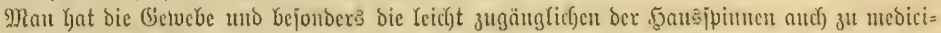

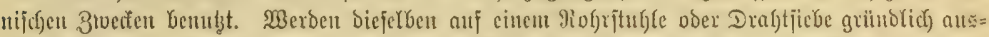

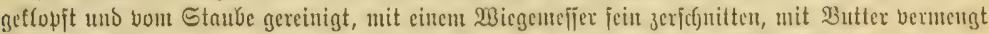

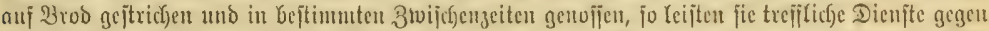

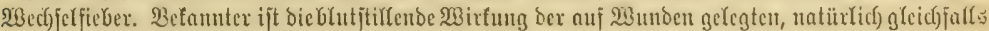
crjt bout Etaube bejreiten Epimnengewebe. Yuch) Gat man verjudjt, jie gleidf ben Eeibenfäben zu

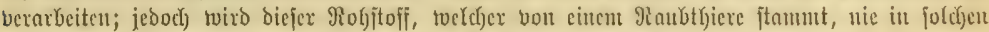
פ)

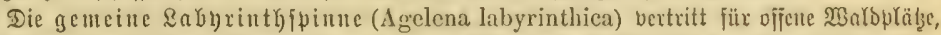

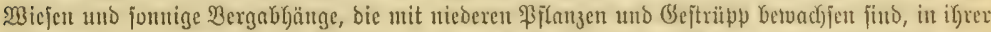

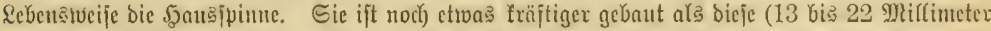

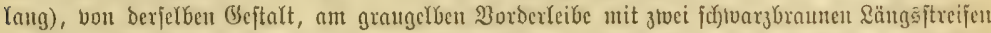

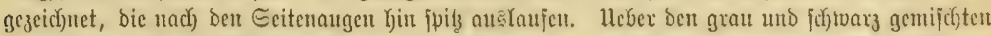

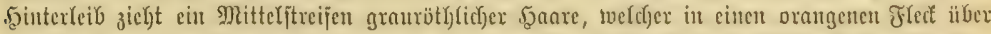

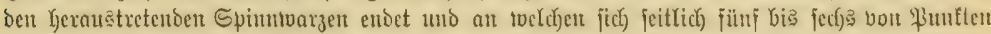

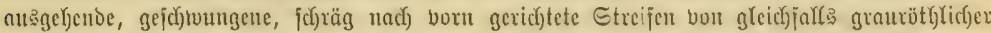

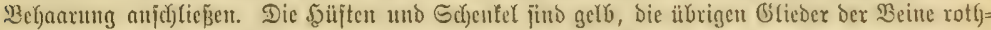

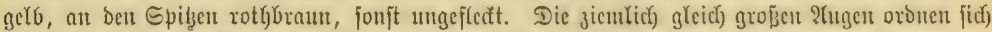

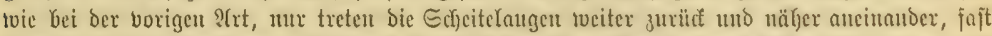

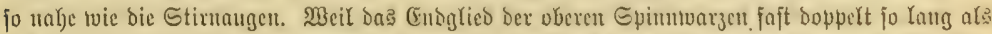

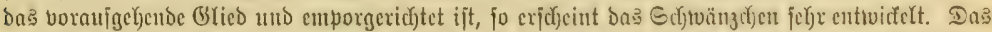

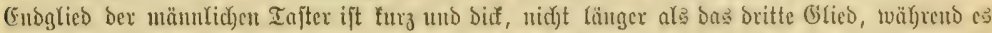

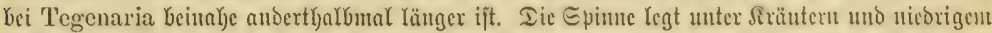

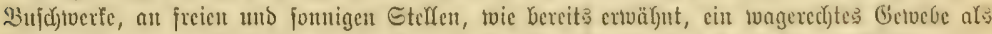

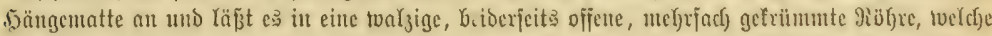

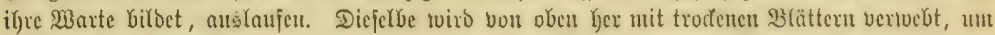

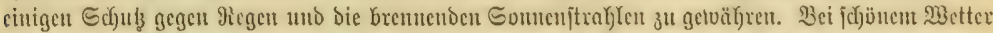

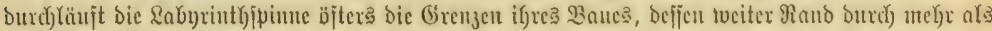

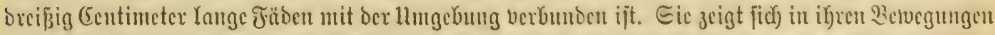

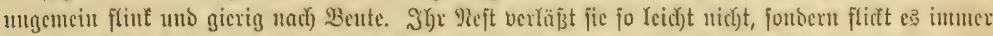

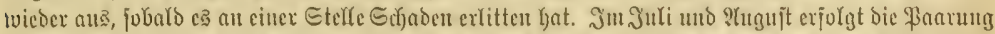

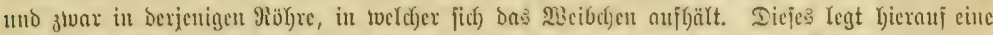

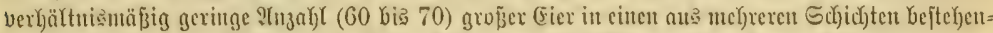

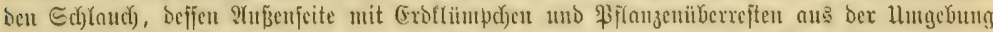

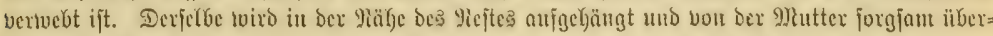

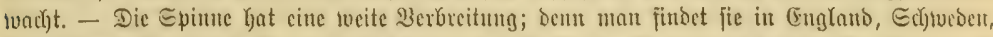

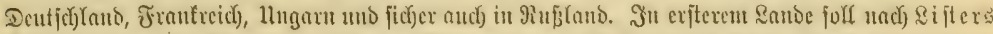

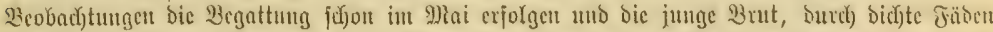

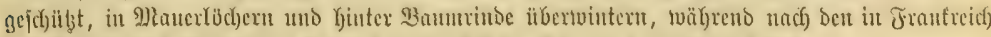

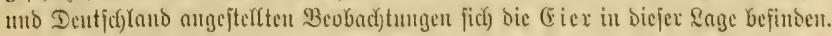

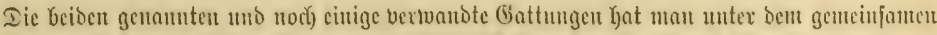

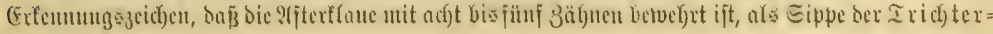




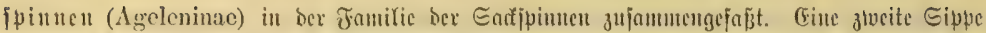

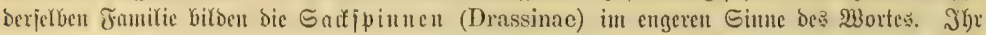

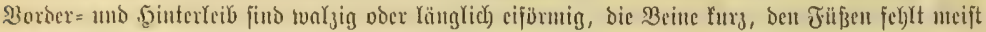

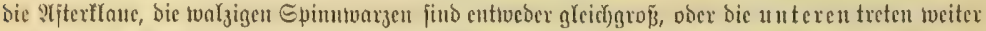

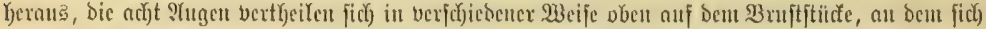

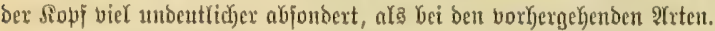

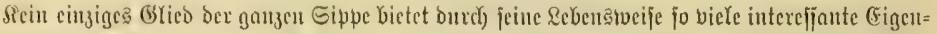
thüulidjteiten, twic bic geme ine $\mathfrak{M}$ afferjpinne (Argyroneta aquatica), eit in jeiner äuferen

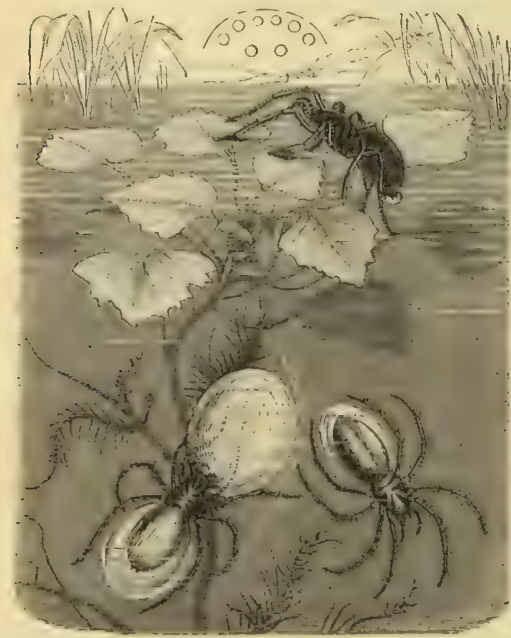

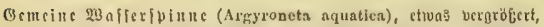

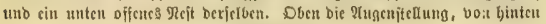
ber scicber. (Exjcheimung uichts tventiger als ausgezeid)= netes Ifier. Weil bei ifyr nod) cine ntelyr=

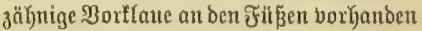
uno ber hodjgetoulbte Borbertheil, ber:

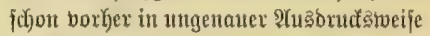
ala Sopi bezeidanet tourde, von Dem îbri=

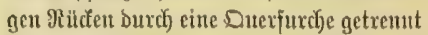
ift, hat man fie audid) wob) mit ben Irichtex= ipitmen bereinigt; in श̂trefyung ber ilbrigen Sterfmale paft fie aber befjer hierher. Giegen bie bei bent meiften übrigen Spinnen geltende Fegel Hbertrifft bas fräftigere,

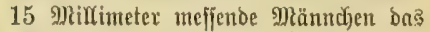
reidy)(ict) 12 Mriffimeter Iange Weibdyen. Bon ben adjt untex fich gleichgro pen श(ugen ftehen bie vier borberen in einem flachen, nad) born geridyteten, bie übrigen in einen

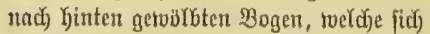

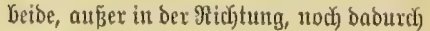
unterjucheiden, bas in vorberen bie ein= zelnen Iugen nux etwa un bie halbe \&änge ifres Durchmeffers, in rjinteren Dagenen

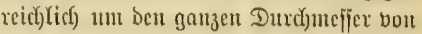
cinander abjtefen, wäbreno bic Mrittel=

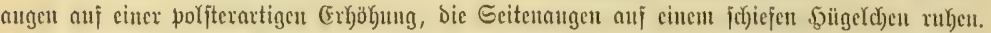

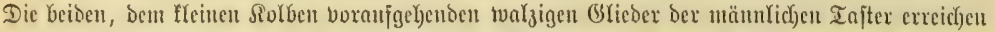

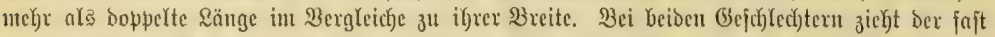

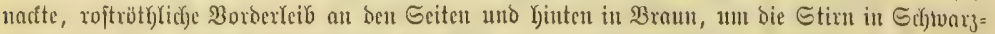

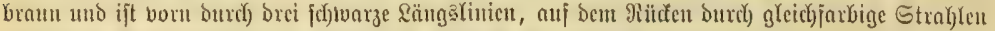

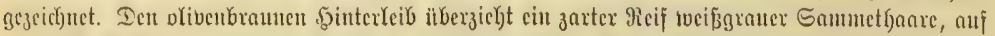

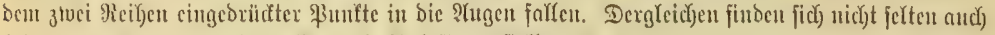

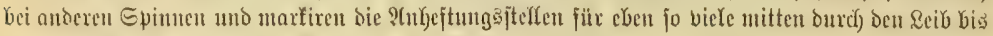

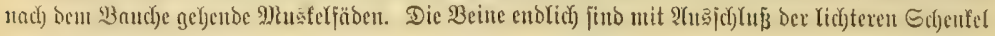
uno Süipten olibenbram.

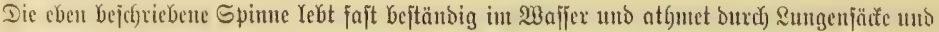

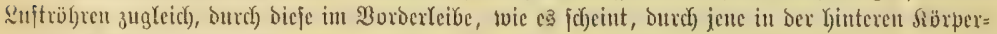

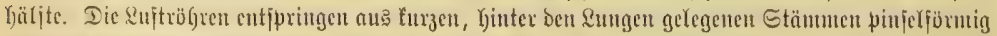

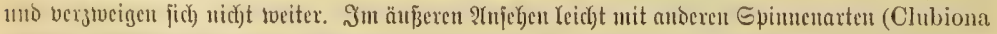

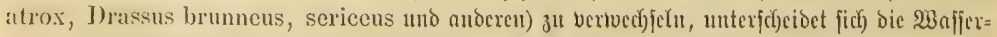

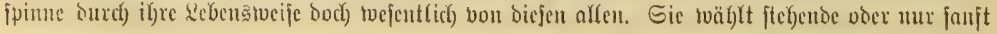




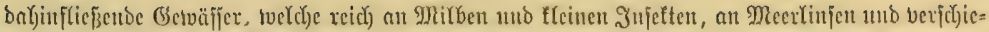

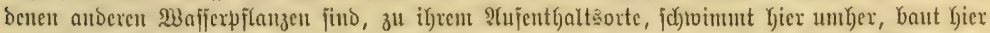

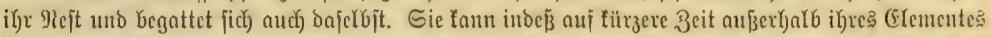

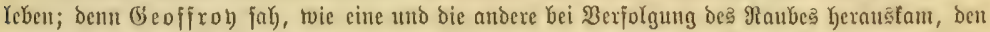
ergriffenen aber mit jidh Yjinab nahm, mo $\mathfrak{B}$ alfenaex beobachtete bei einer Gelegenlyeit eme

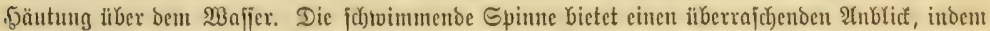

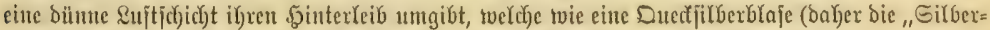

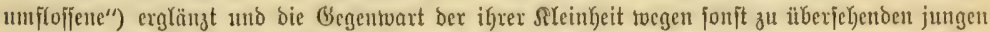

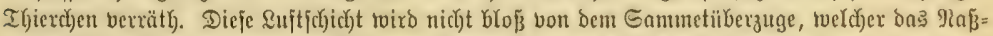

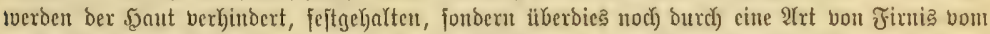

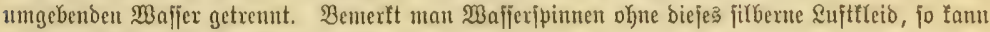
man barauj rechunen, baß̄ fie trant jino.

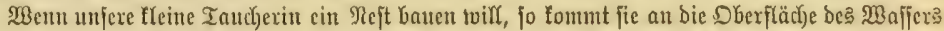

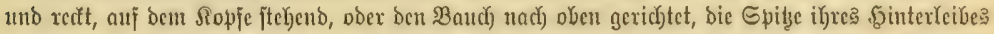

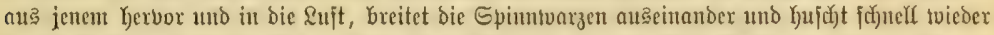

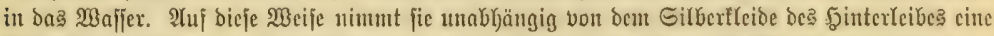

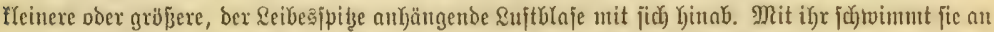

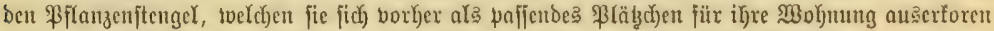

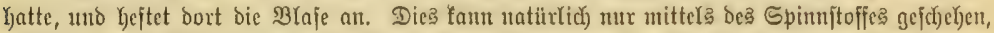

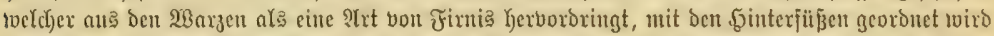

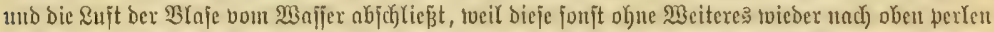

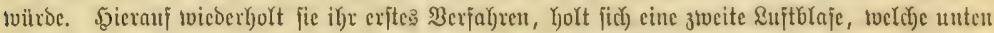

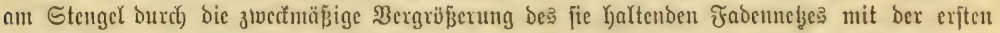

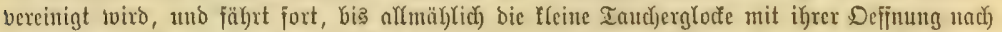

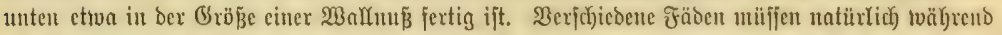

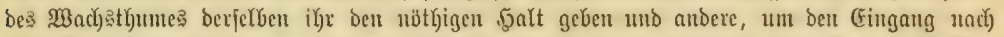

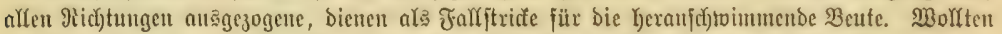

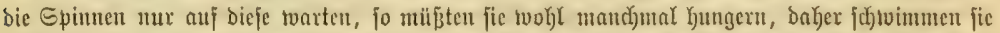

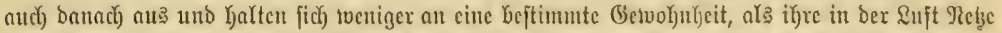

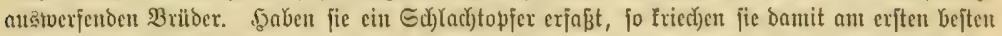

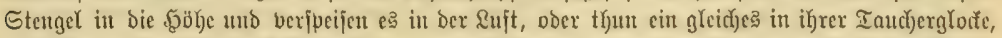

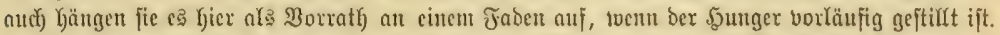

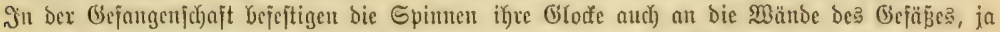
De Iroiş

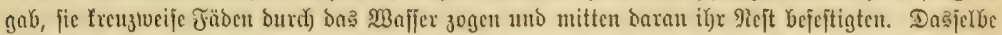

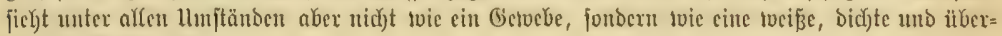

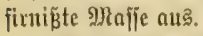

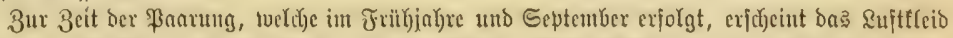

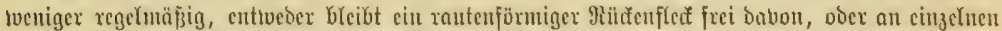

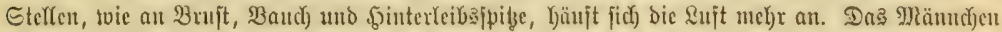

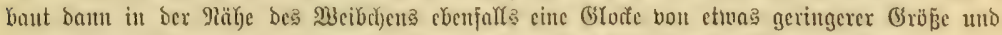

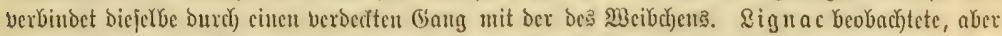

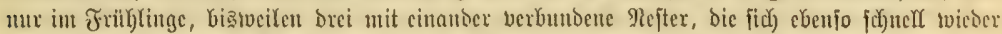
tremen fömmen, tvie fie fich bercinigten, twent Die Epinnen in Streit getatyen; Denn in biejer 3cit

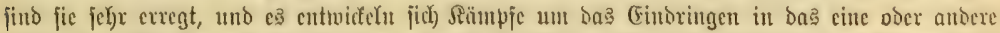

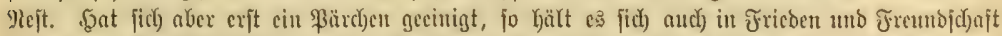

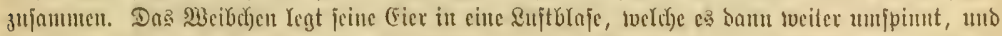

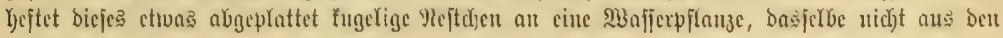




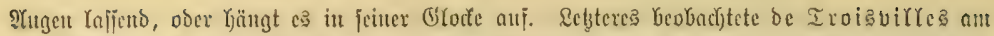

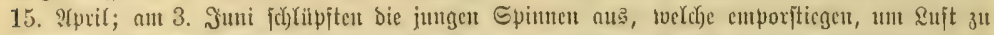

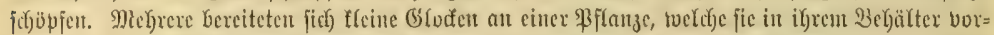

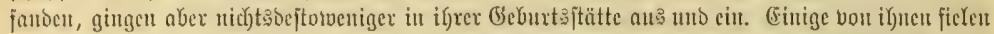

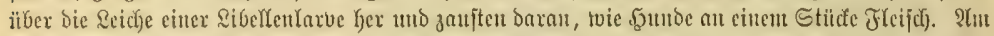

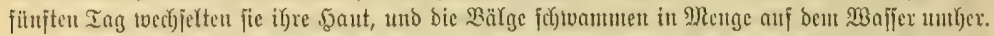

YGer and zum Minteraufenthalte bienen bie Gifocfen. Degeer fing in Geptentber eine

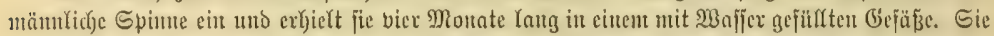

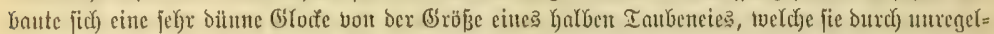

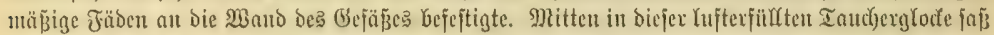

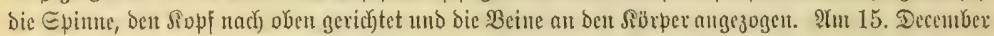

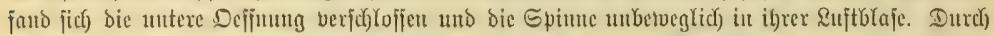

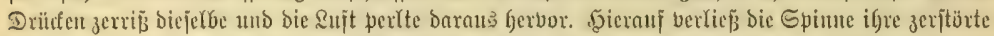

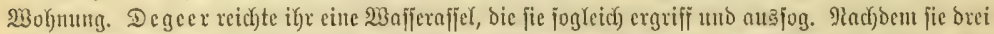

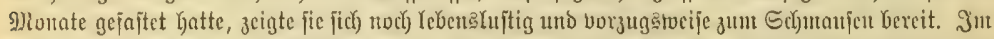

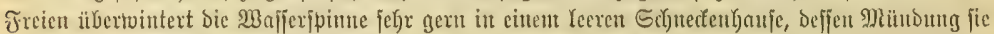

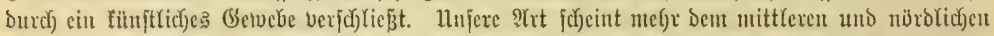

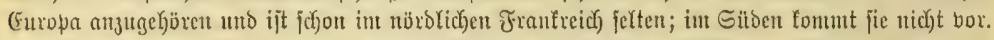

Die übrigen zahlreichen, auj mehrere Battungen vertbeilten Gadjpimnen leben meijt verftectt

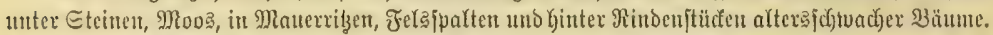

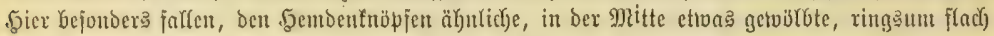

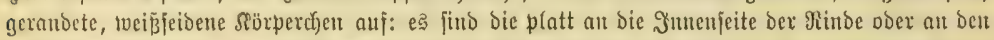

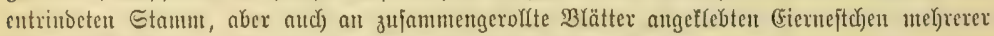

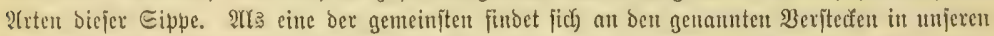

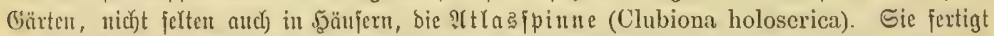

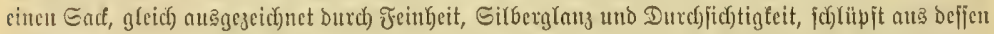

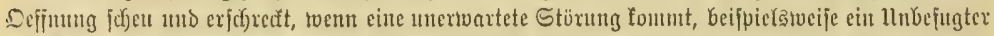

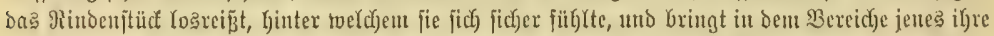

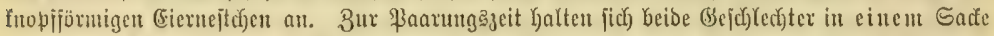

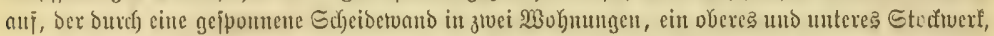

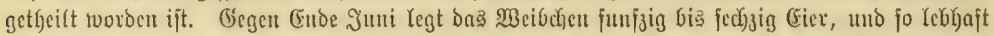

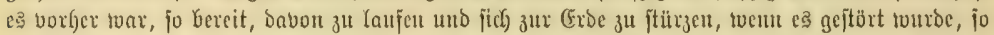

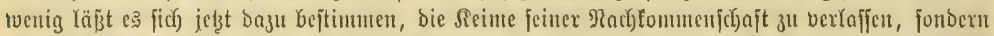

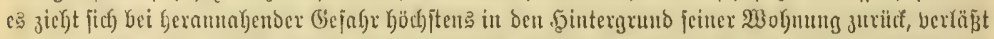

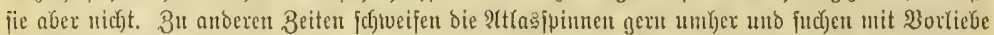

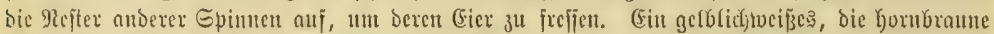

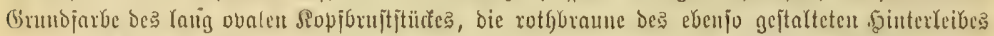

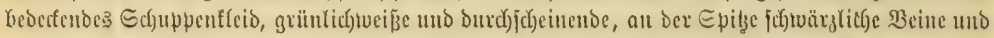

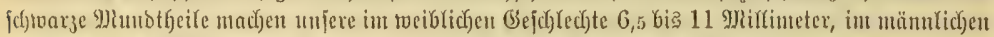

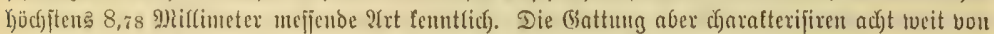

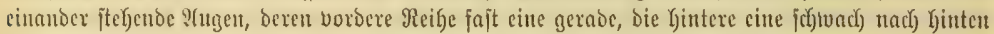

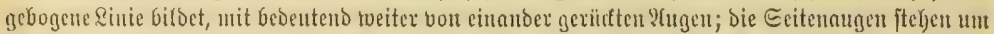

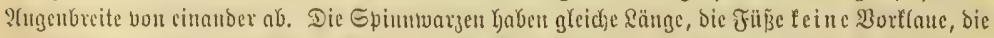

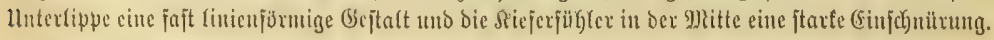

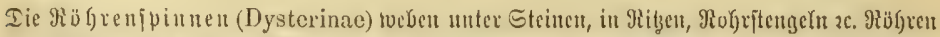

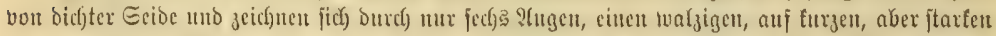

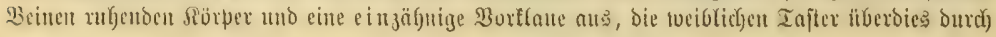


cine ungezähnte Rralle. Sie bildent bie britte Sippe ber Satfpinuen (T'ubitelae, Drassidac),

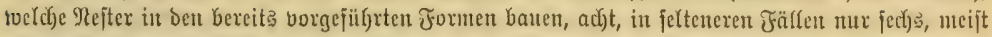

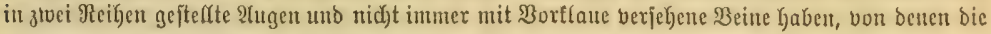
beiben mittleren Paare ftets bie füzeren find.

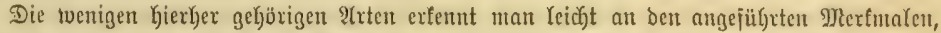

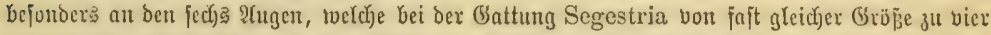

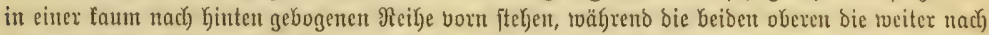

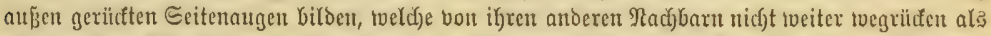

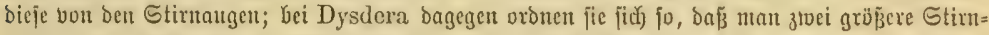

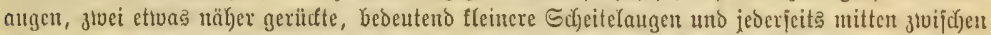

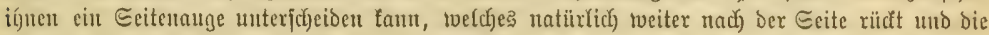

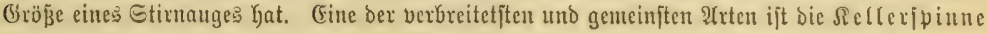
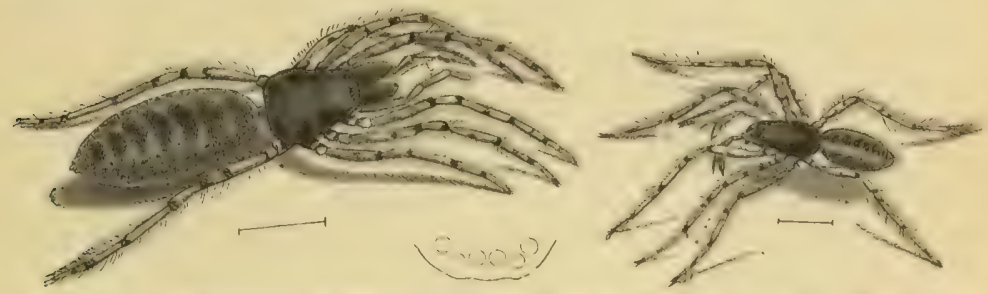

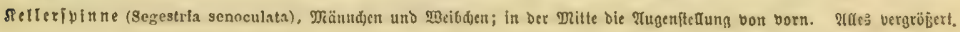

(Segestria senoculata), Die unter Steuten, Baumrinoc, Mtoos, in Mauerłüchern uno Strohböchern

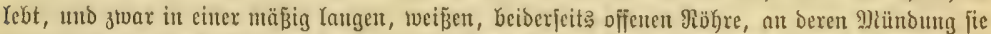

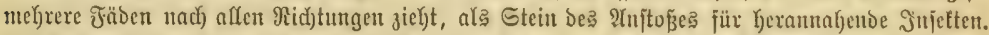

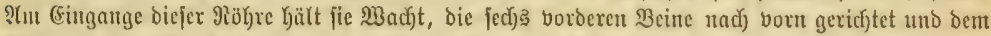

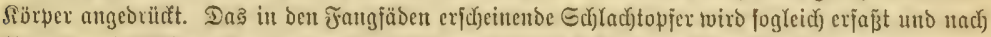
Yinten in bie giögre mitgenommen. Die Epime zeigt fick bei ifren ?tugriffen tüfn uno getwanot:

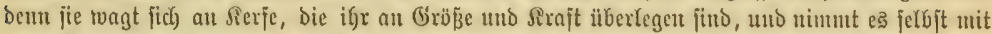

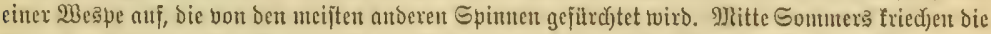

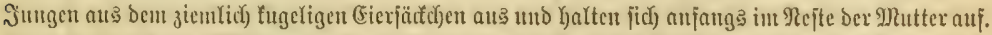

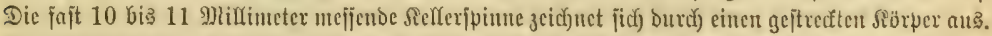

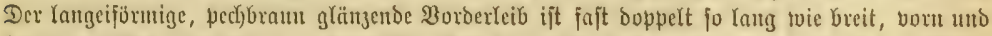

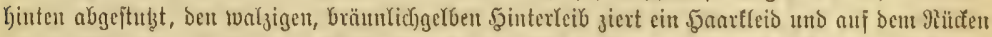

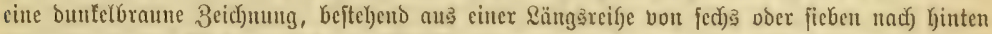

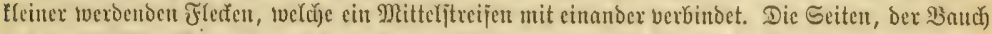

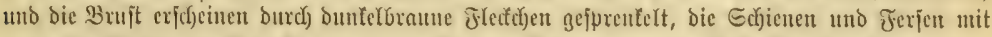

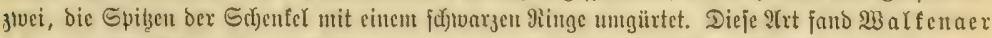

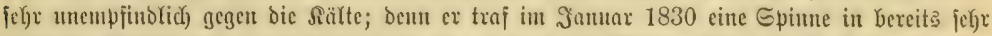

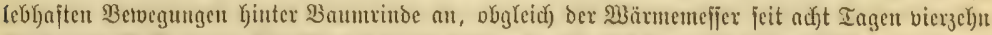

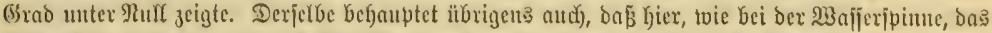

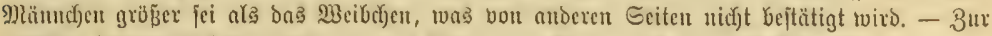

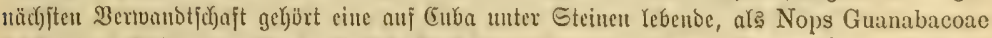

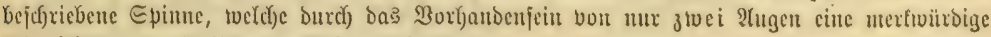
श(btueidung vom Mrbilde ber Spiuncu Yiejert. 


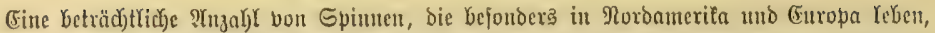

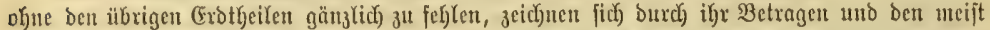
platt gebrilăten Sïxpex bor alfen anderen aus. Sie find als $\Omega$ rabbenfpinnen (Laterigradac,

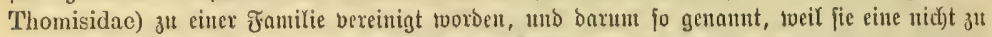

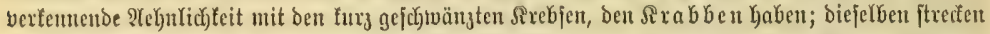
nämlidy igre Bcine, von Denen bie beiben Yjinterften ßaare gegen bie vorberen an \&änge auffalfento

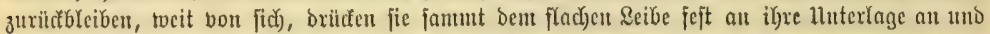

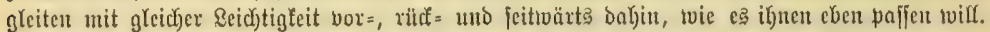

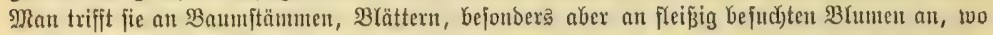

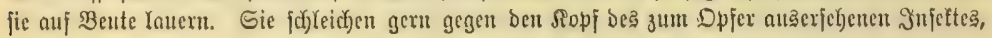

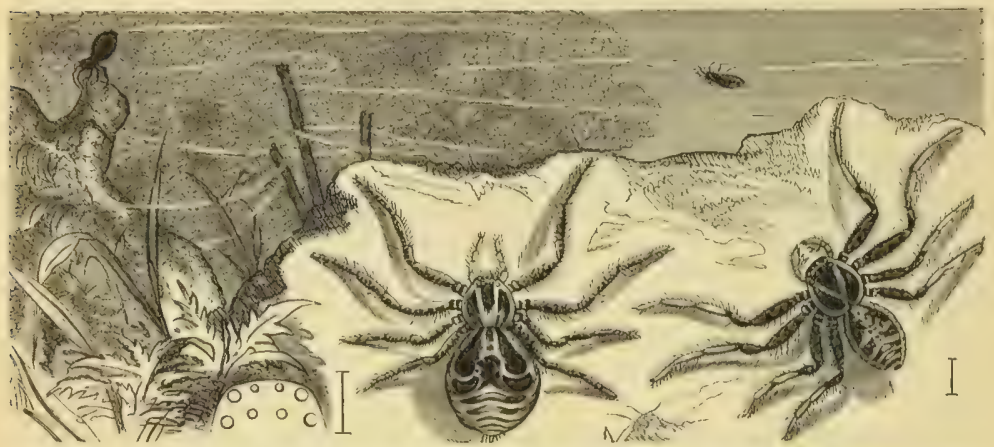

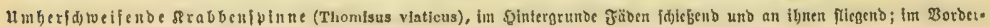

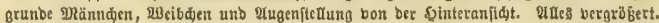

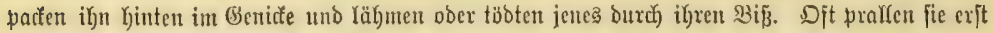

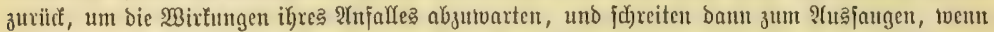

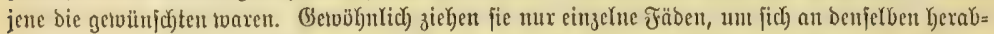

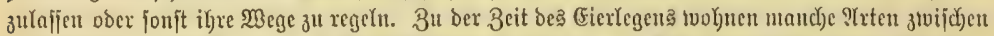

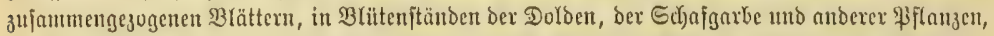
bie fie intoendig mit einem melyr ober weniger bid)ten (Getwebe austeriben, anbere juchen fich wieber

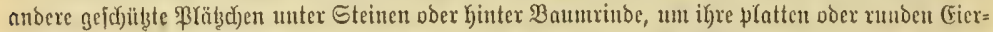

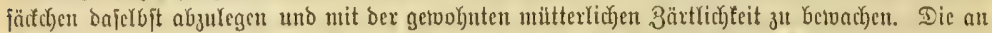

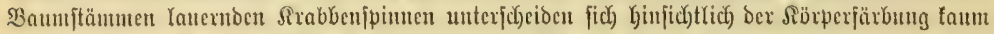
bon biejen, und bie grüulidge Rrabbenfpinne (Thomisus oder Sparassus virescens), von

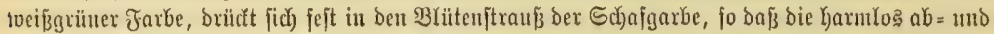

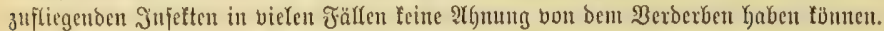

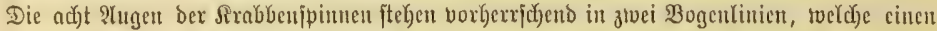

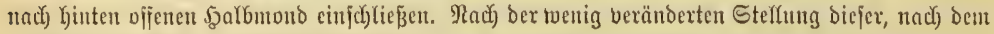

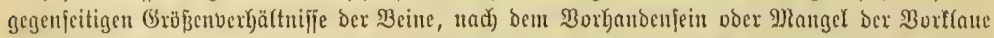

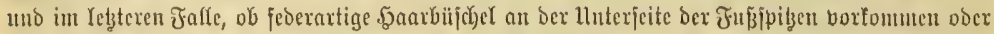

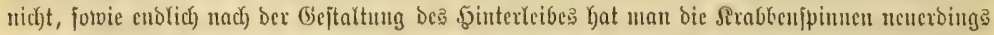

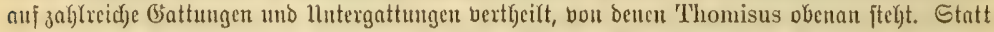
alfer fei hier ber umberfablueifenden firabbenjpiune (Thomisus oder Xysticus viaticus)

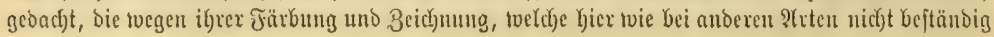




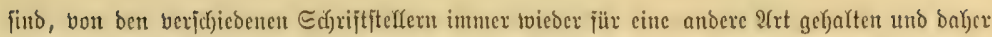

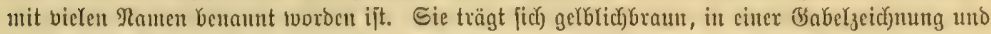

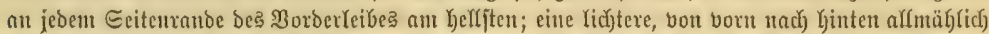

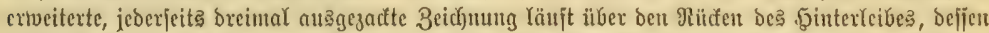

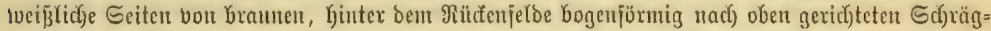

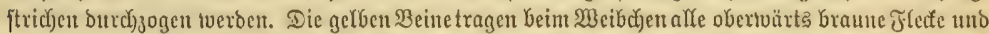

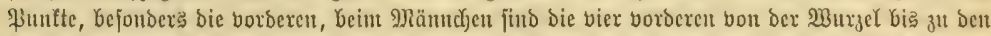

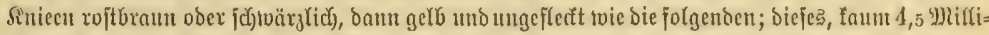
meter lang, ift iut alfgemeinen bunf(er uno greffer gezeichnet, alङ bas reid)lich 7 Mtiffineter mefjentoe,

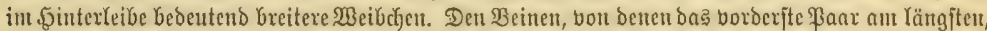

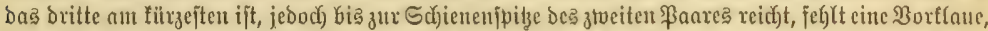

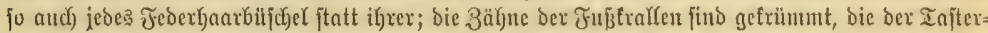

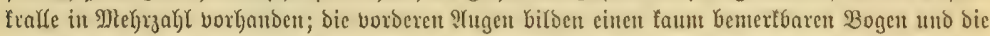

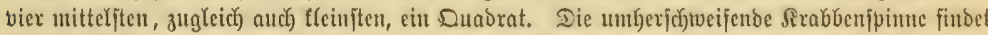

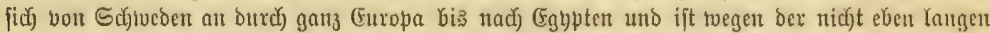

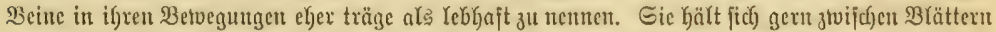

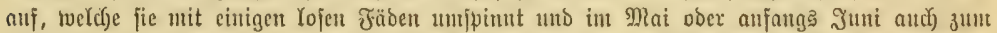

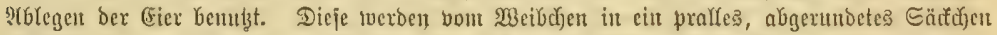

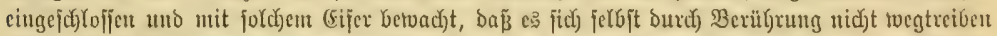

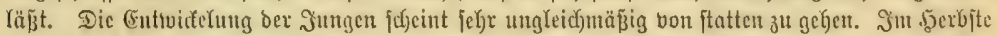

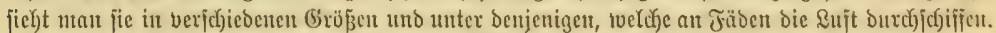

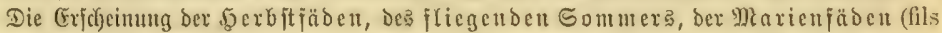

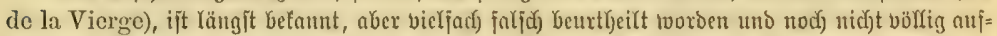

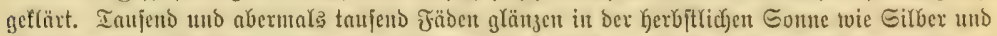

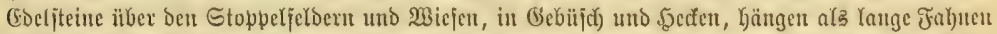

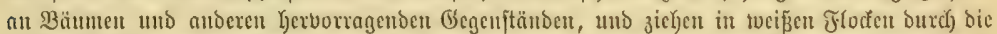

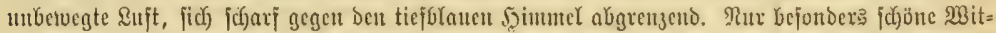

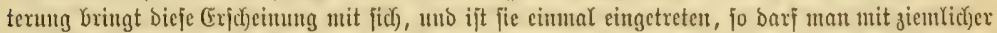

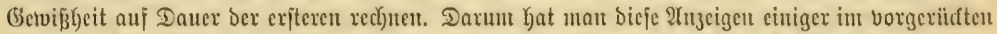

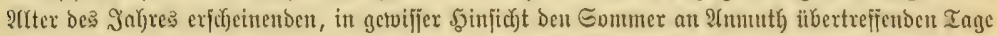

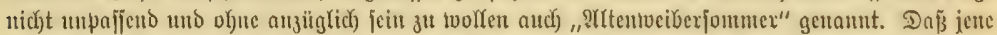

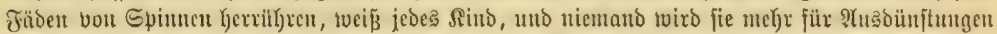
von \$flnusen halten, wie in vergangenen, wentger aufgetlärten 3eiten gejudeben ijt. Wie aber

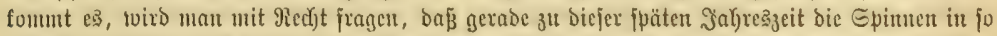

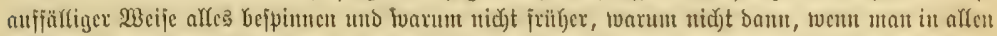

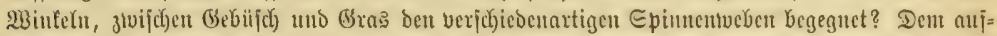

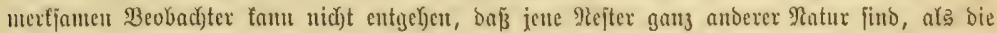

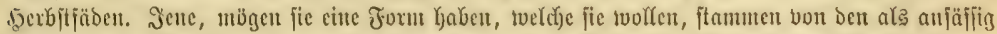

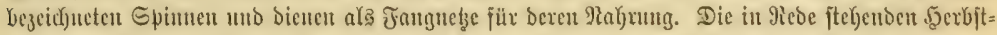

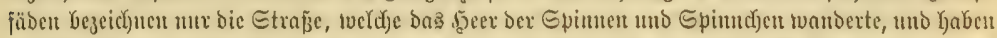

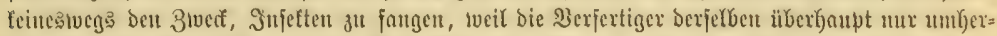

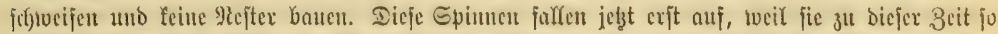

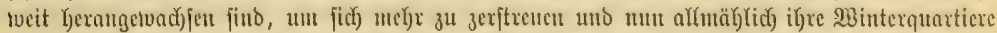

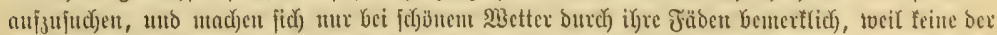

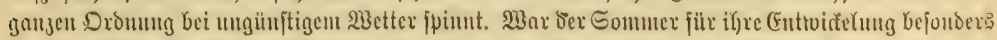

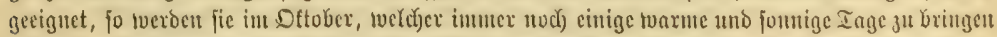

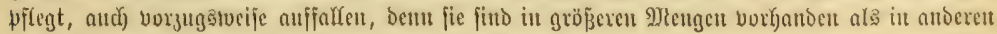

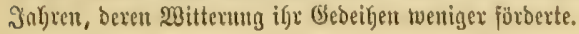




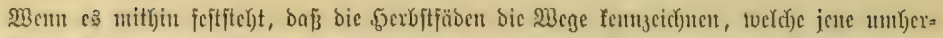

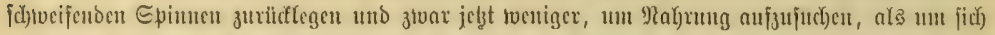

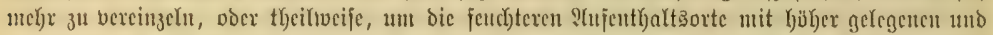

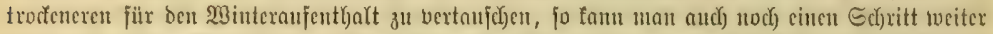

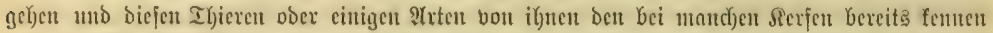

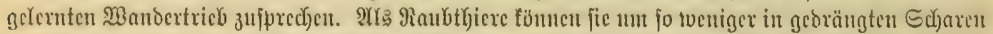

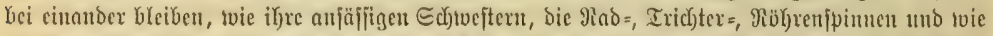

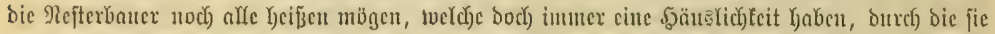

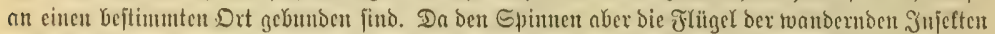

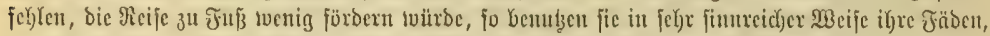

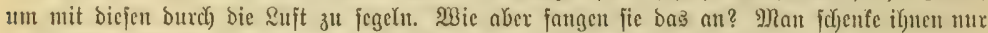

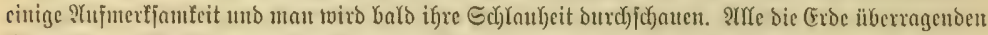

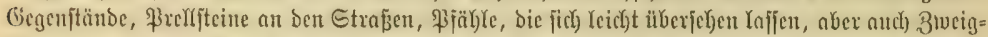

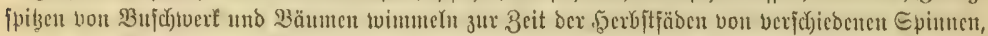

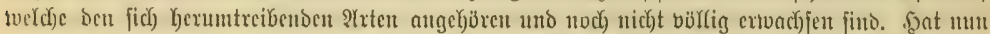

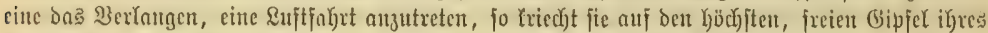

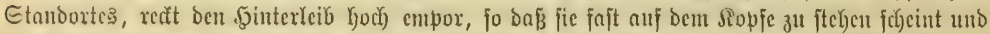

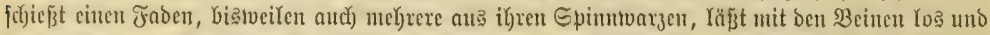

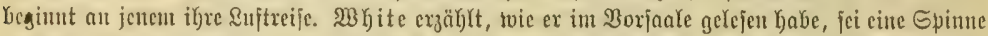

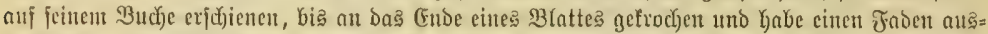

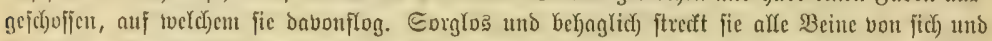

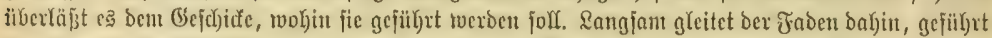

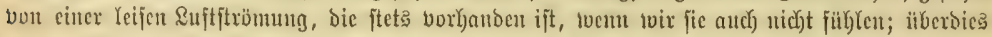
mag worf) Der negativ eleftrijd)e Faben von ber pojitiven (Eleftricität in ber \&uft angejogen weroen.

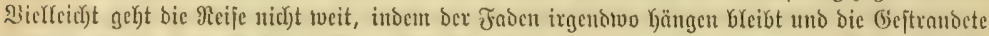

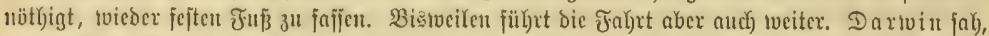

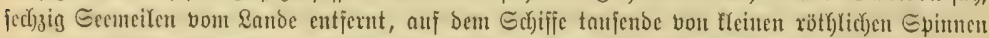

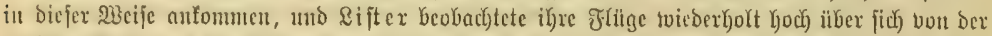

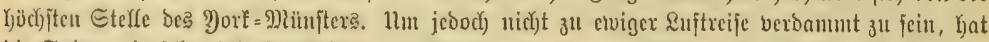

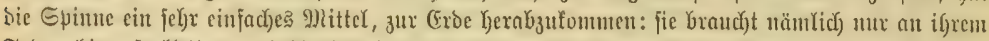

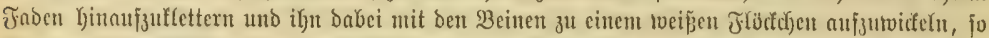

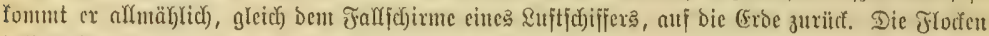

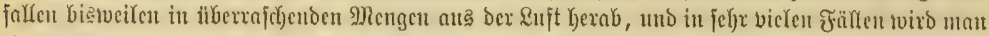

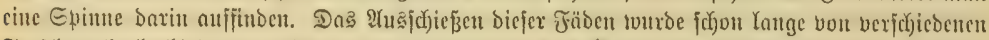

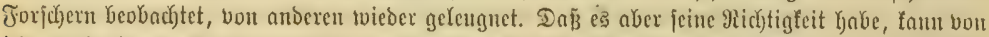

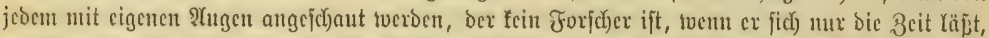

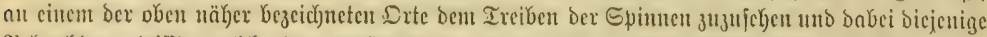

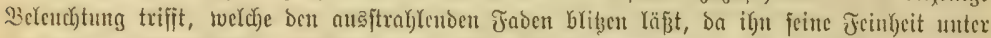

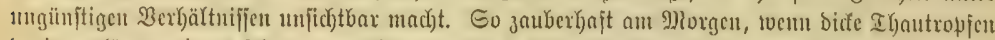

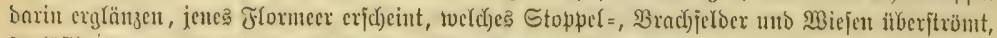

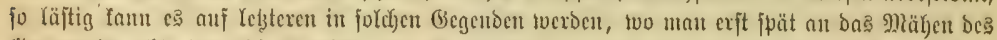

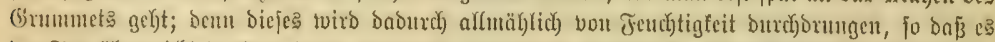

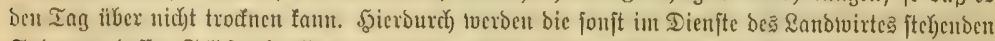

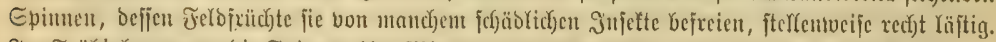

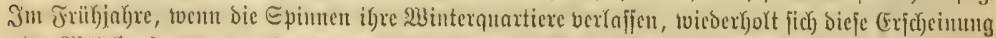

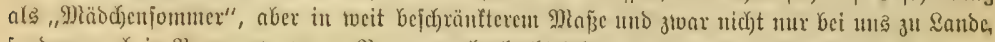

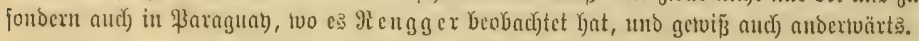




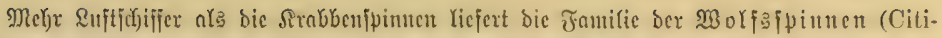

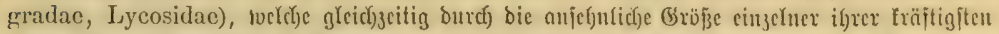

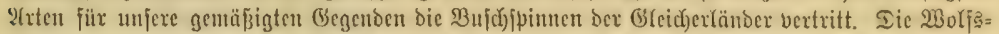

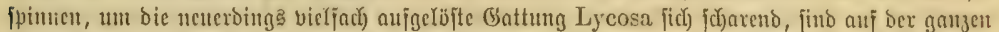

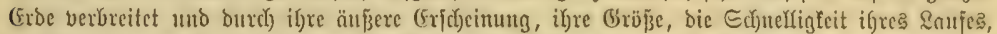

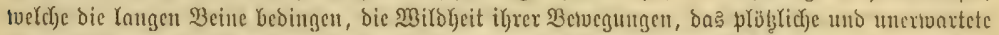

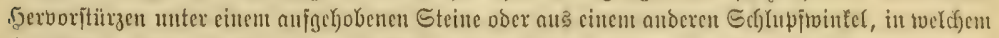

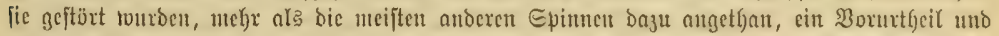

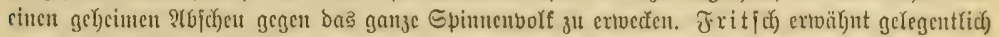

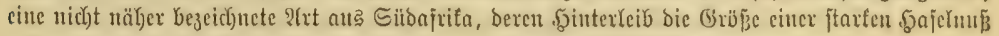
und beren mittlere Beine cine Spantweite bon etiva 157 Miflimeter

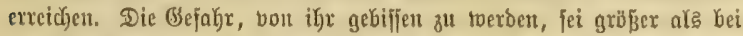

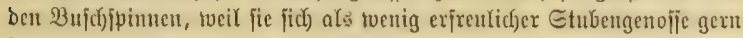

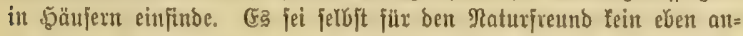

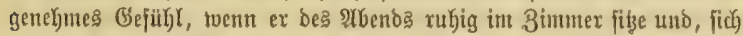

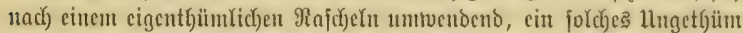

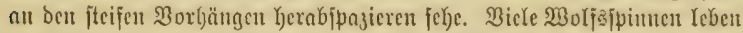

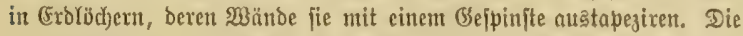
eitrent tragen ihr (Fierfädd)en an Baud)e mit fidc unther ober filzen wie

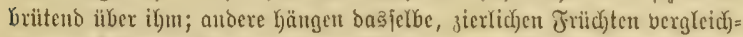
Gar, nu Sicjernabeln ober niedere Pflanzen in ber Weije, wie bie neben=

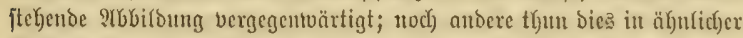

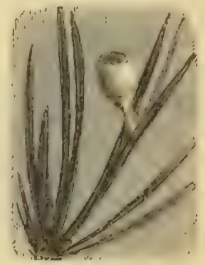

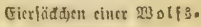
ipintic.

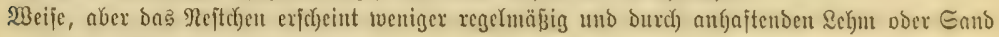

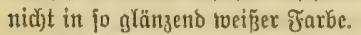

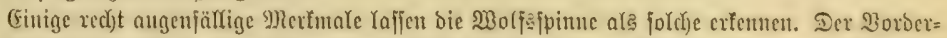

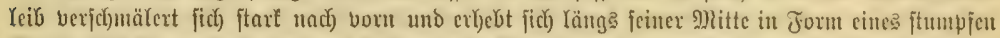

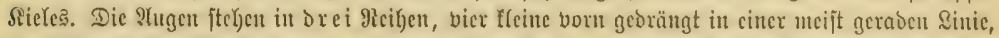

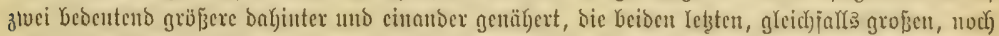

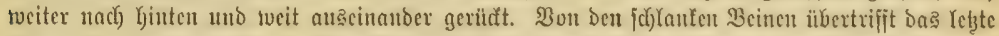

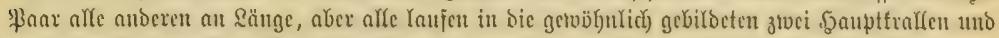

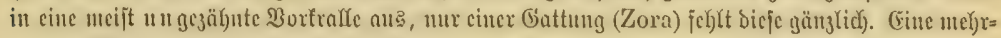
zägnige Silnue bcivebrt bie sveib(id)en Iajtex.

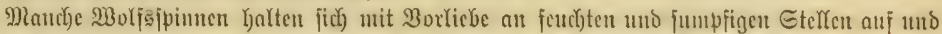

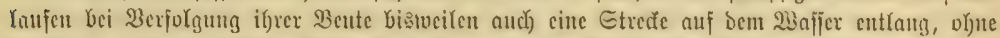

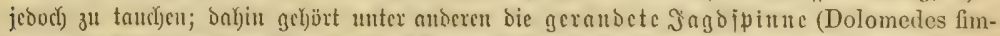

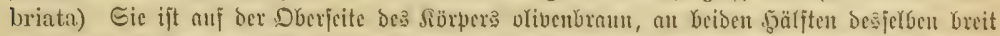

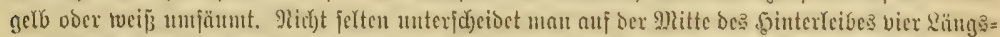

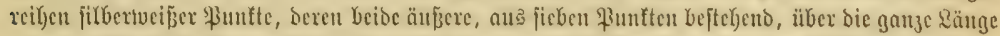

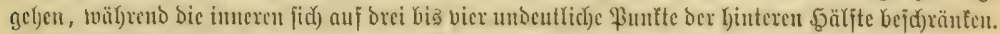

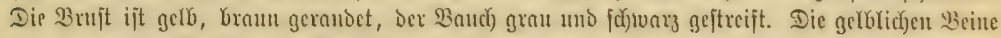

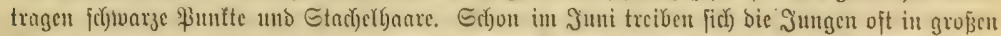

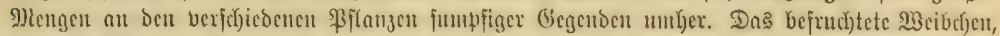

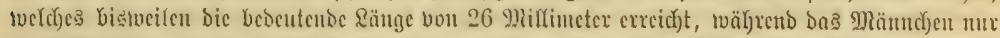

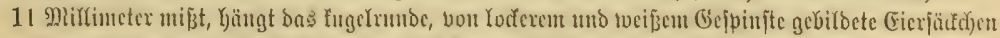

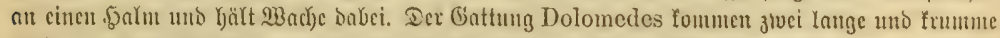

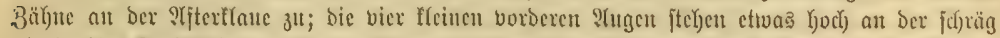

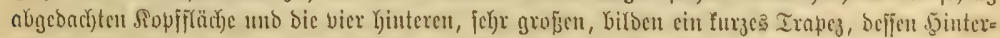

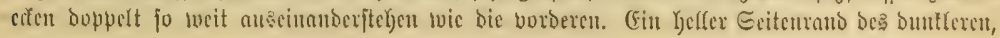




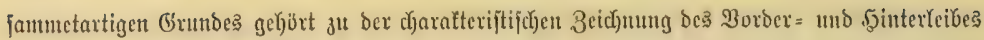
fäntmutliçer Giattungägenoljen.

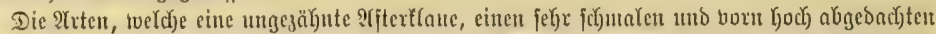

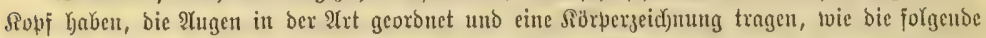

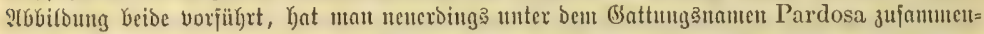

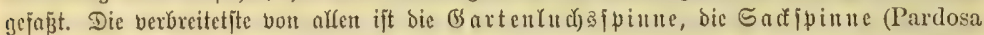

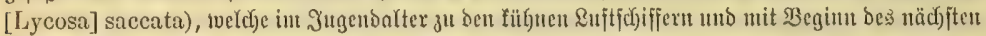

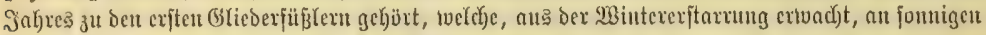

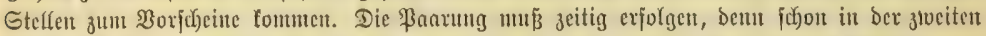

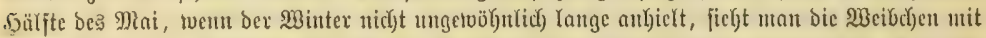

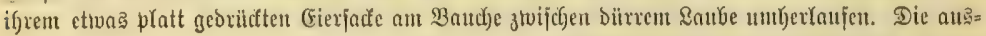

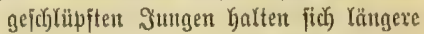

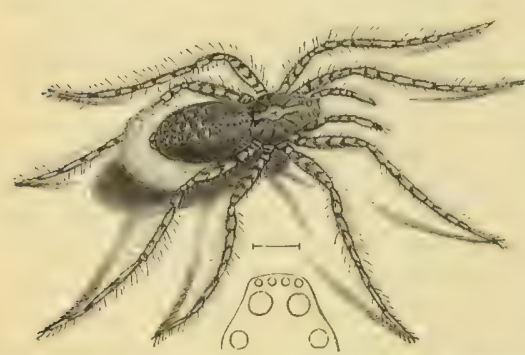

(1) a rentud) sipinne (Pardoss sacenta), Weibden mit bent (Eierfade,

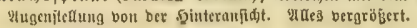
3eit in bemferfen autf, friecthen auch) auf

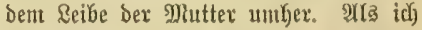
cinjt methrere biefer Spiment in Bein $^{2}$ geift getworjen Katte, war idj) nidft toenig erftaunt, eine großje 2 Inzafil \$unger in Der Flajche zu finben, weldye fid) int Tobe? = fampfe aus bem Eierfacte herauşgenrbeitet

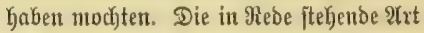
ift Gyöchiftens 6,5 \$2tiffimeter Iang, Graun= grat bon Farbe und hat einen gelblichen

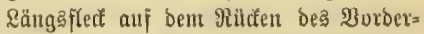
Yeibes, cincen fdjwarzen Goberffect aut

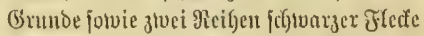

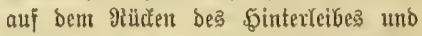

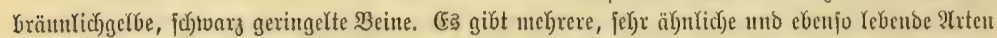

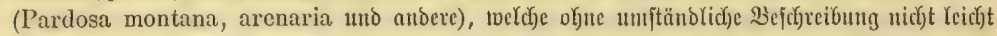

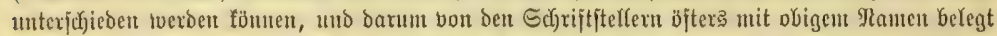

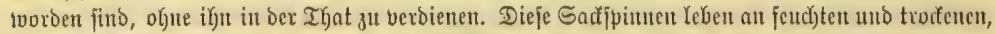

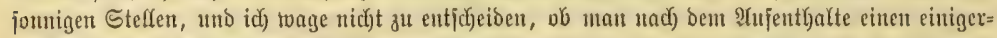
maß̧en ficheren Sđf) Doer tveniger untermif dyt vortommen.

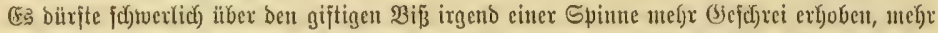

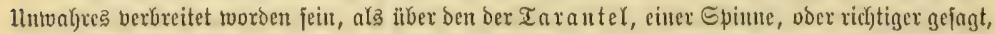

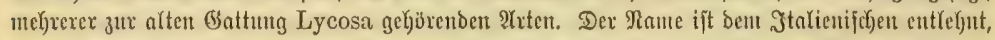
wo man unter Tarantola uriprï̈nglich) eine giftige Epimue (audd) Solofizzi genaunt) begreift, weeldye

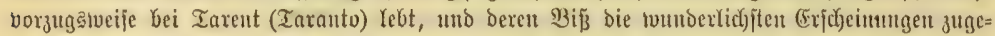

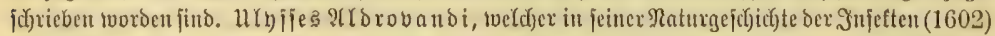

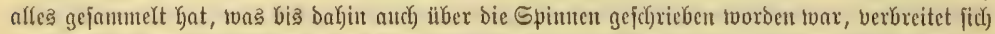

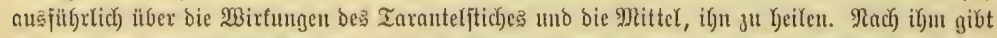

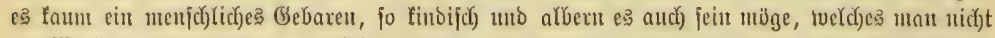

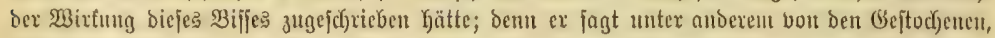
"I'urantulati": Die einen fingen fortwäfrend, bie anbexen Yad)en, tweinen, janutern; bie cinen

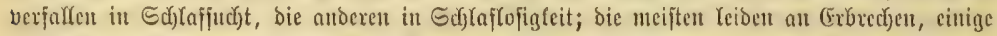

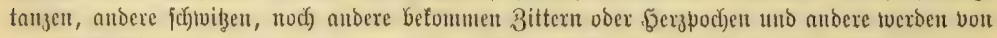

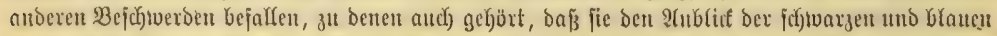

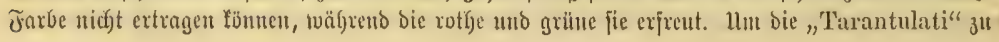


Keilen, fpielt man ihnen auf irgento cinem Injtrumente ztoei Melobien bor, bie "\$aftorale"

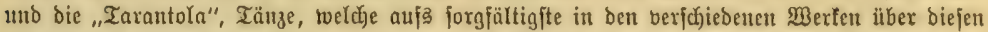

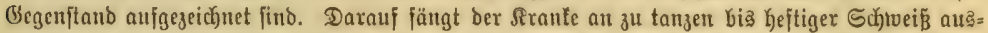

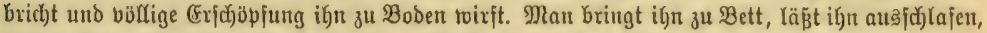
und nach bem (Erwadjen ift er geheilt, weiß aber uichts von alle bem, was mit ifm borgegangen

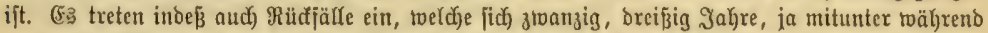

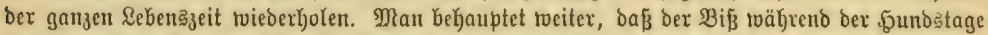

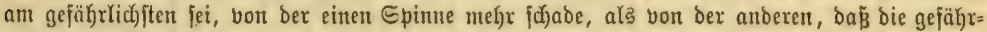

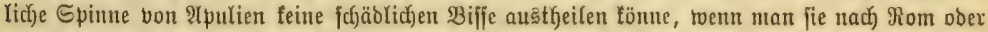

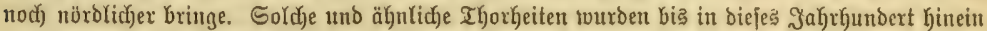

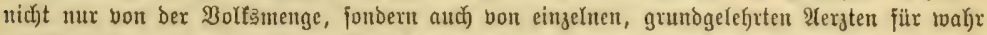

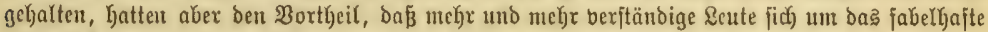

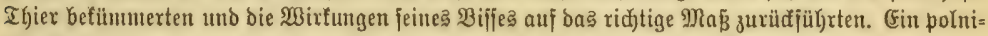

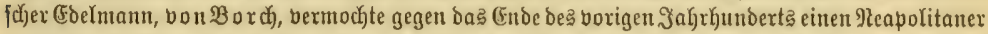
gegen ein (Gef d)ent, fid) in feiter Giegentvart in ben Finger beipen zu Yaffen. Die .̧and entzündete

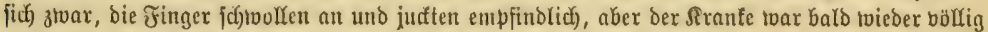

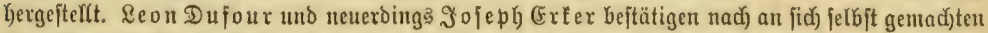

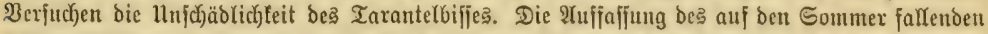

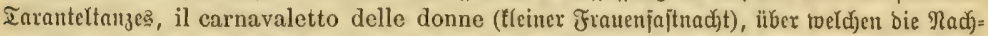

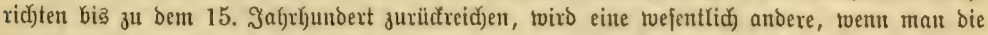

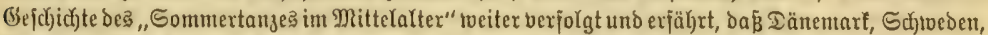
(England, Franfreid) und Deutjd)lanto gans äfnlidje (Exjd)eiungen aujutueijen baben wie bie

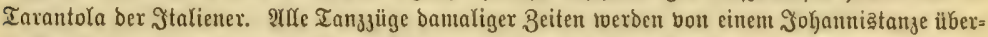

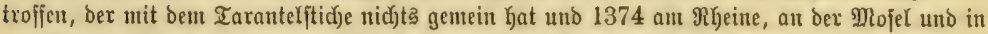

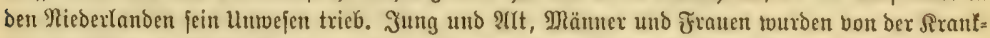

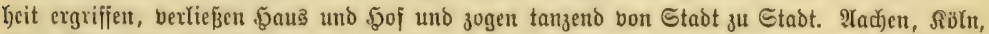
Mełs, Majtricht, Rüttid) und andere Drte twerben uambajt gemacht, too man auf ben Straßsen, in

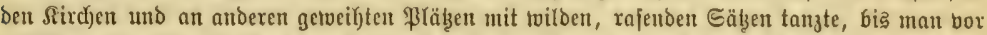

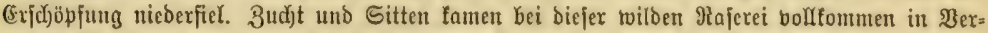

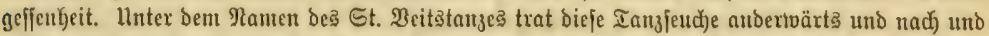

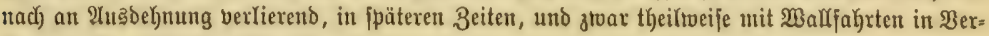
binbung, immex twieber einmal auf.

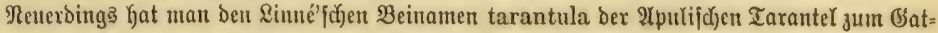

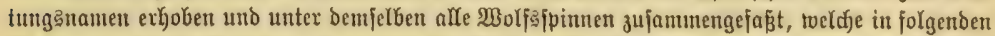

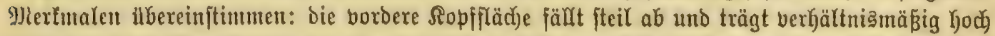

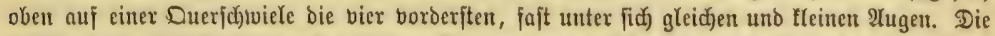

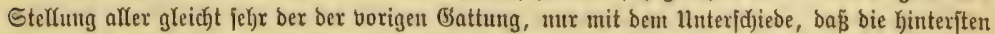

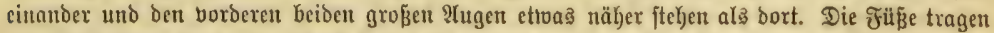

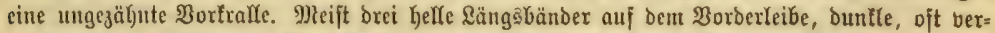

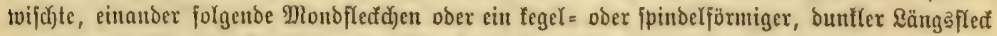

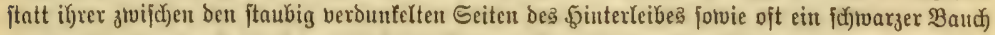

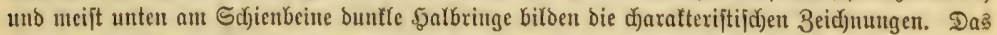
Weibchen bejeftigt jein fleine

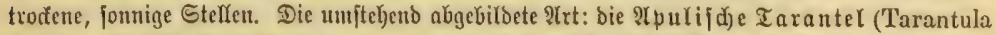

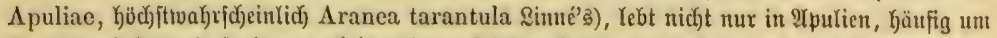

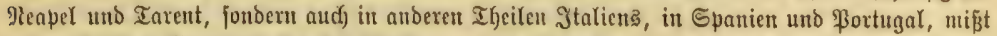

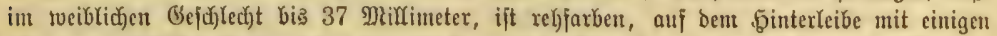

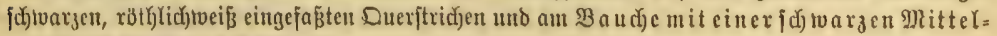




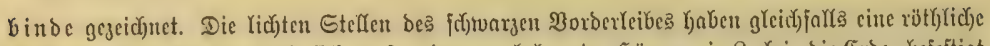

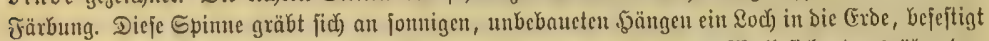

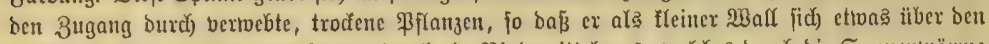

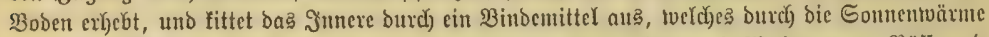

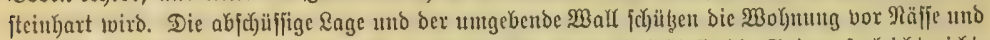

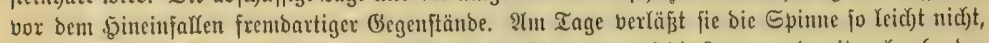
jondern nur nad) Eomenuntergang legt fie fich) ant (Eingange auj oic \&ater, und mit anbrechenoer

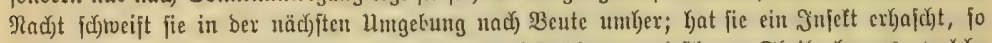

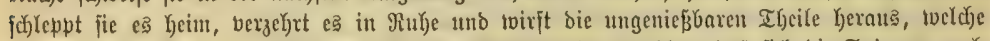

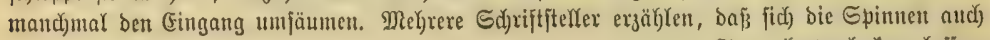

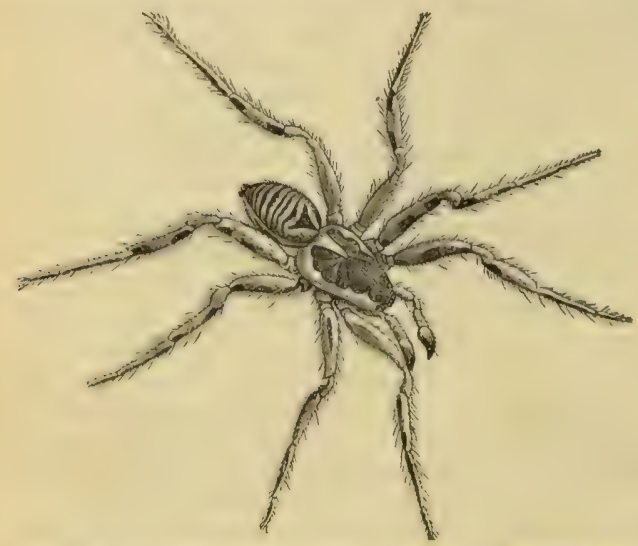

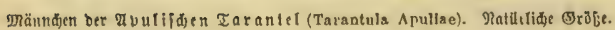
ant Tage Kerworlorten Yajjett, เoenn man mit einem ఇohrkałme it Dasิ \&od hinein blaje in einex das Sumuten ber Biene nady)= ahmenden Weife, twas bie apu= lifochen Ranoleute jefyr nut ver= jteben. Nom Dttober bis zum Frübjabre findet man bie $\mathfrak{W} \circ\}=$ mung ber Iarantel zum Ẽdjuze gegen bie rauke Jahreszeit mit einem $\mathfrak{B a l l e n}$ von alferlei trofe $=$ nen uto durch) (Seppinjtjäben ver= bundenest ßflanzentbeilen ver= ftopft. 31 (Ende ifrer twinter= lichen (Eritariung fann es ge=

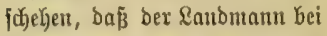
Bearbeitung eines längex brach gelegenen' Stüc: Randes mandje Iarantelwolysung umftitrzt uno zeritört. Dann aber zeigt fidu

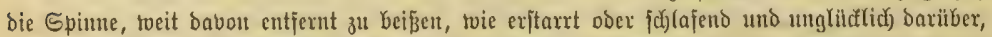

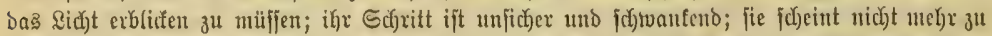

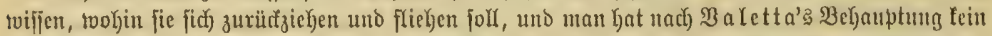

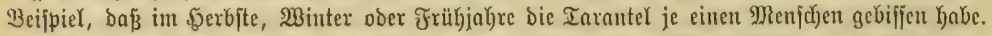

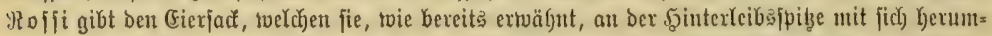

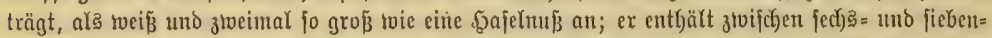

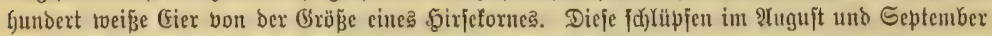

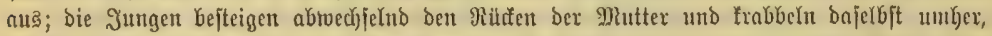

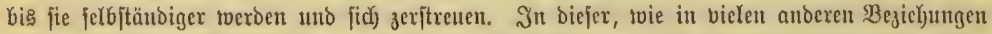
3cigt mithin bie gefür(f)tete Iarantel biejelben Erfcheinungen, wie bie vielen Battungägenvfien

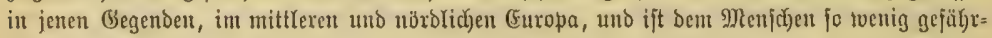
licif) twie biefe.

Derfelben Familie, toenn audid) anderen (Gattungen, gebjut ficher cin Theil ber abenteuertictyen

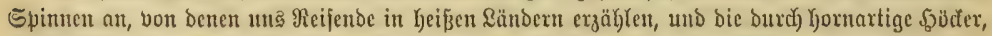

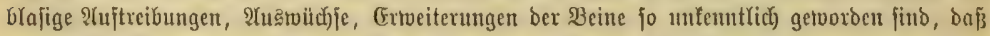

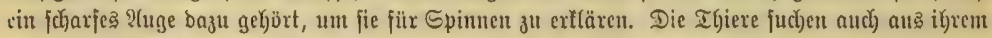

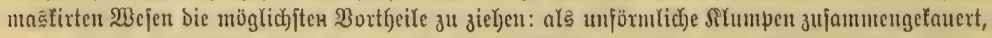

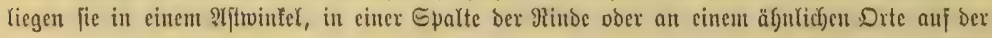




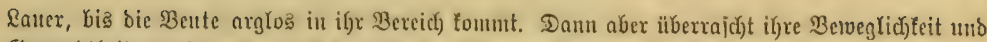

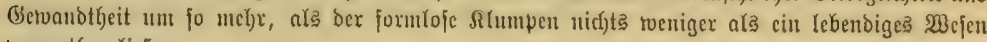
bermutfen rieß.

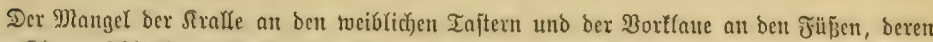

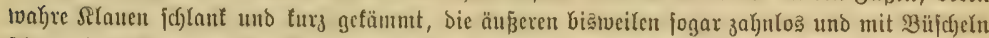

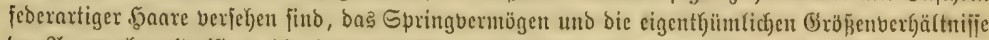

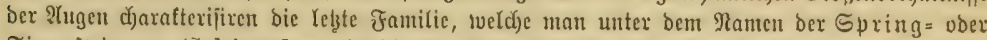
Iigerfpinuen (Saltigradac, Attidae) zujammengejajt hat. Die vicr \&ugen ber vorberen

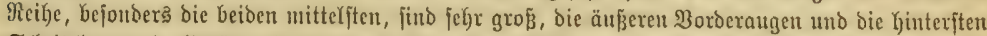

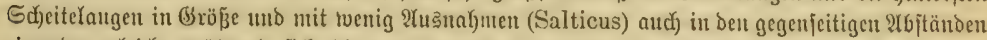

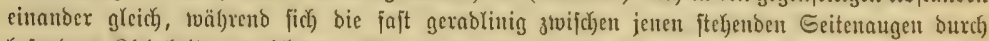

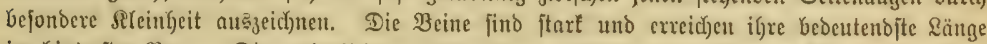

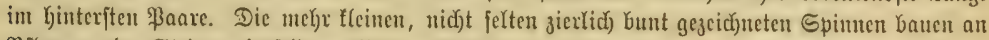

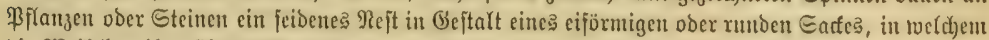
bie Meibdjen ihre (Eier aufberwahren.

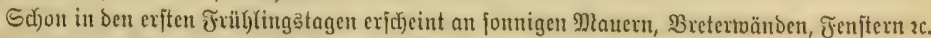

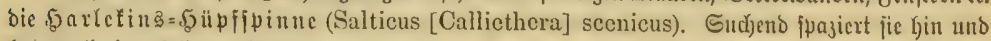
Lex, nady) einer Frisge, einem

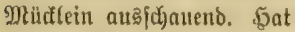
fie ein Dpfer exipäht, fo fdj) (eiç)t fie unter Uumftünocn notic) etron näber Keran uno fib̨t bempelben mit cinem Sprunge, babei einen ibr Đerabjallen fictjernden Faben Ginter fich gieljent, auf bem Rücten. CFin, zwoci \$ijfe ma= d)en bie überrajd) Fle Fiege fdunell roiberftandsunjäbig;
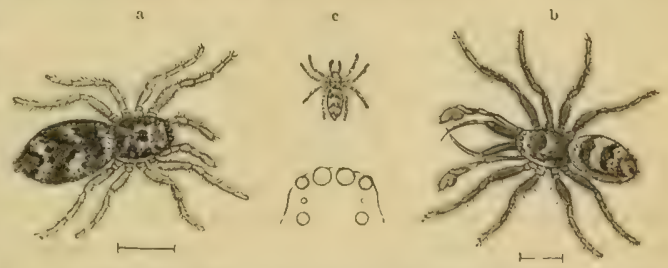

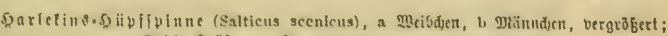

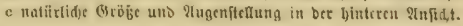

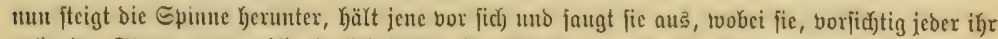

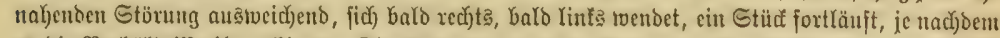

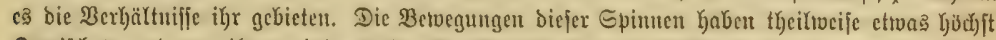

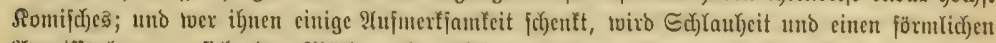

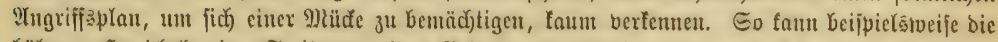

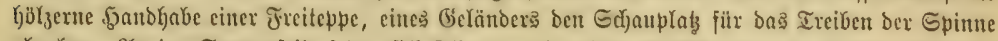

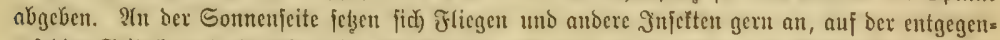

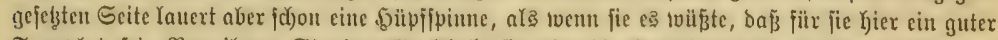

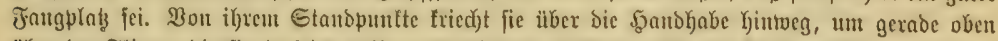

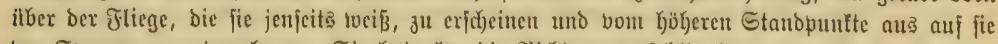

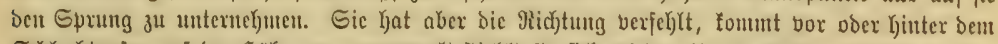

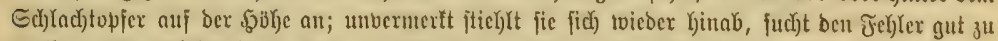

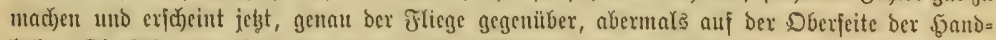

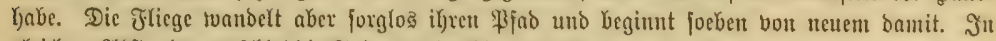

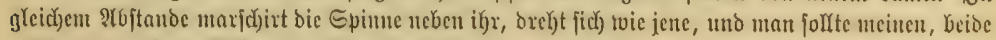

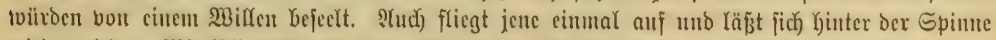

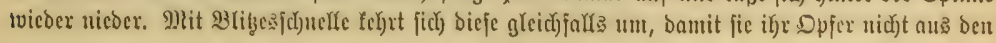




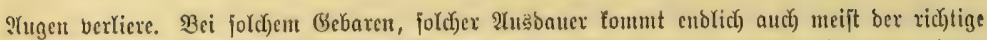

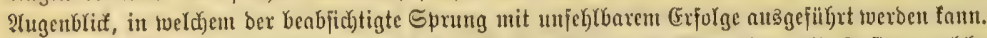

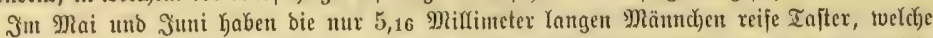

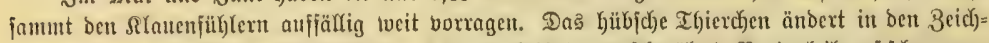

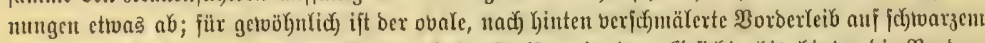

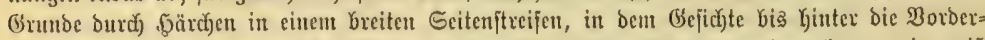

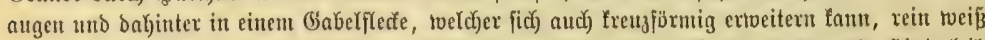

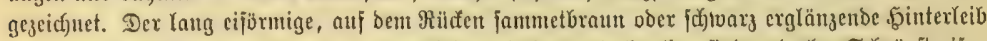

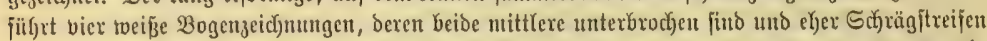

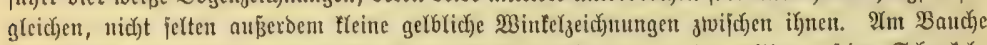

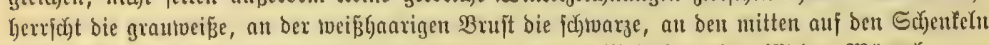

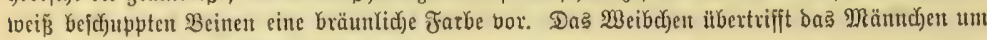
2,25 Milfimeter in ber Rörperłänge.

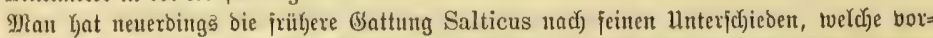

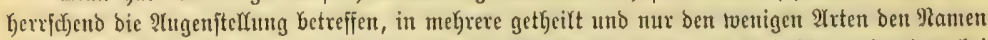

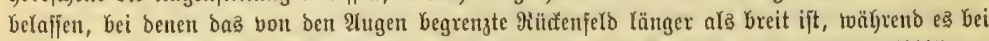
ben meiften anberen unferer heimatlichen Tigerfpinnen, wie aud aus ber beigegebenen T(bbildung

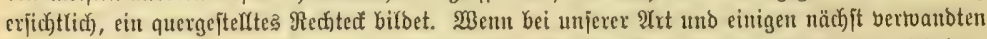

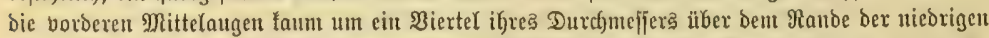

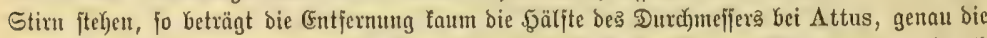
5älfte Gei Dendryphantes uno brei Biertel ober bariber bei ber Gattutrg Euophrys. - Durd) befondere Edjünheit iffer 2trten zeid)net fich bie int füblidjen und feltener fdoon im mittleren

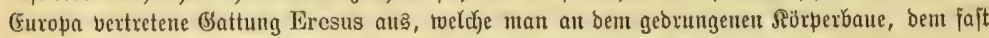

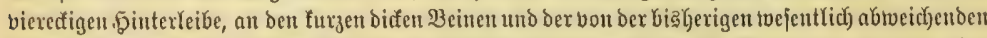

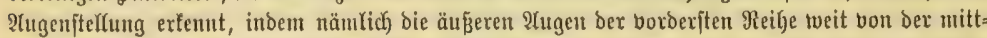

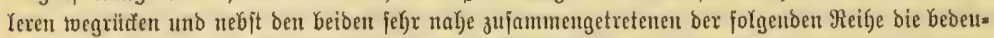
tenbfte (Srtöpe erfangen. Die fajt 10 Mtiflimeter meffende farminrotge Springipinne (Eresus cinaberinus ober quadriguttatus) gejört зи ben fdjönften Spiunen (Enropas. Sie ift fanumet=

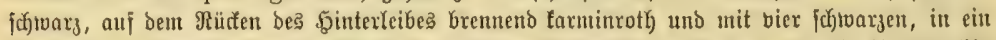

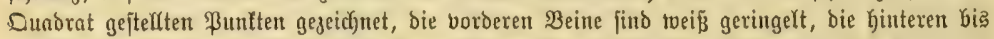

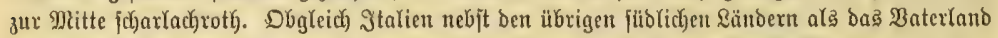

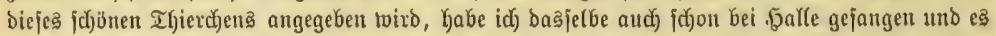

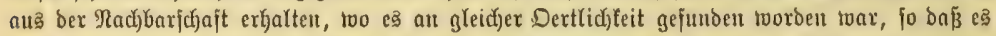

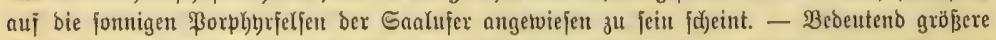

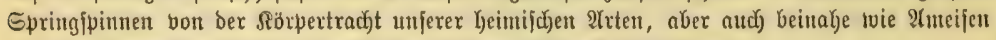

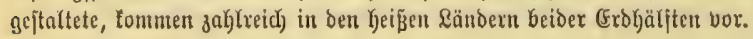




\section{Dritte Oromung.}

\section{Dic Milfen (A carina).}

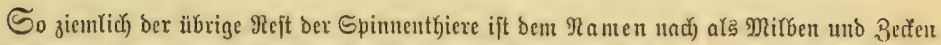

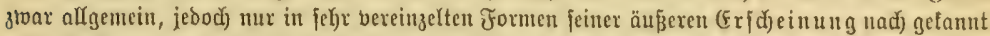

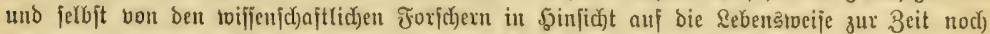

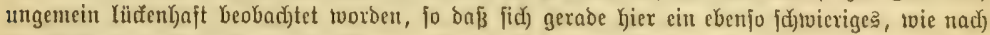

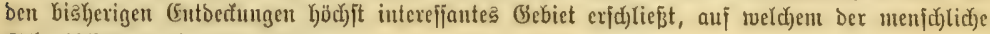
Suljarfblid exprobt werben fann.

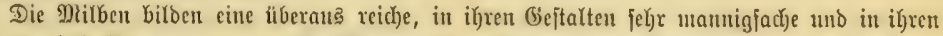

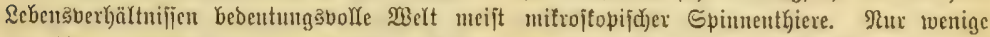

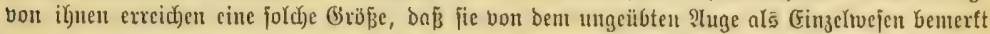

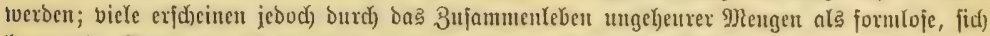

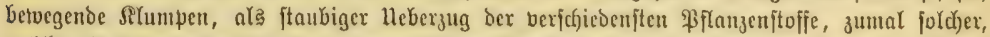

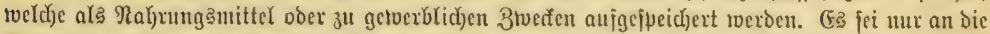

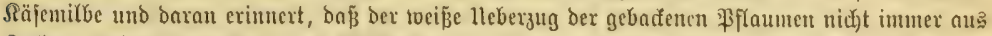

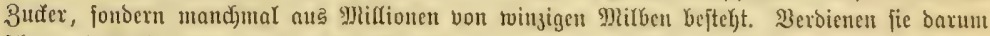

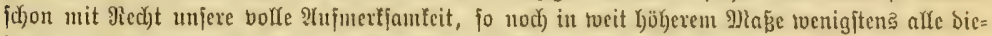

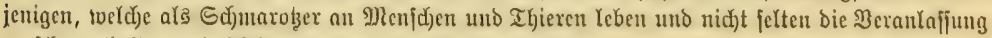

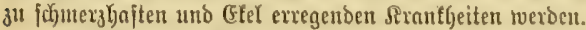

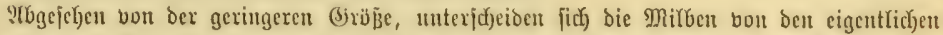

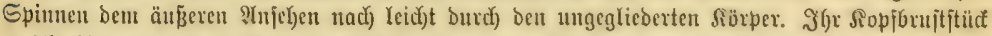

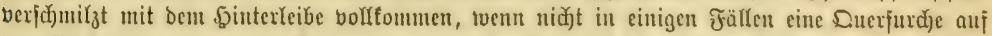

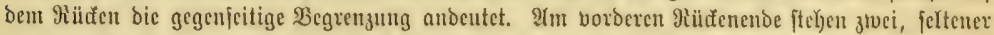

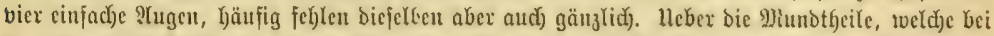

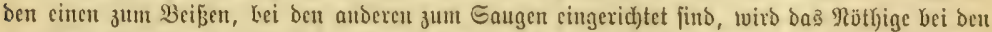

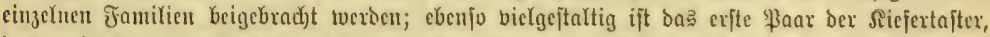

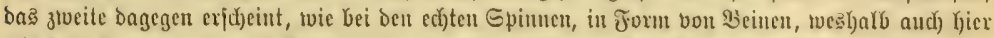

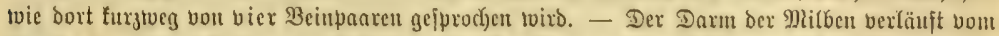

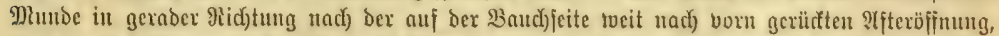

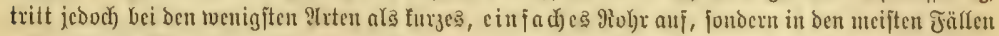

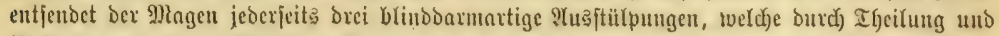

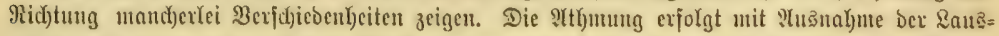

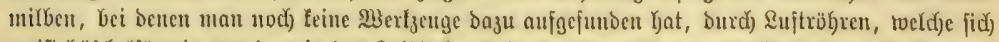

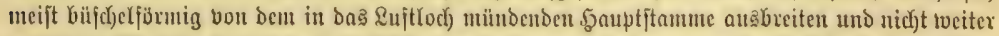

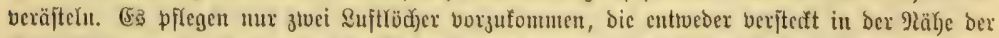

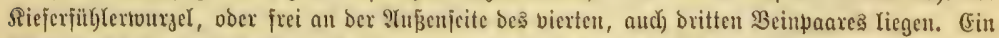

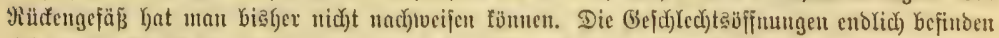

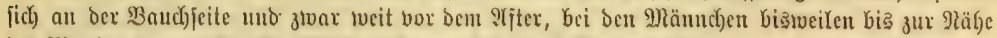

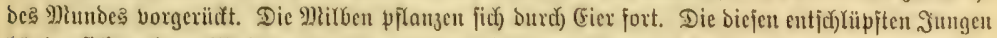

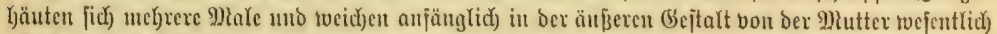

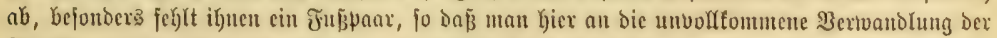

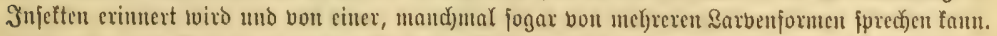

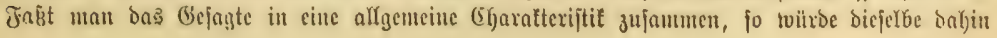




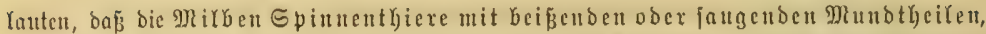
ungegliebertem Reibe unb beinformigem ztoeiten siejerpante find, toeldae meijt

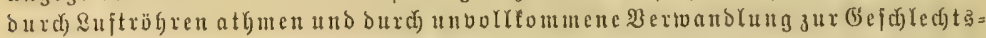
reife gelangen.

Die gemeine Sammetmilbe, Roch) enilfmilbe, bas Sammetfänferden (Trombi-

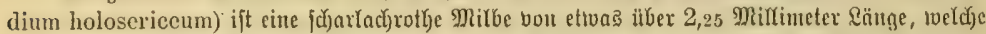

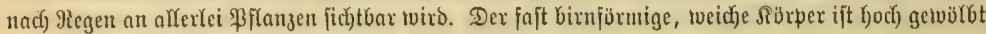

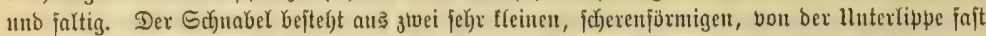

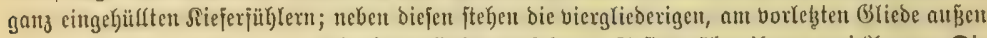

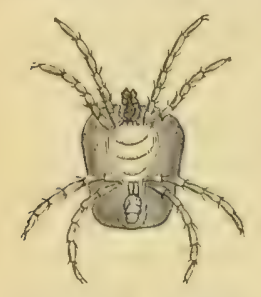

Sod)cnitlatitbe (Trombldium holosericeuns) von ber Haudjeite; ad)tutal bergrỏsert.

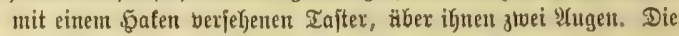

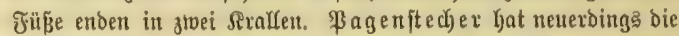

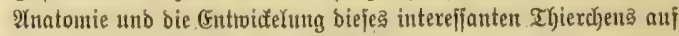
basె ausfübrlidjfte betannt gemacht, jeboch fann hier nidjt genauer

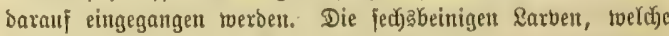

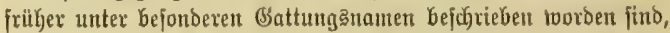

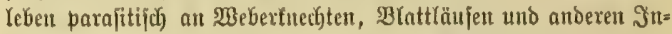

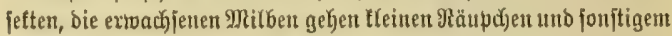

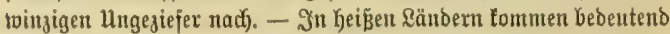

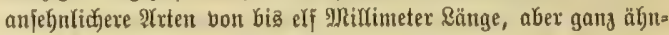

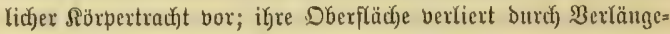

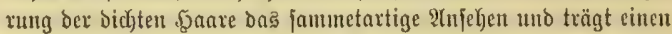

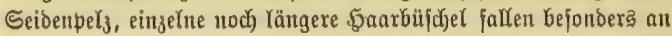

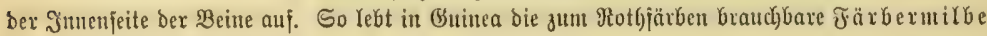
(Trombidium tinctorium).

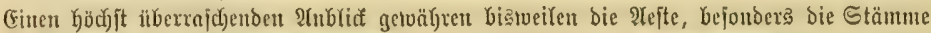
alter Sinden, wenn fie, ifyer $\mathfrak{B}$ lättex bernubt, von oben bis unten auf ber Sonnenjeite mit einem wie (Fiß glizernden Gefpinjtüberzuge verfeben finb. Bei genauerer Betrad)tung finbet man

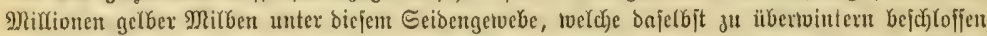

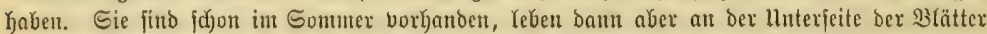

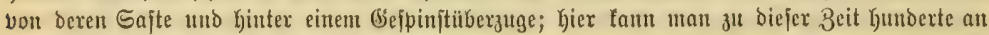

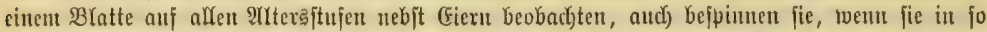
bedentenden Mengen vorkanden find, bie ITejte, falfen aber tvegen bes Raubes tveniger in bie शugen. Die Mirbenipinne (Tetranychus telarius ober tiliarum oder socius), um tweldje ę

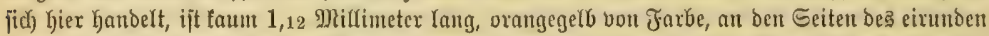
¿eibes mit je einem roftgelben Flefficen berziert und fein befaart. Die Siteferfüler find nabel=

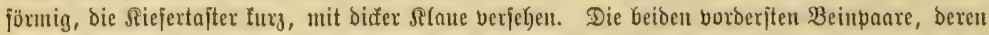

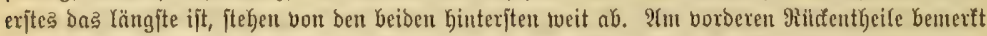

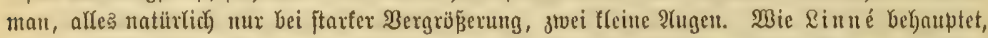

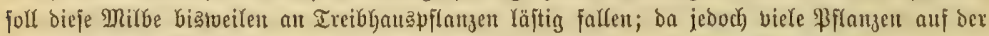

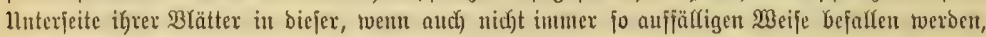

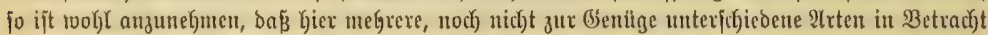

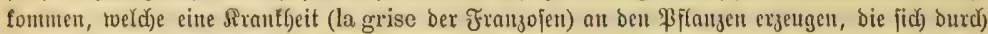

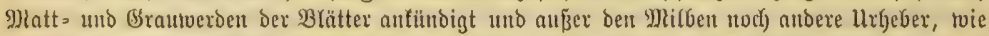

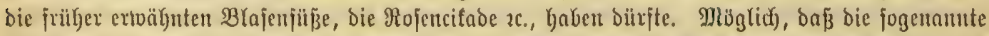

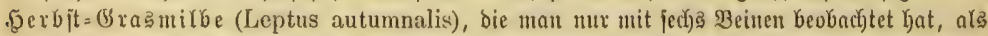

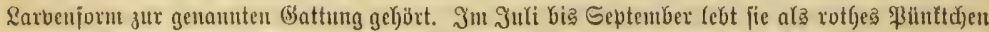

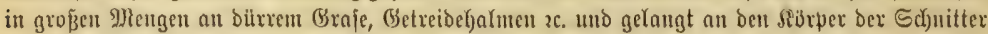

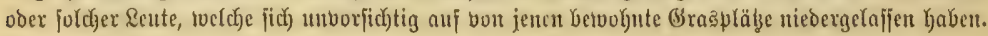




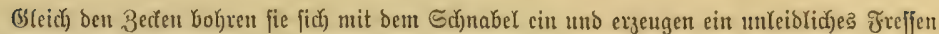

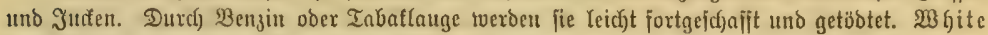

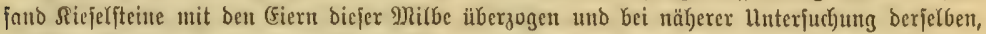

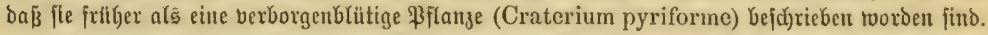

(jierker blixften auch) biejenigen Milken zu verweijen fein, beren Battunganame Phytoptus

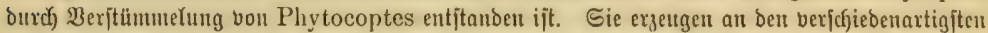

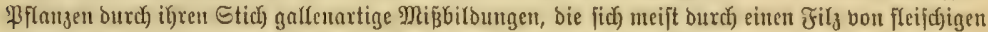

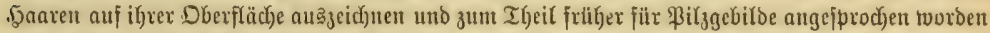

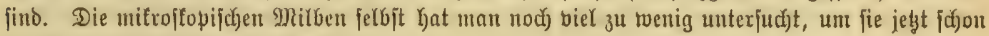

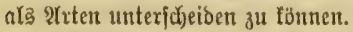

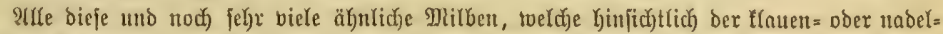

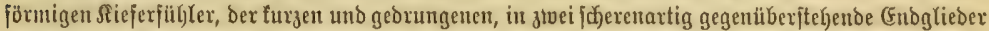

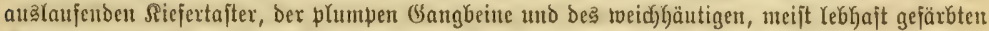

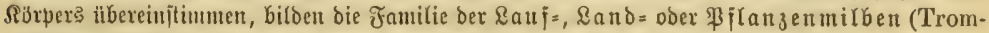

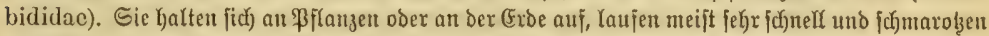

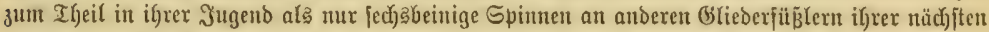

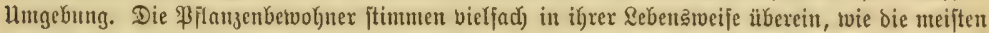

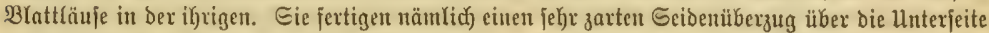

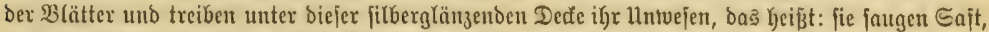

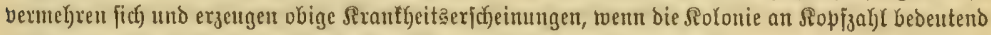

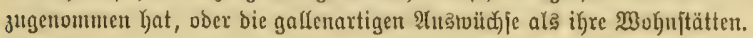

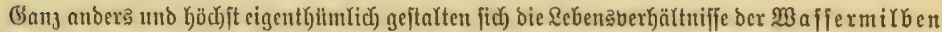

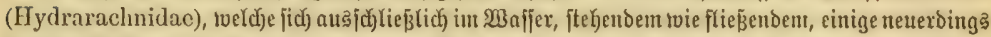

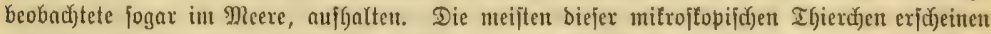

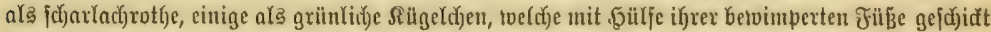

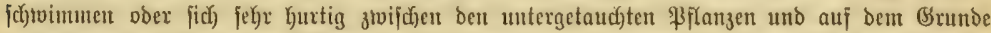

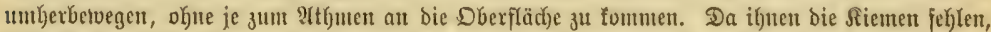

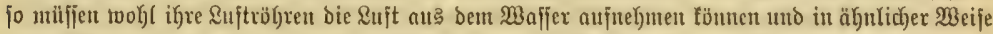

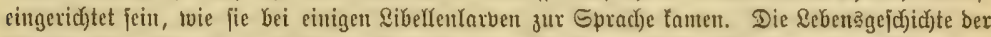
Wajpermilben ift reidy an feltfamen (Exjd)einungen; fo fommen beijpiels̈tveife mehrere 2 rten vor,

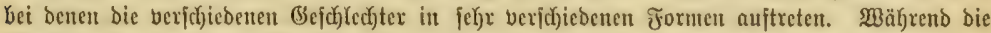
Weibchen ber Gerrfhchenden fugelform tren bleiben, endigen bie Mänudjen in eitten fdytwanzartigen

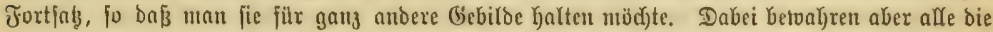

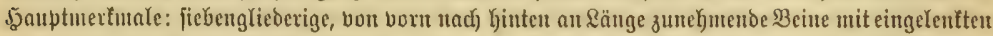

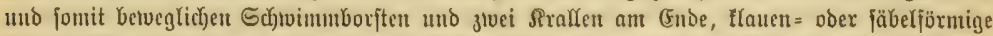

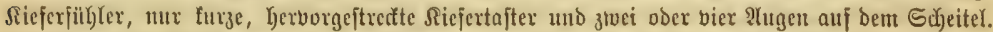

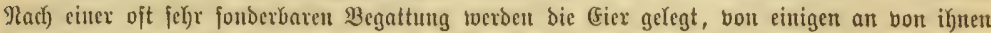

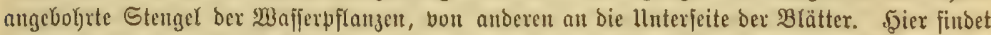

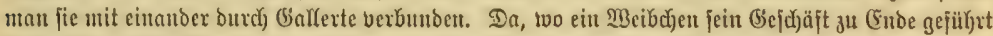

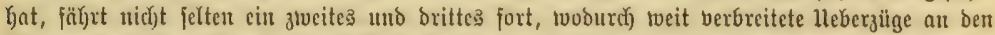

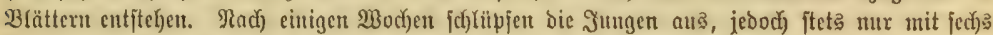

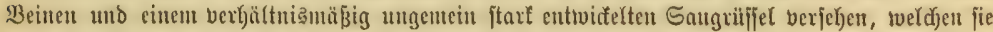

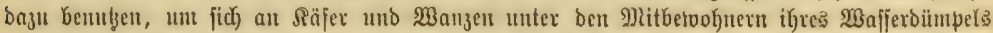

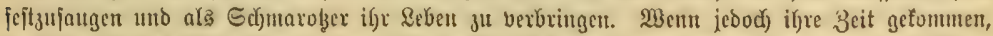
verlafjen fie bas Mohntgier, häuten jid̛), twobei bie Beine turzer twerden, gehen auf ben Boben 


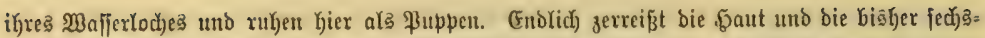

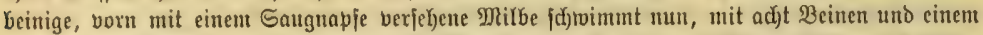

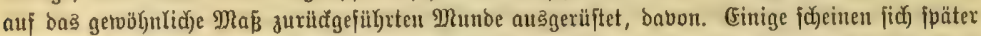
nod)mals feftzujeb̧en, bieşmal aber an ciner Bafjerpflanze, unb eine soeitere इäıtung zu befteben,

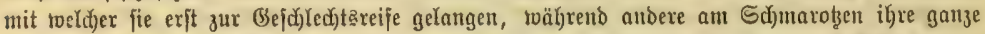

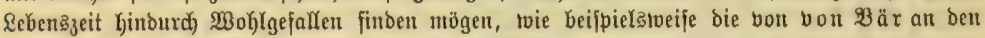

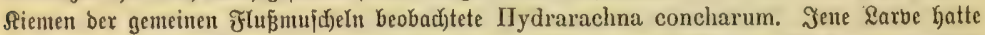

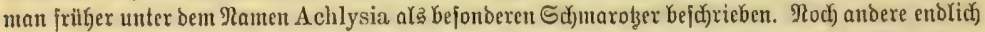

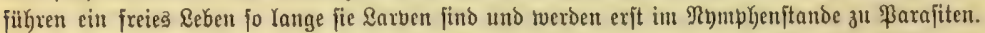

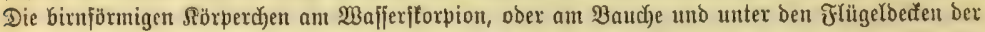

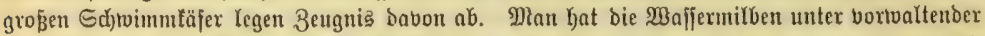

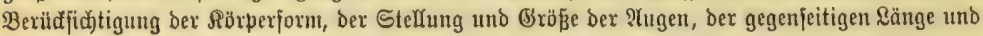

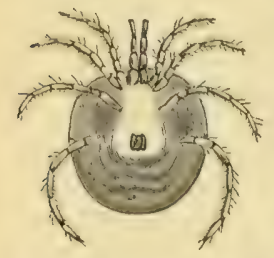

Rugelige ₹fubmilbe (Atax sly.

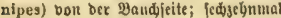
virgröbert.

Bildung Der Tajterglieder, twie Der Beine in mehrere Battungen getheilt, bon denen Atax und Nesaea bie artenreidjiten find.

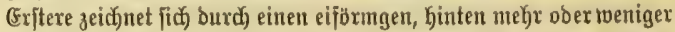
abgeîtubsten Reib, toeit atseinanber ftekenbe, mit einem Seiten=

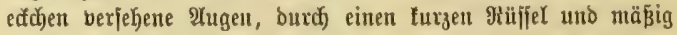
lange, fpindelförmige Tajter aus. Dex Schnabel bejteht aus einer lanzettjörmigen Dbexlippe, zwei Yanzettfürmigen, etraas gebogenen Siefen, einer fleinen 3unge und ben vierglieberigen, am vor=

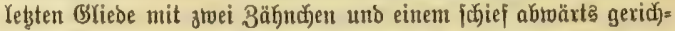

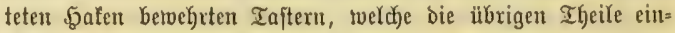
hüllen. Die hierber gehörigen IGierdyen fütb bedäd)tige, in ifgren

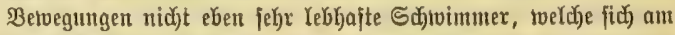
liebften an ruhigen Stellen fleiner Getväffer aufhalten uno mit auggebreiteten Beinen nahe ber

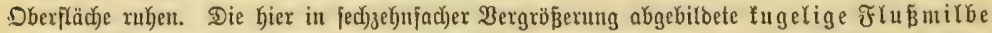
(Atax [Hydrarachna] spinupes) d)arafterifirt fidd) burd) cinen faft fugeligen, hinten fajt regelmäpig

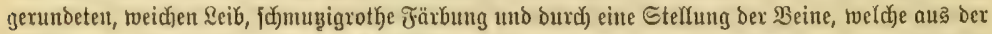

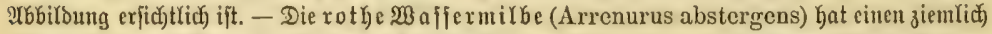

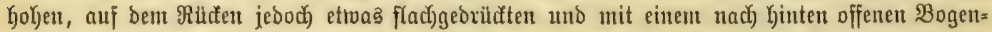

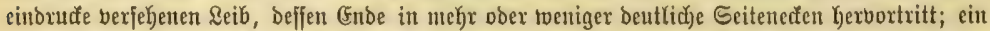

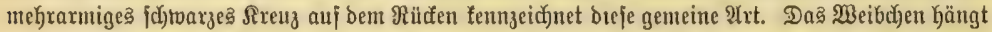

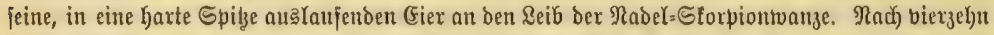

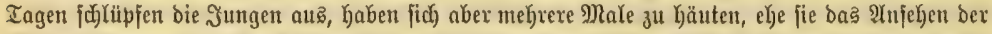

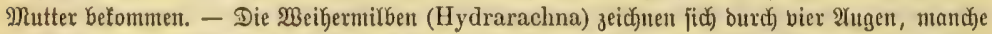

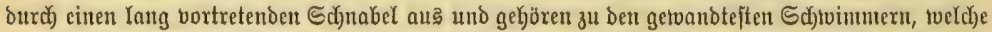

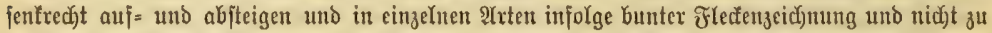
beneutender Rleinheit von einem aujmerfjamen Beobachter twahrgenommen twerben tömen.

Die Schmarob̧er= oder Thiermilben (Gamasidae) haben foberenförmige Siejerfübler,

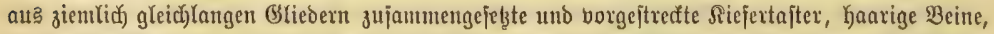

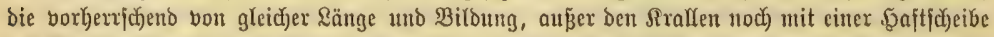

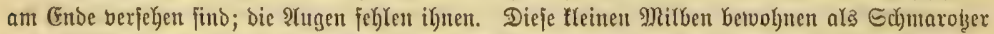

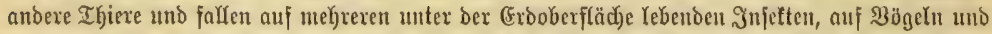

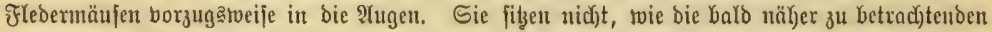

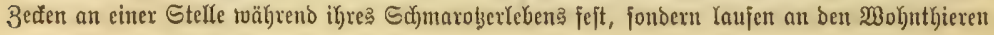




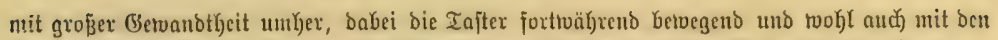
Dorberbeinen tajtend. (Fine ber häufigiten Mrten ift bie gemeine $\mathfrak{I} a ̈ f e r m i l b c$ (Gamasus coleoptratorum), ein jiemlid) hartes, rothgelbes Ifierd)en von ourd) fdidnittlid) 1,12 Mliflimeter

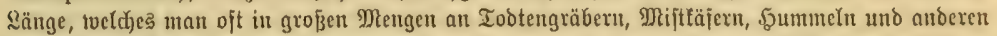

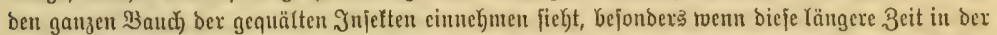

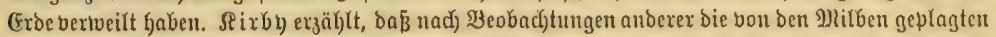

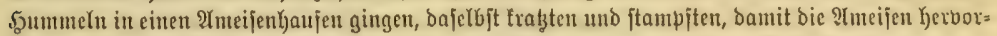

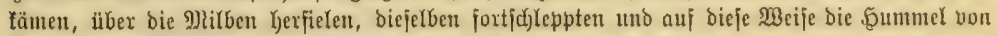

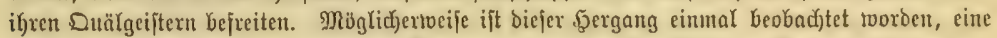
ermattete .

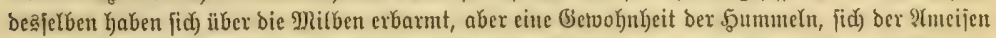

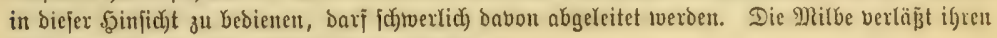
Wirt, wenn ex toot ift, Yebte in ifrem Sugend= alter zroeifelogolyne in feudfter (Frbe und frod)

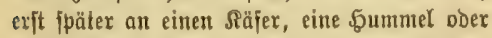

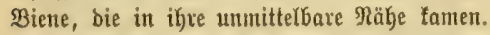
Die (Seftalt ber Siäjermillbe \äßt fidc) aus umferer 2rbbiloung exjehen, es jei mux nod) barauf auj= mexfjam gentad, baß̄ bie Botberbeine am läng= ften, bie rächiften am bicifiten find, Daß burch) einen Quereinorud bex Sinterłeib bom $\Omega$ opfs

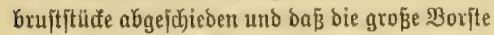
anf ber Sdjulter betoeglid) ift. (Es fommen nod) andere $\mathfrak{A}$ rten mit biejem Ielzeteren Merfmale vor, twäbrend ben meiłten übrigen bie betweglid)e

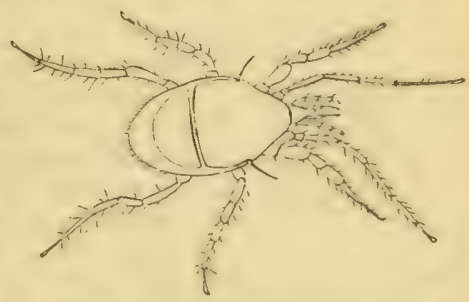

Bemeine Säfermilbe (Gamasus colenptratoruni), frart vergrö̈zert.

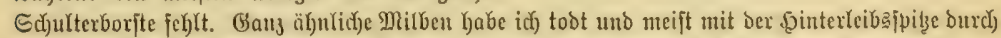

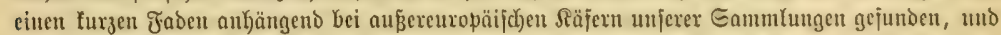

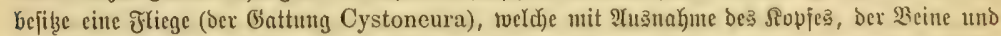

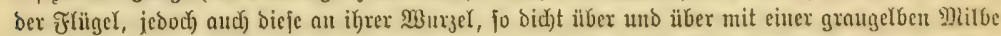

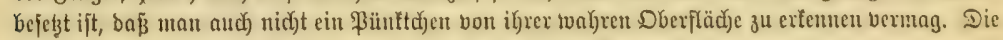
Milbe gebỏnt einer anderen Battung bon mełx länglidjer Form ant:

In näd)jtex Bertwandijd)ajt su ben Räfermilben ftelyen bie tweidjbäutigen, in beioen Ge=

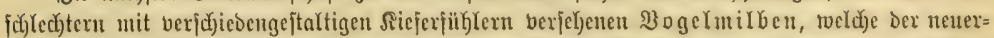

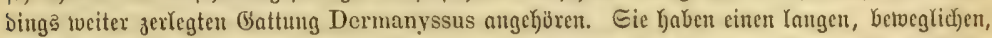

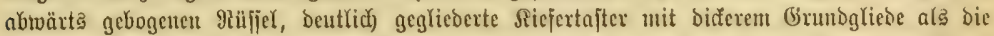

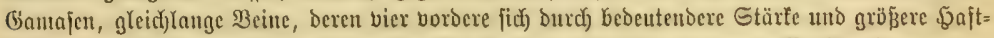
(d)eiben vor ben Kinteren auşeid)nen; fie alfe gelentent nahe bei einander am Bruftrande cin.

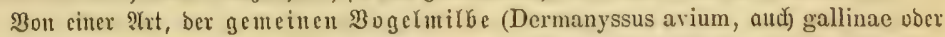

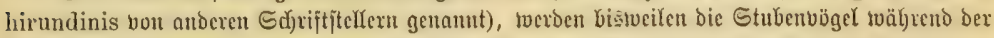

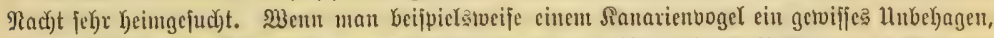

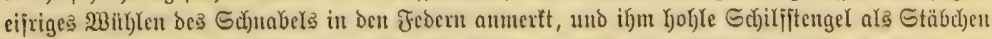

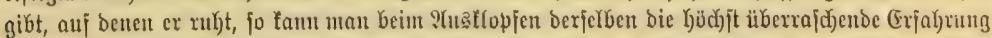

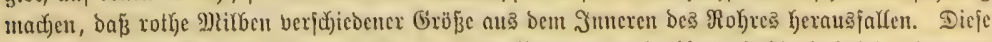

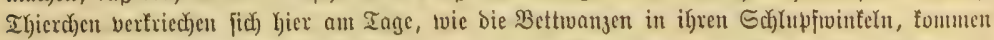

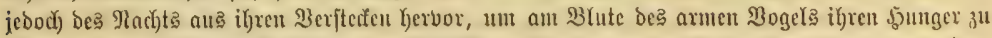

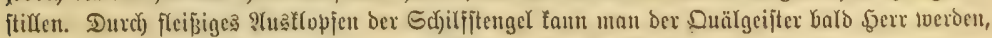

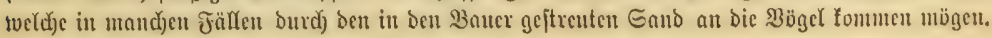




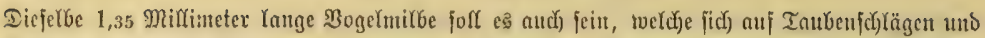

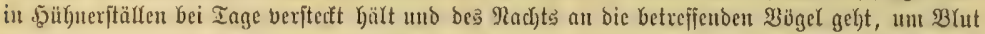

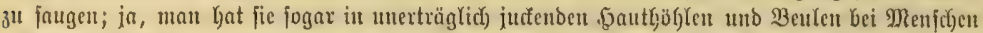

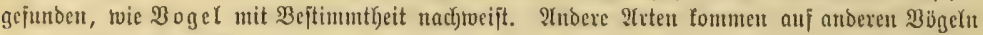
vor und eine auf ber Mauts.

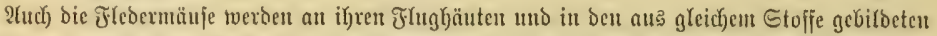

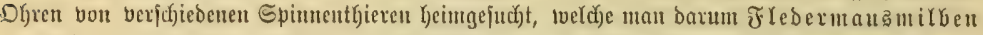

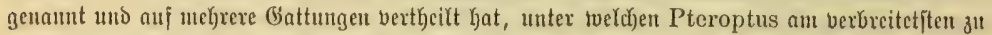

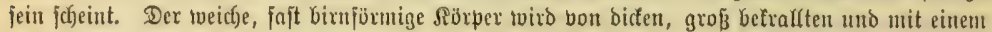
Saugutapje verfégenen Beinen getragen, beren vier finterjte weit entfernt von ben vorderen eingelentt

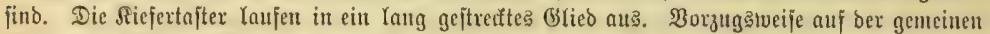

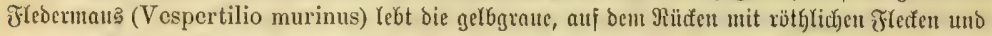
braunen Welfen gezeichnete gemeine \$lebermausmilbe (Pteroptus vespertilionis), von

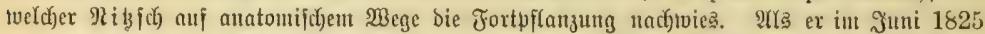

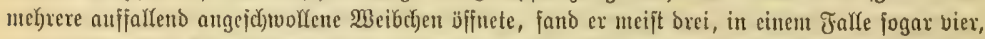

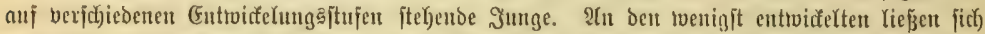
nur fech)

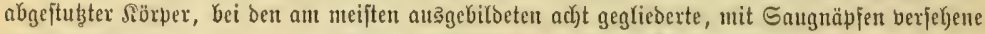

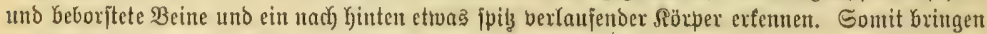

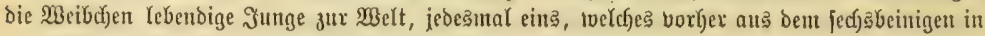

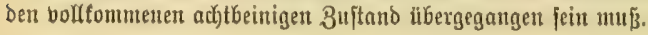

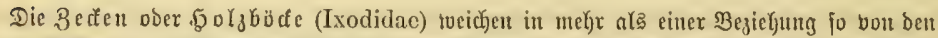

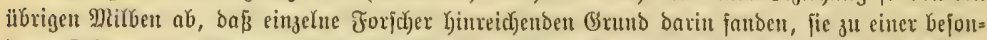

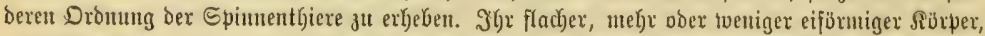
obgleid) mit horniger ober Yederartiger şaut befteidet, befizgt einen jo hohen (5rad bon Deljubar=

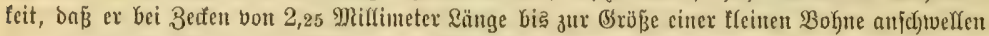

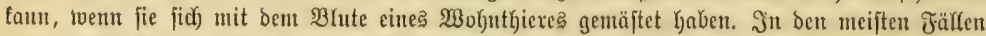

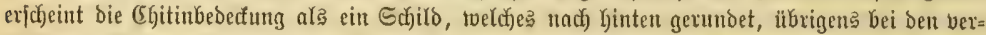

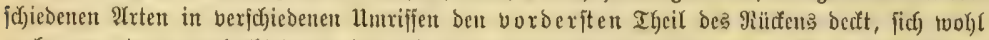

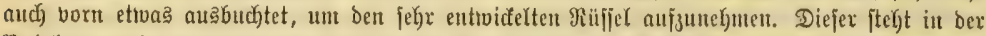

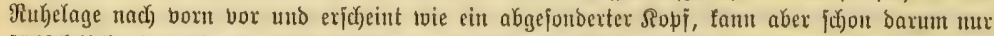

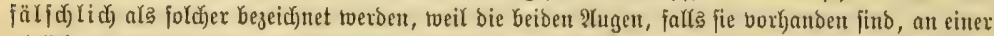

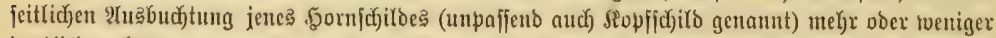

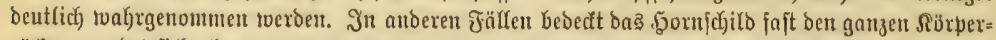

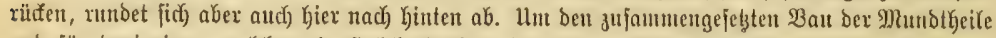

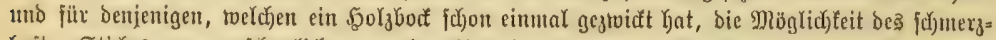

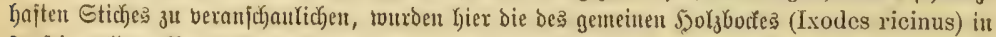
junjzigmaliger Bergrößerung, und ztwar von ber llnterpeite abgebildot. Sin a exblictt man ein

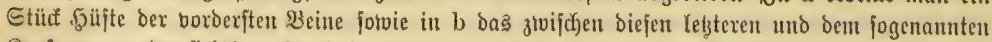

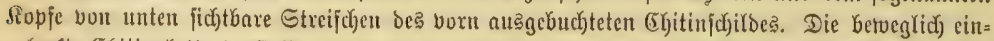

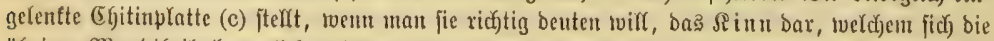

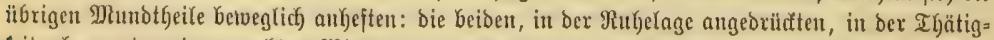
feit aber unter cinem rechten Winfel nbgelentten $\mathfrak{I} a$ fter, bie nut vier Brlieberu $(d, e, f, g)$

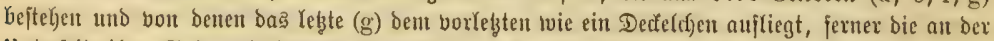

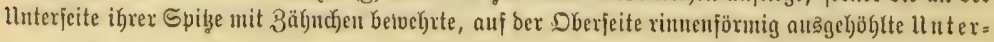




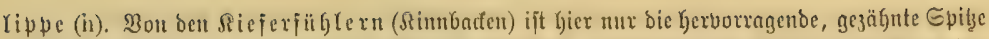

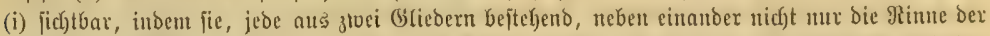

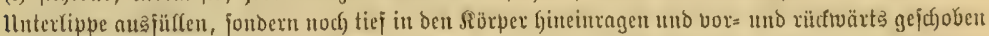

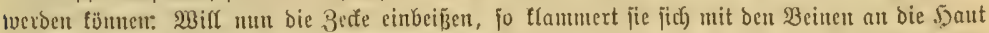

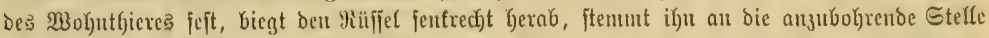

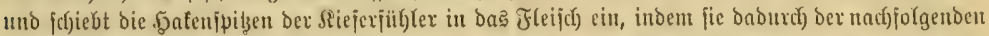

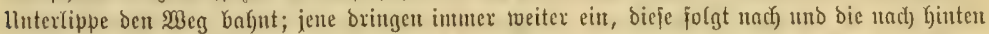

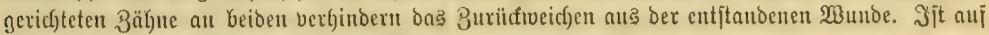

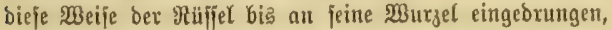

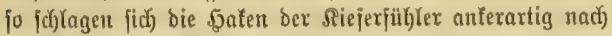
rechts und Yints un, bie stiejertnjter legen fick beiderieita bex Munbe jeft bent fleijodje an, uno bie Bedfe, welche jebst nicht mehri getwaltjant herausgesogen weroen fann, ohne baß̧ ber Rüfiel zurürfbleibt, Gat bie ifr zum Saugen genełme Stelfutg eingenommen. Das Saugrwerfzeltg jelbjt bejteht aus ciner

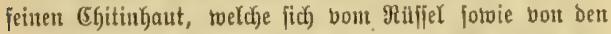
Seiten und bem übermagendem Rande ber Mundyägle her in bieje glofenfönmig einjtuilpt. Die gleichgeitalteten Beine

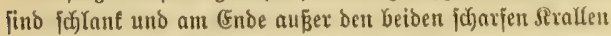

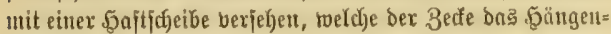

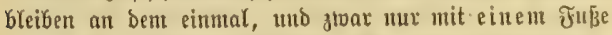
exjaß̧ten Begenftande ermöglidyt. Die beiben eimsigen \&ujt= löd)er befinden fich) in einem (É)itinplättchen, tweldyes jeder=

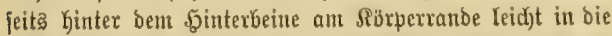

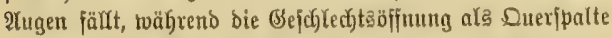
mitten auj ber Brujt zu judfen ijt. Die jungen Bedfen Kaben แur je d)

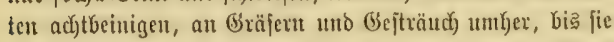

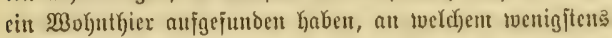

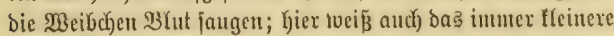
Männd)en ein Meibchen ju finden, un fid) mit benlelben зи

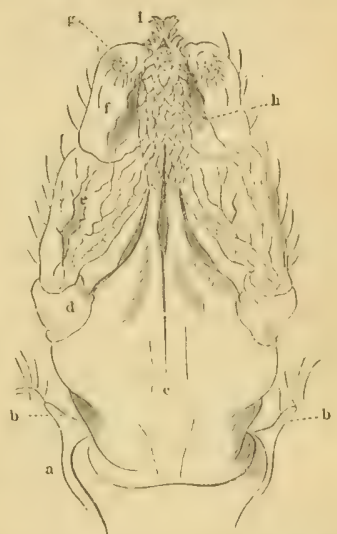

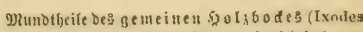
ricinus) vou ber Untericite unb funfigigad ver.

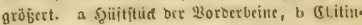
fofliblpitje, c Stimt, d, e, f, g Sicicrtajlergtieber, is Borbertbeil der lututerippe, i Evibe ber Stim. baden. pararen. Diejer Sergang bietet cin hohes Jutereffe uno wurbe bis anf bie neuejte Beit nicht richtig

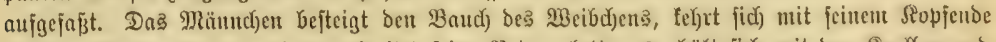

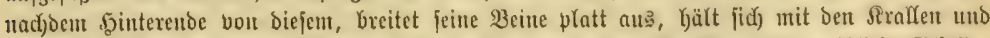

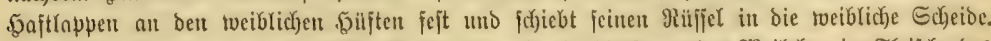

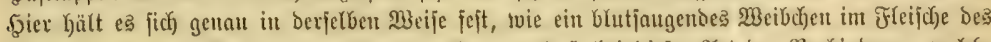

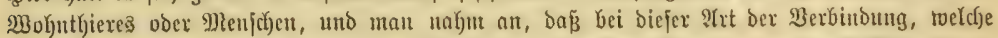

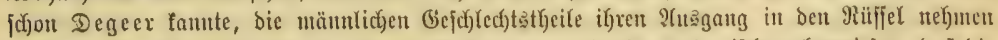

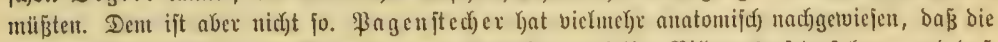

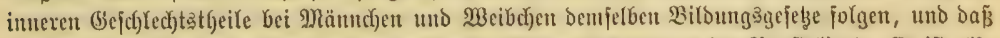

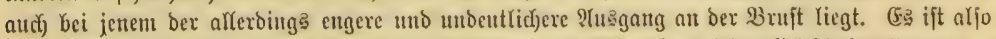

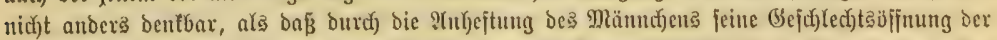

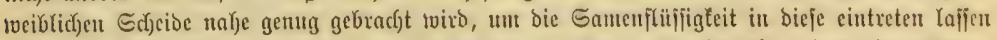

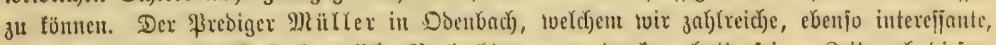

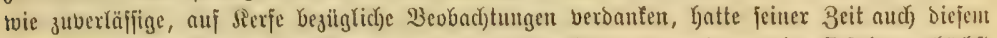

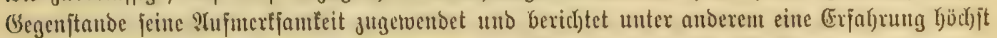

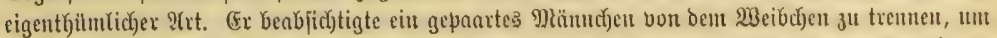

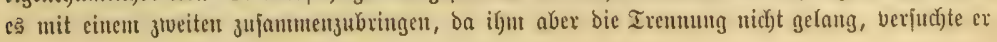




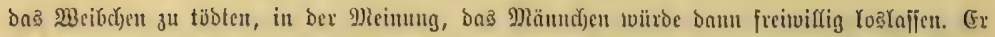

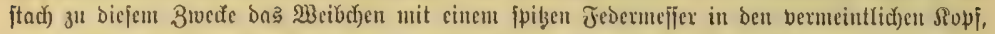

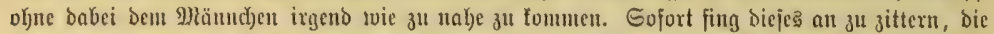

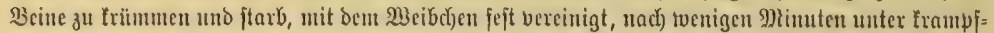

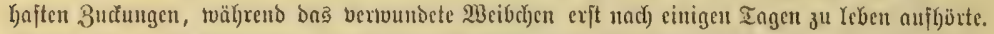

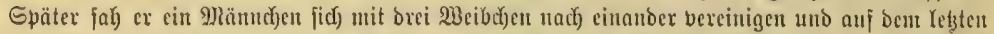

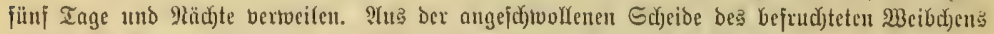

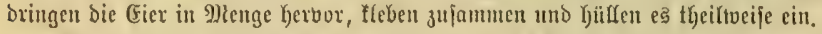

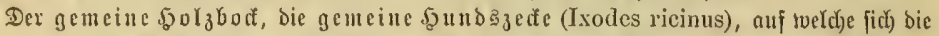

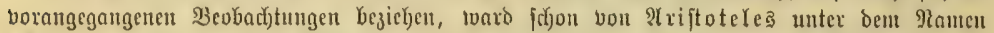

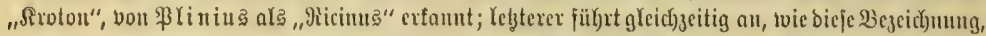

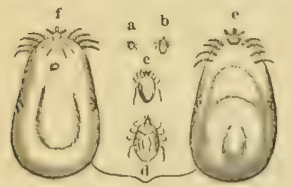

Cenciner soljood (Ixodes ricinus). a. Juncubjuftand mit fuds greincu, 6 Imgeno.

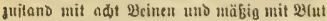

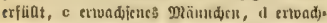

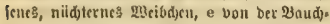
isile vollgciogen, f bagicibe vou ber giaden. icite. (ante Jigureu in sweimaliger $2 \mathrm{Ber}$. gröietung.)

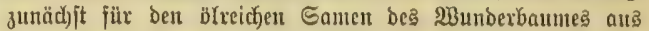
(Eglypten geltend, auf biejes verijaß̧te Tfier übertragen worden fei. Menn \$lutard) in feiner Weije mit ben Ricinus bie

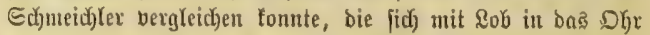
brängen uno nicht toieder auszutreiben fino, toenn fie fid cinmal

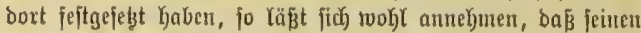

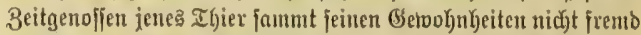
gerbejen fein fantu. PRadjoen Degecr Den Mamen Ricinus an cine \&nusgattung vergeben Katte und Acarus bic Milben iiber:

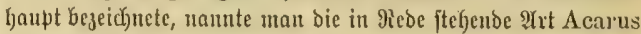

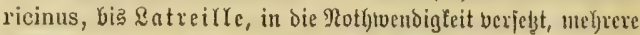
Mlitbengattungen zu unterfidscioen, fie Ixodes ricinus naunte. Ixodes bedeutet aber fo viel twie: "tleberig", "ankajtend".

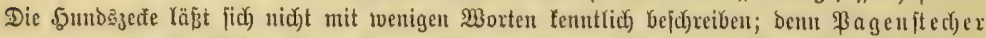

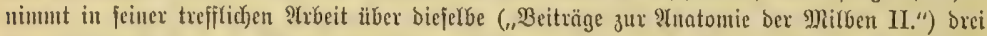

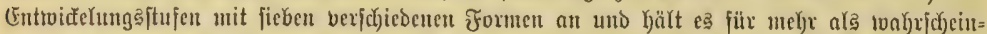

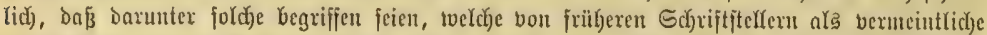

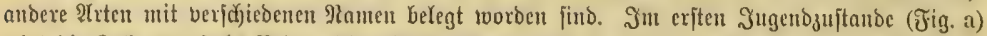

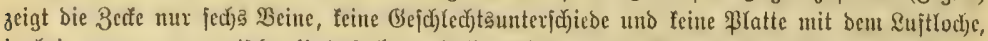

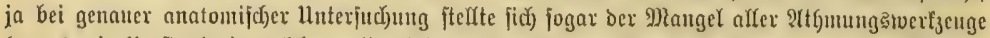

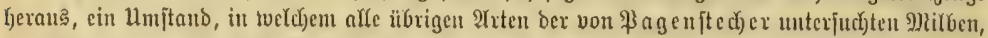

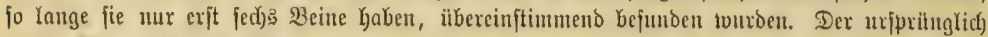

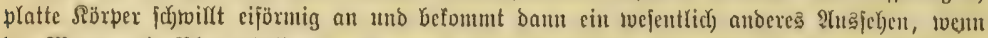

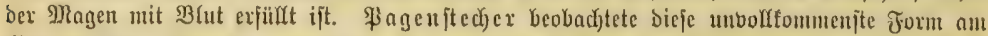

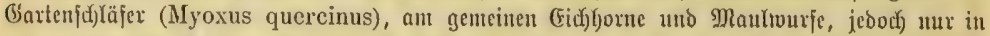

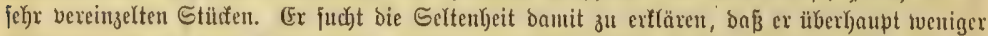

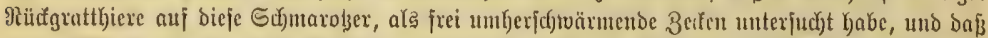

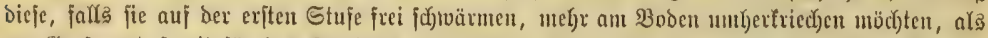

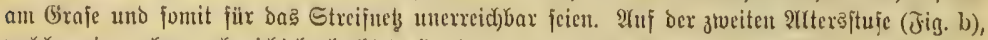

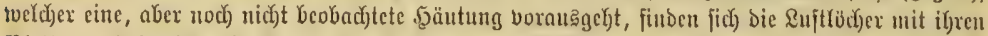

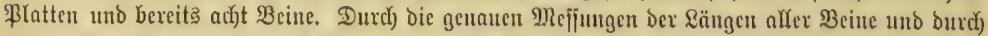

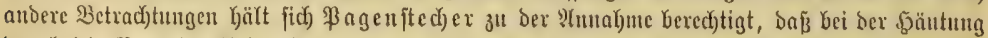

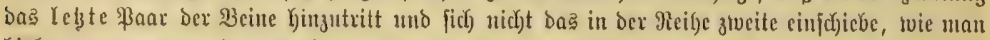

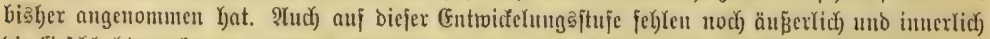

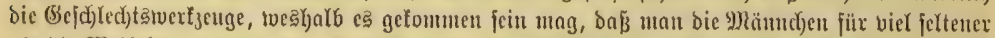

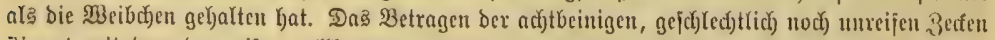

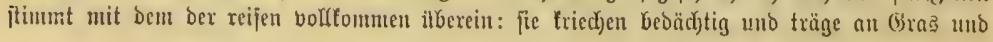




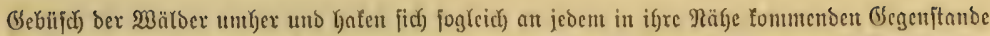

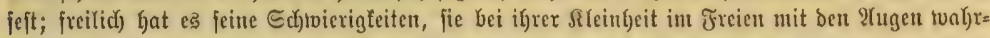

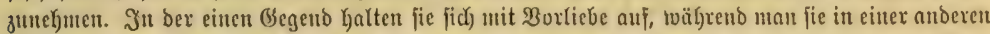

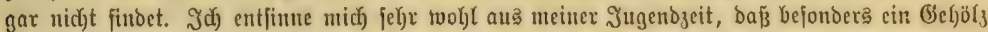

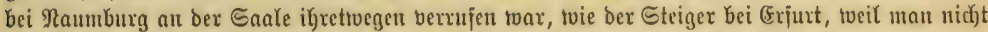

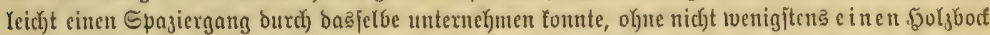

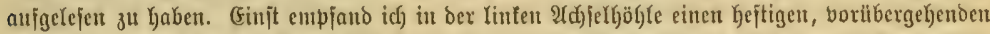

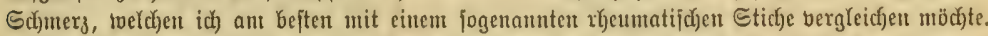

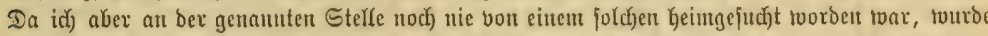

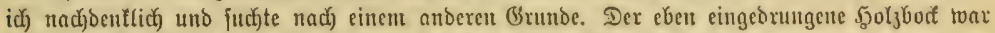

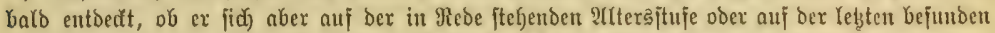

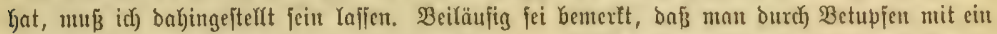

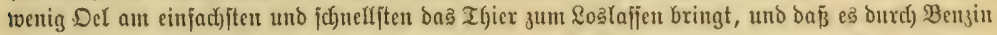

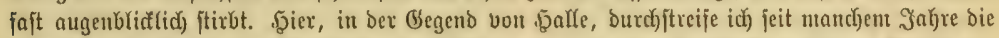

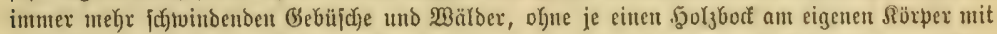

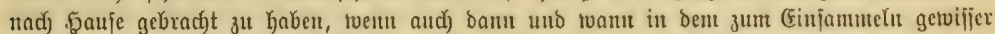

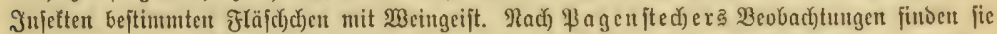

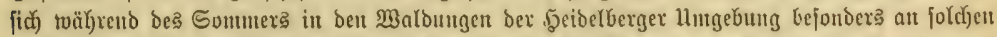

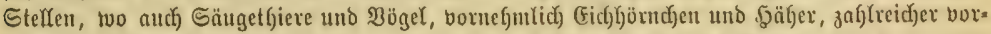
fonmen, oder two Jud

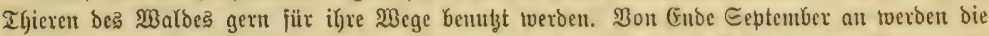

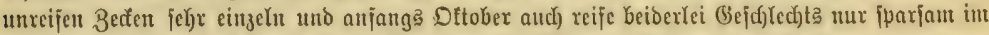

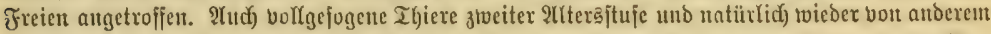

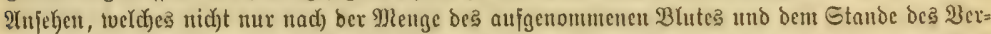

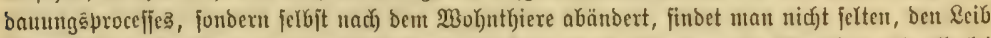

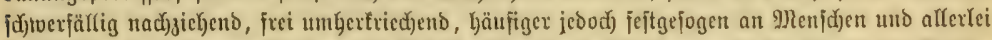

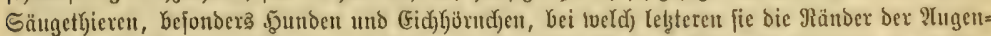

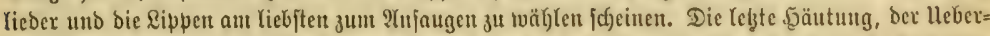

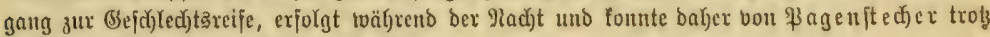
allex Bemilifungen nidjt beobadjtet tuerben.

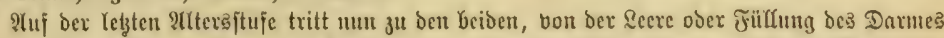

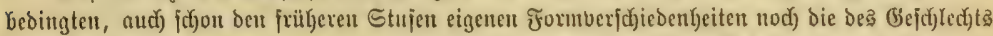

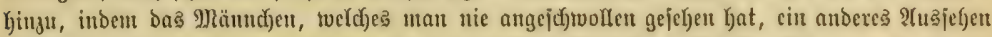

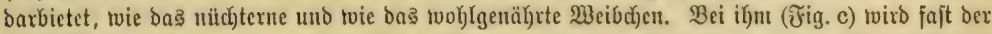

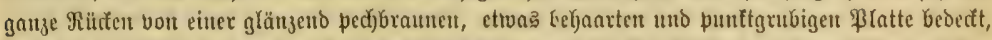

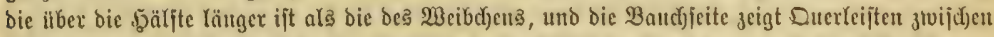

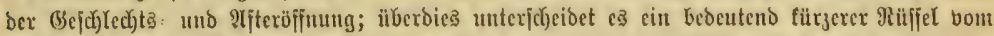

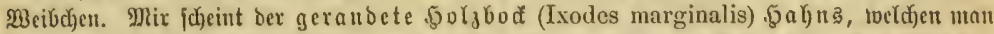

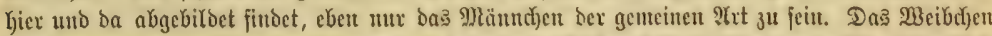

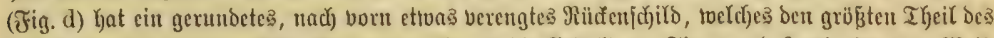

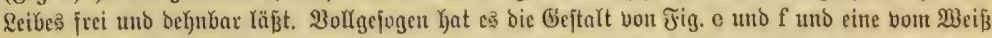

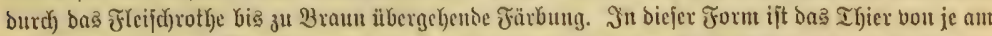

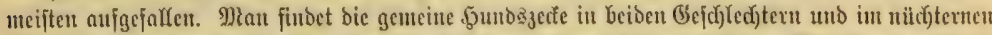

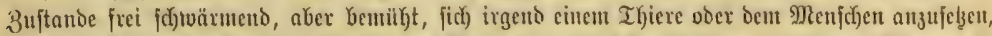

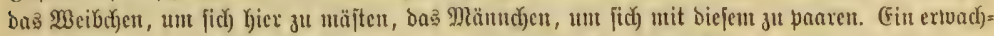

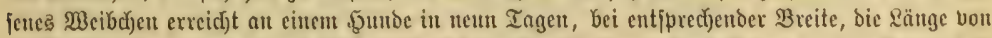

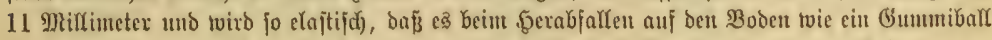

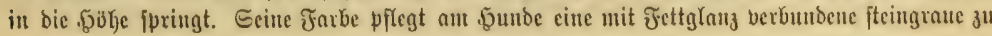




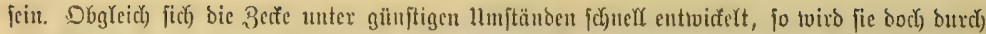

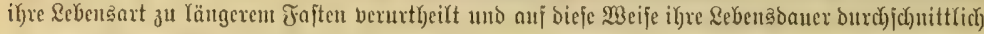
auf bie Zeit bom Mrai bis Dttober ausgebehnt.

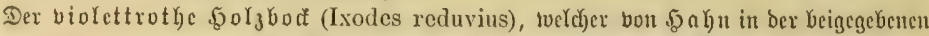

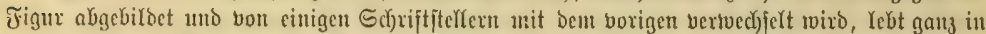

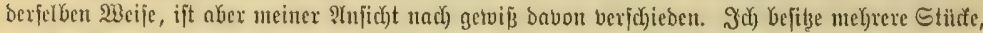

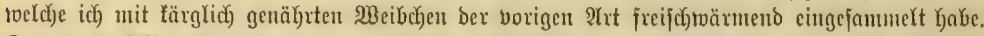

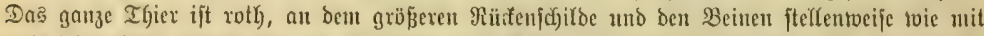

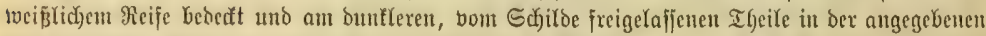

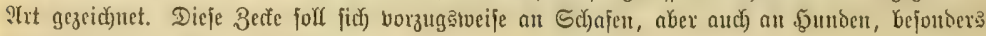
Jagbhundert und ßinbern, finden.

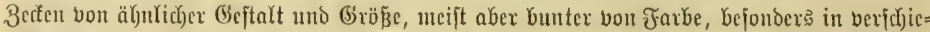

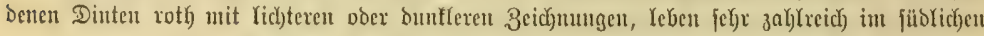

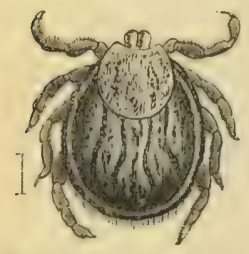

Biolelliotiger Syoljood (1xo des reduvius), vergrö́pert.

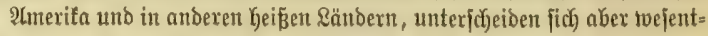

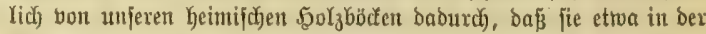

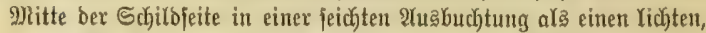

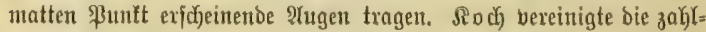

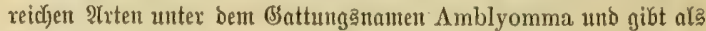
Siennzeichen für bas Weibchen cinen fajt einfarbigen, Debnbaren \&cibes=

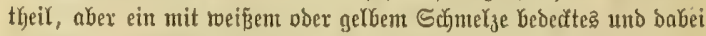

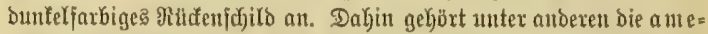
ritanifude Malolaus (Amblyomma amerieanum), weld)e, ben

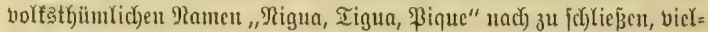
fack mit bent Sandfloke berwedyjelt soorden zu fein ficheint, eine ber

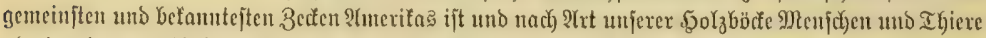

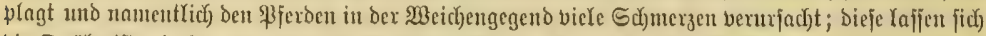

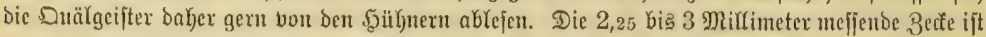

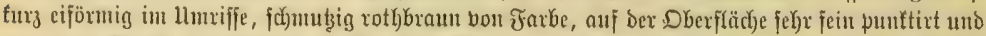

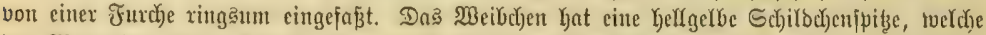

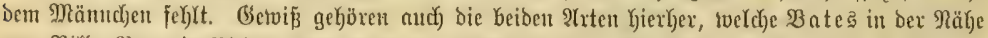

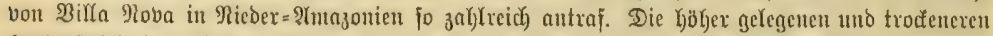

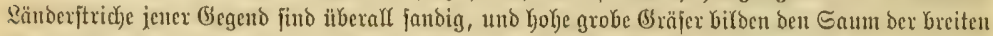

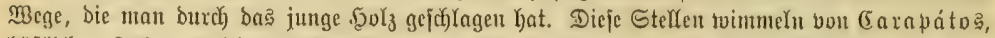

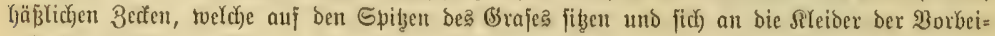

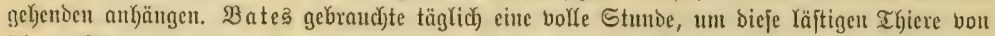

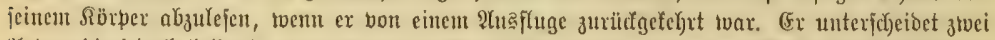

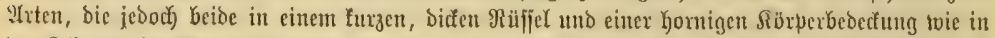

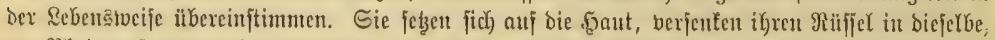

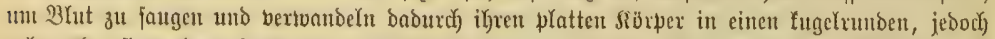

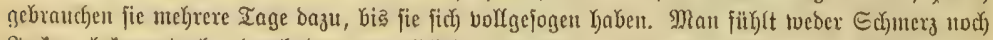

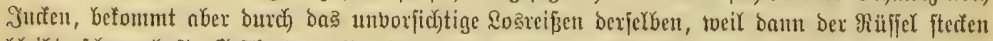

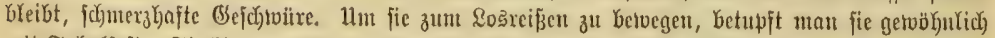

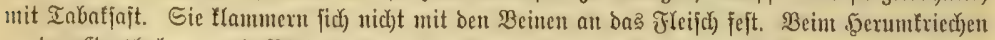

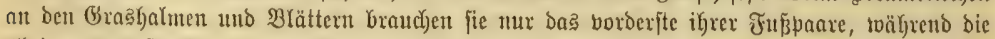
ïbrigen ausgeftrectt und immer bereit gebnalten toerden, ein borbeiftreifendes Dpfer zแ exfaffen. Die

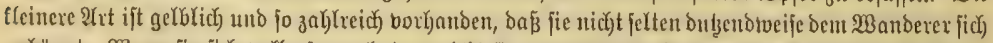

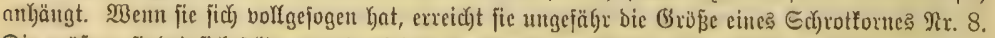

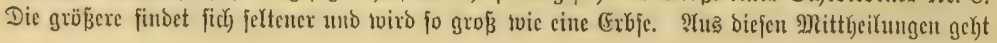




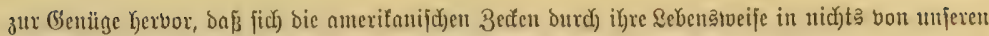
geimijacten unterjudeiben.

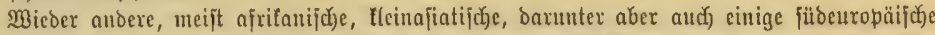

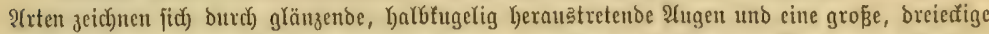

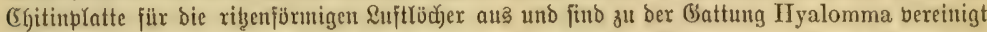

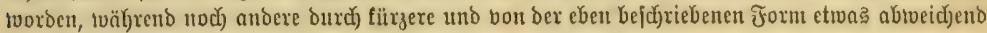
gebilbete Munotfeile weitere Trennungen nöthig gemadjt haben.

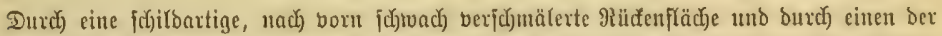

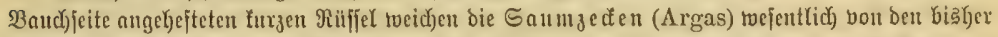

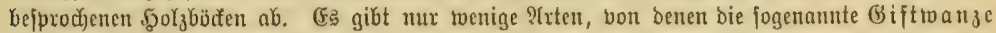

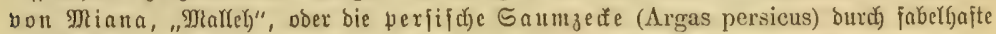

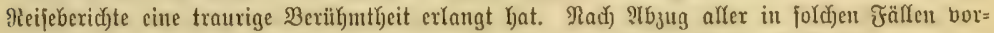

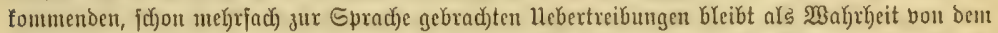

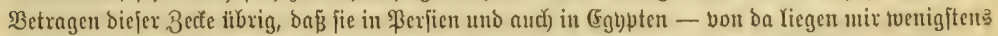

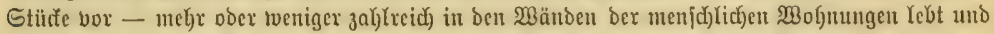

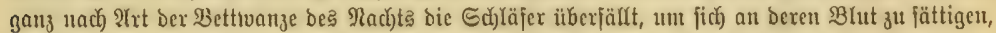

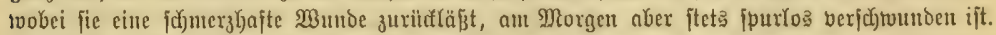

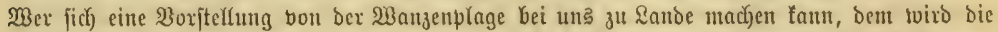

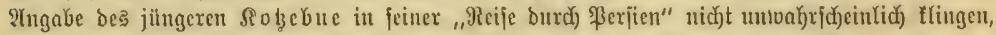

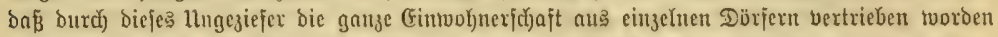

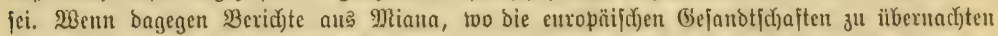

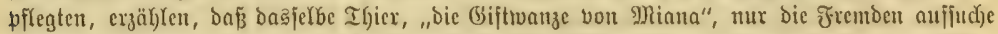

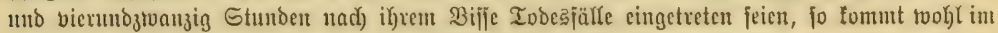

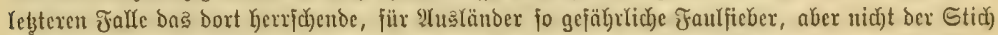

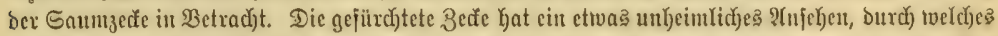

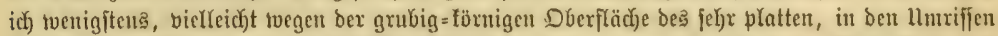

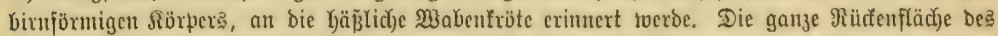

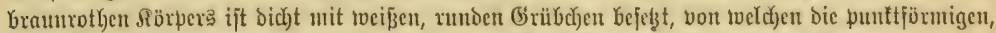

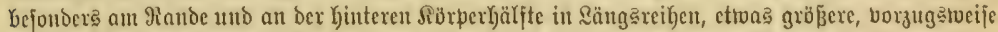

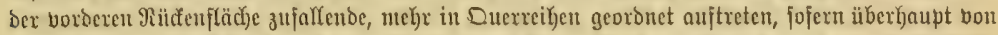

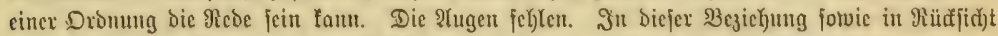

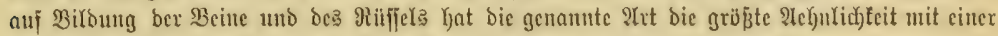
z'veiten, tweldye als beutiche eine nähere Bexüdficthtigung berdient.

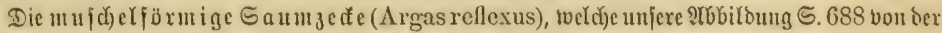

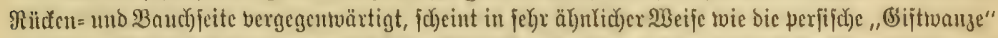

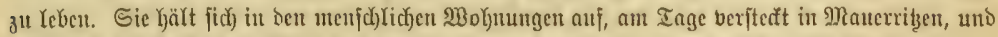

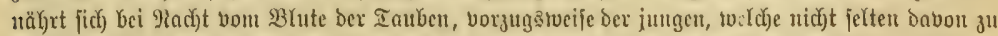

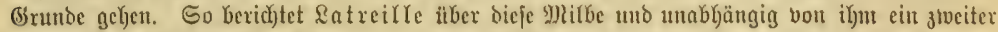

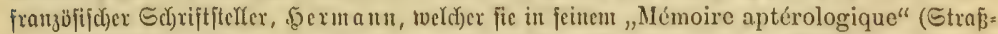

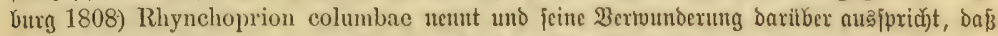

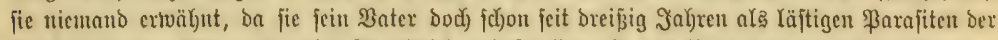

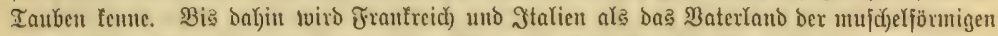

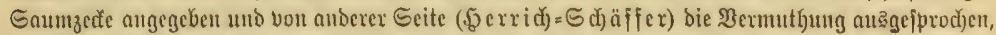

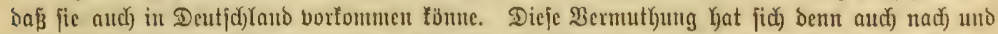

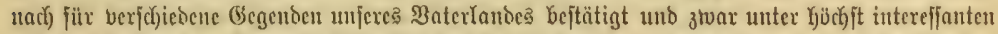

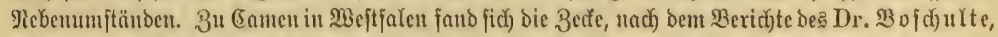

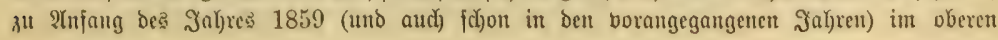




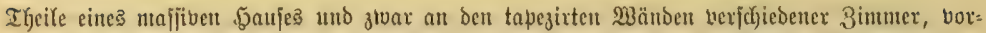

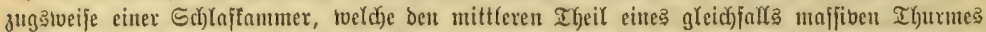

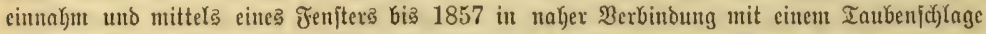
gejtanden hatte. Den weiteren Bexid)te zujolge faß̃ bie Becfe an Den Wänden ber bezeich)neten

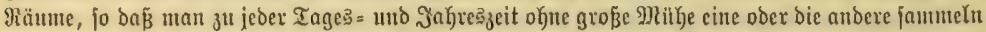

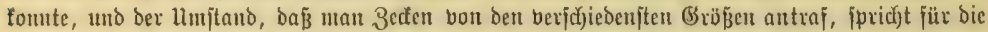

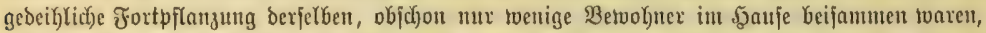
feine Tauben in Derbindung mit bemferben meGr ftanden und angeblid alfe bemertten Stïcte

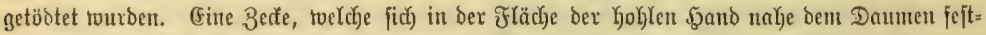

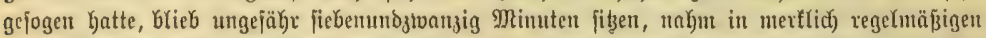

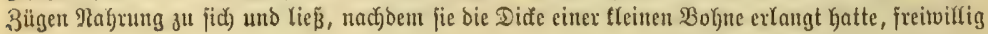

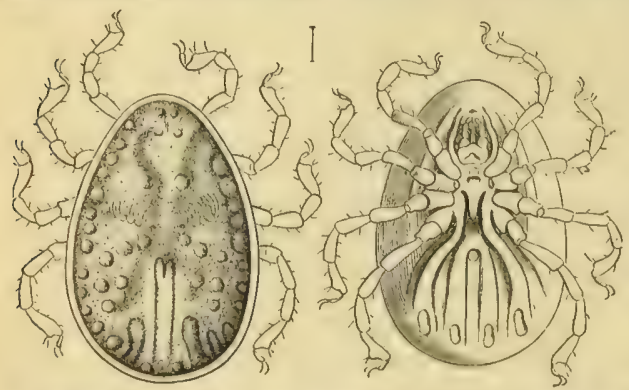

Du|d)efförmige 5 aumgede (Argas rellexus), bon ber ortden , unb Paudjeite; flarl bergrögert.

Ios. İn Jahre 1863 liejerte der: \$rebiger zu Friedeburg an ber Saale ztwei lebende Saumzedten auf bem Kiejigen 3oologiflyen Mujeum ab, uno burch jeintı Beridjt abermala ben Betweiz, it roie naker Beziefyung oie genannte Saumzerfe zu Den Tauben jteht. Bis зum Jahre 1859 toar unter bem Bimmer, in weld bem fic da bas Ingeziejer zeigte, eine Thorjabrt

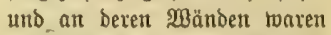
Iaubenthählen getvejen. Seitbem Gatte man die Iforeinfayrt in cine Stube umgetwandelt uno bie

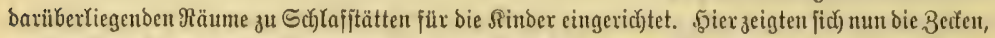

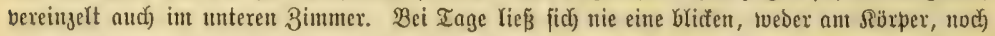

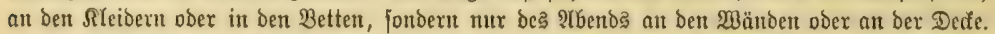

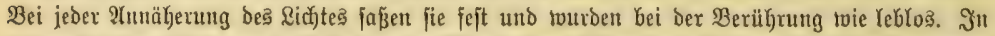
biejem Betragen fand man auch) basె einzige Mitter, fie zu befämpjen. Bor bem 3ubettegehen wurbe

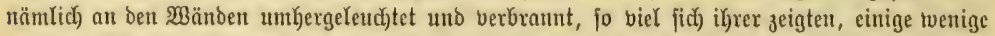

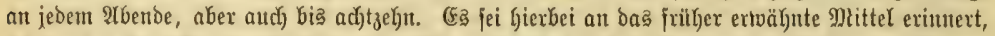

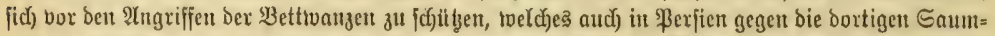

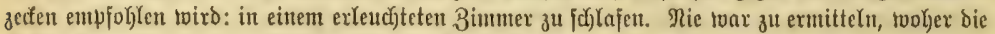
Berfen tanten, wie eine bollgejogene zu treffen, nie cine befonders fleine, Denn fie Gatten burch)=

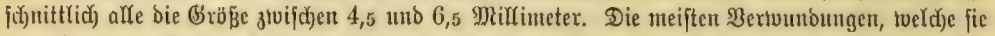

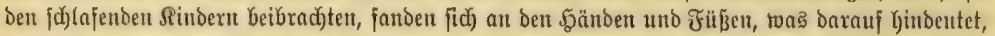

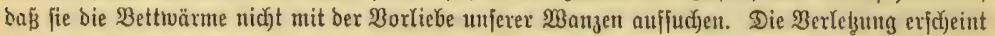

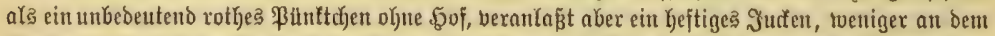

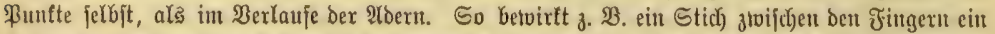

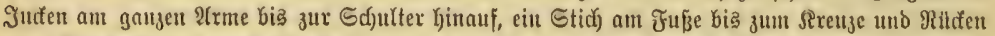

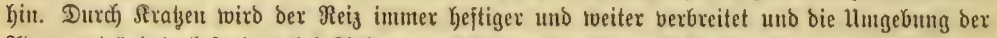

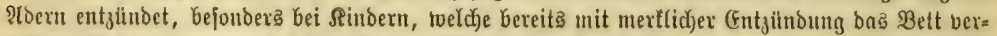

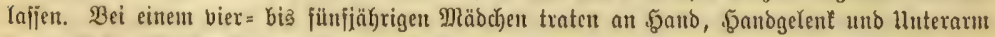

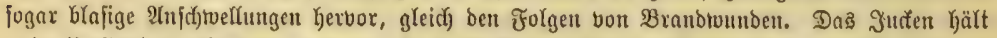

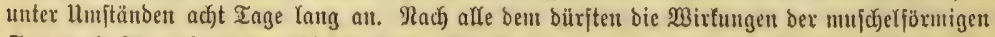

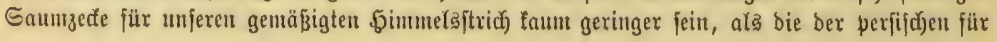




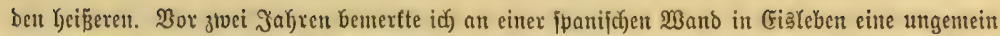

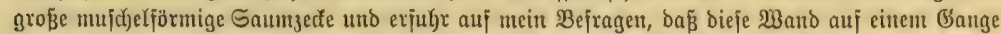

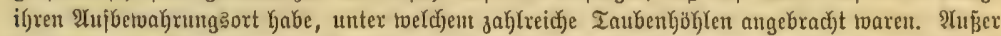

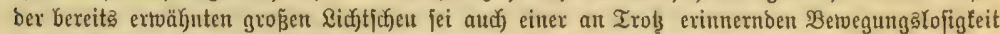

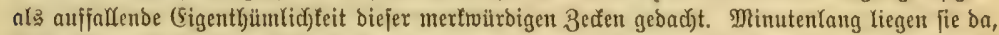

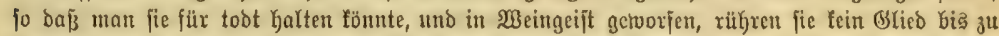

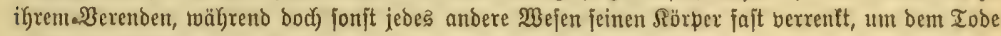
Durd) (5xträntuıg gu entrinner.

Die intereffante Beče, weldye nad) ben mitgetheilten (Exjahruntgen fich mit ben Iauben

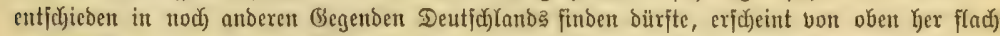

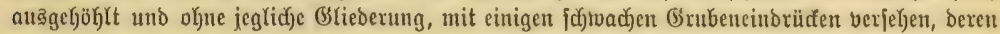

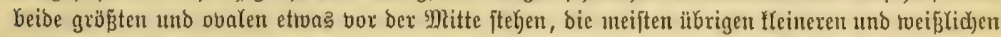

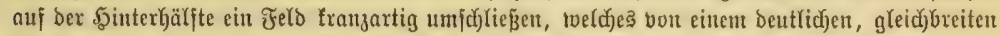

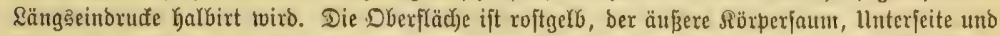

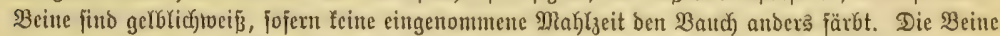
gelenfen an unbetweglidjen .Jüften nałe bei sinanoer ein uno gehen in je zlvei ftarf gefrümute

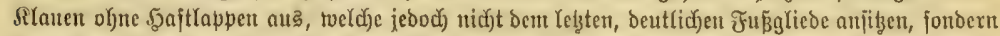

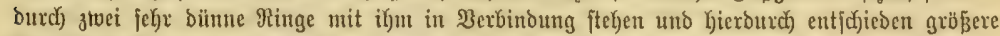

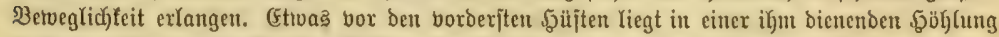

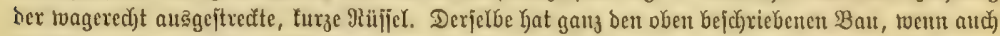

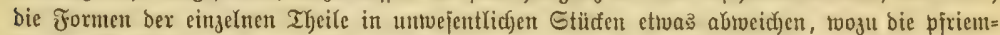

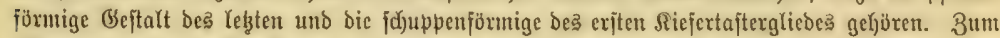

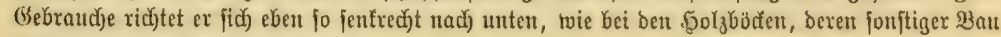
(idi) auch hier zut toiederholen jodjeint.

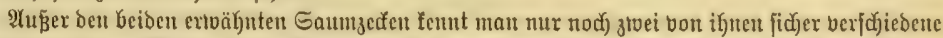

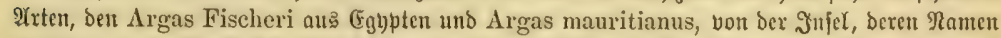

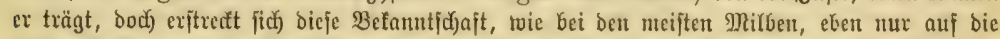

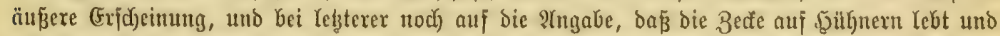
bieje zutpeilen zu Grmbe ridjtet. Der Argas Savignyi aus (Egt)pten ijt, tweil ex auj ber unteren

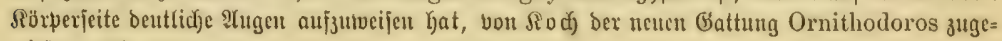
roiefen worbent.

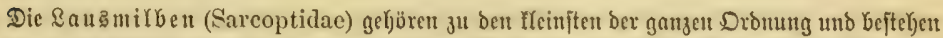

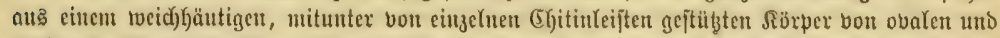

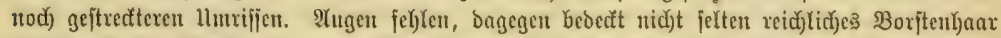

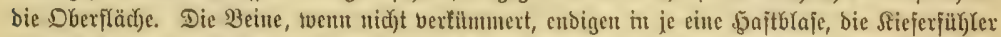

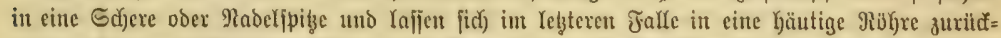

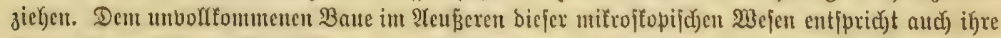

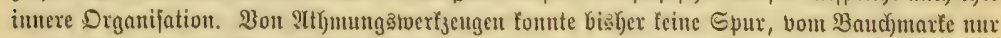

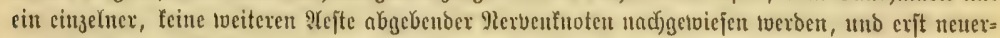

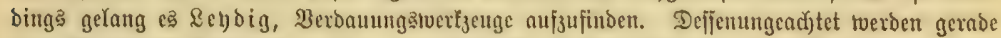

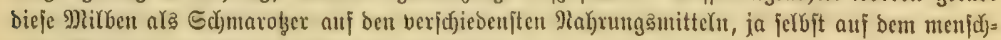

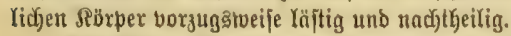

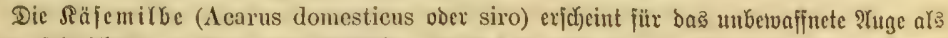

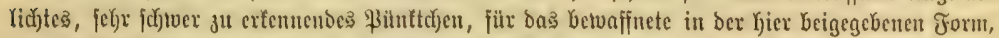

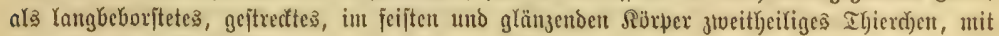

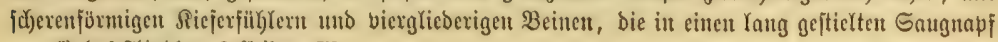




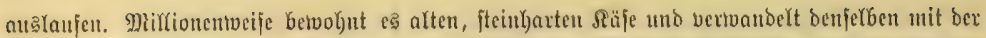

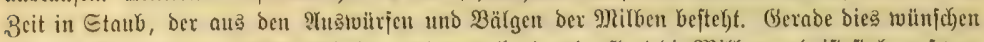
aber geviffe 3ungen ber Siafeliebhaber, und man hegt uno pflegt bic Milben und ift fitory auf bon

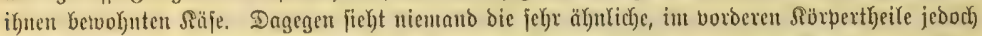

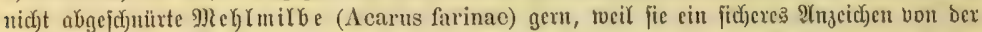

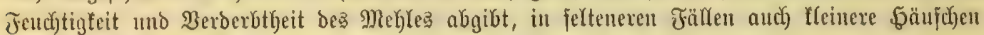

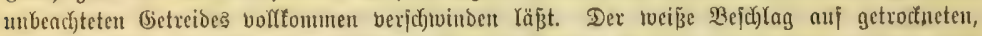

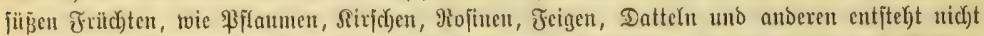

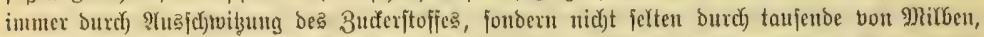

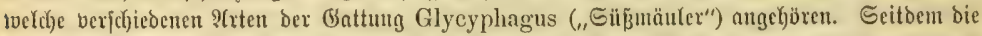

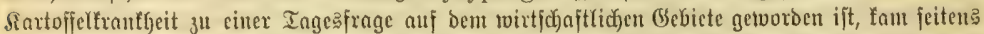

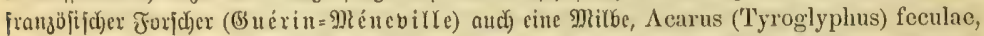

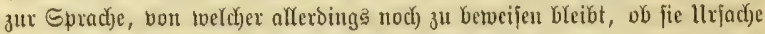

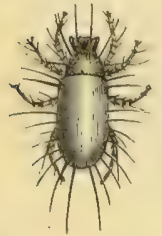

Räfemilbe (Acarus do. mestieus), breigigmal ver: gröfert.

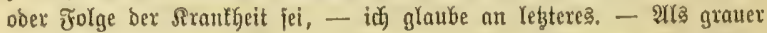

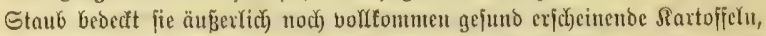

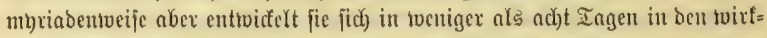

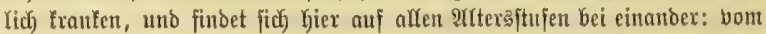

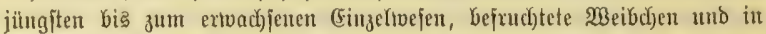

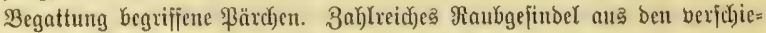

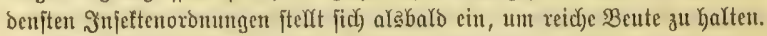

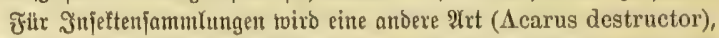

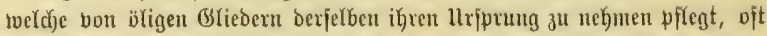

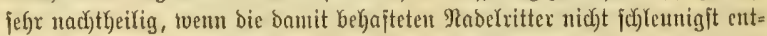

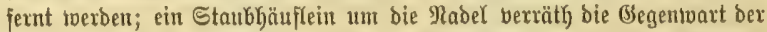

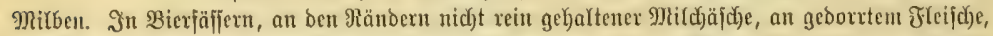

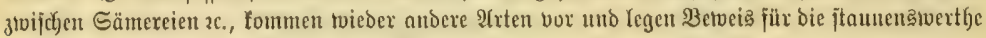
Yugbreitung uno श्रtannigfaltigteit bex Mtilben ab.

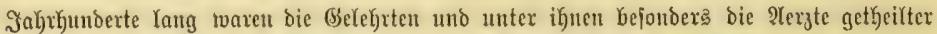

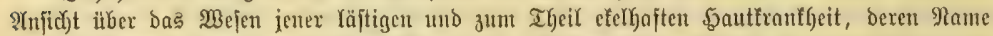

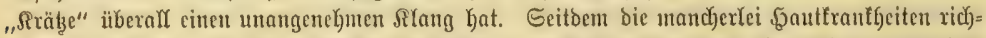

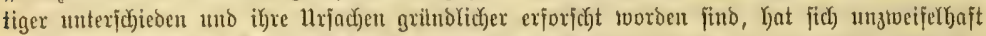

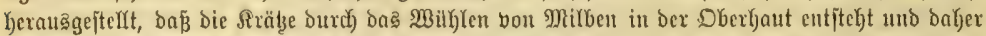

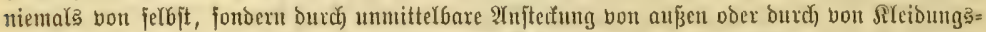

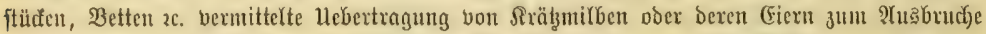

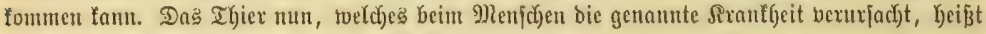

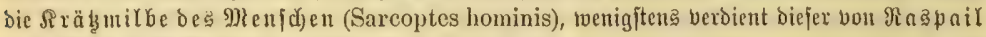

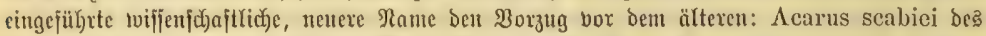

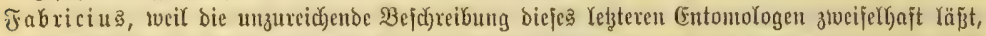

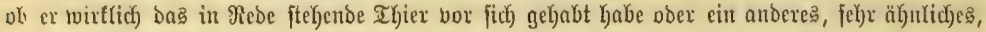
dexen eș noch mehreve gibt.

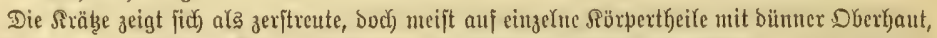

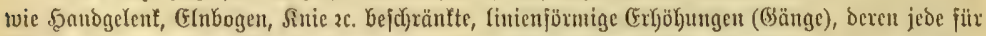

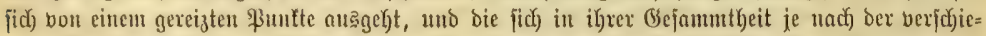

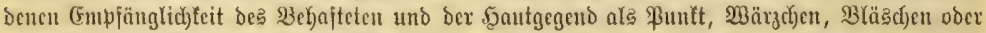

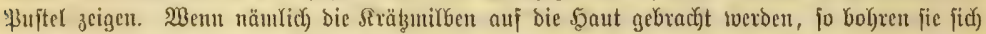

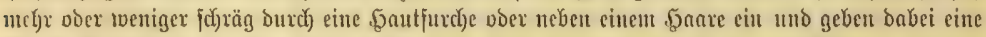

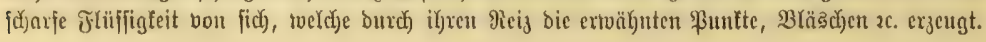




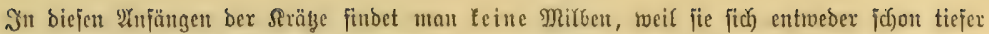

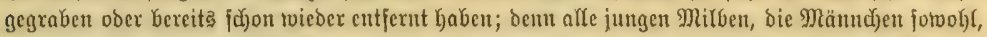

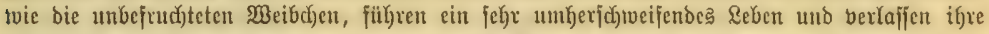

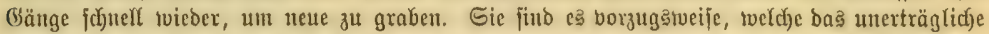

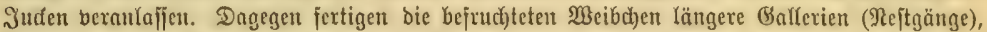
welde fie nidgt wicoer verlaffen; fie fetzen in biefen ibre (Fier ab uno twerden toot in bent

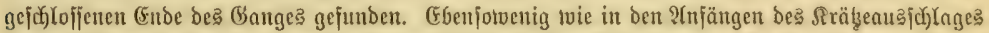

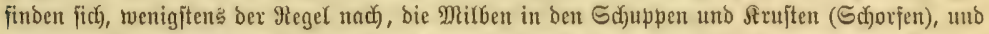

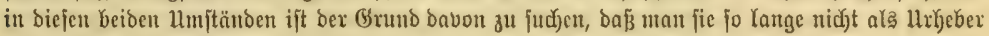
ber SRantheit anerfennen roolte.

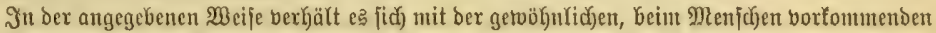

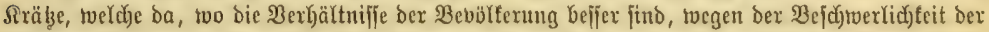

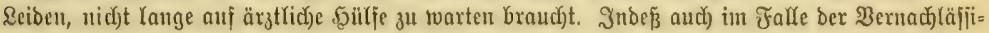

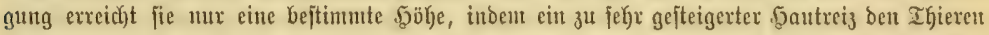

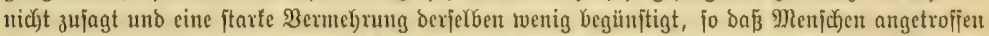

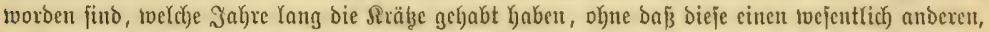
ała ben gewübnlidjen (Ebarafter angentonmen hatte. Wenn fich bagegen bie Milben unter befon=

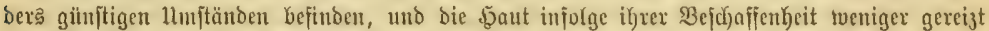

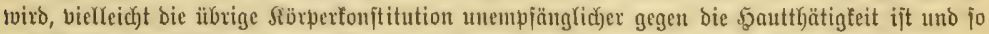

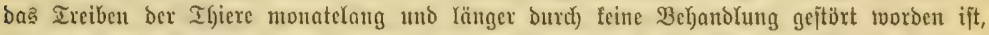

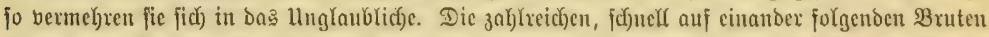

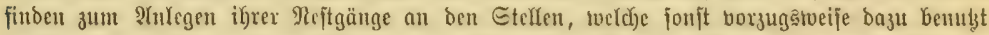

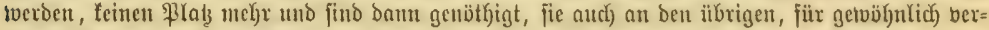

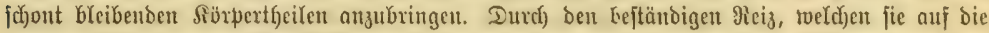

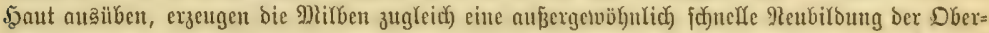

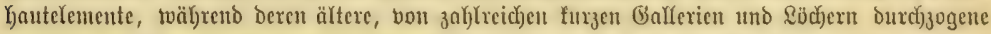

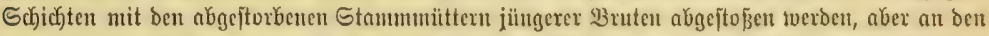

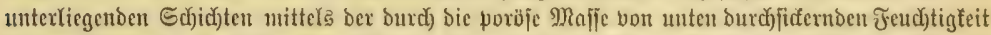

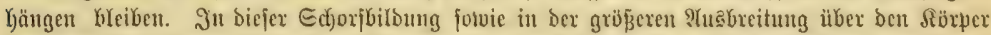
Yiegt Der (EGarafter ber bei weitem felteneren, aber and) bỉsartigeren "Gর্d)orffräbe", einer Form,

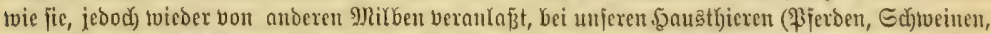

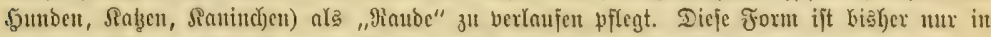

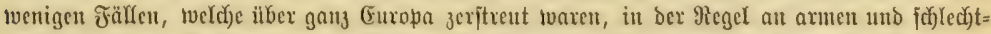

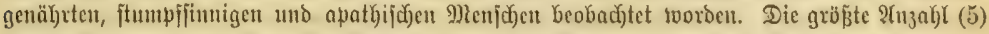

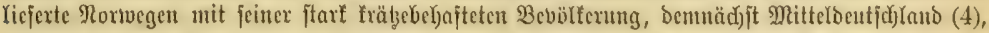

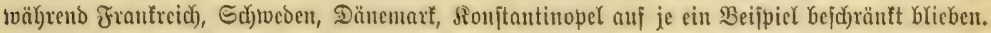

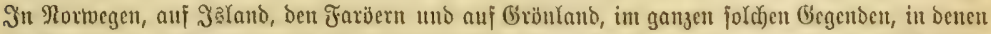

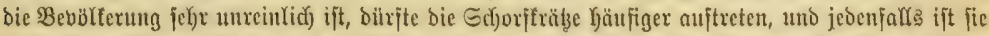

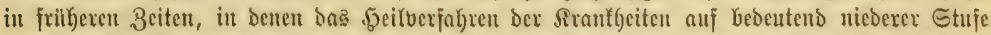

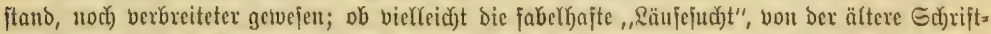

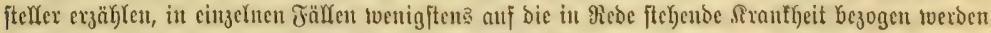
miijife, twer roiff uno fan barüber enogiultig entjucheiden?

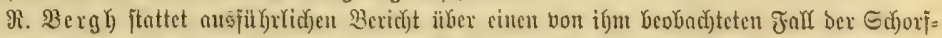

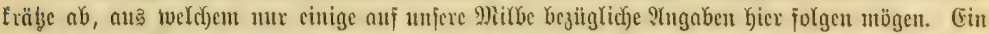

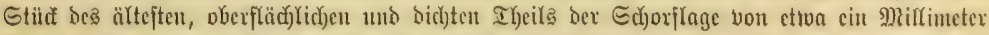

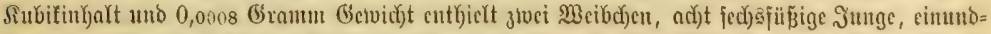

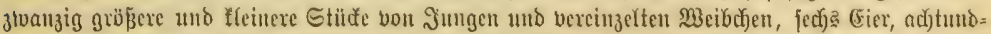

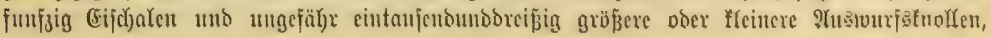




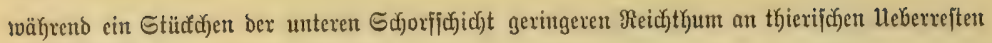
crfennen Xieß̄.

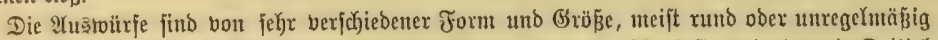

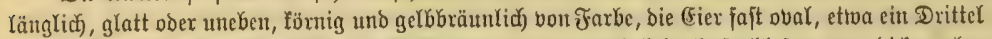

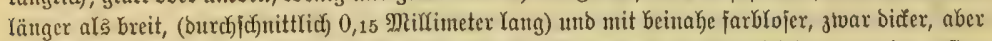

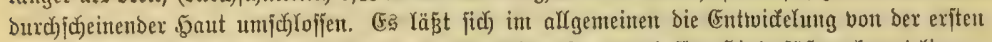

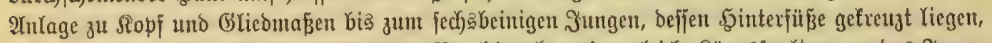

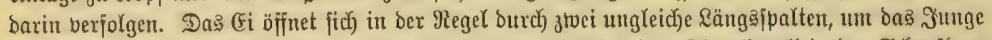

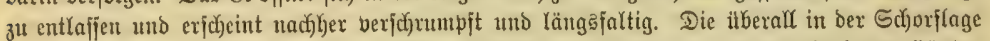

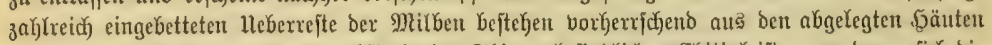

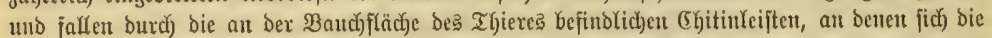

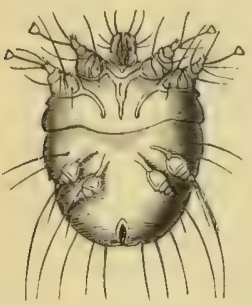

Sräknitbe bę Drenid)en (Sarcoptes hominis), Wribdien bou ber Waud. late, in adgtgigfaujer 23 ergröfcruag.

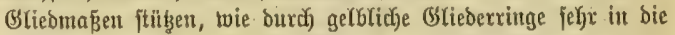

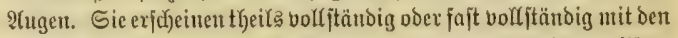

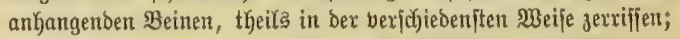
toote Millben fanden jid fajt immer in volljtänoigem 3 ujtande.

Waa nun bie Yebenden Mitben felbit anlangt, fo fommen fie in brei verichiedenten birundoformten und jwar als achtbeinige, an bem

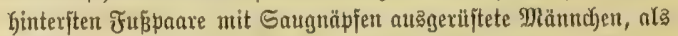
achtbeinige, mit bloken Borjten an ben beiben Ginteren \$aaren

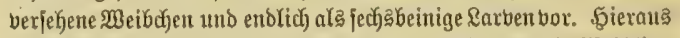
ergibt fich aljo, baß̧ twix in ber beigegebenen 2lbbildoung ein Weibchen

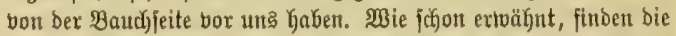
(Stieomaßen in Efitinleiften ihren Stübzuntt, bie Borberbeine an einer gemeinfdhaftlidfen, jitc) vorn gabelnben, jebes der itbrigen an jeiner eigenen, von benen bie bes ztweiten ßares ftärter und länger jinto als die vier Reijten ber binteren Beitte. Die brei Reiften ber vorberen Paare erfidjeinen

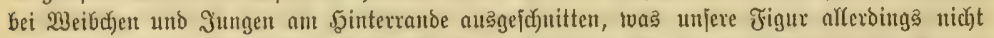

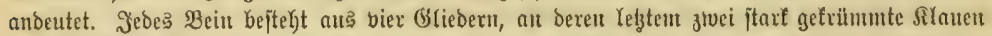

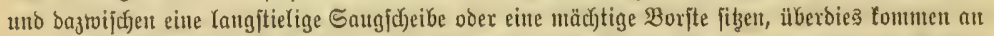

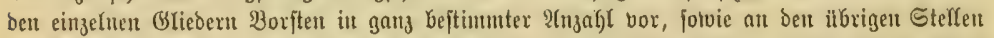

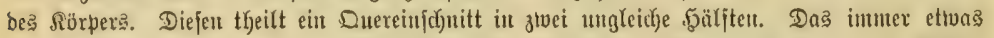

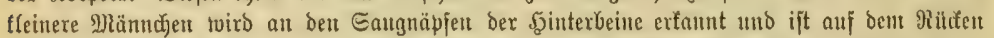

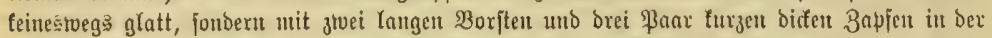

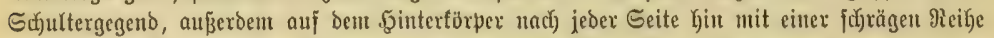

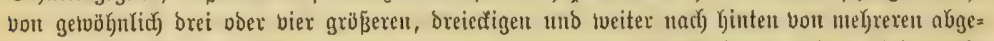

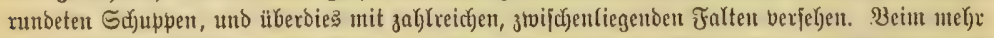

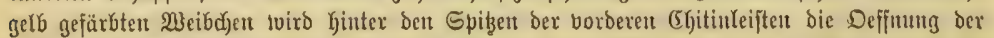

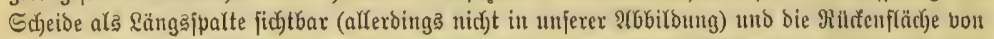

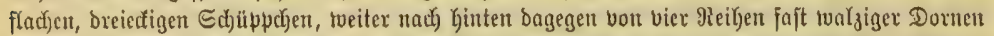

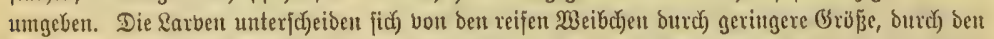

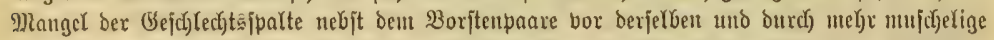

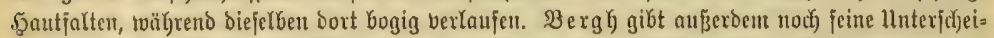

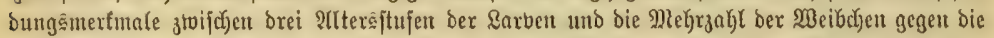

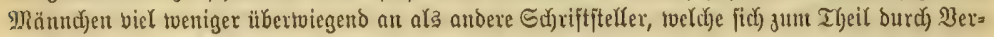

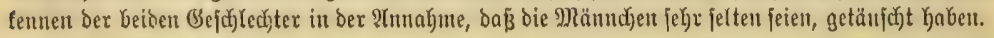

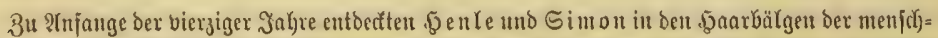

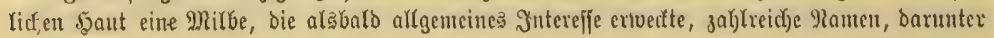




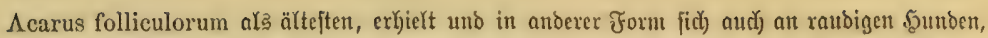

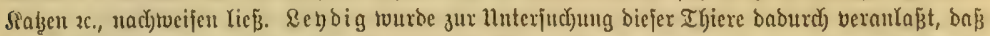
er am Bauche einex jurinnmijoben fledermans (Phyllostoma hastatum) cine ctro erbjengroß̧e

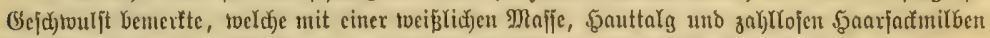

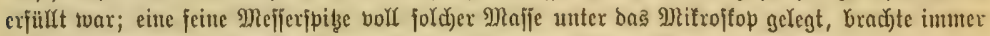

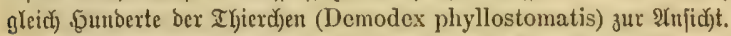

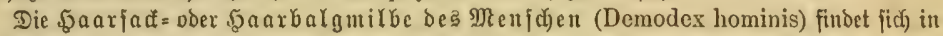

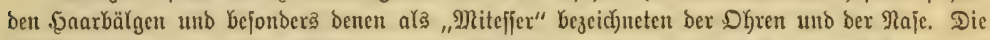

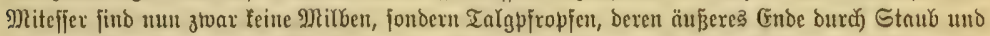

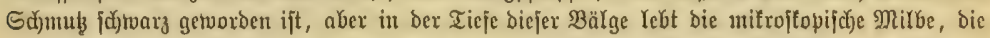

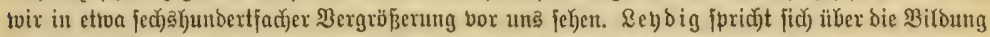

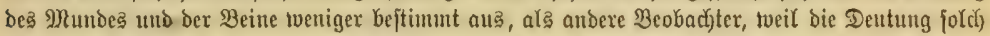

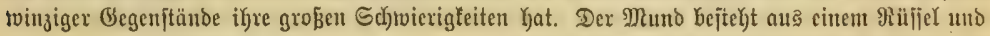

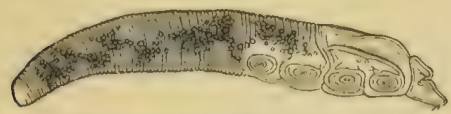

Saarbalgmilbe bes Meniden (Denodex Lominis), fcós)bundertmal vergröfert. groei nach born und unten rauben Tajtern; bie furzen biden Beine enden in je vier Rrallen. Freine Duerriefen, weld je fid nady Den itbrigen

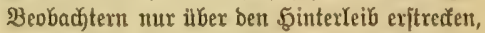
findet \&eboig aucic auf ben furzen ßorberteib

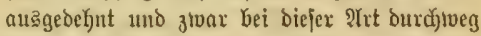
breiter unঠ ftärfer, als bei dex Şaarbalgmilbe

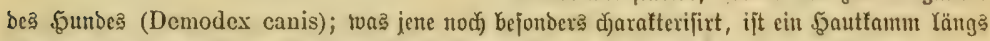

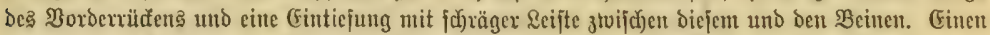

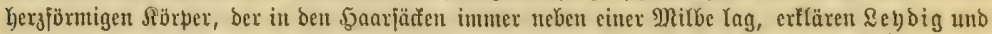

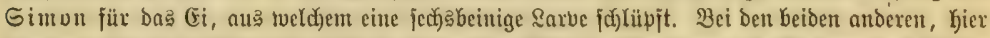

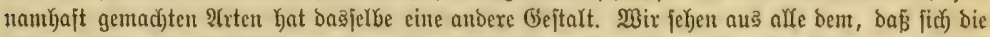

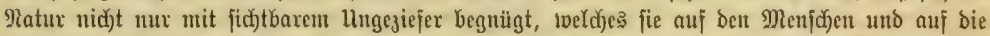

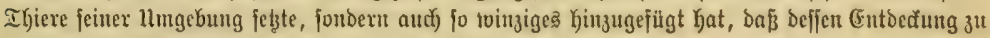
Den bon bem Ilitroftope Gerborgesauberten झundern gehört.

\section{Jierte (10ronung.}

\section{Dic 3 tugntwintuer (Pentastomidae, Linguatulidae).}

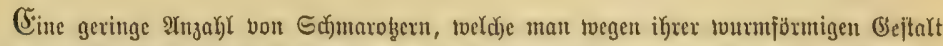

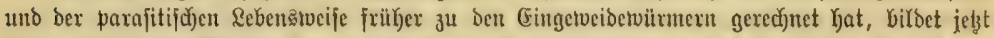

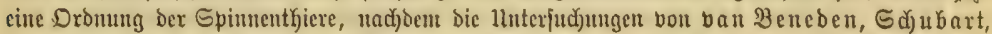

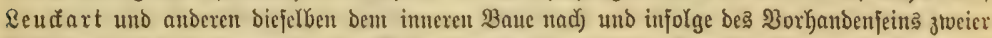

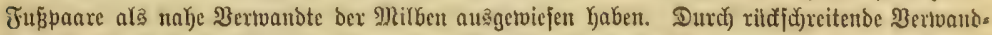

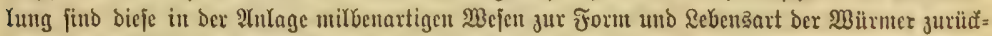

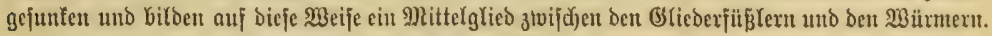

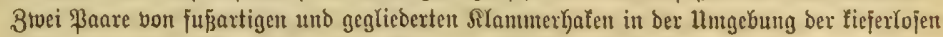

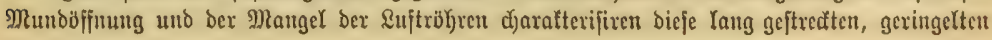




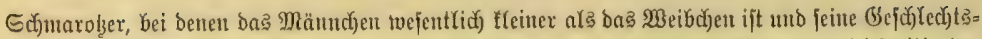

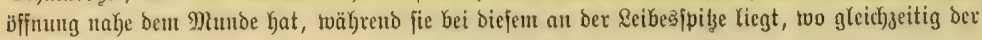
Rjtex münoet.

Der band tw urmartige 3 ungentw urm (Pentastomum taenioides) fonmt vortyerrichend int

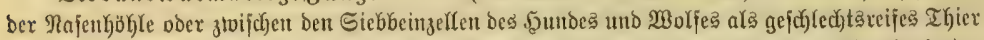
vor; vereinzelt hat man ifyn aucic) bei Bferben, Maultgieren uno Biegen gejunden. Die abgelegten

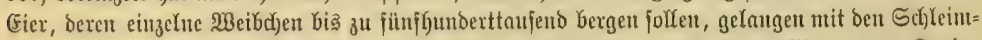
abjonderungen in bas Freie, alio and an Pflanzentbeile und von ba in ben Magen von Sanin=

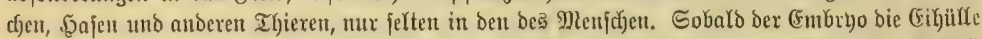
verlaffen hat, Durchbringt er, gleich ber Tridjine, Den Darm und gelangt in bie Reber. Sier fapielt

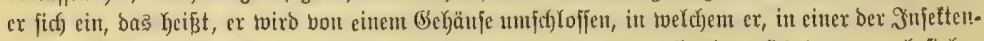

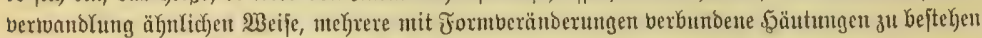

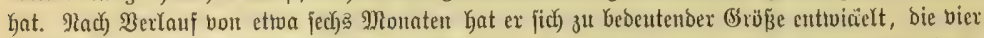

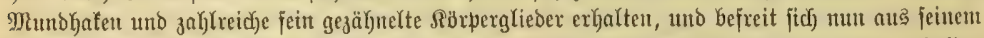

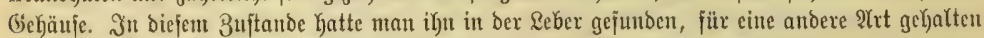

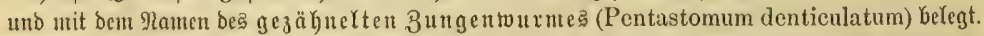

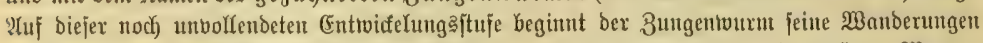

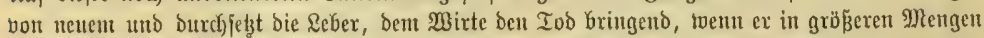

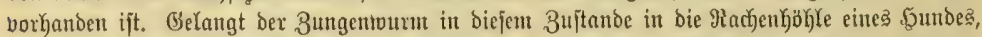

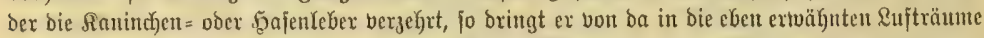

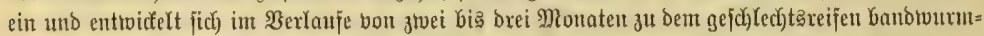

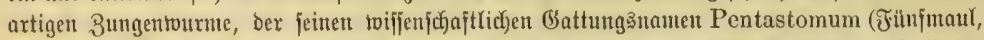
Fïnfloch) won Dem Mmitande erhalten hat, on

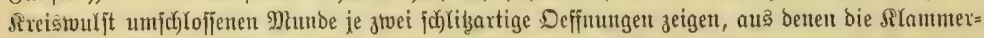

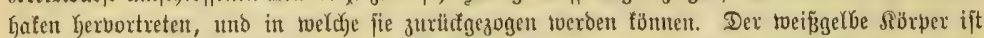

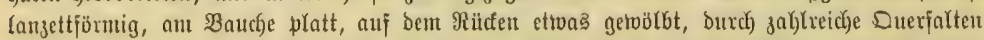

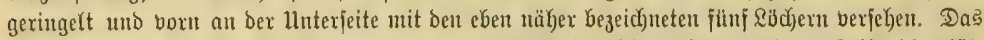

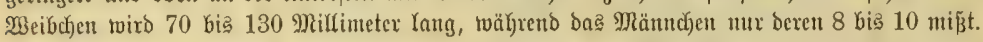

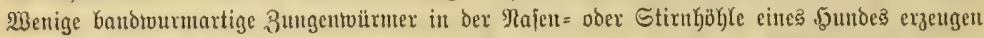

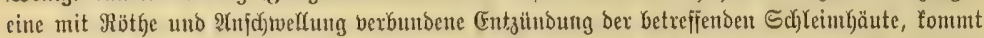

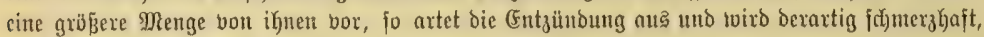

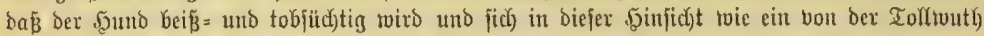
befalfener gebaren tantu.

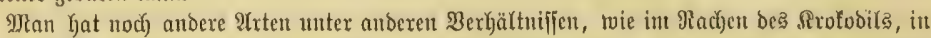

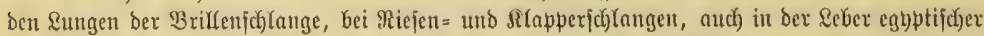

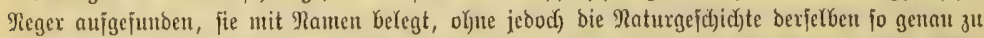

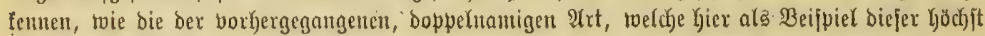
interefijanten Gejóchöpie genügen mag. 


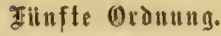

\section{Die Strebs = Dder 2flielipimten (Pantopoda, Pyenogonidae).}

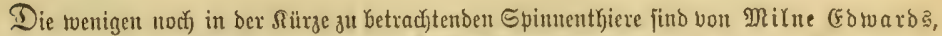

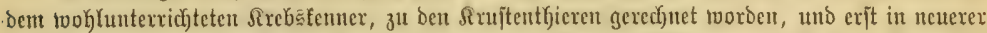

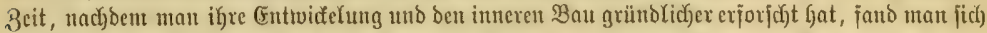

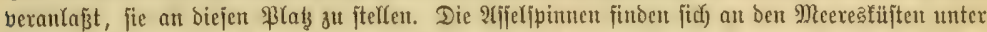

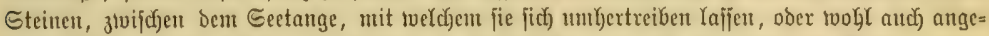
flammert an andere Thiere und bejtehen ber 5auptjad)e nad) aus vielglieberigen Beinen, indent

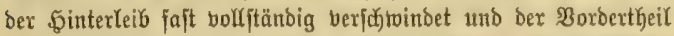
vierghiederig uno nur jo roeit entwidelt erjideint, um ben Élieb=

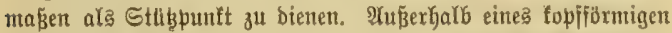

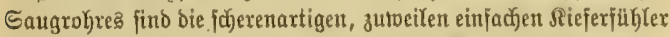
eingelenft, bie mandijmal jammt bent erjten Siejertafterpaare gänz= (idx) Feblen, tuährend bas jolgende \$aax ber Tajter genau bem Bildungägejeķe ber tibrigen Beine jolgt, bie aus fieben bis neun

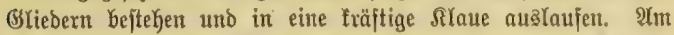

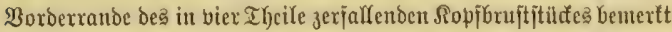
man, cistem bुörfer auffizend, vier eiufache शtugen. - Der Darm= fanal bexläuft zrwax in geraber Ridjtung bom Mlunbe nad) bem

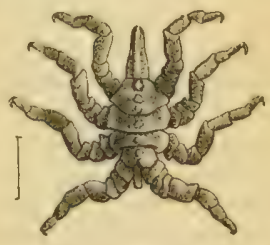

Ulfer.spindelafiel (Pycaogonum littor ale), vergribsert.

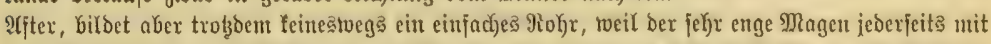

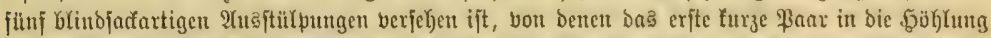

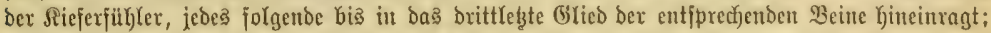

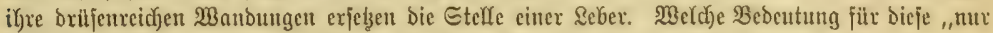
Bein" Darjteffenden Epinnen (\$antopoden) die Beine Kaben, erhelft tweiter auß ber \&age ber

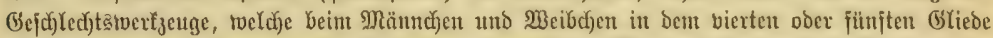

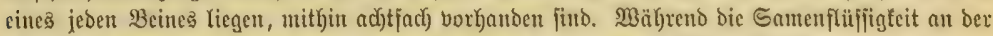

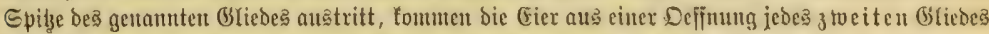

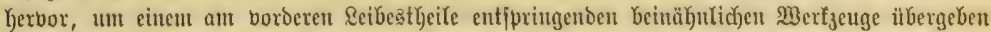

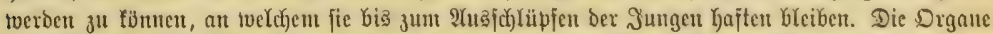

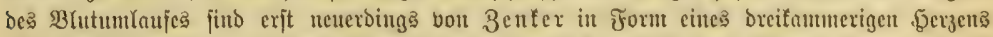

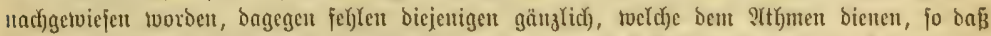

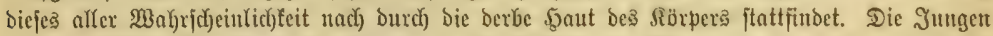

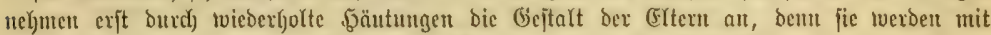

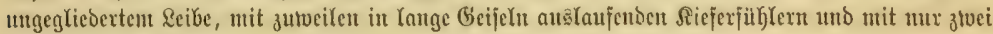
Beimpaaren geboten.

Die llfers Spindelaffel (Pycnogonum littorale) exreidft bie \&änge von 13 Mriflinteter

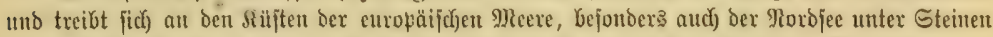

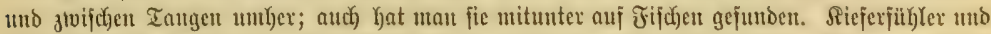

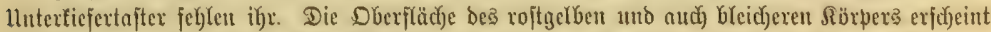

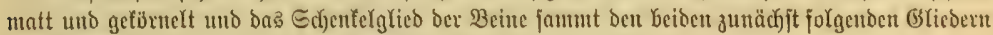
an ben Spizen mit je zroei twarzenjörmigen $30 x p$ pritngen berjehen.

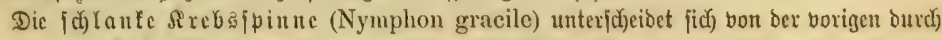

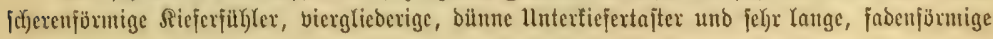




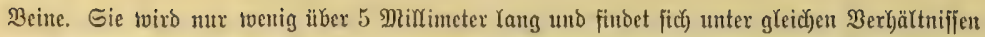

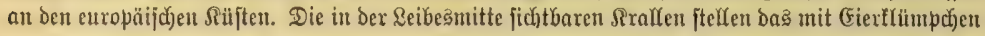

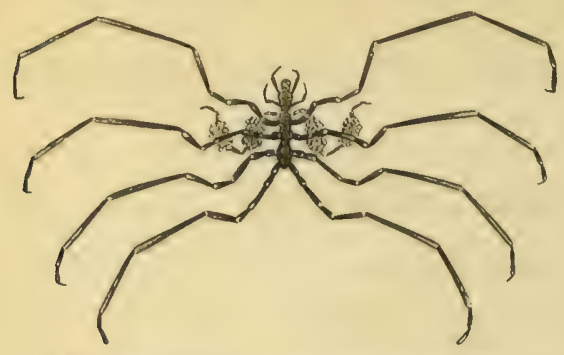

E⿺辶冋lante Arebofpinne (Nymplion graclle), farl vergröbert. bekaftete Beinpaar bor, ineldedes mur bem Weibchen jufommt. Heberbies jei nod) barauf hingerviejen, ba $\bar{\beta}$ fid bei

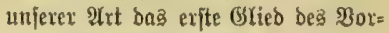
Derleibes anffällig gegen bie utbrigen verlängert uno in ber Mlitte einjúcynurt. Die bier oder fünf ఏüftglieder, bie fich) unterhalb dea Schentelgliedes einjodie: ben und wejentliç) zur ßerlängerung

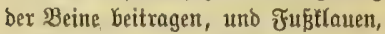

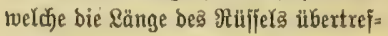
fen, gehören nod) zu Den Rennzeichen Der Obattung. Bei Ammothoa jind bie

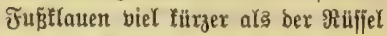

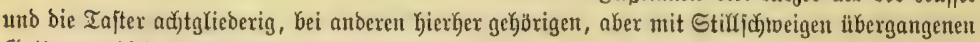
Gattungen bieje $\mathfrak{B}$ erthältniffe abermals anbers.

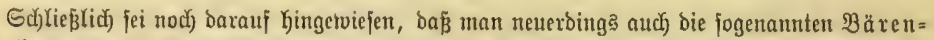

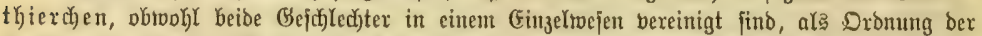

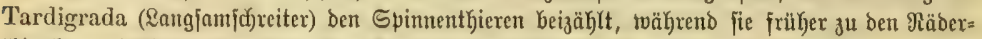

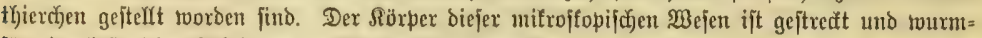

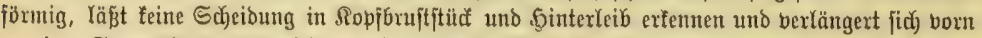

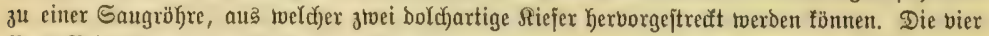
ßaar Beine find ftummelfajt, ungegliebert unb endigen in mebreren Rlauen; bas leb̧te berjelben

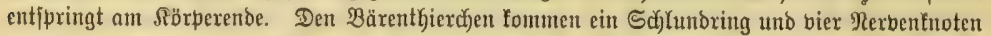

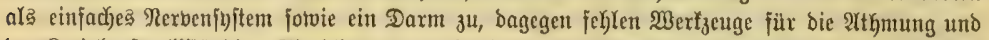

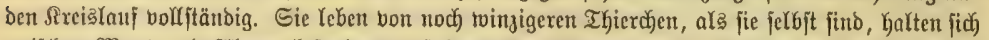

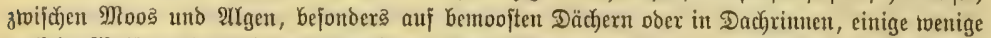

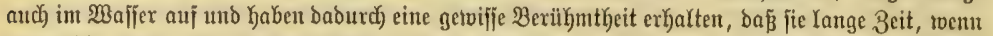
ifnen bie nüthige Feuchtigteit fehlt, wie todt baliegen, aber vieder zu neuer \&ebensthätigfeit

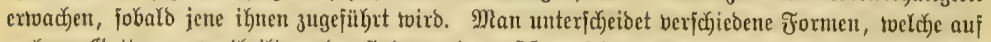
mebrere Gattungen bertheilt tourben fut, bon benen Macrobiotus cine ber berbreitetiten fein oitrite. 


\title{
Aamenver?eiduid
}

\author{
des neunten $\mathfrak{B a n b e r . ~}$
}

\section{2).}

शasิtäfer 59. 62

- rotbjalfiger 63.

- fdtwargglantzenber 62 .

- vierpunttiger 63 .

26enopfauenauge 373.

Abia 339.

Abraxas grossulariata 422 .

Acanthocinus aedilis 174 .

Acanthosoma dentatum 615.

Acarina 677.

Acarus destructor 690 .

- domesticus 689.

- farinae 690 .

- feculae 690 .

- folliculorum 693.

- ricinus 684.

- seabiei 690 .

- siro 689.

Acherontia Atropos 368.

- Mredor 368.

Achlysia 680.

Acilius 48 .

- sulcatus 48

शđ̆ereulen 413.

- rinbenfarbige 415 .

शrtereutenmotten 436 .

2Aderglathwespe 284.

Acridiodea 547.

Acridium 555.

- peregrinum 555.

- tataricum 555.

Aeronycta aceris 406 .

Adela viridella 435 .

Ademonia tanaceti 187.

Adephagi 44

अbmitnI 356.

2bonis 366 .

Aelia acuminata 615 .

Aeschna 518.

- grandis 518.

- juncer 516.

2reugler 361.

- bilftere 361 .

-- burdffidtige 361.

- fleine 361.

- foredine 361

effenlaus 574. 21fterbienen 204.

थiterbüce 168.

थ્ffterfrüb)lingofliegen 506.

21 ftergalwespen 296.

2fiterraupen 326.

Uiterrüffelfäfer 141.

थfterfforpione 639.

@iteripinnen 642 .

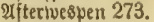

Irnatoonel 409.

Agelastica alni 187.

Agelens labyrinthica 663 .

Ageleninae 664.

Agenia domestica 278.

- punctum 278.

Ageronia feronia 368

Aglossa pinguinalis 429 .

Agrilus 98.

- biguttatus 98.

Agrion Amalia 514

- forcipuls 516.

Agriotes segetis 104.

Agriotypus armatus 502 .

Agrotis 413.

- corticea 415.

- exclamationis 414.

- innuba 413.

- pronuba 413.

- segetum 413.

2horn = \$icilmotte 406 .

அilantbus = Svinner 381

Ifulenten 199.

भIt

Aleurodes 576 .

Aleurodes Chelidonii 580 .

งิrformes 576 .

Allantus serofulariae 337 .

Allotria 301. 307.

Altica = Haltica 188.

Alucita polydactyla 439 .

Alysia manducator 310 .

Amblyomma americanum 686 .

Amblyteles 320.

2uneife, acterbautreibente 266.

- braune 264.

- gelbe 264.

- rethe 266.

- ftallfütternoe 260.

2umeifen 253
Imei enfreunbe 259.

Ameifenungier 490.

- ungefledte 492.

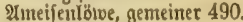

- Iangfübleriger 492.

Ametabola 568.

Ammophila sabulosa 281.

Amphidasis betularia 418 .

थแผนxiโนริ 348.

Anax formosus 516 .

- Parthenope 516.

Andrena 227.

- cineraria 229.

- fulvicrus 229

- ovina 229.

- Schrankelta 229.

Andrenidae 204.

Andricus 298.

Androctonini 639.

Androctonus 637

Anergates 257.

Anisoplia 89.

- fruticola 89.

গnifolliet 89.

Anobium paniceum 116.

- pertinax 115.

- striatum 116. 310

- tessellatum 115.

Anomalon circumflexum 316.

Anomma arcens 264.

Antheraea 382

Anthidium 232

Anthocharis cardaminis 354

Anthomyia 479 .

- brassicae 479.

- ceparum 479.

- conformis 479 .

- dentipes 311.

- furcata 429.

- lactucae 479

- radicum 479 .

Anthomyidae $\mathbf{4 7 9}$.

Antlonomus druparum 150.

- pomorum 149.

- pyri 149.

Anthophila 203.

Anthophora 223.

- hirsuta 223.

- parietina 223. 
Anthophora pilipes 129.

- retusa 223.

Anthrax morio 462 .

- semiatra 462.

Anthrenus museorum 71 .

Anthribini 162

Anthribus albinus 163.

Anthrobia mammuthica 645 .

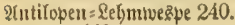

Antliata 440.

A patura 359.

- Ilia 360.

- Iris 360

A pathus 235.

- aestivalis 235.

- campestris 235.

- rupestris 235 .

- saltuum 235.

2(pjelbaun = Ssefpinftmotte 435.

21pfelbaum = Blasflügler 376 .

ripfelbaum = Sdinauzenmotte 435 .

2) felbattlaus, grüne 587.

- rötblide 587.

2(pfelbliitenftedjer 149

2xpelfauger 593.

2lpfeltuidter 428.

Aphaenogaster 265.

2(vhibier 307.

Aphidina 586.

Aphilothrix 297.

Aphis cerasi 587.

- fabao 589.

-n mali 587.

- persicae 588.

- ribis 587.

- rosae 587 .

- sorbi 587.

- ulmariae 587.

- viburni 587

Aphodius 70.

- fossor 81.

A phrophora lacrymans 594.

— salicis 594.

- spumaria 594.

A pidae 204.

Apion apricans 139.

- assimile 139.

- craccae 139.

- flavipes 139.

- radiolus 140

- Sayi 139.

- trifolii 139.

-- ulicicola 139.

- ulicis 139.

Apis fraciata 215

- ligustica 215.

- mellifiea 205.

$\Lambda$ poderus coryli 140 .

- longicollis 141.

Aptera 568.

Arachnoida 630.

Aradus 607

- corticalis 608.

Aranea tarantula 673 .

Araneïla 644

Arctia caja 379.

- purpurea 379.

Argas Fischeri 689.

- mauritianus 689.

- persicus 687.

- reflexus 687.

-. Savignyi 689.

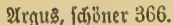

Argynnis 355 .

- Aglaja 355

- paphia 355.

Argyroneta aquatica 664.

Arilus serratus 606 .

Arindia 381.

Armadillo 628 .

Aromia moschata 168.

Arrenurus abstergens 680 .

Arthrogustra 631 .

Ascalaphus macaronius 493.

Asemorhoptrum lippulum 259.

Asilidae 459.

Asilus 461.

- erabroniformis 461 .

- cyanurus 461.

Asopia farinalis 430 .

- glaucinalis 431.

Aspatherium 502.

धTivenbout 175.

2(3ื)nfalter 359.

था[elppinnen 695 .

Astynomus 175.

Atax 680 .

- spinipes 680 .

Ateuchus sacer 79.

- variolosus 79.

Athalia rosae 337 .

- spinarum 336.

Athous hirtus 101.

attก3 380 .

2t Tas [pinne 666.

Atropos pulsatorius 521 .

Atta 265, 272.

Attagenus pellio 70 .

Attelabus curculionoides 141.

Attidae 675 .

Attus 676

Atypus piceus 653 .

- Sulzeri 653.

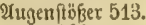

Aulax 301.

- Brandti 300.

- Hieracii 301.

- Potentillae 301.

- Rhoeadis 301.

- Sabaudi 30L.

2urorafalter 354

भนวิtufezeidjen 414.

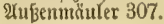

\section{$\mathfrak{B}$.}

Baccha 467

Badläufer, gemeiner 605.

Badimüiden 448.

Badjlveibeneule 416.

Bacillus Rossii 546.

Bactria 546

- aurita 546.

Bล̊, brumex 15, 379.

Bล̌renfamilie 377 .

Bärentbierdyest 696.

Balaninus glandium 149.

- nueum 148.

- turbatus 149.

- venosus 149.

- villosus 299.

Barloadjinjpinne 659 .

Ballenbiene 229.

- grofie 230.
Banchus falcator 315 .

- venator 315 .

Banontaus 363.

Banbafiel woit Babla 623.

- Elappernbe 623.

- rottse 623

Banoalfeln 621 .

Banbit 36.

Baridius 155.

- chloris 155.

- cuprirostris 156

- picinus 156.

Baris 155.

Bassus albosignatus 314.

Baudjammier 204.

Baumliut je 590 .

Baummanze, rothbeinige 615.

Belonogaster 251.

Belostoma grando 603.

Bembex 284

- rostrata 285.

Berg $=$ खebjpiune 659 .

Berytus tipularius 613 .

Bettivanze 608.

- getvimperte 609.

Bibio hortulanus 457

- Marci 456.

Bidjo 487.

Bieste, afrifanifdje 215.

- egloptifide 215.

- italienif die 215.

- norbídje 215.

Bienen 203.

- gerellige 222.

Bienenfäfer, rotfdulteriger 128.

BieneuInเ 485.

Bienerumtotte 431.

Bienentwolf, bunter 285.

Bieğfliegen 470.

Binfert = B Lattfloly 592 .

Biorhiza aptera 299.

Birfenbu[dufpanner 422.

Sitfenfreunb 142.

Birfen = Ћnovifgormusope 339 .

Birtenipanner 418 .

Birfentedjer, (d)tuarger 146.

Sirn= Ssepinituvespe 332

Birmfnospenitedier 149.

Birníauger 593.

Birnjpanner 418 .

Birn = Trauermüden 452.

Bifambod 168.

Bittacus tipularius 498.

Blabera gigantea 539.

Bläulinge 365.

Blaps mortisaga 118

- producta 118.

Blafenfïber 567 .

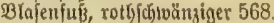

Bhafentiffer, grofer 112 .

2la lentoof, roitrotíer 470 .

Blajemvanzen 607.

Blastophagus minor 159.

- piniperda 158.

Blatta germanica 535 .

- Japponica 537.

- maculata 537.

Blattflisge 592

Blattbiomer 77.

BLatthorntäfex 77.

Blattina 540 .

Blattth̆fer 179 


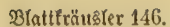

Blattrăuje 586.

Blattlaus ber tleinen Rüfterngalfe 591.

Błattlausfliegen 493.

23 lattlausliolve 493.

Blattriuber 418.

BIattrioyemitedier 147.

Bglattroder 142

23lattfuaber 152.

23lattjdyteiber 233.

- gemteiner 233.

Blattfdurede, gefeniferte 558 .

iglathvespe, gelbgebörnte 337.

- griue 337.

BCattwespen 333.

- Breitleibige 331.

s laufante, grogie 358 .

- tleine 358.

s8 tauforf 405.

Bfinbanteijen 261.

Blinbbremie 458

Blinbtönfe 593.

Blinbrvanzen 609.

Bliitenfted)er 149.

Bluntenflieger 479.

Blumenfäfer 92.

3)

Bุ(ntโกแธ 590.

Błutsitröpidien 378.

Boctfüfer 164 .

Böde 164.

Bobnenblattlants 589.

Bohnentäfer 178.

Bobrfficgert 480.

Wobrfäfer, meffinggelber 114.

Bombatbirfäfer 38.

Bombus 218.

- hortorum 221.

- lapidarius 221.

- muscorum 221

- Serimshiranus 273.

Bombycidae 380.

Bombylius 463.

- venosus 463.

Bombyx mori 15. 385.

Boreus hiemalis 498.

- nivoriundus 498.

Burfenttäfer 157.

- nemeimer 159.

Zoritenf divänge 568.

Boritenwomaen 610.

Bostrychidae 157 .

Bostrychus bispinus 158.

- dactyliperda 158.

- dispar 161.

- typographus 159.

Botydae 429.

Botys $\mathbf{4 3 0 .}$

- frumentalis 430 .

- lupulina 431

- margaritalis 431.

- silacealis 431 .

Brachelytra 54.

Brachinas 38.

iBraditsfer 88.

Bradyceren 444.

Brachycerus 134.

Brachygaster minuta 306.

Brachytarsus seabrosus 163.

- varius 163.

Brueon 309.
Bracon dispar 105.

- palpebrator 309.

Braconidae 306.

Braconibest 306.

Jraula coeca 485.

Braunvurz = DJlattjđjaber 152

B raumvury $=$ B3lattwespe 337.

Breitböde 165.

Brement 470

Bremien 457.

- glauăugige 458.

Brenner 149 .

Brenthidae 161.

Brenthus Anchorago 162.

Bretid́nueiber 513 .

Brillentbogel 405.

Brifeis 362 .

Brombeer $=$ Sallivespe 300 .

Brotheas maurus 638.

Brottäfer 116.

Brotolomia meticulosa 409.

Bruchidae 176.

Bruchus granarius 178.

- lentis 178.

- pisi 177.

- rufimanus 178.

Brummer $\$ 76$

Budjbruder 159

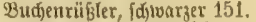

Budodenfpinner 392. 404 .

Qutfienjpringer 151.

Bładetipritgrüßler 151.

Budfelbierter 235.

9utdelfliege, bide 482.

Budfelwansen 607.

Butdelmanze, berivanote 607 .

2ưdelairpent 595.

Büdjerffursion 639.

Bürftenbiene, raubfübsige 227.

Buntfüfer, ameijenartiger 113.

Buols= $=23$ idfer 426 .

Bupalus piniarius 420 .

Buprestidae 96.

Bujdypinmen 649.

Buthus occitanus 635. 639.

Byrrhus 72.

Byturus tomentosus 72.

(5.

Calandra granaria 157.

- oryzae 157.

Balntoriben 156

Calliethera scenica 675.

Callidium variabile 171

- violaceum 172.

Calligrapha 186.

Callimorpha dominula 379.

- Hers 379.

Calliphora vomitoria 476 .

Calocoris striatellus 610 .

Caloptenus italicus 554 .

Calopteryx 516 .

- splendens 516.

- vesta 516.

- virgo 516.

Calosoma inquisitor 3 .

- sycoplianta 36 .

Calotermes 530.

- Aavicollis 530 .

Camponotus herculeanus 262.

- ligniperdus 262
Campylidao 101.

Cantharidae 122

Capricornia 164.

Capsini 609.

Capsus 610.

Carabicida 32

Carabus auratus 35 .

- auronitens 36.

- gemmatus 35.

- hortensis 35.

Cassida 179. 190.

- nebulosa 190.

Catocala 416.

- elocata 416.

- fraxini 416.

- nupta 416

Cecidomyia 453

- destructor 453.

- fagi 453.

- pericarpiicola 453.

- polymorpha 453.

Cemonus unicolor 293.

Centrotus cornutus 595 .

Centrurini 638.

Centrurus 637.

- americanus 639.

- hottentottus 639

Cephalomyia ovis 472

Cephenomyia rufibarbis 472

- stimulator 472 .

- trompe 472

Cephus compressus 331.

- pygmaeus 330.

Cerambycidae 166.

Cerambyx cerdo 167.

- heros 167.

Ceraturgus 459 .

Cerceris 286.

- arenaria 287.

- bupresticida 287.

- vespoides 286.

Cercopis bivittata 595 .

- sanguinolenta 595.

Ceria conopsoides 468

Cermatia araneoides 621 .

Cerocoma Sehaefferi 126.

Ceroptres 296.

Cetonis aurata 93. 259.

- marmorata 94

- speciosissima 94.

Cetonidae 92.

Eetonie, marntorirte 94.

Ceuthorhynchus 153.

- assimilis 154 .

- macula alba 155.

- sulcicollis 154.

Shalcibier 304.

Chalcis clavipes 305.

Chalcophora Mariana 97.

(5halcophoriben 97.

Chalicodoma muraris 231, 29:?

Ehangeant, fleiner 363.

Charaens graminis 408 .

Chatergus apicalis 243 .

- chartarius 212.

Cheimatobia brumatr 419

Chelifer cancroides 639.

- cimicoides 640

Cheloniariae 377.

Chermes 15.

- Abietis 580.

- laricis 582 
Chermes viridis 580 .

Chilocorus bipustulatus 194 .

Chilognatha 625

Chionobas 361.

Chlorops nasuta 482.

- taeniopus 481.

Cholustoma florisomne 291.

Chrysidae 289.

(ธ็นที่рมนธ 366.

Chrysis cyanea 291.

- fulgida 291

- ignita 241. 291.

- regia 292.

- Zetterstedti 292

Chrysocharis conspicua 152.

Chrysomels 184.

- cerealis 184.

- diluta 184.

- fastuosa 184.

- graminis 184.

- speciosa 184

- superba 184.

- violacea 184.

Chrysomelinae 179.

(Shrif) fomelinen 183.

Chrysopa vulgaris 493.

Chrysops coecutiens 458 .

Cicada atra 601.

- concinna 601.

- haematodes 601.

- montana 601.

- orni 600 .

-- plebeja 601.

- septendecim 21.

- speciosa 600.

Cicadellina 593.

Ciendina 593.

(Sidjano 487.

Cicindela campestris 30 .

Cidaria chenopodiata 422.

- ocellata 430.

Gitaben 593.

Cimbex betulae 339 .

- femorata 340.

- sylvarum 340.

- variabilis 340 .

Cimex ciliatus 609

- lectularius 608.

Cionus scrofulariae 152.

Cis 117.

Citigradae 671 .

(Sitrunenfalter 354

Cixius nervosus 597.

Claviger 57.

- foveolatus 57.

- longicornis 59.

- testaceus 57.

Cleonus ophthalinicus 286.

Cleopatro 354.

Clerus formicarius 113.

Gliboitenten 307 .

Clubiona holoserices 666.

Clythra 182

- quadripunctata 182.

Clytus arietis 172

- arvicola 172

- rhamni 172.

Cnemidotus caesus 48 .

Cnethocampa pinivora 402.

- pityocampa 403.

- processiouea 402.

Сосciua 575.
Coccinella 193.

- dispar 194.

- impustulata 194.

- septempunctata 193.

Coccinellidae 192

Coccus cacti 576.

- lacea 578.

- manniparus 578 .

(5obrinen 302.

Coelioxys 237.

Coenonympha 361.

Coleophora lariciuella 438.

Coleoptera 25.

Colias Edusa 355.

- Hyale 355.

Colletes hirta 230.

Collyris longicollis 32 .

(Solorabo = Rartofjeltäfer 184.

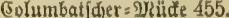

Conopidae 469.

Conops 469

- auripes 469.

- ehrysorrhoeus 469.

- flavipes 469.

- rufipes 469.

- vittatus 470 .

Copris 80.

Coprophaga 78.

Cordulia 515. 520.

Coreodes 612

Coreus 612.

- quadratus 613.

Coriacea 483.

Corixa femorats 602.

- Geofiroyi 601.

- mercenaria 602.

Corotocs 54

Cosmetus 643.

Cosmia affinis 412

- diffinis 412 .

- pyralina 412.

- trapezina 412.

Eolifunioen 157.

Cossus ligniperda 376.

Crabro 287.

- lapidarius 291.

- patellatus 288.

- striatus 288.

Crabronea 279.

Crambidae 429, 431

Crematogaster 253

Crepuscularia 367

Crioceris 179

Crioceris asparagi 181.

- duodecim-punctata 181.

- merdigera 181.

Crossocerus elongatulus 238.

- seutatus 288.

(5rnptiben 313.

Cryptocephalus 182.

Crypto-pentamera 130.

Cryptops 623.

Cryptus 321.

- tarsoleucus 321.

Cteniza fodiens 652

Ctenophora atrata 419.

(5ucubano 103.

(डicujo 103.

Culex annulatus 416 .

- molestus 448

- pipiens 447

- pulicaris 418 .
Culex trifurcatus 448 .

(Eulicibert 446

Curculionina 130.

(5)

Cybister Roeseli 48.

(5) by loftomen 307.

Cydnus 614.

Cynipidae 293

Cynips 15. 297.

- agama 298.

- albopunctata 301.

— folii 297.

- gemmae 298.

- glutinosa 301.

- lignicola 298.

- longiventris 298.

- Psenes 298.

- radicis 300 .

- seutellaris 297

- solitaria 301.

- tinctoria 298.

Cynthia 381.

Cyphocrania acanthopus 546 .

Cyrtoneura pabulorum 452.

- stabulans 311.

2.

Dactylosphaera 582

Dämmerunถู่f falter 367.

Damalis 409

Danais Chrysippus 366.

Daphne 356

Sascilliben 106.

Dascillus cervinus 106

Dajielflicge 470.

Dasychira pudibunda 392.

- salicis 393.

Dasypoda hirtipes 227

Dasypogon teutonus 460 .

Decticus 558 .

- verrucivorus 558

Demodex canis 693.

- hominis 693.

- phyllostomalis 693.

Dendryphantes 676 .

Depressaria 436.

- nerrosa 436.

Dermanyssus avium 681

- gallinae 681.

- hirundinis 681

Dermestes lardarius 68.

Dermestidae 67.

Desoria glacialis 569.

Diactor bilineatus 613 .

Diastrophus glechomae 300 .

- rubi 300.

Didftonie 366

Ditffouf 395

Didfopffliegen 469.

- geitreifte 470.

Didfopfrin bler, langhalfiger 111.

Diđmaulrüblet 132.

- gejurdyter 134.

- idinarger 132.

Diđ̛übler 133.

Diffidjentel 612 .

Dicranorrhina Smithi 93.

Dieb 114.

Dielocerus Ellissi 327.

Diloba coeruleocephala 405 .

Dinorhina 89. 
Dioctria oelandica 459.

Diplolepis puparum 304.

Diplonychus rusticus 603.

Diplopoda 625.

Diploptera 237

Dipneumones 653.

Diptera 440.

Difterfalter 357

Diurna 347.

Docophorus adustus 571 .

Dolfitwespe, rothfëpftge 274 .

Dolerus 335.

Dolomedes fimbriata 671 .

Donacia 179.

- clavipes 180.

- menyanthidis 180.

Donnerfäfer 87.

Dorcadion 173.

- atrum 173

- crux 173.

- fuliginator 173 .

Dorngolbweste, glänzende 291.

Dornidjecte, genteime 556 .

Dormidrrecten 555.

Durnjpinne, zangenartige 658.

Dornzirtie, gefiornte 595.

Dorthesia 576.

- Urticae 579

Dorylidae 262.

Dorblitoen 264

Doryphorn 186.

Drnchenfliege 513.

Drabtivurm 102.

Drassidae 667.

Drassinae 664

Drassus brunneus 664 .

- sericeus 664.

Diedjiler 142.

Drebflïgler 562

Drebtiffer 49.

- taudjender 50.

Dreílyoril 83.

Drüfertameifen 261.

Dryophantha 297.

Ditnenfäfer 87

Dutfatenfalter 364 .

Dunģfäer, grabender 81.

Dynastes Hercules 91.

Dynastidae 90.

Dyschirius 39.

Dysterinae 666.

Dyticidae 43

Dyticus 48

- dimidiatus 46.

- marginalis 44

Dytiscus 14.48 .

\section{(s:}

Earinus 309.

Eccoptogaster destructor 161.

- scolytus 161.

Echinomyia fera 474

- ferox 474 .

- grossa 474

Leiton drepanophorum 268.

- hamatum 268.

-- levionis 267.

- rapax 267.

(5'citons 267.

(sctflitglex 356 .

(5)elftein = Ruuftifer 35.
Eldielboljrer, grober 149.

- Hleinter 149.

Fiđjenbaumlaus 590.

(sid)enerbfols 189.

Eidiengaltwessten 297.

Eidien = Broceffionsifintuer 401.

Eidjentisbenlaus 581 .

Eidieníailblaus 576.

Eidenidjillexdien 363.

Eidienfeibenipinuer, dine il dyex 382

- tabanefít cier 384.

Eidjenzapfen: Salliwespe 298.

Gieriwespe 303.

Eintiornjáted̛e, bebornte 557.

(simmicter 296

Einpaarfïī̌er 620.

Eintagsflieger 507.

- gemeine 508.

Gis = Ranter 642 .

cisoogel, grober 359 .

Elampiben 292.

Elampus aeneus 293.

- bidentulus 293.

Elaphrus riparius 33 .

Elateridae 99.

(5) tefant 91.

Eleutherata 25.

Empidae 461.

Empis tessellata 462.

Empusa pauperata 544.

Ennerling 86.

Entblătterer 418.

Epeira diadema 653.

Epeiridae 653.

Ephemera vulgata 508 .

Ephemeridae 501.

Ephialtes imperator 323

Epicauta cinerea 128

- vittata 128.

Epichnopteryx 392

Epinephele 361.

- Iyperanthus 362

- Janira 362.

Epitheca 515. 520.

Erblenblattlats 587.

(Erbientäfer 177

Erbjenwidfler, monoflectiger 427 .

- rehjarbener 427.

Erbafiel 623 .

- elettrifdie 623.

- Babriel3 623.

- Iaugfüblerige 623.

(5rbbiene 227.

- Braungefdienfelte 229.

- nreife 229.

Erobod 173.

- nreifer 173.

- Ireugtragender 173.

- fifivarzer 173

(5rbfall 413.

(Eroflühe 188.

(Eroflol, bogiger 190 .

- nelbftrciflaer 190.

Erobutnmel 221.

Erofrebs 562.

Erobwanzer 614

Erbivolf 562

Erebis 361.

Exemit 95.

Eresus cinaberinus 676 .

- quadriguttatus 676.

Exgates faber 161 .
Eriocampa adumbrata 335.

Eristalis tenax 467.

ErYen= Blattfäfer 187.

Erlentwürger, tweifbunter 152.

Exnteoogel 559 .

(Ert)a 381.

(5ruciniben 367.

Cidjencitabe, tleine 600.

Eucera longicornis 224.

Euchirus longimanus 95 .

Gucremiben 100.

Eucorybas crotalus 623.

Eule, mattgezeidinete 407.

(EuTen 404.

Eumenes coarctata 241.

- pomiformis 241. 292.

Eumenidae 238

Euophrys 676

Euprepia caja 15.

- villica 15.

Eupithecia centaureata 423.

- signata 423.

Eurydema oleraceum 614.

Eurygaster maurus 615.

Eutermes 528.

Evania 306.

Evaniadae 305.

Exenterus marginatorius 314

Exephanes occupator 410.

Exetastes 315.

5robontel 307.

๘.

Fรaben[d)

- gefäumter 44 .

Trabenfforvion, geidulualnter 640 .

frädjerflïgler 502 .

isädjertriger, feltfamer 120.

Gäibermilbe 678 .

valleăfer 182.

Faltemive špert 237.

Jatter 341 .

Fongldirede 542.

- argentinifaje 542.

- carolinisuse 543.

Jeberbujdutifer 126.

reberleidntliege 467 .

federfinge 570.571

icoermottert 439.

Treiftüier 118.

శ్togritfe 559.

Joeloheu[drecten 547.

テॅelo = Sanbtäfer 30 .

relb = Sđ)marotserbummel 235.

Jeloftorpion 634.635. 639

feloulmeneule 412

Felfest= Sdymarobertyummel 235.

Gerferiforpion 638.

Feniteripisme 661.

Jettjdrabe 429.

Æeuerfalter, geflectter 364 .

fisterfiegen 102.

Fenerfichröter 73.

วัentervogel 364 .

Fenerwanze, flügellofe 610.

Jiditent $=$ B3lattivesue, ge fellige 332 .

Jiditenbortenfafer, ad)tzălymijer 159.

fidstent $=50$ I3luestre 328 .

Jidotenrilijelfäier, grober 136.

- flcimer 137.

Figitioen 301. 
Figites 301 .

- scutellaris 302.

Til3lıuß 575 .

Fingertäfer 39 .

Fiifdden 569.

Flata limbata 597 .

Ilatterflicge 467 .

- surdy jocinente 467.

- bummelartige 467.

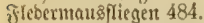

j゙lebermausmilbe, geneine 682.

Jebermatsmilbeit 682.

Frlcifdsfiege, gtaue 474.

irleifdifrefier 44.

Tliebermotte 437.

8) Iodblumenisaumerchent 423.

Tĭbörauteule 408.

Flob, gemeiner 486.

Torfliear, gemteine 493 .

त्रfußmilbe, fugelige 680 .

Foenus assectator 306 .

- jaculator 306.

70̈6rempanmer 420 .

Forficula giganten 564 .

- auricularia 565.

Forlente 411.

Formica congerens 259.

- cunicularia 259.

- fuser 259

- pratensis 257

- rufa 65. 94. 182. 259.260. 400 . 262.

- sanguiner 263.

Formicidae 261.

Formicina 253.

Foritbod 165.

Jranfenftügler 567.

Jrau 416.

Froftíbartiter, grofier 418.

- tleiner 419.

Früblutgâftiegen 499.

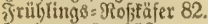

Judje, grofer 358.

- fléiner 358.

Jugentäjer 72

Fulgora candelaria 598.

- Iaternaria 598.

Fulgorina 596 .

Fumer 392.

Frurcittī fer 187.

Juttergraseule 408.

\section{(5).}

(S)abernaje 93.

(Sabelidjwan, grober 403.

(3äก์ โf

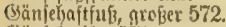

Bänfefncifer 571

Galeodes araneoides 632 .

- fatalis 633

- vorax 633

Galeruca 187.

- viburni 187.

- xanthomelaena 187.

(5) IIavfeไuesose, genteine 297.

(Sallentăufe 592 .

Gallerir mellonella 431 .

Galleriae 429

Sraflıuีidfert 453.

(S)allivespen 293.

Gamasidae 680
Gamasis coleopterorum 62 - coleoptratorum 681.

(5)amma 415

Bartenbirn pinner 395

Sarten = Doldincope 275

(Sartentraarmüde 457.

Sartenlyummel 221

Barter $=$ \&aubtäfer 90 .

(Sarten $=2$ autjfafer 35 .

(3artentucisfpinne 672 .

(5a)tameifen 259.

Gasteracantha arcuatn 658.

Gastropacha castrensis 389.

- lanestris 22.

- neustrir 389

- pini 15.387.

- potatoria 15.

- quercifolia 15.

- quercus 15.

Gastrophilus equi 471.

Gastrus equi 471

(3) birnz = \$orbkenue 36 .

(Scifelf torpione 641 .

Beitit 642.

(Sciftuen 439.

Semeinflienen 473.

(Semeinfdyveber 463.

Geometridae 417.

Geophilus electricus 624 .

- Gabrielis 623.

- longicornis 623

Geotrupes 81.

- stercorarius 82.

- Typhoeus 83

- vernalis 82

(5)erabflitigler 505.

(5) terber 87. 165.

Gerris 605 .

(Seid) Yofíf

(Seivenft = \&auffïfer 38 .

Selpenitidjrede, bornfübige 546 .

- Roifi's 546

(Seipentîtidoreden 544

(3) fpinitblattweske 331.

- rotbföbfige 332

Stetreibe = B la enfuí 568 .

Setreide = Qaubfäfer 89.

Stetreibe $=$ Rauffäfer 40 .

Betreibeberwilfter 453 .

(Setreibezingler 430.

Siditneste 306.

(3iebelfredier 147.

(3iftrumse bon YXan 687.

(Siniter $=$ BIattfloh 593

(Sitterflïgler 489.

(3) lanzfäfer 66.

(3) In:funglex 375.

(5)inttuegsen 284

Sleibtäfer, fleiner 98.

(5)let fjerffol, 569.

(3)et diernaft 498

(tieberfpuntuen 631.

Glomerina 628

Glomeris gattulata 629.

- limbata 629.

- marginata 629.

Glossata 341.

Glossina morsitans 478

Gluvia striolata 633 .

Glycyphagus 690.

Glypta resinanae 325.

Gniken 455 (3)olbafter 393

Stoloimgen 493.

(3)olbene 2dist 355.

Bolbeulen 415.

(Sololienue 35.

(Solbtäfer 93.

- gemeiner 259.

(5oloruthenfalter 364 .

(S)oldjdymies 35.

(5) lomeşue, blaue 291.

- fleifdrotbe 290

- aemeitre 241. 291.

- tönialicje 291.

- rofige 291.

Bolbivespen 289.

Goliathus Druryi 93.

- giganteus 93.

Gomphocerus 548.

- grossus 548. 553 .

- rufus 553 .

- sibiricus 553 .

Goniocotes 571.

Goniodes falcicornis 571 .

Gonyleptes curvipes 643.

(5ottesanbeterin 540.

(3rabkeuldirefon 564.

(3) tabivester 275. 279.

Gracilaria syringella 437.

Grapholitha dorsana 427.

- funebrana 428.

-. nebritana 427.

- pomonella 428.

(Srajeule 408.

(3)

(5raß̧hübfer 546.

- biffer 553

-- Yintiirter 553.

(Sinsplerbe 546.

(5) raturïß]ler, Yiniitter 131.

Greisftĥfer 106.

(Sstibelmüden 455.

(Srillen 546.

Grïnnuge, Bandfï̄iges 481.

(5)ïnriizler 134.

Srïntuidtler 426.

Gryllodea 564.

Gryllotalpa vulgaris 562 .

Gryllus campestris 559 .

- devastator 559 .

- domesticus 561.

- proboscideus 498.

(5)unbermam = (3allweske 300.

Gymnognatha 505.

Gyrinidae 51

Gyrinus 49.

- mergus 50.

- natator 50

- strigipennis 49.

Gyropus gracilis 572

- ovalis 572

\section{5).}

5narbalgmilbe bez $\mathfrak{M}$ Renj djen 693. 5narlinge 570.

Saarfactmilbe D. Menjidjen 693.

5abidit

Hadans lepidotus 285.

IIadena basilinea 406

- infesta 407.

Hadites tegenarioides 645 .

Hrematopinus eurysternus 575. 
IIaematopinus macrocephalus 575 .

- piliferus 575.

- stenopsis 575.

- tenuirostris 575.

- urius 575.

Hacmatopota pluvialis 288. 458.

Iraemonia 179.

IIacmylis daucella 436.

Sinfte 507.

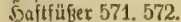

Salboecter 573.

5albbed" = 93odtafex, grofjer 170 .

IIrlictus 229.

IIaliplus 49 .

5almuespe, gemeine 330 .

II altica eruere 189.

- oleracea 189.

5anowerfer 167.

soarlefin 422

5arYetins 5 5übifpinne 675 .

IIarpactor cruentus 607.

5ajelböđđ)en 176.

Sajel=Didfoofrübler 140.

5afelnußrüßler 148.

Saubedjelfalter 366.

5ausbiene 205.

5)

Sansigrilfe 561.

Saltsinutter 413.

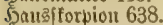

5aแ⿰彳 pintue 661 .

Soutbreme bes গinbes 472.

Soutflügler 195.

Sautroanzer 607

soefentoeisling 352.

Hedychrum lucidulum 292.

- roseum 292.

5eerfijlange 450.

5eerivurm 450.

- amerifanifjer 410.

seertourm $=$ Tratermü

IIeilipus 135.

Seindi)en 561.

Seftor 360.

5ुelb bod 167.

Helophilus 468.

- pendulus 468 .

- trivittatus 468 .

IIeliopsyche Shutleworthi 502.

Heliotlirips haemorrhoidalis 558 .

Seไutzirpen 596.

Selntaine, Gotse 596.

IIemerobius 494.

- hirtus 494 .

- perla 493.

Homipters. 573.

IIemiptycha punctata 596 .

IIemiteles aroator 321.322

IIenicops 622.

5erbiteulen 406.

Serbit: (Srasimilbe 678.

Serfulestäfer 91.

Ilesperia comma 366.

Iesperidse 366.

Hetaerius quadratus 65 .

- sesquicornis 65 .

IIeterogyna 273.

Seteroginen 273.

IIeteromern 117

Heteronotus reticulatus 596 .

IIeterostoma 623.

IIetrodes horridus 557.
Hetrodes spinulosus 557.

5eupferbe 546.

5ุeupfero, gefdivån

- grobes braume 558.

- arobes grïnes 558.

Seuidireden 546.

5eujarede, banoirte 553.

- italienifdje 554.

- tatarifje 555.

Hibernis aurantisria 419.

- defoliaria 418.

- leucophaearia 419.

- progemmaria 419.

5imbeermabe 72

5immelspferb 513.

Ilippoboscidro 483.

Hippobosea equina 484.

5ir\{d täfer, gemeiner 73.

Sirjengragffalter 362 .

Sirjegundొer 431.

IIispa 179.

Histeridae 64.

Iister fimetarius 65 .

- sinuatus 65 .

Hodotermes 526. 530.

5 öđer=Drüfenameifen 264.

Solzameife, fdiwarge 264 .

5jolibierte 225.

- tafirifidje 225.

- violettflingelige 225.

5ुolyböđe 164. 682.

5olgbod, gemeiner 684 .

- geranbeter 685 .

- violettrotber 686 .

5olzbolyrer 117. 374.

jolzlaus 521.

- liniirte 521.

- vicrpunttige 521.

5olgtweäpe, gemeine 327.

गิ) fluespen 326 .

5onigbiene, gemeine 205.

Joniggrn 3 falter 362 .

sonigmotte 430 .

Iloplocamps fulvicornis 335 .

5ornbiene 224.

- gemeine 224.

5ornifie 246.

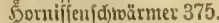

5ofenbiene 227.

Sottentottent $=$ Sforpion 639 .

Sottentotten $=23$ anze 615 .

Sünelameife 262.

Silinerlaus 572.

5ึitlentuurm 500.

Soแnuแeไı 218.

5umntelf(h)wärmer 374

Sunbelaus 571.

- edite 575 .

5unbertfüß̄ex 620 .

5ँunbsizede, gemeine 684.

5ungersuespe 305.

- Heine 306.

IIyalomma 687.

Iydaticus 48.

Hydrarnchna concharum 680.

- spinipes 680.

Hydrarachnidae 679 .

Hydrocanthari 43.

Hydrocores 601.

Hydrodromici 604 .

Hydrometra paludum 605.

Ilydrophilidae 51.
Iydrophilus 51.

- aterrimus 53.

- piceus 51.

Hydroporus 48.

- elegans 48.

- nigrolineatus 48 .

Hydrous caraboides 53

Hylaeus 229

- grandis 230.

Hylesinus piniperdia 158

- testaceus 158

IIylobates 604.

Hylobius abietis 136 .

- pinastri 137.

Hylotoma berberidis 338 .

- rosae 338.

Hylotrupes bajulus 170 .

Hymenoptera 195.

- phytophaga 325.

- terebrantia 199.

Hypoderms Actaeon 473 .

- bovis 472.

- Diana 473.

- tarandi 473 .

Hyponomeuta malinella 435 .

Kypsauchenia balista 596.

Hyptia minuta 306.

3.

Jagbivinne, geranbete 671 .

Ibalia cultellator 302 .

Ichneumon 319.

- fusorius 320.370 .

- pisorius 320. 370

§dneumonen 313 .

Ichneumones 313.

Ichneumonidae 311.

Jiner 487.

3nimen 195.

รmmenbreme 503

Эntmentäfer, gemeiner 113.

Yinger 86

Iniquiteles 659

Inocellia erassicornis 495 .

Znfeftenregen 112.

Jolyannisbeerblattlaus 587

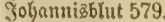

Jobannistäfer 88.

Эo5nแmisıi

- Fleines 108.

Iulobiben 97.

Julodis fascicularis 97.

Julus guttulatus 626 .

- sabulosus 626

- terrestris 626.

Junifthfer 88.

Exodes marginalis 685 .

- reduvius 686 .

- ricinus 684

Lrodidae 682

\section{ก.}

Sinbinetfaffer 71

Răjer 25.

Riffer, breizeçize 192

- fünfzertige 26.

- verfdicbentsefige 117.

- viergelyige 130.

siăfermirbe, genteine 681.

Rärter 500 
Rüiemitte 689.

finkneidyettviduler 426.

Raifermantel 355.

suterlaf 537.

Ramelbalsfliege, ståfïblerige 495

Sammborntäer 76 .

Ranmmmideren 449.

sanfer 642 .

Raria 530.

Sarmefinbeere 576.

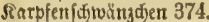

Raulerfe 505 .

siegelbiene 237.

Sellexibinne 667.

Rermes 576 .

Kermes tinetorum 576.

Sermesbeere 576.

Rerntesీidilblaus 576 .

Reulentäfer, gelber 57.260.

Sitefernblattwesve, grobe 332.

Sìieferneule 411.

Sicferstgallen = 2Bidter 426 .

Siefern $=50$ olgroeşpe 327.

నiejern = §ammbormuesిpe 333.

Riefermmarttiffer, groper 158.

- fleiner 159.

Rieiern= Braditfäfer 97.

Slefert = Proceffiont fpinner 402 .

siefernriiffeltäfer, tleiner 137.

Siefern|djuärmer 370 .

Siejerrifpantter 420

siefernipinner 15.387.

Riefernpinner=ङidjelivespe 316.

Sieferntrieb $=28$ idtler 426 .

Rieferstuveis $=2$ aitfafer 158 .

Rirjdblattlaus 587.

Ririd)blattweşpe, fdivarge 335.

Sirfdifliege 480.

Rlapperkeufditede 553.

ภTtciberlaus 574

freibermotte 434.

RTeinfalter 424.

RTeingirpen 593.

ภTetterłauffäfer 36.

- fleiner 37.

RTopftäfer, Eunter 115 .

Siteifer 571.

Sinotenameifen 262. 265.

Rnotenivespen 286.

fntotengirpen 595 .

Rutenzirpe, netanderige 596 .

Rodsentile 576

- feitre 578

- orsinthre 578.

- polnildie 579

- vilbe 578

Rodjentilmilbe 678.

Ribderfliege, geftriente 500 .

- rautenflectige 499.

fiof) $[=$ (Erofloh 189.

sobrfiege 479 .

soligalletrübler 154

Soblidunate 448.

Rolitivanze 614 .

Soblyeißlin, grofier 350 .

- fleiner 352

Rolben= Bafferfäfer 51 .

- Iauffäferartiger 53.

- vedjidjuarzer 51.

- duluarzer 53.

ropfbinner 392

Jopflaus 574.
Sornmotte 433.

Rornwurm, fdiwarzer 157.

- iveiber 433.

Sotbtäfer 80 .

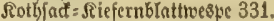

Sotbivange 606 .

Rrabbenfpimnen 668 .

srabbenfuimue, grïutliçe 668 .

- umberidiveifento 668.

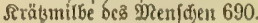

Rrrüuterbieb 114

กrcbspintutet 695

Srebsipinne, (d) lante 695.

Rreuspitune, gemteine 653 .

Rriegsivurm 450 .

Ruldjenjdyabe 537.

Rïmmelfdabe, Duntelrippige 436.

Runelbichen 232

Rugelfäfer 192

R่ublat: 571 .

Rิuffbienter, eiufame 222.

surzftingler 54. 259.

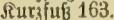

กurghörner 134. 444.

\section{I.}

Labidura gigantea 564 .

Labidus 264.

Sabbtinthfpinne, gemeine 663 .

Lachnus longirostris 260 .

- punctatus 590.

- quercus 590.

Sadfidfilblaủ 578.

Lacon murinus 101.

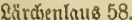

\&ärdien = Minirmotte $\mathbf{4 3 8}$.

¿ăure 574.

Lamellicornia 77.

- laparostictica 78.

- pleurostictica 78

Lamiidae 172

Lampra 97.

Lampyris noctiluca 108.

- splendidula 108.

\&anojungfer, rauke 494.

Ranbutilben 679 .

Eangfüblex, arüner 435 .

Sanghbörnet 164.224.444.

Eaugtäfer 161

Eantwanzen 610.612.

Laphria gilva 460 .

Laphystia sabulicola 460 .

Eappentüß̧е 132.

- braunbeiniger 134

Larentia 421.

- chenopodiata 422

- hastata 422

- tristata 422

Largus 610.

Lasius 264.

- alienus 258. 264

- emarginatus 264.

- flayus 258.264.

- fuliginosus 258. 260. 264

- niger 258. 264.

Laterigradae 668

Enternenträger, djine[tidjer 598.

- europäifidjer 597.

- furinamilájer 598.

Latonir 356.

Latrodectus tredecimguttatus 660 .
Sattidintiege 479.

Eaubtäfer 78, 84.

Eaubteujdjreden 556.

Sautfitifer 32 .

- gologriiner 35.

Saumilben 679 .

\&aus̆ftiege» 483.

\&a1tomtilbe1 689 .

Lecanium hesperidum 15.

- ilicis 576

- quercus 576

- vitis 576

Sebertïfer 95 .

Ledra aurita 594.

Sebntureshen 238.

Rebmbesse, zabnbeinige 240.

Lems 179.

Lepidoptera 341.

Lepisma saccharina 569 .

Lepismatidae 568.

Leptinotarsa decemlineata 184.

- junctr 185.

Leptocircus Curius 350.

Leptogaster 459.

Leptothorax 255.257.

Leptura aquatica 180.

Lepturini 168.

Leptus autumnalis 678 .

Lestes 516

- sponsa 516

Lethrus cephalotes 83 .

Leucania extranea 410

Letcanien 410 .

Reuçttäfer, genteinter 108.

Reucitzitpent 596.

Libellula 515

- depressa 518.

- pedemontana 516.

- quadrimaculata 519 .

Libellulidas 520.

Sidjtmotten 429.

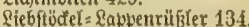

Qinufterídjuirnter 369 .

Siltenbăbndien 181.

Qifientafer 181

Limenitis populi 359.

Limnobates stagnorum 604 .

Limnophilus rhombieus 499 .

Lina populi 183.

- tremulae 183

Rinden : \$raditfifer 97.

\&inbenfd)lvätrmer 373.

Linguatulidae 693.

Sinfentäfer 178.

Linyphia montana 659 .

Liotheidae 571

Liotheum 572.

Sipariben 392.

Liparis dispar 15.

- ochropoda 15.

Lipëurus 571.

Lipoptena cervi 484

Sippenfïbler 620 .

Lithobius forcipatus 622

- forficatus 62 ?

Lithocoletis 433 .

Livir juncorum 592.

Riurcernutue 389.

Lixus paraplecticus 135 .

Locusta cantans 559 .

- caudata 558.

- viridissima 558 
Locustina 556.

Lomechusa 54.

Longicornia 164.

Lophyrus pini 314, 321. 333.

Lucanidae 76.

Lucanus capreolus 73 .

- cervus 73

-- hireus 73.

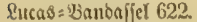

Lycrena 365.

- Adonis 366.

- Alexis 366.

- Iearus 366.

Lycosa blanda 649.

- saccatr 672 .

Lycosidae 671.

Ly da 331.

- campestris 331

- clypeata 332.

- erythrocephala 332.

- hypotropica 332.

- inanita 332.

- pratensis 332.

- pyri 332.

- stellata 332.

Lygaeodes 610 .

Lygaeus equestris 611.

Lythria purpuraria 421

Lytta vesicatoria 127.

\section{Mi.}

Macrobiotus 695 .

Macrocentrus marginator 308 .

Macrocera 224.

Macroceren 444.

Macrocheirus longipes 156.

Macroglossa 373.

— bombyliformis 374 .

- fueiformis 374.

- oenotherae 373.

- stellatarum 374.

Macrophya 337.

Mäx = 5aarmủltc 456 .

9tanenbreme bes भierseo 471.

Maififer, semtiner 84.

9Raimum 122.

- gcmeiner 125.

Malnchius renens $\mathbf{1 1 2}$

Malacodermata 106.

Malmiguatte 660.

Mamestra persicaria 408.

Mrautn= (sifnob 600 .

Dauma $=$ Sthilo lnแ3 578 .

Mranoinc = 2Imcife 270.

Danigolocule 409.

Mantis argentina 542.

- carolina 543.

- religiosa 540 .

Mantodea 542.

Marientïfer, fiebenwuthtister 193.

9)(aricufäferdjeแ 192.

Marmor, gelber 422.

Mrassaridae 238.

Mauerargus 363.

פ) ใnuerbiene 233.

- getürnte 233.

- rotbe 233

פสmerfudis 363.

Draner = Relmuse sue 239

MRanctivesิpen 238.

9taulbecipiuner 15, 385.

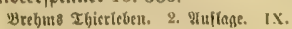

Maulfäjer 162.

- weikflediger 163.

Maultuıríg grille 562.

Intauterbiene, gemeine 231.

Maurer = Spimnentïbter 280 .

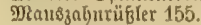

- pedjdjuarzer 156.

- rotbrifjeliger 156.

Meconema varium 557.

MReerläujer 604 .

Megrachile 233.

- centuncularis 233.

Megalosoma elephas 91.

Rebrtfäier 119.

Dehlmillbe 690.

Mehinurm 119.

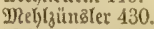

Melanophora blanda 629 .

Melasomata 117.

Melecta 236.

- Iuctuosa 237.

- punctata 237.

Meligethes neneus 66 .

Melipons 215.

- seutellaris 216. 217.

Meliponen 215.

Melitaea 356.

Melitophila 92.

Melitreplus scriptus 466 .

- taeniatns 466 .

Mellinus 284

- arvensis 281.

- sabulosus 284 .

Meloë 122.

- cicatricosus 124.

- erythrocnemus 121.

-- majalis 125.

- proscarabaeus 125.

- Schnefferi 126.

- variegatus 125.

Melolontha 8.

- fullo 87.

- hippocastani 84

- vulgaris 84.

Melophagus ovinus 484.

Dichyriben 112

Membracina 595.

Membracis cruenta 596

- clevata 596.

Membranacei 607.

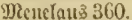

Menopon pallidum 572.

Merilegidao 227.

Mesoleptus testaceus 317.

Mesomphahia conspersa 192.

Mesostenus gladiator $32 \%$.

Motallites 134.

Metoecus paradoxus 120 .

Ninstor metralous 20 .

Micraspis duodecimpunctata 192.

Microgaster 307.

- glomeratus 308.

- nemorum 308.

Microlepidoptera 424 .

Midas 81.

niliben 677.

P̈ilbenfpime 678 .

Niltogramma conica 289.

- punctata 289.

2)tinircifabe, geripste 597.

- gefüumte 597.

Mtinirjpinuen 652 .
Miris 610 .

Ditîtüfer 78 .

Miftlieb, erzfarbener 56.

Mijt $=$ Stubtififer 65 .

Mtoderfäfex $5 \mathrm{a}$

- goloftreifiger 55 .

- rotbflïgeliger 55

- ftuifenber 56.

Mqörtel6ícite 231

Molorentopf 391.

Mobrenfforbion 638.

Miololworf 562.

Moma Orion 406.

Monedula signata 285.

Monomorium 265.

Mooslyummel 221

Yorbfliegen 474

Morbfliege, gelbleibige 460 .

Diorofäjer 36 .

Detorauter 412.

Thoropipine, pedboraune 653.

Morobeşผen 275. 276.

Mormolyce phyllodes 38 .

Morvtsiber 360.

Morpho Laërtes 360.

- Neoptolemus 360.

Mroictus

Miosititos 4.6.

Motten 432.

Päden 445.

MRïller 119.

9)illerftifer 87 ,

9Rıffelfäfer 176 .

Musca caesarea 478.

- domestica 475

- rudis 284

- vomitoria 476 .

Muscidae 473.

Mutilla curopaea 273.

Mutúca 285.

Mycetophilidae 449.

Mygale avicularia 619 .

- Blondii 650.

- Ietzii 276.

Mylabris Fuesslini 127.

Myopa ferruginea 470.

Myriopoda 619.

Myrmica atrata 259.

- canadensis 267.

- laevinodis 266

- molifierns 266.

Myrmicidae 262. 265.

Myrmecoleon 490.

פ)

Myrmeleon 490.

- formicalynx 492 .

- formicarius 490.

- tetragrammicus 492 .

Mgurtenblatt, Lyüpfenbe\$ 558.

g.

Rabefirizen 596.

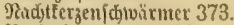

Padibfoumenmane, treines 385

- mittleres 385 .

- Wiener 385.

Raberholgbod, fumbörutiger 170.

- zlueibindiger 170.

Tabeliforviomvanje 603.

Naenia typica 318.

Nafujer 134. 
Rajenbreme bes Gdiafeశ 472.

Rajenidrede, europäi idje 555.

9aborntäter 91.

Naucoris cimicoides 603.

Necrophorus germanus 62.

- humator 62.

- vespillo 60.

Nectarinia 243

Necydalis bumeralis 128.

Necydalis major 170.

Nematus 334.

- salicis 33.4

- ventricosus 15.334 .

Nemeobius Lucina 366.

Reoptolcum! 360 .

Nepa cinerea 603

Nepini 602.

Nosaea 680.

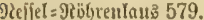

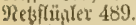

Neuronia lolii 408 .

- popularis 408.

Neuroptera 489.

Nouroterus 15.

Newportia 623.

গligut 481

grivbe 356

Niptus 114.

Nirmus 571

Nitidula bipustulata 66 .

Nitidulariae 66.

Soctuet 40.4.

Noctuina 404 .

Nomada 235.

- Roberjeotiana 236.

Nonagria 410.

- typhae 410.

Porute 397.

Nops Guanabacose 667.

Notonecta glauca 602.

Notonectini 601.

Nyctalemon Patroclus 417

Yrumbraliber 355 .

Nymphon gracile 695.

D.

Oberea linearis 176

Obisium corticalis 640

- muscoruin 640.

Obiturnbe 428.

Dbftuidícr 428

Dajfentukge, gróвев 362

Ddj jem 361

Oeneria dispar 395.

- eremita 397.

- monacha 397.

Ocypus olens 56 .

Odontomachidre 261.

Odontomachus 264.

Odynerus Antilope 240.

- parietum 239. 292.

- spixipes 210.

Oecodoma cephalotes 270.

Oedipoda coerulescens 553.

- fasciata 553.

- germanica 553

- migratoria 551.

Deffäjuc 122.

- Isunter 125

Oelnutter 12.)

Oestridac 470 .
Oestrus hominis 470 .

- maculatus 472 .

- ovis 472 .

Direnzirpe 594.

Dhrmurm, aemeinet 565 .

- srofier 564.

Drcanberfdumärmer 371

Omalus auratus 293

Omatius 459.

Onthophagus $8 n$

Ophion 317.

Ophionidae 314.

Opilio glacialis 642

- parietinus 643.

Opistophthalmus capensis 638

Orbitelae 653

Orchestes fagi 151.

Drbensbintinoer 416 .

Drbenşbanb, blaue 416.

Oreina 184.

Orgyia pudibunda 15.

Driolt 406.

Ornithobis pallida 481.

Ornithodoros 689

Ornithoptera Amplurisus 348.

- I'riamus 349.

Ormyrus tubulosus 298

Orthoptera 505 .

Oryctes nasicornis 91 .

Oscinis frit 482

Osmia 233.

- bicornis 233.

- parietina 221.

- rufa 233

Osmoderma eremita 95.

Otiorhynchus 132.

- ligustici 134.

- niger 132

- nigrita 134.

- picipes 134

- sulcatus 134.

Oxybelus uniglumis 288

Oxyporus rufus 56 .

Drivure! 302.

\section{\$.}

Pachygnatha, 659 .

Pachymerus calcitrator 331,612 .

Pachyrhynchus 133.

Pachytylus cinerascens 553 .

- migratorius 551 .

- stridulus 553 .

Pnobicuut = 2Amcife 269.

Paederus riparius 56 .

Palingenia 509.

- horaria 509.

- longicauda 509.

ßalnbolyter, javanifaber 156.

Palpicornia 51.

Paniscus 317.

Panorpa communis 497

Pantopoda 695.

ßapierwesิpe, franzöfi jue 244

- fanbivespenartige 251.

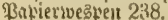

Papilio Machaon 349.

- Mernnon 14

- Ormenus 14

- podalirius 349

- Turnus 14.

BappeY= Blattfijer, grober 183.
Bappel = B3Latttäper, Fletuer 183.

Bappelbod, arojer 175.

Tappel = (3allenInus 588. 591.

நappel] (d)uårmer 372

Baypelftedier 146.

Pararge 361.

- Megraera 363.

Pardosa arenaria 672

- montana 672

- saccata 672.

Parnopes carnea 290.

Paropsis 187.

Passalidao 76.

Pectinicornia 76.

Pediculina 574

Pediculus capitis 574

- eurygaster 574

- tabescentium 575

- vestimenti 574

Pedipalpi 641.

Pedirapti 602.

Pediremi 601.

ßeitfdyrauken 405.

Pelopoeus 280.

- chalybeus 281

- destillatorius 280 .

- fistularius 281.

- spirifex 281.

ßelsbiente 223

- abgeftubte 223.

- raublanarige 223

ßelzflitgler 499.

gel zirefier 570.

selääfer 70.

Yelsmotte 434.

Pemphigus bursarius 588, 591.

- terebinthi 592

- vitifolii 58 ?

Pentamera 26.

Pentastomidae 693.

Pentastomum denticulatum 694.

- trenioides 694.

Pentatoma rufipes 615.

Perga Lewisii 327.

Periplaneta americana 539.

- orientalis 537.

Peritymbia vitisana 582 .

Perla bicaudata 506 .

Perlarise 506.

Pertbiube, fleimite 366.

ßerImutterfalter 355 .

- grofer 355 .

Pezomachus 313.

झुfautenjpiegel 356.

SBFu = Feberfing 571

Э̧feifentäfer 142.

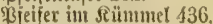

ßreiltröner 306.

gferoe = Laußfirge 484

\$firficiblattraub 588.

\$flamzenumilber 679.

Эiflanzenwe šben 325

Blapterfüfer 122.

giflaumenbofyrer 147.

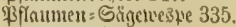

झ̊laumteuvidler 428.

Phalaenidao 417.

Phalangida 642.

Phalangium opilio 642 .

Phanacus 80.

Pharyngobolus africanus 473 .

Pharyugomyia picta 472 . 
Pliasma 546.

Phasmodea 544 .

Phigalia pilosaria 418.

Philonthus aeneus 56.

Philopteridae 571.

Phora incrassata 482.

P'lotinus pyralis 109.

Phryganea striata. 500.

Phryganeodea 499.

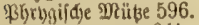

Phrynus Iunatus 641.

Phthirius inguinalis 575 .

- pubis 575 .

1 bycidae 429.

Phygadeuon 320.

- pteronorum 321.

phyllium siccifolium 546 .

Phyllobius 134.

l'hyllopertha horticola 90.

Phylloptera 557.

- fenestrata 558.

- myrtifolia 558.

Phyllotreta flexuosa 190.

- nemorum 190.

Phylloxera quereus 581 .

- vastatrix 582.

Phytocoptes 679.

Phytocoridae 609.

Phytocoris 610 .

Phytoptus 679.

Phytospheces 325 .

Pieridao 350.

Pieris brassicae 350 .

- crataegi 353.

- napi 352.

- rapa 352

Piezata 195.

Biflenbtelsex, Yeilliger 78

- poctemnrbiger 79.

Biffentäfer 72

Biflentue äse 241.

Bifzturftiigler, rotlier 56 .

Bilzmủdet 449.

Pimelia distincta 119.

Pimpla instigator 324 .

Pimplariae 313.

Himtlatier 313.

Binien= \$roceffionsipinner 403.

Winfeftäfer 92

- nebinberter 95.

- lamuarmiger 95

Piophilia casel 476

Pissodes notatus 137.

Blattbaud, gemeiner 518.

- vierflediger 519 .

Platycnemis pennipes 518.

Platygaster Boscii 199.

Platyparer poeciloptera 480.

Platypterix falcula 322.

Ploteres 604 .

Plusia 415 .

- gamma 415 .

ไtufien 415.

Podilegidae 222

Poduridae 569.

Podura aquatica 569 .

- plumbea 570.

- villosa 570

Poecilonota rutilans 97

Polistes diadema 244.

- gallica 244.

Polybia ampultaria 243.
Polybia cayenuensis 243.

- liliacea 243.

- rejecta 242.

- sedula 242.

Polydesinus complanatus 627

Polydrosus 134.

Polyommatus Phlaeas 364.

- virgaureae 364.

Polyphylla 87.

Polyzonium germanicum 628.

Pompilidae 275.

Pompilus 276.

- formosus 276.

- natalensis 276

- trivialis 278 .

- viaticus 278

Poneridae 261. 264.

Porphyrophora polonica 579.

Porthesia auriflua 395.

- chrysorrhoea 393.

Gokentifedier 142.

ßradjttäfer 96.

Bractftäfertöbter 287.

Briamu 249.

Priocnomis variegatus 278.

Prionidae 165

Prionus croriarius 165

Brocéfíns raupe 401.

Broctotruniben 302.

Psammophila hirsuta 281.

Pselaphidae 56.

Psen ealiginosus 293.

Pseudophana europaea 597.

Psilogaster 301

Psoeus 521.

- lineatus 521

- quadripunetatus 521.

P'sycho 15.

Psyche apiformis 15. 391.

- graminella 391.

- helix 390

- unicolor 391.

- viciella 391

Psychina 390.

Psylla genistae 593.

- mali 593.

- pyri 593.

Psylliodes chrysocephala 186.

Bteromalinen 304

Pteromalus puparum 304

Pterophorus fuscus 439 .

- pentadactylus 439 .

- pterodactylus 439

Pteroptus vespertilionis 682.

Ptiniores 117.

Ptinus fur 114

- hololeucus 114.

Pulex irritans 486.

Pupipara 483.

Buppengebarer 483.

Buppenräuber 36.

93 urtutrbär 379.

Pyenogonidae 695.

Pycnogonum littorale 695

Pyralididae 429

Pyralidina 429.

Pyrophorus 102.

- noctilucus 103.

Pyrrhocoris apterus 610 .

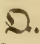

Duedeneute $40 f$.
$\Re$.

Rabiesdenfliege 479.

Mabfyinuen 653.

Mabruanze 606.

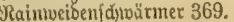

Ranatra linearis 603.

Rambafier 627.

- Wratte 627.

Ranobanbiugler 361.

Ranbbuange, rautenfötntige 613 .

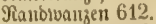

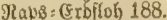

Ra):s= (SImutäfer 66 .

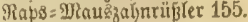

Fa\}enamei[e 265.

Raubameife, blutrotbe 263.

भinubnumeijen 259.

Raubfitiene, Gornififenartige 461 .

Rnubfliejcu 459.

Ranbronizen 606.

yimbivesten 237.

Raulgltingelovespe 305.

Nautsenfliene 474

- gröste 474.

- wilde 474

graupentöbter 279.

- gelbftügefiger 279.

- weiß burdj|duittenter 279

Reblau 582

Rebenfdyneioer 83.

rebenptedjer, ftaljiblauer 142.

Reduvini 606 .

Reduvius personatus 606.

Regenbremie 458.

Tetibtäier 157.

Reitfröte 562 .

Mcistïjer 127.

Retina Buolinna 426. resinella 426 .

Reutivurm 562.

Rhax 633 .

Rhagiun 169.

- bifasciatum 170

- indagator 170

Rlaaphidia crassicomis $\$ 95$.

Ihhipiphoridao 120.

Rhipiptera 502 .

Rhizotrogus solstitialis 88 .

Rhodites Eglanteriae 301.

- rosae 300.

Rhodocera Cleopatra 351.

- Rhamni 354.

Rhopslocera 347.

Rhynchites 142.

- alliariae 147

- betula 146.

- betuleti 142

- conicus 147.

- cupreus 147

Rhynchophorus Schacl 156.

Rhynchoprion columbae 687.

- penetrans 487.

Rhynchota 573 .

Rhyssa persuasoria 322.

9tiegraşfalter 362 .

Ricien= Finnerfäfer 39.

Miejen: (oliatly 93

Riejenfäfer 90.

Riejen= 5olzwestye 328.

Ricienictabe 539.

Riejen=-Sdywimmuvanze 603 . 
Rinbenläuाe 580 .

Minbenlaus, molltragenoc 590 .

Rinbeniforpion 640 .

Stinbentwanze, genteine 608 .

Mintentwanzen 607.

Minberbremie 457.

Minblauछి, Greitbrüjtige 575.

- fpibföłfige 575

Rinosbiesfliege 472.

Ringelid divürmer 378.

Mingelipinner 389.

Riubuta 606

Riparii 605.

Rittcrumse 611.

Möbren

Irogas 310 .

Molireulen 410.

Tohrtolbeneule, gemciute 410 .

Jioliafieln 628.

Yiolitfyiere 628

Molfwespen 275.

9o Jenblattlaus 587.

Yofen = Bürftbornvę) 338 .

Mofencifabe 593.

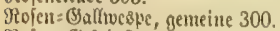

Ro/en = (Siefyinftucespe 332.

Mofentiffer 93.

Tofenfüier, Kleiner 90.

Tofzancife 262.

Pobtifer 81

- vreilyürniger 83.

- nemeinter 82

Robifaftanien = Raubtäfer 81.

Roftinbe 361 .

Rotbjún)wanz 392.

Ruberfüber 601 .

Tuberwanze, (Sicoffrot)' $\mathrm{GO1}$.

Riiben= B Iathuespe 336.

Ritbiantufeifer 431.

Rikf fatueifling 352.

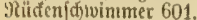

- genteiner 602.

Ruiifieltäfer 130.

- grobier brauner 136

- jujnarzer 132.

Rüfichutien 431 .

Riüter = \$aarnaflenlก!เ 591.

giijteriplintfäper, großzer 161.

Runbuäuler 307 .

9tunlelryliege 479.

Ruteliben 89

\section{ธ.}

Santidinelififer 104

Sndtäfer 182.

- vierfuntiger 18 ?

Sactränet 390

- gemeiter 391.

Satfipiure 672 .

Godivimen 664. 667.

Sïbelfótreden 556.

Gänebod 165.

Sänefäfer 182.

Singerullo 40 s.

8alda elegantula 606 .

Saldiula 605.

Salticus scenicus 6750 .

Saltigradae 675.

Samentifier 176

- gemeiner 178.

Gammetfüแlerdyen 678
Sammetmilbe, gemcine 678

Sambaijer 626.

Sanbauge 362.

Subbienen 227.

Sanbflob 487.

Smbtäpr, langhalfiger 32.

Sand= Jinotenueaspe 287.

Sanbivesive, gemeine 281.

- raulye 281.

Saperda 175.

- carcharias 175.

- populnea 175. 324

Sapholytus 296.

- connatus 298

Saprines 65.

Saprinus 65.

Sarcophaga carnaria $\mathbf{4 7 4}$

- latifrons 477.

Sarcoptes hominis 690 .

Sarcoptidae 689.

Saturnia Arindia 381

- Atlas 380.

- carpini 385.

- Cynthia 381.

- Pernyi 382

- Polyphemus 15.

- pyri 385

- spini 385

- Yama mayu 381.

Satyridae 361 .

Satyrus 361 .

- Alcyone 362.

- Briseis 362

- Semele 36.2.

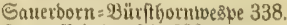

Saugafiel, beutidse 628 .

Saumzede, muidjelfürmige 687.

- Herfídic 687 .

Saumzeden 687.

Scapelosoma satellitia 412.

Scaphidium 54

Scarabüen 78.

Scarabaeidae 77.

Scardia polypori 324 .

Scarites abbreviatus 39 .

- anthracinus 39.

- pyracmon 39.

Gdjabe, amerifanifje 539.

- beutiç 535.

- geflectite 537.

- Iapplänbídie 537

Sdjaben 432. 540.

Sdjüffer'icher Matuenuurm 126.

Sdaf = Daffelfliege 472

Schafsecte 484.

Sdjalenaffel 629.

- ge äumte 629.

- getulufte 629.

ธduntrad) länfe 575.

Sdraumcifabe 594

Sdiatenfalter 356 .

Sdeibenbodtäfer, werïnberlidier 171.

Strvibentäfer, blanter 172.

Sdyenfelfammlex 203.

Sduenteliveispe, gelbflectige 305 .

- geftielte 305.

Sdienterfanintler 203.

Sthilbafiel, fpinmenattige 621.

Strifonileln 621.

Stbilotüfer 190.

nebelinger 190.
Sưirbäure 575

Sd)ilbwanzen 613.

Edjilftäfer 179.

- teulenbeintiger 180.

Scyillerfarter 359

Sehizocerß 339.

Schizoneura lanigera 590.

- lanuginosa 591.

Sdilammftiene $466^{\prime}$

Sdlangenzirpe 596.

Sdjlantjungfer, Ereitbeinige 518

Sd)lantiungieru 516.

Sd)ltwfwesten, edjte 311.

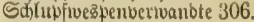

Sdimalbaud) 98

- jweiflectiger 98.

Sd)malbod, gefwornter 168.

- veränderlidier 169

- vierbintiger 169

Sd)malbide 168.

Sdmmaljungfer, grof́e 518.

Sdmmalzzümster 429.

Sffmaroberbienen 235.

Sdmatober= Sallivesైe, mefferföt: mige 302.

Sdymarober= (3alfuesิpen 296. 301.

Sdimarolserhunmeln 235 .

Sd)marobermilben 680

Sdimaroberwespen 238.

Sdumetinfliege 476 .

Sdimetterlinge 341

Sdmutterling

Sdimetterlinghafte 499.

Sdimieb, rauller 101.

Sclimiebe 99.

Sdunbelnrifle 498.

Sd)unbellungfer, gridentartige 498

- midenartine 498.

Sthabelterfe 573.

Schnobercáteden 555 .

Situraten 448.

Sdmtembanze 613

Sdynaแzenbienc 129

ธdинuzenbienen 223.

Gauceballblattlans 587.

Sdinecballen = Fitudittüfer 187.

Sdneetvïruter 110.

Srbneiber 642 .

Gdnellfliegen 474.

Sdutufitifer 99

- mälifeglauer 101.

Sdynellzitwen 594.

Sanevienfliene, getwiblelte $\mathbf{4 6 2}$.

Schmurafjeไn 625

Sdiúlfrant = \&aits 580.

Sdiönvanze, acfitreifte 610 .

Sdirn̈ntopfbode 166.

Sdiranfo (5tobicne 229.

Edyreiner 174.

Sdreitwange, bluttothe 607.

Sd)reitumanjen 606.

Sdirotfäfer 163

Sdjufter 642 .

Sdivitumer 367.

- breitleibige 373

Sdyualben= Rausffiege 48.1.

Edywalbenfdiromis 349.

Sduvamm = Sallowsue 239.

Sdywanmipinmer 395

Sdivan 395

Sodjuarge ßliege 568

Scbroargeâfer 117. 
Sojwebfliegen 465.

Sdiveifruanze 603 .

Sdjvimutăfer 43.

Sd)toimmuanze; gemeine 603 .

- oftindifdye 603 .

Sdjwirrfliege, monbfledige 466.

Sd)tvirrfliegen 465 .

Sciara 450.

- militaris 450 .

- Thomae 450.

Scolia campestris 275.

- capitata 275.

- erythrocephala 274.

- haemorrhoidalis 274.

- hortorum 275.

- procer 275.

Scolopendra 622 .

- borbonica 622.

- Brandtiana 623.

- electrica 623.

\section{- Lueasi 622.}

Seolopendropsis bahiensis 623 .

Scolopocryptops rufa 623 .

Scolytidae 157.

Scorpio 637.

- afer 635. 638.

- carpathicus 638 .

- europaeus 658.

- tunetanus 639.

Scorpionini 638.

Scorpiops Hardwicki 638.

Scutati 613.

Seutellera 616.

Scutigera coleoptrata 621 .

Securipalpen 193.

Sedentariae 653.

Seejungfer 516.

- gemeine 516.

- verlobte 216.

Gegelfalter 349.

Segestria senoculata 667 .

Seibenbiene, raulie 230.

Seibenfliegen 457.

Seibenipinuter 385.

Selandria adumbrata 335.

- fulvicornis 335 .

Selenobia 15.

Sembloder 506.

Semele 361.

Sesia 375 .

- empiformis 375

- myopiformis 376.

- sphegiformis 324.

- tenthrediniformis 375 .

Sialis fuliginosa 497.

- lutaria 496.

Siderwespen 314

Sicbenbriber 378.

Siebenbunft 193.

Siebruespe 287.

- gefielte 288.

Sirbermumbluespen 287.

Silberitrid) 355 .

Silpha 62.

- atrata 62.

--- laevigata 63.

- obscura 63.

- quadripunctata 63.

- reticulata 63.

- thoracica 63.

Silphales 59.

Silphidae 59 .
Simulia 455.

- Columbaczensis 455.

- maculata 455 .

- pertinax 455 .

Sintgairpe, prïd)tige 600.

Singzirpen 598.

Sirex gigas 328 .

- juveneus 327.

Sisyphus Schaefferi 80.

Sitaris muralis 128.

Sitones lineatus 131

Sitophilus granarius 157 .

Stolopenter 622.

Sforpion, amerifanifder 639.

- capenier 638.

- farpatbífdjer 638.

- verjdobebenfarbiger 638.

Sforpionfliege, geneine 497 .

Sforpionmilbe, wanzenartige 640 .

Sforpionjpinnell 641

Smerinthus ocellatus 15. 373.

- populi 15. 372.

- tiliae 373.

Smicra clavipes 305.

- sispes 464 .

Solenobia lichenella 391.

- triquetrella 391.

Solenopsis fugax 256. 258.

Solifugre 631

Solipugae 631 .

Solpuga araneoides 632 .

Sommer $=$ Sdjmaroberbunumel 235.

Sommertwanze 613.

Sontenfdirmameife 271.

Sonnentuenotäfer 88.

Spätfing 419.

Spalthorn 339.

Spanifoc faljne 379.

Spanifdue fliege 127.

Spanter 417.

Spargerftiene 480.

Spargefbälyndien 181.

Spathegaster bacearum 301.

- tricolor 301

Spathius clavatus 310 .

Svedftäfer 67. 68.

Sphaerotherium 629.

Sphecodes 235.

Sphegidae 279.

Sphex 279.

- albisecta 279.

- flavipennis 279

- maxillosa 279

Sphingidae 367.

Sphinx convolvuli 369.

- Elpenor 386.

- euphorbiae 371.

- ligustri 15. 369.

- nerii 371.

- pinastri 370 .

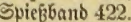

Spieß̧́buct 167.

Spleßrwespe, gemeine 288.

Spilographa cerasi 481.

Ŝliminer 644.

- anfäffige 653.

- umberjómeifento 653.

Spintentameife, eutopäiifde 273.

Spinnentbiere 630.

Spintentioter 280

- blauer 281

- ufeifender 281.
Spinturer 380.

Spirachtha 54.

Spibböte 172.

Spibbrüftige $\Re$ äfer 100.

Spibtopf 134.

Spibling 615.

Spißzmüusdjen, ponneliebenbes 139.

Splinttäfer 161 .

Spondylis buprestoídes 166.

Sprengiel 546.

Sivtentelfüßer 572 .

S)ringiđivăn 568. 569.

Springiduwanz, bleigrauer 570.

- zottiger 570 .

Springipinne, farminrothe 676

Springlpinnten 675 .

Sprodivurm 500.

Spurbiene 23.

Stabjdirede 546.

- geöbrte 546.

Stadjelameife 261, 264.

Stadielbeer $=$ BIattwe obe 334

Stadjelbeerpantuer 422 .

Stadelrwanze, gezäbnte 615 .

Staphbline, furgbaarige 56.

Staphylinidae 54.

Staphylinus 55 .

- cresareus 55.

- erythropterus 55.

- pubescens 56.

Staublaus 521.

Stauropus fagi 404.

Stedyfliege 478.

Stedimuide, gemteine 447.

- geringelte 447.

Steifbart, beutjider 460 .

Steinbred = 293 ibberdien 378 .

Steinfruditbohrer 150.

Steinthummel 221.

Steinftiedjer, brauner 622.

Stelita trenaria 645 .

Stengelbobrer 147.

- Iribmender 135.

Stenobothrus 553.

Stenopteryx hirundinis 484

Sternoxia 100.

Stielhorniliege 468.

Stierzirpe 596.

Stilbum splendidum 291.

Stirnzirpe, blutflectige 595.

- boppeltbanbirte 595 .

Stirnzirpen 594.

Stomoxys calcitrans 478.

Strachia 614

Strangalia armata 168.

- quadrifasciata 169.

Stratiomys chamaeleon 464

- furcata 463.

- Iongicornis 463.

Strepsiptera 502 .

Stridifalterdien 366.

Striferipinte, geitrectte 657 .

Stridulantia 598.

Strongylognathus testaceus 259 265.

Stubenfliene 475.

Stubtïfer 64. 259.

Stylopidae 502.

Sulzerfpiutu 653.

Siumpfionfiperłäufer 605

Synergus 296.301.

- facialis 310. 
Synergus pallicornis 298.

- Tscheeki 298.

Syngnatha 620 .

Syntomis Phegea 378.

Syromastes marginatus 613.

Syrphidae 465.

Syrphus pyrastri 466.

- seleniticus 466.

Syrtis $60 \%$.

\section{T.}

Tabanidae 457.

Tabanus bovinus 457 .

- glaucopis 458.

Tachins 474.

Tagialter 347.

Tagpfanenauge 356 .

Ingidimetterlinge 347 .

รamnentäfer 8 ?

รammenไäu 580 .

ญatnentaus 580.

Tanneupfeiగ 370 .

รansfliegent 461.

Tanztifer 151

Tapezierbiente 233.

Tapinoma 253.

- caespitum 258

zarantel 672.

- ajulidare 673.

Tatanteliforpion, langarmiger 641.

Tarantula Apuliae 673.

- inquilina 278.

Tardigrada 696.

รafterbörner 57.

Tatua morio 242.

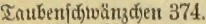

Tauditñfer 43.

Taumeltäfer 49 .

Taujenbfïblex 619.625.

Tegenaria domestica 661.

รeid) Iäufer 604.

Tefe 484.

Teleas 389.

-- laeviuseulus 303.

- phalaenarum 303.

- terebrans 303.

Telegonini 637.

Telegonus versicolor 638 .

Tetemadus 360 .

Telewhoriber 112

Telephorus fuscus 111.

- obscurus 112 .

Telyphonus eaudatus 610 .

Tenebrionidae 117.

Tenebrioniben 117.

Tenebrio molitor 119.

Tenthredinidae 333.

Tenthredo 337.

- flavicornis 337.

- scalaris 337.

- viridis 337.

Teras terminalis 299. 301 .

Terebintben = (a)lentans 592

Termes arda 531.

- arenarius 525.

- bellicosus 524.530.

- destruetor 530.

- dirus 530.

- fatalis 530 .

- Lespesi 526.
Termes lucifugus 531.

- mordax 525.

- obesus 530.

- regina 531.

- Rippertii 528.

- similis 220.

Termite, gelbbalfige 530 .

- friegerijdye 524. 530.

- ridetidieue 531.

- magere 530.

- fdrrectfidje 530.

- verbăanuisoolle 530.

Termiten 522.

Termitina 522 .

Termopsis 530 .

Tetragnatha extensa 657 .

Tetragona 215.

Tetramera 130

Tetramorium caespitum 265.

Tetraneura uImi 591.

Tetranychus socius 678 .

- telarius 678.

- tiliarum 678.

Tetrapneumones 652 .

Tetrix 555 .

- subulata 556

Tettigonia 600 .

- quadripunctata 594

Tettix 555. 599.

Tetyra maura 615 .

Teแfeไsెn

Thecla quercus 363 .

- rubi 364 .

Thecophora fovea 368 .

Theisblitite 512

Therididae 659

Theridium lineatum 660 .

- ovatum 660.

- redimitum 660 .

Thiermilken 680 .

Thomisidae 668 .

Thomisus viaticus 668 .

- virescens 668.

Thripidae 567

Thrips cerealium 568.

ร Gurm[dreden 555 .

Thynnus 273.

Thyreopus patellatus 288.

Thysanoptera 567.

Thysanura 568 .

Tiger 87.

Tigerfpirumen 675 .

Timarcha 184.

Tinea 433.

- granella 433.

- pellionella 434

-- proletella 580.

- tapetzella 434.

- vivipara 15.

Tineïna 432.

Tingis affinis 607 .

Tiphia 275.

Tipula 448

- oleracea 448.

Tipulariae 445

Tob 642 .

Tobtengräber 60 .

- beutidjer 62.

- gemeitier 60 .

Tostenfops 368 .

Tobteriuly 115.

Töfferwestue 287. इöpfermesobe, flïdytige 287.

- gemeine 287.

- goroptiznige 287.

- weisfïbige 287.

Tomicus 159.

Tomisus citricus 281.

Tortricina 424.

Tortrix resinana 324 .

Torymus regius 298. 304

Touóca 267

Toxotus meridianus 169.

Trachea piniperda 411 .

Trachys minuta 98.

Ixauterbiene 236.

Irauerfufer, gemeiner 118 .

Trauermautel 357.

Trauermilitell 450.

Iraterid)yeber 462.

Iraueripamer 422.

Treiberameife 264.

Trichiidae 92.

Trichius fasciatus 95 .

Trigona 215.

- cilipes 217

- flaveola 216. 218.

Trichodectes 571.

- elimax 571.

- latus 571

- sealaris 571

Trichodes apiarius 113.

Tridbterfpinuen 664

Tridsterwidffler 146.

Trinotum conspureatum 572.

Triphaena 413.

Trochilium apiforme 375

Troctes pulsatorius 521.

Trombididae 679 .

Trombidium holosericeum 678 .

- tinetorium 678.

Trommler 539

Trobfobf 115.

Truxalis 547. 555 .

- nasuta 555.

Trypetinae 480.

Truptyoniben 314.

Trypoxylon 287.

- albitarse 287.

- aurifrons 287.

- figulus 287. 291.

- fugax 287.

Tfet $\mathrm{e}=$ Friene 478 .

Tubitelae 667.

Typhlatta 265

Typhlocyba rosae 593.

Typhlopone 253.

Tyroglyphus feculae 690 .

U.

Mferaas 509.

Mierfliege, znei[ajwăngige 506.

llferläufer 605 .

- ziertider 606.

llfer= Miobertäfer 56 .

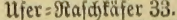

llfer= Spinbelaffel 695.

lumen= đurdutttăfer 187.

Umbonia 596.

lingeftünelte 568 .

linglidđshyafte 522.

Urodacus hollandiae 638 . 
D.

Vaejovis 638.

Vagabundae 653.

Vanessa 356

- Antiopa 357.

- Atalanta 356.

- cardui 357.

- Jo 356

- polychloros 358 .

- urticae 358.

Vates 544.

Velia currens 605

Berborgenrüв̈ter 153.

- äbnlidber 154.

- gejurdthalinger 154.

Verlusia rhombica 613.

Bertvantolungšlofe 568.

Vesicantia 122.

Vespa 245.

- erabro 246.

- germanica 248.

- holsatica 248.

- media 248.

- rufa 148

- silvestris 248.

- vulgaris 248.

Vesparia 237.

Vespidae 238

Biehfliegen 457.

Bielfuß, gemeiner 626 .

- getuipter 626 .

Bicreicjenfalterdsen 363.

Bierlungler 652

Bifitenameife 269. 270.

Bogelmilbe, gemeine 681 .

2ogermilben 681 .

Bogelipinuen 649 .

Volucella 467.

- bombylans 273. 467.

- pellucens 467.

- plumata 273. 467.

29.

23adj8

Wabeliftedier 478 .

20xfenbiene 236.

- genteine 237.

- bunftirte 237.

23affenfliege, gemeine 464 .

warbanteife, rothe 262.

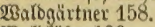

Malbtäfer 166.

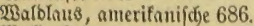

23alb= Sdutarotierbummel 235.

Maldowespe 248.

walfer 87.

Malsenböđe 175

WBalgencifabe, vierpunftine 594 .

פgalzenfpime, gemeine 632 .

20algenpiunen 631 .

ISandefnbe 83 lätter 546 .

Manberbeuidfrecte 551.
Wanberbeu[d)refe, [übafritanijdje 549.

23anb = \$el

23arzenbeißer 558 .

Warzentäfer 111.

ख3aiferflob 569.

W3afferflorfiege, nemeine 496.

- rubjarbige 497.

DBaffertäfer 51

2Sajferläufer 604 .

$23 x$ ilermilbe, rotbe 680.

23ajiermilber 679.

20affermotten 499.

פaj[erfforpion, gemeiner 603 .

23 aiferiforpionwanzen 602 .

23ajferpintue, gemeine 664

IBajlertreter 48.

פSaffertuanzen 601.

Meber, djagrinituter 173.

IBsebertnedit 642

TEebjpinue, befränate 660 .

20ебpimuen 644, 659 .

פsegtrittipanner 424 .

23eglvestse 276.

- gemeine 278

- natalenifidse 276

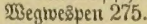

2Beibertiobter, geífinwänster 640 .

2Beidhtäfer 106.

2Beidftäfer, gemeiner 111.

Weibenbaumlauß 590.

23eibenbolyrer 376.

meibencifabe 594.

Wetben=Drbenšbanb, rothes 416 .

Meibenrüвler 152.

23eibenjpinner 393

S3eithermilbe 680.

93eintäfer 87.

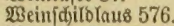

झ3einidjuärmer 386

2Beisfted 378.

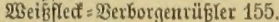

2keiß̉linge 350.

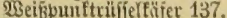

\$erftyolzfäfer 115.

- geftreifter 116 .

23erre 562

Wespe, beutidie 248.

- gemeine 248.

- mittlete 248.

- rothe 248.

23espent 237

- gefellige 241.

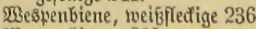

25espenbienen 235.

SBicfler 424.

wibberfäer, gemeiner 172 .

23iejenvogel, genteiner 362 .

2iefentwanzen 609.

Minsig 369 .

23inhufa 606

2sinterpinut 661

28 interianteule 413.

פSinterfipamer 419

Birberfäjer 49. आixbeไtweôpe 284.

- gemeine 285.

SSirrborntäfer 126.

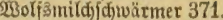

20ㅇำ

आ3olibienen 232.

जुolltäuje 587.

230แtaus 591.

B3йrg[рінтен 649 .

S3urmotadje 450 .

23urzel= (B)allweose, ftïgello[e 299.

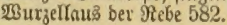

$x$.

Xenos Peckii 503.

- Rossii 503

Xiphydria 330.

Xylocopa 225 .

- caffra 225.

- laticeps 225

- viloacea 225.

Xylophagi 117.

Xylotropha 374

Xysticus viaticus 668 .

- virescens 668 .

\section{श).}

9ppitoneule 415.

\section{3.}

$Z$ abrus gibbus 40 .

3ac̛en[ (d)wärnter 372.

Zanģentamei jen 261.

3angenaífeln 622

Sungenböde 169.

3apjenvicfíer 142.

3ecfen 682.

Zephonia 629.

Biegenlaus 571

Simmerbod 174.

Yimmermau 166

Birpent 593.

3irpfäferđen, swölipunttiges 181

Zora 671

Botten [đॅvänze 568

3udergnit 569.

Buderfäer 76.

Bünoler 429

3ugameife 270.

3 ugbeufárecte 551.

Rungenvitixmer 693

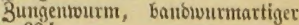
694.

3tweifritgler 440

3roeignbitedier 147.

3 tweibaarfilibler 625.

3iviebclftiege 479.

3roicbeltyorntüfer, groß̈töpfiger 83 .

3.witjdjerfeujdjrefe 559.

Zygaena 378.

- chrysanthemi 378.

- filipendulae 378. 
Drut vom פibliographifichen Jintitut in Seipsig. 